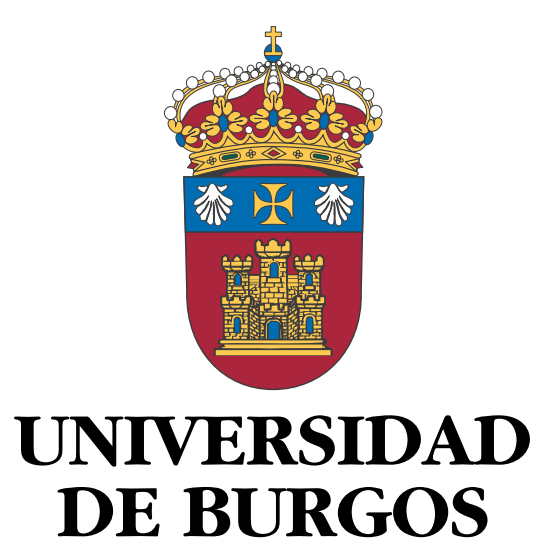

FACULTAD DE HUMANIDADES Y COMUNICACIÓN DEPARTAMENTO DE CIENCIAS HISTÓRICAS Y GEOGRAFÍA

TESIS DOCTORAL

\title{
CAMINOS BURGALESES: LOS CAMINOS DEL NORTE (Siglos XV y XVI)
}

\section{Salvador Domingo Mena}

Dirigida por Juan José García González

Catedrático de Historia Medieval de la Universidad de Burgos

BURGOS, 2015 

A Cari,

Elena

Eva

Juan

Javier

Alex

y Toño. 

TOMO

I

\section{CAMINOS BURCALESES: \\ Los Caminos del Norte \\ (Siglos XV y XVI)}





\section{Resumen}

L presente trabajo desarrollado como Tesis de Doctorado se enmarca dentro del pro-

- grama de la Universidad de Burgos que lleva por título "La vida cotidiana en Castilla y León” y ha sido realizado bajo la dirección del doctor D. Juan José García Conzález, catedrático de Historia Medieval.

El contenido se identifica con los itinerarios que unían la ciudad de Burgos con los puertos del Cantábrico centro-oriental y, en concreto, con los de Santander, Laredo, CastroUrdiales, Bilbao y Portugalete. El autor aspira en este plano a la restitución más fidedigna posible de sus trazados y de las variantes que fueron incorporando.

Su ámbito territorial comprende la mitad septentrional de la actual provincia de Burgos, el tramo oriental de la Comunidad Autónoma de Cantabria y el segmento occidental de las provincias de Álava y Vizcaya. El marco cronológico se circunscribe a los siglos XV y XVI o, si se prefiere, al período que opera como puente de paso de la Edad Media a la Edad Moderna.

A pesar de que el territorio burgalés es y ha sido siempre una encrucijada de caminos, los estudios que se les han dedicado están bien lejos de cubrir las expectativas. Con los límites de espacio y tiempo ya glosados, se pretende contribuir con este trabajo a colmar dicha laguna.

Palabras clave: Historia, Geografía, Urbanismo, Arquitectura, Caminería, Burgos, Santander, Laredo, Castro-Urdiales, Bilbao, Portugalete.

\section{Abstract}

his dissertation presented as a Doctoral Thesis fits within the Burgos University program. The title is "the daily life in Castille and León" and it has been directed by Dr. Juan José García González, Professor of Medieval History.

The contents of this Doctoral dissertation focuses in the different routes that connected Burgos with the central-eastern ports of the Cantabrian cost, especially Santander, Laredo, Castro-Urdiales, Bilbao and Portugalete. The author's intention is to present these routes and their evolution over time, in the most accurate way possible.

From a geographic perspective, it has been considered the northern part of the current province of Burgos, the eastern part of the Cantabrian region and the western part of Álava and Vizcaya during the XV and XVI centuries or, in other words, the period which marks the transition between the Middle Ages to the Modern Time.

Despite the fact that the territory of Burgos has always been a crossroads, the different studies that have covered the subject so far are distant from satisfying any expectation. Considering the limits of space and time already commented, the intention of the author is to fill this gap. 



\section{Índice general}

TOMO I

I.- PRESENTACIÓN

II.- INTRODUCCIÓN ..........................................................................................................................................23

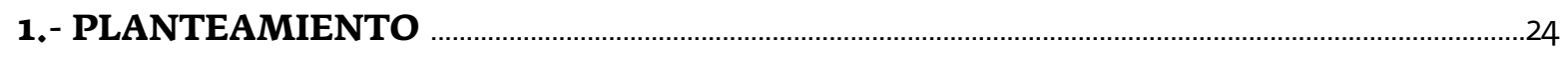

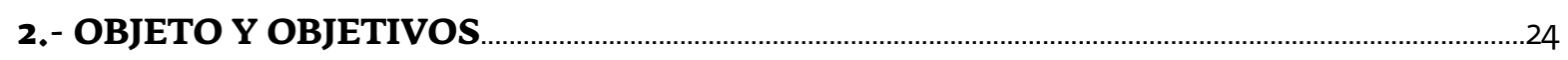

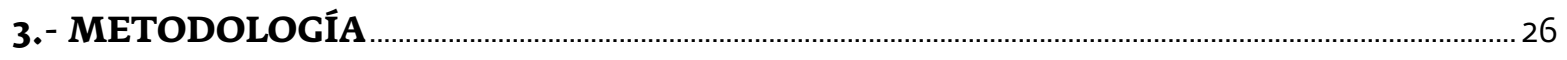

A.- FUENTES MANEJADAS

a.- Fondos documentales ................................................................................................................2

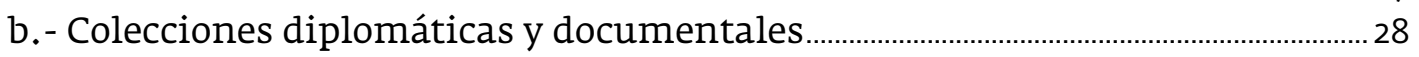

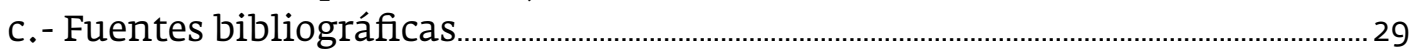

• Estudios de carácter general ..................................................................................................2

- Estudios de alcance regional, comarcal y local............................................................3

d. - Itinerarios históricos de caminos ........................................................................................ 39

e. - Memorias y testimonios de caminantes y viajeros.................................................... 43

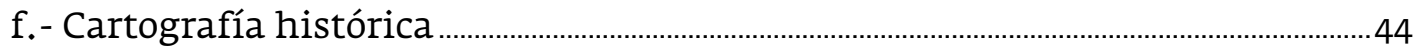

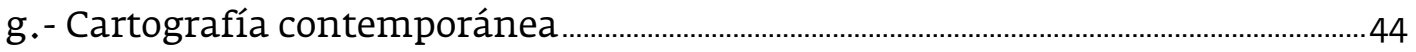

h.- Fotografía aérea y cartografía digital …………................................................................ 45

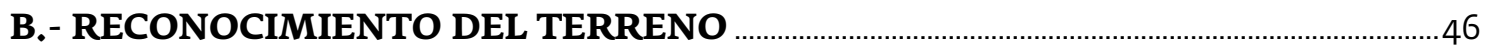

4. - CONTENIDOS

5. - PROYECCIÓN DE RESULTADOS

III.- ESTADO DE LA CUESTIÓN

1.- LOS CAMINOS EN LA HISTORIA DE LA PENÍNSULA ……………..................................... 50

2.- CONDICIONES GENERALES DEL TRANSPORTE ………………………………………….... 54

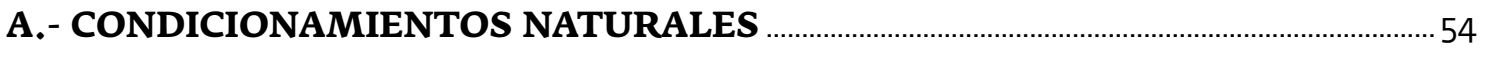

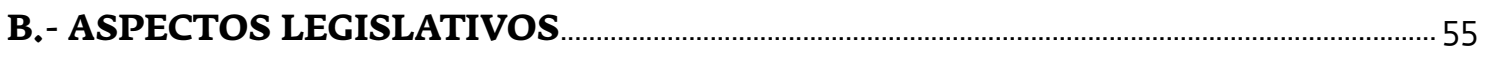




\section{Capítulo I}

\section{LOS CAMINOS DEL NORTE (siglos XV y XVI)} Encuadramiento Geohistórico

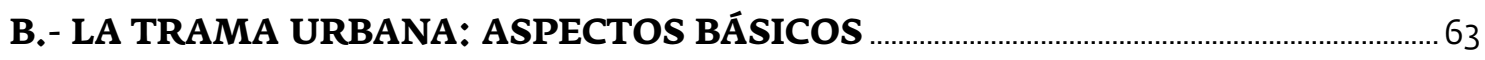

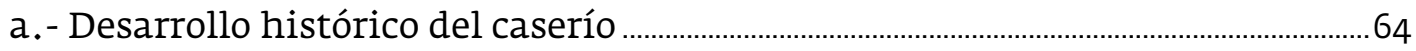

b. - Puntos habituales de la actividad comercial..............................................................65

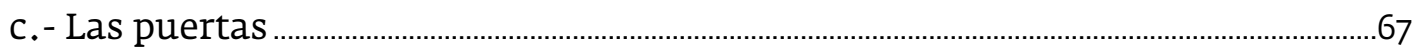

- El portazgo de la puerta de San Juan............................................................................................68

- El ensanche de la puerta de San Gil...............................................................................................70

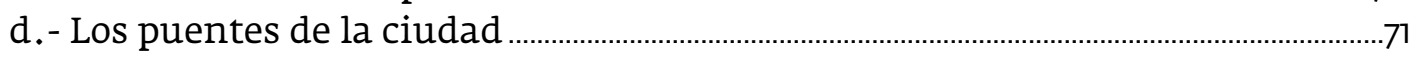

- Reparaciones de los puentes .....................................................................................................75

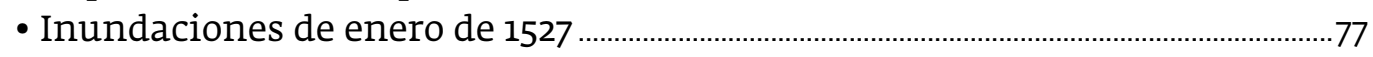

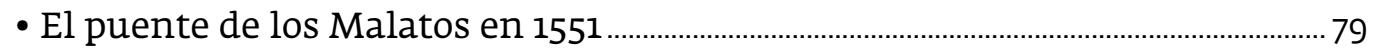

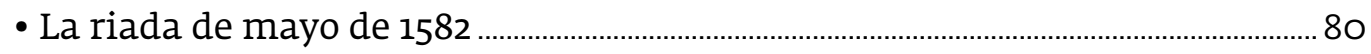

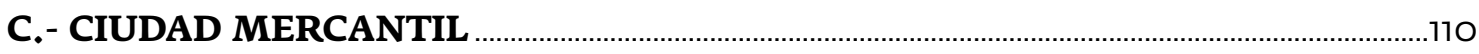

a. - Enclave comercial y lanero ……………………………………………………………..... 115

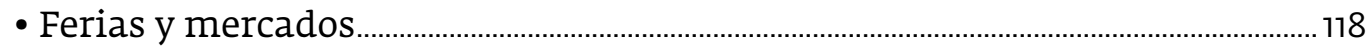

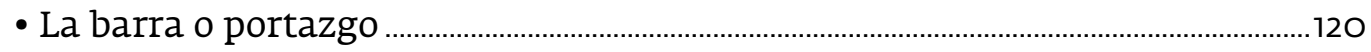

b. - Actividad mercantil .......................................................................................................... 129

- Exenciones de los comerciantes y arrieros burgaleses............................................. 129

- El monasterio de Las Huelgas y el mercado de la Llana.............................................130

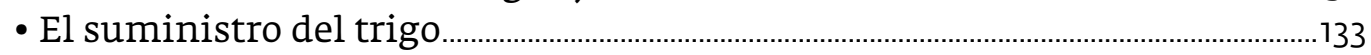

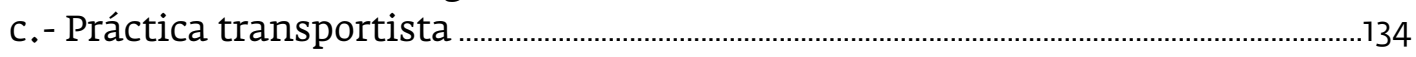

• Encrucijada de caminos .........................................................................................................137

• La Universidad de los Mercaderes ………………................................................................143

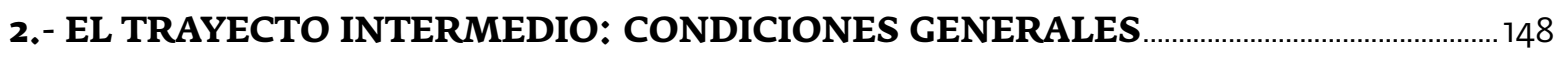

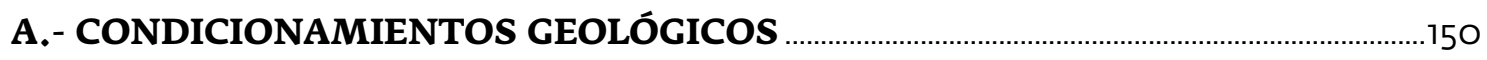

B.- CONDICIONAMIENTOS GEOMORFOLÓGICOS ………………………………………... 156

C. - CONDICIONAMIENTOS HIDROGRÁFICOS ……………………………………………….... 159

a.- La cuenca del Ebro. El Ebro como eje ................................................................................ 159

b.- La cuenca del Cantábrico. Los ríos del Valle de Mena...................................................160

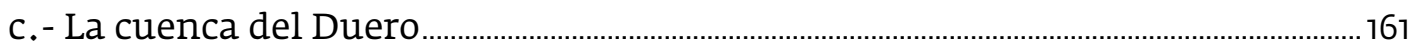

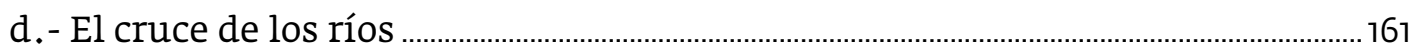

3. - LOS PUERTOS DEL CANTÁBRICO COMO TÉRMINO DE LLEGADA …….....................166

A.- LAS CUATRO VILLAS DE LA COSTA DE LA MAR

a.- San Vicente de la Barquera.............................................................................................. 169

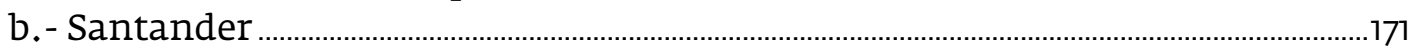

c. - San Martín de la Arena ...............................................................................................................173 


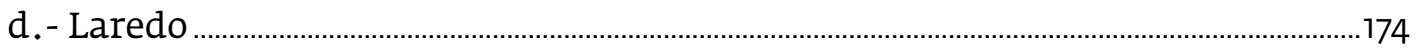

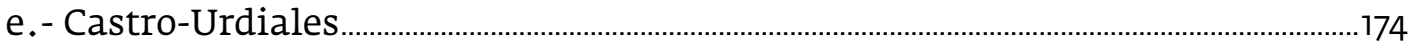

B. - LOS PUERTOS VASCOS

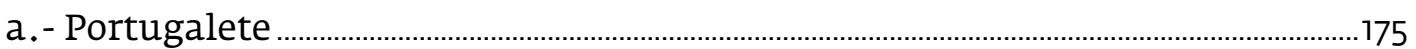

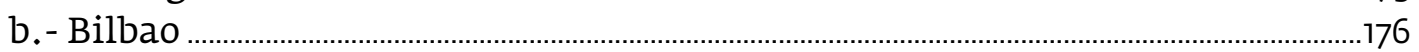

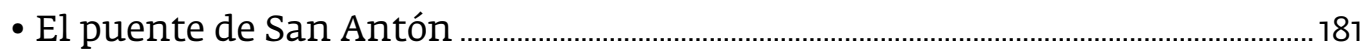

• El Consulado de Bilbao ................................................................................................................183

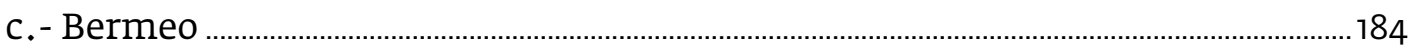

d. - Deva

\section{4.- EVOLUCIÓN HISTÓRICA DE LAS VÍAS DE COMUNICACIÓN}

ENTRE BURGOS Y LA COSTA ……………………………………………………………………...

A. - VİAS ROMANAS

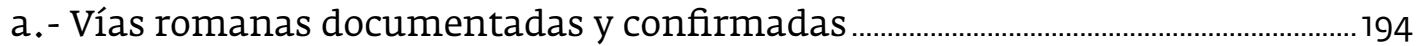

- Vía de Hispania in Aquitania. Ab Asturica Burdigalam..........................................194

- Vía de Italia in Hispanias ............................................................................................................ 195

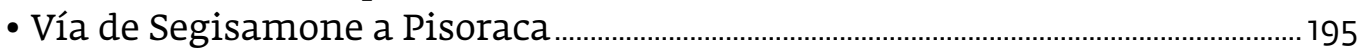

• Vía de Pisoraca a Iuliobriga ............................................................................................... 195

- Vía de Iuliobriga a Portus Blendium ..................................................................................196

• Vía de Iuliobriga a Flavióbriga ...............................................................................................196

- Vía de Flaviobriga a Uxama Barca y Veleia ..........................................................................197

- Vía de Uxama Barca a Deobriga ............................................................................................197

b.- Vías romanas dudosas o inexistentes ……………………………………………..............197

- Vía de Agrippa o camino costero …………………………………………………….........197

- Vía Sasamón-Amaya .....................................................................................................................199

• Camino del Escudo..............................................................................................................................199

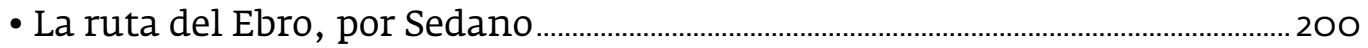

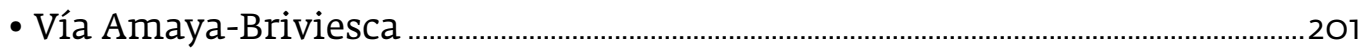

- Vía Briviesca-Orduña o El Ribero................................................................................................201

• Vía Pancorbo-Flavióbriga ...................................................................................................................201

c.- Consideraciones generales sobre la viaria romana ........................................................202

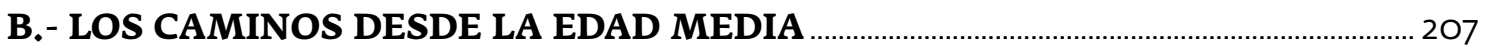

\section{Capítulo II}

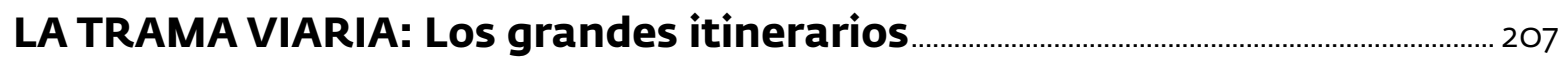

1.- CAMINOS DE BURGOS A SANTANDER ………………………………………………………….....209

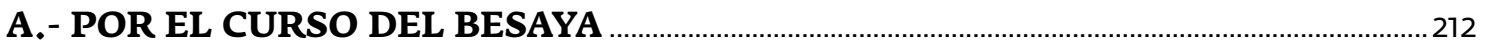

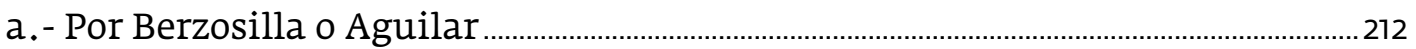

- El camino en las guías itinerarias ........................................................................................215

- Referencias documentales ................................................................................................... 217

- Las llevas de pan a Santander ...................................................................................................... 217

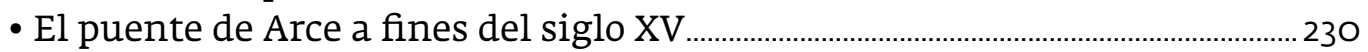

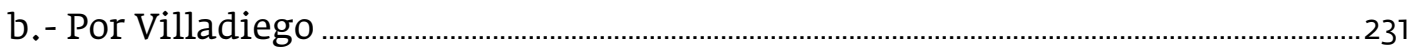

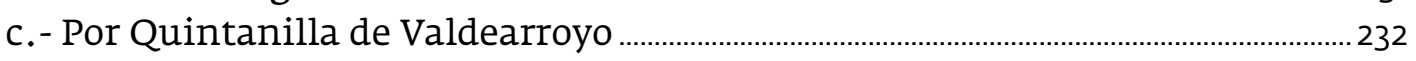


B.- POR LA SIERRA DE EL ESCUDO.

a. - Por el Tozo, barrio de Corconte y puerto homónimo ....................................................232

- La Universidad de los Mercaderes constructora de caminos ................................236

- Puente y caminos de Valcallejo y el paredón de Bárcena ................................240

- Construcción del almacén de lanas en Corconte...................................................242

- El transporte de la lana por el puerto de Santander ...................................................243

- El seguimiento de las sacas en el camino..............................................................................244

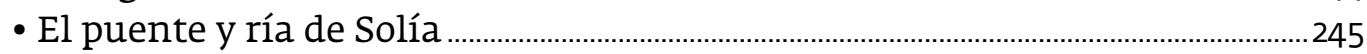

- Conciertos entre la Universidad de los Mercaderes y Santander.......................249

b.- Por el barrio de Corconte y sierra de El Escudo .............................................................25

c. - Entronque entre la vía de Reinosa y la del puerto de Corconte ............................260

d. - Por Lanchares y la vía del puerto de Corconte....................................................................261

e.- Por el puente de Rampalay y el puerto de Corconte........................................................262

- Llegada a Santander de la reina Ana de Austria ...........................................................264

f. - Por Soncillo, Cubillos del Rojo y puerto de Corconte ........................................................ 266

C. - POR VILLARCAYO

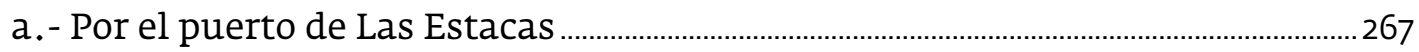

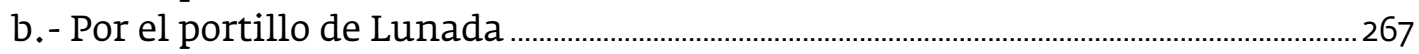

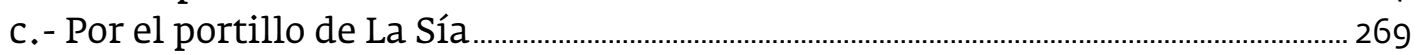

2.- CAMINOS DE BURGOS A LAREDO

A.- POR LOS HOCINOS, MEDINA DE POMAR

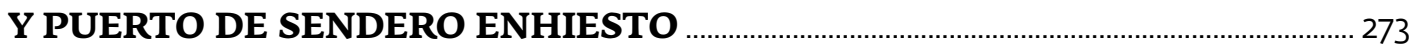

a.- Camino antiguo por Quintanajuar ............................................................................... 273

b.- Camino consolidado por Peñahorada y Cernégula .........................................................276

- El camino en las guías itinerarias ......................................................................................279

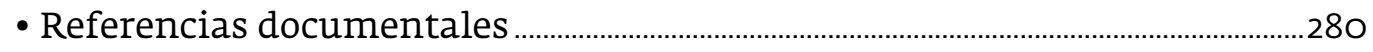

- Proyecto de fines del siglo XV para la mejora del camino ..................................... 294

- El puente de Bolado. Intervenciones desde 1499..........................................................317

- Las inundaciones de 1511. El camino de Laredo a Agüera .......................................319

- Cuentas de la villa de Laredo sobre los caminos..........................................................323

- Cuentas del Consulado sobre el camino de Laredo......................................................326

- La venida del emperador en 1556..................................................................................326

- La llegada de la Reina en 1570......................................................................................334

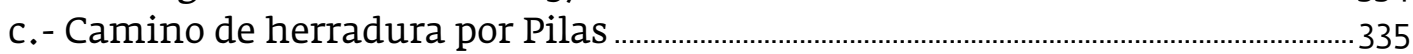

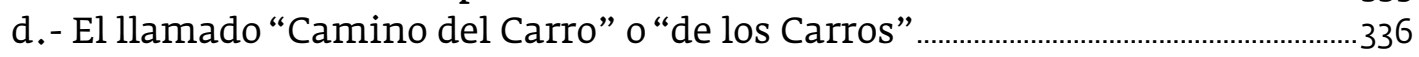

- Camino de Laredo a Agüera por la Hoz de Herada..........................................................338

- Camino de Agüera a Burgos por Valderredible...............................................................342

B.- POR LOS HOCINOS, VILLARCAYO Y PUERTO DE SENDERO ENHIESTO _.....345

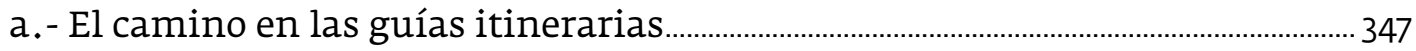

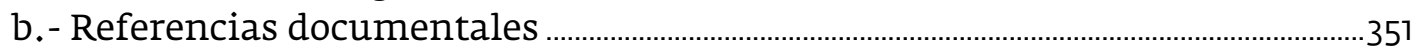

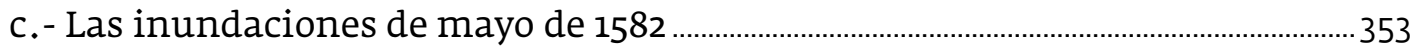

d. - Reparo del puente de Puente-Arenas y del paso de los Hocinos.............................356

e.- Arrendamiento de Laredo para el mantenimiento

del camino entre Laredo y Agüera ........................................................................................... 357

f. - Entradas y salidas de mercaderías y bastimentos en Laredo.....................................365 
C.- POR LA HORADADA, MEDINA DE POMAR

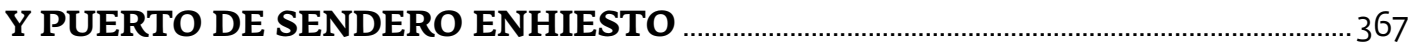

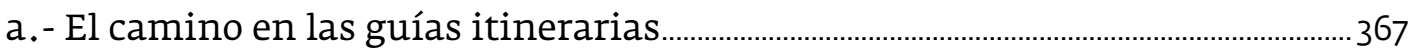

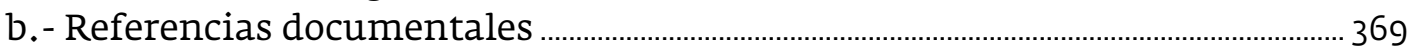

D. - POR LA HORADADA, LA COMPLACERA Y LANZAS AGUDAS …..........................

E.- POR EL PORTILLO DE LA SÍA

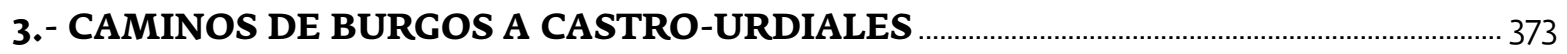

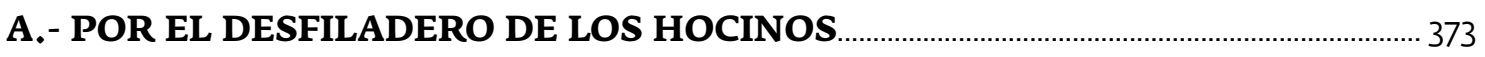

B. - POR EL DESFILADERO DE LA HORADADA

C. - POR PANCORBO Y LOSA

4. - CAMINOS DE BURGOS A BILBAO

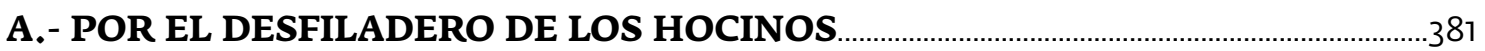

a.- Por el puerto del Cabrio, Villasana y Valmaseda................................................................381

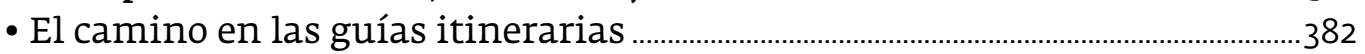

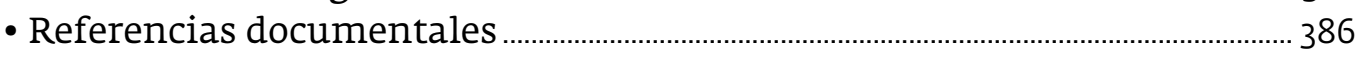

- El puente de Valmaseda .............................................................................................................. 396

- La riada de junio de 1495 en la zona de Valmaseda.....................................................397

- Riadas de junio y septiembre de 1553 en la zona de Valmaseda ......................... 399

- Provisión de 1589 para los puentes del Valle de Mena

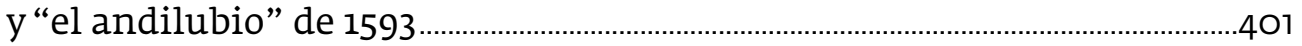

- La cuchara de las oturas de Valmaseda ..............................................................................404

๖.- Variante en el Valle de Mena por Burceña........................................................................408

c.- Por Medina de Pomar, la Magdalena y Valmaseda ............................................................. 411

B.- POR EL DESFILADERO DE LA HORADADA

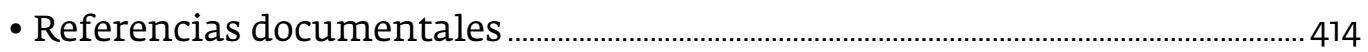

- Los reparos del puente de Poza sobre el río Homino .....................................................4 415

- Los reparos de los puentes de Briviesca, Oña y Trespaderne ...................................417

a.- Por la Complacera, Menamayor y Valmaseda.....................................................................419

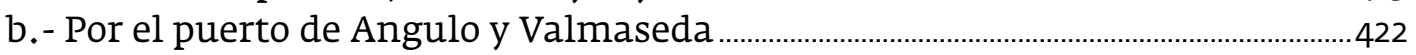

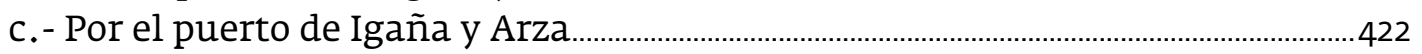

d. - Por el puerto de Angulo y Arciniega .................................................................................423

e.- Por el puerto de Angulo y Llanteno …………………..............................................................425

C. - POR LA SIERRA SALVADA Y PORTILLO DEL ARO

D.- POR LA SIERRA SALVADA Y PEÑA DE ORDUÑA

a.- El camino de Bayona entre Burgos y Pancorbo ...............................................................429

- El camino en las guías itinerarias .......................................................................................430

- Las referencias de viajeros .......................................................................................................432

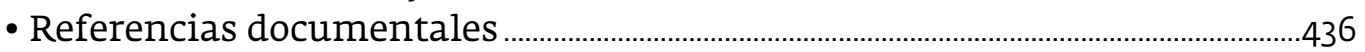

b.- Por Coldecho. La intervención de 1553 para el paso de carros ................................443 
• Desde Briviesca por Frías, Herrán y Bóveda........................................................................447

- Desde Briviesca por Frías, Herrán y Valpuesta................................................................... 451

c.- Por el paso de San Bartolomé. El intento para el tránsito de carros...................452

- Desde Pancorbo por Puentelarrá y Berberana ..................................................................459

- El camino en las guías itinerarias ..........................................................................462

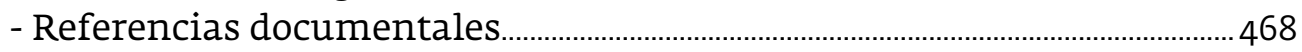

- El conflicto entre Orduña y las tierras de Álava .....................................................484

- El reparto para el camino de Orduña de 1492 .........................................................487

- Los derechos del Condestable en Orduña....................................................................489

- Los descaminos por el vado de Echévarri .........................................................................490

- La fundación de Ugao-Miravalles ......................................................................................493

- Los reparos de los caminos de Ayala y las Provisiones de 1576 ........................... 494

E.- EL CAMINO ENTRE SAN PEDRO DE BERAZA Y DARDOZA ……………............496

F. - LAS JUNTAS GENERALES Y LA REPARACIÓN

DE LOS CAMINOS DE VIZCAYA ……………………………………………………..... 498

5.- CAMINOS DE BURGOS A PORTUGALETE ………………………………………………………....505

\section{Capítulo III}

\section{CULTURA Y PRÁCTICA CAMINERA}

1.- ENTRETENIMIENTO DE LAS VÍAS DE COMUNICACIÓN...

A.- ADVERSIDADES SOBREVENIDAS.

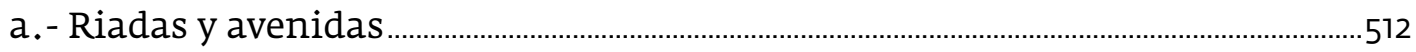

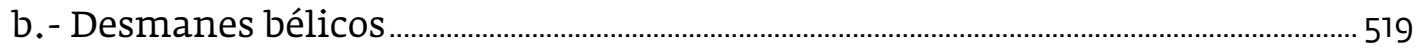

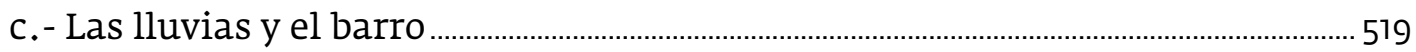

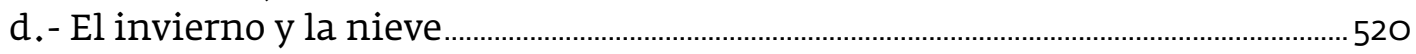

B. - MANTENIMIENTOS Y REPARACIONES ……................................................................... 523

a. - Las circunstancias especiales ........................................................................................... 524

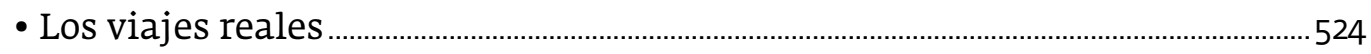

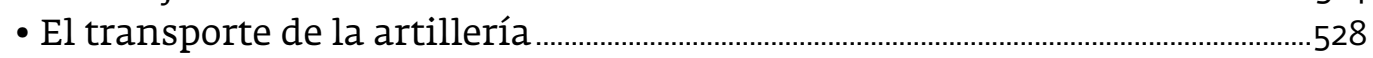

b. - Formas habituales de financiación .......................................................................................5 535

- Financiación por las localidades ……………………………………………………...536

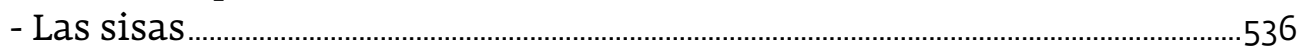

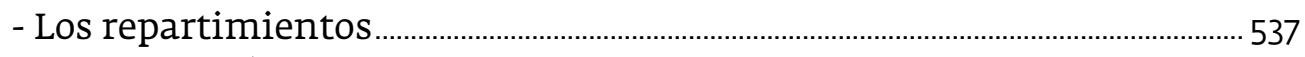

- La imposición o los portazgos y peajes ……………………………………………....540

- Financiación por los usuarios.................................................................................542

- La Universidad de los Mercaderes de Burgos.........................................................543

- Las cofradías de mulateros ...............................................................................................550

C. - MODALIDADES DE CONSTRUCCIÓN Y/O DE REPARACIÓN ………..........................552

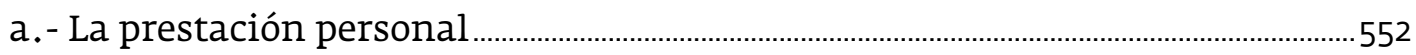

b.- La adjudicación pública..............................................................................................................55

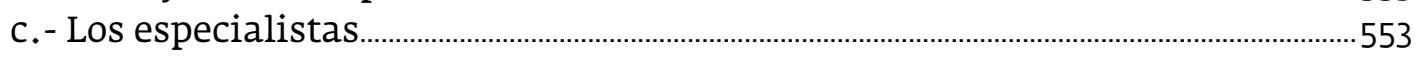




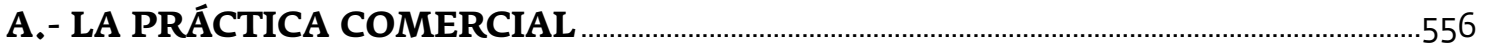

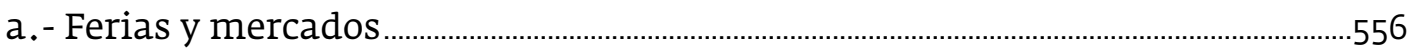

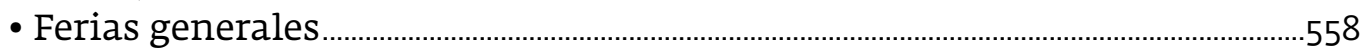

- Ferias y mercados comarcales y locales …………………………………………………......558

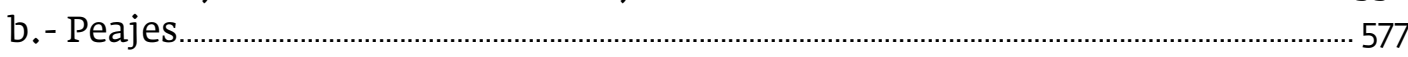

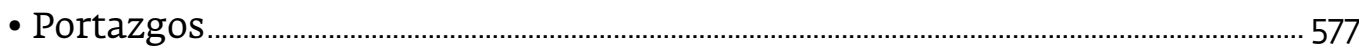

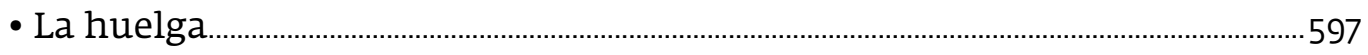

c. - Aduanas generales. Los diezmos de la mar …………………………………………...597

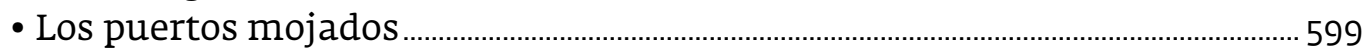

- Los puertos secos ......................................................................................................................601

- La aduana de Valmaseda...................................................................................................602

- La aduana de Orduña.........................................................................................................604

- La aduana de Vitoria.....................................................................................................607

- El cobro del diezmo a partir de 1559 ....................................................................................607

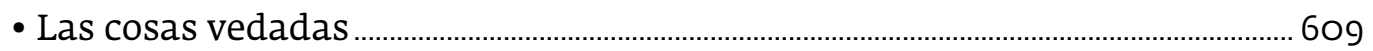

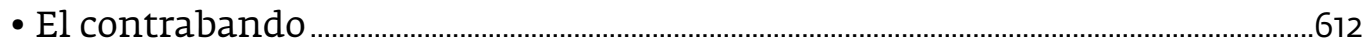

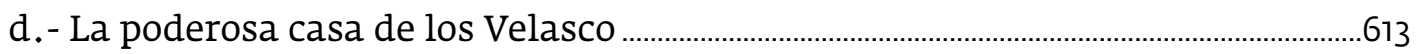

• El control de las vías comerciales ....................................................................................614

- El control de los diezmos de la mar ..........................................................................................622

• El señorío de Medina de Pomar .................................................................................................625

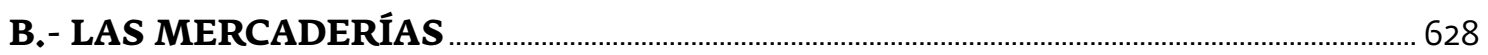

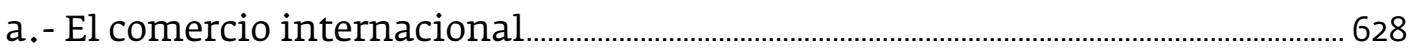

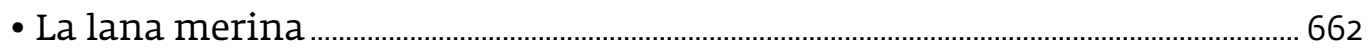

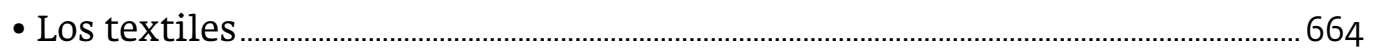

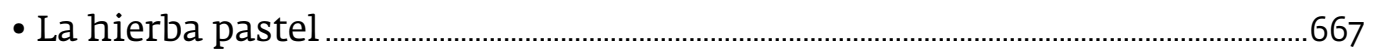

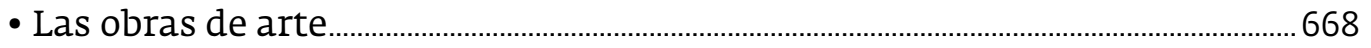

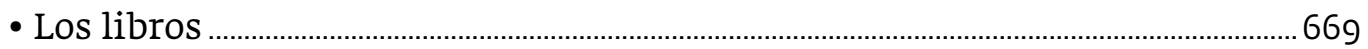

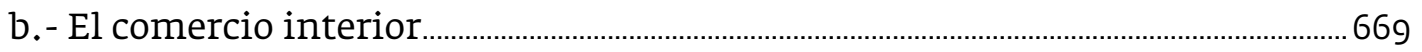

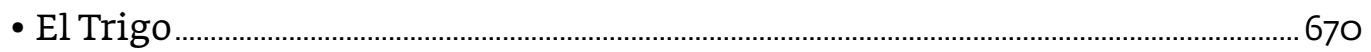

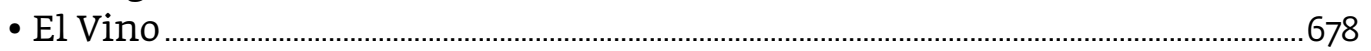

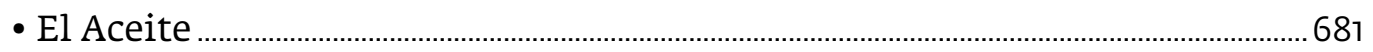

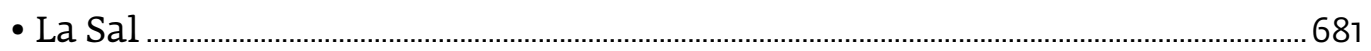

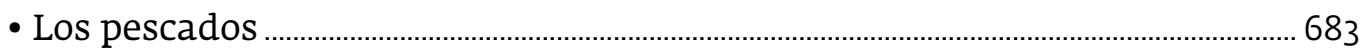

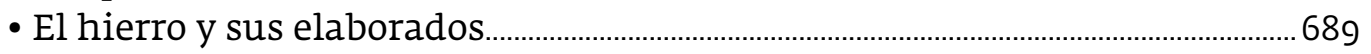

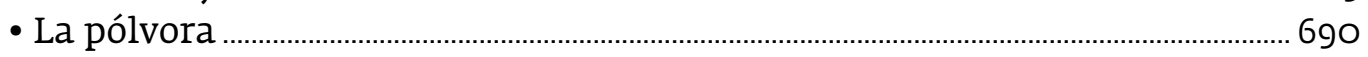

C. - TRANSPORTE DE MERCADERÍAS ………….................................................................... 691

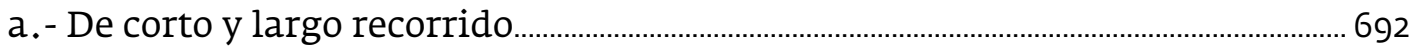

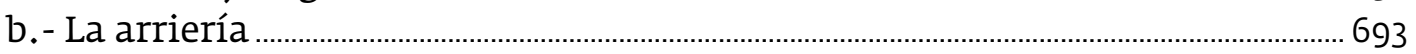

• Los arrieros ………………………………………………………………………………....69

• Las caballerías mayores ..........................................................................................................696

- La caballerías menores …………………………………………………………………………....696

c. - La arriería en las tierras del norte........................................................................................697

- La arriería entre Burgos y los puertos de mar .....................................................................697

- La cofradía de mulateros y viandantes entre Burgos y Laredo.............................701

- Los arrieros en el norte de Burgos ………………………………………………………......707

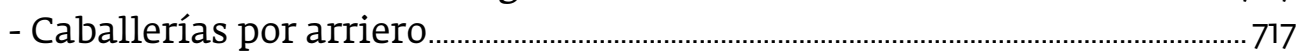

- Zonas arrieriles …………………………………………………………………………..... 720 
d. - El transporte rodado. La carretería …………………………………………...............727

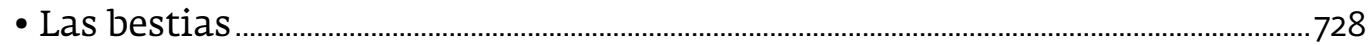

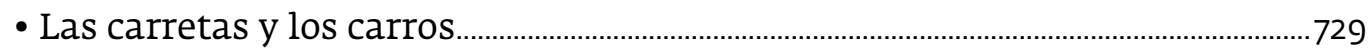

- Los carros de cuatro ruedas ……………………………………………………………......736

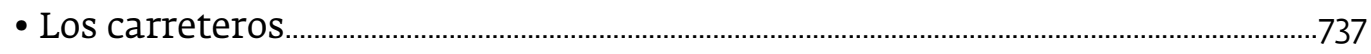

- La Junta y Hermandad de la Cabaña Real de Carreteros .........................................739

e.- Circulación de carros por los caminos de Santander ......................................................741

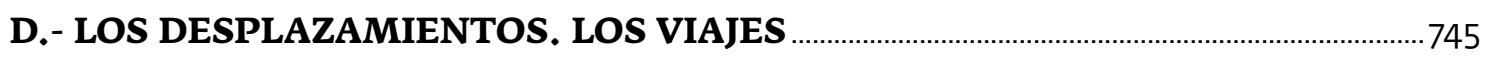

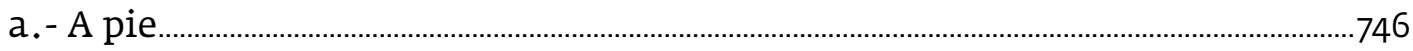

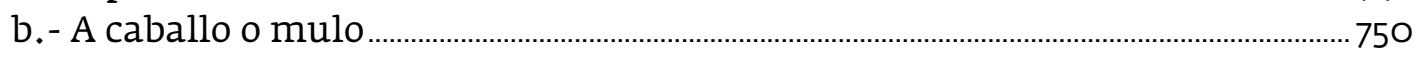

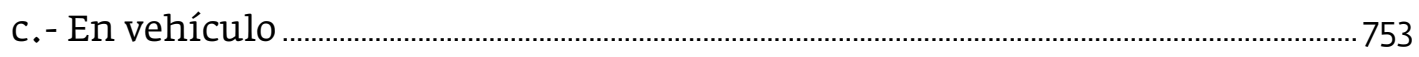

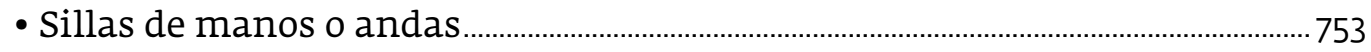

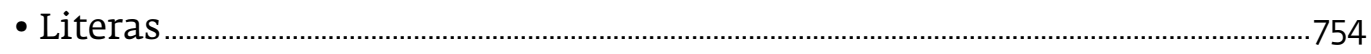

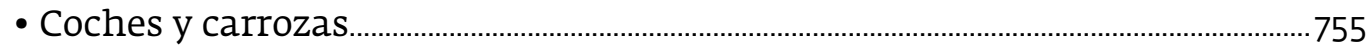

d. - Los desplazamientos reales ………………………...................................................758

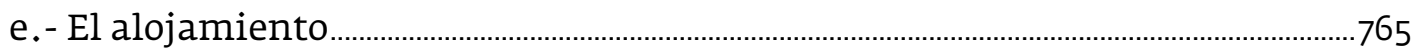

- Ventas y mesones en los caminos de Santander ............................................................768

- Ventas y mesones en los caminos de Laredo .......................................................................770

- Ventas y mesones en el camino de Castro-Urdiales .....................................................782

• Ventas y mesones en los caminos de Bilbao .....................................................................783

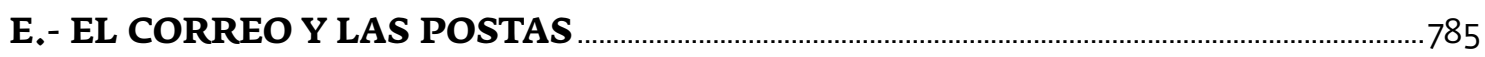

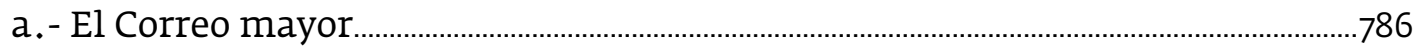

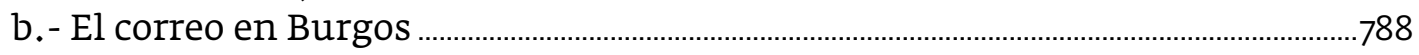

c. - El Consulado y el correo ...........................................................................................................793

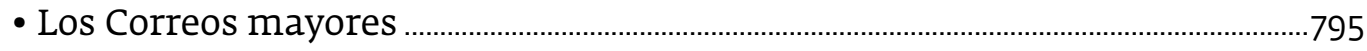

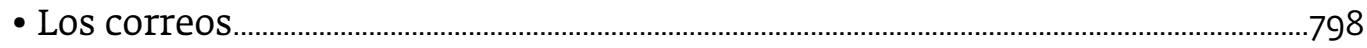

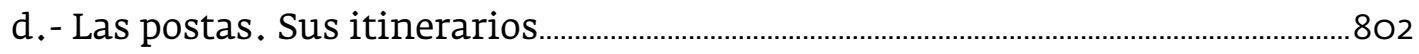

F.- LA SEGURIDAD DE LOS CAMINOS

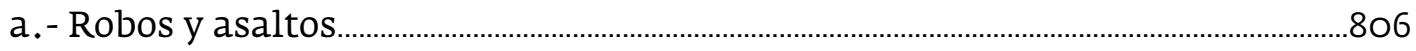

- La Santa Hermandad .............................................................................................................80

- Bandoleros y salteadores .......................................................................................................

- Los señores de los castillos y caballeros ladrones ......................................................... 814

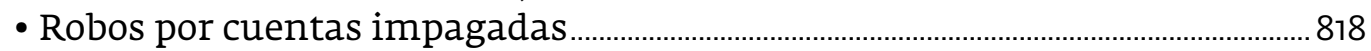

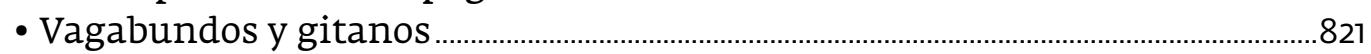

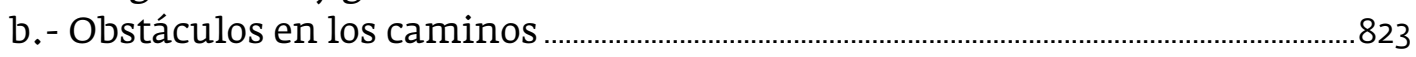

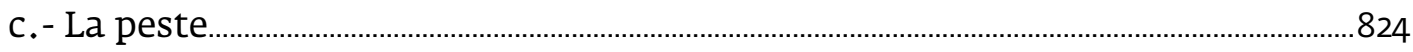

d. - El lobo y otros animales ........................................................................................................... 829 
TOMO II

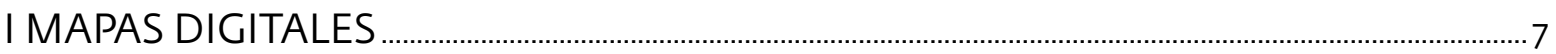

II FUENTES _...1.

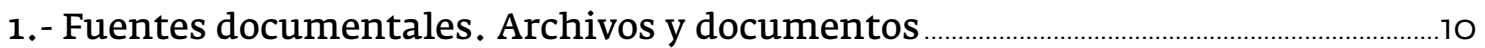

2.- Fuentes impresas y colecciones diplomáticas y documentales ………..........................

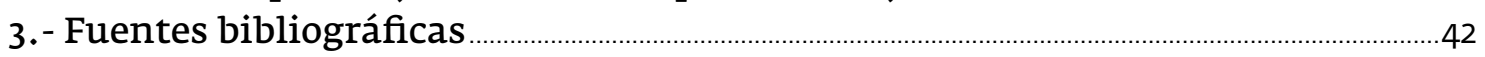

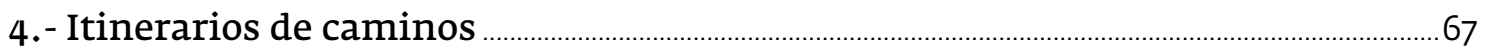

5.- Memorias y testimonios de caminantes y viajeros. Estudios ...........................................71

III APÉNDICES

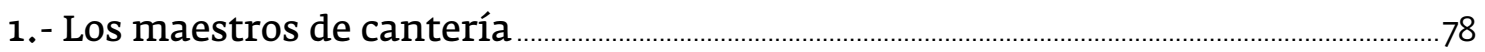

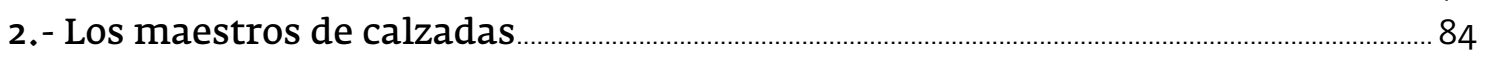

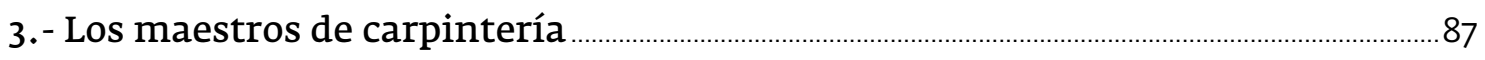

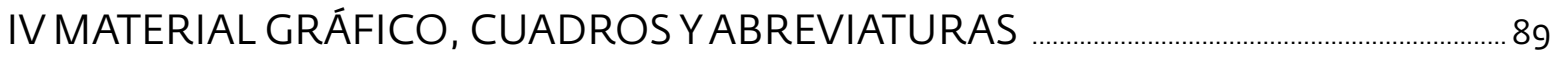

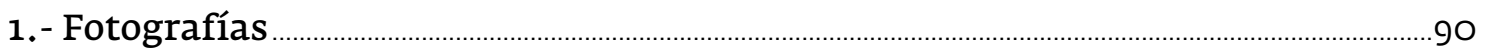

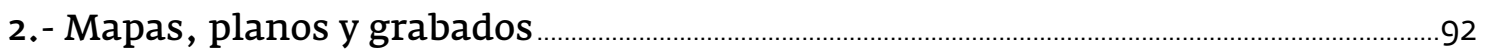

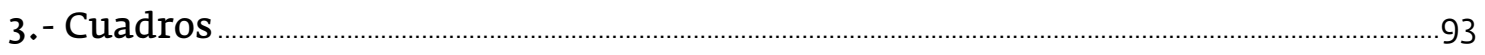

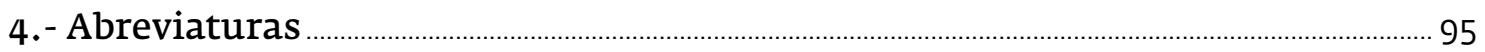





$$
\begin{gathered}
\text { I } \\
\text { PRESENTACIÓN }
\end{gathered}
$$



ste trabajo forma parte del programa de doctorado del Departamento de Ciencias Históricas, Facultad de Humanidades y Comunicación de la Universidad de Burgos cuyo título es "La vida cotidiana en Castilla y León", y ha sido realizado bajo la dirección del catedrático de Historia Medieval de dicha Universidad Don Juan José García González, con el fin de obtener el grado de doctor. Con el título de "Caminos Burgaleses: los Caminos del Norte. Siglos XV y XVI", se ha pretendido realizar un acercamiento a los hechos históricos relacionados con la caminería, los transportes y los desplazamientos, a través del conocimiento de su soporte físico como son los caminos que en sentido Sur-Norte, comunicaron la ciudad de Burgos con los puertos del Cantábrico. Para ello se ha manejado no solo la documentación histórica y bibliográfica sobre el tema sino también los itinerarios históricos, los testimonios de viajeros, la cartografía histórica y la fotografía aérea, todo contrastado con el reconocimiento directo del terreno.

El ámbito geográfico del estudio incluye la mitad norte de la actual provincia de Burgos, la mitad este de la comunidad de Cantabria y una franja vertical que engloba zonas del Oeste de las provincias de Álava y Vizcaya, y cronológicamente se parte de los siglos medievales, aunque se centra básicamente en los siglos XV y XVI. Es en estos momentos cuando se registran fases de expansión económica y comercial y la ciudad de Burgos adquiere un especial protagonismo, siendo los caminos tratados, el soporte físico que permitirá alcanzar dicha expansión.

A pesar de que las tierras burgalesas se asientan en un territorio propicio, en el ámbito de la península, para el desarrollo de los caminos, y por ellas han discurrido en todas las épocas vías importantes en diferentes direcciones, tal realidad no ha venido acompañada hasta ahora de la elaboración de unos estudios que nos permitiesen conocer aspectos tan importantes de la caminería como son los trazados, mantenimiento, construcción, segu- 
ridad, tráficos, etc. de tales caminos. Esta es la laguna que modestamente pretende salvar el trabajo que se presenta dentro de los límites geográficos y cronológicos mencionados.

Quisiera en este apartado manifestar mis agradecimientos a las personas que me han ayudado para la realización de este trabajo. En primer lugar al catedrático de Historia Medieval de la Universidad de Burgos, Dr. D. Juan José García Conzález, director de este trabajo, a quien deseo expresar mi más profunda gratitud por su inestimable apoyo y magisterio.

Mi agradecimiento, igualmente, a Francisco Ruiz García que ha elaborado los mapas digitalizados, manejando para ello fotografías aéreas antiguas junto con las fotografías realizadas desde satélite. También, a todos los que me han acompañado en el reconocimiento de los caminos utilizados en el pasado por arrieros y carreteros: José Javier Fernández, de Río de Losa; Roberto Fernández, de Trespaderne; Jesús Arce y Pedro Barcina, de El Almiñé; Abel Cámara, de Villalacre; Jesús Mari Martínez, de Espinosa de los Monteros; Eduardo Rojo, de Oña; Chomin Robina, de Orduña; Antonio Gallardo, de Medina de Pomar; Bonifacio Gómez, antiguo alcalde de Tobalina; Luis Porras, de San Martín de Humada; José María Sáez, de Miranda de Ebro; Carlos Ortiz, de Pancorbo; Ricardo Martínez, de Santa Gadea del Alfoz y Judith Trueba y Luis Mari Angulo, del Valle de Mena.

También quiero resaltar mi reconocimiento a Félix Andino de Villarcayo, y a Miguel Conzález por su ayuda en la elaboración de las fotografías, a Isabel Aguirre, del Archivo de Simancas; a Carmen de Miguel, de la Biblioteca de Castilla y León de Burgos; a Aixa Saiz, de Recuperación de Archivos Municipales de la Diputación de Burgos; a Milagros Moratinos y a Beatriz Fernández, del Archivo Municipal de Burgos; a la directora y personal auxiliar del Archivo Histórico de Cantabria; a $M^{\underline{a}}$ Jesús Olivares, del Archivo Municipal de Briviesca; a Jesús María Preciado por su valioso apoyo y a Isaac Moreno que tanto nos ha enseñado sobre la viaria romana. Quisiera reconocer también la contribución de Alberto Labarga, que con gran esmero ha realizado la maquetación de este trabajo.

Un lugar especial en este capítulo lo ocupa mi esposa Cari, que tanto ha compartido y apoyado el desarrollo de este trabajo, acompañándome con frecuencia en los desplazamientos realizados para conocer "in situ" los caminos que estudiamos. 


\section{II}

INTRODUCCIÓN

1.- PLANTEAMIENTO

2.- OBJETO Y OBJETIVOS

3.- METODOLOGİA

A.- FUENTES MANEJADAS

a.- Fondos documentales

b.- Colecciones diplomáticas y documentales

c.- Fuentes bibliográficas

d.- Itinerarios históricos de caminos

e.- Memorias y testimonios de caminantes y viajeros

f.- Cartografía histórica

g.- Cartografía contemporánea

h.- Fotografía aérea y cartografía digital

B.- RECONOCIMIENTO DEL TERRENO

4-- CONTENIDOS

5.- PROYECCIÓN DE RESULTADOS 


\section{1.- PLANTEAMIENTO}

Las tierras del norte peninsular han tenido históricamente una gran importancia para garantizar la conexión entre el interior de la Península y los territorios de la franja costera cantábrica y, por ende, con los países de la Europa Atlántica, relevancia que no siempre se ha correspondido adecuadamente, creemos, con el desarrollo de estudios que permitieran conocer este mundo relacionado con la caminería y sus diferentes aspectos, entendido como soporte básico de dicha conexión y de las relaciones comerciales, políticas, económicas, etc. establecidas entre Castilla y Flandes, Oeste de Francia y Sur de Inglaterra.

Este trabajo pretende, modestamente, hacer una aportación que contribuya a solventar la ausencia referida y responder, en la medida que ha sido posible, a algunos de los aspectos relacionados con la creación, mantenimiento y reparación de caminos, calzadas y puentes, los transportes y transportistas, los medios empleados, la seguridad, alojamiento, etc., para lo que se ha realizado un esfuerzo especial en aportar nueva documentación que nos permitiera ir más allá de las habituales menciones superficiales, realizadas cuando se tratan los temas relacionados con la caminería en el sector oriental del centro-norte peninsular durante la transición de la Edad Media a la Moderna.

\section{2.- OBJETO Y OBJETIVOS}

Por lo general, la geología y la hidrografía han predeterminado los corredores que las primeras comunidades humanas comenzaron a seleccionar, y los lugares y parajes por donde les convenía desplazarse, convirtiendo los pasos tradicionales y de uso reiterado en caminos progresivamente consolidados. Esto ha resultado decisivo en la configuración de los caminos entre la Meseta castellana y los puertos del Norte cantábrico, con una cordillera intermedia, como la Cantábrica, difícil de superar.

Los caminos se perfilan, igualmente, como uno de los grandes indicadores del devenir histórico de las sociedades que los crean y utilizan, de tal manera que su crecimiento o declive se suele corresponder con el grado de estabilidad que dichas sociedades atraviesan en cada momento. Su creación, mantenimiento, desarrollo o declive nos habla de fases expansivas o regresivas y, en ocasiones, son la respuesta inmediata a procesos concretos de tipo social, económico, político, religioso. etc.

Entendemos, por tanto, que su estudio es básico para conocer las sociedades históricas y su desenvolvimiento, y ello no sólo en los aspectos técnicos relacionados con los propios caminos, y con el cada vez más amplio espectro de elementos que mantienen la caminería como eje básico y principal, sino también, y esto es lo importante, para acercarnos al conocimiento de unas comunidades que debían resolver en cada momento unos problemas inmediatos y aportar unas soluciones que en muchos casos tenían relación con los aspectos camineros.

Los caminos y su estado han sido, en definitiva, la respuesta ante unos problemas de transporte y comunicación entre personas, y con ellas, sus ideas y culturas, y sobre 
todo han funcionado como el canal por el que se relacionaron las diferentes sociedades, y podrían ser en sí uno de los factores que explicarían en muchos casos el nacimiento, progreso o decadencia de determinadas comunidades y núcleos de población, así como un elemento decisivo para dicho proceso por encontrarse a veces en su mismo origen. Una decisión política sobre determinados caminos ha podido causar, y ha ocasionado de hecho, el progreso o la ruina de zonas y sociedades concretas.

Es conocido, por lo demás, el importante papel que la ciudad de Burgos jugó en el desarrollo del comercio internacional desde los siglos XII-XIII, proceso expansivo que se extendió hasta el siglo XVI, aunque en su segunda mitad experimentó un grave y sistemático declive. Pero si el comercio recibía el impulso y se organizaba desde la capital del Arlanzón, estimulado por un colectivo de emprendedores mercaderes, el tráfico debía canalizarse hacia unos puntos concretos de destino. En efecto, si este potente comercio internacional de referencia fluía desde la ciudad de Burgos y llegaba a sus destinos allende los mares (Flandes, Francia e Inglaterra) a través de puertos intermedios como los de Santander, Laredo, Castro-Urdiales, Portugalete y Bilbao, entre otros de menor importancia, tenía, sin embargo, que discurrir por un espacio intermedio extremadamente agreste y complejo, utilizando unas vías cuyo mantenimiento requería una dedicación permanente.

No se pueden comprender adecuadamente las actividades comerciales de referencia si no se conocen con detalle aspectos tan importantes como la problemática de los caminos por donde discurrían y la complejidad de los sistemas de transporte que se empleaban en los caminos de montaña. Desde fechas relativamente tempranas se organizó entre Burgos y los puertos de la mar un creciente tráfico de mercaderías, entre las que destacaban las lanas en las idas y los paños, lienzos, pescados y, más tardíamente, la hierba pastel en los retornos, tráfico que, por lo general, se desarrolló siempre en condiciones muy precarias, como comprobaremos en este trabajo. Salvo en recorridos concretos, en que las características del terreno permitían el transporte en vehículos de ruedas, todo el tráfico discurrió a lomos de bestias, principalmente de mulos, dirigidas por arrieros que desarrollaron su labor en unas condiciones muy duras y en un medio geográfico extremadamente adverso.

Aunque en todos los trabajos que han abordado el funcionamiento de este comercio, así como el desarrollo de las actividades mercantiles de la Universidad de los Mercaderes de Burgos, se ha reservado siempre un cierto apartado descriptivo a la red caminera, estimamos que esta no ha sido todavía tratada con el detalle y la amplitud que merece por su importancia intrínseca y como soporte de las relaciones culturales, sociales y mercantiles que promovía. Ya en 1974 Ortega Valcárcel lo subrayaba con energía y nosotros afirmamos con igual convicción que muy pocas novedades se han producido desde entonces sobre el conocimiento de la infraestructura viaria, de las comunicaciones y de los transportes que ponían en relación Burgos con los puertos cantábricos ${ }^{1}$. Consideramos, en definitiva,

1 ORTEGA VALCÁRCEL, José: "La Transformación de un Espacio Rural. Las Montañas de Burgos”. Universidad de Valladolid, 1974: 130, nota 4. Indica el autor en las fechas de su trabajo que el estudio de las comunicaciones y el transporte estaba por hacer, siendo expresivo que en las obras generales se ignore o se dediquen a este tema apenas unas líneas que no hacen sino resaltar la ignorancia sobre ello. Sirva como ejemplo negativo el espacio dedicado a los caminos en el trabajo de BASAS FERNÁNDEZ, Manuel: "El Consulado de Burgos en el siglo XVI". Consejo Superior de Investigaciones Científicas. Madrid, 1963. Reedic. Excma. Diputación Provincial de Burgos, 1994, en el que apenas se dedican al apartado“Puentes y caminos de los puertos” tres páginas y dos láminas, pp. 149-152. 
que es muy deseable para el mejor estudio de las sociedades históricas un mayor conocimiento de todo lo concerniente a los transportes y a las vías de comunicación en aspectos tan básicos como las características de los caminos, la calidad de los firmes, los lugares de sus trazados, sus reparaciones y mantenimientos, los problemas de los acarreos, las infraestructuras de apoyo para viandantes y viajeros, la seguridad en los desplazamientos, la creación de ferias y mercados, etc. De todos estos aspectos trataremos con detenimiento en el trabajo que presentamos al Tribunal como Tesis de Doctorado.

\section{3.- METODOLOGÍA}

Con la confesada finalidad de obtener un más amplio conocimiento de los caminos utilizados históricamente entre Burgos y los puertos cantábricos incluyendo los diferentes aspectos con ellos relacionados, hemos consultado la bibliografía disponible, la documentación e itinerarios históricos, los testimonios de los viajeros, la cartografía histórica y actual y realizado labor de campo, con la esperanza de mejorar el estado de la cuestión en la medida que nos permitían nuestras posibilidades.

Partíamos de una realidad ampliamente constada, a saber, que los documentos manejados hasta el momento por los autores de artículos o trabajos relacionados con la caminería de las tierras que estudiamos eran realmente muy escasos y que las citas contenidas en algunos de ellos se venían repitiendo machaconamente con mínimas aportaciones nuevas. Pero, además, la situación se complicaba al constatar que algunas de las citas arrastraban errores de signatura, fecha o transcripción, y que, en bastantes casos, ni tan siquiera especificaba su procedencia. En conjunto, los resultados de nuestra incursión documental han sido muy satisfactorios, y el manejo de una importante masa de nuevos originales nos ha permitido plantear el estudio con una sensible mayor cantidad de datos, situándonos en virtud de todo ello en mejores condiciones para entresacar conclusiones más fundadas y fiables sobre la caminería del norte peninsular, y sobre determinados aspectos concretos con ella relacionados.

Aunque contábamos con un esquema previo para encarrilar nuestro trabajo, la documentación manejada, una gran parte inédita, nos ha ido orientando hacia una realidad que en muchas ocasiones apenas teníamos entrevista y nos ha obligado a perfilar un esquema parcialmente diferente, mucho mejor adaptado a los datos que íbamos conociendo. De esta manera cabe apreciar mejor una de las grandes finalidades de este trabajo: no sólo colaborar a detectar y corregir las lagunas científicas existentes en el conocimiento de la caminería de la zona durante los siglos de referencia sino también superarlas con nuevas aportaciones. 


\section{A.- FUENTES MANEJADAS}

Además de utilizar los trabajos históricos generales y de consultar la bibliografía relacionada con esta problemática, hemos recurrido a la consulta de los itinerarios de caminos que se publicaron a partir del siglo XVI, al igual que al conocimiento de las descripciones que realizaron sobre el espacio que centra nuestra atención, los viajeros que le recorrieron. Como los datos documentales y las referencias bibliográficas se debían contrastar lo más posible con el territorio, hemos acudido al manejo de los mapas históricos y de la cartografía actualmente disponible al igual que a la fotografía aérea, sobre todo la producida por el conocido “vuelo americano". En este mismo orden de cosas, tal vez la actuación más importante que hemos realizado, y que nos ha permitido confirmar o descartar la ubicación de tramos concretos de determinados itinerarios, ha sido la labor de campo, es decir el conocimiento "in situ" del territorio y de su red caminera, tarea que hemos realizado con una cierta constancia y dedicación.

\section{a.- Fondos documentales}

La consulta de los documentos resulta determinante para conocer los diferentes aspectos de la problemática a tratar, ya que, bien de manera directa, (mencionando actuaciones y construcciones, reparaciones, portazgos o desplazamientos), bien de forma indirecta (en relación con actividades de diferente motivación), hacen referencia a la existencia, trazado y avatares que han experimentado las vías de comunicación. Con tal finalidad se han consultado varios archivos nacionales, como el Archivo General de Simancas, especialmente sus secciones de la Cámara de Castilla serie Cámara-Pueblos, Registro General del Sello, Consejo Real y Patronato Real, el Archivo de la Chancillería de Valladolid, principalmente los Registros de Ejecutorias, y el Archivo Histórico Nacional, de manera particular las secciones de Clero y Nobleza. Por su parte, la Biblioteca Nacional nos ha proporcionado las respuestas que fueron remitidas para la elaboración del mapa de Tomás López, a fines del siglo XVIII.

Como cabe imaginar, la consulta documental se ha extendido a diversos archivos provinciales, como el Histórico Provincial de Burgos, el de la Diputación Provincial de Burgos (fondos del Consulado del Mar y del Catastro del Marqués de la Ensenada), el de la Diputación Foral de Álava, el Histórico Foral de Vizcaya, (donde se custodian los fondos del Archivo Municipal de Orduña), el Histórico Provincial de Vizcaya y el Histórico Provincial de Cantabria (Sección de Jurisdicciones Territoriales Antiguas y fondo del Archivo Municipal de Laredo). El Archivo del Corregimiento de Villarcayo ha resultado de gran valor para conocer las reparaciones e intervenciones habidas en los caminos de las Merindades de Castilla.

Los archivos municipales de un elevado número de Ayuntamientos nos han aportado datos de interés. Así, por ejemplo, el de Burgos, de una gran riqueza informativa, pero también los de Bilbao, Santander, Vitoria, El Almiñé, Briviesca, Espinosa de los Monteros, Frías, Medina de Pomar, Miranda de Ebro, Pancorbo, Poza de la Sal, Santa Gadea del Cid, Valle de Mena y Villalacre. Por último, el Archivo Cartográfico y de Estudios Geográ- 
ficos del Centro Geográfico del Ejército que custodia, entre otros documentos, itinerarios camineros del siglo XIX de gran interés así como planos y mapas no impresos.

No todos los documentos disponibles son manuscritos, dado que, desde el siglo XVI, comenzó a elaborarse un buen número de textos impresos, como circulares, repartimientos, instrucciones, crónicas de viajes, itinerarios, etc. Con el discurrir del tiempo, se han publicado las colecciones diplomáticas y documentales de numerosos centros eclesiásticos de la zona objeto de nuestro interés, cuya información resulta a veces relevante. También se encuentran impresas las crónicas de los reyes castellanos con sus continuos desplazamientos, que proporcionan datos valiosos sobre el estado de la caminería. En diversos momentos se han publicado actas de sesiones, como las de las Juntas y Diputaciones de Guipúzcoa, Juntas Generales de Álava y Juntas y Regimientos de Vizcaya, de gran interés por conocer las disposiciones adoptadas para el mantenimiento de los caminos en el País Vasco.

\section{b.- Colecciones diplomáticas y documentales}

Desde la publicación de los corpus preparados por Berganza ${ }^{2}$ y Flórez 3 o desde la edición de la colección de "Cédulas, Cartas-patentes, Provisiones, Reales Órdenes del País Vasco", de Tomás Conzález ${ }^{4}$, un gran número de trabajos recopilatorios de documentos han sido dados a la imprenta. Destacan, fundamentalmente, los realizados por el Padre Luciano Serrano5, Juan del Álamo ${ }^{6}$ y Alonso Andrés7, al igual que los de Ismael García Rámila y de Julio Conzález ${ }^{8}$. Desde 1980, el Área de Historia Medieval de la Universidad de Burgos ha llevado a cabo un ambicioso proyecto de transcripción documental, que, a través de la Colección "Fuentes Medievales Castellano-Leonesas", ha dado a la luz en 26 volú-

2 BERGANZA, F. de: 1719 y 1721.

3 FLÓREZ, Enrique: "España Sagrada”. t. XXVI y XXVII. Madrid, 1772; t. XVII. Chronicón del Monge Silense. Madrid, 1789; t. XX. Historia Compostelana. Madrid, 1791.

4 GONZÁLEZ, Tomás: "Colección de cédulas, cartas-patentes, provisiones, reales ordenes y otros documentos concernientes à las Provincias Vascongadas". t. I y II Condado y Señorío de Vizcaya, 1829. t. III Provincia de Guipúzcoa. t. IV Provincia y Hermandades de Álava. Imprenta Real. Madrid, 1829 y el V 1830.

5 SERRANO, Luciano: "Colección Diplomática de San Salvador de El Moral". Fuentes para la Historia de Castilla. t. I. Valladolid, 1906; "Cartulario del Infantado de Covarrubias". Fuentes para la Historia de Castilla. t. II. Santo Domingo de Silos-Valladolid, 1907; "Becerro Gótico de Cardeña”. Fuentes para la Historia de Castilla. t. III. Santo Domingo de Silos-Madrid-Valladolid-París, 1910; "Cartulario de San Pedro de Arlanza. Antiguo monasterio benedictino". Junta para ampliación de estudios e investigaciones científicas. Madrid, 1925; "Cartulario de San Millán de la Cogolla". Junta para ampliación de estudios e investigaciones científicas. Madrid, 1930; "El Obispado de Burgos y Castilla Primitiva desde el s. V al XIII". Instituto de Valencia de don Juan. Madrid, 1935. Tres tomos.

6 ÁLAMO, Juan del: "Colección diplomática de San Salvador de Oña (822-1214) y (1215-1284)". C. S. I. C. Escuela de Estudios Medievales. Madrid, 1950. Textos XII. Dos tomos.

7 ANDRÉS, Alonso fray: "Monasterio de San Juan. Apuntes y documentos (1091-1200)". Boletín de la Real Academia de la Historia, t. 7, cuad. I-III. Madrid, 1917. pp. 117-136; “El Hospital del Emperador en Burgos”. B. C. P. M. H. A., no 87. Burgos, 1944. pp. 382-390 y no 90, 1945. pp. 449-455; "El monasterio de Santa María de Obarenes". Boletín de la Institución Fernán González, 159, 161 y 162. Burgos, 1962, 1963 y 1964. pp. 415-434; 613-625 y 20.

8 GONZÁLEZ y GONZÁLEZ, Julio. "Alfonso IX": Consejo Superior de Investigaciones Científicas. Dos tomos. Madrid, 1944; "El reino de Castilla en la época de Alfonso VIII". Escuela de Estudios Medievales. I: Estudio; II: Docs. 1145-1190 y III: Docs. 1191-1217. Consejo Superior de Investigaciones Científicas. Madrid, 1960. Tres tomos; "Reinado y Diplomas de Fernando III". Publicaciones del Monte de Piedad y Caja de Ahorros de Córdoba, 1980, 1983 y 1986. Tres vols. 
menes algo más de cinco mil manuscritos. En el País Vasco, otro ambicioso proyecto ha sido acometido por la Sociedad de Estudios Vascos, que, bajo la denominación de "Fuentes Documentales Medievales del País Vasco", ha editado más de 140 tomos. En Santander, la Fundación Marcelino Botín también ha acometido otro notable proyecto a través de una serie específica, la "Documentación Medieval de Cantabria". Cabe incluir también en esta relación, las ediciones de documentos preparadas por Inocencio Cadiñanos ${ }^{9}$ y Conzalo Martínez ${ }^{10}$.

\section{c.- Fuentes bibliográficas}

No es ciertamente muy abundante la bibliografía que trata sobre los diferentes aspectos relacionados con la caminería. La relativa a las vías pertenecientes al espacio comprendido entre la ciudad de Burgos y los puertos de la Cornisa Cantábrica es aún más escasa, circunscrita en alto grado a comunicaciones en congresos y jornadas y a artículos publicados en revistas especializadas. Esta reducida producción bibliográfica sobre la caminería medieval y moderna, contrasta notablemente con la abundante elaboración de trabajos de investigación, que sobre las vías y obras públicas romanas, se ha venido realizando en los últimos tiempos.

\section{Estudios de carácter general}

Aunque, como acabamos de señalar, la bibliografía sobre la caminería tardomedieval y moderna relativa a la zona que centra nuestra atención es realmente escasa, contamos con algunos estudios de interés y obligada referencia. No pocos de ellos han sido desarrollados por ingenieros de caminos y, aunque en algunos casos, tienen ya una gran antigüedad, siguen conservando aún cierto atractivo por tratar sobre diferentes aspectos de la caminería histórica española.

Por orden cronológico, el primer estudio que encontramos es la "Historia de las Obras Públicas en España"11, cuyo autor es el ingeniero de caminos autor del Plan de Ensanche de Bilbao, Pablo Alzola y Minondo. Su primera edición se remonta a 1899, y tiene, entre otros, el mérito de ser un trabajo pionero y de manejar documentación histórica de pri-

9 CADIÑANOS BARDECI, Inocencio: "Ordenanzas de la villa de Miranda de Ebro (año 1561)". Estudios Mirandeses, no 2. Miranda de Ebro, 1982. pp. 5-28; "El alfoz de Miranda: Tres momentos de su Historia”. López de Gámiz, Bol. del Instituto Municipal de Historia X-XI. Miranda de Ebro, marzo 1986. pp. 31-42; "Fondos documentales para la historia de Burgos y su provincia (1 1 parte)" Estudios Mirandeses, no 6. Miranda de Ebro, 1986. pp. 111-134; "Santa Gadea del Cid: Notas de Geografía, Historia y Arte". Estudios Mirandeses, ํㅡ․ Miranda de Ebro, 1987. pp. 45-104; "El monasterio de Santa María la Real de Vileña, su Museo y Cartulario". Ayuntamiento de Villarcayo, 1990; "Monasterios Mirandeses: Herrera y San Miguel del Monte". Miranda de Ebro, 1999; "Fuero de Miranda de Ebro" Edición facsímil y transcripción de Francisco Cantera Burgos con notas de Cadiñanos. Nuclenor; "El monasterio Cisterciense de Santa María de Rioseco. Valle de Manzanedo-Villarcayo". Asociación Amigos de Villarcayo. Villarcayo, 20oz; "Monasterio de San Martín de Ferrán. Año: 4 julio 852". Transcripción A. Ubieto Arteta. Ayuntamiento del Valle de Tobalina.

10 MARTÍNEZ díEZ, Gonzalo: "Diplomatario de San Cristóbal de Ibeas". B. I. F. G. n‥ 185 y 186. Burgos, 1975. pp. 689-720 y 1976. pp. 845-872; "Libro Becerro de las Behetrías". León, 1981. 3 vols.; "Fueros locales en el territorio de la provincia de Burgos". Caja de Ahorros Municipal de Burgos, 1982; "Colección documental del monasterio de San Pedro de Cardeña". Caja de Ahorros del Círculo Católico de Obreros de Burgos, 1998; con GONZÁLEZ SÁNCHEZ, Vidal: "Colección diplomática Monasterio Cisterciense de Santa María la Real, Villamayor de los Montes". Burgos, 2000.

11 ALZOLA y MINONDO, Pablo: "Las obras públicas en España: estudio histórico". Madrid, 1899 Reedición "Historia de las Obras Públicas en España". Colegio de Ingenieros de Caminos, Canales y Puertos. Ediciones Turner. Madrid, 1979. 
mera mano, sobre todo la relativa al País Vasco. A pesar de su antigüedad, a él debemos acudir como punto de partida para el conocimiento general de la materia, y para emprender cualquier estudio sobre las Obras Públicas de la Península Ibérica, circunstancia que explica su utilización por toda la historiografía posterior.

Conzalo Menéndez Pidal, catedrático de Ceografía e Historia, también ha tratado y estudiado temas relacionados con la caminería. Su primera obra fue publicada en 1951 con el título "Los caminos en la Historia de España"12. En ella ya manifestaba un interés temprano por los caminos peninsulares. No obstante, es una obra desigual, en la que proporciona una visión excesivamente general y, en no pocos casos, superficial de aspectos que consideramos básicos. Entendemos que la obra se resiente de su ambicioso planteamiento, dirigido a analizar un ámbito cronológico tan amplio como el comprendido entre la Antigüedad y la irrupción del ferrocarril. Aún así, resulta de obligada consulta para obtener una visión de conjunto, ya que se ocupa de las vías romanas, de los puentes, de los medios de transporte y de los repertorios de caminos, al igual que de la navegación fluvial o de las posadas. Esta pionera publicación sirvió de base para la que realizó dicho autor en 1992 con el título "España en sus caminos"13, en la que se ampliaron algunos capítulos de la obra mencionada, principalmente el referido al siglo XVIII y se rehicieron otros, como el dedicado al siglo XIX. Destaca también el esfuerzo del autor por complementar la obra con un profuso aparato ilustrativo.

También merece el calificativo de "clásico" el estudio publicado en 1990 con el título "Historia de los caminos de España"14 por el ingeniero de caminos José I. Uriol Salcedo. Se trata de una obra en dos volúmenes, aunque el más interesante para nuestro trabajo es el primer tomo, que aborda la problemática caminera hasta principios del siglo XIX. Pretende y consigue realizar el estudio de la caminería en España tomando como base los trabajos anteriores de Alzola y Minondo y de Menéndez Pidal, pero no deja de aportar un enfoque propio mediante la utilización de documentos originales. Es eminentemente descriptivo, siguiendo, en este sentido, la tónica marcada por los trabajos que le precedieron.

Por otro lado, pero en este mismo orden de cosas, cabe reseñar que, desde 1992, se vienen organizando los Congresos Internacionales de Caminería Hispánica, dirigidos por Manuel Criado de Val ${ }^{15}$ e impulsados por el Patronato Arcipreste de Hita con la colaboración del CEHOPU (Centro de Estudios Históricos de Obras Públicas y Urbanismo) y de otras varias instituciones. Tienen como finalidad facilitar el intercambio entre técnicos y humanistas sobre la problemática de las vías de comunicación, poniendo el acento en el significado cultural de las mismas. Las actas recogen numerosos y variados artículos

12 MENÉNDEZ PIDAL, Gonzalo: "Los caminos en la Historia de España”. Ediciones Cultura Hispánica. Madrid, 1951, y“Caminos en la España medieval”, Varia Medievalia. II, Madrid, 2003, pp. 199-310.

13 MENÉNDEZ PIDAL, G.:"España en sus caminos". Caja Madrid. Madrid, 1992. Versión actualizada de "Los caminos en la Historia de España".

14 URIOL SALCEDO, José I.: "Historia de los caminos en España". 2 tomos. Colegio de Ingenieros de Caminos, Canales y Puertos. Madrid, 1990.

15 Los Congresos, se realizan cada dos años y el último fue el XII en 2014. Manuel Criado de Val, ha fallecido en marzo de 2015. 
sobre la caminería e incluyen trabajos relacionados con las iniciativas más recientes, no pocas de ellas de ámbito local.

Cabe destacar el artículo de Máximo Diago Hernando y de Miguel Ángel Ladero Quesada titulado "Caminos y ciudades de España de la Edad Media al siglo XVIII". Se trata de una excelente síntesis sobre dicha problemática, en la que ambos autores muestran sus profundos conocimientos sobre el tema y abordan un amplio abanico de aspectos relativos a la caminería histórica española ${ }^{16}$.

En relación con la viaria romana, debemos subrayar el trabajo realizado por Isaac Moreno, ingeniero técnico de Obras Públicas, sobre el territorio de Castilla y León. Utilizando con profusión medios arqueológicos, fotografía aérea, prospecciones de campo, cartografía histórica y documentación antigua, ha logrado identificar y describir el trazado de 27 vías romanas. Se trata de un modelo de identificación de caminos romanos realmente solvente, ampliamente avalado por unos resultados muy satisfactorios ${ }^{17}$. Las vías que discurren por la provincia de Burgos son la de Segisamvncvlvm-Legio VII (Cerezo de Riotirón a León); la de Vxama-Clvnia (Osma a Clunia); la de Clvnia-Septimanca (Clunia a Astorga); la de Septimanca-Astvrica (Clunia a Astorga), la de Virovesca-Veleia (Briviesca a Vitoria), la de Segisamone-Pisoraca (Sasamón a Herrera de Pisuerga), la de Pisoraca-Iuliobriga (Herrera de Pisuerga a Reinosa), la de Segisamone-Ocelo Durii (Sasamón a Villalazán), la de Nvmancia-Nova Avgvsta-Segisamone (Numancia a Lara y a Sasamón), la de Clvnia-Segisamone (Clunia a Sasamón) y la de Flaviobriga-Vxama Barca (Castro Urdiales a Vitoria y a Miranda).

En relación con la problemática de los puentes, los trabajos sobre su técnica constructiva son sumamente instructivos, como el realizado por Arenas de Pablo, que, tras realizar un repaso minucioso de diversos puentes medievales europeos, constata que la baja Edad Media supuso una etapa de libertad y progreso en la construcción de puentes ${ }^{18}$. El trabajo del arquitecto Santiago Huerta Fernández sobre “Estática y geometría: el proyecto de puentes de fábrica en los siglos XV al XVII" insiste en la problemática técnica de los diversos tipos de puentes históricos y hace continua alusión a las propuestas de arquitectos clásicos como Alberti, Palladio, Juanelo, Fray Lorenzo de San Nicolás o Simón García ${ }^{19}$.

En cuanto a la Península Ibérica, cabe destacar la obra que el ingeniero de caminos Carlos Fernández Casado presentó en 1950 en el II Congreso de Ingeniería ${ }^{20}$. Del mismo autor es el volumen "La Arquitectura del Ingeniero" que recoge sus principales estudios ${ }^{21}$. Desarrolló además una amplia y variada bibliografía, abordando con sabiduría, entre otras materias, la problemática de las obras públicas realizadas por los romanos. Son clá-

16 DIAGO HERNANDO, Máximo y LADERO QUESADA, Miguel Ángel: “Caminos y ciudades de España de la Edad Media al siglo XVIII". En la España Medieval, 2009, vol. 32. pp. 347-382.

17 MORENO GALLO, Isaac: "Vías romanas en Castilla y León”. Junta de Castilla y León. Valladolid, 2012.

18 ARENAS de PABLO, Juan José: "Los puentes en la Baja Edad Media”. XXII Semana de Estudios Medievales de EsteIla, 17 al 21 julio 1995. Gobierno de Navarra. Pamplona, 1996. pp. 111-151.

19 HUERTA FERNÁNDEZ, Santiago: "Estática y geometría: el proyecto de puentes de fábrica en los siglos XV al XVII". Actas del 3ํㅡㄹ Congreso Nacional de Historia de la Construcción. Sevilla, 2000. pp. 513-526.

20 FERNÁNDEZ CASADO, C.: "Breve Historia de la Ingeniería Española". II Congreso de Ingeniería, 1950. Editorial Dossat. Madrid, 1950

21 FERNÁNDEZ CASADO, C.: “La Arquitectura del Ingeniero”. Editorial Alfaguara. Madrid 1975. 
sicos sus trabajos sobre los acueductos romanos en España ${ }^{22}$. Para nuestro propósito, son de gran interés los doce artículos que publicó desde marzo de 1955 en la revista Informes de Construcción. Fueron reeditados en $1980^{23}$ incluyendo al final una larga recensión del trabajo de Abásolo Álvarez “Comunicaciones de la época romana en la provincia de Burgos”, que más adelante comentaremos.

Sobre los puentes romanos, destaca también el trabajo realizado por el ingeniero de caminos Manuel Durán Fuentes con el título "La construcción de puentes romanos en Hispania"24. Efectúa un repaso exhaustivo de los puentes romanos de la península aportando para ello su vasto conocimiento de las obras efectuadas por los ingenieros romanos a lo largo y ancho del Imperio. En cuanto a la provincia de Burgos, tan solo clasifica como romanas dos alcantarillas, la de San Ciprián, sobre el arroyo Rudera, y la del arroyo San García, ambas en Cerezo de Riotirón. No duda en negar la autoría romana al resto de los puentes burgaleses tradicionalmente clasificados como romanos.

Más centrado aún en el escenario geográfico que concita nuestra atención, se sitúa el trabajo que realizó Aramburu-Zabala sobre el estado de los puentes de Castilla y León entre los años 1575 y 1650. Se trata de una síntesis de su tesis doctoral, en la que aporta una visión de conjunto sobre la construcción de puentes, con numerosas referencias a los puentes burgaleses, a la organización de las obras públicas en Castilla y a la nómina de maestros canteros que trabajaron en la zona por esas fechas estudiadas ${ }^{25}$.

Por su parte, Carlos Calderón ha realizado un relevante trabajo sobre los puentes de la Castilla bajomedieval, profundizando en cuestiones relacionadas con su tipología, construcción y reparación. Cabe destacar su ponderada y sistemática introducción ${ }^{26}$.

Sobre los transportes, es destacable el trabajo realizado por David R. Ringrose, "Los transportes y el estancamiento económico de España (1750-1850)”27, así como la obra en dos tomos de Santos Madrazo con el título "El sistema de transportes en España, 17501850"28. El volumen I trata sobre la "Red viaria” y el II sobre el “Tráfico y los Servicios”. Aunque el ámbito temporal del estudio se extiende al siglo que media en los años centrales de las centurias decimoctava y decimonovena, resulta relevante para nuestros intereses por las interesantes proposiciones que formula en la introducción general sobre la caminería anterior a 1750.

22 FERNÁNDEZ CASADO, C.: "Acueductos romanos en España". Seis artículos publicados a partir de enero de 1968 en la Revista "Informes de la Construcción" del Instituto Eduardo Torroja de la Construcción. Recopilación Madrid 1970.

23 FERNÁNDEZ CASADO, C.: "Historia del puente en España. Puentes romanos". Doce artículos publicados en la Revista "Informes de la Construcción". Recopilación Madrid, 1980.

24 DURÁN FUENTES, M.: "La construcción de puentes romanos en Hispania”. Xunta de Galicia. Consellería de Cultura, Comunicación Social e Turismo, 2004.

25 ARAMBURU-ZABALA, M. A.: "La arquitectura de puentes en Castilla y León, 1575-1650”. Junta de Castilla y León. Valladolid, 1992.

26 CALDERÓN, Carlos: "Los puentes en la Castilla bajomedieval” Cuadernos de Historia de España, LXXI. Universidad de Buenos Aires, 1989. pp. 29-110.

27 RINGROSE, David R.: "Los transportes y el estancamiento económico de España (1750-1850)", en Siglo XXI de España. Tecnos, Madrid, 1972. $2^{\underline{a}}$ edic. en Siglo XXI de España. Madrid, 1987.

28 MADRAZO MADRAZO, Santos: "El sistema de transportes en España, 1750-1850", vol. 1. La Red Viaria y vol. 2. El Tráfico y los Servicios. Colegio de Ingenieros de Caminos, Canales y Puertos. Ediciones Turner. Madrid, 1984. 


\section{Estudios de alcance regional, comarcal y local}

En relación con los estudios publicados sobre caminos provinciales, cabe rememorar aquí diversos trabajos que tratan dicho tema en relación con las provincias de Palencia, Cantabria, Vizcaya o Álava, y que, en uno u otro grado, afectan al territorio objeto de nuestra atención. Sobre la provincia de Palencia, es relevante el artículo de Miguel Vicente Basterra Adán que lleva por título "Las antiguas vías de comunicación de la montaña palentina"29, al igual que el realizado sobre los puentes palentinos en la Edad Moderna por Inocencio Cadiñanos, centrado concretamente en el siglo XVIII ${ }^{30}$.

Los trabajos de este tenor sobre Cantabria son más numerosos y variados. El estudio de Iglesias Gil y Muñiz Castro sobre las vías romanas hace un repaso exhaustivo de las consideradas como tales, aunque se excede, en nuestra opinión, adscribiendo algunas para las que faltan los datos concluyentes ${ }^{31}$. Vega de la Torre aborda también la viaria romana en Cantabria y efectúa un breve repaso de los yacimientos y miliarios de la vía del Besaya, incluyendo un plano bastante expresivo32. González de Riancho, por su parte, centra la atención en una hipotética vía romana de El Escudo. Aunque el origen romano es muy dudoso, aporta datos de gran interés para documentar un camino antiguo que discurría por lo alto de la Sierra de El Escudo y por las divisorias de aguas de valles de Luena y Toranzo33.

Álvarez Llopis y Blanco Campos presentaron un trabajo en el I Encuentro de Historia de Cantabria sobre las vías de comunicación en Cantabria en la Edad Media. Para su elaboración, se sirvieron de las fuentes documentales, la toponimia, los pasos de los ríos, las ventas y mesones, los portazgos y el mantenimiento de los caminos ${ }^{34}$. A todo lo anterior, cabe añadir el trabajo de Ángel Vega Zamanillo, que, bajo el título "Puentes y túneles históricos de Cantabria", hace hincapié en dicha problemática sin profundizar demasiado en ella ni realizar aportaciones significativas 35 .

En cuanto a la bibliografía caminera sobre el País Vasco, cabe citar a Magallón Botaya, que, en un detallado artículo, trata de la red viaria romana. Analiza con detalle la vía $A b$ Asturica Burdigalam, profundiza en las comunicaciones transpirenaicas de la Antigüedad, que estudia por tramos, especula sobre la adscripción histórica de varios caminos escasamente documentados y revisa las vías existentes entre Oiasso y Pompaelo y entre Pisoraca y Flavióbriga ${ }^{36}$.

29 BASTERRA ADÁN, Miguel Vicente: “Las antiguas vías de comunicación de la montaña palentina”. Publicaciones de la Institución Tello Téllez de Meneses, 80. Palencia, 2009. pp. 109-149.

30 CADIÑANOS BARDECI, I.: "Los puentes de la provincia de Palencia...": 1998: 297-367.

31 IGLESIAS GIL, José Manuel y MUÑIZ CASTRO, Juan Antonio: "Las Comunicaciones en la Cantabria Romana”. Universidad de Cantabria, Librería Estvdio. Santander, 1992.

32 VEGA de la TORRE, José R.: "Las vías romanas en Cantabria: Estado actual de las investigaciones sobre la del Besaya". Simposio sobre la red viaria en la Hispania romana. Institución Fernando el Católico. Zaragoza, 1990. pp. 431-442.

33 GONZÁLEZ de RIANCHO MAZO, Javier: "La vía romana de El Escudo". Colegio Oficial de Arquitectos de Cantabria, Santander, 1988.

34 ÁLVAREZ LLOPIS, Elisa y BLANCO CAMPOS, Emma: "Las vías de comunicación en Cantabria en la Edad Media". En I Encuentro de Historia de Cantabria. Santander, 1999, tomo I, pp. 491-521.

35 VEGA ZAMANILLO, Ángel: "Puentes y túneles históricos de Cantabria”. Ediciones Tanín. Santander, 1997.

36 MAGALLÓN BOTAYA, Må Ángeles: “La red viaria romana en el País Vasco”. Isturitz, 8. 1997. pp. 207-231. 
Joseba Aguirreazkuneaga Ziorriaga ha publicado igualmente un cuaderno en el que, de manera muy esquemática, trata sobre la red de caminos y carreteras del País Vasco en la Historia. No es realmente otra cosa que un trabajo de aproximación al tema sin ninguna profundidad37. Por su parte, Labayru y Coicoechea dedicó en la Historia del Señorío de Vizcaya, realizada a fines del siglo XIX, varios apartados a los caminos y al comercio de Vizcaya. Teniendo en cuenta la fecha de publicación, la aportación de documentos históricos constituye un detalle digno de mención ${ }^{38}$.

La tesis doctoral de María Ángeles Larrea Sagarminaga, titulada "Caminos de Vizcaya en la segunda mitad del siglo XVIII"39, aborda la historia de la construcción de los principales caminos en Vizcaya, entre los que ocupa un protagonismo importante el camino entre Pancorbo y Bilbao por Orduña, acondicionado para el tránsito de carros en el siglo XVIII. Aunque el estudio se centra en fechas tardías para nuestro estudio, su introducción posee un elevado interés.

Elingeniero de caminos Juan Vidal-Abarca ofrece en el trabajo "Historia de los caminos de Álava" un panorama muy completo de los caminos históricos de dicha provincia, con una rica perspectiva general, en la que muestra un profundo conocimiento del tema que aborda40. Por su parte, Azkarate Garai-Olaun y Palacios Mendoza publicaron a finales del siglo pasado un magnífico y exhaustivo trabajo sobre los puentes alaveses, ofreciendo un catálogo prácticamente cerrado y definitivo. Además de proporcionar una buena introducción general, en la que esbozan el estudio histórico de dichas estructuras, tratan aspectos como su financiación y mantenimiento, la tipología de los maestros de obra, las adjudicaciones de las contratas y la estructura constructiva. Hacen una valoración de cada puente y analizan su importancia, todo ello acompañado de una buena documentación fotográfica ${ }^{41}$.

Para desarrollar un estudio sobre las comunicaciones en época romana en Álava, Navarra y La Rioja, Ángel Miguel de Miguel de Hermosa efectúa una valoración de la información existente sobre dicha problemática, es decir, sobre los textos antiguos, las publicaciones recientes y los datos arqueológicos disponibles. Utiliza con profusión el Itinerario de Antonino y el Anónimo de Rávena para restituir las mansiones viarias y describir las vías correspondientes ${ }^{42}$.

Sobre los caminos de la provincia de Burgos no se han efectuado estudios a la altura de su conocida importancia como enclave estratégico. Tampoco han sido particularmen-

37 AGUIRREAZKUNEAGA ZIORRIAGA, Joseba. "La red de caminos y carreteras del País Vasco en la Historia". Gobierno Vasco. Vitoria, 1990.

38 LABAYRU y GOICOECHEA, Estanislao Jaime: "Historia General del Señorío de Vizcaya". Casa Editorial "La Propaganda". 6 tomos. Bilbao-Madrid, 1895-1903. Reedición 1968.

39 LARREA SAGARMINAGA, Mángeles: “Caminos de Vizcaya en la segunda mitad del siglo XVIII”. Editorial la Gran Enciclopedia Vasca. Bilbao, 1974.

40 VIDAL-ABARCA, Juan: "Historia de los caminos de Álava". Actas de las Juntas Generales de Álava. t. VI. Juntas Generales. Vitoria, 1996. pp. VIII-CXCIX.

41 AZKarate GARAI-OLAUn, A. y PALACIOS MENDOZA, V.: "Puentes de Álava". Gobierno Vasco. Departamento de Cultura. Vitoria, 1996

42 MIGUEL de HERMOSA, Ángel Ramón de: "Las comunicaciones en época romana en Álava, Navarra y La Rioja". Trabajos de Arqueología de Navarra, 10. Años 1991-1992. Institución Príncipe de Viana. pp. 337-363. 
te abundantes las comunicaciones en congresos, las jornadas académicas y los artículos científicos. Entre los trabajos publicados, el más relevante es el de Jean-Pierre Molénat ${ }^{43}$, que se ocupa de varios caminos de nuestro interés utilizando un método riguroso y una documentación precisa e inédita hasta entonces. Nos ha sido de gran ayuda para encarrilar nuestro estudio.

También sobresale por su valor intrínseco y su fiabilidad el trabajo de tipo geográfico realizado por José Ortega Valcárcel como tesis doctoral sobre la zona de las Merindades burgalesas. Todo lo relativo a la caminería brilla con luz propia, incluyendo una serie de acertadas y oportunas precisiones con amplio respaldo en la documentación histórica44. También cabe destacar el estudio del catedrático de Historia Moderna Vicente Palacio Atard sobre "El comercio de Castilla y el puerto de Santander en el siglo XVIII"45. Aunque se ocupa de las comunicaciones entre la ciudad de Burgos y el puerto de Santander en fechas posteriores al ámbito temporal de nuestro estudio, incluye en el capítulo inicial interesantes referencias al comercio y a la caminería de siglos anteriores. Aporta, además, valiosos datos que ayudan a comprender el fenómeno del transporte y de las construcciones de caminos entre la ciudad castellana y uno de los principales puertos cantábricos.

La única obra editada que ha tratado de manera monográfica hasta el día de hoy la caminería burgalesa, bien que circunscrita a la red viaria romana, es el trabajo publicado por el profesor Abásolo Álvarez en 1975 con el título "Comunicaciones de la época romana en la provincia de Burgos" 46. Basándose fundamentalmente en el Itinerario de Antonino, se enfrenta en el primer capítulo a la identificación de las tres vías que discurren por la provincia de Burgos. En el segundo apartado, titulado "Las vías romanas no mencionadas en el Itinerario de Antonino", se esfuerza por identificar nuevos itinerarios tomando en consideración la información que liberan los yacimientos arqueológicos, los miliarios y diversasconstruccionesantiguas, procedimiento que nole salva dealgunas identificaciones realmente aventuradas, cuando no harto dudosas o abiertamente erróneas. En el apartado dedicado a "Otras vías antiguas se incluye una relación de caminos de diferentes épocas y de importancia diversa. En general, el trabajo adolece de un escaso y deficiente manejo de la documentación histórica, obviando el empleo de los corpus documentales ya disponibles, que, sin embargo, aportan valiosos datos sobre los caminos tradicionales, con referencia a sus límites y reparaciones. Ello no obstante, la obra tiene el notable valor de ser la única publicada hasta la fecha que aborda la identificación y estudio de los caminos dentro del marco geográfico de la provincia de Burgos. Del mismo autor es el trabajo "Las vías romanas de Clunia”47, en el que, sirviéndose de una metodología muy parecida,

43 MOLÉNAT, Jean-Pierre: "Chemins et ponts du nord de la Castille au temps des Rois Catholiques". Melanges de la Casa de Velázquez, t. VII. Paris, 1971. pp. 115-162.

44 ORTEGA VALCÁRCEL, J: 1974.

45 PALACIO ATARD, V.: "El comercio de Castilla y el puerto de Santander en el siglo XVIII. Notas para su estudio". Consejo Superior de Investigaciones científicas. Escuela de Historia Moderna. Madrid, 1960.

46 ABÁSOlO ÁlVAREZ, J. A.: "Comunicaciones de la época romana en la provincia de Burgos". Publicaciones de la Excma. Diputación Provincial de Burgos. Burgos, 1975

47 ABÁSOLO ÁLVAREZ, J. A.: "Las vías romanas de Clunia". Publicaciones de la Excma. Diputación Provincial de Burgos. Burgos, 1978. 
reconstruye el trazado de las vías que tenían a dicha ciudad como enclave principal o que, próximas a ella, discurrían por el convento jurídico de su titularidad. En esta ocasión, incorpora datos realmente sustanciales y novedosos.

En relación con la mencionada viaria romana, Sagredo San Eustaquio y Pradales Ciprés publicaron en 1993, como parte de una historia general de la provincia de Burgos, el trabajo "La red viaria del territorio burgalés en época romana", cuyo principal valor estriba en constituir una aceptable puesta al día de los conocimientos sobre el tema por esas fechas ${ }^{48}$.

Sobre el caso concreto de la vía Aquitana, Teodoro de Izarra publicó en 1939 el artículo “¿Por dónde pasaban los Romanos los Montes Obarenes para ir a Puente Larrá”, compendio de hipótesis poco o nada contrastadas, con erróneas localizaciones de Vindeleia en Santa María Ribarredonda y de Deobriga en Puentelarrá, que hacía pasar dicha vía por los Montes Obarenes y por el actual monasterio de Santa María de Obarenes ${ }^{49}$. Del mismo autor es el trabajo que trata sobre la vía de Cerezo de Riotirón a León por Briviesca5o.

Sobre la vía de Italia a Hispania, es decir, sobre la vía que desde Tarraco y Cesaraugusta discurría por Cerezo de Riotirón y entroncaba en Briviesca con la vía Aquitana, realizó Isaac Moreno Gallo en 2001 un interesante trabajo de identificación, aportando una nueva perspectiva de la misma y logrando restablecer su trazado en algunos tramos que habían estado claramente en entredicho hasta ese momento51. Algunos otros trabajos de dicho autor han insistido sobre este mismo trazado52

En 1964, José Bustamante Bricio publicó un trabajo sobre la vía Pisoraca-Flavióbriga en el Valle de Mena, confundiéndola en dicho tramo con el camino medieval actualmente denominado de Las Enderrozas, que discurría por Burceña y Arceo. De hecho, la vía romana en cuestión circulaba por el valle más al Sur, por Villasana de Mena53. De José Luis Banús es el artículo titulado "La llamada vía Pisoraca-Flaviobriga", en el que trata de restituir diversos tramos de la misma, haciéndola pasar por Castrobarto y Amaya54. Más recientemente, en 1996, Fernández Fonseca ha publicado un trabajo titulado "Nuevos restos viarios romanos en el Norte de Burgos. ¿Vía Flaviobriga-Ivliobriga?”. Se trata de un intento de reconstrucción del trazado de dicha arteria caminera por medio de sistemas de información geográficos, que”, sin embargo, fallan en su intento por tratarse tan solo de

48 SAGREDO SAN EUSTAQUIO, Luis y PRADALES CIPRÉS, David: "La red viaria del territorio burgalés en Época Romana". En Historia 16 de Burgos. Burgos, 1993. pp. 195-206.

49 IZARRA, Teodoro de: "¿Por dónde pasaban los Romanos los Montes Obarenes para ir a Puente Larrá". Boletín Institución Fernán González, 67. Burgos, 1939. pp. 232-239.

50 IZARRA, Teodoro de: "De Lybia a Virobesca. (En la vía romana Tarragona-Astorga)". Boletín de la Comisión Provincial de Monumentos, 80. Burgos, 1942. pp. 88-95.

51 MORENO GALLO, Isaac: "Descripción de la vía romana de Italia a Hispania en las provincias de Burgos y Palencia". Diputaciones de Burgos y Palencia, 2001.

52 MORENO GALLO, Isaac: "Características técnicas de la vía romana de Zaragoza a León”. V Congreso Internacional de Caminería Hispánica, t. I. Valencia 17 al 22 julio. Valencia, 2000. pp. 87-116; "Ingeniería romana en los Caminos de Santiago: I-La vieja carretera castellano-leonesa". Revista Cimbra, 346. 2002, y Publicaciones de la Institución Tello Téllez de Meneses, 73. Palencia, 2002. pp. 335-364.

53 BUSTAMANTE BRICIO, José: "La calzada romana Pisorica-Flaviobriga en el Valle de Mena". Boletín Institución Fernán González, 163. Burgos, 1964. pp. 272-276.

54 BANUS y AGUIRRE, José Luis: "La llamada vía Pisoraca-Flaviobriga”. Altamira XLIV. Santander, 1983-1984. pp. 87-111. 
un camino enlosado, el denominado de "San Román", cuyas características nada tienen que ver con una vía de construcción romana55.

En el librito publicado por Fray Valentín de la Cruz en 1979, titulado "Burgos puentes y caminos", hace un repaso general de los diferentes trazados camineros de la provincia. A pesar de tratarse de un trabajo realmente superficial, el autor no pretende otra cosa, tiene el mérito de ser el primero que busca acercarse al fenómeno caminero burgalés con carácter general, tratando por igual la viaria romana, los ferrocarriles, el Camino de Santiago que el resto de la caminería medieval56.

El artículo elaborado por José Luis Rodríguez de Diego en 1985 con el título "Rutas y puentes de Burgos a mediados del siglo XVI. El puente de Tardajos" analiza de manera monográfica el repartimiento efectuado para la reparación del citado puente y los enredos procesales a que dio lugar 57 .

El trabajo de Aramburu-Zabala sobre las obras públicas burgalesas durante el Renacimiento dedica un importante apartado al estudio de los puentes, especialmente de los que estaban operativos en la segunda mitad del siglo XVI, incorporando no pocos de los conocimientos adquiridos en su precedente monografía sobre la arquitectura de los puentes de Castilla y León ${ }^{58}$.

Aunque, por lo general, los temas camineros relativos a la provincia de Burgos han sido tratados de forma exigua, el trazado que más interés ha despertado entre los investigadores es el de Burgos a Laredo. Cabe referenciar, entre otros, el artículo realizado en 1980 por Pérez Bustamante con el título "El marco jurídico para la construcción y reparación de caminos. Castilla, siglos XIV y XV", que centra su atención en el sistema legal que avalaba la obtención de los recursos económicos necesarios para afrontar las intervenciones. A título ilustrativo, analiza la intervención de 1499 en el camino de Burgos a Laredo, incorporando un mapa de su trazado y una relación de los puentes reparados entre 1475 y $1495^{59}$.

En 2008, Elisa Álvarez Llopis presentó una comunicación en el Congreso de Caminería Hispánica sobre el camino Laredo-Burgos en la Edad Media ${ }^{60}$, temática parcialmente tratada ya por Manuel López Rojo en 1985 en el artículo “Aproximación a la importancia de los caminos que relacionaban a Burgos con las más antiguas merindades de Castilla-Vieja: los Hocinos y la Horadada”. Cabe decir en este caso que se trata de un trabajo parcialmente

55 FERNÁNDEZ FONSECA, Ma Jesús: "Nuevos restos viarios romanos en el Norte de Burgos. ¿Vía Flaviobriga-Ivliobriga?. Intento de reconstrucción del trazado por medio de sistemas de información geográficos". Veleia, 13. Instituto de Ciencias de la Antigüedad. Universidad País Vasco, 1996. pp. 143-173.

56 CRUZ, Fray Valentín de la:"Burgos, puentes y caminos". Páginas para nuestro pueblo. Caja de Ahorros Municipal. Burgos, 1979 .

57 RODRÍGUEZ de DIEGO, José Luis: "Rutas y puentes de Burgos a mediados del siglo XVI. El puente de Tardajos". La ciudad de Burgos. Actas del Congreso de Historia de Burgos. Junta de Castilla y León, 1985. pp. 307-319.

58 ARAMBURU-ZABALA, Miguel Ángel: "Las obras públicas del Renacimiento en el territorio burgalés", en El arte del renacimiento en el territorio burgalés. Universidad Popular. Burgos, 2008. pp. 117-135.

59 PÉREZ BUSTAMANTE, Rogelio: "El marco jurídico para la construcción y reparación de caminos. Castilla: siglos XIV y XV", Les communications dans la Péninsule Ibérique au Moyen-Age. Actes du colloque tenu à Pau les 28 et 29 Mars 1980. Bordeaux, 1981, pp. 163-178.

Go ÁLVAREZ LLOPIS, Elisa: "Un itinerario histórico: el camino Laredo-Burgos en la Edad Media". En Caminería Histórica. Actas del VIII Congreso Internacional. Ministerio de Fomento, CEDEX-CEHOPU. Madrid, 2008. pp. 1-18. 
fallido en su pretensión de ofrecer una revisión actualizada del camino de referencia, elaborado con pocas novedades y redactado con cierta precipitación ${ }^{61}$.

En 1999, Fernando Inés, José Ángel Lecanda y Juan José Rodríguez publicaron en el V Congreso de Arqueología Medieval Española el artículo "Caminería histórica por el norte de Burgos y rutas de peregrinación”. Abordaron las actuaciones habidas en los caminos de El Berrón a Cabañas de Virtus por Espinosa de los Monteros y de El Berrón a Burgos, coincidente con el camino de Laredo, y se extendieron con más detalle en la descripción del tramo de calzada entre El Almiñé y la ermita de la Virgen de la $\mathrm{Hoz}^{62}$. En 1832 y con ocasión de la inauguración del nuevo trazado por la Mazorra, se imprimió la "Memoria sobre el origen del camino de Burgos a Bercedo", cuya transcripción fue publicada por Ismael García Rámila y fue reeditada en facsímil en 1998 por la Asociación Española de Autopistas, Túneles, Puentes y Vías de Peaje ${ }^{63}$.

El artículo elaborado por Eduardo Rojo en 2003 con el título "Breve relación de las dificultades que encontraron los caminos para atravesar el Desfiladero del Río Oca” es un trabajo meritorio, sustentado en una intensa labor de campo, que aporta datos novedosos sobre un itinerario deficientemente documentado. Contiene interesantes y agudas observaciones sustentadas en un conocimiento directo y minucioso de los desfiladeros del río Oca y de la barranca de la Horadada64.

Por esas mismas fechas, en 2002, Inocencio Cadiñanos, realizó una serie de artículos sobre los puentes de la provincia de Burgos, dedicando dos de ellos a los localizados en el norte. Se trata en este caso de trabajos escuetos, fundamentados en un limitado número de citas entresacadas de la documentación del siglo XVIII del Archivo Histórico Nacional. Cabe conceptuar dichos estudios como una más que aceptable relación cuantitativa de puentes, que, sin embargo, adolecen de un tratamiento sistemático y afinado ${ }^{65}$.

Sobre la problemática de la arriería y de la carretería en Castilla y León, cabe mencionar la aproximación efectuada en 1983 por Palomar del Río y Merino de la Fuente, que constituye una especie de estado de la cuestión sobre unos temas poco estudiados y mal conocidos $^{66}$. En el ámbito provincial burgalés, dicha temática cuenta con muy pocos tra-

61 LÓPEZ ROJO, Manuel: "Aproximación a la importancia de los caminos que relacionaban a Burgos con las más antiguas merindades de Castilla-Vieja: los Hocinos y la Horadada". La ciudad de Burgos. Actas del Congreso de Historia de Burgos. Junta de Castilla y León, 1985. pp. 375-383.

62 INÉS, Fernando; LECANDA, José Ángel y RODRÍGUEZ, Juan José: "Caminería histórica por el norte de Burgos y rutas de peregrinación". Actas del V Congreso de Arqueología Medieval Española. Junta de Castilla y León. Valladolid, 1999. pp. 467-478.

63 GARCÍA RÁMILA, Ismael: "Memoria sobre el origen del camino de Burgos a Bercedo". Boletín de la Institución Fernán González, 140, 141 y 143. Burgos, 1957 y 1958. pp. 672-683; 770-777 y 147-156. ANÓNIMO: "Memoria sobre el origen del Camino de Burgos a Bercedo, mandado construir por Real Decreto de 20 de julio de 1828 . Medios empleados al efecto y resultado que han producido, con un Apéndice en que se insertan varios documentos relativos al objeto". Burgos, 1832. Imprenta de D. Ramón de Villanueva. Facsímil editado por la Asociación Española de Autopistas, Túneles, Puentes y Vías de Peaje, 1998.

64 ROJO DÍEZ, Eduardo: "Breve relación de las dificultades que encontraron los caminos para atravesar el Desfiladero del Río Oca”. López de Gámiz, XXXVI. Boletín del Instituto Municipal de Historia. Miranda de Ebro, 2003. pp. 73-90.

65 CADIÑANOS BARDECI, I.:"Los puentes del Sur de la provincia de Burgos...": 1996: 7-44; "Los puentes del centro de la provincia de Burgos...": 1999: 155-201; “Los puentes del norte de la provincia de Burgos...": 2002: 60-89 y 376-400.

66 PALOMAR del RÍO, Javier y MERINO de la PUENTE, Marisa:"Arrieros y carreteros por los viejos caminos de Castilla y León". Ediciones La Horaca. Valladolid, 2010. 
bajos, aunque son dignos de destacar los publicados por Fernández Díaz-Sarabia sobre la arriería de la Merindad de Sotoscueva a partir de los datos obtenidos en el Catastro del Marqués de la Ensenada ${ }^{67}$. Sobre la Cabaña Real de Carreteros de Burgos-Soria, cabe hacer referencia al trabajo de Pedro Gil Abad, que trata de manera monográfica la trayectoria de tan reputada asociación carreteril ${ }^{68}$.

\section{d.- Itinerarios históricos de caminos}

Aunque la mayor parte de los itinerarios han sido publicados a partir del siglo XVIII, hemos consultado con detalle estos y los de fechas anteriores por entender, que gran parte de los caminos que incluyen eran herederos de los de épocas precedentes. Su estudio nos ha sido muy útil para confirmar con precisión su vigencia, obteniendo en muchos casos detalles informativos de gran interés.

La considerada primera guía de caminos de España es el "Liber Peregrinationis", que, conservado en el Liber Sancti Iacobi, desmenuza el itinerario realizado entre 1130 y 1140 por el clérigo francés Aymeric Picaud. En el caso de la provincia de Burgos reseña el paso del mismo por Redecilla, Belorado, Villafranca, Montes de Oca, Atapuerca, Burgos, Tardajos, Hornillos, Castrojeriz y el puente de Itero ${ }^{69}$.

A partir del siglo XVI, se editaron obras que recogían los itinerarios camineros, de gran utilidad sobre todo para correos y mulateros. El primer trabajo que recogió de manera global los caminos de la península, excepto el territorio de Portugal, fuela denominada "Descripción y Cosmografía de Fernando Colón"70, manuscrito iniciado en agosto de 1517, que contiene una caminería completa, entendida como una relación de caminos operativos y una considerable aportación de detalles de interés del autor ${ }^{71}$. Todos los informes consignados son anteriores a junio de 1523, fecha en la que Carlos V ordenó a Colón interrumpir su trabajo, por lo que este quedó incompleto. Hay indicaciones sobre las localidades descritas y los caminos que parten de ellas hacia los pueblos más próximos, incluyendo, a veces, las distancias. Es, además, el mayor repertorio de puentes de piedra o madera y de puentes de barcas, al igual que de parajes vadeables. En nuestro caso, el libro confirma el recorrido del camino de Burgos a Laredo y Bilbao por Valmaseda y el de Burgos a Bilbao por Orduña.

Pero la fuente clásica para conocer la red de los caminos históricos de España realizado por Pero Juan Villuga es el "Repertorio de todos los caminos de España", editado en

67 FERNÁNDEZ DÍAZ-SARABIA, Pedro: "La arriería en la Merindad de Sotoscueva". Boletín de la Institución Fernán González, 227. Burgos, 2003. pp. 413-436.

68 GIL ABAD, Pedro: "Junta y Hermandad de la Cabaña Real de Carreteros. Burgos-Soria". Publicaciones de la Diputación de Burgos. Burgos, 1983.

69 PICAUD, Aymeric: "Codex Calixtinus. Liber Peregrinationis". Liber V. h. 1140. Transcrito por BRAVO LOZANO, Millán en "Guía del peregrino medieval". Sahagún, 1989.

70 COLÓN, Fernando: "Descripción y Cosmografía de España”. (manuscrito de la Biblioteca Colombina de 1517) Boletín Sociedad Geográfica. 3 vol., Madrid, 1908-1915. Publicado por A. Blázquez y Delgado y reeditado en facsímil por Padilla libros. Sevilla, 1988. Sobre el valor del documento y de su edición, ver MARÍN MARTÍNEZ, T.:"Memoria de las obras y libros de Hernando Colón". Madrid, 1970. Fue realizado entre el 3 de agosto 1517 y el 13 junio 1523.

71 CRIADO de VAL, Manuel: "La cosmografía de Hernando Colón". Actas del I Congreso Internacional de Caminería Hispánica. t. I, 1992. pp. 335-350. 


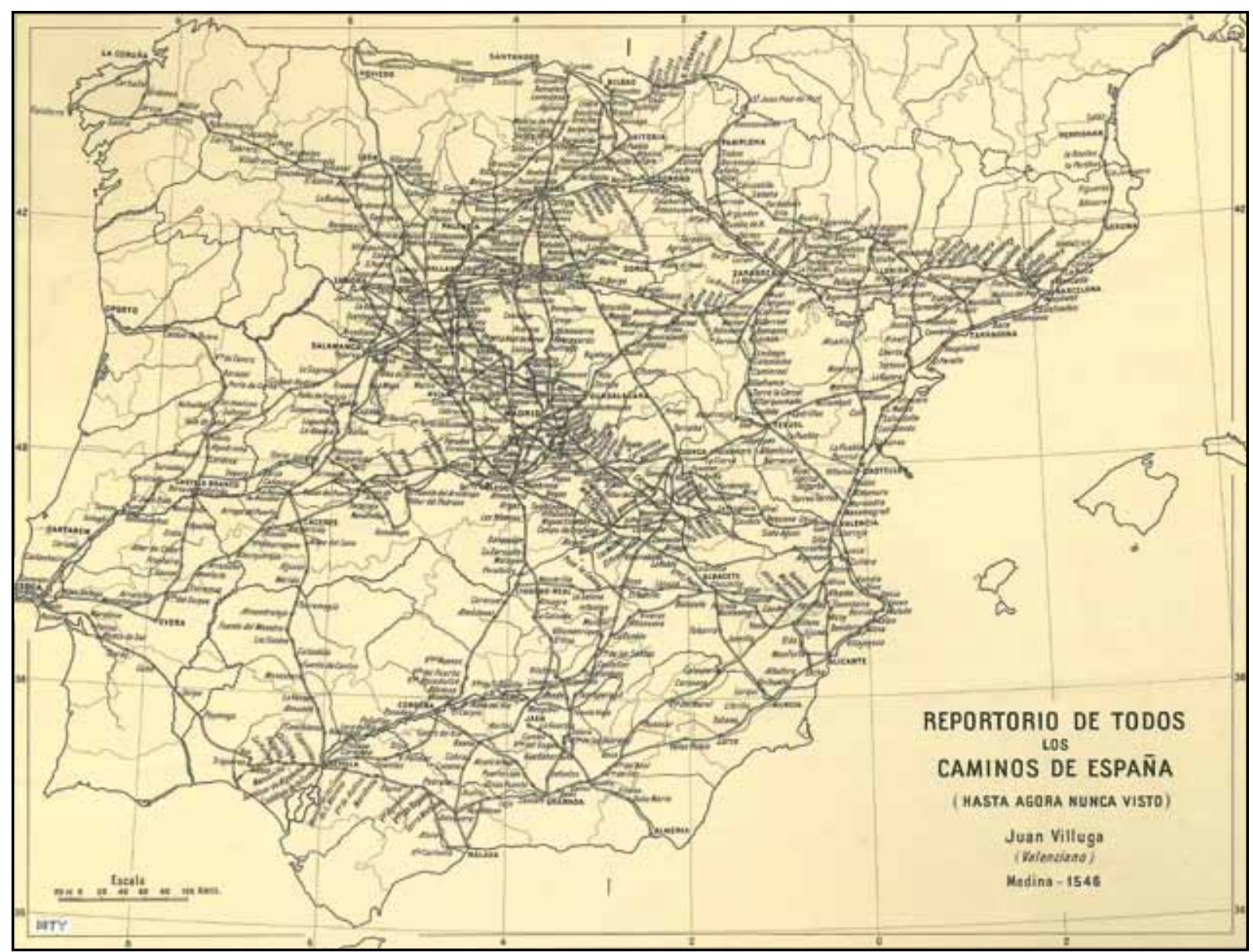

Mapa de todos los caminos del Itinerario de Pero Juan Villuga, en el que solo se recogen desde Burgos los caminos a Laredo y a Bilbao por Orduña.

Medina del Campo en $1546^{72}$. Es la primera guía itineraria que pretende tratar sobre los caminos peninsulares de manera global y sistemática. Uno de los aspectos más valiosos es quizá su propia cronología, debido a que, como los caminos han mantenido por lo general un alto grado de estabilidad, al ser sus transformaciones muy lentas, según lo prueba la documentación, podemos presumir que los itinerarios relacionados en ella fueron utilizados bastantes años antes de 1546, y sin duda pervivirían en fechas posteriores, por lo que lo que se describe es una red caminera que desde la Edad Media se prolongaría largo tiempo. Cabe indicar, sin embargo, que faltan en ella bastantes caminos, algunos importantes, aspecto que se repetirá en casi todos los itinerarios editados antes del siglo XVIII. Tampoco proporciona indicaciones sobre el tipo de camino de que se trata, aunque para la zona que estudiamos eran casi todos mulateros, y se omiten varios itinerarios de nuestro sector. De hecho, tan solo hace referencia a los caminos de Burgos a Bilbao por Orduña, de Santa María del Paular a Laredo, de Carrión de los Condes a Medina de Pomar y de Medina de Pomar a Aranda de Duero y no incluye ninguno de los caminos de Burgos al importante puerto de Santander y que del trayecto de Burgos a Bilbao tan solo incorpora

72 VILLUGA, Pero Juan: "Repertorio de todos los caminos de España; hasta agora nunca visto en el qual allaran cualquier viaje que quieran andar muy prouechoso para todos los caminantes. Conpuesto por Pero Juan Villuga valenciano". Medina del Campo 1546. Reimpresiones Bibliográficas. Madrid, 1950. 
el camino de Orduña73. Esta obra conoció sucesivas ediciones hasta al menos 1671, y ha sido utilizada por todos los investigadores que han tratado sobre la caminería de nuestras tierras, sin considerar que los trazados que recoge, aunque importantes, no son sino una pequeña muestra de los que los caminantes y comerciantes utilizaron por entonces.

Por su parte, el "Repertorio de Caminos" de Alonso de Meneses, publicado en 1576, reproduce básicamente el elaborado por Villuga, con algunas leves modificaciones ${ }^{74}$, recogiendo el camino de Burgos a Bilbao por Orduña, el de Carrión de los Condes a Medina de Pomar y el de Laredo a Sta. María del Paular. No se menciona el de Medina de Pomar a Aranda de Duero que sí incluía el de Villuga.

Ottavio Cotogno, lugarteniente del Correo Mayor de Milán, confeccionó un itinerario en 1608, en el que detalla el camino de Madrid a Bilbao por Orduña, el único de los que discurren por el sector que se estudia en este trabajo75. Algo después, en 1656, Martinus Zeillerus $^{76}$ recoge en su itinerario tan solo algunos grandes caminos, como el de Bayona a Madrid por Somosierra, el de Burgos a Valladolid y el camino Francés a Santiago. En 1705, Pedro Pontón publica un nuevo Itinerario77, que no es más que la traducción de una guía publicada en francés en 1674 y que copia básicamente el Repertorio de Villuga, aunque no incluye, entre otros, el camino de Burgos a Laredo.

En el "Nuevo estilo y formulario de escrivir cartas missivas..." se describe, entre otros, el itinerario de Burgos a Bilbao por Orduña. Aunque publicado en Madrid en 1756, la primera impresión tuvo lugar en Orihuela en $1701^{78}$. En el "Reglamento Ceneral para la Dirección y Cobierno de los Oficios de Correo Mayor y Postas de España, en los viajes que se hicieren", emitido en 1720, se reproduce el "Itinerario para Postas", y ya se apunta el sistema radial de caminos que se desarrollará en ese mismo siglo79. En 1750, Udal ap Rhys publica el trabajo "A tour trough Spain and Portugal, $\Theta C^{\prime \prime}$, que apenas es otra cosa que un calco de los itinerarios contenidos en el Repertorio de Villuga 80 .

73 En el espacio de nuestro trabajo, ponemos cuatro ejemplos: en el Norte, no están mencionados el itinerario de Burgos a Santander, el de Vizcaya por Valmaseda, el camino de Briviesca a Orduña ni el de Oña a Bilbao por el puerto de Angulo.

74 MENESES, Alonso de: "Repertorio de Caminos ordenado por Alonso de Meneses. Correo. Añadido el Camino de Madrid a Roma. Con un memorial de muchas cosas sucedidas en España". Sebastián Martínez. Alcalá de Henares, 1576. Edición en facsímil Ministerio de Educación y Ciencia. Madrid, 1976. Este trabajo reproduce básicamente el Repertorio de Villuga.

75 COTOGNO, Ottavio: "Nvovo Itinerario delle Poste Per tutto il Mondo, d'Ottavio Cotogno Luogotenente del Corriero Maggiore del presente Stato di Milano". Milano, 1608, $1^{\text {a }}$ edic.

76 ZEILLERUS, Martinus: "Itinerarium Hispaniae oder Reiss Beschriebung durch die Königreiche Hispaniem und Portugal...".

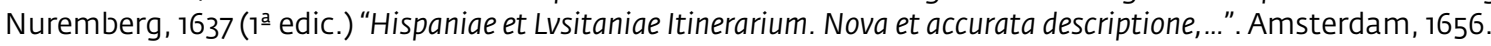

77 PONTÓN, Pedro: "Gvia de caminos, para ir y venir por todas las Provincias mas afamadas de España, Francia, Italia. y Alemania". Traducida del francés por Pedro Pontón. Madrid, 1727. Recoge los itinerarios del Repertorio de Villuga.

78 "Nuevo estilo y formulario de escrivir cartas missivas, y responder a ellas En todos géneros y especies de correspondencias à lo moderno, conforme al uso, que oy se practica... Antes impreso en la ciudad de Orihuela y añadida nuevamente la Guia de Caminos, para ir, y venir por todas las Provincias de España, y para ir a Roma...". Editado a fines del siglo XVII, la censura de la primera edición se da en Orihuela en 1701, y se reeditó al menos 12 veces hasta en Madrid en 1757.

79 "Reglamento General para la Dirección y Gobierno de los Oficios de Correo Mayor y Postas de España, en los viajes que se hicieren". Madrid, 23 de abril de 1720.

80 UDAL ap RHYS: "A tour trough Spain and Portugal, \&". Londres, 1750. pp. 301-360. Recoge los itinerarios del Repertorio de Villuga. 
El volumen "Carreras de Postas, establecidas en España, y Leguas que hay de distancia de unos à otros Lugares, $y$ han de satisfacer à los que hizieren viages, y cobrar los Maestros de Postas" fue publicado por Thomas Manuel Fernández de Mesa en 1756. Se trata básicamente der una reproducción de las carreras de postas recogidas en el "Reglamento General" de $1720^{81}$. En el "Itinerario de las Carreras De Posta de dentro, y fuera del Reyno", editado por Pedro Rodríguez Campomanes en 1761, se relacionan con cierto detalle las principales carreras de postas que, desde Madrid, alcanzaban Bilbao, Burgos, Santander, San Sebastián, Vitoria e Irún, al igual que las de Valladolid a Burgos ${ }^{82}$. Bernardo Espinalt y García, administrador principal de los correos de Valencia, volvió a publicar en 1785 las mencionadas postas, reeditadas en 1804 con un mapa de la Península 83.

El itinerario publicado en 1810 por Charles Picquet incluye las vías principales que comunicaban Madrid con Bayona, San Sebastián, Vitoria, Bilbao, Miranda de Ebro, Santander, Reinosa, Burgos y Aranda de Duero. También describe el camino de Bayona a La Coruña. Se trata de un conjunto de datos valiosos utilizados por los contingentes de civiles y militares franceses que por esas fechas estaban en campaña en la Península ${ }^{84}$. 20 años después, en 1830, Francisco Xavier Cabanes publicó una "Guía General", que contiene un mapa itinerario de la Península de gran interés ${ }^{85}$. En este siglo, será editado y reeditado un considerable número de itinerarios, indispensables para viajar por unos caminos que, en su mayor parte, carecían de señalización.

Pero los itinerarios más completos y de mayor precisión relacionados con el espacio que nos afecta fueron dos: en primer lugar, el de José Matías Escribano ${ }^{86}$, editado en 1758, del que se realizaron varias reediciones hasta el siglo XIX, copiado además, repetidamente, entre otros por Francisco Brusola ${ }^{87}$ y Santiago López ${ }^{88}$. En segundo lugar, el publicado en 1771 por Miguel Bañuelos, intendente de la provincia de Burgos ${ }^{89}$, que recoge con

81 FERNANDEZ de MESA, Thomas Manuel: "Tratado Legal, y Politico de Caminos Publicos, y Possadas. Reglamento General para la Dirección y Gobierno de los Oficios de Correo Mayor y Postas de España, en los viajes que se hicieren...". Parte II. Capitulo XIII. pp. 182-192. Valencia, 1756.

82 RODRÍGUEZ CAMPOMANES, Pedro: "Itinerario de las Carreras de Posta de dentro, y fuera del Reyno". Madrid, 1761.

83 ESPINALT y GARCIA, Bernardo: "Guia General de Postas, y Travesias de España, Para este presente año de 1785 ". Madrid, 1785.

84 PICQUET, Ch.: "Livre des postes d'Espagne et de Portugal en espagnol et en français, Indiquant Les Routes de Postes..." Paris, 1810.

85 CABANES, Francisco Xavier de: "Guía General de Correos, Postas y Caminos del Reino de España, con un mapa itinerario de la Península". Madrid, 1830.

86 ESCRIBANO, Josefh Mathias: "Itinerario Español, ó Guia de Caminos para ir desde Madrid à todas las Ciudades, y Villas mas principales de España". 1aㅡ edición. Madrid, 1758. Este trabajo se reeditó y copió en numerosas ocasiones hasta el S. XIX.

87 BRUSÓLA, Francisco (editor): "Noticia de todas las ciudades, villas y lugares de este Reyno de España; con las leguas que median entre sí, tanto por los caminos de ruedas, como por los de herradura; para la mas fácil inteligencia de todo caminante, y saber según los puestos...". Valencia, 1810. Es copia de los itinerarios de Matías Escribano.

88 LÓPEZ, Santiago: "Nueva Guia de Caminos para ir desde Madrid por los de rueda y herradura, a todas las ciudades y villas más principales de España y Portugal, y tambien para ir de unas ciudades a otras". Madrid, 1809. Este trabajo, es copia de los itinerarios de Escribano.

89 BAÑUELOS, Miguel: "Itinerarios que ha formado Don Miguel Bañuelos, desde Burgos a diferentes Capitales de su Provincia, por su curiosidad, y para Gobierno". Madrid, 12 de marzo 1771. Incluido en el t. III, pp. 281-285 de "Descripción Natural, Geografica y Economica de todos los pueblos de España, en continuación del Correo General de España, para beneficio común de labradores..." obra de Francisco Mariano Nipho, Madrid 1769-1772. También se incluyó en "Memorias políticas y económicas sobre los frutos, comercio, fábricas y minas de España..." de Eugenio Larruga. t. XXVII, 1793. pp. 98-102. EI 
detalle los caminos pertenecientes a este espacio. Ambos incluirán por primera vez y de manera sistemática todas las vías importantes que enlazaban Burgos con los puertos de la mar, modificadas muy poco desde la Edad Media y utilizadas de manera habitual con posterioridad.

También tienen un gran interés los itinerarios que se realizaron durante el siglo XIX con fines militares, y que son descripciones detalladas y concisas de un gran número de caminos, conservados en el Archivo Cartográfico y de Estudios Ceográfico del Centro Ceográfico del Ejército (A.R.C.G.E.).

\section{e.- Memorias y testimonios de caminantes y viajeros}

Hemos consultado también las memorias y testimonios de los escasos caminantes y viajeros que transitaron hasta el siglo XVI por los caminos que nos interesan. Tales memorias se inician en su mayoría en el siglo XV, aunque también existe alguna de siglos anteriores, como las relativas a los caminos de Bayona o al Camino Francés por Logroño y Nájera realizadas por peregrinos europeos que caminaron a Santiago. También hemos consultado los itinerarios de reyes o apuntes particulares, como el de los emisarios del lugarteniente del rey de Navarra enviados a la corte de Pedro I de Castilla en Sevilla9o.

Constatamos, en general, que los caminos entre Burgos y los puertos cantábricos fueron utilizados mucho menos que los de Burgos a Bayona, a Valladolid, a La Rioja y a Madrid, o al menos así parecen reflejarlo las memorias, quizá como consecuencia de que no se trata de caminos de paso, sino que son vías que comienzan o terminan en los puertos y por ello, condicionan los viajes interiores al tener un único punto fijo de destino o inicio. Para completar el elenco de caminos citados por caminantes, es obligada la referencia al trabajo de José García Mercadal91, al igual que a algunas otras obras posteriores, tanto generales como relativas a viajes concretos. Por otra parte, las memorias elaboradas por militares, principalmente franceses e ingleses, que estuvieron en la Península durante la Guerra de la Independencia, describieron, a veces con gran detalle, sus experiencias personales y lugares recorridos.

Por su parte, los itinerarios y crónicas de los reyes, al igual que las descripciones de los desplazamientos de la corte, son también de gran ayuda para el conocimiento de los caminos, pues utilizaron muchos y muy diversos, descritos en no pocos casos con gran detalle.

Intendente de la provincia de Burgos Miguel Bañuelos, formó un completo itinerario de caminos desde la ciudad de Burgos.

90 SERRANO-PIEDECASAS FERNÁNDEZ, Luis: "Estella a Sevilla: un camino en 1352". En "Les communications dans la Péninsula Ibérique au Moyen-Age", Paris, 1981, pp. 191-205. Comenta el viaje descrito en el trabajo de SÁNCHEZ VILLAR, Ma. Desamparados:"Desde Estella a Sevilla, cuentas de un viaje. 1352", Textos Medievales, 7. Valencia, 1974.

91 GARCÍA MERCADAL, José: “Viajes de extranjeros por España y Portugal”. Editorial Aguilar. Tres tomos. Madrid, 1952-1962. Reedición Junta de Castilla y León. Consejería de Educación y Cultura. 6 vols. Valladolid, 1999. 


\section{f.- Cartografía histórica}

Como cabe imaginar, tiene un gran interés para nuestros propósitos cotejar los datos de la cartografía histórica con los que proporciona la documentación conservada. Aunque existen ejemplares de gran antigüedad, como el plano de la villa de Aranda de Duero, realizado el año 1503, la mayor parte de la cartografía histórica ha sido elaborada en siglos posteriores, principalmente a partir de la segunda mitad del siglo XVIII. Destacan los fondos del Archivo Municipal de Burgos (A. M. B.), que conserva planos de la ciudad y de sus alrededores; también, los del Archivo de la Diputación de Burgos (A. D. B.), que custodia los proyectos de obras de caminos del siglo XIX y los croquis del Catastro del Marqués de la Ensenada.

Al respecto, son de extrema importancia, igualmente, la sección de Mapas, Planos y Dibujos del Archivo General de Simancas (A. G. S.). Por su parte, el Archivo de la Real Chancillería de Valladolid (A. Ch. V.) custodia en su sección de Planos y Dibujos gran número de planos y panorámicas correspondientes a los pleitos dirimidos en su sede. También es relevante la selección de Mapas y Dibujos del Archivo Histórico Nacional (A. H. N.), al igual que la sección Mapas, Planos y Dibujos de la Biblioteca Nacional (B. N.), donde también se custodian los croquis que proporcionaron los informantes para la elaboración del mapa de Tomás López a fines del siglo XVIII. El Archivo Cartográfico y de Estudios Geográficos del Centro Geográfico del Ejército (A.R.C.C.E.) Madrid custodia, igualmente, magníficos planos de la segunda mitad del siglo XVIII y sobre todo del siglo XIX, así como la Cartoteca del Servicio Histórico Militar (S. H. M.) Madrid y del Archivo General Militar (A. G. M.) Madrid92.

\section{g.- Cartografía contemporánea}

El conocimiento y utilización de mapas modernos a escala 1/25.000, 1/50.000 y a 1/200.000 nos parece imprescindible. Las primeras ediciones de los mapas 1:50.000 correspondientes a la zona que estudiamos se remontan a los años 1918 (hoja no 312 , de Baltanás), 1922 (hoja no 198, de Osorno) y 1926 (hoja nํㅜㄷ, de Herrera de Pisuerga), realizados por la Dirección General del Instituto Ceográfico y Estadístico o Geográfico y Catastral, hoy Instituto Geográfico Nacional (I. G. N.). Reflejan una situación ecogeográfica muy anterior a la actual, pues sus datos corresponden a una labor de campo realizada bastantes años antes. Tienen además la enorme ventaja de que reflejan las características que poseía el territorio antes de que se realizasen las grandes obras públicas (como pantanos o autopistas) y, de manera muy especial en el espacio que centra nuestra atención, antes del desarrollo de los trabajos de concentración parcelaria y de repoblación forestal, trabajos que tanto han afectado a la conservación de los caminos históricos. Con posterioridad se han editado nuevos planos con las referidas escalas y un mayor detalle y precisión, confeccionados a partir de la información digital aérea. Si bien han ganado en exactitud to-

92 CHÍAS NAVARRO, Pilar y ABAD BALBOA, Tomás:"Las vías de comunicación en la cartografía histórica de la cuenca del Duero". Ingeniería Civil, 149. 2008. pp. 79-94. 
pográfica, con unas curvas de nivel más precisas y detalles de una gran exactitud, tienen el inconveniente para nuestro trabajo de que han perdido información sobre la existencia y estado de los caminos antiguos, sobre los nombres de los términos y sobre otros componentes, que sí tenían los primitivos.

\section{h.- Fotografía aérea y cartografía digital}

La fotografía aérea es sumamente útil para detectar la presencia de caminos históricos, no sólo los que han perdurado, aunque ya no se utilicen, sino también los desaparecidos, que en muchos casos se perciben desde el aire por la diferencia en las tonalidades de las tierras de labor en determinadas estaciones del año. Pero los documentos más útiles son los que proceden de vuelos antiguos, cuando no se habían llevado a cabo las concentraciones parcelarias y muchas de las obras públicas.

El primer vuelo de cobertura nacional se realizó en 1946 por el Army Map Service de los Estados Unidos, conocido como "Serie A", y se convirtió en el principal centro de producción cartográfica española. Un segundo vuelo fotogramétrico sobre el territorio español fue realizado entre 1956 y 1957 por el ejército de los Estados Unidos, en colaboración con el Servicio Geográfico del Ejército y el Instituto Ceográfico Nacional, conocido como "Serie B" o "vuelo americano de 1956". Este último, tiene una escala de 1:33.000 y ofrece una valiosa información sobre los usos del suelo, el paisaje y la estructura territorial anterior al éxodo rural y al desarrollismo. De las series A y B existen copias en el Centro Cartográfico y Fotográfico del Ejército del Aire (CECAF). Un tercer vuelo, que daría lugar a la "Serie C", fue realizado entre 1967 y 1968 por el CECAF, aunque no abarcó la totalidad del territorio nacional.

Entre 1977 y 1983 se efectuó un vuelo interministerial conocido como IRYDA (Instituto de Reforma y Desarrollo Agrario), cuyas imágenes custodian actualmente varios organismos. Este vuelo es uno de los más solicitados por su estado de conservación y grado de cobertura nacional, con una escala de 1:18.00o y con aproximadamente 23.000 sesiones. En 1984 y 1985 el Instituto Geográfico Nacional, en colaboración con el Servicio Geográfico del Ejército, realizó un nuevo vuelo de cobertura nacional. La producción cartográfica se ha ido ampliando con otros vuelos y con diferentes objetivos. La mayoría se ha producido bajo la dirección del CECAF/ICN, pero también otros organismos han elaborado su propia cartografía. Hay que destacar que en la actualidad muchas Comunidades Autónomas realizan vuelos para producir una cartográfica propia93.

En lo que se refiere a las fotografías realizadas mediante satélites y ofrecidas por Internet, podemos destacar Coogle Maps, nombre de un servicio gratuito de Google que es un servidor de aplicaciones de mapas en la web. Ofrece imágenes de mapas desplazables así como fotografías por satélite e incluso la ruta entre diferentes ubicaciones o imágenes a pie de calle. Desde el 6 de octubre de 2005, Google Maps es parte de Coogle Local. Existe una variante llamada Google Earth que se ofrece también de forma gratuita. En este mismo orden de cosas, el Sistema de Información Geográfica de parcelas agrícolas (SICPAC) 
es una aplicación SIC del Cobierno de España (Ministerio de Agricultura, Alimentación y Medio Ambiente) que permite identificar geográficamente las parcelas declaradas por los agricultores y ganaderos en todo el territorio español.

Para este trabajo, se ha realizado una cartografía especial, que, tomando como base el Modelo Digital del Terreno del Instituto Geográfico Nacional y utilizando los mapas digitalizados 1:50.000 y 1:25:000 al igual que los mapas históricos del Instituto Geográfico Nacional, así como del Plan Nacional de Ortofotografía Aérea, y de acuerdo con las fotografías del Vuelo Americano de 1956, se ha superpuesto la totalidad de la información obtenida en la documentación histórica que hemos revisado. Los datos esenciales de esta cartografía se pueden sintetizar así:

\begin{tabular}{|l|l|}
\hline Base Cartográfica & Modelo Digital del Terreno MDT/o5-LIDAR. Inst. Geográfico Nacional \\
\hline Digitalización: & MTN50 RASTER. Mapa Topográfico Nacional 1:50.000 \\
& MTN25 RASTER. Mapa Topográfico Nacional 1:25.000 \\
& MTN50 HISTORICO. Instituto Geográfico Nacional. \\
& PNOA. Plan Nacional de Ortofotografía Aérea. \\
& Vuelo Americano de 1956. Instituto Tecnológico Agrario. (ITACYL) \\
\hline
\end{tabular}

\section{B.- RECONOCIMIENTO DEL TERRENO}

Hemos realizado también un especial esfuerzo por conocer de manera directa el territorio por donde discurrían o, felizmente, discurren todavía, los caminos objeto de nuestra atención. Entendemos que ningún trabajo que trate sobre la historia y desarrollo de los caminos y vías de comunicación puede resultar completo si no se efectúa un conocimiento "in situ" de los caminos implicados, o, mejor aún, de lo que se conserva más o menos explícitamente de ellos. Es, por lo demás, de gran importancia el conocimiento personal para comprender mejor las dificultades que tuvieron que superar todos aquellos que, de una u otra manera, los crearon y utilizaron. De esta manera, sobre el terreno, se perciben mucho mejor las soluciones que se aplicaron, y se entiende el por qué de determinados rodeos o trazados, sobre el mapa poco racionales. Además, merced al conocimiento del terreno, en algunos casos hemos descubierto la existencia de caminos, algunos importantes, de los que no quedan vestigios relevantes, o bien se los daba por desaparecidos. No pocos de estos han conservado restos de fábrica, de mayor o menor relevancia en zonas agrestes, donde han podido subsistir por quedar a salvo de concentraciones parcelarias y repoblaciones forestales y por el abandono de los mismos cuando en fechas más recientes, irrumpió el automóvil.

Por otro lado, el conocimiento "in situ" permite solucionar muchas dudas puntuales relacionadas con el empaque de las obras, la dirección de las mismas, el sentido de los trazados y los esfuerzos empleados. También posibilita la localización fehaciente de tramos específicos de los trazados, tal como sucede con los puertos y portillos, que han quedado abandonados y en muchos casos se ha perdido hasta su recuerdo. Con frecuencia, 
ante nuestra sorpresa y, a veces, ante la de las personas del lugar que nos acompañan, se descubre gracias al recorrido pormenorizado del terreno el lugar exacto por donde los caminos superaban las líneas de cumbre, las divisorias de aguas o los anticlinales.

\section{4.- CONTENIDOS}

El primer capítulo del presente trabajo estudia las características del espacio comprendido entre la ciudad de Burgos, centro emisor y receptor de las mercaderías y capital comercial y empresarial de Castilla, y los puntos de llegada o de embarque de dichas mercaderías, es decir, los puertos de Santander, Laredo, Castro-Urdiales, Bilbao y Portugalete. Desarrolla por tanto los aspectos que en Burgos tenían relación con una actividad tan importante para la ciudad como era el tráfico mercantil. También repasa las características del espacio intermedio, geográficamente difícil y complicado, que los caminos debían superar a través de páramos, valles, ríos, desfiladeros, montañas y la Cordillera Cantábrica como barrera intermedia. Finalmente repasa brevemente las características de las villas portuarias que, como receptoras y emisoras, basaban gran parte de su prosperidad en el tráfico comercial.

El segundo capítulo desarrolla de una manera detallada las características de los caminos principales que pusieron en comunicación a la ciudad de Burgos con los puertos referidos. Mientras la conexión con Santander y Bilbao se realizó por más de un camino, la utilizada para llegar a Laredo fue prácticamente única lo que facilitó la concentración de esfuerzos para su mantenimiento y mejora. Por otra parte, los caminos que llegaban a Castro-Urdiales y a Portugalete, no eran otra cosa que una prolongación de los caminos mencionados. En el trabajo se pondrán de manifiesto los diferentes aspectos concernientes a cada vía, así como algunos de los problemas surgidos por su deterioro y reparación.

En el tercer capítulo se tratará de los diferentes aspectos que atañen a la caminería en general y a la desarrollada en el sector que tratamos en particular. Así, cuestiones relacionadas con las destrucciones catastróficas de los caminos o de los inconvenientes provocados por avenidas, lluvias o nieve, o los mantenimientos y reparaciones de dichos caminos que debían superar los problemas de su financiación, serán desarrolladas en dicho capítulo. Otro apartado que se trata con amplitud, son los de los aspectos relacionados con las ferias y mercados locales y comarcales, los portazgos, las aduanas y los puertos secos o los productos transportados. No se olvidan asuntos importantes como son aquellos relacionados con el transporte arrieril o carretero, lo relativo a los desplazamientos y viajes y sus vehículos, los correos o la seguridad en los caminos. Por último, se trata con cierto detalle un aspecto escasamente conocido como es el de la poderosa influencia que la casa de Velasco ejerció en el tráfico mercantil de toda la zona estudiada, que además del beneficio que obtenía dicha casa con las importantísimas rentas de los diezmos de la mar, percibía los derechos de tránsito de mulateros y transportistas, utilizando para ello las infraestructuras que poseía en Medina de Pomar, capital de su señorío.

El cuarto capítulo se refiere a las conclusiones extraídas del trabajo que presentamos. 


\section{5.- PROYECCIÓN DE RESULTADOS}

Entendemos que el presente trabajo, puede contribuir a la ampliación del conocimiento de aspectos poco conocidos sobre el sector estudiado, cuya importancia entendemos que es básica para entender el mundo de la caminería en una sociedad tan dinámica como la castellana y burgalesa, en unos momentos de transición en los que la ciudad de Burgos se erigió como capital económica y mercantil de Castilla. Pero tal desarrollo se tuvo que asentar sobre el trabajo de unos profesionales que con sus acémilas, los arrieros, o con sus carros, los carreteros, fueron elementos imprescindibles en este proceso. Tales mulateros o carreteros, que tuvieron que realizar su labor por unos caminos difíciles y, en ocasiones, peligrosos, procedían en una gran mayoría de las Merindades burgalesas, llegando a constituir tal dedicación, en algunos casos, en la principal fuente de recursos de determinados núcleos de población.

Al haber realizado con cierto detalle un análisis de la caminería ya mencionada, entendemos que hemos contribuido a nivel científico, a poner en valor un aspecto básico para el conocimiento histórico de la sociedad del centro-norte peninsular de los siglos XV y XVI, en aspectos tales como el comercio, los desplazamientos, los transportes, las construcciones y reparaciones de puentes y caminos, los correos o la seguridad.

También hemos podido estudiar los problemas y situaciones que debieron superar los transportistas, espina dorsal de los transportes, para afrontar en su trabajo cotidiano no solo las dificultades de un territorio difícil y agreste, sino también los obstáculos que concejos y señores territoriales les ponían en el camino. Arrieros y carreteros procedían de unas tierras que, por su pobreza, les obligaba a buscar en los caminos con sus bestias los medios de vida que tales tierras les negaba.

Por otra parte, entendemos que con este trabajo contribuimos en cierta medida al conocimiento de un importante Patrimonio vinculado a lo más profundo de la vida de nuestros antepasados, escasamente valorado hasta el presente, que desde hace años desaparece de manera acelerada sin que se haya protegido y mantenido. La conservación de lo que queda de las vías antiguas, que creemos imprescindible, contribuiría a enriquecer nuestra identidad histórica al tiempo que complementaría el atractivo de zonas, hoy deprimidas, fomentando un turismo activo y de aire libre. No son pocos los puertos y portillos que aún se conservan y caminos que discurren por parajes de gran valor y atractivo medioambiental que, con el paso de los años, permanecen olvidados incluso para los naturales del territorio donde se encuentran.

Además, no son pocas las construcciones y edificios que sin corresponder a las infraestructuras que todo camino precisa, son parte insustituible de tales vías. Los caminos, han ejercido y ejercen un papel urbanizador que, en muchas ocasiones, han provocado el nacimiento de núcleos a su vera o influido poderosamente en la evolución y crecimiento de dichos núcleos. Con las vías de comunicación se encuentra relacionado un importante patrimonio arquitectónico que adquiere todo su sentido cuando se le vincula con dichas vías.

Entendemos que la recuperación de los caminos históricos debe partir, entre otras iniciativas, de los estudios pertinentes que contribuyan a dar toda la importancia que merece un patrimonio como el que presentamos. 


\section{III \\ ESTADO \\ DE LA CUESTIÓN}

1.- LOS CAMINOS EN LA HISTORIA DE LA PENÍNSULA

2.- CONDICIONES GENERALES DEL TRANSPORTE

A.- CONDICIONAMIENTOS NATURALES

B.- ASPECTOS LEGISLATIVOS 
El estudio de la caminería y de los muchos aspectos con ella relacionados no ha tenido la suerte historiográfica de otros aspectos o ámbitos temáticos, aunque cabe subrayar, como excepción, que en los últimos tiempos se han multiplicado de manera verdaderamente significativa los trabajos relacionados tanto con la red viaria romana como con el Camino de Santiago, en este caso con un crecimiento exponencial realmente apabullante desde que en 1948-1949 Vázquez de Parga, Lacarra y Uría le dedicaran su célebre trilogía94.

\section{1.- LOS CAMINOS EN LA HISTORIA DE LA PENIINSULA IBÉRICA}

Los caminos han surgido en la historia al compás de la presencia y actividad de los seres humanos y, en su origen, carecieron de cualquier connotación política o planificación, predominando en prácticamente todos los casos el más prosaico espontaneismo sustentado en la necesidad de desplazamiento. Se ha dicho, no sin razón, que los caminos han surgido justo allí donde la reiteración del paso de los seres humanos ha dejado huella. Los desplazamientos, el comercio o el crecimiento e integración de las propias comunidades humanas, depende en gran parte de las facilidades existentes para el desarrollo de sus caminos. Cuando hay caminos adecuados, el comercio es una de las actividades que primero se potencia. Esto provoca, además, la dinamización económica, cultural y social de los territorios implicados, ya que alrededor de los caminos y de su tráfico van surgiendo elementos estructurales y complementarios de gran incidencia en los colectivos humanos, como los puentes, las ventas, los mesones, los albergues, los hospitales, los paradores, los almacenes y las industrias. Correlativamente aparecen, cada vez más potenciadas, las profesiones vinculadas al tráfico caminero, como los arrieros, carreteros, venteros, mesoneros, empedradores, etc. En fin, la dinamización termina por alcanzar todo su esplendor cuando aparecen las ferias y mercados, que, con frecuencia y en mayor o menor grado, estimulan el desarrollo de la comarcas colindantes. Las Partidas, redactadas en la segunda mitad del siglo XIII, se hacen considerable eco de este tema en los siguientes términos: "Las tierras e los lugares, en que vsan los mercadores, a leuar sus mercadurias, son por ende mas ricas e mas abondadas, e mejor pobladas: e por esta razon deue plazer a todos con ellos"95.

Como es bien sabido, la creación de un estado universal circunmediterráneo tuvo un efecto altamente positivo en la dotación de caminos, circunstancia que proporcionó a la Península Ibérica la primera gran red viaria de su historia. Con posterioridad, sin embargo, la dislocación del Imperio Romano tuvo un efecto de cataclismo sobre la caminería en general y sobre la propia del centro-norte peninsular en particular, deterioro que no consiguieron frenar ni los visigodos, ni los musulmanes ni los primeros estados

94 VÁZQUEZ de PARGA, Luis; LACARRA, José Mā. y URÍA RÍU, Juan: "Las peregrinaciones a Santiago de Compostela”. Consejo Superior de Investigaciones Científicas. Madrid, t. I 1948; t. II 1949 y t. III 1949.

95 LAS SIETE PARTIDAS/ Quinta Partida. Título VII. Ley IV. En "Los Códigos Españoles, Concordados y Anotados". Tomos II al IV. Antonio de San Martín, editor. Madrid, 1872. 2ª edición. Se comenzaron a redactar en 1256, concluyéndose en 1263, durante el reinado de Alfonso X. 
cristianos del septentrión peninsular. La antigua red caminera romana, que había surgido para interconectar regiones y capitales muy distantes entre sí, perdió su función original al compás de la fragmentación territorial, de la creciente ruralización de la sociedad, del declive del comercio y del hundimiento de la vida urbana. En su lugar, surgió una tupida y mediocre red de caminos de corto recorrido que interconectaba los núcleos de población circunvecinos y los mercados inmediatos, dando lugar a una trama viaria peculiar, que condicionaría seriamente las comunicaciones en el futuro.

Largo tiempo después, sin embargo, con el desarrollo de los reinos cristianos del septentrión y el empuje de fenómenos religiosos, sociales y económicos de procedencia foránea, la caminería comenzó a experimentar un considerable y sostenido salto hacia adelante. Fue ese el momento en que empezaron a tejerse las relaciones mercantiles entre Castilla y los puertos atlánticos, circunstancia que puso de manifiesto la necesidad de crear una red caminera de nueva planta para dar cobertura a las crecientes demandas mercantiles. Como es de imaginar, los caminos iniciales de largo recorrido no pudieron ser carreteros, sino mulateros, adaptados a las características de una zona particularmente agreste. En realidad, el desarrollo caminero fue general, es decir, a escala de la totalidad de la Península Ibérica, y, al compás del mismo, surgieron o se vivificaron importantes enclaves urbanos, destacando en el norte Santiago de Compostela, Burgos, Valladolid, León y Palencia; en el centro, Toledo y Madrid y, en el sur, Murcia, Sevilla y Córdoba.

Tras la esplendorosa fase constructiva del Imperio Romano, la época más activa y fructífera en lo concerniente al desarrollo de los caminos, de los transportes y del comercio fue la correspondiente al reinado de los Reyes Católicos. Es bien sabido que impulsaron una política administrativa fuertemente centralizadora y otorgaron al comercio una importancia vital para el desarrollo e integración de sus reinos ${ }^{96}$. Entre las actuaciones más relevantes en torno a la caminería, cabe destacar la firme y constante exigencia de que fueran los municipios quienes conservaran en buen estado los caminos de sus respectivas jurisdicciones. No procede, sin embargo, valorar sobremanera la profundidad de su política caminera, pues realmente no crearon caminos nuevos, ni implicaron al Tesoro Real en la financiación de las actuaciones que emprendieron. De hecho, esta fue la tónica general de la Corona en el futuro. Más allá de acciones puntuales en caminos y puentes, indispensables para mantener las vías en servicio y para garantizar el tráfico, no existiría una política decidida de resolución de los problemas camineros que padecía la Península hasta el siglo XVIII.

Cabe contabilizar en el haber de los caminos su funcionamiento como canales habituales de distribución y suministro de productos de primera necesidad tales como el trigo, el vino, el aceite, la sal, el vinagre, la cebada, los pescados, etc, circunstancia que ha contribuido poderosamente a dinamizar las comarcas por donde discurrían y a fijar su poblamiento. Y no solo eso. Con frecuencia han actuado también en el decurso histórico como promotores de urbanización o como responsables del nacimiento de núcleos de población. Fue hasta cierto punto habitual que, con la existencia o construcción de un determinado puente, o junto al trazado de una vía muy transitada o cruce de caminos, 
e incluso en el entorno de una determinada venta o edificación auxiliar, se instalara un incipiente caserío que, con el paso del tiempo, habría de convertirse en un auténtico núcleo urbano. En tales ocasiones, el camino real terminó por convertirse en la calle principal97. Este tirón urbanizador de la caminería resultó especial en torno al Camino de Santiago pero, en la práctica, funcionó por igual un poco por todas partes. Como cabe imaginar, el pulso vital del camino así nacido se mantuvo íntimamente ligado al devenir del camino y a la entidad de su tráfico.

Como estamos viendo, los caminos han cumplido en la historia funciones muy variadas y, entre ellas, no fue la menor la de actuar como mojones en la fijación de las parcelas y de los términos, según lo prueban algunos fueros municipales. Así, por ejemplo, ocurre en el Fuero de Lerma, concedido por Alfonso VII en 1148, donde se establecen los siguientes límites municipales: "Termino de Lerma que parte cum Lara moion laguna Sanguisuela, e va por el camino que viene de Burgos a Ruuiales e a Sancto Domingo e por somo val andrinoso... e desta otra parte (assil como sale a la Fuente del Olmo, e a Finojosa, e al camino que passa so) Torreçilla, e a oter de ladrones, $e$ va el camino ayuso por la deffesa de Balzalamio, fastal camino que va a Burgos,... e torna por el camino e salle a la deffesa de Santa Maria de Fanovequez"98.

El entretenimiento de los caminos era siempre fundamental, pues, en caso contrario, el resultado estaba cantado: o bien el abandono de un tramo del mismo o su total sustitución por una vía alternativa. La mayor parte de los caminos de la Edad Media tenían un simple firme de tierra, por lo que era frecuente que las lluvias provocasen la aparición de barro, circunstancia que, en no pocas ocasiones, inutilizaba la totalidad o amplios tramos de sus trazados. Por otro lado, los puentes y los paredones que afianzaban los caminos en determinados pasos quedaban frecuentemente arruinados por la crecida de las aguas, incidencia que, según los casos, podía dificultar, retrasar o impedir la circulación. El hecho de que la mayor parte de los puentes fuese de madera hasta mediados del siglo XV no hacía sino incrementar y generalizar el problema. Muy frecuentemente por ello, los viajeros debían cruzar los ríos por vados naturales, condicionados a periodos de aguas bajas. En 1465, la comitiva de caballeros que acompañaba al noble bohemio León de Rosmithal en su viaje de Bilbao a Valmaseda tuvo que vadear el curso del Cadagua hasta en 17 ocasiones 99. En términos generales, tan sólo a partir del siglo XV se afrontó con seriedad y decisión el problema del paso de los ríos, promoviéndose la construcción de puentes en los lugares precisos $^{100}$.

Basándose en la triple distinción viaria que realiza José Ángel García de Cortázar ${ }^{101}$ y manejando las referencias que aparecen en los documentos altomedievales, Manuel Za-

97 Los ejemplos son numerosos: Puente la Reina, Santo Domingo de la Calzada, Miranda de Ebro, Aranda de Duero, Puentelarrá, etc.

98 MARTÍNEZ DÍEZ, G.: 1982: 152-153.

99 ROSMITHAL DE BLATNA, L. de: "Dos relaciones del viaje: de Shaschek y de Gabriel Tetzel" 1465-1467; GARCíA MERCADAL, J.: 1952: t. I. 263-266 y 295-297; HERBERS, Klaus y PLÖTZ, Robert: 1999: 108-112. "en un espacio de cinco millas vadeamos diecisiete veces este río...".

100 ARÍZAGA BOLUMBURU, Beatriz y MARTÍNEZ MARTÍNEZ, Sergio: 2006: 48-49.

101 GARCÍA de CORTÁZAR, J. A.: 1992: 41. 
balza ${ }^{102}$ clasifica los caminos en tres órdenes: via publica, camino publico y un genérico via/ uia, habitualmente unido al verbo en presente: que discurrit, venit, vadit, exit. Por su mayor o menor uso, distingue dos rangos: por un lado, las karreras/carreras, destinadas al tránsito de carretas o animales de carga, de grandes grupos a caballo y/o de paso de rebaños; por otro lado, los senderos (semderos, semitarios, semdarios), las calzatas/calzadas y los caminos, destinados al desplazamiento a pie y en pequeños grupos. El empaque, el trazado o la antigüedad jugaban su papel en voces comunes como viam maiorem, grandem viam, karrera directa, viam rectam, $\mathrm{y}$, sobre todo, en aquellas, más especializadas, que recordaban las viejas vías romanas: carrera antiqua, vía calzata o strata.

En cuanto a la huella toponímica vinculada a la caminería, Sojo y Lomba ${ }^{103}$ ha revisado a través de la documentación de Cantabria los topónimos anejos a los caminos con antecedentes romanos, cuyas conclusiones se pueden extender igualmente al resto de la zona que estudiamos. Muy influyente ha sido al respecto la palabra carrera ${ }^{104}$ con sus variantes karraria o carraria, que se encuentra ya en documentos de los siglos XI y XII para referirse a un camino por donde sólo podía pasar un carro, a diferencia de las vías y calzadas que según Lomba, eran más anchas. En el mismo sentido, topónimos relacionados con voces como concha, cuarta, estrada ${ }^{105}$, horca ${ }^{106}$, muno, muño y muñeca ${ }^{107}$ se encuentran estrechamente vinculados a caminos importantes, cuando no a restos de vías romanas.

Ya desde la Edad Media, y con creciente profusión después, se han generado topónimos relacionados con voces vinculadas a accidentes geográficos que denotan trayectos camineros peculiares, como congosto, costana y costanilla, al igual que hoz ${ }^{108}$ y sus derivados: hoceja, hocejo, hocilla, hocina, hocino, hocín. También se han construido topónimos a partir de voces que hacen referencia a tajos o pasos en la roca, como horada, horadada, puerta, puerto, portillo, portilla, retortillo, retuerta, retuerto, torno o tornos ${ }^{109}$, varga, varguilla, etc. Existen igualmente topónimos que derivan de elementos genuinamente camineros, como calzadilla y puente y sus derivados: pontejos y puentecillas. Se registran igualmente topónimos relacionados con voces como carro y carreta, entre ellos Valdecarros, Carrieto, Carrera de Valdetote, Carrera de Valdecamas, Carrayram, Piencarrera o Valle Viatero.

\footnotetext{
102 ZABALZA DUQUE, Manuel: 1998: 486.

103 SOJO Y LOMBA, Fermín de: 1947: t. 83, 7-71.

104 Del latín carrus, vía por donde podían circular carros.

105 Del latín strata, vía afirmada con empedrado.

106 Del latín furca, que señala collados o lugares de paso entre montañas.

107 Voz que designa altura, cerro o elevación del terreno.

108 Paso estrecho y en curva junto a un río.

109 Camino que da muchas vueltas. Se suele aplicar a los caminos que suben o bajan de puertos empinados.
} 


\section{2.- CONDICIONES GENERALES DEL TRANSPORTE}

\section{A.- CONDICIONAMIENTOS NATURALES}

Las condiciones naturales de la Península Ibérica, en general, y, en particular, las de la gran cornisa que, en sentido latitudinal, separa el borde litoral cantábrico de la Meseta Superior son poco o nada favorables para la intercomunicación regional y comarcal. De hecho, tan solo las cuencas fluviales ofrecen alguna facilidad entre tantos inconvenientes. En la zona que centra nuestra atención, la importancia de la red fluvial es determinante al respecto. En la vertiente meridional de la Cordillera Cantábrica, la cuenca del Ebro, de sentido este-oeste, resulta decisiva para la conexión con la línea de cumbres por la orientación norte-sur que cobran sus afluentes septentrionales. Dichos cauces serán los utilizados por los caminos que analizaremos en este trabajo. En la vertiente oceánica de dicha cordillera, los ríos, en general de corto recorrido, se orientan perpendiculares al mar, con un radical trazado Sur-Norte. Las cuencas de referencia se encuentran separadas por una poderosa cadena montañosa de orientación latitudinal, cuya superación exige el uso de pasos o puertos fuertemente afectados por la climatología adversa, principalmente la nieve, durante el invierno. Esta cadena montañosa ha tendido de manera natural a aislar geográficamente la franja costera y los puertos de mar y a dificultar la relación con el traspaís castellano ${ }^{110}$.

En términos históricos, la red caminera de la Península Ibérica ha adolecido de graves problemas infraestructurales por dos razones principales: en primer lugar, por la compleja y atormentada geografía que ha actuado como soporte de sus trazados; por otro lado, la constante precariedad que ha presidido su mantenimiento, motivada por una grave escasez de medios y por una habitual ausencia de políticas comprometidas. He aquí algunos de los principales inconvenientes vinculados tanto a la geografía como a la política:

${ }^{1}$ ㅇ. La complicada y accidentada orografía peninsular, que obligaba a dirigir los caminos por estrechos desfiladeros, a superar puertos de montaña y a atravesar páramos inhóspitos, que se cubrían de nieve varios meses al año, obstaculizando e incluso en ocasiones cerrando temporalmente su tránsito.

$2^{\circ}$. Las cíclicas riadas e inundaciones, con tintes, a veces, catastróficos, que dañaban con frecuencia los puentes, caminos y demás obras de ingeniería, interrumpiendo con ello el tráfico caminero.

$3^{\circ}$. La deficiente calidad de los firmes, casi todos de tierra, que en épocas de lluvias se embarraban y anegaban fácilmente.

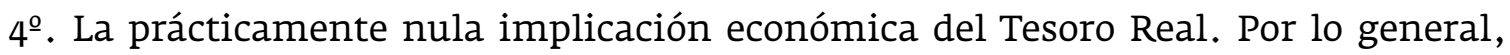
la Corona no colaboraba económicamente en la construcción de caminos, ni en el reparo y mantenimiento de las vías de comunicación. De hecho, habitualmente se limitaba a autorizar a través del Consejo Real las obras a realizar en los caminos importantes, contro- 


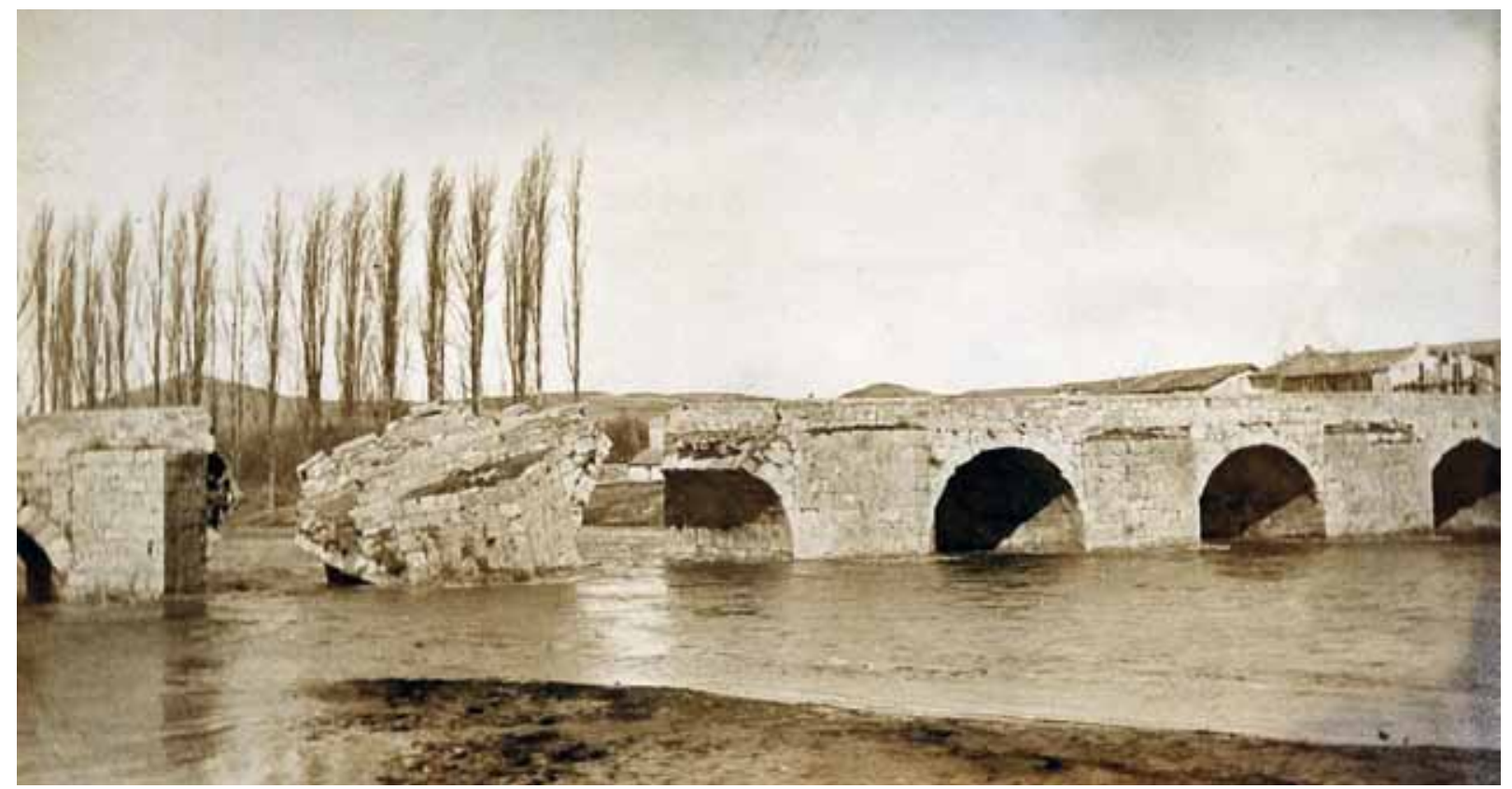

Efectos de la riada de 13 de febrero de 1900 en el puente de los Malatos de Burgos. (A. M. B., FC-2364 Cortés).

lándolas por medio de los corregidores, y a dar luz verde a las acciones encaminadas a la obtención de fondos para llevarlas a término o para realizar las reparaciones pertinentes.

$5^{\circ}$. La inadecuada estructura administrativa existente, que no era capaz de dar respuestas urgentes y complicaba y retrasaba excesivamente las intervenciones.

\section{B.- ASPECTOS LEGISLATIVOSיי}

Teniendo como antecedente el Derecho Romano y el Fuero Juzgo, un amplio conjunto de normas de tipo jurídico y administrativo fueron promulgadas a partir del siglo XIII sobre las vías de comunicación, contemplando aspectos tales como el dominio público viario, su construcción, conservación y financiación, sus características técnicas, su uso y defensa o la seguridad de los transeúntes. Ya en la segunda mitad de dicho siglo con Alfonso X, se definen los caminos como bienes de dominio público ${ }^{112}$. Como consecuencia de este carácter, no pueden ser objeto de ocupación ni apropiación por particulares y ni "en los exidos, nin en los caminos que son comunales de las cibdades, e de las villas, e de los otros lugares, non debe ningun ome fazer casa, nin otro edificio, nin otra lauor. Ca estos lugares atales, que fueron dexados para apostura por pro comunal de todos los que y vienen, non los deue ninguno tomar nin labrar para pro de si mismo"113. En términos similares el Fuero Juzgo había establecido la prohibición de ocupar el camino

111 GARCÍA ORTEGA, Pedro: "Historia de la legislación española de caminos y carreteras". Ministerio de Obras Públicas y Urbanismo. Madrid, 1982. pp. 31-32; SÁNCHEZ REY, Agustín: 2007: 51-64.

112 LAS SIETE PARTIDAS/ Tercera Partida, Título XXVIII, Ley VI. "Ios caminos publicos pertenescen a todos los omes comunalmente, en tal manera que tanbien pueden vsar dellos los que son de otra tierra estraña, como los que moran, e biuen en aquella tierra, do son".

113 LAS SIETE PARTIDAS/ Tercera Partida, Título XXXII, Ley XXIII. 
o cerrarlo ${ }^{114}$, y de evitar que construcciones próximas entorpeciesen la circulación. En el Fuero Real se alude a ello115, y también en las Ordenanzas Reales se hace referencia a los cierres y embargos de los caminos ${ }^{116}$, algo que se reitera en el ordenamiento de Alcalá de 1348 , disponiéndose la libre circulación por los mismos ${ }^{117}$. Además, los caminos no se podían interrumpir ni estrechar ${ }^{118}$. También el Fuero Juzgo regula el terreno que se debe dejar libre junto al camino119.

En relación con la construcción y mantenimiento de los caminos, se dicta un conjunto de normas al menos desde el siglo XIII. Sobre el monarca recaía la facultad de su construcción, y en las Partidas se establece con toda claridad ${ }^{120}$. También las Partidas tratan sobre la conservación de puentes y caminos ${ }^{121}$. Los reyes mandan en 1497 a las Justicias y concejos que velen por el correcto estado de los caminos ${ }^{122}$.

114 FUERO JUZGO/ Libro VIII, Título IV, Ley XXIV. En"Los Códigos Españoles, Concordados y Anotados". Tomo primero. Antonio de San Martín, editor. Madrid, 1872. 2a edición. Códice visigodo (primera versión de 654) y traducido al romance en 1241, fue reconocido por Alfonso X en las Cortes de Zamora (1274). Se indica que "si algun omne cierra la carrera pública de seto ó de valladar, el que crebantar el seto ó el valladar non sea tenudo de la emienda, y el que cercó la carrera, si es siervo, préndalo el iuez, é fagalo aducir al seto, é fagral dar C. azotes: e costréngalo que abra la carrera cuemo solia ser, maguera que tenga y mies. E si es omne poderoso el que lo faz, peche XX sueldos".

115 EL FUERO REAL DE ESPAÑA/ Libro IV, Título VI, Ley I. "De los que cierran los caminos, e egidos, e los rios"; Ley II. "Como qualquier puede desfacer la carrera que estuviere cerrada"; Ley III. "Como los caminos que entran à la Ciudad deben estar abiertos, è muy grandes, como solia haberlos". En "Los Códigos Españoles, Concordados y Anotados". Tomo primero. Antonio de San Martín, editor. Madrid, 1872. 2ª edición. pp. 410-411. Se indica que "si alguno cerrare camino ò carreras usadas, por la osadia peche treinta sueldos al Rey:... è lo que fizo desfagalo por su mision", y se insiste que "quien quier que hallare camino, ò carrera usada cerrada, desfaga el valladar, ò la cerradura sin caloña ninguna qualquier que sea" y que "los caminos que entran à la Ciudad, è que van à las otras tierras, finquen bien abiertos, é tan grandes como suelen estar: è los herederos de la una parte, è de la otra no sean osados de los ensangostar: mas si quisieren facer cerraduras à sus tierras, ò à sus heredades, faganlas en lo suyo".

116 ORDENANZAS REALES DE CASTILLA/ Libro VIII, Título XIX, Ley XXVIII. En“Los Códigos Españoles, Concordados y Anotados". Tomo sexto. Antonio de San Martín, editor. Madrid, 1872. 2ª̣ edición.

117 NOVÍSIMA RECOPILACIÓN DE LAS LEYES DE ESPAÑA/ Libro VII, Título XXXV, Ley I/ Ordenamiento de Alcalá promulgado por Alfonso XI en las Cortes celebradas en 1348. En "Los Códigos Españoles, Concordados y Anotados". Tomos VII al XII. Antonio de San Martín, editor. Madrid, 1872. 2ª edición. París, 1846. Se dispone que "el que cierra ó embarga los caminos, ó las carreras, ó las calles por donde las viandas suelen andar con bestias ó con carretas, á llevar ó traer viandas ó mercadurías de unos lugares á otros, que peche cien maravedís para nuestra Cámara, y desfaga la cerradura, ó embargo que fizo, á su costa dentro de treinta dias".

118 LAS SIETE PARTIDAS/ Tercera Partida, Título XXIX, Ley VII. "plaça, nin calle, nin camino, nin defesa, nin exido, nin otro logar qualquier semejante destos que sea en vso comunalmente del pueblo de alguna çiudad, o villa,... o de otro lugar non lo puede ningund ome ganar por tiempo".

119 FUERO JUZGO/ Libro VIII, Título IV, Ley XXV. Se establece que "la carrera por que los omnes suelen ir á las cibdades ó á las villas nengun omne no la cierre, mas dexen la meatad descubierta sin él al que prende de cada una parte, que aquellos que van carrera, que puedan aver espacio de folgar. E si algun omne viniere contra esta nuestra ley, si es omne poderoso peche XV sueldos, ó si fuere omne de menor guisa, pecheVIII sueldos... E quien a alguna mies, ó vinna, ó prado cerca de la carrera, cérquelo de seto, é si lo non puede facer por pobreza, faga y valladar".

120 LAS SIETE PARTIDAS/ Segunda Partida, Título XI, Ley I. Se indica que los Reyes "deuen mandar labrar las puentes, $e$ las calçadas, e allanar los pasos malos, porque los omes puedan andar, e lleuar sus bestias, e cosas desembargadamente de un logar a otro; de manera que las non pierdan en los passajes de los rios, ni en los otros lugares peligrosos por do fueren".

121 LAS SIETE PARTIDAS/ Tercera Partida, Título XXXII, Ley XX. Se indica que "apostura, e nobleza del Reyno es, mantener los Castillos, e los muros de las Villas, e las otras Fortalezas, e las calçadas, e las puentes, e los caños de las Villas, de manera que non se derriben, nin se desfagan: e como quier que el pro desto pertenezca a todos, pero señaladamente la guarda, e la famencia destas lauores, pertenesce al Rey".

122 NOVÍSIMA RECOPILACIÓN DE LAS LEYES DE ESPAÑA/ Libro VII, Título XXXV, Ley II/ Medina del Campo 1497. “Obligacion de las Justicias y Concejos a tener abietos, reparados y corrientes los caminos carreteros de sus términos". "Ias Justicias y Concejos, que fagan abrir y adobar los carriles y caminos por do pasan y suelen pasar y andar las carretas y carros, cada Concejo en parte en su término, por manera que sean del anchor que deban, para que buenamente puedan pasar y ir y venir por los caminos; y que no consientan ni den lugar los dichos Concejos, que los dichos caminos sean cerrados ni arados, ni dañados ni ensangostados". 
Pero si la construcción y el mantenimiento de los caminos estaban entre las atribuciones reales, su financiación debía correr a cargo de los municipios ${ }^{123}$. Es decir, que ya en la segunda mitad del siglo XIII se achaca a estos la responsabilidad de la construcción o mantenimiento, y deben afrontar los gastos a costa de sus propios, y si no alcanzasen o no los tuvieren, el coste deberá repartirse entre todos los vecinos, incluyendo a los caballeros y clérigos, algo totalmente novedoso. Queda claro y se insiste en la Partida primera que todos deben colaborar ${ }^{124}$. En 1455 Enrique IV concede autorización a los concejos y sus vecinos para la construcción de puentes a su costa, y sin que "puedan imponer, ni pongan imposiciones ni tributos algunos"125. Dicha obligación tributaria iba aparejada a la de efectuar los vecinos prestaciones personales y a la aportación de los utensilios de trabajo y bestias de carga o carros.

Para asegurar técnicamente las obras, se indica que las deben llevar a cabo maes$\operatorname{tros}^{126}$. En 1500 se manda que las obras públicas "se hagan a menos costa y a menos provecho del Concejo que ser pudiere: $y$ las personas que en ello hobieren de entender sean tales, que lo hagan fielmente, y no hagan costa demasiada, salvo la que fuere necesaria para que la obra sea bien hecha"127. La anchura de las vías ya se había establecido en el Fuero Viejo de Castilla ${ }^{128}$.

Garantizar el uso del camino era algo prioritario y quedaba totalmente prohibido, como se ha dicho, el estrechamiento del camino ocasionado por ocupar el dominio público los propietarios colindantes. El aprovechamiento de las márgenes del camino para apoyo de mulateros y carreteros fue también objeto de regulación. Así se establece en el Fuero Juzgo $^{129}$ y en el Fuero Real130.

123 LAS SIETE PARTIDAS/ Tercera Partida, Título XXXII, Ley XX. Se indica que "si en las Cibdades, o en las Villas han menester de fazer algunas destas lauores, si han rentas apartadas de Comun, deuen y ser primeramente despendidas. Ė si non complieren, o non fuesse y alguna cosa comunal, estonce deuen los moradores de aquel lugar pechar comunalmente, cada vno por lo que auiere, fasta que ayunten tanta quantia, de que se pueda cumplir la lauor: e desto non se pueden escusar Caualleros, nin Clerigos, nin biudas, nin huerfanos, nin ningun otro cualquier, por preuillejo que tenga. Ca pues que la pro destas lauores pertenesce comunalmente a todos, guisado, e derecho es, que cada vno faga y aquella ayuda que pudiere".

124 LAS SIETE PARTIDAS/ Primera Partida, Título VI, Ley LIIII. que no se "pudiessen escusar de ayudar los clerigos a los legos. Assi como en las puentes que fazen nueuamente en los logares, do son menester, para pro comunal de todos. E otrosi en guardar las que son fechas, como se mantengan, e se non pierdan". "Esso mismo deuen fazer en las calçadas de los grandes caminos, o de las otras carreras, que son comunales".

125 NOVÍSIMA RECOPILACIÓN DE LAS LEYES DE ESPAÑA/ Libro VI, Titulo XX, Ley VII/ Córdoba, 1455, pet. 26. También se manda, "que ningun Perlado, ni Caballero ni otra persona alguna, no sean osados de impedir ni estorbar que se no hagan las dichas puentes, porque digan que tienen barcos ó otros derechos en los rios".

126 LAS SIETE PARTIDAS/ Tercera Partida, Título XXXII, Ley XX. El Rey “deue y poner omes señalados, e entendidos en estas cosas, e acuciosos, que fagan lealmente el reparamiento, que fuere menester, a las cosas que de suso diximos. Otrosi dezimos, que deue dar a estos omes, lo que ouieren menester para cumplimiento de la lauor. Pero si en las Cibdades, o en las Villas han menester de fazer algunas destas lauores, si han rentas apartadas de Comun, deuen y ser primeramente despendidas".

127 NOVİ́IMA RECOPILACIÓN DE LAS LEYES DE ESPAÑA/ Libro VII, Titulo XXXIV, Ley I/ g junio 1500.

128 FUERO VIEJO DE CASTILLA/ Libro V, Título III, XVI. "De las particiones; e de que anchura deven ser las carreras". En "LoS Códigos Españoles, Concordados y Anotados". Tomo primero. Antonio de San Martín, editor. Madrid, 1872. 2ª edición. p. 299. "que carrera que sale de viella, e và para fuente de agua, deve ser tan ancha que puedan pasar dos mugeres con suas orças de encontrada; e carrera que và para otras eredades, deve ser tan ancha que si se encontrasen duas bestias cargadas, sin embargo que pasen; e carrera de ganado deve ser tan ancha que si se encontraren duos canes que pasen sin embargo".

129 FUERO JUZGO/ Libro VIII, Título V, Ley XXVII. "Que los pastos que non son cerrados non sean defendidos á los que pasan por camino". "Los omnes que van por camino, en los campos, ó en los logares de pascer, que non son cerrados, puédense deportar en ellos, ó dar á pascer á sos ganados é á sus bestias, assí que non deven estar en nengun logar mas de dos dias...".

130 EL FUERO REAL DE ESPAÑA/ Libro IV, Título VI, Ley IV. "De los que cierran los caminos, e egidos, e los rios". pp. 410-411. Se establece que "los viandantes puedan meter sus bestias, è los otros ganados à pacer en los lugares que no son cerrados, ni 
Para la señalización de los caminos se recoge en la Novísima Recopilación un acuerdo de 1586 que ordena que los del "Consejo provean y den órden como se pongan pilares en los puertos para señalar los caminos, por los peligros que en tiempos de nieves incurren los que caminan por ellos"131. Incluso las ramas de los árboles que invadieran el camino, se podían cortar sin pedir autorización a los propietarios ${ }^{132}$.

La Corona concedió una especial importancia a que los caminantes transitasen salvos y seguros, manteniendo esta seguridad en dos espacios públicos, centros de la actividad económica y comercial: el camino y el mercado. Era en estos puntos donde más fácilmente se podían percibir los tributos y donde era más posible la comisión de irregularidades. El quebrantamiento del camino era uno de los delitos más castigados por la legislación medieval. Así se establece en el ordenamiento de Alcalá de $1348^{133}$. La pesquisa real estaba reservada para los casos más graves ${ }^{134}$.

Para combatir la inseguridad y los asaltos en los caminos, en las Cortes de Valladolid de 1351 se establece un sistema de policía rural y se llega a detallar la manera en que las autoridades locales debían actuar para la persecución y captura de los malhechores ${ }^{135}$, y en las Leyes de Estilo, se establecen las penas que se deben imponer ${ }^{136}$, distintas según la

defendidos, y puedan y descargar, y folgar por un dia, ò por dos al mas, si el dueño del lugar gelo otorgáre: è guardense de desaraygar, ni de cortar arboles que lleven fruto, ò otros arboles grandes que sean para labores, que no sean de cortar".

131 NOVÍSIMA RECOPILACIÓN DE LAS LEYES DE ESPAÑA/ Libro VII, Título XXXV, Ley V/ Cortes de Madrid de 1586 a 9०. "Construcción de pilares en los caminos para que se distingan en tiempo de nieves".

132 LAS SIETE PARTIDAS/ Séptima Partida, Título XV, Ley XXVIII. “...quando la figuera, o algund arbol, colgasse sobre la carrera publica, de manera, que los omes non pudiessen pasar por y desembargadamente; que cualquier que cortasse las ramas que assi colgassen, non deue auer porende pena ninguna".

133 ORDENAMIENTO DE ALCALÁ. Ley XLIX. En "Los Códigos Españoles, Concordados y Anotados". Tomo primero. Antonio de San Martín, editor. Madrid, 1872. 2ª edición. "Que fabla de los caminos cabdales como sean seguros". "Ios Caminos cabdales el vno que và à Santiago, è los otros que van de vna Cibdad à otra, è de vna Villa à otra, è à los mercados, è à las ferias, sean guardados, è sean amparados que ninguno non faga en ellos fuerça, nin tuerto, nin robo, è el que lo ficiere peche seiscientos maravedis desta moneda vsual al Rey".

134 FUERO VIEJO DE CASTILLA/ Libro II, Título IV, II. "De las cosas por que deve el Rey mandar facer pesquisa, e sobre que cosas deven ser emplazados para casa del Rey". "Estas son las cosas del fuero de Castilla, por que deve el Rey mandar facer pesquisa: auiendo querellosos de quebrantamiento de Igresia, o de quebrantamiento de camino o de muerte de ome...".

135 "Cortes de Valladolid celebradas en la era 1389 (año 1351) por D. Pedro, unico de este nombre". Madrid, 1842?. Biblioteca de Castilla y León. Signatura: g-f-11422. "si la muerte ó el robo ó el maleficio acaesciere en camino ó en otro lugar yermo, quel querelloso venga á la primera cibdad ó villa ó lugar que mas cerca fuere ende, ó lugar do entendiere que mas ayna puede ser acorrido, é que dé y la querella al alcalde ó á los alcaldes ó á los oficiales ó merino ó alguacil ó juez ó otro que tenga y officio de la justicia..., e que estos oficiales..., fagan repicar la campana, é que salgan luego á voz de apellido é que vayan en pos de los malfechores por do quier que fueren", lugares donde también debían hacer repicar las campanas. "Si esto acaesciere en las merindades de Castiella, é de Leon é de Gallizia do hay merinos mayores ó otros merinos que andan por ellos, e fuer fallado el merino ó recudiere, que vaya él con ellos é que sigan los malfechores fasta que los tomen ó los encierren". "E si los tales malfechores se encerraren en alguna villa ó lugar regalengo ó de otro sennorío qualquier, que los oficiales del concejo de aquel lugar seyendo requeridos por los que seguieren el apellido ó pór qualquier dellos, que sean tenudos de gelos entregar". También se contempla "que las cibdades é villas do ha gentes de cavallo, que den de cada una de las mayores veynte omes de cavallo é cinquenta omes a pie".

136 LAS LEYES DEL ESTILO, QUE POR OTRA MANERA SE LLAMAN DECLARACIÓN DE LAS LEYES DEL FUERO. COlección de sentencias del tribunal de la Corte de Alfonso X. Ley LXXI. "Del las fuerzas del que roba à viandantes contra razon, qué pena ha". En "Los Códigos Españoles, Concordados y Anotados". Tomo primero. Antonio de San Martín, editor. Madrid, 1872. 2a edición. p. 321. "el que robase los hombres viandantes, que peche quatro tanto de lo que robáre. Esta Ley se entiende del que roba en camino à algun hombre, è que no habia alguna manera de razon porque robarle. Y este tal robador ha de pechar esto que robó con el quatro tanto, è cient maravedís de la moneda nueva, por camino quebrantado". 
reincidencia137. En el Fuero Real se insiste sobre los castigos a los ladrones de caminos ${ }^{138}$. También se regula en el Fuero Real ${ }^{139}$ y en las Partidas ${ }^{140}$ la protección de los peregrinos que no debían pagar portazgos ${ }^{141}$, y se ampara legalmente el tránsito de los comerciantes ${ }^{142}$. Sobre la instalación y condiciones de ventas y mesones, incluimos su detalle en el apartado del alojamiento.

En Vizcaya también se legisla sobre los caminos. En el Fuero Viejo de Vizcaya de 1452 se regulan sus características y protección ${ }^{143}$. El Fuero Nuevo de Vizcaya de 1526 recoge artículos sobre el estado de los caminos, señalando que "... en Vizcaya hay extrema necesidad del reparo de caminos, por ser muy fragosos, y la tierra muy lluviosa, y muy fragosa de andar...". La anchura general de doce pies del Fuero Viejo parece ampliarse ahora hasta los veinte ${ }^{144}$, lo cual puede relacionarse con el aumento del tráfico comercial y con una mayor utilización de las carretas como medio de transporte ${ }^{145}$. También se dispone que se atienda su reparación ${ }^{146}$.

137 LAS LEYES DEL ESTILO, QUE POR OTRA MANERA SE LLAMAN DECLARACIÓN DE LAS LEYES DEL FUERO. LeY LXXII. "Del que roba à viandante teniendo alguna razon de le tomar, què pena ha, è cómo se entiende en las otras Leyes del Fuero". p. 321. Pero si el "hombre que no fuere ladron conoscido o encartado, è robáre en camino, peche lo que ha robado doblado à su dueño, è al Rey cient maravedis... E si fuere ladron conoscido, ò encartado, è robáre camino, muera por ello, è de lo que hoviere peche à su dueño el robo doblado. Es à saber, que la muerte es en lugar de los cient maravedís del camino quebrantado, y el doblo es para la Parte que robaron".

138 EL FUERO REAL DE ESPAÑA/ Libro IV, Título IV, Ley XVIII. "Qué pena ha el que robáre viandante, ò que estuviere fuera labrando". p. 408. Que "ningun home no sea osado de furtar, ni de robar, ni de forzar en camino a home viandante,... y el que robare, ò forzare tales homes, peche quatro tanto à aquellos que robare: è si otro daño ficiere, tambien de muerte como de otra cosa, peche el daño segun manda la ley: ca los caminos,... seguros deben ser".

139 EL FUERO REAL DE ESPAÑA/ Libro IV, Título XXIV, Ley I. p. 408. "porque queremos que los fechos de Dios, è de Sancta Iglesia por nos sean mas adelantados: mandamos, que los romeros, è mayormente los que vienen en romeria à Santiago, quienquier que sean, ò do quier que vengan, hayan de nos este privilegio por todos nuestros Reynos: ellos, è sus compañas con sus cosas, seguramente vayan, è vengan, è finquen:... è que por ningun tuerto que hayan de recebir, no dexen de venir, ni de cumplir su romeria... Otrosí, mandamos, que tambien en las alverguerías, como fuera de ellas, puedan comprar las cosas que hubieren menester, è ninguno no sea osado de les mudar las medidas ni los pesos derecho porque los otros de la tierra venden, é compran...".

140 LAS SIETE PARTIDAS/ Primera Partida, Título XXIV, Ley II. Se manda que "los romeros e pelegrinos que vienen a Santiago, que ellos e sus compañas, e sus cosas, vayan, e vengan saluos e seguros, por todos nuestros reynos".

141 LAS SIETE PARTIDAS/ Primera Partida, Título XXIV, Ley III. "de las bestias, e de las cosas que traen consigo, por razon de su camino, que non den portadgo, nin renta, nin peaje, nin otro derecho ninguno".

142 LAS SIETE PARTIDAS/ Quinta Partida, Título VII, Ley IV. "mandamos, que todos los que vinieren a las ferias de nuestros reynos, tan bien cristianos, como judios, e moros: e otrosi los que vinieren en otra sazon, qualquier, a nuestro Señorio: maguer non vengan a ferias, que sean saluos, e seguros, sus cuerpos, e sus aueres, e sus mercadurias, e todas sus cosas".

143 FUERO VIEJO DE VIZCAYA/ Decretado en 2 junio 1452. En LABAYRU y GOICOECHEA, E. J. de: 1899: t. III, 206-207. Se dispone que "... los caminos que son reales que se abran en ocho o doze pies, dende las coderas de los caminos que sean de veinte pies", anchura que permitía el cruce de dos carros en direcciones contrarias. Se ordena además, que nadie pueda "... plantar arboles ni poner setos ni zerradura ni embargar los caminos, y si alguno los pusiese... sea thenido de arrancar e cortar los arboles e frutos e desembargue el camino...". También, para que los carros si "... entraren en el camino puedan pasar los unos a una parte los otros a otra sin embargo alguno,...", se ordenaba que “... todos los tales caminos de los puertos a las sierras y de las sierras a los puertos por do pasan los carros, puedan sean en ancho quatro brazadas y media".

144 FUERO NUEVO DEL SEÑORÍO DE VIZCAYA DE 1526/ Ley II, Título XXVII. "El Fuero, Privilegios, Franquezas y Libertades del M. N. y M. L. Señorío de Vizcaya" Introducción de Areitio y Mediolea, Darío. Bilbao 1950. En LARREA

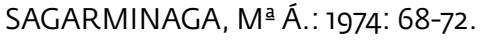

145 FUERO NUEVO DEL SEÑORÍO DE VIZCAYA DE 1526/ Ley IV, Título XXVII. Se manda “... a los jueces del Condado que apremien a los pueblos a que reparen los caminos, cada pueblo lo de dentro de su anteiglesia, y se hagan repartimiento o repartimientos necesarios para ello; y que todas las penas arbitrarias de que han de hacer condenacion las apliquen para el reparo de los dichos caminos".

146 FUERO NUEVO DEL SEÑORÍO DE VIZCAYA DE 1526/ Ley X, Título XXXV. “... los fieles de cada pueblo, por el mes de Mayo, en todo el dicho mes visiten todos los caminos reales de su pueblo, y tomen por memorial las partes, donde hay necesidad de reparar los dichos caminos, y lo que costaran poco mas, o menos los tales reparos", y tal memorial será presentado al corregidor. 



\section{CAPÍTULO I}

\section{LOS CAMINOS DEL NORTE (siglos XV y XVI) Encuadramiento Geohistórico}

1.- LA CIUDAD DE BURGOS COMO PUNTO DE PARTIDA

\section{A.- ENCLAVE CAMINERO}

B.- LA TRAMA URBANA: ASPECTOS BĀSICOS

a.- Desarrollo histórico del caserío

b.- Puntos habituales de la actividad comercial

c.- Las puertas

d.- Los puentes de la ciudad

C.- CIUDAD MERCANTIL

a.- Enclave comercial y lanero

b.- Actividad mercantil

c.- Práctica transportista

2.- EL TRAYECTO INTERMEDIO: CONDICIONES GENERALES

A.- CONDICIONAMIENTOS GEOLÓGICOS

B.- CONDICIONAMIENTOS GEOMORFOLÓGICOS

C.- CONDICIONAMIENTOS HIDROGRÄFICOS

a.- La cuenca del Ebro. El Ebro como eje

b.- La cuenca del Cantábrico.

Los ríos del Valle de Mena

c.- La cuenca del Duero

d.- El cruce de los ríos

\section{3.- LOS PUERTOS DEL CANTÁBRICO \\ COMO TÉRMINO DE LLEGADA}
A.- LAS CUATRO VILLAS DE
LA COSTA DE LA MAR
a.- San Vicente de la Barquera
b.- Santander
c.- San Martín de la Arena
d.- Laredo
e.- Castro-Urdiales

B.- LOS PUERTOS VASCOS
a.- Portugalete
b.- Bilbao
c.- Bermeo
d.- Deva

4.- EVOLUCIÓN HISTÓRICA DE LAS VİAS DE COMUNICACIÓN ENTRE BURGOS Y LA COSTA
A.- VİAS ROMANAS
a.- Vías romanas documentadas y confirmadas
b.- Vías romanas dudosas o inexistentes
c.- Consideraciones generales sobre la viaria romana

B.- LOS CAMINOS DESDE LA EDAD MEDIA 


\section{1.- LA CIUDAD DE BURGOS COMO PUNTO DE PARTIDA}

La ciudad de Burgos fue fundada en el año 884 como una plaza situada al sur de un cerro fortificado con el fin de dominar el estrecho pasillo encajado entre dicho cerro y el río Arlanzón, por donde discurría la vía romana de Burdeos a Astorga o vía Aquitana. Fue desarrollándose desde dichas fechas como plaza militar, con una pequeña población, junto al castillo, que controlaba el dicho paso estratégico, llegando a ser uno de los puntos fuertes cristianos contra las aceifas musulmanas de siglos posteriores, y ciudad mercantil después, extendiendo su traza urbana al asentarse por la ladera sur del cerro y ocupando de manera progresiva las zonas más bajas junto al río.

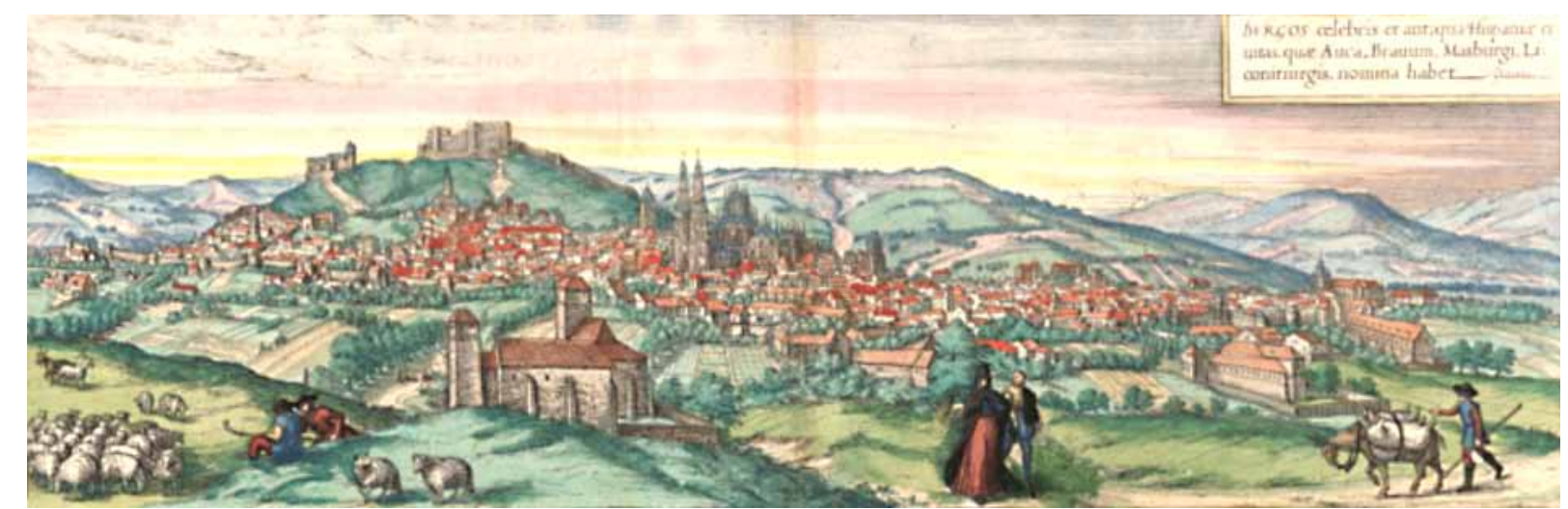

Vista de la ciudad de Burgos desde el Sur. Civitates Orbis Terrarum 1572.

\section{A.- ENCLAVE CAMINERO}

Situada la ciudad en un lugar estratégico sobre el eje Este-Oeste junto a la vía Aquitana, sus fundadores ya detectaron quizá que su ubicación resultaría clave también en un futuro para situarse como un lugar central en otras vías desarrolladas en distintas direcciones, algo que junto con la iniciativa de los comerciantes, convertirá a la ciudad en un importante centro de intercambios. Las vías principales eran:

- Entre Galicia y las tierras riojanas, aragonesas y catalanas en un eje Este-Oeste. Sigue el trazado del Camino de Santiago o Camino Francés que, en Logroño, se une con el camino de Aragón y tierras catalanas.

- Entre Europa y Galicia y Portugal. Coincide básicamente con la mencionada vía romana de Burdeos a Astorga. El camino, procedente de Burdeos, penetra en la Península por Irún y en Burgos se bifurca para ir a Galicia o a Portugal por Valladolid.

- Entre el Cantábrico y el interior peninsular. Los puertos del Cantábrico de Santander, Laredo, Castro-Urdiales y Bilbao conectarán con el interior de la Península a través de Burgos, constituyendo un eje político y económico Norte-Sur de gran proyección a partir del siglo XV. 


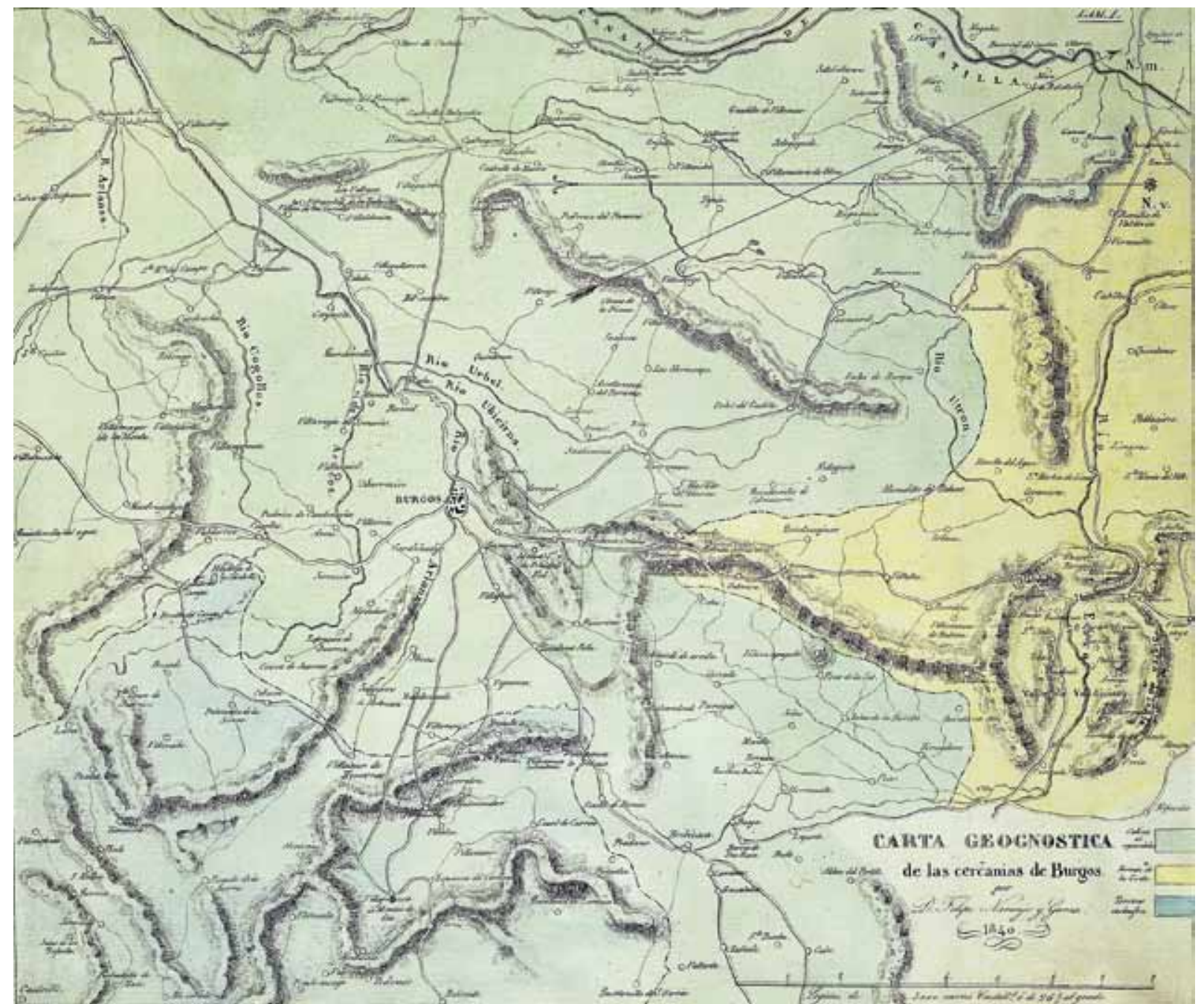

Carta de 1840 de las cercanías de Burgos, donde el Norte se encuentra a la derecha (B. N., R. 9359).

- Entre Valencia, Cuenca y Soria y los puertos del Cantábrico. La ciudad fue punto de conexión, tanto de los caminos que de Valencia se dirigían a los puertos del Cantábrico, como los que iban de Valencia a Galicia.

En clave local, Burgos será también el centro de una importante red radial que permitirá su conexión con las más importantes localidades de su entorno y con las ferias castellanas de Villalón, Medina del Campo y Medina de Rioseco.

\section{B.- LA TRAMA URBANA: ASPECTOS BÁSICOS}

Desde su fundación, la ciudad de Burgos va creciendo arropada por el castillo como poderosa referencia. Por la importancia política que adquiere la fortaleza, que en el año 932 se convierte en sede de la cabeza del Condado de Castilla y en 1175 en Palacio Real, la ciudad incrementa su población y se convierte en centro político y administrativo de la Corona, constituyéndose como punto de atracción de grupos humanos que se instalan en los aledaños del primitivo poblamiento. 


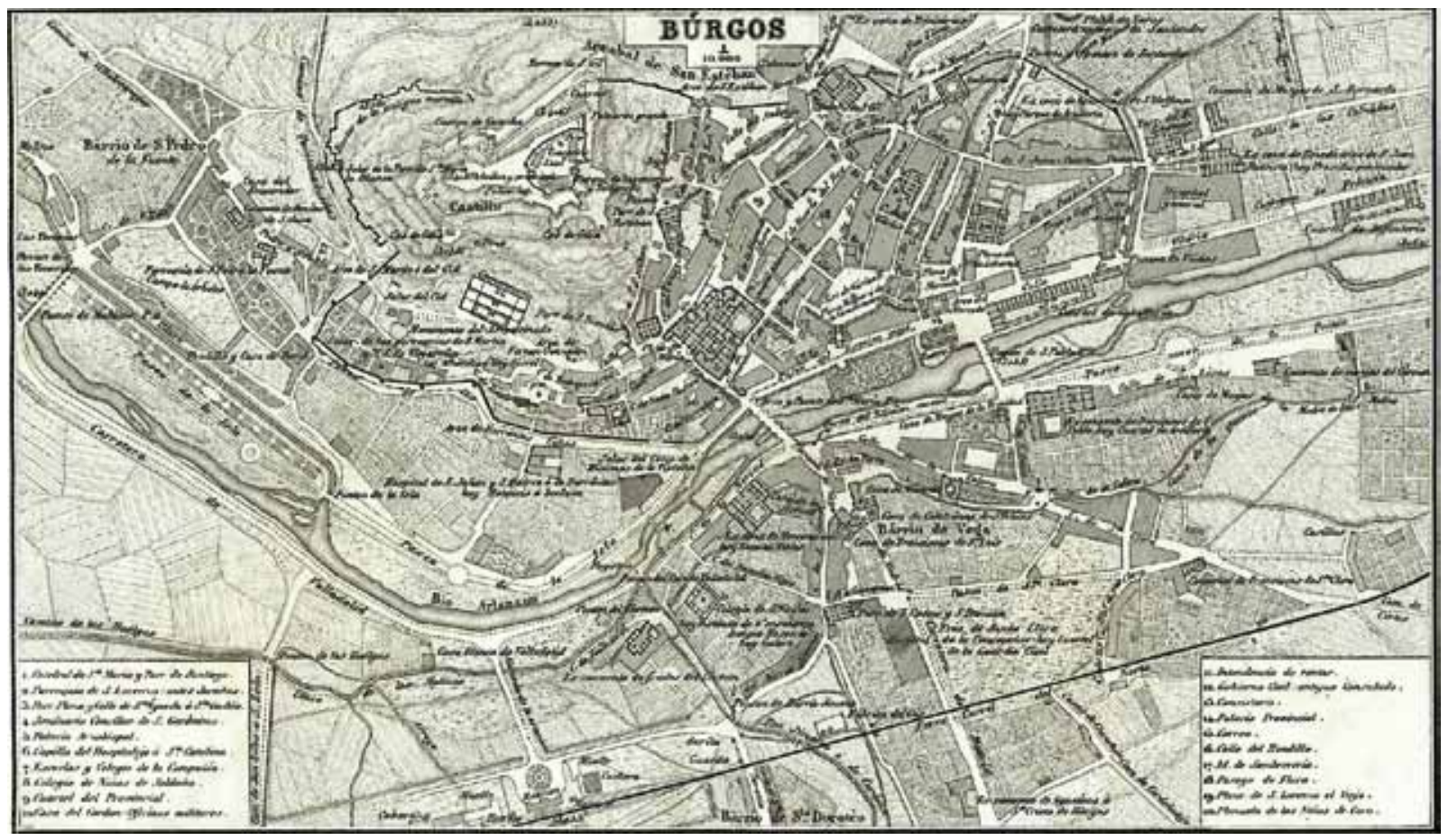

Mapa de Burgos publicado por Francisco Coello en 1868.

\section{a.- Desarrollo histórico del caserío}

En el siglo XI la ciudad se extiende hacia el Sur ocupando las laderas del cerro protegida de los fríos vientos del norte, con unas calles trazadas sobre sus curvas de nivel, y se van consolidando otros núcleos periféricos pero dependientes jurídica y físicamente de ella. Son los barrios de San Pedro de Eras, San Zadornil y Rebolleda. En el siglo XII va imponiéndose la influencia del Camino de Santiago en la formación del plano urbano, que, también adaptado a las curvas de nivel de la zona media-baja del cerro, va actuando como eje Este-Oeste. Quedan plenamente constituidos los barrios que, en torno a sus parroquias, se desarrollan en las laderas del cerro: Santa Águeda, San Andrés, Santa Cruz, San Esteban, San Gil, San Lorenzo, Santa María la Blanca, San Martín, San Nicolás, San Román, Santiago de la Fuente y Nuestra Señora de Viejarrúa.

En el siglo XII y primera mitad del XIII Burgos adquiere unos caracteres sociales y comerciales plenamente urbanos que hacen que la antigua puebla adquiera la categoría de auténtica ciudad, debido al fortalecimiento de su papel como centro de poder y en concreto al establecimiento de la sede episcopal y de varios organismos políticos. Así los elementos dirigentes estarán representados por el castillo, la catedral y el propio Camino Francés. En el siglo XIII la ciudad se mantiene dentro de los límites de la primitiva cerca, ocupando de manera compacta sus solares, pero también comienza a sobrepasar estos límites. Así aparece la puebla de San Juan, en torno al Monasterio del mismo nombre junto al Camino Francés y el que viene de Bayona.

A partir del siglo XIV se consolidan las diferencias sociales. Los intereses de la burguesía urbana, con una cada vez más alta capacidad económica, se oponen a los privilegios que ostenta la nobleza que gobierna el castillo -desde dicho siglo la Corona cede su gobier- 
no a nobles de su confianza-. El desarrollo económico que se produce en estos momentos favorece el crecimiento de la población dentro de sus nuevas murallas ${ }^{147}$, que precisa de un mayor espacio para su expansión, y se van ocupando las zonas bajas más cercanas a la vega del río. Se traspasan las murallas y se van consolidando los arrabales, mientras que el cerro y sus laderas se comienzan a desocupar y quedan relegados al establecimiento de gentes de una más baja condición social y grupos socialmente marginados ${ }^{148}$.

En el siglo XV se siguieron ocupando los solares situados en el interior de las murallas, y se desarrollaron fuera del recinto amurallado los arrabales de Vega, San Francisco, San Pedro de la Fuente y San Juan. Prosigue el proceso de abandono de los barrios altos más cercanos al castillo, como consecuencia del desplazamiento de la población hacia el Sur, estableciéndose en las zonas bajas, más llanas y cómodas, donde los espacios, servicios y accesos eran más favorables. Este proceso fue acelerado por el asedio del castillo que tuvo lugar entre 1475 y 1476 y su posterior conquista por los Reyes Católicos, lo que provocó la destrucción de un gran número de edificios situados en las laderas del cerro. Como se indica en la Crónica de Hernando del Pulgar, los sublevados del castillo no obedecían, y tenían "al Rey de Portogal por su Rey é que habian quemado mas de trecientas casas cercanas al castillo en una calle principal de la cibdad, que se llamaba la calle de las armas". En 1476 "con los ingenios que tenian en la fortaleza, tiraban á la cibdad, é destruian é derribaban muchas casas, é facian tanta guerra, que ninguno podia andar seguro por las calles de la cibdad"149.

Durante el siglo XVI el plano se modificó en dos direcciones, ya que mientras el caserío se ampliaba, y se completaban y aparecían calles nuevas, se aceleraba el proceso de abandono y degradación de los sectores altos de la ciudad, como ya se ha indicado, con una progresiva desaparición de edificios y calles que a fines del siglo llegó a su máxima expresión, dando lugar a la aparición de una ciudad muy distinta150.

\section{b.- Puntos habituales de actividad comercial}

La venta de los productos que llegaban a la ciudad debía realizarse dentro de la muralla y en las proximidades de algunas de sus puertas. Los productos básicos para el consumo tenían unos lugares fijos y en algunos casos eran puntos de venta obligatoria. Su situación estaba determinada en general por los caminos a través de los cuales llegaba la mayor parte de dichas mercaderías. El pescado de mar tenía su mercado en la puerta de San Esteban, lugar de acceso directo desde los puertos de Laredo y Castro-Urdiales, mientras el que se vendía en las pescaderías entraba por la puerta de San Gil. En cambio el pescado de río se debía vender en la plaza y subida del Azogue ${ }^{151}$. La madera, leña y paja tenían su punto de venta en la puerta de Santa María, lugar de entrada de las carretas que venían de la Sierra,

147 Las murallas se construyeron a partir de 1276 y se finalizaron en la primera mitad del s. XIV. CRESPO REDONDO,

J.: 2007: 392-394.

148 CRESPO REDONDO, J.: 2007: 15-16.

149 PULGAR, Hernando del: "Crónica de los señores Reyes Católicos Don Fernando y Doña Isabel de Castilla y de Aragón". Imprenta de Benito Monfort. Valencia, 1780: 62-63 y 69.

150 IBÁÑ̃Z PÉREZ, A. C.: 1990: 14.

151 El Azogue, se situaba en la subida a San Nicolás. 
y por esta misma puerta, entraban los cereales que se debían vender en el mercado de la Llana ${ }^{152}$. Hay no obstante dos grandes plazas, llamadas del Mercado Mayor y del Mercado Menor, que constituyen por excelencia la verdadera base mercadera de la ciudad ${ }^{153}$ donde se vendía la mayor parte de los productos de consumo.

Tenemos numerosas y tempranas referencias sobre los mercados burgaleses. Ya en 1120 la reina Urraca, a ruego de Domingo de Falcóniz, sacristán de la catedral, concede a esta y a su obispo Jimeno el diezmo del mercado y de los baños de Burgos para el alumbrado y ornamento de la catedral ${ }^{154}$. Alfonso VII otorgará en 1128 al obispo y su Cabildo, el diezmo de los derechos reales sobre diversos bienes y el "mercato et de la plana", siendo esta la primera referencia que encontramos sobre el mercado de La Llana155. Otra referencia aparece en 1241, cuando se cambian entre el convento de Santa María de Frías y Martín Conzález unas casas en el barrio de Cantarranas junto a otras casas delante del mercado de Burgos ${ }^{156}$.

En 1312 se concreta que "qualquier que traye pan a uender a Burgos que lo deue traer a La Llana", y ese año se cita una casa que el monasterio de las Huelgas tiene, "en el Açoge, do venden el pan cocho", "et que aquellos bancos que alla auien que ge los daua el conçeio en la carneçeria del mercado"157. El concejo de Burgos y el cabildo de la Catedral otorgan en 1334 escritura de concordia, resolviendo el pleito que litigaban acerca del derecho de las "cuezas", percibido por dicho Cabildo en la Llana158.

Por cédula de Enrique IV se ordenaba en 1463 a la Justicia de Burgos que cumpliese el privilegio por el cual todos los pescados frescos que llegasen a la ciudad, debían entrar por la puerta de San Esteban, descargar y pesar en la red junto a la iglesia, y repartir en ella para la red la plaza del Azogue y el Mercado159.

En las ordenanzas de la ciudad de 1497 se detalla dónde se situaban las pescaderías, ya que los "ueynte pescadores sean rrepartidos por los fieles en esta guisa; que los diez dellos esten en el Mercado Mayor y los otros seys en el Azogue y los otros a Santisteban", y que "puesto alli el pescado, los pescadores e mulateros que estobieren en el Mercado Mayor para bender alli el pescado fresco, sean tenidos y obligados de dar del pescado que alli biniere a los monjes del monesterio de Miraflores..." ${ }^{160}$, es decir, que la mayor parte del pescado fresco se vende en el Mercado Mayor. En 1562 se alude a "la entrada de las carniçerias por la parte del Mercado Mayor y Menor que esta hecho de madera"161.

152 IBÁÑ̃EZ PÉREZ, A. C.: 1990: 187.

153 El Mercado Mayor, se situaba en las actuales plazas de Santo Domingo y de la Libertad, ya que el edificio de los soportales de Antón no se construyó hasta varios siglos después. El Menor, se asentaba en la actual plaza Mayor.

154 A. Cat. B./Vol. 24, f. 1/1120; MONTERDE ALBIAC, C.: 1996: doc. 152: 239-240; SERRANO, L.: 1935: t. III. doc. $79,147-148$.

155 A. Cat. B./ Vol. 2, parte 1, f. 6/ 8 julio 1128; SERRANO, L.: 1935: t. III. doc. 89, 161-162.

156 A. H. N./ Ntra. Sra. de Bujedo. P. 9/ Burgos? 1241; MENÉNDEZ PIDAL, R: 1919. doc. 192, 247.

157 A. M. H. B./ Leg. 26, num. 1.057/ 21 y 25 enero 1312.

158 A. M. B./ HI-1784/ Burgos, 2 y 9 abril 1334.

159 LÓPEZ MATA, T.: 1952: 15-16.

160 A. M. B./ HI-1438/ Burgos, 15 febrero 1497; Palencia, 4 junio 1522 y Madrid, 27 abril 1528.

161 A. M. B./ HI-1659/ Madrid, 17 agosto y Burgos, 29 octubre 1562. 


\section{c.- Las puertas}

A la ciudad llegaba un buen número de caminos, y cada uno de ellos se correspondía con una de las puertas de su muralla. El acceso se realizaba por calles determinadas, que debían tener un firme reforzado capaz de soportar el maltrato que realizaban las carretas y carros cargados, y que debían poseer además una determinada anchura tanto para permitir la circulación de los vehículos, como para maniobrar y permitir el paso en las dos direcciones.

En el exterior del recinto amurallado la ciudad crece a la vera de las principales vías de comunicación, que en su mayoría se encontraban empedradas ${ }^{162}$, dentro de unos arrabales que crecen con la instalación de mesones, posadas, almacenes de mercancías, conventos y monasterios. De las ocho puertas -aparte de la más pequeña de Santa Gadea y el portillo de doña Lambra- con anchura adecuada, tenemos las vías siguientes:

- Por la puerta de San Martín salía el camino que llevaba las mercaderías por la actual carretera de Quintanadueñas a Santander, San Vicente de la Barquera y Campoo. También por el antiguo arrabal de San Pedro de la Fuente y puente de los Malatos, salía el camino de Palencia, Valladolid, Medina del Campo, Medina de Rioseco, Zamora, Portugal y el Camino de Santiago por Carrión de los Condes y León. En lugar cercano se instaló el monasterio de Las Huelgas (1187) y el Hospital del Rey (1195).

- La puerta de Santa María era la más importante y transitada, y alojaba el regimiento de la ciudad. Por ella y el arrabal de Vega salían los caminos de Segovia, Madrid -de importancia creciente tras establecerse la capital y sede de la corte en 1561-, Aranda, Soria, Arcos y Santa María del Campo. Dicho arrabal será el punto de mayor desarrollo extramuros de la ciudad en el siglo XVI, y donde se instalen los conventos de San Felices o cistercienses calatravas (1568) y el de San Luis (1537). Más allá, ya se encontraba el de San Agustín (1215).

- Por la puerta de las Carretas, como su nombre indica, llegaban las carretas de Valladolid, Medina del Campo, Aranda, Soria, Segovia y Madrid, que accedían directamente a la plaza del Mercado Menor. Por no encontrarse frente a puente alguno, su acceso se debía realizar desde una rampa del puente de Santa María por la orilla derecha del Arlanzón aguas arriba, entre el río y la muralla.

- La puerta de San Pablo recibe el nombre del convento dominico de San Pablo (1224) y daba acceso directo a la plaza del Mercado Mayor. Su utilización fue más discreta como consecuencia de que el puente de su nombre no permitía el paso de carretas, y se mantuvo en un estado deficiente. Para salir de la ciudad en dirección Sur se utilizó mayoritariamente la Puerta de Santa María.

- Por la puerta de San Juan, arrabal de San Juan y calle de las Calzadas, salía el camino de Bayona que se dirigía a Pancorbo, Vitoria y Francia, el de Bilbao por Orduña y el Camino de Santiago a La Rioja y Aragón. Junto al camino se asentó el monasterio benedictino de San Juan (1091) y el convento de San Bernardo (1569).

162 A. M. B./ HI-4188/Valladolid, 23 febrero 1554, "y para adereçar çiertos caminos y hazer una calçada en el arrabal de Sant Juan"; A. G. S./ Cámara de Castilla. Pueblos, leg. 4-1, doc. 55/ Burgos, 1510, "libraron a maestre Guillen enpedrador e a sus consortes de resto de la calçada de San Françisco". 
- La puerta de Santander y la Margarita carecieron de importancia para el tráfico y circulación exterior. Se encontraba muy cerca el convento de agustinas de San Ildefonso (1456), único instalado intramuros de la ciudad.

- Por la puerta de San Gil y arrabal de San Francisco salía el camino empedrado, actual calle de San Francisco, a Laredo, Castro-Urdiales y Bilbao por Valmaseda, y el que iba a Poza de la Sal y Oña. Fue la puerta principal para el comercio burgalés, ya que era la salida natural hacia los puertos mencionados desde el mercado de la Llana, donde se comerciaban las lanas. Soportaba un tráfico intenso de carros y carretas, por lo que en 1570 el regimiento procedió a ensanchar sus accesos derribando casas. Se instalaron junto al camino los conventos de los Trinitarios (1207) y de San Francisco (h. 1230).

- La puerta de San Esteban, aunque en un principio fue puerta importante como salida para Villatoro y el Norte, acabó siendo una salida y acceso secundario ${ }^{163}$ ya que, en las fechas que estudiamos, los barrios altos habían perdido vitalidad e importancia. No obstante, era la salida hacia los mismos lugares que los de la puerta de San Gil.

- En caminos secundarios se asentaron los conventos de La Victoria o frailes mínimos (1581), Santa Clara (1234), San José y Santa Ana (1582), Madre de Dios (1558), La Merced (1248), Ntra. Sra. del Carmen (1606) y Santa Dorotea (1387-1429).

\section{El portazgo de la puerta de San Juan}

El portazgo de la madera, la sal y otras minucias de la puerta de San Juan fue concedido por Alfonso VIII al monasterio de San Juan de Burgos en 1178, así como los diezmos reales de la villa de Castro-Urdiales y de su puerto164. Ese año concede además "totum portagium et de lignis omnibus et omni madera, et de sale et carbone et de omnibus aliis minuciis, que per barrium Sancti Iohannis transeunt", y el diezmo del portazgo de Monasterio de Rodilla y de Santa Gadea165. En febrero de 1256 Doña Alez y su hermana venden por 30 mrs. a Conzalo Pérez, juez del prior del monasterio de San Juan, todas las casas que tienen en el barrio de San Juan, "so la puerta Uieia"166. Las referencias a "la puerta vieja" en el barrio de San Juan serán desde ahora abundantes ${ }^{167}$.

Hacia 1386 el monasterio de San Juan tenía arrendado el portazgo de la puerta homónima por 1.000 mrs. ${ }^{168}$, algo que el concejo burgalés disputó en diversas ocasiones como en 1386 cuando el prior interpuso un pleito contra el concejo, indicando que el monasterio estaba en posesión de coger "el portadgo de lenna e de sal e de carbon e de maderas, e de todas las otras menunçias que entrauan a la dicha çibdat", por la puerta de San Juan, y que el concejo le despojó del dicho portazgo desde hacía unos 23 años, llevando hasta 1.000 mrs. cada año. Pedía

163 A. H. N./ Clero. Pergaminos. carp. 203, № 17/ Burgos, 9 diciembre 1400, "la cal e el camino corriente que sale de la dicha çiudad de Burgos por la puerta de Sant Esteuan que va contra Villatoro".

164 A. M. B./ S/c/ Burgos, febrero 1178; PEÑA PÉREZ, F. J.: 1983: doc. 36, 47-48.

165 A. M. B./ 1-10-16/ Burgos, 2 septiembre 1178; PEÑA PÉREZ, F. J.: 1983: doc. 38, 51-54.

166 A. M. B./ 3-4-12/ 17 febrero 1256; PEÑA PÉREZ, F. J.: 1983: doc. 87, 128-129.

167 A. M. B./ 1-11-25/ Burgos, 13 mayo 1285; PEÑA PÉREZ, F. J.: 1983: doc. 105, 159-161; / 3-7-15/ Burgos, 20 agosto 1331. doc. 130, pp. 207-208; / S/c./ 1356. doc. 150, pp. 241-258; / S/c./ Burgos, 19 mayor 1371. doc. 153, pp. 264-266; / 3-4-5/ Burgos, 21 junio 1378. doc. 156, pp. 278-282.

168 A. M. B./ Becerro de San Juan, fol. 51r-51v; ed. pág. 58/ C. 1386; PEÑA PÉREZ, F. J.: 1983: doc. 161, 291. 
que el concejo desembargase el portazgo y devolviese las cantidades percibidas en esos años. El concejo respondió que la ciudad poseía los portazgos de tanto tiempo que "non era memoria de ommes en contrario, a tanbien los portadgos de las cosas que entrauan por la puerta de Sant Iohan, commo por todas las otras puertas de la dicha çibdat", y que estaba "en posesion pacifica de auer e leuar continuadamente los dichos portadgos", por lo que no habían hecho tal despojo.

Tras la respuesta del prior sobre que "si alguna posesion ouierades o auiades del dicho portadgo, dixo que la abriades violenta, la qual vos fuera siempre contradicha por los priores del dicho monasterio", se dio por probado que el monasterio estaba "en posesion de coger e leuar en los tiempos pasados el portadgo de todas las lennas, e de toda madera e de sal e de carbon, e de todas las otras menunçias que entrauan a la dicha çibdat" por la puerta de San Juan, y que el monasterio había sido desprovisto de él sin razón ni derecho, y se mandó al concejo que desembargase el portazgo en favor del monasterio. En junio de 1386 por sentencia definitiva se mandó al concejo que devolviese al monasterio todo lo que los portazgueros juraren que ha rendido el portazgo, y le pague 409.000 mrs. de las costas ${ }^{169}$.

El abad del monasterio de San Juan indicó en 1521 que de tiempo inmemorial están en posesión "de llebar çierta rrenta del portazgo desta çibdad ques de la leña e otras cosas que entran por la puerta de San Juan", que lo tienen por privilegio muy antiguo, y que ahora "con estos mubimyentos pasados, la cumunydad de hecho como no avia justiçia, nos lo quytaron a aun hasta agora no nos lo an dexado coger", y pide que nadie impida dicha posesión. El Rey manda al corregidor en junio de 1521 que provea sobre ello para que "çese la novedad fecha en tiempo de la cumunydad". Juan López de Benavente, en nombre del concejo, respondió que no estaban obligados a nada de lo pedido porque el monasterio no había llevado el portazgo que dice, y si lo hubiese llevado sería sin título ni buena fe, y como el monasterio no habría llevado el dicho portazgo por tanto tiempo como para poder adquirir derecho alguno, el privilegio que menciona no podía ser guardado. En septiembre se condena a la ciudad y sus regidores, y se confirma al monasterio la posesión del portazgo de San Juan ${ }^{170}$.

En enero de 1537 el concejo dio un mandamiento a la guarda de la barra de la puerta de San Juan para que no dejase entrar por ella a ninguna persona con carro, carreta, caballería con leña u otros bastimentos, por el perjuicio que recibía el puente de dicha puerta. El monasterio alegó que era muy perjudicial para él y los vecinos del barrio de San Juan, en especial porque el portazgo de todos los géneros que entrasen por dicha puerta pertenecía al monasterio, y presentó una ejecutoria y otros argumentos. En noviembre de 1539 la Chancillería libra una ejecutoria a favor del monasterio y revocó el citado mandamiento, mandando que pudiese pasar libremente cualquier mercadería en carretas por el referido puente y puerta de San Juan. Parece ser que tras esta ejecutoria la ciudad concertó con el monasterio el portazgo de esta puerta, pagando al monasterio $4.500 \mathrm{mrs}$. anuales por dicho portazguillo ${ }^{171}$.

169 A. M. B./ Hca. 1-11-25/ Burgos, 18 junio 1386; PEÑA PÉREZ, F. J.: 1983: doc. 162, 291-297.

A. M. B./ Histórica, C-3-2-10/1/17 junio 1521. 


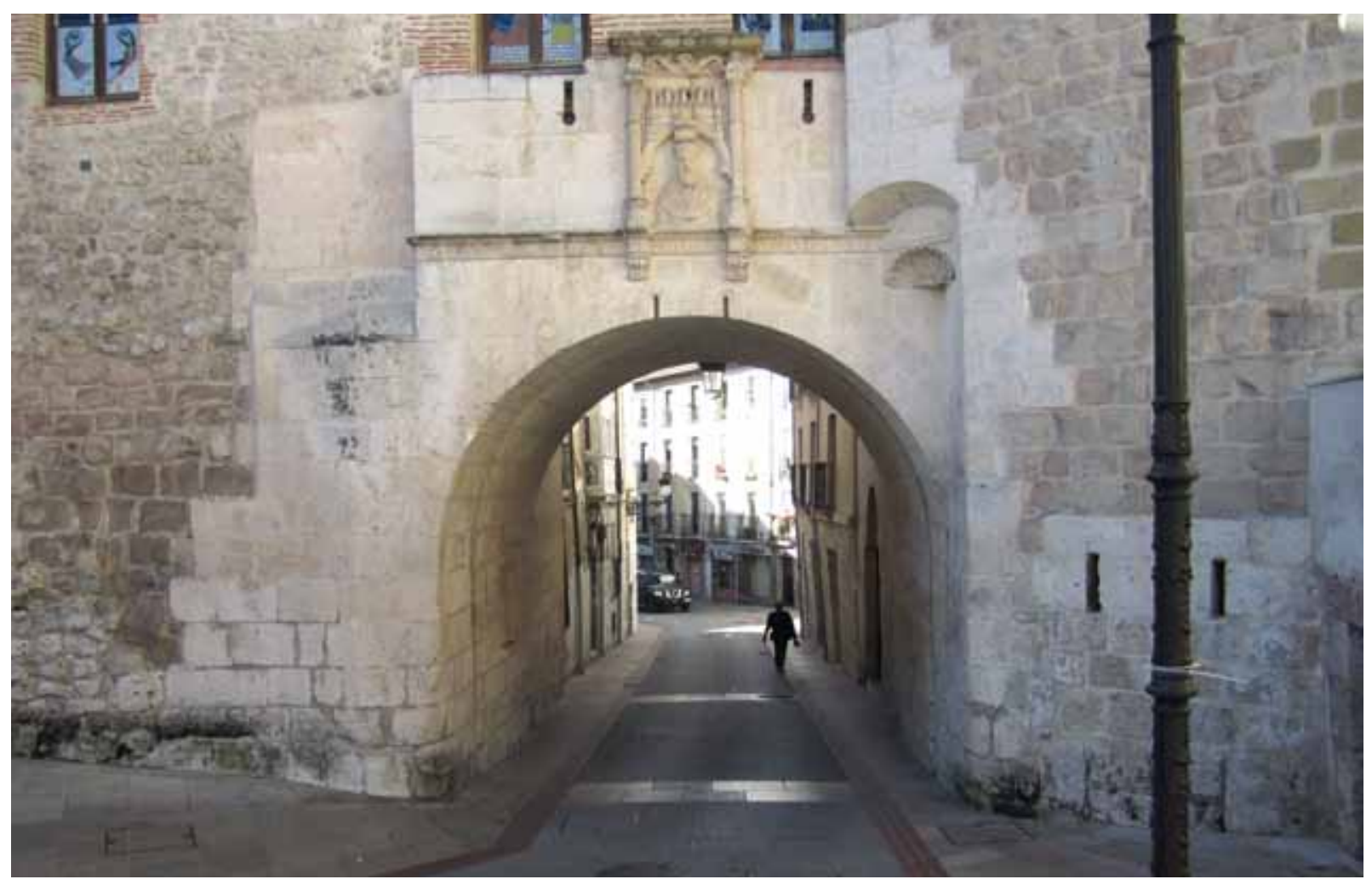

Puerta de San Gil de Burgos.

\section{El ensanche de la puerta de San Gil}

En regimiento de agosto de 1570 los procuradores mayores de la ciudad de Burgos dijeron que hacía mucho tiempo que se trataba sobre el ensanche del paso de la puerta de San Cil, por ser la dicha entrada y calle "muy estrecha, y una de las mas pasaxeras, y en donde mas gente concurre desta cibdad, e por donde entran todas las mercaderias que bienen de Flandes, Francia e otras partes a estos rreynos, e por donde entran e salen la carreteria que biene de montañas, asi como pastel, lanas e otras cosas", además de haber a su salida dos monasterios importantes, como son el de la Trinidad y el de San Francisco, y dentro la iglesia de San Gil, además de pasar por dicha puerta y calle gran parte de los mantenimientos que llegan a la ciudad. Era habitual que cuando un carro entraba o salía por esa puerta, no podía cruzar nadie a caballo ni apenas a pie, y se topaban además los carros para entrar y salir. Por ello "se padesze muy gran trabaxo y nezesidad, y la gente que quiere entrar o salir se detiene, y aun acaheze ponerse a peligro de pasar casi enttre los pies de los bueyes y mulas, de suerte que la dicha entrada es muy ynfame para qualquiera publico". Además, como "la rreyna nuestra señora a de benir,... a desembarcar en uno de los puertos desta costa, y a de enttrar por la dich a puerta y calle, toda la corte y caballeria que con ella biene, y su rrecamara", algo que ocurrió el 23 de octubre de ese año, era necesario ensanchar dicha entrada y calle. El regimiento mandó derribar con urgencia las casas, vuelos y saledizos necesarios, desde las casas de Diego de Soria a la misma puerta de San Cil a cordel, y todo cargado a los gastos del recibimiento de la Reina ${ }^{172}$.

En septiembre de 1573 Isabel y Bernardina de Miranda, monjas en Villamayor de los Montes, otorgaron cartas de pago y finiquito al haber recibido de la ciudad 106.533 mrs., 
como herederas de sus padres Juan de Miranda e Isabel de Frías, sobre los 500 ds. más 400 rs. de interés por la demora del pago de la compra de unas casas que dichas herederas tenían en la rúa de San Gil cerca de la puerta de San Gil, lindando con casas de Alonso de Valdivielso y con otras de los clérigos de San Gil por la parte de adelante, y a los lados con la calle, placeta y paso público que va a la iglesia y puerta de San Cil, derribadas para ensanchar la calle y plazuela de San Gill73. Todavía en septiembre de 1578 Alonso de Valdivielso, vecino de Burgos, otorgó escritura de censo perpetuo y subrogación en favor del mayorazgo que fundó su abuela, Isabel de Santotis, de 161.250 mrs. de principal y 4.745 de renta, por los mismos que depositó la ciudad de Burgos por el valor de unas casas que la ciudad compró y derribó en la rúa de San Gil para ensanchar la entrada y hacer calle y plaza pública ${ }^{174}$.

\section{d.- Los puentes de la ciudad}

La ciudad estaba flanqueada por el Sur por el río Arlanzón y por el Este por el Vena, actuando ambos, como fosos naturales de sus murallas. Además, por su casco urbano discurrían tres ríos urbanos o esguevas sangradas al río Vena: la Algebina o río Merdoncho, la de Trascorrales, bifurcada en la de Santa Cadea y la de la Panadería, y la de La Moneda, y que actuaban en beneficio de la higiene pública. Pero si exceptuamos los puentes urbanos sobre las esguevas ${ }^{175}$, cuatro eran los destacados, tres sobre el río principal o Arlanzón: El de San Pablo, Santa María y los Malatos, y uno sobre el río Vena: el de San Juan. El que arroja fechas más antiguas es el de los Malatos, con citas del año 1165. El de Santa María se menciona por primera vez en un documento del siglo XII, y el de San Pablo sabemos que se deteriora en 1242 por una riada. En 1527 se menciona el puente de San Juan, aunque dicho puente o su antecedente debió construirse a fines del siglo XI, con motivo de la fundación del monasterio de San Juan. Estos cuatro puentes mencionados sufrieron a lo largo de su historia gran número de riadas, que en muchos casos los deterioraron gravemente.

En agosto de 1165 Don Pedro obispo de Burgos dona de acuerdo con el Cabildo a Arnaldo, a sus familiares y a los leprosos del hospital de los Malatos una heredad "in barrio Santi Petri, iuxta pontem" de los Malatos, con la condición de que se hicieran vasallos de los citados donantes y del pago anual de una carga de juncos ${ }^{176}$. En mayo de 1209 Martín de Villalbilla y Urraca, donan al Hospital del Rey una tierra situada debajo del dicho puente, a cambio de una pasada de tierra y 30 mrs. y Adán cede a Pelayo y Pedro, freires del hospital "de la Reina”, una tierra situada bajo este puente a cambio de una pasada de tierra en casa de Pe-

173 A. M. B./ HI-1583/ Burgos, 23 febrero a 10 abril 1573; HI-992/ Burgos, 19 junio a 3 agosto 1573 y HI-993 y $994 /$ Villamayor de los Montes, 8 septiembre 1573.

174 A. M. B./ HI-1375/ Burgos, 30 septiembre 1578.

175 Hubo al menos 17 puentes, de los que tan sólo los dos del Bayllo se situaban extramuros. Sobre la esgueva Algebina, se encontraba el puente de San Gil. Sobre la de Trascorrales, los puentes del Bayllo Menor, Tanerías y Trascorrales. Sobre la de Santa Gadea, el de Gallinería, Panadería, Cerrajería, Sarmental, Caldabares y Santa Gadea. Sobre la de la Panadería, los puentes de Pescadería y de Panadería. Por último sobre la esgueva de La Moneda, los puentes del Bayllo Mayor, San Ildefonso, La Moneda, Trigueros y del Arco de la Cárcel.

176 A. Cat. B./ Vol. 53, fol 681/ agosto 1165; GARRIDO GARRIDO, J. M.: 1983: doc. 168, 271. 


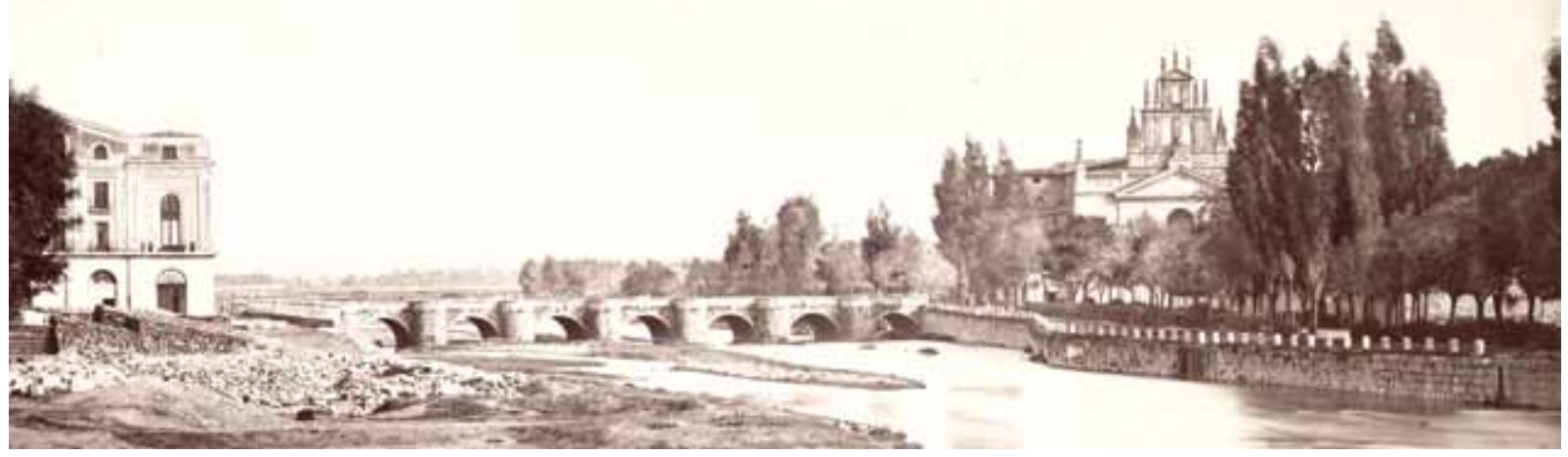

Puente de San Pablo de Burgos en 1864. (B. N., Auguste Muriel. Archivo Ruiz Vernacci Casa fotográfica de Laurent).

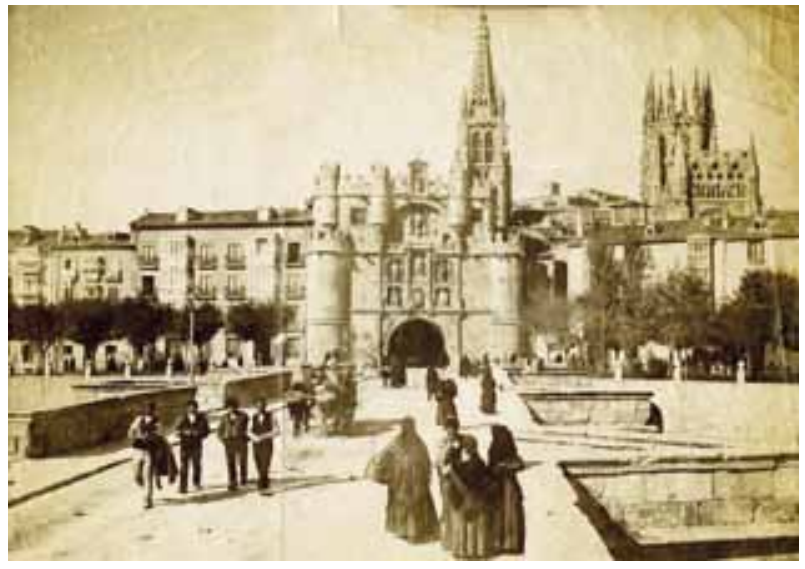

Puente de Santa María de Burgos hacia 1885. (A. M. B., FC-4084 L. Lévy).

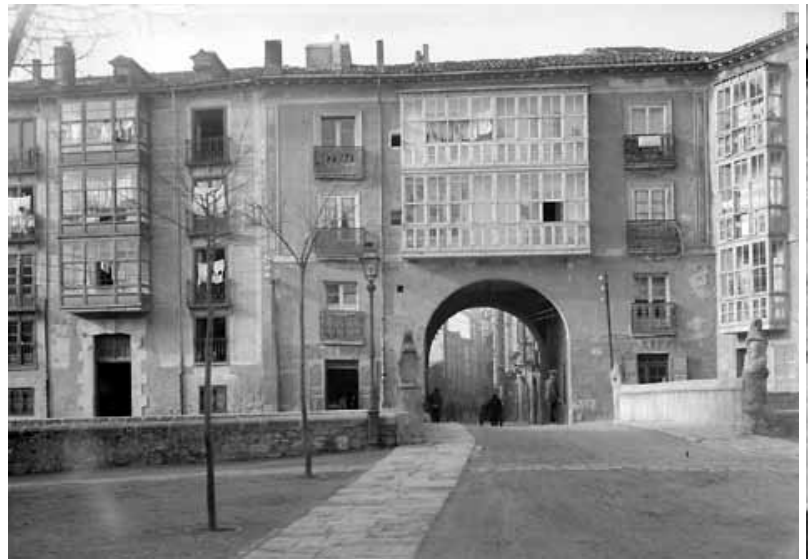

Puente y puerta de San Juan de Burgos. (A. M. B., FO-0238).

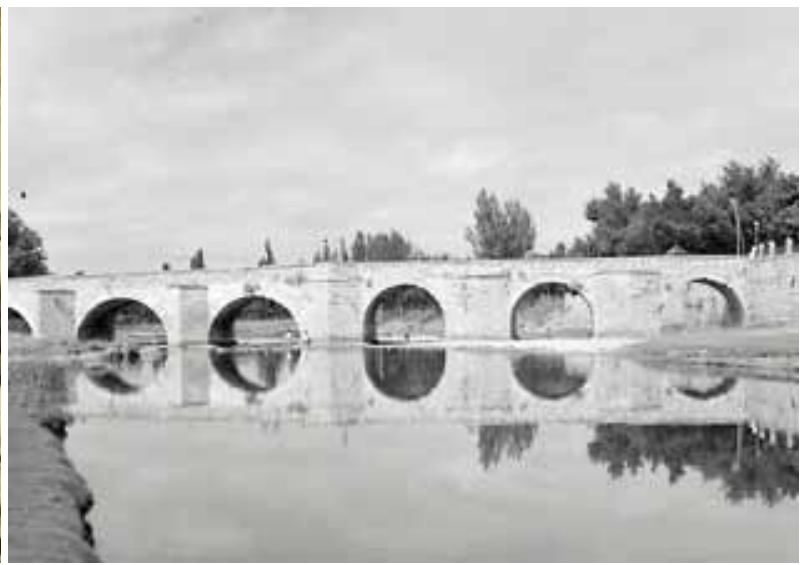

Puente de los Malatos de Burgos entre 1927 y 1936. (B. N., Arch. Loty António Passaporte).

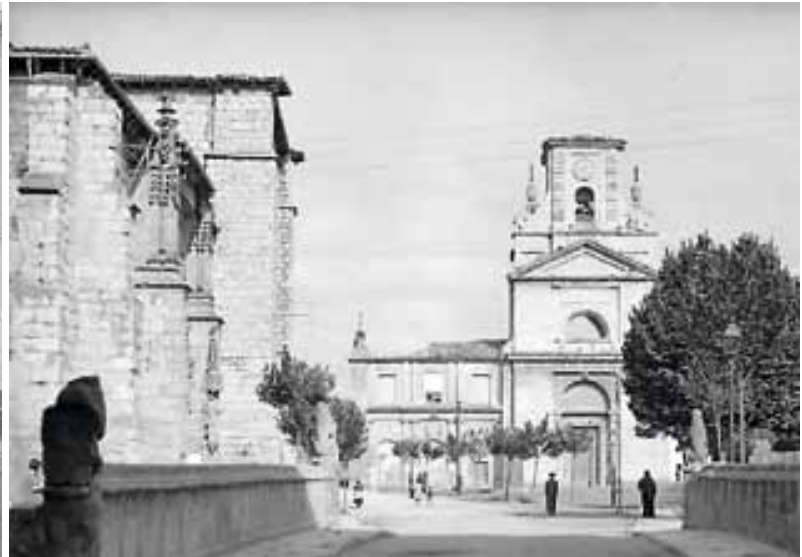

Puente de San Juan de Burgos 1927-36. (B. N., Arch. Loty António Passaporte)

dro Robert y 16 mrs., y Ava y su hermana Estefanía ceden a dichos freires, dos tierras que tienen bajo el mismo puente a cambio de una pasada de tierra en casa de Pedro Robert y 85 mrs. ${ }^{177}$. En octubre de 1210 se dan a la reina Leonor para el Hospital del Rey tierras situadas bajo el puente de los Malatos: Gonzalo de Vivar y María Pérez a cambio de una pasada

177 A. Palacio Real/ Libro Tumbo, fols. 374r y 274V/ mayo 1209; PALACÍN GÁLVEZ, Mª C. y MARTÍNEZ GARCÍA, L.: 1990: docs. 28, 30 y 31: 33, 34 y 35-36. "Ospital de la Regina, que es so el Monasterio de Sancta Maria Regalis, cerca del camino so la puente de los Malaptos". 
de tierra y 70 mrs.; Juan de Soto y su mujer, a cambio de una pasada de tierra y 20 mrs.; Diego Romo a cambio de una pasada de tierra y 11 mrs. alfonsinos y Martín Fernández del Rincón, a cambio de una pasada de tierra y $30 \mathrm{mrs}$. alfonsinos. Las menciones a este puente serán continuas durante 1210 y $1211^{178}$. En 1232 el capellán de la infanta Constanza realiza, por mandato de esta, el apeo de las propiedades del monasterio de Las Huelgas, en el que se alude al puente de los Malatos ${ }^{179}$. Juan II ordena en julio de 1422 a Juan Martínez, alcalde de Burgos, que reciba información acerca del estado de las cuentas, rentas y gastos del concejo tras la solicitud realizada por este para imponer una sisa sobre el vino con el fin de reparar este puente, la torre de Santa María y la cerca de la ciudad ${ }^{180}$.

En febrero de 1178 Alfonso VIII concede autorización a los usufructuarios de casas y heredades del barrio de San Juan, situadas entre el molino del Conde, el puente de San Gil, el río Arlanzón y cauce, para que puedan venderlas, empeñarlas o donarlas, siempre que se garantice al monasterio de San Juan el cobro de los censos y diezmos correspondientes ${ }^{181}$. En 1527 una riada se llevó el puente de San Juan, encargándose su reconstrucción a los maestros de cantería Ochoa de Arteaga y Juan de Salas, especificando en 1533 la anchura del puente, el remate de las esquinas y las escaleras para "subir a la barbacana del un cubo $e$ del otro..."182.

En el s. XII Pedro Martínez, prior de la iglesia de Burgos, dona a la catedral un molino sito bajo el puente de Santa María y una heredad en el pontón de Bayllo con la condición de que los disfruten sus hijos y sus herederos, pagando a la catedral cierta cantidad anual para los canónigos, pobres y alumbrado de una lámpara ${ }^{183}$.En julio de 1209 se pronuncia sentencia judicial por el arcipreste Diego de Frías y Juan el carpintero en el pleito sostenido entre el cabildo de Burgos y don Pedro, capellán de la Reina, sobre el molino de Orejuelo y el del puente de Santa María propiedad del Cabildo, para que Pedro deshaga la presa que tiene hecha y el agua de las avenidas no haga daño al molino ${ }^{184}$. El concejo de Burgos dona en 1273 a Sancho Pérez, notario de la Cámara del Rey, un solar propiedad del Concejo tras la torre del puente de Santa María ${ }^{185}$. Pedro Carrillo envía carta a la ciudad de Burgos en 1395, en respuesta de otra, sobre conseguir una provisión para que cerca del puente de Santa María, Juan Sánchez de Vergara construya una aceña, a lo que se opuso el monasterio de las Huelgas, pero a pesar de esto, manifiesta que solicitará al Rey dicha Provisión por entender que no perjudica al monasterio. El Consejo Real libró la Provisión ${ }^{186}$.

178 A. Palacio Real/ Libro Tumbo, fols. 374V y 375r/ octubre 1210; PALACÍN GÁLVEZ, Mª C. y MARTÍNEZ GARCÍA, L.: 1990: docs. 38, 39, 40, 41, 42, 43, 45 y 46: 44, 45.

179 A. Palacio Real/ Caja 183, exp. 6/ 1232; LIZOAIN GARRIDO, J. M.: 1985: t. II: doc. 269, 21-26. "Otra serna ha la puent de los Malatos".

180 A. M. B./ HI-3784/ Ocaña, 19 julio 1422

181 A. M. B./ HI-108/ Burgos, febrero 1178.

182 A. M. B./ Actas municipales; LÓPEZ MATA, T.: 1949: 232.

183 A. Cat. B./Vol. 70, nํ5 52 y 180/ siglo XII; GARRIDO GARRIDO, J. M.: 1983: docs. 342 y 345, 132 y 135. "et illo meo molino qui est de yuso de la ponte de Sancta Maria, qui fuit de me auuelo; et tota mia terra quam habeo al ponton de Uayllo...".

184 A. Cat. B./ Vol. 70, no 256/ 15 julio 1209; GARRIDO GARRIDO, J. M.: 1983: doc. 418, 215.

185 A. M. B./ HI-806/ Burgos, 4 agosto 1273.

186 A. M. B./ HI-586/ 28 septiembre 1395. 
En agosto de 1523 Carlos I dice al corregidor de Burgos y a los alcaldes, jueces y justicias de la ciudad, que está pendiente un pleito en la Chancillería entre la ciudad y el cabildo de la Iglesia, sobre las casas y boticas que la ciudad hace en el puente de los Trigueros, en el que, a pedimiento del procurador del Cabildo, la Audiencia mandó que no continuasen dichas obras y estuvo la obra parada. Después de pasado el plazo el procurador de la ciudad pidió licencia para continuar, y dio fianzas para demolerlo si fuesen condenados. El Presidente y oidores mandaron dar carta a fin de que la ciudad pudiese edificar las dichas casas y boticas, recibiendo fianzas para que si fueren condenados, demolerían a su costa lo realizado, y fue acordado levantar el embargo ${ }^{187}$.

En diciembre 1569 Andrés de Santotís dio una escritura a favor de la ciudad de Burgos, que indicaba que como sus justicias y regimiento no querían dar licencia para hacer un puente de madera, pero por hacerle merced, se cometió al regidor para que lo viese y determinase si se había de hacer o no, y que aunque la ciudad no estaba obligada dio licencia para hacerlo, a condición de que Santotís haga el puente a su costa, lo ponga a nombre de la ciudad, y fortifique el paredón que al objeto de hacer el puente se ha de romper. La ciudad no tendrá ningún gasto, y lo quitará cuando lo manden las justicias y ayuntamiento. Santotís indica que se le hace mucha merced y se obliga a hacer el puente a su costa y fortificará el paredón que se ha de romper, y cuando la ciudad le mande deshacer, lo quitará y lo pondrá todo como ahora está ${ }^{188}$.

En agosto de 1589 se ponen las condiciones que ha de tener el puente de Bayllo que se ha de hacer para pasar al prado. Irá desde el paredón de piedra que está al cabo de la calleja, hasta el otro paredón de piedra que está en el mismo prado, y ha de tener 12 pies de ancho sin los andenes. Tendrá dos puercas encadenadas con sus estacas en sus agujeros, y en estos llevará en cada puerca dos postes espigados y dos marranas de olmo, de al menos un pie de escuadra. Ha de llevar 6 vigas de olmo en gruesas de banda a banda en que carguen las soleras, e irá cuajada de soleras por encima, de cuatro dedos de grueso de roble u olmo, y dos andenes a los lados con sus barandas bien cepilladas y achaflanadas de tres en tres pies de poste, labra ochavada en los postes espigados y bien clavados. Ha de tener tres barandas de lado a lado y las vigas, puercas y marranas han de ir clavadas como convenga. Habrá dos postes en medio de 9 pies, por si tuviere que tener puerta con su horca y pueda pasar una carreta. El maestro pondrá todos los materiales y clavazón, tanto para hacer el puente, como para quitar el agua y volverla a la ciudad, y tres vigas en el arroyo junto a la casa de Juan de Quintanadueñas, pagándole lo que se concertare. La ciudad le dará seis olmos de los ejidos de la ciudad, además de la madera vieja y despojos del puente. Hernando del Río maestro de carpintería y vecino de Burgos, hizo postura en 24 ducados, dejándolo hecho para San Miguel de 1589. En septiembre compareció de nuevo dejando la postura con las mismas condiciones en 22 ducados. Visto por el corregidor y no habiendo otra mejor postura, remató la obra en Hernando del Río en dichos 22 ducados ${ }^{189}$.

187 A. M. B./ HI-3787/Valladolid, 18 agosto 1523.

188 A. M. B./ HI-4930/ Burgos, 21 diciembre 1569.

189 A. M. B./ HI-4934/ Burgos, 24 agosto y 5 septiembre 1589. 


\section{Reparaciones de los puentes}

La ciudad ha padecido grandes inundaciones ocasionadas por los ríos Pico y Vena y Arlanzón, que aunque con poco agua en verano, en épocas de lluvias y sobre todo cuando estas coincidían con los deshielos, sus caudales alcanzaban alturas considerables. De las abundantes riadas, a veces catastróficas, que afectaron a la ciudad nos han llegado noticias de las ocurridas en 1242, 1255, 1286, 1527, 1571 y 1582, siendo las de 1527 y 1582, las que más destrozos ocasionaron. Esta realidad, obligaba a realizar continuas reparaciones, y a veces su utilización quedaba interrumpida durante largos periodos como consecuencia de la lentitud de las intervenciones.

En 1432 se realizan obras de reparación en el puente de los Malatos, para lo que Juan II otorga licencia a fin de imponer sisa por 3 años sobre el vino, "dos meajas al maravedi, de todo el vino que se vendiese en esta çibdad e rravales evarrios"190.

En septiembre de 1510 el corregidor mandó comparecer a los "canteros" Francisco de Colonia y Rodrigo de Pontecillas para recibir información sobre las intervenciones que se debían realizar en torres, cercas y puentes de la ciudad. Visitaron, entre otros puntos, dos arcos del puente de San Pablo con sus tres pilares, dos pretiles del puente de los Malatos que estaban muy peligrosos y otros dos del mismo puente mal reparados. Vieron también en el puente de Santa María ocho arcos con ocho pilares que dijeron que necesitaban remedio, tasando todas las intervenciones necesarias en unos 2.000 ds. de oro ${ }^{191}$. Para afrontar estos gastos, la ciudad realiza una memoria de sus propios y rentas, de lo que paga de ordinario anualmente y de lo que se gasta cada año de manera extraordinaria ${ }^{192}$.

En octubre de 1547 Carlos I recibe petición del concejo de Burgos diciendo que en término y jurisdicción de la ciudad y camino real, "hay muchas puentes y pontones caydos y llebados de las grandes aguas de los ynbiernos pasados, e que con las grandes abenidas, estaban los caminos muy perdidos e abia muy malos pasos a do pereçia much gente, y pasaban muy gran trabajo los caminantes que pasaban a Guipuzcoa, Bizcaya y Nabarra y a Françia", y que la ciudad recibía gran daño por ser de acarreo y no poder llegar a ella los mantenimientos. Además, dentro de la ciudad el río mayor había comido un cauce que llevaba agua a muchas huertas y molinos y era necesario hacer un azud de cal y canto de 600 tapiales que costaría 600.000 mrs. Por una Provisión real se habían repartido a la ciudad $350.000 \mathrm{mrs}$. para el edificio del puente de Tardajos, que estaba caído "en el camyno françes, una legua de hesa dicha çibdad", y para el daño causado hacía unos 6 años por un terremoto, en los muros y cerca de la ciudad. Como la ciudad era muy pobre de propios y rentas y no podía remediar nada de lo expuesto, porque debía más de 500.000 mrs. de "la puente y calçada de Bunyel en el camyno real de Valladolid, y la otra la puente y calçada de Castil Cerraçin por donde venyan muchos bastimentos a esa dicha çiudad", que el corregidor había hecho, pidió al Rey licencia para echar por sisa en los mantenimientos 4.000 ds., ya que si no se hiciese con brevedad se necesitaría después mayor cantidad de mrs. El Consejo acordó dar licencia para poder echar por sisa en los mantenimientos que se vendieren hasta 1.500 ds., los cuales se debían gastar en las cosas necesarias y no en otra cosa ${ }^{193}$.

190 A. M. B./ Actas municipales, 1431-1433, fol. 42, 43, 62 y 75/ Burgos, 1432.

191 A. G. S./ Cámara de Castilla. Pueblos, leg. 1-1 doc. 55 (bis)/ Burgos, 23 septiembre 1510.

192 A. G. S./ Cámara de Castilla. Pueblos, leg. 4-1, doc. 55/ Burgos, 1510.

193 A. M. B./ HI-1438/ Aranda de Duero, 21 octubre 1547. 
El concejo de Burgos indica que para pagar lo que fue repartido con destino al reparo de los puentes de la ciudad y del de Quintana, Tardajos y otros, aderezar ciertos caminos, hacer una calzada en el arrabal de San Juan, y acabar la cárcel, tuvo licencia para echar por sisa hasta 2.000 ds., los cuales se habían gastado en ello, y como el edificio de la casa y caminos no estaban acabados, pidió nueva licencia para echar por sisa otros 4.000 ds., sobre lo cual el Consejo mandó que se detallase en qué se habían gastado los 2.000 ds. anteriores, y se obtuviese información sobre los mrs. que faltaban para acabar las obras. El Consejo acordó en febrero de 1554 dar licencia para echar por sisa sobre los mantenimientos que en la ciudad se vendieren hasta 1.500 ds. para dichos edificios, indicando que se deben depositar en poder del mayordomo de la ciudad o de otra persona honrada para que no se gasten en otra cosa194.

El concejo de la ciudad dijo al Rey que desde 1569 hasta fin de 1573, se habían hecho repartimientos para reparos de puentes por valor de 654.006 mrs. , y como no tenían de donde pagarlos pidieron licencia para echar por sisa dicha cantidad en los mantenimientos que con menos daño de los vecinos se pudiesen recaudar. El Consejo mandó al corregidor que hiciese sobre ello cierta información y con su parecer se lo enviase, y dio licencia en junio de 1574 para echar sisa sobre el vino que en la ciudad se vendiere hasta 792.000 mrs. que se habían repartido para los puentes, y se vaya depositando en poder de una buena persona vecino de la ciudad ${ }^{195}$.

En las Juntas de Vizcaya de septiembre de 1574 se trató sobre que en los últimos años, mediante provisiones del Consejo Real a pedimento de algunos pueblos, se les habían repartido para los puentes de Pancorbo y Burgos más de 16.000 mrs., y para cobrarlo había ido un ejecutor con comisión del alcalde mayor del Adelantamiento de la partida de Burgos. Como según ellos estos repartimientos eran injustos, porque el Señorío no tenía ningún aprovechamiento de tales puentes y no tenía dineros suficientes por no tener propios, acordaron pedir al Rey la anulación de tales repartimientos ${ }^{196}$.

Con motivo de la gran avenida de mayo de 1582 que trataremos con detalle, el puente de Santa María se encontraba arruinado en 1583, el de San Pablo no se carreteaba y solo servía de paso para la gente de a pie y de a caballo, porque corría riesgo de hundirse, y el de los Malatos tampoco se carreteaba.

El concejo, justicia y regimiento de Burgos comunicó al Rey que había pagado 662.000 mrs. y después 700.000 mrs. más de repartimientos para puentes de fuera, tomándolos prestados. Pero como no tenía propios ni rentas para pagarlos, pidieron al Rey licencia para tomar a censo sobre sus propios $700.000 \mathrm{mrs}$. El Consejo con la información, diligencias y detalle de cuentas que envió el corregidor, acordó dar licencia en mayo de 1587 para que sobre los propios y rentas, pudiesen tomar a censo al quitar los dichos 700.000 mrs. para pagar los repartimientos de puentes, no pudiéndolos tomar a menos de 14.000 mrs. el millar ni a más de a 20.000, y como garantía de los concejos y personas que dieren los dichos mrs. a censo, pueda el concejo obligar sus propios y rentas y otorgar sobre ello las escrituras y contratos necesarios $^{197}$.

\footnotetext{
194 A. M. B./ HI-4188/Valladolid, 23 febrero 1554.

195 A. M. B./ HI-4168/ Madrid, 2 junio 1574.

196 A. J. R. B./ Actas de la Tierra Llana. t. II/ Bermeo, 28 septiembre 1574.

197 A. M. B./ HI-4151/ Aranjuez, 16 mayo 1587.
} 
El concejo informaba en julio de 1594, que había contribuido "para el reparo y adreço de puentes y calzadas desde 1574 hasta la fecha de esta data, para muy diversos lugares destos rreynos", con una cantidad de 3.246.025 mrs., y lo hacía constar, porque ahora reclamaba ayuda para el reparo de sus puentes ${ }^{198}$.

\section{Inundaciones de enero de 1527}

En la Crónica del emperador Carlos V, realizada por Sandoval, se narran las graves inundaciones acaecidas en Burgos en enero de $1527^{199}$. En abril el Rey recibió petición del concejo porque las avenidas de enero de ese año habían hecho muchos destrozos, suplicando licencia para echar por sisa y por repartimiento los maravedís necesarios. El Consejo Real mandó al corregidor que recibiese información de maestros sobre los dineros necesarios para reparar los puentes de Santa María, de San Juan, todo él caído, de Trascorrales, que está la mitad caído, la torre y puerta de las Carretas, los arcos por donde entra el agua a la casa de la Moneda y otras obras semejantes, que ascendió a 3.500.000 mrs. y más. El Consejo acordó dar licencia a la ciudad para repartir y echar por sisa 4.000 ds. de oro sobre los mantenimientos y otras cosas que en la ciudad se vendieren. Una vez cobrados, no se pedirá más so las penas en que incurren los que cogen nuevas imposiciones sin tener licencia. Los que administren los dineros deberán dar cuenta con detalle y pagarán lo que les fuere alcanzado, no librándose de otra manera, so pena de que los que lo libraren lo paguen de sus propios bienes ${ }^{200}$.

El concejo acordó en abril de 1527 echar sisa en el vino del mercado y la taberna a un mr. por azumbre y un azumbre en la cántara, y cometió al corregidor y a los letrados Pedro Orense y Juan Pérez de Cartagena, para que el cabildo de la Iglesia y otros religiosos contribuyan, porque "en quanto a los puentes e caminos e calçadas e fuentes, que los clerigos son obligados a contribuir, porque es igual probecho suyo que de los legos". Ante la negativa de estos el regidor dijo

198 GARCÍA RÁMILA, I.: 1942: 50.

199 SANDOVAL, F. P. de: 1618: 813-814. "Las nieues demasiadas que cayeron en Otubre, Nouiembre, y Diziembre del año passado, se cuaxaron con los grandes yelos: despues ablandó el tiempo, y derritieronse de suerte que los rios crecieron con gran espanto... Assi fue que creció el rio Arlançon, vn viernes en la noche a la hora de las doze. Començó a venir tan grande furia de agua por aquella ribera, que desde la vega de Miraflores, hasta el campo de Gamonal al traues toda la tierra era vn mar, y entró la ribera tan crecida por la parte de S. Francisco y por la ciudad, y por la parte de Vega, que nunca tal se vio ni oyó... Que desde el huerto del Rey, y por casa de Diego de Soria, entre la casa de Andres de la Cadena con tres corrales, y la cerrageria, y sarmental, carneceria y odreria, con los dos mercados, y las dos cantarranas, y comparada con la puebla, y con el varrio de S. Iuan, y S. Alifonso, con la casa de la moneda hasta juntar con la casa de Pedro de Cartagena, las aguas yuan tan crecidas por todas las partes, y en las calles, y casas de vn gran estado de hombre en alto, que no auia cauallo, si bien poderoso fuesse, que lo pudiera passar. Esta creciente duró hasta el sabado dos horas despues de medio dia. Lleuó la puente de San Lesmes, y vn torrejon que estaua cerca della, y la casa del peso de la harina, y el mismo peso con hasta cincuenta cargas de harina. Tomó en la puente vn azemilero que yua por leña, y se ahogó alli luego, y la azemila fue a parar con mucho trabajo a Vega. Lleuó gran parte de la puente de Santa Maria, y en ella diez y siete hombres y mugeres, que ninguno escapó. En el Monasterio de S. Ilefonso no quedó Monja, que todas salieron huyendo con harto trabajo, fauoreciéndolas Caualleros que con peligro de sus vidas entraron por ellas. El Condestable estaua a esta saçon en Burgos de camino para la Corte, y tenia consigo a la Reyna Leonor, y Delfines de Francia. Visto lo que passaua mouido de piedad subió en vn cauallo, y con otras veynte caualgaduras fue a la puente de Santa Maria por socorrer a las Monjas de S. Dorotea: quiso Dios ayudarle, quando ya entraua en el varrio de Vega, la puente se hundió, que si tardara tres credos mas en la passar, el Condestable, y los que con el yuan perecieran. Finalmente los daños fueron tantos y tan grandes, que sería largo dezirlos. No dexo trox, ni bodega, ni casa que no destruyesse: porque en todas auia vn estado de agua. No quedó pared de huerta en toda la ciudad, ni molinos que no assolasse. En el hospital Real hizo de daño mas de tres mil ducados. Quedó la ciudad de manera que perecian de hambre pobres, y ricos. En otras partes se padecieron otros daños semejantes, porque fue general en España la demasia de aguas, y nieues".

200 A. M. B./ Actas municipales, 1527, fol. 82v/Valladolid, 5 abril 1527; MARTÍNEZ BURGOS, M.: 1952: 31-33. 
que por los graves daños que podrían suceder en la dilación de las intervenciones, y no habiendo dinero para ello si no se hiciere la sisa, se debía volver a requerir al Cabildo para que comprueben que la ciudad no tiene recursos. Se acordó, además, pedir al Consejo que mande que los clérigos contribuyan y, entretanto, manda que se comiencen las dichas obras $^{201}$. A petición de la ciudad, Carlos I dice en julio a Pedro de Valverde, juez conservador del Cabildo Catedral, que había procedido contra la ciudad y sus representantes, que la ciudad tiene licencia para echar por sisa 4.000 ds. de oro. Como las obras se debían realizar, mandó al deán, Cabildo y otros eclesiásticos que contribuyan en la dicha sisa y al juez conservador, "vos rogamos y encargamos que alçeys e quiteys qualesquier çensuras que sobrello ayays fulminado, e absolbays a las personas que teneys dexcomulgados"202.

Juan de Burgos, en nombre de la ciudad, compareció ante el corregidor con una Carta real de julio de 1529 que hacía saber, que aunque el Rey mandó a los clérigos que contribuyesen por estar obligados, y así lo cumplieron todos los eclesiásticos de la ciudad y monasterios de los arrabales, los compases del hospital del Rey y de las Huelgas no lo hicieron, siendo todos sus vecinos y como tales, pacían y rozaban sus términos y poseían en la ciudad y sus arrabales, gran número de casas, rentas, heredades y huertas y a ellos más que a otros importaban los dichos reparos. El procurador del Monasterio y del Hospital dijo que la licencia mandaba expresamente que la sisa se cobre de lo que se vendiere dentro de la ciudad, y ni ellos son sus vecinos, ni están en su arrabal, ya que son lugares distintos de la ciudad y tienen término limitado civil y criminal.

En enero de 1530 los clérigos alegaron por su parte ante el Consejo que estaban "esentos de semejantes contribuçiones por todo derecho dibino e umano", por lo que lo pretendido atentaba "contra libertad eclesiastica y hesençiones della", y que "no se ha guardado ni guarda la forma que en ello se debe tener, porque no a seido consultado para ello con nuestro muy santo padre, e que para los dichos hedefiçios bastan las facultades de las personas legas desa dicha çiudad", porque la ciudad tiene de propios más de 2.000 ds. que se deben gastar en lo más necesario como el dicho puente. Añaden que "ay personas particulares que haran la dicha puente a su costa, y aun dar en rrenta a la dicha çiudad porque les degen edeficar casas y boticas a los lados della". El Consejo mandó, no obstante, que los clérigos de la ciudad contribuyan sin que en ello se ponga excusa alguna. El procurador del Monasterio y del Hospital alegó que sus partes eran personas eclesiásticas y casas de religión que les hacían inmunes de tal imposición, aunque quisiesen pagar la dicha sisa, no lo podrían hacer "sin yncurrir en las penas e çensuras en que yncurrian lo que consentian las tales ynpusiçiones, puestas contra libertad eclesiastica".

Los oidores pronunciaron sentencia en octubre de 1535 condenando al Monasterio, al Hospital y a sus compases a contribuir en los 4.000 ds. mandados echar por sisa. Estos alegaron que la sentencia era injusta y que ellos no se beneficiaban del dicho puente ni lo necesitaban, ya que sus carretas y acémilas no pasaban por él, ni ellos vendían cosa alguna en la ciudad, y aun cuando algún vecino de los compases llevase a vender a la ciudad y se le cargase sisa, sería como a particular solamente por lo que vendiese. El concejo dijo que además de los 4.000 ds. de la sentencia, se habían echado en sisa otros 8.000 para

201 A. M. B./ Actas municipales, 1527, fol. 82v/ Burgos, 27 abril 1527; MARTÍNEZ BURGOS, M.: 1952: 33-34.

202 A. M. B./ HI-2895/Valladolid, 6 julio 1527. 
dichos reparos, por lo que debían contribuir en 12.000 ds. Los oidores dieron sentencia en mayo de 1545, condenando al Monasterio, al Hospital y a sus compases a contribuir en los otros 8.000 ds. y en todos los demás mrs. que en adelante fueren echados y repartidos con licencia del Rey ${ }^{203}$.

\section{El puente de los Malatos en 1551}

En julio de 1551, ante el teniente de corregidor, pareció el procurador del concejo y presentó la Provisión dada en junio en la que el Rey dice al corregidor que el procurador mayor de la ciudad le comunicó que gran parte del puente de los Malatos estaba derrocada y para caerse, de tal manera que sus pilares se caerán muy pronto, y también estaban caídos dos pedazos grandes de la muralla de la ciudad, y la torre de doña Lambra estaba también para caerse, por lo que la ciudad recibiría de daño más de 20.000 ds. Se podría todo remediar si se diese licencia a la ciudad para repartir o echar por sisa la cantidad necesaria sobre los mantenimientos. El Consejo mandó que se haga información sobre la necesidad de tales reparos, cuántos mrs. se necesitarán, como se podrán cobrar con menos daño de vecinos y moradores, etc., y con su parecer, se envíe al Consejo. En agosto, ante el teniente de corregidor en Burgos, pareció el procurador de la ciudad y presentó por testigos para la dicha información a Martín de Echavarría, Sancho de Echavarría y maestre Ochoa de Arteaga, maestros de cantería, y a Miguel de Pino, procurador de causas, vecinos de Burgos. Martín de Echavarría indicó que el puente de los Malatos tenía gran parte de sus pretiles caídos y de no repararse, se caerían todos y peligraría la gente, siendo necesarios 200 ds. o más y con la muralla y torre incluidos 1.100 ds. Sancho de Echavarría dijo que para todos los aderezos se necesitaban por lo menos 1.600 ds. o más, y que aumentarían si se tardaba en el reparo. El maestre Ochoa de Arteaga, como persona experimentada en muchas obras, dijo que todo se podría hacer con 1.600 ds. y si no se remediaba pronto, no se podría hacer con 1.800 porque cada día se caen más y se llevan la piedra. Miguel del Pino informó que el puente estaba muy maltratado y tenía derribados todos los alares de una parte y los de la otra se habían empezado a caer, y caída la mayor parte de sus pretiles, siendo necesarios más de 300 ds., haciendo todo 1.700 ds.

En agosto, el corregidor dijo que ha visto todos los desperfectos y que debe remediarse de inmediato. Pero como la ciudad está muy necesitada y no puede ayudar a las dichas obras ni pagar lo que adeuda para obtener las cantidades de los repartimientos de los puentes de Tardajos y Quintana del Puente, se debe pedir licencia para que se echen en sisa, lo cual se debía mandar proveer, aunque ni en este año ni en el venidero se podría remediar todo, y que para 1553 se les dé licencia para echar en sisa los 1.500 ds. que los oficiales declaran que serán necesarios para las obras pendientes, y que si no se invertían ahora después se gastarían más de 6.00o. Añadió que lo mejor para obtener dicha suma es de la sisa del vino, porque por experiencia había visto que el pueblo está mejor provisto y más barato cuando hay sisa que cuando no la hay, a causa de que los forasteros no vienen a comprar el vino por no pagar la sisa, y que en ningún otro mantenimiento se puede hacer con menos daño204.

203 A. M. B./ HI-1438/Toledo, 2 julio 1529 a Valladolid, 23 diciembre 1546; HI-1842/Valladolid, 23 diciembre 1546.

204 A. M. B./ HI-1658/Valladolid, 21 junio y Burgos, 30 agosto 1551. 


\section{La riada de mayo de 1582}

Tras la ruina del puente de Santa María por una riada, se inicia un largo proceso en que su reedificación se remata en 1584 en los maestros Lope Carcía de Arredondo y Domingo de Hazas. Al surgir problemas técnicos y de diverso tipo, la obra aún no se había terminado en 1597, acabando Hazas en prisión.

Entre el 23 y 24 de mayo de 1582 una importante avenida del río Arlanzón afecta a los tres puentes burgaleses sobre dicho río, además de causar destrozos a numerosos paredones, caminos y calzadas de la ciudad. Fue una de "las mayores y mas estraordinarias auenidas y creçientes de aguas que se an uisto ni oydo jamas, e ynundaron la dich a çiudad y sus cassas, y el arraual de Uega que confina con el dicho rrio, llegando y entrando donde nunca se uio llegar ninguna abenida, e hiçieron grandes y notables daños publicos y particulares, en las dichas cassas y haçiendas que auia en ellas, y en las heredades y huertas que estauan çerca del dicho rrio desçercandolas y dejandolas yermas y sin çerraduras, y tanbien en los templos e yglesias y sepulturas...". Además de dañar los puentes de San Pablo y los Malatos, el puente de Santa María, el principal de la ciudad, quedó arruinado ya que la riada "lleuo totalmente quatro arcos prinçipales..., de siete que thenia y los tres que dejo, quedaron sentidos, arruynados y socauados"205. Dos días después comparecieron ante el corregidor, el alcalde mayor y los regidores varios oficiales y maestros de cantería y carpintería, que dijeron que mientras se construía el de piedra más costoso y complejo, se debía hacer uno de madera para la carretería, la caballería y las gentes de Vega cuatro pies más alto que el de cantería anterior, suavizándolo en los extremos para facilitar el paso de la carretería, con pies de olmo y tramado encima con soleras también de olmo.

Se produce un debate entre maestros de cantería y carpintería sobre la madera más idónea a utilizar, indicando Juan de las Suertes, maestro de carpintería, que si el puente se puede hacer con la madera encima en línea recta, sería bueno para que los carros no hagan dos giros, y remite a los canteros, pues los oficiales han afirmado que para el puente es mejor el olmo que el pino y para su edificación pone de postura 50 ds., que los pagaría de la parte caída ${ }^{206}$. El 28 de mayo, los maestros de cantería Pedro de Castañeda y su hijo

\footnotetext{
205 A. M. B./ HI-1661/ 1583.
}

206 Pedro de Castañeda y Domingo de Hazas, maestros de cantería opinan que debiera ser de roble por ser más duradero, y Pedro García de Velasco, que los regones en el agua y todo el encadenado debe ser de olmo y las carreras de pino. Los carpinteros Pedro de Llanos, García de Bustamante y Cristóbal de Logroño, indican que para que el edificio se haga antes y a menos coste, conviene que sea de pino para 8 o 10 años, y Juan de las Suertes, opina que conviene que se hagan las puercas de abajo de roble, y si se pudiere los pies y torgas de arriba y los travesaños de olmo. Simón de Berrueza maestro de cantería, indica que conviene que las puercas que van bajo tierra, sean de roble verde y los pies que van sobre las puercas sobre los que se asienta el edificio, sean olmos rollizos sin que se labren por ninguna parte, sólo cortados a cintrel por arriba y por abajo guardando sus espigas, y las carreras del extremo y lados del puente que van cargando sobre las puercas altas, sean de olmo tabladas por dos lados, y lo más gruesas posible, y todo el maderamiento de zancas y contrapontos, de olmo y lo demás del puente, de pino con sus soleras de roble y olmo. Por encima, se han de echar sus puercas en vacío entre una y otra de las que se afirman en ese suelo, con sus tornapuntas y puntales, y fundadas a plomo sobre las puercas en ese suelo, y por encima de las tornapuntas sus encadenamientos que las traben entre sí. Pedro Jaques de Bueras ensamblador, Juan de Fonfrida carpintero, Bartolomé de Chaves albañil, Martín de la Haya y Baltasar de Castañeda, indican que conviene que todo sea de olmo, porque de otra manera no durará mucho tiempo.

Juan de las Suertes, decía que el olmo es más duradero y resistente que el pino, ya que el pino se quiebra antes, y ha visto demoler muchos edificios en tierras donde hay olmos y pinos, principalmente en Valladolid, y el pino queda podrido y el olmo sano, y vuelve a servir para el edificio como aquí hace el roble. Una pequeña gotera pudre en poco tiempo una viga de pino, y la de olmo resiste mucho mejor. Ha visto edificios que trabajan en el agua, como aceñas, molinos y pisones, y todos son de olmo o roble, y si algún edificio de pino se hace en el agua, es porque es verde y con su corteza y la verdura que tiene, resiste más tiempo antes de corromperse. Si se utiliza pino seco, por 
Baltasar de Castañeda, y los de carpintería Juan de las Suertes y Juan de Fonfrida, informaron que el puente de madera disponiendo de los materiales y clavazón, lo harían en 30 días de labor, siendo necesaria la siguiente madera de olmo:

- 14 maderos de 44 pies de largo para puercas que tengan buen cuerpo.

- 28 postes de 24 pies de largo de marco algo grueso.

- 16 piezas de 40 pies de largo como mínimo para madres.

- De estas madres largas, se necesitan 30 vigas de 22 pies de largo de marco de las grandes.

- Para atravesarlas encima de las madres, 160 piezas de 40 pies de largo y si no las hubiere, podían servir de cualquier largo.

- 24 olmos largos para antepechos aunque no sean muy gruesos.

- 12 olmos largos derechos y delgados para antepechos.

- 30 olmos medianos para brazas y puntales.

- 24 vigas de 22 pies de pino y todo lo demás ha de ser de olmo, más 24 machones y algunas vigas de a dos que cada día se comprarán.

- Se necesitará para cosas en la obra todo el despojo, ramas gruesas y puntas de estos olmos, y para quitar el agua serán precisas 200 estacas de haya y su rama de salcina.

Tres días después, se nombró por sobrestante para la obra a Sebastián de Vallejo y se mandó que Suertes y Fonfrida, juntamente con Medel de Lara y el guarda mayor de los montes y términos, vayan a señalar los olmos necesarios entre los que la ciudad tiene en sus ejidos. Estos dijeron que los olmos necesarios son:

\begin{tabular}{|c|l|}
\hline 14 & de 44 pies \\
\hline 16 & de 40 pies \\
\hline 30 & de 22 pies \\
\hline 180 & de 20 pies \\
\hline 24 & largos delgados para pasamanos \\
\hline 30 & medianos para puntales de pino \\
\hline 24 & vigas de 22 pies \\
\hline 20 & machones \\
\hline
\end{tabular}

Como en los ejidos concejiles no habían los olmos necesarios, los encontraron en el monasterio de San Cristóbal de Ibeas y en la casa de la Vega, y como parecía que eran buenos, mandaron comparecer a Francisco de Castellanos encargado de dicha casa por el Con-

sus hendiduras se meterá el agua y empapará pudriéndose. El pino no es madera adecuada para sufrir tormento de carros y además su clavazón se desclava muy pronto y en olmo no, porque una crecida grande puede desclavar y demolerlo, pero de olmo la clavazón se hace mas prieta y queda fuerte por ser madera más dura. Deshecho el puente, se sacarán más dineros del despojo del olmo, y si dicen que el olmo no se gasta en este pueblo es por no haber quien lo traiga a vender y porque hay roble, pero no porque no sea bueno. Pedro de Castañeda compró 1.500 rs. de olmo y si lo quisiera vender lo venderá en un año, y si en algunas partes hay puentes de pino, es por no haber olmo ni roble, y el pino ser mejor y más graso que el de aquí, y quemado sacan de él resina y esta defiende del agua. 
destable. En junio se acordó que se traigan los olmos que hay en los ejidos, comprándose los que faltan y como los monjes de San Cristóbal no quisieron dar los olmos a menos de 20 rs. y los de la casa de la Vega tenían un precio mejor y desde dicha casa la distancia es más corta, acordaron que se concierte con Castellanos y que Sebastián de Espinosa, obrero de Burgos, haga buscar carros para traerlos, señalando un oficial de carpintería más olmos, ya que 30 no bastaban. Dos días después, Suertes informó que han señalado 6 olmos, además de los 30 ya cortados, pagando por los 36 olmos 3.366 mrs. Se mandó que Espinosa y Lara vayan a Villímar, Villatoro y otros lugares a concertar mulas, bueyes y carros para llevar los olmos al pie de la obra ${ }^{207}$.

Para ir preparando el puente de piedra, Sebastián de Vallejo tomó más obreros para que fuesen sacando la piedra del derruido que está en el río y la extiendan por el cascajo. Juan de la Torre, maestro de cantería, defendía que se debía derribar la casa que se encuentra junto al puente en el barrio de Vega, en que vive Diego Pérez Sillero y propiedad de Francisco Orense Manrique, alférez mayor de Burgos, para que los arcos del puente de cantería puedan ser mayores y quepa más agua, aunque también para hacer el de madera a nivel del banco y del cabo de arriba, y así las vigas y pies derechos del de madera, vayan 12 pies desviados de las cepas y tajamares del de piedra ${ }^{208}$. Se estableció un debate entre los canteros y carpinteros, que indicaron que es más útil que el puente de madera vaya encima de lo que queda del de piedra, pero el maestro de cantería Pedro de la Torre Bueras opinaba lo contrario ${ }^{209}$. Como los oficiales eran de diferentes pareceres, se votó en 4 de junio

207 El convento de los Vitorinos o frailes Mínimos de Nuestra Señora de la Victoria, se encontraba en el lugar que hoy ocupa el palacio de la Audiencia de Burgos.

208 Añade que vaya el puente de madera a primer y segundo tajamar del de piedra que quedó en pie, derribándose los antepechos necesarios. Para fundarlo, los pies han de ser espigados en las puntas de abajo, y sus puntas de hierro serán aceradas, con sus cintas que salgan por arriba y bien clavados para que rompan el cascajo hasta buscar greda y buen cimiento, y así se irán asentando todos los pies necesarios con un mazo y quedar firmes. Los pies llevarán unas cintas de hierro para que no se hundan al golpearlos, serán desplomados uno contra otro y por encima se echarán una vigas espigadas, donde descarguen las vigas que prosiguen por el puente adelante, y encima de estas irán unas cintas de hierro que las ciñan, para que bajen por los pies, tres pies, y se claven a los pies derechos para que quede firme. Se cuajará de machones atravesados, se empedrará y pondrán antepechos de madera y yeso para que resista el tráfico. Así el puente no hará daño al de piedra cuando se edifique, porque si se hace el de madera por encima del caído, se irá falseando cuando se vayan sacando las cepas, no será capaz de recibir el tráfico y no dejará edificar el de cantería sino con mucho más coste, y tendrá tanta pendiente que no podrán subir las carretas por la parte de Vega.

209 Los maestros y carpinteros dicen que Torre Bueras "se engaña porque antes sera de mucho prouecho para hedeficar la dicha puente de piedra, y la rraçon hes porque la misma puente serbira de andamios, y para fixar qualesquier rruedas y tornos que sean menester para el dicho hedeficio, dexandole aquel desaogamiento que por el parescer hesta declarado y ansi digo que si esta puente no se hiziese encima de la cayda,... seria nescesidad para el dicho hedeficio hazer otros nuebos andamios y camaras para fortalescer las gruas, tornos, rruedas que fuesen menester para el seruicio del y si esto... se hiziese, seria tanta la costa destos andamios como la mitad de la puente y mas", lo que se evitaría si se hiciese el puente sobre el de piedra, porque en los mismos pies del de madera, se asentaban los andamios necesarios para el de piedra. Dicen además que cuando Torre Bueras abra para las cepas los pies del puente harán esfuerzo, pero que ese es el más fácil remedio que hay en la obra, porque estos se pueden ahondar con facilidad para asentar las puercas hasta tierra firme y poder echar el cimiento de la cantería, y en esto habrá ventaja porque se sabrá la hondura necesaria de los cimientos. Además el puente de madera será más firme, por ser los pies 406 pies más largos y se puede hacer de 24 pies de ancho, y así no estorbará subir la cantería hasta los antepechos, y será más fuerte y barato y se podrá subir gran parte del edificio por el mismo puente. Además, si los maestros determinan que los arcos sean más desahogados para el agua, es fácil acordar el reparto necesario y determinado, y se pueden hacer y repartir los pies del puente para que no estorben al edificio. El puente de madera que dice Torre Bueras, es 1/3 más costoso que el que proponen, aunque no se haga cargo del coste de las casas que se tomen para el servicio.

Baltasar de Castañeda manifestó que para edificar el puente de madera, había hecho una traza con lo que quedó del de piedra, y para hacerlo más rápido y con menor coste, deberá ser de 24028 pies de ancho, que es suficiente 
y se acordó hacerlo según el parecer de Pedro de la Torre, aguas arriba del de piedra, por la brevedad y porque para hacerlo no se gastaría tanto como trayendo ingenieros y oficiales de fuera. El corregidor y regidores dijeron que como el puente se debía hacer con rapidez, que Pedro de la Torre que tenía gran experiencia y pericia, y cuyas razones son suficientes, comience a labrar y aparejar la madera y que si entre tanto hubiere otro maestro, que lo vea y dé su parecer.

En 13 de junio Diego de Sisniega maestro de cantería, vecino de San Mamés en la junta de Boto, dijo lo que conviene para construir el puente de madera y para las fábricas

para pasar dos y aún tres carretas a la vez, porque hoy tiene el puente 38, ahorrándose así 1/3 del trabajo, materiales y coste, y haciéndolo en línea recta con sus puercas, carreras, aspas y entramados de olmo, y aunque dure el puente de olmo 10 años, vendrá a valer después el dinero que costó, y además viendo las granjerías que se buscan en su compra y traerlo, y que el pino de esta tierra es flojo, y le ha de dar el agua y el sol, y el olmo por ser mucho más pesado que el pino, resistirá mejor las avenidas, por lo que se suelen cargar los puentes por encima para que el agua de las avenidas no los lleve. El olmo, para 70 u 80 piezas que faltaren, se hallará en la casa de la Vega, en San Zoles y en el molino de Diego de Bernuy. Haciendo el puente de 24028 pies de ancho, el servicio con el guindaste, será más fácil que haciéndolo del ancho que hoy tiene el de piedra, y el servicio aun con poleas colgándolas del mismo puente, se puede servir muy bien en cada cabo donde se hiciere la obra de cantería, y en cuanto a la planta de las puercas, se han de meter bajo tierra dos o cuatro pies y a otros tantos de los pilares, porque aunque vengan avenidas, no harán daño al puente de madera y plantándolas por dicho orden, se podrán abrir los cimientos sin daño para el puente, y además los arcos vendrán a ser mayores ganando en viaje desde junto a la calleja hasta las casas de Orense, y quitando a cada pilar dos o tres pies para que no sean tan gruesos como antes, bastará tener cada uno 13014 pies de grueso, y haciéndolo así, los arcos tendrán 406 pies más de hueco que los de antes, lo que ayudará a circular mejor el agua, y así se podrán abrir los cimientos, sin perjuicio del puente de madera, y sin que se estorbe el paso ni haga mal alguno al de madera. Se pueden quitar una o dos puercas, y recibirlas sobre soleras con sus zanjas y quitar las soleras de abajo y los pies, y todo esto es sencillo y sin coste derribando la casa, y después atravesar hasta embocar con el que quedó de piedra, y como ha de hacer vuelta, haciéndolo de pino, cada día será necesario remediar el que una carreta muy cargada quebrare lo de encima, y si se hiciese cargada de tierra y empedrada no valdría nada. Sobre el pino y sobre el olmo, después de que esté tramado por encima y echadas sus hijuelas, se enrrajará echando el dicho tramo de olmo sin labrar entre uno y otro de sus rajas toscas, con su cal y arena y se enjutará y ripiará hasta igualar con la madera que se echare más alta, y allí no será necesario más que echar cascajo y tierra, y poner sus antepechos como se muestran en la traza, guardando trazado suave para que el puente de madera pueda quedar cuatro pies más alto que el de cantería.

Torre Bueras indicó que no se haga el puente de madera por encima del caído, sino aguas arriba, comenzando por el pilar que está en pie hacia la ciudad, quitando la mitad del antepecho del tajamar, y de allí irá circundado hasta la casa de Francisco Orense, para que queden libres los tajamares y el puente que se debe rehacer, y para la entrada y salida del de madera se demolerá dicha casa para hacer el de piedra, y así será más llano, ya que fundándole encima del caído tendrá de ancho 24 pies, 10 más ancho que el de San Pablo, y si se hiciese de madera de pino duraría más de 10 o 12 años, y se haría más rápido porque se hallaría madera en Burgos. Pero como la ciudad tiene algunos olmos con vigas largas, se hará de olmo y pino poniendo cada madera donde sea duradera y perpetua. El puente de madera se debe hacer aguas arriba, porque si no, sería de gran estorbo para el de piedra, que para ser más duradero y seguro los arcos debían ser más anchos y podría ir algún pilar en la parte donde estuviesen los pies de madera, y aunque no se debiesen quitar esos pies, los pilares estarán tan cerca que cuando se rompan sus cepas se arruinaría el dicho puente o sería necesario quitar los pies que estorbasen y ponerlos en otra parte, corriendo peligro al ser mucho el hueco de unos pies a otros, y mudándolos quedarán en vacío los extremos de muchas vigas aunque estén interpoladas, y al venir una rueda de carreta cargada por encima de tales extremos, podrían quebrarse algunas puntas con peligro. Añade que quedando los pies junto al rompimiento de las cepas, habiéndose de ahondar mucho hasta buscar buen suelo, con el peso del puente y los golpes de las carretas moverán los terreros junto a las cepas al ser de arena y cascajo, aunque sean reforzados con maderas porque podrían faltar algunas, y cuando no faltaren, sería necesario poner tanta madera que estorbaría al asiento y cascajo que se ha de sacar de las cepas. Cuando se rompieren los cimientos de las cepas y pilares podría manar tanta agua que para buscar buen cimiento será necesario sacarla con bombas y otros ingenios, los cuales no se podrían poner bien ni gobernar si estuviese allí el de madera. Si no se hallaren buenos cimientos como se ve por la obra que se cayó, se harán artificiales, hincando grandes maderas golpeándolas fuertemente para que desciendan más de 40 pies y las hagan entrar hasta topar con tierra firme y quedar fuertes. Por el estorbo del de madera, costaría más hacer el puente de cantería ya que los materiales se habían de llevar al asiento a brazo, y cuando subiese la obra cerca del puente habría tan poca anchura que ocasionaría gran daño y coste, y mucho trabajo para los que en él anduviesen. Y no estando por encima del puente caído, se harán grúas y pescantes para llevar y subir piedras y materiales, más barato que a brazo, de más descanso y menos peligro. No siendo tan ancho el puente de madera será más barato que haciéndole sobre el caído, porque desembarazando el caído y la fundación de sus pilares, pasarán varios días que si se hace sobre él. 
de ambos puentes ${ }^{210}$. Las maderas estarán encajadas y fuertemente ligadas con clavijas de hierro, y en las juntas se irán echando cintas de hierro bien clavadas, y el puente tendrá 26 pies de ancho para que puedan cruzarse dos carros y así, no hará más que una sola curva y quedará fuerte y mejor acomodado a ese espacio ${ }^{211}$. Se nombraron maestros de carpintería a Juan de las Suertes y Juan de Fonfrida, a 4,5 rs. por día.

El corregidor y los regidores diputados de puentes dijeron que han enviado a buscar otros maestros peritos además de los de Burgos, para que den alguna traza tanto para el puente de piedra como para el de madera y no se hallan. Una vez traídos casi todos los olmos de la casa de la Vega, Suertes y Fonfrida mandaron que se desvíe el río por la parte no caída del puente, para comenzar a hacer el de madera y que Sebastián de Vallejo empiece a hacer la estacada. El 26 de junio, con el agua del río bajo la parte sana del puente, se mandó que los sobrestantes contraten más gente para comenzar a trabajar, y como faltan azadones y no se hallan, mandaron que Espinosa haga de inmediato 12 azadones y 12 palas de hierro, y que se corten los demás olmos de los ejidos concejiles, hasta 150 más y si no hubiere suficientes se comprarán a los particulares, aunque Espinosa dijo que ha andado por todos los términos de Burgos y no ha hallado para pies olmo alguno aprovechable. Le mandaron que juntamente con Suertes y Fonfrida mire los de particulares, los concierten y los hagan cortar con brevedad. En julio se mandó que Pedro de Llanos, maestro de carpintería, asista con Fonfrida y Suertes, con el mismo salario que los dichos, ya que gran parte de los materiales están a pie de obra. Se mandó que para el puente de madera se compren los olmos que faltan y que el corregidor concierte los de la casa de la Vega.

210 Indica que el de madera se debe hacer aguas arriba del puente caído, comenzando por el segundo tajamar siguiendo más allá de su punta derecha hasta llegar 18 pies más adelante, donde está la calzada, y donde el puente hará una punta a manera de tajamar y de allí volver en línea recta hasta la casa de Francisco Orense, que se derribará para hacer la salida del puente, y en la parte que éste ha de hacer la punta a manera de tajamar, se formará una figura triangular y a la parte de abajo hará un ochavo donde cargarán las maderas del puente, y en cada triángulo que hiciere, se pondrá su pie derecho y poste para recibir dichas maderas y así formado el puente, quedará con solo una curva, y el sitio donde se fabrique el de cantería quedará conveniente, porque comenzando así, el ochavo que ha de hacer en la parte de abajo se ha de hallar desviado de las puntas de los tajamares a la parte de arriba 20 pies en línea recta, y asimismo han de ser elegidos para hacer el de cantería, el cual ochavo será muy útil para el puente y hacer punta a la parte de arriba y cortar y llagar ya la de abajo, y con fuerza por entibarse las maderas y abrazarse unas con otras, no pueden ser desencajadas, si no fuese haciéndose pedazos y además serán de gran provecho por ir en medio del puente, donde ha de ser más frecuentado "ansi de aguas y benidas del rrio, como de carros, coches y rrecuas, e otras cossas que por ello an de pasar", y por hacerlo allí más ancho que en otra parte y encontrarse todas las maderas unas con otras, con mayor fuerza que en otro sitio, quedará más sólido el puente, siendo bien fabricado por el maestro para fundarlo como conviene para su conservación, y para fijar los postes de madera sobre los que ha de cargar el puente. Se echarán en todo él sus carreras de largo a largo, hundidas debajo del cascajo todo lo que se pueda y de 20 en 20 pies, que será donde se han de asentar los pies derechos o postes, y se echarán sus traviesas bien encajadas en las rejas dichas, para que todo el puente quede bien encajado en la parte baja con sus marcos, y el agua no pueda causar daño, y para hacer fuertes las vigas o carreras necesarias, se han de echar tornapuntas en la parte baja, y se podrán hacer fuertes por la mucha carga y trabajo que deben soportar de carros y coches, y por la parte alta con sus tijeras estribando en las mismas vigas sobre los postes de abajo, y con esto aunque tengan 20 pies o menos, conforme a como cupieren, se podrán hacer muy fuertes.

211 Por donde iba el puente caído no podía estar fuerte, a no ser que cada día se quite y ponga porque si se pretende hacer el puente de piedra ha de quedar el sitio libre para abrir las zanjas y cimientos, y siendo así, los postes y cajas donde el puente se debía asentar habían de ser removidos y quitados para abrir los cimientos, porque no solamente se ha de evitar hacer allí el puente de maderas, sino también quitar todos los postes que allí dejó el agua y no siendo así, no se podrá hacer el puente de piedra de una vez sino a pedazos y en edificios tales, no solamente han de ser macizados los pilares, sino también que cojan huecos de arcos tan suficientes como los pilares, que de no hacerse así, suelen arruinarse los edificios como ha ocurrido con este, porque las avenidas socavan la tierra y fundamentos por hallar flojos y mal ligados unos pilares con otros, y estas razones son suficientes para que no se permita que el puente de madera se haga sobre el caído. 
También mandó el corregidor a Pedro de Castañeda y a Sebastián de Espinosa, que por ir el agua baja, vean los puentes de San Pablo y los Malatos, y los malos pasos, caminos, puentes y trampales que en los términos de Burgos necesitaban remedio urgente, e informen sobre los daños y su solución, y que Sebastián de Vallejo se encargue de ello. Dicen al corregidor que el daño hecho "en los caminos que desta çiudad salen para la uilla de Madrid, Ualladolid, Santiago de Calicia y a todos los puertos de la mar y a otras partes, por donde entran los bastimentos a esta dicha çiudad y otras cossas de acarreo", y que junto con cuatro vecinos los han medido y tanteado, requiere unas actuaciones que ascienden a 1.804.314 mrs. ${ }^{212}$. Añaden que el

212 El resumen de los destrozos es el siguiente:

- Dos cárcavos grandes que la riada hizo delante de la iglesia de San Lucas "junto al monesterio de San Josepe ques de las descalzas", uno de 10 pies de hondo, 221 de largo y 20 de ancho, y el otro de cuatro pies de hondo y de ancho y 70 de largo, que se han de cegar de cascajo con 7.000 mrs.

- Otros dos cárcavos que ahondó el río junto a las casas y eras del deán, que llenándose de cascajo costarán 650 mrs.

- Un mal paso junto al puente real, en el camino real que va a la Sierra, que tiene 200 pies y 15 de ancho, que en todo hay 60 tapias de empedrado de piedra gruesa tosca, con sus traviesas de 15 en 15 pies y sus adoquines labrados, que costará cada tapia 11 rs., puestos los materiales 22.500 mrs.

- Otro cárcavo y mal paso en el dicho camino en la puerta real de Miraflores, de 660 pies de largo y de ancho 20 en el que se ha de hacer una calzada de piedra tosca con adoquines a los lados, y sus traviesas de 15 en 15 pies que son 160 tapias a ducado por tapia, y costará 60.000 mrs.

- Otro mal paso y cárcavo junto a la pared de la huerta del convento de Santa Clara, que se ha de empedrar de guijarro del río y tiene de largo y ancho 100 tapias, y se ha de hacer a tres rs. la tapia y se darán adoquines si fueren necesarios, monta $10.200 \mathrm{mrs}$.

- Otro mal paso junto a éste y un arroyo en medio, que es el paso de toda la carretería que viene de la Sierra a la ciudad con leña y carbón, y se ha de aderezar con cascajo grueso del río echado por orden donde convenga, y tendrá de coste $20.400 \mathrm{mrs}$.

- Otro cárcavo y mal paso y tremedales, "questa como ban desta çiudad al barrio de Cortes", en el que se ha de hacer una calzada de piedra tosca gruesa con una hilada de adoquines a la parte de abajo para que afiance el empedrado, que tiene de largo y ancho 50 tapias a $11 \mathrm{rs}$. Ia tapia a toda costa de manos, piedras y adoquines que montan $18.750 \mathrm{mrs}$. - Otro mal paso más adelante como se va al dicho barrio, que se ha de encañar de piedra tosca gruesa, que tiene 420 pies y 10 de ancho, son 84 tapias a ducado cada tapia suma 31.500 mrs.

- Otro mal paso que está junto al dicho barrio de Cortes, que tiene 104 pies de largo y 10 de ancho que son 21 tapias a 11 rs. la tapia, y se ha de hacer una calzada de piedra tosca crecida con sus adoquines a los lados y sus traviesas de 15 en 15 pies y suma 7.872 mrs.

- Otro mal paso y cárcavo que hay donde Ilaman la Calleja Honda, "como ban desta çiudad a los puertos", que tiene de largo 420 pies y de ancho 10 y se ha de aderezar echando guijarro perdido, recebado con arena, que son 80 tapias a $500 \mathrm{mrs}$. la tapia porque está el guijarro lejos $40.000 \mathrm{mrs}$.

- Los malos pasos y tremedales que hay antes de llegar al "barrio de Villatoro en el camino rreal que ba a Medina de Pumar y a Laredo y a otros puertos", que tienen de largo 1.088 pies y 10 de ancho, que son 432 tapias a 20 rs. la tapia, y se ha de remediar con hacer una calzada a un lado de piedra tosca gruesa y de adoquines, de 10 pies de ancho en todo el dicho largo, y sus traviesas de 15 en 15 pies que suma todo 293.760 mrs.

- Otro mal paso "questa en el otro camino rreal que ba a las dichas montañas, questa debaxo de las postreras cassas del... barrio de Billatoro", al final de las eras hasta un arroyo en medio del barrio, que tiene 420 pies y de ancho 10, que son 84 tapias a ducado la tapia, lo cual se remediará con una calzada de piedra tosca y adoquines por un lado y sus traviesas de 15 en 15 pies y monta 31.500 mrs.

- Otro mal paso que está en el dicho camino antes de llegar a Villatoro, "como ban a las yelseras", que tiene 1.836 pies y 10 de ancho que son 434 tapias a dos ducados la tapia por estar la piedra lejos, se ha de hacer una calzada de piedra tosca crecida, con sus adoquines a un lado y sus traviesas como lo de arriba y monta todo $325.500 \mathrm{mrs}$.

- Otro "mal passo questa en el camino rreal que ba desta çiudad a Santander y a otros puertos ques mas aca de Quintanadueñas a do dizen la Muñeca", que tiene 12.440 pies y 10 de ancho que son 500 tapias, que se ha de remediar haciendo una calzada con sus adoquines y traviesas de piedra tosca y guijarros, costando cada tapia $10 \mathrm{rs}$. por estar la piedra lejos y monta $170.000 \mathrm{mrs}$

- Seis tramos de empedrado que la dicha creciente desempedró en la calzada que va de la pontezuela debajo del cimiento hasta pasado el molino de Arévalo, que es necesario empedrarse, y todo tendrá 40 tapias, a tres rs. la tapia por estar cerca el guijarro, monta $4.080 \mathrm{mrs}$.

- Los paredones que las riadas derribaron debajo de la Merced junto al Puente Quebrado, que tiene 612 pies que son 130 tapias, y un poco más que se ha de derribar de lo viejo y tendrá de alto 10 pies y 5 de ancho, costará cada tapia con la piedra que está allí a $3.000 \mathrm{mrs}$. monta $390.000 \mathrm{mrs}$. 
puente de San Pablo tiene cuatro arcos que deben encadenarse de manera alamborada con buenas piezas de piedra tosca, donde emboca el agua y donde se despide, y como los 8 ar cos están cubiertos de cascajo, no pueden ver si tienen algún daño y si están descalzados. También tiene algunos sillares y dovelas desgastados, necesitando traer piedra de Hontoria para reformar las partes precisas, debiéndose rajar y revocar tanto los arcos como los lados, apretar con unos arneses las dovelas, rajar y revocar la bajada del puente y alzarlo un poco. El coste sería de 119.600 mrs:

\footnotetext{
- Los cárcavos que la riada hizo en el "camino rreal que ua desta ciudad a Valladolid y Santiago de Galicia", que son tan hondos y anchos que no se podrá caminar por él a pie ni a caballo, desde el Puente Quebrado hasta la esquina de la huerta de las Huelgas, hay 1.860 pies y de ancho 70 , lo cual se ha de remediar con llenarlo todo de cascajo y abrir allí la madre del río, y con el cascajo que viene de dicha madre se han de llenar y cegar los dichos cárcavos, monta $131.250 \mathrm{mrs}$.

- En todo este largo se ha de hacer una defensa de piedra o estacada con su fajina y cascajo dentro, con 2.00o estacas o más, que echada su barda por dentro y fuera y mahazado de tierra y cascajo, valdrá a 1,5 rs. la estaca asentada, bardada y llenada como ha de estar y monta $92.850 \mathrm{mrs}$.

- Se ha de poner una estacada en todo el largo del paredón que la creciente llevó y se ha de hacer de nuevo, para lo que son necesarias 350 estacas, que por traerlas de la Sierra, apuntarlas y asentarlas por su orden costará 20 mrs. la estaca, $7.000 \mathrm{mrs}$.

- Otro cárcavo que está derecho del puente de los sauces de Paternina en el "camino real que ba a Valladolid", de 68 varas y de ancho 20 pies, se remediará llenándole de cascajo, 5.100 mrs.

- Se midió un caballete de piedra y estacada con mucha piedra y céspedes cerca del puente de los Malatos, que llevó la riada y se debía remediar, contornar y dejar como estaba, $17.000 \mathrm{mrs}$.

- Otros cárcavos desde el puente de los Malatos hasta la mitad de la olmeda del Hospital del Rey, los cuales están en el camino real a Valladolid y Santiago, que tiene 2.136 pies de largo y costará 300 rs. de allanarlo y llenarlo de cascajo y tierra, $10.200 \mathrm{mrs}$.

- Otros cárcavos "desde el umilladero del Ospital del Rrey abajo asta el molino questa junto a do se parten los dos caminos a Valladolid y Tardajos", que se deben cegar con cascajo hasta donde están unos plantones puestos de nuevo que se deberán cortar, 17.200 mrs.

- Debajo hay otros cárcavos que hizo la creciente, que se deben cegar con el cascajo que está cerca y costará 6.800 mrs.

- Junto al dicho molino "adonde se parten los dichos dos caminos para Valladolid y Tardajos" hay otros cárcavos hondos que necesitan cegarse con tierra y cascajo, y allanar unos terreros que están junto a ellos que costará 5.100 mrs. - Otros cárcavos grandes y hondos antes de llegar a la cruz entre los dos caminos de cara al molino, hasta llegar al calce que viene del Hospital del Rey, que son muy grandes y hondos y atraviesan el camino. Se han de cegar con cascajo grueso y aunque allí hay parte de ello, se ha de traer de lejos lo que faltare y costará 27.200 mrs.

- En dicho sitio se necesita ahondar el calce que atraviesa el camino y mudar el pontón que está en la parte de arriba, y hacer un pedazo de calzada desde la que viene del Hospital del Rey hasta el dicho calce, y todo costará 27.200 mrs.

- A la orilla del dicho calce hacia la parte de Valladolid, se ha de hacer un alamborado de piedra tosca bien crecida y ahondar el calce que todo monta 10.000 mrs.

- Desde el dicho calce hasta la cuesta de San Vitores camino de Valladolid, 2.136 pies y de ancho como 6o, donde hay muchos cárcavos muy hondos y llenos de agua que ocupan todo el camino, por lo que ningún caminante puede pasar, y a los de a caballo les llega el agua a la rodilla de sus cabalgaduras, y todo necesita rellenarse de cascajo que está lejos y por esto costará 51.000 mrs.

- Se vio "el pontonçillo de Santiago como ban a Tardaxos", que está desguarnecido y alamborado y necesita reparo, costará $6.000 \mathrm{mrs}$.

- Se debe arreglar un tramo de calzada en "el camino como ban a Tardaxos en derecho del molino de los Guindales ques del Ospital del Rrey", que llevará 20 tapias de empedrado, y hacer un pedazo de estacada en el dicho sitio para que el calce no salga a la calzada y camino, $5.100 \mathrm{mrs}$.

- Otros dos cárcavos en el dicho camino, uno derecho de la dicha calzada y el otro más abajo, que necesitan cegarse y allanarse y costarán 1.360 mrs.

- Más abajo en medio del dicho camino hay otros dos cárcavos, el uno muy hondo de 20 pies de largo y 15 de ancho y se han de remediar con fajina de sauce y cascajo, todo costará $6.000 \mathrm{mrs}$.

- Se debe hacer un pontón de madera antes de llegar a estos cárcavos, en un calce que sale del Arlanzón, para que pueda pasar la gente que viene y va a Tardajos y a Santiago, porque siendo verano no pueden pasar sin descalzarse y costará $2.250 \mathrm{mrs}$.

- Una calzada que está como suben de los obradores de Santa Dorotea a San Bartolomé, que mucha parte de ella necesita empedrarse, y llevará 76 tapias de piedra tosca y gruesa a cinco rs. la tapia porque faltan adoquines y está la piedra lejos, $12.920 \mathrm{mrs}$.
} 
- 150 carretadas de piedra tosca, cada una ha de tener 10, 11012 quintales, que puesto en obra costará a $8 \mathrm{rs}$. la carretada porque han de ser piedras grandes, 40.800 mrs.

- 30 carretadas de piedra de Hontoria de piezas grandes y pequeñas, que costará la carretada $10 \mathrm{rs}$. de sacar, desbastar y traer, $10.200 \mathrm{mrs}$.

- 100 cargas de cal, a $56 \mathrm{mrs}$. cada una puesta en obra, 5.600 mrs.

- De arena para la dicha cal, 3.000 mrs.

- De labrar la piedra y asentarla, quitar el agua, hacer andamios, revocarla y rajarla a lo largo del puente, por debajo de los arcos y tajamares a ambos lados, y encadenar los 6 arcos que parecen estar desencadenados y descubiertos, porque los demás están cegados, $60.000 \mathrm{mrs}$.

En el puente de los Malatos, se hará otro tanto en la parte que parece estar desencadenado que serán otros tres arcos, rajarlo, revocarlo y apretarlo con sus cuñas y encajar algunas piedras donde faltan. Se deben cortar unos sauces que ocupan sus ojos a ambos lados, abrir un poco la madre del río aguas abajo, y después de encadenados los arcos, estacar los encadenados y estribos, con 1.000 estacas. El coste por aderezar los arcos, encadenarlos, revocarlos y recalzar los tajamares es de $102.980 \mathrm{mrs}$ :

- De piedra tosca de piezas crecidas, 150 carretadas que cada una ha de tener 10, 11 012 quintales, y puesta en obra cada carretada a 8 rs. de sacar, desbastar y traer, $40.800 \mathrm{mrs}$.

- 30 carretadas de piedra de Hontoria de piezas grandes y pequeñas a 10 rs. la carretada de sacar, desbastar y traer al dicho puente, $10.200 \mathrm{mrs}$.

- 80 cargas de cal a 56 mrs. la carga puesta en obra, $4.480 \mathrm{mrs}$.

- De arena para la dicha obra con la cal, $2.500 \mathrm{mrs}$.

- De labrar la piedra y asentarla, quitar el agua, hacer andamios, revocarla y rajarla en todo el largo del puente por debajo de los arcos y tajamares a ambos lados, y encadenar los 5 arcos a la parte de las Huelgas, porque los demás están cegados con mucho cascajo, $45.000 \mathrm{mrs}$.

Visto el informe y como la ciudad no tenía propios ni rentas, acordaron que la información detallada se envíe al Consejo Real para hacer el repartimiento.

En audiencia de puentes se informó el 9 de julio que habían comenzado a asentar las puercas para el puente de madera, y ha habido algunas diferencias sobre una que está asentada y alta, y habiendo oído los diferentes pareceres, mandaron que se asiente para que el puente vaya lo más igual que se pueda al de piedra. También mandaron que antes de que se asienten las puercas en el río, se compruebe que haya buen cimiento conformes todos los maestros, notificándose a Llanos, Fonfrida y Suertes. El 16 de julio se dijo que faltan de traer ciertos olmos para las puercas, porque los vecinos de Gamonal no los quieren llevar por estar ocupados en sus agostos, por lo que mandaron que los que tuvieren carretas y bueyes los traigan, y se les pague bien su trabajo. Se acordó que como las vigas que faltan para tramar el puente serán hasta 100 de 20025 pies, Espinosa y Medel de Lara, 
recorran los términos de la ciudad y los corten si los hubiere, y no habiéndolas, las concierten y compren a los particulares.

Fonfrida y Suertes informaron el 1 de agosto que faltaban hasta 24 álamos largos y delgados para tramar el puente, mandando de nuevo a Espinosa que los traiga de inmediato. El corregidor y regidores dijeron que los 10 olmos grandes que se han traído de la casa de la Vega para puercas se paguen a tres ducados por olmo. Como todavía faltaba mucha madera para tramar el puente, se mandó a Espinosa que busque y compre otros 100 olmos más con mucha urgencia. Como el sobrestante Sebastián de Vallejo ha trabajado en el puente dos meses, pidió que el ayuntamiento le diese ayuda de costa por asistir todos los días de la mañana a la noche, y por la mucha asistencia y trabajo que tiene y como con el salario señalado de 1,5 rs. diarios no se puede sustentar, acordándose que se le den $3.000 \mathrm{mrs}$.

Suertes y Fonfrida dijeron que para tramar y cuajar el puente se precisan 200 olmos, y mandaron que Espinosa los compre buenos y largos, acordando que se comience a echar tierra o broza en el puente de madera para su empedrado, y como Pedro y Baltasar de Castañeda dijeron que antes conviene que se encespede y ripie, mandaron que así se haga. Como se debían aderezar los puentes de San Pablo, de Santa María y de los Malatos con celeridad por la cercanía del invierno, se mandó que los caballeros diputados puedan traer más canteros, piedra y materiales precisos. Acordaron también que Espinosa haga pasar el agua del río por el puente de madera el próximo sábado, para comenzar con los arcos de piedra, y que se haga el azor y paredón de piedra que está en el calce que va al convento de la Victoria.

El 28 de agosto la ciudad manda que se tomen las casas de Francisco Orense, por ser su demolición necesaria para los accesos del puente de madera por la parte de Vega ${ }^{213}$. El corregidor pide información, para lo que Juan Sánchez de Angulo presentó testigos los cuales dijeron que se debe derribar la casa para dar paso desde Vega, y ser preciso para el ensanche del futuro puente de piedra. En septiembre el corregidor nombró de oficio como tasadores a Pedro y Baltasar de Castañeda, maestros de cantería, y a Pedro de Rada, maestro de carpintería, vecinos de la ciudad, que dijeron que la casa como antes estaba alcanzaba los $324.000 \mathrm{mrs}$. El corregidor dijo que Orense se contentaba con que se le den $310.000 \mathrm{mrs}$, , por lo que mandó que se le paguen ${ }^{214}$.

Como la ciudad estaba falta de propios, pidió al Rey que mientras se hacía el repartimiento diese licencia para tomar a censo 3.000 o 4.000 ds. El Consejo acordó dar facultad para que sobre sus propios y rentas, se tomase a censo al quitar de cualquier persona o concejo que los quiera dar, hasta 3.000 ds. para el puente de madera de tres ojos y 2.000 ds. para los otros puentes, caminos y calzadas, y para la seguridad de los que tomasen el censo puedan obligarse con sus propios y rentas. Era necesario que todo se reparase con brevedad, porque el puente de Santa María "hera uno de los pasos mas publicos y mas pasageros de nuestros Rreynos, y lo mesmo hera por las otras puentes de Sant Pablo y de los Malatos y por los caminos, carreras y calçadas por donde se entraua en esa dicha çiudad y se tomaua el paso de las dichas puentes", siendo preciso que se repartiesen 25.000 ds. entre las localidades que recibían aprovechamiento, porque mientras se hacían las obras, se debía dar paso por los tres puentes y reparar de

213 A. M. B./ HI-1680/ Burgos, 26 mayo a 1 diciembre 1582.

214 A. M. B./ HI-912/ Burgos, 25 septiembre 1582. 
inmediato los caminos y calzadas. Los 3.000 ds. tomados en agosto no fueron suficientes y serían poco útiles si no se acabasen los reparos antes de las aguas y nieves del invierno, además del gran peligro que corrían las personas, bestias y cargas por los malos pasos y barrancos que se hacían en los caminos, por lo que fueron necesarios otros 2.000 ds. más ${ }^{215}$.

En agosto se había acordado que se debía realizar el encadenado de otro arco del puente de San Pablo junto a la bajada que va a la charquería, recalzar una esquina y cebar de piedra y cascajo un pozo muy hondo bajo dicho arco, acabar de revocar los lados del puente y bajarlo, porque lo demás estaba acabado. También se debían encadenar y recalzar los tres arcos que quedaron del puente de Santa María, que se estaba descubriendo por orden de Pedro de Castañeda, y hacer un fragmento de paredón para recibir un trozo de un arco hacia la parte de Vega, porque estaba sentido. Cometieron al regidor Juan Martínez de Lerma que haga el trozo de paredón que derribó la creciente bajo el puente, y recalzarle hasta el convento de la Victoria, a Andrés de Larrea el reparo del camino entre los molinos de Aleba y del Hospital del Rey, y de allí al camino de Valladolid hasta la cuesta de San Vitores, y asimismo reparar el camino que va a Tardajos hasta el mojón de Ramón Bonifaz, recrecer el arco de la Moneda, remediar la "ponticella de Michelote", y recalzarla por la parte de abajo, y a Gonzalo López de Polanco el aderezo del puente de los Malatos.

En septiembre en audiencia de puentes se dijo que entre las puertas de las Carretas y de Santa María, hay unos terreros que hacen un gran daño a los puentes porque ocupan la madre del río, mandando que se limpie de inmediato y que los carreteros del mercado cuando se vayan, lleven una carretada cada uno de la dicha tierra donde se les señalare. Acordaron que la piedra de los estribos y de los arcos del puente de Santa María se saque de la madre del río y se guarde, y que el sobrestante Sebastián de Vallejo tome obreros. Mandaron que se ahonde y haga madre en el río debajo de los arcos y frente a sus ojos y a los huecos del puente de madera. Convinieron que Domingo de Hazas haga lo que está caído del paredón y calce que va de la puerta de Santa María a la Victoria, haciendo los cimientos y toda la obra a vista y satisfacción de Pedro de Castañeda, maestro de las obras de ella, y que Espinosa dé los materiales necesarios a pie de obra. Hazas se obliga a dar acabado el puente de madera para el mes de octubre. En 26 de septiembre se acordó que además de las obras encargadas y aderezos de puentes y caminos, se haga una estacada en el azor que llevó la avenida de cara al molino de Aleba y, con brevedad, otro pedazo de estacada debajo del puente de los Malatos para que vaya el río por su madre, ya que el agua está destruyendo los caminos. Gonzalo López de Polanco informó de que son necesarios 280 carros de piedra tosca para el reparo del puente de los Malatos y mandaron que se traigan. En diciembre el corregidor, justicia y diputados de puentes, acordaron que como el de madera estaba acabado, se conceda a los maestros Suertes y Fonfrida, que han asistido mientras ha durado la obra y han trabajado con los calores, además de los 4,5 rs. del salario fijado, 10 ds. a cada uno y otros dos a Suertes por el trabajo de salir para los árboles que se habían de cortar y señalar, asistir a cargarlos y otras cosas ${ }^{216}$.

215 A. M. B./ HI-4141/Lisboa, 31 agosto y 27 noviembre 1582; A. M. B./ HI-4934/ Lisboa, 27 noviembre 1582 y Burgos, 26 junio 1593; A. M. B./ HI-1680/1582.

216 A. M. B./ HI-1680/ Burgos, 26 mayo a 1 diciembre 1582. 
Para obtener los recursos necesarios se realiza en 1583 un interrogatorio según lo mandaba la Provisión real. La primera pregunta trataba sobre si tenían noticia del puente de Santa María y de los caminos, carreras, calzadas y paredones arruinados que eran los siguientes:

- El camino de Burgos para Valladolid desde la Merced hasta pasado el Hospital del Rey y ventas del Galguillo.

- El camino desde Burgos a Tardajos y toda Campos.

- El camino desde Burgos a Covarrubias y Valencia.

- El camino desde Burgos a Lerma y Madrid.

- El camino desde Burgos a Arcos y Segovia.

- El camino desde Burgos por Villatoro a Santander y Laredo.

- El camino desde Burgos a Bilbao, San Sebastián y Francia.

- El paredón desde la Merced por el río abajo, derribado en más de Goo pasos.

- Un pedazo de paredón que va desde el puente de Santa María a los Mínimos.

- Otro pedazo de paredón delante de la iglesia de San Lucas.

- Los daños y ruinas que el puente, caminos, carreras, calzadas y paredones de Burgos han recibido con las crecientes y avenidas del río Arlanzón, y si tienen noticia de las crecientes y avenidas de dicho río y en especial de la de mayo de 1582.

- Otra si sabían que el puente de Santa María es "una de las mas prinçipales y mas publicas, neçesarias y pasageras destos rreynos y mas frequentadas de todos, y pasan... por ella a pie y a cauallo y con carreteria y tragineria, los de los pueblos y lugares del contorno y comarca y prouinçia y arçouispado de la dicha çiudad, y las personas y mercaderias y mantenymientos y otras cosas, que uienen del condado de Vizcaya y prouinçia de Guepuzqua y montañas, y las que uienen de Flandes y Françia y aportan en los puertos de las dichas prouinçias, y las que se traen de Rioja y Bureua y Reyno de Aragon y las quatro uillas de la costa de la mar, Soria y Logroño y tierra de Yanguas y Atiença y Reyno de Nauarra, que passan y se lleuan para Valladolid, Ruyseco, Medina del Campo, Salamanca, Segouia, Toledo, Seuilla, Madrid y Andaluçia y el Alcarria y otras partes y para sus ferias y para la corte de su Magestad,... [por ser el río] Arlançon grande y de tanta agua que no se puede pasar por el, si no es por la dich a puente espeçial en tiempo de hibierno y aguas, nieues y auenidas".

- Si sabían que el puente de San Pablo, "no se carretea ni puede carretear y solo sirue de passo de gente de a pie y de a cauallo, por ser tan estrecha y angosta que apenas caue una carreta por ella y porque tanuien es de tan flaco y deuil hedifiçio, que por esto y por pasar como pasan por ençima della dos fuentes de las prinçipales desta çiudad, si se carretease correria rrisgo grande de haçer sentimientos y caherse en breue tiempo, y por esto de tienpo muy antiguo a esta parte, estan en ella puestos hitos de piedra porque no pasen carros ni carretas".

- Si sabían que el puente de los Malatos, que por estar en el extremo de Burgos, "y por ser tanbien estrecha y de fragil y deuil hedifiçio, y no tan fuerte como la dicha puente de Sancta Maria y el peligro que podria correr en ello, no se carretea, y ay tanbien de tienpo muy antiguo, puestos hitos en ella para que por alli no pasen carros ni carretas, y que demas desto tanpoco se puede carretear comodamente para entrar por ella a la dicha çiudad y salir della, porque la entrada de la dicha çiudad por aquella parte es tan agria y 
dificultossa y mala de subir que apenas puede subir por ella una carreta uazia, quanto mas cargada, y la misma puente en si no tiene tan buena y façil entrada y salida para carretearsse como conbernya".

- Si sabían que los dichos caminos, carreras y calzadas son muy pasajeros, y se va por ellos a pie, a caballo y con carretería y trajinería para todos los pueblos, provincias y reinos, y que en mayo de 1582 el Arlanzón tuvo las mayores "auenidas y creçientes de aguas que se an uisto ni oydo jamas, e ynundaron la dicha çiudad y sus cassas y el arraual de Uega que confina con el dicho rrio, llegando y entrando donde nunca se uio llegar ninguna abenida, e hiçieron grandes y notables daños... en las dichas cassas y haçiendas que auia en ellas y en las heredades y huertas que estauan çerca del dicho rrio, desçercandolas y dejandolas yermas y sin çerraduras, y tanbien en los templos e yglesias y sepulturas y capillas dellas", y además dicha creciente llevó cuatro arcos principales del puente de Santa María de los siete que tenía y los otros tres "quedaron sentidos arruynados y socauados", haciendo daños también en los puentes de San Pablo y de los Malatos, dejándolos dañados y socalzados.

- Si sabían que dicha creciente y otras posteriores deshicieron el paredón que está entre el río y el camino público junto al convento de la Merced, para defensa del camino y deshizo más de 600 pasos entrando el río por él, y también deshizo otro pedazo del paredón junto al río entre el puente de Santa María y el convento de los Mínimos y otro fragmento entre el Arlanzón y el camino real cerca de la iglesia de San Lucas, y encima del convento de San Pablo, entrando por el camino público.

- Si sabían que dichas crecientes deshicieron los dichos caminos, carreras y calzadas públicas, y también se desbarataron con lo mucho que llovió el día de la Ascensión y de San Juan de Ortega y otros días del invierno pasado, haciendo tantas cárcavas, concavidades y balsas que no se puede pasar ni carretear, especialmente en tiempo de invierno y de lluvias en que se corre más riesgo y peligro, y que ciertos reparos de estacadas y otras cosas realizadas en defensa de los caminos públicos después de las primeras avenidas del año pasado, los llevaron las últimas crecientes.

- Si sabían que para todas las obras serán necesarios unos 25.00o ds., y que la ciudad solo tiene unos 3.000 ds. de propios para pagar salarios, costes de pleitos y otras obras y reparos que se ofrecen cada día, y aún no tiene suficiente para ello, y que Burgos también está adeudada en 16.000.000 mrs. de principal de censos al quitar, que tiene cargados sobre sí y sus propios, con facultad real para pagar los réditos cada año, por los grandes gastos hechos, entre otros, en el recibimiento de la Reina, en la guerra de Granada, y de los muchos repartimientos que paga para puentes lejanos de la ciudad y no tan pasajeros como el de Santa María, y que por ser la ciudad tan pobre de propios y estar tan endeudada, se vale de sisas ordinarias para pagar los dichos réditos y censos.

- Si sabían que por haber como hay sisa de ordinario para la paga de los censos y deudas públicas, y tener la ciudad sobre sí tantos censos de que paga réditos, no se puede sacar lo necesario para las obras y reparos por esta vía, y tomándolo a censo no se hallaría quien se lo diese por no haber fincas, más de los que buenamente puede pagar, ni podría pagar tantos réditos, y se tardaría por esta vía mucho más tiempo en hacer los reparos y podrían las crecientes llevar lo que quedó y hacer mayores daños.

- Si sabían que la ciudad "no esta en la prosperidad que solia sino mas arruynada que nunca, y con mucha menos xente y ueçindad que solia, por los ynfortuynos y daños suçedidos por la peste, y con auer çessado su cometido y contrataçion que hera lo prinçipal con que se solia sustentar, y con las alteraçiones de Françia 
y Flandes", y que estando tan fatigada, cargándola con nuevos censos para estas obras no podría pagar ningún gasto extraordinario para servir al Rey ${ }^{217}$.

El puente de madera se usaba ya en diciembre de 1582, por lo que se debía edificar ya el de piedra. Su construcción sufrió demoras porque más de un año después, Fructuoso López, en nombre de la ciudad, dijo al Rey que era necesario que el puente de Santa María se reparase con brevedad, y como la ciudad estaba sin recursos, era justo que se repartiesen los 25.000 ds. necesarios, y lo que correspondiese a la ciudad se pudiese echar por sisa sobre el vino. El Consejo acordó en 24 de marzo de 1584 mandar al corregidor que ponga en pregón la obra del puente de piedra y se rematase en quien ofrezca mejores condiciones. También da licencia para repartir la mitad de su coste a la ciudad, pudiéndolo echar por sisa sobre los mantenimientos que en ella se vendiesen por menudo, exceptuando el pan cocido, en cuya sisa contribuyan todos sin exceptuar a nadie. La otra mitad se repartiría entre las localidades de 20 leguas de la ciudad que recibieren aprovechamiento ${ }^{218}$.

El corregidor mandó en abril que la obra se pregone en la ciudad y en las principales ciudades y villas más cercanas, para que acudan el 15 de junio todos los maestros y oficiales interesados. Se remató al fin en los maestros de cantería Domingo de Hazas, vecino de Burgos, y Lope García de Arredondo, vecino de Bárcena merindad de Trasmiera, por 8.400 ds. y el Consejo libró Provisión aprobando dicho remate y repartimiento ${ }^{219}$. No obstante, y ante las propuestas de los maestros de cantería Pedro de Castañeda, Martín de la Haya, Francisco del Río, Juan de Naveda y Juan del Río, dicho remate quedó en suspenso, ya que dijeron que no les parecía conveniente que la obra se hiciese con ninguna de las trazas y condiciones presentadas, haciendo una nueva traza por mandato del corregidor. Dicen que vieron el sitio y corriente del río y lo que está caído y fabricado y lo que falta por hacer, de acuerdo con las mismas trazas, e indican que les parece que se debe respetar lo realizado, así en esviaje como en los largos de pilares, tajamares, estribos y adornos de cornisamientos y parapetos, como estaba en las condiciones y en la traza que se les mandó hacer. Además se deberá quitar la bajada a la ribera que está hecha y romper la isla que confina con ella en todo el largo desde el mismo puente hasta delante de la puerta de las Carretas.

El maestro deberá poner cuatro escudos de armas reales y de Burgos de seis pies de alto con sus leones "como se acostumbra en semejantes obras", dos a la entrada del puente hacia la puerta de Santa María y los otros dos a su fin hacia Vega. Conforme a la traza y condiciones y lo que han declarado todos los maestros y oficiales, conviene tomar parte de ciertas casas y mesones que son de Juan Martínez de Lerma, Francisco Orense y otros particulares, y que están en la madre del río, para que tenga libre su corriente, porque esto podría causar el daño y caída del puente. El maestro deberá pagar lo que se tome, el daño que se cause y su derribo, y la ciudad se lo ha de hacer dar a tasación. Asimismo, el maestro en quien se rematare deberá quitar a su costa todos los terreros de la ribera del río desde el puente de San Pablo al de Santa María, a raíz de la barbacana y mesón que se hace de las Carretas, para que el agua entre por los arcos del puente más derecha, y la ribera quede

217 A. M. B./ HI-1661/1583.

218 A. M. B./ HI-4150/ Madrid, 24 marzo 1584

219 A. M. B./ HI-1679/ Madrid, 19 marzo 1584 y 12 septiembre 1585 y Burgos, 23 octubre 1587. 


\section{libre, porque se entiende que esta tierra fue la causa de la ruina del puente. Dicho maestro deberá dar fianzas suficientes de que cumplirá todo lo dicho 220 . También se pidieron otras}

220 Añaden que para ampliar la anchura del río y facilitar el paso del agua en sus crecidas, se debieran hacer tres arcos y que el mayor y principal sea el que ligue con lo viejo y tenga de hueco 37 pies, y así con los dos pilares de 36 pies de hueco cada uno que se han de hacer, que tendrán 14,5 pies de grueso, vienen a ser 138 pies que es la longitud que hay desde el estribo de Vega hasta el pilar que está en lo que quedó en pie, que es el tercero, y así no es necesario demoler nada del estribo de Vega, sino solamente lo necesario para enjarjar la vuelta del arco que acaba en él. - Para la fundación de las dos cepas que "se quite el agua con sus estacadas y engenios que al maestro le pareciere", y se abran los cimientos en todo el largo y ancho de los pilares con cuatro pies a cada lado, así en los estribos y tajamares como en todo lo demás, y con este ancho y largo, se ahondarán 8 pies contados del nivel y primera hilada de piedra de Hontoria de los estribos, y si "no paresçiere el firme fundamento, se ara artifiçial con los yngenios a semejantes edefiçios necessarios, que sera yncando muchas estacas y espesas con sus tramos de pino y las estacas de aya muy bien yncadas, asta que se entienda auer llegado a buen fundamento", y en los intervalos se echará piedra menuda y cal viva, y puestas las dos cepas a nivel, para que cargue todo el peso junto, se fundarán las dos cepas de 22 pies de ancho y 73 de largo, y todo ello será de grandes piezas de 1,25 pies de alto y queden después de desbastadas las de la superficie a 10 y a 12 quintales, advirtiendo que se echen a tizón de 10 en 10 pies y las de la médula serán de 7 y 8 quintales, tomando buenas ligazones, y de estas piezas galgadas irá lleno el cimiento y todas las demás hiladas, hasta donde se han de encajar los dichos pilares con el grueso dicho que será a nivel de los lechos, recogiendo en cada hilada de las dichas medio pie para zapata, se pondrán a nivel así en la médula como en las demás con muy buena "froza" de cal y arena. Toda esta piedra será tosca y traída del término de la ciudad.

- Subidos los cimientos al alto dicho, se erigirán los pilares con sus estribos y tajamares, dejando medio pie de zapata a cada hilada de a 14,5 pies de grueso y 65 de largo como están los hechos, que serán de piedra de Hontoria en la superficie, de dos pies de lecho y de trecho en trecho sus tizones y de cuatro pies de lecho y dos de largo, y subirán los pilares hasta la cornisa que está sobre las dovelas al ándito del puente, todo bien labrado y asentado y en cuanto a la"froza" y médula, se harán las cuatro hiladas primeras de piedra tosca galgada como la de los cimientos, y hasta arriba serán de buenos ripios bien solidado y rehenchido.

- Los tres arcos que se han de hacer, se montarán como se muestra en la traza, y las dovelas serán así en los arcos como en lo demás, labradas y asentadas como está lo hecho en el puente, y asimismo se harán los enjutamientos y enveladuras que en todo ello se guardará el orden de lo demás y la cornisa del ándito y losado y empedrado, todo se hará como está lo hecho para que todo parezca una cosa.

- Los huecos de los tres arcos nuevos sean encadenados en todo su largo a 138 pies, más cuatro a cada lado que son 73 de ancho, todo lo que en la planta se ocupa. Estos encadenados serán fabricados para que en todo el largo por los dos extremos se hinquen en cada lado dos órdenes de estacas a pie una de otra, terciadas y bien hincadas, y lo que causare entre la estacada de la entrada y salida sea de buenos sillares de 7 a 10 quintales y 1,5 pies de grueso, todos con sus juntas, labrados a picón y alamborados a la entrada y salida, advirtiendo que haga un poco de caída por medio de los arcos. Su sobrelecho será el nivel de la zapata postrera y con este mismo orden se encadenarán y los harán los arcos y pilares que ahora están hechos y todo quede hecho un cuerpo.

- Se hará una manguardia río arriba que tenga de largo 62 pies, que llega a la calle que baja desde Vega al río, que irá rasgada a la parte de Vega según muestra lo que está hecho, la cual era fundada 5 pies más hondo en el ándito del agua y subirá de la superficie de la tierra 10 pies, será el haz de fuera en lo que se ve desde donde se encajare arriba, de sillería tosca labrada a picón, y desde allí abajo de buenas piedras crecidas como conviene y de grueso 5 pies después de encajada, y el cimiento 6 pies y por la parte contra las casas que no se ve, irá de buena mampostería. - Se hará otra manguardia del río abajo que salga del diente del arco cabero, que tenga de largo 500 pies, e irá en línea recta por la parte del río, y baja a dar en las casas que están al fin de la ribera, tomando en ella por el rincón que ahora hace a la parte de arriba 10 pies contados desde la pared de las casas adentro hasta el haz de la manguardia por la parte del río, que se entiende en todo el grueso de pared de allí adentro, y allí se guiará de manera que vaya a dar 10 pies desviado de los dos álamos primeros, llegando los 10 pies hacia el convento de la Merced porque así conviene para que el río tenga más madre, y los dichos 500 pies se entienden desde lo que ahora está hecho abajo, la cual será fundado en lo de arriba y con el mismo alto y de la misma manera irá hasta salir de las casas, y de allí abajo irá cinco pies encima de la tierra, contados por la parte de la calle, de manera que siempre se ahonde el cimiento cinco pies y tenga de ancho 6 porque de allí arriba ha de tener cinco de grueso hasta su final y en esta se hará una bajada al río donde convenga.

- La mezcla en los fundamentos y alto de cuatro pies sobre el agua y en lo necesario a los arcos para fijarlos y enrejar, se hará la mitad cal y la mitad arena y todo lo demás será mezclado, dos partes de arena y una de cal. La arena será buena y de terrero y no del río "porque esta desjugada" y los morteros mezclados un mes antes de que se gaste y aguados, que así conviene para esta fábrica.

- El maestro encargado de la obra estará obligado a hacerla bien y de la manera que en estos capítulos va declarado, y lo demás que está hecho lo ponga en toda perfección a satisfacción del maestro veedor que el corregidor nombrare, y la ha de dar hecha y acabada en tres años.

- Deberá poner todo lo necesario, así materiales como todo lo demás, hasta su finalización y puesta en perfección, pero se le han de dar todos los despojos que hay de lo caído, así en el río como en la ribera sacado como está, y sin que por los dichos despojos se les lleve cosa alguna. 
trazas y condiciones a García de Alvarado, Diego de Praves y Felipe de la Cajiga, a los que se pagaron tres ducados a cada uno, y otra traza y parecer a Juan de la Fragua, maestro de cantería, pagándole dos ducados. El corregidor con acuerdo de los diputados aceptó la traza y condiciones de Pedro de Castañeda, Martín de la Haya, Francisco del Río, Juan de Naveda y Juan del Río, y mandó que con ellas se haga el puente de Santa María y se pregone para que los interesados hagan posturas.

Pedro de Castañeda indicó que lo primero que se debe hacer es que los huecos de los arcos, estribos y tajamares se encadenen en todo el largo, y luego se recalcen los pilares de la parte de Vega, y los que quedan de la parte de la ciudad se encadenen de nuevo, porque el que tienen no es bastante. También que entre los despojos y la piedra que se cayó del puente, no entran los despojos del puente de madera que está hecho, porque son de la ciudad. Y por esto se le den 100 ds. de prometido y siendo en él rematado, dará fianzas de que lo hará y cumplirá así hasta los dichos 8.400 ds., y puso a Lope García de Arredondo, como su fiador y Domingo de Hazas como principal deudor. La obra se deberá realizar en 3 años, y la cantidad en que se remate se pagará la cuarta parte al comenzar y lo demás en 6 partes durante los 3 años, de seis en seis meses, de manera que la última paga se le dará después de acabada la obra, que será dada por buena por dos maestros nombrados por el corregidor y por el maestro de la obra ${ }^{221}$. En agosto de 1584 se da cuenta del repartimiento hecho por el corregidor entre los vecinos de los lugares comprendidos en 20 leguas a la redonda, en el que constan las cantidades que a cada lugar le tocaban, según la población obtenida por las personas que fueron en 10 veredas a su averiguación ${ }^{222}$.

En febrero de 1585 el procurador mayor de Burgos informó al corregidor que cuando se remató la obra no se incluyó la realización de una bajada al río, ya que pareció que no convenía que se hiciese por la parte que antes estaba, pero que se ha considerado la necesidad de hacerla, tanto para bajar a lavar y llevar a beber a las cabalgaduras, como para proveerse de agua en los casos fortuitos de incendios. Pide que se vea donde conviene que se haga, se pregone para hacer propuesta de su traza y se remate en la oferta más favorable. Su coste se deberá incluir en la cuantía de la obra y las condiciones se detallan para que gentes de a pie, de a caballo y carretas cargadas y vacías, puedan bajar con facilidad a la ribera del río 223 . Los maestros Martín de la Haya, Domingo de Hazas, Juan Ortega de

\footnotetext{
- Para cumplir y acabar la obra se le han de dar canteras libres y pastos cerriles, sin que pague cosa alguna excepto si hicieren daño en panes, prados, pastos guardados o heredades de particulares que lo ha de pagar el maestro, porque la ciudad solo ha de dar lo que fuere ejido público.

- El maestro encañará a su costa el agua de la fuente de Santa María a lo largo del puente.

- El corregidor nombrará un veedor maestro de cantería que sirva de sobrestante, para que vea los materiales que se colocan y si la obra va como conviene conforme a la traza y condiciones, y el maestro en quien se rematare ha de pagar $29.000 \mathrm{mrs}$. al año para el salario del veedor.

- Desde las cuatro hiladas arriba que se manda ripiar, se echará una cadena a lo largo del dicho pilar por su centro de dos pies de ancho, que iguale con las hiladas de afuera y que la atraviese del dicho pilar de 6 en 6 pies, se vayan echando sus cadenas y los huecos entre ellas y se macicen de mampostería hasta llegar a las hiladas.
}

221 A. M. B./ HI-1679/ Madrid, 19 marzo 1584 y 12 septiembre 1585 y Burgos, 23 octubre 1587.

223 Las condiciones de la calzada para bajar del puente a la ribera del río son:

- Comenzará por la parte del río junto al estribo hacia la puerta de Santa María, volviendo hacia la puerta de las Carretas derecho a la escala que está hecha, y allí se ha de hacer una placeta de 18 pies de largo y 15 de ancho, haciendo cuadrado dicho estribo con el que se gana el ancho de la calzada, que serán 15 pies de tercia de vara y ha de 


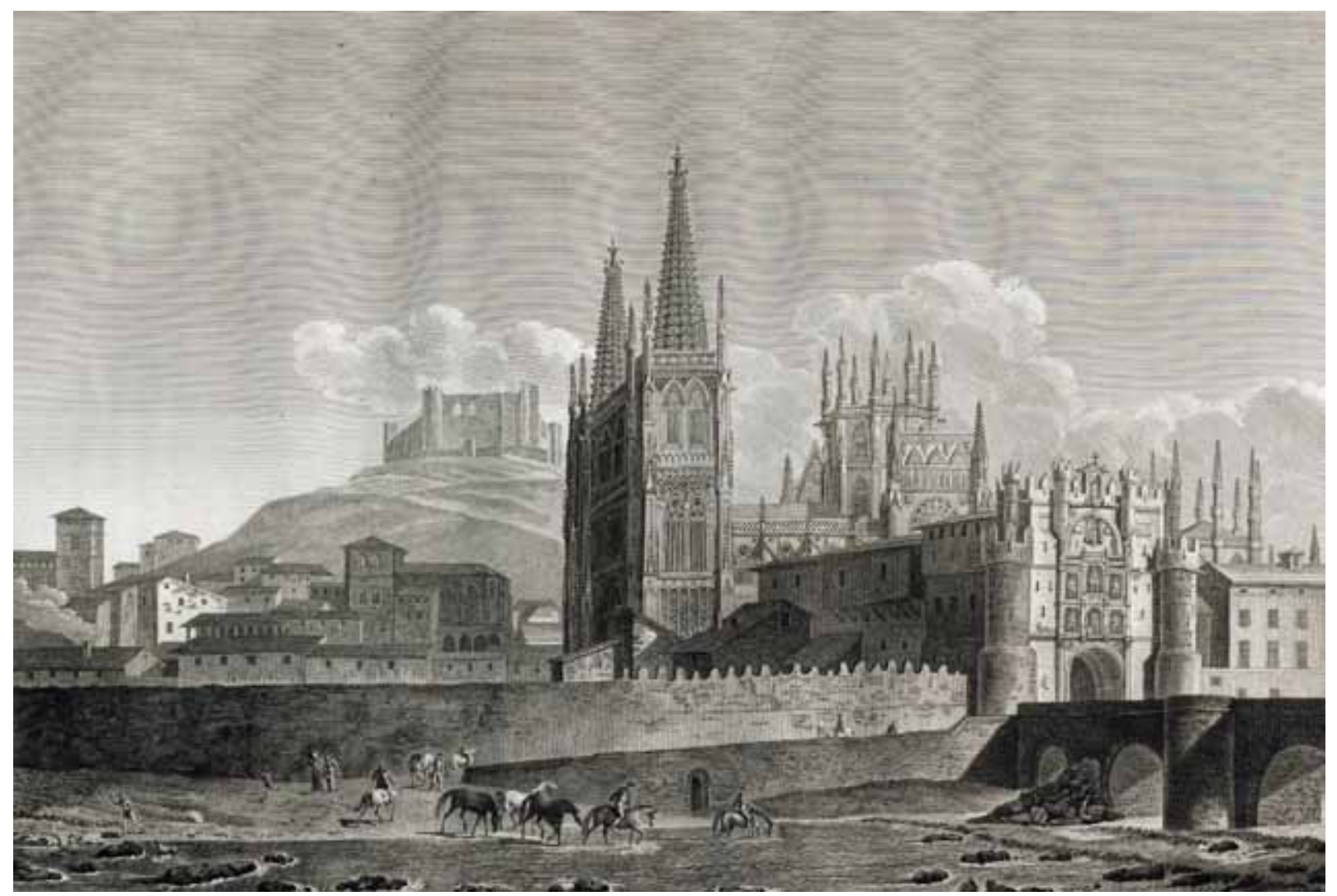

Vista publicada por Laborde en 1820, donde se refleja la rampa del puente de Santa María.

Castañeda y Juan de la Fragua, vecinos de Burgos, dijeron que conocen la bajada que había, casi en medio del puente hacia Vega contra la corriente del agua, y que después que el río lo llevó se vio que la bajada estaba en "lugar yndeçente y no conbeniente", donde "quando abia alguna cresçida, hazia rrepressa y balsa de cascajo delante de la dicha bajada y hazia una ysleta mas alta que la madre del rrio, de suerte que por poco quel rrio cresçia, hazia grandissimo daño a la dicha puente, asi açia la

estar encadenada en todo el ándito de la calzada de 10 en 10 pies, con piedras labradas y escuadradas de 1,5 pies de ancho y dos de grueso, que entren al hondo de la cantería, y en todo el largo de 80 pies ha de llevar otra hilera de piedra y del mismo grueso y ancho por el medio de la calzada, asentadas por derecho y concertadas y ajustadas en los cuatro lados, y entre los cuadrados que las losas hacen y sus encadenamientos "se a denpedrar de creçidos guijarros metidos lo mas largo" hacia la profundidad.

- Se buscará en todo lo largo y ancho de la calzada buen cimiento con 6 pies de profundidad, midiendo los de la superficie de la tierra hacia dentro y si no se hallare suelo firme, se hagan artificiales fuertes y seguros como conviene al edificio y después de abiertos y limpios y por nivel, se ocuparán de buenas piedras crecidas y con buena "froza" de cal y bien macizo y asentado, y subirá en el dicho cimiento de cantería y con los 6 pies de hondo y en todos los 80 pies de largo y en 18 de ancho.

- Después de igualados los cimientos, se encajará por el lado del río la pared de sillería en dos pies de hondo, y los sillares de aquel lado tendrán de lecho unos 2,5 pies y otros más, dejando a la elección y encaje de la primera hilada un pie en la mampostería del cimiento, y en la tercera medio pie en talud dejando un arquillo por debajo del ándito para desaguadero del conducto que allí va, y el lado de la calzada hacia el río en toda su longitud y alto y los lechos arriba declarados y bien ajustados ha de ser de sillería y de piedra de Hontoria, y lo demás, ancho y largo de la calzada y su profundidad hasta el ándito de ella, ha de ser macizo de piedra y cal hasta trabar con el paredón que está hecho al otro lado sin sacar de él piedra alguna.

- Encima del ándito de la calzada y sobre la sillería por la parte del río, ha de llevar un antepecho de 3,5 pies de alto y 1,5 de grueso, rebajada en él la moldura del pasamano y bien labrado, conforme a la caída de la calzada y con sus rafas de hierro fuertes y emplomadas, y en sus lechos contra la sillería, sus aguijones de hierro en los 80 pies de largo y en los 20 que tiene la placeta.

- En la punta de la calzada y encima de los cimientos y a regla con el ándito y en lo más hondo de ella, se asentará una hilada de piedras labradas y crecidas como están en la traza, donde estribará la hilada primera del encadenado y su empedrado y lo que no estuviere en la traza, que los maestros hagan la obra no quitando de ella cosa alguna. 
parte de Bega como a la parte de la puerta de Santamaria", y azotando las paredes llegó al pilar por donde el puente se descalzó y hundió.

Convenía, añadieron, que se haga una bajada en medio del puente aguas abajo hacia los lavaderos, embutida en uno de los dos pilares y del mismo grueso que el estribo, porque aquí será muy útil para lavar la ropa y para que toda la gente de a pie y de a caballo tenga acceso, y así se dejará ribera a ambos lados y "no estara en parte donde hechen ynmundiçias, ques lo que se ha de hebitar para la linpieça de la çibdad, y aunque se podra hazer en otra parte hazia la çibdad, mas por ocasion de las ynmundicias que de la çiudad se hechan, y porque los rrios de los dos Bayllos, y el arroyo que cahe del seruicio de la cassa del arçobispo, de continuo biene turbio y con ynmundiçias, y por estas causas y otras no conbiene se aga la dicha bajada hazia la çibdad", y donde se propone es mejor lugar y más limpio para lavar la ropa y coger el agua, y fortalecerá además el puente porque esta nueva bajada no obstaculiza la madre del río, ya que el agua tiene mucha ribera a ambos lados. Domingo de Hazas dice, no obstante, que conviene que se haga la bajada arrimada al estribo extremo de la puerta de Santa María hacia el puente de San Pablo, porque allí no estorbará la madre del río. El corregidor mandó que la bajada se pregone para recibir posturas. Lope García de Arredondo hizo postura en 550 ds. con 30 de prometido, nombrando fiador a García de Arredondo, escultor vecino de Burgos, y a Pedro de Rugama, maestro de carpintería vecino de Bárcena. Juan Ortega de Castañeda lo puso en 510 ds. con 10 de prometido, y Lope Carcía de Arredondo puso la obra y edificio en 500 ds. sin prometido alguno, aceptando el corregidor esta postura.

Por otra parte, el corregidor dijo que como se ha hecho la averiguación de las poblaciones incluidas en 20 leguas de Burgos y su vecindad, mandó que Andrés de Larrea y Juan Ortega de Medina, hagan el repartimiento de la mitad del precio en que fue rematada la obra del puente y de sus costas. En marzo Larrea y Ortega de Medina dijeron al corregidor que han hecho tal repartimiento fielmente, considerando al tamaño y vecindad de cada lugar y al aprovechamiento que cada uno recibe del puente. El corregidor lo aprobó y mandó que se junte con los demás autos, y se envió un traslado de todo ello al Consejo Real. Se hicieron 9 veredas "conforme a nuebe caminos rreales", más la de la jurisdicción de la ciudad, para ir a todos los lugares incluidos en las 20 leguas en contorno y averiguar su vecindad $^{224}$.

224 - A Gaspar de Salazar por 24 días que se ocupó en la primera vereda a ducado por día, más 5,5 rs. de los testimonios que trajo montan 9.562 mrs. Fue por la vereda que va desde Burgos hasta Cabezón junto a Valladolid, y desde la mano izquierda hasta Segovia y hasta topar con el camino de Madrid por Aranda de Duero.

- Al dicho Gaspar de Salazar por 26 días que se ocupó en la segunda vereda a ducado por día montan 9.750 mrs. Fue por la vereda desde Burgos camino de Segovia y los lugares que hay hasta el camino que va de Burgos a Atienza, y topar con el de Aranda de Duero y Madrid.

- A Alonso de Calzada por 21 días que se ocupó en la vereda tercera a ducado por día, más 8 rs. de los testimonios que monta todo $8.147 \mathrm{mrs}$. Fue por la vereda que va camino de Atienza y sobre la mano izquierda hasta topar con el camino que va a Soria.

- A Pedro de Flandes por 25 días que se ocupó en la vereda cuarta a ducado por día con 6 rs. de los testimonios, monta todo 9.579 mrs. Fue por la vereda que va camino de Soria y sobre la mano izquierda hasta topar con el camino de Logroño y Vitoria.

- A Juan de Renello por 21 días que se ocupó en la vereda quinta a ducado por día, más 4,5 rs. de los testimonios, monta 8.028 mrs. Fue por la vereda del camino que va desde Burgos a Logroño y desde allí sobre la mano izquierda hasta topar con Vitoria.

- A Gonzalo López por 37 días que se ocupó en la vereda sexta a ducado por día con 6 rs. de los testimonios, monta 14.079 mrs. Fue por la vereda que va hasta Vitoria y sobre la mano izquierda hasta topar con el camino real que va desde Burgos a Laredo. 
Se remató al fin la mencionada bajada al río en Lope García de Arredondo, maestro de cantería, que ya tenía la obra del puente en 540 ds. con prometido, y por el salario que se ha de dar a un maestro por los 3 años que durará la obra, visitarla y andar sobre los oficiales a 15.000 mrs. por año, 45.000 mrs., y para más costas que se han de hacer y quiebras del repartimiento, pagar a los escribanos y el trabajo del repartimiento, y costas para no hacer después otro repartimiento, se ponen $151.800 \mathrm{mrs}$., montando todo, puente y bajada 3.819.158 mrs., y conforme a la Provisión, la mitad se reparte a la ciudad de Burgos y la otra mitad a los lugares dentro de las 20 leguas. En septiembre de 1585 se manda que se notifique a los concejos implicados en el repartimiento, que en 20 días depositen la cantidad repartida en el depositario de la ciudad, y para el cobro de estos mrs. pueda nombrar una o dos personas que con vara de justicia vayan a las localidades que no hubieren pagado ${ }^{225}$.

Pedro de Castañeda y Juan de la Fragua presentaron al corregidor en septiembre de 1586 una petición que decía que el corregidor les nombró veedores de la obra y edificio del puente, para que se hiciese conforme a las condiciones establecidas. Dicen que si la primera paga a los maestros fue para proveerse de materiales y empezar la obra, ya tienen adquiridas la piedra, cal, arena y herramientas, y ya se trabaja con las cepas, para hacerlo antes de que venga el mal tiempo con las lluvias, por lo que se les debía pagar la sexta parte de las 6 restantes que se dicen en la condición, por lo que se mandó que Andrés de Larrea, depositario general, pague a Hazas y Arredondo 500 ds. a cuenta de lo que han de cobrar del segundo cuarto del precio del remate.

El corregidor, el obrero mayor y Larrea, regidor diputado para la obra, mandaron que Juan de la Fragua, sobrestante del puente, y Pedro de Castañeda, maestro de las obras de la ciudad, averigüen si Arredondo y Hazas van abriendo las cepas y tienen el hondo suficiente para que se pueda asentar el cimiento del puente conforme a las condiciones del remate y vean las cepas y las nivelen. Dijeron que Arredondo y Hazas están obligados a ahondar las cepas ocho pies para asentar los cimientos, y como no tiene más de siete, faltaba un pie, y hasta que esto no se haga, el cimiento no queda conforme con las condiciones. El corregidor mandó que Arredondo y Hazas ahonden un pie más como están obligados, y no pongan el cimiento ni comiencen la obra hasta que él, los veedores y maestros, se hallen presentes con los diputados de la ciudad. García de Arredondo agraviado por ello, pide al corregidor que mande que Baltasar de Castañeda, vecino de la ciudad, y Juan de Aguirre, vecino de Miranda de Ebro, maestros de cantería, hagan su

\footnotetext{
- A Bartolomé de Orellano por 19 días que se ocupó en la vereda séptima a ducado por día, más 14 rs. de los testimonios $7.600 \mathrm{mrs}$. Fue por la vereda que va desde Burgos derecho a Laredo y vuelve sobre la mano izquierda hasta topar con el camino que va desde Burgos a Santander por Villadiego.

- A Pedro de Segovia por 30 días que se ocupó en la vereda octava a ducado por día, más 17,5 rs. de los testimonios, es todo 11.845 mrs. Fue por la vereda que va desde Burgos camino de Santander por Villadiego, y vuelve sobre la mano izquierda hasta topar con el camino que va de Burgos a Carrión por el camino de Castrojeriz.

- Juan Ortega de Medina por 9 días que se ocupó en la vereda novena a ducado por día 3.375 mrs. Fue por la vereda que va desde Burgos camino de Carrión de los Condes y desde allí sobre la mano izquierda hasta topar con Cabezón junto a Valladolid.

- A Pascual de Alcedo por 6 días que se ocupó en la vereda de los lugares de la jurisdicción de la ciudad y alfoz de Burgos y de Doña Isabel Osorio, a ducado por día $2.250 \mathrm{mrs}$. También se pagaron $4.000 \mathrm{mrs}$. al escribano Andrés de Carranza por los derechos que ha dado para este repartimiento y por los pregones de fuera, y ocupaciones de estas veredas; por los pregones que se dieron en la costa de la mar, Valladolid, Logroño y otras partes, 52 rs.
} 
declaración porque ellos tienen conocimiento suficiente para poder asentar el cimiento y fundación del puente, aceptando el corregidor que Aguirre y Baltasar de Castañeda, juntamente con Pedro de Castañeda y Juan de la Fragua, vean y nivelen la cepa abierta y declaren si se cumplen las condiciones, y si es suficiente para fundar los cimientos para que la obra quede firme y segura.

Arredondo y Hazas dijeron al corregidor dos días después, que habían ahondado el sitio donde se ha de erigir la cepa primera cerca de ocho pies, y por haber hallado cascajo vivo y sólido, no pudieron ahondar más con barras ni picos, y por los grandes manantiales que del río acuden, afirman que lo que está ahondado es suficiente para fundar la cepa. Además, tienen fabricada una caja de madera muy fuerte sobre la que fundar los cimientos y cepa que de por si bastará para que sea firme, aunque no estuviere ahondado cuatro pies, pues la obra antigua no tenía tres pies de cimiento ni fue armada sobre caja alguna. Añaden que ha sido imposible ahondar más, aunque han hecho invenciones e instrumentos diversos para agotar el agua, y el parecer que Fragua y Castañeda han dado, "no es precisamente neçesario ni aun çierto, porque no falta lo que ellos diçen, ni se puede medir tan preçisamente que se sepa si es çierta la medida, porque por una parte estara quatro dedos menos y por otra seis mas, pues debajo de agua no se pudo cauar ha nivel en todas partes, y para saber si lo estaua, hera neçesario echar una rregla plana por debajo lo qual no se puede haçer por la dicha hondura ques mucha", e indican que Fragua y Castañeda son apasionados en esta causa y principalmente Juan de la Fragua, que como "heçimos cierta declaraçion sobre lo del meson, se a jactado que nos a de echar a perder, y pues U. m. be y por bista de ojos, la ynposibilidad que ay de aondarse mas por los grandes manantiales, y por ser el pico bibo y aber llegado a cascajo solido y maçiço, mande que otros dos maestros o tres o mas peritos en el arte y desapasionados, bean la dicha obra e lo nibelen y declaren", si se puede hacer un edificio perpetuo con lo ahondado hasta ahora, y se les dé licencia para comenzar a cimentar, ya que el próximo invierno no podrán proseguir la obra.

El corregidor mandó que Castañeda y Fragua, nombrados por él, y Juan de Aguirre y Baltasar de Castañeda, nombrados por Arredondo y Hazas, vean la obra, y juntamente con Bernardo Turriano, ingeniero residente en Burgos, declaren para proveer justicia. Estos cuatro maestros dijeron que la cepa está abierta por la parte de la ciudad y la han nivelado y tanteado, y que conforme a las condiciones, Arredondo y Hazas están obligados a ahondar la cepa ocho pies y que al presente no está ahondada más de siete, aunque no obstante, se puede fundar el pilar, tajamar y toda la cepa guardando el nivel de los dichos siete pies, y haciéndose así y guardando en todo lo demás las condiciones del remate, el edificio será tan fuerte y seguro como si se ahondaran los ocho pies, aunque del precio del remate se les debe quitar en proporción lo que dejaren de ahondar. El corregidor mandó a Turriano que lleve la gente necesaria para que ayude a nivelar y tantear la obra y cepa.

En octubre de 1586 Hazas y Arredondo presentaron al corregidor una petición que decía que tienen ahondada y descubierta la segunda cepa, donde se ha de fundar el arco del puente, conforme a la traza y condiciones del remate, hasta haber hallado base firme, por lo que piden licencia para comenzar de inmediato a hacer el fundamento de cantería antes de que entre el invierno. El corregidor mandó que Castañeda y Fragua comprueben si la cepa está abierta conforme a las condiciones, y junto con Andrés de Larrea, regidor y diputado del puente, lo vieron y nivelaron, e hicieron asentar con barras 
de hierro el cimiento y planta de la cepa y la golpearon toda ella, hallando que el cimiento estaba bueno y con un nivel de cepa de 7,5 pies de hondo. Limpiando las orillas para asentar la primera hilada conforme a la condición hasta ahondar medio pie de vara para los ocho pies que estaban obligados a ahondar, y que solamente igualando las orillas se puede bien fundar la obra que quedará fuerte y firme. Declaran que se ha de deducir a Hazas y Arredondo lo que montare el dicho medio pie, a condición de que en el edificio guarden todo lo demás.

Dos días después, Arredondo y Hazas afirmándose en los requerimientos antes hechos, dicen al corregidor que habiendo pedido el parecer de los maestros veedores, pudiesen erigir el cimiento y cepa segunda pues tenían ahondado todo y hallado tierra firme, como confirma el parecer de los dichos veedores sin haber inconveniente, pero que por la "ynformaçion de personas ynteresadas y que desean que la dicha obra no se acaue ni comiençe tan presto", el corregidor ha proveído que no se prosiga la obra ni se erija la dicha cepa, de lo que se seguirá notable daño, porque teniendo cavado lo necesario para asentar el cimiento, y preparados todos los materiales en que solo lo tocante a la dicha cepa vale más de 1.500 ds., el agua llevará en invierno los materiales y cerrará la zanja hecha para el cimiento, y como está cavado cerca de los pies del puente de madera cualquier creciente lo podrá llevar, por lo que piden licencia para proseguir con el cimiento y cepa, pues no se podía retrasar. Piden además que lo revisen los veedores, asistiendo el corregidor y no personas interesadas. El corregidor mandó que los veedores con otros dos maestros de cantería vean y nivelen la dicha cepa y declaren si está ahondada lo preciso, si conviene que el cimiento y cepa se ahonde más, si la base está en tierra firme y si se puede comenzar a edificar. Ante el corregidor, los obreros mayores, el procurador mayor de la ciudad y algunos caballeros del ayuntamiento, nivelaron la dicha cepa y cimiento ahondado y dicen que la cepa y cimiento está ahondada ocho pies y que "el çimiento esta firme e bueno y se puedeçimentar conforme a las condiçiones". El corregidor mandó que prosiga la obra y que asistan a ella los cuatro maestros hasta que esté hecha la primera hilada para que se asiente a nivel226.

En mayo de 1587 Baltasar de Castañeda, Juanes de Lasa y Domingo de Alvitiz, maestros de cantería, dijeron al corregidor que han visto la obra del "puente de Santamaria, e bisto lo questa fabricado y se ba fabricando, teniendo las condiçiones en la mano, e lo an medido e nibelado muy bien", y declaran que la cepa, pilar y tajamar de hacia Vega está bien hecho, y que se podrá ir asentando y fabricando conforme a las condiciones. Indican que en el cimiento de los dos pilares, tajamares y estribos han gastado mucha cantidad de dinero, así como en madera para cimbras, andamios y aparejos, y cal y arena, y que tienen a pie de obra gran cantidad de piedra que habían comprado, sacado y desbastado en las canteras de Hontoria, y además de dichos materiales, trabajan con muchos oficiales para avanzar antes que les cojan las lluvias y se interrumpa la obra por el mal tiempo. Dicen que se podría dar libranza de su sexta parte y para tasar lo que tienen hecho, y viendo los pilares y el gasto realizado en deshacer lo viejo, en las estacadas para quitar el agua y abrir cimientos, y en herramientas, cal, arena, estacas y piedra franca y tosca que tienen comprada y desbastada, cimentar los dos pilares, estribos y tajamares y madera para cimbras y andamios, calculan que

226 A. M. B./ HI-1679/Madrid, 19 marzo 1584 y 12 septiembre 1585 y Burgos, 23 octubre 1587. 
entre lo gastado y lo hecho vale 3.350 ds. El corregidor mandó que se libren a Arredondo y Hazas, 400 ds. a cuenta, pagando 100 cada semana.

Cuatro días después, declaran que Hazas y Arredondo van haciendo dos cepas con sus estribos y tajamares, el último del puente hacia la parte de Vega y el otro el cuarto, midieron y nivelaron, y comprobaron si los pilares "an echo sentimiento para no proseguyr". Hallan que para ir fabricando el pilar hacia Vega se han de quitar hasta 16 o 17 piedras de las haces de fuera, y volverlas a asentar a tizón con lo hecho de dos pies que se indica en la condición, y después podrán ir asentando el dicho pilar. Sobre el pilar, estribo y tajamar que van ensalmerando no deben asentar más, porque al estar el agua muy crecida no pueden ver si los lechos de las piedras de la zapata de hacia Vega están conforme a las condiciones. El corregidor dijo que los maestros están obligados a que en los fundamentos y alto de cuatro pies sobre el agua y en lo necesario a los arcos para fijarlos y enrejar, la mezcla sea la mitad de cal y la mitad de arena, y todo lo demás sea de dos partes de arena y una de cal. Los oficiales, maestros y veedores que han visto la obra, dicen que conviene que en toda ella "se mezcle la mitad de cal y la mitad de arena para su firmeza e perpetuidad", por lo que mandó que así se haga en toda la obra de cantería, y que el mayor gasto de cal se le pague aparte.

En junio de 1587 Lasa y Alvitiz dijeron al corregidor que han vuelto a ver el pilar primero que nuevamente se edifica hacia la parte de la ciudad, y hallan que en el arco por la parte de hacia Vega algunas de las piedras de la zapata no tienen los dos pies que la condición exige y no entran en el pilar como conviene, por lo que las piedras se deben quitar y poner a tizón, y hacer un talud en todo el largo de la zapata para que quede medio pie de zapata, y el talud ha de ir alamborado conforme a la caída del encadenado que ha de haber, y en lo último del estribo en la parte de abajo, se han de quitar las piedras necesarias a vista del veedor y sobrestante 227 . En agosto el corregidor dijo que como la obra no va como conviene, y sabiendo que Pedro de la Torre Bueras es oficial y perito en el arte y persona de confianza, le ha enviado a buscar a Ezcaray para que declare si la obra y el arco del puente va bien, y conforme a la traza y condiciones. Torre Bueras dijo que el arco "no se a fecho conforme a su çircuferençia e buelta, e por no se aber hecho asi tiene ciertos corcobos que son feos, aunque a su fortaleza y seguridad del arco no le haçen perjuiçio mas de ser feos", y asimismo el dicho arco sube medio pie de vara más de lo que tenía que subir, para que la cornisa que va bajo los antepechos pase a nivel, por lo que el arco tendrá menos carga de lo que debía tener conforme a la traza. Además, las cabezas de las dovelas de la parte de afuera no van en línea recta y si quedase el arco como está, se debería remediar rehundiendo por la parte de abajo del arco los córcovos que tiene para que se quite la fealdad, y asimismo las cabezas de la parte de afuera se rehundirán en línea recta para que no haya ningún torcido ni córcovo, y para que pase la cornisa bajo los antepechos a nivel se deben quitar de las piedras de las cabezas del arco lo que mandare el nivel de la cornisa, para que en las dovelas que se vuelvan a hacer allí se esculpa y haga la cornisa.

Para evitar inconvenientes será mejor que se desasiente el arco hasta cuatro o cinco hiladas de las que están asentadas, hasta donde está asentado con cal, y hacer nueva cimbra para ponerlo en perfección y circunferencia, y en su altura tener cuidado de que

227 A. M. B./ HI-1679/ Madrid, 19 marzo 1584 y 12 septiembre 1585 y Burgos, 23 octubre 1587. 
no suba más del lecho de la cornisa como está en la traza, y para esto y su coste, la ciudad podría ayudar a los maestros por el descuido que los veedores de la dicha obra han tenido. Ese mismo día Arredondo y Hazas dijeron al corregidor que como el arco que hacen ha parecido al corregidor y a los caballeros comisarios de la obra que no iba con el arte, circunferencia y alto que manda la traza y condiciones, y que esto fue por error del asentador, para que la obra vaya perfecta y no quede con ninguna fealdad, ofrecen deshacer el arco y volverlo a hacer bien trazado y dar la circunferencia y recto de la traza, con tanto que la ciudad les de 50 ds. por lo que costará volver a hacer el arco y cimbra. El corregidor, el alcalde mayor y los regidores, aceptaron lo dicho y la ciudad les dará los 50 ds., aunque los dichos maestros estaban obligados a hacerlo a su costa.

En septiembre de 1588 Andrés de Larrea y Diego de Riaño, obreros mayores de la ciudad, y Juan Martínez de Lerma, comisario del puente de Santa María, pidieron al corregidor que nombrase un veedor para que viese si el puente se hacía conforme a las condiciones. El corregidor nombró a Pedro de Castañeda para que asista como veedor y vea los materiales que en ella se utilizan para que en todo se cumplan las condiciones ${ }^{228}$.

En agosto de 1589 los provisores del Arzobispado de Burgos hacen saber a sus clérigos que por parte del concejo de la ciudad les dijeron que no saben qué personas, clérigos o legos, varones o mujeres, "con poco temor de Dios y en gran cargo y peligro de sus animas y conciencias, le an tomado y tienen oculta y encubierta la traça original de la puente y edefiçio que se açe de la puente de Santa Maria desta çiudad, y a causa de no pareçer no se puede acauar ni llebar adelante la dicha obra...", por lo que les fue pedido procediesen contra ellos. Mandan a sus clérigos que en sus iglesias todos los domingos y fiestas requieran a los que tomaron la traza original, para que en tres días que les asignen restituyan al secretario del ayuntamiento dicha traza y los encubridores se lo digan a su cura. Y si cumplida la carta admonitoria dichas personas no la hubieren restituido y siguieren rebeldes y contumaces, mandan que en sus iglesias todos los domingos y fiestas los denuncien públicamente por excomulgados 229 .

En 1590 el Rey dice al licenciado Fernando Arias de Tapia, su juez de comisión para los repartimientos que se hacen para los puentes del partido de Burgos, que el puente de Santa María, entre otros, necesitaba hacerse, y se dio licencia para que se repartiese entre los lugares comarcanos y se echase sisa para ello, y ha sido informado que "aunque se auian cobrado los marauedis de los dichos rrepartimientos, no se auian fecho ni rreparado las dichas puentes y calçada, y el dinero hestaba en poder de los tesoreros en quien se deposito", por lo que mandó a la justicia que se informase sobre la situación de tal repartimiento. Además la justicia debía tomar cuenta de todos los mrs. que estuviesen en poder de sus depositarios, y en 40 días enviar al Consejo relación de dichas cuentas y el estado de la obra, y como no ha enviado la dicha relación y conviene que se tome la cuenta y se sepa en qué estado esta la obra, y en poder de quién está el dinero y confiando que las justicias hagan lo que les está mandado, el Consejo acordó en agosto mandar a Arias de Tapia que vaya con vara de justicia a Burgos y reciba información sobre el repartimiento mandado, y en qué cantidad, y si se cobró en quien se depositó y si se remataron las obras en cuántos mrs., y en qué estado está la obra, y contra

228 A. M. B./ HI-1679/ Madrid, 19 marzo 1584 y 12 septiembre 1585 y Burgos, 23 octubre 1587.

229 A. M. B./ HI-1069/ Burgos, 26 agosto 1589. 
los culpables procederá en justicia. Si le pareciere haber sido malgastado o como no debía y fuere apelado, otorgue su apelación durante la cual sobresea su ejecución, y si no, lo ejecute en las personas y bienes de los que fueren obligados a pagar, y lo deposite en poder del mayordomo de la ciudad para que se gaste en reparar el puente, y después de 20 días de acabado este asunto, irá personalmente al Consejo a dar razón de lo que hubiere hecho.

En octubre el Rey manda a Arias de Tapia que en cumplimiento de su comisión tiene "tomadas y fenesçidas las quentas y bisita de la puente de Santa Maria de la dicha çiudad de Burgos" de un repartimiento hecho, por lo que debe presentar dichas cuentas 230 . Habiendo visto el juez de comisión los recaudos presentados para dicho repartimiento, la probanza hecha por Sebastián de Larrauri y por el procurador de la ciudad, así como la partida de $97.736 \mathrm{mrs}$. de los pueblos que no pagaron por estar eximidos o puestos dos veces, la de 101.609 de las costas hechas en la ejecución del dicho repartimiento, y la de 56.250 mrs. que la ciudad gastó en beneficio del puente, mandó que se descuenten del cargo que a Andrés de Larrea y a Larrauri le están hechos. Prosiguieron las cuentas para las que Larrauri dijo que no tenía más descargo que dar, que montan 3.309.501 mrs. y que bajados de los 3.819.158 mrs. del dicho cargo, se le alcanza en 509.657 mrs. así de lo cobrado del repartimiento como de lo que era a cargo de la ciudad, que se comprende en los 3.000.00o del dicho cargo. Vistas las cuentas por el juez, las aprobó y del dicho alcance mandó que se otorgase depósito a Larrauri. En octubre compareció Larrauri en nombre de Larrea, su tío, depositario general de Burgos, y dijo que otorgó depósito de los 509.657 mrs. en que ha sido alcanzada la ciudad en las cuentas del repartimiento hecho, y se obligaría a tenerlos preparados para la obra y no disponer de ellos sin orden del juez, y para ello se obligó con su persona y bienes y los de Larrea, dando poder a las justicias y en especial a Arias de Tapia231.

En virtud de la comisión y prórroga, el juez Arias de Tapia procedió contra Arredondo y Hazas por no haber acabado la obra dentro del término obligado, y por haber recibido más cantidad de dinero de lo que debían, conforme a lo que estaba hecho del puente, mandando dar traslado al fiscal Esteban Eraso, alguacil de la comisión del dicho juez, para seguir la causa. En sentencia definitiva pronunciada en 5 de octubre de 1590 , se les condenó a que en dos meses acaben de hacer todo el antepecho del puente y le empiedren, y por la superficie revoquen lo nuevamente fabricado para que las aguas no lo destruyan, so pena de $20.000 \mathrm{mrs}$, y la obra que falta la acaben en un año conforme a las condiciones y a satisfacción de maestros peritos, so pena de otros 50.000 mrs., y en 8 días depositen 1.000 ds. en el depositario general de la ciudad, para que con ellos y lo que queda en el dicho depósito, se compren los materiales y lo demás necesario, y den fianzas de otros 2.00o ds. para que se obliguen al cumplimiento de la sentencia, porque parece que han recibido más de 100 ds. de más, para dar acabado el puente conforme a las condiciones, y además les falta por hacer obra por más de 3.000 ds. Habiendo pasado casi un año del término de su edificio no tienen al presente más de 130 ds. de materiales y por haber sido remisos en acabarlo, llevando la piedra y otros materiales para diversas obras y lo demás que en el proceso consta, les condenó en los 12 días de salarios del juez y de sus oficiales, en 2.000 mrs.

230 A. M. B./ HI-1679/ Madrid, 19 marzo 1584 y 12 septiembre 1585 y Burgos, 23 octubre 1587.

231 A. M. B./ HI-2461/ Burgos, 4 octubre 1590 a 1 septiembre 1602. 
para gastos de justicia y en las costas de esta causa. Ese mismo día el escribano les notificó la sentencia en la cárcel real de Burgos donde estaban, y como no cumplieron con la dicha sentencia, el juez mandó vender en pública almoneda un juro de Arredondo de 600 ds. de principal, situado sobre las alcabalas de Burgos a razón de $13.500 \mathrm{mrs}$. el millar, y con lo que procedió del dicho juro y con los 400 que pagó Hazas al contado, se juntaron los 1.000 ds. de la sentencia, que se depositaron en Sebastián de Larrauri232.

En 27 de noviembre de 1590 Arredondo recibe de Larrauri, en nombre de Andrés de Larrea, 200 ds. de esta manera: 100 ds. para Juanes de Lasa por el antepecho y empedrado del puente, 50 para los sacadores de la piedra y los 50 restantes para él mismo y Juanes de Lasa para la piedra y encadenamiento que se va haciendo en un arco 233 . Dos días después, como el corregidor no puede asistir a la fábrica, Arias de Tapia mandó al escribano que saque una fe de esta causa con traslado de su provisión y de la sentencia pronunciada contra Arredondo y Hazas, y del depósito que en virtud de ella se hizo en el depositario de la ciudad, y lo entregue con el proceso original del puente, al escribano del ayuntamiento de Burgos ante quien ha pasado la causa y autos del puente y se notifique al corregidor para que haga acabar el puente y reciba las fianzas de 2.000 ds. de los maestros conforme a la sentencia.

En julio de 1591 el corregidor dijo que como Arredondo hace el encadenamiento del puente de Santa María y abre los cimientos para las manguardias "y otras cossas de ynportançia", y para que todo se haga conforme a las condiciones con que se hizo el remate, nombró por su veedor y sobrestante a Juan de Esquivel, maestro de cantería, vecino de Burgos, para que asista y vea la obra y para ello se le den las condiciones y los demás papeles. Arredondo dice al corregidor que Esquivel, como es notorio, es apasionado contra él y su enemigo capital por muchas razones evidentes, y porque siendo el maestro de la obra que el arzobispo hace en sus casas, "se le quito la maestria y se me dio a my, y ansi se a jactado y alauado que por todas las bias que pueda, me a de haçer mal y daño el y sus conpañeros y destajeros que entendian en la dicha obra, y ansy yendo a ver la dicha puente, a tratado mal de palabra y aciendo fieros a los ofiçiales que en ella trayo, y ansi por su aspereza an cesado y çesan de trauajar" y no es justo que habiendo maestros cualificados a quién nombrar para ver la dicha obra, se nombre "a mi enemigo capital, por tanto yo le recuso por odioso y sospechoso y a los destajeros que en la obra del dicho arçouispo trujo, y juro a Dios... que esta recusacion no la ago con malicia". Pide que se nombre a una persona desapasionada y perita para que vea la obra, que él quiere cumplir y acabar todo lo que fuere a su cargo.

Seis días después Francisco de Peñaranda en nombre del concejo, dice al corregidor que se debe mandar que Esquivel haga su oficio de veedor para el que está nombrado, y que la recusación de Arredondo es frívola y hecha maliciosamente por entender que Esquivel es "ofiçial de los mas peritos y espertos, y ombre muy cristiano y tan recto y verdadero, que por ningun respecto vmano dejara de açer su ofiçio con toda retitud". Desea Arredondo, dice, que se nombre persona que no sea de estas partes y calidades, sino amigo suyo e interesado, y aunque hubiere lugar a su recusación, no hay a quién nombrar por ser los demás oficiales, fiadores e interesados en la obra y sus amigos, y se debe considerar que el nombramiento es de oficio, y no por parte de la ciudad, por lo que no puede ser recusado ni hay sospecha alguna en el

232 A. M. B./ HI-1679/Madrid, 19 marzo 1584 y 12 septiembre 1585 y Burgos, 23 octubre 1587.

233 A. M. B./ HI-4616/ Burgos, 27 noviembre 1590 a 30 octubre 1593. 
nombrado de oficio. Cuatro días después el corregidor dijo que el edificio que Arredondo hace, especialmente en el encadenamiento de la obra y los cimientos de las manguardias, "no ba bien echo ni conforme a las condiçiones, ni como conbiene para la perpetuidad y firmeça de la dicha obra", por lo que mandó que Esquivel le informe de todo.

Ese mismo día compareció Esquivel y dijo que ha visto la obra del encadenamiento del puente por debajo de los arcos, y que no va conforme a las condiciones con que se remató en cosa alguna, porque las piedras que pone, debiendo de ser de 7 a 10 quintales, no lo son sino más pequeñas porque 9 de 10 no llegan a 7 quintales, y la mayoría no tienen tanto con mucho, y además "estan mal esquadradas, e las juntas mal hechas e quebradas, que haçen muchas aberturas por donde podra entrar el agua, en gran daño e perjuicio de la obra y hedifiçio de la dicha puente, e las ligaçones estan malas y no conforme a la condiçion y arte, e que tanpoco ba lanboreado en la salida, ni por medio tiene la caida que diçe la condiçion, e que tanbien a bisto la cal questa batiendo e mezclando en la dich a puente la qual no ba como conbiene a la obra, porque lleba mucha arena y poca cal", debiendo tener la mitad de cal conforme al acuerdo que con Arredondo y Hazas se hizo. Ha visto la zanja y cimientos abiertos para las manguardias que se han de hacer, y no están tan abiertos y hondos como han de estar, y un pedazo del antepecho que se hizo estando el juez de puentes, tampoco está bien hecho ni conforme a las condiciones, porque las piedras "son pequeñas e mal libradas e asentadas, e algun pripiano ba con dos pieças debiendo ser una entera", y esto lo declara Esquivel como tal veedor bajo juramento.

En agosto de 1591 Francisco de Gámiz en nombre de García de Arredondo, dice que Juan de Esquivel fue recusado como veedor por justas y razonables causas y por tener enemistad con Arredondo, por haberle quitado la obra del arzobispo. Se debe nombrar maestro sin sospecha y desapasionado y no se ha hecho, por lo que se le sigue notable daño y se le impide la actuación en la obra porque un día asiste y otro no y lo que un día ha aprobado, lo reprueba otro para que no se pueda acabar la obra y llegue el invierno, y se impida y destruya lo echo con los aguaduchos, y para que los oficiales que su parte trae no prosigan en la obra que son muchos y así haga grandes gastos. Pide al corregidor que mande nombrar oficial sin sospecha que asista a la obra. Siete días después, Esquivel dice al corregidor que como veedor de lo que falta de hacer en el puente se le dio un traslado de las condiciones y ha asistido con mucho cuidado y trabajo, y sin embargo la obra no va como conviene ni conforme a las condiciones, porque los encadenados desde la entrada a la salida han de ser de piedras crecidas de 7 a 10 quintales y ninguna o tan pocas que no es considerable, no son del dicho peso ni grosor, sino tan menudas que la primera riada y por no ir tan bien labradas ni asentadas las levantará y llevará. Además los paredones no llevan cinco pies de hondo sino 3,5 y asienta los cimientos sin que él no asista a verlo y así, además de ir contra las condiciones, es obra falsa. Pide que se le exonere del cargo y se ponga persona con autoridad y mando de justicia, que haga cumplir las condiciones por las descomposturas que los oficiales le hacen.

Al día siguiente Francisco de Gámiz dice al corregidor que su parte y él han recusado a Esquivel y a todos sus compañeros, por apasionados y enemigos conocidos de su parte, ya que sobre los cimientos del paredón y manguardia que se va haciendo bajo el puente, y sobre el tamaño de las piedras que ha de llevar el encadenado se ha producido duda, aunque su parte dice que cumplen con la traza y condiciones y con ventaja, y así lo han 
visto peritos desapasionados. Pide que dé por recusado a Esquivel "y sus conplices" y nombre por visitador otra persona sin pasión. Juan de la Fragua y Juan de Naveda dijeron que, por encargo del corregidor, han visto la obra en presencia de Andrés de Larrea, siéndoles leídas las condiciones con que se remató el edificio y creen que se deben realizar algunas actuaciones correctoras 234 .

Arredondo dijo al corregidor que había venido a Burgos con ánimo de acabar lo que estuviere a su cargo del puente, y encadenar lo que faltare de los arcos y hacer todo lo necesario, y para que se vea lo que falta de hacer y qué dineros hay, es necesario que el corregidor envíe algún maestro con la traza y condiciones, y que Domingo de Hazas asista con él al cumplimiento de lo que faltare, y que mande a una persona de ciencia y experiencia que vea lo que está hecho y lo que falta por hacer conforme a la traza y condiciones, y que se cierre la cuenta y el dinero que está gastado para que él y Hazas cumplan lo que está a su cargo y se les pague lo que se les debiere 235 .

En septiembre de 1592 el corregidor manda a Larrea, que de los mrs. que tiene a su cargo para el puente de Santa María, pague a Arredondo 50 ds. a cuenta del precio en que fue rematada la obra, para que se gasten en ella y no en otra cosa a vista de Sebastián de Larrauri, y en agosto de 1593, volvió a mandar a Larrea que pague a Larrauri otros 50 ds. para que pague la piedra, cal y otros materiales y a los oficiales que fueren necesarios para el reparo del puente, a cuenta del precio principal del remate. Arredondo declara que con los 50 ds. se pagó a los carreteros, sacadores de piedra, oficiales y peones que se han ocupado en el encadenamiento que se hizo en el arco segundo, y cal y arena. En octubre, el corregidor manda a Larrea que pague a Arredondo 35 ducados para los pretiles del puente hacia la parte de Vega ${ }^{236}$.

En julio de 1595 Domingo de Hazas pide al corregidor que se nombre un oficial por él y otro por su parte, para ver lo que falta de hacer y acabar el puente de Santa María, dando a

\footnotetext{
234 - El tamaño de las piedras del enlosado y encadenado del puente, que deben ser de ciertos quintales no se cumple, por ser menores en su mayor parte. Para su remedio, se deben echar a los extremos del enlosado y encadenamiento dos hiladas en cada parte de la entrada y salida, como en la condición se indica, y que los intervalos no sean tan grandes como la condición dice, ya que por no ser todas de un tamaño, no faltará el enlosado y encadenado si los extremos de la entrada y salida están fuertes y firmes, que es por donde el río acostumbra romper. Y que en lo que está comenzado a enlosar y encadenar en el primer arco hacia Vega, Arredondo le corte un pedazo de un ojo que entre debajo del dicho arco en medio de la corriente, que conviene para la mejor salida del río.

- Sobre si el cimiento del paredón que se va fundando hacia las casas de Juan Martínez de Lerma tiene el hondo que dice la condición, declaran que han hecho calar el cimiento por dos partes, una al principio entre lo nuevo y lo viejo, y la otra en medio del paredón y manguardia que se hace y al fin del viejo, nivelándolo hasta la zapata del dicho arco, y conforme al nivel y lo que la condición declara, le falta ahondar como un pie, y la cala que hicieron entre la manguardia vieja y nueva que se va haciendo, está la vieja fundada más alta que la nueva. Para la firmeza de la obra y en recompensa de lo que falta ahondar del dicho cimiento, el maestro deberá asentar dos hiladas de piedra crecida desde el enlosado del arco hasta la esquina de las casas de Juan Martínez, que tengan de falda unos cuatro pies y asentadas con la corriente del dicho arco, alamboradas hacia la madre del río y al fin de las dos hiladas se hinque una serie de estacas a un pie una de otra, al nivel del alto de las piedras para la fortificación de la obra y que el río no dañe el dicho paredón.

- Sobre si la manguardia y paredón se podía hacer como conviene, sin tomar y cortar lo que la condición declara de las casas de Juan Martínez, dicen que está claro que tomándose la línea conforme la dicha condición, el agua tendrá más "despidiente". Y en caso de que no se derribe lo de las dichas casas, se podía hacer sin perjuicio del puente porque el agua no repara ni vuelve a ofender al dicho puente, porque tiene más "despidiente" el río en aquella parte que tienen de tragadero los arcos del puente.
}

235 A. M. B./ HI-1679/ Madrid, 19 marzo 1584 y 12 septiembre 1585 y Burgos, 23 octubre 1587.

236 A. M. B./ HI-4616/ Burgos, 27 noviembre 1590 a 30 octubre 1593. 
los oficiales las condiciones para acudir a hacer lo necesario para la perpetuidad de la obra, y haciéndose, les den los dineros depositados. Añadió que para que se vea si ha cumplido y lo que le falta de hacer, nombraba por veedor a Baltasar de Castañeda, maestro de cantería, y que la ciudad nombre otro. El regidor de Burgos nombró por veedor a Juan de Esquivel, y después por mandado del corregidor y del regidor, comparecieron ambos maestros, vecinos de Burgos, y dijeron que han visto la obra de cantería que Hazas y Arredondo se obligaron a hacer, con las condiciones con que se remató, y hallaron que en cuanto al paredón, faltan de hacer 310 pies de largo mas 70 pies que están hechos de lo viejo que es lo que ocupan las casas. Detallan las siguientes actuaciones que faltan y que costarán 11.140 rs:

- Todo y los 310 pies que les falta de nuevo del dicho paredón, lo podían hacer por 6.400 rs.

- Les falta conforme al contrato, abrir la madre del río a 50 pies de ancho desde la puerta de las Carretas hasta los tajamares 500 rs.

- Les falta de encadenar un pedazo en el arco segundo hacia Vega y encadenar en todo el largo de los tres arcos viejos, hacia la puerta de Santa María a cuatro pies de la salida, y los huecos de los tajamares y estribos como en la condición se dice, y recalzar los pilares viejos de los tres arcos en las partes necesarias. Costará 1.500 rs.

- Tienen duda, porque ahora con el agua no se ve, que el arco primero de hacia Vega no está encadenado, y si no lo está costará 1.800 rs.

- Lo que les falta de enrrajar, revocar y cerrar todos los agujeros de los mechinales de los tres arcos nuevos, costará 30 ducados.

- Les falta de estacar en ciertas partes y lo del arco dicho, que les costará 500 rs.

- Les falta un león conforme a las condiciones, que costará 10 ducados.

Opinan que no se hagan de nuevo los 310 pies que faltan de hacer del paredón, sino en el arco de 250 pies de largo. Desde la esquina de cantería de las casas de Vega, hasta una balsa que el agua hace frente a la puerta del convento de la Merced, se debe hacer una estacada con estacas de haya, y al fin de ellas por las cabezas, vayan un pie más hondas que el suelo holladero de la calle de la Merced y el camino, y la estacada doblada será bien maciza y entretejida de su fajina de sauce, y detrás en todo el largo, se rehenchirá de cascajo y tierra bien maceado e igualado. Añaden que la madre del río no se abra, si no se hace desde la corriente que pasa junto a las casas de Vega hasta la corriente que pasa por la parte del primer arco hacia la puerta de Santa María. Y que se quite todo el cascajo de debajo del puente, que son dos isletas que están altas y no dejan pasar el agua, y con lo que de ellas se quitare, se rellenen los ojos de los fosos que el agua tiene hechos en la parte inferior de los dos arcos hacia la puerta de Santa María.

En agosto de 1597 Francisco de Peñaranda en nombre del concejo de Burgos, dice al corregidor que la obra del edificio del puente la tienen Domingo de Hazas y Lope García de Arredondo de mancomún, y por no haber cumplido con lo que estaban obligados, se mandó que viesen las faltas Juan de Esquivel y Baltasar de Castañeda, y su declaración se trasladó a los susodichos no alegando cosa alguna, ni cumplido con lo que estaban obligados. Además, han aparecido otras faltas como también declaró Esquivel en agosto de 1591, sobre que el puente corría riesgo si no se hacía lo que faltaba y reparase lo maltratado. 
Peñaranda pide que se ponga en la cárcel a Hazas hasta que cumpla con todo lo que está obligado, acabe de hacer lo que falta y repare todo lo que está maltratado. El corregidor mandó que se dé un auto de prisión contra Domingo de Hazas, hasta que cumpla con lo que está obligado conforme a las declaraciones hechas. En octubre Pedro de la Torre Bueras y Juan de Cea, pintor, vecinos de Burgos, dicen que la obra que se remató en Hazas y Arredondo en 8.400 ds. con ciertos prometidos, se debía acabar en 3 años después de que se les hiciese la primera paga.

Para que cumplieran las condiciones y traza, se obligaron y les pusieron como fiadores entre otros, como consta en la escritura de obligación y fianza dada en junio de 1584, por Andrés de Larrea, regidor y depositario general que fue, y por Sebastián de Larrauri, regidor y depositario general que es de la ciudad, y aunque en el reparo no se han guardado las condiciones, para que Hazas pueda acabar mejor la obra, se le debiera pagar la cantidad de mrs. que pareciere al corregidor, a cuenta de lo que se le queda debiendo, y aunque no se le deba nada por no haber acabado y cumplido, todo lo que se le pagare lo consienten, aprueban y se obligan, y aseguran que Hazas dará acabada y en toda perfección el dicho edificio, conforme a las condiciones. Sobre el encadenamiento de los arcos que faltan por encadenar, lo hará ese mes de octubre, y lo que falta, lo dará acabado y correcto antes de fin de agosto de 1598. Tendrá oficiales que de ordinario trabajen y los materiales necesarios para poderlo acabar, y en caso de no cumplirlo así, ellos como tales fiadores y principales pagadores, lo cumplirán sin pleito alguno, y si así no lo cumplieren, consienten que el corregidor o la justicia y regimiento, puedan dar a hacer lo que faltare o lo que no estuviere bien hecho a los maestros y oficiales que quisieren, y lo que costare se cobre de ellos y sus bienes. Ese mes, Domingo de Hazas dice al corregidor que como le ha mandado prender hasta que acabe la obra y edificio del puente, y por ser tiempo de invierno, no puede acabar la obra como está obligado. Tras el auto de prisión, el encadenamiento de los arcos del puente no se puede proseguir, y tiene dadas fianzas para acabar la obra, y para que lo pueda continuar necesita 200 ds., por lo que pide que se le paguen a cuenta de la dicha obra237.

Todavía en 1599 Felipe III recibe de la ciudad de Burgos una petición sobre que sus tres puentes principales que son el de Santa María, San Pablo y de los Malatos, se habían descalzado con las crecientes y avenidas, desencadenando algunos de sus arcos y llevados algunos taludes y paredones que los defendían, y para que no se ahondasen y abriesen los caminos, sería muy necesario su reparo para evitar mayores daños y gastos. Como la ciudad no tenía propios, se había acordado pedir licencia para sacar los 2.000 ds. necesarios de la sisa del vino. El Consejo concede facultad para adjudicar las obras en quien mejores condiciones ofreciese, siendo rematada la obra, aderezo y paredón de San Pablo y San Lucas, en Lucas de Curulla maestro de cantería, en 420 ds. y 100 rs. que había ganado de prometido Juan de Esquivel en su primera postura, y como había costado 400 ds. el reparo que se había hecho el año pasado de los puentes de San Pablo y los Malatos, todo lo que había costado y había de costar montaba 310.900 mrs. El Consejo, acordó en septiembre

237 A. M. B./ HI-1679/Madrid, 19 marzo 1584 y 12 septiembre 1585 y Burgos, 23 octubre 1587. 
de 1599, dar licencia para que de la sisa del vino echada en la ciudad, se puedan sacar los dichos 310.900 mrs. y se depositen en poder del mayordomo de la ciudad ${ }^{238}$.

Las estacadas, eran algo imprescindible para canalizar el agua del cauce medio de un río como el Arlanzón, y evitar que dicho río erosionase sus orillas. Antes de mayo de 1586 se presentaron las condiciones realizadas por Francisco de Maluenda, para hacer unas estacadas, abrir la madre del río, y remediar el daño que sus crecientes hacen "uaxo de la puente de los Malatos asta la carrera e camino que atrabiesa del hospital del Rrey a los prados que esta uaxo de las tanerias", y evitar los grandes daños que se causan con frecuencia en las tierras del Hospital, en los caminos reales que salen de Burgos y en los prados y pastos que el río va derribando y gastando por la parte de las tenerías. El maestro que lo tome, había de comenzar la obra en los primeros días de mayo y dar todo acabado antes del día de la Virgen de septiembre de 1587, no pudiendo interrumpirla hasta darla acabada y de acuerdo con las condiciones, y de las personas que el hospital del Rey y la ciudad le pusieren²39.

En diciembre de 1586 Alonso Fernández dijo al corregidor, regidores y obreros mayores de la ciudad, que hacía postura de la obra y estacada, y que abrirá la madre del río Arlanzón para reparar los daños que sus crecientes han hecho bajo el puente de los Malatos, hasta la carrera y camino que va del hospital del Rey a los prados que están bajo las tenerías, en 220 ds. con 10 de prometido. Miguel de Ranero maestro de cantería, vecino del valle de Curiezo, hizo baja en la postura, y la puso en 180 ds., con seis de prometido, y siendo en él rematada dará fianzas bastantes para así hacerlo y cumplir conforme con la traza y condiciones, dando por su fiador a Juan de la Torre, vecino de la ciudad. En mayo de 1587 el corregidor, regidor y obrero mayor, aceptaron la postura presentada por Miguel

238 A. M. B./ HI-4141/ Madrid, 13 septiembre 1599.

239 A. M. B./ HI-1678/ Burgos, 14 diciembre 1586 a 11 agosto de 1587. Las condiciones son:

- En el daño hecho bajo el puente, cerca de la salceda primera por la parte del hospital, hacia los prados de la ciudad, en 70 pies de ancho y 298 varas de largo, se ha de ahondar la zanja hasta la madre del río para que éste no se detenga más por una parte que por otra. En estas 193 varas de media, se ha de hacer una fuerte estacada con estacas de haya de dos andanas, que es doblada, y ponerse donde pasa la madre del río a 12 pies, y las estacas a 10 pies cada una y de buen grueso.

- Se han de hundir las estacas que atraviesan la madre del río que lo más hondo tiene cuatro pies, y se han de echar en la madre unas soleras tendidas por lo más hondo, donde estribarán unas riostras puestas de 10 en 10 pies, contra unas cintas de machones de madera clavados contra las estacas, para que con las crecientes estén firmes, y estas estacadas han de estar cerradas en seco de fajina y en toda su altura, de tierra y céspedes, y la calle central tendrá cuatro pies de ancho por fuera, y dentro echadas sus fuerzas de cascajo y tierra como allí se hallare, esto se entiende en la fuerza donde se ha de tapar la madre del río, y en lo demás se hará por el mismo orden hasta cumplir las 190 varas, excepto que no se echarán riostras ni maderas en lo hondo, salvo las cintas clavadas por las dos partes, y esta estacada se pondrá hacia la parte del hospital del Rey, excepto que en la ribera de la parte de la ciudad se hagan unos plantíos de sauce para reforzar la tierra.

- En toda la longitud, anchura y hondura de las 190 varas, el maestro también deberá apartar a los lados toda la tierra y cascajo, fortificando la estacada hasta su altura, todo lo que las quedare encima de la madre del río, quedando limpia y abierta y que las estacas queden hincadas y no haya entre una y otra, más de una tercia de vara.

- Más abajo, por donde se sufre gran daño y donde el río ha hecho madre, se ha de hacer otra estacada con la misma traza, y la de atrás donde cae la madre del río que ahora hace el daño, se ataje como la otra y con las estacas del mismo tamaño y riostradas, así fortificadas a tercia de largo, y en este segundo refuerzo y madre del río se han de abrir 224 varas castellanas, con 70 pies de ancho y de ellos cuatro dedos de ancho la dicha estacada.

- En la parte de los prados hacia la ciudad, donde el río va gastando la tierra, se hará otra estacada desviada del dicho terrero como 30 pies y con dos andanas de estacas. Se abrirá la madre del río, echando el cascajo entre la estacada y el terrero hasta igualar con lo más alto del campo y prado, y tendrá 99 varas castellanas.

- El maestro, hará otra contraestacada donde está señalado en la traza, para que se ponga delante del rompimiento y que el cascajo quede fuerte y la tierra firme y maciza, todo lo cual está señalado para que por allí no se haga más rompimiento.

- La ciudad y el hospital del Rey, darán las estacas de madera de pino y roble y la clavazón necesarias. 
de Ranero con el dicho prometido y mandaron que se pregone y remate, presentando a Pedro del Agüero y Miguel de la Magdalena, vecinos del valle de Curiezo, como principales deudores y a Juan de la Torre, morador en Cantarranas la Menor de Burgos, como su fiador y principal pagador ${ }^{240}$.

En agosto de 1587 ante el teniente de corregidor, compareció Francisco de Peñaranda en nombre del concejo, justicia y regimiento de Burgos, y dijo que en Miguel de Ranero fue rematada la obra de la estacada bajo el puente de los Malatos, y no solo no hace la estacada, sino que siendo ahora el tiempo en que se debe hacer, nadie trabaja en ella. Pide que mande prender a Ranero y a su fiador, y por el peligro que hay en la tardanza y no dando seguro y fianza de que realizará la obra y acabarla en el plazo acordado, la mande poner en quiebra y se pregone, y por lo que se rematare lo mande ejecutar y pide costas. El dicho teniente mandó que la ciudad reciba información sobre esto para lo que se tomaron testimonios de Hernando del Río, maestro de carpintería, Diego de Vivanco, Juan Gómez de Angulo y Sebastián de Espinosa, vecinos de Burgos, y dijeron que Miguel de Ranero no hace desde más de tres semanas las dichas estacadas, "antes la a dexado e desamparado porque diçen que pierde en ella muchos dineros", ni se trabaja en ellas, y que Miguel está recluido en el Hospital del Rey y está solo por este negocio, de manera que nadie trabaja en esta obra a pesar de que se han pagado "dineros al dicho Miguel de Rrenedo para quenta de la dicha hobra". Tres días después, el teniente de corregidor mandó prender a Miguel de Ranero y a sus fiadores y 6 días después Francisco de Peñaranda, en nombre del concejo, presentó al teniente de corregidor una petición que decía que se mande dar su requisitoria para las justicias del hospital del Rey o donde Miguel de Ranero fuere hallado, para que sea preso y enviado a la cárcel pública de la ciudad a su cuenta, accediendo el teniente a ello ${ }^{241}$.

En septiembre de 1589 , se ponen las condiciones para hacer la estacada del paredón de los Mínimos:

- La estacada ha de ir desde el arco del puente de Santa María hasta los sauces que están pasada la iglesia de los Mínimos, llegando hasta el segundo sauce.

- Ha de llevar 200 estacas de 12 pies de largo, que se han de hincar al lado del río bajo tierra cuatro pies, y entre una a otra habrá tres pies.

- Ha de llevar 100 estacas pequeñas de cuatro pies de largo, y de estaca a estaca ha de ir clavada una hilada de cuarterones tres pies por encima del agua, con clavos en cada estaca tan largos que pasen el cuarterón y la estaca y se puedan doblar.

- Se han de cortar de los olmos que fueren necesarios de la ciudad, para hacer 100 represones de seis pies de largo, y para asentarlos se les han de hacer dos agujeros, uno a cada cabo, y al lado del río ha de ir trabado y metido por el agujero con una estaca de las grandes, y a su lado ha de ir clavado con una estaca de las pequeñas, ya que todas las grandes irán por debajo y por arriba de los cuarterones, insertados de fajina muy apretada y bien hecha. 
- Se ha de hacer toda la obra antes del día de San Francisco próximo, so pena de que se busque quién lo haga y pueda ser ejecutado a su costa.

- Por cortar los olmos y labrarlos y hacer los agujeros de los represones, hacer toda la estacada, derribar las mochas de sauces que fuere necesario, y traer la fajina de ellas y los olmos al pie de la obra, la ciudad pagará 330 ducados conforme vaya la obra. La ciudad pondrá al pie de la obra estacas, cuarterones y clavos, le dará los olmos y le pagará lo que costaren las mochas de los sauces de donde se ha de cortar la fajina, y el adjudicatario cortará y traerá a su costa lo demás.

- Se ha de obligar a que quede firme y sin que el agua lleve la estacada por un año, que será hasta el día de San Francisco de 1590, y si algo llevare el río, lo volverá a hacer a su costa dentro del dicho año.

- La zanja necesaria para sacar la estacada y poner los represones, la ciudad la hará a su costa.

- Todo se ha de hacer a satisfacción de Luis de Artiaga y caballeros obreros, y hará lo que le mandaren sin dar otra interpretación a las condiciones.

- Dará fianzas a contento de la ciudad para cumplir lo dicho y si durante este tiempo anduviere remiso en la obra y no pusiere la diligencia y cuidado necesario para su brevedad, podrá ser a su costa la cantidad de gente que sea necesaria.

El corregidor mandó que la estacada del paredón de la Victoria se pregone en la ciudad, por si hay quien la quiera hacer en un precio justo, hasta el 5 de septiembre. Fernando del Río, vecino de Burgos y maestro de carpintería, propuso hacer y acabar la obra con las condiciones y en el tiempo dichos, en 30 ducados. El 20 de septiembre pareció Alonso Fernández, panadero, morador en el barrio de San Pedro de Burgos, y se obligó a hacer y cumplir con su persona y bienes si Fernando del Río no lo hace, lo que tiene prometido en dicha estacada ${ }^{242}$.

\section{C.- CIUDAD MERCANTIL}

La ciudad de Burgos, tuvo un crecimiento vinculado desde sus orígenes con el desarrollo de actividades mercantiles. En el siglo XII y primera mitad del XIII, el comercio y la artesanía de la ciudad reciben un gran impulso, la población aumenta y el espacio urbano crece. La concentración de poder político y eclesiástico fue la base de su desarrollo urbano, sin olvidar los efectos que en la población provocó el Camino de Santiago. A partir de los siglos XIII-XIV, la ciudad medieval se transforma en una ciudad mercantil que llegará a adquirir un especial protagonismo en los intercambios comerciales del interior castellano así como en los mercados de la Europa atlántica.

Burgos será el centro del comercio castellano con el resto de Europa, canalizado por unas vías que cambian la dirección Este-Oeste, que hasta entonces era la preponderante, por la Sur-Norte entre el Centro y sur de la Península, la ciudad y los puertos del Cantábrico. La población se va a extender en torno a los puntos relacionados con esta actividad, es 
decir, las calles comerciales y los mercados. Dentro de las murallas aumentarán las zonas construidas, ubicándose en los espacios vacíos los mercados necesarios para el comercio, que irán convirtiendo a la ciudad en un importante centro mercantil. La zona aristocrática se establece en y en torno a lo que hoy es la calle de Fernán González, la primitiva vía de Santiago, donde se construyen las residencias nobiliarias principales medievales y renacentistas.

En la fase que Hilario Casado denomina "la edad de oro del comercio burgalés” (entre 1425 y 1550 aproximadamente), la ciudad vive los momentos más florecientes de su vida comercial, y se convertirá en una dinámica y próspera plaza mercantil de proyección internacional, cuyos mercaderes tuvieron una notable presencia en los principales mercados europeos de la fachada atlántica, a la vez que desarrollaron una intensa actividad en el interior peninsular, muy diversificada, pero que tenía sus actividades principales en la exportación de lanas y la importación y distribución de paños y materias primas, principalmente hierba pastel, utilizada como tinte para la manufactura pañera castellana ${ }^{243}$.

La consolidación de la ciudad como un enclave mercantil en la Edad Media, fue consecuencia según apunta Basas ${ }^{244}$, de diferentes factores:

$1^{\circ}$. Capitalidad política de Castilla. La ciudad, fundada en 884 sobre el cerro que domina el estrecho pasillo por donde discurre la vía Aquitana, entre este cerro y el río Arlanzón, era ya cabeza de condado en 899 y el 915 recibía la consideración de civitas. Desde que el monarca leonés Ramiro II decidió en 932 integrar los microcondados existentes en estas tierras, en un único condado bajo la autoridad del conde Fernán González, Burgos pasó a ser la capital y centro administrativo del nuevo Condado ${ }^{245}$.

Ya hacia el año 950 se constata la existencia de una pequeña población asentada sobre la falda sur del cerro del Castillo hacia la vega del Arlanzón, con pequeños núcleos cercanos pero asentados en zonas más llanas, junto a la vía Aquitana. En la venta de una herrén y unos casares en el barrio burgalés de San Pedro de las Eras (actual San Pedro de la Fuente), se indica que está junto a la "vía discurrente"246. En 961 Proba y Froilo se entregan a San Pedro de Cardeña con todos sus bienes, entre otros unas casas con su iglesia en Barrio de Eras junto a la calzada247, y en 982 ya existen dos tiendas en la calle principal que bordea el cerro del Castillo, situadas a ambos lados de la vía romana, que el conde García Fernández y su esposa donan al monasterio de San Pedro de Cardeña ${ }^{248}$. Esto confirmaría que en estas fechas, existía una población que se iba especializando en la transformación y mercantilización de los productos agrarios ${ }^{249}$.

243 CASADO ALONSO, H.: 1994: 175-247; DIAGO HERNANDO, M. y LADERO QUESADA, M. A.: 2009: vol. $32,364$.

244 BASAS FERNÁNDEZ, M.: 1954: 56-64; 1963 У 1994: 29-30.

245 GARCÍA GONZÁLEZ, J. J.: 2008: 32-47.

246 MARTÍNEZ DÍEZ, G.: 1998: doc. 79 de 16 septiembre 950. “...in loco que dicitur Uarrio de Eras iusta kasas de Uermudo, de alia pars uia discurrente"

247 MARTÍNEZ DÍEZ, G.: 1998: doc. 98 de 3 febrero 961. “...in Barrio de Eras kasas cum sua ecclesia, et cum corte cum sua ayacentia, siue ortys, molinis, et sernas in Paramo, et duas sernas in Sancti Martyni, et una uinea iusta calzata,...".

248 BECERRO GÓTICO DE CARDEÑA. f. 18r-18v/ 24 febrero 982; MARTÍNEZ DÍEZ, G.: 1998: doc. 189 de 24 febrero 982 "...donamus atque concedimus in nostra uilla propria quem nuncupant Uurgos duas tiendas in media uilla, unam ad dexteram et aliam ad sinistram, per medium uia publica que discurrit ubique ab Oriente et ab Occidente a Meridie et ab Septentrionalem partem,...".

249 GARCÍA GONZÁLEZ, J. J.: 2008: 32-41. 
La ciudad seguirá ostentado esa misma capitalidad cuando el Condado se constituya en reino de Castilla en 1035, con lo que esa misma posición actuó como foco de atracción, estimulado además por la protección e impulso que los reyes ejercieron para favorecerla, dotándola de un gran protagonismo político al ser “Cámara Regia” y “Cabeza de Castilla”.

$2^{2}$. El Camino de Santiago. Fue un elemento fundamental para que Burgos llegase a ser una ciudad eminentemente mercantil. La ciudad llegó a ser uno de los centros más importantes de toda la vía jacobea, y al situarse en un punto estratégico en el centro peninsular de dicha vía, se benefició del asentamiento en su trama urbana de artesanos y comerciantes que procedentes de otros lugares, tanto del campo próximo como del reino de Castilla, y sobre todo de otros reinos extranjeros, desarrollaron su actividad al servicio de unos caminantes que en gran número circulaban por sus calles y demandaban artículos y servicios. Estos comerciantes, gozaban del privilegio de inmunidad y la protección del Rey, ya que sin estas garantías, ni la peregrinación ni el comercio se hubiesen desarrollado250. Según Luis Martínez, se registraron en esta fase los nombres de 160 hombres y 20 mujeres de origen presuntamente franco, la mayoría eclesiásticos, artesanos y comerciantes, que son entre el 20 y $25 \%$ de todos los antropónimos documentados de la ciudad en los últimos 30 años del siglo XII ${ }^{251}$.

Entre los siglos XI y XIII la peregrinación jacobea experimentó un extraordinario desarrollo. Algunos autores, han estimado un número, quizá exagerado, no inferior a 200.000 peregrinos anuales ${ }^{252}$. Pero excesivo o no, lo cierto es que lo que se constata es el gran impacto que un excepcional movimiento de personas que iban y venían de Santiago de Compostela, ocasionaron en las localidades del Camino en general y en una ciudad tan destacada como Burgos, en particular, con un comercio concentrado principalmente en la actual calle de Fernán Conzález y sus aledaños. El emplazamiento de la ciudad gozaba de una excelente posición, que con una fuerte presencia en un camino internacional tan importante, recibía las valiosas aportaciones que llegaban de Europa, e iba conformando su personalidad comercial y cosmopolita con el paso de peregrinos y comerciantes. Este enorme contingente de romeros provocó el desarrollo de la artesanía y de oficios relacionados con el consumo de alimentos, la elaboración textil, del calzado y del metal, la guarnicionería y algo muy importante que será fundamental para el despegue y futuro desarrollo del comercio burgalés ultramarino: los servicios cambistas. Se desarrollaron por ello, además de las tiendas para la venta directa, los talleres artesanales, así como los mercados semanales y las ferias anuales ${ }^{253}$. En resumen, el impacto de la ruta jacobea contribuyó a la transformación urbana y económica de Burgos en los siglos XI y XII, acelerando una significativa evolución que transformó una villa rural en una importante plaza mercantil e industrial, al propiciar el establecimiento de comerciantes, que serán la base social que soportará y promoverá básicamente el desarrollo comercial posterior ${ }^{254}$.

\footnotetext{
250 VÁZQUEZ DE PARGA, L.; LACARRA, J. Mª . y URÍA RÍU, J.: 1948: t. I, 255-256. Este apartado lo trata José Mª Lacarra.

251 MARTÍNEZ GARCÍA, L.: 2004: 102.

252 MARTÍNEZ GARCÍA, L.: 2004: 100.

253 MARTÍNEZ GARCÍA, L.: 2004: 102.

254 BASAS FERNÁNDEZ, M.: 1954: 59
} 
$3^{\circ}$. Presencia y proximidad de los puertos del Cantábrico. Castilla tenía la salida natural al mar siguiendo el curso del río Duero hasta Oporto, pero una frontera política impidió dicha salida y obligó a buscar otra alternativa. Aunque el territorio que media entre Burgos y los puertos del norte, es difícil, agreste y complicado, Castilla no tuvo otra opción para canalizar su comercio internacional, que utilizar estos puertos por ser los más cercanos a dicha capital. Cualquier otra alternativa resultaba mucho más lejana y costosa por ello. Como la ciudad ocupaba un lugar estratégico entre el interior y los puertos del Cantábrico, dicha situación propició que se convirtiese en el centro redistribuidor por excelencia de productos y abastecimientos.

Del siglo XIII se conocen unos aranceles que prueban la existencia en estas fechas, de un movimiento comercial ya consolidado por los puertos del Cantábrico ${ }^{255}$. Pertenecían a la diócesis de Burgos, y sus diezmos correspondieron a la mesa episcopal burgalesa, una de las más ricas de la Península, y a algunos de sus monasterios.

La relación de la ciudad con los puertos del norte comienza en fechas antiguas. Ya en febrero de 1178 Alfonso VIII concede al monasterio de San Juan de Burgos, los diezmos reales de la villa de Castro-Urdiales y de su puerto ${ }^{256}$. En mayo de 1183 hace donación a dicho monasterio, de la iglesia de San Pedro de Castro-Urdiales y de todas las que se erijan allí en el futuro con todos sus diezmos, derechos y pertenencias y le confirma los diezmos de todas las rentas reales de la villa y de su puerto y de los derechos reales de Medina de Pomar257. Tal donación será confirmada por Alfonso X en 1255 y por Fernando IV en 1298. En julio de 1192 el rey cede al obispo de Burgos y su catedral, el diezmo eclesiástico de todo el portazgo perteneciente a la Corona en el puerto de Santander y todos los del Cantábrico, situados dentro de la diócesis burgalesa, así como al monasterio de San Juan, el diezmo de todas las rentas reales de la villa de Castro-Urdiales y de todas las mercaderías que llegasen a su puerto, excepto el portazgo correspondiente a paños, armas y "querambre", que lo concedía al obispo 258 .

$4^{\circ}$. El despegue de las relaciones comerciales entre el Norte y Sur de Europa. Tras el bloqueo que realizó Inglaterra de sus exportaciones de lana a Flandes, Burgos se beneficiará del impacto de un comercio próspero, fomentado por unos mercaderes que tenían como centro de sus operaciones comerciales a la propia ciudad, que pasará a depender de manera progresiva, de los intereses de una oligarquía financiera que copó los puestos municipales y controló su vida cotidiana, y a la vez la beneficiaba y sostenía. Castilla conoció un gran desarrollo marítimo en el siglo XIII, y los mercaderes burgaleses se establecieron en fechas tempranas en las plazas mercantiles del Atlántico norte, entre las que destacó especialmente la ciudad de Brujas con su “estapla” de lanas.

$5^{\circ}$. La expansión de la ganadería lanar. Hubo un gran desarrollo en Castilla del ganado ovino y de una institución clave como fue el Real Concejo de la Mesta, creado en 1273

255 CASTRO, A.: 1921 a 1923.

256 A. M. B./ S/c/ Burgos, febrero 1178; PEÑA PÉREZ, FCo. J.: 1983: doc. 36, 47-48.

257 A. M. B./ S/C./ Burgos, 11 mayo 1183; PEÑA PÉREZ, FCo. J.: 1983: doc. 44, 62-64.

258 SERRANO, L.: 1935: t. II, 137-138; A. M. B./ HI-130/ Covarrubias, 11 julio 1192; PEÑA PÉREZ, FCo. J.: 1983: doc. 53, 7476. 
por Alfonso X. El Real Concejo, impulsó la ganadería merina que producía una lana de excelente calidad, base de las exportaciones burgalesas y del gran desarrollo comercial y económico que la ciudad experimentó desde la baja Edad Media. Esto fue favorecido por su posición geográfica entre los puertos cantábricos y vascos y las grandes cañadas de la Mesta, además de ser punto de enlace entre dichos puertos y las zonas ganaderas del interior: Sierra burgalesa y soriana, Segovia, Guadalajara o Cuenca.

Con estos antecedentes, no será difícil que cuando los tiempos sean propicios, la ciudad despegue con fuerza como el gran centro comercial y exportador del norte de Castilla, a la vez que entraba en contacto muy pronto con los prósperos países del norte de la Europa Atlántica, especialmente con Flandes, y aparezcan en estas fechas, una serie de linajes autóctonos, que se constituyeron en una poderosa clase mercantil y burguesa que dirigió el desarrollo burgalés hasta el siglo XVI.

Algunos viajeros así lo indican, como Nicolás de Popielovo, noble polaco nacido en Silesia, que llega por mar para ir a Santiago, rodea la Península por Lisboa., y sale por Cataluña, y que aunque no pasa por Burgos, menciona en 1485 la gran prosperidad de la ciudad y de sus mercados 259 . Lucio Marineo Sículo, tiene en 1530 sobre Burgos y los burgaleses, una muy favorable opinión ${ }^{260}$.

Habrá a partir de ahora tres ámbitos dentro del comercio exterior de la ciudad:

1. Comercio local entre las poblaciones urbanas y campesinas. Se trajinaba productos básicos como trigo, vino, pescado, etc.

2. Interregional con intercambio de productos agrarios o manufacturados y redistribución de productos extranjeros. Se transportaba principalmente a los mercados, hierro, aceite, pescado, vino, trigo, sal, etc. y artesanía.

3. Internacional, que consistirá en el comercio promovido por grandes y medianas empresas mercantiles que se dedicarán a la exportación e importación. Se exporta básicamente lana merina. En los siglos XV y XVI los mercaderes burgaleses exportaban dicha lana para tres naciones: Flandes, Francia e Italia. En Flandes, se enviaba básicamente a la "estapla" de Brujas desde los puertos cantábricos, principalmente por Santander, y en segundo término por Laredo ${ }^{261}$. También fue muy importante para el tráfico de las lanas burgalesas el puerto de Bilbao, rival portuario de Santander y comercial de Burgos. De los puertos guipuzcoanos, solo cargaron los burgaleses de una manera muy discreta en el puerto de Deva. Se exportaba además trigo, vino, sal, pieles, hierro, cueros, frutas,

259 POPIELOVO, Nicolás de: "Relación del viaje"/ 1485; GARCÍA MERCADAL, J.: 1952: t. I: 307-326. “...Además hay otra ciudad, Burgos, capital de Castilla, a ciento veinte millas de Sevilla. Es una plaza de mercado de las mejores mulas; de allí las Ilevan a Portugal, Aragón, Cataluña, a toda España, a Italia, Roma, y también a Francia".

260 MARINEO SICULO, Lucio: "Obra Compuesta por Lucio Marineo Siculo Cronista de sus Majestades de las cosas memorables de España”. Año de M. D. XXXIX. Libro tercero, fol. XVI. "La gente desta ciudad es muy amorosa con los estrangeros: muy fiel con sus Reyes: y suffrida con los huespedes. No ay en ella gente ociosa ni baldia sino que todos trabajan, ansi mugeres como honbres y los chicos como los grandes, buscando la vida con sus manos y con sudores de sus carnes. Unos exercitan las artes mecanicas: y otros las liberales. Los que tratan las mercaderias y hazen rica la ciudad son muy fieles y liberales... Los que rigen y gouiernan la republica procuran el bien comun: y no hazen como otros muchos que buscando sus intereses destruyen a los pueblos. Ansi que haziendo cada vno lo que deue la ciudad cada dia cresce mas y cada dia se haze mas noble... Es de mas desto la ciudad muy adornada de casas principales: de plaças: de mantenimientos y otras cosas necessarias de negociantes y tratos: de muy buenas y largas calles...".

261 BASAS FERNÁNDEZ, M.: 1961: 61 y 62. 
especias, etc. y se importaban vinos de Burdeos, pescado seco, pastel y productos manufacturados como textiles, muebles, armas, libros, vidrio, quincallería, mercería, tapices, joyería, alabastros, obras de escultura y pintura, etc.

\section{a.- Enclave comercial y lanero}

Como se ha mencionado, la ciudad de Burgos desarrolla desde sus orígenes una importante actividad comercial. De 1339 nos llega una referencia sobre mercaderes que comercian con Flandes. Alfonso XI concede un privilegio para que "algunos mercaderos de la dicha çibdat que van a Flandes e Monpesler ${ }^{262}$ e a otras partes fuera del nuestro señorio por tierra", puedan vender sus rocines sin incurrir en pena ${ }^{263}$. No obstante García de Quevedo ${ }^{264}$ indica que el más antiguo documento que habla de estas relaciones comerciales, alcanza el año 1267, con una carta de la condesa Margarita. Los mercaderes castellanos obtuvieron importantes privilegios de los duques de Flandes: de Roberto III en 1312 y de Luis II en 1348, 1367 y $1384^{265}$.

Juan I dice en 1388 al concejo de la ciudad de Burgos, que en las Cortes de Briviesca de 1387 ordenó que ningún regatón comprase viandas en Burgos a menos de cinco leguas alrededor para venderlas a regatería, para que la ciudad estuviese mejor abastecida y a menores precios. Y manda que ningún regatón compre vino para vender a regatería de cuba ni de acarreo en Burgos ni fuera, de lo que viniese de Toro ni de cualquier otro lugar, salvo lo que los regatones trajeren en sus bestias o en sus carretas, comprándolo fuera o en las villas o aldeas donde lo tuvieren en cubas o tinajas ${ }^{266}$.

En 1445 el concejo de Burgos dice al Rey que Juan de Luján alcaide del castillo de Burgos, comete excesos y cobra por derechos de castillería a los de fuera que no son vecinos ni francos, y aun a algunos de los vecinos de la ciudad, sin razón y sin derecho, sobre más cosas de las que han tenido por costumbre de las que traen a la ciudad, por lo que muchos dicen que no quieren ir a Burgos a vender los géneros que se solían traer. El concejo pidió que se cobren los siguientes derechos ${ }^{267}$ :

\begin{tabular}{|l|l|}
\hline Producto & Derecho a pagar \\
\hline De carga o carretada de varas & una vara \\
\hline De carga de orégano & un manojo \\
\hline De carga de aguijadas & una aguijada \\
\hline De carga de ramos & un ramo \\
\hline De carga de tejos y de arzones y de toda fustambre & un fuste \\
\hline De los palominos & uno de cada 1o palominos \\
\hline De carro de cellos & un cello \\
\hline
\end{tabular}

262 Montpellier.

263 A. M. B./ HI-96/Madrid, 28 noviembre 1339.

264 GARCÍA de QUEVEDO, E.: 1905 y 1995: 20-21.

265 SUÁREZ FERNÁNDEZ, L.: 1958.

266 / Burgos, 20 febrero 1388; GARCÍA SÁINZ de BARANDA, J.: 1967: II. doc. 55, 478.

267 A. M. B./ HI-11/ Fuentesauco, 27 octubre 1445. 


\begin{tabular}{|l|l|}
\hline De carreta de cocinas & una cocina \\
\hline De carro de palas & una pala. \\
\hline De carretada de ejes, de estevas y de arales & de cada una un fuste \\
\hline De carga de vidrios & de cada carga un vidrio \\
\hline De carga de mimbres & un manojo \\
\hline De carga de ollas & una olla \\
\hline De carga de tajadores y de estodillas & de cada una un fuste. \\
\hline De carga de altamias y de otra labor de tierra & de cada carga una labor. \\
\hline $\begin{array}{l}\text { De toda la sal que trajeren los de fuera, se traiga poca o mucha. } \\
\text { Y si no viniere ninguna, que no lleven ninguna cosa de carga }\end{array}$ & cada semana 4 celemines \\
\hline De cestas & una cesta \\
\hline De carga de escobas & una escoba \\
\hline De carga de trueares & una truera \\
\hline
\end{tabular}

Los vecinos que lo trajesen y vendiesen no tenían que pagar cosa alguna, como se venía haciendo de mucho tiempo acá. Juan II manda que el alcaide no cobre otros derechos de castillería sobre los géneros que los no vecinos llevasen a vender a la ciudad, que los contenidos en la relación como acostumbraron a llevar los anteriores alcaides y castilleros, y que no tome de los vecinos cosa alguna de las dichas.

Los procuradores de la ciudad presentaron en el Consejo algunas quejas sobre los agravios que recientemente recibían de sus alcaldes mayores y regidores, porque los fieles llevan nuevamente a los boticarios con el nombre de aguinaldos por Navidad cierta cuantía, y también a los regatones un cuartillo de real por tienda y a los carniceros por cada banco un cuarto de carnero. Además a los mesoneros donde suelen posar los mulateros que traen el pescado fresco, un sexto del pescado, lo cual, dicen, lo llevan sin título y contra las ordenanzas de la ciudad. Los Reyes mandan en febrero de 1497 que los fieles no lleven ningún aguinaldo, so pena de $5.000 \mathrm{mrs}$. por la primera vez, y por la segunda otros 5.000, pierdan el oficio y estén 20 días en la cadena en la cárcel pública. Además, de poco tiempo acá, dichos fieles llevan cada viernes 25 libras del pescado fresco que llega, y como se quejan muchos mulateros, mandan que no se lleve pescado de ningún mulatero, so pena que el fiel pague lo que llevó, y los 2/7 sean para el mulatero perjudicado, 3/7 para edificios públicos y reparos de la ciudad y 2/7 para los presos de la cárcel. Ordenan además que cuando vayan los mulateros a vender salmones y lampreas, los jueces de los fieles junto con los mismos fieles, fijen su precio de venta.

Por otro lado, como algunos de los pescaderos que venden el pescado fresco no siguen el orden como deben y obtienen el favor del oficial, se pretende remediar tanto la elección de los pescaderos, como la forma que han de usar de sus oficios, por lo que la justicia y los procuradores mayores y los de las vecindades, elegirán cinco hombres buenos para que nombren 40 pescaderos vecinos de la ciudad, y estos echen a suertes para que 20 sean repartidos por los fieles, 10 para el Mercado Mayor, seis en el Azogue y los otros cuatro en San Esteban, y elijan dos de ellos para que en la red del pescado en San Esteban donde lo llevan los mulateros, lo reciban y repartan por los tres lugares donde se ha de vender el pescado. Mandan que los pescaderos y mulateros que vendieren el pescado fresco en el 
Mercado Mayor, vendan primero el pescado a los monjes del monasterio de Miraflores, frailes del de San Juan, San Pablo, San Francisco y San Agustín y monjas de observancia, y luego venderán a los oficiales del Ayuntamiento el pescado que necesitaren para ese día, antes que a otras personas. Nadie podrá salir al camino a tomar el pescado fresco, para que todo llegue a la red de la ciudad, so pena de 599 mrs. y de 20 días en la cadena. Ningún pescadero podrá llevar a su casa carga ni cesto de pescado para dar ni vender a otro, para que todo se venda en las plazas y lugares autorizados. Los 20 pescaderos elegidos llevarán por el trabajo de cortar y pesar el pescado, y por la tara del cesto y juncias, de cada cesto de Laredo 2,5 libras, y de cada cesto de Bermeo cinco libras ${ }^{268}$.

En junio de 1522, el concejo de la ciudad dice que hicieron una ordenanza para que sus fieles hiciesen un libro en que escribiesen todas las penas de $48 \mathrm{mrs}$. puestas a los regatones y otras personas, que venden los mantenimientos más caros de cómo están fijados o hacen pesos falsos, y que para hacer la ordenanza, quisieron saber quiénes eran los regatones que no cumplían para poderlos castigar. Por otro lado, los regidores y procuradores de la ciudad dijeron que como esta se provee de acarreo de todos los mantenimientos necesarios, hay muchos regatones en ella y mucho desorden en los precios, y engaños por pesos y medidas falsas, y que aunque tienen ordenanzas y juzgado de fieles, no se puede ejecutar justicia porque los regatones, apelan las condenas ante los alcaldes del crimen de Valladolid, aunque sean de menos de $100 \mathrm{mrs}$, y como esas condenas son siempre pequeñas quedan los regatones sin castigo, por lo que suplicaron se mandase a los alcaldes del crimen que no admitiesen dichas apelaciones si las penas fuesen de menos de $6.000 \mathrm{mrs}$. El Consejo mandó al corregidor en abril de 1528, que las condenas que se hicieren contra cualquier regatón inferiores a $300 \mathrm{mrs}$. se ejecuten a pesar de cualquier apelación que de ellas se interponga ${ }^{269}$.

La ciudad de Burgos se quejaba de que Francisco de Rojas, capitán que entendía en la fábrica de munición y artillería en Burgos, tomaba las carretas que llevaban bastimentos a la ciudad para traer las cosas que necesitaba y que por ello los mantenimientos han subido de precio, porque al ser la ciudad de acarreo, las carretas dejan de venir. La ciudad pidió que se mandase que no se tomen estas carretas, ni de personas pobres, y las que se necesiten, se pidan al corregidor o al regimiento, para que la ciudad y vecinos no recibiesen daño. El Consejo, acordó en agosto de 1543 mandar que el capitán y el corregidor provean de fuera de la ciudad las carretas necesarias, y no se tomen las carretas que con mantenimientos lleguen a la ciudad 270 .

En marzo de 1548 el Rey aprueba las ordenanzas de Burgos. Su apartado IIII indica que para fijar los precios de los mantenimientos, se deben poner los precios y posturas para todo el año en la carne, pescado cecial, vino, candelas y cosas semejantes, con acuerdo del regimiento y de los dos regidores nombrados por jueces de fieles, fieles y procuradores mayores, como se contiene en la Provisión real de septiembre de 1494, pero en los otros mantenimientos y provisiones que se venden en la ciudad, así como el pescado fresco,

268 A. M. B./ HI-1438/ Burgos, 15 febrero 1497; Palencia, 4 junio 1522 y Madrid, 27 abril 1528.

269 A. M. B./ HI-1438/ Burgos, 15 febrero 1497; Palencia, 4 junio 1522 y Madrid, 27 abril 1528.

270 A. M. B./ HI-3320 y 3416/Valladolid, 30 agosto 1543. (Burgos, 15 junio 1597) 
fruta, hortalizas u otras cosas menudas, que los fieles los puedan fijar libremente sin que los regidores ni jueces de fieles, les pongan impedimento alguno, pero los precios de salmones y lampreas, los pondrán los regidores que fueren jueces de fieles o uno de ellos, con los dichos fieles. En dichas ordenanzas se dispone que sobre la elección de los pescaderos y de cómo han de usar de sus oficios, se guarde y tenga la orden que dispone el capítulo 32, y de cómo han de ser repartidos los pescaderos, se guarde el capítulo 33. Para que no se haga fraude cerca de este oficio se pone en los otros capítulos de la dicha Provisión. En lo que toca a las medidas del pan y vino, se guarde lo contenido en el 6o capítulo y la misma medida sea para las legumbres, el yeso y todas las otras cosas que se suelen medir por fanegas y por celemines. Los fieles de la ciudad, asentarán las penas en que cayeren los tratantes, regatones y vendedores de mantenimientos y provisiones de la ciudad, que excediendo en pesos, pesas, medidas o precios, o hicieren otro engaño o fraude, se lleven ante la justicia según se contiene en carta y Provisión real de 4 de junio de 1522. Como la ciudad se provee de acarreo de todos los mantenimientos y provisiones, los tratantes, vendedores y regatones son necesarios para su buena provisión, pero dicen que los jueces de fieles les ponen las provisiones a tan bajos precios que perdían su caudal, ya que si vendían al precio justo los penaban y prendaban, por lo que muchos regatones y tratantes se han ido a vivir a otras partes. Se manda se pongan a los mantenimientos precios justos y moderados, considerando lo que les hubiere costado ${ }^{271}$.

En junio de 1597 el procurador mayor de Burgos requiere con la real Provisión de agosto de 1543 a Juan Girón, capitán de la artillería, para que no se saquen carretas de la ciudad, ya que Cirón había mandado embargar las carretas que trajeron vino y otras provisiones, causando gran daño a la ciudad. Deberá dejar libres a las carretas para que vuelvan a traer provisiones a la ciudad, y si las necesita, se junte con el corregidor para que las carretas necesarias se traigan de fuera, según manda la Provisión. Cirón dijo que no debe obedecerla por cuanto él tiene una Cédula real de octubre, en que se le manda que con la mayor brevedad, envíe a la armería de Hugey 2.700 coseletes alemanes para con ellos hacer nuevas armas, y que los 30 maestros y oficiales armeros que el Rey tiene en dicha armería para hacerlas los están esperando, y si no se enviasen con brevedad, se haría daño a su servicio, y no cree que la ciudad reciba ningún daño en el dicho embargo. Notificó al corregidor la Cédula real para llevar las dichas armas, y a la ciudad para que le den las carretas necesarias, y dándoselas está presto a alzar el embargo que tiene hecho, y si no se las dan hoy, informa sobre el daño que puede venir a la Hacienda real y procederá con rigor contra las personas que lo contravinieren ${ }^{272}$.

\section{Ferias y mercados}

La ciudad de Burgos acogerá muy pronto en sus calles ferias y mercados, como corresponde a una población eminentemente mercantil. Recibe un privilegio en marzo de 1230 , por el que Fernando III concede facultad para la celebración de un mercado, designando para ello el lugar de la glera, en el espacio comprendido entre los ríos Arlanzón y Vena, el

271 A. M. B./ HI-1438/ Aranda de Duero, 21 marzo 1548.

272 A. M. B./ HI-3416/ Burgos, 15 junio 1597. 
puente de piedra y el de madera hasta el monasterio de San Juan²73. En 1233 Ferrán Ruiz, vende al Hospital del Rey la parte que le correspondía en el portazgo de Burgos los jueves de mercado en 5 mrs. menos tercio ${ }^{274}$. Alfonso X ordena en 1278 al concejo de Burgos, que impida los agravios que ciertas personas hacen a vecinos de Atapuerca, vasallos de la orden del Hospital de San Juan, exigiéndoles sal al concurrir al mercado de la ciudad ${ }^{275}$.

La feria de Burgos tiene su origen en la concesión de Alfonso XI al concejo en 1339 de una feria franca anual, de 15 días a partir del 24 de junio, día de San Juan, eximiendo del pago de portazgo a los que concurran a ella y dando normas para garantizar la paz del mercado, por haberse coronado en la ciudad: "que vengan todos los que quesieren venir... saluos e seguros, e que puedan en ella conprar e vender e trocar en aquella manera que se auenieren; et que en este tienpo de la dicha feria, que todos los que a ella venieren que sean quitos de portadgo, que lo non paguen de las cosas que traxieren o leuaren en quanto durare la dicha feria; et que ninguno non les faga fuerça nin tuerto nin otro mal ninguno, nin sean prendados nin tomado ninguna cosa de lo suyo por deubda nin por otra rrason ninguna, saluo si fuese por carta o por contrabto que ally feziesen o en otro lugar en que se desaforasen" 276 .

Entre las condiciones que en 1465 la ciudad impone para declararse a favor del infante Alfonso, hay dos que hablan del pan y del mercado franco. Una dice que se regule la alcabala del pan al precio acostumbrado, porque al pedir más los arrendadores se impide a veces su llegada, algo grave porque la ciudad no podía autoabastecerse. La otra que los jueves haya mercado franco de todo lo que se trae para vender, ya que Burgos tiene más necesidad de ello que otras ciudades que ya lo tienen ${ }^{277}$. En 1475, Fernando V concede un mercado franco de alcabalas los sábados de cada semana ${ }^{278}$.

Los Reyes ordenan en abril de 1487 a todos aquellos que hubieren efectuado ventas el día de mercado franco en Burgos, que paguen las alcabalas devengadas por tales ventas a Conzalo de Molina, arrendador mayor de dicha alcabala, si realmente el concejo de Burgos no estaba en posesión del privilegio de mercado franco 279 .

En 1494 los Reyes dicen a sus arrendadores y recaudadores mayores y menores de las rentas reales, y de las alcabalas de Burgos y su partido, que el Rey dio en Burgos en junio de 1475 carta de Privilegio por la que concedía mercado franco a la ciudad todos los sábados, para que todo lo que en él se vendiere, como vino traído de fuera en cueros, carnes vivas, aves y caza de cualquier calidad, pescado fresco de mar y de río y frutas, sean libres y exentos de alcabala, de forma que sus vendedores y compradores no la paguen, y les sean guardados tanto a los vecinos de Burgos, como a los de fuera, por ida, venida o estada,

273 A. M. B./ HI-120/ Muñó, 10 marzo 1230; GONZÁLEZ y GONZÁLEZ, J.: 1980, 1983 y 1986: t. II documentos. doc 264: 264. “... concedo quod mercatum uestrum fiat semper in la glera, in illo loco qui est inter Arlançonem et riuum de Uena a ponte lapideo, per pontem ligneum usque ad monasterium Sancti Iohannis, mandans et firmiter precipiens quod nullus sit ausus predictum mercatum disturbare, cambiare uel mutare, uel facere ibi forçiam uel de magis".

274 A. Palacio Real/ Libro Tumbo, fol. 77v/ enero 1233; PALACíN GÁLVEZ, Må del C. y MARTÍNEZ GARCÍA, L.: 1990: doc. 161: 147.

275 A. M. B./ HI-2913/Valladolid, 15 abril 1278

276 A. M. B./ HI-98/ Madrid, 28 noviembre 1339.

277 A. M. B./ Actas municipales, 1465, fols. Ggr y v./ Burgos, 15 julio 1465; MONTERO MÁLAGA, A.: 2012: doc. 98, 134.

278 A. M. B./ HI-1089/Burgos, 15 junio 1475

279 A. M. B./ HI-3788/ Córdoba, 21 abril 1487. 
todos los privilegios, libertades y exenciones que se guardan a los que van a los mercados francos de todas las localidades de sus Reinos y señoríos. Los que compren las cosas contenidas en la dicha franqueza para volverlas a vender en el mercado no deberán pagar alcabala de ello, pero el vendedor al que se lo vendieren la deberá pagar a los compradores en el lugar de venta. Asimismo, pagarán la alcabala en su lugar, si las personas de cualquier lugar llevaren a vender al mercado cualquier cosa de lo contenido en la franqueza, y que el que vendiere o comprare en días de mercado cualquiera de los mantenimientos dichos, goce para siempre de todos los privilegios, libertades y exenciones y todo lo que debe ser guardado a los que van o vienen a los mercados francos ${ }^{280}$. En realidad, el dicho privilegio fue una compra, ya que el regimiento tuvo que pagar la considerable suma de 2.000.000 mrs., teniendo que echar sisa en el vino durante un determinado número de años para poder pagarlo281. Sí fue un Privilegio real, la concesión dada en 1520 para celebrar un mercado franco los martes, mediante una instrucción enviada por el Rey al Condestable para que hiciera saber a la ciudad la autorización para dicho mercado, y ofreciendo confirmar el del sábado ${ }^{282}$.

\section{La barra o portazgo}

La ciudad de Burgos fue como se ha dicho un núcleo comercial de importancia desde fechas tempranas. Ya en los fueros de la villa de Palenzuela de 1074 se exime a esta villa del pago del portazgo en Burgos 283 .

En 1273 Alfonso X ordena al merino de Burgos que vele para que los arrendadores del portazgo, paguen al cabildo de la Iglesia de Burgos el diezmo del portazgo de la ciudad ${ }^{284}$. Sancho IV concederá privilegio en 1293, por el que el concejo pueda recaudar para sí y para siempre el portazgo y la martiniega ${ }^{285}$.

Fernando IV otorga en 1308 al obispo y cabildo de Burgos 2.00o mrs., como reconocimiento al préstamo de 1.000 doblas de oro que necesitaba enviar a Roma. Los $2.000 \mathrm{mrs}$. van cargados sobre los 6.000 mrs. que el concejo de Burgos ha de pagar anualmente por razón del portazgo ${ }^{286}$.

En febrero de 1320 el concejo de Burgos concertó la manera en que los arrendadores debían percibir el portazgo y la alcabala cada año, y las condiciones y manera con que el dicho portazgo y alcabala se arrendó, como se recoge en el cuaderno de aranceles de las rentas del portazgo, alcabala, barra y otras rentas establecidas por el concejo de la ciudad:

280 A. M. B./ HI-65/ Madrid, 11 diciembre 1494

281 A. M. B./ HI-4158/ Madrid, 22 febrero 1495.

282 A. M. B./ HI-3789/Valladolid, 19 diciembre 1520

283 A. M. P./ 1074; SERRANO, L.: 1906: doc. II. 17-30. “... homo de Palençiola non det portagium in Burgos ni en Castro ni en todo meo regno...".

284 A. Cat. B./ vol. 2, p. 1, fol. 40/ Segovia, 1 junio 1273; PEREDA LLARENA, Fco. J.: 1984: 154-155: doc. 107; MANSILLA REOYO, D.: 1971: doc. 796; “Catálogo del Archivo Histórico de la Catedral de Burgos” vol. I. Sección Volúmenes (I), nº 801 .

285 A. M. B./ HI-157/Valladolid, 21 mayo 1293

286 A. Cat. B./ V. 18, f. 520/ Burgos, 10 octubre 1308; "Catálogo del Archivo Histórico de la Catedral de Burgos" vol. I. Sección Volúmenes (I), nำ1098. 


\begin{tabular}{|c|c|}
\hline De diez salmones, el que vendiere & un salmón \\
\hline El que los compre, de cada salmón & un dinero \\
\hline Del delfín, quien le vendiere o comprare & un dinero \\
\hline De las truchas a la cesta & un maravedí \\
\hline Si no hubiere cesta de truchas, de dos hasta veinte & cada una \\
\hline De los barbos si fueren palmares y de anguilas y de lampreas & de 10 uno \\
\hline Carga de todo pescado & cinco mrs. \\
\hline Del que comprare el pescado, por cada carga & tres dineros \\
\hline Carga de sardinas & tres mrs. \\
\hline Al que comprare las sardinas, por cada carga & tres dineros \\
\hline Carga de hierro y de acero & tres dineros \\
\hline Carga de comino & 15 dineros \\
\hline Carga de cera y de pimienta & cuatro mrs. \\
\hline El odre de aceite y de la filaza & ocho dineros \\
\hline Carga de cañamones & cuatro dineros \\
\hline Carga de todo paño de color, de seis paños arriba & siete mrs. \\
\hline De la pieza de la valancina & cinco dineros \\
\hline Del santomur, del ras y de la narbonesa & medio maravedí \\
\hline Todo paño tinto y de los ulados de grana & seis dineros \\
\hline La pieza de escarlata & siete dineros \\
\hline Carga de sayal & ocho dineros \\
\hline Carga de cobre & cuatro mrs. \\
\hline Carga de estaño & ocho dineros \\
\hline Carga de argibino, grana y salvagina & cuatro mrs. \\
\hline Carga de pellejos & ocho dineros \\
\hline Docena de las cabrunas & dos dineros \\
\hline Carga de carderinas & ocho dineros \\
\hline Del cuero de la vaca o del buey & un dinero \\
\hline Del cuero de la bestia & medio dinero \\
\hline Del tocino & dos meajas \\
\hline Del pucho & un sesen \\
\hline De la vaca o del buey & dos dineros \\
\hline \multicolumn{2}{|l|}{$\begin{array}{l}\text { Cordero extremeño o de la tierra que mame, no pague nada } \\
\text { antes de San Juan }\end{array}$} \\
\hline De la bestia mayor & medio maravedí \\
\hline De la bestia menor & cuatro dineros \\
\hline Del carnero, oveja o cabra & dos meajas \\
\hline Carga de fruta & tres dineros \\
\hline Carga de fruta de Extremadura & ocho dineros \\
\hline Carga de sebo & cuatro dineros \\
\hline Carga de lana, de pluma y de vino & ocho dineros \\
\hline Carga de sal & dos dineros \\
\hline
\end{tabular}




\begin{tabular}{|c|c|}
\hline Carga de garbanzos, de habas y de toda legumbre & cuatro dineros \\
\hline Carga de rasina, soga, pez, queso y quesada & tres dineros \\
\hline La carretada de la madera cargada & tres dineros \\
\hline La carreta basta & un dinero \\
\hline $\begin{array}{l}\text { La carga de cordobanes, badanas, guadamecíes o badanas so- } \\
\text { bermejas, hasta diez docenas }\end{array}$ & cuatro mrs. \\
\hline Más de diez docenas & pague por carga \\
\hline La docena de cordobanes & cuatro dineros \\
\hline La docena de badanas y de los baldeses & dos dineros \\
\hline Carga de marga & ocho dineros \\
\hline $\begin{array}{l}\text { Carga de almendras, pasas, milgranas, higos, limones, naranjas } \\
\text { o dátiles y de miel }\end{array}$ & ocho dineros \\
\hline Corambre comprada en la villa, adobada para suelas, por mr. & una meaja \\
\hline Carga de segovianos y de palentinos tintos & 3 mrs. y dos dineros \\
\hline De la libra de seda & dos dineros \\
\hline Del cardado de la seda & medio maravedí \\
\hline De la libra de azafrán & un dinero \\
\hline Carga de arroz, de brasil, de alvin o de lata y de blanque & ocho dineros \\
\hline Carga de fustán o de hutedano & ocho dineros \\
\hline Carga de buhonería & cuatro dineros \\
\hline Todo búho collero & la 20 cincuentena \\
\hline La carreta de vino & tres dineros \\
\hline La peña de cinco tiras & un dinero \\
\hline Peña blanca & tres dineros \\
\hline Peña vera & medio maravedí \\
\hline Peña troncosa y peña de armiños blancos & tres dineros \\
\hline Carga de puches y de especiería & cuatro mrs. \\
\hline Carga de pasa & tres mrs. \\
\hline Carga de tea & dos fustes \\
\hline La muela para el molino & cuatro dineros \\
\hline Muela para amolar & un dinero \\
\hline Caldera nueva y tachón dorado & dos dineros \\
\hline Carga de ajos & dos dineros \\
\hline Piezel nuevo y manta nueva & un dinero \\
\hline Lecho blanco & un sueldo \\
\hline Cera nueva & un dinero \\
\hline Carga de peines o de vasos & 8 dineros 02 fustes \\
\hline Carga de añil & cuatro mrs. \\
\hline Carga de alumbre, de cuernos o de porrino & ocho dineros \\
\hline Carga de jabón & cuatro dineros \\
\hline Carga de unto y de manteca & seis sueldos \\
\hline Carga de sebo & tres sueldos \\
\hline Carga de rubia & dos dineros \\
\hline
\end{tabular}




\begin{tabular}{|l|l|}
\hline La bestia mayor del vino & medio maravedí \\
\hline La bestia menor del vino & tres sueldos \\
\hline Carga de astas y de astillones si se compra en la villa, cada mr. & una meaja \\
\hline Carga de agallas moriscas & tres mrs. \\
\hline Carga de goma y de asul & cuatro mrs. \\
\hline Carga de linueso & tres sueldos \\
\hline Cargas de lámparas & tres lámparas \\
\hline Carga de vidrios & dos labores \\
\hline Carga de alcancías o de pucheros, de redomas o de calabazas & dos \\
\hline Carga de lienzos & dos dineros \\
\hline Carga de zumaque & ocho dineros \\
\hline Carga de aceite de linaza & tres sueldos \\
\hline El lino que se vendiere en el mercado de diez cerros & uno \\
\hline Del carro que se trajere a vender & tres dineros \\
\hline Del eje del carro y de la cuba de cada palmo & un dinero \\
\hline Del carro de los cellos & cuatro cellos \\
\hline De la carga de los orios & un orio \\
\hline De la carga de las ollas & dos ollas \\
\hline De la carga de las nutrias & dos mrs. \\
\hline La carreta del carbón & tres dineros \\
\hline La carga del carbón & un dinero \\
\hline La carga de conejos & dos conejos \\
\hline Y si trajere los conejos a cuestas, de cada diez & uno \\
\hline & \\
\hline
\end{tabular}

También se debe pagar portazgo tanto si se vendiere como si no, llegando a Burgos o pasando por su término. El que no pagare, lo pague doblado por la primera vez, por la segunda lo peche con sus novenas, y por la tercera perderá cuanto llevare. Todos los de Rio Ubierna han de pagar la mitad del portazgo en el recuaje de "Bunieles", 15 días antes de San Antolín y 15 días después, y lo pagarán todos los que fueren y vinieren a Palencia mientras dure la feria, salvo los que son francos y tengan privilegio de no pagar recuaje. Se acuerda que el que arrendare la alcabala vieja, cobre de alcabala lo siguiente:

\begin{tabular}{|l|l|}
\hline Del carnero o de la oveja o de la cabra o del cabrón & medio maravedí \\
\hline $\begin{array}{l}\text { Del pescado fresco o salado que se lleve vender a la villa o a su térmi- } \\
\text { no, si no lo vendiere pague de cada costal }\end{array}$ & un dinero \\
\hline El que lo sacare fuera de la villa, que pague de cada costal & un dinero \\
\hline Del salmón, quien lo vendiere y el que lo compre, y del delfín & un dinero \\
\hline $\begin{array}{l}\text { La venta de bestia mayor en la villa o en el mercado, y el comprador } \\
\text { al trato }\end{array}$ & dos dineros \\
\hline El vendedor de toda la bestia menor. El comprador al trato & un dinero \\
\hline El que venda o compre vaca para venderla en otra parte & noven y medio \\
\hline Del puerco & un noven \\
\hline Del carnero, oveja, cabrón, cabra y tocino & medio noven \\
\hline
\end{tabular}




\begin{tabular}{|c|c|}
\hline Del buey para arar, quien lo vendiere y quien lo compre & un dinero \\
\hline Del pan que se venda de Arcos, del almuz & medio noven \\
\hline Más de un almuz, hasta una carga & un dinero \\
\hline Los que de fuera trajeren vino a vender, den de la carga mayor & un dinero \\
\hline De la carga menor & medio noven \\
\hline Los paños de cola, quien los compre de la pieza de la escarlata & seis dineros \\
\hline Del cabra de gante y de luay, pague de camuza de pelo cada pieza & 2,5 dineros \\
\hline Mitán fuerte de grana, la cuerda & un dinero \\
\hline Mitán fuerte milanés, la cuerda & medio noven \\
\hline Todos los otros paños de cola no incluidos aquí, cada pieza & un dinero \\
\hline Los otros paños de lana hechos en España, el comprador pague por carga & ocho dineros \\
\hline De carga de marga & un dinero \\
\hline Quien comprare carga de lana, lino o cáñamo. El vendedor al trato & dos dineros \\
\hline Quien comprare el quintal de la pluma. El que la vendiere al trato & un dinero \\
\hline Quien comprare carga de filaza. El que la vendiere al trato & seis dineros \\
\hline Del quintal de cera & dos dineros \\
\hline De la arroba de pimienta & medio noven \\
\hline De carga de aceite y de sebo & un dinero \\
\hline De carga de hierro & medio noven \\
\hline De carga de cobre & noveno y medio \\
\hline De carga de estaño & un dinero \\
\hline La carga de plomo, la arroba de argebina y la carga de sal & medio noven \\
\hline $\begin{array}{l}\text { De los paños de la seda, quien los comprare. Hasta } 10 \text { dé un dinero, } \\
\text { de } 10 \text { a } 30 \text { dé dos dineros y de } 30 \text { a } 100 \text { cuatro dineros }\end{array}$ & dos mrs. \\
\hline De la cuerda de la tela & un dinero \\
\hline De la libra de la seda & medio noven \\
\hline De la peña vera, quien la comprare & cuatro dineros \\
\hline Quien la vendiere, y pague toda la alcabala al arrendador & dos dineros \\
\hline De la peña blanca, quien la comprare & dos dineros \\
\hline Quien la vendiere, y pague toda la alcabala & un dinero \\
\hline De la peña armiña, quien al comprare & cuatro dineros \\
\hline Quien la vendiere, y pague toda la alcabala & dos dineros \\
\hline De la peña deslomada, quien la comprare & dos dineros \\
\hline Quien la vendiere, y pague toda la alcabala & un dinero \\
\hline De la de seis tiras apuradas, quien la comprare & noven y medio \\
\hline Quien la vendiere, y pague toda la alcabala al arrendador & un dinero \\
\hline De la peña de a cinco tiras, quien la comprare & medio noven \\
\hline Quien la vendiere, y pague toda la alcabala & medio noven \\
\hline De la docena de los guadamecíes, quien los comprare & un dinero \\
\hline El vendedor de los guadamecíes & medio noven \\
\hline Carga de segovianos o de palentinos o picotes blancos y de sayal & ocho dineros \\
\hline El comprador de trujillo y de conejos. El vendedor al trato & tres dineros \\
\hline El vendedor de la carga de las lebrunas. El comprador al trato & dos dineros \\
\hline
\end{tabular}




\begin{tabular}{|l|l|}
\hline El vendedor de la carga de aborrones. El comprador al trato & cuatro dineros \\
\hline El comprador de carga de las otras corambres. El vendedor al trato & cuatro dineros \\
\hline El vendedor de la carga de cominos y de la macha abruna & un dinero \\
\hline El comprador de los cominos y de la macha abruna & dos dineros \\
\hline El comprador de la libra de azafrán. El vendedor al trato & medio noven \\
\hline El vendedor de carga de astas. El comprador al trato & medio noven \\
\hline El vendedor de carga de fruta al mayor. El comprador al trato & un dinero \\
\hline El vendedor de carga de fruta al menor. El comprador al trato & medio noven \\
\hline El vendedor de carga de uva & dos dineros \\
\hline El que comprare la uva & un dinero \\
\hline El vendedor de carga de greda. El comprador al trato & dos dineros \\
\hline El vendedor y el comprador del horno del yeso y el de la cal & dos dineros \\
\hline El vendedor del millar de teja y de ladrillos. El comprador al trato & medio noven \\
\hline El vendedor de la carga de los orios. El comprador al trato & medio noven \\
\hline El vendedor de la cuba del vino & dos dineros \\
\hline El vendedor del fuste de la cuba. El comprador al trato & un dinero \\
\hline Quien vendiere un carro. El que lo comprare al trato & un dinero \\
\hline Quien vendiere la carreta de la madera. El comprador al trato & medio noven \\
\hline Quien vendiere la carga de grana. Quien la comprare al trato & tres mrs. \\
\hline El de fuera de la villa que encerrare vino en bodegas, por cuba & seis mrs. \\
\hline El de fuera de la villa que encerrare pan en Burgos por cada alfolí & un almuz \\
\hline El de fuera de la villa que trajere carreta de vino a vender & medio maravedí \\
\hline Cada tienda del mercado, quien las poblare cada jueves & un dinero \\
\hline Cada tablero del azogue & tres dineros \\
\hline El vendedor de legumbre verde y seca. El comprador al trato & un dinero \\
\hline
\end{tabular}

Las carnicerías de Burgos y los lugares de los vanos y las casas del mercado que están cerca de la carnicería, pagarán alcabala. También entra en la alcabala, el cadalso del vano de la Pellejería, San Martín, la Moque, Comparada, Santa Gadea, San Pedro y el de los yeseros de San Martín. Han de pagar 800 mrs. cada año, de la carnicería del mercado, $265 \mathrm{mrs}$. de la de enmedio, 85 mrs. de la de San Martín y de la baja 50 mrs., sumando las cuatro carnicerías 1.200 mrs. Las tiendas de la calle de San Llorente deben pagar mediado febrero, bajo juramento, la alcabala de cuantos paños compren. Los yeseros, los tejeros y los caleros deben pagar por los hornos que venden y paguen la alcabala por el comprador. La barra se cogerá de esta manera:

\begin{tabular}{|l|l|}
\hline Toda carga de paños que entrare en la ciudad & dos mrs. \\
\hline Carga cerrada de grana o de cordobán y lo que se sigue con ello & un maravedí \\
\hline $\begin{array}{l}\text { Toda carga castellana así como filaza, lana, badana, acero, hierro y } \\
\text { las otras cosas que se siguen }\end{array}$ & seis dineros \\
\hline Carga de pescado fresco, dos costales por carga & cinco dineros \\
\hline Carga mayor de pescado seco y salado cualquiera que sea & un maravedí \\
\hline Carga menor del pescado seco & seis dineros \\
\hline Carga de pan, vino y de leña de bestia mayor & tres dineros \\
\hline
\end{tabular}




\begin{tabular}{|c|c|}
\hline Carga de pan, vino y de leña de bestia menor & dos dineros \\
\hline Todo el pan que fuere por el término de la ciudad & lo dicho \\
\hline Carga de sal que saliere de la ciudad o pasare por su término & cuatro dins. \\
\hline Carretada o carro de leña de bestias mayores & cinco dineros \\
\hline Carretada de leña de bueyes y carga de carbón & tres dineros \\
\hline Carretada de madera de cualquiera que sea & cinco dineros \\
\hline Carretada de carbón y de vino y carga de toda caza & un maravedí \\
\hline Carga de gallinas & cinco dineros \\
\hline Carga de huevos & tres dineros \\
\hline $\begin{array}{l}\text { El dueño de la carguería de la carreta que trajere cualquier carga, pa- } \\
\text { gará lo dicho, y el dueño de la carreta }\end{array}$ & seis dineros \\
\hline La bestia menor & dos dineros \\
\hline $\begin{array}{l}\text { El dueño de la carguería de la bestia mayor que viniere cargada y al- } \\
\text { quilada, pagará lo dicho, y el dueño de la bestia }\end{array}$ & tres dineros \\
\hline Toda bestia que entre cargada de hierba o paja para vender & dos dineros \\
\hline Carga de arzones o de otra madera cualquiera & tres dineros \\
\hline Cada vaca, buey u otro ganado mayor, vendidos o para vender & cinco dineros \\
\hline El ternero o ternera de menos de un año trayéndolo para vender & dos dineros \\
\hline $\begin{array}{l}\text { Cada cabeza de carnero, oveja, cabrón o cabra que entrare a la ciudad } \\
\text { o sus arrabales, vendidos o para vender }\end{array}$ & dos dineros \\
\hline Cada cabrito o cordero, trayéndolos vendidos o para lo vender & un dinero \\
\hline Cada puerco o puerca, trayéndolos vendidos o para vender & tres dineros \\
\hline Todo cochino que anduviere sin madre & un dinero \\
\hline \multicolumn{2}{|l|}{ Los cochinos que anduvieren con su madre, que no paguen nada } \\
\hline \multicolumn{2}{|l|}{$\begin{array}{l}\text { Todo el ganado dicho que pasare por la ciudad o por su término, que } \\
\text { pague la mitad de lo que aquí se dice }\end{array}$} \\
\hline Cada bestia mayor que se alquilare para traer uva u otra cosa por día & dos dineros \\
\hline La bestia menor que se alquilare & un dinero \\
\hline $\begin{array}{l}\text { Todos los aguadores "que acarrean agua para la cibdad o para la judería", } \\
\text { que pague al día cada bestia }\end{array}$ & un dinero \\
\hline Todo molinero que entre o trajere saco de harina, al día & un maravedí \\
\hline Todo salmón que entre en la ciudad & un maravedí \\
\hline Toda bestia que entre vacía, pague al día viniendo por camino & un dinero \\
\hline Toda carga de fruta que entre en la ciuda & tres dineros \\
\hline
\end{tabular}

Sobre todo lo mencionado se cobrará como se ha dicho, pero todo el pan, vino, uvas, frutos, sarmientos, leña, alcatores, hierbas de los prados y huertas de la ciudad, no pagarán nada salvo si lo trajeren para venderlo. Así se ha de recoger la renta de menucel sobre lo que saliere de la ciudad:

\begin{tabular}{|l|l|}
\hline Todos los que sacan carga de congrios secos y de carga de arenques & Dos mrs. \\
\hline $\begin{array}{l}\text { De carga de pescado seco, mielgas, luias, sardinas, bogas u otro pes- } \\
\text { cado seco y salado, y del salmón }\end{array}$ & un maravedí \\
\hline De carga de pescado fresco & cinco dineros \\
\hline De un costal & 2,5 dineros \\
\hline
\end{tabular}




\begin{tabular}{|l|l|}
\hline De carga y de carretada de acero, pague según que pagare por carga & un maravedí \\
\hline De carga de hierro y de carretada & cinco dineros \\
\hline De carga de estaño, de plomo y de cobre & dos mrs. \\
\hline Del odre de aceite, de miel y de unto & un maravedí \\
\hline De carga de queso, de candelas y de sebo & un maravedí \\
\hline De arroba de cera que saliere de la ciudad & cuatro dineros \\
\hline De carga de astas, de astillones y de pluma & un maravedí \\
\hline De carga de esparto, serones, sogas y de cada labor de esparto & cinco dineros \\
\hline De carga de cáñamo labrado o por labrar & un maravedí \\
\hline De carga de pan & seis dineros \\
\hline
\end{tabular}

Además, lo que han de pagar a la entrada de la ciudad en esta renta es:

\begin{tabular}{|l|l|}
\hline $\begin{array}{l}\text { De carretada de madera de roble, pino, haya u otra madera cual- } \\
\text { quiera y de muelas de molinos y de herreros y de carbón }\end{array}$ & un maravedí \\
\hline De carretada de bueyes con leña y de cada carga de carbón & cinco dineros \\
\hline De carga de zumaque y de corteza & cinco dineros \\
\hline De carga de sal & cuatro dineros \\
\hline Carga de toda madera labrada o por labrar & cinco dineros \\
\hline
\end{tabular}

No pagarán la renta los vecinos de la ciudad que sacaren grano para sembrar en su término, o en las aldeas a cinco leguas de la ciudad o para dar de comer a sus hombres, caseros o pastores. Todo el que matare carne en Burgos, en sus arrabales y en sus barrios o en la judería para venderlo, pagará la renta de la carne de esta manera:

\begin{tabular}{|l|l|}
\hline De cada cabeza de vaca, buey o novillo & doce mrs. \\
\hline De cada carnero & doce dineros \\
\hline De cada oveja y de cada cabeza de cabrón o de cabra & un maravedí \\
\hline De cada ternero o ternera & tres mrs. \\
\hline De cada puerco añal o mayor & dos mrs. \\
\hline De cada puerco que no tuviere año cumplido y de cada tocino & un maravedí \\
\hline De cada cordero y cabrito & tres dineros \\
\hline
\end{tabular}

Los hombres buenos y buenas dueñas, clérigos o legos, no pagarán esta renta de la carne si matasen en sus casas para su consumo. Ningún carnicero ni otro alguno, podrá matar en sus casas para venderlo, y no podrán levantar los pellejos de la carne que mataren, a menos que llamen al arrendador o al que lo hubiere de recaudar por él, para que cuente los pellejos y cobren su derecho, y el que no lo hiciere, perderá la carne y pechará al arrendador $48 \mathrm{mrs}$. Todo vecino de la villa a quien hallaren carne escondida para venderlo en las carnicerías, en las plazas de la villa o de fuera o en sus casas, no habiendo pagado la renta dicha, perderá la carne y pagará la pena dicha ${ }^{287}$. 
En 1331 a petición de Diego López de Haro, la ciudad de Burgos, concede a los vizcaínos la exención de los portazgos en ella ${ }^{288}$. Enrique II concede en 1366 al concejo de Burgos que sus vecinos y moradores no paguen portazgo alguno, en ningún lugar del Reino por ellos ni por sus mercaderías. También manda que todos los que fueren a la ciudad con mercaderías, paguen portazgo o cualquier otro pecho, aunque tengan mercedes reales que los exima, haciéndolo en Burgos como en Toledo, Sevilla y Murcia en que todos deben pagar portazgo, aunque tengan privilegios reales para no hacerlo289.

Juan II concede privilegio a la ciudad en 1407 para que sus arrendadores no pongan guardas, ni demanden a los mercaderes de la ciudad que exhiban sus paños y mercaderías, ni por ello los lleven a pleito ni los demanden sobre las cosas que les son vedadas fuera de la ciudad, para que se guarden sus buenos usos y costumbres, algo que se ha usado desde tiempos de Enrique III y sus antecesores ${ }^{290}$. En 1431 Juan II otorga privilegio por el que confirma otro dado a la ciudad por Enrique II, haciéndole donación de la renta de la barra y el portazgo y asimismo de la medida de la Llana, mantenimiento de caballos, compra de bienes de judíos y otras cosas ${ }^{291}$.

En 1475 Fernando el Católico concede facultad para que Burgos pudiera rematar en Fernando de Estella el derecho de la barra y portazgo. Para ello mandó que se pusiese la sisa ya puesta en el vino blanco, y de una blanca por azumbre sobre el vino tinto que llegue a la ciudad, hasta fin de diciembre próximo. Desde esa fecha hasta fin de agosto de 1476, la sisa por azumbre de vino tinto sería de un mr., y los taberneros de la ciudad pagarían de sisa de cada carga de vino que entrase durante ese tiempo, una cántara de vino además de lo que ya pagaban. Mandó que contribuyesen todos los caballeros y eclesiásticos y seglares, y los regatones de la corte. Además del millón de mrs. que dio el concejo al Rey, le socorrieron con otros $200.000 \mathrm{mrs}$. para la paga de la gente que estaba en el sitio del castillo, y para compras de pertrechos y otras cosas necesarias para el dicho sitio, y para esto tuvieron que doblar el derecho de barra puesto en la ciudad, y lo arrendaron hasta fin de 1476 a Fernando de Estella por 194.000 mrs. , que fue la mayor cantidad en que esa renta y derecho se puso. Suplicaron al Rey que a las puertas de la ciudad, por donde entraban las mercaderías que debían pagar el derecho de la barra, den a las guardas las prendas que el arrendador pusiere por lo que montare el derecho de la barra, y que nadie pase sin pagarlo ni dar la prenda. El Rey así lo manda y cumplido el dicho tiempo, no consentirá que la barra se siga cogiendo ${ }^{292}$.

En 1477 los Reyes dicen a los alcaldes, juez y merinos de Burgos, que en el pleito entre Martín Pérez de Anda, en nombre de Vitoria, y los barreros y cogedores de la barra y derechos de Burgos, se presentó Martín Pérez e indicó que los barreros, guardas y cogedores de los dichos derechos, injustamente le habían llevado derechos a él y a otros vecinos de Vitoria, y estos bienes y mercaderías, eran libres de peaje, portazgo u otro tributo alguno,

288 A. M. Bilbao/ Pergaminos, 9/ 13 marzo 1331; ENRÍQUEZ FERNÁNDEZ, J.; HIDALGO de CISNEROS AMESTOY, C.; MARTÍNEZ LAHIDALGA, A.: 1999: doc. 48.

289 A. M. B./ HI-Libro Viejo (s. XVI), f. 204r-206v/ Burgos, 18 abril 1366; GONZÁLEZ DÍEZ, E.: 1984: doc. $204,378$.

290 / Segovia, 15 abril 1407; GARCÍA SAINZ DE BARANDA, J.:"1967: II. doc. 64, 489.

291 A. M. B./ HI-4459/Valladolid, 23 mayo 1431.

292 A. M. B./ HI-4156/ Burgos, 25 octubre 1475. 
según privilegios reales que Vitoria tenía; privilegios que mostró junto con una sentencia y aclaración en favor de los habitantes de Vitoria, dada por el alcalde de Burgos y por el juez y corregidor. Pidió a los alcaldes reales que les mandasen restituir lo que les habían llevado y guardar los privilegios que tenían. Los cogedores de la barra alegaron que no conocían dichos privilegios, y en cuanto los viesen guardarían tales derechos. En lo tocante a la dicha barra, portazgo y derechos de la ciudad de Burgos, los vecinos de Vitoria habían acostumbrado pasar en la paga de la barra y los otros derechos, por la vía y forma que pagan los vecinos de Burgos, desde hacía 40 años. Además, los cogedores de la ciudad, reconocieron ante los alcaldes mayores que los vecinos de Vitoria habían pasado en los tiempos antiguos por dicha forma, y dieron sentencia en que sobre la paga de la barra y derechos de Burgos, los vecinos de Vitoria han de pagar como pagan los vecinos de Burgos, por lo que las guardas y cogedores de los tributos, barra y derechos, no cojan de los vecinos de Vitoria sus bienes y mercaderías, tributos, portazgos, barra, ni otros derechos ${ }^{293}$.

En octubre de 1517 el concejo de Frías se querelló, entre otros, contra el concejo de Burgos que por fuerza les cobraba el derecho de la barra y otros derechos, porque Frías estaba exenta de ese pago por un privilegio concedido por Fernando III en 1249 y confirmado por los reyes posteriores. Su procurador pide justicia al rey Carlos para que no se hiciese pagar a ningún vecino ni morador de Frías ningún portazgo, ni otro derecho en Burgos y se condenase a sus portazgueros. En la Chancillería se condena en enero de 1522 al concejo de Burgos y a los que en su nombre recaudan el derecho de la barra, a que no lleven portazgo ni pontaje alguno a los vecinos de Frías ${ }^{294}$. El procurador de Burgos dijo que la sentencia era injusta, porque Burgos tenía privilegio para coger la barra, así de los vecinos de Frías como de cualquier otro, y además Frías no tenía privilegios para no pagarla, y si algunos privilegios presentara, no fueron usados ni guardados. Además por el privilegio que Burgos tenía, se derogaban todos los demás, de manera que Frías no se podía eximir. La Chancillería en diciembre de 1522, confirma la sentencia definitiva, y manda que los privilegios presentados por Frías vayan incorporados en la carta ejecutoria de la sentencia ${ }^{295}$

En el pleito litigado entre el Cabildo Catedral y la ciudad de Burgos sobre el impuesto de la barra, se redacta un memorial en 1592, ya que el estado y personas eclesiásticas estaban libres de pagar su portazgo'296.

\section{b.- Actividad mercantil}

\section{Exenciones de los comerciantes y arrieros burgaleses}

Ya en 1190 Alfonso VIII concede privilegio en virtud del cual los hombres del monasterio de San Juan de Burgos, quedan exentos de pagar portazgo y recuaje en todo

293 A. M. Vitoria/ Secc. 8, leg. 8, no. 24/ Burgos, 14 diciembre 1477; DÍAZ de DURANA, J. R.: 1994: doc. 43.

294 A. M. Frías/ H-9/Valladolid, 7 octubre 1517 a 24 julio 1523.

295 A. M. Frías/ H-9/Valladolid, 24 enero 1522 a 24 julio 1523.

296 A. Cat. B./ V. 8, ff. (870-880), ff. 879-880/ Burgos, 1592; "Catálogo del Archivo Histórico de la Catedral de Burgos" vol. IV. Sección Volúmenes (I), noำ7712. 
el Reino cuando trasladen mercaderías y ganado de la casa monacal ${ }^{297}$. Al día siguiente, les otorga además, privilegio de exención de portazgo y montazgo sobre los ganados, y de montazgo sobre la leña y madera ${ }^{298}$. Será confirmado por Fernando IV en noviembre de 1298. En 1285 Sancho IV hace saber a todos los concejos, alcaldes y merinos de los lugares donde se toman los portazgos en Castilla y León, que el obispo de Burgos se le querelló porque tomaban portazgo a sus vasallos, a pesar de que estaban exentos de ello por antiguo privilegio. En consecuencia ordena que se respete dicho privilegio299.

En abril de 1304 Fernando IV otorga un privilegio por el que concede a los vecinos y moradores de Burgos que andan con sus mercaderías, la merced de que pagando los derechos reales, no puedan ser embargados, escudriñados ni cohechados por los guardas de las cosas vedadas en ningún camino ni lugar del Reino, a no ser en sus puertos y salidas como se guardaba en tiempos de su abuelo Alfonso X, así como de no tenerse que proveer de albalaes para ir de un punto a otro300. Dicho Rey concede en 1309 a los mercaderes de Burgos que sus mercaderías no sean registradas al venir de los puertos, si traen albalaes de haber satisfecho los diezmos, salvo que el registro sea ordenado por los alcaldes de Burgos ${ }^{301}$.

Enrique II concede en 1366 al concejo de Burgos lo que pidieron por merced, para que los vecinos y moradores de la ciudad no paguen en ningún lugar del Reino, por ellos ni por sus mercaderías portazgo alguno ni ningún otro tributo, ni aquellos que las llevaren por ellos, según que lo tenían Toledo, Sevilla y Murcia302. El concejo mostró en 1379 a Juan I la carta de Enrique II, y le pidió que como algunos de sus vecinos que iban por sus Reinos con mercaderías y otras cosas, no podían llevar dicha carta, que se les diese privilegio en que fuese incorporada la merced. El rey manda en las Cortes de Burgos a todos los concejos que guarden y hagan cumplir dicha franqueza y libertad, a los vecinos y moradores de Burgos $^{303}$. Enrique III confirma en abril de 1391 el privilegio de Enrique II y Juan I, por el que declaraba a los vecinos de Burgos francos de portazgos o de cualquier otro tributo en sus Reinos, por la conducción de sus mercaderías a cualquier ciudad, villa o lugar según lo eran Toledo, Sevilla o Murcia304.

\section{El monasterio de Las Huelgas y el mercado de la Llana}

El monasterio de Las Huelgas de Burgos poseía tres bancos en las carnicerías viejas del Azogue, trasladados a las carnicerías nuevas del Mercado, y los derechos de "las cuezas" sobre la venta del pan en el mercado de la Llana, que consistía en que todos los moradores de Burgos debían dar de cada fanega que vendiesen de su cosecha, un dinero

\footnotetext{
297 A. M. B./ S/C./ Burgos, 13 julio 1190; PEÑA PÉREZ, F. J.: 1983: doc. 50, 69-71.

298 A. M. B./ S/c./ Burgos, 14 julio 1190; PEÑA PÉREZ, F. J.: 1983: doc. 51, 71-72.

299 / Burgos, 27 marzo 1285; NIETO SORIA, J. M.: 1981: doc. 27.

300 A. M. B./ HI-103/ Burgos, 7 abril 1304.

301 A. M. B./ HI-100/ Madrid, 28 febrero 1309.

302 A. M. B./ HI-Libro Viejo (s. XVI), f. 204r-206v/ Burgos, 18 abril 1366; GONZÁLEZ DÍEZ, E.: 1984: 378: doc. 204.

303 A. G. S./ Libros de privilegios y confirmaciones. Libro nํ 268, art. 15/ Burgos, 25 agosto 1379; GONZÁLEZ, T.: 1830: t. V, 368-370, doc. CXXIV; A. M. B./ HI-111/ Burgos, 6 abril 1560.

304 A. M. B./ HI-91/ Madrid, 7 abril 1391.
} 
en la Llana, y pagar al monasterio de todo el pan que trajeren de otra parte a vender, medio celemín por fanega, y de cada carga dos celemines. Así en 1279 Alfonso X ordenó al concejo de Burgos que repusiese en dichas carnicerías nuevas, los tres bancos de los que el monasterio había sido desposeído con ocasión del traslado de los puestos de venta305. En 1285 Sancho IV ordena a aquellos que arrendaren las reales tercias y que compraren pan con para la reventa en Burgos, que satisfagan a las Huelgas los derechos sobre la venta del pan en la Llana ${ }^{306}$. Sancho IV ordena en 1294 al concejo que haga que los recaudadores y arrendadores de las tercias reales vendan el trigo traído a Burgos en la Llana, pagando el derecho de "las cuezas" que se debe al monasterio307.

En enero de 1312 por mandato de Fernando IV, se realiza una pesquisa sobre los derechos que Las Huelgas tenía en las carnicerías de Burgos y en el mercado de la Llana, tomando como base los privilegios y disposiciones de Alfonso VIII (1-VI-1187), Fernando III (12-XII-1219), Alfonso X y Sancho IV (24-V-1285 y 30-VIII-1294). La abadesa y el monasterio mostraron al abad de Santa María de Obarenes y al alcalde del Rey, el privilegio de Alfonso $\mathrm{X}$ que les concedía las propiedades de la Llana, y otros privilegios reales que lo confirmaban. Pidieron que se hiciese interrogatorio, y los testigos dijeron que si el pan que traían de sus heredamientos era para su consumo, no pagaban cuezas, pero si lo vendían en la Llana pagaban al monasterio un dinero de cada fanega, y que todo el pan que se traía para vender, se debía llevar a la Llana y pagar una cueza por fanega, dándolo tanto los judíos y moros como los cristianos. Si alguno lo vendiere sin permiso en alguna casa o posada a las que iban viandantes, perdería el pan y las bestias, y el que lo encubriere o los de la casa donde se vendiere, pecharían al monasterio 60 sueldos de los buenos, y además, le quebrantarían en la puerta la medida con que lo vendieron.

Un testigo recordaba que él quebrantó dos medidas por sus manos, una en Vega, y la otra en el Corral de los Infantes, y el que compró el pan perdió los dineros. Si los de Burgos trajesen pan de fuera, deberían dar las cuezas al monasterio, una vez deducido el pan para su consumo, así como todo lo que se vendiere en Burgos como limieso, habas, garbanzos y otras legumbres y castañas, nueces, avellanas, nísperos o piñones, y todo lo que se midiese a fanega, media, cuarta o celemín, y si lo pusiesen en alfolíes o en sus casas, debían comunicar al que las cobra por el monasterio, cuánto pan tienen para dar las cuezas cuando lo vendieren. Todos aquellos que vendieren sal en Burgos en el mercado o en las posadas, desde el miércoles hasta el jueves, deben dar en la Llana un dinero por carga, lo venda o no. Además, el monasterio poseía una tienda en el barrio de San Lorenzo, tres tiendas en la Coronería y otras tres en la Sillería ${ }^{308}$. Fernando IV ordena al concejo que entregue al monasterio los tres bancos en la forma en que habían dispuesto por privilegios reales, que indicaban como daban al monasterio las casas que fueron de Pedro Franco con su carnicería, y como el rey Alfonso, mandó que no hubiese ninguna carnicería entre las casas ni las tiendas, sino que fuesen apartadas, el concejo deshizo la carnicería que el monasterio

305 A. M. H. B./ Leg. 38, no 1847/ Toledo, 12 abril 1279; LIZOAIN GARRIDO, J. M.: 1987: 105-107: t. III. doc. 592.

306 A. M. B./ HI-1845/ Toledo, 24 mayo 1285

307 A. M. B./ HI-1845/ Burgos, 30 agosto 1294.

308 A. M. H. B./ Leg. 26, num. 1.057/ 21 y 25 enero 1312; CASTRO GARRIDO, A.: 1987 y 1988: 86: doc. 242. 
tenía en el Azogue. Sobre esto Alfonso X y Sancho IV mandaron que el concejo entregase al monasterio los tres bancos en una de las carnicerías de Burgos, tan buena como la que tenían en el Azogue, y no se la entregaron ${ }^{309}$.

Como el concejo, alcaldes y merino de Burgos impedían que se sacase pan de la ciudad, los mercaderes y los que lo traían a vender, no lo llevaban a la Llana al puesto que el monasterio de Las Huelgas tenía, y lo vendían en otros lugares, con lo que disminuían mucho las cuezas y derechos de la abadesa. Alfonso XI ordena en mayo de 1326 que todo el pan que llegare a Burgos se venda en la Llana, y se paguen al monasterio las cuezas y derechos acostumbrados, y que todos los que llevaren pan a vender, lo puedan hacer en la bodega de Lien o de Gamonal, donde dicen que lo suelen vender, o en cualquier otro lugar de la ciudad, sus arrabales o sus términos y paguen las cuezas y los derechos al monasterio como si lo vendiesen en la Llana310. En abril de 1334 tras el pleito entablado entre las Huelgas, que decía que los de Burgos no pagaban las cuezas como debían, y el concejo de Burgos, que alegaba que la abadesa demandaba más de lo que le correspondía y que los de Burgos no debían pagar cuezas, ambas partes concertaron entre otras cláusulas, que todos aquellos que llevaren pan en grano o en harina para vender, que lo lleven a la Llana y paguen sus cuezas, sin descargarlo en ninguna casa, y que nadie salga de Burgos a los caminos ni a las calles y plazas a comprar el pan que entrare antes de llegar a la Llana. El regatero vecino de Burgos, que trajere pan comprado fuera para vender en sus casas, a celemines o por menudo, a medias fanegas y a fanegas, deberá pagar las cuezas, y si algún vecino comprare pan en las aldeas o en otros lugares para que se lo traigan los labradores, que estos paguen las cuezas, y si los vecinos lo compraren en las aldeas o en otros lugares para traerlo a su costa, que no las paguen, bajo juramento de los vecinos de Burgos que lo compraren. Los de los barrios de Villatoro, Cortes y Villímar, deberán pagar un dinero de cada fanega del pan que trajeren a vender, y si estos trajeren pan comprado en otras aldeas para vender a regatería, pagarán las cuezas de este pan como los vecinos de Burgos ${ }^{311}$.

Pedro I concede en 1351 carta de privilegio, confirmando la de Alfonso XI de mayo de 1326, confirmatoria de la de Fernando IV de marzo de 1312, por la que se reconocía que la Llana de Burgos pertenecía al monasterio de Las Huelgas, debiendo cobrar sus rentas como se usó en el pasado ${ }^{312}$. También da una Provisión en 1352 a los alcaldes y merino de la ciudad, ordenándoles que se respete al monasterio el privilegio que tenía, confirmado por Alfonso XI y por él mismo en las Cortes de Valladolid, según el cual debían percibir ciertos dineros del trigo que se vendiese en la Llana por privilegio de las cuezas ${ }^{313}$. Además ordenó ese año a los alcaldes y merino de la ciudad, que hagan cumplir a los vecinos dicho privilegio por la venta de cereales y legumbres en la Llana de Burgos ${ }^{314}$. En 1368 el monasterio

309 A. Palacio Real/ Caja 3.049, №. 16/ Valladolid, 2 marzo 1312; CASTRO GARRIDO, A.: 1987: 105: doc. 244.

310 A. M. B./ HI-1845/ Burgos, 12 abril 1326; GONZÁLEZ DÍEZ, E.: 1984: 311: doc. 174.

311 A. M. B./ HI-1784/ Burgos, 2 y 9 abril 1334; GONZÁLEZ DÍEZ, E.:1984: 334: doc. 187.

312 A. M. H. B./ Leg. 30, num. 1.334-C/ Cortes de Valladolid, 23 septiembre 1351; DÍAZ MARTíN, L. V.: 1997: 341: Cuatro tomos. t. I. doc. 262.

313 A. M. H. B./ Leg. 36, num. 1.753/Valladolid, 4 marzo 1352; A. M. B./ HI- 1780/ (copia de un traslado de 1353); DÍAZ MARTÍN, L. V.: 1997: 35: t. III. doc. 696.

314 A. M. H. B./ Leg. 2, num. 48/Valladolid, 10 agosto 1352; DÍAZ MARTÍN, L. V.: 1997: 84: t. III. doc. 738. 
de Las Huelgas y Hospital del Rey, mostraron privilegios y cartas a la reina Juana para que nadie posase en la Llana de Burgos, porque el palacio y las casas y moradas de la Llana eran para acoger a los ceneriegos y a los que llevaban pan, harina y legumbres, a las bestias y carretas que lo traían, y para los que recaudaban las cuezas del pan y demás derechos del monasterio.

Pero como algunos tomaban posadas en dichos palacio, casas y moradas, causaban gran daño al monasterio y hospital, y según estos, perdían mucho en las cuezas y en los derechos del pan y legumbres, quedando desamparados los ceneriegos y los que llevaban el pan. Como en la Llana ni en sus casas y moradas, no se permite que posen caballeros ni escuderos ni otras personas de palacio, porque se impide la llegada del pan y legumbres para el mantenimiento de la ciudad, y porque disminuyen las alcabalas y otros derechos que el Rey y el concejo tienen sobre lo que se trae a la Llana, y para guardar los privilegios y derechos que el monasterio y hospital tienen, la Reina manda que no se den posadas a nadie dentro de la Llana. Y si las quisieren dar, que los caseros y moradores no acojan a compañas de palacio, y que se guarden los privilegios que el monasterio y hospital tienen, y que no se menoscaben las alcabalas y cuezas, ni reciban daño los ceneriegos y los que llevan el pan y legumbres 315 .

\section{El suministro del trigo}

La ciudad de Burgos debía suministrarse de acarreo, y así lo indica Andrea Navagiero en $1528^{316}$. Aunque el suministro de trigo era fluido y permitía a la ciudad disponer habitualmente del cereal, hubo ocasiones en que la situación se agravó por malas cosechas, o por circunstancias especiales, llegando a producirse escasez e incluso carencia de pan tanto en la ciudad como en sus tierras inmediatas.

Fernando V a petición del concejo, ordena al corregidor en septiembre de 1504 que averigüe el pan disponible en la ciudad y en un radio de 10 leguas en contorno, y dejando lo pertinente para la siembra y mantenimiento de dichos lugares, el resto se debía traer a vender a Burgos a causa de la carestía ${ }^{317}$. En octubre, la ciudad y su estado eclesiástico dijo al Rey que muchos mercaderes de la ciudad tienen concertado abastecerla de pan, pero que la ciudad no podría afrontar los gastos de traerlo de los puertos o de otras partes, y que para cumplirlo era necesario que el pan se pudiese vender a como costare, puesto en la ciudad a vista del corregidor y regidores, por lo que pedían licencia para ello, tanto para lo que trajeren los mercaderes concertados, como lo que trajeren otras personas en nombre de la ciudad. El Consejo dio licencia a la ciudad para que pudiesen vender el trigo en grano que a ella se trajere por mar de otros Reinos, al precio que costare y lo puedan comprar sus vecinos y moradores; y si el pan que se trajere fuese de estos Reinos, así de lo que se vendiere en trigo como en pan cocido, se guarden las Pragmáticas reales ${ }^{318}$.

\footnotetext{
315 A. M. H. B./ Leg. 3, no 81/A/ Burgos, 30 junio 1368; PEÑA PÉREZ, Fco. J.: 1990: 227-230: doc. 268.

316 GARCÍA MERCADAL, J.: 1952: t. I; NAVAGERO, A.: 1983: 82-83. "en tierra de Burgos se cria poco vino, y el trigo que se coge no es bastante, por lo que todo se trae á la ciudad en carros y en mulos; pero no falta nada de lo necesario para la vida y por ser pueblo muy rico se venden muchas mercancías que se llevan de todas partes, y los mejores vinos de España".

A. M. B./ HI-3020/ Medina del Campo, 28 septiembre 1504 
Fernando V comunica en enero de 1506 al concejo de Burgos la inminente llegada a la ciudad de los Príncipes herederos, y le faculta para que provea lo necesario para el abastecimiento de la ciudad y efectuar repartimiento de grano en un radio de 10 leguas ${ }^{319}$. En febrero, el Rey da facultad al concejo para imponer una sisa sobre los mantenimientos por valor de 600.000 mrs. para cubrir los gastos previstos para la llegada de Felipe y Juana y pagar ciertas deudas municipales ${ }^{320}$. El concejo, alcaldes y regidores de la ciudad, dicen en abril que debido a la falta de pan que había en la ciudad, habían hecho todas las diligencias posibles para comprarlo y por no hallarlo en la comarca, lo trajeron de muy lejos aumentando el coste, y como no tenían propios y se tardaría mucho en recuperar por sisa todo su coste, suplicaban que se mandase proveer para que la ciudad pudiese abastecerse del pan necesario sin tanto coste. El rey Fernando, Felipe I y doña Juana dieron licencia para que a costa de la ciudad, pudiesen comprar el pan donde lo hallaren, y el coste de traerlo y lo que han traído de fuera, lo puedan cargar sobre el precio del trigo en grano y sobre el pan cocido que en la ciudad se vendiere, y los que quisieren traer de fuera pan en grano, que lo puedan vender al precio de la Pragmática cargando sobre cada fanega de trigo 3 mrs. y de cebada 2 mrs. por legua y no más ${ }^{321}$. El Rey manda en septiembre a los concejos de las localidades de la tierra y jurisdicción de Burgos y a los que se incluyen en 1o leguas a la redonda, que lleven a la ciudad el pan que les está repartido a cada uno para sustento de la corte, bien como pan cocido o en grano, y lo vendan al precio que quisieren, y cuando lo trajeren se presenten ante los alcaldes de la ciudad y el corregidor para que les den fe de como lo han llevado, y lo vendan en sus plazas y mercados ${ }^{322}$.

\section{c.- Práctica transportista}

En enero de 1303 Fernando IV otorga un privilegio a los mercaderes y moradores de Burgos que transitan con carretas y acémilas llevando mercaderías y mantenimientos, "porque los mas de los omes que moran en la dicha çiudat, bienen por mercadurias e an de andar por la mi tierra en vnos logares a otros, et demas de la mantenençia desta çibdat asi de paños e mercadurias e de pan e de vino, de carnes e de las otras viandas como todas las otras cosas que an mester", para que no sacando de sus Reinos cosas vedadas y pagando los derechos de las villas y lugares, lo hagan libremente sin poder ser prendados ni detenidos por ningún concejo ni persona de cualquier calidad que sea, excepto cuando se trate de deudas personales ${ }^{323}$.

Tenemos una reseña antigua de la existencia de mesones en la ciudad. En diciembre de 1400 el vicario del obispo de Burgos, sanciona el acuerdo establecido entre los herederos de Pedro Fernández de Villegas y fray Pedro de Lodoso, ministro del monasterio de la Trinidad de Burgos, al determinar que las casas sobre las que recaían $300 \mathrm{mrs}$. anuales, que Fernández adjudicó en su testamento al monasterio, eran las casas del mesón en el

319 A. M. B./ HI-3023/ Buena Madre, 29 enero 1506

320 A. M. B./ HI-4290-20/ Salamanca, 26 febrero 1506.

321 A. M. B./ HI-3024/Valladolid, 2 abril 1506.

322 A. M. B./ HI-52/ Burgos, 11 septiembre 1506; A. M. B./ HI-3025/ Burgos, 11 septiembre 1506.

323 A. M. B./ HI-104/Villalpando, 28 enero 1303. 
arrabal que llaman la Tejera, cerca de la puerta de San Esteban. Pero como Fernández no declaró qué casas eran y allí había dos mesones, su yerno pidió que se les asignase el mesón en que vive Juan Sánchez de Villatomil con su solar adjunto, en la calle y camino que por la puerta de San Esteban iba a Villatoro, sobre las eras de San Esteban ${ }^{324}$. Los herederos de Pedro Fernández, confirman los términos del testamento y el acuerdo alcanzado ante el vicario del obispo por el que concretaban los bienes sobre los que debían recaer los 300 mrs. asignados 325 .

Juan Alonso del Castillo, procurador mayor de Burgos, dijo al Emperador que "las puentes y caminos que ay en los terminos y las calles desa dicha çibdad, y de los lugares de su tierra y jurisdiçion y comarca estan caidas, hundidas y de manera que por muchas partes dellas no se puede andar ni pasar espeçialmente en tiempo de ynbierno, lo qual diz ques a causa de las grandes carretas que suelen yr a esa dicha çibdad de Medina del Campo y otras partes, cargadas de grandes mercadurias y con cada quatro o çinco pares de mulas". Pidió al Rey que prohibiese que se traigan las dichas carretas tan cargadas ni con tantos pares de mulas, salvo con sendos pares. El Consejo acordó en octubre de 1544 mandar al corregidor, para que envíe relación del perjuicio causado a los puentes y caminos por el peso de las carretas para proveer lo que convenga ${ }^{326}$. Juan de Álava en nombre de la ciudad dijo al Rey, que estando mandado que no pueden andar carretas con más de tres mulas en Burgos y su jurisdicción, muchas personas andan con cuatro y seis mulas, y que por ello se destruyen los puentes, caminos y calzadas, y tanto los puentes de fuera de la ciudad como los de dentro, sufren mucho deterioro por el gran peso de las carretas. El Consejo mandó en enero de 1546 que ningún carretero pueda llevar carreta con más de tres mulas ni pasar por los dichos puentes, so pena de $600 \mathrm{mrs}$. al carretero infractor, un tercio para el denunciante, otro para el juez y el resto para el reparo del puente por donde ha pasado, y los portazgueros de esos puentes, que lo denuncien a las justicias para que lo hagan cumplir ${ }^{327}$.

Alonso de Madrid en nombre de la ciudad dijo al Rey que en la ciudad y fuera de ella, se habían empedrado recientemente muchas calles, caminos y calzadas en lo que se había gastado gran suma de mrs., pero por andar carretas muy cargadas con tres y cuatro mulas cada una, los empedrados recibían mucho daño y en breve tiempo se debían volver a empedrar, por lo que pidió que se remediase de manera que ningún carretero pudiese pasar por las calles y calzadas, salvo con solo dos mulas. El Consejo acordó en febrero de 1555 mandar al corregidor o juez de residencia, que ningún carretero pueda llevar carreta con más de dos mulas por las calles y calzadas de la ciudad, so pena de 600 mrs. para el carretero denunciado, y se manda a las guardas, portazgueros y vecinos de las calles, que lo denuncien para que se cumpla328.

En octubre de 1583 la ciudad dijo al Rey que como todo lo que necesita le viene de acarreo, convenía que hubiese un mesón grande para las carretas que acudían con man-

324 A. H. N./ Clero. Pergaminos. carp. 203, nำ17/ Burgos, 9 diciembre 1400; GARCÍAARAGÓN, L.: 1985: 400: doc. 193.

325 A. H. N./ Clero. Pergaminos. carp. 203, nำ17/ Burgos, 11 diciembre 1400; GARCÍA ARAGÓN, L.: 1985: 403: doc. 194.

326 A. M. B./ HI-3778/Valladolid, 27 octubre 1544.

327 A. M. B./ HI-1438/ Madrid, 12 enero 1546.

328 A. M. B./ HI-3384/Valladolid, 14 febrero 1555. 
tenimientos y otras mercaderías, señalando un lugar extramuros desde la puerta de las Carretas hasta el Matadero, donde se podría hacer con poca costa, y así se aumentaría el comercio, ya que cada vez acudían menos carretas al no haber donde dejarlas. Como no había propios para ello, se solicitó licencia para obtener por sisa los fondos necesarios, mandando el Rey al corregidor que enviase al Consejo relación sobre si era necesario el mesón, lo que costaría hacerlo, si había algún inconveniente en hacerse y qué propios tenía la ciudad. El Consejo acordó a la vista de dicha relación, dar licencia para construirlo en el lugar referido, y recoger en él los carros y carretas que llegaban con mantenimientos, autorizando echar sisa en el vino que se vendiere al por menor, para obtener los 2.100 ds. que según la relación, eran necesarios para la obra ${ }^{329}$. En junio de 1584 el mesón se está construyendo junto a la puerta de las Carretas, ya que en relación con las obras propuestas para el puente de Santa María, dicen los maestros de cantería que el maestro en quien se rematare, deberá quitar a su costa todos los terreros que hay en la ribera del Arlanzón, " $a$ rraiz de la barbacana e meson que se haçe de las Carretas", para que el agua entre por los arcos del puente más directa330.

El nuevo mesón, reconstruido en 1589 tras haberse quemado, alteraba la situación existente hasta ese momento, y los que acogían en sus casas a los carreteros, se sienten perjudicados, al no permitirse la entrada de las carretas en la ciudad. De esta manera, en 1591, Francisco de Valmaseda en nombre de María Sáenz de Quincoces, se querella contra Jorge del Campo, arrendatario del mesón que la ciudad "nueuamente a hedificado en esta çiudad fuera de la puerta de las Carretas della" junto a la plaza y pegado a la muralla, y dice que María y sus antecesores viven de tiempo inmemorial en su casa del mercado y plaza pública de la ciudad, junto a la puerta de las Carretas, acogiendo en ella a "los carreteros que vienen a ella de tierra de Ualladolid, Toro y Zamora y Toledo e Madrid y otras partes, que traen prouision a esta çiudad e dibersas cargas y mercadurias", que dejaban sus carretas cargadas o descargadas delante de su puerta, y de otras cercanas donde también se acogen, pero Jorge del Campo recientemente y para que los carreteros vayan a posar y descargar en el mesón que tiene arrendado, con autoridad de la justicia y regimiento de la ciudad según dice, sale al camino e impide la entrada de las carretas a la ciudad, diciendo que las han de recoger en su posada, y que les hará castigar si hacen lo contrario. Con ello, María y los demás vecinos reciben notable daño, muchos de los cuales tienen alquiladas sus casas por solo el aprovechamiento de la entrada de los carreteros, y el depósito de las carretas a sus puertas. Solo su parte, dice, tiene de daño anual más de 200 ds., además del perjuicio causado a la ciudad, porque con no dejar tener las carretas en la plaza pública donde acostumbran, hacen gastar a los carreteros muchas de sus haciendas al hacerles ir al mesón, extorsionándolos si no llevan también sus mulas y comen y duermen en él, por lo que por evitar molestias, se irán a otras partes y cesará la provisión y el comercio. Valmaseda pide a la ciudad que mande a Jorge del Campo que no impida la entrada a la ciudad de las carretas, su carga y descarga y tenerlas en la plaza pública pues a nadie perjudican, y pague a su parte el daño causado.

El concejo responde a los querellantes que piden que se revoque el decreto que hizo

329 A. M. B./ HI-4189/ Madrid, 26 octubre 1583.

330 A. M. B./ HI-1679/ Madrid, 19 marzo 1584 y 12 septiembre 1585 y Burgos, 23 octubre 1587. 
el 27 de junio pasado, por el que mandaba que no entren carros dentro de los muros de la ciudad a los que no sean vecinos de ella, que los carros de los vecinos no hacen daño por ser poca la carga que traen, y dice que no se debe hacer cosa alguna de lo pedido, porque por entrar los carros y carretas forasteros se crean grandes inconvenientes, al ser muchas y estar detenidas en la plaza, ocupando gran parte de ella e impidiendo el paso a la panadería y carnicería. Además, con la carga y movimiento de los carros se quebraban los caños de la fuente de la plaza y se desempedraban las calles, y como las carretas se dejaban cargadas en la plaza, al no tener los mesones portales capaces para recogerlos, se han robado muchas veces lo que en ellos traen. También era gran inconveniente "que quando benian rreligiosas o mugeres en las dichas carretas, abia mucha publicidad dello por que se apeaban con neçesidad en la plaça a uista de todos", por lo que "pareçe muy indeçente cosa, apearse en medio de la plaça a vista de toda la gente" y para acabar con esto, la ciudad hizo un mesón grande y capaz, donde se recogiesen todos los carros y carretas que a la ciudad acudieren y también tener guardadas las mercaderías. Además esto no es estanco ni se prohíbe a nadie que tenga mesón y acoja libremente a quien quisiere, tan solo se manda que no entren los carros y carretas dentro de los muros de la ciudad331.

A petición de la ciudad, se otorga Provisión real en noviembre de 1591 para que la ciudad pudiera hacer su probanza ante la Chancillería, en el pleito entre el concejo de Burgos, de una parte, y Hernando Benito y otros carreteros vecinos de la ciudad de la otra, y Diego Álvarez Osorio, Hernando Benito, Jorge del Campo, María de Saldaña mujer de Domingo de Guía mesonero y María Sáenz de Quincoces mujer de Juan de Lezcano que fueron llamados para este pleito en rebeldía, sobre si los carros manchegos pueden entrar dentro de los muros de la ciudad 332 .

\section{Encrucijada de caminos}

Como ya se ha indicado, la ciudad de Burgos, se sitúa en un punto estratégico que actúa como centro de una importante red de vías del norte de la Península. A los caminos de dirección Norte-Sur, de Santander, Laredo, Castro-Urdiales y Bilbao a Burgos, y Burgos a Madrid y a Segovia por Roa, se sumaban los de dirección Este-Oeste de Logroño a Burgos y de Burgos a León y los diagonales de Valencia a Burgos por San Esteban de Cormaz y Cuenca, de Burgos a Valladolid, y de Bayona y Vitoria a Burgos. A través de estos caminos que tenían a Burgos como punto central, entraron en contacto ciudades, villas y regiones que en la época que estudiamos cumplieron un papel muy relevante en la articulación del Reino y la monarquía castellana.

Así se menciona en 1583 en una de las preguntas propuestas para realizar un interrogatorio sobre la importancia del puente de Santa María de Burgos: Pasan por él "las personas y mercaderias y mantenymientos y otras cosas, que uienen del condado de Vizcaya y prouinçia de Guepuzqua y montañas, y las que uienen de Flandes y Françia y aportan en los puertos de las dichas prouinçias, y las que se traen de Rioja y Bureua y Reyno de Aragon y las quatro uillas de la costa de la mar, Soria y Logroño y tierra de Yanguas y Atiença y Reyno de Nauarra, que passan y se lleuan para Valladolid, Ruyseco, Medina del Campo,

331 A. M. B./ HI-5282/ Burgos, 1591.

332 A. M. B./ HI-3408/Valladolid, 16 noviembre 1591. 


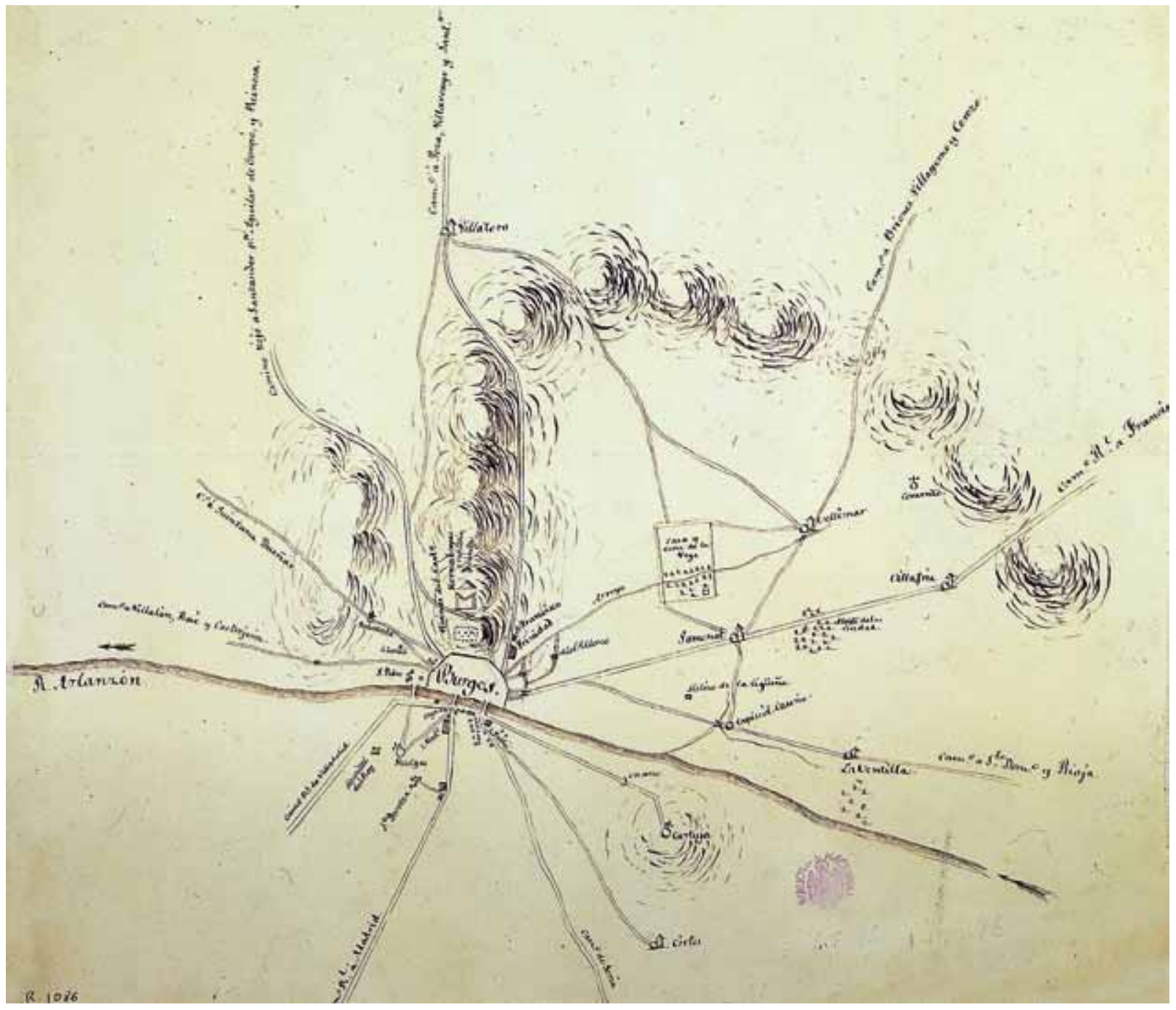

Croquis de los alrededores de Burgos en 1800 (B. N., R. 1086).

Salamanca, Segouia, Toledo, Seuilla, Madrid y Andaluçia y el Alcarria y otras partes, y para sus ferias y para la corte"333.

En agosto de 1500, tras la petición realizada por la ciudad en el Consejo Real para que se hiciese cumplir una Carta real para que todos los concejos de seis leguas alrededor, reparasen cada uno en su término los caminos "questauan muy destruydos e mal rreparados en los que non se podia andar", y no lo quisieron hacer, el Consejo ordena a los alcaldes de la ciudad que se desplacen a las villas y lugares de seis leguas en contorno donde fuere necesario el reparo de los caminos y calzadas dañados o derribados, y manden a sus concejos y vecinos reparar ese verano sus caminos y calzadas dañados y derribados, que necesitaren reparo, antes de que el invierno entrase porque sería menor el coste. Piden que los concejos "que son obligados de derecho de rreparar e adobar los dichos caminos e calçadas", los reparen "segund e como e en los tiempos pasados los han rreparado"334. Los Reyes ordenan al corregidor en abril de 1503 que obtenga información

333 A. M. B./ HI-1661/ 1583.

334 A. G. S./ Registro General del Sello, VIII-1500, fol. 147/ Valladolid, 22 agosto 1500 y A. M. B./ HI-3780/6/ Valladolid, 22 agosto 1500. 
sobre el estado de puentes y caminos en un radio de cinco leguas alrededor de la ciudad, y asimismo, sobre quiénes reciben beneficio de su uso y están obligados a contribuir para su mantenimiento, así como las cantidades a que ascenderían las reparaciones 335 .

En diciembre de 1511 se deben reparar puertas, muros, torres, calzadas, puentes y caminos de la ciudad de Burgos y los puentes de Buniel, Tardajos y Las Quintanillas. Además se debían hacer otros de nuevo y aderezar los caminos y calzadas cercanos a la ciudad, ya que por no estar bien reparados dejaban de llegar muchos mantenimientos y se caerán y no se podrían volver a hacer sino con mucha suma de mrs. Como la ciudad tenía vendidos al quitar $152.500 \mathrm{mrs}$. de renta anual sobre sus propios, la reina Juana da licencia para que pudiese echar por sisa en los mantenimientos y otras cosas que en ella se vendiesen, 4.000.00o de mrs. para hacer los dichos reparos, y que de los primeros dineros que se obtengan, se desempeñen los 152.500 mrs. La Reina mandó dar esta carta para que cuando la ciudad ponga la sisa, la arriende públicamente al mejor postor ${ }^{336}$. Tras la petición realizada por la ciudad de Burgos que decía que "tiene estrema nesçesydad de adobar çiertos caminos que estan arrededor della e de linpiar los rrios e calles que por ella pasan e que asy para esto tomo para pagar los mensajeros e personas que van a hazer los dichos rreparos...", la Reina concede a la ciudad en junio de 1512 facultad para tomar por una vez a cambio, 60.000 mrs. para reparar los caminos cercanos a la ciudad y limpiar los ríos y calles de ella337.

Por mandato real se había echado sisa en los mantenimientos de la ciudad de Burgos los años 1513 y 1514, para quitar los mrs. de juro que la ciudad tenía vendidos para el reparo de sus muros, torres, puentes y calzadas. Como aún quedaban obras por realizar, y si no se hiciesen sería necesaria mucha mayor cuantía, la ciudad pide que se tomen 50.000 mrs. de la dicha sisa. Juana I ordena en julio de 1514 al corregidor que se informe sobre el coste de las calzadas, puentes y muros que necesitan reparación, y si la ciudad dispone de propios o si queda algo de las sisas, para lo que se le deben tomar las cuentas de los tres últimos años, y todo lo que se hallare malgastado o como no debe se cobre de los responsables y se ponga en poder del mayordomo de la ciudad para que se gaste como convenga, y la dicha información con su parecer lo remita al Consejo338.

Juan del Castillo procurador mayor de la ciudad, dijo que se había hecho relación de los caminos, malos pasos, calzadas y puentes que en los términos de la ciudad y su tierra estaban deteriorados, y se había mandado que se hiciesen reparar como convenía, y aunque se había comenzado a trabajar en ello, por no haberse declarado que se hiciese a costa de los propios y rentas de la ciudad y de los lugares comarcanos de su tierra y jurisdicción, no se han querido repartir los mrs. necesarios ni a la ciudad, ni a los lugares de su tierra y comarca, sino que se ha comenzado a hacer solamente a costa de la ciudad, por lo que pedía que todos los mrs. se repartiesen tanto a la ciudad como a los lugares y pueblos de su jurisdicción y comarca según la utilidad y beneficio que cada uno reciba. El Consejo mandó en octubre de 1544 al corregidor que todos los mrs. que se gastaren en la obra, repa-

335 A. M. B./ HI-3780/4/ Alcalá de Henares, 22 abril 1503.

336 A. M. B./ HI-4645/ Burgos, 1 diciembre 1511.

337 A. M. B./ HI-4146/ Burgos, 23 junio 1512.

338 A. M. B./ HI-3780/ Segovia, 9 julio 1514. 
ros y aderezos de los puentes, caminos y malos pasos mandados reparar, se paguen de los propios de la ciudad y su tierra339.

En agosto de 1562 Felipe II dice al corregidor de Burgos que la ciudad le comunicó que se había caído parte de los muros y cercas de la ciudad y en otros puntos estaban para caer, y que si no se remediase podría ocasionarse mucho más daño, y para evitarlo y para el reparo de los puentes y calzadas y aderezar las paredes y madre del río Arlanzón, habían acordado echar por sisa en el vino la cantidad de maravedís que fuere necesaria, pidiendo licencia para ello. El Consejo mandó que se haga informe sobre los muros y cercas que se han caído, los puentes y paredes del río que necesitan reparo, lo que costarían y si la ciudad tiene propios y rentas, y en caso de que no los tenga, si es bueno echar por sisa, y dicha información la envíe al Consejo para que provea lo que sea de justicia. La ciudad encarga un memorial a maestros de cantería y otras personas, sobre el estado de los muros, cercas y puentes que necesitan hacerse y repararse y lo que costaría. Todas las obras alcanzan un presupuesto de 12.000 ds. Las principales son:

- El paño de pared de la cerca detrás de las casas del Mercado que está caído, desde el matadero hasta cerca de la puerta de las Carretas.

- Los paredones de piedra del Arlanzón hasta Vega que se han de recalzar, revocar y subirlos cuatro pies.

- El paredón que está encima del monasterio de San Juan que Ilaman la Cantera hasta el río Arlanzón, que está todo socavado del agua, mucha parte caída.

- El paredón de piedra que está caído debajo de la Merced junto al puente Quebrado, ya que entra el río por el camino de Valladolid y no se puede pasar.

- El paredón desde la casa de la mancebía hasta la puerta de Santa Gadea.

- Los "puentes y calçadas de Gamonal que es camino muy pasajero y por donde biene probision a la çibdad", y es necesario hacer bien los puentes y empedrar el camino, costará todo ello unos $100.000 \mathrm{mrs}$.

- Ahondar el río de la Moneda desde la entrada del agua hasta la salida de las carnicerías, costara unos 100.000 mrs. porque es río ancho y muy necesario.

- La entrada de las carnicerías por la parte del Mercado Mayor y Menor que está hecha de madera y como está descubierta, se cae cada día y no se puede pasar en tiempo de lodos a pie ni a caballo, y es necesario hacer dos paredones y unos arcos para sobre ello empedrarlo, y que sea consistente, porque se gasta cada año mucho dinero en madera, costará $750.000 \mathrm{mrs}$.

- En las Varguillas hay un paso junto a la cerca que es necesario cerrarlo para que sirva de camino, porque no se puede pasar por otra parte, costará $136.000 \mathrm{mrs}$.

- Se ha de hacer la madre del río Arlanzón y encañar el río, y todo costará unos $50.000 \mathrm{mrs}$. al año y algunos años más.

Se interroga a los maestros de cantería Juan de Hinestrosa, vecino de Hinestrosa, Simón de Bueras, Juan de Vallejo, Sebastián de Espinosa, Diego de San Miguel y Julián de Soto, vecinos de Burgos, este último licitador muchos años de la ciudad, y dicen que la ciudad necesita aderezar todos los edificios que se contienen en el memorial, por estar arruinados y caídos y ser muy necesarios. Muchos y los azores del río, si no se remedian de 
inmediato, tendrán un mayor daño y gasto, y su coste dicen, es mayor de lo que se contiene en el memorial, "porquesta todo mal rreparado e adrezado e tiene gran neçesidad de lo rreparar como de todo ello se be por bista de ojos". En octubre de 1562 el teniente de corregidor de Burgos dice que conforme con la Provisión real presentada por la ciudad, mandó hacer la información necesaria con maestros y otras personas, que dicen que se deben aderezar y reparar las cosas contenidas en el memorial, y como la ciudad no tiene propios, se debía mandar echar en sisa sobre el vino, con lo cual manda a la ciudad pida facultad para echar la dicha sisa para que el Consejo provea lo que más convenga340.

El empedrador Luis de Buen Vecino otorga una escritura en favor de la ciudad de Burgos por la que queda obligado desde el 1 de enero de 1568 por 5 años, a mantener todas las calles y empedrados de la ciudad y sus arrabales, "y aderezar en ellas todos los oyos e rroderas de carretas" y lo que estuviere hundido y deshecho, y queda obligado a empedrar hasta 10 tapias en cada una de las calles a su costa, salvo en la calle que se desempedrare toda entera, y lo que hiciere de más, lo pagará la ciudad y vecinos. Queda también obligado a hacer lo mismo en:

\begin{tabular}{|l|}
\hline El arrabal del barrio de San Pedro hasta el puente de los Malatos. \\
\hline Del puente de Santa María hasta Santa Dorotea. \\
\hline El arrabal de San Juan hasta el Hospital de los Caballeros. \\
\hline El arrabal de San Esteban y San Francisco hasta la calle que va a Bayllo. \\
\hline El arrabal de Vega y calzadas hasta San Agustín. \\
\hline Por el puente de San Pablo y la Calera hasta Santa Clara. \\
\hline La calzada de la Merced, todo lo que se encuentra de la pontezuela allá. \\
\hline La calzada del puente de Santa Gadea hasta el río. \\
\hline La calzada que va de San Pablo a Vega. \\
\hline La calzada que va desde la puerta de San Gil hasta el arrabal de San Esteban. \\
\hline
\end{tabular}

Todo lo ha de mantener a su costa, y no haciéndolo así, se mandará hacer a costa de Buen Vecino. La ciudad le pagará 15.000 mrs. cada año por tercios, y hecha la dicha postura, dijo que se obligaba a cumplir lo dicho con su persona y bienes ${ }^{341}$. Ese año, se realiza una memoria en la que se detalla el estado de los empedrados de las calles de la ciudad que Luis de Buen Vecino debe reparar ese año ${ }^{342}$. Asimismo se describen las calzadas de la

340 A. M. B./ HI-1659/ Madrid, 17 agosto y Burgos, 29 octubre 1562.

341 A. M. B./ Histórica, C-2-11-15/7// 1568?.

342 A. M. B./ Histórica, C-1-7-16/5// Burgos, 25 abril 1568.

- Una calle que está muy mal reparada en que habrá en ella más de lo que Luis está obligado.

- Otro pedazo de calle que está saliendo de la plaza de Vega, como van a San Pablo hasta fin de casa de Diego de Espinosa.

- En la calle del barrio de San Juan hay dos pedazos desempedrados en frente de la casa de Lope Rodríguez Gallo y más arriba otro.

- En la calle detrás de la casa de Juan de Santo Domingo hasta la rúa de San Gil.

- Otro pedazo como suben al Hospital de los Ciegos delante de las casas de Diego de Aguayo.

- Otros dos pedazos delante la iglesia de San Esteban.

- Otro pedazo en la calle de los Cabestreros.

- Junto a las casas de Diego Ochoa de Avellaneda otro pedazo.

- En la puerta trasera de la Alhóndiga, 3 o 4 pedazos, y se necesita un poco de azur en la subida de la puerta.

- Otro pedazo en la Pontecilla que está en la puerta de Santa Gadea.

- Junto a las casas del Hospital de Dios hay otros dos pedazos. 
ciudad cuyo reparo también se debe realizar dicho año343. La Chancillería otorga una ejecutoria a favor de la ciudad sobre la demanda puesta contra el monasterio de Las Huelgas y el Hospital del Rey, sobre el pago de 400.000 mrs. que les correspondió en los 12.000 ds. que por Facultad real, impuso la ciudad de sisa sobre los alimentos para el reparo de sus puentes, fuentes y calzadas. En la Chancillería se dio sentencia en noviembre de 1568 , condenando al monasterio y hospital y sus compases, a que en 20 días repartan entre sí por sisa, 105.000 mrs. en que moderaron la parte correspondiente, y que debieron satisfacer como parte de los mencionados 12.000 ds. que la ciudad había impuesto en sisa344.

En noviembre de 1578 el Consejo da una Provisión a pedimiento de la ciudad de Burgos, mandando al corregidor que toda persona eclesiástica o de cualquier estado o condición, contribuya en la sisa mandada echar en el vino para el pago de 1.501.821 mrs. gastados en los reparos de fuentes, puentes y calzadas. Se había mandado sin embargo, por una cédula librada por el Consejo de la Guerra, que los artilleros que en la ciudad residen no pagasen esa sisa, por lo que se manda que estos presenten en lo días las provisiones que tienen del Consejo de Guerra para ver si están exentos 345.

En mayo de 1580 se traslada la carta ejecutoria del pleito litigado entre Francisco de Maluenda, vecino y regidor de la ciudad de Burgos, y el Hospital del Rey de dicha ciudad, sobre el aderezo y reparo de ciertos caminos y plantas ${ }^{346}$.

Felipe II encarga a la ciudad de Burgos en agosto de 1592 que no haga ninguna prevención para su recibimiento, por si determina ir por otro camino "porque hasta agora no estoy resuelto de passar por essa ciudad, por depender de otras cosas que conciernen al seruicio de nuestro señor y tambien mio", aunque avisaría con tiempo lo que determinase. Al final estará en Burgos entre el 6 y el 30 de septiembre de dicho año347. En octubre, el concejo de la ciudad recibe del Rey licencia para tomar a censo hasta 10.000 ds. para la obra que se ha hecho en el monasterio de San Agustín, donde fue aposentado, y para el aderezo de caminos y calzadas

\footnotetext{
- En la Lencería otros dos o tres pedazos.

- Se debe actuar en la Cerrajería y calle del Sarmental, aunque hay más de lo que Luis está obligado.

- En la calle de Cantarranas es necesario remediar el aguilón de enmedio que está perdido.

- Cantarranas la Mayor tiene algunas roderas.
}

343 A. M. B./ Histórica, C-1-7-16/5// Burgos, 25 abril 1568.

- Se debe desbaratar toda la calzada que va desde pasado San Francisco hasta la Casa Blanca y volverla a empedrar, que son unas 112 tapias y necesita piedra porque toda la que saliere, será necesaria para ser reutilizada.

- La calzada desde la dicha Casa Blanca hacia Villatoro, tiene unos tramos deshechos y otros que se deben alargar para remediar los malos pasos que hay en invierno, en que habrá en todo unas 80 tapias.

- En la calzada que va desde Santa Dorotea a Santa Ana hay un pedazo deshecho, derecho hacia la heredad de Hernando de Miranda que tiene 20 tapias. En ella necesario colocar seis hitos de piedra, para que no entren por ella las carretas.

- En la calzada desde la ermita de Santa Ana hasta el caño de Arcos, son necesarios cuatro hitos, para que no entren las carretas. Además se debe apremiar a los dueños de las heredades después de cogido el pan, para que ahonden los arroyos porque entra el agua en todo lo largo de la calzada.

- En la calzada de los Hornos hay uno o dos pedazos deshechos, que tendrán 7 tapias desempedradas.

- La mayor parte de la calzadilla que está encima de la calzada grande, como se va a San Bartolomé, está deshecha por las carretas y necesita remediarse porque no se puede pasar.

344 A. M. B./ HI-1844/Valladolid, 5 noviembre 1568.

345 A. M. B./ HI-34O2/ Madrid, 13 noviembre 1578.

346 A. Ch. V./ Registro de Ejecutorias, caja 1415.0055/Valladolid, 14 mayo 1580.

347 A. M. B./ HI-485/ Valladolid, 2 agosto 1592. 
y otros gastos que se han hecho en su recibimiento, y como la ciudad no tiene propios, el Rey concede licencia para que la ciudad pueda tomar a censo hasta 6.000 ds., los cuales con sus réditos manda que se paguen de lo que procediere de la sisa del vino que se vende por menudo, que está impuesta para otros efectos, y que lo que se fuere cobrando, se deposite en poder del mayordomo de la ciudad, para que se vaya quitando lo principal del censo que se cargare, sin invertirlos en otra cosa, y sacados los 6.00o ds. cese la sisa348.

Como están cobrados los repartimientos hechos con licencia real para aderezar y hacer los puentes, pontones y caminos de Burgos y Villímar y los de los puentes y caminos de Llodio, y no se comienza la obra con mucho daño de los viandantes, en Junta de Álava de noviembre de 1596 se acuerda que se escriba a Juan de Urrutia a Madrid y ponga diligencia con el solicitador y procurador de Álava para que el Consejo dé provisiones para que se comiencen y acaben las obras, pues por dilatarse, se siguen daños y solo sirve para que los depositarios se aprovechen del dinero349.

\section{La Universidad de los Mercaderes}

Los Consulados del Mar surgen en la Edad Media como instituciones jurídico-mercantiles, regidas por un Prior y varios cónsules, y actúan como tribunales especiales para resolver los asuntos concernientes a la práctica mercantil, llegando a abarcar la totalidad de las actuaciones en el ámbito comercial.

El comercio internacional burgalés comienza entre el siglo XIII y principios del XIV, creándose ya en 1296 la Hermandad de la Marina de Castilla como organización de los mercaderes de los puertos cantábricos. Tras superar una fase regresiva entre mediados del siglo XIV y 1420/30, el comercio castellano en Europa tendrá su edad de oro entre 1420/30 y 1570/80. Burgos dispondrá ya desde 1455 de una Universidad de Mercaderes, asociación que negociaba en Flandes y tenía la facultad de nombrar allí cónsules exclusivos para los mercaderes de su jurisdicción 350 . Se fue consolidando una situación que tendrá su plasmación oficial con la creación el 21 de julio de 1494 del Consulado del Mar de Burgos, como Universidad de Mercaderes, con el fin de defender sus intereses, canalizar sus iniciativas, monopolizar los procesos del comercio de la lana, entender en los pleitos entre mercaderes, asegurar las mercaderías, controlar la fiscalidad y flete de navíos y cargazones y actuar como órgano de garantía ante terceros. El Consulado burgalés tendrá el monopolio de la exportación de la lana, el hierro y el aceite de Castilla a los Países Bajos351. Los centros principales con los que el Consulado mantendrá fuertes relaciones comerciales son: Brujas en primer lugar, Amberes, Nantes en Bretaña, Ruan en Normandía, La Rochelle, Toulouse, Lyon y Burdeos.

A la época de esplendor que conoce la ciudad en los siglos XV y XVI, le sigue a partir de los años 70 del siglo XVI un largo periodo de crisis. En 1569, año del secuestro de naves por la reina de Inglaterra, el Consulado no cargó ninguna saca de lana para Flandes en

348 A. M. B./ HI-4191/ Santo Domingo de la Calzada, 6 octubre 1592 y Burgos, 27 junio 1593.

349 A. J. G. A. Tomo X/Vitoria, 19 noviembre 1596. 
Santander, y solo unos miles para Francia en otros puertos. De esta manera, desde 1570 la exportación burgalesa se dirigió en su mayor parte hacia Francia, como consecuencia de las guerras con los Países Bajos que privaba a los comerciantes burgaleses de su mercado tradicional de lanas ${ }^{352}$. Se sucederán años de malas cosechas y plagas de peste. La población disminuye debido al declive del comercio, consecuencia directa de la guerra con los Países Bajos, a la alta mortalidad, a las constantes levas de soldados y a los movimientos migratorios. Además, con motivo de la toma de Middelburgo en 1574, los holandeses capturaron una importante flota castellana, lo que unido a la pérdida de naves y mercaderías, el Consulado tuvo que afrontar los cuantiosos desembolsos que como entidad aseguradora había suscrito, lo que le produjo pérdidas irreparables, con su correspondiente repercusión en la economía de la ciudad. El Consulado no se recuperará jamás, aunque prosiguió con sus tratos hasta entrado el siglo XVII. De esta manera en 1583, se destaca en un interrogatorio que "esta çiudad no esta en la prosperidad que solia, sino mas arruynada que nunca y con mucha menos xente y ueçindad que solia por los ynfortuynos y daños suçedidos por la peste, y con auer çessado su cometido y contrataçion que hera lo prinçipal con que se solia sustentar"353.

La Universidad cumplió también un papel de constructora y mantenedora de caminos. El Prior Juan de Castro, dice en un pleito en 1547 que "an hecho adereçar algunos caminos y seran causa que las mercaderias de aqui adelante vengan desde la costa de la mar, e vayan desta ciudad a la costa en mejores prescios, porque desde Laredo podran ir en carros a la ciudad de Burgos... que siempre los desta dicha unibersidad de Burgos an tenido e tienen cargo de adereçar caminos ansi para la villa de Bilbao como para otras partes..." 354 .

En marzo de 1496 el Prior y cónsules de la Universidad, dijeron a los Reyes que tienen todo el trato por todos sus reinos y señoríos con sus mercaderías y haciendas, y dicen que de un tiempo a esta parte había algunas poblaciones que les hacen pagar nuevos portazgos y en otros sufrían incremento, especialmente en las ciudades de Segovia y Sigüenza, en las villas de Molina, Medinaceli, Almazán, Roa, Aranda y Aguilafuente y en los lugares de Villafuertes, Tordomar, Peña de Orduña, el puente de Duero, Herrera, Villafrades y Herrín de Campos. Se manda al doctor Diego de Díaz de Puebla que recabe información sobre los derechos que llevan a los mercaderes y a los que por allí pasan, y por quiénes, con qué títulos, si lo que así llevan es impuesto nuevo o antiguo, desde cuando se llevaba y si se ha incrementado, y la información se envíe al Consejo para que se haga justicia, y entre tanto, si se hallare que los dichos derechos se han puesto de manera irregular o se llevan sin títulos, se suspendan 355 .

El bachiller Antón de Ariz en nombre del concejo, mercaderes y maestres de naos de Bilbao y ría y canal, y fieles y diputados de los dichos mercaderes y maestres, dijo que el Prior y cónsules del Consulado de Burgos, habían hecho ligas para que ninguno de los mercaderes de su cofradía, cargase ninguna mercadería en navío ni nao de Bilbao, haciendo que ciertos maestres que vinieron de Flandes se obligasen a no descargar en dicha villa.

352 BASAS FERNÁNDEZ, M.: 1961: 63

353 A. M. B./ HI-1661/ 1583.

354 A. G. S./ Consejo Real de Castilla, leg. 204-3/ 1547; BASAS FERNANDEZ, M.: 1963 y 1994: 150.

355 A. G. S./ Registro General del Sello, III-1496, fol. 136/ Valladolid, 6 marzo 1496. 
Además dice que escribieron a todos sus amigos y mercaderes, del Reino y de fuera para que así lo hicieren, como respuesta a que Bilbao no aceptó ciertos capítulos que los mercaderes de Burgos les pidieron, por ser contra privilegio y costumbre inmemorial de la villa y contra pragmáticas de los Reinos. Pidió a la Reina que mandase revocar las tales ligas, y que cualquier persona pudiese cargar en las naos y navíos de Bilbao cualquier mercadería. El Consejo acordó mandar en diciembre de 1505 al corregidor o juez de residencia del Señorío de Vizcaya, que se informase sobre qué ligas y monipodios son los que se han hecho y quién los hizo, y si fuere así los revoquen, y mande castigar a los que los hicieron ${ }^{356}$.

Esta situación se repite ya que los procuradores de Bilbao dijeron que en los 5 años siguientes, los mercaderes de Burgos han puesto impedimentos para que ningún mercader de su cofradía, tanto de Burgos como de Valladolid, Segovia y Medina de Rioseco y factores que tienen en Flandes, Inglaterra, Bretaña y otras partes, carguen en Bilbao lanas, rollo, peletería, fardeles ni otras mercaderías, que sacan o traen de retorno, y que no fleten ningún navío de Bilbao. Para que esto se cumpla, lo tienen capitulado, y por esto y por temor a las penas que sobre ello imponen, dicen los procuradores que las mercaderías ya no van por Bilbao, ni siquiera las que solían ir y venir de retorno y el flete y carga de los navíos de vecinos de Bilbao, por lo que ocasiona a la villa mucho daño y provoca el que no se hagan en ella más naos, y que los que las solían hacer y tener, se dediquen a otros tratos y maneras de vivir. El Consejo, consultado con el rey Fernando, acordó mandar en junio de 1511 a los corregidores de Burgos y del Condado y Señorío de Vizcaya, al Prior y cónsules de los mercaderes y a los mercaderes, tratantes y otras personas de Burgos, Segovia, Valladolid y Medina de Rioseco y demás poblaciones, que no hagan liga ni ordenanza alguna que impida a los mercaderes llevar sus mercaderías, ni traer las de retorno, o cargar las propias $\mathrm{u}$ otras que tuvieren en encomienda, en los navíos de Bilbao, así a esta villa como a otras partes, y que fleten las naos de los vecinos de Bilbao cómo hasta ahora lo solían hacer, y se revoca cualquier liga, confederación, ordenanza o conveniencia que se hiciere357.

En Burgos en junio de 1532 el Prior y un cónsul en nombre de la Universidad de Burgos acuerdan con dos vecinos de Santander, en nombre de dicha villa, otorgar una carta de concordia. Se indica que entre Santander y la Universidad hay pleito ante el Consejo Real, porque la villa pide ciertos derechos por cargar y descargar en los postodios de Mobardo y Solía, las sacas, pasteles y otras mercaderías que luego en su puerto se cargan y descargan en naos o fustas de la Universidad. Esta mantiene que no está obligada a pagar ningún derecho pues la dicha villa y puerto es del Rey. Además no lo han pagado en los últimos 30 años que tienen contratación con la villa, ya que de muchos años a esta parte hay mucha hermandad y tienen mucha contratación, por lo que el puerto y villa de Santander es más frecuentado y será más en adelante si entre ambos cesa el dicho pleito. Acuerdan para ello una concordia para que todas las naos y carabelas de la Universidad que se cargaren en Santander para Flandes, Francia u otra parte, sea nao o carabela grande o pequeña, pague a la villa seis mrs. por cada una, y que cualquier nao que en Santander descargare

356 A. M. Bilbao/ Caja 1, reg. 1, no 5 (2)/ Salamanca, 17 diciembre 1505; ENRÍQUEZ FERNÁNDEZ, J.; HIDALGO de CISNEROS AMESTOY, C.; MARTÍNEZ LAHIDALGA, A.: 2000: doc. 294.

357 A. M. Bilbao/ Caja 1, reg. 1, nº5 (3)/ Sevilla, 7 junio 1511; ENRÍQUEZ FERNÁNDEZ, J., HIDALGO de CISNEROS AMESTOY, C. y MARTÍNEZ LAHIDALGA, A.: 2000: doc. 334 
pastel, mercaderías o ropa de cualquier calidad del reino de Francia, traiga poca o mucha o sea grande o pequeña, pague a la villa $1.000 \mathrm{mrs}$. para el reparo de sus muelles. Si la nao viniere de Flandes a descargar ropa, trigo u otro cualquier género de mercadería, pagará a la villa 500 mrs.

Santander y su concejo cuidarán de que todas las mercaderías de la Universidad que en la villa cargaren o descargaren, sean bien tratadas así como las personas a su servicio, y si alguna nao derrotada o en peligro llegare al puerto o a sus alrededores, la villa se obliga a hacer salir gente a su remedio, y lo mismo si las naos que estuvieren en los puertos, por temporal $u$ otra causa necesitaren algún socorro, pagando a las personas o pinazas que acudieren a la ayuda. También se conciertan otras medidas sobre fletes, estolajes, cargas y descargas, etc. La capitulación concertada, afecta a todas las naos que carguen y descarguen mercaderías de las personas de la Universidad, así los de Burgos como los de fuera que entran en la Universidad y su cofradía, como son los de Segovia, Logroño, Valladolid, Medina de Rioseco, Palenzuela, Castrojeriz y Carrión 358 .

El concejo de Santander y Juan Páez Arnaton representante de la Universidad de Burgos, otorgan carta de iguala y conveniencia en mayo de 1542, para negociar las condiciones para el transporte y embarque de mercaderías de los comerciantes burgaleses por el puerto de Santander y lugares de su jurisdicción, que sin perjuicio del derecho que la Universidad debe pagar por las sacas de lanas, pasteles y otras mercaderías de sus miembros que entraren y salieren por tierra en Santander, por los muchos gastos que el concejo había tenido en hacer el puente de Solía, para que puedan pasar los carros, trajineros y mulateros con las sacas de lanas y los pasteles, fardeles y otras mercaderías que en Santander descargaren los de la Universidad, y que puedan conservar el dicho puente y los caminos, calzadas y pasos peligrosos de sus términos, tanto en invierno como en verano.

El concejo de Santander dice que ninguna mercadería se podía cargar ni descargar en los postodios de Mobardo ni de Solía, para llevarla en barco a Santander ni sacarla por ellos de la villa, y nadie podía meter ni sacar por agua ninguna mercadería de la villa sin su licencia, teniendo que llevar todo por tierra pasando por el puente de Solía, y asimismo dice que "con toda carga de lana, que son dos sacas por carga que en esta dicha villa entrare por tierra", ha de traer el carretero o mulatero para venderlo cuatro celemines de trigo, vayan las sacas en carros o en acémilas, y con ello pague la alcabala y el propio a la villa, al igual que los que lleven carga de pasteles y otras mercaderías, para que con dicha venta, paguen los derechos que deben, $23 \mathrm{mrs}$. por carga de acémila y 15,5 mrs. por carga de rocín o bestia menor, excepto en el mercado franco del sábado, en que se ahorra la mitad de los derechos. Juan Páez Arnatón en nombre de la Universidad, responde que no están obligados a nada de lo que pide Santander, ya que ellos pueden enviar libremente sus sacas y mercaderías de los postodios de Mobardo y Solía a la villa de Santander en barcos, y usar de ello a su voluntad como hasta aquí han hecho, por ser la ría, canal y agua del Rey. Los de la Universidad pueden sacar libremente del puerto, pasteles y otras mercaderías por la dicha ría y canal en barcos y pinazas hasta los postodios de Solía y Mobardo sin pagar ningún derecho ni pedir licencia, y cuando ellos quieran elegir entre enviar o sacar sus mercaderías en carros

358 A. H. P. C./ J.T. A. leg. 37-7/ Burgos, 30 junio y 17 agosto 1532. 
o acémilas por tierra a Santander, lo pueden hacer sin ser obligados a meter ningún trigo ni a pagar ningún derecho ni portazgo. Sus mercaderías son libres y exentas, y no les pueden llevar los dichos derechos ni el dicho trigo, porque además, los vecinos de Burgos por privilegio que la ciudad tiene, son libres y exentos de cualquier otra imposición y todas sus mercaderías lo son en todo el Reino.

Como los pleitos y diferencias provocarán "muchas costas e enojos, e por conserbar la mucha $e$ antigua amistad y hermandad e contrataçion que entre las dichas partes a abido de muchos tienpos a esta parte", convienen concertarse para que por todas las sacas de lana y balas de pastel que los de la Universidad tanto de Burgos como de Logroño, Valladolid, Segovia, Castrojeriz, Palenzuela, Medina de Rioseco y Carrión metieren o sacaren de Santander por tierra en carros o acémilas, se pague a la villa y concejo $3 \mathrm{mrs}$. por cada saca o bala, sin que les puedan demandar nada más, porque con estos 3 mrs., los de la Universidad serán francos, libres y exentos, y si además de lo dicho, por las sacas y pastel de la Universidad o carros de bueyes, acémilas o rocines otra cosa debieren, que sea la villa la que pague por ellos. La Universidad se obliga a no hacer estapla, ni postodio, ni descarga de lanas y pasteles desde las ventas del Caballar a Santander, ni por otro camino a cuatro leguas de la villa, so pena que por cada bala y saca que se descargare desde las dichas ventas, o de las cuatro leguas a la villa, pague su dueño dos rs. de plata, siendo los 2/3 para reparos de los caminos de su jurisdicción.

Santander y su concejo, se obligan a hacer a su costa los caminos que están por hacer en su jurisdicción, y actuar en los que están por reparar y procurará tener aderezados los demás desde la villa hasta el puente de Solía, de manera que los carros de bueyes y acémilas puedan circular desde Santander hasta el fin de su jurisdicción libremente por buen camino. La villa cuidará de todas las mercaderías que de la Universidad lleguen, así como de las personas que fueren en su servicio. Sus bueyes o acémilas podrán pacer en términos y ejidos comunes de la villa, y hacer en ellos la suelta que los carreteros quisieren, y si llegare al puerto o a sus alrededores alguna nao derrotada y en peligro, la villa deberá hacerla socorrer, y lo mismo si las naos que estuvieren en su puerto necesitasen algún socorro, porque para eso y para que tengan reparado el puente y caminos dichos, la Universidad paga los 3 mrs. por bala y saca. También se conciertan otras medidas sobre fletes, plazos, estolajes, carga y descarga, etc. La capitulación y concordia se hace por 5 años, entre 1542 y 1546359 .

En un informe jurídico realizado en junio de 1563 sobre la diferencia que Santander tiene con la Universidad de Burgos en el concierto existente entre ellos, porque la Universidad no ha guardado lo capitulado y no cumple la contrata, queriendo impedir la carga de las lanas por la villa, e impidiendo que las metan en sus límites, sin traer los dos celemines de trigo por saca como antes lo solían hacer, o sin pagar a la villa por cada saca un tanto por los daños que Santander recibe con la carretería de las sacas y con la estancia y estiba de las naos. La villa tiene una escritura, por la que los mercaderes de la Universidad, para meter las sacas en Santander, se comprometían a llevar dos celemines de trigo por saca. El letrado dice que como la Universidad no ha cumplido lo capitulado, la villa no 
está obligada a respetar la capitulación y podrá pedir su mejora, salvo si la Universidad o maeses de naos viniesen pagando las penas, por las naos que no vinieron a la villa. Sobre si la villa podía impedir a los mercaderes que no carguen las sacas por ella, u obligar a que lleven los dos celemines de trigo por saca, dice el letrado que no se les podía impedir pues el Rey lo consiente, pero sobre los daños que la villa y vecinos reciben, se puede obligar a los mercaderes a que paguen este daño o condenarles a que traigan los dos celemines de trigo por saca. Además, la carretería que trae las sacas hace gran daño en las mieses, sembrados, viñas y heredamientos, por lo que de derecho lo deben satisfacer, ya que la villa tiene poca cosecha, y si lo poco que coge lo consumen las naos, estibadores y carreteros, los vecinos quedan damnificados. Lo que la villa puede hacer es pedir a la justicia que como la Universidad no ha cumplido con lo capitulado, apremie a los mercaderes y factores de las sacas, para que conforme a la antigua costumbre y su ordenanza, traigan con cada saca dos celemines de trigo o en su defecto les mande que no las traigan por Santander, por los grandes daños que reciben sin provecho360.

La ordenanza XXI del Consulado de Burgos de 1538 refiere que la Universidad y Prior y cónsules de ella, tienen que hacer muchos gastos, entre ellos los que son para pleitos en defensa de la jurisdicción de la Universidad y de las "libertades de portazgos é imposiciones que siempre se nos mueven", y que les cobran algunos señores, ciudades y villas, contra los privilegios que tienen de los Reyes ${ }^{361}$. Las segundas ordenanzas son del 1 de agosto de 1572 , confirmadas en Madrid por el Rey. La número XXVII indica que la Universidad tiene muchos pleitos en la Chancillería y en el Consejo Real, tanto en defensa de los privilegios que tienen para no pagar portazgos en muchos lugares, como sobre los caminos de los puertos para el transporte de sus lanas y otras mercaderías, y que para defenderlos, se ordena que el Prior y cónsules tengan en Valladolid y en la corte los letrados, procuradores y solicitadores que convengan ${ }^{362}$.

\section{2.- EL TRAYECTO INTERMEDIO: CONDICIONES GENERALES}

Por la provincia y tierras de Burgos y debido principalmente a su singular situación geográfica, ha venido discurriendo desde tiempos prehistóricos, una gran parte de los caminos esenciales que integraron la red básica de comunicaciones de la mitad norte de la Meseta. Baste con recordar la función que tradicionalmente ha tenido el desfiladero de Pancorbo como paso obligado para la salida o el acceso desde el continente Europeo a la Meseta y oeste y sur de la Península. O la importancia que tiene la sierra de Atapuerca como asentamiento de gran parte de las poblaciones prehistóricas y posteriores. Los ro-

360 A. H. P. C./ J. T. A. leg. 37-9/ Santander, 18 junio 1563.

361 Ordenanzas del Consulado de Burgos de 1538/ Valladolid, 18 septiembre 1538; GARCÍA de QUEVEDO y CONCELLÓN, E.: 1905 y 1995: 199-203. Ordenanza XXI.

362 Reales Ordenanzas del Consulado y Casa de Contratación de Burgos/ Ordenanza no XXVII/ Madrid, 1 agosto 1572 en LARRUGA, E: 1793: 216-297: t. XXVII. 
manos hicieron discurrir por estas tierras las importantes vías De Hispania in Aquitaniam. Ab Asturica Burdigalam y la De Italia in Hispanias que unidas en Briviesca se dirigían a Astorga, y la Ab Asturica per Cantabriam Caesaraugustam que discurría por Clunia.

El camino más importante del norte de la Península durante la Edad Media fue el que comunicaba Francia y Pamplona con Estella, Nájera, Burgos y León, llamado Camino de Santiago o Francés, que a su vez a partir de La Rioja, es una prolongación de la antigua vía del Ebro, que desde la costa mediterránea iba por Zaragoza, y que adquiere en esta época además de su significación jacobea y comercial, una clara importancia militar363. Precisamente en este camino se encuentra el puente de mayor calidad ejecutado en esos años: el puente de Puente la Reina sobre el río Arga, que según Fernández Casado es "el más hermoso puente del románico español"364. Pero la vía que irá consolidándose y que se acabará convirtiendo en el camino más activo a fines de la Edad Media, desde el Continente hasta el corazón de la Península y Portugal con una marcada dirección Este-Oeste, será el camino de Bayona que se bifurca en Burgos hacia Salamanca por Valladolid y o hacia Segovia, Madrid y Andalucía.

También discurrieron por estas tierras del centro-norte peninsular los caminos que seguían los cursos de los ríos. No debemos olvidar que una copiosa red fluvial se extendía por la provincia de Burgos y drenaba a los tres mares, a través de los ríos Duero y sus afluentes hacia el Atlántico, el Ebro y sus afluentes hacia el Mediterráneo y el Cadagua y Ordunte situados en la cuenca del Cantábrico.

A pesar de lo irregular del territorio, Ortega Valcárcel indica que el espacio montañés de Burgos poseía un contexto favorable para el establecimiento de los caminos que comunicaban la Meseta con el litoral Cantábrico, por contener lo que este autor denomina como "una infraestructura natural y técnica privilegiada para las comunicaciones" 365 , ya que se ofrecía una suavización de los obstáculos en un espacio como el comprendido entre Burgos y los centros costeros cantábricos, con lo que estos caminos irán adquiriendo paulatinamente una mayor importancia a lo largo de la Edad Media, finalizando esta con unas vías consolidadas y canalizadoras de un muy importante tráfico de mercaderías, que pusieron en contacto las diferentes tierras de la Península Ibérica con los países de la fachada atlántica a través del mar. Pensamos no obstante, que la fijación de tales caminos es la consecuencia de la adaptación de su recorrido por los puntos más favorables, como son los puertos de montaña, cursos fluviales y puentes, algo que obligaba a fijar los caminos por dichos lugares, lo que no quiere decir que tal espacio en su conjunto reuniese unas condiciones favorables, que pensamos que no las reunía.

Dichos caminos, que se fueron asentando a partir de la alta Edad Media, comenzaron comunicando los pequeños núcleos de población con unos puertos de mar que comenzaban a desarrollarse. Además, su estado era deplorable, como consecuencia principalmente de las características geográficas de los territorios por donde debían discurrir. Esto se

363 URIOL SALCEDO, J. I.: 1990: 58: t. I.

364 FERNÁNDEZ CASADO, C.: 1987: 60.

365 ORTEGA VALCÁRCEL, J: 1974: 131. 


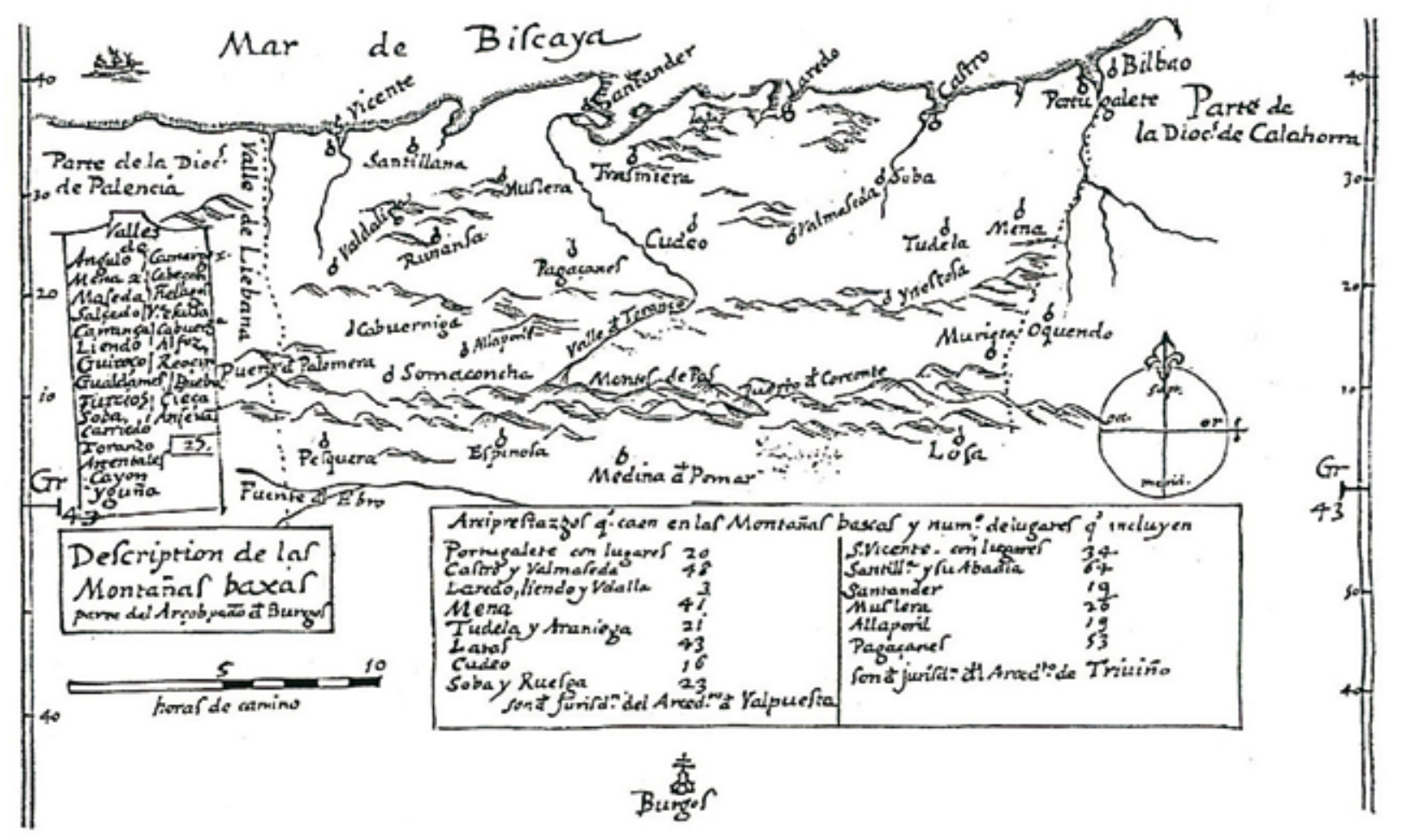

Descripción de las montañas bajas. Plano relativo al viaje realizado por Pellegrino Zuyer en 1660.

hace más evidente en los itinerarios que se realizan desde 1154, fecha en que Al-Edrisi366 confecciona el suyo, en los que estos caminos nunca aparecen entre la a veces larga relación de caminos peninsulares. Además, frente al gran número de testimonios de caminantes que nos hablan de otros caminos, como era el caso del Camino de Santiago, tampoco encontramos relatos de viajeros por estas vías, hasta bien entrado el siglo XV, como consecuencia quizá, de que a pesar de su intensa utilización comercial en esas mismas fechas, no comunicaban núcleos importantes, por situarse los puertos de mar junto a poblaciones de escasa importancia.

\section{A.- CONDICIONAMIENTOS GEOLÓGICOS}

La dinámica estructural, la geomorfología y el desarrollo fluvial, son los componentes geológicos que tienen un papel más importante en la formación del soporte por el que discurrirán las infraestructuras viarias. La situación y el desarrollo de las vías que discurren entre la Meseta y los puertos del mar Cantábrico, obliga a conocer los fenómenos geológicos que predominan en las tres Grandes Unidades Morfoestructurales por las que discurren dichas vías, y que son la cuenca del Duero, la cuenca intraplaca cenozoica del Ebro y la Cantábrica.

La Orogenia Alpina, en sus fases tectónicas más importantes que son la Larámica y la Pirenaica, ha sido la encargada de estructurar, compartimentar y sobre todo elevar la uni- 
dad morfoestructural Cantábrica y las cuencas terciarias del Duero y del Ebro. En cada una de las tres Grandes Unidades dicha orogenia ha actuado de manera diferente, dejando su huella de tal manera que los materiales mesozoicos han sido deformados intensamente, mientras que los sedimentos terciarios apenas sufrieron distorsión. Para entender el contexto geológico de la franja territorial por donde discurren los caminos que estudiamos, debemos tener en cuenta que Cantabria y Burgos son las únicas provincias españolas que drenan a los tres mares. Este fenómeno va a imponer una serie de patrones en la configuración orográfica del terreno, y será un factor determinante que condicionará la disposición de los caminos y el trazado de dichas infraestructuras. Las vías que desde Burgos iban a los puertos del Norte (Santander, Laredo, Castro-Urdiales y Bilbao), debían salvar importantes desniveles y notables dificultades orográficas. No hay que olvidar que partimos de una altitud de $856 \mathrm{~m}$ y llegamos a nivel del mar en menos de $160 \mathrm{~km}$ Pero gracias a los ríos como agente geológico, junto con otros procesos erosivos relacionados con procesos geodinámicos externos, se pudieron implantar básicamente las vías por aquellos lugares menos angostos y más propicios. Los caminos que estudiamos parten de la ciudad de Burgos con dirección norte, que se asienta en las formaciones miocénicas y cuaternarias de la Cuenca del Duero. En los primeros kilómetros hasta la Sierra de Ubierna no encuentran ninguna dificultad en su trazado, porque se trata de materiales muy blandos y fáciles de erosionar y labrar, y no han sufrido deformaciones de consideración, como plegamientos o tectónica. En este primer tramo las pendientes son muy suaves y tendidas, porque el río Duero y sus tributarios apenas sufren encajamiento en su red y su única actividad erosiva es la de desgastar y vaciar lentamente los sedimentos terciarios de toda la cuenca desde hace unos cinco millones de años.

La primera dificultad orográfica la encontramos en la Sierra de Ubierna. Esta Subunidad Morfoestructural de la Cantábrica se caracteriza por la presencia de materiales calcáreos del Cretácico (Mesozoico Superior), muy resistentes a los fenómenos erosivos y que actuaron como área suministradora del relleno de la Cuenca Terciaria del Duero. Esta sierra ya se encuentra fuertemente tectonizada con pliegues, fallas y diaclasas y los caminos utilizarán para atravesarla los cañones labrados por los ríos, que durante gran parte del Cuaternario drenaron sus aguas hacia el Duero. En la actualidad, los únicos ríos que surcan estas estribaciones son el Ubierna y el Úrbel, que desaguan en el río Arlanzón y el río de la Hoz en Peñahorada que vierte en el Ubierna, ya que el resto de los tributarios han sido capturados por los afluentes del río Ebro, dejándonos valles decapitados como el de Villaverde-Peñahorada o colgados como el de Rioseras-Tobes y Rahedo.

A partir de este punto los caminos van a discurrir por trazados muy diferentes. La variante más Noroccidental para llegar a Santander, continúa por el accidente geológico conocido como la falla del Úrbel o del Ubierna. Esta actúa como corredor tectónico entre la banda plegada de Montorio y la plataforma estructural de los Páramos hasta el límite provincial con Palencia. La debilidad cortical desarrollada a lo largo de esta franja, ha sido aprovechada por los fenómenos diapíricos para extruir y salir al exterior, por lo que al ser arcillas, yesos y margas, materiales muy deleznables y poco compactos, van a contribuir a trazar la infraestructura de manera poco costosa. A partir del límite provincial con Palencia el camino traza una orientación $\mathrm{N}-\mathrm{NE}$, con suaves pendientes y recorrido sin apenas 
dificultad. Pero a partir del límite territorial con Cantabria la vía va a presentar las primeras dificultades orográficas por el encajamiento de la red de drenaje de los afluentes del río Ebro. Esta red fluvial produce considerables desniveles en el terreno debido a su alto poder erosivo, y aprovecha los materiales deleznables del diapiro de Mataporquera y de las facies blandas, que constituyen los niveles mesozoicos para incidir en el encajamiento de sus valles. Continuando hacia el mar, tenemos que salvar una nueva dificultad orográfica, con desniveles de mayor envergadura, que están ocasionados por los afluentes y el propio río Besaya. Este río pertenece a la cuenca hidrográfica del norte y en consecuencia su poder erosivo es mucho mayor que los de las cuencas antes mencionadas. El resultado sobre las formaciones rocosas, es el de un profundo desgaste y un elevado grado de encajamiento de la red, debido al carácter torrencial del flujo acuático. En este último tramo del camino, el fenómeno hidrológico impone al itinerario fuertes pendientes y la constante aparición de zonas inestables en su trazado.

El resto de los caminos trazados para llegar a los puertos de mar seguían una dirección norte. Esta trayectoria obligaba a buscar los lugares más adecuados para construir la infraestructura, porque la orografía en la Cantábrica cambia de manera radical por una serie de fenómenos geológicos, que se detallan a continuación.

En primer lugar, se pasa de tener en las Cuencas del Duero y del Ebro unas pendientes suaves y tendidas, a un relieve que presenta un carácter abrupto y escarpado, puesto que las formaciones geológicas de la Unidad Morfoestructural Cantábrica se encuentran fuertemente tectonizadas y levantadas. Pero el condicionante geológico fundamental es la dirección estructural NO-SE de las capas en la Cantábrica. Dicha dirección es oblicua a los trazados camineros que estudiamos y la consecuencia más visible es que pasan a tener un recorrido más angosto y de mayor dificultad, discurriendo por aquellos lugares donde los agentes geológicos, principalmente los ríos, han labrado estas grandes estructuras.

Una vez atravesada la Sierra de Ubierna, los caminos entran en la cuenca del Ebro y discurren sin apenas dificultad orográfica, porque los materiales terciarios que afloran apenas han sufrido deformación y su disposición tabular facilita el trazado de dichas vías $^{367}$. Por otra parte, el ascenso desde la ciudad de Burgos hasta la zona de los páramos es paulatino, debido a la peneplanización del territorio y a la incipiente actividad tectónica de la zona. Se trata de anticlinales o sinclinales, pliegues con charnelas horizontales debido al enorme espesor de las capas y a la amplitud de la longitud de onda. Tras haber discurrido por la Sub-unidad de la plataforma estructural de los Páramos de edad mesozoica, los caminos comienzan a sortear los obstáculos impuestos por las geoformas del relieve, y normalmente lo hacen aprovechando el trabajo realizado por la red de drenaje del Ebro y de la cuenca del norte. La primera dificultad orográfica viene marcada por una secuencia plegada, en la que encontramos el sinclinal del Valle de Valdivielso y el anticlinal de la sierra de La Tesla. Para acceder al valle desde el páramo, el trazado salva el desnivel topográfico a través de un ruz o curso fluvial resecuente ${ }^{368}$, labrado en el flanco sur del sinclinal de Valdivielso y dentro de una estructura de crestas seriadas formadas por materiales

367 Es el sector de las parameras de Masa y Villalta.

368 La bajada desde la ermita de Ntra. Sra. de la Hoz hasta la localidad de El Almiñé. 
duros conocidas con el nombre de "chevrons". Una vez en el valle, el camino utiliza los desfiladeros de los Hocinos y de la Horadada, estrechos pasos realizados en la sierra de La Tesla por el Ebro en un fenómeno geológico conocido como "sobreimposición". En ambos casos, el río ha seccionado de manera perpendicular una estructura plegada, el anticlinal de la Tesla. Esta geoforma denominada "cluse", es el resultado de un fuerte encajamiento de la red de drenaje. Conviene recordar que el Ebro tiene un alto poder erosivo y su perfil longitudinal está en constante cambio, debido a las diferencias de cota que existen entre su nacimiento y su discurrir por la depresión Miranda-Treviño.

Los desfiladeros de los Hocinos, la Horadada y Pancorbo, y el paso de una menor altitud de la Sierra de Oña-Montes Obarenes del Portillo de Busto, eran los únicos puntos por donde se podía atravesar la zona montañosa de las sierras de La Tesla, de La Llana, de Oña y los Montes Obarenes. Esta geoforma responde a un profundo encajamiento de la red fluvial, que se ha tallado en las formaciones calcáreas del Cretácico superior. La clasificación fisonómica es la de una forma simple con un valle en uve, donde el agua al circular a mayor velocidad tiene un régimen turbulento. Este carácter torrencial con crecidas esporádicas, acentúa los procesos de incisión en el valle, sin que haya podido ampliar su anchura, quedando un trazado con paredes verticales y angostas que hacían que los pasos por estas zonas fueran muy peligrosos, ya que el desarrollo de los caminos no podían realizarse con la suficiente seguridad y estabilidad, como consecuencia de la abrupta topografía impuesta por las formaciones rocosas. Otros factores geológicos que inciden en la aparición de estas geoformas son el control tectónico, la gran extensión de los materiales carbonatados, el constante cambio de nivel de base del río Ebro y por lo tanto de todos sus tributarios, y los fenómenos hidrogeológicos que contribuyen a aumentar el desgate y vaciamiento rápido de los sedimentos calcáreos.

El paso a través del Portillo de Busto (1.00o m), se realizaba por los materiales terciarios de la Bureba hasta las estribaciones de los Montes Obarenes. Para ascender hasta la cumbre de esta área montañosa se diseña el trazado por los glacis de erosión situados al pie de este relieve abrupto y luego se continúa ganando altura, siguiendo una de las direcciones estructurales de la capa caliza. Una vez alcanzada la cumbre, se inicia el descenso hasta la población de Frías, a través de la incisión fluvial ejercida por el río Ranera o Molinar. Este tributario del Ebro discurre de manera paralela a los pasillos ortoclinales de los materiales más blandos de las formaciones calcáreas del Cretácico superior, pero antes de la localidad de Tobera talla en la sierra de la Llana un pequeño desfiladero en dirección a Frías, como consecuencia del cambio de dirección que sufre provocado por la imposición tectónica. Después de atravesar la estructura tectónica de La Tesla y los Montes Obarenes, nos encontramos con un relieve en cuesta donde el predominio es el de los valles cataclinales o valles que discurren a favor del buzamiento de las capas y de manera perpendicular a ellas.

La variante del camino que pretende alcanzar el actual puerto del Escudo no llega a atravesar la depresión Villarcayo-Medina, y va a discurrir de manera paralela a la dirección estructural predominante en esta parte de la Cantábrica. Para ello, aprovecha los pasillos ortoclinales creados en los sedimentos mesozoicos y que responden a formaciones constituidas por tramos margosos, materiales menos competentes y resistentes a la 
degradación. Las primeras estribaciones de la Cordillera Cantábrica nos aparecen en la Sierra del Escudo y a partir de este momento la orografía vuelve a hacerse mucho más abrupta, ya que nos encontramos en la cuenca del norte y la red de drenaje tiene un carácter torrencial, lo que provoca una fuerte incisión en el modelado del relieve. La principal vía de desagüe de todo el entorno es el río Pas, que nos acompañará casi hasta el final del recorrido en el puerto de Santander. Como sus homólogos en la cuenca del Ebro, este río y sus afluentes atraviesan las estructuras tectónicas de la provincia de Cantabria de manera perpendicular a la dirección de deformación. La primera estructura que encontramos es el sinclinal de Entrambasaguas y la infraestructura se adecúa de la misma manera que lo hizo en la provincia de Burgos. Posteriormente, continuamos por el valle de Toranzo y en este lugar el trazado ha seguido las pautas marcadas por el río Pas, cuyo desgaste de materiales ha facilitado la construcción y asentamiento del camino. A continuación, la ruta atraviesa de manera perpendicular el frente de cabalgamiento que se encuentra próximo a la localidad de Puente Viesgo. Cuando abandona esta población nos introducimos en el área deprimida de Parbayón, constituida por lutitas rojas y negras del grupo Pas, y dicha formación nos acompaña hasta la ciudad de Santander y su puerto.

Las variantes que alcanzan los puertos de Laredo y Castro-Urdiales continúan por la depresión Villarcayo-Medina. Corresponde a un sinclinal de dirección NO-SE, pero a diferencia de los materiales mesozoicos, esta zona deprimida está constituida por sedimentos cenozoicos muy frágiles y deleznables. Estas propiedades intrínsecas de los materiales, favorecen la construcción de los caminos sin apenas obstáculos. Rebasada esta depresión, los caminos ascienden por los relieves en cuesta de la zona norte de las Merindades, aprovechando los cursos cataclinales de los afluentes del Ebro, hasta alcanzar la vertiente Cantábrica. El descenso desde la Meseta hacia el puerto de Laredo se inicia por el puerto de Sendero Enhiesto ${ }^{369}$ y atraviesa el valle de Soba, siguiendo los patrones naturales marcados por los afluentes del río Asón y que no son otros que una fuerte incisión en el terreno, que nos deja unas pendientes abruptas y escarpadas. Dicho valle está constituido por materiales calcáreos del Cretácico inferior y superior de composición carbonática, que favorecen el encajamiento de la red del Gándara. Este río se une al Asón en Ramales de la Victoria, tras describir el Asón un recodo de $90^{\circ}$, que le obliga a un cambio brusco en su dirección para fluir hacia el Norte. En esta localidad las calizas urgonianas se disponen rodeando una estructura llamada Cuña sobreelevada de Ramales, poniendo de manifiesto la existencia de un domo anticlinorial en esta zona. Las partes altas de esta Cuña han sido erosionadas dando lugar a un amplio valle, rodeado por las crestas de calizas en lo que se llama el "anfiteatro de Ramales". Continuando hacia Ampuero, nos encontramos con unos depósitos aluviales de tipo torrencial, que se encuentran situados sobre los niveles de terraza del Asón, lo que evidencia que este río estuvo encajado en el accidente tectónico de la mencionada Cuña de Ramales. Estos condicionantes topográficos se mantienen en un largo recorrido en la provincia de Cantabria, y solo alcanzan pendientes suaves cuando nos aproximamos a la zona de las marismas existentes entre las localidades de Ampuero y Laredo.

369 El puerto mulatero de Sendero Enhiesto, también Ilamado "Sandiniesto", salvaba el desnivel del actual puerto de Los Tornos de 920 ms. y se encuentra muy cerca de éste. 
Por otro lado, el camino que se dirige a Castro-Urdiales accede a la zona deprimida del Valle de Mena a través de una de las innumerables fracturas radiales que existen en los Montes de la Peña. Este tipo de fracturación es típica de los fenómenos de diapirismo y surgen como consecuencia del empuje ejercido por los materiales yesíferos en su afán por salir al exterior, mediante procesos halocinéticos, y una vez compensada la diferencia de presión ejercida por los materiales más densos, se produce un frenado en el empuje por parte de los materiales más blandos, y su exposición a los agentes erosivos les obliga a tener un comportamiento muy débil y por ello su desgaste se realiza más fácilmente, creando amplias depresiones que favorecen la instalación y construcción de las infraestructuras. A este proceso geológico hay que añadir que el río Cadagua, principal vía de drenaje, pertenece a la cuenca hidrográfica del norte y su alto poder erosivo facilita el vaciado del diapiro de Mena. Para atravesar la provincia de Vizcaya los caminos (variantes de los Montes de la Peña y de Peña de Angulo), van acondicionándose al resultado del desgaste realizado por la red de drenaje, salvando los desniveles sin apenas dificultad hasta llegar en unos casos al puerto de Castro-Urdiales desde Valmaseda y en otros siguiendo el curso del Cadagua al puerto de Bilbao.

Por último, la variante más oriental y la más importante para el tráfico de mercaderías entre Burgos y Bilbao, es el eje Burgos-Pancorbo-Orduña-Bilbao. Sus comienzos en Burgos discurren sin dificultad, porque el camino se traza por los materiales de la cuenca del Duero y estos no oponen resistencia alguna. La infraestructura viaria continúa por el corredor tectónico de la Bureba o estrecho de Burgos, que era la zona por donde estaban comunicadas las cuencas terciarias del Duero y del Ebro, cuando tenían un carácter endorreico en el Mioceno medio. A finales del Mioceno se produce la desconexión de ambas cuencas y se establece la primera divisoria de aguas, que se halla en constante proceso de cambio por retroceso de la cuenca del Duero. Es a partir de las estribaciones del puerto de la Brújula cuando se produce un cambio orográfico de consideración al pasar a la cuenca del Ebro, que tiene un mayor encajamiento de la red. La vía discurre por los materiales terciarios de esta cuenca, con lo cual apenas encuentra dificultad para desarrollarse, ya que los agentes tectónicos han actuado de manera incipiente. El camino alcanza su primera dificultad en Pancorbo, y para salvar esta estructura tectónica en la que nos encontramos con un anticlinal tumbado cabalgando la serie terciaria del Ebro, un sinclinal y una intensa fracturación del terreno (fallas inversas de gran ángulo y fallas de tipo normal), se ha usado el trabajo erosivo que realizó en un principio el río Oca, que creó un desfiladero angosto, y que actualmente es surcado por el río Oroncillo.

Después de superar la estructura geomorfológica del desfiladero, el camino va atravesando de manera perpendicular todas las formaciones, hasta llegar a la Sierra Salvada y Monte Santiago, donde vuelve a encontrarse con una nueva dificultad orográfica como es el puerto de Orduña. De nuevo la dinámica fluvial realizada por el río Nervión, ha sido la encargada de erosionar y vaciar el diapiro de Orduña, y de provocar un enorme vaciamiento en su entorno, creando desniveles de una enorme importancia y dificultad para un trazado caminero. Cuando se salva el puerto, la vía continúa por el curso fluvial del Nervión, como curso cataclinal que se ha encajado de forma perpendicular en la zona monoclinal de Amurrio. Posteriormente, atraviesa la estructura plegada del anticlinal de Miravalles- 
La Cuadra de igual manera que los afluentes del Ebro, es decir, trazando su curso de agua de forma perpendicular a la estructura tectónica y tras atravesar el área tectonizada de Arrigorriaga-Basauri, llega al puerto de Bilbao sin apenas dificultad, discurriendo paralelamente al valle del Nervión.

\section{B.- CONDICIONAMIENTOS GEOMORFOLÓGICOS370}

Las condiciones naturales de este espacio, no son ni han sido históricamente favorables para el establecimiento de unas vías de comunicación adecuadas para poner en contacto la Submeseta norte y la Cornisa Cantábrica. Su complejidad hidrográfica y sobre todo orográfica, fue el elemento primordial que condicionó la articulación de este espacio y los usos del territorio, y con ello, el establecimiento de los caminos. La vía natural que bajo el punto de vista geográfico ofrecía una más favorable salida y entrada a la Meseta desde el mar, era la vía del Duero que siguiendo junto a su curso podía alcanzar el mar en Oporto. Pero como las fronteras del Reino de Portugal lo impidieron, no quedó otra alternativa para el desarrollo del comercio y de las relaciones internacionales que la de canalizar el tráfico de mercaderías, abastecimientos y desplazamientos, por los más cercanos puertos del Cantábrico centro-oriental. Además y debido a las condiciones orográficas del territorio, no existían en este sector ríos navegables, ya que los que tienen una dirección meridiana no eran propicios para la navegación fluvial por tener un corto desarrollo, ser de poco caudal y tener que salvar un gran desnivel entre sus cabeceras y el mar.

Por otra parte, los mismos puertos Cantábricos, además de potenciar la navegación de cabotaje, no tenían otra alternativa para asegurar su desarrollo que la de crear unas infraestructuras adecuadas para facilitar una comunicación lo más fluida y adecuada posible con sus traspaíses y tierras del interior, y asegurar así la existencia de un hinterland adecuado. Para ello, se debía superar la cordillera Cantábrica dispuesta paralela al mar y un territorio muy accidentado, desarrollando los transportes y caminos en una dirección meridiana. Debemos tener en cuenta, que en la zona que estudiamos, existe un gran número de puertos de montaña cuya altitud se encuentra por encima de los $1.000 \mathrm{~m}$, que durante el invierno padecían largas temporadas de nieve, y unos páramos que superan en algunos casos la mencionada altitud. El desplazamiento de los caminos que de la ciudad de Burgos salían en dirección norte, se complicaba tras superar los desolados y llanos páramos, porque después se sucedían en un discurso interminable, valles, montañas con sus puertos, sierras y cordilleras, desfiladeros y gargantas hasta llegar al mar, tras haber atravesado en algunos casos zonas de marismas y aguas superficiales. Antes de llegar a la zona costera se debía abandonar la Meseta atravesando la cordillera Cantábrica, que con una altitud media de $1.200 \mathrm{~m}$ desciende abruptamente, y cruzar los 50 o $60 \mathrm{~km}$ del pasillo existente hasta llegar al mar. Se han definido en la mitad norte de la provincia de Burgos las siguientes unidades fisiográficas ${ }^{371}$ : 
1. - La Montaña Burgalesa. Representada por las sierras situadas entre el sur de Cantabria, Oeste de Vizcaya y el norte de la provincia de Burgos, con cotas medias que oscilan entre 1.000 y $1.200 \mathrm{~m}$ que se corresponden con las estribaciones de la Cordillera Cantábrica. Presenta las siguientes subunidades:

1a. Los Montes de Transición entre dicha Cordillera y los Montes Vascos, con los montes del Escudo, Somo, Valnera y Ordunte. Su relieve es muy accidentado con alturas que oscilan entre los 1.000 y $1600 \mathrm{~m}$, con buen número de collados y laderas escarpadas surcadas por ríos y arroyos fuertemente encajados.

1b. La Depresión de Mena, con una forma circular como consecuencia sobre todo de la intrusión diapírica de los materiales del Keuper, con una cuenca que se orienta al Cantábrico. Dicha depresión incluye el Valle de Mena, que a su vez se divide en tres: el de Mena propiamente dicho, el de Angulo y el de Tudela.

1c. Las Cuestas de la Montaña Burgalesa, se extienden entre los pies de los montes del Escudo, Somo, Valnera, la Peña y sierras Carbonilla, Salvada y Orduña, por el Norte, hasta el borde norte de las Parameras, con las sierras de La Tesla, La Llana, Oña y Pancorbo y Montes Obarenes. Presenta relieves en cuestas con pequeñas depresiones lineales y estrechas, como las de Valdebodres-Bedón, de Losa o de Espinosa. Es el dominio del río Ebro y de sus afluentes principales de su orilla izquierda, que crean valles como los burgaleses Valdebezana, Zamanzas, Bricia, Manzanedo, Sotoscueva, Valdivielso, Tobalina y Losa y el alavés de Valdegovía. También son capaces de originar numerosos desfiladeros o cañones, que son en ocasiones aprovechados por los caminos, con el fin de atravesar sectores de las sierras de la Tesla, la Llana, los Obarenes y Arcena con una fuerte densidad de roquedal. Los principales son las cluses profundas de Los Hocinos, Oña, La Horadada, Tobera, Sobrón y Pancorbo y los boquetes cataclinales del Jerea y Purón. Tales caminos se debían encajar en paredes, a veces cortadas a pico, que obligaban a tallar en la misma roca para lograr obtener un espacio continuo, que correspondido con otro ganado al río sobre un paredón asentado en su lecho, llegaba a constituir una precaria vía sujeta a las crecidas temporales que podían provocar su ruina.

1d. Depresión de Villarcayo-Medina, incluye el valle de Tobalina, y es de carácter tectónico. Se encuentra en el centro de Las Cuestas y su estructura viene marcada por un importante sinclinal de dirección NO-SE. La recorren los ríos Nela y Jerea y está limitada al NE por la sierra de Arcena y al Sur por el río Ebro.

1e. Depresión Miranda-Treviño. De forma alargada con dirección ONO-ESE, se prolonga por la provincia de Álava. La erosión diferencial da lugar a relieves interiores y a unas zonas más deprimidas en las que se emplazan los ríos Ayuda y Zadorra, creando este último el paso de la Concha de Arganzón.

2.- Las parameras serranas. Desarrolladas sobre materiales cretácicos plegados, que tras procesos de erosión, han dado lugar a superficies más o menos planas, de paisaje similar a la de los páramos terciarios. De una altitud que oscila entre unos 1.000 y $1.100 \mathrm{~m}$, se ubican aquí los páramos de Masa, Villalta, Lora y Tozo, que actuaban negativamente en los meses de clima más duro sobre el tránsito de mercaderías. A los vientos, fríos y lluvias, con muy pocas posibilidades de refugio por estar los páramos escasamente poblados, se añadía el problema de las nieves, que ocultaban los trazados de los caminos e impedía 
los desplazamientos cuando tales nieves eran copiosas. A cambio, podían ser transitados por los carros. Se da aquí un fuerte encajamiento de los ríos, que da lugar a espectaculares cañones como los del Ebro, Rudrón, Úrbel, Ubierna y la Hoz en Peñahorada, que facilitan en su recorrido la instalación de los caminos.

3.- La Campiña de la Bureba. Representa un espacio de transición entre las cuencas del Ebro y del Duero, compuesto por materiales terciarios y está caracterizado por presentar un relieve suave y alomado, con numerosos ríos y arroyos como el Homino, Oca y Tirón, que drenan al Ebro.

4.- Los páramos calcáreos. Están constituidos básicamente por los páramos dominados por el río Arlanzón y sus afluentes de la cuenca del Duero, donde se sitúa la ciudad de Burgos, con un relieve de superficies suavemente onduladas y laderas abruptas que las unen con la campiña.

Por otro lado, tras superar las llanas y altas parameras, o por el Este las tierras de la Bureba con un relieve suave y alomado, las estructuras y la evolución morfológica del norte burgalés, han dado origen a una región de fisonomía específica. Una región de montaña, con altitudes que sobrepasan los $1.000 \mathrm{~m}$, y superan en muchos puntos los $1.200 \mathrm{e}$ incluso los 1.400, que se manifiesta en un relieve contrastado, que opone junto a áreas deprimidas a 500-700 $\mathrm{m}$ e incluso menos, hasta casi los $200 \mathrm{~m}$, zonas enhiestas situadas por encima de los $900 \mathrm{~m}$. La importancia que adquieren las pendientes elevadas, es un rasgo que atestigua la pertenencia montañosa. Entre Reinosa y Álava, la Cordillera Cantábrica no ofrecen excesivas facilidades para los caminos. Los pasos occidentales se encuentran en torno a los $1.000 \mathrm{~m}$ y su repentina ascensión desde Castilla, se corresponden con un abrupto descenso, circunstancias estas que tradicionalmente han supuesto dificultades, que se agravaban con la presencia de la nieve372. Desde el puerto de El Escudo o Corconte a $1.011 \mathrm{~m}$, se desciende a San Miguel de Luena a $457 \mathrm{~m}$ en seis $\mathrm{km}$, y desde los $920 \mathrm{~m}$ del puerto de Los Tornos o Sendero Enhiesto, se desciende a Lanestosa a $289 \mathrm{~m}$ Estos inconvenientes se repiten, aunque algo más atenuados en el sector más oriental, en los montes de la Peña, donde desde los puertos de El Cabrio de 740 m, La Magdalena de 846 m, La Complacera de $940 \mathrm{~m}$ o Angulo a $700 \mathrm{~m}$, se desciende al Valle de Mena donde Villasana se encuentra a $311 \mathrm{~m}$ de altitud. En la sierra Salvada existe la excepción del puerto de San Bartolomé, que desde los $900 \mathrm{~m}$, se llega en unos cinco km a los $283 \mathrm{~m}$ de la ciudad de Orduña. La energía del relieve, consecuencia de una disección avanzada, y de los fuertes contrastes entre espacios erguidos y rehundidos, es una de las características de este espacio con un carácter diferente al de tierras más meridionales, que en las cuencas terciarias del Duero y Ebro (tierras de Burgos, Campos y Bureba) ofrecen como elemento más destacado su planitud, la debilidad de las diferencias topográficas, la uniformidad de las culminaciones y las altitudes por debajo de los 900-1.000 m373.

Para superar esta complicada orografía, los caminos debieron atravesar dichas sierras y montañas por los puntos de menor altitud y más propicios, muchos con nieve durante varios meses al año. De esta manera, nos encontramos en el camino de Santander por Reinosa con puertos como el de Pozazal (987 m), o por el del Escudo con Carrales (1.020 m) y el propio 
de El Escudo o Corconte (1.011 m). Desde Espinosa de los Monteros, el puerto de Estacas de Trueba (1.166 m) y La Braguía (720 m), o el portillo de Lunada (1.350 m), Asón (682 m) y Alisas $(574 \mathrm{~m})$ y el portillo de La Sía (1.200 m). En el camino de Laredo, debemos sobrepasar el Páramo de Masa (1.050 m), Tamarizos entre Pesadas y Villalta (1.040 m), La Mazorra (1.000 m) o la Virgen de la Hoz (985 m), Bocos (780 m), Los Tornos o Sendero Enhiesto (920 m) y en el de Castro-Urdiales, el de Las Muñecas (410 m). En los diferentes caminos a Bilbao, nos encontramos con El Cabrio (740 m), La Magdalena (846 m), Complacera (940 m), Angulo (700 m), La Brújula (981 m), Portillo de Busto (1.00o m), en Orduña Goldecho (930 m) y San Bartolomé (900 m), Altube (638 m), Barázar (604 m) y Urquiola (700 m)

\section{C.- CONDICIONAMIENTOS HIDROGRÁFICOS374}

La franja situada entre Burgos y el mar Cantábrico se encuentra afectada por las tres cuencas españolas: la Mediterránea, la Cantábrica y la Atlántica. El desarrollo hidrográfico de todo este sector muestra en general una clara continuidad con el pasado, tanto en lo referido a las divisorias de cuencas, como a la disposición fluvial propiamente dicha. Lo mismo en la cuenca del Ebro como en los cursos de la cuenca Cantábrica, se pueden identificar huellas de una antigua red fluvial evolucionada. Sobre las calizas se han conservado las huellas, hoy disfuncionales, de un trazado jerarquizado de afluentes, que son claras en el alto Nervión en el monte de Santiago, o en el puerto de Sendero Enhiesto o de Angulo. Tales huellas también son patentes en el río Ebro encajado en las parameras calcáreas de La Lora, y dicho río ofrece testimonios de un curso antiguo que discurrió sobre dichas parameras a unos 900-950 m375.

Los caminos que tratamos tienen como punto de partida la ciudad de Burgos, situada en la cuenca del Duero junto al río Arlanzón a $856 \mathrm{~m}$ de altitud, y todos ellos para llegar a su destino deberán traspasar la del Ebro para por último penetrar en la del Cantábrico y llegar al mar. Como consecuencia de los espacios montañosos e irregulares que obligatoriamente debían atravesar, los ríos marcarán de una manera decisiva el trazado de estos caminos hacia los puertos, de tal manera que gran parte de sus desarrollos, se establecerán junto a cursos fluviales, obligando a realizar a veces costosas obras de ingeniería, como desmontes, encajes tallados en las paredes rocosas, paredones sobre los cauces para soportar las vías, manguardias, y un buen número de puentes que obligarán a un mantenimiento permanente para el que no se dispusieron nunca, de los medios financieros adecuados.

\section{a.- La cuenca del Ebro. El Ebro como eje}

El río Ebro se constituye como un eje o espina dorsal, dispuesta de Oeste a Este, de una red de afluentes que se incorporan en dirección claramente meridiana por ambos 
márgenes. Su cuenca ocupa la casi totalidad del tercio norte de la provincia de Burgos, región denominada "las Montañas de Burgos", exceptuando el Valle de Mena, siendo sus límites por el Norte los establecidos por los puertos de Palombera (1.260 m), Escudo, La Magdalena (905 m), Estacas de Trueba, Lunada, La Sía y de Los Tornos o Sendero Enhiesto, el del Cabrio, La Magdalena, La Complacera y el de Angulo. Por el sur de Vizcaya, será su divisoria la Sierra Salvada y entre Berberana y Orduña los puertos de Coldecho y de San Bartolomé. La cuenca por el Sur, se encuentra limitada con la divisoria con la cuenca del Duero ya mencionada.

Los afluentes que se incorporan por la margen izquierda al Ebro son el Nela con el Trema, el Trueba con el Cerneja, Salón y Pucheruela, el Jerea con el Nabón, el Purón, Omecillo, Bayas, Zadorra y Ayuda, y por su margen derecha, el Rudrón, Oca con el Homino, Ranera o Molinar, Oroncillo y el Tirón con el Urbión. Aunque el Ebro tiene una trayectoria subadaptada de tipo ortoclinal desde que penetra en el valle de Tobalina por Trespaderne hasta su salida por Sobrón, son todos sus afluentes los que realizan de una manera más directa el modelado de la cuenca, mucho más que el propio río Ebro.

El río Ebro con su dirección de Oeste a Este, se constituye en un obstáculo que deberán salvar todos los caminos que estudiamos, ya que estos presentan una dirección SurNorte. Se impone por ello, la concentración del trazado viario de dirección meridiana en los puntos concretos donde se ubican los puentes, que en el sector que estudiamos son los de Pesquera de Ebro, Rampalay, Puente-Arenas, Horadada, Frías, Puentelarrá y Miranda de Ebro. Por el contrario, los márgenes de sus afluentes con una clara tendencia Sur-Norte, sí serán utilizados en muchos casos por dichos caminos.

\section{b.- La cuenca del Cantábrico. Los ríos del Valle de Mena}

A la cuenca del mar Cantábrico pertenecen todos los ríos que nacen al norte de las cumbres de la cordillera Cantábrica y sus estribaciones, y que discurren en dirección SurNorte por las provincias de Vizcaya y Cantabria, si exceptuamos en esta el Valle de Valderredible que drena al Ebro. También pertenecen a esta cuenca el burgalés Valle de Mena. Los ríos de esta red de drenaje, poseen un carácter torrencial, al ser de corto recorrido y tener que salvar grandes desniveles desde sus nacimientos hasta el mar, lo que provoca el desarrollo de fuertes procesos erosivos que ocasionan unas grandes incisiones en el modelado de su relieve.

Los ríos más importantes son el Besaya, el Pas con el Pisueña, el Miera, el Asón al que se juntan el Calera y el Carranza, y el Cadagua, que recoge las aguas del Ordunte, Ayega, Romarín y Miguel que nacen en el Valle de Mena. Más al Este, el Nervión formará la ría bilbaína de su nombre, al que se le había unido el Bayas. En este sector, los ríos se constituirán, como hemos indicado, en el soporte básico de la instalación caminera, máxime cuando el territorio es agreste y orográficamente complicado, debiendo utilizar los márgenes fluviales encajados entre montañas, como la solución ideal para lograr un trazado más suave y adecuado.

En esta vertiente destacan los valles cántabros de Buelna, Luena, Toranzo, Cayón, Camargo, Pas, Carriedo, Ruesga, Soba y Guriezo, los vizcaínos Carranza, Trucíos, Arcen- 
tales y Gordejuela, los burgaleses Mena, Angulo y Tudela y el alavés Ayala. Valles suaves en general, donde los caminos se asientan sin excesiva dificultad.

\section{c.- La cuenca del Duero}

La cuenca del Duero, en la zona que estudiamos, se encuentra limitada al Este por el propio río Pisuerga, al Norte por el puerto de Pozazal, un punto entre Pedrosa y Llanillo a 960 m y el páramo de Villalta, por el Este los puertos de La Brújula y de La Pedraja y por el Sur por el propio río Arlanzón. Marcada la cuenca por los dichos ríos Pisuerga y su sufragáneo el Arlanzón, recoge este las aguas que le llegan por su orilla derecha del río Pico (hoy desviado) con el Vena, del Rioseras con el Ubierna, del Úrbel y del Ruyales con el Hormazuelas. El Brullés con el Odra desembocará en el Pisuerga.

En general son ríos de escaso caudal al no tener un gran desarrollo, y que en general no supusieron grandes obstáculos para la circulación y para el asentamiento de los caminos, exceptuando como es natural, los que pudieron suponer los creados por las grandes crecidas estacionales.

\section{d.- El cruce de los ríos}

Hablar de los caminos es básicamente hablar de los puentes, ya que concentraban la a veces dispersa disposición de las vías, y eran edificios muy costosos que necesitaban un permanente mantenimiento. Solían ser el símbolo de la comunidad y el fruto de uno de sus esfuerzos económicos más importantes, que en numerosas ocasiones acabaron con sus escasos recursos. No en vano, en no pocos casos, la villa o ciudad que los conservaba, los presentaba orgullosa en su escudo heráldico. Buena parte de la documentación que hemos manejado se encuentra relacionada con ellos, bien con su construcción o bien con sus reparaciones ${ }^{376}$.

La fórmula más primitiva y sencilla para el cruce de los ríos, fue la de utilizar los vados o lugares con poca profundidad que permitían su paso a pie. Su utilización estaba condicionada por el caudal del río, que en el caso de ser copioso de manera permanente, o en los momentos de crecidas estacionales y épocas del año con mayores niveles de caudal, se convertían en inviables. En nuestros caminos encontramos muchos pasos fluviales compuestos por vados, que naturalmente, fueron sustituidos con el tiempo por puentes de fábrica que permitían el paso del río de una manera y permanente.

Cuando el río era poco profundo o muy estrecho, se utilizó un sistema que consistía en colocar sobre el lecho del río soportes de piedra de cierta entidad, a escasa distancia unos de otros, y encima grandes losas de piedra, o bien se podía instalar una precaria estructura de madera, que permitía el paso a pie enjuto, sin realizar grandes obras de fábrica. Se los denominó pasarelas y facilitaban el paso a los peatones. Por otro lado, cuando no existía una instalación permanente para el paso de los ríos, o bien en momentos en los que los puentes se encontraban deteriorados o destruidos, se podía recurrir a soluciones 


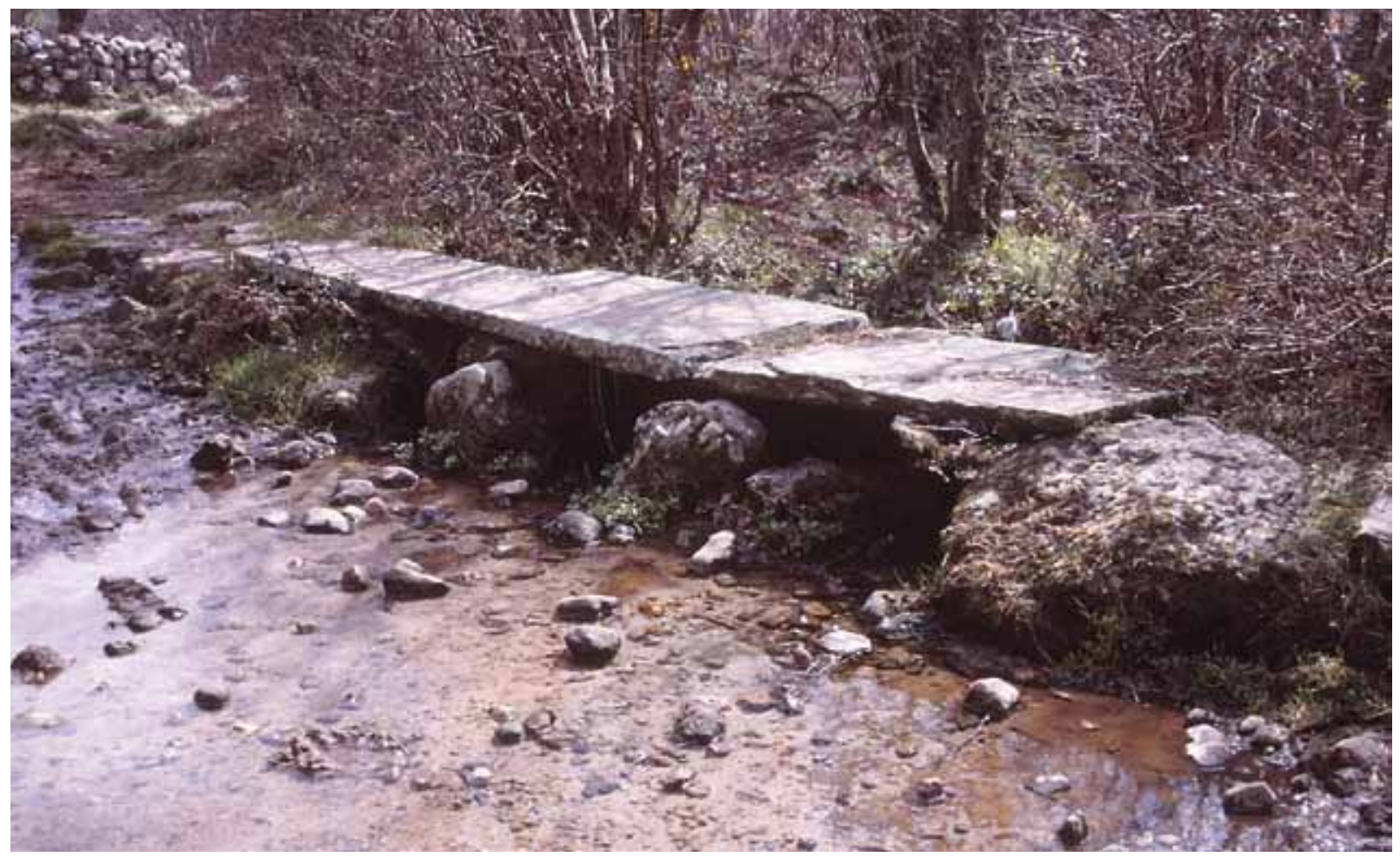

Pasarela en las Machorras.

coyunturales utilizando barcas o almadías. Hasta nosotros nos han llegado informaciones de que en nuestro territorio existieron barcas o almadías para el cruce de los ríos, al menos en Cillaperlata, Barcina del Barco y La Nave cerca de Miranda. Naturalmente no era una solución definitiva, y su utilización podía dar respuesta a necesidades puntuales.

Pero la solución que garantizaba el paso de los ríos en todas las épocas del año de una manera estable, fueron los puentes. Eran no obstante unas construcciones que requerían una gran inversión económica y un elevado coste de mantenimiento, ya que padecían de manera muy acusada, tanto por la utilización de transeúntes, arrieros y sobre todo carreteros, como y esto es lo más grave, por las numerosas avenidas, muchas de ellas de carácter torrencial. No tenemos referencias sobre la instalación de puentes flotantes o de barcas en este sector, pero sí de las otras modalidades de puentes: de madera, de fábrica, mazonería o piedra y mixtos.

Sobre puentes de madera tenemos buen número de referencias, y varios de ellos, han sido y siguen siendo denominados en la actualidad "de la Tabla", referencia clara a haberse construido en su origen a base de madera o tablas. Los puentes de madera, que fueron mayoritarios hasta bien entrado el siglo XV, tenían el gran inconveniente de que no podían soportar un tráfico intenso ni pesado, resistían menos el embate de las riadas y eran perecederos, por ser la madera un material que se pudría y deterioraba. Tenían no obstante grandes ventajas, como la de la rapidez de su construcción y sobre todo la economía de su construcción, ya que eran estos mucho más baratos que los de piedra.

A veces, se construyeron grandes puentes de madera, como en la ciudad de Burgos tras la fuerte riada del 23 y 24 de mayo de 1582, en que el puente de Santa María sufre un fuerte deterioro. Para poder cruzar el río mientras el puente de piedra se reconstruía se realizó uno grande de madera, para lo que maestros de cantería y carpintería dijeron que 
"ellos an bisto la dicha puente de Santamaria e que para hazer la puente de madera para el passo en el interin que se haze de piedra". Se piden informes a maestros carpinteros sobre la calidad de la madera necesaria y un maestro dice que "bemos que en la parte do estamos ay puentes crezidas de madera de olmo y no pino y algunas an quitado grandes y estaba la madera muy buena. La qual fue la puente de Arlançon... Vemos que toda madera de pino junto de humidad se podreze presto, y el pino para sofrir tormente de carros no es madera hebidente,... y la clauazon yncada en pino despide muy presto y en madera de olmo no, porque a benir una crezida grande puede desclabar e demoler la dicha puente de pino, y si es de olmo la clauacon haze mas presa y esta fuerte en el olmo por ser madera mas dura"377.

Los puentes mixtos o pontones, se componían de unas zapatas de sillería o mampostería que servían de base, con la disposición en horizontal de vigas de madera que sobre las zapatas constituían su plataforma. Tenían la ventaja de su bajo coste y fácil reparación, pero los inconvenientes de que en muchos casos no permitían el paso de carros y cargas pesadas, el deterioro a corto plazo de la madera y la nula resistencia a las crecidas. Además, la escasa distancia que debía haber entre las zapatas para contrarrestar la debilidad de unas vigas excesivamente largas, obligaba a estrechar el espacio para el paso del agua o bien a aumentar el número de zapatas. Para reforzar su resistencia se utilizaban jabalcones o tornapuntas, que evitaban además el pandeo de la plataforma. Este es el tipo de pontón que en 1501 informaba un maestro: "La puente de Bolado costara porque se ha de faser perfecta de pilares de cal e canto,... ençima de maderas gruesas, han de ser trauadas las esquinas vna con otra de trauas de fierro con su plomo" 378 .

No obstante el sector geográfico estudiado, que como se ha dicho se encuentra recorrido por una gran cantidad de ríos, conserva innumerables puentes de fábrica, sobre todo en las cuencas del Ebro y Cantábrica. Los más importantes en la del Duero en los caminos que tratamos son, el de Los Malatos, Santa María y San Pablo en Burgos y Vivar del Cid. En la del Ebro los de Agüera de Montija, de la Blanca, Briviesca, Frías, de la Horadada, Medina de Pomar, Miranda de Ebro, Pesquera de Ebro, Puente-Arenas, Puentelarrá, QuintanaEntrepeñas, Quintanilla de Pienza, Quintarnaza, Rampalay, Trespaderne o el Vado. En la Cantábrica los de Arce, Bolado, Cartes, Híjar, Matamorosa, Solía o Valmaseda. Son muchos los que se siguen denominando como “del Canto", alusión clara a su construcción de piedra.

Varios de ellos ya estaban realizados en el siglo XV, pero el mayor desarrollo constructivo tuvo lugar sobre todo a partir de la segunda mitad de ese siglo, con la implantación de los repartimientos, y la actividad promotora que llevaron a cabo las cofradías de mulateros y la Universidad de los Mercaderes de Burgos. En el País Vasco, fueron decisivas las Juntas provinciales y del Señorío de Vizcaya, que desarrollaron una importantísima actividad en la construcción y conservación de los caminos y puentes de sus respectivas demarcaciones.

En muchos casos los puentes se fortificaban con puertas o torres, con el fin de controlar el paso que por ellos se realizaba, pero sobre todo, para el cobro del correspondiente portazgo o pontaje. La torre de tal fortificación podía ubicarse bien sobre el puente como en Frías o Valmaseda, o bien en un lugar cercano o a su entrada como en Aranda, Burgos,

377 A. M. B./ HI-1680/ Burgos, 26 mayo a 1 diciembre 1582.

378 A. G. S./ Registro General del Sello, VI-1501, fol. 460/Valladolid, 5 junio 1501. 


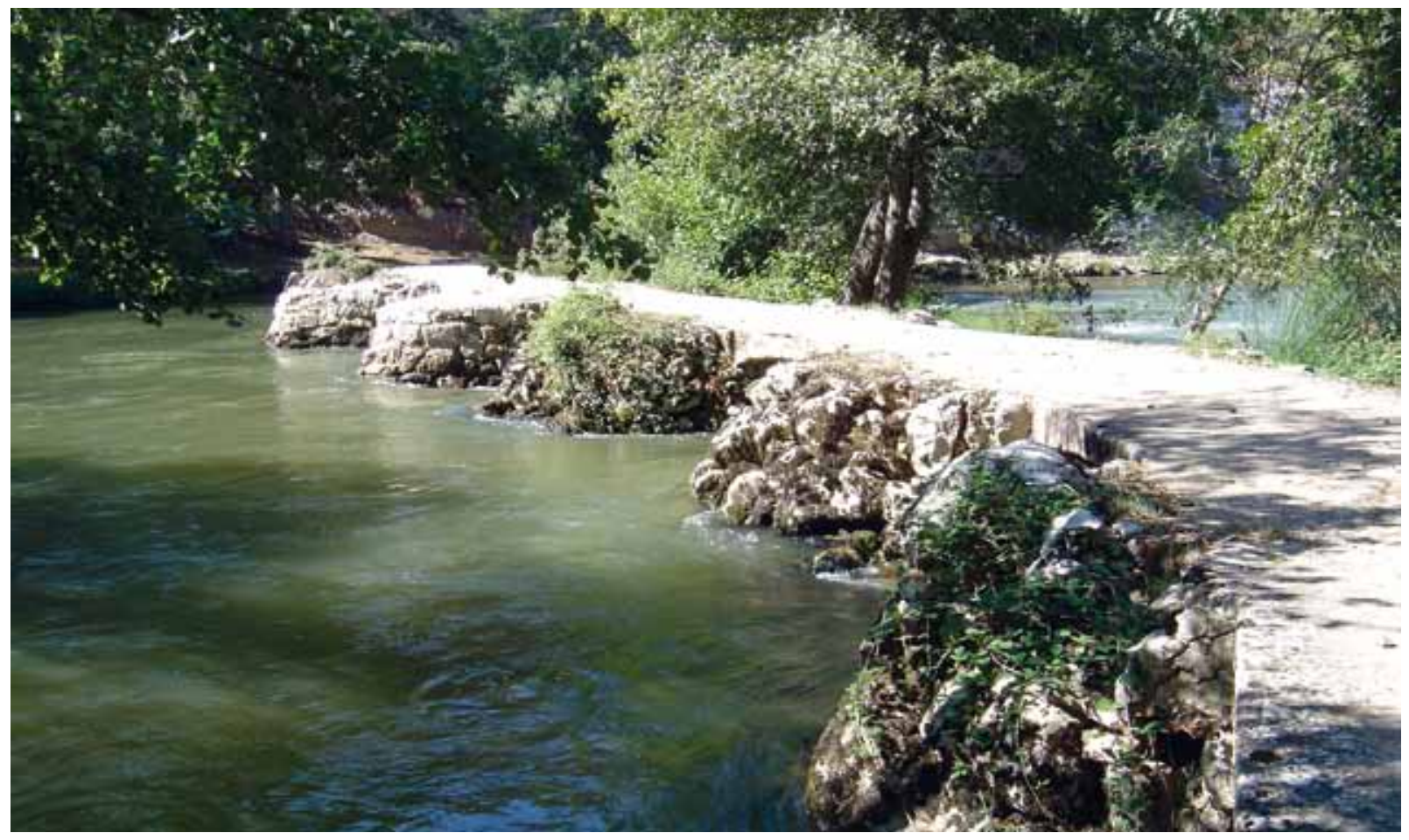

Pasarela en Cidad de Ebro, sobre dicho río.

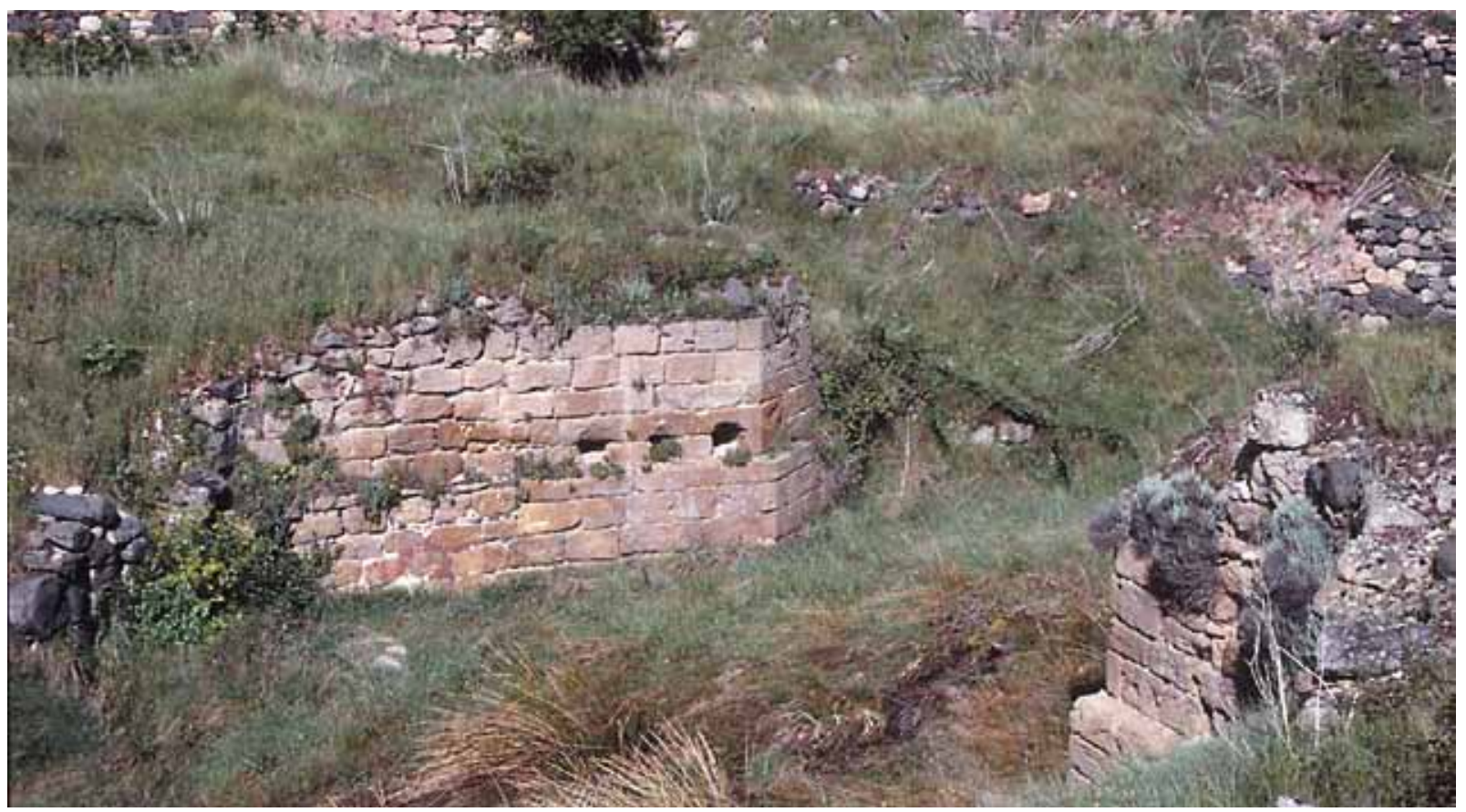

Puente Verde de Poza de la Sal. Pontón donde se observan los mechinales para soportar los jabalcones.

Puentelarrá, El Vado, de la Horadada, Villasandino o Covarrubias. Por otra parte, existe cierta aspiración a dotar a los puentes de cierto carácter simbólico y cuidar su ornato, y a partir de la segunda mitad del siglo XVI, cuando se fabricaba un puente importante, se colocaban a modo de custodios a ambos lados de sus extremos, unos leones tenantes que ostentaban los escudos reales y los de la ciudad o villa donde se ubicaban. En la provincia de Burgos nos han quedado ejemplos de esta instalación en los puentes de la Epitafia de Briviesca, en el puente de Miranda de Ebro aunque más tardío, y en el de San Juan de 


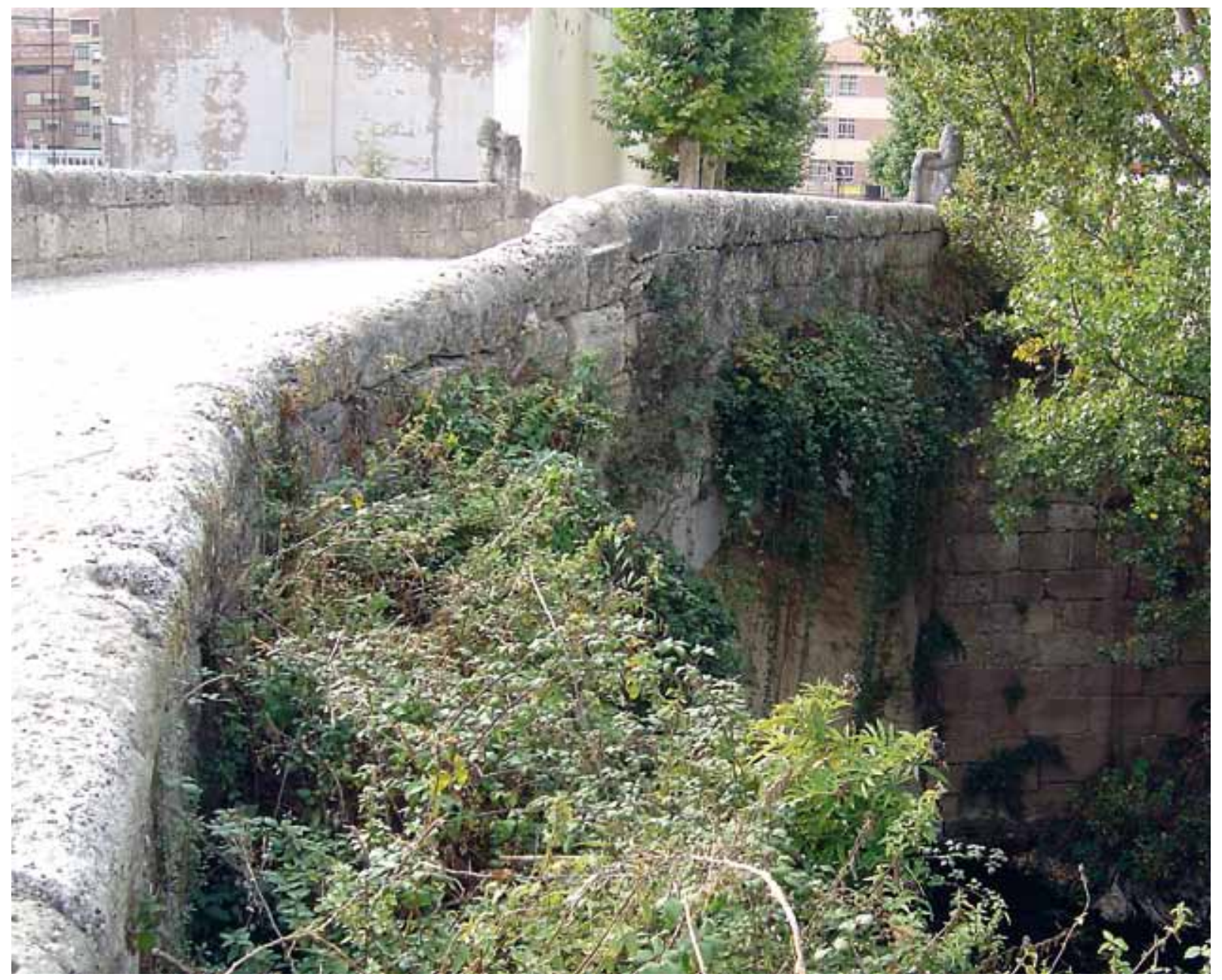

Leones del puente de la Epitafía de Briviesca.

Burgos, aunque los leones de este fueron sustituidos recientemente por otros nuevos. Se solían incluir en el proyecto de construcción, y de lo dicho tenemos un claro ejemplo en la reconstrucción del puente de Santa María de Burgos, tras las riadas de 1582.

En junio de 1584 los maestros de cantería Pedro de Castañeda, Martín de la Haya, Francisco del Río, Juan de Naveda y Juan del Río, incluyeron en la traza una condición para que el maestro encargado de la obra, pusiera "quatro escudos de armas rreales e desta çiudad, los dos a la entrada de la puente a la puerta de Santa Maria en la parte que mas conbenga, e los otros dos al fin de la dicha puente açia Bega con sus leones como se acostunbra en semejantes obras del alto de seis pies". En julio de 1595 todavía les faltaba colocar "vn leon conforme a las condiçiones", que costaría 10 ducados379. A veces, no obstante, se pretenden realizar obras sin un motivo justificado, o por lo menos eso alegan algunos lugares en diciembre de 1582, en el repartimiento del reparo del puente de Puentelarrá. Dicen que la obra no es prioritaria, ya que "solo se pretiende haçer a la entrada de la dich a puente de la vna parte y de la otra, çierta obra a manera de galantería, para solo dar algún lustre y buen paresçer de la dicha puente y no para adreço y rreparo de el daño que obiesen hecho las abenidas de las aguas" 380 .

379 A. M. B./ HI-1.679/Madrid, 19 marzo 1584 y 12 septiembre 1585 y Burgos, 23 octubre 1587.

380 A. J. G. A./ t. VII/ Vitoria, 24 diciembre 1582. 


\section{3.- LOS PUERTOS DEL CANTÁBRICO COMO TÉRMINO DE LLEGADA}

Para el desarrollo del comercio era imprescindible contar con unas vías de comunicación e infraestructuras adecuadas, que tenían una repercusión directa en la calidad, rapidez y costes del transporte. El acarreo a lomos de mulos era el más costoso, por lo que siempre que era posible se intentaba potenciar el tráfico sobre ruedas. Pero el sistema que ofrecía unas mayores posibilidades y ventajas era y es el tráfico marítimo, como consecuencia de que la capacidad de desplazamiento y el alcance de sus medios, abarataban de una manera considerable los costes de dichos transportes.

La Costa Cantábrica se halla salpicada de ensenadas y rías donde los barcos pueden encontrar resguardo frente a los vientos, el oleaje y las tormentas. Sin embargo la acumulación de arenas ocasionada por el arrastre fluvial y las mareas, reducía su calado, causando dificultades para la maniobra de los barcos de gran tonelaje, sobre todo en las riberas. Mientras no hubo muelles donde poder atracar sin riesgo de que los barcos encallaran, fue preciso realizar las operaciones de estiba empleando naves de pequeño tonelaje, ordinariamente dedicadas a la pesca, para llevar las cargas al puerto o a las naves, por lo que para resolver la situación, a partir del siglo XV las villas marineras que deseaban consolidar el tráfico de sus puertos, lucharon por la construcción de costosas instalaciones como cays y malecones para facilitar su utilización portuaria 381.

Hasta la segunda mitad del siglo XII la Costa Cantábrica había sido una zona claramente marginal, ya que el eje principal que canalizaba las relaciones del norte de la Península tenía una clara dirección Este-Oeste, como es el caso del Camino de Santiago. La zona costera había tenido hasta dichas fechas un menor interés para las comunicaciones con el interior y los transportes, además de que sus condiciones orográficas no favorecían dichas comunicaciones terrestres y provocaban a su vez su aislamiento, por encontrarse tras una cadena montañosa que complicaba el establecimiento de unas vías adecuadas con el interior peninsular. Pero la situación cambiará a partir de finales de dicho siglo, al irse consolidando varios ejes con una clara dirección Sur-Norte, que comunicarán el interior de la Península que comenzaba a desarrollarse, con la costa atlántica europea, lo que provocará la activación de un proceso de fundación de villas tanto en el interior como en la costa marítima, que apoyarán el desarrollo de tales vías. Se produjo así una ampliación de la actividad marítima entre las costas del Cantábrico y la costa flamenca, de la que saldrán beneficiadas tanto las pesquerías como el comercio.

Por otro lado, a partir del siglo XII las tierras atlánticas de Francia, Inglaterra y sobre todo los Países Bajos, desarrollaron una industria textil que fue adquiriendo importancia de manera progresiva. Para satisfacer adecuadamente la creciente demanda de sus manufacturas pañeras y textiles, estos países precisaban abundante materia prima como era la lana, producto que la ganadería más cercana no podía abastecer con la abundancia que se requería, por lo que se hizo necesaria su importación. En Castilla existía producción de 
lana de gran calidad y la Corona se mostró dispuesta a satisfacer la creciente demanda. Alfonso VIII promovió el desarrollo de la economía del Reino, dando una mayor importancia a la ganadería ovina e iniciando un proceso que culminó con la creación en 1273 de la "Real sociedad de ganaderos de la Mesta”, según un privilegio de Alfonso X. Los grandes propietarios recibieron privilegios y apoyos por los cuales sus rebaños podían pastar en cualquier lugar del Reino sin que nadie pudiera oponerse, aumentando con ello la cabaña ovina y la producción de lana.

Además, Castilla iniciaba en estos momentos un periodo de cierto despegue económico, que demandaba un impulso de su actividad comercial, e hizo necesaria la creación de unas infraestructuras adecuadas que permitiesen el transporte de las mercaderías hasta los puertos de la costa Cantábrica, la salida más cercana desde Castilla hacia los mercados destinatarios. Pero estas tierras poco pobladas y con una deficiente organización tenían muy pocos caminos, que además de deficientes, carecían de la infraestructura básica para que se pudiese desarrollar un transporte a mayor escala. Además, existía una muy baja red de entidades poblacionales que permitiesen el apoyo de un comercio emergente, y los lugares de embarque no poseían las mínimas condiciones para el atraque y la carga y descarga de las naves.

El rey castellano trató de superar estas graves limitaciones mediante la fundación de nuevas poblaciones, que servirían de base y apoyo a los caminos y a los puertos de la costa que se debían crear y adecuar, garantizando un tráfico organizado, seguro y asistido. El mayor impulso surgió tras el matrimonio de Alfonso VIII realizado en 1170 con Leonor hija del rey de Inglaterra, al recibir Alfonso como dote el ducado de Gascuña, con lo que necesitaba potenciar un camino directo entre Castilla y dicho territorio sin tener que atravesar un reino ajeno como el de Navarra, y sobre todo a partir de la incorporación de las tierras alavesas y guipuzcoanas a Castilla en 1201, con lo que esta nueva situación favoreció de manera importante las relaciones económicas.

A partir de este momento se llevará a cabo un decidido proceso repoblador y urbanizador, con el establecimiento de una serie de núcleos que resultaron vitales para la conexión entre la costa y el interior castellano. Alfonso VIII entre 1160 y 1210 concederá fueros en el litoral cantábrico, a Castro-Urdiales en 1163, a Santander en 1187, a Laredo en 1200, a Fuenterrabía en 1203, en 1209 a Motrico y confirma Guetaria y en 1210 a San Vicente de la Barquera. En el interior y con el fin de consolidar la comunicación entre la Meseta y los puertos concede fuero en 1177 a Miranda y en 1199 se funda Valmaseda, primera villa fundada en Vizcaya. Durante el reinado de Fernando III Orduña recibe fuero en 1229 y Bermeo hacia 1236. Alfonso X fundará en 1256 Tolosa, Segura y Salvatierra y en 1268 Villafranca de Ordicia. Lanestosa en 1287 y en 1300 Bilbao ${ }^{382}$. Por los mismos años y por idénticas razones Sancho VI de Navarra funda San Sebastián hacia 1180, y concede fueros el año siguiente a Vitoria, a Cuetaria entre 1180 y 1194 y a Arganzón en 1191. La seguridad jurídica que suponía la posesión de fueros reales, tuvo entre otras consecuencias, la de dinamizar el desarrollo económico, comercial y demográfico de las villas aforadas.

382 ARÍZAGA BOLUMBURU, B. y MARTÍNEZ MARTÍNEZ, S.: 2006: 21-23. 
En estos puertos comenzó el desarrollo de la fabricación de naves y surgió en el s. XIII una fuerza naval que resultará decisiva para el avance de los ejércitos castellanos y el desplazamiento de las fronteras de Castilla hacia el Sur. Tripulaciones y barcos del Cantábrico lograron abrir el estrecho de Gibraltar a la navegación castellana, con lo que lograron extender su actividad desde el Mar del Norte al Mediterráneo y desde Irlanda a las Islas Canarias. Castilla conoció un gran desarrollo marítimo en este siglo, y no es casual que el mercader burgalés Ramón Bonifaz, participase con sus naos en la toma de Sevilla en 1248 . En estos momentos comenzó a tener una mayor relevancia la presencia de las armas en las naos, lo que contribuyó a reafirmar la preponderancia naval de las gentes del Cantábrico en la fachada atlántica europea durante los siglos XIV y XV. Consolidados sus puertos mediante la intensa actividad marítima, tanto pesquera como mercantil y militar, su potencia naval constituyó un formidable poder marítimo que sirvió de base al gran desarrollo comercial de Castilla hasta el siglo XVI.

Además, la demanda de productos de lujo como consecuencia de la expansión castellana y la mejora de los medios de transporte marítimo, contribuyó también al impulso de los puertos cantábricos para facilitar la entrada de los productos manufacturados que la industria castellana no podía entonces ofrecer. La fundación de las villas y la concesión por parte de los monarcas de privilegios proteccionistas, estimularon el desarrollo comercial marítimo y determinaron la nueva dirección Sur-Norte de los intercambios. Los puertos de la costa se convirtieron en centros muy activos del comercio donde se embarcaban productos castellanos, especialmente lana, materias primas de Andalucía, cueros, armamento, maderas, hierro, etc. hacia Irlanda, Inglaterra, Flandes o la fachada marítima francesa a través del mar Cantábrico. De retorno, llegaban a las villas portuarias diversas manufacturas como tejidos, objetos de uso doméstico, piezas suntuarias, ajuar, joyas, mobiliario, obras de arte, etc. para ser distribuidas por los mercados castellanos del interior 383 .

Para la defensa de este comercio marítimo ante la competencia de otros reinos y para la resolución de los conflictos derivados de su práctica, las villas costeras crearon el 4 de mayo de 1296 la llamada Hermandad de la Marina de Castilla o Hermandad de las Marismas, que estuvo constituida en un principio por las villas de Santander, Laredo, CastroUrdiales, Bermeo, Guetaria, San Sebastián y Fuenterrabía, más Vitoria la única del interior. Así en este siglo, se produce un intento de regulación del comercio marítimo, y en las Cortes de Jerez de 1268 se autoriza en concreto a los puertos de San Sebastián y Fuenterrabía en Cuipúzcoa, Santander, Laredo y Castro-Urdiales en Cantabria, Avilés en Asturias, y en Galicia, La Coruña, Ribadeo, Vivero, Betanzos, Ortigueira, Cedeira, Ferrol, Bayona, La Guardia, Pontevedra, Padrón y Noya, para la carga y descarga y el tráfico de mercaderías ${ }^{384}$

Como hemos visto, en esta primera fase las Cuatro Villas de la Costa de la Mar se habían fundado entre 1163 y 1210 y Bermeo hacia 1236, teniendo que esperar hasta 1300 para que Bilbao se funde en un lugar que gracias a su mejor posición geográfica, y sobre todo a la iniciativa de sus pobladores, ocupe en poco tiempo una posición hegemónica en detri-

383 DÍAZ HERRERA, C.: 2002.

384 SOLÓRZANO TELECHEA, J. A.: 2009-2010: 46. 
mento de Bermeo, único puerto existente de la costa vizcaína antes de 1300. Una segunda fase para la costa vizcaína se puede establecer entre 1290 y 1338. Según Arízaga/Martínez el interés fundacional irá dirigido a articular la costa con la creación de cinco puertos: Bilbao (1300), Portugalete (1322), Lequeitio (1325), Ondarroa (1327) y Plencia (1299), relacionado todo ello con el incremento de la producción lanera y el aumento de la extracción del mineral de hierro, como material de exportación y con la importación de productos manufacturados, básicamente paños ${ }^{385}$.

\section{A.- LAS CUATRO VILLAS DE LA COSTA DE LA MAR}

San Vicente de la Barquera, Santander, Laredo y Castro-Urdiales, eran villas aforadas que impulsaron notablemente desde finales del siglo XII y principios del XIII su economía local. Fueron las únicas en toda Cantabria que tuvieron murallas, lo que evidencia su importancia y capacidad económica. Juntas formarán la Hermandad de las Cuatro Villas de la Costa del Mar, que perduró hasta el siglo XVIII. Desde sus orígenes dirigieron sus actividades mercantiles hacia las tierras del interior castellano, más que hacia los cercanos valles de La Montaña, como lo evidencia el estado y carácter precario de sus caminos interiores, a excepción de las tres vías básicas. La debilidad de su comercio local se pone de manifiesto cuando se comparan dichos caminos, con los tres principales que en dirección Norte-Sur comunicaban los puertos con Castilla.

En 1634 el cosmógrafo real y cartógrafo portugués Pedro Texeira386 indica cuando se refiere a la Montaña, que "los lugares de mas consideracion y trato son los que tiene en su costa, llamados Laredo, Santander, Castro y San Vicente, tomando el nombre de estas cuatro villas mas principales. Goza de seis puertos de mar, no de mucha consideracion salvo el de Santander, que por su capacidad y grandeza, aunque ni es de todo seguro, es nombrado en España. Tres dellos son con muelles y los otros tres, rios con no buenas barras"387.

\section{a.- San Vicente de la Barquera}

Alfonso VIII funda la villa en 1210. Presenta una disposición portuaria semejante a la de Santander, aunque las rías que lo circundan, la del Brazo Mayor y la de San Vicente disponen de un menor calado388. Como puerto de exportación lanera en general y para el comercio burgalés en particular, tuvo una escasa importancia. Fue sobre todo un puerto pesquero que apenas conoció el tráfico mercantil como consecuencia de su aislamiento con el interior castellano, al tener unas vías de comunicación aún más duras que las de los puertos de Santander o Laredo. Se debe descartar por tanto la idea de unas Cuatro Villas

385 ARÍZAGA BOLUMBURU, B. y MARTÍNEZ MARTÍNEZ, S.: 2006: 23-24

386 PEREDA, F. Y MARÍAS, F.: 2002.

387 PEREDA, F. y MARÍAS, F.: 2002; CASADO SOTO, J. L.: 2000: 265.

388 LANZA GARCÍA, R.: 2010: 202. 


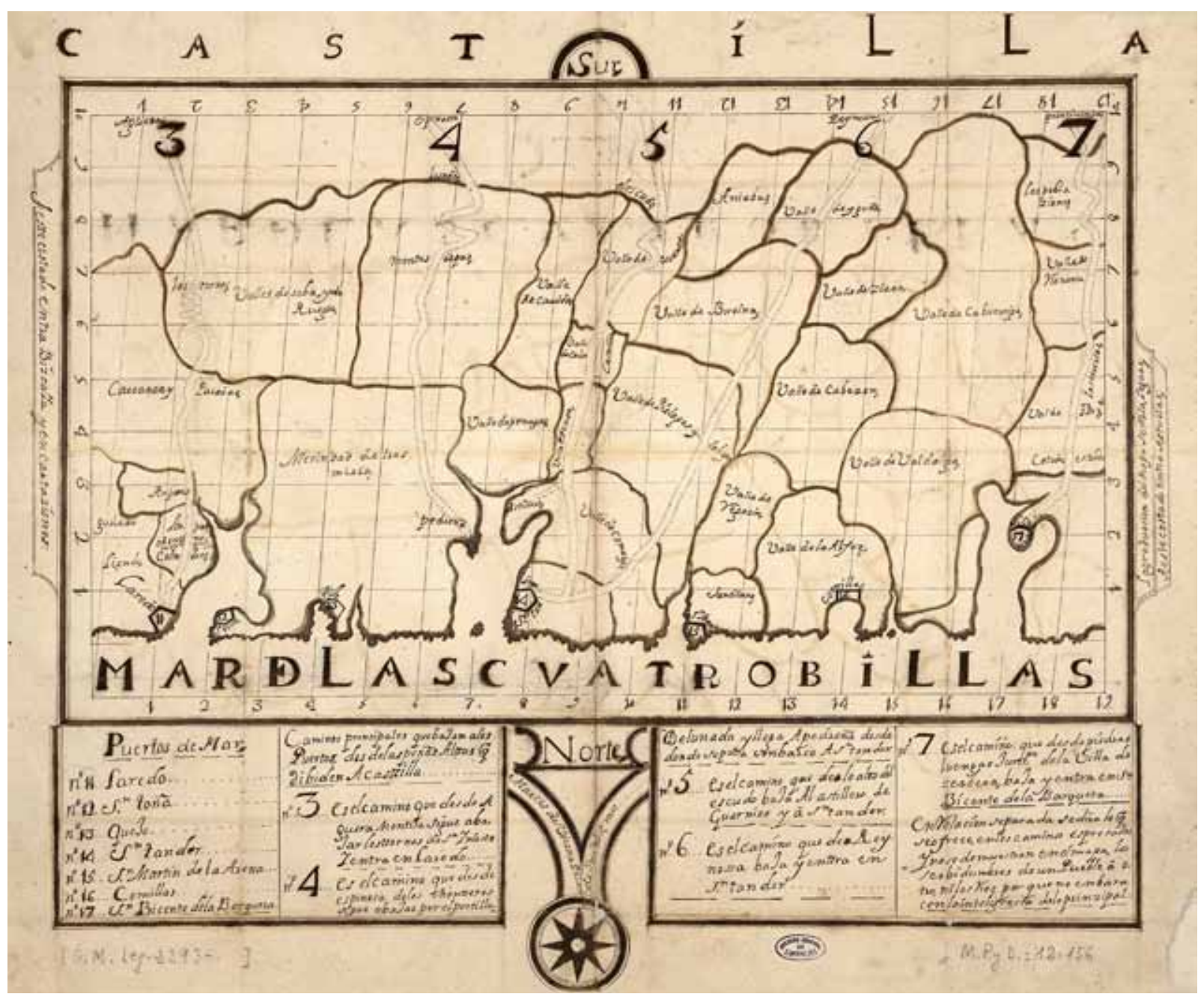

"Caminos principales que bajan a los Puertos, desde las peñas Alttas que dibiden a Castilla", en un plano del siglo XVIII. (A. G. S., MPD 12,156):

"no 3 es el camino que desde Agüera Montija sigue abajar los ttornos de san Yniesto y entra en Laredo.

no 4 es el camino que desde Espinosa de los Montteros sigue abajar por el portillo de Lunada y llega a Pedreña desde donde se pasa con barco a Santander.

$n^{\circ} 5$ es el camino que de lo altto del Escudo baja al astillero de Guarnizo y a Santander.

no 6 es el camino que de Reynossa baja y enttra en Santander".

de la Costa de la Mar, como cuatro grandes focos del comercio en el litoral Cantábrico389. Podría haber tenido un desarrollo mayor, ya que San Vicente tuvo cierta actividad marítima aunque no mercantil, pero lo dificultó el poco calado de su puerto39o. Sin embargo, las peculiaridades de dicho puerto originaron el diseño de embarcaciones pequeñas muy marineras, que se utilizaron en la pesca y en la guerra naval, como las llamadas "chalupas de San Vicente".

Pedro Texeira, nos previene en 1634 sobre el limitado fondo de la bahía y su peligrosa barra, y añade que la villa está situada "en vna punta de tierra que azen dos rios o braços de mar, quedando de hun lado y del otro çercada dellos y tan apretado su çitio que, con no çer el lugar de muncha poblaçion, se le entra la mar munchas bezes por las calles. Y fuera muy ordinario alagarse se lo demas de la uilla no es-

389 BASAS FERNÁNDEZ, M.: 1963 y 1994: 257-257.

390 BARÓ PAZOS, J.: 2011. 


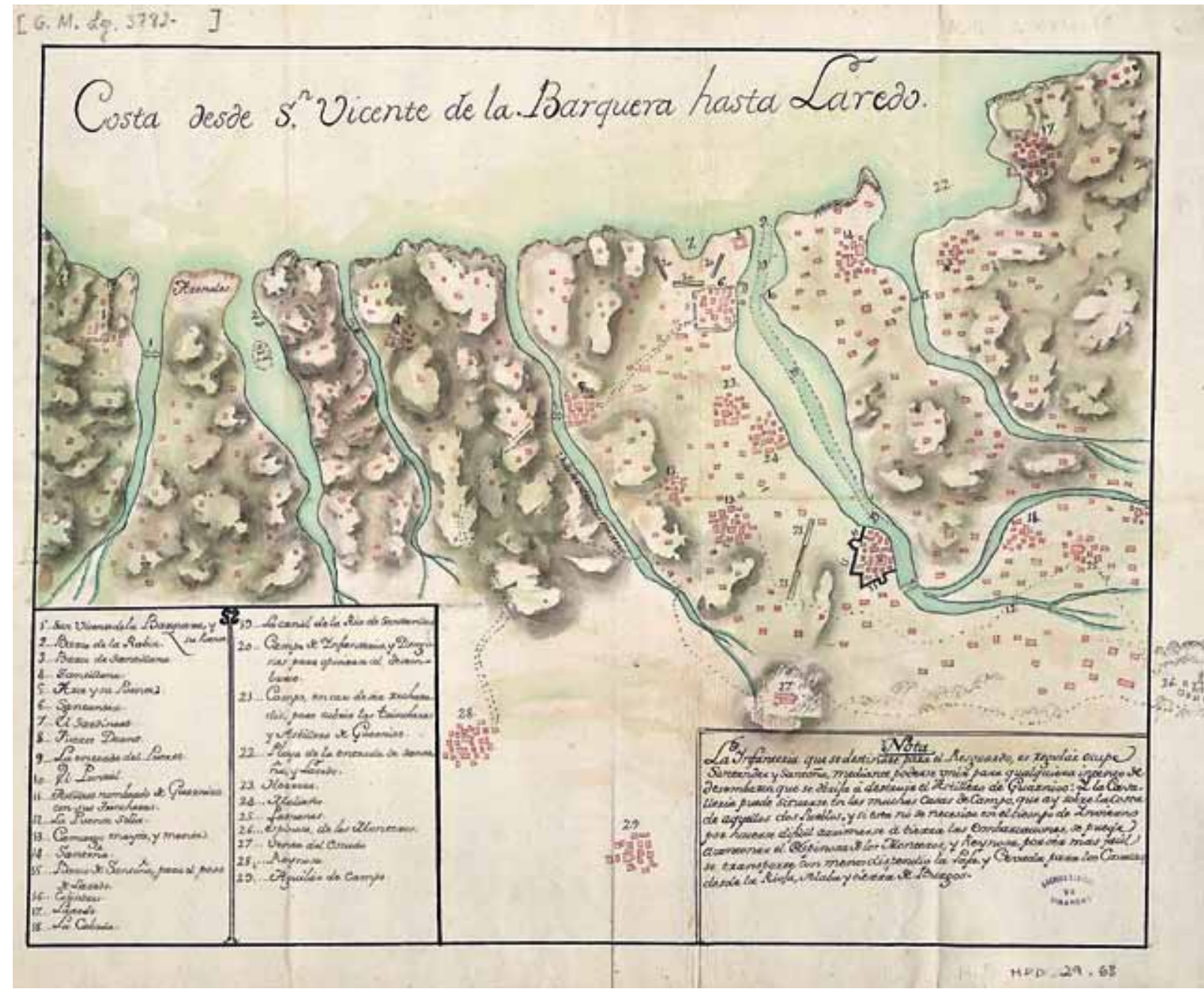

Costa de San Vicente de la Barquera hasta Laredo, s. XVIII (A. G. S., MPD 29,068).

tubiera en cuesta. Y para salir o entrar en ella se toman dos puentes que le quedan de los dos lados, ponientee leuante, tan costozas asi en su fabrica como en grandeza. El puerto no es de los mejores desta costa, por ser de muy poco fondo y caze lleno de bancos de arena, con que la barra no dexa de tener algun peligro. Y asi el maior trato deste lugar es el de la pescaria con que sus bezinos se sustentan. Y para ello fabrican barcos grandes con que salen a la mar y le lleban a otras partes desta costa. Tiene para el dezenbarcar vn muelle"391.

\section{b.- Santander}

La villa de Santander fue fundada por Alfonso VIII en 1187. Su puerto fue en diferentes momentos el principal de Burgos y por donde se canalizó junto con el de Bilbao, el mayor volumen del tráfico lanero. Además de los comerciantes burgaleses también acudían a él 


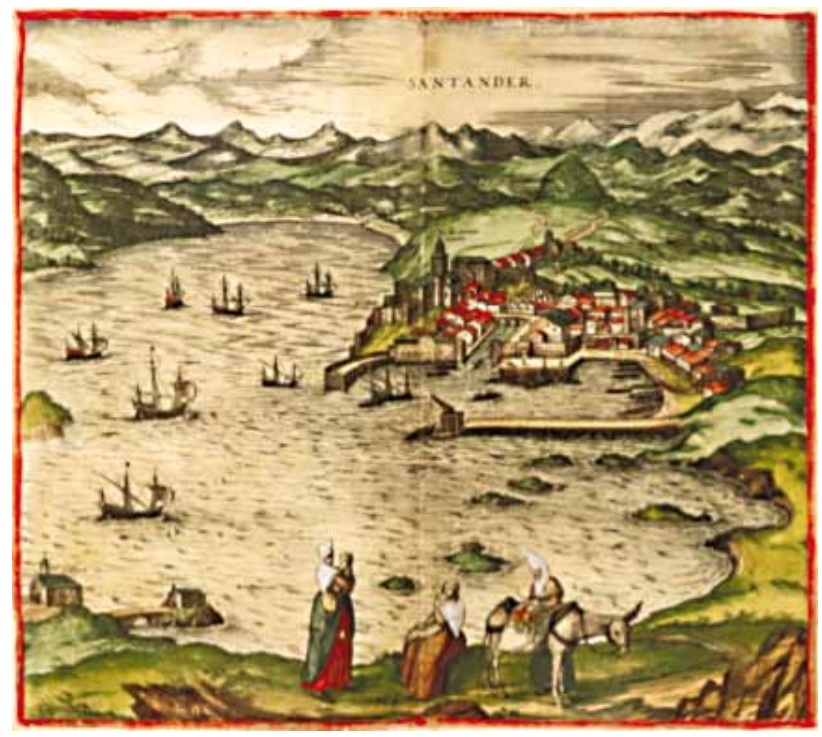

Vista de Santander. Civitates Orbis Terrarum 1575.

los segovianos, palentinos y riojanos, miembros de la Universidad de Burgos, y en menor medida genoveses y de Medina de Rioseco y del Campo392.

Era puerto importante tanto por su amplitud, como por el calado de su bahía, en la que desembocan al Oeste la ría de Raus y al Suroeste las tres rías menores de Boo, Solía y San Salvador o Tijero, y la mayor de todas al Este, la de Cubas, tramo final del río Miera393. Según Lapeyre era el mejor de todo el Cantábrico394. El comercio exterior y el tránsito de personas y mercaderías, fueron los principales responsables del auge de la vida económica de la villa. Al norte de la Bahía se encuentra el emplazamiento original de la Abadía de San Emeterio, que fue el referente del desarrollo de su puebla, sobre un promontorio situado al sur de una pequeña península y separado de ella por la desaparecida ría de Becedo, que dividía las pueblas Vieja y Nueva395. Esta situación, se encuentra reflejada en la panorámica de Santander publicada en $1575^{396}$.

Pedro Texeira indica que la villa está situada "en vna punta de su ria, destante de la barra poco mas de media legua, gozando de la mar de su puerto y del que le queda por el lado del mediodia. Es lugar çercado y de buena poblaçión... De la parte del leuante esta el puerto, que le azen dos muelles, donde entran nauios no de munchos toneles ny que demanden muncho fondo, por no lo aber. Dentro dellos fabrican en este puerto algunos baxeles. Fuera de los muelles, hun quarto de legua distante dellos, dan fondo los nauios y galeones grandes de la armada que a este puerto de ordinario bienen por ser el mas capaz de toda esta costa... Es este puerto de poco abrigo aunque capaz de munchos baxeles. Para los que no pueden entrar en sus muelles, por ser descubierto a la mar y el tienpo que benta della, es menester estar con buenas ancoras por la muncha y rezia mar que mete..."397.

\footnotetext{
392 BASAS FERNÁNDEZ, M.: 1961: 62.

393 LÓPEZ GARCÍA, D.: 2010: 91.

394 LAPEYRE, H.: 2008: 171.

395 LANZA GARCÍA, R.: 2010: 201-202.

396 "Civitates Orbis Terrarum". Georg Braun coordinador. Georges Hoefnagel dibujante. Franz Hogenberg grabador. Editado en 6 volúmenes entre 1572 y 1617.

397 PEREDA, F. y MARÍAS, F.: 2002: 320; CASADO SOTO, J. L.: 2000: 274.
} 


\section{c.- San Martín de la Arena}

Además de los cuatro puertos principales había otros de menor importancia en diferentes abrigos de la costa, y todos sujetos a la jurisdicción marítima de alguna de las Cuatro Villas. Los más destacados fueron los de Comillas y San Martín de la Arena en Suances, a algo más de $20 \mathrm{~km}$ al Oeste de Santander, que tuvieron una escasa relevancia en su relación con el comercio castellano, aunque el de San Martín de la Arena tuvo no obstante una gran importancia en la pesca de ballenas. Este puerto dependía de la villa de Santander, como se reconoció en 1440 después de un pleito. A partir del siglo XVII, y como consecuencia del proceso de colmatación de la ría, sus actividades marítimas se vieron profundamente afectadas.

En relación con este puerto, el concejo de Santander se quejó a los Reyes en 1488, de que de tiempo inmemorial, la villa "tiene la posesyon de un puerto que dise de Santa Mariande de Arena, el qual... esta junto con el marquesado de Santillana, e dis que la dicha villa tiene por priuillejo que ninguna carga ni descarga, se pueda facer en el dicho puerto sin lo facer saber primeramente en la dicha villa de Santander e pagar alli los derechos". Alega que si la carga o descarga del pescado en el dicho puerto se hiciese sin la licencia de Santander, "todas las mercadurias e trato de la dicha villa se perderian" y las rentas reales disminuirían. Añaden que los marqueses de Santillana, siempre respetaron el privilegio pero que recientemente, Hurtado de la Vega, nuevo poseedor del puerto, pide que los derechos que a los Reyes se han de pagar en Santander, se paguen al duque del Infantado, que además ha hecho poblar "un lugar en el dicho puerto, el qual dis que sy se poblase, seria cabsa que la dicha villa e uecinos della se pasaran a benir a el, e se despoblaria la dicha villa de Santander". El concejo de Santander se juntó con la justicia para continuar la posesión del puerto, y que por esto dicen que Hurtado de la Vega mandó que ningún mantenimiento del marquesado ni de otros puertos, como pan, vino, leña, madera, toneles ni otras mercaderías se llevase a Santander, ni se moliese en sus molinos ni en los del marquesado que tenían los vecinos de Santander. Los Reyes mandaron en septiembre de 1488 a Hurtado de la Vega que revoque el mandamiento que había dado en que mandaba "que no se metiesen los dichos bastimentos a la dich a uilla de Santander, e dexeis e consyntays a los vecinos del dicho marquesado e de otras partes, contratar librar e desenbargadamente con los uecinos de la dicha uilla, e moler en sus molinos e façer todas las otras cosas que solian faser e acostunbrauan", y mandan a los concejos del marquesado que libremente contraten con los vecinos de Santander y les den mantenimientos, leña, madera y lo necesario, y los dejen moler en sus molinos sin ninguna pena398.

En una ordenanza de Santander anterior a 1513 se prohíbe cargar o descargar trigo, aceite, vino u otras mercaderías en ningún lugar de la bahía de Santander ni en San Martín de la Arena, ni en su puerto, ni en ningún abra ni ría "ni costa braba hasta el puerto e abra de esta dicha villa", sin licencia y consentimiento de ella, so pena de que las mercaderías, se pierdan "e se pueda quemar la tal pinaça o pinaças o nabio o nabios", y el dueño de la mercadería pague 2.000 mrs. de pena399.

398 A. G. S./ Registro General del Sello, IX-1488, fol. 125/Valladolid, 12 septiembre 1488.

399 A. M. S./ Leg. A 1, no 64. Fols. gr-gv/ s. XV- anterior a 1513; SOLÓRZANO TELLECHEA, J. A.: "Colección Diplomática...". 436: doc. 260 . 


\section{d.- Laredo}

La villa fue fundada por Alfonso VIII en 1200. Su puerto surgió al Este de una pequeña ensenada al Sur de la boca de entrada a la ría de Santoña, protegido por un promontorio situado al Norte y por el Oeste por un arenal que llega hasta la boca de dicha ría. Con un buen calado, los barcos podían fondear sin grandes dificultades. Las obras del puerto fueron comenzadas en 1494, y en 1512 aún no estaban terminadas 400 .

Juan de Peñalosa administrador de los diezmos de la mar de Castilla, realiza en 1564 un informe que indica que los puertos de San Vicente, Santander, Laredo y Castro-Urdiales, "y principalmente Laredo,... es donde mas contratacion hay..." 401.

Texeira indica que es "de maior poblaçion que todas las demas... Esta çituada a la parte del leuante en huna ermosa ensenada de mas de huna legua de boca, al pie de vn alto monte que le guarda las espaldas de la parte de la mar. El puerto esta al poniente donde tiene dos muelles capazes de recoxer buenos nauios. Y dentro dellos fabrican munchos y otro genero de enbacaçiones menores que nauegan por la costa. En el prinçipio de vno de los muelles, el que mira a la mar, tiene echa vna plataforma de thierra y faxina donde esta quatro pieças de artilleria de bronze y, aunque pueden azer daño, no es defença bastante para la calidad de su puerto... [Es] muy frequentado de nauios estrangeros, que bienen a cargar de los frutos de la tierra"402.

\section{e.- Castro-Urdiales}

Alfonso VIII fundó la villa de Castro-Urdiales en 1163 y adquirió muy pronto un importante papel en el tráfico mercantil. En 1178 el monasterio de San Juan de Burgos percibía las décimas de todos los bienes que entraban en la villa por tierra y por mar, algo que se confirmó 14 años más tarde, excepto de las de los paños, armas y cueros, lo que evidenciaba que el tráfico de estos productos era ya rentable para la Corona. La villa consiguió la exención del pago del portazgo en Medina de Pomar, con el fin sin duda de potenciar la comunicación con Burgos y el interior de Castilla.

Existen testimonios de fines del siglo XIII que destacan el papel comercial de la villa. Así, en 1293 la cuantía de los diezmos de los productos comercializados por su puerto era equivalente a la que alcanzaba el puerto de Santander y era ligeramente inferior a lo consignado por el puerto de San Sebastián. De hecho, el puerto de Castro-Urdiales fue muy importante en este sector de la costa, hasta la fundación y desarrollo del puerto de Bilbao, que al adquirir la hegemonía del comercio cantábrico, provocó la decadencia del puerto de Castro y acabó con un movimiento comercial que hasta ese momento se había mantenido de una manera sostenida.

400 A. G. S./Cámara-pueblos, leg. 10, $n^{\circ} 54$ y otro documento sin $n^{\circ}$ : cédulas reales de 1511 ordenando pagar ciertas sumas a la villa de Laredo como ayuda a los trabajos del muelle.

401 A. G. S./ Secretaría del Consejo de Hacienda. Cartas 1564/23 mayo 1564; GONZÁLEZ, T.: 1829: 248: t. II. doc. CXLV.

402 PEREDA, F. y MARÍAS, F.: 2002: 319-320; CASADO SOTO, J. L.: 2000: 270-272. "A la parte del poniente desta ensenada, frontero de Laredo, se llebanta vna altissima montaña, con que remata por la parte del poniente la ensenada, que llaman peña Santoña, que tiene de çercuyto vna grande legua. Cercala toda casi la mar, comonicandose por vna angosta punta de tierra con la firme que, con aguas bibas, se cubre y queda de todo ysla. En cuia falda de la parte del mediodia esta vn lugar que llaman del Puerto, tomando el nonbre del que le ase vn rio que por junto al dicho luguar desagua en el mar, aziendo algunos recodos donde con muncha seguridad estan los nauios dados fondo. Y de ordinario bienen a este puerto a cargar, de todas las partes del norte, limones y naranjas, de que toda esta costa y sus lugares abunda en gran cantidad". 
En 1296 Castro se convierte en la capital de la Hermandad de las Marismas, que aglutinaba los siete puertos del Cantábrico y la villa de Vitoria. Las principales rutas mercantiles en las que se constata la presencia de maestres o mercaderes de Castro, fueron las de cabotaje por el litoral cantábrico para el intercambio de productos costeros, así como las rutas hacia Inglaterra con periodos de comercio regular bastante activo, con un sistema de flotas periódicas orientadas entre otras hacia el intercambio directo de productos como el hierro o la lana, o bien el transporte de vinos desde Gascuña a los puertos ingleses. También fueron habituales las rutas hacia los puertos franceses y flamencos para traer paños, armaduras, vestidos y otros artículos 403 .

El puerto está emplazado junto a una pequeña ensenada abierta al Nordeste y protegido de los temporales por un promontorio situado al Norte sobre el que se asienta la iglesia de Santa María. Pedro Texeira indica que la villa está situada "en vna punta de tierra alta, que por los trez lados les çerca la mar. Y entra tanto este cabo en el que parese mas ysla que tierra firme, aziendo con la demas costa dicha, vna gran ensenada, boluiendo la faz de la uilla y su puerto al mediodia. Y a la parte de tierra, es vna plaia con dos costossisimos muelles para el abrigo de los nauios. La villa es abierta, sin cerca ny muralla, siendo de muy gran poblaçion... Suele enbraueserse en este parage el mar, de manera que munchas vezes ronpe los muelles, con ser en bastantemente fuertes y grueços. Y afirman los naturales desta villa auer los años pasados cresido el mar de manera que sobrepujo la altura del castillo... Ylellebo gran parte de sus almenas que, demas de ser muy alto, esta çituado en lo mas yminente de la punta de tierra..."404.

\section{B.- LOS PUERTOS VASCOS}

Los principales puertos vizcaínos fueron el de Santurce, Portugalete, Bilbao, Plencia, Bermeo, Cuernica, Lequeitio y Ondarroa, de los que para el comercio burgalés, tan solo tuvieron importancia los de Portugalete, Bilbao y Bermeo. De los guipuzcoanos, solo los de Deva y de San Sebastián del Pasaje tuvieron alguna relevancia. Alejados de la ciudad de Burgos, el de San Sebastián fue utilizado básicamente para el tráfico guipuzcoano, riojano, navarro y aragonés y por el de Deva, se canalizó no obstante algún envío de lanas del Consulado.

\section{a.- Portugalete}

Pedro Texeira dice en 1634 que "Adelante de el [punta Galea], esta la barra del rio de Bilbao y, media legua della, junto al río de la parte del poniente, esta çituada la villa de Portogalete, donde dan fondo todos los nauios que van a Bilbao, aguardando la marca para subir por el rio. Y este espaçio de tienpo les vezitan los de Puertogalete, de que Bilbao reçibe, ansi en la juridiçion como en el trato, mucho daño. Tiene esta villa de Puertogalete vn muelle y en el vn terrapleno con quatro pieças de artilleria para la defença de la barra. Cargase en este puerto muncha cantidad de hierro en mineral, que lleban a laurar a Guepuscoa y otras partes, de que reçibe la barra muncho daño y conosidamente se ua cada año serrando, y por tienpos se ara yncapaz de poder

403 DÍAZ HERRERA, C.: 2002: 82-83.

404 PEREDA, F. y MARÍAS, F.: 2002: 319; CASADO SOTO, J. L.: 2000: 268-270. 
entrar por ella nauios considerables. Y es que todos los que bienen a cargar el hierro,... vienen uazios y les obliga uenir con muncho lastre, y para tomar la carga todo desaligan en la plaia y con las abenidas del rio le lleba a la barra. Y aunque es conoçido este daño no tratan del remedio, por el ynteres que se les sigue de vender el mineral. Y conosese este daño en la uilla de Bilbao porque solian venir munchos nauios de grande porte cargados de mercancias a ella y oy no se atreuen con el peligro de la barra y assi se le ba acabando el trato" 405.

Doña María Díaz de Haro, mujer que fue del infante don Juan, señora de Vizcaya, otorga en 1322 a todos los vecinos de Portugalete el fuero de Logroño. Con la fundación de esta villa en la boca de la ría se completaba su plan de desarrollo, que comenzó con la fundación de la villa de Bilbao en 1300. La ría de Bilbao se convertirá a partir de ahora, en el centro de la economía del Señorío de Vizcaya.

La carta-puebla de fundación de Portugalete autoriza que la villa cobre el tercio de toda la dezmería de Santurce. Fija su territorio cuyos términos delimita "fasta la Luchana, e los pescadores que moraren en este termino que vengan con el pescado a la dicha villa de Portogalete,...". Manda que en estos términos, "non aya otro ninguno carga nin descarga de pan nin de sal nin de otra cosa ninguna, saluo en la dicha villa de Portogalete", y que no den en toda su tierra peaje, recuaje ni ningún otro derecho, y que sean francos para que puedan comprar todo lo que quisieren. Manda a todos los concejos de sus villas de Vizcaya y Encartaciones que no les puedan tomar ninguna cosa en razón de los portazgos y peajes como usan en Bermeo, en Bilbao y en las otras villas del Señorío406. A pesar de las condiciones favorables que se detallan, la villa no tuvo el desarrollo pretendido por tener la competencia de la cercana Bilbao, más dinámica y mejor situada para controlar todo el tráfico de la ría.

El puerto de Portugalete fue básicamente de madera y de discreto tamaño en sus orígenes, como lo era el de Bilbao. El mayor problema para el acceso a la ría fueron los depósitos de arena situados en las inmediaciones de Portugalete, provocados por el movimiento de la marea. Se formaba una barra de arena de grandes dimensiones perpendicular al eje de la ría que taponaba su entrada. Como la ría tenía obstáculos y pasos difíciles además de la mencionada barra, Portugalete y Bilbao debieron colaborar en su solución, ya que tenían un interés común. En 1530 comenzó la realización de un muelle de 6 o brazas, obra que animó a los bilbaínos a realizar unos años más tarde el remate de 350 brazas, de 5 brazas de cimientos y 4 de altura. En 1538 los Consulados de Burgos y Bilbao, se comprometieron a proseguir las obras financiadas con las imposiciones sobre sus mercaderías. Así en 1540 el muelle llegaba a las 400 brazas y en 1558 Burgos, Bilbao y Portugalete acordaron seguir repartiendo entre ellas el coste 407 .

\section{b.- Bilbao}

Pedro Texeira dice que "Esta la famosa villa de Bilbao distante de la barra al mediodia dos leguas. Çituada en la orilla de su rio de la parte del leuante, y de la del poniente tiene vn gran arrabal. Es luguar de

405 PEREDA, F. y MARÍAS, F.: 2002: 318.

406 Salón de plenos del Ayuntamiento de Portugalete/ Segovia, 21 agosto 1432; HIDALGO de CISNEROS AMESTOY, C.; LARGACHA RUBIO, E.; LORENTE RUIGÓMEZ, A.; MARTÍNEZ LAHIDALGA, A.: 1987: doc. 1, 4; A. H. F. B./ Privilegios Reales. Registro 1, ํㅜ 1 .

407 ARÍZAGA BOLUMBURU, B. y MARTÍNEZ MARTÍNEZ, S.: 2006: 207. 
muncha poblaçion y de buenos ydifiçios, murada lo antiguo... Llegan los nauios a descargar sus mercançias en vn cais junto a las mismas cazas y puente de la uilla"408.

La villa se estableció en el lugar donde las aguas del río Ibaizábal-Nervión se juntan con las del mar, exactamente donde llegan los últimos efectos de la marea sobre la ría, lo que permitía aprovechar su flujo y reflujo para la navegación. Se asienta en el punto más cercano a la costa por donde la ría se podía atravesar a pie en marea baja, y donde su calado con la pleamar ascendía 3 metros, permitiendo así la navegación. También se situaba muy cerca de la desembocadura del Cadagua, que facilitaba su comunicación con las Encartaciones y las Merindades burgalesas 409 .

Aunque el puerto de Bilbao tenía unas características que lo hacían propicio para el movimiento del comercio castellano, sus cualidades naturales y su situación a más de 10 km del mar, no eran ni con mucho decisivas, ya que no era el único protegido. Al menos

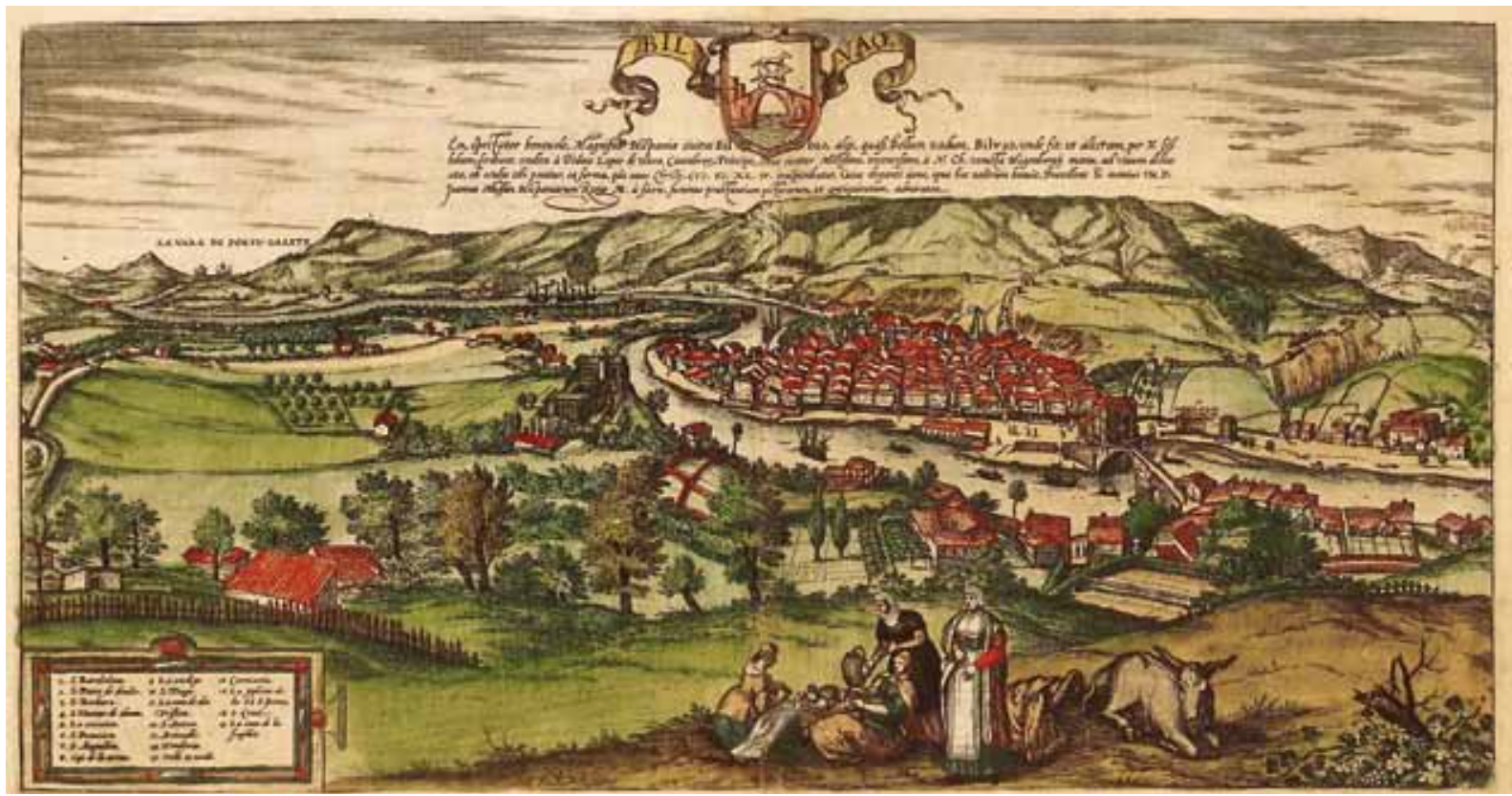

Vista de Bilbao. Civitates Orbis Terrarum 1575.

los puertos de Santander, Laredo y Guernica ofrecían condiciones similares o mejores que las de Bilbao. Existía cierta dificultad para atracar en su puerto con mar embravecida410, por lo que en ocasiones concretas llegaba a depender del de Laredo. No obstante, en 1494 también Laredo sufría en invierno las malas condiciones de abrigo, ya que al no tener muelle debían poner las barcas sobre la plaza para su seguridad411. Si la villa acabó siendo

408 PEREDA, F. y MARÍAS, F.: 2002: 318

409 ARÍZAGA BOLUMBURU, B. y MARTÍNEZ MARTÍNEZ, S.: 2006: 4-5.

410 A. G. S./ Registro General del Sello, VIII-1502, fol. 394/ Toledo, 27 agosto 1502; A. D. B./ C-220/ Toledo, 27 agosto 1502. "quando venian sus mercadurias de los Rreynos comarcanos si no fuese la mar muy uella no podrian las naos que las trahen entrar en Biluao segund que dezian, mas antes diz que avnque no quisiesen los maestros de las dichas naos, entrauan en el puerto de la dicha villa de Laredo e que alli se descargauan sus mercaderias".

411 A. G. S./Cámara-pueblos, leg. 10, № 34. Información hecha por Laredo en 1494, para mostrar la necesidad que tiene de un cay. 
el punto de confluencia de los caminos que discurrían por toda esta zona, por delante de Portugalete o Bermeo, fue básicamente porque lo propició, bien una carta de fundación o decreto como el de 25 de junio de 1310 que luego veremos, que supuso el declive de Bermeo, o porque su propio dinamismo económico fue capaz de hacer rectificar la dirección natural del camino del Cadagua, ya que este río desemboca en Zorroza y no en Bilbao, imponiéndose a la villa de Portugalete412.

El 15 de junio de 1300 Diego López de Haro V, señor de Vizcaya, concede carta-puebla y establece nueva población y villa en Bilbao. Manda que sus pobladores y vecinos sean francos y quitos de todos los pechos, veredas, y otros derechos según el fuero de Logroño. Fija un amplio territorio cuyos términos delimita con todas las anchuras, ejidos, montes, aguas y lugares, de tal manera que los pobladores puedan labrar, plantar, ensanchar y hacer todas las ganancias y mejorías, y comprar y vender francamente heredades como hombres francos y libres. Otorga libertad de tránsito por la ría para las embarcaciones que van o vienen al puerto de Bilbao: "que en el nuestro puerto de Portogalete nin en la barra nin en toda la canal que non aya peçio ninguno de naue nin de baxel que uengan o salan del lugar cargados con sus mercaduras, e mostrando recabdo que uienen a esta villa de Biluao o van della e pagando las costumbres e los derechos del sennor" "413. Con esta carta-puebla Bilbao se benefició entre otros aspectos, de incentivos al comercio y la industria, estableciendo un mercado semanal los martes, y libertad de tránsito comercial por la ría para las naves que fuesen o viniesen de su puerto. Con ello adquieren un monopolio sobre el tránsito mercantil por la ría, al impedir la descarga en las orillas del Nervión, en la amplia zona que separa la villa del mar, de otras mercaderías que las específicamente destinadas a las poblaciones del trayecto, algo que utilizaron con gran beneficio para la villa414.

El 4 de enero de 1301 Fernando IV a ruego de Diego López de Haro su alférez, concede privilegio al concejo de Bilbao, y les da las mismas franquezas y libertades que a los de Bermeo. Los exime del portazgo en todos los lugares del Reino, salvo en Toledo, Sevilla y Murcia y del treintazgo, oturas, enmiendas, peajes o de entrada y salida, tanto por mar como por tierra. Manda que sus vecinos puedan andar, pescar, comprar y salar, como lo hacen los de Castro, Laredo y otros puertos, y que todos los que vinieren con mercaderías a este puerto "que carguen e descarguen las mercaderias que truxieren francamente, en tal manera que no den y diezmo ninguno, mas que lo vaian dar a Vitoria o a Pancorbo o a otro lugar qualquier de los mis puertos, do ellos mexor se pudieren avenir con aquellos que recaudaren los diezmos por nos, e a los que fallaren que van por otro lugar que les tomen quanto les fallaren por descaminados". También se equipara a los comerciantes bilbaínos con los gascones y genoveses en Sevilla y manda que anden salvos y seguros por todos sus reinos, y no sean prendados ni sus cosas embargadas, salvo por sus deudas conocidas o por fiadura manifiesta 415 .

412 ARÍZAGA BOLUMBURU, B. y MARTÍNEZ MARTÍNEZ, S.: 2006: 45.

413 A. M. Bilbao/ Pergaminos, 1 (actualmente se halla en la casa consistorial)/Valladolid, 15 junio 1300; ENRÍQUEZ FERNÁNDEZ, J.; HIDALGO de CISNEROS AMESTOY, C. y MARTÍNEZ LAHIDALGA, A.: "Colección documental del Archivo Histórico de Bilbao (1300-1473): 1999: doc. 1.

414 ARÍZAGA BOLUMBURU, B. y MARTÍNEZ MARTÍNEZ, S.: 2006: 25.

415 A. M. Portugalete/ Sección C- Caja 1- n.ำ (1) fol. 16r.- 24r. y 30r.- 33r./ Tudela de Duero, 23 Agosto 1506; HIDALGO de CISNEROS AMESTOY, C.; LARGACHA RUBIO, E.; LORENTE RUIGÓMEZ, A.; MARTÍNEZ LAHIDALGA, A.: 1987: doc. 
El 25 de junio de 1310 María López de Haro, mujer del infante Juan y señora de Vizcaya, otorga nueva carta de fundación "en Biluao de partes de Vegonna, poblaçion e villa, qual dizen el puerto de Biluao", al confirmar la carta-puebla que hizo su tío Diego López de Haro en 1300, y le concede privilegio de aforamiento. Añade que todo lo contenido en dicha carta-puebla lo otorga a los pobladores de Bilbao y a los futuros vecinos, y manda "que seades francose quitos en todol mio sennorio, e en todos los mios lugares de portagos e de peages, e de emiendas, e de oturas, $e$ de cueças, e de requage, de todas las cosas e mercaderias que traxierdes elleuardes tanbien por mar como por tierra". Manda además que "el camino que ua de Ordunna a Vermeo que pasa por Echauarri, que uaya por aquesta mi villa de Biluao e non por otro lugar sinon por esta Biluao, et qualquier o qualesquier que otro camino tomasen si non este de Biluao, mando al mio prestamero de Vizcaya e a los mios merinos e al preboste de y, de la villa, que les tomen todo quanto les fallaren por descaminados" y lo guarden para hacer lo que tuvieren por bien, y que "ninguno non sea osado de tener conpra ni venta ni regateria ninguna, en todol camino que ua de Areta fasta la uilla de Biluao", y al que lo hallaren que peche $100 \mathrm{mrs}$. de la moneda nueva, y el merino que lo hallare tome para si aquella reventa. Este documento es copia casi literal de la carta-puebla de 1300 , salvo el traslado del mercado de los martes al miércoles y la obligación de pasar por Bilbao a los que fueren a Bermeo por el camino de Pancorbo y Orduña. Además, prohibía la "conpra ni venta ni regateria ninguna, en todol camino que ua de Areta fasta la uilla de Biluao"416. Con estas disposiciones, el puerto de Bilbao, situado en un punto que acortaba el camino de Pancorbo al puerto de Bermeo en un día (6,5 leguas), mantuvo una situación tan favorable que le permitió en poco tiempo destacarse como el puerto hegemónico de Vizcaya, en detrimento del de Bermeo, que comenzó así su decadencia, hasta quedar relegado como puerto pesquero ${ }^{417}$. Alfonso XI confirmará en julio de 1315 el privilegio de franquicias fiscales otorgado por Fernando IV418.

Pedro I en abril de 1350, a petición de Juan Núñez de Lara señor de Vizcaya y su alférez y mayordomo mayor, ratifica el privilegio de 1301 y para favorecer a los vecinos de Bilbao, los recibe en su guarda, encomienda y defensa, a ellos y a todo lo suyo, para que anden salvos y seguros por todos sus reinos, mientras no sacaren cosas vedadas, y que no sean presos ni prendados ellos ni ninguna cosa de lo suyo, salvo por deuda conocida o por fiadura manifiesta ${ }^{419}$.

44, 156; A. H. F. B./ Privilegios Reales. Registro 1, no 1/ Burgos, 4 enero 1301; A. M. Bilbao/ Cajón 8, regํㅜ, no 1. Caja 199, Libro Copiador de Privilegios (fol. 4)/ Burgos, 4 enero 1301; ENRÍQQUEZ FERNÁNDEZ, J.; HIDALGO de CISNEROS AMESTOY, C. y MARTÍNEZ LAHIDALGA, A.: "Colección documental del Archivo Histórico de Bilbao (1300-1473)": 1999: doc. 2; HIDALGO de CISNEROS AMESTOY, C.; LARGACHA RUBIO, E.; LORENTE RUIGÓMEZ, A.; MARTÍNEZ LAHIDALGA, A.: 1987: doc. 1.

416 A. M. Bilbao/ Pergaminos, 2. (se halla en la casa consistorial)/Valencia. 25 junio 1310; ENRÍQUEZ FERNÁNDEZ, J.; HIDALGO de CISNEROS AMESTOY, C. y MARTÍNEZ LAHIDALGA, A.: "Colección Documental del Archivo Histórico de Bilbao (1300-1473)".: 1999: docs. 3 y 10; A. M. Bilbao/ Cajón 1, reg. 1, noำ12-Pergaminos 12/ Bermeo, 20 junio 1334.

417 ARÍZAGA BOLUMBURU, B. y MARTÍNEZ MARTÍNEZ, S.: 2006: 27.

418 A. M. Bilbao/ Cajón 8, regำ 1, nำ 1- Caja 199, Libro Copiador de Privilegios (fol. 5ro-6roํ)/ Burgos, 30 julio 1315; ENRÍQUEZ FERNÁNDEZ, J.; HIDALGO de CISNEROS AMESTOY, C. y MARTÍNEZ LAHIDALGA, A.: "Colección documental del Archivo Histórico de Bilbao (1300-1473)".: 1999: doc. 4.

419 A. M. Bilbao/ Cajón 8, reg. 1, no 1-caja 199 (fol. gr-gv)/ Sevilla, 22 abril 1350; ENRÍQUEZ FERNÁNDEZ, J.; HIDALGO de CISNEROS AMESTOY, C. y MARTÍNEZ LAHIDALGA, A.: "Colección documental del Archivo Histórico de Bilbao (1300-1473)": 1999: doc. 21. 
Juan I, siendo infante, otorga Privilegio real que mejora en enero de 1372 el fuero concedido en 1300. Después será confirmado por el mismo Juan, ya rey, en agosto de 1379 y por Enrique III en diciembre de 1393. Destacan las cláusulas sobre que a los bilbaínos se les libra de portazgo, treintazgo, oturas, enmiendas, peaje y entrada o salida en todo el Señorío, y que justificando que la nave, bajel o batel va o viene de Bilbao con sus mercaderías, no pague pecio420 alguno en Portugalete, ni en la barra, ni en todo el canal, ni en Santurce, ni en Merana ni en Arrigurenaga, pagando los derechos del señor. El mercado semanal se concede los miércoles con todos los cotos y caloñas como se contienen en el Fuero de Logroño, y que ningún "ome andariego que non sea osado de entrar ni estar en la villa de Bilbao sin mandado de los alcaldes de Biluao dende mas de vn dia". Desde Bilbao hasta Areta, Baracaldo o Zamudio421, no podrá haber ninguna reventa, y si se hiciere, que el preboste y el merino real, la tomen para ellos y el revendedor pague $500 \mathrm{mrs}$. Los que hayan pasado por Bilbao usarán el camino que va por Echévarri, y si no fuere así, que el preboste de Bilbao los tome por descaminados ${ }^{422}$. En resumen, se amplía la libertad de los bilbaínos para comerciar, y las mercaderías podrán entrar y salir de la villa sin traba alguna. Se confirma el monopolio bilbaíno sobre el área de la ría concediendo a los tramos Bilbao-Baracaldo y BilbaoZamudio la misma categoría que tenía ya el tramo Bilbao-Areta ${ }^{423}$, e incrementando las competencias bilbaínas en materia comercial.

El procurador de Bilbao dijo al Rey que en la villa, de hacía mucho tiempo, había bajado el contrato que solía haber por no acudir los mercaderes y otras personas con sus mercaderías, y que por los bandos, peleas, robos y fuerzas de caminos y otros daños que acaecen entre los caballeros y escuderos de ella, especialmente en hacer daños y requisas a sus vecinos y a los caminantes que a ella acudían, y por no tener propios ni rentas para arreglar los muros, adarves y muelles que están sobre la ría, ni para tener hombres de armas para guardar y defender la villa y los caminos y los otros tratantes, necesitaban obtener fondos. Pedía por ello licencia para echar sisa en el pan, vino, carne y pescados e hierro y lanas, paños, lienzos y fustanes y otros productos que se vendiesen y cambiasen por cualquier vecino y morador, para poder hacer los reparos mencionados y atender los sueldos de los oficiales y peones. El Rey da licencia en junio de 1470 para que el concejo pueda echar sisa por 4 años, para que "lo que montaren y rendieren la dicha sysa e ynpusyçion podades reparar la dicha villa e paga del dicho sueldo, para otras cosas que tenedes fechas e fizierdes de aqui adelante". Y si alguien no lo quisiere pagar, manda a las justicias que ejecuten en sus bienes todo lo que debieren y fueren obligados a pagar por razón de la dicha sisa424.

\footnotetext{
420 Derecho que el señor del puerto de mar exigía de las naves que naufragaban.

421 Villas situadas en los caminos de acceso a Bilbao: Areta en el camino de Orduña, Baracaldo en el de Valmaseda y Zamudio en el de Bermeo.

422 A. M. Bilbao/ Cajón 8, reg. 1, nº 1 -Caja 199 (fol. 4Or-41r)/ Burgos, 11 enero 1372; ENRÍQUEZ FERNÁNDEZ, J.; HIDALGO de CISNEROS AMESTOY, C. y MARTÍNEZ LAHIDALGA, A.: "Colección documental del Archivo Histórico de Bilbao (1300-1473)": 1999: doc. 29; A. G. S. V./ Casa de Juntas de Guernica. Privilegios Reales. Reg. 1- no 2/ Madrid, 15 diciembre 1393; HIDALGO de CISNEROS AMESTOY, C.; LARGACHA RUBIO, E.; LORENTE RUIGÓMEZ, A.; MARTÍNEZ LAHIDALGA, A.: 1986: doc. 5 .

423 ARÍZAGA BOLUMBURU, B. y MARTÍNEZ MARTÍNEZ, S.: 2006: 28.

424 A. M. Bilbao/ Cajón 12, reg. 3, no 42-Caja 305, reg. 1, no 2 (fol. 30v-31v)/ Segovia, 15 junio 1470; ENRÍQUEZ FERNÁNDEZ, J.; HIDALGO de CISNEROS AMESTOY, C. y MARTÍNEZ LAHIDALGA, A.:"Colección Documental del Archivo
} 


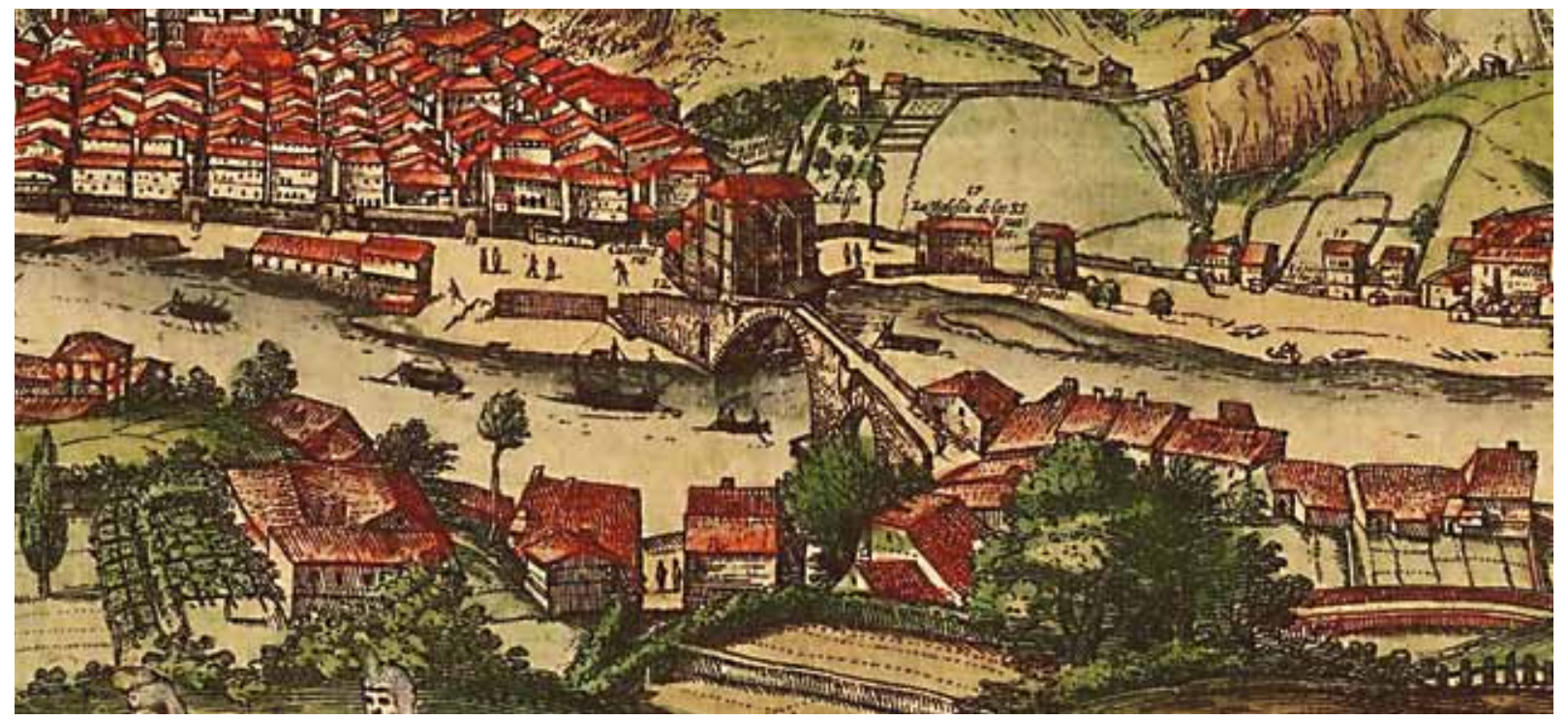

Detalle del puente de San Antón, único existente sobre la ría de Bilbao en el s. XVI. Civitates Orbis Terrarum 1575.

A petición del concejo, los Reyes conceden en abril de 1475 salvoconducto a los vecinos de la villa para que puedan comerciar libremente en todos los puertos y mercados públicos del reino ${ }^{425}$, y también a petición de dicho concejo, se prohíbe en mayo de 1476 a Juan y Lope de Salazar y otros vecinos de Portugalete que cobren portazgo a los vecinos de Bilbao426.

\section{El puente de San Antón}

Aunque el asentamiento de Bilbao se produjo junto a un vado natural sobre la ría utilizable con marea baja, muy pronto existió la necesidad de construir un puente que comunicase de manera segura y estable ambas orillas, pero las necesidades de la navegación, obligaban a realizar un puente con un arco de cierta altura para permitir el paso de las naves. Un primer puente se construyó hacia 1325 y así queda reflejado en la panorámica de Bilbao realizada en 1575, que presenta el puente de San Antón con dos arcos y un aliviadero en su orilla derecha. Su tablero estaba fuertemente alomado como consecuencia de la gran flecha del arco mayor ${ }^{427}$. Este puente era vital para el comercio de la villa, porque además del tráfico cotidiano entre las dos orillas, lo utilizaban los caminos a Castilla tanto de Valmaseda como de Orduña. Fue tan importante para la villa, que quedó reflejado en su escudo. Dicho puente se utilizó además para controlar las cargas que entraban y salían de la villa. En 1485 los vecinos debían asistir en el puente "por donde entran las tales bestias, por turno dos cada semana, los cuales tienen libro y razon donde se asientan las tales bestias que entran con carga,

Histórico de Bilbao (1300-1473)": 1999: doc. 98.

425 A. M. Bilbao/ Cajón 4, reg. 2, noำ (1)/Valladolid, 10 abril 1475; ENRÍQUEZ FERNÁNDEZ, J.; HIDALGO de CISNEROS AMESTOY, C.; MARTÍNEZ LAHIDALGA, A.: "Colección Documental del Archivo Histórico de Bilbao (1473-1500)".: 1999: doc. 103.

426 A. M. Bilbao/ Cajón 37, reg. 6/Valladolid, 6 mayo 1476; ENRÍQUEZ FERNÁNDEZ, J.; HIDALGO de CISNEROS AMESTOY, C. y MARTÍNEZ LAHIDALGA, A.: "Colección Documental del Archivo Histórico de Bilbao (1473-1500)".: 1999: doc. 104.

427 "Civitates Orbis Terrarum". Georg Braun coordinador. Georges Hoefnagel dibujante. Franz Hogenberg grabador. Editado en 6 volúmenes entre 1572 y 1617. 
para dexar que salgan con carga...". Se exigía que solo se podía sacar carga si previamente se habían introducido mantenimientos de trigo y cebada 428 .

El concejo de Bilbao dice a Juan Núñez de Lara, señor de Vizcaya y alférez del Rey, que debían "faser muy grande costa en adobar la puente que es y en Bilbao", y no lo podían realizar si no les hiciese alguna merced sobre alguna renta para construirlo. Doña María, mujer de Juan Núñez y señora de Vizcaya, autoriza en febrero de 1325 para su reparo y mantenimiento, el cobro a cada acémila mayor cargada que por él pasare de dos dineros nuevos, y a las bestias asnales un dinero nuevo. Y si alguno de los que llevaren las s acémilas y bestias no lo quisiere pagar, manda al concejo, alcaldes y a su preboste que les prendan hasta que lo paguen ${ }^{429}$. Alfonso XI en junio de 1334, concede al concejo la renta del puente por 5 años para "la lauor de la çerca de la dicha villa", hasta 1.500 mrs. cada año430. En noviembre de 1476, y a petición del concejo, se concede un proveimiento al preboste de la villa para que en lo sucesivo no cobre pontazgo a sus vecinos ${ }^{431}$.

El concejo de Bilbao envió petición a los Reyes diciendo que hacía más de 100 años se dieron privilegios a Bilbao para que cobrase el pontaje para los reparos del puente, y que por ellos se mandaba al preboste prendar a los que no lo pagaren, pero por ser el oficio de preboste perpetuo y no haber estado suspendido, el preboste pasado y Juan Martínez de Bedia curador del actual preboste, les tiene usurpado el dicho pontaje. Dicen que muchas veces le han requerido para que se les restituya el oficio con las rentas que ha llevado y que no lo ha querido hacer, respondiéndoles que él no llevaba pontaje sino portazgo, siendo notorio que Bilbao tiene privilegios especiales para que en la villa no haya portazgo alguno. Pedían que se mandase a Juan Martínez y al preboste Ochoa Ortiz de Bedia, que desembarguen dicho pontaje y lo restituyan con todo lo que ha rentado. Los Reyes mandan en julio de 1479 al corregidor que determine lo que hallare por derecho de acuerdo con el fuero 432 .

Nada se hizo, porque en 1484 el concejo volvió a quejarse antelos Reyes, porque aunque poseían el derecho de cobrar el pontaje de Bilbao, por privilegios y concesiones reales y de los señores de Vizcaya, por los edificios y reparos del puente de la villa, y confirmados y por los dichos Reyes, el preboste de Bilbao, "ynjusta e non deuidamente, en algunos tienpos pasados les

428 ORTEGA y GALINDO de SALCEDO, Julio: "Bilbao y su Hinterland". p. 50/ 1485.

429 A. G. S./ Registro General del Sello, VI-1485, fol. 14/ Oña, 24 febrero 1325 y Córdoba, 13 junio 1485; ENRÍQUEZ FERNÁNDEZ, J.; HIDALGO de CISNEROS AMESTOY, C.; MARTÍNEZ LAHIDALGA, A.: 2003: doc. 418; A. M. Bilbao/ Cajón 8, reg. 1, no 1-caja 199 (fol. 55V)/ Lerma, 24 febrero 1325; ENRÍQUEZ FERNÁNDEZ, J.; HIDALGO de CISNEROS AMESTOY, C. y MARTÍNEZ LAHIDALGA, A.: "Colección Documental del Archivo Histórico de Bilbao (1300-1473)".: 1999: doc. 16; GONZÁLEZ, T.: 1829: t. I. 395-396.

430 A. M. Bilbao/ Cajón 1, reg. 1, no 11-Pergaminos 11/ Bermeo, 25 junio 1334; ENRÍQUEZ FERNÁNDEZ, J.; HIDALGO de CISNEROS AMESTOY, C. y MARTÍNEZ LAHIDALGA, A.:"Colección Documental del Archivo Histórico de Bilbao (13001473)".: 1999: doc. 12

431 A. M. Bilbao/ Cajón 4, reg. 2, nํ55/Toro, 14 noviembre 1476; ENRÍQUEZ FERNÁNDEZ, J.; HIDALGO de CISNEROS AMESTOY, C. y MARTÍNEZ LAHIDALGA, A.: "Colección Documental del Archivo Histórico de Bilbao (1473-1500)".: 1999: doc. 117.

432 A. G. S./ Registro General del Sello, VII-1479, fol. 68/ Trujillo, 17 julio 1479; ENRÍQUEZ FERNÁNDEZ, J.; HIDALGO de CISNEROS AMESTOY, C.; MARTÍNEZ LAHIDALGA, A.: "Archivo General de Simancas. Registro General del Sello. Vizcaya (1478-1479)".: 2002: doc. 112; A. M. Bilbao/ Cajón 14, reg. 3, no2-Caja 241, reg. 1, no 2/ Trujillo, 17julio 1479; ENRÍQUEZ FERNÁNDEZ, J.; HIDALGO de CISNEROS AMESTOY, C. y MARTÍNEZ LAHIDALGA, A.: "Colección Documental del Archivo Histórico de Bilbao (1473-1500)".: 1999: doc. 138 
[ha] leuado el dicho derecho de pontaje deziendo que es derecho perteneçiente [a su] ofiçio de preuostad", y en todo este tiempo dicen que lo cobrado podía rentar unos $300.000 \mathrm{mrs}$. Pedían que como ellos habían edificado el puente y habían gastado en hacerlo y repararlo más de 20.000 florines de oro cada año, se mandase al preboste que les pagase los $300.000 \mathrm{mrs}$. Los Reyes mandan en julio de 1484 al preboste que pague al concejo de Bilbao los dichos 300.000 mrs. , o en su defecto acuda al Consejo a responder y alegar todo lo que considere433. El concejo de Bilbao sigue luchando por sus derechos, por lo que suplicó a los Reyes la confirmación de la carta de privilegio de 1325 y la merced en ella contenida, accediendo estos en junio de 1485 por hacer bien y merced, y confirman la dicha carta de privilegio incorporada y todo lo en ella contenido, a la villa de Bilbao y a sus vecinos y moradores, y mandan que les sea guardada en todo 434 .

Durante el siglo XVI el concejo debió realizar continuas reparaciones del puente, y la inundación de 1593 afectó de manera grave a su pilar central, haciendo peligrar la estabilidad del edificio. A pesar de la urgencia necesaria, el concejo tardó 5 años en encargar las obras al cantero Pedro de la Torre 435 .

\section{El Consulado de Bilbao}

Desde el nacimiento de la villa, el comercio exterior del puerto de Bilbao estuvo monopolizado por los mercaderes burgaleses, que obtenían una salida al mar y las naves necesarias para su comercio. Ya en el siglo XV, cuando Bilbao comienza a despegar e inicia su desarrollo económico, los maestres de naves y comerciantes bilbaínos van haciendo nuevos planteamientos para obtener autonomía y evitar la tutela burgalesa. Comienza una competencia entre Bilbao y Burgos por lograr la hegemonía comercial con los puertos del Atlántico, llevando Burgos la delantera con la creación de su Consulado en julio de 1494, como Universidad de mercaderes, algo que consolidaba su situación y cuya jurisdicción incluía a todos los mercaderes de Castilla, incluidos los bilbaínos. Pero aunque supuso un contratiempo para estos, muy pronto lograron la creación del Consulado o Universidad de Bilbao, por real Cédula de 22 de junio de 1511. En esta nueva situación se produjeron continuos roces y enfrentamientos entre ambos Consulados por diversos motivos, y mientras en la segunda mitad del siglo XVI el Consulado burgalés comenzó un lento e irreversible declive, el de Bilbao, prosiguió de una manera sostenida como un instrumento capaz de favorecer el desarrollo mercantil y económico de la villa.

En abril de 1517 el fiel, diputados, maestres y mercaderes de la Universidad de Bilbao, para el bien de dicha Universidad, y para que los privilegios, exenciones y franquezas de la villa sean mejor guardados y los negocios y su trato y mercaderías anden mejor, hicieron ordenanzas aprobadas por los Reyes en 28 de enero de 1518, que mandan que se guarden y

433 A. M. Bilbao/ Cajón 14, reg. 3, nº 3-Caja 241, reg. 1, nº 3/Valladolid, 13 julio 1484; ENRíQQUEZ FERNÁNDEZ, J.; HIDALGO de CISNEROS AMESTOY, C. y MARTÍNEZ LAHIDALGA, A.: "Colección Documental del Archivo Histórico de Bilbao (1473-1500)".: 1999: doc. 168.

434 A. G. S./ Registro General del Sello, VI-1485, fol. 14/ Oña, 24 febrero 1325 y Córdoba, 13 junio 1485; ENRÍQUEZ FERNÁNDEZ, J.; HIDALGO de CISNEROS AMESTOY, C. y MARTÍNEZ LAHIDALGA, A.: 2003: doc. 418; A. M. Bilbao/ Cajón 8, reg. 1, nº 1-Caja 119 (fol. 56r)/ Córdoba, 13 junio 1485; ENRÍQUEZ FERNÁNDEZ, J.; HIDALGO de CISNEROS AMESTOY, C. y MARTÍNEZ LAHIDALGA, A.: "Colección Documental del Archivo Histórico de Bilbao (1473-1500)".: 1999: doc. 172. 
cumplan en todo436. Mandan que todas las naos y carabelas de la Universidad de Bilbao que se cargaren en la ría y canal hasta la punta Galea para Inglaterra, Flandes, Bretaña, Francia y otras partes con lanas, hierros y otras mercaderías que al fiel han de pagar por la licencia para su carga, están obligados a contar averías ante el dicho fiel y pagar para las necesidades de la Universidad una blanca por tonelada. Lo que deben pagar de cada producto, es:

\begin{tabular}{|l|l|}
\hline $\begin{array}{l}\text { Por cada saca de lana y costal de peletería, caja de azúcar, guantes, quintal } \\
\text { de pimienta u otra pieza de mercaderías semejante de la Universidad }\end{array}$ & un mr. \\
\hline Por cada quintal de hierro que se cargare a la Universidad & 1/2 blanca \\
\hline Por quintal de acero, una blanca & una blanca \\
\hline $\begin{array}{l}\text { Por cada fardel de Flandes, tanto de paños como de lienzos, holandas, mer- } \\
\text { cerías, tapicerías, barril o cofre u otra cosa semejante de hasta media carga }\end{array}$ & $5 \mathrm{mrs}$. \\
\hline $\begin{array}{l}\text { Por cada roldana de cobre de la Universidad u otra roldana semejante de } \\
\text { otras mercaderías y los barriles pequeños, en proporción }\end{array}$ & $5 \mathrm{mrs}$. \\
\hline $\begin{array}{l}\text { Por cada tonel de mercería de la Universidad y caja grande labrada de lien- } \\
\text { zos, armas, mercería o de cualquier otra mercadería }\end{array}$ & $10 \mathrm{mrs}$. \\
\hline La ropa de Londres de la Universidad por paño & un mr. \\
\hline Por pieza de cordelate & $1 / 2$ blanca \\
\hline Por pan de estaño & un mr. \\
\hline Por pan de plomo & una blanca \\
\hline Por las medias pipas de sebo & un mr. \\
\hline Por cada barril pequeño de sebo y de las otras mercaderías, al respecto & una blanca \\
\hline $\begin{array}{l}\text { Por la ropa de la Universidad que viene de Francia y Bretaña, por cada fardel } \\
\text { de lienzos blancos o crudos o por cada cesta de cardas, sacos o cañamazos }\end{array}$ & tres mrs. \\
\hline Por cada fardel paquete de cañamazas de la Universidad & dos mrs. \\
\hline Por cada olona de la Universidad & una blanca \\
\hline Por cada costal de regaliz de la Universidad & media blanca \\
\hline Todas las otras mercaderías que fueren o vinieren de la Universidad & en proporción \\
\hline Por cada fardel de media carga de papel de la Universidad & tres blancas \\
\hline
\end{tabular}

En las Juntas de Vizcaya de mayo de 1567 se trató acerca de la imposición real de dos ducados por saca que en el canal de Bilbao se cargan a las lanas, "lo qual por ser cosa de ynpusiçion", los señores del Regimiento, Tierra Llana y Villas acordaron, excepto la villa de Bermeo, suplicar al Rey que lo anulase. No obstante el dicho acuerdo se deberá suspender por ahora, pues no se habían valorado suficientemente las consecuencias que esto podría traer al Señorío437.

\section{C.- Bermeo}

Pedro Texeira dice que "En toda la costa deste señorio de Biscaya [no] ay luguar que represente antegüedad y grandeza como la uilla de Bermeo, siendo çercada de muro bien alto con sus torres y cubos, mostrando en lo que se estiende la çerca aber sido de grande poblaçion... Esta fundada esta villa de Bermeo en vna punta

436 A. M. Bilbao/ Consulado de Bilbao. Libro 450/ 3 junio 1512 y Bilbao, 11 diciembre 1520; ENRÍQUEZ FERNÁNDEZ, J.; HIDALGO de CISNEROS AMESTOY, C.; MARTÍNEZ LAHIDALGA, A.:"Archivo Foral de Bizkaia. Sección Notarial (14591520). Consulado de Bilbao (1512-1520)".: 2007: doc. 29.

437 A. J. R. B./ Actas de la Tierra Llana. t. I/ Bilbao, 10 mayo 1567. 
o recodo que la costa con vna ensenada ase, con que biene su puerto a quedar a la parte del leuante, teniendo en el dos muy costosos muelles capazes de muchos nauios. Dentro dellos fabrican algunos. El maior trato deste lugar es el de la pescaria"438.

La villa de Bermeo fue fundada hacia 1236 por Lope Díaz de Haro II y su mujer Urraca. Su puerto tuvo una posición hegemónica hasta principios del siglo XIV, por ser el único existente en este sector, capaz de comerciar con cierta entidad con las tierras de la fachada atlántica europea. Sin embargo, entre 1299 y 1327, surgieron una serie de competidores que provocaron su declive comercial sin posibilidades de recuperación, ya que en 1299 se refundó Plencia, en 1300 Bilbao, en 1322 Portugalete, en 1325 Lequeitio y en 1327 Ondarroa, lo que acabó con la posición que hasta esos momentos había ostentado Bermeo. Pero de todas las villas dichas, será Bilbao la que le causará un mayor perjuicio, al no poder competir con éxito con el dinamismo y pujanza bilbaínos, teniendo en cuenta además, que el embarque de las mercaderías en Bilbao suponía para los arrieros el ahorro de casi seis leguas o una jornada completa sobre el acarreo a Bermeo. Además, la carta otorgada a Bilbao en 1310, obligaba a ir por Bilbao a todo mulatero que fuese de Pancorbo a Bermeo por Orduña 439 .

\section{d.- Deva}

Pedro Texeira indica que el río Deva con una "no menos peligrosa barra, tiene en la orilla de la parte del oriente vna villa que tanbien llaman Deba, lugar abierto y de buena poblaçion, sin nesisitar de maior defença que de la dificultad de su barra y costa por ser conosido el peligro a los que a ella se arrimaren y yntentaren tomar"440.

La villa de Deva fue trasladada en 1343 al lugar que hoy ocupa, por privilegio de Alfonso XI con el nombre de Monreal de Deva, fecha en que recibió carta puebla y el fuero de Vitoria. Su desarrollo estuvo vinculado a la pesca y en menor medida al comercio, manteniendo cierta industria de ferrerías. El poco calado de su puerto cuando las naves ampliaron su tonelaje, redujeron paulatinamente su actividad mercantil.

A pesar de ser un puerto distante de Burgos, tuvo una cierta actividad en el siglo XVI como puerto de las lanas burgalesas. Un camino más largo, seguía el camino real de Burgos a Vitoria, continuaba por el alto de Arlaban, Mondragón y Vergara, y bordeando la margen derecha del río Deva llegaba hasta su desembocadura.

Encontramos testimonios de este comercio en las cuentas del Consulado de Burgos. Son dos pagos realizados en 1547 de fletes de naves con sacas de lanas. En 14 de junio se dieron 3.400 mrs. para "yr a ver los caminos de aqui a Portogalete y carros y mulateros y al despacho de las 9 naos que se afletaron 5 de Portogalete y 4 de Deua". En septiembre se le dieron en dos veces a Sebastián de la Moneda, vecino de Burgos, 4.080 mrs. que para "yr a negocios de la unibersidad, para yr a Sodupe e Amurrio, azer pasar los carros con sacas para Deua e Portogalete" 441.

\footnotetext{
438 PEREDA, F. Y MARÍAS, F.: 2002: 317.

439 ARÍZAGA BOLUMBURU, B. y MARTÍNEZ MARTÍNEZ, S.: 2006: 232-133.

440 PEREDA, F. y MARÍAS, F.: 2002: 316.

441 A. D. B./ R-3/ Libro de caja de la Universidad de Burgos/ Burgos, 1539-1549. "Libro de quentas de la Vnibersidad comenzado en dos de otubre de I.DXXXIX seyendo nonbrados por prior y consules los señores Juan de Castro rregidor. E Yñigo del
} 


\section{4.- EVOLUCIÓN HISTÓRICA DE LAS VÍAS DE COMUNICACIÓN ENTRE BURGOS Y LA COSTA}

En el norte peninsular y más concretamente en el espacio existente entre el sector central de la provincia de Burgos con la ciudad como su punto clave, y la franja costera del Cantábrico donde se ubican los puertos marítimos castellanos y vascos, las dificultades generales para el transporte se acrecentaban por las características del territorio, especialmente accidentado y con un clima de extremada dureza. Los tiempos invernales con la nieve, y los meses lluviosos con el barro, hacían difícilmente transitables los caminos, obligando a realizar grandes esfuerzos a sus usuarios para superar unos peligros reales. Los meses veraniegos eran especialmente secos y calurosos, lo que tenía una especial incidencia en los pastos que las bestias necesitaban para su manutención. Además, las actividades agrícolas influían en el transporte, al ocupar en temporadas fijas del ciclo anual las caballerías necesarias para el transporte, sobre todo en los meses de invierno para arar y sembrar y en verano para la siega 442 .

Entre la costa y la Meseta se suceden sin solución de continuidad páramos, valles, desfiladeros, ríos a veces torrenciales, puertos y portillos de montaña y fuertes pendientes, que han condicionado los trazados de sus caminos y convierten la circulación de personas y mercaderías en una permanente superación de obstáculos, que retrasaban y encarecían el desplazamiento, al tiempo que tales características no facilitaban la utilización de otros medios de transporte más eficaces, y obligaban a sostener un sistema mucho más lento, incómodo y costoso, como era el realizado a lomos de caballerías que por sus propias limitaciones, creaba dificultades para el desplazamiento de grandes cargas.

Las vías de comunicación utilizadas desde la Edad Media para poner en contacto a la ciudad de Burgos con los puertos del Cantábrico, son además de un conjunto de importantes infraestructuras, uno de los principales soportes en los que se basó la vida y riqueza de las tierras relacionadas con dicha ciudad durante siglos, al ser utilizadas como cauce principal de su próspero comercio, además de garantizar una comunicación hegemónica en el norte castellano, como consecuencia de la favorable situación geográfica y potencia económica y política. Por ellas circularon no solo personas y mercancías, sino también se difundieron ideas y corrientes culturales y artísticas, y todo ello facilitó la prosperidad de la ciudad y de su amplia zona de influencia durante el largo periodo que canalizó en las dos direcciones la mayor parte del comercio castellano. No obstante, esta relación intensa y prolongada no fue la consecuencia natural de la difícil situación geográfica de ambas partes. Esta no permitía resolver de manera ventajosa el problema del transporte para el comercio interior, ni reportaba a priori mejoras económicas, al obligar a realizar el acarreo a lomos de caballerías, no permitiendo la utilización de carros en la mayor parte de sus recorridos.

Espital e Françisco de Maluenda donde se asentaran los devdores y acredores que tocan a la Vnibersidad de que fue thesorero de la dicha Unibersidad Andres Nuñez de Aragon". 
La meseta de Castilla y León forma una amplia región natural, flanqueada por tres sistemas montañosos al Norte, Este y Sur (la cordillera Cantábrica, la cordillera Ibérica y el sistema Central), que forman un arco de C invertida desde el Noroeste al Suroeste, que dejan una única salida natural al mar por el Oeste, sin barreras naturales y con unos desniveles suaves en un terreno muy propicio para el tráfico carreteril siguiendo el curso del Duero, verdadero eje vertebrador de la Meseta y que la atraviesa por su parte media, hasta llegar a Oporto, "el puerto", llamado así por ser desde su nacimiento el verdadero puerto natural y punto de contacto entre las amplias tierras del interior peninsular y el océano Atlántico. La posición geofísica de Oporto le tenía reservado un gran destino como puerto y cabeza de una de las regiones naturales más extensas y prósperas de la Península, para que a través del mismo se canalizasen las relaciones mercantiles de la Meseta con el mundo exterior ${ }^{443}$. Pero la Historia condicionó esta salida natural cuando se alzaron unas firmes barreras de carácter político, al interponerse en este camino una frontera que desde 1139 marcaba los límites entre el reino de Castilla y el de Portugal, lo que impedirá en el futuro cualquier actividad mercantil y comunicación segura y estable por esta vía, -el corto periodo desarrollado entre 1580 a 1640 en que Portugal pasó a depender de la Corona española, fue escasamente relevante, principalmente por corresponder ya a un periodo de intensa actividad bélica y al declive del próspero comercio burgalés-, lastrando el propio desarrollo de Oporto al reducir de manera considerable su hinterland y obligando a su vez a la Meseta a buscar otros puertos por donde dirigir su comercio internacional. Como indica Palacio Atard, Castilla y Oporto se desconocieron y cortaron de manera radical las vías naturales que la naturaleza ofrecía dándose la espalda 444 .

Castilla, sobre todo la Castilla de la Submeseta norte, se vio obligada a buscar desde los primeros momentos de su desarrollo mercantil, otras vías alternativas para canalizar su tráfico comercial con garantías. Aunque sí existieron importantes relaciones mercantiles con Italia a través de los puertos mediterráneos, y se utilizó asimismo el puerto de Sevilla para el comercio con América, estos tráficos fueron en comparación con los establecidos a través del Cantábrico ciertamente mucho menos relevantes para la exportación de los productos castellanos, ya que las distancias que era necesario salvar hacían menos competitiva cualquier exportación desde unas tierras tan lejanas, al gravar de una manera desmesurada sobre la mercadería acarreada los costes de su transporte, al tiempo que aumentaba los días del desplazamiento, con el consiguiente deterioro de la mercadería. Por ello, los productos laneros, al menos en el caso del puerto de Sevilla, procedían básicamente de las dehesas de las serranías andaluzas, que eso sí, estaban en parte controladas por los burgaleses 445 .

Por su parte, todo puerto que aspire a ser importante necesita para su desarrollo poseer un hinterland adecuado, lo más extenso y ramificado posible, lo que le permitirá constituirse como un centro básico para la canalización de productos y transeúntes, provenientes o destinatarios no solo de su comarca más inmediata, sino también y esto es

443 ORTEGA Y GALINDO de SALCEDO, J.: 1951: 72

444 PALACIO ATARD, V.: 1960: 19-20. 


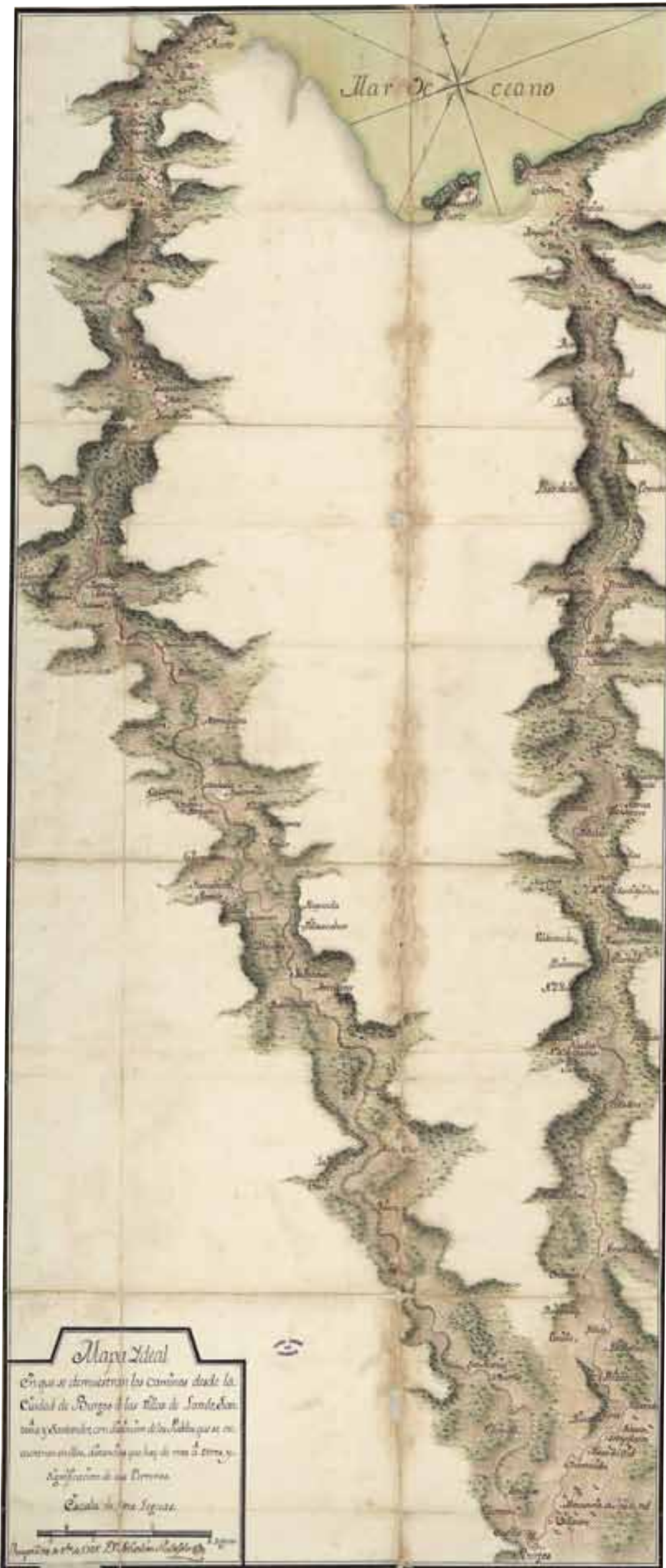

Mapa de 1748 con los caminos desde Burgos a Laredo, Santoña y Santander por Reinosa (A. G. S. MPD 21,055). 
lo más importante, de las tierras del interior. Y el centro estratégico y punto neurálgico del hinterland de los puertos cantábricos que mencionamos, era la ciudad de Burgos y la amplia zona que en los siglos XV y XVI dependía de ella, por lo que los intereses de los navieros, mercaderes y transportistas, siempre se decantaron por potenciar este tráfico comercial de una manera lo más adecuada y fluida posible, principalmente a través de la mejora de los caminos, puentes, cays portuarios y demás infraestructuras, como factor clave para el crecimiento de sus puertos, sus núcleos urbanos y su propia economía.

Aunque las distancias desde Burgos a los puertos marítimos más cercanos a la ciudad no eran considerables, ya que existían $185 \mathrm{~km}$ a San Vicente, $180 \mathrm{~km}$ a Santander, $150 \mathrm{~km}$ a Laredo, $153 \mathrm{~km}$ a Castro-Urdiales y $180 \mathrm{~km}$ a Bermeo. Asimismo a Bilbao $157 \mathrm{~km}$ por Valmaseda, $145 \mathrm{~km}$ por Oña o $150 \mathrm{~km}$ por Orduña, distancias todas ellas que no eran excesivamente exageradas para un tráfico arrieril o carretero que discurriese por tierras llanas y cómodas, la realidad de este espacio intermedio era muy diferente. Entre Burgos y todos estos puertos de mar, no solo se extendía una cordillera agreste como la Cantábrica, sino que se debían atravesar páramos colapsados por la nieve en invierno, con unas altitudes por encima de los $1.000 \mathrm{~m}^{446}$ seguir por desfiladeros que con cada crecida de los ríos deterioraban o cortaban los caminos y destrozaban los puentes, cruzar el importante curso del río Ebro, los montes Obarenes, puertos de montaña abruptos, etc. El relieve y la hidrografía son en este sector ciertamente muy complicados y muy diferentes a los de la propia cuenca del Duero, mucho más suave y amable.

Entre el elevado número de caminos que en dirección básicamente Sur-Norte comunican la ciudad de Burgos, y con ella una amplia zona de Castilla, con el mar Cantábrico, destacan cuatro, entre otros muchos, que son los que a lo largo de los siglos canalizaron la mayor parte del tráfico, y salvo algunos tramos del de Valderredible, han persistido hasta nuestros días:

$1^{\circ}$. El camino de Burgos a Santander por Reinosa.

$2^{2}$. El camino de Burgos a Santander por Valderredible y el puerto de Corconte.

$3^{0}$. El camino de Burgos a Laredo por Medina de Pomar o Villarcayo, con un ramal en Bercedo para llegar por Valmaseda a Castro-Urdiales o Bilbao.

$4^{\circ}$. El camino de Burgos a Bilbao por Pancorbo y Orduña.

A estas cuatro vías, debemos añadir otros tres caminos que tuvieron también cierta importancia, y aunque fueron utilizados de manera continua, lo fueron con distinta intensidad, decayendo en beneficio de los otros caminos a Santander o Bilbao ya mencionados:

$1^{\circ}$. El camino de Burgos a Santander por Rampalay.

2‥ El camino de Burgos a Bilbao por Oña y puerto de Angulo.

3ํ․ El camino de Burgos a Bilbao por Briviesca, Frías, Herrán y Orduña.

Todos ellos, salvo el de Reinosa, solo podían ser utilizados para el transporte por recueros o mulateros, ya que no eran aptos para carros -salvo en cortos tramos de su recorrido- y mucho menos para carretas, como consecuencia según se ha indicado, de lo agreste de sus recorridos, la desigualdad en sus desniveles, los deficientes firmes y el precario 
mantenimiento que recibían. En 1502 los representantes de la Universidad de los Mercaderes de Burgos afirmaban sobre el camino de Burgos a Laredo "que todos los caminos se caminan syn calçadas"447, es decir, que la mayor parte del firme de dichos caminos era de tierra, y barro cuando llovía.

Como resumen de lo dicho, insertamos parte de un informe realizado para el Rey en 1832 referido a Castilla, que aunque muy tardío, resume de manera real lo que fueron las comunicaciones en la zona que estudiamos y lo convierte en un documento válido incluso para los siglos XV y XVI. Indica que "si sus comunicaciones con la costa del norte hubieran estado espeditas, en términos de que llegasen á ella los frutos del interior, sin el considerable recargo que por falta de buenos caminos les ha alejado de la concurrencia en los mercados extrangeros, y aun de los nuestros en la parte meridional y occidental de la península: entonces icuan distinto sería el aspecto que presentase! No habria afectado, como sucedió mas de una vez, la tierna sensibilidad del Rey nuestro señor cuando al viajar por este pais en 1828 , le vio en parte desierto..." 448 .

La historia de estas vías es el resultado de una lucha constante y dura para superar las difíciles circunstancias que provocaban las adversas condiciones de la zona. Los continuos contratiempos y percances provocados por la climatología en una zona de áspera orografía, se debían resolver con una gran precariedad de medios. Los arrieros debían superar un conjunto de inconvenientes y problemas para hacer llegar sus cargas al destino, soportando además las condiciones climatológicas de una zona caracterizada por la extrema dureza de dichas condiciones. Por si esto fuera poco, la infraestructura del alojamiento en ventas y mesones era muy precaria, y los mulateros debían acomodarse en unos espacios, cuando los había, muy pequeños e incómodos obligados por las tormentas, interrupciones de los caminos o simplemente para pernoctar, teniendo en cuenta que estos espacios, a veces no podían dar cabida a una cantidad numerosa de tales mulateros. Estos profesionales, con unos medios tan insuficientes, son los que sostuvieron un tráfico importante y rentable como era el de la lana, y formaron el soporte de una cadena que impulsó la prosperidad de los mercaderes burgaleses y por ende, del gran desarrollo que la ciudad de Burgos experimentó en los siglos XV y XVI.

Los firmes y trazados viarios eran muy deficientes. No obstante, las cuencas y cursos fluviales sirvieron siempre como soportes básicos de la red caminera, aunque los pasos estrechos y sin apenas espacio para establecer sólidos cimientos, dejaban los caminos a merced de los periódicos "andiluvios" e inundaciones. Las altas posibilidades de accidentes o de interrupción del camino, tanto por daño o desaparición de puentes arrastrados por las aguas, como por los cortes en los sectores de los caminos encajados en los desfiladeros, creaban una gran inseguridad e incertidumbre con pérdidas o deterioros de mercancías, cuando además de las riadas muchas veces violentas, grandes sectores de los caminos se convertían en auténticos lodazales que dificultaban sobremanera las comunicaciones, además de la presencia de la nieve que obligaba a cerrar los puertos de montaña o enmascaraba los trazados camineros 449 .

447 A. G. S./ Registro General del Sello, VIII-1502, fol. 394/ Toledo, 27 agosto 1502.

448 ANÓNIMO: "Memoria sobre el origen del Camino de Burgos a Bercedo, mandado construir por Real Decreto de 20 de julio de 1828. Medios empleados al efecto y resultado que han producido, con un Apéndice en que se insertan varios documentos relativos al objeto". Burgos, 1832: 3.

449 LANZA GARCÍA, R.: 2010: 200-201. 
Las vías que estudiamos han constituido la red básica de caminos arrieriles y en menor medida carreteros, que desde la Edad Media hasta la irrupción del tráfico motorizado, han puesto en comunicación a la ciudad de Burgos con los lugares portuarios del Cantábrico. Estos caminos, en realidad como los de toda la península, permanecieron sin grandes labores de mejora durante siglos, si exceptuamos los pequeños trabajos de mantenimiento que en general realizaban los vecinos de las localidades aledañas, con motivos especiales como los viajes reales o provocados por acontecimientos singulares, recibiendo eso sí actuaciones puntuales en los casos de graves alteraciones e impedimentos en su tráfico, ocasionados por deterioros catastróficos que en general, se llevaban a cabo después de un largo periodo de tiempo y de complejos procesos burocráticos.

Desde los tiempos medievales los caminos entre la Meseta castellana y los puertos de la costa cantábrica relacionaron dos sociedades y mundos diferentes, a veces antagónicos pero que poseían intereses comunes y necesidades complementarias. Si unos tenían los puertos de embarque, los otros disponían de las mercaderías que se debían embarcar, y otros a su vez poseían medios para desplazar y comercializar los productos que llegaban o salían de esos puertos. Además, a una escala interna, ambas zonas poseían una economía diferente, ya que si el norte era deficitario en abastos y excedentario entre otros artículos en productos del mar como la pesca, el interior solventaba esas carencias con sus excedentes en cereales y otros mantenimientos.

Hasta el siglo XIII los caminos más importantes del norte peninsular tenían una dirección Este-Oeste, que tras entrar en la península por Irún, iban por Vitoria y Burgos o bien tras atravesar los Pirineos por Roncesvalles o Somport, iban por Logroño y Burgos hacia el Oeste de la Península, enlazando en Burgos o Logroño con el eje que seguía la depresión del Ebro hacia el Mediterráneo. Esta vía coincide en parte con la del Camino de Santiago, que por la franja sur de la Cordillera Cantábrica articulaba todo el espacio comprendido entre esta y el valle del Duero. Las vías que desde el Camino Jacobeo enlazaban con el Cantábrico tenían un carácter secundario, ya que la costa era un lugar marginal. Sin embargo, a partir de dicho siglo el espacio costero constituirá la base fundamental que utilizará una Castilla en pleno auge comercial para realizar su actividad con la Europa Atlántica. La franja cantábrica abandona la posición que hasta ese momento había tenido para situarse en el centro de un eje que tendría sus extremos en Castilla y en los puertos atlánticos de Francia, Flandes e Inglaterra. Además, el entorno de las villas marineras era pobre y la franja entre la Cordillera Cantábrica y la costa también, por lo que era imprescindible para ellas contar con unas comunicaciones adecuadas con aquellas tierras que constituían su verdadero hinterland y granero, como eran la Tierra de Campos, la Bureba, la Rioja y la Cuenca del Duero. Estas tierras llanas y de gran producción agrícola y ganadera y sedes de algunas de las más destacadas ciudades y villas del reino de Castilla, serán las idóneas para facilitar a la población de la franja del Cantábrico su desarrollo comercial y urbano45o.

Aunque el tráfico marítimo desde Castilla se realizó a través de Santander, Laredo, Castro-Urdiales, Portugalete, Bilbao, Bermeo, Lequeitio y San Sebastián del Pasaje, los ca-

450 ARÍZAGA BOLUMBURU, B. y MARTÍNEZ MARTÍNEZ, S.: 2006: 44-45. 
minos entre Burgos y los puertos del mar canalizarán el tráfico más importante, que era el que se dirigía sobre todo a cuatro puntos principales: Santander, Laredo, Castro-Urdiales y Bilbao. Se evidenció una pugna permanente por lograr la hegemonía en este tráfico a través del Cantábrico, entre Bilbao y los puertos de Santander y Laredo y entre estos dos últimos, algo que se dejará sentir desde el mismo origen de este comercio. En 1555 la villa de Santander informaba al Consulado de Burgos que los caminos de Santander son abyertos y mejores, porque della se pueden sacar las mercaderias en carretas y carros y guiarse en ellos para todas las partes d'España, lo que no puede ser hecho de Vilbao ni Laredo syno por pie de mulo"451.

Se pretendió por parte de Santander, con el respaldo de la Monarquía, resolver la situación a su favor con la construcción en 1752 del nuevo camino de Santander por Reinosa, pero tal pugna se decantará a favor del puerto de Bilbao, cuando por iniciativa del Consulado y villa de Bilbao y el Señorío de Vizcaya, se abra un nuevo camino carretero en 1774 tras realizar una costosa intervención, acondicionando el antiguo camino por la peña de Orduña. El intento por reactivar la comunicación con Laredo al construir el nuevo camino de Burgos a Bercedo en 1833, llegará tarde y no conseguirá los objetivos pretendidos. Incluso la prolongación de este camino por el Valle de Mena y Valmaseda hasta Bilbao, no pudo sustituir al mencionado por Orduña.

Existen antecedentes de algunos de estos caminos, pero en realidad la vida comercial y consolidación de estas vías entre Burgos y los puertos del Cantábrico, comienza básicamente en el siglo XIII, ya que las fundaciones o concesión de fueros a las villas de Cantabria y Vizcaya corresponden al siglo XII y sobre todo al XIII ${ }^{452}$. Para conocer los antecedentes camineros de la zona, daremos un breve repaso a los que existían en la época romana, a pesar de que no tuvieron continuidad en la Edad Media.

\section{A.- VİAS ROMANAS}

El espacio geográfico objeto de nuestro estudio abarca un amplio territorio, de forma tendencialmente cuadrada, delimitado por la propia ciudad de Burgos en el centro de su base, la localidad de Aguilar de Campoo por el Oeste, al Este Miranda de Ebro y Orduña, y por el Norte la costa Cantábrica, e incluye, la mitad norte de la provincia de Burgos, la mitad Este de Cantabria y una franja vertical que engloba zonas del Oeste de las provincias de Álava y Vizcaya.

Es ciertamente un marco geográfico con una orografía e hidrología irregular y compleja con una sucesión de montañas, valles y páramos que en nada ha facilitado la construcción, asentamiento y conservación de sus caminos y, por ende, de unas vías de comunicación, como las romanas, que tenían como objetivo poner en contacto amplios y lejanos espacios, y cuyo trazado debía facilitar el transporte de un alto número de usuarios

451 A. M. S./ Leg. A-3, no 62/ 27 agosto 1555.

452 En 1163 Castro-Urdiales recibe el título de villa, primera de la costa cantábrica, en 1187 Santander y en 1199 Valmaseda, primera de Vizcaya. En el siglo XIII, en 1201 Laredo, en 1210 San Vicente de la Barquera, en 1220 Orduña, antes de 1236 Bermeo, en 1287 Lanestosa, en 1300 Bilbao, en 1322 Portugalete y en 1375 Miravalles. 
y mercancías, obedeciendo en muchos casos a intereses que procedían de una metrópoli tan lejana como Roma.

Los ingenieros romanos buscaban para sus trazados espacios llanos, evitando los grandes desniveles, y permitir así el discurso y acceso cómodo y ágil a núcleos o zonas de interés económico, estratégico, político, administrativo, minero o militar. Pero nuestro sector presenta, como se ha dicho, una topografía complicada que condicionó los trazados de las pocas vías que hemos podido identificar en él. Además, este sector, como consecuencia de su tradicional pobreza, presentó un escaso interés para los romanos al ser una zona de economía agrícola precaria y, sobre todo en el Norte, de economía ganadera desarrollada por pastores con un espacio interno surcado a lo sumo por escasos caminos de tierra ceñidos a los valles de los que apenas tenemos indicios 453 .

Es por lo que en este sector no se construyeron grandes vías de comunicación en época romana, aunque no podemos descartar la existencia en esos momentos de otros caminos que no teniendo las características técnicas de las vías, pudieron ser utilizadas por aquella sociedad para comunicar el interior con la costa siguiendo el curso de los ríos. Existen, no obstante, algunas vías confirmadas y otras apuntadas o defendidas por distintos autores. Estas, que no están admitidas de manera unánime, tienen en algunos casos una adscripción dudosa al mundo romano y, en otros, esa relación no se detecta de manera manifiesta o bien esas presuntas vías ni siquiera han existido.

Esta aproximación no pretende el estudio de las comunicaciones de nuestro sector en la época romana, ya que el objetivo de nuestro trabajo se centra en las comunicaciones de momentos muy posteriores, sino poner en común las aportaciones que han realizado los especialistas en este campo con el fin de comprobar el grado de pervivencia y proyección de esos caminos en el tiempo. Nuestro objetivo, en este caso, no es otro que el de conocer los antecedentes viarios del territorio que pretendemos estudiar, territorio que a través de los distintos avatares históricos ha condicionado en todas las épocas, como es obvio, el trazado y la existencia de los diferentes caminos. Las vías de comunicación se encuentran íntimamente relacionadas con cada momento histórico, que en definitiva es el que obliga a su nacimiento y condiciona su desarrollo o declive y muerte. Los caminos surgen cuando las circunstancias de cada momento los hacen necesarios obedeciendo a distintas leyes económicas, políticas, sociales, religiosas, militares, etc., y perviven siempre que siguen siendo útiles, aunque incluso hayan perdido el fin primitivo que justificó su nacimiento.

En relación con el tratamiento histórico de los caminos antiguos, y dentro de ellos de las vías romanas, quisiéramos hacer algunas matizaciones.

$1^{\circ}$. Cuando se habla de vías romanas se considera como tales todos aquellos caminos que han tenido una construcción realizada o mejorada en época romana por especialistas o ingenieros romanos que planificaban tanto su trazado como su morfología. Su desarrollo estaba en función del enlace de lugares distantes del Imperio y, por ello, su planificación obedecía a los intereses y necesidades de dicho Imperio.

2ํ․ Existían, no obstante, en esa misma época, como no podía ser de otra manera, otros caminos realizados en fechas anteriores o contemporáneas por los mismos romanos, 
o bien por los habitantes de los pueblos conquistados, que sin tener la estructura y planificación de aquellos también eran utilizados por dicha sociedad.

$3^{\circ}$. Partiendo de la premisa anterior, no todos los caminos existentes en la época romana y, por ello utilizados durante el Imperio eran vías romanas, aunque sí eran o podían ser caminos utilizados por los romanos.

$4^{\circ}$. Debemos considerar además, que las propias vías romanas no fueron un fenómeno monolítico ni congelado en un momento concreto, sino fruto de la presencia romana en Hispania durante más de cinco siglos. Desde la fase de la conquista, con unas necesidades claramente militares y de asentamiento y consolidación de la presencia romana, a la fase de paz y dentro de un esquema imperialista la explotación de los recursos económicos, hasta llegar a fines del siglo III cuando se inicia una inestabilidad política y crisis del poder central, se produjo la evolución y adaptación de esos caminos a cada momento o fase histórica con modificaciones, ampliaciones y mejoras ${ }^{454}$, sufriendo después un progresivo deterioro como consecuencia de su abandono, o mejor dicho, del abandono de su mantenimiento al perder el interés estratégico y económico que tuvieron con el Imperio. Después la situación de estas vías no concordó en muchas ocasiones con la articulación del nuevo espacio político y social nacido en la Edad Media455. De hecho existen evidencias de caminos creados de nuevo en fases medievales que abandonando las vías romanas siguen su misma dirección y destino, como en el caso del Camino de Santiago entre Burgos y Carrión, que discurriendo ambos caminos entre estas localidades, no coinciden en ningún punto de su trazado. Con el conocimiento de estas vías podremos comprobar en el periodo de nuestro estudio si, tras la caída del Imperio, han seguido vigentes y en qué grado.

\section{a.- Vías romanas documentadas y confirmadas}

Son aquellas vías documentadas por los itinerarios, por prospecciones de campo, fotografía aérea, documentos históricos, etc., que se encuentran localizadas en la actualidad en amplios tramos de sus desarrollos sin que tengan duda razonable.

\section{Vía de Hispania in Aquitania. Ab Asturica Burdigalam 456}

También llamada Vía Aquitana es la que el Itinerario de Antonio incluye con el número 34. Pone en comunicación Burdeos con Astorga, como su nombre indica, y es la más importante que existe en el sector objeto de nuestro estudio. Discurre por su límite sur, procedente de Veleia, por la Puebla de Arganzón, Burgueta, Estavillo, Arce Mirapérez (Deobriga), Miranda de Ebro, Ameyugo, Pancorbo, Vindeleia, Santa María Ribarredonda, Cubo de Bureba, Fuentebureba, Briviesca (Virovesca), Prádanos de Bureba, Castil de Peones, Monasterio de Rodilla, Alto de Rodilla (Tritium), Las Mijaradas, Hurones, Villayerno-Morquillas, Burgos, Villalonquéjar, Alto de Tardajos (Deobrigula), Las Quintanillas, Villanueva de

\footnotetext{
454 MUÑIZ CASTRO, J. A.: 1999: 297-301; BANUS y AGUIRRE, J. L.: 1983-1984: 88.

455 MARTÍNEZ GARCÍA, L.: 2004: 79.

456 ROLDÁN HERVÁS, J. M.: 1975: 99-101; ABÁSOLO ÁLVAREZ, J. A.: 1975: 73-129.
} 
Argaño, Sasamón (Segisamone), Padilla de Abajo, Melgar de Fernamental, Melgar-Osorno (Dessobriga), Osorno y prosigue hacia Astorga.

Esta vía que, según Abásolo, era la más importante de cuantas comunicaban por los pasos del Pirineo occidental Hipania y Gallia, ha sido tratada por un numeroso grupo de especialistas en caminería romana, por lo que no nos vamos a extender en identificarla. El tramo burgalés ha sido fijado con bastante precisión, salvo en algunos pequeños sectores que han permanecido discutidos hasta fechas recientes. Estos eran principalmente dos: el que se relaciona con el paso del Ebro en la zona de Miranda, y el tramo entre Hurones y Deobrigula, en el que Moreno Callo propone el paso del río Ebro junto a la ermita de la Nave al norte de Miranda457, y en el segundo sector mencionado García Conzález propuso su paso por el futuro centro de la ciudad de Burgos 458 .

\section{Vía de Italia in Hispanias 459}

Esta vía que el Itinerario de Antonino identifica con el número 1 y la hace proceder de Milán, discurre por Tarragona y Zaragoza y, en la zona que estudiamos, por Tormantos, Cerezo de Riotirón (Segisamunclo) y Briviesca (Virovesca) donde enlaza con la vía 34 ya mencionada, y desde aquí ambas comparten su trazado en dirección a Astorga. Comunicaba la costa mediterránea con Astorga a través de la vía natural del Ebro por Zaragoza y es, según Abásolo, la vía romana más antigua. El tramo burgalés está completamente identificado y se conserva en su mayor parte.

\section{Vía de Segisamone a Pisoraca}

Vía ya apuntada por Moreno Gallo en 2001, este autor la identifica y describe con detalle en 2012460. Procedente de Sasamón, discurre por el lugar donde se encuentra el puente no romano de Trisla, prosigue junto a Villamayor de Treviño, La Arroba e Hinojal de Riopisuerga y conecta en Herrera de Riopisuerga (Pisoraca) con la vía que arranca de aquí en dirección a Iuliobriga. Desaparecida en importantes zonas, se detectan, no obstante, varios tramos de su recorrido siguiendo una minuciosa observación desde perspectivas aéreas.

\section{Vía de Pisoraca a luliobriga}

Es la vía descrita por Iglesias y Muñiz ${ }^{461}$ y por Moreno Gallo462. Asciende por el valle del río Pisuerga y discurre entre Herrera de Riopisuerga (Pisoraca) y Retortillo (Iuliobriga). Tras cruzar el río Pisuerga por un lugar próximo al actual puente de Herrera, pasa por San Quirce de Riopisuerga, Villela, Santa María de Mave y Mave para cruzar de nuevo el

\footnotetext{
457 MORENO GALLO, I.: 2012. Recoge el tramo de Virovesca a Veleia con el no 17 , ya que desde Virovesca a Asturica se incluye en el 01

458 GARCÍA GONZÁLEZ, J. J.: "Del castro al castillo...". 1995: 71-166. Después lo incluye MORENO GALLO, en su "Descripción de la vía romana de Italia a Hispania en las provincias de Burgos y Palencia". 2001.

459 ROLDÁN HERVÁS, J. M.: 1975: 38-43; ABÁSOLO ÁLVAREZ, J. A.: 1975: 130-141; MORENO GALLO, I.: 2001; MORENO GALLO, I.: 2012. Identifica esta vía con el no 01 .

460 MORENO GALLO, I.: 2001. p. 94; MORENO GALLO, I.: 2012. Estudia esta vía y le da el nํㅜ․

461 IGLESIAS GIL, J. M. y MUÑIZ CASTRO, J. A.: 1992: 97-136.

462 MORENO GALLO, I.: 2012. Identifica la vía con el nํㅜ19.
} 
Pisuerga. Asciende por el valle de Monte Cildá atravesando el castro y pasa por Valoria de Aguilar, Aguilar de Campoo, Nestar, Cordovilla de Aguilar, La Quintana, Camesa-Rebolledo, Fombellida, Celada-Marlantes, collado de Peña Cutral ${ }^{463}$, Cervatos y llega a Retortillo donde se encuentra la ciudad de Iuliobriga.

\section{Vía de Iuliobriga a Portus Blendium464}

Es la prolongación de la vía Pisoraca-Iuliobriga, mencionada anteriormente, por el pasillo del río Besaya hasta llegar a Suances, también llamado San Martín de la Arena (Portus Blendium). La vía desde Iuliobriga discurriría por Requejo, Aradillos, Santiurde, Pesquera, Somoconcha, Mediaconcha, Pie de Concha, Cobejo, Molledo, Pedredo, Villayuso, Collado, Lobado, San Mateo, Barros, Las Caldas de Besaya, Yermo, Minas de Mercadal, Reocín, Puente San Miguel, Santillana y Suances, o bien desde Puente de San Miguel por Mijares, Queveda, Peredo e Hinojedo a Suances. Iglesias y Muñiz proponen que en un punto cercano a Yermo, existiría una bifurcación hacia Portus Victoriae (Santander) por Riocorvo, Barreda, Boo, Santa Cruz de Bezana y Santander. Según Iglesias y Muñiz 465 la vía completa, que algunos autores prolongan por el Sur hasta su conexión en Dessobriga con la vía de Hispania in Aquitania. Ab Asturica Burdigalam, es la ruta principal de las comunicaciones romanas que conducen a Cantabria y el más relevante de los caminos que enlazan la Meseta del Duero con los puertos cantábricos.

\section{Vía de luliobriga a Flavióbriga466}

Algunos autores hablan de la vía Pisoraca-Flavióbriga, incluyendo en ella la que hemos denominado vía Pisoraca a Iuliobriga y esta de Iuliobriga a Flaviobriga. Es una vía cuya existencia es defendida por muchos especialistas y con evidencias claras como son la presencia de varios miliarios en las zonas de Otañes y Cijano. Moreno Gallo sigue su trazado con precisión entre Castro-Urdiales y Bercedo, discrepando con la mayoría de los autores en el tramo comprendido entre Nava de Ordunte e Irús, ya que estos hacen discurrir la vía por el puente de Ranero -bajo las aguas del pantano de Ordunte-, Burceña y Arceo, atribuyendo algunos de ellos, los restos de calzada entre Arceo e Irús, claramente medieval o más bien moderna, a época romana. Moreno indica que este camino "solo responde al Camino Viejo de Nava de Ordunte, un camino de mulas empedrado, pero malo yestrecho como tantos otros de nuestra geografía que no conocieron los romanos"467. A partir de Bercedo hacia el Oeste, no obstante, han existido muchas dificultades para identificar su trazado.

Partiendo de Castro-Urdiales (Flaviobriga) seguiría por Samano, Santullán, Otañes y, tras entrar en Vizcaya por el puerto de Las Muñecas, continuaría por la localidad de Las

463 CEPEDA OCAMPO, J. J.: 2004: 391.402.

464 SOJO Y LOMBA, Fermín de: 1947: t. 83, 54-58; IGLESIAS GIL, J. M. y MUÑIZ CASTRO, J. A. :1990: 277-292; VEGA de la TORRE, J. R.: 1990: 431-442; IGLESIAS GIL, J. M. y MUÑIZ CASTRO, J. A.: 1992: 97-136.

465 IGLESIAS GIL, J. M. y MUÑIZ CASTRO, J. A.: 1992: 98.

466 SOJO Y LOMBA, F. de: 1947, t. 83, 49-50; ABÁSOLO ÁLVAREZ, J. A: 1975: 186-197; ESTEBAN DELGADO, Milagros: 1990. pp. 71-75; IGLESIAS GIL, J. M. y MUÑIZ CASTRO, J. A.: 1992: 163-170; DOMINGO MENA, S.: 2007: 183-185; MORENO GALLO, I.: 2012. El tramo Villasante-Flavióbriga, lo numera con el 27.

467 MORENO GALLO, I.: 2012: 3 y 10. Vía no 27. 
Muñecas, Mercadillo, San Martín de Carral, Avellaneda, Calzadilla y Valmaseda donde cruzaba el río Cadagua. Por su margen derecha penetraría en el Valle de Mena por el Berrón y proseguiría por Cayuela, Cijano, Tarriba, Cereceda, Ungo, La Presilla, Cerezo, Villasana de Mena donde cruza el Cadagua para continuar por la margen izquierda por Barrasa, Los Paradores de Taranco, Paradores de Concejo, Vivanco, Irús, Laya, El Cabrio y Bercedo. Desde aquí las localidades por las que podía discurrir la vía sin evidencias claras, serían Quintana de los Prados, sur de Espinosa de los Monteros, Barcenillas de Cerezo, Quintanilla del Rebollar, Quisicedo, Quintanilla-Sotoscueva, Vallejo, Entrambosríos, Pedrosa, y desde aquí, bien por Dosante, Cabañas de Virtus, Corconte, Lapoblación, La Costana, Villasuso, Medianedo y Horna, o bien por Virtus, Arija, Bimón, Llano, Las Rozas y Arroyo llegaría a Retortillo (Iuliobriga).

\section{Vía de Flaviobriga a Uxama Barca y Veleia}

Es la vía que Moreno Gallo468 identifica con el número 27 de su clasificación. Coincide con la vía de Iuliobriga a Flavióbriga entre Castro-Urdiales y Bercedo, y desde aquí, discurría por Villasante de Montija, El Ribero, Tabliega, Salinas de Rosío y Návagos, desde donde comienza una larga curva al norte de Oteo por Cabañes de Oteo, Calzada, San Llorente, Lastras de Teza, sur de Teza, norte de Fresno de Losa, Mambliga y Hozalla, y por el sur de Berberana entraba en Álava para llegar a Osma, Fresneda y cerca de Cárcamo conectar con la Uxama Barca romana. Desde aquí prosigue por Guinea, Barrón, Artaza, Escota, Ormijana, Subijana, Montevite, Ollavarre y Nanclares de la Oca y, coincidiendo con la carretera, cruza el río Zadorra para después bordear el meandro del río frente a Villodas y llegar a Veleia en Trespuentes, donde conecta con la vía de Hispania in Aquitania. Ab Asturica Burdigalam.

\section{Vía de Uxama Barca a Deobriga}

Otra vía romana ${ }^{469}$ pone en comunicación Vxama Barca y Deobriga siguiendo de manera aproximada la carretera A-2625 desde Fresneda en la vía descrita anteriormente y, por Villamaderne, discurre entre Espejo y Tuesta, Alcedo y Fontecha donde llega junto al río Ebro, sigue por su margen izquierda y pasa por Comunión. Conecta en La Nave con la vía de Hispania in Aquitania. Ab Asturica Burdigalam, donde dicha vía cruza el Ebro.

\section{b.- Vías romanas dudosas o inexistentes}

Algunos autores han apuntado y defendido ciertas vías que a nuestro entender son dudosas o inexistentes. Podemos citar las siguientes:

\section{Vía de Agrippa o camino costero}

Esta controvertida vía no tendría como función, por discurrir hipotéticamente con una dirección Este-Oeste por un estrecho pasillo limitado por el mar Cantábrico y la cordi-

468 MORENO GALLO, I.: 2012: Denomina la vía con el nํㅜ․ 27.

469 MORENO GALLO, I.: 2012: En la vía ํㅜ27, menciona esta vía, p. 39 y ss. 
llera Cantábrica, poner en comunicación importantes territorios ni inexistentes entidades de población, sino en todo caso la de conectar los establecimientos costeros de Portus Amanum-Flaviobriga (Castro-Urdiales), Portus Victoriae Iuliobrigensium (Santander), Portus Blendium (Suances) y Portus Veseiasueca (San Vicente de la Barquera), unidos con Ossaron (Oyarzun) por el Este y con Noega (quizá Cijón) y Bricantia (Cidadela, Sobrado dos Monxes) por el Oeste 470 . La existencia de esta vía ofrece grandes dudas, ya que presenta serias dificultades orográficas e hidrográficas para que, incluso en la alta Edad Media, existiese una vía por este pasillo si la consideramos no como una unión de pequeños tramos entre poblaciones, sino como un camino de largo recorrido 471 .

Sojo y Lomba ${ }^{42}$, entre otros autores, menciona la existencia de esta vía que, viniendo de la costa de Vizcaya, pasaría por Castro-Urdiales y seguiría junto a la costa hasta encontrarse con la ría de Oriñón y río Agüera, donde indica dicho autor que aunque no puede precisar el punto donde la vía cruzaba la ría, "el paso romano debió ser por barca seguramente". Por Villaviad y el alto de Seña llegaría a Colindres el Viejo y a la ría de Treto, que según el autor es "punto seguro de la vía" y pasaría en barca la citada ría del Asón, paso que "debió de estar defendido por una torre". Después por Adal, Cicero, Bárcena de Cicero, Gama, Ambrosero, Beranga, Praves, Anero, Término, Hoznayo y Bosque Antiguo, cruzaría el río Miera en barca por el barrio de Vallabarca y más tarde por Puenteagüero a más de dos km al Norte y por Orejo, salvando una zona de marismas, pasaría por Heras, Santiago de Heras y llegaría a Solía. Pasada la ría de Solía por el puente homónimo473, el autor indica que existía "una bifurcación romana bien comprobada". Uno de los ramales iría rodeando el Ponzón de la Dolores y, por Escobedo, pasaría el río Pas en Arce y seguiría por Oruña, Rumoroso y Polanco para llegar a la barca de Barreda y cruzar el río Saja aguas abajo de su entronque con el Besaya. El otro ramal por Parbayón y Renedo, donde cruzaría el río Pas, seguiría por Vioño y Zurita hasta juntarse con el otro ramal en el mismo paso de Barreda. Después por Viveda y Queveda seguiría por Santillana, Viallán y Oreña, Caborredondo, Toñanes, Cóbreces, Ruiloba, La Concha y por Comillas seguiría ceñida a la costa cruzando las rías de la Rabia, San Vicente de la Barquera, Tina Menor y Tina Mayor para entrar en Asturias. Solana pone en duda la existencia de este camino por considerar más lógica la existencia de uno más al interior "donde los ríos tienen menos caudal y son más fáciles de vadear" 474.

Milagros Esteban e Iglesias y Muñiz 475 indican que esta vía es de las "más controvertidas dentro de las investigaciones sobre las red viaria hispanorromana", y añaden que la inexistencia de hallazgos arqueológicos viarios y las referencias de los documentos medievales o el Anónimo de Rávena no permiten precisar su existencia, ya que ninguno de los topónimos ubicados entre Ossaron y Bricantia pueden ser relacionados con esta pretendida vía. Añaden que "se carece de argumentos explicativos que coadyuven a demostrar la existencia y génesis romana de la ruta

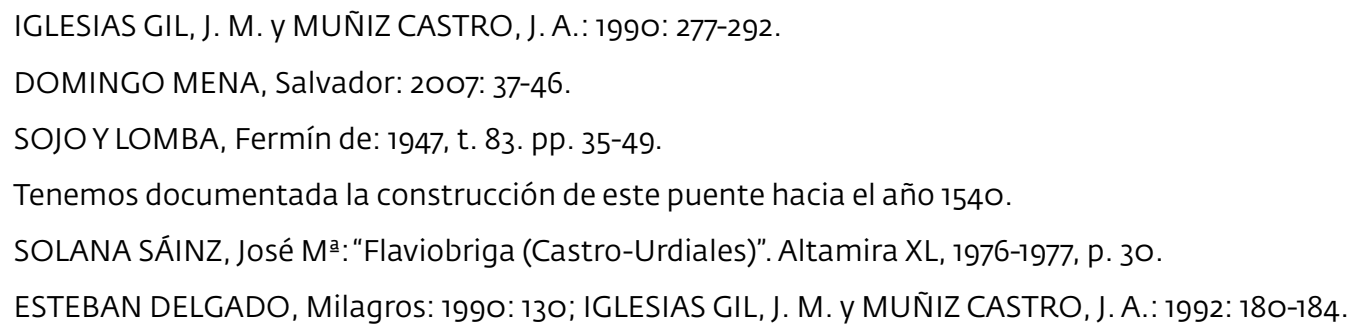


cantábrica". Solo en el recorrido cántabro de esta vía, debería cruzar o vadear 11 rías con sus correspondientes marismas: Oriñón (Agüera), Limpias, Rada, San Salvador, Solía, Mogro (Pas), San Martín de la Arena (Saja), La Rabia, San Vicente, Tina Menor y Tina Mayor y cuatro ríos con cierto cauce: Agüera, Miera, Pas y Saja-Besaya, además de innumerables arroyos y rayas de agua. También debía franquear varios pasos montañosos en los que la vía se encajonaría en el terreno: Candina, Jesús del Monte y Pesués, entre otros. Todas estas dificultades orográficas dificultaban sobremanera la existencia de cualquier camino o vía en estas fechas, máxime cuando tenían la posibilidad de comunicar los puertos por mar utilizando navíos. En resumen, concluyen que "resulta problemático considerar viable la existencia de una ruta costera cantábrica bajo la óptica de una vía romana".

\section{Vía Sasamón-Amaya}

Esta hipotética vía cuya existencia deduce Abásolo476 por el hallazgo del puente de San Miguel junto a Sasamón que califica como romano, por la necesidad de comunicar las dos ciudades próximas y por la comprobación en fotografía aérea, discurriría desde Sasamón por Tapia, Sandoval de la Reina y Peones para llegar a Amaya. Propone dicho autor que su prolongación hacia el Norte, aunque no existen referencias, habría que buscarla en dirección al valle del Pisuerga. No obstante, no hemos hallado informaciones que nos permitan certificar como romana la existencia de esta vía, teniendo en cuenta además que el puente de San Miguel no es romano.

\section{Camino del Escudo}

Esta vía pondría en comunicación la Meseta a través del valle de Valdebezana con Portus Victoriae. Apuntada por Sojo y Lomba en $1947^{477}$, fue publicada como vía romana por Riancho en $1988^{478}$ en un trabajo en el que hace una minuciosa descripción itineraria. Abásolo la recoge como camino antiguo.

Riancho, que describe esta supuesta vía desde Soncillo hacia el Norte, nada indica sobre su prolongación desde esta localidad hacia el Sur, y propone que desde Soncillo bordearía la llanura de la Virga por el Este para llegar a Corconte. Después, por un agreste territorio, llegaría a El Pombo donde se bifurcaría. El camino de la derecha iría por Sel de la Carrera, Sel de la Peña, Retuerta, Entrambasmestas, Sel del Tojo, Alceda, Ontaneda, San Vicente de Toranzo, San Martín, Acereda, Santiurde de Toranzo y Villasevil, donde entroncaría por la izquierda con el ramal que había discurrido por la montaña por el Monte Cildá, Castillo Pedroso, Quintana de Toranzo, Salcedillo y Prases. Después por Iruz, Escobedo, Pando, Pomaluengo, Escobedo, Cacicedo y Peña-Castillo llegaría a Santander. El trabajo es fruto de una intensa labor de campo que sigue minuciosamente este camino en la mayor parte de su trazado y, aunque en algunos lugares se pierde, detecta con detalle la existencia de una importante vía de largo recorrido que en amplios sectores estuvo empedrada. Curiosamente discurre por un pasillo que coincide de una manera precisa, en

476 ABÁSOLO ÁLVAREZ, J. A: 1975: 211-214.

477 SOJOY LOMBA, Fermín de: 1947: 52-54: t. 83.

478 GONZÁLEZ de RIANCHO MAZO, J.: 1988. 
casi todo su trazado, con las líneas divisorias de términos municipales, lo que evidencia que este camino es anterior a la delimitación municipal que lo utilizó como referencia estable. Dudamos, no obstante, de su adscripción al mundo romano ya que este camino, aunque antiguo, posee unos empedrados muy superficiales, disposición típicamente medieval o posterior y carece de la estructura que presentan las vías romanas. Según parece, y a falta de su documentación arqueológica, no se detecta un afirmado adecuado bajo la capa superficial cuando esta desaparece, algo que las vías romanas sí tenían.

Pudimos conocer un pequeño tramo de este camino en un sector que normalmente se encuentra inundado por el pantano del Ebro, pero que en las fechas de aguas bajas de nuestra visita (julio de 2012), asomaba por su orilla 479 . Se encontraba en la orilla norte del mencionado pantano en dirección a Herbosa desde el Norte, aunque por tratarse de un corto fragmento, no nos fue posible conocer su dirección general y, aunque su constitución era a base de piedras y morrillos, algunos de gran tamaño, bien organizados y delimitados en un pasillo de unos 2,40 $\mathrm{m}$ de anchura, no se detectaba substrato que permitiese asegurar su cimentación. Más bien se trataba de una capa de grandes piedras, quizá como soporte de una desaparecida capa de piedra más menuda, dispuesta para el tráfico en una zona pantanosa pero que carecía de la disposición y estructura que posee una vía romana. Consideramos que no tiene fundamento constatado la afirmación que hace Riancho de que "sobre esta base se colocaron grandes piedras planas muy bien acopladas hasta conseguir una superficie de rodadura o andadura muy perfecta".

Creemos que es un camino importante posterior a la época romana y que algunos de sus tramos se utilizan en el s. XVI, como se constata en los reparos e intervenciones que la Universidad de Mercaderes de Burgos realiza y cuyos gastos registra el Consulado de Burgos en sus libros de cuentas, como cuando en 1551 se recogen los gastos de los reparos de los caminos y en "hacer la puente y calzada de piedra en la Birga de Canpo, que conbenya mucho para el pasar de las sacas a Santander"480.

\section{La ruta del Ebro, por Sedano}

En Iglesias y Muñiz en 1992 y Muñiz en $1999^{481}$ se hace referencia a esta hipotética vía que partiendo de Iuliobriga, pasaría por Peña Cutral, Celada-Marlantes, Las Quemadas, Los Carabeos, Arroyal, Arcera, Bárcena de Ebro, Otero, Arantiones y Polientes. Desde aquí, los autores proponen la bifurcación en dos caminos: uno que por Ruerrero, Santa María de Hito, Báscones de Zamanzas, valle de Manzanedo, Hocina, valle de Valdivielso y Oña llegaría a Briviesca, y el otro, que por Rocamundo subiría a la Lora y por Sargentes y Sedano, enlazaría en Úrbel del Castillo con la vía que, según ellos, discurre entre Amaia y Virovesca. Los autores indican que esta vía no tiene "apoyatura documental directa que recoja su existencia", pero que parece ser el camino de las relaciones comerciales entre la parte meridional de Cantabria y el valle del Ebro. Tampoco nosotros encontramos argumentos históricos ni topográficos suficientes para defender la existencia de esta ruta del Ebro.

\footnotetext{
479 GONZÁLEZ de RIANCHO MAZO, J.: 1988: 80-83.
}

480 A. D. B./ R-6/ Manual del libro de cuentas de la Universidad de Burgos/ Burgos, 1549-1557. "Manual del libro de quentas de la Vniversidad començado en primero de junio de quinientos e quarenta y nuebe años seyendo prior Martin Alonso de Salinas rregidor y Juan de Sant Martin y Alonso de Maluenda consoles y tesorero Alonso de San Bitores Maluenda". 


\section{Vía Amaya-Briviesca}

Esta vía que Abásolo482 recoge como vía antigua, iría entre Amaya y Poza de la Sal por un camino no concretado. El mismo autor indica que la prolongación de la vía desde Poza hacia Amaya "tropieza con el tantas veces aludido inconveniente de la escasez de restos". Entre Poza de la Sal y Briviesca existen, no obstante, varios caminos que históricamente han comunicado estas dos localidades, pero en ninguno de estos se ha detectado dato alguno que nos permita cualquier adscripción a época romana.

Este hipotético camino ofrece muchos problemas para trazarlo con coherencia, y más, si hacemos una prospección sobre el terreno483. Un somero análisis del territorio entre Briviesca y Amaya evidencia la extrema dificultad y escasa posibilidad de que haya existido algún camino consistente con esa dirección en dicha zona, como lo confirma además el hecho de que no conocemos ningún tipo de huella o indicio sobre su existencia. En este sector hay una continua sucesión de páramos y valles fluviales, sometidos además aquéllos a la dureza del clima de esta zona, que hacen muy difícil el desplazamiento EsteOeste por estas tierras. El recorrido en esa dirección se produjo históricamente más al Sur, en la franja por donde discurre la vía Aquitana. La comunicación romana con Amaya desde la zona de la Bureba debía pasar por Burgos, y de aquí a Segisamone. Lacarra también cuestiona la existencia de este camino por no existir dato, estudio ni huella alguna que lo confirme ${ }^{484}$.

\section{Vía Briviesca-Orduña o El Ribero}

Según Moreno Gallo esta vía discurriría desde Virovesca por Los Barrios y Hermosilla a Salionca (Poza de la Sal), coincidiendo en este sector con la vía Amaya-Briviesca ya mencionada. Después por Castellanos de Bureba y Terminón llegaría a Oña y, por Penches y Barcina de los Montes, conectaría en Ranera con el camino que propone Abásolo 485 como camino antiguo. Podemos considerar que fue uno de los "utilizados en época romana" que partiendo de Briviesca, iría por Quintanillabón, oeste de Busto de Bureba, Portillo de Busto, Zangández, Ranera, Tobera, Frías, Quintana Martín Galíndez, Herrán, Ribera, Bóveda, Fresno de Losa, Villaño y Orduña.

Moreno Gallo propone que la vía tomaría desde Frías otra dirección por Trespaderne, Nofuentes y Moneo y desde Medina de Pomar llegaría a El Ribero donde entroncaría con la vía ya descrita de Flaviobriga a Uxama Barca y Veleia.

\section{Vía Pancorbo-Flavióbriga}

Corresponde con un tramo de la vía que Iglesias y Muñiz ${ }^{486}$ denominan vía PisoracaFlavióbriga que concuerda con la Vía Aquitana hasta Pancorbo. Coincidiría también entre Puentelarrá y Uxama Barca con la Uxama Barca a Deobriga ya mencionada, y asimismo, desde

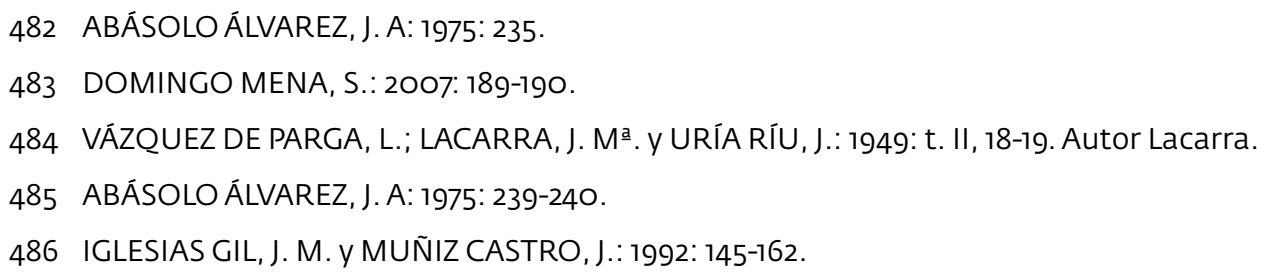


Gijano en Mena hasta Castro-Urdiales con la vía de Iuliobriga a Flavióbriga, las tres confirmadas como se ha comentado. Pero del recorrido intermedio entre Pancorbo y Gijano en el Valle de Mena los autores nada dicen, por lo que a través de un poco preciso plano que insertan, debemos suponer que este supuesto tramo discurre por Puentelarrá y Berberana y desde aquí por Orduña o por el valle de Losa, conecta en Mena con la vía IuliobrigaFlavióbriga. Este tramo que como se ha mencionado los autores no precisan, es altamente dudoso, exceptuando la vía que por el valle de Losa desde Uxama Barca, llega al Valle de Mena por Villasante de Montija, aunque esta vía los autores no la plasman en su plano y no la describen.

Citada por Ángel Ramón de Miguel como vía Puentelarrá-Osma de Valdegovía487, Milagros Esteban propone la continuidad de esta vía desde Orduña en paralelo al río Nervión por Saracho, Castillejo de Mendijur (Amurrio), Luyando y Llodio, donde cruzaría el río Nervión, y por los caseríos de Laguardia y el palacio de Catuca iría a Arteta y Bilbao488.

\section{c.- Consideraciones generales sobre la viaria romana}

Llama la atención la ligereza con que tradicionalmente se han adscrito los caminos empedrados a la autoría o fábrica romana. Lo sorprendente es que, no solo esta atribución la han venido realizando las gentes que han conocido o utilizado tales calzadas, sino que autores de estudios históricos o arqueológicos y diversos investigadores han realizado y realizan semejante adscripción en muchos casos, por el solo hecho de que determinado camino está calzado o empedrado. Algo parecido ha ocurrido con la atribución de los puentes de piedra, a veces de manera automática, a la labor constructora de los romanos y de hecho, tan solo en casos muy especiales y escasos puede corresponderse con la realidad.

En el apartado de vías documentadas y confirmadas, si exceptuamos las importantes vías situadas en la zona sur del sector de nuestro estudio mucho más llana y abierta y que discurren en sentido Este-Oeste (vía de Hispania in Aquitania. Ab Asturica Burdigalam y vía de Italia in Hispanias), nos encontramos con seis vías con ciertas evidencias de su origen romano que parten de las mencionadas, se orientan en dirección norte y conectan las tierras de la Meseta con la costa Cantábrica: De Segisamone a Pisoraca, de Pisoraca a Iuliobriga, de Iuliobriga a Portus Blendium, de Iuliobriga a Flavióbriga, de Flaviobriga a Uxama Barca y Veleia y de Uxama Barca a Deobriga.

Si observamos sus direcciones, todas, incluida la Iuliobriga a Flavióbriga que tiene un largo tramo en dirección Este-Oeste, comunican espacios de Sur a Norte como se ha indicado, y siguen esta misma dirección básicamente por el trazado que marcan los ríos y los valles y señalan los pasos utilizados para atravesar la cordillera Cantábrica, situándose en este caso a media ladera, huyendo tanto de la humedad del fondo de los valles como de las extremas temperaturas de lo alto de las sierras.

En el segundo apartado, aunque tenemos dudas sobre la adscripción romana de las vías incluidas creemos, no obstante, que son caminos antiguos los siguientes: vía 
Sasamón-Amaya, Camino del Escudo, vía Briviesca-Orduña o El Ribero y vía PancorboFlaviobriga.

El camino que discurre de Briviesca a Orduña y Bilbao pero no al Ribero que, como se ha dicho, sale de Briviesca e iría por Quintanillabón, oeste de Busto de Bureba, Portillo de Busto, Zangández, Ranera, Tobera, Frías, Quintana Martín Galíndez, Herrán, Ribera, Bóveda, Fresno de Losa, Villaño y Orduña, es camino antiguo que pervivió en fechas posteriores y puso en comunicación a la ciudad de Burgos con el puerto seco de Orduña, siendo sustituido por el que desde Pancorbo tenía el mismo destino por Berberana y que cobró una mayor importancia. Este camino de Pancorbo a Orduña y Bilbao fue vía destacada en la baja Edad Media y convivió durante un largo periodo con el camino, ya aludido, que desde Briviesca tenía el mismo destino. Después, podía desviarse hacia Castro-Urdiales aunque desde Burgos no era el más directo.

\section{B.- LOS CAMINOS DESDE LA EDAD MEDIA}

Tres son las fases que podemos establecer para estudiar las formas de intervención en la construcción y reparación de puentes y caminos, consecuencia de las distintas concepciones que las instituciones tuvieron desde la Edad Media489:

- Hasta los Reyes Católicos la construcción y reparo de los caminos y puentes y su financiación correspondía en exclusiva a los concejos, para que cada uno mantuviese en buen estado los caminos de su término. En algún caso excepcional también lo hicieron los titulares de señoríos e instituciones religiosas. Los constructores intentaban en este caso, recuperar la inversión por medio del cobro de portazgos y peajes.

- Durante el reinado de los Reyes Católicos hasta la década de 1530, las obras en caminos y puentes se considerarán obras de interés general, en el que todos los vecinos de cada municipio serán responsables y contribuyentes y a la vez beneficiarios. No se contemplará a cada municipio de manera individual, sino que a partir de ahora serán tratados en conjunto porque todos se benefician de la construcción y buen estado de las vías, en proporción a su distancia con el punto de intervención por entender que dicha distancia condiciona su aprovechamiento, simplificación que ocasionará muchas reclamaciones. Aparecerá así el repartimiento, en el que la Corona será el órgano promotor y supervisor a través del Consejo Real y de los corregidores.

- En 1534 se realiza una solicitud en las Cortes de Madrid para que se "de orden como se hagan las puentes, y se aderecen los caminos y calçadas, de que hay muy gran falta en estos reynos, y que en las cabeças de las prouincias o obispados se dipute una persona que tenga especial cuydado dello, el qual pueda repartir lo que fuere necesario, y que de cuenta y razon dello". El emperador responde que mandará que los corregidores y justicias provean lo que convenga cada uno en su jurisdicción 490 . En 3 años poco se hizo, porque en 1537 los procuradores indican en las Cortes de Valladolid que los "que andan en estos rreynos rreçiben grand daño, por la falta de puentes y por mal adereço que ay en los caminos

489 RODRÍGUEZ de DIEGO, J. L.: 198: 308-309.

490 COLMEIRO, M.: 1882: 613: t. IV. Cortes de Madrid 1534, petición 105. 
y calçadas, y por el gran daño que hazen los rrios y arroyos que salen de madre que destruyen mucha parte de las heredades, de que se rreçibe muy gran daño y pereçen muchas gentes, espeçialmente en los ynviernos, y se dexan a esta causa de labrar y sembrar muchas tierras", y piden que los corregidores o alcaldes de los adelantamientos, "vean los dichos dapnos con ofiçiales expertos en el arte, y rrepartan a los lugares y partes donde les pareçiere que rreçiben notorio provecho o dapno, lo que asy declaren los tales ofiçiales ques menester" 491 .

En las Cortes de Toledo de 1538 se recordó que en las Cortes de 1534 se pidió que "se señalasen personas que toviesen cuydado en el reparo y rehedificio de las puentes y fuentes y caminos, lo qual Vuestra Magestad proveyó que los corregidores é sus juridiciones proveiesen lo que en esto conviniese, y es ansi que los dichos corregidores avnque ocurren las tales necesidades, no quieren entender en ello sin que especialmente se les mande por vuestro real consejo, de que se sigue que por la dilacion, costas que ay en ello no se provee o se dilata la provision de las dichas nescesidades al vso publico y comun de todas", por lo que se pide que se mande que los corregidores, juntamente con el regimiento de sus ciudades, provean y repartan lo que conviniere sin esperar una nueva provisión ${ }^{492}$. Lo realizado en estos 5 años, supondrá la concesión a los corregidores de la responsabilidad de mantener en buen estado los caminos y puentes, así como la consideración de la provincia como ente territorial sobre el que realizar los repartimientos, algo más adaptado a la nueva realidad política y económica del Reino.

La red caminera medieval permaneció muy poco alterada y era en general muy deficiente. A pesar de que las mejoras y los cambios no eran habituales hay, no obstante, algún ejemplo que demuestra lo contrario como el caso de la refundación de Bilbao en 1310, en cuya carta de privilegio se indicaba claramente que el camino de Orduña a Bermeo debía desviarse para pasar por la villa de Bilbao. La jornada de viaje que se evitaba al cargar y descargar las mercaderías en Bilbao y no en Bermeo, hizo decaer aceleradamente a esta villa al disminuir de manera drástica su comercio y, por el contrario, fue la causa principal del desarrollo de Bilbao.

Superada la fase en que los microcondados de Brañosera/Campoo, Lara, Lantarón/ Cerezo y Álava que, junto con Castella Vetula y Castilla de Burgos son concentrados en 932 por Ramiro II en un macrocondado con capital en Burgos bajo la autoridad de Fernán Conzález en $932^{493}$, se produce en la segunda mitad del s. X la consolidación de un espacio que coincidiría con la actual provincia de Burgos, más la de Vizcaya, Cantabria y las esquinas nororiental de Palencia, oriental de Soria y norte de Segovia. Para proyectar e impulsar este Condado fue necesario potenciar su relación interna a través de la utilización de sus caminos. En el espacio comprendido entre la costa y la ciudad de Burgos los caminos existentes eran las vías romanas, que como hemos visto, dejaban amplias zonas sin comunicación por ser su número muy escaso y que en unos espacios de montaña presentarían tramos tan deteriorados que difícilmente podrían responder a las necesidades del momento, máxime cuando la estrategia expansiva promovida por la Corona se orientaba claramente hacia el Sur. Su antiguo trazado obedecía a unas necesidades y un espacio social, eco-

491 Cortes de Valladolid de 1537. Ed. Academia de la Historia, tomo IV. Madrid 1882. p. 654.

492 Cortes de Toledo de 1538. Ed. Academia de la Historia, tomo V. Madrid 1903. p. 121.

493 GARCÍA GONZÁLEZ, J. J.: 2008: 32-47. 
nómico y político que había cambiado. También existían caminos precarios y otros que iban naciendo para comunicar las aldeas que iban surgiendo, pero que no respondían a trazados de un mayor recorrido que el que mediaba entre aldea y aldea, y mucho menos con una dirección orientada al Sur, ya que se iban construyendo de lo local a lo comarcal y regional ${ }^{494}$. En este momento no era posible por la pobreza de medios, y sobre todo con la realidad política y social de Castilla, crear caminos que obedeciesen a otras necesidades y estrategias.

A la ciudad de Burgos (fundada el año 884) le faltaban todavía muchos años hasta su despegue comercial que, tras un inicial desarrollo con motivo del paso por la ciudad del Camino de Santiago, se produjo a partir de los siglos XII y XIII vinculado a unos puertos marítimos que en el s. X aún no existían. No obstante, ya tenemos referencias sobre algunos de los caminos que con el discurrir de los tiempos serán vitales para el desarrollo del comercio burgalés y castellano.

Por ejemplo, ya se cita en 945 una vía que discurre junto al Cuerno de Butrón495 hasta la laguna de Uitagan, en la entrega de una villa con todo su término al monasterio de San Pedro de Cardeña496. En 1045 cuando Carcía de Nájera, rey de Pamplona, agrega los monasterios de Santa María de Guinicio y Santa María de Quijera al de San Millán de la Cogolla, se menciona el puente de Puentelarrá como perteneciente al Rey por depender de Término (actual Santa Gadea) que es villa realenga. También se alude al cobro de portazgo 497. Ambos lugares, Puentelarrá y Santa Gadea, se encuentran en el camino de Burgos a Orduña.

Y ya desde el siglo XIII las vías de comunicación utilizadas para poner en contacto a la ciudad de Burgos con los puertos del Cantábrico serán, además de un conjunto de importantes infraestructuras, uno de los principales soportes en los que se basó durante siglos la vida y riqueza de las tierras relacionadas con dicha ciudad, y de la ciudad misma, al ser utilizadas como los ejes de su próspero comercio, además de garantizar una comunicación hegemónica en el norte castellano como consecuencia de su estratégica situación geográfica y potencia económica y política.

El Camino de Santiago experimentó un extraordinario desarrollo a partir del siglo XI, siendo el soporte de un número creciente de infraestructuras camineras como puentes, alberguerías, hospitales, santuarios, albergues, etc. También lo fue de una importante red comercial de carácter internacional, pero todo ello tuvo un carácter muy diferente al de las vías que estudiamos, ya que su dirección y su tráfico comercial, más relacionado con la peregrinación jacobea y sus peregrinos, difería de manera sensible de los intereses y el

494 MARTÍNEZ GARCÍA, L.: 2004: 65.

495 El Cuerno de Butrón, corresponde a la localidad de Villalta, en el camino de Burgos a Laredo.

496 Becerro Gótico de Cardeña. f. 75V A/ 3 septiembre 945; MARTíNEZ, G.: 1998: doc 53, 53. "id est, de ualleggo de Fratre ad Penna Forata, dein ad Uilla Escusa ad fonte de Azerio et directo ad fonte Albiella de Cuerno de Buetrone, uia que discurrit tras Buetrone adta lacuna de Uitagan".

497 A. H. N./ Cartulario de San Millán de la Cogolla. Becerro, fol. 157-157V/ 31 octubre 1045; UBIETO ARTETA, A.: 1976: 231-232: doc. 237. “... in Ebro ubi cadet rivo de Termino, de parte ad parte, ad integritate. Et illa casa de Ponte, cum illa villa de Larate, ad integritate. De illa defesa de Tega, medietate. De illo mercato, medietate. De illas calonias et illo portatico. Et ipso mercato, ad fuero de Cereso populato, medio ad termino et medio ad Sancti Emiliani presbiteri. Duos asinos de Sancta Maria de Genezo, et uno de casa de Ponte, sine alvara ambulent ad suos mercatos absolutos". 
tráfico que estudiamos que tenía dirección Sur-Norte.

Una nueva fase en la construcción y mantenimiento de los caminos comenzó con el reinado de los Reyes Católicos. Fue una época de reactivación del comercio que obligó a prestar una mayor atención al estado de los caminos como soportes básicos de ese comercio. La documentación existente sobre los reparos e intervenciones en caminos realizados en estos momentos es abundante, y denota un incremento importante de la actividad en este ámbito. La construcción, reparoy mantenimiento de los caminos se consideraba obligación de los municipios en cuyos términos se encontraban, así como de los que los utilizaban y causaban los deterioros por su uso, como eran las corporaciones de mulateros y sobre todo las de comerciantes. Cuando un camino o sobre todo un puente sufrían un deterioro, se acudía tradicionalmente a los municipios donde tal infraestructura se encontraba y se les obligaba a acometer a sus expensas la reparación, aunque en alguna ocasión también los nobles y los monasterios tuvieron iniciativas en este sentido. Este sistema acarreaba un sinnúmero de problemas, ya que los municipios alegaban, y muchas veces era cierto, que no tenían medios ni propios para afrontar los gastos derivados de la actuación. Además realizaban una apelación constante a que los reparos debían realizarlos y pagarlos aquellos que los utilizaban y recibían beneficio de tales actuaciones, como eran los mulateros y los mercaderes. Para superar favorablemente esta situación, se fue implantando en esta fase otro sistema que de una manera más eficaz pretendía resolver el más grave inconveniente de estas actuaciones en infraestructuras necesitadas cada vez de mayores inversiones, como fue el repartimiento.

Durante el reinado de los Reyes Católicos se hizo un especial esfuerzo en mantener adecuadamente los caminos principales, además de construir tramos nuevos y puentes. Aunque la labor fue continuada en los años del reinado de Juana y monarcas posteriores y se realizarán un gran número de actuaciones para crear, reparar y mantener la infraestructura de los caminos reales, no existió una verdadera política proyectada desde la Corona, encaminada a la creación de una red caminera global que resolviese con eficacia el grave problema que Castilla siempre tuvo en sus caminos. Para esto hubo que esperar dos siglos, ya con la llegada de los Borbones.

Los mulateros a través de la cofradía de los mulateros y viandantes entre Burgos y Laredo, impulsaron activamente y contribuyeron económicamente, al principio del siglo XVI, al mantenimiento del camino de Burgos a Laredo. También los mercaderes de la Universidad de Burgos durante dicho siglo, aportaron fuertes cantidades para mantener los caminos, principalmente los de Burgos a Santander y a Laredo, en condiciones aceptables, aunque en este caso también abrieron nuevos tramos. 


\section{CAPÍTULO II}

\section{LA TRAMA VIARIA: Los grandes itinerarios}

\section{1.- CAMINOS DE BURGOS A SANTANDER}

\section{A.- POR EL CURSO DEL BESAYA \\ a.- Por Berzosilla o Aguilar \\ b.- Por Villadiego \\ c.- Por Quintanilla de Valdearroyo}

B.- POR LA SIERRA DE EL ESCUDO

a.- Por el Tozo, barrio de Corconte y puerto homónimo

b.- Por el barrio de Corconte y sierra de El Escudo

c.- Entronque entre la vía de

Reinosa y la del puerto de Corconte

d.- Por Lanchares y la vía del puerto de Corconte

e.- Por el puente de Rampalay y el puerto de Corconte

f.- Por Soncillo, Cubillos del Rojo y puerto de Corconte

\section{C.- POR VILLARCAYO}
a.- Por el puerto de Las Estacas
b.- Por el portillo de Lunada
c.- Por el portillo de La Sía

\section{2.- CAMINOS DE BURGOS A LAREDO}

\section{A.- POR LOS HOCINOS, MEDINA DE POMAR Y PUERTO DE SENDERO ENHIESTO \\ a.- Camino antiguo por Quintanajuar \\ b.- Camino consolidado por Peñahorada y Cernégula \\ c.- Camino de herradura por Pilas \\ d.- El Ilamado "Camino del Carro" o"de los Carros"}

\section{B.- POR LOS HOCINOS, VILLARCAYO Y PUERTO DE SENDERO ENHIESTO \\ a.- El camino en las guías itinerarias \\ b.- Referencias documentales \\ c.- Las inundaciones de mayo de 1582 \\ d.- Reparo del puente de Puente- Arenas y del paso de los Hocinos \\ e.- Arrendamiento de Laredopara el mantenimiento del camino entre Laredo y Agüera \\ f.- Entradas y salidas de mercaderías y bastimentos en Laredo}

\footnotetext{
C.- POR LA HORADADA, MEDINA DE POMAR Y PUERTO DE SENDERO ENHIESTO

a.- El camino en las guías itinerarias

b.- Referencias documentales
}

\author{
D.- POR LA HORADADA, LA COMPLACERA \\ Y LANZAS AGUDAS
}

E.- POR EL PORTILLO DE LA SİA

3.- CAMINOS DE BURGOS A CASTRO-URDIALES
A.- POR EL DESFILADERO DE LOS HOCINOS
B.- POR EL DESFILADERO DE LA HORADADA
C.- POR PANCORBO Y LOSA

\section{4.- CAMINOS DE BURGOS A BILBAO}

\section{A.- POR EL DESFILADERO DE LOS HOCINOS}
a.- Por el puerto del Cabrio, Villasana y Valmaseda
b.- Variante en el Valle de Mena por Burceña
c.- Por Medina de Pomar, la Magdalena y Valmaseda

B.- POR EL DESFILADERO DE LA HORADADA
a.- Por la Complacera, Menamayor y Valmaseda
b.- Por el puerto de Angulo y Valmaseda
c.- Por el puerto de Igaña y Arza
d.- Por el puerto de Angulo y Arciniega
e.- Por el puerto de Angulo y Llanteno

\section{C.- POR LA SIERRA SALVADA Y PORTILLO DEL ARO \\ D.- POR LA SIERRA SALVADA Y PEÑA DE ORDUÑA a.- El camino de Bayona entre Burgos y Pancorbo \\ b.- Por Goldecho. La intervención de 1553 para el paso de carros \\ c.- Por el paso de San Bartolomé. \\ El intento para el tránsito de carros}

\section{E.- EL CAMINO ENTRE SAN PEDRO DE BERAZA Y DARDOZA}

\section{F.- LAS JUNTAS GENERALES Y LA REPARACIÓN DE LOS CAMINOS DE VIZCAYA}

\section{5.- CAMINOS DE BURGOS A PORTUGALETE}




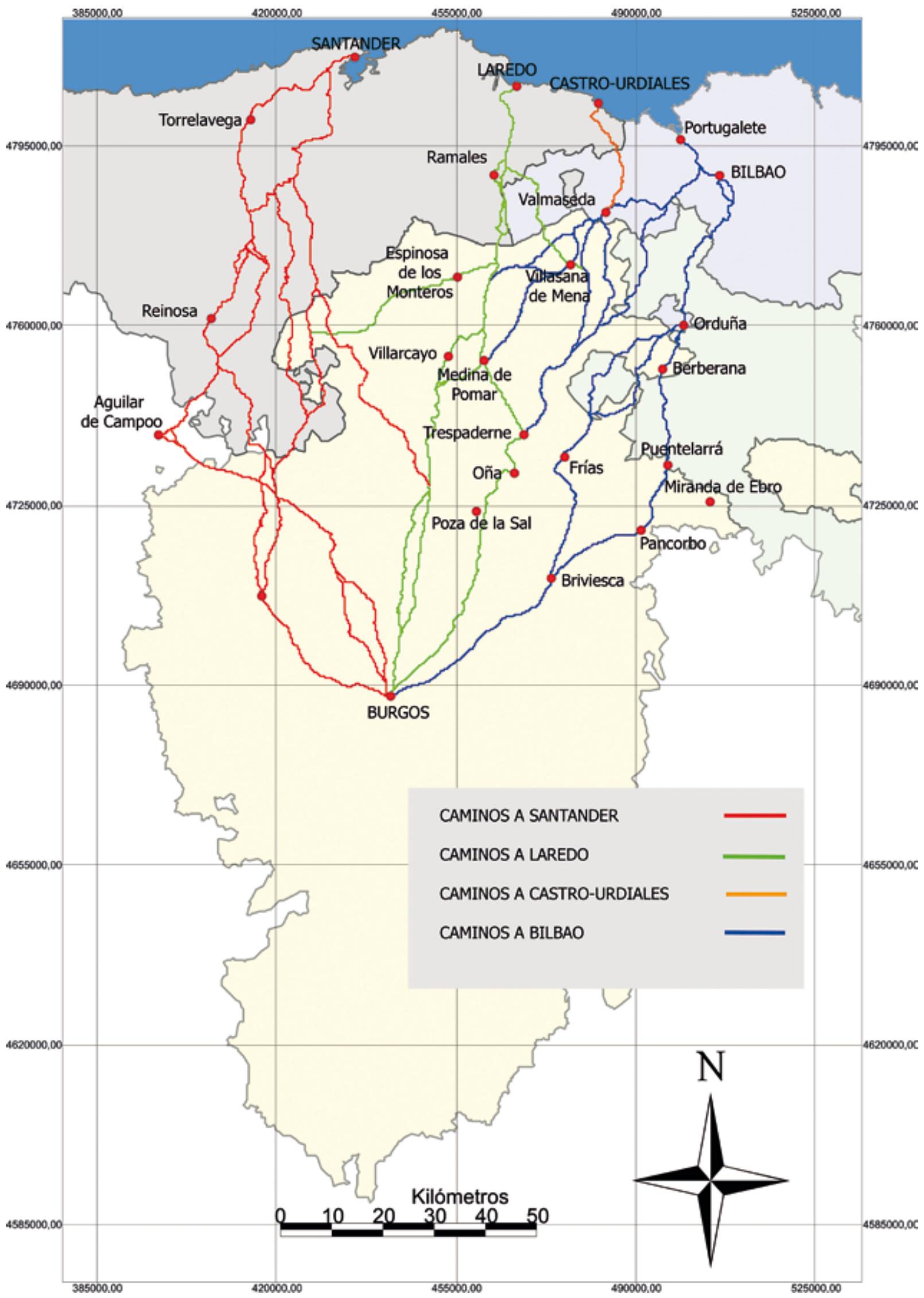

Mapa general de los caminos de Burgos a los puertos de Santander, Laredo, Castro-Urdiales, Portugalete y Bilbao. 
La provincia de Burgos poseía una amplia red viaria, que puso en comunicación los diferentes núcleos de población y la relacionaron con lugares más lejanos, incluso con destinos allende los mares. Entre la ciudad de Burgos y los puertos del Cantábrico destacaron algunos caminos que gozaron de una cierta oficialidad, con la que obtenían el nombre de "Caminos Reales", y que fueron utilizados con asiduidad. A pesar de tan pomposo nombre, muchos de ellos no pasaban de ser tradicionales senderos de herradura, es decir, por los que solo se podía viajar a pie o a lomos de una caballería, y a veces con mucha dificultad. Cuando sus trazados se asentaban sobre una orografía favorable, permitían en muchos casos el tránsito de carros y carretas: eran los caminos carretiles o carreteros.

\section{1.- CAMINOS DE BURGOS A SANTANDER}

La ciudad de Burgos debía gran parte del potente desarrollo comercial y económico que adquirió en los siglos XV y XVI, a la relación que estableció con los puertos de la cornisa Cantábrica, como consecuencia del arranque comercial de una Castilla que necesitaba dichos puertos para canalizar sus exportaciones. También el puerto de Santander basó su desarrollo y proyección en la creación de un hinterland en el que la ciudad de Burgos ocupaba un lugar preferente. Con dicho puerto esta relación fue intensa y comenzó en fechas muy tempranas, canalizada a través de varios caminos utilizados con distinta intensidad según los diferentes momentos. Dos grandes vías, la del Besaya y la de la sierra de El Escudo, canalizaron todas las variantes, además de otros tres caminos que parten de Villarcayo:

A.- A Santander por el curso del Besaya. Discurría junto al Besaya por los valles de Iguña, Buelna y Piélagos. De Burgos seguía por Úrbel del Castillo, Santa Cruz del Tozo, venta de Valladar, Berzosilla, Valderredible, puerto de Pozazal, Reinosa, Bárcena de Pie de Concha, Arenas de Iguña, Los Corrales, Las Caldas de Besaya, Cartes, Torrelavega, Arce, Peñacastillo y Santander.

a- Desde Burgos, se podía ir por Berzosilla como se ha dicho, por camino más corto, o seguir por Basconcillos del Tozo, Pedrosa de Arcellares, Fuencaliente de Lucio, Aguilar de Campoo, Quintanilla de las Torres y Canduela, hasta el puerto de Pozazal, tras haber dado cierto rodeo por Aguilar.

b- Camino por Villadiego. De Burgos iba por Las Quintanillas, Palacios de Benaver, Olmos de la Picaza, Villadiego, Barrios de Villadiego, Fuencaliente de Puerta y Arcellares y entroncaba en Berzosilla con el descrito. Desde Villadiego, había otra alternativa por Tablada de Villadiego, Villalbilla de Villadiego, Talamillo del Tozo hasta la venta de Valladar.

c- Por Quintanilla de Valdearroyo. Desde Fombellida, iba por Celada-Marlantes, Medianedo, Quintanilla de Valdearroyo, llano de la Virga, Monegro, San Miguel de Aguayo, y tras un tramo de montaña, llegaría a Bárcena de Pie de Concha.

B.- A Santander, por la sierra de El Escudo, se utilizaron desde Burgos al menos seis vías o tramos diferentes:

a- Camino por el Tozo, barrio de Corconte y puerto homónimo. Fue el camino princi- 


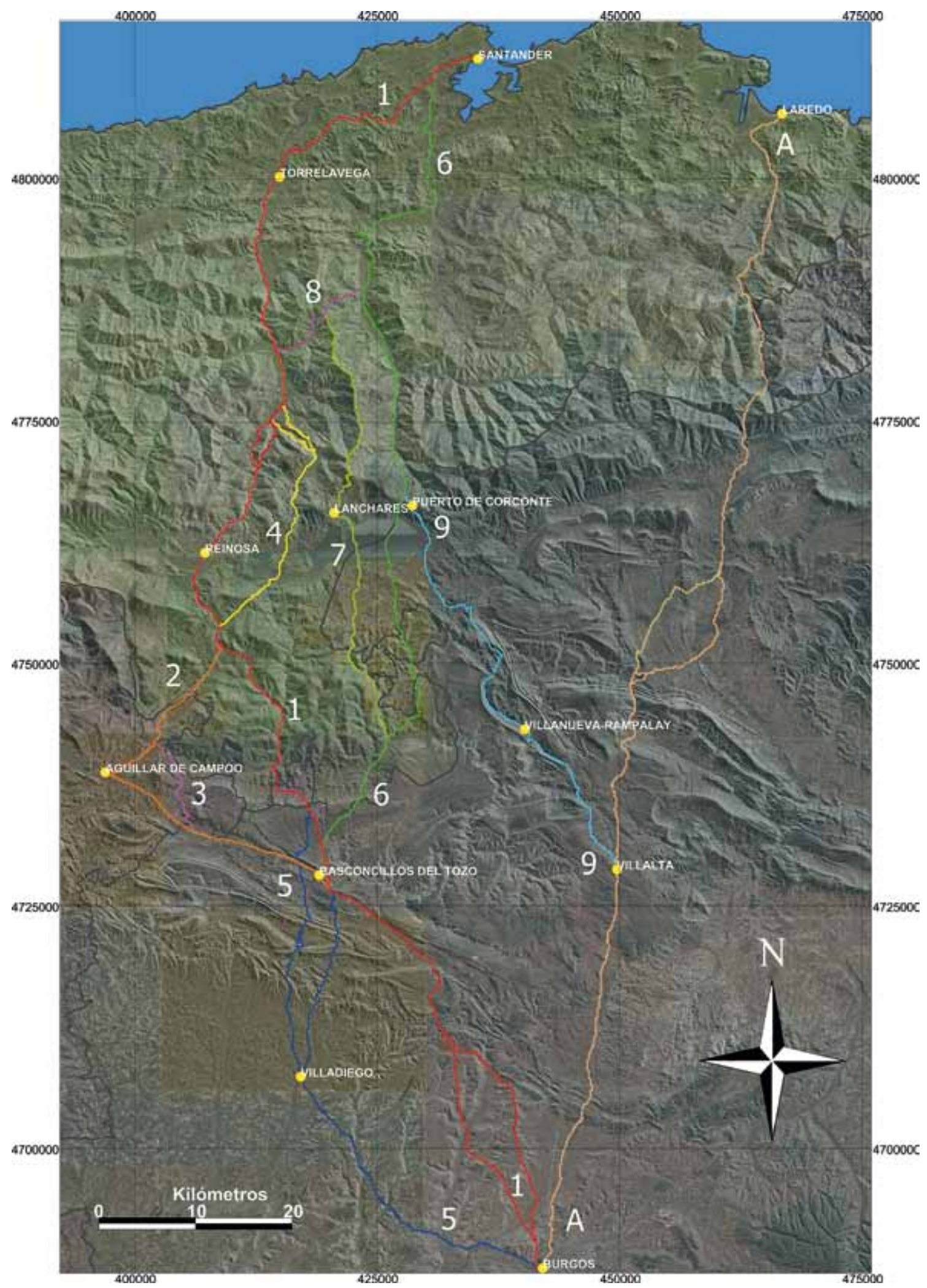

Mapa general de los caminos de Burgos a Santander:

1.- Camino principal por Reinosa.

2.- Rodeo del anterior camino por Aguilar de Campoo.

3.- Camino más corto por Pomar de Valdivia. 4.- Tramo por Quintanilla de Valdearroyo. 5.- Tramo de Burgos por Villadiego.
6.- Camino principal por el puerto de Corconte y puente de Solía.

7.- Camino por Lanchares.

8.- Entronque entre la vía de Reinosa y la de Corconte por Quintana de Toranzo.

9.- Camino por Villanueva Rampalay. 


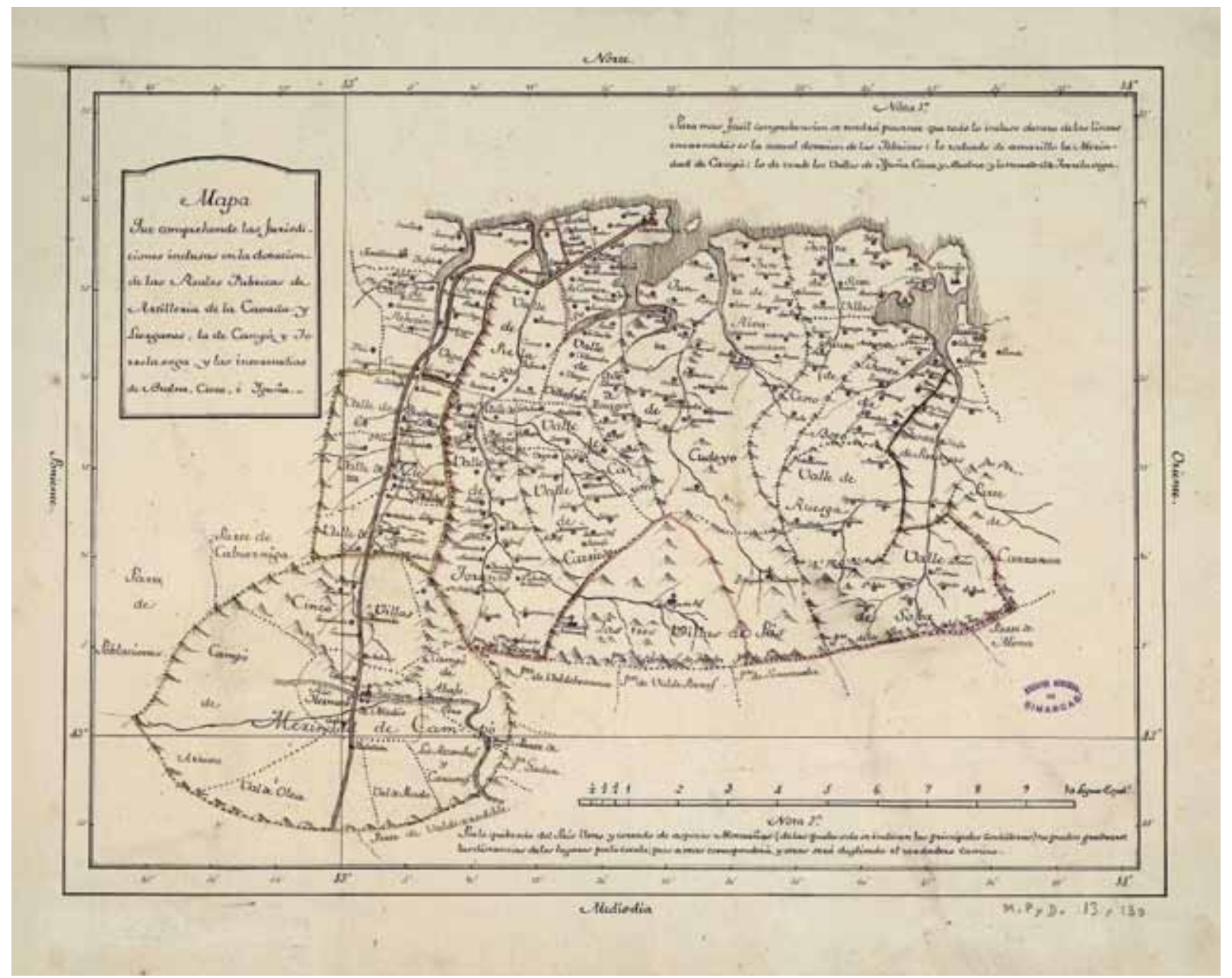

Mapa del siglo XVIII de las jurisdicciones de la Cavada y Liérganes, Campoo, Torrelavega, Buelna, Cieza e Iguña, con el camino de Reinosa (A. G. S., MPD 13,130).

pal, utilizado con dificultades por los carros. Discurre por el Tozo, valle de Valderredible, Corconte, puerto de Corconte y los valles de Toranzo, Cayón y Camargo, siguiendo el curso del Pas. Iba por Sotopalacios, Montorio, Úrbel del Castillo, Santa Cruz del Tozo y venta de Valladar. Bajaba a Valderredible y por Ruerrero, Linares de Bricia y Herbosa, cruzaba la Virga hasta Corconte. Luego por San Miguel de Luena, Vejorís, y Villasevil, podía dirigirse por la margen izquierda del Pas por Ontaneda, San Vicente de Toranzo y Prases. Después por Iruz, Pomaluengo, Obregón, Solía y Peñacastillo llegaba a Santander.

b- Camino por el barrio de Corconte y Sierra de El Escudo. Desde Soncillo y por Corconte, pasaba por los términos de montaña denominados La Calzada y Mediajo Frío y llegaba a El Pombo, donde se bifurcaba. El camino de la derecha entroncaba con el camino que venía del Tozo, ya descrito, por Sel de la Carrera y Sel de la Peña. El ramal de la izquierda que había discurrido por el Monte Cildá, Quintana de Toranzo y Prases entroncaba poco antes de Villasevil con el camino mencionado del Tozo.

c- Entronque entre la vía de Reinosa y la del puerto de Corconte. Utilizado para conectar ambos caminos, se desvía del de Reinosa tras pasar Arenas de Iguña; y por San Juan de Raicedo, Villasuso en el valle de Anievas y Quintana de Toranzo, bajaba a Prases; y entre Santiurde y Villasevil, entronca con el camino que viene del Tozo. 
d- Camino por Lanchares. Se separaba del que iba por Berzosilla, dos $\mathrm{km}$ después de la venta de Valladar. Seguía por Rocamundo, Ruerrero, Santa Gadea, Arija, llano de la Virga, La Población y Lanchares. Desde aquí el camino debía seguir por montaña, junto al arroyo de Lanchares aguas arriba, hasta entroncar en el término de Mediajo Frío con el camino por Corconte y sierra del Escudo ya descrito.

e- Camino por el puente de Rampalay y puerto de Corconte. Camino de herradura importante, seguía el camino de Laredo hasta Villalta y por Porquera del Butrón y Quintanilla-Colina, cruza el Ebro por el puente de Villanueva-Rampalay. Después por Gallejones y Población de Arreba, o por Ailanes y Arreba, seguía por Munilla, Bezana y Cilleruelo de Bezana, para llegar al puerto de Corconte. Otra variante es la que desde Arreba sigue por Hoz de Arreba a Soncillo, y de aquí por Quintanaentello y Cabañas de Virtus llega al puerto de Corconte.

f- Camino por Soncillo y puerto de Corconte. Escasamente utilizado para ir a Santander antes del siglo XVIII, fue activado en este siglo. Discurría por el camino de Laredo hasta Incinillas y por Cubillos del Rojo, Soncillo, Quintanaentello y Cabañas de Virtus llegaba al puerto de Corconte.

C.- A Santander por Villarcayo. Existieron además tres caminos mulateros que utilizando el camino de Laredo, salvaban desde Villarcayo la cordillera Cantábrica por puertos de mayor altitud, aunque su utilización fue muy baja y tardía:

a- Por el puerto de Las Estacas. Camino que iba por Mozares, Torme, Cornejo, puerto de las Estacas, y por el curso del Pas, Vega de Pas, Vega Escobosa, Gamonal y Corralmayor entroncaba con el camino de Corconte. Desde Vega de Pas existía otra alternativa por el puerto de la Braguía, Villacarriedo, Santa María de Cayón y Sarón, donde coincidía con el que venía de Corconte.

b- Por el portillo de Lunada. Discurría por Mozares, Torme, Bedón, Espinosa de los Monteros, Las Machorras, portillo de Lunada, y por el curso del río Miera por La Concha, San Roque de Riomiera, Rubalcaba, El Mercadillo, Solares, El Astillero, Maliaño, Peñacastillo llegaba a Santander.

c- Por el portillo de la Sía. Iba por Mozares, Torme, Bedón, Espinosa de los Monteros, Las Machorras, portillo de La Sía, Asón, Socueva, Arredondo, Bustablado, La Cavada, Ceceñas, Solares, El Astillero, Maliaño, Peñacastillo y Santander.

\section{A.- POR EL CURSO DEL BESAYA}

Para la comunicación con Santander por el curso del río Besaya se utilizaron desde Burgos al menos tres caminos diferentes: por Berzosilla o Aguilar, por Villadiego y por Quintanilla de Valdearroyo.

\section{a.- Por Berzosilla o Aguilar}

Fue el camino más importante, tanto desde la Edad Media como a partir de la segunda mitad del siglo XVIII, cuando se construyó el nuevo camino para carretas. Salía 


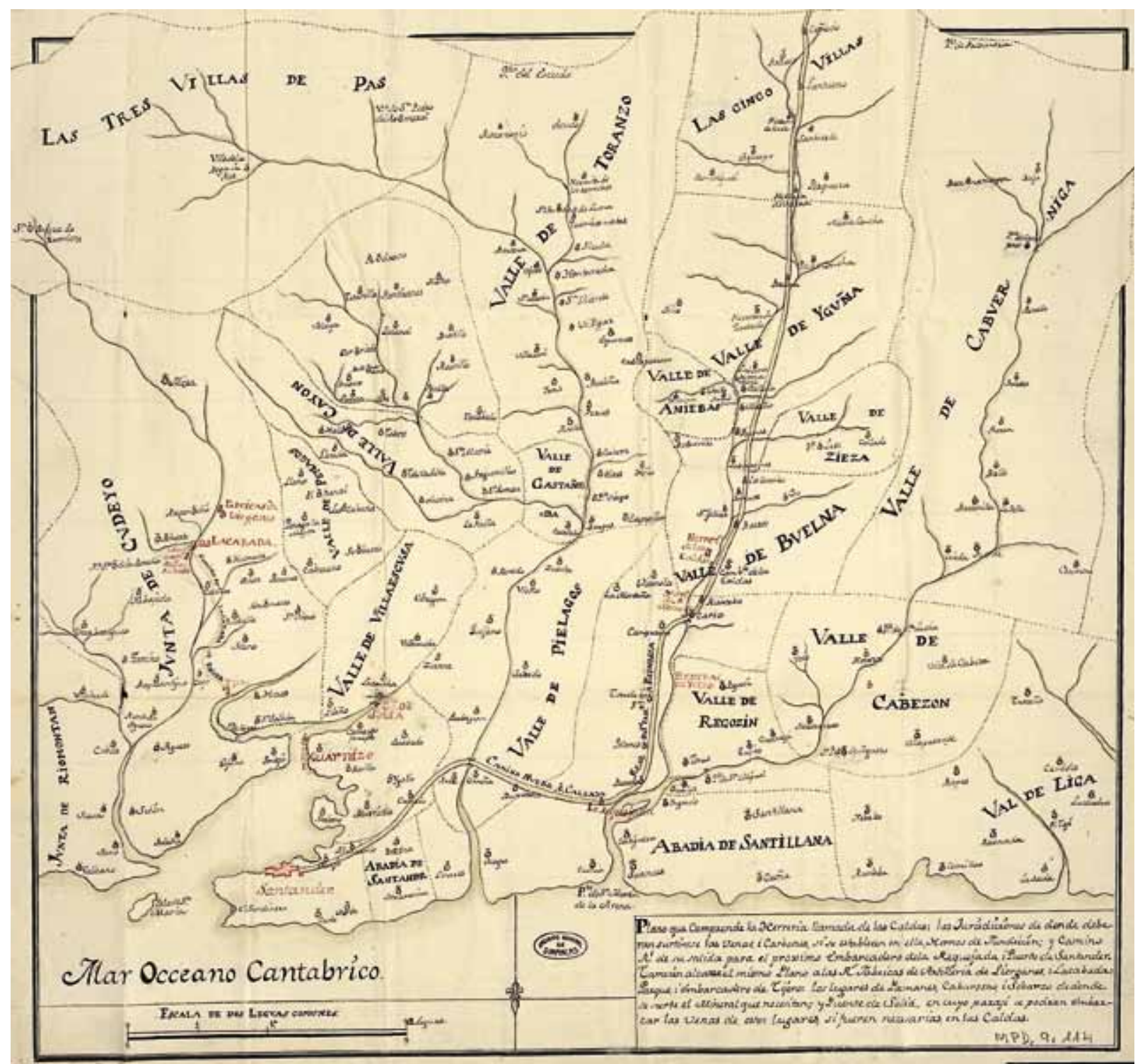

Plano del siglo XVIII donde se detalla el nuevo camino por Reinosa y el puente de Solía (A. G. S., MPD o9,114).

de Burgos por la puerta de San Martín y se bifurcaba para ir, el ramal de la izquierda, por Quintanadueñas, Arroyal, Mansilla de Burgos, Miñón, Ros, portillo de El Caracol y Úrbel del Castillo. El otro ramal había seguido por Villarmero, Sotragero, Villanueva de Río Ubierna, Huérmeces, Ruyales del Páramo y se unía con el descrito dos km antes de El Caracol para entrar juntos en Úrbel del Castillo. Seguía por Santa Cruz del Tozo, y dos $\mathrm{km}$ antes de Basconcillos del Tozo, se dirigía por la venta de Valladar a Berzosilla y junto al río Ebro aguas arriba, seguía por Villanueva de la Nía, Bárcena de Ebro, Reocín de los Molinos y junto al río Polla aguas abajo, alcanzaba el puerto de Pozazal, donde llegaba la vía que venía de Valladolid por Palencia y Aguilar. Luego por Fombellida, Cervatos, Matamorosa, Reinosa, Cañeda, seguía junto al río Besaya por Lantueno, Santiurde de Reinosa, Ventorrillo de Pesquera, Pesquera, Somaconcha, Media Concha, Pie de Concha, Bárcena de Pie de Concha, Santa Olalla, Molledo, Santa Cruz, Arenas de Iguña, Las Fraguas, Somahoz, Los Corrales de Buelna, San Mateo, Barros, Las Caldas de Besaya, Riocorbo, Cartes 

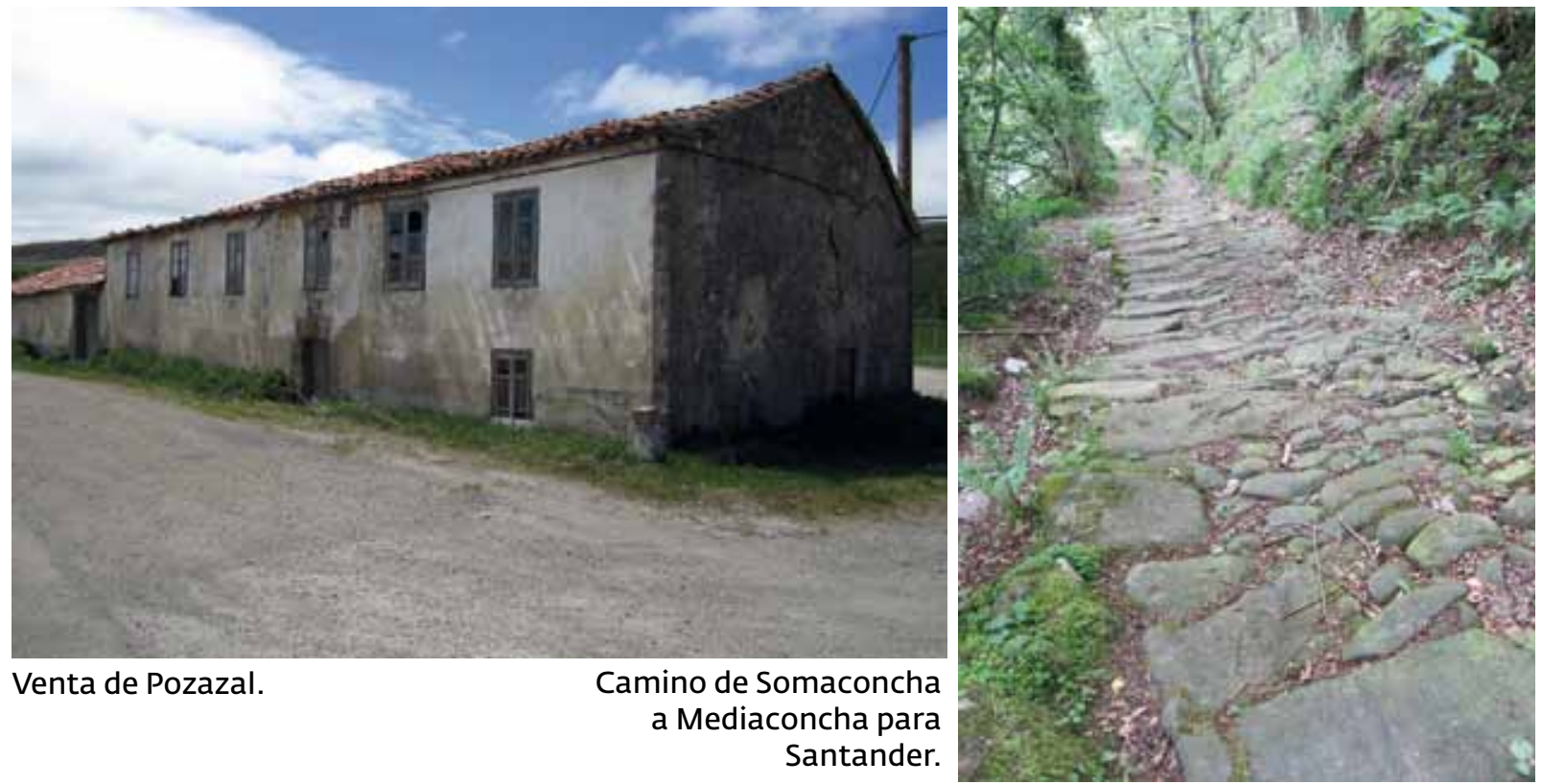

y puente sobre el Besaya, Santiago de Cartes, Campuzano, Torrelavega, Barreda, Ramera, Posadillo, Soña, Rumoroso, Oruña, Arce y puente sobre el Pas en el valle de Piélagos, Igollo, Cacicedo, Peñacastillo y Santander. El tramo cercano a Burgos, que es común para los caminos por Reinosa, por Lanchares, por Quintanilla de Valdearroyo y por Corconte, ha sido denominado históricamente como Camino Real de Santander.

Para ir por Aguilar, pero dando un rodeo y utilizado en épocas más tardías, el camino descrito podía seguir por Basconcillos del Tozo, Pedrosa de Arcellares, Llanillo, Fuencaliente de Lucio, Camesa y tras entroncar en Aguilar de Campoo con el camino que venía de Valladolid y Palencia, seguía por Cabria, Quintanilla de las Torres y Canduela y conectaba en el puerto de Pozazal con el camino mencionado.

Esta vía ha tenido a lo largo de su historia varias modificaciones o alternativas, tanto en Burgos como en Palencia y Cantabria, sobre todo con el ramal entre Aguilar y Matamorosa, que discurría cerca de Grijera y Nestar, La Quintana, La Cuadra y Casasola, o las continuas variaciones realizadas en las cercanías de Santander, muy condicionadas por el estado de los puentes. Aunque algunos tramos podían ser utilizados por la carretería del país, el camino era más adecuado para la arriería, hasta que fue renovado y mejorado a mediados del siglo XVIII.

La documentación consultada señala que era el camino más utilizado para el transporte del trigo y vino, productos básicos de los que Santander carecía, y para los retornos de pastel, hierro y pescado. Por él llegaban a Santander los mulateros con el trigo castellano y se acarreaba el pescado fresco o salado hacia Castilla por el curso del Besaya y valle de Iguña. También por él se accedía al puerto de San Martín de la Arena, sobre todo desde que en 1440, tras un pleito, se reconoció a San Martín como perteneciente a la villa de Santander. Aunque fue la principal vía del transporte de la lana que promovía el Consulado de Burgos, lo compartió en ciertas fases del siglo XVI con el camino que discurría por Corconte, que luego trataremos. 
Era básicamente un camino de herradura utilizado también por las carretas, aunque estas debían trasvasar sus cargas en varios de sus tramos o recorrerlos sin carga, algo para lo que algunas ventas disponían de recuas a fin de salvar los repechos y los vados, situación que se mantuvo hasta la construcción del nuevo camino en $1753^{498}$.

\section{El camino en las guías itinerarias}

Se encuentra recogido en todos los itinerarios publicados desde el siglo XVIII. El Itinerario de Matías Escribano de 1758 lo incluye con el título "Madrid para Santander. Camino nuevo de Ruedas" 499. También Rodríguez Campomanes lo recoge en 1761 con la denominación "Carrera desde Madrid a Santander"500. Miguel Bañuelos, intendente de la provincia de Burgos, en

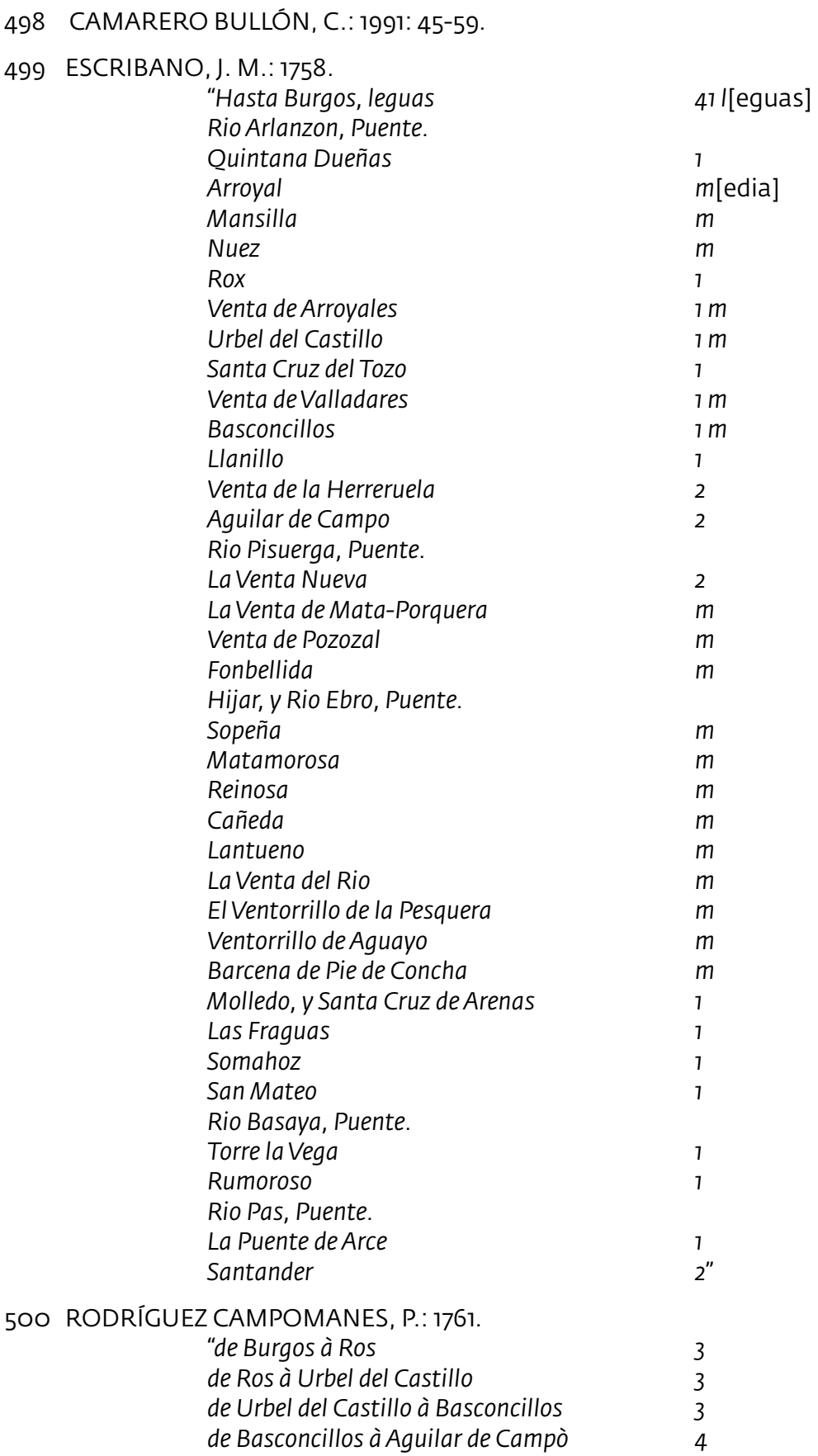


1771 detalla esta ruta con el recorrido por Berzosilla y Bárcena de Ebro501, con un total de 29 leguas y media. Bernardo Espinalt también lo detalla en su Guía de Postas de 1785 con el título "de Madrid a Santander"502. Ch. Picquet, en 1810, destaca el camino con el nombre de Madrid a Santander: por Segovia, Valladolid y Burgos; otro por Aranda de Duero y Burgos, y otro por Medina del Campo, Valladolid y Burgos. También lo describe con la denominación “De Santander à Madrid, por Reynosa, Burgos, Valladolid y Segovia" y "De Santander à Madrid, por Burgos y Aranda de Duero"503.

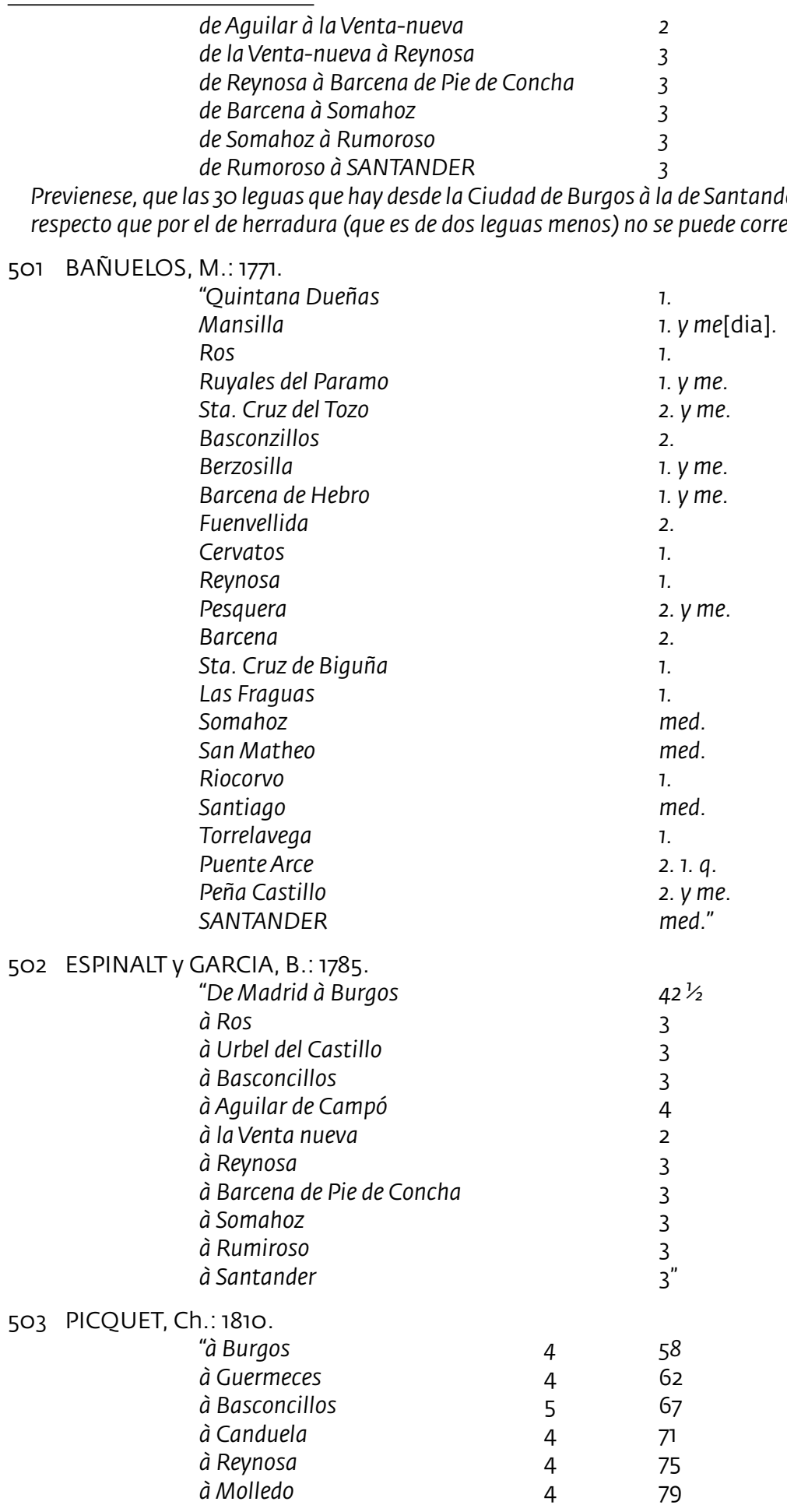


Otros itinerarios posteriores, como la Guía de Francisco Xavier de Cabanes, de 1830, también lo recoge con el nombre de "Carrera montada de Madrid a Santander por Medina del Campo, Valladolid, Burgos y Reinosa" y que, para acortar el camino sin tener que llegar al vértice de Aguilar, utiliza un desvío en un punto entre Villarén y Rebolledo de la Inera del camino de Burgos a Aguilar, y por Porquera de los Infantes entroncaba en Cabria con el camino procedente de Aguilar504.

\section{Referencias documentales}

Sobre la práctica comercial de los vecinos de Santander, existe una referencia de enero de 1255 sobre la concesión por Alfonso X de un privilegio, por el que "quyto e franqueo a todos los vesinos moradores de Santander para sienpre jamas" del pago del portazgo en todos sus reinos, salvo en Sevilla y Murcia, en agradecimiento a los servicios prestados a su padre y a él mismo en la toma de Sevilla505.

Aunque a partir de la segunda mitad del siglo XV se halla abundante documentación, tenemos una primera referencia sobre el camino de Santander a Valladolid por Palencia. Alfonso X otorga en 1263 Carta de privilegio al concejo de Valladolid para hacer dos ferias, con franquezas para que todos los mercaderes que a ellas fueren no paguen portazgo por entrada ni por salida de ninguna cosa en Cabezón ni en Valladolid, mientras duraren las ferias, y manda que vayan por el camino más derecho de Santander a Valladolid y no se desvíen por Carrión. El portazgo que pagaban en Carrión lo deberán pagar en Monzón506.

Ya en 1348 constatamos que existe un portazgo en Pie de Concha. El abad de Santa María de Aguilar indica que, debiendo percibir ellos el cuarto del portazgo de Pie de Concha por privilegio de Alfonso X, recibido a cambio de lo que el monasterio percibía en

$\begin{array}{lll}\grave{a} \text { Torrelavega } & 4 & 83 \\ \text { à Santander } & 4 & 87^{\prime \prime}\end{array}$

504 CABANES, FCo. X. de: 1830.

"Burgos, posta

á Quintana Dueñas

á Huérmeces, posta 3

á Urbel del Castillo $\quad 2^{\frac{1}{2} / 2}$

á Basconcillos, posta 3

á Llanillo $1 \frac{11 / 2}{21}$

á Canduela, posta $\quad 2 \frac{1}{2}$

á Fuenvellida $\quad 2 \frac{1}{2}$

á Matamorosa 1

á Reinosa, posta $1 / 2$

á Bárcena de Pie de Concha 3

á Molledó, posta 1

á Cartes $\quad 3^{1 / 2}$

á Torre la Vega, posta

áArce 1

á Peña Castillo 2

á Santander, posta

505 B. M. S./ Col. Eguaras, ms. 219, t. 1, pp. 247-250/ Burgos, 8 enero 1255; SOLÓRZANO TELLECHEA, J. A.:"Patrimonio documental...", 17-19: doc. 2. Este privilegio fue confirmado posteriormente por Sancho IV (Toro, 2 noviembre 1284); Fernando IV (Valladolid, 12 agosto 1295) y Alfonso XI (Valladolid, 22 febrero 1326, Teba, 28 agosto 1330 y Alcalá, 15 marzo 1348).

506 B. M. S./ Col. Eguaras, ms. 219, t. I, pp. 256-257/ Valladolid, 20 julio 1263; SOLÓRZANO TELECHEA, J. A.:"Patrimonio documental...", 24-25: doc. 5. 


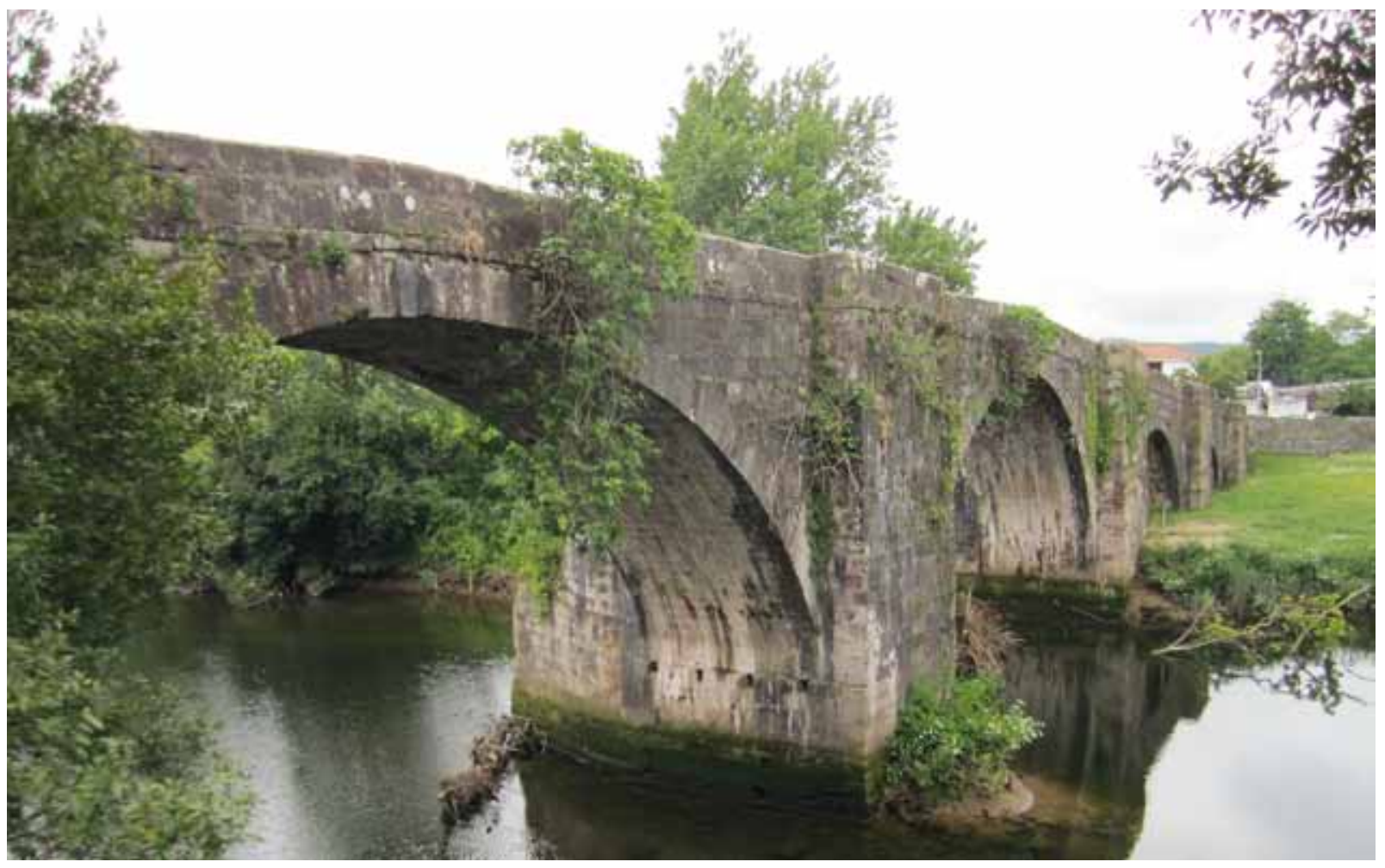

Puente actual de Arce-Oruña.

Aguilar de Campoo, algunos de los que pasan no quieren pagarlo porque dicen que están exentos por privilegios reales. El Rey manda a los recaudadores que todo el que deba pagar lo haga por muchas cartas o privilegios que tenga, y al merino mayor de Castilla y al concejo, alcaldes y juez de Pie de Concha, que ayuden para que esto se cumpla507.

En 1476 encontramos referencias al transporte de piezas de artillería, algo que obligaba a resolver una serie de problemas camineros como consecuencia del gran peso de la carga. De esta manera, el concejo de Santander paga 2.600 mrs. "para levar la lonbarda a Burgos"508.

Este camino presentaba en 1482 serios deterioros, ya que en el puente de Arce comparecieron en octubre ante el alcalde en el marquesado de Santillana, el procurador general y los regidores de Santander y dijeron que el "camyno real por donde todos los viandantes, camyneros e mulos e otras bestias, solian pasar e camynar caualgando e a pie, para yr y venyr a la dicha villa de Santander e a otras partes, que es a la puente de Arze junto cabe el rio de Pas, que era entre el dicho rio y la myer de Overa que es del conçejo de Orunna, el qual dicho camyno se avia perdydo a cabsa de las grandes aguas e avenydas que el dicho rio venyeron, e que los dichos viandantes camyneros, no avian lugar por donde podyesen pasar por el dicho camyno, a cabsa de lo qual se les recreçian grandes dampnos, y an rodeos para aver de yr e venyr a la dicha villa de Santander por le ser ynpedido el dicho pasaje, y era neçesario que los tales camyneros e viandantes, asy cabalgando commo a pie e muleteros, avian de aver camyno libre e desenbargado para yr e venyr a la dicha villa". Como el camino pertenecía a Santander, pedían que la vía fuese por la mier de Overa, para lo que requirieron

507 A. H. N./ Clero. Pergaminos. carp. 1.674, nำ 2. Aguilar de Campoo/ Tordesillas, junio 1348; GONZÁLEZ CRESPO, E.: 1985: 592: doc. 336.

508 A. M. S./ Leg. B iz, 306, nº 3b/ Santander, 1476; SOLÓRZANO TELLECHEA, J. A.: “Colección Diplomática...." 183-185: doc. 134. 
al alcalde que apremiase a los vecinos de Oruña, la Puente y herederos de la mier de Overa para que les facilitasen camino libre, ancho y firme. El alcalde mandó pagar a los propietarios los 4.000 mrs. en que se tasaron las heredades necesarias y se acordó que si el camino se estropease, los herederos quedaban obligados a dar el camino real libre, abierto y ancho, y las heredades quedarían en poder de Santander, y que cualquier caminero podría abrir sin pena alguna las dichas heredades cuando en el camino no hubiere paso libre509.

En 1483 los habitantes del valle de Iguña se oponen por la fuerza a la apertura de un camino, que iría por la Sierra de los Portillos de Obios entre Reinosa y el marquesado de Santillana, argumentando entre otras razones que este camino arruinó los caminos reales antiguos ${ }^{510}$.

García Ruiz, en nombre del concejo de Corral de la Fuente de la merindad de Campoo, dijo que siendo francos y libres por Privilegio real tanto de pechos como de llamamientos

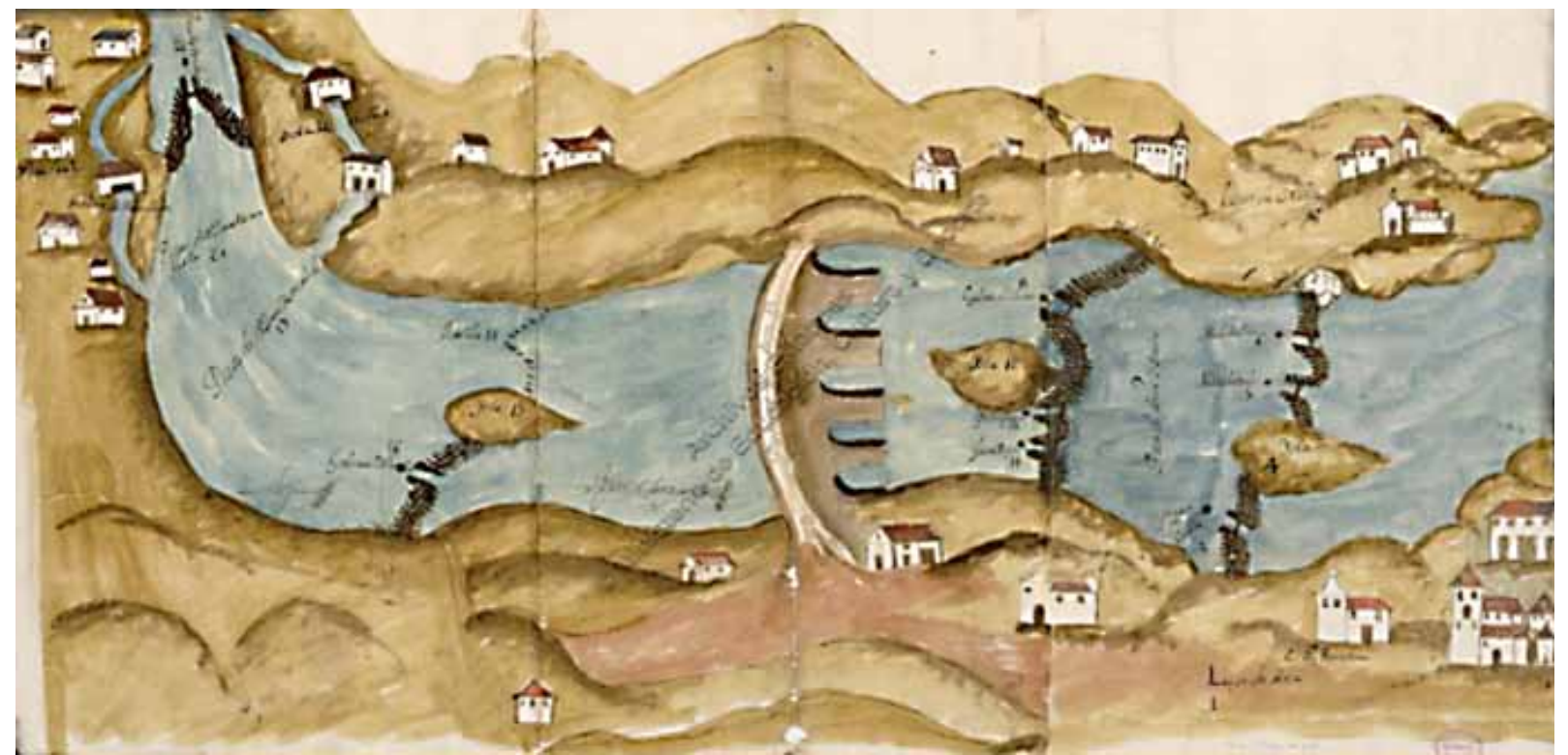

Mapa de 1702 de Oruña y Arce con el puente, procedente de un pleito solventado en la Chancillería de Valladolid (A. Ch. V., PDD 319)

y de otras cosas, pide al Consejo que tal privilegio sea confirmado porque ellos se encargan de reparar el hospital de la alberguería y "rreparar e abrir el puerto de la Concha, ques montaña e puerto brauo por donde entran a las montañas", como en dicho privilegio se contiene, e indica que los repartidores de la hermandad de Caños de Medio los han agraviado al repartirles tres peones siendo libres, y añade que si el privilegio les es quebrantado, su concejo dejaría de abrir el puerto y de reparar el hospital, con lo que "los rromeros que van al dicho ospital" recibirían daño y las rentas detrimento. El Consejo Real mandó en abril de 1486 que no se les repartan peones al dicho concejo, con tanto que el concejo de Fresno se obligue a reparar el hospital y camino de la Concha, como en el privilegio se contiene, y si algunas prendas les han tomado por esta causa, las deberán restituir ${ }^{511}$.

509 A. M. S./ Leg. A-1, no 24/ Puente Arce, 29 octubre 1482; SOLÓRZANO TELECHEA, J. A.: "Colección Diplomática...". 194-197: doc. 139.

510 A. G. S./ Cámara de Castilla. Pueblos, leg. 9, docs. 236 y 237/ 1483. Lo cita MOLENAT, J. P.: $1971: 131$.

511 A. G. S./ Registro General del Sello, IV-1486, fol. 64/ Medina del Campo, 4 abril 1486. 
En noviembre de 1493 los Reyes mandan al bachiller Gonzalo Sánchez de Castro que se informe acerca de la acusación de Pedro González de Villanueva de que se han levantado unas ventas en términos fuera de Santander, donde se venden, cargan y descargan mercancías con perjuicio de la villa512.

Los concejos de Valdáliga, Cabezón, Cabuérniga, Hoz de Lloredo y Río de Agüera513 denuncian que en la Loma de Hoyos, el Puente Pumar, Las Fraguas, Pie de Concha y en otros de esas comarcas, algunas personas cobran ciertos mrs. de peaje por las bestias de carga que por allí pasan diciendo que son para reparar caminos y puentes, pero que para ello no tienen licencia real y es impuesto nuevo, además de no utilizar esos dineros en reparar fichos caminos y puentes, oerjudicando a los recueros y caminantes que por ellos pasan. Los Reyes mandan en noviembre de 1494 al corregidor que realice las actuaciones necesarias para evitar dichas imposiciones y peajes y castigue a los infractores ${ }^{514}$.

En marzo de 1496, los Reyes ordenan al presidente y oidores de la Chancillería que sentencien el pleito pendiente entre la villa de Santander, por una parte, y el condestable Bernardino Fernández de Velasco y el concejo y vecinos de Herrera de Pisuerga por otra, "sobre rrason de çiertos mulos e rroçines e sal que a la dicha villa de Santander dis que fue tomada" en dicha villa de Herrera515.

García de las Bárcenas, procurador del valle de Cama, dijo en el Consejo que los vecinos y moradores del dicho valle no se pueden sustentar sin traer de Castilla las provisiones de pan y vino necesarias, porque en esa tierra no se coge provisión alguna y los caminantes no hallarían ninguna provisión ni mantenimiento si no saliesen a por ellas con sus carros a Castilla. Dice que desde Gama hasta Villasirga hay muchos caminos dañados por las muchas aguas y que los concejos no los quieren reparar, aunque han sido requeridos muchas veces para ello y, aunque los carreteros los intentan arreglar, no les dejan cortar la leña y madera necesarias. Como los vecinos de Gama y de las Montañas reciben mucho daño al no poder pasar en algunas partes con sus carros, suplicó que se mande a los concejos donde "los caminos y cajiles" están dañados, que cada uno en su término los repare o les dejen cortar la leña y madera necesaria para ello. El Consejo mandó en 1498 al corregidor de Campoo y Reinosa y a los alcaldes y justicias de las villas y lugares entre el valle de Gama y Villalcázar de Sirga, que vean los caminos reales que están dañados y que las villas y lugares los reparen, y los cajiles que no estuvieren en los caminos reales, los dejen reparar a los carreteros, dejen cortar la leña y madera necesaria, y no se consienta que se ponga ninguna imposición a los caminantes, carros, bestias y mercaderías que por los caminos pasaren ${ }^{516}$.

La zona de Aguilar de Campoo se iba constituyendo en una zona clave en las relaciones de la Montaña con la Meseta. Algunos vecinos informan a los Reyes que en Reinosa,

\footnotetext{
512 A. M. S./ Leg. A-1, nํ 37. fols. 7r-8r/ Zaragoza, 24 noviembre 1493; SOLÓRZANO TELECHEA, J. A: "Colección Diplomática...". 268: doc. 177.

513 Actualmente Lloredo y Rudagüera.

514 A. G. S./ Registro General del Sello, XI-1494, fol. 343/13 noviembre 1494.

515 A. G. S./ Registro General del Sello, III-1496, fol. 74/ Valladolid, 10 marzo 1496.

516 A. G. S./ Registro General del Sello, IX-1498, fol. 142/Valladolid, 11 septiembre 1498.
} 
Aguilar de Campoo y en otras villas y lugares de la merindad de Campoo llevaban de los recueros, mercaderes y los que por allí pasaban, $6 \mathrm{mrs}$. por acémila y bestia y nuevos derechos, por lo que piden que se quiten dichas imposiciones. En agosto de 1499, los Reyes Católicos mandan al juez de residencia de la merindad de Campoo que se informe sobre los portazgos, derechos e imposiciones que en la dicha Merindad y sus términos se llevan de los ganados, recueros y mercaderías que por allí pasan, y quién los cobra, desde cuando, en qué lugares y con qué títulos; y si lo que así llevan es impuesto nuevo o si se acrecentó, quién lo hizo, y si se hacen extorsiones a los que llevan sus ganados, mercaderías y recuas; y haga que presenten los títulos que tienen y dicha información se remita al Consejo y, entretanto, si se hallare que tales imposiciones son realizadas sin título, mande que no se lleven 517.

En diciembre de 1501, los habitantes de los pueblos afectados solicitaron la reparación de un puente y una calzada en Quintanadueñas sobre el río Ubierna, un puente, una calzada y un mal paso sobre el río Úrbel entre La Nuez de Abajo y Miñón, y otros puentes sobre dicho río. Dicen que estaban hechos por la ciudad de Burgos para ir a Quintanadueñas, Arroyal y otros lugares del entorno y "a las montañas e puertos de San Biçente e Santander", así como para "todo el valle de Valldelusio fasta Aguilar de Campo con sus comarcas, e todo el Balderredible con Renosa e sus tierras"518.

El concejo de Santander ordena en 1504 que se haga una pesquisa sobre la grave situación en que se encuentra la villa a causa de la peste que llegó con el séquito de la princesa Margarita en $1497^{519}$. En noviembre se realiza un interrogatorio preguntando si saben que en la villa había habido gran trato de mercaderías, pesquería y cosecha grande de vinos porque había gente para labrar las viñas, y que la villa tiene necesidades muy grandes, tanto de reparar caminos y calzadas como de reparar el puente de Arce y otros puentes que están en la Hoz del Valle de Buelna, por donde transita el trato y mulatería para llevar provisiones y pescado fresco y cecial, y que tales caminos están perdidos y mal reparados porque cesa el trato por ellos ${ }^{520}$. Los testigos respondieron que hacía 45050 años había más de 1.000 vecinos en la villa "asy de ruanos e mercaderes e mareantes y pescadores, e avia en ella grande trabto de lanas e fierro e maderas e pannos e otras mercaderias..., e vido muchas tiendas de traperos $e$ merçeros e caldereros e cochilleros, e vido cargar muchos fierros e maderas para el Andalozia". Y también "avia cargason de sacas de lanas de burgaleses para Flandes, e avia naos e carabelas en esta villa... e agora non hae en la dicha villa, segund la grande pestilençia de ella".

En el alfolí del hierro, dicen, había vecinos que tenían 500 o 600.000 quintales de hierro y mucho trato de otras cosas para Sevilla y Portugal, pero que ya no había en la villa ni gente, ni tratos. Además "avia mucha pesqueria que yvan muchas pinaças a la mar a besugos, e agora non va la meytad de la gente que solian yr en los annos antepasados,... porque no osan entrar en ella los forasteros y estan acotados, e los alrrededores que non entren en ella nin trayan ninguna probesyon para la

517 A. G. S./ Registro General del Sello, VIII-1499, fol. 141/Valladolid, 13 agosto 1499.

518 MOLÉNAT, J. P.: 1971: 130.

519 Margarita de Austria llegó a Santander desde Flandes el 8 marzo 1497.

520 A. M. S./ Leg. A 2, no 10 fols. 1r-3r/ Santander, 20 noviembre 1504; SOLÓRZANOTELECHEA, J. A.: "Colección Diplomática...". 393-396: doc. 254. 
dicha villa". Añadieron que "ha menos de siete e ocho annos de que bino aqui la nuestra prinçesa de Flandes, nunca ha faltado en esta villa pestilençia y es muerta much a gente en ella, e non hay dosyentos vesinos en ella,... e a esta cavsa esta toda esta villa perdida... y es notorio a cavsa de la grave pestilençia, de los prençipales de la villa, avia çient vesinos que non hae agora en ella dies vesinos,... hasta agora en la dicha villa son muertos mas de seys myll personas" y los que quedan no son más de 400 hombres, vecinos y casados en la villa y sus arrabales. Añadieron que Santander ha de reparar los puentes de Arce, el de las Hoces y otros, y caminos para que lleguen los bastimentos, pero que según las necesidad y fatiga de la villa y la poca gente que hay "a cabsa de la pestilençia que en ella anda, non se pueden reparar las dichas puentes e caminos e calçadas..., por do biene grande danno a la dicha villa e rentas de sus altesas, por non benir nin poder pasar... los mulateros a ella con sus mantenimientos, e lieban el pescado fresco e salado e traen trigo a la villa, e agora las dichas puentes e caminos estan mal reparados a cavsa de la pobresa de la dicha villa"521.

La situación no mejoraba, según indica un informe de dicho año sobre el camino entre Reinosa y San Vicente de la Barquera, que indicaba que todas sus subsistencias tenían que venir de acarreo, por unos difíciles caminos de montaña y unos puentes deteriorados, que necesitaban además grandes y continuas reparaciones. Se indica que los vecinos de los lugares en cuyos términos están los caminos, puentes y calzadas, no lo quieren hacer, especialmente los de "Seto e Barrio e Espinilla e Renosa, e otros lugares de la dicha merindad de Canpo,... e ha mucho tienpo que estan caydas y no las quieren haser ni reparar, asy mismo el valle de Cauerniga y los lugares e vesinos e moradores del, dis que son obligados a haser e tener fechas e en pie las puentes que son en el dicho valle en el rio Saje que por el pasa, la una que disen la puente de los Trechos y la otra que se dise de Barçinillas y la otra que disen de Vadones, las quales dis que ha mas de tres años que estan caydas..., e que asy mismo el dicho valle es obligado a haser e reparar el camino del puerto de Palomera y de la cuesta de los Tojos, que es en el dicho valle iendo como va fasta la Hoz de Santa Lusya..."522.

Carlos I en su primer viaje a Castilla desde Flandes, desembarca en Villaviciosa el 20 de septiembre de 1517. Tras llegar a San Vicente de la Barquera, come y duerme en Treceño. Después pasó por Cabezón, Cabuérniga, Los Tojos y Soto, llegando el 15 de octubre a Reinosa, donde se alojó a un cuarto de legua, en casa de un "descendiente de moros". Ya por este camino prosiguió el 22 de octubre por Nestares y Aguilar de Campoo, donde descansó hasta el 27, continuando después por Herrera de Pisuerga y Abia de las Torres hacia Valladolid523.

En mayo de 1524, Carlos I manda al concejo de Santander que para que la villa esté bien provista, desde el 1 de enero de 1526 en que saldrá el encabezamiento de las rentas de la villa, se haga en ella un mercado los sábados libre de alcabala. Los vecinos y moradores que tengan casa poblada y estén avecindados podrán vender y cambiar en sus casas o en el mercado. Para que la puebla vieja no se acabe de despoblar, todos los estantes y forasteros que acudan con mercaderías o mantenimientos los venderán un día de mercado en la puebla vieja y otro día en la puebla nueva, y a todos ellos el Rey les toma bajo su amparo no pudiendo ser detenidos ni embargados, a condición de que se pague alcabala de todo lo

521 A. M. S./ Leg. A 2, nำ10 fols. 3r-23v/ Santander, 21 noviembre 1504; SOLÓRZANO TELECHEA; J. A.: "Colección Diplomática...". 396-429: doc. 255.

522 En MOLÉNAT, J. P.: 1971: 132: A. G. S./ Registro General del Sello, IX-1504/ agosto 1504.

523 FORONDA y AGUILERA, M. de: 1914: 100-104; GARCÍA MERCADAL, J.: 1952: 691-694: t. I. Lorenzo Vital. 
que se vendiere o cambiare ese día. Manda a todos los que recauden en renta o en fieldad las rentas de las alcabalas de la villa y su tierra, que no lo hagan los sábados en los lugares mencionados. Si el concejo quisiere gozar de esta franqueza, lo podrá hacer pero pagando al Rey el precio del encabezamiento durante el tiempo que durase, pero no se franquean los diezmos de la mar pertenecientes al Rey524.

En abril de 1535, el alcalde de Santander dice a las autoridades de Aguilar de Campoo, Valle de Ordejón, Amusco, Buelna, Pie de Concha y otras villas y lugares, que entre Santander y el condestable de Castilla hay cierto pleito, porque este pretendía desviar por otros puertos los fardeles y demás mercaderías que llegaban a la villa, y para que, como señor de los diezmos de la mar permita sin pleito que los fardeles y mercaderías sigan llegando a Santander, se debía obtener información de cómo antiguamente se solían guiar por el puerto y ría y no por otras partes. El procurador general propuso preguntar si saben:

- Que cuando los diezmos de la mar de Castilla se incorporaron a la casa de Velasco, y aún después, ha habido vecinos de Santander y de fuera que recaudaban los diezmos de las mercaderías que de otros reinos entraban en su puerto y daban el albalá de guía para que las guardas puestas por sus señores en el camino no tomasen las cargas por descaminadas, y que esto se usaba cuando los diezmos de la mar se cobraban por los recaudadores de los reyes, y asimismo se han guiado las mercaderías que llegan a Santander después de que los diezmos de la mar pasasen al Condestable.

- Que cuando las mercaderías se descargaban en Santander y las guiaban los dezmeros, tanto de los reyes anteriores como de los puestos por el Condestable, las guardas de Pie de Concha, Reinosa y otras partes las dejaban pasar libremente.

- Que como los dezmeros que el Condestable tiene en los puertos de la mar, además de impedir que las mercaderías se descarguen en el puerto de Santander y se guíen por él, hacen salir a las naos de este puerto para que vayan a Laredo, Bilbao y otras partes, por lo que la villa recibe gran daño, las rentas reales disminuyen y los propietarios de las mercaderías sufren otros muchos daños, costas y perjuicios.

Para este interrogatorio, ante el alcalde del calle de Buelna, el procurador de Santander presentó por testigos a un vecino de Cartes, otro de Barros, otro de Llano y dos de Somahoz, los cuales dijeron que hacía más de 60 años habían visto pasar por Cartes o por el valle de Buelna mulos, rocines y acémilas que procedían de Santander, donde habían pagado el diezmo al rentero de los reyes, recibiendo los albalaes correspondientes. Llevaban fardeles de paño, lienzos, mercerías, "arzueros" y otras mercaderías a Castilla, Pie de Concha, Aguilar y Burgos, y los mulateros y trajineros decían que las naos venían de Flandes, Bilbao y otros lugares. Nunca habían oído decir que lo contradecía ninguna persona de Velasco y nunca vieron pedir los diezmos en Pie de Concha, Reinosa ni en otra parte a los que llevaban los albalaes, aunque los mercaderes burgaleses descargaban allí paños, mercerías y "arzueros" y los llevaban por el valle de Buelna arriba. Declararon que veían pasar a los trajineros y mulateros por casa de Ruiz García del Magujón, vecino del valle de Buelna, mesonero cosario ya difunto, y los mercaderes que venían de Santander cargados con fardeles de paños, lienzos y cajas de mercerías, comían y posaban en dicho

524 A. H. P. C./ J. T. A. leg. 38-5/ Valladolid, 24 julio 1546. 
mesón y allí descargaban e iban por el valle de Buelna derecho a Castilla de donde eran los mercaderes.

El procurador general de Santander pedirá estas informaciones en febrero de 1547 para probar cómo antiguamente, se solían cargar y descargar en el puerto de Santander las sacas de lana de los mercaderes de Burgos que se mandaban a Flandes, Francia y otras partes y los fardeles de paños, lienzos y otras mercaderías que de retorno se guiaban a Castilla y otras partes. La villa las necesita para probar su derecho ante las justicias de Aguilar y valles de Ordejón y Buelna, "sobre las cargas e descargas e guias que antiguamente se solian hazer por el puerto desta dicha villa, de los fardeles e mercaderias que... se cargavan e descargaban"525.

El Consulado de Burgos estaba exento del pago de portazgos, por lo que sus libros de cuentas recogen gastos de pleitos que ganaron, relacionados con el portazgo de Aguilar de Campoo. De esta manera, en mayo de 1550 se anotan 1.122 mrs. que gasta Juan de Palencia por ir a Aguilar a notificar la ejecutoria que tras los pleitos manda que no les deben cobrar los portazgos. Ese mes, el bachiller Juan Rodríguez paga $12.543 \mathrm{mrs}$. por los pleitos hasta fin de 1549, en relatores y letrados y seis ducados de las albricias de las ejecutorias de Aguilar, dos por las de Cabezón y otras dos de Fuentidueña526.

En julio de 1582 el corregidor manda a Pedro de Castañeda y Sebastián de Espinosa que vean el daño de las crecientes que en Burgos ha habido en mayo de 1582, "en los caminos que desta çiudad salen para... todos los puertos de la mar y a otras partes por donde entran los bastimentos a esta dich a çiudad y otras cosas de acarreo", y se calcule el coste de su reparación y de dónde podrán venir los materiales necesarios. Se indica que en el camino de Santander se midió un mal paso y cárcavo que hay donde llaman la Calleja Honda, "como ban desta çiudad a los puertos", que tiene de largo 420 pies y 10 de ancho y se ha de aderezar echando guijarro perdido puesto por orden, recebado con arena; que son 80 tapias a 500 mrs. la tapia porque está el guijarro lejos. También se midió "otro mal passo questa en el camino rreal que ba desta çiudad a Santander y a otros puertos ques mas aca de Quintanadueñas a do dizen la Muñeca", que tiene de largo 12.440 pies que son 500 tapias, lo cual se remediará haciendo una calzada de 10 pies de ancho con sus adoquines y traviesas de piedra tosca y guijarros, costando la tapia 10 rs. por estar la piedra lejos ${ }^{527}$.

Juan del Castillo, en nombre del concejo de Cartes, dijo al Rey que se había rematado la obra del puente y calzada de Santiago de Cartes en 3.800 ds. y se habían repartido entre las poblaciones de 15 leguas en contorno, pero muchos habían pretendido eximirse del pago con privilegios u otras causas, y el corregidor de Reinosa había dejado libres a muchos de los repartidos en más de 400 ducados, "y asi no se acabaria de sacar la canttidad nezesaria ni sin ella se podia hazer la obra", si no se incrementasen los mrs. entre los demás pueblos del primer repartimiento. Tras enviar el corregidor, en mayo de 1587, relación de las quiebras y bajas realizadas, que ascendían a 160.000 mrs., el Consejo acordó repartir dicha cantidad entre las localidades del primer repartimiento en proporción, y se ejecute y cobre

525 A. H. P. C./ J. T. A. leg. 37-2/ Los Corrales de Buelna, 14-15 mayo 1535.

526 A. D. B./ R-12/ Libro de caja de la Universidad de Burgos/ Burgos, 1549-1557. pp. God y 68d. "Libro de caxa de las quentas de la Vniversydad comenzado en primero de junyo de 1549 syendo prior Martyn Alonso de Salynas y Juan de San Martyn y Alonso de Maluenda consules y tesorero Alonso de San Bitores Maluenda". 
conforme a la Provisión y Comisión real, para que la obra finalice. El corregidor, en enero de 1588, puso un plazo de 6 días para que las localidades repartidas, pagasen a Rodrigo de Bustamante, vecino de Cartes, los mrs. asignados, apercibiéndoles de que pasado el plazo enviaría alguacil a su costa para cobrarlos. A los no cumplidores el corregidor mandó a Alonso Velarde, vecino de Laredo, que fuese con vara de justicia e hiciese ejecución en las personas, bienes y concejos hasta cobrar lo repartido, y a los que fueren remisos e inobedientes, "prendedles los cuerpos y presos..., los traed ante mi a la carzel publica desta uilla, y a los que no pudieredes prender les sacrestad sus bienes" 528 .

Con motivo del retorno de la Armada Invencible, el Rey manda al corregidor de Burgos, en octubre de 1588, "que acuda al remedio de los enfermos y heridos que uienen en el Armada que a llegado a Santander". Añade que la gente que viene sana se aloje en los lugares de aquella costa y en los de tierra adentro y, como la mayor parte de ellos irán a su distrito, le manda que nombre comisarios para que asistan a los que lleguen y dispongan y prevengan a sus vecinos para que el alojamiento se haga "comodamente y sin ruydos ni escandalos, pues esto a de durar muy pocos dias"529. En las cuentas dadas por los delegados de la ciudad, sobre los gastos ocasionados por la ida a Santander a auxiliar al duque de Medina Sidonia, se detallan los pagos ${ }^{530}$ :

\begin{tabular}{|l|r|}
\hline Concepto & Mrs. \\
\hline A cuatro arrieros vizcaínos por llevar 253 arrobas, a 2,5 rs. cada una & 21.505 \\
\hline A otro arriero que llevó unas arcas de 21 arrobas a 2,5 rs. cada una & 1.785 \\
\hline A Juan Pérez por una mula de ida y vuelta & 816 \\
\hline A Juan Pérez de un mozo por la mula en Santander porque le tomó la suya el duque & 102 \\
\hline $\begin{array}{l}\text { A Juan Pérez de una guía que tomó una noche yendo con las acémilas 68 mrs., } \\
\text { 5 rs. que dio al que llevó los escudos para volverse, y 30 rs. de su comida y de su } \\
\text { mula desde Burgos a Santander que allá y a la vuelta comió con los demás }\end{array}$ & 1.258 \\
\hline A Juan Pérez de 12 días que se ocupó uno aquí y once en ir y venir y estar & 1.632 \\
\hline $\begin{array}{l}\text { Del alquiler de 9 mulas, 7 días de ida y estada en Santander y se pagaron 6 por- } \\
\text { que un día holgaron }\end{array}$ & 3.672 \\
\hline De 5 mulas de silla de Santander a Burgos con uno que estuvieron allá & 1.360 \\
\hline De un mozo de mulas que estuvo 11 días a dos rs. por día & 748 \\
\hline De otro mozo que estuvo 7 días hasta que tomó el duque las mulas & 476 \\
\hline $\begin{array}{l}\text { De7 acémilas y dos hombres de Santander para traer los criados, por haberles toma- } \\
\text { do las mulas el duque y sus camas de 4 días a dos rs. por día y tres a cada acémila }\end{array}$ & 3.400 \\
\hline $\begin{array}{l}\text { De la comida de los señores y criados y los criados de la ciudad y de las mulas y } \\
\text { acémilas a la vuelta que eran } 14 \text { personas, lo mulas y dos acémilas en 11 días. }\end{array}$ & 20.705 \\
\hline A un alférez por mandado de la ciudad & 1.360 \\
\hline De limosna a dos frailes por mandado de la ciudad & 816 \\
\hline De ayuda de costa por su trabajo 6 ducados & 2.244 \\
\hline De 4 ducados a otro soldado italiano que mandó darlos la ciudad & 1.360 \\
\hline & 63.239 \\
\hline
\end{tabular}

528 A. H. P. C./ Corregimiento, leg. 3-12/ Madrid, 26 mayo 1587 y Reinosa, 6 enero 1588.

529 A. M. B./ HI-471/ San Lorenzo, 1 octubre 1588.

530 A. M. B./ Histórica, C-1-11-22/8// Burgos, 15 octubre 1588. 


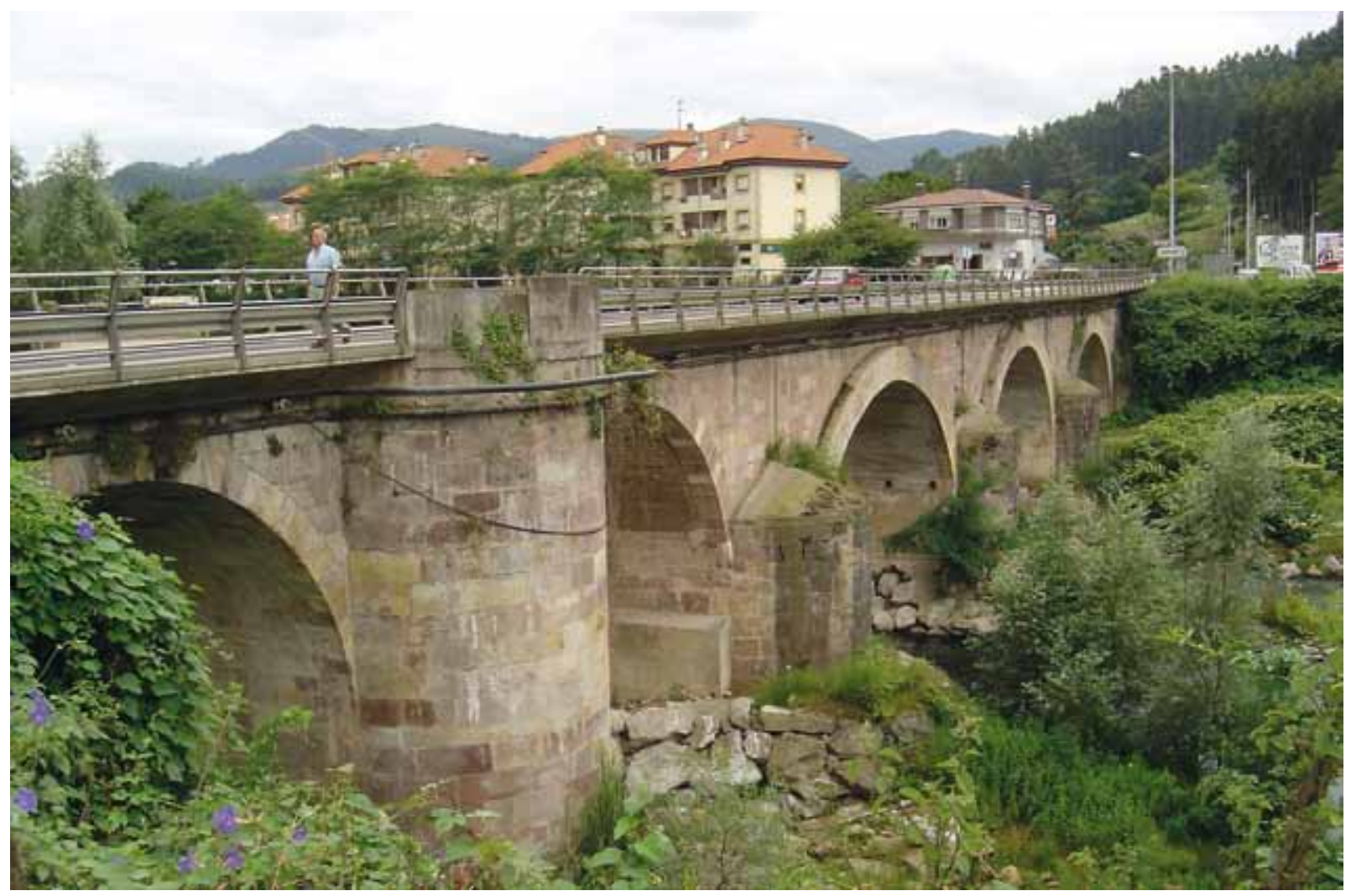

Puente actual de Cartes.

En abril de 1589 el Rey dice que está informado de que "las puentes de Matamorosa y de Rrocamunda y de Arçilla y de Hernan Pelaez y de Arze y de Cartes tenian neçesidad de haçerse y rrepararse", y que para ello se mandó repartir los mrs. necesarios entre los lugares que los utilizaban, pero aunque están cobrados, las obras no se han hecho y el dinero está en poder de los tesoreros, y como "las rrelaciones e ynformaçiones que sobre ello nos ynuiaron no fue con la berdad y puntualidad que se deuia, y porque... conuiene que se aberigüe y sepa lo que çerca de lo susodicho ha pasado e passa, y se tome quenta del dinero que se cobro de los dichos rrepartimientos", el Consejo Real acordó mandar al juez Juan López de Salcedo que averigüe en los dichos lugares los repartimientos hechos en esos puentes y, si se han cobrado, quién los tiene y en quién se remataron las obras, y si se han reparado o en qué estado están y, en su caso, por qué no se han hecho. Contra los culpables procederá con justicia y si le pareciere que los dineros han sido malgastados, lo ejecute en las personas y bienes de los responsables y todo lo deposite en poder del mayordomo de cada uno de los lugares. En agosto, Salcedo manda al alguacil Juan de Neila, que vaya a Cudón, la Torre de la Vega, Laredo y demás partes necesarias y se informe por sus vecinos y de los escribanos ante quienes han pasado los mandamientos y comisiones para cobrar los mrs. repartidos con destino al puente de Arce, de quienes los cobraron y las quiebras, autos y procesos que sobre ello se han causado, para con ello porveer justicia531.

El canónigo suizo Pellegrino Zuyer, enviado por el nuncio del Papa en España para obtener información sobre la desmembración de la Montaña de la diócesis de Burgos, sale de Burgos a mediados de octubre de 1660, dirigiéndose por Pancorbo a Bilbao, desde donde

531 A. H. P. C./ Corregimiento leg. 3-13/ Madrid, 18 abril y Santander, 28 agosto 1589. 
recorre el litoral hasta San Vicente de la Barquera, para volver a Burgos por el camino que hiciera Carlos I, por Cabuérniga, Los Tojos y Reinosa, continuando por Valderredible y el páramo hasta Burgos532. Según relata, "desde Reynosa hasta Burgos hay quince leguas, y durante tres leguas discurre el camino casi todo llano,... A una legua y media se pasa por la venta de Pozaçal, dejando Cervatos a mano derecha... Desde la venta de Pozaçal hasta Reozin de los Molinos hay otra legua y media, que discurre casi siempre por la ribera del rio Ebro, donde hay diversos molinos hasta la aldea... Otra media legua mas adelante se pasa junto a la aldea de Barcena, que es poca cosa. Y de aqui hasta la venta de Verzoncilla533, el camino es muy penoso y dificil de encontrar... Desde esta venta hasta otra que se llama Valladar hay otra legua y media de aspero camino, sobre todo en tiempo de invierno... Desde esta hospederia hasta Urbel de la Piedra hay tres leguas de muy buen camino, pasandose a mitad del trayecto por la aldea de Santa Cruz... Y de aqui hasta Ross hay tres leguas sin encontrar casa alguna, pasandose siempre por una campiña rasa que se llama Pisca534... Desde Ros hasta Burgos hay tres leguas, todo camino llano, y se atraviesa una aldea cada legua"535.

Las obras del camino carretero entre Reinosa y Santander se impulsarán tras la Real Orden de 29/11/1748 a cargo de la Real Hacienda, planteadas como un primer tramo de la carretera Burgos-Santander. Aunque estas obras se acabaron en 1752 y los remates duraron hasta 1753, las de Quintanilla de Cabria a Burgos se prolongaron hasta 1790. Construido básicamente sobre el antiguo trazado, replantea no obstante algunos trazados y modifica el ancho y el firme.

\section{Las llevas de pan a Santander}

Santander, como las demás villas de la costa del norte, padecía una grave carencia de vino y sobre todo de trigo, ya que dichas tierras no lo producían o no lo hacían en la cantidad suficiente para garantizar el suministro de sus habitantes, además de producir un vino de muy baja calidad. Aunque alguna partida de trigo llegaba por mar, el volumen principal venía de las tierras del interior de Castilla, tierra de Campos y provincia de Burgos. Fue una preocupación constante del concejo velar por la continuidad del suministro, para lo que recurrió de manera permanente al recurso de obligar a los comerciantes y arrieros que a la villa llegaban con otras mercaderías, principalmente lanas, a acompañarlas con determinadas cargas de trigo o pagar una cantidad establecida como compensación. También obligaba, bajo severas multas, a los arrieros que fueren a cargar al puerto a no ir de vacío, sino cargados del cereal.

En 1290 el concejo de Santander alegando que están pobres y por "la quema que les acaesçio", pide a Sancho IV que "les quitase el diesmo de todas las viandas que veniesen de fuera de nuestros regnos". El Rey ordena a sus dezmeros y guardas de los puertos que "de aquy adelante non tomedes diesmo ninguno de pan nin de vino nin de otras viandas ningunas, que qualesquier omes troxieren a Santander"536.

532 CASADO SOTO, J. L.: 2000: 289-345.

533 Berzosilla.

534 Se refiere al páramo de La Pinza.

535 La primera es Arroyal y la otra Quintanadueñas. Llegó a Burgos el 5 de diciembre.

536 A. Fam. González Camino/ Copia libro privilegios, f. 27r/ Palencia, 14 marzo 1290; SOLÓRZANO TELECHEA, J. A.: "Patrimonio documental...". 27: doc. 10. Este privilegio fue confirmado posteriormente por Fernando IV (Palenzuela, 8 octubre 1299) y Enrique II (Toro, 21 septiembre 1371) 
Los procuradores de Burgos pidieron a Juan II que por los servicios que la ciudad hizo a Enrique III, su padre, y a él, la ciudad merecía ser relevada de la lleva del pan a Santander y a otras partes, como se hizo desde tiempo de sus antecesores. En marzo de 1407 el Rey manda a sus contadores que nadie obligue a la ciudad a la dicha lleva y en febrero de 1408 Burgos pide que se mandase cumplir la merced y dar carta de Privilegio, lo que el Rey hizo mandando que todas las poblaciones lo cumplan537.

Rodrigo de las Cortinas se obligó ante el concejo de Santander, en octubre de 1461, a traer a la villa hasta fin de mayo "tanto trygo con cada saca de lana que ha esta villa truxere e metiere en este año", por cuenta de Alvar García Platero y de Alonso de Santa Cadea, su hijo, mercaderes vecinos de Burgos, el cual se obligó a traer el pan en ese plazo por la vía y forma que lo tiene en Laredo, y a venderlo en la villa al mismo precio que se vendiere en el palacio del trigo de dicha villa538.

Nicolás y Andrés, criados de los hermanos Alonso y Juan Fernández de Espinosa, mercaderes de Medina de Rioseco, se obligaron en abril de 1464 ante el concejo de Santander a llevar a la villa 800 celemines de trigo castellano hasta el mes de julio, por llevar por la villa 400 sacas de lana. Si los criados no trajeren el trigo en dicho plazo, perderán $10 \mathrm{mrs}$. por saca, que se les devolverían si en dicho plazo lo trajeren. Se puso como condición que traigan el trigo en carros y si no, en rocines que no lleven otra carga, y no en los mulos en que traen carga a la villa. El trigo se pondrá en una lonja a su costa y lo venderán por la medida y precio del palacio. Si trajeren más trigo de lo que están obligados, lo podrán vender al precio del palacio del trigo y si trajeren más sacas de las dichas en el plazo mencionado, las podrán cargar en el puerto depositando los $10 \mathrm{mrs}$. por saca, o trayendo dos celemines de trigo por saca, jurando que son de sus amos. No podrán alonjar las sacas ni pasarlas por el puerto hasta que lo sepa el concejo, so pena de 600 mrs. por saca al huésped que las alonjare. Además, los criados dejaron en el concejo 16 florines y tres enriques de oro y una corona nueva, en prenda de los $4.000 \mathrm{mrs}$. que montan las 400 sacas, a condición de que no pongan en la villa y su término ninguna de las 400 sacas hasta que lleven a Santander los 4.000 mrs. o el dicho trigo539.

En junio de 1470 el concejo de Santander arrienda a Ruy Vélaz de Entrambasaguas, mercader vecino de la villa, la renta de las sacas que al puerto llegaren por tierra por 68.500 mrs., entre 1471 y 1475, con la condición de que Vélaz recaude 5 mrs. por cada saca de lana que entrare en la villa que no venga acompañada del trigo correspondiente, y de las sacas que trajeren en mulos o en rocines con trigo no se llevará nada540. En septiembre de 1472 el concejo arrendó por 12.600 mrs. y en las mismas condiciones, la renta de las sacas que llegaren durante el año 1476 a Catalina Fernández de Pamanes, viuda Vélaz, después de cumplido el tiempo de los 5 años ${ }^{541}$.

537 A. M. B./ HI-84/ Segovia, 19 marzo 1407 y Alcalá de Henares, 20 febrero 1408.

538 A. H. P. C./ J. T. A. leg. 37-6/ Santander, 30 octubre 1461- 18 junio 1470; A. H. P. C./ Diversos. leg. 52, no 7, fols. 2r-3r/ Santander, 19 abril 1464 .

539 A. H. P. C./ J. T. A. leg. 37-6/ Santander, 30 octubre 1461- 18 junio 1470; A. H. P. C./ Diversos. leg. 52, nº 7, fols. 2r-3r/ Santander, 19 abril 1464 .

540 A. H. P. C./ Diversos. leg. 52, nº 7, f. 3 r/ 18 junio 1470; SOLÓRZANO TELECHEA, J. A.: "Patrimonio documental... ". 140-141: doc. 62.

541 A. H. P. C./ J. T. A. leg. 40-4/ Santander, 22 diciembre 1470 y 30 septiembre 1472. 
En junio de 1563 se realiza un informe jurídico sobre que la Universidad de Burgos, no guarda lo concertado con Santander ya que la villa, quería impedir la carga de las lanas por su puerto si no lo acompañan con dos celemines de trigo por saca, como antiguamente lo solían hacer, o pagar a la villa un tanto por saca, para compensar los daños que realiza su carretería y por la estancia y estiba de las naos, ya que para esto se consume mucho pan y mantenimientos en la villa, por lo que "en el pan haçen el daño, en pan le deben rresacar". Además, dice el informe que la carretería, cuando trae las sacas, hace gran daño en las mieses, sembrados, viñas y heredamientos, por lo que de derecho lo debe satisfacer en lo mismo, como es el trigo, para que la villa no padezca necesidad; porque tiene poca cosecha y si lo poco que coge lo consumen las naos, estibadores y carreteros, los vecinos quedan damnificados ${ }^{542}$. Otro informe jurídico realizado en septiembre dice que se deberá probar con testigos la esterilidad de la villa, y que en ella no se coge pan bastante para el sustento de sus vecinos, por lo que se provee de acarreo y alcanza excesivos precios aunque en Castilla valga barato, y valdría mucho menos si no fuese por la mucha gente que envía la Universidad de carreteros, marineros y estibadores. Se deberá también tratar que la pena que se les pusiere por no meter el trigo les obligue a cumplir y que los de la Universidad acepten, como mal menor, llevar con cada saca los dos celemines de trigo; pues podrán dar en alquiler las dichas sacas con la condición de meter el trigo, y los carreteros o trajineros que las lleven no dejarán de ganar con ello, pues como compraron lo venderán.

En septiembre, el ayuntamiento de Santander da poder especial al procurador general de la villa para la dicha demanda, y alegue el daño que la villa recibe por no haber acompañado a cada saca con los dos celemines de trigo, prohibiendo que entren las sacas sin el trigo, y en su caso, pueda la villa pedir restitución. La información que se ha de dar sobre el dicho embargo deberá ser también sobre los daños ocasionados por no meter con cada saca los dos celemines de trigo, y que todos los trajineros y carreteros que a la villa van por carga no la sacan "sin meter trigo o çeuada o açeite porque a no se haçer, los vezinos de la dicha villa e personas que a ella bienen padeçerian hanbre, como es tierra pobre esteril e de poco pan es neçesario se guarde la dicha costunbre, la qual ansimismo ay en las villas de Laredo e Biluao e Portugalete y en los demas villas e puertos desta costa de mar, que no sacan cargas sin meter cargas de bastimentos"543.

En marzo de 1574 el procurador general de Santander dice que la villa tiene una ordenanza que habla del pan que deben traer los mulateros y trajineros que lleguen para recoger carga para Castilla, y pide al alcalde que el Ayuntamiento la presente al Rey y su Consejo para su confirmación. Tal ordenanza decía que en Santander de tiempo inmemorial todos los mulos que llegaban para llevar carga a Castilla, salvo hierro, sal, naranja o limón, pastel o rubia, traían para su aprovisionamiento, "hanega y media de trigo por cada vna bestia mular, y por cada roçin o bestia asnal una hanega de trigo", y la justicia y regimiento de Santander ordenó que en adelante se cumpliese como está dicho y que la bestia que no lo traiga no saque carga alguna salvo las exceptuadas, y que el trigo lo puedan vender al precio que pudiesen, para que se reparta entre los vecinos y estantes y por el orden que la justicia y regimiento estableciere ${ }^{544}$.

542 A. H. P. C./ J. T. A. leg. 37-9/ Santander, 18 junio 1563.

543 A. H. P. C./ J. T. A. leg. 37-11 a, b y c/ Santillana, 7 septiembre 1563.

544 A. M. S./ Leg. B-306, nํ26/ Santander, 10 marzo 1574. 


\section{El puente de Arce a fines del siglo XV}

El reparo y mantenimiento del tramo entre Santander y el marquesado de Santillana, con el puente de Arce incluido, situado a unos $12 \mathrm{~km}$ de Santander, correspondía a dicha villa. Entre Santander y el río Saja, este camino es común con el que se dirige a San Vicente de la Barquera, por lo que ambos comparten el puente de Arce. Pellegrino Zuyer detalla en 1660 que "desde Sant Ander a Santillana hay cinco grandes leguas, pudiendose recorrer por dos caminos, el mas corto discurre pasando dos brazos de mar en barcas, que son la de Mogro, a dos leguas de Sant Ander, y la de Santo Domingo, una legua mas alla. Por ser esta travesia de algun peligro dada la poca comodidad de la barca, he tomado el camino del puente de Arce, que solo supone media legua de rodeo y esta a dos leguas de Sant Ander, casi todo buen camino"545.

En 1495 la villa de Santander dijo a los Reyes que está muy pobre, despoblada y sin trato por los grandes daños y gastos originados por diferentes causas, y que ahora el puente de Arce, "por donde pasan todos los mantenimientos y mercaderias e otras cosas que van e vienen a la dicha villa", en que han gastado muchos mrs. para su aderezo, las avenidas del mes de junio lo han llevado y eran necesarios más de 200.000 mrs. para su reparo. Pedía licencia para echar imposición tanto a los que fueren cabalgando o a pie como a bestias y ganados cargados o vacíos que pasaren por él, hasta obtener dicha cantidad. El Consejo acordó en junio mandar al corregidor de las Cuatro Villas que se informase acerca del daño del puente, quiénes son los que lo utilizan, cuántos mrs. serán necesarios, y si será mejor que la cuantía precisa se eche por sisa o por repartimiento, y dicha información la envíe al Consejo para que provea546. En 1496 el puente seguía impracticable y en mayo, ante la villa, Sancho Gutiérrez de Barcenilla "se obligo de fazer la puente de Arze, que es de esta villa, de madera, en çierta forma y la tener reparada y en pie veynte e çinco annos", según se contiene en la escritura de obligación, recibiendo 46.00o mrs. y asimismo el dicho Sancho Gutiérrez salió fiador por Rodrigo de Barcenilla y Rodrigo Cutiérrez de Gajano que se obligaron a rehacer de cantería sus pilares547. La obra no se realizó y el puente sufrió un mayor deterioro. Tras el fallecimiento de Sancho Gutiérrez en octubre de 1499, el teniente de corregidor obliga a Juan Fernández de Palacio, Rodrigo Cutiérrez y Rodrigo de Barcenilla, sus herederos, a la construcción de dicho puente ${ }^{548}$.

En noviembre Rodrigo de Barcenilla alega que "si algo el rio llevo de la dicha puente, fue por caso fortuito a causa de la gran llena e sobra de agua que paso por la dicha puente"549. Para esclarecer este asunto, se interroga a vecinos de Santander presentados por la villa, sobre si sabían que Sancho Gutiérrez concertó en 1496 con el concejo hacer "a su costa e mençyon, la puente de Arze..., fuerte e buena de maderas e clabazon por nos, e pondria en ello todas las maderas e costas neçesarias contenydas en una obligaçion que çerca de ello otorgo", asegurando que no caería ni se quebrantaría por ninguna cosa que faltare y lo daría hecho antes de Santa María de septiembre de ese año por 46.00o mrs.

545 CASADO SOTO, J. L.: 2000: 333.

546 A. H. P. C./ J.T. A. leg. 39-23/ Burgos, 27 junio 1495.

547 A. M. S./ Leg. B izdo. 191 bis. c)/ C. 1500; SOLÓRZANO TELECHEA, J. A.: "Colección Diplomática...". 434-436: doc. 259.

548 A. M. S./ Leg. B izdo. 191 bis. ํำ / Santander, 29 octubre 1499; SOLÓRZANO TELECHEA, J. A: "Colección Diplomática.... 346-347: doc. 216.

549 A. M. S./ Leg. B izdo. 191 bis. nํ7, fol. 1v-2v/ Santander, 4 noviembre 1499; SOLÓRZANO TELECHEA, J. A: "Colección Diplomática...". 348-350: doc. 218. 
Que Sancho Gutiérrez fue requerido y amonestado varias veces para que hiciese el puente en el plazo marcado y no lo quiso hacer. Que la villa no pudo obligar a "que la feziese, porque era persona poderosa e tal que ninguno podia con el, saluo lo que el queria hazer e quando le plazia, e por su culpa de non cumplir lo que estava obligado se cayo e quebranto la dicha puente, o mucha parte de ella". Que por no hacer el puente y caerse por ello, se causó un gasto de unos 2.00o rs. de plata en volverlo a reparar. Que tras la muerte de Sancho Gutiérrez fueron requeridos sus herederos para su reparación y no lo quisieron hacer, poniendo además pleito contra ella. Que Fernando de Rosillo y Juan Fernández, después de esto, se obligaron a hacer ciertas obras y edificios de cantería en el puente y reparar sus pilares para que durasen 25 años, por 8.210 mrs. que les dio la villa. Que Sancho Gutiérrez, como fiador y principal pagador de Fernando de Rosillo, se obligó a reparar de cantería los pilares y puente o se le devolvería a la cárcel pública de la villa donde estaba preso en 30 días, como reza la fianza. Que como Fernando de Rosillo y Rodrigo Gutiérrez no repararon los pilares y puente de cantería como se obligaron, uno de los pilares se abrió y se requirió para ello a Rodrigo Gutiérrez y Rodrigo de Barcenilla y como no lo quisieron hacer, la villa los reparó por más de 40.000 mrs. 550 .

Nada sabemos del interrogatorio, pero hacia 1500 el procurador general de Santander dice que como Sancho Gutiérrez y aquellos por quiénes salió fiador no cumplieron tras su fallecimiento, se puso demanda a estos como poseedores de los bienes de Sancho Cutiérrez. Fueron condenados Rodrigo de Barcenilla y María Cutiérrez de Escalante, viuda de Rodrigo Cutiérrez y tutora y tenedora de sus hijos y bienes, para que cumpliesen lo contratado y como no habían cumplido, la villa había reparado los pilares de cantería, así como las maderas que Sancho Cutiérrez estaba obligado a poner, gastando más de 60.00o mrs. , para lo que están obligados los bienes de Rodrigo Cutiérrez y de Rodrigo de Barcenilla. Y, además, como parte de las maderas que Sancho Gutiérrez puso en el puente están quebradas y está por ello en peligro de caer, se requiere a Rodrigo de Barcenilla y a María Cutiérrez para "que reparen la dich a puente de manera que este fixa al dicho tiempo que son obligados a la tener fixa y en pie", y no haciéndolo, se reclaman contra sus personas y bienes todos los daños y costas que a la villa se le hicieren, a causa del peligro que recibe el puente, y si la villa tomare carpinteros, será a costa de sus personas y bienes ${ }^{551}$.

\section{b.- Por Villadiego}

Un camino mulatero que entroncaba con el principal era el que iba por Villadiego. Fue poco utilizado para ir de Burgos a Santander, si tenemos en cuenta que tan solo hemos encontrado una referencia de 1585 que lo cita. Salía de Burgos por la puerta de San Martín y seguía junto al Arlanzón por Villalonquéjar, Las Quintanillas, Palacios de Benaver; cruzaba el Hormazuelas frente a Villorejo, Manciles, Olmos de la Picaza, Villadiego, Barruelo, Barrios de Villadiego, Portillo del Infierno, Fuencaliente de Puerta, San Mamés de Abar, Arcellares y entroncaba con el camino por Reinosa en Berzosilla. Desde Villadiego había

550 A. M. S./ Leg. B izdo. 191 bis. fols. Gr-7v/ ca. 1500; SOLÓRZANO TELECHEA, J. A.: "Colección Diplomática...". 353355: doc. 227.

551 A. M. S./ Leg. B izdo. 191 bis. c)/ c. 1500; SOLÓRZANO TELECHEA, J. A.: "Colección Diplomática...". 434-436: doc. 259. 
otra alternativa por Tablada de Villadiego, Villalbilla de Villadiego, Hormicedo, venta de Colmenares, Talamillo del Tozo y por la venta de Valladar seguía por el camino de Reinosa.

En un repartimiento realizado en 1585 se menciona una de las veredas utilizadas desde Burgos por los oficiales para conocer el número de vecinos de cada localidad con el fin de fijar la cantidad repartida, de la manera siguiente: "bereda que ba dendesta çiudad camino de Santander por Villadiego..."552.

\section{c.- Por Quintanilla de Valdearroyo}

La Universidad de Burgos paga 6.00o mrs. en agosto de 1550 a Garci Rabin, porque ha de "hazer la puente de Quintanilla de Baldearroyo y cargarla y hazer una calçada de piedra" de lo cual hizo obligación ante escribano553. No hemos encontrado más referencias sobre dicho puente ni sobre cualquier otro lugar de un hipotético camino que cruzase el río Ebro por este lugar, por lo que nos inclinamos a pensar que la iniciativa mencionada no tuvo ningún desarrollo. Avala esta suposición el que la referencia citada indica que se pretende hacer una calzada de piedra, por lo que no estaba realizada en esas fechas. Quintanilla de Valdearroyo es una localidad hoy desaparecida bajo el pantano del Ebro, que en el siglo XVI se encontraba fuera de las principales rutas comerciales que estudiamos. No encontramos una razón aceptable para la construcción del puente referido, si no forzamos la suposición de un camino del que no tenemos ningún otro dato.

No obstante, y como decimos, de manera muy forzada, adelantamos un posible camino que discurriría en paralelo al camino de Reinosa ya tratado, entre las localidades de Fombellida y Bárcena de Pie de Concha. Partiendo de la dicha localidad de Fombellida, discurriría por Celada-Marlantes, Medianedo, donde cruzaría el río Ebro, Quintanilla de Valdearroyo, el término de La Venta, llano de la Virga, Monegro y San Miguel de Aguayo, y superando un largo tramo de montaña y pasando junto a la actual presa de Alsa, seguiría por este camino hasta Bárcena de Pie de Concha, desde donde proseguiría por el camino de Reinosa.

\section{B.- POR LA SIERRA DE EL ESCUDO}

Para la comunicación con Santander por la sierra de El Escudo y los cursos del arroyo de la Magdalena y río Pas, se utilizaron desde Burgos al menos seis caminos diferentes: por el Tozo y Corconte, por Corconte y sierra de El Escudo, el entronque de la vía de Reinosa, por Lanchares, por el puente de Rampalay y por Soncillo.

\section{a.- Por el Tozo, barrio de Corconte y puerto homónimo}

En el siglo XVI el Consulado de Burgos repara y construye algunos tramos de un ca- 
mino acondicionado para ruedas 554 . Fue vía principal, utilizada con dificultades por los carros y discurre por el Tozo, valle de Valderredible, Corconte, puerto de Corconte y los valles de Toranzo, Cayón y Camargo, siguiendo el curso del Pas.

Salía de Burgos por la puerta de San Gil, e iba por Villatoro, Vivar, Sotopalacios, Ventas de Quintanaortuño, Ubierna, San Martín de Ubierna, Montorio, Quintana del Pino, Úrbel del Castillo, Santa Cruz del Tozo y venta de Valladar555. Bajaba al valle del Ebro por Rocamundo, vado del Ebro, Arenillas, Ruerrero, Repudio, Linares de Bricia, Villamediana, Lomas, Montejo de Bricia, Arnedo y Herbosa. Desde Herbosa cruzaba la llanura de la Virga hasta el barrio de Corconte y puerto homónimo y por los valles de Luena y Toranzo, seguía el curso del arroyo de la Magdalena y su continuación junto al río Pas. De Corconte proseguía por Bollacín, San Miguel de Luena, San Andrés, Entrambasmestas, Alceda, cruce del río Pas, Vejorís, San Martín, Santiurde de Toranzo y Villasevil. Entre Alceda y Villasevil, el camino también podía dirigirse por la margen izquierda del río Pas, por un terreno más agreste, por Ontaneda, San Vicente de Toranzo, Villegar, Borleña y Prases, pudiendo a su vez proseguir por esta misma orilla del Pas por Puenteviesgo y Vargas. Después por Iruz, Pando, puente sobre el Pisueña, Pomaluengo en el valle de Cayón, venta del Caballar556, La Penilla, La Encina, Sarón, Obregón, Villanueva, Solía, donde cruzaba la ría de su nombre, valle de Camargo, Muriedas y Peñacastillo, llegaba a Santander.

De Herbosa partía en dirección Este el camino que en los documentos se menciona como "el camino de los carros", que se prolongaba hasta Laredo por Sotoscueva, Espinosa de los Monteros y Agüera, camino que fue utilizado para transportar cargas pesadas. Así, cuando en 1552 se va a tratar sobre un puente hecho para pasar los carros entre Cilleruelo y Virtus, se pagan 136 mrs. "a Diego Lopez de Gustamante escribano, porque fue con él a Erbosa a hazer los rrequerimientos" 557 .

Este será el camino por el que la Universidad de Mercaderes de Burgos llevará gran parte de sus sacas de lanas al puerto de Santander, al menos en las décadas centrales del siglo XVI, y en el que dicha Universidad realizará sus actuaciones más decididas con el fin de mantenerlo operativo. Realizará tramos completos, puentes, obras de consolidación, etc. soportado todo con sus propios recursos económicos.

El 8 de marzo de 1497 desembarca en Santander la duquesa Margarita de Austria para encontrarse con el príncipe Juan. Trajo un voluminoso y rico equipaje y "ciertos extraños vehículos de cuatro ruedas, llamados carrozas". Tras descansar unos días en Santander, marchó hacia Burgos, encontrándose en Villasevil con el rey Fernando y el príncipe Juan, su marido558, continuando juntos por el puerto de Corconte. De Santander a Burgos tardó la duquesa 9 jornadas, lentitud debida a los bueyes que debieron tirar de las carrozas al ser áspero el ca-

554 Se le llama en los documentos "camino de los carros", que por Sotoscueva iba a Laredo.

555 Valladar es un despoblado en el término y a $800 \mathrm{~m}$. al E.-N.E. de Basconcillos del Tozo, en la entrada de la garganta atravesada por el camino de esta localidad a Barrio-Panizares, después conocido como venta de Valladar: MARTÍNEZ DÍEZ, G.: 1987: 397.

556 Ramón Lanza sitúa la venta del Caballar en Cayón. LANZA GARCíA, R.: 2010: 203.

557 A. D. B./ R-6/ Manual del libro de cuentas de la Universidad de Burgos/ Burgos, 1549-1557.

558 Se casaron por poderes en Malinas, el 5 de noviembre de 1495, representando al novio el embajador de España, Francisco de Rojas. 
mino559. Según Jerónimo Zurita, se encontraron en el valle de Toranzo "junto a Reinosa"560, algo que no es exacto, por no pertenecer Reinosa a dicho valle, donde sí lo está Villasevil. Luego, indica que los contrayentes siguieron juntos por Aguilar para llegar a Burgos. Por otra parte, Alonso de Santa Cruz en su Crónica de los Reyes Católicos ${ }^{561}$ dice que el Condestable fue a Santander para acompañar a la duquesa hasta Burgos, donde el rey Fernando la esperaba tres leguas antes.

El encuentro se produjo en Villasevil como se ha dicho, en la casa de Diego de Villegas, que como autor de una muerte, pidió el indulto aprovechando la ocasión. Suplicó al rey que como el desposorio de los príncipes se celebró en su casa, le perdonase. El Rey dice en mayo de 1497 que por "quel casamiento e desposorio de los ylustrisymos prinçipes don Juan e prinçesa doña Margarita,... se feziese e çelebrase como se hizo en su casa del dicho Diego de Uillegas, e otrosy por la alegria e plazer que yo oue con la venida de la dicha prinçesa, que vsando con el de clemençia le perdonase", le perdonaba de los dichos delitos y muertes ${ }^{562}$. La versión de Villegas difería de la que dan los padres del fallecido, y el Rey utilizando la declaración de estos dice a Villegas que este con 18 hombres "alevosamente e a trayçion, ...matastes al dicho Françisco de Çaballos estando dormiendo en la cama en su casa". El Rey no obstante, ratificó el perdón para Villegas, pero no para sus cómplices ${ }^{563}$.

La Universidad de los Mercaderes de Burgos, utilizó este camino con intensidad, al menos a mediados del siglo XVI, para el transporte de sus sacas de lana a Santander, teniendo como punto central el almacén de lanas de Corconte, construido por ella en esas mismas fechas, antes de bajar el puerto de Corconte.

Los procuradores de los concejos de Herrera, Igollo y Cacicedo en Camargo, comparecieron en Santander en septiembre de 1542 y dijeron que como la justicia y regimiento de Santander trataba pleito contra ellos sobre el maltrato que hicieron a Juan Díaz de Luena y Diego de Castañeda de Monegio, carreteros y trajineros que llevaban y traían mercaderías a Santander, sobre el estrechamiento de los caminos de la Mier en sus concejos, y sobre otras cosas que están ante el juez, dichos concejos quieren evitar costos y daños y desean conservar su buena vecindad; algo posible porque Santander también tiene la misma vo-

559 RIBAS de PINA, M.: 1949: 123-124. FERNÁNDEZ de OVIEDO, G: 2006. Había traído a Castilla por primera vez, los denominados carros franceses de cuatro ruedas, poco adecuados para la complicada orografía de Castilla y demasiado costosos: "a causa de la comunicaçion de Flandes, ay muchas literas, e ovo un tiempo carros de quatro ruedas cada uno (que truxo a Castilla la prinçesa Madama Margarita, mi señora, en que, algunas veces, con particulares damas de Su Alteza, se salia al campo); pero como esos carros no los podian sostener (con cuatro o çinco cavallos que han menester) sino personas de estado, e no son sino para tierra Ilana e Su Alteza, despues que embiudo, se torno a Flandes, çesaron tales carros, e quedose la costumbre de las literas".

560 ZURITA, G.: 1580: 117. "Mandaron el Rey, y la Reyna hazer grandes apercibimientos, para recibir la Princesa Margarita su nuera: y lo primero fue mandar yr a Garcia de Cotes, que era corregidor de Burgos, a la villa de Santander: donde se ordenaua, que viniesse a desembarcar: para que tuuiesse toda la comarca muy bien proueyda: .... Por el mes de Março deste año de MCCCCXCVII Ilego al puerto de Santander la armada de España, que traya de Flandes a la Princesa,... Salieron a recibir a la Princesa el Rey, y el Principe, acompañados de don Diego Hurtado de Mendoça Patriarcha de Alexandria, y de muchos grandes: y vieron se junto a Reynosa, en medio del valle de Toranço: y en aquel lugar les tomo las manos el Patriarcha de Alexandria: y de alli fueron por Aguilar a Burgos: donde se celebraron los desposorios el Domingo de Ramos, con mucha solenidad."

561 SANTA CRUZ, A. de: 1951: 164-165 "... y se partio [el condestable] de Burgos muy acompañado de señores y cavalleros y muchas otras jentes, y fue donde estava la Princesa, y la trajo a la ciudad de Burgos, haciendoles muchas fiestas y regocijos en todos los lugares por do pasaron. Y tres leguas antes de llegar a la ciudad, le salio el Rey Catolico al camino, y la vino acompañando y hablando con ella y con los que con ella venian, con mucho placer y regocijo".

562 A. G. S./ Registro General del Sello, V-1497, fol. 17/ Burgos, 6 mayo 1497.

563 A. G. S./ Registro General del Sello, VIII-1497, fol. 85/ Medina del Campo, 9 agosto 1497. 
luntad. En cuanto a las acusaciones de maltrato a los carreteros, queda a cargo de los procuradores el que satisfagan daños y costas, y sobre el camino de la Mier de Herrera dijeron que aceptaban lo que fuere acordado entre Juan de Escalante y el prior de Santillana y pagar los gastos hechos a Santander. También se obligaron a que ni el gobernador de Santillana ni otra justicia procediesen contra el alcalde de la hermandad, regidor y escribano de Santander por haber entrado en el marquesado de Santillana con vara de justicia sobre el conflicto por los pastos entre Juan Cómez de Herrera y Juan Díaz de Luena, carretero564.

Para trasladar en 1551 un importante número de piezas de artillería que procedente de Flandes había desembarcado en Laredo, se hace un informe sobre el camino más conveniente para desplazar tan pesado cargamento desde Limpias, donde estaba, hasta la ciudad de Burgos, y se planteaba que el tren de artillería iría por el camino de los carros, por Espinosa de los Monteros hasta Herbosa, donde conectaría con el camino carretero que de Santander venía por Corconte, llano de La Virga y Herbosa. Así, se indica que después de Herbosa "esta Arnedo y Montejo y Lomas y Villamediana y Rrepullo565 y Rruaherrero que todo esta dentro de quatro leguas... De Rruaherrero se ba a Rrocamuda vna legua, pasase el bado d'Ebro por medio del camino destos dos lugares, pasado Rrocamuda prençipia a subir vna cuesta muy braba y de muy malas bueltas y larga de media legua... Ay de Rrocamuda a Valladar dos leguas... De Valladar a Santa Cruz dos leguas... A Quintana del Pino vna legua... De Quintana del Pino a Montoyo ay una legua y una cuesta... A la Ubierna dos leguas... A la Benta de Quintana Hortuño [una legua]... De alli a Sotopalaçios y a Bibar y Villatoro hasta Burgos ay dos leguas"566.

En septiembre de 1570 se había elaborado un itinerario para que la reina Ana de Austria fuese desde Laredo por Medina de Pomar y un itinerario alternativo más suave para la circulación de los coches de su séquito "por donde pueden venir los coches" hasta Burgos. Sobre este último camino, se indica que en Agüera de Montija "se an de apartar los coches a Espinosa de los Monteros, y a Rruy Herreros y a Rocamundo y ban dando la buelta por tierra llana a Burgos aunques rodeosa", dejando en este caso que la Reina siguiese en literas por Medina. Como vemos, es el mismo camino que en 1551 se menciona para trasladar el tren de artillería567.

En 1589 Felipe II dice que se hizo repartimiento para reparar los puentes de Rocamundo y de Arcilla ${ }^{568}$ entre los lugares que los utilizaban, pero aunque estos han pagado, dichos puentes no se han reparado, por lo que se debía averiguar lo ocurrido. El Consejo mandó al juez que averigüe los repartimientos realizados, en poder de quién están, en quién se remataron las obras y por qué no se han reparado, y si los dineros han sido malgastados lo ejecute en las personas y bienes de los responsables ${ }^{569}$.

Este camino seguía teniendo atenciones, ya que en 1640 se repartieron $27.778 \mathrm{mrs}$. al Valle de Mena para el edificio del puente de Arija, pagados por el procurador de Mena a Fernando Sigler, vecino de Reinosa570.

564 A. H. P. C./ J. T. A. leg. 34-12/ Santander, 17 septiembre 1542.

565 Se refiere a la villa de Repudio.

566 A. G. S./ Guerra y Marina. leg. 42, fol. 118/1551.

567 A. G. S./ Patronato Real, leg. 57, doc. 90/ Antes del 3 octubre 1570.

568 Parece referirse al puente de Arenillas de Ebro.

569 A. H. P. C./ Corregimiento leg. 3-13/ Madrid, 18 abril y Santander, 28 agosto 1589.

570 A. H. V. M./leg. 6, p. 356 a 365/Villanueva de Mena, 8 marzo 1641. 


\section{La Universidad de los Mercaderes de Burgos, constructora de caminos}

La Universidad de Burgos, para garantizar un tránsito adecuado con el puerto de Santander, se preocupó de que los caminos estuviesen en un estado aceptable, por lo que tomó parte activa en su acondicionamiento. En sus libros de caja y contabilidad se recogen los pagos efectuados para realizar las construcciones, reparaciones y mantenimientos de estos caminos y puentes. Se registran gastos e inversiones en el camino del Carro que desde Burgos por el Tozo iba a Laredo, y en el camino de Laredo por los Hocinos, el de Portugalete y el de Santander por Lanchares o Quintanilla de Valdearroyo; pero sobre todas estas iniciativas, destaca ampliamente la participación, cuando no la asunción en solitario, de actuaciones en el camino de Burgos a Santander por Corconte. Este fue el camino que acaparó la mayor parte de los esfuerzos constructores de la Universidad de los Mercaderes, al menos en los 50 años centrales del siglo XVI, lo que evidencia la importancia que le concedieron.

Entre los años 1539 y 1588, fechas de los libros de contabilidad conservados en el Archivo de la Diputación de Burgos, encontramos un gran número de referencias sobre los mencionados gastos. Incluso en una ocasión, asumió cierta responsabilidad en un accidente mortal ocurrido en un puente construido por el propio Consulado571.

También encontramos que los vecinos del barrio de Corconte trataban de impedir en 1550 el paso de las mercaderías por su término, cuyo motivo ignoramos. La Universidad pagó en agosto $1.020 \mathrm{mrs}$. a Pedro de Ochandiano para que fuese allí con un receptor que puso el alcalde mayor "para que los lugares de aquella comarca no estorben el paso a los carreteros que lleban las sacas a Santander por Corconte". Se gastaron además $136 \mathrm{mrs}$. con los testigos que se detuvieron en Corconte y 1.547 pagados a Ochandiano por los 13 días que estuvo con el receptor para hacer la probanza de cómo "ympedian el camino de aqui a Santander". En octubre se pagaron $3.084 \mathrm{mrs}$. de salario y costas al receptor que "fue a prender a los de Corconte" y 5.151 mrs. a Diego de los Ríos por el gasto de 26 días que estuvo a "desenbargar el camino de Corconte", a 5,50 rs. por día y por otros gastos del viaje ${ }^{572}$.

En el que llaman "camino de Corconte", Rodrigo de Alcedo gastó en 1560, 25.748 mrs. en aderezarlo para pasar los carros con las sacas a Santander. En 1563 el mismo gastó $5.100 \mathrm{mrs}$. y $2.295 \mathrm{mrs}$. del resto de $7.395 \mathrm{mrs}$. en el aderezo de estos caminos por 13 días que se ocupó a 102 mrs. por día y otros gastos 573 . En 1568 se habían gastado hasta mayo $7.158 \mathrm{mrs}$. en el reparo de este mismo camino y $3.774 \mathrm{mrs}$. por el trabajo de Alcedo de 37 días a tres rs. por día574.

Sobre el tramo entre Arenillas y Ruerrero en Valderredible, el Consulado concedió 300 rs. "para yr a Rruy Herreros", pagando en 1541 al Prior 5.304 mrs. y al secretario los 4.896 mrs. restantes en la ida a Ruerrero, estada y vuelta con Juan de Castro, Gómez de Quintanadueñas y el licenciado Salamanca cuando fueron a hablar con los de Santander ${ }^{575}$. Se dieron 5.100 mrs. en 1568 a García Martínez, vecino de Arreba, "por el trauajo que toma en hazer

571 A. D. B./ R-15/ Libro de caja o Mayor del Consulado/ Burgos, 1568-1577. "Libro de los muy magnificos señores prior y consules de esta Vniversidad de Burgos comenzados en prinzipio de este año de 1568 que para seruicio de Dios y de su bendita madre sea amen".

A. D. B./ R-6/ Manual del libro de cuentas de la Universidad de Burgos/ Burgos, 1549-1557.

A. D. B./ R-14/ Libro de caja de la Universidad de Burgos/ Burgos, 1557-1567. 
la puente en el bado de la Concha en Balderredible junto al lugar de Arenillas", sobre el río Ebro, "aunque no heramos obligados a darlo" 576 .

El tramo de la llanura de la Virga, por ser terreno pantanoso no era propicio para asentar caminos de cierta importancia, pero se hizo uno de nueva construcción, algo que solo se podía emprender con el empeño decidido de una institución como la Universidad, que apuesta por este camino superando serios inconvenientes para su asentamiento y firmeza. De hecho, la Universidad realiza en el llano pantanoso un puente frente a Corconte, hoy bajo el pantano de Arija, por donde este camino salvaba el arroyo de la Virga y que pensamos que puede tratarse del que entre 1544 y 1561 recibe las actuaciones del Consulado de Burgos. De esta manera, en 1544, la Universidad gastó $476 \mathrm{mrs}$. "en adreçar la puente de la Bilga"577. En 1551 se pagan 11.250 mrs. a Diego de los Ríos por su salario de 6o días entre el 16 de junio que partió de Burgos y el 14 de agosto que volvió, a medio ducado por día, que se ocupó en "hacer la puente y calzada de piedra en la Birga de Canpo, que conbenya mucho para el pasar de las sacas a Santander" 578 . En 1556 se gastan 1.874 mrs. que dio por cuenta Rodrigo de Alcedo, criado de Diego López Gallo, para "aderezar los malos pasos que abia en Corconte y por alli zerca camino de Santander"579. En 1560 Alcedo gastó 3.468 mrs. en aderezar dicho puente y en 1561 se le deben $65.240 \mathrm{mrs}$. que había gastado, entre otras actuaciones, en "aderezar la puente Birga" por 16.847 mrs. para pasar los carros con las sacas a Santander y 9.000 mrs. por su salario580.

Para el aderezo del camino en Luena, Diego de Bernuy envió en 1548 en dos veces a Luena 42.900 mrs. a Alonso de Sanvitores Maluenda, para el "adreço de los caminos de Santander". Sanvitores gastó $63.771 \mathrm{mrs}$. en el aderezo de estos caminos con $11.152 \mathrm{mrs}$. de su salario de 41 días a 8 rs. por día ${ }^{581}$.

En junio de 1571 Sanvitores da cuenta de 44.700 mrs., gastados en "la puente que se hiço nueba en Cayon" y en el aderezo y reparo de los caminos ${ }^{582}$.

Para el que llaman "camino de Camargo" se pagaron en 1549 a Juan Ruiz de Escalante $2.232 \mathrm{mrs}$. En 1560, Alcedo debe $1.258 \mathrm{mrs}$. por aderezar en agosto y septiembre el camino en el valle de Camargo para pasar los carros con las sacas a Santander. En 1561 Alonso de Compludo gastó 110 rs. en "adereçar el camino de Camargo la Menor" y 6 rs. que pagó a Leonardo de Santiago por empedrar un arroyo y en 1563, se gastan 9.922 mrs. en "aderezar el camino de paso de Camargo" y en el edificio del paredón de Bárcena.

La Universidad construye puentes como "la puente dela Molina que se hizo nueua", que aunque sabemos que se encuentra en este camino, no hemos podido fijar su situación. Así, en 1561, se pagan 36.707 mrs. por lo que Rodrigo de Alcedo hace en este puente, y en 1563 Alonso de Compludo gastó $37.169 \mathrm{mrs}$. en "los rreparos de los caminos a saber en la puente de la Mo-

576 A. D. B./ R-15/ Libro de caja o Mayor del Consulado/ Burgos, 1568-1577.

577 A. D. B./ R-3/ Libro de caja de la Universidad de Burgos/ Burgos, 1539-1549.

578 También gastaron 5.848 mrs. en piedra tosca y sillares, 1.632 en cal y arena, 1.904 en madera gruesa y menuda, 748 de clavazón y pagó $14.535 \mathrm{mrs}$. a los que trabajaron en hacer este puente y calzada en diversos días.

579 A. D. B./ R-6/ Manual del libro de cuentas de la Universidad de Burgos/ Burgos, 1549-1557.

580 A. D. B./ R-14/ Libro de caja de la Universidad de Burgos/ Burgos, 1557-1567.

581 A. D. B./ R-3/ Libro de caja de la Universidad de Burgos/ Burgos, 1539-1549.

582 A. D. B./ R-15/ Libro de caja o Mayor del Consulado/ Burgos, 1568-1577. 
lina", y en lo que se dio a Alcedo. Pedro de Rucavo, vecino de Santander, da cuenta en 1566 de los gastos en puentes y caminos y, entre otras actuaciones, dio 121 rs. a Sancho Ruiz de Villegas por "vna tierra que se le compro para la puente de la Molina".

Otro puente situado en este mismo camino, que también la Universidad reparó y que no hemos localizado, es el puente de Vallejo. En 1561 se pagó a Rodrigo de Alcedo 65.240 mrs., entre otros conceptos, 2.686 mrs. para "aderezar la puente de Uallejo y los caminos de Corconte" y $9.000 \mathrm{mrs}$. por su salario cuando se ocupó en dichos puente y caminos. Solo hemos encontrado esta referencia, por lo que es muy posible que la anotación contable se refiera al puente de Valcallejo.

En 1565 se menciona el gasto de 8.050 mrs. en "el camino de la parada del Somo" realizado por la intervención de Rodrigo de Alcedo, y tampoco sabemos a qué punto del camino se refiere.

Sobre los reparos de "los caminos de Santander", referidos al camino entre Burgos y Corconte, encontramos un gran número de referencias a gastos realizados entre 1544 y 1584 . Como encargados de estas actuaciones destacan Pedro de Rucavo, que realizó intervenciones entre 1545 y 1566; Diego de los Ríos, que trabajó en estos caminos entre los años 1549 y 1557; Rodrigo de Alcedo en 1553, criado de Diego López Gallo, que se ocupó en ello entre 1553 y 1569 , y Juan Soga entre 1566 y 1568583.

583 - En mayo de 1544, Rodrigo de Miranda, criado de Diego de Bernuy, debe dar cuenta de los 3.190 mrs. que se le dieron en 1540 para "adereçar los caminos de Santander", y dice que ha gastado más y lo demanda. Se sacan 59.605 mrs. para que se gaste en aderezar los caminos. En noviembre, se acordó pagar 8.000 mrs. a Juan Páez por su trabajo de "6o dias que se ocupo en lo de los caminos".

- Diego López Gallo da cuenta en mayo de 1545, de los 54.974 mrs. que "a gastado en adereçar los caminos de Santander" los años pasados. Diego Ruiz de Miranda recibió 16.771 mrs. y carta de 12 ds. en octubre para despachar las naos y aderezar los caminos. También se pagan $646 \mathrm{mrs}$. a Pedro Marcos, de los $6.368 \mathrm{mrs}$. de costas que hizo para los caminos. En septiembre Pedro de Rucavo cobra en Santander 12.531 mrs. por 4 naos de la flota para Flandes por el aderezo de caminos y puentes. En diciembre se dieron a Rucavo $2.250 \mathrm{mrs}$. por la mitad de los 12 ds., por el "trauajo que tuvo en lo de los caminos" y López Gallo da 7.779 mrs. a Rucavo por aderezarlos.

- En marzo de 1547 el Consulado dio 10.104 mrs. para allanar los caminos, y en mayo, se gastaron 69.692 mrs. en su aderezo.

- En julio de 1549, se deben 10.200 mrs. de las costas de los caminos de Santander, Laredo y Portugalete: 100 rs. que gastó Diego de los Ríos que fue a visitarlos con maestre Ochoa, cantero, y volvió por el camino de Santander, y se detuvo 18 días. En agosto de los Ríos gastó en aderezar dichos caminos 17.000 mrs. que le dio Alonso de Valencia cuando partió de Burgos.

- En marzo de 1550 se gastaron 12.432 mrs. en aderezar los caminos de Santander y Laredo, y en mayo, se dieron $17.000 \mathrm{mrs}$. a de los Ríos para lo que ha de "gastar en el camino que fue a aderesçar de aqui a Santander". Francisco de Maluenda pagó 9.610 mrs. a de los Ríos por el resto de la cuenta de los caminos, y 27.200 mrs. que envió a de los Ríos para aderezarlos. En junio, Juan de Santibáñez envió 51.000 mrs. a de los Ríos y en julio, 7.500 a Rodrigo Cachopín. En agosto, se dieron 1.020 mrs. a Pedro de Ochandiano para aderezar los caminos, y a de los Ríos 9.610 mrs. de gasto de los caminos y $19.261 \mathrm{mrs}$. de su salario y costas de los 103 días que estuvo aderezándolos, entre abril y agosto a 187 por día. También se le deben 112.749 mrs. de gastos, jornales y materiales de los reparos. En noviembre se pagan 4.5O2 mrs. para ir a "los caminos de Santander de hazer adereçarlos y hazer llebar las sacas a los carreteros". En diciembre Alonso de Compludo gastó en los reparos, 101.380 mrs. que cobró en la Montaña de las sacas para Flandes, Nantes y Ruán a 5 mrs. por saca. También se gastan 51.192 mrs. en reparar los caminos de Santander y Laredo, "por donde bayan las sacas en carros", cobrándose 105.324 mrs. de las sacas cargadas a 5 mrs. por saca, y se ha de cobrar en 1551 de las sacas que se cargaren. De los Ríos dio 24.667 mrs. por el "adrezo del camino para los carros que ban a Santander", $5.848 \mathrm{mrs}$. de su salario por Go días y $14.535 \mathrm{mrs}$. por la gente que trabajó.

- En marzo de 1551 Pedro González de Escalante cobró 33.200 mrs. de las averías desde mayo de 1550, de los fardeles que habían venido a 8 mrs. por fardel, que se aplicaron a los caminos. En mayo, Leonardo de Santiago debe por costas de los reparos 17.305 mrs. cobrados de las 4 naos que despachó, por las sacas a 5 mrs. por saca. En julio de los Ríos da cuenta de la ida a la Montaña para lo que se llevó 3.400 mrs. para aderezar los caminos que entiende con Lope García de Porres por ser en su tierra, y también da cuenta de los 9.800 mrs. gastados en la ida para tales aderezos. En octubre, se contabilizan 15.105 mrs. de dichos gastos.

- En diciembre de 1552, Valencia pagó 5.063 mrs. a de los Ríos por 9 días de ir y venir a Santander llevando 32.800 mrs. con dos mozos y una acémila, alquiler de ella, y su salario y el de los mozos.

- En abril de 1555, de los Ríos gastó 5.622 mrs. en aderezar los caminos de Santander. 
- Debe además en abril de 1556, 27.910 mrs. que le dio Melchor de Múgica en Santander, para aderezarlos. En abril, de los Ríos gastó $94.732 \mathrm{mrs}$. en aderezar los caminos de Santander, de los que $28.560 \mathrm{mrs}$. eran por su salario y trabajo de 105 días que se ocupó con su cabalgadura, a 272 mrs. por día, estando también en Santander a ayudar a Múgica. - En marzo de 1557, de los 137.067 mrs. gastados en los caminos de Santander, 66.665 mrs. son por 11.236 sacas a 6 mrs. por saca menos el $6,75 \%$ y lo demás es de otras dos flotas, $51.430 \mathrm{mrs}$. por 8.669 sacas que fueron a Flandes en 6 naos y $18.972 \mathrm{mrs}$. por 3.198 sacas, de la otra flota. Valencia pagó a de los Ríos 34.000 mrs. para aderezar los caminos, y a Múgica 17.000 mrs. para ir a Santander. En abril, de los Ríos debe 4.500 mrs. que le dio Sebastián de Muncharaz para dar a Vallejo, cantero, para ir al camino. En mayo, de los Ríos debe 3.400 mrs. que le dio Muncharaz el pago a los oficiales.

- En agosto de 1560, Rodrigo de Alcedo debe 13.600 mrs. que dio a Pedro de la Puebla para que le llevase a aderezar los caminos. En octubre se deben por el despacho de las sacas, $3.375 \mathrm{mrs}$. a $10 \mathrm{mrs}$. por saca para los caminos. En noviembre Alcedo gastó $170 \mathrm{mrs}$. de sacar piedra y $7.500 \mathrm{mrs}$. por su trabajo de 74 días.

- En junio de 1561, se dan a Alcedo 17.000 mrs. para el aderezo de los puentes y caminos.

- En junio de 1563, se ingresan $74.005 \mathrm{mrs}$. de 14.801 sacas a $5 \mathrm{mrs}$. por saca, para los reparos. En octubre Compludo debe por los caminos de Santander $81.410 \mathrm{mrs}$. que cobró de 7 naos a $10 \mathrm{mrs}$. por saca. En el despacho de las naos, la Universidad debe $104.376 \mathrm{mrs}$. con las costas de los que despachan las naos "y los pleytos y aderezos de caminos en que se gastan muchos dineros".

- En julio de 1564, Compludo debe 42.366 mrs. contados a las naos de del Hoyo y Herrera que despachó en mayo, de los que $35.275 \mathrm{mrs}$. son por $1 / 2$ real por saca para los caminos y costas de pleitos.

- En enero de 1565, se deben 26.507 mrs. entre otras cosas, por las costas hechas en el aderezo de los caminos. Alcedo debe por dichas costas 2.162 mrs. que contó a la nao que fue a Ruán por 116 sacas a 2,5 mrs. por saca, son 290 mrs. y a 17 por saca para caminos. En febrero se debe de los reparos de 1564, 68.088 mrs. En marzo, de Santiago debe por averías de Universidad 1.155 mrs. que cobró de avería del galeón que fue a Nantes y llevó 54 sacas a 17 mrs. por saca para dichos reparos. El mismo debe otros $45.279 \mathrm{mrs}$. que cobró de averías de la nao de Bertendona que llevó 2.301 sacas, contando para dichos reparos a medio real por saca, monta $39.117 \mathrm{mrs}$. También debe $30.176 \mathrm{mrs}$. que cobró de la nao de Ochoa de la Sierra que despachó en marzo y llevaba 1.527 sacas que a 17 por saca, fueron 25.959 mrs. para reparos de caminos. En abril Alcedo debe 10.200 mrs. que le mandó dar Lope de Gauna a cuenta de lo que se le debe de lo gastado en los caminos. En diciembre de Santiago debe por averías de Universidad 29.650 mrs. que cobró de la nao de del Hoyo despachada en agosto, por 1.400 sacas que llevó a Flandes y que a medio real por saca para los caminos y pleitos son $25.500 \mathrm{mrs}$

- En abril de 1566, Alcedo debe a Múgica 17.00o mrs. enviados para el reparo de los caminos. En diciembre de averías de Universidad, se deben 300.000 mrs. puestos para lo gastado en los reparos de puentes y caminos, y Alonso de Madrid en costas del pleito de las naos y lo que sobra es para lo que está dado a Alcedo, Rucavo y Antonio de Cisneros para puentes y caminos. En diciembre, las averías de Universidad deben por costas 505.456 mrs. que están gastados en costas, pleitos y caminos.

- En mayo de 1568 los gastos del reparo de los caminos y en el pleito sobre la mayoría de las naos, alcanzan 37.208 mrs. de resto de su cuenta para lo que está dado a Alcedo para puentes y caminos. En diciembre, Alonso de Sanvitores da cuenta de $320.349 \mathrm{mrs}$. de las sacas que ha despachado que son 16.423 a 19,5 mrs. por saca, que se aplica a costas de los que van a despachar las flotas, pleitos y aderezo de caminos. Alcedo debe $10.930 \mathrm{mrs}$. de los 27.200 mrs. que se le enviaron en dos veces para reparos de caminos, de acuerdo con los 10.000 mrs. que ha de dar Bartolomé Martínez su maestro vecino de Castrojeriz. De las costas hechas en tales reparos y en el pleito sobre las naos, quedan $17.028 \mathrm{mrs}$. para los reparos de los puentes y caminos que en adelante se hicieren y repararen.

- En abril de 1569, se dan 1.020 mrs. de limosna a cuenta de reparos de caminos. La cuenta del viaje que hizo Sanvitores a la Montaña para reparar los puentes y caminos, debe en octubre $153.000 \mathrm{mrs}$. por 4.500 rs. que le envió Hernando en esta manera: 51.000 mrs. cuando se fue, 51.000 mrs. que le envió con Rodrigo de Agüero vecino de Camargo en julio y 51.000 mrs. por mano de Juan de Agüero en agosto. El "adreco de los caminos y puentes por donde ban las sacas a Santander", deben en octubre, $194.191 \mathrm{mrs}$. que Sanvitores ha gastado en tales aderezos y reparos, más 44.000 mrs. por su trabajo de 88 días que se ocupó en el viaje a 500 mrs. por día. Alonso de Madrid gastó 536 mrs. en ganar una provisión para que las justicias hagan aderezar los caminos y puentes en sus jurisdicciones.

- En octubre de 1570, el aderezo de los caminos y puentes por donde van las sacas a Santander, deben $187.855 \mathrm{mrs}$. y se han de contar a las dichas sacas. Se envían $41.650 \mathrm{mrs}$. de las sacas, para el aderezo de los caminos y puentes a $8,5 \mathrm{mrs}$. por saca a esta partida y la del medio real por saca, se ponía en una partida que montaba $124.949 \mathrm{mrs}$. Del "adreço de los caminos y puentes por donde ban las sacas a Santander" se deben $146.205 \mathrm{mrs}$. lo cual y lo que se gastare se ha de contar a las sacas.

- En octubre de 1571, Sanvitores da contados 10.378 mrs. de 1.221 sacas que iban en 5 navíos a 8,5 mrs. por saca, para los caminos y $134.300 \mathrm{mrs}$. que contó de dichas sacas a $8,5 \mathrm{mrs}$.

- En septiembre de 1572, el aderezo de los caminos y puentes por donde van las sacas a Santander cuesta 46.227 mrs. Además hay 4.000 mrs. para dichos aderezos de tres navíos para Flandes.

- En 1573, el "adreço de los caminos y puentes por donde ban las sacas a Santander", deben 42.227 mrs. que se han de contar a las sacas que por allí fueren.

- En noviembre de 1580, Juan de Ceballos vecino de San Andrés de Luena, recibe 3.400 mrs. a cumplimiento de 400 rs. para aderezar los caminos y en noviembre de 1581, se deben de averías 2.626 mrs. que se dieron a García Rabin para el aderezo de algunos pasos. 


\section{- Puente y caminos de Valcallejo y el paredón de Bárcena}

La Universidad construyó en el camino por Corconte un puente sobre el río Pas, llamado "la puente de Balcalleja que es camino de Santander", entre Alceda, Vejorís y Bárcena de Toranzo. En 1566 se pagan 110 rs. para "acauar de hazer la puente de Balcallejo e 100 rs. que costo adrezar el paso junto a la puente de Bejoris" 584 , algo que nos podría indicar que se trata de dos puentes diferentes; pero al referirse a "hacer la puente", por un lado, y a "adrezar el paso junto a la puente", por otro, deja una duda razonable sobre que puede tratarse del mismo puente denominado de dos maneras. No obstante, esta es la única alusión al puente de Vejorís que hemos encontrado.

A fines de 1539 el Consulado conviene con García Conzález del Castillo que debe hacer dicho puente "toda de nuebo de maderas de rroble" en un plazo establecido y mantenerlo 12 años a su costa, pagando la Universidad $45.000 \mathrm{mrs}$. En 1541 se firmó el finiquito, liquidando a "Carçi Gonçales del Castillo que hizo esta puente" los 17.500 mrs. que quedaban por pagar ${ }^{585}$.

Rodrigo de Alcedo, criado de Diego López Gallo, indica que en 1553 gastó en el "adereço de los caminos de Ualcallejo" $13.668 \mathrm{mrs}$. y en 1556 presentó los gastos de $32.675 \mathrm{mrs}$ de "hazer la puente de Balcallejo y otros malos pasos que abia en Corconte y alli çerca", así: 170 mrs. dados a la justicia y regidores del valle por la licencia para cortar la madera en la dehesa; $1.819 \mathrm{mrs}$. por la madera comprada para yugos, peones, "guindastas y rrodestes"; $68 \mathrm{mrs}$. de partes de cartas; $1.172 \mathrm{mrs}$. de "pane bino quando se alzauan los pilares dela puente"; $10.670 \mathrm{mrs}$. de 174 pares de bueyes que trajeron la madera; 4.716 mrs. de 69 obreros; 3.500 mrs. por dos quintales de hierro labrado de clavazón para el puente; 1.874 mrs. de aderezar los malos pasos en Corconte camino de Santander; 544 mrs. en sogas de cáñamo; 2.992 mrs. por cuatro carpinteros que trabajaron 32 días; $272 \mathrm{mrs}$. del oficial que seleccionó a la gente; $3.450 \mathrm{mrs}$. que gastó en comer y la posada de Alcedo y $1.428 \mathrm{mrs}$. por 42 días ocupados en ayuda del trabajo, a real por día586. En septiembre de 1560 se pagaron a "Alzedo que tiene cargo de adereçar los caminos y puente de Balcallexo", 27.200 mrs. para el "adereço de los caminos y puente de aqui a Santander" y en noviembre se le deben 14.750 mrs. por aderezar en agosto y septiembre dicho puente ${ }^{587}$.

En 1560 se pagaron a Pedro de la Puebla 7.480 mrs. por el gasto en "hir a derribar la presa que Sancho Rruiz de Billegas azia en Toranzo" que causaba gran daño porque se mojaban las sacas. En 1568 se dieron a Juan Soga 3.400 mrs., de resto de la obra que hizo en el paso bajo el molino de Gonzalo Muñoz conforme a lo que mandaron el Prior y cónsules, Rucavo y Alcedo.

Se comienza en 1563 una obra importante en Bárcena de Toranzo, consistente en la construcción de un gran paredón junto al río Pas. De esta manera, en septiembre de 1563 se dieron para el aderezo de los caminos para Santander 3.400 mrs. a Gonzalo Muñoz del Alsar para "vna estacada que a de azer ante su casa entre tanto que se aze el paredon" en Bárcena de Toranzo, y a Diego de Castañeda, vecino de Bárcena de Vejorís, cuando “fue a beer el edefiçio del

La Universidad paga a Ceballos 16.400 mrs. en enero de 1582, para aderezar los caminos. En marzo dio Villasante a

Ceballos $13.600 \mathrm{mrs}$. para aderezar los caminos de Santander.

- En mayo de 1584, se dan 1.122 mrs. a Juan de la Portilla de Santander a cuenta del puente que reparó.

584 A. D. B./ R-14/ Libro de caja de la Universidad de Burgos/ Burgos, 1557-1567.

585 A. D. B./ R-3/ Libro de caja de la Universidad de Burgos/ Burgos, 1539-1549.

586 A. D. B./ R-6/ Manual del libro de cuentas de la Universidad de Burgos/ Burgos, 1549-1557.

587 A. D. B./ R-14/ Libro de caja de la Universidad de Burgos/ Burgos, 1557-1567. 
paredon que se haze en el camino de Santander". En octubre, Alcedo recibe para "el paredon que se ha de hazer en Barzena" 22.100 mrs. para comenzar a proveer los materiales, y se gastaron 9.922 mrs. en reparos de los caminos de Santander, en aderezar el paso de Camargo y en los gastos que hizo con Castañeda, cantero que le llevó a ver el edificio del paredón de Bárcena, cobrando este $3.400 \mathrm{mrs}$. por la visita. También gastó $7.319 \mathrm{mrs}$. en el camino y estacada y en su salario. En abril de 1564, Alcedo debe 17.000 mrs. que dio a Juan Gómez, vecino de Vejorís, en julio se pagan a Alcedo 5.100 mrs. más 17.000 mrs. enviados a Bárcena. En septiembre recibe $27.200 \mathrm{mrs}$. y en octubre $6.800 \mathrm{mrs}$. que le dio Arlanzón en Santander, todo gastado en los "rreparos de los caminos y paredon que se aze en Barzena". En 1565 los gastos hechos por Alcedo en el aderezo del puente de Valcallejo y construcción del paredón alcanzan 140.474 mrs., de los que 111.199, lo fueron para dicho paredón: de cal, hierro y angarillas 17.952 mrs.; de oficiales de cantería y obreros 59.356 mrs.; de carreteros que llevaron la piedra $19.151 \mathrm{mrs}$.; en agotar el río $12.478 \mathrm{mrs}$.; en hacer la estacada $800 \mathrm{mrs}$. y en correos que envió a Burgos y Santander pidiendo dineros 1.462 mrs. Además, por su trabajo de 173 días en estas labores 15.000 mrs. más 6.225 mrs. "gastado en aderezarla puente de Balcallejo", pero "no se le mando pagar el rresto della por parezer cosa demasiada", y se ordenó que vaya a verlo Vallejo el cantero para tasarlo. En 1566, Alcedo cobró 28.900 mrs. con que se acaba de pagar lo que se le debía de resto, del paredón y aderezos de caminos y lo demás que son 6.174 mrs.

En julio de 1566 Pedro de Rucavo da cuenta de los gastos de los reparos del puente y caminos, y debe $11.254 \mathrm{mrs}$. por 331 rs. que enviaron con Juan Soga, para invertir en esta y otras actuaciones. También se dan 13.600 mrs. a Antonio de Cisneros, vecino de Burgos, que fue a la Montaña para "dar quexa de los que cortaron las bigas de la puente de Balcallejo", ante el alcalde mayor. En octubre de 1567, Cisneros debe $3.629 \mathrm{mrs}$. del resto de lo que se le dio para "hazer castigar los que cortaron las bigas", y justifica los gastos de $9.971 \mathrm{mrs:} 5.814 \mathrm{mrs}$. por los 19 días que se ocupó a 9 rs. por día y el resto que pagó al receptor que llevó. En diciembre, se pagan 110 rs. a Juan Soga para "acauar de hazer la puente de Balcallejo e 100 rs. que costo adrezar el paso junto a la puente de Bejoris" 588 . Alcedo gastó $5.338 \mathrm{mrs}$. en 1568 en el aderezo del puente y $3.774 \mathrm{mrs}$. por su trabajo de 37 días a tres rs. por día.

En este puente hubo un accidente mortal, por lo que la Universidad pagó en abril de 1569 una limosna de 1.020 mrs. a Inés González, viuda de Juan Pérez, vecino de Bárcena de Toranzo, "el qual cayo de la puente de Balcallexo y murio"589.

Todavía en enero de 1582 Diego Conzález de Villasante, portero de la Universidad, debe 3.400 mrs. que le dieron para ir a Aguilar de Campoo a lo del pleito que puso Diego de Castañeda, vecino de Bárcena de Vejorís. En marzo, la Universidad pagó 2.261 mrs. a Villasante cuando fue a Aguilar a responder "al pleito de las puentes" que puso Castañeda59o.

588 A. D. B./ R-14/ Libro de caja de la Universidad de Burgos/ Burgos, 1557-1567.

589 A. D. B./ R-15/ Libro de caja o Mayor del Consulado/ Burgos, 1568-1577.

590 A. D. B./ R-30/ Libro de caja del Consulado de Burgos/ Burgos, 1582-1588. "Lybro de caxa de los señores prior y consules. Desde año 1582 asta $1588 "$. 


\section{- Construcción del almacén de lanas en Corconte}

Con el fin de depositar las sacas en un lugar seguro y controlado por la propia Universidad, esta acomete en 1567 la construcción de un almacén o lonja en el barrio de Corconte, perteneciente al concejo de La Población de Yuso, situado a medio camino entre Burgos y Santander, lugar idóneo para el depósito de las sacas cuando se realizaba, si era preciso, el cambio de carretas a carros o mulos 591 antes de la bajada del puerto de Corconte. Después, el transporte se efectuaba en carros hasta Santander ${ }^{592}$. Además, la lonja también se utilizaría para la reparación de las sacas que hasta aquí se habían deteriorado en su transporte. Quedan encargados de construirlo Juan Sigler, vecino de Corconte, y el concejo de La Población al que pertenece el barrio, cobrando para ello 3 mrs. por cada saca que pasase por la casa. Esta se debió de terminar en 1569, porque a partir de ese año no se registra ningún pago para su construcción.

Así, en mayo de 1567 Juan Sigler recibe de la Universidad 100 ds. "para ayuda de azer la casa" a cuenta de los 200 ds. comprometidos conforme a las escrituras ${ }^{593}$. En 1568, en lugar de los otros 100 ds. que se le debían dar para Navidad, se pagaron 50 ds. a Luis de Ceballos, Diego López y Juan Conzález, sastre, en nombre del concejo de La Población, y a García Montes, su fiador, vecino de Burgos, porque "han de acauar la casa en Corconte para las sacas". Los 150 ds. adelantados los han de "cobrar y pagar en lo que se contare a las sacas que fueren a descargar y alojar a Corconte" desde 1568. En 1569 se prestaron a Sigler otros 20 ds. debiendo pagar los 120 ds. en 4 años a 30 al año, que comienzan el 9 de febrero de $1569^{594}$.

Todavía en abril de 1578 Juan Sigler y el concejo seguían debiendo los 170 ds. "y tienen hecha obligaçion de que es pasado el tiempo y ha se tratado con el, de que esto se desquente del derecho de las sacas que metieren en la casa que el hizo, camino de Corconte, para la qual se le dio este dinero que de una manera u de otra se ha de procurar de cobrar". Para devolver los 150 ds. adelantados, Juan de la Sierra, vecino de Santander, ha de ingresar para la casa de Corconte $16.458 \mathrm{mrs}$. que cobró de 5.486 sacas a 3 mrs. por saca, que entraron en Santander desde 1576 hasta mayo de 1578 que lo tuvo a su cargo, por la liquidación que Sigler hizo con él en enero de 1579. Este año Sierra pagó 12.555 mrs., por lo que quedó debiendo 3.903 mrs. Además, Toribio de la Puebla, vecino de Santander, debía pagar 16.417 mrs., como reconocía en carta de enero de 1579, por las 2.985 sacas que entraron en Santander desde agosto de 1578 a 5,5 mrs. por saca, de los que 3 mrs. eran para la Universidad y casa de Corconte, uno para el concejo y Sigler, y las tres blancas restantes, para Sigler por su oficio de alguacil. Sigler y el concejo y García Montes, su fiador, deben en octubre de 1579, 24.075 mrs. por lo que monta el resto que se han de cobrar de las sacas que se descargasen en Corconte como se concertó. Aún en enero de 1582 se siguen debiendo los $24.075 \mathrm{mrs}$. del resto, de lo que costó la casa. Toribio de la Puebla había cobrado hasta fin de 1581, 50.080 mrs. de la partida de averías y por esto se hace deudor de dicha partida595.

591 BASAS FERNÁNDEZ, M.: 1963 y 1994: 251.

592 En mayo de 1550, se dieron 748 mrs. a Juan de Santibáñez vecino del valle de Toranzo para que "ande en seguimiento de los carreteros y haga llebar las sacas".

593 A. D. B./ R-14/ Libro de caja de la Universidad de Burgos/ Burgos, 1557-1567.

594 A. D. B./ R-15/ Libro de caja o Mayor del Consulado/ Burgos, 1568-1577.

595 A. D. B./ R-19/ Libro de caja o Mayor del Consulado de Burgos/ Burgos, 1578-1581. 


\section{El transporte de la lana por el puerto de Santander}

En los mencionados libros de Caja de la Universidad de Mercaderes se ofrece una amplia información sobre gastos relacionados con el transporte de las sacas de lana y sus condiciones, en el período entre 1539 y 1588, sobre todo entre Burgos y Santander por el camino de Corconte.

En 1550 se registran pagos de 1.020 mrs. para reparos de los caminos de Burgos a Santander y a Laredo que se dieron a Ochandiano "para yr con un rrezetor que nos dio el alcalde mayor para Corconte, para que los lugares de aquella comarca no estorben el paso a los carreteros que lleban las sacas a Santander por Corconte"596.

Para la construcción y aderezo de los caminos el Consulado obtenía los recursos económicos necesarios del cobro al mercader por cada saca exportada, de 5, 6 o 10 mrs. hasta 1563, y $17 \mathrm{mrs}$., desde 1564. Los recursos para el aderezo de las sacas que se deterioraban en su transporte se obtenían a través del cobro de averías, 800 mrs. a cada nao que transportase las lanas exportadas.

En 1560 Juan de la Sierra recibió de García de Salamanca 6.800 mrs., por 200 rs. para pagar a los carreteros que "llebaban sacas a Corconte" y Cutiérrez de Santiago recibe de Miguel de Salamanca 51.000 mrs. para tomar carros y enviar las sacas a Santander597. Se pagan también 7.480 mrs. a Pedro de la Puebla "en benefizio de la cargazon delas sacas", por el derribo de la presa que Sancho Ruiz de Villegas hacía en Toranzo "de que se rrezebio gran daño e mojaban las sacas"598.

En septiembre de 1561 se pagan 57.601 mrs. a Juan de la Sierra por llevar de Burgos a Corconte 488 sacas, y 34.000 mrs. por los 1.000 rs. que le envió Miguel de Salamanca con Juan Conzález, vecino de Corconte ${ }^{599}$. En octubre, se pagan 19.505 mrs. a de la Sierra para llevar de Burgos a Corconte 138 sacas, y debe por costas de sacas $32.187 \mathrm{mrs}$. pagados a los carreteros que llevaron a Corconte 225 sacas de lana, 204 a cuatro rs. y un cuartillo, cuatro sacas a cuatro rs. y 17 a tres rs. y tres cuartillos. En diciembre, se pagan $146.001 \mathrm{mrs}$. a de la Sierra por llevar de Burgos a Santander 488 sacas, a 297,5 por saca60o. En 1562, se gastan 879.995 mrs. en marga, parella y lavadero para hacer 501, 5 sacas y en los carros para llevarlas a Santander. También se cargan 6.060.973 mrs. para cerrar una cuenta de 488 sacas, de unas 8,5 arrobas cada una, que se hicieron ese año con todos los gastos hasta estar puestas en Santander y que se vendieron a Alonso de Haro ${ }^{601}$.

En 1573 se pagan 21.590 mrs. por llevar 105 sacas de Corconte a Santander y 340 por ir a Corconte a lo del hierro de Gaspar de Vallejo. En marzo de 1574, se pagan $31.301 \mathrm{mrs}$. por llevar a Corconte 135 sacas a 5 rs., menos $1 / 6$ las 44 sacas y el resto a 8,5 rs. Se pagaron 510 mrs. por 86 balines de parella comprados de almansas, 120 por 38 de hilo de remendar sacas, 17 de traerlas a casa y 170 mrs. a Bustillo, arriero, para llevarlo a Santander. En abril,

596 A. D. B./ R-6/ Manual del libro de cuentas de la Universidad de Burgos/ Burgos, 1549-1557.

597 A. D. B./ R-29/ Diario de García y Miguel de Salamanca/ Burgos, 1560-1561. "Manual del libro de los negocios de compañia de nos Garçia e Miguel de Salamanca comenzado de prençipio deste año de 1560".

598 A. D. B./ R-14/ Libro de caja de la Universidad de Burgos/ Burgos, 1557-1567.

599 A. D. B./ R-109/ Manual de cuentas de García y Miguel de Salamanca/ Burgos, 1561-1562. "Libro de Sierra de nos Garçia e Miguel de Salamanca comenzado con la graçia de Dios en 12 de setienbre deste año de 1561".

600 A. D. B./ R-29/ Diario de García y Miguel de Salamanca/ Burgos, 1560-1561.

601 A. D. B./ R-109/ Manual de cuentas de García y Miguel de Salamanca/ Burgos, 1561-1562. 
se gastan 168.533 mrs. en las carreterías de 330 sacas desde Burgos a Laredo y Santander. También 78.208 mrs. por llevar desde Corconte y Valderas hasta Laredo y Santander, 258 sacas que están a cargo de Diego de la Mora. En noviembre, se deben 10.149 mrs. de las carreterías enviadas a Laredo y Santander por llevar en septiembre a Corconte 63 sacas: 30 sacas y 2.682 mrs. a Pedro García, 16 sacas y 2.380 a Pablo Saiz, 15 sacas y 612 mrs. más dos sacas que fueron a la postre. En 1575 se deben $16.830 \mathrm{mrs}$. de carreterías de sacas enviadas de Burgos a Valderas, 105 sacas a cuatro y a cinco rs. por saca602.

\section{El seguimiento de las sacas en el camino}

Un capítulo importante en el transporte de la lana era el de procurar que las sacas desplazadas no sufriesen deterioro y, en caso necesario, realizar su reparación; ya que un acarreo tan accidentado, que discurría por caminos de barro o polvo y con pasos estrechos, flanqueados por zarzas, arbustos y rocas y con unos firmes en un estado deficiente, además de los inconvenientes producidos por las inclemencias del tiempo, actuaban negativamente sobre la conservación e integridad del género603, cuyo peso unitario oscilaba entre 8 y 10 arrobas $^{604}$, es decir, entre 92 y $115 \mathrm{~kg}$, lo que hacía que el sacón fuese además de pesado, muy voluminoso. Los mulos podían llevar una saca como apunta Basas ${ }^{605}$, o bien dos como indica el concejo de Santander en $1543^{606}$ y las carretas entre seis y ocho, existían posibilidades de que ocurriese alguno de los mencionados deterioros. Para ello, el Consulado puso en el trayecto unos encargados para que fuesen por los caminos a recoger la lana y recuperar las sacas que por diversas circunstancias se quedaban abandonadas o distraídas.

Al objeto de que un producto tan cotizado como la lana estuviese perfectamente protegido para no perderse, deteriorarse o ensuciarse por el camino, las sacas debían estar bien acondicionadas. Tras su lavado, la lana se enfardaba apretada con estibas en sacas o sacones de marga ${ }^{607}$, y parella o cañamaza para los retales y refuerzos. En caso necesario, se debía volver a lavar la lana y si las sacas se deterioraban, se debían reparar con marga, parella o cañamaza para remiendos y retales e hilo para ellos, y marcadas con pintura de almagre ${ }^{608}$.

En septiembre de 1549 Alonso de Sanvitores compró por 5.100 mrs. , 10 varas de raso

602 A. D. B./ R-33/ Libro de Sierra/ Burgos, 1573-1575. "Libro de quenta y razon, de las que tenían con diferentes personas la compañia de los herederos de Bernardino de Uallexo y Bentura del Castillo el qual empezo en 23 de nouiembre de 1573 y siguio asta el año de $1575^{\prime \prime}$.

603 Así se indica en unas alegaciones realizadas por vecinos de Orduña en 1553, aunque referidas al camino de Vitoria a Bilbao: "desde Bitoria hay 17 leguas de muy mal camino, lleno de montes, atolladeros y arroyos, por cuya causa no pueden conducirlas a [Bilbao] sino en berano, y es forzoso descargarlas, y muchas beces se quedan en los campos mojadas y llenas de lodo. Y cuando mas seguras en las puertas de los mesones, donde estan detenidas muchos meses y cuando llegan a la dicha villa de Bilbao, es con grande diminucion, asi en la calidad como en la cantidad".

604 BASAS FERNÁNDEZ, M.: 1963 y 1994: 134, 253 y 256.

605 BASAS FERNÁNDEZ, M.: 1963 y 1994: 261-262.

606 A. H. P. C./ J. T. A. leg. 37-8/ Santander, 29 mayo 1542. "con toda carga de lana que son dos sacas por carga".

607 La marga era una tela grosera y basta para hacer la saca y proteger la lana, que se compraba por rollos a peso, por arrobas. Había marga blanca, la más cara, y negra, que costaban entre 600 y 800 mrs. la arroba. BASAS FERNÁNDEZ, M.: 1961: 50.

608 El almagre era una sustancia arcillosa y untuosa de color rojo o negro, usada para "listar" o marcar las sacas, pintando el distintivo comercial de cada mercader. BASAS FERNÁNDEZ, M.: 1963 y 1994: 244. 
de Valencia a Alonso de la Torre, trapero, para regalar al gobernador de Toranzo a fin de que "tenga cuidado de mirar por las sacas que pasan por aquel valle", y Alonso de Compludo lo debía cargar en averías en las naos cargadas en Santander ${ }^{609}$. En noviembre, Compludo debe 400 mrs. para dar "al merino de Toranço que entiende en haçer que las sacas que ban a Santander no queden en los caminos", y otros 400 mrs. para el presente que se envió al gobernador de Toranzo y otras cosas ${ }^{610}$.

Juan de Santibáñez, vecino del valle de Toranzo, fue en nombre del Consulado por estos caminos haciendo pequeños reparos en ellos, pero sobre todo vigilando que no se perdiesen las sacas, ni se distrajesen por parte de los carreteros o vecinos de los lugares por donde discurrían. En mayo de 1550, se pagaron 748 mrs. a Santibáñez a cuenta de los 12 ducados anuales que se le dan para que "ande en seguimiento de los carreteros y haga llebar las sacas", más dos ducados para ayuda del calzado. En octubre, se contabilizan $5.250 \mathrm{mrs}$, , por los 12 ducados para que "asista en el camino de aqui a Santander... asi en hazerle aderesçar, como prinçipalmente para hazer entrar las sacas y andar sobre los carreteros, porque muchas bezes se las dexan en sus casas y en los caminos sin acabar el biaje", más los dos ducados del calzado ${ }^{611}$.

En 1560 se deben 1.700 mrs. a Diego de Frías por 10 días que se detuvo a llevar las sacas a Santander, con el remiendo de tres sacas y el alquiler de la mula de dichos días, y 1.044 mrs. que gastó cuando fue a "Corconte y Santander a hazer yr las sacas que abia por los caminos, que gasto en rremendar y labar y estiuar muchas sacas que yban maltratadas", más los gastos de $3.870 \mathrm{mrs}$. de él y su cabalgadura en los 35 días que se detuvo en Santander y en los caminos hasta que fue a Burgos, y 1.925 mrs. del alquiler de la mula ${ }^{612}$.

Alonso de Compludo pagó 14.428 mrs. en 1563 a Juan Gómez, vecino de Vejorís, "porque tuvo cargo de hacer yr las sacas desde Corconte a Santander, por que no quedase ninguna por los caminos", por lo que los dueños de las 9.619 sacas le debían pagar a tres blancas por saca613.

En 1571 se reparan unas sacas y se indican los gastos en el "adreço dellas yen parella y marga para balines y rremiendos y en ylo y cola y almagre"614. Su remiendo y reparación debía tener cierta complejidad, ya que en febrero de 1574 se pagan a una mujer de Santa Gadea 3.315 mrs. por 4,28 arrobas de marga a 23 rs. la arroba que dio "termino marguero, de que se hiçieron 8 sacas para enbiar a Laredo, con 28 de ylo de sacas, a 40 y 34 por rrepulgar e ylo para ellas"615.

\section{El puente y ría de Solía}

La ría de Solía, a pesar de situarse en zona de marisma, era el punto más cercano a los caminos de Castilla y permitía el acceso directo por mar al puerto de Santander. Las mercaderías que hasta los años 40 del siglo XVI se llevaban por los caminos de Corconte no llegaban por tierra a la villa, sino que en Solía se embarcaban en los postodios de Solía

609 A. D. B./ R-6/ Manual del libro de cuentas de la Universidad de Burgos/ Burgos, 1549-1557.

610 A. D. B./ R-12/ Libro de caja de la Universidad de Burgos/ Burgos, 1549-1557.

611 A. D. B./ R-6/ Manual del libro de cuentas de la Universidad de Burgos/ Burgos, 1549-1557.

612 A. D. B./ R-29/ Diario de García y Miguel de Salamanca/ Burgos, 1560-1561.

613 A. D. B./ R-14/ Libro de caja de la Universidad de Burgos/ Burgos, 1557-1567.

614 A. D. B./ R-15/ Libro de caja o Mayor del Consulado/ Burgos, 1568-1577.

615 A. D. B./ R-33/ Libro de Sierra/ Burgos, 1573-1575 
y Mobardo, seguían por la ría de Solía y cruzaban la bahía de Santander, unas dos leguas en total. Con ello, los arrieros y carreteros se ahorraban las dos leguas largas que había por tierra y se abarataba el transporte al hacer este último tramo en barcos y pinazas. Esto cambió hacia 1540, cuando Santander construyó el puente sobre la ría de Solía ${ }^{616}$ y los carros de bueyes pudieron llegar a la villa, lo que motivó que esta obligase a que las mercaderías siguiesen por tierra hasta Santander sin transbordos, algo que los mercaderes de la Universidad no aceptaban, como consecuencia del ahorro que obtenían al realizar el transporte por la bahía.

Para asegurar la actividad de su puerto y garantizar los beneficios que esto conllevaba, Santander aprobó una ordenanza en fechas anteriores a 1513, por la que prohibía cargar o descargar trigo, aceite, vino u otras mercaderías en la bahía ni en otros lugares de la costa entre Galizano y Suances. Detalla que no se podía cargar ni descargar en el Puntal, Pedreña, Elechas, Pontejos, Heras, Socabarga, la Concha, Mobardo, Cuarnizo, Maliaño, Estaños, Camargo, ni en otro lugar del puerto o de la bahía de Santander ni en San Martín de la Arena, ni en ningún abra ni ría "ni costa braba, hasta el puerto e abra de esta dicha villa", ni en el canal de Galizano sin su licencia so pena de perder las mercaderías, "e se pueda quemar la tal pinaça... o nabio", y el dueño de la mercadería pague 2.000 mrs. de pena ${ }^{617}$. En el caso del tráfico de la Universidad de Burgos, Santander acabó otorgando licencia para descargar las lanas en los postodios de Solía y Mobardo, para seguir por la ría y la bahía de Santander hasta su puerto.

La Universidad de Burgos se quejaba porque en la casa o almacén que había en Mobardo, donde se depositaban las sacas que venían de Burgos a la espera de ser embarcadas para el puerto, "los bateleros e barqueros de los... puertos e de las rriberas de Movardo e de otras partes" llevaban las mercaderías donde tenían por bien desde el lugar donde los carros y acémilas las dejaban, no sabiendo quién las llevaba ni dónde llegaban. Visto por el Consejo, se mandó en febrero de 1520 a las autoridades de Santander que los bateleros y barqueros no carguen "las dichas sacas e cosas de mercaderias que asi descargan en la dich a cassa de Monvardo ni en otras partes, a ninguna parte contra voluntad de sus dueños" ${ }^{618}$.

En la carta de capitulación y concordia de junio de 1532, el Prior de la Universidad dice que Santander pide por las sacas, pasteles y otras mercaderías que por su puerto se cargan y descargan en naos o fustas de la Universidad, ciertos derechos en los postodios de Mobardo y Solía, siendo obligatoria su licencia. Como los mercaderes niegan esta obligación ni la de pedir la licencia, el Prior ordena que en el caso de que la villa "en algund tienpo hiziese puente para que por carros puedan yr las sacas a Santander, y para sacar los pasteles y otras mercaderias por alli syn tener que fazer con ellas en Mobardo ni en Solia por mar,... sy los desta dicha unyversydad heligieren de llevar las sacas por tierra hasta la... villa de Santander, e ansymismo traer desde la dicha villa por tierra pastel o otras qualesquier mercaderias", que no sean obligados a pagar nada de lo contenido en dicha capitulación. En agosto, ambas partes acuerdan que cada año la Universidad debe pedir a

616 RUIZ BEDIA, Maㅡ.; j JESÚS CLEMENTE, M. del y FERRER TORÍO, R.: 2000: 63-73.

617 A. M. S./ Leg. A 1, nº 64. Fols. 9r-9v/ s. XV- anterior a 1513; SOLÓRZANO TELECHEA, J. A.: "Colección Diplomática...". 436: doc. 260.

618 A. D. B./ C-206/Valladolid, 2 febrero 1520. 


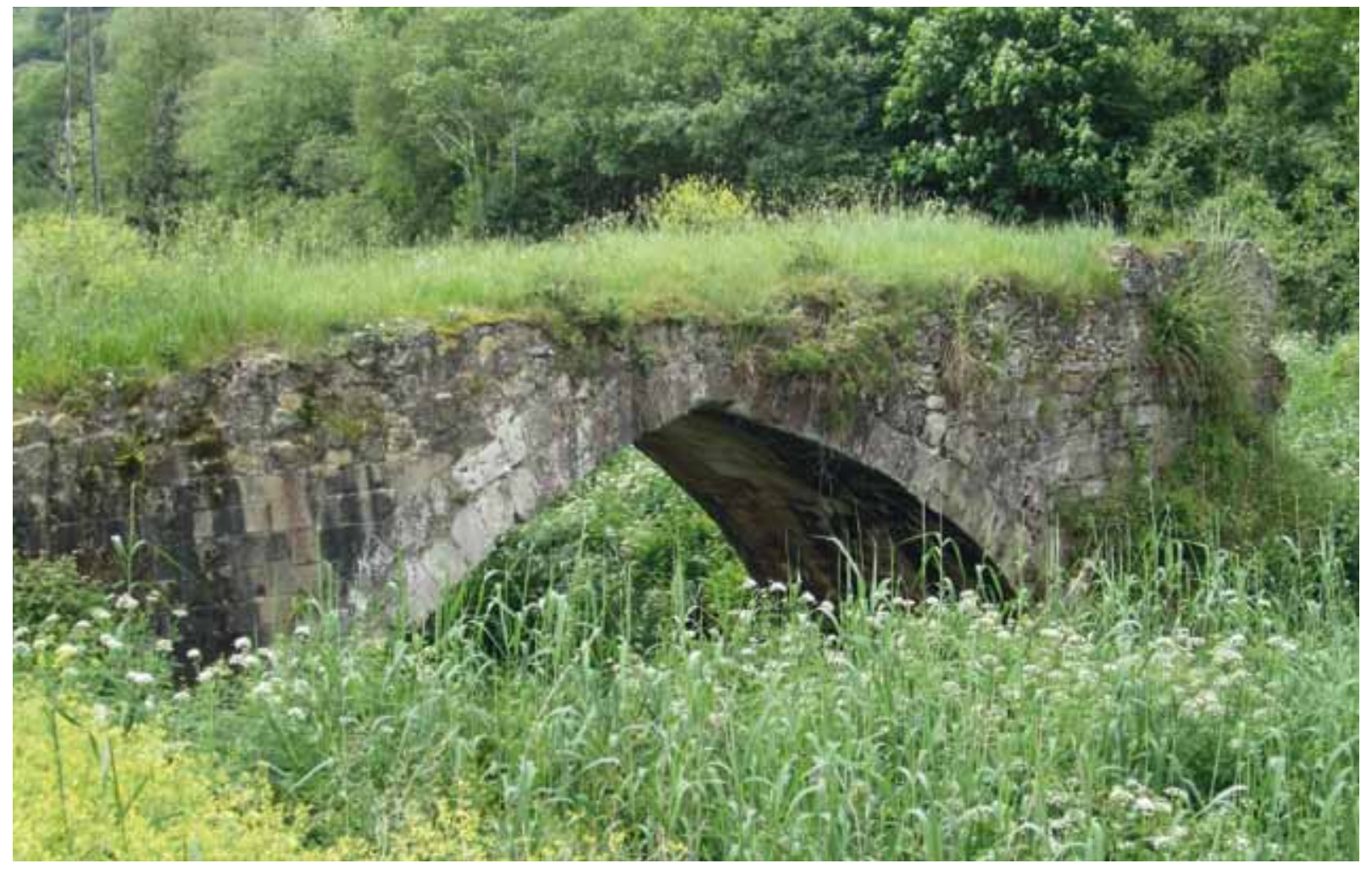

Restos del puente de Solía.

la villa licencia para cargar y descargar con bateles en los postodios de Solía y Mobardo, y la villa está obligada a darla "fasta tanto que se faga la puente de Solia e se rreponen los camynos de la dicha villa de Santander al dicho puente, de manera que puedan yr e venyr libremente carros a la dicha villa". Las pinazas que llevan sacas a Bilbao, Laredo o a otras partes de la costa solo tendrán que descargar en Santander una o dos sacas para reconocimiento y, esto hecho, seguirán viaje libremente, pidiendo el maestre de la pinaza licencia a la villa para ir a Solía o a Mobardo a recibir las sacas. La Universidad queda obligada a trasladar por tierra a Santander todas las mercaderías que por su puerto cargaren y descargaren, y si por falta de reparos los carros no pudiesen llegar a la villa como era el caso, esta deberá dar licencia para llevarlas por la bahía. Si la villa tuviere licencia real para cobrar pontaje o portazgo por el dicho puente o caminos, no lo podrá llevar a las personas, mercaderías, cabalgaduras ni ganados de la Universidad ${ }^{619}$.

En 1535 el ayuntamiento de Santander otorga poder al escribano para que dé al Consejo Real las cuentas de la villa, rentas y alcabalas del encabezamiento de 1531 a 1534, pague lo que alcanzare a la villa, y pida carta de finiquito del encabezamiento de dichos años, para poder proseguir con el pleito contra el gobernador de la villa y marquesado de Santillana sobre la prisión que hizo en el canal de Solía a ciertas personas y oficiales de Santander, y contra los valles de Carriedo, Cayón, Penagos, Villaescusa y Camargo sobre el repartimiento del puente de Solía y poderlo acabar ${ }^{620}$.

619 A. H. P. C./ J. T. A. leg. 37-7/ Burgos, 30 junio y 17 agosto 1532.

620 A. H. P. C./ J.T. A. leg. 38-4/ Santander, 2 noviembre 1535. 
Aunque no todos los caminos que desde Solía conducen a Santander estaban debidamente acondicionados, parece que en 1542 se ha acabado de construir el puente de Solía, ya que la villa exige que todas las mercaderías se conduzcan por él y no embarcadas en la ría621. De esta manera, el concejo de Santander y Juan Páez, representante de la Universidad de Burgos, pretenden negociar las condiciones para el transporte y embarque por su puerto y lugares de su jurisdicción, sin perjuicio del derecho que la Universidad debía pagar por las lanas, pasteles y otras mercaderías de sus comerciantes que fuesen por tierra, por los muchos gastos que Santander había tenido en hacer el puente de Solía, por donde puedan pasar seguros y sin daños los carros, trajineros y mulateros que llevaren las sacas, fardeles y otras mercaderías para Flandes, y sacar las mercaderías que en Santander descargaren, y para que "rreparen y entretengan e conserben a sus propias costas, la dicha puente, e los caminos e calçadas, $e$ pasos fraguosos e peligrosos que ay en los terminos de la dicha villa, para que con menos dapño e mas façil e seguramente asi en tienpo de ynbierno como de berano, puedan entrar y salir los carros e mulaterias por la dich a puente e caminos". Ambas partes acuerdan que como entre Santander y la Universidad hay pleitos y diferencias sobre que el concejo de Santander dice que ninguna mercadería puede ya cargar ni descargar "en los postodios de Mobardo ny de Solia, para las traer con barco fasta dicha villa de Santander, ni sacar nynguna mercadoria desta dicha villa por los dichos postodios", por ser de Santander estos y la ría y canal, y que nadie pueda meter ni sacar ninguna mercadería de la villa por agua sin su licencia, sino que han de ir y venir por tierra, "pues ay puente e caminos por donde puedan entrar".

Juan Páez, en nombre de la Universidad de Burgos, había indicado que ellos podían despachar libremente sus sacas y mercaderías en barcos desde los dichos postodios a la villa y puerto por la ría y bahía, "como fasta aqui se a hecho, e que la dicha uilla no lo puede bedar ni enpedir por ser la dicha rria e canal e agua de su Magestad y comun, para que sus subditos e naturales del Reyno puedan nabegar por las dichas rrias con sus mercaderias libremente", y podían sacar libremente del puerto, en barcos y pinazas, pasteles y otras mercaderías por la bahía hasta los dichos postodios, sin pagar derecho ni pedir licencia, como hasta aquí se había hecho. Al final, acuerdan en 1542 que Santander se obliga a hacer en su jurisdicción los caminos que están pendientes y acabar los que están por reparar, y procurará tener arreglados los otros caminos desde la villa "hasta la dicha puente de Solia, de manera que los carros de bueis e azemilas que metieren las dichas sacas en... Santander, e sacaren della los dichos pasteles, puedan yr y benir por los dichos caminos y calçadas que ay de la dicha villa... fasta el fyn de su juridisçion libremente por buen camino"622.

En agosto de 1542 el regimiento de Campoo informó al corregidor sobre el daño que recibían los vecinos que llevaban las sacas y balas porque, entre otras cosas, los mercaderes antes los solían alquilar de Solía a Burgos y viceversa, "y agora los fazen pasar a Santander que es dos leguas grandes mas adelante syn les acresçentar cosa alguna en el alquiler"623.

El secretario del Rey le da cuenta en septiembre de 1570, de los trabajos de aprovisionamiento realizados en Santander, con motivo de la inminente llegada de la Reina. Dice que él partió para la villa y llegó "a una rria en que se a de pasar una legua e no se hallo barca ni horden de

621 El puente entró en funcionamiento por estas fechas, con lo que los carreteros y mulateros ya no descargaban en Solía para que las mercaderías fuesen por la bahía de Santander, sino que debían proseguir por tierra hasta la villa.

622 A. H. P. C./ J. T. A. leg. 37-8/ Santander, 29 mayo 1542.

623 A. D. B./ R-193/Valladolid, 22 noviembre 1542. 
pasar ${ }^{624}$, e ansi me ube de detener en un lugarcito y en amanesçiendo primero de septiembre pase [a la villa], y... halle que tenian mediana prouision de pan, por que de mas del pan que abia en el pueblo, tenia alli alguna cantidad de trigo un honbre de Seuilla que lo auia traido de Canpos"625.

\section{Conciertos entre la Universidad de los Mercaderes y Santander}

Entre el Consulado de Burgos y la villa de Santander hubo habituales relaciones e intereses comunes, cuyos términos se plasmaron en una variedad de acuerdos que no siempre se cumplieron. La villa necesitaba que se canalizasen las mercaderías por su puerto para asegurar su actividad y economía, y los comerciantes burgaleses demandaban un puerto donde las condiciones económicas y sus infraestructuras les fuesen favorables. En agosto de 1453, el concejo de Santander de una parte y Fernando Martínez de Soria, mercader y procurador de la Cofradía de los Mercaderes de Burgos, de la otra, se juntan en Burgos para tratar sobre las ordenanzas que "sobre rason de leuar nuestras sacas e otras mercadorias de esta dicha çibdat a la villa de Santander, commo del presçio del ostelaje de ellas e de la ordenança e manera que entre nos e ellos se ha de tener, commo çerca de las posadas e de adobar los caminos, e de todas otras cosas", que son de interés de la dicha cofradía. Conciertan que para que los mercaderes "vengan a esta dicha vylla e traygan sus lanas e otras mercadorias a ella libre e desenbargadamente", se recojan en una escritura, entre otros, los siguientes capítulos y ordenanzas que ambas partes, se obligan a cumplir por 15 años:

- Que los mercaderes y sus criados puedan llevar a Santander sacas de lanas y otras mercaderías sin pagar tributo ni imposición alguna y sin tener que llevar con ellas trigo, pan ni otras vituallas. Pagarán para el reparo de los muelles y bastida de la villa, un mr. por saca llevada en carros por tierra y por las rías, abras y puertos, pero no las que llegaren por mar de Laredo, Castro, Bilbao, Bermeo, Portugalete u otros lugares de Vizcaya. No pagarán este maravedí si traen con cada dos cargas de lanas u otras mercaderías, una bestia cargada de trigo según se acostumbró.

- Que los mercaderes, factores y criados puedan cargar y descargar en Santander libremente pagando un mr. por saca, más el almacenamiento a sus hospedadores, y el que cargare o encubriere sacas $u$ otras mercaderías sin pagar dicho mr. o su almacenamiento o sin tener licencia, que pague 50 mrs. por cada saca que encubriere y que no las puedan cargar en ningún navío.

- Que los mercaderes puedan posar en la villa con sus sacas y mercaderías donde quisieren, pagando lo acostumbrado a sus hospederos y el almacenamiento de sus mercaderías, y que ni la villa ni sus vecinos puedan poner otro precio, pero sí pueda poner tasa la villa sobre los bastimentos que reciba cada vecino en su casa.

- Que nadie pueda comprar ni dar en prestado sobre las sacas o fardeles de los mercaderes que algún carretero o mulatero le quisiere vender o empeñar, so pena que el que lo comprare o prestare pierda lo que pagó y el mercader propietario recupere lo suyo libremente, salvo si el que lo empeñare o vendiere tuviere licencia para ello ${ }^{626}$.

\footnotetext{
624 Es la ría de Solía.

625 A. G. S./ Patronato Real, leg. 57, doc. 32/ Laredo, 3 septiembre 1570.

626 A. H. P. C./ Diversos. leg. 52, no 3/ Burgos, 5 julio 1453; SOLÓRZANO TELECHEA, J. A.: "Patrimonio documental...". 126-128: doc. 52; A. H. P. C./ J. T. A. legs. 37-3, 4 y 5/ Santander, 8 agosto 1453.
} 
Como no se respetaba una capitulación anterior el regimiento y procurador general de Santander encarga en 1515 a Diego de Escobedo que vaya a Burgos e informe a su Universidad que por "guiar sus recuas por esta villa, no reçibe la villa provecho salvo dapno, ansi en la carretera que no nos trahen provisiones, ansi de pan commo de hierro e maderas e otras cosas", como quedaron por la capitulación que hicieron, no cumpliendo tres de sus capítulos, como el que embarcarían las sacas en las naos de los vecinos de la villa o que les proveerían de pan en tiempo de escasez y que guiarían por ella los fardeles que viniesen de Flandes y de otras partes. Si no quisieren cumplirlos, dicen, será causa de que no se guarden ni los unos ni los otros 627 .

Francisco de Robles, en nombre de la Universidad de Burgos, dijo al Rey que solían contratar el transporte de sus sacas de lana y otras mercaderías para llevarlas a Santander y otros puertos, y que los que las llevaban se quejaban porque algunas personas de dicha villa, marquesado de Santillana, condado de Castañeda, valles de Toranzo y Valdegama y otras partes les detenían las sacas en sus casas contra su voluntad, para llevarlas ellos mismos por el mismo precio. El Consejo mandó en 1520 a la villa, marquesado, condado y valles que dejen a los que llevaren las sacas y demás cargas que los mercaderes enviaren a Santander, llevarlas libremente ${ }^{628}$.

En Santander compareció en mayo de 1532 ante su alcalde, el procurador general de la villa y dijo que como esta trata pleito con la Universidad de Burgos sobre llevar mercaderías por su puerto, y como había habido contratos entre la villa y ciertos vecinos, se requiera al escribano para que todos los autos y arrendamientos sobre este asunto los localice para guarda de su derecho. El alcalde mandó al escribano que sacase un traslado de los dos registros localizados de 30 de octubre de 1461 y de 19 de abril de 1464 que trataban sobre la obligación de introducir pan en Santander 629.

En junio de 1532 se juntan en Burgos el Prior y cónsul de la Universidad de los mercaderes con Diego Ruiz de Arce y Hernando de Herrera, en nombre de Santander, y otorgan carta de iguala y conveniencia. Dicha capitulación y concordia indica que la villa pide por las mercaderías que por su puerto se cargan y descargan en naos o fustas de la Universidad, ciertos derechos por cargar y descargar en los postodios de Mobardo y Solía, siendo obligatoria su licencia. Los mercaderes niegan esta obligación ni la de pedir la licencia y dicen que la villa y puerto son del Rey, por lo que la Universidad y sus mercaderías están exentas, no habiéndolo pagado en los últimos 30 años en que tienen contratación con la villa y de más tiempo atrás. En provecho de ambas partes, y como la contratación que ha habido debe aumentar, el Prior ordena entre otros los capítulos siguientes:

- Los hospedadores de Santander no podrán llevar por el almacenamiento de los pasteles u otras mercaderías más de lo que comúnmente han llevado en Bilbao, so pena que si alguien lleva más lo devuelva y pague el doble.

- Sobre lo que la villa pide a los dueños de los pasteles por dejarlos pasar por Mobardo

627 A. H. P. C./ Diversos, leg. 51, no 18/ 1515; SOLÓRZANO TELECHEA, J. A.: "Patrimonio documental..... 278-282: doc. 222.

628 A. D. B./ C-206/Valladolid, 2 febrero 1520.

629 A. H. P. C./ J. T. A. leg. 37-6/ Santander, 30 octubre 1461- 18 junio 1470; A. H. P. C./ Diversos. leg. 52, no 7, fols. 2r-3r/ Santander, 19 abril 1464. 
y Solía para llevarlos al puerto de Santander, que sean obligados a pagar a la villa 5 mrs. por cada carga de pastel, que son a 5 blancas por "baleta".

- Quedan anuladas las fianzas y prendas que algunas personas de la Universidad pagaban a la villa por cargar las sacas o cualquier otra causa, y la villa ni los bateleros lo lleven a ninguna persona que anduviere con las dichas sacas, pasteles y otras mercaderías de los de la Universidad.

- La Universidad pedirá licencia anual para cargar y descargar en Mobardo y Solía, sin pagar derecho alguno, y la villa deberá dar dicha licencia. En adelante ni las sacas, ni el pastel ni otra mercadería será obligada a pagar más de lo dicho.

- La Universidad, cuando haga sus fletes para Flandes, conocerá las naos de Santander y siendo buenas y suficientes las fleten como al Prior y cónsules pareciere.

- Mientras la Universidad guarde lo contenido en esta capitulación, nadie podrá detener ninguna de sus mercaderías, ni hacerles otro pedido ni derecho alguno por ninguna carta ni privilegio, salvo lo que han de pagar por las naos.

- La villa cuidará del buen trato de todas las mercaderías de la Universidad, así como de las personas que fueren en su servicio, porque esta capitulación "es por rrazon del amory buena amystad que esta universidad ha tenido e tiene con la dich a villa, e para que tengan rreparados los dichos cays e camynos".

- En el caso de que Santander hiciese un puente para que los carros puedan llevar las mercaderías sin tener que ir por mar a Mobardo ni Solía, y si los de la Universidad eligieren llevarlas por tierra, que no sean obligados a pagar nada para que la villa solo reciba el beneficio de la carga y descarga en ella, más un florín de oro por cada nao que allí cargare y descargare para el reparo de muelles y caminos.

Esta capitulación afecta a todas las naos que carguen y descarguen mercaderías de los de la Universidad, tanto los de Burgos como los de Segovia, Logroño, Valladolid, Medina de Rioseco, Palenzuela, Castrojeriz y Carrión.

Sobre estas condiciones ambas partes acuerdan en agosto de 1532, que la Universidad debe pedir a la villa licencia cada año para cargar y descargar con bateles en los postodios de Solía y Mobardo, y la villa deberá darla mientras se hace el puente de Solía y se reponen los caminos por el dicho puente, para que puedan transitar carros libremente. Hecho el puente y reparados los caminos, la Universidad se obliga a llevar y traer por tierra a Santander todas las mercaderías. Si, por no estar reparado el puente, no pudiesen pasar los carros, la villa deberá dar licencia para llevar las mercaderías por mar hasta que haga el reparo, y en caso de que la villa tenga licencia para cobrar pontaje o portazgo por el dicho puente o caminos, no lo podrá cobrar a los de la Universidad ${ }^{630}$.

Todo cambia una vez acabado de construir el puente de Solía hacia 1542. La villa exige que ninguna mercadería puede ya cargar ni descargar en Mobardo ni en Solía sin su licencia, sino que han de ir y venir por tierra, "pues ay puente e caminos por donde puedan entrar". Añade que con toda carga de lana, que son dos sacas por carga, pasteles $u$ otras mercaderías que en Santander entraren por tierra en carros, rocines, machos, acémilas o cualquier género de bestias menores, el carretero o mulatero ha de traer cuatro celemines de trigo

630 A. H. P. C./ J. T. A. leg. 37-7/ Burgos, 30 junio y 17 agosto 1532. 
para venderlo; y de eso pague de alcabala y derechos, $23 \mathrm{mrs}$. por carga de acémila y por la de rocín o bestia menor 15,5 mrs., excepto en el mercado franco del sábado, en que tales recueros ahorran la mitad de los derechos.

Juan Páez, en nombre de la Universidad, responde que no están obligados a cosa alguna de lo que la villa pide, ya que ellos pueden enviar libremente al puerto de Santander sus sacas y otras mercaderías desde Mobardo y Solía como habían hecho hasta aquí y que la villa no lo podía impedir, por ser común la ría y canal, y pueden navegar por ellas libremente sin pedir licencia ni pagar derecho alguno. Asimismo, pueden sacar libremente de Santander pasteles y otras mercaderías por dicha ría y agua en barcos y pinazas hasta los postodios y podrán enviar o sacar de Santander sus mercaderías por tierra en carros, acémilas o rocines sin ser obligados a meter ningún trigo, ni pagar derecho ni portazgo. Las mercaderías de los de la Universidad y acémilas o carros que las cargaren y carretearen son libres de todo portazgo u otra imposición, además de que los vecinos de Burgos, por privilegio que la ciudad tiene, también lo son. Sobre lo cual, por tener paz y concordia y evitar pleitos y "muchas costas e enojos, e por conserbar la mucha e antigua amistad y hermandad e contrataçion que entre las dichas partes a abido, de muchos tienpos a esta parte", conciertan en mayo de 1542 una capitulación y concordia para 5 años, desde entre 1542 a 1546, que será guardada so pena del pago de 1.000 ds. de oro, con las siguientes condiciones:

- Todas las sacas y balas que los miembros de la Universidad, tanto de Burgos como de Logroño, Valladolid, Segovia, Castrojeriz, Palenzuela, Medina de Rioseco y Carrión metieren y sacaren en Santander en carros o acémilas, pagarán a la villa 3 mrs. por saca o bala, sin que a dichas mercaderías ni a sus dueños y factores, criados o quienes las llevaren, ni a los carros de bueyes o acémilas, la villa ni el arrendador de ella, les puedan obligar a meter trigo ni pagar derecho alguno, alcabala ni imposición, porque con el pago de los $3 \mathrm{mrs}$., serán francos y exentos de cualquier demanda; y si las mercaderías de los de la Universidad o sus carros o acémilas deben lo que la villa pidiere, que esta sea obligada a pagarlo por ellos y, asimismo, por "el gran benefiçio e probecho que a la dicha villa se le sigue de la frequentaçion de su puerto e villa", si las sacas y pastel de la Universidad otra cosa debieren, la villa lo pagará por ellos.

- Las personas de la Universidad, sus criados y los que llevaren a Santander las sacas y sacaren las balas se obligan a no hacer estapla ${ }^{631}$ ninguna, ni postodio, ni descarga desde las ventas del Caballar a la villa ni por otro camino desde cuatro leguas, so pena de que por cada bala y saca que se descargare, pague su dueño dos rs. de plata, 1/3 para la Cámara Real y los 2/3 para reparos de los caminos de Santander.

- Santander se obliga a hacer a su costa los caminos de su jurisdicción y procurará tener reparados todos hasta el puente de Solía, de manera que los carros de bueyes y acémilas puedan ir y venir por dichos caminos y calzadas libremente, porque para esto la Universidad da los 3 mrs. por bala y saca.

- La villa y sus regidores procurarán que las mercaderías sean bien tratadas, así como las personas que fueren con ellas, y sus bueyes o acémilas podrán pacer en términos comu-

631 La staple o étape era un centro donde los comerciantes y sus clientes concurrían, con la seguridad de que allí podrían encontrarse para hacer sus transacciones y donde se almacenaban las mercaderías para su venta y distribución. PARKER, G.: 1976: 127. 
nes de la villa sin impedirlo ni pedir cosa alguna, y hacer en los dichos términos cualquier suelta de bueyes y bestias en los ejidos y pastos acostumbrados.

- Los huéspedes de la villa no podrán llevar por estolaje de las mercaderías que recibieren más de lo que comúnmente han llevado en Bilbao, so pena que el huésped que más llevare lo devuelva y pague el doble ${ }^{632}$.

En Reinosa el regimiento de la merindad de Campoo informó al corregidor en 1542, sobre el daño que recibían los vecinos que llevaban la sacas de lana y balas de pastel, porque recientemente los mercaderes y sus factores habían aumentado su peso, de manera que tres balas de ahora pesaban tanto como cuatro de las que solían alquilar y, por ser gente pobre, los factores les solían adelantar los dineros y alquilarles las cargas en invierno cuando mayor necesidad tenían, para llevarlas en verano, y así las llevaban por la mitad de lo que merecían o por lo que los factores les querían dar; o cuando alquilaban en verano, los factores hacían liga para dar el alquiler al precio que concertaban, y con ello quitan el trabajo a los carreteros y se lucran los factores y mercaderes y, como los alquileres disminuyen las labranzas, se recoge poco pan y al ser los alquileres pequeños, no ganaban para mantenerse. Además, antes los solían alquilar de Solía a Burgos y de Burgos al postodio de Solía, y ahora lo hacen desde Santander, aumentando el recorrido más de dos leguas sin incrementarles cosa alguna, por lo que "la gente comund se perderia, porque meresçen... de Santander a Lanchares de alquiler de cada saca e vala de pastel a tres reales y medio, porque no lieuan dos pares de bueys saluo quatro o çinco pasteles o sacas, y tardan en el camino ocho dias e con mal tiempo mas, e no les dan de alquiler saluo a sesenta mrs. o dos rreales por manera que matan sus bueyes e no ganan de comer, e lo mismo pasa de Lanchares a Burgos". El corregidor mandó que ningún vecino pueda alquilar bala ni saca de Lanchares a Santander ni de Santander a Lanchares por menos de 3,5 rs., "e que a este mismo preçio lieven vala de pastel de Lanchares a Burgos y saca de Burgos a Lanchares", so pena de 300 mrs. por cada carro que a menor precio se alquilare. Esto fue rechazado por la Universidad de Burgos porque, según ellos, las personas que lo pidieron habían seguido su interés en perjuicio del bien común y sus consideraciones no eran ciertas ya que estos "tenian muchos bueyes y trayan gente a carretear con ellos", y que aunque estuviese puesta tasa, iban por su interés, y la gente común de la Merindad que vivía de la carretería querían tener libertad en los alquileres de sus carros. Además, todas las mercaderías se encarecerían y por ello disminuiría el trato y comercio, especialmente el de Burgos. El Consejo acordó en noviembre de 1542 mandar que no se aplique dicha orden, ni que por ella se lleve ninguna pena a los vecinos de la Merindad633.

En agosto de 1555 Santander presenta a la Universidad de Burgos una serie de peticiones para que cuando salgan las sacas por el puerto de Santander cumplan con los retornos de las naos, conforme con la Pragmática real. Como por Santander se guiaban antiguamente las mercaderías que venían de Flandes y otros reinos, y los Condestables querían impedir que entrasen por este puerto, la villa propone dar libre la guía bajo el compromiso de la Universidad de que guiaría por ella sus mercaderías de retorno, ya que dicha Universidad había ordenado que las mercaderías que venían de Flandes no se

632 A. H. P. C./ J. T. A. leg. 37-8/ Santander, 29 mayo 1542.

633 A. D. B./ R-193/Valladolid, 22 noviembre 1542. 
descarguen y guíen por ella. La villa envió personas a Villalón y Medina del Campo para pedir a los mercaderes que guiasen los retornos por Santander, los cuales lo aceptaron y con ello se envió a prevenir las recuas de Valdezamanzas, Castilla Vieja, Ordejón, Cabezón y otras partes para que acudiesen a la villa para guiar las mercaderías de retorno, e hicieron aderezar puentes y caminos y preparar ventas y mesones, en lo que gastaron 500 ds. Pero cuando en Flandes quisieron consignar sus mercaderías por Santander, los cónsules de Flandes pusieron pena de 2.000 ds. a las naos y maestres para que fuesen a Laredo y no a otra parte. Por contra, dicen que "las sacas de lana que traen daño sin benefiçio a los puertos por do se guian, no hallan otro puerto por do se cargar sino por Santander", por lo que ocasionaban a la villa los daños siguientes:

- Los "que solian labrar las viñas y eredamientos de los veçinos desta villa, se an tornado carreteros en toda su comarca, y a la causa no ay quien las labre, y se an encaresçido los jornales" tanto que ocasiona de daño a los vecinos 2.000 ds. al año, que se evitaría no saliendo por ella las sacas, con lo que bajarían los jornales y volverían a labrar sus heredamientos, pues es su principal trato y de lo que viven.

- Los carreteros de la Montaña, en los meses que debían traer pan y vino de Castilla, dejan de hacerlo por llevar sacas a la villa, por lo que sus vecinos padecen necesidad, en especial en tiempo de guerra cuando no llega por mar, y como no encuentran carretería que lo traiga, y si hay alguna es tres veces más cara, se crea a la villa otro daño que no se solventaría con otros 2.000 ds. al año.

- Los carros y bueyes que llevan las sacas deterioran los puentes y caminos, lo que, además de los 3 mrs. que pagan por saca y de la piedra que los vecinos echan en los caminos para aderezarlos, cuesta a la villa $50.000 \mathrm{mrs}$. al año.

- Los carreteros que traen las sacas, además de los pastos para sus bueyes, siegan la hierba y los panes, comen las uvas y fruta y cortan los montes para ejes, cambas y estadojos y hacen otros daños, que solo el que la villa recibe en su jurisdicción no se pagaría con 200 ds. al año.

- Los tripulantes de las naos encarecen el pan que llega a la villa para su consumo, así como el pescado, la carne y demás bastimentos; por lo que los vecinos lo compran 1/3 más caro y les ocasiona un daño de más de 500 ds. al año. Además, si se gastase el vino, los vecinos podrían recibir algún beneficio, pero las naos no gastan nada ya que traen vino y sidra para su estiba y viajes, y el vino que han de beber lo traen en carros del marquesado de Santillana por ser más barato.

Añaden que todos estos daños los han padecido por conservar la amistad que siempre han tenido con la Universidad, y "tratando a sus fatores y hazedores y carreteros y maestres y gente de naos, mejor que a los propios veçinos", y lo mismo a sus sacas y haciendas recogiéndolas en sus calles y casas como propias, esperando siempre que se les recompensaría con traer sus mercaderías de Flandes por la villa, pero al no ser así, piden que lleven por ella los retornos conforme a la Pragmática, y dicen:

- Que como en 1553, 54 y 55, de la cargazón del Morezo han salido por el puerto de Santander 24.000 sacas, por las que conforme con la Pragmática están obligados a traer en retorno 2.00o fardeles de lienzos a media carga y 4.00o paños, y no los han traído salvo lo que trajo la galeaza de Juan de Escalante, el Prior y cónsules deben hacer volver por la villa 
en el viaje de retorno a las naos que en este año cargaren sacas, con toda la ropa y mercaderías que trajeren de Flandes.

- En el caso de que las naos fueren embargadas para alguna empresa real y fueren a La Coruña, Laredo o cualquier otro puerto, si trajeren fardeles y mercaderías, que no los puedan descargar en ningún otro puerto, sino que sean obligados los maestres de esas naos a descargarlo en Santander, y lo mismo si por tormenta o por cualquier otra causa fueren a otro puerto.

- Que como se necesita trigo para la flota, carretería y vecindad, el Prior y cónsules traigan en dos meses 1.000 cargas de trigo para que se vendan en la villa.

- Que el Prior y cónsules hagan traer los retornos en la primera flota que de la villa fuere al condado de Flandes y en las otras sucesivamente, y si la cargazón y retorno no se hiciere en las flotas y naos en que fueron las lanas y hubieren de fletar otras naos o fustas, sean obligados a hacerlas venir a la villa a descargar, y si por fortuna u otra causa, las naos y fustas que trajeren las mercaderías fueren a otro puerto, que sus maestres sean obligados a venir con ellas y con el retorno a descargarlo a la villa.

- Que se obliguen el Prior y cónsules y den por fiadores a los maestres de las naos que en la villa cargaren, y se obliguen todos mancomunados con pena de $300 \mathrm{ds}$. de oro por cada nao que no cumpliere lo dicho, que se aplicarán para los daños que recibe la villa, y que la nao que no cumpliere sea retenida por el Prior y cónsules ${ }^{634}$.

En relación con lo dicho, la villa de Santander señala las razones "que se presumen, porque el condestable no quiere dexar guiar las mercaderias por Santander y los probechos y daños que dello se syguen", ya que desde que se le quitó a la villa la guía general, se ha ido despoblando y entrado en mucha regresión, e indica las ventajas de descargar las mercancías, por Santander y no por Bilbao o Laredo:

- El Condestable no lo deja guiar por Santander porque de aquí "a Çilleruelo ${ }^{635}$ ques del condestable, no ay lugar suyo ni de Çilleruelo a Burgos, porque todos los demas son del Rey y de otros señores, y guiando las mercaderias por Laredo e Vilbao, los mas de los lugares que ay de alli a Burgos son del condestable, y en ellos gastan las biandas, pagan portazgos y derechos, y de todo el benefiçio se goza en su tierra".

- Santander es el "mas antiguo puerto abierto donde a la entrada y salida, no resçiben peligro como en Bylbao que es barra y tiene la ria, donde se cargan y descargan y estyban mas seguras las mercaderias y mejor, que no en Laredo que es concha y mas peligrosa", y sus caminos "son abyertos y mejores, porque della se pueden sacar las mercaderias en carretas y carros y guiarse en ellos para todas las partes d'España, lo que no puede ser hecho de Vilbao ni Laredo syno por pie de mulo".

- Guiándose en carros, los dueños de las mercaderías reciben gran beneficio porque "no descabeçan sus mercaderias, syno las guian enteras como vyenen de Flandes", y ademas toda la carretería de Campoo y las montañas comarcanas "que es la mas y mejor d'España", confina con el camino de Santander a Burgos y no con el de Laredo y Bilbao y por ello, los mercaderes guían sus mercaderías mejor y más barato por Santander, y además de no descabezar las mercaderías "los alquiles de los carros, les son mas baratos la terçia parte que los de los mulos, y el camino muy mejor".

634 A. M. S./ Leg. A-3, no 62/ 27 agosto 1555; SOLÓRZANO TELECHEA, J. A.:."Patrimonio documental...". 283-285: doc. 225 .

635 Cilleruelo de Bezana, situado sobre el camino que en dirección a Burgos se bifurca por Villanueva Rampalay o por Ruerrero y el Tozo. 
- Las rentas reales se acrecientan, porque Santander "seria mas poblada, [y] porque en ella se paga alcabala al Rey y en Bylbao no, porque es libre de alcabala".

- Las naos, fustas y navíos que traen las mercaderías reciben beneficio al guiarse por Santander, porque al "ser el puerto e ria tan buenos, entran e salen mejor y con cualquier tiempo y estan dentro mas seguras, que no en Bilbao ni Laredo".

- Las naos que hay en Santander que vienen de Flandes, por "no las dexar guiar, las ynbian en pynaças a Laredo y en ello resçiben grave daño y peligro, asy en tiempo de paz por el ryesgo de la mar, como en el de guerra de la mar y de enemigos".

- La guía que se le quita es de los fardeles de paños, lienzos y otras cosas semejantes, "pero sacas y pastel y pescado se guia siempre y çera algunas bezes, y los retablos y escaparates y cosas grandes que no se pueden descabeçar ni guiar en mulos sino en carros", se guían por Santander.

- A los traperos de la villa el dezmero siempre les da guía para llevar sus paños a las ferias de Santillana, Cartes y Treceño, donde los venden a los de Aguilar y otras partes que lo llevan y guían, y habría que mirar si guiarlos por Santander beneficia en algo porque siempre lo han hecho636.

Para confirmar sus propuestas, la villa plantea en dicho año 1555 un interrogatorio a testigos que ella presenta, del que no conocemos sus respuestas, algo que hubiera aportado una muy interesante información. Preguntaban si saben que:

- El puerto de Santander es abierto y más seguro para entrar y salir que el de Bilbao, en el que, por ser barra y por otras causas, entran y salen las mercaderías con mucho más peligro. Además, tiene ría y lugar muy seguro y aparejado para cargar, descargar y estibar en él las mercaderías mejor y a menos coste que en Laredo, donde es concha y más peligrosa.

- Desde Santander salen y "ay caminos e puentes muy derechos, convenibles y seguros, por los quales se pueden guiar todas mercaderias en carros y en mulos e bestias para todos estos reynos d'España, y de todos los dichos reynos para el dicho puerto sin hazer carga ni descarga, mas de tomarlo al dicho puerto y llebarlo en los carros a los lugares que quisieren, y traerlo de los dichos lugares y con los carros ponerlo al dicho puerto enjuto, a do se carga y descarga en las naos".

- Desde los puertos de Laredo y Bilbao "no se pueden sacar, llebar ni traer mercaderias en carros para las guiar por los lugares destos dichos reynos" a sus destinos, y que todo ello ocasiona gran trabajo, gastos y retrasos a los dueños de las mercaderías, y en especial, en que "no se lleban de los dichos puertos ni traen a ellos, tan presto ni tantas mercaderias, sin carros como con ellos, ni tan seguras", y porque "muchas dellas se an de descabeçar por ser grand carga y no la poder llebar en vn mulo, se a de partir para la llebar en dos o tres y en el partir, coser y descoser y cargar y descargar en tantas partes y enviar la partida e dismenbrada y en pedaços y no entera se diminuye pierde y gasta mucho".

- El camino de Santander "es camino de carro muy derecho y convenible para llebar y traer todas mercaderias al dicho puerto y del, ay muy grand aparejo de bueys e carros y honbres muy expertos en las carretear,... y tan buen aparejo de pastos que en toda España no se puede hallar para el caso tanto aparejo ni tan bueno". Por ello, se guían por él las mercaderías mejor, más rápido, más seguras y a mucho menor coste que por Laredo o Bilbao, por donde las viandas y alimentos son mucho más caros.

- Desde Santander a Laredo hay 7 leguas y a Bilbao 14, y llevar las mercaderías del

636 A. M. S./ Leg. A-3, no 62/ 27 agosto 1555; SOLÓRZANO TELECHEA, J. A.: "Patrimonio documental... ". 283-285: doc. 225 . 
puerto de Santander a dezmarlas a Laredo o Bilbao para que se les dé cédula de guía, ocasiona gran coste, trabajo y peligro de la mar, y por el tiempo adverso o por los enemigos de estos Reinos que las toman en el camino; y así se pierden las mercaderías, pinazas y navíos y la gente que las lleva.

- El puerto de Santander, al ser tan bueno y tan seguro como es, las naos y fustas que llegan reciben gran beneficio porque es abierto y en cualquier tiempo, por fortuna o tempestad, pueden entrar y estar seguras; y en Laredo y Bilbao es al contrario. De hacerse carga y descarga y de dezmarse en Santander las mercaderías y recibir albalá y cédula de poder para ir seguras, además de los provechos que se siguen, y de los peligros, costas, trabajos y daños que se evitan, las rentas reales aumentarán, porque la población de Santander se incrementaría, dado que se guiarían por allí muchas más mercaderías y "porque en Santander se paga alcauala al Rey y en Viluao no".

- En los últimos años el Condestable y sus dezmeros han intentado no dar cédula de guía de ciertas mercaderías que van al puerto de Santander y las hacen llevar en pinazas a dezmar a Laredo y Bilbao, y en especial se han negado a dar cédula en los fardeles de paños, lienzos y otras cosas semejantes.

- Antiguamente los fardeles de paños, lienzos y demás mercaderías que iban a la villa de Santander, se dezmaban en ella y daban cédula, y con ella iban seguros, dejándolas las guardas pasar libremente y por todos los lugares, excepto ahora, que de poco acá han intentado esta innovación.

- La costumbre antigua y general de dezmar y dar cédula de todas las mercaderías en Santander se ha usado y usa en las "sacas y pastel y pescado y retablos y escaparates, y en todas las otras cosas grandes que no se pueden comodamente llebar en mulos". Para aplicar esto, había dezmero en la villa de tiempo inmemorial que daba cédulas de guía y con ellas circulaban, pero esto ha cambiado recientemente en las cosas dichas, y ahora el dezmero tan solo da estas cédulas a los traperos de la villa para llevar sus mercaderías y paños a venderlos a las ferias ${ }^{637}$.

Ocho años después, en un informe jurídico realizado en junio de 1563, sobre el incumplimiento del concierto que la Universidad de Burgos tiene con Santander en las sacas que la Universidad envía a Flandes y otras partes, pretendiendo la villa impedir la carga de las lanas por su puerto si no lo acompañan con dos celemines de trigo por saca, o recibir la villa un tanto por saca por los daños que realiza su carretería y por la estancia y estiba de las naos, se indica que la villa tiene una escritura por la que los mercaderes de la Universidad se comprometían a llevar los dos celemines de trigo, pero como no lo ha cumplido, Santander no estaba obligada a respetarla. El letrado indica que no se podía impedir a los mercaderes llevar libremente las sacas, pues el Rey lo consiente; pero sobre los daños ocasionados, se alega que antes condenarán a los mercaderes a que paguen el daño realizado, que no a que traigan los dos celemines.

Además, esto se confirma con que en la estiba y carga de las sacas se consume en la villa mucho pan y por esto se perjudica a la villa y sus vecinos y que la carretería, cuando trae las sacas, hace gran daño en las mieses, sembrados, viñas y heredamientos. Además la villa trató de que viniesen los fardos para que viniese trigo con ellos, como antiguamen-

637 A. M. S./ Leg. A-3, no 62/ 27 agosto 1555; SOLÓRZANO TELECHEA, J. A.: “Patrimonio documental...". 283-285: doc. 
te lo traían y si no lo traen, será bueno el pago de un tanto por saca por los grandes gastos que la villa hace en aderezar los caminos, calzadas y puentes, dañados por la carretería. Lo que la villa puede hacer, dice el letrado, es que el procurador general haga un pedimiento a la justicia en que diga que como ella y la Universidad habían capitulado lo dicho y esta no lo había cumplido, que apremie a los mercaderes y factores de las sacas para que traigan con cada saca los dos celemines de trigo y, en su defecto, que no traigan las sacas por la villa por los grandes daños que recibe ${ }^{638}$.

El concejo acabó embargando naves de la Universidad sobre lo que se realiza otro informe jurídico, en septiembre de 1563, que dice que visto el embargo que la villa hizo en las naos de la Universidad y sobre lo que quiere saber el concejo de Santander para seguir el pleito, para que se lleven los dos celemines de trigo con cada saca y se paguen los derechos acostumbrados, que de lo pedido y actuado se mande dar traslado a los fiadores del factor y señores de las naos que se embargaron, y que de nuevo se les mande que no introduzcan en adelante en la villa, puerto, rías, ni canales saca alguna sin que lo acompañen con dos celemines de trigo, pagando los carreteros o trajineros que metieren las sacas con el trigo, 23 mrs. por saca de carga por acémila y 15 mrs. por bestia menor, como se había hecho siempre y que, de no cumplirlo, no les consientan introducir las sacas.

Se deberá probar, dicen, el gran deterioro de sus caminos y puentes, causado por los carreteros al llevar las lanas a la villa, y la destrucción de sus panes, prados y viñas, así como la costumbre de que nadie pueda sacar carga sin meter trigo, cebada, aceite y otros bastimentos, excepto vino cuando la villa lo tenga de su cosecha, y que si no fuese por la ordenanza y costumbre, padecerían gran necesidad. También se probará que la villa tiene a su cargo las alcabalas del Rey y da un tanto por ellas sobre el pan, cebada y otras mercaderías que entran, y de no entrar se perdería su trato y comercio, el Rey recibiría deservicio y la villa y puerto se perdería. Probarán también el daño recibido por no haberse cumplido la última capitulación de abril de 1559, al no haberse cargado y fletado hacia la villa 1/3 de las mercaderías que se cargaban en el condado de Flandes y otras partes, Si lo dicho no se efectúa con brevedad, "sera bien las primeras lanas que se ubieren de cargar, se enbarguen quitandose las belas a las naos hasta que den fianzas llanas e abonadas de traer el dicho trigo segund las sacas que vbieren cargado" y así pagar el daño recibido.

El ayuntamiento de Santander da poder a su procurador general para la demanda, demostrando el daño que la villa ha recibido por no haber traído los dos celemines de trigo con cada saca, para que pueda pedir restitución contra cualquier capitulación asentada entre la villa y la Universidad ${ }^{639}$.

\section{b.- Por el barrio de Corconte y sierra de El Escudo}

Como se ha indicado en el apartado de las vías romanas, este camino fue apuntado por Sojo y Lomba en $1947^{640}$ y publicado como vía romana por Riancho en $1988^{641}$. En un

638 A. H. P. C./ J.T. A. leg. 37-9/ Santander, 18 junio 1563.

639 A. H. P. C./ J. T. A. leg. 37-11 a, b y c/ Santillana, 7 septiembre 1563.

640 SOJO Y LOMBA, Fermín de: 1947: 52-54: t. 83.

641 GONZÁLEZ de RIANCHO MAZO, J.: 1988. 


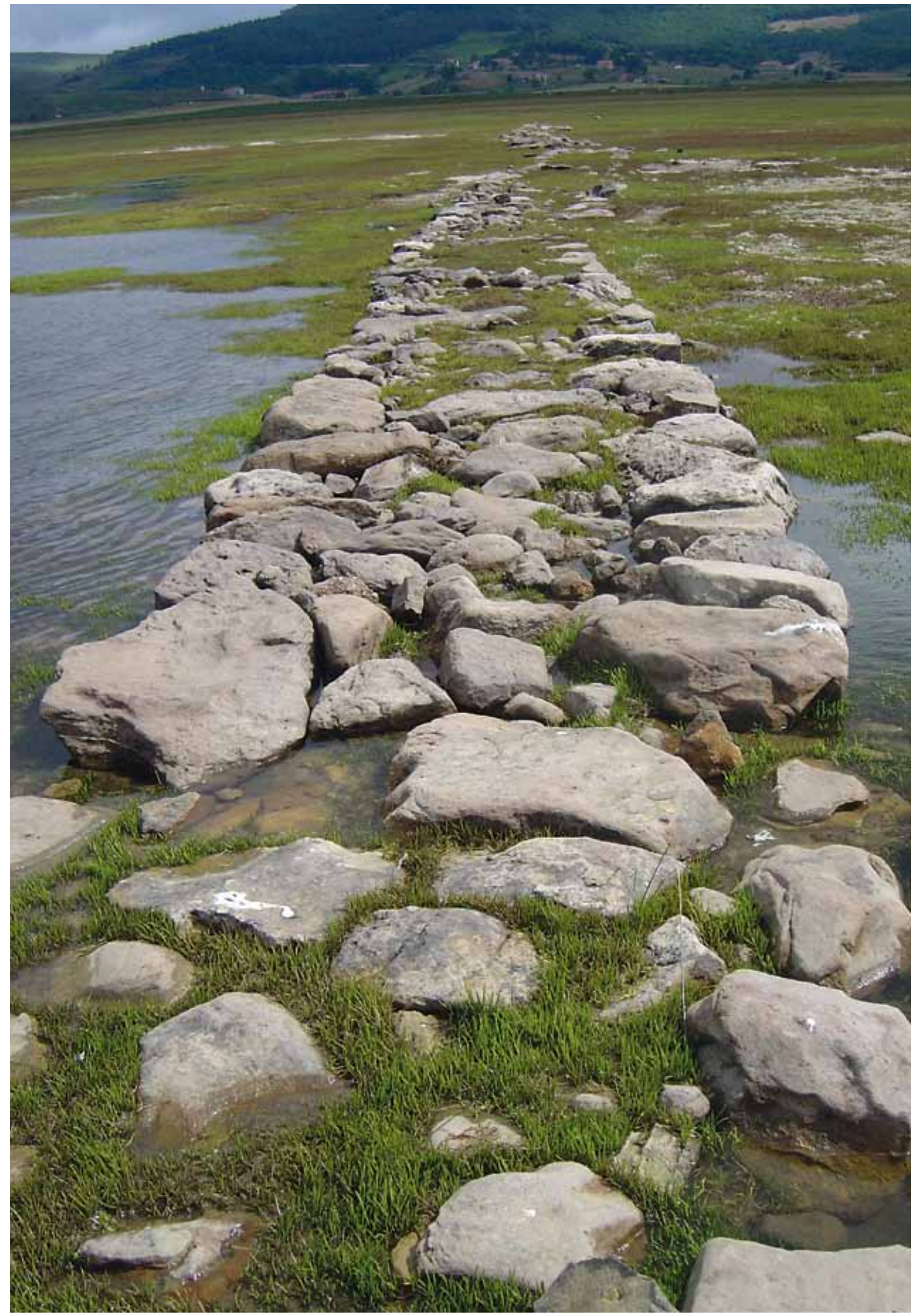

Base del camino empedrado bajo el pantano de Arija. 
trabajo en el que hace una minuciosa descripción de su recorrido, propone que desde Soncillo bordearía la llanura de la Virga por el Este para llegar a Corconte, aunque nada indica sobre su continuidad hacia el Sur. Después pasaba por los términos denominados La Calzada y Mediajo Frío y por un agreste territorio llegaría a El Pombo, donde se bifurcaba. El camino de la derecha iría por Sel de la Carrera y Sel de la Peña, y poco antes de Entrambasmestas, entroncaba con el camino que venía del Tozo, ya descrito. El ramal de la izquierda, que había discurrido por montaña por el Monte Cildá, términos de Cruza-camino y El Portillón, Quintana de Toranzo, Salcedillo y Prases, entroncaba poco antes de Villasevil tras cruzar el Pas por un vado, con el camino mencionado del Tozo. Riancho describe este camino en la mayor parte de su trazado y aunque en algunos lugares se pierde, detecta la existencia de una vía importante de largo recorrido, que en ciertos sectores estuvo empedrada. El camino coincide con los límites municipales, lo que evidencia su antigüedad, al servir su trazado como referencia ya existente y estable para la delimitación municipal, aunque sobre él, no hemos localizado referencia documental alguna.

En la orilla del pantano del Ebro, aflora un pequeño tramo de este camino, en un sector que normalmente se encuentra inundado pero que aflora en periodos de aguas bajas, (mes de julio de 2012) ${ }^{642}$. Se encontraba en la orilla norte del mencionado pantano y se dirigía en dirección a Herbosa. Aunque se organizaba a base de piedras y morrillos, algunos de gran tamaño, colocados y delimitados en una franja de unos 2,40 $\mathrm{m}$ de anchura, no se detectaba substrato que permitiese asegurar que tenía cimentación. Más bien se trataba de un pasillo de empedrado, quizá como soporte y base de una desaparecida capa de rodadura de piedra más menuda, dispuesto para el tráfico en una zona pantanosa.

\section{c.- Entronque entre la vía de Reinosa y la del puerto de Corconte}

Tenemos documentada su utilización al menos en tres ocasiones. El camino se desvía del de Reinosa tras pasar Arenas de Iguña, por la derecha aguas arriba junto al río Casares por San Juan de Raicedo, Barriopalacio, Cotillo y Villasuso en el valle de Anievas, divisoria de aguas, Quintana de Toranzo, Salcedillo, bajada a Prases, vado del río Pas, y entre Santiurde de Toranzo y Villasevil, entronca con el camino que viene del Tozo y puerto de Corconte ${ }^{643}$.

Es la vía que utilizó el séquito de Carlos I, tras su llegada a Villaviciosa de Asturias el 19 de septiembre de 1517, cuando tuvo que rectificar el camino que llevaba de Santander a Burgos por Corconte, tras recibir la contraorden del rey para que en vez de ir a Burgos, donde había peste, se dirigiese por Reinosa a Tordesillas, donde estaba su madre la reina Juana. Subía la comitiva y equipajes por el valle del Pas y al llegar al de Toranzo recibieron la dicha contraorden. Por Villasevil y Prases pasaron del valle del Pas al del Besaya, cruzando la divisoria de aguas y bajando por las orillas del arroyo Casares siguieron hacia el Sur por Arenas de Iguña. Llegados a Molledo, donde comienza un áspero desfiladero y en la subida hasta Santa Olalla, los conductores de los carros del equipaje se vieron obligados a reforzar sus tiros ${ }^{644}$.

642 GONZÁLEZ de RIANCHO MAZO, J.: 1988: 16 y 80-83

643 GONZÁLEZ de RIANCHO MAZO, J.: 1988: 19

644 RIBAS de PINA, M.: 1949: 127-128. 
Carlos I envía desde Bruselas a la ciudad de Burgos una Carta, en abril de 1522, por la que indica que tiene preparada su armada y vendrá de inmediato a estos reinos y en especial a Burgos, y que todo lo "que a esa çiudad tocare, tengo de tener etengo como negoçio propio mio"645. Habiendo desembarcado el 16 de julio de 1522 en Santander con una escolta de 2.000 soldados de su guardia, el 26 sale por el camino de Corconte hacia Palencia, donde llegó el 6 de agosto ${ }^{646}$. El emperador fue por Parbayón, donde come; en Villasevil cena y pernocta y al día siguiente, 27, se desvía de este camino para ir por el de Reinosa y va a cenar y dormir a Molledo, llegando el 28 a Reinosa; el 29 a Brañosera, el 30 a Aguilar donde estará el 31, el uno de agosto a Herrera y el dos a Melgar de Fernamental, de donde saldrá el 4 para dormir en Amusco camino de Valladolid ${ }^{647}$. La artillería que lo acompañaba se envió por otro camino a Burgos, arrastrada por 1.064 pares de mulas ${ }^{648}$.

En 1605 el embajador inglés lord Nottingham, para regresar a Santander desde Valladolid tras la firma de las paces entre España e Inglaterra, pasa por Dueñas, Frómista, Osorno, Herrera, Aguilar y llega a Reinosa el 23 de junio. El 24 come en "Villa Concha" y duerme con su séquito en "Villa Civil" "49, indicándose en la relación del viaje que este era el peor camino y el peor pueblo de cuantos vieron en España65o.

\section{d.- Por Lanchares y la vía del puerto de Corconte}

Se separaba del que iba por Berzosilla dos km después de la venta de Valladar. Seguía por Rocamundo, Arenillas, Ruerrero, Riopanero, Santa Gadea, Arija, llano de la Virga, donde aún existe el puente sobre el arroyo de la Virga, La Población y Lanchares. Desde aquí el camino debía seguir por montaña, junto al arroyo de Lanchares, aguas arriba por su orilla izquierda, hasta entroncar en el término de Mediajo Frío con el camino por Corconte y sierra del Escudo, ya descrito.

Sobre este camino, existe documentación al menos desde 1253. El concejo de Santander protestó ese año porque Juan Díaz de Frómista, "les tomaba portadgo en Poblaçion" 651 , y como nunca lo pagaron en tiempo de Fernando III ni de la reina Berenguela, Alfonso X emplazó a Juan Díaz y a los de Santander para que fuesen ante él. Se obtuvo información sobre si "tomavan a los de Santander portadgo en Poblaçion en tiempo del Rey don Fernando,... y de la Reyna donna Verenguela", y se halló que nunca lo cobraron en dicho tiempo, ni se cobró hasta hacía 2 años que el rey murió. El Rey manda en julio que ni Juan Díaz ni ningún otro pueda tomar a los de Santander, portazgo en Población, y el que lo tomase deberá pagar al Rey 1.000 mrs. y a los de Santander el daño doblado652.

El regimiento de Campoo informó al corregidor en agosto de 1542, sobre el daño que

\footnotetext{
645 A. M. B./ HI-357/ Bruselas, 5 abril 1522.

646 RIBAS de PINA, M.: 1954: 69.

647 FORONDA Y AGUILERA, M. de: 1914: 205-206.

648 SANDOVAL, F. P. de: 1634: 560-561.

649 Pie de Concha y Villasevil.

650 RIBAS de PINA, M.: 1949: 128-129; VILLA-URRUTIA, W. R. de: 1907: 45-68.

651 Aunque existen en Cantabria varias villas con este nombre: Población de Abajo, de Arriba o de Suso, pensamos que lo más probable es que se trate de La Población junto a Lanchares.

652 A. H. P. C./ Diversos. leg. 52, nº 1, f. 9r-8v/ Sevilla, 17 julio 1253; SOLÓRZANO TELECHEA, J. A.: "Patrimonio documental...." 17: doc. 1.
} 


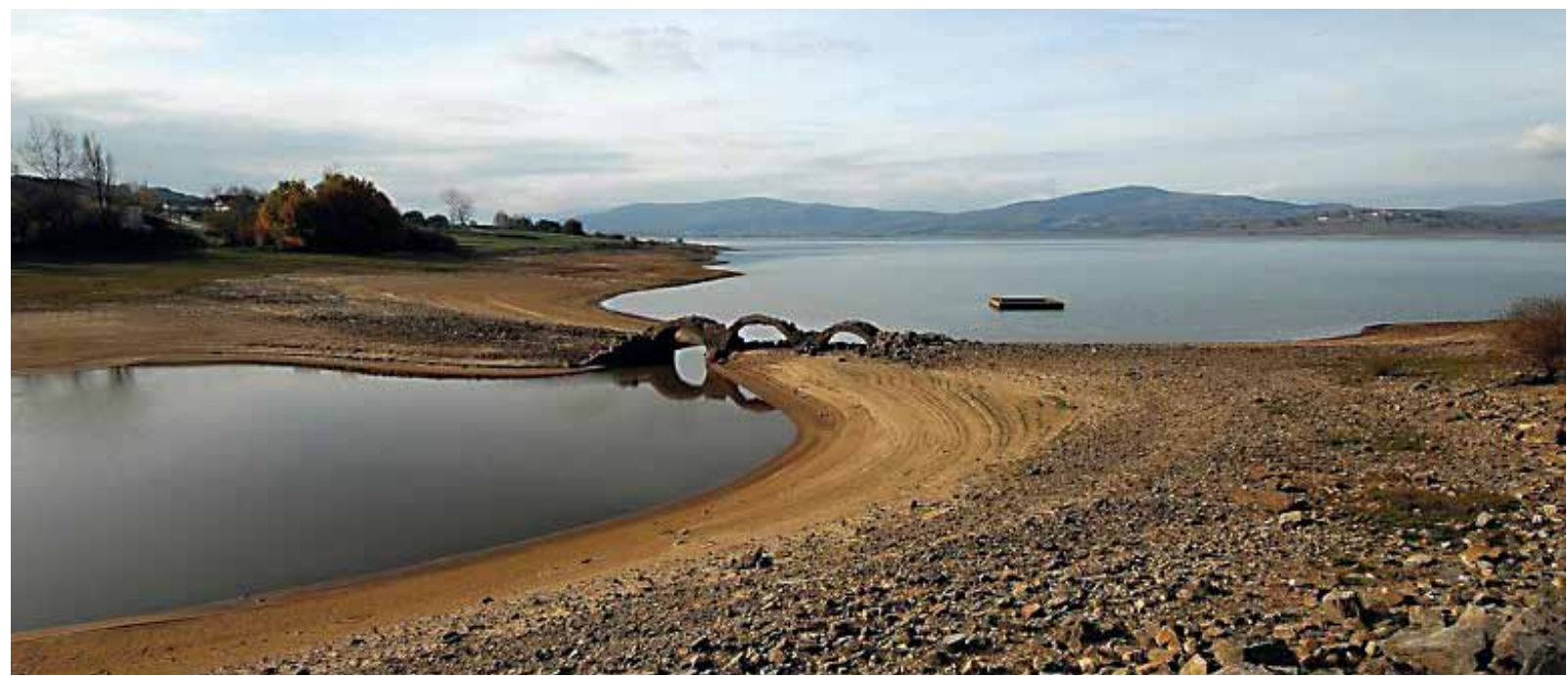

Puente sobre el arroyo de la Virga bajo el pantano de Arija (FOTO FÉLIX ANDINO).

recibían los vecinos que llevaban las sacas y pasteles, por haber acrecentado los mercaderes su peso; además, antes de construirse el puente de Solía, les alquilaban el transporte "de Solia a Burgos y de Burgos a Solia, y agora los fazen pasar a Santander que es dos leguas grandes mas adelante", sin pagarles más. El corregidor mandó que ningún vecino de la Merindad, "pudiese llebar ninguna saca de lana ni vala de pastel de Lanchares a Santander ni de Santander a Lanchares, menos de a tres rreales y medio cada vala de pastel y cada saca de lana"653.

En el diario de 1560-1561 de los negocios de compañía de García y Miguel de Salamanca, mercaderes de Burgos, se menciona el camino y la localidad de Lanchares como posible almacén ${ }^{654}$, ya que en 29 de julio de 1560 se registra que Gutiérrez de Santiago debe 12.444 mrs. que ha pagado "de alquiler de Burgos a Lanchares" de 122 sacas que allí ha enviado, y en septiembre el mismo debe por Miguel de Salamanca 28.679 mrs. que ha pagado "dellevar de Burgos a Lanchares" 295 sacas.

\section{e.- Por el puente de Rampalay y el puerto de Corconte}

Fue camino de herradura importante, utilizado desde fechas antiguas para ir de Burgos a Santander. Seguía el camino de Laredo por el páramo de Masa hasta Villalta, y de aquí por Villaescusa del Butrón, o desde Pesadas, iba por Porquera del Butrón, Quintanilla-Colina, cruzaba el Ebro por el puente de Villanueva-Rampalay y por Gallejones, Báscones de Zamanzas y Población de Arreba; o pasado el puente de Rampalay iba a la derecha por Ailanes y Arreba. Seguía por Munilla, Torres de Arriba, Bezana y Cilleruelo de Bezana, para llegar al puerto de Corconte por la orilla este del pantano del Ebro.

Otra variante de este camino es la que desde el barrio del Castillo de Arreba sigue por Hoz de Arreba y Torres de Abajo a Soncillo, y de aquí por Quintanaentello y Cabañas de Virtus llega al puerto de Corconte o El Escudo. Es el que Francisco Javier Cabanes recoge en $1830^{655}$.

\footnotetext{
653 A. D. B./ R-193/Valladolid, 22 noviembre 1542.

654 A. D. B./ Diario de García y Miguel de Salamanca. R-29/ 1560-1561. pp. 12r, 21V.

655 CABANES, FCo. X. de: 1830

"Comunicacion de Santander con Burgos por el camino principiado de Rioja. De Santander á Soncillo (camino real de Rioja) leguas 12
} 


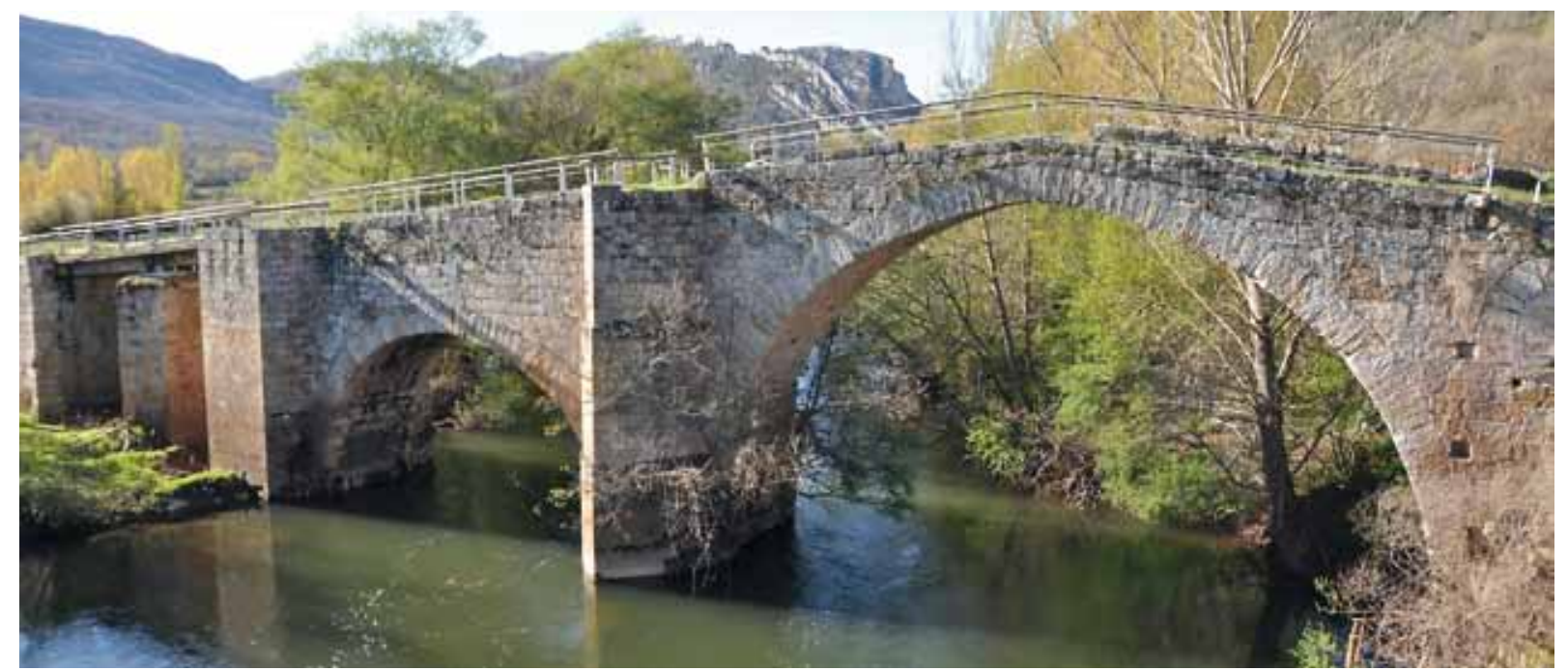

Puente de Villanueva-Rampalay (FOTo FÉLIX ANDINo).

El camino se incluye en el Itinerario de Matías Escribano de 1758 como "camino antiguo de herradura"656. En el interrogatorio de Tomás López, realizado en 1784, se indica que en el término de Quintanilla Zamanzas "se halla la puente sobre el rio Hebro titulada de Rampaliz y en lo antiguo de Hernan Pelaiz sirbe para el camino que en el dia ua a Santander y es mui buen puente"657.

Ya en marzo de 999, el conde Sancho y su mujer Urraca conceden al abad Juan y a los monjes y sucesores del lugar de Cervatos en el territorio de Campoo, fuero de albedrío con exención del portazgo en todo el condado. Aunque es un documento falso, se menciona por primera vez el "cornu de Vezana"658.

En las preguntas de un interrogatorio realizado en agosto de 1555, se hace alusión a que en el camino de Santander por el puerto de Corconte, el Condestable solo posee la villa de Cilleruelo de Bezana. Se indica que el Condestable "nolo dexa guiar por Santander, porque desde

$\begin{array}{ll}\text { al puente de Rampelaez (paso del Ebro) } & 2^{\frac{1}{2} 2} \\ \text { á Pesadas } & 2 \\ \text { á Cermegula } & 2^{\frac{1}{2}} \\ \text { á Peña-horadada } & 3 \\ \text { á Burgos } & 2^{\frac{1}{1} 2^{\prime \prime}}\end{array}$

656 ESCRIBANO, J. M.: 1758

$\begin{array}{ll}\text { "Hasta Burgos } & 41 \\ \text { LaVenta de Quintana Ortuño } & 2 \\ \text { Robledillo de la Polea } & \\ \text { Quintanajua } & 2 \\ \text { Villalta } & \\ \text { Gallejones } & 2 \\ \text { Cilleruelo } & 3 \\ \text { Escudo } & 3 \\ \text { Tramasmestas } & 3 \\ \text { Nuestra Señora del Soto } & 2 \\ \text { Puente de Arce } & 2 \\ \text { Santandér } & 3 \\ \end{array}$

657 B. N./ Tomás López. ms. 7.296, f. 1 al 16/ Merindades, post. a septiembre 1784.

658 A. Cat. B./ Vol. 71, no 142/ 2 marzo 999; ZABALZA DUQUE, Manuel: 1998: 437-449: doc 61 “... et usque ad Pennas de Flauato et usque ad castrum de Castella Uetera et usque ad portellum de Salarzar et usque ad cornu de Vezana et ad Sanctam Gadeam et per totam siluam de Ysedo et usque ad rio Concho et deinde a Polla usque ad Morosum et deinde ad Cueuam usque ad Mercadiello". 
Santander a Çilleruelo ques del Condestable, no ay lugar suyo ni de Çilleruelo a Burgos porque todos los demas son del Rey y de otros señores"659.

Esta es la vía que sigue la reina Ana de Austria en su viaje a Burgos tras llegar en 1570 a Santander desde Flandes, cuyo detalle se tratará en el apartado siguiente.

El Rey indica en abril de 1589, que mandó hacer repartimiento porque varios puentes entre los que se encontraba el "de Hernan Pelaez... tenian neçesidad de haçerse y rrepararse", pero "no se han fecho ni rreparado", y como se debía averiguar lo ocurrido y tomar cuenta de lo que se cobró, el Consejo mandó al juez que se informe sobre los repartimientos hechos, en poder de quién están y en quién se remataron las obras, y si se han reparado en qué estado están ${ }^{660}$.

Sir Richard Wynn, caballero de la Cámara del príncipe de Gales Carlos Estuardo, sale el 2 de mayo de 1623 de Santander hacia Madrid por este camino de Rampalay pasando por Burgos ${ }^{661}$.

\section{Llegada a Santander de la reina Ana de Austria}

Aunque se esperaba a la Reina en Laredo, desembarca el martes tres de octubre de 1570 en Santander procedente de Flandes. Al día siguiente, el cardenal de Sevilla, ante los hechos consumados, resalta alguna de las ventajas de que la comitiva vaya a Burgos desde dicha villa, pues aunque el camino de Laredo por Medina de Pomar "esta proveydo ya y el de Santander a Burgos no, es muy clara razon pues con enuiar dos alguaziles delante, proueeran quanto fuere menester, y como el camino es junto a Campos, es facilisimo proueer de trigo y ceuada que es la principal prouision". Además viniendo por Medina "no puede la Reyna... ni las mugeres que uienen con ella aprouecharsse de los carros que traen, y yendo por el camino de los carros desde Santander a Burgos pueden muy bien yr"662.

659 A. M. S./ Leg. A-3, no 62/ 27 agosto 1555; SOlÓRZANO TELECHEA, J. A.: "Patrimonio documental...". 283-285: doc. 225.

660 A. H. P. C./ Corregimiento leg. 3-13/ Madrid, 18 abril y Santander, 28 agosto 1589.

661 WYNN, R.: 1729: 297-341; CASADO SOTO, J. L.: 2000: 198-253. Escribe que "no pudimos partir antes de las doce en punto... Esa noche caminamos a paso de arriero durante tres leguas y alli se pararon, pues nuestras mulas no soportaban nuestro paso mas alla por esa noche; alli no habia mas refugio que un establo, lo que nos forzo a pasar toda la noche sobre el heno esparcido encima de las tablas. A la mañana siguiente partimos temprano..., recorriendo unas ocho leguas hasta un pueblo Ilamado Ereruela(") que pertenecia al gran don Pedro ("*), hijo del que fue comandante en jefe en el ochenta y ocho,... La mayor parte del viaje ese dia fue montaña arriba... Cuando llegamos a lo mas alto, nos encontrabamos mucho mas arriba de la nieve que yacia en pendientes bastante inferiores a nosotros. Hacia tanto frio alli en esa epoca del año, como en Inglaterra en mitad del invierno... Estos mulateros no necesitaban cuatro dias para trasladarnos hasta Burgos, pues hubieran sido suficientes tres faciles jornadas, pero los bribones a fin de prolongar el tiempo de viaje y evitar conducir rapidamente sus mulas, nos llevaron por ese camino donde es imposible para cualquiera trepar, excepto para estas mulas. Fuimos a lo largo de seis millas por un estrecho camino, por lo menos a una milla de altura sobre un rio, por donde un tropiezo habria precipitado a un hombre una milla mas abajo. A mitad de este sendero cruzamos un rio llamado Ebro, que parte de Castilla la Vieja... Al final Ilegamos a un pueblo llamado Turfo Esculada (**) , hacia las seis de la tarde, y como estaba muy entumecido, desmonte contra el deseo de los mulateros... Resueltos a quedarnos, nos dirigimos a la mejor casa que alli habia, donde fuimos muy bien tratados; tuvimos un buen y gordo pavo para cenar y muy buenas camas... No obstante, aunque sea maravillosamente seguro viajar por sus caminos reales, las montañas y los bosques estan llenos de osos salvajes y lobos que no solo causan estragos al ganado, sino que a veces matan hombres... Al mediodia tomamos un refrigerio en un pueblecito a nueve millas de Burgos, y por la tarde encontramos en nuestro camino (cerca de la orilla de un rio, en campo abierto) a un muchacho que conducia dos yeguas atadas juntas... Continuamos durante cinco millas..., cuando ya estabamos a la vista de Burgos, una hermosa ciudad extendida sobre un valle...". (") Puede corresponder a Cilleruelo de Bezana, tras subir como dice, el puerto del Escudo, perteneciente a la casa de Velasco. (**) Quizá se refiera a Bernardino Fernández de Velasco, que fue condestable de Castilla entre 1613-1652, ya que el último Pedro Fernández de Velasco, ostentó el título de condestable entre 1528 y 1559 . (****; Puede referirse a Turzo y a Escalada, aunque estos dos pueblos se encuentran ligeramente desviados de este camino por Rampalay. También es posible que el camino que realizaron, fue por un tramo secundario, que desde Turzo, seguía en dirección al Sur por encima de Escalada, hasta encontrar el Ebro por su orilla izquierda por la parte alta de los acantilados que en dirección Este, cruza dicho río en el puente de Pesquera de Ebro.

662 A. G. S./ Patronato Real, leg. 57, doc. 62/ Laredo, 4 octubre 1570. 
El 10 de octubre de 1570 se acuerda que la Reina parta de Santander y que la primera jornada duerma en el valle de Camargo a 1,5 leguas de Santander; la segunda en Villasevil a 3,5 leguas; la tercera en el lugar de Luena a tres leguas; la cuarta en Cilleruelo de Bezana a tres leguas; la quinta en Pesadas a cinco leguas; la sexta en Hontomín a cinco leguas y a Fresdelval cuatro leguas o al monasterio de las Huelgas cinco pequeñas. Se manda que el alcalde Ortiz prepare carros, rocines y mulas, y en los malos pasos y lugares precisos se pongan bueyes para ayudar a sacar los carros de la Reina, y azadoneros y personas que vayan con los dichos carros. Se indica que se deberá advertir que irá a comer a las Huelgas de Burgos ${ }^{663}$.

El cardenal de Sevilla y el duque de Béjar, delegados por el Rey para tal asunto, le informan sobre las etapas que la Reina hacía en su desplazamiento, que se realizaron como estaba previsto. Partió de Santander el lunes 16 de octubre a las 12,30 h., y llegó aquella noche al valle de Camargo. El 17 durmió en Villasevil y el día 18 va de Villasevil a Luena "aunquel camino no es llano ny apacible por haber llobido"664. El 19 sale de Luena y duerme en Cilleruelo de Bezana, donde fue necesario detenerse el viernes para reparar los carros ${ }^{665}$. El 21 sale de Cilleruelo y duerme en Pesadas y el domingo 22 después de haber oído misa y comido, fue a dormir a Hontomín. El 23 de octubre hizo noche en el compás de Huelgas, y no en el monasterio de Fresdelval, "ques vna casa sola en el campo”, porque debía oír misa el martes y tras comer en el monasterio entró solemnemente en Burgos ${ }^{666}$. Tardó la Reina 8 días de Santander a Burgos, "donde se tuuo gran cuenta con adereçar todos los caminos que cerca de la Ciudad auia: y de hazer muy buenas puentes sobre el rio, para que sin rodeo pudiesse su Magestad passar a las Huelgas, donde auia de dormir. Entro su Magestad lunes,... en las Huelgas"667. En una crónica de ese mismo año, se detalla que la noche anterior se alojó en el monasterio de las Huelgas, y para "venir al monasterio fue cosa admirable y de notar ver las arboledas que se cortaron para hazer camino a su Magestad, y ver romper y derribar las murallas de canto y hazer entradas y salidas para que con toda Magestad, entrasse sin ningún detenimiento de puerta"668. La Reina se alojará en la casa del Cordón hasta el 28 de octubre. El resumen de su viaje es el siguiente:

663 A. G. S./ Patronato Real, leg. 57, doc. 68.2/10 octubre 1570.

664 A. G. S./ Patronato Real, leg. 57, doc. 80/ Luena, 18 octubre 1570.

665 A. G. S./ Patronato Real, leg. 57, doc. 82/ Cilleruelo de Bezana, 20 octubre 1570.

666 A. G. S./ Patronato Real, leg. 57, doc. 81/ Burgos, 26 octubre 1570.

667 B. N./ R. 4.969/ Imprenta de Felipe de Junta/ Burgos, 1581: "Relacion verdadera, del recibimiento, que la muy noble y muy mas leal ciudad de Burgos, Cabeça de Castilla, y Camara de su Magestad hizo a la Magestad Real de la Reyna nuestra señora, doña Anna de Austria, primera de este nonbre: passando a Segouia, para celebrar en ella su felicissimo casamiento con el Rey don Philippe nuestro señor, segundo de este nonbre". Impresso en Burgos en casa de Philippe de lunta. Año de. M. D. LXXXI.

668 Imprenta de Bernardino de Santo Domingo/ Valladolid, 1570: "Relacion muy verdadera del alto recibimiento, que la ciudad de Burgos hizo a la Serenissima y muy poderosa señora la Reyna doña Anna, señora nuestra, hija del Emperador Maximiliano. En el qual se hallaron muchos cavalleros ilustres, assí destos Reynos, como estrangeros, y de las maravillosas invenciones y realissimos arcos, figuras y antiguallas destos Reynos: y cosas dignas de eterna memoria que alli se vieron, que assí a los nuestros naturales, como a los muchos estrangeros que con su Magestad venian, les fue cosa de admiración". Impresso en Valladolid por Bernardino de Sancto Domingo al prado de la Magdalena. Año de MDLXX; SANZ, María Jesús: "Festivas demostraciones de Nimega y Burgos en honor de la Reina doña Ana de Austria". B. S. A. A. XLIX. Valladolid, 1983. pp. 375-395. 


\begin{tabular}{|c|l|}
\hline Lunes 16 de octubre & Sale de Santander y duerme en el valle de Camargo \\
\hline Martes 17 & Sale del valle de Camargo y duerme en Villasevil \\
\hline Miércoles 18 & Sale de Villasevil y duerme en Luena \\
\hline Jueves 19 & Sale de Luena y duerme en Cilleruelo de Bezana \\
\hline Viernes 20 & Descansa en Cilleruelo de Bezana \\
\hline Sábado 21 & Sale de Cilleruelo de Bezana y duerme en Pesadas \\
\hline Domingo 22 & Sale de Pesadas y duerme en Hontomín \\
\hline Lunes 23 & Sale de Hontomín y duerme en el compás de Huelgas \\
\hline Martes 24 & $\begin{array}{l}\text { Come en Las Huelgas, entra solemnemente en Burgos y } \\
\text { se aloja en la casa del Cordón, donde estará hasta el 28 }\end{array}$ \\
\hline
\end{tabular}

\section{f.- Por Soncillo, Cubillos del Rojo y puerto de Corconte}

Este camino, escasamente utilizado para ir a Santander antes del siglo XVIII, fue activado en dicho siglo. Discurría por el camino de Laredo hasta Incinillas, e iba por Cubillos del Rojo, Soncillo, Quintanaentello, Cabañas de Virtus hasta el puerto de Corconte por el límite este de la llanura de la Virga (actual pantano del Ebro). Coincidió desde la venta de Villalaín, a partir de la segunda mitad del siglo XVIII, con el camino real carretero promovido por los viticultores riojanos para dar salida a sus productos por el puerto de Santander para América.

Viene incluido en el itinerario de Cabanes de $1830^{669}$ y otros posteriores, aunque en este caso lo hace pasar por el puente de Rampalay. Este mismo autor recoge otro camino por el puerto de Corconte o del Escudo, que coincide con este hasta Soncillo670.

669 CABANES, FCo. X. de: 1830.

"Comunicacion de Santander con Burgos por el camino principiado de Rioja.

De Santander á Soncillo (camino real de Rioja) leguas 12

al puente de Rampelaez (paso del Ebro) $\quad 2 \frac{1}{2}$

á Pesadas

á Cermegula

2

á Peña-horadada

á Burgos

$2 \frac{1}{2}$

3

$2 \frac{1}{2}$

670 "Comunicacion de Santander con Frias por el camino real llamado de Rioja.

$\begin{array}{ll}\text { De Santander á Renedo, leguas } & 3 \\ \text { á Villigar } & 3 \\ \text { á Entrambas mestas } & 1 \\ \text { al Puerto del Escudo } & 2 \\ \text { á Soncillo (hasta aqui camino real) } & 3 \\ \text { á Villarcayo } & 3^{\frac{1}{2} 2} \\ \text { á Monco } & 2 \\ \text { áTrespaderne } & 2^{\frac{1}{2} 2} \\ \text { á Frias } & 2\end{array}$

Este camino es el que llaman de Santander á la Rioja; el cual en vez de pasar el Ebro por Trespaderne, se dirige al puente de Frias para salir á Ameyugo en el camino real. Desde Santander á Soncillo es camino carretero, y de Soncillo a Frias de herradura". 


\section{C.- POR VILLARCAYO}

Para ir de Burgos a Santander, se utilizaron principalmente los caminos ya descritos por el curso del Besaya y por la Sierra de El Escudo. No obstante, existieron tres caminos que, utilizando hasta Villarcayo el camino de Laredo, pasaban los puertos de los montes de Valnera. Su utilización, no obstante, fue muy baja y tardía, sin llegar nunca a ser alternativa a los caminos a Santander mencionados.

\section{a.- Por el puerto de Las Estacas}

Discurría desde Villarcayo por Villacanes, Mozares, Campo, Torme, Bedón, Espinosa de los Monteros, Bárcenas, Las Machorras, puerto de las Estacas, y por el curso del Pas, Yera, Vega de Pas, Candolías, La Curueba, Vega Escobosa, Gamonal, Arrielas, Bárcena y Corralmayor, para entroncar con el camino de Corconte en Vejorís.

Otro camino desde Vega de Pas se dirigía hacia el Norte a Santander por el puerto de la Braguía, Selaya, Villacarriedo, Bárcena de Carriedo, Vega, Santa María de Cayón, La Abadilla, Sarón, Obregón, Villanueva, Solía, Herrera, Muriedas, Peñacastillo y Santander, coincidiendo en este último tramo con el camino que venía de Corconte.

Camino de herradura secundario, su puerto de $1.166 \mathrm{~m}$ de altitud se convertía en impracticable durante largas temporadas del año a causa de las nieves. Un tramo de esta vía viene recogido como camino a Carriedo, en el itinerario de Miguel Bañuelos ${ }^{671}$.

\section{b.- Por el portillo de Lunada}

Camino mulatero irrelevante en la época que estudiamos, lo mencionamos tan solo por dejar constancia de su existencia. Discurría desde Villarcayo por Villacanes, Mozares, Campo, Torme, Bedón, Espinosa de los Monteros, Bárcenas, Las Machorras, Salcedillo, portillo de Lunada, y desde aquí seguirá el curso del río Miera por La Concha, San Roque de Riomiera, Ajanedo, Miera, La Vega, Mirones, Rubalcaba, La Vega, El Mercadillo, Calgar, Hermosa, Solares, San Salvador, El Astillero, Maliaño, Muriedas, Peñacastillo y Santander.

$\begin{array}{cl}671 \text { BAÑUELOS, M.: 1771. } & \\ \text { "Villatoro } & \text { 1. } \\ \text { Quintanilla de Vivar } & \text { med. } \\ \text { Vivar } & 7 . q . \\ \text { Soto Palacios, y Ventas } & 7 . q . \\ \text { Villaverde junto á Peñaorada } & 7 . q . \\ \text { Peñaorada } & 3 . q . \\ \text { Ontomin } & 7 . \text { me. } \\ \text { Cernegula } & 7 . \text { me. } \\ \text { Villalta } & 2 . \\ \text { Pesadas } & 7 . \\ \text { Armiñe } & 7 . \\ \text { Puente Arenas } & \text { me. } \\ \text { Villarcayo } & 2 \\ \text { Espinosa } & 3 . \\ \text { LaVega de Pas } & 3 . \\ \text { CARRIEDO } & 7 . "\end{array}$


Este camino se reactiva en la segunda mitad del siglo XVIII, cuando se pone en marcha el Real Astillero de Guarnizo y sobre todo las Reales Fábricas de Artillería de la Cabada y Liérganes, aunque por ser Lunada un puerto de $1.350 \mathrm{~m}$ de altitud, permanecía grandes temporadas cerrado a causa de la nieve. Ha sido siempre camino de herradura y viene incluido en el itinerario de Cabanes de $1830^{672}$.

En 1779 se trata en Santander sobre un camino "mui ymporttantte y uenttajosissimo para exporttar los muchos y preziosos frutos que produzen las prouinzias de Rioja, Alaua, Nauarra, Aragon y Cattaluña, que son mui yntteresanttes para el comerzio con estte puerto, y de el comunicarles los frutos y efecttos que se reciuen de la America para surtirlos dellos y de otros esttrangeros de que nezessittan para sus manufacturas, fabricas y abasttos a que concurre el beneficio de fazilittarsse que por el mismo conductto y a mui poca costta... los carbones para las fauricas de artilleria de La Cauada y Lierganes que hazen suma faltta, maderas para construczion de bageles de comerzio y de cassas que se pueden sacar y esttraher de los yntactos monttes de Espinosa. Deue dirigirsse desde el Camino Real de estte puertto a una legua escasa de disttanzia por el Valle de Camargo, terreno llano al puentte de Solia, Obregon y orillas del rio del lugar de Miera, que solo distta de la Real Faurica de La Cauada vna legua y de alli al Portillo de Lunada, Barzena de Espinosa de los Montteros disttantte de Lierganes siette leguas..." ${ }^{673}$.

En un documento realizado en Villarcayo en 1782, y dirigido a Santander, se indica que "el camino unico, maesttro y mas breue desde Burgos para esa ciudad [Santander], Santtoña, Laredo y Casttro; es el que pasa por estta villa y desde ella a la ventta de Quinttanilla de Pienza. Desde aqui o desde el lugar de Caiangos, media legua mas occidenttal a dicha ventta, debiera sacarse el ramo de camino que por Espinosa, Lierganes o La Cauada auia de enttrar en esa ciudad; desde dicha ventta toma derecho el de Laredo y Santoña y con ygual derechura tambien al de Casttro, pueblos que no tienen otro desde las Casttillas, y ttoda aquella parte del Reyno"674.

672 CABANES, Fco. X. de: 1830 .

"Comunicación de Santander con Espinosa de los Monteros y Villarcayo con dirección á Burgos por el puente de Arenas (herradura)

$\begin{array}{ll}\text { De Santander á la Cabada, leguas } & 2 \frac{1}{2} \\ \text { á Liérganes } & 1 / 2 \\ \text { á San Roque } & 2 \frac{1}{2} \\ \text { á Salcedillo } & 2 \frac{1}{2} \\ \text { á Espinosa de los Monteros } & 1 \\ \text { á Villarcayo } & 3\end{array}$

Aunque este camino es una legua mas largo, es preferible al que viene por Bustablado, tanto por ser mejores los pueblos, como porque no se cubre tanto de nieves". El camino que viene de Bustablado es el que pasa por el portillo de la Sía que trataremos a continuación.

673 A. M. S./ Leg. A-22a, no 64/ Santander, 8 a 11 marzo 1779.

674 A. M. S./ Leg. A-22b, no 193/Villarcayo, 26 diciembre 1782; A. M. E. Mont./ no 4.208/ Espinosa de los Monteros, 15 diciembre 1802 a Burgos 25 junio 1803. En 1802 se constata en Espinosa de los Monteros que “... los caminos reales... desde las Merindades de Castilla la Vieja a desembarcar al puerto de Lunada para la carrera de Santander, se hallan intransitables por su situacion pantanosa y aspera en muchas partes de su giro, a causa de no haverse reparado por falta de medios de modo que las gentes, caballeria y carroages que pasan por el, estan en conocido peligro de exponer sus vidas y haciendas... el nominado camino es el mas comodo y brebe para la espresada ruta de las Merindades de Castilla la Vieja al puerto de Santander, por el que se surten los mercados de Villarcayo, esta dicha villa y el de Lierganes,... el camino real que ocupa el transito de esta jurisdizion y tiene su principio desde el portillo de Bedon confinante con las Merindades de Castilla la Vieja y sigue via recta hasta tocar con el puerto de Lunada cuya ruta se dirige a la ciudad de Santander que tiene la latitud de dos leguas y media por lo correspondiente a esta dicha villa...". 


\section{C.- Por el portillo de La Sía}

El camino mulatero discurría desde Villarcayo por Villacanes, Mozares, Campo, Torme, Bedón, Espinosa de los Monteros, Bárcenas, Las Machorras, portillo de La Sía, Cañedo y siguiendo el curso del río Asón, hasta Arredondo por el puerto de Asón, Asón, Val de Asón, Socueva, Arredondo, El Avellanal, Bustablado, Tabladillo, La Garma, Angustina, La Cavada, Ceceñas, Solares, San Salvador, El Astillero, Maliaño, Muriedas, Peñacastillo y Santander.

Fue utilizado de manera muy escasa para ir a Santander como camino de herradura, tenía un carácter agreste y permanecía largas temporadas cubierto de nieve, al tener el portillo de la Sía una altitud de $1.200 \mathrm{~m}$. Esta vía viene incluida en el itinerario de Matías Escribano de 1758 con la denominación "Otro para Santander por el Camino de Bilbao hasta Villarcayo", aunque en su último tramo, se dirige a Pedreña, para cruzar por mar la bahía de Santander 675 .

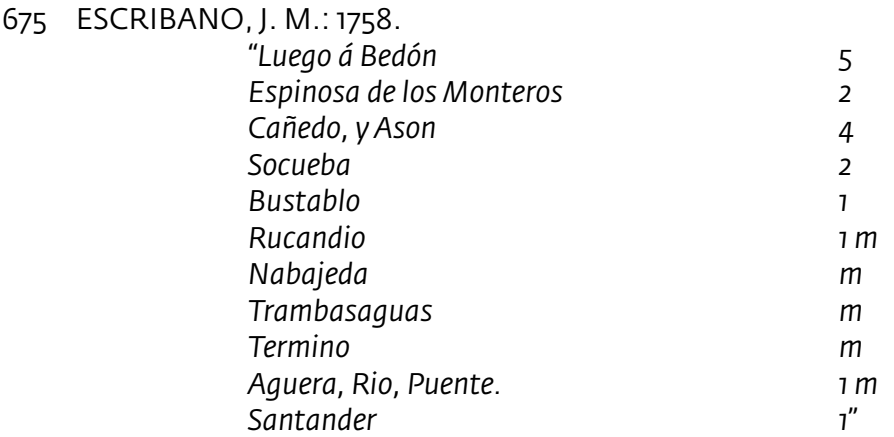


270 a Caminos burgaleses: Los caminos del Norte

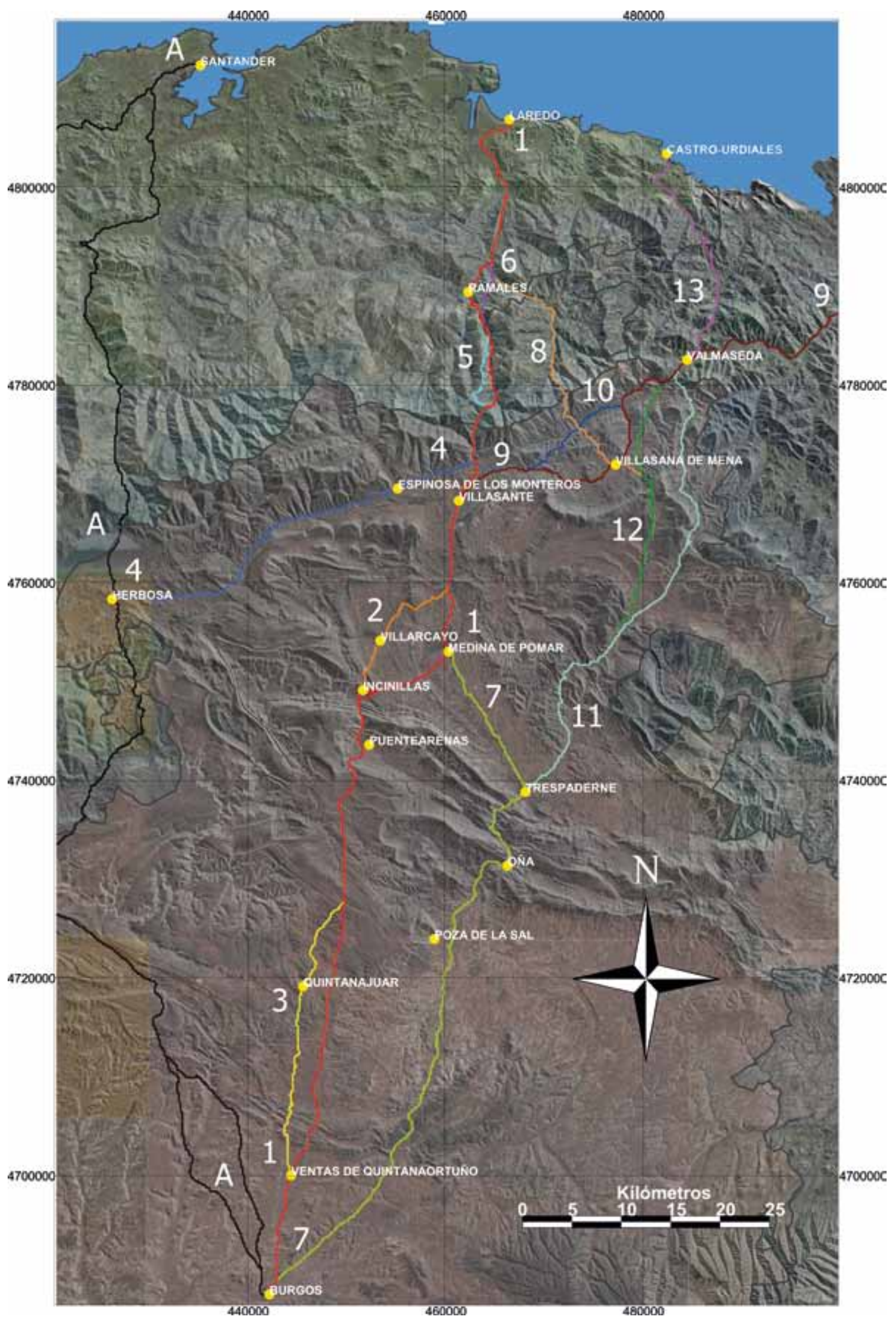

Mapa general de los caminos de Burgos a Laredo y Castro-Urdiales:

1.- Camino principal de Burgos a Laredo por Medina de Pomar 2.- Rectificación por Villarcayo realizada en 1562

3.- Tramo por Quintanajuar 4.- Camino "del carro"
5.- Tramo por la Hoz de Herada 6.- Tramo por Gibaja

7.- Camino por La Horadada

8.- Camino por el puerto de Lanzas Agudas

9.- Camino a Bilbao y Castro-
Urdiales por Valmaseda 10.- Tramo por Ordunte 11.- Camino por el puerto de Angulo 12.- Camino por La Complacera 13.- Camino a Castro-Urdiales por el puerto de Las Muñecas 


\section{2.- CAMINOS DE BURGOS A LAREDO}

Laredo fue puerto importante en los siglos XV y XVI y tuvo a la ciudad de Burgos como cabeza de su hinterland al acaparar el comercio burgalés la mayor parte de su tráfico comercial a través, básicamente, de su Universidad de Mercaderes. Para la comunicación entre ambos centros, se utilizaron varios caminos; los principales fueron:

A.- El camino principal, y más transitado, para ir de Burgos a Laredo fue el que iba por el páramo de Villalta; cruzaba el Ebro en Puente-Arenas, pasaba por Los Hocinos, Medina de Pomar y puerto de Sendero Enhiesto ${ }^{676}$. Después por Lanestosa, Ramales y, por el curso del río Asón, llegaba a Laredo a través de Colindres.

Este camino tuvo variantes y mejoras que, en muchos casos, se hicieron sobre nuevos trazados. Las principales fueron:

a.- Camino por Quintanajuar. Desde las Ventas de Quintanaortuño, discurría por Gredilla la Polera, Robredo-Sobresierra, Quintanajuar y, en el Cuerno se encontraba con el camino principal que venía por Peñahorada.

b.- El camino por Peñahorada y Cernégula que fue el camino principal.

c.- Camino por Pilas. De herradura, discurre desde el puente de Puente-Arenas por lo alto de la Sierra de la Tesla y la ermita de Ntra. Señora de Pilas, a Bisjueces para ir a Villarcayo por Villalaín, o bien a Medina de Pomar por Barruelo y La Aldea evitaba el paso de los Hocinos cuando alguna circunstancia interrumpía dicho paso.

d. - El llamado "Camino del Carro" o "de los Carros". Fue el resultado de las modificaciones planteadas en el s. XVI, con el fin de hacer el camino transitable para carros. Se planteó un nuevo trazado entre Agüera y Lanestosa por la Hoz de Herada evitando el puerto de Sendero Enhiesto; otro desde Valnera hasta Lanestosa y, finalmente, otro para evitar los puentes de Bolado y San Pedro de Ramales, desde La Haza de Ramales por Guardamino al puente de Bolado, ya en el camino principal.

También se modificó y mejoró el Camino de Agüera a Burgos por Espinosa de los Monteros, Valderredible y el páramo del Tozo para el transporte de cargas pesadas. Desde Laredo iba por el principal camino hasta Agüera, donde se desviaba por Espinosa de los Monteros, Quisicedo, Pedrosa, Santelices, Cilleruelo de Bezana y Herbosa, entroncando allí con el camino carretero que, desde Santander, venía por Corconte, y seguía por Montejo de Bricia, Villamediana, Ruerrero, Valladar, Santa Cruz del Tozo, Montorio, Venta de Quintanaortuño, Sotopalacios y Burgos.

B.- El camino por Los Hocinos, Villarcayo y puerto de Sendero Enhiesto. Es el mismo camino por Medina ya descrito, con la única variación que entre Incinillas y el puente de Quintanilla de Pienza, iba por Villalaín, Villarcayo y Villacomparada de Rueda hasta Bocos. Después por Céspedes, llegaba al puente de Quintanilla de Pienza sobre el Trueba, donde entroncaba con el camino de Medina ya tratado.

C.- El camino a Laredo por la Horadada. Iba desde Burgos por Hurones, Rublacedo de

676 El puerto mulatero de Sendero Enhiesto, también Ilamado "Sandiniesto", salvaba el desnivel del actual puerto de Los Tornos de 920 ms. y se encuentra muy cerca de este. 


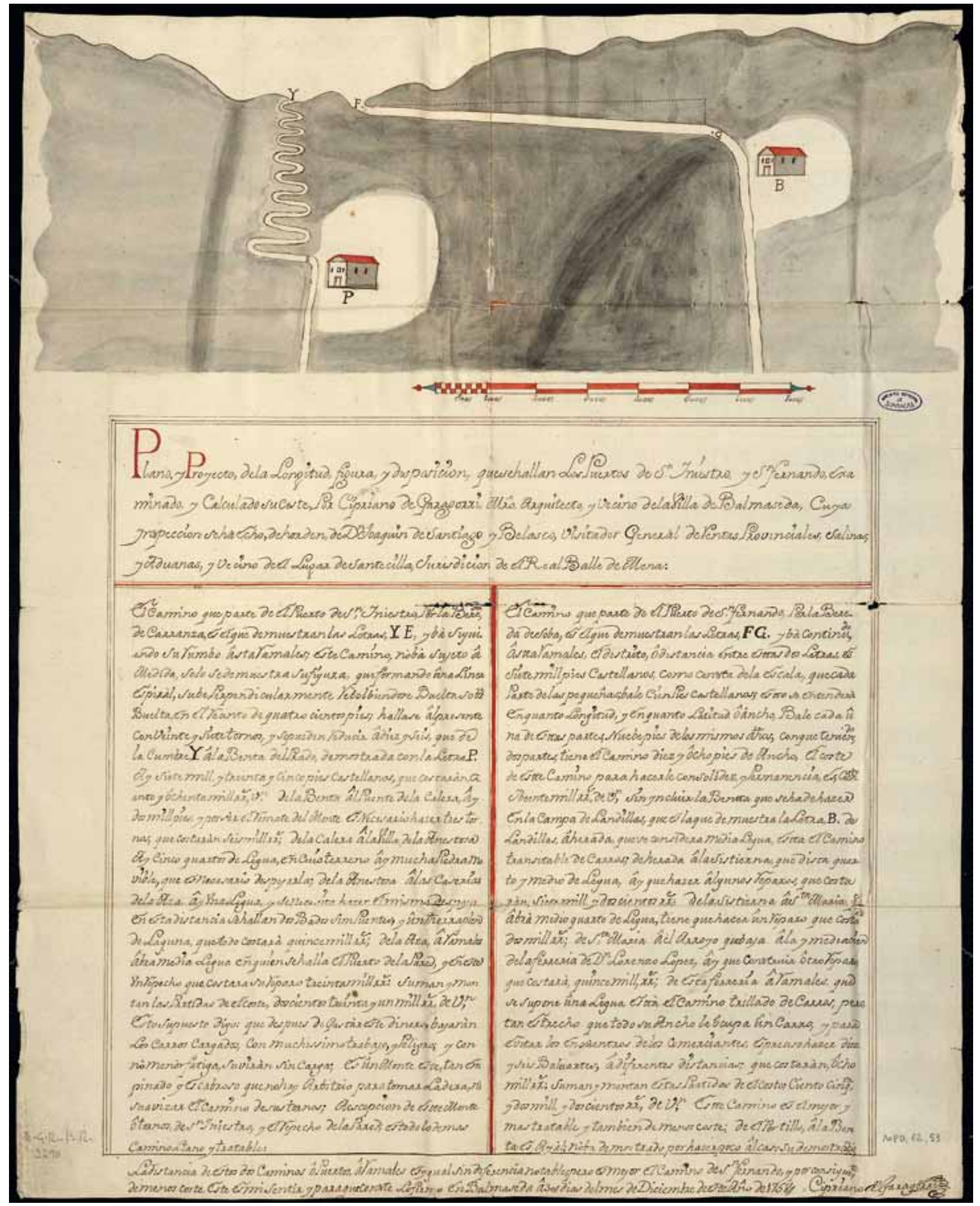

Plano de 1758 "de longitud, figura y disposicion, que se hallan los Puertos de San Yniestro y San Fernando" (A. G. S., MPD 62,053) 
Arriba, Lences, Salas de Bureba, Terminón, Oña, desfiladero de la Horadada, Trespaderne y Nofuentes. Esta vía entroncaba con la principal de los Hocinos en Medina de Pomar hasta la década de 1560, o con el de Villarcayo en el puente de Quintanilla. Un tramo diferente discurría junto a Villayerno-Morquillas al Norte, Tobes y Rahedo, Melgosa y Arconada, a juntarse en Lences con el camino descrito.

D. - A Laredo por la Horadada, la Complacera, Villasana de Mena y Lanzas Agudas. Este camino arrieril que baja del portillo de la Complacera, se separa del que va a Valmaseda pasando Cilieza. Después por Villasana, Caniego, Hornes, puerto de Lanzas Agudas, Manzaneda de la Sierra, La Concha, Pondra y, en Riancho, entroncaba con el camino que venía de Guardamino. Finalmente por Gibaja llegaba a Laredo.

E.- Camino mulatero por el portillo de La Sía. Discurría desde Villarcayo por Villacanes, Mozares, Campo, Torme, Bedón, Espinosa de los Monteros, Bárcenas, Las Machorras, portillo de La Sía, Cañedo, curso del río Asón por el puerto de Asón, Asón, Val de Asón, Socueva, Arredondo, Riba, Ogarrio, San Bartolomé de los Montes, Portillo de Güeras, Hoz de Marrón, Marrón; y posteriormente en Limpias se unía con el principal camino de Sendero Enhiesto.

\section{A.- POR LOS HOCINOS, MEDINA DE POMAR Y PUERTO DE SENDERO ENHIESTO}

El camino más utilizado para transitar entre Burgos y Laredo es el que, por el páramo de Villalta, valle de Valdivielso, desfiladero de Los Hocinos y Medina de Pomar hasta la década de 1560, se encamina por Sendero Enhiesto hasta el puerto de Laredo. Tenía un trazado tortuoso porque debía discurrir por el alto y desolado Páramo de Villalta que, con altitudes, algunas superiores a los $1.000 \mathrm{~m}$, se cubría de nieve los meses invernales, bajar de manera abrupta a la vega del Ebro, y salvar el río en la merindad de Valdivielso para ir encajado por el desfiladero de Los Hocinos, afectado con frecuencia por las crecidas del Ebro. Debía cruzar después la merindad de Castilla Vieja, y luego ir por la de Montija, bajar el puerto de Sendero Enhiesto y junto a los ríos Calera y Asón llegar a Laredo. No obstante, un testigo afirma en 1511 que "dicho camino es el mejor e mas llano para yr e venir desde la çibdad de Uurgos a la dicha villa de Laredo e a otras partes"677. Recibió algunas variantes y mejoras, que en muchos casos lo fueron sobre nuevos trazados, pero siempre en tramos concretos y sin grandes modificaciones de la vía principal.

\section{a.- Camino antiguo por Quintanajuar}

Se trata de una vía muy antigua utilizada para ir a Laredo, y fue sustituida por el camino actual que va por Peñahorada en un momento de la Edad Media que no podemos precisar, aunque el cambio se produjo en un periodo temporal amplio, que permitió la convivencia de ambos caminos y la pervivencia del antiguo durante muchos años. Era el que, saliendo de la ciudad de Burgos por la puerta de San Gil, iba por Villatoro, Vivar del

677 A. G. S./ Consejo Real de Castilla, leg. 26-17/ Burgos, 5 octubre a 12 diciembre 1511. 


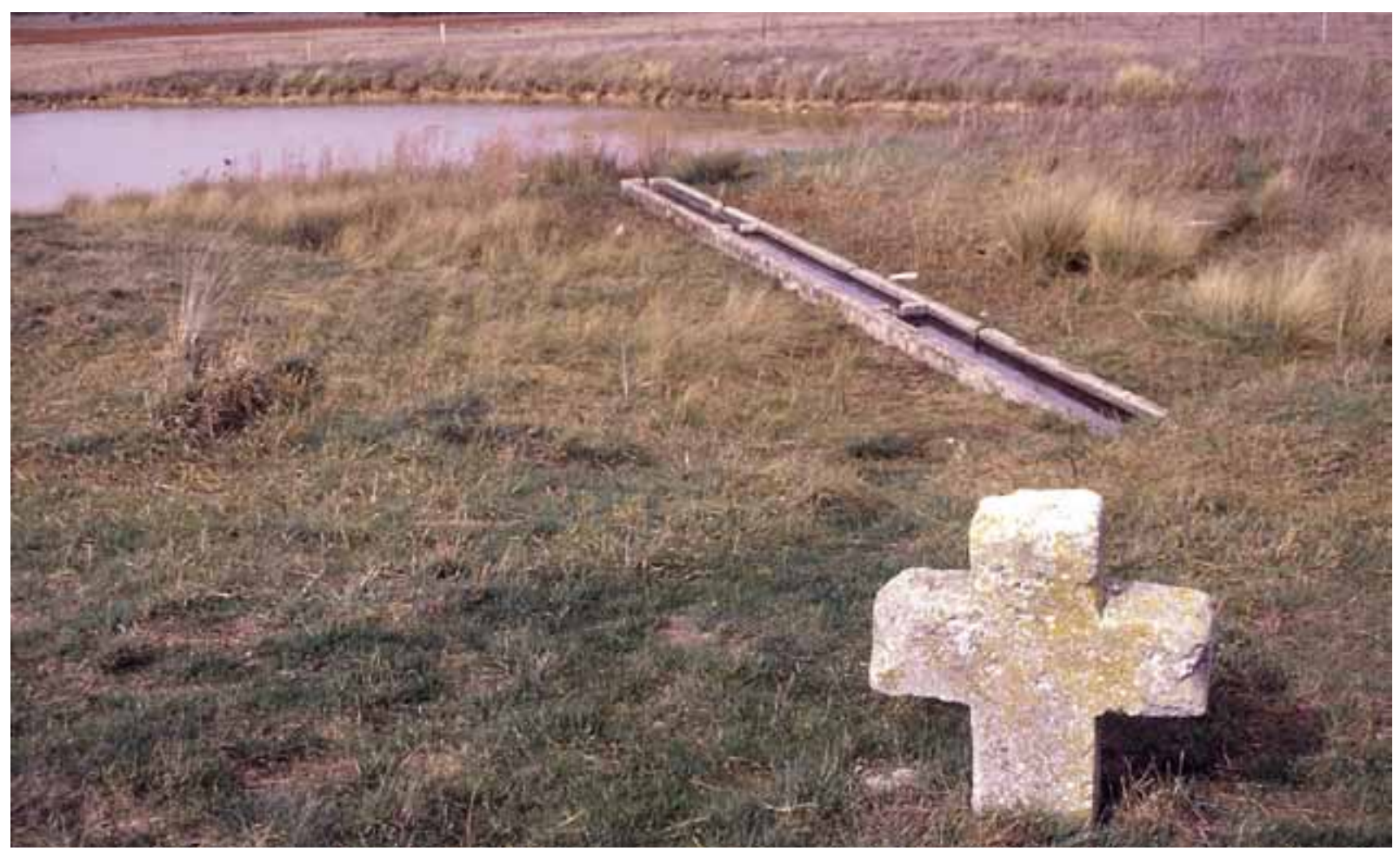

Término de la Venta la Perra.

Cid, Sotopalacios y, desde las Ventas de Quintanaortuño, proseguía por Gredilla la Polera, Robredo-Sobresierra, Quintanajuar y en el Cuerno, se encontraba con el que después fue el camino principal que venía por Peñahorada. En su primer sector, existía otra alternativa desde Quintanaortuño por Ubierna. Hay un término denominado Venta la Perra junto a la laguna homónima, situado sobre esta antigua vía entre Quintanajuar y Villalta que, aunque no presenta en la actualidad restos de construcción, su nombre es sin duda el vestigio de una antigua venta de este camino. Según Inocencio Cadiñanos, Quintanajuar fue un punto de enlace entre el valle del Ubierna y el páramo, así como entre el Homino y tierras de Sedano y Villadiego, donde existió durante siglos una venta ${ }^{678}$.

La documentación consultada se refiere a esta vía como un camino entre localidades rurales, sin hacer referencia en ningún momento a una vía de largo recorrido ni a las villas de Laredo y Santander, salvo una tardía de 1758. La última referencia documental, corresponde al año 1466, aunque todavía en 1758, Matías Escribano lo incluye dentro de uno de los caminos de Madrid a Santander recogidos en su itinerario, calificado como "Camino antiguo de Herradura". Desde Villalta por Gallejones, Cilleruelo y El Escudo, llegaba a Santander 679 .

678 CADIÑANOS BARDECI, I.: 2002.

679 ESCRIBANO, J. M.: 1758.

"Hasta Burgos

La Venta de Quintana Ortuño

41 leguas

Robledillo de la Polea

Quintanajua

Villalta

Gallejones

2
2
2
2
3


Ya en 909, el Becerro Gótico de Cardeña hace referencia al camino de Burgos a Ubierna ${ }^{680}$ y en 945 se cita el Cuerno de Butrón ${ }^{681}$, cita que se repite en $984^{682}$.

En un documento de 1137 sobre una donación de heredades en el alfoz de Ubierna, realizada por el conde Rodrigo Gómez al abad y al monasterio de Oña, se mencionan los pontones del río Rioseras y de Quintanaortuño ${ }^{683}$, y cuando el conde Rodrigo dona al mismo abad ciertas heredades en 1146, se cita el "ponton de Quintana Fortun que dicitur las Arroturas de Uillauerde"684.

Alfonso VII y sus hijos Sancho y Fernando, cuando donan en 1150 el lugar de Cernégula a Santa María de Quintanajuar, mencionan el camino que va de Quintanajuar al Cuerno685. Igualmente en la donación de unas tierras en Quintanaortuño realizada en 1173 al monasterio de Rioseco y a su abad, se indica que “...ad illam parte de Quintana Fortum, latus uia que discurrit, exalia pars Petrus Petri..." ${ }^{\prime 66}$.

Por otra parte en el privilegio que da Alfonso VIII, confirmando en 1186 la donación de Hocina con sus montes y bosques, hecha por su abuelo el Emperador al abad de Quintanajuar, se menciona la vía del Cuerno a Quintanajuar ${ }^{687}$, y en 1200 , el abad de Oña, concede a Conzalo y a su mujer una heredad en Quintanaortuño, citándose el "puente de Quintanaortuño"688. El año siguiente, el conde Conzalo Rodríguez confirma al abad de Oña todas las donaciones hechas por sus padres, citando el "pontón de Quintanaortuño que se dice las Arroturas de Villaverde"689. Más tarde se realiza en 1221 un trueque entre don Polo y el abad de Rioseco, de tres tierras en Cendrera por una en Quintanaortuño, mencionando el puente de Nava y el que hay en Cendrera junto a Sotopalacios. En la carta de venta hecha por Ferrant Fernández a dicho abad, de tres tierras en Cendrera por 30 mrs. , tam-

$\begin{array}{ll}\text { Cilleruelo } & 3 \\ \text { Escudo } & 3^{\prime \prime}\end{array}$

680 Becerro Gótico de Cardeña, fol. 19, col. 1; BERGANZA, F. de: 1719 y 1721: t. II, 372/ 1 febrero 909 y t. I, 184/ 23 julio 909; SERRANO, L.: 1910: doc. LXII, 75-76 y doc. LXI, 74-75. “.., ab occidente, via que discurret ad Obirna,...”, y “..., et alia parte via discurrente de Vurgos,...".

681 Becerro Gótico de Cardeña. f. 75V A/ 3 septiembre 945; MARTÍNEZ, G.: 1998: 53: doc. 53. "id est, de ualleggo de Fratre ad Penna Forata, dein ad Uilla Escusa ad fonte de Azerio et directo ad fonte Albiella de Cuerno de Buetrone, uia que discurrit tras Buetrone adta lacuna de Uitagan".

682 BERGANZA, F. de: 1719 y 1721: t. II, 414-415/ 1 diciembre 984; ZABALZA DUQUE, M.: 1998: 417-419: doc. 58. “..., tras Castrellum, Poza et quator terras et duas vineas in Poza de iuso et totam aliam hereditatem un villa que dicitur Castrellum cum suis terminis et suis montibus, is est, de Vallejo de Fratre ad Pennam Foratam, deinde ad Villam Escalantem Alviellam et del Cuerno de Buitrone et de via que discurrit tras Buitrone usque ad lacunam de Vitagan, ista omnia...".

683 A. H. N./ D. P. de Oña. carp. 274, num. 6/ Burgos, 1137; ÁLAMO, J. del: 1950: 215-217: t. I. doc. 179. “..., et cum illa serna del ponton del Rio de Seras, et illa serna del Uerral et cum illa serna del ponton de Quintana Fortun que dicitur les Arroturas de Villauerde, et cum illa serna del semdero,...".

684 A. H. N./ D. P. de Oña. carp. 274, no14/ 21 septiembre 1146; ÁLAMO, J. del: 1950: 233-235: t. I. doc. 198.

685 A. H. N./ D. R. de Oña. carp. 275, num. 1/ León, 14 febrero 1150; ÁLAMO, J. del: 1950: 248-249: t. I. doc. 205. "...uiam que ducit de Quintanasuuar ad Cornu...".

686 A. H. N./ Códices. 91-B, fol. 45V/ 28 julio 1173; CADIÑANOS BARDECI, I.: 2002: 126: doc. 21.

687 A. H. N./ Clero, carp. 352 (3 y 4)/ Soria, 28 enero 1186; CADIÑANOS BARDECI, I.: 2002: 139: doc. 38. "...terminis earum in circuitum a portello de Auagiis usque ad terminum de Cornu, et usque ad uiam que ducit de Cornu ad Quintanam Suar".

688 A. H. N./ D. P. de Oña. carp. 279, num. 15/ 1200; ÁLAMO, J. del: 1950: 399: t. I. doc. 329.

689 A. H. N./ D. P. de Oña. carp. 279, num. 22/1201; ÁLAMO, J. del: 1950: 411-412: t. I. doc. 340. 
bién se cita el puente de Nava69o. Junto a lo anterior, hay que indicar que en la sentencia arbitraria dada en 1439 entre la granja de Quintanajuar y Masa, se revisan los mojones para los pastos, y se dice que "dende al camino real de los mulateros que va a Quintanilla de Sobresierra, la reguera de Pennas del Busto fasta las lagunas que estan en el dicho camino real" y se añade que "va ençima de la penna que asoma al camino real que viene de Quintanilla de Sobresierra eva a Quintanasuar"691.

La última referencia documental que conocemos sobre este camino, se refiere a la sentencia arbitraria de 1466 entre la granja de Quintanajuar y Quintanilla Sobresierra, en que se revisan los mojones para los pastos, mencionándose "el camino real que biene de Robredo para Quintanaxuar", el "camino real de Quintana Xuar a Quintanilla de Sobresierra” y el "camino real que va del Cuerno a Quintanilla"692.

\section{b.- Camino consolidado por Peñahorada y Cernégula}

Fue el camino más directo y principal desde Burgos al puerto de Laredo, aunque como todos los que desde la ciudad se dirigían a la costa, extremadamente accidentado. La mayor parte de su recorrido era mulatero pero poseía algunos tramos, como el del páramo, por donde podían discurrir los carros y carretas. Los documentos lo denominan en plural como "caminos e calzadas que ay desde la çibdad de Burgos fasta la villa de Laredo", y es el utilizado de manera continua e intensa entre Burgos y Laredo, desde la Edad Media hasta nuestros días.

Salía de Burgos por la puerta de San Gil y discurría por Villatoro, Vivar del Cid, Sotopalacios, Ventas de Quintanaortuño, Villaverde-Peñahorada, Peñahorada, Hontomín, Cernégula, El Cuerno o Villalta, Pesadas, El Almiñé, Puente-Arenas, desfiladero de Los Hocinos, Hocina, Incinillas, Bisjueces, El Vado, Medina de Pomar, Santurde, puente de Quintanilla de Pienza, Revilla de Pienza, Barcenillas del Ribero, El Ribero, Villasante -de donde se bifurca el camino a Bilbao-, Agüera de Montija, puerto de Sendero Enhiesto, El Prado, Valnera, Lanestosa, Ramales, y por el curso del río Asón, Bárcena, Rasines, Cereceda, Rocillo, Ampuero, Limpias, Colindres y Laredo.

A pesar de que el paso por Villarcayo era algo más corto y cómodo, los Condestables se encargaron, mientras pudieron, de obligar a los mulateros y caminantes a desviarse por Medina de Pomar, capital de las Merindades dependiente de la poderosa familia de los Velasco, con el fin de controlar tan importante vía comercial y percibir con ello en esa su villa, los tributos y portazgos relacionados con ese tráfico, obligando a la ruta a dar un pequeño rodeo desde Incinillas, por Bisjueces, el Vado, Medina y Santurde hasta el puente de Quintanilla de Pienza. Así fue hasta 1562, año en que por orden de Felipe II, se traslada la capitalidad de las Merindades a Villarcayo, y todo el tráfico comenzará a circular por la nueva capital dependiente de la Corona siguiendo un trazado más corto ya existente, desde Incinillas por Villalaín, Horna, Villarcayo, Villacomparada de Rueda, Bocos, Céspedes y puente de Quintanilla de Pienza, lo que causará la dura oposición del Condestable y un

690 A. H. N./ Códice 91-B, fol. 50v./ junio 1221 y fol. 51v./ julio 1221; CADIÑANOS BARDECI, l.: 2002: 190: docs. 107 y 108.

691 A. H. N./ Clero, libro 18.961/ Quintanajuar, 25 junio 1439; CADIÑANOS BARDECI, I.: 2002: 494: doc. 379.

692 A. H. N./ Clero, carp. 365 (2)/ 18 abril 1466; CADIÑANOS BARDECI, I.: 2002: 583: doc. 433. 


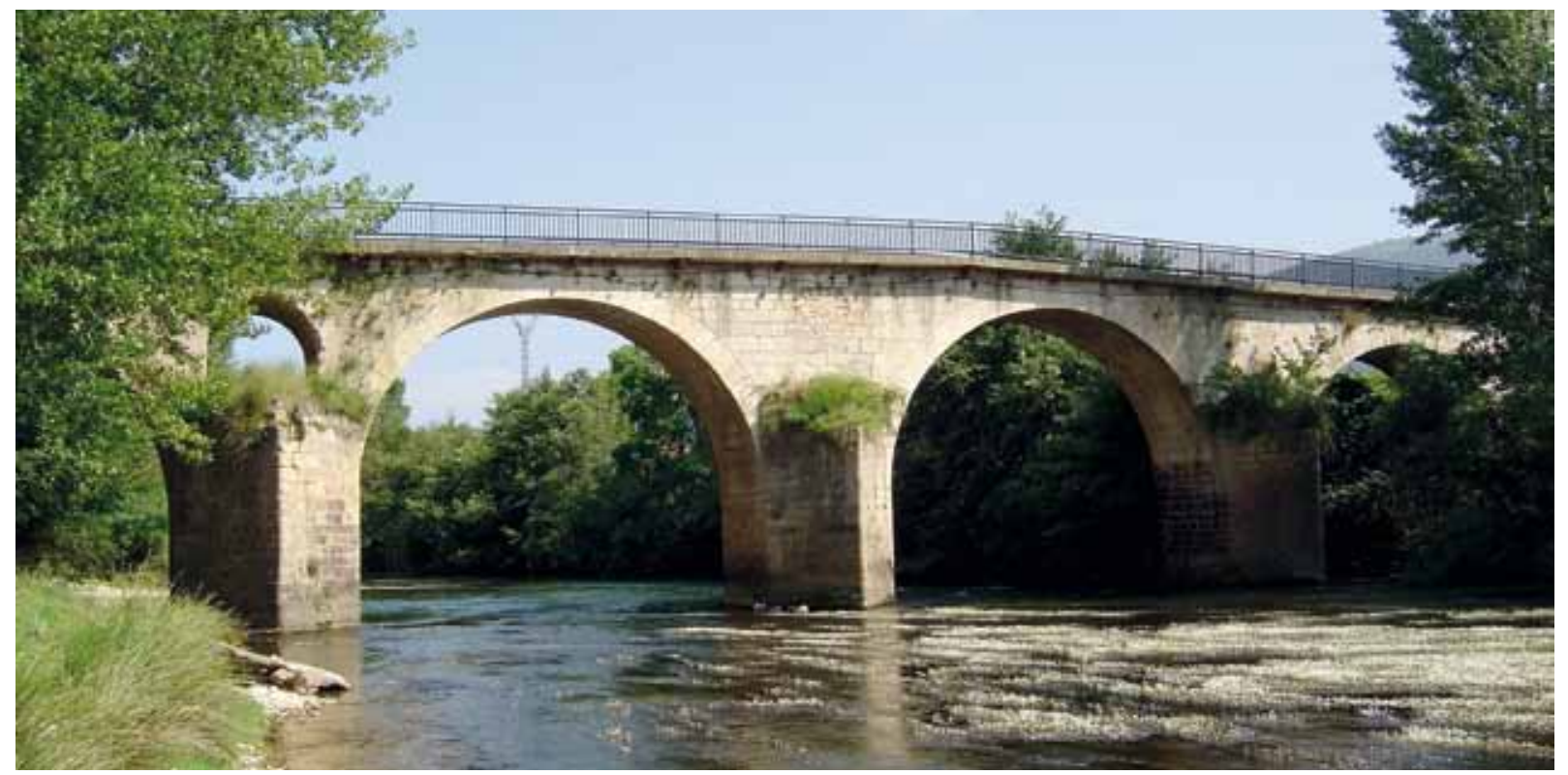

Puente de Puente-Arenas.

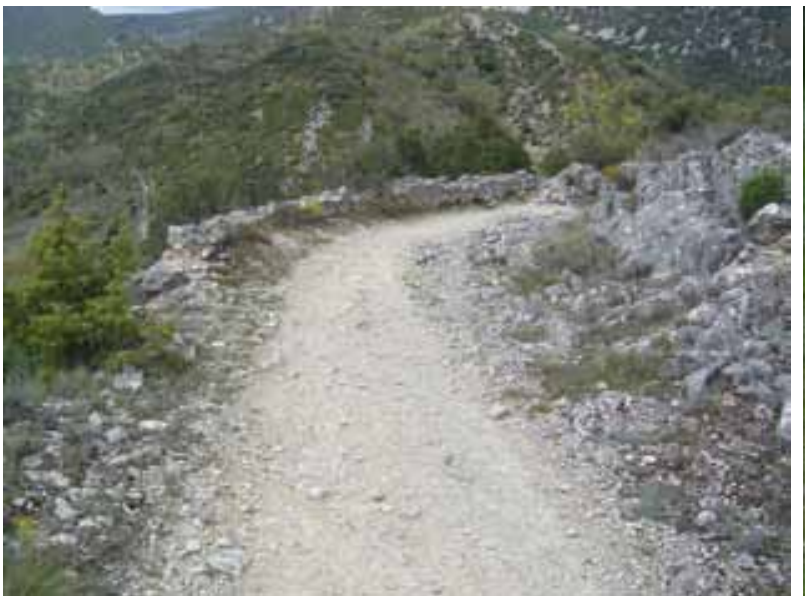

Camino antiguo de Puente-Arenas a los Hocinos.

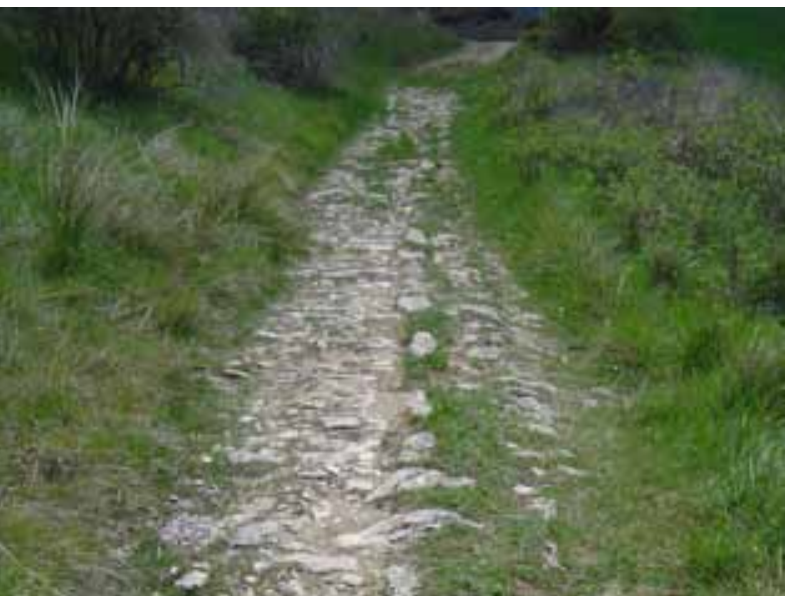

Empedrado del camino antiguo de Puente-Arenas a los Hocinos.

largo periodo de pleitos y conflictos promovidos por él, al pretender recuperar la situación perdida.

Después de cruzar el extenso y despoblado páramo de Villalta, por donde podían circular carretas, el camino descendía bruscamente al valle del Ebro en la merindad de Valdivielso, y cruzando este río por el puente de Puente-Arenas seguía junto a él aguas arriba por el desfiladero de Los Hocinos, luego a través de las cuencas del Nela y Trueba y después junto al río Cerneja, franqueaba una nueva línea montañosa, la cordillera Cantábrica, y descendía bruscamente por el puerto de Sendero Enhiesto para seguir aguas abajo junto al curso de los ríos Calera y Asón hasta Laredo. En Villasante, se bifurcaba hacia Bilbao por el Valle de Mena y Valmaseda, y constituyó, después del camino por Orduña, la segunda gran vía de acceso al importante puerto de Bilbao693.

Viniendo de Laredo, entre El Almiñé y el páramo de Villalta, existió más de una vía

693 GARCÍA de CORTÁZAR, J. A.: 1966: 160-161. 


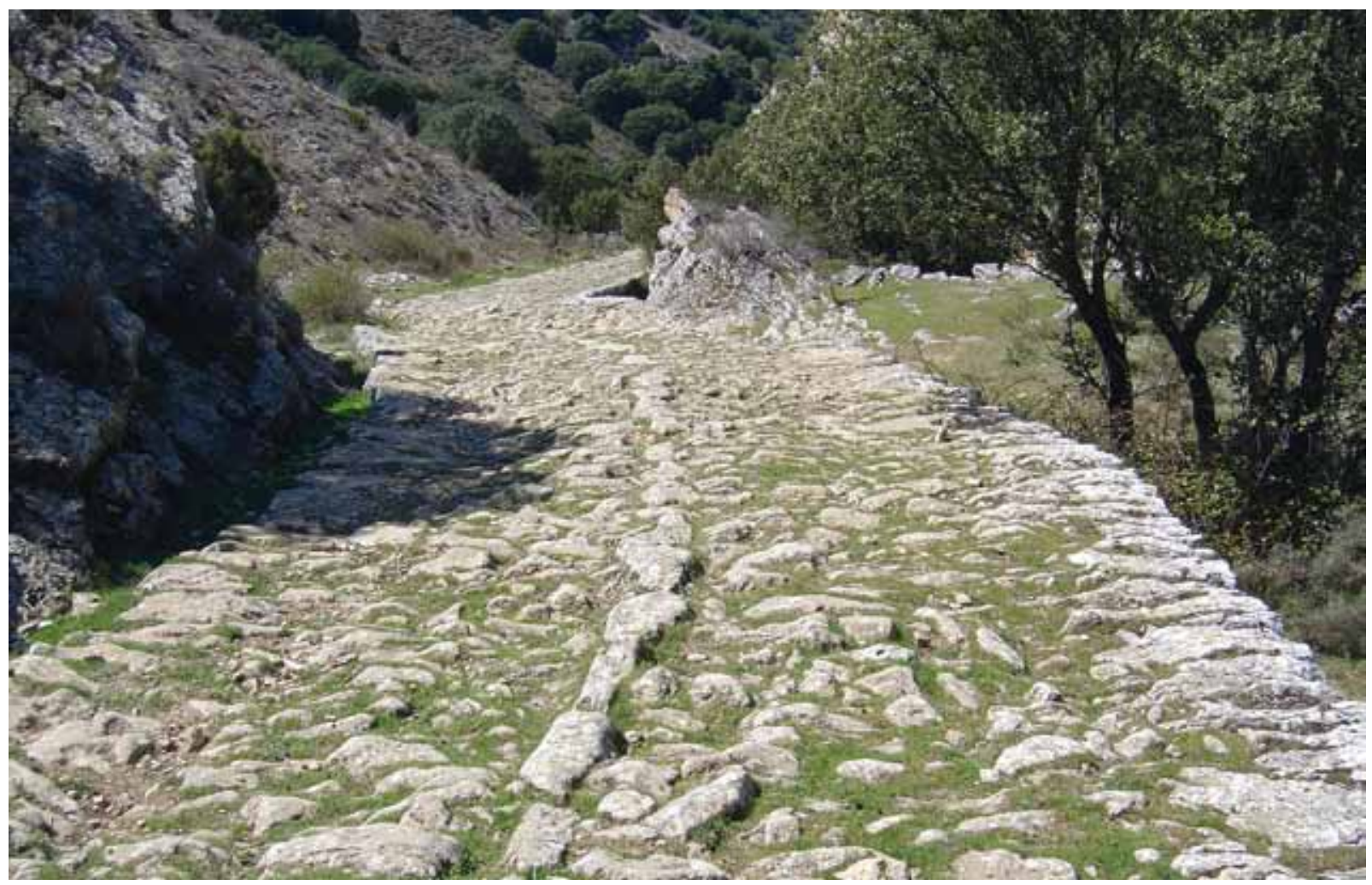

Camino de El Almiñé a la ermita de la Virgen de La Hoz.

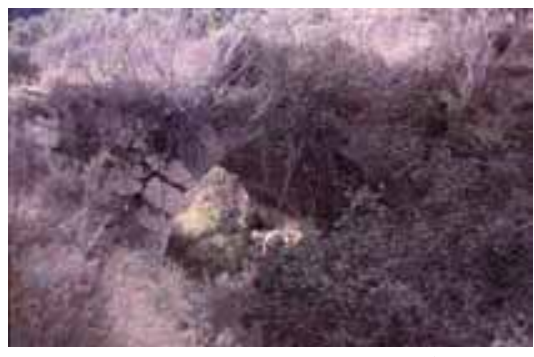

Camino antiguo de El Almiñé al páramo 1ํ puente.

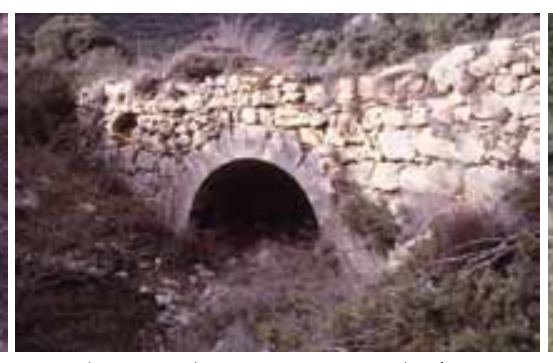

Camino antiguo de El Almiñé al páramo $2^{\circ}$ puente.

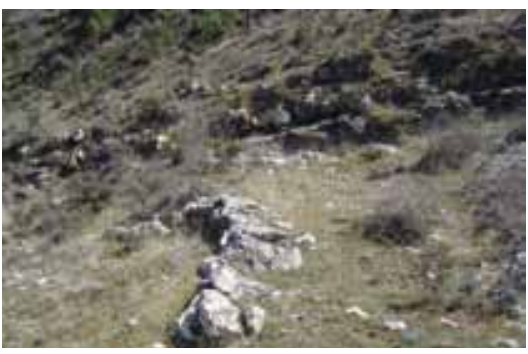

Camino antiguo de El Almiñé al páramo.

en la cuesta de ascenso desde el valle del Ebro. Según un documento de 1499, había dos caminos "fasta ençima el puerto de Santa Maria de la Hoz, el uno que ba a la yglesia y el otro al lugar de Pesadas, y entramos caminos acuden al lugar del Cuerno"694. Se alude sin duda a la bifurcación que existe a algo más de un km de El Almiñé, tras la cual, el camino empedrado de la izquierda llega directamente a la ermita de la Virgen de la Hoz, y el de la derecha, se encuentra con dos puentes de fechas posteriores de buena fábrica y de un solo ojo que salvan un pequeño arroyo, y dan acceso a un antiguo camino que sube al páramo haciendo curvas y contracurvas para superarlo de una manera más suave.

Desde Burgos existía, como se ha dicho, otro camino que trataremos, que por Oña y el desfiladero de La Horadada llegaba a conectar con este de Los Hocinos en Medina. En 1556 y en referencia a estos dos caminos se indica que "son caminos tan reales públicos y caudalo-

694 A. H. N./ Nobleza. Frías, C. 235, D. 55/ Medina de Pomar, 15 enero 1499. 
sos, por donde la mayor parte o casi todas las mercaderías que salen destos reinos o bienen a ellos de reinos estranxeros, Flandes, Yngalaterra, Yndias y otras muchas e dibersas partes, pasan e se traxinan... son y an seido caminos públicos reales y muy pasageros y nezesarios para yr e pasar, como an ydo e pasado y pasan por ellos con mercaderías que an aportado y aportan en los puertos de Laredo y Castro de Urdiales y Bilbado, a la cibdad de Burgos y Balladolid y a las ferias de Medina del Campo y Ruseco y Billalón e para otras muchas e dibersas partes..." , y que "el camino de los Ocinos es el mas pasagero e prenzipal e por el pasan mas mercaderias que por el de la Oradada"695. En 1570 se informa que desde Medina de Pomar "se puede venir a Burgos por dos caminos, el uno es por Oña y el otro por Hontomin, el de Hontomin es mas breue de legua y media poco mas, aunque si haze mal tienpo es mas trabajoso"696.

\section{El camino en las guías itinerarias}

A pesar de su importancia y tráfico, esta vía no se caracteriza por estar muy reflejado en las guías de caminos. Son escasas las referencias que recibe. Se mencionan, no obstante, partes de ella en la Cosmografía de Fernando Colón comenzada a realizar en $1517^{697}$. En el tomo I se indica que "hasta medina de pumar ay tres leguas de montaña, y vase por orilla de ebro dos leguas y vase por vizuezes, y hasta el alamyn ${ }^{698}$ ay media legua llana salvo que en llegando al alamyn se abaxa una cuesta de peñas, y en saliendo de baldevieso se pasa la puente que corre al rrio a la mano dizquierda y hasta val de nazedo ${ }^{699}$ ay media legua llana, y salen por la dicha puente y van el rrio arriba". "Laredo... hasta limpias ay una legua y base por calindes y hasta anpuero 2 leguas". También detalla Colón el itinerario de Burgos a Bilbao70o.

695 A. C. V./ nº 18. doc. 3, hojas 28 a 48/ Medina de Pomar, 7, 8, 9 y 21 enero 1556.

696 A. G. S./ Patronato Real, leg. 57, doc. 90/ Antes del 3 septiembre 1570.

697 COLÓN, F.: 1910, 1908 y 1915. Facsímil 1988.

698 Se refiere a El Almiñé.

699 Se refiere a Valdenoceda.

700 “De burgos a villa toro media legua.

De villa toro a villa verde tres leguas.

De villaverde a peña horadada una legua.

De peña horadada a hontonyn una y media.

De hontonyn a cerneglua una y media.

De cerneglua a cuerno una e media.

De cuerno a pesada una legua.

De pesada a almyne dos leguas.

De almyne a la puente de valdibieso una legua.

De la puente de baldivieso a valdemera una legua.

De valdemera a bieneces una legua.

De bieneces a medina despunar una legua.

De medina despunar a quintanilla de piença una legua.

De quintanylla de piença a billasante dos leguas.

De billasante a veçedo una legua.

De veçedo a la haya una legua".

En el tomo II, "La puente de valdeviejas [Puente de Valdivielso] es lugar de setenta vecinos e esta en un valle entre syerras que tiene el valle de anchura cerca una legua de syerra a syerra e pasa junto con el lugar un rio dicho ebro e es lugar muy fresco de huertas e muchos nogales e fasta medina de pinar ay tres leguas e van por viçareças [Bisjueces] legua e media de syerras muy agras e fasta valdenoçada e valdeviñas [Valdivielso] ay media legua llana e en salyendo de la puente pasan a ebro por puente que corre a la mano dizquierda". "La puente de valdeviejas e fasta el almyne ay media legua de tierra doblada e como cuesta arriba e en salyendo la puente pasan al dicho ryo ebro que corre a la mano dizquierda e fasta en enzynillas ay media legua pequeña e en salyendo pasan el dicho ryo que corre a la mano dizquierda", "riberas abaxo de ebro que queda el ryo a la mano derecha e fasta çarmegala ay dos leguas e media e van por el almynes de la puente media legua e fasta el cuerno ay tres leguas e van por el 
En el repertorio de caminos publicado en 1546, obra de Pero Juan Villuga, se incluye esta misma vía, aunque pasando por Villarcayo y no por Medina, denominada como "de Santa Maria del Paular a Laredo". También recoge una parte de ella en el que denomina como camino "de Medina de Pomar a Aranda de Duero"701.

La Corona no parece que estuviese seriamente interesada en la mejora de este camino antes de las postrimerías del s. XV, ya que los trabajos efectuados antes de esta fecha, correspondieron tanto a iniciativas y soluciones locales como a las de sus principales usuarios. Pero será en este momento cuando los Reyes muestren preocupación por el mantenimiento y mejora de un camino tan importante, por dos razones principales: por facilitar las relaciones políticas que se comenzaban a establecer con Flandes, y para apoyar y fomentar el comercio de Castilla con Europa y sobre todo con Flandes. El Consulado de Burgos y la Cofradía de Mulateros fueron partes importantes en la protección de esta vía, aunque para mantener y reparar estos caminos, puentes y calzadas, se siga apelando de manera directa a los concejos y villas en cuya jurisdicción se encuentran, algo que causará muchos problemas como consecuencia de la falta de recursos que padecen. Cuando la obra era importante y alcanzaba una elevada cuantía, se obtendrán los recursos a partir de ahora por medio del repartimiento, sistema que se llegó a perfeccionar a fines del siglo $\mathrm{XV}$, y que tuvo en este camino uno de sus primeros ejemplos; sistema por otra parte, que tampoco estuvo exento de problemas por las dificultades existentes para el cobro de las cantidades repartidas.

Lo que la Corona intentaba evitar fue el método de obtener recursos por medio de la imposición, es decir, del cobro de una determinada cantidad por el paso del ganado, acémilas, carros o viandantes por un camino o puente, a no ser que lo impusiese un concejo que previamente hubiese realizado a su costa la reparación ${ }^{702}$; aunque como veremos, la imposición nunca desapareció y se fue imponiendo progresivamente como consecuencia de la necesidad, siempre acuciante, de obtener recursos.

\section{Referencias documentales}

Los primeros datos que conocemos sobre la existencia de algún tramo de este camino, se remontan a septiembre del 80o. En esa fecha se constata la existencia de un antiguo camino cerca de Agüera de Montija cuando el abad Vitulo y su pariente el presbítero Ervigio, fundan la iglesia de San Emeterio y San Celedonio de Taranco, y someten a la

almynes media legua e fasta enzinyllas de los hozinos ay una legua grande la media legua de medio es fragosa e fasta rex molino ay una legua de tierra la media legua de medio en llegando a rex molino pasan a ebro por puente que corre a la mano dizquierda".

701 VILLUGA, Pero J.: 1546.

"a la Venta de Moroquien

a Valdiuieso

al Cuervo

a Siruela

a Hontonil

a Peña Orada

a Burgos

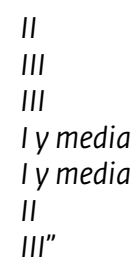

702 A. G. S./ Registro General del Sello, VII-1495, fol. 187/ Burgos, 9 julio 1495. "que çiertas ynposiçiones que se lleuan a los mulateros e viandantes en çiertas puentes e calçadas no se lleuasen saluo aquellos puentes donde los lugares fazian las dichas calçadas e puentes a su costa". 
misma las de San Martín de "Area Patriniani in territorio Castelle" y San Esteban de Burceña, construidas también por ellos. El Área Patriniana situada en territorio de Castilla, se encontraba entre Pando y Noceco $\mathrm{SeCo}^{703}$, en un lugar sobre un camino cercano a la localidad de Agüera y cercano también a la vía que, procedente de la costa, que iba por el paso de Sendero Enhiesto hacia el Sur. En el documento se citan numerosas vías, una calzada, un puente y un vado704.

En la venta de unas tierras en Cendrera, al norte de Sotopalacios, reralizada en 1179 por Miguel Fernández de Rioseras al abad de Rioseco, una de las tierras está "In la de Berral una pars uia discurrit, de alia pars don Munno..."705. En la permuta hecha entre Martín de Cendrera y su esposa con dicho abad de la heredad que los primeros tenían, por cinco tierras que en Cendrera tenía el convento, se menciona en 1219 el puente de Sotopalacios entre ambos ríos ${ }^{706}$ y lo mismo el año siguiente ${ }^{707}$. En 1246, Ferrán Fernández y su mujer, venden al Hospital del Rey una tierra sita en los Puentes de Villatoro, término de Burgos, por $12 \mathrm{mrs} .708$.

En el punto 46 del fuero de Medina de Pomar, ratificado por Alfonso VIII en 1181, se menciona entre otros, el camino de Medina por los Hocinos, cuando se indica que si el que gobierna Medina por el Rey, convocase a un vecino de Medina ante la corte para celebrar juicio, lo acompañará hasta el puente de Frías, hasta Oña, hasta los Hocinos o hasta Espinosa, no estando obligado a seguir con él709.

La cita más antigua sobre el puente de Valdivielso, después llamado de Puente-Arenas, corresponde a una cita de 1203 sobre un cambio de tierras realizado en San Pedro de Tejada que una de ellas es "nostram terram quam habemus iuxta illo camino qui venit ad pontem, in loco qui dicitur Pagiares"710. En la concordia establecida en 1255 por Aparicio obispo de Burgos, también se cita dicho puente en la demanda que hicieron los "clerigos de Arenas e de Teiada e de la Puent, por siempre iamas" al prior de Tejada sobre el pago de oblaciones, diezmos y pri-

703 A. H. N./ Cartulario de San Millán de la Cogolla. Becerro, fol. 180/ 12 noviembre 807; SERRANO, L.: 1930: doc. 2, 4-5; UBIETO ARTETA, A.: 1976: doc. 3, 12-13. "...fecimus in territorio de Area Patriniani, in loco qui dicitur inter Pando et Nozeto sicco, cum illo termino de roigo ad roio et de via de radice usque ad summa serra ab omni integritate cum terras et mazanares et cetera pomifera,...".

704 A. H. N./ Cartulario de San Millán de la Cogolla. Becerro, fol. 179-180/ 15 septiembre 800; SERRANO, L.: 1930: 2-4: doc. 2; UBIETO ARTETA, A.: 1976: 10-12: doc. 2.

705 A. H. N./ Códices. 91-B, fol. 46/ 14 enero 1179; CADIÑANOS BARDECI, I.: 2002: 132: doc. 30

706 A. H. N./ Códice 91-B, fol. 48v/ 24 abril 1219; CADIÑANOS BARDECI, I.: 2002: 185: doc. 101.

707 A. H. N./ Códice 91-B, fol. 50/ agosto 1220; CADIÑANOS BARDECI, I.: 2002: 188: doc. 104.

708 A. Palacio Real/ Libro Tumbo, fol. 78r/ 1246; PALACÍN GÁLVEZ, M C. y MARTínEZ GARCÍA, L.: 1990: 212: doc. 259:.

709 MARTÍNEZ DÍEZ, G.: 1982: 165-168. "Qui Medinam tenuerit de manu regis, si convocaverit populatorem de Medina ad aulam regis ad accipiendum cum eo iuditium, populator eat cum eo usque ad pontem de Frias vel usque ad Oñate vel usque ad Ocibus vel usque ad Espinosa et non teneatur cum eo ire in antea, sed revertatur ad villam populator cum domino villae, et recipiat iuditium de suo alcalde".

710 ÁLAMO, J. del: 1950: 427-428: t. I. doc. 352. 
micias $^{711}$. Las referencias a este puente serán continuas desde ahora, en $1265^{712}, 1284^{713}$, $1292^{714}, 1293^{715}$ o $1347^{716}$.

La comunidad de Oña arrienda en 1261 a Martín de Santa Marina y a Marcos de Recuenco ciertas heredades, mencionando el puente de Quintarnaza, también llamado de Santa Marina, junto a Medina de Pomar sobre el Nela, primera cita que conocemos sobre este puente ${ }^{717}$.

Alfonso X dispone en 1272, que todos los martes haya mercado en Hontomín. Todos los que vayan a él, deberán estar salvos y seguros con sus mercaderías y ninguno podrá ser embargado ni prendido, si no fuere por deuda conocida o por fiadura que ellos mismos hubiesen hecho ${ }^{718}$.

María de la Fuente y sus hijos Elvira y Juan Conzález, venden en 1306 a Juan Pérez de Medina de Pomar, calzador, un solar con su palomar poblado, una colmena y un parral, sitos en el puente de la Tabla de Medina de Pomar ${ }^{719}$. El abad del monasterio de Santa María de Rioseco, encomendó en 1315 amojonar las heredades que tenía el monasterio en El Almiñé, y entre otras propiedades "vn parral que auia a la cabeça de la iglesia de San Nicolas, so el camino que va de Meñe ${ }^{720}$ a Enzinillas, con vna viña... entre al camino del rey... [y un] linar que es so el camino que va de hondon de Villa e Enzinillas"721. En la relación de las heredades sitas en Villalaín que mandó Pedro Gómez de Isla en 1368 al monasterio de Rioseco, se menciona una de media fanega en Campo de Zorita, "a surco el camino del rey"722.

Fernando de Encinillas, vecino de Burgos, vende en enero de 1471 a Pedro Barrio, vecino

711 A. Cat. B./ V. 25, f. 347/ Quintanadueñas, 27 julio 1255; "Catálogo del Archivo Histórico de la Catedral de Burgos" vol. I. Sección Volúmenes (I), no 717; OCEJA GONZALO, I.: 1983: 139: t. I, doc. 161.

712 A. H. N./ Clero. carp. 288, no 8/ junio 1265; OCEJA GONZALO, I.: 1983: 179-180: doc. 186. Elvira García vende en 1265 al monasterio de San Salvador de Oña por 400 mrs., heredades en diferentes lugares y menciona el Puente de Valdivielso.

713 A. H. N./ Clero. Pergaminos. carp. 296, no 11/ Oña, 6 noviembre 1284; OCEJA GONZALO, I.: 1983: 370-371: doc. 256. San Salvador de Oña, arrienda en 1284 a Martín González de Quecedo "el nuestro monesterio de Sant Yuannes de la Puente", por 100 mrs. anuales.

714 A. H. N./ Clero. Pergaminos. carp. 300, nº 20/ Oña, 7 marzo 1292; OCEJA GONZALO, I.: 1986: 139-140: doc. 365. Gonzalo Alfonso de Valdivielso vende en 1292 al monasterio de San Salvador de Oña un solar en "la Puente de Ualdeuielso" por $45 \mathrm{mrs}$

715 A. H. N./ Clero. Pergaminos. carp. 301, n 13/ Oña, 15 enero 1293; OCEJA GONZALO, I.: 1986: 168-170: doc. 383. EI monasterio de San Salvador de Oña arrienda en 1293, a Gonzalo Alfonso, de "Ia Puente de Valleuielso", la casa de San Claudio con todas sus pertenencias y derechos con $250 \mathrm{mrs}$. al año.

716 A. M. B./ Hca. 3-4-12/ Burgos, 22 julio 1347; PEÑA PÉREZ, FCo. J.: 1983: 233-236: doc. 143. Doña Juana y su hijo Día Sánchez, vecinos de Burgos y moradores en la calle de San Lorenzo, reconocen unos censos que debían pagar al monasterio de San Juan de Burgos, por el uso de unos huertos en el barrio de San Juan. En el documento, aparece un tal Lope, del Puente de Valdivielso.

717 A. H. N./ D. P. de Oña. carp. 287, num. 15/ 5 junio 1261; ÁLAMO, J. del: 1950: 670-671: t. II. doc. 553 "damos et otorgamos a uos don Martino de Sancta Marina, et a uos, Marcos de Recuenco, el nuestro solar que es a la puent de Quintananaçar".

718 A. H. N./ D. R. de Oña. carp. 289, num. 13/ Huete, 9 julio 1272; ÁLAMO, J. del: 1950: 718: t. II. doc. 603.

719 A. Cat. B./ / Burgos, 8 marzo 1306; MANSILLA REOYO, D.: 1971: 1062.

720 Se refiere a El Almiñé.

721 A. H. N./ Códice 91-B, fol. 69v./ Santa María de Rioseco, 27 septiembre 1315; CADIÑANOS BARDECI, I.: 2002: 273: doc. 222.

722 A. H. N./ Códice 91-B, fol. 39v./ Entre 1368 y 1379; CADIÑANOS BARDECI, I.: 2002: 356: doc. 290. 
de Incinillas, un parral en ese término, operación "fecha e otorgada... en la venta de los Oçinos"723.

Eustache Delafosse va en 1479 a la Costa de Cuinea desde Brujas, y por L'Ecluse y Pentecôte llega a Castilla por el puerto de Laredo. Después desde Burgos y Medina del Campo, va por Toledo, Córdoba y Sevilla a Cádiz ${ }^{724}$.

Roger Machado describe en un diario el viaje de una embajada inglesa a la corte de los Reyes Católicos. El 23 de febrero de 1479, los embajadores dejaron Laredo y durmieron en Lanestosa, el 24 fueron a almorzar a Villasante por un paso "que se llama Sandenjesco, y que esta sobre una montaña elevada, y que en el invierno esta lleno de nieve que a menudo mucha gente muere y se pierde", y durmieron en Medina de Pomar. El 25 "llegaron a una villa llamada Coirino725 que está a seis leguas de Medina de Pomar" donde durmieron, el 26 comieron en Hontomín y llegaron a Burgos hacia las cinco de la tarde ${ }^{726}$.

La Universidad de los Mercaderes de Burgos, dijo en 1484 que desde hacía unos 10 años los de Villasante, de manera "ynjusta e non devidamente de fecho e contra derecho", llevaban una nueva imposición sobre las mercaderías que salen y entran en Laredo, de 10 mrs. por carga de mercadería, y 5 por carga de lana. En esta década, se habían cobrado a los mercaderes unos 100.000 mrs. y cuando la Universidad les requirió su devolución, los de Villasante no lo quisieron hacer. El Consejo Real manda al alcalde de Castilla Vieja y a Pedro Sánchez el herrero, vecino de Villasante, que no lleven a los mercaderes de la Universidad las nuevas imposiciones y les devuelvan los 100.000 mrs. más las costas y daños causados ${ }^{727}$.

García Ruiz de Hornillalatorre, procurador de los mulateros de Castilla Vieja, se quejó en diciembre de 1487 porque en Lanestosa, Ramales, Ampuero, Laredo, Colindres, Valmaseda, Bilbao, juntas de Parayas, Avellaneda, Castro-Urdiales y valles de Limpias, Salcedo y Mena, "por do pasan con sus mulos e aberios, señaladamente en la dicha uilla de Lanestosa", habían hecho algunos puentes, pontones y calzadas sin licencia real, "non seyendo en pro ni vtilidad comun dellos", poniendo peajes, pasajes y pontajes contra toda razón y justicia, en algunos lugares medio real y en otros $12 \mathrm{mrs}$. Obtuvieron la prohibición de cobrar "peajes e pontajes e calçadas ni otro tributo alguno", y la orden de que se les deje pasar libremente con sus mulos y mercaderías ${ }^{728}$. Aunque se mandó a los concejos demandados que en 20 días compareciesen en el Consejo con sus títulos y derechos, no lo hicieron, por lo que García Ruiz pide que se les restituyan los mrs. indebidamente cobrados, estimados en 50.000 mrs. y las costas $^{729}$

La Carta real se notificó en febrero de 1488 a los concejos de Colindres, Limpias, Ampuero, Ramales y Lanestosa, pidiéndoles lo mismo que a Laredo. Todos contestaron que estaban dispuestos a su cumplimiento, por lo que García Ruiz les puso plazo para que com-

723 A. H. N./ Clero, carp. 365 (9)/Venta de los Hocinos, 16 enero 1471; CADIÑANOS BARDECI, I.: 2002: 594: doc. 440.

724 DELAFOSSE, Eustache: "Voyage a la cote occidentale d'Afrique en Portugal et en Espagne (1479-1480)". Publicado por R. Foulché-Delbosc. Paris, 1896

725 Se trata de la actual villa de Villalta, llamada entonces el Cuerno de Butrón.

726 BELLO LEÓN, J. M. y HERNÁNDEZ PÉREZ, B.: 2003: 185-187.

727 A. G. S./ Registro General del Sello, II-1484, fol. 256/ Agreda, 12 febrero 1484.

728 A. G. S./ Cámara de Castilla. Pueblos, leg. 10, doc. 32/ Burgos, 17 diciembre 1487; A. G. S./ Registro General del Sello, XII-1487, fol. 63/ Burgos, 17 diciembre 1487.

729 A. G. S./ Cámara de Castilla. Pueblos, leg. 10, doc. 32-2/ Laredo, 1487. 
pareciesen ante el Consejo ${ }^{730}$ y la Carta real se mandó pregonar en Burgos y localidades mencionadas ${ }^{731}$. García Ruiz presentó en el Consejo una estimación de los daños causados por los dichos concejos, y como estos no se habían presentado, pide justicia. El Consejo acordó, no obstante, dar este asunto por concluso732. Pero como todo seguía sin resolverse, en julio los mulateros manifestaron que estaban muy agraviados porque dichos concejos, cuando ellos pasan "con sus mulos e averios por los dichos logares, e por algunas puentes e pontones $e$ calçadas, dis que los han leuado e lievan contra toda rrason e justiçia, e contra su voluntad en algunos de los dichos logares, por cada mulo a medio rreal e en otros a dose mrs. e dende arriba", y señalan que si esto no se remedia deberán abandonar el trato de la mulatería por ser más las imposiciones que lo que les renta su oficio. El Consejo encarga al alcalde de Castilla Vieja, que averigüe quiénes llevan los tributos e imposiciones, qué título o privilegio tienen, cuánto cobran por mulo o bestia y desde cuándo, y si los portazgos los invierten en los caminos o calzadas, y le envíe tal información 733 .

El concejo de Medina de Pomar, dijo en julio de 1488 que cerca de la villa, hay "una puente mucho antigua que se llama la puente de Villanueva por la qual, de nesçesario diz que han de pasar todas las gentes e mulaterias que van e vienen a la montaña, la qual puente diz que esta derrocada e para caher de todo punto, por manera que sy se acaba de caer [causará] muy gran daño a todas las tierras comarcanas, e que por estar mal rreparada, han peligrado algunas personas e bestias". Para repararlo serían necesarios más de $20.000 \mathrm{mrs}$. , y como la villa no tiene propios y sus vecinos "estan tanto fatigados e pobres", suplicaron que se autorizase poner imposición sobre las bestias cargadas y ganados que por allí pasaren. El Consejo mandó a la abadesa de Santa Clara, al guardián del monasterio de San Francisco de Medina y al alcalde de Castilla Vieja, que se informasen sobre el estado del puente y su utilidad, si hay otros por donde los caminantes pueden pasar, qué concejos o personas deben contribuir a su reparo y qué costará, y cuánto tiempo podría durar la imposición para obtener la cantidad necesaria, a 2 mrs. por mulo, 6 por carreta y 1 a cada bestia menor cargados, y la información, se envíe al Consejo para proveer lo que convenga734. Nada se hizo porque 9 años después, en abril de 1497, el concejo de Medina afirmó que cerca de la villa, hay "una puente muy antigua y se llama la puente de Villanueva, por la qual dis que pasan todas las mercaderias e muleteros e carros y otros caminantes que van y vienen a la montaña e pasan de vnos lugares para otros", que está a punto de caerse y que por ello, las personas peligran. Su reparo necesita más de 200.000 mrs. y si se cayese, dicen que no se volvería a hacer por su alto coste, pero que ahora se podría reparar a costa de los mercaderes, mulateros, carreteros, viandantes y concejos que lo aprovechan. El Consejo vuelve a pedir al alcalde de Castilla Vieja, que averigüe qué necesidad de reparo tiene el puente, su coste y quiénes se aprovechan de él para que contribuyan en su reparo, y le envíe la información para hacer lo que fuere justicia735.

A. G. S./ Cámara de Castilla. Pueblos, leg. 10, doc. 32-1/ Laredo, 24 febrero 1488

A. G. S./ Cámara de Castilla. Pueblos, leg. 10, doc. 32-3/ Laredo, 27 marzo 1488.

A. G. S./ Cámara de Castilla. Pueblos, leg. 10, docs. 33bis y 33ter/ Burgos, 1 y 2 abril 1488.

A. G. S./ Registro General del Sello, VII-1488, fol. 188/ Burgos, 4 julio 1488.

A. G. S./ Registro General del Sello, VII-1488, fol. 101/ Burgos, 16 julio 1488.

A. G. S./ Registro General del Sello, IV-1497, fol. 119/ Burgos, 22 abril 1497. 
El concejo de Laredo indicó en julio de 1489, que el camino que salía de la villa para Castilla no estaba hecho como debía y no se podía utilizar cuando subía la marea, por lo que los mulateros tenían que rodear o esperar a su bajada. Dicen que habían comenzado a hacer un camino por una sierra para pasar en tiempo de creciente, pero que por estar muy pobres y lo costoso del nuevo camino, no lo pueden acabar. Piden licencia para cobrar una imposición razonable a los mulateros que lo utilizaren, hasta obtener los $50.000 \mathrm{mrs}$. necesarios. El Consejo manda al corregidor que envíe información sobre la necesidad del nuevo camino, si cumple al bien de la villa y mulateros, cuánto puede costar y a quién se puede cargar la imposición ${ }^{736}$.

El merino de Laredo comunicó en noviembre de 1489, que el corregidor de las Cuatro Villas y merindad de Trasmiera, ejerce un oficio que le corresponde a él y no se lo deja usar, algo que no ha hecho ninguno de los anteriores corregidores, ya que procedía de un portazgo antiguo anexo al oficio de merino. El Consejo manda que si es como dice, el corregidor debe dejar libre al merino el portazgo que ocupa, y le devuelva todos los mrs. que ha cobrado en el dicho portazgo737.

El concejo de Laredo dijo que el mar "en los tienpos que ay fortunas destruye todas las casas", de manera que en poco tiempo "diz que podria destruyr la dicha villa" por lo que necesitaban hacer un muelle, pero como tiene pocos propios y rentas, querían echar alguna sisa en los mantenimientos que en la villa se gastan y en algunas mercaderías, por lo que pedían licencia para echar por sisa 200.000 mrs. en 4 años. Los Reyes mandan al corregidor en julio de 1494, que averigüe si el muelle es necesario, cuánto costaría y sobre qué mantenimientos se podría echar la sisa con menor perjuicio de los vecinos, y que envíe la información con su parecer al Consejo738. Laredo sufría por la falta de este muelle las malas condiciones de abrigo, y en invierno, se debían poner las barcas sobre la plaza para su seguridad, por lo que la pesca no podía realizar la misma actividad que en Santander o Castro-Urdiales739.

Aunque los Reyes prohibían el cobro de imposiciones sobre el paso por puentes y caminos, existía un constante empeño de los directos interesados en que los reparos se realizasen de la manera, económicamente, menos lesiva para ellos en el caso de los concejos, o con mayor urgencia en el caso de los mulateros y mercaderes, por lo que procuraban aplicar imposiciones intentando incluso obtener de paso, algún beneficio económico añadido; motivo por el cual, el Consejo Real denegaba de manera sistemática la concesión de licencias de imposición para estos fines. Por ello en 1495, García Ruiz de Hornillalatorre y Juan Ortiz de Villasante, procuradores de los mulateros, dijeron que los Reyes habían "mandado que çiertas ynposiçiones que se lleuan a los mulateros e viandantes en çiertas puentes e calçadas, no se lleuasen saluo aquellos puentes donde los lugares fazian las dichas calçadas e puentes a su costa", ya que por esto se habían dejado de reparar muchos de ellos, pero como "agora la lluuia que hubo en el condado de Vizcaya e Merindades susodichas, diz que lleuo todas las dichas puentes e calçadas de que la

736 A. G. S./ Registro General del Sello, VII-1489, fol. 347/ Jaén, 9 julio 1489.

737 A. G. S./ Registro General del Sello, XI-1489, fol. 67/ Úbeda, 18 noviembre 1489.

738 A. G. S./ Registro General del Sello, VII-1494, fol. 353/ Segovia, julio 1494.

739 A. G. S./Cámara-pueblos, leg. 10, º 34. Información hecha por Laredo en 1494, para mostrar la necesidad que tiene de un cay. 
tierra quedo muy destruyda, de manera que los dichos mulateros e viandantes no pueden pasar por ellas"740, pidieron que se mandase que los lugares donde estaban los puentes y calzadas los volviesen a hacer. Como algunos no tenían recursos, pedían licencia para que "los mercaderes $e$ otras personas que por alli pasasen, pagasen e contribuyesen para ello que ellos estauan prestos e aparejados de contribuyr".

El Consejo acordó pedir a los corregidores de Burgos, Castilla Vieja, Encartaciones y Montañas, Valles y Tierra de Mena, información sobre los puentes, pontones y calzadas dañados o destruidos, cuánto costaría su reparo y quiénes debían contribuir741. Parece ser que los mulateros pagaron alguna intervención y pretendieron por su cuenta recuperar lo adelantado ya que 20 días después Juan de Angulo, vecino de Quintanilla de Pienza, en nombre de los vecinos de los concejos del Tercio de Abajo de la junta de Montija, denunció que Juan Ortiz, Fernán Sánchez y Pedro Sánchez, vecinos de Villasante, con García Ruiz, vecino de Hornillalatorre, en nombre de los mulateros, cobraban en dichos términos sin licencia a los caminantes calzadas y pontaje por un poder que les dieron algunos mulateros, con el pretexto de que habían reparado con un coste que, según Angulo, no superaba los 4.000 mrs. , el puente de Quintanilla de Pienza de seis ojos y las calzadas de Revilla de Pienza y Barcenillas del Ribero. El alcalde mayor proveyó sentencia contra cuatro vecinos de Quintanilla y Barcenillas, por lo que estos apelaron ${ }^{742}$. El Consejo, revocó la sentencia porque tales derechos no se podían "poner ni cojer ni levar, y que no se cojese ni llevase mas dende en adelante, segund mas largamente en la dicha sentençia se contenia", por parte de "los mulateros e caminantes e viandantes e vniversydades de la mulateria". Estos alegaron nuevas razones y visto de nuevo este asunto, el Consejo condenó a los mulateros a una pena de 5.000 mrs. ${ }^{743}$.

La villa de Laredo tenía necesidades económicas para los pagos, principalmente para el salario del corregidor, el reparo de algunos caminos y calzadas y ciertos pleitos, por lo que necesitaba hasta $100.000 \mathrm{mrs}$. Como no tenía propios ni rentas, el Consejo le dio facultad en marzo de 1497, para repartir hasta $25.000 \mathrm{mrs}$. con que atender dichas necesidades 744 . Sin embargo por estos caminos, con autorización real o sin ella, se siguió obligando a los mulateros a contribuir pero sin beneficiarse estos de unas grandes mejoras del camino. Ni siquiera parece haber sido ocasión propicia para su reparo el desplazamiento de la Reina con su hija Juana a Laredo, para su partida a Flandes en agosto de 1496. No obstante en 1497, el corregidor de las Cuatro Villas, previniendo la llegada a este mismo puerto, de la princesa Margarita desde Flandes 745 con la misma flota, lo que se produjo en marzo aunque al puerto de Santander; mandó arreglar los caminos por donde preveía que iba a pasar. Con este motivo, Limpias ensanchó sus caminos en media legua, pero esto provocó que se hiciesen "muchos tremendales e otros pasos malos, en los quales dis que han pasado de po-

740 El río Cadagua se desbordó hacia el 17 de junio de 1495, provocando serios destrozos en Valmaseda, con otros ríos del Norte.

741 A. G. S./ Registro General del Sello, VII-1495, fol. 187/ Burgos, 9 julio 1495.

742 A. G. S./ Registro General del Sello, VIII-1495, fol. 51/ Burgos, 8 agosto 1495.

743 A. G. S./ Registro General del Sello, X-1496, fol. 168/ Burgos, 13 octubre 1496.

744 A. G. S./ Registro General del Sello, III-1497, fol. 6/ Laredo, 2 marzo 1497.

745 Margarita, hermana de Felipe el Hermoso, venía para contraer matrimonio con el príncipe Juan, heredero del trono. 
cos dias aca muchas bestias de los caminantes, porque dis que es camino rreal muy seguido". Pidió Limpias que los concejos del camino y particulares de la comarca, contribuyesen a su reparo porque debía hacerse antes del invierno. Se mandó al corregidor en mayo de 1497, que recabase información sobre qué concejos necesitan que el camino se repare, cuántos mrs. serían necesarios y qué concejos y personas deben contribuir746.

El procurador de Colindres comunicó en diciembre de 1498, que en su término, desde la Magdalena al barco de Treto, había un puente y calzada que llevó el temporal del mar hacía 6 o 7 años, de manera que los que por allí pasaban habían de ir por el agua con gran peligro de sus personas, bestias y ganados. Visto el paso por el corregidor y los procuradores de Laredo, Colindres y juntas de Cesto y Voto, trajeron maestros que lo comenzaron a reparar, pero una nueva tormenta lo destruyó de nuevo apareciendo un gran lago. Decidieron hacer un puente nuevo en otro lugar para mejorar la seguridad, encargándolo a dos maestros por 45.000 mrs., pero como no tenían más de 15.000 mrs. obtenidos del reparto de 3.000 mrs. a Laredo, 5.000 mrs. a Colindres, a la junta de Cesto 4.000 mrs. y a la junta de Voto 3.000 mrs., les faltaban 30.000 mrs. que no se podían conseguir sin poner imposición a caminantes, ganados y bestias que por allí pasaren. El Consejo, mandó al corregidor que para hacer repartimiento se informase sobre qué concejos utilizan el puente y calzada, y que no "pueda aver en la dicha puente, ni calçada, ni caminos, ninguna ympusiçion ni se lieue ni pueda lleuar otro derecho, sy non que libremente puedan pasar e pasen los caminantes e rromeros e otras personas por la dich a puente e caminos e calçada"747.

Por fin, en 1499, un amplio plan de mejora fue preparado a instancias de los mulateros que, desde ahora, harán un permanente seguimiento del proceso para reparar los caminos, puentes y calzadas desde Burgos hasta Laredo, cuyo desarrollo y detalle trataremos en el siguiente apartado.

En relación con los $325.000 \mathrm{mrs}$. "para el adobo e rreparo de las puentes e caminos e calçadas que uan de la çibdad de Vurgos a la villa de Laredo", los mulateros siguen solicitando en 1502 su cobro en los Hocinos y la Horadada por donde los dichos mulateros pasan habitualmente. La respuesta del Consejo se mantuvo inalterable, es decir, que los mrs. "no se cogiesen por manera e via de ynpusyçion" y se repartiese entre los mulateros "a cada uno segund las uestias que touiere"748.

Pedro Ezquerra de Rozas, en nombre de los concejos del valle de Soba, decía que muchos de sus vecinos, llevaban mercaderías a "Medina de Pumar e a otras villas e lugares de tierra de Canpos e a otras partes que tienen el dicho trato de tiempo ynmemorial", y que habían de pasar por el valle de Montija. Añade que siempre descargan allí sus recuas y apacientan sus bestias, pero ahora sus vecinos los prenden cuando paran y duermen en sus términos. El Consejo Real dio carta en septiembre de 1506, para que cuando pasen de día o de noche por Montija, se les deje apacentar sus bueyes y bestias de carga en los términos comunes y concejiles, sin llevarles cosa alguna. La merindad de Montija responde en 1507 que la carta mencionada no les obligaba, porque los de Soba no tenían derecho a apacentar sus ganados en su valle por tenerlo prohibido de tiempo inmemorial; y además, se mandó tras un pleito,

746 A. G. S./ Registro General del Sello, V-1497, fol. 25/ Valladolid, 30 mayo 1497.

747 A. G. S./ Registro General del Sello, XII-1498, fol. 8/ Ocaña, 3 diciembre 1498.

748 A. G. S./ Registro General del Sello, VI-1502, fol. 315/ Toledo, 16 Junio 1502. 
que no podían apacentar en Montija porque a este valle le faltan provisiones por estar muy poblado. Los de Soba reiteraron que no se les dificultase el paso libre por Montija, y apacentar en él sus bestias y bueyes conforme a la costumbre y a la dicha carta. El Consejo, falló de nuevo que los vecinos del valle de Soba, cuando pasaren entre el 1 de septiembre y el 31 de marzo, puedan apacentar sus animales de noche y de día en el valle de Montija, respetando panes, viñas, huertas dehesadas, prados de guadaña y prados acotados, y que desde el 1 de abril hasta el 31 de agosto, puedan apacentar de día sus bestias de carga, y de noche descarguen en poblado y duerman en él, y no puedan pacer de noche sin licencia del concejo, pues en esos meses no lo hacen los vecinos, pero que en el término comunero del valle, en que sus vecinos pueden pacer de noche en ese tiempo, podrán hacerlo también los de Soba sin pena alguna749.

Juan Barahona, vecino de Villanueva de Ladrero 750 y procurador de los viandantes y mulateros de la merindad de Castilla Vieja, Sotoscueva y Sonsierra, presentó en el Consejo una petición diciendo que "çiertos besynos de la uilla de Medyna de Pumar, an coechado a los dichos mulateros... muchas contyas de mrs., lleuandoles por cada azemilla çinquenta mrs. en cada un año, a dos mrs. de cada carga cada mantenimiento, e un marabedy por el aluala", y que les hacen otros muchos agravios. Añadió que en las merindades de Castilla Vieja, Mena y puente de Nava, llevan a los mulateros y a los merchantes de ganados mayores y menores que por allí pasan, muchos mrs. de "portazgos e pontajes e otros derechos e nuebas ynposyçiones que nuebamente an puesto e ponen de cada dia, no seyendo ellos hobligados a pagar cosa alguna, los qual diz que les lleban syn tener titulo ni derecho alguno para lo poder llevar, e que sy alguno se pone en no lo querer pagar, les toman prendas e los maltratan $e$ fatygan en pleytos, de que se les syguen a los dichos sus partes muchas costas e gastos, e que porque no los maltraten se dexan coechar e pagan todo lo que les piden avnque no lo deven", y pide que se mande devolver todo lo que les han llevado más los gastos ocasionados, y se castigue a los que lo cobraron. El Consejo mandó en febrero de 1515 al corregidor de las Tres Villas de la Costa de la Mar751, que vaya a Medina de Pomar y a las merindades de Castilla Vieja, Mena y puente de Nava y recabe información sobre lo que se ha llevado a los mulateros y por qué causa, cuánto a cada uno, quién lo lleva, con qué título y desde cuándo, y si se lleva más de lo que se acostumbraba y cuánto y si se lleva en los lugares y pasos que se solía, y todo ello con una copia de los privilegios y títulos que tales personas tienen, lo envíe al Consejo.

En septiembre comparecieron Juan Barahona y Pedro de Brizuela ante el corregidor y juez de las Tres Villas de la Costa de la Mar, y dijeron que los mulateros reciben mucho daño por lo que les llevan por razón de la huelga cuando hay nieve752. Indican que en el puerto de Sandiniesto, por quitar la nieve les llevan muchos mrs. y muy largo tiempo, y piden al corregidor que mande comparecer a los que lo cogen y a Pedro de Velasco, vecino de Valdeporres, y al abad de Vivanco y a Gallarde de Velasco, vecinos de Mena, que los mandan, para que muestren los títulos que tienen753. También pidieron al corregidor

749 A. H. P. C./ Valle de Soba, leg. 32, doc. 2/ Valladolid, 7 septiembre 1506 y Burgos, 10 noviembre 1507.

750 Se refiere a la actual localidad de Villanueva la Blanca, cerca de Villarcayo.

751 Las Cuatro Villas con la exclusión de San Vicente de la Barquera.

752 La huelga consiste en abrir los puertos cuando hay nieve, haciendo los vecinos un pasillo para facilitar el tránsito.

753 A. G. S./ Consejo Real de Castilla, leg. 84, fol. 2-III/ Valladolid, 26 junio 1513 a Salazar, 25 septiembre 1515. 
sobre los portazgos que les llevan contra derecho, las guardas y dezmeros del Condestable en Medina de Pomar y en otras partes de la jurisdicción de Castilla Vieja, "syn tener tytulo ni rrason, ni derecho alguno para los poder llevar", obligándolos contra su voluntad a ir por Medina de Pomar, cuando van por su camino derecho por los valles de Espinosa, Valdeporres y Castilla Vieja y hacerles pagar portazgo. Los mulateros hacen igualas con los portazgueros, los cuales han llevado a muchos de ellos más de 6.000 ds. de oro; asimismo a los que no querían hacer tales igualas los detenían en los caminos que iban derechos por Castilla hacia la montaña fuera de la jurisdicción y términos de Medina.

Los portazgueros del Condestable, indican que hará unos 15 años el Condestable754 encargó a su mayordomo, que hiciese pesquisa sobre las quejas de las "fuerças y biolençias que se fasyan por los dichos portazgueros a los dichos mulateros y biandantes" porque lo quería remediar, y los mulateros responden que reconociendo los Condestables no tener título ni razón para llevar ni mandar coger los dichos portazgos e imposiciones, ni para obligar a los mulateros a ir por Medina de Pomar para pagarlos, habían otorgado ciertos compromisos para que cesase el dicho pleito. Piden al corregidor que apremie a los vecinos de Medina de Pomar, a los portazgueros y al Condestable y sus mayordomos, a que le presenten "qualesquier titulos e prebillejios" por los que les han llevado los dichos portazgos en los caminos reales en Medina de Pomar.

El corregidor mandó el 15 de septiembre en Medina de Pomar, que se notificase al alcalde mayor del Condestable, a su procurador, al alcaide de los alcázares, al portazguero García de Santayana y a los herederos de Lope Sáez de Pereda, de Martín López de Medina, de Pedro de Pereda, de Sancho García Contador, de Pedro Gómez de Isla y a Pedro de Santayana, vecinos de Medina de Pomar, portazgueros que habían sido por el Condestable, la Carta real y el auto de pedimento hecho por Barahona en nombre de los mulateros, y les mandó que en 3 días vayan a la posada de Ruy Sáez Barahona del lugar de Campo donde está aposentado, a alegar su derecho.

Pedro Fernández de Salinas regidor y procurador de Medina de Pomar, en nombre del Condestable 755 , toma la voz de todos los portazgueros, y dice que pagará todo lo que contra ellos fuere sentenciado "por aber cobrado el portazgo debido al dicho mi parte, y por aber apremiado a los dichos mulateros a que fuesen y pasasen por dentro de la villa de Medina de Pumar". Respondiendo a la petición hecha por Barahona, dice que la relación hecha no es cierta, y que ni el Condestable, ni sus mayordomos, cogedores y oficiales han hecho nada con fuerza contra los mulateros, ni agravio ni cosa indebida, porque por privilegios usados de tiempo inmemorial, todos los mulateros y viandantes "que bienen de otros puertos comarcanos, y salen por los puertos de Sandrinyesto, e la peña de Mena y puerto de Haya, e por la peña de Angulo, son hobligados a yr y pasar por dentro de la villa de Medina de Pumar, porquel camino rreal que sale de los dichos puertos va a la dicha villa, en la qual esta de tienpo ynmemorial aca, casa de aduana y guarda sobre los diezmos de la mar, pertenesçientes a su alteza y al dicho señor mi parte en su nonbre" y además todos los mulateros que salen por dichos puertos, son obligados a pagar portazgo en Medina, "que es dos mrs. de cada carga de lazo, e de cada carga de vyno e de pan çinco cornados de par de las cargas, e lo mesmo se ha de haser en los que buelben de Castilla para estas montañas e pasan por el puerto de la Horadada, y por otras partes pasando los que bienen

754 Bernardino Fernández de Velasco, I duque de Frías, fue condestable entre 1492 y 1512.

755 Îñigo Fernández de Velasco hermano de Bernardino, fue condestable entre 1512 y 1528 
por la dicha Horadada y puentes y el rryo de Neva y ba fasta la parte de Medina,... y no lo hasyendo... pueden ser tomados por descaminados e pierden quantas mercaderias llevan", porque el Condestable y el concejo de Medina, "han de tener rreparadas syenpre dos puentes grandes y muy costosas que ay en el dicho rrio de Nela, e otra puente grande que ay en el rryo de Trueba ${ }^{756}$ que son de cal e canto", y otros pontones y calzadas con mucho coste anual, sin los cuales los mulateros no pueden transitar.

Además, prosigue, todos los ganados que pasan por Villacomparada757 y Villarcayo, deben de portazgo al Condestable una blanca por cabeza de ganado mayor y media blanca por cabeza menor, haciéndose así de tiempo inmemorial. Los mulateros que han intentado no pagar, "han seydo descaminados e prendidos, e pagadas las dichas penas e prendas quieta e paçificamente", por tener el Condestable la jurisdicción en esa tierra, porque "mas de çient años antes que fuesen señores de la dicha villa, ni tubiesen la jurediçion de Castilla Vieja, se husaba lo susodicho antes despues que tiene la dicha jurediçion", pero los mulateros, dice, "han tenido mas atrebimiento para començar novedades", pensando que los Condestables lo consentirían. Los mulateros desde hace 10 años, añade, en menosprecio de la justicia y despojando al Condestable de su posesión, han presumido de hacer avíos nuevos y dejando el camino real, usurpan los diezmos y otros tributos debidos a la Reina y al Condestable, y como las guardas los hacían ir por donde debían, "han fecho muchas ligas e monepodios para matar e ferir las dichas guardas, y otras muchas bezes se han llegado a rrepique de canpana, armados de diversas armas syn mandamiento ni liçençia de juez, $e$ han ydo contra las dichas guardas y rresystenles las dichas prendas fasyendoles e dixiendoles muchas ynjurias".

Fueron especialmente graves los sucesos ocurridos en junio de 1513, cuando al ir a prender a los que iban descaminados, "se juntaron a rrepique de canpana mas de dosyentos honbres, e armados de dibersas armas, fueron tras las dichas guardas, e que lo que peor es y digno de mayor castigo, que juntos los dichos mulateros en el dicho escandalo e asonada, acordaron de ahorcar a las dichas guardas", y después no teniendo facultad y usurpando el poder real, dice, sacaron dos alcaldes entre los mulateros, que tomaron "baras de justiçia e fueron aconpañados de la dicha gente,... tras las dichas guardas disyendo ¡mueran, mueran!, y asy los syguieron fasta el lugar de Barzena, donde los mataran, sy no se acogyeran a una torre del dicho lugar, e despues de alogados en la dicha torre les tentaron de poner fuego a ella", y solo unas personas del valle de Montija los defendieron "e fue gran marabilla no morir aquel dia mucha gente, a cabsa de los dichos desconçilios e atrebimientos que las dichas partes contrarias, en cada dia fazen e dizen conforme a esto, muchas amenazas e escandalos".

Si algunas veces se les había permitido ir por otros caminos, indica, sería sin saberlo el Condestable, porque los mulateros se concertaban con algunos portazgueros para pagar en Incinillas y no ir a Medina, ya que todos estaban obligados a pagar el portazgo en esta villa y el portazguero, por hacerles el favor, se avenía a coger el portazgo en lugar más conveniente para los mulateros y por ello, no pueden quejarse de lo que se hizo por su ruego y consentimiento. Además, los Condestables "syenpre acostunbraron fazer merçedes a vnos por seruiçios, a otros por limosnas, a otros por truhanes e chocarreros e por otros fines desa calidad", y pide al corregidor que se prenda a Barahona y confisque todos sus bienes y a los que hallare culpables.

756 Son los puentes de Quintarnaza y El Vado sobre el Nela y el de San Miguel de Medina sobre el Trueba.

757 Localidad situada a 1 km. al Sur. del puente de San Miguel de Medina de Pomar, en el camino que procede de La Horadada. No confundir con Villacomparada de Rueda, 1 km. largo al Norte de Villarcayo. 
Dos días después, Pedro de Brizuela, en nombre de los mulateros, indicó que si alguna posesión ha tenido el Condestable, lo que niega, fue por ser "persona muy poderosa e tener la justyçia de las dichas merindades de Castylla Bieja, e no aver persona que le hesiese yr a la mano y enpedirgelo", por lo que el Condestable había hecho a los mulateros muchos agravios e injusticias. Pidió que se tome información de los agravios que se les hacen, estando como estaban en posesión de "veynte años a esta parte e mas tiempo, de yr por el dicho camino rreal que ba por Castilla Bieja a Laredo e a Baldeporres, syn yr por la dicha villa de Medina ni pagar portazgo".

Así, entre el 18 y el 25 de septiembre de 1515, el corregidor tomó juramento a los testigos presentados por los mulateros: uno de Bedón, otro de Bocos, seis de Campo, uno de Cornejo, cinco de Fresnedo, uno de Hocina, uno de Hornillalastra, cinco de Hornillalatorre, tres de Hornillayuso, tres de Incinillas, cinco de Mozares, cinco de Pereda, uno de Quintana de Rueda, dos de Quintanaedo, siete de Salazar, dos de Santelices de Valdeporres, nueve de Torme, dos de Valdeporres, dos de Villacanes, tres de Comparada, 22 de Villanueva de Ladrero, uno de Villarán, uno de Villarcayo y cuatro de Villasante, todos arrieros más tres sacerdotes y dos escribanos. Se les debía preguntar si conocían los caminos reales que van y vienen de Castilla para los puertos de Castro, Laredo, Portugalete y Bilbao. También si sabían:

- Que estos caminos que van por las Merindades son muy utilizados, y sin ir por Medina de Pomar son más cortos en una o dos leguas, en especial para los mulateros y viandantes de las merindades de Castilla Vieja, la Sonsierra y Sotoscueva, porque estos van y vienen "por sus casas por el camino derecho, e eziendolos yr a Medina de Pumar, se les sygue mucho rrodeo de sus mulas e personas e aziendas, en cantidad de mas de tres o quatro leguas a los mas dellos es cada camino de yda o uenida".

- Que las Merindades son desde tiempo inmemorial de la Corona real, así como sus vecinos y moradores y que desde hace 20 años, los mulateros pueden ir y venir por estos caminos sin pagar portazgo en Medina ni en otras partes.

- Que en estos caminos, algunos vecinos de Medina y portazgueros del Condestable desde hace 10 años, "poderosamente mano harmada con favor del dicho Condestable, han fecho e cometydo contra los mulateros de las dichas merindades... e de otras partes, muchas fuerças e violençias en espeçial entre Quintanahedos, e Barzena, e Gayangos, Enzinillas e las ventas de Baldemera, que estan en los dichos caminos rreales, llevandolos por fuerça sus personas e mulos e mercaderias a la dicha villa de Medina Pumar que hay dos leguas grandes", no llevando las cosas que perteneciesen a los diezmos salvo hierro, vino y otras mercaderías que llevan o traen de Castilla para la provisión de las villas de la costa.

- Que puede hacer 2 años que los portazgueros, salieron al camino real que va a la merindad de Montija, y tomaron por fuerza a un mulatero que iba para los puertos con sus mulos cargados de vino, y le llevaron a él y a sus mulos y mercaderías a Medina siendo preso. La hermandad de Castilla Vieja se levantó y los portazgueros quedaron cercados en la torre de Bárcena, hasta que el alcalde de Castilla Vieja los sacó, los llevó a Medina y devolvió los mulos a Juan López, y por fuerza como justicia del Condestable, hizo que se le diese fianza.

- Que en Villacomparada, Fernando Díaz y sus hijos y otras personas y en otros lugares de las Merindades, por mandado del Condestable y de sus portazgueros, han 
cogido portazgo continuando las dichas fuerzas, no solamente por los mulos que llevaban sino también por los ganados que los mercaderes llevaban a los dichos puertos.

- Que todas las fuerzas, violencias, portazgos y cohechos realizados a los viandantes que van por estos caminos de las Merindades, para que pasen por Medina de Pomar, se hacen con el favor del Condestable, y si saben que si la Reina permitiese estas fuerzas, sería motivo para que la tierra se despoblase.

- Que los Condestables y los vecinos de Medina, no tienen ningún título ni privilegio para llevar los portazgos, ni hacer los cohechos que hacen por su mandado.

- Que los portazgueros y vecinos de Medina con el favor del Condestable, habían "rrobado e coechado ellevado por fuerça en los dichos caminos rreales e en sus casas" a los mulateros, más de 10.000 ds. de oro, por ser tan poderosos y no haber nadie que lo impidiese, y a cada uno por ir por estos caminos de Castilla Vieja, le echaban de imposición 40 o 50 mrs. por mulo y año por iguala, además de los peajes y el albalá, pero que desde hace 4 años, los dejan ir y venir pagando un mr. por el albalá aunque no fuesen por Medina, y por Orden real fue quitada la fuerza hace más de 14 años, hasta que los portazgueros han hecho de nuevo las dichas fuerzas.

Las respuestas fueron prácticamente unánimes, indicando que todos conocían a Juan Barahona y a muchos mulateros, viandantes y caminantes, así como a vecinos de Medina de Pomar, a los portazgueros Lope Saiz Barbero y a García de Santayana y a los Condestables, tanto a Bernardino como a su hermano Íñigo. Sabían que por los caminos reales de Castilla Vieja pasaban muchos mulateros, viandantes, caminantes y mercaderes con ganados grandes y pequeños, y que "avantayan los dichos mulateros de las dichas merindades, en no yr por la dicha villa de Medina de Pumar vnos vna legua, otros dos, otros tres leguas", porque a estos "les es grand rrodeo en yr por la dich a villa de Medina... e seles syguen muchas costas egastos". Todos responden que los vecinos de las Merindades son y se tienen por vasallos de la Corona.

No obstante, desde hacía unos 13 años, los mulateros de las Merindades podían ir y venir por estos caminos reales, sin pasar por Medina ni pagar nada, excepto cuando traían cargas que debiesen diezmo, pero que hacía 304 años que "hyendo Juan Lopez e su hijo, mulateros vesynos de Villanueba de Ladrero, cargados de bino por... Castilla Vieja para Valmaseda,... çerca de Gayangos, salieron a ellos... diez onbres que desyan que heran de la billa de Medina, e les tomaron los mulos e mercaderias... desyendo... que abian de yr por Medina de Pumar e como la tierra lo supo, con el alcalde de la hermandad fueron tras ellos, hasta que se les ençerraron en vna casa del señor condestable que es en do dizen Varzena, e alli vino el alcalde de Castilla Bieja e entregaron los mulos y la mercaderia de bino a sus dueños con fyanças que dieron", y que hacía 5 o 6 años, "ha la entrada de los Oçinos dos leguas de Medina ançia Castilla, yendo Comez Lopez por el camino rreal con sus mulos cargado de fierro, çiertos besynos de Medina..., le tomaron ellevaron a Medina con sus mulos e mercaderías, ele tienen halla fasta oy el fierro, que no gelo han querido dar".

Indican que en las merindades de Castilla Vieja no había portazgo excepto de hacía 15 años, "que lo han llevado los arrendadores de Medina e Ferrando Díaz e sus hijos en Billaconparada por los dichos arrendadores", y han cogido los portazgos de los puercos, vacas, ovejas y otros ganados, y que los portazgueros dicen que hacen ir a la villa a los mulateros con el favor del Condestable, a "les gastar sus biandas e mantenimientos, e conprarles los çapatos e otras mercaderías, e a nobleçerle la billa", y todas las dichas fuerzas se hacen para "que bayan por Medina, e por que no 
vayan los dichos mulateros e biandantes por las dichas Merindades, por que en Medina paguen el portazgo e sea mas nobleçida". Saben que si la Reina permitiese estas fuerzas, los mulateros "rresíbirian mucho dapño e agrabio por el mucho rrodeo que ay en yr por la dicha villa..., e que antes venderian los dichos mulateros [sus] rrequas que no yr por... Medina, o se dexarian coechar de los portazgueros e besynos de la dich a billa..., como antyguamente le solian haser porque les dexasen yr por los dichos caminos rreales de las dichas merindades, o se matarian con ellos", y las Merindades quedarían perjudicadas por los mantenimientos que dejarían de traer los mulateros.

Los testigos creen, además, que los Condestables no tienen ni han tenido nunca privilegio o título para llevar los portazgos, y que han hecho las fuerzas no por tener justicia, sino por ser "el dicho condestable e sus antepasados grandes señores, e aver tenido la jurediçion e juzgado de las dichas merindades, e por no aver hosado ninguno, de se poner contra el dicho condestable". Añaden que los portazgueros y vecinos de Medina han llevado "mucha quantya de mrs. e coechos e ygoalas, porque los dexasen yr e benir por los dichos caminos reales a sus casas, e no les hesyesen yr por Medina", y un testigo lo sabe porque había tenido 9 años recua de cuatro mulos, y "se ygualaba e ygualo e pagaba e pago a çinquenta mrs. por mulo en cada vn año, e mas dos mrs. de portazgo de cada mulo, por cada camino de los que hasyan sobre juramento, e mas un mry. del albala", que pagó a Carcía de Santayana y a Lope Saiz Barbero, y esto se ha pagado hasta hace unos 3 años que no se paga, por virtud de una Carta real de amparo que trajo Juan Barahona.

El corregidor interrogó a Fernando Díaz, cogedor del portazgo en Villacomparada, y le mandó que mostrase el título por el que lleva dicho portazgo, respondiendo que nunca lo tuvo y que lo tenía arrendado por 7 u 8 años a Juan Rosales y a Pedro García Horrador, como arrendadores del Condestable. Tal portazgo, dice, no lo había cogido desde que fue requerido con una Carta real hacía unos 2 años y que lo había visto coger en Villacomparada e Incinillas desde hacía más de 45 años, y que los arrendadores de Medina le dijeron que debía cobrar por cabeza mayor una blanca, y de cada cinco cabezas menores, un mr.

Ese mes de septiembre, el procurador de los mulateros dice al corregidor, que como no hallaba letrado en Medina de Pomar ni en las Merindades le ayudase, porque "por miedo del dicho señor condestable", y ser el Condestable "gran señor e tener la jurediçion del juzgado de las dichas merindades, no abia ningund letrado que contra el quisiese abogar", y como buscar a otro fuera ocasionaría muchas costas, pedía que le ayudasen para garantizar el derecho de sus partes. El corregidor mandó a Juan de Salazar, que abogue por ellos y los defienda en esta causa so pena de 20.000 mrs., contestando Salazar que "como quier quel no quesyera entender en el dicho negoçio, pero por ser hobediente al mandamiento del señor corregidor en nonbre de la Rreyna nuestra señora, y por yncurrir en las penas del dicho mandamiento, quel estaba presto de entender en la dicha cabsa en las cosas que tanbien su justiçia y no en mas".

En octubre de 1515, se realiza interrogatorio a los testigos presentados por el Condestable y uno de ellos dice que "tenia hazemillas ele hasyan yr las personas que tenian el portazgo por la dicha calle mayor, e a otros muchos mulateros que venian de Castylla o de las montañas les hasyan los dichos portazgueros yr por la dicha calle". Al final, el corregidor declarará culpables a los portazgueros que habían concertado igualas de $50 \mathrm{mrs}$. y por haber tomado los mulos y las cargas, y confirma que los mulateros recibieron un gran perjuicio por haber sido forzados a pasar por Medina. Manda que si todos deben pagar un peaje, pasando o no por el término 
de Medina, este debía ser percibido en Incinillas, donde se bifurcaban los dos caminos 758 .

El problema ya planteado en 1489 sobre el camino de acceso a Laredo, que está a una cota tan baja que lo inundan las mareas, sigue sin resolverse. En 1525, el concejo dijo que la villa necesitaba hacer un camino nuevo salvando la pleamar, porque sus vecinos "e los dichos caminantes e rrecueros que a ella ban, suelen estar esperando mucho tiempo syn poder pasar, e que otras bezes las bestias se pierden e mancan en el dicho paso, e algunas personas corrian peligro por se atreber a pasar por la dicha mar". El nuevo camino iría por la orilla del mar, desde las casas del concejo hasta el Risco que es el secadero de las naos, pinazas y bateles donde se hacen y reparan las naves, pero como no hay camino los vecinos, mercaderes y marineros que van con sus mercaderías y fustas, reciben mucho daño porque con pleamar, han de ir en barcas hasta donde tienen sus naos y mercaderías, y si quieren ir por tierra han de rodear por un camino áspero con mucha dificultad. Por otra parte, por el centro de la villa pasa el río de Barrón que está cubierto de madera y causa dificultades y fealdad a la villa. No pueden pasar carros, y cuando pasan algunas bestias rompen sus patas en las maderas, y cada año su reparo le cuesta a la villa muchos mrs., por lo que se ha comenzado a cubrir el río con bóveda de mazonería en plazas, mercados y calles. Para esto se necesitan 4.000 ds., y como la villa no tiene propios ni rentas, pedía facultad para echar por sisa en 4 años, 1.000 ds. al año. Tras la información recibida por el corregidor en abril de 1525 sobre la necesidad de estos edificios, la cantidad necesaria de mrs. y de donde se podrían obtener, el Consejo dio facultad para que se eche sisa en los mantenimientos y otras cosas que en la villa se vendieren hasta $500.000 \mathrm{mrs}$, , y que a fin de año se les envíe relación de lo que se hubiere cobrado y cómo se ha gastado759.

Pedro González Cachopín, vecino de Laredo, dijo que, en nombre de otros vecinos, había pedido al corregidor que cumpliese una Carta real para que las sisas puestas entre 1529 y 1533 para hacer el camino de Laredo a Colindres, no se distribuyan porque ningún edificio se había hecho. Todos los mrs. de las sisas, los regidores los habían gastado en pleitos y otros gastos, y dice que el corregidor en lugar de mandarles guardar dicha Carta, mandó trasladarla a los regidores y al procurador, y este respondió que el corregidor, teniente y regidores, gastaban las sisas en perjuicio de la villa. Además, este año se había echado mucha más sisa al añadir 2 mrs. en cada azumbre de vino, por lo que se debía presentar la cuenta de lo recaudado desde 1529, y averiguar en qué se había gastado, y mientras que no se cobrasen las sisas. El Consejo mandó al corregidor en mayo de 1533, que en 30 días reciba todas las cuentas de los que han tenido el cobro, y se informe de cómo se han gastado estos dineros ${ }^{760}$.

\section{Proyecto de fines del siglo XV para la mejora del camino ${ }^{761}$}

A fines del s. XV, existe preocupación por el estado de este camino, principalmente por parte de los mulateros que son los que lo utilizan de manera más habitual, y con este

758 A. G. S./ Consejo Real de Castilla, leg. 84, fol. 2-III/ Valladolid, 26 junio 1513 a Salazar, 25 septiembre 1515; MOLÉNAT, J. P.: 1971: 149-150.

759 A. H. P. C./ Villa de Laredo, leg. 22, num. 11/ Madrid, 6 abril 1525.

760 A. H. P. C./ Laredo, leg. 13, num. 15/ Madrid, 15 mayo 1533

761 PÉREZ BUSTAMANTE, R.: 1981: 168-171. 
motivo los Reyes promueven un plan para su rehabilitación que, por las dificultades en cobrar las cantidades repartidas, no se llevó a cabo en su totalidad, aunque supuso un avance muy importante en las iniciativas camineras en Castilla. La importancia del camino y el interés que poseía para todas las partes implicadas, en especial para los mercaderes y mulateros, hizo que de una manera decidida, estos reclamaran una intervención integral para la reparación, ensanche y mejora de todo su recorrido, instando al Consejo Real a que promoviera acciones para su adecuada utilización. El Consejo autorizó el proyecto y su ejecución, y tras unos años de trámites y obras, tal proyecto fue decayendo sin ver finalizada su ejecución, a pesar del empeño y seguimiento constante que de él hicieron los mulateros denunciando y exigiendo cumplimientos de plazos y compromisos de las localidades, personas y mercaderes implicados. Será el primer repartimiento realizado en este camino del que tenemos constancia, y aunque la iniciativa no tuvo todos los resultados que se pretendían, fue una de las más ambiciosas que, en materia de caminos y promovidas por la Corona, se tomaron en Castilla hasta esas fechas. A pesar de que el planteamiento inicial era intervenir en todo el camino, las actuaciones principales se concentraron en el sector comprendido entre Laredo y el puerto de Sendero Enhiesto, destacando por su importancia la construcción del puente de Bolado sobre el río Carranza o Marrón en el término de Ramales, entre Bárcena y Gibaja.

Entre la cofradía de los mulateros y viandantes de la provincia de Burgos, la Universidad de Burgos y la villa de Laredo, se trató pleito en 1498 tras comunicar los mulateros a los Reyes, que los caminos, puentes y calzadas situados desde Burgos a Laredo, "estauan algunas de las dichas puentes caydas e otras mal rreparadas e que con las muchas aguas e fortunas de los ynuiernos, las calçadas estauan desfechas e los caminos estauan dañadose tales que no se podian andar, e que algunas de las dichas puentes, asy de piedra como de madera con las abenidas e cresçientes de las aguas, se las auian lleuado de manera que muchas gentes e bestias peligrauan e se perdian las mercaderias e mantenimientos", y que si no se reparasen o se hiciesen de nuevo, no se podría circular y cesaría todo el trato762.

Por una Carta real de enero de 1499, se mandó al corregidor de las Cuatro Villas y al alcalde mayor de Castilla Vieja, que fuesen con maestros que supiesen del oficio de cantería a ver los puentes, calzadas, pasos y vados, y viesen los que se deben de hacer y reparar, averiguando lo que costaría y quiénes se beneficiarían del reparo para su contribución y todo con su parecer lo enviase al Consejo763. En Ampuero el teniente de corregidor y el alcalde de Castilla Vieja recibieron juramento de Ruy Sánchez de Criales, cantero vecino de Criales, para que informase sobre el coste de las obras que se debían realizar para tener acondicionado el camino. Criales hace una descripción detallada, valorando su estado y adelantando presupuesto de la intervención. Además da alternativas para eliminar malos pasos y racionalizar su trazado abaratando con ello su mantenimiento, pensando en todo momento en convertir el camino en carretero, algo que no se llegó a conseguir en su totalidad hasta el siglo XIX. Incluimos a continuación un resumen de lo que según Ruy Sánchez se debía realizar:

762 A. G. S./ Registro General del Sello, VI-1501, fol. 460/Valladolid, 5 junio 1501; MOLÉNAT, J. P.: 1971: 157-160.

763 A. G. S./ Registro General del Sello, I-1499, fol. 50/ Ocaña, 15 enero 1499. 
- En el término de Laredo 192 brazas de calzada y pared, y desmatar, limpiar y ensanchar en muchos lugares el camino, tasado en $10.337 \mathrm{mrs}$.

- En el término de Colindres 429,5 brazas de calzada a 35 mrs. la braza, y otras según esté la piedra cerca o lejos, tasadas en 28.334 mrs.

- En el término de Limpias 95 brazas de calzada, ya que 267 "estaban fechas por çiertos veçinos del dicho lugar por mandado de los dichos corregidor e alcalde pasados e por pedimiento de los dichos procuradores de los biandantes, por la nezesidad grande que dellas abian por no se poder andar el camino" y que se deben, lo que hace un total de 362 brazas, a $56 \mathrm{mrs}$. la braza por estar la piedra lejos, $20.272 \mathrm{mrs}$.

- En el término de Ampuero 165 brazas de calzada a 50 mrs. cada una por estar la piedra apartada, más 163 a 36 que estaban hechas en el término de Rocillo, que son $14.138 \mathrm{mrs}$. y 120 brazas de arroyo para apartar el agua del camino, que a 10 mrs. son 1.200. En el mismo lugar, se rehízo el puente de madera por $6.500 \mathrm{mrs}$., que para su perpetuidad se ha de hacer de mazonería con tres arcos, y los estribos de ambas partes largos con sus pretiles y calzada, que se tasa en $100.000 \mathrm{mrs}$. por tener que bajar la piedra desde la sierra en etapas, al no poder subir el carro y no hacer al día más de tres viajes con cal y arena.

- En el término de Cereceda 250 brazas de calzada, a 50 mrs. la braza por 12.500 mrs., al encontrarse la piedra lejos.

- En el término de Rasines, Bárcena y Ramales se han de hacer hasta Ramales 310 brazas de calzada, más 200 que estaban hechas y que se deben, más otras 7, en total 517, tasadas unas a 25 mrs., y otras entre 35 y 50, en 19.592 mrs. El corregidor y alcalde anteriores, mandaron aderezar el puente de Bolado 764 , pero se cayó al comienzo de la obra y se volvió a hacer, tasándose en $27.000 \mathrm{mrs}$. de los que se pagaron 20.000, aunque temen que no durará más de la primera avenida como ha ocurrido otras veces. También encargaron a Pedro Ruiz carpintero de Ramales, hacer el puente de madera de San Pedro de Ramales por $8.000 \mathrm{mrs}$. En los 30 últimos años, se han gastado muchos mrs. en estos puentes, porque se han hecho varias veces de madera. Una vez se hizo el de Bolado de calicanto y dos veces el de San Pedro de Ramales, pero se cayeron por no asentarse en tierra firme. Ruy Sánchez dijo que según la longitud y altura que debían tener al ser el agua caudalosa, costarían de calicanto, $800.000 \mathrm{mrs}$. pero como tenía muchas dudas de que fuesen firmes, se miró otro emplazamiento. Para evitar estos puentes, dice Ruy Sánchez, se puede hacer nuevo camino para la carretería y mulatería llano, ancho y seguro 765 , desde el puente de Bolado sin cruzarlo hasta Gibaja, y luego por Guardamino hasta La Haza, y para mayor seguridad, se debiera hacer junto al puente un paredón de piedra de 20 brazas de largo y una de alto y rellenarse de piedra, porque cuando el agua crece toma este camino, tasado en $2.000 \mathrm{mrs}$. a 100 la braza. Si se hacen 600 brazas de calzada de piedra y arena a $68 \mathrm{mrs}$. que por estar la piedra apartada montan 40.800 , se evitarían aquellos puentes para siempre. Si se continuase por el camino viejo por estos puentes, se deberían hacer 400 brazas hasta La Pared y Lanestosa, que a $30 \mathrm{mrs}$. la braza son 12.760 . Se han de hacer en ambos caminos, donde dicen Río Sequillo hasta La Pared, 50 brazas de calzada que a 34 mrs. hacen 1.700 y para "se escusar otras dos puentes de madera questan fechas la una a rrio Sequillo, e la otra a la en Pared e porque sirba a los dos caminos, al viejo e al que se a de fazer nuebo", se ha de hacer una pared de calicanto de tres pies de ancho y relleno de piedra, de cuatro brazas de alto y 25 de largo que a castellano cada braza son $12.125 \mathrm{mrs}$.

- En el término de Lanestosa hay dos puentes de madera, uno en dicho lugar y otro en Valnera, que "son costosas e se hazen mui a menudo", y según Ruy Sánchez, no se

764 El puente de Bolado, se encontraba sobre el río Carranza o Marrón en el término de Ramales, entre Bárcena y Gibaja.

765 Este camino por Gibaja era antiguo y fue utilizado hasta los años 70 del siglo XV. 


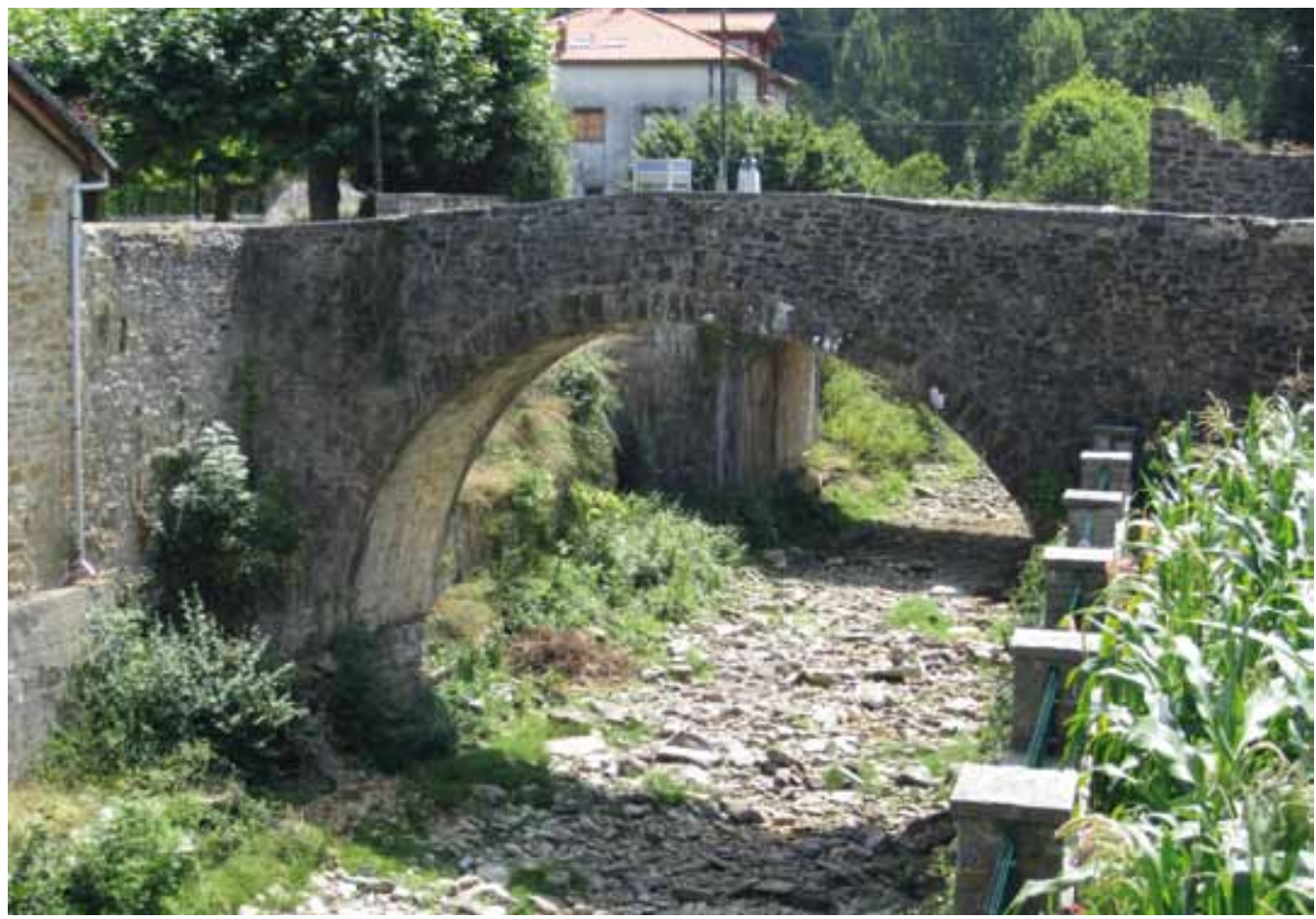

Puente viejo de Lanestosa en el centro de su casco urbano.

harían de cal y canto con 120.000 mrs. Para evitarlos se puede hacer un camino desde Lanestosa hasta el puente de Valnera junto al río, sin pasar por ninguno de esos puentes, y para hacerlo llano y adecuado para los carros, se harían las calzadas necesarias por $30.000 \mathrm{mrs}$., cuando de madera no se haría el puente por 12.000 mrs., y no duraría más de un año ni soportaría los carros, pero haciéndose el nuevo camino, los vecinos de Lanestosa por su interés mantendrían los dichos puentes, cuando ahora no quieren pagar nada y esto mismo harían los de Ramales. También se han de hacer hasta el puente del Prado, 250 brazas de calzada salvados los dichos puentes, retirar del río mucha piedra que dificulta el camino y poner algunas barandas en la orilla del río, por $8.000 \mathrm{mrs}$.

- Junto al lugar de El Prado se debe hacer de calicanto el puente de madera para soportar los carros, con estacas, pretiles y calzadas que han de llegar de una orilla a otra, con un arco que se tasó en $30.000 \mathrm{mrs}$. ya que aunque el caudal es pequeño, crece muy rápido. Además en el puerto de Sendero Enhiesto766, "ques mui mas aspero e mui mas alto", para que se pueda utilizar por los carros, se deberán hacer algunas vueltas más largas y calzadas. Según Ruy Sánchez, hay personas en El Prado y en Montija que lo podrán hacerlo por $40.000 \mathrm{mrs}$. y como "es puerto mui neçesario y en ninguna manera se puede escusar", si se interviene solo para ser utilizado como camino mulatero, costará $30.000 \mathrm{mrs}$. Previamente se habían hecho en este puerto por orden del corregidor y alcalde anteriores a petición de los mulateros, 225 brazas de calzada con sus barandas, reparos de madera, pretiles y rompimiento de peñas, a $36 \mathrm{mrs}$. braza, que todo montó $8.100 \mathrm{mrs}$.

Hay desde "Lanestosa otro camino para el carro mui mas llano e mas seguro e sin piedras por el puerto que dizen de Herada ques en el balle de Soba", que arreglando algunas calzadas, costaría como mucho 15.000 mrs., aunque no es camino para la mulatería por

766 Así se llamaba el puerto o también "Sandiniesto", con sendero arrieril que salvaba el desnivel del actual puerto de los Tornos. 
ser más largo y no tener mesones. Sería mucho mejor aunque algo más costoso, hacerse todo por el puerto de Sendero Enhiesto, pero se debe hacer desde el Prado hasta arriba del puerto "ques mui mas aspero e mui mas alto, para que se ande mui mas llano e a menos costa, e para andar el carro por el con qualquier carguerio, [se deberán hacer] algunas buelgas mas largas de las que agora estan y calzadas y barandas". Se han de hacer unos atolladeros arriba en lo llano, 50 brazas de calzada y romper 20 brazas de peñas en medio del camino, tasadas a 34 mrs. en 2.380 y se quitará en este término "mucha piedra de que le enbarazan mucho, e cortar hayas e rrobres que estan en medio del camino que enbarazarian mucho la carreteria, e quebrar algunas peñas treinta hombres, tasados... a treinta mrs. que se mantengan dellos", que montan $900 \mathrm{mrs}$.

- En el término de Agüera están "socalzadas la puente que dizen del Canto, los pilares devaxo que no tienen petriles y es mui agria". Se deben recalzar los pilares y hacer los pretiles y calzada para el paso de recuas y carretería, tasado en $5.000 \mathrm{mrs}$. Desde dicho puente hasta Agüera hay un puente de madera, el de la Tabla, y otro en Agüera y como todo el coste y peligro está en estos puentes, se han buscado otros caminos para evitarlos. Se puede hacer uno ancho y llano con facilidad por la parte del río, desde el puente del Canto hasta Agüera, tanto o más para la carretería que el camino actual, sin tener que utilizar los dichos puentes, y hay personas en Agüera y Villasante que pueden hacer estas calzadas por 15.000 mrs., y como los vecinos necesitan los puentes, los sostendrán a su costa.

- De Agüera a Villasante no se ha de hacer nada. En Villasante "se apartan los caminos vno para Laredo e otro para Bilbao e a Castro e Portogalete. Es gran paso el deste lugar".

- Hasta El Ribero nada hay que hacer pero aquí hay un puente de mazonería descalzado por una parte, y con un pilar llevado que ahora está en seco por la otra, y para recalzarlo y pueda pasar la carretería y mulatería y hacer el pilar de nuevo y los pretiles necesarios, se tasa en $4.000 \mathrm{mrs}$. Como el caudal es pequeño, solo se utiliza el puente cuando hay crecida. Arriba y abajo del dicho puente, el río ha derribado muchos terreros y a poco que crezca el agua, circulará por el camino ahondándolo tanto, que el cauce pronto irá por el camino y quedará el puente en seco. Para su remedio se debe hacer una estacada de 50 brazas hacia el cascajo y echarlo a la otra parte, de manera que la madre del río vuelva a su sitio y no se pierda el puente, porque no se haría otro con $100.000 \mathrm{mrs}$. Serían necesarias para repararlo, 6 yuntas de bueyes y 12 obreros por 12 días a $30 \mathrm{mrs}$. cada yunta y obrero $2.340 \mathrm{mrs}$. Se han de hacer aguas abajo del puente dos presas y ensanchar la madre del río, porque en las crecidas el agua va por el camino hasta Barcenillas y daña mucho el camino, obligando a las recuas a salir por las heredades. Se tasó todo en 2.000 mrs.

- En el término de Barcenillas son necesarias 20 brazas de calzada y quebrar 10 de peña, tasándose en 1.050 mrs. a 35 mrs. por braza.

- En los términos de Revilla y Quintanilla de Pienza el corregidor y alcalde pasados habían encargado a Ruy Sánchez por 65.000 mrs. los dos arcos que se cayeron del puente de Quintanilla y un pilar, reparar los pretiles que quedaron, y hacer pretiles en lo nuevo y la calzada y estacada hacia el molino de Juan Sánchez de Angulo.

- En el término de Santurde hasta San Miguel de Miñón se han de hacer 83 brazas de calzada que se tasaron en 3.440 mrs., a 40 la braza.

- En el término de La Aldea, Queciles y Barruelo hay "tres caminos que todos tres salen al lugar de Bizuezes uno de la puente del Vado fasta el lugar de Bizuezes, el otro que ba de Medina a la puente de Santa Maryna por do dizen a la Hortiçuela e otro que ba de la dicha puente de Santa Marina al lugar de Villarias"767. Ambos puentes, son de mazonería y muy buenos para los carros y recuas. El camino que va por El Vado a Bisjueces, es

767 En realidad los caminos entre Medina y Bisjueces son dos: Medina, puente del Vado, norte de La Aldea y Bisjueces, y el otro Medina, puente de Quintarnaza o Santa Marina, Villarías y Bisjueces. 
el más usado porque en los lugares de La Aldea, Queciles y Barruelo 768 hay muchos mulateros y mesones. Se han de hacer hasta llegar al término de Bisjueces 400 brazas de calzada y quebrar peñas, a $34 \mathrm{mrs}$. la braza, lo que monta 13.600.

- En el término de Bisjueces se han de hacer hasta allí 800 brazas de calzada y quebrar peñas a $40 \mathrm{mrs}$. la braza, que por estar la piedra apartada monta $32.000 \mathrm{mrs}$. Dice que por cualquiera de los otros caminos resulta la mitad de estas brazas, y menos por La Aldea, Queciles y Barruelo, que recibirían gran daño y se haría a la mulatería mucho mal por las buenas posadas que en estos lugares hay. Se midieron 10 brazas de calzada y 50 de peña, en la Rad término de Bisjueces, Incinillas, convento de Rioseco y Villalaín, debiéndose quebrar y allanar los portillos que a 34 mrs. la braza, monta 2.040. Se han de hacer en término de la venta de Medinilla hasta la de Valdemera, 48 brazas de pared de calicanto, y ensanchar tres pies el camino y las vueltas del carro, tasados a $125 \mathrm{mrs}$. por braza en 6.000 , y quebrar en el portillo asomando a la venta de Valdemera, un pedazo de peña para ensanchar la entrada y quepa un carro, que es peña muy recia y se ha de quemar y gastar vinagre, tasado en $3.100 \mathrm{mrs}$. Desde esta venta hasta el término de Villalaín, Bisjueces e Incinillas y ribera del Ebro, se deben hacer 515 brazas de pared de calicanto de tres pies de ancho y rellenar con piedra seca entre la pared y el camino, muy necesario en ciertos lugares para ensanchar el camino para el carro, a 120 mrs. la braza 61.600, y desde la venta de Valdemera hasta el término de Bisjueces y Villalaín, 70 brazas de calzada y quebrar peñas a $34 \mathrm{mrs}$. la braza 2.380 .

- En el término de Valdivielso desde la peña donde llega el término de Bisjueces hasta el puente de Valdivielso, 206 brazas de calzada que a $34 \mathrm{mrs}$. son 7.004. Junto al Ebro, 185 brazas de pared para ensanchar el camino para el carro y hacer la concavidad entre la pared y el camino de piedra seca, a $120 \mathrm{mrs}$. por braza, 22.200 mrs.

- Desde el puente de Valdivielso hasta El Almiñé 200 brazas de calzada que a $34 \mathrm{mrs}$. son 6.800, y desde El Almiñé "fasta ençima el puerto de Santa Maria de la Hoz [hay dos caminos], el uno que ba a la yglesia y el otro al lugar de Pesadas y entramos caminos acuden al lugar del Cuerno", es necesario aderezar los dos, que medidos con las peñas que se han de quebrar son 290 brazas, que a $34 \mathrm{mrs}$. la braza montan 9.860 . Se deben hacer junto a la venta de El Almiñé 20 brazas de pared de tres pies de ancho desde debajo del arroyo, y rellenar de tierra y piedra seca el hueco entre el camino y la pared, que con el quebrar del portillo de la peña, a $120 \mathrm{mrs}$. son 2.400 .

- En las ventas del lugar de El Cuerno hay necesidad de agua porque en las cinco leguas desde El Almiñé hasta Cernégula, no hay "agua ninguna salbo en las dichas ventas, e alli poca espezialmente los meses de junyo e jullio e agosto e setienbre, e años ay, no ay agua ninguna, ay mucha necesidad de se fazer una fuente donde abia abasto de agua en que a de aver un alverque de cal y canto uitunado de veinte pies en largo e diez pies en ancho e ocho pies en alto", pudiendo costar $40.000 \mathrm{mrs}$.

- En el término de Cernégula hay que hacer 150 brazas de calzada que por estar la piedra lejos se tasaron a $70 \mathrm{mrs}$. en $10.500 \mathrm{mrs}$.

- En el término de Hontomín se han de hacer 70 brazas de calzada que se tasaron a $80 \mathrm{mrs}$. la braza en $5.600 \mathrm{mrs}$. por estar la piedra muy lejos.

- En el término de Villaverde venta de Quintanaortuño, Vivar y Villatoro "e fasta la entrada de la Calleja" se midieron 1.000 brazas de calzada a 80 mrs. la braza 80.000 mrs. Se han de repartir los puentes de Vivar y Villaverde, que tres arcos de los menores están caídos y los otros descalzados y comenzados a caer. Ruy Sánchez in-

768 La Aldea se encuentra 300 m. al sur del camino de Medina a Bisjueces, y el despoblado de Queciles también estaba al sur de dicho camino. Barruelo se sitúa a más de 1,5 kms. al sur de La Aldea, por lo que para ir de Medina a Bisjueces, el paso por Barruelo obligaría a dar un gran rodeo. Más bien este lugar se encuentra en otro camino, el que viene de Trespaderne y discurre por Quintanalacuesta, Baillo, Barruelo, Bisjueces y Villalaín. La Aldea y Barruelo también se situaban en el sendero que de Medina iba por la ermita de la Virgen de Pilas a Puente-Arenas. 
dicó que era necesario recalzar y hacer de nuevo los arcos caídos y las calzadas y pretiles por $30.000 \mathrm{mrs}$. Se han de hacer "del dicho lugar de Villatoro fasta salir al camino rreal a la calzada de Burgos que ba a San Françisco", 650 brazas de calzada a 80 mrs. por estar la piedra lejos, en $52.000 \mathrm{mrs}$.

En resumen:

\begin{tabular}{|c|c|}
\hline Se prevé la actuación en 7.395 brazas de calzada & 394.527 mrs. \\
\hline $\begin{array}{l}\text { Se deben hacer de nuevo dos puentes de calicanto y reparar otros siete de } \\
\text { calicanto y una fuente }\end{array}$ & $312.840 \mathrm{mrs}$. \\
\hline Suman las 888 brazas de pared que se han de hacer & $109.425 \mathrm{mrs}$. \\
\hline Los tres caminos nuevos que evitarían los ocho puentes de madera & $85.000 \mathrm{mrs}$ \\
\hline Monta todo & $901.792 \mathrm{mrs}$. \\
\hline Para pagar a los escribanos, oficiales y personas que han de realizar la labor & $\begin{array}{l}\text { más de } \\
100.000 \text { mrs. }\end{array}$ \\
\hline Total & $1.098 .212 \mathrm{mrs}$. \\
\hline
\end{tabular}

El teniente y el alcalde mayor dicen que para hacer el camino para carros, se mandaría quitar un tributo que tienen los trajineros desde mucho tiempo atrás, algo necesario porque muchos de los pobladores de las localidades, "tenian por partido para su vivir, fazer puentes prestadas y calzadas perdidas e coxer con ellas lo que merezyan, e mui bien lo que no mereçian, de que esto se mande fazer como conbiene, a la clara muestran que no an dello plazer".

Se propone un primer repartimiento sobre las localidades por donde discurre el camino, así como sobre la Universidad de Mercaderes de Burgos y los mulateros:

\begin{tabular}{|c|c|}
\hline $\begin{array}{l}\text { Laredo "por el mucho probecho que esperan rreçibir andando el carro, por la carga e } \\
\text { descarga que en ella se a de fazer" }\end{array}$ & $100.000 \mathrm{mrs}$ \\
\hline Colindres "que a de ser el paso por medio del que ay en el" & $12.000 \mathrm{mrs}$ \\
\hline Limpias & $10.000 \mathrm{mrs}$. \\
\hline $\begin{array}{l}\text { Ampuero "porque la puente que se a de fazer en ella esta dentro del dicho lugar } e \\
\text { non puede bibir sin ella... e son los mas vesinos mesoneros" }\end{array}$ & $50.000 \mathrm{mrs}$ \\
\hline Cereceda & $6.000 \mathrm{mrs}$. \\
\hline Rasines y su partido & $30.000 \mathrm{mrs}$. \\
\hline Lanestosa "los mas dellos mesoneros e sin el paso non podrian bibir" & $20.000 \mathrm{mrs}$. \\
\hline El Prado que los 25 "vesinos son todos mesoneros" & $20.000 \mathrm{mrs}$. \\
\hline $\begin{array}{l}\text { La merindad de Montija además de los } 10.000 \text { mrs. que dieron para comen- } \\
\text { zar el puente de Quintanilla de Pienza }\end{array}$ & $10.000 \mathrm{mrs}$. \\
\hline Los mesoneros de Agüera, Villasante y ventas de El Ribero y de Revilla & $20.000 \mathrm{mrs}$. \\
\hline Medina de Pomar & $10.000 \mathrm{mrs}$. \\
\hline La Aldea, Queciles y Barruelo que "ay algunos mesones e los otros, mulateros" & $15.000 \mathrm{mrs}$. \\
\hline Bisjueces, Villalaín e Incinillas, con mesones en Bisjueces e Incinillas & $20.000 \mathrm{mrs}$. \\
\hline La venta de Medinilla & $2.000 \mathrm{mrs}$. \\
\hline Al abad de Rioseco porque consigue provecho & $3.000 \mathrm{mrs}$. \\
\hline La venta de Valdemera & $6.000 \mathrm{mrs}$. \\
\hline Al valle de Valdivielso "porque de andar el carro rreçiben gran provecho" & $40.000 \mathrm{mrs}$ \\
\hline
\end{tabular}




\begin{tabular}{|l|c|}
\hline $\begin{array}{l}\text { El Cuerno, Pesadas, Dobro, Escóbados y Quintanaloma para la fuente del } \\
\text { Cuerno y por tener 40 mesones }\end{array}$ & $25.000 \mathrm{mrs}$. \\
\hline Hontomín y Cernégula & $6.000 \mathrm{mrs}$. \\
\hline Villaverde y Peñahorada & $5.000 \mathrm{mrs}$. \\
\hline Quintanaortuño, Quintanilla-Vivar y Villatoro & $15.000 \mathrm{mrs}$ \\
\hline Burgos “por cuerpo de çibdad e por lo que se a de fazer en su termino” & $60.000 \mathrm{mrs}$. \\
\hline A la Universidad de los Mercaderes, por el ahorro que consiguen con el carro & $265.000 \mathrm{~ms}$. \\
\hline
\end{tabular}

Se reparten a los mulateros por los puentes que se evitan y por el provecho que reciben por los caminos aderezados, además de evitar los daños al caminar de noche con pescados frescos y demás mercaderías, y las grandes derramas que continuamente se les hacían: 260.000 mrs. en 2 años, pues en uno no se podría hacer la obra.

Llama la atención la poca cantidad repartida a Medina de Pomar con el argumento de que "en sus terminos no ay camino del aderezar por estar rreparados en las puentes della, ni tanpoco ay en ella mulateros ni mesones donde acojan mulateros, pero por algun prouecho que esperase seguir si el carro anda", algo incomprensible si no fuese por la presión ejercida por el Condestable, que a su vez "no sele rreparte cosa alguna, porque por doquiera que las mercaderias salgan, le an de pagar sus diezmos eninguna cosa leba que salgan por vn puerto que por otro, pues por doquier que las mercaderias salgan an de ser dezmadas e si vuestra alteza algo manda que pague, sera como sera a su seruiçio", cuando es el principal beneficiado del tráfico de mercaderías por este camino, lo que demuestra que en esta operación ha ejercido su poderosa influencia. El argumento de que el Condestable "ninguna cosa leba que salgan porvn puerto que por otro" porque recibe los mismos diezmos, pretende quitar valor al hecho de que tales diezmos son obtenidos del tráfico que se realiza, precisamente, por los caminos que se pretenden reparar.

De Laredo a Burgos se cruzan 17 puentes, diez de madera y siete de mazonería. Si el nuevo camino se hace con nuevo trazado, de estos diez de madera que de mazonería costarían más de 1.500.00o mrs., se evitarían ocho. Hacer de nuevo los otros dos de calicanto y reparar los otros siete, cuesta $312.840 \mathrm{mrs}$. Como quedan algunos mrs. de aportaciones anteriores, se mandó que se haga pesquisa y se aplique ${ }^{769}$.

769 Se detalla además, que para recuperar la piedra de los puentes caídos de Bolado y San Pedro de Ramales, que valía muchos dineros y fue llevada por vecinos y concejos, se averigüe quienes se la han llevado y la paguen tasada por oficiales.

- Que entre Burgos y Laredo es necesario que circule libre la carretería, y si hicieren daño al pan y al vino lo paguen, ya que hay más pastos que los que necesitan los pueblos para sus ganados

- Que la leña para quemar los caleros para las paredes que se han de hacer, sea franca y que las maderas necesarias para atravesar las calzadas, hacer barandas donde hay peligros y cimbras de los puentes, que se corten libremente en los montes comunes del lugar donde se hubiere de hacer, y que las maderas que la carretería necesite para enrejar sus carros, las sobrecamas y otros aparejos, las puedan cortar francamente porque aunque hay grandísimas montañas "es la gente achacosa".

- Que se pueda tomar libremente, la piedra necesaria para cal o para las obras.

- Que las bestias y bueyes afectos a las obras puedan pastar libremente en los términos y prados comunitarios no dehesados ni vedados, sin pagar nada por ello.

- Que los lugares donde "se an de fazer los caminos nuebos no los ynpidan ni enbarazen, pues se an de fazer por exidos conzegiles e no se toma heredad ninguna, ni parral ni cosa alguna de que se puedan quexar".

- Que los lugares de Gibaja y Guardamino, sostengan perpetuamente un puente que tienen sobre el río Carranza, pues se ha de hacer el camino nuevo por alli y como obtienen mucho provecho, han preferido hacerlo ellos.

- Que el puente de madera que atravesaba el camino real, que hizo Juan Sánchez sobre el cauce del molino junto al camino de Quintanilla de Pienza, lo haga de calicanto y él y sus sucesores, queden obligados a sostenerlo.

- Que se mande tasar el salario de las personas que tengan el cargo de cobrar, gastar y andar sobre la labor hasta que sea acabada la obra, "porque de personas de la tierra no se debe confiar, porque como es dicho, no an plazer de que se haga 
Los mulateros, pidieron además el arreglo de otros puentes y calzadas muy necesarios y contribuir con lo que les corresponda. De esta manera, en Montija el puente de cada villa y otros en la Nava y en Villasorda, se valoraron en 2.100 mrs., pero como esto era más de lo ordenado en la Provisión real, sería necesario para las Merindades mandar que se haga el repartimiento de los pontones de la Nava de Villasorda, porque los vecinos no lo han querido hacer esperando que otros los reparasen. Se manda que paguen $3.000 \mathrm{mrs}$. y los hagan. Asimismo, el teniente y el alcalde nombraron para el cobro desde Burgos hasta donde llega el juzgado de Castilla Vieja a Andrés de la Cadena, mercader vecino de Burgos, "ques honbre honrrado e bien avonado"; a Juan Sánchez de Angulo, vecino de Quintanilla de Pienza, para el juzgado de Castilla Vieja; y a Pedro Ruiz Cachopín, vecino de Laredo, en lo que alcanza el juzgado de Laredo.

El teniente y el alcalde mayor envían al Consejo con su parecer, la relación de todo lo que se necesita reparar y su coste, y el repartimiento propuesto a los mercaderes, venteros, mesoneros, mulateros, concejos y a todos los que por allí pasaren. También trabajaron para saber dos cosas: una si por dicho camino podrían circular carros, porque esas tierras "serian mucho aprobechadas e a menos costa e trabaxo basteçidas, segund la ysperienzia lo muestra en las otras partes donde anda la carreteria", y la otra que como el coste mayor era en los puentes que se debían rehacer por las continuas avenidas, y como los de madera duraban tan poco, si se evitaban algunos de ellos, se quitaría el tributo que los mulateros y viandantes han tenido desde tiempos remotos.

Los mulateros son los mayores y, en ocasiones, únicos interesados en que los caminos estén practicables y bien reparados con urgencia. Para ello tendrán un permanente seguimiento de este proceso, e insistirán de manera constante ante el Consejo Real para que se haga todo sin demora, desde el cobro de los repartimientos, hasta la recuperación del dinero malgastado o no aplicado al fin previsto. Por ello, en julio de 1499 comparecieron los procuradores de los mulateros ante el alcalde y el teniente, y dijeron que tras ver en el camino todo lo que se necesitaba hacer, "asi puentes e pontones como calzadas sangraderas, quebrantar peñas, ensanchar caminos e todas las otras cosas conplideras al rreparo de los dichos caminos", protestaban por si por dilatar el trámite, los caminos se dejasen de andar y el abastecimiento del Reino cesase, y dicen que todo el daño que recibiesen por no realizar la intervención, además de todas las costas y daños causados, sería a cargo del alcalde y teniente, por lo que se quejarían de ellos ante los Reyes como remisos a cumplir los mandamientos770.

El Consejo dicta algunas disposiciones para reunir los fondos necesarios, dando en agosto de 1499 otra Carta real, para que corregidor y alcalde, hiciesen sin demora el repartimiento que monta 1.113.000 mrs., pusiesen interés en hacer las obras planteadas para carretear el camino donde se pudiere, y en cobrar los mrs. a los concejos y personas,

bien e averle an de qualquiera cosa que se caya e desvarate e por su mano no se ternia seguridad que buena cosa se fiziese". Estas personas, deberán acudir al corregidor y alcalde más de una vez al mes a dar cuenta de lo que se hace y gasta.

- Que no se dificulte a la carretería el paso por los puentes de calicanto, puesto que lo que ahora se ha de gastar en ellos hará que estén muy firmes.

- Que la carretería no pague peaje, pontaje ni ninguna otra imposición.

- Que hechas las calzadas, paredes y puentes, que cada pueblo en su término sea obligado a sostenerlo y repararlo en adelante, pues lo harán a muy poca costa si lo mantienen cada año, evitando así deterioros mayores. 
enviando al Consejo el detalle de todo ello771. También mandó pagar 150 mrs. diarios al corregidor y al alcalde por los días ocupados y por salir fuera de sus jurisdicciones ${ }^{722}, 70$ mrs. al escribano y al cantero por ir a tasar las obras, y 80 mrs. a Juan de los Ríos por ir a la corte 773 .

El mismo día, el procurador de "la confradia de los mulateros rrecueros de la çibdad de Burgose de la uilla de Laredo e sus comarcas", se queja ante el Consejo de que en los últimos 10 años se les han repartido fuertes sumas para reparar estos caminos, cobrándolo algunas personas que jamás "han dado cuenta ni rrason de lo que asy han cobrado e rresçibido". El Consejo intenta recuperar las sumas mencionadas que se han despilfarrado o desviado, y manda al corregidor y al alcalde mayor, que se informen sobre los repartimientos realizados, y a los que los han recibido y gastado les pidan que presenten las cuentas y todo lo que no se ha gastado en caminos, puentes y calzadas, que lo entreguen para hacer las obras 774 , algo que no se cumplió, porque en agosto de 1500 , el procurador de los mulateros se vuelve a quejar de que no se ha cumplido la orden dada, y no se han tomado las cuentas a los que habían recaudado los repartimientos, ni recuperado lo que no se había gastado en los reparos, y que por eso están "muchos quentos de mrs. en poder de los cogedores que asy lo han rrecabdado e no se han adobado los dichos caminos".

El Consejo manda que en 6 días se junten para cumplir la Carta real y hagan todo lo que por ella se manda775. Como los trabajos seguían sin ejecutarse y las órdenes sin cumplirse, el procurador se queja porque habían ganado una Carta y Provisión real para que el corregidor hiciese cobrar los 1.113 .000 mrs. repartidos en 1499, pero afirma que no lo ha querido hacer "poniendo a ello... escusas e dilaçiones yndevidas". Los caminos siguen deteriorados, y pide que se mande cumplir la Carta, porque "sy agora en verano non se rreparasen e viniese el ynuierno syn se rreparar, non se podrian andar los dichos caminos". El Consejo reitera al corregidor y al alcalde mayor, la orden de recibir el dinero del repartimiento776.

En el repartimiento realizado, tocó a la cofradía de los mulateros de la merindad de Castilla Vieja, 260.00o mrs. repartidos en 2 años, por ser los principales beneficiarios de la intervención y por evitar con ella las grandes derramas que se les hacían continuamente. El corregidor y el alcalde habían estimado que la manera más factible de percibirlos era la de cargar 1 real a cada bestia de carga que pasase por el camino, dando mandamiento para ello, lo que era irregular. Los mulateros echaron los 130.000 mrs. del primer año por imposición, arrendando en 1499 por un año el cobro de ese real por acémila a Fernando Ruiz de Cenares, escribano y vecino de Medina de Pomar, por dichos 130.000 mrs. En agosto de 1500, el prior de los mulateros dijo al Consejo que Cenares no quería pagarles la renta de ese año y el Consejo manda al corregidor y al alcalde, que si el contrato mencionado trae

771 A. G. S./ Registro General del Sello, VIII-1499, fol. 253/Valladolid, 27 agosto 1499

772 A. G. S./ Registro General del Sello, VIII-1499, fol. 196/ Valladolid, 27 agosto 1499.

773 A. G. S./ Registro General del Sello, VIII-1499, fol. 202/Valladolid, 27 agosto 1499

774 A. G. S./ Registro General del Sello, VIII-1499, fol. 44/Valladolid, 27 agosto 1499.

775 A. G. S./ Registro General del Sello, VIII-1500, fol. 50/ Valladolid, 4 agosto 1500.

776 A. G. S./ Registro General del Sello, VIII-1500, fol. 365/Valladolid, 3 agosto 1500. 
aparejada ejecución se ejecute777. También mandará que no se ponga ninguna imposición en dichos caminos, y que todos los carreteros, mulateros, mercaderes y caminantes puedan pasar libremente $77^{78}$.

En octubre, Cenares, compareció ante el Consejo con motivo de la Carta real, que mandaba ejecutar contra él y sus bienes la obligación de los $130.000 \mathrm{mrs}$, y dijo que la Carta era muy injusta, porque al no mandar pagar a los mulateros 1 real por mulo, recua o bestia, era nueva imposición al cargar el pago a las villas y lugares de la comarca y no a los mulateros ni a sus bestias y por ello estos se resistían al pago, y que había requerido al alcalde mayor que le había hecho el arrendamiento y no hizo nada. Además el alcalde no quiso ir donde se debía coger la renta, por miedo a que lo "matasen los dichos mulateros e lacayos que con ellos benian", y si Cenares llevaba algún merino para ayudarle lo amenazaban, e incluso a uno le quebraron la vara y quisieron matar. Estaba dispuesto a pagar lo que había recaudado, pero que por no haber podido cobrar la dicha renta, él recibía mucho daño. Pedía que se mandase sobreseer la ejecución, porque cuando supo que la renta era imposición nueva no la osó cobrar. El Consejo reiteró que no se echase imposición alguna por ir contra el tenor de la carta y leyes de los reinos, y que Cenares dé cuenta de todo lo cobrado y lo devuelva779.

Como el alcalde echó por imposición 1 real a cada acémila, mulo o rocín que pasase por la Merindad, medio real a cada bestia menor, y a los ganados y puercos cierta cantidad, y los procuradores de los mulateros lo consintieron y dieron lugar a que se arrendase, los Reyes quieren saber el motivo que se tuvo, y mandan que en 15 días se presenten ante el Consejo ${ }^{780}$. Un mes después, como el procurador de los mulateros no ha comparecido, dan un nuevo plazo de 20 días ${ }^{781}$. El Consejo, acordó en diciembre de 1500, apremiar a Cenares, para que dé cuenta al corregidor de todos los mrs. que había cobrado de la renta, y devuelva todos los mrs. que debe, haciéndole sobre ello todas las prendas, prisiones, ejecuciones, ventas y remates que convengan ${ }^{782}$. Para el pago de los $260.000 \mathrm{mrs}$. que tocaba a los mulateros, el Consejo mandó que el 15 de enero de 1501, se junten todos los procuradores de los mulateros en el lugar de Prado con Fernando Diáñez de Alcocer, continuo de la casa y corte real, y enviado por el Consejo para que ordene este asunto783. Se mandó pues a Diáñez, que hiciese el repartimiento y recibiese de Cenares lo que cobró, y que se repartan los 260.000 mrs., entre los mulateros de la cofradía, y que sus procuradores los entreguen. También manda que los concejos, valles y personas repartidos, acudan con los mrs. recaudados, por lo que Diáñez, al margen de las apelaciones que fueren interpuestas, hará ejecutar el repartimiento y dará cuenta en el Consejo ${ }^{784}$.

777

A. G. S./ Registro General del Sello, VIII-1500, fol. 52/ Valladolid, 17 agosto 1500.

A. G. S./ Registro General del Sello, VIII-1499, fol. 253/Valladolid, 27 agosto 1499.

A. G. S./ Registro General del Sello, X-1500, fol. 444/Valladolid, 1 octubre 1500.

A. G. S./ Registro General del Sello, X-1500, fol. 476/Valladolid, 1 octubre 1500.

A. G. S./ Registro General del Sello, XI-1500, fol. 233/Valladolid, 3 noviembre 1500.

A. G. S./ Registro General del Sello, XII-1500, fol. 337/Valladolid, 4 diciembre 1500.

A. G. S./ Registro General del Sello, XII-1500, fol. 364/Valladolid, 4 diciembre 1500.

A. G. S./ Registro General del Sello, II-1501, fol. 447/ Valladolid, 30 enero 1501. 
Cenares fue incapaz de presentar las cuentas exactas. Los procuradores de los mulateros habían visto la cuenta dada por él, correspondiente al peaje de cerca de seis meses, cuando se pudo coger bien por ser cuando las recuas continuaban hasta los puertos. Lo que presentaba no llegaba a 60.000 mrs. y además quería cargar muchas costas por el cobro. El Consejo mandó en marzo, que Diáñez se informe por los que han cobrado los peajes, para saber lo que se debe descontar a Cenares del tiempo que no cobró el peaje y que según el arrendamiento lo debía cobrar, y determine una cantidad justa785. Se había mandado a Diáñez que debía cobrar los mrs. del repartimiento en un plazo de 60 días y como no lo había podido cumplir, se le dieron otros sesenta786.

Dichos procuradores habían tratado con Diáñez que no podrían pagar los 260.000 mrs. que les fueron repartidos, sino cobrando a los mulateros de la provincia de Burgos cierta cantidad por las acémilas que cada uno tenía, y que los que más tuviesen más pagasen, poniendo personas para cobrarlo en dos o tres puertos de los más transitados, y que si esto no era suficiente, que se diese licencia para que se pudiesen valorar las acémilas de cada mulatero y repartir por millar lo que fuese necesario "o que se pudiese coger por rrenta e arrendamiento", que era lo que más les convenía. El Consejo reitera que lo que cabe pagar a los mulateros, se haga repartiendo según las bestias que cada uno tuviere y no por vía de imposición, y mandó a Diáñez que con acuerdo de los procuradores, reparta sobre cada uno de los recueros y mulateros de la Universidad según las acémilas, rocines y asnos que cada uno tuviere ${ }^{787}$. Pedro Ruiz de Sedano, procurador de los mulateros, dijo que por la renta que Cenares cobró de los mulateros, fue condenado por el Consejo y que aunque ha sido requerido, no lo ha querido hacer ni cumplir. La sentencia condenaba a Cenares a pagar 90.00o mrs. descontando lo que le correspondiese por su trabajo, y lo que depositó en poder de Andrés de la Cadena. En octubre, se manda al corregidor que averigüe lo que Cenares debe cobrar por su trabajo y se descuente de los 90.000 mrs., depositando el resto, y que el corregidor de Burgos cumpla y ejecute la sentencia como en ella se contiene ${ }^{788}$.

Se hizo un nuevo repartimiento contra el que hubo un cúmulo de alegaciones motivadas, básicamente, por ser la primera vez que las Merindades participaban en el reparo de sus caminos. Hasta ese momento las reparaciones las habían efectuado las localidades por donde este camino discurría, contribuyendo en ocasiones los mulateros y comerciantes. Las Merindades eran tierras de realengo y sus habitantes eran en su mayoría hidalgos, con un inmenso orgullo de su pasado histórico ${ }^{789}$ y tomaron esta medida como un agravio. Así, los procuradores de las merindades de Castilla Vieja, Valdivielso y Cuesta-Urria dijeron a los Reyes, que se repartieron a la de Castilla Vieja y ciertos lugares de ella 62.00o mrs. , a la de Valdivielso 65.000 mrs. y a la de Cuesta-Urria otros mrs., pero que como no los pagan, Diáñez quiere hacer ejecución de ellos en sus bienes. El Consejo acordó man-

785 A. G. S./ Registro General del Sello, III-1501, fol. 604/Valladolid, 19 marzo 1501.

786 A. G. S./ Registro General del Sello, III-1501, fol. 593/Valladolid, 19 marzo 1501.

787 A. G. S./ Registro General del Sello, III-1501, fol. 592/Valladolid, 20 marzo 1501.

788 A. G. S./ Registro General del Sello, X-1501, fol. 313/Granada, 23 octubre 1501.

789 LÓPEZ ROJO, M.: 2008: 150. 
dar que Diáñez cobre los mrs. repartidos, y que después se vean las causas que aducen790. También las Merindades alegaban que tal repartimiento era injusto, porque la provisión fue dictada "con falsa rrelaçion e callada la verdad", y decían que de tiempo inmemorial las calzadas se aderezaban a costa de los que utilizaban esos caminos, y nunca dieron ni contribuyeron para ello "los dichos valles e Merindades, ni los que moran en ellos que son caballeros e fijosdalgo cosa ninguna, e que no son tenidos ni obligados a pagar ni contribuir en semejantes cosas, eque se an seruido [a los Reyes y sus] anteçesores a sus costas con grandes trabajos e muertes de muchos onbres", por lo que no había razón para que se les pusiese nueva imposición, ya que los dichos valles y Merindades no se aprovechan de las calzadas ni las necesitan, por lo que los que debían pagar eran los mulateros y viandantes, los mercaderes de Burgos, los que viven en los puertos y los mesoneros y personas semejantes, que eran los que recibían provecho791.

El procurador de la merindad de Montija, dijo que la cantidad de 57.400 mrs. "auia seydo muy ynjusta y agrauiada contra los dichos sus partes, e que auia seydo ganada con falsa e no verdadera rrelaçion", porque siempre los reparos de esas calzadas se hicieron a costa de los que las utilizaban, y que sus vecinos no estaban obligados a ello792. También el procurador del concejo de Medina de Pomar y de Queciles, Barruelo y La Aldea, dijo que por ciertas libertades y exenciones que tienen, no pagan los $25.000 \mathrm{mrs}$. que les fueron repartidos 793 , y el procurador del concejo de Lanestosa, expone sobre los $20.000 \mathrm{mrs}$. asignados, que nunca contribuyeron en repartimiento alguno para ese fin porque ellos tienen sus caminos bien aderezados, y no reciben provecho de los que se mandan reparar794. También el procurador de los concejos de Ampuero que debía pagar 50.000 mrs. y Cereceda, 6.000795 y el de los de Limpias con 10.000 y Colindres con 12.000 , alegaron similares razones para justificar su negativa al pago796.

La ciudad de Burgos, la Universidad de los Mercaderes, el concejo de Prado y otros concejos, valles, Merindades y particulares, indicaron que están muy agraviados, unos porque no estaban obligados a contribuir porque para esas obras nunca les repartieron cosa alguna, otros porque se les repartió más de lo que se debía y a otros concejos no se les repartió cosa alguna o no todo lo que debían pagar, otros que harto tenían con reparar sus puentes, caminos y calzadas, otros que los puentes y caminos de su jurisdicción lo querían reparar a su costa a cuenta de lo que se les iba a cobrar, y otros en fin, que tenían privilegios. Como se habían presentado tantas alegaciones, el Consejo, acordó en abril de 1501, que para que las obras no se demorasen y se hagan con menos perjuicio de las partes, los representantes de los afectados traten con Diáñez sobre ello para que mande lo que convenga, y mientras, que Diáñez paralice el cobro y su ejecución ${ }^{797}$. Los mulateros

790 A. G. S./ Registro General del Sello, III-1501, fol. 601/Valladolid, 16 marzo 1501.

791 A. G. S./ Registro General del Sello, III-1501, fol. 600/Valladolid, 16 marzo 1501.

792 A. G. S./ Registro General del Sello, III-1501, fol. 378/ Valladolid, 18 marzo 1501.

793 A. G. S./ Registro General del Sello, III-1501, fol. 386/ Valladolid, 18 marzo 1501.

794 A. G. S./ Registro General del Sello, III-1501, fol. 382/Valladolid, 23 marzo 1501.

795 A. G. S./ Registro General del Sello, III-1501, fol. 597/ Valladolid, 24 marzo 1501.

796 A. G. S./ Registro General del Sello, III-1501, fol. 590/Valladolid, 30 marzo 1501.

797 A. G. S./ Registro General del Sello, IV-1501, fol. 322/Valladolid, 24 abril 1501. 
a su vez se quejan de que por todas estas excusas, no se efectúan los reparos necesarios. Para evitar gastos a las Merindades, concejos y personas agraviados, el Consejo acordó que Diáñez cobre los mrs. que a cada uno le tocaban, y oídas las partes, envíe información con su parecer al Consejo, sobre si esos concejos y Merindades han acostumbrado pagar los reparos, a que costa se hacían, quién los reparaba, si sus vecinos se aprovechan de ellos, y que distancia hay de sus lugares a los puentes y caminos 798 .

Los mulateros también propusieron que algunos de estos caminos se podían trazar por partes menos ásperas y más convenientes, pudiéndose hacer sin nueva provisión económica, logrando con ello una traza más corta y menos accidentada ${ }^{799}$. Propusieron para ello que era necesario con el fin de que puedan pasar los carros, hacer el puente de Bolado e ir por camino más llano y corto, valorado en $260.000 \mathrm{mrs}$. Había repartidos 50.000 mrs. para hacer el otro camino que se evitarían si se hace este puente, y otros $75.000 \mathrm{mrs}$. que se habían cobrado de los mercaderes de Burgos para lo mismo. El Consejo encomendó a Diáñez que envíe información sobre la necesidad de estos cambios, si los caminos serían más llanos y menos peligrosos, y el puente necesario, cuánto podría costar todo, y si algún concejo recibe agravio y las heredades daño ${ }^{800}$.

Con el fin de señalar ciertas partes del camino para los tiempos de nieves en las partes elevadas del recorrido, se debían colocar mojoyas o mojones de fábrica. Los procuradores de los mulateros dijeron que en los puertos del Butrón y de Sendero Enhiesto, que son cinco leguas "de despoblados porque son puertos muy altos e cargan en ellos muchas nieues", era necesario poner 150 mojoyas de calicanto de 10 pies de altura. Han de ser espesas porque con la ventisca alcanza poco la vista y que sin ellas, peligraban muchas personas y acémilas porque no podían seguir el camino, las cuales fueron valoradas en 22.500 mrs., a 150 cada una. Pidieron que contribuyesen Villaescusa del Butrón y Quintanilla de Pienza y sus ventas, que se habían olvidado en un repartimiento anterior. El Consejo mandó en marzo de 1501, que Diáñez se informe sobre si las mojoyas son necesarias y qué provecho obtienen de ello los mulateros, quiénes deben contribuir y cuánto podrían costar. Si son necesarias para evitar los peligros, las deberá hacer repartiéndolo entre los que recibieren beneficio ${ }^{801}$.

El procurador de Gibaja, Guardamino, Helguera y del Agua de Silienzo más allá de la parte del lugar de Ojebar, que con Fresno "son fuera del camino rreal que va de Burgos a Laredo", dijo que les habían mandado depositar 20.000 mrs. en Juan Conzález de Ramales, y que sus lugares no debían contribuir en estos caminos y puentes por no estar en ellos, acordando el Consejo que se les mandase devolver dichos mrs. ${ }^{802}$. Como los cobros tenían continuos retrasos, problemas y alegaciones, algo que repercutía directamente en la falta de liquidez para afrontar las reparaciones, estas no se llevaban a cabo de acuerdo con los planes de 1499, y se retrasaban o paralizaban de manera exasperante. Así en mayo de 1501 se realiza una conferencia en el Consejo en la que se dan algunas precisiones sobre los trabajos.

\footnotetext{
798 A. G. S./ Registro General del Sello, III-1501, fol. 605/ Valladolid, 29 marzo 1501.

799 A. G. S./ Registro General del Sello, III-1501, fol. 591/Valladolid, 20 marzo 1501; MOLÉNAT, J. P.: $1971: 147$.

800 A. G. S./ Registro General del Sello, III-1501, fol. 603/ Valladolid, 20 marzo 1501.

801 A. G. S./ Registro General del Sello, III-1501, fol. G02/Valladolid, 22 marzo 1501; MOLÉNAT, J. P.: $1971: 146$.

802 A. G. S./ Registro General del Sello, VI-1501, fol. 456/ Valladolid, 4 junio 1501.
} 
Fernando Diáñez con los procuradores de Burgos, Universidad de los Mercaderes de esa ciudad, merindades de Valdivielso, Montija y Castilla Vieja, Medina de Pomar, Prado de Concha, Lanestosa, junta de Parayas, Cereceda, Ampuero, Limpias, Colindres, Laredo y tres procuradores de los mulateros y viandantes, trataron sobre cómo se debían hacer las intervenciones a menor coste y daño de las partes, acordando que solo se cargue la contribución a los lugares que están en el camino real y a los mesoneros. Salvo algunos lugares que no podían responder por tener muy pocos vecinos, todos los demás debían hacer los reparos en sus términos, y se les dan instrucciones para que procedan a los pagos que correspondan y realicen las intervenciones necesarias, de la siguiente manera:

- La ciudad de Burgos hará en el camino real, todas las brazas de calzadas de su término que están pendientes.

- Que Vivar, Quintanaortuño, Villaverde, Peñahorada, Hontomín y Cernégula arreglen los caminos de sus términos y se ayuden entre ellos conforme al repartimiento. Peñahorada hará mojoyas y Hontomín todas las brazas de su término, 6 mojoyas hasta los Olmos y dos pontones, pagando los mesoneros del lugar $1 / 3$ de todo y los vecinos los otros $2 / 3$, y el concejo $3.000 \mathrm{mrs}$. para las costas, no estando obligados a pagar a ningún otro concejo ni que otro concejo ayude a Hontomín.

- Del Cuerno a Masa son necesarias 100 mojoyas de 12 pies de alto, y las deben hacer el valle de Sedano y el lugar de Masa cada uno en su término, "e ayan sus señales para conosçer a que parte van". No ayuda Quintanaloma porque ya lo hace en las otras.

- De Cernégula a la Horca, Cernégula debe hacer 15 mojoyas a piedra seca de 10 pies de alto seguidas y bien anchas, "con sus señales que sepan qual va a Burgos e qual va al Cuerno", y del dicho término a la Hoz del Almiñé 80 mojoyas de la misma manera, hechas a vista del procurador de los mulateros y del de Valdivielso. Las harán los lugares de Quintanaloma, Escóbados, Dobro y Villaescusa, y si Villaescusa no les quiere ayudar, que pague a los que las hicieren $4.000 \mathrm{mrs}$. de los depositados.

- Desde El Cuerno hasta la Peña Palomera en los Hocinos, entre la merindad de Valdivielso y Castilla Vieja, lo harán de calzadas donde fuere necesario y en los Hocinos, harán pared de mazonería y romperán algunas peñas, a juicio de canteros, de los procuradores del valle y de los mulateros. Los mesoneros pagarán $2 / 3$ con "Ia venta en que biue Luxan", y el otro 1/3 Pesadas, El Almiñé y Puente-Arenas. Se les dará a los pueblos $4.000 \mathrm{mrs}$. de ayuda, de los mrs. pagados por mercaderes y mulateros.

- Los del Cuerno han de pagar 3.000 mrs., repartidos 2.000 a los mesoneros y 1.000 a los pueblos de El Cuerno, Pesadas, Dobro, Escóbados y Quintanaloma. Hasta la Peña Palomera en los Hocinos, lo han de hacer los dichos lugares, y desde la Peña Palomera lo hará el procurador de Castilla Vieja, con los 4.00o mrs. que dé Sancho Díaz por su venta en los Hocinos. Harán paredes de mazonería y quitarán las peñas sobre el camino y las calzadas hasta llegar al término del abad de Rioseco, dándoles para ayuda sin lo de Sancho Díaz, $10.000 \mathrm{mrs}$. de los mercaderes y mulateros.

- En los Hocinos, pasado el término de Llano de la merindad de Castilla Vieja, entra el del abad de Rioseco y harán lo que fuere necesario de pared de cal y canto, calzadas y romper algunas peñas.

- En el término de Bisjueces sin que haga el abad de Rioseco su término, le quedan muchas brazas de calzada hasta llegar al de La Aldea con pocos vecinos. Jurarán cuántos venteros hay y pagarán 1.000 mrs., y lo demás a cumplimiento de la Merindad o harán todo lo que faltare en sus términos. Se les dará para ayuda 12.000 mrs. de los mercaderes y mulateros, y lo que más costare menos los mrs. de los mesoneros, el procurador los repartirá por vecinos.

- Medina de Pomar reparará todo su término, desde el de Bisjueces hasta el de Montija, que entra en La Aldea, hasta el molino de Juan Sánchez de Quintanilla, que 
como rompió el camino real para hacer su molino, hará allí un puente de madera o de cal y canto y lo mantendrá en adelante.

- Para el puente de Quintanilla de Pienza, pagaron los de Montija 10.000 mrs., y los mesoneros que están en el camino real darán otros 6.000 mrs., y los repartirá su procurador. Cuando los mesoneros paguen, harán en la Merindad las calzadas, quebrarán peñas, allanarán el camino real, darán arreglados los puentes de Agüera y del Ribero, y se repartirá por su procurador todo lo que haya en el término, de manera que quede bien hecho. Además de los 16.000 mrs., se han de dar para el puente de Quintanilla de Pienza 49.000 más.

- En las Llamosas de "Sandeniesto", han de pagar $2.380 \mathrm{mrs}$. de calzadas, quebrar algunas peñas, y poner unas 6 mojoyas encima del puerto. Aquí hay que hacer calzadas anchas, poner barandas y echar maderos en la orilla de la calzada de la parte de abajo. En El Prado, los tres mesoneros pagarán $5.000 \mathrm{mrs}$. y los vecinos 4.000. Los $13.000 \mathrm{mrs}$. que faltarán para este puerto, que se paguen de los de los mercaderes y mulateros, y el puente de madera está bien por ahora. El que se encargue de hacer las mojoyas, deberá plantar en el puerto en invierno 12 quejigos pequeños de pie.

- Los de la Calera arreglarán el pontón y un poco de calzada hasta la punta de la sierra hacia Lanestosa.

- En Valnera hay que hacer algunas calzadas antes de llegar a Lanestosa, y otras desde Lanestosa hasta el puente de la Pared. En Lanestosa tienen hecho un puente y deberán mejorar el que está torcido al molino y para este puente y las calzadas de su término, se les darán 6.500 mrs.

- En Ramales hicieron dos puentes de madera y como pasa la recua por ellos, deberán ser ayudados con $2.000 \mathrm{mrs}$. del valle de Ruesga, $2.000 \mathrm{mrs}$. de la Junta de Voto y otros $10.000 \mathrm{mrs}$. de los mercaderes y mulateros para hacer lo que falta del camino más allá del río, allanar la cuesta y romper algunas peñas. Este camino que va derecho al molino de Pedro Sánchez Sarabia, lo harán los mesoneros de Ramales.

- Los vecinos de Bárcena de Bolado, ayudarán en su término con 4 días a su costa, en las calzadas y lugares necesarios más cercanos o paguen 200 mrs. Faltarán de Ramales a Bárcena 5.000 mrs. para que lo hagan los de los lugares, que se darán de los mrs. de los mercaderes y mulateros.

- Rasines hará su término desde Bolado hasta el castaño de Armontín, junto con Laredo y Ampuero lugares de su Merindad, y ayudará Cereceda en el puente de mazonería, pues por no seguir el camino del Carro, es suficiente que sea de madera.

- Limpias deberá hacer en su término lo que está pendiente y los pontones, alargarán sus caminos de 8 codos de ancho donde haya lugar, y reharán las calzadas que están rotas, todo según el cantero y el procurador de los mulateros.

- Colindres alargará sus caminos de 8 codos de ancho hasta llegar al pueblo, y donde se pueda, harán todo el camino de calzadas bien anchas. Se les darán 10.000 mrs. de los dineros de los mercaderes y mulateros.

- Laredo hará todo desde Colindres a Laredo con sus términos.

Todos estos caminos y puentes se deben hacer para fin de septiembre de 1501, perfectamente a vista de los procuradores de los mulateros y de cada Merindad, con un cantero en cada término, pagándoles la mitad de lo que está tasado al comienzo de la obra, y la otra mitad después de realizada.

La mayor parte de los puentes estaban aún previstos en madera, pero un proyecto importante fue el del puente de Bolado con sus pilares de mazonería y maderas gruesas, con un coste de 360.000 mrs. Una comisión de los mercaderes de Burgos, la villa de Laredo y los mulateros concierta el contrato, lo iguala con los maestros y vela para que el puente 
se acabe en septiembre de 1502, nombrando una persona experta, para que vea si la obra se hace en las condiciones acordadas. Se registrarán todos los gastos, y todo lo que han de pagar los mercaderes, mulateros y Laredo, se depositará bajo la custodia de Andrés de la Cadena y Fernando Ruiz de Villasante.

El Consejo acordó en junio de 1501 hacer todo antes de que llegase el invierno mientras se resolvían las reclamaciones, y sin perjuicio del derecho que cada uno decía poseer, y si después del pago se hallare que alguno no está obligado a ello, se mandará devolver lo adelantado. Los mercaderes de Burgos se quejaron sobre los 1.000 florines repartidos en el primer repartimiento, porque decían que Laredo y los recueros, viandantes y otras personas, recibían más provecho y utilidad que ellos, por lo que se acordó que de los 1.000 florines (265.000 mrs.), se repartan a la Universidad de los Mercaderes 150.000 mrs., 50.000 mrs. a la villa de Laredo y a los mulateros y recueros 65.000 mrs. además de los 260.000 mrs. que ya tenían del primer repartimiento, y mandan que se los devolverán si después pareciere que la Universidad no debe pagar cosa alguna, o tanto como se les asignó. También se manda que se acaben de recaudar los mrs. que tocan a los recueros, para que con ellos y con los que se manda pagar a la Universidad y a Laredo se haga el puente de Bolado. Como se han de cobrar a los mulateros los $260.000 \mathrm{mrs}$. del primer repartimiento, descontando lo que ya han pagado más los 65.000 mrs. que se les carga ahora, y para que en su recaudo no haya fraude ni echen sisa, repartimiento ni imposición en ningún camino ni puente, se manda que el procurador de los mulateros convoque a sus miembros para repartir lo que les corresponde de acuerdo con las bestias que cada uno tiene, hasta alcanzar los 325.000 mrs. , y se asigne plazo para que lo paguen a Fernando Ruiz de Villasante en el lugar de Villasante y lo aplique al puente de Bolado, y si no pagaren mandan a Fernando Ruiz que los cobre de los contantes, ya que no se puede cobrar de nadie que no sea cofrade. También se mandó que Laredo deposite en Fernando Ruiz sus 50.000 mrs., y que los 150.000 mrs. que debía pagar la Universidad, lo hagan en Andrés de la Cadena ${ }^{803}$.

El Prior y cónsules de los mercaderes de Burgos, habían recibido 45.000 mrs. de un resto de cada cosecha que se había cogido para el reparo del puente de Bolado, que debían depositarlos en Andrés de la Cadena procurador de la Universidad de Burgos, y como no lo hicieron, Diáñez tomó en Medina de Pomar a Alonso de Castro mercader de Burgos ciertas balas de fustanes y los puso en almoneda por dicha cantidad, que era la que la Universidad debía. Para que Castro pudiese cobrar el daño y costas que del remate de los fustanes se seguía, pide justicia al Consejo, que mandó en junio de 1501 a Andrés de la Cadena, la restitución de los dichos 45.000 mrs. ${ }^{804}$.

El procurador de los mulateros dijo al Consejo que se había mandado a Diáñez el cobro de 10.000 mrs. a Juan Sánchez de Briviesca, vecino de Medina de Pomar y antiguo alcalde mayor de Castilla Vieja, en que fue condenado por el Consejo, y que Diáñez recibiese además, de los herederos de Pedro Pérez de Salinas, los 3.327,5 mrs. que quedaron por pagar de los mrs. que cobró Salinas a los de Rasines. El Consejo manda en junio de 1501 que en 15 días paguen los mrs. que ambos deben, y si no lo pagan, que los alcaldes y justi-

803 A. G. S./ Registro General del Sello, VI-1501, fol. 460/Valladolid, 5 junio 1501; MOLÉNAT, J. P.: 1971: $157-160$.

804 A. G. S./ Registro General del Sello, VI-1501, fol. 360/ Valladolid, 17 junio 1501. 
cias de Medina de Pomar los apremien y hagan todas las ejecuciones, ventas y remates de bienes que convengan, y su producto se entregue a Andrés de la Cadena ${ }^{805}$. Cinco días después, los mulateros dijeron en el Consejo que Juan Sánchez hizo repartimientos y que por una comisión real que se mandó al corregidor de las Cuatro Villas y a Sánchez, este cobró algunos mrs. y recibió 80.000 que los Reyes le facilitaron, de los que no ha dado cuenta ni razón. El Consejo mandó al corregidor de Burgos, que reciba la cuenta de Sánchez con todo lo que ha cobrado de los repartimientos y de la libranza de los 80.000 mrs., ante un procurador de la Universidad, otro de los mulateros y otro de Laredo para que no se haga fraude alguno, y que todo lo que se ha malgastado, lo deposite en poder de Andrés de la Cadena, y se envíen al Consejo las cuentas, gastos y alcances ${ }^{806}$.

Los Reyes recuerdan al Prior y cónsules de los mercaderes en julio de 1501, que les mandaron depositar en Andrés de la Cadena los 150.000 mrs. del segundo repartimiento, de los 1.000 florines que les estaban asignados en el primero, y de los $45.000 \mathrm{mrs}$. que habían tomado de los herederos de Pedro Pérez de Salinas para gastarlos en el puente de Bolado y en las otras obras y reparos. Los mercaderes, la villa de Laredo y los mulateros debían enviar a sus procuradores para hacer el puente, por lo que se dio una nueva Carta real para que los mercaderes y los de Laredo enviasen a sus procuradores a Rasines, cerca del río de Bolado, y no lo quisieron hacer ni iniciar la obra "poniendo a ello vuestras chansas e dilaçiones yndeuidas", por lo que el procurador de los mulateros dijo al Consejo que si se diese lugar a aceptar la postura de los mercaderes, los puentes, caminos y calzadas no se podrían reparar. El Consejo mandó que, a pesar de las súplicas de los mercaderes, pongan en obra lo que se ha mandado ${ }^{807}$. Siendo requeridos el Prior y cónsules de la Universidad para pagar las cantidades que les correspondían, los Reyes volvieron a mandar su pago y no quisieron hacerlo, por lo que los mulateros pidieron que se cobrasen a los mercaderes los 195.000 mrs. El Consejo acordó que ejecuten lo ordenado y pongan en poder de Andrés de la Cadena, los $195.000 \mathrm{mrs}$, , con apercibimiento de que si no lo hicieren, se enviará a su costa una persona de la corte que lo ejecute ${ }^{808}$.

En el pleito entre los mercaderes, la villa de Laredo y los mulateros, sobre que, la Universidad no quiere pagar cosa alguna alegando que si tuviesen que contribuir, sería contra toda razón y justicia; el Consejo manda que los corregidores de Burgos y las Cuatro Villas, reciban a las partes a la prueba de todo lo que han alegado, y se le remita todo para proveer justicia ${ }^{809}$. Siete días después, el Consejo informa a los corregidores, que los procuradores de los mercaderes, de Laredo y de los mulateros, fueron citados a prueba en 60 días ${ }^{810}$. El procurador de los mulateros dijo que, ante el Consejo, fue tratado pleito entre ellos y los hijos del difunto Pedro Pérez de Salinas sobre cierto cobro que este les hizo para reparar los caminos, puentes y calzadas de la provincia de Burgos, y que de él quedaron en poder de

805 A. G. S./ Registro General del Sello, VI-1501, fol. 454/Valladolid, 21 junio 1501.

806 A. G. S./ Registro General del Sello, VI-1501, fol. 453/Valladolid, 26 junio 1501.

807 A. G. S./ Registro General del Sello, VII-1501, fol. 545/Valladolid, 3 julio 1501.

808 A. G. S./ Registro General del Sello, VII-1501, fol. 129/Valladolid, 21 julio 1501.

809 A. G. S./ Registro General del Sello, VII-1501, fol. 543/Valladolid, 1 julio 1501 y A. G. S./ Registro General del Sello, VII-1501, fol. 500/Valladolid, 1 julio 1501.

810 A. G. S./ Registro General del Sello, VII-1501, fol. 339/Valladolid, 8 julio 1501. 
Pedro Pérez 3.700 mrs. Dice que el Consejo mandó que los pagasen sus herederos y, siendo requeridos con una Carta real, no lo han querido hacer. El Consejo mandó al corregidor de Burgos, que los herederos de Salinas paguen los dichos 3.700 mrs., para el reparo de los puentes, caminos y calzadas entre Burgos y Laredo ${ }^{811}$.

El Consejo había acordado en junio de 1501, mandar a los mercaderes, Laredo y mulateros, que en 12 días nombren a sus diputados para que se haga un nuevo puente de pilares de cal y canto sobre el río de Bolado, y que mientras se construye, se haga otro de madera para el próximo invierno. También se mandó que todo lo preciso para hacer la cal, y la leña y madera necesarias, se pueda tomar libremente de cualquier término junto al río donde se haga el puente ${ }^{812}$. Algunas comunidades y personas obligadas al pago, pusieron poca diligencia por no estar la cuestión de derecho resuelta, y en octubre de 1501, al término de la temporada adecuada para los trabajos, el procurador de los mulateros se queja porque, aunque algunos han depositado ya los mrs. repartidos y otros lo han comenzado a hacer, no han recibido lo que debían para acabar las obras porque no lo han querido pagar. Por ello algunos concejos no han reparado en sus términos lo que les cupo, y el puente de Bolado, que se encargó por 360.00o mrs., no se acaba de hacer por no recibir los mrs. del depósito. El Consejo mandó al corregidor de Burgos, que vaya en persona a los caminos y puentes y lo que no estuviere hecho que lo mande hacer pagándolo con los mrs. depositados. Este manda a todos los concejos y justicias que hagan los reparos, de manera que "lo mas presto que ser pueda, sean fechas e reparadas las dichas puentes e caminos e calçadas, porque desque en ora buena vengan los ylustrysymos prinçipes don Felipee doña Juana archiduques de Avstria duques de Borgoña,... esten fechos e rreparados"813.

El procurador de los mulateros dijo que les correspondía pagar 325.00o mrs. y que, a pesar de que se mandó que no se cogiesen por vía de imposición, esta se puso y los mulateros para no pagar, iban por otros caminos, por lo que sigue solicitando que los mrs. se pudiesen coger "en los logares de los Hoçinos e la Horadada por donde los dichos mulateros pasan mas continuamente". La respuesta del Consejo se mantuvo sin cambios, ya que en junio de 1502 mandó al corregidor de las Cuatro Villas, que haga juntar a los mulateros con sus procuradores, y se repartan los 325.000 mrs. según las bestias que cada uno tuviere, y que cada uno lo ponga en poder de Fernando Ruiz ${ }^{814}$.

Los trabajos del puente de Bolado se encontraban paralizados por la falta de fondos, y en julio de 1502 las cosas habían avanzado muy poco. El procurador de los mulateros dijo que para reparar los caminos, puentes y calzadas, mandaron a cada villa y lugar que hiciese lo que estuviere en su término, ayudados con algunos mrs. dados por los mercaderes de Burgos y de otros concejos, y aunque las localidades habían sido requeridas para que los reparasen, algunas no lo habían querido hacer y otras aunque lo han hecho, no lo desarrollaban adecuadamente. El Consejo mandó a los corregidores de Burgos y de las Cuatro Villas, que apremien a los concejos y personas encargadas ${ }^{815}$.

811 A. G. S./ Registro General del Sello, XI-1501, fol. 203/ Écija, 5 noviembre 1501.

812 A. G. S./ Registro General del Sello, VI-1501, fol. 455/Valladolid, 21 junio 1501.

813 A. G. S./ Registro General del Sello, X-1501, fol. 312/ Granada, 23 octubre 1501.

814 A. G. S./ Registro General del Sello, VI-15O2, fol. 315/ Toledo, 16 Junio 1502.

815 A. G. S./ Registro General del Sello, VII-15O2, fol. 398/ Toledo, 30 julio 1502. 
En agosto de 1502 se apercibieron de que, ciertos lugares desplazados del camino habían sido olvidados en el repartimiento, ya que en el término entre la cueva Palomera (en los Hocinos) y las ventas del Cuerno, quedaron fuera del repartimiento otros lugares que lo utilizan, como Quintana de Valdivielso y Valdenoceda, lo que según el procurador de los mulateros sería injusto para los otros lugares repartidos. El Consejo mandó al corregidor de Burgos, que envíe información con su parecer sobre si dichos lugares están en el término y camino entre la cueva Palomera y las ventas del Cuerno, por qué no entraron en el repartimiento para hacer los caminos de su término, qué parte deben hacer de ello y qué es lo que se les debe repartir ${ }^{816}$.

En el Consejo Real comparecieron en agosto de 1502 los procuradores de la Universidad de los Mercaderes, el de los mulateros y el de Laredo, defendiendo los tres una postura para no pagar o, por lo menos, reducir la cantidad asignada. Pedro de Durango en nombre de la Universidad de Burgos, intentó justificar que las cantidades repartidas eran excesivas basando toda su alegación en falsedades e inexactitudes, como que utilizaban muy poco el camino de Laredo, o la sorprendente afirmación de que no usaban los puentes por hacer sus transportes en verano. Dijo que la Carta real de junio de 1502 agraviaba a sus partes porque ellos no debían los 150.000 mrs., ni estaban obligados a pagarlos, y "non tenian nesçesidad de las dichas calçadas e caminos e puentes e reparo dellos para la uilla de Laredo, porque los dichos sus partes enbiauan comunmente todas sus mercaderias a la villa de Bilbao para las aver de enbarcar e enbiarlas a Flandes, e que a Laredo no enbiaban mercaderias para que touiesen nesçesydad de las dichas calçadas e caminos e puentes, e que sy algunas mercaderias los dichos sus partes enbiauan a la villa de Laredo o trayan della para Burgos que heran muy pocas", y lo hacían en verano cuando muchos ríos se secan y los puentes no se necesitan. Añade que ya pagan por esos reparos, que todos los caminos se utilizan sin calzadas y que los puentes no estaban a su cargo sino al de los mulateros. Indicó que, según derecho y común costumbre, bastaba con que ellos pagasen los reparos en los términos de la ciudad de Burgos, pero que no estaban obligados a contribuir en otros arreglos de este camino porque no lo necesitaban.

Como enviaban todas sus mercaderías por Bilbao, Portugalete y otros puertos, pedían que todo fuese a su libre voluntad para elegir los caminos, y que cuando traían mercaderías por Laredo y otros puertos no necesitaban estos reparos. Reitera que si algún provecho obtenían, era como el que "rreçiben los del Rreyno de Toledo, e tierra de Canpos, e de otras partes de estos Rreynos que van a Laredo", u "otras personas de Valladolid e Segouia... e del Andaluzia", y que la mayor necesidad de la intervención es desde el puerto de Sendero Enhiesto y desde el río de Bolado, hasta Laredo que está a tres leguas de la villa y 23 de Burgos, siendo grave que contribuyesen en unas actuaciones que estaban tan cerca de Laredo, que era quien recibía el mayor provecho de los mantenimientos que por ellos les llegan, y de los pescados y mercaderías que envían a Castilla. También en invierno, cuando se destruían los caminos con las aguas y nieves, era cuando los mulateros andaban trayendo pescados y llevaban de retorno trigo, vino y otras cosas. Añade que el camino de Burgos a Bilbao es camino muy útil a sus partes, tanto o más que el de Laredo, y que para ir por él no era necesario andar por este, ya que van por Briviesca, Pancorbo y Orduña, y reitera que los mulateros son los

816 A. G. S./ Registro General del Sello, VIII-1502, fol. 396/ Toledo, 30 agosto 1502. 
que deben contribuir, y que si se pusiese imposición, sus partes estarían de acuerdo en que cada uno contribuyese por las cargas que llevare, y en tal caso debería ser menor la contribución en invierno que en verano, por lo que pidió que no fuesen obligados a contribuir salvo para los términos de Burgos, y que se les devolviesen los mrs. que depositaron ${ }^{817}$.

El procurador de los mulateros alegó que la Universidad de Burgos estaba obligada a contribuir en los reparos de este camino, porque lo utilizaban continuamente y era de gran utilidad para ellos por las mercaderías que trataban en Laredo y llevaban desde Burgos o venían de Flandes, y las cargas de pescado y viandas para la provisión de la ciudad, y que los mercaderes no se podían eximir de la contribución por decir que hay otro camino que va de Burgos a Bilbao, Portugalete y Castro-Urdiales; porque al tratar con diversas mercaderías, unas las enviaban a Bilbao y otras a Laredo, Portugalete o Castro-Urdiales, según les convenía. Además, aunque se dirijan a otros puertos, van por el camino de Laredo hasta Villasante, pasando por las merindades de Castilla Vieja y muchos ríos y puentes que necesitaban reparos, especialmente el de Quintanilla de Pienza y otras calzadas. Tampoco excusaban a los mercaderes cuando decían que no deterioraban los caminos por tener el trato y transporte de sus mercaderías en verano, "syendo lo contrario porque en tienpo de berano se echaban a perder mas los caminos, porque quedan tan atormentadas las calçadas e los rreparos e adobos que estauan fechos en los dichos caminos e calçadas e puentes, que luego como venia el agua o la niebe lo llebaba todo e lo desbarataua, quanto mas que los dichos mercaderes nunca çesaban de andar e llebar e traher las dichas mercaderias del dicho camino, de la dicha çibdad de Burgos a la villa de Laredo e que por la mayor parte, los rrios que pasaban la mayor parte de berano no se puede pasar syn las dichas puentes". Añade que la probanza fue realizada por personas que sabían poco del trato que los mercaderes tenían en Laredo, y por los mesoneros del camino de Bilbao, que es por Orduña. Por estas razones, pidió que se mandase contribuir a los mercaderes ${ }^{818}$.

El procurador de Laredo alegó, por su parte, que se había mandado a la villa que reparase las 2,5 leguas de su término, en que se debían hacer 1.050 brazas o más de calzadas y 130 brazas de cauce y que además pagase 50.000 mrs., siendo ese repartimiento muy injusto y debía ser enmendado por no estar obligados a hacer cosa alguna en dichos caminos, porque siempre los mercaderes y mulateros los hacían y reparaban por ser los que recibían más beneficio. Los mercaderes no podían alegar que no realizaban sus tratos por Laredo porque eso no estaba en sus manos, ya que cuando venían sus mercaderías de los otros reinos, las naos no podían entrar en Bilbao si no estaba la mar muy mansa, y aunque los maestres no quisiesen, tenían que entrar en el puerto de Laredo descargando allí. Dijo que estando como estaban los caminos, caían en los ríos y lagunares con sus acémilas y estas se perdían, y que en solo los alquileres de una sola flota recibían más de 1.000 ds. de intereses, cuanto más que por el camino de Burgos a Laredo iban sus mercaderías a Bilbao por 17 leguas hasta la bifurcación para Bilbao, y que de allí a Laredo no hay más de 9 leguas y como los lugares situados entre Burgos y Laredo ayudan con la mitad del coste de lo que mandan hacer, le echan a Laredo con gran número de calzadas y arroyos, una gran suma

817 A. G. S./ Registro General del Sello, VIII-1502, fol. 394/ Toledo, 27 agosto 1502; A. D. B./ C-220/ Toledo, 27 agosto 1502.

818 A. G. S./ Registro General del Sello, VIII-15O2, fol. 394/ Toledo, 27 agosto 15O2; A. D. B./ C-220/ Toledo, 27 agosto 1502. 


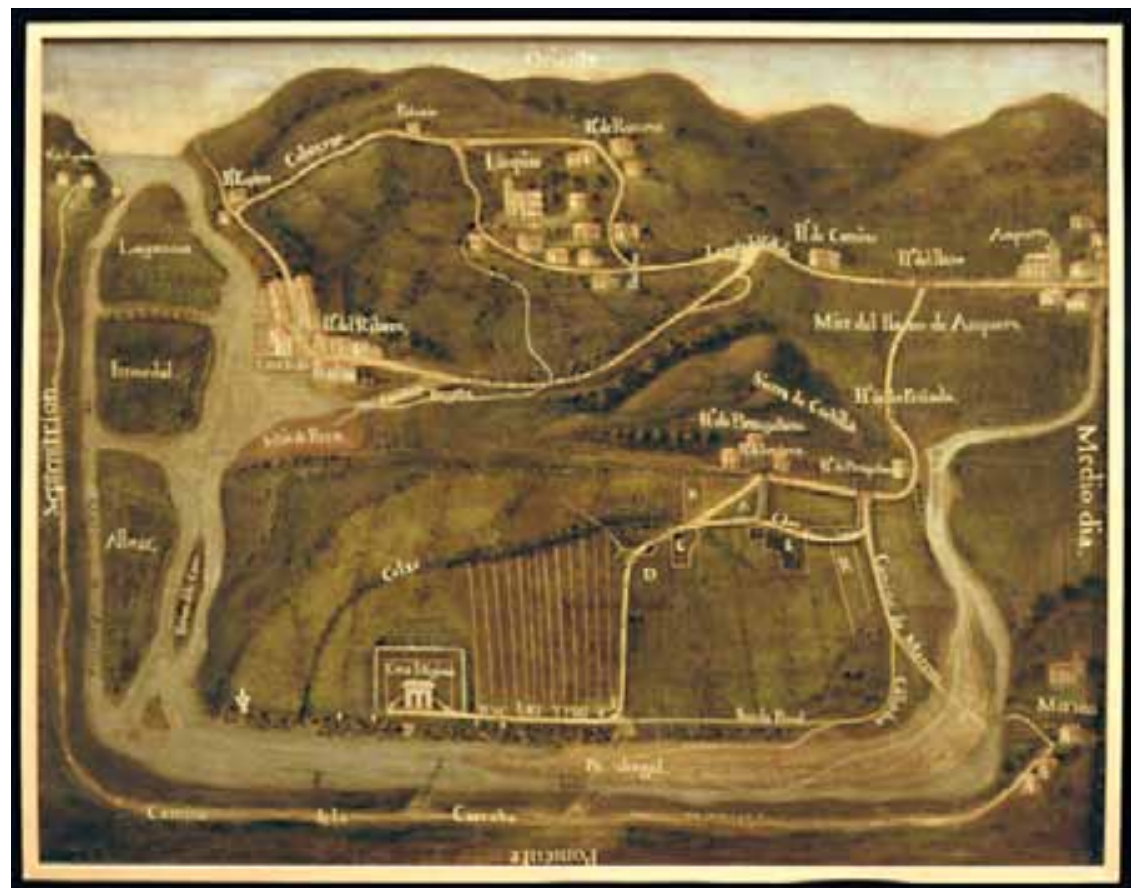

Panorámica del s. XVII del río Marrón entre Ampuero y Limpias, procedente de un pleito dirimido en la Chancillería de Valladolid (A. Ch. V., PDO. 41).

de mrs., y que a "la çibdad de Burgos que hera vna çibdad tan prospera e populosa e que tanta vtilidad rresçibia de que los dichos caminos se fagan", solamente se le mandaba que hiciese 400 brazas de calzada sin tener que contribuir con ningún maravedí. Además, el puente para el que se manda contribuir a Laredo no está en su término, y que de las leguas que hay desde donde se divide el camino para Bilbao, bastará con que la villa hiciese sus dos leguas sin otra imposición.

En el primer repartimiento fue echado a Laredo $100.000 \mathrm{mrs}$. haciéndose el camino del Carro del que recibía algún provecho; y como ahora habiéndose de hacer solamente lo que los mercaderes y mulateros solían hacer, les echaban más de 200.000 mrs. por lo que pidió que se mandase que la villa no pagase nada y que se mandase ayudar para los reparos en sus términos como a los otros lugares. A pesar de todo lo alegado por los tres, el Consejo ratificó el repartimiento realizado y dio el pleito por concluso en agosto de 1502 . Mandó que la Universidad pague los $150.000 \mathrm{mrs}$. y $50.000 \mathrm{mrs}$. la villa de Laredo, como se contenía en la Carta ${ }^{819}$.

El Prior y cónsules de los mercaderes dijeron en 1503, que en estos reparos no se pone la diligencia conveniente ni se hacen como se debe, y como ellos han contribuido con 150.000 mrs. más otros 40.000 mrs., pidieron que les diesen facultad para enviar una persona a entender en los reparos, porque otras veces los mrs. depositados, se habían malgastado. Pidieron también que se mandase que si quedaban algunos de los mrs. repartidos, que cada una de las partes gozase de sueldo en proporción a su contribución. El Consejo acordó en julio de 1503, encomendar al corregidor de las Cuatro Villas que vea si los

819 A. G. S./ Registro General del Sello, VIII-1502, fol. 394/ Toledo, 27 agosto 1502; A. D. B./ C-220/ Toledo, 27 agosto 1502 . 


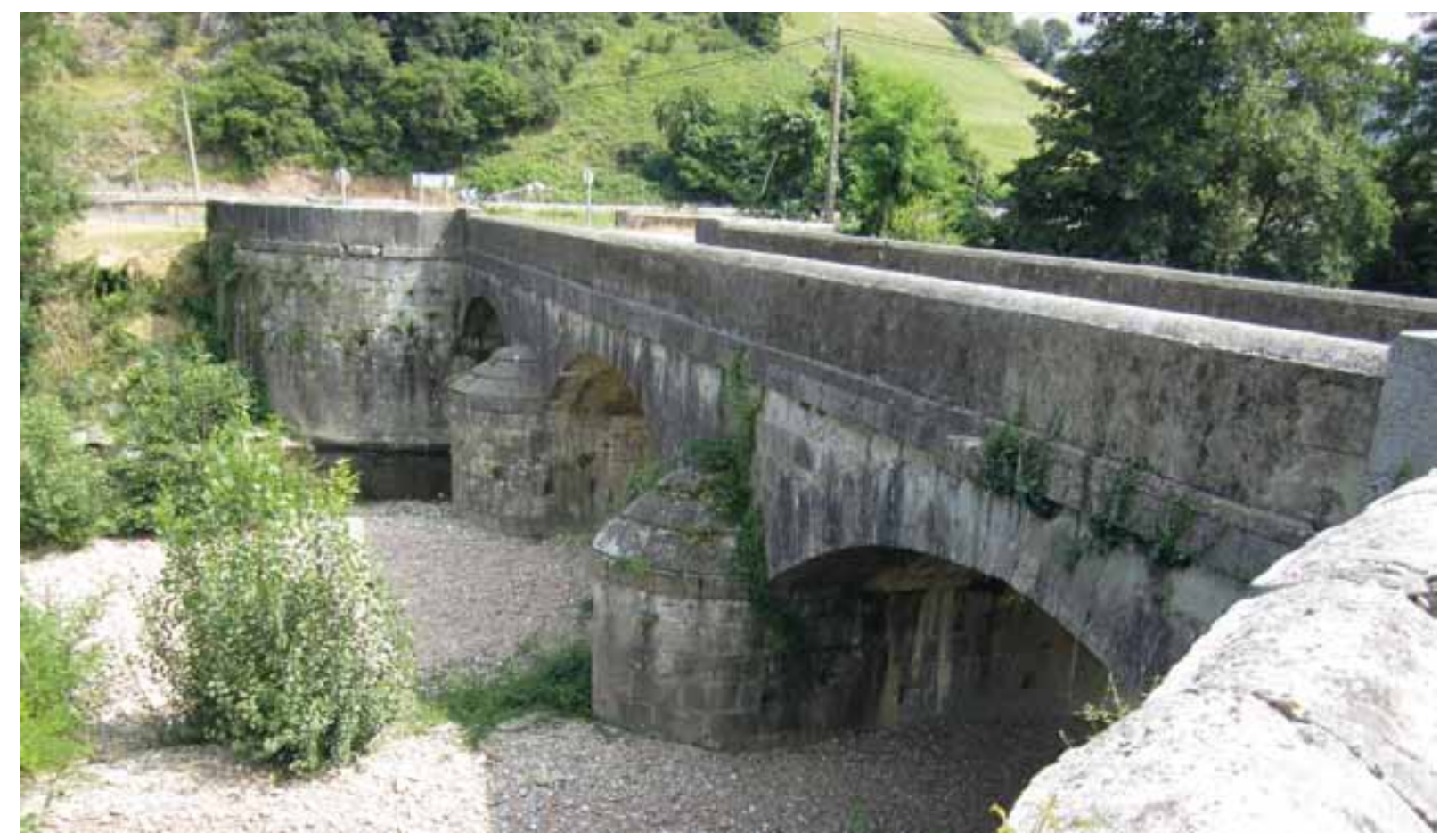

Puente actual de Bolado.

caminos y calzadas están hechos como conviene, y si en ello se han gastado las cuantías que para ello se cobraron, y que si todo estuviere bien, se informe si han sobrado mrs., para devolverlos a los que lo pagaron en proporción a lo que cada uno aportó y si los caminos y puentes no estuvieren acabados, que se hagan y reparen como está mandado ${ }^{820}$.

La operación del cobro no era fácil como lo demuestran las dificultades encontradas para cobrar a los mulateros, los primeros interesados en las mencionadas reparaciones y originales promotores de esta iniciativa ${ }^{821}$. Estos se quejan en 1504, de que los corregidores de Burgos y de las Cuatro Villas no querían aplicar las órdenes sobre el tema ${ }^{822}$. El corregidor de las Cuatro Villas, como juez comisario para el cobro de los mrs. repartidos "para los reparos e aderezos de las puentes e calçadas desde esta çibdad de Burgos a la villa de Laredo", requirió en abril de 1505 al Prior y a los cónsules de la Universidad para que le paguen todos los mrs. que del repartimiento faltan de pagar, para mandarlos gastar en los reparos de los puentes y calzadas. El Prior y cónsules pidieron los decretos de pago de lo que habían abonado y de lo que les quedaba por pagar, ya que estaban dispuestos a contribuir como se manda ${ }^{823}$.

El puente de Bolado aún no se había acabado en 1510, ya que el procurador de Laredo dijo al Consejo que, para ayuda del dicho puente que está fuera de su término, la villa depositó $50.000 \mathrm{mrs}$, pero como el depositario no era llano ni abonado se habían gastado sin hacer el puente, por lo que pidió que se recuperase tal cantidad, y como los que lo habían recibido no eran de su jurisdicción sino de la de Montija, se mandase dar comisión

820 A. D. B./ C-182/ Madrid, 20 julio 1503.

821 A. G. S./ Registro General del Sello, II-1503/ Alcalá de Henares, 25 febrero 1503. En MOLÉNAT, J. P.: $1971: 144$.

822 R. G. S., 23-II-1504. MOLÉNAT, J. P.: 1971: 148.

823 A. G. S./ Cámara de Castilla. Pueblos, leg. 4-1, doc. 215/ Burgos, 15 abril 1505 
para ello. El Consejo acordó en junio de 1510, mandar al corregidor de las Cuatro Villas que reciba información sobre quién tiene dicho depósito, los recupere y los ponga en poder de una buena persona vecina de Laredo para hacer el puente como fue mandado ${ }^{824}$. En 1514 Juan Alonso del Prado, procurador de los mulateros, explica que a consecuencia de una anterior petición, el corregidor de Laredo les hizo pagar la cantidad fijada y la depositó cerca de un habitante de la villa. Una nueva Provisión ordena cumplir la de 1510, y guardar los 50.000 mrs. destinados al puente de Bolado. Laredo indica que podía hacer 14015 años que la villa había pagado dichos mrs. para este puente y sus caminos, y como no se había construido en piedra sino en madera, el río se lo había llevado. Como fue ignorado por 6 o 7 años, tiempo suficiente para encontrar el dinero, la villa por tener un claro escepticismo sobre una eventual construcción del puente, quería recuperar el dinero para otros trabajos ${ }^{825}$.

Después de tantos años el repartimiento de 1500-1501 no había sido aplicado en su totalidad, provocando que el desarrollo del plan fuese reducido y sus logros limitados. Deben tenerse en cuenta las alegaciones realizadas por unos concejos, que no tenían posibilidad de afrontar los gastos de las intervenciones en el camino, algo que estuvo en contradicción con todo el esfuerzo realizado por la administración de los Reyes Católicos, y en particular con este repartimiento de 1501, que no excluye, sino al contrario, los esfuerzos que hicieron dichos concejos.

\section{El puente de Bolado. Intervenciones desde 1499}

En la iniciativa promovida por los mulateros para la mejora del camino de Laredo a fines del siglo XV, destaca por su importancia la construcción del puente de Bolado sobre el Carranza o Marrón en el término de Ramales, entre Bárcena y Gibaja. Hubo un puente de Bolado primitivo que, por asentarse en terreno no apropiado, se lo llevó la riada, reconstruyéndose después tantas veces como avenidas lo afectaban. El primitivo, según unos testigos de Cibaja interrogados en 1512, no era muy antiguo, ya que hasta alrededor de 1477 el camino iba por de Gibaja, que "hera el camino rreal antigo, avnque de treynta e çinco años a esta parte poco mas o menos, los mulateros auian tornado el camino por Rramales e a la puente de Bolado"826.

A pesar del empeño por parte de los promotores y del corregidor, no se logró en 14 años la construcción del puente por problemas financieros. Este importante puente, que constituía una parte esencial del plan en la zona, fue también una prueba de que una obra de esta magnitud no se podía realizar en esos momentos por la pobreza de los pueblos, lo que da una idea de lo ajustado con que estaban administradas las sumas destinadas a los trabajos al no existir, caso de alguna alteración, margen para su financiación ${ }^{827}$.

En el informe que realiza el cantero Ruy Sánchez de Criales en 1499, sobre el coste de las obras que se pretendían acometer, se indica que el corregidor y alcalde anteriores

824 A. G. S./ Cámara de Castilla. Pueblos, leg. 10, doc. 52/ Madrid, 28 junio 1510.

825 A. G. S./Cámara-pueblos, leg. 10, Laredo, sin n. MOLÉNAT, J. P.: $1971: 152$.

826 A. G. S./ Consejo Real de Castilla, leg. 26-17/ Burgos, 5 octubre a 12 diciembre 1511; MOLÉNAT, J. P.: 1971: 161-162 y BASAS FERNÁNDEZ, M.: 1963 y 1994: 161.

827 MOLÉNAT, J. P.: 1971: 151-152. 
mandaron aderezar este puente, pero por no asentarse en tierra firme y "comenzandola a desbolber, se cayo toda ese torno a fazer e se apreçio por ofiçiales juramentados en veynte e siete mill mrs., tornanse tornase a preziar donde se ace, se pagaron con veinte mill mrs., y esperase que no turara mas de quanto benga la primera abenida segund se a visto por otras muchas que se an fecho en este mismo lugar" 828 . Habiendo pagado dichos 20.000 mrs., y añade que en los últimos 30 años ha costado mucho dinero porque se ha hecho varias veces de madera, y el que se hizo de mazonería se cayó "por no aver dispusiçion para se edeficar de tierra firme".

En marzo de 1501 los mulateros indican que era necesario "faser vna puente en el agua de Marron do dizen Bolado por ques muy nesçesario por ser el camino mas llano e mas corto", debiéndose edificar sobre seis pilares de cal y canto muy altos para salvar las crecidas de $35.000 \mathrm{mrs}$. cada uno, y que la plataforma debía ser de recias maderas con sus calados y barandas para que puedan pasar carros, lo que hace un total de $260.000 \mathrm{mrs}$, , cantidad ya repartida para hacer otro camino por Cibaja ${ }^{829}$ que se evitaría si se hace este puente, más otros 75.000 mrs. de ciertos cobros hechos a los mercaderes de Burgos para este mismo puente. El Consejo encomendó a Diáñez que enviase información sobre si el puente propuesto era necesario, cuántos mrs. se tenían y cuánto podría costar, y si con él se evitaba el rodeo que se hace ${ }^{830}$.

Según tasación de mayo de 1501, el puente se debía hacer con unos 360.000 mrs. con pilares de mazonería, maderas gruesas encima, y esquinas trabadas con grapas de hierro con su plomo. Una comisión integrada por los mercaderes de Burgos, la villa de Laredo y los mulateros, concierta el contrato, lo iguala con los maestros, vela para que se acabe en septiembre de 1502, y nombra a un experto para que haga seguimiento de la obra ${ }^{831}$. El Consejo Real acordó en junio de 1501 mandar a los mercaderes, villa de Laredo y mulateros, que nombren a sus diputados para que promuevan la construcción del nuevo puente y que, mientras se construye, se haga otro de madera para el próximo invierno. También se manda que lo preciso para hacer la cal, y la leña y madera necesarias, se puedan tomar libremente de los montes junto al río, y que los que tengan los sillares del puente caído los devuelvan para ser reutilizados ${ }^{832}$. En octubre, el puente encargado por 360.000 mrs., no se acababa de hacer por no recibir los mrs. depositados ${ }^{833}$, y en julio de 1502, no se había avanzado de manera significativa ${ }^{834}$.

Todavía en 1510, el puente no se había finalizado aunque los 50.000 mrs. que Laredo depositó en 1502, ya se habían gastado ${ }^{835}$. El Consejo mandó que el corregidor recupere el depósito de los 50.000 mrs., y los ponga en poder de una buena persona vecina de Laredo ${ }^{836}$. En 1511 hubo una fuerte avenida que afectó gravemente a los puentes de este

828 A. H. N./ Nobleza. Frías, C. 235, D. 55/ Medina de Pomar, 15 enero 1499.

829 Este camino por Gibaja, ya fue utilizado en el siglo XV.

830 A. G. S./ Registro General del Sello, III-1501, fol. 603/Valladolid, 20 marzo 1501.

831 A. G. S./ Registro General del Sello, VI-1501, fol. 460/Valladolid, 5 junio 1501; MOLÉNAT, J. P.: 1971: $157-160$.

832 A. G. S./ Registro General del Sello, VI-1501, fol. 455/Valladolid, 21 junio 1501.

833 A. G. S./ Registro General del Sello, X-1501, fol. 312/ Granada, 23 octubre 1501.

834 A. G. S./ Registro General del Sello, VII-1502, fol. 398/ Toledo, 30 julio 1502.

835 A. G. S./ Cámara de Castilla. Pueblos, leg. 10, doc. 52/ Madrid, 28 junio 1510.

836 A. G. S./ Cámara de Castilla. Pueblos, leg. 10, doc. 52/ Madrid, 28 junio 1510. 
camino, y se llevó lo que quedaba de este puente, encargándose a Sancho de Salcedo que informase sobre ello. Este indica que se ha de hacer el puente donde estuvo por ser camino más derecho, "e que sabe que agora por no estar echas estas puentes, ban los mulateros por caminos muy travajosos e peligrosos e tales, que estan un dia e dos syn poder pasar", por estar el puente caído y ninguna acémila podía pasar por él sin mucho peligro ${ }^{837}$.

Una nueva Provisión ordena en 1514 observar la de 1510, y guardar los 50.000 mrs. que Laredo había destinado para este puente. Como no había sido construido en piedra sino en madera, el río se lo había llevado y la villa, por tener un claro escepticismo sobre su construcción, pretendió recuperar el dinero abonado ${ }^{838}$.

\section{Las inundaciones de 1511. El camino de Laredo a Agüera}

En octubre de 1511, Fernando del Hoyo en nombre del concejo de Laredo, dijo a la Reina que hacía poco tiempo que crecieron tanto algunos ríos, que se llevaron los puentes de madera del camino real que va a Burgos y, por ello, no se puede circular por esos caminos cesando el trato. Pedía que se mandase a los concejos en cuyo término se hallaban los puentes y pontones, que los reparasen con presteza y que si fuere necesario, los recueros y caminantes contribuyesen en su reparo. La Reina dio Carta mandando al corregidor, que fuese a los dichos lugares a recibir información sobre los puentes y pontones afectados, cuántos mrs. serían precisos para su reedificio y si hay rentas para ello, y juntamente con su parecer lo envíe al Consejo para que provea y, entre tanto, que mande a los concejos que reparen los puentes y pontones que están en sus términos. En noviembre el procurador general de Laredo presentó la Carta al corregidor de las Villas de la Costa que encargó su resolución a Sancho de Salcedo su oficial y alcalde.

Salcedo llegó a Ampuero y halló un puente de madera medio caído por donde han de pasar "todos los que de la dicha villa de Laredo han deyr a la çibdad de Burgos e a otras partes". Los testigos dijeron que el puente está en el camino real de Laredo a Burgos, y que no había otro lugar por donde pudiesen pasar los que venían por Sandiniesto, si no fuese con un rodeo de 40 5 leguas, y como el puente está caído los que pasaban lo hacían con mucho peligro, "sy no se rremedya de presto, que la acabara de llevar el agua". El puente estaba casi en medio de Ampuero y hacerlo de madera costaría entre 8.000 y 10.000 mrs. y se podrían arreglar entre 15 y 30 días trabajando seis o siete oficiales con buen tiempo. Si este puente y los que hay hasta Medina de Pomar no se hiciesen, no podría entrar en esta tierra pan, vino ni bastimentos, ni se sacarían pescados ni otras mercaderías. Salcedo viendo como estaba el puente mandó a los vecinos que lo reparasen en 30 días adelantando su coste.

Salcedo halló en el término de Rasines, un puente de maderas caído en el camino real, y viendo que no podían pasar acémilas ni persona alguna, preguntó a los testigos, que dijeron que conocían este puente llamado del Cubo, y que al caerse no pueden pasar los caminantes ni recueros y debían rodear por otros caminos con muchos ríos y arroyos, o bien quedar retenidos un día o dos y aun más, para después pasar con mucho peligro,

837 A. G. S./ Consejo Real de Castilla, leg. 26-17/ Burgos, 5 octubre a 12 diciembre 1511; MOLÉNAT, J. P.: 1971: 161-162 y BASAS FERNÁNDEZ, M.: 1963 y 1994: 161.

838 A. G. S./Cámara-pueblos, leg. 10, Laredo, sin n. MOLÉNAT, J. P.: 1971: 152 


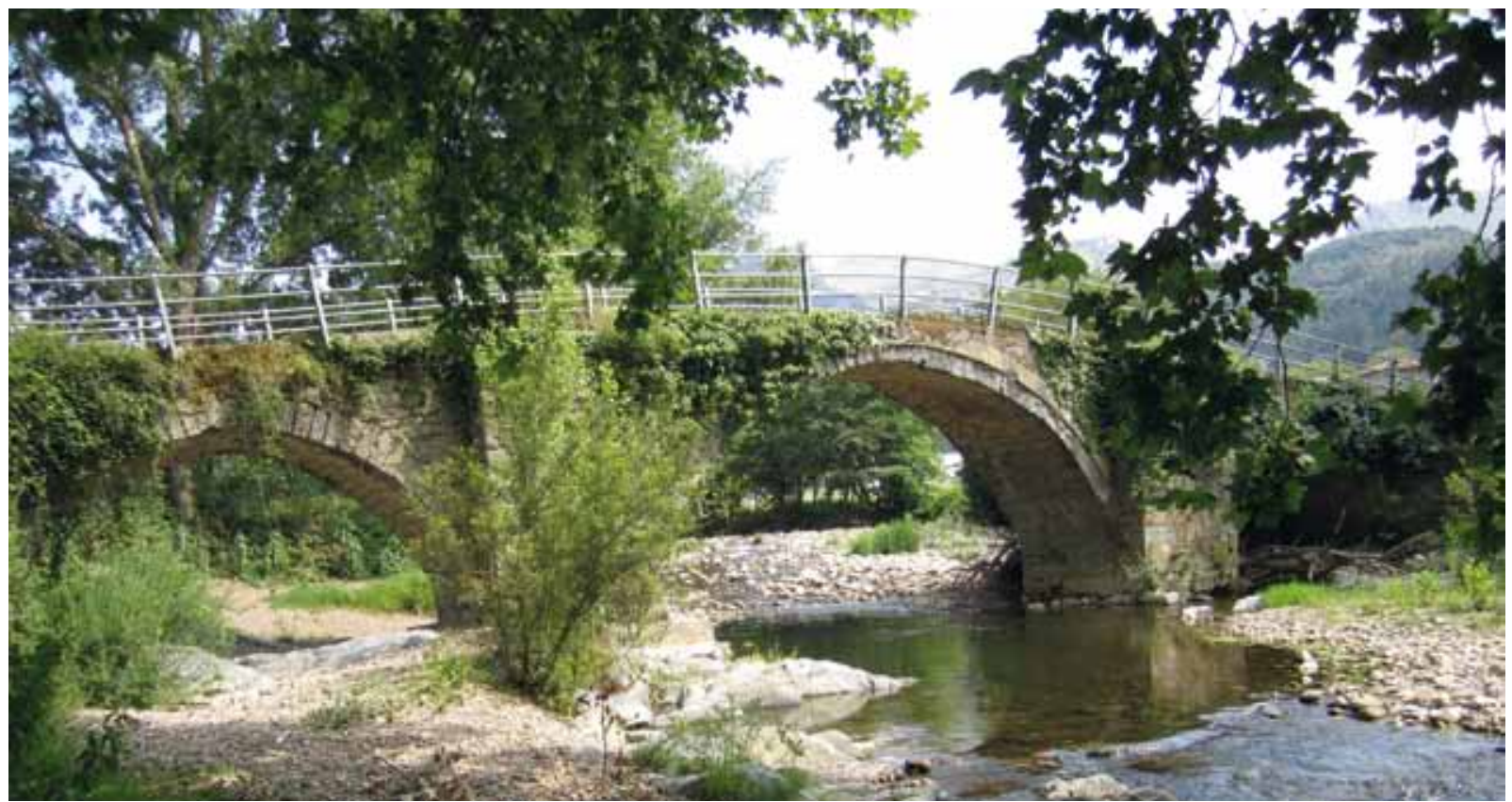

Puente de Gibaja.

y "que para aver de yr syn arrodear, que se ha de faser dicha puente e la puente que dizen de Bolado donde antiguamente estuvo, que avn es camino mas derecho, e que este la vio echa e paso por ella e que sabe que agora, por no estar echas estas puentes, ban los mulateros por caminos muy travajosos e peligrosos". Para que el puente se hiciese adecuadamente, era necesario hacer siete pilares de piedra que podrían costar por lo menos 600.000 mrs. más las maderas entre pilares que costarían 20 o $25.000 \mathrm{mrs}$, y que si se hacía todo de madera no quedaría perfecto y costaría 60 o 70.000 mrs., con unos montes tan talados que no habría maderas para hacerlo. Otro indicó que los pilares debían ser cuatro y de piedra, que podrían costar $400.000 \mathrm{mrs}$. y las maderas entre pilares 40 o $50.000 \mathrm{mrs}$. y todo de madera costaría $100.000 \mathrm{mrs}$. Un tercero dijo que por lo menos se debían hacer tres pilares de calicanto por unos 300.000 mrs. y lo restante de madera, que costaría $40.000 \mathrm{mrs}$. pero como no había monte para hacerlo todo de madera, costaría más de 80.000 mrs. y no duraría 2 años. El puente no se podría hacer hasta el verano y después "enviando conpañia de ofiçiales e dyneros... se podria dar echa" en piedra en 2 años. En madera se podría hacer en el verano. Vista la necesidad, Salcedo mandó a los vecinos de Rasines que lo hiciesen en 10 meses, so pena de 30.000 mrs. Los vecinos de Rasines protestaron, porque ellos "avnque bendiesen todas las haziendas" que tenían, no lo podían pagar.

Salcedo notificó la Provisión real a Rodrigo Saravia, procurador de Ramales y junta de Parayas, y mandó hacer sus puentes. Los testigos dijeron que conocen los puentes de los Loros y el de Cijedo que "estan en el camino rreal por donde agora costunbran yr e venir los mulateros e viandantes, e sy sabe quel dicho camino es el mejor e mas llano para yr e venir desde la çibdad de Uurgos a la dicha villa de Laredo", "avnque antiguamente yvan por otro camino". Sabían que los puentes tienen una parte caída y la otra para caerse, por lo que no permiten el paso de ningún mulatero ni bestia sin mucho peligro. Sus reparos costarían más de $30.000 \mathrm{mrs}$. y el remedio urgente podría costar 6 o 7.000 mrs. Para hacerlos de nuevo, habría que esperar hasta el verano, pero se podrían hacer en 30 o 40 días. Visto que sus reparos no aprovecharían mientras no 
se hiciesen los puentes de Rasines y Bolado, y solo serían necesarios si se acondicionasen los vados de Bolado para cruzarlos en verano, mandó a los vecinos que reparasen los puentes antes de marzo de 1512, so pena de 20.000 mrs.

En Cibaja, los testigos dijeron que el puente llamado de Gibaja "hera el camino rreal antigo, avnque de treynta e çinco años a esta parte poco mas o menos, los mulateros auian tornado el camino por Rramales e a la puente de Bolado". Sabían además que en tiempo de invierno no hay camino ni puente válido, y que el puente estaba caído de manera que ninguna acémila podía pasar sin mucho peligro. Los mulateros con unos 1.000 mrs. habían juntado algunas vigas y comprado otras para, de manera precaria, poder pasar algunas acémilas, pero se caería si no se reparase de inmediato, ya que el puente "hademas que no tienen de anchor mas de dos codos o tres, es la madera vieja e podrida". Hacerse de nuevo costaría más de $20.000 \mathrm{mrs}$. y repararse en ese momento más de 5.00o, pero si el puente no se hacía estando como estaba caído el de Ramales, no podrían caminar los mulateros por esa montaña, especialmente en invierno, y ellos y esa tierra recibirían mucho daño aunque, dicen que, el concejo de Gibaja "no rreçibiria dapño avnque no se fiziese la dicha puente". Para hacerlo de nuevo se debía esperar al verano, pero se podría hacer de inmediato en unos 20 o 30 días. Como su reparo era necesario, Salcedo mandó a los vecinos que lo hiciesen en 30 días so pena de 10.000 mrs., y los responsabilizaba del daño que los viandantes recibiesen.

En Lanestosa los testigos dijeron que conocen los puentes de San Pedro, de Las Puentes, de Sierras Luengas y el que está bajo El Prado, porque están en el término de Lanestosa salvo el puente debajo del Prado, que la mitad está en Lanestosa y la otra en el lugar del Prado, y saben que no se puede ir ni venir de Laredo a Burgos sin pasar por dichos puentes no siendo con muchos rodeos y por caminos muy ásperos, y que dichos puentes tienen caídas muchas de sus partes y lo que queda se caerá si no se remedia pronto. Por el de San Pedro no podían pasar mulos, y por el de Las Puentes no pasaba ninguna acémila si no era con mucho peligro. No tenían vado bueno salvo el de San Pedro y el del Prado, que se pasaban cuando el agua no iba muy crecida. El puente de San Pedro costaría más de 8.000 mrs., el de Las Puentes necesitaba hacerse completo de madera y costaría más de 18.000 mrs., el de Sierras Luengas 2.000 y el del Prado entre 5 y 8.000, correspondiendo la mitad a Lanestosa. Se necesitaban entre tres y seis meses para hacer cada puente de nuevo. Salcedo mandó a los vecinos que hiciesen en seis meses los cuatro puentes, so pena de $20.000 \mathrm{mrs}$.

En el lugar de El Prado, los testigos dijeron que el puente del Prado tiene la mitad en la jurisdicción de Lanestosa y Carranza y la otra en El Prado y valle de Soba, y el de Piera Limpia está en su término. Saben que no se puede ir ni venir de Laredo a Burgos, sin pasar por estos puentes para salir de la montaña por el camino real. El puente del Prado se ha comenzado a caer y ningún mulo puede pasar por él si no es con mucho peligro, y si no se remedia pronto se caerá, costando todo unos 3.000 mrs. reutilizando las maderas. El de Piera Limpia lo llevó el río y costaría unos 1.500 mrs. Trabajando cinco o seis oficiales, el de Piera Limpia se podría remediar en 30 días y el del Prado entre 10 y 30 días. Salcedo mandó a los vecinos que los reparasen, e hiciesen el puente de Piera Limpia en 15 días y la mitad del de El Prado en 30 so pena de 10.000 mrs. , afrontando además lo que los puentes costasen. 
En Agüera Salcedo notificó la Provisión real a su procurador, diciendo los testigos que en dicho término están los puentes de Agüera y de la Tabla, y que el de Agüera está dentro del dicho lugar y el de la Tabla en término de la junta de Agüera y Montija, ambos en el camino real de Laredo a Burgos. Estaban por el suelo porque los llevó el agua y por ellos nadie puede pasar aunque cuando el río va pequeño pasan por el vado, pero aumenta el peligro cuando va grande. Hacer de nuevo el puente de Agüera costaría unos $7.000 \mathrm{mrs}$. y el de la Tabla 5.00o. Indican que podría hacer unos 16 o 17 años que el de Agüera lo llevó el agua, y la reina Isabel mandó 200 rs. de su cámara para volverlo a hacer. Dichos puentes los podrían realizar cinco o siete oficiales en unos 50 o 60 días. Salcedo ante la necesidad que había de arreglarlos, mandó a los vecinos que los hiciesen en dos meses so pena de 10.000 mrs. y los condenaba a pagar el daño que los viandantes recibiesen. El 7 de diciembre Salcedo notificó la sentencia al procurador que dijo que apelaba el mandato, porque como el tiempo era muy breve y en invierno los vecinos no lo podían hacer. Además el puente de la Tabla estaba en término suyo y de toda la junta de Montija y lo que se mandaba, lo tenía que hacer la dicha Junta y no Agüera.

Preguntados todos si los puentes tenían rentas para su reparo, todos dijeron que ningún puente tenía renta alguna para ello, y sobre quiénes los habían reparado y pagado otras veces, dijeron que los viandantes y mulateros pagaban su coste según las acémilas que cada uno traía, "porque los dichos mulateros quebrantaban las dichas puentes e calçadas", y la tierra daba francos los montes para cortar las maderas necesarias y ayuda para traerlas. Sobre quién recibiría el daño si los puentes y caminos no se hiciesen, dijeron que en tiempo de invierno no podrían caminar los mulateros y viandantes sin mucho trabajo y fatiga, $\mathrm{y}$ por ello, la tierra no se podría sostener porque no tendrían provisión. Además todos apelaron lo mandado por Salcedo, alegando que no estaban obligados a aderezar estos puentes, diciendo que los mulateros y viandantes, que eran los que los "rronpian e desasyan e rreçibian el probecho e hutilidad dello", habían pagado siempre lo que costaba, y pedían que se apremiase a los mulateros para que pagasen su coste, y que ellos harían lo que les correspondiese.

Sancho de Salcedo, informó que cumpliendo la Provisión real, fue desde Laredo hasta Agüera a ver los puentes del camino, que son uno en Ampuero, otro en Rasines, en Ramales dos, en Cibaja otro, en Lanestosa tres y medio, en el Prado uno y medio y en Agüera dos, y los 12 puentes, "estan todas caydas a lo menos tales que ningund honbre hosa pasar cabalgando por ninguna dellas". Su parecer por ello era que "sy las dichas puentes non se rremedian, e asy mismo los caminos que estan todos desfechos e perdidos, quel dicho camino en tienpo de ybierno en ninguna manera se podra caminar", y por no coger en esa tierra pan ni vino ni otras provisiones, se despoblaría y muchos mulateros recibirían mucho daño. Por su pobreza, estos lugares no podían hacer dichos puentes y calzadas, y algunos ni vendiendo lo que tienen. Añade que si la Reina no manda que los aderecen los mulateros, los lugares no lo podían sostener, y pide que se mande ver un repartimiento hecho por el conde de Cabra, siendo presidente en 1499, porque parece no estar cumplido. Si dicho repartimiento se cumpliese, pues fue hecho a petición y consentimiento de todos, tanto de los pueblos, como de los mercaderes de la Universidad de Burgos, de la villa de Laredo y de los mulateros, dichos puentes y calzadas se podrían hacer, pero si la Reina no provee qué personas mandarán ejecutar el repartimiento y cómo se han de sostener, según la calidad de la tierra y acémilas que por ella pa- 


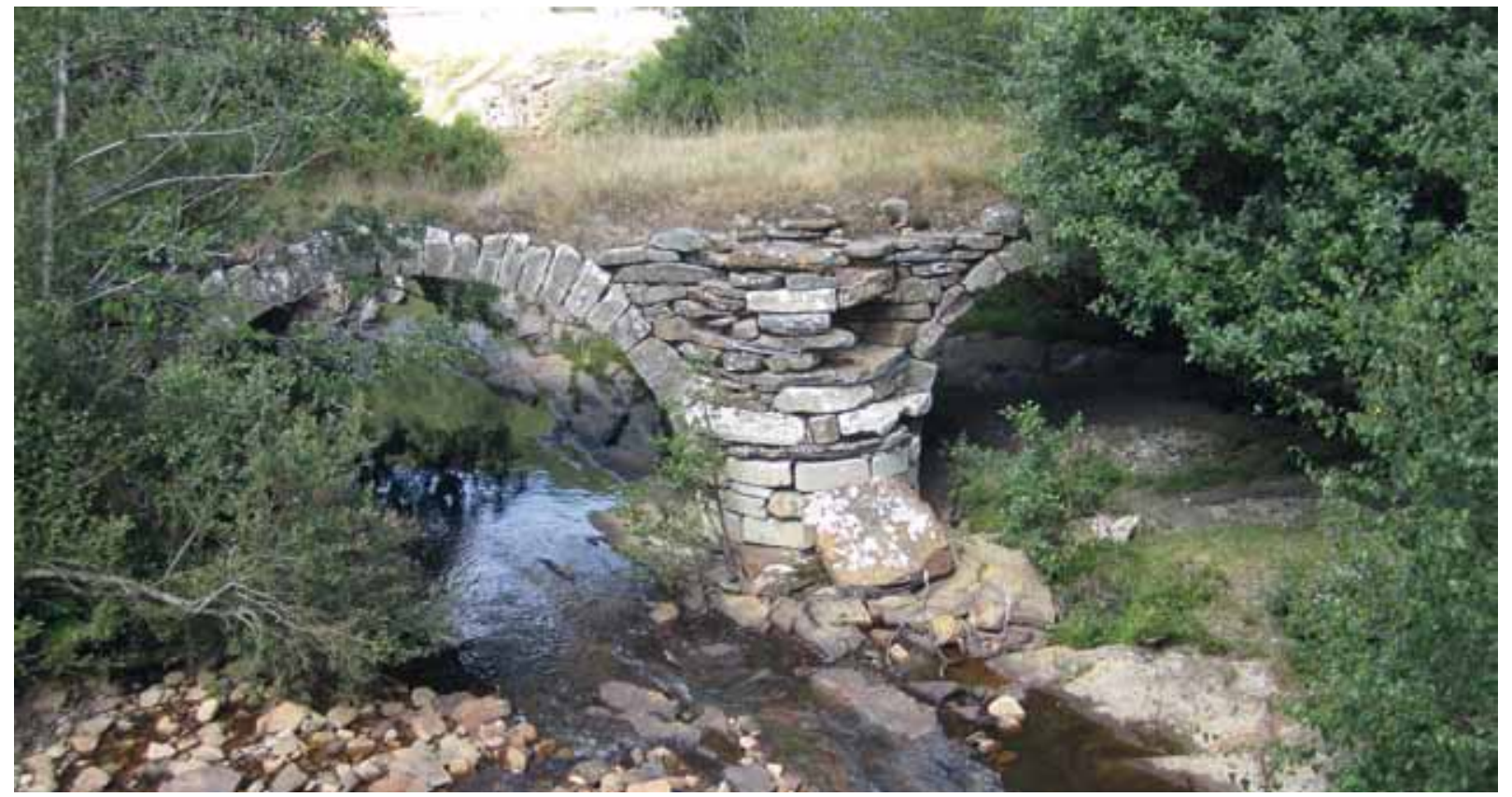

Puente de Agüera.

san, no se logrará cosa alguna. El parecer de Salcedo sobre estos puentes que "estan todosdesfechos e perdidos", nos indica que no eran lo suficientemente sólidos como para resistir otra crecida como la que se produjo. Después de largo tiempo y tras diversos intentos, ninguna reparación seria se había efectuado ${ }^{839}$. El informe de Salcedo fue categórico: la pobreza de las localidades era tal que no podían hacer sus puentes y calzadas siendo la costumbre hacerlo y pagarlo los mulateros 840 .

Rodrigo Saravia procurador de Ramales, declara en 1513 haber rehecho los puentes de los Loros y de Gijedo que estaban hundidos en su término 2 años antes, y demandaba el pago de los 55.000 mrs. gastados. Hacía decir a sus testigos que los dos puentes llevaban hundidos medio año y que él los había rehecho por la demanda de los mulateros. Afirmaba que la localidad estaba demasiado pobre para pagar, que de tiempo inmemorial eran los mulateros los que sufragaban las reparaciones, y que los habitantes de Ramales, como era costumbre, no contribuían en nada ${ }^{841}$.

\section{Cuentas de la villa de Laredo sobre los caminos}

En el libro de cuentas de la villa de Laredo entre los años 1539 y 1553, se detallan los cobros y pagos hechos por el municipio recogiendo, entre otros, los realizados para los caminos que la villa debía mantener y aderezar, o los ingresos de los recaudadores de "las penas en que yncurrieran los mulateros por sacar en sus machos cargas syn traer trigo o mantenimientos a esta billa", que debían ser dos fanegas de trigo por mulo, aplicado todo a los caminos y calzadas de la villa, conforme a la sentencia que sobre ello dio el juez de comisión. Tales penas alcanzaron:

839 A. G. S./ Consejo Real de Castilla, leg. 26-17/ Burgos, 5 octubre a 12 diciembre 1511; MOLÉNAT, J. P.: 1971: 161-162 y BASAS FERNÁNDEZ, M.: 1963 y 1994: 161.

840 MOLÉNAT, J. P.: 1971: 151-152.

841 MOLÉNAT, J. P.: 1971: 151. 


\begin{tabular}{|l|l|c|}
\hline Año & Recaudador de las penas del trigo & Maravedís \\
\hline 1539 & De Hernando de Rueda & $57.361 \mathrm{mrs}$. \\
\hline 1548 & $\begin{array}{l}\text { De los que } 186.350 \text { mrs., eran a cargo de Juan } \\
\text { Pérez de Puerta }\end{array}$ & $193.058 \mathrm{mrs}$. \\
\hline 1549 & & $275.955 \mathrm{mrs}$. \\
\hline 1550 & De Hernando Pérez de Santander & $159.961 \mathrm{mrs}$. \\
\hline 1551 & De Luis del Puerto & $170.810 \mathrm{mrs}$. \\
\hline 1553 & De Luis del Puerto & \\
\hline
\end{tabular}

Los cobros realizados desde mayo de 1548 a los mulateros y viandantes que llegan a Laredo y a Ampuero, por Hernando Sáenz de Espina, vecino de Ampuero, y otros arrendadores por orden de la villa y con Provisión real, cuyas cantidades se destinan a reparar los puentes, caminos y calzadas, son:

\begin{tabular}{|l|l|l|}
\hline 1548 & Hernando Sáenz de Espina Terreros & $64.855 \mathrm{mrs}$. \\
\hline 1549 & García de Escalante y Hernando Sáenz de Espina & $77.469 \mathrm{mrs}$. \\
\hline 1550 & Hernando Sáenz de Espina Terreros & $74.239 \mathrm{mrs}$. \\
\hline 1551 & Hernando Sáenz de Espina Terreros & $76.993 \mathrm{mrs}$. \\
\hline 1552 & Hernando Sáenz de Espina Terreros & $75.926 \mathrm{mrs}$. \\
\hline 1553 & Hernando Sáenz de Espina Terreros & $84.524 \mathrm{mrs}$. \\
\hline
\end{tabular}

También se detallan los ingresos por los arriendos de las sisas echadas en 1546 con licencia real para la obra del cay y reparos de caminos, cuyos remates fueron:

\begin{tabular}{|l|l|c|}
\hline Juan Pérez de Puerta & Sisas del vino un mr. por azumbre & $82.035 \mathrm{mrs}$. \\
\hline Juan Pérez de Puerta & La media sisa del pan & $16.175 \mathrm{mrs}$. \\
\hline Juan Pérez de Puerta & Sisa de la de tabla y resina & $2.234 \mathrm{mrs}$. \\
\hline Juan Pérez de Puerta & Sisa del hierro & $3.905 \mathrm{mrs}$. \\
\hline Esteban de Hoz boticario & Sisa del pescado & $13.246 \mathrm{mrs}$. \\
\hline Francisco de Bayona & Sisa del sebo y cera & $5.544 \mathrm{mrs}$. \\
\hline $\begin{array}{l}\text { Juan Pérez de Nadal, } \\
\text { que la tuvo hasta San Juan }\end{array}$ & Sisa de la carne & $21.952 \mathrm{mrs}$. \\
\hline \multicolumn{2}{|c|}{ Total } & $145.091 \mathrm{mrs}$. \\
\hline
\end{tabular}

De esta manera, se registran pagos efectuados entre 1547 y 1553 al cantero de la villa Juan de Cubas ${ }^{842}$. También Íñigo de Avellaneda "maestro de las calçadas", hizo entre dichos

842 En 1547 por "abrir y endereçar los caminos e calçadas de la Haça [Situado en el término de Ramales] e cay de la pared", se pagaron 41.250 mrs. para la obra de "las calçadas e caminos que esta villa haze en el camino de la mulateria". Además le deben 119.025 mrs. por 810 brazas de calzadas que hizo, pagadas 450 brazas a 170 mrs. y las otras 360 a 90 mrs., pero por haber diferencia entre él y la villa, se le pagaron $77.250 \mathrm{mrs}$., y los $41.775 \mathrm{mrs}$. restantes al hacer las obras, dando fianzas de que las mantendrá por quince años. También $92 \mathrm{ds}$. a cuenta y $5.183 \mathrm{mrs}$. a Paricio de Layseca que gastó cuando los regidores fueron a Agüera y La Haza a ver los caminos, más $1.125 \mathrm{mrs}$. por ir los regidores con un oficial a medir las calzadas. En 1549, 15.000 mrs, por lo que se le debía, más 2.361 mrs. En 1550, 7.500 mrs. a Hernando de Santander, a cuenta de lo que se le debe por hacer las calzadas, más 40 ds., de lo que debía Diego de Espina del cobro de los mulateros, más 20 ds. En 1551, la villa "bisto todo por los señores regidores venideros", le debe 19.275 mrs. 
años varias actuaciones en este camino por encargo de Laredo ${ }^{843}$. Además, en estas cuentas se recogen diversos pagos para mantener de manera adecuada los caminos. En 1539, uno de 11.730 mrs. a Juan Pando, cantero vecino de Cicero, para hacer un camino y calzada de 85 brazas en la Serna antes de entrar en Colindres, a 138 mrs. la braza. En 1544, 1.517 mrs. al teniente, procurador y escribano regidor por "yr a ber los caminos asi a Ramales". Otro de 1.360 mrs. se hizo a Rodrigo del Perujo, cantero, por "hazer el camino de las Casillas e romper una peña para que pudiesen pasar los mulateros viandantes que bienen a esta villa", y tres ducados al escribano que "fue por nuestro mandado a Ramales e otras partes sobre los caminos", y se ocupó 6 días. En 1547, 9,5 ds. a Arnao del Hoyo Somado, por ir "a Burgos a entender en la contrata del camino de entre esta villa e Burgos, a los caminos con los que venieron a verlos", más cuatro rs. a Paricio de Obra de "çierta obra de un pedaço de la puente que estaba caido", y 6.00o mrs. a Antón de Amor por aderezar el camino de la cantera y empedrar cabo la Guardia. De los 300 ds. que Juan del Hoyo recibió de la Universidad de Burgos, 200 para hacer los caminos y calzadas de mulateros, y 100 para hacer el camino de los Carros, y pagó dos ducados a Juan de Rueda, vecino de Colindres por ir a Burgos a traer los 300 ds.

En 1548 al escribano Juan Ruiz Cachopín 10 ds. para la visita de los caminos, más 6.574 mrs. por ir a El Prado, a averiguar sobre el agravio hecho a los mulateros y viandantes por ciertos cobros allí realizados, que fueron de resto de su salario y de los gastos hechos en 14 días el teniente y otras personas. Se hicieron en el camino de la Atalaya 130 brazas que a dos rs. la braza, montaron 8.840 mrs. En 1549, 1.797 mrs. por los gastos hechos con la justicia, regidores y procurador general cuando fueron a ver el camino desde Laredo a Ampuero, más tres ducados a García de Escalante, al teniente y al escribano, que fueron a ver los puentes de Cibaja y de Ampuero para su reparo y a hacer abrir los callejos en la Mier de Ampuero, más 1.436 mrs. de un presente realizado a los que vinieron de Burgos a visitar los caminos. Se pagaron 23 rs. a Diego Saiz de Espina, regidor, por el gasto hecho con las personas que fueron a medir las calzadas, más 15.000 mrs. a ciertas personas por la heredad que se les tomó con su acuerdo para abrir el arroyo de agua que había por el ca-

para acabarle de pagar las calzadas que hizo, y se encarga a Hernando Sáenz, que lo pague del cobro a los mulateros. En 1552, se pagan 4.500 mrs. y 3.750 mrs. en 1553.

843 Se le pagan $15.084 \mathrm{mrs}$. en 1547 por empedrar los tramos de la calzada que lo requerían, 14.533 mrs. para acabar de pagar 584 brazas que hizo en el término de Colindres y Limpias y 61 ds. "por hazer las calçadas para mulateros". En 1548, 6.000 mrs. para lo mismo y se dio cuenta de 675 brazas que hizo: 50 brazas desde la casa de Pedro Gil hasta la fuente entrando en el monte de Colindres, y 625 desde las cruces del monte de Limpias hasta Collado y hasta las últimas casas del camino, junto a la Mier de Ampuero, y con las dos calzadas que empedró, una a la parte del rio de Gibaja "y otra de la parte de allende" en que gastó lo dicho, según lo dio el maestro cantero Pedro Ochoa, que a 90 mrs. la braza, son 60.750 mrs. Hubo de cobrar este año 69.590 mrs. de los que recibió de Hernando Sáenz 46.759 mrs., descontando los 8 reales dados a Ochoa por medirlas, así que recibió en total, 67.234 mrs., estando obligado a reparar las calzadas caídas. Del cobro de $64.855 \mathrm{mrs}$. a los que pasan por el camino, se le pagaron a Avellaneda $47.031 \mathrm{mrs}$. con 8 rs. que se dieron a Ochoa por medirlas. En 1549, cobró 35.642 mrs. En 1550, se pagaron 631 mrs., 495 por la madera para la grúa y $136 \mathrm{mrs}$. de un correo que se le envió para que fuese a hacerlas, más $8.000 \mathrm{mrs}$. De los $74.239 \mathrm{mrs}$. cobrados en 1550 a los mulateros, se le pagaron $44.730 \mathrm{mrs}$. por las 497 brazas que hizo este año en los caminos por donde pasan las recuas en los términos de Colindres, Limpias y Ampuero a 9o mrs. la braza, más 4.270 mrs. En 1551, de los 76.993 mrs. cobrados a los mulateros se pagaron a Avellaneda 9.750 mrs. y 24.804 mrs. para acabarle de pagar los "caminos y calçadas por donde pasan los dichos mulateros" hechos ese año. En 1552, Hernando Sáenz le pagó 75.926 mrs. "para las calçadas que tiene cargo de hazer para los biandantes" y 6 rs. a un correo que fue a llamarle, y a él y a Ochoa, por ir a medir las calzadas que por mandato de la villa había hecho, y a Hernando Sáenz que fue con ellos a traer la razón de las brazas hechas y por el tiempo que en ello se ocuparon, 677 mrs. En 1553, 57.250 mrs. por 7 libranzas. 
mino de Ampuero, más 5.375 mrs. para aderezar el puente de Ampuero, adelantados por Laredo y que cupo a los mulateros su reparo. Se pagó prestado para aderezar el puente de Cibaja y empedrarlo $1.749 \mathrm{mrs}$.

En 1550, 4.270 mrs. a Juan Sarabia, vecino de Cereceda, por aderezar el puente de Ampuero, más 429 mrs. a 8 hombres que allí estuvieron para hacer abrir el salegar de Limpias para que corriese el agua y no ocupase el camino, más 3.000 mrs. a Diego Guerra, vecino de Ramales, para hacer aderezar el lado del Obregaz, más 810 mrs. a un maestro cantero que fue a medir las calzadas y por abrir una acequia en el monte de Limpias para canalizar el agua. En 1551 cinco rs. a Pedro de Elguero, por ir a Herada y al Prado con cartas de la villa para los que habían de hacer el camino de "Sandiniesto", más 428 mrs. a unos obreros que abrieron unos arroyos de los caminos de Ampuero. En 1552 a Francisco Cachopín, regidor, que fue a "Sandiniesto" a ver los malos pasos del puerto con Pedro Ochoa, cantero de la villa, y 816 mrs. por el tiempo que allí se detuvo, y de sus jornales 228 mrs. En 1553 Hernando Sáenz pagó 2.284 mrs. por los pasos de los pontones que se hicieron en el arroyo que viene de Rocillo, por la madera que para ello se tomó y 2.250 mrs. por aderezar otro pontón que estaba caído, con lo que pagó a los oficiales que lo hicieron y a los que fueron a "Sandeniesto" a medir las calzadas, y él con ellos, con un regidor de la villa y con el maestro a ver los malos pasos que había ${ }^{844}$.

\section{Cuentas del Consulado sobre el camino de Laredo}

En los libros de cuentas de la Universidad de los Mercaderes de Burgos, se recogen pagos relacionados con el portazgo de Laredo, en los años 1543 y $1545^{845}$, y a partir de 1547 los gastos vinculados con el reparo e intervención en este camino, que ya recogemos en el apartado del "Camino del Carro".

La Universidad desarrolló una amplia actividad en la construcción y mantenimiento de estos caminos. El Prior indica en 1547 que "an hecho adereçar algunos caminos y seran causa que las mercaderias de aqui adelante vengan desde la costa de la mar, e vayan desta ciudad a la costa en mejores prescios, porque desde Laredo podran ir en carros a la ciudad de Burgos..." 846.

\section{La venida del emperador en 1556}

Los preparativos para acondicionar los caminos con motivo de la llegada de Carlos V,

844 A. H. P. C./ Laredo. Cuentas de la villa de Laredo, f. 24r-24V/ Laredo, 1539; f. 43V-51v/ Laredo, 1541; f. 8or-81v/ Laredo, 1544; f. 95V-96r/ Laredo, 1546; f. 107r-116r/ Laredo, 1547; f. 120r-135r/ Laredo, 1548; f. 139r-151V/ Laredo, 1549; f. 157V-168r/ Laredo, 1550; f. 174V-191v/ Laredo, 1551; f. 199r-206r/ Laredo, 1552; f. 212V-219V/ Laredo, 1553; VALDOR ARRIARÁN, M.: 2002: doc. 2, 79-80; doc. 4, pp. 112-116; doc. 7, pp. 176-179; doc. 9, pp. 208-209; doc. 10, pp. 227-251; doc. 11, pp. 257-285; doc. 12, pp. 292-311; doc. 13, pp. 321-337; doc. 14, pp. 348-372; doc. 15, pp. 384-394; doc. 16, pp. 404-415

845 A. D. B./ R-3/ Burgos, 1539-1549. p. 69i. y 107i. Así en abril de 1543, Francisco de Santamaría pagó 4.116 mrs. del alquiler y portazgos de 24 barriles de pólvora que se enviaron de Burgos a Laredo. En junio, se prestaron a Gonzalo del Río hasta fin de 1545, 12.000 mrs. por tantos de Raimundo del Hospital vecino de Burgos y Gonzalo de Río de la Concha, de que hicieron obligación los dos, por hacerle buena obra y porque prometió que "no lleuaria portasgo de las sacas que pasan por delante su casa". En septiembre, se pagaron $4.323 \mathrm{mrs}$. a Juan de Rebolleda y Juan Vélez y compañeros, del alquiler de Laredo a Burgos de 41 barriles de pólvora que envió Pedro del Hoyo, que pesó con tara 134 arrobas, a ducado carga de 12 arrobas que es 4.203 mrs. con 7 de portazgos por carga y 102 de alcabala con la renta de lo que costó subirlo al castillo. En octubre, se pagaron $537 \mathrm{mrs}$. a Juan de Rebolleda del alquiler y portazgos de Laredo a Burgos de 5 barriles de pólvora que envió del Hoyo.

846 A. G. S./ Consejo Real de Castilla, leg. 204-3/ 1547; BASAS FERNÁNDEZ, M.: 1963 y 1994: 150. 
que llegó al puerto de Laredo el 28 de septiembre de 1556, comenzaron con cierta antelación. De esta manera en diciembre de 1555, Antonio Cacharro teniente de alcalde mayor en las Merindades y lugarteniente por el Condestable, alcalde y justicia mayor de dichas Merindades, notificó al Ayuntamiento general de las Merindades en Miñón, la venida del Emperador, "y como mediante la boluntad dibina abia de desembarcar con toda su corte en la villa de Laredo, en todo el mes... de enero y que..., hera necesario que los pueblos desta jurisdicion estuviesen bien bastecidos de todos mantenimientos, y los caminos y puentes todo bien reparado". Indicó que el verano pasado, había mandado hacer dos puentes de nuevo y reparar otros dos principales en la merindad de Montija, en el camino que el Rey iba a seguir, y que la actuación no había costado nada a las Merindades porque el alcalde había buscado y debía la mayor parte de lo que se gastó, además de lo que se cobró a los viandantes, y que ahora era justo que todos ayudasen a reparar los caminos y malos pasos, en especial en los Hocinos, la Horadada y en los llanos del término de Bisjueces y Villalaín. También mandó proveer de bastimentos lo que fuese posible. Todos los presentes acordaron que debían consultar con sus Merindades y juntas, y que harían todo lo que pudiesen en servicio del Rey.

En enero de 1556 el doctor Cacharro informó el ayuntamiento general en Miñón que el doctor Durango del Consejo del Rey, juez diputado para el reparo y bastimento de los caminos por donde el Rey ha de pasar, dejó al alcalde un mandamiento y provisión en el que hacía saber a las merindades de Castilla Vieja, que en "el camino real que ba de Laredo a Burgos que es el que su Magestad a de traer, he hallado en él muy malos pasos en los términos de las dichas Merindades en especial el paso de los Ocinos y el paso de la Oradada, y lo que va del dicho camino desde donde se acaba la jurisdicción de Medina de Pumar hasta llegar a los Ocinos... y los Ocinos desde el llano de Bisjueces fasta llegar a la puente de Valdivielso". Y como convenía remediarlo, mandó que se reparasen con urgencia y nombren veedores y maestros que dirijan la obra. Manda al alcalde mayor y su lugarteniente que lo hagan cumplir, y apremien a todos los vecinos y concejos de las Merindades para que lo hagan. Todos dijeron que a pesar de que dichos caminos son pasos generales para todo el Reino, y que las Merindades no tienen obligación de repararlos ni nunca lo hicieron, porque siempre lo han atendido los que los destruyen con sus bestias y cargas y los mercaderes que llevan por mar sus mercaderías, por ser para el servicio del Rey están dispuestos a hacer las obras posibles. Dicen que vea el alcalde lo que las Merindades deben hacer "sin prejudicar a sus libertades y sin que para ello se obliguen a lo que no deben, ni nunca debieron sino solamente a serbir a su Magestad", a pesar de la pobreza de la tierra y especialmente ese año por haberse apedreado las cosechas. El alcalde dijo que, como las principales reparaciones están apartadas de los lugares y que por ello sería costoso y de poco provecho enviar peones por adra, que las Merindades ayuden con un repartimiento de hasta 200 ds., y contribuyan también los trajineros como suelen hacer, mientras el Consejo manda proveer su total reparo.

El ayuntamiento, acordó dar 40.000 mrs. para que estos caminos se comiencen a reparar, con la condición de no adquirir nueva obligación sino solamente para el servicio del Rey, y que el alcalde provea que los viandantes trajineros contribuyan, pues "son a cuya causa se suelen hacer los dichos caminos y malos pasos y no los naturales desta tierra e Merindades". Se dará poder a una persona principal para que vaya al Consejo Real, y les informe sobre los grandes gastos que acarrean los caminos y malos pasos de la Horadada hasta subir a Oña, y los Hocinos desde el llano de Bisjueces hasta llegar al puente de Valdivielso y encima de El Almiñé, y cómo 
"los huellan y destruyen, abarrancan y malean, todos los que ban y bienen destos reinos a los puertos de la mar, y de los dichos puertos a los dichos reinos con cargas y mercaderias y bastimentos", y los manden reparar de una vez. Acuerdan pedir al Consejo que dé provisión para que los gastos se carguen a los trajineros y mercaderes de Burgos, Medina del Campo, Rioseco, Villalón, Valladolid, Toledo y otras villas principales, que son los que los usan, y cuyas mercaderías se trajinan por esos caminos, para lo que otorgan poder a Juan López de Rueda, abad de Rueda, para que comparezca ante el Consejo, pida lo acordado y gane las provisiones necesarias para que se eviten gastos y peligros, como los ha habido por no haberse reparado del todo ${ }^{847}$.

$\mathrm{El}$ acuerdo no satisface al procurador general de las Merindades, que manifiesta que no están obligados al reparo porque "son caminos tan reales públicos y caudalosos por donde [va] la mayor parte, o casi todas las mercaderías que salen destos reinos o bienen a ellos de reinos estranxeros, Flandes, Yngalaterra, Yndias y otras muchas e dibersas partes, pasan e se traxinan por los dichos caminos...", y los deshacen los mercaderes, tratantes, mulateros y trajineros. Añade que de tiempo inmemorial, los reparos se han hecho a costa de los trajineros por repartimiento y no a su costa, por lo que "seria cosa yntolerable" que el gasto de más de 5.00o ds., corriera a cargo de las Merindades, tierra de montaña y muy pobre, porque son los que menos se aprovechan. Además, ya han contribuido en el reparo de otros pasos, caminos y puentes, algunos muy lejanos, por lo que suplica al Rey, que mande que estos gastos se repartan entre las poblaciones que se aprovechan del camino, o entre los mercaderes y trajineros que los utilizan, para lo que se debe obtener información de testigos. Se preguntará si conocen:

- Los caminos reales de las Merindades, en especial el que va de Laredo a Burgos por la Horadada o por los Hocinos y puente de Quintanilla de Pienza.

- Que los "caminos de los Ocinos y la Oradada que sale a Oña, son caminos de los mas publicos reales y caudalosos y pasaxeros deste reino, por donde todas las mercaderias o casi todas que aportan a los puertos de Bilbao, Portogalete, Castro de Urdiales, Laredo y las que deste reino, se enbarcan y an enbarcado en los dichos puertos, pasan y se traxinan por los dichos caminos... especial por el de los Ocinos".

- Que los que reciben provecho y más los necesitan, son los mercaderes y mulateros que por ellos trajinan, porque son caminos por donde las mercaderías "nezesariamente las an de traer y lebar y sacar el fierro y azero y los pescados que salen de los dichos puertos, y se labra en las herrerias de Bizcaya e Montaña".

- Que estos caminos, además de ser tan necesarios, son "muy peligrosos ansi por ser muy estrechos en muchas e diversas partes que no tienen tres pies de ancho, e porque confinan con el rrio de Hebro que es muy caudaloso e furioso, donde suelen peligrar muchas personas e bestias, e tienen de largo una legua e muy ordinariamente con poca creciente, se toman e ynpiden de manera que no se pueden pasar en dos y tres y mas dias".

- Que para que se aderecen como conviene y se trajine sin peligro, se han de gastar más de 5.000 ds., porque "se an de quemary ronper muy grandes e dibersas e muy asperas peñas, y se an de fundar muy grandes estribos e paredones de cal y canto e maderas dentro del dicho rio".

- Que cuando se han reparado estos caminos, ha sido por repartimiento a los que los utilizan, y se ha cargado a las mercaderías y machos y bestias que por esos caminos pasan, y no a las personas ni haciendas de las Merindades, ni se les han repartido dineros, ni peones, ni cosa alguna para ello.

847 A. C. V./ nº 18. doc. 3, hojas 23 a 28/ Miñón, 5 enero 1556 y nํ⒈873, doc 1, hojas 3 a 4/ Miñón, 5 enero 1556. 
- Que si los vecinos de las Merindades los hubiesen de reparar a su costa, no lo podrían soportar ni bastarían sus haciendas por ser tierra de montaña y muy pobre y estéril, y porque han de reparar otros muchos malos pasos y caminos que caen en las Merindades, que tienen de largo más de 15 leguas por donde el Rey y su corte ha de pasar y pasan las mercaderías y trajineros.

- Que dichos vecinos de las Merindades contribuyen ya en el gasto del puente de Quintana del Puente, Lantadilla y Villarente en el reino de León.

Comparecieron como testigos un escribano vecino de Villarcayo, y los mulateros Pedro Sarmiento, vecino de Bisjueces, que "a andado en camino con requa de bestias por los dichos caminos e puentes de mas de quarenta años", Juan Martínez de Brizuela, vecino de Torres, Juan Díez, vecino de Incinillas, Hernando Alonso, vecino de Bisjueces, y Alonso de Rámila, vecino de Remolino, y respondieron:

- Que conocen esos caminos y puentes, y especialmente los caminos reales que van del puerto de Laredo, Castro-Urdiales, Bilbao y Portugalete a las Merindades, Burgos y otras partes de Castilla, y los caminos reales de la Horadada y los Hocinos, el puente de Quintanilla de Pienza y el camino que va por El Almiñé hasta subir la cuesta para ir a Burgos. Juan Martínez de Brizuela dice que hace unos 10 meses pasó por un puente junto a la venta del Ribero en el camino real, y por allí fue y vino en un día y atravesó el camino que por allí pasa yendo y viniendo a Espinosa de los Monteros.

- Que ambos caminos son principales del reino y "son y an seido caminos públicos reales y muy pasageros y nezesarios, para yr e pasar como an ydo e pasado y pasan por ellos, con mercaderías que an aportado y aportan en los puertos de Laredo y Castro de Urdiales y Bilbado, a la cibdad de Burgos y Balladolid y a las ferias de Medina del Campo y Ruseco y Billalón, e para otras muchas e dibersas partes...", y "el camino de los Ocinos es el mas pasagero e prenzipal e por el pasan mas mercaderias que por el de la Oradada". Los mulateros pasan ordinariamente con cargas de las ferias, tierra de Campos y otras partes a los puertos de la mar y las montañas, y no saben que haya otros caminos más directos que los de la Horadada y los Hocinos y que si no pasasen por ellos, deberían rodear mucho. Juan Díez ha visto pasar por el camino de los Hocinos "muchas mercaderías que byenen e an benido de los puertos de Laredo e Bylbao e Castro, e tanbién pescado cecial e fresco de los dichos puertos e hierro hecho en las Montañas y en Bizcaya, y tanbién a visto traer y llebar a los dichos puertos desde Castilla por el dicho camino de los Ocinos, mucho pan e bino e lanas...". Otro testigo indica que ha pasado por este camino "con mercaderías que traiya de puerto de Laredo que hera çalazon, naranja e hierro de la Montaña y lo llebaba a Castilla". Hernando Alonso dice que por los Hocinos pasó mercaderías que traía de Laredo y Bilbao para Castilla, y de Castilla llevó trigo y vino, y que una vez llevando vino junto con otros mulateros que lo traían de Castilla, pasaron por la Horadada porque había nieve.

- Que los que los suelen utilizar son los mulateros y trajineros, y cuando no sacan cargas de los puertos, suelen traer pescado en salazón, naranjas y el hierro y acero labrado en Vizcaya y La Montaña, y también llevan desde Campos, pan, vino y otros mantenimientos. Los que más provecho reciben, son los mercaderes por llevar sus mercaderías, y los mulateros por ganar para comer, aunque también se benefician todos los que pasan por ellos, por ser "caminos publicos e muy nezesarios y pasageros para yr a muchas e dibersas partes destos reinos", y si por ellos no pueden pasar a pie o cabalgando, los mulateros deberían dar un gran rodeo. 


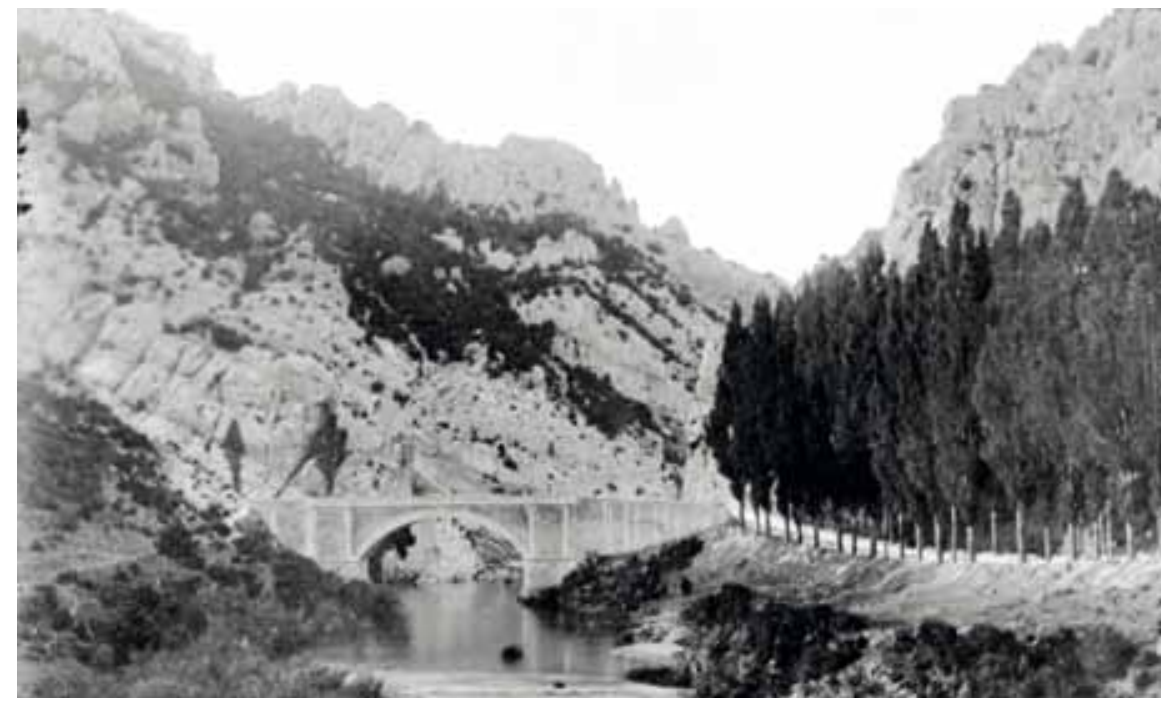

25. ALREDEDORES. PENA Y PUENTE DE LA HORADADA SOBRE EL EBRO Sitio en que seguia la leyenda tuvo lugar un sangriento combate entre el Conde fuadador del Monasterio y un Rey moro del castillo de Frias

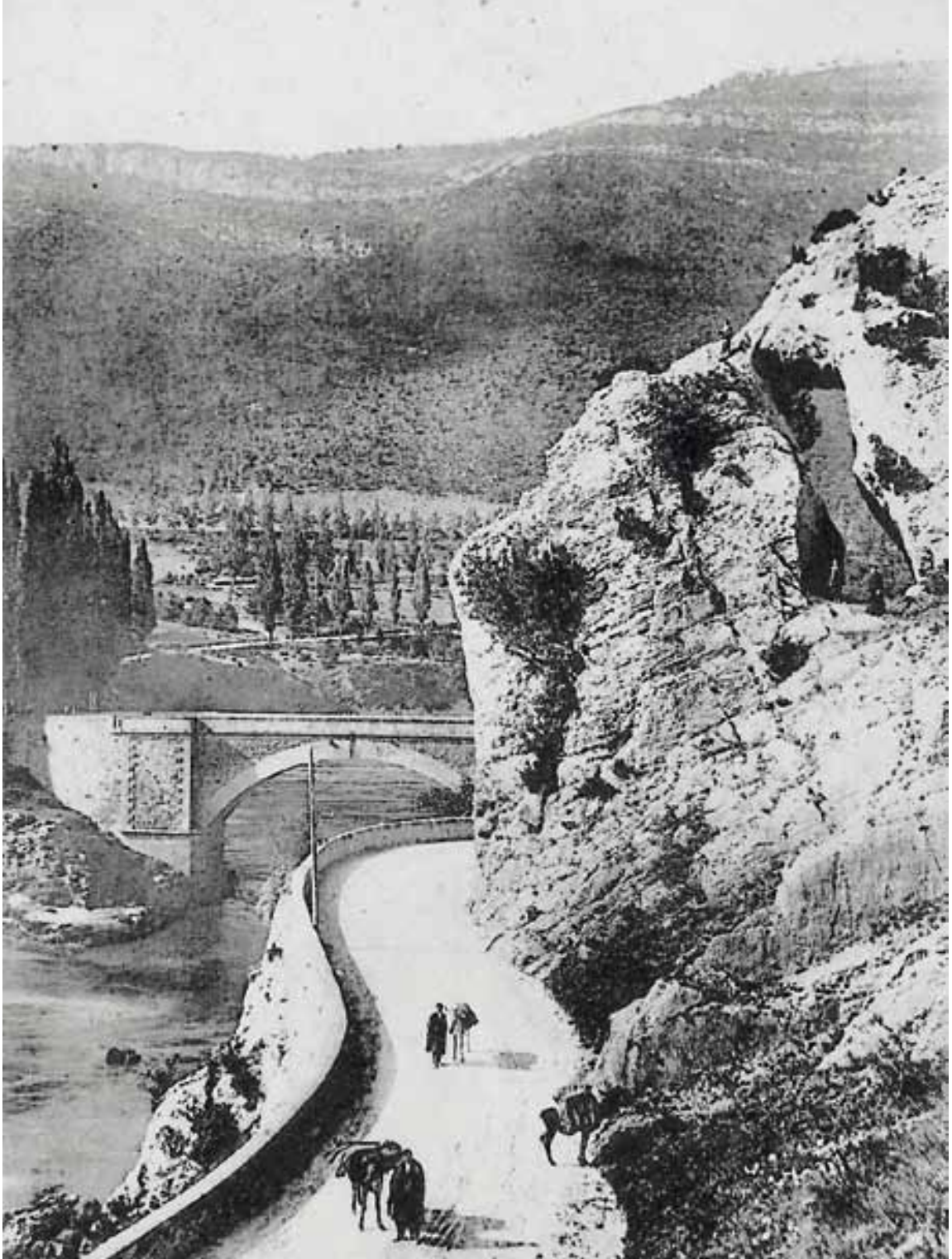

Desfiladero de la Horadada. 
- Que a pesar de ser caminos tan necesarios, son muy peligrosos tanto para los que cabalgan como para las bestias cargadas, y dice un testigo que "ansi por ser muy estrechos en muchas e diversas partes, que no tienen tres pies de ancho e porque confinan con el rio de Hebro que es rio muy cabdaloso y furioso, donde a visto peligrar algunas bestias e a oydo que an peligrado personas". Otro indica que "a visto despeñadas bestias en el dicho camino, y aun se despeño alli en el dicho camino un macho que agora balia cinquenta ducados". Señalan que en los Hocinos, se había ahogado un mancebo de la Sonsierra que pasaba con su recua a pie, poniéndose una cruz enfrente de donde sucedió. Dicen que "con poca cresçiente del dicho rio se toma muchas bezes el dicho camino de los Ocinos en parte, de manera que no se puede pasar... en dos y tres dias, y aun algunas bezes quando ay niebe y ba creçido el rio en mas y a esta causa, a acaeszido y acaesze, estar los mulateros con sus bestias y con mercaderias y otras cosas e otras personas asi de a pie como de a caballo, detenidas" aguardando la bajada del agua en una venta que está fuera de los Hocinos. Otro añade que yendo a por vino a Valdivielso con sus bestias y "queriendo pasar por los dichos Ocinos, no pudo por estar tomados del agua, e asy se fue por una syerra que llaman Tesla". Una vez, estuvo cortado el camino unos 6 días a causa de un portillo que había elevado el río. También había algunos pasos peligrosos y angostos en la Horadada, que se solía inundar en partes, pero que desde hace unos 50 años no vieron hacer reparos ni obras en ella, ni que se haya hecho repartimiento alguno entre los vecinos de las Merindades para reparar esos dos caminos, ni que ellos trabajasen en tales obras, ni que pusiesen peones ni obreros sino que lo pagaban "los que hollaban los dichos caminos", y que lo mismo hacían en los puentes que se reparaban de las Montañas.

- Que para adecuar los caminos de los Hocinos, la Horadada y las Pedrosas, el puente de Quintanilla de Pienza y el camino y cuesta de El Almiñé y se utilicen sin peligro, se han de gastar más de 4.000 ds., porque se han de "romper e quemar muy grandes e dibersas e muy asperas peñas, e se an de fundar muy grandes estribos y paredones de cal y canto y maderas dentro del dicho rio", los cuales se han de hacer muy firmes y fijos porque el río es caudaloso y fuerte, y lo puede llevar todo.

- Que han visto dos veces reparar algunos malos pasos en los Hocinos, una hará unos 32 años con muchos obreros, cuando Alonso Martínez, vecino de Villalaín, y Miguel de Pereda, escribano vecino de Quecedo de Valdivielso, cobraron a los mulateros con licencia real para el gasto de aquella obra, 1 real de cada macho o mula cargada, y cuartillo y 8 mrs. de cada bestia, rocín o bestia asnal, y a uno de ellos le pidió por un asno que iba con leña hasta la venta de Valdemera en los Hocinos, 8 u 8,5 mrs., haciendo aquí un calero para aderezar el camino. Juan Díez dijo que hará unos 30 años él, con mandamiento del alcalde de las Merindades, cobró en Incinillas para el reparo a los mulateros de Ahedo del Butrón, Valdezamanzas y otras partes, medio real por macho o mula cargada y 8,5 mrs. por cada bestia asnal. Un segundo reparo se hizo haría unos 20 años, y lo que se gastaba lo cobraba a los que por el camino pasaban, Alonso García de la Manadera, vecino de Castilla Vieja, conforme a las bestias cargadas que cada uno llevaba, a medio real o cuartillo por cada rocín y bestia menor, y el doble a cada bestia mayor. Hernando Alonso dijo que Lope de Rutin, ventero de la venta de Afuera en los Hocinos era el que lo cobraba, y oyó decir que como lo hacía sin licencia le habían echado de pena 5.00o mrs.

- Que si los vecinos de las Merindades hubiesen de reparar a su costa los caminos de la Horadada, los Hocinos y las Pedrosas, puente de Quintanilla de Pienza y camino y cuesta 


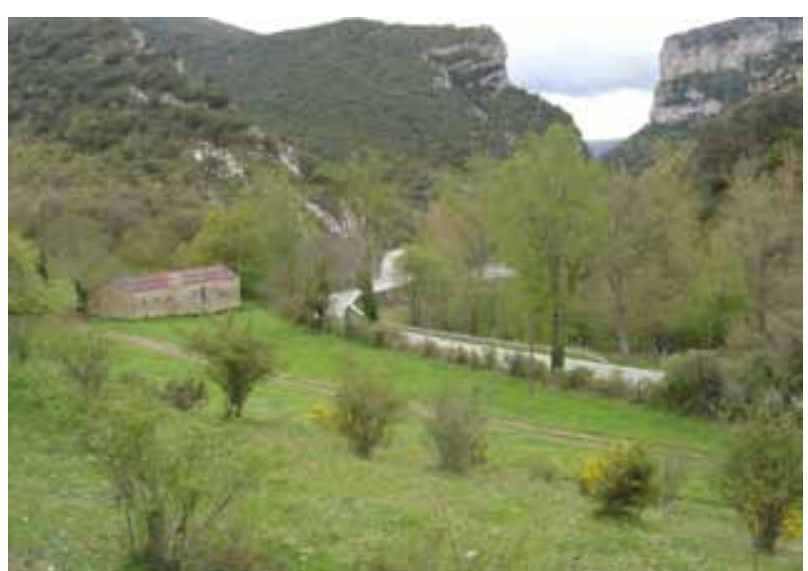

Desfiladero de los Hocinos con la venta de Adentro.

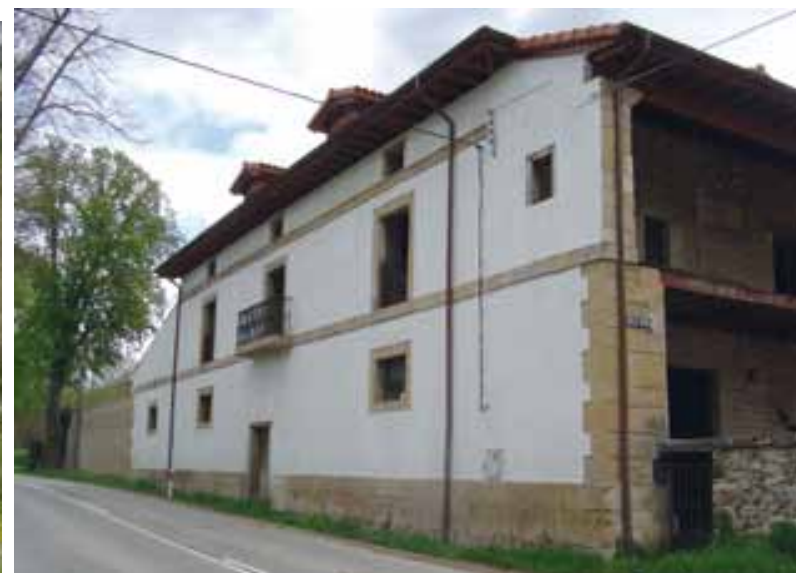

Venta de Afuera.

de El Almiñé, sería gran quebranto por ser necesaria una gran cantidad de mrs., y por ser tierra estéril y de montaña, está la mayor parte de la gente muy pobre, por los años duros y faltos de frutos que ha habido y porque también ellos han reparado muchos puentes y malos pasos en sus términos. Alonso de Rámila indica que pasando por el camino de los Hocinos en enero de ese año, vio aderezado un portillo "desta parte del barco", y también vio cavadas y allanadas unas lindes que habían hecho los vecinos de Valdenoceda y Quintana en su término, habiendo otros muchos pasos peores sin reparar, siendo el total de lo arreglado muy poca cosa.

- Que se han repartido en las Merindades 8,5 o 9 mrs. a cada vecino en dos o tres veces y en la merindad de Losa 3 mrs. por vecino para hacer el puente de Quintana del Puente. Además les parece que se pedía también a los vecinos de Castilla Vieja para el puente de Lantadilla ${ }^{848}$.

El abad de Rueda llevó al Consejo Real una memoria con la información mencionada, para que el gasto del reparo de los caminos se reparta entre las localidades que se aprovechan, como se han repartido los puentes de Quintana del Puente, Mansilla, Lantadilla y Villarente, y si no se pudiere, procurará que se reparta entre todos los viandantes y pasajeros, cargando una parte a las mercaderías y otra a las bestias que por ellos pasan ${ }^{849}$. Dijo al Consejo que en las Merindades hay caminos reales "muy pasajeros e frequentados de mercaderes y otros camynantes, los quales estan destruidos y deshechos en tal manera, que pasan gran dificultad, travajo y peligro los que pasan por los dichos caminos, especialmente el camino que dizen de los Ocinos y la Horadada, que estan de manera que se pasa con gran peligro por ellos y en el paso an muerto y peligrado muchos", y que el doctor Durango mandó su aderezo, para lo que se "an de ronper grandes peñas y se han de hazer grandes paredones y estribos y maderadas dentro del río de Hebro, porquel dicho río pasa por los dichos caminos, siguiendo a la larga con ellos e los come, gasta y deshace tanto que hoy casi no se puede pasar por ellos", y como para ello son necesarios 5.000 ds., pide que al ser caminos generales y ser su tierra pobre, se repartan entre los pueblos que se aprovechan. El Consejo manda que los repare cada uno en su jurisdicción y que se dé privilegio para que las poblaciones de Castilla contribuyan en esos reparos ${ }^{850}$.

848 A. C. V./ nº 18. doc. 3, hojas 28 a 48/ Medina de Pomar, 7, 8, 9 y 21 enero 1556.

849 A. C. V./ no 1.873, doc. 3, hojas 7 y 8/ enero 1556.

850 A. C. V./ nำ1.873, doc. 13, hojas 38 y 39/ Miñón, enero 1556. 


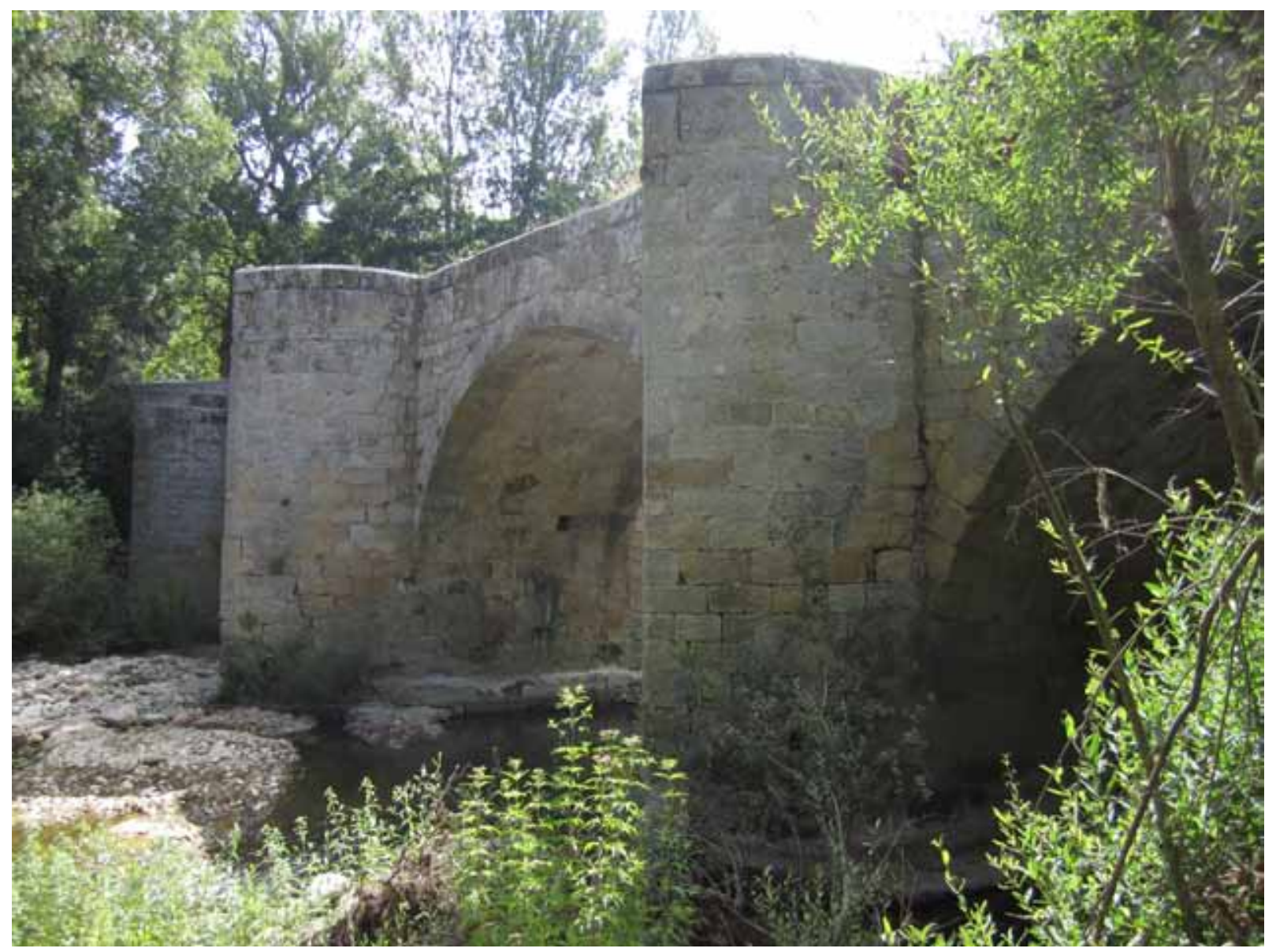

Puente de Quintanilla de Pienza de seis ojos.

El 17 de septiembre de 1556, Carlos V sale de Flesinga en el navío "Spiritu Santo", acompañado de sus hermanas María y Leonor y una gran comitiva, en una flota compuesta por 56 embarcaciones. Llegará a Laredo el 28 de septiembre por la tarde donde descansó, y no será hasta el 6 de octubre cuando el Emperador emprenda ruta hacia Yuste. Partió a las 12 h. después de comer para ir a dormir a dos leguas, en Ampuero. El miércoles 7 pernoctó en Lanestosa, el 8 duerme en Agüera y g llegó a Medina de Pomar donde permaneció enfermo el 10 de octubre, a consecuencia de haber comido "Thon frais"851.

El domingo 11 sale de Medina a medio día y va a dormir a Pesadas, el 12 pernocta en Hontomín y el martes 13 de octubre, llega a Burgos, donde estará hasta el 16, día que sale de la ciudad y va a Celada hacia Valladolid ${ }^{852}$. Fray Prudencio de Sandoval, comenta sobre este viaje que "de Laredo le traxeron poco a poco, vnas vezes en silla a brazos de hombres, y otras en litera.... Saliolos a recibir Don Pedro Fernandez de Velasco, condestable de Castilla y de León, haziendoles la costa con tanta grandeza, qual siempre la usaron estos Señores en servicio de sus Reyes. Entro el Emperador en Burgos con las Reynas, donde fueron muy regalados y servidos del condestable, y desta generosa ciudad"853.

\footnotetext{
851 Escabeche.

852 FORONDA y AGUILERA, M. de: 1914: 655 a 658; CADENAS y VICENT, V. de: 1999: 274.

853 SANDOVAL, F. P. de: 1681: 607.
} 


\section{La llegada de la Reina en 1570}

Con motivo de la prevista llegada a Laredo de la reina Ana de Austria procedente de Flandes, cosa que se produjo el 3 de octubre de 1570 pero en Santander, el alcalde Ortiz escribe el 3 de septiembre al secretario del rey y le dice que "el camino de las carretas, se a hecho $e$ se acabara de hazer todo lo mejor que la dispusiçion de la tierra da lugar, y me afirman que el camino es hecho de las dos leguas de Oña y de las dos leguas de los Hoçinos que es ribera de Hebro abaxo, y las de Oña de Hebro arriba los a acabado de hazer muy bien el... corregidor de las Siete Merindades con los mandamientos que yo le dexe, y que se pueden muy bien andar en litera y se puede muy bien escusar lo de la silla a honbros como su magestad lo manda, y los coches se lleuaran en carretas muy bien hasta Burgos, no serie malo poner las postas daqui a Burgos como tengo escripto"854. Se da una relación detallada del camino que la Reina debía seguir desde Laredo "por donde pueden venir los coches":

- Desde Laredo a Colindres media legua, “los coches vernan mejor por Pereda que queda a la mano isquierda".

- Desde allí a Limpias media legua.

- A Ampuero una legua "es buen lugar y puedese aloxar alli aunques çerca".

- Desde allí a Ramales dos leguas "que todo es casi poblado de lugarillos".

- Desde allí se sube "vn portezuelo que llaman la Pared algo aspero", hay media legua y otra media a Lanestosa donde hay buen alojamiento.

- Desde allí por el camino de Hoz de Herada a La Calera una legua, y derecho a Agüera tres leguas, "donde tambien ay aloxamiento... de aqui se an de apartar los coches a Espinosa de los Monteros" y a Ruerrero y a Rocamundo y van dando la vuelta por tierra llana a Burgos.

- Si la Reina decidiese no ir por este camino de carro por ser más largo, "puede yr en literas desde Aguera adelante".

- A Villasante una legua. Al Ribero otra legua. A Medina de Pomar dos leguas "adonde habra muy buen aloxamiento en treze leguas de Laredo. De aqui se puede venir a Burgos por dos caminos el uno es por Oña y el otro por Hontomin, el de Hontomin es mas breue de legua y media poco mas, aunque si haze mal tienpo es mas trabajoso".

- Por Hontomín, se viene desde Medina "a las ventas de los Paños ques vna ribera del rio Ebro la qual es algo trabajosa, aunque ay calçadas ay vnas bueltas no buenas aunque se pueden pasar bien sea a Valdivielsso ay hasta alli dos leguas" y a El Almiñé media legua.

- De aquí a Pesadas legua y media, "subese un portezuelo façil de subir ay alli comodidad de aloxamiento".

- De allí a las ventas del Cuerno legua y media y a Cernégula otro tanto, son tres leguas de sierra llana aunque complicada con mal tiempo.

- De allí a Hontomín legua y media donde hay alojamiento "y alli pueden uenir los coches a reçibir a su Magestad en çinco leguas de Burgos".

- De allí se va a Peñahorada legua y media. A Villaverde una legua. A la venta de Quintanaortuño media legua y a Vivar, Villatoro y Burgos dos leguas todo ${ }^{855}$.

Llama la atención la propuesta de pasar por Medina y no por Villarcayo, cuando ya se ha trasladado la capitalidad de las Merindades, quizá porque la villa del Condestable posee

854 A. G. S./ Patronato Real, leg. 57, doc. 32/ Laredo, 3 septiembre 1570.

855 A. G. S./ Patronato Real, leg 57, doc. 9o/ Antes del 3 octubre 1570. 
mejores condiciones para el alojamiento de la Reina, o bien por la influencia del mismo Condestable para el paso por su villa. Aunque desde 1562, el tráfico mercantil discurre por Villarcayo, parece que el prestigio e infraestructuras de Medina actúan como un elemento de atracción para el paso de personajes singulares.

El 4 de octubre de 1570 el Cardenal de Sevilla informa al secretario del Rey que, como la Reina no ha desembarcado en Laredo como estaba previsto, el que la comitiva vaya a Burgos desde Santander tiene alguna ventaja, ya que viniendo por Medina "no puedela Reyna nuestra señora ni las mugeres que uienen con ella, aprouecharsse de los carros que traen y yendo por el camino de los Carros desde Santander a Burgos pueden muy bien yr". La verdad es que es una respuesta dada ante unos hechos consumados que no tienen alternativa ${ }^{856}$.

\section{c.- Camino de herradura por Pilas}

Un camino de herradura muy duro, que discurre desde el puente de Puente-Arenas, por lo alto de la Sierra de la Tesla y la ermita de Ntra. Señora de Pilas, yendo a Bisjueces para ir a Villarcayo por Villalaín, o bien a Barruelo y La Aldea pasando por El Vado para llegar a Medina de Pomar, evitaba ir por los Hocinos cuando se encontraba dificultado o interrumpido por las aguas. En 1499 se indica que en los lugares "dela Aldea e Queçilese Barruelo, ay muchos mulaterose mesones", y que si no se pasa por los dichos lugares "rreçibirian gran daño e a la mulateria se le haria mucho de mal a cavsa de las posadas buenas que en estos lugares ay"857.

Según Cadiñanos ${ }^{858}$, el camino por Pilas era antiguo y utilizado antes de acondicionar el difícil paso de los Hocinos, ya que este desfiladero presentaba en sus orígenes paredes verticales en puntos concretos, que hacían su paso muy complicado hasta que no se encajó el camino en la orilla izquierda del río Ebro, tallándose en la roca, como se hizo, y ensanchándolo sobre la corriente del río fundando "muy grandes estribos e paredones de cal y canto e maderas dentro del dicho rio"859, a veces de gran altura, que las periódicas acometidas del Ebro se encargaban de descalzar ${ }^{860}$. Si lo que afirma Cadiñanos es cierto, la capillita realizada a principios del siglo XIII denominada Ntra. Señora de Santi Spiritus ${ }^{861}$, que se encuentra en la venta de Adentro junto al Ebro en los Hocinos, confirmaría dicha antigüedad en función de este camino por Pilas, ya que de la venta de Adentro arranca un camino directo a Pilas, que podría canalizar por aquí el tráfico arrieril que venía de Villarcayo-Espinosa de los Monteros para salir a Puente-Arenas, evitando con ello transitar por el difícil paso de los Hocinos.

856 A. G. S./ Patronato Real, leg 57, doc. 62/ Laredo, 4 octubre 1570.

857 A. H. N./ Nobleza. Frías, C. 235, D. 55/ Medina de Pomar, 15 enero 1499. Queciles es un despoblado que se encontraba fuera de este camino.

858 CADIÑANOS BARDECI, I.: 2002: 44.

859 A. C. V./ no 18. doc. 3, hojas 28 a 48/ Medina de Pomar, 7, 8, 9 y 21 enero 1556.

860 A. C. V./ no 1.873, doc. 13, hojas 38 y 39/ Miñón, enero 1556. "se an de ronper grandes peñas y se han de hazer grandes paredones y estribos y maderadas dentro del río de Hebro, porquel dicho río pasa por los dichos caminos siguiendo a la larga con ellos e los come, gasta y deshace".

861 Con este nombre se menciona en el plano mapa de 1748 de los caminos desde Burgos a Laredo, Santoña y Santander A. G. S. MPD 21,055. 


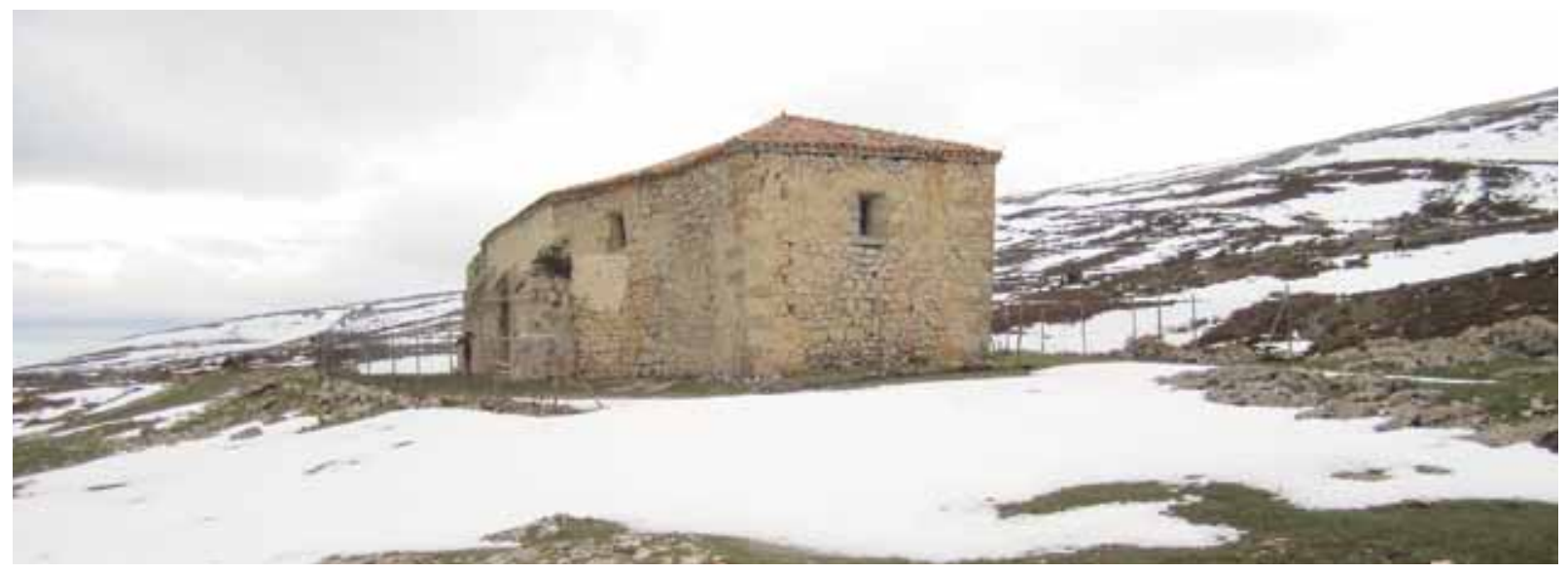

Ermita de la Virgen de Pilas entre Puente-Arenas y Medina de Pomar.
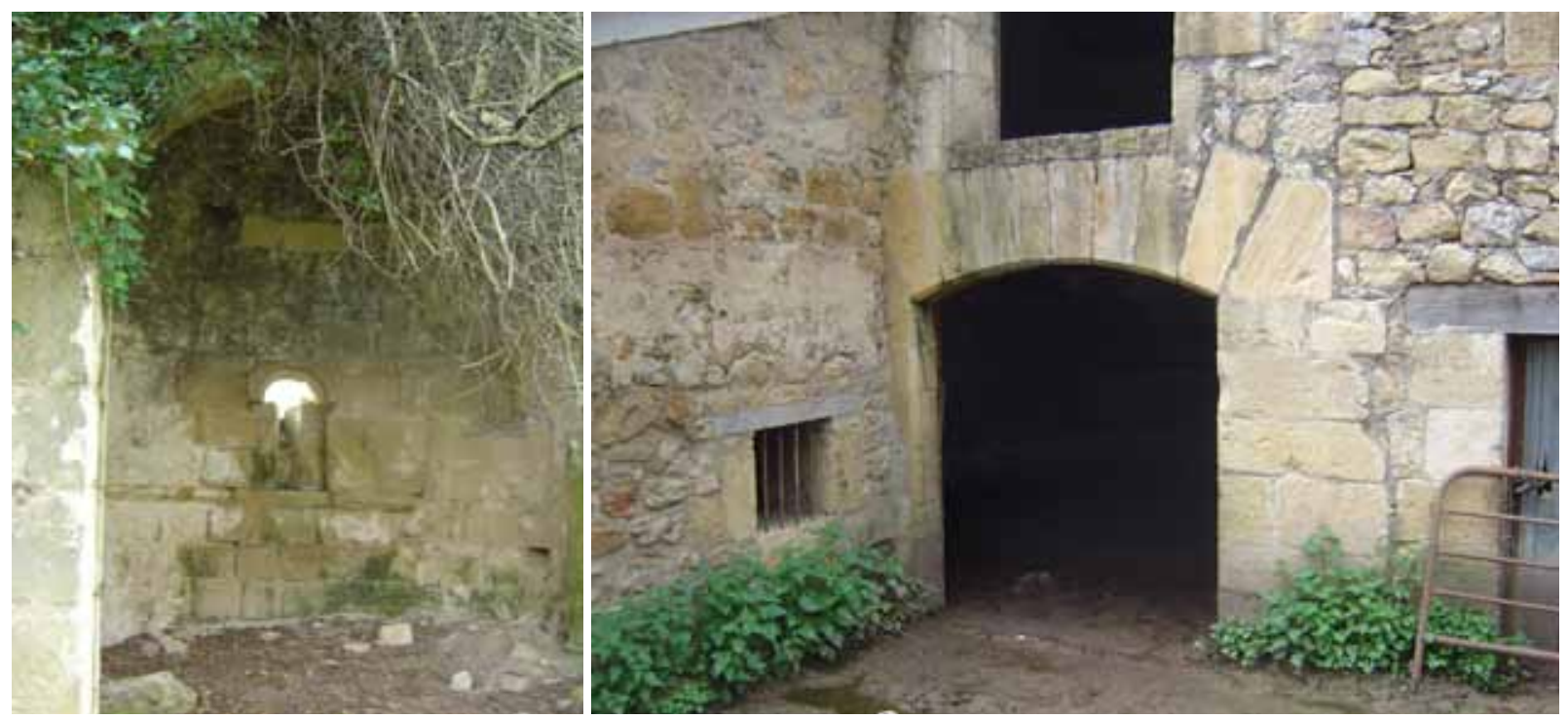

Ábside de la iglesia románica de Ntra. Sra. de Santi Spíritus junto a la venta de Adentro.

A la derecha, puerta de la venta de Adentro.

Posteriormente, este camino alternativo fue utilizado por los mulateros para evitar las interrupciones y demoras, sobre todo, cuando transportaban productos perecederos en los momentos que el paso por los Hocinos se encontraba impracticable por riadas o desprendimientos. Así lo confirma en 1556 el mulatero Hernando Alonso, vecino de Bisjueces, cuando dice que el paso de los Hocinos se inunda "por algunas partes y suele estar tomado dos y tres dias algunas beces y otras menos, e yendo... por bino a Baldybyelso con sus bestyas, y queriendo pasar por los dichos Ocinos, no pudo por estar tomados del agua e asy se fue por una syerra que llaman Tesla"862.

\section{d.- El Ilamado "Camino del Carro" o "de los Carros"}

En el plan de actuación en el camino de Burgos a Laredo desarrollado en 1499, se proponen ya intervenciones en tramos concretos con el fin de acondicionarlo para el tránsito de carros, ensanchando la vía y buscando trazados más suaves. No obstante, muchas de las actuaciones propuestas no se llevaron a cabo por los graves problemas que tuvieron

862 A. C. V./ no 18. doc. 3, hojas 28 a 48/ Medina de Pomar, 7, 8, 9 y 21 enero 1556. 
para su financiación, quedando amplios tramos incapacitados para el paso de carros, lo que obligaba a hacer el transporte completo a lomos de mulos, o bien a utilizar los carros en diversos tramos y trasvasar las cargas a las recuas cuando dichos carros no pudiesen proseguir. En el informe realizado por el cantero Ruy Sánchez de Criales en 1499, sobre las actuaciones que se debían llevar a cabo para que el camino de Burgos a Laredo quede "mui llano e bueno para la mulateria e carro e personas", además de las actuaciones para reparar los malos pasos y puentes de dicho camino, se propone su ensanche y la creación de tres tramos nuevos:

- Uno "para la carretería y mulatería muy llano, ancho y seguro", desde el puente de Bolado sin cruzarlo, hasta La Haza de Ramales pasando por Gibaja, Riancho y Guardamino, evitando el camino por Ramales y el paso por los puentes de Bolado y de San Pedro de Ramales que se habían derruido, pero se debía cruzar el río Carranza por el puente de Gibaja. Aunque era un camino que los arrieros utilizaron hasta alrededor de 1476, se intentó acondicionar en 1499 para el tránsito de carros, pero al no reunir las condiciones necesarias para ser utilizado por ruedas y por ser más corto, lo empleó la mulatería. Los carros siguieron circulando con dificultades por Ramales, junto al Asón y Gándara aguas arriba.

- Otro desde Lanestosa hasta Valnera entre los dos puentes, junto al río Calera por la orilla derecha que al no cruzarlo, se evitaban ambos puentes.

- Y el tercer camino de nuevo trazado que se informa, denominado "de la Hoz de Herada", discurre por este puerto entre Lanestosa y Agüera y evita el puerto de Sendero Enhiesto ${ }^{863}$.

El informe realizado en 1511 por Sancho de Salcedo, pone en evidencia las dos variantes del camino, entre el puente de Bolado y La Haza de Ramales. El ramal más antiguo y que se utilizó hasta alrededor de 1476, pasaba por Gibaja ya que refiriéndose al puente de este lugar, un testigo indica que "la dicha puente hera el camino rreal antigo, avnque de treynta e çinco años a esta parte poco mas o menos, los mulateros auian tornado el camino por Rramales e a la puente de Bolado". Es decir, que desde esa fecha el camino se dirigió por el puente de Bolado, El Portillo y Ramales. Otro testigo lo confirma cuando dice que los puentes de los Loros y de Gijedo de Ramales, "estan en el camino rreal que agora se anda avnque antiguamente yvan por otro camino, e que sabe quel dicho camino es mas llano e meyor". No obstante, en 1511, el puente de Bolado estaba intransitable por lo que el camino por Ramales se encontraba interrumpido y por estar caído el puente de Rasines llamado del Cubo, no pueden los caminantes ir por el camino real, debiendo rodear por otros caminos con muchos ríos y arroyos. Para "yr syn arrodear, que se ha de faser dicha puente e la puente que dizen de Bolado, donde antiguamente estuvo, que avn es camino mas derecho, e que este [testigo] la vio echa e paso por ella, e que sabe que agora por no estar echas estas puentes, ban los mulateros por caminos muy travajosos e peligrosos" 864 . Parece ser que esos otros caminos peligrosos, corresponden al antiguo por Gibaja ${ }^{865}$.

En 1541 se intenta de nuevo adecuar este camino para el paso de carros, y en el las cuentas de Laredo de ese año, se constata el gasto de $348 \mathrm{mrs}$. en cierto pescado y en mensajeros que lo llevaron a Soba y a Ruesga, para ver como se podría "azer mejor el camino del

863 A. H. N./ Nobleza. Frías, C. 235, D. 55/ Medina de Pomar, 15 enero 1499.

864 A. G. S./ Consejo Real de Castilla, leg. 26-17/ Burgos, 5 octubre a 12 diciembre 1511. pp. 17r; 21r; 28r.

865 A. G. S./ Consejo Real de Castilla, leg. 26-17/ Burgos, 5 octubre a 12 diciembre 1511. p. 28 r. 
Carro". Las actuaciones se mantienen en 1544, ya que se pagan a Juan de Villota del Hoyo 20 ds. por ir a Valladolid a pedir "liçençia para echar sisas e por el camino del Carro", y a Miguel Bañes, escribano, dos ducados sobre unas escrituras que se sacaron "sobre el camino del Carro". En 1545 se recoge el pago de 1.500 mrs. al letrado de Laredo en el Consejo Real para el pleito de este camino y otros negocios, y se dio libranza de $17 \mathrm{rs}$. para, entre otros asuntos, obtener información sobre él. Se averiguó además la cuenta con Diego Osorio, solicitador de Laredo, para los negocios de corte que Laredo tenía "sobre hazer el camino del Carro"866.

La Universidad de Burgos vuelve a intentar en 1547 la construcción de un camino carretero entre Laredo y Burgos. En junio de ese año gastó Francisco de Santander 6.400 mrs. en "yr de Burgos a Laredo por el camino de Espinosa y de los otros lugares por donde se a de azer el camino de los carros de Burgos a Laredo", junto con Martín Ochoa cantero y Hernando del Hoyo. La intervención se debía realizar en dos sectores: el camino de Laredo a Agüera por la Hoz de Herada; y el camino de Agüera a Burgos por Espinosa de los Monteros, Valderredible y el páramo del Tozo.

\section{Camino de Laredo a Agüera por la Hoz de Herada}

Esta alternativa, pretendía evitar el pendiente puerto de Sendero Enhiesto, desviando el tráfico por un trazado que aunque algo más largo, tenía pendientes más suaves capaces de permitir el paso de carros. Como antecedente de esta actuación, ya en un informe de 1499, se indica que el camino para el carro propuesto desde Lanestosa va "mui masllano e mas seguro $e$ sin piedras, por el puerto que dizen de Herada ques en el balle de Soba, que se aderezara quando mucho con quinze mill mrs. algunas calzadas que en el ay de fazer, pero este no es camino para la mulateria e por ser mas largo que del Sendero Yniesto, como por no aver mesones por aquellas partes". Sería un camino carretero que desde Lanestosa salvaría, por el puerto de Herada, el desnivel que supera el actual puerto de Los Tornos pero de una manera más suave. No obstante y según el informe, sería mucho mejor aunque algo más costoso, acondicionar el camino por el puerto de Sendero Enhiesto867. Aunque en esta propuesta la vía va desde Lanestosa por el puerto de Herada a Agüera, sin pasar por el puerto de Sendero Enhiesto; en una descripción itineraria realizada en 1570 se indica que hay un camino que tiene desde Lanestosa "a La Calera vna legua, donde se toma el camino de Hoz de Herrada y derecho a Aguero que ay tres leguas"868, es decir que después de ir por el camino de Hoz de Herada va a la Calera, y desde aquí a Agüera por el puerto de Sendero Enhiesto, algo que plantea algunas dudas al no evitar esta alternativa el dicho puerto, motivo principal de este camino. Pensamos que la alusión a la Calera, se realiza en relación con el término y no con el lugar, por lo que se trataría del camino referido.

La villa de Laredo y la Universidad de los Mercaderes, conciertan en 1547 una actuación coordinada para la adecuación del que llaman Camino de los Carros, entre Laredo y Agüera, en la que la Universidad pagaba la mayor parte de la intervención, y el concejo de Laredo que debía desarrollar los trabajos se obligaba a mantenerlo. El Consulado trataba de conectar este camino en Agüera, con otro que se estaba construyendo por Espinosa de los Monteros,

866 A. H. P. C./ Laredo. Cuentas de la villa de Laredo, f. 43V-51v; 80r-81v y 88r-91v / Laredo, 1541; VALDOR ARRIARÁN, M.: 2002: 112-116; 176-179 y 193-200: docs. 4, 7 y 8.

867 A. H. N./ Nobleza. Frías, C. 235, D. 55/ Medina de Pomar, 15 enero 1499.

868 A. G. S./ Patronato Real, leg 57, doc. 90/ Antes del 3 octubre 1570. 
Valderredible y páramo del Tozo. Para ello el Prior de la Universidad declara en un pleito que el Consulado siempre se había ocupado de la reparación y conservación de estos caminos, especialmente los de Laredo y Bilbao, y añade que se han hecho reparar algunos para que "las mercaderias de aqui adelante, vengan desde la costa de la mar e vayan desta çiudad a la costa en mejores presçios, porque desde Laredo podran ir en carros a la çiudad de Burgos" 869 . Así en febrero de 1547, se concertaron en Burgos el Prior y cónsules de la Universidad, con dos vecinos de Laredo, en nombre de su concejo, para el acondicionamiento de los caminos y calzadas necesarias, para que pudiesen transitar "los carros e las carretas cargadas de mercaderias y sacas de lanas, desde esta dicha çiudad de Burgos fasta la villa de Laredo", algo que interesaba sobremanera a los mercaderes del Consulado. Distinguen en el concierto dos caminos diferentes en el tramo entre Laredo y Agüera: uno dedicado a la carretería y el otro a la mulatería. Las condiciones son:

- La villa de Laredo "se obliga de açer, rromper e açer de nuevo, vn camino que se pueda vien carretear desde el lugar de Aguera, ques una legua mas alla d'Espinosa de los Monteros asta Hoz de Herada, e desde alli al mesmo pueblo e lugar de Herada, e del dicho pueblo e lugar de Herada a Balnera, y de Balnera a Sangrizes y al Collado de Mohondal, e a Xibaja e a la uista del termino de Rrasines, dexando la Concha de Volado a la mano syniestra, e desde alli a Toritro e Anpuero e Collado e Rreicoba e a Laredo". Debe tener al menos 16 pies de ancho y dos o tres más en las partes donde se puedan encontrar dos carros. Donde hubiere arroyos o fuere necesario hacer calzadas, se harán alamboradas para que el agua no se detenga, y donde se deban hacer vueltas para que el camino vaya más suave, se harán lo más largas posible, y se romperán peñas y lastras donde sea preciso, debiendo comprar las tierras necesarias para su ensanche.

- Para que el "camino de los carros se pueda mas tiempo e mejor sostenerlo, sin rreçibir daños de la mulateria si ubiese de yr e benir por el", Laredo se obliga a aderezar "el camino de los mulateros", para que se pueda transitar en todo tiempo. Y para que este camino de los mulateros se repare bien, Laredo se obliga a gastar en ellos 400 ds. de oro, para lo que la Universidad ayudará con 200 ds. que pagará cuando comiencen las obras, que devolverán si no lo hicieren.

- La Universidad de Burgos se obliga a pagar a Laredo para los gastos de este camino, 600 ds. de oro que valen 225.000 mrs., 300 pagados cuando se comience a hacer para herramientas, oficiales y cosas necesarias, y los otros 300 cuando estuviere hecho y abierto hasta Ampuero, y además de los 600 ds. , para que el camino se haga más rápido, les prestará otros 200 ds. de oro por un año, dando Laredo un fiador en Burgos que los devolverá cumplido el año.

- Laredo se obliga a mantener el camino bien acondicionado y de manera que se pueda carretear durante 12 años, y si en este tiempo se dejare de carretear por no estar bien aderezado, pagará al Consulado el interés y 100 ds. de pena.

- Dicha villa se obliga a que "todas las sacas de llana e peloterias, e otras qualesquier mercaderias que fueren desta çiudad de Burgose de su vnibersidad, e benieren a la dicha villa, de Flandes e Rroan y Bretania e otras partes, por mar e por tierra, que a la entrada ni salida de la dich a villa de Laredo en carros o en carretas, no les puedan poner ni pongan ninguna ynpusiçion ni trebuto, ni portazgo ni cesa ni derecho nuevo", y si se pusiere en otros lugares, la villa pedirá que no se permita y lo defenderá a costa de la Universidad, aunque tal imposición sea puesta por el Rey.

869 A. G. S./ Consejo Real de Castilla, leg. 204-3/ 1547; BASAS FERNÁNDEZ, M.: 1963 y 1994: 150. 
- Laredo facilitará a los carreteros que lleven las sacas y otras mercaderías a la ida y venida, los pastos y abrevaderos de la villa y sus términos, libres y exentos, sin poderles poner derecho ni tributo alguno, guardándose prados, cercados y heredades sembradas, viñas y otros heredamientos.

- La villa confirma que de Agüera hasta la villa, no hay ningún portazgo excepto en Laredo y que si se echare por el Rey, le suplicarán que no lo eche.

- Laredo se obliga a dar abierto y perfectamente acabado el camino del Carro desde Agüera hasta Laredo, el día de Pascua del Espíritu Santo de 1548, y el de la mulatería el día San Miguel de 1547, todo hecho a su costa.

- También se obliga a no pedir a la Universidad para hacer y abrir estos caminos, más de los 800 ds. mencionados, más los 200 ds. que se les prestan, aunque la cantidad presupuestada aumente.

- Para que haya más comercio en Laredo, la villa se obliga a dejar sacar libremente en los carros todos los pasteles que llegaren, sin que sean obligados a meter trigo ni otra cosa alguna si no fuere por voluntad de los carreteros, con tanto que por cada bala de 7 arrobas que se saque, pague a la villa 2 mrs. y que otras mercaderías pesadas y peligrosas se puedan sacar en los carros sin que deban pagar nada ${ }^{870}$.

El camino que se propone en este concierto, como se ha dicho, iría dirigido desde Agüera donde se juntan los caminos que vienen de Villarcayo y de Espinosa de los Monteros, hasta Hoz de Herada, Herada, Valnera, Sangrices, collado de Mohondal, Cibaja, Rasines, Toritro, Ampuero, Collado, Rucoba y Laredo. Se distingue claramente, la pervivencia y utilización del camino ya existente, que llaman "el camino de los mulateros que oy ay", y el que se pretende construir de nuevo trazado por la Hoz de Herada, que coincide con el propuesto en 1499, salvo en el tramo entre Herada y Lanestosa, que en vez de ir directo entre estos dos puntos, pasa por Valnera y Sangrices.

Laredo detalla en sus cuentas de 1547, las sisas que la villa echó con licencia real para pagar este camino del Carro y reparar el cay, y que de los 300 ds. recibidos de la Universidad, 100 son para hacer el camino. La villa pagó 6 ducados a Juan de Villota para ir a ver los caminos de los Carros con el maestro que enviaron los de Burgos y 22 al cantero Juan de Vizarrim, por aderezar el camino de la cantera y cay que hizo para este camino. En 1548, las sisas que se echaron con Provisión real para este camino, y para lo demás contenido en la provisión, montan 222.936 mrs. Se pagó además a Francisco de la Torre 2.057 mrs. por ir a verlo con otras personas. En 1549, lo que rentaron las sisas suman $265.269 \mathrm{mrs}$., que libraron a Juan de Villota del Hoyo y Arnao del Hoyo Somado, tomadores de este camino del Carro para hacerlo. Además se liquidó la cuenta con dichos tomadores, que recibieron en 1548 otros 197.290 mrs., más cuatro ducados a Hernando de Amada, Sancho de la Puente y los otros que fueron a Agüera a visitarlo con los que vinieron de Burgos. Las sisas rentaron en 1550, 224.417 mrs. que recibieron Juan de Villota y Arnao del Hoyo, a cuenta de lo que han de cobrar por abrir el camino, y ambos han recibido $911.984 \mathrm{mrs}$. a cuenta hasta fin de 1550 .

En 1551 se recoge en estas cuentas, que se han de cobrar 100 ds. de Bartolomé de Palacio, arrendador de la sisa del vino, porque lo demás es de los tomadores del camino del

870 A. H. P. C./ Laredo, leg. 22, num. 13/ Burgos, 2 febrero 1547. 
Carro. Las sisas echadas con licencia real suman $220.713 \mathrm{mrs}$, , de los que se pagaron para este camino $183.213 \mathrm{mrs}$. a los tomadores. Lo que estos han recibido por hacerlo entre 1550 y 1551, son 911.984 mrs. , y en 1551 además 183.213 mrs. de las sisas. Lo que estas montan en 1552 son $224.618 \mathrm{mrs}$. de los que $149.618 \mathrm{mrs}$. se dieron a Arnao del Hoyo y Juan de Villota. En 1553, consta que se pagaron a Arnao del Hoyo 67.500 mrs. del resto de 1.312.500 mrs. que debían cobrar Arnao y Juan del Hoyo "de lo del camino del Carro", con lo que se liquidó todo lo que estaba pendiente ${ }^{871}$.

La justicia y regimiento de Laredo, arrendó entre 1584 y 1586 y de 1587 a 1590 a Juan de Monesterio, maestro empedrador de calzadas, el derecho de cobrar a los arrieros por su paso por el camino real entre Laredo y Agüera, a cambio de tener reparados los caminos por una cantidad concertada. También realizaron intervenciones en el camino del Carro en febrero de 1585 , cuando se valoró en 250 rs. la ocupación de 65 oficiales en este camino entre Ramales y la Hoz de Herada para quebrantar peñas, abrir recodos, hacer henchimientos, allanar terreros y hacer sangraderas. Lo que hizo Monesterio desde febrero de 1585 hasta el 6 de diciembre de 1589, fueron 16 brazas de calzada a la entrada de La Haza de Ramales, donde se deja el camino del Carro, que a 1,5 brazas de ancho hacen 24; Juan de Alvarado regidor de Laredo, hace las cuentas cuyo gasto es de $10.915 \mathrm{mrs}$. de pagos por los desembarazos y terreros que cortó, y calzadas que empedró Monesterio. En 1590 se tasan las actuaciones realizadas en los malos pasos en "el camino del carro que va de La Nestossa hasta Aguera por lo alto sierra haçia Soba"872. Los oficiales y obreros que han entrado en el camino del Carro como se detalla, son 54 que a 3,5 rs. el oficial con el obrero montan 189 rs. que son 6.426 mrs. , más 56 brazas de calzada a 80 mrs. la braza son 4.480 mrs. Suma todo lo del camino del Carro 10.906 mrs.

En los años 1590, 1592 y 1593, Pedro Sáenz del Campillo, vecino de Campillo de Mena,

871 A. H. P. C./ Laredo. Cuentas de la villa de Laredo, f. 107r-116r; 120r-135r; 139r-151V; 157V-168r; 174V-191v; 199r-206r; 212V-219V; 292-311/ Laredo, 1553; VALDOR ARRIARÁN, M.: 2002: doc. 10, 11, 12, 13, 14, 15 y 16, 227-251; 257-285; 321-337; 348-372; 384-394 y 404-415.

872 Las actuaciones previstas y los trabajadores necesarios, son: En el vado del puente del Canto, más acá del puente Herada, como van derecho a Agüera hacia la izquierda, se hizo una estacada en la parte del río, y se rompió un terrero en que entrarían 7 oficiales. Se vieron otras peñas que se rompieron en cuatro partes y se allanó para la subida del carro, donde comienza el camino para ir a Herada y se aparta del de la mulatería, donde entraron 6 oficiales. Un poco más arriba se picaron y rompieron unas piedras para pasar el carro, entrando un oficial. De allanar unos terreros cerca del Somo de Hoz de Herada y de henchir unas lamas de piedra, 4 obreros. Se picaron unas peñas en lo alto del Somo, como quien baja al portillo de Hoz de Herada, junto a una cruz de palo y se cortó un terrero en el recodo de abajo, 6 oficiales. Más abajo de la cruz, se cortaron unos terreros y se condujo el camino por allí, porque más abajo estaba comido por el agua y no se podía pasar, 5 obreros. Más abajo se empedró la calzada de piedra en el segundo codo al bajar a Herada y entrar al hayal, 18 brazas que a 1,5 brazas son 27. Más abajo al salir de lo empedrado, por donde corre un poco de agua, se empedraron otras 10 brazas de calzada que son 15 brazas. Más abajo se despuntó una peña para pasar el carro que lo hizo un oficial. Más abajo como se baja a Hoz de Herada, se empedraron en dos pedazos dos brazas de calzada sencillos. De picar unas peñas que están como quien baja el dicho sendero a la derecha, tres oficiales. Más abajo se empedraron otras 8 brazas de calzada que son 12 brazas. Más abajo en un retorno en lo último de la calzada como se va a Herada, se midieron otras dos brazas de calzada de dos de ancho, son cuatro. Al bajar del camino como quien va a Fresnedo, se atravesaron 10 maderos pequeños en medio del camino y se cortó un terrero en una vuelta más abajo y pudieron entrar en todo, 6 obreros. De picar unas peñas en el camino en lo alto del sendero junto a Lanestosa a salvo de unos robles, cuatro obreros. Más abajo junto a unos prados de picar unas peñas para el carro, un oficial. De sacar unas piedras como se baja a Lanestosa, frontero de una haza cerrada en dos pedazos, tres obreros. Debajo, de sacar otras piedras y cortar un terrero, otro obrero. Más otro pedazo como quien baja a Lanestosa a salvo de los robles, se allanó un pedazo de camino y se cortó un terrero hacia la izquierda en que entraron cuatro obreros. Al llegar de Lanestosa al cabo de la cuesta como se va al camino del Carro, de romper unas peñas y hacer un paredón, dos obreros. Se le pasan otros 44 rs. que gastó en el pretil de piedra del puente de Herada. 
maestro empedrador, fue el arrendador del mencionado derecho por $40.000 \mathrm{mrs}$. al año y lo mismo por braza de calzada y calzada de puente. En este camino hizo en esos años 16 brazas donde parte el camino del Carro, junto a las cruces de Collado ${ }^{873}$.

\section{Camino de Agüera a Burgos por Valderredible}

Este camino era ya carretero al menos en 1497 , cuando los concejos, justicias y regidores de las villas y lugares de "los valles de Porrase Vezena e de la merindad de Sotoscueva e Sonsierra e Valdebodres e de las otras villas elugares de la merindad de Castilla Vieja", dijeron que sus vecinos "van e enbian con sus carros e bueys e bestias a las villas e lugares de tierra de Canpos e a otras partes para traer pan e vino e otros basteçimientos" para su provisión ${ }^{874}$.

La construcción del "Camino de los Carros" de Agüera a Burgos por Espinosa de los Monteros, Sotoscueva, Valderredible y el páramo del Tozo, fue emprendida prácticamente en exclusiva por la Universidad de los Mercaderes, dentro del plan de 1547 para la adaptación del camino de Laredo para el tránsito de carros, sin la colaboración del concejo de Laredo, como consecuencia de la necesidad de abaratar los costos del transporte utilizando carros, y de la imposibilidad de que por los pasos de los Hocinos y de la Horadada pudiesen transitar de una manera adecuada estos vehículos, para rentabilizar el acarreo al permitir aumentar no solo el peso, sino también el volumen de la carga desplazada, algo que no se podía conseguir con la mulatería.

Tenía un trazado algo más suave que el que iba por Villarcayo o Medina de Pomar, y se modificó y mejoró aunque ya era carreteril para utilizarlo, a pesar de su gran rodeo, para el transporte de cargas pesadas entre Laredo y Burgos. Desde Laredo iba por el camino principal ya tratado, hasta subir el puerto de Sendero Enhiesto. Después desde Agüera se desviaba a la derecha por Noceco, Espinosa de los Monteros, Quintanilla del Rebollar, Quisicedo, Rozas, Pedrosa, Santelices, Argomedo, Virtus, Cilleruelo de Bezana y Herbosa, donde entroncaba con el camino carretero que desde Santander venía por Corconte, cruzaba el llano de la Virga y seguía por Arnedo, Montejo de Bricia, Lomas, Villamediana, Repudio, Ruerrero, Rocamundo, Valladar, Santa Cruz del Tozo. Quintana del Pino, Montorio, Ubierna, Venta de Quintanaortuño, Sotopalacios, Vivar, Villatoro y Burgos, donde entraba por la puerta de San Gil.

En los libros de cuentas de la Universidad de los Mercaderes de Burgos, se detallan los gastos realizados en la creación de este camino nuevo por Espinosa de los Monteros, que llaman el "camino de los carros de Burgos a Laredo". De esta manera, en enero de 1547, la Universidad gastó 2.971 mrs. para un presente dado a García de Escalante y Arnao del Hoyo, consistente en un cuero de vino blanco, 12 capones, 12 conejos, dos cabritos y una carga de cebada, cuando se fue a Laredo a negociar con ellos "lo del capitulo y camino del Carro". Tres días después, se dieron a Francisco de Santander, vecino de Burgos, $3.400 \mathrm{mrs}$. por ir "a la uilla de Laredo a señalar y ver el camino que se haze del carro" y otros negocios, pagándose también 4.125 mrs. al cantero Martín Ochoa de Arteaga que lo acompañó, por los 11 días ocupados. En mayo, se dieron 187.500 mrs., a cuenta de los 800 ds. que el Consulado prometió a Laredo,

873 A. H. P. C./ Laredo, leg. 22, num. 15/ Laredo, 23 febrero 1585 a 12 enero 1597.

874 A. G. S./ Registro General del Sello, II-1497, fol. 323/ Burgos, 12 febrero 1497. 
200 para hacer los caminos de la mulatería y 600 para los caminos de los Carros. En junio, se pagaron 6.400 mrs. a Francisco de Santander cuando fue con Martín Ochoa, cantero, y Arnao del Hoyo Somado, a ver los caminos "de Burgos a Laredo por el camino de Espinosa y de los otros lugares por donde se a de azer el camino de los carros de Burgos a Laredo". El concejo de Laredo debía 112.500 mrs. por los 300 ds. de oro que se pagaron a Juan de Rueda enviado por la villa, 200 para los caminos de la mulatería y los otros 100 a cuenta de los 600 ds. "que se les prometio para azer los caminos de los carros de aqui a Laredo por bia de Espinosa e Agüero". En septiembre, se dieron a Diego López Gallo 75.00o mrs. que se le prometieron dar en feria de agosto "para los caminos que se azen de aqui a Laredo" por Arnao del Hoyo Somado, a cuenta de los 600 ds. En octubre, se pagaron 600 mrs. a Diego López Gallo por los 200 ds. que dieron para estos caminos. En mayo de 1548, se pagan a maestre Martin Ochoa 4.896 mrs. por ir con con Francisco de Santander "a ber los caminos de Laredo que se abian de mudar a otra parte como estaba conçertado", y se le pagó a 18 rs. por dia 875 .

En julio de 1549 se deben 10.200 mrs. de las costas de los caminos de Santander, Laredo y Portugalete, dados 6.800 mrs. a Martín Ochoa "que fue a bisitar los caminos de Laredo" y empleó 12 días, a 18 rs. por día para su costa y trabajo, y 3.400 mrs. a Diego de los Ríos que fue con él y volvió solo por Santander que en todo se detuvo 18 días. En marzo de 1550, se pagaron 12.500 mrs. a Arnao del Hoyo "por los caminos que hiço haçer para Laredo". En junio, dicho Arnao pagó 112.500 mrs. a Diego López Gallo, obligándose a "debolber los dineros si no estuviesen acabados los caminos" por cuenta de la villa ${ }^{876}$. Ese mes, se gastan en los reparos de los caminos de Santander y Laredo 7.500 mrs., que se dieron a Rodrigo Cachopin para "aderesçar los caminos del monte Carrales y Argomedo y la Puente de San Helizes y la Cuesta de Rroças". En diciembre, se pagan $51.192 \mathrm{mrs}$. , que se han gastado en "rreparar dichos caminos por donde bayan las sacas en carros" habiéndole hecho buenos 105.324 mrs. que se cobraron de 21.665 sacas cargadas este año para Flandes, Ruan y Nantes a $5 \mathrm{mrs}$. por saca, que se echó de averías para estos caminos, debiéndose cobrar en 1551 de las sacas que se cargaren a dicha cantidad por saca $^{877}$

La Universidad debe en junio de 1552, 408 mrs. que gastó Diego de los Ríos cuando fue a Santander sobre el "camino de una puente que esta hecha para pasar los carros con las sacas entre los conçejos de Silleruelo e Bertus", 272 mrs. en Reinosa al licenciado Pedrosa por los requerimientos que ordenó y 136 mrs. a Diego López escribano que fue con él a Herbosa a hacerlos. En septiembre de 1556 Arnao del Hoyo debe 9.660 mrs. gastados en 1555 en estos caminos de Laredo ${ }^{878}$. En junio de 1557, la Universidad debe a Diego de los Ríos 27.389 mrs. por lo que se gastó en ir a visitar "los caminos nuebos que se pretenden hazer de aquy a Laredo y Portugalete", con la traza de Lorenzo de Adonza, donde fueron el dicho Adonza con Vallejo el cantero y Diego de los Ríos, más 11.988 mrs. que se dieron a los maestros por su trabajo. En noviembre de 1558, la Universidad debe a Arnao del Hoyo 4.125 mrs. que gastó ese año en el "adereço del camino del Carro en los pasos malos", para que pudiesen llevar las sacas a Laredo. En noviembre

875 A. D. B./ R-3/ Libro de caja de la Universidad de Burgos/ Burgos, 1539-1549.

876 A. D. B./ R-12/ Libro de caja de la Universidad de Burgos/ Burgos, 1549-1557.

877 A. D. B./ R-6/ Manual del libro de cuentas de la Universidad de Burgos/ Burgos, 1549-1557.

878 A. D. B./ R-12/ Libro de caja de la Universidad de Burgos/ Burgos, 1549-1557. 
de 1559, Arnao del Hoyo paga 4.080 mrs. obtenidos de las sacas de ese año, para el aderezo del camino de Carro cuando fueron las sacas ${ }^{879}$.

En 1550, llega a Laredo un importante cargamento de piezas de artillería que se depositó en Limpias, y en 1551 se debía trasladar hasta Burgos. Con el fin de evitar toda improvisación, se realizó un informe sobre la ruta a seguir. Debido al enorme peso de las piezas y a la reducida maniobrabilidad de los carros reforzados o fabricados ex profeso, era necesario dirigirlos por caminos que tuviesen un perfil lo más regular posible, con mínimos desniveles y curvas abiertas. Se detalla el itinerario que, para evitar el desfiladero de los Hocinos y la subida de El Almiñé, debe desviarse del camino de Laredo a Burgos una vez pasado Agüera; pero hasta esta localidad sigue el camino tradicional que, para carros, según se indica, es "mal camino" con un puerto de "muy malas bueltas":

- Desde Limpias se irá por camino carretero a Ampuero 1/4 de legua y luego "se sube vna cuesta con algunas bueltas que ba a dar a Xibaja" que serán 1,5 leguas.

- Desde allí se va a Ramales y de Ramales a Lanestosa "que son dos leguas y media de mal camino".

- Se llega a la Venta del Prado "y buelbe sobre la mano derecha el puerto de La Ynestosa ques agro puerto y de muy malas bueltas" y va a dar el camino a Agüera. Indica que hay de "La Ynestosa" a Agüera por el camino de las carretas cinco leguas.

- De Agüera se va a Espinosa de los Monteros a 1,5 leguas y "ay algunos malos pasos", con lo que se desvía en Agüera del camino directo a Burgos por Villarcayo o Medina. Luego a dos leguas está Quintanilla del Rebollar encima del camino, ya en Sotoscueva.

- De allí se va a Quisicedo donde "ay vna cuesta", y a una legua de allí el lugar de Rozas y "çerquita del", Pedrosa y Santelices todo dentro de media legua.

- De allí a Argomedo hay media legua.

- De allí a Virtus una legua.

- A Cilleruelo de Bezana $1 / 4$ de legua y a Herbosa una legua. Luego Arnedo, Montejo de Bricia, Lomas, Villamediana y en Valderredible Repudio y Ruerrero, todo en cuatro leguas.

- Entre Ruerrero a Rocamundo hay una legua, y se pasa el vado del Ebro. Pasado Rocamundo se "prençipia a subir vna cuesta muy braba y de muy malas bueltas" y de media legua de largo.

- De Rocamundo se sube al páramo del Tozo y a Valladar ${ }^{880}$ dos leguas.

- De Valladar a Santa Cruz del Tozo, dos leguas.

- A Quintana del Pino una legua.

- De Quintana del Pino a Montorio hay una legua y una cuesta.

- A Ubierna dos leguas.

- A la venta de Quintanaortuño una legua.

- De allí a Sotopalacios, Vivar y Villatoro hasta Burgos hay dos leguas ${ }^{881}$.

879 A. D. B./ R-14/ Libro de caja de la Universidad de Mercaderes de Burgos/ Burgos, 1557-1567.

880 Valladar, es un despoblado en el término y a $800 \mathrm{~m}$. al E.-N.E. de Basconcillos del Tozo, en la entrada de la garganta atravesada por el camino de esta localidad a Barrio-Panizares, después conocido como venta de Valladar: MARTÍNEZ DÍEZ, G.: 1987: 397.

881 A. G. S./ Guerra y Marina. leg. 42, fol. 118/1551. 
En septiembre de 1570, con motivo de la llegada de Ana de Austria, esperada en Laredo, se confecciona una relación detallada del camino que la Reina podía seguir a Burgos y se menciona este "camino de Carro" por donde pueden venir los coches. Así de Laredo a Colindres, "los coches vernan mejor por Pereda que queda a la mano isquierda". Desde allí se iría por Limpias, Ampuero y Ramales. Después se sube "vn portezuelo que llaman la Pared algo aspero", y por Lanestosa se toma el camino de Hoz de Herada y por La Calera, se va derecho a Agüera donde "se an de apartar los coches a Espinosa de los Monteros" -ya que la Reina seguiría por Los Hocinos-, y por Ruerrero y Rocamundo van dando la vuelta por tierra llana a Burgos "aunques rodeosa". Como vemos, es el mismo camino que pretendían utilizar en 1551, para trasladar el tren de artillería, por ser más suave para la circulación de los coches que, pensaban, traería la Reina. Indican en esta relación, no obstante, que en Hontomín es donde "pueden uenir los coches a reçibir a su Magestad en çinco leguas de Burgos"; es decir, que desde Santa Cruz del Tozo o Montorio, podían ir los coches a recoger a la Reina en un lugar que ya estaba fuera de los pasos complicados del camino de los Hocinos, para que así pudiese entrar en Burgos en coche ${ }^{882}$.

En el libro de Sierra de la compañía de los herederos de Bernardino Vallejo y Ventura del Castillo, se menciona Valderas como posible almacén en el camino carretero de Laredo. En abril de 1574, se pagaron 168.533 mrs. que montan las carreterías de 330 sacas desde Burgos a Laredo y Santander y $78.208 \mathrm{mrs}$. de lo que costó llevar desde Corconte y Valderas hasta Laredo y Santander, 258 sacas a cargo de Diego de la Mora. En 1575, las carreterías de sacas enviadas deben en marzo 16.830 mrs. que costó llevar de Burgos a Valderas 105 sacas, a cuatro y a cinco rs. por saca ${ }^{883}$.

En agosto de 1590, se manifestaba que en Santelices "se juntavan dos grandes rrios que llamavan rrio Nela e rrio La Laguna ${ }^{884}$, por donde pasava la artilleria nuestra, e todo el trato e carruajes que yba de tierra de Campos, con provision para los puertos e villas e lugares de las montañas, y por no estar la dicha puente para pasar y estar caida e maltratada, e los rrios yr por la mayor parte grandes, el dicho trato de carreteria avia cesado en gran daño de la rrepublica, e muchas veces por se atrever las jentes a pasarlas, se avian aogado personas e bueyes, lo qual cesaria si la dich a puente se alargase y ensanchase para que pudiesen pasar con dichos carros"885. Como se ve, en 1590 este camino seguía siendo el que canaliza la "artillería nuestra".

\section{B.- POR LOS HOCINOS, VILLARCAYO Y PUERTO DE SENDERO ENHIESTO}

Es el mismo camino por los Hocinos ya tratado, con una única variación entre Incinillas y el puente de Quintanilla de Pienza, que coincidía básicamente con la carretera

882 A. G. S./ Patronato Real, leg 57, doc. 90/ Antes del 3 octubre 1570.

883 A. D. B./ R-33/ Libro de Sierra/ Burgos, 1573-1575

884 Es el río Engaña.

885 A. G. S./ Registro General del Sello, VIII-1590/ Madrid, 11 agosto 1590; Citado en ARAMBURU-ZABALA, M. A.: 2008: 117-135. 
actual por Villalaín, Horna, Villarcayo, Villacomparada de Rueda hasta Bocos. Después por Céspedes y la venta de Ontañón, conectará cerca del puente de Quintanilla de Pienza sobre el Trueba con el camino que viene de Medina, y seguirá por la villa de Quintanilla, Revilla de Pienza, Barcenillas del Ribero, El Ribero y Villasante.

Fue utilizado como camino principal, a partir del traslado de la capital de las Merindades a Villarcayo en 1562 por orden de Felipe II, con el traslado también de la aduana para que todas las mercaderías que fuesen por este camino, pagasen los tributos en dicha villa y no en Medina. Villarcayo, al ser villa realenga, se constituye desde ahora como la capital de las Siete Merindades de Castilla, lo que obligará a rectificar el camino dirigiéndolo por ella, con lo que se acortará el recorrido. Algún tramo podía ser utilizado por carros, pero casi todo él era mulatero.

Aunque este camino ya existía y era utilizado para el transporte de mercaderías por ser más corto, los Condestables lo impedían y ejercían una permanente presión sobre los mulateros para canalizar todo el tráfico de mercaderías y ganados por Medina de Pomar, manteniendo en la villa una cierta infraestructura de hospedaje, utilizando para ello medios a veces coactivos. Así se menciona en una alegación de 1515, realizada por el procurador del Condestable en que dice que "todos los ganados que pasan por Villacomparada y Villarcayo, deben cierto portazgo al dicho señor conde mi parte, que es una blanca de cada cabeça de ganado mayor e media blanca de cada caveça menor, e lo mesmo pagan los dichos ganados que pasan por la dicha villa", y así se ha usado de tiempo inmemorial. Los mulateros indican que los portazgueros de Medina, salen "a tomar en el camino rreal..., estando como estavan en posesion de... veynte años a esta parte e mas tiempo, de yr por el dicho camino rreal que ba por Castilla Bieja a Lareduo e a Baldeporres, syn yr por la dicha villa de Medina". Un mulatero, añade que "sabe que se aventaja en yr por los dichos caminos rreales de Castylla Vyeja o yr por Medina, vna e dos e tres leguas cunplidas ay, que en espeçial a los mulateros e biandantes de las dichas merindades de Castilla Vieja e la Sonsyerra e Sotoscueba, que ha estos les es mucho vtyl e probechoso que a otros en yr por los caminos rreales e venir, que no yr por la dicha villa de Medina". Esto venía provocando un profundo descontento entre los habitantes de las Merindades y sobre todo entre los mulateros, que en ocasiones se habían resistido y habían elevado sus protestas al Consejo Real ${ }^{886}$.

Los oficiales del Condestable obligaban, a veces con violencia, a pasar por Medina a los que según ellos iban "descaminados", provocándoles el consiguiente retraso, el encarecimiento del transporte y a veces la pérdida de las mercaderías y mantenimientos, además de hacerles pagar unos impuestos que ellos rechazaban por considerarse exentos, y sobre los que alegaban que se cobraban "syn tener titulo ni derecho alguno". Un testigo recuerda que unos mulateros que "venian de Castilla cargados e llegando a... Enzinillas que es legua e media de Medina, çiertos portazgueros de la... villa de Medina los tomaron por fuerça e contra su voluntad", y llevaron a Medina. Según los mulateros, daban con ello un rodeo "de mas de tres o quatro leguas a los mas dellos, en cada camino de yda o uenida". Si el mulatero se resistía, le incautaban los mulos y las cargas, y le llevaban preso a la cárcel de Medina. Así se indica que "los dichos portazgueros mano harmada, salieron al dicho camino rreal que ba a la merindad de Montyja,... e alli tomar por fuerça otro mulatero que llama Juan Lopez que benia de Castilla para los dichos puertos de mar, con sus mulos cargados de

886 A. G. S./ Consejo Real de Castilla, leg. 84, fol. 2-III/ Valladolid, 26 junio 1513 a Salazar, 25 septiembre 1515. 
probision e alli le tomaron por fuerça a el e a sus mulos e mercaderias, para llevar a la dicha villa de Medina asy llevandolos presos"887.

No es extraño que con estos antecedentes, cuando Felipe II decida en 1562 trasladar la capital de las Merindades a Villarcayo, y ordene instalar allí la aduana para dirigir por aquí todas las mercaderías, y pagar el tributo en dicha villa y no en Medina, tal medida fuese apoyada de manera mayoritaria en las Merindades, utilizando el viejo camino por Villarcayo, ya sin miedo a represalias, para ir por la nueva capital. Desde ahora todos los tributos los percibirá el Monarca, y el Condestable que había sido el beneficiario de las alcabalas que correspondían al Rey, así como de portazgos y rediezmos, no aceptará la nueva situación y promoverá continuos y dilatados pleitos. El tramo comprendido entre Incinillas y El Ribero de Montija que pasaba por Medina de Pomar, aunque nunca se abandonó como consecuencia de la importancia que mantuvo la villa, quedó convertido en una vía de mucha menor importancia, aunque el Condestable no renunciará a sus antiguas prerrogativas, y obligará a los mulateros en varias ocasiones y a veces de manera violenta, a que siguiesen pasando por Medina.

\section{a.- El camino en las guías itinerarias}

El trazado completo de este camino ya fue recogido por Villuga en 1546, que denomina "de Santa Maria del Paular a Laredo". Va por Villarcayo, al mencionar la localidad de Bocos y no la de Medina de Pomar ${ }^{888}$. Después Meneses, incluirá en su repertorio de 1576 el mismo camino, pero en sentido inverso, que denomina "Laredo para S. Maria del Paular"889.

\begin{tabular}{|c|c|}
\hline 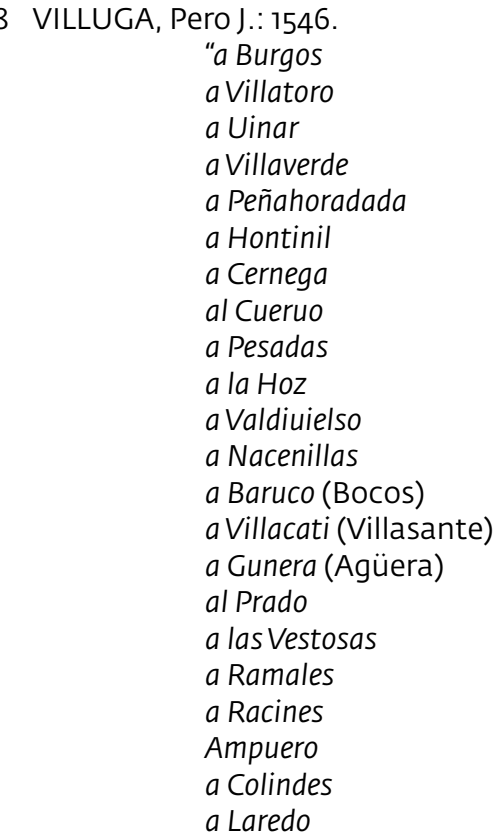 & $\begin{array}{l}\text { II } \\
\text { media } \\
\text { I } \\
\text { I } \\
\text { I y media } \\
\text { I y media } \\
\text { I y media } \\
\text { I y media } \\
\text { I y media } \\
\text { I y media } \\
\text { I y media } \\
\text { I y media } \\
\text { III } \\
\text { III } \\
\text { media } \\
\text { II } \\
\text { II } \\
\text { II } \\
\text { II } \\
\text { I } \\
\text { media } \\
\text { media" }\end{array}$ \\
\hline
\end{tabular}

889 MENESES, A. de: 1576.

$\begin{array}{ll}\text { "Colindes } & \text { III } \\ \text { Ampuero } & \text { III } \\ \text { Racines } & \text { I } \\ \text { Ramales } & \text { II } \\ \text { LaVestosa } & \text { II } \\ \text { El Prado } & \text { II }\end{array}$


En mayo de 1663, con motivo del repartimiento que se realiza para reparar el "puente de Hernan Pelaez", el Valle de Mena alega que se encuentra a más de las 12 leguas del puente. Dicho Valle promueve un interrogatorio para probar lo que alega y eximirse del pago, diciendo un testigo que "desde la puente de Hernan Pelaiz sita en el Balle de Baldeçamanças sobre el rrio Hebro, hasta el lugar de La Aya ques el primero del dicho Balle de Mena,... que el camino real ay mas de treçe leguas de distançia, por cuya causa y aber desde la dicha puente a el dicho lugar de Porquera mas de dos leguas, y del dicho lugar de Porquera a el del Almiñe otras dos, y desde el dicho lugar del Almiñe a el de Arroyo legua y media, y desde el dicho lugar de Arroyo a el de La Puente otra legua y media, y desde el dicho lugar de La Puente a el de Yncinillas vna, y de Incinillas a Villalain media, y desde Villalain a esta uilla [Villarcayo] mas de otra media, y desde esta uilla a la de Bocos vna legua, y de alli a el lugar de Quintanilla de Pienza otra legua, y desde el dicho lugar a la benta del Rribero otra legua, y desde la dicha benta a el de Villasante media. y desde el dicho de Villasante a el de Berecedo vna legua, y desde el dicho lugar de Bereçedo a el dicho lugar de Laya vna legua"89o.

Matías Escribano incluye en su Itinerario de $1758^{891}$ este camino en el que va a Bilbao

\begin{tabular}{|c|c|c|}
\hline & $\begin{array}{l}\text { Gunera } \\
\text { Villacati } \\
\text { Baruco } \\
\text { Nacenillas } \\
\text { Valdiuiesso } \\
\text { La Hoz } \\
\text { Pesadas } \\
\text { El Cuerno } \\
\text { Cernega } \\
\text { Hontinil } \\
\text { La Peña Horadada } \\
\text { Villa verde } \\
\text { Auinar } \\
\text { Villatoro } \\
\text { Burgos }\end{array}$ & $\begin{array}{l}\text { II } \\
\text { media } \\
\text { III } \\
\text { III } \\
\text { I y media } \\
\text { I y media } \\
\text { I y media } \\
\text { I y media } \\
\text { I y media } \\
\text { I y media } \\
\text { I y media } \\
\text { I y media } \\
\text { I } \\
\text { I } \\
\text { media" }\end{array}$ \\
\hline 890 & $\begin{array}{l}\text { A. H. V. M./ leg. 6, p. } 184 \text { a 196/ } 27 \text { a } 29 \\
\text { Puente de Hernán Pelaiz } \\
\text { Porquera } \\
\text { El Almiñé } \\
\text { Arroyo } \\
\text { La Puente de Valdivielso } \\
\text { Incinillas } \\
\text { Villalaín } \\
\text { Villarcayo } \\
\text { Bocos } \\
\text { Quintanilla de Pienza } \\
\text { Venta del Ribero } \\
\text { Villasante } \\
\text { Bercedo } \\
\text { La Aya }\end{array}$ & $\begin{array}{l}\text { más de } 2 \text { leguas } \\
2 \\
1,5 \\
1,5 \\
1 \\
0,5 \\
\text { más de } 0,5 \\
1 \\
1 \\
1 \\
0,5 \\
1 \\
1\end{array}$ \\
\hline 891 & $\begin{array}{l}\text { ESCRIBANO, J. M.: } 1758 . \\
\text { "Camino de ruedas. } \\
\text { Hasta Burgos, leg. } \\
\text { Rio Arlanzon. } \\
\text { Las Ventas de Quintanilla, } \\
\text { Ontomin } \\
\text { Cernegula } \\
\text { Villalta } \\
\text { Pesadas } \\
\text { El Almiñe } \\
\text { Arenas, Rio Ebro, P. }\end{array}$ & $\begin{array}{l}41 \\
102 \mathrm{~m} \\
2 \\
1 \mathrm{~m} \\
2 \\
1 \\
1 \\
\mathrm{~m}\end{array}$ \\
\hline
\end{tabular}


por Valmaseda, que es común hasta Villasante, y el de Burgos a Laredo, lo recoge en las dos direcciones ${ }^{892}$. El catálogo de Udal ap Rhys de 1760 , lo incluye íntegro en el Camino de Laredo a Santa María del Paular, copiando el de Meneses ${ }^{893}$. El Itinerario de Miguel Bañuelos de 1771 también recoge el camino de Burgos a Villarcayo. En el camino a Carriedo lo detalla también hasta Villarcayo, antes de desviarse por Espinosa ${ }^{894}$. El itinerario de

$\begin{array}{ll}\text { Encinillas } & 2 \\ \text { Villarcayo } & 1 \\ \text { Villa-Comparada, y Bocos } & 7 \\ \text { Venta de Pajares } & 7 \\ \text { Venta de Revilla } & \mathrm{m} \\ \text { El Rivero } & 1 \mathrm{~m} \\ \text { Villasante } & 7 \\ \text { Bercedo } & \mathrm{m}^{\prime \prime}\end{array}$

892 "Para Laredo.

$\begin{array}{ll}\text { Hasta Villasante } & 60 \\ \text { Despues á Aguera, y los Tornos } & 7 \\ \text { La Nestosa } & 7 \\ \text { Ramales } & 2 \\ \text { Rasines } & 2 \\ \text { Laredo } & 4 "\end{array}$

“LAREDO PARA Burgos.

$\begin{array}{ll}\text { Ramales } & 4 \\ \text { Los Tornos } & 3 \\ \text { El Ribero } & 2 \\ \text { Venta de Pajares } & 2 \\ \text { Villarcayo } & 2 \\ \text { Arenas } & 3 \mathrm{~m} \\ \text { Pesadas } & 2 \mathrm{~m} \\ \text { Cerneula } & 2 \mathrm{~m} \\ \text { Antomin } & 1 \mathrm{~m} \\ \text { Las Ventas de Quintanilla } & 2 \\ \text { Burgos } & 2 "\end{array}$

893 UDAL ap RHYS: 1750: 301-360. Copia los itinerarios del Repertorio de Meneses.

894 BAÑUELOS, M.: 1771.

\begin{tabular}{|c|c|}
\hline Villatoro & 1. \\
\hline Quintanilla de Vivar & med. \\
\hline Soto Palacios, y Venta & med. \\
\hline Peñaorada & 1. \\
\hline Ontomin & 1. me. \\
\hline Cernegula & 1. me. \\
\hline Villalta & 2. \\
\hline Pesadas & 1. \\
\hline Armiñe & 1. \\
\hline Puente Arenas & me. \\
\hline Incenillas & 1. yme \\
\hline VILLARCAYO & 2." \\
\hline “A CARRIEDO. & \\
\hline Villatoro & 1. \\
\hline Quintanilla de Vivar & med. \\
\hline Vivar & 1. $q$. \\
\hline Soto Palacios, y Ventas & 1. $q$. \\
\hline Villaverde junto á Peñaorada & 1. 9 . \\
\hline Peñaorada & 3. 9 . \\
\hline Ontomin & 1. me. \\
\hline Cernegula & 1. me. \\
\hline Villalta & 2. \\
\hline Pesadas & 7. \\
\hline
\end{tabular}


Brusola de 1810, es copia exacta del Matías Escribano, por lo que repite sus caminos ${ }^{895}$. En cambio, el itinerario de Santiago López de 1809, aunque también es copia del Matías escribano, introduce algunas mejoras ${ }^{896}$. En 1832, se edita una memoria sobre la construcción del nuevo camino de Burgos a Bercedo, en el que se recoge este itinerario a Bilbao con el nombre de "Antiguo camino por Valmaseda", que comparten ambos hasta Villasante ${ }^{897 .}$

\begin{tabular}{|c|c|c|}
\hline & $\begin{array}{l}\text { Armiñe } \\
\text { Puente Arenas } \\
\text { Villarcayo } \\
\text { Espinosa }\end{array}$ & $\begin{array}{l}1 . \\
\text { me. } \\
2 . \\
3 . "\end{array}$ \\
\hline 895 & BRUSÓLA, F.: 1810. & \\
\hline 896 & $\begin{array}{l}\text { LÓPEZ, S.: } 1809 . \\
\text { "Otro camino de rueda para Bilbao hasta }\end{array}$ & \\
\hline & $\begin{array}{l}\text { Burgos. } \\
\text { Rio Alarzo, puente. }\end{array}$ & 42 \\
\hline & Venta de Quintanilla y Quintanaorduña. & $2 m$ \\
\hline & Ontomia. & 2 \\
\hline & Cerneguela. & $1 \mathrm{~m}$ \\
\hline & Villalta. & 2 \\
\hline & Resadas. & 1 \\
\hline & El Almiñe. & 1 \\
\hline & Arenas. & $m$ \\
\hline & Rio Ebro, P. & \\
\hline & Encinillas. & 2 \\
\hline & Villarcayo. & 1 \\
\hline & Villa Comparada y Bocos. & 1 \\
\hline & Venta de Pajares. & 1 \\
\hline & Venta de Revilla. & $m$ \\
\hline & El Rivero. & $7 \mathrm{~m}$ \\
\hline & Villasante. & 7 \\
\hline & Bercedo. & $7 "$ \\
\hline & $\begin{array}{l}\text { "Laredo para Burgos. } \\
\text { Camino de } \mathrm{H} \text {. }\end{array}$ & \\
\hline & Ramales. & 4 \\
\hline & Los Tornos. & 3 \\
\hline & El Ribero. & 2 \\
\hline & Venta de Pajares. & 2 \\
\hline & Villarcayo. & 2 \\
\hline & Arenas. & $3 m$ \\
\hline & Posadas. & $2 \mathrm{~m}$ \\
\hline & Cernuela. & $2 \mathrm{~m}$ \\
\hline & Antomin. & $1 \mathrm{~m}$ \\
\hline & Las Ventas de Quintanilla. & 2 \\
\hline & Burgos. & $2 "$ \\
\hline
\end{tabular}

897 ANÓNIMO: "Memoria sobre el origen del Camino de Burgos a Bercedo, mandado construir por Real Decreto de 20 de julio de 1828. Medios empleados al efecto y resultado que han producido, con un Apéndice en que se insertan varios documentos relativos al objeto". Burgos, 1832. Imprenta de D. Ramon de Villanueva.

"Burgosá

Quintanaortuño $2 \frac{1}{2}$

Ontomin 2

Cérnegula $\quad 7^{\frac{1}{2}}$

Villalta $\quad 7^{\frac{1}{2}}$

Pesadas 1

El Almiñé 1

Arenas 1

Incinillas $\quad \mathrm{O}^{\frac{1}{2}}$

Villarcayo 1

Bocos $\quad 0^{\frac{1}{2}}$

Venta de Pajares 1

Venta de Revilla $\quad \mathrm{O}^{\frac{1}{2}}$ 


\section{b.- Referencias documentales}

Los Reyes mandaron en 1499 al corregidor de las Cuatro Villas y al alcalde mayor de Castilla Vieja, que hiciesen pesquisa sobre los malos pasos que había entre Burgos y Laredo. El procurador de los mulateros, pidió que también se aderezasen otros puentes y calzadas, y contribuir ellos con lo que les correspondiese. Se puso de manifiesto que en Montija se debían aderezar dos puentes en el término de Loma; uno con sus pilares de calicanto descalzados y plataforma de madera, otro de madera en Villalázara y otro pontón en término de Hedesa que estaban sobre aguas crecidas y todo se apreció en 15.000 mrs. Entre estos puentes, se debían hacer 110 brazas de calzada a 40 mrs. la braza que montaba todo 4.400 mrs. En Castilla Vieja, se debía rehacer el puente de Bocos, que necesitaba aderezo de calicanto en los pilares, y se apreció en 8.000 mrs. para la madera y pilares, y a un lado y otro del puente en los términos de Bocos y Barruso, 150 brazas de calzada a $40 \mathrm{mrs}$. la braza, que montaba 6.00o mrs. En Villarcayo un puente de madera sobre el río Nela, y en el cauce de los molinos otro, cuyas maderas se habían de traer de lejos, valorados los dos en 15.000 mrs. y 60 brazas de calzada de una cava a la otra, que a 40 mrs. son 2.400 mrs. Esto era más de lo que se incluía en la Provisión real, ya que en esta fecha todo el tráfico debía pasar por Medina, pero como era muy necesario para la merindad de Castilla Vieja, se mandó que los 15.000 mrs. de los puentes de Loma, Villalázara y Hedesa los hiciesen y pagasen los dichos lugares ya que sus vecinos no podían labrar sus campos sin ellos. De los $4.400 \mathrm{mrs}$. de las 110 brazas de calzada entre estos puentes, pagarían la mitad los dichos pueblos y la otra mitad los mulateros y viandantes a un maravedí por mula y año. Para los 8.000 mrs. del puente de Bocos, pagaría Bocos 4.000 mrs. y los otros 4.000 Fresnedo, la Zarzosa y Barriosuso. Para los 6.000 mrs. de las calzadas, pagarán Bocos y Fresnedo los 3.000 mrs., y los otros 3.000 los viandantes a $3 \mathrm{mrs}$. la acémila y a tres blancas la bestia asnal al año, hasta ser acabados de cobrar. Para los 15.000 mrs. de los puentes de Villarcayo y de los Molinos y los 2.400 mrs. de las calzadas que se habían de hacer en los puentes, pagará Villanueva 5.000 mrs., Villarcayo 4.000, Villacanes 1.000, Quintana 2.000, Campo 1.000 , Mozares otros 1.000 y Torme 3.400 mrs. Además para suavizar la contribución a los pueblos, pagarán la mayor parte en obreros y darán para las obras y repartimiento piedra, madera y otras cosas necesarias ${ }^{898}$.

El concejo y vecinos de Vivar del Cid dicen, que junto a Vivar, pasaba "un rio caudal que a la continua venia muy crescido y especialmente en imbierno y tiempo de aguas y nieues" 899 , de manera que las gentes de a pie y de a caballo y bestias, no podían pasar por el vado. Como "era passo y camino real muy passagero por donde venian de fuera destos nuestros reynos todas las mercaderias que en ellos entran, assi para esta corte como para Toledo y otras partes del Reyno por ser camino forçoso", y por ello se les había dado licencia para hacer un puente, habían realizado en un primer repartimiento cinco arcos que por entonces pareció que bastarían. Pero por las grandes crecidas que había habido,

$\begin{array}{ll}\text { El Rivero } & 0^{1 / 2} \\ \text { Villasante } & 7^{\prime \prime}\end{array}$

898 A. H. N./ Nobleza. Frías, C. 235, D. 55/ Medina de Pomar, 15 enero 1499.

899 Es el río Ubierna. 
se debía alargar el puente, adecuar otros dos arcos, hacer sangraderas para vaciar el agua de avenidas, dos manguardias, y una salida para el servicio de los campos y coger agua por no haber otra en el dicho lugar, y que si todo no se hiciese, serviría de poco lo que en él se había gastado, porque con las riadas y lluvias no se podría utilizar. Como el lugar era pobre y sin recursos, se debía dar licencia para un segundo repartimiento. El Consejo mandó pregonar la obra, y se remató en Rodrigo de la Maza, maestro de cantería, en 1.340 ds. En junio de 1584, se manda al corregidor de Burgos que haga repartir los mrs. entre los mismos lugares y personas del primer repartimiento, y requerir a las poblaciones incluidas en las 12 leguas de Vivar, para que en 15 días, depositen los mrs. que les toquen en poder de Andrés de Larrea, depositario general de Burgos, y que si no lo hicieren, se enviará un alguacil para ejecutarlos 900 . En marzo de 1585 Diego Gutiérrez, en nombre del concejo de la villa de Poza y Cubo, pagó en Burgos los tres ducados que les fueron repartidos por el segundo repartimiento901.

En las Juntas de Vizcaya de junio de 1586 Francisco de Urquiza, escribano, presentó en nombre de Lanestosa una petición, diciendo que en la villa hay un puente muy pasajero que está caído y con gran peligro si no se remedia, y que para ello se hiciese un repartimiento de hasta 2.000 ds. Se proveyó que, como no había posibilidad de dar dineros, se vería en próximos regimientos ${ }^{902}$.

Nicolás Muñoz en nombre de Quintanilla de Pienza, indica que por sus términos pasan los ríos Trueba y Cerneja que se juntan cerca del puente de dicho lugar, y que las grandes avenidas de los últimos años se habían llevado dos pilares del puente quedando tan maltratado que no se podía utilizar. "Por ser paso muy neçesario y por do forçosamente, abian de pasar todas las mercadurias que uenian de la costa y puertos de Bizcaya a estos rreynos, y passo hordinario para los que se yban a enbarcar para yr a los estados de Flandes", se debía reparar a costa de los lugares que recibían beneficio, ya que Quintanilla no tenía propios ni renta alguna. Visto por el Consejo en julio de 1586, junto con el remate que de la obra se hizo de 1.580 ds. en Hernán Saiz del Prado, maestro de cantería y vecino de Lanestosa, se mandó hacer el repartimiento de esa cantidad entre los lugares de 20 leguas en contorno, y al alcalde mayor que lo ejecute, para que los concejos implicados depositen en 20 días los mrs. repartidos en el depositario general de la Merindad.

En 1587, el corregidor de Burgos repartió al Hospital del Rey de Burgos para este puente 6.000 mrs., incluyendo los lugares de su jurisdicción de San Mamés, Villacienzo, Cardeñadijo, Arroyal, Marmellar de Arriba, San Medel y Villarmero, que Burgos también los repartió. El procurador del dicho Hospital, requiere al teniente de corregidor de Burgos, para que revoque su repartimiento, por ser esos siete lugares de la jurisdicción del Hospital, por lo que este ya había hecho en ellos el repartimiento. El escribano del concejo de Burgos certifica que se repartieron los $80.000 \mathrm{mrs}$. que tocan a la ciudad y su jurisdicción, y entre otros, se incluían los 7 lugares dichos, dando mandamiento para cobrarlos. En julio, el teniente de corregidor remitió la determinación de esta causa al alcalde mayor de las merindades de Castilla Vieja a quién está cometida por comisión del Rey, para que haga justicia903.

900 A. M. Poza/ no 65/ Madrid, 2 junio y Burgos, 25 junio 1584.

901 A. M. Poza/ no 65/ Madrid, 2 junio y Burgos, 25 junio 1584.

902 A. J. R. B./ Actas de la Tierra Llana. t. IV/ Bilbao, 17 junio 1586.

903 A. M. B./ HI-1766/ Madrid, 24 julio 1586 a 1 julio 1587. 
En agosto de 1588, el Ayuntamiento general de las merindades de Castilla Vieja, con su alcalde mayor y los procuradores generales de todas ellas, otorgan poder a los procuradores de Cámara de los Consejos y corte del Rey en Madrid, para el pleito que tienen en el Consejo Real contra el concejo de Bascuñuelos porque, como por una Provisión real se manda notificar a los concejos y Merindades, que les devuelvan los mrs. que se les hubiesen llevado por repartimiento para el puente de Quintanilla de Pienza, Bascuñuelos tiene la pretensión de eximirse de su pago y repartimiento904.

En 1592, se realiza un amojonamiento de las propiedades en El Almiñé en que se cita el Camino Real: "devaxo de la yglesia camino real, los dichos apeadores... rrenobaron otros dos monjones el uno a la parte de rregañon a linde con huerta de Rrodrigo de la Gala y el otro a la parte de solano a linde con casas de Diego Alonso a la entrada del camino rreal que ay de monjon a monjon siete varas y media"905.

\section{C.- Las inundaciones de mayo de 1582}

En julio de 1582 el corregidor de Burgos mandó a Pedro de Castañeda y a Sebastián de Espinosa que visitasen, junto con cuatro vecinos, los daños que las crecidas habidas en la ciudad de Burgos el 23 de mayo de 1582 han causado en los caminos que, de Burgos salen para todos los puertos de mar por donde entran los bastimentos a dicha ciudad y otras cosas de acarreo, midiendo y tanteando su coste y proponiendo de donde se podrán traer los materiales necesarios. Se proponen las siguientes actuaciones:

- Se ha de reparar un mal paso y cárcavo donde llaman la Calleja Honda, "como ban desta çiudad a los puertos", que tiene 420 pies de largo y 10 de ancho, echando guijarro perdido puesto por orden, recebado con arena que son 80 tapias a $500 \mathrm{mrs}$. la tapia porque está el guijarro lejos, $40.000 \mathrm{mrs}$.

- Los malos pasos y tremedales que hay antes de llegar al "barrio de Villatoro en el camino rreal que ba a Medina de Pumar y a Laredo y a otros puertos", que desde una heredad del camino hasta un pradillo pasado el dicho barrio son 1.088 pies y 10 pies de ancho, que son 432 tapias, y se deberá hacer una calzada a un lado de 10 pies de ancho en todo el largo, de piedra tosca gruesa y de adoquines, y sus traviesas de 15 en 15 pies a 20 rs. la tapia, todo por 293.760 mrs.

- Otro mal paso "questa en el otro camino rreal que ba a las dichas montañas questa debaxo de las postreras cassas del dicho barrio de Billatoro", al final de las eras hasta llegar a un arroyo que baja por medio del dicho barrio, que tiene 420 pies de largo y 10 de ancho que son 84 tapias, lo cual se remediará con una calzada de piedra tosca y adoquines por un lado, y traviesas de 15 en 15 pies, a ducado la tapia, son 31.500 mrs.

- En otro mal paso que está antes de llegar a Villatoro "como ban a las yelseras", que tiene 1.836 pies y 10 de ancho que son 434 tapias, se ha de hacer una calzada de piedra tosca crecida, con sus adoquines a un lado y sus traviesas como lo de arriba, a dos ducados la tapia por estar la piedra lejos, cuesta todo 325.500 mrs. ${ }^{906}$.

En julio de 1582, Pedro de Liendo Cristóbal procurador general de Laredo, dice que des-

904 A. C. V./ no / Villarcayo, 1 agosto 1588.

905 A. Almiñé/ 1592.

906 A. M. B./ HI-1680/ Burgos, 26 mayo a 1 diciembre 1582. 
de esta villa a Espinosa de los Monteros, llevan los arrieros y mulateros las mercaderías que llegan de Flandes y otras partes, y también de Castilla a la villa y comarca el pan y vino con que se proveen, pues en Laredo no se coge pan y hay poco vino. Como los caminos, calzadas y puentes están deshechos por las muchas lluvias y avenidas de mayo de ese año, y deben repararse para evitar el riesgo y peligro, Liendo hace interrogatorio para proceder a su aderezo. Al día siguiente, presentó por testigos a Juan Ruiz de 29 años y arriero desde los quince, vecino de Bisjueces, Sebastián Garrote arriero de 50 años, vecino de Hijes en tierra de Atienza, a Juan Gallo de 30 años y arriero desde los 15, vecino de Robredo de Zamanzas, y a Hernando Saiz de Barguen de 60 años, natural de El Prado y vecino de Laredo. Dijeron que los dichos "caminos y calçadas dela mulateria", van desde Laredo hasta Espinosa y que hay entre ellos, 11012 leguas de caminos y calzadas que dicen de la mulatería, con "algunas puentes como hera en Aguera y Lanestosa y Xibaxa y Anpuero", por donde los viandantes y arrieros llevan del puerto de Laredo los pescados y mercaderías a la corte y las que vienen de Flandes y otras partes con sus mulos y recuas, algunos por alquiler, y llevan trigo, vino y otros bastimentos de Castilla para los lugares que están en los caminos y sobre todo a Laredo. Dicen que este año han caído muchas lluvias, aguas y "andelubios" que han deshecho los caminos y calzadas en muchas partes, por lo que no se pueden utilizar sino con mucho trabajo y riesgo, y que las aguas han derribado "la puente de Aguera que era grande y de piedra y muy costosa, y otra puente en Lanestosa, y otra en Cibaxa, yotra en el lugar de Anpuero que era de piedra y grande y costossa" y otros de madera, y que conviene que se reparen o hagan de nuevo con toda brevedad siquiera de madera, para que se puedan llevar las mercaderías seguras ${ }^{907}$.

En septiembre, Liendo dice que los puentes de Ampuero y Gibaja son necesarios "para todo el paso destos rreinos, e para el comerçio e trato de las mercadurias que bienen al puerto de esta uilla, fuera destos rreinos para el rreino de Castilla y España". Dentro de un mes o dos con la entrada del invierno, quedaría cerrado el paso de los ríos, por lo que mucha gente de la villa padecería hambre. Pide al Rey que se ponga remedio urgente, y se apremie a los vecinos de ambos lugares y Laredo, para que paguen lo necesario para hacer de madera los puentes y el Consejo dé licencia para que se repartan, entre los lugares que los utilizan, los mrs. precisos para hacerlos de piedra. Liendo ofrece información sobre que, en casos similares, Laredo favorece el edificio y reparo de los puentes y como Ampuero y Cibaja no tienen propios ni rentas, ni tampoco Laredo porque "esta muy enpeñada, e los propios e rrentas que tenia se an gastado en rreparos y cosas que su magestad mando hazer, para defensa de la harmada que se esperaua de don Antonio de Portogal", realiza un interrogatorio a seis vecinos de Laredo, para prueba de lo contenido en su pedimento, que confirmaron lo que había indicado.

Ese mismo mes el teniente de corregidor, los regidores perpetuos y el procurador general de Laredo dijeron que habían tratado con los vecinos de Cibaja para hacer el puente, y que no hubo nadie que lo tasase. Dichos vecinos respondieron que si Laredo los favorecía, darían para el edificio toda la madera necesaria puesta al pie del puente, y Laredo prometió que por esta vez pagarían de sus propios y rentas lo que costare hacer el puente, dando Gibaja la madera. Convinieron que García Cil de Cibaja y Luis de la Montaña maestros de carpintería vecinos de Gibaja, harían el puente y lo acabarían para el día de Todos

907 A. H. P. C./ Laredo, leg. 22, num. 14/ Laredo, 9 julio 1582. 
los Santos próximo, haciendo Laredo a su cargo el empedrado del puente. García Gil y Luis de la Montaña dijeron que, como Laredo les había encargado hacer el puente de madera, se comprometen a que dicho día, darán el puente bien hecho, y recibieron de Laredo para comenzar 50 ds. En marzo de 1583 ante su regimiento parecieron San Juan de Aguirre y Pedro Ruiz de Ramales el viejo, vecinos de Ramales, nombrados para averiguar el coste del puente de madera y clavazón de Gibaja, junto con García Gil y Luis de la Montaña y los canteros que entraron para nivelar los asientos de los pilares, y asentar los petrales con las suelas donde debían cargar, y dijeron que lo habían visto y tasado tanto la madera que lleva, como la clavazón y cantería908. Añaden que el coste del maderamiento del puente según lo tasado y su escritura, solo de carpintería, cantería y toda la clavazón que el puente lleva, y labrar y cortar la madera en el monte, alcanza 87.000 mrs.

El Rey dice que Juan de Vergara, en nombre del concejo de Laredo, le informó que las grandes lluvias se habían llevado los puentes de la villa y su jurisdicción, utilizados por los caminantes y mulateros "que hiuan con sus rrequas de machos y otras cabalgaduras por pescados, ansi frescos como salados e mercadurias de los estados de Flandes para el probimiento de nuestra corte y de las demas çiudades, uillas e lugares de nuestros rreinos, e para la buelta que dauan los dichos arrieros con mantenimientos que uoluian de rretorno para el sustento de los uezinos de la dich a uilla e lugares de su tierra, por ser montaña e misera de cosecha de frutos y a caussa de no hauer las dichas puentes por donde pasarse, hiuan a otros puertos de hesa dich a costa e para benir a ella a cargar, arrodeaban mucho de que rreçebian mucho daño", y que la villa había acordado pedir licencia para hacerlos de madera antes del invierno, siendo su coste a cargo de sus propios, mientras se hacían de cal y canto. El Consejo dio provisión en octubre de 1583, para que el corregidor ponga en pregón la obra y edificio, y lo remate en quien mejores condiciones ofreciere.

En 1586 se pagan 7.500 mrs. a García Cil y Luis de la Montaña, en quienes se remataron los puentes de madera de Ampuero y Cibaja, por ajuste que Laredo hizo con dichos maestros solamente del coste de la manufactura, ya que la madera la pusieron dichos lugares; y en abril de 1587 Diego de Quijas en nombre de García Cil y Luis de la Montaña, dijo que se daba por contento y pagado de los 87.000 mrs. tasados por maestros carpinteros, para la fábrica del puente de Gibaja que hicieron sus partes por los años 82 y 83 y otorgaba el finiquito de todo el dicho edificio909.

\footnotetext{
908 El resumen del informe en el que no se detallan los precios de los materiales ni de la mano de obra, es:

- Lleva de largo el puente 170 pies hasta sus remates.

- Lleva en las 4 malladas de hueco, 38 petrales.

- Lleva 12 soleras sobre los pilares sobre que descargan los petrales mayores.

- Lleva una solera con dos postes de roble que tienen 18 codos los pies y solera.

- Lleva encima del puente 23 soleras donde descargan los pies y las barandas como están espigadas y clavadas como parece en el puente.

- Llevan de largo las barandas y soleras debajo, para defensa de lo empedrado más 44 pies donde descargan las barandas como están asentados, espigados y clavados de una parte y de la otra, que los dichos pies tienen más de 90 codos de madera y lleva 914 codos de madera.

- Lleva en el tramo principal en medio del puente 12 braceras con sus soleras que tienen 74 codos.

- Lleva en medio del puente arriba, 4 tornapuntas con sus pies derechos y bracera que tienen 68 codos de madera.

- Lleva en los rremates 5 braceras que tienen 45 codos.

- Más 25 braceras para reforzar las barandas de arriba a dos codos cada bracera que son 45 codos.

- Más en lo tocante a la cantería de cal y manos y servicio.

- Más del clavazón necesario para clavar la dicha madera como ahora está hecha 2.650 mrs.
}

909 A. H. P. C./ Corregimiento leg. 3-11/ Madrid, 3 octubre 1583 y Laredo, 4 noviembre 1583. 


\section{d.- Reparo del puente de Puente-Arenas y del paso de los Hocinos}

Aparecen repetidamente referencias a que este camino tiene cierto peligro, en especial el puente de Puente-Arenas y el paso de los Hocinos. En 1556, se realiza un interrogatorio en que se preguntaba a los testigos entre otras cosas "si saben que los... caminos de los Ocinos y la Oradada, de mas de ser como son tan neszesarios e probechosos a estos reinos... son caminos muy peligrosos ansi por ser muy estrechos en muchas e diversas partes, que no tienen tres pies de ancho e porque confinan con el rrio de Hebro que es muy caudaloso e furioso"910.

En noviembre de 1597, Juan de Naveda, maestro de cantería, como principal deudor y en nombre de Juan del Río y Diego, Gonzalo y Juan de Sisniega, maestros de cantería y vecinos de San Mamés de Arás, dice que el remate del reparo del puente de Valdivielso y calzadas de los Hocinos, por real Provisión obtenida a instancia de las merindades de Castilla Vieja, fue rematado en dicho Juan de Naveda en 6.000 ds. Juan de Naveda se obliga a dar acabada la obra y reparos, en el plazo y de la manera que se contiene en la traza y condiciones, y consiente que el alcalde mayor o la persona a cuyo cargo estuviere la obra, pueda hacer todo ello o lo que faltare y por el precio establecido, así por vía de remate como por jornales, sin que sea necesario llamarle, ni hacer otra diligencia y todo pueda cobrarse de sus personas y bienes ${ }^{911}$.

Juan de Alvear, en nombre del concejo y vecinos de Puente-Arenas, dijo al Rey que sobre el río Ebro, "auia una puente quel llamauan La Puente de Ualdibielsso y una calzada que decian de los Ocinos, por la qual dicha puente y calzada que hera el camino general de los puertos de Uiluao, Laredo, Santander, Castro, Portugalete y otros puertos de aquellas costas, y las mercadurias que en ellos se descargauan, para benir a la çiudad de Burgos y uilla de Medina del Canpo, Ualladolid y esta dicha uilla de Madrid y çiudad de Toledo y otras partes destos rreynos, forzosamente [habían] de pasar por la dicha puente de Ualdibielsso y calzada de los Ocinos", pero con las avenidas y nieves del invierno, estaba el puente tan descalzado que, si no se reparaba, se caería en breve tiempo, y además la calzada está tan perdida que no se podía utilizar porque como el Ebro era muy caudaloso, cualquier crecida la cubría por falta de cimiento, por lo que si esto no se remedia, no se podría volver a hacer con 50.00o ds. Y como el lugar de PuenteArenas era muy pobre, de no más de 36 vecinos y sin propios ni hacienda para hacer el reparo, pidieron que se mandase que el alcalde mayor de las Merindades vea el puente y calzada acompañado de maestros de cantería, y se repartiese entre los concejos beneficiados.

En mayo de 1598, se extiende una real Provisión para el remate de la obra, haciéndolo en Juan de Naveda maestro de cantería, en 6.000 ds. con 66 ds. y 7 rs. y 11 mrs. de principal. El Consejo mandó repartir la cantidad rematada entre las localidades a 12 leguas a la redonda incluyendo, entre otros, a los concejos y vecinos del Valle de Mena y Angulo que están a 12 leguas, para pagar 30.000 mrs. Se mandó al alcalde mayor que ejecute el repartimiento y haga notificar a los concejos afectados, que en 30 días paguen lo que les está repartido. El alcalde mayor depositará los mrs. obtenidos, en el depositario general de las Merindades, y pondrá una persona a pie de obra para que el dinero se gaste no se gaste en otra cosa. En junio de 1598, el teniente de alcalde y justicia mayor en las Merindades y

910 A. C. V./ nำ 18. doc. 3, hojas 28 a 48/ Medina de Pomar, 7, 8, 9 y 21 enero 1556. Hay que indicar que tres pies, son $0,836 \mathrm{~m}$.

911 A. H. P. C./ Protocolos, Junta de Voto, leg. 1.097, fols. 312 y s.s./ Rada, 2 noviembre 1597. 
valles y tierra de Valdegovía, mandó a Juan Íñiguez o a Nicolás de Escalante que, con vara alta de justicia vayan a las localidades contenidas en el repartimiento que les da por vereda, y los requieran para que en 30 días, envíen los mrs. que les tocan al administrador de las alcabalas de las Merindades y su depositario general en Villarcayo ${ }^{912}$.

Tenemos una evidencia de 1663 que nos informa sobre los rodeos que se debían realizar cuando el puente de Valdivielso se encontraba impracticable para cruzar el Ebro. Los caminantes, al no poder cruzar el río por el camino recto, debían dirigirse al puente o vado más cercano que era el de Arroyo de Valdivielso. En un interrogatorio un testigo hace la descripción del itinerario entre El Almiñé y el Valle de Mena y detalla que “... desde el dicho lugar del Almiñe a el de Arroyo legua y media y desde el dicho lugar de Arroyo a el de La Puente otra legua y media y desde el dicho lugar de La Puente a el de Yncinillas vna..." ${ }^{13}$, debiendo hacer casi $10 \mathrm{~km}$ de más.

\section{e.- Arrendamiento de Laredo para el mantenimiento del camino entre Laredo y Agüera}

La justicia y regimiento de Laredo, arrendaba por 304 años el derecho del cobro a los arrieros por su paso por el camino real entre Laredo y Agüera, al maestro empedrador de calzadas que más pagase. El arrendatario se comprometía a su vez a tomar a su cargo el reparo de dicho camino, recibiendo de la villa el precio por braza de calzada de camino y de calzada de puente que se hubiere estipulado. Llama la atención el interés que Laredo ponía en tener reparado y en buen uso el camino hasta Agüera, cuando el trazado excedía con mucho sus términos jurisdiccionales:

En 1582 y 1583 se arrendó el servicio por 42.000 mrs. al año a Juan de Avellaneda, vecino del concejo de Sopuerta, y entre 1584 y 1586, a Juan de Monesterio, vecino de Irús, por 47.00o mrs. al año, ambos maestros empedradores de calzadas. Por la hechura de cada braza de calzada, Laredo les pagaba a 80 mrs. y tres rs. por braza de calzada de puente. Entre 1587 y 1590, se arrendó a dicho Juan de Monesterio (murió en 1590) en 40.000 mrs. por año, por el mismo precio la braza con ciertas condiciones de manera que montó el cobro de los 4 años, 160.000 mrs. que por los 7 años que Monesterio tuvo dicho cobro y hechuras, hacían un total de 301.000 mrs. más las brazas de calzadas que hizo en los caminos y puentes. En 1590, 1592 y 1593 se arrendó al maestro empedrador Pedro Sáenz del Campillo, vecino de Campillo de Mena, por 40.000 mrs. al año y lo mismo por braza de calzada y calzada de puente, y en 1594, 1595 y 1596 a dicho Sáenz del Campillo, por 35.000 mrs. al año y lo mismo por braza.

La villa de Laredo mandó a Pedro de Monesterio y Pedro Sáenz del Campillo, "a cuyo cargo esta el rreparo de las calçadas del camino Real desde esta uilla al lugar de Aguera por arrendamiento", rematado por 3 años desde enero de 1591, que paguen a los herederos de Juan de Monesterio, 76.250 mrs. importe que pagó a Laredo dicho Juan de Monesterio, cuando tuvo a su cargo las calzadas, que los deben pagar de la renta y arrendamiento de las calzadas, en los 3 años en los que están obligados a reparar las calzadas, sin que por esta ocasión se deba

912 A. H. V. M./ leg. 6, p. 348 a 355/ Madrid, 29 mayo y Villarcayo, 16 junio 1598.

913 A. H.V.M./leg. 6, p. 184 a 196/27 a 29 mayo 1663 
cesar la obra y todo se repare donde señalare el comisario de la villa. En Irús en noviembre de 1593, comparecieron los herederos de Juan de Monesterio y dijeron que, como se les habían librado por la justicia y regimiento de Laredo, $76.250 \mathrm{mrs}$. se daban por pagados.

Mateo de Agustina hace la cuenta en noviembre de 1593. Se le cargan a Pedro Sáenz del Campillo, maestro empedrador, 120.000 mrs. que valió la renta de las calzadas que tiene arrendadas en 1591, 1592 y 1593 a 40.000 mrs. por año. Campillo ha de pagar 197.987 mrs., que descontados los dichos 120.000 mrs. que tienen cargo, se le siguen debiendo a Campillo, $77.987 \mathrm{mrs}$, , y dio las cuentas de todo el tiempo que las tuvo a su cargo, tomadas por Juan de Alvarado914.

En diciembre de 1593 se pregonó en Laredo una convocatoria a petición de Juan de Monesterio, vecino de Campillo de Mena, para que quien quisiere tomar el reparo de los caminos y calzadas desde Laredo a Agüera, bajar el precio por cada braza de calzadas, y subir la renta que pagan los arrieros que utilizan los caminos, comparezca en Laredo antes de Navidad para hacer postura. También se hizo público en Espinosa de los Monteros, Mena y Lanestosa. En enero de 1594, Pedro Sáenz del Campillo puso de renta 35.00o mrs. , la braza de calzada de puentes a tres rs. y la de calzada a $80 \mathrm{mrs}$. En enero de 1597 se hizo una nueva convocatoria en Prado, Valmaseda y Villanueva de Mena en términos similares, fijando el arriendo de lo que pagan los arrieros que pasan por estos caminos en 1 real por macho y medio por rocín o jumento al año, asignando el remate para el 15 de ese mes por 3 años que comenzarán 915 .

Los arrendatarios desarrollan una labor de mantenimiento de los caminos como se ha dicho. Así, en la visita que realizaron en febrero de 1585, el regidor de Laredo, con Pedro de Zorrilla y Juan de Avellaneda, maestros empedradores, para tasar lo que Monesterio hizo en 1584, midieron las brazas de calzadas, desembarazos y obras de puentes, que sumaron 78.846 mrs. Fruto de tal visita, se hizo un detalle de las actuaciones con la valoración precisa916.

\footnotetext{
914 En la cuenta ha de haber:

- 56.017 mrs. que montan todos los paredones y malos pasos que Pedro Sáenz, ha hecho, roto y aderezado desde principio de 1591 hasta fin de 1593.

- 61.720 mrs. que montan todas las brazas de calzadas y puentes que en los tres años ha empedrado.

- 3.000 mrs. que pagó a Mateo de Agustina por los 6 días que se ocupó en ir a medir las calzadas y caminos desde Laredo a Agüera.

- 1.000 mrs. pagados a Pedro del Cerro y García Gil vecinos de Gibaja, por tasar los paredones, rompimientos y malos pasos por tres días que se ocuparon con el regidor y maestro.

915 A. H. P. C./ Laredo, leg. 22, num. 15/ Laredo, 23 febrero 1585 a 12 enero 1597.

916 Por este informe, podemos conocer además de las intervenciones, los nombres de los términos por los que discurre el camino entre Laredo y Agüera de Montija:

- En el monte de Colindres a la cuesta de Mar 9 brazas. En medio del monte de Colindres antes del regato de Linares 6 brazas. Pasado el regato de Linares en el monte de Limpias 4,5 brazas.

- Más adelante del monte de Limpias tres brazas y otras 6 más adelante.

- Junto a Espina al monte de Limpias 10 brazas. Más adelante antes de Espina 15 brazas. El pontón de Espina que hizo de nuevo se le pagó 10 rs.

- Al Ribero de Limpias 36 brazas. A Limpias, un paredón de 4 brazas tasado por Juan de Avellaneda en 40 rs. Al molino de Limpias 7,5 brazas.

- En Limpias a la Calleja de Rucoba, por dos paredones secos y quitar dos terreros altos atravesados en el camino hechos por el "andilubio", se le tasó en 55 rs.

- En Limpias al puente de los Casares, hizo un paredón bien labrado de cal y canto para el puente, que se tasó en 190 rs. y pasando el río de este puente, 9,5 brazas.

- Más adelante a los Casares en dos pedazos, tres brazas.

- Bajando más arriba, a la calleja en dos pedazos 35 brazas.

- Antes de la Cruz de Collado, 14,5 brazas en la que entra una braza por una sangradera que hizo.
} 
La justicia y regimiento de Laredo, manda en enero de 1586 a Juan de Monesterio, que pague a Juan de Avellaneda $37.816 \mathrm{mrs}$. por todo lo que ha hecho en las calzadas que están a cargo de la villa, librados del derecho que Monesterio tiene de la renta de las calzadas, del resto de 52.164 mrs. que se le debían, "adbirtiendo que de la dich a cantidad de mrs. se a de azer pagando Juan de Monesterio lo que justamente a de aber de lo que gasto en el reedificar el paredon a do dizen Conpenil".

Lo que ensanchó Monesterio en 1587 en el puente de Agüera "para pasar la rrecua", se tasó en 14.000 mrs. por Juan Sainz de la Puente y Juan Gutiérrez de San Martín, con seis vigas grandes que tiene el dicho puente, dos de 40 pies y las otras cuatro de 24 pies, las seis hacen 7.000 mrs.; 14 maderos que atraviesan el puente y sustentan las barandas 2.000 mrs. ; veinticuatro cadenas de maderas que están a los lados 1.500 mrs. y cuatro teladas de barandas con sus postes de 80 pies, 3.000 mrs. más 500 de clavazón.

En septiembre de 1588, la villa de Laredo manda a Juan de Monesterio, que de los mrs. que están a su cargo por el arrendamiento que tiene de los derechos que pagan los mulateros, se debe quedar 94,5 rs. por 21 brazas de calzada que hizo en el camino viejo de San Llorente, por donde pasan algunas veces los arrieros con su recua, a 4,5 rs. por braza en que se le tasó por haber llevado de lejos la tierra y piedra. Los $64.880 \mathrm{mrs}$. tasados de los puentes y desembarazos de caminos que hizo este año fueron, de las lastras y paredones de Lanestosa 6.120 mrs., del puente de la Calera 3.060 mrs., de las barandas de "Sandenihesto"16.700 mrs., del puente de la Tabla antes de llegar a Agüera 25.000 mrs. y del puente de Agüera 14.000 mrs.

En diciembre de 1589, Pedro Ezquerra el mayor y Pedro Ezquerra el mozo, regidor de Lanestosa, uno nombrado por Juan de Alvarado, y el otro por Juan de Monesterio, vieron la obra de lastras y paredones que Juan de Monesterio hizo en la jurisdicción de Laredo con

\footnotetext{
- Junto a Ampuero antes de llegar, 23 brazas. Más allá de Ampuero, a la calleja de la ermita de San Roque 12. Más adelante, antes del pontón 20 brazas. Pasado el pontón en tres pedazos 13 brazas.

- Más allá de Rocillo a los Casares, se quitaron dos árboles atravesados y un terrero, 20 rs.

- A la carcavilla de Bolado 10 brazas y reedificar una braza que se había empezado a deshacer.

- En la concha de Bolado, deshizo unas peñas atravesadas que impedían el paso de machos, se tasó en 88 rs. y un paredón que hizo en la orilla del río que estaba desbaratado, se tasó en 40 rs. En la concha se midieron 9 brazas de calzada y cascajo.

- A la entrada y salida del puente de Gibaja, se reedificaron 4 brazas a cargo de Avellaneda. En dicho puente, un paredón que se tasa en 6 rs. Pasado Guardamino 7 brazas de calzada.

- En Copenil un paredón de 10 brazas que estaba caído en la fuente, tasado en 8 ducados. Sobre este paredón se hicieron 10 brazas de calzada que a 1,5 son 15 brazas.

- Al puente de Lanestosa 21,5 brazas. En las faldas de la salida y entrada del puente, se hicieron tres paredones tasados en $11 \mathrm{rs}$

- En la subida de "Sandenihesto" en la primera haya, rompió una peña tasado en 50 rs.

- Más arriba de esta haya 7 brazas a dos son 14 brazas.

- Al torno primero de arriba del vado de los Canales 27 brazas. Arriba del vado de los Canales, rompió un pedazo de peña para que pudiesen pasar mejor los machos, tasado en 8 ducados.

- Más arriba del torno de la peña que se rompió 9 brazas. Debajo del Cantejón 17,5 brazas.

- Al Cantejón 58,5 brazas y un paredón que se le tasó en 11 rs. Arriba del Cantejón 10,5 brazas.

- Debajo de la haya oscura, se atravesó una haya grande en el camino, y para quitarla se ocuparon tres oficiales que a tres rs. cada uno son $9 \mathrm{rs}$. A la haya oscura 16,5 brazas.

- Arriba de las barandas del medio 22,5 brazas. A los espinos 22 brazas.

- A las lastras junto al mojón de Retuerto, se hicieron en dos pedazos dos paredones de piedra y otro en los Bernachos, se tasó todo en 80 rs. más 14 brazas de calzada.

- Se le han de pagar 6 ducados a Juan de Bayona por la visita de las calzadas hasta Agüera, que se ocupó 6 días por mandato de la villa.

- En las Llamas de lo llano de "Sandenihesto", abrir dos sangraderas y despejar el agua encharcada en el camino, se ocuparon 4 oficiales y se tasó en 12 rs.
} 
más de Go obreros, que a 3 rs. cada uno hacen 6.120 mrs. También nombraron a Juan Sainz del Prado regidor del Prado y a Juan de Treta, para tasar un puente hundido en las casas de la Calera junto a la casa de Hernando de la Peña, y que hizo en 1587 trayendo los maderos que son cuatro madres, embarandarlo, guarnecerlo y hacer un paredón por la parte del río de abajo, sin los maderos que compró en Hosca en Carranza, con 30 oficiales que a tres rs. fueron 3.060 mrs.

Además, las brazas de calzada que desde febrero de 1585, Juan de Alvarado midió a Monesterio, a dos varas y tercia de largo y otro tanto de ancho, son $1.884,5$ brazas que a 80 mrs. braza, montan 152.760 mrs. que Juan de Bayona, regidor de Laredo, le tomó y midió hasta diciembre de 1589. Hay asimismo 95 brazas de puentes que a $102 \mathrm{mrs}$. por braza del dicho largo y ancho, montan $9.690 \mathrm{mrs} .{ }^{917}$.

917 El detalle es el siguiente:

- En Colindres, junto a la casa de Juan de Alvarado y más adelante en dos pedazos 12 brazas.

- En el barrio de Ganzada, frente a la casa de Pedro de Alvarado Palacio, otras 6,5 brazas.

- Delante de la puerta de Juan de Castillo Sotillo se midieron otras 4,5 brazas de calzada.

- Más adelante de la casa de Juan de Castillo, hasta llegar a casa de Juan Garci de la Serna como sube la cuesta, se midieron 39 brazas. Donde dicen la Redonda, frente a la calleja de Pomaler se midieron tres brazas. Un poco más arriba, frente a dicha calleja se midieron otras 15,5 brazas.

- Como se baja a la cuesta de casa de Pedro Gil de la Redonda, 5 brazas. Más adelante de la casa de Pedro Gil, como se baja la cuesta hasta llegar a la entrada de las huertas de Ruiseco, 33 brazas.

- Algo más abajo, como se va por la calzada hasta llegar a la fuente de Ruiseco, otras 24 brazas. Más adelante de dicha fuente, como se sube la cuesta para ir derecho a Limpias, otras 8,5 brazas.

- Un poco más adelante junto a un castaño, se midieron otras 6 brazas.

- Más adelante derecho a los molinos desde cuesta de Mar, otras 4,5 brazas.

- Más adelante frontero a una salcera junto al primer arroyo, otras 4,5 brazas.

- Antes de llegar al mojón que parte términos entre Colindres y Limpias, otras 6 brazas.

- En el monte de Limpias junto a unos robles gruesos, se midieron en dos pedazos 6,5 brazas de calzada. Más adelante se midieron en otros dos pedazos 3,5 brazas. Un poco más adelante, antes de llegar a un roble junto al camino a mano derecha, como se va a Ampuero, se midieron 10,5 brazas.

- Un poco más adelante, donde está un roble a la derecha que se va derecho a Ampuero, "que tiene una berruga grande en el tuero", otras 6 brazas de calzada.

- Junto a las primeras viñas de Limpias, se midieron otras 10 brazas.

- Junto a una cruz a la izquierda como se va a Ampuero, se midieron 18 brazas.

- Derecho a Limpias junto a unas cercas arriba del camino, se midieron otras 10,5 brazas.

- Más adelante antes de llegar a las casas de Espina se midieron tres brazas. En el barrio de Espina desde la ponteci-

Ila, como va la cuesta arriba antes de llegar al límite, otras 25,5 brazas.

- Adelante junto de la casa de Pedro García de Bernales se midieron 35 brazas.

- Junto a una huerta de naranjos, se midieron otras 8 brazas junto a unos cerezos.

- Junto a la casa de María del Rivero, se midieron otras 35 brazas.

- Algo más adelante de una huerta de Juan de Bayona, a la parte del mar, del camino hasta la primera casa cerca de la de Juan Gil del Rivero, otras 108,5 brazas.

- Junto al horno del dicho Juan Gil del Rivero, otras 10 brazas. En medio de las casas del Rivero otras 48 brazas. Más adelante del molino del Rivero se midieron otras 6,5 brazas.

- Más adelante al arroyo que baja de la fuente que llama del Amor, entre unas salceras 27 brazas.

- Un poco más arriba, antes de entrar en la calleja de las cruces de Collado, 10,5 brazas.

- Donde hay unas paredes antes de las cruces de Collado se midieron 7,5 brazas. En Ampuero, más adelante de las cruces de Collado al bajar de la cuesta, otras 12 brazas de calzada.

- Cuesta abajo antes de llegar a las casas del llano de Ampuero 9 brazas.

- Más abajo delante de las casas del camino, otras 15 brazas.

- Donde se acaba la calzada, derecho como se va a Ampuero a las últimas casas 10 brazas.

- En el puente de Ampuero se midieron otras 17 brazas a tres rs. cada una.

- En la poza más acá de Rocillo, se midieron 13,5 brazas. En los Llamosos antes de llegar a dichas casas, se midieron 16 brazas de largo que a 1,5 brazas hacen 24. Entre las dos casas primeras de Rocillo junto a un paredón, se midieron 3.5 brazas de largo y media de ancho que son 5 brazas.

- Pasadas las dichas casas, se midieron otras 11,5 brazas de calzada sencillas.

- Al salir de unas cajigas, más acá de la fuente que está en el camino, se midieron otras 14,5 brazas de largo que a 1,5 brazas hacen 21,5. Más adelante, al subir una cuesta pequeña se midieron otras 10,5 brazas de largo que hacen 
con el ancho 15,5. Más adelante al cabo de la calzada se midieron otras 7 brazas de largo, que a 1,5 brazas de ancho son 10,5 .

- Más allá de Rocillo la del Medio junto a unas mimbreras, 4,5 brazas que con el ancho hacen 6.

- Junto a unas cajigas otras 4,5 brazas de largo que con el ancho hacen 6,5.

- Pasado Rocillo la del Medio, al subir de una cuesta pequeña que tiene a mano derecha un manzanal, se midieron otras 4,5 brazas de largo que con el ancho hacen 6,5 .

- Pasadas las últimas casas de Rocillo, la de Arriba que tiene unas heredades a la mano derecha como se va a Castilla, se midieron otras 27,5 brazas sencillas. Un poco más adelante, en una calleja estrecha que tiene entre ambos lados unos terreros, se midieron 18,5 brazas.

- Más acá de una torre de Rasines en la primera casa 6 brazas que a 1,5 brazas de ancho son 9. A través de la casa de Sarabia antes de la iglesia, otras 7 brazas de calzada sencillas. Entre la iglesia y la primera casa, se midieron otras 4 brazas de calzada. Mandó que se aderece a su costa un pozo que falta aquí. Más adelante de la casa de Juan de Cariga, se midieron otras 9,5 brazas sencillas.

- Junto a las casas de García de Luru, otras 5 brazas. Más adelante, en la bajada de la cuesta de Parayas a la vista del río, otras 7 brazas que a 1,5 hacen 10,5 brazas.

- En la concha de Bolado más acá del molino, otras g brazas sencillas de calzada.

- En Gibaja, arriba del molino donde se toma el camino del vado, y se deja el del puente de Gibaja, se midieron 9,5 de largo que a 1,5 brazas de ancho hacen 14. Más adelante como se va al dicho vado donde está un hoyo a la derecha, otras 7 brazas de largo, que a 1,5 brazas de ancho hacen 10,5.

- A la entrada del puente de Gibaja 4,5 brazas de calzada con el ancho. Más otras 6 brazas a la entrada del dicho puente, que se ponen en el margen por ser de puentes y pagarse más, dijo que las había medido Juan de Bayona el año antes y las llevó el río.

- En Gibaja bajo la casa de Juan de Ahedo, a la subida de Cerrillo se midió un pedazo de calzada en que hubo 33 brazas, que a razón de 1,5 brazas de ancho hacen 49.

- En las casas de Cerrillo a la entrada del castañal, como se viene de Castilla y se toma el camino del vado dejando el del puente, se midieron 15,5 brazas que a 1,5 brazas de ancho hacen 23 .

- Al salir de las casas de Gibaja entre el castañal, otro pedazo de calzada de 32 brazas que a 1,5 de ancho hacen 48 Algo más adelante otras 14 brazas de calzada que a 1,5 de ancho hacen 21 brazas.

- En Ramales, al entrar en las encinas de Ramales junto a las casas del barrio de Riancho, se midieron 6 brazas de calzada que a 1,5 de ancho hacen 9 brazas.

- En medio del monte de Ramales en la primera calzada a la entrada y a la salida, se midieron dos pedazos de calzada de 10 brazas de largo, que a 1,5 de ancho hacen 15.

- A la entrada de La Haza de Ramales donde se deja el camino del Carro y se toma el de La Haza, se midieron 16 brazas que a razón de 1,5 brazas de ancho hacen 24 .

- En La Haza de Ramales arriba de los primeros retornos, otras 15 brazas de calzada, que a 1,5 brazas de ancho hacen 22,5 . Aquí se le mandó que aderece un paso a su costa en medio del dicho paso.

- Algo más arriba 14 brazas de largo y porque todas no tienen 1,5 brazas de ancho, se le dan 18.

- Más arriba antes de subir al portillo, se midieron otras 5 brazas de calzada que por no ser todas de un ancho, se le hacen buenas 6 brazas. En lo alto de La Haza de Ramales en medio del portillo a ambas partes, se midieron 31 brazas de largo que por no ser todas de 1,5 brazas de ancho, se le ponen 40.

- Enfrente del mojón que divide la jurisdicción de la junta de Parayas y Lanestosa, se midieron otras 7 brazas que a 1,5 de ancho son 10 brazas.

- En Lanestosa, más adelante del dicho mojón, se midieron otras 15 brazas de calzada, que tienen en medio una sangradera, que a 1,5 brazas de ancho hacen 22,5 .

- Un poco más adelante en el monte de Lanestosa, frente a la peña alta que está a la derecha como se va a Castilla, se midieron otras 8 brazas. Otro poco más adelante entre unas peñas planas, se midieron otras 6 brazas de calzada que con 1,5 brazas de ancho son 9 . Más adelante de subir una cuesta pequeña que tiene a la derecha una peña redonda, 4 brazas que con el ancho dicho hacen 6 .

- Al salir del monte de Lanestosa, bajando una cuesta pequeña, se midieron en dos pedazos, 4 brazas que a 1,5 brazas hacen 6 . Más adelante de Lanestosa entre los dos vados en las Lastras, se midieron en 7 pedazos que tenían 7 brazas de largo, que a razón de 1,5 brazas de ancho, hacen 70,5.

- Encima de las casas de Tobar, se midieron otras tres brazas que con el ancho hacen 4,5.

- En la Herrería de Martín Ezquerra por donde baja el río Hoz de Herada, se midieron otras 55 brazas de calzada, que a 1,5 brazas de ancho hacen 76,5. Más adelante se midió otro pedazo de calzada al fin de un arroyo que baja de Carranza, en que hubo 42 brazas que a 1,5 brazas de ancho hacen 63.

- Antes de llegar al puente de la Calera, donde hay un roble grande, se midieron otras 10 brazas que a 1,5 brazas de ancho hacen 15. En el puente de la Calera a la entrada y salida, se midieron dos pedazos de calzada en que hubo 9 brazas que a 1,5 de ancho cada una hacen 13,5 .

- Antes de llegar a las casas de El Prado junto a unos robles, se midió otro pedazo de calzada que son 10 brazas que a 1,5 brazas de ancho hacen 15. Más arriba junto a las casas de Pedro Sainz de Abajo, se midieron otras 6 brazas que hacen 9 con el ancho. Más arriba junto a la casa de Diego Sainz del Callejo, se midieron 12 brazas de largo que tiene cada una dos de ancho que hacen 24. Más adelante arriba de la iglesia de El Prado se midieron otras 9 brazas que a dos de ancho son 18 
En diciembre de 1589, Juan Sainz de la Puente y Juan Gutiérrez de San Martín, vecinos de Agüera, maestros carpinteros nombrados por Juan de Alvarado y Juan de Monesterio, tasaron las barandas de "Sandenihesto" que hizo Juan de Monesterio en 1586, en 1.700 mrs. los 6 marranos que están atravesados en la primera baranda de "Sandenihesto", con sus barandas, contrabarandas y clavazón, y en 15.000 mrs. de 20 maderos marranos atravesados en la última baranda en lo alto de "Sandenihesto", que tienen 10 y 11 pies de largo, con sus barandas y contrabarandas, 41 varas de calzada de 7 pies cada vara, que hacen 287 pies de largo y la baranda doblada por arriba y abajo con su clavazón y pies, por todo lo que está así junto con el coste de las maderas. También se tasaron en 1589 las maderas y obra del puente de la Tabla de Agüera que hizo Juan de Monesterio en 1586, por los maestros oficiales carpinteros Juan Sainz de la Puente y Juan Gutiérrez de San Martín, nombrados por Juan de Alvarado, y Pedro Cano y Juan Zorrilla nombrados por Juan de Monasterio, que monta $26.000 \mathrm{mrs} .{ }^{918}$. También Juan de Alvarado regidor de Laredo, visitó los pasos e indica que se le deben tasar los 146 obreros que suma el pliego, y que la mayor parte de los oficiales son canteros. Se les dan 3,5 rs. que suman 511 rs. Suma el memorial 555 rs., que son $18.870 \mathrm{mrs}$. de los pasos, caminos y obras que Juan de Monesterio ha hecho ${ }^{919}$.

\footnotetext{
- Encima de las casas de El Prado subiendo derecho a "Sandenihesto", en una calleja estrecha hasta la primera haya donde hay una peña llana, se midieron otras 40 brazas de calzada que a 1,5 brazas de ancho hacen 60 . Más arriba se midió otro pedazo que tiene de largo 19 brazas, 8 de dos de ancho y 11 de 1,5 brazas que hacen 32,5.

- En la primera vuelta bajo el vado de los canales en el dicho puerto, se midieron otras 12 brazas que a midieron otras tres brazas de largo, que a 1,5 brazas de ancho hacen 4,5.

- Más adelante en el dicho puerto, se midió un pedazo grande de calzada y se acabó enfrente de 8 o 10 espinos grandes que están como se sube a mano izquierda que tuvo 49 brazas, que a razón de 1,5 brazas cada una de ancho son 73. Más arriba de los dichos espinos a una vuelta sobre la mano derecha junto a un roble tuerto, se midieron otras 30 brazas y se acabó junto a un espino que tiene debajo de la raíz una losa, que a 1,5 brazas de ancho hacen 45. - Más adelante en el dicho puerto junto a unas losas, se midieron 18 brazas de calzada que a 1,5 brazas son 27. Más arriba al llegar al principio de las últimas barandas, se midieron otras 17 brazas de calzada que a 1,5 brazas de ancho hacen 25,5 .

- Otras 6 brazas de calzada a la entrada y salida del puente del Canto, como van a Agüera, que a dos de ancho son 12 brazas. Tiene el dicho puente de hueco, otras 11 brazas sencillas.

- En el puente de la Tabla más acá de Agüera, tres brazas de largo que a dos de ancho son 6 , y en el hueco del puente otras 8 brazas. Otras 9,5 brazas a la salida del puente que son sencillas. Se midieron en el puente de Agüera en el hueco 8 brazas sencillas.
}

918 El detalle del puente de la Tabla es el siguiente:

- Las 4 madres principales del puente, de 44 pies cada una, ya puestas $6.000 \mathrm{mrs}$.

- Las 10 piezas de tramos que tiene el puente de 25 pies cada pieza ya puestas, otros $6.000 \mathrm{mrs}$

- Cuatro marranos con dos asnillas y 5 postes que sustentan el puente, cada uno de 16 y 18 pies, de largo, 5.000 mrs., que están los pies hincados con sus boches en la peña de abajo.

- 9 maderos travesaños en medio del puente, a 14 pies uno con otro que sustentan las barandas de una parte a otra $1.000 \mathrm{mrs}$. Otros 14 maderos que llaman cadenas, a lo largo del puente $1.500 \mathrm{mrs}$

- 18 postecillos que sustentan las barandas con sus riostras y barandas 1.000 mrs., y las barandas 2.000 mrs. que es todo 3.000 mrs. La clavazón de hierro con sus clavijas y trabaderos 1.000 mrs.

- Los paredones de piedra para sustentar los pilares, uno a la entrada y otro a la salida, 1.500 mrs.

919 El resumen de lo que Monasterio ha realizado, es:

- En el paso de Colindres junto a la fuente de Ruiseco, entraron dos obreros a quitar un terrero.

- En las cruces de Collado 5 obreros, que bajaron a desembarazar un terrero que cayó en el camino.

- En las conchas de Bolado debajo de Parayas, donde cayeron de lo alto gran cantidad de peñas, para quebrarlas y desembarazarlas fueron necesarios 44 obreros.

- Más adelante enfrente de la iglesia de Gibaja se hizo un paredón y se rozaron 20 brazas de peñas que impedían pasar por el camino, que llevó 24 obreros.

- Antes de llegar al puente de Gibaja, un obrero en quebrar unas peñas.

- En el monte de Ramales, donde hay un hoyo y una peña en que se divide el agua, se desembarazó un roble que llevó dos obreros. En el monte de La Haza de Ramales se desembarazaron 4 encinas gruesas y quitaron unas peñas y unas hayas frente a la cueva, que llevó en todo 18 obreros. 
En diciembre de 1590, Juan de Alvarado hace las cuentas para liquidar con María López de las Roldanes, vecina de Irús y viuda de Juan de Monesterio, y Juan, vecino de Campillo, Pedro, vecino de Irús, María y Juana de Monesterio, sus hijos y herederos, lo que quedó pendiente tras su fallecimiento920. Juan de Monesterio debía $380.990 \mathrm{mrs}$. de los puentes, calzadas y otras cosas que ha hecho, de los cuales se le han de descontar 3.740 mrs. por el paredón de Copenil contenido en la dicha libranza. Visto el cargo que se hace a Monesterio de los $301.000 \mathrm{mrs}$. y lo que ha pagado de sus obras por libranzas de la justicia y regimiento, alcanzan a Laredo y a la obra de las calzadas que están a su cargo 76.250 mrs. según la cuenta, que ha hecho Juan de Alvarado.

Según el memorial que el regidor hizo en septiembre de 1593 tras la visita de los paredones y malos pasos reparados, y peñas que ha roto Pedro Sáenz del Campillo, en el camino de Laredo a Agüera desde 1590 hasta 1593, ascendía todo a 56.017 mrs. ${ }^{921}$.

- Bajando a la curva en el río que venía por el camino abajo que invadía el camino y para cortar el agua, se pusieron 8 obreros.

- Dos obreros por quitar dos nogales de una la pared, dificultando el paso de las cargas. Más adelante en otro vado donde hay una cruz, se quitaron unas piedras que embarazaban el paso, dos obreros.

- De la entrada donde dicen Copenil hasta salido todo el monte que con la tormenta se desarraigaron muchas hayas, llevaron 12 obreros.

- Derecho de la herrería de Martín Ezquerra, se quitó el terrero de la calera que llevó 5 obreros.

- En el puerto de "Sandenihesto" en el vado de las Canales, se hundió un terrero que llevó 14 obreros. Más arriba bajo la haya oscura, se hizo un paredón y se desatravesó una gran haya, que se debió sacar la piedra y hacerlo 6 obreros. - En la fuente de la Sardinera se quitó otro árbol que llevó un obrero.

- En el pretil del puente de Canto Herada que está desde "Sandenihesto" a Agüera, se pusieron unos pretiles que llevó de costa y cal 4 ducados que son 44 rs.

- Estos oficiales entraron en los desembarazos de los caminos, cortaron terreros y peñas y todo lo necesario para que se pasase por esos caminos, por las muchas avenidas de aguas que han venido, y la mayor parte de estos pasos y caminos, la justicia y regimiento de Laredo mandó a Monesterio que los reparase, para "que los arrieros que andan el dicho camino no se quejasen".

920 El resumen de lo que se debe liquidar con los herederos de Juan de Monesterio es:

- Se hace cargo a Monesterio de 301.000 mrs. que costaron las calzadas de renta que tenía arrendadas entre 1584 y 1590.

- 3.213 mrs. que se pagó por el empedrado de la calzada de San Lorenzo como parece por libranza de la justicia y regimiento de 19 de septiembre de 1588.

- 37.816 mrs. que pagó Monesterio a Juan de Avellaneda su empedrador, que hizo de alcance por libranza de la justicia y regimiento de 17 de enero de 1586

- 152.760 mrs. de 1.884,5 brazas de calzada que Juan de Alvarado midió, a 80 mrs. por braza.

- 9.690 mrs. que montaron 95 brazas de calzada, que Monesterio empedró en los puentes de Ampuero, Gibaja, La Calera y Agüera, a tres rs. la braza.

- 6.120 mrs. que hubo que pagar por los paredones y lastras que hizo en Lanestosa, tasado por Pedro Ezquerra el mayor y Pedro Ezquerra el mozo, vecinos de Lanestosa.

- 3.060 mrs. que hubo que pagar por los maderos y oficiales del puente de la Calera, tasado por Juan Sainz del Prado y Juan de Treto, maestros carpinteros.

- 16.700 mrs. que se han de pagar por las barandas de "Sandenihesto" y oficiales que las pusieron, por tasación de Juan Sainz de la Puente y Juan Gutiérrez.

- $25.000 \mathrm{mrs}$. que hubo que pagar por las hechuras y maderamiento del puente de la Tabla de Agüera, por tasación de Juan Sainz de la Puente y Juan Gutiérrez maestros carpinteros.

- 14.000 mrs. por ensanchar el puente de Agüera y maderas de él, tasado por dichos oficiales.

- 18.870 mrs. que se han de pagar por 146 obreros que se ocuparon en abrir caminos, quebrar peñas y cortar hayas que con las grandes avenidas, cayeron en los caminos, tasado cada obrero en 3,5 rs.

921 El resumen del memorial, es el siguiente:

- En Colindres en el arroyo de Raposil se hizo un paredón tasado por García Gil y Pedro del Cerro, nombrados por el regidor y por Pedro Sáenz del Campillo, en dos peones que a 3,5 rs. en $238 \mathrm{mrs}$.

- Una puentecilla que aderezó en medio de Colindres, un obrero en $119 \mathrm{mrs}$., más una puentecilla que hizo de madera en Limpias en dos obreros en 238 mrs. En las casas primeras de Rocillo en 150 mrs.

- En el Salanal entre los dos Rocillos, otra puentecilla que la volvió a hacer de madera en 300 mrs.

- En Rasines donde dicen Parayas, rompió unas peñas para permitir el paso, en 2.500 mrs. 
Las 695 brazas de calzadas que Sáenz del Campillo ha hecho entre Laredo y Agüera desde principio de 1590 hasta fin de 1593, vistas por Mateo de Agustina y medidas por García Gil y Pedro del Cerro, vecinos de Gibaja, a 80 mrs. la braza, montan 55.600 mrs., más 60 brazas de calzada en los puentes que a tres rs. valen $6.120 \mathrm{mrs} .{ }^{922}$.

\footnotetext{
- Al Canjilón de las primeras casas de Gibaja, un paredón de un arroyo que hizo, 700 mrs. Derecho a la iglesia de Gibaja, rompió una peña en 1.000 mrs. Junto al arroyo en Gibaja, un paredoncillo 300 mrs. En la cuesta de Gibaja al castañal, rompió y allanó unas peñas de 18 brazas de largo, 1.500 mrs.

- En lo alto de la cruz para bajar a Guardamino, rompió unas peñas que impedían el paso de unas 31 brazas de largo, en $2.320 \mathrm{mrs}$.

- En La Haza rompió una peña y puso otras piedras grandes abajo porque se despeñaban por allí los mulos, en 600 mrs. Quitar unas peñas caidas que estaban atravesadas en el paso, en 500 mrs.

- En La Haza más arriba puso una haya que se había caído, para que sirviese de baranda, en 408 mrs.

- En la pared donde pega el rio con las peñas, rompió unas peñas de la parte de arriba y ensanchó el camino para pasar la recua, en 1.000 .

- Adelante de la pared rompió 138 brazas, camino nuevo entre peñas para atajar los vados del río, en 16.150 mrs. Entre las ventas de Valnera y La Calera, hizo en la parte del río una defensa para que no peligrase la recua, en 1.734 mrs. Junto a un arroyo que está debajo de La Calera, quitó un gran terrero que cayó en el camino, en 890 mrs. con unos arroyos que hizo el diluvio. Más arriba del Prado quitó unos terreros que cayeron sobre el camino al subir del puerto, en $408 \mathrm{mrs}$.

- En la cuesta de "Sandenihesto" cayó un haya y un terrero en el camino y lo desembarazó, en 500 mrs. Más arriba se quitó un gran terrero que cayó sobre la calzada, 680 mrs. Subiendo a la mitad de la cuesta, hizo un paredoncillo en 4 rs. Más arriba donde hay unos espinos, hizo un paredón en 20 rs. Algo más arriba se cayó un paredón y le hizo en un pedazo de calzada en 750 mrs. Más arriba junto a lo alto, unas barandas de roble debajo de las otras que estaban antes, las que deshizo en $748 \mathrm{mrs}$.

- En las lamas de "Sandenihesto" abrió unas zanjas y arroyos en 4 partes por donde corra el agua, se tasó en 21 peones que a 3.5 rs. montan $2.500 \mathrm{mrs}$.

- Al bajar del puente de piedra limpia, rompió hasta 18 brazas de peña en 2.000 mrs.

- Al mojón de Retuerto rompió un camino por la parte de la Sierra, dejando el río abajo que fueron 96 brazas en 13.000 mrs. Más donde dicen la fuente de La Sardinera en el término de Agüera, rompió hasta 63 brazas de peñas para abrir camino, en $3.468 \mathrm{mrs}$.

- Reparó además unos paredoncillos en unos arroyos que entre La Calera y Valnera hizo el "andilubio" de septiembre de 1593 , en 500 mrs.
}

922 El detalle es el siguiente:

- A la entrada de Colindres en la Serna 36 brazas de calzada. Al arroyo de Raposil 12 brazas. En Colindres delante de la casa de Juan de Alvarado regidor tres brazas. En Colindres en la puentecilla de Hedino 8 brazas. Adelante antes de llegar al arroyo que divide los términos de Colindres y Limpias 21 brazas. Al arroyo que parte el término dos brazas. Un poco más adelante otras 5 brazas.

- Al monte de Limpias 23 brazas. Junto a las casas primeras de Limpias 19 brazas. En Limpias a las casas de Espina 25 brazas. Junto a la puentecilla del molino de Limpias 10,5 brazas.

- Al otro puente como se va a Ampuero 10 brazas. Donde se parte el camino del Carro junto a las cruces de Collado 16 brazas. En la calleja bajando a las cruces de Collado 13,5 brazas.

- A las casas del camino junto a Ampuero 15 brazas.

- En el Sacinal entre los dos Rocillos 6 brazas. En la pontecilla entre los dos Rocillos 4 brazas.

- En la entrada de Rocillo el de medio 6 brazas. En Rocillo la de medio 6 brazas.

- En Rasines frontero de nuestra Señora de Villasomera 8 brazas.

- A la bajada de la cuesta de Parayas junto a la de Bolado 17 brazas.

- En Gibaja al canjilón del Haro 10 brazas. Más adelante junto a la iglesia de Gibaja 19,5 brazas.

- Al vivero antes de entrar en el puente de Gibaja 11 brazas. En el puente de madera de Gibaja con entradas y salidas y ancho 39 brazas. Pasado el puente de Gibaja 20 pies.

- Adelante donde dicen Palazuelos 13 brazas. Adelante a la calzada del Cerrillo 18 brazas.

- Pasada la cruz para ir a Guardamino 5 brazas. A la entrada del monte bajo Guardamino 13 brazas.

- A la fragua antes de llegar a Ramales 15 brazas.

- En Ramales a la salida 7 brazas. En La Haza 16 brazas. Junto a la pared tras las losas 42 brazas.

- A la pared de la cueva 63 brazas de calzada nueva en el rompimiento que hizo encima del río 63 brazas. En el puente de madera de Lanestosa 13 brazas. Saliendo de dicho puente 4 brazas.

- En el Prado al cabo de las calzadas 6 brazas. En el Prado junto a una rebolla a las casas bajeras 10 brazas. Junto a la iglesia delante del mesón del Prado 12 brazas.

- A la entrada de la cuesta de "Sandenihesto" 14 brazas de calzada. Más arriba 5 brazas. Al principio de la cuesta 38 brazas. Más arriba en dicha cuesta 35 brazas. Más arriba en la cuesta 7,5 brazas.

- En medio de la cuesta 23 brazas. Más arriba junto a una haya grande que está sobre el camino 7 brazas. A los espinos de la dicha cuesta debajo de las barandas 7,5 brazas. A las barandas de "Sandenihesto" en lo alto 13,5 brazas. 


\section{f.- Entradas y salidas de mercaderías y bastimentos en Laredo}

Todas las tierras del Norte, padecían una gran escasez de productos básicos como trigo, cebada, aceite y vino, por no ser zona productora. Por otro lado, eran emisores de pescado que en cierta cantidad llegaba a sus puertos y que debía transportarse al interior en un corto espacio de tiempo por ser producto perecedero, aunque esto se podía remediar aplicando al pescado diversos tratamientos para alargar su conservación, como cecial, curado o en salazón. Para evitar en lo posible esta carestía, el concejo de Laredo, impuso siempre la obligación de que los arrieros que acudían al puerto a cargar el pescado, los paños u otros productos, debían llevar a la villa carga de trigo, imponiendo un recargo o multa a los arrieros que no cumplían con esta obligación. No obstante en febrero de 1488, García Ruiz de Hornillalatorre, procurador de los "mulateros caminantes de Castilla Vieja" presentó al alcalde y regidores de Laredo una Carta real, y expuso que algunos mulateros y viandantes o sus criados, iban a comprar a Laredo pescados y otras mercaderías y llevaban a vender pan, vino y otras cosas, cobrándoles por mandato de los regidores $2 \mathrm{mrs}$. por quintal de pescado, e impidiendo que nadie comprase sin su licencia las mercaderías que llevaban, lo que era injusto. Pedía que les dejasen comprar y vender libremente sin pagar los dichos derechos ${ }^{923}$.

En 1493 los concejos de Colindres y Limpias, afirmaron que el concejo de Laredo, "con animo e proposyto de le faser mas e dapño a los dichos vesinos e moradores" a causa de cierto pleito que con ellos tiene, ha hecho ciertas ligas y monopolios contra derecho, y contra la posesión que tienen de tiempo inmemorial, prohibiendo bajo grandes penas, que ningún vecino de Laredo y su tierra fuese a moler a los molinos de Limpias o Colindres, y que ningún mulatero descargase o vendiese trigo, vino u otra provisión en sus poblaciones, y si los mulateros hicieren lo contrario, mandaba que ningún vecino de Laredo contratase en adelante con ellos ni les diese cargas para llevar a parte alguna, lo cual les causaba perjuicio, "porque diz que [no] tienen otros bienes de que se mantener, saluo de los dichos molinos e de las cosas e prouisyones que vienen de acarreo, por ser como diz que son los dichos lugares asperos e esteriles de pan e vino e ganados e mantenimientos", por lo que pidieron que se revocasen tales ordenanzas, para que los mulateros pudiesen llevar provisiones y mercaderías y venderlas libremente como siempre han hecho. El Consejo Real, mandó al corregidor de Trasmiera y Cuatro Villas, que haga cumplimiento de justicia924.

En 1496, Laredo reitera que de tiempo inmemorial, todos los arrieros que llegan a por pescado o fardeles de paños, suelen llevar sus bestias cargadas de trigo para el mantenimiento de la villa, poniéndolo en el enlosado del cementerio de la iglesia de Santa María, lugar señalado por el concejo, donde se repartía equitativamente entre los vecinos según las personas que había en cada casa, pero como el trigo era siempre escaso, algunos vecinos compran mucho trigo de las recuas que iban a por el pescado, y guardan el grano en sus casas para revenderlo, por lo que el pan se encarece y escasea. Piden que se mande

923 A. G. S./ Cámara de Castilla. Pueblos, leg. 10, doc. 32-1/ Laredo, 24 febrero 1488.

924 A. G. S./ Registro General del Sello, XI-1493, fol. 123/Valladolid, 26 noviembre 1493. 
llevar el pan al lugar señalado por el concejo para que se reparta como se acostumbraba y el Consejo manda al corregidor que lo remedie ${ }^{925}$.

García de Escalante, vecino de Laredo, dijo en 1522 que hay costumbre y ordenanza, para que los mulateros que van a sacar pescados y otras cosas, han de llevar cierta cantidad de trigo o pagar 100 mrs. por bestia sin carga, y que para que paguen dicha pena, los fieles les tasan su pan a la mitad de lo que les cuesta en los mercados de Medina de Pomar, Espinosa de los Monteros y otros, de manera que pierden la mitad de lo que han pagado además de los gastos del transporte, por lo que prefieren pagar la pena porque les sale más barato. Además el trigo lo hacen llevar a una red o espacio enlosado cerrado del cementerio de la iglesia de Sta. María, y los fieles lo reparten a precios bajos a las personas principales, a los parientes mayores que les concedieron los oficios de fieldad y a la justicia de la villa, perjudicando a la gente menuda y pobre. El pan tan barato solo se reparte entre 40 o 50 casas, y quedan sin abasto más de 400 vecinos, pero lo peor es que los beneficiados del reparto toman más de lo que necesitan, y algunos lo revenden a precios doblados, obligando por ello a ir a buscarlo a otras partes. Pedía que se mandase que todo el pan, trigo y cebada que llegase, se vendiese en su plaza libremente y a los precios que quisieren, para que todos lo puedan comprar, y que no se llevase a la red, ni los fieles les pongan precio ni lo repartan. El Consejo, mandó que el corregidor lo remedie como se propone y que en ello no haya fraude ${ }^{926}$.

Cristóbal Pérez en nombre del cabildo de San Martín de los Navegantes y Mareantes de Laredo, dijo al Consejo en 1574, que Laredo necesitaba más pan que ninguna otra villa de la costa, por acudir a ella mucha gente por mar y tierra, y para proveer a vecinos y forasteros y por no producirlo, debía llegar forzosamente de acarreo llevado por los mulateros de Burgos y Castilla Vieja. Pero en el camino, había muchos lugares con personas que tenían por trato la compra de este trigo para revenderlo más caro en grano, en pan o en harina a los vecinos de Laredo y otros de la comarca, recibiendo las maquilas del trigo en sus molinos, con gran perjuicio en especial a los pobres, agravándose la situación al no venir ya el trigo por mar de Francia y Flandes como solía, por lo que pidieron que se penase a todos los lugares del camino que tuviesen este trato, salvo lo que necesitaren para sus casas, y los que quisiesen lo fuesen a comprar a los mercados de Medina de Pomar, Espinosa de los Monteros y Burgos. El Consejo mandó al corregidor, que haga lo que se propone y no consienta que nadie compre a los arrieros ni a otras personas más trigo de lo que necesitare ${ }^{927}$.

En el s. XVII, las merindades de Castilla Vieja, dicen al corregidor que el doctor de la Cámara, alcalde mayor que les envió el Rey hará año y medio, les causa muchos daños y agravios; entre otros, el que a los arrieros que pasan por Villarcayo, "que es camino pasajero para esta corte", los detiene y quita los pescados, la mayoría de las veces sin pagarlos, por lo que los arrieros evitan pasar por dicho lugar y se pierden los acarreos. Por ello suplican que se mande dar el oficio a otra persona benemérita928.

925 A. G. S./ Registro General del Sello, XII-1496, fol. $297 / 7$ diciembre 1496.

926 A. H. P. C./ Laredo, leg. 28, num. 9/ Burgos, 12 febrero 1522.

927 A. H. P. C./ Villa de Laredo, leg. 1, num. 23, fols. 40-41/ Madrid, 1574.

928 A. G. S./ Cámara de Castilla. Pueblos, leg. 5, doc. 257/ Villarcayo, s. XVII. 


\section{C.- POR LA HORADADA, MEDINA DE POMAR Y PUERTO DE SENDERO ENHIESTO}

Camino también importante fue el de la Horadada, con algunos de sus tramos muy utilizados por la carretería, al evitar las grandes altitudes y, con ello, estar más libre de nieves. Utilizado para diferentes destinos, principalmente Bilbao por el puerto de Angulo, tuvo un papel secundario para ir de Burgos a Laredo, ya que aunque su trazado era más llano, y por ello, más favorable para la circulación de carros, obligaba a dar cierto rodeo frente al de los Hocinos que discurría tendencialmente recto. Tenía además dos desfiladeros seguidos, el de Oña y el propio de la Horadada, que no dejaban de plantear problemas por su angostura y sus paredes verticales. Ambos trazados, se hacen evidentes en 1556, cuando se manejan dos opciones entre Burgos y Laredo para el paso del Emperador: el camino por los Hocinos y el de la Horadada, aunque al fin, Carlos V fue por el de los Hocinos, prueba de que era el preferido y el que más ventajas ofrecía.

El camino a Laredo por la Horadada, iba desde Burgos por Hurones, Temiño, Rublacedo de Arriba, Rublacedo de Abajo, Carcedo de Bureba, Lences, Salas de Bureba, Castellanos de Bureba, Terminón, Tamayo, Oña, desfiladeros de Oña y de la Horadada, Trespaderne, Nofuentes, Moneo y en Medina de Pomar entroncaba con el principal de los Hocinos hasta la década de 1560, o después con el de Villarcayo en el puente de Quintanilla. Un tramo diferente discurría junto a Villayerno-Morquillas al Norte, Tobes y Rahedo, Melgosa, Valdearnedo, Arconada a juntarse en Lences con el principal camino descrito. Entre Burgos y Trespaderne, era común con el que iba a Bilbao desde Trespaderne.

Cuando el paso por los Hocinos quedaba deteriorado o interrumpido por alguna riada, o cuando las condiciones meteorológicas adversas desaconsejaban su utilización, fue utilizado como camino alternativo al estar más abrigado de nieves extremas, por no alcanzar su desarrollo las alturas del páramo de Villalta. Así se subraya en 1676, en que un testigo indica en relación con este camino que no hay "otro camino mas preçiso, porque aunque tanbien ay otro que llaman los Ozinos questa distante quatro leguas poco mas o menos, que ambos los son y no ay otros sino con mucho rodeo, el dicho de la Oradada es el mas conbeniente y por donde continua mas jente, porque el otro en tienpo de niebes se cierra muchas bezes y este no, por estar en tierra mas baja y calida"929. Carretero pero con muchos tramos de herradura, su tránsito dependía del estado de los desfiladeros de Oña y de la Horadada, muy atacados por las crecidas de los ríos Ebro y Oca y alterado en ocasiones por los derrumbes de sus paredones.

\section{a.- El camino en las guías itinerarias}

El tramo por la Horadada hasta Trespaderne se recoge en el itinerario de Matías Escribano de 1758, en el "camino de Herradura Para Bilbao"930. Miguel Bañuelos en su itinerario

929 A. C. V./ nำ195/ 23 mayo 1676 a 30 marzo 1677.

930 ESCRIBANO, J. M.: 1758.

"Hurones

Los Rulacedos

Salas 
de 1771 lo incluye íntegro en el camino "a Laredo", y en el camino a Castro-Urdiales, hasta el cruce de Villasante931. En el Santiago López de 1809, se recoge hasta Trespaderne en el camino a Bilbao ${ }^{932}$ y la "Cuía General de Correos" de Francisco Xavier de Cabanes, de 1830, también lo incluye con el nombre de "Carrera de Madrid a Laredo", aunque lo lleva por Briviesca, y otro que llama "Otra comunicación de Briviesca con Santander (herradura)"933.

\begin{tabular}{|c|c|c|}
\hline & $\begin{array}{l}\text { Oña R.P. } \\
\text { Trespaderne }\end{array}$ & $\begin{array}{l}7 \mathrm{~m} \\
2^{\prime \prime}\end{array}$ \\
\hline \multirow[t]{41}{*}{931} & $\begin{array}{l}\text { BAÑUELOS, M.: } 1771 . \\
\text { "A LAREDO }\end{array}$ & \\
\hline & Villimar & 1. \\
\hline & Urones & 7. \\
\hline & Riocerezo & 1. \\
\hline & Temiño & 7. \\
\hline & Rublacedo de arriba & 1. yme. \\
\hline & Carcedo & 2. \\
\hline & Lences & 7. \\
\hline & Salas & 1. yme. \\
\hline & Terminon & 7. \\
\hline & Oña & 1. \\
\hline & Torrepadierne & 2. \\
\hline & Nofuentes & 1. y me. \\
\hline & Moneo & 7. \\
\hline & Medina & 2. \\
\hline & Quintanilla & 2. \\
\hline & Rivero & 1. \\
\hline & Villasante & 7. \\
\hline & Aquera & 7. \\
\hline & Balnera & 1. yme. \\
\hline & La Nestosa & med. \\
\hline & Ramales & 7. \\
\hline & Resines & 1. \\
\hline & Ampuerco & 7. \\
\hline & Colindres & 1. y me. \\
\hline & LAREDO & 7. \\
\hline & & $30 "$ \\
\hline & “Urones & 2. \\
\hline & Roblacedo & 3. \\
\hline & Carcedo & 1. \\
\hline & Lences & 1. \\
\hline & Salas de Bureva & 7. \\
\hline & Terminon & 7. \\
\hline & Oña & 7. \\
\hline & Trespaderne & 2. \\
\hline & Nofuentes & 7. \\
\hline & Moneo & 7. \\
\hline & Medina de Pomar & 7. \\
\hline & La Venta de Quintanilla & 2. \\
\hline & Villasante & 2. \\
\hline & Bercedo & 5." \\
\hline
\end{tabular}

932 LÓPEZ, S.: 1809

"Camino de herradura para Bilbao hasta Burgos. 42. Aquí se aparta el camino á la izquierda á

$\begin{array}{ll}\text { Harones. } & 2 \\ \text { Los Rulacedos. } & 2 \\ \text { Salas. } & 3 \\ \text { Oña, rio y puente. } & 7 \mathrm{~m} \\ \text { Tres Praderna. } & 2^{\prime \prime}\end{array}$

933 CABANES, FCo. X. de: 1830.

"De Briviesca á los Barrios de Bureba, leg. $\quad 2 \frac{1}{2}$ á Oña $\quad 2 \frac{1}{2}$

á Mijangos; se pasa el Ebro por Oradada 2

áMonco

á Medina de Pomar 


\section{b.- Referencias documentales}

En 1170, Alfonso VIII y doña Leonor, conceden a Carcía III, abad dimisionario de Oña, las villas de Encinillas y Castrillo y el monasterio de San Juan de Cillaperlata, citando la vía de Medina a Trespaderne934. Ese año el infanzón Día Álvarez y otros individuos determinan las heredades que pertenecían a Oña y a Santa María de Nájera en Trespaderne y Castrillo, y establecen los mojones concejiles entre esta aldea e Incinillas, aludiendo a esta misma vía935.

En el punto 46 del fuero de Medina de Pomar, ratificado por Alfonso VIII en 1181 se menciona, entre otros, el camino de Medina a Oña, ya que se indica que si el que gobierna Medina por el Rey, convocase a un vecino ante la corte para celebrar juicio con él, lo acompañará hasta el puente de Frías, hasta Oña, hasta los Hocinos o hasta Espinosa, no estando obligado a ir con él más adelante ${ }^{936}$. Cuando dicho Rey confirma y renueva en junio de 1187, la dotación de Incinillas a favor del monasterio de Oña, menciona la vía de Medina a Trespaderne937. Ese mismo día también entrega el Llano del Rey con todas sus pertenencias, como la hacienda que tiene en Peñahorada de Dentro, Peñahorada de Fuera y Villaverde, además “in Transpaderne, sernam de era de Tedera, que iacet inter ambos pontes" 938 .

En 1281, Roy Pérez ejecuta la sentencia que los jueces árbitros dictaron tras el pleito sostenido en 1280, entre el monasterio de Oña y el concejo de Frías sobre titularidad de diversos bienes y derechos. Se mencionan "los caminos de Nofuentes e Frias que uan a Medina"939.

Los Reyes mandaron al corregidor de las Cuatro Villas y al alcalde mayor de Castilla Vieja, que hiciesen pesquisa sobre el estado del camino y los malos pasos que hay entre Burgos y Laredo. En el informe que el cantero Ruy Sánchez de Criales hizo en junio de 1499 sobre lo que podían costar las obras precisas, incluyó las que, según el procurador de los viandantes, "son neçesarias de se fazer porque la mulateria de la merindad de Castilla Vieja, aparta para yra sus casas por vn camino en la merindad de

\begin{tabular}{cc}
\hline á Villasante & $2 \frac{1}{2} 2$ \\
á la Nestosa & 3 \\
á Cereceda & 3 \\
á Laredo & 2 \\
Esta carrera es montada hasta Briviesca, y de aqui á Laredo se esta trabajando, y sirve la mayor parte para carros". \\
"De Briviesca á los baños de Bureba, leguas $2 \frac{1 / 2}{2}$ \\
á Oña \\
á Trespaderne pasando el Ebro por la Oradada 2 \\
á Moneo \\
áVillarcayo & $2 \frac{1 / 2}{2 "}$
\end{tabular}

934 A. H. N./ D. R. de Oña. carp. 276, num. 5/ Nájera, 7 noviembre 1170; ÁLAMO, J. del: 1950: 285-286: t. I. doc. 237; GONZÁLEZ y GONZÁLEZ, J.: 1960: 258: t. II. doc. 151 "... et usque ad uiam que ducit ad Medina et ad Traspaterno,...".

935 A. H. P. C./ Cartulario..., fols. 33V-34V/ h. 1170; OCEJA GONZALO, I.: 1983: doc. 63, "... usque ad uadum de la Parras et usque ad uiam que ducit ad Medina et ad Traspaderno,...".

936 MARTÍNEZ DÍEZ, G.: 1982: 165-168. "Qui Medinam tenuerit de manu regis, si convocaverit populatorem de Medina ad aulam regis ad accipiendum cum eo iuditium, populator eat cum eo usque ad pontem de Frias vel usque ad Oñate vel usque ad Ocibus vel usque ad Espinosa et non teneatur cum eo ire in antea, sed revertatur ad villam populator cum domino villae, et recipiat iuditium de suo alcalde".

937 A. H. N./ Oña. R-81/ Burgos, 21 junio 1187; GONZÁLEZ y GONZÁLEZ, J.: 1960: 829: doc. 481. “..., et usque ad uiam que ducit ad Medinam et ad Transpaderno, et ex alia parte protendibur usque ad fontes de Nozentes, et usque ad uiam que uenit de Sancto Tirso et ducit ad uiam de Palatiolos,...".

938 A. H. N./ Clero. Pergaminos. carp. 1915, no 8/ Burgos, 21 junio 1187; LIZOAIN GARRIDO, J. M.: 1985: 17-28: doc. 14.

939 A. H. N./ Clero. leg. 1247/ Oña, 2 abril 1281; ÁLAMO, J. del: 1950: 832-836: t. II. doc. 701; OCEJA GONZALO, I.: 1983: 337-341: doc. 233 
Cuesta deVrria con alguna parte de Tovalina". En el informe se indica que en La Horadada, "paralosquese apartan de la merindad de Cuesta de Vrria para yr a Oña e a Burgos en el lugar de Trespaderne, en la puente de Nela", se ha de recalzar dicho puente y hacer un arco y sus pretiles, tasado por Alonso de Maza, cantero vecino de Ruesga, en 16.000 mrs. ${ }^{940}$. Como la propuesta es más de lo que se mandó en la Provisión real, es necesario mandar que "para lo que se a de fazer en la Horadada con la puente de Trespaderne", se haga el repartimiento siguiente: la merindad de Cuesta-Urria que pague $15.000 \mathrm{mrs}$. Los lugares de Tobalina y de la jurisdicción de Frías, Cebolleros, Villavedeo, Pedrosa, Cadiñanos, Santotís, Valujera y La Orden $11.324 \mathrm{mrs}$. Trespaderne $3.000 \mathrm{mrs}$. además de lo que le cupiere pagar con la merindad de Cuesta-Urria. El abad de Oña pagará 10.00o mrs. , y la villa de Oña 15.000. Para que a los pueblos no les haga tanto daño la contribución, pagarán la mayor parte en obreros y darán para la obra y repartimiento del Carreaja piedra, madera y cosas necesarias ${ }^{941}$.

En 1556, con motivo del previsto paso de Carlos V hacia su retiro en Yuste, se revisan los caminos para elegir el más cómodo, ya que el Emperador no gozaba de un buen estado de salud. El doctor Durango alcalde de su casa y corte, y "juez deputado para el reparo y bastimento de los caminos por donde su Magestad e su corte... a de pasar", dice que“...he hallado en él muy malos pasos en los términos de las dichas merindades en especial el paso de los Ocinos y... caminos y malos pasos de la Oradada de como sale Hebro a Trespaderne fasta sobir a Oña..."942. Al final, para el paso del emperador, se optó por el camino de los Hocinos por ser el más directo.

Este mismo año un testigo decía que los "caminos de los Ocinos y la Oradada que sale a Oña, son caminos de los mas publicos reales y caudalosos y pasaxeros deste reino, por donde todas las mercaderias o casi todas que aportan a los puertos de Bilbao, Portogalete, Castro de Urdiales, Laredo y las que deste reino se enbarcan y an enbarcado en los dichos puertos, pasan y se traxinan por los dichos caminos y por qualquier dellos especial por el de los Ocinos". Otro testigo decía que "son caminos publicos y reales y caminos prenzipales deste reino aunque el de los Ocinos es mas prencipal que el de la Oradada, enpero ambos son caminos prenzipales y publicos e reales..., e a visto que por los dichos caminos de la Oradada y los Ocinos pasan la mayor parte de las mercaderias que aportan a los puertos de Laredo y Castro e Bilbao e Portogalete". Otro decía que "el camino de los Ocinos es el mas pasagero e prenzipal e por el pasan mas mercaderias que por el de la Oradada", y otro indicó que "no sabe que aya otros caminos mas derechos ny nezesarios para yr y benir para los puertos y de los puertos de Castilla, que es los que se dizen

\footnotetext{
940 El detalle es el siguiente:

- 30 brazas de paredón en Santaolalla, y adelante al primer horado de la Horadada, se tasó en 3.600 mrs. a 120 la braza, aunque se ha de "ensanchar el camino ques rribera de Hebro".

- Más adelante al canal 10 brazas de calzada, a 30 mrs. que son 300 mrs.

- Más adelante en el arroyo de Tartalés, 10 brazas de calzada a 40, son 400 mrs.

- Más adelante en Peña Palomera, se ha de hacer el camino por otra parte, que costará 1.00o mrs.

- Más adelante en la Calleja, una pared con ciertas calzadas, todo en $5.000 \mathrm{mrs}$

- Más adelante en el Pino de la Condesa, 6 brazas de calzada a 34 son 204 mrs.

- Más en el Prado de las Barcenillas, dos sangraderas para el agua que viene de arriba, con 15 brazas de calzada de una parte y de la otra tasado todo en $1.000 \mathrm{mrs}$.

- Más adelante desde el dicho paso hasta el puente de la Horadada, se han de hacer 40 brazas de pared para ensanchar el camino y rellenarlo de piedra y tierra para allanar el paso y el puente, a $120 \mathrm{mrs}$. la braza son $4.820 \mathrm{mrs}$. y 30 brazas de calzada a $34 \mathrm{mrs}$. son 1.020 mrs. más los pretiles del puente que tiene trozos caídos y aderezar la calzada del puente que está a trozos desbaratada y que se tasó en $5.000 \mathrm{mrs}$. haciendo un total de $10.820 \mathrm{mrs}$.

- Bajada la cuesta pasado el puente y hacia Oña, se ha de hacer en la ladera de Piña un camino más alto que el actual al salir encima del Reventón. Con las peñas que se han de quebrar y portillos que se han de ensanchar, serán hasta 20 brazas de pared sobre el agua para ensanchar el camino, 15.000 mrs.
}

941 A. H. N./ Nobleza. Frías, C. 235, D. 55/ Medina de Pomar, 15 enero 1499. 
de la Oradada y los Ocinos, y que si no obiesen de pasar... por los dichos dos caminos, que los biandantes e mulateros abrian de rodear mucho para yr su biaxe por otros caminos desbiados y se rezebiria gran perjuicio y daño". Hernando Alonso, mulatero vecino de Bisjueces, declara que por el camino de la Horadada venían cargadas recuas de Tobalina, y los mulateros de aquella comarca decían que debían pasar por la Horadada llevando mercaderías de Laredo a Castilla e iban a sus casas, por lo que creía que por eso llevaban este camino. Una vez llevando vino, pasó por la Horadada porque había nieve y fueron con él otros mulateros también con vino que traían de Castilla943.

Felipe II llega a Laredo el 8 de septiembre procedente de Flesinga. Al día siguiente parte a la una de la tarde para ir a Colindres, en cuyo momento comenzó una fuerte tormenta que duró todo el día y toda la noche. El 11 de ese mes fue a dormir a Medina de Pomar, el 12 al monasterio de Oña y el 13 llega a Burgos ${ }^{944}$. Como el equipaje del Rey y su comitiva no había podido ser desembarcado a causa de las intensas tormentas, el Rey partió sin ellas. Gregorio Flórez del Busto, escribano y alcalde para la comisión de repartir 150 carros para el transporte de todo ese equipaje, confirma no obstante que tiene mandado que, tanto los carros de bueyes repartidos desde el 14 de septiembre, como los 20 carros que estaban registrados en Castilla Vieja y en otros lugares, no vayan a Laredo sin su voluntad y les dio por libres, pudiendo ir si quisieren, pero no forzados, para lo que Juan de Salazar, escribano en nombre del alcalde de la merindad de Castilla Vieja, dice personarse en Agüera el 19 de septiembre945.

En los preparativos para la llegada de la Reina Ana esperada en Laredo, el Rey da instrucciones para su desplazamiento a Burgos, e indica que "paresçe que el mejor camino es el de Medina de Pomar y Oña, embiando a mandar a los corregidores de Laredo y Burgos y alcalde mayor de las merindades, que cada vno haga adereçar luego los caminos de su districto de manera que si se pudiere, puedan passar carros"946. El 3 de octubre de 1570, antes de su llegada, se dio una relación del camino que la Reina podía seguir de Laredo a Burgos y "por donde pueden venir los coches". Se indica que de Medina de Pomar "se puede venir a Burgos por dos caminos el uno es por Oña y el otro por Hontomin. El de Hontomin es mas breue de legua y media poco mas, aunque si haze mal tienpo es mas trabajoso". Añaden que, si van por Oña, hay desde Medina 7 leguas cortas y de alli a Burgos 8 y todo es muy poblado y abastecido medianamente ${ }^{947}$. Ese mismo día, el alcalde Ortiz escribe desde Laredo al secretario del Rey, y dice que "me afirman que el camino es hecho de las dos leguas de Oña y de las dos leguas de los Hoçinos, que es ribera de Hebro abaxo, y las de Oña de Hebro arriba los a acabado de hazer muy bien el... corregidor de las Siete Merindades, con los mandamientos que yo le dexe y que se pueden muy bien andar en litera y se puede muy bien escusar lo de la silla a honbros, como su magestad lo manda y los coches se lleuaran en carretas muy bien hasta Burgos"948.

\section{D.- POR LA HORADADA, LA COMPLACERA Y LANZAS AGUDAS}

Este camino arrieril que baja del portillo de la Complacera, se separa del que va a Valma-

943 A. C. V./ nº 18. doc. 3, hojas 28 a 48/ Medina de Pomar, 7, 8, 9 y 21 enero 1556.

944 GARCÍA MERCADAL, J.: 1952: 1096-1097: t. I. Viaje descrito por Juan de Vandenesse.

945 A. C. V./ no 1.873, doc. 1, hoja 5/ 14 septiembre 1559.

946 A. G. S./ Patronato Real, leg. 57, doc. 18/ Madrid, 3 agosto 1570.

947 A. G. S./ Patronato Real, leg. 57, doc. 90/ Antes del 3 octubre 1570.

948 A. G. S./ Patronato Real, leg. 57, doc. 32/ Laredo, 3 septiembre 1570. 
seda, pasando Cilieza. Después, por Covides, Villasana de Mena, Caniego, Palacio de Hornes, Hornes, puerto de Lanzas Agudas, Manzaneda de la Sierra, La Concha, Ambasaguas, Molinar, Rioseco, Pondra y en Riancho, entroncaba con el camino que venía de Cuardamino y, por Cibaja, se dirigía a Laredo. En noviembre de 1593, para obtener información sobre la situación de los puentes del Valle de Mena tras la inundación de septiembre de ese año, el teniente de corregidor en Mena acompañado de cuatro maestros canteros y carpinteros, fue a ver y tantear los puentes de dicho Valle. Proponen reparos para el "camino rreal que entra porla peña de la Conplazera y atrabiessa el Ualle de Mena desde La Rioja a los Ualles de Carranza, Soba e Trasmiera, uillase puertos de Laredo e Santander" en el puente de Ovilla, que llevó el río de Covides en el diluvio de septiembre, los puentes de Valmaseda, el puente del Juncal de Caniego que, por estar llevado, necesita hacerse de un arco y todo costará 150 ds., el carel de Caniego, que necesita 80 brazas de pared de cal y canto, y en el "camino enzima de una peña y sobre un rio, que es cossa muy aspera yespantosa y de mucho peligro", se debe romper esta peña viva para su ensanche que costará 150 ds. y el puente de Vado sobre el río Ordunte, más abajo de Burceña, necesita hacerse de dos medios pilares de piedra labrada con su manguardia y un estribo, 200 varas de piedra labrada a 12 rs. cada una y la cubierta de madera, 20 ds. para madera y otros 20 para cal y otros materiales necesarios ${ }^{949}$.

\section{E.- POR EL PORTILLO DE LA SÍA}

Este camino de herradura, discurría desde Villarcayo por Villacanes, Mozares, Campo, Torme, Bedón, Espinosa de los Monteros, Bárcenas, Las Machorras, portillo de La Sía, Cañedo, curso del río Asón por el puerto de Asón, Asón, Val de Asón, Socueva, Arredondo, Riba, y desde Ogarrio por San Bartolomé de los Montes, Portillo de Cüeras, Hoz de Marrón y Marrón; y en Limpias se unía con el principal camino de Sendero Enhiesto. No fue camino cómodo, y fue escasamente utilizado al tener el portillo de la Sía una altura de $1.200 \mathrm{~m}, 280 \mathrm{~m}$ más que el de Sendero Enhiesto. Tenía un carácter agreste y permanecía largas temporadas cubierto de nieve. En todo caso, su mayor utilización fue desde el s. XVIII para ir a Santander, aunque siempre de una manera local, siguiendo en común hasta Arredondo, para luego dirigirse hacia Laredo.

Viene recogido en el itinerario de Matías Escribano de 1758950. Es la desviación a la derecha del camino que recoge esta misma guía del camino para Santander por La Sía, una vez pasado este puerto951.

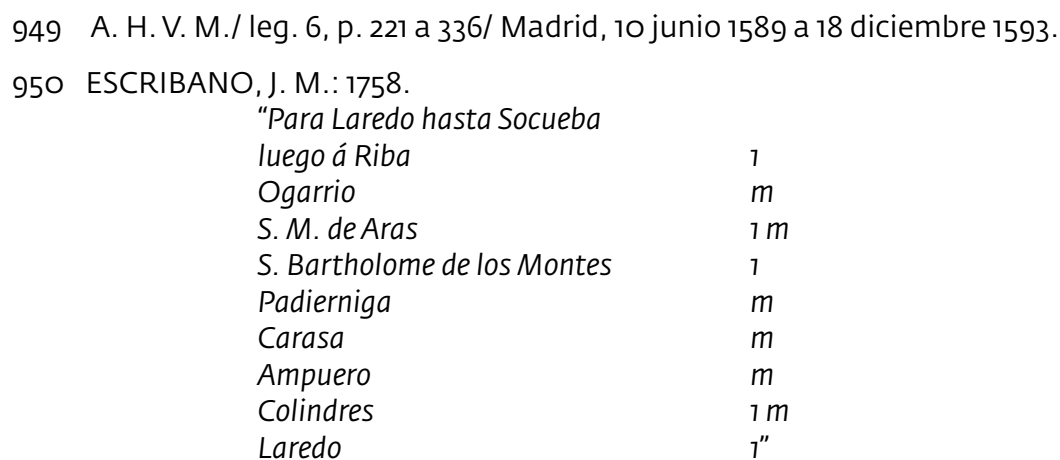




\section{3.- CAMINOS DE BURGOS A CASTRO-URDIALES}

El camino a Castro-Urdiales, llegaba desde Burgos por el de Laredo hasta Villasante de Montija, donde se desviaba hacia Bilbao por el puerto del Cabrio, Villasana de Mena, y Valmaseda. Aquí, abandonaba el camino a Bilbao, para dirigirse al Norte por la venta del Sol, Malabrigo, Avellaneda, Carral, Sopuerta-Mercadillo, Capetillo, Los Cotarros, Rojadillo, La Venta, Las Muñecas, puerto de Las Muñecas, Otañes, Santullán y Sámano hasta la villa de Castro.

Aunque el camino parece prácticamente un ramal arrieril desgajado en Valmaseda para ir hasta Castro-Urdiales, del camino que se dirigía a Bilbao, fue en realidad el camino único utilizado desde fechas antiguas para ir a Castro desde el interior, y una de las razones del nacimiento de la villa de Valmaseda, y la principal salida de su comercio por el mar durante años. Después, tras la fundación de Bilbao en 1300, esta villa fue sustituyendo a la villa de Castro, variando Valmaseda su antigua dependencia. No obstante, Castro-Urdiales tuvo una importancia muy relativa para el comercio internacional burgalés y, aunque participó en este proceso, lo hizo de una manera más discreta que Santander o Laredo.

La villa de Castro-Urdiales, al margen de su origen romano conocida como Flavióbriga, fue fundada por Alfonso VIII de Castilla en 1163, y cuando la villa de Bilbao se pueble 137 años después, la conexión de Bilbao con Castilla se realizará a través de una prolongación de esta vía desde Valmaseda hasta la villa recién fundada.

\section{A.- POR EL DESFILADERO DE LOS HOCINOS}

En septiembre de 1495, el concejo, justicia y regidores de Castro-Urdiales dijeron a los Reyes Católicos y Consejo, "que las avenidas e lluvias grandes que venieron el año pasado derribaron muchas calçadas e puentes, de que murieron muchas personas". A petición de los vecinos de Sopuerta y Galdames, donde dicen que hay muchos mulateros que suelen utilizar tales puentes y calzadas, la villa reparó a una legua el puente de Otañes y las calzadas necesarias, acordando con los vecinos la realización de dicho reparo. Alegan que ahora que los de Sopuerta y Galdames han visto aderezados el puente y las calzadas, no les quieren pagar según estaba acordado. Los Reyes mandaron al corregidor de Trasmiera y al corregidor y juez de residencia del condado y señorío de Vizcaya, que oídas las partes provea lo que convenga952.

En abril de 1503 el teniente de corregidor, los tres regidores, y el fiel de Castro-Urdiales, mandaron al fiel Pedro de Cestona que fuese a Valmaseda a requerir a su concejo y

$\begin{array}{ll}\text { Espinosa de los Monteros } & 2 \\ \text { Cañedo, y Ason } & 4 \\ \text { Socueba } & 2^{\prime \prime}\end{array}$




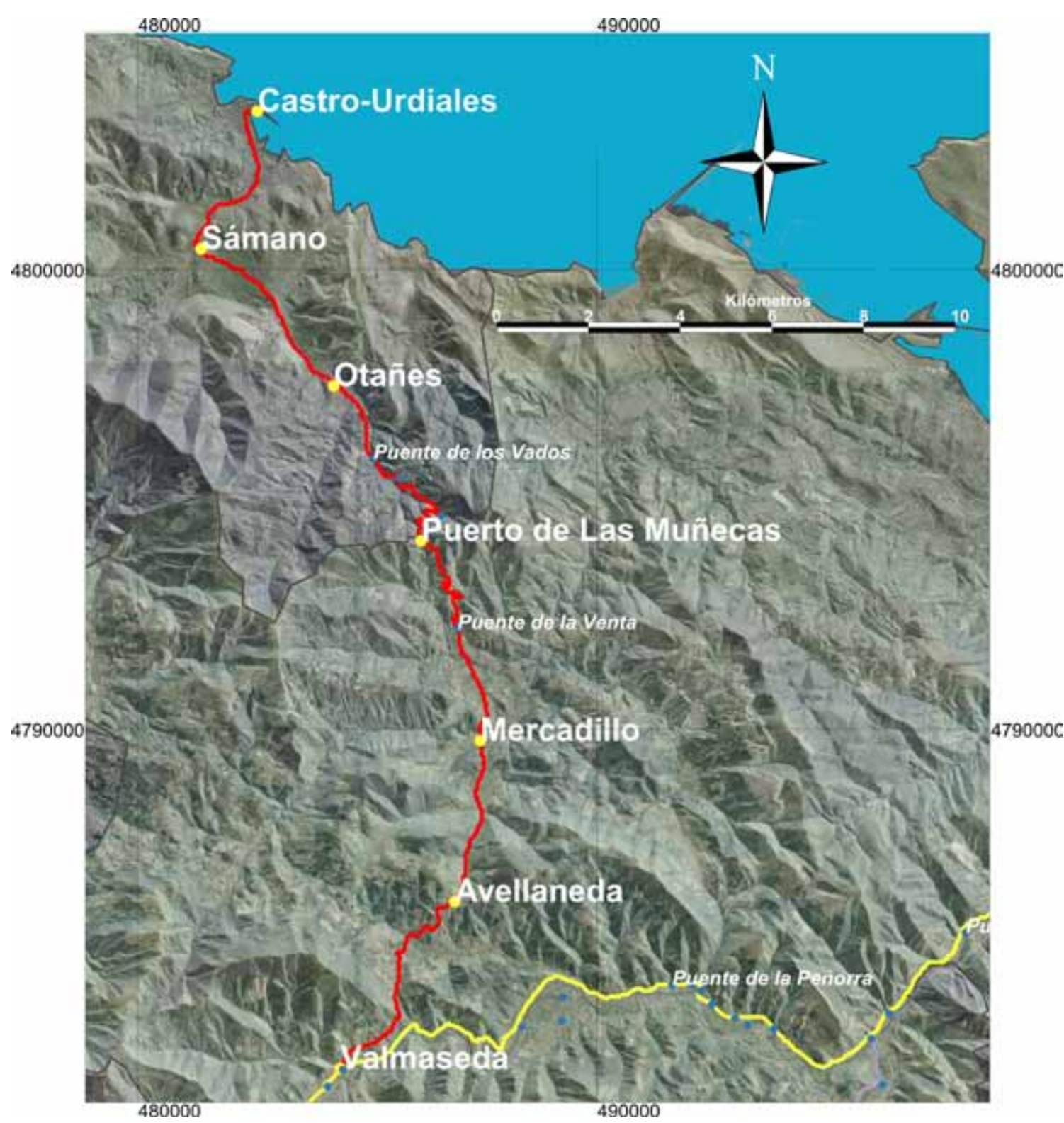

Mapa del camino de Valmaseda a Castro-Urdiales por el puerto de las Muñecas.

tomar testimonio, porque impiden que se lleve trigo y harina a la villa de Castro. Se acordó darle 50 mrs. diarios 953 .

El corregidor de las Villas de la Costa de la Mar de Castilla Vieja y merindad de Trasmiera, notificó a la junta de Sámano, que el Rey había enviado una carta desde Londres que decía que venía con su armada a Laredo -llegó el 16 de julio de 1522 a Santander-, y que después debía ir a Bilbao por la junta de Sámano, por lo que convenía que los caminos estuviesen arreglados, y les mandaba que en 8 días hiciesen reparar los caminos que iban de Sámano a Valmaseda y a Castilla, por donde se esperaba el paso del Rey, no atribuyendo a

953 A. M. Castro-Urdiales/ Leg. 21, doc. 1/ Castro Urdiales, 21 abril 1503; BLANCO CAMPOS, E., ÁLVAREZ LLOPIS, E. y GARCÍA DE CORTÁZAR, J. A.: 1996: 288: doc. 15. 


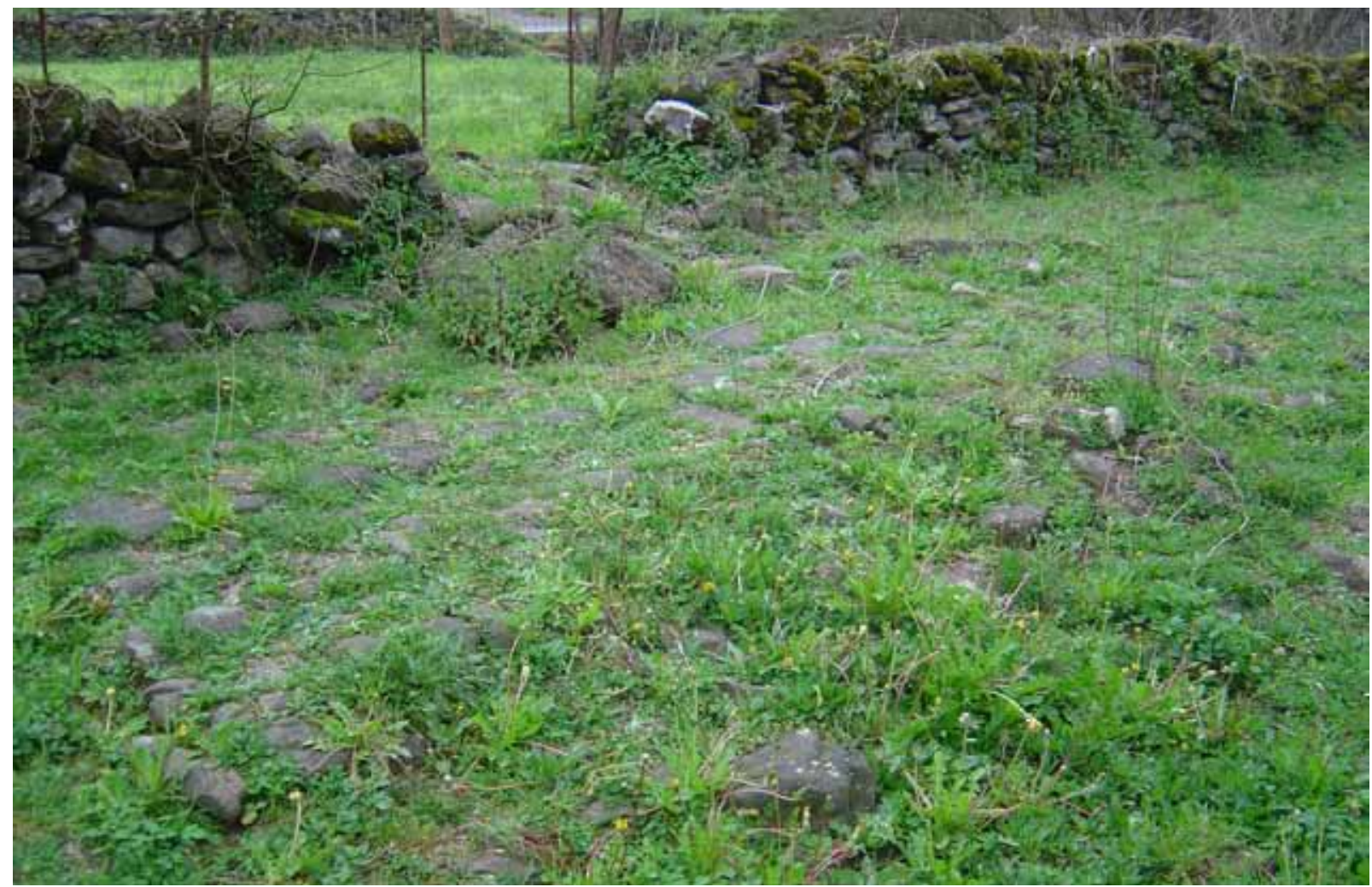

Camino empedrado en el Puerto Las Muñecas.

Castro obligación alguna sobre el aderezo. Se acordó no obstante que, para el repartimiento de los gastos los concejos, se juntasen con los regidores de Castro, por lo que Francisco de Mioño, el procurador del concejo de San Nicolás de Sámano y los regidores de Otañes, acordaron con la justicia y regidores de Castro que la villa pagase 50 hombres, el concejo de Sámano 50 y el de Otañes 30 para hacer el camino desde Castro hasta Son de Sámano, límite de la jurisdicción de Castro-Urdiales, en los 6 días que comenzarían el primer jueves.

Como el procurador de Sámano se quejó de que el alcalde de Castro hacía agravio a su concejo, mandándole aderezar los caminos que no estaban en su término, el corregidor dijo al alcalde de Castro que no mandase a Sámano lo dicho mientras no lo motivase. El alcalde respondió que él había mandado a los concejos y junta de Sámano que hiciesen aderezar dichos caminos, "para la venida de... el rrey, dentro de ocho dias, de la dicha billa de Castro para la çibdad de Burgos e hera camino rreal", acordando el reparto a cada pueblo de los peones necesarios, cumpliendo el concejo de Otañes pero no los de Sámano que, por no hacer el camino, fueron al corregidor para excusarse. El procurador de Castro recordaba al alcalde el acuerdo que se tomó para aderezar los caminos de Racalzada, Salto Caballo y Oriñón, y que todos lo obedecieron excepto el valle de Sámano y, aunque se le pusieron las penas correspondientes, no habían enviando los peones acordados. El alcalde de Castro pronunció sentencia contra Sámano, por no aderezar los caminos de Castro hasta el barco de Oriñón y hasta Oriñón y Son de Sámano, en especial el camino de Racalzada, ni dar los 50 peones acordados, condenando al valle de Sámano y sus vecinos, en 50.000 mrs. . Como muchos caballeros y otra gente comenzaban a llegar para el recibimiento del emperador, el alcalde amenazó con imponer otra pena al valle de Sámano, de 1.000 ds. si en 4 días no enviaban los dichos 50 peones. El concejo de San Nicolás de Sámano recurrió, por lo que en marzo de 1523 se pronunció sentencia 
revocando la que pronunció el alcalde de Castro, y absolviendo al valle y concejo de Sámano de todo lo contra él demandado sobre los caminos y pena impuesta, y como el alcalde juzgó y sentenció mal y como no debía, se le condena a las costas que tasaron en 3.450 mrs. 954 .

En 1571 se indica que por el "balle de Mena y Salzedo pasaba el camino real a la billa de Bilbao y Castro de Hurdiales e otras partes, por donde pasaban muchos tragineros y biandantes por ser las dichas billas puertos de mar, y las calçadas estaban tan malas que los dichos tragineros padeszian mucho y peligraban muchos machos y bestias dellos..." 955 .

En un interrogatorio realizado en 1625 a arrieros de las Merindades, sobre los descaminos realizados por oficiales del Condestable, para obligar a ir a los arrieros por Medina y no por Villarcayo para cobrarles el rediezmo y portazgo, un arriero manifiesta que "ssabe que las mercadurias que el y los demas arrieros y traxineros que pasan por las dichas merindades, sacan de los puertos de Bilbao, Castro y Laredo, las registran y diezman en las aduanas de Laredo, Castro y Balmasseda que son partes diputadas para el efecto de donde toman albalas del dicho diezmo y registro" 956 .

En 1641 se documenta que en Mena el camino es "por donde forzossamente se a de pasar para yry benir a el puerto de Bilbao y billa de Castro, de donde sale tant a cantidad de pescados frescosy ssalados, y ottras muchas mercadurias que bienen a la billa de Madrid, Balladolid, Ssalamanca, ttierra de Campos, Burgos" y otras partes957.

\section{B.- POR EL DESFILADERO DE LA HORADADA}

El camino que, por Oña y Trespaderne, ya hemos descrito cuando tratamos el camino de Burgos a Laredo, seguía hasta Villasante donde, por Valmaseda, llegaba a Castro. Miguel Bañuelos, en sus Itinerarios de 1771, detalla esta ruta desde Burgos $95^{8}$, con un total de 31 leguas y media.

954 A. Ch. V./ Registro de Ejecutorias, caja 0373.0042/ Valladolid, 27 marzo 1523 y 25 octubre 1524.

955 A. H. V. M./ leg. 6, p. 204 a 211/ Madrid, 11 septiembre, Avellaneda, 29 octubre y Laredo, 26 diciembre 1571 y Villanueva de Mena, 28 enero y 1 febrero 1572.

956 A. C. V./ no 83/ Madrid, 11 septiembre 1621 y Madrid, 9 octubre 1624.

957 A. H. V. M./ leg. 6, p. 356 a 365/Villanueva de Mena, 8 marzo 1641.

958 BAÑUELOS, M.: 1771.

$\begin{array}{lc}\text { "Urones } & 2 . \\ \text { Roblacedo } & 3 . \\ \text { Carcedo } & 1 . \\ \text { Lences } & 7 . \\ \text { Salas de Bureva } & 1 . \\ \text { Terminon } & 1 . \\ \text { Oña } & 7 . \\ \text { Trespaderne } & 2 . \\ \text { Nofuentes } & 1 . \\ \text { Moneo } & 1 . \\ \text { Medina de Pomar } & 1 . \\ \text { LaVenta de Quintanilla } & 2 . \\ \text { Villasante } & 2 . \\ \text { Bercedo } & 5 . \\ \text { El Aya } & 1 . \\ \text { Busceña } & 2 . \\ \text { Nava } & 1 . \\ \text { El Berron } & 1 . \\ \text { Balmaseda } & 1 . \\ \text { Sopuerta } & 1 . \\ \text { Otañez } & 2 . \\ \text { CASTROURDIALES } & 2 .\end{array}$




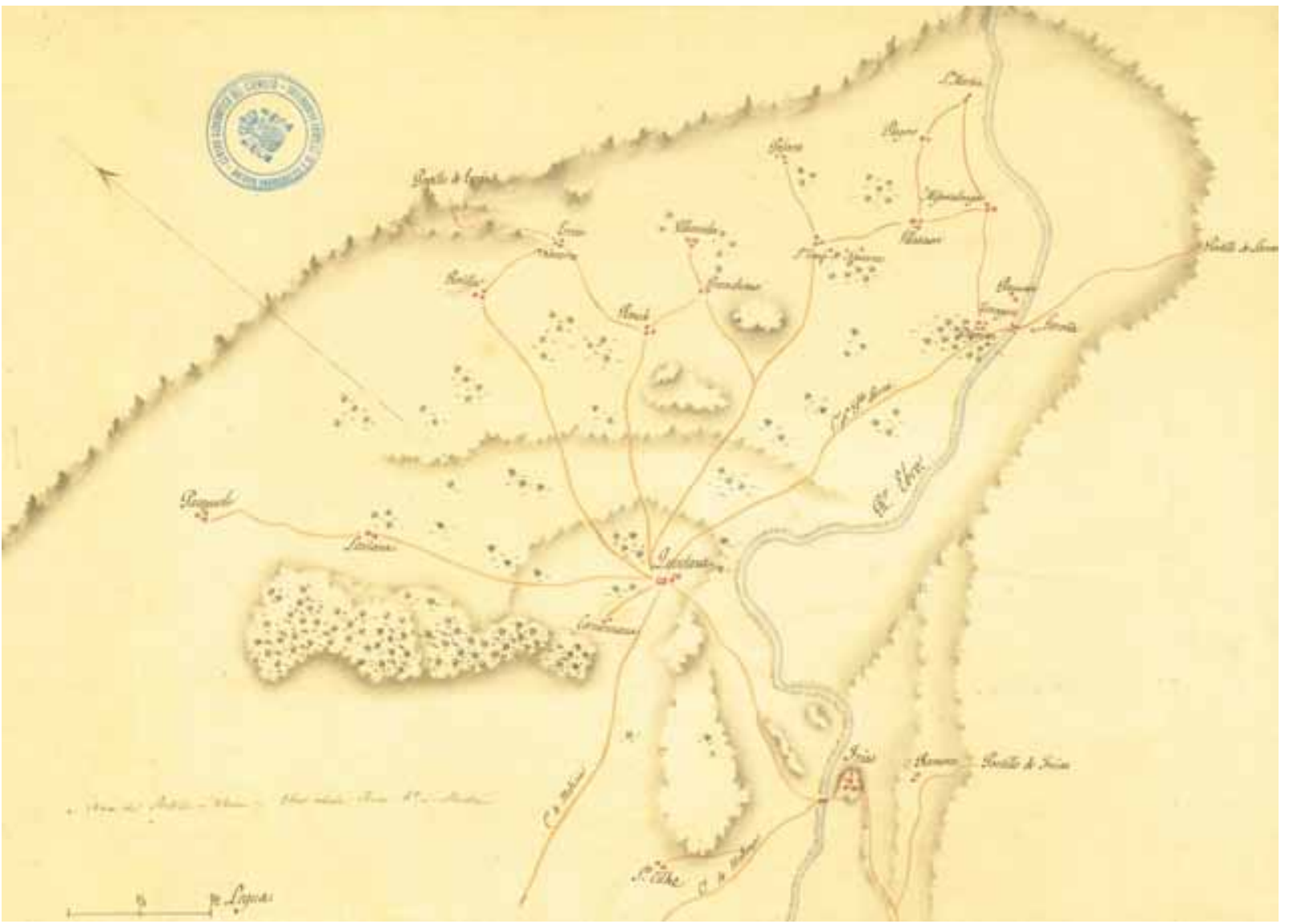

Valle de Tobalina hacia 1810. Quintana Martín Galíndez se encuentra en el centro de una red de caminos que van a Garoña y Miranda, Frías, Medina, Herrán y Angulo por Parayuelo (ARCGE Ar.E-T.6-C.1-114).

\section{C.- POR PANCORBO Y LOSA}

Tenemos constancia por un documento de julio de 1232, de la utilización de un camino que llegaba a Castro-Urdiales desde Pancorbo del que, no obstante, no hemos encontrado ninguna otra referencia; cuando Fernando III confirma el resultado de la pesquisa realizada en Santa Gadea, Puentelarrá, Espejo, Caranca, Osma, Villacián de Losa, Atiega y Salinas de Añana por el abad del monasterio de Obarenes, para informarse sobre el camino que utilizaban los vecinos de Pancorbo para ir con sus recuas a Castro-Urdiales, coincidiendo todos los testigos en que "que uiron et sabien a la fin del rey don Alfonso, et en su uida andar a los de Pancoruo et sus requas por el camino de la Puent de la Rat, et por Losa a Castro sin premia ninguna". Además, la selección de las localidades donde se interroga, salvo Atiega y Salinas, nos indica claramente que el camino entre Pancorbo y Osma era coincidente con el camino de Pancorbo a Orduña, desviándose por Villacián de Losa, evitando Orduña para dirigirse más hacia el Oeste en dirección a Castro-Urdiales959.

959 A. M. Pancorbo/ Burgos, 30 julio 1232; GONZÁLEZ y GONZÁLEZ, J.: 1983: 551: doc. 478. “...que uiron et sabien a la fin del rey don Alfonso et en su uida andar a los de Pancoruo et sus requas por el camino de la Puent de la Rat et por Losa a Castro sin premia ninguna...". 


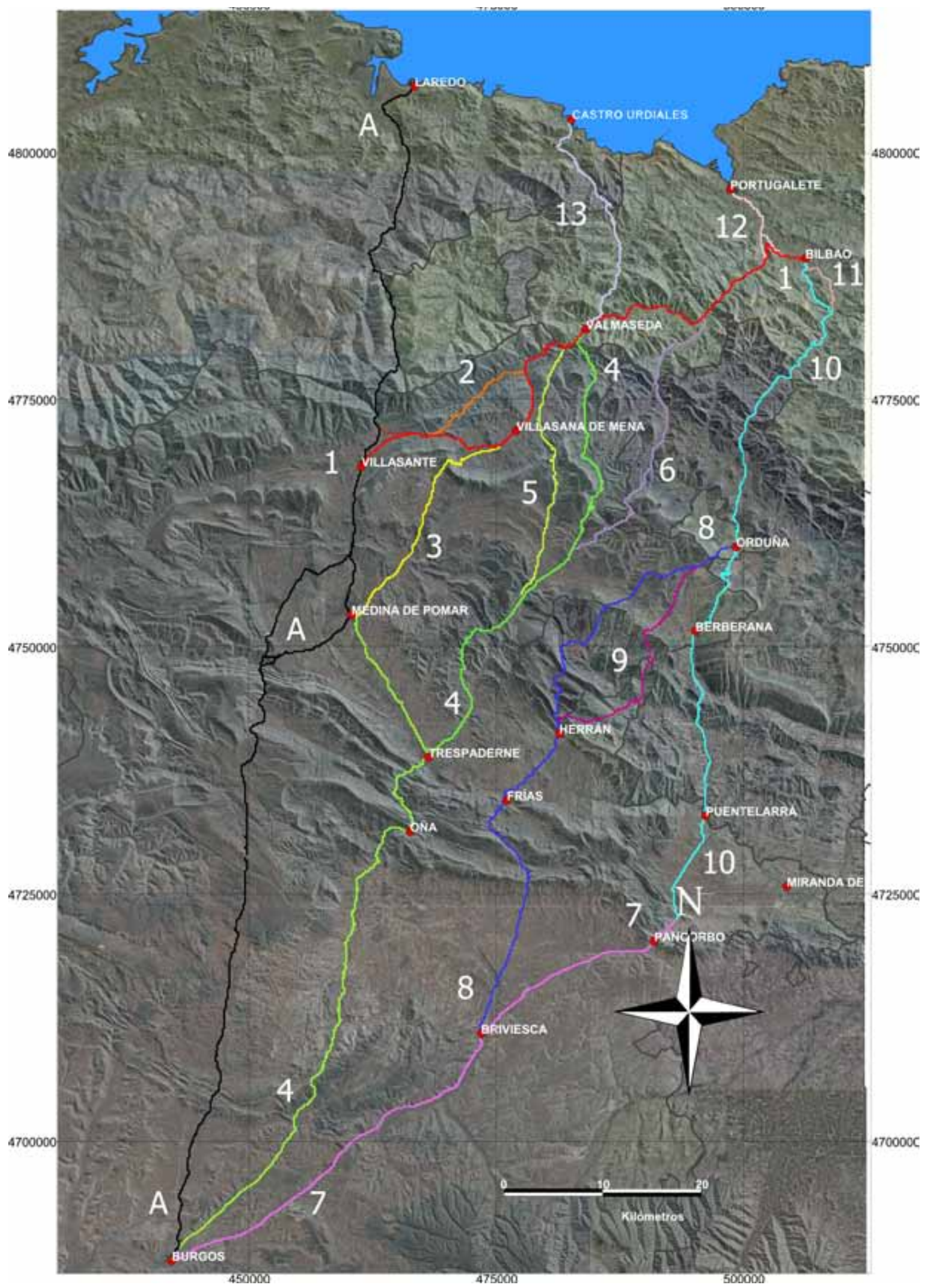

Mapa general de los caminos de Burgos a Castro-Urdiales, Bilbao y Portugalete:

1.- Camino principal de Villasante a Bilbao por Valmaseda

2.- Camino de Ordunte

3.- Camino por La Magdalena

4.- Camino por La Horadada y Angulo

5.- Camino por La Complacera
6.- Camino por el portillo del Aro 7.- Camino principal de Madrid a Bayona

8.- Camino de Briviesca a Orduña por Valderejo

9.- Camino de Briviesca a Orduña por Valpuesta
10.- Camino principal por Puentelarrá y Orduña

11.- Tramo junto a Bilbao por el vado de Echévarri

12.- Camino a Portugalete

13.- Camino de Valmaseda a Castro-Urdiales 


\section{4.- CAMINOS DE BURGOS A BILBAO}

Tanto el concejo de Bilbao como su Consulado, comprendieron muy pronto la necesidad de establecer una buena red de comunicaciones con el traspaís castellano, para impulsar debidamente los intercambios comerciales ${ }^{960}$. Ya desde el siglo XIV, Bilbao ejemplificó perfectamente el desarrollo económico vivido en el Señorío de Vizcaya, basado principalmente en un comercio que necesitaba unas adecuadas vías de comunicación. En las Juntas de Vizcaya se indica en 1569 que tres fueron los caminos reales principales del Señorío "que son el camino que ba de Vilvao para Valmaseda y el otro de Vilvao para Horduña y el otro dende Vermeo asta Hochandiano"961, utilizados los dos primeros para llegar y salir de Bilbao; y de estos dos que comunicaban la villa con el interior peninsular, el de Orduña fue, a pesar de su dificultad, el preferido ${ }^{962}$.

Hubo una pugna entre la villa de Bilbao y la ciudad de Burgos por ostentar la hegemonía comercial con Flandes, Francia e Inglaterra a través del Cantábrico y obtener con ello los mayores beneficios. Aunque los armadores y comerciantes de Bilbao tuvieron en las fases iniciales una cierta dependencia de Burgos, tras la creación de un Consulado propio en Bilbao en 22 de junio de 1511 inspirado en el Consulado burgalés, los comerciantes bilbaínos adquirieron un mayor peso e influencia, alcanzando un desarrollo importante y consolidando con ello una tradición que se remontaba a las fechas de la fundación de su villa. No obstante, ambas localidades estaban condenadas a entenderse, ya que si los burgaleses necesitaban las naos bilbaínas y su puerto para el transporte de sus mercaderías, los bilbaínos estaban condicionados por la necesidad de tener garantizada la carga de sus navíos, debiendo mantener un hinterland en el que el comercio burgalés, era su soporte principal y más potente.

Los caminos de Burgos a Bilbao, se pueden dividir en tres grandes grupos:

A.- A Bilbao por el desfiladero de los Hocinos, con tres vías diferentes:

a- Por el puerto del Cabrio, Villasana, Valmaseda y valle del Cadagua. El camino de Burgos a Laredo seguía desde Villasante por el puerto de El Cabrio, Irús, Villasana, Nava, Valmaseda, Sodupe, Alonsotegui, Alto de Castrejana y Bilbao.

b- Variante en el Valle de Mena por Burceña. Iba desde Irús por Arceo, Burceña y Nava donde, junto al puente de Nava, entroncaba con la vía que venía de Villasana.

c- Por Medina de Pomar, la Magdalena y Valmaseda. En Incinillas se desviaba del camino de Laredo para ir por Bisjueces, Medina de Pomar, La Cerca, Salinas de Rosío y Castrobarto, para entrar en el Valle de Mena por el puerto de la Magdalena, y por Cadagua, entronca en Vallejo de Mena con el camino de El Cabrio.

B.- Por el desfiladero de la Horadada iban cinco caminos, que tenían en común el tramo que desde Burgos iba a Río de Losa, por Hurones, Rublacedo de Arriba, Lences, Salas de Bureba, Terminón, Oña, desfiladero de la Horadada, Trespaderne, Cadiñanos, Pedrosa de Tobalina, Criales y Río de Losa.

960 DIAGO HERNANDO, M. y LADERO QUESADA, M. A.: 2009: 359: vol. 32.

961 A. J. R. B. /Actas de Villas y Ciudad. t. I/ Guernica, 5 junio 1569.

962 ARÍZAGA BOLUMBURU, B. y MARTÍNEZ MARTÍNEZ, S.: 2006: 217. 
a- Por la Complacera, Menamayor y Valmaseda. Seguía desde Río de Losa por Villaluenga, Quincoces de Yuso, Relloso, portillo de la Complacera, Menamayor y Cayuela, conectando con el camino principal de Mena en El Berrón.

b- Por el puerto de Angulo y Valmaseda. Desde Río de Losa y por la orilla izquierda del Jerea, iba por San Llorente, bajaba el puerto de Angulo y seguía por Encima-Angulo, Santiago de Tudela, La Llana y, junto al río Ayega, pasaba por San Pelayo, Antuñano y Valmaseda.

c- Por el puerto de Igaña y Arza. El camino no pasaba por ningún puerto seco y discurría por el mismo camino de la Complacera, y en Relloso se desviaba a la derecha para pasar el puerto de Igaña y descender hasta Santa Olaja, donde conectaba con el camino que venía del puerto de Angulo. Por Santiago de Tudela, La Llana, San Pelayo, Arza, El Pontón, Gordejuela y en Sodupe, conectaba con el camino de Valmaseda.

d- Por el puerto de Angulo y Arciniega. No fue importante para el comercio de Castilla. Desde el puerto de Angulo se dirige por Encima-Angulo, Arciniega, Venta de Ureta, Las Llanas, El Pontón, Gordejuela y Sodupe, donde conecta con el camino que viene de Valmaseda.

e- Por el puerto de Angulo y Llanteno. Camino de escasa importancia, desde el puerto de Angulo se dirige por Encima-Angulo, Haedo de Angulo, Cozuela, Retes de Llanteno, Llanteno, Venta de Ureta, Las Llanas, El Pontón, Gordejuela y Sodupe, donde conecta con el camino de Valmaseda.

Los caminos que atraviesan la Sierra Salvada eran el del portillo del Aro, los tres por Orduña y el que discurre entre San Pedro de Beraza y Dardoza.

C- Camino por el portillo del Aro. Camino mulatero que no pasa por ningún puerto seco, iba desde San Llorente por Lastras de Teza y llega al portillo del Aro. Después, por Lejarzo, conecta en Erbi con el camino que viene de Encima-Angulo. Otro acceso al portillo del Aro es el que, después de Osma en el camino de Orduña, discurre por Villalba de Losa y Llorengoz. Desde el portillo del Aro, también se podía llegar a Bilbao o a Portugalete por Quejana, Oquendo, Jandiola, Azcaray y Sodupe.

D- Los caminos por Orduña. La vía que desde Burgos se dirige por Villafría, Monasterio de Rodilla, Briviesca, Grisaleña y Pancorbo, se utilizaba para ir a Bilbao, bien desde Briviesca por el camino de Frías, o bien desde 3,5 km de Pancorbo por el camino de Puentelarrá.

a- Por Briviesca, Frías, Herrán y Bóveda, a Orduña por el paso de Coldecho. El camino desde Briviesca, iba por Busto, Portillo de Busto, Ranera, Frías, Herrán, Lalastra, Bóveda, Fresno de Losa, puerto de Goldecho, Orduña, Amurrio, Llodio, Areta, Ugao-Miravalles, Arrigorriaga, Venta Alta o Beteluri, Ollargán y Bilbao.

b- Por Briviesca, Frías, Herrán y Valpuesta a Orduña por el paso de Goldecho. Este camino que llegaba de Briviesca y Frías, iba desde Herrán por Villafría de San Zadornil, San Millán de San Zadornil, Valpuesta, Hozalla, Villalba de Losa, Mijala, puerto de Goldecho y Orduña.

c- Por Pancorbo, Puentelarrá y Berberana a Orduña por el paso de San Bartolomé. Era la vía principal de acceso a Vizcaya desde Castilla; discurría desde Pancorbo, por Santa Gadea, Puentelarrá, Bergüenda, Osma, Berberana, Puerto de San Bartolomé y Orduña. 
Desde aquí seguía el curso del río Nervión hasta Arrigorriaga por Amurrio, Llodio, Areta, Ugao-Miravalles, Arrigorriaga, Venta Alta o Beteluri, Ollargán y Bilbao.

E- El camino entre San Pedro de Beraza y Dardoza. Iba paralelo y al Este de el de Orduña, Amurrio y Llodio. Evitaba el paso por la ciudad de Orduña y su aduana, y procedente de Berberana, iba y por el monte de Santiago bordeando el gran acantilado del Salto del Nervión para llegar a Unzá. Pasaba entre los altos de San Pedro de Beraza y de Dardoza y desde el puente de Berganza, donde conectaba con el camino que venía de Altube, seguirá por Astepe, Andramaría y Bengoechea para entroncar con el camino que viene de Orduña en Areta.

Aunque poco utilizados para ir a Bilbao desde Burgos, eran los caminos que pasaban por Vitoria con su aduana. Aun siendo muy importantes para el tráfico general hacia otros destinos o desde otras procedencias, no lo fueron para el comercio burgalés por el puerto de Bilbao. Tres eran los principales que conectaban Vitoria con Bilbao: por el puerto de Altube, por el de Barázar y sobre todo por el de Urquiola y Durango.

Los caminos por Valmaseda y por Orduña con sus aduanas, serán los más utilizados y además los mayores beneficiarios en muchas ocasiones, de una mayor atención e inversión en el mantenimiento de sus infraestructuras. Aunque estos caminos poseen gran cantidad de puentes e incluyen pasos muy complicados y difíciles, sobre todo en tiempos de lluvias y crecidas, recibirán una cierta atención en una época en que la falta de recursos económicos y la inexistencia de una estructura capaz de hacer frente a las necesidades de construcción y mantenimiento de puentes, calzadas y caminos, dilataban en exceso las actuaciones emprendidas, a veces de manera exasperante.

\section{A.- POR EL DESFILADERO DE LOS HOCINOS}

Tres son los caminos que por Los Hocinos van por Valmaseda a Bilbao: por el puerto del Cabrio y Villasana; por el puerto del Cabrio y Burceña que es una variante del anterior; y por Medina de Pomar, la Magdalena y Villasana.

\section{a.- Por el puerto del Cabrio, Villasana y Valmaseda}

Del camino de Burgos a Laredo, que ya hemos tratado, sale de Villasante una ramificación carretera muy utilizada que pasaba por el puerto del Cabrio (740 m) y seguía el curso del Cadagua, por Valmaseda, para llegar a Castro-Urdiales, Bilbao o Portugalete963. Aunque el acceso a Bilbao por este camino tuvo un tráfico importante como gran vía, desde el siglo XVI se irá quedando relegado tras el desplazamiento causado por la mayor utilización de la vía de la Peña de Orduña964, más apoyada por la propia villa de Bilbao, a pesar de que existía una percepción de que aquel era el camino más corto, como se indica en la infor-

963 A. H. N./ Nobleza. Frías, C. 235, D. 55/ Medina de Pomar, 15 enero 1499. "En este lugar de Villasante se apartan los caminos vno para Laredo e otro para Bilbao e a Castro e Portogalete es gran paso el deste lugar". 
mación remitida en 1784 sobre las Merindades de Castilla a Tomás López, respondiendo al interrogatorio realizado por este, que dice que a Villarcayo le atraviesa el camino real "antiguo que jira a ellas [las dos Castillas] desde Bilbao y es mas corto y enjuto que el nuebamente abierto por Orduña..."965.

El camino de Laredo seguía desde Villasante por Bercedo, puerto de El Cabrio, venta de La Haya, Irús, Vivanco, Urbaneja, Lezana de Mena, Villasuso de Mena, Vallejo, Villasana, Mercadillo, Cerezo, Entrambasaguas, Maltrana, La Presilla, Ungo, Cereceda, Nava, La Vega, La Pinilla, Valmaseda, La Herrera, Ibarra, Mendieta, Zalla, Aranguren, Muñeran, Cüeñes, Lazier, Sodupe, La Cuadra, Zaramillo, Alonsotegui, Alto de Castrejana, Basurto y entraba en Bilbao por el puente de San Antón.

Los puentes que tenía el camino en el Valle de Mena eran los de Irús y La Exa entre Vivanco y Villasuso sobre el río Hijuela, el de Vallejo, Cerezo y Nava, sobre el Cadagua, y el de el Berrón y las Olías sobre el río Romario o Vaduvela; todos en el camino real y "camino que ua al Ualle de Gordojuela y Encartaçiones y Señorio de Uizcaya y Bermeo y Lequeytio desde las dichas puentes de Erus"966. El tramo existente entre El Berrón y Valmaseda, es en 1495 el "camino que sellama Peña Tajada".

\title{
El camino en las guías itinerarias
}

Fernando Colón en su Cosmografía de España, describe en 1517 este camino entre Burgos y Bilbao967, en el que hasta Villasante, coincide con el camino a Laredo.

Esta vía se encuentra recogida en todos los itinerarios que se publican desde el siglo XVIII. Así el Itinerario Español de Matías Escribano de 1758, lo incluye con el título "Otros

\author{
965 B. N./Tomás López. ms. 7.296, f. 1 al 16/ Merindades, post. a septiembre 1784. \\ 966 A. H.V. M./ leg. 6, p. 221 a 336/ Madrid, 10 junio 1589 a 18 diciembre 1593. \\ 967 COLÓN, F.: 1910, 1908 y 1915. Facsímil 1988. \\ "De burgos a villa toro media legua. \\ De villa toro a villa verde tres leguas. \\ De villaverde a peña horadada una legua. \\ De peña horadada a hontonyn una y media. \\ De hontonyn a cerneglua una y media. \\ De cerneglua a cuerno una e media. \\ De cuerno a pesada una legua. \\ De pesada a almyne dos leguas. \\ De almyne a la puente de valdibieso una legua. \\ De la puente de baldivieso a valdemera una legua. \\ De valdemera a bieneces una legua. \\ De bieneces a medina despunar una legua. \\ De medina despunar a quintanilla de piença una legua. \\ De quintanylla de piença a billasante dos leguas. \\ De billasante a veçedo una legua. \\ De veçedo a la haya una legua. \\ De la haya a beruz una legua. \\ De beruz a bruçeña una legua. \\ De bruçeña a xixana una legua. \\ Dexixana al berron una legua. \\ Del berron a balmaseda una legua. \\ De balmaseda a sedupe dos leguas e media. \\ De sedupe a bilbao dos e media."
}




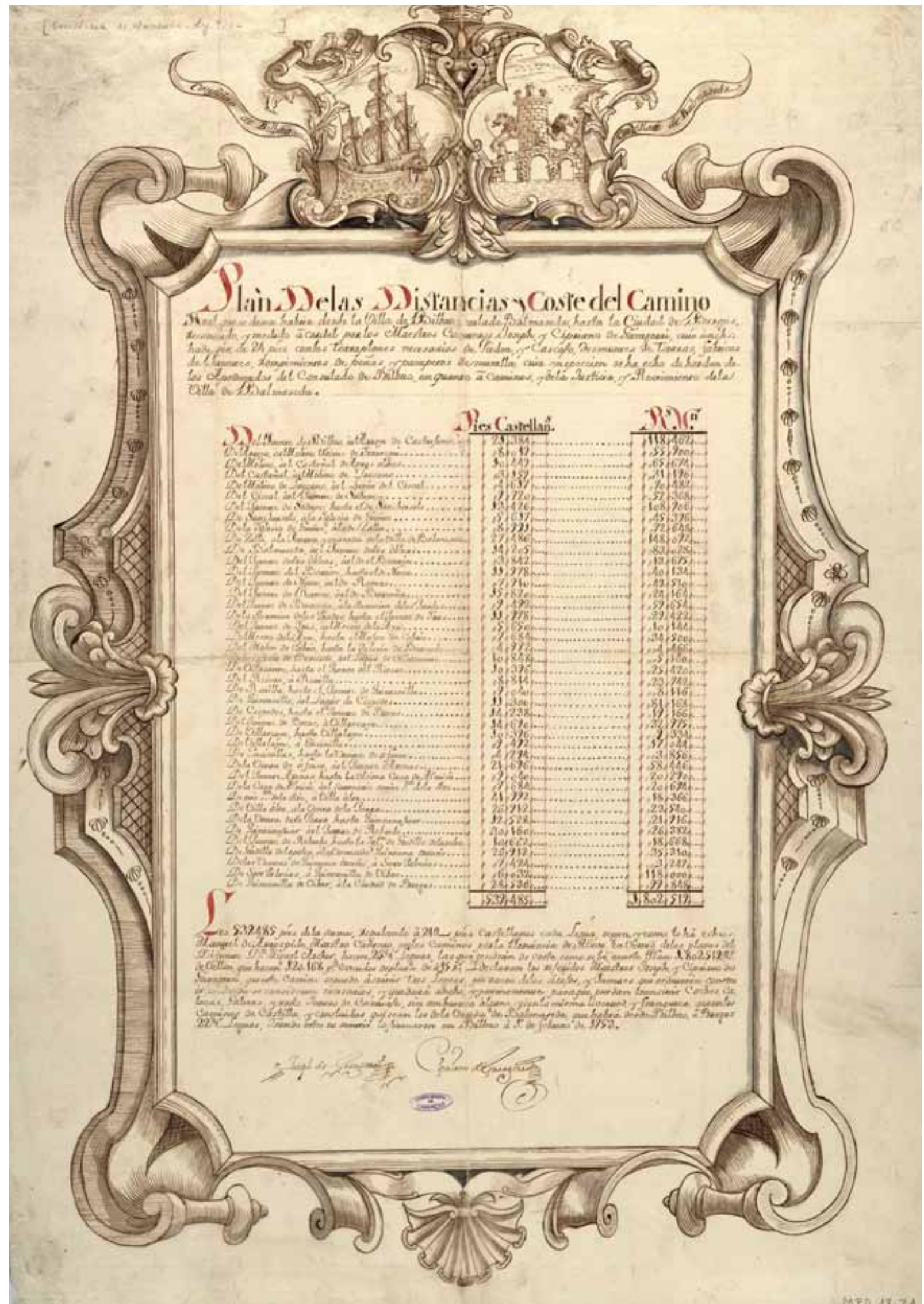

"Plan de las distancias y coste del Camino Real que se desea habrir desde la villa de Bilbao por la de Balmaseda, hasta la ciudad de Burgos", realizado en 1753 (A. G. S., MPD 17,031). 


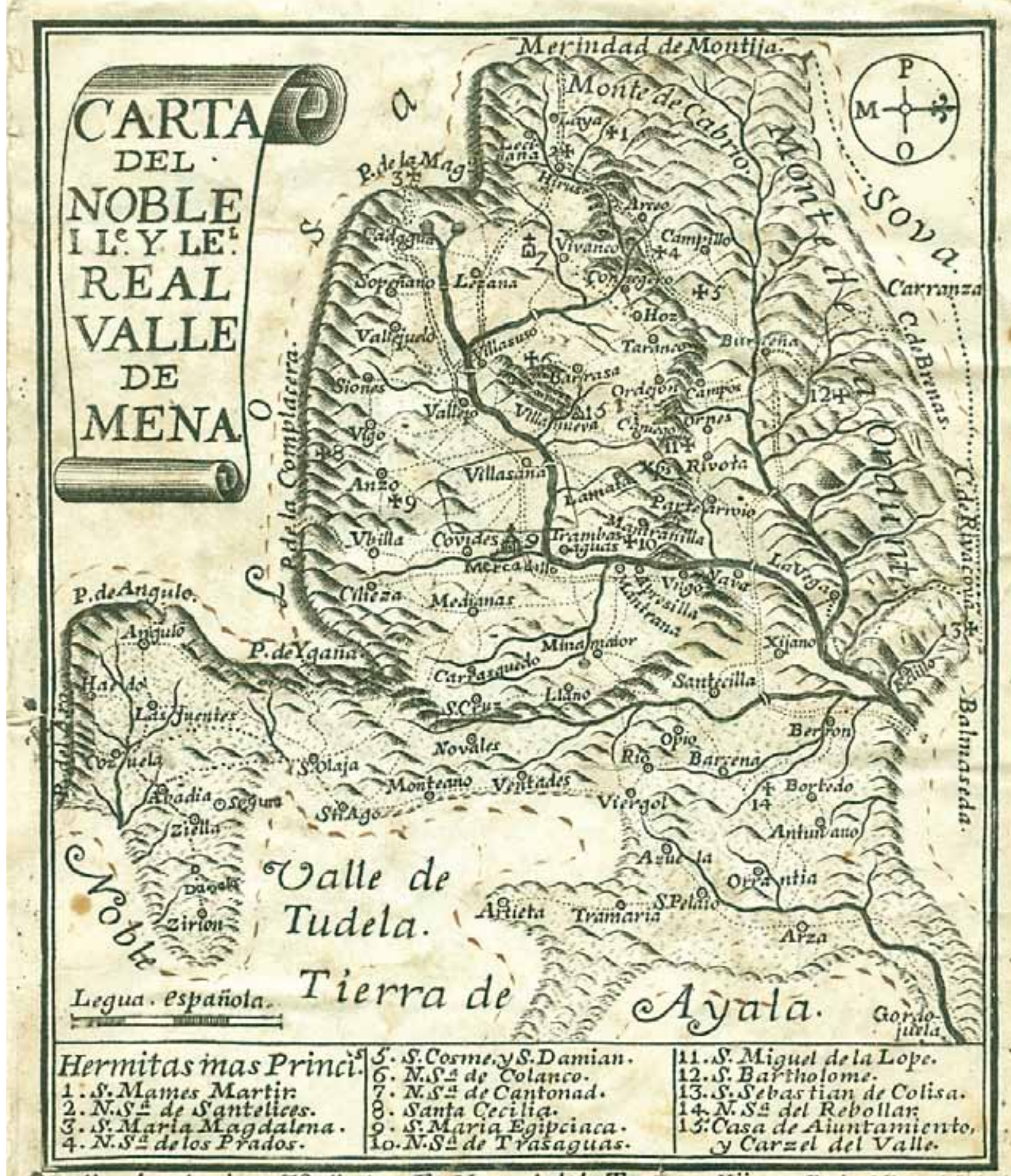

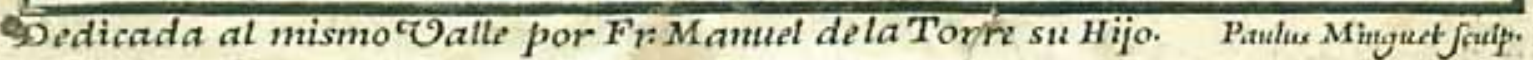

Plano de 1740 del Valle de Mena donde se detallan todos sus caminos (B. N.). 


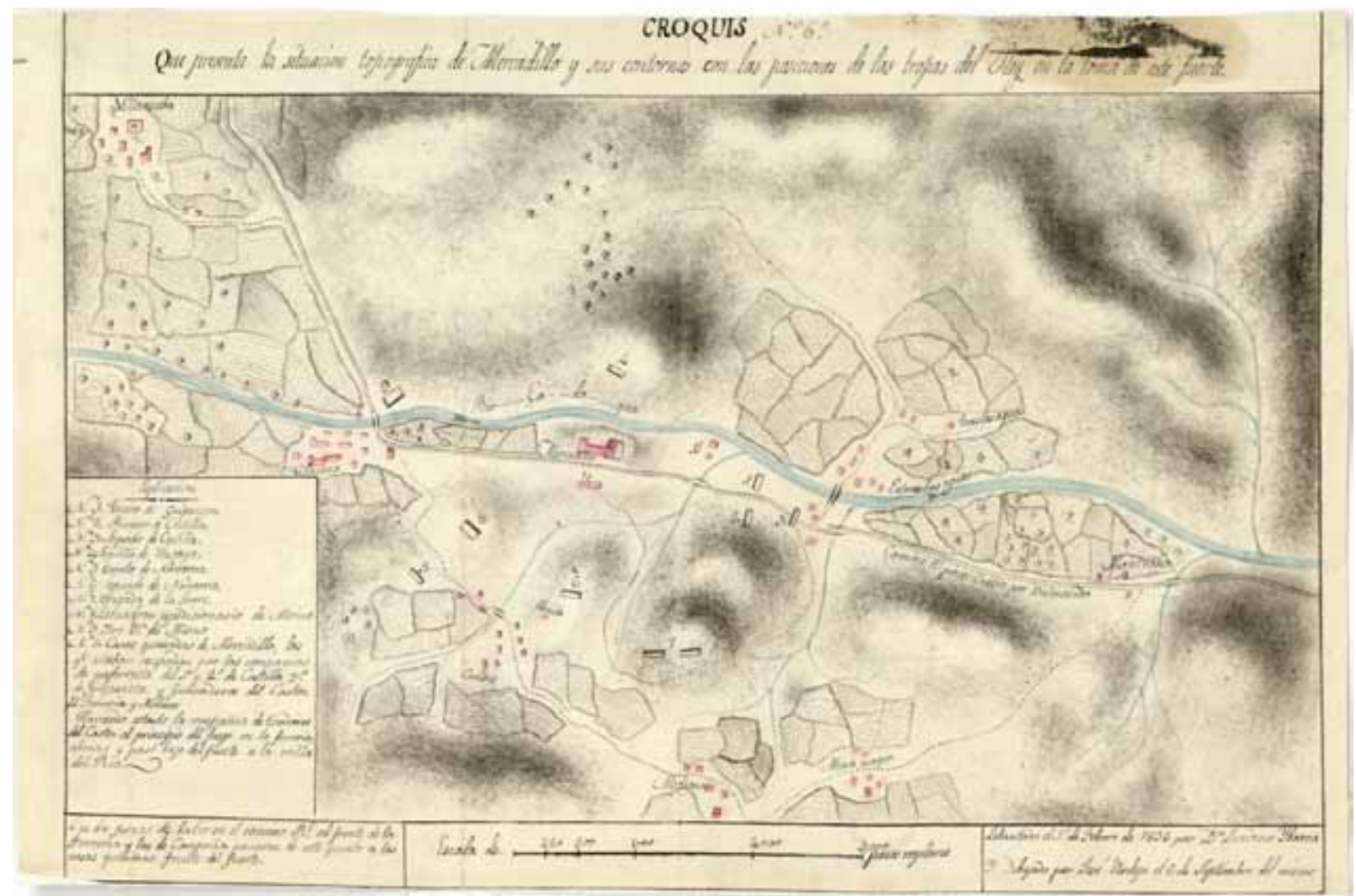

Croquis de 1836 sobre Villasana, Mercadillo y sus contornos en Mena (ARCGE Ar. E-T.6-C1-104).

caminos para Bilbao. Camino de ruedas"968. Brusola969 y Santiago López ${ }^{970}$, editan copias

968 ESCRIBANO, J. M.: 1758.

$\begin{array}{ll}\text { "Hasta Burgos, leg. } & 41 \\ \text { Rio Arlanzon. } & \\ \text { Las Ventas de Quintanilla, y de Quintanaortuño } 2 \mathrm{~m} \\ \text { Ontomin } & 2 \\ \text { Cernegula } & 7 \mathrm{~m} \\ \text { Villalta } & 2 \\ \text { Pesadas } & 7 \\ \text { El Almiñe } & 7 \\ \text { Arenas, Rio Ebro, P. } & \mathrm{m} \\ \text { Encinillas } & 2 \\ \text { Villarcayo } & 7 \\ \text { Villa-Comparada, y Bocos } & 1 \\ \text { Venta de Pajares } & 7 \\ \text { Venta de Revilla } & \mathrm{m} \\ \text { El Rivero } & 7 \mathrm{~m} \\ \text { Villasante } & 1 \\ \text { Bercedo } & \mathrm{m} \\ \text { El Haya, y Hirus } & 1 \\ \text { Burceña, y Nava } & 2 \\ \text { El Berron, R. Cadagua. P. } & 7 \\ \text { Balmaseda } & 1 \\ \text { Zalla, y Gueñes } & 2 \\ \text { BILBAO } & 2 \mathrm{~m} "\end{array}$

969 BRUSÓLA, FCo.:"Noticia de todas las ciudades, villas y lugares de este Reyno de España"/ 1810. Reedita en Valencia el Itinerario de José Matías Escribano, publicado en 1758, y reeditado o copiado de manera exacta en numerosas ocasiones hasta el siglo XIX.

970 LÓPEZ, S.: 1812. La Guía de caminos o Itinerario de Santiago López realiza la segunda edición en 1812 y la cuarta en 1828. Es otra de las copias del Itinerario de Escribano, un trabajo que se reeditó o copió en numerosas ocasiones 
del itinerario de Escribano, y también incluyen lo mismo. En 1832, se edita una memoria sobre la realización del nuevo camino de Burgos a Bercedo, en el que se recoge esta vía con el nombre de "Antiguo camino por Valmaseda", que coincide hasta Villasante con el camino de Burgos a Laredo971.

\section{Referencias documentales}

El Valle de Mena fue recorrido desde antiguo por un buen número de vías. En el año 800 , se constata la existencia de un antiguo camino por Taranco, cuando el abad Vitulo y su pariente el presbítero Ervigio, fundan la iglesia de San Emeterio y San Celedonio de Taranco "in loco qui dicitur Taranco in territorio Maniense", y someten a la misma las de San Martín de "Area Patriniani in territorio Castelle" y San Esteban de Burceña, construidas también por ellos. En el documento, se citan numerosas vías, una calzada, un puente y un vado: "via que vadit de Taranco ad Orcelione", "et vadit ad via angustina et via que discurrit ad Illicino", "iuxta via cum agro Maurenti", "via qui discurrit ad Ilicinio et ad illa via qui discurrit ad illa Vallicella" "calzata qui discurrit ad Sala", "presuras de illa ponte ad illas lamellas", "via qui vadit ad vado de Linares"972, y en 807 se menciona de nuevo el camino antiguo por Taranco en el Valle de Mena: "Ego Armentarius presbiter sic me trado pro remedio anime mee cum ipso meo mazanare cum fundus terre qui est in territorio de Taranco iuxta via qui vadit ad Cella ad ecclesia S. Emeteri et Celedoni et ad tibi abbati Erbigio"973.

El concejo de Bilbao pide 25 años después de su fundación a Juan Núñez de Lara, se-

durante el siglo XIX.

971 ANÓNIMO: "Memoria sobre el origen del Camino de Burgos a Bercedo, mandado construir por Real Decreto de 20 de julio de 1828. Medios empleados al efecto y resultado que han producido, con un Apéndice en que se insertan varios documentos relativos al objeto". Burgos, 1832. Imprenta de D. Ramon de Villanueva.

\begin{tabular}{|c|c|}
\hline Quintanaortuño & $2 \frac{1}{2}$ \\
\hline Ontomin & 2 \\
\hline Cérnegula & $7^{1 / 2}$ \\
\hline Villalta & $7 \frac{1}{2}$ \\
\hline Pesadas & 7 \\
\hline El Almiñé & 7 \\
\hline Arenas & 1 \\
\hline Incinillas & $0^{1 / 2}$ \\
\hline Villarcayo & 1 \\
\hline Bocos & $0^{1 / 2}$ \\
\hline Venta de Pajares & 1 \\
\hline Venta de Revilla & $01 / 2$ \\
\hline El Rivero & $0^{1 / 2}$ \\
\hline Villasante & 1 \\
\hline El Haya é Hirús & $0^{1 / 2}$ \\
\hline Nava & 2 \\
\hline El Berron & 7 \\
\hline Valmaseda & 1 \\
\hline Güeñes & 2 \\
\hline Sodupe & 1 \\
\hline Iraurequi & 2 \\
\hline á Bilbao & $7 "$ \\
\hline
\end{tabular}

972 A. H. N./ Cartulario de San Millán de la Cogolla. Becerro, fol. 179-180/15 septiembre 800; SERRANO, L.: 1930: 2-4: doc. 2; UBIETO ARTETA, A.: 1976: 10-12: doc. 2. "Ita tradimus et confirmamus per hanc scriptura omnem nostram facultatem hic supra notatas, et ipsas baselicas S. Martini, S. Romani et S. Stefani ad ecclesia S. Emeteri et Celedoni de Taranco, ut sint in auxilium servis Dei et peregrinorum vel ospitum qui hic viverint comuniter cum illis vivant".

973 A. H. N./ Cartulario de San Millán de la Cogolla. Becerro, fol. 180/ 12 noviembre 807 y 20 septiembre 912; SERRANO, L.: 1930: 4-5: doc. 2; UBIETO ARTETA, A.: 1976: 12-13: doc. 3. 
ñor de Vizcaya, que debían "faser muy grande costa en adobar la puente que es y en Bilbao", y como no lo podrán realizar si no les "fisiese alguna merced", Núñez autoriza en febrero de 1325 el cobro de dos dineros nuevos a todas las acémilas mayores cargadas y bestias asnales que pasaren por dicho puente, destinados a dicha obra. Y si alguno de los acemileros no lo quisiere pagar, manda al concejo, alcaldes y preboste de Bilbao que les prendan por ello hasta que lo paguen 974 .

En marzo de 1475 los mercaderes Yuce Leal y Mose Zazón, por sí y en nombre de otros judíos de Medina de Pomar, dijeron a los Reyes que desde hacía mucho tiempo, acostumbraban ir a Bilbao a comprar "las mercadurias de paño e sedas e lienços e otras cosas que alli se vendiane venden, para las traer en trato de mercaduria por estos nuestros reygnos", pero que últimamente Bilbao mandó que no se permitiese a ningún judío comprar ni sacar de la villa mercaderías para vender, salvo a los que vivían en ella, lo cual era según ellos monopolio en perjuicio de los Reyes y sus súbditos, porque según alegaban, así se venderán más caras las mercaderías a los vecinos de Bilbao. Los Reyes mandaron al concejo que dejen a los judíos de Medina ir libremente a comprar las mercaderías, paños, lienzos, sedas y otras cosas traídas por forasteros, y sacarlas para vender a cualquier parte de sus reinos, como siempre se acostumbró975.

Los problemas seguirán y así los judíos de Medina de Pomar se vuelven a quejar ante los Reyes, que dicen en agosto de 1490 que les informaron que por el derecho canónico y leyes de estos reinos, "los judios son tolerados e sufridos e que nos los mandamos tolerar e sofrir, e que viban en nuestros rreynos como nuestros subditos e naturales, e que vendan e conpren e contraten por ellos quieta e paçificamente", y como súbditos y vasallos que son, dicen que los tienen los Reyes bajo su amparo, "et dis quellos... tienen contrataçion en la dicha villa de Biluao y en la prouinçia de Guipuscoa, donde dis que compran paños e otras mercaderias, e pagan el diezmo dello e lo lievan a las ferias de la villa de Medina del Canpo y a otras ferias e logares destos nuestros rreynos, a lo vender e venden e pagan el alcauala dello". Dicen que la contratación de Bilbao, les ha sido hasta aquí libre "porque ellos han tratado y tratan onesta e limpiamente en sus tratos e mercaderias", pero que ahora el corregidor, el alcalde y el preboste de Bilbao, han ordenado sin tener poder ni facultad para ello, "que ningund judio ni pudiese estar ni dormir noche alguna" en Bilbao, y que nadie pudiese recibirlos en su casa para pasar la noche, y que como "Byluao no tyene arrauales donde los dichos judios se puedan salir a dormir y estar las noches, saluo çiertas caserias pobres e muy peligrosas, e estarian en ellas a muy grand peligro de sus personas e de sus fasyendas", hará que no hagan en Bilbao contratación con perjuicio de las rentas, diezmos y alcabalas, y desabastecimiento de las ferias. Los Reyes mandan revocar la nueva ordenanza y al corregidor de Vizcaya, alcalde y regidores de Bilbao, que dejen entrar y estar en Bilbao a los judíos de Medina de Pomar como hasta aquí han estado976.

El concejo de Burgos presentó en 1476 en el Consejo Real una petición diciendo que

974 A. G. S./ Registro General del Sello, VI-1485, fol. 14/ Oña, 24 febrero 1325 y Córdoba, 13 junio 1485; ENRÍQUEZ FERNÁNDEZ, J.; HIDALGO de CISNEROS AMESTOY, C. y MARTÍNEZ LAHIDALGA, A.: 2003: doc. 418; GONZÁLEZ, T.: 1829: 395-396: t. I.

975 A. G. S./ Registro General del Sello, III-1475, fol. 303/ Medina del Campo, 12 marzo 1475; ENRÍQUEZ FERNÁNDEZ, J.; HIDALGO de CISNEROS AMESTOY, C.; MARTÍNEZ LAHIDALGA, A.: "Archivo General de Simancas. Registro General del Sello. Vizcaya (1475-1477)".: 2002: doc. 6; GONZÁLEZ, T.: 1829: 45-47: t. I. doc. V.

976 A. G. S./ Registro General del Sello, VIII-1490, fol. 253/ Burgos, 12 agosto 1490. 
hace unos 3 años, el concejo de Valmaseda puso de tributo a cada carga de paños que por allí pasase, 10 mrs. y cinco a cada carga de lana, y además querían poner otro nuevo sobre los mantenimientos a todos los que por allí pasaban, causando gran perjuicio a sus mercaderes. La Reina manda a Valmaseda que cumpla con la ley de 19 de diciembre de 1475, promulgada tras las denuncias recibidas por los portazgos y peajes puestos contra derecho, mandando que nadie tome portazgo, peaje, roda ni castillería sin tener cartas ni privilegios que lo respalden 977 .

Enrique IV había dado licencia al concejo de Valmaseda porque la villa no tenía propios ni rentas, para que se echase cierta imposición y sisas en la villa, "para faser la çerca e puentes en los lugares que estavan derocadas", que se cogió hasta ahora prorrogado por los Reyes. Y como la cerca y puentes se han quedado sin reparar porque algunos invirtieron los dineros en sus propios intereses, los Reyes encomiendan en febrero de 1477 a Pedro Suarez de Figueroa alcaide de la fortaleza de Valmaseda y al alcalde de la villa, que se informen sobre cuánto tiempo hace que las sisas se echaron, cuánto han rentado, quiénes las han cobrado y en qué se han gastado, y hecha la pesquisa, se obligue a devolver las cantidades gastadas en intereses propios 978 . Y como la fortaleza de Valmaseda está muy mal reparada y fortificada, los Reyes mandan a su concejo aplicar la mitad de lo recaudado en la sisa desde enero de 1477 en su reparo, y la otra mitad para el de los muros y puentes, por lo que Pedro Suarez de Figueroa, tomará la mitad de todo lo que ha rendido la imposición y sisa desde enero979.

En 1483 Fernando Sáez de Fresnedo, vecino de Villanueva de Ladrero, en nombre de los mulateros de Castilla Vieja dijo a los Reyes que de tiempo inmemorial han pasado libremente con sus mulos por el camino real de la Ordunte que va a Castro y a Bilbao y que, desde hace unos 8 años los alcaldes de Villasana y el merino de Mena los prenden y obligan a ir por el camino de Villasana, que dice "ques mas largo e mas fraguoso, que no el dicho camino del Ordunte por donde diz que sienpre acostunbraron yr". Los Reyes mandan al concejo de Villasana y al merino de Mena que dejen a todos los mulateros transitar libremente por el camino real de la Ordunte980.

García Ruiz de Hornillalatorre, procurador de los mulateros y caminantes de Castilla Vieja, se quejó en 1487 porque en algunas villas del camino de Laredo y Valmaseda, Bilbao, juntas de Parayas, Avellaneda y Castro Urdiales y valles de Limpias, Salcedo y Mena, "por do pasan con sus mulos e aberios", hacen algunos puentes, pontones y calzadas sin licencia real, "non seyendo en pro ni vtilidad comun dellos", y ponen peajes, pasajes y pontajes en gran suma. Los Reyes mandaron que no se cobre a los mulateros nada por esta causa y se les deje pasar

977 A. G. S./ Registro General del Sello, III-1476, fol. 143/Valladolid, 19 diciembre 1475 y 16 marzo 1476; GONZÁLEZ, T.: 1829: t. I. doc. IX, 54-56; ENRÍQUEZ FERNÁNDEZ, J., HIDALGO de CISNEROS AMESTOY, C. y MARTÍNEZ LAHIDALGA,

A.: "Archivo General de Simancas. Registro General del Sello. Vizcaya (1475-1477)".: 2002: doc. 32.

978 A. G. S./ Registro General del Sello, II-1477/ Toledo, 20 febrero 1477; GONZÁLEZ, T.: 1829: 59-61: t. I. doc. XI.

979 A. G. S./ Registro General del Sello, II-1477, fol. 285/Toledo, 26 febrero 1477; ENRÍQUEZ FERNÁNDEZ, J., HIDALGO de CISNEROS AMESTOY, C. y MARTÍNEZ LAHIDALGA, A.: "Archivo General de Simancas. Registro General del Sello. Vizcaya (1475-1477)".: 2002: doc. 64.

980 A. G. S./ Registro General del Sello, VIII-1483, fol. 184/ Santo Domingo de la Calzada, 23 agosto 1483. 
libremente ${ }^{981}$. Dicho procurador pide que se restituya los mrs. cobrados indebidamente o $50.000 \mathrm{mrs}$., y que en adelante no les pidan los dichos pasajes ${ }^{982}$. Prosiguiendo con este litigio, en julio de 1488, los mulateros manifestaron que estaban muy agraviados, porque cuando pasan "con sus mulos e averios por los dichos logares e por algunas puentes e pontones e calçadas, dis que los han leuado e lievan contra toda rrason e justiçia, e contra su voluntad en algunos de los dichos logares, por cada mulo a medio rreal e en otros a dose mrs. e dende arriba", y dicen que esto provocaría el abandono de la mulatería, por superar los tributos el provecho de su actividad. El Consejo manda al alcalde de Castilla Vieja, que averigüe en esas villas y lugares quiénes llevan las imposiciones, qué título o privilegio tienen, cuánto llevan por cada mulo o bestia y desde cuándo, y si los portazgos los gastan en los caminos o calzadas, y envía dicha información ${ }^{983}$.

En julio de 1488 Bartolomé de Lantadilla, vecino de Burgos, dijo a los Reyes que, en Valmaseda, hay contratación de hierro y herraje porque las ferrerías están cerca de la villa, y muchas personas van allí a comprarlo por grande y por menudo, y añade que el concejo y personas singulares de Valmaseda, tienen hecho monopolio para que ninguno de fuera pueda comprar menos de 10 quintales de hierro, por lo que le tienen prendados ciertos bienes y los van vendiendo. Los Reyes mandan al concejo que deje comprar en la villa todo el hierro y herraje que quisieren los compradores, anulen la ordenanza y monopolio que tiene hecho, y restituya a Bartolomé de Lantadilla todos los bienes prendados. Y si existe alguna razón para no cumplir lo mandado, se emplaza a los de Valmaseda para que muestren lo que avala su derecho984.

En octubre de 1498 Juan Ruiz de Bolívar, vecino del valle de Salcedo, dijo que Juan de Salcedo, alcalde que fue de Güeñes, tenía una casa fuerte sobre un puente y camino real en el despoblado de Aranguren, y que por los robos, desafueros e imposiciones que desde su casa hacía, y porque robó a mercaderes de Burgos y de otras partes, la justicia la derribó hacía unos 25 años con la orden de no reedificarla. Hace 20 años Juan de Salcedo la volvió a edificar y "mucha mas fuerte dos vezes e mas grueso el muro, porque agora tiene diez pies de muro e mas, que es tan fuerte que con muy rrezia artelleria no se podria derribar, e demas desto diz que tiene su barrera con muchas troneras e saeteras e la casa esta muy alta de mas de quinze tapias", cometiendo los mismos delitos y llevando imposiciones nuevas. Además con su oficio de alcaldía y por ser pariente mayor, tenía sojuzgada la tierra que, con el pretexto de "que le ayuden para alguna nesçesidad, fazen rrepartimiento entre si e los dichos sus parientes e amigos", llevando en total más de 1.000.000 de mrs. Pidió que se mandase demoler la casa fuerte y restituir todo lo que se había llevado injustamente. El Consejo acordó pedir información al corregidor de Vizcaya para que hacer lo que fuere justo985.

Los Reyes mandaron al corregidor de las Cuatro Villas y al alcalde mayor de Castilla Vieja, que hiciesen pesquisa sobre los malos pasos que hay entre Burgos y Laredo. En junio

981 A. G. S./ Cámara de Castilla. Pueblos, leg. 10, doc. 32/ Burgos, 17 diciembre 1487; A. G. S./ Registro General del Sello, XII-1487, fol. 63/ Burgos, 17 diciembre 1487 .

982 A. G. S./ Cámara de Castilla. Pueblos, leg. 10, doc. 32-2/ Laredo, 1487.

983 A. G. S./ Registro General del Sello, VII-1488, fol. 188/ Burgos, 4 julio 1488.

984 A. G. S./ Registro General del Sello, VII-1488, fol. 89/ Burgos, 21 julio 1488; GARCíA de CORTÁZAR, J. A.: 1966: 397: doc. 26.

985 A. G. S./ Registro General del Sello, X-1498, fol. 251/Valladolid, 30 octubre 1498. 
de 1499 el cantero Ruy Sánchez de Criales, fue a ver cuánto podían costar las obras, y vió además otras cosas necesarias como que se aderezase en Montija un puente en Bercedo, que se valoró en 5.000 mrs. Como esto es más de lo que se mandó y era muy necesario, y los de Bercedo no pueden ir a labrar sin él y no lo han querido hacer esperando que lo hagan los mulateros, se manda que lo haga el concejo o pague los $5.000 \mathrm{mrs}$. presupuestados ${ }^{986}$.

La Junta General de Vizcaya, envía en 1507 una petición al Consejo, diciendo que "los caminos por donde se lleva destos... reynos... [al] condado, la prouision e mantenimientos e otras cosas que son menester, estan muy malos, de manera que non se pueden andar, nin caminar por ellos a pye ni a cauallo, nin con bestias cargadas nin basias, syno a mucho riesgo e peligro" de los caminantes y bestias, especialmente y entre otros "desde la cunbre de la penna de la çibdad de Hordunna fasta la villa de Biluao, y desde la penna de Mena fasta dar en la dicha villa por la villa de Valmaseda", que son caminos muy transitados, y por donde se llevan desde Castilla las provisiones y mantenimientos y vuelven a Castilla otras mercaderías. La Reina manda al corregidor que reciba información, y la envíe ante el Consejo para que provea lo que fuere justicia, y que todas las penas impuestas se empleen en el dicho reparo987.

El concejo de Bilbao mandó en 1509 que, como era "grand desofensa e deseruiçio de Nuestro Sennor Dios e de Nuestra Sennora e sus santos, en andar con mulas e vestyas cargadas, en dias de pascoase domingos e en otros dias vedados", nadie pueda traer ninguna bestia a Bilbao ni a sus arrabales, ni salir de ellos con carga alguna en un gran número de días festivos ${ }^{988}$. En las fiestas declaradas ninguna bestia puede andar, so pena de pagar por cada bestia cargada $200 \mathrm{mrs}$., excepto las que vinieren de Castilla con provisiones y otras mercaderías. También mandó el concejo que no "sean hozados, besynos nin foranos, de tomar nin alquilar cargas ningunas adelantadas para Castilla, saluo los mulateros duennos de las hazemillas o los huespedes de los mulateros, seyendo presente los mulateros, e syn que los mulos que han de llebar las cargas esten en la villa", ya que algunos toman las dichas cargas no teniendo mulos y las realquilan por menos de lo que han alquilado ellos mismos ${ }^{989}$.

El concejo de Bilbao dijo en 1509 que han surgido nuevas ferias en algunos lugares, "ganadas con syniestras relaçiones que para ello avyan fecho a su altesa", que hacían mucho daño a Bilbao, a sus tratantes y vecinos, porque los que venían de Castilla con trigo y otras provisiones y retornaban con paños, lienzos y otras mercaderías dejaban de ir, porque esperaban a las dichas ferias encareciendo los mantenimientos y perjudicando a la villa y a todo el

986 A. H. N./ Nobleza. Frías, C. 235, D. 55/ Medina de Pomar, 15 enero 1499.

987 A. G. S. V./ Casa de Juntas de Guernica. Provisiones Reales. Reg. 1- no 12(1)/ Palencia, 27 abril 1507, Guernica, 20 enero 1508; HIDALGO de CISNEROS AMESTOY, C.; LARGACHA RUBIO, E.; LORENTE RUIGÓMEZ, A. y MARTÍNEZ LAHIDALGA, A.: 1987: doc. 69.

988 Dichos días son "Ios dias de la Pascoa de Nabydad e Anno Nuevo, e los dias de los Reyes y en todos los domingos, e los dias de Pascoa de Resurreçion, e el dia de Asençion, e el dia de Corpus Christy, e la Pascoa de Pentecoste que dysen Pascoa de Mayo, e el dia de la Trasfyguraçion, los quales son dias e fyestas pertenesçientes a Nuestro Sennor Dios, e asy vien que guarden la fyesta de Nuestra Sennora e la Encarnaçion de Nuestro Sennor, e el dia de la Natybidad de Nuestra Sennora, e el dia de la Consençion de Nuestra Sennora, e el dia de la Asençion de Nuestra Sennora, e el dia de la Visytaçion de Nuestra Sennora, que son fyestas de Nuestra Sennora. E asy vien que guarden todas las fyestas de los apostoles, e el dia de Sant Juan Bautysta, e el dia de Santa Maria Madalena".

989 A. M. Bilbao/ Cajón 16, reg. 2, no 2 (fol. 1r- 87v; 89r; 88r; 89v- 91v; 96r- 96v; 92r- 94v; 97r- 108v)/ Bilbao, 2 enero 1509- 1 enero 1510; ENRÍQUEZ FERNÁNDEZ, J.; HIDALGO de CISNEROS AMESTOY, C.; LORENTE RUIGÓMEZ, A.; MARTÍNEZ LAHIDALGA, A.: 1995: doc. 1. 
Condado. Además los traperos y tratantes de Bilbao perdían su trato, porque los extranjeros que iban a comprar sus paños y mercaderías a sus casas, habían dejado de acudir por ir a las dichas ferias, por lo que obligados por la necesidad, iban los tratantes de Bilbao a las ferias con sus paños y mercaderías haciendo muchos gastos en idas, venidas y alquileres, y como lo que vendían era poco y las costas muy grandes, todo el trato de la trapería que era el mayor de la villa, se perdería en poco tiempo. Ordenaron que nadie "sean hozados de llebar nin enviar nin yr con los dichos pannos e lienços nin otras mercaderias, direte nin ynderetemente, a otras ferias algunas saluo a las ferias reales e a las otras antiguas del reino de Castilla"99o.

Para evitar el fraude el concejo y regimiento de Bilbao encargó en 1509 a Juan de Zamudio, que vigile "en la ribera e ryo, quien e quales mulateros descargan sacas de lanas o pelleterias o otras mercaderias en Çorroça, o en Olabeaga, o en Çubileta para Portogalete, e asy vien fardeles de mercaderias que traen los bateles de Portogalete, e descargan en los sobredichos lugares para mulateros, para los sacar para Castilla, e que los tomen por descaminados"991.

A petición del lugar de Nava en Mena, la Reina había mandado al corregidor de las Tres Villas de la Costa de la Mar que obtuviese "ynformaçion sobre vna puente que se abia caydo en el rryo cabdal, la qual se avia caydo con seys azemilas cargadas de merçeria, e que por ser la dicha puente muy grande ellos no la avian podido faser", para saber lo que costaría su reparo, si era necesario, si el concejo la podría reparar a su costa y si había otros lugares que recibirían provecho, acordando el Consejo en junio de 1513, mandar al corregidor que reparase dicho puente y se gastase todo lo que fuere necesario, debiendo contribuir los lugares comarcanos que se aprovechan.

Juan Barahona, vecino de Villanueva de Ladrero, procurador de los viandantes y mulateros de Castilla Vieja, Sotoscueva y Sonsierra, se quejó en el Consejo que en Mena y en el puente de Nava, llevan a los mulateros y a los merchantes de ganados mayores y menores, muchos mrs. de "portazgos e pontajes e otros derechos e nuebas ynposyçiones, que nuebamente an puesto e ponen de cada dia,... los qual diz que les lleban syn tener titulo ni derecho alguno para lo poder llevar, e que sy alguno se pone en no lo querer pagar, les toman prendas e los maltratan e fatygan en pleytos, de que se les syguen a los dichos sus partes muchas costas e gastos, e que porque no los maltraten se dexan coechar e pagan todo lo que les piden avnque no lo deven". Pide que se mande devolver todo lo que les han llevado, más los gastos ocasionados, y se castigue a los que lo cobraron. El Consejo mandó en febrero de 1515 al corregidor que vaya a Mena y al puente de Nava, y reciba información sobre los mrs. que han llevado a los mulateros, sobre qué cosas, quién lo lleva y por orden de quién, con qué título y desde cuándo, y si se lleva más de lo que se acostumbraba; y todo ello, con una copia de los privilegios y títulos que tales personas tienen, lo envíe al Consejo.

En septiembre de 1515 Pedro de Brizuela y Juan Barahona, procuradores de los mulateros y viandantes de las merindades de Castilla Vieja, Sonsierra y Sotoscueva tratan pleito contra el Condestable y sus portazgueros, y contra otros vecinos de las merindades

990 A. M. Bilbao/ Cajón 16, reg. 2, no 2 (fol. 1r- 87v; 89r; 88r; 89v- 91v; 96r- 96v; 92r- 94v; 97r- 108v)/ Bilbao, 2 enero 1509- 1 enero 1510; ENRÍQUEZ FERNÁNDEZ, J.; HIDALGO de CISNEROS AMESTOY, C.; LORENTE RUIGÓMEZ, A.; MARTÍNEZ LAHIDALGA, A.: "Libro de Acuerdos y Decretos Municipales de la Villa de Bilbao (1509 y 1515)". 1995: doc. 1.

991 A. M. Bilbao/ Cajón 16, reg. 2, no 2 (fol. 1r- 87v; 89r; 88r; 89v- 91v; 96r- 96v; 92r- 94v; 97r- 108v)/ Bilbao, 2 enero 1509- 1 enero 1510; ENRÍQUEZ FERNÁNDEZ, J.; HIDALGO de CISNEROS AMESTOY, C.; LORENTE RUIGÓMEZ, A.; MARTÍNEZ LAHIDALGA, A.:"Libro de Acuerdos y Decretos Municipales de la Villa de Bilbao (1509 y 1515)". 1995: doc. 1. 
de Castilla Vieja, de Mena y del puente de Nava, por los muchos mrs. de portazgos e imposiciones que les llevan "syn tener tytulo ni rrason, ni derecho alguno para los poder llevar sobre rrason de muchas prendas, syn rrasones e agrabios que sobre ello nos han fecho e fasen". El corregidor mandó que Juan de Velasco de Nava escribano, Sancho Pérez Gil, Juan Macho, Pedro Macho y Ochoa de la Cuadra, vecinos de Nava, trajesen el poder para coger el portazgo del puente de Nava, y la cuenta de los mrs. que han cogido. Al día siguiente Lope de Obregón, alcalde en los valles y tierra de Mena, y dichos vecinos mostraron al corregidor y juez de comisión una Provisión de junio de 1513, que mandaba hacer el repartimiento del puente. También presentaron una información, que Lope de Obregón había hecho de los lugares que recibían provecho del puente, que son "muchoslugares que ban açia Biluao e Castro e Salzedo e Portogalete e sus comarcas, e otros lugares que van ançia Castilla Vieja e otros lugares, que ban al Butron e a Espinosa e a Montyja e a sus comarcas". Asimismo presentaron dos contratos del remate que se hizo en unos canteros de Trasmiera en 37.000 mrs., y en unos carpinteros de Mena en 13.000 mrs., y dos obligaciones que Obregón hizo para averiguar si había habido fraude en la obra, y pareció que la cantería fue bien rematada, pero en la carpintería apreciaron que lo hecho valía 3.000 mrs. menos de lo que se remató, por lo que Obregón mandó al concejo que los reclamase, quedando el puente en 47.000 mrs., de los que se mandó que el concejo de Nava pagase $7.000 \mathrm{mrs}$. por el provecho que recibe, y el resto los mulateros de la comarca, para lo que proponía el cobro por el paso de 30 mrs. por mulo, 20 por rocín, 15 por asno, dos por cabeza mayor de buey y vaca y un mr. por cabeza de oveja y cabrón.

Para cobrar el peaje se nombró escribano a Ochoa de la Cuadra, y cogedor a Sancho Pérez Macho y, tras su muerte, a Sancho Gil. Ese día el corregidor recibió juramento de Sancho Gil, Ochoa de la Cuadra y Juan Macho de la Cuadra, vecinos de Nava, y les mandó que trajesen la cuenta de los 21.270 mrs. que habían recaudado desde agosto de 1514 . Preguntó a Sancho Pérez Macho, a Sancho Gil, a Ochoa de la Cuadra y a los cogedores, si habían cobrado más mrs. de los dados por cuenta, si habían hecho en ella fraude o engaño, y si sabían que otras personas habían cogido más mrs. , y dijeron que no habían cobrado más mrs. que los que habían dado por cuenta. El corregidor dijo que la Provisión real no estaba clara, ya que por ella se podía coger peaje para el dicho puente, y que hay más posibilidad de hacer fraude en el peaje que en el repartimiento, y mandó que no se cobre más, y al alcalde que no consienta ningún peaje para cubrir los 18.662 mrs. que quedaban debiendo, y que se repartan entre los lugares que recibían provecho, según la vecindad de cada uno. También en 1515, los procuradores de los mulateros y viandantes de la merindad de Castilla Vieja y de la de la Sonsierra y Sotoscueva dijeron al corregidor que en la peña de Mena y en Bercedo, para bajar al Valle de Mena, llevan a los mulateros muchos mrs. y muy largo tiempo por quitar la nieve, y le piden que mande parecer a las personas que lo cogen y a los que lo mandan, que son Pedro de Velasco, vecino de Valdeporres, y el abad de Vivanco y Callarde de Velasco, vecinos de Mena para que muestren los títulos que tienen 992 .

En 1547 el Prior de la Universidad de los Mercaderes de Burgos, declara en un pleito que "siempre los desta dicha unibersidad de Burgos an tenido e tienen cargo de adereçar caminos ansi para la

992 A. G. S./ Consejo Real de Castilla, leg. 84, fol. 2-III/ Valladolid, 26 junio 1513 a Salazar, 25 septiembre 1515. 
villa de Bilbao como para otras partes...", y así las mercaderías tendrían mejores precios ${ }^{993}$.

En las Juntas de Vizcaya de junio de 1569 se acordó que se hagan los tres caminos reales y principales del Señorío: el que va de Bilbao para Valmaseda, el de Bilbao para Orduña y el de Bermeo hasta Ochandiano; y que para ello, se repartan 300 ds. a las Villas y Ciudad y 300 a la Tierra Llana, la cuarta parte en el camino de Valmaseda, y lo demás en los otros dos caminos, y que se reparen según la necesidad. Estuvieron conformes todos los procuradores salvo los de Ondarroa, Regoitia y Elorrio y encargaron para el reparo del camino de Bermeo a Ochandiano a Diego Ortiz de Zárate y de los otros dos caminos a Ochoa de Larrinaga994. En las Juntas de Tierra Llana de julio se ordenó lo acordado en las Juntas de Villas y Ciudad de junio995, y en las de la Tierra Llana de septiembre, se trató como en el regimiento último en Bermeo, se mandaron hacer los dichos tres caminos haciendo repartimiento996.

Luis de Orive en nombre del concejo, justicia y regimiento de Valmaseda dijo al Rey que por el "balle de Mena y Salzedo pasaba el camino real a la billa de Bilbao y Castro de Hurdiales e otras partes, por donde pasaban muchos tragineros y biandantes por ser las dichas billas puertos de mar, y las calçadas estaban tan malas que los dichos tragineros padeszian mucho y peligraban muchos machos y bestias dellos, lo qual se remediaria con que las dichas calçadas se adereçasen a costa de los lugares comarcanos", y suplicaba que se mandase que cada lugar aderece las calzadas y caminos de su jurisdicción. El Consejo Real mandó en 1571 a los corregidores de Vizcaya y de las Cuatro Villas y a las justicias del Valle de Mena y Salcedo, que hagan reparar de inmediato los caminos y malos pasos referidos, a costa de los propios de los concejos en cuya jurisdicción están, para que puedan pasar los caminantes y recuas, y en 30 días envíen al Consejo relación de lo que hubieren hecho. En octubre, Juan López de la Puente, vecino de Valmaseda, en nombre de su concejo, notificó la Provisión real al corregidor del Señorío y Encartaciones, y dio comisión al teniente general de las Encartaciones, para que averigüe cómo están los caminos y malos pasos que necesitan reparos y lo envíe al corregidor, y en enero de 1572, Julián de Velasco requirió con la Provisión real en la audiencia de Villanueva de Mena, al teniente de corregidor en Mena. En dicha audiencia en febrero, el teniente dijo que los caminos reales de la jurisdicción de Mena, "estan bien y sufiçientemente reparados y adereçados por la mayor parte, y que continuamente se entiende en el reparo y adereço dellas, y que si en alguna parte desta juridicion en los dichos caminos, ay algunos malos pasos o estan por reparar y aderesçar, el esta presto y çierto de los yr a ber en persona, y que se le diga y señale por parte de la dicha billa de Balmaseda, en que partes y lugares desta juridicion de Mena estan o ay los dichos malos pasos, y que hallando que tienen neçesidad de reparo les hara reparar y adereçar con todo cuidado y diligençia" 997.

En las Juntas de Vizcaya de octubre de 1579 el procurador de Valmaseda, pidió que los caminos del Señorío se reparen por cada pueblo, ya que así estaba decretado por los regimientos, y que desde Bilbao a Valmaseda, "estaban tan fragosos e malos que a pie ni a caballo

993 A. G. S./ Consejo Real de Castilla, leg. 204-3/ 1547; BASAS FERNÁNDEZ, M.: 1963 y 1994: 150

994 A. J. R. B./ Actas de Villas y Ciudad. t. I/ Guernica, 5 junio 1569.

995 A. J. R. B./ Actas de la Tierra Llana. t. I/ Bermeo, 20 julio 1569.

996 A. J. R. B./ Actas de la Tierra Llana. t. I/ Durango, 7 septiembre 1569.

997 A. H. V. M./ leg. 6, p. 204 a 211/ Madrid, 11 septiembre, Avellaneda, 29 octubre y Laredo, 26 diciembre 1571 y Villanueva de Mena, 28 enero y 1 febrero 1572. 
no se podia caminar por ellos", y que el Rey recibía perjuicio porque, al no pasar las cargas por el camino derecho, se dejaban de dezmar al no ir por la aduana. Acordaron que todos los oficiales del regimiento, lleven memoriales sobre los malos caminos y pasos del Señorío, para que se dé el remedio que conviene ${ }^{998}$.

En junio de 1588 se manda hacer el reparo y composición de caminos y calzadas desde Bilbao hasta el puente de las Olías en Mena, a costa de la villa de Bilbao, Valmaseda y los concejos de Güeñes y Zalla999.

En las Juntas de Vizcaya de noviembre de 1591 el procurador de Orduña propuso que la persona que fuere a la corte, pida en el Consejo que se dé cedula para que sobre las cargas de mercaderías que salen del Señorío para Castilla, se cargue sobre cada una 1 real para reparos de los caminos reales que hay en la jurisdicción de la ciudad, pues en el Valle de Mena, por "no ser de la frequençia y continuaçion deste dicho Señorio", se le concedió cédula10oo.

En 1593 los puentes del Valle de Mena, estaban muy maltratados por lo que en noviembre el teniente de corregidor, cumpliendo con una Provisión real y comisión del corregidor, fue a ver los puentes del valle para valorar las intervenciones que se deben realizar, acompañado de los maestros canteros y carpinteros Juan de Madrid, Francisco de Hano, Toribio del Campo y Juan Zorrilla. Entre otros, visitaron los puentes que se encuentran en el camino real que pasa por Villasana y se va a juntar con el que viene de Burceña en Nava, y desde allí como un solo camino, va a las villas y puertos de Castro, Portugalete, Bilbao, Bermeo, Lequeitio y puerto y aduana de Valmaseda y valle de Cordejuela y Encartaciones. Tras la visita los maestros proponen:

- Puente de Irús, uno de los dos sobre el río Cabrio o Hijuela, se ha de hacer con dos pilares de piedra y el arco de madera que costará 70 ducados.

- Puente de Leja, Ox o la Exa, entre Vivanco y Villasuso en el río Cabrio, necesita hacerse de un arco, dos estribos y sus manguardias que llevarán 230 varas de piedra labrada a ducado la vara, y de cal, cimbras y ahorrazón 300 rs.

- Puente del lugar de Vallejo, sobre el Cadagua, se encuentra donde se une este camino con el real que entra por la peña y puerto de la Magdalena y va a Valmaseda. Está muy maltratado del último diluvio y necesita reparar las cepas principales que están muy perdidas, sus manguardias y 30 dovelas en el arco principal que están comidas, y para todo ello se necesitan 207 varas de piedra labrada a dos ducados la vara, y de cal y otros materiales 50 ducados.

- En Villasana hay dos puentes de cal sobre el Cadagua, el de arriba es el más necesario e importante pero está de madera muy viejo y sin ningún servicio, por lo que necesita hacerse de tres arcos principales con dos cepas, estribos y manguardias de piedra labrada. Llevará 1.200 varas a tres ducados la vara, porque la cantera principal está a más de una legua y de mal camino. De cal y piedra tosca, ahorrazón, cimbras y otros materiales necesarios 200 ds.

998 A. J. R. B./ Actas de Villas y Ciudad. t. II/ Bilbao, 27 octubre 1579; Actas de la Tierra Llana. t. III/ Bilbao, 27 octubre 1579 .

999 Archivo Consulado de Bilbao. Índices, tomo II, folio 7, número 6, en ALZOLA y MINONDO, P.: 1979: 159-160/4 julio 1588.

1000 A. J. R. B./ Actas de Villas y Ciudad. t. III/ Bilbao, 29 noviembre 1591. 
- Puente de Cerezo en el río que baja de Covides, está llevado y descimentado. Necesita hacerse de dos pilares y un arco, y son precisas para ello 400 varas de piedra labrada a 16 rs. la vara y de cal, cimbras y ahorrazón 30 ducados.

- Puente del lugar de Entrambasaguas en el camino real, sobre el Cadagua, aunque en pie está muy perdido, y se ha de mudar algo más abajo y hacerse de dos arcos, una cepa y dos pilares y otro arco pequeño para los calces de los molinos, y todo llevará 375 varas de piedra labrada sin lo que tiene el dicho puente, a 17 rs. la vara, y de cal 80 ducados, de cimbras y ahorrazón 100 ducados.

- Puente de Valladornedo sobre el río que baja de Menamayor, tiene un arco y necesita que se le hagan manguardias y otros reparos que costará 150 ducados. Aunque en pie, quedó de manera que se debía derribar para hacerse de nuevo.

- Puente de Maltrana sobre el Cadagua y camino real, tiene dos arcos de madera, muy viejo y perdido con una cepa en medio también vieja. Se ha de poner más abajo y hacerse de dos arcos, una cepa y dos pilares; y además de su despojo, tiene que llevar 700 varas de piedra labrada a 18 rs. la vara, y de cal, cimbras y ahorrazón 180 ducados.

- Puente del lugar de Ungo en el Cadagua, tiene tres arcos sobre pies de madera todo muy viejo y peligroso. Necesita hacerse de tres arcos con dos cepas y dos pilares con sus manguardias, y todo serán 1.000 varas de piedra labrada a 19 rs. la vara. De cal 90 ducados y de cimbras y ahorrazón 180 ducados.

- Puente de Nava sobre el Cadagua. Tiene tres ojos principales de 20 pies de hueco y las cubiertas de maderas muy viejas. La cepa central y principal está tan vieja y perdida que se ha de hacer de nuevo, y llevará 500 varas de piedra labrada. El puente ha de ser de cuatro arcos y a cada lado su manguardia, los tres principales llevarán 3.000 varas de piedra labrada. El otro pilar con sus manguardias, cada una de unos 60 pies de largo y 10 de alto y con el arco menor 300 varas y algo más, de piedra labrada a 1,5 ducados la vara porque la cantera está muy lejos, y otros materiales y de cal 7o ducados y de maderas para cimbras y ahorrazón, y el coste de toda la obra son 380 ds.

- Puente del Berrón sobre el Pastrina. Es de un arco viejo con una parte comenzada a caer, se necesita reparar una manguardia por la parte de abajo de 10 brazas de pared de tres pies de ancho, y costará cada braza 25 rs. porque la cantera está lejos.

- Puente del Berrón encimero, junto a la casa de Juan Ortes sobre el río Romario o de Vadubela. Es de un arco pequeño y muy perdido y necesita hacerse un arco mayor y dos estribos con una manguardia que llegue a la viña, que ha de tener dos brazas de alto y cuatro pies de ancho sin el aprovechamiento que tiene el puente. Necesita 200 varas de piedra labrada para el arco a 1,5 ds. la vara, y 80 brazas de pared a 32 rs. y los estribos 12 pies de ancho cada uno, 100 varas sin lo del arco de piedra labrada a 1,5 ds. la vara. De cal 30 ds. y de ahorrazón de los estribos y de cimbras 34 ducados ${ }^{1001}$.

- Puente de las Olías sobre el Romario, era de un arco y está llevado, se ha de hacer de un arco un poco más arriba, que llevará 20 varas de piedra labrada a 13 rs. la vara. De cal 5 ducados, de ahorrazón y cimbras 5 ducados y de los estribos 30 ds. ${ }^{1002}$.

1001 A. H. V. M./ leg. 6, p. 221 a 336/ Madrid, 10 junio 1589 a 18 diciembre 1593.

1002 A. H. V. M./ leg. 6, p. 221 a 336/ Madrid, 10 junio 1589 a 18 diciembre 1593. 
Ante la epidemia de peste, en las Juntas de Vizcaya de octubre de 1598 el regimiento dijo que si se permitiese que en Bilbao, entrasen trajineros $u$ otras personas con bastimentos de partes sanas y sin sospecha de enfermedad contagiosa, podrían resultar graves inconvenientes para la villa, por lo que el corregidor ordenó que dos personas de confianza asistan y residan la una en Beteluri y la otra en Castrejana, que son puestos acomodados y libres de la enfermedad y "por donde forçossamente, an de pasar ansi de la çiudad de Urduña como de la villa de Valmaseda, en que se abraçan los caminos cosarios e frequentados que ay para la dicha villa de Vilvao de las partes de Castilla la Vieja e todas las Montañas", y que dichas personas no dejen pasar ningún trigo, aceite, vino ni otros bastimentos, sino que los descarguen en estos sitios y vayan allí los que los quisieren comprar a precios justos ${ }^{1003}$.

En las Juntas de Vizcaya de mayo de 1603 el licenciado Zumalabe, en nombre de Valmaseda, dijo que como el camino desde Bilbao a Valmaseda y también desde Valmaseda hasta salir del Señorío estaba mal reparado, pidió alguna ayuda para repararlo. Se acordó que se guarde esta petición para que en los primeros regimientos, se provea lo que convenga ${ }^{1004}$.

\section{El puente de Valmaseda}

El camino real, llegaba a Valmaseda por la orilla derecha del río Cadagua, y para entrar debía utilizar el puente Viejo también llamado de la Muza o "la puente Vieja", y proseguir hacia Bilbao por la orilla izquierda. Dicho puente, que es el que ostenta el escudo de la villa, fue construido sobre otro anterior que posiblemente se situó sobre un vado preexistente, y se vincula directamente con los orígenes de la villa. Unía el barrio extramuros de El Cristo con el de San Lorenzo o antigua judería. La construcción actual sobre el basamento antiguo no parece ser anterior al s. XV. Sin embargo, su estructura lo hacía incómodo para el paso de las caballerías por el gran alomamiento de su tablero, motivo por el que se construyó otro puente en el centro de la villa en el s. XVII. Con arco central elevado y otros dos menores a ambos lados; sobre una de sus cepas se levanta un torreón del siglo XV que, como puerta de entrada a la villa, se utilizó para el cobro de los derechos aduaneros a los trajineros y comerciantes que llegaban de Castilla o que venían del puerto de Bilbao. En el siglo XV para evitar los carros que desde Burgos transportaban la lana, la penosa pendiente de este puente, se habilitó y empedró un vado enfrente del convento de las monjas ${ }^{1005}$.

En este puente, también se cobraron las oturas ${ }^{1006}$. Así, en mayo de 1588 Puente Hurtado de Mendoza, merino mayor de la villa, da en arrendamiento a Constanza de Carranza, las oturas y rentas reales a él pertenecientes, "que se cobran en los mercados rreales y puente de la dicha villa asi en trigo y çebada como en dinero"1007.

Shaschek, uno de los dos autores que describen el viaje que hizo el noble bohemio León de Rosmithal, que desde Bilbao va a Burgos y, en Valmaseda, dice que "hay sobre este río [Cadagua] un puente de madera no muy largo, y en uno de sus extremos una torre de bella arquitectura,

1003 A. J. R. B./ Actas de la Tierra Llana. t. VI/ Zubiaur de Zornoza, 1 octubre 1598.

1004 A. J. R. B./ Actas de Villas y Ciudad. t. IV/ Bilbao, 7 mayo 1603; Actas de la Tierra Llana. t. VII/ Bilbao, 13 mayo 1603. 1005 MADOZ, P.: 1845-1850; 470: t. 15. Reeditado por Editorial Ámbito organizado por provincias. Valladolid, p. 183.

1006 Tributo sobre los granos y legumbres que llegaban a su mercado.

1007 A. G. S./ Consejo de Hacienda, leg. 319/ San Lorenzo, 9 junio 29 diciembre 1590. 


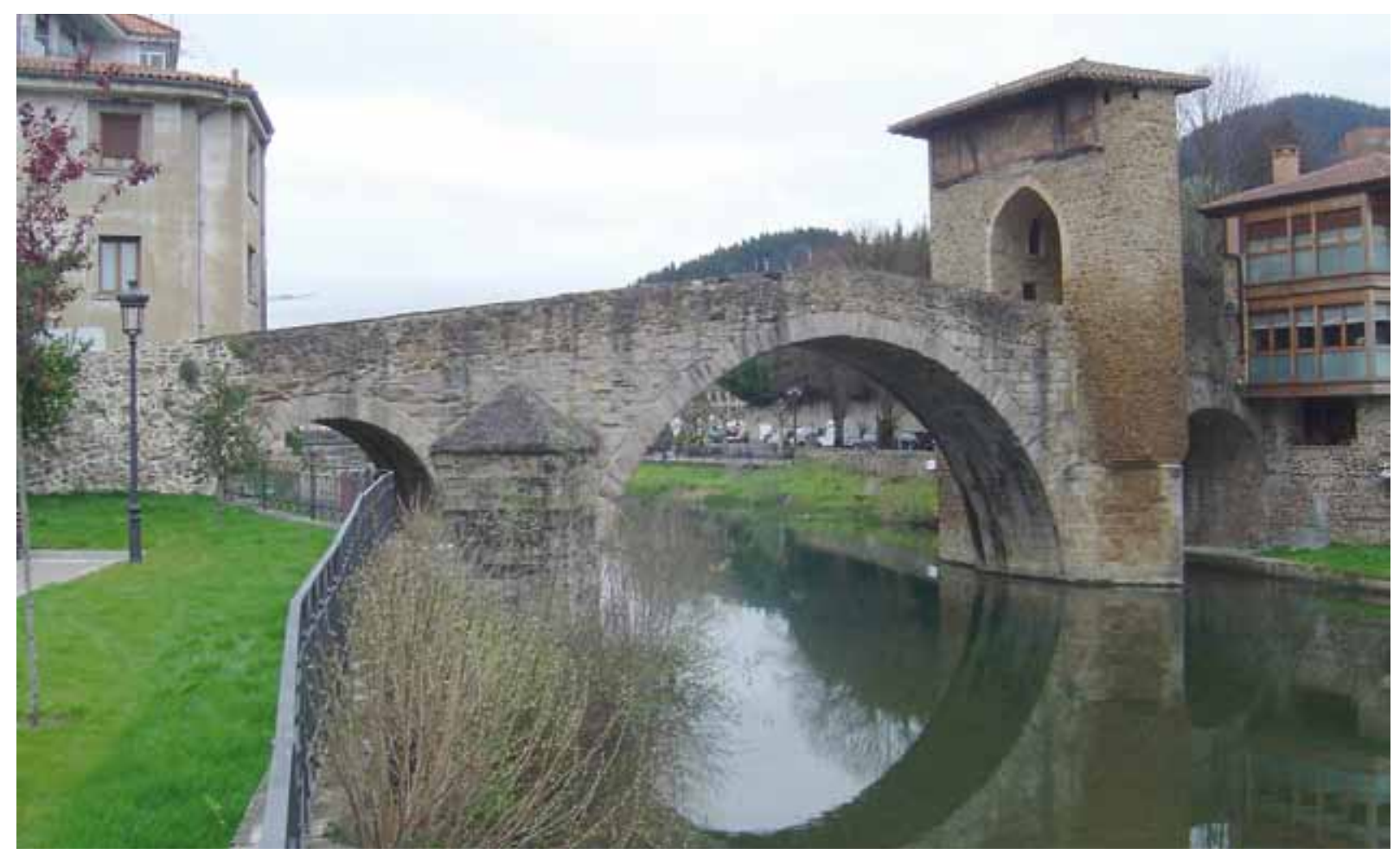

Puente de Valmaseda.

en la que residen los que cobran el pontazgo a los caminantes", donde Rosmithal y los suyos tuvieron un percance con los portazgueros por negarse a pagar el portazgo. En Valmaseda, dice "nos ocurrió un caso notable. Hay sobre este río [Cadagua] un puente de madera no muy largo, y en uno de sus extremos una torre de bella arquitectura, en la que residen los que cobran el pontazgo a los caminantes; cuando llegamos al puente, como no habíamos pagado esta especie de tributo en ninguna parte, nos negamos a hacerlo, y los caballos que llevaban nuestros bagajes fueron tomados por los publicanos y demás gente que había en la torre, que nos quiso matar. Para repeler el ataque apuntamos contra ellos nuestras escopetas; pero el Señor prohibió que se dispararan y que se tiraran flechas; porque si heríamos a alguno de aquellos, nos matarían a todos... Satisfecho este tributo, nos volvieron los caballos y recibimos las cartas preinsertas para que, si nos acontecía otra cosa semejante, estuviéramos con su protección más seguros"1008.

\section{La riada de junio de 1495 en la zona de Valmaseda}

A primeros de junio de 1495, hubo una gran avenida en Valmaseda. El concejo de 18 de junio dio carta de poder a Pedro Sánchez de Haedo, para comparezer ante los Reyes y su Consejo y oidores de su audiencia, y presentar petición sobre "el dapño que en esta su villa de Valmaseda fiso la aguada que ovo de benir, en que lebo las çercas y muros y rrondas y puentes y calçadas", para que lo manden remediar ${ }^{1009}$. En julio, García Ruiz de Hornillalatorre y Juan Ortiz de Villasante, procuradores de los mulateros de la ciudad de Burgos, condado de Vizcaya y Encartaciones, dijeron que aunque los Reyes habían mandado que no se cobrasen imposiciones

1008 ROSMITHAL DE BLATNA, Leon de: "Dos relaciones del viaje: de Shaschek y de Gabriel Tetzel"/ 1465-1467; GARCÍA MERCADAL, J.: 1952: 263-266 y 295-297: t. I; HERBERS, K. y PLÖTZ, R.: 1999: 108-112. 
a los mulateros en ciertos puentes y calzadas, salvo en aquellos donde los lugares eran los que los hacían a su costa, y como la lluvia que hubo en Vizcaya y Merindades, "lleuo todas las dichas puentes e calçadas de que la tierra quedo muy destruyda, de manera que los dichos mulateros e viandantes no pueden pasar por ellas de que rresçiben mucho daño", suplicaron al Consejo que mandase que los lugares donde se situaban los volviesen a hacer, y que si no tenían recursos, que se diese licencia para que paguen los que los utilizan, ya que ellos estaban dispuestos a contribuir. El Consejo acordó mandar a los corregidores de Burgos, Castilla Vieja, Encartaciones y tierra de Mena, que se informen sobre los puentes, pontones y calzadas que están dañados o destruidos, cuántos mrs. son necesarios para su reparo y quiénes deben contribuir, enviando la información para que el Consejo provea como más convenga a los lugares y mulateros y viandantes ${ }^{1010}$.

El concejo de Valmaseda informó a los Reyes que hacia el mes de junio vino "vna grand fortuna e tenpestad de aguas, que diz que llebo casas e viñas e molinos, e puentes e ferrerias, e heredades e vn pedaço de la çerca de la dicha villa, a no dexar cosa enhiesta e que sobre esto cayeron en los caminos muchas peñas e arboles, de que dis que estan çiegos e destroçados los dichos caminos, por manera que no puede entrar bastimento a la dicha villa, ni las vestias pueden andar de vna parte a otra", y "destruyo e desbarato el camino rreal y prinçipal que viene y va a Castilla para la villa de Valmaseda, y rronpio y... llevo dos puentes grandes que ende estauan de madera con dos lienços de la çerca de la dicha villa y con vn pedaço de la puente prinçipal de piedra della". Pedían licencia para poner imposición a vecinos, caminantes y pasajeros para realizar los reparos oportunos, porque de otra manera no lo podrían hacer. El Consejo mandó al corregidor del Señorío, que recabe información sobre los daños causados, cuántos mrs. necesitarán para su reparo, quiénes son los que se aprovechan de los caminos y deben contribuir, y dicha información la envíe al Consejo.

En agosto, en el campo de las Olías junto al río "de Todas Aguas"1o11 jurisdicción de Valmaseda, pareció ante el corregidor el procurador de Valmaseda para ver los daños con los canteros Pedro García de Herrada, vecino de Herrada, los hermanos Andrés y Juan García de San Mamés, vecinos de San Mamés de Aras, y a Juan de Ruesga, vecino de Rasines, y cinco vecinos de Valmaseda. Dijeron que han visto los puentes de San Cibtin y el otro que está en el camino que va a Castilla, y la calzada de Peña Tajada. Estiman que solo la intervención en los puentes, muros y Peña Tajada montaría unos 200.000 mrs. En cambio los vecinos dicen que romper las peñas y reparar los caminos, costaría entre 16.000 y $20.000 \mathrm{mrs}$. aunque no se podría reparar todo el daño causado. Los testigos de Valmaseda dijeron que los que más andan y tratan en la villa con sus acémilas, son sus vecinos y los de "la Junta e tierra e Valle de Mena, e toda la tierra e valle de Salzedo, e toda la tierra de Sopuerta, e valle de Galdames e Somorrostro e su tyerra, e Arzentales e Troçios e Carrança, e valle de Villaverde, y el valle de Gordojuela, e los de Arrigorriaga e Llodio e Luyando, e toda la tierra de Losa e los de Salillinas de Rrosio, e Medina de Pumar e toda su juridiçion, e Castilla Vieja e toda su juridiçion, e los del balle de Valdevielso e su Merindad e los de los Butrones que es Dobro e Villascusa e Pesadas y Masa e Santibañes e su tierra y la villa de Castro d'Ordiales, e la Junta de Samano, y otrosy suelen pasar e andar en esta villa algunas beses los de la tierra de Toro e algunos de Villabellad elos de las Nuebe villas de Canpos", y Montija, Tobalina, ciudad de Burgos, Sierra y Urueña.

1010 A. G. S./ Registro General del Sello, VII-1495, fol. 187/ Burgos, 9 julio 1495.

1011 Se refiere al río Cadagua. 
El corregidor realiza un informe sobre los daños que vio con los oficiales, y sobre la suma necesaria para su reparo, comprobando que los causó el río Cadagua junto con otros arroyos, que destruyeron el camino real de Castilla a Valmaseda, y muchas viñas, heredades y molinos, y llevaron dos puentes grandes de madera, con dos lienzos de la cerca de Valmaseda y una parte del puente principal, causando gran daño y la pérdida de los molinos. Serían necesarios entre 50 y 60.000 mrs. para que pudiesen transitar en invierno los mulateros con sus bestias, y "prinçipalmente los visinos de la dicha villa e dende fasia Burgos, todos quantos vienen e ban por el e las prouisyones que vienen e van a Castilla y de Castilla a Portogalete y a Biluao, y podrian y deberian contribuyr", y además para el reparo de los puentes serían necesarios otros 20030.000 mrs., debiendo participar en estos los mismos que para el camino ${ }^{1012}$.

Los mulateros y viandantes de Burgos y de Vizcaya dijeron a los Reyes que como la lluvia que cayó en Vizcaya y Merindades había destruido la mayor parte de los puentes, pontones y calzadas, no podían pasar por ellos, y pedían que se mandase al corregidor de Vizcaya que informase al Consejo Real sobre cuántos mrs. serían necesarios para su reparo y quiénes debían contribuir. Esto ya se trató en la Carta real que decía que para repararse los puentes, pontones, calzadas y caminos eran necesarios unos $150.000 \mathrm{mrs}$, , suplicando que se mandase hacer el reparo y se hiciese repartimiento entre los mulateros. El Consejo, mandó en agosto de 1495 al corregidor y a las justicias de Burgos y de las villas y lugares de Castilla Vieja y de las montañas y Valle de Mena que se hagan reparar, entre los pueblos en cuya jurisdicción están, los caminos, puentes y otros pasos destruidos ${ }^{1013}$. En septiembre, pareció el procurador de Valmaseda ante el corregidor, para que se informase sobre los daños en los puentes y caminos de Valmaseda, y que el Consejo Real mandase hacer repartimiento hasta $1.000 \mathrm{mrs}$, , entre los lugares que están a cinco leguas alrededor y las personas que utilizan dichos caminos ${ }^{1014}$. Una Carta real de octubre, decía que el concejo de Valmaseda volvió a pedir lo que ya hizo en julio para poder imponer alguna contribución entre los caminantes y pasajeros para pagar los aderezos, por no tener la villa propios para poderlo hacer, y se mandase obtener información sobre el daño hecho, los mrs. que costaría el reparo, y los concejos y personas que más se aprovechaban de los puentes y caminos. Hecha por el corregidor la pesquisa, el Consejo acordó mandar repartir entre los concejos que estuvieren en cinco leguas alrededor de Valmaseda, los 80.000 mrs. necesarios para reparar los caminos y rehacer los puentes derribados, repartiendo a cada uno lo que debe pagar según la utilidad y provecho que reciben ${ }^{1015}$.

\section{Riadas de junio y septiembre de 1553 en la zona de Valmaseda}

En abril de 1554, García de la Puente, fiel y procurador general de Valmaseda, otorga poder a Julián de Santiago, vecino de Valmaseda, y a Esteban de Corostiza y Pedro de Mena, residentes en Valladolid, para que pidan licencia a los Reyes con el fin de que el

1012 A. G. S./ Cámara de Castilla. Pueblos, leg. 21-2, doc. 185/ Burgos, 17 julio y Valmaseda, 10 agosto 1495; Registro General del Sello, VII-1495, fol. 259/ Burgos, 17 julio 1495.

1013 A. G. S./ Registro General del Sello, VIII-1495, fol. 260/ Burgos, 7 agosto 1495.

1014 A. G. S./ Cámara de Castilla. Pueblos, leg. 21-2, doc. 184/ Bilbao, 5 septiembre 1495.

1015 A. G. S./ Registro General del Sello, X-1495, fol. 124/ Burgos, 8 octubre 1495. 
concejo pueda repartir los mrs. necesarios a los mulateros y trajineros, para el reparo de los caminos de Peña Tajada que se cayeron con las riadas del año 1553. Julián de Santiago dirigió un escrito al Rey, en el que dice que Valmaseda es la villa "mas pasagera de caminantes y recueros y mulateros que ay en toda la montaña, y tiene vn camino que se llama Peña Tajada, que es junto a la dicha villa de Balmaseda y pegada a una peña alta, y por debaxo del dicho camino ba vn rio caudal y el dicho camino es muy angosto, y las abenidas de las aguas deste ynbierno an sido tantas, que an derrocado y llebado la dicha calçada y camino por manera que no se puede pasar y si alguno pasa es con gran peligro", por lo que conviene que el camino se repare, siendo necesarios para ello más de 400 ds. Pero como la villa no tiene propios y como los mulateros que "ban con mercadurias a las villas de Bilbao, Portogalete, Castro de Hurdiales y Bermeo y la prouinçia de Guipuzcoa, y en retorno buelben con otras mercadurias a estos Reynos de Castilla,... pasan por el dicho camino y no tienen otro", no dejarán de contribuir a su aderezo. Y como no hay otro medio, pide licencia para echar sisa por un año entre los recueros, mulateros y viandantes hasta 400 ds., y se cobren por una persona abonada para que maestros expertos lo hagan aderezar. García de la Puente pidió al Rey licencia para cobrar a los viandantes las cantidades necesarias, y poder recibir información de testigos, preguntando si conocen Valmaseda, el río Cadagua y otros arroyos que pasan junto a la villa, los caminos reales y los puentes que están a la salida de la villa por donde se pasan los arroyos del Campo y de Fuera la Villa, y si tienen noticia de las dos avenidas que hubo en 1553 en el río Caudal y arroyos, una en junio y la otra el 14 de septiembre. También si saben que:

- En la riada de junio, el agua del arroyo de la Piedra bajó por el camino real, calzada y cuesta que dicen de la Piedra abajo, arrancando las paredes de la calzada, de manera que se desbarató el camino real que va a las Encartaciones, Portugalete, Castro-Urdiales y Laredo, y necesitaba rehacerse ya que no se podía pasar.

- La creciente del arroyo Fuera de la Villa, descalzó el puente por ambos lados, y arrancó las piedras de sus cimientos y las paredes de la orilla junto a él, y si no se repara brevemente, le podría acabar de llevar el río si viniese otra creciente, y si saben que el otro puente del arroyo del Campo en la villa necesita aderezarse.

- La crecida del Cadagua de septiembre, hizo mucho daño en los caminos reales de Peña Tajada, porque llevó gran parte de las paredes que los sostienen y defendían del agua para que no se derrumbasen hacia el río, y además de lo que se llevó de las paredes y camino, mucha parte de él quedó atormentado y que si no se aderezan las personas, ganados, machos, acémilas y otras bestias que por ellos pasan, corren gran riesgo de caer al río Caudal y difícilmente se podrán andar.

- La villa está pobre y adeudada en mucha cantidad y no tiene propios ni rentas para reparar dichos caminos, por lo que no se podrán aderezar los caminos y puentes mejor ni con menos daño y brevedad, que echando el coste de sus reparos a los que pasasen por ellos, por ser los que más provecho recibirán.

- Para los reparos de los caminos de Peña Tajada, calzada de la Piedra y puentes de Fuera la Villa y del Campo se gastarán más de 300 ds.

Ante el alcalde ordinario, pareció García de la Puente y presentó por testigos a cinco vecinos de Valmaseda, que dijeron que conocen el río Mayor de Cadagua que pasa junto a los muros de la villa, los dos arroyos y puentes de la villa, y el camino real de Peña Tajada 
"que biene de anzia el Valle de Mena y Lossa y Castilla" y los otros lugares, villas, caminos y arroyos. Recuerdan que la avenida de junio hizo daño en el camino de la Piedra, ya que entró por el camino de la calzada abajo y arrancó mucha parte y piedras de él, por lo que la villa y sus vecinos volvieron a hacer la calzada a su costa, porque no se podía pasar si no se aderezaba. Un testigo dice que "bio como al tiempo de la dicha creçida... paso por la dicha calzada que ba el camino rreal..., que hera una ora o dos antes que biniese la dicha avenida, que a la buelta que bolbio a la dicha villa, bio como la creçiente de la dicha agua, abia quitado toda la calzada que estaba hobrada en junto de la peña y lo rredoco todo y lo llebo por alli abaxo". Vieron cómo la avenida llevó parte del puente de Fuera la Villa y lo descalzó, y está muy peligroso porque una nueva avenida se lo puede llevar, por lo que les parece que es muy urgente su reparo y reedificación, y que el puente del arroyo del Campo de la Villa, está desbaratado por los caireles y también necesita reparo.

Asímismo, han visto cómo las avenidas de septiembre, llevaron las presas de la herrería de la villa, y derribaron mucha parte de los caminos de Peña Tajada hacia la parte del río Mayor, y las paredes de hacia el arroyo cayeron y se hundieron hacia el río, de tal manera que "con mucha dificultad puede pasar una azemila sola, y en ninguna manera pueden pasar dos a causa del dicho hundimiento de calzada e petriles de paredes que estaban hechas para rretener el dicho camino", y si no se repara se acabará de perder y no podrán pasar recuas, viandantes, ni peatones por estar muy peligrosos. En los caminos de Peña Tajada, correrán mucho riesgo las personas y las acémilas, recuas y machos que por él pasaren, por ser como es camino arrimado a una peña muy alta, sin poder hacerlo por otra parte. Saben que la villa no tiene propios ni rentas con que poder realizar los reparos y que está pobre y endeudada. Creen que lo más conveniente para obtener los mrs. necesarios, es que se cobren a los viandantes, trajineros y mulateros que por ellos pasan, como se hace en las Encartaciones "porque todos los caminos son vnos y los azen a costa de biandantes". Para reparar y reedificar los caminos y puentes como conviene, les parece que son necesarios más de 300 ds., porque el camino está en peña viva que se ha de cortar. Vista la información, el Consejo Real dijo en junio de 1554 que no ha lugar a lo que pide Valmaseda, y que si quisiere la carta ordinaria para que cada uno en su jurisdicción adecue los puentes y caminos conforme a la ley, que se le dé1016.

\section{Provisión de 1589 para los puentes del Valle de Mena y "el andilubio" de 1593}

Juan de Vergara en nombre del Valle de Mena y de la villa de Villasana, informó al Rey que en el Valle "auia mas de cinquenta puentes de piedra y madera en tres rios crecidos y caudalosos, que por el pasauan por donde se ba y benia de todas las partes de Castilla a ese correjimiento y Señorio con diuersas mercaderias y pertrechos, muniçiones y bastimentos que con carros y caualgaduras selleuauan, ansi para nuestras armadas que de ordinario se juntauan y hacian en aquella costa, como para el Señorio de Uizcaya" y otras partes, "y las crecientes y auenidas que de ordinario se sucedian, derrocauan y lleuauan las dichas puentes y quedauan los caminos cerrados por muchos dias, sin se poder andar ni trajinar por ellos a causa de no poder badearse los dichos rios, de lo qual se recreçia estar muchas jentes, carros y requas detenidas, sin poder acudir a las cosas de nuestro seruiçio, con la dilijençia y vreuedad que conuenia y por otra parte cesaua la prouision que al dicho Señorio de Vizcaya y a las montañas se lleuaba que por no cojerse pan y vino en ellas", y la gente padecía necesidad sobre todo en tiempo de invierno. Además como los bastimentos en tiempos

1016 A. G. S./ Consejo Real de Castilla, leg. 504-14/Valmaseda, 24 abril 1554. 
semejantes elevaban el precio, muchas personas con riesgo por la ganancia, se atrevían a pasar los vados y remansos de los ríos, y perdían las cabalgaduras y mercaderías sin poder ser socorridas, y como los ríos eran tan furiosos y caudalosos no admitían barcas.

Todo cesaría si los dichos puentes o "en particular quatro dellas que eran las que llamauan la puente de Renero y la de Naua y la de Villasana y la de Burçeña por ser las mas neçesarias", estuviesen siempre reparados para tener paso franco, los cuales eran tan grandes y llevaban cada año tantos reparos, que por ser el Valle y villa pobres, no tenían propios y no los podían tener como convenía, por lo que la mayor parte estaban hundidos; y además, el Valle tenía tantos caminos y calzadas que cada año se repartían por el corregidor más de 200.000 mrs. para repararlos y no bastaban, con lo que estaban sus vecinos fatigados y eran tan pobres y pocos, que en estos repartimientos y en los que se les hacían para los puentes de Valdeporres y Quintanilla de Pienza, de más de 100.000 mrs., se les consumían sus haciendas. Por ello Vergara pidió que se mandase que los puentes se aderezasen, y que lo que costare se repartiese entre las poblaciones de 20 leguas alrededor. El Consejo manda, en junio de 1589, al corregidor de las Cuatro Villas que vaya al Valle de Mena y Villasana, y se informe sobre los puentes afectados, en qué ríos están y a qué partes conducen, qué necesidad tienen de repararse, qué cantidad será necesaria, y si el Valle y villa tienen propios y rentas y si será bueno repartirlo entre las localidades de 20 leguas en contorno, y la información con su parecer y las cuentas de los propios y rentas del Valle y villa y de lo que rentan, lo envíe al Consejo para que se provea justicia. En Laredo, en julio de 1589, compareció el procurador general del Valle y requirió al corregidor con la Provisión real, para que vaya al Valle de Mena y haga la averiguación que en ella se le manda. El corregidor remitió el asunto a su teniente en el Valle, ante quien compareció el procurador general y le requirió con la Provisión, para que vea el estado de los puentes y caminos.

Nada se hizo en 4 años, ya que en abril de 1593 se volvió a requerir con la Provisión real de 1589 al corregidor y justicia mayor de las Cuatro Villas. El corregidor remitió de nuevo el cumplimiento de la Provisión a su teniente en el Valle de Mena. Pero con motivo de una gran inundación o "andilubio" ocurrido en septiembre de 1593, se reactivó el asunto de una manera acuciante, ya que los puentes del Valle "quedaron del dicho dilubio de septiembre ultimo, maltratadas y muchas del todo llebadas". En la audiencia de Villanueva de Mena, en noviembre de 1593, el procurador general del Valle requirió al teniente de corregidor y este, mandó a los maestros canteros y carpinteros Juan de Madrid y Francisco de Hano, vecinos de Escalante merindad de Trasmiera, a Toribio del Campo, vecino del valle de Hoz de Anero en la junta de Ribamontán, y a Juan Zorrilla, vecino de Agüera de Montija, que fuesen con él para ver y tantear todos los puentes de Mena, especialmente los que están en los caminos reales. Las actuaciones que se proponen, se detallan en los apartados de los diferentes caminos.

Ese mes de noviembre, el teniente de corregidor y juez de comisión tomó en el Berrón juramento como testigos a los arrieros Pedro Sainz vecino de Báscones de Ebro, Tomás López Borricón vecino de Hornillayuso, Pedro Ruiz vecino de Ahedo del Butrón, Hernando de Pereda vecino de Pereda, Diego de Pereda vecino de las Hornillas, Juan Martínez vecino de Miedes de Atienza, Francisco María vecino de Galve de Sorbe, Juan Pérez vecino de Cadima tierra de Ayllón, Ortega de Prado vecino de Cantabrana, Juan Roldán vecino de Miedes de 


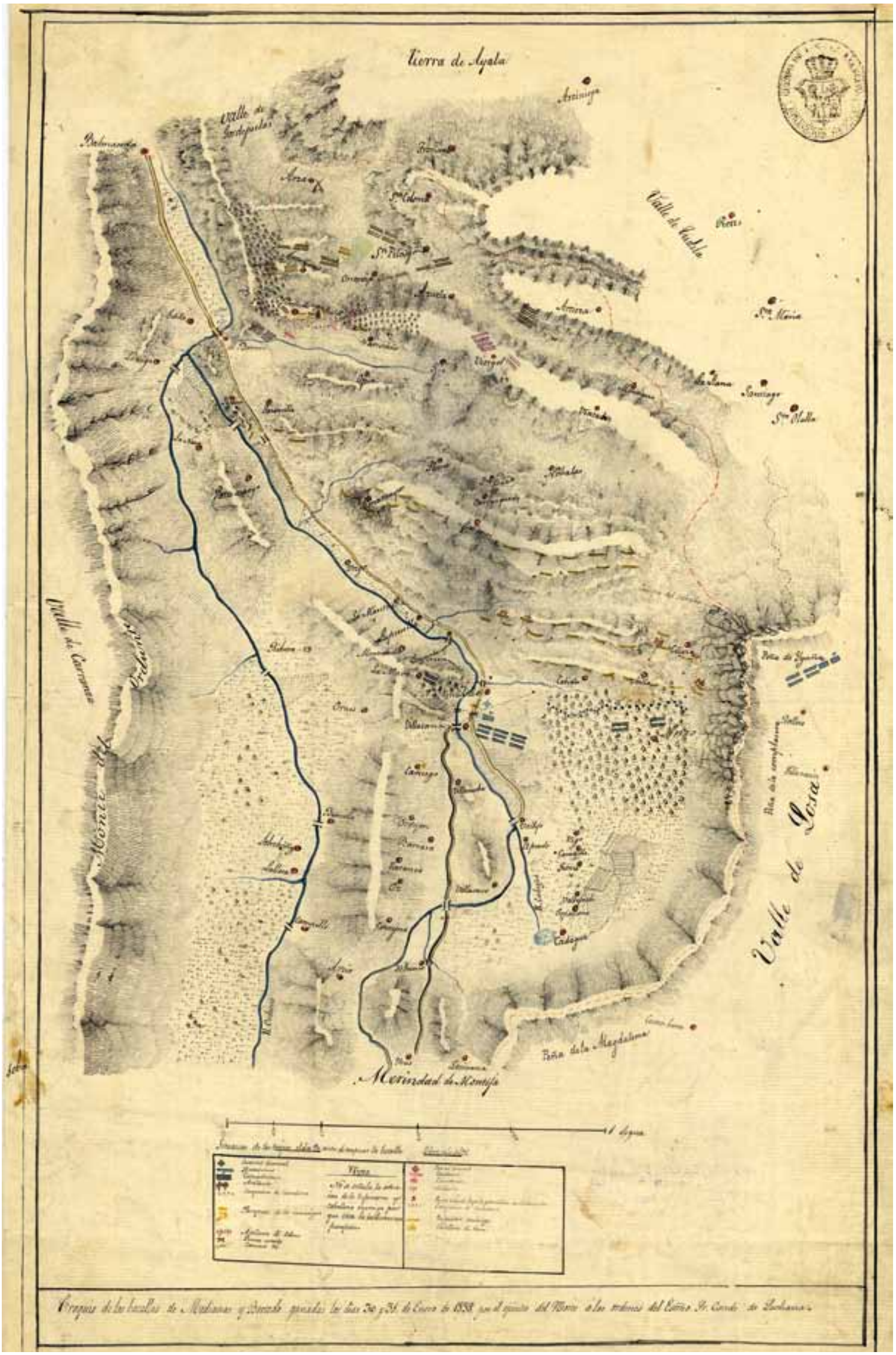

Croquis de las batallas de Medianas y Bortedo en Mena en 1838 con el camino por Villasana y Valmaseda (ARCGE Ar. E-T.6-C-1-117). 
Atienza y a Francisco Negro vecino de la villa de Madrid. Dijeron que conocen los caminos reales del Valle de Mena y sus puentes, porque son arrieros trajineros ordinarios, y han pasado por ellos con sus recuas desde muchas partes de Castilla la Vieja y Nueva y La Rioja, a la villa y aduana de Valmaseda y villas y puertos de Bilbao, Castro-Urdiales, Portugalete, Bermeo, Lequeitio, San Sebastián del Pasaje y a las ciudades y ferias de Orduña, Vitoria y Nájera, Encartaciones y Vizcaya, y a las villas y puertos de Laredo y Santander con bastimentos de aceite, pan, vino, pescado y otras mercaderías para provisión de las armadas del Rey y otras veces suyos propios o de otros mercaderes particulares por alquiler y compradas.

Añaden que todos los puentes están sobre ríos caudales y caminos reales, donde hay muchas herrerías, molinos y caminos forzosos para las dichas villas y puertos y de allí a Castilla. Los que están en pie necesitan repararse y los caídos ser levantados con brevedad, porque los testigos y otros muchos viandantes, han estado detenidos diversas veces varios días con sus recuas y cabalgaduras y sin ellas, por no poder pasar por las grandes crecidas que tienen al ser tierra montañosa y áspera, donde sus avenidas hacen mayor daño en puentes y caminos. Les parece que su reparo se debe repartir en las localidades de 20 leguas en contorno, porque la tierra es dispersa y de poca vecindad, y además pagan sus puentes y otros de fuera por mandato del Rey, además de los millones y alcabalas con que le sirven. Reparan las calzadas de los caminos del Valle y los puertos y peñas de Lanzas Agudas, Tejeda o Raisada, Cabrio, La Magdalena, La Complacera y la peña de Igaña, "que todos son caminos enpedrados y de mucha costa". Han oído quejarse en las posadas del Valle a huéspedes, mesoneros y vecinos, de que el Valle no tiene propios ni rentas, y tan solo unos 1.000 vecinos, la mayoría tan pobres que, a causa de tantos repartimientos como pagan, muchos se han ido. Añadieron que han visto ahogarse en dichos ríos algunas personas y muchas cabalgaduras y otros ganados y animales, por la falta o deterioro de esos puentes.

El procurador general del Valle de Mena, dice que para que el Rey dé licencia para el reparto de esos puentes, se presente la información al Consejo con su parecer. En diciembre Domingo de Villanueva, juez de comisión para el cobro de las alcabalas del Valle, no halló propios, juros, rentas ni otros aprovechamientos. Solo había en algunos lugares "tabernas y panaderias, que unos a que rinden algo y otros no nada", y que ello y toda la alcabala de lo vendido, no llegaba a $68.000 \mathrm{mrs}$. la mitad de los $136.000 \mathrm{mrs}$. que cada año paga el Valle de alcabala, y consta que sus vecinos pagan los millones y otros repartimientos para puentes y lo que falta de las alcabalas. Además había en mayo de 1593 en el Valle 1.081 vecinos, de los que se han desavecindado algunos por ser pobres y no poder pagar los millones y repartidos ${ }^{1017}$. Nada sabemos de cómo acabó este asunto por no haber encontrado dato alguno sobre su resolución.

\section{La cuchara de las oturas de Valmaseda}

El merino mayor de Valmaseda, tenía el cargo de recaudar un tributo llamado oturas que, mientras estuvo vigente, fue muy gravoso para los que llevaban granos y legumbres a su mercado. Consistía en que cada bestia que llegaba de fuera al mercado de Valmaseda 
con trigo o cebada, pagaba cuatro o 5 mrs. y por cada fanega de los mismos granos, dos cucharones que medían como medio cuartillo que venían a montar cada 2,5 fanegas un celemín sin rasar. En 1420 Diego López tenía arrendadas las oturas, y pretendió cobrarlas de varios trajineros y moradores del solar de Mediavilla, Cubillos de Losa, monasterio de Tabliega y otros lugares de las merindades de Castilla Vieja que habían ido con granos al mercado de Valmaseda y se negaron. Diego López presentó demanda ante el alcalde, y los demandados alegaron que sus solares tenían antiguos privilegios confirmados hasta por Juan II, eximiéndolos de oturas, martiniega y otros tributos. El alcalde falló que los demandados estaban libres de oturas y del pago de cualquier otro derecho. Se volvió a suscitar semejante demanda con vecinos de los mismos pueblos en 1442 y 1495, y los alcaldes de Valmaseda fallaron de la misma manera. En 1499, el alcalde y el corregidor de Vizcaya en apelación, absolvieron también a los de Zalla de pagar oturas de cuantas mercaderías, vituallas, trigo, cebada, centeno, borona, mijo y otros productos llevasen al mercado de Valmaseda1018.

Con el malestar que provocaba un tributo que los perjudicados consideraban injusto, se llegó a 1590 en que por muerte de Puente Hurtado de Mendoza, quedó libre el oficio de merino mayor. El concejo del Valle de Mena, informó al Rey sobre esta vacante, con cuyo oficio, todos los que lo han poseído han cobrado a los vecinos del Valle y demás comarcanos, "çierto derecho e nueba ynpusiçion que llaman oturas, que es que del trigo que se lleba a bender al mercado de la dicha billa toman çierta medida pequeña y de otras personas çiertos mrs.", soportando molestias y vejaciones por parte de los merinos y sus arrendadores. Aunque han pretendido su eliminación por considerarla injusta, se aplazó hasta que el oficio vacase, y así pedir la concesión del dicho oficio de merino mayor de Valmaseda. El Rey manda en junio de 1590 al corregidor de Vizcaya, que se informe sobre quién, en qué forma y con qué título ha usado el dicho oficio y cobrado esa imposición, y desde cuándo y qué daños e inconvenientes se causan por ello y a quién, y si convendría anular el oficio o concederlo a Mena para que lo cobre la persona nombrada cada año o redimirles de ese derecho; y en caso de que esto se hiciese, cuántos mrs. serán los justos respecto a la calidad, derechos y aprovechamiento que con él tienen los que lo usan, y todo lo envíe al Consejo. En noviembre de 1590, Francisco Ortiz de Velasco vecino y representante de Mena, presentó la Cédula real al corregidor para que la mande cumplir, dando comisión al teniente general de las Encartaciones. Ortiz presentó a nueve testigos vecinos de Villasana y cinco vecinos de Valmaseda y dijeron:

- Que conocen el oficio de merino de Valmaseda y exacción de oturas a él anexas, por haber visto usar y ejercer el dicho oficio y cobrar las oturas, y conocieron a Puente Hurtado de Mendoza último tenedor del oficio de merindad y oturas, y ahora por su muerte hará unos 6 meses, el dicho oficio está vacante.

- Que Puente Hurtado, tuvo y administró el oficio de merindad de Valmaseda por más de 30 años, y que lo compró a Tristán de Leguizamón, vecino de Bilbao, que lo había tenido unos quince años, poniendo por merino y cobrador a Fernando de los Llamos y García de Marquina, vecinos de Valmaseda, que traían vara de justicia y cobraban en su nombre las

1018 MADOZ, P.: 1845-1850: 475-476: t. 15. Valmaseda. 
oturas del trigo y cebada. El oficio de merindad y exacción de oturas, se suele arrendar por unos 50 ds. al año, y hubo un arrendamiento de 4 años a Puente Hurtado y Constanza de Carranza viuda de Martín de Liendo por dicha cantidad.

- Que el derecho y exacción de oturas, es llevar "una cucharada de cada anega de trigo o çebada que se entra y lleba a la dicha billa de Balmaseda y a sus mercados, bendiendose en el mercado de la dicha billa y esto se lleba a los bezinos del dicho balle de Mena, que lleban el dicho trigo a la dicha uilla de Balmaseda, y ademas [han] oido dezir... que a çiertos uezinos de Losa que es arriba de la peña de la Madalena, les lleban de la dicha exaçion de oturas çiertos mrs. de cada carga de trigo", que "son çinco mrs. de cada carga de bestia".

- Que hará unos 45 años, la ejecución de oturas "ha seido y es ynpusiçion ynjusta", causada por los administradores de la vara de merindad por ser poderosos, y se dice que se lleva sin título ni causa legítima. Dicen que se les hace notorio agravio y que, aunque han pedido que se les muestre el título para llevarlas, no lo han podido mostrar por no tenerlo, y además, sus mayores también se habían quejado de este cobro. Uno de los testigos, "ha uisto quexarse y rreclamarse dello a muchos bezinos del dicho ualle de Mena y Losa,... que fue en el año de setenta e uno, siendo este testigo alcalde en la dicha uilla, algunas personas del dicho balle de Mena se quexaron de Martin de Liendo y su muger, a cuyo cargo estaban las cobranças de las dichas oturas por mano del dicho Puente Hurtado, deziendo que por su autoridad les quitaban las prendas y los molestaban", y el testigo mandó por auto a "Martin de Liendo mostrasse titulo, rrazon e caussa por donde quitaba las dichas prendas y llebaba las dichas oturas, y... Martin de Liendo no le mostro", ni lo ha "mostrado hasta agora".

- Que algunos de Mena no pagan las oturas, como Francisco Ortiz de Medianas que "hera honbre poderoso en el dicho balle de Mena, e bendia mucho trigo e çebada en la dicha billa de Balmaseda". Tampoco el comendador de Vallejo ni los habitantes de su encomienda, ni los vecinos de Villasana que es del Condestable, ni este por la hacienda que tiene en el valle, y creen que este derecho, "fue ynpusiçion causada por los administradores del dicho ofiçio de merindad", de forma que los que "pagan en el dicho balle de Mena, fue por ser gente pobre e ynorante y por ser oprimidos e molestados" y no saberse defender. Aseguran que tampoco las pagan "los abades seglares de Siones y Bibanco, y los clerigos del dicho balle de Mena... ni la hazienda del arçobispo de Burgos ni del cabildo de las yglesias, de forma que los poderosos no [las] pagan". Añaden que "no ha auido ni ay tasa ni medida çierta, mas de una cuchara que sacan corronbada de cada talegada, y dos si ai dos anegas en el costal". Otro testigo dice que "tienen en su mano creçer y menguar la dicha medida pues que no ay bisita della ni padron con que la cotejar".

- Los que tienen su cobro a la entrada del mercado, "les suelen quitar las prendas para segurarse de que no saldran de la uilla, sin pagar el dicho derecho de trigo e çebada en abriendo sus talegas, e los molestan con rrigor y axperidad y muchas uezes despues de auer pagado, los ha bisto este testigo andar molestados aguardando por ellas y trocandoseles algunas bezes, y otras bezes ha bisto quitarles las jaquimas de las bestias", y han visto "andar los tales a buscar la prenda a unas partes y a otras en que padesçen trabajo, y aun algunas bezes han bisto pleito sobre el volver de las dichas prendas", y "no traiendo çedula, los hazen volver de la puente de la dicha billa, y se les causan otras bexaçiones e molestias e muchas bezes los ha bisto quexarse dello a la justiçia de la dicha billa" por la detención, y otras veces de noche no los dejan salir.

- Por los inconvenientes que a los vecinos de Mena se les causan, "procuran en el mercado de... Balmaseda bender mas caro su trigo y çebada que es daño general, e aun muchos no acuden al dicho mercado por no pagar las dichas oturas", y otros muchos "lleban a bender el dicho trigo y çebada a Arziniega y al balle de Cordojuela e a otras partes mas lejos", "aunque se les causan mas costa e trabajo y dizen que lo quie- 
ren mas bender en otra parte un rreal menos en la anega que no en la dicha billa", y "otros muchos que pueden, detienen en su casa los dichos trigos y çebada y lo benden en ell a en los tiempos mas caros del año", "haziendo juramentos que por rrazon de no pagar las dichas oturas no lo an de traer en su bida a bender al mercado de la dicha billa", lo que provoca carestía y daño general a Valmaseda, a las Encartaciones, y principalmente a las personas pobres y necesitadas.

- De redimirse esta exacción, cesarían todos los daños e inconvenientes declarados, se beneficiaría Valmaseda y todas las comarcas, y estaría el Rey "mas bien servido, porque acudiria mucha mas gente al mercado de la dicha billa, y se aumentaria el comersio e trato della porque baldrian mas baratos los trigos y çebadas", y sería más útil al patrimonio real el redimirse esta exacción.

- Si se vende o se da de otra manera este derecho y oficio en caso de que deba ir junto, el que lo llevaría más a propósito sería el Valle de Mena, porque así cesarían los daños declarados, no pagarían sus vecinos las oturas y sería beneficioso para Valmaseda, porque se acudiría con más voluntad a vender sus trigos y cebadas a su mercado, valdría más barato y estaría mejor provisto. Además en Mena hay muchos caballeros y gente noble y honrada, y sus habitantes han hecho muchos servicios a la Corona en la guerra de Cranada, en tiempo de las Comunidades, en la jornada de Navarra y en Flandes e Italia, y además personas señaladas han salido "con much a presteza a la defensa de los puertos de la mar, abiendo rrebatos como ha auido".

En noviembre de 1590, Francisco Ortiz dice que para más prueba, se deben sacar las escrituras de los arrendamientos que con el oficio de merino ha tenido Puente Hurtado. Se hallaron dos, una de mayo de 1588, en que Puente Hurtado da en arrendamiento por 4 años a Constanza de Carranza viuda de Martin de Liendo vecina de Valmaseda, las oturas y rentas reales "que se cobran en los mercados rreales y puente de la dicha villa, asi en trigo y çebada como en dinero", y cobrará en su nombre y para ella todos los derechos, pan y dinero a él pertenecientes como tal merino mayor, y le da poder para que lo pueda cobrar por 200 ds. por los 4 años, y otra de noviembre de 1588 , en que Puente Hurtado concede otra carta de arrendamiento a la misma por otros 2 años, entre San Miguel de septiembre de 1593 y el de 1595.

En diciembre de 1590, el corregidor de Vizcaya dice que parece que el oficio de merino mayor fue de Tristán de Leguizamón y después lo tuvo Puente Hurtado de Mendoza, que llevaron el derecho de oturas, "que es una cucharada de cada media anega de trigo y cebada", y que los que lo han tenido arrendado hacen muchas vejaciones y molestias a los vecinos del Valle de Mena, y algunas personas principales y lugares que no lo han querido pagar no lo han hecho, pero que los pobres que no tienen poder para defenderse, son los que padecen molestias y daños y que por esto el trigo se encarece en los mercados de Valmaseda.

Pedro de la Puente Hurtado de Mendoza hijo, suplicó al Rey que le conceda el dicho oficio, ya que por privilegios reales del Señorío de Vizcaya, se ha hecho merced a Valmaseda para que los oficios realengos y derechos a ellos pertenecientes que vacaren, se den a los hijos mayores de los caballeros e hidalgos y no a otros, sin que se hayan vendido jamás ni el Rey consentido, para que los tengan los caballeros del Señorío de Vizcaya, y asimismo están probados los muchos y notables servicios que su padre y sus antepasados han hecho al Rey. Mena alega que sus vecinos quieren eliminar la vejación y molestia que se les hace, a causa de que como todos los oficios de gobernación son anuales y no hay otro voto perpetuo sino el de la dicha merindad, el que tiene el título de ella ha nombrado cada año a quien ha querido, muchas veces "botando por ombres debiles y bajos ofiçios, y ponyendo en 
mano dellos el gobierno". Solo pretende que no se le cobren las oturas por ser daño de toda la montaña y, por ello, el Rey debe denegar a Hurtado hijo la remisión que pide, y mandar que el Consejo de Hacienda tome resolución con el dicho Valle sobre el derecho de oturas para que finalice, que además de ser en utilidad y provecho del real patrimonio, el Valle recibirá particular bien ${ }^{1019}$.

Propusieron los meneses capitalizar la renta por 1.435 .365 mrs. y admitida la propuesta, se les declaró por Cédula real de 24 de marzo de 1597, dueños de las oturas de Valmaseda pudiendo arrendarlas, administrarlas o consumirlas. En abril el teniente de corregidor y los procuradores de Mena, recibieron en Valmaseda al fin, el cucharón de cobre y el sello de hierro, con que se sellaban las cédulas y albalaes que se daban a los trajineros y otras personas que querían salir de la villa en sus cabalgaduras ${ }^{1020}$.

\section{b.- Variante en el Valle de Mena por Burceña}

Denominado "camino real de la Ordunte", es una variante dentro del Valle de Mena del camino ya tratado que va por Valmaseda, y estuvo también muy transitado. Iba desde Irús por Arceo, Burceña y puente de Ranero y Nava de Ordunte donde junto al puente de Nava entroncaba con la vía principal que venía de Villasana. Incluía los puentes siguientes: Irús sobre el río de Cabrio o Hijuela, uno más arriba de Burceña, Burceña y del Ranero, sobre el río Monte u Ordunte.

El camino se encuentra recogido en todos los itinerarios publicados desde el siglo XVIII. Así el Itinerario Español de Matías Escribano de 1758, lo incluye con el título Camino de ruedas para Bilbao ${ }^{1021}$.

Ya en agosto de 1483 el arriero Fernando Sáez de Fresnedo, vecino de Villanueva la

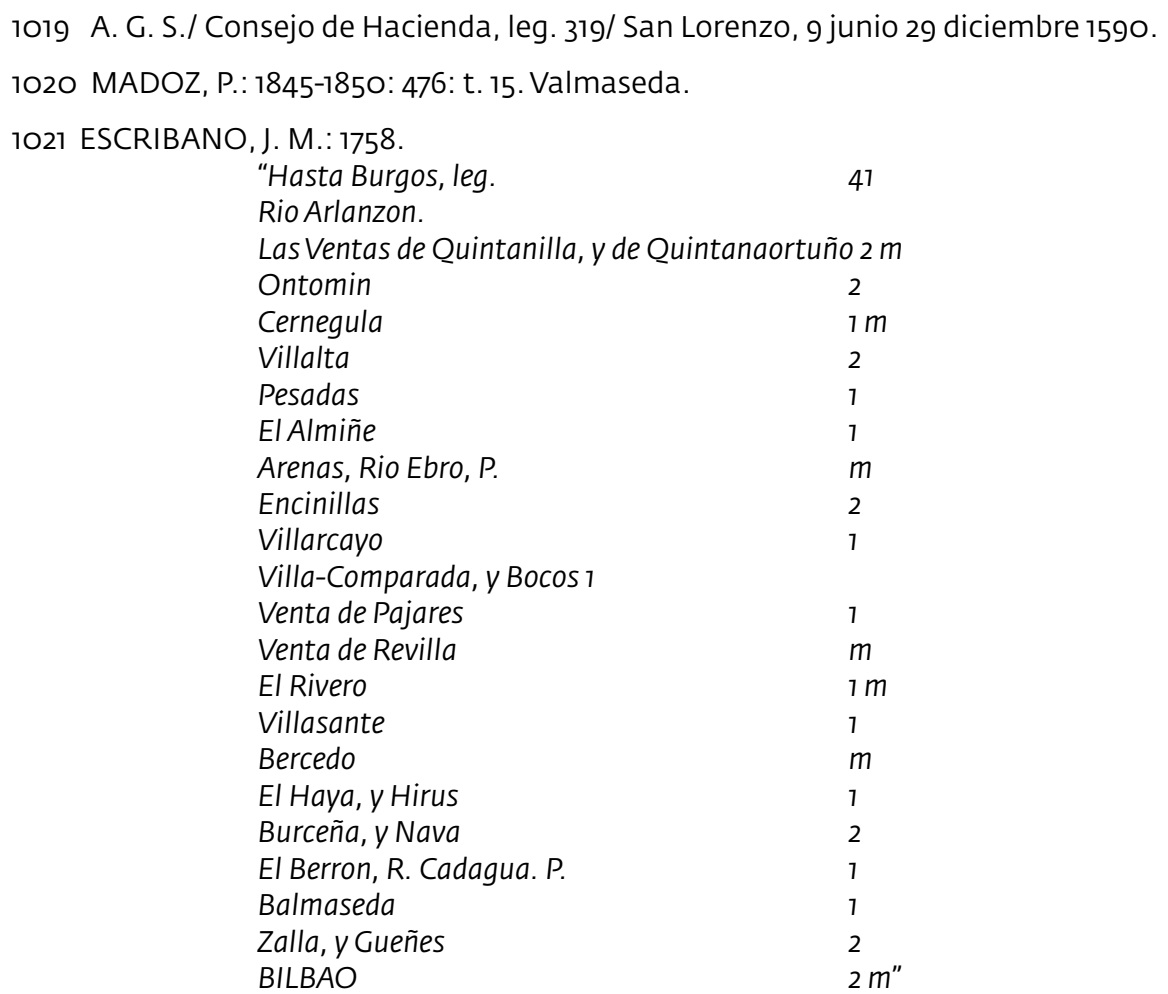




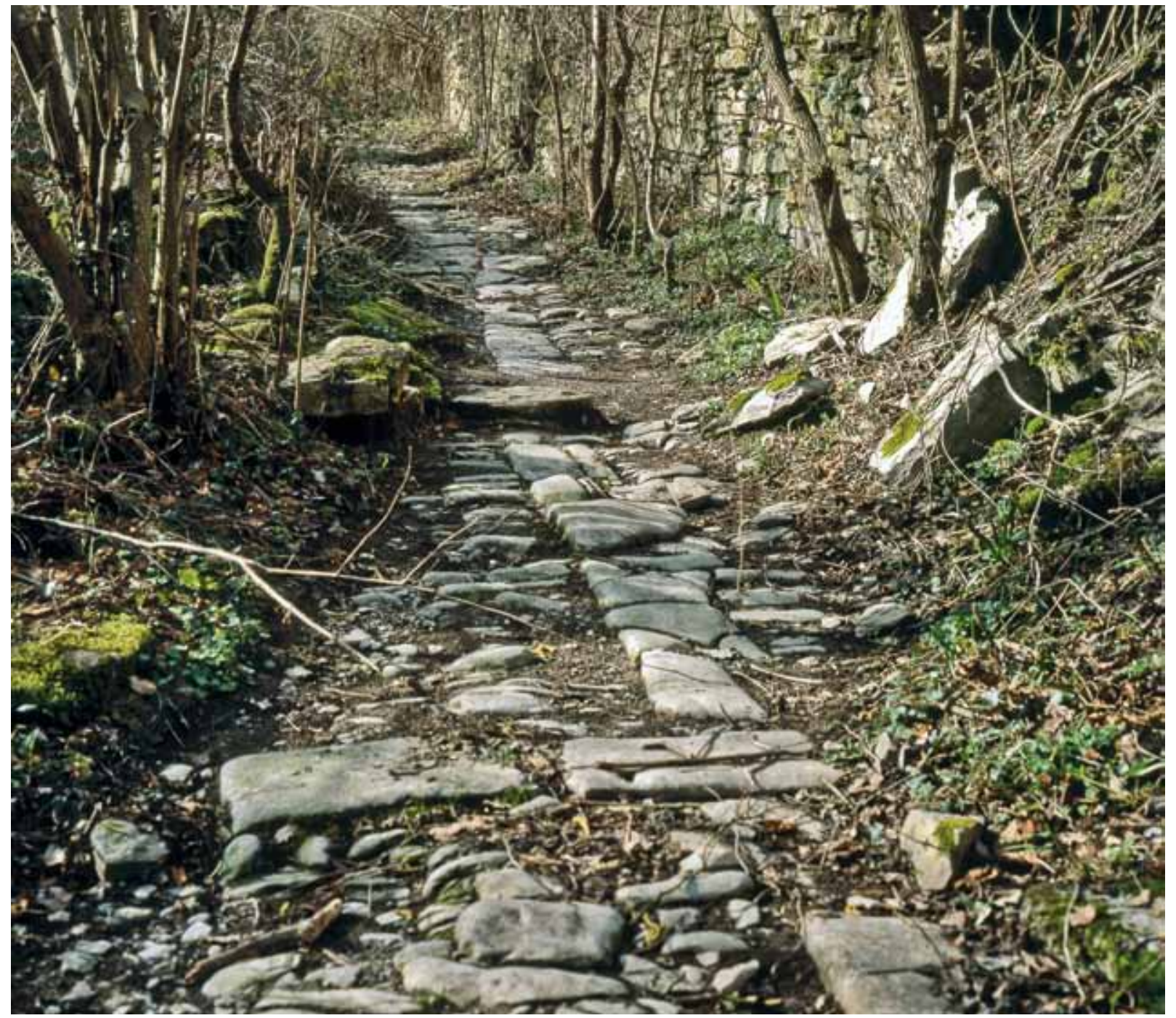

Empedrado del camino de Ordunte entre Irús y Arceo (Foto SANTIAGo Alonso).

Blanca, en nombre de los mulateros de Castilla Vieja, la Sonsierra y hermandad de Dobro, Villaescusa y Pesadas, dijo a los Reyes que "de tienpo ynmemorial a esta parte, continuamente los mulateros e biandantes de Castilla Vieja e de las otras partes destos nuestros Rreynos, han ydo e pasado libremente con sus mulos e vestias por el camino rreal que disen de la Vrdunte que va a Castro e a la villa de Viluao por el Valle de Mena", pero que desde hacía unos 8 años, el concejo y alcaldes de Villasana y el merino del Valle de Mena, los prenden en dicho camino obligándolos a ir por el de Villasana, "ques mas largo e mas fraguoso que no el dicho camino del Ordunte por donde diz que sienpre acostunbraron yr". Los Reyes mandan al concejo de Villasana y al merino de Mena, que dejen a los mulateros reclamantes "e todas las otras personas mulaterose biandantes destos nuestros Rreynos", transitar libremente con sus mulos y acémilas cargadas o vacías por el camino real de la Ordunte, porque siempre se ha caminado por él, sin llevarles cosa alguna por ello ${ }^{1022}$.

En 1568, Martín de Zaldívar en nombre de Bernardino de San Pantaleones, vecino de San Pantaleón, Pedro el Rojo, vecino de Las Hormazas y Llorente García, vecino de Escaño, dijo al Consejo que sus partes eran arrieros cosarios "que de contino trayan y lleuaban cargas de la

1022 A. G. S./ Registro General del Sello, VIII-1483, fol. 184/ Santo Domingo de la Calzada, 23 agosto 1483. 


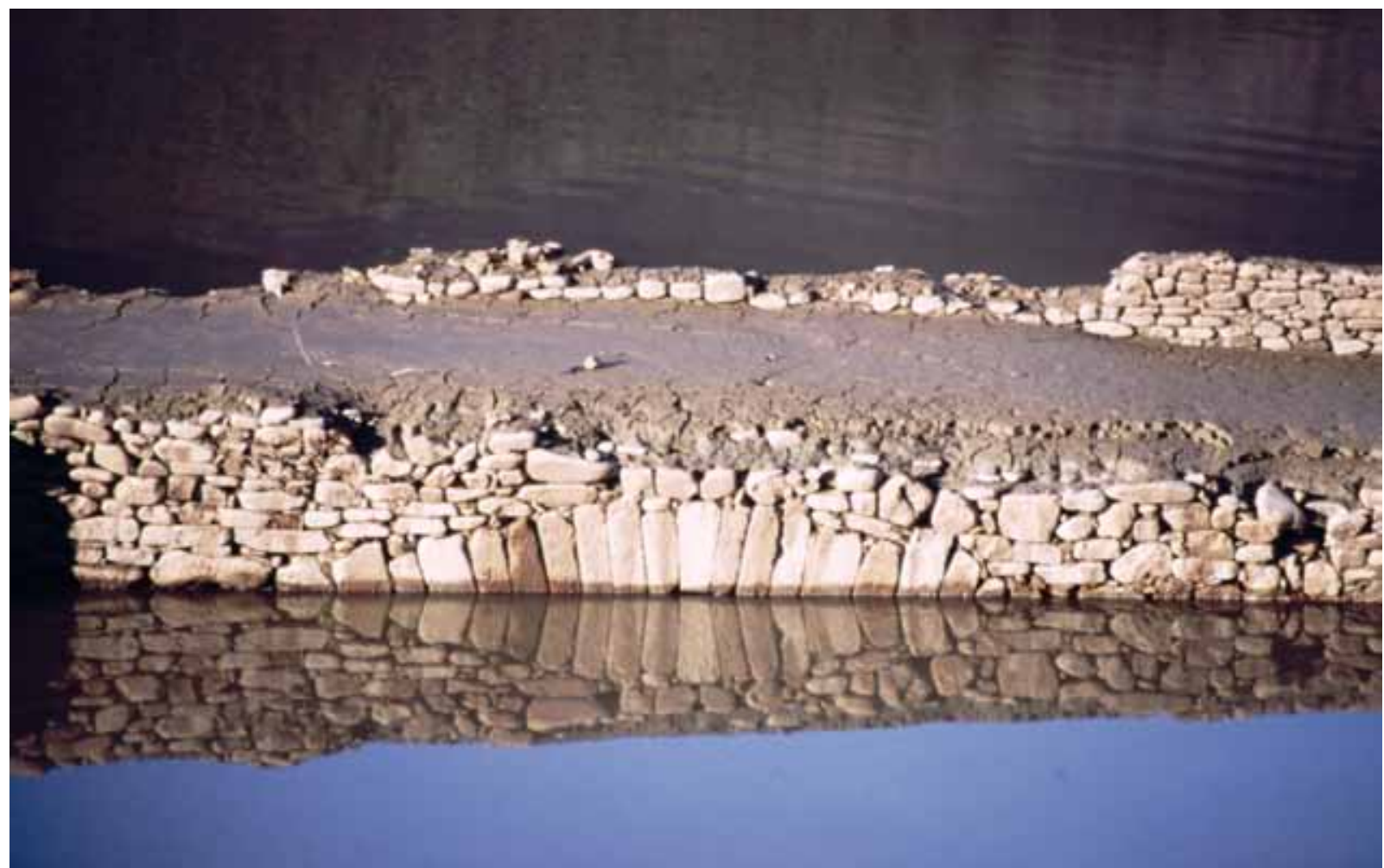

Puente Ranero frente a Partearroyo bajo las aguas del pantano de Ordunte.

villa de Vilbao, Laredo y Castro y otros puertos de mar para Burgos, Valladolid, Toledo, Seuilla y otras çibdades destos reinos y de hordinario, avian passado y passauan con sus requas por el camino rreal, que pasan por el Valle de Mena, desde las Enderrosas hasta el molino de Arla y la Peña de Mena y las peñas de Riobolga y otros caminos y passos, y la puente del Rranero questa en medio del camino real, los quales dichos caminos y puentes heran pasos forçosos por donde sus partes auian de pasar y todos los demas arrieros del Reino, los quales de presente estauan mui mal reparados y adereçados y peligrosos, que por ninguna de sus partes podian pasar por ellos con sus requas de noche ni de dia, a cuya caussa se auian perdido... los machos de sus partes y las cargas de vino y otras cossas de vastimientos que lleuaban a muchas partes destos reinos, de que... resçiuian grandes agrauios y vexaçiones y perdidas en sus haçiendas, que por ninguna uia lo podian sufrir, y es ansi que porque los dichos caminos y pasos y puentes estauan lexos de los pueblos susodichos", y por no tener propios estos lugares y como por Provisión real se habían reparado a costa de los arrieros, cobrando por bestia lo que se les mandaba por la justicia del Valle de Mena, lo que "auia sido cossa muy justa y nesçesaria y como tal sus partes lo querian y consentian", suplicó que se diese Provisión para que los caminos, puentes y malos pasos de Mena se aderezasen para poder ser utilizados sin ningún peligro, y que los gastos se repartiesen entre los arrieros, bestias y ganados que por allí pasaren. El Consejo Real acordó en julio de 1568, mandar al corregidor de las Cuatro Villas o a su lugarteniente en Mena, que procuren que dichos caminos se reparen y los arrieros no reciban agravio. En la audiencia de Villanueva de Mena, comparecieron en febrero de 1569 los procuradores de los caballeros e hijosdalgo del Valle de Mena y pidieron que se notificase esta Provisión al teniente de corregidor, que dijo que cumpliría lo que por ella se mandaba1023.

1023 A. H. V. M./ leg. 6, p. 33bis a 35/ Madrid, 23 julio 1568 y Villanueva de Mena, 7 febrero 1569. 
En noviembre de 1593, para informarse sobre la situación de los puentes del Valle de Mena tras la riada de septiembre, el teniente de corregidor cumpliendo con la Provisión real y comisión del corregidor, y acompañado de cuatro maestros canteros y carpinteros, fue a ver todos los puentes del valle. En los puentes de este camino real que baja del puerto del Cabrio y venta de La Haya, y acaba en el puente de los Arroyos, que va de Castilla a "las uillas y puertos de Castro, Portogalete, Uilbao y Bermeo y puerto y aduana de Balmaseda y Encartaçiones de Bizcaya" y montañas, se propone:

- En Irús, de los dos puentes sobre el río Cabrio o Hijuela, uno "en el camino real de la Hordunte", está derribado por el diluvio y necesita hacerse de un arco con sus pilares de piedra labrada que llevará 660 varas a 12 rs. la vara, y de cal 30 ducados. De cimbras, ahorrazón y otros materiales necesarios 40042 ducados.

- En el río Ordunte o de Monte de la Ordunte, más arriba de Burceña hay otro puente, que se ha de hacer de dos pilares de piedra y el arco de madera, costando 70 ds.

- Puente de Burceña sobre el mismo río, es de madera y está muy perdido, y debe ser de dos arcos con su manguardia y tajamar, una cepa en medio y dos estribos a los lados. Necesita 2.00o varas de piedra labrada a 12 rs. la vara. De cal 60 ds. y cimbras, ahorrazón, piedra de mampostería y demás materiales necesarios 265 ds.

- Puente del Ranero ${ }^{1024}$ en el término de Partearroyo, en el río Ordunte. Se lo llevó la avenida sin haber quedado nada y se ha de hacer de un gran arco de 30 pies de hueco con sus dos estribos, pilares y lo demás necesario, 870 varas de piedra labrada a 12 rs. la vara. De cal, cimbras y ahorrazón y demás materiales necesarios 270 ds. ${ }^{1025}$.

- Puente de Nava sobre el río Cadagua en el camino real, "esta al presente de tres ojos principales de a ueinte pies de hueco y de madera muy uiejo, y la una cepa del medio esta perdida que se a de deshazer de nuebo, y la dicha puente a de ser de quatro arcos y a cada lado su manguardia".

- En el "camino real de la Hordunte donde dizen los Tojos", puente sobre el río Ordunte que está caído, necesita hacerse de cinco pilares de piedra labrada, cada uno de dos brazas de alto y todos llevarán 700 varas de piedra labrada a 8 rs. cada una. De cal Go ducados, de maderas y carpintería para cubiertas 100 ds. y de ahorrazón de los cinco pilares y abrir los cimientos 120 ds.

\section{c.- Por Medina de Pomar, la Magdalena y Valmaseda}

Es camino de herradura utilizado con intensidad hasta el siglo XVI por los mulateros desde Medina de Pomar. Entra en el Valle de Mena por "el camino real que baja por las peñas de la Conplazera y de la Magdalena que uan a las dichas villas y puertos y aduana de Balmaseda y Señorio de Uizcaya..."1026.

En Incinillas se desviaba del camino que venía de Burgos para ir por Bisjueces, El Vado, Medina de Pomar, Torres, Villatomil, La Cerca, Salinas de Rosío, Villalacre y Castrobarto, para entrar en el Valle de Mena por el puerto de la Magdalena. En Mena discurre por Cadagua, Las Casetas y Prado, para entroncar en Vallejo de Mena con el camino que viene de El Cabrio. Era la vía más directa entre Medina de Pomar y Villasana de Mena hacia Bil-

1024 Este puente se encuentra bajo el pantano de Ordunte.

1025 A. H. V. M./ leg. 6, p. 221 a 336/ Madrid, 10 junio 1589 a 18 diciembre 1593.

1026 A. H. V. M./ leg. 6, p. 221 a 336/ Madrid, 10 junio 1589 a 18 diciembre 1593. 
bao y fue muy utilizada hasta que el camino por el Cabrio, la relegó a un segundo plano.

Es el camino que sigue en 1465 León de Rosmithal, noble bohemio que con un séquito de caballeros viene de Bilbao, y por Valmaseda, Villasana de Mena, Salinas de Rosío, Medina de Pomar (donde está el 24 de junio), y luego por Cernégula, llegará a Burgos. Shaschek, uno de los dos autores que describen el viaje, dice que en Bilbao hay un puente de piedra ${ }^{1027}$, y habla del puente de Valmaseda, donde cobraban el peaje. En Valmaseda "pueblo murado, aunque pequeño y pasa junto a él un rí llamado Cadecum ${ }^{1028}$; en un espacio de cinco millas vadeamos diecisiete veces este río". Después Shaschek relata que "Villasana dista cinco millas de Medina de Pomar, ciudad que está a la falda de los montes y que parece que está sujeta a un conde; pasa junto a ella un rí llamado Rivero, y se ve cerca un hermoso monasterio. A dos millas hay un lugar del mismo conde, en el cual se hace sal de este modo: el agua se recoge en piscinas o lagunas, donde se deja algún tiempo para que se cuaje y endurezca, y esta sal se pone como piedras ${ }^{1029}$. De Medina de Pomar hay siete millas a Ezernelum ${ }^{1030}$; pasado este pueblo entramos en unos montes donde no crecen más árboles que bojes, y anduvimos por ellos tres días,..." ${ }^{1031}$.

El camino junto al puerto, estaba salvaguardado por la torre de Castrobarto, dependiente de los Velasco, como se indica en un documento del siglo XV: "En la merindad de Losa tienevuestra señoria dos torres, la una en Castro de Barto, que esjunto al camino real por donde pasan a las montañas,..." ${ }^{1032}$.

En Villasana en septiembre de 1515 comparecieron Pedro de Brizuela y Juan Barahona, en nombre de los mulateros y viandantes ante el corregidor y juez de las Tres Villas de la Costa, y dijeron que los mulateros y viandantes reciben mucho daño por lo que les llevan en la peña de Mena y en otros lugares por razón de la huelga cuando hay nieve. El corregidor recibió juramento de cinco testigos vecinos de Villasana que dijeron que, desde hacía 20 años, han visto llevar por hacer la huelga a los criados del abad de Vivanco, un mr. por cada bestia grande o pequeña que pase por la peña de Mena, haya mucha o poca nieve, y aunque en esos caminos no hubiese nieve y pasase un mulatero 20 veces al día, le cobraban este maravedí cada vez. Indican que en la peña de Mena y en Bercedo para bajar los valles de Mena y el puerto de Sandiniesto, llevan a los mulateros muchos mrs. durante largo tiempo por quitar la nieve, y piden al corregidor que mande comparecer a las personas que los cogen y a los que los mandan, que son Pedro de Velasco, vecino de Valdeporres, el abad de Vivanco y Gallarde de Velasco, vecinos de Mena, para que muestren los títulos que tienen ${ }^{1033}$.

En las ordenanzas de Villalacre de agosto de 1548, se menciona el camino real que va a la Magdalena. En junio de 1571, el alcalde mayor de Villalacre mandó que los mulos de trajineros que vinieren de camino, puedan pacer en lo acotado y en todo se les respete ese día como a los bueyes de arada, y que lo mismo sea al día siguiente aunque huelguen, y el que le tuviere cojo pueda estar en dicho acotado dos días y no más, y los demás días que

\footnotetext{
1027 Es el puente de San Antón.

1028 Río Cadagua.

1029 Se refiere a Salinas de Rosío.

1030 Se trata de Cernégula.

1031 Es evidente que los montes de bojes y los tres días empleados, es fruto de la fantasía. ROSMITHAL DE BLATNA,

L. de: "Dos relaciones del viaje: de Shaschek y de Gabriel Tetzel"/ 1465-1467; GARCİA MERCADAL, J.: 1952: t. I, 263-266

y 295-297; HERBERS, K. y PLÖTZ, R.: 1999: 108-112.
}

1032 A. H. N./ Nobleza. Frías, C. 252, D. 4/ s. f. [s. XV]

1033 A. G. S./ Consejo Real de Castilla, leg. 84, fol. 2-III/ Valladolid, 26 junio 1513- Salazar 25 septiembre 1515. 

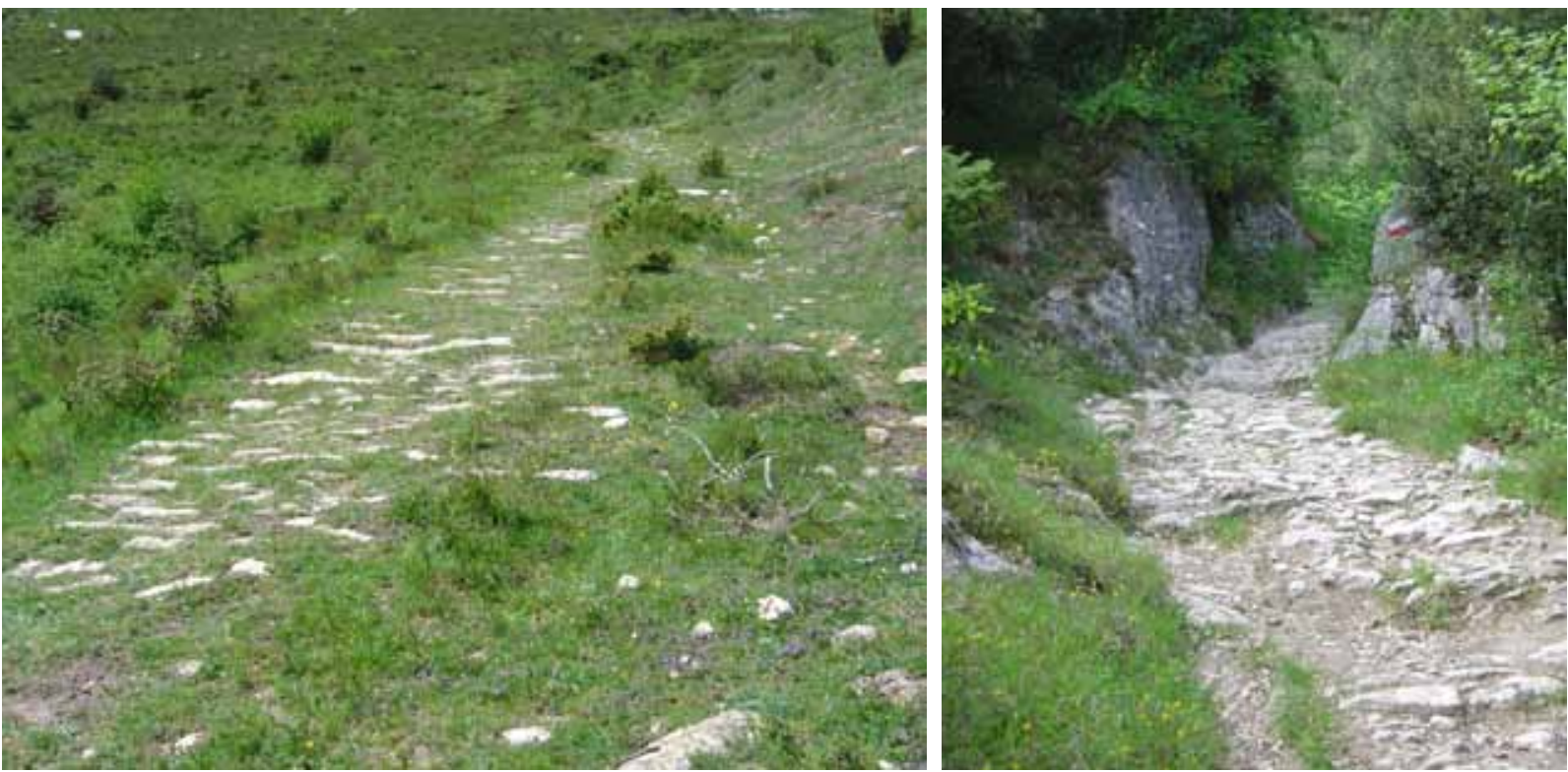

Camino por la Magdalena a Lezana.

estuvieren en el pueblo, puedan andar fuera de las hacenderas debajo del camino real si no es en el acotado ni en los arroyos, porque es pasto de sus bueyes. En junio de 1593, se manda que los propios y penas del concejo de Villalacre, se gasten en cosas convenientes al concejo "y rreparos de puentes, malos passos e no agan rrepartimientos algunos..." 1034 .

En noviembre de 1593, el teniente de corregidor en Mena cumpliendo con la Provisión real y comisión del corregidor, acompañado de maestros, fue a ver los puentes de Mena, y "en el camino real que entra por la peña e puerto de la Magdalena y ua a las dichas villas de Ualmaseda y ... a los puertos e uillas de Bilbao, Castro de Urdiales, Portugalete y a San Sebastian del Passage y a Bermeo y a las Encartaçiones y Señorio de Bizcaya y a las uillas y puertos de Laredo y Santander y ferias y çiudades de Naxera y Orduña", hay un puente en el lugar de Vallejo sobre el rio Cadagua que está "muy maltratada del andilubio ultimo deste año"1035 .

En el pleito que se trata entre las Merindades de Castilla Vieja y el Condestable, por los cobros y descaminos que hacen las guardas de Medina de Pomar, a los mercaderes y arrieros que pasan por las Merindades, se realiza en diciembre de 1624 un interrogatorio a arrieros y trajineros, que indican que el lugar idóneo para ver si los arrieros y mercaderes tienen registradas las cargas y mercaderías es Villasante, donde estuvo hace unos 30 años, sitio donde se juntan los caminos que vienen de los tres puertos ${ }^{1036}$ para la corte y demás partes de Castilla, pero los arrieros de la jurisdicción del Condestable, rebaten la propuesta y declaran que desde el "puerto de Bilbao los arrieros del ualle de Mena y otros de la Merindad de Lossa, por la mayor parte salen a la peña que llaman de la Madalena, que esta entre los dichos Balle de Mena y Merindad de Lossa, lo qual haçen por acudiry benir a sus cassas donde tienen sus moradas, y el dicho camino de la Madalena ua a dar a la dicha uilla de Medina y tanbien por otras partes al lugar de Trespaderne y a Oña, lo qual haçen los dichos arrieros de aquellos partidos por acudir a sus casas"1037.

1034 Archivo de Villalacre/ Villalacre, 9 agosto 1548; 24 septiembre 1570; 25 junio 1571; 21 junio 1593.

1035 A. H. V. M./ leg. 6, p. 221 a 336/ Madrid, 10 junio 1589 a 18 diciembre 1593.

1036 Laredo, Castro-Urdiales y Bilbao.

1037 A. C. V./ no 83/ Madrid, 11 septiembre 1621 y Madrid, 9 octubre 1624. 


\section{B.- POR EL DESFILADERO DE LA HORADADA}

Fue este camino por la Horadada en algunos de sus tramos, muy utilizado por la carretería y el más cómodo porque evita las grandes altitudes, y por ello, el más libre de nieves. No obstante, el paso de la Horadada, era muy estrecho y peligroso. En un interrogatorio realizado en 1556 , se preguntaba a los testigos "si saben que los... caminos de los Ocinos y la Oradada, de mas de ser como son tan neszesarios e probechosos a estos reinos... son caminos muy peligrosos ansi por ser muy estrechos en muchas e diversas partes, que no tienen tres pies de ancho e porque confinan con el rrio de Hebro que es muy caudaloso e furioso"1038.

Cinco eran los caminos que tenían en común el mismo tramo entre Burgos y Río de Losa por la Horadada: uno por La Complacera, otro por la peña de Igaña y tres por el puerto de Angulo. Esta vía hasta Río de Losa era de herradura y discurría por Hurones, Temiño, Rublacedo de Arriba, Rublacedo de Abajo, Carcedo de Bureba, Lences, Salas de Bureba, Castellanos de Bureba, Terminón, Tamayo, Oña, desfiladero de Oña, puentes de la Blanca y de la Horadada, desfiladero de la Horadada y Trespaderne, coincidiendo hasta aquí con el camino que va a Laredo por el desfiladero de La Horadada y Medina de Pomar. Desde Trespaderne discurría por Santotís, Cadiñanos, La Orden, Pedrosa de Tobalina, Valujera, Lechedo, debajo de Hierro, Criales, Quintanilla la Ojada, San Pantaleón de Losa y Río de Losa.

\section{Referencias documentales}

En 947, Bermudo Cudestios se entrega al monasterio de San Pedro de Cardeña y a su abad Esteban y les hace donación de su villa de Lacio o Placio, sita en el alfoz de Ubierna, entre Villímar, Sotopalacios, Celada de la Torre y Hurones. Son sus límites Villacistierna, Fuente Sabugo y el camino hacia Castilla Vieja y Poza de la Sal' ${ }^{1039}$.

En 1187 ya se habla de dos puentes en La Horadada cuando Alfonso VIII dona al abad de Oña, cuanto le pertenece en Peñahorada y Villaverde a cambio de los derechos de Oña en San Felices ${ }^{1040}$.

En 1256 se realiza un cambio de heredamientos entre el cabildo de la iglesia de Santa María de Burgos y el monasterio de San Juan. El primero da sus propiedades de Morquillas, y el segundo las suyas de Villayerno, y se cita la carrera de Hurones ${ }^{1041}$.

Gutier Fernández dispone en 1267 su enterramiento en el monasterio de Oña y concierta la celebración de un aniversario por su alma, entregando dos parrales y una villa en Salas de Bureba, mencionando el camino del Rey ${ }^{1042}$.

El abad de Oña arrienda, en diciembre de 1280, al concejo de Cereceda la serna de

1038 A. C. V./ no 18. doc. 3, hojas 28 a 48/ Medina de Pomar, 7, 8, 9 y 21 enero 1556.

1039 Becerro Gótico de Cardeña. f. 74V B/ 27 abril 947; MARTÍNEZ, G.: 1998: doc 59, 90-91. "id est, de termino de uilla Cisterna et de strata qui discurrit ad Castella; et de alia parte strata qui discurrit ad Poza...".

1040 Cartulario Sto. Toribio de Liébana/ Leg. 1.346, nำ13/ Burgos, 21 junio 1187; SÁNCHEZ BELDA, L.: 1948: 144-145: doc. 117 "et quantum habeo et ad me pertinet in Pennaforata de dintro et in Pennaforata de foras, et quicquid ad me pertinet in UiIlauiridi; et in Transpaderne sernam de era de Tedeia que iacet inter ambos pontes".

1041 A. M. B./ Hca. 1-7-17/ 15 julio 1256; PEÑA PÉREZ, FCO. J.: 1983: 129-131: doc. 88. "Ia tierra de Morquiellas que es entre amos los barrios, ont son aladannos, de la una part, la carrera que ua a Furones, e de la otra part, la carrera que ua al molino de Morquiellas, ... de la una part, Aluar Garcia; de la otra part, el camino, e en fondon, el arroyo con sus salzes".

1042 A. H. P. C./ Cartulario de Oña fols. 7Ov-71v/ 1267; OCEJA GONZALO, I.: 1983: 181: doc 188. "el uno es Sant Ynes e son aladannos, de la una part, Domingo Ortinez; de la otra part es el camino del rey e, de la otra part, la carrera que ua a Omino...". 
Cuevarana sobre el puente nuevo de la Horadada ${ }^{1043}$, por la mitad de la vendimia, de la fruta y del diezmo como renta anual ${ }^{1044}$.

En enero de 1285 el monasterio de Oña y el clérigo de Castellanos intercambian viñas en términos de este último lugar, citando la carrera de Burgos a Oña ${ }^{1045}$. En septiembre se hace en Oña alusión a la Calzada cuando Juan Pérez de Campos, vecino de Oña, vende al limosnero mayor del monasterio un parral en la villa por 2.000 mrs $^{1046}$.

En junio de 1456 fray Juan de Gumiel y fray García de Valladolid, van de Valladolid al monasterio de Oña. Salen de Burgos el 23 y a las 9 h. llegan a Santa María la Vieja (entre Poza y Salas de Bureba) y comen allí. Ese día llegarán a Oña ${ }^{1047}$.

Con motivo del repartimiento para la intervención en el puente de Tardajos, realizado en la década de 1540, la localidad de Salas de Bureba alega que deben gastar mucha cantidad en reparar calzadas, pontones y un puente de madera "e que saben que por no tener para fazer de piedra, no la fazen"1048.

\section{Los reparos del puente de Poza sobre el río Homino}

En las Juntas de Álava de enero de 1575 trataron sobre el repartimiento que se les hace de los puentes de Oña y Poza, a muchos lugares de la hermandad de La Ribera y tierra de Ayala y en otros de Valdegovía, Valderejo y Lacozmonte, Vitoria y otros lugares, lo que, además de que son puentes, dicen, que ninguno de estos lugares utilizan, se hace más perjuicio al hacer el repartimiento a lugares particulares, no incluyendo otros muchos de fuera de la provincia más cercanos a esos puentes. Al día siguiente se encarga a Domingo López de Mandojana que vaya ante el alcalde mayor, en el Adelantamiento de Castilla del partido de Burgos, y haga diligencias en nombre de los lugares a quiénes se hace el repartimiento, y las traiga al Diputado para que las envíe al Consejo y se remedie este asunto, porque el alcalde mayor y sus ministros por causas injustas, dicen, proceden con rigor contra las hermandades alavesas ${ }^{1049}$. En julio, García de Sisniega, por él y en nombre de Juan del Río, ambos maestros de cantería vecinos del lugar de San Mamés, dijo al alcalde mayor en el Adelantamiento de Castilla que la obra, y edificio del puente de Poza se remató en Juan del Río que la tomó para ambos, y habiendo comenzado a ahondar los cimientos ${ }^{1050}$, hubo diferencias entre ellos y la villa, y para que se viese si los cimientos y planta

\footnotetext{
1043 Aquí se juntan los ríos Oca y Ebro.
}

1044 A. H. N./ D. P. de Oña. Carp. 293, num. 19/ Oña, 22 diciembre 1280; ÁLAMO, J. del: 1950: 822-824: t. II. doc G96. "Ia nuestra serna de Couarana que es sobre la puente nueua del Ebro allent del rio". Del puente Nuevo aludido, quedan en las paredes de roca, unas entalladuras donde se encajaban los arranques de sus arcos.

1045 A. H. N./ Clero. Pergaminos. Carp. 296, no 14/ Oña, 17 enero 1285; OCEJA GONZALO, I.: 1986: doc. 267, 3-4. "en Uinna Naua, que es surquero Pedro Diaz e, en fondon, la carrera que ua de Burgos a Onna".

1046 A. H. N./ Clero. Pergaminos. Carp. 297, nำ 15/ Oña, 4 septiembre 1285; OCEJA GONZALO, I.: 1986: 30: doc. 286. "el myo parral de la Calçada, de que son aladanos: de la una part, el parral del almosneria del monesterio de Onna, e de la otra part, son aladannos don Pero, el del molino,...".

1047 PÉREZ ÁLVAREZ, V.: 2007, 139-148: XXXI; A. H. N./ Clero regular y secular, Leg. 7731, ㄲo 58 "rrelaçion de las cosas que fezimos en el camino".

1048 A. G. S./ Consejo Real de Castilla, leg. 109-67. Citado en RODRíGUEZ de DIEGO, J. L.: 1985: 314.

1049 A. J. G. A./ t. VII/ Vitoria, 8 enero 1575

1050 A. M. Poza/ no 1187/ Tardajos, 22 julio 1575. 


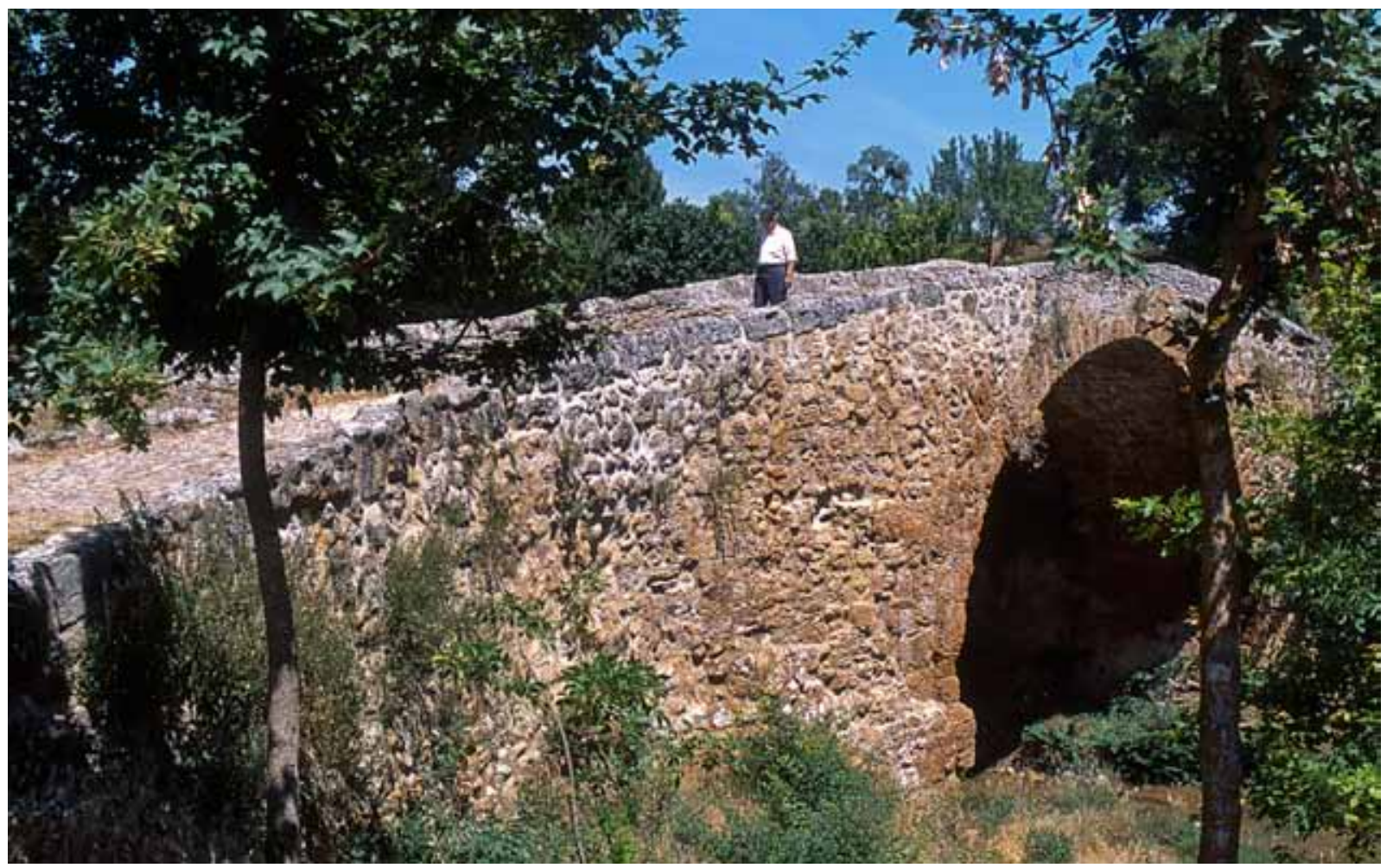

Puente de Poza en la localidad de Lences (Foto Santiago Alonso).

de la obra iban conforme a la traza y condiciones del remate, la villa nombró a Matías de Castañeda y ellos a Domingo Martínez, vecino de San Mamés, y Juan del Cerro, vecino de Llanoz, todos maestros de cantería y, no poniéndose de acuerdo, Sisniega pide que se nombre a otra persona para que dé su parecer ${ }^{1051}$. El alcalde mayor manda a Juan Cutiérrez maestro de cantería, vecino de Hozabejas, que vaya a ver el puente y sin dilación alguna se junte con los nombrados por el concejo de Poza y por Sisniega, y les dé su parecer para hacer la obra de acuerdo con él, ya que de su tardanza vendría perjuicio si viniese alguna crecida por estar las zanjas abiertas. De esta manera, Juan Gutiérrez y Matías de Castañeda, hicieron su declaración que se notificó a la justicia y regimiento de la villa1052.

1051 Domingo Martínez, declara que vio los materiales que Matías de Castañeda puso en los cimientos de una cepa y manguardia del puente, y vio la obra y los cimientos de la cepa y manguardias de la parte de Poza, que están cimentados sobre tierra firme y que aunque se hagan de más, no se hallará peña ni otro cimiento mejor. En cuanto a haber mudado el sitio, indica que es más conveniente que se haga donde está fundado, porque se halla más firme al estar contra las cepas que quedaron del puente viejo, y en lo de las manguardias dice que tienen por base 6 pies de grueso y por la erección cinco pies.

Juan del Cerro declara que el estribo está dolido con una manguardia en la parte de arriba del lado de Poza, y cavando hasta el fundamento de la obra, y tomando el hondo del agua en el ancho que tiene el puente y lo más hondo del cimiento puesto y nivelado, halló estar el cimiento del pilar dos pies más que lo más hondo del río, y aunque se ahonde más, no habría mejor cimiento porque no había peña, siendo el cimiento muy fuerte al ser greda fina y mezclada con peña. El fundamento no puede resbalar como lo podría hacer de una peña, no haciendo carga en ella. En cuanto al fundamento del puente dice que en la parte elegida, está más firme por estar como está metido entre los pilares viejos, y también que en cuanto a lo que dice Castañeda que está alto el fundamento, dice que Sisniega y del Río han cumplido con creces las condiciones y aunque estuviere erigido más alto, habiéndose de alamborar según las condiciones, pudiera estar fuerte y perpetuo al ser fuerte el encadenado y tan hondo.

1052 Dicen que en cuanto a fundar el puente entre los dos pilares viejos, como lo van fundando del Río y Sisniega, a pesar de que la traza y condiciones mandan hacerlo 10 pies más arriba, el puente estará fuerte y firme entre los dos pilares, tanto como si se fundara 10 pies más arriba. 


\section{Los reparos de los puentes de Briviesca, Oña y Trespaderne}

En los años setenta del siglo XVI, se procedió a la reparación de varios puentes, entre los que se encontraban los de Briviesca, Oña y Trespaderne, para lo que se realizó el correspondiente repartimiento en un espacio donde se encontraba Vizcaya, incluyendo localidades del Señorío, lo que ocasionó severas protestas por entender que tal medida atacaba a sus fueros y privilegios.

En enero 1573 los vecinos y moradores del barrio de Cortes de Burgos comparecen ante el corregidor, y dicen que no tienen propios de concejo ni otro aprovechamiento, para pagar los cuatro ducados repartidos al dicho barrio para los reparos del puente de Oña, y además el dicho barrio jamás pagó semejantes gastos porque la ciudad paga por sus barrios y arrabales, y sería imponer sobre ellos nuevo tributo, ya que la sisa la pagan a los arrendadores de Burgos. Piden que se ordene que no paguen ni se les haga molestia sobre este repartimiento ${ }^{1053}$. En abril el alcalde mayor del Adelantamiento de Castilla, da por exentos a los vecinos de Villatoro, Villímar, Cortes y Villagonzalo-Arenas, de este repartimiento, porque ya contribuyen con Burgos por ser de sus barrios y sus moradores vecinos de la ciudad ${ }^{1054}$. La Hermandad de Montes de Oca, Valderredoza y Val de San Lorenzo presenta pleito este año contra el concejo, justicia y regimiento de Belorado, sobre el repartimiento que hizo la justicia de Belorado entre las Hermandades para la construcción del puente de Trespaderne ${ }^{1055}$.

En las Juntas de Vizcaya de septiembre de 1574 se trató que por provisiones del Consejo Real a pedimento de algunos pueblos, se les han repartido por el alcalde mayor de las Merindades de Castilla la Vieja 168.000 mrs. para la reedificación del primer tercio del puente de Trespaderne, y a Bilbao 68.00o mrs. y para cobrarlo, ha ido un ejecutor con comisión del alcalde mayor del Adelantamiento de Burgos. Alegan que este repartimiento es injusto porque el Señorío no tiene ningún aprovechamiento del puente, y si lo tuviere tiene que hacer más reparos que ninguna otra provincia y no había dineros suficientes por no tener propios, sino solamente lo que recauda haciendo repartimientos para ello. Ordenaron que se pida al Rey que mande suspender lo procedido contra el Señorío y mandaron al letrado que recurriese, ante el alcalde mayor de las Merindades, el repartimiento hecho ${ }^{1056}$.

\footnotetext{
- Sobre el pilar y manguardia cimentado hacia Poza, no vieron el cimiento y suelo sobre el que está comenzado a edificar, y no pueden determinar si está edificado sobre tierra firme.

- Mandaron que del Río y Sisniega abran una zanja hacia la parte del río pegada a la cantería que tienen asentada hasta el hondo del cimiento, para que se vea el suelo de la obra, lo que deberán hacer antes de que asiente piedra alguna en ese pilar y manguardia, y así descubierto el cimiento, lo vea Juan Gutiérrez para que determine si es firme y si tiene la hondura necesaria, y en caso de que parezca estar el cimiento sobre tierra firme y no tener la hondura necesaria, declararon que se ahonden dos pies más abajo del cimiento hecho, y se echen sus piezas de 12 quintales arriba, arrimadas en 18 pies del largo del pilar, para que sobre ellas se eche el encadenado que ha de elevar el puente y en unos 10 pies que faltan de abrir en la manguardia, se ahonde el cimiento dos pies más del edificado hacia la parte de arriba, y en la manguardia que está por edificarse, ahonde otros dos pies más del cimiento edificado, guardando los gruesos de las condiciones en todas las manguardias y pilares.

- El cimiento del pilar y manguardias abierto hacia La Bureba, se debe ahondar a nivel con el estribo viejo de cantería. La manguardia de la parte de arriba la pondrán a nivel antes que se cimente, y la de abajo se ahonde como el mismo pilar, guardando sus gruesos y largo según las condiciones.

- La piedra "a la haz del rrio, se gaste piedra tosca e no arenaza, assi en pilares como en manguardias" según las condiciones.
}

1053 A. M. B./ HI-4930/ Burgos, 22 enero 1573

1054 A. M. B./ HI-1682/ Arenzana de Yuso (La Rioja), 7 abril 1573.

1055 A. Ch. V./ Sección de Pleitos Civiles, Fernando Alonso. Caja 99, 2/ 1573/ 1576.

1056 A. J. R. B./ Actas de la Tierra Llana. t. II/ Bermeo, 28 septiembre 1574 
Sobre el repartimiento que se hace a Álava de los puentes de Oña y Poza, las Juntas de enero de 1575 encargaron a Domingo López de Mandojana, que comparezca ante el alcalde mayor del Adelantamiento de Castilla del Partido de Burgos, y haga los autos y diligencias para que se remedie esta asunto en nombre de los lugares a quienes se hace el repartimiento. Las diligencias las enviará el Diputado al Consejo ${ }^{1057}$.

Como los repartimientos que se han hecho al Señorío para el reparo y reedificación de los puentes de Lerma, Briviesca, Trespaderne, Oña y de otras partes, van contra su Fuero y privilegios, se trató en las Juntas de Vizcaya de junio de 1575 que se hagan las diligencias debidas. Gracián de Menceta entregó ciertas cédulas y peticiones dadas por parte del Señorío ante el Rey y su Consejo, y en la Audiencia de Valladolid. En la corte, Menceta y Martín Ruiz de Muncharaz, pidieron al Consejo Real que se mandase remediar, y como también Guipúzcoa litigó lo mismo, aun no siendo tan privilegiada como el Señorío, salió con ejecutoria para no contribuir en semejantes repartimientos ${ }^{1058}$. Las Juntas de Vizcaya de noviembre, en lo tocante a los repartimientos que, contra sus fueros y privilegios se reparten para el reparo de los puentes de Trespaderne, Lerma, Briviesca y Oña, acordaron que se pida la devolución de lo que se ha pagado y que no se le hagan semejantes repartimientos, pues hasta ahora ha sido guardada su libertad. Acordaron de nuevo que se hagan todas las diligencias posibles en defensa del Señorío y que Simón de Barrutia vaya a Valladolid a recibir el Fuero original y lo que está impreso, corregido y tasado lo traiga, y en la corte procure que se haga diligencia para eximirse de los repartimientos ${ }^{1059}$.

En Juntas anteriores, se decretó diversas veces y se mandó a los síndicos, que se hiciesen las diligencias necesarias para que la Encartación y la merindad de Durango contribuyesen con la Tierra Llana, conforme a la costumbre antigua, en los gastos de la confirmación del Fuero y privilegios para lo de los puentes de Trespaderne, Lerma y Briviesca, y debiendo pagar la Encartación $1 / 3$ y la Merindad 1/6 hasta ahora, no han pagado cosa alguna ni han hecho la diligencia debida. Se acordó de nuevo que se haga diligencia y que el corregidor provea como mejor convenga, pues de derecho están obligados a ello los de la Encartación y la Merindad ${ }^{1060}$.

En las Juntas de Vizcaya de abril de 1576, se mandó solicitar la supresión de la nueva imposición que al Señorío se le había puesto hacía 45 años, en un repartimiento hecho para los puentes de Trespaderne, Lerma, Briviesca y Oña, en especial de un año a esta parte. Los jueces de comisión habían cobrado al Señorío más de 1.500 ducados, por lo que se ganó Provisión en febrero de 1576, que decía que nunca se le había mandado pagar al Señorío semejantes repartimientos, por ser libre de ellos por Fuero, uso y costumbre inmemorial, y para que no cesase el trato y comercio de los reinos de Castilla, como cesaría si no se reparan las calzadas, puentes y pontones del Señorío; repartiendo entre sí, por no tener propios, gastaban cada año más de 6.000 ds., porque lo que un año se hacía y reparaba, se perdía y gastaba el siguiente por las muchas crecidas que el Señorío padecía. Además, como habían gastado en los reparos muchos mrs. y de ello se recibía gran beneficio a causa del trato y comercio, nunca se había

1057 A. J. G. A./ t. VII/ Vitoria, 8 enero 1575.

1058 A. J. R. B./ Actas de la Tierra Llana. t. II/ Guernica, 14 junio 1575.

1059 A. J. R. B./ Actas de la Tierra Llana. t. II/ Bilbao, 8 noviembre 1575.

1060 A. J. R. B./ Actas de la Tierra Llana. t. II/ Bilbao, 9 noviembre 1575. 


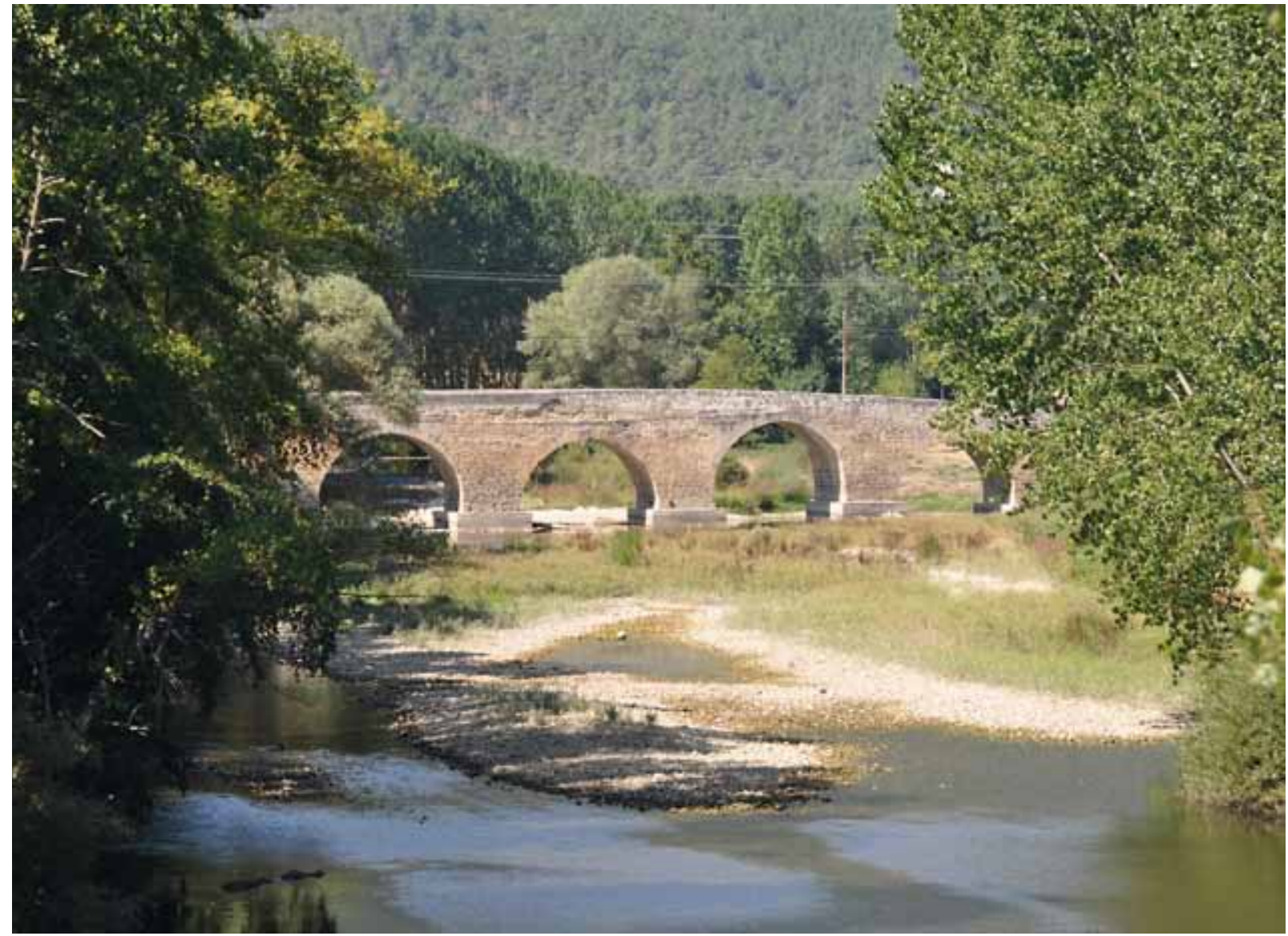

Puente de Trespaderne.

ayudado al Señorío ni él lo había pedido, pero las villas de Lerma, Oña, Briviesca y Trespaderne sí, y habían enviado juez de comisión para el cobro de los repartimientos que habían ejecutado llevando presos a los bolseros a pesar de su Fuero y, antes que el Señorío y su Junta Ceneral lo supiesen, los bolseros por no padecer tantas molestias, buscaron con que pagar los repartimientos aunque se había apelado para que se revocasen las provisiones. Y como por lo mismo se habían anulado a Guipúzcoa todos los repartimientos que se le habían efectuado, y no se había hecho lo mismo con el Señorío aunque lo tenía pedido, y como cada vez que se le hacía cualquier repartimiento, debía tener pleitos gastando más cantidad que lo que se le repartía, fue suplicado que se les concediese cédula y provisión, para que en adelante no se le repartiese ningún mr. para estos puentes ni para otros de fuera. Se dio una Carta mandando que al Señorío no se le hagan repartos para el reparo de puentes, por ningún consejo ni justicia de fuera del Señorío, como aparece en la Provisión realio61.

\section{a.- Por la Complacera, Menamayor y Valmaseda}

Este camino mulatero, seguía desde Río de Losa por Villaluenga, Calzada, Quincoces de Yuso, Relloso, portillo de la Complacera, Cilieza, Medianas, Menamayor, Santecilla, Cayuela, conectando con el camino principal de Mena en El Berrón. En el ya mencionado do-

1061 A. J. R. B./ Actas de la Tierra Llana. t. II/ Bilbao, 2 abril 1576. 


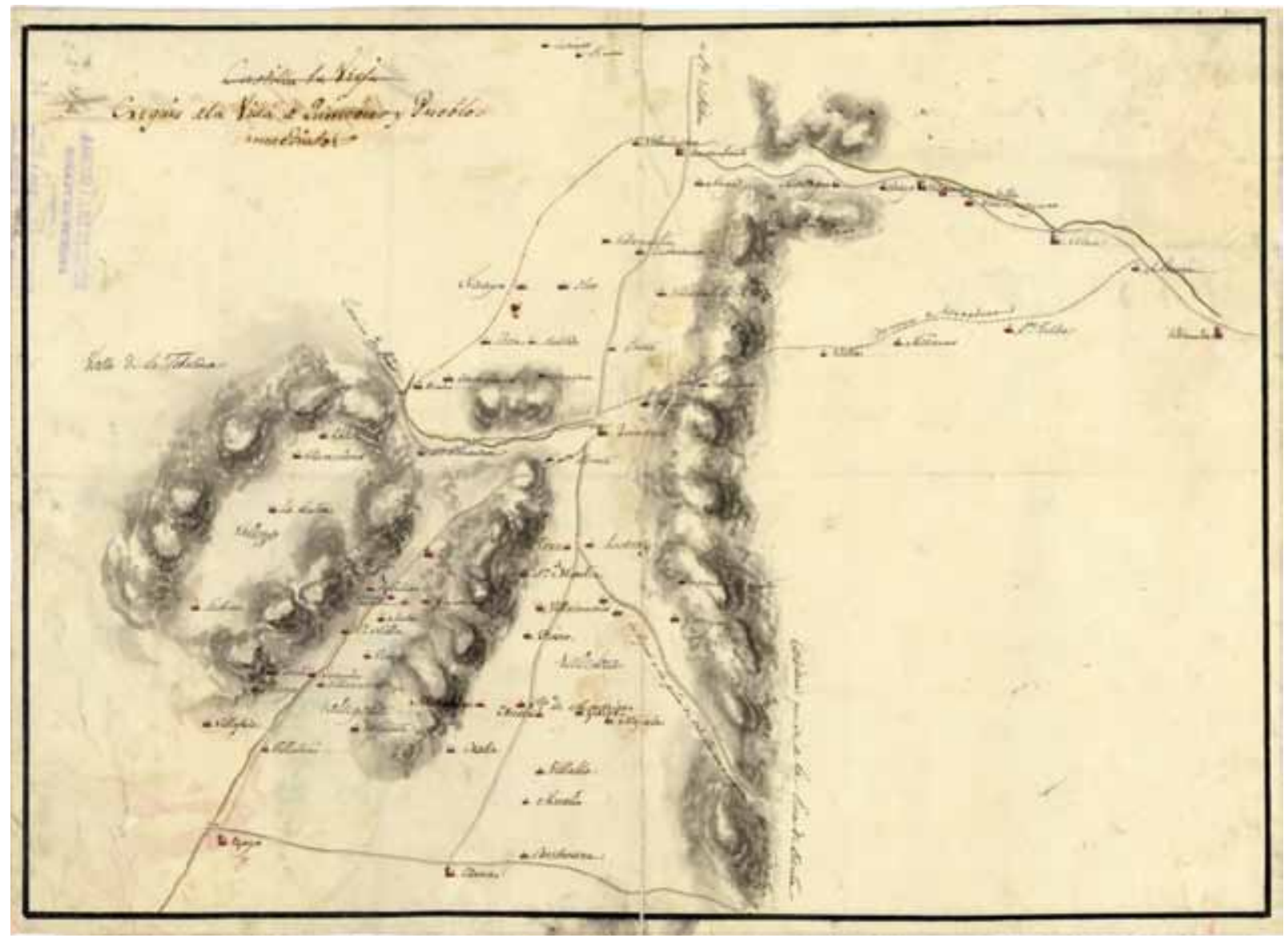

Croquis realizado hacia 1810 de la zona cuyo centro se dispone en Quincoces de Yuso (ARCGE Ar. E-T.6 C1N 115).

cumento de 1593 del Valle de Mena se alude al "camino real que entra por el puerto e peña de la Conplazera... que uan a las dichas villas y puertos y aduana de Balmaseda y Señorio de Uizcaya..." ${ }^{\circ 662}$. En noviembre de dicho año, el teniente de corregidor en Mena, cumpliendo con la Provisión real y comisión del corregidor y acompañado de maestros canteros, fue a ver los puentes del Valle de Mena, y visitó los que estaban en este camino real, y un testigo decía que en "el camino real que entra por el puerto e peña de la Conplazera... las puentes de Obilla y Medianas que a oydo deçir que las llebo el rio por el suelo el andilubio ultimo de septiembre pasado". Vieron los siguientes puentes de este camino:

- Puente de Medianas, sobre el río de Medianas.

- Puente de Menamayor sobre el río que baja del puerto en el camino real, está por el suelo y necesita hacerse de un arco con sus dos pilares y manguardias, 280 varas de piedra labrada a 14 o 15 rs. la vara. De cal, cimbras y ahorrazón 50 ducados.

- Puente de Revolga en el Vadubela, que está por el suelo y se ha de mudar algo más arriba y hacerse de un arco y dos pilares y para todo necesita 250 varas de piedra labrada a 13 rs. la vara. De cal 100 rs. y de cimbras y ahorrazón 10 ducados.

- Puente en Santecilla en el río de Vadubela, que está muy perdido a causa del diluvio de septiembre y de ningún provecho. Es de madera y necesita hacerse de un arco y dos pilares de piedra labrada, que serán 400 varas a 15 rs. cada una. De cal 100 rs., y otros 100 de cimbras, ahorrazón y materiales necesarios. 


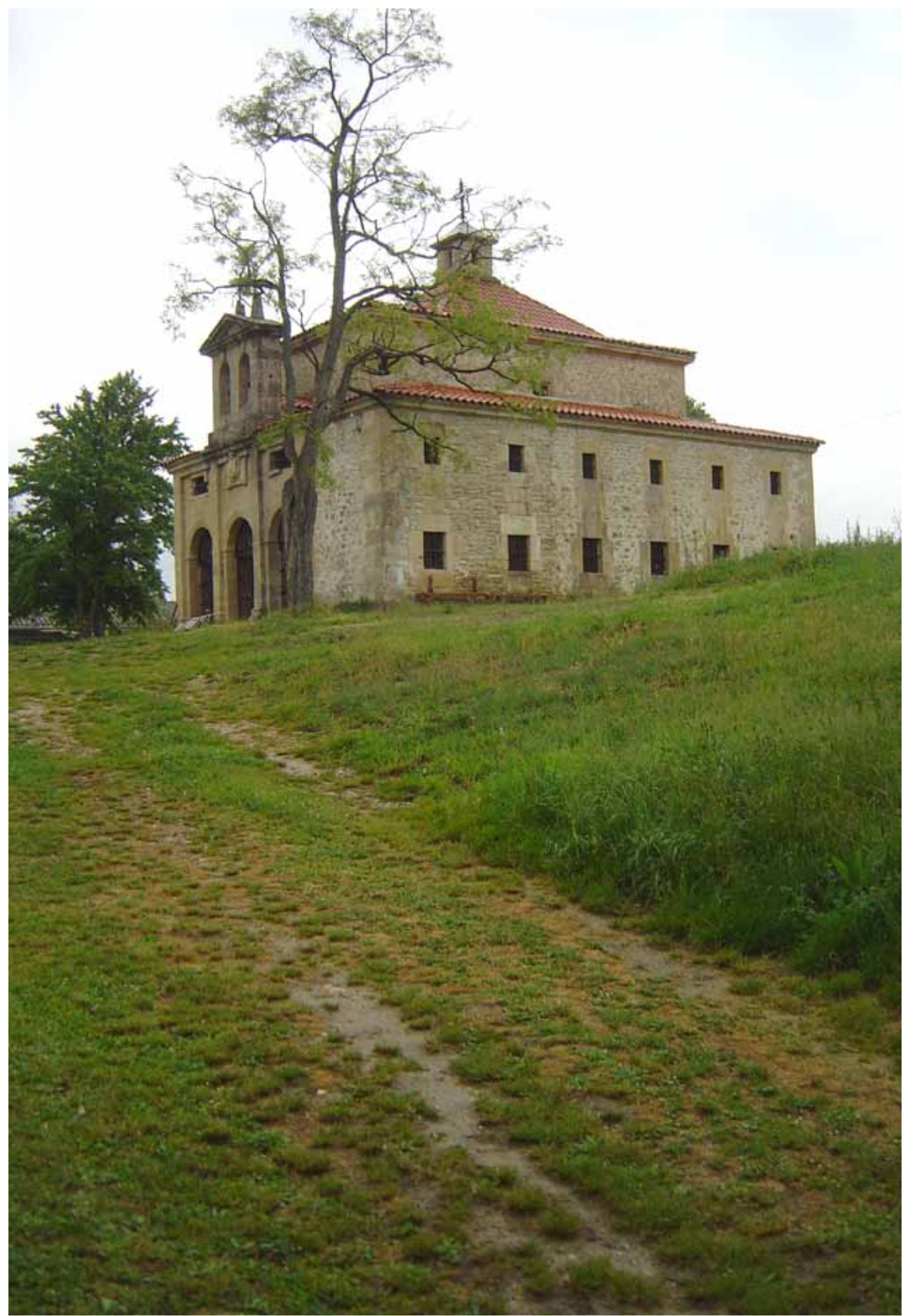

Ermita de San Antonio en Villaluenga de Losa junto al camino de Angulo. 
- Otro puente aguas abajo de Santecilla en el Vadubela, está perdido a causa del diluvio y necesita hacerse de un arco de piedra labrada, que llevará 180 varas y los pilares 150 varas de piedra labrada a 13 rs. la vara, 200 rs. De cal, cimbras y ahorrazón otros 200 rs. ${ }^{1063}$.

\section{b.- Por el puerto de Angulo y Valmaseda}

Desde Río de Losa, por la orilla izquierda del Jerea este camino de herradura iba por la actual ermita de San Antonio, frente a Villaluenga y San Llorente, para luego bajar el puerto de Angulo y seguir por Encima-Angulo, Santa Olaja, Santiago de Tudela, La Llana, y seguía por la orilla izquierda aguas abajo del río Ayega hasta San Pelayo, y por Orrantia, Antuñano y la Pinilla llegaba a Valmaseda.

Un testigo indica en 1593 “...que saue y a bisto otras puentes en el Ualle y conzejo de Ayega ques jurisdicion del dicho Valle de Mena que estan en caminos reales y rios caudales y los caminos uajan por la peña de Angulo para los dichos puertos e villas y Señorio de Bizcaya, de Bilbao, Portogalete y Bermeo..."1064.

\section{C.- Por el puerto de Igaña y Arza}

Se trata de un camino mulatero de escasa importancia. No pasaba por puerto seco alguno y discurría por el mismo camino de la Complacera ya mencionado hasta Relloso, donde se desviaba a la derecha para descender abruptamente el puerto de Igaña, hasta conectar en Santa Olaja con el camino que venía del puerto de Angulo y seguía en común hasta San Pelayo. Después iba por Arza, Rodayega, Iratzagorria, Allende, El Pontón, Cordejuela, Zubieta y Sodupe, donde conectaba con el camino que viene de Valmaseda.

En noviembre de 1593, un testigo indica que "el camino que entra por la peña de Ygaña y ba por el Valle de Angulo jurisdicion del de Mena y sobre el rio que por el passa, que el dicho camino real dixo ua desde La Rioja y Castilla Uieja a Uilbao y las demas partes". El teniente de corregidor en Mena acompañado de cuatro maestros, fue en dicha fecha a ver los puentes de Mena dañados en la última avenida. Visitó en este camino real que va al valle de Cordejuela y los puertos y villas de Vizcaya, Bilbao, Portugalete y Bermeo, tres puentes en el valle de Ayega sobre el río Ayega o Garguera.

- Puente de San Pelayo, está por el suelo y necesita hacerse de un arco y dos pilares, 25 pies de hueco, que todo llevará 400 varas de piedra labrada a 12 rs. la vara. De cal, cimbras, ahorrazón y demás materiales necesarios 160 ducados.

- Puente de las Arenas que está llevado, necesita hacerse de un arco y dos pilares y llevará todo 300 varas de piedra labrada, cada vara a 14 rs. De cimbras, ahorrazón y otros materiales y cal 40042 ducados.

- Puente bajero de Arza que está llevado, necesita hacerse de un arco con sus estribos y manguardias de 20 pies de hueco. Llevará 470 varas de piedra labrada a 13 rs. De cimbras, ahorrazón, cal y otros materiales 130 ducados ${ }^{1065}$.

1063 A. H.V. M./ leg. 6, p. 221 a 336/ Madrid, 10 junio 1589 a 18 diciembre 1593. 1064 A. H.V. M./ leg. 6, p. 221 a 336/ Madrid, 10 junio 1589 a 18 diciembre 1593. 1065 A. H.V. M./ leg. 6, p. 221 a 336/ Madrid, 10 junio 1589 a 18 diciembre 1593. 


\section{d.- Por el puerto de Angulo y Arciniega}

Es un camino mulatero poco importante para el comercio de Castilla por no pasar por ningún puerto seco. Desde el puerto de Angulo, se dirige por Encima-Angulo, Ciella, Valluerca, Gordéliz, Arciniega, Barratauren, Venta de Ureta, Artecona, Las Llanas, Allende, El Pontón, Gordejuela, Zubieta y Sodupe, donde conecta con el camino que viene de Valmaseda. Se incluye en todos los itinerarios que desde el siglo XVIII se publican. El Itinerario Español de Matías Escribano de 1758, lo denomina "Camino de herradura Para Bilbao desde Burgos"1066. También lo recogen Francisco Brusola en 1810 y Santiago López en 1812, que son copias del Escribano1067.

En julio de 1495 los Reyes indican que Lope de San Pelayo, en nombre de la villa y tierra de Arciniega, les dijo que hacía mes y medio que hubo gran diluvio y tempestad de piedra y agua, que llevó todos sus puentes y muchas casas y torres fuertes, y destruyó todos los heredamientos y panes, de manera que no tienen facultad para rehacer los puentes ni con que mantenerse y, como son muy necesarios, si no se mandasen reparar recibirían mucho daño. El Consejo acordó mandar al corregidor y juez de residencia de Vizcaya, que vaya a Arciniega y recoja información de qué puentes son los que se derribaron y qué necesidades tienen, así los de la Villa y Tierra como los de la comarca, y qué personas son las que por allí pasan, cuántos mrs. son necesarios para su reparo y quiénes lo deben pagar, y dicha información con su parecer, la envíe al Consejo para que provea lo que proceda ${ }^{1068}$.

\begin{tabular}{|c|c|}
\hline "Hurones & 2 \\
\hline Los Rulacedos & 2 \\
\hline Salas & 3 \\
\hline Oña R. P. & $7 \mathrm{~m}$ \\
\hline Trespaderne & 2 \\
\hline Criales & 3 \\
\hline Venta de Tegera & $m$ \\
\hline San Llorente & 7 \\
\hline Angulo & $7 \mathrm{~m}$ \\
\hline Lorcio & 1 \\
\hline Arceniega & 1 \\
\hline Gordejuela & 2 \\
\hline Sodupe & 7 \\
\hline BILBAO & $2^{\prime \prime}$ \\
\hline
\end{tabular}

1067 LÓPEZ, S.: 1812

"Camino de herradura para Bilbao hasta Burgos. 42

$\begin{array}{ll}\text { Harones. } & 2 \\ \text { Los Rulacedos. } & 2 \\ \text { 49 Salas. } & 3 \\ \text { Oña, rio y puente. } & 7 \mathrm{~m} \\ \text { Tres Praderna. } & 2 \\ \text { Heriales. } & 3 \\ \text { V. de Tejada. } & \mathrm{m} \\ \text { San Llorente. } & 7 \\ \text { Angulo. } & 1 \mathrm{~m} \\ \text { Lorcio. } & 1 \\ \text { Arceniega. } & 1 \\ \text { Gordejuela. } & 2 \\ \text { Sodupe. } & 1 \\ \text { 65 m Bilbao. } & 2^{\prime \prime}\end{array}$

1068 A. G. S./ Registro General del Sello, VII-1495, fol. 241/ Burgos, 21 julio 1495. 
En Junta de Álava de noviembre de 1549 se acordó dar poder a Juan Pérez de Urrutia para que vaya al Consejo Real y a Juan Paché, residente en la Chancillería, para que hagan seguimiento de los pleitos que sobre la derrama de los puentes de Gordejuela y Quintana del Puente, tienen establecidos ${ }^{1069}$.

Sobre el repartimiento que por comisión del Consejo Real, ha hecho el alcalde mayor del valle y tierra de Ayala para sufragar los gastos del puente y pontones que Arciniega quiere hacer, en el que se han incluido más vecinos de los que hay, la Junta de Álava de noviembre de 1590 acordó que el procurador de Ayala, vaya a tratar sobre ello con el alcalde mayor para que lo reparta conforme a la vecindad de cada lugar ${ }^{1070}$. El alcalde mayor de Ayala dijo que lo pedido no era de su oficio por ser solo juez ejecutor, por lo que acordaron que se despache al solicitador de Álava en la corte, para que gane provisión del Consejo y se remedie la excesiva cifra de vecinos puesta en Ayala ${ }^{1071}$. En Junta de enero de 1591 se trató sobre este repartimiento hecho a las hermandades de Álava, y el Diputado Ceneral encargó a Gabriel de Orue, vecino de Luyando, que siga la causa en nombre de la Provincia ante el alcalde mayor de Ayala1072. El Diputado Ceneral dijo que en Consejo Real había habido auto sobre dichos puentes, y que habían pedido que el juez los recibiese a prueba en 40 días, para lo que se encargó al Diputado General que fuese a la corte ${ }^{1073}$. Este dijo a los comisarios y diputados que había recibido una carta y Provisión real, para que la Provincia hiciese sus probanzas sobre este repartimiento. Se acordó que el procurador de la hermandad de Aspárrena, haga las diligencias necesarias sobre ello en seguimiento y defensa del pleito entre la Provincia y la hermandad de Arciniega ${ }^{1074}$.

En Junta de mayo algunos procuradores dijeron que en Arciniega no hay río caudal para hacer en él los puentes que se pretenden, y como de parte de la Provincia se ha traído Provisión del Consejo Real para hacer su probanza, mandaron que el procurador de Aspárrena, vaya a Arciniega a ver el lugar donde se pretenden hacer los puentes, y hagan informe al Diputado Ceneral para que con su parecer, reciban de la Provincia la probanza, y si se entendiere que a esta le conviene quitarse del pleito, cometieron al Diputado Ceneral y a los comisarios y diputados de la Provincia, para que puedan tomar con Arciniega el medio mejor para evitar las costas del pleito. El Diputado Ceneral informó, que se acordó que Álava concertase con Arciniega el repartimiento hecho a las hermandades, y que el procurador de Aspárrena que fuese a Arciniega para ver el lugar de los puentes que la villa pretendía hacer, y recibida la probanza, se enviase al Consejo Real ${ }^{1075}$.

Poco se hizo en algo más de 2 años porque, en Junta de Álava de mayo de 1593 el juez de comisión del Rey notificó un mandamiento sobre los puentes y pontones que Arciniega pretendía hacer, y se acordó que fuese a Arciniega el procurador de la hermandad de

1069 A. J. G. A./ t. IV/ Vitoria, 23 noviembre 1549.

1070 A. J. G. A./ t. IX/Vitoria, 13 noviembre 1590.

1071 A. J. G. A./ t. IX/Vitoria, 19 noviembre 1590.

1072 A. J. G. A./ t. IX/Vitoria, 10 y 17 enero 1591.

1073 A. J. G. A./ t. IX/Vitoria, 31 enero, 1 y 22 febrero y 1 abril 1591.

1074 A. J. G. A./ t. IX/Vitoria, 5 abril 1591.

1075 A. J. G. A./ t. IX/Vitoria, 7 y 21 mayo 1591. 
Aríñez, para su remate ${ }^{1076}$. Este manifestó que en la Provincia estaban agraviados por cargarles más vecinos de los que tenían, y que también en el entorno de las 12 leguas del repartimiento, faltaban muchos lugares. La Junta mandó que el procurador, haga las diligencias que convengan ${ }^{1077}$. En junio el Diputado General mandó que se enviase una carta al escribano de Luyando, para que vaya a Arciniega y saque el testimonio de la baja que se hizo para estas obras, y lo envíe a Vitoria para mandarlos al Diputado General en la corte, y allí se pida lo que convenga ${ }^{1078}$. En Junta de septiembre el Diputado Ceneral dijo que el diputado en Madrid, le había enviado Provisión real para que el corregidor de Miranda de Ebro ponga en pregón la obra de estos puentes, y la remate en el oficial que presupueste más bajo, y haga diligencias sobre si en el remate anterior hubo algún fraude. Envió otra Provisión para que el alcalde mayor del valle de Ayala revise el repartimiento que se hizo a la provincia y hermandades de Álava, y si estuviere incorrecto lo repare, y para tratar este asunto había ordenado que viniesen a esta Junta ${ }^{1079}$. Se nombró a Lucas de Larrea, para que como persona con experiencia hiciese lo conveniente, así para que el alcalde mayor desagravie a la Provincia de lo que le ha cargado de más, como para que el corregidor abriese el remate de los puentes e hiciese las demás diligencias. Y que para que viesen si podría haber baja en el remate, llevase consigo a Juan de Lespeitia y Juan Vélez, maestros canteros $^{1080}$. Siete días después el Diputado General mandó al escribano que, para el viaje que debía hacer Larrea sobre estos puentes, sacase del archivo de la Provincia las matrículas de los pagadores, para ver los agravios que a las hermandades se habían hecho en el repartimiento ${ }^{1081}$, lo que hicieron de inmediato ${ }^{1082}$.

\section{e.- Por el puerto de Angulo y Llanteno}

Es un camino mulatero de escasa importancia por no pasar por puerto seco alguno. Desde el puerto de Angulo, se dirige por Encima-Angulo, Haedo de Angulo, Las Fuentes, Cozuela, Erbi, Retes de Llanteno, Llanteno, Inorza, Venta de Ureta, Artecona, Las Llanas, Allende, El Pontón, Molinar (Gordejuela), Zubieta y Sodupe, donde conecta con el camino que viene de Valmaseda.

En noviembre de 1593 el teniente de corregidor en Mena, acompañado de maestros canteros, fue a ver los puentes del valle de Angulo, en el camino real que entra por el puerto y peña de Angulo, que va a las villas y puertos y Señorío de Vizcaya, desde la Rioja y Castilla Vieja. De los 7 puentes que tenía, 6 los llevó la avenida sin dejar nada provechoso de ellos y el que quedó estaba muy maltratado:

- Puente de Encima-Angulo, sobre el río que baja de la peña de Angulo, está perdido

1076 A. J. G. A./ t. X/Vitoria, 7 mayo 1593.

1077 A. J. G. A./ t. X/Vitoria, 13 mayo 1593.

1078 A. J. G. A./ t. X/Vitoria, 28 junio 1593.

1079 A. J. G. A./ t. X/Vitoria, 14 septiembre 1593.

1080 A. J. G. A./ t. X/Vitoria, 7 octubre 1593.

1081 A. J. G. A./ t. X/Vitoria, 12 octubre 1593.

1082 A. J. G. A./ t. X/ Vitoria, 14 octubre 1593. 
por un lado y necesita hacerse de un arco y dos estribos pilares, que llevarán 280 varas de piedra labrada a 13 rs. cada una; y de cal, cimbras y ahorrazón 50 ducados.

- Puente de Centrales sobre el dicho río en el camino real, está caído y se ha de hacer de un arco y dos pilares que llevarán 270 varas de piedra labrada, cada una a 15 rs. De cal, cimbras y ahorrazón 35 ducados.

- Puente del lugar de Molinuevo en el dicho Valle, río y camino real, está llevado del todo y necesita hacerse de dos arcos con una cepa central, dos pilares y sus manguardias, llevará todo 500 varas de piedra labrada a 25 rs. cada una. De cal, cimbras y ahorrazón 150 ducados.

- Puente de Pontrada en el Valle y río de Angulo, está también caído y necesita hacerse de un arco con dos pilares y llevará todo 250 varas de piedra labrada a 15 rs. la vara. De cal, cimbras y ahorrazón 30 ducados.

- Puente de Martijana que está por el suelo, necesita hacerse de dos arcos, una cepa y dos pilares y llevará todo ello 300 varas de piedra labrada a 13 o 14 rs. la vara. De cal, cimbras y ahorrazón 50 ducados.

- Puente del Sartal en el dicho Valle y río de Angulo que está caído, necesita hacerse de un arco con dos estribos y llevará todo 370 varas de piedra labrada a 17018 rs. cada vara. De cal, cimbras y ahorrazón 55 ducados.

- Puente de Linares en el dicho Valle y río que está por el suelo, necesita hacerse de dos arcos con su cepa y dos pilares, y serán necesarias 395 varas de piedra labrada a 20 rs. la vara. De cal, cimbras, ahorrazón y otros materiales 70 ducados ${ }^{1083}$.

\section{C.- POR LA SIERRA SALVADA Y PORTILLO DEL ARO}

Los caminos que atraviesan la Sierra Salvada, eran el del portillo del Aro, los tres de Orduña y el que discurre entre San Pedro de Beraza y Dardoza.

El camino por el portillo del Aro era mulatero y no pasaba por ningún puerto seco. Desde San Llorente se dirigía a Lastras de Teza y, por el camino de los Mulateros, llegaba al portillo del Aro. Después, por Lejarzo, conectaba en Erbi con el camino que viene de Encima-Angulo y por Retes de Llanteno, Llanteno, Inorza, Ventas de Ureta, Artecona, Las Llanas, El Pontón, Gordejuela, Zubioeta y en Sodupe entroncaba con el camino que venía de Valmaseda. Otro acceso al portillo del Aro es el que, desde 500 mts. después de Osma en el camino a Orduña, discurre por Villalba de Losa, Zaballa, Llorengoz y cabañas de la Covata. Desde el portillo del Aro, también se podía llegar a Bilbao o a Portugalete por Oceca, Quejana, puente sobre el Izalde, Ibagüen, Zuaza, Oquendo, Jandiola, Zaldu, Azcaray, Padura y Sodupe. Así se recoge en unos pagos que la Universidad de Burgos realiza en 1547 para arreglo de caminos, en el caso de que el puente de Mariquejana sea el de Quejana: "En 18 de mayo 69.692 que dio gastados Francisco de Porres en adereçar los caminos, por yr los carros y mulateros dende la puente de Mari Quexana asta la puente de Sudupe para llebar las sacas a Portogalete", y en 1448, "70.828 que se an gastado en allanar los caminos de Portogalete para que bayan los carros y carretas con sacas

1083 A. H.V. M./ leg. 6, p. 221 a 336/ Madrid, 10 junio 1589 a 18 diciembre 1593. 
que se adereçaron desde Amurrio fasta Sudupe y Portugalete desde la Puente de Mariquexana hasta la puente de Sudupe"1084.

El año 864 el conde Diego agrega varias iglesias sitas en los valles de Mena y Ayala al monasterio de San Felices de Oca, citándose la vía pública de Salvada a Salmantón: “de illo roio de Salvata per summa ripa de Barcena usque ad illa via publica qui discurrez de Salvata apud Salvanton, et per illo semitario qui discurrez de Faro ad Coronellas,..." ${ }^{1085}$.

Entre los años 1315 y 1351 se entabló un pleito entre Orduña y Villalba de Losa, como consecuencia de que Villalba desviaba el tráfico por su villa y por el portillo del Aro, impidiendo que pasase por Orduña. El Rey manda que los arrieros que salgan de Villalba hacia Castro-Urdiales, Valmaseda, Vizcaya o Ayala, pasen a la ida y a la vuelta por Orduña ${ }^{1086}$.

En un pleito entre Orduña y las tierras de Orozco, Llodio, Ayala, Oquendo y Urcabustaiz, motivado porque los de Orduña pretendían que los de dichas tierras pasaran por la ciudad, "e non por otro puerto nin camino alguno", cuando fuesen con mercaderías a Castilla o desde Castilla, se falla en mayo de 1452 a favor de los vecinos y moradores de las mencionadas tierras, todas pertenecientes al señorío de Pedro López de Ayala, para que puedan comerciar y comunicarse por el portillo del Aro con Medina de Pomar, Oña, Frías u otros lugares, sin tener obligación de pasar por Orduña, y que "puedan yr e benir, syn pena alguna de la dicha çibdad nin de vezino e morador della nin de otra persona alguna, todo tiempo que quisieren e por bien touieren por el puerto del Aro, e non por otro camino alguno, desde el dicho puerto del Aro, fazia la dicha çiudad", aunque si fueren por otro camino entre el mencionado puerto del Aro y Orduña, deberían perder las mercaderías y sus acémilas ${ }^{1087}$.

\section{D.- POR LA SIERRA SALVADA Y PEÑA DE ORDUÑA}

La ciudad de Orduña, por ser aduana para todos los productos que entrasen o saliesen de Vizcaya, canalizó un muy importante flujo del comercio y pasaje entre Castilla y los puertos vascos, principalmente Bilbao. Ya en 1492, se registraba un alto tráfico mulatero: "Asy mismo, pregunto quántas azemilas e vestias entendian que pasarian por el dicho camino en cada vn año, vn año con otro, a lo qual el dicho Juan de Çaballa dixo quel auia tenido el cargo de coger la porta de los que pasaban por la porta de Jorduña por tiempo de quatro años, e que segund lo que auia visto, le paresçia que pasarian vn año con otro, tres mill azemilas e vestias,..."1088.

1084 A. D. B./ R-3/ Libro de caja de la Universidad de Burgos/ Burgos, 1539-1549.

1085 A. H. N./ Cartulario de San Millán de la Cogolla. Becerro, fol. 108/ 2 mayo 864; SERRANO, L.: 1930: 12-14: doc. 9; UBIETO ARTETA, A.: 1976: 15-17: doc. 7

1086 A. Ch. V./ Sección de Pleitos Civiles. Zarandona y Balboa (olv), c. 523-11/ 11 octubre 1315-15 noviembre 1351 "...que enbargaban y defendian forçosamente e sin razon e sin derecho que los caminantes que no fuesen por los dichos caminos a Horduña mas que fuesen porVillalba e por esta razon que el dicho conçejo de Horduña e sus vezinos que resçiben grandes daños...".

1087 A. M. Vitoria/ 4-15-2/ Salvatierra, 22 mayo 1452. “...puedan yr e benir, syn pena alguna de la dicha cibdad [Orduña] nin de vezino e morador della nin de otra persona alguna, todo tiempo que quisieren e por bien touieren por el puerto del Aro e non por otro camino alguno, desde el dicho puerto del Aro, fazia la dicha çiudad. E sy por otro camino pasaren desde el dicho puerto del Aro fazia la dicha çibdad, que pierdan lo que asy lleuaren o troxieren con las azemilas que lo troxieren o lleuaren...".

1088 A. G. S./ Cámara de Castilla. Pueblos, leg. 3-2, doc. 248/ Orduña, 20 enero 1492. 


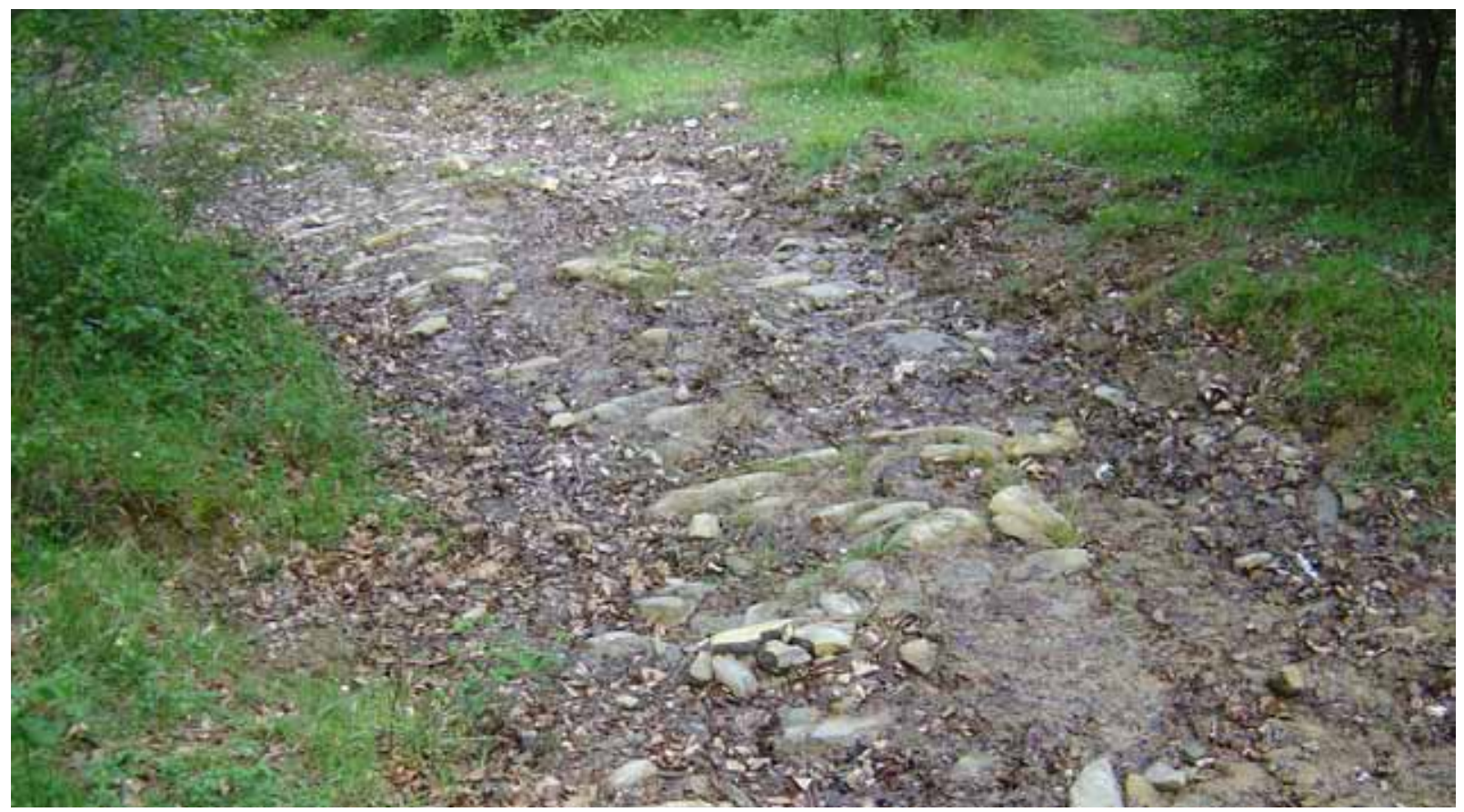

Restos del camino antiguo por San Bartolomé en Orduña.

Sus caminos, no obstante, tuvieron siempre el gran inconveniente de tener que salvar el difícil y abrupto paso de sus puertos de montaña. La llamada Peña de Orduña, o simplemente "La Peña", forma un escarpado roquedal de caliza que corre de Este a Oeste dentro de la Sierra Salvada. La elevación de este corte escarpado destaca desde largas distancias si se mira desde el Norte, aunque desde el Sur por la parte del valle de Losa se llegaba a la Peña suavemente, descubriendo allí una pronunciada y repentina caída de $600 \mathrm{~m}$ en un muy corto espacio de terreno, algo que actuó históricamente como una barrera difícilmente practicable para el comercio y el transporte de mercancías, y que obligó a adoptar, en todas las épocas, medidas extraordinarias para atravesarla en las mejores condiciones. En los inviernos, el alto se cubría de nieve con facilidad, que llegaba hasta el santuario de Nuestra Señora de la Antigua a las afueras de la ciudad de Orduña. No obstante, la necesidad de comunicación y el comercio de los puertos vizcaínos con Castilla, así como la voluntad decidida de los bilbaínos, hicieron superar todos los inconvenientes que la naturaleza y la orografía presentaban.

Había otras alternativas en la zona para evitar este paso tan abrupto, pero el empeño de Bilbao, por ir por el camino de San Bartolomé, el más corto de la zona, le obligó a invertir grandes sumas de mrs. y realizar complejos trabajos de ingeniería para encajar en las paredes de La Peña, un camino que solo estuvo adecuado para los carros, a pesar de intentos anteriores, en el siglo XVIII.

Tres eran los caminos que, por la ciudad de Orduña llegaban a Bilbao: por Briviesca, Frías, Herrán y Bóveda, otro por Briviesca, Frías, Herrán y Valpuesta, ambos por el paso de Coldecho, y el tercero por Pancorbo, Puentelarrá y Berberana a Orduña por el paso de San Bartolomé, el más importante y utilizado.

El camino más antiguo de acceso a la meseta es el que se llamaba "de la venta de Ar- 
bín” por la ermita de San Bartolomé, ermita que ya en 1764 había desaparecido1089. Son muy abundantes las noticias relacionadas con este camino en el siglo XV y principios del XVI. Existe incluso una Ordenanza de 1506 en la que se regulan las condiciones de la guía de la Peña ${ }^{1090}$. El camino antiguo, que solo era de herradura, se utilizaba con muchas dificultades y no en todas las estaciones del año. Tras alcanzar el puerto, el suave descenso hacia la Meseta se encontraba a una legua con Berberana en el Valle de Losa. Este fue el paso que se pudiera llamar "oficial" para la aduana de Orduña, indica un documento de 1653. "era necesario reparar la Peña de la Guía de San Bartolomé, camino para la aduana de la ciudad"1091.

Otro paso importante y muy transitado fue el llamado de Coldecho que, a pesar de los intentos para convertirlo en camino carretero, nunca se logró y siguió siendo utilizado solo por bestias y peatones.

\section{a.- El camino de Bayona entre Burgos y Pancorbo}

La vía que desde Burgos, se dirige por Gamonal, Villafría, Rubena, Quintanapalla, Monasterio de Rodilla, Santa Olalla, Quintanavides, Revillagodos, Briviesca, Cameno, Grisaleña, Zuñeda, Pancorbo, Ameyugo, Orón, Miranda de Ebro, Venta de Rivabellosa, Armiñón, Venta de Burgueta, La Puebla de Arganzón, Venta de Ayatanes, Ariñez, Comecha, Venta de Armentia a Vitoria, y prosigue por Irún a Bayona, fue una de las más importantes de Castilla y la que se utilizaba para ir a Bilbao, bien desde Briviesca por el camino de Frías, o bien desde 3,5 km pasado Pancorbo por el camino de Puentelarrá. En este camino existió alguna variante como la que hubo entre Burgos y Monasterio de Rodilla, por la Venta de Hurones, Las Mijaradas, barrio de Santa Marina ${ }^{1092}$ y Monasterio de Rodilla, así como entre Monasterio de Rodilla y Briviesca, por Castil de Peones y Prádanos de Bureba, por la orilla derecha de los ríos Cerrata y Oca. Trataremos por ello el tramo hasta Pancorbo, a pesar de proseguir como se ha dicho hasta Bayona. Así consta en las ordenanzas de la Universidad de Burgos, cuando se indica que los miembros de dicha Universidad por aranceles de averías, han de pagar entre otras mercaderías, por "saca de lana que fuere por tierra à Francia, Flandes, Bretaña o Roan, por Navarra o Fuenterrabia o otra parte, pague de averías doce maravedís y medio..."1093.

Fue utilizado también desde la segunda mitad del siglo XV como camino para ir a Santiago, conviviendo con el tradicional camino Francés, pero ya en una época tan tardía,

1089 ARMONA y MURGA, J. A.: 2002, 138. "Cuando se abrió este rudo camino [1764], se descubrieron los cimientos de la ermita de San Bartolomé, y una vasija con algunas monedas dentro; pero hubo tan poca atención sobre una cosa tan digna de examen, que nadie da hoy razón de ellas, aunque se dice que algunas se llevaron a Bilbao".

1090 A. H. F. B./ Munic. Orduña, Caja 84, leg. D, fol. 1 r.-6 v.; 33 r.o-; 7 r.-32 v.; 34 r.- 51 r./ 1506-1527. ENRÍQUEZ FERNÁNDEZ, J.; HIDALGO de CISNEROS AMESTOY, C.; LORENTE RUIGÓMEZ, A.; MARTÍNEZ LAHIDALGA, A.: "Colección Documental del Archivo Municipal de Orduña (1511-1520),... Tomo II". 1994: doc. 47.

1091 A. H. F. B./ Munic. Orduña, caja no 19, carp. 7/ Orduña, 26 mayo 1653.

1092 A. H. N./ Nobleza, Frias, Leg. 371, D. 2-3/ Sevilla, 22 febrero 1402. Enrique III concede en 1402, mercado franco a Monasterio de Rodilla, en el barrio de Suso o de Santa Marina, algo que solo se justifica si el camino real pasa por dicho barrio: "do la dicha liçençia para que se faga mercado en el dicho lugar de Monesterio de Rrodilla en el Uarrio de suso en dia de sabado de ocho a ocho dias".

1093 GARCíA de QUEVEDO y CONCELLÓN, E.: 1905 y 1995: 204. 
que las peregrinaciones medievales se encontraban en clara decadencia, lo que junto con las dificultades militares, ideológicas y religiosas del siglo siguiente, provocó la escasa proyección de este Camino a Santiago en los siglos siguientes ${ }^{1094}$.

\section{El camino en las guías itinerarias}

Fernando Colón recoge esta vía en su Descripción y Cosmografía de 1517, desde Burgos a Bilbao por Hurones, Monasterio de Rodilla, Castil de Peones, Prádanos, Briviesca, Grisaleña, Zuñeda y Pancorbo'095.

La utilización todavía en estas fechas de una parte de la vía romana por Hurones, ha entrado en franca regresión en beneficio de la que discurre por Quintanapalla y, ya en 1495, Hermann Künig von Vach no menciona ese tramo de la vía y von Harff transita en 1498 desde Burgos, por Villafría, Rubena y Quintanapalla. No obstante la vía por Hurones seguirá teniendo, aunque baja, una cierta utilización. Los repertorios de Villuga, Meneses y Pontón, recogerán este mismo recorrido en uno de sus itinerarios y en 1672 Jouvin, lo utiliza en su viaje y describe de manera pormenorizada. Así, en el Repertorio de caminos de Pero Juan Villuga de $1546^{1096}$, se recoge de manera precisa el camino de Vitoria a Burgos, y en el que llama “camino de Burgos a Bilbao", hay una variante entre Burgos y Monasterio de Rodilla que discurre junto a la venta de Hurones, coincidiendo con la Descripción mencionada de 1517 de Fernando Colón. También el Repertorio de Meneses de 1576, incluye los mismos caminos y localidades descritos en el de Villuga, es decir, de "Burgos para Bilbao" y de "Burgos para Vitoria"1097.

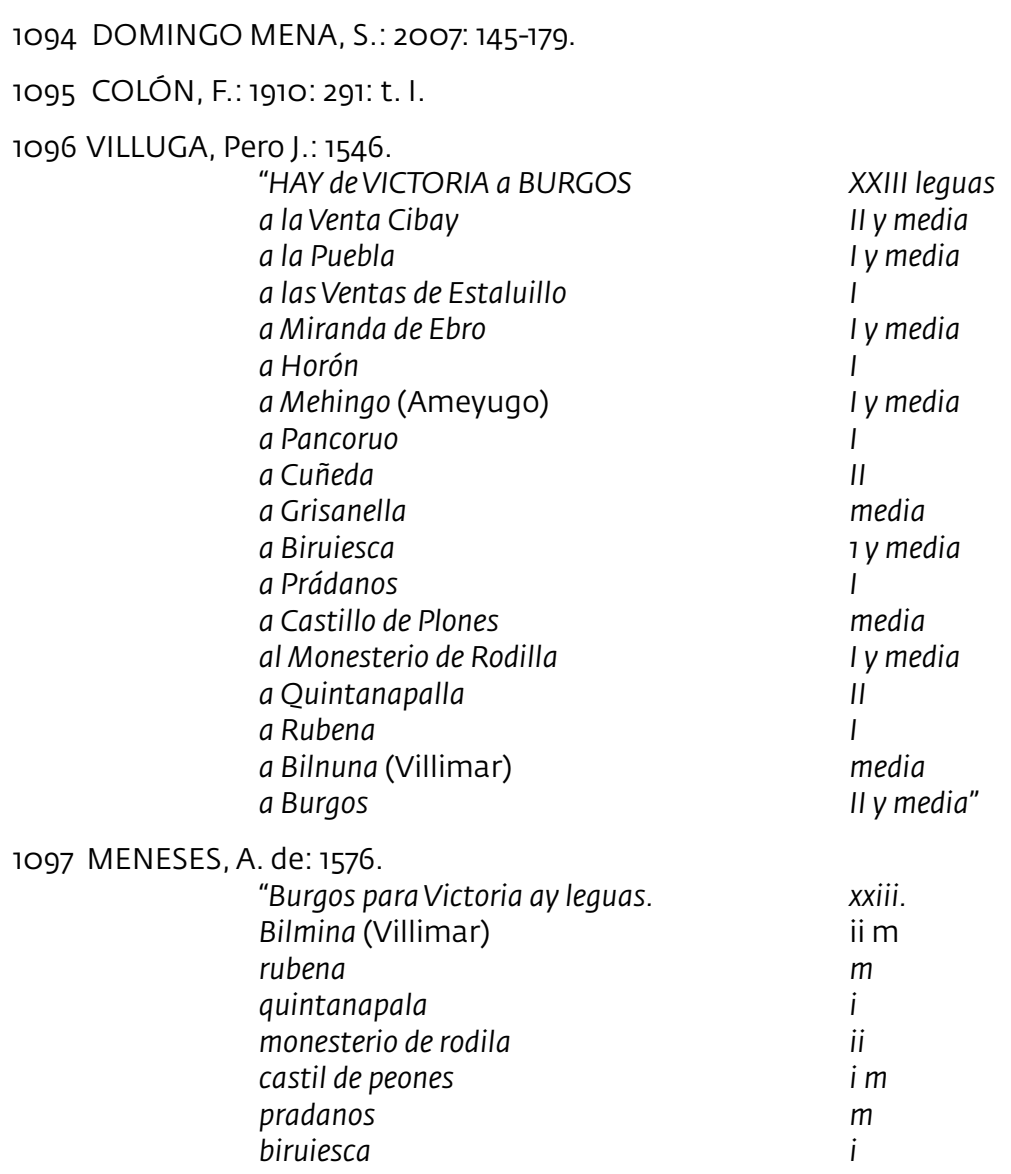




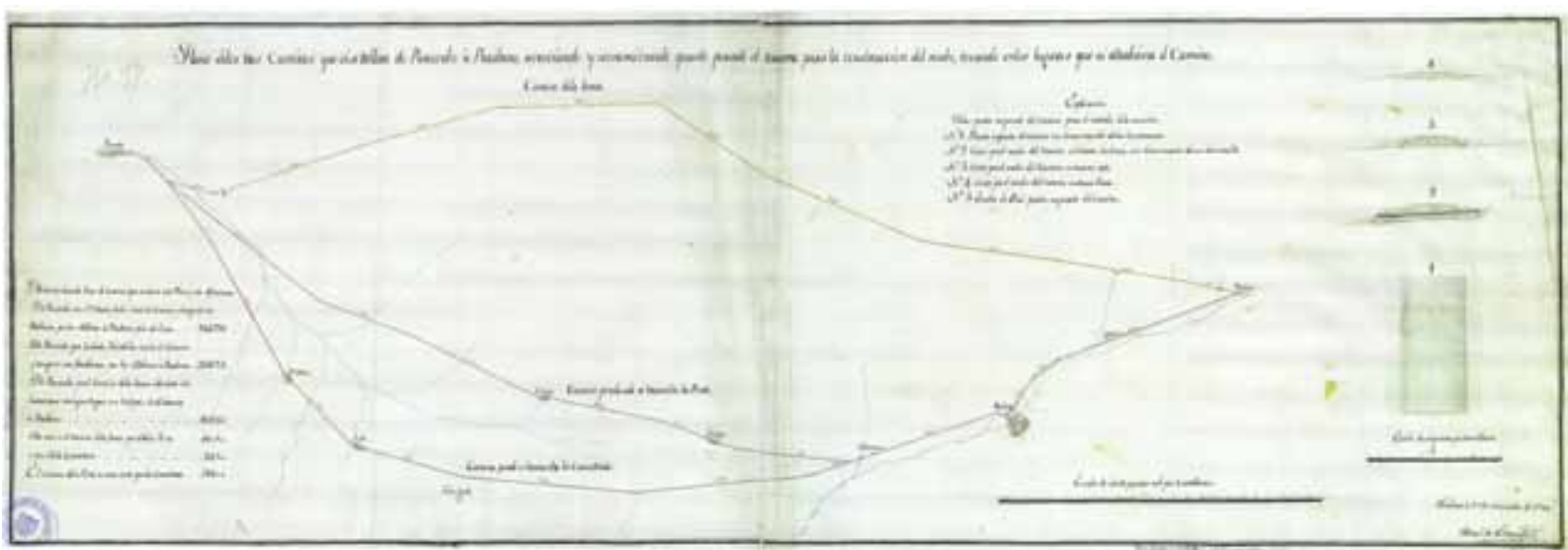

Plano de Echánove de 1784 sobre los tres caminos que iban de Prádanos a Pancorbo, realizado con motivo del nuevo camino a Francia (ARCGE Ar. E-T. 37).

En el itinerario francés de 1525 "Le Chemin de París à Saint Jacques en Gallice dit Compostelle; et combien il y a de lieues de ville en ville", se citan las localidades por las que discurre esta ruta que, partiendo de París, pasaba por Irún, túnel de San Adrián, Vitoria, La Puebla de Arganzón, Miranda, Pancorbo, Briviesca y Burgos para seguir después por el camino clásico hasta Compostela1098. Nicolás Bonfons en su "Nouvelle Gvide des Chemins" de 1583, detalla en el camino a Compostela el paso por el túnel de San Adrián, Vitoria, La Puebla, Miranda, Pancorbo, Briviesca, Castil de Peones, Monasterio de Rodilla y Burgos ${ }^{1099}$.

\begin{tabular}{|c|c|}
\hline grisaleña & im \\
\hline çuñeda & $m$ \\
\hline pancoruo & ii \\
\hline mehingo (Ameyugo) & $i$ \\
\hline horon & im \\
\hline Miranda de ebro & $i$ \\
\hline ventas de estaluillo & im \\
\hline la puebla & i \\
\hline la venta cibay & im \\
\hline Victoria & ii m" \\
\hline "Victoria para Burgos, ay leguas. & xxiii \\
\hline La venta cibay & ii m \\
\hline la puebla & i m \\
\hline las ventas de estaluillo & i \\
\hline Miranda de hebro & i m \\
\hline horon & i \\
\hline ameyugo & im \\
\hline Pancoruo & $i$ \\
\hline çuñeda & ii \\
\hline grisaleña & $m$ \\
\hline Biruiesca & $i m$ \\
\hline pradanos & i \\
\hline castil de peones & $m$ \\
\hline monesterio de rodilla & i m \\
\hline quintanapalla & ii \\
\hline rubena & i \\
\hline bilnuna (Villimar) & $m$ \\
\hline Burgos & ii m" \\
\hline
\end{tabular}

1098 FOULCHÉ-DELBOSCH, R.: 1896: 25; PORTILLA VITORIA, M. J.: 1991: 28. Se trata de un itinerario que compró Fernando Colón en León en 1535.

1099 HUIDOBRO y SERNA, Luciano. t. III, 1951: 725. 
En 1599-160o el alemán Jacob Cuelvis incluye en su "Thesoro chorographico de las Espannas", las localidades de Vitoria, La Puebla, Miranda de Ebro, Pancorbo, Briviesca, Caborredondo y Burgos ${ }^{1100}$. Es novedosa la referencia a la localidad de Caborredondo entre Briviesca y Burgos que hace alusión a un camino mucho menos frecuentado, que desde Briviesca pasaba por el citado pueblo, Temiño y Hurones.

Ottavio Cotogno, lugarteniente del Correo Mayor de Milán, publica su Itinerario de Postas en 1608 en que detalla los caminos de Burgos y describe el de Burgos a Vitoria ${ }^{1101}$.

En una hoja impresa en París en 1621, que detalla el itinerario del camino a Santiago de Galicia se recoge el trayecto por Vitoria, La Puebla, Miranda de Ebro, Pancorbo, Briviesca, Castil de Peones, Monasterio de Rodilla y Burgos. Desde aquí prosigue por el Camino Francés tradicional ${ }^{1102}$.

\section{Las referencias de viajeros}

La primera cita sobre la utilización jacobea de este camino, se remonta a 1428, cuando un comerciante y patricio de Nüremberg fue a Santiago de Compostela, y a la vuelta, encuentra al rey "en Burgos, y Su Majestad estaba en aquel momento a punto de partir en dirección a Bayona, a donde el rey de Francia, en donde se habían citado para negociar sobre la guerra... Cabalgamos un par de

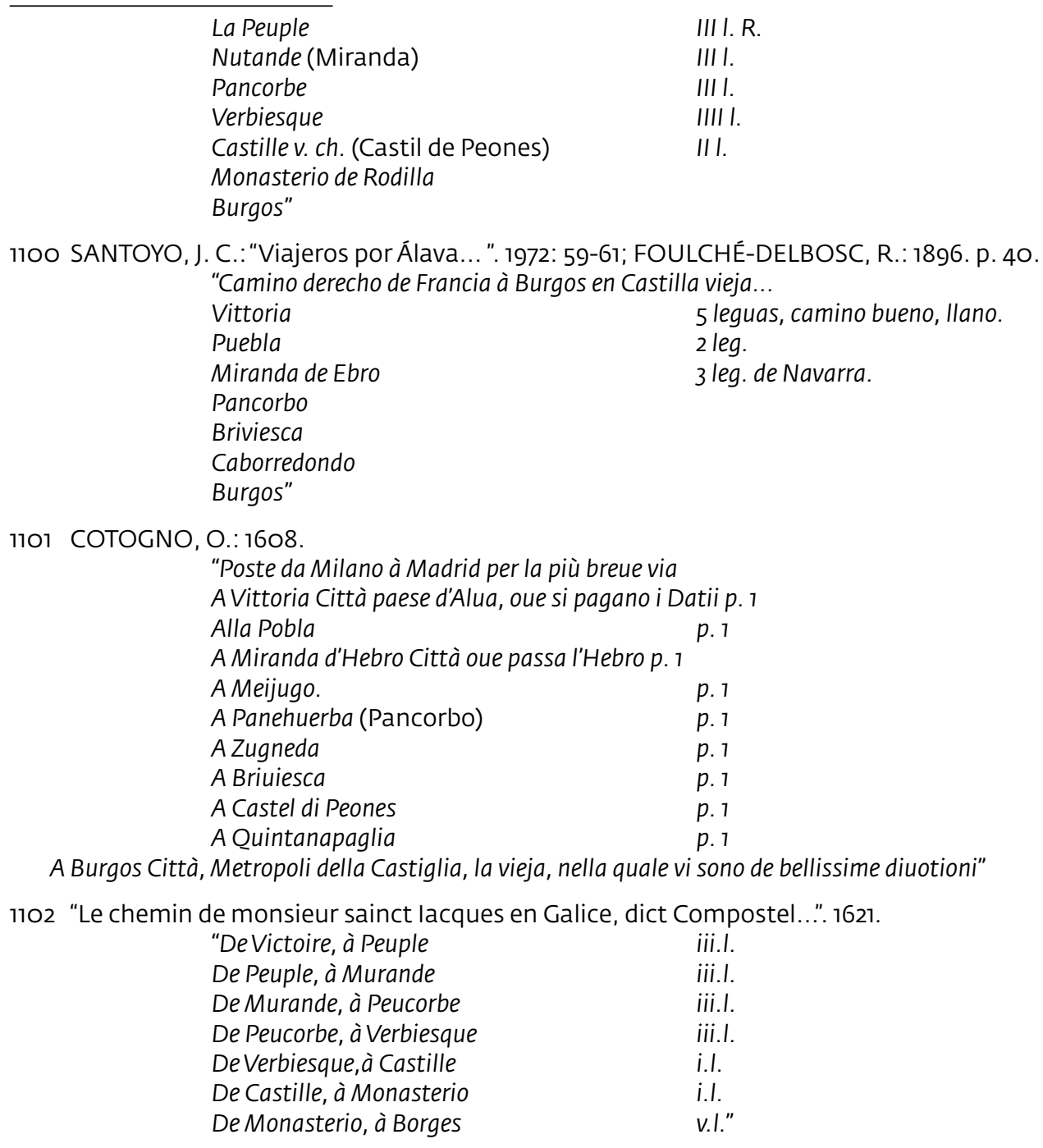


días juntamente con el rey... Luego nos dirigimos al encuentro del rey de Francia, con quien nos encontramos a tres millas de Bayona... de Dolosa a Beana [Bayona] y a través de Pisskey [Vizcaya] 100 millas hasta Purges [Burgos]"1103.

Enrique IV se desplaza en 1463 de Burgos a Bayona, según se recoge en su itinerario, y así entre el 13 y el 15, va a Miranda de Ebro, donde está hasta el 19. El 30 y el 31 se aloja en Vitoria, y el 2 de abril llega a San Sebastián. Después, volverá a Burgos por el camino de Santo Domingo de la Calzada1104.

Fernando el Católico va de Burgos a Vitoria por Briviesca, Pancorbo y Miranda en junio de 1476. En octubre vuelve por el mismo camino1105.

En 1495 Hermann Künig von Vach regresa de su peregrinación a Compostela ${ }^{1106}$. En Burgos, alude a la existencia de una bifurcación junto a una cruz de piedra a la salida de la ciudad hacia el Este -von Vach la sitúa antes de entrar en la ciudad pero pensando en la dirección hacia Compostela-. Sin duda se refiere a la cruz denominada Crucero de Gamonal situada junto al camino real y en el límite de los términos de Burgos y Gamonal1107, según se recoge con claridad en el plano realizado con motivo de un pleito en el siglo XVIII sobre las propiedades del monasterio de San Juan ${ }^{1108}$. En la bifurcación, nos dice que se puede ir por la izquierda, es decir por Briviesca, Miranda y "Portem Berge" (Puerto de San Adrián), o bien por la derecha por Atapuerca y Villafranca Montes de Oca siguiendo uno de los caminos clásicos. Nos encontramos con la primera referencia clara sobre el tránsito por Rubena y Quintanapalla a Briviesca sin utilizar el camino por Hurones y Las Mijaradas y sobre la diferenciación de los dos caminos: el que va por Atapuerca y el de Briviesca.

Al regreso de su peregrinación a Compostela en 1498, el peregrino alemán Arnold von Harff, también nos indica la misma bifurcación mencionada por von Vach, es decir, un camino por la derecha hacia Logroño y otro por la izquierda que es el que utiliza y que describe con detalle, por Villafría, Rubena, Quintanapalla, Monasterio de Rodilla, Quintanavides, Briviesca, Crisaleña, Zuñeda, Pancorbo, Ameyugo, Orón, Miranda de Ebro, La Puebla de Arganzón y Vitoria hacia París ${ }^{1109}$.

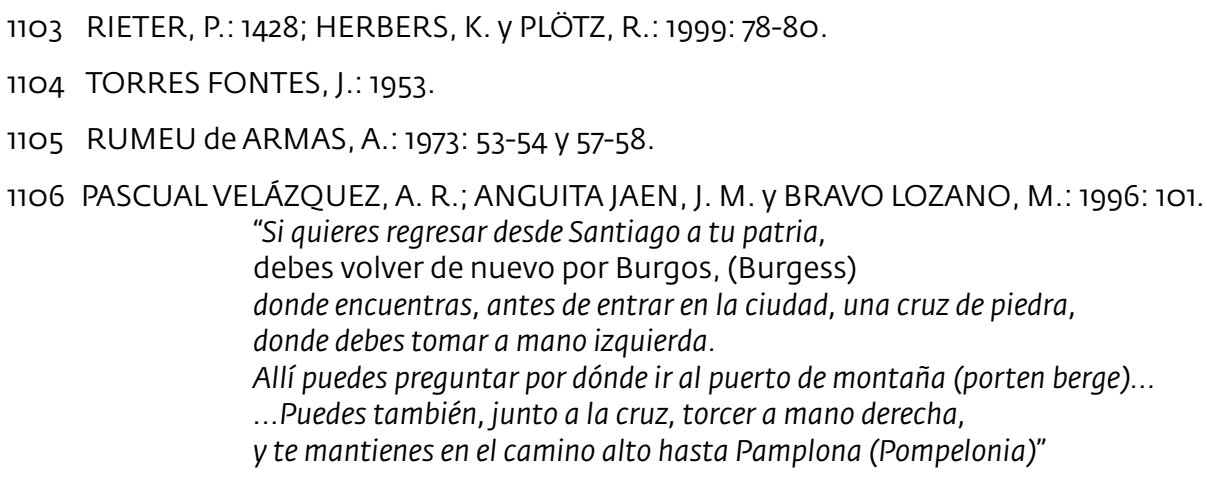

1107 Esta cruz de Gamonal, que hoy se encuentra frente a la iglesia de Gamonal, Huidobro la sitúa en origen hacia la cava de la Casa de la Vega, cerca de la ciudad de Burgos, para después ser trasladada al cementerio frente al ábside de la iglesia de Gamonal (HUIDOBRO SERNA, L.: 1926: 72). El mismo autor, en fecha posterior, sitúa la misma cruz de Gamonal según cita de 1495, próxima a Villayuda y al molino de la Cigüeña en el cauce que salía del río Arlanzón, lindando con tierras de San Pedro de Cardeña. HUIDOBRO Y SERNA, L.: t. II, 1950: 362.

1108 A. M. B./ S. H. C. 3-3-12 bis.

1109 HERBERS, K. y PLÖTZ, R.: 1999: 222 y 229. “Item en Burgos, ... nos sentamos de nuevo sobre nuestros caballos y cabalga- 
Los príncipes Felipe y Juana realizan su primer viaje a Castilla en 1502. Vienen de Bruselas por Francia y están en Vitoria el 4 de febrero, en Miranda el 7, el 9 en Crisaleña, el 10 en Briviesca, el 11 en Monasterio y el 12 llegan a Burgos ${ }^{1110}$.

Peter Rindfleisch va, a Santiago en el invierno de 1506-1507 por el camino de San Adrián, y en Compostela se encuentra con Enrique de Sajonia que había entrado también por Irún ${ }^{1111}$.

En 1510 el prelado Robert Langton Clerke incluye en su itinerario a Compostela el camino por Vitoria, puente de Armiñón, Miranda de Ebro, Pancorbo, Briviesca y Burgos ${ }^{1112}$. Frédéric Wittelsbach (Federico II, elector palatino) viene de Francia en 1520 por Vitoria y Burgos en su camino a Toledo ${ }^{1113}$.

En 1521-1522 peregrina a Santiago Sebald Örtel de Nüremberg y viene por Vitoria, Miranda, Briviesca, Monasterio de Rodilla y Burgos ${ }^{1114}$.

Según el Diario de los viajes de Carlos V de Juan de Vandenesse, el emperador viene

mos hacia Parijs. Y antes de la ciudad hay un convento que se llama ad sanctam Maríam gaminael [Sta. Mª de Gamonal]. Después de él se bifurca el camino, uno hacia la derecha, por el que habíamos venido desde Venecia, y otro hacia la izquierda en dirección a Parijs, que nosotros tomamos en dirección noreste.

Item de Burgis a Villa ferris [Villafría], un pueblo,

Item de Villa ferris a Robena, un pueblo,

II Leguas.

Item de Quintana palea a Monasterium rodila, un pueblo, I Legua.

Item de Rodila a Quinta in vedis [Quintanavides], un pueblo, I Legua.

Item de Quintana in vedis a Barbisco [Briviesca], una pequeña villa, II Leguas.

Item de Barbisco a Salinich [Grisaleña], una exención, I Legua.

Item de Salinich a Suneta [Zuñeda], un pueblo, II Leguas.

Item de Suneta a Pancorbo, [hay] II Leguas. Ésta es una pequeña villa que está situada entre dos montañas muy altas, puntiagudas y que están apenas separadas la una de la otra. Allá arriba hay una fortaleza que es un bastión fronterizo (puerta) para todo el territorio de Hyspanien.

Item debes mostrar aquí el documento que has recibido en Lagrunea [Logroño] en el otro camino [y que acredita] que has introducido contigo el caballo en el país...

Item de Parcorbo a Amigugo, una pequeña villa,

Item de Amigugo a Oron, un pueblo,

I Legua.

I Legua.

Item de Oron a Merenda, [hay] II Leguas, una ciudad castellana está situada al lado de un río caudaloso que se llama Ebro. Por encima de él pasa un puente de piedra. Encima de la montaña que hay sobre la ciudad está situada una fortaleza muy imponente. Aquí también se te da el certificado de despacho aduanero en caso de que hayas comprado un caballo en el país. Item de Miranda a Popula de Argansón, una pequeña villa, II Leguas. Item de Popula a Victoria, una hermosa ciudad III Leguas".

1110 GARCÍA MERCADAL, J.: 1952: 446-448 y 453-454: t. I. "De Vitoria a Miranda, adonde monseñor llegó el lunes, 7 del mes [febrero], son cinco leguas, a cuyo encuentro salieron las buenas gentes del país, y estuvo allí el martes de Cuaresma. El miércoles de Ceniza se alojó en Grisaleña a seis leguas de allí. El jueves caminó una sola legua y durmió en Briviesca. El viernes, en el monasterio de Rodilla. El sábado comió a una legua de Burgos, donde fueron a su encuentro el condestable de Castilla... El sábado 19 [febrero], Antonio de Lalaing, señor de Montigny... Carlos de Lannoy, señor de Saintzelles y Antonio de Quiévranis, señor de Monceaux, partieron de Burgos para ir a Santiago".

111 VÁZQUEZ DE PARGA, L. et alii: 1948: t. I, 105. Autor Vázquez de Parga.

1112 BRIAN TATE, R. y TURVILLE-PETRE, T.: 1995: 98.

$\begin{array}{ll}\text { "Victoria } & \text { iiii } \\ \text { Le pont Darmenian [puente de Armiñón] } & \text { ii } \\ \text { Miranda } & \text { iii } \\ \text { Paucoruo } & \text { iiii } \\ \text { Breuisco } & \text { viii } \\ \text { Burgus" } & \end{array}$

1113 FOULCHÉ-DELBOSCH, R.: 1896: 28.

1114 PASCUAL VELÁZQUEZ, A. R.: 1999: 377. “Desde allí cabalgamos hacia Vitoria (Witdoria), a tres millas. Allí hay que inscribir a los mulos y asnos en los que se entra a la ciudad. Gastamos cuatro reales. De allí a Miranda de Ebro (la Punda Dormurug) hay cuatro millas. Alli gastamos ocho darges. De alli a Briviesca (Mermiste) hay cuatro millas. Gastamos un real y dos darges. De allí a Monasterio de Rodilla (Mestir Derodilla) hay tres millas, gastamos dos reales y dos darges. De allí cabalgamos hacia Burgos (Wurges), a cinco millas". 
en 1524 por Vitoria y llega el 7 de marzo a Miranda, el 8 a Briviesca donde se queda hasta el día 10, día que llega a Monasterio de Rodilla y el 11 entra en Burgos ${ }^{1115}$.

El embajador veneciano Andrea Navagiero, va en 1528 desde Poza de la Sal hacia Francia por Busto, Cubo, Pancorbo, "Maijugo" (Ameyugo), Miranda de Ebro, Ventas de Armiñón, La Puebla y Vitoria'1116.

El excartujo y médico inglés Andrew Boorde, volverá a realizar la romería por Burdeos y Bayona unos años después de emprender su peregrinación por Santo Domingo de la Calzada en $1532^{1117}$.

En una Real Cédula emitida en 1535 relativa al hospital de Nuestra Señora del Cabello de Vitoria, se indica de manera explícita que este camino es por donde se viene de romería a Santiago ${ }^{1118}$.

Juan de Vandenesse señala en su Diario que, en 1539, Carlos V viniendo de Valladolid, llega el 22 de noviembre a Burgos y el 24 a Vitoria'1119.

J. A. Goris Louvain publica en 1925 la "Relación detallada de un viaje hacia Madrid en 1562" en que se incluye Vitoria, La Puebla, Miranda, Ameyugo, Zuñeda, Castil de Peones Quintanapalla y Burgos ${ }^{1120}$.

El italiano Giovanni Battista Venturino, componente del séquito oficial del legado pontificio y patriarca de Alejandría, regresó de Lisboa en 1571-1572, por Salamanca, Burgos, Miranda de Ebro, Ventas de Armiñón y Vitoria ${ }^{1121}$.

San Francisco de Borja sale de Madrid el 2 de enero de 1572 llega a Burgos el 7 de enero, come el día 9 en Pancorbo y duerme en Miranda. El 10 llega a Vitoria ${ }^{1122}$.

En la "Relación de la Corte de España hecha en 1572 por un gentilhombre del séquito de Antonio Tiépolo, que fue embajador cerca del Rey Católico" se hace referencia al viaje a Madrid desde Francia por Vitoria y Burgos ${ }^{1123}$.

Lupold von Wedel en su relato de viajes y experiencias bélicas de 1580 , describe su viaje a Madrid por Vitoria, La Puebla, Miranda, Pancorbo, Briviesca y Burgos ${ }^{1124}$.

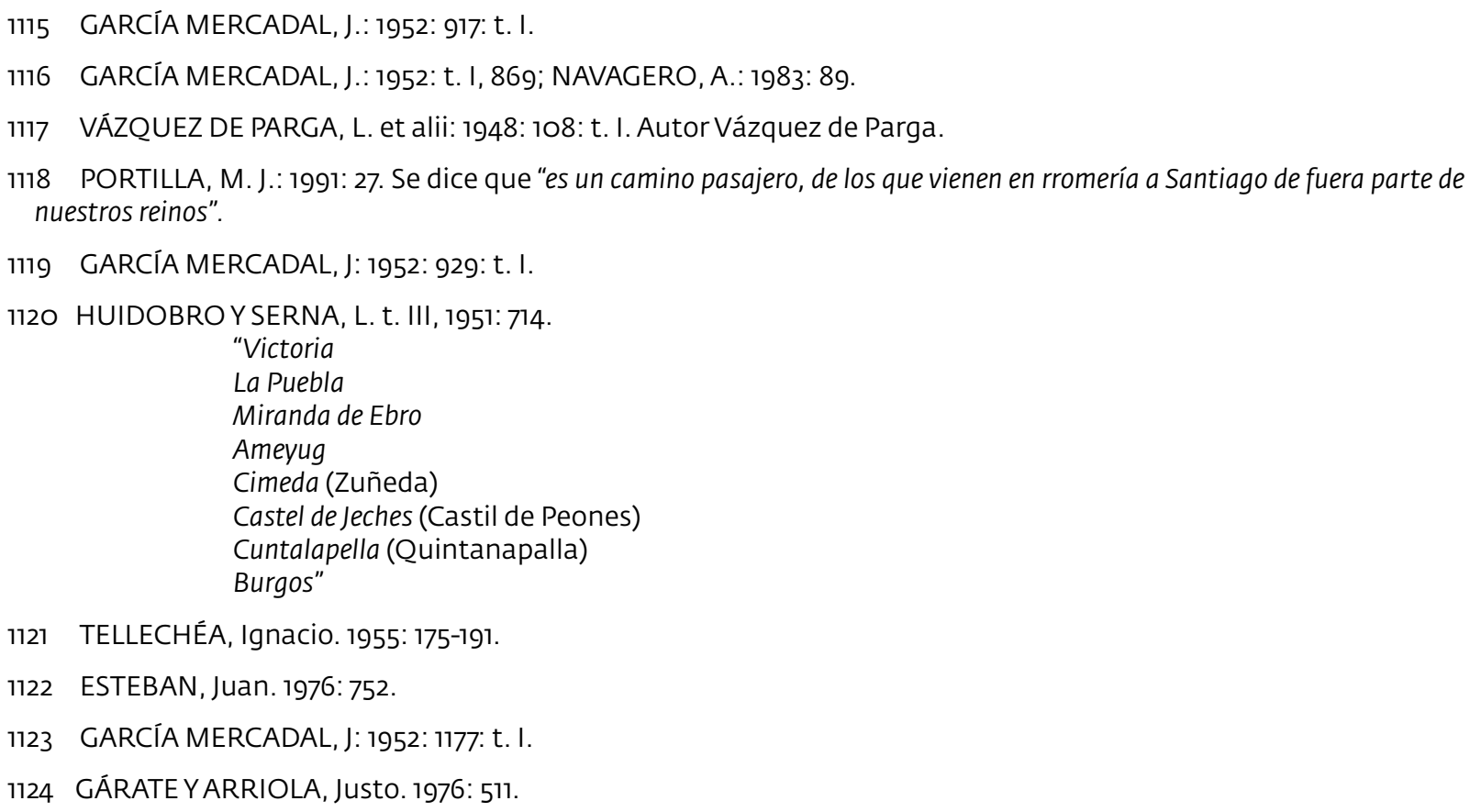


Jacobo Sobieski, en su peregrinación a Santiago en 1611, va por Logroño, Santo Domingo y Burgos. Después llega a Madrid y regresa por Burgos y Vitoria ${ }^{1125}$.

En 1612 un viajero francés anónimo relata en su "Relation d'un voyage en Provence, Espagne, Portugal, Anglaterre et Holande", su camino de Valladolid a Irún por Burgos y Vitoria ${ }^{1126}$.

La comitiva española que acompañaba a la infanta Ana de Austria hasta la frontera para contraer matrimonio con Luis XIII de Francia, partió de Burgos el 24 de octubre de 1615 -el Rey le acompaña una legua- y llegará a Fuenterrabía el 10 de noviembre realizando las siguientes etapas:

\begin{tabular}{|c|c|}
\hline 24 octubre & Burgos-Quintanapalla \\
\hline 25 octubre & Quintanapalla-Briviesca \\
\hline 26 octubre & Briviesca-Pancorbo \\
\hline 27 octubre & Pancorbo-Miranda \\
\hline 28 octubre & Miranda-La Puebla-Vitoria \\
\hline Sale de Vitoria el 30 & Vitoria hacia Fuenterrabía \\
\hline
\end{tabular}

Una vez hecho el canje a orillas del Bidasoa el 9 de noviembre, la comitiva regresa ese mismo día por el mismo camino con la infanta francesa Isabel de Borbón que viene para casarse con el futuro Felipe IV. Después de dormir en Quintanapalla el 21 de noviembre, llegará a Burgos el 22 donde será recibida por el Rey y el príncipe ${ }^{1127}$.

François Bassompierre embajador francés, va a Madrid en 1621 por Vitoria, Miranda de Ebro, Pancorbo, Briviesca y Burgos y regresa por el mismo camino. En 1628 Monsieur de Monconys, va de Francia a Salamanca por el túnel de San Adrián, Vitoria, Pancorbo y Burgos $^{1128}$.

El franciscano inglés Francisco Bell, para ir en 1633 al capítulo de la Orden en Toledo, va por Vitoria, La Puebla, Miranda de Ebro y Burgos ${ }^{1129}$.

Hacia 1640 un viajero francés anónimo realiza la "Descripción del camino de Yrun para Madrid y Portugal”, en que va a Madrid por San Sebastián y Burgos ${ }^{1130}$.

\section{Referencias documentales}

El año 943, Munio y Cutier entregan a San Juan y San Millán de Hiniestra una tierra entre Cameno y Briviesca, junto a la calzada. Es el primer documento que hace referencia

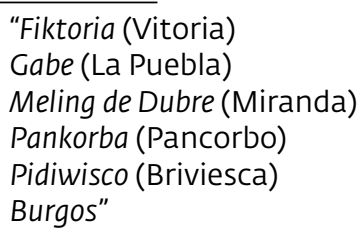

GARCÍA MERCADAL, J: 1952: 325-327: t. II.

1126 FOULCHÉ-DELBOSCH, R.: 1896: 42.

1127 FOULCHÉ-DELBOSCH, R.: 1896: 46. Viaje descrito en la "Relación de la jornada de la reina de Francia".

1128 FOULCHÉ-DELBOSCH, R.: 1896: 51 y 57.

1129 SANTOYO, Julio César. 1972: 87-89.

1130 FOULCHÉ-DELBOSCH, R.: 1896: 59. 
a un tramo de este camino como es el de Cameno a Briviesca al que denomina calzada: “... una terra inter Cameno et Birivesca, iuxta calzata"1131.

En 963, se menciona el tramo de Villafría a Rubena. Mientras a otros caminos los llama vías y al que sale de Briviesca lo llama carrera (posiblemente la vía Aquitana), a este camino lo denomina "strata", probable indicio de su temprana importancia1132.

En 999, se menciona la via antigua junto al río Vena, “... et trado similiter ad integro serna que est iusta uilla Fontes, ex una parte uia antiqua, de alia parte prato et riuulo de Uena..."1133.

En 1042, Diego Muñoz con su mujer Elo y sus sobrinos, someten el monasterio de San Clemente de Ribarredonda al de San Millán, “... et terra una in ponte de Fonte Burueva..." 1134 .

En 1135, Alfonso VII y su esposa doña Berenguela, dan al hospital de Rubena la villa de Ollola, vecina de Fenestra y Milanes. Este hospital, que debe su existencia a su situación junto a un camino importante, ha sido vinculado a la asistencia a los peregrinos a Santiago: “... pro remedium anime mee et parentum meorum, dono et concedo albergerie de Rio de Uena, uillam illam que nuncupatur Ollola, que est uicina de Fenestra et de Milanes.... Domnus Lupus de Rio de Uena, recuperauit suprascriptam uillam ad seruicium albergerie et peregrinorum"1135.

En el fuero de Pancorbo de 1147 , se indica que "... ac transit rivum de Oron et vadit ad primum portellum que est inter Amexugum et Mirandam, et inde vadit per senderum de latronis... Item conçedo vobis montes de Fonte atalon usque ad Iberum, quos de mandato meo homines de Lantaron et omes duos de Çiville de Tovalina vobis per conpusiçione dederunt, uti ipsi non dent portaticum in Pontecurbo"1136.

Flórez refiere que en 1150, San Juan de Ortega entre las calzadas y puentes que construyó, "dura tambien hoy un pequeño puente del Santo junto al lugar de Cubo seis leguas de Ortega, cuyos vecinos venian en el dia del Santo a su iglesia"1137.

En 1155 Sancho III, con asentimiento de su padre Alfonso VII el emperador, da licencia a la iglesia de Calahorra y a su obispo Rodrigo, para edificar el puente de Miranda y cobrar sus derechos ${ }^{1138}$.

1131 A. H. N./ Cartulario de San Millán de la Cogolla/ Becerro, fol 116v/ 943; UBIETO ARTETA, A.: 1976: 47: doc 34.

1132 Becerro Gótico de Cardeña, fol. 6, col 1; BERGANZA, F. de: 1719 y 1721: 399: t. II/ 5 julio 963; SERRANO, L.: 1910: 20-22: doc. XV. "... et de Castaniares via que vadit ad Villa frida, et de Villa frida strata que pergit ad Rivo de Vena, de inde per summa serra de Adtaporka... de una pars karrera qui exiit de Verbesca et pergit ubique;....".

1133 Becerro Gótico de Cardeña. Fol. 16, col. $3 / 22$ noviembre 999; SERRANO, L.:"1910: 64-65: doc. LII.

1134 A. H. N./ Cartulario de San Millán de la Cogolla. Becerro, fol. 141v-142/ 1042; SERRANO, L.: 1920: 125: doc. 105; UBIETO ARTETA, A.: 1976: 217: doc. 221.

1135 A. H. N./ D. R. de Oña. carp. 273, num. 17/ 5 mayo 1135; ÁLAMO, J. del: 1950: 207-208: t. I. doc. 173.

1136 A. M. Silos/ ms. 10, fol. $3 / 8$ marzo 1147; MARTínEZ, Gonzalo: "Fueros locales en el territorio de la provincia de Burgos". 151: doc. XVIII.

1137 FLOREZ, E.: 1772: tomo XXVII, 372/ h. 1150.

1138 A. Cat. Calahorra/ no 6o/ Nájera, 23 julio 1155; GONZÁLEZ y GONZÁLEZ, J.: 1960: 38: t. II: doc. 19; RODRÍGUEZ de LAMA, Ildefonso: "Colección diplomática medieval de la Rioja (923-1225)" 256-257: t. II. doc. 182; A. Cat. Calahorra/ Calahorra, 1273; RODRÍGUEZ de LAMA, I.: 1989: t. IV. doc. 331, 297-299. "... de illo ponte de Miranda, ut fabricetis et faciatis eum, et abeatis super eum meam regiam potestatem; et absoluo eum uobis ab omni portaticu. Ita do et concedo eum uobis, cum quanto boni et religiosi homines dederint et dederunt, et cum quanto eidem ponti pertinet; et amplius ibi portaticus non requiratur... et hanc eandem penam subeat quicumque hereditatem predicti pontis inquietare uel contrariare uoluerit, uel de rebus ipsis per uiolentiam quicquam abstulerit, et quid super eundem pontem, potestamen aliquam exercere presumpserit nisi cui Calagurrensis episcopus gratuita uoluntate dederit". 
En el Fuero de Miranda de Ebro de $1177^{1139}$, se refuerza el valor del puente como paso estratégico del Ebro: "Además, todos los hombres de tierra de Logroño, o Nájera, o Rioja, que pretendan pasar mercancías hacia Álava, o a otra tierra del lado allá del Ebro; a todos los de Álava o de otra tierra cualquiera [que pretendan pasar] hacia Logroño, Nájera o Rioja, pasarán por Miranda y no por otros lugares. Si no, pierdan las mercancías. Y desde Logroño a Miranda no haya puente ni barca"1140.

En 1180 Alfonso VIII concede al concejo de Burgos la facultad de poner viñaderos y mesegueros, e indica que "en la calzada, en término de Gamonal". “... Dono itaque uobis prenominato concilio et pro foro habendum concedo ut in terminis Burgensis episcopi et canonicorum, scilicet, in terminis Sancte Marie de Gamonar in Calzada, et in termino..."1141

En 1194, Alfonso VIII y doña Leonor donan al obispo de Calahorra y a su iglesia, la alberguería de la Morcuera, con sus molinos, para las necesidades del puente de Miranda, “..., dono et concedo Deo et uobis domino Garsie, Calagurrensis ecclesie instanti episcopo, uestrisque successoribus, ad opus pontis de Miranda, albergariam illam que uocatur la Morcuera, in alfoz de Miranda sitam, integre cum molendinis suis et omnibus hereditate ad eam spectante, et cum omnibus directuris et pertinenciis suis, iure hereditario imperpetuum habendan et irreuocabiliter possidendam"1142.

En 1205, Domingo presbítero de Bujedo, confirma al nuevo abad Juan, la donación de dos tierras -una junto al puente de Orón y la otra cerca de los frailes- que con su hijo Íñigo había hecho el abad Sancho “... una est juxta pontem de Oron, altera est circa ipsos fratres"1143.

En 1217, Fernando III para resolver la contienda entablada entre los concejos de Riocerezo y Hurones, de una parte, y el monasterio de San Cristóbal de Ibeas de la otra sobre los términos de las Mijaradas, mandó al merino mayor que enviase pesquisidores para averiguarlo. El merino, envió al portero del Rey y al merino del alfoz de Burgos, que fueron a los concejos de Rubena, Villayerno y Cótar, y a "la carrera que uiene de Riocereço e ua a Riouena", y tomaron omes buenos de los tres concejos para que informasen sobre los términos de las Mijaradas en tiempo de Alfonso VII, y dijeron que tiene entre otros límites el que por somo La Nava va derecho por "la carrera que atrauiessa la Calçada e ua a Riouena"1144.

A mediados del siglo XIII, se describe el camino que desde Sahagún va por Carrión de los Condes, Frómista, Castrojeriz, Hornillos del Camino, Tardajos, Burgos y Monasterio de Rodilla hasta Pancorbo, haciendo alusión a una tempestad de vientos abrasadores que venía de occidente. Es la referencia más antigua que conocemos sobre la consideración de los tramos de Irún a Burgos por una parte, y de Burgos a Santiago por otra, como un único camino ${ }^{1145}$.

1139 MARTÍNEZ DÍEZ, G.: 1982: 59-61. Fechado el fuero en 1099, Gonzalo Martínez lo considera un plagio forjado sobre un diploma auténtico, y propone la fecha de 1177 en base al análisis de una serie de datos.

1140 A. M. Miranda/ En confirmación de Fernando IV, Valladolid, 24 febrero 1298/ diciembre 1177; CANTERA y BURGOS, FCO: 1980.

1141 A. M. B/ Palencia, 29 enero 1180; GONZÁLEZ y GONZÁLEZ, J.: 1960: t. II. doc. 334.

1142 A. Cat. Calahorra/ no 145/ Palencia, 24 abril 1194; GONZÁLEZ y GONZÁLEZ, J.: 1960: 109: t. III. doc. G23; RODRÍGUEZ de LAMA, I.: 133-134: t. III: doc. 352.

1143 Libro Becerro de Sta. Mํㅡㄹ de Bujedo de Candepajares/ Becerro, fol. 12r-12V, no XXXIX/ 24 enero 12O5; RUIZ de LOIZAGA, S.: 2000: 145-146: doc. 113.

1144 A. Cat. B./ Vol. 79, fol. 4/ mayo 1217; GARRIDO GARRIDO, J. M.: 1983: 324: doc. 505.

1145 Gonzalo de Berceo/ Coplas 389.1 a 391.2/ med. siglo XIII; BERCEO, G. de.: 1992:

"Llegó a Sahagún quemó una partida, 
En julio de 1285 los monasterios de San Salvador de Oña y San Pablo de Burgos, intercambian una tierra y una herrén en Quintanavides, aludiendo al camino de Quintanavides a Castil de Peones: "Nos uos damos la nuestra tierra del Maçanar, de que son surqueros: del un cabo, don Diago Lopez de Salzedo; e del otro cabo, uos mismo, e en somo, la carrera que ua a Castriel de Peones, e en fondon, el calze del molino... e de la otra parte, el camino que ua a Castriel de Peones..."1146.

En 1342, Pedro Santos se puso en camino para ganar del Papa un rescripto contra el obispo de Burgos, y se indica que “..., este dia en Burgos, fuera de la puerta vieia de Sant Johan, al hospital que dicen de don Miguel Estevan que es commo van a Gamonar en el camino françes,..."1147.

En 1404 se hace alusión al camino que desde Burgos va a Briviesca, en un apeo procedente del monasterio de la Trinidad de Burgos. Se alude a una tierra sita en el lugar de La Calzada y que linda por un lado con el camino de Casa de la Vega y por otro con el camino que va a Briviesca. Dado que el camino de Casa de la Vega, cruza el trazado de la vía Aquitana, debemos deducir que tal camino coincide, al menos en este primer tramo, con la vía romana. Entre Burgos y Monasterio de Rodilla el camino que se menciona sigue un buen tramo por la antigua vía romana por Hurones hasta después de Las Mijaradas, en que la abandona para llegar a Monasterio de Rodilla y desde allí, por Castil de Peones y Prádanos llega a Briviesca:“...la qual dicha tierra es a do dizen Calçada, de la cual tierra son adaldannos... el camino que va a la Casa de la Vega et de la otra parte el arroyo que dize del camino de la Cruz que va a Berviesca..."1148. También en un apeo de la catedral burgalesa de 1446, se cita el camino de Burgos a Briviesca, coincidente con la vía Aquitana, por la zona de la Casa de la Vega: “...otro pedazuelo ençima de las vinnas que llega al Camino Real que va a Beruiesca"1149.

Los mercaderes Juan y Diego Pardo y Lope Alonso de Burgos, presentaron querella en el ayuntamiento de Burgos en 1462, contra el conde de Haro, porque les había prendado en su villa de Briviesca unos fardeles de paños por un valor de 15.000 mrs. que le debían por libramiento hecho al alcalde García Martínez de Lerma, y pedían al alcalde de Burgos que lo solucione. Acordaron enviar a Francisco Bocanegra y a Pedro Ruiz a hablar con el conde de Haro sobre esta represalia y otras ${ }^{1150}$.

En 1463 se mencionan las Calzadas, hoy calle de las Calzadas, que salía de la puerta de San Juan camino de Gamonal, junto al monasterio de San Juan de Burgos: "Esta huerta estaba inmediata a la Calleja, que pasa desde la Glera o eras de San Juan a las Calzadas o camino de Gamonal,

fue cerca de la media de Carrión ardida;
por poco fuera toda Frómista consumida,
Castro entre las otras no remanso sencida.
Hornillos del Camino fincó mañ socarrada,
Oterdajos que yace en una rinconada;
acorrióle a Burgos que yacía derramada,
ca no era entonces en un lugar poblada.
Quemó en Monesterio cuanto delante priso,
en Pancorbo diez casas, ca parcir no le quiso..."

1146 A. H. N./ Clero. Pergaminos. Carp. 297, nº 11/ Oña, 15 julio 1285; OCEJA GONZALO, I.: 1986: doc 282, 25-26.

1147 A. Col. Covarrubias/leg. VI, no 13/ Burgos, 30 octubre 1342; SERRANO, L.: 1907: 193-194: doc. CLXIII.

1148 A. H. N./ Trinidad. Clero. Pergaminos. Carp. 204, nº 4/ 1404

1149 A. Cat. B./ Libro de apeos. 12. fols. 8v y gr/ 1446.

1150 A. M. B./ Actas municipales, 1462, fols. 110r. y v./ Burgos, 9 septiembre 1462; MONTERO MÁLAGA, A.: 2012: 129: doc. 80 . 
junto al Hospitalejo, la cual calleja está inclusa en nuestra huerta y encima de ella y entre la Tesorera se dio a la ciudad, un lugar de aquella calleja que hoy sirve de paso"1151.

Pedro de Santa Cruz curador de Gregorio, Juan, Francisco, María y Catalina, menores e hijos de Fernando de Burgos, mercader vecino de Burgos, ya difunto, dijo en el Consejo en marzo de 1493 que entre los dichos menores y Fernando de Burgos, mercader y primo, están pendientes ciertos pleitos de 607 años y más tiempo, entre otros, sobre que de un molino que está en el término de Burgos, en "la calçada camino de Gamonal", dicen que pertenece a los dichos menores una tercera parte ${ }^{1152}$.

En 1504 los mulateros de la cofradía de "Sant Anton de tierra de Alaba", se quejan del estado de los caminos, y en concreto a lugares situados fuera de la provincia de Álava, "...en los prados de entre Burgueta e la Puebla e a do disen Retuerta que es camino real, e parte termino comunero de la Puebla e Pangua e Burgueta, e entre la villa de Pancorbo e Çuneda, e entre Guisaleña e Birbiesca, e en otras partes e lugares en tierra de Alaua estan muy malos pasos e peligrosos e çerrados e estragados los caminos o pasados e caydas e ronpidas algunas puentes..."1153.

En febrero de 1529 se realiza un interrogatorio a mulateros y maestros de calzadas que informan que lo que debe ser reparado de manera urgente por el gran peligro y daño que se hace a los caminantes, es el paso estrecho en el camino de Pancorbo hacia Miranda de Ebro, Vitoria, Guipúzcoa y Fuenterrabía, en el desfiladero que llaman la Hoz ${ }^{1154}$, donde cayeron muchas peñas de lo alto, y el camino real está muy cerrado, lo que crea mucho peligro y dificultad en especial cuando crece el Oroncillo, que en ocasiones ha arrastrado alguna acémila. Cuando no se puede pasar a pie ni a caballo, se obliga a los arrieros a dejar el camino para ir con sus recuas por encima de las sierras con mucha incomodidad y peligro. Hay otros malos pasos, más abajo en la misma $\mathrm{Hoz}$, en el lugar de Hontoria o Fuente Hontoria, por donde no pueden pasar gente ni bestias porque las lleva el agua ahogándose allí una acémila, y otros pasos peligrosos más abajo en La Riba, en el camino que va a Ameyugo y otro en Carrasalineros. En el camino real de Pancorbo a la Bureba y a Burgos, Valladolid, Tierra de Campos y todo el Reino, cerca de Pancorbo hay un paso muy malo en Santa Cruz y otro mucho peor y peligroso más adelante, en el camino de Zuñeda del puente de Prado a la Varga de Zuñeda, hasta la Frecha y el puente de Vallarta, que tiene cerca de media legua, otro en el prado de Tremaledo y otro en Rontondiago, tan malos que en invierno no se pueden utilizar, obligando a ir por las heredades, cayéndose muchas bestias y perdiéndose más de 100 fanegas de sembradura, por lo que los dueños de las heredades se enfrentan a los mulateros ${ }^{1155}$.

En Junta de Álava de noviembre de 1537 se otorga comisión al procurador de Vitoria y al procurador de Cuartango, para que vayan a negociar con el Condestable o con quien fuere necesario, acerca de los perjuicios causados a los de la provincia de Álava en los puentes

1151 "Libro Becerro o Dietario de este Real, Pontificio monasterio de San Juan Baptista de la ciudad de Burgos"/ 1463; GARCÍA, F. P.: 1950: 80.

1152 A. G. S./ Registro General del Sello, III-1493, fol. 29/ Olmedo, 12 marzo 1493.

1153 A. G. S./ Registro General del Sello, VIII-1504/ 26 agosto 1504; MOLÉNAT, J. P.: 1971: 140-141.

1154 Desfiladero de Pancorbo.

1155 A. G. S./ Consejo Real de Castilla, leg. 324-24/ Madrid, 28 mayo 1517 y Pancorbo, 30 diciembre 1529. 


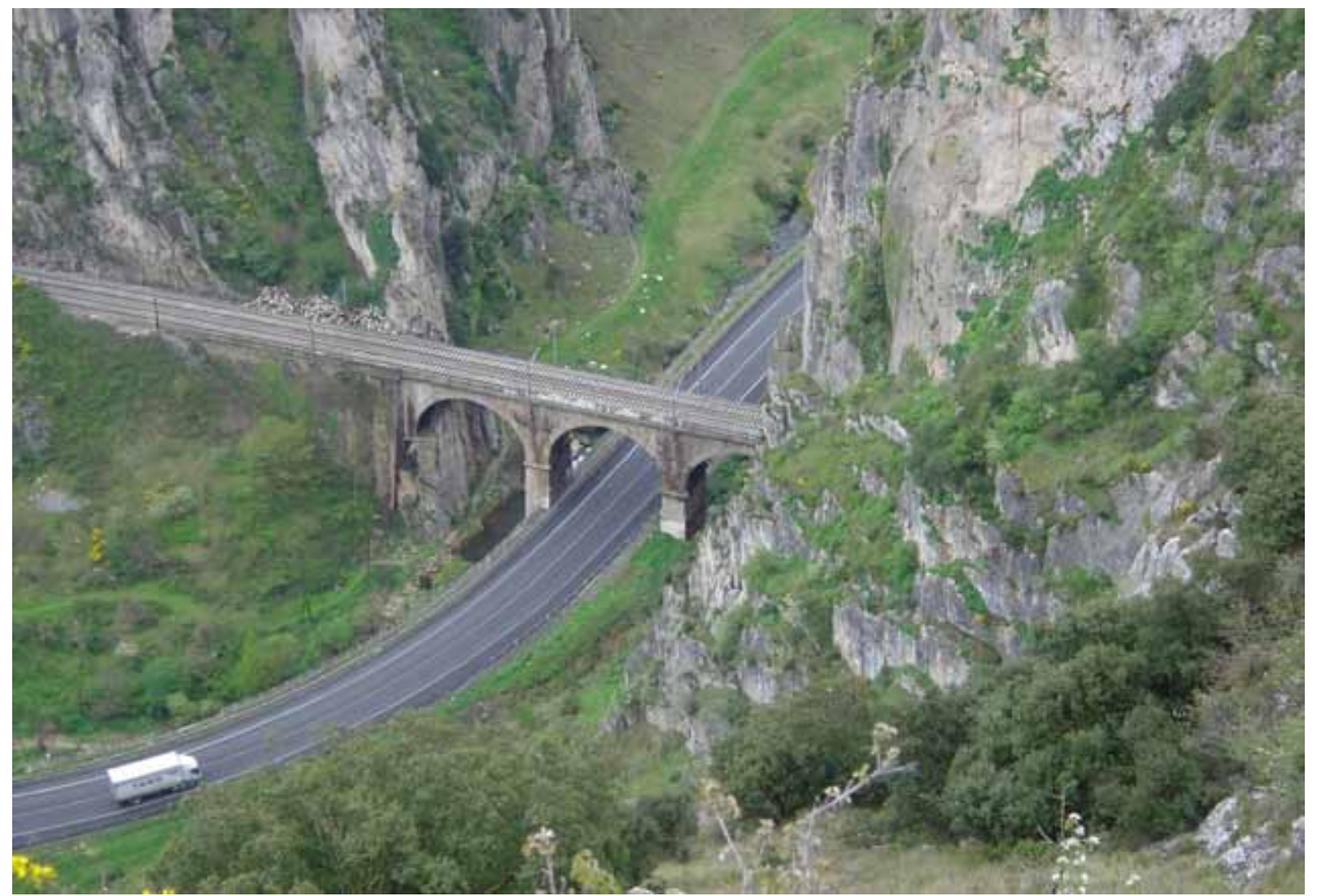

Panorámica del desfiladero de Pancorbo.

sobre el Ebro de Miranda, Haro, San Vicente y Puentelarrá1156. En Junta de mayo de 1538 ambos procuradores presentaron lo que habían negociado con el Condestable y con los concejos, justicias y regimientos de Miranda y Haro sobre los perjuicios en los puentes de Haro y Miranda. Presentaron la carta del Condestable a la provincia y las cartas de contestación de las villas y la Junta acordó que dichos procuradores, traten con el Condestable la solución de los perjuicios ${ }^{1157}$.

El canónigo César de Blanquis, rector del hospital de San Lucas de Burgos, otorga en 1542 un censo a favor del odrero Nofio de Burgos y Francisca de Covarrubias, su mujer, de una finca que el dicho hospital posee en la calzada de Gamonal, que hace siete fanegas de sembradura1158.

En 1560 se pretende intervenir junto al camino que sale de la puerta de San Juan, que atraviesa una zona vadosa de huertas. Así se realiza una petición para reparar la esquina del paredón de defensa del cauce "que ba por junto a la Bitoria questa socabada", acordándose que los señores obreros la hagan aderezar como conviene ${ }^{1159}$.

En un memorial realizado en 1562 sobre los muros, cercas y puentes de Burgos, se indica que es necesario reparar "las puentes y calçadas de Camonal que es camino muy pasajero y por

1156 A. J. G. A./ t. III/ Vitoria, 23 noviembre 1537.

1157 A. J. G. A./ t. III/ Vitoria, 4 mayo 1538.

1158 A. Cat. B./ V. 5O, P. 1, ff. 247-250/ Burgos, 9 febrero 1542; "Catálogo del Archivo Histórico de la Catedral de Burgos" vol. II. Sección Volúmenes (I), nํ 3971 .

1159 A. M. B./ HI-4930/1560? 
donde biene probision a la çibdad y es menester hazer bien las dichas puentes y enpedrar el camino", todo por unos 100.000 mrs. ${ }^{1160}$.

En la Junta particular de Álava de junio de 1563, el Diputado General hizo la convocatoria para tratar sobre la situación de los puentes que recientemente las avenidas han llevado en Briviesca, y los caminos y calcadas que están mal reparados, y por ser camino tan transitado y necesario para los que van a pie y a caballo, y trajineros de la provincia y de otras partes, y para dar orden de que se pida que se hagan los puentes y reparen los malos pasos y calzadas, porque no habían venido los diputados Andrés Ortiz de Letona y Juan de Urrutia, que están en Valladolid, se determinó "que por haora no se entienda ni trate en lo susodicho por parte desta prouinçia"1161.

En las Juntas de Vizcaya de diciembre de 1571 se trató que la villa de Miranda había pedido a la Junta General que escribiese una carta para que el Rey no permitiese tasa en el trigo, y como esta perjudicaba al Señorío ya que en la ciudad de Vitoria no había tasa, se acordó que se debía dar la carta1162.

En las Juntas de Vizcaya de septiembre de 1574 se trató sobre que mediante provisiones del Consejo Real a pedimento de algunos pueblos, se les han repartido para los puentes de Pancorbo y Burgos, más de 16.000 mrs., y para cobrarlos ha ido un ejecutor con comisión del alcalde mayor del Adelantamiento de Burgos. Como estos repartimientos dicen que eran injustos porque el Señorío no tiene ningún beneficio de los puentes, y si lo tuviera, tiene que hacer más reparos que ninguna otra provincia, y para poderlos hacer aún en parte, no tenía dineros suficientes por no tener propios, sino solamente lo que recauda por repartimientos, ordenaron que se pida al Rey que retire lo procedido contra el Señorío1163.

Para la reparación del puente de Briviesca y otros, se realizó el correspondiente repartimiento, algo que ya tratamos en el camino a Bilbao por el desfiladero de la Horadada. Como en el espacio del reparto de las cargas se encontraba el Señorío de Vizcaya, tal jurisdicción también fue incluida en los años 1575 y 1576, lo que ocasionó severas protestas por entender que tal medida iba en contra sus fueros y privilegios.

En Junta de Álava de enero de 1579 Juan de Corcuera, procurador de la hermandad de Nanclares y tierra de La Ribera, dijo que desde hacía un mes, la justicia y regimiento de Miranda de Ebro, cobraba una blanca más de pontaje a todas las cabalgaduras que por su puente pasaban, teniendo la provincia y sus vecinos costumbre de no pagar más de una blanca. Y visto lo perjudicial de la imposición por estar el puente en camino tan pasajero, y que si se acepta, cada día la vendrían a alterar, acordaron que el Diputado General dé una carta a Corcuera para que vaya a Miranda, y les informe sobre el perjuicio que reciben con ella los vecinos de la Provincia, pidiéndoles que vuelva el pontaje al estado anterior ${ }^{1164}$. En Junta de abril Corcuera dijo que Miranda en respuesta de la carta, le dio otra significando que el Rey ha mandado que se lleve el nuevo aumento, y que si Álava quisiese ver los recaudos que tienen los mostrarían

1160 A. M. B./ HI-1659/ octubre 1562.

1161 A. J. G. A./ t. V/ Vitoria, 14 junio 1563.

1162 A. J. R. B./ Actas de la Tierra Llana. t. II/ Durango, 17 diciembre 1571.

1163 A. J. R. B./ Actas de la Tierra Llana. t. II/ Bermeo, 28 septiembre 1574.

1164 A. J. G. A./ t. VII/ Vitoria, 24 enero 1579. 
a quien la Provincia ordenase ${ }^{1165}$. En Junta de mayo Corcuera informó que Miranda, había respondido que no había lugar a la alegación realizada, acordándose que por ser negocio tan importante y habiendo visto un traslado de la Cédula real por la que cobraban la nueva imposición de un mr., remitieron todo al Diputado General y a los comisarios y diputados de la provincia, para que proveyesen el remedio necesario ${ }^{1166}$. En esta Junta se dijo que con diligencia se procure que se suspenda la Cédula real y que si se olvidase, se quedaría la imposición perpetuamente. Vista la necesidad de que por la Provincia vaya una persona a Madrid para asistir en este negocio ${ }^{1167}$, en Junta de junio se acordó que Corcuera vaya a Madrid ${ }^{1168}$.

\section{b.- Por Goldecho. La intervención de 1553 para el paso de carros}

El paso llamado de Coldecho, también de Charlazo, fue un paso muy transitado que se situaba una legua al norte de el de San Bartolomé. Fue siempre mulatero a pesar de los intentos de los siglos XVI y XVII para convertirlo en camino carretero. Constaba de una serie interminable de vueltas y revueltas que salvaban el fuerte desnivel de unos $600 \mathrm{~m}$, que existía entre la ciudad de Orduña y el alto situado a algo más de $900 \mathrm{~m}$ Era el paso que utilizaban los dos caminos que a él llegaban por Briviesca, Frías y Herrán, y de aquí uno por Bóveda y el otro por Valpuesta.

En las cuentas del ayuntamiento de Orduña del año 1561, se incluyen los pagos de 2.040 mrs. a maestros canteros por 30 oficiales que fueron a abrir los pasos de la Peña de Goldecho. En 1577, se pagaron 3.522 mrs. para aderezar las Peñas de San Bartolomé y de Coldecho, y en 1582, 7.650 mrs. por la obra que se hizo en dicha Peña. En 1583 se gastaron 21 rs. para 7 oficiales a tres rs. cada uno, que fueron a aderezar la tierra del camino que se llevó el agua en la Peña de Goldecho y que impedía el paso, y por un día ocupado en ella tres rs. En 1585 se pagaron 4.140 mrs. para el reparo de esta Peña; en 158711.900 mrs. a Juan Alonso de Arcillero, oficial cantero, por el paso que hizo en la lastra de la Peña de Coldecho, y 6.165 mrs. en romper esta Peña y entrada porque no se podía andar por ella, sino con gran peligro, y finalmente en 1593 se gastaron 15.022 mrs. en los reparos de las Peñas de San Bartolomé y Goldecho, que hicieron Juan de Retes Ibarrola, Agustín de Armona y Juan de Aguirre Cotara1169.

En 1553, se realiza una importante intervención en este paso. A solicitud de Orduña, Carlos I da facultad a la ciudad, para acondicionar el camino viejo de Goldecho para el tránsito de carros cargados desde Portugalete a Castilla. No obstante, y aunque las ventajas para la ciudad eran indudables, los daños provocados según algunos vecinos serían importantes, ya que si por ir en carros las lanas no se alojan en la ciudad, esta no recibirá beneficio, pero se quedará con la molestia causada por las carretas castellanas, con los caminos deshechos y consumidos sus pastos, montes, sembrados y viñas. Sus dueños querrán además conducirlas en los mismos carros hasta Bilbao, sin descargar más que dos

\footnotetext{
1165 A. J. G. A./ t. VII/ Vitoria, 1 abril 1579

1166 A. J. G. A./ t. VII/ Vitoria, 6 mayo 1579.

1167 A. J. G. A./ t. VII/ Vitoria, 9 mayo 1579.

1168 A. J. G. A./ t. VII/ Vitoria, 16 junio 1579

1169 A. H. F. B./ Munic. Orduña, L/ 005 y 054/1561-1594.
} 


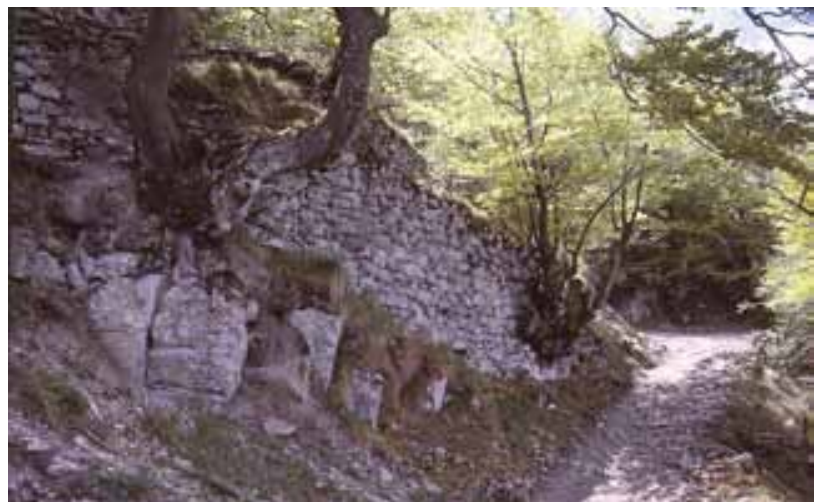

Camino de Goldecho.

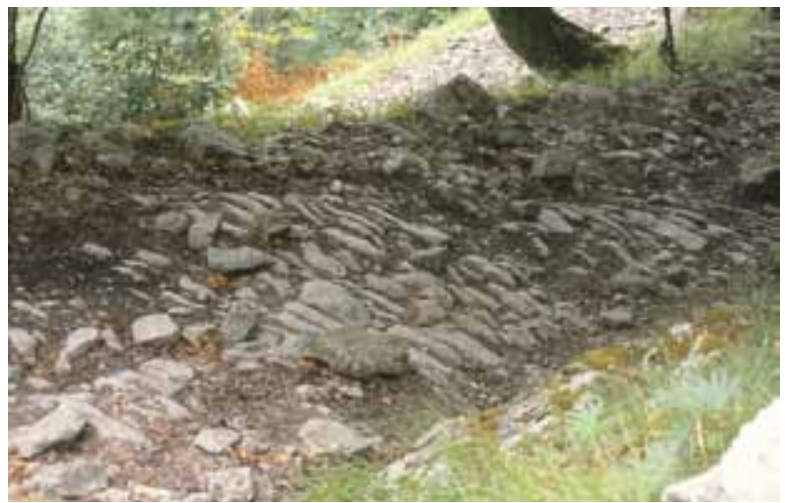

Empedrado del camino de Goldecho.

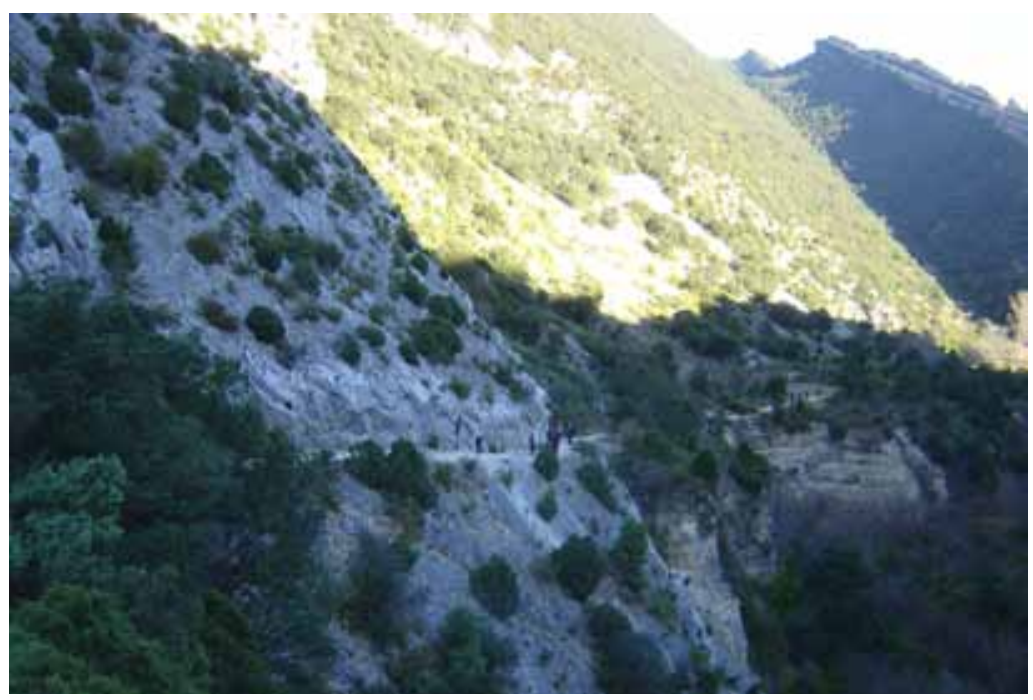

Panorámica del camino de Herrán.

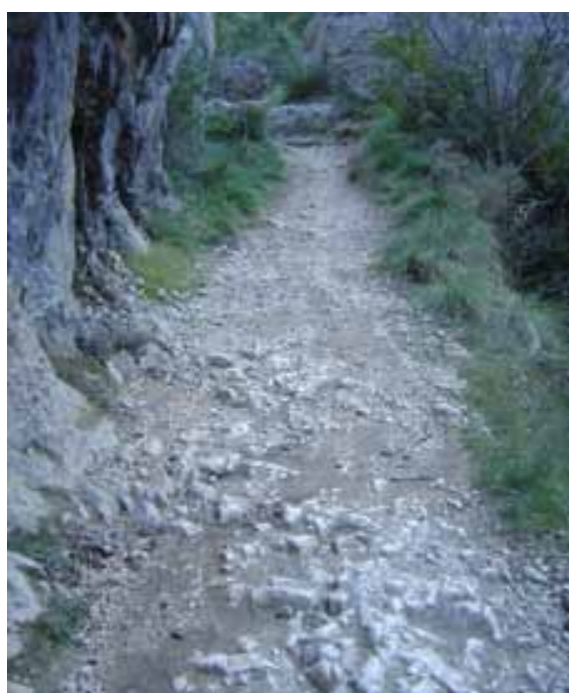

Camino de Herrán.

o cuatro sacas para pesarlas en la aduana, como suele hacerse para el pago de los derechos reales, lo cual "es muy factible por la facilidad de disponer el camino para carros desde esta ciudad a la villa de Bilbao, pues en el estado presente se llebaran lanas en carros hasta el convento de la Encarnacion ${ }^{1170}$ bordeando el rio". Añaden que los comerciantes conseguirán con el tiempo, como alguna vez han intentado, que los derechos de las lanas que se pagan en las aduanas de Orduña, Vitoria y Valmaseda, lo hagan en la legua del agua y en tal caso no se dejarán las lanas en Orduña. Además siempre se dependerá de la voluntad de los mercaderes, de no alonjar las lanas en la ciudad cuando tuvieren el navío próximo para embarcarlas.

Otro inconveniente grave según los vecinos, era que cuando las recuas bajan por el camino de Goldecho no pasan por Orduña, pues atajan más de una legua por Mendeica y Echegoyen, llegando pronto a Sagarribay ${ }^{1171}$, como hubiesen llegado a Orduña si vinieran por el camino carretero, y los carreteros que antes se quedaban en la ciudad se irán al mesón de Sagarribay o a otro de la tierra de Ayala con perjuicio de la ciudad, porque es la recua la que más beneficio deja. Por el contrario, las ventajas que obtiene Bilbao, su casa de Contratación y los mercaderes, son según los de Orduña inmensas, porque por Orduña

1170 El convento femenino de la Encarnación, se sitúa en la orilla derecha de la ría de Bilbao.

1171 Sagarribay es un barrio de Amurrio. 
se ahorran 29 o 30 rs. en cada carga de lanas en carros, sobre lo que costaría rodeando por Vitoria. Desde Orduña a Bilbao no se pagan más que dos ducados de porte por carga a lomo, y en carro el coste sería mucho menor, mientras que desde Vitoria, se pagan ordinariamente 50 rs. de porte por carga de lanas. Esta ventaja, con ser grande, no es la única, ya que desde Orduña a Bilbao, se pueden llevar las lanas sin riesgo en un día durante todo el año, porque no hay más de seis leguas mientras que desde Vitoria hay once de muy mal camino, "lleno de montes, atolladeros y arroyos, por cuya causa no pueden conducirlas a la dicha billa sino en berano, y es forzoso descargarlas, y muchas beces se quedan en los campos mojadas y llenas de lodo". Y si se dejan en las puertas de los mesones donde pueden quedar varios meses, llegan a Bilbao con gran pérdida, tanto en la calidad como en la cantidad.

Además, añaden los dueños de las lanas que si van por Orduña podrán alonjarlas en la ciudad sin pagar los derechos reales, hasta venderlas o embarcarlas a su conveniencia. Estas ventajas "son tan grandes y tan notorias que no es menester ponderarlas, basta saber las beras con que las provincias de Alaba y Guipuzcua procuraran embarazar el reparo de este camino, y que todo lo que las dichas probincias suponen an de perder por este medio", ha de ir en beneficio de Bilbao por ser el puerto donde todos han de ir, consolidando su comercio sin riesgo de los accidentes que en otros tiempos han acaecido, cuando resurgió y creció el comercio en San Sebastián, Santander y otros puertos a costa del de Bilbao. Por esta y otras consideraciones, Bilbao y su casa de Contratación, fomentaron en los años pasados el reparo de este camino; y por el contrario, las provincias de Álava y Guipúzcoa, han procurado entorpecerlo, "atrebiendose la de Alaba a desmoler y derribar, como en efecto desmolio y desizo, el camino de carro que por la parte de Unza" y Artómaña hizo Orduña, "con asistencia de la dicha casa [de Contratación] y hombres de negocios" sin tener facultad para ello. Álava no tenía más derecho para su oposición, que el de la parte del camino a Castilla que estaba en su jurisdicción pero, según ellos, no tenía el apoyo de los lugares alaveses en cuyos términos estaba el camino y que habían consentido y solicitado su mejora. Las partes más interesadas en el reparo del camino viejo de Coldecho y en colaborar en su coste, son el Concejo de la Mesta, la Cabaña Real de Carreteros, la casa de Contratación y la villa de Bilbao, y los mercaderes de Segovia, Madrid, Cuenca y otras partes de Castilla. Orduña había traído los mejores maestros que se han hallado desde Burgos a la mar, para que reconociesen la planta y condiciones de la obra y se rematase en el mejor postor como se ha hecho, y que habiendo enviado repetidas veces sus comisarios a Bilbao y su casa de Contratación a solicitar su aportación, no han hallado un gran apoyo. Y aunque Orduña se halla muy necesitada, porque desde hace 4 años, ha pagado voluntariamente cerca de 4.000 ds. para obras públicas, acudirá para esta obra con 4.000 dentro de los 4 años previstos a 1.000 ds. por año, y las otras partes interesadas deberán valerse de arbitrios y otros medios para obtener el dinero restante ${ }^{1172}$.

La villa de Bilbao, también se dirigió a Carlos I en 1553 para hacer el camino carretero mencionado hasta el puerto de Portugalete, para abaratar y facilitar el transporte con Castilla del hierro y las mercaderías. El parecer de los maestros, indicaba que se puede hacer un camino bueno y consistente por donde había más ferrerías, para que en el retorno de los mantenimientos y vinos que iban de Castilla, pudiesen llevar más de 28.000 quinta-

1172 A. H. F. B./ Munic. Orduña, caja nº 19, carp. 4/ Madrid, 17 mayo 1553. 


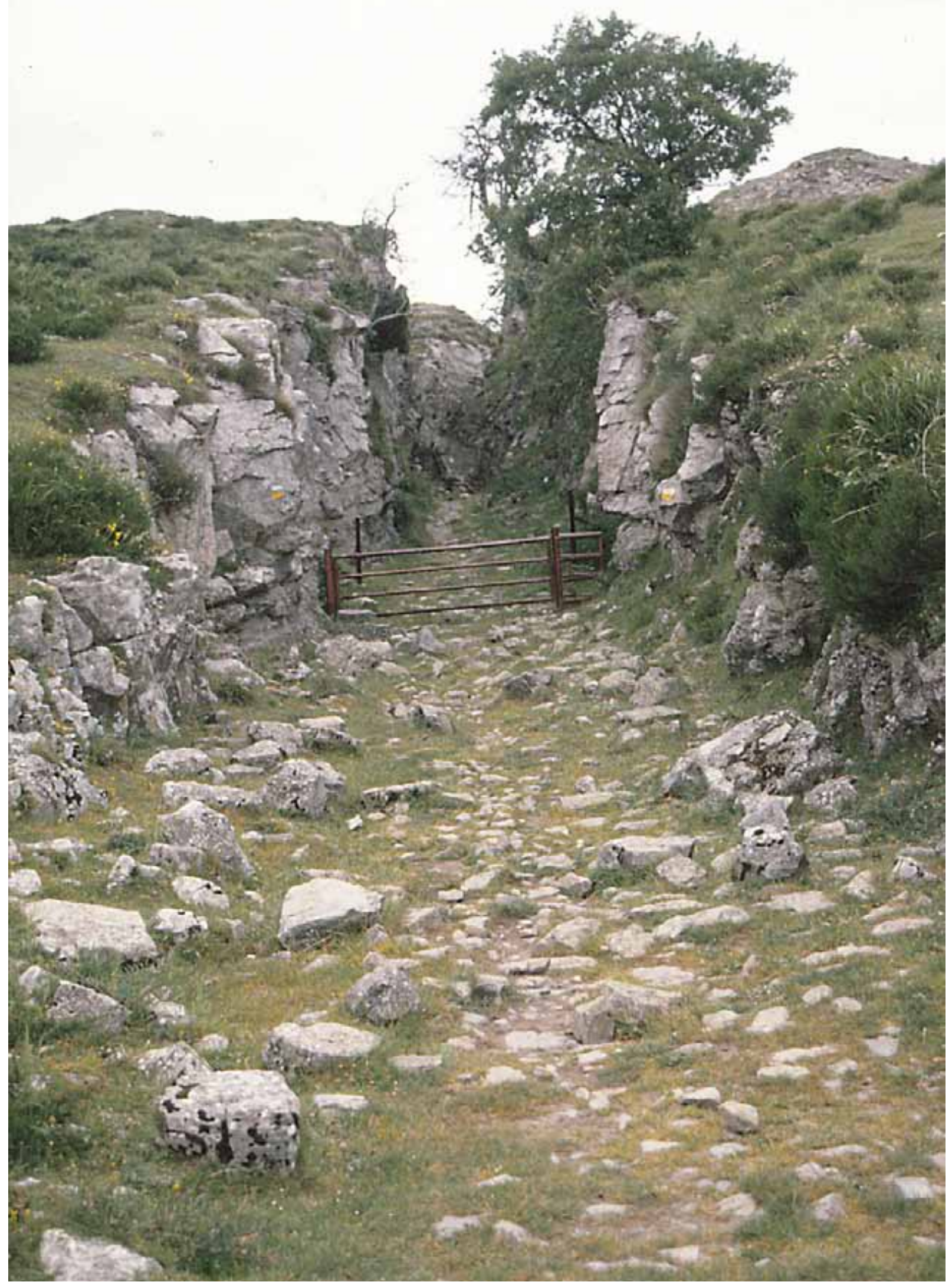

Pasillo tallado en el alto de Goldecho para permitir el paso de los carros. 
les de hierro y 6.000 de acero, que según ellos se labraban en ese camino a Portugalete, puerto de donde se puede traer todo el hierro necesario por estar en mar abierto y de donde salen más de 500.000 quintales de vena para Vizcaya, Guipúzcoa y Galicia. El camino se podría hacer con 8.00o ds. desde Losa hasta Portugalete, que dicen que son 10 leguas de montañas hasta donde andan los carros de Burgos y Castilla. El Rey da una Provisión al corregidor para que reciba información sobre la necesidad de hacerse el camino carretero desde Losa al puerto de Portugalete, y se informe con oficiales y expertos sobre si, para la conservación del camino, convenía que se hiciese por la parte que Ochoa de Salazar tenía trazado ${ }^{1173}$, o por otra más conveniente, y que la información obtenida la envíe al Consejo para proveer lo que convenga.

El regidor de Orduña, por su parte, pidió que se ordenase que esos caminos se hiciesen allanando la Peña de Orduña, por lo que el Consejo así lo acordó. Todo lo que fuere necesario hasta Berganza y de Berganza a Bilbao, se deberá allanar para que puedan ir carretas a Portugalete, informándose de por donde se hará mejor y con menos coste, pregonándose la obra para recibir posturas, y asimismo se averiguará cómo se pagará lo que costare cada camino, quiénes recibirán aprovechamiento, y si será mejor que el coste se eche por sisa, repartimiento o que paguen algún portazgo los que lo utilicen. La información obtenida con el parecer del corregidor, se enviará al Consejo para proveer lo que proceda ${ }^{1174}$. Parece ser que se comenzaron las obras pero, de manera inmediata, las provincias de Álava, Guipúzcoa y reino de Navarra se opusieron frontalmente, por temer los grandes perjuicios que causaría a sus pueblos y comercio el camino carretil proyectado. Los alaveses destruían de noche lo que se realizaba de día por lo que el Señorío debía poner gente armada para impedirlo1175, y Navarra y Guipúzcoa mantenían continuos pleitos con el fin de que la obra no se llevara a cabo. Tras estos conflictos y reclamaciones, el Rey creyó oportuno rebajar las tensiones provocadas, ordenando ese mismo año de 1553 la suspensión de los trabajos ${ }^{1176}$.

\section{Desde Briviesca por Frías, Herrán y Bóveda}

Camino de herradura a partir de Briviesca, en 1677 se alude a él al tratar sobre algunos puentes de Tobalina “...por ser camino real dichas puenttes, para esta nuestra corte y los puertos de Santander, Laredo, Castro de Urdiales, Bilbao, Bitoria, San Sebastian y otras partes, ademas de las desgrazias de aogarse e peligrar muchajente, bagajes y azienda que trajinaua por dichos rrios como se auia esprimentado el dicho año en el dicho rrio Puron, que se auian agogado tres personas por no lo azer los demas mas de diez leguas de camino..."1177.

Del puente de Frías se dice en 1708 que “...esttando como estta en camino real tan preciso y nezesario, asi para el transito de la prouinzia de la Rioja a las uillas de Laredo, Biluao y Santtander, como de los puerttos de Guadarrama y Somosierra para dichas uillas y demas puerttos de mar..."1178.

\footnotetext{
1173 Ignoramos los detalles del trazado de Ochoa de Salazar.

1174 A. H. F. B./ Munic. Orduña, caja no 19, carp. 5/ Madrid, 17 mayo 1553.

1175 LARREA SAGARMINAGA, Mํㅗ A.: 1974: 115.

1176 LABAYRU Y GOICOECHEA, E. J.: 1900: t. IV, 285-286.

1177 A. C. V./ nº 1.998/ 20 julio 1677 a 18 septiembre 1678.

1178 A. C. V./ no 315/29 noviembre a 1 diciembre 1708.
} 
El camino iba de Burgos por Gamonal, Villafría, Rubena, Quintanapalla, Monasterio de Rodilla, Santa Olalla, Quintanavides y Revillagodos a Briviesca, y por Quintanillabón, Busto, Portillo de Busto, La Aldea del Portillo, Ranera, Tobera, Frías, puente de Frías, Quintana Martín Galíndez, Promediano, Herrán, desfiladero del Purón, Ribera, Lalastra, Bóveda, Fresno de Losa, Villaño, puerto de Coldecho, Orduña, Saracho, Amurrio, Luyando, Gardea, Llodio, Areta, Zuloaga, Arrancudiaga, Arene, Ugao-Miravalles, Aguirre, Arrigorriaga, Venta Alta o Beteluri, Buya, Ollargán, puente de San Antón y Bilbao.

El camino de Burgos a Frías, se encuentra recogido en el Itinerario Español de Matías Escribano de 1758, como recorrido de Madrid para Burgos y Frías ${ }^{1179}$. También se encuentra en el Itinerario de Miguel Bañuelos de $1771^{1180}$. La "Guía General de Correos" de Francisco Xavier de Cabanes de $1830^{1181}$, recoge este camino en la "Carrera de Madrid a Frías".

En el trabajo de Argáiz de 1675, se indica claramente que el monasterio de Pontecerci es el de San Martín de Herrán ${ }^{1182}$. En el del Padre Flórez de 1771, se dice que dicho monasterio se fundó en 852 , aludiendo en ambos casos a la existencia del puente entre las peñas ${ }^{1183}$. Según Cadiñanos, estaría primero en los contornos de la ermita de San Felices, en

1179 ESCRIBANO, J. M.: 1758.

"Hasta Bribiesca

Busto

La Fresneda

Frias

1180 BAÑUELOS, M.: 1771.

"A FRIAS.

Gamonal

Villafria

Ruvena

Quintanapalla

Monasterio de Rodilla

Quintanaembides

Pradano

Briviesca

LaVid

Busto

La Aldea

Ranera

FRIAS

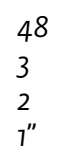

med.

med.

1.

1.

1.

1.

1.

7.

1.

1.

1.

med.

med.

12."

1181

CABANES, FCo. X. de: 1830.

"Hasta Briviesca, leg. $\quad 50 \frac{1}{2}$

De Briviesca á Busto $\quad 2 \frac{1}{2}$

á Frias $\quad 2^{\frac{1}{2}}{ }^{\prime \prime}$

1182 ARGAIZ, F. G. de: 1675: 628. "Llamauase el Lugar Pontacèr. De el se acordò el Rey Casto en su Priuilegio: significa lo mismo, que Pons acer, ò Pons acerbus. Puente agria, y dificultosa, por ser de singular artificio; pues corriendo encañado el Rio por entre dos peñas, y siendo forçoso hazer por alli camino la gente, fabricaron sobre èl vna puente como media caña, que abraça todo lo estrecho de las dos peñas, y empotrada en ellas, sigue el edificio aquella estrechura, no atrauesando el agua, como por las puentes ordinarias, sino siguiendola por encima, hasta que salen à espacio que se puede tomar el camino de la tierra. Aqui, pues, fundaron el Monasterio de Ponte-Cerci, ò Pontacer, que despues dixeron San Martin de Ferran,...".

1183 FLOREZ, E.: 1771: 90-91: tomo XXVI. El año 852, “Pablo, Juan y Munio (Abad, Presbytero y Clerigo) fundaron el Monasterio en el lugar de Pontecerci, o Pons acer, asi llamado por motivo de un aqueducto formado entre dos peñas, por donde era preciso caminar la gente y el rio lo impedia: pero haciendo montar el agua sobre el aqueducto, abrieron paso, y llamaron al sitio Pons acer, o acerbus y vulgarmente Pontecerci, en el Valle de Tobalina (entre Frias y Miranda) territorio Castellense, como dice la Escritura (que es la Castilla legitima) y por tanto añade al fin; Regante Roderico Comite in Castella. El nombre del Monasterio de S. Martin de Pontacer, y Pontecerci, pasó despues a S. Martin de Ferran, por haber sido del Patronato del Conde Fernan Gonzalez, como refiere Argaiz". 


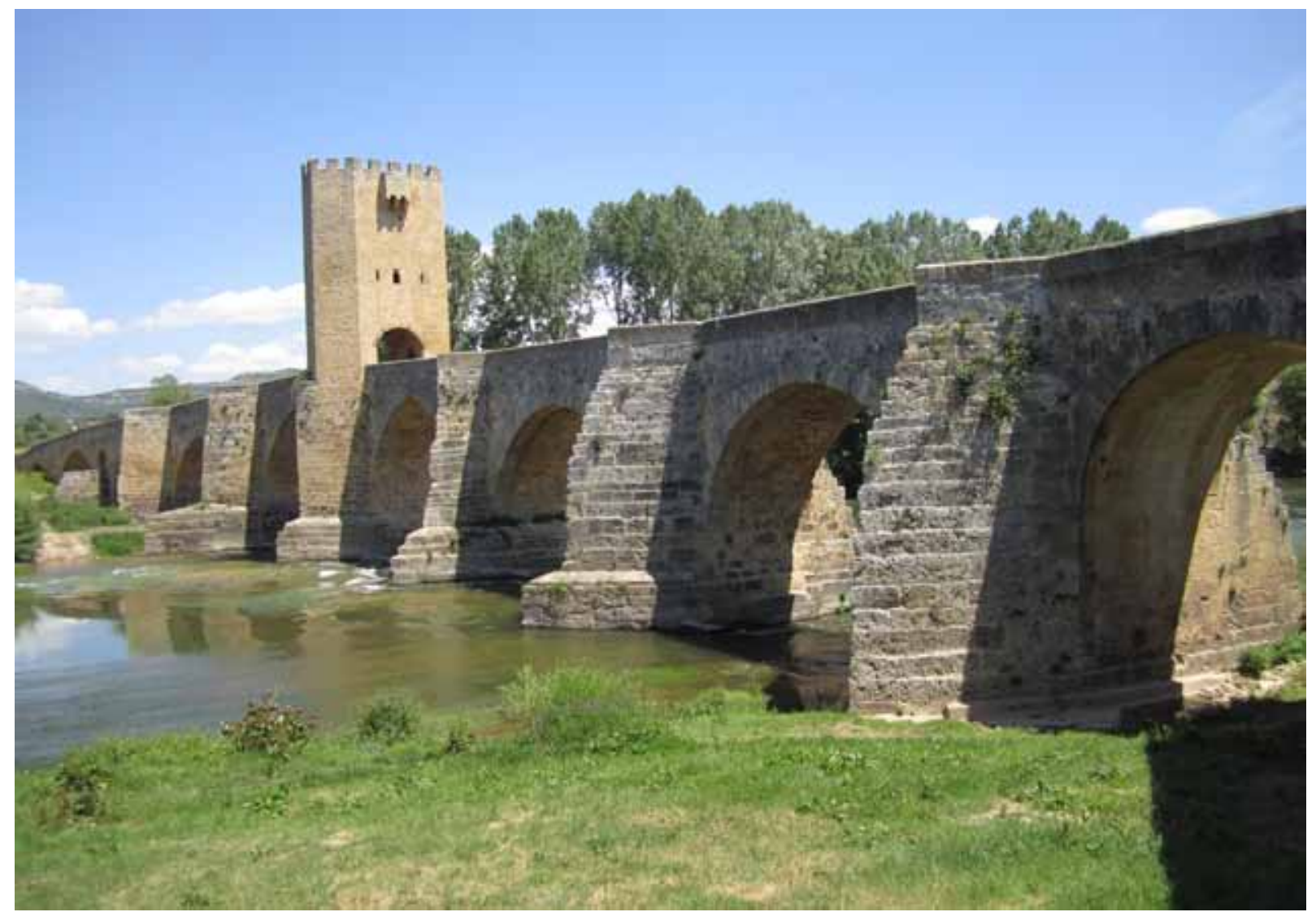

Puente de Frías.

pleno desfiladero del río Purón, de ahí el nombre de Pontecerci, lugar del que se desplazó al que hoy se localiza junto a una necrópolis ${ }^{1184}$.

En el fuero de Medina de Pomar, ratificado por Alfonso VIII en 1181, se menciona el puente de Frías, ya que se indica que si el que gobierna Medina por el Rey, convocase a un vecino de Medina ante la corte para celebrar juicio, lo acompañará entre otros lugares, hasta el puente de Frías ${ }^{1185}$, y en septiembre de 1219 , se vuelve a mencionar dicho puente, en un documento copia del Fuero de Medina ya citado ${ }^{1186}$.

En las actas del pleito sostenido en 1280 ante los alcaldes árbitros nombrados por el infante Sancho, entre el monasterio de San Salvador de Oña y el concejo de Frías, por interferencias en sus respectivas áreas de dominio, se hace constar la existencia del puente de Frías, del portillo de Petralata y del portillo de Busto ${ }^{1187}$.

En julio de 1513, la justicia y regimiento de la ciudad de Frías y su tierra y los vecinos

1184 CADIÑANOS BARDECI, I.: "Monasterio de San Martín de Ferrán. Año: 4 julio 852". Transcripción A. Ubieto Arteta. Ayuntamiento del Valle de Tobalina.

1185 MARTÍNEZ DÍEZ, G.: 1982: 165-168. “Qui Medinam tenuerit de manu regis, si convocaverit populatorem de Medina ad aulam regis ad accipiendum cum eo iuditium, populator eat cum eo usque ad pontem de Frias vel usque ad Oñate vel usque ad Ocibus vel usque ad Espinosa et non teneatur cum eo ire in antea, sed revertatur ad villam populator cum domino villae, et recipiat iuditium de suo alcalde".

1186 A. G. S./ Libros de privilegios y confirmaciones. Libro no 304, art. 14/ Aguilar, 22 septiembre 1219; GONZÁLEZ, T.: 1830: t. V. doc. XXXVIII, 141-147... de Medina ad aulam Regis ad accipiendum cum eo juditium, populator eat cum eo usque ad pontem de Frias vel usque ad Oñate",...

1187 A. H. N./ Clero. Códice 76/B; 104 fols./ 13 julio 1280; OCEJA GONZALO, I.: 1983: 234-336: doC. 231. 


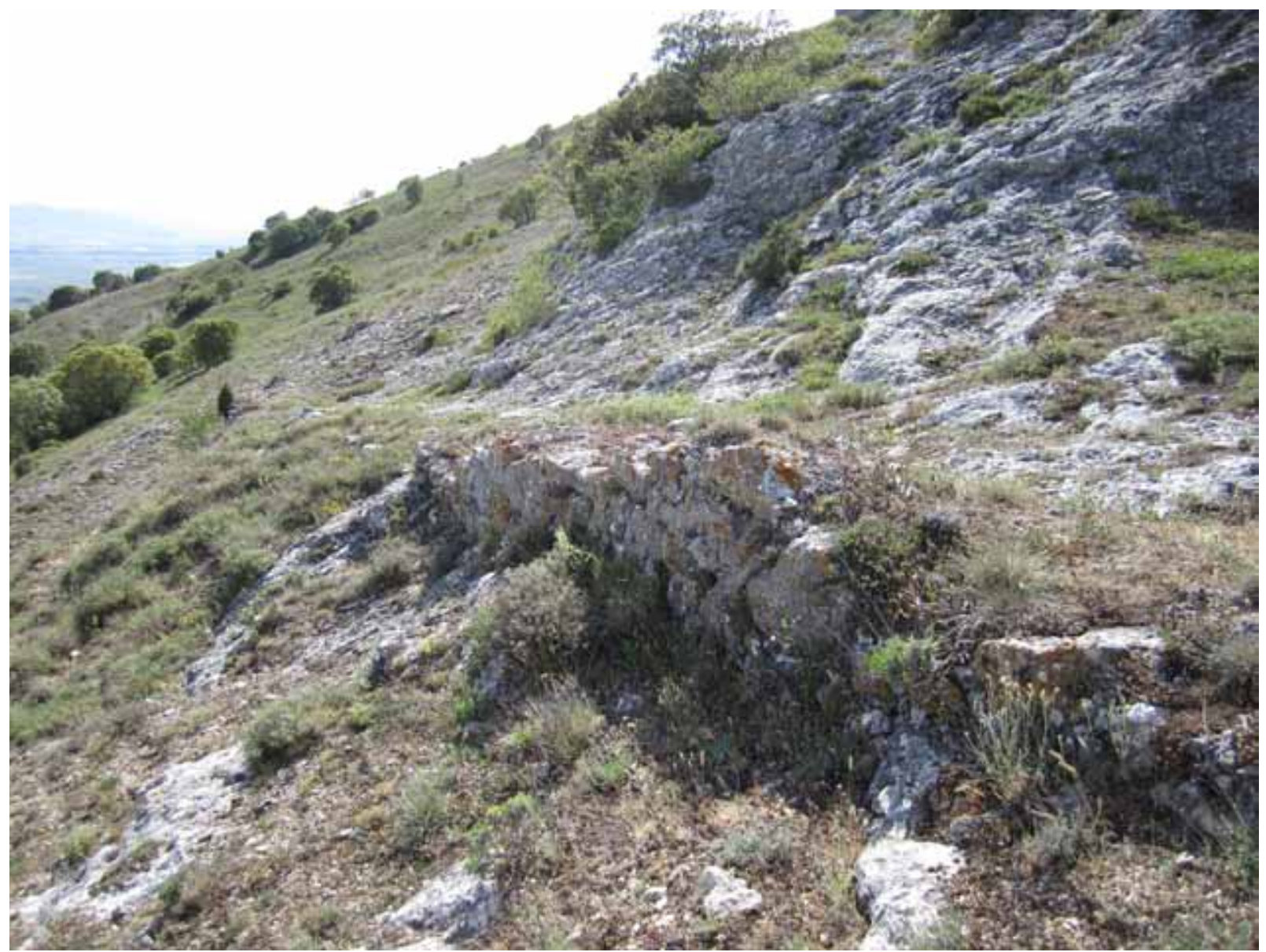

Subida antigua al portillo de Busto para ir a Frías.

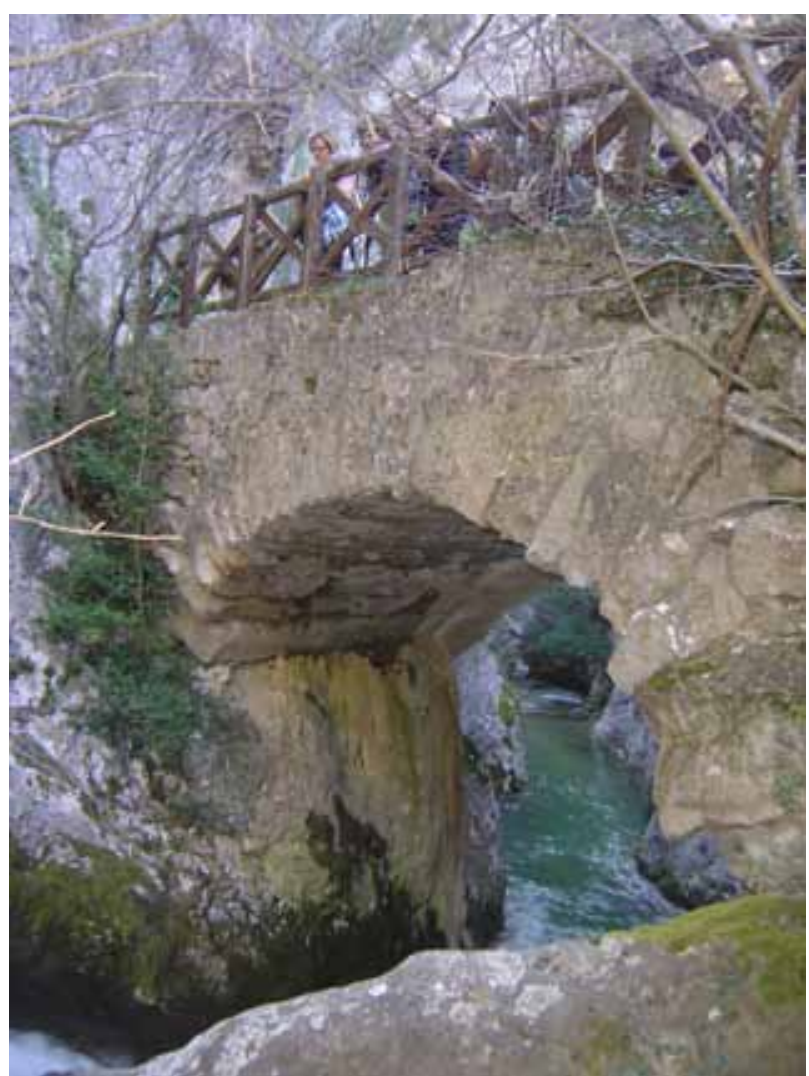

Primer puente de Herrán.

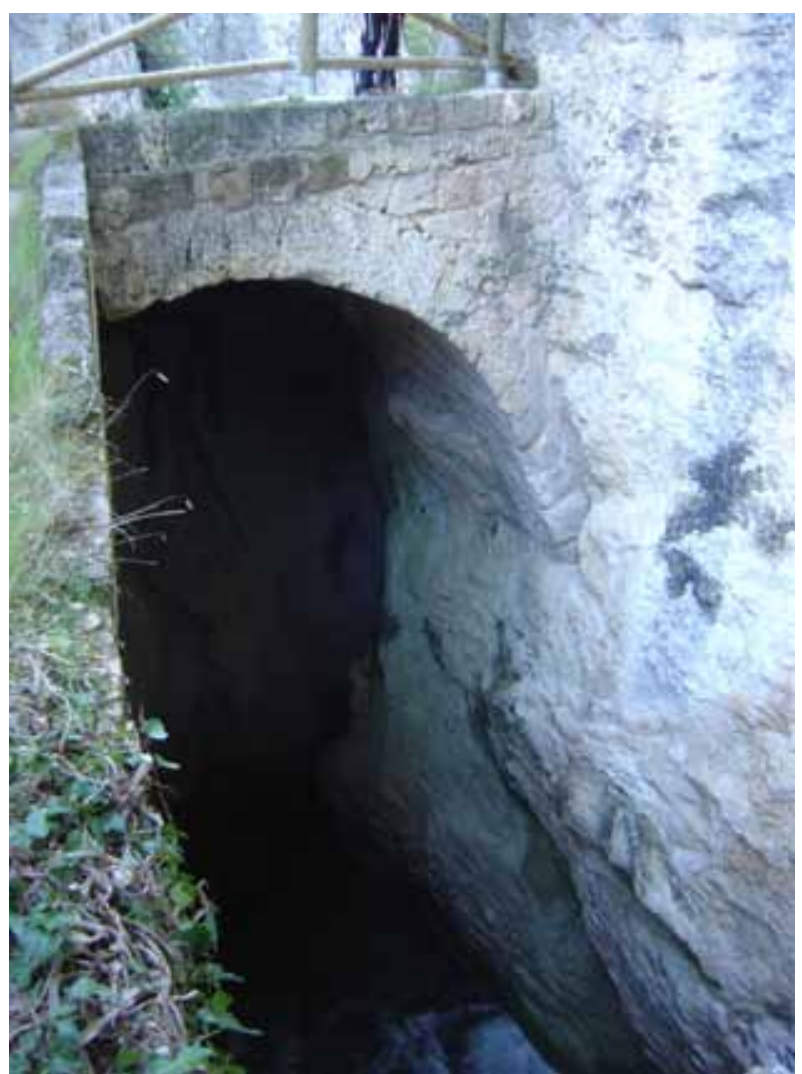

Segundo puente de Herrán. 
y regidores del valle de Tobalina juntamente, encargan la construcción del puente nuevo de Pesquera en Montejo de Cebas, término de Frías, a Martín Sáez de Arriaga, cantero vecino de Montejo de Cebas, para que lo haga a su costa y entregarlo acabado de argamasa y de un arco con un hueco de 14 pies de pilar a pilar, y 11 pies del agua a la clave, un ancho de 10 y en el paso otros 10. Ha de hacer dos pretiles de dos palmos de alto y pie y medio de ancho, y en cada uno de los estribos habrá por lo menos cinco pies y si fuere necesario su saneamiento lo haga a su costa, debiendo hacer una calzada de hasta 12 pies de anchura, del puente hacia Montejo. Pagarán a Martín Sáez 12.000 mrs. 1/3 en el encargo, otro 1/3 haciéndose la obra y el resto acabada, y se obligaron con los bienes propios de la ciudad y tierra. Martín Sáez, se obliga ante los regidores de la ciudad, que hará el puente por el dicho precio y condiciones ${ }^{1188}$.

En la década de 1540, unos testigos de Quintanillabón indican respecto a su puente que está "por do pasan todo el valle de Tobalina e Frias y Valpuesta e Fuertos". Dicho puente es de madera y lo destruye el río con frecuencia ${ }^{1189}$.

En octubre de 1580 uno de los dos puentes de Herrán está arruinado, y se indica que el paso por ambos, es "paso muy general e ymportante para toda tierra de Losa y Balderrejo, Baldegobia y Orduña, Biluao, Burgos y otras muchas partes"... y que esto "era causa de baler las cosas muy mas caras..."119o.

En Junta de Álava de mayo de 1584 se trató sobre lo que se ha de hacer para evitar los excesivos repartimientos que a las hermandades y lugares de Álava se han hecho para el reparo de puentes, y se cometió al Diputado Ceneral para que haga lo que convenga, ya que uno de los puentes es el de Herrán que está más cercano a Ayala y Arciniega y, que según dicen, no es puente de camino que toque a las hermandades de Ayala, Arciniega y Arrastaria y a las demás de la Provincia. Y para evitar lo repartido, encomendaron a Martín de Aldama procurador de la hermandad de Ayala, que en adelante cuando sea necesario, haga las diligencias que pudiere para su defensa y de las demás hermandades a quien tocare este puente ${ }^{1191}$.

\section{Desde Briviesca por Frías, Herrán y Valpuesta}

Este camino que venía de Briviesca y Frías, iba desde Herrán por Villafría de San Zadornil, San Zadornil, San Millán de San Zadornil, Valpuesta, Mioma, Hozalla, Villalba de Losa, Mijala, puerto de Coldecho y Orduña.

La "Cuía Ceneral de Correos" de Francisco Xavier de Cabanes de $1830^{1192}$, recoge este camino en dos tramos: la "Carrera de Madrid a Frías" ya citada en el anterior camino, y el otro tramo "Comunicacion de Bilbao con Frias".

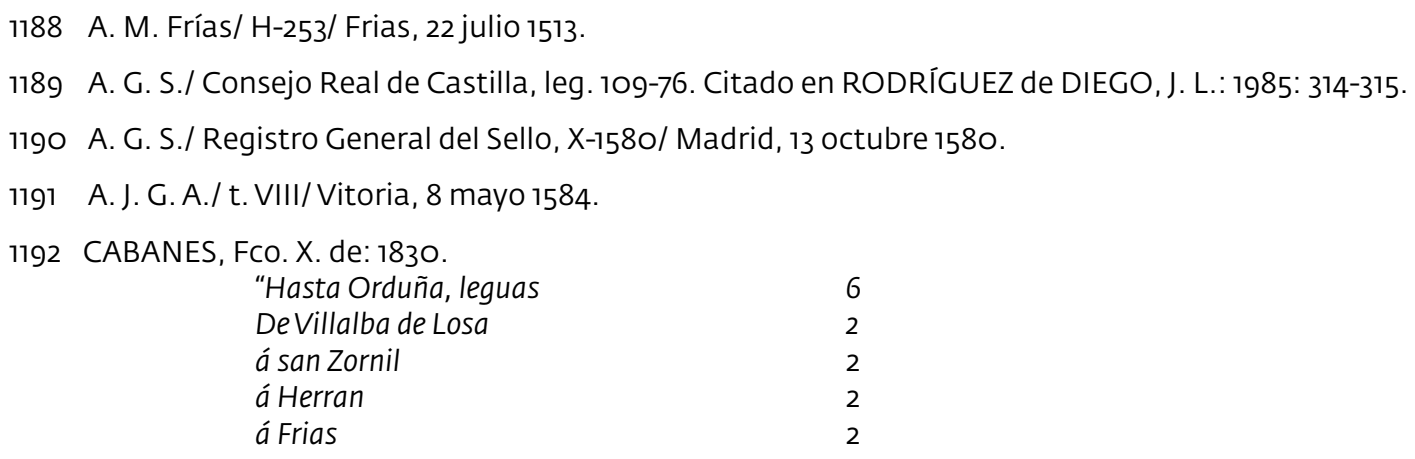




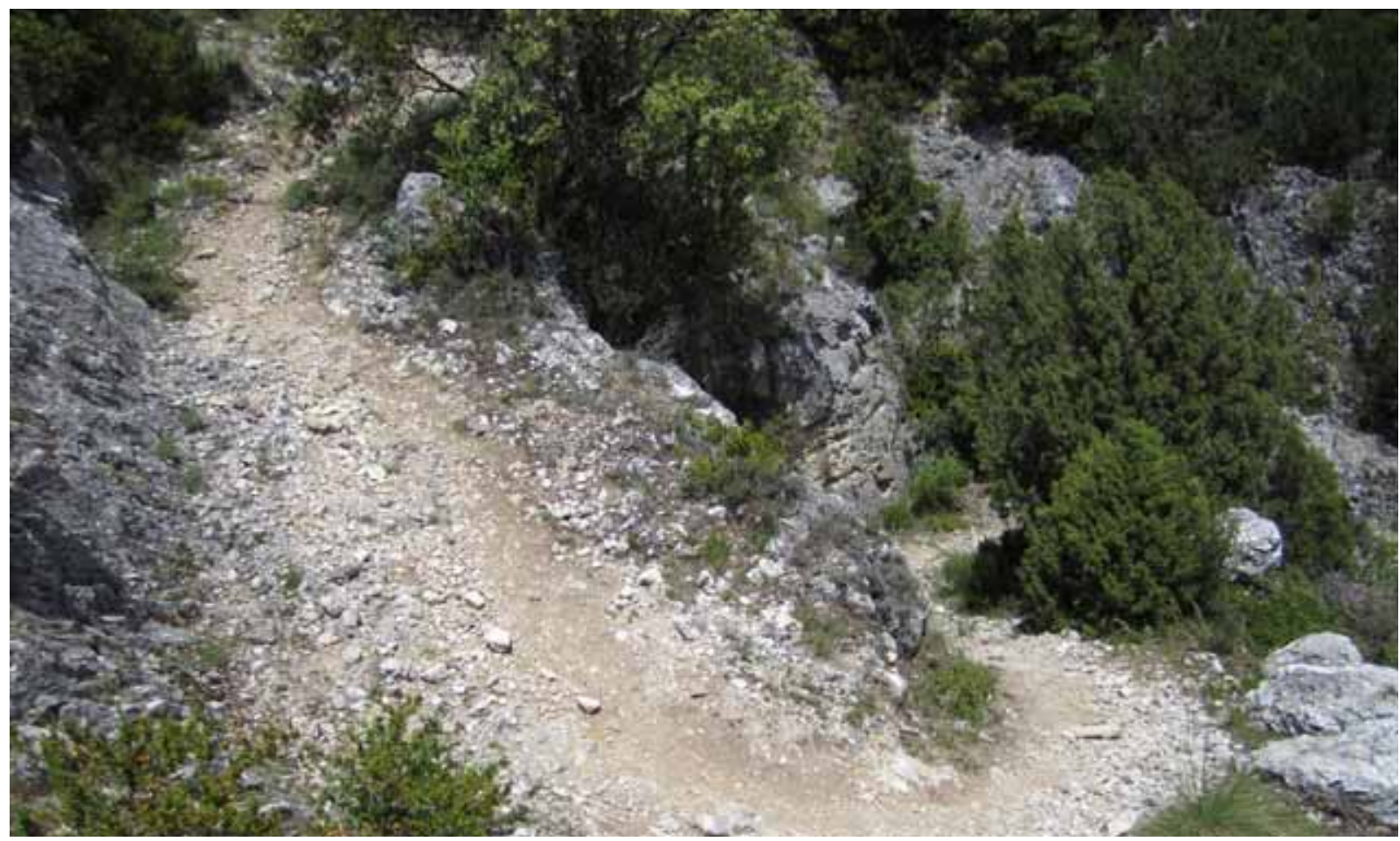

Camino a Orduña por San Zadornil.

\section{c.- Por el paso de San Bartolomé. El intento para el tránsito de carros}

Era el paso que ha pervivido hasta hoy como carretera tras ligeros cambios en su trazado. Un sendero de mulas debía salvar desde Orduña el desnivel de unos $550 \mathrm{~m}$ hasta lo alto de la cresta a unos $850 \mathrm{~m}$ de altura, tras una continua sucesión de vueltas y revueltas que agotaban a bestias y hombres, una legua larga de permanente subida. Ya en un pleito de 1494 entre la ciudad de Orduña y la villa de Villalba de Losa sobre términos y dehesas en la Sierra Salvada, se menciona "el camino real que ba de San Bartolome a Berberana"1193.

Según las cuentas del ayuntamiento de Orduña del año 1561, se pagaron 680 mrs., a los 10 oficiales a dos rs. cada uno, que repararon en la Peña de San Bartolomé el camino y pasos por haberlos roto el agua1194.

En las Juntas de Vizcaya de junio de 1562 Juan de Herrán en nombre de la ciudad de Orduña, comunicó que el Rey había dado provisiones para que la Peña se abriese, y pedía que escribiesen al Rey y a su Consejo para que fuesen favorecidos, pues era de interés para el Señorío. A esto se respondió que cuando se hubiese de escribir al Rey y a su Consejo para otros casos, se incluiría este asunto ${ }^{1195}$.

En las Juntas de Vizcaya de enero de 1578 a petición de Bilbao, se acordó dar poder a las personas que la villa nombrare para, entre otros, el reparo de los daños que los carreteros hacen en los caminos de la vía de Orduña, que Bilbao y otras anteiglesias remedian y re-

1193 A. H. F. B./ Munic. Orduña, caja no 15- leg. 23/Valladolid, 22 mayo 1494; ENRÍQUEZ FERNÁNDEZ, J.; HIDALGO de CISNEROS AMESTOY, C.; LORENTE RUIGÓMEZ, A.; MARTÍNEZ LAHIDALGA, A.: "Colección documental del Archivo Municipal de Orduña (1271-1510). Tomo I". 1994: doc. 25.

1194 A. H. F. B./ Munic. Orduña, L/ 005 y 054/1561-1594.

1195 A. J. R. B./ Actas de Villas y Ciudad. t. I/ Bilbao, 3 junio 1562 
paran $^{1196}$. En agosto muchas personas se quejaban de que el camino de la Peña de Orduña estaba mal reparado, y por ello no podían pasar por él "los tragineros y gente de caballo y recua". Como había algunos mrs. pagados por los que pasaban por la Peña, mandó el alcalde de la ciudad que se nombrase una persona para cobrar a los que pasaren por ella y lo que se cogiere o arrendare, se gaste en el reparo de la Peña y camino de ella y no en otras cosas, so pena de $2.000 \mathrm{mrs} .{ }^{1197}$.

Consta en las cuentas del concejo de Orduña que, en 1579, se gastaron 1.908 mrs. en abrir el puerto de la Peña de San Bartolomé, que estaba cerrado por la nieve, porque los pasajeros estaban retenidos en Orduña, y no podían pasar. En 1580 se pagaron $17.034 \mathrm{mrs}$. por una cuenta por menudo en el reparo del camino de la Peña y en 1581, 24.400 mrs. por el reparo de los malos pasos de la Peña, 2.250 mrs. por su reparo y 8 rs. con los señores del ayuntamiento cuando fueron a ver lo que hacían allí los oficiales, y en 1582 se pagaron 11.000 mrs. a Francisco de la Lastra y a Juan Alonso canteros, por la obra que hicieron en el camino y Peña de San Bartolomé1198.

En las cuentas de 1583, se recogen los pagos de 928 mrs. cuando fue la justicia y regimiento de Orduña a ver la Peña para que se reparasen los malos pasos; de 11 rs. al regidor Tomás de Larrea, por 4 días que anduvo por la Peña a reparar estos malos pasos con los oficiales y un ducado a Martín de Orue por estar en la Peña otros 4 días con los oficiales. Se pagaron también a San Juan Rodríguez de Ubilla 52 1 1/2 rs. por los 15 días que empleó en ir a Villalpando y traer la respuesta de la carta que el corregidor envió al Condestable, para que contribuyese en el reparo de este camino de la Peña. En 1584 se pagaron 10.123 mrs. a Francisco de la Lastra por la obra que hizo en la Peña, y 750 mrs. en ir a la ermita de San Bartolomé el día de este santo con un clérigo, escribano y alguacil, para la conservación de la jurisdicción que Orduña tiene y $4.800 \mathrm{mrs}$. en el reparo de la Peña de San Bartolomé. En 1585 , se gastaron 7.846 mrs. en abrir el camino de la dicha Peña, cuando las grandes nieves ${ }^{1199}$.

En las Juntas de Vizcaya de junio de 1586 el procurador general de Orduña presentó petición para que en los dos caminos que hay en la Peña de Orduña en su jurisdicción, que son San Bartolomé y Goldecho, el Señorío y sus villas ayuden a su reparo. Se proveyó que, como no había dinero, en los primeros regimientos y repartimientos se tenga cuenta por ser cosa justa, y se mandó que para la ayuda del camino de la Peña, se les den 50 ds. para el socorro que tienen pedido en el Regimiento de la Tierra Llana y Señorío1200. En las cuentas del ayuntamiento de Orduña consta que se gastaron ese año, 8.414 mrs. en abrir el puerto de San Bartolomé que estaba cerrado por la nieve y se pagaron $7.956 \mathrm{mrs}$. a Jorge López de Salazar, dezmero por hacer abrir la Peña por segunda vez. En 1587 se gastaron 3.052 mrs. el segundo y tercer día de Pascua de Flores en abrir el puerto de San Bartolomé cerrado por la nieve, $1.335 \mathrm{mrs}$. en hacer las zanjas y aguaneras del puente de la Torre hasta la venta y re-

1196 A. J. R. B./ Actas de Villas y Ciudad. t. II/ Bilbao, 29 enero 1578.

1197 A. H. F. B./ Munic. Orduña, L/ 005 y 054/1561-1594.

1198 A. H. F. B./ Munic. Orduña, L/ 005 y 054/1561-1594.

1199 A. H. F. B./ Munic. Orduña, L/ 005 y 054/1561-1594.

1200 A. J. R. B./ Actas de la Tierra Llana. t. IV/ Bilbao, 17 junio 1586. 
coger las aguas para que no saliesen al camino real y 4.500 mrs., por los 7 días empleados en un viaje a Bilbao para el cobro de los 50 ds. que por la Tierra Llana, fueron librados para los reparos de la Peña y puerto de San Bartolomé. Se gastaron además 23.178 mrs. en el reparo, paredones y empedrado hechos en lo alto del puerto y Peña de San Bartolomé, hasta la ermita de Santa Lucía más abajo y 612 mrs. el día de San Bartolomé, en llevar un sacerdote a decir misa a dicha ermita con el escribano de cámara y un alguacil. Se ingresaron $18.750 \mathrm{mrs}$. que la Tierra Llana del Señorío, libró a Orduña sobre el valle de Orozco para el reparo de la Peña y puerto de San Bartolomé. En 1588, se gastaron $8.840 \mathrm{mrs}$. en el reparo del camino y puerto que va de Orduña a Castilla por esta Peña, y en 1589 se pagaron 5.304 mrs. a Juan Alonso de Arcillero, cantero, por 52 obreros que habían aderezado los malos pasos de San Bartolomé, más 1.227 mrs. del gasto que se hizo en la Peña y $1.132 \mathrm{mrs}$. que costó otro aderezo ${ }^{1201}$.

En las Juntas de Vizcaya de febrero de 1590 el procurador de Orduña, dijo que está junto a la ciudad, la Peña y puerto de San Bartolomé, "por donde de neçesidad se andan y pasan a este Señorio, y del a las partes de Castilla, las recoas y mantenimientos y mercadurias que entran en este Señorio por mar y por Castilla, y del dicho Señorio y puertos del, salen para Castilla y por mar a otros reynos, que como hera notorio, hera uno de los pasos mas ynportantes que avia en los confines deste dicho Señorio, $y$ los caminos y pasos que ay en el conturno de la dicha Peña y paso estavan deshechos y perdidos", que no se podrían reparar con 1.000 ds. . Como era muy necesario el arreglo, pidió a Bilbao y a todos los que lo utilizan que acometiesen su remedio, pues era algo común de todo el Señorío, y porque también la ciudad contribuye en otros gastos que no le tocan, tanto como las demás Villas y Tierra del Señorío, y que se ayudase hasta en 300.000 mrs. La decisión fue remitida a los primeros Regimientos generales, así como lo que el Señorío y Villas y Ciudad y en particular Bilbao, que es el más interesado en los reparos, pueden ayudar a Orduña ${ }^{1202}$.

En las Juntas de Vizcaya de abril de 1591 Orduña pidió que el Señorío y Villas le den poder para pedir al Rey que mande repartir los gastos para abrir y hacer camino suficiente en la Peña de Orduña como paso tan necesario para todo el Reino, porque si no es así, la ciudad no podría abrir la Peña ni hacer el camino como conviene ${ }^{1203}$. Este camino real "por donde de neçesidad pasan y andan deste dicho Señorio, para casi a toda Castilla y Aragon y Nabarra y a otras muchas partes, $y$ de las dichas partes para este dicho Señorio, asy a cavallo como a pie, y todo genero de mercadurias, que vienen por mar y por tierra" en recuas con mucho peligro y coste por ser tan áspero, "no pueden andar ni pasar carros", con las mercaderías, bastimentos y vituallas sin antes acondicionar el camino, cuyo remedio importa mucho a toda Castilla. Se debiera pedir al Rey y su Consejo, licencia para que se haga repartimiento general entre todas las poblaciones que tienen provecho, para abrir el puerto y Peña de Orduña y se puedan llevar por él sin ningún peligro las mercaderías, vituallas y bastimentos con recuas y carros a pie y a caba1lo. Dieron poder a Diego de Orue alcalde ordinario de Orduña y a ocho procuradores en los Consejos y corte del Rey, para pedir dicha licencia ${ }^{1204}$.

1201 A. H. F. B./ Munic. Orduña, L/ 005 y 054/1561-1594.

1202 A. J. R. B./ Actas de la Tierra Llana. t. IV/ Bilbao, 23 febrero 1590; Actas de Villas y Ciudad. Tomo III/ Bilbao, 23 febrero 1590

1203 A. J. R. B./ Actas de Villas y Ciudad. t. III/ Bilbao, 20 abril 1591.

1204 A. J. R. B./ Actas de la Tierra Llana. t. V/ Bilbao, 29 abril 1591; Actas de Villas y Ciudad. t. III/ Bilbao, 29 abril 1591. 
En las cuentas del ayuntamiento de Orduña de 1592, se incluyen gastos de 3.706 mrs. en el reparo de la Peña de San Bartolomé ${ }^{1205}$ y en las Juntas de Vizcaya de abril de 1593 el procurador de Orduña pidió que se le dé ayuda de costa para este reparo respondiendo que no ha lugar ${ }^{1206}$. En las cuentas de Orduña de este año, se recogen gastos de $15.022 \mathrm{mrs}$. en los reparos de San Bartolomé y Goldecho, que hicieron Juan de Retes Ibarrola, Agustín de Armona y Juan de Aguirre Cotara. En 1594 se gastaron 782 mrs. el día de San Bartolomé para confirmar la jurisdicción de Orduña y en ir a decir misa con el sacerdote, escribano y alguacil ${ }^{1207}$. En las Juntas de Vizcaya de septiembre de 1596 Julián de Rubina regidor de Orduña, presentó una petición de socorro y ayuda de costa para reparar la Peña, acordándose que cada concejo repare los caminos de su distrito ${ }^{1208}$.

En las Juntas de Vizcaya de abril de 1600 el regidor de Orduña presentó una petición diciendo que la ciudad aderezaba la Peña de San Bartolomé, que es camino real pasajero para Castilla, y por tener más de media legua, gastaba más de 40.000 mrs. al año. Además, en solo quitar y abrir ventisqueros para abrir el paso, ha gastado más de 25.000 mrs. y todavía estaba el paso muy peligroso por las muchas nieves y aguas. Para aderezarle eran necesarios otros $100.000 \mathrm{mrs}$, , para lo cual y por lo mucho que al Señorío le importaba pidió que se le ayudase. El corregidor mandó que se dé instrucción al comisionado en la corte, para que ayude al que fuere de parte de Orduña a obtener cédula y Provisión real para el repartimiento de este camino ${ }^{1209}$.

En las Juntas de Vizcaya de mayo de 1603 el alcalde ordinario de Orduña dijo que en la Peña, en el camino principal y de más utilización a pie y a caballo y de trajinería, se cerraba en los tiempos de heladas y nieves, y Orduña para abrirlo gastaba más de 500 ds. anuales, por lo que pidió que se diese cada año una buena cantidad. Se acordó que se guarde esta petición para resolverla en los primeros regimientos ${ }^{1210}$.

Entre los años 1567 y 1579, se produjo un primer intento por resolver un problema grave apoyado tanto por los mercaderes, como por la villa de Bilbao y su Consulado, como era el de la adecuación del camino de la Peña para el tránsito de carros. A pesar de los esfuerzos realizados, esta actuación no se podrá llevar a cabo y habrá que esperar al siglo XVIII para que esto mismo se resuelva adecuadamente.

En las Juntas de Vizcaya de mayo de 1567 se acordó sobre la petición que el procurador de Orduña hizo para abrir la Peña según está mandado, que se dé instrucción sobre ello al que ha de ir a la corte ${ }^{1211}$. En las Juntas de abril de 1568 dicho procurador presentó un memorial por el que pedía que se dé orden de que se abra la Peña y que el Señorío mande que se den para ello 3.000 ds., porque lo restante hasta los 17.000 necesarios, se deberá

1205 A. H. F. B./ Munic. Orduña, L/ 005 y 054/1561-1594.

1206 A. J. R. B./ Actas de la Tierra Llana. t. V/ Bilbao, 1 y 3 abril 1593.

1207 A. H. F. B./ Munic. Orduña, L/ 005 y 054/ 1561-1594.

1208 A. J. R. B./ Actas de la Tierra Llana. t. VI/ Bilbao, 24 septiembre 1596; Actas de Villas y Ciudad. Tomo III/ Bilbao, 27 septiembre 1596 .

1209 A. J. R. B./ Actas de Villas y Ciudad. t. III/ Bermeo, 7 abril 1600.

1210 A. J. R. B./ Actas de Villas y Ciudad. t. IV/ Bilbao, 7 mayo 1603; Actas de la Tierra Llana. t. VII/ Bilbao, 13 mayo 1603.

1211 A. J. R. B./ Actas de la Tierra Llana. t. I/ Bilbao, 10 mayo 1567. 
repartir en todo el Reino, siendo esto muy conveniente para el Señorío "porque abriendose la dicha Peña puedan entrar façilmente las carretas que bienen de Castilla", lo que hará que los mantenimientos sean más baratos y abundantes. Añade que Bilbao debe hacer sus diligencias sobre los caminos como lo tiene ordenado, y Orduña siga su justicia y que ambos abran la Peña y presenten su provisión ${ }^{1212}$.

Las Juntas de Vizcaya en Junio de 1571 acuerdan procurar que el Consejo Real lleve a efecto la apertura de la Peña de la ciudad de Orduña, conforme a lo que el mismo Consejo ordenó1213. En dichas Juntas de junio de 1572 se trató sobre la Provisión real conferida para que se haga el camino de la Peña para que puedan pasar carros, y suplicaron al corregidor que haga las diligencias que manda la dicha Provisión ${ }^{1214}$.

En 1573 la ciudad de Orduña pidió al Rey licencia para obtener 15.00o ds., con los que "hazer camino que se pudiese carretear" por la Peña de Orduña, para el transporte a Castilla de todas las mercaderías que venían por mar a Bilbao, Portugalete y otros puertos. Con las carretas se abarataría el porte y quedaría beneficiado el Señorío, al poder vender en todo el Reino el hierro de sus ferrerías su principal granjería. Con el retorno se traería todo lo necesario, que con su porte más barato, bajaría el precio del hierro 1 real por quintal. Además, ese camino evitaría los "grandes peligros que se siguian ansi a los que por el caminaban como a los arrieros que lleuaban mercaderias y las trayan por la dificultad y aspereza del camino", y decían que como el arreglo beneficiaba a todo el Señorío, se repartiesen 4.000 ds. y que el resto, se cargase a las mercaderías que circulasen por la Peña, pagando de cada carga de mercadería cerrada 1 real y de la abierta medio real, hasta obtener los 15.000 ds. necesarios, con tanto de no cargar el portazgo en el pan, vino y otros artículos de primera necesidad. El Consejo Real acordó mandar al Prior y cónsules del Consulado de Burgos, a pesar de tener Bilbao Consulado propio, que se informasen sobre este asunto y sobre la necesidad de hacer el camino carretero, el beneficio que se obtendría y qué daños e inconvenientes se ocasionarían si no se hace, qué costaría abrirle, y si convendría la imposición en las cargas que por el camino pasaren, y todo se enviase para que el Consejo resuelva ${ }^{1215}$.

En 1574 se emite una real Provisión para que el Consulado de Bilbao informase sobre este camino y en las Juntas de Vizcaya de junio de 1575 se mandó que un representante vaya a la corte, para que se resuelva mejor lo que hasta ahora se ha intentado ${ }^{1216}$. En las de julio se acuerda de nuevo que Jerónimo de Nogales, representante de Orduña, informe al Consejo sobre el estado en que se encuentra la apertura de la Peña, conforme a lo que ese mismo Consejo había ordenado ${ }^{1217}$. En las Juntas de noviembre se informó que el Consejo había respondido que el Señorío y las casas de la Contratación de Burgos y Bilbao, hagan las diligencias oportunas para dicha apertura, y acordaron que el Señorío haga lo que sea

\footnotetext{
1212 A. J. R. B./ Actas de Villas y Ciudad. t. I/ Bilbao, 27 abril 1568.

1213 A. J. R. B./ Actas de la Tierra Llana. t. II/ Bilbao, 25 junio 1571.

1214 A. J. R. B./ Actas de Villas y Ciudad. t. II/ Bermeo, 19 junio 1572.

1215 A. D. B./ C-210/ Madrid, 21 noviembre 1573.

1216 A. J. R. B./ Actas de Villas y Ciudad. t. II/ Guernica, 14 junio 1575.

1217 A. J. R. B./ Actas de Villas y Ciudad. t. II/ Bilbao, 1 julio 1575.
} 
necesario ${ }^{1218}$. También las villas de Bermeo, Durango, Elorrio, Placencia, Ondarroa, Lequeitio, Guernica, Ochandiano, Villaro, Ermua y Regoitia, dijeron que Simón de Barrutia había negociado en la corte y traído una Provisión para el corregidor, ya que quería obligar a todos a participar en la fábrica del puerto y camino, lo cual, además de exceder la Provisión real, iba en perjuicio de las dichas villas, que tenían en sus jurisdicciones y en la del Señorío muchos caminos importantes y urgentes que mantener, por los que llegan de acarreo todos los mantenimientos y cuyo remedio era de mucho coste, siendo necesario para ello acudir no solo con los propios sino con sus propias haciendas. Dice la mayoría de las villas, que no tenían ningún aprovechamiento del camino de Orduña, salvo Bilbao, Valmaseda, Portugalete y Encartaciones que están cercanas a él, y los mercaderes de Burgos, cuyas posibilidades son muchas "por las gruesas haziendas que posen y negoçios y mercaderias de mucha utilidad que lieban y traen por el dicho camino". Por ello no se les debía incluir en este camino, sino obligarles a mantener los propios, de que tienen provecho por los bastimentos que por ellos les llegan. Suplican que el asunto se resuelva de manera que lo puedan cumplir sin que contribuyan para el camino de Orduña. El corregidor dijo que conforme a la Provisión, tras vista ocular de todos los caminos reales de Vizcaya, proveerá lo que convenga ${ }^{1219}$.

En 1576, se informa al ayuntamiento de Orduña sobre la gran utilidad que tendría para el Señorío, que se acabe de abrir el camino de la Peña de San Bartolomé y que esta obra está rematada desde hace varios años en Jerónimo de Nogueras, con la condición de obtener a su costa las licencias reales para ese fin ${ }^{1220}$. En el Libro de cuentas de la Universidad de Burgos se refleja en mayo de 1576, el pago de 6.800 mrs. a Alonso de Madrid secretario del Consulado de Burgos, para el "biaje que hizo a lo de la Peña de Orduña"1221. En las cuentas del ayuntamiento de Orduña de 1577, se pagaron dos ducados a Juan de Luyando, por el viaje que hizo a la corte para abrir la Peña y 3.522 mrs. para aderezar las Peñas de San Bartolomé y de Goldecho, más 782 mrs. a Lope de Cotara y 2.800 a Lucas de Romarate por el viaje a Burgos "sobre lo de la Peña" y 1.054 mrs. a Juan de la Cruz, por ir a dar la traza del dicho camino ${ }^{1222}$.

También en 1577 se pagaron 18.919 mrs. al secretario del Consulado de Burgos ${ }^{1223}$, cuando fue con los maestros de cantería Pedro de la Torre Bueras y Martín de la Haya a ver el puerto y Peña de San Bartolomé, conforme a la Provisión real y a Juan de Lárriz, maestro de cantería, que fue de Bilbao a Orduña para tratar con ellos sobre dicho puerto y Peña "para ber y entender si se puede abrir y hazer camino por ella para carros como se pretende, y rremediar el paso tan malo y peligroso como al presente tiene la dicha Peña, que mas se puede llamar despeñadero que camino rreal". Habiendo medido y tanteado su altura y longitud, dicen que se podrá hacer camino llano para que puedan subir y bajar carros por él, y tan ancho que puedan pasar dos carros sin estorbarse, y las bestias cargadas puedan andar con facilidad. Además las actuaciones

1218 A. J. R. B./ Actas de la Tierra Llana. t. II/ Bilbao, 8 noviembre 1575.

1219 A. J. R. B./ Actas de la Tierra Llana. t. II/ Bilbao, 8 noviembre 1575

1220 A. H. F. B./ Munic. Orduña, L/ 005 y 054/ 1561-1594.

1221 A. D. B./ R-15/ Libro de caja o Mayor del Consulado/ Burgos, 1568-1577. p. $350 i$.

1222 A. H. F. B./ Munic. Orduña, L/ 005 y 054/ 1561-1594.

1223 A. H. F. B./ Munic. Orduña, L/ 005 y 054/ 1561-1594. “...18.919 mrs. al secretario del Consulado de Burgos y oficiales que vinieron de Burgos a ver el puerto y peña de San Bartolomé, para dar su parecer sobre la apertura de la Peña, conforme a la provisión real y a Juan de Larriz maestro de cantería que vino de Bilbao para encontrarse con ellos en Orduña...." 
recogidas en las trazas de la obra mostradas por el regimiento de Orduña, "serian muy trabajosas y agrias, a causa de se yr aprobechando por algunas partes del camino que al presente esta echo, y se arian muchos contornos y bueltas, espezial en lo alto de la dicha Peña, que serian de mucho trabajo y dificultad para la subida e bajada de ella, que es lo que prinçipalmente se a de huir y ebitar", y proponen una serie de actuaciones concretas ${ }^{1224}$.

El Prior y cónsules mandan la respuesta al Consejo Real en junio de 1577, diciendo que "an ynbiado maestros praticos y expertos, que la han bien bisto y mirado, medido e nybelado, y hallan que por la dicha Peña se puede hazer camino carretero tan ancho y espazioso y tan llano, que fazilmente puedan subir e bajar por el dos carros sin se estorbar uno a otro..., porque la dicha Peña y paso que hagora tiene, es muy dificultoso e peligroso y a los que por ella pasan, por ser su altura muy grande con terrible y espantoso despeñadero, y como es notorio, el dicho paso es muy general y nezesario y que todo el Rreino se sirbe y aprobecha del, sin le poder ebitar ni mudar por otra parte, por ser como es la entrada para Uizcaya y a otras partes de la costa de la mar". Ellos como parte interesada, se muestran en contra del pago por el paso de sus mercaderías, por lo que para el "rrepartimiento e contribucion desta obra, les paresze que no conbiene al seruizio de su Magestad ni al bien de la contratazion, que se haga a las mercaderias, porque aunque se rrepartiese un rreal y aun dos por carga, no se acabaria de sacar toda la costa de la obra en mas de veinte años, y ansi los que pagasen e contribuyesen no podrian gozar del benefizio ni berla acabada, y aun seria causa de crezer el prezio de las mercaderias con ocasion de pagar este derecho,... y la mercaderia esta el dia de oy tan cargada de costas y derechos, que no se sufre echarle mas pues todo redunda en daño comun y general, y en la cobranza deste derecho,... seria causa que los mulateros que pasan con las cargas, rrezibiesen molestias y malos tratamientos, lo qual por huir y ebitar se irian por otras partes y caminos remotos y apartados, de que podria rresultar daño y peligros a las mercaderias y dueños de ellas, y su Magestad podria ser desfaudiado en sus derechos, que se pagan e cobran en la aduana de la dicha ziudad de Orduña, ques la mas prenzipal y de mas balor de todas, y... conbiene... que la dicha obra se haga con toda brebedad, y lo que costare, se reparta en general por todas las ziudades, villas e lugares del Rreyno, pues el probecho e benefizio es comun y general, y los que pagaren y contribuyeren haziendose con brebedad, se aprobechen y sirban de ello". Indican que el fiel y cónsules de Bilbao y el corregidor, son también del parecer de que se haga repartimiento general ${ }^{1225}$.

En las Juntas de Vizcaya de octubre de 1579, los procuradores de Orduña pidieron, que como por carta ejecutoria está mandado abrir la Peña y como "por contrariedad de algunas perssonas abia çessado el remedio dello", que al procurador que fuese a la corte se le diesen instrucciones para que se procure su ejecución, y lo mandaron así el corregidor y el regimiento ${ }^{1226}$. En dichas Juntas se pidió que el puerto y Peña de San Bartolomé, que por el Rey y el Consejo se

\footnotetext{
1224 A. D. B./ C-210-1/ Burgos, 22 junio 1577. "que se arrimen y metan con el camino en unas peñas grandes que estan al prinzipio y entrada de la dicha peña por la parte de arriba a la mano yzquierda, y de alli bayan deribando y prosiguiendo la bajada por las partes señaladas que dejamos puestas, de manera que en toda la altura de la dicha peña no ha de aber mas de tres bueltas y todo el camino a de ser de diez y ocho pies de ancho... sin el petril y paredon que a de llebar hanzia la parte de abajo, en las partes que fuere nezesario ansi y para la pertuydad y seguridad del camino, como para ebitar el peligro y despeñadero y quitar el pabor y miedo que pone la grande altura de la peña, ha de aber sus plazas y descansos a trechos para que si los carros quisieren reparar y soltar los bueyes y pastarlos en muy buenos pastos que ay alrrededor de la dicha peña", para "que todo quede ygual y llano, de tal manera que a diez pies de largo se le ha de dar uno de alto y no mas con lo qual quedara muy dulze y suabe de andar,... porque la dicha peña tiene de altura mill e nobezientos pies poco mas o menos y el largo, por donde a de ir este camino y traza es de diez y nuebe mill y nobezientos pies, y ansy cabe a cada diez pies de largo uno de alto como esta dicho que sera tan llano y fazil de andar como por la esperienzia se podra ber"
}

1225 A. D. B./ C-210-2/ Burgos, 27 junio 1577.

1226 A. J. R. B./ Actas de Villas y Ciudad. t. II/ Bilbao, 27 octubre 1579. 
había mandado hacer, y no quedaba sino realizar las diligencias necesarias en la corte para que se conceda el repartimiento, se pidió que se den instrucciones a Pedro de Villela para que haga en la corte las diligencias necesarias, y el Regimiento General lo mandó así. Las villas de Bermeo y Durango y algunos regidores, dijeron que si se pidiere algún repartimiento para abrir la Peña, no sean obligados a contribuir, porque no reciben aprovechamiento alguno de su apertura, y esta se haga a costa de los que reciben beneficio ${ }^{1227}$.

En las cuentas de Orduña consta que en 1579 se pagaron $5.625 \mathrm{mrs}$. al maestro cantero Domingo de Alguiarro, a cuenta del reparo del camino de la Peña y 5.90o mrs. a Martin de Mendico, como liquidación del pago de la calzada y paredones que se hicieron ese año en dicho camino y puerto ${ }^{1228}$.

Todavía en abril de 1591 se trató este asunto en las Juntas de Vizcaya. En este camino real por donde pasan "asy a cavallo como a pie, y todo genero de mercadurias que vienen por mar y por tierra" en recuas, con mucho peligro y coste por ser tan áspero, "no pueden andar ni pasar carros" con las mercaderías, bastimentos y vituallas, sin antes acondicionarlo. Se debe pedir para ello al Rey y su Consejo licencia para que se haga repartimiento general entre todas las poblaciones que tienen provecho, para abrir el dicho puerto y Peña de Orduña ${ }^{1229}$.

\section{Desde Pancorbo por Puentelarrá y Berberana}

El camino más importante de los que cruzaban la Sierra Salvada el de la Peña por San Bartolomé, iba de Burgos a Pancorbo por el camino de Francia, y en Pancorbo seguía hacia Bilbao por Orduña. Esta vía se consolidó como la principal vía de acceso a Vizcaya desde Castilla, y fue por la que los mercaderes de Burgos declararon en 1502, que transportaban la mayor parte de sus lanas, afirmación que hicieron no obstante de manera interesada para no contribuir al reparo del camino de Laredo ${ }^{1230}$.

A pesar del gran obstáculo que suponía el paso de la Peña de Orduña, este camino contaba con la ventaja de que tal obstáculo era prácticamente la única dificultad de dicha vía, pues el resto discurría por terrenos mucho más suaves. La elección de la Peña de Orduña como paso de este camino, responde Según Arízaga/Martínez, a una obcecación de los bilbaínos en buscar la vía más directa, ya que con un simple rodeo se podía haber optado por soluciones más sencillas, como el camino por Unzá1231.

El camino discurría por Briviesca, Grisaleña, Pancorbo, Encío, Santa Gadea, convento de El Espino, Puentelarrá, Bergüenda, Venta Blanca, Espejo, Venta del Monte, Osma, Berberana, Murita, Puerto de San Bartolomé y Orduña. Desde aquí sigue el curso del río Nervión hasta Arrigorriaga por Saracho, Amurrio, Luyando, Gardea, Llodio, Areta, Zuloaga, Arrancudiaga, Arene, Ugao-Miravalles, Aguirre, Arrigorriaga, Venta Alta o Beteluri, Buya, Ollargán, puente de San Antón y Bilbao.

1227 A. J. R. B./ Actas de Villas y Ciudad. t. II/ Bilbao, 27 octubre 1579; Actas de la Tierra Llana. t. III/ Bilbao, 27 octubre 1579 .

1228 A. H. F. B./ Munic. Orduña, L/ 005 y 054/ 1561-1594.

1229 A. J. R. B./ Actas de la Tierra Llana. t. V/ Bilbao, 29 abril 1591; Actas de Villas y Ciudad. t. III/ Bilbao, 29 abril 1591.

1230 A. G. S./ Registro General del Sello, VIII-1502, fol. 394/ Toledo, 27 agosto 1502; A. D. B./ C-220/ Toledo, 27 agosto 1502.

1231 ARÍZAGA BOLUMBURU, B. y MARTÍNEZ MARTÍNEZ, S.: 2006: 47-48. 


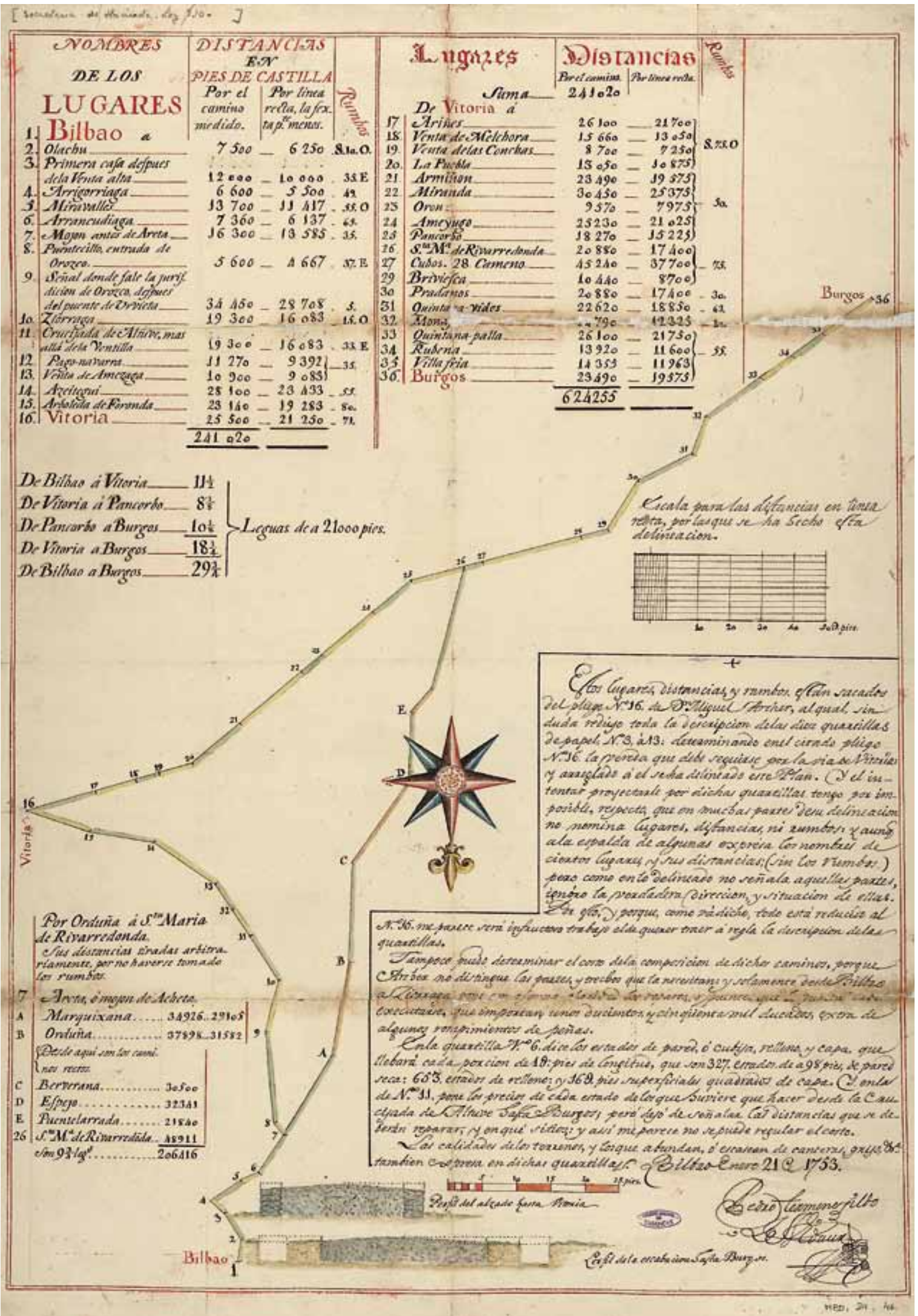

Cuadro de 1753 sobre la distancia del camino real que parte de Bilbao por Orduña hasta Burgos (A. G. S., MPD 24,046). 


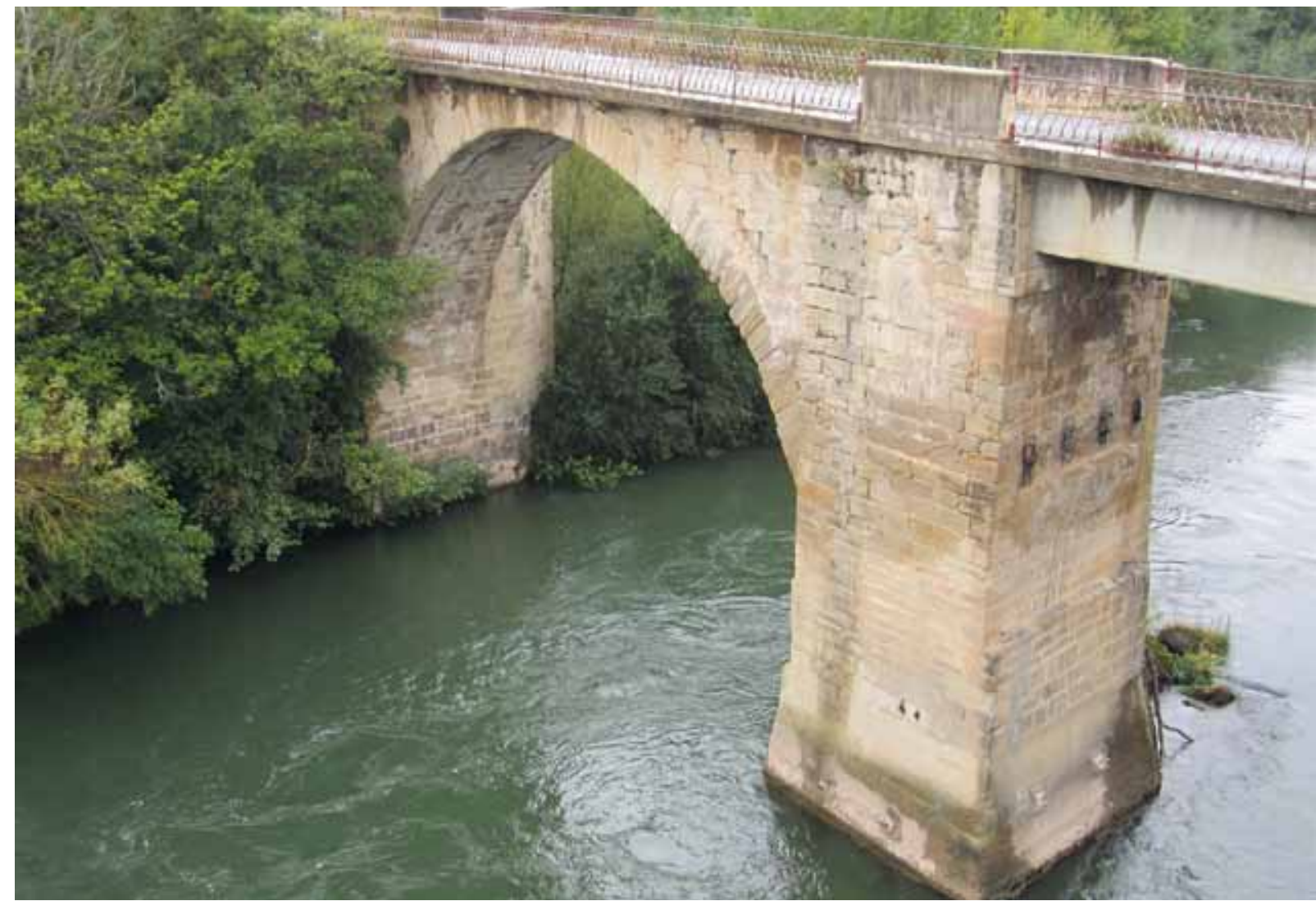

Puente de Puentelarrá.

En Orduña el caminante para ir a Castilla, debía superar una imponente pared caliza de unos $600 \mathrm{~m}$ de desnivel por un sendero de innumerables vueltas y revueltas que tras una legua larga de continua subida, llegaba a lo alto de la cresta. Superado el puerto, de unos $850 \mathrm{~m}$ de altitud, la principal dificultad había sido superada. El descenso hacia la Meseta era sencillo alcanzándose rápidamente la localidad de Berberana en el Valle de Losa a $624 \mathrm{~m}$ de altitud. La ruta continuaba en dirección sur hasta Puentelarrá, donde se cruzaba el Ebro y llegaba hasta la entrada de la hoz o desfiladero de Pancorbo. En este punto la ruta enlazaba con el camino de Vitoria y Miranda de Ebro a Burgos.

A comienzos de la Edad Media el puente de Puentelarrá era el único paso sobre el Ebro en este sector para ir de Burgos a Vitoria y puertos cantábricos, puesto que no existía el puente de Miranda y solo de manera precaria le hacía competencia un puerto fluvial con barcas en la Nave, a media legua corta al norte de Miranda. En sentido inverso, ocurría otro tanto al transportar la sal de Añana hacia la Bureba. A este tramo de camino, que enlazaba con Bujedo, se le denominaba "camino de Salinos"1232.

Este camino de herradura, utilizado desde fechas antiguas para comunicar Castilla y La Rioja, con Castro-Urdiales, Valmaseda y Bermeo, había sufrido varias intervenciones para intentar suavizar su principal obstáculo, como era la "espantosa" Peña de Orduña. Con el desarrollo del puerto de Bilbao, pasará a tener una clara dependencia de esta villa, de tal manera que su conservación y mejora será la consecuencia directa de sus intensas

1232 CADIÑANOS BARDECI, I.: 2008: 11 
relaciones comerciales y de los intereses de su puerto, que realizó continuos esfuerzos para asegurarse una fluida comunicación con su hinterland. Fue la vía más importante para comunicar Castilla y Burgos, como centro comercial, con el puerto de Bermeo primero, y con Bilbao después.

\section{- El camino en las guías itinerarias}

Todos los itinerarios mencionan este camino. El 3 de agosto de 1517 Fernando Colón comienza a realizar su Cosmografía y, en su descripción de los caminos de España, lo describe de manera detallada ${ }^{1233}$. En el primer repertorio de caminos publicado en España como tal en 1546 por Pero Juan Villuga ${ }^{1234}$, se incluye con una variante entre Burgos y Monasterio de Rodilla que discurre junto a la venta de Hurones, coincidiendo con la Descripción ya mencionada de Fernando Colón y con las referencias que se harán en los itinerarios de 1576 y 1705 y en el viaje de Jouvin de 1672. Meneses, incluirá en su repertorio editado en 1576, el mismo camino $^{1235}$. Ottavio Cotogno, lugarteniente del Correo Mayor de Milán, publica su Itinerario

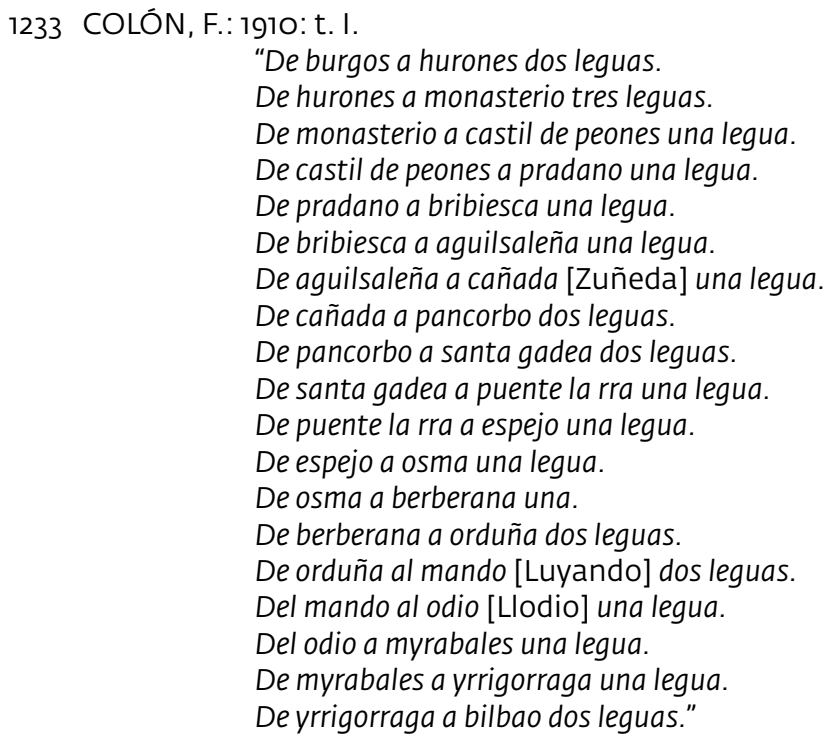

1235 MENESES, A. de: 1576.

$\begin{array}{ll}\text { "Burgos para Bilbao ay leguas. } & X X X . \\ \text { La venta Hurones II } & \\ \text { Monesterio de Rodilla } & \text { III } \\ \text { Castil de Peones } & \text { Iy media } \\ \text { Venta de Pradanos } & \text { media } \\ \text { Biruiesca } & 1 \\ \text { Grisaleña } & 1 \\ \text { Çuñeda } & 1 \\ \text { Pancoruo } & \text { II }\end{array}$


de Postas en 1608 y describe el camino completo de Burgos a Bilbao por Orduña ${ }^{1236}$. La Guía de caminos publicada en francés en 1674, fue traducida por Pedro Pontón y publicada en España en 1705, de la que se hicieron reediciones como esta de $1727^{1237}$.

La obra "Nuevo Estilo y Formulario de Escrivir Cartas Missivas y responder a ellas en todos generos,..." de 1756 , es otra de las numerosas reediciones de la primera de 1693, aunque en esta no aparece el itinerario. El itinerario inserto en la obra de 1756, como "Guía de Caminos, para ir, y venir por todas las provincias de España, y para ir a Roma, partiendo de Madrid à Barcelona, por el camino mas breve, que se halla à los Caminantes", es una copia del de Pedro Pontón ${ }^{1238}$. También Matías Es-

$\begin{array}{lc}\text { Sancta Gaeda } & \text { III } \\ \text { Berguenda } & 1 \\ \text { Espejo } & 1 \\ \text { LaVenta } & 1 \\ \text { Veruerana } & 11 \\ \text { Orduña } & 11 \\ \text { Luyando } & 11 \\ \text { Lodio } & 1 \\ \text { Miraualles } & 11 \\ \text { Rogoriaga } & 1 \\ \text { Bilbao } & \text { II" }\end{array}$

1236 COTOGNO, O.: 1608.

"Poste da Madrid à Bilbao

Madrid Città.

Da essa Città per infino à Burgos, hauete le Poste a fol. 87 che questo è il suo camino.

Dapoi à Quintanapaglia p. 1

a Castel de Peones p.1

a Briuiesca p. 1

Di quì auanti non vi sono le Poste frequenti, ma si possono concertare così.

A Pancorno P. 2

a Santa Gadea p. 1

alla Venta p. 1

a Beruerana p. 1

a Orduña p. 1

a Lusciandro p. 1

a Mirauallis p. 1

a Bilbao Città, \& Port, e Metropoli di Biscaglia"

1237 PONTON, P.: 1705

$\begin{array}{ll}\text { "BURGOS PARA VILBAO. } & \\ \text { LaVenta Hurròn, } & \text { dos. } \\ \text { Monasterio de Rodillas, } & \text { tres. } \\ \text { Castillo de Peones, } & \text { vna y med. } \\ \text { Venta de Pradanos, } & \text { media. } \\ \text { Briviesca, } & \text { vna. } \\ \text { Gasaleña, } & \text { vna. } \\ \text { Zuñeda, } & \text { vna. } \\ \text { Pancorbo, } & \text { dos. } \\ \text { Santa-Gadeo, } & \text { tres. } \\ \text { Vergueda, } & \text { vna. } \\ \text { Espejo, } & \text { vna. } \\ \text { LaVenta, } & \text { vna. } \\ \text { Berverana, } & \text { dos. } \\ \text { Orduña, } & \text { dos. } \\ \text { Luyando, } & \text { dos. } \\ \text { Lodio, } & \text { vna. } \\ \text { Miravalles, } & \text { dos. } \\ \text { Rigoriaga, } & \text { vna. } \\ \text { Vilbao, } & \text { dos. } \\ \text { Son treinta leguas." } & \end{array}$

1238 ANÓNIMO: "Nuevo Estilo y Formulario de Escrivir Cartas Missivas y responder a ellas en todos generos, ...." 1656: XX-LXVIII. 
cribano incluye en su Itinerario de 1758 esta vía ${ }^{1239}$. El Itinerario de Udal ap Rhys $1760^{1240}$,

$\begin{array}{ll}\text { "Burgos para Vilbao } & \\ \text { LaVenta Hurrón, } & 2 \text { leguas } \\ \text { Monasterio de Rodillas, } & 3 \\ \text { Castillo de Peones, } & 7 \frac{1 / 2}{2} \\ \text { Venta de Pradanos, } & 7 / 2 \\ \text { Briviesca, } & 7 \\ \text { Gasaleña, } & 7 \\ \text { Zuñeda, } & 7 \\ \text { Pancobo, } & 2 \\ \text { Santa Gadéa, } & 3 \\ \text { Vergueda, } & 7 \\ \text { Espejo, } & 7 \\ \text { LaVenta, } & 7 \\ \text { Serveraña, } & 2 \\ \text { Orduña, } & 2 \\ \text { Luyando, } & 2 \\ \text { Lodic, } & 1 \\ \text { Millavalles, } & 2 \\ \text { Rigoriaga, } & 1 \\ \text { VILBAO, } & 2 \\ \text { Son treinta leguas." } & 2\end{array}$

1239 ESCRIBANO, J. M.: 1758.

"MADRID PARA BURGOS, Orduña, y Bilbao. Camino de Ruedas.

BURGOS

Rio Arlanzon, Puente.

Gamonál

Villafria

Rubena

Quintana Palla

El Monasterio de Rodillas

Santa Olalla, y Quintanavides

Castil de Peones

Pradano

Bribiesca

Venta de Cameno

Cubo

Santa Maria

Pancorvo

Santa Gadea

Rio Ebro, Puente de la Rad.

Berguenda

La Venta Blanca

Espejo

Rio Omecillo, Puente.

La Venta del Monte

Osma

m

1

1

1

m

1

m

2

m

1

3

Berberaña

La Venta de la Peña

Orduña

Rio de Saracho, Puente.

Amurrio

Luyando

Llodio y Areta

Miravalles

1

m

m

Arrigoriaga

La Venta Alta

BILBAO

Zamudio

Mungia

Bermeo

1

1

1240 UDAL ap RHYS: 1760. 
también es copia pero del Meneses ya citado. El Itinerario de Campomanes de $1761^{1241}$ lo recoge, así como en la Guía General de Postas de Espinalt de $1785^{1242}$.

El Itinerario de Picquet ${ }^{1243}$ realizado en 1810 para el ejército de ocupación francés

$\begin{array}{ll}\text { "From Burgos to Bilbao } & 30 . \\ \text { La Venta de Hurones } & 2 \\ \text { Monasterio de Rodilla } & 3 \\ \text { Castillo de Peones } & 7^{\frac{1}{2}} \\ \text { Venta de Pradanos } & 0^{\frac{1}{2} 2} \\ \text { Biruiesca } & 7 \\ \text { Grasaleña } & 7^{\frac{1}{2}} \\ \text { Zuñeda } & 0^{\frac{1}{2} 2} \\ \text { Pancoruo } & 2 \\ \text { Santa Gadea } & 3 \\ \text { Berguenda } & 7 \\ \text { Espejo } & 7 \\ \text { LaVenta } & 7 \\ \text { Verberana } & 2 \\ \text { Orduña } & 2 \\ \text { Luyando } & 2 \\ \text { Lodia } & 7 \\ \text { Miravalles } & 2 \\ \text { Rigoriaga } & 7 \\ \text { Bilbao } & 2 "\end{array}$

1241 RODRÍGUEZ CAMPOMANES, P.: 1761

"CARRERA DESDE MADRID à Bilbao

$\begin{array}{ll}\text { de Burgos à Quintanapalla } & 3 \\ \text { de Quintanapalla à Castil de Peones } & 3 \\ \text { de Castil de Peones à Bribiesca } & 2 \\ \text { de Bribiesca à Zuñeda } & 2 \\ \text { de Zuñeda à Ameyúgo } & 3 \\ \text { de Ameyúgo à Espejo } & 3^{\frac{1}{2} 2} \\ \text { de Espejo à Berberana } & 2 \\ \text { de Berberana à Orduña } & 3 \\ \text { de Orduña à Llodio } & 3 \\ \text { de Llodio à BILBAO } & 3^{\frac{1}{2} 2}\end{array}$

Previenese, que en Ameyúgo està la ultima Posta reglada, y que en las siguientes de Espejo, Berberana, Orduña, Llodio y Bilbao deben aprontarse por las Justicias los cavallos necesarios, pagando los derechos que previene el Reglamento General expedido por S. M. mientras se establezcan de cuenta de la Real Hacienda estas Postas".

1242 ESPINALTY GARCIA, B.: 1785

"De Madrid à Bilbao.

De Madrid à Ameyugo por la Carrera antecedente $55^{\frac{1}{2}}$

à Espejo $\quad 3 \frac{1}{2}$

à Berberana 2

à Orduña 3

à Llodio 3

à Bilbao $\quad 3^{\frac{1}{2}}$

1243 PICQUET, Ch.: 1810.

"№ 30 CARRERA MONTADA

De Madrid à Bilbao, por Segovia, Valladolid y Burgos.

à Burgos

al Monasterio de Rodilla

$4 \quad 58$

à Briviesca

$62 \frac{1}{2}$

à Pancorbo

$\begin{array}{ll}4 \frac{1}{2} & 62\end{array}$

à Miranda de Ebro

$70 \frac{1}{2}$

à Berguenda

$4^{1 / 2} \quad 70$

à la Venta del Hambre $\quad 4 \quad 81$

à Orduña $\quad 1 \quad 82$

à Amurrio $\quad 2 \quad 84$

à Llodio

286


durante la Guerra de la Independencia, recoge las vías principales de Madrid-ArandaBurgos-Miranda-Vitoria, Madrid-Burgos-Santander y Madrid-Burgos-Bilbao. La Cuía de caminos o Itinerario de Santiago López realiza la segunda edición en 1812 y la cuarta en 1828. Es otra de las copias del Itinerario de Escribano, un trabajo que se reeditó o copió en numerosas ocasiones durante el siglo XIX ${ }^{1244}$. El brigadier de infantería Fran-

\begin{tabular}{|c|c|c|}
\hline à Bilbao & 2 & $88 "$ \\
\hline \multicolumn{3}{|c|}{ De Bilbao à Madrid, por Burgos, Valladolid y Segovia } \\
\hline De Bilbao à Llodi & 2 & \\
\hline à Amurrio & 2 & 4 \\
\hline à Orduña & 2 & 6 \\
\hline à la Venta del Hambre & 1 & 7 \\
\hline à Berguenda & 4 & 11 \\
\hline à Miranda de Ebro & 3 & 14 \\
\hline à Pancorbo & $3^{1 / 2}$ & $17^{1 / 2}$ \\
\hline à Briviesca & $4^{1 / 2}$ & 22 \\
\hline al Monasterio de Rodilla & $3^{1 / 2}$ & $25^{1 / 2}$ \\
\hline à Burgos & $4^{1 / 2}$ & $30 "$ \\
\hline \multicolumn{3}{|l|}{ “№ 135 CARRERA MONTADA } \\
\hline \multicolumn{3}{|c|}{ De Bilbao à Madrid, por Burgos y Aranda de Duero. } \\
\hline De Bilbao à Llodio & 2 & \\
\hline à Amurrio & 2 & 4 \\
\hline à Orduña & 2 & 6 \\
\hline à la Venta del Hambre & 1 & 7 \\
\hline à Berguenda & 4 & 11 \\
\hline à Miranda de Ebro & 3 & 14 \\
\hline à Pancorbo & $3^{1 / 2}$ & $17^{1 / 2}$ \\
\hline à Briviesca & $4^{1 / 2}$ & 22 \\
\hline al Monasterio de Rodilla & $3^{1 / 2}$ & $25^{1 / 2}$ \\
\hline à Burgos & $4^{1 / 2}$ & $30 "$ \\
\hline
\end{tabular}

1244 LÓPEZ, S.: 1812.

"MADRID PARA BURGOS, Orduña, Bilbao y Berméo, y al márgen para otras ciudades y villas grandes que se irán anotando. Camino de rueda.

BURGOS. $1 \mathrm{~m}$

Rio de Almarza, $P$.

Gamonal. $m$

Villafria.

Ruvena. $\quad 1$

Quintana Palla. 1

El Monasterio de Rodillas. 1

Santa Olalla, y Quintanavides $\quad 1$

Castil de Peones. $\mathrm{m}$

Pradanos. $m$

Briviesca. 1

Venta de Cameno. $\mathrm{m}$

Cuvo. 2

Santa María. $\mathrm{m}$

PAN-CORVO. 1

A media legua de aquí se aparta el camino que va á Bilbao á la izquierda, y el de la derecha vá á Miranda de Ebro, Vitoria, Tolosa, Irun y Bayona de Francia.

$\begin{array}{ll}\text { Santa Gadea. } & 3 \\ \text { Rio Ebro, y puente de la Rad } & 7 \\ \text { Berguenda. } & 7 \\ \text { Venta blanca. } & \mathrm{m} \\ \text { Espejo. } & \mathrm{m} \\ \text { Rio Omedillo, puente. } & \\ \text { Venta del Monte. } & \mathrm{m} \\ \text { Osma. } & \mathrm{m} \\ \text { Berberaña } & \mathrm{m}\end{array}$


cisco Xavier Cabanes, publica en 1830 esta Guía General, con un mapa itinerario de la Península1245.

Entre los caminantes destaca Pellegrino Zuyer, que sale de Burgos a mediados de octubre de 1660, y va por Pancorbo y Orduña a Portugalete, desde donde recorrió todo el litoral hasta San Vicente de la Barquera, para volver a Burgos por Valderredible y el páramo del Tozo. Anota con detalle el recorrido realizado por este camino ${ }^{1246}$.

Venta de la Peña de Orduñar

ORDUÑA.

"Alcalá de Henares, Berlanga, Abejar, Haro, Orduña y Bilbao.

Camino de herradura.

Arce, R. Ebro y P.

Fontecha.

Espejo.

Berberaña.

Provincia de Vizcaya.

53 m Orduña.

Miravalles.

Go Bilbao.
$7 "$

1

2

$2 m^{\prime \prime}$

1245 CABANES, FCo. X. de: 1830.

"IX. BILBAO. Carrera de Madrid á Bilbao.

De Pancorvo á Ameyugo (aqui se separa la carrera montada) leguas 1

$\begin{array}{ll}\text { á Berguenda } & 2^{\frac{1}{2} 2} \\ \text { á Berberana } & 3 \\ \text { á Orduña } & 2^{\frac{1}{2} 2} \\ \text { á Areta } & 3 \\ \text { á Bilbao } & 3\end{array}$

Esta carretera es montada hasta Ameyugo, y de aqui á Bilbao carretera real".

1246 Archivo Secreto Vaticano/ Archivo Consistorial. Acta Congregationis Consistorialis, vol. I, fols. 499-534/ 1669; CASADO SOTO, J. L.: 2000: 289-345. "La primera aldea que se encuentra a media legua de Burgos, se llama Gamonal, muy pequeña,... a media legua, se pasa por otra aldea del mismo tamaño llamada Villafria... la primera aldea que se encuentra, a una legua de Villafria es Rubena, que es poca cosa,... A otra legua se atraviesa el lugar de Quintanapalla, de las mismas dimensiones que Rubena... Desde aqui se caminan dos leguas hasta el monasterio de Rodillas,... Del mismo tamaño es Quintavides,... Después de otra legua, se pasa Pradanos, aldea igual a las dos antecedentes... a Briviesca, hay una legua... A una legua de camino siempre llano tras salir de Briviesca, se pasa por la aldea de Grisaleña, y a otra se encuentra Cinueda. Ambos lugares tienen el mismo tamaño,... se caminan dos leguas sin pasar por ninguna aldea, hasta el puerto de Pancorvo, que es lugar todo amurallado situado al pie de una montaña pequeña llamada El Puerto, y hasta alli la carretera es llana y muy buena, por haber pasado poco antes su Magestad trasladándose a San Sebastián, para cuya ocasión fueron reparados todos los malos pasos, de manera que pudieran recorrerla carrozas, mas adelante no se pudo... Nada más salir del Puerto de Pancorvo se entra entre dos altísimas montañas, a lo largo de dos leguas, siempre con mal camino, hasta un lugar que llaman Santa Gadea por donde no pueden pasar literas, las cuales hacen otro rodeo a mano derecha. A un cuarto de legua fuera de Pancorvo, se divide el camino que va a San Sebastián del que va a Bilbao con una cruz que señala para una y otra parte. Santa Gadea [a dos leguas] es un lugar, casi todo el amurallado... está situado al pie de un monte sobre el que se ven ciertos vestigios de un castillo... A trescientos pasos de Santa Gadea hay un convento de San Benito con diecisiete religiosos, ... y a igual distancia hay otro convento de San Francisco con diez religiosos. Una legua mas adelante se pasa el rio Ebro sobre un puente muy bello de seis arcos, y allí hay una aldea de diez casas que toma el nombre del puente, llamandose Puente de Ra... A otra legua de camino se pasa por Berguenda,... y a menos de media legua se encuentra Espejo, aldea del mismo tamaño... Y después de un cuarto de legua se entra en el obispado de Calahorra, nada mas pasar la casa que llaman Venta del Monte, y en menos de legua y media se atraviesan las aldeas de Osma y Berberana,... Estos dos lugares estan situados sobre la montaña que llaman el puerto de Orduña, que es muy alto y aspero de cruzar y, en tiempo de invierno, cuando esta cubierto de nieve, es casi impracticable y peligrosisimo, y por lo que he oido, cada año suceden muchas desgracias, pero no habiendo nieve, se pasa sin peligro alguno siempre a caballo hasta la bajada de la montaña, que dura una buena media legua y es necesario hacerla a pie (Goldecho). El camino de literas va por otra parte (San Bartolomé), prolongando la bajada de dicha montaña mas de una legua y media. En menos de media legua se llega a la ciudad de Orduña, que dista de Berberana dos grandes leguas... Una vez parti de la ciudad de Orduña, entre en las montañas que llaman Bajas y valles por los que se pasa, dejando el camino de Bilbao a mano derecha y tomando el de la izquierda, directamente a Portugalete,... A media legua de la ciudad de Orduña se encuentra Saracho,... donde no vi mas de seis o siete casas juntas, las demas se encuentran muy alejadas unas de otras,...". 


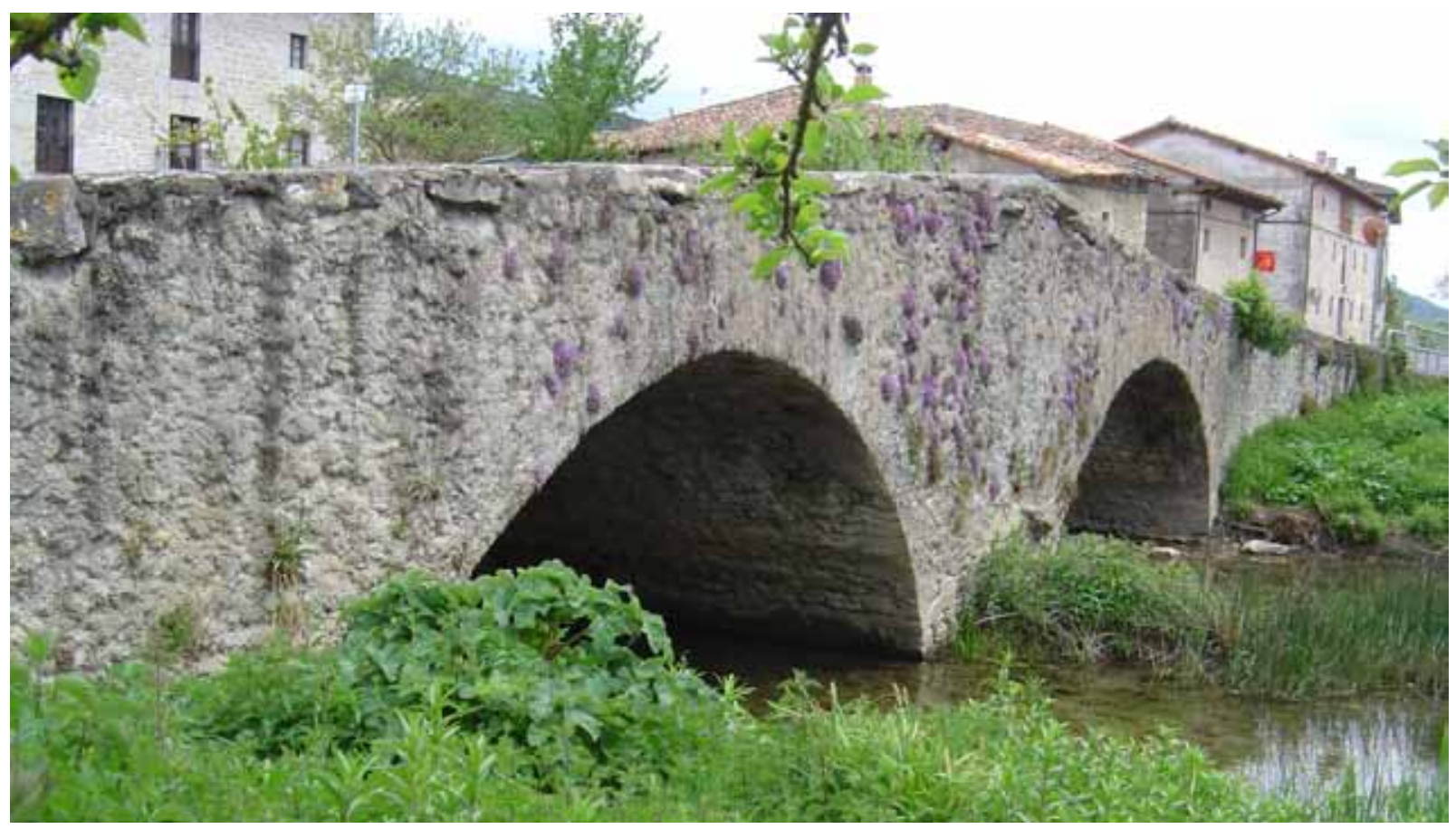

Puente de Osma.

\section{- Referencias documentales.}

En 1045 cuando García de Nájera, rey de Pamplona, agrega los monasterios de Santa María de Guinicio y Santa María de Quijera al de San Millán de la Cogolla, se menciona el puente de Puentelarrá como perteneciente al Rey, por depender de Término ${ }^{1247}$ que es villa realenga. También se alude aquí al cobro del portazgo ${ }^{1248}$.

En 1148 Alfonso VII extiende un privilegio confirmando otro de García de Nájera a favor de Santa Gadea en el que, al fijarse términos con sus respectivos límites, se menciona el puente de Puentelarrá1249.

Fernando III confirma en 1232 la pesquisa hecha en Santa Cadea, Puentelarrá, Espejo, Caranca, Osma, Villacián de Losa, Atiega y Salinas de Añana por el abad del monasterio de Obarenes, acerca del camino que utilizaban los vecinos de Pancorbo para ir con sus recuas a Castro-Urdiales, en la que coinciden todos los testigos en que seguían desde la época de Alfonso VIII el camino por Puentelarrá y Losa. Además, la selección de las localidades donde se interroga, salvo Atiega y Salinas, nos indica claramente que el camino entre Pancorbo y Osma, era coincidente con este camino, pero que al desviarse por Villacián, evitaba Orduña en dirección a Castro-Urdiales ${ }^{1250}$.

\section{Santa Gadea del Cid.}

1248 A. H. N./ Cartulario de San Millán de la Cogolla. Becerro, fol. 157-157V/ 31 octubre 1045; UBIETO ARTETA, A.: 1976: 231-232: doc. 237. "... in Ebro ubi cadet rivo de Termino, de parte ad parte, ad integritate. Et illa casa de Ponte, cum illa villa de Larate, ad integritate. De illa defesa de Tega, medietate. De illo mercato, medietate. De illas calonias et illo portatico. Et ipso mercato, ad fuero de Cereso populato, medio ad termino et medio ad Sancti Emiliani presbiteri. Duos asinos de Sancta Maria de Genezo, et uno de casa de Ponte, sine alvara ambulent ad suos mercatos absolutos".

1249 A. M. Santa Gadea/ doc. 26/ Carrión de los Condes, 13 octubre 1148? (Transcrito por CADIÑANOS BARDECI, I.: 1987: 76-78 “... y de ay ba por la ribera del rio Hebro hasta el puente que se llama de la Rad la qual puente es de Santa Gadea...".

1250 A. M. Pancorbo/ Burgos, 30 julio 1232; GONZÁLEZ y GONZÁLEZ, J.: 1983: t. II doc. 478, 551. “...que uiron et sabien a la fin del rey don Alfonso et en su uida andar a los de Pancoruo et sus requas por el camino de la Puent de la Rat et por Losa a 
En 1257, Alfonso X para favorecer el poblamiento de Orduña (fundada en 1229) y que sus vecinos "sean mas ricos e mas abonados e me puedan azer mejor serbiçio", les otorga un privilegio confirmado por Sancho IV, Alfonso XI y Juan II, que ordena el paso obligatorio por Orduña, de todos los mercaderes y caminantes que vayan o vengan entre Castro-Urdiales o Valmaseda y Santo Domingo de la Calzada, Nájera o Logroño, por los puentes de Puentelarrá y Miranda, Salinas de Añana o Vitoria. También obligaba a pasar por Orduña a los de Oquendo, Llodio, Orozco o Ayala, que fuesen a Vitoria o retornasen con hierro u otras mercaderías, debiéndolo cumplir, bajo penas de prisión y la pérdida de mercaderías ${ }^{1251}$. Se otorga con ello a Orduña una especie de monopolio de todo el tráfico mercantil existente en una amplia zona, que se extiende desde las villas de la ribera del Ebro o afluentes, hasta las Encartaciones y la costa, y entre Vitoria y la zona de Oquendo, Ayala, Llodio y Orozco, lo que será la causa principal del gran desarrollo de Orduña desde el siglo XIII.

El 15 de junio de 1300, Diego López de Haro V, señor de Vizcaya, concede carta-puebla y hace nueva población junto al puerto de Bilbao, y dice a sus pobladores y vecinos que sean francos y quitos de todos los pechos, veredas, fonsaderas, enmiendas, oturas y mañerías según el fuero de Logroño. Otorga libertad de tránsito por la ría para las embarcaciones que van o vienen al puerto de Bilbao: "que en el nuestro puerto de Portogalete, nin en la barra nin en toda la canal, que non aya peçio ninguno de naue nin de baxel que uengan o salan del lugar cargados con sus mercaduras, e mostrando recabdo que uienen a esta villa de Biluao o van della e pagando las costumbres e los derechos del sennor", y que no sean retenidos ni embargados por razón de pecio ${ }^{1252}$. Concede además mercado el martes de cada semana ${ }^{1253}$.

En enero de 1301 Fernando IV dio al concejo de Bilbao y sus vasallos, para que se poblase mejor, las mismas franquezas y libertades que a los de Bermeo. Manda que todos los que fueren con mercaderías al puerto de Bilbao, las puedan cargar y descargar francamente, y no den diezmo alguno, más de lo que den en Vitoria, Pancorbo o en otro lugar cualquiera de sus puertos, donde ellos mejor se pudieren avenir con los que los recaudaren; y a los que hallaren que van por otro lugar, que les tomen cuanto lleven por ir descaminados, pagando los otros derechos como deben en sus lugares, manda que anden salvos y seguros por todos sus reinos, y que no sean prendados ni embargados por ninguna razón ellos ni sus cosas, salvo por sus deudas conocidas o por fiadurías ${ }^{1254}$.

Castro sin premia ninguna...".

1251 A. M. Orduña/ Caja no 97- leg. G (fol. 4r- 5v)/ Burgos, 5 octubre 1257; ENRÍQUEZ FERNÁNDEZ, J., HIDALGO de CISNEROS AMESTOY, C., LORENTE RUIGÓMEZ, A. y MARTÍNEZ LAHIDALGA, A.: "Colección documental del Archivo Municipal de Orduña (1271-1510). Tomo I". 1994: doc. 4.

1252 Derecho que el señor del puerto de mar exigía de las naves que naufragaban.

1253 A. M. Bilbao/ Pergaminos, 1 (actualmente se halla en la casa consistorial)/Valladolid, 15 junio 1300; ENRÍQUEZ FERNÁNDEZ, J.; HIDALGO de CISNEROS AMESTOY, C. y MARTÍNEZ LAHIDALGA, A.: 1999: "Colección documental del Archivo Histórico de Bilbao (1300-1473)".: doc. 1.

1254 A. M. Portugalete/ Sección C- Caja 1-n.ำ1 (1) fol. 16r.- 24r. y 3or.- 33r./ Tudela de Duero, 23 Agosto 1506; HIDALGO de CISNEROS AMESTOY, C.; LARGACHA RUBIO, E.; LORENTE RUIGÓMEZ, A.; MARTÍNEZ LAHIDALGA, A.: 1987; 156:

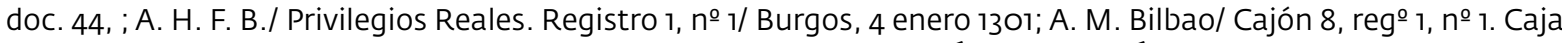
199, Libro Copiador de Privilegios (fol. 4)/ Burgos, 4 enero 1301; ENRÍQUUEZ FERNÁNDEZ, J.; HIDALGO de CISNEROS AMESTOY, C. y MARTÍNEZ LAHIDALGA, A.:"Colección documental del Archivo Histórico de Bilbao (1300-1473)".: 1999: doc. 2; HIDALGO de CISNEROS AMESTOY, C.; LARGACHA RUBIO, E.; LORENTE RUIGÓMEZ, A. y MARTÍNEZ LAHIDALGA, A.: 1986: doc. 1. 
En el concejo de Burgos se mostró una carta de Fernando IV de febrero de 1304, que les dice que Diego López de Haro, señor de Vizcaya, le comunicó que sus vasallos del concejo de Bilbao, tenían privilegio real para no pagar portazgo alguno de "las cosas que truxesen 0 llebasen en ningun lugar de mi reino, saluo en Toledo e en Seuilla e en Murçia", pero como el concejo de Burgos les toma lo que traen para que paguen el portazgo y las otras cosas de que el Rey les eximió, este está “marabillado de como sodes osados de lo fazer e consentir". El Rey les manda que guarden y cumplan este privilegio, y que si algo les han prendado, que lo devuelvan de inmediato. Para tratar sobre ello los seis alcaldes, el merino y los hombres buenos, viendo que lo que se pide es al servicio del Rey y que entienden que "hera bien de fazer el ruego que don Diego les hazia", acordaron guardar dicha merced sobre el portazgo ${ }^{1255}$.

En enero de 1306 Lope Díaz de Haro titular del portazgo del puente de Puentelarrá, fue a Oña y vio que el monasterio estaba exento de portazgo en toda Castilla, pero le dijeron que los portazgueros de Puentelarrá se lo demandaban de las acémilas que traen la sal de Añana. Como el monasterio está exento, "non tengo yo por bien quel pechen nin quel den en la Puente de Carat, nin en Bozo, nin en Santa Cadea", ordena a los portazgueros de Puentelarrá, que no cobren a dicho monasterio por el traslado de sal desde Añana, portazgo ni usaje de las acémilas. Y manda además a los alcaldes y al merino de Santa Gadea que si fuere necesario lo hagan cumplir ${ }^{1256}$.

El 25 de junio de 1310, doña María, mujer del infante Juan y señora de Vizcaya, confirma la carta-puebla de Bilbao de 1300 , y le concede privilegio de aforamiento. Manda "que seades francos e quitos en todol mio sennorio, e en todos los mios lugares, de portagos e de peages, e de emiendas e de oturas, e de cueças e de requage, de todas las cosas e mercaderias que traxierdes e lleuardes, tanbien por mar como por tierra en qualquier manera", y que "el camino que ua de Ordunna a Vermeo que pasa por Echauarri, que uaya por aquesta mi villa de Biluao e non por otro lugar..., et qualquier o qualesquier que otro camino tomasen si non este de Biluao, mando al mio prestamero de Vizcaya e a los mios merinos e al preboste de y, de la villa, que les tomen todo quanto les fallaren por descaminados", y lo guarden para hacer lo que tuvieren por bien, y que nadie "sea osado de tener conpra ni venta ni regateria ninguna, en todol camino que ua de Areta fasta la uilla de Biluao", y al que lo hallaren que peche 100 mrs. de la moneda nueva, y el merino que lo hallare tome para si aquella reventa. Este documento copia casi literalmente la carta-puebla de 1300, salvo el cambio del mercado de los martes a los miércoles y tres añadidos importantes: La exención de impuestos sobre la circulación de mercaderías por todo el Señorío, salvo el "peage de las venas" que retiene para ella; la obligación de pasar por Bilbao, de todos los que vayan de Orduña a Bermeo y la prohibición de instalar venta o regatería, entre Areta y Bilbao ${ }^{1257}$.

1255 A. M. Bilbao/ Cajón 38, reg. 27, no 156-Caja 52, reg. 1, no 2 (fol. 87v-94v)/ Burgos, 3 enero 1346; ENRÍQUEZ FERNÁNDEZ, J.; HIDALGO de CISNEROS AMESTOY, C. y MARTÍNEZ LAHIDALGA, A.:"Colección Documental del Archivo Histórico de Bilbao (1300-1473)".: 1999: doc. 20.

1256 R. A. H./ Biblioteca, col, Salazar y Castro O-18, fol. 117-117v/ Oña, 3 enero 1306; OCEJA GONZALO, I.: 1986: 362-363: doc 505 .

1257 A. M. Bilbao/ Pergaminos, 2. (se halla en la casa consistorial)/ Valencia. 25 junio 1310; ENRÍQUEZ FERNÁNDEZ, J.; HIDALGO de CISNEROS AMESTOY, C. y MARTÍNEZ LAHIDALGA, A.: "Colección Documental del Archivo Histórico de Bilbao (1300-1473)": 1999: doc. 3; A. M. Bilbao/ Cajón 1, reg. 1, no12-Pergaminos 12/ Bermeo, 20 junio 1334; ENRÍQUEZ FERNÁNDEZ, J.; HIDALGO de CISNEROS AMESTOY, C. y MARTÍNEZ LAHIDALGA, A.: "Colección Documental del Archivo Histórico de Bilbao (1300-1473)".: 1999: doc. 10. 
En enero de 1346 Martín Martínez de Ochanduri, vecino de Bilbao, mostró ante el concejo de Burgos una carta de diciembre de 1345, en que Juan Núñez de Lara, señor de Vizcaya, les hacía saber que el concejo de Bilbao le recordó que cuando la villa se pobló nuevamente, se concedió a los vecinos de Bilbao la exención del portazgo en Burgos, pero sus portazgueros se lo demandan. Ruega que vean la merced y franqueza que tenía Bilbao y sus vecinos y que la guarden en adelante, y añade que eso mismo haría él por Burgos "en qualquier cosa que me ynbiasedes rogar". Se presentan documentos de 1304 y el concejo burgalés accedió a cumplir con dicho privilegio. Los de Burgos mandaron a Bernal de Pero Sáenz recaudador del portazgo de los vinos, y a los que en adelante lo recauden, que guarden a los vecinos de Bilbao la dicha franqueza, y que no les demanden ni embarguen nada por razón de portazgo ${ }^{1258}$.

El infante Juan confirma y mejora en enero de 1372 el fuero concedido a Bilbao en 1300. Después será confirmado en agosto de 1379 por el mismo Juan I ya rey, y por Enrique III en diciembre de 1393. Destacan las cláusulas relativas a que a los de Bilbao se les libra de portazgo, treintazgo, oturas, enmiendas, peaje y entrada o salida en todo el Señorío, y que ningún "ome andariego, que non sea osado de entrar ni estar en la villa de Bilbao sin mandado de los alcaldes de Biluao dende mas de vn dia". También la prohibición de instalar reventas entre Areta y Bilbao y la ampliación a los tramos de Bilbao hasta Baracaldo y de Bilbao hasta Zamudio ${ }^{1259}$, y si se hicieren tales reventas, que el preboste y el merino real las tomen, y el revendedor pague 500 mrs. por cada vez, y que usen el camino que va por Echévarri los que ya hayan pasado por Bilbao, y si no fuere así, que el preboste los tome por descaminados ${ }^{1260}$.

En 1473 Juan de Uribarri, criado de Martín de Enderica, vecino de Bilbao, cuando venía de Aragón hacia la villa con una acémila y 100 libras de azafrán, el alcaide de la fortaleza de Puentelarrá, vasallo del conde de Salinas junto con dos hombres, le apresaron en el puente, llevándole a la torre para luego llevarle a Salinas de Añana, donde estaba el Conde. El apresado tuvo que pagar para su rescate $15.000 \mathrm{mrs}$. perdiendo el azafrán, y además el alcaide le tomó un enrique castellano. El Rey en 1476 mandó que el Conde devuelva a Uribarri los 15.000 mrs. y el enrique que le habían tomado, no sin antes fijar un plazo por si el Conde quisiere alegar en su favor ${ }^{1261}$.

En 1475 Martin Ortiz de Guecho, vecino de Martiarto, "pariente mayor e ome poderoso", en

1258 A. M. Bilbao/ Cajón 38, reg. 27, nำ156-Caja 52, reg. 1, no 2 (fol. 87v-94v)/ Burgos, 3 enero 1346; ENRÍQUEZ FERNÁNDEZ, J.; HIDALGO de CISNEROS AMESTOY, C. y MARTÍNEZ LAHIDALGA, A.: "Colección Documental del Archivo Histórico de Bilbao (1300-1473)".: 1999: doc. 20.

1259 Villas situadas en los caminos de acceso a Bilbao: Areta en el camino de Orduña, Baracaldo en el de Valmaseda y Zamudio en el de Bermeo.

1260 A. M. Bilbao/ Cajón 8, reg. 1, nº 1 -Caja 199 (fol. 40r-41r)/ Burgos, 11 enero 1372; ENRÍQUEZ FERNÁNDEZ, J.; HIDALGO de CISNEROS AMESTOY, C. y MARTÍNEZ LAHIDALGA, A.: "Colección Documental del Archivo Histórico de Bilbao (1300-1473)".: 1999: doc. 29; A. G. S. V./ Casa de Juntas de Guernica. Privilegios Reales. Reg. 1- no 2/ Madrid, 15 diciembre 1393; HIDALGO de CISNEROS AMESTOY, C.; LARGACHA RUBIO, E.; LORENTE RUIGÓMEZ, A.; MARTÍNEZ LAHIDALGA, A.: 1986: doc. 5 .

1261 A. G. S./ Registro General del Sello, VII-1476, fol. 526/ Vitoria, 16 julio 1476; ENRíQUEZ FERNÁNDEZ, J., HIDALGO de CISNEROS AMESTOY, C. y MARTÍNEZ LAHIDALGA, A.: "Archivo General de Simancas. Registro General del Sello. Vizcaya (1475-1477)".: 2002: doc. 44. "...viniendo del regno de Aragon para la dicha villa de Viluao e trayendo vna azemila consigo e en ella fasta çient libras de açafran del dicho su amo; e dis que pasando por la Puente de Larrada, el alcayde de la dicha fortaleza e otros dos omes suyos, por fuerça e contra su voluntad le tomaron en la dicha puente e le traxieron a la dicha torre e fortaleza, e que luego enbio a la villa de Salinas...". 
Puentelarrá y acompañado de gente armada, robó todo cuanto llevaban los arrieros Martín Sáez de Salices y Juan de Arnoeta, criado de Juan Martínez de Arratia, cuando iban a Bilbao con cinco acémilas y un asno cargados de vino de San Martín, con sus azacanes, cueros y todos sus aparejos, lo que podía valer unos 65.000 mrs. En otra ocasión el dicho Martín Ortiz, tomó por fuerza dos acémilas cargadas de paveses, más 15 rs. de plata, al dicho Martín Sáez cerca de Ornasa y aunque devolvió las acémilas, se quedó con los paveses y los reales, que podían valer unos 2.00o mrs. Los Reyes mandan a Martín Ortiz que devuelva a Juan Martínez y a Martín Sáez, todo lo que les ha tomado: cinco acémilas, asno, vino, cueros, azacanes, aparejos, paveses y reales robados, o los 67.000 mrs. de su estimación ${ }^{1262}$.

En junio de 1481 ante el alcalde ordinario de Bilbao, pareció Fortun Martínez de Abando fiel de Bilbao, y presentó un libro de ordenanzas del concejo que entre otras cláusulas decía que cualquier mulatero que llegare a la villa con mulo vacío, pague dos rs. por bestia y que esos mulos no saquen cargas. Cuando los acemileros trajeren acémilas vacías, que los fieles reciban información sobre el motivo, y se cumpla lo que mandaren. El mulatero que llevare trigo al mercado y no lo pudiere vender el primer día, lo pondrá franco en el azogue durante tres días y después, su dueño lo podrá llevar donde quisiere, y si no lo llevare, cualquier vecino lo podrá tomar al precio del mercado. Las panaderas ni otras personas, no podrán echar mano a bestias algunas que traigan trigo u otra legumbre para vender en la villa, ni sobre el trigo $u$ otra legumbre que se vaya a vender en el azogue, so pena de $10 \mathrm{mrs}$. Como los mulateros traían vinos y recibían cargas de retorno, causando gran daño a la villa y sus vecinos, porque llegaba menos provisión de trigo y no podían vender sus vinos, ordenaban que no se den cargas en Bilbao a los mulateros que vinieren vacíos sin traer cargas de provisión, de lanas o de otra mercadería, so pena de que el mulatero pague por cada carga dos rs. y vaya vacío; y que el que le diere carga, sabiendo que llegó vacío, pague 100 mrs. por cada carga que le diere. Cualquier jurado que no ejecutare esta pena y dejare ir con la carga, que pague a los jurados 100 mrs. por carga y quede 10 días en la cadena ${ }^{1263}$.

Ochoa López de Barriga, vecino de Orduña, recibe en julio de 1483 una incitativa real para que devuelva los 30 rs. que cobró del diezmo de las mercaderías a su paso por Orduña, al criado de Álvaro de Carrión, joyero y cordonero de los Reyes, cuando iba de Bilbao para la corte, ya que el oficio de joyero y cordonero real está libre de todos los pechos, derechos de alcabala, diezmo, aduanas, etc. y de todos los derechos de las mercaderías para él o sus criados. Además Ochoa López deberá pagar la pena prevista de $10.000 \mathrm{mrs}$. por esta infracción más las costas y daños ocasionados ${ }^{1264}$.

La reina Isabel sale el 31 de agosto de 1483 de Santo Domingo de la Calzada, y va por

1262 A. G. S./ Registro General del Sello, XII-1475, fol. 811/ diciembre 1475; ENRÍQUUEZ FERNÁNDEZ, J., HIDALGO de CISNEROS AMESTOY, C. y MARTÍNEZ LAHIDALGA, A.: "Archivo General de Simancas. Registro General del Sello. Vizcaya (1475-1477)".: 2002: doc. 25.

1263 A. M. Bilbao/ Cajón 12, reg. 3, no 42-Caja 305, reg. 1, no 2 (fol. 27r-28r)/ Bilbao, 26 junio 1481; ENRÍQUEZ FERNÁNDEZ, J.; HIDALGO de CISNEROS AMESTOY, C. y MARTÍNEZ LAHIDALGA, A.: "Colección Documental del Archivo Histórico de Bilbao (1473-1500)".: 1999: doc. 146.

1264 A. G. S./ Registro General del Sello, VII-1483, fol. 69/ Santo Domingo de la Calzada, 21 julio 1483; ENRÍQUEZ FERNÁNDEZ, J., HIDALGO de CISNEROS AMESTOY, C. y MARTÍNEZ LAHIDALGA, A.: "Archivo General de Simancas. Registro General del Sello. Vizcaya (1483)".: 2002: doc. 228. 
Pancorbo, Santa Gadea, Puentelarrá, Espejo, Berberana, Orduña, Llodio y Arrigorriaga a Bilbao, donde llega el 6 de septiembre ${ }^{1265}$.

Orduña y Villalba de Losa reciben una carta de emplazamiento en junio de 1485, para que se personen en la causa iniciada contra ellos por Vitoria, la Hermandad de Álava y la tierra de Ayala, por cobro de impuestos y portazgos que, según ellos, son injustos y van contra las leyes, a los que llevan pan a Orduña para su venta y también a los que lo compran, y sobre el derecho que dicen que cobra también injustamente la ciudad por la guía y guarda de la Peña de Orduña. Los alaveses pidieron que los Reyes manden que no se lleven los dichos derechos por ser, como dicen, imposición nueva ${ }^{1266}$.

En la ordenanza de Bilbao de 1485 confirmada por la Reina, se indica que los arrieros que trajesen a la villa trigo y cebada, pueden sacar de ella otras mercaderías. Una cláusula dice "que no entren en esta villa ningunas bestias de acarreo ni trayan los trajineros, si no fuere con carga de mantenimientos de trigo y cebada, y que los que no traxieren los dichos mantenimientos no saquen cargas so ciertas penas". Los vecinos deberán asistir en el puente de San Antón "por donde entran las tales bestias, por turno dos cada semana, los cuales tienen libro y razon donde se asientan las tales bestias que entran con carga, para dexar que salgan con carga"1267.

En diciembre de 1485 los Reyes ordenan al mariscal Pedro López de Ayala y a las justicias de Llodio, que hagan cumplir la sentencia dictada hacía 2 años por el doctor Villasandino, enviado por el Rey para resolver sobre ciertas imposiciones que habían sido cobradas indebidamente a los caminantes, para reparar los puentes y calzadas de aquella tierra, y que no se habían reparado. Se condenó al merino Martín Ochoa, y a los alcaldes Diego Fernández de Ugarte, Pedro Ortiz de Anuncibay y Sancho de Currea, al pago de una multa de 25.000 mrs., habiéndolo abonado tan solo Martín Ochoa ${ }^{1268}$. Los Reyes dan comisión a los alcaldes y jueces de la tierra de Llodio, para que entiendan en la demanda de Martín Ochoa, que decía "que estando los caminos e calçadas desa tierra muy perdidos e destruydos, e peligrando e trabajando mucho los omes e bestias que por ellos pasauan", el mariscal Pedro de Ayala señor de dicha tierra, le dio licencia a él, a Diego Fernández y a Pedro Ortiz, para que hiciesen las calzadas y reparasen los caminos de esa tierra, según lo que fue tasado por dos buenas personas, y pagado con las imposiciones hechas a los caminantes. Ellos traspasaron el encargo a Fernando de Urrutia, vecino de esa tierra, quien tras cobrar el salario, no realizó el reparo mencionado, por lo que piden que se mande cumplir lo que se obligó y pague los daños y costas que por su culpa se habían acarreado ${ }^{1269}$.

El concejo de Bilbao presentó ante el Consejo Real una petición diciendo que tienen privilegios reales, que confirman que sus vecinos están exentos de pagar portazgos, treintazgos, oturas, enmiendas, etc. en todos sus reinos y señoríos, y que en Burgos hay "grande agrauio e perjuizio de la dicha villa, e en quebrantamiento del dicho su preuillejo e franqueza, dis que han contado e quentan de faser pagar a los veçinos de la dicha villa, portadgo e barra contra el tenor e forma de los

1265 RUMEU de ARMAS, A.: 1973: 115-116.

1266 A. G. S./ Registro General del Sello, VI-1485, fol. 182/Valladolid, 15 junio 1485; ENRÍQUEZ FERNÁNDEZ, J.; HIDALGO de CISNEROS AMESTOY, C. y MARTÍNEZ LAHIDALGA, A.: 2003: doc. 422.

1267 ORTEGA y GALINDO de SALCEDO, Julio: "Bilbao y su Hinterland". p. 50/ 1485.

1268 A. G. S./ Registro General del Sello, XII-1485, fol. 164/Valladolid, 17 diciembre 1485.

1269 A. G. S./ Registro General del Sello, XII-1485, fol. 124/Valladolid, 17 diciembre 1485. 
dichos sus preuillejos". Los Reyes mandan en febrero de 1489 a los de Burgos y a los de todas las localidades, que los privilegios que Bilbao tiene, se guarden y cumplan ${ }^{1270}$.

En julio de 1491 la Junta de la Provincia, de la ciudad de Vitoria y sus merindades de Álava, presentó ante el Consejo Real una petición que decía que entre Villarreal de Álava y Ochandiano, en invierno, "se fasen tantos e tan grandes lodos en el camino rreal por donde pasa la rrecua para el dicho condado de Biscaya, e ay otros arroyos e tan malos pasos que en cada un año mueren muchos ganados de los que ban cargados que caen en los dichos pasos". Añaden que junto a Orduña, desde la jurisdicción de la tierra de Ayala hasta otras de la provincia de Álava, están los caminos "fraguosos e las calçadas e puentes antiguas perdidas", y existiendo el mismo daño en otras partes de la Provincia, y no pudiendo los concejos reparar ellos solos los caminos, puentes, calzadas y malos pasos, pedían licencia para cobrar a los caminantes una pequeña costa que, junto con la aportada por cada concejo, permitiese la intervención. En el Consejo Real se acordó encomendar a Juan de Medina y a Juan Martínez de Lasarte, vecinos de Vitoria, que se informen sobre los pasos y caminos que se deben reparar, qué puentes y calzadas están caídos, cuánto costaría, qué lugares y vecinos hay en aquellas comarcas, cuántos mrs. se deben repartir, si se podría proveer de otra manera sin imponer la sisa solicitada, sobre qué personas, bestias y cosas se deberá imponer y por cuánto, y cómo se debe hacer el cobro para que no exista fraude ni engaño, y la información se envíe ante el Condestable y el Consejo Real1271.

Los Reyes confirman en 1491 el acuerdo entre el concejo de Orduña y tierra de Ayala y Álava, Urcabustáiz y Salvatierra, sobre el cobro de los 2 mrs. que en Orduña se hacía al comprador sobre cada fanega de trigo y un mr. sobre la de cebada, lo que los afectados decían que era imposición indebida. Por evitar inconvenientes, se avienen todos a realizar concordia, acordando que en Orduña no se lleve a ningún comprador más de un mr. por cada fanega de trigo y una blanca por la de cebada1272.

En el repartimiento realizado en 1502 para la composición del camino entre Burgos y Laredo, Pedro de Durango procurador de la Universidad, alegaba que sus mercaderes no utilizaban ese camino para ir a Bilbao "porque van e pueden yr por las villas de Briuiesca e Pancorbo e Santagadea e la çibdad de Horduña". Por su parte, el procurador de la cofradía de los mulateros, decía que los mercaderes no se podían excusar para no pagar "por dezir que ay

1270 A. M. Bilbao/ Cajón 4, reg. 4, ํำ180 (1)-Caja 17, reg. 1, ํำ44 (1)/Valladolid, 31 enero 1489; ENRÍQUEZ FERNÁNDEZ, J.; HIDALGO de CISNEROS AMESTOY, C. y MARTÍNEZ LAHIDALGA, A.: "Colección Documental del Archivo Histórico de Bilbao (1473-1500)".:1999: doc. 188; A. G. S./ Registro General del Sello, II-1489, fol. 105/ febrero 1489.

1271 A. G. S./ Registro General del Sello, VII-1491, fol. 110/ Burgos, 26 Julio 1491. “...vos ynformades e sepades la verdad que pasos e calçadas e caminos ay de adobar desde la dicha villa de Villarreal fasta la villa de Ochandiano, e desde la çibdad de Orduña fasta Ugas, e que puentes e calçadas son las que asy estan caydas e que ayan neçesario rreparos, declarando los dichos pasos e caminos donde son e la distançia e lexura dellos, e declarando asy mismo que quantia de mrs. sera menester para lo faser e rreparar, e que lugares ay en aquellas comarcas, e que vecinos ay en ellos para que seyan de pagar e contribuyr en ello, e que quantias de mrs. dello se deben echar e rrepartir a los tales lugares, e sy abrian otras cosas o se podrian prober por otra manera para ser adobados e rreparados los dichos caminos e puentes e pasos syn averse de ynponer la dicha sisa e ynposiçion pedida por la dicha junta, e que quantias seran menester de se echar e ynponer para lo susodicho, e sobre que personas e bestias e cosas para averse los mrs. que para ello fuere menester, e por que tanto tienpo se debe de ynponer e echar sobre las dichas cosas $e$ quanto sobre cada cosa, e a que personas se debe de encomendar que cobre la dicha ynposiçion de los caminantes e lo que a los dichos lugares fuere rrepartido para que lo espienda e gaste en las dichas labores e rreparos, e para que lo fagan fielmente syn que en ello ynterbenga fraude nin engaño alguno...".

1272 A. G. S./ Registro General del Sello, XII-1491, fol. 4/ El Real de la Vega de Granada, 11 diciembre 1491. 
otro camino que va de la dicha çibdad de Burgos a la villa de Biluao e a Portogalete e a Castro de Vrdiales porque no fazia al caso, aunque algunas vezes vayan por el otro camino e non por el de la villa de Laredo", y que la probanza no lo impedía porque fue hecha "por los mesoneros del camino de Biluao que es por Horduña e por Briuiesca". Pedro de Durango añade que estaba probado que el camino a Bilbao por Orduña es muy transitado y útil a sus partes, y que para ir a Bilbao no era necesario andar por el de Laredo ${ }^{1273}$.

El bachiller Antón de Arez, en nombre del concejo de Bilbao, dijo que por Miravalles pasa todo el trigo y mantenimientos que van de Castilla a Bilbao y Encartaciones, y que sus vecinos "por fuerça toman a los mulateros y recueros todo el trigo y los otros mantenimientos que llevan, e les fasen descargar sus cargas y vender las dichas prouisyones, a cavsa de lo qual dis que quitan a la dicha villa de Vilbao e Encartaçiones, toda o la mayor parte de los mantenimientos que lesllevan", de tal manera que algunas veces no tienen qué comer. Pedía por ello que se mandase a los de Miravalles, que dejasen pasar libremente todo el trigo y mantenimientos. El Consejo, mandó en diciembre de 1505 al corregidor del Señorío de Vizcaya, que provea para que los vecinos de Miravalles no detengan los mantenimientos que por allí pasaren ${ }^{1274}$.

En 1507 la Junta Ceneral del Señorío de Vizcaya, envía una petición al Consejo Real, diciendo que los caminos por donde se llevan al Condado los mantenimientos y otras cosas necesarias están muy malos, de manera que no se pueden utilizar a pie, a caballo, ni con bestias cargadas ni vacías sino con mucho peligro, especialmente desde la Peña de Orduña hasta Bilbao, desde la peña de Mena a Bilbao por Valmaseda y desde Ubidea hasta Miravalles, que son caminos muy transitados, y por donde van las provisiones a Vizcaya, y que gran parte de esos caminos van por tierra de Llodio y valle de Ayala, que son del conde de Salvatierra. Solicitan que se aderecen esos caminos, que se haga repartimiento si fuere necesario, y se mande que el valle de Ayala, la tierra de Llodio y otras villas y lugares que se aprovechan, reparen a su costa su parte. La Reina manda al corregidor que reciba información sobre los caminos y calzadas que necesitan hacerse y repararse, si hay concejos y particulares que están obligados a hacer esos reparos, si hay rentas o propios dedicados al reparo y sobre todo lo que considere de interés, y esa información con su parecer la envíe ante el Consejo para que resuelva. También manda que todas las penas arbitrarias, se empleen en el dicho reparo ${ }^{1275}$.

Juan de Ariz en nombre de Bilbao, dijo que por "estar los caminos desde la çibdad de Ordunna fasta la dicha villa de Bilvao muy malos, diz que non pueden yr a la dicha villa e a las otras villas e partes de Vizcaya, los vyandantes e caminantes e recueros e bestias cargadas que van con trygo e otras provisiones e mantenimientos". Pidió que se obtuviese información sobre la necesidad que había de reparar dichos caminos, y que cada concejo reparase los que estuviesen en su término. El Consejo mandó en junio de 1509 al corregidor de Vizcaya, que reciba información sobre qué ha pasado, qué caminos son los que Bilbao quería reparar, qué necesidad tienen de dichos

1273 A. G. S./ Registro General del Sello, VIII-1502, fol. 394/ Toledo, 27 agosto 1502; A. D. B./ C-220/ Toledo, 27 agosto 1502.

1274 A. M. Bilbao/ Cajón 4, reg. 4, no 180 (2)-Caja 17, reg. 1, nº 44 (2)/ Salamanca, 12 diciembre 1505. ENRÍQQUEZ FERNÁNDEZ, J.; HIDALGO de CISNEROS AMESTOY, C. y MARTÍNEZ LAHIDALGA, A.: 2000: doc. 292.

1275 A. G. S. V./ Casa de Juntas de Guernica. Provisiones Reales. Reg. 1- no 12(1)/ Palencia, 27 abril 1507, Guernica, 20 enero 1508; HIDALGO de CISNEROS AMESTOY, C.; LARGACHA RUBIO, E.; LORENTE RUIGÓMEZ, A.; MARTÍNEZ LAHIDALGA, A.: 1986: doc. 69. 
reparos, qué concejos y personas se aprovechan de ellos y deben contribuir, y de donde se podrán obtener los mrs. necesarios con menos daño de los concejos y personas que contribuyeren, etc., y la envíe al Consejo para que haga lo que fuere justicia' ${ }^{1276}$.

A principios del siglo XVI, en este camino real había algunos puentes y pontones tan mal reparados que los caminantes no podían pasar a pie ni a caballo, y que había otros malos pasos de acequias y valladares por donde pasan las carretas y recuas que llevan bastimentos a Burgos con mucho peligro de personas y bestias, y que por ello hay en la ciudad mucha falta de mantenimientos. El Consejo acordó en octubre de 1511 mandar al corregidor de Burgos que vaya a las villas y lugares contenidos en un memorial que le será dado, y mande a todos sus vecinos, que "rreparen a su costa los caminos e calçadas, e puentes e pontones, $e$ malos pasos que ouiere en sus terminos e pertenençias, e los tengan byen adobados e rreparados por manera, que libremente puedan pasar e pasen por ellos, los camynantes e carretas e rrecuas que por los dichos caminos vinieren o traxieren mantenimientos", y que para ello repartan entre si los peones necesarios, según los vecinos que cada uno tuviere ${ }^{1277}$.

Entre los acuerdos tomados por la villa de Bilbao en 1515, hay uno que indica que el arrendador que tuviere la renta del azogue, y las personas que por él estuvieren en el dicho azogue, que "coja vna blanca por cada fanega de trygo elegunbre que beniere en bestyas a la dicha villa, asy de Castilla commo de otras partes, e todas las azemilas e bestyas que benieren a la dicha villa e sus rebales, quel trygo e legunbre que truxyeren e descargaren, que lo descarguen en el mercado publico de la dicha villa e non en otra parte ninguna", so pena de 1.000 mrs. a cada uno ${ }^{1278}$.

Los procuradores generales del Señorío de Vizcaya se dirigen en 1516 a la Reina, diciendo que en el Condado hay muy malos caminos y que por ser la tierra pobre y estéril no los han podido reparar, con lo que se causan muchos inconvenientes y daños. El Consejo mandó al corregidor que provea para que se reparen a costa de los pueblos, pagando cada uno lo que le corresponda y, en adelante, manda que todas las penas arbitrarias se apliquen para el reparo de esos caminos ${ }^{1279}$.

En noviembre de 1517 en Pancorbo, ante el corregidor de Burgos y su lugarteniente en Pancorbo y el alcalde, compareció el procurador de Pancorbo con una Provisión real emitida tras recibir una petición de Alonso Rascón en nombre de la villa y sus vecinos, que decía que el camino que va a Guipúzcoa por Vitoria y se bifurca hacia Bilbao por Orduña en el término de Pancorbo, es el camino "mas pasajero que todos los que por alli ay, y que agora de pocos dias aca, diz que se a quebrantado vna peña y juntadose con otra, y çerrado y çegado el dicho camino", por lo que se dificulta el tráfico y es urgente su reparo, siendo necesarios unos $120.000 \mathrm{mrs}$. Se acuerda encomendar al corregidor de Burgos que obtenga información para saber qué calzadas son las que se deben reparar, qué perjuicio se causa por no estar arregladas, qué concejos

1276 A. M. Bilbao/ Cajón 4, reg, 3, ㄲo 112- Caja 16, reg. 1, no 23/Valladolid, 14 junio 1509; ENRÍQUEZ FERNÁNDEZ, J.; HIDALGO de CISNEROS AMESTOY, C. y MARTÍNEZ LAHIDALGA, A.: 2000: doc. 315.

1277 A. M. B./ HI-3780/2/ Burgos, 15 octubre 1511.

1278 A. M. Bilbao/ Cajón 16, reg. 3, nº 3/ Bilbao, 9 febrero 1515- 31 diciembre 1515; ENRÍQUEZ FERNÁNDEZ, J.; HIDALGO de CISNEROS AMESTOY, C.; LORENTE RUIGÓMEZ, A.; MARTÍNEZ LAHIDALGA, A.: "Libro de Acuerdos y Decretos Municipales de la Villa de Bilbao (1509 y 1515)". 1995: 207-208: doc 2.

1279 A. G. S. V./ Casa de Juntas de Guernica. Provisiones Reales. Reg. 1- no 19/ Madrid, 14 marzo 1516; HIDALGO de CISNEROS AMESTOY, C.; LARGACHA RUBIO, E.; LORENTE RUIGÓMEZ, A.; MARTÍNEZ LAHIDALGA, A.: 1986: doc. 92. 
y personas recibirán mayor beneficio del reparo, qué costaría y quiénes deben contribuir y con cuánto. También deberá informar si será mejor que el recaudo se eche por sisa o por repartimiento, y cómo se cumple mejor con los concejos y caminantes ${ }^{1280}$. Parece ser que nada se realizó hasta 1526, ya que ante el alcalde y lugarteniente del corregidor en Pancorbo, se presentó Juan Navarro, vecino y procurador de su concejo con la comisión de 1517, pidiendo que se cumpliese lo que en ella se mandaba, obteniendo información de testigos sobre los caminos, calzadas y malos pasos de Pancorbo y sus términos, y se envíe al Consejo Real para que provea lo necesario. El interrogatorio se realizó en septiembre 1526 a un vecino de Encío, otro de Bozoo y a un vecino de Torquemada, mulatero y trajinero ${ }^{1281}$.

En febrero de 1529, dos años y medio después, prosiguió el interrogatorio con un vecino de Soto de Bureba, los "maestro[s] de hazer calçadas" Diego de Angostina, vecino de Altable, de 37 años y Pedro Sáez de Anguiano, vecino de Pancorbo, de más de sesenta, y mulateros y trajineros de Prádanos, Ibarra del valle de Munguía, Murga de Ayala, Izoria de Ayala, Betoño, Amurrio, Olabézar de Ayala y Gobeo ${ }^{1282}$. Además de los reparos que se debían hacer en el camino de La Bureba a Vitoria, dijeron que en el camino real que va a Vizcaya, Santa Gadea, Salinas de Añana, Orduña, Ayala, Bilbao y Encartaciones, hay un paso malo en las Esperillas y otros dos muy malos y peligrosos, especialmente en invierno, poco antes del lugar de Encío, donde se caen muchos caminantes, las acémilas quiebran sus patas y se pierden muchas bestias debiendo dar los lugareños su ayuda para poderlas levantar. Hay otro más adelante frente a su iglesia, por lo que los caminantes van por las sierras y por las heredades cultivadas con gran perjuicio de los dueños de las tierras. Según los testigos, recibirán beneficio de su reparo todos los que vienen de Guipúzcoa y Vizcaya de los puertos a Castilla, y especialmente los trajineros, mulateros, caminantes y mercaderes que van de Burgos a Orduña, Bilbao, Álava, Vitoria, Guipúzcoa y otras partes, y que por su mal estado no vienen los de tierra de Campos porque no se pueden utilizar en invierno. También los vecinos de Salinas de Añana, Santa Gadea, Orduña, Bilbao, Ayala y las Encartaciones, y los concejos de Miranda, Santa Cadea Ameyugo, Briviesca, Valderredoca y Valdemonesterio, Bureba y lugares de ella, especialmente Zuñeda, Vallarta, Quintanilla San García, Santa María Ribarredonda, Cubo, Villanueva de Teba, Busto, Berzosa, Poza y otros muchos lugares.

Los testigos indican que, para reparar dichos caminos, se necesitarían entre 120.000 mrs. y más de 150.000 mrs. solo para lo imprescindible. No obstante los dos maestros de calzadas, indican que se han de hacer unos 4.000 estados de calzadas, que con el coste de traer la piedra, tierra, servicio y manos de maestros a 3 reales cada estado, harían un total de 11.000 rs. o más. Añaden que los que deben contribuir a los reparos son los concejos más cercanos y los caminantes y recueros que utilizan esos caminos al ser los más beneficiados; y a estos, se les ha oído decir que si se arreglan dichos caminos, pagarían lo que les pidiesen por el bien que recibirían. Los trajineros informan que llevan a Bilbao pan, vino y otras cargas y traen a Castilla provisión de pescados y sardinas, paños, pasteles, papel,

1280 A. G. S./ Consejo Real de Castilla, leg. 324-24/ Madrid, 28 mayo 1517.

1281 A. G. S./ Consejo Real de Castilla, leg. 324-24/ Pancorbo, 12 septiembre 1526.

1282 A. G. S./ Consejo Real de Castilla, leg. 324-24/ Pancorbo, 9 febrero 1529. 
hierro, acero, herrajes y otras mercaderías. El alcalde mayor y juez en Pancorbo, envía toda la información al Rey para que provea lo que proceda, indicando "que el rreparo que en los dichos caminos y pasos malos se hiziere, sera en... pro y bien de las probinçias de Alaba y Lepuzca y Bizcaya, en espeçial de las çiudades de Bitoria y Horduña y billa de Bilbao, y otras billas y logares de las dichas montañas y puertos dellas" y que "sera menester para el dicho rreparo hasta en quantia de çiento y treynta mill mrs. y avn mas,... los quales si a su Magestad paresçiere se deban mandar pagar por los años que su Magestad fuere serbido, rrepartiendo a las azemilas y bestias de los recueros y tragineros que por la dicha villa pasaren... a cada vna bestia tres blancas o dos mrs." 1283 .

Según Cadiñanos el puente antiguo de Puentelarrá estaba algo más abajo que el actual y fue la mitad de Santa Gadea y la otra mitad del Señorío de Vizcaya. En 1521 Antonio Padilla señor de la villa y adelantado de Castilla, aseguraba que el pontazgo le pertenecía desde antiguo, y añadía que siempre habían pasado los transeúntes por la noche pagando el correspondiente derecho, porque los de Puentelarrá tenían colocada una cadena que de noche impedía el paso, lo que perjudicaba sus intereses. Aseguraba que había sido colocada con ocasión de las alteraciones de las Comunidades contra su partidario el conde de Salvatierra, pero la realidad era que se le había quitado su control por ser familiar de los comuneros toledanos, así como también del obispo Antonio de Acuña. Como los comerciantes iban por otros lados, Carlos I mandó retirarla. A mediados del siglo XVI la Universidad de Burgos pleiteaba por el portazgo con los Padilla, pretendiendo que sus miembros no lo pagaran. Aunque en principio se les dio la razón, en sentencia de revista se reconoció el justo cobro del portazgo en Santa Gadea. Nunca pagaron pontazgo en este puente "por su vecindad" los trajineros y comerciantes de Frías, Briviesca, Belorado, Haro, Miranda, Bergüenda, Espejo, Tuesta, Pancorbo, Berzosa, Fuentebureba, Orduña, Valpuesta y algún otro lugar de Álava ${ }^{1284}$.

Tras la petición que hizo al Rey Pedro de Mena en 1536, en nombre de la provincia y hermandades de Álava, manifestando que tenían muchos malos pasos, con puentes caídos o mal reparados y algunos caminos peligrosos, y que se debían reparar antes del invierno, pedía que el Diputado General, se informase de qué puentes, caminos y malos pasos se debían reparar a costa de la hermandad donde estuviesen y de las otras hermandades que se beneficiaban. Se mandó, que tras recabar la información, se reparasen de manera que los caminantes y mulateros pudiesen pasar sin peligro ${ }^{1285}$.

En Junta de Álava de noviembre de 1537 se otorga comisión a un procurador de Vitoria y a otro de Cuartango para negociar con el condestable de Castilla o con el que fuere necesario, acerca de los perjuicios causados a los naturales de la provincia de Vitoria, en los puentes sobre el Ebro de Puentelarrá, Miranda, Haro y San Vicente ${ }^{1286}$.

En 1548 el procurador de Orduña dijo en las Juntas de Vizcaya de octubre, que la ciudad necesitaba reparar los caminos de su jurisdicción, por lo que pidió ayuda para su aderezo, pero los procuradores de las villas respondieron que cada pueblo en su jurisdicción

1283 A. G. S./ Consejo Real de Castilla, leg. 324-24/ Madrid, 28 mayo 1517 y Pancorbo, 30 diciembre 1529.

1284 A. H. N. Consejos, leg. 2.951; CADIÑANOS BARDECI, I.: 2008: 11-12.

1285 A. D. F. A./ D. H., 246-6/Valladolid, 9 diciembre 1536.

1286 A. J. G. A./ t. III/ Vitoria, 23 noviembre 1537. 
tenía también sus caminos y que no había lugar a lo que pedía ${ }^{1287}$. En Junta de Álava de noviembre se acordó que Juan Ochoa de Mendiguren vaya al puente de Puentelarrá con un mandamiento suyo para que el dezmero comparezca en ella, dentro del segundo día so pena de $5.000 \mathrm{mrs} .{ }^{1288}$. En esa misma Junta, tras haber tratado sobre los portazgos y el registro de los ganados en Haro, Ríogil y puente de Puentelarrá, y del mucho perjuicio que reciben los vecinos de la Provincia, acordaron pedir provisión al Consejo Real para que los portazgueros muestren los títulos que tienen para cobrar los portazgos, y los procuradores de la Provincia pongan diligencia en ello ${ }^{1289}$. En Junta de mayo de 1549 se trató acerca del desorden que tienen los dezmeros de Orduña en el cobro de los derechos. Para ello se encarga a Juan Martínez de Aguirre, procurador de Ayala, para que se informe sobre ese desorden, y se provea lo que convenga1290.

En Junta de Álava de mayo de 1553 Pedro de Oquendo, vecino de Saracho, pidió que a costa de la Provincia, se mande reparar un puente que está caído en dicho lugar. Se encargó al Diputado General que tanto en lo tocante a este puente, como en las demandas sobre reparos de otros puentes y malos pasos de la Provincia, obtenga información sobre su necesidad y sobre quién y cómo ha de contribuir, y se manden hacer los reparos a costa de quiénes lo deben pagar, conforme a las comisiones reales que el Diputado General tiene para reparar los puentes y malos pasos ${ }^{1291}$.

En noviembre de 1557, se establece un pleito entre Juan López de Azcoeta, promotor fiscal y acusador, y Juan Ochoa de Amézola, vecino de Abando, y acusado de ser regatón y revendedor de mantenimientos en Bilbao, y de recibir cohechos de los trajinantes y mulateros por permitirles introducir mulos sin provisiones, lo cual estaba prohibido por las ordenanzas de la villa, y de encarecer los productos que se vendían al ejercer el oficio de trujamán ${ }^{1292}$.

Se realiza en 1560 un requerimiento para que Simón Ruiz, mercader de Medina del Campo, se declare deudor del condestable Pedro Fernández de Velasco de $33.521 \mathrm{mrs}$. por 11 obligaciones sobre los diezmos de las mercaderías que pasaron por la aduana de Orduña, a él pertenecientes ${ }^{1293}$.

En Junta de Álava de noviembre de 1562 se trató sobre los portazgos y derechos de escribanía que se cobran en los puentes de Haro y Puentelarrá, contra el tenor de la Provisión real que la Provincia tiene para no pagar esos derechos, y la mucha fatiga que provoca a los vecinos de la Provincia. Acordaron que el alcalde ordinario de Vitoria reciba información y se envíe a los solicitadores de la Provincia, para que se quejen ante el Consejo Real, se

\footnotetext{
1287 A. J. R. B./ Actas de Villas y Ciudad. t. I/ Bermeo, 18 octubre 1548.

1288 A. J. G. A./ t. IV/ Vitoria, 21 noviembre 1548.

1289 A. J. G. A./ t. IV/ Vitoria, 24 noviembre 1548

1290 A. J. G. A./ t. IV/ Vitoria, 8 mayo 1549.

1291 A. J. G. A./ t. IV/ Vitoria, 4 mayo 1553.

1292 A. Ch. V./ Registro de Ejecutorias, caja 0900,0038/ 27 noviembre 1557.

1293 A. H. N./ Nobleza. Frías, Leg. 1469, D. 14/ 1 febrero 1560.
} 
ponga el remedio necesario, y que hagan la diligencia el procurador de Vitoria y el de la hermandad de las tierras del Conde de Salinas ${ }^{1294}$.

En las Juntas de Vizcaya de junio de 1569 se acordó que se suplique al Rey que sobre los caminos de la jurisdicción de Ayala entre Bilbao y Orduña, se notifique a los de Ayala la Provisión que para ello hay, y se den instrucciones al que vaya a la corte y que la ciudad de Orduña haga esta diligencia. Se mandó además que se hagan los tres caminos reales y principales del Señorío, entre los que está el de Bilbao para Orduña, y que para ello se repartan 600 ds., la mitad a las Villas y Ciudad y la otra mitad a la Tierra Llana, gastando los 3/4 en este camino con el de Bermeo hasta Ochandiano. Estuvieron conformes todos los procuradores, salvo los de Ondarroa, Regoitia y Elorrio, y acordaron que se enviase por Provisión real para que la Tierra Llana contribuya con la mitad. Para los caminos de Bilbao a Valmaseda y de Bilbao a Orduña, diputaron para su reparo a Ochoa de Larrinaga ${ }^{1295}$. En las Juntas de julio se acordó que Orduña y Durango hagan diligencias con la provincia de Álava y villa de Villarreal, para que hagan los caminos de Ibarbala, entre Ochandiano y Villarreal y el camino de Ayala, que va de Bilbao para Orduña, y para esto se les notifique la Provisión y se pida al Rey su cumplimiento. Se ordenó además lo acordado en las Juntas de junio ${ }^{1296}$, y en septiembre se trató sobre que en el regimiento último, se había mandado realizar el camino de Bilbao para Orduña, haciendo repartimiento. Para que contribuyese la Encartación y la merindad de Durango con la Tierra Llana, se mandó a los síndicos que tratasen con ellos y, como no lo habían hecho, les mandaron de nuevo que hiciesen la diligencia ${ }^{1297}$.

Las cuentas del ayuntamiento de Orduña de 1581, recogen el pago de $12.613 \mathrm{mrs}$. por mandamiento del corregidor a Pedro de la Riaga empedrador, por la calzada que se hizo en Saracho ${ }^{1298}$.

En diciembre de 1582 el corregidor de Miranda de Ebro, a solicitud de los vecinos de Santa Gadea, hizo repartimiento entre otros, a varios lugares de las hermandades de la provincia de Álava, para el reparo del puente de Puentelarrá. Dichos lugares consideraron excesiva la cantidad, y alegaron "que la dicha puente al presente se está en el ser y estado que a estado desde çiento y más años a esta parte, y no está agora más nesçesitada que antes, y que solo se pretiende haçer a la entrada de la dicha puente, de la vna parte y de la otra çierta obra a manera de galantería, para solo dar algún lustre y buen paresçer de la dicha puente y no para adreço y rreparo de el daño que obiesen hecho las abenidas de las aguas de este año pasado, que ninguno a hecho, y quel rreparo quando alguno se obiese de hazer se haría con poca cantidad". Consideran que se debe obtener información de testigos para presentarla en el Consejo Real, junto con el testimonio de la apelación ${ }^{1299}$.

En 1583 se extiende Provisión real mandando al corregidor de Miranda de Ebro, que suspenda la ejecución de los repartimientos hechos a las hermandades de la provincia de

1294 A. J. G. A./ t. V/ Vitoria, 18 noviembre 1562.

1295 A. J. R. B./ Actas de Villas y Ciudad. t. I/ Guernica, 5 junio 1569.

1296 A. J. R. B./ Actas de la Tierra Llana. t. I/ Bermeo, 20 julio 1569.

1297 A. J. R. B./ Actas de la Tierra Llana. t. I/ Durango, 7 septiembre 1569.

1298 A. M. Orduña/ Munic. Orduña, L/ 005 y 054/ 1561-1594.

1299 A. J. G. A./ t. VII/ Vitoria, 24 diciembre 1582. 
Álava para los gastos derivados del arreglo del puente ${ }^{1300}$. También se reparten en la Provincia y hermandades los puentes de Bergüenda y de las ventas de Armiñón sobre el Zadorra, recurriéndose esta medida "por ser los dichos rrepartimientos muy esçesiuos y agrauiados, y en espeçial el de la puente de Bergüenda por no tener... las hermandades de esta prouinçia aprouechamiento ni passo alguno" y que "la obra de las dichas puentes en rrealidad de la verdad, no cuesta ni por ella se lleba con mucho el preçio que los rremates suenan" ${ }^{1301}$. A cuenta de la Provincia se habían tomado 198 ds. a censo para pagar entre otros, los gastos que se hicieron en la exención de los repartimientos a las hermandades de Álava para los puentes de Herramélluri, Puentelarrá y Bergüenda ${ }^{1302}$.

En las cuentas del ayuntamiento de Orduña del año 1583, se gastaron $5.222 \mathrm{mrs}$. en el recurso contra el repartimiento que se echaba a Orduña sobre los puentes de Puentelarrá y Armiñón ${ }^{1303}$.

En el pleito entre el concejo de Orduña y el Condestable ${ }^{1304}$, para que este aderece el camino entre la Peña de Orduña hasta el lugar de Murita porque cobraba la guía de la Peña, responde Pedro Alonso su representante, que jamás han contribuido en el aderezo de la Peña de Orduña, que es término de Orduña, para lo que la ciudad lleva gran cantidad de derechos de tiempo inmemorial. La guía de la Peña, alega Pedro Alonso, se cobra por el tramo del camino que discurre por Murita en el término de Villalba, que acaba junto a la ermita de San Bartolomé y, aunque el dicho camino es áspero por ser todo pedregal y lo toma la nieve, es camino llano, y como ni las aguas ni avenidas lo deterioran, se puede andar con recuas y gentes de a caballo. Cuando cae mucha nieve, dice, los lugares comarcanos que son del Condestable, jurisdicción de Villalba, y Berberana que es de Francisco de Mendoza, hacen huelga para facilitar el paso, no teniendo necesidad de reparo. Desde San Bartolomé hasta cerca de Orduña, el camino es cuesta abajo, por lo que todas las aguas y avenidas van hacia Orduña, cubriendo el camino de las piedras y horrura que llevan las crecidas, y si no se limpiase, sería imposible poderse andar ni pasar con mulos ni otras bestias, y lo que se cierra es jurisdicción de Orduña, que siempre lo ha limpiado sin haberle repartido cosa alguna al Condestable, ni su parte necesitó aderezo jamás. Orduña arrienda además, la guía para limpiar el camino que siempre limpió y aderezó y no el Condestable ${ }^{1305}$.

En marzo de 1583 se trata sobre el repartimiento en la provincia y hermandades de Álava de los puentes de Bergüenda y de las ventas de Armiñón sobre el Zadorra, recurriendo esta medida "por ser los dichos rrepartimientos muy esçesiuos y agrauiados," y porque "la puente de Hermiñón está buena y segura y sin nesçesidad de rreparo alguno que sea considerable, y que en la forma que está puede durar muchos años y siglos con toda seguridad"1306.

\footnotetext{
1300 A. J. G. A./ t. VIII/ Vitoria, 29 marzo 1583.

1301 A. J. G. A./ t. VIII/ Vitoria, 4 marzo 1583.

1302 A. J. G. A./ t. VIII/ Vitoria, 21 noviembre 1583.

1303 A. M. Orduña/ Munic. Orduña, L/ 005 y 054/ 1561-1594.

1304 Iñigo Fernández de Velasco fue condestable entre 1559 y 1585.

1305 A. H. N./ Nobleza, Frias, Leg. 1.392, D. 1/ Entre 1559 y 1585.

1306 A. J. G. A./ t. VIII/ Vitoria, 4 marzo 1583.
} 
En las Juntas de Vizcaya de enero de 1585 Lucas de Romarate, en nombre de Orduña, presentó una petición para que se reparen los caminos reales de su jurisdicción a costa del Señorío. Se mandó, no obstante, que cada villa, ciudad o anteiglesia en su jurisdicción, deben hacer o reparar sus caminos ${ }^{1307}$.

En mayo de 1585 se extiende real Provisión para el repartimiento de las obras del puente de Puentelarrá, para lo que el corregidor de Miranda, manda al alguacil que requiera a las poblaciones situadas en 12 leguas a la redonda, para que paguen las cantidades que les corresponden. Los trabajos se habían rematado en 5.000 ds. con 200 de prometido al maestro de cantería Juan de Ribas, repartiéndose 1.512.550 mrs., y quedándose al final en 4.000 ds. con los 200 de prometido, pero al maestro no se le habían pagado más de 2.200 ds., por lo que se le debían 2.000 sin contar los $156.808 \mathrm{mrs}$. de gastos realizados en el cobro, visitas y salarios de maestros. Además había habido de quiebras $400.298 \mathrm{mrs}$. porque muchos pueblos tenían privilegios y otras causas de exención, y a otros se les habían hecho muchas bajas en las cantidades repartidas, por lo que se debía hacer nuevo repartimiento, reclamando el maestro que se recaudase todo, "porque si no se le pagase correria mucho riesgo la dicha obra". Se provee que, para el segundo cobro, se amplíe el radio en 6 leguas más ${ }^{1308}$.

En las Juntas de Vizcaya de abril de 1591 se trata sobre que el Juez mayor irá en breve al Señorío, y por su autoridad y obligación del Señorío, acordaron que fuese recibido en la entrada de la jurisdicción de Vizcaya, que es más allá de Orduña, por los dos diputados del Señorío, los letrados de su regimiento, síndicos generales y escribanos del Ayuntamiento, y asimismo por los procuradores de las tres cabezas de los tercios de las villas, y le acompañen en el camino hasta Bilbao. Remitieron al corregidor la orden que en ello se ha de tener, para que provea lo necesario1309. En diciembre el procurador de Orduña propuso en las Juntas que la persona que vaya a la corte, pida en el Consejo Real que se dé cedula para que se cargue 1 real sobre cada carga de mercaderías que salen del Señorío para Castilla, para reparos de los caminos reales que hay en la jurisdicción de la ciudad; pues en el Valle de Mena, por "no ser de la frequençia y continuaçion deste dicho Señorio", se le concedió otra tal cédula. Se mandó que para el primer regimiento vengan todos los diputados, regidores y procuradores de la Tierra Llana y Villas y Ciudad para acordar lo que convenga ${ }^{1310}$. La ciudad de Orduña y villa de Elorrio piden ayuda a las Juntas de Vizcaya para hacer los caminos, y se manda que ambas se animen a hacerlos o repararlos, y que en los primeros Regimientos Generales que el Señorío hiciere, se provea sobre lo que se les podrá ayudar1311.

En Junta de Álava de mayo de 1595 se acordó que se dé poder a Martín Ortiz de Uriarte para que vaya al valle de Llodio a ver el remate que se quiere hacer de los puentes del dicho

\footnotetext{
1307 A. J. R. B./ Actas de la Tierra Llana. t. IV/ Bilbao, 30 enero 1585.

1308 A. M. Poza/ no 66/ Madrid, 17 abril 1585 y Miranda de Ebro, 22 mayo 1585.

1309 A. J. R. B./ Actas de la Tierra Llana. t. V/ Bilbao, 22 abril 1591.

1310 A. J. R. B./ Actas de Villas y Ciudad. t. III/ Bilbao, 29 noviembre 1591; Actas de la Tierra Llana. t. V/ Bilbao, 1 diciembre 1591.

1311 A. J. R. B./ Actas de la Tierra Llana. t. V/ Bilbao, 1 diciembre 1591.
} 
valle y hacer sobre ello lo que convenga, a costa de la Provincia1312. La provincia de Vitoria y hermandades, acordaron que a todas las diligencias que se hiciesen, para el pleito sobre el repartimiento de los puentes y el reparo de caminos de dicho valle, asistiesen el diputado y el procurador de la hermandad de Ayala y, si fuere necesario, fuesen al valle con canteros que pudiesen hacer baja de la cantidad en que se remataron las obras. Cinco meses después, se comisiona a Cristóbal de Ugarte para que trate con el corregidor de Vizcaya, a quien el Consejo Supremo había encargado el repartimiento, sobre el agravio hecho a las hermandades, por haberles cargado más vecinos de los que tenían y como en su ejecución se "auian de haçer muchas costas y daños y vejaçiones a esta prouinçia" procurase su remedio"313.

En 1597 el Consulado de Bilbao compra diferentes trozos de terreno en la anteiglesia de Arrancudiaga para el camino carretil y paso de caballerías con lanas y otros efectos, disponiendo el arreglo del camino por el valle de Orozco hasta la entrada de la calle de Miravalles ${ }^{1314}$. En Junta de Álava de mayo de 1597 se trató sobre los puentes, pontones y calzadas del valle de Llodio, que la Provincia y otras partes del Reino habían pagado y no se había hecho nada, estando el dinero en poder del depositario. Por causar todo ello perjuicio a la Provincia y a todos los viandantes que por allí pasan, encomendaron al Diputado General que gane Provisión real para que la obra se haga y acabe, o que se devuelvan a la Provincia los dineros que tiene pagados con las costas, daños e intereses que por no hacerlo, se les han causado ${ }^{1315}$.

En las Juntas de Vizcaya de octubre de 1598 el regimiento dijo en relación con la epidemia de peste, que no se permita que en Bilbao entren trajineros u otras personas con bastimentos de partes sanas y sin sospecha de enfermedad contagiosa, porque podían ocasionar graves inconvenientes. El corregidor ordenó que dos personas de confianza, residan la una en Beteluri y la otra en Castrejana, que son puestos libres de la enfermedad y "por donde forçossamente an de pasar ansi de la çiudad de Urduña como de la villa de Valmaseda, en que se abraçan los caminos cosarios e frequentados que ay para la dicha villa de Vilvao, de las partes de Castilla la Vieja e todas las Montañas", y no dejen pasar a Bilbao ningún trigo, aceite, vino ni otros bastimentos, sino que los descarguen en esos sitios, y vayan allí los que los quisieren comprar ${ }^{1316}$. En dichas Juntas el corregidor mandó a las guardas y portazgueros, que no hagan pagar ni consientan que se pague ningún derecho por las cabalgaduras, a ningún vecino ni residente en el Señorío, so pena de 50.000 mrs. para la cámara del Rey, hasta que muestren los títulos que tienen para llevar esos derechos. El alcalde ordinario de Orduña dijo que desaprobaba lo acordado, y lo apelaba ante el Rey ${ }^{1317}$.

\footnotetext{
1312 A. J. G. A./ t. X/ Vitoria, 7 mayo 1594.

1313 A. J. G. A./ t. X/ Vitoria, 26 junio 1595.

1314 ALZOLA y MINONDO, P.: 1979: 160/1597.

1315 A. J. G. A./ t. X/ Zurbano, 7 mayo 1597.

1316 A. J. R. B./ Actas de la Tierra Llana. t. VI/ Zubiaur de Zornoza, 1 octubre 1598.

1317 A. J. R. B./ Actas de Villas y Ciudad. t. III/ Zubiaur de Zornoza, 14 octubre 1598; Actas de la Tierra Llana. t. VI/ Zubiaur de Zornoza, 16 octubre 1598.
} 


\section{- El conflicto entre Orduña y las tierras de Álava}

En 1257 Alfonso X otorga un privilegio confirmado por reyes posteriores, que ordena a todos los mercaderes y caminantes que se desplacen entre Castro-Urdiales o Valmaseda y Santo Domingo de la Calzada, Nájera o Logroño, por los puentes de Puentelarrá y Miranda, Salinas de Añana y Vitoria, a pasar por Orduña. Lo mismo obligaba a los de Oquendo, Llodio, Orozco o Ayala -a pesar del rodeo que debían hacer los de Orozco-, que fuesen a Vitoria o retornasen. Los incumplidores serían castigados con penas de prisión y la pérdida de sus cargas ${ }^{1318}$.

Entre 1315 y 1351 hubo un pleito entre Orduña y Villalba de Losa, porque Villalba desviaba el tráfico por ella y por el portillo del Aro, impidiendo que pasase por Orduña. El Rey manda que los arrieros que salgan de Villalba para Castro-Urdiales, Valmaseda, Vizcaya o Ayala, debían pasar a la ida y a la vuelta por Orduña1319.

En 1452 se plantea un pleito entre Orduña y las tierras de Ayala, Oquendo, Urcabustaiz, Llodio y Orozco, relativo al paso por Orduña de los arrieros de las mencionadas tierras y señoríos pertenecientes a Pedro López de Ayala. Alegaban los de Orduña que tenían privilegios, para que todas las mercaderías y bestias, cuando fuesen de sus tierras a Castilla o vuelvan de ella, debían pasar obligatoriamente por Orduña pagando el correspondiente portazgo, y no por otro puerto ni camino, y que en el caso de que no lo hicieren, deberían perder las bestias y mercaderías por ir descaminadas. Los de las citadas tierras defendían lo contrario, sosteniendo que no estaban obligados a pasar por la ciudad ni en la ida ni en la vuelta, salvo en el caso de que ellos así lo decidiesen. El fallo de 22 de mayo de 1452 decía que los vecinos y moradores de las tierras del señorío de Pedro López de Ayala podían ir y venir libremente a Medina de Pomar, Oña, Frías y otros logares, debiendo pasar por el puerto del Aro y no por otro camino, siempre que las cargas no debiesen pagar diezmos y derechos al Rey. Podían así ir y venir con trigo, cebada, vino, sidra y fruta por donde quisieren, sin impedirlo los de Orduña, e ir o venir libremente a Vitoria o a la tierra de Álava con cualquier carga que no debiese pagar dichos derechos, pudiendo ir por Altube, Dardoza o San Pedro de Beraza y espacios intermedios, pero deberán ir por Orduña si pasaren entre el puerto de San Pedro de Beraza y Orduña con mercaderías. Se manda que los que lleven o traigan a sus tierras pan, vino, sidra o fruta, puedan ir y venir libremente, y que puedan traer para su provisión por cualquier camino, las blanquetas, bureles y paños que libremente decidan, siempre que estos paños sean de la tierra y no traídos de los puertos de la mar.

También se falla que deberán ir y venir por Orduña, los que lleven cargas que deban pagar derechos reales en la ciudad, o que transporten pescado, congrio o arenque adobado traído de Bretaña, Galicia o de otras partes, así como los que sacaren desde dichas tierras alguna sardina fresca o adobada por encargo de un no vecino. Pero si las dichas sardinas fueren propias, las podrán llevar por los caminos y senderos por donde pueden llevar el

1318 A. M. Orduña/ Caja no 97- leg. G (fol. 4r- 5v)/ Burgos, 5 octubre 1257; ENRÍQUEZ FERNÁNDEZ, J., HIDALGO de CISNEROS AMESTOY, C, LORENTE RUIGÓMEZ, A y MARTÍNEZ LAHIDALGA, A.: "Colección documental del Archivo Municipal de Orduña (1271-1510). Tomo I". 1994: doc. 4.

1319 A. Ch. V./ Sección de Pleitos Civiles. Zarandona y Balboa (olv), c. 523-11/ 11 octubre 1315-15 noviembre 1351 “...que enbargaban y defendian forçosamente e sin razon e sin derecho que los caminantes que no fuesen por los dichos caminos a Horduña mas que fuesen porVillalba e por esta razon que el dicho conçejo de Horduña e sus vezinos que resçiben grandes daños...". 
pan, vino, sidra y las cosas indicadas. Los que traigan lanas, cáñamos y aceite, deberán pasar por Orduña pero, si es para su provisión, podían traer el aceite por donde quisieren, pero sin poderlo sacar ni vender fuera de sus tierras, y si lo sacaren o vendieren, deberán pagar el valor de ese aceite al concejo de la ciudad. También pueden llevar para su provisión 20 libras de cera. Los de la tierra y valle de Orozco, podrán ir y venir desde Belunza a la parte de Zuya por donde quisieren, con cualquier carga que no deba pagar diezmos ni derechos al Rey. Y si entre Belunza y Orduña fueren tomados, perderán las cargas y acémilas, aunque si llevaren cosas dezmeras o que deban pagar derechos al Rey y fueren camino de Burgos o vinieren, deberán ir por Orduña y no por otro camino, pero si con las mercaderías que deban pagar diezmos quisieren ir a Vitoria, donde está el puerto seco, podrán ir allí pagando los derechos y los de Orduña no lo pueden impedir. En el caso de que los vecinos y moradores de las tierras de Pedro López de Ayala no cumplan esto, recibirían como pena la pérdida de las acémilas y cargas por ir descaminados, al no haber pagado los derechos correspondientes ${ }^{1320}$

En 1467 se plantea un pleito entre Orduña y Vitoria, con motivo de que los de Orduña tomaron a Juan López de Gámiz, vecino de Vitoria, dos acémilas cargadas de hierro labrado cuando venían por Altube, por ir según ellos descaminadas. Orduña alega como es habitual, que tiene privilegios del Rey para que pasen por la ciudad todas las cargas de lazos con hierro labrado o sin labrar, o cualquier otra mercadería que fuese por los caminos entre la ciudad hasta San Pedro de Beraza, o bien desde Zuya, Altube, Urcabustáiz, Ayala y Orozco. Añade que todas las mercaderías y bestias que saliesen de Vitoria para ir a las tierras de Orozco, Ayala, Llodio, Oquendo o Bilbao u otras partes, y hasta Vizcaya o Encartaciones o volver desde esas tierras a la ciudad de Vitoria, debían ir y venir por Orduña y no por otro puerto ni camino, perdiendo las mercaderías, cargas y acémilas en el caso de no cumplirlo. Los vecinos de Vitoria alegan que podían llevar y traer de tierra de Orozco y Ayala cualquier mercadería de hierro y acero u otras cualesquier cargas, sin pena ni coto alguno, y que el hierro lo tomaron en tierra y jurisdicción de Ayala, y además, que los privilegios de Orduña, no concernían a los vecinos de Vitoria. La sentencia arbitral manda que los bienes que tienen tomados los de Orduña, se restituyan a los de Vitoria con todas las costas y daños. También se manda que los vecinos de Vitoria y su jurisdicción, podían ir y venir a Orozco, Llodio, Ayala, Oquendo, Bilbao, Vizcaya o Encartaciones, por los dichos caminos y puertos con sus mercaderías, cargas y bestias cargadas o vacías, sin entrar en Orduña y sin ser prendidos por estos, mencionando la sentencia dada en el pleito de mayo de $1452^{1321}$.

En 1480 se denuncia un robo realizado hacia 1473, por hombres del mariscal García López de Ayala, señor de Ampudia, a los mercaderes de Burgos Diego de Soria, Fernando de Mazuelo y Alfonso de Astudillo, cuando iban a la Montaña con una acémila cargada de trigo y 280.000 mrs. ocultos dentro de la carga. Cuando llegaron cerca de la ciudad de Orduña en el camino real, les salieron los escuderos del mariscal y les tomaron la acémila cargada con el dinero. Los Reyes mandan que se restituyan a los dichos mercaderes, la

1320 A. M. Vitoria/ 4-15-2/ Salvatierra, 22 mayo 1452.

1321 A. M. Vitoria/ 4-15-2/ Vitoria, 1 diciembre 1467. 
acémila con los 280.000 maravedís, más las costas y daños que se les han causado, dando al mariscal un plazo de 20 días para sus alegaciones ${ }^{1322}$.

En marzo de 1483 el concejo de Orduña apela a la Reina para que se guarden los privilegios que tiene de tiempo inmemorial, por el que todos los caminantes, mercaderes y tratantes que hubiesen de entrar o salir de las montañas del Señorío, debían pasar por Orduña donde se pagaban los derechos del diezmo y portazgo debidos a los Reyes, y utilizar los puentes de Haro, Miranda o Puentelarrá, y no ir por caminos apartados de Orduña, ya que en este caso, perderían las cargas y sus acémilas por ir descaminados. Los vecinos de Orduña toman libremente de tiempo inmemorial, todas las mercaderías que van descaminadas por estar en su derecho. La Reina indica sobre el mariscal García López de Ayala, que "a cavsa de las diferençias que diz que teneys con los vezinos de la dicha çibdad, por las guerras pasadas entre vos e ellos que se temen e reçelan, les querres perturbar e registir e defender, que non tomen los dichos descaminados de las dichas cargas e mercaderias que por fuera de la dicha çibdad pasaren", y manda en julio al mencionado mariscal y a los concejos de Ayala, Orozco, Llodio, Urcabustáiz, Cuartango, Mena, Angulo y Losa que "non ynquietedes, perturbedes, nin molestedes, nin resistades, nin defendades a los vezinos de la dicha çiudad en la dicha su posesion". Pedro Martínez de Mimenza y Pedro López de Aguiñaga, en nombre de Orduña, requieren a la Junta de la tierra de Ayala, que cumpla esta Carta real sobre el paso obligado de los mercaderes por la citada ciudad ${ }^{1323}$.

En 1490 los Reyes reciben una petición del concejo de Orduña, que decía que entre la ciudad y el señor de la tierra de Ayala, se hizo una iguala sobre el paso de las mercaderías que van y vienen a Vizcaya y que, a pesar de los privilegios que la ciudad tiene, el Mariscal alteró la situación, haciendo pasar las mercaderías de la tierra de Ayala por otras partes, causando perjuicio a la ciudad. Los Reyes comisionan al juez de residencia de Vizcaya, para que se informe y determine lo que proceda1324.

La Junta, alcaldes y procuradores de la provincia de Vitoria y hermandades de Álava, decían que al condado de Vizcaya se lleva mucho pan y otras cosas por parte de los recueros de Vitoria y su provincia, y que los vecinos de Orduña, contra derecho, los apremian para que pasen por la ciudad haciéndoles rodear varias leguas, y añaden que en Orduña les hacen muchos agravios, así en la medida del pan como de la guía y les llevan imposiciones nuevas. Los Reyes mandan en mayo de 1497 al corregidor del Señorío, que no permita a la ciudad que lleve ni pida a los vecinos de Vitoria y provincia nuevas imposiciones, ni haga más agravios a los mulateros y recueros que llevan pan y otras mercaderías a Bilbao y tienen que pasar por Orduña y que los dejen ir al Condado por los lugares donde libremente quisieren ${ }^{1325}$.

En Junta de Álava de mayo de 1509 se mandó que el procurador de Ayala, vaya ante el corregidor de Vizcaya con la Provisión real que el diputado trajo de la corte, sobre los per-

1322 A. G. S./ Registro General del Sello, III-1480, fol. 427/ Toledo, 15 marzo 1480.

1323 A. Ch. V./ Sección de Pleitos Civiles. Zarandona y Balboa (olv), C. 523-11/ Santo Domingo de la Calzada, 7 marzo 1483; A. G. S./ Registro General del Sello, VII-1483, fol. 101/ Santo Domingo de la Calzada, 3 julio 1483; A. M. Orduña/ Caja nº 97- Leg. G (fol. 1r- 3r)/ Saraube, 6 agosto 1483; ENRÍQ UEZ FERNÁNDEZ, J., HIDALGO de CISNEROS AMESTOY,

C, LORENTE RUIGÓMEZ, A y MARTÍNEZ LAHIDALGA, A.: "Colección documental del Archivo Municipal de Orduña (1271-1510). Tomo I". 1994: doc. 18.

1324 A. G. S./ Registro General del Sello, XII-1490, fol. 169/ Sevilla, 25 diciembre 1490.

1325 A. G. S./ Registro General del Sello, V-1497, fol. 19/ Burgos, 3 mayo 1497. 
juicios que los de Orduña causan a los viandantes, y lleve la información obtenida al Diputado General1326. En Junta de noviembre de 1509 los procuradores de Ayala y Llodio, dijeron que algunas personas de Orduña andaban por la Provincia quebrantando su jurisdicción, robando a los viandantes y cohechándolos por cosas que no debían diezmo. Como esto iba contra el servicio del Rey y contra la república, se acordó que los alcaldes de la hermandad de Ayala y Urcabustaiz y otras justicias, si hallasen a estas personas haciendo robos y fuerzas en Álava, los prendiesen y los llevasen con la pesquisa a Vitoria, y que todos ayudasen para que esto no perjudique el diezmo y rentas reales, y si hubiere algún pleito contra los que los prendieren, que la Provincia lo siga a su costa1327.

\section{- El reparto para el camino de Orduña de 1492}

En diciembre de 1491 la Junta, diputados, alcaldes y procuradores de las hermandades de la provincia de Vitoria, Álava y Ayala, solicitan licencia real para el reparto de 150.000 mrs. para el reparo del camino real que va de Orduña a Bilbao y a otros puertos. Alegan que está muy deteriorado y que no se puede utilizar sin gran peligro de las personas y acémilas, en especial cuando van cargadas. Añaden que si no se repara no se podrá transitar encareciendo además las mercaderías transportadas, siendo necesarios los 150.000 mrs. dichos, tasados por maestros canteros. Suplicaron a los Reyes licencia para nombrar dos buenas personas que se informasen a través de maestros, sobre la cuantía necesaria para los reparos y que se pudiese cargar a los caminantes, "segund se acostumbra echar e repartir en semejantes pontajes". El Consejo Real encomendó a Alonso del Castillo, juez pesquisidor en Vizcaya y juez receptor comisario, para que recabe información sobre los caminos, puentes y calzadas afectados, dónde están, qué reparos necesitan y su coste, en qué cosas se podría echar imposición y por cuánto tiempo, qué lugares de la comarca son los que reciben más provecho, qué vecinos pueden contribuir a los gastos, qué cantidades se debieran repartir y si se pudiera proveer de otra manera más provechosa y con menos "cargo o fatiga de los dichos caminantes e pueblos, para ser adovados e reparados los dichos caminos e puentes e calçadas e pasos". Alonso del Castillo, deberá remitir la información obtenida con su parecer al Condestable y al Consejo Real, para que informen si procede la imposición solicitada ${ }^{1328}$.

En enero de 1492 Alonso del Castillo, con el alcalde y oficiales del regimiento de Orduña y los maestros canteros y de calzadas Juan de Zaballa y Pedro Sáez de Echaurren, fueron a ver los caminos "que estaban rrasa la dicha peña de Jorduña... e vieron las braçadas que entendian que serian las que heran nesçesarias de adreçiar". Al día siguiente fueron a Luyando y "les fizo medir los lugares donde

\footnotetext{
1326 A. J. G. A./ t. I/ Vitoria, 4 mayo 1509.

1327 A. J. G. A./ t. I/ Vitoria, 21 noviembre 1509

1328 A. G. S./ Registro General del Sello, XII-1491, fol. 12/ Burgos, 13 diciembre 1491. “...estan çiertas calçadas e puentes en el nuestro camino rreal, que va de la çibdad de Ordunna a la villa de Bilbao e a nuestros puertos de la mar del nuestro condado de Vizcaya, por donde diz que pasan todas las mercaderias que de los dichos puertos vienen a estos nuestros reynos, e que muchas cargas e mulaterias que van e vienen por el dicho camino real, pasan a Castilla e a otras partes que es uno de los pasos e caminos mas principales destos nuestros reynos, e que las dichas puentes e calcadas estan muy malas e destruydas e caydas e derrocadas, e que non se pueden pasar nin caminar syn non a muy grant peligro, asy de las personas como de las azemilas e bestias que por ellas pasan, en espeçial veniendo cargadas, e que si non se labran nin reparan de aqui adelante, non se podran pasar nin caminar, de lo qual diz que se nos seguiria deserviçio, e estos nuestros reynos resçibiran gran danno e se encaresçerian las mercaderias e mantenimientos que de los dichos puertos vienen, e seguirian otros muchos dapnos e que es nesçesario por los evitar, que las dichas puentes e calçadas se hedifiquen e reparen e tornen a fazer e reparar...."
} 
paresçia que auia nesçesydad de adreçiar e rreparar", declarando que se debían reparar 3.200 brazadas con 1.350 obreros y 8.000 canfradas de piedra. Además se necesitaban 650 servidores. La reparación del puente de Saracho podría costar $10.000 \mathrm{mrs}$. y el recaudador de la imposición y supervisor de las obras cobraría unos 8.000 mrs. por año. Según Juan de Zaballa, que había tenido el portazgo de la ciudad, podrían circular unas 3.000 acémilas al año. Al siguiente día, Alonso del Castillo tomó juramento a nueve mesoneros de Luyando, preguntándoles cuántos "mulos e vestias pasarian por el dicho camino vn año con otro, los quales, so cargo del dicho juramento, avido su acuerdo, dixeron que podian ser las que pasaban en cada vn año, vn año con otro, tres mill mulos, pocos mas o menos". También dijeron que las canfradas de piedra necesarias eran 9.000 , siendo precisos 1.340 obreros, y para servir a los canteros eran necesarios 650 servidores para toda la calzada. Para rehacer de madera el puente de Saracho, con un pilar de piedra en el centro y otro que estaba para caer, necesitaría 10.000 mrs. Añadieron que era preciso un "cogedor" de la imposición, para controlar y agilizar las obras, que cobraría 6.00o mrs. al año. Los gastos se debían repartir imponiendo a cada mulo medio real de plata al año, durante 6 años. El Juez preguntó a ocho mulateros en Luyando, que contestaron que "les plazia de pagar qualquier tributo que les echasen conforme a la costa sobredicha, e questo mismo entendian que les plazeria a los otros caminantes". Dijeron que los lugares más cercanos para contribuir, eran Luyando y Amurrio.

Alonso del Castillo consideró al fin, que serían necesarias 8.00o canfradas de piedra que a $17 \mathrm{mrs}$. cada una alcanzaban $136.000 \mathrm{mrs}$, , 1.350 obreros que a real de plata cada uno harían un total de 41.000 mrs. y 650 servidores que a 25 mrs. cada uno montan 15.000 y "para rreazer la puente de Saracho, que es entre Orduña e Lujaondo, que son mester diez mill marauedies. Asy mismo, paresçia que para coger el dicho portazgo es mester vna persona o dos, los quales fan mester en cada año por cogedores e veedores de como se fazen las calçadas", 4.000 mrs. por año, que en 5 años mon$\tan 20.000$. En total, serían necesarios 222.000 mrs., más 10.000 que se han gastado en costas. Los ingresos se obtendrían del paso de 3.000 bestias a medio real cada una, con 5 años de imposición, con un ingreso anual de $46.500 \mathrm{mrs}$. que haría un total de $232.500^{1329}$.

Con la información obtenida, pareció que se debían reparar 3.400 brazas de calzadas que podrían costar con la piedra necesaria los 222.00o mrs. mencionados, y que para recaudar esta cantidad se debía echar contribución sobre las acémilas que utilizan el camino, ya que sus dueños reciben el beneficio de la reparación y además son los que más lo dañan con su tránsito. Se encargó a Sancho de Guinea que cobrase el medio real de plata por acémila, y ocho mrs. a las otras bestias que fueren desde Orduña, aunque no pasen por ella hasta Luyando, de manera que pagándolo una vez, sirva para todo ese año, y mandan que todo se registre en un libro para que se tenga "cuenta e rrazon de todo lo que rrentare la dicha ynpusyçion". Lo recaudado se aplicará a los caminos, para que en unos 5 años acabasen las obras. Mandan también que en diciembre siguiente, se envíe al Consejo detalle de la recaudación, gastos y brazadas reparadas, para hacer la previsión del año 1493, y se declaren los precios y jornales de los canteros, maestros y peones que trabajaron con la liquidación de las cuentas, más los 8.000 mrs. anuales de su salario ${ }^{1330}$. Cuinea deberá

1329 A. G. S./ Cámara de Castilla. Pueblos, leg. 3-2, doc. 248/ Orduña, 20 enero 1492.

1330 A. G. S./ Registro General del Sello, III-1492, fol. 346/ Burgos, 15 marzo 1492. “...enbyeys la rrelaçion en forma, e fagays saber a los del nuestro Consejo quantos mrs. ha rrentado la dicha ynpusyçion, e asymismo quantos mrs. son gastados en las dichas calçadas e caminos, e quantas braçadas se an labrado, porque asy sabydo provean para el año venidero lo que vieren ques 
pagar a los canteros y maestros encargados de las obras, a medida que fuesen rentando los mrs. recaudados. El Consejo Real acuerda prorrogar la imposición por otro año, y "dar cargo de la coger e de faser e rreparar los dichos caminos e calçadas" a Guinea, con la misma cantidad por acémila y el encargo de aplicar lo recaudado al reparo del camino real, y manda que en diciembre de 1493, se envíe la relación de la imposición, cuánto se ha gastado en las calzadas y cuántas brazadas se han labrado1331. Nada sabemos sobre si se realizaron los trabajos pretendidos.

\section{- Los derechos del Condestable en Orduña}

Los Condestables tenían el derecho de percibir como renta cierta cantidad por la Cuía de la Peña de Orduña, que "son derechos antiguos de su casa, y el dicho Condestable y sus anteçesores los an cobrado y cobran de tienpo ymemorial a esta parte, por rraçon de ser suya la villa de Villalba"1332. Según indican, esta renta no obligaba al Condestable a aplicarla al reparo del camino de la Peña entre San Bartolomé y Murita, ya que como derecho que dice que era, le permitía arrendarlo sin asumir ninguna obligación. El arrendatario solía ser el concejo de Orduña que pagaba una determinada cantidad por este derecho durante 6 años, y lo subarrendaba a su vez al mejor postor, que cobraba por el tráfico en el puerto de San Bartolomé las cantidades estipuladas a cambio de la protección de los caminantes y de cierto mantenimiento del camino. Existió, por ello, un permanente litigio entre la ciudad de Orduña y el Condestable para que los mrs. percibidos por la renta, los aplicase a la reparación del tramo de camino desde la Peña a Murita, algo que los Condestables no aceptaban. Por este motivo, se inicia un pleito en 1500, que durará largo tiempo, entre el Condestable y sus sucesores y el concejo de Orduña, por no aplicar los derechos que percibía a la composición del camino de Murita ${ }^{1333}$. El arrendamiento proseguía en 1538, ya que el concejo de Medina de Pomar da un mandamiento en nombre del Condestable, para que Orduña, pudiese seguir cobrando por 6 años dicho arrendamiento del derecho que le pertenecía, sobre la renta de la guía y pasaje de la Peña de Goldecho1334.

Simón Ruiz, mercader de Medina del Campo, recibe un requerimiento en 1560 para que se declare deudor del condestable de $33.521 \mathrm{mrs}$. por 11 obligaciones sobre los diezmos de las mercaderías que pasaron por la aduana de Orduña1335.

En las cuentas del ayuntamiento de Orduña de 1583, se pagaron a San Juan Rodríguez de Uvilla 52,5 rs. por 15 días a 3,5 rs. por día, que empleó en ir a Villalpando a por la respuesta de la carta que el corregidor envió al Condestable para que contribuyese en el reparo

nuestro seruiçio, e mandamos vos que luego questa nuestra carta vos fuere noteficada ante tales cosas fagays juramento... que byen e fiel e verdaderamente vsareys del dicho cargo, e fareys e conplireys todo lo que por esta nuestra carta uos es mandado e encomendado, syn arte e syn engaño alguno e que non leuareys de otras personas e de otras bestias algunas, la dicha ynpusiçion saluo de las dichas asemilas e otras bestias de carguerias de mulateros e que de aquellas solamente levareys a medio rreal e a ocho mrs. segund que por esta nuestra carta va declarado y mandado e non mas...".

1331 A. G. S./ Registro General del Sello, II-1493, fol. 176/ Olmedo, 8 febrero 1493.

1332 A. H. N./ Nobleza, Frias, Leg. 1.392, D. 1/ Entre 1559 y 1585.

1333 A. H. N./ Nobleza. Frías, Leg. 1.392, D. $1 / 1$ enero 1500 a 31 diciembre 1599.

1334 A. H. F. B./ Munic. Orduña, caja nº 19, carp. 1/ Medina de Pomar, 17 octubre 1538.

1335 A. H. N./ Nobleza. Frías, Leg. 1469, D. 14/ 1 febrero 1560. 
del camino de la Peña por el cobro de la guía1336. En las Juntas de Vizcaya de julio de 1584 se mandó que para seguir con este asunto contra el Condestable, se ponga este capítulo en la instrucción para que lo pidan y sigan las dos personas que al presente van a las villas de Valladolid y Madrid ${ }^{1337}$.

En 1584 y 1585 se extienden dos Provisiones reales en que se manda que lo que lleva el Condestable como renta de la guía, se gaste en reparos de la Peña1338. En el pleito entre el concejo de Orduña y el Condestable, para que este aderece el camino desde la Peña hasta el lugar de Murita, responde su procurador que la guía es percibida por su casa de tiempo inmemorial, y en tan poca cantidad que nunca llega a 25.000 mrs. Alega además, que el Condestable jamás ha contribuido en el aderezo de la Peña de Orduña que es término de Orduña, para lo que la ciudad lleva tradicionalmente gran cantidad de derechos. La guía de la Peña, añade, se cobra por el tramo del camino que discurre por Murita en el término de Villalba, que acaba junto a la ermita de San Bartolomé, y como las aguas no lo deterioran, se puede andar con recuas y gentes de a caballo. Desde San Bartolomé hasta Orduña el camino es cuesta abajo, por lo que las aguas, piedras y lodo van hacia Orduña que, al caer en su jurisdicción, siempre lo ha limpiado por su cuenta. Rinde $405.000 \mathrm{mrs}$. menos la parte de la guía que cobra el Condestable a su arrendatario -que suele ser el concejo de Orduña-, que la que obtiene la propia ciudad para limpiar el camino que siempre limpió y aderezó. El Condestable solía arrendar esta guía de la Peña y lleva cierta cantidad de mrs. por ello, que aunque ellos dicen que el Condestable se lleva la mitad de lo que rinde, es al contrario, ya que siempre arrienda la ciudad su mitad de la Peña en 5 o 6.00o mrs. más cada año. El Condestable lo hacía por 6 años por 22.000 o 25.00o mrs., porque cuando hay guerra con Francia o no se portan las mercaderías de Flandes o Francia valía poco ${ }^{1339}$. En las Juntas de Vizcaya de febrero de 1585 se trató sobre la Provisión real para que los derechos que el Condestable percibe en concepto del reparo de la Peña, se gasten y distribuyan para ese fin. El corregidor del Señorío deberá informar sobre ello y enviar relación de lo que ocurre $^{1340}$. Al día siguiente, se acordó sacar provisión para que los derechos que cobra el Condestable, se gasten y distribuyan en el dicho reparo ${ }^{1341}$.

\section{Los descaminos por el vado de Echévarri}

Para ir de Orduña fundada en 1229, a Bermeo fundado hacia 1236, existió un camino que iba directamente y cruzaba el Nervión por el vado de Echévarri, dejando el espacio de la futura villa de Bilbao media legua a la izquierda.

En la carta de refundación de Bilbao de junio de 1310 doña María, señora de Vizcaya, confirma la carta-puebla que hizo su tío Diego López de Haro en 1300, y manda "que el camino que ua de Ordunna a Vermeo que pasa por Echauarri, que uaya por aquesta mi villa de Biluao e non por otro lugar

1336 A. M. Orduña/ Munic. Orduña, L/ 005 y 054/1561-1594.

1337 A. J. R. B./ Actas de la Tierra Llana. t. IV/ Bilbao, 28 julio 1584.

1338 A. H. F. B./ Munic. Orduña, caja no 19, carp. 3/ 1584 y 1585.

1339 A. H. N./ Nobleza, Frias, Leg. 1.392, D. 1/ Entre 1559 y 1585.

1340 A. J. R. B./ Actas de la Tierra Llana. t. IV/ Bilbao, 20 febrero 1585.

1341 A. J. R. B./ Actas de la Tierra Llana. t. IV/ Bilbao, 21 febrero 1585. 
sinon por esta Biluao, et qualquier o qualesquier que otro camino tomasen si non este de Biluao mando al mio prestamero de Vizcaya e a los mios merinos e al preboste de y, de la villa, que les tomen todo quanto les fallaren por descaminados" y lo guarden para hacer lo que tuviere por bien, y que nadie "sea osado de tener conpra ni venta ni regateria ninguna en todol camino que ua de Areta fasta la uilla de Biluao", y al que lo hallaren que peche $100 \mathrm{mrs}$. de la moneda nueva, y el merino tome para si aquella reventa1342.

Desde este momento el concejo de Bilbao, será un fiel y celoso vigilante para que ningún mulatero, pudiese circular por el camino directo de Areta hasta Bermeo por el vado de Echévarri, sin desviarse previamente por la villa de Bilbao, con el fin de pagar el correspondiente derecho. Los bilbaínos eran conscientes de que haciendo discurrir este tráfico por su villa, no hacían otra cosa que consolidarla, en detrimento de otras villas portuarias como era Bermeo, que tenían una antigua tradición comercial.

Así en 1348 Juan Núñez, señor de Vizcaya, dice a los alcaldes de Bilbao que parecieron ante él, Juan Sánchez de Arbolancha, su preboste en Bilbao de una parte, y Juan Pérez de Trobica en nombre de la hermandad de los hijosdalgo de Vizcaya de la otra, sobre las bestias que Trobica reclamaba y que le había tomado sin razón el dicho Arbolancha en el "camino de Hechebarri que va de Areta para Vermeo". Arbolancha mostró un traslado del privilegio de junio de 1310, en el que se mandaba que el camino que va de Areta para Bermeo, fuese por Bilbao y no por otro lugar, y si alguno fuere por otra parte, el prestamero y merinos de Vizcaya y el preboste de Bilbao les tomarían todas las bestias y la carga por ir descaminados. Mostró además una carta de Juan Núñez en la que se contenía confirmación de todos los privilegios y fueros que los de Bilbao tenían, otorgados por los señores que fueron de Vizcaya. Se falló en abril de 1348, que las bestias se tomaron como se debía según el dicho privilegio. Se pidió que Juan Núñez las tomara con derecho, y las mandase desembargar, por lo que mandó a los fiadores que devolviesen las dichas bestias a Arbolancha pagando este la cuantía de los mrs. en que fueran apreciadas. Mandó además a los dichos oficiales, que en adelante tomen todas las bestias descaminadas, según en el privilegio se contiene, y si los de la dicha Hermandad tienen cartas o recaudos para que las cargas puedan pasar por el camino de Echévarri y no por Bilbao, los muestren y se les guardará su derecho. Juan Núñez concede a Arbolancha todo el trigo que tomó por descaminado y además, por hacerle mayor merced, le da 1.200 mrs. de los 4.200 en que fueron valoradas las acémilas que tomó con el trigo'1343.

Juan Núñez hace saber a Juan Sánchez de Salcedo, su prestamero mayor en Vizcaya y Encartaciones, a sus merinos de las merindades de Vizcaya, y a Juan Sánchez de Arbolancha, que el concejo le envió el traslado del privilegio de 1310, y que lo debían guardar y hacer lo que en él se mandase, y que ahora los que debían ir de Orduña a Bermeo, dejaban el camino de Bilbao, e iban por el camino de Echévarri contra el dicho privilegio. Sobre esto, Arbolancha prendió 16 acémilas mulares y caballares cargadas de pan, que iban por

1342 A. M. Bilbao/ Pergaminos, 2. (se halla en la casa consistorial)/ Valencia. 25 junio 1310; ENRÍQUEZ FERNÁNDEZ, J.; HIDALGO de CISNEROS AMESTOY, C. y MARTÍNEZ LAHIDALGA, A.: "Colección Documental del Archivo Histórico de Bilbao (1300-1473)". 1999: docs. 3 y 10; A. M. Bilbao/ Cajón 1, reg. 1, no 12-Pergaminos 12/ Bermeo, 20 junio 1334.

1343 A. M. de Bilbao/ Caja 1, rego2, no21/ Bilbao, 21 junio 1499; ENRÍQUEZ FERNÁNDEZ, J.; HIDALGO de CISNEROS AMESTOY, C. y MARTÍNEZ LAHIDALGA, A.: "Colección Documental del Archivo Histórico de Bilbao (1473-1500)". 1999: doc. 250. 
el camino de Echévarri, pero Juan Sánchez de Villela, hidalgo de Vizcaya, alegó que el dicho pan y acémilas eran suyas y de otros hidalgos de la tierra y lo llevaban para consumo propio, por lo que no las debían perder, ya que si el pan que compran en Orduña o en otras partes "para su comer", lo hubiesen de pasar por la villa de Bilbao, recibirían gran daño por ello. Juan Núñez entiende que el dicho privilegio manda que los que llevaren pan u otras cosas para vender, deben pasar por Bilbao, pero no el pan que los hidalgos y labradores de Vizcaya llevaren para su consumo. En mayo de 1348 manda por ello, que todas las cargas de pan y otras cosas que pasaren por el camino de Echévarri se tomen por descaminadas, salvo el pan que llevaren los hidalgos y labradores de Vizcaya para su alimento, que lo podrán pasar como quisieren. Reitera, no obstante, que si se sabe que lo venderán, se les prenda y se tome todo lo que les hallaren, aunque sean hidalgos o labradores, hasta que pechen todo el pan que llevaron y vendieron y las bestias en que lo llevaron ${ }^{1344}$.

En septiembre de 1497 ante el alcalde, el corregidor y el veedor del condado y señorío de Vizcaya, parecieron de una parte Íñigo de Urieta, morador en La Muza de Llodio, y de la otra Tristán Díaz de Leguizamón, preboste de Bilbao. Urieta puso demanda contra Tristán Díaz porque el día anterior, yendo Urieta "con dos mulos suyos cargados de lanas e vn roçin cargado de çebada, pasado por el vado e yendo por el camino de Echabarri saluo e seguro, non haziendo nin desyendo mal a ninguna presona, antes yendose para la villa de Vermeo con las dichas cargas de lana que llebaba por su alquil, e con el dicho su roçin cargado de çebada, acudio... pasado el dicho bado, Sancho de Vribarri, prebostao, criadoe teniente del dicho Tristan Diaz, preboste,... le tomo los dichos mulos e roçin con sus cargas desyendo que heran descaminados, e que lo avia todo perdido por pasar e yr por el dicho bado e camino de Echabarri", y que por fuerza se los había traído a Bilbao y los tenía en su poder. Pedía al alcalde que apremiase a Tristán, para que le devolviese los dos mulos y rocín con sus cargas. Tristán Díaz dijo que Sancho de Uribarri, su criado y “prebostao”, había ido a guardar el vado y camino de Echévarri por su mandato, y que había hallado a Urieta que había pasado con las bestias cargadas, como había confesado, y que las bestias y cargas, las tenía en su poder por descaminadas. Urieta alegó que no sabía que el vado y camino de Echévarri estuviese vedado, ni lo que por él pasase fuese descaminado, "e que le avia acaesçido por ynorançia", y les rogaba que no le "echasen a perder nin le fesyesen tan grand dapno". Tristán Díaz dijo que el privilegio era notorio en todo el Condado, y que "camino alguno no abya por la dicha Echabarri, saluo quel camino publico hera por esta dicha villa", y "quel avia vsado e vsaba del dicho su prebillejo, por lo qual el dicho Ynnigo de Vrieta non hera de oyr". El alcalde da por descaminados y perdidos los dos mulos y rocín con sus cargas de lanas y cebada, y haber caído en pena de perdimiento por haber pasado "por el dicho vado e camino viejo de Echabarri", y que el preboste lo puede tomar para sí, según el privilegio1345.

En octubre de 1498 se falla pleito entre Juan Sáez de Beraza, morador en la anteiglesia de San Juan de Sondica, Martín de Urraga y Pedro de Iturribalzaga, moradores en la anteiglesia de San Pedro de Munguía, y Tristán Díaz preboste de Bilbao, por el apresamiento

1344 A. M. de Bilbao/ Caja 1, regํ2, no 21/ Bilbao, 21 junio 1499; ENRÍQUEZ FERNÁNDEZ, J.; HIDALGO de CISNEROS AMESTOY, C. y MARTÍNEZ LAHIDALGA, A.: "Colección Documental del Archivo Histórico de Bilbao (1473-1500)". 1999: doc. 250.

1345 A. M. Bilbao/ Cajón 12, reg. 1, nํ10-Caja 303, reg. 1, no10/ Bilbao, 28 septiembre 1497; ENRÍQQUEZ FERNÁNDEZ, J.; HIDALGO de CISNEROS AMESTOY, C. y MARTÍNEZ LAHIDALGA, A.: "Colección Documental del Archivo Histórico de Bilbao (1473-1500)". 1999: doc. 227. 
de ciertas mulas y cargas cuando pasaban por el camino de Echévarri. Visto lo alegado por Beraza, Iturribalzaga y Urraga y lo respondido por Leguizamón, y las cláusulas, privilegio y confirmaciones presentados, el alcalde falla que, como los dichos confesaron que "sus mulos avyan pasado por el camino de Echabarry, que va a Vermeo cargados de lanas, e que asy pasado fueron tomados por el dicho preboste, que segund el thenor e forma de la clausula de los prebilejos que esta dicha villa tyene,... el dicho preboste pudo tomar... los dichos mulos e azemilas con sus cargas", y que por haber pasado contra los privilegios de Bilbao fueron descaminados. Tristán, a quien los privilegios dan facultad para que pueda tomar todo lo que pasare descaminado por dicho camino, tomó como cosa propia los mulos, acémilas y sacas de lana que portaban. Además, se les condena en las costas hechas por el preboste ${ }^{1346}$.

\section{La fundación de Ugao-Miravalles}

En julio de 1373 el infante don Juan, futuro Juan I, señor de Lara y de Vizcaya, dice al concejo y alcaldes de su villa de Bilbao, que vio la petición que trajeron sus procuradores en que le decían que algunos escuderos de la comarca cerca de Bilbao, "por enamistades que han, que han fecho mobimientos de poblar e fazer villa nueba en Vgao, a vna legua de la dicha villa", lo cual no sería a su servicio, crearía gran perjuicio a la villa e iría contra sus privilegios, pidiendo "que no consentiese que la dicha puebla y villa nueba se fiziese en Vgao". Por el contrario, los concejos, hijosdalgo y labradores de Arrigorriaga, Zaratamo, Olabarrieta y Arrancudiaga le pidieron que "les consentiese y los dexase poblar e fazer la dicha puebla de Villa Nueba en Vgao". El infante queriendo guardar los privilegios de Bilbao y porque su voluntad era evitarle cualquier daño, hizo traer los privilegios y se vio que los que poblaron y dieron puebla nueva a Bilbao mandaron, en junio de 1310, que nadie "sea osado de tener conpra ni benta ni regateria ninguna en todo el camino que ba de Areta fasta la dicha villa de Biluao", otorgando a la villa monopolio comercial en este tramo, y el que lo hiciere caería en la pena contenida en el privilegio, pudiendo coger el merino para sí lo que se pusiere a venta o a regatería. También vio que en otro privilegio que él confirmó, se dice que desde Bilbao hasta Areta, Baracaldo o Zamudio no haya ninguna reventa, y si la hicieren, que el preboste y el merino tomen para sí la tal cosa, y además, que pague el que lo hiciere 500 mrs. Indica el infante que la villa nueva no se pueble en Ugao, para que a Bilbao "no benga mal ni danno por esta razon".

Y para que en adelante entre Bilbao y otros lugares no tengan sobre esto desavenencias ni discordias, recuerda la cláusula contenida en los privilegios, que dice que "no aya benta ni rebenta ni regateria desde la dicha villa de Biluao fasta en Areta ni fasta Baracaldo ni fasta Çamudio", y que en adelante se entienda eso mismo, y no haga por ello puebla ni villa nueva. Manda que no consientan que los concejos de Arrigorriaga, Zaratamo, Olabarrieta y Arrancudiaga ni ningún otro, hagan ni pueblen villa nueva en Ugao ni en otra parte entre Bilbao y Areta, ni tengan venta, reventa, regatería ni nada que vaya en perjuicio de la villa o de sus privilegios, y si alguien contra esto quisiere ir, manda a Juan Hurtado de Mendoza, su

1346 A. M. Bilbao/ Cajón 12, reg. 1, no 10-Caja 303, reg. 1, no 10 (fol. 4r-5r)/ Bilbao, 13 octubre 1498; ENRÍQUEZ FERNÁNDEZ, J.; HIDALGO de CISNEROS AMESTOY, C. y MARTÍNEZ LAHIDALGA, A.: "Colección Documental del Archivo Histórico de Bilbao (1473-1500)". 1999: doc. 234. 
prestamero mayor de Vizcaya, y a los alcaldes, merinos e hijosdalgo de Vizcaya, que no lo consientan y que los prendan por la pena contenida en los dichos privilegios ${ }^{1347}$.

No obstante menos de 2 años después, en marzo de 1375, el infante don Juan dice que los vecinos de la comarca de Ceberiano, le pidieron merced para que ellos pudiesen "fazer $e$ poblar eçercar vna billa en llogar que agora dizen Vgao", que está en la dicha comarca. Expedirá por ello carta de población para la fundación de la villa de Miravalles en el lugar de Ugao en un recodo del Nervión, en el camino de Orduña a Bilbao, con el fin de poderse trasladar dichos vecinos para estar mejor defendidos. Se opusieron de nuevo los vecinos de Bilbao, que alegaban que tal fundación iba contra el privilegio de 1310. Por ello dicen que, si Miravalles se poblase por fuerza, "se abrian e de bender e comprar muchas cosas, como sin vender e comprar non se puede mantener ninguna villa". Además, alega Bilbao, que el pan, el hierro y otros productos que en Bilbao se venden, se venderían en la nueva villa si se poblase. El infante manda a Juan Alfonso de Castro Donarto, su veedor en Vizcaya que realice pesquisa, concluyendo que de poblar la dicha villa "no venia perjuicio alguno nin daño a la dicha villa de Bilbao, especialmente porque antes que la dicha villa de Bilbao fuese poblado et despues continuamente, siempre ubo venta en el dicho lugar que dicen Ugao", y que tal fundación era conveniente para los intereses del monarca. El infante, aportando diversos argumentos, fallará "que la dicha villa que se pueble e çerque en el llogar que dize agora Vgao, e que de aqui adelante aya nonbre Villanueba de Miravalles", mandando que todos los habitantes de las comarcas de Ceberiano y Ugao, vayan a vivir a la nueva villa y tomen solares, comprándolos a sus propietarios a precios razonables ${ }^{1348}$.

La fundación de Miravalles, venía a confirmar el continuo trato comercial establecido en el tramo medio del camino entre Orduña y Bilbao, por lo que los labradores y en especial los hijosdalgo pretendían participar en los beneficios económicos de las villas, manteniendo sus fuentes de ingresos tradicionales: la agricultura, la ganadería y la actividad ferrona, aunque no se le concedió la facultad de tener mercado. A pesar de las ventajosas condiciones de la carta-puebla, el desarrollo de la villa fue muy limitado, ya que la competencia de Bilbao era ya hegemónica ${ }^{1349}$.

\section{Los reparos de los caminos de Ayala y las Provisiones de $\mathbf{1 5 7 6}$}

Martín de Zaldívar, en nombre del Señorío de Vizcaya, dijo al Rey que los caminos públicos del Señorío, que iban desde Orduña, Villarreal y Valmaseda hasta los puertos de

1347 A. M. Bilbao/ Cajón 8, reg. 1, no1-Caja 199 (fol. 39v)/Valladolid, 6 julio 1373; ENRíQQUEZ FERNÁNDEZ, J.; HIDALGO de CISNEROS AMESTOY, C. y MARTÍNEZ LAHIDALGA, A.: "Colección Documental del Archivo Histórico de Bilbao (1300-1473)". 1999: doc. 30.

1348 A. M. Miravalles/ Carpeta BIN- 1-n-79/ Almazán, 4 marzo 1375; ENRÍQUEZ FERNÁNDEZ, Javier: "Colección Documental de los Archivos Municipales de Guerricaiz, Larrabezua, Miravalles, Ochandiano, Ondarroa y Villaro". 1991: doc. 3; A. M. Bilbao/ Caja 1, reg. 2, nำ1/ Medina del Campo, 19 junio 1457; ENRÍQUEZ FERNÁNDEZ, J.; HIDALGO de CISNEROS AMESTOY, C. y MARTÍNEZ LAHIDALGA, A.: "Colección Documental del Archivo Histórico de Bilbao (13001473)". 1999: doc. 84. "... Ios homes buenos, asi hijosdalgo como labradores, de la comarca de dicen Ceveriano,... benieron a mi $e$ me pidieron merced que mandase e tobiese por bien e les ficiese merced que ellos, que podiesen facer e poblar e cercar una villa en el logar que agora dicen Ugao, que es en la dicha comarca, porque ellos podiesen y poblar e morar e ser guardados e defendidos e amparados al mi servicio e a pro de ellos e, otrosi, a pro comunal de la mi tierra. E el concejo e homes buenos de la mi villa de Bilbao e sus procuradores, se opusieron contra esto que los dichos escuderos e labradores me demandavan, diciendo que la dicha villa no debia ser poblada en la dicha comarca ni yo lo debia mandar ni consentir por quanto seria en grand perjuicio de la dicha villa de Bilbao, e contra los previllejos que los de la dicha villa han..."

1349 ARÍZAGA BOLUMBURU, B. y MARTÍNEZ MARTÍNEZ, S.: 2006: 294-296. 
la mar, tanto en su jurisdicción como en los valles de Ayala, Orozco y Aramayona, confines a él, "estauan tan mal reparados que con mucha difultad y trauaxo, se podia traxinar y lleuar por ellos los mantenimientos y mercaderias que yban de Castilla al dicho Señorio e del a Castilla, y cada dia se perdian y murian muchas caualgaduras en los dichos caminos, a cuya causa no se atreuian los arrieros a lleuar los dichos mantenimientos y mercaderías, y acaeçia aber muy gran falta en el dicho Señorio y valles de los dichos mantenimientos y mercaderias", y los que llegaban se vendían mucho más caros que en otras partes de la costa que tenían reparados sus caminos. Suplicaba que el corregidor de Vizcaya, fuese a visitar los caminos y malos pasos del Señorío y del valle de Ayala, Orozco, Aramayona y los demás confines, hasta los puertos del Señorío y los hiciese aderezar, obligando a sus vecinos a contribuir, conforme al beneficio que recibirían, o reparar lo que les fuese señalado, "atento que estaban tan mal adereçados y reparados, que nadie podia pasar ni andar por ellos, $y$ se ahogaban y despenaban muchas gentes y cabalgaduras", y porque si no se hiciese así, lo que se reparase en el Señorío no tendría ningún efecto y seguiría empeorando. El Consejo acordó dar dos provisiones en 8 de febrero de 1576, y mandar al corregidor o juez de residencia del Señorío, que "con mucha diligençia e cuydado, agays adreçar e reparar los caminos y puentes y pontones $e$ calçadas e malos pasos que hubiere en los terminos de las villas y lugares y Tierra Llana dese dicho Señorio" y enviase en 15 días relación de lo que hubiere hecho.

En las Juntas de Vizcaya de abril de 1576 se trató sobre las Provisiones mencionadas para el aderezo de los caminos de Vizcaya, Ayala, Llodio, Aramayona y Villarreal, y el requerimiento al corregidor para que viese los caminos reales del Señorío hasta sus puertos, y los de los valles de Ayala, Llodio, Aramayona y villa de Villarreal confines a él, y para reparar suficientemente los dichos caminos, puentes y pontones, repartiendo la parte conforme a la posibilidad de cada lugar, y que todos contribuyesen por ser común el provecho y daño, y se comisionase al corregidor, requiriéndole con la dicha Provisión para que la cumpla y ejecute en su jurisdicción, y lo mismo se debía hacer en los dichos valles y villa de Villarreal, acordándose que las justicias ordinarias de los valles y villa la hiciesen cumplir, y el procurador de Orduña haría la diligencia necesaria en el valle de Ayala y Llodio. También se trató sobre que el Señorío tiene ley particular y Provisión de la reina Juana, para que las penas arbitrarias se apliquen a los reparos de sus caminos públicos, porque como el Señorío no tiene propios, están tan mal los caminos y pasos que nadie puede utilizarlos. El Regimiento General ordenó que, conforme a la ley del Fuero y Provisión, los tenientes del Señorío y los alcaldes y justicias de las Villas y Ciudad, apliquen cada uno en su jurisdicción las tales penas para los reparos de los caminos públicos ${ }^{1350}$.

En las Juntas de Vizcaya de agosto de 1576 se trató sobre que, una vez notificada la Provisión real, se tome testimonio de cómo no han hecho ni reparado los caminos, y se pida comisión para que el corregidor del Señorío salga con vara de justicia de su jurisdicción, y los obligue a que hagan y reparen los dichos caminos suficientemente, para que "los biandantes y tragineros y gente de pie y de caballo puedan andar y anden libremente y syn peligro alguno por los dichos caminos"1351. Nada conocemos sobre el desarrollo de este asunto, ni si se llevó a cabo.

1350 A. J. R. B./ Actas de Villas y Ciudad. t. II/ Bilbao, 2 abril 1576.

1351 A. J. R. B./ Actas de Villas y Ciudad. t. II/ Bilbao, 22 y 23 agosto 1576. 


\section{E.- EL CAMINO ENTRE SAN PEDRO DE BERAZA Y DARDOZA}

Camino mulatero muy relacionado con el tráfico alavés, iba paralelo y al Este del que desde Orduña pasaba por Saracho, Amurrio y Llodio. Evitaba el paso por la ciudad de Orduña y su aduana, por lo que se originaron gran cantidad de pleitos al obligar los de Orduña a los mulateros que iban por esta vía a pasar por la ciudad, y evitar en lo posible que fuesen por otros caminos. Para el tráfico burgalés tuvo más importancia por su contacto con los valles alaveses que para el acceso a Bilbao. Procedía de Berberana, y por el monte de Santiago sin bajar la gran pared de La Peña, cruzaba el río Délica o Nervión muy cerca de su nacimiento, y bordeando el gran acantilado del Salto del Nervión llegaba a Unzá. Iba por el portillo de Beraza de 660 m entre los altos de San Pedro de Beraza y de Dardoza, Videco y desde el puente de Berganza, donde conectaba con el camino que venía de Altube, seguía junto al río Altube por Astepe, Zubiaur, Andramaría y Bengoechea para entroncar con el camino que venía de Orduña en Areta.

Este camino que se separa del de Orduña a 1,5 km de Berberana, y se vuelve a encontrar con él en Areta, hubiese resultado mucho más adecuado para el tráfico mulatero y la carretería entre Burgos y Bilbao que el de la Peña de Orduña, ya que su trazado era mucho más suave y con un muy pequeño rodeo, se evitaba el tener que superar el abrupto espacio de la Peña. De hecho, se indica en 1499 que "los mulateros e caminantes que vienen asy de tierra de Ayala, como dese dicho condado para la dicha çibdad de Bitoria e villa de Briuiesca, e a otras partes destos nuestros Rreynos e pasan por el puerto de Sant Pedro de Veraça e de Ardoça, por ques el camino mas çierto e se ataja por vayr por alli" 1352 .

En mayo de 1452, y con motivo del pleito entre la ciudad de Orduña y las tierras de Orozco, Llodio, Ayala, Oquendo y Urcabustaiz, por obligar los de Orduña a los arrieros de las mencionadas tierras a pasar por su ciudad cuando se desplazasen con mercaderías a Castilla o desde Castilla, se falla a favor de los vecinos y moradores de dichas tierras, todas pertenecientes al señorío de Pedro López de Ayala, para que puedan comerciar con las villas de Medina de Pomar, Oña, Frías u otros lugares, sin tener obligación de pasar por Orduña. Podrán ir o venir libremente a la ciudad de Vitoria o a la tierra de Álava con cualquier carga que no debiese pagar derechos al Rey, "por Altube e por Dardoça e por San Pedro de Beraça, e por qualquier dellos, e por entre medias dellos, por do quisyeren e por bien tobieren; pero que sy aquende del dicho puerto de San Pedro fazia Vrduna alguno de los tales entrare con las tales cargas e mercadurias que el tal o los tales sean tenidos de yr por la dicha çibdad de Orduna", y si fueren por otra parte o entre Belunza y Orduña, perderán las cargas y acémilas por ir descaminados, aunque si llevaren cosas que deban pagar derechos al Rey y fueren o vinieren camino de Burgos, deberán ir por Orduña y no por otro camino ${ }^{1353}$.

En el pleito entre Orduña y Vitoria, con motivo de que fueron tomadas por los de Orduña a Juan López de Cámiz, vecino de Vitoria, dos acémilas cargadas de hierro labrado cuando venía por Altube, por ir según ellos descaminadas, y tener privilegios reales para que todas las cargas que pasasen por los caminos que son de su ciudad hasta San Pedro

1352 A. G. S./ Registro General del Sello, V-1499, fol. 257/ Madrid, 18 mayo 1499.

1353 A. M. Vitoria/ 4-15-2/ Salvatierra, 22 mayo 1452. 
de Beraza, o desde Zuya, Altube, Urcabustáiz, Ayala y Orozco, pasasen por Orduña, la sentencia arbitral manda en 1467, que los bienes se restituyan a los de Vitoria con todas las costas y daños y que los vecinos de Vitoria y su jurisdicción, podían pasar e ir y venir a Orozco, Llodio, Ayala, Oquendo, Bilbao, Vizcaya o Encartaciones, por los dichos caminos y puertos con sus mercaderías, cargas y bestias cargadas o vacías, sin entrar en Orduña1354.

En 1499 Vitoria y su provincia y hermandad de Álava, dijeron que los vecinos de Orduña llevan por la fuerza a dicha ciudad, a sus mulateros y caminantes que desde la tierra de Ayala y el condado de Vizcaya, pasan por el puerto de San Pedro de Beraza y de Dardoza, "por ques el camino mas çierto e se ataja por vayr por alli", y van a Vitoria y Briviesca y a otras partes del Reino, haciéndoles rodear y tomándoles lo que llevan por ir descaminados. Los Reyes mandan al corregidor o juez de residencia de Vizcaya que intervenga para que puedan los mulateros, recueros y caminantes ir libremente por los dichos caminos y puertos sin tener que rodear por Orduña ${ }^{1355}$.

En 1502 el Diputado Ceneral de Álava, ordena a los alcaldes de hermandad y vecinos de Urcabustaiz y Arrastaria que apresen y lleven a Vitoria a los vecinos de Orduña que impidan el paso por Dardoza a los mulateros y viandantes, y si los alcaldes de hermandad fuesen negligentes en la aplicación de esta medida, deberán pagar los daños a tales mulateros y viandantes ${ }^{1356}$.

El hijo de María Ochoa de Berrio, mulatero de Llodio, fue prendido por los de Orduña, con sus acémilas cargadas de mercaderías que no debían dezmería por ir, según ellos, descaminado por el paso de Dardoza, mandando la Junta General al procurador Ortuño de Murga para su defensa. Y como el procurador no la prosiguió, el mulatero perdió las acémilas que dice que valían más de 10.000 mrs., para lo que en su compensación le libraron 1.500 mrs. en la Junta General de Álava de septiembre de 1504, y como liquidación en Junta de noviembre de 1505 se le libraron 4.000 mrs. más ${ }^{1357}$. En Junta de noviembre también se acordó otorgar poder a Ortuño de Murga para hacer una probanza y presentarla en el pleito sobre el descamino hecho a Juan de Ayala y otros, por los vecinos de Orduña en el camino de Dardoza, ya que la Junta y los viandantes, quedaron perjudicados por negligencia de sus abogados y procuradores ${ }^{1358}$.

A petición del procurador de la hermandad de Urcabustáiz, por los robos y asaltos que en el puerto de Dardoza y en el monte de Altube se hacían, y teniendo información de lo necesario para tener en aquellas partes un alcalde general, en Junta de Álava de noviembre de 1515 se puso por alcalde general del campo en la Provincia para los dichos puertos y montes a Martín de Ondona ${ }^{1359}$.

En Junta de Álava de mayo de 1533 se acordó que los alcaldes de hermandad de Ayala, Arrastaria y Urcabustáiz "fagan llano el camino de Dardoça". Si guardas u otras personas lo

1354 A. M. Vitoria/ 4-15-2/ Vitoria, 1 diciembre 1467.

1355 A. G. S./ Registro General del Sello, V-1499, fol. 257/ Madrid, 18 mayo 1499.

1356 A. J. G. A./ t. I/ Vitoria, 20 septiembre 1502.

1357 A. J. G. A./ t. I/ Vitoria, 15 noviembre 1505.

1358 A. J. G. A./ t. I/ Vitoria, 18 noviembre 1505.

1359 A. J. G. A./ t. I/ Vitoria, 23 noviembre 1515 
impidieren e hicieren fuerzas a los trajinantes, deberán recibir castigo, y si para imponer justicia es necesario, se deberá hacer a costa de la Provincia'1360.

En el Libro de cuentas de la Universidad de los Mercaderes de Burgos, se reflejan pagos realizados en mayo de 1541 , de 15.000 mrs. a García de Acíbar, vecino del valle de Orozco, para el aderezo de los caminos de allí a Bilbao y cuando lo hubiese acabado, se le han de dar otros 15.000 mrs. conforme a una escritura que con él se hizo por cuenta del Consulado. En septiembre de 1542, se pagaron a García de Acíbar los 15.000 mrs. restantes en cumplimiento de los $30.000 \mathrm{mrs}$. que hubo que pagar por el aderezo de los caminos que hizo entre la torre de Orozco y las casas de Berganza, el cual está obligado a sostenerlos por 20 años desde el 1 de diciembre de $1540^{1361}$.

En Junta de Álava de noviembre de 1592 los procuradores de la hermandad de Ayala, dijeron que en el monte de Altube, en el camino real que es paso ordinario para los viandantes, tanto de la hermandad de Ayala como para Orduña, Bilbao y otras partes de las Encartaciones y Señorío de Vizcaya, el puente "está medio cayda y muy maltratada, y ay otros muchos malos passos y atolladeros en la juridiçión de la hermandad de Vrcavuztaiz, de tal manera que los viandantes no pueden por allí passar, si no es con muy gran detrimento de sus perssonas y vestias". Conviene que se haga de inmediato el reparo del puente, caminos y malos pasos, acordándose que se dé mandamiento para que las hermandades en cuyas jurisdicciones están, los reparen con brevedad y se puedan transitar con seguridad ${ }^{1362}$.

\section{F.- LAS JUNTAS GENERALES Y LA REPARACIÓN DE LOS CAMINOS DE VIZCAYA}

Las Juntas de Vizcaya tenían competencias en la construcción y mantenimiento de los caminos del Señorío, y tuvieron por ello una preocupación constante por mantenerlos en un estado adecuado. Una parte importante de los acuerdos obtenidos en dichas Juntas, se refieren o tienen relación con las intervenciones en sus puentes y caminos. Tenemos constancia, siguiendo sus libros de actas, de gran número de actuaciones en este campo desde el año 1565. Hasta esas fechas, hubo algunas resoluciones que se canalizaban a través de la autoridad del corregidor o de los procuradores generales. No obstante como veremos, existe reiteración en las instrucciones dadas a las anteiglesias para que estas reparen los caminos reales de su jurisdicción, lo que prueba que tales directrices no se cumplían de manera adecuada.

Ya en 1507, la Junta Ceneral del Condado y Señorío de Vizcaya, envía una petición al Consejo Real, diciendo que "los caminos por donde se lleva destos... reynos... [al] condado, la prouision e mantenimientos e otras cosas que son menester, estan muy malos, de manera que non se pueden andar nin caminar por ellos a pye ni a cauallo, nin con bestias cargadas nin basias", y son caminos muy transitados. La Reina manda al corregidor del Condado que reciba información, y la envíe ante el

1360 A. J. G. A./ t. II/ Vitoria, 7 mayo 1533.

1361 A. D. B./ R-3/ Burgos, 1539-1549. Libro de caja de la Universidad de Burgos/ Burgos, 1539-1549.

1362 A. J. G. A./ t. IX/ Vitoria, 25 noviembre 1592. 
Consejo para que provea lo que fuere justicia. También manda que todas las penas de las condenas pecuniarias impuestas a cualquier persona, se empleen en el dicho reparo ${ }^{1363}$.

Los procuradores generales de Vizcaya se dirigen a la Reina, diciendo que en el Condado y Tierra Llana hay muy malos caminos y que por ser la tierra pobre y estéril no los han podido reparar, con lo que se causan muchos daños e inconvenientes, lo cual dicen que se podría remediar si se aplicasen para el reparo de tales caminos, las penas pecuniarias de las condenas. El Consejo mandó al corregidor en marzo de 1516, que provea para que los caminos se reparen a costa de los pueblos del Condado y Tierra Llana, pagando cada uno lo que le corresponda. También manda que todas las penas arbitrarias que impusiere las aplique al reparo de esos caminos públicos ${ }^{1364}$.

Las Juntas de Vizcaya mandaron en enero de 1565 que sobre el reparo de los caminos públicos del Señorío, se saque traslado de la Provisión real y merced que el Señorío tiene, y se entregue a Juan Cómez para que la lleve a la corte y pida confirmación. El corregidor mandó a los diputados y regidores que en sus localidades y en las comarcanas, manden que estén suficientemente provistas de piedra y guijarros, y den estos a su vez mandamientos a los síndicos de Vizcaya para que las anteiglesias y sus fieles lo cumplan conforme al Fuero 1365 . En las Juntas de febrero de 1565 el corregidor mandó dar mandamiento para que los concejos, anteiglesias, Villas y Ciudad, Encartaciones y merindad de Durango, quiten en 30 días en los términos concejiles y pasos de particulares, plantíos, árboles, zarzas y otras cosas, que impidiesen circular a los caminantes, arrieros y viandantes, y asimismo los plantíos y árboles que estuvieren en medio de los caminos públicos "hasta estado y medio e un hombre" de manera que no causen molestia y queden libres y exentos sin impedimento alguno, so pena de $3.000 \mathrm{mrs} .{ }^{1366}$. En mayo se acordó que los vecinos y fieles de las anteiglesias, den orden para que se reparen los caminos reales, puentes y pontones, cada uno en su pueblo, conforme a lo que dispone el Fuero del Señorío, y presenten ante el corregidor testimonios de cómo han cumplido1367. En julio se mandó que en cada puerto y camino real, se pongan como guardas dos personas, una que sepa leer y escribir y la otra que le acompañe, cobrando 7 rs. al día, pagados la mitad por las Villas y Ciudad y la otra por el Señorío y Tierra Llana. Mandaron que el diputado Juan de Basurto lleve 1.000 mrs. al día, por 10 días que se ha de ocupar en poner buenas guardas conforme a la orden dada, y librar al diputado para su salario y para las guardas que se han de poner 100 ducados ${ }^{1368}$.

1363 A. M. Durango/ Palencia, 27 abril 1507; HIDALGO de CISNEROS AMESTOY, C.; LARGACHA RUBIO, E.; LORENTE RUIGÓMEZ, A.; MARTÍNEZ LAHIDALGA, A.: "Colección Documental del Archivo Municipal de Durango. Tomo III". 1989: doc. 151; A. G. S. V./ Casa de Juntas de Guernica. Provisiones Reales. Reg. 1- no 12(1)/ Palencia, 27 abril 1507, Guernica, 20 enero 1508; HIDALGO de CISNEROS, C., LARGACHA RUBIO, E., LORENTE RUIGÓMEZ, A. y MARTÍNEZ LAHIDALGA, A.: "Colección Documental del Archivo General del Señorío de Vizcaya". 1986: doc. 69.

1364 A. G. S. V./ Casa de Juntas de Guernica. Provisiones Reales. Reg. 1- no 19/ Madrid, 14 marzo 1516; HIDALGO de CISNEROS AMESTOY, C.; LARGACHA RUBIO, E.; LORENTE RUIGÓMEZ, A.; MARTÍNEZ LAHIDALGA, A.: "Colección Documental del Archivo General del Señorío de Vizcaya". 1986: doc. 92; A. M. Bilbao/ Cajón 4, reg. 3, nº 126-Caja 16, reg. 1, no 37/ Madrid, 14 marzo 1516; ENRÍQUEZ FERNÁNDEZ, J.; HIDALGO de CISNEROS AMESTOY, C. y MARTÍNEZ LAHIDALGA, A.: "Colección Documental del Archivo Histórico de Bilbao (1514-1520)" 2001: doc. 397.

1365 A. J. R. B./ Actas de la Tierra Llana. t. I/ Durango, 17 enero 1565

1366 A. J. R. B./ Actas de la Tierra Llana. t. I/ Bilbao, 16 febrero 1565.

1367 A. J. R. B./ Actas de la Tierra Llana. t. I/ Bilbao, 7 mayo 1565.

1368 A. J. R. B./ Actas de la Tierra Llana. t. I/ Bilbao, 19 julio 1565. 
Como en las Juntas de abril de 1567, los síndicos dijeron que los caminos del Señorío estaban mal reparados, acordaron que el corregidor mande que se reparen, y que los síndicos a costa del Señorío los hagan notificar ${ }^{1369}$. En mayo se trató sobre los caminos de fuera de la jurisdicción y se acordó, en conformidad con la Tierra Llana y Villas, que al que hubiere de ir a la corte, se le dé instrucción para que traiga provisión para el reparo de los caminos de Ayala, Llodio e Ibarbala1370.

En las Juntas de junio de 1575 se dio instrucción a las personas que fueron a la corte en nombre del Señorío, para que conforme al Fuero y Provisión concedida por la reina Juana, las penas de cámara se dedicasen al reparo de los caminos, calzadas, puentes y pontones, ya que no los pueden reparar suficientemente por haber muchos caminos y pasos muy peligrosos. Al ser utilizados por los arrieros que vienen de Castilla con fardeles, mercaderías, pescados, clavazón, herraje y otras cosas, y muchas localidades de fuera del Señorío se aprovechan de los reparos, y como el Señorío no tiene propios, se debía pedir provisión para que esas localidades contribuyesen. Para aplicar las penas de cámara, el corregidor obtendrá información, y le requirieron con la Provisión y ley del Fuero ${ }^{1371}$. Se acordó pedir al Rey que mande que las localidades que utilizan los caminos, puentes y pontones del Señorío, contribuyan en sus reparos, y que se les concedan para ello, las penas legales pertenecientes a su Cámara y fisco real1372.

En las Juntas de enero de 1578 se trató sobre que Bilbao y algunas anteiglesias habían reparado sus caminos reales, y que todo este gasto y esfuerzo no tendría ninguna utilidad si no se evitan los daños que hacen al camino los carreteros con sus carros, ya que siguen deshaciendo las calzadas y caminos, "pudiendo andar fuera dellas por sus caminos acostunbrados y antiguos". Se debe pedir provisión al Consejo Real contra los carreteros que hicieren daño a las calzadas y caminos, y para ello Bilbao dará poder a una persona para resolver estos casos, y no queden obligadas las otras Villas y Ciudad, sino que todo ha de ser a costa de la villa de Bilbao1373.

En las Juntas de marzo de 1579, los procuradores se quejaron al corregidor de que los caminos y puentes estaban muy mal, y de manera que los que van a pie y a caballo y las recuas, no pueden andar por el Señorío cuando hace mal tiempo. El corregidor respondió que, conforme a la Provisión que está ganada sobre los caminos y puentes, proveería justicia1374. En octubre, el Regimiento de Tierra Llana y Villas y Ciudad, dieron memoriales sobre los malos caminos y pasos peligrosos de los caminos reales de su jurisdicción, y acordaron que las justicias ordinarias de las villas y los fieles de las anteiglesias, hagan reparar todos los malos pasos, caminos, puentes y pontones del distrito contenidos en los memoriales, así como los otros pasos y malos caminos que estuvieren en su jurisdicción,

1369 A. J. R. B./ Actas de la Tierra Llana. t. I/ Bilbao, 15 abril 1567.

1370 A. J. R. B./ Actas de la Tierra Llana. t. I/ Bilbao, 10 mayo 1567.

1371 A. J. R. B./ Actas de Villas y Ciudad. t. II/ Guernica, 14 junio 1575.

1372 A. J. R. B./ Actas de Villas y Ciudad. t. II/ Bilbao, 25 junio 1575.

1373 A. J. R. B./ Actas de Villas y Ciudad. t. II/ Bilbao, 29 enero 1578.

1374 A. J. R. B./ Actas de Villas y Ciudad. t. II/ Bilbao, 21 marzo 1579. 
de manera que se pueda pasar por ellos sin peligro así de día como de noche, y lo realicen en 20 días ${ }^{1375}$.

En las Juntas de mayo de 1580 hubo quejas de que muchos caminos reales estaban muy mal reparados con muchos pasos peligrosos, a pesar de que en regimientos pasados se había mandado su arreglo. Se mandó que las villas y anteiglesias del Señorío procediesen a su reparo, so pena de enviar particulares a hacerlos, a costa de los remisos. En especial, desde Galbarriarto hasta Munguía, y alrededor de esta villa, el camino real estaba por arreglar y muy peligroso para los de a pie y de a caballo, y aunque se mandó al procurador de Munguía en el último regimiento su aderezo, no se había hecho. Asimismo, desde la iglesia de Erandio hasta Zangróniz, desde Archanda hasta Elorrieta y desde la Encarnación hasta pasar la carnicería de Begoña en Achuri, dijeron que los pasos y caminos estaban muy malos y que los viandantes peligraban. El Regimiento General mandó que Munguía, Larrabezua y todas las villas, anteiglesias y ciudad del Señorío, los reparen en 20 días y lleven ante el corregidor testimonios de su reparo. Nombran para ello, comisarios ejecutores para que hagan reparar los caminos en la estrada y camino que está en el distrito de Larrabezua, desde el distrito de Lezama hasta acabar el de la anteiglesia de Meacaur de Morga, para lo del término de Galbarriarto, para los caminos desde Archanda hasta Sangroniz y Elorrieta y los caminos desde Bilbao a Bermeo, y en especial en la jurisdicción y términos de Munguía, y el camino desde las Encartaciones hasta pasar la carnicería de Achuri1376.

En las Juntas de febrero de 1590 se mandó que los alcaldes hagan el reparo de los caminos conforme a las Provisiones y mandatos realizados, y vean lo que se ha dejado de cumplir y en qué partes y años, y envíen relación de ello al corregidor para que provea. Asimismo a los que van como comisarios por las anteiglesias para lo de las armas, se les dé comisión para que averigüen lo que han dejado de cumplir los fieles de lo que estaban obligados a hacer en calzadas y empedrados, y en qué lugares es más conveniente hacer el reparo, empedrado y calzadas, para que el corregidor lo provea1377.

En las Juntas de abril de 1591 se trató sobre que el año pasado en Regimiento Ceneral, se había mandado que en cada lugar y anteiglesia, sus fieles y vecinos debían hacer un estadio de calzada o empedrado cada año, en los caminos reales de donde son vecinos. Pero como en muchos pueblos no lo habían hecho por negligencia, fueron nombrados comisarios para averiguar cuánto se había realizado en cada anteiglesia en los últimos 6 años y qué fieles habían sido remisos. Acordaron que el teniente general de Vizcaya cuando fuere a hacer visita general, averigüe lo que han obrado de calzadas y empedrados en los caminos, y donde no estuviere cumplido, lo haga cumplir a costa de los fieles que no lo han ejecutado1378.

En las Juntas de diciembre de 1597 se acordó que, aunque diversas veces se ha mandado a los fieles y vecinos de las anteiglesias del Señorío, que cada uno repare los caminos públicos de sus concejos, no lo habían hecho, y antes de proceder contra ellos, se ordena

1375 A. J. R. B./ Actas de Villas y Ciudad. t. II/ Bilbao, 27 octubre 1579; Actas de la Tierra Llana. t. III/ Bilbao, 27 octubre 1579 .

1376 A. J. R. B./ Actas de Villas y Ciudad. t. II/ Bilbao, 10 mayo 1580.

1377 A. J. R. B./ Actas de la Tierra Llana. t. IV/ Bilbao, 23 febrero 1590.

1378 A. J. R. B./ Actas de la Tierra Llana. t. V/ Bilbao, 29 abril 1591; Actas de Villas y Ciudad. Tomo III/ Bilbao, 29 abril 1591. 
que las anteiglesias reparen cada una en su distrito los caminos públicos para San Juan de junio, apercibiendo que pasado este plazo, se nombrarán personas para que hagan esos caminos a costa de los remisos, sin excepción de persona alguna, aunque algunos se quieran excusar diciendo ser vecinos de alguna villa. Y para todo ello se da comisión plena a los dichos fieles, cada uno en su jurisdicción ${ }^{1379}$.

En las Juntas de abril de 1600 se dijo que en todo el Señorío, los caminos reales estaban muy mal reparados, de manera que por ellos no se podía andar a pie ni a caballo sin gran riesgo. Se mandó que para septiembre, los alcaldes de las Villas y Ciudad y los fieles y vecinos de las anteiglesias, reparen los caminos y calzadas conforme al Fuero y lo decretado por el Señorío, y se libren para ello los mandamientos necesarios ${ }^{1380}$.

Por otra parte, las Juntas de Vizcaya rechazaban sistemáticamente los repartimientos que se les hacían para puentes de otra jurisdicción, alegando que estaban exentos por tener fueros y privilegios, y que harto tenían con mantener los suyos. No obstante, en el siglo XVI le fueron repartidos varios puentes de la provincia de Burgos:

- En 1571 se hicieron repartimientos y contribuciones al señorío de Vizcaya para los reparos de puentes de Castilla, en especial los de Trespaderne, Oña, Briviesca y Lerma, y se acuerda que se vea el estado en que está lo solicitado por el Señorío, para que este y sus vecinos queden libres de estos repartimientos y contribuciones ${ }^{1381}$.

- En las Juntas de Vizcaya de septiembre de 1574 se trató sobre que en los últimos años, mediante provisiones reales dadas a petición de algunos pueblos, se les ha repartido por el alcalde mayor de las merindades de Castilla Vieja para el primer tercio del puente de Trespaderne, 168.000 mrs. al Señorío y a Bilbao 68.00o; para el primer y segundo tercios del puente de Lerma 150 ds., más ciertos salarios y costas, y para los puentes de Pancorbo y Burgos, 16.000 mrs.; y para cobrarlo, ha venido un ejecutor con comisión del alcalde mayor del Adelantamiento del partido de Burgos. Visto que estos repartimientos son injustos, según dicen, porque el Señorío no tiene aprovechamiento de los puentes, y si lo tuviera, tiene que hacer en sus puentes más reparos que ninguna otra provincia y para poderlos hacer aún en parte, no había dineros suficientes por no tener propios, sino solamente lo que recauda haciendo repartimientos, ordenaron que se pida al Rey que mande suspender lo procedido contra el Señorío1382.

- En las Juntas de Vizcaya de junio de 1575 se trató sobre el remedio de los repartimientos que se han hecho al Señorío para el reparo y reedificación de los puentes de Lerma, Briviesca, Trespaderne, Oña y de otras partes, por ser contra el Fuero y privilegios particulares que el Señorío tiene. Gracián de Menceta entregó ciertas cédulas y peticiones dadas por parte del Señorío ante el Rey y su Consejo Real, y en la Audiencia de Valladolid. Sobre las provisiones y cédulas reales libradas a petición de Briviesca, Lerma y ciertos lugares de las Merindades de Castilla Vieja, para que el Señorío contribuya al reparo de los puentes de Trespaderne, Briviesca y Lerma, estando el Señorío libre de semejantes repartimien-

1379 A. J. R. B./ Actas de la Tierra Llana. t. VI/ Bilbao, 3 diciembre 1597.

1380 A. J. R. B./ Actas de la Tierra Llana. t. VI/ Bermeo, 14 abril 1600.

1381 A. J. R. B./ Actas de la Tierra Llana. t. II/ Bilbao, 25 junio 1571.

1382 A. J. R. B./ Actas de la Tierra Llana. t. II/ Bermeo, 28 septiembre 1574. 
tos y sin tener aprovechamiento, ha sido apremiado por no haber hecho las diligencias debidas. Gracián de Menceta y Martín Ruiz de Muncharaz, pidieron al Consejo Real que se mandase remediar, y como también la provincia de Guipúzcoa pidió y litigó lo mismo, y aun no siendo tan privilegiada como el Señorío, salió con ejecutoria para no contribuir en semejantes repartimientos, mandaron que este asunto se lleve adelante y se hagan las diligencias debidas ${ }^{1383}$. En las Juntas de noviembre se decretó diversas veces, y se mandó a los síndicos, que se hiciesen las diligencias necesarias para que la Encartación y la merindad de Durango contribuyesen con la Tierra Llana, conforme a la costumbre antigua, en los gastos que se han hecho para lo de los puentes de Trespaderne, Lerma y Briviesca, debiendo pagar la Encartación 1/3 y la Merindad 1/6 hasta ahora, pero como no han contribuido en cosa alguna, se acordó de nuevo que se haga la debida diligencia y que el corregidor provea como mejor convenga, pues de derecho están obligados a ello los de la Encartación y la Merindad. El corregidor irá a obligar a que paguen la parte que les cabe $e^{1384}$.

- En las Juntas de Vizcaya de abril de 1576 se mandó solicitar que se quite la nueva imposición que se había puesto al Señorío hacía 4 o 5 años, en virtud de ciertas Cartas reales para el repartimiento de los puentes de Trespaderne, Lerma, Briviesca y Oña, en especial de un año a esta parte. Los jueces de comisión habían cobrado al Señorío más de 1.500 ds., por lo que se ganó Provisión real de 26 de febrero de 1576 , que decía que nunca se le había mandado pagar semejantes repartimientos fuera de su distrito y jurisdicción, por ser libre de ellos por fuero y por uso y costumbre inmemorial, y porque en el Señorío había 11 puertos de mar, más de 100 caminos reales, más de 200 puentes y muchos pontones en su mayoría de tabla y madera por no haber posibilidad de hacerlos de cal y canto, porque su distrito tenía 19 o 20 leguas de largo y 15 o más de ancho, y además tenía muchas y largas calzadas para llevar mercaderías, mantenimientos y provisiones a Castilla. Para que "no çesase el trato e comerçio destos nuestros reynos de Castilla, como en efeto çesaria a no hazer y reparar las dichas calzadas, puentes e pontones del dicho Señorio", repartían entre sí, por no tener propios cada año, más de 6.000 ds., porque lo que un año se hacía y reparaba, se perdía y gastaba para el siguiente por las muchas aguas y crecidas que sufría. Como habían gastado en los reparos grandes cantidades, y aunque de ello se recibía gran beneficio a causa del trato y comercio, nunca se había ayudado al Señorío ni él lo había pedido, pero las villas de Lerma, Oña, Briviesca y Trespaderne, sí lo habían pedido y sin llamar al Señorío, habían enviado juez de comisión para el cobro de los repartimientos, que habían ejecutado llevando presos a los bolseros a pesar de su Fuero, y antes de que el Señorío y su Junta Ceneral lo supiese, los bolseros buscaron con qué pagar los repartimientos a pesar de que habían pedido que se revocasen las provisiones, y que no se les repartiesen maravedís algunos para las obras de los puentes de fuera. Y como por las mismas causas, a Guipúzcoa se le habían revocado todos los repartimientos que se le habían hecho, y no se hacía lo mismo con el Señorío aunque lo tenía pedido, fue suplicado que se le concediese cédula y Provisión, para que en adelante, no se le repartiese cantidad alguna para puentes de fuera del Señorío. Se dio una carta mandando que al Señorío

1383 A. J. R. B./ Actas de la Tierra Llana. t. II/ Guernica, 14 junio 1575

1384 A. J. R. B./ Actas de la Tierra Llana. t. II/ Bilbao, 9 noviembre 1575. 
ni a su distrito, se le reparta nada para el reparo y aderezo de puentes ni caminos, por ningún concejo ni justicia de fuera del Señorío 1385 .

- En las Juntas de Vizcaya de junio de 1589 el procurador de Orduña, dijo que se les han repartido muchos maravedís, para ciertos edificios y reparos de puentes de fuera del Señorío contra las provisiones que este tiene, pidiendo que a Orduña se le ayude con alguna cantidad por lo que ha pagado, y que se pida al Consejo sobrecarta de las dichas provisiones, para que se puedan defender sin más pleitos y costas ${ }^{1386}$. 


\section{5.- CAMINOS DE BURGOS A PORTUGALETE}

El acceso más utilizado y cómodo para llegar a Portugalete, procedía de las dos vías empleadas para ir a Bilbao. Según un viajero de 1660, "los que quieren ir de Portugalete a Burgos normalmente toman el camino de Bilbao, desde donde se anda siempre por camino transitado por toda suerte de pasajeros, y mas comodo de alojamientos"1387. Fue un camino adaptado para el uso de carros como se indica en 1547 cuando se pagaron 4.080 mrs. "para yr a Sodupe e Amurrio, azer pasar los carros con sacas para Deua e Portogalete"1388. Naturalmente los carros circulaban por un camino junto a la costa pero no podían ser utilizados desde Castilla.

La vía de Valmaseda era la más habitual y muy cerca de Bilbao se desviaba hacia la izquierda pasando el puente de Castrejana, y descendía por la orilla izquierda del Cadagua

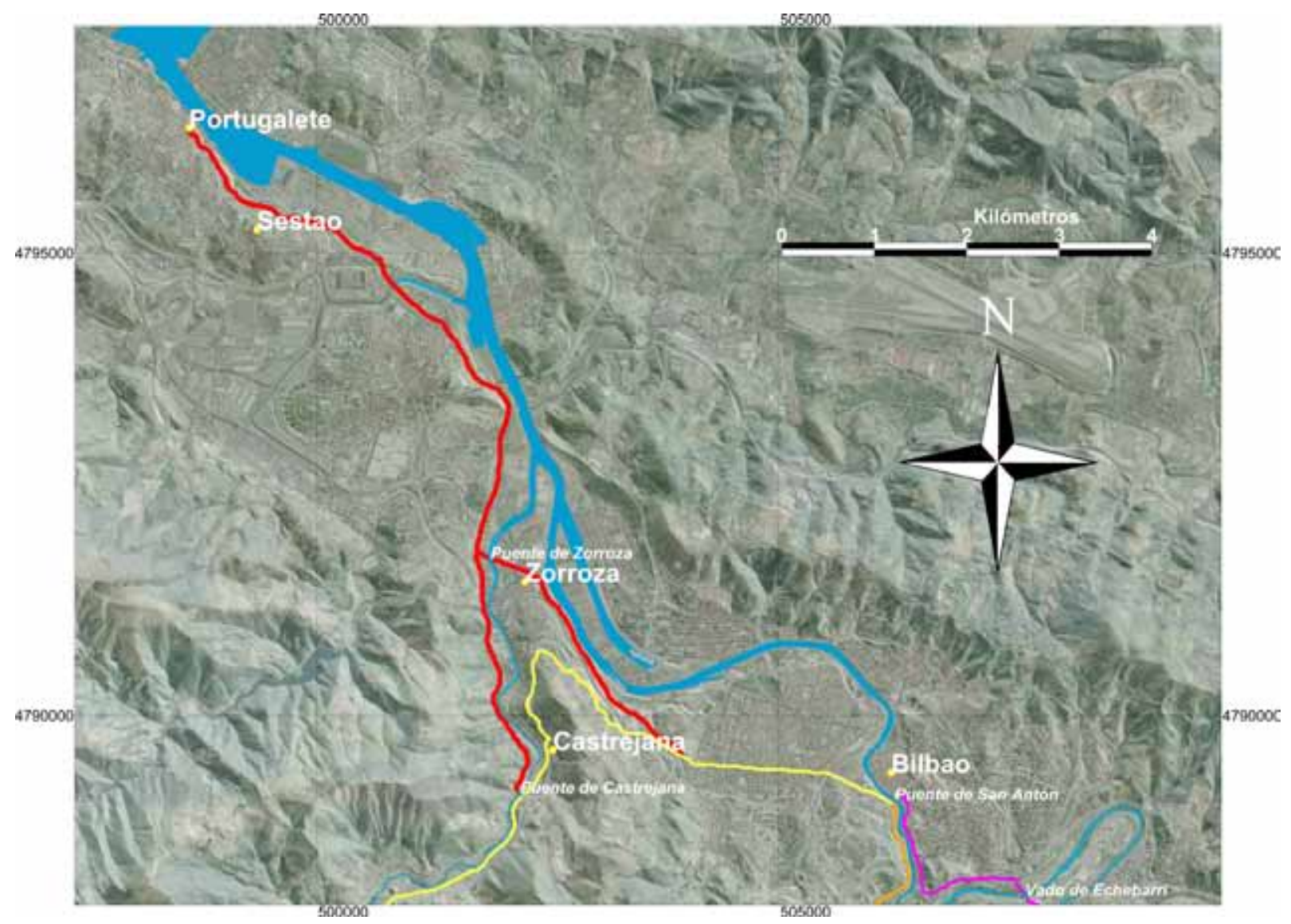

Detalle del camino a Portugalete donde los dos caminos (el de Valmaseda y el de Orduña) se juntan en el puente de Zorroza.

1387 Archivo Secreto Vaticano/ Archivo Consistorial. Acta Congregationis Consistorialis, vol. I, fols. 499-534/ 1669; CASADO SOTO, J. L.: 2000: 307

1388 A. D. B./ R-3/ Libro de caja de la Universidad de Burgos/ Burgos, 1539-1549. "Libro de quentas de la Vnibersidad comenzado en dos de otubre de I.DXXXIX seyendo nonbrados por prior y consules los señores Juan de Castro rregidor. E Yñigo del Espital e Françisco de Maluenda donde se asentaran los devdores y acredores que tocan a la Vnibersidad de que fue thesorero de la dicha Unibersidad Andres Nuñez de Aragon". 
donde se encontraba con el camino que venía de Orduña en Burceña. Desde aquí, por la orilla izquierda de la ría cruzaba terrenos de Luchana y Baracaldo, pasaba el río Galindo y por Sestao llegaba a Portugalete.

La segunda era la vía de Orduña, que desde Ollargan, se dirigía por la orilla izquierda de la ría hasta encontrar el puente de San Antón, y sin cruzarlo, seguía por dicha orilla izquierda por Basurto y Olaveaga, hasta encontrarse en Burceña tras pasar el puente del Cadagua con el camino de Valmaseda mencionado. Pero desde Orduña fue mucho más utilizada para ir a Portugalete, la vía que desde dicha villa iba por Saracho, Amurrio, Respaldiza, Menagaray, Llanteno, Inorza, Venta de Ureta, Artecona, Las Llanas, Allende, El Pontón, Molinar (Gordejuela), Zubieta y Sodupe, donde conectaba con el camino que venía de Valmaseda.

Otra alternativa desde Orduña, nos la apunta el Consulado de Burgos en sus intervenciones del siglo XVI. Iría por Saracho, Amurrio y Luyando donde se apartaba de este camino que iba a Llodio, para ir por el camino de la Venta a conectar en Oquendo con el que por Jandiola, Zaldu, Azcaray y Padura llegaba a Sodupe.

Los caminos, por tanto, eran los mismos que se utilizaban para llegar a Bilbao, aunque no entraban en esta villa. Encontramos alusiones en las cuentas del Consulado, sobre los gastos ocasionados en la construcción y mejora de caminos, donde se menciona un camino como el "camino de Luyando a Sodupe para Portugalete", o "los caminos de Portogalete para que bayan los carros y carretas con sacas que se adereçaron desde Amurrio fasta Sudupe y Portugalete, desde la Puente de Mariquexana hasta la puente de Sudupe", o "los caminos de Portogalete desde Amurrio a Sodupe y a Portogalete". Este camino que pretendía acondicionar el Consulado burgalés era, al parecer, el ya mencionado que, desde Orduña, iba por Amurrio, Oquendo y Zaldu hasta Sodupe.

Doña María, señora de Vizcaya, otorga en 1322 a todos los de Portugalete el Fuero de Logroño. Con la fundación de Portugalete en la boca de la ría, puerto que ya se cita en 1300 en la carta de fundación de Bilbao, se completaba el plan de desarrollo de la ría, que comenzó con la mencionada fundación de Bilbao. La ría se convertirá a partir de ahora, en el espacio central de la actividad económica del Señorío y de los puertos del norte peninsular. La carta-puebla de 1322, manda que en "los caminos..., nonbradamente de Ordunna, e de Arçeniega, $e$ de Valmaseda, e de Castro, e de Bilbao, e de Bermeo, e de Plasençia, fasta la dicha villa de Portogalete", y que "de la puente de Llantada e de la haya de Cubilera, fasta la dicha villa de Portogalete, que non aya açoque nin carniçeria nin medida ninguna para reuender". Les da como término entre otras, las tierras y montes "de la mar desde rio Lonuar, donde se parte la tierra del rey e de Menacos fasta la Luchana, e los pescadores que moraren en este termino que vengan con el pescado a la dicha villa de Portogalete,...". Manda que en sus términos, "non aya otro ninguno carga nin descarga de pan, nin de sal, nin de otra cosa ninguna, saluo en la dicha villa de Portogalete", y que sus vecinos no den en toda su tierra enmienda, oturas, peaje, recuaje, etc. y que sean francos para que puedan comprar todo lo que quisieren ${ }^{1389}$. A pesar de las condiciones favorables que se manifiestan, Portugalete no tuvo el desarrollo pretendido por tener la competencia de la cercana Bilbao, más dinámica y mejor situada para controlar el tráfico de la ría. De la rivalidad y pleitos que se provocaron entre ambas villas, Bilbao salió claramente vencedora.

1389 Salón de plenos del Ayuntamiento de Portugalete/ Segovia, 21 agosto 1432; HIDALGO de CISNEROS AMESTOY, C.; LARGACHA RUBIO, E.; LORENTE RUIGÓMEZ, A.; MARTÍNEZ LAHIDALGA, A.: "Colección Documental del Archivo Municipal de Portugalete". 1987: 4, doc. 1; A. H. F. B./ Privilegios Reales. Registro 1, no 1. 
Cuando en junio de 1300, Diego López de Haro, hace nueva población en Bilbao, otorga libertad de tránsito por la ría para las embarcaciones que van o vienen a su puerto: "que en el nuestro puerto de Portogalete nin en la barra nin en toda la canal, que non aya peçio ninguno de naue nin de baxel que uengan o salan del lugar cargados con sus mercaduras, e mostrando recabdo que uienen a esta villa de Biluao o van della e pagando las costumbres e los derechos del sennor", y que no sean retenidos ni embargados por razón de pecio ${ }^{1390}$.

El Prior y cónsules de la Cofradía de los Mercaderes de Burgos, dijeron al Consejo Real, que Ochoa Ortiz de Montellano y Pedro y Martín de Bilbao, vecinos de Portugalete, habían puesto hacía unos cuatro meses nuevo tributo sin licencia real, sobre todas las mercaderías que pasaban por Portugalete, cobrando $100 \mathrm{mrs}$. por cada fardel de ropa, hasta pagar $32.000 \mathrm{mrs}$. Por ser el tributo contra derecho, la Reina manda en marzo de 1476 que nadie tome ningún nuevo derecho sin tener cartas ni privilegios para ello, y "porque hizieron grand osadia e atreuimiento", se dé a Montellano y a Pedro y Martín de Bilbao la pena adecuada, y si en adelante nuevamente lo pusieren, si el término fuere suyo que sea para el Rey, y si lo tomaren en término ajeno, que devuelvan todo lo que tomaron con el $7 \%$ y pechen 6.000 mrs. ${ }^{1391}$. En mayo, la Chancillería prohíbe a petición de la villa de Bilbao, a Juan y Lope de Salazar y otros vecinos de Portugalete el cobro del portazgo a los vecinos de Bilbao ${ }^{1392}$.

Ochoa de Salazar preboste de Portugalete, dijo a los Reyes que la villa, tanto por privilegios, como por costumbre guardada de tiempo inmemorial, compra, vende y trata sus mercaderías y haciendas, tanto en Bilbao como en todo el Condado, comprando libremente pan, cebada, pescado y otras provisiones y mercaderías para su abastecimiento, y que recientemente el concejo de Bilbao intenta impedir a los de Portugalete la compra de dichas provisiones en su villa, por cuya licencia les llevan dineros, y si no la tienen se las toman por ir descaminadas, lo cual es contra derecho y costumbre del Condado y privilegios de Portugalete. Los Reyes mandan en marzo de 1489 al concejo de Bilbao, que dejen a los de Portugalete contratar en su villa y comprar trigo, cebada y todo lo que quisieren, sin demandar para ello licencia ni tomarlos por descaminados, como lo pueden hacer libremente los de Bilbao en Portugalete ${ }^{1393}$.

Juan López de Arrieta procurador de Portugalete, dijo al Consejo en 1500 que las Universidades de Burgos y de Bilbao, se habían confederado y habían hecho ciertas ligas y monipodios que "los llamáis e nombráis ordenanzas", las cuales dice que van en perjuicio de sus partes y del condado de Vizcaya, ya que ordenaban que los cónsules que se ponen en Flandes y en Londres en nombre de toda la nación de España, solo pueden ser de Burgos y de Bilbao y

1390 A. M. Bilbao/ Pergaminos, 1 (actualmente se halla en la casa consistorial)/Valladolid, 15 junio 1300; ENRÍQUEZ FERNÁNDEZ, J.; HIDALGO de CISNEROS AMESTOY, C. y MARTÍNEZ LAHIDALGA, A.: "Colección documental del Archivo Histórico de Bilbao (1300-1473)". 1999: doc. 1.

1391 A. G. S./ Registro General del Sello, III-1476, fol. 138/ Tordesillas, 16 marzo 1476; ENRÍQUEZ FERNÁNDEZ, J.; HIDALGO de CISNEROS AMESTOY, C. y MARTÍNEZ LAHIDALGA, A.: "Archivo General de Simancas. Registro General del Sello. Vizcaya (1475-1477)". 2002: doc. 33; GONZÁLEZ, T.:1829: 56-59: t. I. doc. X.

1392 A. M. Bilbao/ Cajón 37, reg. 6/Valladolid, 6 mayo 1476; ENRÍQUUZZ FERNÁNDEZ, J.; HIDALGO de CISNEROS AMESTOY, C. y MARTÍNEZ LAHIDALGA, A.: "Colección Documental del Archivo Histórico de Bilbao (1473-1500)". 1999: doc. 104

1393 A. M. Portugalete/ Sección C- Caja 1, № 5, fol. 1v.-3r./ Medina del Campo, 5 marzo 1489; HIDALGO de CISNEROS AMESTOY, C.; LARGACHA RUBIO, E.; LORENTE RUIGÓMEZ, A.; MARTÍNEZ LAHIDALGA, A.: 1987: doc. 10. 
de sus mercaderes y no de otro lugar, habiéndose usado lo contrario de tiempo inmemorial, además de que las averías de todas las mercaderías que se hubieren de cargar en todas las villas y lugares de la costa, se deben contar en Bilbao y no en otra parte, aunque hasta ese momento lo habían hecho en Portugalete, y que todas las mercaderías de los de Burgos debían ir a Bilbao y no a Portugalete. Además habían hecho ordenanza para que no fletasen ni diesen cargas a ninguna nao de Portugalete ni de otras partes hasta que las naos de Bilbao fuesen fletadas, y han puesto muchas sisas y tributos en Bilbao. El Consejo acordó en junio de 1500, mandar que ambas Universidades envíen dichas ordenanzas, y las cartas y sobrecartas que se han dado acerca de lo dicho, y se provea lo que fuere justicia1394.

En julio, ante el fiel del concejo de Bilbao, pareció el procurador de Portugalete, y dijo que los requería como vecinos de Bilbao, para que cumpliesen lo contenido en la Carta real. El fiel, regidores y oficiales de Bilbao, dijeron que todo lo relatado por Portugalete no era cierto, ya que Bilbao "non auia fecho tales monipodios e ligas, con los dichos hunibersydad e pryor e consoles e mercaderos de la dicha çibdad de Burgos", ni los de Burgos con Bilbao, ni hecho confederación no debida, y que si entre ellos había algún concierto, este era lícito, conveniente y provechoso no solo a las dichas partes sino a todo el Reino, y no por lo que Portugalete decía, por lo que esta villa y el que en su nombre tal relación había hecho "meresçian ser asperamente castigados"1395.

El concejo y regimiento de Bilbao, encargó en 1509 a Juan de Zamudio, "que tenga el cargo en la ribera e ryo, quien e quales mulateros descargan sacas de lanas o pelleterias o otras mercaderias en Çorroça o en Olabeaga o en Çubileta para Portogalete, e asy vien fardeles de mercaderias que traen los bateles de Portogalete e descargan en los sobredichos lugares para mulateros, para los sacar para Castilla, e que los tomen por descaminados", siendo la tercia parte de ello para el acusador, y el resto será para Juan de Zamudio por sus trabajos ${ }^{1396}$.

Rodrigo de Ibateo en nombre de Bilbao, dijo al Rey que el concejo y vecinos de Portugalete, sin licencia y facultad real, llevan muchos mrs. por vía de imposición y sisa que echan en los mantenimientos y otras cosas que se compran y se venden en la dicha villa, recibiendo los vecinos de Bilbao y otras partes mucho daño, y que por haberlo hecho sin licencia, han incurrido en graves penas. El Consejo acordó en junio de 1539, mandar al corregidor que vea lo susodicho, y oídas las partes a quien toca, sin dar lugar a dilaciones de malicia, haga lo que hallare por justicia1397.

La Universidad de los Mercaderes de Burgos, realizó gastos para el acondicionamiento del camino que denominan “de Portugalete”. Así en marzo de 1547, se registran 10.104 mrs., que sobran en una cuenta de las costas del 3\% y que se reservaron para "el adereço de los caminos de Portogalete". En mayo se pagan 69.692 mrs. que gastó Francisco de Porres "en adereçar los caminos, por yr los carros y mulateros dende la puente de Mari Quexana asta la puente de Sudupe

1394 A. M. Portugalete/ Sección C- Caja 2- n.ำ7/ Valladolid, 27junio 1500; HIDALGO de CISNEROS AMESTOY, C.; LARGACHA RUBIO, E.; LORENTE RUIGÓMEZ, A.; MARTÍNEZ LAHIDALGA, A.: 1987: doc. 30.

1395 A. M. Portugalete/ Sección C- Caja 2- n.ำ 7. fol. 1v.- 2r./ Bilbao, 14 y 17 julio 1500; HIDALGO de CISNEROS AMESTOY, C.; LARGACHA RUBIO, E.; LORENTE RUIGÓMEZ, A.; MARTIINEZ LAHIDALGA, A.: 1991: doc. 31.

1396 A. M. Bilbao/ Cajón 16, reg. 2, no 2 (fol. 1r- 87v; 89r; 88r; 89v- 91v; 96r- 96v; 92r- 94v; 97r- 108v)/ Bilbao, 2 enero 1509- 1 enero 1510; ENRÍQUEZ FERNÁNDEZ, J.; HIDALGO de CISNEROS AMESTOY, C.; LORENTE RUIGÓMEZ, A.; MARTÍNEZ LAHIDALGA, A.:"Libro de Acuerdos y Decretos Municipales de la Villa de Bilbao (1509 y 1515)". 1995: doc. 1.

1397 A. G. S./ Registro General del Sello, VI-1539/ Toledo, 18 junio 1539; GONZÁLEZ, T.: 1829: 105-106: t. II. doc. CXVII. 
para llebar las sacas a Portogalete". En junio Luis de Cumiel gastó 5.189 mrs. en ir con Pedro del Carro maestro de caminos "que le traxo para bisitar los caminos de Portogalete a la Oca", y por su salario de 11 días que se ocupó de ida y vuelta y hablar con los de Portugalete sobre el concierto con la Universidad. También se pagaron $3.400 \mathrm{mrs}$. para, entre otras cosas, ir a ver los caminos de Burgos a Portugalete que se hacen para el tránsito de carros y mulateros. En julio se enviaron 13.600 mrs. con Juan de Basori, correo de Portugalete, para pagar los caminos que se hacen por la Universidad. Sebastián de la Moneda, vecino de Burgos, debe en septiembre, $4.080 \mathrm{mrs}$. "para yr a negocios de la unibersidad para yr a Sodupe e Amurrio, azer pasar los carros con sacas para Deua e Portogalete". En octubre registran el pago de $34.535 \mathrm{mrs}$. a Juan Alonso del Castillo "para azer los caminos de Sodupe a Portogalete" de que ha de dar cuenta. Los gastos que Sebastián del Amo hizo en "allanar los caminos de Portogalete desde Amurrio a Sodupe y a Portogalete", alcanzan en 26 de octubre, 11.240 mrs. ${ }^{1398}$.

El registro de los gastos prosigue y en febrero de 1548, Antonio Pérez ha gastado 16.000 mrs. en el camino de Portugalete y en mayo se han gastado $70.828 \mathrm{mrs}$. "en allanar los caminos de Portogalete, para que bayan los carros y carretas con sacas que se adereçaron desde Amurrio fasta Sudupe y Portugalete desde la Puente de Mariquexana hasta la puente de Sudupe". También se gastan 26.875 mrs: 10.875 mrs. para pagar a Francisco de Luyando "el adreço del camino de Luyando a Sodupe para Portugalete e de çierta heredad que compro" de que hay escritura, y 16.00o mrs. que gastó Antonio Pérez en varias partidas en el aderezo de dichos caminos ${ }^{1399}$. En abril de 1553, se pagan $1.298 \mathrm{mrs}$. a Trezanos: $187 \mathrm{mrs}$. de portes de cartas después de que dio la cuenta a Diego de los Ríos, 170 que se dio a "los mulateros quelleuaron el trigo a Portogalete", 51 a los que midieron el trigo y 890 que se perdieron en 10 cargas de trigo que compró y volvió a vender. Diego de los Ríos debe en enero de 1557, 14.618 mrs cobrados de las averías para ir al aderezo de los caminos de Portugalete $^{1400}$. En junio, se deben $27.389 \mathrm{mrs}$. por lo que se gastó "en yr a uisitar los caminos nuebos que se pretenden hazer de aquy a Laredo y Portugalete" y por la traza que daba Lorenzo de Adonza para lo que fueron el dicho Adonza, el cantero Vallejo y Diego de los Ríos, por los días que estuvieron allí, más 11.988 mrs. que se dieron a los maestros por su trabajo1401

La villa de Bilbao se dirigió a Carlos I en 1553 para hacer un camino carretero por el puerto de Coldecho en Orduña, porque "era necesario que se hiziese camino de carros hasta el puerto de la villa de Portugalete, y que el dicho camino lo avian visto maestros y dado su parecer, que dezian que se puede hacer bueno y perpetuo y sin pasar rios y por donde ay mas herrerias de hierro y azero", para abaratar y facilitar el transporte del hierro y las mercaderías. El parecer de los maestros indicaba que se puede hacer un buen camino por donde había más ferrerías, para que en el retorno de los mantenimientos y vinos, se puedan llevar más de 28.000 quintales del hierro y 6.00o del acero, que según ellos se labran en ese camino a Portugalete, puerto de donde se puede traer todo el hierro necesario por estar en mar abierto y de donde salen más de 500.00o quintales de vena para Vizcaya, Guipúzcoa y Galicia, y en cuyo retorno "se traera al dicho puerto mucho hierro y pescado, e que el dicho camino se podria hacer con 8.000 ducados desde Losa hasta

1398 A. D. B./ R-3/ Burgos, 1539-1549.

1399 A. D. B./ R-3/ Burgos, 1539-1549.

1400 A. D. B./ R-12/ Burgos, 1549-1557: 365i.

1401 A. D. B./ R-14/ Libro de caja de la Universidad de Burgos/ Burgos, 1557-1567. 
el puerto de la dicha villa de Portogalete, que dicen que son 10 leguas de montañas hasta donde andan carros de Burgos y Castilla". El Rey manda al corregidor que vea la necesidad de hacer el camino carretero desde Losa al puerto de Portugalete, y se informe con oficiales sobre si convenía que se hiciese por la parte que Ochoa de Salazar tenía trazada o por otra más conveniente, y dicha información la envíe al Consejo para que provea lo que convenga.

También Diego Hurtado de Mendoza regidor de Orduña, pidió que se ordenase que esos caminos se hiciesen por la Peña de Orduña, y en el Consejo se mandó "que el dicho camino se haga para que puedan pasar las dichas carretas allanando la peña de Orduña hasta Vergança y Vilvao y se allane otro camino de carretas a Portugalete", tomándose información de por donde se hará mejor y con menos coste, y de como se pagará lo que costare cada camino, quiénes reciben aprovechamiento y si será mejor que el coste se eche por sisa, repartimiento o que paguen algún portazgo los que lo utilicen. Esta información con el parecer del corregidor, se enviará al Consejo para que provea lo que sea justicia ${ }^{1402}$. Carlos I dio una Provisión en 17 mayo de 1553, concediendo licencia a Orduña para abrir la Peña de Goldecho, a fin de que por ella se pudiere transitar "desde la villa de Portugalete a las partes de Castilla"1403. Comenzadas las obras, las provincias de Álava y Cuipúzcoa y reino de Navarra, se opusieron por pensar que el camino carretil proyectado, causaría graves perjuicios a sus pueblos y comercio. Los alaveses destruían de noche lo que se realizaba de día por lo que el Señorío debía poner gente armada para impedirlo1404, y Navarra y Guipúzcoa mantenían continuos pleitos para que la obra no se llevara a cabo. Tras estos conflictos y reclamaciones, Carlos I, creyó oportuno rebajar las tensiones provocadas, y ordenó ese mismo año, la suspensión de los trabajos ${ }^{1405}$.

Pellegrino Zuyer sale de Burgos a mediados de octubre de 1660 y se dirige por Pancorbo a Orduña. Anota que cuando salió de la ciudad, entró en las Montañas que llaman Bajas, y que allí había un cruce con el camino de Bilbao a mano derecha y el de la izquierda iba directamente a Portugalete. Después menciona Amurrio, Sopeña, Llanteno, Saracho y el valle de Oquendo, y "tras haber caminado dos leguas por este valle, se encuentra la aldea de Gordejuela, situada en el valle de Salcedo". Pasa por Sodupe, puente de Castrejana, barca de Baracaldo y llega a Portugalete ${ }^{1406}$. Parece ser que el camino que emplea para ir desde Orduña, era el ya mencionado por Saracho, Amurrio, Respaldiza, Menagaray, Llanteno, Inorza, Venta de Ureta, Artecona, Las Llanas, Allende, El Pontón, Molinar (Cordejuela), Zubieta y Sodupe, y que entre Amurrio y Sodupe caminó “durante sieteleguas entre montañas, siempre por valles de pesimos caminos, andando continuamente sobre rocas y calzadas de guijarros, y por senderos no muy practicados ya que no son pasos hacia lugares grandes".

1402 A. H. F. B./ Munic. Orduña, caja ํำ19, carp. 5/ Madrid, 17 mayo 1553.

1403 A. H. F. B./ Munic. Orduña, caja nº 19, carp. 4/ Madrid, 17 mayo 1553.

1404 LARREA SAGARMINAGA, Maㅗ A.: 1974: 115.

1405 LABAYRU y GOICOECHEA, E. J.: 1900: t. IV, 285-286.

1406 Archivo Secreto Vaticano/ Archivo Consistorial. Acta Congregationis Consistorialis, vol. I, fols. 499-534/ 1669; CASADO SOTO, J. L.: 2000: 306-309. "Una vez parti de la ciudad de Orduña, entre inmediatamente en Las Montañas que Ilaman Bajas, y valles por los que se pasa, dejando el camino de Bilbao a mano derecha y tomando el de la mano izquierda, directamente a Portugalete; y camine durante siete leguas entre montañas, siempre por valles de pesimos caminos, andando continuamente sobre rocas y calzadas de guijarros, y por senderos no muy practicados, ya que no son pasos hacia lugares grandes, pues los que quieren ir de Portugalete a Burgos normalmente toman el camino de Bilbao, desde donde se anda siempre por camino transitado por toda suerte de pasajeros, y mas comodo de alojamientos, de los que apenas encontramos en dichos valles y montañas; y si no hubiera casas cada cuarto de legua, se perderia el camino a cada paso". 


\section{CAPÍTULO III}

\section{CULTURA Y PRÁCTICA CAMINERA}

\section{1.- ENTRETENIMIENTO DE LAS VİAS DE COMUNICACIÓN}

\section{A.- ADVERSIDADES SOBREVENIDAS}

a.- Riadas y avenidas

b.- Desmanes bélicos

c.- Las lluvias y el barro

d.- El invierno y la nieve

B.- MANTENIMIENTOS Y REPARACIONES

a.- Las circunstancias especiales

b.- Formas habituales de financiación

C.- MODALIDADES DE CONSTRUCCIŌN Y/O DE REPARACIÓN

a.- La prestación personal

b.- La adjudicación pública

c.- Los especialistas

\section{2.- ACTIVIDADES CAMINERAS}

\section{A.- LA PRÁCTICA COMERCIAL}

a.- Ferias y mercados

b.- Peajes

c.- Aduanas generales. Los diezmos de la mar

d.- La poderosa casa de los Velasco

\section{B.- LAS MERCADERİAS}

a.- El comercio internacional

b.- El comercio interior

\section{C.- TRANSPORTE DE MERCADERİAS}

a.- De corto y largo recorrido

b.- La arriería

c.- La arriería en las tierras del norte

d.- El transporte rodado. La carretería

e.- Circulación de carros por

los caminos de Santander

D.- LOS DESPLAZAMIENTOS. LOS VIAJES
a.- A pie
b.- A caballo o mulo
c.- En vehículo
d.- Los desplazamientos reales
e.- El alojamiento

E.- EL CORREO Y LAS POSTAS
a.- El Correo mayor
b.- El correo en Burgos
c.- El Consulado y el correo
d.- Las postas. Sus itinerarios

\section{F.- LA SEGURIDAD DE LOS CAMINOS}
a.- Robos y asaltos
b.- Obstáculos en los caminos
c.- La peste
d.- El lobo y otros animales 


\section{1.- ENTRETENIMIENTO \\ DE LAS VIIAS DE COMUNICACIÓN}

Los caminos y las infraestructuras viarias que como los puentes, sufrían un continuo deterioro, debían tener un mantenimiento permanente y ser reparados con frecuencia. En la documentación histórica, hallamos numerosas referencias al estado y deterioro de dichos caminos y puentes, y a los esfuerzos realizados para los reparos consecuentes. En los límites cronológicos de nuestro trabajo, y también en fechas posteriores, se reparan o hacen de nuevo muchos puentes, ya que estos edificios sufrían de una manera especial por el uso, por las inclemencias meteorológicas (lluvias, heladas, nieves) y sobre todo por las continuas avenidas que se producían de una manera en muchos casos violenta, que afectaban a unos edificios frágiles y a veces mal construidos y cimentados. Los caminos tampoco eran una excepción, ya que la dureza climatológica provocaba que, al tener una gran mayoría de ellos firme de tierra, se embarrasen y se convirtiesen en muchos casos en intransitables. Además por el uso, sobre todo con los carros cuando esto era posible, también sufrían un gran deterioro, por lo que sus firmes de manera repetida, se debían reparar y calzar.

A veces, tras el hundimiento de determinado puente, o interrupción de la continuidad de un camino, se produce un encarecimiento de los productos, o al menos eso se alega en alguna ocasión, como cuando con motivo de la ruina de uno de los dos puentes de Herrán, se indica en octubre de 1580 , que esto "era causa de baler las cosas muy mas caras..." ${ }^{407}$. Es evidente que el rodeo en los trayectos a que obliga una interrupción del camino habitual, provoca una subida de los costes del transporte, que debe repercutir indefectiblemente en el precio del producto transportado.

\section{A.- ADVERSIDADES SOBREVENIDAS}

\section{a.- Riadas y avenidas}

Como consecuencia del régimen estacional de tipo mediterráneo que poseen los caudales hídricos de la zona que tratamos, era corriente el fenómeno de las lluvias intensas y de los rápidos deshielos que provocaba de inmediato inundaciones y avenidas, a veces catastróficas. Fue históricamente un hecho que dificultaba de una manera importante, la utilización y conservación de los caminos y de las infraestructuras con ellos relacionados y creando, además, situaciones de gran peligro entre los viandantes. Eran habituales las grandes avenidas de carácter cíclico que causaban el hundimiento o deterioro de puentes y pontones, la ruina de manguardias y muros de contención y refuerzo, y el desmantelamiento de amplios sectores de caminos. Tras la interrupción de la vía muchos mulateros y viandantes, intentaban salvar el obstáculo para no perder la mercancía o simplemente 
para proseguir su ruta con un riesgo tan alto, que no fueron extraños aquellos casos que el intento acabó en desgracia o en la pérdida de bestia y carga. También eran muy peligrosos los pasos y puentes que quedaban maltratados, y que al permanecer a veces largo tiempo en un estado ruinoso mientras se preparaba su reparación, obligaban a su utilización al no existir otra alternativa sin reunir las mínimas condiciones de seguridad, motivo por el que se ocasionaron también diversos accidentes.

Una preocupación permanente fruto de la necesidad, obligaba a su inmediata reparación cuando no a su reedificación. Por tener que utilizar los puentes de manera cotidiana, en especial en tiempo de invierno cuando los ríos no se podían vadear, se intentaba el reparo con la mayor brevedad, algo que no siempre se conseguía. Fue muy frecuente que las obras se alargasen y su fecha de terminación se dilatase en el tiempo de manera exagerada e incluso a veces no se llegasen a finalizar. Casi todos los puentes de piedra situados en los caminos estudiados, han tenido en algún momento reparaciones y a veces importantes intervenciones, de tal manera que es muy difícil encontrar un puente de más de un ojo ${ }^{1408}$, que tras su construcción se haya conservado intacto. Es más frecuente que los puentes de cierta entidad, hayan llegado hasta nosotros después de diferentes intervenciones superpuestas que convierten el edificio en un rompecabezas que hacen muy complicada su atribución cronológica, si no encontramos los documentos de las sucesivas intervenciones. También hemos hallado casos en los que como consecuencia de la debilidad del terreno, se cambia la ubicación del edificio en busca de una mejor cimentación después de haber realizado numerosas reparaciones. Es el caso del puente de Bolado sobre el río Carranza en el término de Ramales ${ }^{1409}$.

Las inundaciones que no suelen traer consecuencias graves para nuestras infraestructuras, han sido y son frecuentes en estas tierras, repitiéndose casi todas las primaveras, y principalmente entre enero y junio, y mes de septiembre; las primeras ocasionadas básicamente por los deshielos, y que podían rebasar los caminos. Cuando esto ocurre, el tráfico se interrumpe uno o varios días a la espera de la bajada de las aguas. Es lo que declara un mulatero de Bisjueces en 1556, que decía que "algunas bezes quando ay niebe y ba creçido el rio... y a esta causa, a acaeszido y acaesze estar los mulateros con sus bestias y con mercaderias y otras cosas e otras personas asi de a pie como de a caballo detenidas, por no poder pasar por los dichos Ocinos a causa de las dichas cresçidas"1410. Un arriero decía en 1529 que el camino por Pancorbo, se tenía que dejar "e yr de por ençima las sierras por el mucho peligro del dicho camino porque algunas bezes quando cresçe el agua no se puede pasar a pie ni cabalgando"1411. Pero no son extrañas aquellas crecidas que poseen un carácter catastrófico cuando a los deshielos se suman lluvias torrenciales que pueden derribar los puentes, demoler los muros de contención y refuerzo y desmantelar tramos

\footnotetext{
1408 Los puentes de un solo ojo, suelen resistir mucho mejor el paso del tiempo, el uso y las riadas, por apearse en tan solo dos puntos, a veces fuera del cauce, evitando el pilar o los pilares ubicados sobre el cauce del agua, que las propias corrientes, se encargaban de irlos socavando y descalzando.

1409 A. H. N./ Nobleza. Frías, C. 235, D. 55/ Medina de Pomar, 15 enero 1499. Una vez se hizo el de Bolado de calicanto y el de San Pedro de Ramales dos veces, pero se cayeron por no asentarse en tierra firme, por lo que se acordó hacer el camino por otra parte.
}

1410 A. C. V./ no 18. doc. 3, hojas 28 a 48/ Medina de Pomar, 7, 8, 9 y 21 enero 1556.

1411 A. G. S./ Consejo Real de Castilla, leg. 324-24/ Madrid, 28 mayo 1517 y Pancorbo, 30 diciembre 1529. 
completos de caminos. En la ciudad de Burgos, eran producidas por el río Arlanzón y por los ríos Pico y Vena.

Sería imposible relacionar todas las inundaciones de tipo catastrófico que ha padecido esta zona por la que discurren los caminos de nuestro estudio. Destacan sobre todas ellas las producidas en 1582, ya que a lo largo de dicho año, fueron destruidos los caminos y puentes de Burgos, camino entre Laredo y Espinosa, Álava, Bilbao u Orduña, riadas que sitúan este año como el más afectado de todo el periodo que estudiamos. Según Nazario Conzález, se puede establecer una cadencia para la ciudad de Burgos de unas tres avenidas cada 100 años ${ }^{1412}$. Las más importantes de las que tenemos noticia en el período que nos ocupa, así como sus consecuencias fueron las siguientes:

- Una avenida ocurrida en 1242, ocasionó un gran daño en el puente de San Pablo de la ciudad de Burgos ${ }^{1413}$.

- En 1255 se destruyeron dos puentes y las casas de Cantarranas de la ciudad de Burgos, por el desbordamiento del río Vena ${ }^{1414}$.

- La noche del jueves 21 de febrero de 1286, hubo una gran avenida de los ríos Vena y Arlanzón, y "creció tanto el Rio Vena que anegó gran parte de la Ciudad de Burgos. Del Hospital quellaman de la Moneda, sacó a vn hombre de su lecho, y le llevó hasta la puente de Santa Maria, y en donde le hallaron ahogado en su lecho. Fuè tanta la madera, que llevaba la crecida, que derribó las puentes de la Ciudad, que parece que eran mas que las que ay ahora"1415. También llevó las puertas del Mercado, y derribó la cerca junto a la casa del Arcediano de Valpuesta, el puente de los Predicadores ${ }^{1416}$, y los puentes del Cirón ${ }^{1417}$ y de los Malatos.

- Hilario Casado menciona terribles destrozos ocasionados en la ciudad de Burgos por las riadas de 1427,1431 y $1475^{1418}$.

- Los Reyes dan comisión a los alcaldes y jueces de la tierra de Llodio en 1485, para que entiendan en la demanda presentada por Martín Ochoa, que decía que estaban "los caminos e calçadas desa tierra muy perdidos e destruydos, e peligrando e trabajando mucho los omes e bestias que por ellos pasauan"1419.

- En julio de 1488 el concejo de Medina de Pomar decía que cerca de la villa, hay "una puente mucho antigua que se llama la puente de Villanueva por la qual, de nesçesario diz que han de pasar todas las gentes e mulaterias que van e vienen a la montaña, la qual puente diz que esta derrocada e para caher de todo punto,... e que por estar mal rreparada, han peligrado algunas personas e bestias".

- En diciembre de 1491 la Junta, diputados, alcaldes y procuradores de las hermandades de Vitoria, Álava y Ayala solicitan licencia para un reparto con destino al reparo del

\footnotetext{
1412 GONZÁLEZ, N.: 2010: 67.

1413 MADOZ, P.: 1845-1850. 16 tomos. Reeditado por Editorial Ámbito organizado por provincias. Valladolid, 1984. p. 176.

1414 BERGANZA, F. de: 1721: partes I y II/ t. II. 161.

1415 BERGANZA, F. de: 1721: partes I y II / t. II. 179 y 590.

1416 Puente de San Pablo, Ilamado de los Predicadores, por conducir al convento dominico de San Pablo.

1417 El puente del Girón correspondía a la antigua puerta de Santa Gadea, llamada después de Barrantes.

1418 CASADO ALONSO, H.: 1987: 29; A. Cat. B., Libro Ro. f. 41/ 1427; A. Cat. B., Libro Ro. f. 41/ 1431; A. Cat. B., Libro Rof. $232 / 1475$.

1419 A. G. S./ Registro General del Sello, XII-1485, fol. 124/Valladolid, 17 diciembre 1485.
} 
"camino rreal que va de la çibdad de Ordunna a la villa de Bilbao, e a nuestros puertos de la mar del nuestro condado de Vizcaya... e que las dichas puentes e calçadas estan muy malas e destruydas e caydas e derrocadas, e que non se pueden pasar nin caminar syn non a muy grant peligro, asy de las personas como de las azemilase bestias que por ellas pasan en espeçial veniendo cargadas..." ${ }^{1420}$.

- En 1494 hubo inundaciones en el camino de Castro-Urdiales, ya que en septiembre de 1495 el concejo de Castro dijo al Consejo, "que las avenidas e lluvias grandes que venieron el año pasado, derribaron muchas calçadas e puentes de que murieron muchas personas", y a petición de los vecinos de Sopuerta y Galdames, donde dicen que hay muchos mulateros que los suelen utilizar, la villa reparó a una legua el puente de Otañes y las calzadas necesarias ${ }^{1421}$.

- A primeros de junio de 1495, una inundación en Valmaseda "lleuo todas las... puentes e calçadas de que la tierra quedo muy destruyda"1422, y “destruyó e desbarato el camino rreal y prinçipal que viene y va a Castilla para la villa de Valmaseda, y rronpio y... llevo dos puentes grandes que ende estauan de madera, con dos lienços de la çerca de la dicha villa, y con vn pedaço de la puente prinçipal de piedra della", además de casas, molinos y ferrerías. Cayeron además muchas peñas y árboles en los caminos, cegándolos y destrozándolos, de manera que no podía llegar bastimento alguno, por lo que pidieron licencia para poner imposición a vecinos, caminantes y pasajeros ${ }^{1423}$. En julio, a petición de Lope de San Pelayo en nombre de la villa y tierra de Arciniega, el Consejo Real acordó mandar al corregidor de Vizcaya que recoja información sobre qué puentes son los que se derribaron y que necesidades tienen, así los de la villa y tierra como los de la comarca, y qué mrs. necesitan para su reparo ${ }^{1424}$.

- El mismo mes y año, una gran avenida destruye el puente de Arce: "las grandes aguas que en aquella tyerra ha llouido en este mes de junio, ha lleuado e derrocado la dicha puente de Arze e diz que para la tornar a faser e rreparar son menester mas de dozientas mill mrs."1425.

- En 1498 los mulateros indican que los "caminos, e puentes, e calçadas que son desde la dicha çibdad de Burgos fasta la uilla de Laredo,... estauan dañados e tales, que no se podian andar, e que algunas de las dichas puentes, asy de piedra como de madera con las abenidas e cresçientes de las aguas, se las auian lleuado de manera que muchas gentes e bestias peligrauan e se perdian las mercaderias"1426.

- Hilario Casado alude a una riada ocurrida en 1501 en la ciudad de Burgos ${ }^{1427}$.

- Los mulateros de la cofradía de San Antón se quejan en 1504, de que "entre la villa de Pancorbo e Çuneda, e entre Guisaleña e Birbiesca, e en otras partes e lugares en tierra de Alaua, estan muy malos pasos e peligrosos e çerrados e estragados los caminos, o pasados e caydas e ronpidas algunas puentes... $" 1428$.

- La Junta General de Vizcaya dice en 1507, que sus caminos "estan muy malos, de manera

1420 A. G. S./ Registro General del Sello, XII-1491, fol. 12/ Burgos, 13 diciembre 1491

1421 A. G. S./ Registro General del Sello, IX-1495, fol. 265/ Burgos, 12 septiembre 1495

1422 A. G. S./ Registro General del Sello, VII-1495, fol. 187/ Burgos, 9 julio 1495.

1423 A. G. S./ Cámara de Castilla. Pueblos, leg. 21-2, doc. 185/ Burgos, 17 julio y Valmaseda, 10 agosto 1495.

1424 A. G. S./ Registro General del Sello, VII-1495, fol. 241/ Burgos, 21 julio 1495.

1425 A. H. P. C./ J. T. A. leg. 39-23/ Burgos, 27 junio 1495.

1426 A. G. S./ Registro General del Sello, VI-1501, fol. 460/Valladolid, 5 junio 1501; MOLÉNAT, J. P.: 1971: $157-160$. 
que non se pueden andar nin caminar por ellos a pye ni a cauallo, nin con bestias cargadas nin basias, syno a mucho riesgo e peligro", especialmente y entre otros "desde la cunbre de la penna de la çibdad de Hordunna fasta la villa de Biluao, y desde la penna de Mena fasta dar en la dicha villa por la villa de Valmaseda"1429.

- En 1511 hubo una fuerte avenida que afectó gravemente a los puentes y pontones de madera del camino de Laredo, y se llevó lo que quedaba del de Bolado. Se indica que, "agora por no estar echas estas puentes, ban los mulateros por caminos muy travajosos e peligrosos e tales, que estan un dia e dos syn poder pasar"1430.

- En enero de 1527, el río Vena y el Arlanzón, se desbordan en Burgos como consecuencia de "las nieues demasiadas que cayeron en Otubre, Nouiembre, y Diziembre del año passado, se cuaxaron con los grandes yelos: despues ablandó el tiempo, y derritieronse de suerte que los rios crecieron con gran espanto... Assi fue que creció el rio Arlançon, vn viernes en la noche a la hora de las doze. Començó a venir tan grande furia de agua por aquella ribera, que desde la vega de Miraflores, hasta el campo de Gamonal al traues toda la tierra era vn mar, y entró la ribera tan crecida por la parte de S. Francisco y por la ciudad, y por la parte de Vega, que nunca tal se vio ni oyó... Esta creciente duró hasta el sabado dos horas despues de medio dia. Lleuó la puente de San Lesmes, y vn torrejon... Tomó en la puente vn azemilero que yua por leña, y se ahogó alli luego, y la azemila fue a parar con mucho trabajo a Vega. Lleuó gran parte de la puente de Santa Maria, y en ella diez y siete hombres y mugeres, que ninguno escapó". Fue una de las grandes inundaciones padecidas por la ciudad, y la reconstrucción del puente de Santa María debió realizarse sin la necesaria solidez, ya que 51 años después, fue destruido por otra crecida1431.

- En 1529, un testigo dice que en el camino por Encío, los arrieros "dexan el camino y ban por las sierras y peligran muchas bestias y azemilas porque las lieba el agua" y van "por las heredades que se labran, y que ha bisto este testigo muchas bezes estar caydos en los dichos pasos muchos caminantes, y aber peligrado en los dichos caminos de las bestias, quebradas las piernas de las azemilas y benir al dicho logar, a pedir que los ayudasen a lebantar las dichas bestias", y que en los pasos del desfiladero de Pancorbo donde se cayeron muchas peñas de lo alto, "peligran muchas bestias y azemilas y a bisto que las lieba el agua y abia visto hahogar una azemila", porque sale el río "por el camino rreal y quando cresçe, sale tanta parte que no pueden pasar las azemilas ni bestias ni la gente por el dicho camino, y sabe que han peligrado bestias en el dicho paso y se las a lebado el rrio"1432.

- En junio y el 14 de septiembre de 1553, hubo dos fuertes avenidas del Cadagua en Valmaseda que destruyó los muros y cercas de la villa así como el camino en Peña Tajada1433. El concejo de Valmaseda dice al Consejo en 1554, que la villa "tiene vn camino que se llama Peña Tajada, que es junto a la dicha villa de Balmaseda y pegada a una peña alta, y por debaxo del dicho camino ba vn rio caudal y el dicho camino es muy angosto, y las abenidas de las aguas deste ynbierno an sido tantas, que an derrocado y llebado la dicha calçada y camino por manera que no se puede pasar y si alguno pasa es con gran peligro", y pide licencia para echar por sisa los mrs. necesarios para los reparos y repartir

\footnotetext{
1429 A. G. S. V./ Casa de Juntas de Guernica. Provisiones Reales. Reg. 1- no 12(1)/ Palencia, 27 abril 1507, Guernica, 20 enero 1508; HIDALGO de CISNEROS, C., LARGACHA RUBIO, E., LORENTE RUIGÓMEZ, A. y MARTÍNEZ LAHIDALGA, A.: "Colección Documental del Archivo General del Señorío de Vizcaya". 1986: doc. 69.

1430 A. G. S./ Consejo Real de Castilla, leg. 26-17/ Burgos, 5 octubre a 12 diciembre 1511; MOLÉNAT, J. P.: 1971: 161-162 y BASAS FERNÁNDEZ, M.: 1963 Y 1994: 161.

1431 SANDOVAL, F. P. de: 1618: 813-814.

1432 A. G. S./ Consejo Real de Castilla, leg. 324-24/ Pancorbo, 9 febrero 1529.

1433 El camino de Peña Tajada, es el primer tramo del camino real que desde Valmaseda se dirige a Bilbao.
} 
los mrs. a los mulateros y trajineros para el dicho camino de Peña Tajada. El Consejo responde en junio, que no ha lugar a lo que se pide y que si quisiere la carta ordinaria para que cada uno en su jurisdicción aderece los puentes y caminos conforme a la ley, que se le dé1434.

- Un testigo declaraba en 1556 sobre el paso de los Hocinos, que "el rio de Hebro el qual es rio caudaloso y furioso, y este testigo a visto despeñadas bestias en el dicho camino, y aun se despeño alli en el dicho camino un macho que agora balia cinquenta ducados segun esto acias le estimaban, y tanbien es notorio que se ahogo en el dicho rio pasando por el dicho camino un mancebo de la Sonsyerra y alli en derecho de donde se ahogo, esta una cruz", y que el río "yendo crecido e suele durar para no se poder pasar el camino, unas beces un dya y otras y muchas dellas un dya y una noche, y a visto estar mulateros detenidos con requas llebando mercaderias y besugos frescos, aguardando a que bajase el rio y aun a bajado pasaron harto trabajo"1435. El abad de Rueda, decía al Consejo que en las Merindades hay caminos reales "muy pasajeros e frequentados de mercaderes y otros camynantes, los quales estan destruidos y deshechos en tal manera, que pasan gran dificultad, travajo y peligro,... especialmente el camino que dizen de los Ocinos y la Horadada, que estan de manera que se pasa con gran peligro por ellos y en el paso an muerto y peligrado muchos"1436.

- En la Junta particular de Álava de junio de 1563, el Diputado General hizo convocatoria para tratar sobre la situación de los puentes que recientemente se habían llevado las avenidas en Briviesca, y sobre los caminos y calzadas que están mal reparados, por ser camino transitado y necesario para los caminantes de a pie y de a caballo y para los trajineros de la provincia y de otras partes ${ }^{1437}$.

- Martín de Zaldívar y otros arrieros dijeron al Consejo en 1568, que "el camino rreal que pasa por el Valle de Mena, desde las Enderrosas hasta el molino de Arla, y la Peña de Mena, y las peñas de Riobolga y otros caminos y passos, y la puente del Rranero,... los quales de presente estauan mui mal reparados y adereçados y peligrosos, que por ninguna de sus partes podian pasar por ellos con sus requas de noche ni de dia, a cuya caussa se auian perdido... los machos de sus partes, y las cargas de vino y otras cossas de vastimientos que lleuaban a muchas partes"1438.

- En 1571 otra riada del río Arlanzón, provocó que en el puente de Tardajos "por pasar por el dicho rrio para yr su camino, se aogaban y peligraban en el gentes asy de pie pelegrinos como de a caballo, y... se aogo en el dicho rrio un hombre de a caballo y le llebo el dicho rrio, y ansy mismo pareçieron aogados en el dicho rrio otros hombres pelegrinos, y otra uez se aogaron y peligraron en el dicho rrio un hombre y tres mulas que traya en una carreta..."1439.

- El 26 de enero de 1582, llega a Burgos desde Palencia Santa Teresa de Jesús, y en Buniel en el camino de Valladolid, tuvo un grave contratiempo por ir crecido el río Arlanzón, cuando intentó pasar cuando el puente se encontraba rebasado por el agua, en "un paso que

1434 A. G. S./ Consejo Real de Castilla, leg. 504-14/Valmaseda, 24 abril 1554.

1435 A. C. V./ no 18. doc. 3, hojas 28 a 48/ Medina de Pomar, 7, 8, 9 y 21 enero 1556.

1436 A. C. V./ no 1.873, doc. 13, hojas 38 y 39/ Miñón, enero 1556.

1437 A. J. G. A./ t. V/ Vitoria, 14 junio 1563.

1438 A. H. V. M./ leg. 6, p. 33bis a 35/Madrid, 23 julio 1568 y Villanueva de Mena, 7 febrero 1569.

1439 A. G. S./ Consejo Real de Castilla, leg. 454-2/ Tardajos, 16 julio 1571. 
hay cerca de Burgos, quellaman los Pontones, y el agua habia sido tanta, y lo era muchos ratos, que sobrepujaba sobre estos pontones tanto, que ni se parecian ni se veia por donde ir, sino todo agua" 1440 .

- Entre el 23 y 24 de mayo de 1582, se produce una gran avenida del río Arlanzón en Burgos. Se destruyeron de nuevo varios arcos del puente de Santa María y afectó también a los puentes de San Pablo y de los Malatos, además de a numerosos paredones, caminos y calzadas de la ciudad, la puerta de las Carretas, el barrio de Vega y el camino de Vallado$\operatorname{lid}^{1441}$.

- También ese mes hubo avenidas en la provincia de Álava y en junio, el Diputado General informó a la Junta sobre los daños y ruinas ocasionados en puentes, calzadas, caminos, panes, dehesas y en todo el campo, por lo que la provincia necesitaba socorro para tan urgente necesidad, para lo que sería necesario pedirlo al Rey ${ }^{1442}$.

- En julio de 1582, el procurador general de Laredo dice que desde Laredo a Espinosa de los Monteros, los caminos, calzadas y puentes de la mulatería están deshechos a causa de las muchas lluvias y avenidas de ese año, por lo que era necesario su reparo. Se hace un interrogatorio para que con las respuestas y con las provisiones reales prorrogadas, se cometa a la justicia de Laredo para que los caminos y puentes se hagan y reparen a costa de quien tocare. Ese año, habían venido muchas lluvias, aguas y "andelubios", y se habían deshecho los caminos y calzadas en muchas partes, por lo que no se podían utilizar sino con mucho trabajo y riesgo, arruinándose los puentes de piedra de Agüera y Ampuero grandes y muy costosos, y los de Lanestosa y Gibaja, y que convenía reparar o hacer de nuevo con toda brevedad, siquiera de madera ${ }^{1443}$.

- En las Juntas de Vizcaya de la Tierra Llana de agosto de 1582 se trató entre el corregidor, regimiento y procuradores de las villas, cómo la villa de Bilbao había alcanzado Provisión del Consejo Real para echar sisa sobre los bastimentos que en ella se vendían en cantidad de 26.000 ds., porque "el dilubio ultimamente pasado abia hecho muchos daños en la dicha villa", así en el puente como en los caminos de Orduña y Valmaseda, acordando por unanimidad, que se deniegue dicha sisa ${ }^{1444}$.

Aramburu Zabala ${ }^{1445}$ indica a este respecto, que hubo un anormal aumento en las precipitaciones con un incremento de las riadas catastróficas, sobre todo a partir del invierno de 1589-90 y continuaron por lo menos hasta julio de 1590. Tales avenidas afectaron a todos los territorios de la Corona y en especial a la Meseta Norte. Parecía tratarse, indica, de un ciclo largo que se repite aproximadamente cada medio siglo.

- En septiembre de 1593, una gran riada se lleva casi todos los puentes del Valle de

1440 SANTA TERESA, P. S. de: 1915 a 1924: t. V, 305 Y 306; GARCÍA RÁMILA, I.: 1942: 20; JESÚS, T. de: "Libro de las Fundaciones". cap. XXXI; Relación de la Madre de Ana de San Bartolomé, B. M. C. t. II, p. 234; UGALDE y AGÚNDEZ, J. M. de: 367 .

1441 A. M. B./ HI-1661/1583.

1442 A. J. G. A./ t. VII/ Vitoria, 15 junio 1582.

1443 A. H. P. C./ Laredo, leg. 22, num. 14/ Laredo, 9 julio 1582.

1444 A. J. R. B./ Actas de la Tierra Llana. t. III/ Durango, 25 agosto 1582; Actas de Villas y Ciudad. t. II/ Durango, 25 agosto 1582.

1445 ARAMBURU-ZABALA, M. A.: 1992: 65 
Mena y el de Valmaseda ${ }^{1446}$. Para obtener información sobre la situación de los puentes del valle, un testigo dice que el camino está "enzima de una peña y sobre un rio, que es cossa muy aspera y espantosa y de mucho peligro" y que se debe romper dicha peña viva para su ensanche ${ }^{1447}$. Ese mismo mes y con motivo del "andilubio", Mateo de Agustina regidor y diputado de Laredo, presenta un memorial sobre los paredones y malos pasos que se han reparado desde 1590 hasta 1593 y peñas que se han roto en el camino de Laredo a Agüera ${ }^{1448}$. En Junta de enero de 1594 el Diputado General de Álava presentó una carta del procurador de Ayala, de cómo el valle de Llodio está haciendo diligencias para sacar Provisión y repartir unos 7.00o ds. , para reparar los puentes y calzadas que se ha llevado el aguaducho que hubo en septiembre de $1593^{1449}$.

- En mayo de 1598, Juan de Alvear en nombre del concejo y vecinos de Puente-Arenas dijo al Rey, que "sobre el rrio que hera Hebro auia una puente quel llamauan La Puente de Ualdibielsso y una calzada que decian de los Ocinos...", pero con las avenidas y nieves del invierno, estaba tan descalzado que si no se reparaba, se caería en breve tiempo, y además la calzada estaba tan perdida que no se podía utilizar, porque como el Ebro era muy caudaloso, cualquier crecida la cubría por falta de cimiento, por lo que si no se remediase, no se podría volver a hacer con 50.000 ds. ${ }^{1450}$.

\section{b.- Desmanes bélicos}

A lo largo de la Historia y en todas las guerras, ha sido habitual la destrucción de infraestructuras camineras para dificultar el avance del enemigo. Tenemos un dato sobre este asunto en un puente de la zona estudiada. Al enterarse en 1306, Juan Núñez y Diego López de Haro señor de Vizcaya, que el rey Fernando IV les perseguía, "salieron de Cerezo é pasaron á Ebro por la puente de la Rada ${ }^{1451}$. É desque sopo el rey que pasaron á Ebro, mandó derribar un arco aquende la puente, é mandó guardar todas las puentes é los pasos que avia en este Ebro, porque non pudiesen aquende pasar. É el rey fuese para Frias...". Intentando después Juan Núñez volver a Aranda a hacer la guerra al monarca, "non falló por donde pudiese pasar á Ebro sinon porla puente de la Rada en esta manera: tomo dos vigas muy grandes é pusolas en aquel arco que avian derrivado, é pasó por ellas é fuese para Aranda"1452.

\section{c.- Las lluvias y el barro}

La mayor parte de los caminos de Castilla a los puertos de la costa hasta el siglo XVI eran arrieriles, y estos tenían unos firmes sin compactar. Las vías calzadas eran muy es-

\footnotetext{
1446 A. H. V. M./ leg. 6, p. 221 a 336/ Madrid, 10 junio 1589 a 18 diciembre 1593.

1447 A. H. V. M./ leg. 6, p. 221 a 336/ Madrid, 10 junio 1589 a 18 diciembre 1593.

1448 A. H. P. C./ Laredo, leg. 22, num. 15/ Laredo, 23 febrero 1585 a 12 enero 1597.

1449 A. J. G. A./ t. X/Vitoria, 18 enero 1594.

1450 A. H. V. M./ leg. 6, p. 348 a 355/Madrid, 29 mayo y Villarcayo, 16 junio 1598.

1451 Puente de Puentelarrá.

1452 BENAVIDES, A.: 1860: tomo I, 162-163.
} 
casas, y en general, los empedrados se ceñían tan solo a determinados tramos, principalmente en zonas concretas que se embarraban con facilidad. En la práctica, sin embargo, estas iniciativas no eran frecuentes, circunscribiéndose los empedrados y encachados a los puentes y a sus accesos, así como a los tramos más abruptos de los puertos y portillos de montaña. Al ser de tierra la mayor parte de los firmes, los caminos se convertían con las lluvias, en muchos casos, en auténticos lodazales, lo que obligaba a los mulateros a proseguir por las tierras de cultivo aledañas, que al destruir panes y viñas, causaban conflictos con sus propietarios.

En un documento de 1491 se reflejan estos problemas, ya que se presentó ante el Consejo Real una petición de la Junta de la provincia de Vitoria y sus merindades de Álava, que decía que entre Villarreal de Álava y Ochandiano en invierno, "se fasen tantos e tan grandes lodos en el camino rreal, por donde pasa la rrecua para el dicho condado de Biscaya, e ay otros arroyos e tan malos pasos que en cada un año mueren muchos ganados de los que ban cargados"1453. Sobre tener que salir del camino, en 1529 un mulatero decía que en el camino que iba a Zuñeda desde Pancorbo, hay un "muy largo trecho y tan malo que en el ynbierno no se puede caminar" y que este y otros malos pasos, están tan malos "que no pueden yr por ellas si no se adoban y a la cavsa ban y bienen por las heredades, y se pierden muchas tierras de panes y los fatigan los dueños de las heredades a los dichos mulateros y tragineros", y otro mulatero dice que "se abia de apear de la cabalgadura que lebaba, y apartarse de los caminos... y que a la causa se rrecresçen muchos daños a los caminantes porque se cahen y rresçiben daños y peligros en los dichos pasos"1454.

\section{d.- El invierno y la nieve'1455}

La nieve era otro de los elementos atmosféricos que tenía una gran incidencia en el tráfico mercantil y que condicionaba la utilización de los caminos que discurrían por las tierras situadas a cierta altitud, es decir, la mayor parte de las tierras de Burgos, por tres razones principales: ocultaba el trazado de la vía, impedía o dificultaba el tráfico si la capa depositada era importante o en fase de deshielo y además, dañaba los caminos.

En un sector como el que estudiamos, existían muchos puertos y portillos de montaña, donde era habitual la acumulación de nieve, a veces durante largos periodos. Ciertamente el número de puertos y portillos que tienen los $1.000 \mathrm{~m}$ de altitud o los superan, son numerosos en la zona que estudiamos: Páramo de Masa (1.050 m), Portillo del Fresno (1.050 m), Carrales (1.020 m), El Escudo (1.011 m), Tamarizos (Pesadas-Villalta) (1.040 m), La Mazorra (1.000 m), Estacas de Trueba (1.166 m), Lunada (1.350 m), La Sía (1.200 m), Pan Crudo $(1.235 \mathrm{~m})$ y Portillo de Busto ( $1.000 \mathrm{~m})$. Con esta realidad, no es nada extraño que la nieve fuese uno de los problemas importantes de nuestras comunicaciones en las fechas invernales.

Sobre todo en los páramos y puertos, la nieve podía ocultar el trazado del camino y causar extravíos o bien provocar la salida del camino, con el consiguiente riesgo en un am-

1453 A. G. S./ Registro General del Sello, VII-1491, fol. 110/ Burgos, 26 Julio 1491.

1454 A. G. S./ Consejo Real de Castilla, leg. 324-24/ Pancorbo, 14 noviembre 1517 a 30 diciembre 1529.

1455 Se trata este tema con detalle en ORTEGA VALCÁRCEL, J.: 1974: 96-98. 


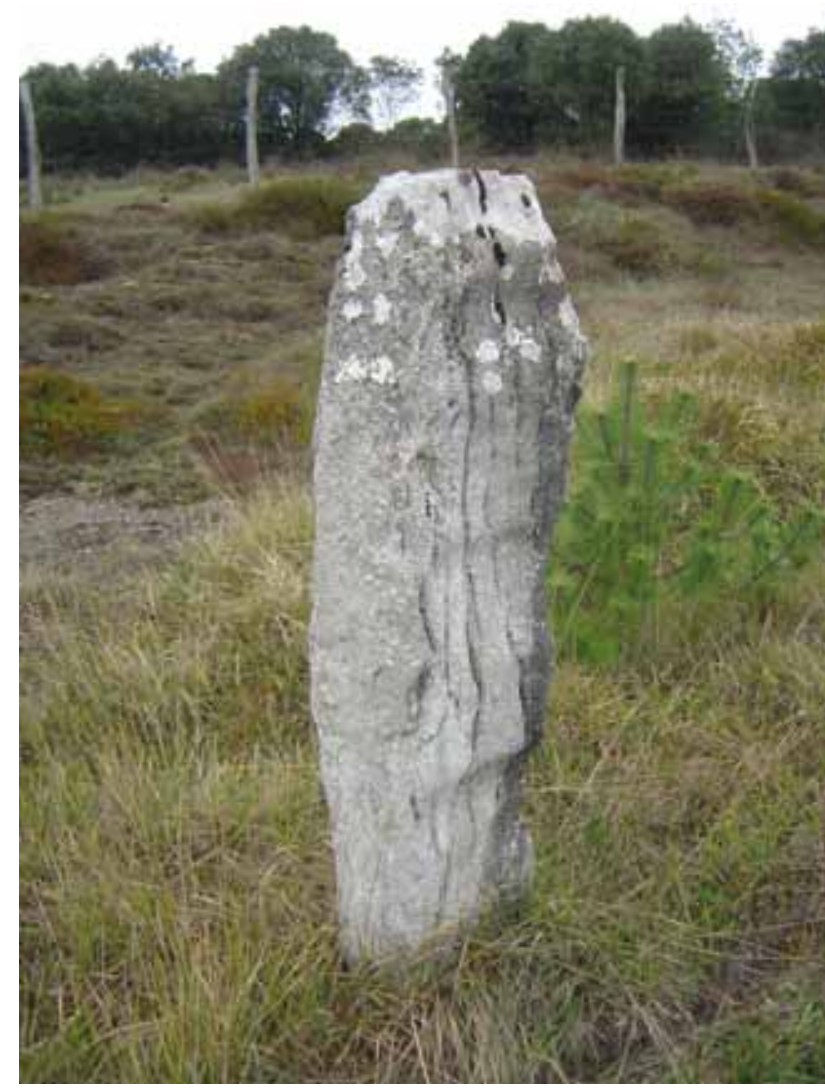

Mojón del antiguo camino de Berberana a Orduña.

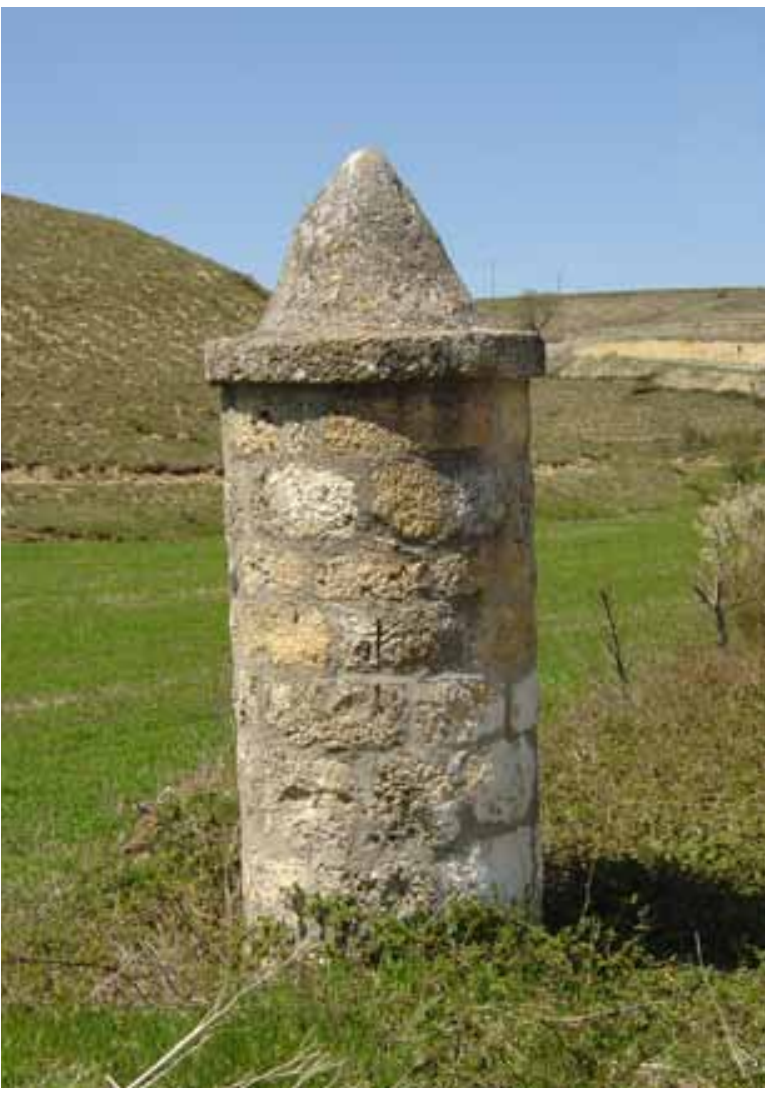

Mojón para la nieve en el camino a Laredo en el páramo de Villalta.

biente hostil, con bajas temperaturas. Para señalarlo en las partes elevadas del recorrido, se colocaban mojoyas ${ }^{1456}$. Ya en la Novísima Recopilación se legisla sobre este asunto y se manda en las Cortes de Madrid de 1586 a 1590 colocar mojoyas de fábrica ${ }^{1457}$. Pero mucho antes ya se habían tomado estas medidas en el páramo de Villalta. Así, en 1501 se acuerda poner en dicho páramo y en la travesía de los montes desde Agüera junto al río Cerneja ${ }^{1458}$, 150 mojoyas de mazonería para que con nieve pudiese proseguir el tráfico. Los procuradores de los mulateros y viandantes habían indicado que existía "mucha nesçesidad en los puertos del Butron e de Sendero Enyesto, que son çinco leguas de despoblados porque son puertos muy altos e cargan en ellos muchas nieues, de se faser mojoyas de cal e canto de diez pies en alto, para lo qual diz que seria menester çiento e çincuenta dellas por que han de ser espesas, porque con la ventisca alcançan poco la vista eque ha falta dellas diz que peligran muchas personas y avn asemilas porque no pueden atinar el camino", las cuales fue-

1456 En la NOVÍSIMA RECOPILACIÓN DE LAS LEYES DE ESPAÑA/ París, 1846. Tomo tercero/ Libro VII, Titulo XXXV, Ley IV/ Cortes de Madrid, 1586 a 1590, pet. 63, se hace constar que "mandamos, que los del nuestro Consejo provean y den órden como se pongan pilares en los puertos para señalar los caminos, por los peligros que en tiempos de nieves incurren los que caminan por ellos; por no estar señalados".

1457 En la Novísima Recopilación de las Leyes de España. París, 1846. Tomo tercero/ Libro VII, Titulo XXXV, Ley IV/ Cortes de Madrid, 1586 a 1590, pet. 63, se hace constar que "mandamos, que los del nuestro Consejo provean y den órden como se pongan pilares en los puertos para señalar los caminos, por los peligros que en tiempos de nieves incurren los que caminan por ellos; por no estar señalados".

1458 Es el tramo de $7 \mathrm{kms}$. del actual puerto de los Tornos entre Agüera y el puerto de Sendero Enhiesto de $920 \mathrm{~m}$. de altitud. 
ron valoradas en 22.500 mrs., a 150 mrs. cada una ${ }^{1459}$. Además, las mojoyas habían de ser "a piedra seca, con sus señales que sepan qual va a Burgos e qual va al Cuerno, de diez pies de alto bien seguidas ebien anchas" 1460 .

Además de ocultar los trazados, la nieve hacía más penoso el tránsito por tener que discurrir sobre un suelo cubierto que, cuando adquiría cierta altura, podía llegar incluso a impedir el paso. Cuando el camino se cerraba por la nieve, los arrieros y transeuntes debían buscar rutas alternativas, como declara en 1556 un mulatero de Bisjueces, que "pasó mercaderias que traiya de los puertos de Laredo e Bilbao para Castilla por el dicho camino de los Ocinos, y de Castilla traiya trigo y bino y algunas veces llebaba del trigo que traiya a Laredo, y que una bez trayendo bino de Castilla, paso por la Oradada porque abia niebe"1461. También cuando la nieve se fundía, provocaba inconvenientes al tráfico por provocar que los caminos se embarrasen.

Para mantener expeditos ciertos pasos importantes se recurría a la "huelga”, es decir a la movilización de los vecinos de los pueblos cercanos para abrir un paso en las zonas de gran acumulación, como eran los puertos, para permitir la circulación de una manera precaria, cobrando a veces una cantidad por haber realizado dicha labor. Estos derechos percibidos por el concepto mencionado, provocó tensiones y protestas en ocasiones, como consecuencia de que los cobros eran abusivos o se realizaban por parte de personas relevantes cuando ya no había nieve en el camino, aun cuando pudiese haberla en las cumbres. Así en 1486, los alcaldes de Orduña denuncian que "çiertos vesinos de... Villalua se pusieron en asechança en la peña de Orduña, robando los caminantes so color de les demandar huelga", pero los citados alcaldes no pudieron prenderlos porque huyeron, por lo que iniciaron contra ellos un proceso ${ }^{1462}$. En 1515 cinco testigos vecinos de Villasana, declaran ante el corregidor que desde hace 20 años, los criados del abad de Vivanco, por hacer la huelga, cobran un mr. por cada bestia que pase por la peña de Mena ${ }^{1463}$ haya mucha o poca nieve, y aunque no la hubiese y pasase un mulatero 20 veces al día, le cobraban este maravedí por bestia y vez. Además, en la peña de Mena y en Bercedo llevan muchos mrs. a los mulateros por quitar la nieve para bajar al valle de Mena y en el puerto de Sandiniesto. Piden al corregidor que mande comparecer a Pedro de Velasco, vecino de Valdeporres, y al abad de Vivanco y Gallarde de Velasco, vecinos de Mena, personas que lo cogen y que lo mandan cobrar para que muestren los títulos que tienen ${ }^{1464}$.

En las cuentas del concejo de Orduña se recoge que en 1579 se pagaron $1.908 \mathrm{mrs}$. para abrir el puerto de la Peña de San Bartolomé1465, que estaba cerrado por la nieve, porque los pasajeros estaban retenidos en Orduña y no podían proseguir. En 1585 se pagaron 7.846 mrs. para abrir el dicho camino cuando las grandes nieves, y en 1586 se gastaron 8.414

1459 A. G. S./ Registro General del Sello, III-1501, fol. 602/Valladolid, 22 marzo 1501; MOLÉNAT, J. P.: 1971 : 146.

1460 A. G. S./ Registro General del Sello, VI-1501, fol. 460/Valladolid, 5 junio 1501.

1461 A. C. V./ no 18. doc. 3, hojas 28 a 48/ Medina de Pomar, 7, 8, 9 y 21 enero 1556.

1462 A. G. S./ Registro General del Sello, III-1486, fol. 184/ Medina del Campo, marzo 1486; ENRÍQUEZ FERNÁNDEZ, J., HIDALGO de CISNEROS AMESTOY, C. y MARTÍNEZ LAHIDALGA, A.: 2003: doc. 484.

1463 Parece referirse al puerto de La Magdalena de $850 \mathrm{~m}$. de altitud.

1464 A. G. S./ Consejo Real de Castilla, leg. 84, fol. 2-III/ 26 junio 1513 a 25 septiembre 1515.

1465 Su altitud es de $900 \mathrm{~m}$. y la del de Goldecho $930 \mathrm{~m}$. 
mrs. en lo mismo y se pagaron 7.956 mrs. a Jorge López de Salazar, dezmero, por hacer abrir la Peña por segunda vez. En 1587 se gastaron 3.052 mrs. el segundo y tercer día de Pascua en abrir San Bartolomé cerrado por la nieve ${ }^{1466}$. Esto lo confirma el Condestable cuando dice que en 1586 y 1587, cuando cae mucha nieve, los lugares de la jurisdicción de Villalba que son suyos y Berberana que es de Francisco de Mendoza, hacen huelga para facilitar el paso ${ }^{1467}$.

En las Juntas de Vizcaya de abril de 1600 el regidor de Orduña presentó una petición sobre que en la peña de San Bartolomé, en solo quitar y abrir ventisqueros para dar paso a la gente y recuas, habían gastado más de 25.000 mrs. y que todavía estaba el paso muy peligroso por las muchas nieves y aguas ${ }^{1468}$. En las Juntas de mayo de 1603 el alcalde de Orduña dijo que en los tiempos de heladas y nieves la peña se cerraba y para abrirla Orduña gastaba más de 500 ds. anuales, cantidad sin duda exagerada, por lo que pidió que se le dé cada año una buena cantidad. Se acordó que esta petición se resuelva en los primeros regimientos ${ }^{1469}$. Entre noviembre y diciembre de 1660 , Pellegrino Zuyer realiza el desplazamiento de Reinosa a Burgos e indica que "por haber estado nevando durante dos dias casi de continuo, se encontraba muy dificil el camino, no obstante pude hacer mas de cuatro leguas y media en el tiempo de nueve horas". Añade que desde la venta de Berzosilla "hasta otra que se llama Valladar hay otra legua y media de aspero camino, sobre todo en tiempo de invierno. Y porque nevaba con fuerza y con viento y la nieve se amontonaba en el camino, tarde seis horas en hacer legua y media, rompiendo de tanto en tanto la nieve de mas de tres carros de altura"1470.

\section{B.- MANTENIMIENTOS Y REPARACIONES}

Los caminos y edificios a ellos vinculados sufrían un gran deterioro como consecuencia no solo de las condiciones meteorológicas y de las circunstancias catastróficas como son las riadas y avenidas, sino también, por el tráfico rodado que deterioraba los firmes y los puentes, sobre todo cuando los carros empleaban ruedas de clavos que gastaban y rompían los firmes. Estas ruedas de clavos consistían en que de la llanta, que no era lisa, sobresalían las cabezas de unos clavos, que aumentaban su agarre en el firme de los caminos. Los puentes sufrían de una manera considerable el tráfico rodado y el arrieril y sobre todo las avenidas, de tal manera, que era un caso muy extraño aquel puente de varios ojos que se conservase completo tras las riadas, por lo que hoy en día, es muy complicado considerar un determinado puente como perteneciente a un único momento constructivo. Cuando llovía o deshelaba el firme se embarraba y se creaban arroyos sobre el propio camino que lo erosionaban y descalzaban. El estado que presentaban los caminos para su cómoda utilización, dependía del grado de atención que recibían, máxime en unas tierras

\footnotetext{
1466 A. M. Orduña/ Munic. Orduña, L/ 005 y 054/ 1561-1594.

1467 A. H. N./ Nobleza, Frías, Leg. 1.392, D. 1/ Entre 1559 y 1585.

1468 A. J. R. B./ Actas de Villas y Ciudad. t. III/ Bermeo, 7 abril 1600.

1469 A. J. R. B./ Actas de Villas y Ciudad. t. IV/ Bilbao, 7 mayo 1603; Actas de la Tierra Llana. t. VII/ Bilbao, 13 mayo 1603.

1470 CASADO SOTO, J. L.: 2000: 343-344.
} 
tan accidentadas y con un clima tan riguroso como es el de la zona que estudiamos, y aunque una tradición que provenía de fechas antiguas, obligaba a mantener los caminos a los vecinos de cada municipio, su estado presentaba en muchos casos graves deficiencias.

\section{a.- Las circunstancias especiales}

Aunque hasta el primer tercio del siglo XVI rara vez la Monarquía o las autoridades tomaron la iniciativa para reparar y acondicionar los caminos sin que existiere riada o calamidad que lo motivase, y en este caso con una intervención que consistía en la concesión de las licencias necesarias para hacer la obra y poder acometer la recaudación de los fondos precisos, existían unas causas especiales que obligaban a la realización de intervenciones inmediatas. Estas eran principalmente los viajes reales y el transporte de cargas especiales.

\section{Los viajes reales}

Algo habitual en todos los viajes de reyes, príncipes o personas de la familia real cuando estos se podían prever, eran las actuaciones encaminadas al arreglo y acondicionamiento de los caminos por donde la comitiva debía pasar. Los viajes reales se preparaban de manera minuciosa cuando existía el tiempo preciso y a veces con mucha antelación, ya que el traslado de un personaje de la familia real representaba el desplazamiento de una numerosa comitiva que necesitaba manutención, asistencia y alojamiento, además del transporte de equipajes y elementos necesarios de tantas personas, con gran número de animales y bestias de acarreo con sus servidores. Como los caminos eran deficientes, se movilizaba a los vecinos de las poblaciones que se encontraban en o cerca del camino, para que con sus bestias y herramientas efectuasen pequeñas intervenciones, como ensanchar la vía, limpiarla de maleza, retirar rocas, reparar baches y socavones, alisar firmes y eliminar lodazales y malos pasos.

De esta manera, cuando la archiduquesa doña Juana debía prepararse para ir a Flandes a encontrarse con su marido Felipe, viaje que se realizó desde Laredo el 22 de agosto de 1496, los Reyes dan instrucción ocho meses antes a Juan de Arévalo, contador en el reino de Galicia y a Pedro Ortiz corregidor de Carmona, para "que fornescan e conpren çiertos proueymientos e betuallas e otras cosas para el proveymiento del armada, que en buena ora ha de yr con la archiduquesa nuestra muy cara e muy amada hija", y mandan que se les facilite "el vino e carnaje $e$ pescado e ganado e otras cosas" contenidas en la instrucción, pagando al precio justo "sin que lo agan dar en mayores preçios", comprando barato, libre y franco de alcabala, diezmo o cualquier otro derecho y "que si los toneles que fueren menester para el dicho vino e agua non hallaren hechos, puedan tomar e tomen todos los maestros, maderas, arcos, minbres e otras cosas que fueren menester para los dichos toneles, pagando a los dichos maestros por sus jornales e por la dicha madera" y que puedan fletar y tomar los navíos que hubieren en los puertos para llevar mantenimientos pagando su justo flete. Los que tienen el vino, vinagre, carnaje, pescado, ganado y demás cosas que no los 
quisieren vender a los precios habituales, Arévalo y Ortiz los podrán tomar pagando por ello esos mismos precios ${ }^{1471}$.

Sancho García Alvarado dijo a los Reyes en nombre del concejo de Limpias, que el que fue corregidor de la merindad de Trasmiera, pensando que la princesa Margarita desembarcaría en el puerto de Laredo a su venida de Flandes -desembarcó el 8 de marzo de 1497 en Santander-, hizo arreglar todos los caminos por donde debía venir, y en Limpias se ensanchó el camino por espacio de media legua. Como había muchos malos pasos pedía que el resto de los concejos contribuyesen a su mantenimiento. Se mandó al corregidor que recogiese información sobre ello ${ }^{1472}$.

El Consejo Real mandó en octubre de 1501 al corregidor de Burgos, que fuese a los caminos, puentes y calzadas entre Burgos y Laredo, y lo que no estuviere hecho lo mandase hacer y reparar, de manera que "lo mas presto que ser pueda, sean fechas e reparadas las dichas puentes e caminos e calçadas, porque desque en ora buena vengan los ylustrysymos prinçipes don Felipe e doña Juana, archiduques de Avstria duques de Borgoña..., esten fechos e rreparados los dichos caminos e puentes e calçadas"1473. No obstante, no llegarán por Laredo sino que en noviembre de 1501 salen de Bruselas y vienen por Francia. El 1 de febrero de 1502 pasan el túnel de San Adrián y llegan a Salvatierra; el 4 entran en Vitoria; el 7 duermen en Miranda; el 9 en Grisaleña; el 10 en Briviesca y el 11 en Monasterio de Rodilla. El 12 de febrero comen a una legua de Burgos y llegan al monasterio de las Huelgas. En Burgos estarán hasta el 23 para después ir por Santa María del Campo, Torquemada y Dueñas a Valladolid ${ }^{1474}$.

Como el Rey había enviado una carta en junio de 1522 desde Londres, en la que comunicaba que venía de camino con su armada a la villa de Laredo ${ }^{1475}$, y que después debía ir a Bilbao por la junta de Sámano, convenía que "los caminos de la dicha yunta, estouiesen aderesçados e allanados bien e sufiçientemente por donde ouiese de pasar". El corregidor de las Villas de la Costa mandó a dicha junta que en 8 días hiciesen arreglar los caminos que iban de Sámano a Valmaseda y a Castilla. Los concejos junto con los regidores de Castro, acordaron hacer repartimiento para lo que Castro pagaría 50 hombres, el concejo de Sámano 50 y el concejo de Otañes 30, a fin de acondicionar en los 6 días siguientes el camino entre Castro y Son de Sámano, límite de la jurisdicción de Castro. Se encargó a los representantes de Sámano y Otañes que repartiesen dicha gente en los lugares donde debían trabajar; pero como el procurador de Sámano manifestó que el alcalde de Castro agraviaba a su concejo al mandarles aderezar caminos de fuera de su término, el alcalde respondió que el corregidor le había enviado otros mandamientos para que hiciese aderezar dichos caminos "para la venida de mi el rrey, dentro de ocho dias, de la dicha billa de Castro para la çibdad de Burgos e hera camino rreal", acordándose en Castro el reparto de los peones necesarios ${ }^{1476}$.

\footnotetext{
1471 A. G. S./ Registro General del Sello, I-1496, fol. 153/Tortosa, 18 enero 1496.

1472 A. G. S./ Registro General del Sello, V-1497, fol. 25/Valladolid, 30 mayo 1497.

1473 A. G. S./ Registro General del Sello, X-1501, fol. 312/ Granada, 23 octubre 1501.

1474 CERRO BEX, V. del: 1973: 59-82.

1475 Llegó a Santander el 16 de julio de 1522.

1476 A. Ch. V./ Registro de Ejecutorias, caja 0373.0042/ Valladolid, 27 marzo 1523 y 25 octubre 1524
} 
Como se confirmaba que el Emperador iba a pasar por el puerto de San Adrián y ya estaba mandado que se reparase el dicho camino, en Junta de Álava de noviembre de 1539 se mandó que fuese a ver el puerto y camino el procurador de la hermandad de San Millán, al que le dieron comisión para que pudiese apremiar a las hermandades circunvecinas y realizar dicha reparación ${ }^{1477}$. Tras una petición de dicho procurador al ser el reparo mucha carga para las dichas hermandades y ser cosa tan necesaria, se mandó que solo por el servicio que hacen al Rey por tener el paso llano y aderezado, se ayude a las hermandades con 6.000 mrs. y que lo reparen con toda brevedad ${ }^{1478}$.

El doctor Antonio Cacharro, teniente de alcalde mayor en las Merindades, notificó en diciembre de 1555 a su ayuntamiento general la venida del Emperador que, con toda su corte, iba a desembarcar en Laredo ${ }^{1479}$, para lo que los pueblos de la jurisdicción debían estar "bien bastecidos de todos mantenimientos y los caminos y puentes todo bien reparado". Indicó que era justo que todos ayudasen a reparar los malos pasos para lo que se debía hacer un repartimiento en todas las Merindades y otro a los viandantes y trajineros. En enero de 1556 se informó que el doctor Durango del Consejo del Rey hacía saber, que en "el camino real que ba de Laredo a Burgos que es el que su Magestad a de traer, he hallado... muy malos pasos en los términos de las dichas merindades, en especial el paso de los Ocinos y el paso de la Oradada, y lo que va del dicho camino desde donde se acaba la jurisdicción de Medina de Pumar hasta llegar a los Ocinos,... y los Ocinos desde el llano de Bisjueces fasta llegar a la puente de Valdivielso y enzima del Almiñe". Todos dijeron que estos caminos son pasos públicos y generales para todo el Reino y que las Merindades no tienen obligación de repararlos ni nunca lo hicieron, pero no obstante, que el alcalde vea lo que deben hacer sin perjudicar a sus libertades, y "sin que para ello se obliguen a lo que no deben ni nunca debieron, sino solamente a serbir a su Magestad".

Por ello, el alcalde propuso que las Merindades debían ayudar para las obras en servicio del Rey con un repartimiento de hasta 200 ds., y que juntamente contribuyan los trajineros como lo suelen y acostumbran hacer y así realizar los reparos convenientes. El ayuntamiento general acordó, con las condiciones declaradas y solamente para el servicio del Rey, dar 40.000 mrs. para comenzar a reparar los dichos caminos y que los viandantes trajineros contribuyan, y que se dé poder a una persona principal para que informe al Consejo Real sobre los grandes gastos que acarrean los caminos y malos pasos de la Horadada, por donde sale el Ebro a Trespaderne hasta subir a Oña, y en los Hocinos desde el llano de Bisjueces hasta llegar al puente de Valdivielso y encima del Almiñé. Como "los huellan y destruyen, abarrancan y malean todos los que ban y bienen destos reinos a los puertos de la mar, y de los dichos puertos a los dichos reinos con cargas y mercaderias y bastimentos", se deberá mandar reparar de una vez, a costa de los que los destruyen y de los mercaderes ${ }^{1480}$. Se manda, no obstante, que cada uno los repare en su jurisdicción y que los lugares de las Merindades contribuyan en esos reparos ${ }^{1481}$.

1477 A. J. G. A./ t. III/ Vitoria, 18 noviembre 1539.

1478 A. J. G. A./ t. III/ Vitoria, 20 noviembre 1539.

1479 La llegada se produjo el 28 de septiembre de 1556.

1480 A. C. V./ nº 18. doc. 3, hojas 23 a 28/ Miñón, 5 enero 1556 y no 1.873, doc. 1, hojas 3 a 4/ Miñón, 5 enero 1556.

1481 A. C. V./ no 1.873 , doc. 13, hojas 38 y 39 / Miñón, enero 1556. 
El Diputado General de Álava dijo en Junta de abril de 1562, que de la corte le informaban sobre la venida del Rey por Vitoria y provincia a visitar San Sebastián y Fuenterrabía y lo que convenía hacer en su recibimiento, debiéndose reparar los caminos y otras cosas necesarias. Se acordó que como está determinado por Juntas Generales pasadas, cada hermandad repare los caminos de su jurisdicción ${ }^{1482}$.

En las Juntas de Vizcaya de la Tierra Llana se trató en marzo de 1565 sobre la venida de la Reina para ir a Bayona a ver a la Reina de Francia, su madre, por lo que mandaron que los caminos sean reparados en abril. El corregidor dio mandamientos para que en adelante no sea visto como alteración del Fuero de Vizcaya, en lo referente al reparo de caminos, y se encargó a los procuradores generales ${ }^{1483}$. En la Junta de Álava de mayo de ese año, se dijo que el Rey mandó al Diputado General que tenga los caminos reparados para el paso de la Reina, y asimismo, los pueblos estén provistos de bastimentos. También se le manda que a costa de la provincia haga reparar el puerto de San Adrián y su calzada, para lo que el diputado Francisco de Isunza concertó con Antón Martínez de Ilárduya, vecino de Zalduendo, que hiciese en el puerto hasta 300 estados de calzada. Aunque la Junta no tenía obligación de aderezar caminos fuera de sus hermandades, consienten que se haga por la breve venida de la Reina y lo paguen aquellos que fueren obligados, y que para ello se haga saca de 200 ducados $^{1484}$. Se acordó además que el diputado, cuando la Reina saliere de Vitoria para su camino, le acompañe con los alcaldes hasta la cumbre del puerto de San Adrián, y que las hermandades circunvecinas al puerto saquen alguna gente, "la más e más luçida que ser pudiere e suban con Su Magestad el dicho puerto, a modo de guarda, e para ello bayan con sus armas, lo mejor que se pudieren adresçar" y cuando la Reina haya entrado en la provincia de Guipúzcoa se vuelvan a sus casas ${ }^{1485}$.

La Reina Ana de Austria debía desembarcar en Laredo procedente de Flandes, aunque al fin llegó a Santander el 3 de octubre de 1570. Para los preparativos el Rey da una instrucción el 3 de agosto de 1570, que indica que para ir de Laredo a Burgos "paresçe que el mejor camino es el de Medina de Pomar y Oña, embiando a mandar a los corregidores de Laredo y Burgos y alcalde mayor de las merindades, que cada vno haga adereçar luego los caminos de su districto de manera que si se pudiere, puedan passar carros". Otra instrucción indica que "paresçe que se deue embiar la litera y coche de Su $M^{\text {ad }}$. para la persona de la Reyna y otros 4 para mugeres, que se hallaran sin mucha difficultad, y doze acaneas, las dos adereçadas para la persona de Su $M^{a d}$., nombrando Su $M^{\text {ad }}$. el cauallero que fuere seruido para que se encargue desto y lo lleue"1486. En 7 de agosto el Rey indica al cardenal de Sevilla que "ya he mandado que el alcalde Ortiz uaya delante, para proueer lo de las uictuallas y cosas neçessarias, y hazer adereçar los caminos hasta Laredo, donde se presupone tomara puerto la Reyna"1487. Ortiz da cuenta el 3 de septiembre al secretario del Rey, de los trabajos de aprovisionamiento realizados en

1482 A. J. G. A./ t. V/ Vitoria, 9 abril 1562.

1483 A. J. R. B./ Actas de la Tierra Llana. t. I/ Bilbao, 27 marzo 1565.

1484 A. J. G. A./ t. V/ Vitoria, 6 mayo 1565.

1485 A. J. G. A./ t. V/ Vitoria, 7 mayo 1565.

1486 A. G. S./ Patronato Real, leg 57, doc. 18/ Madrid, 3 agosto 1570.

1487 A. G. S./ Patronato Real, leg 57, doc. 24/ Madrid, 7 agosto 1570. 
Laredo ${ }^{1488}$. No obstante, estima que no son suficientes para la gran afluencia de personas que se espera. Intenta por ello que desde Castilla llegue el menor número de personas para evitar el consumo de las provisiones almacenadas, y sobre llegar el Cardenal y el Duque a Ampuero y Ramales para recibir a la Reina, Ortiz dice desde Laredo que vayan solos sin su séquito ${ }^{1489}$.

Al fin la Reina llega pero a Santander y, ante los hechos consumados, se adaptan a la nueva situación. El cardenal de Sevilla dice al secretario del Rey que el ir la comitiva a Burgos por el camino de Santander tiene alguna ventaja, ya que aunque el camino de Laredo por Medina "esta proveydo ya y el de Santander a Burgos no, es muy clara razon, pues con enuiar dos alguaziles delante, proueeran quanto fuere menester y como el camino es junto a Campos, es facilisimo proueer de trigo y ceuada que es la principal prouision"1490.

\section{El transporte de la artillería}

Con la irrupción de la artillería y su empleo en las batallas en campo abierto ${ }^{1491} \mathrm{y}$,sobre todo, para los asedios de plazas fortificadas, se hace necesario el transporte de las piezas para su utilización en los puntos requeridos. En nuestra zona el mencionado transporte se realizaba sobre todo para introducir las piezas en el interior de Castilla procedentes de las fundiciones de Flandes, y que por vía marítima llegaban a los puertos de Santander o Laredo. Para ello se debía superar un difícil territorio que dificultaba enormemente las condiciones de su transporte.

El peso de las piezas era variable, llegando algunas a alcanzar varias toneladas. El de las grandes bombardas del siglo XV podía llegar hasta los $6.000 \mathrm{~kg}$ y el peso de sus proyectiles, si eran de hierro, podía alcanzar los $250 \mathrm{~kg}$. Ya en el siglo XVI el peso del sacre podía ser de unos $1.000 \mathrm{~kg}$, y el de la culebrina de $5.900 \mathrm{~kg}$, con balas de hasta $14 \mathrm{~kg}$, y el cañón podía tener un peso de 3.000. El desplazamiento de la artillería con estos pesos era muy

1488 A. G. S./ Patronato Real, leg. 57, doc. 32/ Laredo, 3 septiembre 1570. Dice que en la villa han decidido "conprar lo mas çerca que se pudiere hallar, otras quinientas fanegas de trigo de mas de las ochoçientas que aca tenemos, e otras quinientas de çeuada de mas de las mill que aca tenemos, todo esto verna aqui dentro de seis dias a mas ocho, porque... emos sacado dineros prestados para las conprar de contado, y ansi con esto que se acresçienta a la prouision que aca teniamos, paresçe que bastara quanto a trigo y çeuada estan hechas, trezientas fanegas de harina e se uan haziendo mas, porque ay agora muchas moliendas en la mar con las aguas biuas deste mes que son las mayores de todo el año. Ay quatro mill cantaras de vino antes mas que menos de Xerez muy bueno, y veynte carrales de uino que son trezientas cantaras de Madrigal e Medina, ay otros vinos tintos de Castilla y de Biuero y Ribaclargas aunque no son buenas, de manera que en lo que toca a binos ay sobrada prouision".

1489 A. G. S./ Patronato Real, leg. 57, doc. 32/ Laredo, 3 septiembre 1570. "aunque se biniese aqui ahorrados con sus personas y siruientes, y la muchedunbre de gentes que traen se quedase en Medina, Castilla Vieja e Toualina, por razon que no se gastasen los mantenimientos de aquí ni se ocupasen posadas, el estar en Anpuero que es dos leguas de aqui y en Rramales que es quatro con toda su gente, ni ahorrados, seria de gran ynconviniente, porque atajaria pan çeuada y uino que por aquel camino se traen de Castilla, uentureros que los traen rrequeros a vender aqui, que es la prouision que comunmente mantiene este lugar, espeçialmente quando ay mercançias y cosas que sacar de aqui..., mi paresçer es que estos dos señores se uengan ahorrados con sus personas e casas a esta uilla y que venidos, haran prouecho e no daño porque ellos traen sus mantenimientos y mucho numero de azemilas, y antes ayudaran a que aqui aya mantenimientos que no a quitallos, mantenimientos de gallinas abra en abundançia porque toda la tierra y comarca esta llena de gallinas y en buen presçio, otras caças no las ay si no fuese a uentura algunos puercos jaualies, frutas ay...". Y añade que "tengo entendido que estos dos señores traen cada uno consigo mucha prouision de trigo y çeuada y carne y vinos... Si fuere ansi como creo que sera, no puede auer falta en la prouision que aca se haze. El camino de las carretas se a hecho e se acabara de hazer todo lo mejor que la dispusiçion de la tierra da lugar, y me afirman que el camino es hecho de las dos leguas de Oña y de las dos leguas de los Hoçinos que es ribera de Hebro abaxo y las de Oña de Hebro arriba los a acabado de hazer muy bien el... corregidor de las Siete Merindades".

1490 A. G. S./ Patronato Real, leg 57, doc. 62/ Laredo, 4 octubre 1570.

1491 En la batalla de Olmedo de 1467, se emplea por primera vez la artillería de campaña. 
complicado, tanto por los medios necesarios, como por el estado de los caminos. En muchos casos se debieron fabricar grandes carretones especiales para este fin, que necesitaban además un alto número de bestias para el tiro obtenidas de sus propietarios arrieros y labradores, con el correspondiente número de peones y arrieros para conducir el tren. Por otra parte, en la zona que estudiamos existen tramos de caminos, principalmente en los puertos y portillos, que además de los fuertes desniveles que se debían superar, discurrían siguiendo un trazado de vueltas y revueltas, a veces muy cerradas, que dificultaban sobremanera las maniobras del transporte de piezas y municiones. No obstante, por lo penoso de los traslados de la artillería cuando el tren estaba conformado por piezas pesadas, se hacía una revisión previa de los caminos por donde se pretendía realizar el transporte, y en su caso, poder acometer previamente las obras básicas de acondicionamiento tratando de evitar en lo posible que se produjesen situaciones imprevistas, con las piezas ya en camino.

Ya en 1476 consta en las cuentas del concejo de Santander el pago a Pedro Sánchez de Hinojedo y Pedro Sánchez Claro, de "dos myll e seys çientos maravedis que les avian da[do] para levar la lonbarda a Burgos"1492.

El rey Fernando dice en diciembre de 1485 a los concejos, corregidores y alcaldes de todo el Reino, que ha mandado a Manuel de Cortinas que, para el transporte de la artillería real, alquile los bueyes con sus carretas al precio y en la manera que él diga, por lo que manda que todos los que quisieren dar en alquiler los dichos bueyes y carros para la artillería real, lo hagan, que el Rey lo mandará pagar en los plazos y en la manera que con Cortinas lo concertasen ${ }^{1493}$.

Los Reyes Católicos comunican en marzo de 1488 a todas las autoridades y vasallos del Reino, que han encargado a Pedro Fernández del Otero, vecino de Villacastín (sur de Segovia), que lleve 500 pares de bueyes para transportar su artillería con sus carretas y bastimentos al Real que el Rey ha "de tener en tierra de moros", por lo que mandan que cuando el dicho Pedro Fernández y los carreteros fueren por los caminos con sus bueyes y carretas, los dejen pasar libremente por sus términos y pacer en sus pastos, tanto a la ida como a la vuelta, y faciliten todas las maderas que para el reparo de las carretas necesitaren siempre que se guarden los panes y vinos, y no se les demanden portazgo, montadgo, ni otros derechos de los bueyes, carnes y otras cosas que para su mantenimiento llevaren. También se les darán todas las viandas necesarias a precios razonables ${ }^{1494}$.

El rey Fernando comunica a los corregidores de Vizcaya y provincia de Guipúzcoa en enero de 1489, que ha mandado al Condado y Provincia hacer ciertas bombardas y otras armas y artillería, para llevarlas a las fortalezas del reino de Sicilia y, como para su transporte a los puertos de mar donde se han de cargar son necesarios medios adecuados, manda a los regidores que "todas las carretas e bueys e asemilas e otras bestias e fustas que fueren menester, para lleuar las dichas artellerias e armas fasta los dichos puertos donde se an de cargar", sean facilitados

1492 A. M. S./ Leg. B iz, 306, nº 3b/ Santander, 1476; SOLÓRZANO TELECHEA, J. A.: "Colección Diplomática... ". 183-185: doc. 134 .

1493 A. G. S./ Registro General del Sello, XII-1485, fol. 44/ Alcalá de Henares, 19 diciembre 1485.

1494 A. G. S./ Registro General del Sello, III-1488, fol. 27/ Valencia, 22 marzo 1488. 
a Francisco Fernández de Sevilla que tiene dicho encargo, el cual, pagará el precio usual a los vecinos de Vizcaya y de Cuipúzcoa ${ }^{1495}$.

La flota que acompañaba a Carlos V llegó a Santander el 16 de julio de 1522, desembarcando un ejército de lansquenetes alemanes y un imponente conjunto de piezas de artillería, que bajo la dirección del capitán Terramonda debía ser trasladado a Burgos. El tren fue de Santander a Torrelavega y de allí por Molledo subió a Reinosa, y bajando a la llanura de Palencia se encaminó a Burgos donde llegó el 20 de octubre. Fue necesario para arreglar el camino, que un caballero fuese delante para reconocer el terreno con cuadrillas de azadoneros que seguían sus instrucciones y acondicionarlo con pendientes suaves, anchura proporcionada a la de las cureñas o carretones y con curvas de gran radio, para que los tiros de las piezas gruesas, formados hasta por 38 pares de mulas, pudiesen tirar en línea recta. Fueron necesarias 1.084 parejas de mulas, con un hombre por pareja, para el transporte a Burgos de las 74 piezas junto con 9 carretones vacíos para sustituir a los que se rompieren, remontando las Hoces por la cuenca del Besaya. Los desperfectos ocasionados por la marcha en los carretones no debieron tener importancia, a juzgar por un recibo que firma su capitán para retirar lo preciso y reparar el cureñaje con la madera existente en el monasterio de las Huelgas de Burgos. En este recibo, fechado en octubre de 1522, figuran 16 pinas, 12 rayos, 9 ejes, tres tablas pequeñas y seis mazos ${ }^{1496}$.

En abril de 1525 se dicta una sentencia en la Chancillería, sobre un pleito litigado por Sancho García de Larrazábal contra el mulatero Martín de Arzubide, ambos vecinos de Durango, por el encargo que aquel hizo al mulatero para el transporte de ciertas cargas de espingardas, lombardas y ballestas desde Durango a Adrada de Pirón, cerca de Segovia, pa-

1495 A. G. S./ Registro General del Sello, l-1489, fol. 71/ Valladolid, 20 enero 1489.

1496 SANDOVAL, F. P. de: 1634: 560-561. “Traxo el Emperador consigo mucha y buena artilleria para armar estos Reynos, que estauan della faltos. La que fue, y el orden con que se lleuaba era: Venia primero la guia, que era vn Cauallero en vn cauallo blanco, y este miraua los passos por donde auia de passar, y tomaua el mas seguro camino por donde passasse mejor, y sin peligro ni trabajo. En pos de la guia venian los primeros, veynte y ocho falconetes de a diez y seys palmos cada vno: los quatro dellos de medio adelante eran rosqueados, y con las Coronas Imperiales: y los 24 ochauados todos, de a diez y seys palmos de largo. Por la boca de cada vno cabia vn puño grande. Cada vno destos traya cinco pares de mulas. Despues venian diez y ocho cañones, a 17 palmos y medio de largo, y de boca casi vn palmo. Los doze destos eran con flores de lis. Tirauan cada vno destos ocho pares de mulas. En pos destos venian diez y seys serpentinas, a diez y seys palmos de largo, y de boca vn palmo de alto. Y las doze dellas trayan flores de lis, y cada vna destas traya veynte y dos pares de mulas. Luego venia vna bombarda de diez palmos de largo, y en la boca dos palmos en ancho: esta trayan treynta pares de mulas. Despues destas venian dos trabucos en vn carreton a quatro palmos de largo cada vno dellos, y a dos palmos en la boca: estas trayan veynte pares de mulas. Otro que dezian Magnus draco, con vna cabeça de serpiente a manera i Dragon con el Rey Don Felipe dibuxado en el, con sus armas Reales, tenia veynte y seys palmos de largo, y vn palmo de boca en alto: a este trayan treynta y quatro pares de mulas. Despues desto venian dos tiros famosos que se dezian el pollino y la pollina, a diez y seys palmos cada vno de largo, y palmo y medio de alto en las bocas: estos trayan treynta y quatro pares de mulas cada tiro. En pos destos venia vn tiro que se dezia, Esperame que alla voy; esse tenia diez y siete palmos de largo, y dos palmos casi, de boca en alto: lleuauanle treynta y dos pares de mulas. Despues deste venian dos tiros, que se dezian Santiago y Santiaguito, y tenian de largo a veynte y seys palmos, y vn palmo en las bocas cada vno dellos en alto, llenos de flores de lis con las armas Francesas, alrededor de los escudos vnos rosarios de veneras de Santiago: cada vno traya treynta y seys pares de mulas. Luego venia vn tiro donde venia el Emperador dibuxado, con las armas Reales de sus Reynos, tenia de largo diez y seys palmos, y palmo y medio en boca: a este trayan treynta y quatro pares de mulas. En pos deste venia la Tetuda, que tenia en largo diez y siete palmos, y casi dos de boca: a este trayan treynta y siete pares de mulas. Luego venia el gran diablo, que auia en el diez y ocho palmos de largo, y casi dos palmos en el alto de la boca: tirauanle treynta y ocho pares de mulas. Despues destos venian nueue carretones destos dichos tiros, y no trayan cosa alguna, sino que venian vacios, y trayan a siete pares de mulas cada vno. Dezian y afirmauan que quedauan en el puerto de municion, y armas, y de peloteria, mas que podian traer mil carros. Por manera que los tiros eran setenta y quatro mayores y menores. Los carretones de los dichos tiros eran nueue que venian vacios, y no trayan cosa alguna: sino que eran para el seruicio de la artilleria. Mas en cada par de mulas venia vn hombre para los guiar, que eran mil y setenta y quatro hombres: estos sin los que trayan prouisiones, y açadoneros para hazer los caminos"; RIBAS de PINA, M.: 1945: 83-90; RIBAS de PINA, M.: 1946: 161-165; RIBAS de PINA, M.: $1949: 129$. 
gándole 7.000 mrs. por el alquiler de dichas cargas y llevar también dos ribadoquines. A la altura de Aguilafuente se le rompió un ribadoquín que tuvo que dejar en Segovia, culpando Sancho García al mulatero de tal rotura por su negligencia, ya "que los dichos rribadoquines heran buenos e sufiçientes, e tales que no tenyan defeto alguno en la soldadura ni en otra parte", y pidiendo por ello 15.000 mrs.: 20 ducados de oro por el ribadoquín y otros 20 de perjuicios y daños. El mulatero alega que la quiebra fue causada por la mala soldadura en su fabricación y que puso toda la diligencia, tanto en el transporte como en las cargas y descargas, ya que "nunca en el dicho camino ni vyaje, los dichos rribadoquines descargo..., arrojandolas de las bestias en que llevavan, syno con mucho cuydado e diligençia". Añade que pedía a sus compañeros "ayuda por la dicha carga para que syn dapño alguno se pudiese cargar e asy cargados los llevavan por los caminos e logares mas llanos que pudiesen hallar". El fallo indica que no está probada la negligencia ni mala intención del mulatero, ni que el ribadoquín se hubiese quebrado por su culpa, pero como dejó quebrado el ribadoquín en Segovia, condenó a Martín a que en 40 días lo lleve a Adrada ${ }^{1497}$.

La ciudad de Burgos se quejaba de que Francisco de Rojas, capitán que entendía en la fábrica de munición y artillería del castillo de Burgos, traía lo necesario para hacer la munición y artillería en las carretas que llevan bastimentos a la ciudad, y que por ello, los mantenimientos se encarecían porque al ser la ciudad de acarreo y traerlos de fuera, los carreteros dejaban de venir. La ciudad pidió que se mandase que no se tomen dichas carretas, ni tampoco a las de personas pobres y, que si necesitaren algunas, se pidan al corregidor o al regimiento sin que la ciudad y vecinos reciban daño. El Consejo acordó en agosto de 1543, mandar que el capitán con el corregidor provean sobre las carretas necesarias de fuera de la ciudad, para traer lo preciso con el fin de hacer dicha munición y artillería, y que no se tomen las que con mantenimientos lleguen a la ciudad ${ }^{1498}$.

Entre 1543 y 1546, se desarrolla un pleito entre Juan Pérez del Campillo de Aranda de Duero y el concejo, justicia y regimiento de Aranda, para el cobro de varios pares de mulas y carretas con las que Juan Pérez trasladó la artillería del Rey desde Santander hasta Aranda de Duero y que según las condiciones el Concejo debía pagar lo estipulado y no lo pagó1499.

En las cuentas de Laredo consta que en 1550 se pagaron 1.020 mrs. cuando el criado del duque de Alba, Arnao del Hoyo y Pedro Ruiz de Villota, fueron con el Duque a mostrarle los caminos hasta Agüera, antes de que la artillería del Rey se descargase en Laredo150o. Llegadas 124 piezas de artillería recién fabricadas en Malinas, se debían trasladar a Burgos bajo el mando del Teniente de Capitán General de la Artillería Luis Pizaño, y mientras el corregidor mandaba pregonar la recogida del ganado de tiro y el contrato a los azadoneros precisos para arreglar el camino, Pizaño se adelantaba a reconocerlo comenzando por el puerto de los Tornos. Para este paso fue necesario emplear el sistema que utilizó la artillería castellana para salvar el Pirineo, cuando cruzó Roncesvalles tras la conquista de Navarra. Consistía en la colocación en lo alto del puerto de una árgana o cabrestante, haciendo

1497 A. Ch. V./ Registro de Ejecutorias, caja 0377.0039/Valladolid, 21 abril 1525.

1498 A. M. B./ HI-3320 y 3416/Valladolid, 30 agosto 1543. (Burgos, 15 junio 1597)

1499 A. Ch. V./ PI. Civiles, Fernando Alonso, caja 1477,1/1543-1546.

1500 A. H. P. C./ Laredo. Cuentas de la villa de Laredo, f. 157V-168r/ Laredo, 1550; VALDORARRIARÁN, M.: 2002: 331 : doc. 13. 
pasar la maroma por poleas ancladas en las revueltas del camino para ir subiendo de uno en uno los carretones o cureñas. Luis Pizaño falleció pocos días después y se encargó de la conducción del tren Pedro Larrisada, vecino de Sestao. Se tuvieron que vencer serias dificultades para reunir los hombres, el ganado y los carros necesarios para este traslado a Burgos $^{1501}$. Las piezas estaban clasificadas en ocho tipos ${ }^{1502}$ :

\begin{tabular}{|l|c|c|c|c|}
\hline \multicolumn{1}{|c|}{ NOMBRE } & $\begin{array}{c}\text { Peso de la } \\
\text { pieza en } \\
\text { quintales }\end{array}$ & $\begin{array}{c}\text { Peso de la } \\
\text { pieza en } \\
\text { kilos }\end{array}$ & $\begin{array}{c}\text { Peso de } \\
\text { la bala } \\
\text { en libras }\end{array}$ & $\begin{array}{c}\text { Peso de } \\
\text { la bala en } \\
\text { kilos }\end{array}$ \\
\hline 18 cañones & 60 & 2.777 & 40 & 18,5 \\
17 medios cañones & 38 & 1.759 & 24 & 11 \\
21 culebrinas & 80 & 3.703 & 24 & 11 \\
21 medias culebrinas & 38 & 1.759 & 12 & 5,5 \\
23 sacres & 22 & 1.018 & 7 & 3,2 \\
24 falconetes & 12 & 555 & 3 & 1,4 \\
Un ribadoquín & 4 & 185 & 1 & 0,46 \\
Un esmeril & 2 & 92,5 & $1 / 2$ & 0,24 \\
\hline
\end{tabular}

Para este transporte, la villa de Laredo pagó en 1551 a Sancha de Carriazo 25 rs. por la posada que dio "al capitan Carreño y su gente que bino sobre la artilleria de su magestad"1503. Tras reconocer el terreno se hace un informe sobre el camino por donde debía ir la artillería desde Limpias, donde estaba, hasta Burgos, que ha sido detallado en el apartado del camino de Agüera a Burgos por Valderredible ${ }^{1504}$.

Se prepara en 1551 un tren de artillería para ir a Pamplona y Estella, y para ello se ha de proceder de la siguiente manera1505:

- Se harán 12 carretas camineras con sus sojados, y en ellos sus tablas fijas para que no se muevan las piezas pequeñas y pelotería y llevar las otras cosas necesarias. Lo que toca a la madera lo hará maese Pedro de Hormaechea y maese Miguel con los ayudantes necesarios, y el herraje Juan de Cendoya y Juan Pérez.

- Han de buscar las ruedas más altas de las que trajo Pedro Pérez para ruedas delanteras, que servirán para las 12 carretas, y si no cumplieren, dicho maese Pedro hará las que faltaren.

- Se remediará la falta de piezas, tanto de cureñas como de ruedas, con la relación de todo como son chapas, pernos, cercos, ojales y todo lo que faltare. Y que se busque en el herraje que trae Pedro Pérez lo que para esto pudiere servir y lo demás lo harán los herreros.

1501 RIBAS de PINA, M.: 1945: 87; RIBAS de PINA, M.: 1946: 231-232. Este autor en el trabajo citado en primer lugar, fecha el desembarco en 1548, pero en el segundo trabajo lo fecha en el 28 de septiembre de 1556 . Pensamos que se refiere en los dos casos a una misma remesa, y que 1550-51 es la fecha correcta de su llegada, para trasladarse como sabemos en 1551 tras la preparación de toda la infraestructura de semovientes y caminos.

1502 RIBAS de PINA, M.: 1950: 158-165.

1503 A. H. P. C./ Laredo. Cuentas de la villa de Laredo, f. 174V-191V/ Laredo, 1551; VALDOR ARRIARÁN, M.: 2002: 351: doc. 14 .

1504 A. G. S./ Guerra y Marina. leg. 42, fol. 118/1551.

1505 A. G. S./ Guerra y Marina. leg. 42, fol. 119/1551. 
- Que hagan hacer en luna menguante de enero próximo, 1.00o nudos de roble mimbreño y los guarden donde se conserven hasta el momento necesario.

- Que habiendo visto los ejes y ruedas que cada pieza de las que han de caminar tiene, se necesita lo siguiente: Si hubiere dos, tres o más piezas de un eje como son de género de cañón o culebrina, que busquen ruedas que vengan los ojales a los ejes y si no fuere posible, que se quiten aquellos ojales y les pongan otros, y si los ojales fueren todos de un tamaño, que se adelgacen los ejes o se les acreciente según esta hablado con maese Pedro de Hormaechea. Las ruedas se escogerán entre las 28 que traen los carromatos y a las que fuere necesario los herreros echarán cabestros u otra cosa, y asimismo se sacarán las necesarias con rayos de madera.

- Como algunas cureñas de las que sobran se podrán aprovechar quitándoles las teleras, maese Pedro lo hará como con el está tratado para que sirvan a estas o a las que les faltare de las que hubieren de caminar a Navarra, si les pareciere que son mejores.

- En lo del cordaje serán necesarios hasta 18 o 20 quintales de dos suertes para llevar la artillería, lo cual se encarga comprar en San Sebastián y costará hasta medio real por libra.

- Se llevará una cabrilla con todo su aparejo de las que trajo Pedro Pérez y un zarnequí grande, dos pares de banquillos y una escaleta.

- Se llevará todo el sebo y grasa que trae Pedro Pérez que son 4 quintales y 70 libras brutas.

- Todas las piezas que han venido, están guarnecidas al modo de Flandes para caminar con 4 ruedas por ser tierra llana, pero como esto es montañoso, será mejor que vayan con ellas porque las culatas son muy pesadas y no habrá par de bueyes que las puedan llevar.

- Se llevará una fragua completa con todo su aparejo de herramientas, herreros y ayudantes para que aderecen lo que se rompiere y cuatro quintales de hierro, tres de pletina, uno de vergazón y $\frac{1}{2}$ quintal de acero.

- Irán con la artillería, maese Pedro y los oficiales necesarios con sus herramientas.

- Se ha de llevar un herrador con su aparejo.

- Que los gastadores vengan del reino de Navarra para ahorrar dinero, y traigan las herramientas necesarias como hachas de cortar y picos, azadones y palas de hierro. Las seis almádanas y dos barras de pie de cabra se podrán hacer aquí a menos coste.

- Se han de proveer de algunas hachas de cera, velas de sebo, linternas, rodetes alquitranados y 4 faroles de los de la munición de Pamplona.

- Que se pongan en el camino por todos los lugares, los hachos de ciscia necesarios.

- Que se lleven de respeto algunas chavetas, agujetas y muletas y de cada género de ruedas seis cabestros.

- Se han de traer de Pamplona 102 tiendas de campo con su aparejo, ya que no las hay aquí.

- Se ha de visitar el camino y acordado por donde se ha de ir, se enviarán unos días antes, gastadores con personas que sepan cómo se ha de llevar la artillería para preparar el firme.

- Vendrá Aguilar con todos los artilleros de Pamplona para ir con la artillería. 
Laredo gastó 4.266 mrs. en 1553, para, entre otras cosas, pagar a los "hombres que se tomaron para mober la artilleria de Fruslera, y en cabalgarla" y a ciertos mensajeros ${ }^{1506}$.

El Ayuntamiento Ceneral de las Merindades faculta en agosto de 1591 a Pedro Díaz de la Peña, para hacer relación de los bueyes, mulas y carros que debían ir de servicio para transportar la artillería y municiones del Rey ${ }^{1507}$.

En la Chancillería se trató pleito ente los procuradores generales de la tierra de Toro, de una parte, y Francisco Cornejo de Cueto, vecino de dicha ciudad, de la otra, sobre que en abril de 1592 Cornejo dijo al corregidor que por especial comisión suya y de los dueños de las mulas, él había partido en septiembre de 1591 con 100 mulas, 50 mozos y 50 carros, para entregar una carga al general de la artillería que estaba en Burgos conforme a la orden del Rey, en lo que se había ocupado 10 días que se le habían pagado. Después se ocupó 145 días más, con las dichas mulas en el ejército y servicio real en Aragón haciendo diversas jornadas y cargas proveyendo a los 50 mozos y mulas de todo lo necesario, para lo que el corregidor le había señalado el pago de 500 mrs. por día, pero los dueños de las mulas a cuya instancia había hecho la ocupación de los 145 días a 500 mrs. diarios, le debían 21 rs. y $10 \mathrm{mrs}$. por mulo. Pidió por ello al corregidor que mandase que los dueños pagasen dicha cantidad, y si no, se embargasen prendas contra cada uno de ellos. El corregidor mandó dar mandamientos contra los dueños, vecinos de Villavendimio, Villardondiego, Peleagonzalo, Abezames, Bustillo del Oro, Pozoantiguo y Valdefinjas, condenando en agosto de 1592 a los dueños de las mulas, a que en tres días pagasen cada uno de ellos a Francisco Cornejo 580 mrs. por el salario de los 145 días. En febrero de 1593 los dueños de las mulas dicen al corregidor que no debían pagar nada, porque no era justo que los que habían dado sus mulas y carretas, perdiéndolas muchos de ellos y otros dejando de aprovecharlas 10 meses "en que abian perdido muchos dineros, e abian dexado de azer su berano e sementera e barbecharia", y que además había recibido cada uno un daño de más de 20.000 mrs., pagasen dichos salarios, por lo que pidieron al corregidor que revocase la sentencia1508.

Sobre estas jornadas también se trató pleito entre Pedro Serrano y el concejo y vecinos de Villanueva de Lugo. En abril de 1592 ante el alcalde mayor del Partido de Campos, compareció el procurador de Pedro Serrano y dijo que el concejo de Villanueva se había concertado con él, en septiembre de 1591, para que les diese dos mulas de carreta y un mozo, y fue con ellas a Burgos para llevar la artillería y munición de dicha ciudad para la guerra de Aragón y Zaragoza, y que por ello, habían quedado en pagarle a costa de sus propios, si el Rey no lo hiciese, 40 ducados por las mulas y 400 mrs. por cada día empleado en la ida, estada y vuelta hasta volver a Villanueva, y que si las mulas volviesen con menoscabos los pagase el concejo, y si alguna muriese el concejo le pagaría 20 ducados. De esta manera, entregó las dos mulas y a Miguel Serrano, su hijo, como mozo, el cual recibió del concejo a su partida 52 rs. Una vez despedido en Zaragoza el 9 de febrero de 1592 por el teniente general de Artillería, llegó a su casa el 20 de ese mes solamente con una de las mulas porque

1506 A. H. P. C./ Laredo. Cuentas de la villa de Laredo, f. 212V-219v/ Laredo, 1553; VALDOR ARRIARÁN, M.: 2002: 404415: doc. 16.

1507 A. C. V./ Leg. 39,7/ Villarcayo, 24 agosto 1591.

1508 A. Ch. V./ Registro de Ejecutorias, caja 1795.0018/ Valladolid, 30 agosto 1595. 
la otra se le había muerto en el camino, de manera que había ocupado en lo dicho 159 días, sumando los salarios de 166 ds. y 6 rs., más 20 ds. de la mula muerta. Para este gasto el pagador general había pagado los mrs. solicitados, pero decía que lo restante lo debía pagar el concejo de Villanueva y no lo había querido hacer, por lo que suplicaba que le pagasen los 186 ds. y 6 rs. La sentencia dada en junio de 1593 condenó al concejo a pagar a Pedro Serrano 36.666 mrs. por los 159 días que Miguel y dos mulas suyas se ocuparon en el transporte de Burgos a Zaragoza, que a 400 mrs. por día, descontando 10 fanegas de trigo que el concejo dio a Pedro Serrano para la compra de una mula y 661 rs. por lo que este recibió de los agentes del Rey en Zaragoza en cebada y dineros ${ }^{1509}$.

En junio de 1597 el procurador de Burgos pide testimonio de como requiere, con la real Provisión de agosto de 1543, a Juan Girón capitán en la fábrica de munición y artillería de Burgos para que no se saquen carretas de la ciudad, y cuando se necesiten se provean de fuera, ya que Girón había mandado embargar las carretas que traían a la ciudad vino y otras provisiones. Deberá dejar libres las carretas y si las necesita se junte con el corregidor para que se provean de carretas de fuera. Cirón responde que en una cédula real se le manda que con la mayor brevedad, envíe a la armería de Hugey 2.70o coseletes alemanes para hacer con ellos nuevas armas y que los 30 maestros y oficiales de dicha armería los estaban esperando. No cree que la ciudad reciba ningún daño en el embargo de las carretas que llegan al mercado y pide a la ciudad que le den las carretas para llevar dichas armas, y con ellas alzará el embargo que tiene hecho y si no se las dan, informa sobre el daño que puede venir a la Hacienda real y procederá con rigor ${ }^{1510}$.

\section{b.- Formas habituales de financiación}

Desde la Edad Media hasta al menos el siglo XVIII no hubo una política viaria de la Monarquía y esta no promovió la construcción de nuevas vías, aunque sí realizó cierta ordenación y supervisión de lo que debían hacer los poderes municipales ${ }^{1511}$. La Corona no asumió, salvo en ocasiones excepcionales ${ }^{1512}$, la intervención directa en los caminos y puentes, bien para su construcción, o bien para su reparación, y no afrontó en general ninguno de sus gastos. Correspondía, eso sí, a la Corona, desde fines de la Edad Media, el estímulo, la aprobación y el control de las obras públicas camineras a través del Consejo Real y de los corregidores de él dependientes. Se reservaba la función de conceder las licencias pertinentes para llevar a cabo las actuaciones y establecer el modo de financiación adecuado, controlar su desarrollo, exigir responsabilidades de acuerdo con las condiciones del contrato, así como, y esto es muy importante, velar por el correcto trámite del procedimiento autorizado para la obtención de los recursos económicos y su aplicación a los fines

1509 A. Ch. V./ Registro de Ejecutorias, caja 1768.0022/Valladolid, 10 septiembre 1594.

1510 A. M. B./ HI-3416/ Burgos, 15 junio 1597

1511 DIAGO HERNANDO, M. y LADERO QUESADA, M. A.: 2009: vol. 32, 353.

1512 Conocemos no obstante al menos un caso en el sector geográfico que estudiamos, en que hacia 1494 la Reina concede directamente un dinero para reparar el puente de Agüera: "podra aver dyez syete años poco mas o menos que las dichas puentes cayeron, e que la Rreyna doña Ysabel de gloriosa memoria, mando de su camara para las tornar ha haser para la vna dozientos rreales". A. G. S./ Consejo Real de Castilla, leg. 26-17/ Burgos, 5 octubre a 12 diciembre 1511. 
establecidos. Para ello, el Consejo Real autorizaba los repartimientos precisos y encomendaba a los corregidores que hiciesen los cobros de tales impuestos directos, o concedía licencias para establecer otros indirectos como las sisas, así como para gastar parte de las rentas habituales de los concejos o propios en las intervenciones precisas ${ }^{1513}$.

Aunque los promotores eran principalmente los concejos, también lo fueron los titulares de señoríos, instituciones religiosas, Juntas de Vizcaya, Guipúzcoa y Álava y además las cofradías y universidades interesadas, como eran las de los mercaderes o las de los mulateros. También la Corona podía serlo en menor medida, y eran los corregidores o jueces de residencia quienes en nombre del Rey o del Consejo, realizaban la gestión y control de estas intervenciones.

\section{Financiación por las localidades'514.}

Tres eran los sistemas que se utilizaban para que los concejos, los principales promotores y financiadores, pudiesen obtener los fondos precisos para acometer una obra pública: la sisa, el repartimiento y la imposición, mientras que las cofradías y universidades, abogaban siempre por la imposición. Se partía de un principio general como era el de que los concejos que poseían en su término el camino o el puente deteriorado, eran los que debían encargarse de su reparación y mantenimiento y así se recogía en la legislación¹515. Para ello se les obligaba a utilizar como principales recursos sus bienes propios y rentas concejiles y afrontar así los gastos de toda la actuación. Pero como dichos propios y rentas eran casi siempre escasos o inexistentes y, en el caso de tenerlos, solían estar afectados para otras finalidades, no alcanzaban lo pretendido impidiendo así el desarrollo adecuado de las actuaciones y obligando por ello a aplicar medios de recaudación extraordinarios.

El Condado y Señorío de Vizcaya y las provincias de Guipúzcoa y Álava, tenían no obstante, un sistema especial de funcionamiento y financiación, ya que sus Juntas eran las que autorizaban la intervención en los caminos y puentes y fijaban los medios de financiación realizando su propio sistema de repartimiento1516. Existieron conflictos en este caso, cuando se pretendía repartir a localidades de dichos territorios puentes y caminos de otros ámbitos, situaciones que sus Juntas siempre intentaban resolver de la misma manera: respondiendo negativamente y apelando a sus privilegios.

\section{- Las sisas}

La sisa era una figura fiscal de obtención indirecta de recursos, por medio de la reducción en las ventas del peso o de las medidas de los productos de primera necesidad y bastimentos como el pan o el vino. El producto de esa mengua se aplicaba a realizar las

\footnotetext{
1513 RINGROSE, D. R.: 1987: 68.

1514 PÉREZ BUSTAMANTE, R.: 1981: 163-178.

1515 NOVÍSIMA RECOPILACIÓN DE LAS LEYES DE ESPAÑA/ París, 1846. Tomo tercero/ Libro VII, Titulo XXXV, Ley II/ Medina del Campo 1497. "Mandamos á las Justicias y Concejos, que fagan abrir y adobar los carriles y caminos por do pasan y suelen pasar y andar las carretas y carros, cada Concejo en parte en su término,... y que no consientan ni den lugar los dichos Concejos, que los dichos caminos sean cerrados ni arados, ni dañados ni ensangostados, so pena de diez mil maravedís á cada uno que lo contrario hiciere".
}

1516 GONZÁLEZ MÍNGUEZ, C.: 1996: 247-253. 
intervenciones. Las poblaciones afectadas podían realizar el "encabezamiento"1517, que consistía en ofrecer una cantidad acordada sin esperar al cobro de ese impuesto.

Se mencionan las sisas cuando Pedro Conzález Cachopín, dijo que en nombre de los vecinos de Laredo había pedido al corregidor que cumpliese una Carta real, para que las sisas que se habían puesto desde 1529 para hacer el camino de Laredo a Colindres no se gasten ni distribuyan, y que de acuerdo con ella, tampoco se gasten las que se echen en adelante porque ningún edificio se había hecho. Los regidores de la villa habían gastado en pleitos y otros gastos, todos los mrs. obtenidos de las sisas y el corregidor no lo impedía, de manera que este, el teniente y regidores gastaban las sisas y además se había echado mucha más que en los años pasados, añadiendo 2 mrs. en cada azumbre de vino y otras muchas sisas más, por lo que pedía que se trajese la cuenta de lo obtenido de sisas desde 1529 y se averigüe en qué se habían gastado, y mientras tanto no se cobrasen. El Consejo mandó en mayo de 1533 al corregidor, que en 30 días reciba las cuentas de todo este tiempo y los que han tenido el cargo de cobrar los mrs., que le den el detalle de donde los cobraron y si se han gastado en otra cosa distinta, en qué y por qué mandado y envíe dicha información al Consejo ${ }^{1518}$.

En las Juntas de Vizcaya de agosto de 1582 se trató entre el corregidor, regimiento y procuradores de las villas, que Bilbao había obtenido Provisión del Consejo Real para echar sisa sobre los bastimentos que en la villa se vendían en cantidad de 26.000 ds., porque "el dilubio ultimamente pasado, abia hecho muchos daños en la dicha villa", así en el puente, como en los caminos de Orduña y Valmaseda y para ello Bilbao pretendía, según ellos, hacer relación siniestra para dañar al Señorío y a las Villas y Ciudad, porque como todos van a Bilbao a comprar provisiones, pagarán la sisa los que llegan de fuera, siendo como era villa muy rica y tener propios y rentas de más de 3.000 ds. anuales más la ayuda de su casa de la Contratación, teniendo además excedentes en la cuenta de la sisa que primero se le concedió por 10.000 ds. y que va sobre todo contra el Fuero del Señorío que prohíbe imposición alguna, y como la villa no tenía más obras ni reparos, debían hacerlo con sus propios, pues el puente tenía poco daño y el reparo de las calles y caminos era de poca costa. Por estar el Señorío y Villas y Ciudad tan necesitados, acordaron que se rechace la dicha sisa ${ }^{1519}$.

\section{- Los repartimientos}

El repartimiento o reparto de la cantidad necesaria entre los vecinos, fue la manera más frecuentemente utilizada para resolver la carencia de recursos económicos, el más grave inconveniente que tenían las actuaciones en infraestructuras, casi siempre necesitadas de grandes sumas, siendo implantado lentamente como un sistema más eficaz y adecuado. Consistía en repartir el presupuesto de la intervención entre todos los vecinos de las localidades incluidas en un área determinada. Dichos vecinos debían contribuir

1517 El encabezamiento o asiento consistía en alquilar el cobro del impuesto al mejor postor, con lo que se aseguraban unos ingresos mínimos, mientras que quien alquilaba adquiría el derecho de cobrar el impuesto correspondiente.

1518 A. H. P. C./ Laredo, leg. 13, num. 15/ Madrid, 15 mayo 1533.

1519 A. J. R. B./ Actas de la Tierra Llana. t. III/ Durango, 25 agosto 1582; Actas de Villas y Ciudad. t. II/ Durango, 25 agosto 1582 
para obtener la cantidad fijada a su localidad. Era por lo tanto una imposición directa e injusta, ya que aunque se cobraba a todos los vecinos sin discriminar personas o clases sociales, no tenía en cuenta el nivel de renta de cada individuo.

En la Ordenanza para Corregidores dada por los Reyes Católicos en 1500, se detalla que los corregidores y sus oficiales no podían consentir ni hacer "derramas sobre los pueblos, sino commo quieren las leyes que disponen que de tres mill mrs. arriua se no faga sin nuestra liçençia"1520. Esta escasa suma de 3.000 mrs. era la cantidad máxima que los concejos podían obtener por repartimiento o sisa sin licencia real. Por encima de esta cantidad debían solicitar la autorización del Rey. El Consejo mandaba a los corregidores que investigasen sobre la necesidad de los trabajos pretendidos, los recursos del concejo, las cantidades necesarias, quiénes se beneficiaban, etc. y si la información obtenida era positiva se concedía la autorización. Si los trabajos no avanzaban lo suficiente, algo muy frecuente, el corregidor debía velar por su correcta ejecución. Era habitual que el concejo interesado pretendiese la participación de las localidades que se beneficiaban de la intervención, resolviéndose este asunto con la inclusión en el repartimiento de todos los lugares ubicados en un radio de un determinado número de leguas a la redonda, dependiendo de la importancia de la actuación. A veces, se repartía en proporción al beneficio que cada localidad recibía de acuerdo a la cercanía con la obra a realizar, de manera que la villa o lugar más afectado pagase una mayor cantidad.

Este sistema de repartimiento se implantó en la zona que estudiamos a partir de las últimas décadas del siglo XV, fechas en que se produjo una intensificación en las obras públicas apoyadas por la Corona, en unos momentos de claro desarrollo de los tráficos mercantiles $^{1521}$. El proceso burocrático del repartimiento era complejo y dilatado en el tiempo:

$1^{\circ}$. El concejo o el directamente implicado solicita al Consejo Real la intervención, justificando los motivos que la hacen necesaria.

2o. El Consejo Real autoriza el inicio de las actuaciones y encarga al corregidor que obtenga la información precisa sobre la situación del puente o camino a reparar, su necesidad y urgencia, los beneficiarios de los reparos, su presupuesto, etc., Una comisión de maestros de cantería bajo juramento debían examinar los desperfectos, proponer las actuaciones adecuadas y adelantar un presupuesto sobre la intervención y el plazo de ejecución. Toda esta información se debía enviar al Consejo.

$3^{\circ}$. El Consejo aprueba la ejecución de la obra y manda elaborar informes a maestros expertos, con las condiciones, trazas y planos de la obra.

$4^{\circ}$. El corregidor manda pregonar la obra entre las villas y ciudades más cercanas para que concurran los maestros de cantería interesados.

$5^{\circ}$. En un día determinado y generalmente mientras dura encendida una vela, se admiten posturas a la baja, en que se debe detallar la cantidad por la que se comprometen a realizar la intervención en el plazo indicado.

1520 A. M. Salinas de Añana/ Caja 26, nº 3, 4 y 5/ Sevilla, 9 junio 1500; POZUELO RODRíGUEZ, F.: "Archivo Municipal de Salinas... 2007: doc. 50. art. XXXIV.

1521 A. H. N./ Nobleza. Frías, C. 235, D. 55/ Medina de Pomar, 15 enero 1499. 
6‥ El Consejo debe admitir las bajas y el remate de la obra. Si no lo admite, se ordena pregonar de nuevo repitiendo la subasta a la baja. El maestro de cantería adjudicatario debe presentar fianzas y fiadores que respondan económicamente en el caso de que el maestro no cumpla y resulte insolvente, acordando con él los plazos de ejecución y los de los pagos, siempre fraccionados, generalmente por tercios.

$7^{\circ}$. Una vez aprobada la intervención y el remate realizado, el Consejo con la cantidad económica ya comprometida en dicho remate, ordena al corregidor como juez de la obra la realización del repartimiento, para lo que se fijan sus límites geográficos que dependiendo de la importancia del puente o camino, podían alcanzar a localidades incluidas en 5,8 , 12, 15 o 20 leguas a la redonda.

$8^{\circ}$. Se nombran verederos que tras zonificar dicho círculo, visitan todas las villas y lugares incluidos en su zona, obteniendo información sobre su número de vecinos (las viudas se consideraban medio vecino).

$9^{\circ}$. Se fija la cantidad que cada población debe pagar en función del número de sus vecinos, y el plazo y lugar del pago, nombrando un depositario que debía ser persona de honradez contrastada.

$10^{\circ}$. Se fija un veedor, a veces asesorado por maestros, para que haga el seguimiento de la obra y verifique si la ejecución se realiza de acuerdo con las condiciones de adjudicación y se emplean los materiales y mezclas adecuadas.

Este sistema lógico y coherente, no estuvo exento de graves problemas que, en muchos casos, provocaron que los objetivos fijados no se llegasen a alcanzar. El mayor problema fue el de la recaudación, ya que tras la fijación de las cantidades que debía aportar cada ciudad, villa, lugar, cofradía, universidad, etc. incluidas en el área fijada, las apelaciones y alegaciones contra esta medida eran abundantes y diversas.

Las alegaciones más corrientes consistían en:

- Que estaban exentos de tales pagos por tener privilegios.

- Que eran pobres o habían tenido malas cosechas, la más común.

- Que su localidad estaba más lejos de las leguas fijadas para la recaudación, lo que en algunos casos era cierto.

- Que no utilizaban ni necesitaban el puente o camino a reparar.

-Que pagasen los que utilizaban y destruían el camino como los arrieros o mercaderes.

- Que tenían menos vecinos de los que se les fijaba.

- Que se les pedía más de lo que les corresponde.

- Que nunca habían pagado, ya que lo hacían los mercaderes y mulateros.

-Que no se encontraban en el camino que se pretende reparar.

- Que ya se gastaban muchos mrs. en los puentes de su jurisdicción, y por ello, harto tenían con sus puentes como para colaborar en otros ajenos. 
El proceso era muy complicado y a pesar de que se solían rechazar todas las alegaciones, muchos contribuyentes no pagaban y obligaban a emprender procesos a veces dilatados en el tiempo. La situación de las obras se agravaba con cierta frecuencia, porque las cantidades recaudadas no alcanzaban para finalizar la actuación al haber aumentado el presupuesto o no haberse recaudado lo previsto, o porque el maestro cantero no cumplía con las condiciones técnicas o plazos establecidos. La falta de los fondos necesarios o el incumplimiento de las condiciones provocaban retrasos en las ejecuciones, haciendo peligrar en ocasiones su continuidad e incluso obligando a su suspensión, y en casos extremos, acabando con el maestro y fiadores en la cárcel.

A veces, se utilizaban varios sistemas de cobro en una misma intervención, incluso en algunos casos se llegaron a emplear los tres para recaudar los mrs. necesarios: la sisa, el repartimiento y la imposición.

En 1491 ya se habla de repartos, y aunque parece que se refiere a imposiciones, también se alude al pago de las localidades. Así en diciembre, la Junta, diputados, alcaldes y procuradores de la provincia de Vitoria, Álava y Ayala, solicitan licencia real para que se "pudiese echar e rrepartir por los caminantes que pasasen e caminasen por las dichas puentes e calçadas". El Consejo Real encomendó al juez pesquisidor en Vizcaya, que recabase información sobre los caminos, puentes y calzadas afectados, donde están, qué reparos necesitan y su coste, en qué cosas se podría echar imposición y por cuánto tiempo, qué lugares de la comarca son los que reciben más provecho, "que vezinos puede aver en cada vno dellos, para que ayades contribuyr en los gastos dellos e que quantias de mrs. dellos se deven echar e rrepartir a los tales lugares, e sy avria otra cosa o se podria prouer por otra manera mas prouechosa, e a menos cargo e fatiga de los dichos caminantes e pueblos, para ser adobados e rreparados... syn averse de inponer la dicha sisa e inpusiçion"1522.

\section{- La imposición o los portazgos y peajes}

Un medio utilizado en muchos casos con fines recaudatorios, aunque justificado para mantener los caminos y puentes en buen estado, fueron los peajes, portazgos y pontazgos, muy extendidos en la red viaria medieval, sobre todo en las proximidades de las ciudades. Uno de los privilegios más frecuentes, que los monarcas concedían a los pobladores en las Cartas Pueblas y Fueros medievales, fue el de la exención del pago de peajes y portazgos. Existieron dos tipos de peajes: aquellos que se cobraban como derecho de paso por un determinado punto o localidad situada en un camino, y los que se imponían con el objetivo de obtener recursos para acometer determinada reparación u operación de mantenimiento de caminos y puentes y que, en teoría, debían cesar cuando la obra concluía. En el primer caso, se mantenían imposiciones sobre el tránsito como un ingreso más de quien lo aplicaba sin utilizarlos para la mejora de caminos y puentes, con la consecuencia de que muchas vías estaban intransitables y los puentes arruinados.

En las Partidas se regula la obligación de pagar portazgos, el castigo al que los elude y los fines de lo recaudado, tomando medidas para que el pago no se evite: "De los Portadgos, e de todos los otros derechos, que han a dar los Mercadores, por razon de las cosas que lleuan de vnos lugares a otros"(ley V), "De los Mercadores que andan descaminados, por furtar, o encubrir los derechos que han a dar, 
de las cosas que lieuan" (ley VI) y "De las rentas que de los portadgos, que se pusieren nueuamente en la Villa, o en otro lugar" (ley VII)1523.

En ocasiones la exención del pago del portazgo tenía un carácter temporal mientras durase la feria o mercado o el evento motivo de la exención. Así en 1339 Alfonso XI concede a la ciudad de Burgos feria anual, durante 15 días, y exime de su pago a los que concurran a ella: "et que en este tienpo de la dicha feria, que todos los que a ella venieren que sean quitos de portadgo, que lo non paguen de las cosas que traxieren o leuaren en quanto durare la dicha feria"1524.

Como se cometían abusos en dicho cobro y aparecían portazgos nuevos, algo que obstaculizaba la libre circulación, encarecía el transporte y dificultaba un comercio que la Corona pretendía promover y apoyaba, el Rey se vio obligado a intervenir poniendo orden. De esta manera, aparece en las Partidas la ley VIII "De como aborrescen los Mercadores a las vegadas de venir con sus mercaderias a algunos lugares, por el tuerto, e demasias que les fazen, en tomarles los portadgos", y la ley IX "Que ningun ome non puede poner portadgo, ni Concejo, ni Eglesia, en todo el Señorio del Rey, sin su mandado"1525. La situación siguió sin resolverse, porque continuaron dictándose medidas para evitar los mencionados abusos tras las protestas dirigidas en prácticamente todas las Cortes convocadas como en las de 1348 de Alcalá, en que se manda que "de aqui adelante ninguno non tome portadgo, nin peaje, nin ronda, ni castelleria, non teniendo cartas, nin previllegios, porque lo puedan tomar"1526.

Cuando se realizaban las intervenciones y reparaciones, se tendía a recuperar la cantidad invertida por medio de la imposición de un cobro llamado portazgo, pontazgo o peaje, sobre el tráfico y tránsito de las mercaderías, ganados y personas utilizando el bien reparado, algo que debía autorizar el Consejo Real. Dicho Consejo fue siempre muy restrictivo a la hora de conceder tales licencias y, cuando las concedía, lo hacía por un tiempo determinado y hasta recibir una cantidad concreta. Esta autorización era frecuentemente solicitada por ser una vía rápida y sencilla de obtención de recursos pero, salvo excepciones, la respuesta del Consejo Real fue negativa, ya que era empeño de la Monarquía evitar la aparición de nuevos tributos como era este caso. Además, se habían dado con demasiada frecuencia hechos que justificaban esta oposición, como los abusos por cobrar más cantidad de la autorizada o, como era lo más corriente, por prolongar el período autorizado para el cobro, manteniéndolo después de realizada y pagada la obra, quedando como un derecho señorial, monacal, episcopal o municipal, el caso más frecuente. También se daban casos cuando, con cierta frecuencia, se cobraban los peajes sin la debida autorización $y$, a veces, sin ninguna obra que lo justificase.

La ley de Enrique IV de 1455 permite a los concejos hacer puentes a su costa sin poner imposición alguna, a pesar de la oposición de prelados y nobles así despojados de los derechos percibidos por el paso de vados y barcas ${ }^{1527}$. La única excepción en la que la Corona

1523 LAS SIETE PARTIDAS/ Quinta Partida, Título VII, Leyes V, VI y VII.

1524 A. M. B./ HI-98/ Madrid, 28 noviembre 1339.

1525 LAS SIETE PARTIDAS/ Quinta Partida, Título VII, Leyes VIII y IX.

1526 ORDENAMIENTO DE ALCALÁ. Ley XXVI. “En que pena caen los que tomaren los portadgos ò peajes en los Logares dò non se deben tomar".

1527 NOVÍSIMA RECOPILACIÓN DE LAS LEYES DE ESPAÑA/ París, 1846. Tomo segundo/ Libro VI, Titulo XX, Ley VII/ Córdoba, 1455, pet. 26. "Tenemos por bien, que las ciudades, villas y lugares destos nuestros Reynos, y otras qualesquier 
permitía imposiciones, era en "aquellos puentes donde los lugares fazian las dichas calçadas e puentes a su costa", es decir, solo se autorizaron en alguna ocasión las imposiciones, cuando previamente los concejos ya habían hecho las actuaciones a su costa y permitir así recuperar la inversión con el cobro de un peaje por un tiempo determinado. Se evitaba con ello, que los promotores iniciasen las obras sin más financiación que la que fuesen obteniendo por los peajes sin ninguna aportación propia.

En 1491 la Junta, diputados, alcaldes y procuradores de las Hermandades de la provincia de Vitoria, Álava y Ayala, solicitan licencia real para repartir 150.000 mrs. para el reparo de las calzadas y puentes del camino real que va de Orduña a Bilbao y a otros puertos. Alegan que el camino mencionado por donde dicen que pasan todas las mercaderías que de los puertos vienen a sus reinos y muchas cargas y mulaterías que van a Castilla, está muy deteriorado y no se puede utilizar sin gran peligro para las personas y acémilas. Añaden que si no se arregla no se podrá transitar, siendo necesarios unos 150.000 mrs. Suplicaron que esa cantidad se pudiese cargar a los caminantes beneficiarios "segund se acostumbra echar e repartir en semejantes pontajes". El Consejo Real acordó encomendar al juez y pesquisidor del condado de Vizcaya, que reciba información sobre los caminos, puentes y calzadas afectados, qué reparos necesitan y qué costaría su reparo, etc. El juez deberá remitir la información obtenida con su parecer, al Condestable y al Consejo Real, para que puedan informar a los Reyes si procede la imposición solicitada y manden "proveer çerca dello, lo que justiçia sea e a nuestro serviçio cumpla"1528.

No obstante, en repetidas ocasiones los propios mulateros solicitan autorización para poner imposiciones, y piden que para que los puentes y caminos se reparen o se hagan, ellos están dispuestos a pagar por su tránsito como consecuencia de la necesidad que tienen de utilizar los puentes y caminos de una manera inmediata, porque han comprobado que otros métodos son más lentos o problemáticos ${ }^{1529}$.

\section{Financiación por los usuarios}

Los más interesados en que los caminos estuviesen en condiciones aceptables además de los propios municipios y sus vecinos, eran los que los utilizaban de manera más directa: los comerciantes y los mulateros y carreteros. Para promover las iniciativas co-

personas puedan hacer y edificar puentes en los rios á su costa, tanto que ellas no puedan imponer, ni pongan imposiciones ni tributos algunos. Y mandamos, que ningun Perlado, ni Caballero ni otra persona alguna, no sean osados de impedir ni estorbar que se no hagan las dichas puentes, porque digan que tienen barcos ó otros derechos en los rios; y si atentaren de impedir y estorbar, que las dichas puentes no se hagan, si fueren legos, que pierdan todos sus bienes, y sean aplicados á la nuestra Cámara; y si Perlado ó otra persona alguna eclesiástica, que por ese mismo hecho pierda la naturaleza y temporalidad que tuviere...".

1528 A. G. S./ Registro General del Sello, XII-1491, fol. 12/ Burgos, 13 diciembre 1491.

1529 A. G. S./ Registro General del Sello, VII-1495, fol. 187/ Burgos, 9 julio 1495. Tras la destrucción de los puentes de Valmaseda por una riada, los Reyes Católicos dicen que como "nos ovimos mandado que çiertas ynposiçiones que se lleuan a los mulateros e viandantes en çiertas puentes e calçadas, no se lleuasen saluo aquellos puentes donde los lugares fazian las dichas calçadas e puentes a su costa, e que a esta causa se dejaron de rreparar muchas dellas, e que agora la lluuia que hubo en el condado de Vizcaya e Merindades, diz que lleuo todas las dichas puentes e calçadas de que la tierra quedó muy destruyda, de manera que los dichos mulateros e viandantes no pueden pasar por ellas de que rresçiben mucho daño, e nos suplicaron $e$ pidieron por merçed que mandasemos que los lugares en cuya tierra estauan las dichas puentes e calçadas, los tornasen a faser e sy nesçesario fuese, faser algunas puentes grandes en que se omitio de gastar, e que algunos de los dichos lugares non las pudiesen faser, que mandasemos que los mercaderes e otras personas que por alli pasasen, pagasen e contribuyesen para ello que ellos estauan prestos e aparejados de contribuyr". 
rrespondientes, existieron dos asociaciones que aglutinaban los intereses de cada una de las partes como eran la Universidad de los Mercaderes de Burgos y las cofradías de mulateros y caminantes de Castilla Vieja.

\section{- La Universidad de los Mercaderes de Burgos}

Ya hemos tratado sobre este tema en el apartado del camino a Santander por Corconte y puerto de El Escudo, así como en las cuentas del Consulado sobre el camino de Laredo y en su participación en la adecuación del Camino de los Carros. No obstante, la intervención de la Universidad en los caminos del Reino fue mucho más amplia y decidida y extendió su actividad en el siglo XVI a la construcción y reparación de un gran número de caminos y puentes. Con el fin de propiciar un tráfico fluido que permitiese y garantizase el transporte de sus mercaderías de una manera adecuada, la Universidad estuvo constantemente interesada en que los caminos a los puertos de la mar se mantuviesen debidamente acondicionados, algo que nunca lograron por completo como consecuencia del territorio tan accidentado que dichos caminos debían atravesar y del continuo deterioro que sufrían, tanto por el tráfico de carretas como, y sobre todo, por las duras condiciones climatológicas. Además, también tomó iniciativas para la construcción de nuevos caminos y tramos, a veces importantes, de dichos caminos. Los recursos provenían de lo que la Universidad obtenía de averías.

Esta preocupación ya se puso de manifiesto en la ordenanza XXI del Consulado de Burgos de 1538, que refiere que la Universidad y Prior y sus cónsules tienen que hacer muchos gastos, entre los que se incluyen los que se realizan "en edeficios de puentes y caminos desta ciudad,é de los puertos de la costa de la mar, para poder llevar y carretear las lanas y otras mercaderías desta dicha universidad, á los dichos puertos para las navegar, é para traer dellos los fardeles é otros géneros de mercaderías que vienen de Flandes o Francia y otras partes"1530. También este aspecto se recogía en las ordenanzas de 1572, en la número XXVIII, que indica que de "las averías que se han de pagarála Universidad", se abonará "por ser en beneficio general de todos... para adereçar los caminos y edeficios de puentes de los puertos de la costa dela mar, que an sido y son de mucha costa y gasto, para poder llevar y carretear las lanas y otras mercaderias que salen destos Reynos por los dichos puertos, y para traer las que vienen de fuera dellos"1531.

Ya desde el siglo XV, los mercaderes burgaleses a través de su Universidad, colaboran en la construcción y mantenimiento de caminos y puentes. A fines de dicho siglo, la Corona toma la decisión de realizar las actuaciones precisas para la mejora del camino de Burgos a Laredo a instancias de los mulateros. En enero de 1499 se decide que el repartimiento se hará sobre las localidades por donde discurre el camino, así como sobre la Universidad de Burgos y sobre los mulateros. A la Universidad, por el ahorro que conseguirán con la utilización de carros, se le asignan 1.000 florines $(265.000 \mathrm{mrs})^{1532}$. En junio de 1501 los mercaderes se quejan a causa de la cantidad que les había sido repartida en el primer repartimiento, y alegaban que Laredo recibe más provecho que Burgos y los recueros y vian-

1530 Ordenanzas del Consulado de Burgos de 1538/Valladolid, 18 septiembre 1538; GARCÍA de QUEVEDO, E.: 1905 Y 1995: 199-203. Ordenanza XXI.

1531 Reales Ordenanzas del Consulado y Casa de Contratación de Burgos/ Ordenanza XXVIII/ Madrid, 1 agosto 1572; LARRUGA, E.: 1793: 216-297: t. XXVIII.

1532 A. H. N./ Nobleza. Frías, C. 235, D. 55/ Medina de Pomar, 15 enero 1499. 
dantes más provecho y utilidad que ellos. Acordó que los $265.000 \mathrm{mrs}$. se repartan de la manera siguiente: $150.000 \mathrm{mrs}$. a la propia Universidad de los mercaderes, 50.000 a la villa de Laredo y a los mulateros y recueros 65.000 , además de los 260.000 ya repartidos ${ }^{1533}$.

Un medio privilegiado para conocer las intervenciones realizadas por dicha Universidad son sus libros de caja y contabilidad, porque recogen los pagos efectuados para realizar las construcciones, reparaciones y mantenimientos de caminos y puentes. La Universidad registraba con detalle todas las intervenciones en infraestructuras camineras en unos cuadernos o manuales mencionados repetidamente en los libros de contabilidad, pero que no hemos podido localizar. Así en 1548 se alude a unas actuaciones "como en el manual por estenso parece"1534, o en 1550 cuando se recuerda que existe "vn quaderno de los caminose puentes e malos pasos que aderesço de aqui a Santander" donde se registran salarios, jornales y materiales "como todo consta por el dicho quaderno de ocho fojas de papel"1535.

Entre el año 1539, fecha de inicio del primer libro, y 1588, año de finalización del último que se conserva ${ }^{1536}$, encontramos muchas referencias a gastos realizados en los reparos y construcción de varios caminos y puentes por parte de la Universidad. Estos libros de cuentas nos ofrecen los siguientes pagos realizados para la construcción y reparo de caminos:

\begin{tabular}{|c|c|}
\hline Año & Gastos en los caminos \\
\hline 1539 & 10.000 mrs. más 7.500 por hacer el puente de Valcallejo \\
\hline 1540 & $\begin{array}{l}\text { 7.19o mrs. pagados a Juan Alonso del Castillo en el despacho de las naos y de allí al } \\
\text { reparo del puente de Valcallejo }\end{array}$ \\
\hline \multirow[t]{7}{*}{1541} & 15.000 mrs. para aderezar los caminos de allí a Bilbao \\
\hline & 27.500 mrs. para hacer el puente de Valcallejo \\
\hline & 5.304 mrs. pagados a Diego Ruiz de Miranda para ir a Ruerrero \\
\hline & 8.250 mrs. que dio para el puente de Valcallejo más otros $9.250 \mathrm{mrs}$. \\
\hline & 3.19o mrs. para aderezar los caminos de Santander \\
\hline & 4.896 mrs. en la ida a Ruerrero a hablar con los de Santander \\
\hline & $\begin{array}{l}\text { 15.00o mrs. en cumplimiento de los } 30.000 \text { por el aderezo de los caminos que hizo } \\
\text { entre la torre de Orozco e las casas de Berganza }\end{array}$ \\
\hline \multirow[t]{2}{*}{1543} & $\begin{array}{l}\text { 7.050 mrs. por } 27 \text { días que fue a Santander, Laredo y Bilbao sobre lo de los caminos } \\
\text { de la Oca y puerto de Escalante }\end{array}$ \\
\hline & 18.553 mrs. en ir a Santander, Laredo y Bilbao sobre los caminos de Oca \\
\hline
\end{tabular}

1533 A. G. S./ Registro General del Sello, VI-1501, fol. 460/Valladolid, 5 junio 1501; MOLÉNAT, J. P.: 1971: 157-160.

1534 A. D. B./ R-3/ Libro de caja de la Universidad de Burgos/ Burgos, 1539-1549. p. 328.

1535 A. D. B./ R-12/ Libro de cuentas de la Universidad de Burgos/ Burgos, 1549-1557. p. 70.

1536 Las signaturas de los libros consultados son:

A. D. B./ R-3/ Libro de caja de la Universidad de Burgos/ Burgos, 1539-1549.

A. D. B./ R-6/ Manual del libro de cuentas de la Universidad de Burgos/ Burgos, 1549-1557.

A. D. B./ R-12/ Libro de cuentas de la Universidad de Burgos/ Burgos, 1549-1557.

A. D. B./ R-14/ Libro de caja de la Universidad de Burgos/ Burgos, 1557-67.

A. D. B./ R-29/ Diario de García y Miguel de Salamanca/ Burgos, 1560-1561.

A. D. B./ R-109/ Manual de cuentas de García y Miguel de Salamanca/ Burgos, 1561-1562.

A. D. B./ R-15/ Libro de caja o Mayor del Consulado/ Burgos, 1568-1577.

A. D. B./ R-33/ Libro de Sierra/ Burgos, 1573-1575.

A. D. B./ R-19/ Libro de caja o Mayor del Consulado de Burgos/ Burgos, 1578-1581.

A. D. B./ R-30/ Libro de caja del Consulado de Burgos/ Burgos, 1582-1588. 


\begin{tabular}{|c|c|}
\hline \multirow[t]{3}{*}{1544} & 8.000 mrs. a Juan Páez por su trabajo de Go días en lo de los caminos \\
\hline & 476 mrs. que gastó en aderezar el puente de la Virga \\
\hline & 59.605 mrs. porque está determinado se gaste en aderezar los caminos \\
\hline \multirow[t]{6}{*}{1545} & $646 \mathrm{mrs}$. de los $6.368 \mathrm{mrs}$. de costas que hizo para los caminos \\
\hline & $12.531 \mathrm{mrs}$. de gasto en aderezo de caminos y puentes \\
\hline & 2.250 mrs. a Pero de Rucabo por el trabajo que tomó en lo de los caminos \\
\hline & 7.779 mrs. de aderezar los caminos \\
\hline & 54.974 mrs. gastados en aderezar los caminos de Santander los años pasados \\
\hline & 16.771 mrs. de despachar las naos y aderezar los caminos \\
\hline 1546 & 901 mrs. gastados en el pleito de Puente de Itero, Valdestillas y Olmedo \\
\hline \multirow[t]{20}{*}{1547} & $\begin{array}{l}\text { 2.971 mrs. que costó un presente que se hizo a García de Escalante y Arnao del } \\
\text { Hoyo, que fueron a negociar lo del capítulo y camino del carro }\end{array}$ \\
\hline & $\begin{array}{l}4.125 \text { mrs. al cantero por } 11 \text { días que se detuvo en Laredo a señalar y ver el camino } \\
\text { que se hace del carro }\end{array}$ \\
\hline & 3.400 mrs. para ir a Santander a ver los caminos del carro \\
\hline & 3.400 mrs. para ir a ver los caminos de Burgos a Portugalete \\
\hline & $13.600 \mathrm{mrs}$. para pagar la obra de los caminos \\
\hline & 34.535 mrs. para hacer los caminos de Sodupe a Portugalete \\
\hline & $\begin{array}{l}\text { 69.692 mrs. gastados en el aderezo de los caminos por ir los carros y mulateros } \\
\text { desde el puente de Mariquejana hasta el de Sodupe para llevar los sacas a } \\
\text { Portugalete }\end{array}$ \\
\hline & $\begin{array}{l}\text { Se han de dar a Laredo } 800 \text { ds.: } 200 \text { para aderezar los caminos de la mulatería y } 600 \\
\text { prometidos para el camino de los carros de Burgos a Laredo por Espinosa y Agüera }\end{array}$ \\
\hline & $10.104 \mathrm{mrs}$. en el aderezo de los caminos de Portugalete \\
\hline & $\begin{array}{l}75.600 \text { mrs. pagados } 75.000 \text { para los caminos que se hacen de Burgos a Laredo y } \\
600 \text { de su concejo }\end{array}$ \\
\hline & $\begin{array}{l}5.189 \text { mrs. a Luis de Gumiel en la ida a Portugalete sobre el concierto con la } \\
\text { Universidad, que gastó para visitar los caminos de Portugalete a la Oca }\end{array}$ \\
\hline & $\begin{array}{l}\text { 6.40o mrs. por los gastos en ir de Burgos a Laredo por el camino de Espinosa y a } \\
\text { los lugares por donde se ha de hacer el camino de los carros de Burgos a Laredo }\end{array}$ \\
\hline & $\begin{array}{l}11.240 \text { mrs. gastados en aderezar los caminos desde Amurrio a Sodupe y } \\
\text { Portugalete }\end{array}$ \\
\hline & $\begin{array}{l}\text { 4.080 mrs. que se le dieron en dos veces para ir a Sodupe y Amurrio a hacer pasar } \\
\text { los carros con sacas para Deva y Portugalete }\end{array}$ \\
\hline & $\begin{array}{l}70.828 \text { mrs. gastados en allanar los caminos de Portugalete, que se aderezaron } \\
\text { desde Amurrio hasta Sodupe y Portugalete desde el puente de Mariquejana hasta } \\
\text { el de Sodupe, para que vayan los carros y carretas }\end{array}$ \\
\hline & $\begin{array}{l}\text { 4.896 mrs. a Martín Ochoa por ir a ver los caminos de Laredo que se habían de } \\
\text { mudar a otra parte como estaba concertado }\end{array}$ \\
\hline & 63.771 mrs. gastados en el aderezo de los caminos de Santander'1537. \\
\hline & $\begin{array}{l}42.900 \text { mrs. enviados en dos veces a Luena para costas del aderezo de los caminos } \\
\text { de Santander }\end{array}$ \\
\hline & $\begin{array}{l}10.875 \text { mrs. pagados por el aderezo del camino de Luyando a Sodupe para } \\
\text { Portugalete y de cierta heredad que se compró }\end{array}$ \\
\hline & 16.00o mrs. gastados en el aderezo del camino de Portugalete \\
\hline
\end{tabular}

1537 A. D. B./ R-3/ Libro de caja de la Universidad de Burgos/ Burgos, 1539-1549. 


\begin{tabular}{|c|c|}
\hline \multirow[t]{6}{*}{1549} & $\begin{array}{l}43.970 \text { mrs, por ciento } 6 \text { días que estuvo en Valladolid a ducado por día a entender } \\
\text { en lo del puente de Cádiz y en el de Quintana del Puente }\end{array}$ \\
\hline & 10.200 mrs. de las costas en los caminos de Santander, Laredo y Portugalete \\
\hline & $2.232 \mathrm{mrs}$. de costas en los caminos de Santander y camino de Camargo \\
\hline & 482 mrs. de las costas del que vino a cobrar lo del dicho puente \\
\hline & 153.000 mrs. para lo del puente de Quintana del Puente \\
\hline & 982 mrs. por cuenta del puente de Quintana del Puente \\
\hline \multirow[t]{19}{*}{1550} & 12.432 mrs. gastados en aderezar los caminos de Santander y Laredo \\
\hline & 12.500 mrs. a Arnao del Hoyo por los caminos que hizo hacer para Laredo \\
\hline & $\begin{array}{l}150.972 \text { mrs. que se pagaron al escribano de Quintana por el repartimiento hecho } \\
\text { a la Universidad para dicho puente además de otros } 400 \text { ds. que repartieron a la } \\
\text { ciudad }\end{array}$ \\
\hline & 500 rs. de lo que se ha de gastar en el camino y aderezar de Burgos a Santander \\
\hline & 27.200 mrs. por 800 rs. para aderezar los caminos \\
\hline & 51.000 mrs. por 1.500 rs. para aderezar los caminos \\
\hline & 1.020 mrs. para aderezar los caminos de Burgos a Santander y a Laredo \\
\hline & $9.610 \mathrm{mrs}$. por el resto de la cuenta y gastos de los caminos \\
\hline & $\begin{array}{l}112.749 \text { mrs. gastados en los caminos, puentes y malos pasos aderezados de Burgos } \\
\text { a Santander }\end{array}$ \\
\hline & $19.261 \mathrm{mrs}$. de salario y costas de ciento 3 días para aderezar estos caminos \\
\hline & $\begin{array}{l}\text { 4.50o mrs. para asistir en los caminos de Santander a hacer aderezarlos y hacer } \\
\text { llevar las sacas a los carreteros }\end{array}$ \\
\hline & $\begin{array}{l}\text { 1.547 mrs. dados a Pedro de Ochandiano por } 13 \text { días que anduvo para hacer probanza } \\
\text { de cómo empiedran el camino de Burgos a Santander }\end{array}$ \\
\hline & $\begin{array}{l}5.151 \mathrm{mrs} \text {. de costas hechas en los reparos de los caminos por } 26 \text { días que estuvo a } \\
\text { concertarlos en el camino de Corconte }\end{array}$ \\
\hline & $\begin{array}{l}5.250 \text { mrs. que se dan cada año para que asista en el camino de Burgos a Santander, } \\
\text { para aderezarlos y hacer llevar las sacas }\end{array}$ \\
\hline & $\begin{array}{l}\text { 7.50o mrs. para aderezar los caminos del monte de Carrales y Argomedo, el puente } \\
\text { de Santelices y la cuesta de Rozas }\end{array}$ \\
\hline & $\begin{array}{l}\text { 6.0oo mrs. para hacer el puente de Quintanilla de Valdearroyo, cargarlo y hacer } \\
\text { una calzada de piedra }\end{array}$ \\
\hline & 101.380 mrs. que se concertó para reparos de los caminos \\
\hline & 227 mrs. de una provisión para el corregidor sobre los caminos \\
\hline & 150.000 mrs. para el puente de Quintana en total en cuatro pagas \\
\hline \multirow[t]{8}{*}{1551} & 51.192 mrs. gastados en los reparos de los caminos de Santander y Laredo \\
\hline & $\begin{array}{l}11.250 \text { mrs. por } 30 \text { ds. para hacer el puente y calzada de piedra en la Virga de Campoo, } \\
\text { que convenía para pasar las sacas a Santander }\end{array}$ \\
\hline & $\begin{array}{l}24.667 \mathrm{mrs} \text {. gastados en aderezar los caminos para los carros que van a Santander, } \\
\text { en piedra tosca y sillares para el puente y calzada }\end{array}$ \\
\hline & $9.800 \mathrm{mrs}$. para el aderezo de los caminos \\
\hline & 3.580 mrs. gastados en ir al puerto de San Adrián \\
\hline & $\begin{array}{l}17.315 \text { mrs. por la mitad de los } 34.629 \text { que debe pagar la Universidad con la ciudad, } \\
\text { para ir al puerto de San Adrián sobre lo del reparo de los caminos de Guipúzcoa }\end{array}$ \\
\hline & $87.980 \mathrm{mrs}$. para el aderezo de los caminos \\
\hline & 20.400 mrs. por Goo rs. para ir al puerto de San Adrián \\
\hline
\end{tabular}




\begin{tabular}{|c|c|}
\hline & $238 \mathrm{mrs}$. por dos peticiones sobre lo del puente de Quintana \\
\hline & $\begin{array}{l}408 \text { mrs. gastados en ir y venir de Villalmanzo a hablar con el alcalde mayor sobre } \\
\text { que no les reparta nada de lo del puente de Lantadilla }\end{array}$ \\
\hline & $17.304 \mathrm{mrs}$. para costes de reparo de caminos \\
\hline & $3.400 \mathrm{mrs}$. por $100 \mathrm{rs}$. que se dieron para ir a aderezar los caminos \\
\hline & 15.105 mrs. de la cuenta de los reparos de los caminos \\
\hline \multirow[t]{2}{*}{1552} & 635 mrs. que gastó en Madrid Diego de los Ríos sobre el pleito de Quintana \\
\hline & $\begin{array}{l}408 \text { mrs. que gastó Diego de los Ríos cuando fue a Santander sobre un puente } \\
\text { hecho para pasar los carros con las sacas entre Cilleruelo y Virtus }\end{array}$ \\
\hline \multirow[t]{2}{*}{1553} & $1.707 \mathrm{mrs}$. que se han pagado sobre lo del puente de Quintana \\
\hline & 5.100 mrs. a cuenta del aderezo de los caminos de Valcallejo \\
\hline 1554 & 4.807 mrs. en costas de pleitos de los portazgos y del puente de Quintana \\
\hline \multirow[t]{2}{*}{1555} & $8.568 \mathrm{mrs}$. gastados en el aderezo del puente de Valcallejo \\
\hline & $5.622 \mathrm{mrs}$. de la ida a aderezar los caminos de Santander \\
\hline \multirow[t]{8}{*}{1556} & 17.000 mrs. a cuenta de la ida a aderezar los caminos de Santander \\
\hline & $\begin{array}{l}27.910 \text { mrs. que le dio Melchor de Múgica en Santander cuando estuvo allí a aderezar } \\
\text { los caminos }\end{array}$ \\
\hline & $66.172 \mathrm{mrs}$. que se gastaron en el aderezo de los caminos de Santander \\
\hline & $28.560 \mathrm{mrs}$. por su salario y trabajo ocupados en aderezar dichos caminos \\
\hline & $94.732 \mathrm{mrs}$. de costas hechas en aderezar los caminos de Santander \\
\hline & 9.660 mrs. que se gastaron en el aderezo de los caminos de Laredo \\
\hline & $\begin{array}{l}32.675 \mathrm{mrs} \text {. gastados en aderezar los caminos de Santander, hacer el puente de } \\
\text { Valcallejo y malos pasos que había en Corconte y allí cerca }\end{array}$ \\
\hline & 51.430 mrs. gastados en el aderezo de los caminos de Santander \\
\hline \multirow[t]{8}{*}{1557} & 14.618 mrs. para ir al aderezo de los caminos de Portugalete \\
\hline & 66.665 mrs. gastados en el aderezo de los caminos de Santander \\
\hline & 18.972 mrs. gastados en el aderezo de los caminos de Santander ${ }^{1538}$. \\
\hline & $\begin{array}{l}725 \text { mrs. que dio a cuenta haber pagado por otra ejecutoria sobre el puente de } \\
\text { Quintana sobre el repartimiento que les hacen pagar }\end{array}$ \\
\hline & 4.50o mrs. para dar a Vallejo el cantero para la ida del camino que hizo \\
\hline & $3.400 \mathrm{mrs}$. dados al contado para pagar a los oficiales \\
\hline & $\begin{array}{l}27.389 \text { mrs. gastados en visitar los caminos nuevos que se pretenden hacer de } \\
\text { Burgos a Laredo y Portugalete }\end{array}$ \\
\hline & 374 mrs. gastados en el pleito del puente de Quintana del Puente \\
\hline 1558 & 4.125 mrs. para el aderezo del camino del carro en los pasos malos \\
\hline \multirow[t]{2}{*}{1559} & 72.748 mrs. para el puente de Quintana repartidos a la Universidad en cuatro pagas \\
\hline & 4.080 mrs. pagados para aderezar el camino de carro \\
\hline \multirow[t]{2}{*}{1560} & $\begin{array}{l}12.469 \text { mrs. para el puente de Quintana pagados al receptor por la cuarta parte de } \\
133 \mathrm{ds} \text {. que repartieron a la Universidad, en fin de marzo y septiembre de } 1560 \text { y de } \\
1561\end{array}$ \\
\hline & $\begin{array}{l}\text { 7.480 mrs. pagados para el despacho y costas de caminos por ir a derribar la presa } \\
\text { que Sancho Ruiz de Villegas hacía en Toranzo }\end{array}$ \\
\hline
\end{tabular}

1538 A. D. B./ R-12/ Libro de caja de la Universidad de Burgos/ Burgos, 1549-1557. 


\begin{tabular}{|c|c|}
\hline & $6.800 \mathrm{mrs}$. que se dieron para el camino \\
\hline & 27.200 mrs. para aderezar los caminos y puente de Valcallejo de Burgos a Santander \\
\hline & $\begin{array}{l}3.375 \text { mrs. que se cobraron de } 270 \text { sacas que en Laredo recibieron, para las costas de } \\
\text { los caminos }\end{array}$ \\
\hline & $\begin{array}{l}\text { 52.894 mrs. gastados en aderezar los caminos para pasar los carros con las sacas } \\
\text { a Santander: } 14.750 \text { para aderezar el puente de Valcallejo; } 25.748 \text { en el camino de } \\
\text { Corconte; } 3.468 \text { en el puente Virga; } 1.258 \text { en el valle de Camargo; } 170 \text { para sacar } \\
\text { piedra y } 7.500 \text { por su trabajo }\end{array}$ \\
\hline \multirow[t]{3}{*}{1561} & 17.000 mrs. pagados para el aderezo de los puentes y caminos \\
\hline & $\begin{array}{l}\text { 3.944 mrs. pagados, } 110 \mathrm{rs} \text {. en aderezar el camino de Camargo la Menor y } 6 \text { rs. para } \\
\text { empedrar un arroyo }\end{array}$ \\
\hline & $\begin{array}{l}65.240 \text { mrs. de esta manera: } 36.707 \text { en el puente de la Molina que se hizo nuevo; } \\
16.847 \text { en aderezar el puente Virga; } 2.686 \text { en aderezar la puente de Vallejo y los } \\
\text { caminos de Corconte y } 9.000 \text { mrs. por su salario }\end{array}$ \\
\hline \multirow[t]{10}{*}{1563} & 74.005 mrs. cobrados de 14.801 sacas y destinados a reparos de caminos \\
\hline & 37.169 mrs. gastados en reparos de caminos y en el puente de la Molina \\
\hline & 5.100 mrs. dados a cuenta para el aderezo de los caminos de Corconte \\
\hline & $\begin{array}{l}\text { 3.40o mrs. gastados en el aderezo de los caminos para Santander para una estacada } \\
\text { que ha de hacer mientras se hace el paredón }\end{array}$ \\
\hline & 7.395 mrs. gastados en el aderezo de los caminos de Corconte \\
\hline & 7.319 mrs. gastados en el camino de Corconte y en la estacada \\
\hline & 81.410 mrs. pagados para los reparos de los caminos de Santander \\
\hline & $\begin{array}{l}\text { 22.100 mrs. pagados para comenzar a proveer los materiales para el paredón que se } \\
\text { ha de hacer en Bárcena }\end{array}$ \\
\hline & $\begin{array}{l}\text { 9.922 mrs. para los reparos de los caminos de Santander, para aderezar el camino de } \\
\text { paso a Camargo y en ir con el cantero a ver el edificio del paredón de Bárcena }\end{array}$ \\
\hline & $\begin{array}{l}\text { 104.376 mrs. que se avanzan en esta cuenta porque se carga en ella las costas de los } \\
\text { que despachan las naos, los pleitos y aderezos de caminos en que se gasta mucho }\end{array}$ \\
\hline \multirow[t]{3}{*}{1564} & $\begin{array}{l}17.000 \text { mrs. por } 500 \text { rs. pagados a cuenta de los reparos de los caminos y paredón } \\
\text { que se hace en Bárcena }\end{array}$ \\
\hline & Se cobraron 35.275 mrs. de 2.075 sacas, destinados a pleitos y reparos de caminos \\
\hline & 5.100 mrs. se gastaron en los reparos de los caminos y paredón \\
\hline \multirow[t]{10}{*}{1565} & 26.507 mrs. para el aderezo de los caminos y en el pleito sobre las naos \\
\hline & $\begin{array}{l}\text { Se pagan } 27.200 \text { mrs. por } 800 \text { rs. en Santander para el aderezo de los caminos y } \\
\text { paredón de Bárcena }\end{array}$ \\
\hline & 6.80o mrs. pagados en Santander para los caminos y paredón de Bárcena \\
\hline & $2.162 \mathrm{mrs}$. de la nao que fue a Ruan por 116 sacas para caminos y pleitos \\
\hline & $68.088 \mathrm{mrs}$. para reparos de los caminos \\
\hline & 72.064 mrs. de las costas hechas en el paredón y en los reparos de caminos \\
\hline & $\begin{array}{l}1.155 \text { mrs. cobrados de averías del galeón Santiago de Laredo que fue a Nantes y } \\
\text { llevó } 54 \text { sacas, para reparos de caminos }\end{array}$ \\
\hline & $\begin{array}{l}45.279 \text { mrs. cobrados de averías de la nao de Antonio de Bertendona que llevó } 2.301 \\
\text { sacas y le contó para reparos de caminos }\end{array}$ \\
\hline & $\begin{array}{l}30.176 \text { mrs. que se han cobrado de la nao de Ochoa de la Sierra y llevaba } 1.527 \text { sacas } \\
\text { y fueron para reparos de caminos }\end{array}$ \\
\hline & $\begin{array}{l}\text { Las costas en caminos fueron } 140.474 \text { mrs: } 17.952 \text { mrs. en cal, hierro y angarillas para } \\
\text { el paredón; } 59.356 \text { de oficiales de cantería y obreros; } 19.151 \text { en carreteros que llevaron } \\
\text { la piedra; } 12.478 \text { en agotar el río para hacer el paredón; } 800 \text { en hacer la estacada; }\end{array}$ \\
\hline
\end{tabular}




\begin{tabular}{|c|c|}
\hline & $\begin{array}{l}1.462 \text { en correos a Burgos y Santander; } 8.050 \text { en el camino de la parada del Somo; } \\
6.225 \text { en aderezar el puente de Valcallejo y } 15.000 \text { mrs. por } 173 \text { días de trabajo }\end{array}$ \\
\hline & 10.200 mrs. dados a Rodrigo de Alcedo y gastados en los caminos \\
\hline & $29.650 \mathrm{mrs}$. de averías por 1.400 sacas para los caminos y pleitos \\
\hline \multirow[t]{5}{*}{1566} & 28.900 mrs. pagados a Rodrigo de Alcedo del resto del paredón y caminos \\
\hline & 6.174 mrs. pagados para la obra del paredón y aderezos de caminos \\
\hline & 17.000 mrs. enviados a Rodrigo de Alcedo para reparo de los caminos \\
\hline & $\begin{array}{l}13.600 \text { mrs. gastados por Antonio de Cisneros para ir a dar queja de los que cortaron } \\
\text { las vigas del puente de Valcallejo }\end{array}$ \\
\hline & $\begin{array}{l}11.254 \text { mrs. por } 331 \text { rs. gastados en reparos del puente de Valcallejo y caminos: } 121 \text { rs. } \\
\text { para comprar una tierra para el puente de la Molina, } 110 \text { rs. para hacer el puente de } \\
\text { Valcallejo y } 100 \text { rs. para aderezar el paso junto al puente de Vejorís }\end{array}$ \\
\hline \multirow[t]{2}{*}{1567} & $\begin{array}{l}3.629 \text { mrs. que se pagaron del resto de los } 400 \text { rs. que se dieron para ir a lo del } \\
\text { puente de Valcallejo sobre las vigas que cortaron }\end{array}$ \\
\hline & $\begin{array}{l}9.971 \mathrm{mrs} \text {. de costas de reparos de caminos, de los que } 5.814 \mathrm{mrs} \text {. fueron por lo del } \\
\text { puente de Valcallejo para castigar los que cortaron las vigas } 1539 \text {. }\end{array}$ \\
\hline \multirow[t]{7}{*}{1568} & $27.200 \mathrm{mrs}$. pagados en dos veces en $500 \mathrm{rs}$. y 300 para reparos de caminos \\
\hline & 37.208 mrs. para puentes y caminos \\
\hline & $\begin{array}{l}16.270 \mathrm{mrs} \text {. que se gastaron: } 5.338 \text { en aderezo del puente de Valcallejo, } 7.158 \mathrm{mrs} \text {. en } \\
\text { el reparo del camino de Corconte y } 3.774 \text { por su trabajo }\end{array}$ \\
\hline & 3.400 mrs. pagados por el aderezo del paso debajo del molino de Gonzalo Muñoz \\
\hline & $\begin{array}{l}5.100 \text { mrs. pagados por el trabajo en hacer el puente en el vado de la Concha en } \\
\text { Valderredible junto al lugar de Arenillas }\end{array}$ \\
\hline & $\begin{array}{l}320.349 \text { mrs. de } 16.423 \text { sacas, para las costas de los que van a despachar las flotas, } \\
\text { pleitos, aderezar caminos y otros gastos }\end{array}$ \\
\hline & $\begin{array}{l}17.028 \text { mrs. de costas en el reparo de los puentes y caminos y en el pleito sobre la } \\
\text { mayoría de las naos }\end{array}$ \\
\hline \multirow[t]{4}{*}{1569} & 536 mrs. a cuenta del aderezo de los caminos y puentes \\
\hline & 153.000 mrs. del viaje a la montaña al reparo de los puentes y caminos \\
\hline & $\begin{array}{l}\text { 194.191 mrs. dados a cuenta para el aderezo de los caminos y puentes por donde van } \\
\text { las sacas a Santander mas } 44.000 \mathrm{mrs} \text {. por el trabajo }\end{array}$ \\
\hline & $9.136 \mathrm{mrs}$. que se da a cuenta de haber gastado \\
\hline \multirow[t]{2}{*}{1570} & 41.650 mrs. para el aderezo de los caminos y puentes \\
\hline & 187.855 mrs. para los caminos y puentes por donde van las sacas a Santander. \\
\hline \multirow[t]{5}{*}{1571} & 146.205 mrs. para los caminos y puentes por donde van las sacas a Santander \\
\hline & $44.700 \mathrm{mrs}$. pagados para hacer el puente nuevo de Cayón y el reparo de los caminos \\
\hline & $10.378 \mathrm{mrs}$. por 1.221 sacas para aderezo de los caminos \\
\hline & 134.300 mrs. que contó más a dichas sacas a 8,5 mrs. para los caminos \\
\hline & 46.227 mrs. en el aderezo de caminos y puentes por donde van las sacas a Santander \\
\hline 1572 & 4.00o mrs. que contó a tres navíos para Flandes para los aderezos de los caminos \\
\hline \multirow[t]{2}{*}{1573} & 42.227 mrs. del aderezo de los caminos y puentes por donde van las sacas a Santander \\
\hline & $\begin{array}{l}19.992 \text { mrs. para el puente de Lerma: } 18.750 \text { del repartimiento hecho, } 1.004 \text { por su } \\
\text { salario y } 238 \text { de sacar las escrituras, autos y carta de pago }\end{array}$ \\
\hline 1574 & 13.804 mrs. por el viaje que hizo a la corte sobre los puentes \\
\hline
\end{tabular}

1539 A. D. B./ R-14/ Libro de caja de la Universidad de Burgos/ Burgos, 1557-1567. 


\begin{tabular}{|c|c|}
\hline \multirow[t]{4}{*}{1575} & 1.700 mrs. dados para ir a Tardajos sobre lo del puente de Lerma \\
\hline & 11.900 mrs. por 350 rs. que se dieron para ir a Tardajos \\
\hline & $\begin{array}{l}\text { 4.420 mrs. gastados en ir y venir a Tardajos y a Lerma a cobrar los } 50 \mathrm{ds} \text {. del puente } \\
\text { de Lerma que se mandaron devolver de la última paga }\end{array}$ \\
\hline & $\begin{array}{l}18.700 \text { mrs. pagados en Lerma por lo que se había pagado del repartimiento del } \\
\text { puente mandado devolver por Provisión real }\end{array}$ \\
\hline 1576 & 6.800 mrs. pagados a Alonso de Madrid por la ida a Orduña sobre lo de la Peña ${ }^{1540}$. \\
\hline \multirow[t]{2}{*}{1580} & 2.626 mrs. para ayuda del aderezo de algunos pasos de los caminos \\
\hline & 3.400 mrs. dados a cumplimiento de 400 rs. para aderezar los caminos ${ }^{1541}$. \\
\hline \multirow[t]{5}{*}{1582} & 16.400 mrs. pagados para ayuda de aderezar los caminos de Santander \\
\hline & $\begin{array}{l}\text { 3.40o mrs. que se dieron para ir a Aguilar de Campoo a lo del pleito que puso Diego } \\
\text { de Castañeda vecino de Bárcena de Vejorís }\end{array}$ \\
\hline & $2.261 \mathrm{mrs}$. que se gastaron cuando fue a responder en Aguilar al pleito \\
\hline & $13.600 \mathrm{mrs}$. pagados para aderezar los caminos \\
\hline & 1.122 mrs. que dio a Juan de la Portilla de Santander por el puente que aderezó 1542 \\
\hline
\end{tabular}

Además de las alusiones genéricas a "gastos en el aderezo de caminos y puentes", "para aderezar los caminos de allí a Bilbao", "gastos en los caminos que van a Santander", "aderezar los caminos de Santander y Laredo" o "caminos nuevos que se pretenden hacer de aquí a Laredo y Portugalete", encontramos menciones a actuaciones concretas y en lugares reconocibles como las realizadas a los caminos de Corconte, Valderredible, puente de Valcallejo, puente Virga, puente de la Molina, paso junto al puente de Vejorís, camino de Camargo la Menor, puente nuevo de Cayón, puente de Quintanilla de Valdearroyo, actuaciones en el valle de Camargo, el paredón en Bárcena, aderezar los caminos del monte Carrales, Argomedo y Valcallejo, puente de Santelices y la cuesta de Rozas, un puente hecho para pasar los carros entre Cilleruelo y Virtus, puente en el vado de la Concha en Valderredible junto al lugar de Arenillas, camino de Espinosa por donde se ha de hacer el camino de los carros de Burgos a Laredo, o desde el puente de Mariquejana hasta el de Sodupe para llevar los sacas a Portugalete, desde Amurrio a Sodupe y Portugalete o de Luyando a Sodupe para Portugalete.

También el Consulado de Burgos colaboró en los repartimientos generales para los puentes de Cádiz, Quintana del Puente, Lantadilla y Lerma. Como vemos, la actividad de los mercaderes en el mantenimiento y construcción de caminos fue muy importante y se evidencia su participación en ello de una manera muy activa.

\section{- Las cofradías de mulateros}

Desde fines del siglo XV encontramos asociaciones de mulateros asentadas en las merindades de Castilla Vieja que participan en la construcción y reparación de caminos y puentes. Cuando se les asigna alguna cantidad con la que como asociación deben con-

1540 A. D. B./ R-15/ Libro de caja o Mayor del Consulado/ Burgos, 1568-1577.

1541 A. D. B./ R-19/ Libro de caja o Mayor del Consulado de Burgos/ Burgos, 1578-1581.

1542 D. B./ R-30/ Libro de caja del Consulado de Burgos/ Burgos, 1582-1588. 
tribuir, hay una continua demanda por su parte para obtener tal suma por medio de imposición, es decir, pagando un peaje por cada bestia de carga que pasase por el camino a reparar. El sistema que los mulateros proponen es el arriendo del cobro de los peajes, y con la cantidad obtenida por dicho arriendo, hacer frente al pago de lo a ellos repartido. Este sistema, no obstante, es algo que el Consejo Real venía rechazando de manera firme respondiendo siempre a esta demanda de la misma manera: la cantidad asignada la deben obtener repartiéndola entre los mulateros.

La Corona toma la iniciativa a fines del siglo XV a instancia de los mulateros con el fin de realizar las actuaciones necesarias para la mejora del camino de Burgos a Laredo. En enero de 1499 se decide hacer repartimiento sobre las localidades por donde discurre el camino, así como sobre la Universidad de Mercaderes y sobre la cofradía de los mulateros de la merindad de Castilla Vieja. En 1501 se reparten a dicha cofradía 260.00o mrs. que debían pagar en 2 años, tiempo necesario para hacer la obra. Dicha cantidad estaba motivada por los puentes que ellos evitarían y por el provecho que obtendrían por tener los caminos aderezados; además de que evitarían los daños que recibían caminando de noche con pescados frescos y demás mercaderías, y las grandes derramas que continuamente se les hacían. Se les incrementará no obstante dicha cantidad con otros 65.000 mrs., lo que hará un total de 325.000 mrs. ${ }^{1543}$. El corregidor y el alcalde habían estimado que la manera más factible de percibirlos era la de cargar 1 real a cada bestia de carga que pasase por el camino y dieron mandamiento para ello. Los mulateros echaron los 130.000 mrs. del primer año por imposición -lo que era irregular-, arrendando en 1499 por dicha cantidad el cobro de ese real por acémila a Fernando Ruiz de Cenares, escribano y vecino de Medina de Pomar, por un año1544.

Como a pesar de esta medida no obtenían las cantidades precisas, los procuradores de los mulateros trataron en 1501 con Fernando Diáñez de Alcocer, persona enviada por el Consejo Real, que no podrían pagar los $260.000 \mathrm{mrs}$. que les fueron repartidos sino cobrando a los mulateros cierta cantidad por las acémilas que cada uno tenía, de manera que pagasen más los que más tuviesen, poniendo personas para cobrarlo en dos o tres puertos de los más transitados y, si esto no fuese suficiente, que se diese licencia para que se pudiesen valorar las acémilas de dichos mulateros y repartir por millar lo que fuese necesario, "o que se pudiese coger por rrenta e arrendamiento" que era lo que más les convenía. El Consejo acordó en marzo de 1501 que lo que les cabe pagar se haga repartiendo según las acémilas, rocines y asnos que cada uno tuviere y no por vía de imposición, y mandó a Diáñez que, con acuerdo de los procuradores, haga el repartimiento sobre cada uno de los recueros y mulateros de la cofradía1545. En 1502 los mulateros dijeron que a pesar de que se mandó que los 325.00o mrs. no se obtuviesen por vía de imposición, esta se puso y los mulateros para no pagar iban por otros caminos, por lo que siguen solicitando que los mrs. "se pudiesen coger e cogiesen en los logares de los Hoçinos e la Horadada por donde los dichos mulateros pasan mas continuamente". La respuesta del Consejo se mantuvo sin cambios y en junio de 1502 mandó al corregidor de las Cuatro Villas que guarde la carta y Provisión dada sobre la manera de repartir y cobrar

1543 A. H. N./ Nobleza. Frías, C. 235, D. 55/ Medina de Pomar, 15 enero 1499.

1544 A. G. S./ Registro General del Sello, VIII-1500, fol. 52/ Valladolid, 17 agosto 1500.

1545 A. G. S./ Registro General del Sello, III-1501, fol. 592/Valladolid, 20 marzo 1501. 
los mrs. , haga juntar a los mulateros con sus procuradores en el lugar más conveniente, y se haga el repartimiento de los 325.000 mrs. según las bestias que cada uno tuviere ${ }^{1546}$.

Tras las inundaciones ocurridas en 1511, quedaron en el camino de Laredo a Agüera 12 puentes seriamente dañados y ante la pregunta de quién había pagado cuando otras veces se habían reparado, dijeron los vecinos que los reparos los habían costeado los viandantes y mulateros según las acémilas que cada uno traía, "porque los dichos mulateros quebrantaban las dichas puentes e calçadas", y la tierra aportaba francos los montes para cortar las maderas necesarias y ayuda para traerlas. Todos alegaban que no estaban obligados a reparar dichos puentes ya que otras veces los mulateros y viandantes, que eran los que los "rronpian e desasyan e rreçibian el probecho e hutilidad dello", pagaron lo que costaba y así se había hecho siempre. Después de largo tiempo y tras diversos intentos ninguna reparación seria se había efectuado ${ }^{1547}$. El procurador de Ramales declara en 1513 haber rehecho los puentes de los Loros y el de Cijedo en término de Ramales hundidos 2 años antes, y demandaba el pago de los 55.000 mrs. que habían gastado. El concejo de Ramales afirmó que la localidad estaba demasiado pobre para pagar y que de tiempo inmemorial eran los mulateros los que pagaban las reparaciones, y los habitantes de Ramales no contribuían en nada según la costumbre para todos los caminos de Burgos a Laredo ${ }^{1548}$.

\section{C.- MODALIDADES DE CONSTRUCCIÓN Y/O DE REPARACIÓN}

Como se asumía que el mantenimiento y conservación de caminos y puentes debía ser realizado por los municipios aledaños al camino, también la financiación se consideraba de su obligación utilizando para ello sus rentas y propios que rara vez alcanzaban para costear lo pretendido. Este sistema solo era válido cuando la importancia o complejidad de la obra eran pequeñas, porque cuando se tenían que acometer intervenciones de mayor calado, se debía contratar maestros para realizarlas y contar con un presupuesto adecuado capaz de financiar obras a veces muy costosas.

\section{a.- La prestación personal}

Desde la Alta Edad Media existía una obligación llamada facendera que afectaba a todos los vecinos de lugares de realengo, referida a la reparación de puentes y caminos de la zona o comarca donde habitaban los contribuyentes. La facendera y otras prestaciones similares con otros nombres, como la carraria, la vereda, la labor de muros y torres, etc. , fue pasando a manos de los concejos cedida por la Corona ${ }^{1549}$. Así, las actuaciones tradicionales en el mantenimiento y conservación de caminos habían consistido básicamente en

1546 A. G. S./ Registro General del Sello, VI-1502, fol. 315/ Toledo, 16 Junio 1502.

1547 A. G. S./ Consejo Real de Castilla, leg. 26-17/ Burgos, 5 octubre a 12 diciembre 1511; MOLÉNAT, J. P.: 1971: 161-162 y BASAS FERNÁNDEZ, M.: 1963 y 1994: 161.

1548 MOLÉNAT, J. P.: 1971: 151.

1549 LADERO QUESADA, M. A.: 2002: 290. 
la prestación personal, cuando era necesario acometer tales intervenciones. Era habitual, y en muchas localidades rurales se ha venido manteniendo hasta fechas no lejanas, la obligación de cada vecino de acudir a la llamada de la autoridad municipal con sus herramientas, aperos, caballerías y carros, para intervenir en determinados caminos públicos de su municipio. En las épocas de nieves debían asistir además a abrir los caminos en una labor denominada huelga o a socorrer y rescatar a los viajeros o viandantes que se quedaban retenidos por esta circunstancia. En ocasiones especiales, como en los casos en que se preveía el tránsito de personas reales, tales vecinos no solo debían contribuir económicamente, sino que además tenían que acudir personalmente con sus bestias, herramientas y carros a realizar los reparos.

Tenemos un ejemplo bien documentado. Para la prevista llegada a Castro-Urdiales del emperador Carlos en 1522, se prevé su paso por la junta de Sámano y el concejo de Otañes, para lo que el corregidor de las Villas de la Costa de la Mar les notificó la necesidad de que sus caminos estuviesen perfectamente reparados y les mandó que los hiciesen aderezar. Los concejos se juntaron con los regidores de Castro y acordaron que la villa pagase 50 hombres, el concejo de Sámano 50 y el de Otañes 30, para hacer el camino desde la villa hasta Son de Sámano, límite de la jurisdicción de Castro-Urdiales ${ }^{1550}$.

\section{b.- La adjudicación pública}

Cuando la importancia o volumen de la obra tenía una entidad que excedía de las posibilidades de actuación de los pequeños municipios, como era el caso de los puentes de piedra de varios arcos o el reparo de los paredones de contención de los caminos, se iniciaba un complicado proceso de ejecución supervisado por el Consejo Real. Tras el proceso, ya comentado, de obtención de los recursos económicos necesarios por repartimiento el promotor de la obra, generalmente un concejo, convocaba públicamente a todos los maestros que quisieren presentar sus ofertas pujando a la baja para obtener la adjudicación. Cerrada la subasta, se procedía a conceder la ejecución de la obra al maestro de cantería que había presentado la oferta más baja y las fianzas y fiadores adecuados acordando los plazos de ejecución y los de los pagos.

El maestro de la obra no siempre cumplía los plazos o las condiciones técnicas, llegando incluso tras sus incumplimientos a ser apresado y a ser objeto de reclamación de las cantidades abonadas que, si no las devolvía, se demandaban a sus fiadores ocasionando a veces el ingreso en prisión del maestro de la obra o de dichos fiadores. Por todo ello muchas obras se dilataron en el tiempo, y obras previstas para uno o dos años llegaron a superar periodos de más de diez.

\section{C.- Los especialistas}

En la documentación que hemos manejado, se han venido mencionando en las diferentes intervenciones realizadas en caminos, puentes y calzadas, tres tipos de especialis- 
tas: los maestros de cantería, los maestros de calzadas y empedradores y los maestros de carpintería.

Los maestros de cantería son los técnicos que realizan planos y proyectos de edificios y caminos, en nuestro caso de puentes o paredones y manguardias de fábrica. Concurren a las subastas y pujas y son los responsables máximos de que las obras se realicen de acuerdo con los proyectos aprobados y en los plazos marcados, que en muchos casos no se cumplían. En las obras de la zona de Burgos y cercanías eran en su mayoría vecinos de la ciudad de Burgos, como consecuencia de que en esa época la ciudad era uno de los centros de mayor actividad constructora y donde existía una mayor demanda de estos técnicos. Para las intervenciones en puentes situados entre Burgos y la costa hubo varios de Agüera de Montija o del valle de Curiezo, pero destacaban sobre todo los procedentes de la merindad de Trasmiera, concretamente de San Mamés de Aras, San Pantaleón de Aras, Rada, Llanez, Bárcena de Cicero, Adal, Cicero, Hazas de Cesto, valle de Hoz de Anero o Escalante. La relación de los maestros de cantería que hemos encontrado en la documentación se incluye en el Apéndice 1.

A los "maestros de hazer los caminos y calçadas", o "maestros canteros e maestros de calçadas" se los denominaba simplemente "canteros", y debían construir y reparar los caminos y acondicionar la caja de estos, realizando taludes y obras de fábrica para salvar arroyos y badenes y demoliendo rocas para su ensanche. Así en 1544 Rodrigo de Perujo debe "romper una peña para que pudiesen pasar los mulateros viandantes"1551. En los desfiladeros y cuando el camino debía encajarse junto a paredes angostas, debían tallar en la roca una parte y construir un gran paredón o malecón sobre el cauce para lograr la anchura precisa del camino. En ocasiones, el cantero llega a la categoría de maestro cantero como en el caso de Martín Ochoa de Arteaga, que lo encontramos trabajando entre 1547 y 1551 en el camino de Laredo como cantero, y este último año informa sobre el puente de los Malatos de Burgos como maestro de cantería ${ }^{1552}$. Otros se especializan como Lucas de Curulla que lo encontramos en 1582 en el aderezo del paredón de San Pablo y San Lucas de Burgos, y en 1599 en el aderezo del mismo paredón ${ }^{1553}$. Este grupo incluye al de los empedradores o "maestros empedradores de las calçadas". La relación de los maestros de calzadas aparecidos en la documentación se incluye en el Apéndice 2.

El empedrado se solía disponer en sectores rellenados con morrillos calzados o piedras de la zona limitados por sillarejos dispuestos en líneas paralelas, una en cada borde delimitando la calzada y una tercera para reforzar el eje de la misma. De esta última podían partir otras hileras a la manera de una espina de pez o bien perpendiculares al eje creando cuadrados o rectángulos, logrando con ello un reticulado completo de la vía. Después se acostumbraba extender como recebo una capa de cascajo o grava fina, cubierta con tierra para igualar el firme. Como es de imaginar, esta última capa era la primera que desaparecía -máxime si no se entretenía adecuadamente, que era lo habitual- ya arrastrada por

1551 A. H. P. C./ Laredo. Cuentas de la villa de Laredo, f. 8or-81v/ Laredo, 1544

1552 A. D. B./ R-3/ Libro de caja de la Universidad de Burgos/ Burgos, 1539-1549; A. H. P. C./ Laredo. Cuentas de la villa de Laredo, f. 174V-191v/ Laredo, 1551; A. M. B./ HI-1658/Valladolid, 21 junio a Burgos, 30 agosto 1551.

1553 A. M. B./ HI-1680/ Burgos, 26 mayo a 1 diciembre 1582; A. M. B./ HI-4141/ Lisboa, 31 agosto 1582 a Madrid, 13 septiembre 1599. 


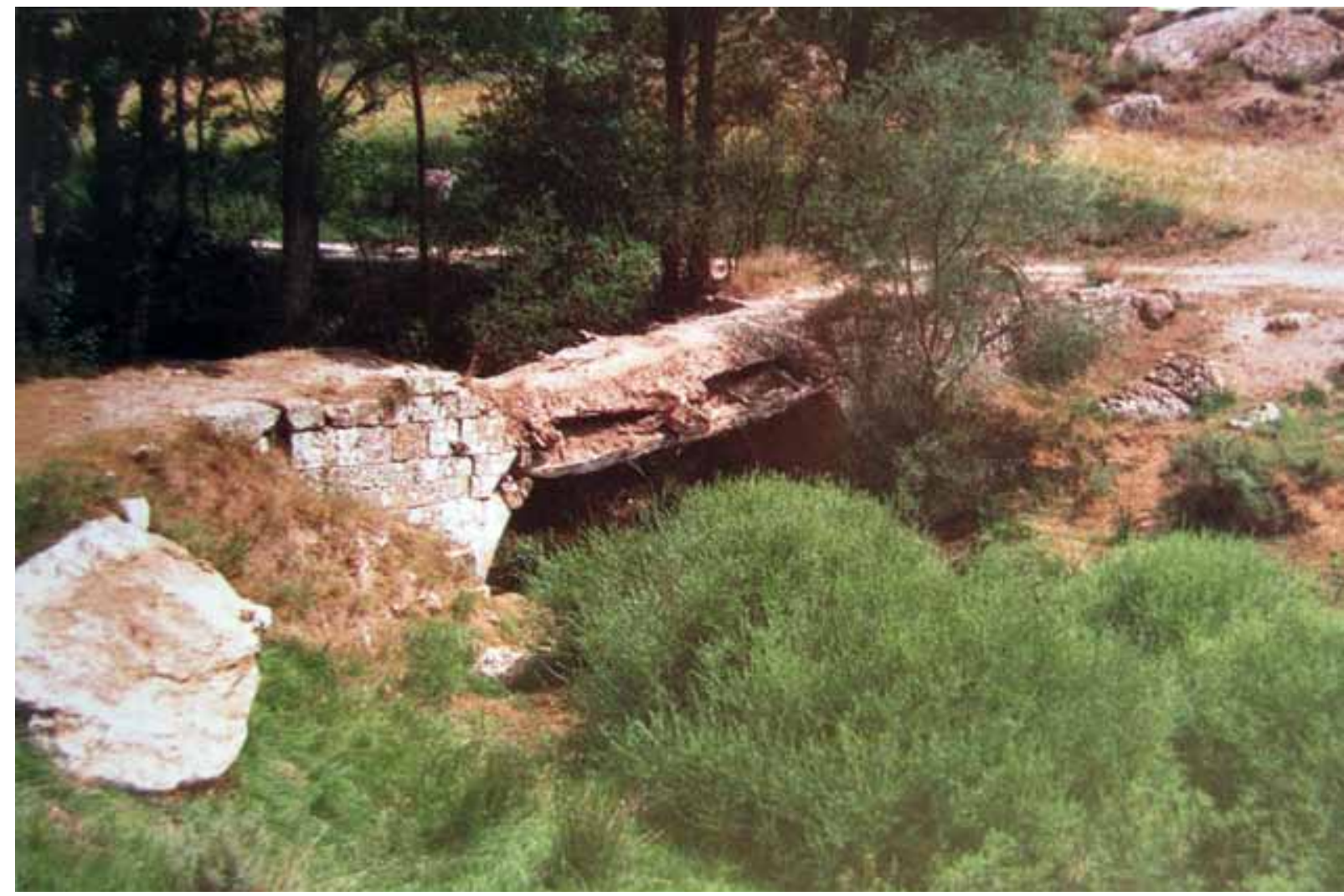

Reutilización del puente de Barriosuso del Val tras su hundimiento.

las escorrentías que generaban las lluvias, ya erosionada por su utilización. El caso más común de empedrado consistía, sin embargo, en la simple colocación de piedras irregulares de mediano tamaño encajadas a hueso, procedimiento que tenía la ventaja de que el deterioro podía ser atajado fácilmente, reponiendo el empedrado con el calce o encaje de otras piedras similares. Por ser una obra costosa y que obligaba a un mantenimiento constante, se solía limitar a sectores especialmente fangosos, en los accesos a los puertos de montaña y en los puentes y sus entornos inmediatos.

Los maestros de carpintería debían realizar los puentes de madera, bien de manera provisional para permitir el paso de los ríos mientras se acababan de construir los puentes de fábrica deteriorados o destruidos, o bien de manera permanente. En este caso estas construcciones, por el continuo deterioro que sufrían por el tráfico, debían ser constantemente reparadas para que no quedasen inservibles prematuramente. Tenían la ventaja de ser más baratos pero no soportaban grandes cargas y su duración era mucho más limitada. A veces, eran la solución duradera de un puente de piedra deteriorado. Por ser de tabla, este era el nombre que recibía gran número de ellos, incluso en algunos casos pervivían con la denominación de "puente de la Tabla" después de que el puente así denominado se había construido de mazonería. Tales maestros eran imprescindibles también como auxiliares de las construcciones de fábrica, tanto para apuntalar la obra que permanecía en pie después del deterioro de un puente, como para realizar los andamios, las cimbras, pasamanos, etc. La relación de los maestros de carpintería detectados en la documentación se incluye en el Apéndice 3. 


\section{2.- ACTIVIDADES CAMINERAS}

\section{A.- LA PRÁCTICA COMERCIAL}

Los antiguos intercambios comerciales generados en la Edad Media hasta el siglo XI eran de muy baja intensidad, y los productos rara vez eran transportados a larga distancia como consecuencia de la fragmentación de los poderes territoriales, el escaso índice de población, el muy pobre desarrollo de la industria, la baja calidad de los caminos y la inseguridad general. Se producirá una reactivación a partir de dicho siglo, tímida al principio, de los tráficos comerciales cuyo desarrollo no tuvo parangón desde la desaparición del Imperio Romano. Con el aumento de la producción y explotación de los recursos naturales, agrícolas y ganaderos, se produjeron excedentes que se podían colocar en lugares a veces lejanos, obteniendo a cambio y de retorno otros productos de los que aquellas sociedades carecían. Este proceso tuvo unas consecuencias que se reflejaron de diferentes maneras entre las que destaca el aumento de la demanda de todos los artículos deficitarios de cada sociedad, así como un incremento en la producción que, cuando era excedentaria, se debía poner en circulación para satisfacer la demanda. También obligó a atender el estado de las vías y cuidar, mejorar y construir caminos e infraestructuras camineras garantizando además la seguridad de sus usuarios. Aumentaron y se consolidaron sectores empresariales relacionados con el transporte como la arriería y carretería y los vinculados a las transacciones comerciales y se desarrollaron los mercados y los sectores agrícolas, ganaderos, mineros, artesanos e industriales vinculados, en este caso sobre todo, con la industria textil.

Desde el siglo XIII en los puertos de Santander, Laredo, Castro-Urdiales y Portugalete y posteriormente Bilbao, se fue consolidando una burguesía mercantil y transportista que nacía a la sombra de un importante comercio con los núcleos industriales de Flandes, sur de Inglaterra y fachada atlántica francesa. En los siglos XV y XVI grandes ganaderos, comerciantes y armadores se repartirán las funciones y el beneficio de un negocio próspero y lucrativo.

\section{a.- Ferias y mercados}

Los mercados son el órgano genuino del intercambio y relación comercial y presentan una peculiar organización. Se desarrollan vinculados al comercio que necesita ciertas garantías y, para ello, se caracterizan como una reunión periódica de vendedores y compradores en lugares determinados, con las garantías de una organización especiall554. Tenían por objeto abastecer a la población de los artículos de primera necesidad o de consumo general, como cereales, alimentos no perecederos, manufacturas textiles, productos artesanos, etc. y ser el vehículo de intercambio de los productos excedentarios. De carácter más

1554 GARCÍA de VALDEAVELLANO, L.: 1975: 26 
agrario que las ferias, concentraban a los mercaderes, artesanos y campesinos del entorno en un día señalado de la semana en las plazas de mercado o azogue ${ }^{1555}$, lugares elegidos para realizar los tratos e intercambios comerciales. El mercado de mayor importancia es el que se celebraba una o a lo sumo dos veces al año: la feria ${ }^{1556}$. Las ferias y mercados que desde la Edad Media fueron surgiendo en nuestras ciudades y villas, fueron un elemento clave para explicar en muchos casos el nacimiento de estas, pero sobre todo contribuirán al desarrollo de las poblaciones que las sustentaban. Se debían hallar aceptablemente comunicadas y en general se situaban junto a caminos de cierto tránsito. Así se indica en las Partidas ${ }^{1557}$, que también contemplan la existencia de los mercaderes ${ }^{1558}$.

Con el aumento de los excedentes en la Edad Media y cuando los desplazamientos eran difíciles y los lugares en los que se podían encontrar los diferentes artículos de uso cotidiano, de lujo o de primera necesidad tan escasos y a veces alejados, aparecieron las ferias como punto de encuentro con el objetivo claro de canalizar los intercambios, ofrecer los aprovisionamientos y facilitar la obtención de artículos y suministros. Se realizaban operaciones que iban desde la compra de productos al por menor, hasta la comercialización de bienes a mayor escala como los cereales, ganados, lanas, etc. En ellas se reúnen en fechas fijas del año, mercaderes de artículos muy variados, comerciantes, campesinos, artesanos, arrieros y carreteros. Para que las ferias del entorno no coincidieran con las propias, se solían desarrollar en fechas escalonadas con el fin de asegurar a cada una la mayor asistencia. Podían ser de carácter general, comarcal o local y, en muchos casos, tenían un componente esencial eminentemente ganadero.

Los reyes y en ocasiones grandes señores utilizaron las ferias para lograr el desarrollo de las villas y ciudades que deseaban impulsar, mediante el fomento de sus actividades económicas y en concreto de los intercambios mercantiles, obteniendo con ello los beneficios que tal desarrollo del comercio y de la artesanía reportaban y el apoyo de la población y de los sectores burgueses. Para ello concedían carta de privilegio con licencia para su creación, en que se recogían las condiciones y las fechas de su celebración, que solían ser de carácter anual o bienal coincidiendo con las fiestas del calendario religioso y pudiendo durar varios días y a veces semanas ${ }^{1559}$.

1555 Nombre de origen árabe relacionado con los zocos o plazas de mercado, y no con el mercurio. También recibe este nombre el mercado que se celebra diariamente.

1556 GARCÍA de VALDEAVELLANO, L.: 1975: 57.

1557 LAS SIETE PARTIDAS/ Quinta Partida, Título VII, ley IIII. "las tierras e los lugares, en que vsan los mercadores, a leuar sus mercadurias, son por ende mas ricas e mas abondadas, e mejor pobladas: e por esta razon deue plazer a todos con ellos".

1558 LAS SIETE PARTIDAS/ Quinta Partida, Título VII. "mercadores son aquellos omes que señaladamente mas vsan entresi vender e comprar e cambiar vna cosa por otra. Porque las riquezas, e las ganancias que fazen comprando las, e vendiendo las, allegan señaladamente en las ferias, e en los mercados mas a menudo que en los otros lugares...".

1559 LAS SIETE PARTIDAS/ Quinta Partida, Título VII, ley III. "ferias, o mercados, en que vsan los omes a fazer vendidas, $e$ compras e cambios, non las deuen fazer en otros lugares, si non en aquellos que antiguamente las costunbraron hazer. Fueras ende si el Rey otorgalle por su priuillejo poder, a algunos lugares de nueuo que las fiziessen. A a vn dezimos, que en estas ferias atales que son fechas nueuamente, que non deuen fazer los Señores del lugar do se fazen las ferias, premia ninguna a los mercadores, que a ellas vinieren. Demandando les ningun tributo, de las cosas que traxeren, por razon de la feria, nin de otra cosa, si non de aquellas que les otorga el priuilejo por que les fue otorgada la feria. E maguer ouiessen a dar debdo conoscido, que fuesse de ante fecho, que la feria fuesse establecida, al Señor del lugar, o a otro qualquier de los moradores en el, non los deuen traer a juyzio sobre ellos: nin prender les, nin tomar les ninguna de las cosas suyas, en quanto la feria durare" 
Los distintos monarcas que promovieron y favorecieron las ferias para obtener la presencia del mayor número posible de mercaderes y asistentes, las declararon en muchos casos francas, eximiéndolas del pago de determinados impuestos como alcabalas, portazgos, montazgos, etc., y ofreciendo otras ventajas como la de proporcionar durante los días de feria a los que acudían a ellas, seguridad para ellos y para sus productos. Eran una fuente muy importante de recursos para los municipios, autoridades eclesiásticas y señoriales y monasterios, que además del movimiento económico que generaban, obtenían unos ingresos por los impuestos no eximidos ${ }^{1560}$.

\section{Ferias generales}

Son las más importantes y aparecen cuando se mejoran las comunicaciones y sobre todo cuando se desarrolla la producción y el comercio. En ellas los mercaderes y los grandes comerciantes aparecen junto a humildes vendedores ambulantes, artesanos y campesinos. En el siglo XV fecha del nacimiento de las de Castilla, se dio en las ferias un gran avance en las prácticas comerciales y fueron apareciendo en ellas diferentes fórmulas de contratación y de servicios, la banca y las compañías mercantiles que desarrollaron la concesión de créditos, cambio de dinero o el giro y cobro de letras de cambio. Los mercaderes y banqueros llegarán a disponer de bancos, mesas o pupitres y algunos construirán sus propios puestos. Estas ferias en Castilla se situaron en la provincia de Valladolid, fueron tres y duraban 40 días cada una: Las de Medina del Campo, que fueron creadas por Fernando de Antequera, señor de la villa, en torno a 1404 y recibieron la consideración de "Ferias generales del Reino" por los Reyes Católicos en 1491. Se realizaban en los meses de mayo y octubre; Las de Medina de Rioseco fundadas por el almirante Alfonso Enríquez en 1423, recibieron en 1477 carta de privilegio de los Reyes Católicos para celebrar dos ferias anuales y un mercado franco. Se llevaban a cabo durante la Pascua de Resurrección y en el mes de agosto; Las ferias de Villalón de Campos, por último, fueron fundadas por el conde Alfonso Pimentel, hacia 1434, y se realizaban por Cuaresma y San Juan ${ }^{1561}$.

\section{Ferias y mercados comarcales y locales 1562}

Junto a la feria que tenía un círculo de carácter territorial amplio, era necesario el mercado semanal con un alcance geográfico más limitado para satisfacer las necesidades

\footnotetext{
1560 LAS SIETE PARTIDAS/ Quinta Partida, Título VII, ley IIII. "todos los que vinieren a las ferias de nuestros reynos, tan bien cristianos, como judios, e moros: e otrosi los que vinieren en otra sazon, qualquier, a nuestro Señorio: maguer non vengan a ferias, que sean saluos, e seguros, sus cuerpos, e sus aueres, e sus mercadurias, e todas sus cosas, ... en viniendo a nuestro Señorio, e estando $y$, en yendose de nuestra tierra. E defendemos, que ninguno non sea osado de les fazer fuerça, nin tuerto, nin mal ninguno. E si por auentura alguno fiziesse contra esto robando alguno dellos lo que truxesse, o tomando gelo por fuerça:... el juez de aquel lugar, do acaesciesse el robo, deue resçebir la jura del catando primeramente, que ome es, e que mercadurias suele vsar e traer. E esto catando, apreciando la quantia,... deue la fazer entregar de los bienes de los robadores, todo quanto jurare que le robaron. Con los daños, e los menoscabos, quel vinieron por razon de aquella fuerça, quel fizieron, faziendo de los robadores aquella justicia, que el derecho manda. E si los robadores non pudieren ser fallados, nin los bienes dellos non cumplieren a fazer la emienda: el concejo o el Señor, so cuyo Señorio es el lugar do fue fecho el robo, gelo deuen pechar de lo suyo".

1561 LADERO QUESADA, M. A.: 1994; ANÓNIMO: "Documentos Feriales en los Archivos Municipales de Medina del Campo, Villalón y Medina de Rioseco".
}

1562 CADIÑANOS BARDECI, I: 2006/2: 373-413 y 2007/1: 203-243. 
de carácter cotidiano. Las ferias y mercados que se realizaron durante el periodo y en la zona burgalesa que estudiamos, fueron las siguientes:

\begin{tabular}{|l|c|c|c|}
\hline Localidad & Fundación Feria & Fund. Mercado & Características \\
\hline Arganzón & & 1191 & miércoles \\
\hline Briviesca & & 1123 & sábados \\
\hline Burgos & 1339 & 1230 & \\
\hline Cornudilla & & 1011 & martes \\
\hline Espinosa de los Monteros & & Antes de 1522 & sábados y diario \\
\hline Frías & Antes de 1523 & 1202 & martes \\
\hline Hontomín & & 1272 & martes \\
\hline Lences & & 1299 & lunes y jueves \\
\hline Medina de Pomar & & 1181 & Lunes, miércoles y viernes \\
\hline Miranda de Ebro & 1254 & 1177 & martes, jueves y sábados \\
\hline Monasterio de Rodilla & & 1402 & miércoles y sábados \\
\hline Oña & & 1203 & martes, después viernes \\
\hline Pancorbo & & 1177 & \\
\hline Poza de la Sal & 1371 & 1371 & sábados \\
\hline Santa Gadea & & 1045 & 1254 \\
\hline Treviño & & 1571 &
\end{tabular}

Todos estos mercados se situaban sobre o cerca de vías de cierta importancia, algo esencial para garantizar un buen acceso no solo para los productos, sino también para las personas que a ellos acudían. Ferias y mercados se realizaban en muchos lugares de la zona que estudiamos y, aunque en ellos se comercializaban diferentes productos, los de las localidades de Cantabria y de Vizcaya eran básicamente ganaderos. El grano y los principales mantenimientos se llevaban principalmente a las ferias y mercados burgaleses. La provincia de Burgos fue desde la Edad Media la más comercial de Castilla, tanto en sus mercados, como en su comercio interior y exterior. De hecho, la feria castellana más antigua que conocemos fue la concedida por Alfonso I el Batallador en Belorado en 1116: "... et die lunis habeatis vestro mercato et de anno in anno feriam habeatis diebus Sancti Michaelis..."1563. Ya en octubre de 1203 Alfonso VIII, con su mujer doña Leonor y su hijo Fernando, dispone que en lo sucesivo no se efectúen más mercados semanales en la Bureba, salvo en Pancorbo los lunes, en Oña los jueves y en Frías los sábados: “...mando et firmiter tenendum statuo, ne alicubi fiat de nouo mercatum un Boroua nisi en Pancoruo et in Onia et in Fridas. Ista siquidem mercata debent in unaquaque istarum uillarum hiis diebus subscriptis perpetuo celebrari; in Pancoruo die lune; in Onia, die iouis; in Fridas, die sabbati." ${ }^{564}$, lo que pone de manifiesto la importancia que en estas fechas va ad-

1563 GARCÍA de VALDEAVELLANO, L.: 1975: 60.

1564 A. H. N./ D. P. de Oña. carp. 280, no 10/ Carrión de los Condes, 14 octubre 1203; ÁLAMO, J. del: 1950: 425-426: t. I. doc. 350. 
quiriendo el comercio en Castilla y la atención que merece del Rey. Las ferias y mercados más importantes en la zona que estudiamos fueron las siguientes:

- Mercados de Arganzón. Arganzón fue un lugar desaparecido cercano a la actual localidad de La Puebla de Arganzón junto a la garganta de su nombre, paso obligado del camino real de Burgos a Vitoria y Bayona. Alfonso VIII lo repuebla en 1191 y le concede fuero en el que se hace constar su mercado: "Quiqumque venerit ad vestram villam cum aliqua mercatura non des leznam in die de mercato"1565. Según Cadiñanos, documentos posteriores indican que el mercado seguía realizándose los miércoles ${ }^{1566}$.

- Mercados de Briviesca. La villa era núcleo principal de la cerealista comarca de la Bureba a lo que unía su situación como cruce de caminos sobre las importantes vías de Burgos a Vitoria y Bayona y a Orduña, motivos por los que su mercado adquirió un gran desarrollo. Pertenecía a la familia de los Velasco desde abril de 1370 por donación de Enrique II a Pedro Fernández de Velasco. En el fuero de la villa de 1123, se indica en su punto 16 que "si quis ad uestrum mercatum uenerit et aliquis eum interfecerit de quarta feria usque in VI feriam in nonstris terminis non habemus homicidium"1567. Tuvo mercado los sábados, aunque después llegaron a ser tres ${ }^{1568}$.

Conzalo obispo de Burgos y Ordoño Pérez, arcediano de Briviesca, reciben en mayo de 1316 de la infanta doña Blanca abadesa de las Huelgas, 500 mrs. anuales cada uno, por haber dado a la abadesa el barrio de Santa María de Briviesca. Los obispos de Burgos percibirán los 500 mrs. sobre las rentas de las salinas de Añana y los arcedianos de Briviesca sobre el mercado de Briviesca ${ }^{1569}$. Las villas de Miranda, Briviesca, Santa Gadea y otras, protestan en 1524 contra el concejo de Pancorbo sobre el mercado franco que el rey Carlos les ha concedido, por entender que les perjudica1570.

- Mercado de Cornudilla. El mercado burgalés más antiguo del que tenemos referencias es el de Cornudilla cerca de Oña, cuyo monasterio ejercía en el s. XI el control sobre el mismo. Cornudilla se encuentra en el norte de la Bureba, zona gran productora de cereal, en el camino y paso obligatorio hacia la mencionada localidad de Oña y el desfiladero de La Horadada para ir a las Merindades y puertos del Cantábrico.

El conde Sancho García y su mujer Urraca fundan en 1011 en Oña el monasterio en honor de San Salvador, Santa María y San Miguel a orillas del río Vesga, hoy Oca, y conceden al monasterio la mitad de los derechos que tenían del mercado y portazgo de Cornudilla "... In illo mercato de Cornudiella, medio portatico..." (en otra versión: "mergato de Burueba")1571. Según Argáiz, Cornudilla "fue Puerto Seco en tienpo de los Condes de Castilla. En el auia Registro y Aduana donde se pagava portazgo" y añade que Fernando I dio Cornudilla en 1056 al abad de Oña con su jurisdicción civil y criminal, "prohibiendo todos los mercados de la Bureba, excepto los de Pancorvo,

1565 A. G. S./ Libros de privilegios y confirmaciones. art 20/ diciembre 1191; MARTÍNEZ, G.: 1982: 171: doc. XLIII.

1566 CADIÑANOS BARDECI, I.: 2007/1: 228.

1567 MARTÍNEZ DÍEZ, G.: 1982: 136

1568 CADIÑANOS BARDECI, I.: 2006/2: 408.

1569 A. Cat. B./ V. 34, f. 70/ Burgos, 9 mayo 1316; MANSILLA, D.: 1971: doc. 1132.

1570 A. G. S./ Consejo Real de Castilla, leg. 451-11/1524.

1571 A. H. N./ Clero, Oña, carp. 269 nำ12/ 12 febrero 1011; ZABALZA DUQUE, Manuel: 1995: 44-49. 
y Cereço, que eran Reales" para que no perjudicasen al de Cornudilla1572. En 1089 se menciona la donación al monasterio de Oña y a su abad, de una tierra "latus uia publica et discurrit al mercado de Lebrana..."1573. Hacia 1157 el mercado de Cornudilla, como se cita a continuación, se traslada a Lebrana1574 junto a Busto de Bureba. Alfonso VIII y su mujer Leonor ordenan, en agosto de 1175 que el mercado que de Cornudilla se había llevado a Lebrana en tiempo de su padre Sancho III ${ }^{1575}$, vuelva a Cornudilla quedando bajo la jurisdicción del abad de Oña según solicitó dicho abad y manteniendo los derechos de portazgo que el conde Sancho García les había concedido ${ }^{1576}$. En el Fuero de Cornudilla de 1187 se libra a sus vecinos del pago del portazgo en dicho mercado1577 y en junio de ese año, Alfonso VIII y su mujer confirman al monasterio de Oña los privilegios y donaciones concedidas anteriormente ${ }^{1578}$. El monasterio de Oña decide entregar en 1215 a la villa de Oña el mercado antiguo que el monasterio tenía en Cornudilla1579, quedando con ello suprimido este mercado.

- Mercados de Espinosa de los Monteros. La villa se sitúa en el flanco sur de la Cordillera Cantábrica y fue centro de una amplia zona de gran importancia ganadera pero escasa de granos. Por concesión de Enrique IV se celebraba un mercado a realizar los martes, en el que se comerciaba con trigo, fruta y ganados ${ }^{1580}$. El 15 de diciembre de 1593, martes de mercado, se firmó en Espinosa de los Monteros un edicto por mandato de la villa de Laredo y se fijó en las puertas de la audiencia de Espinosa y a vista del dicho mercado1581.

- Mercados y ferias de Frías. Juan II otorgó en 1435 a Frías el título de ciudad y en 1446 fue incorporada al patrimonio de Pedro Fernández de Velasco, su camarero mayor, por

1572 ARGÁlZ, F. G. de: 1675: 388, 438, 461.

1573 ÁLAMO, J. del: 1950: 126: t. I. doc. 95.

1574 Despoblado situado a $2.100 \mathrm{~m}$. al Oeste de Busto de Bureba. En dicho lugar existe un pago con el nombre de Lebrana. Según Argáiz ya estaba despoblado en 1675.

1575 Sancho III el Deseado, reinó entre el 21 de agosto de 1157 hasta su fallecimiento en Toledo el día 31 de agosto de 1158.

1576 A. H. N./ D. R. de Oña. carp. 276, no 10/ Medina, 23 agosto 1175; ÁLAMO, J. del: 1950: t. I. doc. 246, 294-295; GONZÁLEZ y GONZÁLEZ, J.: 1960: 386: t. II. doc. 231. “... iniuste acta sunt reseccare et Oniensem ecclesiam proposse meo inter ceteras specialiter ad pristinum statum reuocare, statuo et precipio ut mercatum de Lebrana redeat ad Cornudiella ubi fuit antiquibus, et sub iure et dominio abbatis Onie fiat ibidem imperpetuum. Statuo insuper et confirmo eu homines qui portaticum predicti mercati collegerunt nullus sit ausus inquietare aut aliquam iniuriam eis inferre...".

1577 A. H. N./ D. P. Oña. carp. 277, no 11/ 1187; ÁLAMO, J. del: 1950: 334-336: t. I, doc. 278. “... Quicumque etiam domos habuerit et vicinus fuerit in ipsa villa, non det portaticum in ipso mercato". "Et damus hominibus de ipsa villa... illam del Mercato, por exitu de la villa".

1578 A. H. N./ D. R. Oña, carp. 277, nº 10/ Burgos, 21 junio 1187; ÁLAMO, J. del: J. del: 1950: 329-333: t. I. doc. 276; GONZÁLEZ y GONZÁLEZ, J.: 1960: 826: t. II. doc. 480; Cartulario Sto. Toribio de Liébana/ Burgos, 21 junio 1184; SÁNCHEZ BELDA, L.: 1948: 141-143: doc. 115. "Succedente etiam tempore concessi pretaxato Oniensi monasterio ut mercatum de Lebana rediret ad Cornudellam ubi fuerat antiquibus, et sub iure et dominio abbatis fieret ibidem in perpetuum; et institui quod nemo inquietaret uel contrariaret homines predicti mercati portaticum colligentes, et super his condidi instrumentum stabilitatis et monasterio Oniensi...".

1579 A. H. N./ D. P. de Oña. carp. 282, nº 5/ 1215; ÁLAMO, J. del: 1950: 500-501: t. II. doc. 405. “...damus et concedimus uobis concilio de Onia nostrum mercatum quod fuit in Cornudella, et de Oniensi uilla per iniuriam et contra uoluntatem omnium nostrorum sublatum fuit, et nunc cum auctoritate domini nostri regis Henrici ducimus eum ad Oniam, cum tali conditione, ut omni tempore usque in perpetuum in Oniensi uill a coadunetur,... Et si forte, quod absit, dominus noster rex uel principes terre de Oniensi uilla, illud mercatum supra memoratum abstrahere uoluerit, consimili modo omnes fideliter promittimus, ut consilium et auxilium uobis demus et proposse nostro omnibus modis fideliter laboremus, ut non de Oniensi uilla asbstrahautur".

1580 CADIÑANOS BARDECI, I.: 2006/2: 412.

1581 A. H. P. C./ Laredo, leg. 22, num. 15/ Laredo, 23 febrero 1585 a 12 enero 1597. 


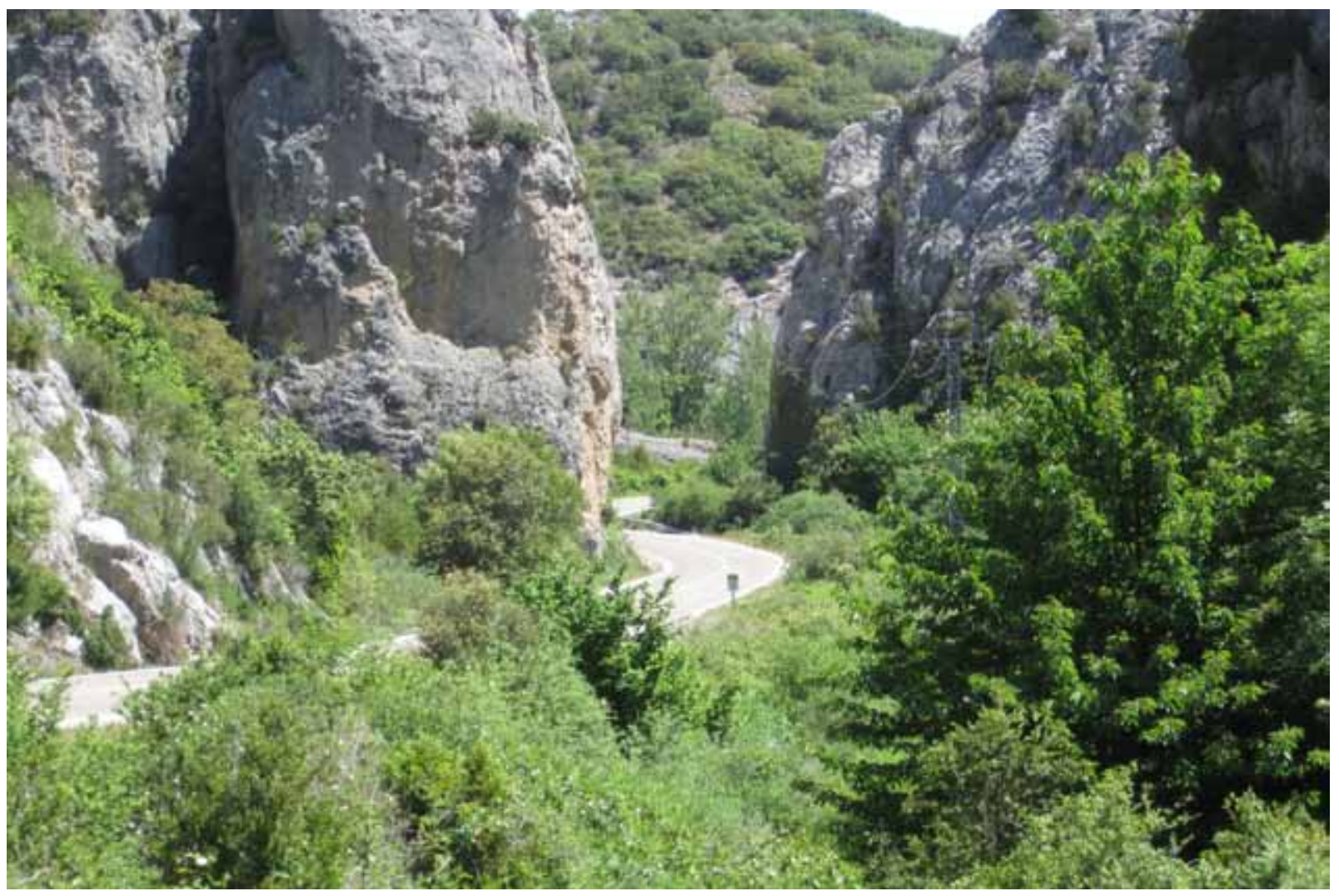

Desfiladero del río Ranera que va a Frías.

permuta realizada por el Rey con la villa de Peñafiel. Tras dura oposición de la población, en 1492 fue recuperada por los Velasco. Se asienta en la salida norte del desfiladero del río Ranera sobre un importante camino medieval que comunicaba la Bureba y Burgos con el puerto de Bilbao por Orduña, y que controlaban por situarse sobre el puente fortificado sobre el Ebro. Tenía mercado diario o azogue en el alto de la Muela, y otro todos los sábados en "el Collado" tras conceder Alfonso VIII a Frías en 1202 el fuero de Logroño con ciertas exenciones, en el que se alude al mercado de los sábados: "quod illud mercatum quod vocatur açog sit sursum in la mola, et aliud mercatum fiat unaquaque die sabbati in collado"1582. Todavía hoy la calle principal se denomina calle del Mercado y en su zona media en el Collado, existe una estrecha plaza con soportales laterales. El Rey dispone en 1203, que en lo sucesivo no se efectúen más mercados semanales en la Bureba sino en Pancorbo el lunes de cada semana, en Oña los jueves y en Frías los sábados. Esta regulación de los mercados de la Bureba, gran productora de cereal, pone de manifiesto el interés creciente de la monarquía por un comercio que iba adquiriendo una importancia progresiva ${ }^{1583}$.

El Condestable ordenaba en 1529 que para "noblesçimiento de la dicha mi çibdad y muela della, que todos los ofiçios, asi de carneçeria y pescaderia y panaderas e otras tyendas de bastimentos, esten dentro de la muela de la dicha mi çibdad y no fuera". Solo se permitiría alguna tienda fija en la zona baja para el abastecimiento de vecinos y caminantes. El mercado se animaba los días cercanos

1582 R. A. H./ Biblioteca, col, Salazar, de col. Velázquez, t. VIII/ Palencia, 1 diciembre 1217. Según MARTíNEZ, Gonzalo: Ayllón, 8 abril 1202; GONZÁLEZ y GONZÁLEZ, J.: 1983: 16: t. II. doc. 9.

1583 A. H. N./ D. P. de Oña. carp. 280, no 10/Carrión de los Condes, 14 octubre 1203; ÁLAMO, J. del: 1950: 425-426: t. I. doc. 350 . 
a la Navidad, y entonces los puestos de venta se extendían por la calle de la Cadena hasta ocupar la plaza del Ayuntamiento. En las ordenanzas de fines del siglo XV, se alude a que se traen a vender a Frías habas, cabritos, sal, fruta, vino, pesca, hierro y leña y, en dichos días, se instalaban quincalleros, pañeros, pasiegos y hortelanos ${ }^{1584}$. Las ferias se celebraban el 1 de noviembre y el 30 de ese mes, día de San Andrés, cuya fecha fue cambiada en el siglo XVI. El regimiento de Frías decía al Condestable en 1523 que "en esta çibdad ay uso y costunbre de aver dos ferias en ella en cada un año, la una en el segundo dia de Pasqua de çinquesma y la otra por el dia de Nuestra Señora Santa Maria de setienbre" y se le pedía que fueran francas y que durase cada una 5 días pero, sobre todo, que como la de Pascua caía en mala época cuando no había trigo y por ello no acudían mercaderes y tratantes, que fuese trasladada al 1 de noviembre como así se hizo ${ }^{1585}$.

- Mercado de Hontomín. En el camino real de Burgos a Laredo y Castro-Urdiales, Alfonso X dispone en 1272 que "ayan mercado en Fuenteomin cada sedmana, et que lo fagan en dia de martes. E todos aquellos que a este mercado uinieren, que uengan et uayan saluos et seguros con sus cuerpos et sus aueres et con todas sus mercaduras" y que ninguno pueda ser embargado ni prendido, si no fuere por su deuda conocida o por fiadura que ellos mismos hubiesen hecho ${ }^{1586}$. No tenemos noticia de su continuidad.

- Mercado de Lences. En el camino que de Burgos va a Oña y la Horadada, en junio de 1299 Fernando IV y su madre María de Molina facultaban a esta localidad "para que pueda tener un mercado franco un dia de cada semana y señaladamente los martes". Tras las tareas del verano los vecinos se dedicaban tradicionalmente a comprar trigo en los lugares cercanos y revenderlo. Quizá en un principio lo hicieran en su mercado y después en los cercanos de Poza y Briviesca. En la segunda mitad del siglo XVI todavía era notable la cantidad de productos agrícolas y ganaderos que se comercializaban en esta villa. La cercanía de dichos mercados y su escasa población, podrían haber sido los motivos de la desaparición de su mercado ${ }^{1587}$.

- Mercados y ferias de Medina de Pomar. Medina se situaba en una zona intermedia entre la ciudad de Burgos y los puertos del Cantábrico y distaba de Burgos un día de camino y otro de Bilbao o de Laredo lo que le convirtió en un centro comercial, de intercambio y de parada obligada de viajeros, trajineros y comerciantes, una de las causas del gran desarrollo que sus ferias y mercados adquirieron. Capital de las extensas posesiones de los Velasco, fue concedida por Enrique II en noviembre de 1369 a Pedro Fernández de Velasco. En 1352, el Libro Becerro de las Behetrías ${ }^{1588}$ señala que "este logar es del rey e fue siempre de los reyes", situación que se mantuvo hasta 1369 cuando Enrique II dio la villa en señorío a su camarero mayor Pedro Fernández de Velasco. Desde ese momento hasta 1562, las ferias y mercados de todas las Merindades estuvieron sometidas al control y jurisdicción de los Condestables, lo que obligaba a todos sus vecinos a acudir a Medina a vender sus productos y proveerse de todo lo necesario. Esto acrecentaba un poder que unía al control de

1584 CADIÑANOS BARDECI, I.: 2007/1: 204-205.

1585 CADIÑANOS BARDECI, I.: 2007/1: 205

1586 A. H. N./ D. R. de Oña. Carp. 289, num. 13/ Huete, 9 julio 1272; ÁLAMO, J. del: 1950: 718: t. II. doc. 603.

1587 CADIÑANOS BARDECI, I.: 2007/1: 210-211.

1588 "BECERRO. LIBRO FAMOSO DE LAS BEHETRÍAS DE CASTILLA". Mandado hacer por Don Pedro I de Castilla: 1866: 215. 
las vías comerciales de la comarca y cobro de portazgos y alcabalas, el de sus mercados y ferias con sus correspondientes beneficios económicos. Según Sainz de Baranda, Medina tenía establecidas desde tiempo inmemorial cinco ferias anuales ${ }^{1589}$ y dos mercados semanales ${ }^{1590}$. El mercado se realizaba los jueves y después también el lunes antes de pasar a Villarcayo ${ }^{1591}$. En 1562 comienza una segunda fase en que tras el traslado de sus ferias y mercados a Villarcayo, estos de Medina experimentarán un profundo declive. Villarcayo fijará los mercados de las Merindades los mismos días que en Medina lo que dio comienzo a un largo periodo de pleitos entre ambas villas.

En el fuero de Medina, ratificado por Alfonso VIII en 1181, se indica en su punto 44 que el poblador de Medina que comprare caballo o yegua, mulo o mula, asno o burra, solo lo podía comprar en el mercado o en el barrio mayor de la villa ${ }^{1592}$. El Condestable se preocupará de que los productos comercializados tengan un precio razonable. Así se indica en la ordenanza $27^{\underline{a}}$ de $1495^{1593}$ y se dice que los géneros de venta más importantes eran paños, sedas, lienzos, ganados mayores y menores, granos y vino. En Junta de Álava de noviembre de 1544 se manda que nadie salga a los caminos, por donde va el ganado a las ferias de Orduña y Medina de Pomar ${ }^{1594}$. En febrero de 1577 se extiende una Provisión, para que en el mercado de Medina den medidas a las Merindades para medir sus granos y que los de Medina no los vendan por muestras ${ }^{1595}$.

- Mercados y ferias de Miranda de Ebro. El puente de Miranda fue clave para el nacimiento y desarrollo de la villa, máxime cuando disfrutaba de un monopolio que le otorgaba el fuero por el que "desde Logroño a Miranda no haya puente ni barca". Se encontraba además en un lugar estratégico, en el camino real de Burgos a Vitoria junto a Álava que era provincia exenta, cerca de la Rioja con buena huerta y vinos y junto a la Bureba, gran productora de cereales, además de situarse en los caminos hacia Vizcaya y los puertos de la mar y de Castilla a Irún, Navarra y Aragón. Tuvo pleitos con Pancorbo por ser mercados que competían y disputaban el comercio del cereal burebano. Los mercados se celebraban en la plaza del Mercado, junto a la entrada de la iglesia de San Juan, los lunes, miércoles y viernes, en los que el comercio de granos era el más relevante. En las ordenanzas de la villa de 1561, se manda que los regatones o revendedores no pudieran comprar producto alguno de los que

Se realizaban los días de la Ascensión, Corpus y San Miguel de septiembre y los dos días siguientes.

1590 GARCÍA SÁINZ de BARANDA, J.: "Apuntes sobre Historia...". 1950: 277.

1591 CADIÑANOS BARDECI, I.: 2007/1: 212-212.

1592 MARTÍNEZ DÍEZ, G.: 1982: 165-168. “Et populator de Medina, si comparaverit equum vel equam, mulum vel mulam, asinum vel asinam non emat nisi in mercato aut in maiori vico villae".

1593 Ordenanzas realizadas en Briviesca, 10 febrero 1495. GARCÍA SÁINZ de BARANDA, J.: 1917: 497. Ordenanza 27 "amonesto, requiero e mando a los mercaderes e marchantes de la dicha mi villa e su tierra, que tratan en comprar e vender mercaderias de paños e sedas e lienzos e ganados mayores e menores, e pan e vino e lo dan fiado ansi a los vecinos e moradores de la dicha mi villa y su vecindad, e en las merindades de Castilla Vieja e en tierra de Tobalina e en otros mis villas e tierras e jurisdiciones, que en las mercaderias o cosas quellos o sus factores vendieren, e mirar mucho en que los precios a que vendieren las dichas mercaderias fiadas sean moderados e razonables, por manera que no sean excesivos e injustos en tanto grado que en derecho e razon, los non escusara ni consienta porque no den causa a que los compradores por aver rescibido agravio e engaño notorio, se ayan de reclamar e quexar ante mi... porque aunque nuestro deseo y voluntad es que en nuestras villas e tierras, aya tratos de mercaderias y de favorecer y ayudar a los mercaderes tratantes...".

1594 A. J. G. A./ t. III/ Vitoria, 22 noviembre 1544.

1595 A. C. V./ Leg. 41,1/ Madrid, 13 febrero 1577. 
llegan a la villa "hasta que taña la campana a visperas", ni salga nadie a los caminos a comprarlo so pena de 100 mrs., impidiendo con ello que pudieran comprar los productos antes que sus vecinos, y evitando así el aumento artificial de los precios ${ }^{1596}$.

En el Fuero de la villa de 1177 se mencionan ya tres mercados en marzo1597, que convertirán a Miranda en el centro comercial de un amplio territorio. En 1213, Alfonso VIII confirma una pesquisa practicada sobre el uso del monte de Cellorigo por los de Arce en que se mencionó este mercado ${ }^{1598}$. Alfonso X otorgó al concejo, en noviembre de 1254, licencia para hacer una feria anual ${ }^{1599}$. A estas ferias se sumaría en abril de 1332 una segunda feria franca anual concedida por Alfonso XI, la "de Cuaresma", mas tarde denominada "del Ángel” y “de Marzo", que llegó a ser la más importante y en la que su comercio principal eran las caballerías mayores y menores. En ellas se comerciaba con todo tipo de alimentos: pan, vino, carne, aves, huevos, frutas, leñas, carbón, paja, aceite, cera, sebo, arroz, pasas, trigo, avena, cebada, centeno, miel, natas, queso, truchas, etc. ${ }^{1600}$.

El concejo dijo en 1492 a los Reyes en el Consejo, que tienen privilegio para hacer tres mercados semanales en lunes, miércoles y viernes, "adonde diz que an venido e vienen continuamente, asy de la tierra e merindad de Burueva, como de todas las partes de nuestros rreygnos a vender pan e trigo e çebada e çenteno e otras cosas" y que ahora el concejo de Pancorbo, quebrantando la posesión de los mercados que tiene Miranda, envían gentes armadas a los caminos reales y, por la fuerza, hacen descargar en Pancorbo a los arrieros que llevan su grano a Miranda, y les obligan a venderlo allí, y añaden que les hacen jurar que no descarguen en Miranda. El Consejo mandó en marzo de 1492 al concejo de Pancorbo, que no perturbe la posesión que tiene Miranda de los tres mercados y deje pasar libremente con sus granos a todos los mercaderes y recueros ${ }^{1601}$. El rey Carlos dice al concejo de Pancorbo en mayo de 1524, que Hernando de Montoya en nombre de Miranda había pedido la Carta real, por la que el Rey había concedido un mercado franco a Pancorbo un día de cada semana porque esto iba en perjuicio de Miranda y de las rentas reales y añadía que si el dicho mercado tuviese efecto, Miranda se despoblaría. A pesar de que el pleito estaba pendiente de resolución, Pancorbo

1596 A. H. N./ Clero, 1.135/1561; CADIÑANOS BARDECI, I.: 2007/1: 219.

1597 A. M. Miranda/ En confirmación de Fernando IV, Valladolid, 24 febrero 1298/ diciembre 1177; Francisco Cantera y Burgos "Fuero de Miranda de Ebro". Diputación de Burgos, 1980. "Y haya en Miranda mercado el miércoles, y por el peso del pan, de la sal o de los frutos, paguen dos dineros de portazgo, y por las otras cosas allí vendidas no paguen portazgo; pero los alcaldes tendrán portazgo de cualquier cosa en tal mercado. Además los que son del alfoz vengan en marzo a tres mercados y contraten en la villa y sean exentos de peaje...". "Además, tengan licencia libre y exenta para comprar ropas, capas, bestias y otros animales para comer... Y si algún vecino, con consentimiento del mercado o en el camino real, compra mula o yegua, asno o caballo, o buey para arar y no sabe de quién, jure que lo compró y no esté obligado a nombrar al vendedor...".

1598 A. H. N./ San Millán de la Cogolla, R-13/ Guadalajara, 5 junio 1213; GONZÁLEZ y GONZÁLEZ, J.: 1960: t. III. doc. 905. 583; RODRÍGUEZ de LAMA, I.: 1979: 230-231: t. III. doc. 455. “... et que les odiera dezir que en tiempo del enperador sabien a los de Arz cortar et pazer, et iazer, e lograr, e ir a mercado de Miranda por foro con mierca de tres dineros; Domingo Martin, ierno de Roy Perez de Trepeana, iuro et dixo que... odio dezir a so suegro que auien a ir por foro a mercado a Miranda con merca de tres dineros...".

1599 A. M. Miranda. Transcripción de CANTERA BURGOS, FCO.: 1938: 144-146: doc. 2. "fagan en su villa fferia una uez en el anno para sienpre jamas, a que sea la fferia cadanno el primer domingo de mayo, e que dure ocho dias... Et mando que todos aquellos que uinieren a esta fferia que uengan saluos e seguros con todas sus mercaduras e con todos sus aueres, e con todas sus cosas. Et dando sus derechos o dar los ouieren, deffiendo que ninguno non sea osado de los contrallar nin de los enbargar a ellos nin a ningunas de todas sus cosas".

1600 SAGREDO FERNÁNDEZ, F., IZQUIERDO ALONSO, M.: 2006: 57-68: vol. 29.

1601 A. G. S./ Registro General del Sello, III-1492, fol. 417/ Burgos, 26 marzo 1492 


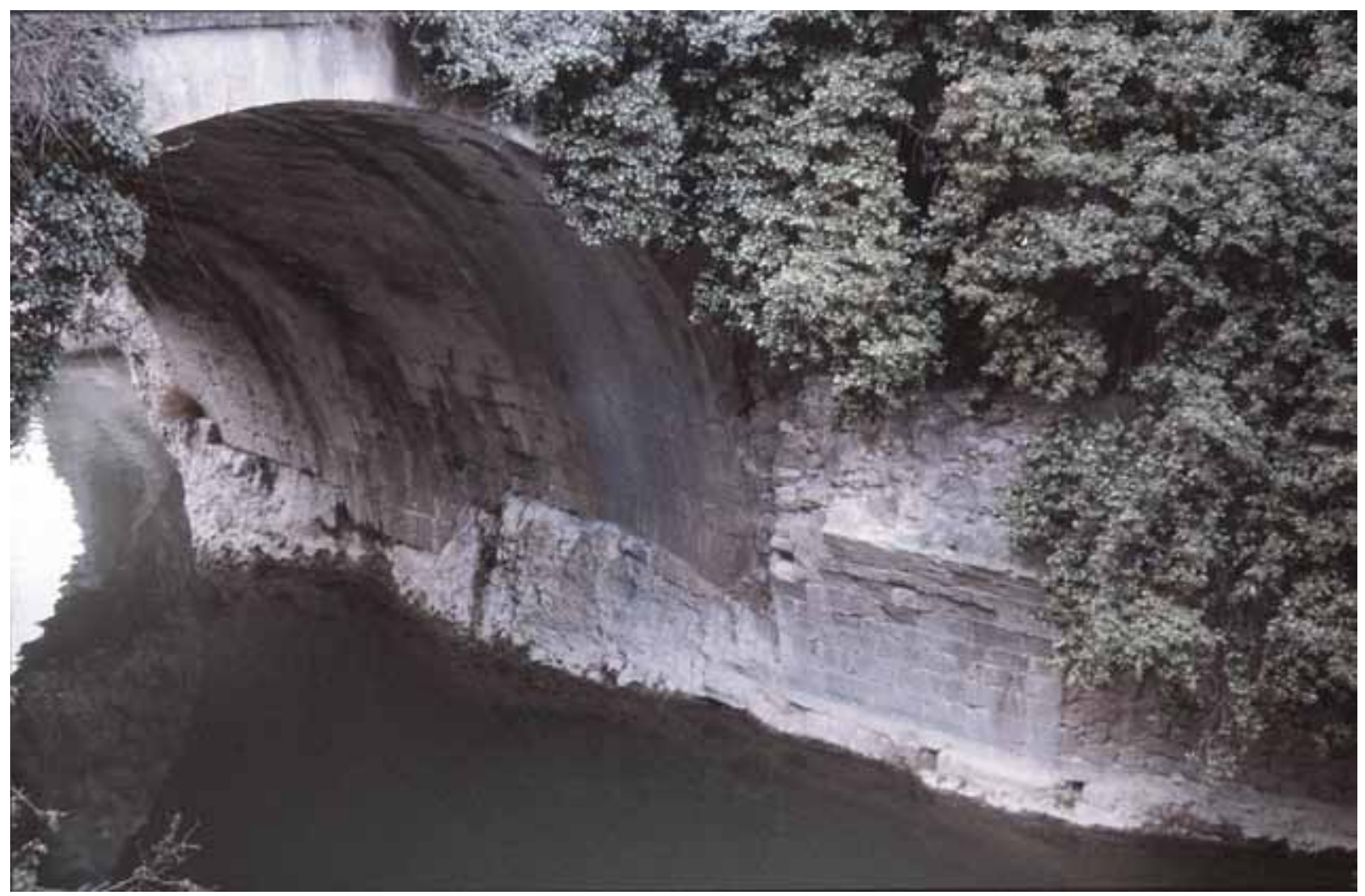

Puente de la Blanca en el desfiladero de Oña. Existió junto a él un puente anterior.

realizaba este mercado franco, pregonándolo por toda la comarca. El Consejo mandó a Pancorbo que hasta que el dicho pleito no se resuelva, no haga el dicho mercado franco y lo deje todo en el estado en que estaba so pena de $10.000 \mathrm{mrs} .{ }^{1602}$.

- Mercados de Monasterio de Rodilla. Enrique III concede en febrero de 1402 mercado franco el sábado de cada semana en el barrio de Suso de Monasterio de Rodilla, a petición de Juan Fernández de Velasco, su camarero mayor y señor de dicha localidad. Manda además, que hagan publicar la carta de concesión en el lugar de Monasterio y en los lugares comarcanos $^{1603}$. Tal mercado se sitúa en el camino real que de Burgos por Briviesca va a Orduña, Pancorbo y Vitoria.

- Mercados de Oña. Sede de un importantísimo monasterio benedictino, se situaba estratégicamente sobre un camino que comunicaba Burgos con el puerto de Bilbao a la entrada del desfiladero de Oña junto al río Oca y del desfiladero de la Horadada. Alfonso VIII dispone en octubre de 1203 , que en lo sucesivo no se efectúen más mercados semanales en la Bureba, sino en Pancorbo el lunes de cada semana, en Oña los jueves y en Frías los sábados ${ }^{1604}$. El abad de Oña decide en 1215 entregar a la villa de Oña, con autorización

1602 A. M. Miranda/ Libro 153, doc. 1/ Burgos, 13 mayo 1524

1603 A. H. N./ Nobleza, Frías, leg. 371, D. 2-3/ Sevilla, 22 febrero 1402; A. H. N./ Nobleza. Frías, Leg. 76. no 2/ Sevilla, 22 febrero 14O2; PEÑA MARAZUELA, M픈 T. de la y LEÓN TELLO, P.: 1955: t. I. doc. 517 “donde no ay mercado porque lo sepane uayan al dicho mercado, e esta dicha liçençia do, no fasiendo perjuysio a otra uilla alguna çercano del dicho lugar de Monesterio donde aya mercado en el dicho dia".

1604 A. H. N./ D. P. de Oña. carp. 280, nº 10/ Carrión de los Condes, 14 octubre 1203; ÁLAMO, J. del: 1950: 425-426: t. I. doc. 350 . 
real, el mercado antiguo que el monasterio tenía en Cornudilla. La concesión se hizo a petición del concejo de Oña, que pagó por ello al abad 170 mrs. ${ }^{1605}$. En 1259, se constata el pago las cuezas del pan en el mercado de cada jueves por parte del concejo de Poza ${ }^{1606}$. Diego Pérez de Tamayo y su mujer Sancha venden al monasterio de Oña en 1282 varios solares en Tamayo y otras heredades, y el abad les da "pro eo quod roborastis uos cumuestra hereditate Oniensi monasterio et pro isto mercato quod uobiscum mercati sumus,..."1607. El mercado se convertirá en un destacado centro comarcal, cuyas ventas ascendían en 1579 a 170.000 mrs. y en 1582 a 202.460 mrs. La razón por la que se mantenía era básicamente por la existencia del potente monasterio benedictino que, además de ser consumidor, poseía unos grandes excedentes provenientes de sus muchas rentas. Además del mercado, también se realizaba una feria el día de San Pedro ${ }^{1608}$.

- Mercados de Pancorbo. La villa se sitúa en la boca del desfiladero por el que se comunicaba Castilla con Bilbao por Orduña, el valle del Ebro, Vitoria y Bayona. Alfonso VIII y su esposa Leonor conceden en julio de 1177 al abad y al monasterio de Oña, el diezmo de todo el portazgo del mercado de Pancorbo según derecho real ${ }^{1609}$. Diez años después, en junio de 1187, Alfonso VIII y Leonor confirman al monasterio de Oña, los privilegios y donaciones concedidos anteriormente ${ }^{1610}$. Alfonso VIII dispone en octubre de 1203, que solo se efectúen en la Bureba los mercados de Pancorbo los lunes, en Oña los jueves y en Frías los sábados ${ }^{1611}$. El concejo de Miranda se había quejado al Consejo porque desde hacía más de 50 años hacían tres mercados semanales, pero que el concejo de Pancorbo obligaba a los de la merindad de Bureba y a los de las otras poblaciones que iban con pan a Miranda, a llevarlo y venderlo en Pancorbo'1612. El Consejo mandó,en marzo de 1492 al concejo de Pancorbo, que no haga contra el mercado de Miranda cosa alguna. Y si contra esto Pancorbo desea alegar alguna razón, que comparezca en 12 días ante el Consejo ${ }^{1613}$. La villa solicitó

1605 A. H. N./ D. P. de Oña. carp. 282, nº 5/ 1215; ÁLAMO, J. del: 1950: 500-501: t. II. doc. 405

1606 A. H. N./ Clero. Oña. Pergaminos. Carp. 287, nº 13/ 15 mayo 1259; ÁLAMO, J. del: 1950: 667: t. II. doc 549; OCEJA GONZALO, I.: 1983: 147: doc 170.

1607 A. H. N./ D. P. de Oña. carp. 277, no 5/ 1282; ÁLAMO, J. del: 1950: 316-317: t. l. doc. 265.

1608 CADIÑANOS BARDECI, I.: 2007/1: 222.

1609 A. H. N./ D. R. de Oña. carp. 276, no 17/ Sitio de Cuenca, 22 julio 1177; ÁLAMO, J. del: 1950: 306-308: t. I. doc. 258; GONZÁLEZ y GONZÁLEZ, J.: 1960: 469: t. II. doc. 285 “... dono et concedo Deo et Sancti Saluatoris de Onia monasterio et uobis domno Iohanni eiusdem abbati uestrique sucessoribus, omnem decimam totius portatici mercati et redditus Pontiscurui, prout ad regale ius spectat, iure hereditario imperpetuum habendam".

1610 A. H. N./ D. R. Oña, carp. 277, nº 10/ Burgos, 21 junio 1187; ÁLAMO, J. del: 1950: 329-333: t. I. doc. 276; GONZÁLEZ y GONZÁLEZ, J.: 1960: 826: t. II. doc. 480 "...et quod domus et decanie Sancti Saluatoris nullum persoluerent in aliquo regni mei mercato portaticum uel tributum uel aliquod usaticum, et liceret domno abbati populare monasteria et serragines suas. Sequenti anno era MCCXV obtuli et tradidi omnem decimam tocius portatici de mercato et redditu Pontiscurui,...".

1611 A. H. N./ D. P. de Oña. carp. 280, nº 10/ Carrión de los Condes, 14 octubre 1203; ÁLAMO, J. del: 1950: 425-426: t. I. doc. 350

1612 Les obligan a venderlo "contra su voluntad en esa dicha villa, e que lo que peor e mas feo diz que es, diz que enbiays gentes armadas a los nuestros caminos rreales, e que mano armada e por fuerça, toman los dichos mercaderes e harruqueros que van a la dicha villa de Miranda con su pan, e que los lleuays a esa dicha villa e les fazeys descargar y descargays en ella, e que sobre ello les feris e descalabrays e que tomays juramentos a los que algunos vezinos dexays pasar que no descarguen el dicho pan la dicha villa de Miranda".

1613 A. G. S./ Registro General del Sello, III-1492, fol. 417/ Burgos, 26 marzo 1492. "que non ynquietedes ni perturbedes ni molestedes en la dicha su posesyon... de los dichos tres mercados a los vecinos de la dicha villa, e que dexedes e consyntades 
en 1524 al Consejo, que de sus tres mercados semanales del martes, jueves y sábados, uno fuera franco de alcabalas, lo que se concedió al del jueves "en tanto que no gozen desta franqueza los vezinos e moradores de la dicha villa que en ella viven e moran... ni los estranjeros estantes en ella". Los vecinos de su alfoz también pagarían alcabalas, aunque los comprendidos dentro de cinco leguas lo harían en sus respectivos lugares ${ }^{1614}$. El concejo de Miranda se quejó ante el Emperador, porque el mercado franco concedido por el propio Rey a Pancorbo perjudicaba a Miranda y las rentas reales, por lo que habían interpuesto un pleito. Como Pancorbo realizaba el dicho mercado franco pregonándolo por todas las comarcas, el Consejo acordó en mayo de 1524 mandar a Pancorbo que hasta que el pleito no se resuelva, no haga el mercado franco so pena de 10.000 mrs. ${ }^{1615}$.

- Mercados y ferias de Poza de la Sal. La villa de Poza tenía carta de privilegio de Enrique II de septiembre de 1371 y confirmada por Juan I y Enrique III, que indicaba que el Rey "por faser bien et merçed a vos el conçejo e omes buenos e vesinos e moradores en Posa, que es en la mia juridicion de Burueba e Rrioja por que el dicho logar se pueble mejor", y que como Sancho Sánchez de Rojas, señor de Poza, murió a su servicio y lo pidió Ruy Díaz de Rojas merino mayor en Cuipúzcoa, concede mercado a la villa los sábados y dos ferias, una el primero de mayo y la otra el día de Ntra. Sra. de septiembre, con "todas las franquesas e libertades que an los otros logares de la comarca en rrason de sus ferias e mercados"1616. En el s. XVI se hacían ya mercados francos los miércoles y los sábados, y se ponían dos tablas de pan bien cocido y sazonado en la plaza tanto para el servicio de sus vecinos como para los forasteros ${ }^{1617}$.

- Mercados de Santa Gadea. El antiguo poblado de Término, antigua denominación de la actual Santa Gadea, se situaba sobre el importante camino que unía Burgos con Bilbao por Orduña en el punto de transición de Castilla con Álava. Con motivo de la agregación de los monasterios de Santa María de Guinicio y Santa María de Quijera al de San Millán de la Cogolla, se menciona en 1045 el mercado de Término, y en el mismo documento se alude al puente de Puentelarrá perteneciente a Santa Gadea y al cobro de portazgo ${ }^{1618}$. Sancho IV otorga un privilegio por el que concede a Santa Gadea un mercado todos los martes. Su hijo Fernando IV, a ruego de su tía Juana Alfonsa, cambia en abril de 1312 el día al miércoles, pero como en Miranda tenían mercado los lunes, miércoles y viernes y se sentían perjudicados por ser el del miércoles el más importante, acaba trasladando el

pasar libremente a los mercaderes e rrecueros que asy pasaren con el dicho pan, e les non descarguedes en su dicha villa, ni les fagays rresystençia alguna saluo que libremente los dexedes pasar elleuar el dicho pan segund que lo solia faser".

1614 CADIÑANOS BARDECI, I.: 2007/1: 224-225.

1615 A. M. Miranda/ Libro 153, doc. 1/ Burgos, 13 mayo 1524

1616 A. G. S./ Patronato Real, leg. 58, doc. 104/Cortes de Toro, 10 septiembre 1371. Burgos, 22 agosto 1379 y Burgos, 20 febrero 1392.

1617 MARTÍNEZ ARCHAGA, F.: 2009: 118.

1618 A. H. N./ Cartulario de San Millán de la Cogolla. Becerro, fol. 157-157v/ 31 octubre 1045; UBIETO ARTETA, A.: 1976 : 231-232: doc. 237"...in Ebro ubi cadet rivo de Termino, de parte ad parte, ad integritate. Et illa casa de Ponte, cum illa villa de Larate, ad integritate. De illa defesa de Tega, medietate. De illo mercato, medietate. De illas calonias et illo portatico. Et ipso mercato, ad fuero de Cereso populato, medio ad Termino et medio ad Sancti Emiliani presbiteri. Duos asinos de Sancta Maria de Genezo, et uno de casa de Ponte, sine alvara ambulent ad suos mercatos absolutos". 
de Santa Gadea al viernes y anulando el de Miranda de este día ${ }^{1619}$. Alfonso XI lo confirma en Carrión de los Condes en marzo de 1317 con la intención de completar, seguramente, los privilegios dados que tendían a favorecer la repoblación de la villa. En marzo de 1490, a petición de las villas y lugares del Señorío de Vizcaya, los Reyes ordenan a Pedro López de Padilla, aposentador mayor de Castilla, que vea la queja de la Junta de que en el nuevo mercado de Santa Gadea no se permite comprar trigo con destino a los puertos del Señorío, y que incluso se les había echado cierta imposición contra las leyes y ordenanzas promulgadas en las Cortes de Toledo de 1480 , y le mandan que guarde dichas ordenanzas ${ }^{1620}$.

En septiembre de 1492, el concejo de Santa Cadea se queja ante el Consejo Real, que desde tiempo inmemorial tiene mercado los lunes, miércoles y viernes de cada semana, al que acuden libremente todos los que desean vender y comprar trigo, cebada, sal y otras mercaderías. Pero desde hacía unos cuatro meses, los de Pancorbo que es de la ciudad de Burgos, molestaban a los que iban por su villa a la feria de Santa Gadea y "enbyavan e fasyan salir gente a los caminos a tomar e que tomavan los mulateros e rrecueros que trayan a vender pan e otras cosas al dicho mercado de Santa Gadea e que lo fasian descargar e vender en la dicha villa de Pancorvo". No contentos con ello, hacían mandamientos por la merindad de Bureba diciendo que Pancorbo era cabeza de esa Merindad y que nadie osase ir al mercado de Santa Gadea, so ciertas penas, por lo que nadie se atrevía a ir a sus mercados. Suplicaron que se obligase a los de Pancorbo a cesar en sus fuerzas y agravios y que pagasen a Santa Gadea y su concejo 1.00o reales de plata, que según calculaban, era el daño recibido. El concejo de Pancorbo alegó que de tiempo inmemorial, habían tenido llana y mercado los dichos tres días por semana, y que de ello tenían privilegios y escrituras reales pero que algunas personas, tanto de Santa Gadea como de otras partes, ponían imposiciones a los que iban a dicho mercado. Además, la Reina mandaba que nadie pudiese cobrar ni hacer daño ni fuerza a los que fuesen al mercado de Pancorbo, poniendo penas a los que hiciesen lo contrario, en las que, según decían, habían caído los vecinos de Santa Gadea. Añadían que las franquezas que se hacían en los mercados de Santa Gadea eran hechas privadamente y sin autoridad alguna. El Consejo condenó al concejo de Pancorbo a que no consienta que se hagan las "dichas fuerças y perturbaçiones e molestaçiones al dicho conçejo e omes buenos de Santa Gadea, ni ya pidan ni enbarguen a los rrecueros e caminantes ni les den estoruo, para que no vayan a la dicha villa de Santa Cadea a descargar e vender su pan en ella, ni les apremien que lo hayan de descargar ni vender en la dicha villa de Pancorvo", so pena de 50.000 mrs. y pagar los daños y costas causados que se fijan en 15.986 mrs. ${ }^{1621}$.

1619 A. M. Santa Gadea/ doc. 5-16/ Carrión de los Condes, 28 marzo 1317 y Valladolid, 6 septiembre 1549. “...el Rey Don Sancho... ttobiera por bien que obiese mercado el dia martes, que lo obiese cada semana el dia miercoles e porque los de Miranda se tenian por agrabiados en esto, porque dezia que hauian ellos esto tres dias en la semana mercado, en el dia de el lunes y de el miercoles e en el dia de el viernes e en el mas prinzipal su mercado que era el dia de el miercoles, yo tobe por bien que los de Miranda escoxiesen quel dia de los sobredichos ello quisiesen en que obiesen mercados que en este dia no le obiesen los de Santa Gadea e los de Miranda escoxiesen el dia de el miercoles e yo tobe por bien que el mercado de el miercoles e el mercado de el lunes que los aya los de Miranda...".

1620 A. G. S./ Registro General del Sello, III-149O/ Sevilla, 20 marzo 1490. GONZÁLEZ, T.: 1829: 237-243: t. I. doc. LIX. Manda que deje a todas las "personas que quisieren pasar por la dicha villa de Santa Gadea e sus terminos, con todo el pan, trigo e cebada que quisieren levar al dicho Condado de Vizcaya, sin les pedir portazgo nin otra impusicion alguna,... so pena de perder la dicha villa de Santa Gadea, e qualquiera que por vos o en vuestro nombre lo llevare en otra cualquier manera, que muera por ello".

1621 A. G. S./ Registro General del Sello, IX-1492, fol. 290/Valladolid, 20 septiembre 1492. 
En el pleito entablado por Santa Gadea hacia 1550 contra Antonio de Padilla, adelantado mayor de Castilla y Luisa de Padilla su mujer, Santa Gadea dice que perteneciendo la jurisdicción, Merindad y derechos de los mercados a su villa, María Manrique en nombre de Padilla, pone alcalde mayor y merino y lleva tales derechos. El procurador de Padilla y su mujer alega que sus partes y María Manrique como usufructuaria de la villa, están en posesión de tiempo inmemorial de poner merinos en ella y en su tierra y de cobrar los derechos de su Merindad y los de los mercados, por sí o por sus arrendadores y cogedores, por privilegio y título. Ortuño de Isasi, en nombre del concejo, responde que no se han dado sentencias ni carta ejecutoria para que María Manrique pueda poner alcalde mayor en la villa, y que su Merindad y mercado les pertenece por derechos y privilegios reales, y por ellos la villa ponía merinos y cobraba tales derechos, siendo despojados de esta posesión de forma violenta. La sentencia indica que el concejo podía poner escribano y merino en la villa pudiendo percibir los derechos de la Merindad, pero no le reconocía los derechos sobre los mercados ${ }^{1622}$.

- Mercados de Treviño. En el fuero de Treviño de 1254 se hace mención a su mercado, de lo que se deduce que ya se realizaba con anterioridad ${ }^{1623}$.

- Mercados y ferias de Villarcayo. A partir del traslado de la capitalidad de las Merindades, una de las mayores aspiraciones de estas para independizarse de la tutela medinesa fue la de solicitar al Rey la concesión de mercados y ferias propios. Con este fin y por considerar que los mercados y ferias debían instalarse en el lugar donde el alcalde mayor ${ }^{1624}$ hubiere de residir, el Rey dice que por ser las Merindades tierra "pobre de manthenimiento e aver poco trato e comercio entre los vezinos dellas, devia dar licencia y facultad para que en el pueblo donde el dicho alcalde mayor huviere de rresedir, se haga un mercado franco un dia de cada semana y dos ferias francas en cada año, en los tiempos que pareciere que mas conviene porque desta manera las dichas Siete Merindades y los vezinos e moradores dellas, seran bien proveidos y abastados de las mercaderias y provisiones y manthenimientos necesarios". En agosto de 1562 encarga a Juan de Peñalosa, administrador de la renta de los diezmos de la mar, que vaya a Villarcayo con el tesorero del Rey, donde reside el alcalde mayor que tiene la memoria de las alcabalas de las Merindades, y los tres vean si convendrá que en la jurisdicción de las Siete Merindades se haga un mercado semanal, qué día y lugar sería más cómodo para los que acudieren, si convendría que sea franco de todas las mercaderías o solamente para las cosas más necesarias, si sería bueno que en esa jurisdicción se hagan dos ferias francas al año, en qué tiempos y lugares y qué cosas se podrán vender y contratar, y tales informaciones con sus pareceres se llevarán a los Contadores mayores para proveer lo que más convenga ${ }^{1625}$.

Peñalosa junto con Juan Díaz de Isla, receptor de la Merindades, envió informe favorable para hacer el mercado, pero en 1566 llegaba la peste a Medina y a Villarcayo, lo que alteró estos planes y el mercado de Medina se llevó a las afueras de esta villa y las ferias

1622 A. M. Santa Gadea/ doc. 5-14/1550?

1623 A. Conde de Oñate/ / 20 diciembre 1254; MARTÍNEZ, G.: 1982: 205: doc. XLIII. "Tod aquel que viniere con alguna mercadura a la villa non de lezna, si non en dia de mercado".

1624 Cargo antecedente del de corregidor.

1625 A. C. V./ no 1.873, doc.24, hojas 60 y 61/ Madrid, 25 agosto 1562. 
al lugar de Pomar ${ }^{1626}$. Ya en julio de 1571, una Provisión real otorgó a las Merindades el derecho a hacer mercado en Villarcayo un día a la semana y dos ferias al año por el tiempo que estuvieren encabezadas. Alegaron los de las Merindades, que de no otorgárseles tal concesión sus habitantes tendrían que ir a pueblos de señorío, como son Medina de Pomar y otros del Condestable, del duque del Infantado, del marqués de Aguilar y de Poza y del conde de Salinas que se encontraban próximos. De esta manera, Villarcayo como cabeza de las Merindades obtuvo un mercado franco todos los sábados y dos ferias francas al año el día de San Miguel de mayo y el domingo de la Santísima Trinidad ${ }^{1627}$. En 1591, el Rey accedía a la petición y otorgaba un privilegio "para que pudiesen juntarse en la villa de Villarcayo... a haçer sus bentas y contrataçiones un dia cada semana y dos bezes al año por tres a quatro dias cada vez". La Junta general decidió que las ferias fueran celebradas en San Miguel de mayo y el Corpus, con una duración de 4 días cada una, lo que tuvo efecto al año siguiente ${ }^{1628}$.

- Mercados de Bilbao. Diego López de Haro V, señor de Vizcaya, otorga carta-puebla el 15 de junio de 1300, y hace nueva población y villa en el puerto de Bilbao a la que concede mercado el martes de cada semana ${ }^{1629}$. En junio de 1310 doña María, señora de Vizcaya, confirma la carta-puebla en un documento que la copia casi literalmente, salvo el cambio del mercado de los martes a los miércoles ${ }^{1630}$.

En las Juntas de Vizcaya de abril de 1599, los síndicos indicaron que, como era notorio, los mercados de Vitoria, Miranda, Santa Gadea, Poza, Oña, Frías, Medina de Pomar y otros de su entorno, estaban fuera de las 10 leguas de los puertos de la mar y que por ello no podían ser exceptuados de la pragmática de la tasa del pan del año 1558. Se mandó que se pida su remedio al Rey y a su Consejo y la ejecución de la dicha pragmática, y que se mande al doctor Pineda de Tapia, juez de comisión del Rey, que averigüe las leguas que hay desde los puertos de la mar a los dichos lugares y haga lo que convenga ${ }^{1631}$. En dichas Juntas de abril de 1600 el corregidor y gobernador, diputados generales, síndicos procuradores del Señorío y procuradores de Bermeo, Bilbao y Durango como diputados, dijeron que como en la corte tenía el Señorío pleito con Vitoria, Santa Gadea, Oña, Frías y otras villas y lugares sobre la tasa del pan, y la averiguación de las leguas que hay de los puertos de mar a estos lugares, debían nombrar por agente para las dichas causas, a Domingo de Irarrazábal Arrieta, residente en la corte ${ }^{1632}$.

\footnotetext{
1626 CADIÑANOS BARDECI, I.: 2007/1: 240.

1627 GARCÍA SÁINZ DE BARANDA, J: "Apuntes sobre Historia.... 1950: 277-278.

1628 CADIÑANOS BARDECI, I.: 2007/1: 240.
}

1629 A. M. Bilbao/ Pergaminos, 1 (actualmente se halla en la casa consistorial)/Valladolid, 15 junio 1300; ENRÍQUEZ FERNÁNDEZ, J.; HIDALGO de CISNEROS AMESTOY, C. y MARTÍNEZ LAHIDALGA, A.: "Colección documental del Archivo Histórico de Bilbao..., 1999: doc. 1.

1630 A. M. Bilbao/ Pergaminos, 2. (se halla en la casa consistorial)/ Valencia. 25 junio 1310; ENRÍQUEZ FERNÁNDEZ, J.; HIDALGO de CISNEROS AMESTOY, C. y MARTÍNEZ LAHIDALGA, A.: "Colección Documental del Archivo Histórico de Bilbao..." 1999: doc. 3; A. M. Bilbao/ Cajón 1, reg. 1, no 12 -Pergaminos 12/ Bermeo, 20 junio 1334; ENRÍQUEZ FERNÁNDEZ, J.; HIDALGO de CISNEROS AMESTOY, C. y MARTÍNEZ LAHIDALGA, A.: "Colección Documental del Archivo Histórico de Bilbao... "1999: doc. 10.

1631 A. J. R. B./ Actas de la Tierra Llana. t. VI/ Bilbao, 20 abril 1599.

1632 A. J. R. B./ Actas de la Tierra Llana. t. VI/ Bermeo, 17 abril 1600. 
- Mercados de Laredo. Enrique IV concede en 1466 a la villa de Laredo el privilegio de tener mercado franco el martes de cada semana, y que no se paguen alcabalas de lo que en el mercado se comprare o vendiere y manda a sus tesoreros, recaudadores y arrendadores, fieles y cogedores que recaudan las dichas alcabalas, que no las demanden a los que vinieren al mercado, de cosa alguna que en él se vendiere y comprare ni a los vecinos de la villa, salvo la del vino que se vendiere atabernado por menudo, carnes muertas que se vendieren a peso o a ojo por menudo, pescado que se vendiere en gavilla remojado y heredades que se vendieren y compraren el dicho día. De estas cosas pagarán la alcabala los que lo vendieren ${ }^{1633}$.

- Mercados y ferias de Orduña. La villa fue fundada en 1229 por Lope Díaz de Haro II, señor de Vizcaya, junto a un importante camino ya existente. Nombrada ciudad por Enrique IV en 1467, con los Reyes Católicos pasó en 1480 a incorporarse al Señorío de Vizcaya. En septiembre de 1288 , la villa recibe privilegio de Sancho IV en el que se le concedía la facultad de celebrar una feria de 15 días, 8 días después de San Miguel ${ }^{1634}$ eximiendo del pago del portazgo o cualquier otro derecho por sus mercaderías a los mercaderes que acudieren. Se trata de la primera feria concedida a una villa vizcaína, alavesa o guipuzcoana y supuso un fuerte estímulo para la actividad comercial de Orduña como centro comarcal $^{1635}$. Existió un pleito en 1393 entre Juan Sánchez de Villanañe, vecino de Santa Gadea, y Diego Ruiz de Ortuño, portazguero de Orduña, por no reconocer este la exención del pago del portazgo que Juan Sánchez tenía como vecino de Santa Gadea, en la venta en el mercado de cuatro fanegas de trigo. El alcalde falla a favor de Juan Sánchez por su derecho para no pagar portazgo ${ }^{1636}$.

Los Reyes tras la petición realizada por el concejo y justicia de la ciudad de Orduña, que alegaban que la ciudad y sus vecinos tienen privilegios reales, dicen en 1491 que "todas las mercadorias asy paños como fustanes e otras qualesquier cosas, que a la feria de la dicha çibdad fuesen a vender, en que se contiene que todas las mercadorias dis que syenpre fueron e son francas de todo diesmo, e dis que agora los fatores del condestable, an intentado de los quebrantar e quebrantan los dichos preuillejos" cobrando impuestos. Por ello encargan al juez de residencia del condado de Vizcaya que se informe acerca de ello y lo envíe al Consejo Real para que provea lo que fuere de justicia ${ }^{1637}$. En septiembre de 1492 se reunió el concejo de Orduña en relación con las ferias de fin de ese mes, las cuales siempre han sido francas y exentas de todos los diezmos y derechos por las mercaderías que en ellas se comercian, pero los diezmeros nombrados por el Condestable no respetaban estos privilegios. Para concertar un acuerdo con el Condestable y sus diezmeros y hacedores, se juntaron en noviembre representantes y el procurador general

1633 A. H. P. C./ Villa de Laredo, leg. 8, num. 4, fols. 106-125/ Segovia, 3 y 15 mayo 1466; CUÑAT CISCAR, V. M.: $1998: 312$ y 315: docs. 98 y 99.

1634 Día 29 de septiembre.

1635 ARMONA y MURGA, J. A.: 2002: 92-94.

1636 A. M. Santa Gadea/ doc. 5-8/ Orduña, 12 agosto y 26 septiembre 1393. “...los uesinos e moradores de la dicha uilla seyendo franqos et quitos de non pagar portadgo en esta dicha uilla de Orduña de tanto tienpo aca que non era memorya de omes en contraryo ni de pagar otro derecho alguno por las cosas que traxiesen o leuasen o conprasen o uendiesen en esta dicha uilla de Orduña...".

1637 A. G. S./ Registro General del Sello, XII-1490, fol. 34/ Sevilla, 25 diciembre 1491. 
de Orduña, con Alonso de Córdoba, diezmero en Valmaseda, y Ochoa López de Barriga el viejo, y Ochoa López de Barriga, su hijo, diezmeros en Orduña, todos ellos nombrados por el Condestable para tratar sobre las ferias y la libertad y franqueza que la ciudad tiene. Los diezmeros mostraron dos cartas del Condestable que manifestaban la buena voluntad del mismo y que reconocía que Ochoa López de Barriga, cogedor de los diezmos de la ciudad, había perturbado la feria obligando a los compradores de los paños a llevar albalaes firmadas por él, cobrándoles además el diezmo. El Condestable manifiesta su voluntad de guardar los privilegios de Orduña y mirar "por sus onrras, como parientes y espeçiales amigos y muy naturales de mi casa", y manda al diezmero que no innove cosa alguna. Los diezmeros asentaron que todos los mercaderes o traperos que compraren en la feria y tiendas de la ciudad cualquier paño traído de la mar y lienzos y fustanes y otras mercaderías, o que lo llevaren a vender, que paguen el diezmo de ello así como si lo trajesen de allende de la mar, de Bilbao o de otros lugares. También asentaron que cualquiera que en Orduña comprare paños, lienzos, fustanes u otras mercaderías para sus vestidos y que lo llevare vareado e hiciere juramento de que es para su uso personal y no para revender, que no pague diezmo manifestándolo previamente al diezmero y llevando el albalá expedido y firmado por el diezmero, so pena de perder la mercadería por ir descaminado, y que el diezmero lleve por el albalá 4 mrs. ${ }^{1638}$.

En Junta de Álava de noviembre de 1544 se denuncia que cuando se lleva el ganado a vender a las ferias de Orduña y otras partes, principalmente bueyes para la labranza, y que antes de que ese ganado llegue, mercaderes y tratantes salen a los caminos y los compran, de manera que se quedan con el mejor ganado para revenderlo a los precios que ellos ponen lo que perjudica a la provincia y sus vecinos, porque como el sustento principal de Álava es la labranza, necesitan comprar los bueyes y yeguas y esos mercaderes los ofrecen a precios excesivos. Por ello, la Junta y Diputado Ceneral, alcaldes y procuradores, mandan que nadie salga a los caminos por donde va el ganado a las ferias de Orduña y Medina de Pomar, ni compre fuera de las plazas y mercados de las ferias para luego revenderlo, y a todos los procuradores que lleven un traslado de ese acuerdo para que lo notifiquen en cada hermandad y asegurar así su cumplimiento1639.

En mayo de 1545 se trató sobre esta prohibición, ya que a pesar de tal acuerdo algunos mercaderes alaveses seguían sin cumplirla, por lo que mandaron que Martín de Isunza, alcalde de hermandad, vaya a Orduña a llevar carta a su justicia y regimiento para que la prohibición se cumpla. No obstante, como en general tal acuerdo ha sido beneficioso para la provincia y sus vecinos facilitando que los labradores puedan comprar el ganado a precios adecuados, se acordó enviar el traslado del acuerdo al Consejo Real para su confirmación ${ }^{1640}$. En Junta de mayo de 1551 los procuradores de Urcabustaiz, Barrundia, y Arrastaria entre otros, dijeron que en la feria de Orduña habían visto que los ganados y bueyes que traían de la parte de las Asturias y de otros sitios, estaban a excesivos precios pidiendo

1638 A. M. Orduña/ Caja no 28- Leg. 20 (fol. 1v- 5r)/ Orduña, 21 septiembre a 19 noviembre 1492; ENRÍQQUEZ FERNÁNDEZ, J., HIDALGO de CISNEROS AMESTOY, C, LORENTE RUIGÓMEZ, A y MARTÍNEZ LAHIDALGA, A.: "Colección documental del Archivo Municipal de Orduña (1271-1510)". 1994: t. I. doc. 24.

1639 A. J. G. A./ t. III/ Vitoria, 22 noviembre 1544.

1640 A. J. G. A./ t. III/ Vitoria, 4 y 6 mayo 1545. 
17 o 18 ducados por buey, y algunos mercaderes y vecinos de la provincia pagaban lo que ellos piden y más de lo que es justo, y que con la intención de venderlos a fiado en los precios que ellos ponen la pobre gente y labradores que los necesitan para sus tierras, no los pueden comprar. Se acordó visto el desorden, dar mandamiento para que los mercaderes de la provincia no compren bueyes por vía de hato ni en otra manera para revenderlos en la provincia si el precio excede de 8 ducados por buey, para que los puedan vender fiados y darlos en justo precio ${ }^{1641}$.

En las Juntas de Vizcaya de septiembre de 1569 los síndicos procuradores generales del Señorío dijeron que siendo el mercado de Orduña franco y libre para que los mulateros, recueros y cualquier persona, puedan comprar trigo, cebada y otras cosas sin limitación alguna, la ciudad había hecho ordenanzas para que ningún mulatero ni recuero pueda llevar de trigo o cebada más de lo que pudiesen cargar dos machos, y como iba en perjuicio del Señorío pidieron que se ponga remedio. El corregidor, diputados y regidores del Señorío y procuradores de las villas, mandaron que dejen libremente a la justicia y vecinos de Vitoria comprar en el mercado de Orduña todo el trigo, cebada y otras cosas que necesitaren sin pena alguna para mulateros y recueros cargando los machos que tuvieren $^{1642}$.

- Mercados y ferias de Reinosa. En 1457, se pregona una Carta real de Juan II con instrucciones para seguridad de las Casas Torre de la Merindad de Campoo. En la vuelta de la carta, se anota "fue publicada esta carta en este mercado de Reinosa, estando asaz gente en dicho mercado público". Se trataba de un mercado eminentemente ganadero, en especial de vacuno, asnal y caballar, al que concurrían gentes de las comarcas limítrofes pertenecientes a los valles altos de Palencia y Burgos. En un apeo de 1404 se indica "...que cobre el Rey allí [en Reinosa] el portazgo de lo que viene allende la loma a se vender, es a saber dos dineros de cada asno o de cada bestia caballar dos sueldos e del carro... que se vende a dos maravedís". Tenemos referencia de que en 1751 existe un mercado semanal mencionado en el Catastro del Marqués de Ensenada1643.

- Mercados de Santander. En mayo de 1524, Carlos I indica al concejo, justicia y regidores de Santander que para que la villa esté más poblada y abastecida por estar en tierra estéril y tener pocos mantenimientos, desde el 1 de enero de 1526, fecha en que saldrá el nuevo encabezamiento de las rentas de la villa, se haga un mercado franco los sábados para que todos los que a él acudan no paguen alcabala, y sus vecinos y moradores y en sus arrabales puedan vender y cambiar el sábado de mercado en sus casas, en el mercado o donde ellos quisieren. Para que la puebla vieja de la villa no se acabe de despoblar, es voluntad real que todos los estantes en Santander y forasteros que llegaren con merca-

1641 A. J. G. A./ t. IV/ Andagoya, 4 mayo 1551.

1642 A. J. R. B./ Actas de la Tierra Llana. t. I/ Durango, 7 septiembre 1569.

1643 RODRÍGUEZ CANTÓN, R.: 1996. “...lunes de cada semana se celebra mercado de granos, que de acarreo y a lomo viene ende tierra de Castilla, para consumo de los naturales de este pais, por no alcanzar su manutención para cuatro meses, de los frutos que en el se recogen, y que en algunos de dichos mercados en tiempo de verano, se bienen a bender algunos zapatos y los forasteros de esta villa y jurisdicción, por no haber en ella oficio alguno de obra prima, y en el tiempo de iberno zapatos de madera que llaman albarcas... y que también vienen a benderse a otros mercados hortaliza y alguna fruta de la tierra de Medina y Liébana por no lo producir este país, que también se zelebran en esta villa dos ferias del año, una de ellas de ganados vacunos y lanares forasteros el día de Santiago y la otra el día de San Mateo también de ganados bacunos, lanares, mulares y cavallares...". 
derías, mantenimientos y otras cosas, los vendan y contraten un día de mercado en la puebla vieja y otro en la nueva y a estas personas el Rey los toma bajo su amparo, y que ni por ir al mercado ni por la alcabala puedan ser detenidos ni embargados, con la condición de que de lo que se vendiere o cambiare ese día se pague alcabala, aunque si las rentas de la villa disminuyesen tanto que no valgan para pagar el situado que en ellas hay, que la villa lo pague enteramente. Y manda a sus arrendadores y recaudadores mayores y receptores y arrendadores menores, fieles y cogedores que recaudan las alcabalas de la villa y su tierra, que no pidan nada a nadie los sábados en los lugares mencionados desde el 1 de enero de 1526. Se entiende que por la franqueza del día de mercado, no se exime a los vecinos de Santander ni de otras partes de pagar los diezmos de la mar pertenecientes al Rey ${ }^{1644}$.

En noviembre de 1535, el concejo de Santander otorga poder a Juan de Bolívar, escribano, para presentar queja ante el Consejo y sus Contadores mayores sobre el agravio que las justicias y otras personas del marquesado de Santillana, Torrelavega y otras partes, hacen a los que van con sus mercaderías al mercado de los sábados, y que les llevan la alcabala de lo que venden, compran y contratan en dicho mercado contra el privilegio real. Bolívar recordó que Santander tiene un mercado franco un día a la semana, pero los del marquesado de Santillana apremian a los de los pueblos comarcanos para que paguen la alcabala de lo que compraron o vendieron en dicho mercado y les piden otras penas, lo cual deja sin ningún efecto la franqueza de su mercado. Pide que se dé Provisión mandando que se guarde dicha franqueza' ${ }^{1645}$.

- Mercados de Valmaseda. La villa de Valmaseda fue fundada en 1199 por Lope Sánchez de Mena, señor de Bortedo, junto a un vado sobre el Cadagua en el camino entre el interior castellano y la villa de Castro-Urdiales (fundada en 1163), sobre un paso que ya tenía cierta tradición como lugar de tránsito por haber discurrido por ese punto la vía romana Pisoraca-Flavióbriga y que pronto será mejorado con las construcción del puente. Para asegurarse una favorable posición económica, la villa logró obtener una serie de concesiones que incrementaban sus privilegios o consolidaban los ya adquiridos, logrando algunas mejoras de carácter comercial. La villa aprovechó su situación sobre un camino importante y transitado, para convertirse en lugar de intercambio y obtener beneficio de las actividades comerciales. Así, Valmaseda trató de adquirir ventajas económicas en exclusiva y eliminar la posible competencia por parte de su entorno, logrando a mediados del siglo XIII que Diego López de Haro III, señor de Vizcaya, concediese un privilegio especie de monopolio comercial, para que entre Villasana de Mena y Sámano1646 nadie "de las otras tierras nin de sus vecindades, [tuvieran] tavernas de vino, ni de medida de trigo, ni de cebada, nin carneceria, nin reventa ninguna de estas cosas, sino vino o sidra de su cosecha e pan coger e porque lo facen agora en guisa a grant menoscabo de la mi villa de Balmaseda, e de todos mios derechos, tengo por bien e mando que daqui adelante non haia reventa, nin taverna de vino, ni sidra, e medida de trigo nin cevada, nin de carneceria

1644 A. H. P. C./ J. T. A. leg. 38-5/ Valladolid, 24 julio 1546.

1645 A. H. P. C./ J. T. A. leg. 38-4/ Santander, 2 noviembre 1535.

1646 Samano se encuentra a unos dos kms. de Castro-Urdiales, y la distancia entre Samano y Villasana contenida en el privilegio es de algo más de $40 \mathrm{kms}$. 
de Villasana fasta en Sandesamano, salvo en la mi villa de Valmaseda, o so vecino otro qual quier que lo obier de su cosecha"1647, lo que obligaba a pernoctar en la villa a cuantos comerciaban con CastroUrdiales. Sus vecinos se vieron favorecidos además, por un privilegio concedido por Alfonso $\mathrm{X}$ en enero en 1256, por el que se les eximía del pago de portazgos en todo el Reino, con las habituales excepciones de Toledo, Sevilla y Murcia, lo que favoreció su participación en la actividad mercantili1648.

Fernando IV concede un privilegio en 1312, con el fin de impulsar el mercado de la villa, que indicaba que "quantos paños e mercaduras llegaren en Valmaseda para benderlo y que sean quitos, que non paguen diezmo de todo lo que se bendiere segund fue usado fasta aqui", lo que hará acrecentar la importancia de su mercado, que se celebraba los miércoles y sábados. En abril de 1554 el fiel y procurador general de la villa pretende el reparo de los muros y cercas que se cayeron en la plaza y mercado de la villa con las riadas del año $1553^{1649}$. Por parte del concejo de Mena se informa al Rey en 1590 que en Valmaseda está libre el oficio de merino mayor, por el que todos los que lo han poseído han cobrado de los vecinos del Valle y demás comarcanos el derecho de oturas. Dicen que los que tienen su cobro, a los de Mena y otras partes que entran en los mercados con trigo y cebada, "les suelen quitar las prendas para segurarse de que no saldran de la uilla sin pagar el dicho derecho de trigo e çebada en abriendo sus talegas, elos molestan con rrigor y axperidad y muchas uezes despues de auer pagado, [andan]... molestados aguardando por ellas y trocandoseles algunas bezes, y otras bezes ha bisto quitarles las jaquimas de las bestias"1650 .

- Mercados y ferias de Vitoria. En marzo de 1484 los Reyes dicen al concejo de Vitoria que en esa ciudad el jueves de cada semana se hace un mercado franco en la zona baja, en la plaza delante de las puertas de la Correría, Zapatería y Ferrería; y una feria anual en junio, y que los vecinos de los barrios altos de la Cuchillería, Pintorería y aljama de los judíos se quejan por hacerse el mercado y feria donde se hacen, porque dichas collaciones y barrios se despoblarían y todos pasarían a vivir a la zona baja. Piden que se hiciesen los mercados y feria franca, uno en las puertas altas y otro en las bajas, y se mandase a todos los mercaderes, merceros, regatones, panaderas y regateras que fuesen con sus mercaderías y otros géneros cada mercado y feria a los dichos lugares. Los Reyes mandan que en adelante se haga el mercado un jueves en la zona baja y otro en la plaza en la zona alta; y las ferias se hagan de la misma manera, un año en lo bajo y a las puertas de la Correría, Zapatería y Ferrería, y otro año en lo alto de las dichas puertas de la Cuchillería, Pintorería y Judería, amparando a todas las personas que a los dichos mercados y ferias fueren. Además, a los de la ciudad, tanto a las panaderas como regatonas, y a todos los que continúan vendiendo en la plaza baja, en los días de mercado y feria que se haga en las calles altas, pongan sus tiendas y mercaderías en las dichas puertas; y dan licencia a los vecinos de estos barrios y collaciones para que los mercaderes, panaderas y regatonas, puedan estar juntos y pon-

1647 ANÓNIMO: "Noticia del Noble y Real Valle de Mena". Sevilla, 1892: 231. Expedido por Diego López de Haro III (1236-1254) señor de Vizcaya, fue confirmado por Diego López de Haro V en 9 de febrero de 1306.

1648 "Privilegio otorgado a la villa de Balmaseda por Alfonso XI". Museo de las Encartaciones. Abellaneda, Sopuerta, Vizcaya. p. 10.

1649 A. G. S./ Consejo Real de Castilla, leg. 504-14/Valmaseda, 24 abril 1554

1650 A. G. S./ Consejo de Hacienda, leg. 319/ San Lorenzo, 9 junio 29 diciembre 1590. 
gan "sus tiendas de tallado postizas" en la dicha plaza, desde la puerta de la Pintorería hasta la iglesia de San Vicente del Castillo ${ }^{1651}$.

En las Juntas de Vizcaya de abril de 1591 el síndico procurador del Señorío dijo que sabía que en Vitoria los días de mercado franco se pagaba de alcabala o portazgo $5 \mathrm{mrs}$. y de hace pocos años hacen pagar medio real o 20 mrs., como les parece a sus cogedores. Por ser muy perjudicial a los que van del Señorío a Vitoria a por trigo y otras cosas, encargaron al alcalde ordinario de Orduña que haga la diligencia necesaria con Vitoria para conocer las razones del aumento. Se trató, también, que estando obligado el mercado de Vitoria a tener en la plaza 50 medias fanegas para medir el pan, no tenían de ordinario ni 30, obligando a los que van por trigo a detenerse y hacer noche en la ciudad, lo que no harían si existiesen las medidas necesarias. Mandaron al alcalde de Orduña que trate con la ciudad cuando allí fuere y busque el remedio para el futuro ${ }^{1652}$.

\section{b.- Peajes}

Los peajes ${ }^{1653}$ eran derechos que se debían pagar a su titular por el tránsito por un camino o puente, de personas, caballerías y carros, con carga o sin ella. A veces se utiliza el término peaje de una manera similar al de portazgo. Estos derechos tenían orígenes diversos y en muchos casos procedían de los cobros que se originaron para realizar antiguas reparaciones y construcciones de caminos y que, una vez finalizadas, se quedaban de manera definitiva, alegando sus perceptores que tales derechos los poseían de tiempo inmemorial. También era habitual la justificación de tales cobros como derechos que los señores, jerarquías e instituciones eclesiásticas o concejos poseían por el solo hecho de transitar por territorios de su jurisdicción. Cuando este derecho se pagaba por el paso por un puente, se denominaba pontaje o pontazgo.

\section{Portazgos ${ }^{1654}$}

Los portazgos eran imposiciones pagadas al rey, señores, concejos, monasterios, obispados, etc., y cargadas sobre el tráfico de mercaderías, bestias o carros al transitar por un lugar determinado de un camino o por introducir productos por la puerta de una ciudad o villa. Además de los portazgos abonados al rey por dicho tráfico en lugares determinados de los caminos, la Corona poseía los diezmos de la mar, que se pagaban por la entrada y salida de mercaderías del Reino.

\footnotetext{
1651 A. G. S./ Registro General del Sello, VIII-1484/Tarazona, 23 marzo y Valladolid, 7 agosto 1484; GONZÁLEZ, T.: 1829: 48-50: t. IV. doc. XV.

1652 A. J. R. B./ Actas de la Tierra Llana. t. V/ Bilbao, 24 abril 1591.

1653 GARCÍA de VALDEAVELLANO, L.: 1975: 148-166.

1654 PORRAS ARBOLEDAS, P. A.: 1992: 161-211.
} 
Los portazgos debían ser autorizados por el Rey o su Consejo como se recoge en las Partidas ${ }^{1655}$, por lo que se prohibía cobrar portazgos sin título ${ }^{1656}$. Las Partidas advierten, en un título a los mercaderes, sobre los portazgos que deben satisfacer ${ }^{1657}$ y dan instrucciones sobre la obligación de pagarlos y las cosas exentas ${ }^{1658}$. Al objeto de que los arrieros y mercaderes no utilicen otros caminos para evitar el pago de portazgos y otros derechos de paso, se detallan también en las Partidas las medidas a tomar1659.

Los portazgueros podían recaudar el derecho "en renta o en fieldad". Los fieles eran oficiales del titular, pero en muchos casos este podía adjudicar a un particular en renta el cobro de tal derecho. En este caso, el adjudicatario realizaba el cobro, tras obtener su concesión, una vez pagada por adelantado una cantidad acordada al titular del portazgo. Este adjudicatario cobraba el derecho a arrieros y viandantes en su propio beneficio y por el tiempo que durase la adjudicación ${ }^{1660}$. Como consecuencia de esta situación, el portazguero era a veces muy riguroso en el cobro, ya que este iba en su propio y directo beneficio, ocasionando, en muchos casos, numerosos enfrentamientos y pleitos, por cobrar de manera

1655 LAS SIETE PARTIDAS/ Quinta Partida, Título VII, ley IX. "nveuamente, non pueden poner portadgo ningun ome nin concejo, nin eglesia, en todo el Señorio del Rey, si non fuere por su mandado. Pero el Rey puede lo poner: e avn otorgar poder a otri, que lo ponga, si entendiere que lo ha menester, por mejorar algun lugar que esta muy pobre, o por ser el camino mas seguro, 0 por otra razon semejante destas. E porende dezimos: que si alguno pusiere portadgo nueuamente, sin mandado del Rey, que non vala: e sea tenudo de tornar doblado todo lo que tomare. E otrosi dezimos, que si el portadguero, maliciosamente acresciere, o menguare el portadgo, que era puesto antiguamente, que deue ser echado por ende de la tierra e lo que de mas tomare, deue lo pechar, assi como dicho es".

1656 NOVÍSIMA RECOPILACIÓN DE LAS LEYES DE ESPAÑA. Tomo segundo/ Libro VI, Titulo XX, Ley XII/ Sevilla, 9junio 1500, París, 1846. Los Reyes Católicos mandan a los corregidores que "se informen de los portazgos,... y otras imposiciones y barcages y estancos, que se llevan en la tal ciudad, ó villa ó lugar, ó en su tierra y comarca, aunque sean de Señorío; y quales son nuevas, y quales son viejas y antiguas, y se han acrecentado; y las nuevas de los términos de su jurisdiccion, que no tienen título ó prescripcion inmemorial para que de derecho las puedan llevar: y provean como no se pidan ni lleven, executando las penas contenidas en las leyes de nuestros Reynos contra los que las impusieren, ó llevaren como no deben; y de las que son fuera de su jurisdiccion nos envien relacion porque Nos mandemos proveer sobre ello".

1657 LAS SIETE PARTIDAS/ Quinta Partida, Título VII. "Ios portadgos, e de todos los otros derechos, que han de dar los mercadores, por razon de las cosas, que passan de vnas tierras a otras, en que ganan, e fazen de su pro".

1658 LAS SIETE PARTIDAS/ Quinta Partida, Título VII, ley V. "que pues que los mercadores son seguros, e amparados del Rey, por todo su Señorio, que ellos e todas sus cosas le conozcan Señorio, dandole portadgo de aquello que a su tierra traxeren a vender, e sacaren ende. E por ende dezimos, que todo ome que aduza a nuestro Señorio a vender algunas cosas, quales quier, tan bien clerigo como cauallero, o otro ome qualquier que sea: que deue dar el ochauo, por portadgo de quanto traxere y a vender, 0 sacare. Fueras ende, si algunos ouieren preuillejo de franqueza, en esta razon. Pero si alguno traxere apartadamente, algunas cosas, que ouiere menester, para si mismo, o para su compaña: assi como por su vestir, o por su calçar, o para su vianda, non tenemos por bien que de portadgo, de lo que para esto traxere, e non lo vendiere. Otrosi dezimos, que trayendo ferramientas algunas, o otras cosas, para labrar sus viñas, o las otras heredades, que ouiere, que non deue dar portadgo dellas, si las non vendiere... E si algunos contra esto fizieren, mandamos, que quanto desta guisa encubrieren que lo pierdan".

1659 LAS SIETE PARTIDAS/ Quinta Partida, Título VII, ley VI. "descaminados andan los mercadores a las vegadas, for furtar, o encubrir, los derechos que han a dar de las cosas que lieuan. Onde dezimos, que qualquier que esto fiziesse, que deue perder todas las cosas que leuare desta manera. Pero si aquel que andouiesse descaminado, ouiesse ya pagado el derecho, o el portadgo, que auia de pagar, mostrando ende aluala, o prueua derecha, que fuesse de creer, non caeria en esta pena sobredicha: nin deuen embargar a el, nin a sus cosas, por esta razon. Otrosi dezimos, que si alguno que fiziesse algunos destos yerros, fuesse menor de catorze años, que non caeria en esta pena, queriendo dar el portadgo. Esso mismo dezimos, que deue ser guardado, si aquel que lo fiziesse fuesse mayor de catorze años, e menor de veinte cinco años: fueras ende sil fuesse prouado, que lo fiziera a sabiendas, maliciosamente".

1660 LAS SIETE PARTIDAS/ Quinta Partida, Título VII, ley VII. "estos portadgos, e los otros derechos, e las rentas del Rey, deuen ser publicamente arrendadas, metiendo las en almoneda, e qual mas diere por ellas, esse las deue auer. Pero qualquier que las arrendare, non las deue tener, mas de tres años. E si en este tiempo, de los tres años, prometyere otro alguno, de dar mas, de la tercera parte, del arrendamiento por ello puedan las tomar, a los que las touieren arrendadas, e dar a aquel que mas diere por ellas". 
desmesurada o indebida a transportistas exentos, o reconducir arrieros por la fuerza hacia el lugar del portazgo, desviándolos de su ruta ${ }^{1661}$.

Los reyes, con el fin de favorecer al concejo o monasterio beneficiario, concedieron gran número de privilegios y exenciones de portazgo, extensivas a todo el Reino o bien limitadas a los portazgos de las localidades que se especificaban. A partir de la segunda mitad del siglo XIII, las exenciones se extendieron a todo el Reino exceptuando los de las ciudades de Toledo, Sevilla y Murcia. Toledo y Sevilla fueron en los siglos XIII y XIV los grandes centros comerciales de Castilla y donde, por conservar los Reyes la propiedad de sus portazgos, cualquier exención podría ocasionar pérdidas de consideración al Tesoro real. En el caso de Murcia, fue concedido por Alfonso X por haber permanecido esta ciudad fiel en los enfrentamientos dinásticos contra el infante don Sancho. Las exenciones son muy numerosas y podemos mostrar algunas:

En 1017 el rey Sancho y su esposa conceden a su hija Tigridia, abadesa de Oña, en sufragio del alma del infante García, el monasterio de Santa María de las Muelas y sus pertenencias y eximen al monasterio de Oña de "fossadera, et non uadant in fossado, nin in talaya ninguna, nec in toto regno pectent portaticum..." 1662 . En 1149 Alfonso VII con sus hijos Sancho y Fernando confirman al abad de Oña todos los privilegios, fueros y donaciones concedidos por sus antecesores ${ }^{1663}$. Alfonso VIII los confirmará a su vez en $1176^{1664}$ y $1187^{1665}$ y también los reyes sucesivos ${ }^{1666}$. Fernando III concede en septiembre de 1217, a favor de los arrieros y mercaderes del concejo de Vitoria, exención del portazgo en todo el reino ${ }^{1667}$. En septiembre de 1219 se indica que los habitantes de Medina están exentos de pagar portazgo en Medina, Nájera, Logroño, Belorado y todo el Reino ${ }^{1668}$.

Ante las disputas producidas entre Alfonso X y los sucesores de Lope Díaz de Haro, el rey arrebató Orduña a los Haro en 1256 y en la refundación de la villa otorga fuero a Or-

1661 LAS SIETE PARTIDAS/ Quinta Partida, Título VII, ley VIII. "Aborrescen los mercadores a las vegadas, de venir con sus mercadurias, a algunos lugares, por el tuerto, e el demas, que les fazen en tomarles los portazgos. E porende mandamos, que los que ouieren a demandar, o a recabdar este derecho por nos que lo demanden de buena manera. E si sospechasen que algunas cosas, leuaren de mas de las que manifiestaren tomenles la jura, que non encubran ninguna cosa. E desque les ouieren tomada la jura, non les escodriñen, sus cuerpos nin les abran sus arquetas, nin les fagan otra sobejania, nin otro mal ninguno... Otrosi dezimos, que si los portadgueros, que ouieren de recabdar los derechos, de los nuestros lugares, tomaren, o forçaren, a los omes que por y passan, alguna cosa de mas, de lo que ouieren a tomar, con derecho, que lo tornen doblado, a aquellos a quien lo tomaren, quando quier que gelo demanden, fasta vn año".

1662 A. H. N./ D. R. de Oña. carp. 269, no 16/27 junio 1017; ÁLAMO, J. del: 1950: t. I. doc. 19, 41-44. La fecha de este documento, es inexacta y el documento se encuentra con varios anacronismos.

1663 A. H. N./ D. R. de Oña. carp. 274, num. 19/ Castillo de Muñó, 26 marzo 1149; ÁLAMO, J. del: 1950: 245-247: t. I. doc. 204. "...et quod nec domus Sancti Saluatoris nec eius decanie proprie in nullo mercato mei regni, donent portaticum nec aliud tributum, uel aliud usaticum".

1664 A. H. N./ D. R. de Oña. carp. 276, no 15/ San Esteban, 15 mayo 1176; ÁLAMO, J. del: 1950: 302-305: t. I. doc. 254.

1665 A. H. N./ D. P. Oña. carp. 277, no 10/ Burgos, 21 junio 1187; ÁLAMO, J. del: 1950: t. I, doc. 276, 329-333.

1666 ANDRÉS, L.: 1916: 134

1667 A. M. Vitoria/ 8-6-13/ Burgos, 10 septiembre 1217; GONZÁLEZ y GONZÁLEZ, J.: 1983: t. II. doc. 3; 9. "Absoluo itaque uos et libero ab omni portatico persoluendo de vestris propriis rebus per omnes partes regni mei interdentes, sic quod nullus sit ausus in toto regno meo a uiano uel mercatore aliquo de Vitoria de suis propriis rebus uel mercaturis portaticum aliquod exigere...".

1668 A. G. S./ Libros de privilegios y confirmaciones. Libro no 304, art. 14/ Aguilar, 22 septiembre 1219; GONZÁLEZ, T.: 1830: 141-147: t. V. doc. XXXVIII. "... populatoribus de Medina praefatis quod nullum dent portaticum in ipsa Medina, nec in Naxera, nec in Lucronio, nec in Belforado, nec in nostro toto regno...". 
duña, basado en el de Vitoria de febrero de ese año, que incluye el privilegio de "que no den portadgo en todo mi regno, sino en Toledo, Sevilla, e Murcia"1669. Fue confirmado por su hijo Sancho $\mathrm{IV}^{1670}$ y sus sucesores.

Los mercaderes que llegaban al puerto de Bermeo se quejaron porque allí se les demanda portazgo, treintazgo y peaje, cuando pagando su diezmo no tenían que pagar todo lo demás, como se hacía en los otros puertos del Señorío de Vizcaya. Alfonso X mandó en 1281 a los alcaldes, jurados y preboste de Bermeo que no demanden portazgo, treintrazgo ni peaje sino el diezmo, como lo demandan en los otros puertos del Señorío, ordenando devolver todo lo prendado por esta razón. En 1293 el concejo de Vitoria se queja ante Sancho IV, porque en el puerto de Bermeo algunos de sus hombres no respetaron la carta real a algunos de sus vecinos que llegaron con mercaderías y otras cosas. El Rey manda que nadie se atreva a embargar ni ir contra la carta real y que se guarde como se guardó desde tiempos de su padre Alfonso $\mathrm{X}^{1671}$.

En 1335 Alfonso XI concede un privilegio sobre la exención de portazgo en todos sus reinos a los vecinos de Santa Gadea durante 3 años, con excepción de los de Sevilla, Toledo y Murcia ${ }^{1672}$.

Para evitar el desorden existente en Castilla sobre los cobros de alcabalas, calzadas, barajas y otras nuevas imposiciones que se llevaban en Burgos y su merindad, en Orduña y en las provincias de Vitoria y Guipúzcoa, condado de Vizcaya y hermandades de Álava y Castilla Vieja, por concejos y algunos caballeros y personas sin licencia real, y a petición de la provincia de Vitoria y hermandades alavesas, la reina Isabel manda en 1483 que se cumpla la ley dada en las Cortes de Toledo, que prohíbe el cobro de imposiciones nuevas, salvo en los lugares que antiguamente "se auian acostumbrado lleuar, fasta el anno de sesenta e quatro", debiendo mostrar en este caso los títulos que les permitían cobrarlas ${ }^{1673}$.

En 1484 la Universidad de Mercaderes de Burgos dijo al Consejo Real que desde hacía unos 10 años los de Villasante, contra derecho, llevan una nueva imposición como tributo de las mercaderías que vienen o van a Laredo, y que por cada carga que sale de esa villa llevan $10 \mathrm{mrs}$. y por cada carga de lana que entra en su puerto $5 \mathrm{mrs}$. Así han llevado a los mercaderes en esos 10 años unos 100.000 mrs. y, como la Universidad les había requerido su devolución y no seguir cobrándolo y no lo habían querido hacer, suplicaron justicia. Los Reyes mandan a Pedro Sánchez, el herrero vecino de Villasante, que no se lleven los dichos tributos y nuevas imposiciones y se devuelvan los dichos 100.000 mrs. más todas las costas y daños causados ${ }^{1674}$.

1669 ARMONA y MURGA, J. A.: 2002: 90-91.

1670 ARMONA y MURGA, J. A.: 2002: 92-94. “E mandamos, que non den portadgo, ni trentadgo, ni peage, ni emienda, ni oturas, ni coezas, ni recoage, ni otra cosa ninguna, que por esta razón se demande en ningun lugar de nuestros reynos por mar, ni por tierra de entrada ni salida; salbo ende en Toledo, Sevilla, y Murcia".

1671 A. M. Bilbao/ Consulado de Bilbao. Cajón 4, reg. 7, no 66, doc. 2 (9v-10v)/Ciudad de Castilla, 15 febrero 1281 y Burgos, 20 marzo 1293; ENRÍQUEZ FERNÁNDEZ, J.; HIDALGO de CISNEROS AMESTOY, C. y MARTÍNEZ LAHIDALGA, A.: "Archivo Foral de Bizkaia. Sección Notarial (1459-1520). Consulado de Bilbao (1512-1520)", 2007: doc. 18.

1672 A. M. Santa Gadea/ doc. 5-9/Valladolid, 22 noviembre 1335.

1673 A. D. F. A./ D. H., 246-5/ Santo Domingo de la Calzada, 17 julio 1483.

1674 A. G. S./ Registro General del Sello, II-1484, fol. 256/ Agreda, 12 febrero 1484. 
En mayo de 1496 el concejo de Valmaseda dijo a los Reyes que como la villa y vecinos habían hecho a sus antecesores grandes servicios, les habían otorgado privilegios, entre ellos, el que los vecinos y moradores de Valmaseda no paguen portazgo, peaje, pontaje ni otro derecho alguno en ningún lugar de sus Reinos, excepto en Sevilla, Toledo y Murcia; pero que de poco tiempo acá, algunas ciudades y villas han quebrantado tales derechos, llevándoles portazgos y otras gabelas. Los Reyes mandaron a los corregidores que vean el dicho privilegio y lo guarden y cumplan ${ }^{1675}$.

La ordenanza XXI del Consulado de Burgos de 1538 refiere que la Universidad y Prior y cónsules de ella tienen que hacer muchos gastos, entre los que se incluyen los que son para pleitos en defensa de las "libertades de portazgos é imposiciones que siempre se nos mueven", que tienen con algunos señores, ciudades y villas, que injustamente les cobran contra los privilegios que conservan de los Reyes ${ }^{1676}$. En sus libros de contabilidad se recogen gastos relacionados con el portazgo de Laredo. Así en junio de 1543 se prestaron a Gonzalo del Río hasta fin de 1545, 12.00o mrs. para pagar a Raimundo del Hospital, vecino de Burgos, y Conzalo de Río de la Concha, porque se obligaron los dos a hacerle buena obra y porque prometió que "no lleuaria portasgo de las sacas que pasan por delante su casa"1677.

Los portazgos más importantes en la zona que estudiamos fueron las siguientes:

- Portazgo de Bozoo. Lope Díaz de Haro, titular del portazgo de Bozoo, ordena en 1306 a sus portazgueros que no lo cobren al monasterio de Oña cuando acarreen la sal desde Añana, ya que dicho monasterio está exento en toda Castilla ${ }^{1678}$. Bozoo se encuentra en el camino que de Miranda de Ebro llega a Tobalina y Frías por Orbañanos.

- Portazgo de Briviesca. Los procuradores de algunas villas del Señorío de Vizcaya, especialmente los de Bermeo y Bilbao, presentaron en 1386 una petición a Juan I, porque muchas veces se le había denunciado que las villas de Vizcaya tenían franquezas y privilegios reales de hacía 10 años y más; y confirmados por él mismo, en que sus vecinos estaban exentos del pago de portazgo en todos sus Reinos y que el Rey, cuando tomó el Señorío de Vizcaya, juró mantenerlos. Pero en Briviesca estos privilegios y franquezas no eran respetados y les obligaban a pagar el portazgo, por lo que pedían que los mandase guardar, y esta misma petición también la hizo el procurador de Vitoria. El Rey manda a Alvar Martínez, su canciller, que viese los privilegios que tienen las villas de Vizcaya y de Vitoria y el privilegio de Briviesca dado por Enrique II a Pedro Fernández de Velasco. Se vio que este era para que hubiese portazgo, según se cogía de bestias y de otras mercaderías en cualquier otra villa y lugar de las merindades de Castilla, y para que nadie se librase de su pago por privilegios y cartas que tuvieren. El Rey falla que como Enrique II no pudo hacer de derecho la merced del portazgo de Briviesca en perjuicio de los privilegios que confirmados por él ya tenían las villas del Señorío de Vizcaya y Vitoria y que a pesar de la cláusula en que se contiene para que nadie se excuse de pagar el portazgo, los privilegios antiguos que

1675 A. G. S./ Registro General del Sello, V-1496, fol. 73/ Morón, 31 mayo 1496.

1676 Ordenanzas del Consulado de Burgos de 1538/Valladolid, 18 septiembre 1538; GARCÍA de QUEVEDO y CONCELLÓN, E.: 1905 Y 1995: 199-203. Ordenanza XXI.

1677 A. D. B./ R-3/ Burgos, 1539-1549. p. 69i. y 1071.

1678 R. A. H./ Biblioteca, col, Salazar y Castro O-18, fol. 117-117v/ Oña, 3 enero 1306; OCEJA GONZALO, I.: 1986: 362-363: doc. 505. 
tienen las villas y lugares de Vizcaya y Vitoria deben ser guardados y cumplidos. Manda a Juan de Velasco, su camarero mayor, señor de Briviesca e hijo de Pedro Fernández, al concejo de Briviesca y a los que recaudan su portazgo, que no tomen ni prendan a los vecinos y moradores de Bilbao, ni ninguna cosa de sus bienes por razón del portazgo y que sean francos de pagarlo en Briviesca y en su término ${ }^{1679}$.

En octubre de 1517 la ciudad de Frías se querelló entre otros contra el condestable de Castilla, porque en Briviesca les cobraban el portazgo, estando dicha ciudad exenta del pago de ese derecho por un privilegio concedido por Fernando III en 1249 y confirmado por todos los reyes posteriores. Su procurador pide al Rey que no se hiciese pagar a ningún vecino ni morador de Frías portazgo, pasaje, asentamiento, pontaje, asadura, barra ni otro derecho alguno en la villa de Briviesca, obteniendo Frías en 1522 sentencia favorable ${ }^{1680}$. La Universidad de los Mercaderes de Burgos tuvo pleitos con el Condestable por el cobro que les hacía del portazgo en Briviesca estando exentos. Así en junio de 1552 se pagaron 2.500 mrs. en Madrid al relator Almorax "por la uista del prozeso contra el condestable sobre el portazgo de Bribiesca"1681. En agosto de 1559 se registran gastos de $7.500 \mathrm{mrs}$. "en sacar la executoria contra el condestable sobre el portazgo de Birbiesca". Parece ser que en septiembre se soluciona este pleito, porque se gastan $5.609 \mathrm{mrs}$. en "las personas que an de aber la rrestituzion que el condestable hizo del portazgo de Birbiesca", más otros 2.441 mrs. en abril, 3.960 en julio de 1560 y 3.396 en junio de $1561^{1682}$.

- Portazgos de Campoo. Algunos vecinos se quejan a los Reyes que en Reinosa, Aguilar de Campoo y en otras villas y lugares de la merindad de Campoo y su comarca, llevaban de los recueros y mercaderes 6 mrs. por acémila y bestia y nuevos derechos; y piden que se quiten dichas imposiciones. En agosto de 1499 los Reyes mandan al juez de residencia de la merindad de Campoo que se informe sobre los portazgos, derechos e imposiciones que en la Merindad se llevan de los ganados, recueros y mercaderes que por allí pasan, quién los cobra, de cuánto tiempo acá, en qué lugares y con qué títulos, y si lo que así llevan es impuesto nuevo, y si se acrecentó quién lo hizo, y si se hacen extorsiones a los que llevan sus ganados, mercaderías y recuas, y haga que presenten los títulos que tienen y dicha información se remita al Consejo y entretanto, si se hallare que tales imposiciones son realizadas sin título, mande que no se lleven ${ }^{1683}$.

En 1535 se mencionan las guardas de Reinosa y otras partes, que comprobaban si las mercaderías llevaban el albalá de guía como justificante de haber pagado el diezmo en Santander, con el fin de dejarlas pasar libremente ${ }^{1684}$. En 1549 la Chancillería libra una

\footnotetext{
1679 A. M. Bilbao/ Cajón 8, reg. 1, no 1 -Caja 199 (fol. 46v-47r)/ Burgos, 20 abril 1386; ENRÍQUEZ FERNÁNDEZ, J.; HIDALGO de CISNEROS AMESTOY, C. y MARTÍNEZ LAHIDALGA, A.: "Colección Documental del Archivo Histórico de Bilbao (1300-1473)" 1999: doc. 37; A. M. Bilbao/ Consulado de Bilbao. Cajón 4, reg. 7, no 66, doc. 2 (17r-21v)/ Burgos, 16 abril 1386; ENRÍQUEZ FERNÁNDEZ, J.; HIDALGO de CISNEROS AMESTOY, C.; MARTÍNEZ LAHIDALGA, A, :Archivo Foral de Bizkaia. Sección Notarial (1459-1520). Consulado de Bilbao (1512-1520)". 2007: doc. 21.
}

1680 A. M. Frías/ H-9/Valladolid, 7 octubre 1517 a 24 julio 1523.

1681 A. D. B./ R-12/ Libro de caja de la Universidad de Burgos/ Burgos, 1549-1557. p. 141 i.

1682 A. D. B./ R-14/ Libro de caja de la Universidad de Burgos/ Burgos, 1557-1567. p. 38i, 43d, 44i y 55d.

1683 A. G. S./ Registro General del Sello, VIII-1499, fol. 141/Valladolid, 13 agosto 1499.

1684 A. H. P. C./ J. T. A. leg. 37-2/ Los Corrales de Buelna, 14-15 mayo 1535. 
ejecutoria en favor de la Universidad y los vecinos y moradores de Burgos y contra el conde y la villa de Aguilar, para que estos no puedan exigir a los de Burgos cuando fuesen a Aguilar los derechos de portazgo o pontazgo ni cualquier otro tributo de las mercaderías que por la villa pasaren ${ }^{1685}$. Sobre este proceso, en mayo de 1550 se anotan 1.122 mrs. que gasta Juan de Palencia por ir a Aguilar a notificar la ejecutoria que manda que no les deben cobrar los portazgos y el bachiller Juan Rodríguez paga 12.543 mrs. por los pleitos hasta fin de 1549 , en relatores y letrados ${ }^{1686}$.

- Portazgo de Frías y exenciones de sus vecinos. Sobre el portazgo de la ciudad de Frías existe una opinión muy extendida de que se cobraba portazgo en su puente sobre el Ebro y como prueba se alude a la torre que dicho puente conserva en su parte central que, según se dice, era el punto fortificado donde se percibía. A pesar de pertenecer la ciudad al señorío de los Velasco, cuyos miembros obtenían cuantiosos beneficios por el tráfico de mercaderías, y situarse sobre el importante camino medieval que desde Burgos iba por Briviesca y Portillo de Busto a Frías y desde aquí llegaba a Bilbao por Orduña, no hemos podido obtener ningún dato documental sobre la existencia de dicho portazgo. Esto puede ser debido a que no hemos tenido la fortuna de encontrar el documento apropiado, o que el portazgo desapareció en fechas tempranas. Lo que sí está debidamente documentado en el Fuero de Frías, otorgado por Alfonso VIII en 1202, es la concesión a Frías del fuero de Logroño, con ciertas exenciones para sus vecinos entre las que se incluía la del portazgo en todo el Reino ${ }^{1687}$.

Fernando III manda en 1249 a los portazgueros de las Cuatro Villas de la Costa, Toledo, Sevilla y a todos los de sus reinos guardar al concejo de Frías la exención de portazgos en todo el reino, y “...que ninguno no sea osado de tomar los portazgos... ni de embargarlos por ello", y añade que "sepades que el concejo de Frias tiene cartas abiertas y plomadas, una de mi agüelo..." ${ }^{688}$. Fernando IV, como Alfonso VIII su bisabuelo, pobló Frías y tuvo por bien que los que morasen en la Muela no pagasen ningún pecho, y mandó en junio de 1305 que todos los que residen en la Muela fuesen exentos de todo pecho y pedido, y de moneda forera de 7 en 7 años, y manda a todos los arrendadores y recaudadores que no les demanden pecho ni prendan ni afinquen a los que moran en la Muela. Cualquiera que vaya contra esto pagará $1.000 \mathrm{mrs}$., y a ellos todo el daño recibido doblado, y manda a Sancho Sánchez de Velasco, su adelantado mayor en Castilla, y a los adelantados y merinos en las Merindades, que lo hagan cumplir ${ }^{1689}$.

En mayo de 1345 Alfonso XI dice a todos los concejos y oficiales aportellados de sus Reinos que, por las grandes necesidades de años pasados, tomó para él todos los portazgos, peajes, pasajes, recuajes, herrajes, etc., para que ningún concejo ni persona estuviese exento de portazgos, aunque tuviesen carta o privilegio de algún rey; pero que, tras la

1685 A. M. B./ HI-3991/1549.

1686 A. D. B./ R-12/ Libro de caja de la Universidad de Burgos/ Burgos, 1549-1557. pp. God y 68d.

1687 R. A. H./ Biblioteca, col, Salazar, de col. Velázquez, t. VIII/ Palencia, 1 diciembre 1217, según MARTíNEZ, G.: Ayllón, 8 abril 12O2; GONZÁLEZ y GONZÁLEZ, J.: 1983: 16: t. II. doc 9 "Et homines de Fridas non persolvant portaticum in regno meo de propiis rebus suis".

1688 A. M. Silos/ ms. 8, fol. 107/ Sevilla, 31 marzo 1249; GONZÁLEZ y GONZÁLEZ, J.: 1983: 350: t. III. doc. 780.

1689 A. G. S./ Contadurías generales. Libro no 765/ 9 junio 1305; GONZÁLEZ, T.: 1830: 277-282: t. V. doc. XCII. 
petición realizada en las Cortes de Burgos, mandó a los portazgueros que los que tenían carta y privilegios dados o confirmados por Sancho IV y confirmados por Fernando IV y por él después de las Cortes de Madrid, se respeten. Como el concejo de Frías le mostró carta y privilegio con franquezas y libertades y otra carta confirmada por Sancho IV, que mandaba a todos sus portazgueros que no les demandasen portazgos, peaje, recuaje, etc., ni otra verea alguna y que pudiesen descargar en todos los lugares en que hay aduanas sin pena alguna, y comprar y vender en yermo y en poblado y andar en camino real con todas sus mercaderías, Alfonso XI manda que los del concejo de Frías "sean francos e exentos a titulo de nobles francos fijosdalgo", y que no paguen las cosas sobredichas en ninguna parte y sean exentos como lo eran antes ${ }^{1690}$.

En octubre de 1517 el concejo de Frías se querelló contra Iñigo Fernández de Velasco, condestable de Castilla, contra Fadrique Enríquez de Cabrera, almirante de Castilla y de Granada de quien es la venta del Moral y la villa de Palenzuela, y contra Diego de Rojas, del que es la villa de Poza; los concejos de Burgos que cobraban el derecho de la barra; y Valladolid, Olmedo, Briviesca y Pancorbo que les cobraban el derecho de portazgo, y dijo que Frías estaba exenta del pago de ese derecho por un privilegio concedido por Fernando III en 1249 y confirmado por todos los reyes, y que por fuerza les hacían pagar portazgos y otros derechos de que estaban exentos. Su procurador pide justicia al Rey para que no se hiciese pagar a ningún vecino ni morador de Frías portazgo, pasaje, asentamiento, pontaje ni otro derecho alguno en Palenzuela, venta del Moral, ni en el portazgo ni asentamiento de las villas de Briviesca, Pancorbo, Valdestillas, Puente Duero, Cabezón y Valladolid y se condenase a los portazgueros de los dichos lugares ${ }^{1691}$. En la Chancillería se falla en enero de 1522 condenando a Fadrique Enríquez y a los que cogen el portazgo y pontaje de Palenzuela y venta del Moral, al concejo de Burgos y a los que cogen el derecho de la barra, al concejo de Pancorbo y a los que recaudan el portazgo y rediezmo de esa villa, y a otros, a que no lleven portazgo ni pontaje alguno a los vecinos de Frías que pasaren con sus bestias, mercaderías y bienes, so pena de 30.000 mrs. para la Cámara y fisco real ${ }^{1692}$.

- Portazgo de Medina de Pomar. La villa fue punto importante para el cobro de los portazgos en el camino de Burgos a Laredo y Castro-Urdiales. Hasta 1369 fue realenga y desde esa fecha, en que pasa a depender de los Velasco, será la cabeza de sus extensos territorios. A pesar de haber pertenecido al rey, los portazgos pasarán a partir de ese momento a ser detentados por dicha familia. Tuvo Medina depósito de mercaderías foráneas y en su aduana se registraban las que venían gravadas con el diezmo de la mar. Los mulateros "syenpre han pasado e son obligados a pasar por la calle mayor de la dicha villa que se suele llamar la calle del Rrey", en la que se pagaba el portazgo ${ }^{1693}$. Tuvo un grupo de comerciantes judíos que llegó a ser tan próspero que en algunas ocasiones se encargó, junto con la villa, de reparar los

1690 A. G. S./ Contadurías generales. Libro nำ765/ Burgos, 14 mayo 1345; GONZÁLEZ, T.: 1830: 277-282: t. V. doc. XCII. 1691 A. M. Frías/ H-و/Valladolid, 7 octubre 1517 a 24 julio 1523.

1692 A. Ch. V./ Registro de Ejecutorias, caja 0361.0026/ 18 mayo 1523; A. M. Frías/ H-و/ Valladolid, 24 enero 1522 a 24 julio 1523 .

1693 A. G. S./ Consejo Real de Castilla, leg. 84, fol. 2-III/ Valladolid, 26 junio 1513 a Salazar, 25 septiembre 1515. 
puentes más transitados ${ }^{1694}$. En el punto 47 de su fuero, ratificado por Alfonso VIII en julio de 1181, se exime a sus pobladores del pago del portazgo en su propia villa y de Nájera, Logroño, Belorado y en todo el Reino ${ }^{1695}$. En septiembre de 1219 se vuelve a aludir a lo indicado en el fuero mencionado, sobre que los habitantes de Medina están exentos de pagar portazgo en las villas citadas ${ }^{1696}$. En 1255 Alfonso X confirma el privilegio otorgado por Fernando III en 1221, para que los vecinos de Laredo no paguen portazgo por sus mercaderías en Medina de Pomar ${ }^{1697 .}$

En las actas del pleito sostenido en 1280 ante los alcaldes árbitros nombrados por el infante Sancho, entre el monasterio de Oña y el concejo de Frías por interferencias en sus respectivas áreas de dominio, se hace constar la existencia del portazgo de Medina ${ }^{1698}$. En 1309 el prior del monasterio de San Juan de Burgos da a renta el portazgo de esta villa por 500 mrs. ${ }^{1699}$. En la presentación de las cuentas del dicho monasterio de San Juan, realizada en 1338 en la visita que realizaron los abades de Santo Domingo de Silos y de San Pedro de Cardeña a requerimiento del papa Benedicto XII, se constatan los derechos que percibe dicho monasterio en Medina, que son diezmos de portazgos, cuezas y caloñas que rentan 450 mrs. ${ }^{1700}$.

Desde 1369, en que Pedro Fernández de Velasco recibe de Enrique II la villa de Medina, su aduana estuvo controlada por la familia de los Velasco, cuyos componentes eran sus principales beneficiarios. Desde este momento, dicha familia será muy estricta en los cobros que realizaban, haciéndolos incluso a los que tenían exención. Ya en 1386 Juan I extiende Provisión ordenando a su camarero mayor, Juan Fernández de Velasco, al guarda y mayordomo mayor del camarero, al concejo, alcaldes y merino y a los que recaudan la renta del portazgo en Medina, que no pueden prender a los vecinos de Laredo que van con sus mercaderías ni cobrarles por ellas, por estar exentos del portazgo, y les manda que devuelvan doblado todo lo recaudado con sus costes, ordenando, so pena de que los Velasco pierdan la villa, el cumplimiento de lo dispuesto en las tres cartas reales aportadas por Laredo. La primera era la sentencia de junio de 1380 , en el pleito entre Laredo y Hernando García y Ruy García portazgueros de Medina de Pomar para que no les cobren este derecho y les devuelvan las prendas que les han tomado. La segunda es la Provisión de Juan I de noviembre de 1380 , que confirma la sentencia anterior y la tercera es la Provisión del mismo Rey, de agosto de 1383, otorgada a Pedro Fernández de Velasco, que dice que después de

1694 CADIÑANOS BARDECI, I.: "Medina de Pomar....": 1991: 24.

1695 MARTÍNEZ DÍEZ, G.: 1982: 165-168. "Concedo praetera populatoribus de Medina praefatis quod nullum dent portaticum in ipsa Medina nec in Naxera nec in Lucronio nec in Belforato nec in nonstro toto regno".

1696 A. G. S./ Libros de privilegios y confirmaciones. Libro no 304, art. 14/ Aguilar, 22 septiembre 1219; GONZÁLEZ, T.: 1830: 141-147: t. V. doc. XXXVIII.

1697 A. H. P. C./ Villa de Laredo, leg. 6, num. 14, fols. 20v-22v y Diversos, leg. 13, num. 40 -J. T. A. 18-11, Pergaminos, num. 20/ Castrojeriz, 1221 y Burgos, 3 enero 1255; A. M. Laredo/ Cartulario, fol. 17/ Castrojeriz, marzo 1221.

1698 A. H. N./ Clero. Códice 76/B; 104 fols./ 13 julio 1280; OCEJA GONZALO, I.: 1983: 234-336: doc. 231.

1699 A. M. B./ Becerro de San Juan, fol. 38r; ed. pág. 48/ 1309; PEÑA PÉREZ, FCo. J.: 1983: doc. 118, 184.

1700 A. M. B./ Becerro de San Juan, fol. 44r-45r; ed. pág. 53-55/ 8 marzo 1338; PEÑA PÉREZ, Fco. J.: 1983: doc. 136, 218. 
que su padre Enrique II le concedió Medina, esta villa demanda portazgo a los vecinos de Laredo, confirmando la sentencia y Provisión anteriores ${ }^{1701}$.

En 1483 Pedro de Revilla, arriero vecino de Revilla de Pienza, dijo en el Consejo Real que Pedro Jiménez le encargó en Bilbao que llevase a Burgos cuatro cargas de lienzos, con una carta sobre la manera que debía diezmarlos en Valmaseda. Su recaudador expidió albalá por las cuatro cargas diezmadas y en Medina el diezmero le tomó 200 varas de lienzo por estar todo diezmado salvo aquello, y así llegó a Burgos y entregó los lienzos a su destinatario. En Bilbao, Jiménez le hizo prender por no haber diezmado como debía y le tuvieron preso hasta que dio fianza y pagó lo juzgado. El arriero quería demostrar su inocencia y que le pagasen costas y daños. Los Reyes mandaron al corregidor de Vizcaya y a los alcaldes de Valmaseda y Medina de Pomar para que hagan a Pedro de Revilla cumplimiento de justicia ${ }^{1702}$.

En 1515 los mulateros de Castilla Vieja, Sotoscueva y Sonsierra se quejan de que se les obliga a dar un rodeo por Medina de Pomar, cuando por Villarcayo van por el camino más corto y para que ningún arriero deje de pagar el portazgo, salen oficiales del Condestable a los caminos, para forzarles a ir por Medina a veces con violencia: "uno de Trasmiera que llevaba unos puercos, que porque se pasaba por el camino rreal que ba por Castilla Uieja a los dichos puertos de la mar, se quexaba el dicho honbre que le abia coechado Juan Diaz hijo de Fernando Diaz de Billaconparada, desyendo que abia de yr por Medina de Pumar". Además, los puntos auxiliares de tal aduana para el paso del ganado se encontraban en Villacomparada y en Incinillas, para evitar que los que fuesen por Villarcayo no pagasen. Un testigo dice que desde "quarenta e çinco años a esta parte ha bisto coger el dicho portazgo en Billaconparada y Enzinillas", y otro que "todos los ganados que pasan por el lugar de Villaconparada e Villacayo, deben çierto portazgo al [Condestable] que es una blanca de cada cabeça de ganado mayor, e media blanca de cada caveça menor"1703.

En 1550 se promueve un pleito que sostuvo el Condestable sobre la merced que de tiempo inmemorial poseía de cobrar portazgo a los vecinos de la ciudad de Burgos en sus villas de Medina de Pomar, Briviesca, Pedraza y otras, a pesar de los privilegios que la ciudad tenía por concesión de Fernando el Católico y su hija Juana. En noviembre de 1561 el Consejo extiende una real Provisión para que tras el fallecimiento del condestable Pedro Fernández de Velasco, el 10 noviembre 1559, y tras la orden dada de quitar la aduana situada hasta ese momento en Medina de Pomar, se enviase al Consejo información de lo que se debía hacer. Aunque el administrador de la renta de los diezmos de la mar en los puertos de Castilla, había sido requerido para informar dónde debía ponerse la aduana de Medina, no lo había hecho, perjudicando a las Siete Merindades y sus vecinos y trajineros. El Consejo le mandó que en 12 días recabe información sobre si conviene que la aduana siga o no en Medina de Pomar y qué inconveniente hay de que siga en ella, qué lugar será el más cómodo y conveniente, qué daño provocaría a las Merindades y a otras personas de

1701 A. H. P. C./ Villa de Laredo, leg. 6, num. 14, fols. 62-67V y 74V-81/Valladolid, 14 junio 1380, Medina del Campo, 6 noviembre 1380, Segovia, 21 agosto 1383 y Burgos, 2 marzo 1386.

1702 A. G. S./ Registro General del Sello, XI-1483, fol. 265/ Vitoria, 15 noviembre 1483; ENRÍQUEZ FERNÁNDEZ, J., HIDALGO de CISNEROS AMESTOY, C. y MARTÍNEZ LAHIDALGA, A.: "Archivo General de Simancas. Registro General del Sello. Vizcaya (1483)". 2002: doc. 278; GARCÍA de CORTÁZAR, J. A.: 1966: 371, doc. 13.

1703 A. G. S./ Consejo Real de Castilla, leg. 84, fol. 2-III/ Valladolid, 26 junio 1513 a Salazar, 25 septiembre 1515. 
Medina, y lo envíe todo ante los Contadores mayores y oidores ${ }^{1704}$. En agosto de 1562 el Consejo extiende una real Provisión requiriendo de nuevo al administrador que recabe información sobre el traslado de la aduana de Medina de Pomar, donde se registraban las mercaderías que van a Castilla y se cobran los derechos, a un lugar realengo más indicado para que "los mercaderes y requeros y tragineros y otras personas que traen dende los puertos de la mar las dichas mercaderias, para que no tuerçan ni rodeen su camino para las yr a registrar en la casa del aduana, y pagar los derechos quesllas devan pagar". Se le manda además, que vaya con el tesorero del Rey a Villarcayo, donde reside el alcalde mayor que por tener la memoria de las alcabalas de las Siete Merindades estará informado de lo que convenga, y los tres se informen sobre si convendrá mudar la aduana, qué ventaja o perjuicio provocaría su mudanza, qué lugar será el más conveniente y cómodo para los mercaderes, recueros y trajineros, de manera que con el cambio no rodeen ni desvíen su camino ni reciban daño, y se envíen estas informaciones a los Contadores mayores para que se provea lo que más convenga ${ }^{1705}$.

- Portazgo de Monasterio de Rodilla. En agosto de 1221 Fernando III concede al monasterio de las Huelgas la percepción del portazgo con que se gravaba el tránsito de la sal a su paso por Monasterio de Rodilla, confirmada por Alfonso X en diciembre de 1254 y por Sancho IV en marzo de 1285: "dono itaque uobis tam regaliter quam liberaliter salis portaticum quod pertinet ad Monsaterium de Rodella,..."1706.

- Portazgo de Oña. Dependió siempre del abad del monasterio. Pedro, abad de Oña, se aviene en mayo de 1259 con el concejo de Poza y con el de Pedrajas porque le rogaron que no les tomen portazgo en Oña, y "dizen ellos que non lu an de dar ni lu dieron nunqua, e nos tenemos que lu an de dar e tomamoslo siempre". Poza le había rogado que no se les tome tal portazgo desde el próximo San Juan hasta el de 1260, a lo que el abad accede, salvo el portazgo de las cuezas del pan que le han de dar cada jueves en el mercado de Oña ${ }^{1707 . ~}$

- Portazgo de Orduña. En 1256 la villa recibe el fuero real por parte de Alfonso X, por el que se eximía a sus vecinos del pago de portazgo salvo en Toledo, Sevilla y Murcia, prueba de que Orduña ya mantenía una cierta actividad comercial.

Sancho IV reconoce en septiembre de 1288, y lo confirma 7 días después, que el cabildo y vasallos de Santa María de Valpuesta están exentos de pagar portazgo y manda que los recaudadores del mismo, particularmente los de Orduña y Valmaseda, no exijan dicho tributo ${ }^{1708}$. Juan I concede en 1379 un privilegio para que los vecinos de Santa Gadea no paguen portazgos en Orduña ${ }^{1709}$. Juan Sánchez de Villanañe sostiene un pleito contra Diego

1704 A. C. V./ no 1.873, doc.12, hojas 36 y 37/ Madrid, 12 noviembre 1561.

1705 A. C. V./ nำ1.873, doc.24, hojas 60 y 61/ Madrid, 25 agosto 1562.

1706 A. M. H. B./ Leg. 4, num. 110/ Burgos, 19 agosto 1221; GONZÁLEZ y GONZÁLEZ, J.: 1983: 170: doc. 142; A. M. H. B./ Leg. 4, nำ110-C/ Burgos, 27 marzo 1285; CASTRO GARRIDO, A. y LIZOAIN GARRIDO, J. M.: 1987: 20 y 214: doc. 11 y doc. 125.; A. M. H. B./ Leg. 6, nำ109-A/ Sin fecha 1298?; A. M. H. B./ Leg. 4, nำ110-C/ Burgos, 27 marzo 1285; CASTRO GARRIDO, A. y LIZOAIN GARRIDO, J. M.: 1987: doc. 11, 20; A. M. H. B./ Leg. 6, no 109-A/ Sin fecha 1298?; CASTRO GARRIDO, A. y LIZOAIN GARRIDO, J. M.: 1987: 214: doc. 125

1707 A. H. N./ Clero. Oña. Pergaminos. Carp. 287, no13/15 mayo 1259; ÁLAMO, J. del: 1950: t. II. doc 549, 667; OCEJA GONZALO, I.: 1983: 147: doc 170.

1708 A. Cat. B./ V. 78, f. 2/ Orduña, 23 y 30 septiembre 1288; "Catálogo del Archivo Histórico de la Catedral de Burgos" vol. I. Sección Volúmenes (I), nº 905 y 906.

1709 A. M. Santa Gadea/ doc. 5-10/ Burgos, 15 marzo y 10 agosto 1379. 
Ruiz de Ortuño, portazguero de Orduña para el año 1393, por no reconocer este la exención que tiene Juan Sánchez como vecino de Santa Gadea, del pago del portazgo por la venta en el mercado de Orduña de cuatro fanegas de trigo. El alcalde falla a favor de Juan Sánchez, reconociéndole el derecho de no pagar dicho portazgo ${ }^{1710}$.

El concejo pone como condición al que arrendare la renta del portazgo de la ciudad para el año 1506 que ha de coger $4 \mathrm{mrs}$. de cada quintal del hierro labrado y acero que pasare por la ciudad; 2 mrs. de quintal de hierro por labrar; de medio quintal abajo de otro mineral, un mr.; y de medio quintal arriba $4 \mathrm{mrs}$. De carga de pescado fresco dos libras; y de carga de sardinas una docena sobre lo que en Orduña se vendiere; pero de lo que pasare sin entrar, no han de pagar cosa alguna. Sus vecinos han de ser francos, tanto para el hierro como para el acero labrado y por labrar y del pescado fresco que vendieren en la villa, así como de las cosas que pasaren para los Reyes. Ningún hierro ni acero labrado que venga de fuera del Reino pagará portazgo si debiere diezmo y ningún foráneo podrá coger portazgo de uno, dos o tres azadones u otras tantas rejas que lleven para Provisión de sus casas, ni de ningún hierro que se venda en Orduña, aunque sea por quintales o por medio quintal, y que el arrendador que debe estar en la plaza de Orduña o en su casa a coger el portazgo dé albalá de guía a cada uno de lo que compró en Orduña, y por el albalá le lleve 2 mrs.; y si los que debieren, pasaren por la ciudad o su jurisdicción sin pagar portazgo porque no les fue demandado y después los alcanzaren, que paguen el derecho por el cuádruplo, más las costas que hicieren él o los que los alcanzaron, y si fueren por otra jurisdicción, que pierdan la mercadería que deba portazgo y sus acémilas.

A veces los que han arrendado el portazgo y otros vecinos salen fuera de la ciudad y su jurisdicción a cobrarlo y a prender a los mulateros que van descaminados para llevarlos a Orduña, conforme a los privilegios que la ciudad tiene. Como muchas veces no llevan consigo estos privilegios o la Carta real para poder realizar dichas prendas, se han provocado conflictos, a veces violentos, entre los arrendadores del portazgo y los dichos mulateros, quejándose muchos vecinos y personas de la comarca de que los de Orduña los asaltan y roban en los caminos reales, no pudiéndolos prender ni llevar presos, por lo que se suscitan muchos pleitos. Por ello, se manda que ningún arrendador del portazgo ni vecino de la ciudad pueda ir a recaudar portazgo ni a prender mulatero ni recuero alguno fuera de la ciudad, sin llevar consigo el privilegio o la Carta real que la ciudad tiene, o sin el poder de la ciudad y del alcalde y su regimiento; y los que hicieren lo contrario sean tenidos por públicos salteadores, forzadores y robadores de caminos y términos reales, mandando que se proceda contra ellos como tales salteadores y sean obligados a pagar todas las costas, daños y pérdidas que se causen ${ }^{1711}$. En las cuentas del concejo de Orduña ${ }^{1712}$ consta que se recibieron por lo que rentó el portazgo, tras realizar los correspondientes remates:

1710 A. M. Santa Gadea/ doc. 5-8/ Orduña, 12 agosto y 26 septiembre 1393. "...los uesinos e moradores de la dicha uilla seyendo franqos et quitos de non pagar portadgo en esta dicha uilla de Orduña de tanto tienpo aca que non era memorya de omes en contraryo ni de pagar otro derecho alguno por las cosas que traxiesen o leuasen o conprasen o uendiesen en esta dicha uilla de Orduña...".

1711 A. H. F. B./ Munic. Orduña, Caja 84, leg. D, fol. 1 r.-6 v.; 33 r.o.; 7 r.-32 v.; 34 r.- 51 r./ 1506-1527. ENRÍQUEZ FERNÁNDEZ, J.; HIDALGO de CISNEROS AMESTOY, C.; LORENTE RUIGOMEZ, A. y MARTÍNEZ LAHIDALGA, A.: "Colección Documental del Archivo Municipal de Orduña (1511-1520)... "1994: doc. 47.

1712 A. M. Orduña/ Munic. Orduña, L/ 005 y 054/ 1561-1594. 


\begin{tabular}{|c|l|c|}
\hline Año & \multicolumn{1}{|c|}{ Arrendador } & Maravedís \\
\hline 1566 & Juan de Vitoria & 7.000 \\
\hline 1568 & Juan de Quincoces & 6.500 \\
\hline 1569 & Pedro Ortiz de Orue & 5.000 \\
\hline 1578 & Sebastián de Acebedo & 5.500 \\
\hline 1579 & Sebastián de Acebedo & 7.000 \\
\hline 1582 & Juan de Vitoria & 4.000 \\
\hline 1587 & $\begin{array}{l}\text { Rentas de la media fanega, guía de la Peña, portaz- } \\
\text { go, peso del averío, red del pescado fresco, etc. }\end{array}$ & 101.500 \\
\hline 1589 & & 10.000 \\
\hline
\end{tabular}

- La guía del puerto de la Peña de San Bartolomé. El derecho de guía consistía en la percepción de una determinada cantidad a los viajeros y transeúntes a cambio de su guía y protección en determinados pasos peligrosos. El concejo de Orduña lo concedía al mejor postor para que realizase esta labor, cobrando unas cantidades estipuladas por el tráfico de mercaderías y el paso de personas por el puerto de San Bartolomé de Orduña a cambio de su protección. El adjudicatario debía pagar a los viandantes el importe de lo sustraído en caso de robo y realizar ciertos mantenimientos del camino. Existía otro derecho de guía que pertenecía al Condestable, pero sobre el camino de Goldecho, menos importante por no ser tan transitado. El cobro de la guía era diferente al del portazgo y al de las alcabalas del Rey y según se manda en 1579 " que la renta de la guia de la Peña de esta ciudad, no se junte con los propios de la ciudad, sino que ande en cuenta diferente, y no se libre ni gaste en otra cosa alguna sino en reparos de los malos pasos y camino que hay en la dicha Peña, y que sobre los reparos, la justicia y regimiento de esta ciudad tenga mucho cuidado de lo hacer repararse"1713.

En junio de 1485 se expide una carta de emplazamiento a Orduña y a Villalba de Losa para que ambos se personen en la causa iniciada contra ellos por Vitoria, la hermandad de Álava y la tierra de Ayala, por cobro indebido de impuestos y portazgos, sobre los derechos que cobran a los que llevan pan a Orduña para su venta, y sobre el derecho que dicen que cobra injustamente la ciudad, por la guía y guarda de la Peña de Orduña. Los alaveses pidieron que los Reyes prohibiesen los dichos derechos, por ser imposición nueva ${ }^{1714}$. En 1497 la Junta, alcaldes, procuradores de los vecinos y tierras de la provincia de Vitoria y hermandades de Âlava dicen que en Orduña les hacen muchos agravios, así en la medida del pan como de la guía y les llevan imposiciones nuevas. Los Reyes mandan al corregidor de Vizcaya que no permita a Orduña que lleve ni pida a los vecinos de Vitoria y provincia nuevas imposiciones ni haga más agravios a los mulateros y recueros que llevan pan y otras mercaderías a Bilbao y tienen que pasar por aquella ciudad y que los dejen ir a Vizcaya por los lugares que libremente quisieren ${ }^{1715}$. En 1506 el concejo de Orduña incluye en

1713 A. M. Orduña/ Munic. Orduña, L/ 005 y 054/1561-1594.

1714 A. G. S./ Registro General del Sello, VI-1485, fol. 182/Valladolid, 15 junio 1485; ENRÍQUEZ FERNÁNDEZ, J., HIDALGO de CISNEROS AMESTOY, C. y MARTÍNEZ LAHIDALGA, A.: "Archivo General de Simancas. Registro General del Sello. Vizcaya (1485-1486)". 2003: doc. 422.

1715 A. G. S./ Registro General del Sello, V-1497, fol. 19/ Burgos, 3 mayo 1497. 
sus ordenanzas las condiciones para los que arrendaren la guía del puerto de la Peña de San Bartolomé y se indica que la guía ha de guardar la seguridad de los caminantes de sol a sol junto con dos compañeros y que de los tres, uno será ballestero y los otros dos lanceros y habrá al menos de continuo un hombre que esté para todo lo que se requiera. Ha de guardar la Peña desde Santa Lucía hasta Corcora durante todo el año, los domingos y las tres Pascuas. No obstante no puede cobrar guía alguna en domingos y Pascuas. La tarifa que se aplicará será la siguiente:

\begin{tabular}{|l|c|}
\hline Tipo de mercadería & Mrs. \\
\hline De cada carga de paños de Castilla & 2 \\
\hline De cada carga de congrio & 2 \\
\hline De carga de cera & 2 \\
\hline De carga de alumbre & 1 \\
\hline De cada carga de lanas y cáñamos & 1 \\
\hline De carga de cominos y regaliz & 1 \\
\hline De carga de pastel, cobre y estaño & 2 \\
\hline De carga de hierro y acero & 1 \\
\hline $\begin{array}{l}\text { De carga de pescado cecial y fresco y besugos y carga } \\
\text { de vino blanco y tinto }\end{array}$ & 1 \\
\hline De carga de trigo, cebada, sal, manzanas y castañas & 1 blanca \\
\hline De carga de madera, tinas y cubas & 1 \\
\hline De bestias vacías & 1 blanca \\
\hline De carga de aceite & 2 \\
\hline De carga de pellejería & 2 \\
\hline De avellana & 1 \\
\hline De los hombres cabalgando & 1 \\
\hline $\begin{array}{l}\text { De cada carga de paños de la mar, sedas, mercería, } \\
\text { lienzos y tapicería }\end{array}$ & 4 \\
\hline De carga de cueros de ganados mayores & 2 \\
\hline De carga de pellejos & 1 \\
\hline De carga de rollos y de márraga & 1 \\
\hline
\end{tabular}

Los vecinos de Villalba y sus aldeas, Berberana, Orduña y sus aldeas y los de las aldeas del valle serán francos. No se exigirá guía a ningún fraile ni romero, y si estos no pagaren, las guardas tampoco les abonarán nada si les roban; y no pagará nada ningún criado de los Reyes, jurando que es su criado, ni el corregidor de Vizcaya ni sus criados. Cobrará de grupos de menos de cuatro hombres de a pie, un mr. a cada uno, y de más de cuatro no les cobrará nada porque irán a su ventura, pero si estos requieren a las guardas, les acompañarán pagando a su guía un mr. cada uno. También pagarán mujeres y mozas si no fueren acompañadas por al menos cinco hombres. Cualquier caminante que pase por el puerto antes de salir el sol o después de ponerse y fuere robado, la guarda no estará obligada a pagar. Tampoco pagará nada al que fuere por el camino de Oyalarte, salvo al que fuere por el camino real a Murita y de Orduña a la Peña. En cuanto al mantenimiento y reparos del 
camino, deberá conducir las aguas por sus lugares corrientes, para que no hagan daño a los caminos de la Peña; y si por no atenderlo se hiciere algún daño, lo deberá reparar a su costa, debiendo cubrir "la pared que esta debaxo de la Penna, con çespedes e la sostenga asi todo el anno". Cualquiera que fuere robado dentro de los límites nombrados deberá dar su nombre en Orduña o en Villalba antes de las tres horas, para que la justicia persiga a los ladrones; pero la guarda no deberá pagar el robo o daño recibido si el robado no hiciere la diligencia. El arrendatario no ha de pagar más de la mitad de lo que robaren y la otra mitad lo pagará la guarda de Villalba, y cobrará 10 mrs. por rebaño de menos de 50 cabezas de cerdos, vacas y carnero, 20 mrs. de más de 50 , y de menos de 20 a blanca por cabeza. Si algún vecino que tome la guía quisiere arrendarla a los factores del Condestable o a algún otro, lo podrá hacer pero con las condiciones establecidas. Si se hubiere de traer trigo, cebada u otro pan, o cutrales, bestias, ovejas, cabras y cerdos para los vecinos de Orduña, aunque los que lo traigan no sean vecinos, si juran que no lo hacen por alquiler, no pagarán guía, pero si lo hicieren por alquiler, que paguen y puedan ser apremiados a juramento, tanto el que lo lleve como al que lo reciba. Deberá ser franco todo lo que pase para los Reyes y los que lo llevan con sus bestias ${ }^{1716}$. Sobre la aplicación de estas normas y si fueron efectivas o no, no tenemos ninguna constancia. En 1538 el concejo, justicia y regimiento de Medina de Pomar da un mandamiento en nombre del Condestable, para que Orduña mediante el arrendamiento que tenia otorgado a su favor por 6 años pudiese "percibir y cobrar el derecho que le pertenecia al dicho Condestable, situado sobre la renta y pasage de su Peña nombrada de Goldecho"1717.

Según las cuentas del ayuntamiento de Orduña de 1561 a 1589, la villa recibió por los remates del arrendamiento de la guía de la Peña:

\begin{tabular}{|c|l|c|}
\hline Año & Arrendador & Maravedís \\
\hline 1561 & Juan García de Aguilar & 37.000 \\
\hline 1566 & Pedro Ortiz de Abecia & 34.000 \\
\hline 1568 & Pedro de Ayala & 32.000 \\
\hline 1579 & Martín de Marquina & 26.000 \\
\hline 1580 & Martín de Mendico & 32.000 \\
\hline 1581 & Juan de Uribe & 32.000 \\
\hline 1582 & Juan de Lezana el padre & 33.000 \\
\hline 1583 & Domingo de Arechaga & 33.000 \\
\hline 1589 & & 28.000 \\
\hline
\end{tabular}

En 1568 se pagaron al arrendador Pedro de Ayala 238 rs., por las 92 brazas de calzadas que hizo a 88 mrs. la braza1718.

En las Juntas de Vizcaya de enero de 1571 se trató sobre una petición de Martín de Urquiza, síndico procurador general, debida a que Bilbao había ganado pleito, quedando

1716 A. H. F. B./ Munic. Orduña, Caja 84, leg. D, fol. 1 r.-6 v.; 33 r.o-; 7 r.-32 v.; 34 r.- 51 r./ 1506-1527. ENRÍQUUEZ FERNANDEZ, Javier; HIDALGO de CISNEROS AMESTOY, Concepción; LORENTE RUIGOMEZ, Araceli y MARTINEZ LAHIDALGA, Adela: "Colección Documental del Archivo Municipal de Orduña (1511-1520)... ". 1994: t. II. doc. 47.

1717 A. H. F. B./ Munic. Orduña, caja nº 19, carp. 1/ Medina de Pomar, 17 octubre 1538.

1718 A. M. Orduña/ Munic. Orduña, L/ o05 y 054/ 1561-1594. 
fuera el Señorío, contra Orduña y los encargados de la Peña sobre el cobro que hacían de tres blancas por cada bestia que pasase, y al dicho pleito asistió el Señorío diciendo ser libres y que no debían pagar nada. Pero este, por negligencia, no hizo declaración, por lo que pidió al regimiento que tomase la defensa del pleito y lo acabasen para que el Señorío fuese también libre del pago ${ }^{1719}$. En las Juntas de diciembre se trató de cómo a los vizcaínos les seguían haciendo pagar cierta cantidad de dineros en la Peña, excepto a los de Bilbao, y que aunque el Señorío asistió al pleito, se había quedado por descuido sin hacer declaración ${ }^{1720}$.

En agosto de 1578 como había alguna cantidad de mrs. cobrados a los que pasaban por la Peña, el alcalde de Orduña mandó que se nombrase una persona fiel para guardar los pagos de los que pasaren y lo que se cogiere o arrendare se gaste en el reparo de la Peña y camino de ella y no en otras cosas, so pena de $2.000 \mathrm{mrs} .{ }^{1721}$.

En el pleito sostenido hacia 1580 entre el concejo, justicia y regimiento de Orduña y el Condestable, para que este reparase el camino desde la Peña de Orduña hasta el lugar de Murita porque cobraba la guía de la Peña, responde el representante del Condestable que tal guía son derechos "antiguos de su casa y el dicho Condestable y sus anteçesores los an cobrado y cobran de tienpo ymemorial a esta parte por rraçon de ser suya la villa de Villalba", en tan poca cantidad que nunca llega a los 22.00o mrs. Además, el Condestable jamás ha contribuido en el aderezo de la Peña, que es término de Orduña. La guía de la Peña, alega, se cobra por el tramo del camino que discurre por Murita en el término de Villalba, que acaba junto a la ermita de San Bartolomé y aunque es todo pedregal es llano y ni las aguas ni avenidas lo deterioran. Cuando cae mucha nieve, dice, los lugares cercanos que son del Condestable y Berberana que es de Francisco de Mendoza, hacen huelga para retirar la nieve. Desde San Bartolomé hasta cerca de la ciudad, todo jurisdicción de Orduña, el camino es cuesta abajo, por lo que todas las aguas van cegando el camino con piedras y lodo y para poder transitar, siempre lo ha limpiado Orduña sin haberle repartido cosa alguna al Condestable por no caer en su jurisdicción. La parte de la guía que cobra el Condestable a su arrendatario rinde 4 o 5.000 mrs. menos que la que arrienda la propia ciudad para limpiar el camino que siempre limpió y aderezó. El Condestable solía arrendar de tiempo inmemorial esta guía de la Peña en unos 22.000 o 25.00o mrs., tanto como los que lleva Orduña, y aunque ellos dicen que el Condestable se lleva la mitad de lo que rinde, es al contrario, ya que la ciudad siempre arrienda la mitad de los 5 o 6.000 mrs. más cada año y la norma que se tiene es que la ciudad arriende por su parte la guía de la Peña a quien más da, y el que la arrienda en Medina de Pomar la vuelve a dar en Orduña al mejor postor. Añade que en la parte que es del Condestable, ningún vecino de Orduña paga derecho alguno, ni en Orduña los vecinos de Villalba y sus aldeas ${ }^{1722}$.

En las Juntas de Vizcaya de julio de 1584 se mandó que para seguir con el pleito de la Peña de Orduña contra el Condestable, se ponga este capítulo en la instrucción para que

1719 A. J. R. B./ Actas de la Tierra Llana. t. II/ Bilbao, 30 enero 1571.

1720 A. J. R. B./ Actas de la Tierra Llana. t. II/ Durango, 17 diciembre 1571

1721 A. M. Orduña/ Munic. Orduña, L/ 005 y 054/1561-1594.

1722 A. H. N./ Nobleza, Frías, Leg. 1.392, D. 1/ Entre 1559 y 1585. 
sigan los dos representantes que al presente van a las villas de Valladolid y Madrid como más convenga y sea necesario. En 1584 y en 1585 se extienden dos Provisiones reales en que mandan que lo que lleva el Condestable como renta de la guía se invierta en reparos de la Peña ${ }^{1723}$. En las Juntas de Vizcaya de febrero de 1585 se vuelve a tratar que los derechos que el Condestable percibe en Orduña se gasten y distribuyan para el reparo de la Peña y se pide que el corregidor del Señorío informe sobre lo que ocurre. Se acordó sacar Provisión para que los derechos que cobra el Condestable en Orduña en concepto de reparo de la Peña se gasten en ella y, si para esto fuere necesario que Orduña haga algunas diligencias, que se haga lo que conviene ${ }^{1724}$. En las Juntas de agosto de 1586 se trató como a Gracián de Meceta y Martín Ruiz de Muncharaz, cuando fueron a la corte a los negocios del Señorío, se les dio encargo para que pidiesen Provisión o cédula con el fin de que los derechos excesivos que cobra el Condestable en Orduña, so pretexto de que son para el reparo de la Peña, se gasten en el dicho reparo ${ }^{1725}$. En las cuentas de Orduña de 1587 se ingresaron 101.500 mrs. que se obtuvieron de las rentas de la media fanega, de la guía de la Peña, del portazgo, peso del averío, red del pescado fresco, etc. que se arrendaron al finalizar el año $1586^{1726}$.

En las Juntas de Vizcaya de octubre de 1598 Ochoa López dijo que siendo libres los vecinos del Señorío de pecho, portazgo ni pedido desde su fundación, de poco tiempo acá la ciudad de Orduña ha puesto guardas y portazgueros para que, sin excepción, paguen todos los que pasaren por la ciudad y Peña, por lo que el Señorío no debía consentirlo1727. En las Juntas de abril de 1599 se acordó de nuevo que en Orduña no se haga pagar la imposición y derechos de la Peña, ni otra cosa alguna a ningún vizcaíno y natural del Señorío; pero el alcalde de la ciudad dijo que apelaba este auto ante el corregidor ${ }^{1728}$. En 1602 Orduña seguía cobrando este derecho a los del Señorío, ya que en las Juntas de Vizcaya de septiembre el síndico dijo que en Orduña, en contravención de los privilegios del Señorío y sin autoridad ni licencia, hacían pagar ciertos derechos a las personas que pasan por la Peña. El corregidor mandó que se guarde y cumpla el Fuero del Señorío y lo decretado por su Regimiento Ceneral1729.

- Portazgo de Pancorbo. En la villa existió un puesto para el cobro del portazgo que pertenecía al Rey, pero también se cobró el diezmo que igualmente le pertenecía. En 1177 Alfonso VIII y su esposa Leonor conceden al monasterio de Oña el diezmo de todo el portazgo del mercado de Pancorbo, según derecho real ${ }^{1730}$. Alfonso XI dice, en abril de 1330 , al concejo y a los cobradores de los derechos del Rey en Pancorbo que el abad de Oña se quejó porque teniendo el monasterio el privilegio de Alfonso VIII y confirmado por los demás

\footnotetext{
1723 A. J. R. B./ Actas de la Tierra Llana. t. IV/ Bilbao, 28 julio 1584; A. H. F. B./ Munic. Orduña, caja no 19, carp. 3/1584 Y 1585.

1724 A. J. R. B./ Actas de la Tierra Llana. t. IV/ Bilbao, 20 y 21 febrero 1585.

1725 A. J. R. B./ Actas de la Tierra Llana. t. IV/ Bilbao, 22 agosto 1586.

1726 A. M. Orduña/ Munic. Orduña, L/ 005 y 054/1561-1594.

1727 A. J. R. B./ Actas de Villas y Ciudad. t. III/ Zubiaur de Zornoza, 14 octubre 1598.

1728 A. J. R. B./ Actas de la Tierra Llana. t. VI/ Bilbao, 28 abril 1599.

1729 A. J. R. B./ Actas de la Tierra Llana. t. VII/ Guernica, 4 septiembre 1602.

1730 A. H. N./ D. R. de Oña. carp. 276, num. 17/ Sitio de Cuenca, 22 julio 1177; ÁLAMO, J. del: 1950: t. I. doc. 258, 206-308; Cuenca, 23 julio 1177; GONZÁLEZ y GONZÁLEZ, J.: 1960: 469: t. II. doc. 285
} 
Reyes para recibir "el diesmo de los derechos e rentas e portadgo, quando acaesçie de las cosas que por y pasauan, asi de ganado como de menudo... de que an a dar portadgo e derecho de que los dichos abat e conuento an de auer su deçima parte", los prestameros que cogen estos derechos y portazgo no se los quieren dar a Oña y muestran cartas y privilegios de Alfonso X, Sancho IV, Fernando IV y de él mismo en que les quitaron el portazgo, por lo que los alcaldes y merino de Pancorbo dan por quitos tales privilegios de Oña. El Rey les manda que vean el privilegio que el abad y monasterio tienen y lo cumplan como en él se contiene ${ }^{1731}$.

En junio de 1351 Pedro I extiende una Provisión ordenando a los alcaldes y merinos de Pancorbo que paguen el portazgo todos aquellos que hubieran conseguido su exención posteriormente a la fecha de la venta de Pancorbo, Briviesca y Salinas de Añana, por el rey Alfonso XI a doña Blanca, hija del infante Pedro y abadesa del monasterio de Las Huelgas, ya que doña Blanca se consideraba perjudicada por los muchos que alegaban exenciones. El Rey manda que los vecinos de Bilbao, Bermeo y otros lugares que dijeren que están eximidos del portazgo en dicho lugar, muestren sus cartas y privilegios y si se viere que fueron dados después de la dicha venta, o si en los que dio él mismo a Juan Núñez, señor de Vizcaya, no especifican puntualmente la exención en Pancorbo, que paguen el derecho que debieren por lo que llevaren, según uso y costumbre ${ }^{1732}$. En octubre de ese año Pedro I ordena a los portazgueros de Pancorbo que, a pesar de su carta de junio, se respete la exención a los vecinos de Vitoria, que la tenían y disfrutaban desde la época de Fernando III ${ }^{1733}$.

Enrique II dice en abril de 1370 que dio al obispo de Burgos Miranda de Ebro con todas sus aldeas y jurisdicción y que después la dio al concejo de Burgos en compensación de Briviesca, que la había concedido a Pedro Fernández de Velasco, su camarero mayor; y como pretende hacer compensación, concede al obispo Domingo y su Cabildo 30.000 mrs. anuales por juro de heredad, sobre los diezmos de Pancorbo o de cualquier puerto de la mar de Castilla y manda a sus cogedores y recaudadores de los diezmos de Pancorbo o de los puertos de la mar que abonen al obispo los dichos $30.000 \mathrm{mrs}$. desde el 1 de enero de ese año por cuatrimestres ${ }^{1734}$. En enero de 1371 entrega a la infanta doña Blanca, abadesa de Las Huelgas, 10.000 mrs. anuales situados sobre los diezmos del puerto de Pancorbo, en compensación por las rentas que la infanta solía tener en Briviesca y Salinas de Añana1735. En septiembre el Rey ordena a su canciller que extienda carta de confirmación de esta donación, así como de otra anualidad de 3.000 mrs. que otorga a dicho monasterio sobre los

1731 A. H. N./ Clero. Pergaminos. carp. 310, nº 5/ Salamanca, 12 abril 1330; GONZÁLEZ CRESPO, E.: 1985: doc. 156, 285; OCEJA GONZALO, I.: 1986: 198-200: doc. 627.

1732 A. M. de Vitoria/ Sección 8, legajo 8, número 14/ Burgos, 2 junio 1351; GONZÁLEZ MíNGUEZ, C.: "Documentos de Pedro I y Enrique II en el Archivo Municipal de Vitoria". 1994: doc. XII.

1733 A. M. de Vitoria/ Sección 8, legajo 8, número 14/ Valladolid, 25 octubre 1351; DíAZ MARTíN, L. V.: 1997: 213: t. II. doc. 477.

1734 A. M. B./ HI-67/ Medina del Campo, 13 abril 1370; BONACHÍA HERNANDO, J. A.: 1978: 154-156: doc. 6; A. Cat. B./ V. 31, f. 345/ Medina del Campo, 13 abril 1370; MANSILLA REOYO, D.: 1971: doc. 1497.

1735 A. M. H. B./ Leg. 5, nº. 163/Valladolid, 30 enero 1371; PEÑA PÉREZ, F. J.: 1990: doc. 280, 264-266 "por esta mi carta mandamos a qualquier o a qualesquier cogedores o recabdadores, que cogieren o recabdaren... en renta o en fialdat o en otra manera qualquier, los diezmos del dicho puerto de Pancoruo este dicho anno e dende delante de cada anno que recudan... a uos, la dicha infanta donna Blanca". 
puertos de la mar y de tierra ${ }^{1736}$. Dos días después confirma la carta de $1371^{1737}$. En agosto de 1379 Juan I confirma el juro de 30.000 mrs. para que se funden unas capellanías ${ }^{1738}$. A su vez, Enrique III confirma al obispo y cabildo de Burgos, en febrero de 1392, los privilegios de Enrique II y Juan I, por los que les dicha renta para dotación de capellanías y servicio de coro ${ }^{1739}$.

En el siglo XVI el alcalde de Santa Gadea compareció ante el corregidor de Pancorbo diciendo que algunos vecinos de Pancorbo han hecho pagar portazgos a vecinos de Santa Gadea, lo cual es injusto, porque ellos son tan libres de portazgos en Pancorbo como lo son los vecinos de Pancorbo en Santa Cadea. Pide por ello al corregidor que mande que sean guardadas dichas libertades y que se devuelvan los portazgos y, si los vecinos de Santa Cadea siguen siendo obligados a pagar, se mande a Pancorbo que muestre el título o derecho que les asiste. En el mismo documento se indica que en el portazgo de Pancorbo, los vecinos de Miranda, Santa Gadea, Briviesca, Belorado y Cerezo han de pagar una blanca por cada carga, salvo si fuere de sal, y si fueren cargas de diezmería que vienen de los puertos pagarán 2 mrs. por carga ${ }^{1740}$.

En octubre de 1517 el procurador de Frías se querelló porque en Pancorbo y otras villas les cobraban el portazgo, siendo que Frías estaba exenta de ese pago por privilegio concedido por Fernando III en 1249 y confirmado por todos los reyes posteriores. Pide justicia para que no se hiciese pagar a ningún vecino ni morador de Frías, portazgo, pasaje, pontaje ni otro derecho alguno en Pancorbo y se condenase a sus portazgueros, obteniendo Frías en enero de 1522 sentencia favorable ${ }^{1741}$.

- Portazgo de Pie de Concha. La villa de Pie de Concha (298 m), se encuentra en la base de un importante puerto de unos cuatro $\mathrm{km}$ del camino a Santander, que salva un desnivel de $413 \mathrm{~m}$ desde Somaconcha (711 m). La reina Urraca eximirá entre 1109 y 1126 del portazgo en Pie de Concha al monasterio riojano de Cillaperriel ${ }^{1742}$. En 1348 el abad de Santa María de Aguilar indica que el monasterio, debiendo percibir el cuarto del portazgo de Pie de Concha por privilegio de Alfonso X, recibido a cambio de lo que el monasterio percibía en Aguilar de Campoo, algunos de los que pasan no quieren pagarlo porque dicen que están exentos por privilegios reales. este manda a los portazgueros que no consientan que nadie que deba pagar lo evite por muchas cartas o privilegios que tenga, y al merino mayor de Castilla y al concejo, alcaldes y juez de Pie de Concha, que ayuden para que se cumpla lo ordenado ${ }^{1743}$. En 1535 se mencionan las guardas de Pie de Concha y otras partes, que

\footnotetext{
1736 A. M. H. B./ Leg. 5, nº. 163/Toro, 21 septiembre 1371; PEÑA PÉREZ, F. J.: 1990: 275-276: doc. 284.

1737 A. M. H. B./ Leg. 5, nº. 163/Toro, 23 septiembre 1371; PEÑA PÉREZ, F. J.: 1990: 276-278: doc. 285.

1738 A. Cat. B./ V. 4, p. 1, f. 19/ Burgos, 30 agosto 1379; MANSILLA REOYO, D.: 1971: doc. 1600.

1739 A. Cat. B./ V. 3, f. 111/ Burgos, 20 febrero 1392; MANSILLA REOYO, D.: 1971: doc. 1677.

1740 A. M. Santa Gadea/ doc. 38-14/ Santa Gadea del Cid, 15...

1741 A. M. Frías/ H-و/Valladolid, 7 octubre 1517 a 24 julio 1523.

1742 PORRAS ARBOLEDAS, P. A.: 1992: 164.

1743 A. H. N./ Clero. Pergaminos. carp. 1.674, № 2. Aguilar de Campoo/Tordesillas, junio 1348; GONZÁLEZ CRESPO, E.: 1985: 592: doc. 336
} 
comprobaban si las mercaderías llevaban el albalá de guía, justificante de haber pagado el diezmo en Santander ${ }^{1744}$.

- Portazgo de La Población. La villa de La Población se encuentra en el camino a Santander por Lanchares y pensamos que es la localidad a la que alude el documento de 1253 , cuando el concejo de Santander protestó porque Juan Díaz de Frómista, "les tomaba portadgo en Poblaçion"1745, y como nunca lo pagaron en tiempo de Fernando III ni de la reina Berenguela, Alfonso X emplazó a Juan Díaz y a los de Santander. Se obtuvo información sobre si "tomavan a los de Santander, portadgo en Poblaçion" en tiempo de Fernando III y de doña Berenguela y se halló que en ese tiempo no lo cobraron ni se cobró hasta hacía 2 años cuando el Rey murió. El Rey manda que nadie, pueda tomar a los de Santander portazgo en Población, y el que lo tomase deberá pagar al Rey 1.000 mrs. y a los de Santander el daño doblado ${ }^{1746}$.

- Portazgo de Puentelarrá. Esta villa se encuentra junto a un importante puente sobre el Ebro, paso obligatorio del camino de Burgos a Bilbao por Orduña, donde se estableció un portazgo. Lope Díaz de Haro, titular del portazgo del puente, ordena en 1306 a sus portazgueros que no lo cobren al monasterio de Oña por el traslado que hacen de la sal desde Añana, ya que el monasterio está exento en toda Castilla1747. En Junta de Álava de mayo 1548 se trató sobre lo que se le había encomendado a Pedro Díaz de Olarte, para hacer todas las diligencias en relación con los derechos que llevan los portazgueros a los trajinantes, para que notifique con un escribano las sentencias y escrituras que la provincia de Álava tiene para no pagar portazgos en las villas de Puentelarrá, Santa Gadea y otras partes ${ }^{1748}$. En Junta de noviembre tras haber tratado sobre los portazgos y el registro de los ganados en Haro, Ríogil y puente de Puentelarrá y del mucho perjuicio que reciben los vecinos de la provincia, acordaron que se haga memoria para que el Consejo Real mande que muestren el título o razón que tienen los de Haro, Ríogil y Puentelarrá para hacer semejantes vejaciones ${ }^{1749}$.

- Portazgo de Santa Gadea. En 1306 Lope Díaz de Haro, titular del portazgo de Santa Gadea, ordena a sus portazgueros que no lo cobren al monasterio de Oña por el traslado que hacen de la sal desde Añana, por estar el monasterio exento en toda Castilla1750. En 1341 Juan Núñez y doña María II, señores de Santa Gadea, conceden a los vecinos de Bilbao la exención de portazgos en su villa1751.

1744 A. H. P. C./ J. T. A. leg. 37-2/ Los Corrales de Buelna, 14-15 mayo 1535.

1745 Aunque existen en Cantabria varias villas con este nombre: Población de Abajo, de Arriba o de Suso, pensamos que lo más probable es que se trate de La Población, junto a Lanchares.

1746 A. H. P. C./ Diversos. leg. 52, no 1, f. 9r-8v/ Sevilla, 17 julio 1253; SOLÓRZANO TELECHEA, J. A.: "Patrimonio documental... ". 17: doc. 1.

1747 R. A. H./ Biblioteca, col, Salazar y Castro O-18, fol. 117-117v/ Oña, 3 enero 1306; OCEJA GONZALO, I.: 1986: 362-363: doc. 505.

1748 A. J. G. A./ t. IV/ Vitoria, 5 mayo 1548.

1749 A. J. G. A./ t. IV/ Vitoria, 24 noviembre 1548.

1750 R. A. H./ Biblioteca, col, Salazar y Castro O-18, fol. 117-117v/ Oña, 3 enero 1306; OCEJA GONZALO, I.: 1986: 362-363: doc. 505.

1751 A. M. Bilbao/ Cajón 8, reg. 1, nº 1-caja 199 (fol. 5or)/ Burgos, 3 febrero 1341. 
En el siglo XVI el alcalde de Santa Gadea compareció ante el corregidor de Pancorbo diciendo que los de esa villa han hecho pagar portazgo a sus vecinos, lo cual dicen que es muy injusto porque la villa y su jurisdicción son libres de ellos como lo son los vecinos de Pancorbo en Santa Gadea, libertad guardada entre las dos villas desde tiempo inmemorial ${ }^{1752}$. En Junta de Álava de mayo de 1548 se trató sobre lo que se había encomendado a Pedro Díaz de Olarte, para que hiciese todas las diligencias necesarias en relación con los derechos que llevan los portazgueros a los mulateros y notifique las sentencias y escrituras que la provincia tiene para no pagar portazgos en Puentelarrá, Santa Gadea y otras partes ${ }^{1753}$.

- Portazgo de Valmaseda. Sancho IV reconoce en septiembre de 1288 que el cabildo y vasallos de Santa María de Valpuesta están exentos de pagar portazgo y manda que los recaudadores del mismo, particularmente los de Orduña y Valmaseda, no exijan dicho tributo ${ }^{1754}$.

- Portazgo de Villasana. La villa es la más importante del valle de Mena y ejercía las funciones de capital del Valle. Perteneció a los Velasco y desde la villa intentaron controlar el tráfico de mercaderías por el camino de Burgos a Castro-Urdiales primero y a Bilbao por Valmaseda después. En agosto de 1483 los oficiales del Condestable obligan a los mulateros que circulaban por Arceo y Burceña a ir por Villasana, posiblemente para pagar el portazgo. Los Reyes mandan al concejo de Villasana y al merino del valle de Mena que dejen a los mulateros transitar libremente con sus mulos y acémilas cargadas o vacías por el "camino real de la Ordunte", porque desde tiempo inmemorial se ha caminado por él ${ }^{1755}$.

\section{La huelga}

En tiempo de invierno los puertos y los páramos burgaleses se cubrían de nieve, que cuando alcanzaba una altura importante podía impedir la circulación. Para mantener expedito el paso se recurría a la huelga, que consistía en la movilización de los vecinos de los lugares cercanos para realizar un pasillo libre de nieve y facilitar así el paso de peatones y recuas. Se cobraba por ello a los arrieros y viandantes una tasa por el beneficio que obtenían para seguir su camino. Estos cobros percibidos por este concepto, que eran ocasionales y no eran portazgos, provocaron en ocasiones tensiones y protestas como consecuencia de que tales cobros eran abusivos o se realizaban por parte de personas relevantes cuando ya no había nieve en el camino.

\section{c.- Aduanas generales. Los diezmos de la mar}

Prueba evidente del nivel de desarrollo que iban alcanzado los centros urbanos del litoral norteño y del tráfico comercial que ya tenían sus puertos, fue el acuerdo del orde-

1752 A. M. Santa Gadea/ doc. 38-14/ Santa Gadea del Cid, 15...

1753 A. J. G. A./ t. IV/ Vitoria, 5 mayo 1548.

1754 A. Cat. B./ V. 78, f. 2 / Orduña, 23 y 30 septiembre 1288; "Catálogo del Archivo Histórico de la Catedral de Burgos" vol. I. Sección Volúmenes (I), no 905 y 906.

1755 A. G. S./ Registro General del Sello, VIII-1483, fol. 184/ Santo Domingo de la Calzada, 23 agosto 1483. 
namiento realizado en las Cortes de Jerez de 1268, cuando se autorizó a los puertos más importantes del litoral cantábrico y gallego para el tráfico de mercaderías. Estos eran los de San Sebastián y Fuenterrabía en Guipúzcoa; ninguno en Vizcaya; Santander, Laredo y Castro-Urdiales en Cantabria; Avilés en Asturias; y en Galicia, La Coruña, Ribadeo, Vivero, Betanzos, Ortigueira, Cedeira, Ferrol, Bayona, La Guardia, Pontevedra, Padrón y Noya. Naturalmente, esta regulación debía ir acompañada de la instauración de unas aduanas que controlasen su tráfico y percibiesen los diezmos ${ }^{1756}$.

En fechas ya posteriores existieron en la zona norte las aduanas donde se cobraban los diezmos de la mar siguientes: Irún, San Sebastián, Guetaria y Zumaya en Guipúzcoa; Tolosa, Salvatierra y Vitoria en Álava; Orduña y Valmaseda en Vizcaya, y en Cantabria, las Cuatro Villas de la Costa: Castro-Urdiales, Laredo, Santander y San Vicente de la Barquera. Las aduanas de Orduña, Laredo, Vitoria, Valmaseda y Santander fueron las de mayor actividad, en las que la de Orduña, en el camino entre Burgos y Bilbao, tenía la primacía ${ }^{1757}$.

Los "diezmos de la Mar de Castilla" eran los derechos aduaneros que la Corona percibía sobre las mercaderías objeto de comercio con el extranjero, tanto las importadas como las exportadas, a través de los puertos cantábricos y que las gravaban teóricamente con el 10\% de su valor. Se cobraban en los puertos marítimos de la cornisa cantábrica y en los puertos secos en el caso de existir territorios con un régimen aduanero especial, como era el caso de las provincias vascas. Los puertos secos del País Vasco relacionados con Burgos eran Valmaseda, Orduña y Vitoria. Tales mercaderías, tras su registro en la aduana, obtenían la correspondiente cédula llamada "albalá de guía", que justificaba el pago del diezmo. En Cilleruelo de Bezana, Herrera de Pisuerga, Medinade Pomar o Briviesca, todas villas de los Velasco, existió una guarda, puesta por estos cuando los diezmos dependieron de dicha familia, para comprobar si los arrieros y mercaderes llevaban el albalá de guía. En estos registros, además, se pagaba un nuevo derecho por cada carga o bestia: el portazgo y rediezmo. A pesar de pertenecer a la Corona, como se ha dicho, fueron enajenados por Enrique IV a favor de Pedro Fernández de Velasco en 1469, cuya familia los mantuvo hasta que Felipe II los recuperó en 1559.

Los recaudadores de los diezmos no eran normalmente oficiales del rey, sino que arrendaban dicho oficio y eran sus adjudicatarios. Realizaban el cobro de ese derecho, tras asiento concedido por el Rey o por el Condestable cuando los diezmos dependieron de él, y haber pagado por adelantado a la real Hacienda o a dicho Condestable la cantidad acordada.

En febrero de 1309 Fernando IV otorga privilegio que ratifica otros otorgados por Alfonso X y Sancho IV, por el que concede a los mercaderes de Burgos que, si llevan los albalaes por el pago de los diezmos, no se les registren sus mercaderías ni escudriñen ni embarguen sus cargas cuando vengan de los puertos; y que en el caso de sospecha de que el mercader trae mercaderías sin haber pagado el diezmo, solo se puedan registrar por mandato de los alcaldes de Burgos ${ }^{1758}$.

1756 SOLÓRZANO TELECHEA, J. A.: 2009-2010: 46.

1757 VÁZQUEZ DE PRADA, V. (Dir.): 1978: 459.

1758 A. M. B./ HI-100/ Madrid, 28 febrero 1309. 
En febrero de 1408 Juan II extiende un privilegio, que confirma otro de abril de 1407, por el que ordena que los arrendadores de aduanas no puedan poner guardas en la ciudad de Burgos, ni demanden ni apremien a sus mercaderes que transportan paños y otras cosas, ni los emplacen diciendo que sacaron cosas vedadas, sino que guarden sus usos y costumbres como se guardaban con Enrique III y otros reyes ${ }^{1759}$.

\section{Los puertos mojados}

Para el cobro de los diezmos de la mar en las aduanas de los puertos de San Vicente de la Barquera, Santander, Laredo y Castro-Urdiales, existía en cada uno de ellos la correspondiente aduana.

Alfonso VIII concede en 1178 al monasterio de San Juan de Burgos, la iglesia de San Pedro y el diezmo de las rentas reales de Castro-Urdiales y le confirma todos sus bienes y privilegios $^{1760}$. El mismo Rey extiende un privilegio en 1192 por el que concede a dicho monasterio el diezmo de las rentas reales de Castro-Urdiales y de las mercancías que lleguen al puerto de dicha villa, excepto el portazgo de paños, armas y querambre, y el portazgo de maderas, sal y otras cosas que pasen por el barrio de San Juan ${ }^{1761}$. El testamento de Alfonso VIII, realizado en 1204, dispone entre otras cosas la entrega de Castro-Urdiales y Laredo al monasterio de las Huelgas, donde se ha de enterrar, para dotación de su aniversario1762.

En marzo de 1249 Fernando III indica a los portazgueros de Castro-Urdiales, Laredo, Santander y San Vicente de la Barquera y a todos los del Reino, que el concejo de Frías tiene cartas de Alfonso VIII y otra suya en que se manda que no paguen portazgo en ninguna parte del Reino y que nadie los tome, ni los prenda ni embargue por ello, y puedan ir libremente con sus bestias, carros, ganados y mercaderías ${ }^{1763}$.

Alfonso X asigna en febrero de 1255 al monasterio de Las Huelgas una renta anual de $1.000 \mathrm{mrs}$. en el puerto de Laredo para atender a las necesidades de pescado de la comunidad ${ }^{1764}$, y Sancho IV ratifica en marzo de 1285 el dicho privilegio ${ }^{1765}$. También confirma el privilegio de Alfonso VIII, por el que otorga al obispo y cabildo de Burgos el diezmo de todas las mercaderías que entraren por el puerto de Santander y por los restantes de la diócesis. En Castro-Urdiales concede solamente el diezmo de paños, armas y querambre ${ }^{1766}$. En mayo dispone que el monasterio de Las Huelgas reciba anualmente una renta de 200

1759 A. M. B./ HI-89/ Alcalá de Henares, 20 febrero 1408.

1760 A. M. B./ HI-77/ Burgos, 2 septiembre 1178.

1761 A. M. B./ HI-130/ Covarrubias, 11 julio 1192.

1762 A. H. N./ Códice 996-B/ Fuentidueña, 8 diciembre 1204; LIZOAIN GARRIDO, J. M.: 1985: 134: doc. 81 "dono pro meo aniuersario monasterio burgensis Sancte Marie Regalis, quod ego et regina uxor mea construximus, ubi corpus meumn tumuletur, Castrum Ordiales et Leredo". Es un primer testamento 10 años antes de su muerte, que debió sufrir notables modificaciones.

1763 A. M. Frías/ H-9/Valladolid, 18 mayo a 24 julio 1523

1764 A. M. H. B./ Leg. 10, nº 330/ Burgos, 24 febrero 1255; LIZOAIN GARRIDO, J. M.: 1985: 298-300: doc. 480.

1765 A. M. H. B./ Leg. 10, nº 330/ Burgos, 27 marzo 1285; CASTRO GARRIDO, A. y LIZOAIN GARRIDO, J. M.: 1987: 23: doc. 12.

1766 A. Cat. B./ V. 71, n. 16/ Burgos, 25 febrero 1255; MANSILLA REOYO, D.: 1971: doc. 704. 
mrs. en el puerto de Laredo como contribución a los gastos de alimentación y de vestido de la comunidad ${ }^{1767}$.

Según un documento de Alfonso IX del año 1324, el treintavo de los puertos de CastroUrdiales, Laredo, Santander, San Vicente de la Barquera y Ríoturbio pertenecía al rey Alfonso VIII y de este treintavo se daba el diezmo a la catedral de Burgos. Después los reyes dispusieron llevar de estos puertos tan solo el diezmo, conformándose entonces la catedral con cobrar el diezmo de este diezmo ${ }^{1768}$.

En mayo de 1524 Carlos I manda al concejo de Santander que, para que la villa esté más provista de las cosas necesarias por estar en tierra estéril, se haga en ella un mercado el sábado de cada semana y ese día no se recauden las rentas de las alcabalas de las compras ni ventas a los que a él acudan, pero sí los diezmos de la mar ${ }^{1769}$.

En abril de 1535 el alcalde de Santander dice a las autoridades de Aguilar de Campoo, valle de Ordejón, Amusco, Buelna, Pie de Concha y otras villas y lugares, que entre Santander y el condestable de Castilla hay pleito para que los fardeles de paños y demás mercaderías sigan entrando por Santander, ya que el Condestable pretende desviar el tráfico por otros puertos. Para que este, como señor de los diezmos de la mar lo permita sin pleito, se debía obtener información, preguntando a vecinos de las villas y valles por dónde tales mercaderías pasaban, y demostrar que antiguamente se acostumbraban cargar en Santander las lanas del Consulado de Burgos, y que las cargas de paños y otras mercaderías que de retorno venían, se remitían a Castilla por dichas villas sin pagar los portazgos que se les pretendían exigir. Se debería preguntar para ello si saben que antes de que los diezmos de la mar se incorporaron a la casa de Velasco, los arrendadores de los Reyes que recaudaban los diezmos de las mercaderías que entraban en Santander desde "rreynos estraños", daban los albalaes a los mercaderes o a los que las llevaban y guiaban, para que las guardas puestas por los señores, no tomasen las mercaderías por descaminadas, y que las mercaderías que iban a Santander se siguieron guiando después de que los diezmos de la mar se otorgaron al Condestable. Otra pregunta sería si saben que cuando las mercaderías descargaban en el puerto de Santander y las guiaban los diezmeros puestos por los reyes, y después por el Condestable, las guardas de Pie de Concha, Reinosa y otras partes las dejaban pasar libremente. Los testigos dijeron que de más de 60 años han visto que las mercaderías que venían de Flandes, pagaban el diezmo al diezmero y rentero vecino de la villa puesto por los reyes, que extendía los correspondientes albalaes. Las bestias que llevaban dichas mercaderías a Castilla, sin contradicción de los Velasco ni de otra parte, pasaban por Cartes, valle de Buelna, Pie de Concha y Aguilar a Burgos, y los mulateros decían que ni en Pie de Concha ni en Reinosa ni en otra parte, se les pedía cosa alguna sobre las mercaderías llevando los albalaes de Santander ${ }^{1770}$.

Cuando el Condestable tuvo la renta de los diezmos de la mar, el capitán de cada nao debía pedir licencia al diezmero del Condestable para descargar las mercaderías en el

1767 A. M. H. B./ Leg. 2, no 34/ Palencia, 3 mayo 1255; LIZOAIN GARRIDO, J. M.: 1985: 301-302: doc. 481.

1768 SERRANO, L.: 1935: 323: t. III.

1769 A. H. P. C./ J. T. A. leg. 38-5/Valladolid, 24 julio 1546.

1770 A. H. P. C./ J. T. A. leg. 37-2/ Los Corrales de Buelna, 14-15 mayo 1535. 
puerto y, tras su registro, dicho diezmero expedía el albalá o cédula de guía. Cuando tales mercaderías pasaban por Cilleruelo de Bezana, Herrera de Pisuerga, Medina o Briviesca, todas villas suyas, en la casa de cata de cada villa eran registradas de nuevo y se comprobaba si llevaban sus albalaes. Aquí se les daban cédulas de paso y pagaban los derechos correspondientes para que otras guardas les dejasen pasar libremente ${ }^{1771}$.

En la relación que Juan de Peñalosa, administrador de los diezmos de la mar, envió al Rey en mayo de 1564, se indicaba que sobre las aduanas de los puertos de la mar no había ninguna duda de que diezmándose a la entrada como se había ordenado, era de mucho beneficio para la Hacienda del Rey, si no hubiera el inconveniente de que todas las personas que traían mercaderías a vender, al tener que pagar cuando descargaren en los puertos de San Vicente, Santander, Laredo y Castro-Urdiales, irían a descargar a Bilbao donde no hay aduana ni diezmo; y aunque la Hacienda no recibe daño de esto, porque cuando vengan para Castilla ya diezmarán, los dichos puertos perderán mucho de su comercio y trato, principalmente Laredo que es el que más contratación tiene, y no lo perderían si en Bilbao hubiere aduana. Y siendo así, estaría bien resuelto si los extranjeros que traían las mercaderías pagasen a la entrada de los puertos los derechos que debían, y no los naturales que las compran como ahora se hace. Lo que los dichos pueblos pretenden, tanto los de los puertos de mar como las otras aduanas de tierra, es que el Rey les hiciese merced de que lo que se consumiese en las aduanas y pueblos estuviese libre del dicho derecho y que todo lo que saliese pagase el diezmo. Así no habría mucho inconveniente, ya que son fronteras y tierra pobre ${ }^{1772}$.

\section{Los puertos secos}

El Señorío de Vizcaya y la provincia de Guipúzcoa, en virtud de tener reconocida la hidalguía general en sus respectivos fueros y aceptada por los Reyes en el siglo XVI, estaban exentos del pago de tributos. La provincia de Álava, aunque sus habitantes no gozaran por fuero del dicho privilegio de hidalguía, disfrutó igualmente de la exención de tributos reales ${ }^{1773}$. Por esto, tenían aduanas o puertos secos que se localizaban en el interior, para que todas las mercaderías que procedentes de otros reinos entrasen por los puertos de mar de Vizcaya y Guipúzcoa o salían de Castilla por dichos puertos, tributasen no en la costa sino en las aduanas interiores establecidas en los límites con Castilla y Navarra. Las aduanas de Valmaseda y Orduña, ya existían al menos en 1412, mencionadas en un documento sobre estos diezmos ${ }^{1774}$.

Por ello, las mercaderías que llegaban a sus puertos eran más baratas en las tierras vizcaínas, alavesas y guipuzcoanas que en Castilla, al no soportar ningún tipo de gravamen y, por contra, se penalizaba la compra de las mercaderías que llegaban de Castilla, salvo los mantenimientos y otros productos para el consumo de los naturales. En Valma-

\footnotetext{
1771 A. D. F./ Legs. 29 y 162. nums. 1 y 2/ Herrera de Pisuerga, 1 agosto 1549.

1772 A. G. S./ Secretaría del Consejo de Hacienda. Cartas 1564/ 23 mayo 1564; GONZÁLEZ, T.: 1829: 237-254: t. II. doc. CXLV

1773 VÁZQUUEZ DE PRADA, V. (Dir.): 1978: 50.

1774 A. G. S./ Escribanía mayor de Rentas. Libros de Rentas años 1412 y 1447/ Tordesillas, 15 diciembre 1412 y Valladolid, 15 abril 1447; GONZÁLEZ, T.: 1829: t. I. doc. 1, 1-28.
} 
seda y Orduña se cobraban los diezmos de la mar y demás tributos debidos a la Corona sobre las mercancías que entraban por el puerto de Bilbao, y en las de Vitoria y Salvatierra tributaban las que venían de Cuipúzcoa. Estas aduanas eran de obligado tránsito para todas las mercaderías, y si estas iban por otros caminos, eran decomisadas por los oficiales del Rey junto con las bestias o carros, por ir descaminadas.

La ausencia de aduanas en la costa de Vizcaya y Guipúzcoa estaba relacionada con la amplia libertad comercial y la necesidad de abastecimiento de estas tierras. Alaveses, guipuzcoanos y vizcaínos gozaban de una generosa exención fiscal sobre los productos foráneos y sobre los autóctonos que se exportaban, que abarataban su precio y facilitaban su consumo1775. Dicha libertad de los vizcaínos se recogía en el Fuero Nuevo de Vizcaya de 1526: "Que havian de Fuero, uso, y costumbre, y establecian por Ley, que por quanto de siempre acá tuvieron los Vizcaynos, costumbre antigua, franqueza, y libertad (por ser Vizcaya tierra montañosa, do no se siembra, ni coge pan, ni tienen las otras vituallas en la tierra) de que se puedan sustentar, y se mantienen, y sustentan de pan, y é carne, y pescado, y de las otras vituallas que les vienen de Francia, y Portugal, é Inglaterra, y de otros Reynos..."1776.

\section{- La aduana de Valmaseda}

Relacionada la villa desde su nacimiento directamente con el tráfico comercial con Castro-Urdiales, su suerte siguió paralela a la de dicho puerto, hasta que a comienzos del siglo XIV una circunstancia ajena a las iniciativas de la villa, como fue la fundación de Bilbao, provocó que Valmaseda recibiera el beneficio del tráfico con el nuevo puerto, desde sus orígenes mucho más dinámico e importante que el de Castro-Urdiales, utilizando para ello una prolongación del antiguo camino de Burgos a Castro-Urdiales, y que desde la villa seguirá desde ahora por Zalla y Sodupe hasta Bilbao.

Valmaseda se consolidó así como plaza comercial e importante puerto aduanero entre el reino de Castilla y Vizcaya con el puerto de Bilbao. Parece que fue Juan II quien estableció en Valmaseda una aduana subalterna de la de Orduña sobre uno de los caminos importantes de entrada a Vizcaya. Además, favorecía el asentamiento aduanero la existencia de un puente de piedra muy seguro que en la villa cruzaba el Cadagua. En todo caso, no queda duda de que la aduana estaba establecida en el reinado de dicho rey y registraba mercaderías de su tráfico con Inglaterra y Flandes. A esta aduana y a las de Orduña y Vitoria se alude en una cédula real de 1412 "por cuanto en los puertos de las villas de Orduña e Valmaseda e de otros puertos, algunos mercaderes e otras personas, asi vecinos de las dichas villas como de otras partes, traen paños e mercadorias e descarganlos en las dichas villas de noche e de dia"1777.

A 1465 corresponde un testimonio algo exagerado sobre el cobro del diezmo con motivo del viaje realizado por León de Rosmithal, sobre el que Shaschek, uno de los acompañantes, nos dejó testimonio detallado: "cuando llegamos al puente, como no habíamos pagado esta especie de tributo en ninguna parte, nos negamos a hacerlo, y los caballos que llevaban nuestros bagajes fueron

1775 TRUCHUELO GARCíA, S.: 2005: 15 .

1776 "El Fuero, privilegios, franquezas y libertades del M. N. y M. L. Señorío de Vizcaya". Publicaciones de la Diputación de Vizcaya. Bilbao, 1977. Ley I. Titulo XXXIII.

1777 A. G. S./ Escribanía mayor de Rentas. Libros de Rentas años 1412 y $1447 /$ Tordesillas, 15 diciembre 1412 y Valladolid, 15 abril 1447; GONZÁLEZ, T.: 1829: 1-28: t. I. doc. 1. 
tomados por los publicanos y demás gente que había en la torre, que nos quiso matar; para repeler el ataque apuntamos contra ellos nuestras escopetas; pero el Señor prohibió que se dispararan y que se tiraran flechas; porque si heríamos a alguno de aquellos, nos matarían a todos... Satisfecho este tributo, nos volvieron los caballos y recibimos las cartas preinsertas para que, si nos acontecía otra cosa semejante, estuviéramos con su protección más seguros". Tetzel, otro de los acompañantes, en un relato con un alto componente de fantasía, nos relata el mismo hecho: Valmaseda, tiene "un puente cuyo paso nos impedían los cristianos, judíos y moros si no dábamos cierto dinero. Atacámosles, pues, y nos abrimos paso entre ellos. Saliéronnos luego al encuentro en un estrecho sendero abierto en la montaña y nos hicieron mucho daño con sus ballestas y dardos, disparando también contra ellos los nuestros que llevaban ballestas. Al cabo nos apuraron tanto y se reunieron en tan crecido número, que mi Señor hubo de pagarles el portazgo, como ellos decían"1778.

En noviembre de 1483 Pedro de Revilla, arriero vecino de Revilla de Pienza, dijo en el Consejo Real que Pedro Jiménez le encargó en Bilbao que llevase cuatro cargas de lienzos a Burgos, dándole una carta sobre la manera que debía diezmarlos en Valmaseda. Pedro de Ahedo, recaudador de esta villa, le requirió el pago del derecho por las cuatro cargas y la carta y albalá que Jiménez le había dado expidiendo albalá de lo diezmado. En Medina de Pomar su diezmero le demandó el albalá, tomándole 200 varas de lienzo por no estar diezmado, y en Burgos entregó el resto de los lienzos. En Bilbao, Jiménez le embargó e hizo prender por no haber diezmado como debía y le tuvieron preso hasta que dio fianza y pagó lo juzgado ${ }^{1779}$.

La Reina dice en noviembre de 1514 al corregidor de Vizcaya y a los alcaldes de la ciudad de Vitoria que Martín Ruiz de Ercilla, procurador de las Villas y Ciudad de Vizcaya, dijo que del Condado acostumbran ir cada año naos y carabelas a pescar a las partes de Irlanda, y que de poco acá algunas personas, sin tener privilegio ni título alguno, les llevan cierto derecho diciendo que es de diezmo en Vitoria, Orduña y Valmaseda, no habiéndolo nunca llevado y estando los vecinos del Condado francos y exentos. El Consejo acordó mandar al corregidor que se informe por testigos, sobre qué derecho se lleva nuevamente a los vecinos del Condado sobre el dicho pescado, desde cuándo y en qué lugares, y si se lleva en otras partes donde no se ha acostumbrado y qué título tienen para ello, y dicha información se envíe ante el Consejo. Y entre tanto, si se hallare que estos derechos, es nuevo impuesto o si se llevan en lugares donde no se han acostumbrado llevar, se suspendan y se mande que no se lleven más ${ }^{1780}$.

El obispo de Burgos y su cabildo tenían participación en las rentas que provenían de esta aduana. Hay un testimonio de 1544 que acredita este derecho a los diezmos de Valmaseda ${ }^{1781}$. En septiembre de 1566 Juan de Liermo, canónigo de Burgos, en nombre del obispo y cabildo de la ciudad requiere a Juan de los Llanos, diezmero de la aduana de Valmaseda,

1778 ROSMITHAL DE BLATNA, Leon de: "Dos relaciones del viaje: de Shaschek y de Gabriel Tetzel"/ 1465-1467; GARCÍA MERCADAL, J.: 1952: t. I, 263-266 y 295-297; HERBERS, K. y PLÖTZ, R.: 1999: 108-112.

1779 A. G. S./ Registro General del Sello, XI-1483, fol. 265/ Vitoria, 15 noviembre 1483; ENRÍQUEZ FERNÁNDEZ, J., HIDALGO de CISNEROS AMESTOY, C. y MARTÍNEZ LAHIDALGA, A.: "Archivo General de Simancas. Registro General del Sello. Vizcaya (1483)" 2002: doc. 278; GARCÍA de CORTÁZAR, J. A.: 1966: 371, doc. 13.

1780 Archivo de la Casa de Juntas de Guernica Registro I‥ de Provisiones reales, num. 17; LABAYRU y GOICOECHEA, E. J.: 1900: 652-653: t. IV. Valladolid, 23 noviembre 1514

1781 A. Cat. B./ V. 4, P. 2, fols. 59-60/Valmaseda, 23 junio 1544. 
para que, en virtud de una carta y sobrecarta real, entregue a sus partes los rediezmos que de dicha aduana corresponden al cabildo ${ }^{1782}$. En 1579 se realiza una visita a esta aduana de Gómez Ojea de Ribera, juez de sacas, siendo aduanero Francisco de Velasco y Diego de Salcedo su escribano ${ }^{1783}$.

\section{- La aduana de Orduña}

La consolidación mercantil de Orduña, se basará en dos privilegios otorgados por Alfonso X. Por el primero, se le concede en 1257 una especie de monopolio sobre el tráfico mercantil en un área territorial que se extiende desde las villas de la ribera del Ebro o afluentes -Nájera, Santo Domingo, Miranda y Puentelarrá- hasta las Encartaciones y la costa (Valmaseda y Castro-Urdiales), que obligaba a los comerciantes a pasar por la villa cuando realizaran desplazamientos por sus inmediaciones, con lo que los mercaderes que fueren de Vitoria a Castro-Urdiales, deberían pasar por Orduña. Por el segundo, de 1260 y de más reducido alcance, se amplía su jurisdicción sobre las heredades de sus vecinas que estuviesen fuera de su término municipal. En 1288 se concede a la villa la facultad de celebrar una feria anual, lo que supondrá un fuerte estímulo para su consolidación como centro comercial.

El desarrollo de la villa en la Edad Media se basó sobre todo en su situación sobre una importante vía de comunicación, cumpliendo un papel de enlace comercial entre el interior castellano y la costa cantábrica, basado en el intercambio de hierro por cereal entre Vizcaya y Castilla, y de lana por productos manufacturados entre Castilla y la Europa atlántica. Incluso en la crisis general del siglo XIV que afectó directamente al comercio, Orduña se vio beneficiada por la exención de tributos que Tello Alfonso de Castilla, señor de Vizcaya, le concede en 1366, que incluía la alcabala, la moneda forera, el yantar, los diezmos de mercaderías fonsaderas y otros. El siglo XV supondrá el relanzamiento definitivo de la villa, ya que a partir de ahora el comercio entre Castilla y los países atlánticos europeos experimentará un fuerte desarrollo, gracias entre otros factores a una especialización productiva de las diferentes áreas económicas ${ }^{1784}$.

El objeto de la Aduana de Orduña era el cobro de las exacciones que gravaban las mercaderías que circulaban entre Castilla y el puerto de Bilbao. La Hacienda Real nunca tuvo un edificio para acoger las funciones propias de la aduana, ni nunca se pensó en otra cosa que en tomar una casa alquilada por poco dinero, situada "en esta calle o la otra, yllamarla aduana, porque en ella se hacia parar a los trajinantes. Así corrio por largos tiempos, y hasta el año 1786"1785.

Aunque Orduña contaba, como se ha dicho, con el privilegio de 1257, que obligaba a los mercaderes y mulateros a pasar por la villa cuando iban por sus inmediaciones y pagarle los correspondientes derechos, hacerlo respetar no les resultó fácil. En especial, por el enfrentamiento secular que el señor de Ayala mantenía con Orduña, que no reconocía ni aceptaba que los vecinos de las tierras de Orozco, Llodio, Ayala, Oquendo y Urcabustaiz,

1782 A. Cat. B./ Lib. 74, fols. 154-155/Valmaseda, 29 septiembre 1566.

1783 A. G. S./ Consejo Real de Castilla, leg. 115-6/ 1579-1580.

1784 ARÍZAGA BOLUMBURU, B. y MARTÍNEZ MARTÍNEZ, S.: 2006: 213-217.

1785 ARMONA Y MURGA, J. A.: 2002: 140. 
todas pertenecientes a su señorío, debiesen pasar por Orduña en sus desplazamientos por sus cercanías ${ }^{1786}$.

En 1476 el Rey nombra escribano de los diezmos y aduanas del puerto de Orduña a Juan de Zárate "mi criado e escriuano de camara por los buenos seruiçios que me avedes fecho e fasedes de cada dia", al haber sido condenado a muerte el anterior escribano Rodrigo de Pinedo. Cobrará 1.500 mrs. anuales situados en Orduña, cantidad que ya cobraba Rodrigo ${ }^{1787}$. Como Zárate no ocupó la plaza, el año siguiente los Reyes, "por faser bien e merçed a vos Iohan Machuca criado de Rrodrigo de Vlloa, nuestro Contador mayor e del nuestro Consejo por los muchos e buenos e leales seruiçios que vos nos avedes fecho e fasedes de cada dya", conceden a Machuca el dicho oficio para toda su vida, pagándole $10 \mathrm{mrs}$. al millar de lo recaudado ${ }^{1788}$.

El arancel de 1488, que regía para las mercaderías que pasaban por los puertos secos de Valmaseda y de Orduña para Castilla procedentes de los puertos de mar, según lo registrado en la Contaduría mayor que recogía de manera pormenorizada todo tipo de mercaderías, principalmente paños y telas, será incluido en el apartado de mercancías importadas de Europa de este trabajo1789.

En Junta de Álava de mayo de 1535 se acordó que los alcaldes de hermandad prendan y castiguen a quienes en la aduana de Orduña, con excusa de diezmería, cometan desafueros en la recaudación del diezmo ${ }^{1790}$.

En 1560 Diego de Montreal, procurador de Pedro Fernández de Velasco, requiere a Simón Ruiz mercader de Medina del Campo, para que se declare deudor de $33.521 \mathrm{mrs}$. por once obligaciones de los diezmos de las mercaderías que pasaron por la aduana de Orduña, pertenecientes al Condestable ${ }^{1791}$.

Conocemos la relación de marzo de 1563 de las cantidades que se debían pagar por las mercaderías que de fuera del Reino entraban en Castilla por las Cuatro Villas de la Costa o por los puertos secos de Valmaseda y Orduña, que detalla todo tipo de géneros, cuyo resumen se incluye en el apartado de productos importados de Europa ${ }^{1792}$.

En las Juntas de Vizcaya de septiembre de 1581 se trató sobre que las beatillas, paños de Durango, guarniciones de espadas y otras cosas semejantes que se fabrican en el Señorío no deben diezmo, pero los diezmeros de Orduña, obligan a las personas que lo llevan a Castilla, a que lo manifiesten y lleven albalaes de guía. Asimismo abrían las cajas de sedas, perlas y otras cosas que llevan al Señorío, aunque se dijese que lo traen para el gasto y servicio de él. Mandaron que Orduña, su alcalde y regimiento, reparen lo dicho y si se supiere que a los vecinos y mercaderes del Señorío y a los que llevan estas mercaderías se

1786 ARÍZAGA BOLUMBURU, B. y MARTÍNEZ MARTÍNEZ, S.: 2006: 213-217.

1787 A. G. S./ Registro General del Sello, I-1476, fol. 2/ Ocaña, 20 enero 1476.

1788 A. G. S./ Registro General del Sello, II-1477, fol. 27/ Toledo, 20 febrero 1477.

1789 LABAYRU y GOICOECHEA, E. J. de: 1899: 424-437: t. III, que recoge un documento del A. G. S.

1790 A. J. G. A./ t. III/ Vitoria, 8 mayo 1535.

1791 A. H. N./ Nobleza. Frías, Leg. 1469, D. 14/ 1 febrero 1560.

1792 A. G. S./ Secretaría del Consejo de Hacienda. leg. 49/ Burgos, 26 marzo 1563. 
les hace pagar derechos en la aduana, contradigan a sus oficiales; y si se resistieren, den noticia al corregidor ${ }^{1793}$.

Como consecuencia del celo que manifestaban los diezmeros de Orduña, se llegaron a producir confictos entre estos y las autoridades y vecinos de la propia ciudad y del propio Señorío. De esta manera, en las Juntas de Vizcaya de agosto de 1582 el procurador general de Orduña hizo saber que los arrendatarios de los diezmos de la mar, habían comprado alrededor de Orduña y ensilado más de 2.000 fanegas de trigo al año, recibiendo con ello el Señorío notorio perjuicio y encarecimiento, y que esto haría más daño en adelante por tener todo el trigo ensilado junto a Vitoria, Salvatierra y otras partes cercanas de donde el Señorío se sustentaba. Se pedía que se mandase que conforme a la real Provisión, se hiciese vender el dicho trigo y en adelante, se pidiese la licencia a los arrendatarios. Además, estos estaban obligados a tener por juez al corregidor de Vizcaya, lo cual no lo querían cumplir, y ellos, sin autoridad de ninguna justicia, hacían sus condenas y tomaban muchas mercaderías por descaminadas, y los pasajeros por no poder alcanzar justicia, dejaban venderlas. También se hacía saber que en esta aduana descaminaban las mercaderías que iban de Castilla al Señorío, como eran sedas, calzas de aguja de seda y otras cosas semejantes, diciendo que los llevaban fuera del Reino, y que esto quebrantaba las exenciones y libertades del Señorío. Los procuradores y oficiales mandaron que se lleve a la corte lo contenido en la petición, para pedir su remedio ${ }^{1794}$.

En las Juntas de Vizcaya de enero de 1585 Lucas de Romarate, en nombre de Orduña, presentó una queja sobre los desafueros que hacen los diezmeros, jueces y oficiales de los diezmos de la mar a los vecinos de la ciudad y su jurisdicción y a los caminantes que van a Bilbao y otras partes y lugares del Señorío con azafrán y otras mercaderías. Las Juntas respondieron que las informaciones que tuviere sobre lo que pide las entregue a los síndicos procuradores generales del Señorío, para que sus procuradores en Madrid pidan el remedio que convenga1795.

En las Juntas de Vizcaya de abril de 1593 se trató sobre que en Orduña no dejan pasar al Señorío sedas y otras cosas que a él vienen de Castilla para consumir y gastar en él, lo cual es contrafuero expreso y daño al Señorío. Se mandó que el licenciado Arcentales y los doctores Bertendona y Sarabia vean lo que convenga y se ejecute. Por otra parte, Hernando Ortiz de Allende dijo que en Orduña piden imposiciones a los que de Castilla llevan al Señorío mercaderías para distribuirlas y gastarlas en él, suplicando que se mande remediar. El regimiento mandó que se haga lo que estaba proveído anteriormente y que Arcentales vaya a Vitoria a tratar con el administrador sobre los derechos de los diezmos de la mar, y le informe sobre los que el Señorío tiene. Este día Juan de Espalza, maestre polvorista, vecino de Bilbao, dijo que en Orduña los administradores y guardas de la aduana hacen extorsión a los que llevan de Castilla al Señorío salitre para hacer pólvora para su servicio

1793 A. J. R. B./ Actas de Villas y Ciudad. t. II/ Bilbao, 8 septiembre 1581; Actas de la Tierra Llana. t. III/ Bilbao, 8 diciembre 1581.

1794 A. J. R. B./ Actas de la Tierra Llana. t. III/ Durango, 25 agosto 1582.

1795 A. J. R. B./ Actas de la Tierra Llana. t. IV/ Bilbao, 30 enero 1585. 
y distribuirlo en él, lo que provocaba gran daño. Se mandó que esto también se trate en Vitoria por Arcentales ${ }^{1796}$.

\section{- La aduana de Vitoria}

La aduana de Vitoria se sitúa en lugar estratégico, en pleno camino real entre Madrid y la Meseta castellana y Francia por Irún; camino muy transitado, que al entrar en la Península discurre por las provincias exentas de Cuipúzcoa y Álava. También, registra las mercaderías desembarcadas en la costa vasca incluso Bilbao, cuando estas no van por Orduña o Valmaseda.

Las Cortes de Castilla que convoca Alfonso XI en 1345 detallan "los lugares de los puertos de la mar e de la tierra do han de dezmar, et otrosi do han de estar las guardas... [y citan el puerto de] Vitoria, sus guardas en Miranda de Ebro e Treviño e Sancta Cruz..."1797.

En Junta de Álava de abril de 1522 se acordó que, como en la provincia no había otra aduana que la de Vitoria, se mandase notificar en toda ella y hermandades que ningún vecino ni morador tome cargo de aduanero que no sea en la aduana de Vitoria, porque a causa de ello se ejercen vejaciones y fatigas a los pueblos y vecinos de la provincia, y el que haga lo contrario pague de pena $10.000 \mathrm{mrs} .{ }^{1798}$. En la Junta General de Álava de mayo de 1536 se presentó un memorial para que los solicitadores de la corte pidan una comisión para que el diputado trate sobre los agravios y vejaciones que hacían a los trajinantes, los diezmeros y guardas de los puertos secos de la provincia ${ }^{1799}$.

En Junta de Álava de noviembre de 1573 Cristóbal de Alegría dijo que, por orden de la provincia, fue al Consejo Real a tratar sobre los nuevos derechos que el Rey había mandado que se pagasen por todos los bastimentos que entrasen en Castilla y, tras haberse suplicado la exención, el Consejo de Hacienda proveyó que todos pagasen los derechos a pesar de los privilegios, usos y costumbres que tuvieren. Por suponer esto tanto perjuicio a la provincia, se trató en el Consejo de Contaduría mayor, amparando a la provincia en la posesión que había tenido de no pagar ningún derecho ${ }^{1800}$.

\section{El cobro del diezmo a partir de 1559}

Tras el rescate de los diezmos de la mar realizado por el rey Felipe II, que hasta 1559 habían estado en poder de la familia de los Velasco, se producen cambios significativos en la percepción de tales derechos. Así, una Provisión de la Contaduría mayor manda en 1564 que, en adelante, las mercaderías que vayan de Castilla a las provincias vascas para su consumo propio paguen también el correspondiente diezmo en las aduanas de los puertos secos, lo que provocará protestas por parte de sus Juntas que no darán ningún resultado. También se manda que se paguen los diezmos cuando las mercaderías entran en la adua-

\footnotetext{
1796 A. J. R. B./ Actas de la Tierra Llana. t. V/ Bilbao, 1 abril 1593; Actas de Villas y Ciudad. Tomo III/ Bilbao, 1 abril 1593.

1797 Cortes de Castilla de 1345.

1798 A. J. G. A./ t. II/ Vitoria, 11 abril 1522.

1799 A. J. G. A./ t. III/Vitoria, 5 mayo 1536.

1800 A. J. G. A./ t. VI/ Vitoria, 20 noviembre 1573.
} 
na y no cuando salen como hasta ahora, por lo que los vecinos de esas localidades obtendrían el producto más caro.

En las Juntas de Álava de febrero de 1564 Cristóbal de Alegría vino de la corte y dio cuenta de que Juan de Peñalosa, administrador de los diezmos de la mar, quería hacer nuevamente que se paguen derechos por las mercaderías y mantenimientos que venían por mar, lo que consideran tan perjudicial y nuevo para Álava, que convenía que el Rey y sus contadores supiesen que Álava tenía el derecho, uso y costumbre de que todas las cosas que llegan y salen de su provincia eran libres de impuestos y que, para verificar este derecho que tienen de tiempo inmemorial, debía venir juez de comisión que lo verifique, por lo que se debían traer testigos de fuera de la provincia para hacer las diligencias. Nombraron a Juan de Arana, procurador de la ciudad, para que haga articulado y preguntas y busque testigos en la parte de Miranda, La Puebla y Treviño. Para buscar testigos en la parte de Logroño y Navarra le encargan a Miguel Martínez de Oquérruri y para la parte de Orduña y Vizcaya a Esteban de Uribe, procurador de Ayala y comisario ${ }^{1801}$.

En mayo, Juan de Peñalosa informó al Rey que los diezmos no se cobraban cuando las mercaderías llegaban a las aduanas, sino solo cuando salían y que diezmándose a la entrada, la Hacienda real tendría mucho beneficio, aunque también entendía que los vecinos de donde están las aduanas se agraviarían por encarecer los productos. Los contadores acordaron que las mercaderías pagasen los derechos a la entrada de las aduanas y no a la salida, porque el pago a la entrada se hace en todos los lugares que las hay, y en estas aduanas entran todas las mercaderías cuando llegan y, una vez metidas, pagan los derechos cuando se sacan de la casa de aduana, y las que no se meten y manifiestan en la dicha aduana las tienen perdidas por descaminadas. También indica que la costumbre de diezmar las mercaderías a las salidas y no a las entradas estaría adquirida en tiempo de los Condestables. Por todo ello, se ejecutó así en Santander, Laredo, Castro-Urdiales y Valmaseda, los cuales se han agraviado suplicando a los contadores que mandasen guardar la costumbre que tenían. Cobrarse los derechos del diezmo a la entrada de las aduanas y no a la salida, como hasta ahora se ha hecho, resulta beneficioso para la Hacienda real, porque todas las mercaderías que se consumen en dichos lugares, si se diezman a las salidas no pagan los derechos, y también quedan libres las que en los dichos pueblos se venden por menudo y las compran los de toda su comarca. Con ello subiría el beneficio de la real Hacienda en más de 12 o 15.000 ds. al año. Estos lugares dicen que las mercaderías que en estos lugares se vendieren para su Provisión debían ir libres de derechos, aunque dan a entender lo contrario unas condiciones de hacía 114 años, con que se arrendaron estos diezmos, en que se manda que antes de que se descarguen las mercaderías de los navíos o bestias en que vinieren, se deben registrar y adeudar so pena de perderlas, así como los navíos y bestias en que vinieren ${ }^{1802}$.

En las Juntas de Vizcaya de enero de 1565 se acordó que, como los diezmeros del Rey en las aduanas de Vizcaya y otras partes llevan demasiados derechos de las mercaderías

1801 A. J. G. A./ t. V/ Vitoria, 8 febrero 1564.

1802 A. G. S./ Secretaría del Consejo de Hacienda. Cartas 1564/ 23 mayo 1564; GONZÁLEZ, T.: 1829: 237-254: t. II. doc. CXLV. 
y cosas que se llevan de Castilla a Vizcaya, se pida al Consejo que mande que no se lleven tantos derechos contra la costumbre que se ha tenido, y mucho menos a las vizcaínas ${ }^{1803}$. En las Juntas de marzo se trató sobre la Provisión que la Contaduría real había dado para que en Orduña se cobren en su nombre ciertos derechos de diezmos a la entrada de la aduana y no a su salida, al igual que en Valmaseda y otras aduanas. Y como convenía al Señorío que no se aplique esta Provisión, por ser "nueva ynpusiçion jamas bista ni acostumbrada", mandaron que se recurra ${ }^{1804}$.

En las Juntas de Vizcaya de noviembre de 1566 dijeron que de hacía pocos días en las aduanas de Orduña y Valmaseda los diezmeros del Rey o sus factores "questan para coger los diezmos de las mercaderias que pasan para Castilla, piden derechos por las que bienen de Castilla para este Señorio, no lo podiendo hazer por ser nueba inpusicion nunca vista, usada y acostunbrada", y los detienen y retienen sus mercaderías, obligándolos a pagar diezmos por ellas. Se mandó a los estantes en la corte, que ante el Consejo hagan todas las diligencias necesarias a fin de que cese el impuesto mencionado ${ }^{1805}$. En las Juntas de abril de 1567 los síndicos dijeron que en el regimiento último se acordó poner remedio sobre los diezmos y derechos no debidos que en Orduña y Valmaseda hacen pagar sobre las mercaderías que vienen de Castilla para el Señorío por ser nueva imposición ${ }^{1806}$. En las Juntas de mayo los diputados y regidores, a petición de los síndicos, dijeron que habían mandado que la persona que hubiese de ir a la corte tratase sobre los diezmos de las mercaderías que por orden real se llevan en Valmaseda y otras partes ${ }^{1807}$.

\section{Las cosas vedadas}

Varios productos, animales y materias primas tenían restricciones o prohibiciones para ser objeto de comercio con el extranjero, motivado por razones estratégicas, económicas o militares. De esta manera, caballos, mulos, oro, plata o monedas, eran artículos que necesitaban licencia real para su comercio con el extranjero y su exportación estaba altamente restringida o prohibida.

En las Partidas se indica "...que todos quantos leuaren del reyno cauallos, o otras cosas quales quier, de las que son defendidas de sacar, deuen perder, todo lo que desta guisa sacaren. Fueras ende, aquellos, a quien nos otorgamos poder, por nuestras cartas, que lo puedan sacar"1808.

Alfonso XI concede un privilegio en noviembre de 1339, a instancia de la ciudad de Burgos, para que "algunos mercaderos de la dich a çibdat que van a Flandes e Monpesler ${ }^{1809}$, e a otras partes fuera del nuestro señorio por tierra" una vez al año y llevan un rocín cada uno, puedan venderlos sin incurrir en pena alguna sin exceder de 400 mrs. por rocín, al tener que volver por mar. El Rey manda a las guardas de las sacas de las cosas vedadas que los mercaderes

1803 A. J. R. B./ Actas de la Tierra Llana. t. I/ Durango, 18 enero 1565.

1804 A. J. R. B./ Actas de la Tierra Llana. t. I/ Bilbao, 27 marzo 1565.

1805 A. J. R. B./ Actas de la Tierra Llana. t. I/ Bilbao, 7 noviembre 1566.

1806 A. J. R. B./ Actas de la Tierra Llana. t. I/ Bilbao, 15 abril 1567.

1807 A. J. R. B./ Actas de la Tierra Llana. t. I/ Bilbao, 10 mayo 1567.

1808 LAS SIETE PARTIDAS/ Quinta Partida, Título VII, ley V.

1809 Se refiere a Montpellier. 
de Burgos que llevaren la carta de su concejo les dejen sacar los dichos rocines y "que non demanden ninguna pena, los mercaderos de la dich a çiubdat por los rroçines que desta guisa sacaren fuera del nuestro señorio..., avnque los non tornen al nuestro Regno", y que no se haga engaño de sacar más de una vez al año rocines por otros puertos ${ }^{1810}$.

Juan I concede albalá en 1379 a Vitoria y su tierra y dice a Garci Ruiz de Burgos, alcalde de guarda de las sacas de cosas vedadas en el obispado de Calahorra, que el concejo de Vitoria se quejaba de que Ruiz hacía inscribir todas las acémilas, muletos y muletas de Vitoria y de toda su tierra, para que le den cuenta de ellos cuando lo mandare y que esto, que nunca fue demandado en tiempos de Alfonso XI y que Enrique II lo mandó, les perjudicaba. El Rey mandó que los vecinos de Vitoria y de su tierra no tenían que inscribir ante los guardas de sacas sus bestias mulares, acémilas y mulos de albarda, mayores ni menores, ni dar cuenta de ellos para desplazarse por los reinos de Castilla, Aragón y Navarra, salvo que Ruiz ponga guardas donde se acostumbra; y si algunos sacaren alguna de las cosas vedadas contenidas en el ordenamiento, que vaya contra ellos y contra sus bienes. Enrique III confirma en febrero de 1392 el dicho albalá y la merced en él contenida ${ }^{1811}$. En mayo de 1382 Ferrand Sánchez de Mijancas, alcalde mayor de las sacas de cosas vedadas en el obispado de Calahorra, traslada a todas las guardas y alcaldes de las dichas sacas de frontera de Aragón y de Navarra del dicho obispado el albalá de 1279 que el concejo de Vitoria le mostró, por lo que el alcalde mayor manda que no se les haga embargo alguno1812.

Enrique III emitió en Tordesillas en 1404 ciertas leyes sobre las sacas y cosas vedadas. Manda entre otras cosas que nadie pueda sacar "fuera de los mis reynos e señorios cavallo, ni yegua, ni roçin, ni puerco, ni potrico, ni mulo, ni mula, ni muleto, ni muleta, grandes ni pequeños, asi de freno como de aluarda e çirreles" y si lo saca, "pierda lo que ha e le maten por justiçia", salvo si las dichas bestias estuvieren inscritas en el libro de las sacas, según se manda en el ordenamiento. Algunos caballeros, escuderos y alcaides de castillos y otras personas se atreven a sacar algunas bestias ajenas por sí y por otros, ayudando a poner a salvo las dichas bestias y a los que las llevan, "e porquesto es muy gran atrebimiento e muy gran deserviçio mio, e daño de la mi tierra, tengo por bien que los que esto fisieren que pierdan lo que han e les maten por justiçia". Como algunas veces estos sacadores, cuando saben que los alcaldes y guardas de las sacas van tras ellos, se esconden en algunas poblaciones o en castillos, casas o palacios intentando escapar, manda que los alcaldes, merinos y otros oficiales, cuando fueren requeridos por el alcalde de las sacas o sus oficiales, dijeren donde están los malhechores, los prendan y los entreguen al alcalde de las sacas con todo cuanto les hallaren. Manda que cuando se trajeren de fuera bestias caballares y mulas de freno, albarda y cerriles, cuando entraren en el Reino en el lugar donde hubiere alcalde o guarda, que se presenten ante él y las inscriban con sus colores y señales, y así puedan andar con ellas con el testimonio de cómo fueron inscritas, y las guardas les dejen sacar hasta tres meses, y el que las inscribiere tome de cada bestia un mr. y si no las inscribieron o no las sacaren del Reino en los dichos tres meses que las pierdan.

1810 A. M. B./ HI-96/ Madrid, 28 noviembre 1339

1811 A. M. Vitoria/ Arm. 8. Leg. 10. 끄. 27/ Burgos, 20 febrero 1392; ESPERANZA IÑURRIETA, A.: 1983: doc. 8.

1812 A. M. Vitoria/ Arm. 8. Leg. 10. n.ํ2//Vitoria, 27 mayo 1382. 
Se manda en 1404 que los romeros puedan sacar fuera "palafrenes que fueron manifiestos que no nacieron en esta tierra", y que a la entrada y a la salida no se les tome cosa alguna. Nadie podrá sacar oro, plata, moneda ni vellón alguno, y el que lo haga lo pierda todo y a los que van a Francia o a alguna otra corte en mercadería, mandadura o en otra manera, que les dejen sacar en oro o en plata todo lo que el alcalde estime que cumple para su despensa e ida, estada y vuelta del camino previsto, tomándole juramento sobre lo que hubiere de hacer. Nadie podrá sacar ganado vacuno, ovejuno, porcuno, cabruno ni otra carne viva ni muerta, ni pan ni legumbre. Como personas de fuera, vienen a comprar bestias caballares y las llevan de noche y algunos colaboran con ello, se manda que sin licencia real nadie les venda, dé ni cambie bestias caballares ni mulares, mayores o menores y, si lo hicieren, que pierdan todo lo que recibieren, y que los alcaldes de las sacas o sus lugartenientes, los apresen hasta que paguen la pena. Nadie de los de otros reinos que vinieren a esta tierra, podrá comprar ni cambiar bestias caballares, grandes ni pequeñas, sin licencia real. Como estas cosas se pueden hacer encubiertamente, se manda a los alcaldes de las sacas que hagan pesquisa sobre ello, y que el alcalde pueda tomar cualquier bestia caballar que hallare en poder de extranjeros o romeros, y prueben cómo las obtuvieron ${ }^{1813}$.

Los Reyes Católicos dicen en septiembre de 1494 a sus alcaldes de las sacas y cosas vedadas, portazgueros y a todos los mercaderes, bordadores, sastres, jubeteros, guarnicioneros, silleros, doradores, plateros, etc., que de hacía poco tiempo "todos estados e profesyones de personas nuestros subditos e naturales, se han desmedido e deshordenado en sus ropas y trajes e guarniçiones jaeses, no midiendo sus gastos cada vno con su estado ni con su manera de beuir", resultando que muchos por cumplir "sus apetitos e presunçiones, malbaratan sus rentas y otros venden y gastan o enpeñan sus bienes o patrimonios o rentas" para comprar brocados y paños de oro tirado y bordados de hilo de oro y de plata para vestirse, y aún para guarnecer sus caballos y mulas y "para dorar e platear espadas y espuelas e puñales y otros jaeses", lo cual no harían si no los hallasen en abundancia, y además en el dorado y plateado sobre hierro, cobre y latón, se pierde mucho oro y plata. Para que nadie gaste sus haciendas y rentas en lo dicho ni que se saque el oro y plata de sus reinos, los Reyes mandan que en 1494 y en los dos años siguientes nadie pueda introducir de otros reinos paños ni piezas de brocado raso, ni paños de oro tirado, ni ropas hechas de ello para vender, ni bordados de hilo de oro o plata, y que nadie pueda cortar, coser ni hacer nada de lo dicho de paño nuevo, y que los que lo trajeren, compraren, urdieren o trocaren, incurran en graves penas. Por acatamiento a la Iglesia, permiten que para ornamentos se puedan meter brocados y otros paños de hilo de oro, plata y bordados y que se pueda coser y bordar sin pena alguna. Mandan también que ningún platero ni dorador, ose dorar ni platear sobre hierro, cobre, latón, espada, puñal, espuelas ni jaez alguno de caballo ni de mula, ni guarnición alguna ni lo traigan de fuera de estos reinos salvo si lo trajeren "de allende la mar de tierra de moros de lo que alla se labrare". No obstante, permiten que las cabezas de las tachuelas para clavar las corazas puedan ser doradas o plateadas ${ }^{1814}$.

Gaspar Pallario, mercader genovés criado de Pantaleón, había comparecido ante los jueces en relación con las tomas que se habían hecho de las sacas de cosas vedadas, que

1813 A. H. P. Álava/ Leg. CLXXI/ Tordesillas, 10 marzo 1404.

1814 A. M. B./ HI-3230/ Segovia, 2 septiembre y Madrid, 18 septiembre 1494. 
realiza Beltrán de Marzana, alcaide de la fortaleza de Puentelarrá y lugarteniente de Conzalo de Espinosa que tiene el cargo por concesión real. Gaspar dice que él iba con su caballo a Ondárroa y Bilbao y, al volver con el mismo caballo a la corte, el dicho alcaide le tomó en Puentelarrá el caballo castaño oscuro, ensillado y enfrenado, por lo que pide su devolución, más los daños y costas ocasionados, ya que se le había tomado sin tener poder ni facultad para ello, ni iba descaminado. Quedando probado que el mercader no iba con intención de vender ni regalar el caballo, ni a sacarle fuera del Reino y que el alcaide no tenía poder ni facultad para tomarlo, fue acordado en 1498 que debía devolver el caballo "tan bueno como estava al tienpo que por vos le fue tomado" con la silla y aparejos que tenía o pagar su precio estimado en $6.000 \mathrm{mrs}$, más las costas y daños provocados tasados en $3.067 \mathrm{mrs} .{ }^{1815}$.

\section{El contrabando}

Alrededor de todas las aduanas y en relación con ellas hizo aparición el fenómeno del contrabando, que permitía a un buen número de personas ganarse la vida llevando mercaderías a Castilla sin pasar por las aduanas, por caminos perdidos no controlados o menos vigilados. La amplia libertad comercial vigente en las provincias vascas y su peculiar organización aduanera facilitaban los intercambios ilegales y el contrabando de todo tipo de artículos, en particular los más lucrativos, como la moneda y las cosas vedadas. En estos fraudes participaba un amplio conjunto de personas, tanto naturales como extranjeras. Está comprobada la intervención de comerciantes extranjeros en el contrabando cantábrico, no solo de reinos amigos de la Monarquía sino también de rebeldes o enemigos, mediante la utilización de intermediarios legales y, asimismo, los propios comerciantes vascos participaban en este lucrativo comercio en las zonas próximas a los puertos secos, zonas costeras y en especial en las villas de Bilbao y San Sebastián ${ }^{1816}$. En este caso, se desarrolló el contrabando utilizando las facilidades que se ofrecían, porque las mercaderías descargadas en los puertos marítimos, que no pagaban ningún derecho, podían esperar la ocasión propicia para ser introducidas en Castilla sin pagar tributo alguno, utilizando otros caminos menos controlados o libres, o burlando el cordón de vigilancia cuando esta se relajaba.

En el Fuero de Vizcaya de 1526, se indica en la Ley I. Título XXXIII, que “... despues que assi vienen las dichas vituallas por Mar, y se descargan en los Puertos de Vizcaya, algunos Vizcaynos, o de fuera parte, sacan las dichas vituallas para las vender fuera de la tierra; y assi queda la tierra defraudada. Por ende, que ordenaban, é ordenaron, que las tales vituallas de pan, y vino, y de otras qualesquier cosas de comer, y de beber (despues que assi fueren descargadas en los dichos Puertos de Vizcaya, para vender) ningunos sean ossados de las sacar, ni llevar á fuera parte, comprandolo para lo revender, ni en otra forma, sin expressa licencia, y mandado de su Alteza... só pena, que el que los contrario hiciere, pierda la Fusta, y el Navío, en que lo sacare, y llevare, éla tal mercaduria;..."1817.

\footnotetext{
1815 A. G. S./ Registro General del Sello, IX-1498, fol. 200/Valladolid, 26 septiembre 1498.

1816 TRUCHUELO GARCÍA, S.: 2005: 11-34.

1817 “El Fuero, privilegios, franquezas y libertades del M. N. y M. L. Señorío de Vizcaya”. Publicaciones de la Diputación de Vizcaya. Bilbao, 1977.
} 
Una Cédula real de 1447 da normas a fin de que todos paguen los diezmos de la mar y evitar la picaresca para no pagarlos. No obstante, algunos mercaderes burgaleses descargan en otros puertos para pagar menos, por existir menor control que en Orduña y Valmaseda. El Rey dice que "los arrendadores e desmeros que cogen e recabdan los diezmos del reino de Galicia e en Asturias, que de poco tiempo aca que han fecho e facen fabla con los mercaderes de Burgos e de otras partes, e facen avenencia con ellos, que los paños e mercadorias que descargaren en los dichos puertos de la mar de Galicia e de Asturias, que les paguen de ciento uno, e a las veces que lo facen por menos precio, e que los dichos mercadores por no pagar enteramente el diezmo que a mi pertenece, a los arrendadores de los diezmos de la mar de Castilla, por la gran suelta que los dichos arrendadores de Calicia e de Asturias les facen,... e despues, que los traen dende a los dichos mis Reinos"1818.

Esta irregularidad también la denunció en 1564 Juan de Peñalosa administrador de los diezmos de la mar, que decía que "era necesario proveer que las mercaderias que de fuera de estos Reinos han de entrar en ellos, entrasen por sus derechos caminos y puertos, como son donde se cobran y recogen estos dichos diezmos de la mar de Castilla", porque tenía información de que muchos mercaderes las descargaban "en los puertos de Asturias, y las traian y metian en este Reino sin pagar derecho alguno, y que tambien otros muchos mercaderes van a los puertos del Reino de Galicia, a comprar muchas mercadurias de las que vienen de los Reinos de Inglaterra y Portugal, y que tambien estos las traen libres de derechos". Peñalosa menciona una condición puesta cuando Juan II arrendó estos diezmos hacía 114 años que decía que como"muchos mercaderes de este Reino, hacen fabla y concierto con los dezmeros de los puertos del Principado de Asturias y del Reino de Calicia, para traer y descargar en los dichos puertos las mercadurias que han de meter en este Reino, y porque esto es en daño y deservicio suyo, manda [Juan II] que dende en adelante qualquiera persona que trugiere y desembarcare en los dichos puertos algunas mercadurias para las traer a estos Reinos, las traiga y meta en ellos por los puertos de Rabanal, que es la entrada de Galicia, y por el puerto de Santa Maria de Harbas que es a la entrada de Asturias, y no por otra parte alguna, so pena de que hayan perdido las tales mercadurias que por otra parte las metieren, las cuales sean para los sus arrendadores". Peñalosa decía que convenía que los Contadores mayores lo mandasen remediar, poniendo diezmeros en los puertos para que tributen las mercaderías que vengan de fuera por los puertos de Galicia y Asturias ${ }^{1819}$.

\section{d.- La poderosa casa de los Velasco}

Los Velasco, condestables de Castilla, eran desde el siglo XV personajes residuales del mundo feudal. Ejercían su dominio en unos amplios territorios que se extendían básicamente por la mitad norte de la actual provincia de Burgos, entre los que se encontraban las merindades de Castilla Vieja. Jurídicamente, estas no formaban parte de dichos territorios por pertenecer al Rey, pero desde tiempo inmemorial los Velasco ejercían sobre ellas derechos señoriales. Eran las Merindades tierras de realengo con una gran mayoría de sus habitantes compuesta por hidalgos que sentían un inmenso orgullo de su pasado histórico, por lo que periódicamente surgían protestas, como la de 1513-1514. Como "la dicha casa de

1818 A. G. S./ Escribanía mayor de Rentas. Libros de Rentas años 1412 y $1447 /$ Tordesillas, 15 diciembre 1412 y Valladolid, 15 abril 1447; GONZÁLEZ, T.: 1829: 1-28: t. I. doc. 1.

1819 A. G. S./ Secretaría del Consejo de Hacienda. Cartas 1564/ 23 mayo 1564; GONZÁLEZ, T.: 1829: 250-252: t. II. doc. CXLV. 
Velasco e por personas que para ello tienen poder en su nonbre, han lebado syn contradiçion alguna, todas las setenas, y omezillos, e marcos, e quebrantamientos de tierra, e mostrencos, e entregas, e execuçiones, e otros derechos pertenesçientes a las dichas merindades", un magistrado procedió a obtener información exhaustiva sobre el problema, consultando archivos e interrogando a testigos presentados por ambas partes. La conclusión fue que dichos "testigos no saben dar rrazon, nin se pudo averiguar por que titulo o preuillegio los señores de la casa de Velasco han tenido o tienen para llebar las dichas merindades, y poner merinos y llebar los derechos"; es decir, que los Condestables carecían de título jurídico alguno que les otorgase derechos sobre las Merindades y, sin embargo, estaban actuando como si estas formaran parte de su señorío ${ }^{1820}$, percibiendo las alcabalas, pechos y el portazgo que cobraban en Medina de Pomar, y nombrando además la justicia, algo que correspondía a la Corona, quedando las Merindades supeditadas a los gravámenes y dependencia jurisdiccional de dicho Señorío ${ }^{1821}$. El Condestable ejercía un poder omnipresente en las tierras de su dominio, algo que le condenó a mantener continuos pleitos con la ciudad de Burgos, los mulateros, la Universidad de Burgos, los habitantes de las Merindades, etc.

\section{El control de las vías comerciales}

Uno de los ámbitos donde los Condestables pusieron un mayor empeño fue en el control de las vías comerciales, con el fin de garantizarse, además del que ya tenían con los diezmos de la mar, un mayor beneficio del tráfico comercial que llegaba o iba a los puertos cantábricos de Laredo y Bilbao. Actuaron en dos direcciones:

- La adquisición de villas y jurisdicciones situadas junto a caminos transitados por el tráfico mercantil.

- El desvío de dicho tráfico, cuando discurría por lugares no sujetos a su autoridad, para canalizarlo por territorios de su señorío.

Algunas de las más importantes vías comerciales se correspondían con caminos en los que los Velasco poseían el señorío de parte de las villas relevantes de esos caminos. Todo esto se hacía en detrimento del tráfico por el puerto de Santander, por no depender del Condestable la mayor parte de las tierras del camino a dicha villa, incluso impidiendo, como hicieron en 1555, que las naos descargasen en este puerto, porque el Condestable "no quiere dexar guiar las mercaderias por Santander, y los probechos y daños que dello se syguen", porque de "Santander a Çilleruelo ques del condestable, no ay lugar suyo, ni de çilleruelo a Burgos, porque todos los demas son del Rey y de otros señores, y guiando las mercaderias por Laredo e Vilbao, los mas de los lugares que ay de alli a Burgos, son del condestable"1822. Los extensos dominios de los Velasco se encontraban emplazados sobre los ejes comerciales más importantes de la Corona de Castilla, los de Burgos con los puertos cantábricos, principalmente Laredo, Castro-Urdiales y Bilbao. Las relaciones e intercambios comerciales entre dichos puertos y las principales villas del

1820 A. G. S./ Consejo Real de Castilla, leg. 84, fol. 2-II/ Madrid, 14 diciembre 1513 y Laredo, 2 enero 1514; PÉREZ, J.: 1977: 465.

1821 SÁNCHEZ DOMINGO, R.: 1994: 49.

1822 A. M. S./ Leg. A-3, no 62/27 agosto 1555; SOLÓRZANO TELECHEA, J. A.: "Patrimonio documental... ". 283-285: doc. 225 . 
linaje como Briviesca, Medina de Pomar, Villasana de Mena o Frías, fueron continuos y muy rentables ${ }^{1823}$.

En los caminos de Santander, no obstante, poseían las villas de Arreba y Cilleruelo de Bezana junto a la vía del Escudo, y Herrera de Pisuerga en la de Reinosa. En marzo de 1496 los Reyes ordenan al presidente y oidores de la Audiencia y Chancillería, que sentencien en el pleito pendiente entre la villa de Santander, por una parte, y Bernardino Fernández de Velasco y concejo de Herrera de Pisuerga, por otra, "sobre rrason de çiertos mulos e rroçines e sal que a la dicha villa de Santander dis que fue tomada" en dicha villa de Herrera ${ }^{1824}$.

El alcalde de Santander dice en abril de 1535 a los concejos de Amusco, Aguilar, valle de Ordejón, Pie de Concha y valle de Buelna, que los oficiales del Condestable impiden la descarga en Santander de las naos procedentes de Flandes desviándolas a otros puertos, lo que motiva que las mercaderías que de Santander penetran en Castilla, al no tener albalaes, las guardas les cobran portazgos en los lugares del camino, estando libres. Por ello entre Santander y el Condestable hay un pleito para que este, como señor de los diezmos de la mar, permita que las mercaderías que a la villa llegaren sean guiadas por ella, debiéndose obtener información a fin de probar "como antiguamente se solian cargar e descargar en el puerto... de Santander, las sacas de lana de los mercaderes de Burgos que yban para Flandes e Françia e otras partes, e los fardeles de paños, e lienços, e otras mercaderias que se trayan e descargaban de rretorno... lo qual se guiaba ellebaba desta dicha bylla", y no por otras partes. Propuso el alcalde que se preguntase entre otras cuestiones, si se sabe que cuando las mercaderías se descargaban en Santander y las guiaban los diezmeros que en la villa estaban, tanto de los Reyes anteriores como los puestos por el Condestable, las guardas de Pie de Concha, Reinosa y otras partes, las dejaban pasar libremente y si saben que "los suçesores e dezmeros quel dicho señor condestable a tenydo e tiene en los puertos de la mar, despues que an enpedido y enpyden que las mercaderias no se descarguen en [Santander], nin se guyen por ella, que las naos quentran en el dicho puerto las hazen salyr del, por que bayan a las byllas de Laredo, Bilbao e otras partes", causan gran daño a la villa y a las rentas reales. Los testigos dijeron que desde el tiempo de los Reyes Católicos habían visto pasar por Cartes o por el valle de Buelna mulos, rocines y acémilas que procedían de Santander, donde habían pagado el diezmo al dezmero y rentero de los Reyes, que les daba los albalaes correspondientes. Llevaban fardeles de paño, lienzos, mercerías, "arzueros" y otras mercaderías a Castilla, Pie de Concha, Aguilar y Burgos, y los mulateros decían que las naos venían de Flandes, Bilbao y otras partes. Nunca habían oído decir que lo contradecía ninguna persona de los Velasco y nunca vieron pedir los diezmos en Pie de Concha, Reinosa ni en otra parte a los que ya traían los albalaes de Santander, aunque los mercaderes burgaleses y de otras partes descargaban allí paños, mercerías y "arzueros" y llevaban los presentes por el valle de Buelna arriba ${ }^{1825}$.

En agosto de 1549 se realizó un concierto entre el Condestable y el concejo de Santander sobre "el guiar de las mercaderias que se descargan por el puerto de la dicha villa...", y se acuerda que el Condestable permitiese la salida por Santander de las mercaderías que descargasen

1823 FRANCO SILVA, A.: 1989: 255-256.

1824 A. G. S./ Registro General del Sello, III-1496, fol. 74/ Valladolid, 10 marzo 1496.

1825 A. H. P. C./ J. T. A. leg. 37-2/ Los Corrales de Buelna, 14-15 mayo 1535. 
cinco naos, “...que fueren de veçinos y moradores que tuviesen sus casas de viviendas y su asiento y continua morada en esa villa, y no otra ninguna mercaderia que venga en otras naos que sean de la villa o de fuera della". El capitán de cada nao deberá pedir licencia al diezmero del Condestable para descargar las mercaderías que, registradas por él, expedirá el albalá o cédula de guía. Esas mercancías deberían ir después a la casa de cata de Cilleruelo o a la de Herrera de Pisuerga, para que sean registradas y se comprueben sus albalaes. Aquí se les darían cédulas de paso, pagando los derechos correspondientes para que las otras guardas les dejasen pasar libremente, según como se hace en las casas de cata de Haro, Medina y Briviesca para los otros puer$\operatorname{tos}^{1826}$.

En agosto de 1555, como por Santander se guiaban antiguamente los fardeles de lienzos, paños y otras mercaderías que venían de ultramar, y "los condestables que an seydo les querian ympedir la guia dellas por este puerto", Santander propone dar libre la guía, pero bajo el compromiso de la Universidad de Burgos de que guiarían sus mercaderías de retorno por dicho puerto. La villa de Santander indica las razones "que se presumen, porque el condestable no quiere dexar guiar las mercaderias por Santander, y los probechos y daños que dello se syguen", que son entre otras, que de "Santander a Çilleruel ${ }^{1827}$ ques del condestable, no ay lugar suyo ni de Çilleruelo a Burgos, porque todos los demas son del Rey y de otros señores, y guiando las mercaderias por Laredo e Vilbao, los mas de los lugares que ay de alli a Burgos son del condestable y en ellos gastan las biandas, pagan portazgos y derechos, y de todo el benefiçio se goza en su tierra". Para apoyar sus propuestas, la villa plantea un interrogatorio del que no conocemos, en el caso de haberse realizado, las respuestas dadas que hubieran aportado una muy valiosa información. Una de las preguntas fue si saben que de hace pocos años el "condestable e sus dezmeros, an tentado de no dar çedula de guia de çiertas mercaderias que vienen al dicho puerto de Santander, sino que las hazen llebar en pinaças por la mar con grand costa, trabajo e peligro dizmar a Laredo e Viluao, en espeçial se an subtraido de no dar la dich a çedula en los fardeles de paños e lienços e otras cosas semejantes" ${ }^{\prime 2828}$.

En el camino de Laredo los Velasco poseían las villas de Puente-Arenas, Quecedo de Valdivielso, Valdenoceda, Bisjueces, Medina de Pomar, Agüera, Valle de Soba, Ampuero, Limpias, Colindres y Laredo, lo que les permitía controlar prácticamente todo el tráfico que discurría por tan importante camino. Los Velasco, desde que adquirieron el señorío de Medina por concesión de Enrique II en noviembre de 1369, promueven con tesón el cobro del portazgo para todas las mercaderías que por Medina pasasen, incluso obligando a los mulateros a ir por ella y cobrando incluso, a los que tenían exenciones. En junio 1380 se pronuncia sentencia a favor de Laredo, tras el pleito interpuesto por la villa contra Hernando García y Ruy Carcía, portazgueros de Medina de Pomar que actúan en nombre del Condestable, para que no se cobre portazgo a los vecinos de Laredo y les devuelvan las prendas que les han tomado por estar exentos. En agosto de 1383 Juan I dice que, después de que su padre Enrique II concedió la villa de Medina a Pedro Fernández de Velasco, este sigue demandando portazgo a los vecinos de Laredo, por lo que confirma la sentencia y

1826 A. D. F./ Legs. 29 y 162. nums. 1 y 2 / Herrera de Pisuerga, 1 agosto 1549.

1827 Cilleruelo de Bezana, situado sobre el camino que por Villanueva Rampalay se dirige a Burgos.

1828 A. M. S./ Leg. A-3, no 62/27 agosto 1555; SOLÓRZANO TELECHEA, J. A.: "Patrimonio documental... ". 283-285: doc. 225 . 
Provisión anteriores y ordena su cumplimiento. Dicho Rey dirige en marzo de 1386 una Provisión a su camarero mayor, Juan de Velasco, al guarda y mayordomo mayor del camarero, al concejo y a los que recaudan la renta del portazgo en Medina, porque a los de Laredo que pasaban por Medina, les seguían cobrando portazgo a pesar de estar exentos. Manda que no les cobren y que devuelvan doblado lo recaudado con sus costes ${ }^{1829}$.

En 1499 comienza una importante actuación con el fin de reparar el camino de Burgos a Laredo. Al objeto de recaudar los fondos necesarios se propone obtenerlos por vía de repartimiento. El teniente de corregidor de las Cuatro Villas y el alcalde mayor de Castilla Vieja fueron requeridos por los procuradores de los mulateros, para ir con oficiales de carpintería y cantería a visitar los caminos, puentes y calzadas que hay entre Burgos y Laredo, a tasar "lo que podia cada cosa costar, fazer y aderezar e lo que se podria rreparar para la contribuzion dello asi al condestable por lo que toca a los diezmos de la mar, como a los mercaderes de Burgos e a las partes por sus mercaderias, e a los dichos mulateros e biandantes e a los venteros e mesoneros, e a los pueblos que desto consiguian probecho". El repartimiento se hará sobre todas las localidades por donde discurre el camino, así como sobre la Universidad de Mercaderes de Burgos, la cofradía de los mulateros e incluso sobre el abad del monasterio de Rioseco y las ventas y mesones del camino, y aunque dicen que en el término de Medina de Pomar "no ay camino del aderezar por estar rreparados en las puentes della, ni tanpoco ay en ella mulateros ni mesones donde la cojan mulateros", por el provecho que se espera obtener si pasan los carros, se asignan a la villa 5.000 mrs. más otros 5.00o. Pero llama poderosamente la atención que al Condestable "no se le rreparte cosa alguna, porque por doquiera que las mercaderias salgan, le an de pagar sus diezmos e ninguna cosa leba que salgan por vn puerto que por otro", cuando es el principal beneficiado del tráfico por este camino. Esto es consecuencia, sin duda, de que el propio Condestable ha presionado y utilizado en esta operación su poderosa influencia. El argumento de que al Condestable le da igual que las mercaderías vayan a uno u otro puerto es inadmisible, porque tales diezmos dependen del tráfico que se realiza por los caminos que se pretenden reparar, así como los portazgos, que benefician directamente al Condestable ${ }^{1830}$.

En 1515 se desarrolla un pleito entre los mulateros de las merindades de Castilla y el Condestable. Según el procurador de los viandantes, el camino real que utilizan para ir a los puertos de Laredo, Castro-Urdiales, Portugalete y Bilbao, es más corto por Castilla Vieja, Sonsierra y Sotoscueva que por Medina de Pomar, porque iba "por el camino derecho, e eziendolos yr a Medina de Pumar, se les sygue mucho rrodeo de sus mulas e personas e aziendas, en cantidad de mas de tres o quatro leguas a los mas dellos, es cada camino de yda o uenida". Decía que tenían derecho desde hacía más de 20 años "de yr por el dicho camino rreal que ba por Castilla Bieja a Laredo e a Baldeporres, syn yr por la dicha villa de Medina", ni pagar el portazgo que se les exigía en Medina ni en otro lugar. Pero que "algunos vesynos de la villa de Medina de Pumar e portazgueros del condestable de Castilla, desde diez años... poderosamente mano harmada con favor del dicho condestable, han fecho e cometydo contra los mulateros de las dichas merindades... e de otras partes, muchas fuerças e violençias en espeçial entre Quintanahedos e Barzena e Gayangos, Enzinillas e las ventas de Baldemera, que estan en los dichos caminos

1829 A. H. P. C./ Villa de Laredo, leg. 6, num. 14, fols. 62-67v/ Valladolid, 14 junio 1380, Medina del Campo, 6 noviembre 1380, Segovia, 21 agosto 1383 y Burgos, 2 marzo 1386.

1830 A. H. N./ Nobleza. Frías, C. 235, D. 55/ Medina de Pomar, 15 enero 1499. 
rreales, llevandolos por fuerça sus personas e mulos e mercaderias a la dicha villa de Medina Pumar"1831. Por dejarles ir por Castilla Vieja tales portazgueros les han llevado más de 10.000 ds. mediante el cobro de una iguala de 40 o 50 mrs. por mulo y año, pagados con el fin de poder transitar sin trabas, además de 2 mrs. por carga y el albalá. El Condestable alega que "por previllejios antiguos husados e guardados de tienpo ynmemorial... a todos e qualesquier mulateros e biandantes que bienen de otros puertos comarcanos, y salen por los puertos de Sandrinyesto e la peña de Mena y puerto de Haya e por la peña de Angulo, son hobligados a yr y pasar por dentro de la villa de Medina de Pumar, porquel camino rreal que sale de los dichos puertos, va a la dicha villa, en la qual esta de tienpo ynmemorial aca, casa de aduana y guarda sobre los diezmos de la mar pertenesçientes a su alteza y al [Condestable] en su nonbre", y donde eran examinadas las mercaderías que iban y venían de los puertos, comprobando si los diezmos se habían pagado, y se cobraba portazgo a todos los mulateros. También afirmó

1831 Varios mulateros, relatan su experiencia:

-Juan Sáez el Viejo, de Villanueva de Ladrero dice "que yendo Martin, hijo deste testigo camino de Castilla, con los mulos de otro hijo suyo... cargados de hierro, entrando junto de los Oçinos le tomaron çiertos vecinos de la dicha villa de Medina, $e$ Ilevaron a Medina que es dos leguas mas atras con los dichos mulos e fierro,... e bio como el otro su hijo cuyos heran los mulos fue a la dicha villa de Medina, e lleuaron vna taça e la dexaron en prendas e asy le boluieron los dichos mulos e fierro de manera que la dicha taça nunca ge la dieron".

-Raimundo Sáez de Barahona vecino de Campo, declara que a su hijo "e a otro hijo de Billacanes que venian de Laredo cargados de hierro con sus mulos, veniendose por el camino rreal [a] sus casas entre Varzena e Quintanahedo, e los saltearon algunos vesynos de la villa de Medina e los hesyeron yr a Medina con sus mulos e fierro e mercaderias e ge lo tomaron e tienen tomado". Lope Martínez vecino de Villanueva de Ladrero, indica que viniendo hacía unos 10 años "de Castilla con otros mulateros cargados de bino e trigo, saliendo de los Oçinos a la venta de Marroquin, salieron a ellos vnos seys onbres de la villa de Medina de Pumar e les querian haser yr por Medina, e les aquedaban las azemillas para que fuesen por el camino de Medina, e que los dichos mulateros se ponieron en defensyon desyendo que no lo abian de haser salvo yrse por su camino dicho e sus casas, e por ser los dichos mulateros nuebe o diez, se salieron con ello e que hubo armas sacadas e se hobiera de alançear sobre ello sy los de Medina no los dexaran benir".

-Juan López de Villanueva dice que hace unos tres años, yendo con un hijo suyo a la Montaña "con sus mulos cargados de bino blanco,... en el camino rreal ques junto de Billalazera e Quintana, salieron a ellos vnos siete o ocho onbres de la villa de Medina con sus ballestas armadas, e ge las ponieron a los pechos a este testigo e al dicho su hijo, e le tomaron los mulos con su bino e ge las llevaron por fuerça e contra su voluntad a Gayangos, e dende alli a la casa del condestable que es en Barzena e alli le ençerraron los dichos mulos e bino, e quel uno de los dichos siete honbres que asy le saltearon a tomar las dichas mulas, e que se llamaba Juan Ybañes besyno de Medina, ... e que despues bino el alcalde mayor de Castilla Vieja e mando que le diesen las dichas azemillas y el dicho bino, e que le vebieron e le falto una cantara de bino blanco de Castilla". Añade que "puede aver syete años... que yba vn criado deste testigo con vn asno suyo, e llebaba vn quintal e medio de fyerro e ge le tomaron en do dizen San Sebastian, e le llebaron el dicho fierro que fasta oy nunca ge lo dieron ni boluieron a este testigo, e que asy mesmo sabe que otra vez veniendo de Canpos este testigo, puede aber diez o doze años junto de la venta de Marroquin, salieron a este testigo e a otros mulateros que benian en su conpañia vnos seys o siete onbres vesynos de Medina, e le aquelaban los mulos por que no veniesen por Castilla Uieja salvo que fuesen por Medina, e porque este testigo e otros siete o ocho conpañeros se defendieron dellos, no los llevaron... e que sobre ello hubo de la vna parte e de la otra armas fuera, e asy se beniera el testigo e los otros por su camino derecho a sus casas, que es por el camino rreal de Castilla Bieja".

- Hernando de la Peña vecino de Campo, indica que "puede aver nuebe o diez años, yendo cargado de pescado fresco con tres mulos e una aca, por el camino rreal de Castilla Vieja, syn aber llegado al termino e jurediçion de la dicha villa de Medina de Pumar, le salieron quatro honbres junto del lugar de Ençinillas, que es acerca de dos leguas pasado de Medina ançia Castilla con sus lanças e ballestas, e por fuerça e contra su voluntad le llevaron a... Medina con los dichos sus mulos, e que despues en... Medina de Pumar a enterçesion de su suegro deste testigo, le soltaron e que le tuvieron a cabsa de lo susodicho vn dia en la dicha villa de Medina, a cabsa de lo qual se le dapño el dicho pescado e perdio en ello mas de dos mill mrs.... e que los que le tomaron como dicho tiene fueron unos criados de Lope Says Çapatero portazguero que ha la sazon hera".

Gómez López vecino de Villanueva de Ladrero, declara que hace unos cuatro años "yendo con sus mulos por el camino rreal cargados de hierro e sardina, y que llevaba quatro mulos e mulas e yba de los dichos puertos a Castilla, no yendo ni pasando por la dicha villa de Medina de Pumar ni por su termino ni juridiçion de la dicha merindad, salieron a el Garçia Gomez de Santayana e -Pero de Medina e Bartolome el sastre e Pero de San Lazaro e Carrança el Çapatero, vesynos de... Medina armados con sus lanças e ballestas y espadas y puñales junto a una benta ques cabo los Oçinos, que es en la jurediçion de las dichas merindades dos leguas de Medina, e le tomaron sus mulos y cargas e ge lo llevaron a la dicha villa de Medina por fuerça e contra su voluntad, e ge los tuvieron en... Medina los dichos mulos en syete semanas, e despues ge los dieron sobre fianças los dichos mulos, y las cargas de hierro en que abia syete quintales de hierro se les quedaron para los gastos de los mulos e las otras cosas, e que este testigo no cobro cosa ninguna dello e que alla se lo gastaron todo e le cuesta para el juramento que fecho tiene fasta oy dia mas de diez e seys mill mrs., el dicho Garçia de Santayana le llevo ademas de lo que dicho tiene quatro rreales de coecho al tienpo que le dieron los dichos mulos". 
el Condestable que el concejo de Medina ha de tener "rreparadas syenpre dos puentes grandes y muy costosos que ay en el dicho rrio de Nela, e otra puente grande que ay en el rryo de Trueba, que son de cal e canto y otros muchos pontones e calçadas, de que cada año se les sygue mucha costa, syn las quales no pueden vibir los dichos mulateros"; y si algunos habían dejado de ir por Medina, era sin saberlo él ni el concejo. Además, el procurador del Condestable dice que "todos los ganados que pasan por Villacomparada y Villarcayo, deben cierto portazgo al [Condestable], que es una blanca de cada cabeça de ganado mayor e media blanca de cada caveça menor, e lo mesmo pagan los dichos ganados que pasan por la dicha villa, e asi se ha husado e acostunbrado del dicho tienpo ynmemorial aca"1832, poniendo de manifiesto que en Villacomparada existía un portazgo auxiliar para los ganados.

El corregidor declara que "çiertos besynos de la uilla de Medyna de Pumar an coechado a los dichos mulateros... muchas contyas de mrs. lleuandoles por cada azemilla çinquenta mrs. en cada un año, a dos mrs. de cada carga cada mantenimiento, e un marabedy por el aluala", y estima que los mulateros recibieron gran perjuicio por haber sido forzados a pasar por Medina. Si todos deben pagar un peaje, pasando o no por el término de Medina, dice, debía ser percibido en Incinillas, donde se bifurcaban los dos caminos ${ }^{1833}$.

El poder del Condestable era tal que ningún letrado se atrevía a defender a los demandantes en este pleito. Así en septiembre Pedro de Brizuela, procurador de los mulateros, pide al corregidor y juez pesquisidor que como él no hallaba letrado en Medina de Pomar ni en las Merindades, "por miedo del dicho señor condestable", y por ser este "gran señor etener la jurediçion del juzgado de las dichas merindades, no abia ningund letrado que contra el quisiese abogar", y como traer otro letrado de fuera sería muy costoso, pedía que le ayudasen. El corregidor mandó a Juan de Salazar, vecino de Salazar, que abogue por ellos y los defienda en esta causa so pena de $20.000 \mathrm{mrs}$. Salazar dijo que "como quier quel no quesyera entender en el dicho negoçio, pero por ser hobediente al mandamiento del señor corregidor en nonbre de la Rreyna nuestra señora, y por yncurrir en las penas del dicho mandamiento, quel estaba presto de entender en la dicha cabsa en las cosas que tanbien su justiçia y no en mas"1834.

En 1550 se promueve un pleito que sostuvo el Condestable don Pedro en unión de su mujer, doña Juliana Ángela de Velasco, sobre la merced que de tiempo inmemorial poseían de cobrar portazgo a los vecinos de Burgos en sus villas de Medina de Pomar, Briviesca, Pedraza y otras, a pesar de los privilegios que la ciudad tenía por concesión de Fernando el Católico y su hija Juana.

En el camino por Lunada, La Sía o Las Estacas, los Condestables poseían Torme y Espinosa de los Monteros.

En el camino de Castro-Urdiales tenían la importante villa de Villasana de Mena, y las villas de Otañes, Sámano y la propia Castro-Urdiales.

En el camino de Burgos a Bilbao por Valmaseda, dependía de los Velasco la dicha Villasana de Mena. También en el que entra en Mena por el puerto de La Magdalena, les pertenecían las villas de Torres de Medina, Rosío y Castrobarto.

1832 A. G. S./ Consejo Real de Castilla, leg. 84, fol. 2-III/ Valladolid, 26 junio 1513 a Salazar, 25 septiembre 1515.

1833 A. G. S./ Consejo Real de Castilla, leg. 84, fol. 2-III/ Valladolid, 26 junio 1513 a Salazar, 25 septiembre 1515; MOLÉNAT, J. P.: 1971: 149-150.

1834 A. G. S./ Consejo Real de Castilla, leg. 84, fol. 2-III/ Valladolid, 26 junio 1513 a Salazar, 25 septiembre 1515. 
Los oficiales de los Velasco, desde su localidad de Villasana, trataban de impedir el paso de los mulateros por el "camino de la Ordunte", obligándolos a desviarse por la citada Villasana. Así en agosto de 1483 Fernando Sáez de Fresnedo, en nombre de los mulateros, dijo que de tiempo inmemorial los mulateros de Castilla Vieja y de otras partes "han ydoe pasado libremente con sus mulos e vestias por el camino rreal que disen de la Vrdunte, que va a Castro e a la villa de Viluao por el valle de Mena", pero que los alcaldes de Villasana y el merino de Mena, los prenden y los obligan a ir por el camino de Villasana, que dice "ques mas largo e mas fraguoso que no el dicho camino del Ordunte". Los Reyes mandan al concejo de Villasana y al merino de Mena que dejen a los mulateros transitar libremente por este camino ${ }^{1835}$.

En la vía de Burgos a Bilbao por el puerto de Angulo, pertenecen a los Velasco las villas de Riocerezo, Extramiana y Quincoces de Yuso.

En el camino de Burgos a Bilbao por Herrán y Orduña, poseían Briviesca, Soto de Bureba y Frías.

En el camino a Bilbao por Orduña les pertenecían Berberana, Murita y Villalba de Losa. Juan Martínez de Marquina, en nombre del concejo de Bilbao, dijo al Consejo Real que el infante don Juan, señor de Lara y Vizcaya, había concedido un privilegio a la villa confirmado por Juan I, para "que no aya venta nin rebenta desde Bilbao fasta Araeta, nin fasta Varacaldo, nin fasta Çamudio y que no se pudiese alli haser puebla nin villa nueva nin otra cosa que fuese en danno nin en perjuyzio de la dicha villa", y que Pedro Fernández de Velasco quiso "hedeficar vna villa en Varacaldo junto con las sus torres de Luchana para hazer alli vn puerto". Indica que cree que lo mismo quiere hacer el Condestable su hijo, porque ha comenzado la obra en Baracaldo y en Zubileta y tiene aparejo para ello, porque cobra todos los diezmos de aquella tierra y porque dice que es suya más de $1 / 3$ de toda ella, y que "sy se consyntiese alli hazer carga $e$ descarga, todo el trato de la dicha villa de Bilbao e de Portogalete se yria alli, e se faria muy grand poblaçion e se despoblarian las dichas villas, y que ternia el dicho condestable mucha parte de Vizcaya, mayormente segund las fortalezas e tierras que tiene alderredor, e porque dis que tiene a todos los mercaderos debaxo de su mano a cabsa de los diezmos de la mar". El Consejo mandó en febrero de 1499 al corregidor o juez de residencia de Vizcaya que vea si su privilegio ha sido usado y guardado, y de cuánto tiempo acá se han hecho los dichos lugares "contra el thenor e forma del dicho preuillegio", qué lugares son los que se han hecho o quieren hacer, quién los ha hecho y qué perjuicio causa a la villa y vecinos el que los dichos pueblos nuevos se hagan, etc., y la información se envíe al Consejo. Si mientras tanto viere el corregidor que alguien hace o innova alguna cosa en perjuicio de Bilbao, hará que se paralice todo hasta que el Consejo determine lo que convenga ${ }^{1836}$.

A principios del siglo XVI se inicia un pleito que durará casi todo el siglo entre Iñigo Fernández de Velasco y el concejo de la ciudad de Orduña sobre la composición y mantenimiento del camino de Murita, por razón de los derechos que el Condestable cobraba

1835 A. G. S./ Registro General del Sello, VIII-1483, fol. 184/ Santo Domingo de la Calzada, 23 agosto 1483.

1836 A. M. Bilbao/ Cajón 37, reg. 9, nº 89-Caja 39, reg. 1, no 2/ Ocaña, 21 febrero 1499. ENRÍQUEZ FERNÁNDEZ, J.; HIDALGO de CISNEROS AMESTOY, C. y MARTÍNEZ LAHIDALGA, A.: "Colección Documental del Archivo Histórico de Bilbao (1473-1500)" 1999: doc. 240; A. H. F. B/ J. Corregimiento, leg. 4.042, no o09 (fol. 45V-50r)/ Ocaña, 21 febrero 1499; ENRÍQUEZ FERNÁNDEZ, J.; HIDALGO de CISNEROS AMESTOY, C.; MARTÍNEZ LAHIDALGA, A.: "Archivo Foral de Bizkaia. Sección Judicial. Documentación Medieval (1284-1520)". 2006: doc. 77. 
allí1837. En 1538 el concejo, justicia y regimiento de Medina de Pomar da un mandamiento en nombre del Condestable, para que la ciudad de Orduña pudiese seguir cobrando por 6 años el arrendamiento del derecho que pertenecía al dicho Condestable sobre la renta de la guía y pasaje de la Peña de Goldecho ${ }^{1838}$.

En Junta de Álava de noviembre de 1540 los procuradores de las hermandades de Valdegovía, Valderejo, Lacozmonte, Cuartango y La Ribera, dijeron que los diezmeros y guardas del Condestable, quebrantando los privilegios que la provincia tenía, les molestaban pidiéndoles el diezmo y otros derechos por el trigo y otros bastimentos. Visto todo y como a todos tocaba, se dio poder a Pedro Díaz de Ulíbarri y a Diego Fernández de Ugarte para que, a costa de la provincia, defiendan sus privilegios contra las imposiciones que realiza el Condestable ${ }^{1839}$. En junio de 1552 el Consulado de Burgos paga al relator Almorax para la vista del proceso que tiene contra el Condestable sobre el cobro indebido del portazgo de Briviesca ${ }^{1840}$. En agosto de 1559 el Consulado registra gastos de 7.500 mrs. "en sacar la executoria contra el condestable sobre el portazgo de Birbiesca". Este pleito parece que en septiembre está solucionado, porque en ese mes se gastan $5.609 \mathrm{mrs}$. en "las personas que an de aber la rrestituzion que el condestable hizo del portazgo de Birbiesca"1841.

En el pleito sostenido hacia 1580 por el concejo, justicia y regimiento de Orduña contra Iñigo Fernández de Velasco ${ }^{1842}$, para que aderece el camino desde la Peña de Orduña hasta el lugar de Murita porque cobra la guía de la Peña, responde el Condestable que lo que cobra no es portazgo sino derecho y es percibido por su casa de tiempo inmemorial, y que ellos jamás han contribuido en el aderezo de la Peña de Orduña, que es término de Orduña, para lo que la ciudad lleva gran cantidad de derechos. La guía de la Peña alega se cobra como derecho por el tramo del camino que discurre por Murita en el término de Villalba, y que acaba junto a la ermita de San Bartolomé todo en el mismo término. El Condestable solía arrendar esta guía de la Peña de tiempo inmemorial en unos 22.00o mrs., por 6 años ${ }^{1843}$.

En las Juntas de Vizcaya de 1584 se mandó que, para seguir con el pleito de la Peña de Orduña contra el Condestable, se disponga que sigan los dos representantes que van a las villas de Valladolid y Madrid como más convenga y sea necesario ${ }^{1844}$. En 1584 y en 1585 se extienden dos Provisiones reales, en que mandan que lo que lleva el Condestable como renta de la guía se invierta en reparos de la Peña ${ }^{1845}$. En las Juntas de Vizcaya de febrero de 1585 se vuelve a tratar sobre dicha Provisión para que los derechos que el Condestable percibe en Orduña por el reparo de la Peña se gasten para ese fin, y se entregó otra Provisión

1837 A. H. N./ Nobleza. Frías, Leg. 1392, D. 1/ 1 enero 1500 a 31 diciembre 1599.

1838 A. H. F. B./ Munic. Orduña, caja nº 19, carp. 1/ Medina de Pomar, 17 octubre 1538.

1839 A. J. G. A./ t. III/ Vitoria, 20 noviembre 1540.

1840 A. D. B./ R-12/ Libro de caja de la Universidad de Burgos/ Burgos, 1549-1557.

1841 A. D. B./ R-14/ Libro de caja de la Universidad de Burgos/ Burgos, 1557-1567. pp. 38i y 43d.

1842 Înigo Fernández de Velasco fue condestable entre 1559 y 1585.

1843 A. H. N./ Nobleza, Frías, Leg. 1.392, D. 1/ Entre 1559 y 1585.

1844 A. J. R. B./ Actas de la Tierra Llana. t. IV/ Bilbao, 28 julio 1584.

1845 A. H. F. B./ Munic. Orduña, caja nำ19, carp. 3/ 1584 y 1585. 
para que el corregidor del Señorío informe. Al día siguiente, se acordó que los derechos que cobra el Condestable en Orduña en concepto de reparo de la Peña se gasten en él y si, para esto fuere necesario que Orduña haga algunas diligencias, se escriba a la ciudad para que haga lo que conviene ${ }^{1846}$. En las Juntas de Vizcaya de agosto de 1586 se trató sobre que a Gracián de Meceta y Martín Ruiz de Muncharaz, cuando fueron a la corte, se les encargó que pidiesen Provisión para que los derechos excesivos que cobra el Condestable en Orduña, so pretexto de que son para el reparo de la Peña, no se hiciesen pagar y que lo que se cobra se gaste en su reparo. Mandaron que en el primer Regimiento Ceneral se trate de su remedio ${ }^{1847}$.

En el Camino de Bayona, los Condestables tenían señorío aparte de Briviesca ya mencionada, sobre las villas de Quintanapalla, Monasterio de Rodilla, Grisaleña, Miraveche, Ameyugo y La Puebla de Arganzón.

\section{El control de los diezmos de la mar ${ }^{1848}$}

Los diezmos de la mar, calificados por las Cortes de Burgos de 1453 como unos de los mejores del Reino, se desprendieron del Patrimonio real en 1469, enajenados por Enrique IV a favor de Pedro Fernández de Velasco ${ }^{1849}$, cuya familia conocía su valor y los pretendía desde hacía algún tiempo, ya que eran más sustanciosos que las rentas que procedían de sus propiedades territoriales. Fueron conservados por los Velasco hasta que Felipe II los recuperó para la Corona en 1559. En 1447 Pedro Fernández de Velasco, I conde de Haro, conocía los ingresos que reportaban los negocios mercantiles y obtiene de Juan II la cuarta parte de los diezmos de la mar. Aprovechó el pleito por la herencia de Moguer como defensor de su sobrino Martín Fernández Portocarrero, despojado este de esta villa por el príncipe de Asturias en favor de la esposa de su privado Juan Pacheco. El I conde de Haro exigió a Juan II reparación para su familia por tal pérdida, obteniendo por 7 años los diezmos de los puertos de Laredo, Valmaseda, Orduña y Vitoria para su sobrino hasta cubrir el valor de Moguer.

En 1454 termina el secuestro de 7 años, obteniendo 8.408.902 mrs. más 700.000 mrs. de mercaderías de los flamencos y de las descaminadas, siendo Laredo el puerto que con diferencia más rinde, seguido por el de Valmaseda, Orduña y por último Vitoria. Se entregaron 4.406.642 a Portocarrero y se deducen los derechos del obispo y cabildo de Burgos, de la iglesia de Laredo, el monasterio de las Huelgas y el Hospital del Rey, los pagos a las guardas y los situados, y de los monasterios de Quijana y Vitoria. En mayo, Enrique IV concede a Pedro, futuro I Condestable y II Conde de Haro, un juro de 200.000 mrs. en los diezmos de la mar, y en diciembre, este recibe otro de 195.000 mrs. situados en los diezmos y alcabalas de San Vicente de la Barquera.

1846 A. J. R. B./ Actas de la Tierra Llana. t. IV/ Bilbao, 20 y 21 febrero 1585.

1847 A. J. R. B./ Actas de la Tierra Llana. t. IV/ Bilbao, 22 agosto 1586.

1848 FRANCO SILVA, A.: 1989: 255-284. Este trabajo trata de manera pormenorizada la posesión que los condestables tuvieron de los diezmos, y de él hemos obtenido las referencias para este resumen; FRANCO SILVA, Alfonso: 1996: 465-498.

1849 LADERO QUESADA, M. A.: 1973: 120-125 
En julio de 1467 se concede al I Conde de Haro un nuevo juro de 350.000 mrs. y en diciembre Enrique IV concede a Pedro, II Conde de Haro, el oficio de Escribano Mayor de los diezmos de la mar con derecho de 10 al millar, por su participación en la batalla de Olmedo contra su hermanastro Alfonso. En abril de 1469, al fin, Enrique IV enajena por juro de heredad, los diezmos de la mar a favor de Pedro Fernández de Velasco, futuro I Condestable, para atraerse su apoyo frente a Isabel, y como prenda hasta que se haga efectiva la donación de 1.000 vasallos comprometidos por el Rey. Si los diezmos alcanzan más cantidad "de lo que podían baler en renta los mil vasallos", el Rey concede "la dicha demasia para que sea vuestra", con el compromiso de respetar los juros, situados y salvados de instituciones religiosas y otras personas.

En 1480 la reina Isabel garantiza dichas rentas en las Cortes de Toledo, tras la revisión de todas las concedidas por Enrique IV, y las vuelve a confirmar para garantizar el apoyo de los Velasco en la guerra de Granada en 1483 y 1489. En julio de 1492 los Reyes confirman al Condestable los diezmos, que también mantiene el oficio de Escribano mayor de los diezmos con el derecho de los 10 mrs. al millar que Enrique IV concedió a su abuelo. En marzo de 1498 la Reina realiza una nueva confirmación de los diezmos y en octubre de 1510 los vuelve a confirmar la reina Juana.

En 1512, a la muerte de Bernardino Fernández de Velasco sin dejar hijos varones, su hermano Iñigo reclama a la Corona la entrega de los diezmos, en poder de su sobrina Juliana Ángela, hija de Bernardino y nieta del rey Fernando, al haber constituido Bernardino un mayorazgo a favor de su hija en 1510, en el que los diezmos constituían la herencia principal. El Rey los confirma a su nieta y los vuelve a confirmar en junio de 1514. En julio de 1519 Carlos I concede los diezmos de la mar a Iñigo Fernández de Velasco, siempre que compense a su sobrina con la entrega de 1.000 vasallos y en enero de 1520 Carlos I ordena a los tutores de Juliana que entreguen al Condestable los diezmos de la mar, cosa que recuperará tras el matrimonio entre los primos Juliana Ángela y Pedro (hijo de Iñigo). En febrero de 1524 se establece una concordia entre padres e hijo y nuera, en que, a cambio de la mitad de los diezmos, Iñigo renuncia a la Alcaldía mayor y oficio de Merino mayor de Castilla Vieja, a la Escribanía Mayor de los diezmos, al oficio de Camarero mayor, a un juro de 180.000 mrs. en los diezmos y a todos los demás juros de su hermano Bernardino, excepto los oficios de Condestable y Copero mayor y el título de duque de Frías. A la muerte de Íñigo en septiembre de 1528 , todos los diezmos pasan a su hijo Pedro y nuera Juliana Ángela, pero ya en esos años la renta no era importante e iba en franca decadencia1850.

El 11 de noviembre de 1559, al día siguiente de la muerte de Pedro, su heredero y sobrino Íñigo Fernández de Velasco toma posesión de la renta de los diezmos. Pero el día 13, Felipe II, que desde hacía algún tiempo deseaba recuperar esta renta para la Corona, aprovecha la oportunidad y manda a los Contadores mayores que pongan orden en todo lo tocante a los diezmos de la mar por pertenecer a los derechos reales. El 16 de ese mes, el Rey los confisca en su favor, por tratarse de una renta que solo podía percibir el Rey y notifica a los corregidores de las Cuatro Villas de la Costa de la Mar, de la provincia de Cuipúzcoa, de Medina del Campo, del Señorío de Vizcaya y de la provincia de Álava, la decisión y el

1850 DÍEZ de SALAZAR, L. M.: 1981: 186-314. 
nombramiento de diezmeros que actuarían en su nombre. Les manda que no se paguen los diezmos de la mar, sino a las personas que ellos mismos nombraren, debiendo recaudarlos a favor de la Real Hacienda.

En julio de 1560 Iñigo Fernández de Velasco interpone una demanda en la Chancillería contra tal confiscación e inicia un pleito que durará hasta 1573. Alegaba el Condestable que la decisión del Rey era injusta porque se trataba de despojar de una propiedad a su legítimo propietario, pidiéndole el fiscal del Rey que presentara los títulos que justificasen la posesión, añadiendo que no era un secuestro sino una acción que reportaba un gran beneficio a la Hacienda del Estado, porque los diezmos forman parte de las regalías de la Corona, y los títulos de donación, si los hubiere, no podían ser auténticos. Indicaba que los beneficios recibidos por los Velasco durante los 90 años que los habían percibido son mucho mayores que los 1.000 vasallos prometidos por Enrique IV en 1469, por lo que han quedado bien pagados.

El Rey debe solucionar estos asuntos con brevedad y en enero de 1561 comisiona a Juan de Peñalosa, administrador de la renta de los diezmos, para administrar y cobrar dicha renta en su nombre, algo que hasta ese momento realizaba el Condestable, y en febrero le da instrucción para la cobranza y administración de los diezmos de ese año de 1561 . Los procuradores de las Merindades dicen, entre otras cosas, que los Contadores mayores y oidores de la Contaduría mayor del Rey habían mandado a Juan de Peñalosa que les enviase relación de lo que se debía hacer, y que no lo había hecho, por lo que las Merindades, trajineros y otras personas reciben daño. En noviembre, los dichos contadores y oidores mandaron a Peñalosa que en 12 días informe sobre si conviene que la aduana esté en Medina o que "por enbargo o utilidad, se sigue que no lo este y que lugar sera comodo y conbeniente para ella, y que daño y agrabio viene a las dichas Siete Merindades e a otras qualesquier personas, que esten en la dich a villa de Medina de Pumar", y dicha información la envíe al Consejo ${ }^{1851}$.

Ya en abril de 1562 se manda que los Alcaldes mayores residan en Villarcayo y en julio se traslada la Carta que se dio para que Juan de Peñalosa y los factores que están en los puertos y aduanas, la hagan pregonar en los dichos puertos, para que desde ese día cobren los diezmos conforme a la Cédula real en las aduanas como los llevaba el Condestable y otro tanto y medio más. En agosto el Rey dice a Juan de Peñalosa que mandó al Alcalde mayor que se informase sobre las cosas que convenía proveer a las Merindades, tanto para su buena gobernación como para su adecentamiento, quien, al tiempo que tomó la residencia a la justicia anterior, envió una relación por la que entre otras cosas dijo que convenía que "la cassa de laduana que está en la villa de Medina de Pomar, donde se rregistran las mercaderías que vienen para estos reinos de Castilla y se cobran los derechos dellas, se ponga en lugar realengo que sea mas a propósito y en camino más derecho, para los mercaderes y requeros y tragineros y otras personas que traen dende los puertos de la mar las dichas mercaderías, para que no tuerçan ni rodeen su camino para las yr a registrar en la casa del aduana y pagar los derechos quesllas devan pagar". Se dio Carta real a Peñalosa para que vaya a Villarcayo con Juan Díaz de la Peña, tesorero, y en presencia del Alcalde mayor se informen si convendrá mudar la casa de la aduana que está en Medina, qué ventajas o perjuicios podrían venir de tal mudanza, a qué personas y concejos y por qué causa, y en caso

1851 A. C. V./ no 1.873, doc.12, hojas 36 y 37/ Madrid, 12 noviembre 1561. 
de que se deba mudar, "en que lugar e parte se pondra que sea mas a propossito, y en mas comodidad de los mercaderes y requeros y tragineros y otras personas, que van y vienen con sus mercaderias por la dich a casa de aduana, por manera que por la mudança della, no arrodeen ni tuerçan su camino ni recivan daño", y todas las informaciones necesarias, con sus pareceres, las llevará Díaz de la Peña ante los Contadores mayores, para proveer lo que más convenga ${ }^{1852}$. En diciembre se manda a Juan de Peñalosa que averigüe el justo y verdadero precio a que se venden y contratan en Burgos, Bilbao, Laredo y otros núcleos todas las mercaderías que se traen de fuera de estos reinos, y se le da instrucción de cómo ha de cobrar los diezmos de la mar.

Todavía en marzo de 1564 el procurador general de las Merindades hizo un requerimiento a Juan de Peñalosa, administrador de los diezmos de la mar, para que reciba información sobre dónde debe estar la Aduana que estaba en Medina ${ }^{1853}$.

En el pleito iniciado por el Condestable en 1560 el fiscal recomienda al Rey que confirme la sentencia que era desfavorable para los Velasco, apresurándose el Rey a tomar tal decisión a fines de 1573. Los Velasco pierden así definitivamente los diezmos de la mar, la más importante de todas las prebendas que tenían de la Corona ${ }^{1854}$.

Pero no conforme con la nueva situación, aún hacia 1600 Juan Fernández de Velasco suplica a Felipe III que se restituyan a su Casa los diezmos de la mar perdidos, cosa que no logró. Unos años después el Condestable, intentando reponer la situación anterior, sigue pretendiendo ejercer los antiguos derechos sobre los portazgos y rediezmos. Sus guardas obligan a veces con violencia a que los mercaderes y mulateros que iban por Villarcayo se descaminen y pasen por Medina de Pomar con el fin de cobrarles allí el rediezmo y portazgo, sin que tuviesen derecho ni título para ello ${ }^{1855}$.

\section{El señorío de Medina de Pomar}

Un hecho especialmente grave se produjo en junio de 1513, cuando las guardas de Medina de Pomar exigían que los mulateros pasasen por dicha villa para pagar el correspondiente portazgo. Cuando estas guardas "husando de la dicha posesyon, querian prender los que yban descaminados, se juntaron a rrepique de canpana mas de dosyentos honbres e armados de dibersas armas, fueron tras las dichas guardas e que lo que peor es y digno de mayor castigo, que juntos los dichos mulateros en el dicho escandalo e asonada, acordaron de ahorcar a las dichas guardas e despues de acordado, por tener mijor color e titulo para ello e no teniendo poder ni facultad, husurpando el poder de su altesa elixieron e sacaron entre sy dos alcaldes de los dichos mulateros, los quales dichos alcaldes syn otro tytulo ni facultad tomaron luego baras de justiçia e fueron aconpañados de la dich a gente, fueron tras las dichas guardas disyendo ¡mueran, mueran!, y asy los syguieron fasta el lugar de Barzena donde los mataran, sy no se acogyeran a una torre del dicho lugar, e despues de alogados en la dicha torre les tentaron de poner fuego a ella y ge le pusyeran, syno por algunas personas que ge lo estorbaran espeçialmente por quel ualle de Montija donde es el dicho lugar de Barzena se llego a ge lo defender, e fue gran marabilla no morir aquel dia mucha gente a cabsa de los dichos desconçilios e atrebimientos que las dichas partes contrarias, en cada dia fazen e dizen conforme a esto muchas amenazas

1852 A. C. V./ no 1.873, doc.24, hojas 60 y 61/ Madrid, 25 agosto 1562.

1853 A. C. V./ Leg. 68,26/ Laredo, 18 marzo 1564.

1854 FRANCO SILVA, A.: 1989.

1855 A. C. V./ no 83/ Madrid, 11 septiembre 1621 y Madrid, g octubre 1624. 
e escandalos y cosas dinas de mucho castigo"1856. Estos incidentes violentos entre los mulateros y los hombres del Condestable no hacen más que constatar un estado general de indignación contra su señor por parte de los habitantes de las Merindades y más concretamente de sus mulateros, y son los antecedentes, según Joseph Pérez, del levantamiento de las Merindades contra él durante las Comunidades ${ }^{1857}$.

De hecho, ya desde los años del reinado de Enrique IV, los Velasco ejercían un poder coactivo sobre las Merindades. En 1515 un testigo nacido hacia 1455 decía que "seyendo vien moço, que porque Pero Rrodriguez de Bostyllo fue al rrey don Enrryque... a demandar juez de su altesa para las dichas merindades, e porque traya las provisyones dello, el conde de Haro... le mando prender, e bio este testigo que le prendio... en casa de Sarmiento el de Enzenillas estando vebiendo, e le llebo preso e le tubo dos años preso..., fasta que sus parientes fueron a Rruseco a suplicar al dicho conde de Haro que les dixiese sy hera muerto 0 vibo... e quel dicho conde de Haro les rrespondio quel... ge le mandaria dar e que despues vn domingo adelante el dicho conde de Haro le mando soltar, e este testigo le uio benir con una barba larga e dixo como le abian tomado las dichas prouysyones e todo lo que traya" 1858 .

En la revuelta comunera, en el contexto del movimiento antiseñorial que siguió a la sublevación de Dueñas el 1 de septiembre de 1520, las Merindades trataron de emanciparse de la tutela del Condestable animadas por la Santa Junta. El 14 de noviembre redactaron una carta que se convirtió en un auténtico manifiesto contra el régimen señorial en general y de forma más concreta contra los privilegios del Condestable. La Junta animó a las Merindades a destituir a los funcionarios nombrados por él y a negarse al pago de unos impuestos que les eran exigidos en nombre de una tradición que no se basaba más que en un claro abuso de poder, y además designó sus propios recaudadores de impuestos. En marzo de 1521 comenzó a ejercer sus funciones una administración disidente y Diego Ramírez de Guzmán se hizo cargo de la zona de Medina de Pomar. Los habitantes de las Merindades, deseosos de escapar de la tutela del Condestable y volver a la situación de territorio realengo, proporcionaron a la Junta una inestimable colaboración en contacto con el conde de Salvatierra, creando dificultades a las tropas reales de Burgos por lo menos hasta fines de marzo de $1521^{1859}$. Al final, el Condestable acabó imponiendo su autoridad en las Merindades sobre una población que le era claramente hostil.

Después de dicha guerra, las Merindades, mantuvieron la reivindicación de sus antiguas libertades y siguieron reclamando al Rey que ejerciese su autoridad y eliminase la dependencia de los Velasco, para quedar bajo su poder directo. Un hecho clave para resolver esta situación fue el fallecimiento del Condestable el 10 de noviembre de 1559. Felipe II, rey desde enero de 1556, aprovechará esta circunstancia y tomará la iniciativa para recuperar su autoridad sobre las Merindades y, con el apoyo de estas, rescatar el oficio de Justicia y Alcalde mayor de ellas y los diezmos de la mar.

Así el doctor Mendizábal, oidor de la Chancillería de Valladolid, como juez de residencia y Justicia Mayor en las merindades de Castilla Vieja, recibe el 28 de agosto de

1856 A. G. S./ Consejo Real de Castilla, leg. 84, fol. 2-III/ Valladolid, 26 junio 1513 a Salazar, 25 septiembre 1515. 1857 PÉREZ, J.: 1977: 45

1858 A. G. S./ Consejo Real de Castilla, leg. 84, fol. 2-III/Valladolid, 26 junio 1513 a Salazar, 25 septiembre 1515. 1859 PÉREZ, J.: 1977: 447 
156o en Miñón las varas de Justicia, del doctor Garavillo, teniente de Justicia mayor de las Merindades y de Diego de Vivanco, procurador general de la merindad de Castilla Vieja, así como de los merinos de las merindades de Montija, Castilla la Vieja, Sotoscueva, Valdivielso, Losa y Valdeporres, del veedor de la de Cuesta-Urria y del alcaide y merino de la cárcel de las Merindades. Cumplía lo mandado en una Provisión real y asumía en su persona los oficios de Justicia mayor y Alcalde mayor de las Merindades, convirtiendo a estas de facto en un corregimiento, al ser un oficial representante del Rey ${ }^{1860}$. A continuación, y en ejecución de una Provisión real para averiguar el lugar más conveniente donde debiera instalarse la Audiencia de las Siete Merindades, que hasta ese momento se ubicaba en Medina de Pomar, recibió información de cinco testigos vecinos de las Merindades. Dijeron que como Medina de Pomar, donde hasta ahora había residido la Audiencia, no era de las Merindades, porque es de Señorío, el lugar más idóneo para situar la nueva era en la merindad de Castilla Vieja por ser la más antigua y porque está en medio de todas ellas. Cuatro testigos dicen que Villarcayo es el lugar más cómodo y mejor, el que está en el centro de todas las Merindades, donde desde hace muchos años se hacen sus juntas y tiene el Archivo con todas las escrituras, provisiones y cartas que el Rey envía a las Merindades. Otro testigo dice que Torme está también en medio y en lugar pasajero y muy bien proveído. Coinciden todos en que el lugar de Miñón, donde se suelen hacer las juntas y recibimientos de las varas no es lugar adecuado, porque no es tan pasajero, es pequeño y de muy poca población, y no tiene ribera ni está tan en el centro como Villarcayo. Ante las discrepancias de algunos testigos, el doctor Mendizábal visitó Torme, Villarcayo y Bisjueces, considerando que como Villarcayo está en medio de los otros dos lugares, tiene el Archivo de las escrituras de la merindad de Castilla Vieja y provisiones y cartas tocantes a las Merindades y "el sitio del, es mas espaçioso e tiene ribera del rio Nela y lugar pasajero de los puertos de mar para Castilla y de Caliçia, e Asturias y de Canpos que bienen y pasan por hel, con probisyones y bastimentos", hizo el asiento de la Audiencia en Villarcayo, donde mandó traer a los presos de la cárcel de Medina para lo que dio mandamiento a su alcaide ${ }^{1861}$.

El 30 de abril de 1562 se extiende una Provisión real para que el corregidor de las Merindades envíe relación de los ministros de justicia de las Merindades, y sobre si convenía que hubiese en ellas Archivo y Casa donde estuviesen los procesos y escrituras sobre ríos, arreglos de puentes y pasos que hay en ellos tocantes a las Merindades, y se manda que los Alcaldes mayores residan en Villarcayo ${ }^{1862}$. En ese año comenzaron a celebrarse en Villarcayo las Juntas Generales de las Merindades confirmándose así como su capital.

1860 SÁNCHEZ DOMINGO, R.. 1994: 89 y 90.

1861 A. C. V./ no 21.174. doc.17,4 f./ Miñón, 28 agosto y Villarcayo, 30 agosto 1560; LÓPEZ ROJO, M.: 1983: 177-182. Transcripción en pp. 200-210.

1862 A. C. V./ Leg. 68,13/ Madrid, 30 abril 1562. 


\section{B.- LAS MERCADERÍAS}

Entre Burgos y la franja cantábrica y sus puertos se produjo, a partir del siglo XIII, un intenso tráfico en las dos direcciones, con la circulación de una gran variedad de productos y mercaderías. Las tierras del norte eran deficitarias en la producción de unos determinados artículos básicos y excedentarias en otros demandados en el interior peninsular. Por otra parte, un notable flujo mercantil utilizó estas tierras como zona intermedia de un importante comercio internacional, para el paso de todo tipo de productos, algunos de alto valor económico como la lana, pero también la hierba pastel, los paños y otros entre el interior de la Península y los países europeos del Atlántico.

\section{a.- El comercio internacional}

Desde el siglo XII y sobre todo el XIII se fue consolidando un tráfico marítimo internacional, que ponía en contacto los puertos castellanos y vascos con ciudades de gran pujanza industrial, económica y demográfica, que demandaban en grado creciente las materias primas que necesitaban sus talleres y otros productos de consumo. Así, Castilla estableció muy pronto relaciones comerciales internacionales con ciudades flamencas, francesas e inglesas, relaciones que alcanzaron su auge entre la segunda mitad del siglo XV y la segunda mitad del siglo siguiente, cuando comenzó su declive.

Todo este movimiento comercial tuvo a la ciudad de Burgos como centro de sus operaciones mercantiles y financieras y motivó el desarrollo de una burguesía emprendedora, que necesitaba defender sus intereses, apoyar y coordinar sus actividades, canalizar sus iniciativas, monopolizar los procesos del comercio, mantener un tribunal que dirimiera sus querellas comerciales, asegurar las mercaderías, controlar la fiscalidad y flete de navíos y cargazones y actuar como órgano de garantía ante terceros. Para ello la Monarquía estableció, en 1494, el Consulado de Burgos o Universidad de los Mercaderes, como institución legal.

Aunque la relación establecida con los países atlánticos europeos procedía de fechas anteriores, en las Cortes de Jerez de 1268 se comienzan a regular algunos aspectos relacionados con el comercio exterior de Castilla y se señalan los puertos de San Sebastián, Fuenterrabía, Santander, Laredo, Castro-Urdiales y Avilés, junto con los gallegos, para canalizar ese tráfico, sin incluir ninguno del condado de Vizcaya. Se establecen los precios de los productos que se importaban y así sabemos que llegaban de Francia, Países-Bajos e Inglaterra tejidos de lana y seda, tales como paños pardos, prietos, tintos y granas, escarlatas, blanquetas, valancinas, frisas, sargas, camelinas, tiritanas, befas, y otros géneros procedentes de Blois, Brujas, Cambrai, Casteldun, Douai, Estampas, Gante, Ypres, Lille, Montpellier, Nantes, Reims, La Rochelle, Ruan, Saintomer, Toulouse, Valenciennes y otras ciudades industrialmente florecientes ${ }^{1863}$.

Entre los productos que ocuparon un puesto relevante entre las importaciones se in-

1863 COLMEIRO, M.: 114-115 
cluyen los manufacturados, como artículos de mercería ${ }^{1864}$ y joyería, obras de arte, muebles, armas o libros, sin olvidar el pescado seco. En la relación de fines del s. XIII ${ }^{1865}$ que veremos se detallan mercaderías muy diversas de un no muy alto precio, como agujas, dedales, tijeras, botones, sortijas, cascabeles, vasos, cucharas, cuchillos y cortaplumas, greales o vasijas, escudillas o platos, talladeros, peines, candados, balanzas, candeleros o cristales. También cruces, incensarios, vinajeras o cajas para incienso. Se mencionan armas y piezas para la cetrería, el citoal, especia usada como condimento, el almastic para perfumes, y por supuesto el pescado. En 1488 se traen artículos de mercería, papel, vidrios y redomas y tocino salado ${ }^{1866}$.

En la relación de $1503^{1867}$ la gama de artículos importados resulta interminable, como baúles y cofres, candeleros, rastrillos, tijeras, alfileres y agujas de coser, dedales, candados, sortijas, espejos, campanillas, saleros, mercería, anteojos de madera y cuerno, balanzas, vidrio, cajas y estuches diversos, incensarios, cortaplumas, cascabeles, tinteros, y un largo etc. También se importan armas como espadas, hachas, espuelas, estribos o cotas de mallas, y pescados como congrio, salmón, arenques.

A principios del siglo XVI se mantendrán los mismos productos importados y sigue ocupando un lugar preferente la entrada de los paños y textiles. También se importan pescados y una buena cantidad de productos diversos como zapatos y botas de cuero, rosarios de Inglaterra, ceñidores, arillos, imágenes de yeso, cadenas para perros, prenderos, agujas, jeringas, cajas de lunas de espejos, armas o papel, y muebles como escribanías, camas de campo y escaparates ${ }^{1868}$.

Según la relación de agosto de $1536^{1869}$, entre una diversidad de productos, sigue ocupando en las importaciones un lugar muy destacado el pastel. También sobresalen diversos productos manufacturados como la mercería o el papel, y los pescados.

En los aranceles de avería del Consulado de Burgos que se detallan en las ordenanzas de $1538^{1870}$, con algunos añadidos en las de 1572 , se incluye en estos la tasa que deben pagar los productos importados sobre todo el pastel, y en 1538 el vino de la Rochelle y Cascuña. En 1572 se registra la mayor variedad de géneros: los textiles en sus distintas versiones, la seda y cajas de sedas y de perlas, cuero de Indias y de Irlanda, trigo, centeno y esclavos ${ }^{1871}$.

1864 En el "Diccionario de Autoridades", tomo IV, 1734, se define como mercería "el trato y comercio de cosas menudas y de poco valor y entidad".

1865 Escorial/ Códice Escurialense, III-Z-13/ Burgos, f. S. XIII; CASTRO, A.: 1921 a 1923: 1-29.

1866 A. G. S./ Contaduría mayor de Cuentas. Inv. 2º Libros de cuentas de los diezmos de la mar de Castilla/ San Sebastián, 7 octubre 1488, Burgos a Salvatierra, 4 junio 1544; GONZÁLEZ, T.: 1829: 328-358: t. I. doc. XCVI.

1867 A. G. S./ Contaduría mayor de Cuentas. Inv. o Libros de cuentas de los diezmos de la mar de Castilla/ San Sebastián, 7 octubre 1488, Salvatierra, 4 junio 1544; GONZÁLEZ, T.: 1829: 328-358: t. I. doc. XCVI; LABAYRU y GOICOECHEA, E. J. de: 1899: 424-431: t. III.

1868 A. G. S./ Contaduría mayor de Cuentas. Inv. $2^{\circ}$ Libros de cuentas de los diezmos de la mar de Castilla/ San Sebastián, 7 octubre 1488, Salvatierra, 4 junio 1544; GONZÁLEZ, T.: 1829: 328-358: t. I. doc. XCVI.

1869 A. G. S./ Contaduría mayor de Cuentas. Inv. $2^{\circ}$ Libros de cuentas de los diezmos de la mar de Castilla/ San Sebastián, 7 octubre 1488, Burgos a Salvatierra, 4 junio 1544; GONZÁLEZ, T.: 1829: 328-358: t. I. doc. XCVI.

1870 Ordenanzas del Consulado de Burgos de 1538/Valladolid, 18 septiembre 1538; GARCÍA de QUEVEDO y CONCELLÓN, E.: 1905 y 1995: 203-207. Ordenanza XXII.

1871 Reales Ordenanzas del Consulado y Casa de Contratación de Burgos/ Ordenanza no XXVIII/ Madrid, 1 agosto 1572 en LARRUGA, E.: 1793: 216-297: t. XXVIII. 
Juan de Peñalosa, por otra parte, realiza un interrogatorio a mercaderes de Burgos y Bilbao en marzo y abril de 1563 con el fin de establecer lo que se debía pagar por las mercaderías que entraban en Castilla por los puertos de Cuipúzcoa, Vizcaya y las Cuatro Villas de la Costa, o que se introducían por los puertos secos de Valmaseda y Orduña ${ }^{1872}$. En sus relaciones sigue destacando por su variedad y volumen la importación de lienzos. Además del pastel de Francia y de las islas Azores, recoge otros productos como manteos de conejos, turones y veros, armiños y conejos y geves para forros, camuzas de Flandes, martas de agua, bimblotes para niños ("joyelicos" de vidrio y estaño), anteojos de cuero y papel o de madera, cajas doradas para anteojos, corales contrahechos de hueso y colorados, vidrio de rocalla, cajas de vidrieras, mazuela de vidrio verde y amarillo, cristalina y margaritas de vidrio, cascabeles de Francia, Lyon, Alemania dobles, Milán y baladíes de Flandes, cruces de estaño doradas en caja, cruces de alquimia grandes, cuentas de ámbar, peines, terno de cofres negros o dorados de Flandes o recamíes, caja de madera de Flandes, cofres de Flandes barrados y de Francia, bombacines de Milán, botas de pergaminos, barajas de naipes, rosarios comunes de Tabor, turqueses y de búfalo, ceñidores de lana sin clavos, tejillos cóncavos, lunas de espejos, espejos de almacén de platilla y redondillas, de cristal, de acero y de botón, tinteros dorados y de escribanías negras, fuella dorada o plateada y de colores, hilo de cartas, relojes de madera, de marfil y de ébano, y relojes de Alemania de campana o de mano, libros de memoria, sortijas de latón, de oro o de plata, o de búfalo y de azabache y camafeos, atriaca de Flandes, papel en resma, ternos de cofres de Lille o cañones de ganso.

También se importan gratas y limas de plateros grandes y pequeñas, brocas y leznas de zapatero, botas de baqueta para hombre, agujeros de cuero para agujas, agujetas de abrochar de cuero, corchetes de hierro macho y hembra y latón, botones de ataujía esmaltados y dorados, botones de vidrio, escobillas para limpiar, cazuelas, bacías y candeleros, cucharas de latón y alquimia, cerraduras de Flandes, bateos que son fuentes como platos, candados de maleta, tijeras de tundir, tijeras de espabilar doradas de ataujía, rastrillos, jeringas para matar fuego, jeringas grandes y pequeñas de barbero y de pelota, fuelles para la lumbre, molinos de Alemania, cuchillos de escribanía, balanzas con su peso, bullones que es bermellón, asedaderas, navajas, cuchillos de Francia, Flandes, Bolduque, Malinas y Bohemia, cuchillos de cabos de madera, agujas de coser pequeñas, agujas de salmar, agujetas de hilo, tijeras de mujer baladíes, dedales de Flandes y Francia de hombre y mujer, alfileres, hilo de coser de todos los colores, alones para velas de navíos, cordaje para navíos, pieza de velas, etc. y también se traía bronce o "metal campanil". En instrumentos y elementos musicales, se incluyen cuerdas para tañer, clavicordios o clavicímbalos, monacordios o trompas de París.

En estas relaciones, un capítulo importante es el de la importación de obras de arte y complementos, así como los muebles y elementos de madera, reseñando la cama de sarga o lienzo con sus goteras, cama de campo de madera, escaparate de madera, sillas de Flandes de caderas guarnecidas de baqueta, cajas de escribanías de Francia, escritorio de

1872 A. G. S./ Secretaría del Consejo de Hacienda. leg. 49/ Burgos, 26 marzo 1563; GONZÁLEZ, T.: 1829: t. II. doc. CXLII, 201-210; LABAYRU y GOICOECHEA, E. J. de: 1900: 352-356: t. IV; A. G. S./ Secretaría del Consejo de Hacienda. leg. 49/ Bilbao, 26 abril 1563; GONZÁLEZ, T.: 1829: 211-230: t. II. doc. CXLIII. 
Alemania, escribanías de asiento de Francia y Flandes, baúles de cuero, cofres o "Carros de Flandes cumplidos". En armas, destacan las hachas de guerra, arcabuces, pistoletes, cotas de malla comunes, cotas finas jacerinas, cadenillas de latón para llaveros y dagas, escarcelas de cordobán con su hierro llano o blancas y de lienzo para caza, y de terciopelo con hierro llano, hierros de escarcelas comunes y de ataujía, hierros de talabartes de Flandes y de baqueta o búfalo, conteras de espada, espadas, dagas doradas o sin dorar, espuelas, estribos o paños de espada.

Hemos detallado todos los productos que se incluyen en la tarifas y aranceles con el fin de conocer la proporción de los diferentes artículos en relación con el conjunto, si bien es cierto, que al no disponer de los detalles del paso de cada una de las mercaderías, no conocemos el volumen de su tráfico. Destacan, no obstante, sobre todos los productos cuyo diezmo se tasa, las importaciones de los textiles en sus diferentes modalidades, hierba pastel, los artículos manufacturados y el pescado seco.

A fines del siglo XIII está confirmado este comercio internacional, a través de los puertos del Cantábrico, en los acuerdos que fijan unos aranceles de aduanas sobre "todas las cosas que deuen dar peaie en Samtander, en Castro d'Ordiales e en Laredo e en Sant Uincent de la Barquera", derechos que pertenecían al Rey ${ }^{1873}$ :

\begin{tabular}{|l|c|}
\hline Mercadería & Arancel \\
\hline Pan, vino, sal o aceite, si viniere por mar & la treintena \\
\hline Carne o pescado, si viniere por mar & la treintena \\
\hline “Pumadas", si vinieren por mar & la treintena \\
\hline Avellanas, nueces, castañas, higos y pasas si vinieren por mar & la treintena \\
\hline Armas, si vinieren por mar & la treintena \\
\hline Mercería de Limoges y cruces, si vinieren por mar & la treintena \\
\hline Incensarios y cajas para incienso, vinajeras y candeleros si vinieren por mar & la treintena \\
\hline Marcos, si vinieren por mar & la treintena \\
\hline Balanzas, candados, cuchillos, “ganivetes" y alium, si vinieren por mar & la treintena \\
\hline Bacines, si vinieren por mar & la treintena \\
\hline Pimienta, si viniere por mar & la treintena \\
\hline Todas las anteriores, si vinieren por tierra no deben pagar nada & \\
\hline Peletería, por carga & 4 mrs. \\
\hline Grana y cera, por carga & $1 / 2 \mathrm{mr}$. \\
\hline Lana y filaza, por carga & $1 / 2 \mathrm{mr}$. \\
\hline Cominos y picotes, por carga & $1 / 2 \mathrm{mr}$. \\
\hline Marfagas y sayales, por carga & $1 / 2 \mathrm{mr}$. \\
\hline Caballos o rocines, cada uno & $1 \mathrm{mr}$. \\
\hline Cuero de vaca, buey, caballo, yegua, bestia mular, asno o de ciervo & 1 dinero \\
\hline Cuero de cabruno y cordobán, la docena & 3 dineros \\
\hline Paños de Gante, Douay e Ypres planos y viados, la pieza & 4 dineros \\
\hline Paños de Ypres reforzados, la pieza & 4 dineros \\
\hline
\end{tabular}

1873 Escorial/ Códice Escurialense, III-Z-13/ Burgos, f. S. XIII; CASTRO, A.: 1921: 1-29. 
Paños blancos de Parelingas (de Poperinghe), Lille o Aboyuilla (de Abbeville), la pieza

Paños planos de Mosterol (de Montreuil-sur-mer), Provins o Ruan, la pieza

Paños de Douay, Camua o Cambrai, la pieza

Escarlatas y todas las camelinas, la pieza

Todos los preses y verdes, la pieza

Las brunetas, estanfortes de Saintomer o contrahechos de otro lugar, la pieza

Plumas de Amiens, la pieza

Estanfortes de Raz, Saintomer, Valancinas (de Valenciennes) o Brujas, la pieza

Estanfortes de Tournai o de Cam, la pieza

Estanfortes de Inglaterra, teñidos o por teñir, la pieza

Estanfortes de Ruan, Chartres, Partenes (de Parthenay en el Poitou) o Mosterol, la pieza

Todos los estanfortes planos o viados, de cualquier parte, la pieza

Viadillos de Ypres, la pieza

Tiritanas y frisas, la pieza

Paños de Longamarca (de Langemark) o viados de Provins, la pieza

Ensays de Brujas, Ypres, Gante o Tournai, la pieza

Capa de Blaos (de Bailleul), la pieza

Frisa de Estampas o de Casteldun, la pieza

Barraganes de Ruan, Belvas, Loherens o de Provins, la pieza

Trojiello de ropa vieja

Carga de pimienta

Cobre o estaño, el quintal

Plomo, el quintal

Telas de ranzal, paño de lino o de seda, cáñamo, "cenbellines", armiños, nutrias, peces o aparejadura

Cendales, porpolas, "jamet”, "ciclatón”, acitaras, alcotonias, "zafrin” o leticias

Orfreses, cintas, cuerdas, cañudos de oro o plata, madejas de oro, plata, lino o cáñamo, ni ningún hilado, seda, cadarzo ni algodón

Correas, hebillas, bolsas, bragueros, bronchas, sortijas, agujas, tijeras, dedales, botones, cristales o cascabeles

Peñas veras, grisas, armiñas, lendesia de conejos, esquilos, abortones, cabritos, lirones, gatos, liebres, peña labrada o"peligot"

Mulo, mula ni palafrén que venga

Badanas, baldreses, sebo, unto, sain, yema o resina

Lino, plata viva, arroz, almendras o "matafalba"

Incienso, laca, brasil, glaza, "orpiment", blanca, bermellón, añil, azur, verdete, "reialgar", oro, piedra, sanguina o piedra azufre

Redomas o alguna cosa de vidrio

Regaliz, zumaque, flor de cardo, jengibre, giroflé, canela, espic, cardamomo, azafrán, nuez de ijarca, nuez moscada, citoal, "almastic", garengal, foli, azúcar, letuario confido o especia, si no es pebre o comino

Altezas que llevan los hombres para "enpresentar"

0




\begin{tabular}{|l|c|}
\hline Sal de compas & 0 \\
\hline $\begin{array}{l}\text { Cáñamo, esparto, cucharales, cucharas, vasos, escudillas, talladeros, } \\
\text { greales, peines de cuerno o de fusta, o cualquier fusta que sea }\end{array}$ & 0 \\
\hline Luvas, cofias o"capiellos de camel" & 0 \\
\hline $\begin{array}{l}\text { Ferretes, cadenas, "clamijeras", trashogares, anclas, hachas, destrales, } \\
\text { azadas o cerrajas }\end{array}$ & 0 \\
\hline Cocedras, pluma, colchas o cobertores de lana & 0 \\
\hline Calderas o paellas & 0 \\
\hline Sombreros, "lijaveras", espuelas, frenos, riendas o cabezadas & 0 \\
\hline Escribanías, pergamino, "esponzas" o libros & 0 \\
\hline Ningún ganado vivo, si no es caballo o rocín & 0 \\
\hline Azor, halcón, "esmerilón", gavilán o cualquier ave & 0 \\
\hline
\end{tabular}

Los productos objeto de exportación fueron muy variados, aunque la mercadería principal y que constituyó la base de tan próspero comercio, fue la lana castellana. Los demás complementaban unos beneficios que eran ciertamente importantes, destacando las pieles y cueros, hierro y ferretería, vinos, aceite, sal, frutos secos, especias, colorantes, cera, etc. El trigo fue un producto que según temporadas o años de buenas o malas cosechas podía ser exportado o importado, siendo habitual su transporte por mar, bien de Andalucía o de países europeos, como indica la villa de Laredo en 1574, cuando dice que "no uenia el dicho trigo por mar de Françia y Flandes como solia"1874.

Entre los productos exportados, destacan en estos aranceles, además de la lana, el trigo, vino, sal o aceite, minerales como el cobre y el plomo, y piezas de ferretería como cadenas, "clamijeras", trashogares, anclas, hachas, destrales, azadas o cerrajas. También, frutos secos como higos, avellanas, nueces, castañas y pasas; paños de lino, peletería; o especias como el azafrán o la nuez moscada; productos medicinales como el regaliz, el jengibre, el espic, el letuario o el garengal; cueros de caballo, vaca, buey o cabra y el zumaque para su curtido, el unto o la resina.

La tabla y rótulo de octubre de $1488^{1875}$ permitió a Pedro Martínez de Igueldo, arrendatario y otros fieles y cogedores, cobrar para el condestable de Castilla los derechos de la renta del diezmo viejo y seco de la mar en San Sebastián y sus puertos. Se ofrece con ella una valiosa información sobre los productos que entraban y salían de Castilla por dicho puerto, aunque es cierto que carecemos de los datos sobre el volumen de mercaderías que entraron:

\begin{tabular}{|l|c|}
\hline Mercadería & Mrs. \\
\hline Por quintal de hierro una blanca & \\
\hline Por quintal de acero & 1 \\
\hline Por quintal de cobre & 5 \\
\hline
\end{tabular}

1874 A. H. P. C./ Villa de Laredo, leg. 1, num. 23, fols. 40-41/ Madrid, 1574.

1875 A. G. S./ Contaduría mayor de Cuentas. Inv. 2º Libros de cuentas de los diezmos de la mar de Castilla/ San Sebastián, 7 octubre 1488, Burgos a Salvatierra, 4 junio 1544; GONZÁLEZ, T.: 1829: t. I. doc. XCVI, 328-358. 


\begin{tabular}{|c|c|}
\hline Por quintal de estaño labrado & 6 \\
\hline Por quintal de estaño sin labrar & 4 \\
\hline Por quintal de plomo & 2 \\
\hline Por quintal de azafrán & 100 \\
\hline Por quintal de pimienta & 30 \\
\hline Por quintal de azúcar y de comino & 15 \\
\hline Por quintal de azul & 100 \\
\hline Por quintal de cera & 16 \\
\hline Por quintal de sebo & 2 \\
\hline Por quintal de grana & 30 \\
\hline Por quintal de grana en polvo & 60 \\
\hline Por quintal de cáñamo y de lino y de lana & 2 \\
\hline Por quintal de estopa & 1 \\
\hline Por quintal de azogue & 10 \\
\hline Por quintal de unto, incienso y corcho & 2 \\
\hline Por quintal de trementina & 3 \\
\hline Por quintal de salitre, de azufre y de pólvora de bombardas & 6 \\
\hline Por pipa de aceite & 50 \\
\hline \multicolumn{2}{|l|}{ Por barrica o cuero se ha de contar al respecto que cabe la pipa } \\
\hline Por pieza de paño de grana & 50 \\
\hline Por pieza de paño & 10 \\
\hline Por media pieza & 5 \\
\hline Por cuartilla o ruela de paño & $2 \frac{1}{2}$ \\
\hline Por brishata que se hace doble como dos cuartillas & 5 \\
\hline Por pieza de fusteda & 6 \\
\hline Por pieza de fustán & 2 \\
\hline Por fardel de paños & 50 \\
\hline Por fardel de telas de lienzo & 30 \\
\hline Por pieza de lona & 3 \\
\hline Por rollo de arpilleras & 4 \\
\hline Por rollo de sayal & 2 \\
\hline Por costal de mercería & 50 \\
\hline Por bala de lana lavada & 6 \\
\hline Por bala de lana sin lavar & 3 \\
\hline Por pipa de miel & 15 \\
\hline Por barrica de melazo & 5 \\
\hline Por millar de sardinas de Cornualles & 2 \\
\hline Por millar de sardinas de Portugal & 1 \\
\hline Por quintal durcela & 12 \\
\hline Por costal de regaliz & 1 \\
\hline Por carga de congrio seco & 8 \\
\hline Por carga de otro pescado seco & 4 \\
\hline
\end{tabular}




\begin{tabular}{|l|c|}
\hline Por millar de arenques seco o verde & 4 \\
\hline Por cuero de vaca, buey o toro castellano o por docena de cueros cabrunos & 1 \\
\hline Por cada cuero terreiño de vaca, buey o toro, blanca y media & \\
\hline Por cada pan de pez o resina que sea hasta un quintal o por barrica de alquitrán & 1 \\
\hline Por carga de pasa o higa & 1 \\
\hline Por docena de adoques y por central de merlangos (pescado) & $1 / 2$ \\
\hline Por pipa de pastel & 25 \\
\hline Por costales al respecto de lo que puede caber en una pipa & \\
\hline Por carga de papel & 25 \\
\hline Por costal de vidrios e redomas de vidrios & 15 \\
\hline Por quintal de tocino salado de fuera del Reino & 10 \\
\hline Por carga de seda en hilo & 50 \\
\hline Por carga de seda tejida & 100 \\
\hline Por cada cozneo (almohadón) & 1 \\
\hline
\end{tabular}

En esta tabla, además de la lana lavada y sin lavar, se incluyen en las exportaciones minerales como el hierro, acero, cobre, estaño y plomo. Especias como el azafrán, pimienta o comino, la cera, sebo, grana, cáñamo, lino y estopa, azogue, unto, incienso, corcho, trementina, el salitre, azufre y pólvora, el aceite, la miel, el regaliz, cueros de vaca, buey, toro o cabra, la pez y resina y las pasas o higas.

Conocemos también los aranceles que en mayo de $1503^{1876}$ se aplicaban a todas las mercaderías que circulaban por los puertos de la mar de Castilla y "que se pagan y acostumbran pagar al señor Condestable" en las casas de las aduanas de los puertos secos de Valmaseda y Orduña, según lo registrado en la Contaduría Mayor, que recogía de manera detallada todo tipo de mercaderías. Consideramos de interés su detalle:

\begin{tabular}{|l|c|}
\hline Mercadería & Mrs. \\
\hline Paño de Ypres mayor entero & 183 \\
\hline Paño de Ypres mayor retazado & 168 \\
\hline Paño de Ypres menor entero & 152 \\
\hline Paño de Ypres menor retazado & 137 \\
\hline Escarlata de Ypres retazado & 320 \\
\hline Paño de Mostreviller (de Montivilliers) & 266 \\
\hline Paño de Lille mayor y mediano & 260 \\
\hline Paño de Verbi y de Contrai menor (de Courtray) & 133 \\
\hline Paño de Brujas mayor & 211 \\
\hline Paño de Brujas de bala & 152 \\
\hline Paño de Menen & 171 \\
\hline Paño de Malinas cluquisis & 183 \\
\hline Paño de Malinas mayores & 270 \\
\hline
\end{tabular}

1876 A. G. S./ Contaduría mayor de Cuentas. Inv. 2º Libros de cuentas de los diezmos de la mar de Castilla/ San Sebastián, 7 octubre 1488, Salvatierra, 4 junio 1544; GONZÁLEZ, T.: 1829: 328-358: t. I. doc. XCVI; LABAYRU y GOICOECHEA, E. J. de: 1899. 424-431: t. III. 


\begin{tabular}{|c|c|}
\hline Paño de bruneta Douay & 211 \\
\hline Paño de conimas & 140 \\
\hline Paño de Blois & 101 \\
\hline Paño de Saint-Lô & 96 \\
\hline Paño de Ruan del Sello & 200 \\
\hline Dos medios paños de Bavila, o dos secenales & 96 \\
\hline $\begin{array}{l}\text { Paño de Rennes, Dinant, Fogueras (de Fougères), Vizcontes, Bela y Roles, } \\
\text { de } 30 \text { vara }\end{array}$ & 100 \\
\hline Paño de Normandía & 68 \\
\hline Paño de Bristol & 135 \\
\hline Paño de Yugas y Mollerón & 43 \\
\hline Paño de village de Inglaterra & 170 \\
\hline Escarlata de Montivilliers & 346 \\
\hline Escarlata de Bruselas, Londres y de Escandin & 460 \\
\hline Paño de Bellarte & 225 \\
\hline Escarlata de Contrai & 220 \\
\hline Escarlata de Brujas & 320 \\
\hline Paño de Gante & 180 \\
\hline Paño de Acental & 101 \\
\hline Paño de Londres de la ciudad & 290 \\
\hline Paño de Bruselas & 210 \\
\hline Paño de cordellate & 40 \\
\hline Cuartilla de binastra & 50 \\
\hline Cuartilla de Inglaterra & 25 \\
\hline Paño de tunes Ypres mayor & 183 \\
\hline Paño de Lyon y Leoquin & 124 \\
\hline Paño de lque & 92 \\
\hline Paño de Blandique y dizquesninas y Bolduque & 81 \\
\hline Paño de San Martín o de Arsaveques & 125 \\
\hline Paño de Dublegrus & 118 \\
\hline Paño de Armentieres & 122 \\
\hline Paño de Pagaringas & 104 \\
\hline Fustán & 16 \\
\hline Fusteda & 48 \\
\hline Borda de hilo & 50 \\
\hline Borda con seda & 100 \\
\hline Bocaranes a 72 docena y seis mrs. cada uno & 72 \\
\hline Vara de tapiz con seda y con oro & 60 \\
\hline Vara de tapiz sin seda & 36 \\
\hline Manta con seda & 100 \\
\hline Manta sin seda & 50 \\
\hline Rebates con seda de una cámara & 56 \\
\hline Rebates de una cámara sin seda & 25 \\
\hline
\end{tabular}




\begin{tabular}{|c|c|}
\hline Bancal de ras con seda & 62 \\
\hline Bancal de ras sin seda & 31 \\
\hline Bancal de Tournai sin seda & 14 \\
\hline Bancal de Tournai con seda & 28 \\
\hline Bancal de Flandes & 6 \\
\hline Pieza de lienzo de Flandes de Go varas & 77 \\
\hline Pieza de lienzo de Holanda de 50 varas & 80 \\
\hline Pieza de lienzo de Rennes y de Cambrai de 24 varas & 83 \\
\hline Pieza de media Holanda de dos orillas de 50 varas & 45 \\
\hline Pieza de manteles sin tobajones & 53 \\
\hline Pieza de tohallones & 33 \\
\hline Pieza de tohallones de 16 uno & 10 \\
\hline Colchas de Flandes, cada una & 25 \\
\hline \multicolumn{2}{|l|}{ Todas las cañamazas a blanca la ana } \\
\hline Lienzos de Bretaña y Sambriolo y Morlaix blancos y crudos, la ana & 1 \\
\hline Reposteros de sobrecama & 20 \\
\hline Docena de cojines con seda & 130 \\
\hline Docena de cojines sin seda & 65 \\
\hline Una cámara de sargas con sus goteras & 170 \\
\hline Un baúl & 25 \\
\hline Un cozneo & 6 \\
\hline Una antepuerta con seda & 80 \\
\hline Una antepuerta sin seda & 40 \\
\hline Madejas de Colonia de 24 una & 30 \\
\hline Madeja de oro y plata de 24 una & 50 \\
\hline \multicolumn{2}{|l|}{ Griselveros y febles, conejos y gatos, a blanca cada uno } \\
\hline \multicolumn{2}{|l|}{ Fuimas de 25 una o lo que valiere } \\
\hline Marcas de 30 una & 150 \\
\hline Lomos de marcas, de 30 una & 50 \\
\hline Terna de baldoque sin oro & 75 \\
\hline Terna de baldoque con oro & 96 \\
\hline Parella prieta & 32 \\
\hline Pieza de sarga & 34 \\
\hline Parella de imperiales & 145 \\
\hline Terna de Ricomes & 96 \\
\hline Pieza de terciopelo de 30 varas & 240 \\
\hline Pieza de sartín y damasco de 30 varas & 100 \\
\hline Pieza de brocado de 30 varas & 600 \\
\hline Pieza de camelote & 90 \\
\hline \multicolumn{2}{|l|}{ Cinta de plata con oro, o sortijas de oro o plata de 31 o lo que valiere } \\
\hline Marco de plata & 14 \\
\hline Quintal de cobre & 53 \\
\hline
\end{tabular}




\begin{tabular}{|c|c|}
\hline Un quintal de plomo & 10 \\
\hline Quintal de estaño labrado de 16 libras & 25 \\
\hline Términos cada uno & 1 \\
\hline Quintal de estaño en barra & 43 \\
\hline Quintal de hoja de latón y de hilo de latón & 77 \\
\hline Quintal de hoja de hierro & 34 \\
\hline Quintal de hilo de hierro & 58 \\
\hline Bonetes dobles sin grana de 16 docenas, a $47 \mathrm{mrs}$. la docena & 750 \\
\hline Bonetes simples sin grana, y camellones simples sin grana de 16 docenas, uno & 375 \\
\hline Bonetes con grana de 16 uno, o camellones de Florencia & 125 \\
\hline Candeleros de sala de 25 , cada uno & 200 \\
\hline Candeleros de tabla de 25 docenas, a 16 la docena & 400 \\
\hline Rastrillos de todas suertes a 25, uno & 75 \\
\hline Cofres de Lille pequeños y ternos de 16 , uno & 150 \\
\hline Cofres ricos de 16 uno o 600 mrs. de 9 varas arriba & 600 \\
\hline Cargas, cada par & 4 \\
\hline Portacas de 16 , uno & 50 \\
\hline Sombreros de vefle de 16 , uno & 60 \\
\hline Bacanes de latón de 16 libras, una & 25 \\
\hline Media roldana de Bramante & 45 \\
\hline Tabinetes de 25 tratas, una & 33 \\
\hline Tijeras de 25 docenas, una & 25 \\
\hline Alfileres de 25 millares, uno & 22 \\
\hline Sortijas de latón de 25 gruesas, una & 25 \\
\hline Espejos de almacén de 25 docenas, una & 9 \\
\hline Campanillas de latón de 25 docenas, una & 40 \\
\hline Dedales de hombre y de mujer de 25 docenas, una & 9 \\
\hline Espejos finos de 25 docenas, una & 75 \\
\hline Candados de 25 docenas, una & 20 \\
\hline Luvas de 25 docenas, una & 150 \\
\hline Tijeras de espabilar, escobillas de limpiar ropa y asedaderas de 25 docenas, una & 40 \\
\hline Bimblotes para niños de 25 docenas, una & 30 \\
\hline Agujas de coser de 25 millares, uno & 80 \\
\hline Hachas de armas de 25, una & 100 \\
\hline Espadas de armas de 25, una & 150 \\
\hline Colobrinas de 25, una & 150 \\
\hline Saleros de estaño de 25, uno & 25 \\
\hline Espuelas y estribos de 25 docenas, una & 140 \\
\hline Tajaranes & 15 \\
\hline Cotas de hierro & 4 \\
\hline Quintal de metralla & 50 \\
\hline Quintal de Caparrosa & 30 \\
\hline Carmín de 25 libras, una o lo que valiere & \\
\hline
\end{tabular}




\begin{tabular}{|c|c|}
\hline \multicolumn{2}{|l|}{ Azarcón genoli de 25 libras, una o lo que valiere } \\
\hline Carga de tierra de Flandes & 28 \\
\hline Carga de pastel & 55 \\
\hline Carga de peñas sin masía & 250 \\
\hline Carga de mercería de Reaminges sin otra masía & 750 \\
\hline \multicolumn{2}{|c|}{ Toda especiería y droguería de 25 libras, una o lo que valiere } \\
\hline Aceros de bata & 2 \\
\hline Cuentas de ámbar, la libra & 100 \\
\hline Bota de pergaminos que es tres docenas bota & 36 \\
\hline Congrio, el quintal & 50 \\
\hline Salmón, el quintal y pescado & 40 \\
\hline Arenques de 25 millares uno & 45 \\
\hline Saca de algodón & 96 \\
\hline Saca de lana merina & 60 \\
\hline Pieza de tapete de seda & 50 \\
\hline Saca de lana grosera lavada & 26 \\
\hline Saca de añinos lavada o de lana lavada & 40 \\
\hline Saca de lana sucia & 16 \\
\hline Costal de cordobán & 55 \\
\hline Costal de badán & $32 \frac{1 / 2}{2}$ \\
\hline Costal de hilaza & 28 \\
\hline Costal cominos & 9 \\
\hline Quintal de hilo guncil & 70 \\
\hline Avices & 10 \\
\hline Tachuelas de 25 millares, uno & 4 \\
\hline Trompas de París de 25 docenas, una & 7 \\
\hline Búfalo prieto y blanco y colorado de 25.000 , uno & 6 \\
\hline Anteojos de madera de 25 docenas, una & 20 \\
\hline Anteojos de cuerno de 25 docenas, una & 40 \\
\hline Balanzas pequeñas de 25 docenas, una & 80 \\
\hline Balanzas mayores de 25, una & 50 \\
\hline Maquilla de vidrio de 25, una & 13 \\
\hline Vidrio de 25 libras, una & $3^{1 / 2}$ \\
\hline Hilo de coser de toda suerte de 25 libras, una & 37 \\
\hline Caja de vidrio & 35 \\
\hline Incensarios de latón de 25, uno & 50 \\
\hline Botonallos para bolsos de 25 gruesas, una & 4 \\
\hline Ganivetes de escribanía de 25 docenas, una & 13 \\
\hline Semielos y capitores de alcoholes de 25 docenas, una & 35 \\
\hline Pelotas de 25 docenas, una & 7 \\
\hline Malla de latón de 25 millares, uno & 12 \\
\hline Cadenillas de latón de 25 docenas, una & 30 \\
\hline
\end{tabular}




\begin{tabular}{|c|c|}
\hline Espejos de marfil de 25 , uno & 100 \\
\hline Seda de zapateros de 25 docenas, una & 30 \\
\hline Agujeros de acero de 25 docenas, una & 3 \\
\hline Estuches de 25 , uno & 100 \\
\hline Mazo de lentejas y abaló de 25 mazos uno. Hay 100 sartas en el mazo & 175 \\
\hline Cajas de escribanías de 25 docenas, una & 32 \\
\hline Cajas de anteojos de 25 docenas, una & 6 \\
\hline Cartas pintadas grandes de 25 , una & 210 \\
\hline Cartas pintadas pequeñas de 25 , una & 100 \\
\hline Cascabeles de 25 docenas, una & 7 \\
\hline Cuerdas de tañer de 25 docenas, una & 9 \\
\hline Canilla de oro de bazán de 25 libras, una & 30 \\
\hline Tenazuelas de 25 docenas, una & 6 \\
\hline Sortijas de paramento de 25 gruesas, una & 40 \\
\hline Brocas de zapateros de 25 millares, uno & 50 \\
\hline Bullones de 25 , uno & 80 \\
\hline Agujetas de abrochar de 25 gruesas, una & 34 \\
\hline Pesos de oro de 25 docenas, uno & 160 \\
\hline Tinteros de 25 docenas, uno & 40 \\
\hline Hierro de leznas de 25 gruesas, una & 65 \\
\hline Corchetes de hierro y latón de 25 millares, uno & 57 \\
\hline Un rollo & 26 \\
\hline Un costal de cera & 85 \\
\hline Un costal de grana & 260 \\
\hline Un costal de cueros & 14 \\
\hline Bolsones de seda de 16 , uno & 150 \\
\hline Bolsos de Chamues de 16 , uno & 50 \\
\hline Mantos de Vernia, cada uno & 25 \\
\hline Torella doble y simple dorado y plateado para dorar y platear la cera la libra & 2 \\
\hline Una cama de lienzo con sus goteras & 135 \\
\hline Tijeras de tundir, el par & 35 \\
\hline Clavos de girofle, por libra & 4 \\
\hline Pieza de locazo & 12 \\
\hline Malla de hierro hace de tasar de 20.000 , uno & 10 \\
\hline \multicolumn{2}{|l|}{ Arroba de rubia } \\
\hline \multicolumn{2}{|l|}{ Canfora } \\
\hline \multicolumn{2}{|l|}{ Corales contrahechos } \\
\hline \multicolumn{2}{|l|}{ Sinopila } \\
\hline \multicolumn{2}{|l|}{ Mina } \\
\hline Machicote & \\
\hline
\end{tabular}


En esta tabla de 1503, además de clasificar la lana en diferentes clases, como lana grosera, lavada o sucia y añinos o lana lavada, se detallan como productos objeto de exportación los minerales como hierro, cobre, plomo o estaño, la especiería como los cominos, y la droguería, el algodón, las pieles y cordobanes, cera, grana, clavos y tachuelas entre otros.

A las mercaderías que pasaban por los puertos de la mar de Castilla y no estaban en la nómina por ser nuevas, se les fijan a principios del siglo XVI sus aranceles, con la conformidad de los dezmeros y de los mercaderes que las han pagado1877:

\begin{tabular}{|l|c|}
\hline Mercadería & Mrs. \\
\hline Sombreros de grana, cada uno & 10 \\
\hline Sombreros sin grana, cada uno & 6 \\
\hline Dagas doradas & 5 \\
\hline Pieza de velut entera & 60 \\
\hline Cordellate en grana de 3o varas & 210 \\
\hline Linstéricas valencianas, la pieza & 30 \\
\hline Quintal de azogue & 100 \\
\hline Quintal de atriaca & 50 \\
\hline Quintal de cera & 60 \\
\hline Quintal de agalla & 30 \\
\hline Docena de juegos de naipes & 4 \\
\hline Quintal de candelas & 34 \\
\hline Quintal de sebo & 30 \\
\hline Quintal pescado abadejo o bacalao & 20 \\
\hline Millar de sardinas de Cornualles & 15 \\
\hline Quintal de mielgas y de suellas & 50 \\
\hline Quintal de lenguados & 60 \\
\hline Quintal de manteca & 30 \\
\hline Carga de rubia & 55 \\
\hline Libra de canfora & 5 \\
\hline Cueros de lobo merino & $21 / 2$ \\
\hline Docenas de cintas de lobo & 175 \\
\hline Docenas de bolsas de lobo & 125 \\
\hline Docenas de servilletas & 180 \\
\hline Paño de Uncuerca & 60 \\
\hline Paño ultrafino & 30 \\
\hline Paño Saint-Bertín & 6 \\
\hline Paño Quismoda & 2 \\
\hline Quintal de azúcar & 5 \\
\hline Pieza de friseta de Inglaterra de 3o varas & 3 \\
\hline & \\
\hline
\end{tabular}

1877 A. G. S./ Contaduría mayor de Cuentas. Inv. 2o Libros de cuentas de los diezmos de la mar de Castilla/ San Sebastián, 7 octubre 1488, Salvatierra, 4 junio 1544; GONZÁLEZ, T.: 1829: 328-358: t. I. doc. XCVI. 


\begin{tabular}{|c|c|}
\hline Docena de rosarios de Inglaterra benditos & 6 \\
\hline Docena de rosarios comunes & 1 \\
\hline Quintal de azufre & 20 \\
\hline Goma & 1 \\
\hline Trenzaderas y cintas de hilo, la libra & $1 \frac{1}{2}$ \\
\hline Libra de goma de dragante, la libra & $1 \frac{1}{2}$ \\
\hline Libra de garito, la libra & $1 \frac{1}{2}$ \\
\hline Incienso, la libra & 1 \\
\hline Libra de Sem & 2 \\
\hline Libra de estoraque líquido & 6 \\
\hline Docena de ceñidores & 4 \\
\hline Pieza de reatas de lana & $1 \frac{1}{2}$ \\
\hline Docena de tejillos con cabo de latón & 6 \\
\hline Dagas con cabos blancos y negros & 3 \\
\hline Boneticos de niño & 2 \\
\hline Sombreros de niño & 1 \\
\hline Docena de valdeses colorados & 6 \\
\hline Docena de valdeses blancos & 4 \\
\hline Quintal de jal, oro pimienta & 30 \\
\hline Paño de Tournai, de peto de 20 y de Albín & 100 \\
\hline Paño de Bousbecque & 125 \\
\hline Quintal de pimienta & 150 \\
\hline Caja de arillos grande & 20 \\
\hline Arillos dorados, el par & 2 \\
\hline “Niños Cristos de yeso”, cada uno & 2 \\
\hline Imágenes de yeso mayores & 4 \\
\hline Cadenas para galgos y perros, la docena & 6 \\
\hline Escribanías que son cajas con sus tinteros, la docena & 3 \\
\hline Un tapete de gante & 12 \\
\hline Sábanas de lienzo que han servido & 3 \\
\hline Paño de Norte de 30 varas & 114 \\
\hline Una carpeta de Gante & 8 \\
\hline Una docena de boneticos de noche & 6 \\
\hline Una cama de campo de madera con su aderezo & 30 \\
\hline Un escaparate de madera & 30 \\
\hline Paño de Aules & 90 \\
\hline Paño de Albín de Lieja y Rotterdam & 125 \\
\hline Una docena de tientes & 4 \\
\hline Millar de prenderos de sayas & 4 \\
\hline Millar de agujas de salmar & 6 \\
\hline Una libra de cerdas de puerco & $1 \frac{1}{2}$ \\
\hline Una docena de jeringas & 6 \\
\hline Calderas de cobre o de latón guarnecidas de hierro, la libra & 1 \\
\hline
\end{tabular}




\begin{tabular}{|l|c|}
\hline Paño de Aelán & 125 \\
\hline Paño de Aul & 118 \\
\hline Paño de Sant Modal & 125 \\
\hline Calzas de paño para hombre & 12 \\
\hline Zapatos, el par & $1 \frac{1}{2}$ \\
\hline Botas de cuero para hombre & 5 \\
\hline Camisas de lienzo que han servido & 2 \\
\hline Docena de artares de madera con su caja & 4 \\
\hline Cuero de búfalo & 15 \\
\hline Cuero de búfalo hecho & 25 \\
\hline Sombreros de sayeta, la pieza & 4 \\
\hline Sombreros de media sayeta & 2 \\
\hline Quintal de cola & 45 \\
\hline Quintal de orchilla & 120 \\
\hline Cajas de lunas de espejos, cada una & 130 \\
\hline Pieza de servilletas o tohalletas & 33 \\
\hline Dezmándose por anas las servilletas o tohalletas de 16 anas & 10 \\
\hline Arnés cumplido con cuello y testero & 265 \\
\hline Resma de papel & 10 \\
\hline
\end{tabular}

Aquí vuelve a aparecer la lana como producto para la exportación, como "pieza de reata de lana", así como la cera, el sebo, la manteca, el azúcar, la pimienta, y los naipes, candela, rubia, canfora, cola, goma, agalla, azogue, azufre, incienso, los cueros de lobo y búfalo o las calderas de cobre y latón.

En Valmaseda, en agosto de $1536^{1878}$, Juan de Salinas informa al tesorero del Condestable que hay mercaderías que pasan por los puertos y que no están incluidas en la nómina. A todos los mercaderes de la Universidad de Burgos, conforme al concierto que sobre ello hay, se les carga la demasía a 740 mrs. el millar, y de allí abajo en proporción, y a los demás mercaderes a 800 mrs. el millar, y si es menos, también en proporción. En la nómina están asentadas las mercaderías con el diezmo como en ella se contiene y, sin embargo, se ha cargado después que la nómina se hizo, con acuerdo del Prior y cónsules de la Universidad de Burgos:

\begin{tabular}{|l|c|}
\hline Mercadería & Mrs. \\
\hline Paño de tunes Ypres mayor & 210 \\
\hline Paño de Armentieres & 175 \\
\hline Marco de plata & 50 \\
\hline Millar de arenques & 50 \\
\hline $\begin{array}{l}\text { Pieza de media holanda, se carga como holanda sin hacer diferencia de uno } \\
\text { a otro que es de 50 varas }\end{array}$ & 80 \\
\hline
\end{tabular}


Quintal de cera

Madejas de hilo, de oro y plata de 24 onzas

Hay, además, en la nómina mercaderías a las que tan solo se les carga el diezmo, tanto a las asentadas en la memoria fuera de la nómina, como las que están en ella:

\begin{tabular}{|l|}
\hline Marco de plata \\
\hline Carga de peines \\
\hline Carga de mercaderías cerradas \\
\hline Papel \\
\hline Higos y pasas \\
\hline Todos los pescados \\
\hline
\end{tabular}

Por ello, lo que se ha de cobrar sin demasía es a las siguientes mercaderías:

\begin{tabular}{|c|c|}
\hline Mercadería & Mrs. \\
\hline Quintal de cera & 108 \\
\hline Quintal de pastel & 29 \\
\hline Alcanfor libra & 7 \\
\hline Cada cuero mayor & 4 \\
\hline Cada cuero de becerros que se llama udelinos cada docena & 22 \\
\hline Cada quintal de pescado abadejo & 22 \\
\hline Cada quintal de pescado fuera del Reino & 40 \\
\hline Cada quintal de congrio & 50 \\
\hline Cada quintal de salmón salado & 40 \\
\hline Cada millar de arenques de Flandes & 55 \\
\hline Cada millar de arenques & 15017 \\
\hline Cada resma de papel & 10 \\
\hline \multicolumn{2}{|l|}{ Cada vara de género crudo o curado 10 cornados } \\
\hline $\begin{array}{l}\text { La vara de angeo } 4 \text { cornados, y si diezman por anas, cada ana de género de } \\
\text { estas } 10 \text { anas de género blanco o crudo y el angeo la mitad. }\end{array}$ & 18 \\
\hline Quintal de Brasil & 36 \\
\hline Cada quintal de cobre & 25 \\
\hline Cada quintal de cobre labrado & 50 \\
\hline Quintal de estaño sin labrar & 75 \\
\hline Quintal de estaño labrado & 120 \\
\hline Quintal de palo de las Indias & 33 \\
\hline De una pieza de fusta & 28 \\
\hline De una carga de mercería de 12 arrobas, y si es más o menos, en proporción & 750 \\
\hline Cada par de cuerdas & 7 \\
\hline Quintal de plomo & 25 \\
\hline Quintal de resina & 15 \\
\hline Vara de cañamaza cuatro cornados & \\
\hline
\end{tabular}




\begin{tabular}{|l|c|}
\hline Carijea blanca & 96 \\
\hline Quintal de mielgas & 50 \\
\hline Cardas, cada par & 7 \\
\hline Hilo negro cada arroba & 52 \\
\hline Docena de pergaminos & 20 \\
\hline Libra de incienso a tres blancas & \\
\hline
\end{tabular}

En el cuadro se hace mención a la exportación de minerales como el cobre, estaño o plomo, cuero, cera, alcanfor, resina, brasil, el incienso, palo de Indias, cardas para la industria pañera y frutos secos como los higos y pasas.

El Consulado de Burgos cobraba, como derecho de avería, una determinada cantidad por cada género o mercadería que exportase o importase por los puertos y aduanas de Santander, Laredo, San Vicente de la Barquera y Castro-Urdiales, que se aplicaba para atender sus gastos generales. Tales aranceles se recogen oficialmente en las ordenanzas de $1538^{1879}$, y con algunos añadidos en las ordenanzas de $1572^{1880}$ :

\begin{tabular}{|l|c|c|}
\hline Mercadería & 1538 & 1572 \\
\hline Saca de lana para Flandes, por mar & 2 dineros & $17,5 \mathrm{mrs}$. \\
\hline $\begin{array}{l}\text { Saca de lana por tierra para Francia, Flandes, Bretaña o } \\
\text { Ruan, por Navarra o Fuenterrabía u otra parte }\end{array}$ & $12,5 \mathrm{mrs}$. & $22,5 \mathrm{mrs}$. \\
\hline $\begin{array}{l}\text { Saca de lana para Italia en la estapla de Florencia y otras } \\
\text { partes }\end{array}$ & $12.5 \mathrm{mrs}$. & $22,5 \mathrm{mrs}$. \\
\hline Saca de lana vendida sin salir del Reino & & $12,5 \mathrm{mrs}$. \\
\hline Quintal de hierro & 4 mitas & $2,5 \mathrm{mrs}$. \\
\hline Quintal de fruta de Jerez & 3 mitas & \\
\hline Quintal de fruta de Valencia y Málaga & 4 mitas & \\
\hline Quintal de alumbre & 4 mitas & $2 \mathrm{mrs}$. \\
\hline Quintal de cera del peso de Flandes & 1 d. y $6 \mathrm{~m}$. & \\
\hline Quintal de jabón & 4 mitas & \\
\hline Quintal de pimienta & 1 dinero & $15 \mathrm{mrs}$. \\
\hline Quintal de jengibre & 2 dineros & \\
\hline $\begin{array}{l}\text { Quintal de canela, clavo, nuez moscada y toda suerte de } \\
\text { drogas }\end{array}$ & 4 dineros & $35 \mathrm{mrs}$. \\
\hline Quintal de sebo & & $3 \mathrm{mrs}$. \\
\hline Quintal de cobre & & $3 \mathrm{mrs}$. \\
\hline Cada 1o quintales de brasil, peso de España & $4 \mathrm{mrs}$. \\
\hline Carga de pastel de dos balas para distribuir en Castilla & 3 mrs. & $6 \mathrm{mrs}$. \\
\hline $\begin{array}{l}\text { Gruesa de pasteles al reino de Valencia, Cartagena, Mála- } \\
\text { ga, Cádiz y Levante }\end{array}$ & 3 mrs. & \\
\hline & & \\
\hline
\end{tabular}

1879 Ordenanzas del Consulado de Burgos de 1538/ Valladolid, 18 septiembre 1538; GARCÍA de QUEVEDO y CONCELLÓN, E.: 1905 y 1995: 203-207. Ordenanza XXII.

1880 Reales Ordenanzas del Consulado y Casa de Contratación de Burgos/ Ordenanza nº XXVIII/ Madrid, 1 agosto 1572 en LARRUGA, E.: 1793: 216-297: t. XXVIII. 


\begin{tabular}{|c|c|c|}
\hline Tonel de aceite & 2 dineros & 20 mrs. \\
\hline Tonel de vino de La Rochelle & 1 dinero & 2 mrs. \\
\hline Tonel de vino de Gascuña & 2 dineros & 2 mrs. \\
\hline Tonel de vino bastardo & 1,5 dineros & \\
\hline Bota de Romania & 12 mitas & \\
\hline Bota de vino de Alicante & 1 dinero & \\
\hline Costal de pastel, carga de una gruesa & 18 mitas & \\
\hline Costal o fardo de pelletería & 4 dineros & $30 \mathrm{mrs}$. \\
\hline Costal o fardo de conejos & 1 dinero & $10 \mathrm{mrs}$. \\
\hline Costal o fardo de hilaza & 1 dinero & $6 \mathrm{mrs}$. \\
\hline Costal de regaliz & 3 mitas & \\
\hline Costal de cominos & 8 mitas & \\
\hline Costal de orchilla & 8 mitas & \\
\hline Libra de azafrán & 3 mitas & $2,5 \mathrm{mrs}$. \\
\hline Libra de seda & 6 mitas & \\
\hline Arroba de grana en ramo o casco & 12 mitas & $5 \mathrm{mrs}$. \\
\hline Arroba de polvo de grana & 1 dinero & $10 \mathrm{mrs}$. \\
\hline Arroba de cochinilla & & $15 \mathrm{mrs}$. \\
\hline $\begin{array}{l}\text { Gruesa o cualquier fardel de lienzo crudo que viniere } \\
\text { de Flandes, Francia, Ruan, Bretaña u otra parte }\end{array}$ & $\begin{array}{l}10 \mathrm{mrs} . \\
\text { por pieza }\end{array}$ & $10 \mathrm{mrs}$. \\
\hline Fardel de seda de cualquier suerte & & $204 \mathrm{mrs}$ \\
\hline Fardel de lienzo blanco de Bretaña & & $30 \mathrm{mrs}$. \\
\hline Fardel de lienzo blanco de Ruan & & $25 \mathrm{mrs}$. \\
\hline Fardel de lienzo blanco de Flandes & & $20 \mathrm{mrs}$. \\
\hline $\begin{array}{l}\text { Fardel de Flandes de anascotes, sargas, tapicería, paños, } \\
\text { bayetas, telillas y otro cualquiera género }\end{array}$ & & $34 \mathrm{mrs}$. \\
\hline $\begin{array}{l}\text { Fardel de paños y bayetas de Francia y de Inglaterra } \\
\text { y cariseas }\end{array}$ & & $34 \mathrm{mrs}$. \\
\hline Fardel de bocaranes de Flandes y Francia & & $17 \mathrm{mrs}$. \\
\hline Fardo de cera & & 1 real \\
\hline Rollo de marga & & $15 \mathrm{mrs}$. \\
\hline Rollo de tria de Castilla, en Navarra & 12 mitas & \\
\hline Caja de azúcar de Portugal & 2 dineros & $15 \mathrm{mrs}$. \\
\hline Caja de azúcar de Valencia & 1 dinero & $15 \mathrm{mrs}$. \\
\hline Caja de azúcar de Santo Tomé & & $5 \mathrm{mrs}$. \\
\hline Caja de terciopelo de Toledo & & 375 mrs. \\
\hline $\begin{array}{l}\text { Caja de sedas de Granada, Valencia, Génova, Florencia, } \\
\text { Luca, Flandes y otras partes }\end{array}$ & & $450 \mathrm{mrs}$ \\
\hline Caja de perlas y aljofar de 100 onzas y en proporción & & $204 \mathrm{mrs}$ \\
\hline Cofre de lienzo de Ruan & & $34 \mathrm{mrs}$. \\
\hline Cofre o fardel de holandas de Flandes & & $102 \mathrm{mrs}$. \\
\hline Bala de arroz & 18 mitas & \\
\hline
\end{tabular}




\begin{tabular}{|l|c|c|}
\hline Bala de almendra & 1,5 dineros & \\
\hline Canfor y Brasil como el arroz y la almendra & 18 mitas & \\
\hline Dátiles como el arroz y la almendra & 18 mitas & \\
\hline Bala de estraza que pese 6 arrobas & & $4 \mathrm{mrs}$. \\
\hline Pieza de raja & & $21 \mathrm{mrs}$. \\
\hline Pieza de camelotes sin seda & & $2 \mathrm{mrs}$. \\
\hline Dos piezas de higos de todas partes & 3 mitas & \\
\hline De cada cuero de Indias o de Irlanda & & $1 \mathrm{mr}$. \\
\hline Tonelada de trigo que se navegare & & $15 \mathrm{mrs}$. \\
\hline Tonelada de centeno que se navegare & & $10 \mathrm{mrs}$. \\
\hline De cada esclavo que se vendiere, comprare o navegare & & $17 \mathrm{mrs}$. \\
\hline
\end{tabular}

A la vista de estos aranceles de averías, podemos destacar que además de la lana exportada por mar, aunque también con mucha menor incidencia, se contempla su transporte por tierra a Francia y a Flandes por el camino de Bayona y Fuenterrabía, o bien por Navarra por el camino Francés ${ }^{1881}$. Se exportaban frutas de Jerez, Valencia y Málaga, arroz, aceite, almendra, dátiles e higos, especias como azafrán, canela, clavo, cominos, jengibre, nuez moscada o pimienta, regaliz, azúcar de Portugal y Valencia, hierro, alumbre, cera, jabón, alcanfor, peletería y conejos, etc. En 1572 se añade el cobre, el sebo, la cera, la marga y la cochinilla, el terciopelo de Toledo y el brasil.

También conocemos la relación que realiza en Burgos Juan de Peñalosa, administrador de los diezmos de la Mar en marzo de 1563, sobre lo que se debía pagar por las mercaderías que entraban en Castilla por la costa de Guipúzcoa, Vizcaya y las Cuatro Villas de la Costa de la Mar, o que se introducían por los puertos secos de Valmaseda y Orduña ${ }^{1882}$. Para ello, Peñalosa se había asesorado por vecinos de Burgos "personas principales e muy honradas, e que tienen esperiencia e saben el valor de las dichas mercadurias y de cada una de ellas, porque son personas que han traido e traen las dichas mercaderias de los estados de Flandes y de los Reinos de Francia e Inglaterra, y que las han comprado y vendido muchas veces ellos y sus factores, asi en los dichos Reinos estraños como en esta ciudad de Burgos y en las villas de Bilbao o Laredo y en otros lugares de la dicha costa".

\begin{tabular}{|l|c|}
\hline Mercadería & Mrs. \\
\hline Armiños, cada timble & 1.020 \\
\hline Alfileres, el millar & 40 \\
\hline Asedaderas, cada una & 12 \\
\hline Anteojos de cuero y papel, la gruesa & 340 \\
\hline Agujeros de cuero para agujas, la gruesa & 160 \\
\hline Agujetas de abrochar de cuero de todas suertes, la gruesa & 40 \\
\hline
\end{tabular}

1881 Hay que tener en cuenta en este caso, que el transporte por tierra era económicamente mucho más costoso, y estaba además sujeto de manera más directa a la situación política y bélica de cada momento.

1882 A. G. S./ Secretaría del Consejo de Hacienda. leg. 49/ Burgos, 26 marzo 1563; GONZÁLEZ, T.: 1829: 201-210: t. II. doc. CXLII; LABAYRU y GOICOECHEA, E. J. de: 1900: 352-356: t. IV. 


\begin{tabular}{|c|c|}
\hline Azarcón, el quintal & 1.500 \\
\hline Genoli, el quintal & 2.800 \\
\hline Arambeles, la pieza & 800 \\
\hline Anascotes, cada pieza & 3.000 \\
\hline Antepuertas, la ana & 375 \\
\hline Bancal de Flandes, a ducado la ana & 375 \\
\hline Veros para aforros, cada manteo & 272 \\
\hline Bimblotes para niños que son joyeles de vidrio y estaño, la gruesa & 68 \\
\hline Búfalo prieto o de colores grande & 1.800 \\
\hline Búfalo prieto o de colores pequeño & 900 \\
\hline Balanzas pequeñas con su peso & 30 \\
\hline Balanzas grandes con su peso & 40 \\
\hline Vidrio de rocalla, la gruesa & 120 \\
\hline Bullones, que es bermellón, la libra & 100 \\
\hline Brocas de zapateros, el millar & 150 \\
\hline Bocacíes de Flandes, de 8 varas la pieza & 187 \\
\hline Bocacíes de Flandes, de doble medida, la pieza & 375 \\
\hline Bocaranes de Francia de 5 a 6 varas pieza & 187 \\
\hline Botas de baqueta para hombre, el par & 238 \\
\hline Botones de ataujía, dorados y esmaltados, la docena & 34 \\
\hline Botones de vidrio negro y de otros colores, la gruesa & 68 \\
\hline Colchas de Francia, la pieza & 400 \\
\hline Cojines con seda, la pieza & 750 \\
\hline Cojines sin seda, comunes & 200 \\
\hline Cama de sarga con sus goteras & 4.000 \\
\hline Cama de lienzo con sus goteras & 250 \\
\hline Cozneos de Francia, cada uno & 238 \\
\hline Cozneos de Flandes, uno & 500 \\
\hline Conejos para aforros, la docena & 34 \\
\hline Corales contrahechos, que son hueso y colorados, la gruesa & 85 \\
\hline Rosario de búfalo, los de a un rosario, la gruesa & 2.250 \\
\hline Rosario de búfalo, los de a tres rosarios, la gruesa & 4.500 \\
\hline Cuchillos de escribanía, la gruesa & 340 \\
\hline Canfora, la libra & 340 \\
\hline Carmín, la libra & 170 \\
\hline Clavos girofle, la libra & 272 \\
\hline Corchetes de hierro y latón, el millar & 68 \\
\hline Cuerdas para tañer, la gruesa & 238 \\
\hline Lienzos pintados groseros para labradores, la pieza & 150 \\
\hline Cuadros grandes de lienzo fino, la pieza & 300 \\
\hline Cuadros pequeños de lienzo fino, la pieza & 150 \\
\hline Cerdas de zapatero, la libra & 204 \\
\hline Cascabeles de Francia, Lyon y Alemania el millar que eran 2.000 casc. & 306 \\
\hline
\end{tabular}




\begin{tabular}{|c|c|}
\hline Cascabeles de Flandes baladíes, la gruesa & 34 \\
\hline Cascabeles de Milán, finos, la gruesa & 408 \\
\hline Cajas de vidrieras, cada una & 1.300 \\
\hline Cajas negras para anteojos, la gruesa & 340 \\
\hline Cajas doradas para anteojos, la gruesa & 510 \\
\hline Cruces de estaño doradas en cajas & 102 \\
\hline Cruces de alquimia grandes, cada una & 680 \\
\hline Quintal de cominos & 750 \\
\hline Cuentas de ámbar, la libra & 750 \\
\hline Cueros de becerro, la docena & 1.000 \\
\hline Cueros de vaca, cada uno & 561 \\
\hline Cargas de peines $7.000 \mathrm{mrs}$. y la docena 17 & 7.000 \\
\hline Carga de pastel & 5.625 \\
\hline Quintal de caparrosa & 854 \\
\hline Cadenas de perros, la docena & 136 \\
\hline Cofres de Flandes barreados, cada uno & 750 \\
\hline Cofres de Flandes, guarnecidos de baqueta & 800 \\
\hline Cardas, cada cesta & 9.000 \\
\hline \multicolumn{2}{|l|}{ Calderas de cobre } \\
\hline Calderas de latón, la libra & 34 \\
\hline Cueras de búfalo, una & 1.020 \\
\hline Todas las cañamazas, cada una & 45 \\
\hline Lienzos de Francia crudos y curados, la ana & 50 \\
\hline Lienzo de Ruan, la ana & 85 \\
\hline Docena de barajas de naipes & 150 \\
\hline Millar de rosarios comunes de Tabor, que traen 14 sartas & 30 \\
\hline Docena de ceñidores de lana sin clavos y de tejillos cóncavos & 68 \\
\hline Docena de baldreses colorados y de tohalletas o servilletas hechas & 408 \\
\hline Docena de escobillas para limpiar, cada una & 25 \\
\hline Dedales de hombre y mujer, el millar & 750 \\
\hline Docena de peletería & 102 \\
\hline Docena de raposos & 236 \\
\hline Ginetas, la pieza & 68 \\
\hline Estaño labrado, la libra & 50 \\
\hline Espuelas, la docena de pares & 238 \\
\hline Estribos, cada par & 51 \\
\hline Espejos de almacén de platilla y redondillas, la gruesa & 102 \\
\hline Carros de Flandes cumplidos & 15.000 \\
\hline Incienso, la libra & 68 \\
\hline Fustedas angostas, la pieza & 800 \\
\hline Fustedas anchas, la pieza & 1.600 \\
\hline Fustanes, la pieza & 650 \\
\hline Fuimas cada pelleja, la pieza & 85 \\
\hline
\end{tabular}




\begin{tabular}{|c|c|}
\hline Fuelle dorada y plateada, la libra & 85 \\
\hline Frisetas de a treinta varas, la pieza & 1.360 \\
\hline Grises, cada manteo tendrá tres timbles & 1.125 \\
\hline Goma, la libra & 30 \\
\hline Goma de dragante que es alquitira, la libra & 102 \\
\hline Gorras de Milán a tres ds. la docena & 1.125 \\
\hline Hilo de coser de todos los colores, e hilo de cartas, la libra & 68 \\
\hline Lienzo de Flandes de Brujas, la ana & 60 \\
\hline Lienzo de Holanda, la ana & 100 \\
\hline Lienzo de Brabante, la ana & 48 \\
\hline Lienzo de Gante, la ana & 60 \\
\hline Lienzo de Betuna, la ana & 51 \\
\hline Libra de estoraque & 408 \\
\hline Leznas de zapateros, la gruesa & 204 \\
\hline Martas de agua, cada una & 90 \\
\hline Mazuela de vidrio que es verde y amarillo, el millar & 4 \\
\hline Malla de hierro para tejedores a 25 mrs. el millar, marco de plata & 2.210 \\
\hline Conejos, cada uno & 34 \\
\hline Manteo de turones, cada uno & 850 \\
\hline Manteo de veros, cada uno & 272 \\
\hline Oro y plata en madejas, la libra de doce onzas & 3.750 \\
\hline Orchilla & 34 \\
\hline Hoja de hierro, el quintal & 1.500 \\
\hline Paño de Túnez, y de San Martín, el paño & 10.000 \\
\hline Paño de Armentieres, cada paño & 7.000 \\
\hline Paño de Menin & 11.000 \\
\hline Paño de Ruan del sello, la ana & 600 \\
\hline Pieza de bayeta de treinta a treinta y una varas & 3.750 \\
\hline Paño de village de Inglaterra & 7.500 \\
\hline Paño de Londres de la ciudad & 10.000 \\
\hline Pieza de carijea & 2.600 \\
\hline Paño de ultrafino & 8.000 \\
\hline Pieza de reatas de lana, la docena & 34 \\
\hline Papel la resma & 150 \\
\hline Pieza de tornasol de lana de a quince varas & 680 \\
\hline Pieza de tornasol con seda, la pieza & 3.000 \\
\hline Cintas de lana para trenzar, la pieza & 30 \\
\hline Pieza de rebenas & 60 \\
\hline Pieza de medias rebenas & 30 \\
\hline Paño de Albín de la espada de quince varas o catorce & 5.100 \\
\hline Quintal de metal campanil & 2.500 \\
\hline Quintal de cobre & 4.000 \\
\hline Quintal de plomo & 850 \\
\hline
\end{tabular}




\begin{tabular}{|c|c|}
\hline Quintal de estaño en barra & 3.000 \\
\hline Quintal de hoja de latón, que es en rollo y plancha & 5.000 \\
\hline Quintal de bitrualla & 2.500 \\
\hline Quintal de brasil & 700 \\
\hline Quintal de azogue & 7.500 \\
\hline Quintal de atriaca & 1.700 \\
\hline Quintal de agallas & 1.500 \\
\hline Quintal de lino rastrillado & 2.000 \\
\hline Quintal de lino por rastrillar & 1.500 \\
\hline Quintal de azufre & 1.300 \\
\hline Quintal de jal de oro pimienta & 600 \\
\hline Libra de pimienta & 150 \\
\hline Quintal de cola & 1.500 \\
\hline Quintal de verdete que es cardenillo & 8.000 \\
\hline Quintal de pabilo & 1.500 \\
\hline Quintal de candelas & 2.500 \\
\hline Quintal de sebo & 2.000 \\
\hline Quintal de pasas & 800 \\
\hline Quintal de hilo de latón de conejo & 5.200 \\
\hline Quintal de hilo de hierro & 1.500 \\
\hline Relojes de madera, la gruesa & 136 \\
\hline Relojes de marfil y de ébano, la gruesa & 306 \\
\hline Sortijas de latón de paramento, la libra & 68 \\
\hline Sortijas de latón sin piedras, la gruesa & 51 \\
\hline Sortijas de latón con piedras, la gruesa & 238 \\
\hline Saetines de Brujas, la pieza & 1.800 \\
\hline Tijeras de mujer baladíes, la docena & 68 \\
\hline Tijeras de espabilar, la docena & 136 \\
\hline Tachuelas, el millar & 34 \\
\hline Trenzaderas y cintas de hilo, la libra & 68 \\
\hline Telillas de monte de hilo y lana y carbonadillas, la pieza & 600 \\
\hline Telillas para jubones listadas con seda, la pieza & 1.200 \\
\hline Telillas para jubones listadas con lana, la pieza & 500 \\
\hline Telillas para jubones con oro o con plata, la ana & 200 \\
\hline Telillas de seda y algodón para ropas de 3/4 de ancho, la pieza & 2.250 \\
\hline Traca de diez cuchillos de cabos amarillos de madera & 68 \\
\hline Talabartes de baqueta, la docena & 750 \\
\hline Un clavicordio o clavicímbalo & 3.000 \\
\hline Un monacordio & 1.500 \\
\hline Una cama de campo de madera & 2.200 \\
\hline Un escaparate de madera & 2.200 \\
\hline Una docena de jeringas grandes de pelotas y mayores & 1.125 \\
\hline Jeringas para matar fuego, una & 250 \\
\hline
\end{tabular}




\begin{tabular}{|l|c|}
\hline Ternos de cofres de Lille negros cada, uno & 500 \\
\hline Ternos de cofres dorados & 1.000 \\
\hline Terciopelo de tripa que es de vellud, cada pieza & 1.300 \\
\hline Sarga de ras y de Lille negras y de colores & 2.000 \\
\hline Pieza de raja & 22.500 \\
\hline Millar de cañones de ganso & 200 \\
\hline Pieza de cotonía ancha & 2.600 \\
\hline Pieza de cotonía angosta, que es el cuarto & 650 \\
\hline Agujetas de hilo de colores de Flandes, la gruesa & 85 \\
\hline Agujetas de Francia, gruesa & 42 \\
\hline Hilo de latón, la libra & 68 \\
\hline Libra de lana de colores & 136 \\
\hline Libra de hileras, y la de cristalina y margaritas & 102 \\
\hline Cacidonias, el millar & 85 \\
\hline
\end{tabular}

Juan de Peñalosa realiza otra relación, en abril de 1563 en Bilbao, de lo que debían pagar las mercaderías que entraban en Castilla por la costa o por los puertos secos de Valmaseda y Orduña, asesorado por vecinos de Bilbao que declaran bajo juramento y presentan "las memorias y cargazones que tienen de mercaderias que han comprado y vendido para que su merced los vea, y que ellos han tasado y valuado la mercaderias contenidas en este memorial"1883.

\begin{tabular}{|l|c|}
\hline Mercadería & Mrs. \\
\hline Almástica, la libra & 272 \\
\hline Armiños, cada timble & 85 \\
\hline Agujas de coser pequeñas, el millar & 280 \\
\hline Agujas de salmar, el millar & 34 \\
\hline Alfileres, el millar & 102 \\
\hline Asedaderas, la docena & 136 \\
\hline Amoniaco, la libra & \\
\hline Hachas de armas & 750 \\
\hline Arenques blancos, cada millar & 68 \\
\hline Aceite de vara, la libra & 570 \\
\hline Anteojos de madera & 136 \\
\hline Anteojos de cuero y papel de todas suertes, la gruesa & 42 \\
\hline Agujeros de cuero para agujas, la gruesa & 17 \\
\hline Agujetas de abrochar de todas suertes de cuero gruesa & 100 \\
\hline Azarcón, la libra & \\
\hline Agujetas de hilo, la gruesa que es doce docenas & \\
\hline
\end{tabular}

1883 A. G. S./ Secretaría del Consejo de Hacienda. leg. 49/ Bilbao, 26 abril 1563; GONZÁLEZ, T.: 1829: t. II. doc. CXLIII, 211-230. 


\begin{tabular}{|c|c|}
\hline Agallas, el quintal & 2.500 \\
\hline Agarico, la libra & 2.650 \\
\hline \multicolumn{2}{|l|}{ Arnés cumplido } \\
\hline Arambeles, cada uno & 700 \\
\hline Argentería fina & 660 \\
\hline Anascote & 350 \\
\hline Amoniaco, la libra & 136 \\
\hline Argentería falsa, la onza & 400 \\
\hline Antepuertas con oro, la ana & 1.220 \\
\hline Antepuertas de Bruselas, la ana & 600 \\
\hline Antepuertas de Gante y Acedernarde & 300 \\
\hline Arcabuces, cada uno & 2.250 \\
\hline Pistoletes, cada uno & 816 \\
\hline Arenques secos, cada millar & 1.000 \\
\hline \multicolumn{2}{|l|}{ Borda de hilo } \\
\hline \multicolumn{2}{|l|}{ Borda de seda } \\
\hline Bancal de Flandes de tapicería, la ana & 306 \\
\hline Baúl de cuero, cada uno & 750 \\
\hline \multicolumn{2}{|l|}{ Veros para aforros } \\
\hline \multicolumn{2}{|l|}{ Geves para aforros } \\
\hline Bimblotes para niños que son joyelicos de estaño, la gruesa & 51 \\
\hline Botas de pergaminos que se ha de tasar por docena & 408 \\
\hline Búfalo prieto o de colores, cada ciento & 1.500 \\
\hline Balanzas pequeñas para pesos con su peso & 408 \\
\hline Balanzas grandes de libra arriba & 816 \\
\hline Vidrio de rocalla, la gruesa & 140 \\
\hline Brocas de zapateros, el millar & 350 \\
\hline Bullones que es bermellón, la libra & 204 \\
\hline Bolsas de seda comunes de Francia, la docena & 95 \\
\hline Bocacíes de Flandes de a 15 a 16 varas cada pieza & 700 \\
\hline Bocaranes de Flandes de 7 a 8 varas y de Francia de 5 a 6 varas comunes, pieza & 170 \\
\hline Botas de baqueta para hombre, el par & 375 \\
\hline Botones de ataujía esmaltados y dorados & 51 \\
\hline Botones de vidrio negros y de otros colores, la gruesa & 34 \\
\hline Cojines con seda, cada uno & 450 \\
\hline \multicolumn{2}{|l|}{ Cojines con oro lo que valieren } \\
\hline Cojines sin seda comunes, cada uno & 300 \\
\hline Cama de sarga con sus goteras & 4.500 \\
\hline Cama de lienzo con sus goteras & 2.600 \\
\hline Cozneos de Francia, cada uno & 272 \\
\hline Cozneos de Flandes, cada uno & 1.500 \\
\hline \multicolumn{2}{|l|}{ Conejos para aforros } \\
\hline Corales contrahechos que son de hueso y colorados & \\
\hline
\end{tabular}




\begin{tabular}{|c|c|}
\hline Carga de rubia & 3.000 \\
\hline \multicolumn{2}{|l|}{ Canfora } \\
\hline Cuchillos de escribanía, la gruesa & 408 \\
\hline Carmín, la libra & 136 \\
\hline Clavos de jirofe, cada libra & 300 \\
\hline Corchetes de hierro, el millar de macho y hembra & 70 \\
\hline Cuerdas para tañer, la gruesa & 612 \\
\hline Canillas de oro de bacín que es falso, la libra de doce onzas & 170 \\
\hline Cartas pintadas grandes, que son cuadros de lienzo finos de dos varas o más & 375 \\
\hline Cartas pintadas medianas que son cuadros de menos de dos varas & 187 \\
\hline Cartas pintadas de a pliego de las dichas & 51 \\
\hline Cerdas de zapateros, la libra & 300 \\
\hline Cascabeles de Francia, Lyon y Alemania dobles, que es dos uno el millar & 4.500 \\
\hline Cascabeles baladíes de Flandes, la gruesa simple & 42 \\
\hline Cajas de escribanías de Francia, la gruesa & 500 \\
\hline Cadenillas de latón delgadas para llaveros y dagas, cada docena & 102 \\
\hline Zumo de regaliz, cada libra & 51 \\
\hline Camuzas de Flandes, cada una & 204 \\
\hline Cajas de vidrieras, cada una & 1.875 \\
\hline Cajas doradas para anteojos, la docena & 75 \\
\hline Cruces de estaño doradas en caja, la pieza & 70 \\
\hline Cruces de alquimia grandes & 680 \\
\hline Cominos, el quintal y cuentas de ámbar, la libra & 1.125 \\
\hline Cañafístula en caña, cada libra & 102 \\
\hline Clavos, cada libra & 136 \\
\hline Cueros becerros, la docena & 816 \\
\hline Cueros de baqueta y cueros de vaca curtidos, cada uno & 680 \\
\hline Cueros de vaca en pelo, cada uno & 340 \\
\hline Carga de peines & 13.500 \\
\hline Cargas de pastel de Francia & 5.625 \\
\hline Carga de pastel de las Islas, la carga & 4.000 \\
\hline Cotas de malla comunes & 1.500 \\
\hline Cotonía entreancha, la pieza & 3.000 \\
\hline Cotas finas jacerinas & 4.500 \\
\hline Cotonía San Antón, la pieza & 750 \\
\hline Caparrosa el quintal & 800 \\
\hline Cadenas para perros de hierro, la docena & 136 \\
\hline Cofres de Flandes barrados de 13 varas & 1.400 \\
\hline Cofres de Flandes de 7 varas anchas & 850 \\
\hline Cañones el millar & 220 \\
\hline Cofres de Flandes guarnecidos de baqueta & 1.400 \\
\hline Cofres de Francia, cada uno & 750 \\
\hline Cardas, de cada par 100 mrs. que sale la cesta a 684 pares & 8.400 \\
\hline
\end{tabular}


Calderas de cobre, el quintal

Calderas de latón labrado, cazuelas, vacías y candeleros, el quintal

Cuchillos de Flandes de Bolduque y Malinas, docena de 24 cuchillos

Cuchillos de Bohemia, la traca que es diez cuchillos

Zarazas para lobos, cada uno

Cuchillos de Francia de todas suertes, cada gruesa

4.500

3.500

280

102

Caja de cuchillos de doce en caja, cada una

34

Cucharas de latón y alquimia, la docena

320

272

Cerraduras de Flandes, cada una

480

102

Carros de Flandes cumplidos, cada uno

15.000

Cintas de lana para trenzar de hasta 40 varas la pieza

40

Colchas de Francia

200

Caja de madera de Flandes

1.500

Lienzos viejos pintados gruesos para labradores, surtidos grandes y medianos, 1

136

Dagas doradas, cada una

Dagas sin dorar, cada una

150

100

Docena de barajas de naipes

Docena de ceñidores de lana sin clavos

120

68

Docena de tejidos con cabos de latón, a real la pieza

34

Docena de baldreses colorados

340

Docena de servilletas de Francia cortadas

612

Docena de tohalletas hechas de Flandes cortadas

612

Docena de escobillas para limpiar de todas suertes

300

Dedales de hombre y mujer, de Flandes y Francia, el millar

1.250

Docena de raposos

Estaño labrado, la libra

48

Estaño en barra, la libra

30

Espuelas, el par

Estribos, cada par

Espadas de armas

Espejos de almacén de platilla y redondillas y otras suertes, la gruesa 119

Espejos de cristal grandes de cuarto de pliego de tamaño y mayor

Espejos de cristal medianos y pequeños de cuarto de pliego, la pieza

Espejos de acero grandes de cuarto de pliego y más, uno

Espejos de acero mediados y chicos, cada uno

Espejos de botón, la docena

Incienso, cada libra

Escritorio de Alemania

Escribanías de asiento de Francia y Flandes una con otra

Escarcelas de cordobán con su hierro llano, a 4 reales docena

Escarcelas blancas y de lienzo para caza, a 3 reales docena

1.500

1.125

Escarcelas de terciopelo con hierro llano, cada una

272

Hierros de talabartes de Flandes, la docena

510 


\begin{tabular}{|c|c|}
\hline Fustedas anchas, cada pieza & 2.100 \\
\hline Fustedas angostas que llaman medias & 1.050 \\
\hline Fustanes de 15 a 16 varas, cada pieza & 750 \\
\hline \multicolumn{2}{|l|}{ Fuinas cada pelleja } \\
\hline Fuella dorada o plateada y de colores, la libra & 102 \\
\hline Frisetas de 30 varas pieza poco más o menos & 1.360 \\
\hline \multicolumn{2}{|l|}{ Fanega de trigo, de centeno o de cebada } \\
\hline \multicolumn{2}{|l|}{ Fanega de metelón que es trigo y centeno } \\
\hline \multicolumn{2}{|l|}{ Fanega de arvejas y de habas } \\
\hline Hierros de escarcelas comunes, la docena & 700 \\
\hline Hierros de escarcelas de ataujía & 1.500 \\
\hline \multicolumn{2}{|l|}{ Grises } \\
\hline Grasa de ballena, el quintal & 680 \\
\hline Goma, cada libra & 30 \\
\hline Goma de dragante que es alquitira, la libra & 170 \\
\hline Galbano, la libra & 204 \\
\hline Gorras de Milán, la docena & 1.125 \\
\hline Jeringas para matar fuego & 400 \\
\hline Jeringas de barbero pequeñas, la pieza & 15 \\
\hline Jeringas de pelota, la pieza & 70 \\
\hline Genoli, el quintal & 2.000 \\
\hline Guantes de perro, el par & 17 \\
\hline Hilo de coser de todos los colores e hilo de cartas, la libra & 68 \\
\hline Hilo de latón de monacordio, la libra & 68 \\
\hline Hilo de hilera blanca, la libra & 102 \\
\hline Hilo de hierro, la libra & 34 \\
\hline Jures avellanada, cada libra & 68 \\
\hline De todas las cañamazas, la ana & 46 \\
\hline Lienzo de Francia crudo y curtido, la ana & 70 \\
\hline Lienzo de Ruan, la ana & 106 \\
\hline Lienzo de Flandes blanco de todas suertes y crudos, la ana & 50 \\
\hline Lienzo de Holanda, cada ana & 100 \\
\hline Latón labrado, el quintal & 3.500 \\
\hline \multicolumn{2}{|l|}{ Lobos de Alemania } \\
\hline Linos para rastrillar, el quintal & 1.125 \\
\hline Lino rastrillado, el quintal & 2.000 \\
\hline Libra de sen & 17 \\
\hline Libra de estoraque & 340 \\
\hline Libra de cornerinas & 1 \\
\hline Leznas de zapateros, la gruesa & 200 \\
\hline Lunas de espejos de todas suertes, el ciento & 117 \\
\hline Libra de escamonea a cuatro dineros libra & 1.500 \\
\hline Libra de lana de colores, la libra & 140 \\
\hline
\end{tabular}




\begin{tabular}{|c|c|}
\hline Latón en rollo para clavar agujetas, el quintal & 5.000 \\
\hline Libra de marcos & 70 \\
\hline Molinos de Alemania, cada uno & 1.500 \\
\hline Tapicería con oro, la ana & 1.200 \\
\hline Tapicería de Bruselas con seda o sin ella, la ana & 600 \\
\hline Tapicería de Oudenaarde o Gante, con seda o sin ella & 300 \\
\hline \multicolumn{2}{|l|}{ Madejas de cotonía } \\
\hline \multicolumn{2}{|l|}{ Media roldana } \\
\hline Manteles de Flandes, la ana & 160 \\
\hline Servilletas de Flandes, la ana & 55 \\
\hline \multicolumn{2}{|l|}{ Martas de agua } \\
\hline \multicolumn{2}{|l|}{ Martas cecilianas } \\
\hline Mantos de Bernia, cada uno & 375 \\
\hline Mazuela de vidrio que es verde y amarillo, el millar & 21 \\
\hline Malla de hierro para tejedores y malla de latón, la libra & 50 \\
\hline Millar de sardinas de Cornualles y millar de sardinas de Francia & 272 \\
\hline Millar de sardinas de Portugal & 340 \\
\hline \multicolumn{2}{|l|}{ Manteos de conejos } \\
\hline \multicolumn{2}{|l|}{ Manteos de turones } \\
\hline \multicolumn{2}{|l|}{ Manteos de verde } \\
\hline Millar de rosarios comunes de Tabor que traen 14 sartas, el millar & 25 \\
\hline Mana & 1.125 \\
\hline “Niños Jesuses de yeso" y otras imágenes de yeso, cada uno & 68 \\
\hline Naipes, la docena de barajas & 120 \\
\hline Oro o plata en madejas, la onza & 375 \\
\hline Orchilla que es para pintores, la libra & 18 \\
\hline Orillos lavari, el ciento & 500 \\
\hline Hoja de hierro y hoja de lata, el quintal & 3.150 \\
\hline Paño de Túnez, cada uno & 11.250 \\
\hline Paño doble de Lyon, cada uno & 9.000 \\
\hline \multicolumn{2}{|l|}{ Paño de Bolduque } \\
\hline Paño de doble cruz & 6.000 \\
\hline Paño Saint-Bertín & 10.500 \\
\hline Paño de Arlambeque y de Copenhague & 5.500 \\
\hline Paño de Armentières & 7.500 \\
\hline \multicolumn{2}{|l|}{ Parella prieta } \\
\hline \multicolumn{2}{|l|}{ Pelotas } \\
\hline \multicolumn{2}{|l|}{ Parellas imperiales } \\
\hline \multicolumn{2}{|l|}{ Pieza de tafete } \\
\hline Pescado cecial, el quintal & 1.500 \\
\hline \multicolumn{2}{|l|}{ Paño de Ypres menor o mayor } \\
\hline \multicolumn{2}{|l|}{ Paño de Ypres menor entero o retazado } \\
\hline Paño de Montevillers & \\
\hline
\end{tabular}




\begin{tabular}{|c|c|}
\hline \multicolumn{2}{|l|}{ Paño de Anaflor } \\
\hline Pieza de raja & 26.000 \\
\hline \multicolumn{2}{|l|}{ Paño de Lille mayor } \\
\hline \multicolumn{2}{|l|}{ Paño Berbi } \\
\hline Saya entrapada de Milán, la vara & 600 \\
\hline \multicolumn{2}{|l|}{ Paño de Contrai } \\
\hline \multicolumn{2}{|l|}{ Paño de Brujas menores o de bala } \\
\hline Paño de Menin, cada uno & 11.250 \\
\hline Paño de Malinas & 12.000 \\
\hline \multicolumn{2}{|l|}{ Paño de Blao } \\
\hline \multicolumn{2}{|l|}{ Paño de Aorlo } \\
\hline Paño de Ruan del sello la ana de Francia & 750 \\
\hline Pieza de bayeta & 4.200 \\
\hline \multicolumn{2}{|l|}{ Paño de Rennes } \\
\hline \multicolumn{2}{|l|}{ Paño de Normandía } \\
\hline Paño de Bristol, cada uno & 7.500 \\
\hline Paño de Fustol de más de suerte & 11.500 \\
\hline \multicolumn{2}{|l|}{ Paño de Brujas } \\
\hline Paño de villaje de Inglaterra & 7.500 \\
\hline \multicolumn{2}{|l|}{ Paño de belarte } \\
\hline \multicolumn{2}{|l|}{ Paño de Gante } \\
\hline \multicolumn{2}{|l|}{ Paño de Acental } \\
\hline Paño de Londres de la ciudad & 12.000 \\
\hline \multicolumn{2}{|l|}{ Paño de Bruselas } \\
\hline Paño de Carisea & 2.500 \\
\hline \multicolumn{2}{|l|}{ Pieza de velas } \\
\hline \multicolumn{2}{|l|}{ Paño de Dunquerque } \\
\hline Paño de Ultafin de 24 a 25 varas & 9.000 \\
\hline Pieza de reatas de lana de Francia, doce piezas & 100 \\
\hline \multicolumn{2}{|l|}{ Paño de Tournai, de Albín o de Busbelque } \\
\hline \multicolumn{2}{|l|}{ Paño de Negrete } \\
\hline \multicolumn{2}{|l|}{ Pieza de servilletas } \\
\hline Papel resma & 170 \\
\hline Pieza de tornasol de lana de 15 y 16 varas & 850 \\
\hline Pieza de tornasol con seda, cada vara & 238 \\
\hline Pieza de rebenas & 80 \\
\hline Pieza de media rebena & 40 \\
\hline Paño de Albín de la espada de 13 a 14 varas & 5.500 \\
\hline Paño de Albín de la espada doble & 11.000 \\
\hline \multicolumn{2}{|l|}{ Paño de Nantes o de Sant Modal } \\
\hline Pieza de camelote con seda & 3.300 \\
\hline Pieza de camelote de 10 a 11 varas y pieza de cordellate de Inglaterra & 1.875 \\
\hline Pieza de cuartillas, cada pieza & 850 \\
\hline
\end{tabular}




\begin{tabular}{|c|c|}
\hline Pieza de bisuatra & 2.250 \\
\hline Plomo el quintal & 750 \\
\hline Quintal de cera & 5.300 \\
\hline Quintal de metal campanil & 3.000 \\
\hline Quintal de cobre & 4.100 \\
\hline Quintal de cecalla & 3.000 \\
\hline Quintal de salmón & 1.125 \\
\hline Quintal de congrio & 1.700 \\
\hline Quintal de pescado bacalao & 510 \\
\hline Quintal de brasil & 816 \\
\hline Quintal de azogue, la libra diez y siete reales & 54.440 \\
\hline Quintal de atriaca de Flandes & 600 \\
\hline Quintal de lampreas & 3.400 \\
\hline Quintal de mielgas & 750 \\
\hline Quintal de lenguados y de suellas & 3.000 \\
\hline Quintal de manteca & 1.500 \\
\hline Quintal de azúcar & 6.600 \\
\hline Quintal de azufre & 800 \\
\hline Quintal de jal de oro pimienta & 150 \\
\hline Quintal de pimienta & 15.000 \\
\hline Quintal de cola & 1.500 \\
\hline Quintal de verdete que es cardenillo & 6.800 \\
\hline Quintal de pabilo y de sebo & 1.700 \\
\hline Quintal de candelas de sebo & 2.000 \\
\hline Quintal de higos & 400 \\
\hline Quintal de pasas & 1.000 \\
\hline Repostero de cama, si es de tapicería con seda de Bruselas & 600 \\
\hline Repostero de cama, si es de tapicería con seda de Audenarde, cada uno & 300 \\
\hline Rastrillos de todas suertes, cada caja & 204 \\
\hline Relojes de madera & 450 \\
\hline Relojes de marfil, la docena & 400 \\
\hline Relojes de Alemania de campana & 2.500 \\
\hline Relojes de mano & 500 \\
\hline Rosarios de búfalo, el millar de cuentas & 30 \\
\hline Ruibardo, la libra & 1.500 \\
\hline \multicolumn{2}{|l|}{ Sinopila } \\
\hline \multicolumn{2}{|l|}{ Señuelos } \\
\hline Sortijas de latón de paramento, la libra & 50 \\
\hline \multicolumn{2}{|l|}{ Sombreros de felpa } \\
\hline Sasti de Brujas, la ana & 112 \\
\hline Sortijas de oro a 6 ducados la docena, y las de plata a 3 reales la docena & 2.250 \\
\hline Sortijas de latón sin piedras, cada gruesa & 280 \\
\hline Sombreros con grana o sin grana & \\
\hline
\end{tabular}




\begin{tabular}{|c|c|}
\hline \multicolumn{2}{|l|}{ Sombrericos de niños } \\
\hline \multicolumn{2}{|l|}{ Sombreros de sayeta y de media sayeta } \\
\hline Sábanas que han servido, la pieza & 170 \\
\hline Sábanas que no han servido, la pieza & 272 \\
\hline Sombreros de lana frisados de Alemania negros y de colores sin guarnecer & 102 \\
\hline Sombreros de los dichos guarnecidos & 204 \\
\hline \multicolumn{2}{|l|}{ Terna de Bolduque sin oro } \\
\hline Terno de cofres negros de Flandes, el terno son tres piezas & 500 \\
\hline Terno dorado de los dichos & 680 \\
\hline \multicolumn{2}{|l|}{ Terno de recanies } \\
\hline \multicolumn{2}{|l|}{ Toda especiería y droguería } \\
\hline Tijeras de mujeres baladíes, la gruesa & 760 \\
\hline Tachuelas, el millar & 34 \\
\hline Trompas de París, la gruesa & 100 \\
\hline Tinteros dorados, la gruesa & 1.000 \\
\hline Tinteros de escribanías negras, cada gruesa & 700 \\
\hline Tijeras de tundir, la pieza & 1.700 \\
\hline Tranzaderas blancas y negras y cintas de hilera, la libra & 70 \\
\hline Telillas de monte de hilo y lana carmenadilla de 15 a 16 varas & 600 \\
\hline Telillas de monte de seda y algodón para ropas, la vara & 137 \\
\hline Telillas para jubones listadas con seda & 1.500 \\
\hline Telillas para jubones listadas con lana de 15 a 16 varas & 400 \\
\hline Telillas para jubones con oro y plata, la vara & 350 \\
\hline Telillas de de espabilar, la docena & 136 \\
\hline Talabartes de baqueta comunes y de búfalo comunes, la docena & 850 \\
\hline Tijeras de de espabilar doradas de ataujía, la docena & 350 \\
\hline Un clavicordio o clavicímbalo & 3.000 \\
\hline Un monacordio & 1.500 \\
\hline Un escaparate de madera & 1.500 \\
\hline \multicolumn{2}{|l|}{ Una docena de jeringas grandes y mayores } \\
\hline Bombacines de Milán, la pieza & 2.090 \\
\hline Bateos, la pieza que son fuentes como platos & 105 \\
\hline Candados de maleta, la docena & 193 \\
\hline Camisas de algodón que son almillas & 190 \\
\hline Cristalina de vidrio, la libra & 95 \\
\hline Cadenilla de alquimia, la docena & 285 \\
\hline Conteras de espada, la gruesa & 190 \\
\hline Granates el millar & 266 \\
\hline Gratas para plateros, la libra & 142 \\
\hline Ébano, el millar & 182 \\
\hline Limas de plateros grandes y pequeñas, la gruesa & 332 \\
\hline Libros de memoria, la docena & 262 \\
\hline Medallas de acero, la docena & 262 \\
\hline
\end{tabular}




\begin{tabular}{|c|c|}
\hline Margaritas de vidrio, la libra & 36 \\
\hline Navajas, la docena & 353 \\
\hline Paños de espada, la docena & 303 \\
\hline Pasamanos de seda, la onza & 60 \\
\hline Pasamanos de oro falso, la onza & 262 \\
\hline Sortijas de búfalo y de azabache y camafeos, la gruesa & 127 \\
\hline Sellos de marfil, la docena & 522 \\
\hline Rosarios turqueses, el millar & 51 \\
\hline Calamos y menjui, la libra & 102 \\
\hline Sedapin, la libra & 136 \\
\hline Trementina, cada libra & 34 \\
\hline Goma yedra, la libra & 272 \\
\hline Sumentecotra, la libra & 238 \\
\hline Cocos de Levante, la libra & 68 \\
\hline Quesos de corazón, el ciento & 375 \\
\hline Bálsamo, la libra & 272 \\
\hline Carave, la libra treinta & 34 \\
\hline Laudano, la libra & 68 \\
\hline Espicanarda, la libra & 204 \\
\hline Tamaros, salmoniaco y cubebas, la libra & 102 \\
\hline Miriabolanos de todas suertes, la libra & 68 \\
\hline Hermodátiles y cercacola, la libra & 102 \\
\hline Capobálsamo, la libra & 136 \\
\hline Galinche, laca, costra y gomalemi, la libra & 102 \\
\hline Espalto, cada libra & 136 \\
\hline Cantarides, cada libra & 102 \\
\hline Hoja de linterna, el ciento & 136 \\
\hline Cáñamo, el quintal & 750 \\
\hline Quintal de brea & 102 \\
\hline Quintal de resina & 136 \\
\hline Alones para velas de navíos, la pieza & 1.125 \\
\hline Quintal de unamo que es cordaje para navíos & 2.000 \\
\hline Plata labrada, el marco & 2.400 \\
\hline Quintal de hierro & 578 \\
\hline Quintal de acero & 952 \\
\hline Hierro de chimenea, cada uno & 375 \\
\hline Sombreros de fieltro de agua y lana sin guarnecer, la docena & 850 \\
\hline Libra de seda a 3 reales la onza, son cuarenta y ocho & 1.632 \\
\hline Fieltros hechos, cada uno & 1.360 \\
\hline Pieza de fieltro & 1.125 \\
\hline Calzas de agujas, el par & 1.500 \\
\hline Máscaras, cada una & 102 \\
\hline Quintal de pluma & 3.000 \\
\hline
\end{tabular}




\begin{tabular}{|l|c|}
\hline Quintal de hierro labrado & 1.125 \\
\hline Fuelles para la lumbre, la pieza & 34 \\
\hline Quintal de regaliz & 374 \\
\hline Vara de brocado sin seda & 3.000 \\
\hline Brocado con seda y tela de plata y oro, la vara & 1.875 \\
\hline Terciopelo, la vara & 1.000 \\
\hline Raso, la vara & 600 \\
\hline Damasco, la vara & 650 \\
\hline Tafetán, la vara & 204 \\
\hline Sillas de Flandes de caderas guarnecidas de baqueta, cada una & 750 \\
\hline Sarga de Lille, pieza & 3.000 \\
\hline Camisas hechas, cada una & 375 \\
\hline Pieza de tripa de velut & 1.600 \\
\hline
\end{tabular}

Destaca la presencia de la lana, cruda o de colores, piezas de reatas de Francia y pasamanos de seda o de oro falso. Además, se exportaba, cuando había remanente, trigo o centeno, cebada, arvejas y habas. También se incluyen las cardas, alcanfor, incienso, azufre, brea, resina, amoniaco, caparrosa, carmín, zumo de regaliz, regaliz, brasil, rubia, cola, verdete o cardenillo, pabilo, candelas de sebo, cera, manteca, sebo, azúcar, aceite de vara o higos, pasas, ébano, droguería, cerdas de zapatero, pluma, goma, goma de dragante que es alquitira, goma yedra, laca, láudano, cáñamo, conejos, raposos, ginetas, bitrualla, azogue, agallas, lino rastrillado o para rastrillar. En especiería cominos y pimienta y en los metales, se incluye el hierro labrado, el cobre, plomo, estaño elaborado o en barra y elaborados como cadenas de hierro para perros, calderas de cobre, latón labrado, clavos de giroflé, tachuelas, medallas de acero, hoja de hierro y de lata, latón en rollo para clavar agujetas o plancha e hilo de latón de monacordio, hilera blanca y de hierro, clavos, plata labrada, hierro, acero, hierro de chimenea, malla de hierro para tejedores y malla de latón, oro y plata en madejas, argentería, argentería falsa o canillas de oro de bacín falso. La peletería ocupa un capítulo de cierta relevancia, con cueros de baqueta y de vaca en pelo, y de vaca curtidos o de búfalo prieto o de colores y de becerro.

\section{La lana merina}

La lana fue el producto que Castilla exportó en mayor cantidad, con mucha diferencia sobre todos los demás integrados en el comercio que estudiamos y el que más rentas produjo. Se obtenía de la oveja merina, una raza que era gran productora de una lana que, por su calidad y finura, fue muy demandada por los centros europeos productores de productos textiles y paños, y que adquirió un gran valor en sus mercados. Era una raza autóctona de la Península, cuya producción se protegió por la monarquía castellana para estimular el crecimiento de un tipo de ganadería de gran rentabilidad económica. Con su comercio, se desarrolló una burguesía mercantil que dejó su impronta e influencia en amplios sectores de la sociedad burgalesa y castellana y favoreció el desarrollo de las finanzas, la cultura, el arte, el derecho mercantil, el transporte, la contabilidad, etc.; dejando clara huella de su pujanza, en la arquitectura civil y religiosa de Castilla y de la ciudad de Bur- 
gos. Los comerciantes burgaleses, todos agrupados en torno a su Universidad, actuaron decididamente en la organización e impulso del comercio internacional y, para ello, no dudaron en promover su actividad en campos diversos como fueron las infraestructuras camineras.

Santander fue el puerto principal que la Universidad de los Mercaderes de Burgos utilizó de manera preferente en el siglo XVI para la exportación de las lanas, seguido por Bilbao y Laredo. De los puertos de Cuipúzcoa, tan solo el puerto de Deva cargó lanas de los mercaderes burgaleses, San Vicente de la Barquera apenas conoció el tráfico mercantil y Castro-Urdiales tuvo una importancia muy pequeña en el tráfico lanero ${ }^{1884}$. De esta manera, el concejo de Santander afirmaba en 1555, que "en los años de çinquenta y tres y çinquenta y quatro y en este presente de çinquenta e çinco en la cargazon del Moreço, se an cargado y salido por el puerto desta villa hasta cantidad de beynte y quatro mill sacas de lana" 1885 .

En los registros creados en 1558 del derecho real sobre la exportación de lanas, dirigidas a Flandes y Francia, se obtienen cifras relativas a la exportación de las lanas que confirman la importancia del puerto de Santander. Según refleja Basas ${ }^{1886}$, las sacas de lanas enviadas a la estapla de Brujas en Flandes fueron:

\begin{tabular}{|l|c|c|}
\hline Puerto & Periodo & No de sacas \\
\hline Santander/Laredo & $1558-1560$ & 19.936 \\
\hline Santander & $1561-1579$ & 50.819 \\
\hline Laredo & $1569-1577$ & 2.204 \\
\hline Bilbao & $1561-1579$ & $6.556,5$ \\
\hline Deva & $1570-1579$ & 3.350 \\
\hline
\end{tabular}

Las sacas con destino a los puertos franceses, principalmente Nantes y Ruan, entre 1559 y 1579 fueron:

\begin{tabular}{|l|c|c|}
\hline Puerto & Periodo & No de sacas \\
\hline Santander & $1559-1579$ & 27.765 \\
\hline Laredo & $1569-1577$ & 1.388 \\
\hline Bilbao & $1561-1579$ & 10.587 .5 \\
\hline Deva & $1572-1578$ & 1.825 \\
\hline
\end{tabular}

Teniendo en cuenta, además, que no incluimos las sacas exportadas a Italia y las que los propios burgaleses conducían desde Sevilla, son ciertamente unas cifras muy altas. La saca de lana que iba a Flandes tenía 8,5 arrobas unos $98 \mathrm{~kg}$, y la que se llevaba a Francia 10 arrobas, unos $115 \mathrm{~kg}^{1887}$, lo que daba unas cifras que explicaban por sí solas, el volumen del

1884 BASAS FERNÁNDEZ, M.: 1963 y 1994: 257-257.

1885 A. M. S./ Leg. A-3, no 62/ 27 agosto 1555.

1886 BASAS FERNÁNDEZ, M.: 1963 y 1994; 261-262.

1887 BASAS FERNÁNDEZ, M.: 1963 y 1994: 261-262. 
tráfico producido y, en consonancia con esto, los esfuerzos que los mercaderes de la Universidad hicieron en el mantenimiento y construcción de los caminos, principalmente en el camino de Santander, como se ha visto en su capítulo. El tráfico por el puerto de Bilbao, también importante, viene auspiciado no solo por los mercaderes burgaleses, sino también por el propio Consulado de Bilbao, el propio concejo y el Señorío de Vizcaya.

En 1582 la Universidad de Burgos se quejaba de la situación de su contratación, porque "aora esta en tan gran diminucion porque avra veinte y cinco o treinta años salian d'este rreino para Flandes, Francia e Italia, en cada un año de 65.000 a 70.000 sacas... y a benido en tanta diminucion que no creemos salgan aoran d'España para Flandes, Francia e Italia, de 20.000 a 25.000 sacas y cada dia nos parece que saldran menos", ya que con las muchas costas e imposiciones que la lana tiene, los que la compran no pueden llevarla fuera del Reino ${ }^{1888}$. Hubo un motivo poderoso en este declive, con motivo de la toma de Middelburgo en 1574 por los holandeses. El Consulado de Burgos perdió con ello, además de las cargas, un gran número de naves que tenía aseguradas, por lo que además de la pérdida de naves y cargas, tuvo que soportar los pagos de las cantidades aseguradas, lo que produjo en el Consulado pérdidas irreparables.

Los mercaderes burgaleses, aprovechaban el viaje de retorno tras sus fletes de lanas, para importar productos de diferentes procedencias remitidos por los mismos factores mercantiles, generalmente sus familiares directos, que se encargaban de la venta de la lana, y tales productos, una vez en Burgos, se distribuían por toda la Península. Entre las importaciones procedentes de la Europa atlántica, destacaron por su importancia y cantidad la hierba pastel y los textiles.

\section{Los textiles}

El grupo de los textiles fue muy importante en el apartado de las mercaderías de retorno. Utilizaban básicamente la lana comercializada desde la ciudad de Burgos que, una vez elaborada en los telares y talleres de los principales centros europeos, era devuelta en gran parte a Castilla en forma de tejidos, paños, lienzos, prendas de vestir, telas confeccionadas y tapices. Ocupan un lugar destacado, como se ha dicho, los paños flamencos, pero también los del Paso de Calais, bretones, normandos e ingleses, y manufacturas textiles como las escarlatas, fustanes, lienzos de lino o algodón flamencos y bretones, bordas, sargas, etc., así como las prendas como las camisas, lencería, calzas, bonetes y sombreros o mantelería, sábanas, servilletas, toallas, colchas, cojines, etc.

La relación de fines del s. XIII' ${ }^{1889}$, como vimos, además de detallar el tipo de productos que se traficaban en esas fechas, nos aporta valiosa información sobre los gustos y necesidades de la sociedad demandante. En ella, se evidencia que la importación de los productos textiles era la dominante, principalmente los paños que provenían de Gante, Douay, Ypres -que podían ser planos o lisos, viados o rayados y reforzados-, Camua; blancos de Poperinghe, Lille, Montreuil, Abbeville y planos de Ruan y Provins, Cambrai, Langemarck o de Caen. También entre los textiles se importan escarlatas, preses, verdes, camelinas, blanquetas, contrahechos, plumas de Amiens; estanfortes de Raz, Saint Omer,

1888 A. G. S./ Div. de Cast. Leg. 10. Fol. II/ 1582; BASAS FERNÁNDEZ, M.: 1963 y 1994: 287-288.

1889 Escorial/ Códice Escurialense, III-Z-13/ Burgos, f. S. XIII; CASTRO, Américo: 1921 a 1923: 1-29. 
Valenciennes, Brujas, Tournai, Inglaterra, Cam, Ruan, Chartres, Parthenay o Montreuilsur-mer; viadillos de Ypres; tiritanas, frisas de Estampas y Casteldun; ensays de Brujas, Ypres, Gante o Tournai; capas de Bailleul o barraganes de Ruan, Belvas, Loherens o Provins. Pero también prendas como luvas o guantes, cofias o cendales. En la tabla de $1488^{1890}$ siguen destacando entre las importaciones los paños y elaborados textiles, como la brishata, la fusteda y el fustán, fardeles de telas y paños, lona, arpilleras y sayal, y seda en hilo y tejida.

En la relación de $1503^{1891}$ se mencionan, de una manera muy destacada los paños de diferentes procedencias. De Flandes vienen de Ypres, Courtray, Brujas, Menen, Malinas, Dinant, Mollerón, Bruselas o Tournai. De Francia proceden de las regiones de Bretaña, Normandía o Paso de Calais, de localidades como Montivilliers, Lille, Douai, Blois, Saint Lô, Rouen, Rennes, Fougères, Armentières, Cambrai o Morlaix. De Inglaterra procedían de Bristol o Londres y de Bolduque en los Paises Bajos. Otros elaborados textiles que llegaban a Castilla por los puertos del Cantábrico eran las escarlatas, fustanes, fustedas, bordas, bocatanes, mantas, rebates, bancales, lienzos, cañamazas, sargas, fuimas, ternas, parellas, terciopelos, brocados o camelotes. También llegaban piezas elaboradas como reposteros de sobrecama, tohallones, manteles, colchas, cojines, cozneos, antepuertas, tapetes de seda y prendas como bonetes, sombreros, mantos o luvas.

A principios del siglo XVI sigue siendo preferente la entrada de los paños procedentes de Saint-Bertín, Tournai, Bousbecque, Aules, Albín, Lieja, Rotterdam, Aelán, Aul o Saint Modal. Otros textiles que se contemplan son el cordellate, friseta de Inglaterra y valdeses. Entre las piezas elaboradas destacan las servilletas, tapetes, sábanas de lienzo, carpetas de Gante o tohalletas. También las prendas como sombreros, "boneticos" y sombreros de niño, calzas de paño y camisas de lienzo ${ }^{1892}$.

En abril de 1516 la Reina da licencia, a pesar de las ordenanzas sobre la fabricación de paños y la Pragmática sobre la prohibición de importar paños de reinos "estraños" y su venta, a todos los mercaderes y tratantes de sus Reinos y del condado de Flandes y ducado de Brabante, para que puedan traer de "los dichos nuestros Reynos e señorios e no de otra parte alguna, e meter e vender en estos nuestros Reynos e señorios de Castilla y de Leon y de Granada" los paños como acostumbraban, debido a su gran falta, lo que permitirá que se puedan vender por cierto tiempo en la forma contenida en la propia provisión, "con tanto que los mercaderes etratantes que obieren de vender los dichos paños a la bara, los vendan mojados a todo mojar e tundidos e medidos sobre tabla segund e de la manera, que por las leys y prematycas destos nuestros Reynos esta dispuesto". En octubre de ese año se da una Cédula real en Bruselas, por la que se concede licencia al Prior y cónsules de la Universidad de Burgos para que puedan vender hasta 1.800 piezas de paño ${ }^{1893}$.

1890 A. G. S./ Contaduría mayor de Cuentas. Inv. $2^{\circ}$ Libros de cuentas de los diezmos de la mar de Castilla/ San Sebastián, 7 octubre 1488, Burgos a Salvatierra, 4 junio 1544; GONZÁLEZ, T.: 1829: 328-358: t. I. doc. XCVI.

1891 A. G. S./ Contaduría mayor de Cuentas. Inv. $2^{\circ}$ Libros de cuentas de los diezmos de la mar de Castilla/ San Sebastián, 7 octubre 1488, Salvatierra, 4 junio 1544; GONZÁLEZ, T.: 1829: 328-358: t. I. doc. XCVI; LABAYRU y GOICOECHEA, E. J. de: 1899: 424-431: t. III.

1892 A. G. S./ Contaduría mayor de Cuentas. Inv. 2ํㅡㄴ Libros de cuentas de los diezmos de la mar de Castilla/ San Sebastián, 7 octubre 1488, Salvatierra, 4 junio 1544; GONZÁLEZ, T.: 1829: 328-358: t. I. doc. XCVI.

1893 A. D. B./ C-123/ Madrid, 23 abril 1516. 
En agosto de $1536^{1894}$ se informa que hay mercaderías que pasan por los puertos y no están incluidas en la nómina. A los mercaderes de la Universidad de Burgos se les carga la demasía a 740 mrs. el millar, y a los demás mercaderes a 800 mrs. La nómina no aclara si los paños de Inglaterra, como granas de Londres y de village de Inglaterra, se diezman por varas; pero para cargarles el diezmo como está en la nómina se hacen de a 30 varas. Los paños de Ruan del sello, vizcontes y petes y todos los paños de Francia y Bretaña se diezman por anas y, para cargarles el diezmo de la nómina, se hacen de a 20 anas, y todos los otros paños se diezman enteros, sin decir las varas salvo cuando vienen en trozos. Entre una gran diversidad de productos, siguen ocupando un lugar muy destacado los paños de Ypres o Armentieres y demás manufacturas textiles, como el angeo, cañamazas, holandas o carijeas.

En los aranceles de avería del Consulado de Burgos, que se detallan en las ordenanzas de $1538^{1895}$ con algunos añadidos en las de 1572 , se registran los lienzos, anascotes, sargas, tapicería, paños, bayetas, telillas, bocaranes, holandas o camelotes sin seda, tanto de Francia como de Flandes así como paños y bayetas de Inglaterra ${ }^{1896}$.

En 1555 el concejo de Santander alega que en compensación de la gran cantidad de sacas de lana que había salido en los años anteriores por su puerto, "por las quales conforme a la prematica y obligaçiones, son obligados de aber traydo a esta villa en retorno dos mill fardeles de lienços de a media carga y quatro mill paños, y para esto no an traydo salbo lo que traxo la galeaça de Juan d'Escalante". Se quejan de que no les conceden la guía para importar mercaderías por su puerto, ya que "la guia que se le quita es de los fardeles de paños e lienços e otras cosas semejantes"1897.

En las relaciones realizadas por Juan de Peñalosa en marzo y abril de 1563, para establecer lo que se debía pagar por las mercaderías que entraban en Castilla por los puertos de la Mar o secos ${ }^{1898}$, sigue destacando por su variedad y volumen la importación de lienzos de Francia, de Ruan y de Flandes, Brujas, Holanda, Brabante, Gante o Betuna; y paños de Túnez, doble de Lyon, Ypres, Courtray, Tournai, San Martín, Alebín, Busbelque, Bruselas, Brujas, Gante, Menen, Malinas, Blao, Aorlo, Dunquerque, Ultafin, Fustol, Lille, Montivilliers, Armentières, Nantes, Sant Modal, Ruan, Rennes, Normandía, Anaflor, Bolduque, Saint-Bertín, Acental, Arlambeque y de Copenhague, Bristol, Londres o villaje de Inglaterra, y negrete. También se importan los anascotes, antepuertas, baldreses, bancal de Flandes de tapicería, bocacíes de Flandes, bocaranes de Flandes y de Francia, bordas de hilo o de seda, cacidonias, cañamazas, carijeas, colorados, estoraques, frisetas, fuimas, fustanes, fustedas, grises, rebenas, saetines de Brujas, sarga de ras y de Lille, tafete, telillas para jubones listadas con seda, lana, oro, plata o seda, fieltro, tela de plata y oro, terciopelo, raso, brocado con o sin seda, damasco, además de elaborados textiles como

1894 A. G. S./ Contaduría mayor de Cuentas. Inv. 2º Libros de cuentas de los diezmos de la mar de Castilla/ San Sebastián, 7 octubre 1488, Burgos a Salvatierra, 4 junio 1544; GONZÁLEZ, T.: 1829: 328-358: t. I. doc. XCVI.

1895 Ordenanzas del Consulado de Burgos de 1538/Valladolid, 18 septiembre 1538; GARCÍA de QUEVEDO y CONCELLÓN, E.: 1905 Y 1995: 203-207. Ordenanza XXII.

1896 Reales Ordenanzas del Consulado y Casa de Contratación de Burgos/ Ordenanza no XXVIII/ Madrid, 1 agosto 1572 en LARRUGA, E.: 1793: 216-297.

1897 A. M. S./ Leg. A-3, no 62/ 27 agosto 1555

1898 A. G. S./ Secretaría del Consejo de Hacienda. leg. 49/ Burgos, 26 marzo 1563; GONZÁLEZ, T.: 1829: t. II. doc. CXLII, 201-210; LABAYRU y GOICOECHEA, E. J. de: 1900: t. IV, 352-356; A. G. S./ Secretaría del Consejo de Hacienda. leg. 49/ Bilbao, 26 abril 1563; GONZÁLEZ, T.: 1829: 211-230: t. II. doc. CXLIII. 
cojines con o sin seda o con oro, colchas de Francia, cozneos de Flandes o Francia, madejas de cotonía, manteles y servilletas de Flandes y de Francia cortadas, sábanas, tohalletas cortadas de Flandes, bayetas, tornasol de lana o de seda, cintas de lana para trenzar, agujetas de colores de Flandes o Francia. También arambeles, tafetán, tejidos con clavos de latón, media roldana, parella prieta e imperial, pieza de raja, cordellate de Inglaterra, sasti de Brujas, telillas de monte de hilo y lana carmenadilla, de monte de seda y algodón para ropas y para jubones listadas con seda, lana, o con oro y plata y telillas de espabilar. Se importaban también prendas como los sombreros de lana frisados de Alemania negros y de colores, los de fieltro de agua y lana, los de sayeta o grana, los sombreros de felpa o los "sombrericos" de niños y las gorras de Milán, bolsas de seda de Francia, mantos de Bernia, saya entrapada de Milán, camelote con seda, terna de Bolduque, trenzaderas blancas y negras y cintas de hilera, camisas de algodón o calzas de agujas.

\section{La hierba pastel}

La industria pañera empleaba una gran cantidad de materias colorantes para teñir la fibra. Se utilizaron diversos productos vegetales, entre los que destacó el pastel, fundamental en la artesanía textil. El pastel era una planta de cuyas hojas se extraía una sustancia colorante, el índigo, con el que se conseguía una tonalidad azul. Su consumo durante la Edad Media y el siglo XVI estuvo muy desarrollado, al necesitar los tejidos grandes cantidades para su teñido, y además en esos años el color azul y sus diversas tonalidades fue el más solicitado en la alta pañería y la moda. Las plantas de mayor calidad producidas en Europa fueron las cultivadas y comercializadas en la región de Toulouse, que era la que abastecía gran parte de las industrias textiles europeas, y las de las islas Azores, de una más baja producción y un menor precio. La irrupción del añil americano en la segunda mitad del siglo XVI, del que se obtenían tonalidades de mayor calidad y mejores precios, arruinó su cultivo y comercialización ${ }^{1899}$. Según Hilario Casado, ya durante los siglos XIV y XV participaron en dicho comercio los mercaderes burgaleses. En 1377 un tal Martí Sancho de Santa Cruz, mercader de Burgos, aparece haciendo negocios en Toulouse ${ }^{1900}$. En esta localidad convertida en el principal centro europeo del pastel, se constata en el siglo XV la presencia de numerosos comerciantes burgaleses. De hecho, según Caster, los compradores de pastel tolosano eran, entre 1475 a 1510 sobre todo de la ciudad de Burgos ${ }^{1901}$. En la tabla de octubre de $1488^{1902}$ ya encontramos el pastel, que tanto significará en adelante para el comercio de retorno.

En el siglo XVI gran número de mercaderes burgaleses traficaban con dicho colorante, participando miembros de las principales familias de la oligarquía urbana burgalesa1903, y el pastel llegó a ser el componente principal de la importación castellana por los

1899 CASADO ALONSO, H.: 1990: 523-525.

1900 CASADO ALONSO, H.: 1990: 525.

1901 CASTER, G.: 1962: 91-124.

1902 A. G. S./ Contaduría mayor de Cuentas. Inv. 2ํㅡㄴ Libros de cuentas de los diezmos de la mar de Castilla/ San Sebastián, 7 octubre 1488, Burgos a Salvatierra, 4 junio 1544; GONZÁLEZ, T.: 1829: 328-358: t. I. doc. XCVI.

1903 CASADO ALONSO, H.: 1990: 526. 
puertos del Cantábrico durante dicho siglo y el que completaba los retornos de las naos. Los burgaleses llegaron a controlar este comercio desde Toulouse no solo con Castilla, sino con toda Europa ${ }^{1904}$. Llegado el producto a Burgos, dichos comerciantes lo distribuían entre los mayores demandantes, que eran los centros dedicados a la fabricación pañera, como Segovia y algunos lugares del reino de Aragón ${ }^{1905}$, e incluso lo exportaban a otros centros europeos.

\section{Las obras de arte}

En la relación de fines del s. XIII ${ }^{1906}$ que hemos visto, se detalla entre otras mercaderías la importación de piezas de esmaltes de Limoges y cruces, incensarios, vinajeras o cajas para incienso. Pero el gran conjunto de obras de arte consistente en retablos completos, trípticos, piezas de orfebrería, tapices, pinturas sobre tabla o lienzo, esculturas, grabados e incluso vidrieras, que llegó a Castilla procedente del condado de Flandes y ducado de Brabante, fue muy intenso e importante entre mediados del siglo XV y la segunda mitad del siglo XVI. En este periodo un gran conjunto de obras de arte flamencas invadió Castilla, auspiciado y fomentado por los comerciantes castellanos, y basado en la gran demanda de tales obras y elementos. Una clientela constituida tanto por la Iglesia con sus catedrales, parroquias y conventos, como por la nobleza y burguesía, adquiría unas obras que se ajustaban a sus gustos y demandas y satisfacían sus necesidades. La importación de estas obras podía ser consecuencia de encargos directos personalizados, que realizaban los comitentes castellanos de manera detallada y exigente a maestros flamencos importantes; o bien a través de las compras de unas obras realizadas en serie en talleres flamencos de manera semi-industrial, tanto en pintura como en escultura, y que se ajustaban a las demandas del mercado castellano. Tal importación se desarrolló especialmente a partir de finales del siglo XV y principios del XVI'1907 y en el caso de las colecciones de tapices flamencos salidos de los talleres de Amberes o Bruselas, se da la circunstancia de que fue utilizada para su confección básicamente la lana procedente de Burgos ${ }^{1908}$.

Las condiciones del transporte de estas delicadas piezas eran muy difíciles, al tener que realizar el trayecto de los puertos de mar a Burgos a lomos de mulos y en ocasiones en carros, cuando las circunstancias lo permitían. En 1555 el concejo de Santander expone, como se ha detallado en su apartado, las causas por las que piensa que no se traen mercaderías de retorno por su Puerto. Indican que aunque se les quita la guía de los fardeles de paños, lienzos y otras cosas semejantes, las sacas, pastel y pescado se guían siempre por Santander, así como "los retablos y escaparates y cosas grandes que no se pueden descabeçar ni guiar en mulos sino en carros", porque de dicha villa "se pueden sacar las mercaderias en carretas y carros y guiarse en ellos para todas las partes d'España, lo que no puede ser hecho de Vilbao ni Laredo syno por pie de mulo". Proponen que se pregunte sobre si la costumbre antigua de dezmar y dar cédula de todas

1904 CASADO ALONSO, H.: 2005.

1905 IBÁÑEZ PÉREZ, A. C.: 1990: 171-172.

1906 Escorial/ Códice Escurialense, III-Z-13/ Burgos, f. S. XIII; CASTRO, A.: 1921 a 1923: 1-29.

1907 IBÁÑEZ PÉREZ, A. C. y PAYO HERNANZ, R. J. . 2005: 135-145.

1908 IBÁÑ̃EZ PÉREZ, A. C.: 1990: 170. 
las mercaderías en dicha villa, se ha usado y usa en el pastel, pescado y "retablos y escaparates y en todas las otras cosas grandes que no se pueden comodamente llebar en mulos"1909.

En las relaciones confeccionadas por Juan de Peñalosa en marzo y abril de $1563^{1910}$, un capítulo importante es el de las obras de arte y complementos, como la tapicería con oro, tapicería de Bruselas, de Oudenaarde o Gante con seda o sin ella, "Niños Jesuses de yeso" y otras imágenes de la misma materia, reposteros de cama si es de tapicería con seda de Bruselas o con seda de Oudenaarde o "lienzos viejos pintados gruesos para labradores", cuadros pintados grandes, medianos y pequeños de lienzo fino, cartas pintadas de a pliego y pinturas como el genoli (pintura amarilla), azarcón (minio, color anaranjado o rojo) u orchilla "que es para pintores".

En mayo de 1614 Juan de Arbeláiz, Correo Mayor de Irún, envía una carta al Conde de la Oliva, capitán de la guardia alemana, sobre que "abia tenido abiso de Santander de la llegada en aquel lugar de las dos caxas de las pinturas para Porta Celi, [y] quando le fuere posible allar carro no se descuydara Alonso de Santiago". Procurará "encaminarlas aunque se aya tardado, assi llegaran bien y se escusaran muchas costas que con riesgo de que llegaran mal tratadas se abian de yr, si porfiaramos que fueran en machos" las dichas pinturas o cuadros ${ }^{1911}$.

\section{Los libros}

La situación estratégica de Amberes y su puerto permitió que la ciudad del Escalda fuese uno de los centros económicos más prósperos de Flandes durante los primeros años del siglo XVI, lo que propició, entre otras cosas, que fuese la plaza con mayor actividad impresora de Europa y, por tanto, uno de los más importantes centros comerciales del libro español. La ciudad contaba durante la primera mitad del siglo XVI con unos 60 impresores, los cuales generaban una gran producción y comercio. Este mercado conoce su edad de Oro entre 1545 y 1570, llegando ciertas imprentas a especializarse en la edición de obras en español. De sus prensas saldrán publicaciones relacionadas con la cultura en lengua castellana, aunque no faltarán las distribuidas en latín. Aunque la producción de este tipo de obras en castellano no se inició hasta mediados del siglo XVI, obras de distintas temáticas como Botánica, Medicina, Geografía, Astronomía-Cosmografía, Matemáticas y Arte Militar ya habían llegado antes a nuestras tierras por los puertos del Cantábrico ${ }^{1912}$.

\section{b.- El comercio interior}

En clave regional, se demandaba en las tierras correspondientes a la franja intermedia entre Burgos y la costa cantábrica una serie de productos que, en muchos casos, eran vitales para la alimentación de sus habitantes, como era el trigo, el vino, el aceite, la sal,

1909 A. M. S./ Leg. A-3, nº 62/ 27 agosto 1555; SOLÓRZANO TELECHEA, J. A.:"Patrimonio documental... ". 283-285: doc. 225

1910 A. G. S./ Secretaría del Consejo de Hacienda. leg. 49/ Burgos, 26 marzo 1563; GONZÁLEZ, T.: 1829: 201-210: t. II. doc. CXLII; LABAYRU y GOICOECHEA, E. J. de: 1900: 352-356: t. IV; A. G. S./ Secretaría del Consejo de Hacienda. leg. 49/ Bilbao, 26 abril 1563; GONZÁLEZ, T.: 1829: 211-230: t. II. doc. CXLIII.

1911 A. G. S./ Cámara de Castilla, DIV, leg 34, doc. 28/, Irún, 15 mayo 1614.

1912 SÁNCHEZ MARTÍN, FCO. J.: 2010: 105-127 
etc. y que sus tierras no generaban. Por otro lado, dichas tierras producían u obtenían otros productos excedentarios muy demandados en la Castilla interior como el hierro o el pescado fresco y curado en sus diferentes variantes.

\section{El Trigo}

El cereal, principalmente el trigo y a menor escala la cebada, es uno de los productos que han tenido siempre una gran demanda y por consiguiente fue objeto de comercio, como consecuencia de ser el alimento básico del sustento humano y de depender su producción de una serie de factores como el clima, la tierra o la altitud, decisivos para la obtención de las cosechas. Como no todas las zonas eran idóneas para su cultivo, las sociedades deficitarias como era el caso de las tierras cantábricas, dependían del suministro procedente de otros puntos. Este comercio dependía de que hubiese comarcas excedentarias, es decir, que existiesen zonas que obtuviesen una producción mayor de la que su población necesitaba.

Las villas y tierras de la costa del norte padecían de manera crónica una grave carencia del trigo que necesitaban para su consumo, ya que dichas tierras no lo producían o no lo hacían en la cantidad suficiente para garantizar el adecuado suministro de su población. El trigo procedía principalmente de las tierras del interior de Castilla, centro de la Meseta, tierra de Campos y provincia de Burgos, aunque dichos espacios en ciertos periodos también tuvieron malas cosechas y sufrieron periodos de escasez. Cuando esto ocurría, la zona cantábrica debía abastecerse de zonas más lejanas del interior o por mar, con el trigo andaluz o extranjero en época de paz ${ }^{1913}$, o bien resignarse a padecer la carencia del cereal llegando en algún caso a sufrir hambrunas. Fue una preocupación permanente de sus concejos garantizar el suministro de su población, para lo que se dictaban ordenanzas por las que se obligaba a los comerciantes y arrieros que llevaban a la villa diversas mercaderías para su exportación, principalmente lanas, a acompañarlas con determinadas cargas de trigo, o pagar una cantidad establecida como compensación. También se obligaba bajo severas multas a los arrieros que fueren a cargar al puerto, a no acudir de vacío, sino cargados de cereal. No obstante, Juan II releva a la ciudad de Burgos, en marzo de 1407, de toda "lieva" de pan a Santander o a cualquier otro lugar del Reino1914. También fue muy común que en el camino el trigo fuese adquirido por los vecinos de las villas aledañas, con el fin de almacenarlo y venderlo en momentos de carestía; especulación que ocasionó repetidas protestas por parte de las villas afectadas.

En 1490 a petición del Señorío de Vizcaya, los Reyes ordenan al aposentador mayor de Castilla que vea la queja sobre que en el nuevo mercado de la localidad de Santa Gadea no se permite comprar trigo con destino a los puertos del Señorío, y que incluso se les había echado cierta imposición contra las leyes y ordenanzas promulgadas en las Cortes de Toledo de 1480; y mandan al dicho aposentador que las guarde y deje "a todase cualesquier personas

1913 A. H. P. C./ Villa de Laredo, leg. 1, num. 23, fols. 40-41/ Madrid, 1574; En Laredo se indica que la situación del trigo es grave porque entre otras causas, "no uenia el dicho trigo por mar de Françia y Flandes como solia".

1914 A. M. B./ HI-84/ Segovia, 19 marzo 1407. 
que quisieren pasar por la dicha villa de Santa Gadea e sus terminos con todo el pan, trigo e cebada que quisieren levar al dicho Condado de Vizcaya, sin les pedir portazgo nin otra impusicion alguna"1915.

En 1496 los vecinos de Laredo dijeron que en la villa de tiempo inmemorial "se ha usado e guardado syn ninguna contradiçion, que todas las personas que entran con rrecuas a la dicha villa por pescado o por fardeles de paños, suelen lleuar las dichas bestias cargadas de trigo para mantenimiento de la dicha villa, por quanto en ella dis que non se acopian ninguno", poniéndolo en el enlosado del cementerio de la iglesia de Santa María, lugar señalado por el concejo desde donde se repartía entre los vecinos; pero como "los moradores dis que non se podian mantener ni sustentar de pan", algunos vecinos lo compran a las recuas que iban a por el pescado y lo guardan en sus casas para revenderlo, de manera que se encarece y no se encuentra. Suplicaban a los Reyes que se mandase que el pan se lleve al lugar señalado para su reparto equitativo. Se manda al corregidor que lo remedie y la villa no reciba agravio ${ }^{1916}$.

El procurador de la cofradía de pescadores de San Martín de la Mar de Santander dijo que en la villa hay una ordenanza que manda que ningún mulatero pueda sacar pescado alguno, si no llevare antes una carga de trigo a la villa, y que el concejo y regidores de Santander ponen tasa a los mulateros en la venta de dicho pan y les mandan que vendan la carga de trigo a 300 mrs. y a menos, cuando valía la carga puesta en la villa 400 mrs., por lo que van muy pocos mulateros a vender allí trigo, causando además perjuicio a su población y pescadores, por no poder vender su pescado si no lo llevan los mulateros que llegan de fuera. Además, como los regidores e hidalgos de Santander reparten entre sí todo el pan que así se vende por tasa sin dar nada a la comunidad, no se halla trigo para su mantenimiento. Pidió que se mandase que los mulateros lo puedan vender libremente sin tasa alguna. Los Reyes mandan al concejo en 1497 que, sobre llevar el pan para sacar el pescado, guarde y haga guardar la dicha ordenanza como en ella se contiene y como se había guardado en los tiempos pasados; y sobre la dicha tasa, mandan que se deje a los mulateros que el pan lo vendan libremente como pudieren y sin tasa alguna, y al corregidor de la merindad de Trasmiera que lo haga cumplir ${ }^{1917}$. El concejo dijo al Consejo que, a causa de esta Carta real, el corregidor quebranta una ordenanza que la villa tiene de tiempo inmemorial, que dispone que cualquier mulatero que fuere a vender trigo para llevar el pescado de Santander ha de entregar cinco celemines por carga de trigo y ponerlos en una casa de la villa, y el resto lo puedan vender libremente. También dispone que el trigo puesto en dicha casa -en tiempo de necesidad, que es muy continua por la esterilidad de la tierra- se reparta entre vecinos y moradores por el precio que tasan los regidores. Pidieron que se aclarase la dicha Carta y que la ordenanza se haga cumplir como siempre se acostumbró. El Consejo manda en 1498 al corregidor que se informe sobre cuánto hace que la villa tiene la ordenanza y cómo se ha guardado, si se debe guardar o que cada uno venda el pan que llega libremente sin poner los cinco celemines por carga en la casa de la villa, y la información obtenida con su parecer la envíe al Consejo para proveer con justicia1918.

1915 A. G. S./ Registro General del Sello, III-1490/ Sevilla, 20 marzo 1490. GONZÁLEZ, T.: 1829: 237-243: t. I. doc. LIX.

1916 A. G. S./ Registro General del Sello, XII-1496, fol. 297/ , 7 diciembre 1496.

1917 A. G. S./ Registro General del Sello, VIII-1497, fol. 343/ Medina del Campo, 31 Agosto 1497.

1918 A. G. S./ Registro General del Sello, VIII-1498, fol. 247/ Valladolid, 20 agosto 1498. 
Juan de Solórzano, procurador de Castro-Urdiales, dijo que en Castro y sus comarcanas no se coge pan para su sustento, por lo que de tiempo inmemorial todos los que iban a sacar pescado debían llevar una carga de trigo por carga de pescado, algo que se había usado pacíficamente. Pero algunas personas que conocen este asiento, y a fin de cohechar a sus vecinos, evitan traer el trigo y lo dejan para cuando vale más caro y, cuando lo traen, no lo descargan en el Azogue como deben, sino que algunas personas y mesoneros lo llevan a sus casas y solo se reparte entre aquellos que tienen el mando de la villa. Los Reyes mandan en diciembre 1498 al corregidor o juez de residencia de las Cuatro Villas que, llamadas y oídas las partes a quién atañe, provea como mejor cumpla al bien común de los vecinos y moradores de la villa y de los lugares de su tierra ${ }^{1919}$.

En abril de 1503 el teniente de corregidor, los tres regidores y el fiel de Castro-Urdiales mandaron al fiel Pedro de Cestona, "que fuese a la villa de Balmaseda a requeryr al conçejo, e tomar testimonio sobre lo que diz que fazen, en que ympiden que no trayan trygo para la dicha villa de Castro nin aryna"1920.

La reina Juana indica en 1505 que el bachiller Antón de Arez, en nombre del concejo, justicia y regidores de Bilbao, dijo que en Orduña y Valmaseda "çiertos vesinos e moradores dellas, han conprado e conpran mucho trigo e otras cosas de los mantenimientos que llevan los mulateros para ese dicho Condado para lo tornar a revender, asi a la dicha villa de Bilbao como a ese dicho Condado y Encartaçiones", y hacen alhóndigas en dichas localidades haciéndose regatones, por lo que los vecinos compran el trigo mucho más caro. Suplicaba que se mandase a los vecinos de Orduña y Valmaseda "que no fuesen osados de faser las dichas alhondigas, nin conprar el dicho trigo nin mantenimientos, e lo dexasen pasar a ese dicho Condado y Encartaçiones". El Consejo mandó al corregidor de Vizcaya que lo remedie como conviene al bien común, y que los vecinos de Orduña y Valmaseda no detengan dichos mantenimientos ${ }^{1921}$.

En julio de 1507 la justicia y regidores de Laredo, junto con el corregidor de la Costa de la Mar y el procurador general, vieron que en la villa "los vesynos e moradores della no syenbran ningun genero de pan", y como los pueblos bien regidos y surtidos de mantenimientos conservan su población, consideran que en los términos de la villa se podrían sembrar alimentos para paliar la mucha necesidad que la villa tenía. Se ordena que todos sus vecinos y moradores siembren por lo menos media fanega de pan, trigo, cebada, centeno, mijo, borona o habas y que al que no tuviere tierra, que el concejo se la dé y la trabaje en vida y a su muerte retorne al concejo ${ }^{1922}$.

Los procuradores del Señorío de Vizcaya dijeron a la Reina que el Condado estaba muy necesitado de pan y algunos extranjeros lo traerían, pero como recelaban de "que serian presos e represados, por algunas cartas de marca e represaria que temian, que mandase que los que truxiesen pan al dicho Condado e Sennorio de Vizcaya, non pudiesen ser presos nin represados ellos nin sus bienes". La Rei-

1919 A. G. S./ Registro General del Sello, XII-1498, fol. 210/ Ocaña, 20 diciembre 1498.

1920 A. M. Castro Urdiales/ Leg. 21, doc. 1/ Castro Urdiales, 21 abril 1503; BLANCO, E., ÁLVAREZ, E. y GARCÍA DE CORTÁZAR, J. A.: 1996: 288: doc. 15.

1921 A. M. Bilbao/ Cajón 4, reg. 4, no 180 (3)-Caja 17, reg. 1, no 44 (3)/ Salamanca, 17 diciembre 1505; ENRÍQUEZ FERNÁNDEZ, J.; HIDALGO de CISNEROS AMESTOY, C. y MARTÍNEZ LAHIDALGA, A.:"Colección Documental del Archivo Histórico de Bilbao (1501-1514)" 2000: doc. 293

1922 A. G. S./ Cámara de Castilla. Pueblos, leg. 10, doc. 50/ Laredo, 23 julio 1507. 
na manda en 1507, a los concejos y regidores de todas las localidades del Condado, que las personas, bienes y haciendas de los que llevaren pan, tanto por mar como por tierra, no puedan ser prendidos ni apresados por virtud de ninguna carta ni represalia que cualquier concejo o persona tenga y que puedan llevarlo libremente sin recibir daño1923.

En 1522 el Rey indica que García de Escalante, vecino de Laredo, le dijo que hay costumbre y ordenanza en la villa por la que los mulateros que han de sacar pescados y otras cosas han de llevar cierta cantidad de trigo con cada bestia de carga, o pagar a los fieles 100 mrs. por bestia y que, para que los mulateros incurran en dicha pena, los fieles les ponen el pan a la mitad de lo que les cuesta en los mercados de Medina de Pomar, Espinosa de los Monteros u otras partes donde lo compran, y los mulateros pierden la mitad del dinero que han pagado, además de lo que les cuesta llevarlo, por lo que estos prefieren pagar los 100 mrs. Si algún mulatero lleva algún trigo, se lo hacen descargar en un espacio cerrado que llaman cementerio y los fieles lo reparten a bajos precios a las personas principales y parientes que les dieron los oficios de fieldad y a la justicia de la villa, en perjuicio de la gente menuda y pobre; de manera que el pan tan barato, se reparte entre 40 o 50 casas y no llega a más de 400 vecinos. Pero lo peor es que no solo toman para sus casas más de lo que necesitan, sino que algunos lo revenden a precios doblados a los vecinos pobres y a otros extranjeros que allí llegan, por lo que algunos vecinos van a buscarlo a otras partes. Si los mulateros pudiesen vender el pan a los precios que quisiesen, llevarían de continuo mucho suministro y la villa estaría provista a precios justos y razonables, por lo que pedía que se mandase que todo el pan, trigo y cebada que los mulateros llevasen a Laredo, lo vendiesen en su plaza pública o en otra parte limitada por el corregidor a precios libres para que todos lo pudiesen comprar, y que no se llevase al dicho cementerio o red, ni los fieles les pongan precio ni lo repartan. El Consejo mandó que el corregidor procure que los que llevaren pan a Laredo lo puedan vender pública y libremente en lugares convenientes y a los precios que quisieren, y cada uno compre lo que necesitare ${ }^{1924}$.

Carlos I dice en 1535 a los alcaldes mayores de los Adelantamientos de Castilla en los partidos de Burgos y Palencia, que García de Salazar y Escalona, en nombre de Laredo, se presentó diciendo que la villa "es muy pobre y esteril de pan porque en ella no se coge ningun pan, ni en dies leguas alrrededor dello", y que es el "puerto mas ymportante e prinçipal destos Rreynos, e adonde ocurren muchos nabios de muchas partes, asi a descargar mercaderias que traen de otras partes como a cargar otras que destos nuestros Rreinos ban a otros, como a se rreparar e rremediar en tiempo de fortuna", y que con las muchas gentes que llegaban el pan valía muy caro y "muchas vezes no fallaban de comer asy los naturales de la tyerra, como los estrangeros y nauegantes que a la dicha uilla e puerto bienen", por lo que la villa se despuebla y "algunas bezes la dicha villa enbia a tierra de Canpos e a otras partes, a comprar algun pan para sustentamiento de los vezinos dell y y estrangeros que a ella vienen"; pero tanto los señores de los lugares donde van a comprar, como sus concejos, no dejaban adquirir el pan diciendo que lo compraban para revenderlo y que conforme a las leyes de estos Reinos no lo podían sacar. Suplicaba que se diese licencia para que la villa pudiese sacar de cualquier

1923 A. M. Bilbao/ Cajón 4, reg. 5, nํ322-Caja 18, reg, 1, nํ33/ Burgos, 12 noviembre 1507; ENRÍQUEZ FERNÁNDEZ, J.; HIDALGO de CISNEROS AMESTOY, C. y MARTÍNEZ LAHIDALGA, A.: "Colección Documental del Archivo Histórico de Bilbao (1501-1514)" 2000: doc. 305

1924 A. H. P. C./ Laredo, leg. 28, num. 9/ Burgos, 12 febrero 1522. 
parte el pan que necesitare, por lo menos hasta 6.000 fanegas anuales, y que se mandase a los prelados, caballeros y justicias de dichos lugares que les dejasen sacar libremente el pan. El Consejo acordó dar licencia a los vecinos de Laredo para que puedan comprar en cualquier localidad el pan necesario para su provisión, a condición de que lo lleven a Laredo y no a vender a otra parte y se deposite en nombre del concejo para que se venda cuando hubiere necesidad al precio justo, obtenido en relación con la distancia del camino de donde se llevare ${ }^{1925}$.

En el cargo de las cuentas de Laredo de 1539 se indica que conforme a la sentencia, los mulateros y viandantes que fuesen a Laredo a sacar carga debían llevar dos fanegas de trigo por mulo, so cierta pena, y por ser un año estéril se concertó con los mulateros, ordenado por la justicia y regimiento, que las penas aplicadas de $57.361 \mathrm{mrs}$, , se destinen a los caminos y calzadas de la villa. En el descargo, se devolvieron $4.522 \mathrm{mrs}$. a los mulateros que llevaron el trigo de su depósito1926.

En Junta de Álava de noviembre de 1540 los procuradores de las hermandades de Valdegovía, Valderejo, Lacozmonte, Cuartango y La Ribera, dijeron que los dezmeros y guardas del Condestable, quebrantando los privilegios que la Provincia tenía, les pedían el diezmo y otros derechos por el trigo y otros bastimentos. Se dio poder a Pedro Díaz de Ulíbarri y a Diego Fernández de Ugarte para que defendieran sus privilegios contra dichas imposiciones ${ }^{1927}$.

El concejo de Santander se queja en 1555 ante el Prior del Consulado de Burgos de que no reciben en su puerto las cargas de retorno de las lanas que se envían desde Flandes, por lo que entre otros argumentos alegan que "todos los carreteros desta montaña, en los meses que habian de traer pan y vino de Castilla, dexan de yr por ello por traer sacas a esta villa, y a la causa sus veçinos padeçen nesçesidad, espeçial en tienpo de guerra que no biene por la mar". Además, por haber sufrido la villa grandes daños, "por el encareçimiento quen estos ultimos años an suçedido en el pan, a causa de sus flotas y carreterias y de presente, ay gran nesçesidad para la dich a flota y carreteria y vezindad de socorro de trigo, que los dichos señores prior e consules, sean obligados de hazer traer a esta dicha villa dentro de dos meses primeros siguientes, mill cargas de trigo, que se bendan en esta dicha villa"1928.

En las Juntas de Vizcaya de la Tierra Llana de septiembre de 1569, los síndicos procuradores dijeron que siendo el mercado de Orduña franco y libre para que los mulateros y recueros puedan comprar trigo, cebada y otras cosas necesarias sin limitación alguna, la ciudad había hecho ordenanzas para que ningún mulatero pudiese llevar más trigo ni cebada de lo que pudiesen cargar dos machos. Se mandó que no se ponga impedimento alguno y que en el mercado de Orduña dejen comprar trigo, cebada y otras cosas a los mulateros y recueros, cargando los machos que tuvieren ${ }^{1929}$.

\footnotetext{
1925 A. H. P. C./ Villa de Laredo, leg. 10, num. 4, fols. 85V-86v/ Madrid, 24 abril 1535

1926 A. H. P. C./ Laredo. Cuentas de la villa de Laredo, f. 24r-24V/ Laredo, 1539; VALDOR ARRIARÁN, M.:2002: 79-80: doc. 2 .

1927 A. J. G. A./ t. III/ Vitoria, 20 noviembre 1540

1928 A. M. S./ Leg. A-3, no 62/ 27 agosto 1555.

1929 A. J. R. B./ Actas de la Tierra Llana. t. I/ Durango, 7 septiembre 1569.
} 
Felipe II dice en 1574 que Cristóbal Pérez, en nombre del cabildo de San Martín de los Navegantes y mareantes de Laredo, indicó que los vecinos y viandantes que iban a la villa necesitaban normalmente más pan que ninguna otra villa de la costa, "ansi por no se coger en ella ningun genero de pan, como por acudir a ella mucha gente por mar y por tierra por ser puerto de mar auierto, y el dicho pan..., auia de yr forçadamente de carreto que lo lleuauan mulateros de Burgos y Castilla Uieja", pero en el camino había muchos lugares que tenían por trato y granjería comprar el trigo que se llevaba a Laredo, para volverlo a vender en trigo, en pan o en harina a sus vecinos y otros lugares de la comarca a mayores precios de como lo compraban, cobrando además las maquilas en sus molinos, y causando así a la villa y comarca muchos daños, en especial a los pobres, siendo más grave la situación porque "no uenia el dicho trigo por mar de Françia y Flandes como solia". Pidieron que el corregidor fuese a todos los lugares del Corregimiento que estuviesen en ese camino y pusiese graves penas a los que tuviesen dicho trato, salvo lo que moderadamente necesitaren para sus casas, y los que quisieren tener el trato lo fuesen a comprar a los mercados de Medina de Pomar, Espinosa de los Monteros y Burgos. El Consejo mandó al corregidor de las Cuatro Villas que no consienta que nadie del Corregimiento compre a los arrieros más trigo, pan o harina de lo que necesitasen para su consumo1930.

En las Juntas de Vizcaya de julio de 1575 se trató cómo en Orduña y otras villas Juan de Peñalosa, administrador del Rey, había mandado que para la armada que se prepara en Santander se tome el trigo que se lleva para la provisión del Señorío, peligrando con ello el sustento de sus gentes por su falta y por la carestía provocada. Indican que como jamás ningún otro administrador, comisario o proveedor de las armadas lo había hecho, porque ordinariamente se había comprado en Burgos, ordenan que se pida al Rey que mande que para hacer bizcocho para fuera de la costa, no compren sus proveedores el trigo que se trae para provisión del Señorío y costas de Poniente, por lo menos en la zona que va desde Miranda y de la Peñas a la costa1931.

En dichas Juntas de marzo de 1582 el corregidor dijo que en virtud de Comisión Real había ordenado conducir desde Burgos y sus comarcas a Vizcaya gran cantidad de trigo para embarcar y llevar a Cádiz. El regidor de Bilbao había ido con cartas del Señorío y de Bilbao ante el corregidor a Santander, para que no se compre ni conduzca el trigo de las villas entre Burgos a Vizcaya, pues era novedad, y porque siempre todo el Señorío se había proveído del acarreo desde esas partes. Si se da lugar a este transporte a Cádiz y otras partes de fuera, dijo, se encarecería mucho y, lo que era peor, no se hallaría lo necesario para la provisión de Vizcaya. Se acordó que para que todo el trigo que manda la Real Comisión se pueda sacar a menos coste, se haga por Santander desde la Tierra de Campos, sin perjudicar al Señorío y sin ocupar a los arrieros que ordinariamente les llevan el trigo y los mantenimientos y, también, que Bartolomé de Zaldívar requiera al corregidor que no diese lugar a esta novedad, ni tome para el acarreo los arrieros que suelen llevarles el trigo, vino y demás bastimentos necesarios a Bilbao y Señorío y, asimismo, que no se conduzca

1930 A. H. P. C./ Villa de Laredo, leg. 1, num. 23, fols. 40-41/ Madrid, 1574.

1931 A. J. R. B./ Actas de Villas y Ciudad. t. II/ Bilbao, 1 julio y 20 agosto 1575. 
más trigo de Burgos ni de ningún lugar a Vizcaya para sacar por mar ${ }^{1932}$. En agosto, Juan de Zornoza, procurador general de Orduña, hizo saber a la Junta que los arrendatarios de los diezmos de la mar habían comprado y ensilado alrededor de Orduña más de 2.00o fanegas de trigo y que de ello el Señorío recibía daño y encarecimiento, y que si esto siguiese haría más daño en adelante, por tener todo el trigo ensilado junto a Vitoria, Salvatierra y otras partes cercanas de donde el Señorío se sustentaba, y que para su remedio, mandasen que, se hiciese vender el trigo y en adelante se pidiese licencia a los dichos ${ }^{1933}$.

Las Juntas de Vizcaya de noviembre de 1591 mandaron que el que hubiere de ir a Madrid por el Señorío traiga Provisión real contra los que entre Burgos y el Señorío y en él hacen venta y reventa de trigo, para que sean castigados, y como se hacen muchos daños por su reincidencia, deberá agravarse dicha Provisión ${ }^{1934}$.

En estos años en Vizcaya se darán normas para impedir que el trigo salga de sus límites geográficos, así como para evitar la reventa, estar abastecidos y que el cereal no alcance precios excesivos. Así en Juntas de Vizcaya de enero de 1596 el síndico general propuso que siendo lo más necesario para el sustento el trigo, centeno y otras ceberas, estos alcanzaban precios desorbitados en los mercados de Vitoria, Miranda, Orduña y Bilbao, porque muchos entrojan grandes cantidades, incluso para un consumo de 2 años, aguardando tiempos propicios para venderlo más caro, no bajando su precio ni en tiempo de abundancia. En el mercado de Bilbao, y contra la carta ejecutoria que el Señorío tiene, a veces lo revenden a los precios que ellos fijan y lo que les queda para sus casas es a precios muy bajos. Suplica el síndico, que se pida al Consejo provisión para que se registren las trojes y silos, haya tasa de las ceberas en las villas entre Burgos y Vitoria, que en Bilbao se registren las lonjas y puestos donde están recogidos centenos y otras ceberas, y se vean si son de la calidad requerida y sus precios justos, y si no, que no se permita su venta. Se acordó pedir al Rey que mande que fuera del Señorío haya tasa en las ceberas y que se haga el registro y repartición propuesta por el síndico general, y se eviten los excesos que se hacen en el mercado de Bilbao'1935. En septiembre los síndicos procuradores generales dijeron que aunque se han puesto medios para evitar reventas, ensilando y entrojando en Vitoria, Orduña, Miranda y Briviesca y otras villas entre Burgos y Bilbao, y tomando algunas personas que tienen por oficio principal comprar en agosto y vender por mayo a precios excesivos, no se ha logrado evitar estos excesos y por ello pidieron su remedio'1936.

El Diputado General dijo en Vitoria en 1598, que se debía evitar la compra de trigo que Juan Pascual, proveedor y pagador general, hace en Miranda, tierra de Burgos y Rioja, bajo el asiento que tiene hecho con el Rey, por ser Álava tan estéril que, si no se abastece en estas partes, sus vecinos padecerían escasez, por lo que convenía juntarse con Guipúzcoa y Vizcaya que corren el mismo riesgo, para suplicar al Rey que mande que compre el trigo en otras partes. Cuatro días después, se había recibido una carta de Guipúzcoa sobre

1932 A. J. R. B./ Actas de Villas y Ciudad. t. II/ Bilbao, 8 marzo 1582.

1933 A. J. R. B./ Actas de la Tierra Llana. t. III/ Durango, 25 agosto 1582.

1934 A. J. R. B./ Actas de la Tierra Llana. t. V/ Bilbao, 29 noviembre 1591

1935 A. J. R. B./ Actas de la Tierra Llana. t. VI/ Bilbao, 27 enero 1596.

1936 A. J. R. B./ Actas de la Tierra Llana. t. VI/ Bilbao, 24 septiembre 1596. 
el daño que las tres provincias recibirían, si prosiguiese la compra del trigo y pan que Juan Pascual hacía. Se acordó escribir a su agente en la corte, para que junto con los de Cuipúzcoa y Vizcaya, pidan al Rey que mande a Pascual que no compre pan y trigo en dichas partes, pues lo podía hacer en otras con tanta comodidad y sin daño a sus provincias ${ }^{1937}$. En Juntas de septiembre los síndicos generales informaron que Pascual tiene licencia real para sacar de Castilla por los puertos que quisiere 6.000 cahices de trigo anuales durante 10 años, y que por haber empezado este año a sacarlo por los puertos del Señorío y llevarlo a Portugal, les han causado graves daños y sería su ruina si en adelante se permitiese. Pidieron al corregidor su remedio en tiempo de tanta escasez de mantenimientos y se ordenó que el agente que vaya a la corte pida al Rey que mande que Pascual no pueda sacar por sus puertos el trigo ni comprarlo desde Burgos ${ }^{1938}$. En las Juntas de octubre se insistió para que se haga sacar el tanto del asiento de la lleva de trigo a Portugal y se hagan diligencias para que no se pueda sacar por los puertos del Señorío ningún trigo'939.

Los síndicos propusieron en las Juntas de Vizcaya de septiembre de 1598 que para reparar los graves daños que hacen los revendedores del pan y carneros en diversos lugares desde Burgos a Vizcaya, se mandase que el Señorío, la provincia de Álava y las Cuatro Villas de la Costa de la Mar enviasen personas para la defensa de esta causa. Pero después, por haberse enfriado la causa por parte del Señorío, la provincia de Guipúzcoa envió un agente al Señorío porque no se había hecho nada en este asunto. El Señorío respondió que ordenaría al agente que tenía en Valladolid que fuese a la corte para que con el que allí asiste a la Provincia hiciesen la diligencia. El corregidor mandó que en el Consejo se pida el castigo de los delincuentes, aunándose para ello con la provincia de Álava y Cuatro Villas ${ }^{1940}$. En Juntas de octubre el alcalde de Cuerricaiz dijo que en Vitoria, Miranda, Salvatierra y tierra de Bureba se encilla mucha cantidad de trigo por los vecinos y particulares. Pide que se aplique lo provisto por el Rey, para que el corregidor haga desencillar los trigos que los mercaderes tienen para revender. Los síndicos informaron sobre el daño que el Señorío recibía por la reventa del trigo y de los demás bastimentos y ganados en Vitoria, Miranda, Briviesca, Santa Gadea, Burgos y en todos los demás lugares que hay entre Burgos y el Señorío, y que para su remedio se había dado parte a Cuipúzcoa y Cuatro Villas de la Costa. El Diputado y regidores nombraron al síndico procurador del Señorío, para que en la corte pida el remedio conveniente para que cesen las reventas ${ }^{1941}$. Los síndicos procuradores informaron en abril de 1599, que en los mercados de Orduña, Bilbao y otros del Señorío se hacían muchas ventas y reventas de trigo diciendo que lo traen para su mantenimiento, pero se revenden al precio que quieren en los mercados después de entrojados por otras vías, lo que por causar muchos daños a sus vecinos se mandó que el corregidor se informe

\footnotetext{
1937 A. J. G. A./ t. X/Vitoria, 12 mayo 1598.

1938 A. J. R. B./ Actas de la Tierra Llana. t. VI/ Amorebieta, 30 septiembre 1598.

1939 A. J. R. B./ Actas de la Tierra Llana. t. VI/ Zubiaur de Zornoza, 16 octubre 1598.

1940 A. J. R. B./ Actas de la Tierra Llana. t. VI/ Amorebieta, 28 septiembre 1598.

1941 A. J. R. B./ Actas de Villas y Ciudad. t. III/ Zubiaur de Zornoza, 14 octubre 1598; Actas de la Tierra Llana. t. VI/ Zubiaur de Zornoza, 16 octubre 1598.
} 
para que se remedie y castigue a los culpables ${ }^{1942}$. Dos días después dieron poder a Gaspar de Aldape para que pida al Rey y su Consejo que manden al doctor Pineda de Tapia, juez de comisión del Rey que conoce sobre las reventas y tasa del trigo que hacen en Burgos, Vitoria y otras muchas villas y lugares comarcanos, que ponga orden en la forma y precio en que se vende el pan cocido, porque en todos estos lugares, como el juez no les puede poner precio ni tasa se hacen muchos fraudes ${ }^{1943}$.

En las Juntas de Vizcaya de octubre de 1598 se trató sobre que la ciudad de Burgos había hecho una nueva ordenanza, en que quiere poner estanco en los mercados que en ella se hacen de trigos y ceberas para que ningún forastero compre trigo ni otros bastimentos hasta cierto tiempo limitado, y que primero fuese provista la ciudad, lo cual iba contra lo dispuesto por leyes y pragmáticas y en gran daño del Señorío1944. El fiel de la anteiglesia de Baracaldo dijo que a ella acuden muchos arrieros para sacar mercaderías, algunos sin traer bastimentos, y por esto podría faltar y causaría notable daño a la anteiglesia. Para evitarlo, pedía que se mandase que el arriero que quisiere sacar carga, llevase necesariamente trigo $u$ otro género de bastimento, bajo cierta pena aplicada a los reparos de los caminos de la anteiglesia1945.

Por el peligro que podía haber si faltase el trigo que llega por mar a Vizcaya y sus puertos si se sacase fuera, se mandó en las Juntas de abril de 1599, que las justicias de las villas y fieles de las anteiglesias no consientan que se saque ningún trigo, cebada o legumbre, y que el vecino del Señorío que sacase estos bastimentos pierda todo y pague $10.000 \mathrm{mrs}$. para reparos de caminos ${ }^{1946}$.

El corregidor, gobernador, diputados generales y síndicos procuradores del Señorío, y procuradores de Bermeo, Bilbao y Durango dijeron en las Juntas de Vizcaya de abril de 1600, que como en la corte tenían pleito con Vitoria, Santa Gadea, Oña, Frías y otras villas sobre la tasa del pan y sobre la averiguación de las leguas que hay de los puertos de mar a estos lugares con el fin de que en ellos se guarde la tasa y pragmática de 1558, debían nombrar por agente a Domingo de Irarrazábal, residente en la corte, para lo que le dieron poder cumplido y promover estas causas ${ }^{1947}$.

\section{El vino}

El vino fue otro artículo de primera necesidad, que las tierras del norte debían obtener de otras zonas. Aunque todas las villas y lugares de Castilla y tierras del norte intentaban mantener una producción de vino suficiente para su autoconsumo, la realidad era otra, ya que en general muchas no lo producían en la cantidad suficiente y, además, el que obtenían era de ordinario de muy baja calidad, como el chacolí de las tierras del norte de Burgos y de Vizcaya. Debían traerlo por ello de otros lugares donde su producción era

1942 A. J. R. B./ Actas de la Tierra Llana. t. VI/ Bilbao, 20 abril 1599.

1943 A. J. R. B./ Actas de la Tierra Llana. t. VI/ Bilbao, 22 abril 1599.

1944 A. J. R. B./ Actas de la Tierra Llana. t. VI/ Zubiaur de Zornoza, 1 octubre 1598.

1945 A. J. R. B./ Actas de la Tierra Llana. t. VI/ Zubiaur de Zornoza, 15 octubre 1598.

1946 A. J. R. B./ Actas de la Tierra Llana. t. VI/ Bilbao, 28 abril 1599.

1947 A. J. R. B./ Actas de la Tierra Llana. t. VI/ Bermeo, 17 abril 1600 
suficiente y, además, de una calidad aceptable. Tales procedencias para esta zona eran los tintos de La Rioja, con Haro como su punto principal; los claros de la Ribera del Duero, con Aranda y Roa; y Nava del Rey con sus vinos blancos. Las ordenanzas municipales velaban en todos los casos por agotar el vino propio, que como hemos indicado era de baja calidad, antes de traer vino foráneo. Esta medida, que se imponía con graves sanciones, pretendía evitar el abandono de la producción propia al no consumir un vino que no podía competir con vinos foráneos.

De acuerdo con lo mencionado y debido a que algunas personas "calladamente, traen binos de fuera parte aqui" no guardando las ordenanzas, el concejo de Bilbao aprueba en febrero de 1399 un ordenamiento para todos los vecinos y pobladores de la villa. Dicho ordenamiento indica que todos los que tengan vinos en Bilbao los podrán vender en la villa sin mezcla de vino de fuera, y si alguno en agosto "conprare o troxiere por conpra o en otra qualquier manera, de vino que non sea de la heredat que non es e non fuere pechero de la dicha villa, que el tal bino quel biertan, avnque aya encubado con el otro bino con que aya buelto" y peche $100 \mathrm{mrs}$. Todos los vecinos que tuvieren vino de la dicha heredad lo venderán por tabernas al precio que el concejo pusiere y, cuando se agoten los vinos de la villa, el concejo lo confirmará y mandará traerlos de fuera, otorgando desde el día de San Miguel de cada año que sean francos hasta 15 días después del año siguiente. También se manda que, mientras hubiese vinos de la villa, nadie podrá traer vinos por mar ni por tierra para vender ni para su beber, hasta que el concejo dé franquía y libertad, y si alguno tal vino trajere, se lo verterán a su puerta y pagará 200 mrs. "Qualquier duenno de bestias de qualquier natura, asi vezinos como foranos, que troxieren a esta villa o a la comarca vino... fasta que sea mandado e dado por conçejo general..., asi para si mismo como para otro qualquier o qualesquier presonas, clerigos o legos o mugeres, que... pierdan las bestias en que los tales vinos troxieren, e qualquier vezino de la villa, que sea justiçia o no justiçia, que lo puedan tomar las tales bestias avnque lo descarguen fuera de la villa y que los tales tomadores que las ayan para si las bestias que asi tomaren, e los vinos, que sean tajados los odres e baziados", y sus dueños pecharán $200 \mathrm{mrs}$. El mulatero que lo trajere será echado en la cadena por 9 días y pechará 100 mrs. y en el caso de que alguien hubiere traído dichos vinos y no le hubieren tomado sus bestias y hubiese sospecha, si dentro del año "por pesquiza o presunçion fuere sabido que qualquier asi aya traido binos... sin coto e sin calonna, alcançado en esta villa o en su termino, quel tome las tales vestias, y el mulatero si fuere tomado, que jaga los dichos nuebe dias en la cadena y que peche los çien maravedis de calona", y al que así hiciere traer vinos que pague $200 \mathrm{mrs}$. Si algún vecino o foráneo, clérigo o lego, trajere vino y lo pusiere en Zubileta, en Tapia o en otro lugar de la comarca diciendo que lo tiene fuera para gastarlo en público o para traer cuando hubiese franquía, que estos vinos no los lleven a la villa ni después de que la franquía sea hecha, y si alguno trae vinos de La Rochela, Calicia, Burdeos o Portugal, los podrá embodegar en Baracaldo, Arriaga o Asua y llevarlos a vender a la villa. Como algunos "ayan negoçio en sus cuerpos o en personas de sus casas, porque ayan menester bino de Castiella, blanco o vermejo" el concejo dará autorización para que hagan traer una cántara de vino blanco o tinto de cualquier lugar, y tales personas lo gastarán en su casa o en 
su negocio no dándolo a otra parte. Enrique III confirma este ordenamiento en septiembre de 1399 y Juan II lo hace en $1420^{1948}$.

El procurador de los mulateros de la merindad de Castilla Vieja dijo en 1488 al concejo de Laredo, que algunos mulateros y viandantes o sus criados, van a comprar a Laredo pescados y otras mercaderías y llevan a vender pan, vino y otras cosas, y les hacen pagar por mandato de los alcaldes y regidores $2 \mathrm{mrs}$. por quintal de pescado e impiden que nadie les compre el pan, vino y demás mercaderías sin licencia ${ }^{1949}$.

El alcalde, diputados y procurador de Bilbao dijeron en 1496, que la villa recibía mucho daño de los vecinos mulateros que en ella sus arrabales viven y tienen sus mulos, porque traen sus bestias cargadas con vinos de Castilla y otras mercaderías y los venden en Alvia, Arrigorriaga, Bujana y otras partes ${ }^{1950}$.

Los concejos de Valdeporres, Valdebezana, Sotoscueva, Sonsierra, Valdebodres, y Castilla Vieja dijeron en 1497 al Consejo, que sus vecinos van con sus carros, bueyes y bestias a tierra de Campos y otras partes para traer pan, vino y otros mantenimientos, y que de poco tiempo acá, en algunos prados y baldíos y en otros lugares, los prendan y llevan muchas penas y achaques ${ }^{1951}$.

En el interrogatorio realizado en 1515 los arrieros declaraban, como algo habitual, que acarreaban vino junto con otros artículos como hierro, trigo y pescados. Así, Juan López de Villanueva decía que yendo con un hijo suyo "a la montaña con sus mulos cargados de bino blanco,... en el camino rreal ques junto de Billalazera e Quintana, salieron a ellos vnos siete o ocho onbres de la villa de Medina con sus ballestas armadas" y le quitaron la carga, y cuando se la devolvieron "le vebieron e le falto una cantara de bino blanco de Castilla". Otro decía que los portazgueros de Medina de Pomar les "an fecho muchos agrabios a los dichos mulateros de las dichas merindades, en deber yr e boluer de los caminos rreales e llevar a Medina asy con fierro como con bino e con pescado", o que "beniendo este testigo de Castilla con otros mulateros cargados de bino e trigo, saliendo de los Oçinos a la venta de Marroquin, salieron a ellos vnos seys onbres de la villa de Medina de Pumar"1952.

Juan Sáez de Igueribar, mulatero vecino de Anzuola (Guipúzcoa), pone pleito en 1538 contra Antonio de Argomániz, criado de Martín Sáez de Vergara, vecino de Oñate, acusándole de que cuando venía con cuatro acémilas y un rocín cargados de vino blanco de Medina del Campo, en compañía de otros mulateros, le quitó 130 rs. de un talegón que llevaba en unas alforjas después de pasar por Ozaeta (Álava)1953.

En Junta de Álava se trató en febrero de 1561 sobre el abuso que se hace en La Rioja, y principalmente en tierra de Laguardia por comprar mosto y vino para la reventa, ensilándolo para venderlo a los precios que conviene a los vendedores como personas

1948 A. M. Bilbao/ Cajón 8, reg. 1, no 1- Caja 199 (fol. 43V-45r y fol. 21V-23v)/Valladolid, 29 septiembre 1399 y Valladolid, 20 marzo 1420/ ENRÍQUEZ FERNÁNDEZ, J.; HIDALGO de CISNEROS AMESTOY, C. y MARTÍNEZ LAHIDALGA, A.:"Colección Documental del Archivo Histórico de Bilbao (1300-1473)" 1999: docs. 47 y 57.

1949 A. G. S./ Cámara de Castilla. Pueblos, leg. 10, doc. 32-1/ Laredo, 24 febrero 1488.

1950 A. M. Bilbao/ Cajón 8, reg. 2, nº 2. Recop. ordenanzas, fols. 79-80/ Bilbao, 6 septiembre 1496; GARCÍA de CORTÁZAR, J. A.: 1966: 435: doc. 42.

1951 A. G. S./ Registro General del Sello, Il-1497, fol. 323/ Burgos, 12 febrero 1497.

1952 A. G. S./ Consejo Real de Castilla, leg. 84, fol. 2-III/ Valladolid, 26 junio 1513 a Salazar, 25 septiembre 1515.

1953 A. Ch. V./ Salas de lo Criminal. Caja 253, 4/1538-1539. 
poderosas, y se acuerda que se escriba al Diputado para que solicite una Provisión real que lo impida, y si se pudiere, cometer a alguno de los corregidores de Santo Domingo, Miranda o Pancorbo y, en su caso, a las justicias ordinarias, para el castigo de los que lo han hecho'1954.

\section{El aceite}

El aceite fue un artículo que en los siglos XV y XVI fue objeto de un intenso tráfico entre las zonas productoras y las tierras del norte peninsular. Procedía de Andalucía y, sobre todo en estas tierras, de Aragón por su cercanía, ya que en Castilla prácticamente no se producía, como en la región de Valladolid que en el siglo XVI fue casi inexistente ${ }^{1955}$. Tenemos constancia de este tráfico desde Zaragoza en un pleito tratado en Valladolid en octubre de 1488, entre Juan Sáez de Murga, vecino de Orduña, y Conzalo del Carrascal y Juan Bonifaz, vecinos de Briones, sobre que Murga envió hacía unos 13 años "con vn onbre suyo desde la çiudad de Çaragoça para la Montaña, siete azemilas cargadas de çebada e azeite, e pasando por el camino real de entre Santo Domingo de la Calçada e la villa de Santa Cadea", junto al lugar de Villalobar, le salieron los dichos Carrascal, Bonifaz y otros por su mandado, tomaron las acémilas con las mercaderías y las llevaron a Briones, por lo que Murga pedía que "le diesen e tornasen las dichas veinte vna fanegas de çebada, e los dichos quinse quintales de azeite 0 su justa estimaçion por ello"1956

\section{La sal}

La sal ha sido siempre un producto básico para la conservación y alimentación, y objeto de una gran demanda. Además de las salinas marinas, existían en el interior, en la provincia de Burgos, dos salinas ${ }^{1957}$ : la de Poza de la Sal, la más importante, y la de Salinas de Rosío, ambas junto a caminos importantes de Burgos a Bilbao o a Laredo: el que va por Oña y el que va por Medina y Castrobarto. Además, existían en Álava otras de las que se obtenía gran producción en la localidad de Salinas de Añana. Estos lugares tenían asignados en muchos casos un amplio territorio para su suministro, lo que obligaba a hacer grandes desplazamientos y a establecer y organizar una red adecuada de distribución y transporte, principalmente arrieril, para colocar la sal en lugares a veces muy lejanos.

Ya en 1137, Alfonso VII da al monasterio de Oña y a su abad un pozo de sal "que se llamaua poço de el Conde, en la villa de Poça", con su portazgo, derechos y dehesa, y manda que todos los que fueren a comprar sal de la otra parte del Pisuerga con sus bestias paguen de portazgo un dinero por cada una, los que vinieren de esta parte del Pisuerga paguen dos panes por bestia, y el que no tuviere bestia, un pan. Y todos los que fueren a comprar sal y trajeren oro o plata $u$ otra moneda real, compren sal del Pozo del Conde. El que huyere sin pagar portazgo y le cogieren en villa castellana, perderá la bestia con todo lo que lleva, y si

1954 A. J. G. A./ t. V/ Vitoria, 20 febrero 1561.

1955 BENNASAR, B.: 1961: 736.

1956 A. Ch. V./ Ejecutorias emitidas, caja 17, nำ1/Valladolid, 31 octubre 1488.

1957 Había una tercera salina en Herrera junto a Miranda de Ebro, pero de mucha menor importancia. 
fuere capturado más allá, pagará 15 sólidos $^{1958}$. Fernando III por otra parte concede en 1223 a los freires del Hospital del Rey, 200 moyos de sal anuales en las salinas de Añana exentos de albalá y portazgo1959. Alfonso X confirma en 1255 esta carta de $1223^{1960}$.

Lope Díaz de Haro, titular del portazgo del puente de Puentelarrá fue a Oña en 1306 y le dijeron que sus portazgueros demandaban al monasterio el portazgo de las acémilas que llevaban la sal de Añana, a pesar de estar exentos en toda Castilla. Por ello, dice que "non tengo yo por bien quel pechen, nin quel den en la Puente de Carat nin en Bozo nin en Santa Gadea", y ordena a los portazgueros de Puentelarrá que al monasterio de Oña no le cobren portazgo ni usaje de las acémilas por el traslado de sal desde Añana. Manda, además, a los alcaldes y al merino de Santa Gadea que si fuere necesario lo hagan cumplir ${ }^{1961}$.

Se produjeron también ciertos conflictos entre las salinas por cuestiones de competencia en la distribución de la sal. Enrique III, a petición del mariscal Diego Fernández de Rojas, señor de las salinas de Poza, ordena en 1392 a los arrendadores de las de Añana que no impidan la circulación y consumo de la sal de Poza en los lugares de Bureba, Rioja, Burgos y su alfoz, Castrojeriz y su tierra, Campos y tierra de Treviño, Santo Domingo de Silos, Lerma, Aranda de Duero y Roa que desde antiguo le correspondían ${ }^{1962}$.

Enrique III ordena en julio de 1403 al conde de Salinas de Añana que no impida el transporte y venta de sal de las Cuatro Villas de la Costa de la Mar en Tierra de Campos, Sahagún, Palencia, Carrión y Valladolid ${ }^{1963}$. Este conflicto prosiguió porque los procuradores de las Cuatro Villas dijeron en 1483, que tienen privilegios reales "de trezientos e mas tiempo a esta parte, para que la sal de los alfolies de las dichas villas,... puedan traer e traygan a vender por toda la tierra de Canpos, $e$ Palençia, e Carrion, e Valladolid, e por sus terminos de ellas". Pero que en tiempo de Juan II algunos de los arrendadores de las Salinas de Añana comenzaron a llevar y vender la sal por la dicha tierra, prendando a los que de las Cuatro Villas iban a vender la sal, por lo que interpusieron un pleito ante el Consejo. La sentencia confirmó los dichos privilegios, reconociendo el derecho de las Cuatro Villas de vender la sal por la tierra de Campos y los otros lugares, pero desde hacía un año los procuradores y arrendadores de Añana, a pesar de los privilegios y sentencia, estorbaban la venta de la sal, andando por las dichas villas y sus términos cohechándolos y amenazándolos para que no la traigan, lo que iba en menoscabo de las rentas reales, ya que de cada fanega de sal que de sus villas se saca, se pagan 8 mrs. al Rey. Se les causa además con ello un gran perjuicio porque los que van a comprar la sal les llevan trigo y, además, porque en los lugares donde se acostumbra vender la sal, se encarece el pan la mitad más del precio anterior. El Consejo manda a los arrendadores de Añana que en adelante guarden y

1958 A. H. N./ Clero. Leg. 1283-84, Privilegios..., fol. 63r-63v/ Burgos, 19 noviembre 1137; OCEJA GONZALO, I.: 1983: 44: doc 52.

1959 A. Palacio Real/ Patronato Burgos. Leg. 6.966/ Valladolid, 11 mayo 1223; PALACíN GÁLVEZ, Ma C. y MARTÍNEZ GARCÍA, L.: 1990: 94-95: doc. 94.

1960 A. Palacio Real/ Caja 3.064, nº 29/ Burgos, 14 enero 1255; PALACín GÁLVEZ, Ma C. y MARTíNEZ GARCíA, L.: 1990 : 274-275: doc. 335 .

1961 R. A. H./ Biblioteca, col, Salazar y Castro O-18, fol. 117-117V/ Oña, 3 enero 1306; OCEJA GONZALO, I.: 1986: 362-363: doc 505 .

1962 A. M. B./ HI-128/ Segovia, 6 octubre 1392.

1963 A. M. S./ Leg. A-2, nº 58. fols. 29v-39r/Valladolid, 6 julio 1403; SOLÓRZANO TELECHEA, J. A.: "Colección Diplomática...". 65-76: doc. 15 . 
hagan guardar los privilegios y sentencia que las villas tienen, "para poder traer a vender la dicha sal por la dicha tierra de Canpos e por las otras villas e logares e sus terminos"1964.

\section{Los pescados}

Los pescados frescos o curados fueron un producto de alto valor en el mercado interior. Su consumo se realizaba por ser un complemento a otros alimentos en la dieta ordinaria, y era especialmente utilizado por los sectores de economía más saneada. Existían diferencias sociales en su consumo, marcadas básicamente por un precio, determinado por la escasez o abundancia de cada especie. Pero, sobre todo, formaba parte de la dieta que la Iglesia prescribía en los días de abstinencia y Cuaresma en los que prohibía el consumo de carne. Tales días llegaron a ocupar $1 / 3$ de los del año. Según Teresa Castro, fue uno de los alimentos propuestos por la cultura monástica para sustituir a la carne ${ }^{1965}$.

De las pesquerías atlánticas eran especialmente apreciados el besugo y la sardina, pero también eran capturadas otras especies como el abadejo, aguja, angulas, bacalao, berdel, cabra, congrio, chicharro, dorada, lamprea, lenguado, lubina, merluza, mero, mielga, pescada, salmón, etc., que se introducían en Castilla desde los puertos del Cantábrico, secos o salados. También se importaba la ballena y sobre todo su grasa. En el interior se podían consumir los pescados de río y en mayor medida los de mar, que en este caso se debía conservar de diferentes maneras, por ser un producto perecedero, y depender de un transporte, que si se dilataba en el tiempo impedía su consumo en fresco. Para tal conservación, cuando no era posible su consumo inmediato, se recurría a diferentes formas y tratamientos. Los principales fueron cecial ${ }^{1966}$, curado ${ }^{1967}$, salpresado ${ }^{1968}$, salado o prensado ${ }^{1969}$, arencado ${ }^{1970}$, escabechado ${ }^{1971}$, anchoado ${ }^{1972}$, frescal ${ }^{1973}$ o refrigerado ${ }^{1974}$. En 1572 se indica en Laredo que "para el proueimiento desta nuestra corte y de otras çiudades y uillas destos rreynos, hordinariamente acudian a la dicha uilla muchas gentes a conprar pescados, y para los traer mejor tratados algunas de las tales personas que los conprauan los solian freyr y escauechar en la dicha villa"1975.

Tenemos un ejemplo de lo ajustado que se debía realizar el transporte del pescado para su consumo en fresco, cuando se perdió la carga por solo un día de retraso. Hacia 1505

1964 B. M. S./ Col. Pedraja. Ms. 213, doc. 18, no 10/ Madrid, 8 enero 1483; SOLÓRZANO TELECHEA, J. A: "Patrimonio documental...". 148-150: doc. 69

1965 CASTRO MARTÍNEZ, T. de: 1996: 137-142.

1966 El cecial era un método de secado y curado al aire, sobre todo para conservar la merluza/pescadilla o congrio. Podía ser remojado o seco.

1967 El curado era un tratamiento de la merluza y el bacalao, salado y secado al aire.

1968 El salpresado, era una preparación de la sardina en capas con sal o salmuera.

1969 Saladas o prensadas, se preparaban las sardinas prensadas con sal sin grasa, con vísceras y cabeza.

1970 En el arencado, las sardinas enteras se salaban, secaban, ahumaban y prensaban.

1971 El escabechado consistía en tratar en salsa de vinagre y laurel el bonito, chicharro, besugo y sardinas, limpiados y salados, se secan, fríen y embarrilan.

1972 El anchoado conservaba en aceite, o curaba en salmuera con parte de su sangre el boquerón o anchoa.

1973 El frescal era cuando el besugo y salmón desangrado, se trata con muy poca sal.

1974 Refrigerado era cuando el pescado se transportaba fresco en hielo.

1975 A. H. P. C./ Laredo, leg. 1, num. 23, fol. 30/ Madrid, 19 diciembre 1572. 
un mulatero que "yendo cargado de pescado fresco con tres mulos e una aca por el camino rreal de Castilla Vieja,... le salieron quatro honbres junto del lugar de Ençinillas,... e por fuerça e contra su voluntad, le llevaron a... Medina con los dichos sus mulos, e que despues... a enterçesion de su suegro deste testigo, le soltaron e que le tuvieron a cabsa de lo susodicho vn dia en la dicha villa de Medina, a cabsa de lo qual, se le dapño el dicho pescado e perdio en ello mas de dos mill mrs." ${ }^{1976}$.

Era tan importante para los monjes su consumo en fresco, que en el monasterio de Oña se construyeron hacia 1516, bajo el mandato del abad Diego de Liciniana, unos estanques con el fin principal de embalsar el agua de un manantial cercano y abundante y dedicarlo a la cría de anguilas y truchas ${ }^{1977}$.

En la tabla de precios de octubre de 1488 , de los productos importados por los puertos ${ }^{1978}$, los pescados ocupan una parte reseñable, trayéndose sardinas de Cornualles y de Portugal, congrio seco, arenques y adoques o merlangos. A principios del s. XVI se importa el bacalao o abadejo, las sardinas de Cornualles y las mielgas, suellas y lenguados ${ }^{1979}$. En agosto de 1536 se importan pescados como el abadejo, congrio, salmón salado o arenques de Flandes o la mielga1980; y en 1563 se importaba cecalla, salmón, congrio, bacalao, lampreas, mielgas, lenguados, suellas, arenques secos, sardinas de Cornualles, Francia y Portugal, pescado cecial y del mar también se traía grasa de ballena ${ }^{1981}$. En estas diferentes relaciones de aranceles que hemos conocido en páginas anteriores, se alude al siguiente pescado:

\begin{tabular}{|l|c|c|c|c|c|}
\hline & $\mathbf{1 4 8 8}$ & $\mathbf{1 5 0 3}$ & s/f & $\mathbf{1 5 3 6}$ & $\mathbf{1 5 6 3}$ \\
\hline Sardinas de Cornualles & $\mathrm{X}$ & & $\mathrm{X}$ & & $\mathrm{X}$ \\
\hline Sardinas de Portugal & $\mathrm{X}$ & & & & $\mathrm{X}$ \\
\hline Sardinas de Francia & & & & & $\mathrm{X}$ \\
\hline Congrio seco & $\mathrm{X}$ & $\mathrm{X}$ & & $\mathrm{X}$ & $\mathrm{X}$ \\
\hline Arenques & $\mathrm{X}$ & $\mathrm{X}$ & & $\mathrm{X}$ & $\mathrm{X}$ \\
\hline Adoque o merlango & $\mathrm{X}$ & & & & \\
\hline Salmón salado & & $\mathrm{X}$ & & $\mathrm{X}$ & $\mathrm{X}$ \\
\hline Bacalao o abadejo & & & $\mathrm{X}$ & $\mathrm{X}$ & $\mathrm{X}$ \\
\hline Mielga & & & $\mathrm{X}$ & $\mathrm{X}$ & $\mathrm{X}$ \\
\hline Suella & & & $\mathrm{X}$ & & $\mathrm{X}$ \\
\hline Lenguado & & & $\mathrm{X}$ & & $\mathrm{X}$ \\
\hline Cecalla (quizá caballa) & & & & & $\mathrm{X}$ \\
\hline
\end{tabular}

1976 A. G. S./ Consejo Real de Castilla, leg. 84, fol. 2-III/Valladolid, 26 junio 1513 a Salazar, 25 septiembre 1515.

1977 BARREDA, I. de: 2014: 418-420.

1978 A. G. S./ Contaduría mayor de Cuentas. Inv. o Libros de cuentas de los diezmos de la mar de Castilla/ San Sebastián, 7 octubre 1488, Burgos a Salvatierra, 4 junio 1544; GONZÁLEZ, T.: 1829: 328-358: t. I. doc. XCVI.

1979 A. G. S./ Contaduría mayor de Cuentas. Inv. 2º Libros de cuentas de los diezmos de la mar de Castilla/ San Sebastián, 7 octubre 1488, Salvatierra, 4 junio 1544; GONZÁLEZ, T.: 1829: 328-358: t. I. doc. XCVI.

1980 A. G. S./ Contaduría mayor de Cuentas. Inv. 2º Libros de cuentas de los diezmos de la mar de Castilla/ San Sebastián, 7 octubre 1488, Burgos a Salvatierra, 4 junio 1544; GONZÁLEZ, T.: 1829: 328-358: t. I. doc. XCVI.

1981 A. G. S./ Secretaría del Consejo de Hacienda. leg. 49/ Bilbao, 26 abril 1563; GONZÁLEZ, T.: 1829: 211-230: t. II. doc. CXLIII. 


\begin{tabular}{|l|l|l|l|l|l|}
\hline Lamprea & & & & & $\mathrm{X}$ \\
\hline Cecial & & & & & $\mathrm{X}$ \\
\hline Grasa de ballena & & & & & $\mathrm{X}$ \\
\hline
\end{tabular}

Destaca, como vemos, la sardina, el congrio y los arenques, como los pescados que se importaron de una manera más sostenida desde la segunda mitad del siglo XV, y el salmón, el bacalao o abadejo, la mielga, la suella y el lenguado llegaron a Castilla durante todo el siglo XVI.

Fernando de Matute, en nombre de los tratantes mercaderes de pescado, sardina y aceites, vecinos de Aranda, dijo que tales vecinos tenían privilegio y sentencia de Juan II para que "podiesen libremente vender pescado, e congryo, e sardina, e otras çiertas mercaderías", a pesar de cierta ordenanza dictada por el concejo de Aranda que dicho Rey revocó por ir en perjuicio de dichos vecinos, revocación confirmada por los Reyes Católicos. Pero a pesar de esto, el concejo les había prendado porque tenían tiendas donde llevaban el pescado y otros mantenimientos, y les hacía pagar 2.000 mrs. a cada uno, y como la dicha sentencia y confirmación dicen que no la quisieron cumplir, pidieron que se les restituyesen las prendas que les tomaron. Los Reyes mandan en 1483 al concejo de Aranda que vean el dicho previlegio, sentencia y confirmación que tienen los tratantes y mercaderes, lo cumplan y les restituyan las prendas tomadas ${ }^{1982}$.

El concejo de la ciudad de Burgos dijo que, sabiendo los Reyes el desorden que había sobre la venta del pescado fresco que a Burgos llega, dio una carta sobre lo que el Consejo había mandado para que los mulateros que trajesen el pescado fresco lo llevasen a la red y casa señalada, y de allí se repartiese por las plazas del Azogue, del Mercado y de San Esteban; y si los dichos mulateros lo quisieren vender directamente como se hace en las demás poblaciones, que lo pudiesen hacer al precio puesto por los fieles y se les dé peso y pesas sin pagar cosa alguna, y en caso de que los mulateros no quieran pesar el pescado por venir fatigados o por otra razón, alcaldes y regidores pongan pesadores que lo vendan como antiguamente lo han hecho. Los Reyes mandan en 1489 a los alcaldes, merinos y regidores de la ciudad que cumplan y ejecuten la ordenanza incorporada ${ }^{1983}$.

Los regidores, procuradores y oficiales de la villa de San Vicente y de los valles de Cabezón, Cabuérniga, Valdosaella y alfoz y valle de Valdegama y Ezan y merindad de Campoo dijeron que la dicha villa, valles y Merindad acostumbran de tiempo inmemorial alquilar bestias a fin de llevar los pescados que en las dichas villas se toman, para lo que tienen sus pastos cerriles y lugares para su mantenimiento; pero ahora dicen que Aguilar y su tierra, Becerril, Huertas de Aya, la Corva, Nogales, Trempo, Llano de Campos y lugares comarcanos les molestan diciendo que de antiguo han usado y se han aprovechado para pacer con sus bestias y bueyes cuando van a traer pan o vino para la dicha villa, Merindad $\mathrm{y}$ valles, y dicen que han cerrado y angostado los caminos y secuestran los ejidos y pastos comunes, por lo que ellos no se podrían sostener si sus bestias, recuas y bueyes de carros que llevan el pan, vino y provisiones no tienen con que sostenerse por los caminos. Pidie-

1982 A. G. S./ Registro General del Sello, XI-1483, fol. 140/Vitoria, 15 noviembre 1483.

1983 A. G. S./ Registro General del Sello, I-1489, fol, 88/ Valladolid, 30 enero 1489. 
ron que se mandase abrir dichos caminos y restituir los términos, prados y pastos para que sus bestias y bueyes tuviesen donde pacer y dormir, de la manera que se acostumbra. Los Reyes mandan al corregidor de la merindad de Trasmiera en 1489 que, de acuerdo con la ley hecha en las Cortes de Toledo, determine y pronuncie sentencia1984.

El transporte del pescado fresco debía realizarse con suma rapidez, de tal manera que cualquier retraso o contratiempo podía echar a perder la carga. Alonso Álvarez, vecino de Amusco, pareció en el Consejo diciendo que él y otros vecinos llevan provisión de pescados frescos a Valladolid donde está la corte, y que los arrendadores de Dueñas y otros vecinos que tratan en pescados frescos, "por los faser mal e dapño, aunque por que lo den a menos preçios los dichos pescados que asy trahen, dis que çierran las puertas desa dicha villa de noche", lo cual nunca se hizo, ya que siempre estaban las puertas abiertas, y lo hacen para llevar ellos a vender los pescados en Valladolid "muy mas caros que se venderian sy las dichas puertas estuuiesen abiertas como solian estar". El Consejo mandó en 1493 al concejo, alcaldes y regidores de Dueñas y a sus arrendadores del pescado que las puertas de la villa estén "abiertas de noche e de dia segund que las soliades tener, e non consyntades ni dedes logar que los alcaualeros ni otra persona alguna las çierre ni pueda çerrar, e dexe pasar los dichos pescados cada e quando viniere, syn poner en ello enbargo ni contrario alguno segund que fasta aqui se fasia", so pena de 10.000 mrs. a cada uno que lo contrario hiciere ${ }^{1985}$.

En 1496 el concejo, diputados y procurador de Bilbao dijeron que la villa recibía mucho daño de los vecinos mulateros que en ella y sus arrabales viven y que traen sus bestias cargadas con vinos de Castilla y otras mercaderías, y además no solían traer trigo, cebada, ni otras legumbres, y lo peor era que las cargas que en la villa había para las partes de Castilla y Aragón, como el pescado fresco o cecial, congrio o sardina, paños, pasteles y otras cargas, ellos lo tomaban para otros viajes, sacándolos en otros mulos suyos fuera de Bilbao ${ }^{1986}$.

Los procuradores y otras personas de Burgos se quejaron ante el Consejo sobre algunos agravios que los vecinos reciben. De algún tiempo acá, los fieles de la ciudad llevan cada viernes 25 libras del pescado fresco que se ha de vender a peso en la ciudad, venga poco o mucho y, como se quejan muchos mulateros por este agravio, los Reyes mandan en 1497 que ningún fiel lleve las dichas 25 libras de ningún mulatero, so pena que el fiel pague lo que llevó; y que la justicia de la ciudad sea diligente en la ejecución de esto, so pena de 2.000 mrs. por cada vez que lo dejare de ejecutar. Ordenan, además, que cuando fueren los mulateros a vender a la ciudad salmones y lampreas, los jueces de los fieles se junten con los fieles y acuerden el precio de venta. Mandan que nadie salga al camino a tomar el pescado fresco, ni lo meta en ninguna parte hasta que llegue a la red de la ciudad, ni lleve a su casa ni a otra alguna carga ni cesto de pescado para dar ni vender a otro, y todo se venda públicamente en las plazas y lugares dichos ${ }^{1987}$.

La reina Juana mandó en 1507 al corregidor de las Cuatro Villas de la Costa que los pescadores y mareantes de la comunidad, cofradía y universidad de San Martín de La-

1984 A. G. S./ Registro General del Sello, III-1489, fol. 310/ Medina del Campo, marzo 1489.

1985 A. G. S./ Registro General del Sello, XII-1493, fol. 128/Valladolid, 19 diciembre 1493.

1986 A. M. Bilbao/ Cajón 8, reg. 2, no⒉ Recop. ordenanzas, fols. 79-80/ Bilbao, 6 septiembre 1496; GARCíA de CORTÁZAR, J. A.: 1966: 435: doc. 42

1987 A. M. B./ HI-1438/ Burgos, 15 febrero 1497; Palencia, 4 junio 1522 y Madrid, 27 abril 1528. 
redo vendan el pescado en la villa a precios justos y que, como Laredo está mal proveído de mantenimientos de pescados, "ningun pescado, ansi pescadas como congrios o meros, como otros qualesquier pescados, no puedan ser uendidos ni se bendan a ninguna persona ni a mulatero ni rregaton, fasta que primeramente la dicha villa y bezinos de ella y biandantes que a ella benieren, sean probeydos y tomen lo que obieren menester para su probesion y mantenimiento". Se añade que a Laredo llegan muchos y diversos pescados "ansi como guolondrinos, iscachos, cabras, ajujas y llubinas, mubles y doradas, berdeles y cuerbas, angulas y mielguas, e jamas, e urtas, e brecas y chicharos y otras muchas e dibersas maneras"1988.

En 1513 se concertaron el alcalde, fieles, regidor y sindico procurador de Portugalete con Ortuño de Zaballa, vecino de esta villa, en nombre de todos los maestres de pinazas de sardina, para que cuando "quiera que Dios les diere a los dichos pescadores alguna sardina que mataren" y cuando trajeren más de 3.000 y siendo la mar bella o no siendo tarde, que las puedan llevar a vender en sus pinazas a Portugalete; pero si trajeren menos de 3.000 sardinas o siendo tarde o con mala mar, pidan ir a Santurce; y si ocurriese que a Santurce llegaren algunos mulateros o regateras de Portugalete a comprarles la sardina, que los dichos pescadores lo vendan concertando el precio con las regateras y a condición de que tales mulateros, después de haber comprado las sardinas a las regateras, lo "ayan de traer a salazar a la dicha villa con moças e non en bestias", y que de otra manera ningún maestre se lo pueda vender ${ }^{1989}$.

El procurador de Vizcaya denunciaba que del Condado iban cada año naos y carabelas a las partes de Irlanda a pescar y que de poco tiempo acá algunos sin tener privilegio ni título les cobran cierto derecho en Vitoria, Orduña y Valmaseda, diciendo que es de diezmo cuando introducían el dicho pescado en Castilla, no habiéndolo usado nunca al ser los vecinos del Condado francos y exentos por privilegio. El Consejo mandó en 1514 al corregidor de Vizcaya que se informe para ver qué derechos se cobraron antiguamente de los pescados que los del Condado traían de Irlanda y de otras partes y los que ahora se cobran, desde cuándo y en qué lugares, si lo hacen en otras partes y si se ha aumentado, quién lo hizo y qué título tiene para ello y todo se envíe al Consejo. Entretanto, si se ha acrecentado, suspenda lo que se llevare sin título1990.

En las ordenanzas de Orduña de 1519 el concejo pone las condiciones para los que arrienden las tiendas para vender los abastos públicos: han de abastecer todo el año de pescado cecial, remojado y seco y sardinas, a $11 \mathrm{mrs}$. la libra de pescado cecial seco; la libra de cecial remojado a 8 mrs. y las sardinas blancas y arencadas tres al mr. Además, han de comenzar a servir el primer día de Cuaresma hasta el martes de Carnaval del año próximo, siendo obligados a dar los bastimentos necesarios de pescado y sardinas a todas las personas que lo fueren a pedir en cualquier hora. También, que cualquier vecino o foráneo tenga libertad para vender cualquier mantenimiento que llegue a la ciudad, salvo las provisiones de pescado seco o remojado, arenques y sardinas. Además, se manda que los

1988 A. H. P. C./ Cofradía pescadores de San Martín de Laredo, (133) leg. 3, num. 14/ Palencia, 9 julio 1507.

1989 A. M. Portugalete/ Actas, fol. 76r y 76v/ Portugalete, 27 septiembre 1513; HIDALGO de CISNEROS AMESTOY, C.; LARGACHA RUBIO, E.; LORENTE RUIGÓMEZ, A. y MARTÍNEZ LAHIDALGA, A.: 1988: doc. 153.

1990 LABAYRU y GOICOECHEA, E. J. de: 1900: 652-653: t. IV. Valladolid, 23 noviembre 1514. Registro Io. de Provisiones reales, num. 17. Archivo de la Casa de Juntas de Guernica; A. G. S. V./ Casa de Juntas de Guernica. Provisiones Reales. Reg. 1- nำ17/ Valladolid, 23 noviembre 1514; HIDALGO de CISNEROS AMESTOY, C.; LARGACHA RUBIO, E.; LORENTE RUIGÓMEZ, A. y MARTÍNEZ LAHIDALGA, A.: "Colección Documental del Archivo General del Señorío de Vizcaya". 1986: doc. 89. 
arrendadores "den el pescado vien remojado e que lo tengan en la coçina sacado del agua, por manera que no le pesen corriendo agua". Los tenderos que vendieren pescado, sardina o congrio a más precio del autorizado o dieren peso o medida falsa, caerán en la pena de 600 mrs. ${ }^{1991}$.

El corregidor de Vizcaya puso a Orduña varias condiciones en el primer cuarto del s. XVI para tratar el pescado fresco, mandando que el concejo ponga una red junto al auditorio con su cerradura y dentro de ella se pongan unos tajos de madera y sus pesos y pesas. Ningún vecino podrá tomar pescado fresco a los mulateros que lo traen y los fieles de la ciudad acompañarán hasta dentro de la red al mulatero que trae el pescado para su pesaje, sin que nadie pueda entrar. Se pondrá precio justo para la ciudad y para el mulatero, y ningún fiel llevará de derechos más de una libra de cada carga de pescado fresco y una docena de sardinas cada uno, no pudiendo llevar otra cosa aunque los mulateros se lo den. Como "los mulateros no quieren parar en esta çiudad e porque ellos lo sepan e bean lo que esta probeydo, mando que luego mannana publicamente e por los lugares acostunbrados sea plegonado". Para que pare en Orduña pescado fresco y otros mantenimientos, se manda que los fieles, sobrefieles o alcalde puedan tomar las cargas necesarias y se paguen a precio justo. Ningún vecino hablará sobre los precios salvo los fieles, sobrefieles o alcalde, porque por esto se encarece ${ }^{1992}$.

Laredo pagó en 1547 a Francisco Cachopín y al mulatero Juan de Villarán 6.271 mrs., "por raçon de dos cargas de pescado y empanadas que se enbiaron a Valladolid a los letrados e procurador", y del alquiler de ello y llevarlo1993. Estos pescados, sin duda, eran un obsequio que como artículos de lujo se enviaban a Valladolid para "agradecer" los trabajos de ciertos oficiales en los pleitos que se sostenían.

Al menos entre los años 1549 y 1555 la Universidad de los Mercaderes concedió una limosna en especie, que con motivo de la Cuaresma consistía en donar pescados a 14 conventos y monasterios de Burgos y a algunos otros más lejanos, más dos beaterios. En junio de 1549 se registran gastos de $6.560 \mathrm{mrs}$. del "pescado e sardina que se dio de limosna esta quaresma, a los monesterios como se suele hacer cada año y diose a los monesterios siguientes: A Santa Clara, a Santa Durutea, Rrenunçio, Avsin, Castil de Lences, Belorado, Rribas, Sant Alifonso, Bibar, beatas de San Cil, beatas de Sant Pedro, San Françisco, San Esteban de los fraires, San Pablo, Sant Agustin, la Merçed". Se dio a cada comunidad una arroba de pescado y 200 sardinas, excepto a las beatas de San Pedro, que se les dio media arroba de pescado y 100 sardinas. En mayo de 1550 se gastan $6.288 \mathrm{mrs}$. en las 15,5 arrobas de pescado y 3.100 sardinas que se compraron "para dar la quaresma pasada, de limosna", dándose a los mismos conventos la misma cantidad, salvo a las beatas de San Gil que se les dio media arroba de pescado y 100 sardinas, igual que a las beatas de San Pedro. También se dio media arroba de pescado y 100 sardinas a los presos de la cárcel1994. En 1552 la Universidad gastó 10.610 mrs. por las 15,5 arrobas de pescado y 3.100 sardinas "que

1991 A. H. F. B./ Munic. Orduña, Caja 84, leg. D, fol. 1 r.-6 v.; 33 r.o; 7 r.-32 v.; 34 r.- 51 r./ 1506-1527; ENRÍQUEZ FERNÁNDEZ, J., HIDALGO de CISNEROS AMESTOY, C., LORENTE RUIGÓMEZ, A. y MARTÍNEZ LAHIDALGA, A.:"(1511-1520), de la Junta de Ruazabal y de la Aldea de Belandia. t. II". 1994: doc. 47.

1992 A. H. F. B./ Munic. Orduña, Caja 84, leg. D, fol. 1 r.-6 v.; 33 r.o- 7 r.-32 v.; 34 r.- 51 r./ 1506-1527; ENRÍQUEZ FERNÁNDEZ, J., HIDALGO de CISNEROS AMESTOY, C., LORENTE RUIGÓMEZ, A. y MARTÍNEZ LAHIDALGA, A.:"(1511-1520), de la Junta de Ruazabal y de la Aldea de Belandia. t. II". 1994: doc. 47.

1993 A. H. P. C./ Laredo. Cuentas de la villa de Laredo, f. 107r-116r/ Laredo, 1547; VALDOR ARRIARÁN, M.: 2002: 227-251: doc. 10.

1994 A. D. B./ R-12/ Libro de caja de la Universidad de Burgos/ Burgos, 1549-1557. 
se dieron la quaresma pasada de limosna hordinaria", a los mismos del año 1550 y con las mismas cantidades. Costó el pescado 74 rs. el quintal, que son 10.070 mrs., más 540 de traerlo de Laredo1995. En 1556 se deja de dar el pescado, aunque se mantiene la limosna pero en metálico, ya que en 1 de mayo se registran los gastos de $11.594 \mathrm{mrs}$. de "limosnas generales que se dan por la uniuersidad", y se dieron a los mismos monasterios y personas "esta quaresma pasada, en lugar de pescado y sardina que les soliamos dar"1996.

Luis de Orive, en nombre del cabildo de San Martín de los Mareantes de Laredo, informó al Rey en 1572 que el principal trato de la villa era el de la navegación y pesquería y que ordinariamente acudían muchas gentes a comprar pescados, y para su conservación, algunos "los solian freyr y escauechar en la dicha villa, de lo qual hauia venido y uenia notorio uenefiçio" a la villa, a sus vecinos y a las rentas reales; pero que últimamente los regidores de Laredo, "por hazer mal y daño a los dichos sus partes y por su particular ynteres, hauian procurado que no se dexase ni consintiese que las personas que conprasen los dichos pescados los friesen ni escauechasen en la dicha uilla, porque no fuese ninguna persona a comprar los dichos pescados", por lo que muchos habían dejado de acudir e iban a otras villas de la costa. Pidió que se mandase al corregidor que se dejase freír y escabechar los pescados a los que fuesen a la villa como lo solían hacer, porque si no el trato se perdería y los vecinos no podrían vivir en ella por no haber otra granjería ni trato. El Consejo mandó al corregidor de las Cuatro Villas que en 10 días envíe relación de lo ocurrido, para proveer lo conveniente ${ }^{1997}$.

\section{El hierro y sus elaborados}

Desde tiempos medievales se producía en las numerosas ferrerías vizcaínas y guipuzcoanas y en menor medida cántabras y del valle de Mena, hierro en barra y también elaborado. Mantenían una gran producción, que al superar con creces la demanda local, necesitaban canalizarla hacia su exportación, tanto para Castilla como en otras direcciones.

En 1467 se plantea un pleito entre Orduña y Vitoria, al ser tomadas por los de Orduña a un vecino de Vitoria dos acémilas cargadas de hierro labrado cuando iban por Altube por ir según ellos descaminadas. Orduña alega que tiene privilegios, para que todas las cargas de lazos con hierro labrado o sin labrar u otra mercadería que pasase por los caminos entre su ciudad hasta San Pedro de Beraza, o desde Zuya, Altube, Urcabustáiz, Ayala y Orozco, debía ir por la ciudad de Orduña. Los vecinos de Vitoria alegan, por el contrario, que podían llevar y traer de tierra de Orozco y Ayala cualquier mercadería de hierro y acero u otras cualesquier cargas, sin pena ni coto alguno1998.

En 1488 Bartolomé Lantadilla, vecino de Burgos, dijo que en Valmaseda hay contratación de hierro y herraje a causa de que las ferrerías están cerca de la villa, y que muchos vecinos de Burgos y de otras partes van allí a comprarlo al por mayor y al menudo y, añade que el concejo y personas singulares de Valmaseda tienen hecho monopolio para que

1995 A. D. B./ R-6/ Manual del libro de cuentas de la Universidad de Burgos/ Burgos, 1549-1557.

1996 A. D. B./ R-12/ Libro de caja de la Universidad de Burgos/ Burgos, 1549-1557.

1997 A. H. P. C./ Laredo, leg. 1, num. 23, fol. 30/ Madrid, 19 diciembre 1572.

1998 A. M. Vitoria/ 4-15-2/ Vitoria, 1 diciembre 1467. 
ninguno de fuera pueda comprar menos de 10 quintales de hierro, por lo que dice que le tienen prendados ciertos bienes y que los van vendiendo ${ }^{1999}$.

La villa de Bilbao se dirigió a Carlos I en 1553 para construir el camino carretero hasta el puerto de Portugalete, con el fin de abaratar y facilitar el transporte del hierro y las mercaderías a Castilla. Según los maestros se podía hacer un camino bueno y consistente por donde había más ferrerías, para que en el retorno de los mantenimientos y vinos que llegaban de Castilla puediesen llevar más de 28.000 quintales del hierro y 6.000 del acero, que según ellos se labran en ese camino a Portugalete, puerto de donde se puede traer todo el hierro necesario por estar en mar abierto y de donde salen más de 500.000 quintales de vena para Vizcaya, Guipúzcoa y Galicia, y en cuyo retorno se traería del dicho puerto hierro y pescado 2000 .

En 1573 Orduña pidió al Rey licencia para obtener 15.00o ds. con los que "hazer camino que se pudiese carretear" por la Peña de Orduña, para el transporte a Castilla de todas las mercaderías que venían por mar a Bilbao, Portugalete y otros puertos. Con las carretas se abarataría el porte y quedaría beneficiado el Señorío, "en especial del yerro que se hazia en las errerias de Bizcaya y se gasta en todo el Rreino, e como esto era la mas principal grangeria de esa tierra". Con el retorno se traería todo lo necesario, que con su porte más barato bajaría el precio del hierro 1 real por quintal 2001 .

La villa de Valmaseda llegó a especializarse en el siglo XVI en la producción de calderas de cobre, muy apreciadas por su calidad. Marcos de Zumalabe, vecino de Valmaseda, levanta en la villa en los años 20 del siglo XVI el primer martinete de cobre. En una respuesta que da en diciembre de 1525 , dice que las mercedes y privilegios recibidos por sus opositores no podían perjudicar al "edificio de molino de martillo de cobre e de hierro que tenia hecho"2002.

\section{La pólvora}

El castillo de Burgos fue una de las más importantes fábricas de pólvora del Reino y desde la ciudad se enviaron repetidamente partidas a los puertos. Ya durante el reinado de Juan II se indica que "el principal almacén que tenían los reyes de Castilla era Burgos, porque en el castillo de la ciudad había fábrica de pólvora y en el se recogía artillería, armas, municiones y otros pertrechos de guerra"2003. Fernando V convierte la fortaleza, a principios del siglo XVI, en una gran Maestranza donde se fabrica y almacena artillería, municiones y otros útiles artilleros ${ }^{2004}$.

La Universidad de los Mercaderes de Burgos registra gastos relacionados con el transporte de pólvora. Sólo en el año de 1543 se recogen pagos en enero de $969 \mathrm{mrs}$. a "Françisco de Nafuentes, arriero, del alquiler de Bilbao aquí de tres cargas de poluora que torno ha ynbiar Iohan Paez por no

\footnotetext{
1999 A. G. S./ Registro General del Sello, VII-1488, fol. 89/ Burgos, 21 julio 1488; GARCíA de GARCíA de CORTÁZAR, J. A.: 1966: 397 , doc. 26.

2000A. H. F. B./ Munic. Orduña, caja no 19, carp. 5/ Madrid, 17 mayo 1553.

2001 A. D. B./ C-210/ Madrid, 21 noviembre 1573.

2002 MADOZ, P.. 1845-1850: 474-475: tomo 15.

2003 ARACAMA TORRES, J. J. y SANCHEZ-MORENO del MORAL, F.: 1989: 54.

2004 ARACAMA TORRES, J. J. y SANCHEZ-MORENO del MORAL, F.: 1989: 68.
} 
ser bueno a nueue rreales la carga". En abril Francisco de Santamaría paga $4.116 \mathrm{mrs}$. del alquiler y portazgos de 24 barriles de pólvora que se enviaron de Burgos a Laredo. En septiembre, la Universidad paga $4.323 \mathrm{mrs}$. "a Iohan de Rrebolleda e Iohan Belez e sus compañeros del alquiler de Laredo a Burgos, de 41 barriles de polbora que ynbio Pedro del Oyo que peso con tara134@128 a ducado carga de 12 @ que es 4.203, con 7 de portasgos por carga e 102 del alcauala con la renta de lo que costo subirlo al castillo ..." y en octubre se pagan $537 \mathrm{mrs}$. a "Iohan de Rrebolleda del alquiler y portasgos de Laredo aquí, de 5 barriles de poluora que ynbio Pero del Oyo..." más 3.468 mrs. a "Mançio de Llama e sus compañeros carreteros de Meueçes, del alquil de Rruseco aqui de 124 @ de poluora en XXIIII- barriles a XXXIIII - la harroba, de que se les rrebatio 750 porque no llegaron en termino limitado como se conçerto con ellos, ela rresta de vn barril nuebo que se hizo e de lo descargar"2005.

La ciudad de Burgos se quejaba de que el capitán que entendía en la fábrica de munición y artillería en Burgos, transportaba las cosas necesarias para hacer en el castillo la munición y artillería en las carretas que traían bastimentos a la ciudad y que, por ello, los mantenimientos habían subido sus precios. El Consejo acordó en 1543 mandar que el dicho capitán con el corregidor provean cómo se traen las carretas necesarias de fuera de la ciudad, y que no se tomen las carretas que lleguen con mantenimientos ${ }^{2006}$. El problema no se soluciona porque en 1597 el procurador de Burgos pide testimonio de cómo requiere con la real Provisión de agosto de 1543 a Juan Girón, capitán en la fábrica de munición y artillería de Burgos, para que no se saquen carretas de la ciudad, y cuando se necesiten se provean de fuera, ya que Girón había mandado embargar las carretas que traían vino y otras provisiones 2007 .

Según Aracama/Sánchez-Moreno, la producción de los molinos del castillo de Burgos alcanzó en 1564 la cifra de 20 quintales diarios, gracias a las órdenes del Rey para surtir salitre al molino, y en 1572 comienza el periodo de máximo esplendor ${ }^{2008}$.

\section{C.- EL TRANSPORTE DE MERCADERİAS}

Las características del territorio por donde discurren los caminos que estudiamos hacían que estos fuesen irregulares y deficientes, lo que provocaba que el medio de transporte más adecuado y utilizado básicamente fuese el arrieril, por lo que el mayor volumen de la carga transportada hasta al menos el siglo XVIII ${ }^{2009}$, por los caminos de Burgos a los puertos del Cantábrico, se hizo a lomos de acémilas. Un considerable número de arrieros, algunos a tiempo completo, utilizaron estos caminos e hicieron posible la comunicación de la Meseta Castellana con la zona costera norteña y fueron un eslabón importantísimo de la cadena que hizo posible la prosperidad y desarrollo económico de Burgos y otras plazas castellanas a través de la práctica mercantil. No obstante, cuando las características

2005 A. D. B./ R-3/ Burgos, 1539-1549. p. 69i. y $107 i$.

2006 A. M. B./ HI-3320 y 3.416/ Valladolid, 30 agosto 1543. (Burgos, 15 junio 1597)

2007 A. M. B./ HI-3416/ Burgos, 15 junio 1597.

2008 ARACAMA TORRES, J. J. y SANCHEZ-MORENO del MORAL, F.: 1989: 83.

2009 MADRAZO MADRAZO, S.: 1984: 76: v. I. 
del terreno lo hacían posible, algo poco común en el territorio que estudiamos, se utilizaron los carros y las carretas, tirados principalmente por yuntas de bueyes, con lo que se aumentaba la carga por bestia y se lograba un abaratamiento del coste del transporte. En este caso, en algunos lugares inmediatos a los puertos de montaña, como en Corconte junto al puerto de Corconte o Escudo, o en el borde del páramo junto a la ermita de Nra. Sra. de La Hoz, antes de bajar a El Almiñé, se recurría al trasvase de las mercaderías de los carros o carretas a las mulas y viceversa, pero en la mayoría de las ocasiones, los recorridos se realizaban por completo a lomos de mulas, como apunta Lapeyre para fines del siglo XVI, por ser más cómodo realizar los recorridos sin interrupciones y evitar así los numerosos trasvases e interrupciones.

Existe un tipo de trajín que, aunque parezca anacrónico existía, como era el del transporte sin caballería alguna, es decir, el acarreo a la espalda del trajinante. Esto solo se puede comprender si tenemos en cuenta la pobreza de sus protagonistas. Aunque del siglo XVIII, se recoge en el Catastro de Ensenada un caso en Pesquera de Ebro: "Francisco Merino mayor de Go por sus dos hixos Manuel y Francisco, que handan el uno con una caualleria menor y el otro a cuestas al trato todo el año de los maçones, ajos y sardinas, en el que le consideran de utilidad doscientos y diez rs. de vellon"2010.

El sistema de transporte tenía una gran dependencia del clima y del ciclo agrario. Diciembre y enero eran meses poco propicios por ser fríos y lluviosos, haciendo pantanosos y de difícil tránsito los caminos, al tiempo que la nieve dificultaba los pasos de montaña. Por contra, escaseaba el pasto en agosto, septiembre y octubre, los tres secos. En enero y febrero se necesitaban los animales para arar y sembrar, y en junio y julio para la siega ${ }^{2011}$.

\section{a.- De corto y largo recorrido}

En la zona que estudiamos existían dos tipos de transporte, el de corto recorrido, que se realizaba principalmente para suministrar productos básicos a los mercados y poblaciones ubicadas en este sector, y el de largo recorrido, que comunicaba el interior de la Península con los puertos cantábricos y la Europa atlántica, utilizando estas tierras como un sector intermedio que se debía superar para transportar unas mercaderías que tenían como destino o procedían de los puertos europeos. Como es lógico, esto se encontraba directamente relacionado con el tipo de mercaderías transportadas y con el mismo sistema de los transportes, condicionando además las características de los profesionales que se dedicaban a este oficio. Ringrose establece, no obstante, tres tipos de demanda para el siglo XVIII ${ }^{2012}$. En base a esta clasificación, pero para los siglos XV y XVI, el más activo fue el del transporte estacional y barato para acarrear bastimentos locales y regionales, recorriendo distancias relativamente cortas. Un segundo tipo procedía del tráfico de materias primas, manufacturas y mercaderías importadas, que implicaba un pequeño conjunto de bienes de alto precio, en el que la lana, el pastel y los paños eran objeto de un comercio

2010 A. D. B./ Catastro Marqués de Ensenada, 1752. Respuesta 32: Pesquera de Ebro t. 1.366.

2011 RINGROSE, D. R.: 1987: 65

2012 RINGROSE, D. R.: 1987: 38 
cuantioso transportado a distancias más largas, y el tercer tipo de demanda fue el que originó la Monarquía demandando transportes para el Ejército, suministros navales, etc. y para la provisión de Madrid como nueva capital.

\section{b.- La arriería}

El arriero es la persona que transporta cargas o trajina con bestias de carga y se ocupa de ellas. El término proviene del verbo arrear, que significa estimular a las bestias para que echen a andar, sigan caminando o aviven el paso. También significa poner arreos, que son las guarniciones de las caballerías de tiro y de carga. Esta palabra, a su vez, proviene de la voz jarre!, interjección utilizada para estimular a las bestias ${ }^{2013}$.

El medio de transporte mulatero fue el mejor adaptado a las características del territorio y a las de los caminos existentes entre Burgos y los puertos del Cantábrico, la mayor parte de herradura. Según Braudel, sería el movimiento de acarreo practicado por los arrieros el que habría hecho a España, al determinar las tendencias profundas de la economía del país. La circulación básica dirigida al Norte desde el siglo XIII, se intensificó a partir del reinado de los Reyes Católicos, con las activas comunidades de Medina del Campo, Burgos y Bilbao, planteando la nueva tendencia de la economía castellana, cada vez más ligada a la de la Europa septentrional ${ }^{2014}$.

Era habitual que, para resolver problemas de transporte de tipo diverso, se recurriese a los embargos de bestias y en 1428 , se dan algunas normas legales sobre dichos embargos. Juan II quiere evitar "los daños que nuestros súbditos y naturales reciben de ser apremiados á dar carretas y acémilas y otras bestias, para llevar cargas de unos lugares á otros contra su voluntad", por lo que manda que no se tomen contra la voluntad de los dueños por persona alguna, "de qualquier estado 0 preeminencia o dignidad que sean", salvo para "la nuestra Cámara y de la Reyna nuestra muger, y del Príncipe nuestro fijo, pagándolas primeramente ántes que partan de los lugares donde se tomaren"2015. El mismo Juan II regula en 1442 la utilización de acémilas y las condiciones de los embargos ${ }^{2016}$ y en 1480 el Rey vuelve sobre la forma de utilizar las bestias de arriería para su desplazamiento 2017 .

2013 Diccionario de la Lengua Española. Real Academia Española.

2014 BRAUDEL, F.: 1976: 68-69

2015 NOVÍSIMA RECOPILACIÓN DE LAS LEYES DE ESPAÑA. París, 1846. Tomo segundo/ Libro VI, Titulo XIX, Ley II/ Segovia, 24 octubre 1428.

2016 NOVÍSIMA RECOPILACIÓN DE LAS LEYES DE ESPAÑA. París, 1846. Tomo segundo/ Libro VI, Titulo XIX, Ley I/ Valladolid, 1442, pet. 33; Toledo, 1462, pet. 8; Salamanca, 1465 pet. 11 y 1566. "quando que se hobieren de dar guias de carretas ó acémilas ó mulas ó asnos, para las personas que Nos mandáremos dar, las quales no puede tomar persona alguna por su propia autoridad, mas que el Juez del lugar, ó Regidor ó persona diputada por el Concejo, vea las de que tuviere necesidad, y las dé, tasándolas en lo que justamente mereciere por cada dia, andando cargada, á ocho leguas, y dos tercios dello por la vuelta... y que las paguen ántes que partan con ellas, del lugar donde hobieren de partir".

2017 NOVÍSIMA RECOPILACIÓN DE LAS LEYES DE ESPAÑA. París, 1846. Tomo segundo/ Libro VI, Titulo XIX, Ley III/ Toledo, 1480. El Rey mandaba que "quando que Nos hobiéremos de partir de un lugar á otro, y fueren para ello menester hombres ó carretas ó bestias de guia, que el nuestro Mayordomo ó Mayordomos se junten con los del nuestro Consejo, y vean lo que fuere menester, y hayan su informacion segun el camino, tiempo y costumbre de la tierra, quanto se debe tasar por cada cosa; y con esta consideracion fagan nuestras cartas de nómina de lo que fuere menester para Nos, y para aquellos que ellos vieren que se deban dar, y las señalen para que Nos las firmemos, y por ellos enviemos á mandar á los nuestros Alguaciles ó á qualquier dellos, que tomen las personas, bestias y carretas que por la dicha nómina fueren señaladas para cada uno; y que 


\section{Los arrieros}

Las personas que trajinan con bestias de carga aparecen en los documentos con los nombres de acemilero, arriero, atijarero, borriquero, corredor de bestias, cosario, mulante, mulatero o muletero, mulero, recuero, trajinante, trajinero o tratante, que con estos nombres son denominados, todos con una función similar salvo la del tratante, que desarrolla a veces la labor de comprar géneros para revenderlos, es decir, tendría una actividad más itinerante que la del el arriero, con un menor radio de acción y desarrollando una función doble: como transportista y como pequeño comerciante.

Con la denominación de arrieros o mulateros, coexistieron personas con diferentes perfiles. Principalmente eran de dos tipos: los profesionales o arrieros puros y los de media dedicación o dedicación esporádica, que eran aquellos que al no ejercer por completo esta actividad, por ser en general labradores, alternaban el trabajo de la agricultura con el transporte, aprovechando las épocas del año en que disminuye el trabajo en el campo y trajinaban "alguna corta parte del año sin faltar a sus labranzas"2018 durante un periodo que podía oscilar entre dos semanas y ocho meses por año2019. Utilizaban además sus animales de trabajo para la práctica arrieril, buscando un complemento para sus economías familiares sin alejarse demasiado de sus lugares de residencia ${ }^{2020}$. Fue esta la figura más habitual de los arrieros procedentes de nuestras tierras.

Para otros muchos por el contrario, la arriería fue actividad principal en la que "se exerzittan en dicho ofizio la mayor partte del año"2021, ocupándose de una manera permanente en este oficio. Pero incluso entre estos se dieron también notables diferencias, puesto que unos se limitaron a prestar servicios de transporte a terceros, mientras que otros, por el contrario, utilizaron sus acémilas para transportar mercancías que previamente habían comprado o adquirido a trueque por otras, y que debían buscar y obtener mercadería de retorno para no volver de vacío. Muchos, combinaron las dos facetas, tratando de sacar el máximo partido a sus desplazamientos ${ }^{2022}$.

Procedentes de toda la geografía española, aunque con un mayor índice de las tierras más pobres, los arrieros fueron el nervio principal y los que dieron vida a unos trabajosos y duros caminos y pusieron en contacto tierras y lugarese hicieron posible un comercio que requería de sus imprescindibles servicios, a través del intercambio necesario entre las zonas excedentarias y las demandantes, a costa de fatigas, esfuerzos y duro trabajo. Expuestos a dormir al raso, solían frecuentar incómodas ventas y mesones y sufrían las inclemencias y a veces los desastres ocasionados por una inestable meteorología. Era un

ántes que las entreguen á quien las han de llevar, lo fagan pagar luego lo que mandare la tasa, segun el camino donde fuere, contando ocho leguas para cada dia, y contando de la tornada dos tercios de lo que montare la ida; y de otra guisa, fasta que paguen, no entreguen los Alguaciles las bestias, ni den los nombres para guia".

2018 A. D. B./ Catastro Marqués de Ensenada 1752. Respuesta 32. Noceco 1.190.

2019 RINGROSE, D. R.: 1987: 65-67.

2020 A. D. B./ Catastro Marqués de Ensenada, 1752. Respuesta 32: Condado de Valdivielso t. 578. En Condado de Valdivielso "Gregorio Ruiz de Somouilla uecino de este lugar, de oficio labrador, el qual tiene tres pollinos con los que se ocupa en trajinar la terzera parte del año y lo demas en su labranza".

2021 A. D. B./ Catastro Marqués de Ensenada 1752. Respuesta 32. Huéspeda 912.

2022 DIAGO HERNANDO, M.: 2004: 223. 
grupo humilde obligado por la necesidad a buscar sus medios de vida que procedía habitualmente de zonas donde los recursos eran escasos. Cuando podían, iban en pequeños grupos para auxiliarse, aunque era corriente la figura del arriero solitario. Gil y Carrasco lo resumía en 1839 refiriéndose a los arrieros maragatos: "Los hombres buscan en la arriería lo que su ingrato suelo les rehusa; y durante su ausencia las mujeres corren con las faenas de la labranza"2023.

Varios grupos importantes de arrieros surgieron en diversos lugares, como los mencionados arrieros maragatos de Astorga y su comarca, los arrieros yangüeses de la Tierra soriana de Yanguas ${ }^{2024}$ o los de Atienza, grupo que constituirá un colectivo potente y cohesionado que, con un alto grado de especialización, desarrollarán una gran actividad en todo el norte de la Península, entre las que se incluyen las tierras que estudiamos. Su cofradía, fundada en fechas antiguas, mantendrá su actividad hasta momentos relativamente recientes ${ }^{2025}$. Fernando III, concede en enero de 1234 la merced de seguro y salvoconducto a todos los recueros de Atienza, para que anden de manera segura por todas las partes del Reino con sus mercaderías, sus bestias y con cuantas cosas llevaren consigo, no sacando del Reino cosas vedadas y sin que nadie pudiera embargarlos ni prendarlos, si no fuere por deuda manifiesta o por fianza que ellos hubiesen hecho, concediéndoles seguridades en todo el Reino ${ }^{2026}$, condiciones confirmadas por todos los reyes posteriores ${ }^{2027}$.

Los recueros, arrieros y atijareros decían que ellos andaban con sus reatas y atijaras llevando pan, vino, sal, hierro, carbón, lanas y otras mercaderías y que en los caminos, necesitaban parar sus recuas y soltar sus bestias para pacer y descansar, pero algunos concejos no les dejaban en sus términos y que si, por azar, entraban en panes o viñas, aunque no hiciesen gran daño, les llevaban grandes penas, por lo que no podían pasar por esos lugares ni llevar provisiones. Añadían que algunos concejos o particulares, araban y estrechaban los caminos, no dejándoles más que lo que cabe una bestia; y como no se podían desviar, si se salían les llevaban penas desproporcionadas aunque se quejasen a los concejos y justicias. Indicaban que la situación no se remediaba ni se arreglaban los caminos, y los concejos consentían y daban lugar a que los fatigasen y cohechasen. El Consejo mandó en julio de 1502 a todos los concejos que cuando los arrieros pasaren con sus recuas los dejen estar, pasar y soltar sus mulos, rocines, asnos y bestias, y pacer y beber en todos sus términos, debiendo guardar los panes, viñas, huertas, olivares y otras heredades particulares, dehesas adehesadas y prados de guadaña, y todo lo que vedan y el daño que hicieren, lo paguen según sus ordenanzas. Manda, además, que cada concejo en sus términos abra y repare los caminos y calzadas por donde los recueros y caminantes suelen andar, para que "sea de anchor que pertenesca, para que puedan bien yr e venir syn que ayan de yncurrir

2023 GIL Y CARRASCO, E.: 1839: 57-60; RUBIO PÉREZ, L. M.: 1995.

2024 DIAGO HERNANDO, M.: 2005: 115-144.

2025 LAYNA SERRANO, FCO.: 2004

2026 A. C. S. T. A./ Peñafiel, 18 enero 1234; GONZÁLEZ y GONZÁLEZ, Julio: 1986: 23: t. III doc 510.

2027 A. C. S. T. A./ Burgos, 28 octubre 1255, Córdoba, 12 julio 1282, Atienza, 18 enero 1285, Salamanca, 12 octubre 1295 , Valladolid, 2 julio 1314, Atienza, 16 marzo 1329 y Madrid, 20 abril 1391; TAMAYO, A.: 2004: doc. 1ํ, p. 89, doc. 20, p. 91, doc. $3^{\circ}$, p. 93 , doc. $4^{\circ}$, p. 95 , doc. $6^{\circ}$, p. 103 y doc. $7^{\circ}$, p. 109 
en pena alguna por falta de caminos, e non consintades [que] sean çerrados, ni arados, ni ensangostados, ni dañados los dichos caminos" por las aguas y avenidas ${ }^{2028}$.

\section{Las caballerías mayores}

Las menciones que en los documentos se realizan a las bestias arrieriles, diferencian entre bestias mayores y menores. Las bestias mayores se referían al caballo y al mulo o macho, y las menores a los asnos.

El empleo principal de los caballos fue el de la monta para los desplazamientos y el de la guerra. Para el transporte, en este caso llamados rocines, fueron muy poco utilizados como bestias de carga o para el tiro o acarreo, aunque sí se emplearon en la mulatería como el animal sobre el que se desplazaba el arriero. También como peculiaridad, muchos tratantes llevaban tan solo un caballo o dos, que emplean a la vez tanto para su monta como para llevar sus mercancías.

El mulo o macho fue el animal básico utilizado por la arriería, por encima del asno. Era duro para el trabajo, soportaba más carga y era más dócil que el burro. Denominado también acémila, macho, muleto -de 2,5 a 3 años hasta la doma-, machito o machuelo, podía ser de dos tipos: burreño, burdégano o macho romo, nacido de cruce de caballo y burra, que era más dócil y menos fuerte que el yeguato. Este procedía de cruce de burro y yegua, y era más grande y fuerte que el burreño. La yeguata era la más cotizada. En un tratado de 1831 se indica que "tiene del asno la bondad del casco y la seguridad y solidez delas piernas; sus riñones son muy fuertes, y lleva pesos mas considerables que el caballo"2029.

Durante toda la historia de los transportes de mercaderías, estos dependieron en gran medida de este animal tan adaptado a este tipo de trabajo. De esta manera, en 1492, un mesonero de Luyando decía que por el camino entre Orduña y Bilbao "podian ser los que pasaban en cada vn año, vn año con otro, tres mill mulos, pocos mas o menos"2030. En dicho tratado de 1831 se indica que "la cria de mulas está extendida en España, y puede creerse que, á no ser por las leyes que absolutamente lo prohiben en ciertas partes, apenas quedarian caballos"2031.

\section{Las caballerías menores}

El burro era también llamado asno, borrico o jumento. El garañón era el semental y el pollino el burro joven y cerril. En el tratado de 1831 se indica que "los burros de las montañas se distinguen por la pequeñez de su alzada, por su agilidad y por la fuerza de sus piernas. Sirven para acarrear pesos y para toda especie de arriería"2032. Para el transporte de grandes cargas fue menos utilizado que el macho, aunque también ocupó un papel de cierta importancia integrado en recuas constituidas por asnos en su totalidad, o bien conviviendo en esas mismas reatas con machos. Tuvieron un papel de cierta relevancia para el transporte de productos en régimen local o comarcal, poniendo en contacto las localidades rurales entre sí y con las

\footnotetext{
2028 A. G. S./ Registro General del Sello, VII-1502, fol. 132/ Toledo, 23 julio 1502.

2029 "Tratado del ganado caballar, asnal y mular". 1831: 79.

2030 A. G. S./ Cámara de Castilla. Pueblos, leg. 3-2, doc. 248/ Orduña, 20 enero 1492.

2031 "Tratado del ganado caballar, asnal y mular". 1831: 84

2032 "Tratado del ganado caballar, asnal y mular". 1831: 77.
} 
ferias locales y comarcales. También fue utilizado, en menor medida que el caballo, para llevar en sus lomos al arriero que iba a cargo de la recua.

\section{c.- La arriería en las tierras del norte}

La arriería fue, como se ha indicado, el medio básico del transporte de mercaderías, utilizado en las tierras del norte peninsular hasta prácticamente el siglo XIX. Era el sistema mejor adaptado a la orografía del país y a las características de los caminos que existían en dicha zona, incluso muchos de estos, no admitían otra posibilidad de transporte; aunque también es cierto que en los espacios más llanos y propicios, convivió con los carros y carretas que se fueron implantando. Los carros y carretas facilitaban el transporte de cargas más voluminosas y pesadas pero, en contrapartida, no podían ser utilizados en los caminos que tenían pasos estrechos, gran pendiente o mal estado, que era la característica general de los caminos que estudiamos.

Existió en estas tierras de manera permanente o esporádica un gran número de arrieros que fueron capaces de garantizar el intenso tráfico que discurrió por estos caminos. Un testigo decía en un interrogatorio realizado en 1515 que "sabe que ay muchos mulateros de las dichas merindades, e que es ofyçio que se trata mucho en las dichas merindades e que oy lo seran vnos y mañana los seran otros...", y que hacía unos 12 años había "en las dichas merindades mas de dosyentos e çinquenta mulos, e que abia mas que no hagora, porque se ganaban mas dineros"2033. Se dedicaban tanto al suministro de las poblaciones ubicadas en este sector del norte y al abastecimiento de los mercados regionales y locales de dichas poblaciones, como a mantener el comercio internacional a través de los puertos de mar.

En la zona del norte de Burgos, existieron localidades, en las que una gran parte de sus vecinos se dedicaban a la arrieria, constituyendo como veremos sagas familiares en las que el oficio se transmitía de padres a hijos.

\section{La arriería entre Burgos y los puertos de mar}

Cada mulo yeguato podía llevar sobre sus lomos en distancias cortas hasta 11 arrobas, unos $126 \mathrm{~kg}$, pero lo habitual era que desplazase en distancia larga entre 6 y 8 arrobas (entre 70 y $90 \mathrm{~kg}$ ), y el animal pequeño $1 / 3$ menos. El terreno accidentado de las tierras que estudiamos obligaba a rebajar las cargas ${ }^{2034}$. Basas nos indica que cada mulo podía llevar una saca de lana que pesaba si iba a Flandes 8,5 arrobas, unos $98 \mathrm{~kg}$; pero si se llevaba la lana a Francia, la saca debía ser de 10 arrobas, unos $115 \mathrm{~kg}$, y este fue el tamaño de las sacas que se fijó durante siglos, condicionado a este tipo de acarreo 2035 .

De 1266 tenemos una primera referencia sobre la arriería, cuando la comunidad de Oña y su abad dejan a los vasallos de Villela, Gornaz y Rebolledillo, ciertas sernas en determinadas condiciones, y para acarrear el pan que deben entregar al monasterio, los de Villela lo llevarán desde la Era, los de Gornaz desde Valdecal, los del tercio de San Julián

2033 A. G. S./ Consejo Real de Castilla, leg. 84, fol. 2-III/ Valladolid, 26 junio 1513 a Salazar, 25 septiembre 1515

2034 RINGROSE, D. R.: 1987: 61.

2035 BASAS FERNÁNDEZ, M.: 1963 y 1994: 261-262. 
de Cornaz y los de Rebolledillo desde Santa María de Canaleja y los de San Andrés y de San Juan de Rebolledillo, todos al palacio del abad de Santa Olalla de Villela. El día que lo acarrearen, la casa dará a 10 bestias una fanega de cebada, y a los hombres que las trajeren sendas libras de pan, así como a los de la vendimia. Y el año que les manden llevar el pan a Santa Olalla de Villela, no tendrán que llevar la recua del pan a Oña ${ }^{2036}$.

El Infante Don Sancho manda en 1279 a los alcaldes y merino de Burgos que pregonen para que todos los recueros que traen pan, vino, carne y pescado y todas las otras viandas vayan con sus recuas a Ágreda llevando todo género de alimentos, por estar él allí desde el domingo primero de cuaresma para entrevistarse con el Rey de Aragón, y no se les cobre portazgo por donde pasaren, y cuando lleguen a Ágreda "yo los fare pagar muy bien todo lo que dellos costaren"2037.

Los Reyes dicen en febrero de 1486 al corregidor, alcalde y alguacil de Burgos que en la Chancillería hay pleito entre Pedro de Mugaburu, arriero vecino del valle de Orozco, como acusador, y Pedro de Vitoria y Francisco de las Heras, mercaderes, Diego de Vitoria, hijo de Pedro y vecino de Burgos, y Martín de Salvatierra, vecino de Salvatierra y criado de Pedro, como acusados. Mugaburu dijo que por la feria de mayo de Medina del Campo llevó ciertas mercaderías de Pedro de Vitoria y Francisco de las Heras de Burgos a Medina y que le pagarían en la dicha feria. Estando en la calle de la Rúa de Medina del Campo en junio de 1484, dijo "a los dichos Pero de Vitoria e Françisco de las Heras que le pagasen lo que le deuian, diz que arremetieran a el todos los susodichos, dandose fauor e ayuda los vnos a los otros... con animo e proposito de le ferir e matar", y dice que Pedro de Vitoria le trabó de los cabellos y de las Heras "diz que le diera una bofetada, e con vn tavde que tenia en la mano, le diera muchos golpes en la cabeça fasta que diz que le fiso pedaços e le descalabro con el", y Martín de Salvatierra o alguno de los otros, "le diera con vn puñal vna puñalada en la cabeça, de que le ronpieran el cuero e paso el casco, e diz que le fisieran vna ferida mortal de que estuuiera en la cama muchos dias, ellegara a punto de muerte e non pudo trauajar nin caminar por espaçio de siete meses", y que había gastado más de 50.000 mrs. hasta quedar "pobre del todo". Añade que Diego ayudaba a su padre y a los otros, y le agarraba para pegarle y que el conocimiento de esta causa pertenecía a los alcaldes por ser como era "onbre pobre e miserable persona, diz que a cabsa de la dicha puñalada, auiendo estado enfermo della e perdido e gastado diz que quanto tenia, e se le murieran dos mulos que tenia e otro diz que tenia para morir, por lo el no poder governar, estando como diz que estaua enfermo e doliente en cama, tanto tienpo de la dich ferida e diz que non podiendo trauajar en su ofiçio de recuero, por manera quel non tenia que comer". Los alcaldes reales condenaron a Salvatierra por "echor e perpetador del dicho delito de que fue acusado... a que le cortasen la mano derecha ele diesen çinquenta açotes publicamente en la dicha çibdad de Burgos" o donde fuese hallado, y le condenaron también en $14.078,5$ mrs. de daños y costas ${ }^{2038}$.

En 1496 el concejo, diputados y procurador de Bilbao dijeron que la villa recibía mucho daño de sus vecinos mulateros que en ella y sus arrabales viven y allí tienen sus mulos, y que traen sus bestias cargadas con vinos de Castilla y otras mercaderías y los venden

2036 A. H. N./ D. P. de Oña. carp. 288, num. 10/ abril 1266; ÁLAMO, J. del: 1950: t. II. doc. 573, 688-689.

2037 A. M. B./ HI-2916/ Atienza, 9 febrero 1279.

2038 A. Ch. V./ Ejecutorias emitidas, caja 1, nำ14/Valladolid, 12 febrero 1486; ENRíQUEZ FERNÁNDEZ, J.; SESMERO CUTANDA, E.; MARTÍNEZ LAHIDALGA, A. y HIDALGO de CISNEROS, C.:"Archivo de la Real Chancillería de Valladolid. Registro de ejecutorias emitidas. Vizcaya (1486-1502). Regist. 1 a 20". 2010: doc. 3. 
en Alvia, Arrigorriaga, Bujana y otras partes, y no solían traer trigo, cebada, vinos, ni legumbres a la villa, aunque para sus bestias, compraban toda la cebada que traían a la villa otros mulateros y lo hacían entrojar, y aunque algún vecino lo necesitaba no le solían dar nada; y lo peor era que las cargas que en Bilbao había para Castilla y Aragón, como el pescado fresco o cecial, congrio, sardina, paños o pasteles, ellos lo tomaban para otros viajes sacándolos en otros mulos suyos, por lo que los mulateros que llevaban de continuo trigo y otras legumbres no encontraban carga de retorno. Además, Bilbao tenía ordenanza que mandaba pagar 2 reales de plata sobre cada mulo que llegase vacío, y como la pena era pequeña, los mulateros de la villa y sus arrabales seguían trayendo sus bestias vacías haciendo por ello otros fraudes. Por ello se mandó que ningún mulo de vecinos o moradores de Bilbao o sus arrabales pueda traer bestia sin carga de trigo, legumbre, sacas u otras mercaderías, bajo la pena de seis reales de plata por bestia vacía, y que de día ni de noche puedan comprar en el mercado ni en el azogue cebada en menudo ni en grueso para sus bestias bajo la misma pena. Además, si vinieren de vacío, no podrán sacar de Bilbao carga alguna2039.

En 1504 los mulateros de la cofradía de San Anton de Álava se quejan del mal estado de los caminos, pero parte de sus quejas conciernen a lugares de fuera de su provincia, en parte del término comunero de la Puebla, Pangua y Burgueta, entre Pancorbo y Zuñeda y entre Cuisaleña y Briviesca, "e en otras partes e lugares en tierra de Alaua, estan muy malos pasose peligrosos e çerrados e estragados los caminos o pasados e caydas e ronpidas algunas puentes" 2040 .

Pedro Ezquerra, decía en nombre de los concejos del valle de Soba, que muchos de sus vecinos llevaban mercaderías en sus bestias a Medina de Pomar y otros lugares de tierra de Campos y otras partes, y que, para ir y volver a Soba, han de pasar por el valle de Montija, descargando allí sus recuas y apacentando sus bestias; pero ahora sus vecinos procuran ahora prenderlos cuando paran y duermen en sus términos. El Consejo falló en 1507 que los vecinos de Soba, cuando pasaren con sus rocines y bestias de carga por Montija entre septiembre y marzo, puedan apacentar sus bestias de noche y de día en Montija, guardando panes, viñas, dehesas dehesadas, prados de guadaña y los otros prados acotados que los vecinos guardaren; y que de abril a agosto, puedan apacentar sus bestias en dicho valle, no pudiendo pacer de noche sin licencia del concejo, debiendo, en este caso, descargar en poblado y dormir en él, pues en esos meses no lo hacen las bestias de Montija; pero en el término comunero de este valle en que sus vecinos pueden pacer de noche en ese tiempo, podrán hacerlo los de Soba sin pena alguna ${ }^{2041}$.

En 1515 se establece un pleito entre Alonso de Sanzoles, mercader de Burgos, y Sancho Ortiz, escribano del valle de Cordejuela, sobre que Alonso de Sanzoles dio a Alonso de Ayala ocho sacas de lana fina para llevar a Bilbao y este las entregó a unos mulateros de

2039 A. M. Bilbao/ Cajón 8, reg. 2, no⒉ Recop. ordenanzas, fols. 79-80/ Bilbao, 6 septiembre 1496; GARCíA de CORTÁ-

ZAR, J. A.: 1966: 435, doc. 42.

2040 A. G. S./ Registro General del Sello, VIII-1504/ 26 agosto 1504; MOLÉNAT, J. P.: 1971: 140-141.

2041 A. H. P. C./ Valle de Soba, leg. 32, doc. 2/Valladolid, 7 septiembre 1506 y Burgos, 10 noviembre 1507. 
los que uno de ellos era criado de Sancho Ortiz. Al no hacer efectiva la entrega, Sanzoles le embargó dos mulas con sus aparejos ${ }^{2042}$.

El corregidor y los regidores de Laredo acordaron en 1538 poner arancel en la puerta de la villa sobre los derechos que han de pagar los mulateros que salgan con recuas al arrendador que tuviere la renta del peaje: por cada mulo u otra bestia cargada o vacía, 3 mrs. más de portazgo, y de cada carga que lleve de alquiler un mr. , y si la carga fuere suya, una blanca, pero no ha de pagar si las cargas son de algún vecino ${ }^{2043}$.

En las ordenanzas de Villalacre de agosto de 1548, se manda que todos los del lugar que tuvieren machos y mulas de trajinería no puedan bajar ni andar con ellos fuera de las hacenderas, según costumbre de lo acotado, ni del camino real abajo ningún domingo del año ni fiesta de guardar, so pena de $10 \mathrm{mrs}$. por cada cabeza2044.

A veces, los mulateros no solo transportaban cargas y mercaderías, sino que basándose indudablemente en la confianza que inspiraban, llevaban dinero en metálico, como se constata en un encargo realizado por la Universidad de Burgos. En 1553 Alonso de Compludo debía a Hernando de Trezanos 170.000 mrs. "que son por 5.000 rreales que por bia de Laredo se ynbiaron a Arnao del Oyo Somado con Alonso Martinez mulatero, vezino de Muneo", para que de allí los enviase a Santander ${ }^{2045}$. También lo transportaban oculto entre la mercadería, como ocurrió en un robo realizado hacia 1473 cerca de la ciudad de Orduña por hombres del mariscal García López de Ayala a unos mercaderes de Burgos cuando iban a la Montaña, con "vna azemila cargada de trigo, y dentro de la carga dozientas e ochenta mill maravedis porque non se paresçiese", es decir, ocultos dentro de la carga ${ }^{2046}$.

En 1571 se mandó que los mulos de los trajineros que fueren de camino puedan pacer en lo acotado de Villalacre y en todo se le respete ese día como a los bueyes de arada, y que lo mismo sea al día siguiente aunque huelguen. El que tuviere al animal cojo podrá estar dos días y no más en dicho acotado, y los demás días que estuvieren en el pueblo puedan andar fuera de las hacenderas debajo del camino real, fuera del acotado y de los arroyos, porque es pasto de bueyes ${ }^{2047}$.

En abril de 1587 se concede una ejecutoria y otras providencias en que se declara exentos para el servicio del Rey a los caballeros hijosdalgo y nobles de las Merindades que no fuesen arrieros o carreteros de profesión ${ }^{2048}$.

Diego Hernández de Gandía, arriero de Rucandio y Diego de la Peña, arriero de Cantabrana, se comprometen en 1597 a entregar a Jerónimo de Madrid, tratante en frutas, 72 arrobas de pero blanco que llaman "de Villabueno", por precio de un macho bozal de pelo negro de 30 meses, con su manta2049.

2042 A. Ch. V./ Sección de Pleitos Civiles, Fernando Alonso. Caja 1321, 1/ 1515-1517.

2043 A. H. P. C./ Villa de Laredo, leg. 10, num. 4, fol. 89/ Laredo, 22 noviembre 1538.

2044 Archivo de Villalacre/ Villalacre, 9 agosto 1548; 24 septiembre 1570; 25 junio 1571; 21 junio 1593.

2045 A. D. B./ R-6/ Manual del libro de cuentas de la Universidad de Burgos, p. 75r/ Burgos, 1549-1557.

2046 A. G. S./ Registro General del Sello, III-1480, fol. 427/ Toledo, 15 marzo 1480.

2047 Archivo de Villalacre/ Villalacre, 9 agosto 1548.

2048 A. C. V./ Leg. 39/ 8 abril 1587.

2049 A. Sta. Clara/ 82.12/ 1597. 
En el s. XVII las Merindades de Castilla Vieja dicen que el alcalde mayor que les envió el Rey realiza muchos agravios y daños, como que a los arrieros que pasan por el lugar donde reside, que es camino pasajero para la corte, los detiene y quita los pescados que llevan no pagándoles casi nunca, por lo que los arrieros evitan pasar por dicho lugar y se pierden los aprovechamientos 2050 .

En agosto de 1605 Diego Ruiz de Ahumada, vecino de Frías, otorga carta de obligación para enviar a Juan Fernández de Carrión, de Burgos, cuantas arrobas de pábilo para velas pudiese comprar en Frías y su tierra y otras partes, no comprando "pabilo para otra ninguna persona y que poco o mucho que comprare, a de ser para el, el qual pabilo a de ser bueno y blanco de dar y tomar", entregándolo en Frías al arriero Juan de Mendoza para que lo lleve a Burgos por su cuenta y riesgo, siendo por cuenta de Juan Fernández el pago al arriero ${ }^{2051}$.

\section{La cofradía de mulateros y viandantes entre Burgos y Laredo}

Desde al menos el año 1483 encontramos referencias a asociaciones o cofradías de mulateros asentados en las Merindades de Castilla Vieja que comparecen ante las autoridades para defender los derechos de sus miembros. Posiblemente se asocian de manera coyuntural para presentarse unidos y representados por un procurador, por lo general otro arriero, cuando un motivo concreto los obliga a ello, ya que entre 1483 y 1515 aparecen con distintas denominaciones como veremos. En ocasiones actúa como corporación o hermandad, como en 15110 12, cuando un mulatero que entre Gayangos y Quintanilla iba "con sus mulos cargados de bino blanco, yendose por el camino rreal ançia la montaña a Biluao o a Laredo, e salieron al dicho por fuerça e contra su voluntad e le llebaban a Medina, e despues como los vesynos de las dichas merindades lo sopieron, algunos dellos fueron a repique de canpana con el alcalde de la hermandad tras los que le tomaron los dichos mulos e vino"2052.

Después de 1515 no hemos encontrado más alusiones a ninguna otra cofradía o asociación de mulateros. Dichas cofradías con su nombre de referencia, son:

\begin{tabular}{|c|l|l|}
\hline Año & \multicolumn{1}{|c|}{ Denominación } & \multicolumn{1}{|c|}{ Procurador } \\
\hline 1483 & $\begin{array}{l}\text { “los escuderos, fijosdalgo e labradores de Castilla Vieja e la Sonsierra } \\
\text { e hermandad e confradia de Dobro e Villaescusa e Pesadas"2053 }\end{array}$ & $\begin{array}{l}\text { Fernando Sáez } \\
\text { de Fresnedo }\end{array}$ \\
\hline 1487 & “los mulateros caminantes de la dicha Castilla Vieja"2054 & $\begin{array}{l}\text { García Ruiz de } \\
\text { Hornillalatorre }\end{array}$ \\
\hline 1488 & “los mulateros y viandantes de la merindad de Castilla Vieja"2055 & $\begin{array}{l}\text { García Ruiz de } \\
\text { Hornillalatorre }\end{array}$ \\
\hline 1488 & “los mulateros caminantes de la merindad de Castilla Vieja"2056 & \\
\hline
\end{tabular}

2050 A. G. S./ Cámara de Castilla. Pueblos, leg. 5, doc. 257/ Villarcayo, s. XVII.

2051 A. H. P. B./ Protocolos, 2.965, fol. 1.136/ Burgos, 4 agosto 1605.

2052 A. G. S./ Consejo Real de Castilla, leg. 84, fol. 2-III/ Valladolid, 26 junio 1513 a Salazar, 25 septiembre 1515.

2053 A. G. S./ Registro General del Sello, VIII-1483, fol. 184/ Santo Domingo de la Calzada, 23 agosto 1483

2054 A. G. S./ Cámara de Castilla. Pueblos, leg. 10, doc. 32/ Burgos, 17 diciembre 1487.

2055 A. G. S./ Cámara de Castilla. Pueblos, leg. 10, doc. 32-1/ Laredo, 24 febrero 1488.

2056 A. G. S./ Registro General del Sello, VII-1488, fol. 188/ Burgos, 4 julio 1488. 


\begin{tabular}{|c|c|c|}
\hline 1495 & $\begin{array}{l}\text { "Ios mulateros e viandantes de la dicha çibdad de Burgos e del } \\
\text { condado de Vizcaya, Encartaçiones e otras susodichas } \\
\text { merindades e lugares"2057 }\end{array}$ & $\begin{array}{l}\text { García Ruiz de } \\
\text { Hornillalatorre } \\
\text { y Juan Ortiz de } \\
\text { Villasante }\end{array}$ \\
\hline 1495 & $\begin{array}{l}\text { "los mulateros e viandantes ansy de la çibdad de Burgos como } \\
\text { del condado de Vizcaya e Encartaçiones e Tierra Llana"2058 }\end{array}$ & \\
\hline 1496 & $\begin{array}{l}\text { "los mulateros e caminantes e viandantes e vniversydades } \\
\text { de la mulateria"2059 }\end{array}$ & $\begin{array}{l}\text { García Ruiz de } \\
\text { Hornillalatorre }\end{array}$ \\
\hline 1499 & "Ios mulateros e viandantes de las partes de la dicha Castilla Vieja" & Pedro de Espinosa \\
\hline 1499 & $\begin{array}{l}\text { "los mulateros biandantes destas merindades de Castilla Vieja } \\
\text { e probinçia de Burgos" }\end{array}$ & Pedro de Espinosa \\
\hline 1499 & "los mulateros biandantes de las partes de la dicha Castilla Vieja" & Pedro de Espinosa \\
\hline 1499 & "los biandantes que continan de andar de Burgos a Laredo" & Pedro de Espinosa \\
\hline 1499 & $\begin{array}{l}\text { "Ia unibersidad de los mulateros e biandantes de la probinzia } \\
\text { de Burgos e merindades de Castilla Vieja e los otros lugares e tierras } \\
\text { dende la dicha çibdad de Burgos fasta la dicha villa de Laredo" }\end{array}$ & $\begin{array}{l}\text { Fernando Sáez } \\
\text { Delgado }\end{array}$ \\
\hline 1499 & $\begin{array}{l}\text { "los mulateros e biandantes de la probinzia de Burgos fasta } \\
\text { la costa de la mar" }\end{array}$ & \\
\hline 1499 & $\begin{array}{l}\text { "Ia confradia de los mulateros rrecueros de la çibdad de Burgos } \\
\text { e de la uilla de Laredo e sus comarcas" } 2060\end{array}$ & \\
\hline 1499 & $\begin{array}{l}\text { "Ia cofradia de los mulateros e rrecueros de la çibdad de Burgos } \\
\text { e de la villa de Laredo e sus comarcas"2061 }\end{array}$ & \\
\hline 1500 & $\begin{array}{l}\text { "la Vniversydad de los mulateros e viandantes de las Montañas } \\
\text { e merindades de Castilla Vieja e peñas adentro e de las prouinçias } \\
\text { de Burgos e de las otras partes e logares" } 2062\end{array}$ & $\begin{array}{l}\text { Fernando de } \\
\text { Valmaseda }\end{array}$ \\
\hline 1500 & $\begin{array}{l}\text { "los mulateros e viandantes que andan de la çibdad de Burgos } \\
\text { a la villa de Laredo y a las Encartaciones de Vizcaya e } \\
\text { a la merindad de Castilla Vieja"2063 }\end{array}$ & $\begin{array}{l}\text { García Ruiz de } \\
\text { Hornillalatorre }\end{array}$ \\
\hline 1500 & $\begin{array}{l}\text { "Ios mulateros e viandantes de Burgos a Laredo e de las } \\
\text { Encartaçiones de Viscaya e de las merindades de Castilla Vieja"2064 }\end{array}$ & $\begin{array}{l}\text { García Ruiz de } \\
\text { Hornillalatorre y } \\
\text { Fernando de Prado }\end{array}$ \\
\hline 1500 & $\begin{array}{l}\text { "los mulateros e rrecueros de la prouinçia de Burgos y de la merindad } \\
\text { de Castilla Vieja e de las Encartaçiones e Vizcaya"2065 }\end{array}$ & $\begin{array}{l}\text { García Ruiz de } \\
\text { Hornillalatorre y } \\
\text { Fernando de Prado }\end{array}$ \\
\hline 1500 & $\begin{array}{l}\text { "Ios mulateros de las dichas merindades e de toda } \\
\text { su universidad e cofradia"2066 }\end{array}$ & \\
\hline
\end{tabular}

2057 A. G. S./ Registro General del Sello, VII-1495, fol. 187/ Burgos, 9 julio 1495.

2058 A. G. S./ Registro General del Sello, VIII-1495, fol. 260/ Burgos, 7 agosto 1495.

2059 A. G. S./ Registro General del Sello, X-1496, fol. 168/ Burgos, 13 octubre 1496.

2060 A. H. N./ Nobleza. Frías, C. 235, D. 55/ Medina de Pomar, 15 enero 1499. Se recogen en este documento, las siete denominaciones de 1499.

2061 A. G. S./ Registro General del Sello, VIII-1499, fol. 44/Valladolid, 27 agosto 1499.

2062 A. G. S./ Registro General del Sello, V-1500, fol. 322/Valladolid, 12 mayo 1500.

2063 A. G. S./ Registro General del Sello, VIII-1500, fol. 365/Valladolid, 3 agosto 1500.

2064 G. S./ Registro General del Sello, VIII-1500, fol. 51/Valladolid, 18 agosto 1500.

2065 A. G. S./ Registro General del Sello, VIII-1500, fol. 315/Valladolid, 25 agosto 1500.

2066 A. G. S./ Registro General del Sello, XII-1500, fol. 352/Valladolid, 3 diciembre 1500. 


\begin{tabular}{|c|l|l|}
\hline 1500 & "la confradria de los mulateros de la merindad de Castilla Vieja"2067 & \\
\hline 1501 & $\begin{array}{l}\text { "los mulateros e viandantes y de las merindades } \\
\text { tierras de Castilla Vieja"2068 }\end{array}$ & $\begin{array}{l}\text { Pedro Ruiz } \\
\text { de Sedano }\end{array}$ \\
\hline 1501 & "los mulateros e vyandantes de la prouinçia de Burgos"2069 & $\begin{array}{l}\text { Gómez Fernández } \\
\text { de Isla y } \\
\text { Juan de Rueda }\end{array}$ \\
\hline 1502 & $\begin{array}{l}\text { "Ia cofradia de los mulateros y viandantes } \\
\text { de la prouinçia de Burgos"2070 }\end{array}$ & $\begin{array}{l}\text { Pedro Fernández de } \\
\text { Brizuela y } \\
\text { Juan Barahona }\end{array}$ \\
\hline 1515 & $\begin{array}{l}\text { "los mulateros e uiandantes de la meriendad de Castilla Vieja } \\
\text { e de la merindad de la Sonsyerra e Sotoscueba"2071 }\end{array}$ & $\begin{array}{l}\text { "los mulateros e viandantes de la junta e meriendad de Castilla Vieja } \\
\text { e de la merendad de la Sonsyerra e Sostescueba"2072 }\end{array}$ \\
\hline
\end{tabular}

En 1483 Fernando Sáez de Fresnedo, vecino de Villanueva de Ladrero, en nombre de los mulateros dijo que siempre han pasado libremente por el camino real de la Ordunte que va a Castro-Urdiales y a Bilbao por el valle de Mena, pero que desde hace unos 8 años, el concejo de Villasana y el merino de Mena los prenden y les obligan a ir por el camino de Villasana que dice que es más largo y fragoso. Los Reyes mandan al concejo y al merino que dejen a estos mulateros "e todas las otras personas mulaterose biandantes destos nuestros Rreynos" transitar libremente con sus mulos y acémilas cargadas o vacías por el camino real de la Ordunte 2073 .

En 1488 García Ruiz de Hornillalatorre, vecino de Hornillalatorre, procurador de los mulateros de Castilla Vieja, presentó ante el alcalde y regidores de Laredo una Carta real y dijo que algunos de los mulateros o sus criados van a comprar a Laredo pescados y otras mercaderías y llevaban a vender pan, vino y otras cosas, cobrándoles 2 mrs. por quintal de pescado e impedían, sin tener licencia, que nadie les compre sus mercaderías. Pedía que les dejasen comprar y vender libremente en la villa sin llevar los derechos que les llevaban. Se notificó además en los lugares de Colindres, Limpias, Ampuero, Ramales y Lanestosa dicha Carta real a sus alcaldes, pidiéndoles que la hiciesen cumplir, contestando todos que la obedecían. No obstante, a los alcaldes de Limpias, Ampuero, Ramales y Lanestosa, García Ruiz les dijo que, por ciertos agravios que en sus villas se les habían hecho, les ponía plazo para que compareciesen ante los Reyes o ante su Consejo ${ }^{2074}$. Después García Ruiz dice en el Consejo Real que dichos concejos habían sido emplazados y que tras ser presentada una petición con la estimación de todos los daños causados a los mulateros,

2067 A. G. S./ Registro General del Sello, XII-1500, fol. 364/Valladolid, 4 diciembre 1500.

2068 A. G. S./ Registro General del Sello, VI-1501, fol. 456/ Valladolid, 4 junio 1501.

2069 A. G. S./ Registro General del Sello, XI-1501, fol. 203/ Écija, 5 noviembre 1501.

2070 A. G. S./ Registro General del Sello, VIII-1502, fol. 394/ Toledo, 27 agosto 1502.

2071 A. G. S./ Consejo Real de Castilla, leg. 84, fol. 2-III/ Valladolid, 26 junio 1513 a Salazar, 25 septiembre 1515

2072 A. G. S./ Consejo Real de Castilla, leg. 84, fol. 2-III/ Valladolid, 26 junio 1513 a Salazar, 25 septiembre 1515.

2073 A. G. S./ Registro General del Sello, VIII-1483, fol. 184/ Santo Domingo de la Calzada, 23 agosto 1483.

2074 A. G. S./ Cámara de Castilla. Pueblos, leg. 10, doc. 32-1/ Laredo, 24 febrero 1488. 
no se han presentado; por lo que suplica que manden ver el pleito y todos los autos para proceder con justicia ${ }^{2075}$.

En 1495 García Ruiz y Juan Ortiz de Villasante, procuradores de los mulateros, dijeron ante el Consejo que los Reyes habían mandado que no se llevasen las imposiciones que se cobraban a los mulateros y viandantes en ciertos puentes y calzadas, salvo en los lugares que los hacían a su costa, pero como tras las riadas de Vizcaya y Merindades los mulateros no podían pasar, suplicaron que mandasen que los lugares donde estaban los puentes y calzadas los volviesen a hacer, y que si algunos no tenían recursos, que diesen licencia para que los mercaderes y las personas que por allí pasaren contribuyan a ello, ya que ellos estaban dispuestos ${ }^{2076}$.

En 1499 comienza un largo proceso en el que los mulateros promueven la reparación del camino de Burgos a Laredo. Para ello se rectificarán antiguos trazados y se construirán nuevos puentes, labor siempre condicionada por la escasez económica y por los impagos de las localidades y entidades incluidas en los repartimientos. Así, en enero de ese año Pedro de Espinosa, procurador de los mulateros, dijo que los Reyes habían mandado, a petición de la cofradía, dar una Carta para el corregidor de las Cuatro Villas y el alcalde mayor de Castilla Vieja, mandándoles que viesen el estado de los caminos entre Burgos y Laredo, ya que muchas gentes y bestias peligraban y se perdían las mercaderías. En la pesquisa realizada se vio que, entre otros, recibían beneficio los mulateros y viandantes ${ }^{2077}$. En agosto, los mulateros dicen que para reparar dichos puentes, calzadas y caminos se les habían repartido en 10 años muchas cuantías de mrs., cobrándolos algunas personas que no han dado razón de lo recibido, por lo que pidieron que se tomase cuenta de lo que les habían cobrado. El Consejo mandó que el corregidor y el alcalde mayor recaben información sobre los repartimientos hechos, quiénes los habían cobrado, y los que los habían gastado presenten las cuentas verdaderas y sin fraude ante los mulateros y recueros señalados por la cofradía 2078 .

En agosto de 1500 García Ruiz dijo en el Consejo Real que por su parte fue ganada una Provisión para que el corregidor hiciese cobrar los mrs. repartidos a los mercaderes y lugares comarcanos para el reparo de dichos caminos, puentes y calzadas, pero que el corregidor no lo había querido hacer ${ }^{2079}$. García Ruiz añadió que los Reyes también mandaron al corregidor y al alcalde mayor que tomasen las cuentas a los que habían recaudado los repartimientos hechos por ciertos concejos y otras personas, para que lo que no se había gastado en el reparo lo recuperasen ${ }^{2080}$. Carcía Ruiz indicó también que los Reyes mandaron, además, que como tales reparos eran muy necesarios tanto para los viandantes como para los mercaderes y lugares cercanos, se debían repartir entre todos ellos, e indica que en el repartimiento, tocó pagar a los mulateros $260.000 \mathrm{mrs}$. Añade que dicha cantidad se

2075 A. G. S./ Cámara de Castilla. Pueblos, leg. 10, docs. 33bis. y ter./ Burgos, 1 abril 1488.

2076 A. G. S./ Registro General del Sello, VII-1495, fol. 187/ Burgos, 9 julio 1495

2077 A. G. S./ Registro General del Sello, I-1499, fol. 50/ Ocaña, 15 enero 1499.

2078 A. G. S./ Registro General del Sello, VIII-1499, fol. 44/Valladolid, 27 agosto 1499.

2079 A. G. S./ Registro General del Sello, VIII-1500, fol. 365/ Valladolid, 3 agosto 1500.

2080 A. G. S./ Registro General del Sello, VIII-1500, fol. 50/Valladolid, 4 agosto 1500. 
podría recaudar cobrando por imposición 1 real a cada acémila, y como era más conveniente arrendar su recaudación, lo habían rematado por $130.000 \mathrm{mrs}$. en un año ${ }^{2081}$.

No obstante, en octubre, los Reyes dicen al alcalde de Castilla Vieja, a Pedro Ruiz Cachopín, vecino de Laredo, y a Fernando de Prado, procurador de la cofradía de los mulateros, que por una carta que dieron para hacer el repartimiento a petición de los mulateros, mandaron que no se echase cosa alguna por imposición, porque las leyes de los Reinos lo prohíben ${ }^{2082}$. En noviembre, los Reyes dicen a Ruiz Cachopín y Fernando de Prado que habían mandado que pareciesen en el Consejo a dar cuenta de cómo había consentido que se echase imposición de 1 real sobre cada macho que pasase por Castilla la Vieja y cierta cantidad sobre los ganados, estando prohibido ${ }^{2083}$. En diciembre, los Reyes dicen a los mulateros que les cupo el pago de $260.000 \mathrm{mrs}$. en el repartimiento hecho, para lo que echaron a cada acémila, mulo o recua 34 mrs., a cada bestia menor la mitad y a los ganados y puercos cierta cantidad, y los arrendaron en $130.000 \mathrm{mrs}$.; pero como el arrendamiento e imposición se había puesto contra el tenor de la Carta real, mandan que no se cobre ${ }^{2084}$.

En enero de 1501 los Reyes comunican a los mulateros que el arrendamiento de los 130.000 mrs. por un año, se había hecho contra las leyes y las Cartas y Provisiones reales, mandando que no se cogiesen y que se devolviese lo que se había cobrado para repartir el resto entre los mulateros de la cofradía ${ }^{2085}$. En marzo, los Reyes comunican a Fernando Diáñez de Alcocer, persona enviada por el Consejo, que los procuradores de los mulateros dijeron en el Consejo Real que se había cogido el dicho peaje cerca de seis meses, y lo que se había cogido no llegaba a 60.000 mrs. ${ }^{2086}$. Los Reyes indican a Alcocer que los mulateros dijeron que algunos de los caminos por donde andan desde Burgos a Laredo, se podrían trazar por otras partes menos ásperas y más convenientes para que con menos trabajo se pudiesen utilizar, pudiéndose hacer sin provisión de la tierra y sus vecinos ${ }^{2087}$. Los Reyes habían mandado a Alcocer que fuese a coger los mrs. repartidos; sobre lo cual y sobre el repartimiento de los 260.000 mrs. de los mulateros, trataron en Medina de Pomar que solo se podía hacer el repartimiento cobrándose por acémila, en dos o tres puertos por donde más continuamente pasasen, y si esto no fuese suficiente, que se diese licencia para valorar las acémilas de cada mulatero y repartir por millar lo que fuese necesario o que se pudiese coger por renta o arrendamiento. El Consejo determinó que, como es voluntad de los Reyes que lo que deben pagar los mulateros se haga repartiendo a cada uno lo que le corresponde y no por vía de imposición, y acordó que se debía mandar a Alcocer que, con acuerdo de sus procuradores, haga el repartimiento sobre las bestias de cada recuero y lo paguen en el plazo señalado, y si no lo pagaren, haga ejecución en ellos y en sus bienes ${ }^{2088}$.

2081 A. G. S./ Registro General del Sello, VIII-1500, fol. 52/ Valladolid, 17 agosto 1500.

2082 A. G. S./ Registro General del Sello, X-1500, fol. 476/Valladolid, 1 octubre 1500.

2083 A. G. S./ Registro General del Sello, XI-1500, fol. 233/Valladolid, 3 noviembre 1500.

2084 A. G. S./ Registro General del Sello, XII-1500, fol. 364/Valladolid, 4 diciembre 1500.

2085 A. G. S./ Registro General del Sello, II-1501, fol. 447/ Valladolid, 30 enero 1501.

2086 A. G. S./ Registro General del Sello, III-1501, fol. 604/Valladolid, 19 marzo 1501.

2087 A. G. S./ Registro General del Sello, III-1501, fol. 591/Valladolid, 20 marzo 1501; MOLÉNAT, J. P.: $1971: 147$.

2088 A. G. S./ Registro General del Sello, III-1501, fol. 592/Valladolid, 20 marzo 1501. 
Ruiz de Sedano dijo en el Consejo que los Reyes habían mandado que los mulateros pagasen en total $325.000 \mathrm{mrs}$. para el reparo de los puentes, caminos y calzadas que van de Burgos a Laredo, y que se depositasen en poder de Fernando Ruiz de Villasante. Pero como Ruiz de Sedano dice que los mulateros iban por otros caminos para no pagar, suplicó que se diese carta para que los mrs. se pudiesen coger en los lugares de los Hocinos y la Horadada, por donde pasan más continuamente. El Consejo mandó en junio de 1502 al corregidor de las Cuatro Villas, que se junte con los mulateros y sus procuradores en el lugar más conveniente y se haga el repartimiento de los 325.000 mrs. según las bestias que cada uno tuviere, y que cada uno lo lleve a Fernando Ruiz de Villasante2089. Ruiz de Sedano dijo que los mulateros han mandado hacer y reparar los caminos entre Burgos y Laredo y que, para hacerlo, mandaron a cada villa y lugar que está en esos caminos que hiciese lo que estuviere en su término, y que dichas villas y lugares fuesen ayudados con algunos mrs. dados por los mercaderes de Burgos y de otros concejos, y dice que aunque los han requerido para que lo hiciesen, algunos no lo han querido realizar y otros, aunque lo han hecho, no lo desarrollan como se les ha mandado. El Consejo mandó en julio a los corregidores de Burgos y de las Cuatro Villas que se hagan las intervenciones, apremiando a los concejos y a las personas a quienes se mandó para que hagan cuanto antes los dichos caminos ${ }^{2090}$.

En relación con este proceso, pareció en el Consejo Pedro de Durango en nombre de la Universidad de los Mercaderes y dijo que la Carta real agraviaba a sus partes, y que los puentes de estos caminos, según derecho, no estaban a cargo de sus partes ni de los dueños de las mercaderías, sino "que antes serian a cargo de los mulateros e rrecueros, que por sus jornales e alquileres llebaban las dichas mercaderias de un logar a otro, llebando cosa tasada por carga". También alegó que "el aprouechamiento de los dichos caminos e rreparo dellos, hera para la dicha vylla de Laredo e para los dichos mulateros e tragineros, que lleuan e traen sus pescados en la fuerça del ybierno de aguas $e$ niebes, con las quales e con el caminar que hazen al dicho tienpo, se perdian e destruyan los dichos caminose calçadas", y que "los dichos mulateros que en la dicha fuerça de ybierno andan los dichos caminos trayendo pescados elleuando los mantenimientos a la dich a villa de rretorno, de trigo e vyno e otras cosas de que se seguia muy grand prouecho e vtilidad a la dicha villa de Laredo e a los dichos mulateros", por lo que suplicó se mandase que sus partes no fuesen obligadas a la contribución. Después Rodrigo Cachopín en nombre de Laredo, dijo en el Consejo que el repartimiento y provisión, era muy injusto para la villa y sus vecinos, porque "de tienpo ynmemorial a esta parte, los mercaderes e mulateros fazian e rreparaban los dichos caminos, como por que la nesçesidad de los dichos caminos tenian los dichos mercaderes e mulateros, e que ellos rreçibian la utilidad e prouecho de que los dichos caminos e puentes estouiesen fechas"2091. El proceso prosiguió varios años sin lograr todos sus objetivos, aunque sí se realizaron actuaciones importantes.

En agosto de 1500 García Ruiz y Fernando de Prado, vecino del lugar de Prado, dijeron en el Consejo Real que han sido procuradores de los mulateros de la provincia de Burgos, de Castilla Vieja y de las Encartaciones de Vizcaya, y que por ellos fue proveído pagarles a

2089 A. G. S./ Registro General del Sello, VI-1502, fol. 315/ Toledo, 16 Junio 1502.

2090 A. G. S./ Registro General del Sello, VII-15O2, fol. 398/ Toledo, 30 julio 1502.

2091 A. G. S./ Registro General del Sello, VIII-1502, fol. 394/ Toledo, 27 agosto 15O2; A. D. B./ C-220/ Toledo, 27 agosto 1502. 
cada uno 2.00o mrs. al año, más 1 real de plata cada día que realizasen labores de representación de los mulateros; y que como les deben ciertas cuantías, les han requerido para que les paguen y no lo quieren hacer; lo cual visto en el Consejo, fue acordado mandar al corregidor de las Cuatro Villas y al alcalde mayor de Castilla Vieja que averigüen la verdad y administren justicia ${ }^{2092}$.

Juan Barahona, vecino de Villanueva de Ladrero y procurador de los mulateros, presentó en el Consejo, en febrero de 1515, una petición diciendo que "çiertos besynos de la uilla de Medyna de Pumar, an coechado a los dichos mulateros... muchas contyas de mrs., lleuandoles por cada azemilla çinquenta mrs. en cada un año, a dos mrs. de cada carga cada mantenimiento, e un marabedy por el aluala". Añadió que en las merindades de Castilla Vieja, Mena y puente de Nava llevan a los mulateros y viandantes y a los merchantes de ganados mayores y menores, muchos mrs. de "portazgos e pontajes e otros derechos e nuebas ynposyçiones que nuebamente an puesto e ponen de cada dia, no seyendo ellos hobligados a pagar cosa alguna,... e que sy alguno se pone en no lo querer pagar, les toman prendas e los maltratan e fatygan en pleytos,... e que porque no los maltraten se dexan coechar e pagan todo lo que les piden avnque no lo deven", y suplica que se mande devolver todo lo que les han llevado más los gastos ocasionados y se castigue a los que lo cobraron.

Los mulateros dijeron al corregidor en septiembre que reciben mucho daño por lo que les llevan cuando hay nieve en el puerto de Sandiniesto, y le piden que mande comparecer a los que lo cogen y a los que los mandan, para que muestren los títulos que tienen. También presentaron un pedimento sobre los portazgos y fuerzas declaradas y le dicen que hallará por la pesquisa y testigos que le serán presentados por los mulateros, las muchas extorsiones y agravios que les hacen por los portazgos que les llevan contra derecho las guardas y dezmeros del Condestable en Medina de Pomar y en otras partes de Castilla Vieja, "syn tener tytulo ni rrason, ni derecho alguno para los poder llevar", obligándolos a ir por Medina de Pomar, cuando van por su camino derecho por los valles de Espinosa, Valdeporres y Castilla Vieja y haciéndolos pagar portazgo. Los mulateros hacen igualas con los portazgueros, los cuales han llevado a muchos de ellos más de 6.000 ds. de oro y, asimismo, a los que no las querían hacer, los detenían fuera de la jurisdicción de Medina. Indican que hará unos 15 años que el Condestable cometió a su mayordomo que hiciese pesquisa sobre las quejas de las "fuerças y biolençias que se fasyan por los dichos portazgueros a los dichos mulateros y biandantes", porque el Condestable lo quería remediar. Piden al corregidor que apremie a los vecinos de Medina de Pomar, a los portazgueros y al Condestable y sus mayordomos a que le presenten "qualesquier titulos e prebillejios por donde a los dichos mis partes han llevado los dichos portazgueros en los dichos caminos rreales en la dicha villa de Medina de Pumar, e para cometer las dichas fuerças y biolençias que a mis partes se an cometido"2093.

\section{Los arrieros en el norte de Burgos}

La zona norte de Burgos, coincidente con la comarca de Las Merindades, tuvo una actividad arrieril considerable, ejercida por los mulateros vecinos de dicha comarca. Varios documentos nos indican sus procedencias. En septiembre de 1495 un arriero, testigo en

2092 A. G. S./ Registro General del Sello, VIII-1500, fol. 315/Valladolid, 25 agosto 1500.

2093 A. G. S./ Consejo Real de Castilla, leg. 84, fol. 2-III/ Valladolid, 26 junio 1513 a Salazar, 25 septiembre 1515. 
un interrogatorio realizado sobre el camino que pasa por Valmaseda, declara que los arrieros que más de continuo andan y tratan en esta villa, son los de "toda la junta e tierra e valle de Mena, e toda la tierra e valle de Salzedo, e toda la tierra de Sopuerta, e valle de Galdames, e Somorrostro e su tyerra, e Arzentales, e Troçios, e Carrança, e valle de Villaverde y el valle de Gordojuela, e los de Arrigorriaga, e Llodio, e Luyando, e toda la tierra de Losa, e los de Salillinas de Rrosio, e Medina de Pumar y toda su juridiçion, e Castilla Vieja e toda su juridiçion, e los del balle de Valdevielso e su Merindad, e los de los Butrones que es Dobro e Villascusa, e Pesadas y Masa, e Santibañes e su tierra, y la villa de Castro d'Ordiales e la junta de Samano y otros y suelen pasar e andar en esta villa algunas beses los de la tierra de Toro, e algunos de Villabellad e los de las Nuebe villas de Canpos"2094. Como vemos, además de los mulateros de las zonas cercanas a Valmaseda se mencionan otros lugares más distantes como los Butrones o Valdivielso que son sin duda de donde proceden, ya que su alusión no se justifica por la importancia comercial o económica de tales lugares.

También encontramos alusiones indirectas a estos mulateros como las de 1556, cuando se habla de que "se abia aogado un manzebo de la Sonsierra, yendo con requa", o que se cobraba cierta cantidad "en el lugar de Encenillas, de los mulateros de Ahedo del Butron y Baldeçamanças y de otras partes" para el reparo del camino de los Hocinos ${ }^{2095}$. Todos estos datos serán confirmados por los diferentes documentos en los que constan los nombres y procedencias de tales mulateros. Pasemos a detallarlos:

\begin{tabular}{|r|l|l|l|}
\hline Año & Nombre & Edad & Vecindad \\
\hline 1483 & Pedro de Revilla & & Revilla de Pienza \\
\hline & Fernando Sáez de Fresnedo & & Villanueva de Ladrero \\
\hline 1487 & García Ruiz de Hornillalatorre & Hornillalatorre \\
\hline 1492 & Juan & & Villabasil \\
\hline 1495 & García Ruiz de Hornillalatorre & Hornillalatorre \\
\hline & García Ruiz de la Iglesia & Hornillalatorre \\
\hline & Juan Ortiz de Villasante & Villasante \\
\hline & Fernán Sánchez de Villasante & Villasante \\
\hline & Pedro Sánchez de Villasante & Villasante \\
\hline 1497 & Juan López & Agüera de Montija \\
\hline & Diego Izquierdo & La Aldea de Medina \\
\hline & Juan de la Dehesa el Mozo & Ampuero \\
\hline & Juan de la Correde & Ampuero \\
\hline & Sancho de Guardamino & Ampuero \\
\hline & Diego de Agüera & Ampuero \\
\hline & Juan & & Arroyo de Valdivielso \\
\hline & Lope & Baillo \\
\hline & Pedro & Baranda \\
\hline & Sancho & Barriosuso \\
\hline & García López & Barruelo \\
\hline
\end{tabular}

2094 A. G. S./ Cámara de Castilla. Pueblos, leg. 21-2, doc. 185/ Burgos, 17 julio y Valmaseda, 10 agosto 1495. 2095 A. C. V./ no 18. doc. 3, hojas 28 a 48/ Medina de Pomar, 7, 8, 9 y 21 enero 1556. 


\begin{tabular}{|c|c|}
\hline Rodrigo Herrero & Barruelo \\
\hline Capillas & Barruelo \\
\hline Juan de Torres & Barruelo \\
\hline Diego & Bercedo \\
\hline Pedro & Bercedo \\
\hline Pedro de Marrón & Bernales (Ampuero) \\
\hline Juan & Bernales \\
\hline Pedro & Bisjueces \\
\hline Pedro & Briviesca \\
\hline Diego Marroquín & Burgos \\
\hline Chapado & Burgos \\
\hline Juan de Roldán & Burgos \\
\hline Andrés & Burgos \\
\hline Juan & Butrón \\
\hline Sancho criado de Juan & Butrón \\
\hline García & Butrón \\
\hline Lope & La Cerca \\
\hline Juan hijo de Sancho & Cereceda \\
\hline Gonzalo de Peroabad & Dobro \\
\hline Rodrigo de Peroabad & Dobro \\
\hline Alonso & Dobro \\
\hline Juan Díaz & Dobro \\
\hline Pedro Martínez & Dobro \\
\hline Alonso de la Peña & Dobro \\
\hline Alonso Gómez & Dobro \\
\hline Sancho Barayo & Gibaja \\
\hline Rodrigo hijo de Juan García Barayo & Gibaja \\
\hline Juan Guerra & Guardamino \\
\hline Juan del Valle & Guardamino \\
\hline Ruy Díez de la Hornilla & \\
\hline Diego & Hornillalatorre \\
\hline Sancho Escudero & Lanestosa \\
\hline Juan de Angulo & Moneo \\
\hline Fernando & Nofuentes \\
\hline Pedro & Oña \\
\hline Juan Gómez & Padiérniga \\
\hline Juan del Río & Padiérniga \\
\hline Sancho de las Llamosas & Padiérniga \\
\hline Juan de Peroabad & Pesadas \\
\hline Juan Alonso & Pesadas \\
\hline Rodrigo & Poza \\
\hline García & Queciles \\
\hline Pedro & Queciles \\
\hline
\end{tabular}




\begin{tabular}{|c|c|c|c|}
\hline & Pedro Gil & & Ramales \\
\hline & Pedro hijo de Pedro Ortiz & & Ramales \\
\hline & Juan & & Rosío \\
\hline & Juan & & Salinas de Rosío \\
\hline & Ochoa de Bintada & & Sopuerta \\
\hline & Broquel & & Sopuerta \\
\hline & Juan de Someano & & Sopuerta \\
\hline & Juan & & Tabliega \\
\hline & Lope & & Torres \\
\hline & Pedro & & Trueba \\
\hline & Fernando & & Valdenoceda \\
\hline & Alonso & & Valdenoceda \\
\hline & Fernando Caballero & & Valdivielso \\
\hline & Juan de la Puente & & Valdivielso \\
\hline & Sancho & & Valdivielso \\
\hline & Juan & & Valdivielso \\
\hline & Juan de Villar & & Valmaseda \\
\hline & Fernando & & Villabasil \\
\hline & Pedro de Prado & & Villaescusa del Butrón \\
\hline & Juan & & Villaescusa del Butrón \\
\hline & Diego & & Villalázara \\
\hline & Pedro & & Villamagrín \\
\hline & Juan Ruiz & & Villatarás \\
\hline \multirow[t]{14}{*}{1498} & Lope Fernández & & Villanueva de Ladrero \\
\hline & Lope García & & Villanueva de Ladrero \\
\hline & Fernando Ortiz & & Villanueva de Ladrero \\
\hline & Fernán Ruiz Cachopín & & Villanueva de Ladrero \\
\hline & Pedro Ruiz Cachopín & & Villanueva de Ladrero \\
\hline & Pedro López & & Villanueva de Ladrero \\
\hline & Pedro López su hijo & & Villanueva de Ladrero \\
\hline & Fernando de la Peña & & Villanueva de Ladrero \\
\hline & Nan de la Peña su hermano & & Villanueva de Ladrero \\
\hline & Juan Ortiz & & Villanueva de Ladrero \\
\hline & Pedro hijo de Diego Fernández & & Villanueva de Ladrero \\
\hline & Pedro hijo de Gonzalo Sánchez & & Villanueva de Ladrero \\
\hline & Gómez hijo de Martin López & & Villanueva de Ladrero \\
\hline & Martín hijo de Martín Fernández & & Villanueva de Ladrero \\
\hline 1499 & Pedro de Espinosa & & Loma de Montija \\
\hline \multirow[t]{3}{*}{1500} & García Ruiz de Hornillalatorre & & Hornillalatorre \\
\hline & Fernando de Prado & & Prado \\
\hline & Pero Ruiz Cachopín & & Laredo \\
\hline \multirow[t]{2}{*}{1515} & Pedro López de Bedón & 60 & Bedón \\
\hline & Pedro de Sojo & $30 / 32$ & Bocos \\
\hline
\end{tabular}




\begin{tabular}{|c|c|c|}
\hline Juan de Espinosa & & Butrera \\
\hline Fernando de la Peña (hermano de Juan) & 50 & Campo \\
\hline Juan Martínez Navarro & 60 & Campo \\
\hline Lope Fernández de Brizuela & 46 & Campo \\
\hline Ruy Sáez Barahona & 40 & Campo \\
\hline Raimundo Sáez de Barahona & 90 & Campo \\
\hline Juan Gómez del Campo & 65 & Campo \\
\hline Juan Barahona & 55 & Cornejo \\
\hline Fernando Sáez de Barruso & 60 & Fresnedo \\
\hline Juan Fernández de Sanvicente & & Fresnedo \\
\hline Juan Gutiérrez de Gayangos & 42 & Fresnedo \\
\hline Pedro Ruiz de la Peña & 45 & Fresnedo \\
\hline Juan hijo de Pedro Ruiz & & Montija \\
\hline Juan García de Fresnedo & 90 & Fresnedo \\
\hline García de Gayangos hijo de Juan García & & Gayangos \\
\hline Juan del Condado & 90 & Hocina \\
\hline Andrés López (hijo de Juan López) & & Horna \\
\hline Juan de Pereda & 45 & Hornillalastra \\
\hline García Martínez & & Hornillalatorre \\
\hline García Ruiz de la Iglesia & 75 & Hornillalatorre \\
\hline García de Pereda & 40 & Hornillalatorre \\
\hline Juan Ruiz de Hornillalatorre & 60 & Hornillalatorre \\
\hline Caso Ruiz & & Hornillayuso \\
\hline Juan López Borricón & & Hornillayuso \\
\hline Pedro Moral & 50 & Hornillayuso \\
\hline Pedro Martínez de Incinillas & & Incinillas \\
\hline Juan de Condado el Mozo & & Incinillas \\
\hline Sancho Díaz & & Incinillas \\
\hline Pedro Fernández de Mozares & 55 & Mozares \\
\hline Pedro López & & Mozares \\
\hline Juan López de Mozares & & Mozares \\
\hline Martina López mujer de Pedro García & & Mozares \\
\hline Elvira López mujer de Diego Fernández & & Mozares \\
\hline Juan de Concha & 40 & Pereda \\
\hline Fernando Sáez de la Cuesta & & Pereda \\
\hline Fernando Sáez de Pereda & 45 & Pereda \\
\hline Juan de Pereda & 35 & Pereda \\
\hline Gonzalo García de Pereda & 65 & Pereda \\
\hline Hernando Ruiz de Pereda & 65 & Pereda \\
\hline Ruy López de Quintana & 65 & Quintana de Rueda \\
\hline Juan Sáez de Baranda & & Quintanaedo \\
\hline Sancho López de Quintanahedo & 50 & Quintanaedo \\
\hline Pedro López de Vallejo & & Salazar \\
\hline
\end{tabular}




\begin{tabular}{|c|c|c|}
\hline Juan de la Peña (hermano de Fernando) & $43 / 44$ & Salazar \\
\hline Pedro López de Salazar & 65 & Salazar \\
\hline Alonso García de Robradillo & & Salazar \\
\hline Alonso García & 65 & Salazar \\
\hline Pedro Fernández Bravo & 55 & Santelices de Valdeporres \\
\hline García Gómez de Sanvicente & 60 & Torme \\
\hline Diego de Bustillo & 60 & Torme \\
\hline Pedro de Bustillo & 40 & Torme \\
\hline Pedro hijo de Pedro de Bustillo & & Torme \\
\hline Fernando Sáez de Soto & & Torme \\
\hline Martín hijo de Fernando Sáez de Soto & & Torme \\
\hline Juan Fernández Barahona & 30 & Torme \\
\hline Juan Fernández Herrero & 60 & Torme \\
\hline Juan Fernández de Sanvicente & 55 & Torme \\
\hline Juan López de Mozares & 40 & Torme \\
\hline Herrán Sáez de Soto & 58 & Torme \\
\hline Pedro Fernández de Sanvicente & 60 & Torme \\
\hline Diego Fernández de Sanvicente & 45 & Torme \\
\hline Fernando López & & Torme \\
\hline Gonzalo de Valderas & & Valdeporres \\
\hline Lope de Valderas & & Valdeporres \\
\hline Sancho Gómez (2 hijos mulateros) & 60 & Villacanes \\
\hline Diego López & 75 & Villacanes \\
\hline Lope García de Rueda & 60 & Villacomparada \\
\hline Diego Fernández de Villacomparada & 54 & Villacomparada \\
\hline Juan López de Villacomparada & 60 & Villacomparada \\
\hline García de Brizuela & 45 & Villanueva de Ladrero \\
\hline Gómez Pérez & & Villanueva de Ladrero \\
\hline Pedro Gómez de Salazar & 70 & Villanueva de Ladrero \\
\hline Gil García & & Villanueva de Ladrero \\
\hline Lope Martínez & 55 & Villanueva de Ladrero \\
\hline Lope García de Villanueva & & Villanueva de Ladrero \\
\hline Fernán Ruiz Cachopín (1 hijo mulatero) & 65 & Villanueva de Ladrero \\
\hline Pedro Fernández de Brizuela & 85 & Villanueva de Ladrero \\
\hline García Fernández de Brizuela & & Villanueva de Ladrero \\
\hline Diego Fernández Gil & 65 & Villanueva de Ladrero \\
\hline Juan Sáez de Villanueva el Viejo & 60 & Villanueva de Ladrero \\
\hline Juan Sáez de Villanueva el Mozo & 35 & Villanueva de Ladrero \\
\hline Juan Sáez de Villanueva & 44 & Villanueva de Ladrero \\
\hline Fernando Ortiz & 60 & Villanueva de Ladrero \\
\hline Juan López de Villanueva el Viejo (2 hijos) & 65 & Villanueva de Ladrero \\
\hline Alonso García de Villanueva & 60 & Villanueva de Ladrero \\
\hline Juan Barahona & & Villanueva de Ladrero \\
\hline
\end{tabular}




\begin{tabular}{|c|c|c|c|}
\hline & Diego Fernández & 65 & Villanueva de Ladrero \\
\hline & Pedro García de Villanueva & 50 & Villanueva de Ladrero \\
\hline & Gómez López & 30 & Villanueva de Ladrero \\
\hline & Juan de Ladrero Sáez & & Villanueva de Ladrero \\
\hline & Juan Gutiérrez & & Villanueva de Ladrero \\
\hline & García Guerra & 47 & Villanueva de Ladrero \\
\hline & Hedo Ortiz & & Villanueva de Ladrero \\
\hline & Sancho Gómez & & Villarán \\
\hline & Pedro de Barahona & 60 & Villarcayo \\
\hline & Pedro Saiz de Villasante & 70 & Villasante \\
\hline & Juan Sáez de Villasante & 80 & Villasante \\
\hline & Fernando Sáez del Campo & 75 & Villasante \\
\hline \multirow[t]{4}{*}{1529} & Ortuño de Chave & 36 & Amurrio \\
\hline & Sancho Leal & 40 & Izoria de Ayala \\
\hline & Juan de Mendívil & 45 & Izoria de Ayala \\
\hline & Juan de Panino & 35 & Prádanos \\
\hline 1553 & Alonso Martínez & & Moneo \\
\hline \multirow{4}{*}{1556} & Pedro Sarmiento & $55 / 60$ & Bisjueces \\
\hline & Hernando Alonso & 50 & Bisjueces \\
\hline & Alonso de Rámila & 30 & Remolino \\
\hline & Juan Martínez de Brizuela & 50 & Torres \\
\hline \multirow[t]{3}{*}{1568} & Llorente García & & Escaño \\
\hline & Pedro el Rojo & & Las Hormazas \\
\hline & Bernardino de San Pantaleones & & San Pantaleones \\
\hline \multirow[t]{3}{*}{1582} & Juan Ruiz & 29 & Bisjueces \\
\hline & Sebastián Garrote & 50 & Hijes en tierra Atienza \\
\hline & Juan Gallo & 30 & Robredo Zamanzas \\
\hline \multirow[t]{16}{*}{ h. 1590} & Martín Ruiz Trechuelo & 64 & La Aldea de Medina \\
\hline & Francisco Díez de Andino & 78 & Barruelo \\
\hline & Hijos de Francisco Díez de Andino & & Barruelo \\
\hline & Domingo de Argüeso & 60 & Gallejones \\
\hline & Simón Martín & & Hornillayuso \\
\hline & García López Borricón & 84 & Hornillayuso \\
\hline & Tomás López Borricón & & Hornillayuso \\
\hline & Juan López Borricón & & Hornillayuso \\
\hline & Pedro López Borricón & 68 & Hornillayuso \\
\hline & Andrés López Quintano tío de Domingo & 70 & Hornillayuso \\
\hline & Domingo López sobrino de Andrés & & Hornillayuso \\
\hline & Juan Ruiz Cotorro & 76 & Hornillayuso \\
\hline & Pedro de Pereda & 66 & Pereda \\
\hline & Miguel Fernández & 54 & Pesadas \\
\hline & Juan García & 44 & Pesquera \\
\hline & Juan Gil & 28 & Pesquera \\
\hline
\end{tabular}




\begin{tabular}{|c|c|c|c|}
\hline & Pedro de Pereda de Miñón & 62 & Torme \\
\hline & Hijo de Pedro de Pereda de Miñón & & Torme \\
\hline & Pedro de Roldán & 72 & Tudanca \\
\hline & Domingo Ortiz & 50 & Villalaín \\
\hline & Miguel Sáez & 84 & Villanueva-Rampalay \\
\hline & Diego Sáez Roldán & 57 & Villanueva-Rampalay \\
\hline \multirow[t]{9}{*}{1593} & Pedro Ruiz & 50 & Ahedo del Butrón \\
\hline & Pedro Sainz & 42 & Báscones de Ebro \\
\hline & Ortega de Prado & 44 & Cantabrana \\
\hline & Francisco María & 26 & Galbe de Atienza \\
\hline & Tomás López Borricón & 38 & Hornillayuso \\
\hline & Diego de Pereda & 48 & Las Hornillas \\
\hline & Juan Martínez & 46 & Miedes de Atienza \\
\hline & Juan Roldán & 42 & Miedes de Atienza \\
\hline & Hernando de Pereda & 50 & Pereda \\
\hline \multirow[t]{2}{*}{1597} & Diego de la Peña & & Cantabrana \\
\hline & Diego Hernández de Gandía & & Rucandio \\
\hline \multirow[t]{26}{*}{1621} & Martin Ruiz Trechuelo & 64 & La Aldea de Medina \\
\hline & Francisco Díaz & 54 & Arreba \\
\hline & Pedro de Zárate & & Bañares \\
\hline & Francisco Díez de Andino & 78 & Barruelo \\
\hline & Juan de la Peña & 42 & Cidad de Ebro \\
\hline & Agustín Ruiz & 58 & Cidad de Ebro \\
\hline & Miguel Ruiz de Bustamante & 62 & Gallejones \\
\hline & Diego del Alcalde & 50 & Gallejones \\
\hline & Juan del Alcalde & 48 & Gallejones \\
\hline & Domingo de Argüeso & 60 & Gallejones \\
\hline & García López Borricón & 94 & Hornillayuso \\
\hline & Juan López Borricón & fallec. & Hornillayuso \\
\hline & Pedro López Borricón & 68 & Hornillayuso \\
\hline & Tomás López Borricón & fallec. & Hornillayuso \\
\hline & Juan Ruiz Cotorro & 76 & Hornillayuso \\
\hline & Andrés López Quintano & 70 & Hornillayuso \\
\hline & Domingo López sobrino de Andrés López & & Hornillayuso \\
\hline & Simón Martín & & Hornillayuso \\
\hline & Pedro de Pereda & 66 & Pereda \\
\hline & Miguel Fernández & 54 & Pesadas \\
\hline & Juan García & 44 & Pesquera \\
\hline & Juan Gil & 28 & Pesquera \\
\hline & Pedro de Pereda de Miñón & 60 & Torme \\
\hline & Pedro de Roldán & +70 & Tudanca \\
\hline & Diego Ruiz de la Peña & 90 & Villanueva de Ladrero \\
\hline & Miguel Sáez & 84 & Villanueva-Rampalay \\
\hline
\end{tabular}




\begin{tabular}{|r|l|r|l|}
\hline & Diego Sáez Roldán & 57 & Villanueva-Rampalay \\
\hline & Pedro Ruiz de Bisjueces & 78 & Villalaín \\
\hline & Domingo García & 50 & Villalaín \\
\hline 1641 & Mateo Ruiz & & Huidobro \\
\hline 1655 & Agustín Martínez & 45 & Moneo \\
\hline & Pedro de Hoz & 32 & Madrid de Caderechas \\
\hline 1663 & Pedro Sáez de Baranda & 56 & Baranda \\
\hline & Diego Martínez de Santamaría & 49 & Espinosa de los Monteros \\
\hline 1704 & José de Reguera & & Atienza \\
\hline & Juan de Bárcena & & Bentretea \\
\hline
\end{tabular}

Esta relación está extraída básicamente de las menciones de testigos presentados para realizar interrogatorios y condicionada por tanto por la selección previa que el interrogador realizaba. No obstante los datos que nos aporta, nos permiten extraer varias conclusiones:

$1^{\circ}$. Que todos los lugares de procedencia de los arrieros se sitúan en un pasillo de 30 $\mathrm{km}$ de anchura, que tiene como eje el camino de Burgos a Laredo y se corresponden con lugares en los que la agricultura no era especialmente productiva, lo que obligaba a sus vecinos a buscar medios alternativos de subsistencia.

$2^{\circ}$. Que destacan pequeñas zonas en las que la actividad arrieril es hegemónica o muy importante, como la Hermandad y cofradía de Dobro, Villaescusa y Pesadas, los Partidos de las Cinco Villas y de la Sonsierra en la merindad de Sotoscueva y la merindad de Castilla Vieja. Ya con menor importancia se encuentran otros grupos como un pequeño núcleo al sur de Medina de Pomar, el valle de Valdivielso, la merindad de Montija, el valle de Caderechas, zona norte de Medina de Pomar y en la zona oeste del mencionado pasillo hay otro grupo junto al valle de Zamanzas.

$3^{\circ}$. Destacan sobre todas las localidades, Villanueva de Ladrero en la merindad de Castilla Vieja ${ }^{2096}$, que con 24 mulateros en 1515 tenía casi toda su población en edad apta para el trabajo, dedicada a la arriería ${ }^{2097}$, Hornillayuso en el Partido de las Cinco Villas, que entre 1590 y 1624 tenía 20 mulateros y Torme, que en 1515 tenía 14, pequeñas localidades todas ellas, que fueron capaces de mantener una cabaña mulateril y un número de arrieros profesionales muy importante.

$4^{\circ}$. Existían familias que transmitieron el oficio a través de varias generaciones, y destaca sobre todas ellas la de López Borricón de Hornillayuso, en la que encontramos un Juan López Borricón en 1515, y hacia 1590 cuatro hermanos que se siguen dedicando a la arriería: García, Pedro, Tomás y Juan. En 1621, seguían la labor García y Pedro ya que Tomás y Juan habían fallecido. Era corriente que los mulateros heredasen el oficio de su padre y tuviesen hermanos dedicados a lo mismo.

2096 Hoy llamada Villanueva la Blanca, cerca de Villarcayo.

2097 A mediados del s. XIX, la localidad tenía 41 habitantes. MADOZ, P.: 1845-1850. 16 tomos. Reeditado por Editorial Ámbito organizado por provincias. Valladolid, 1984. 


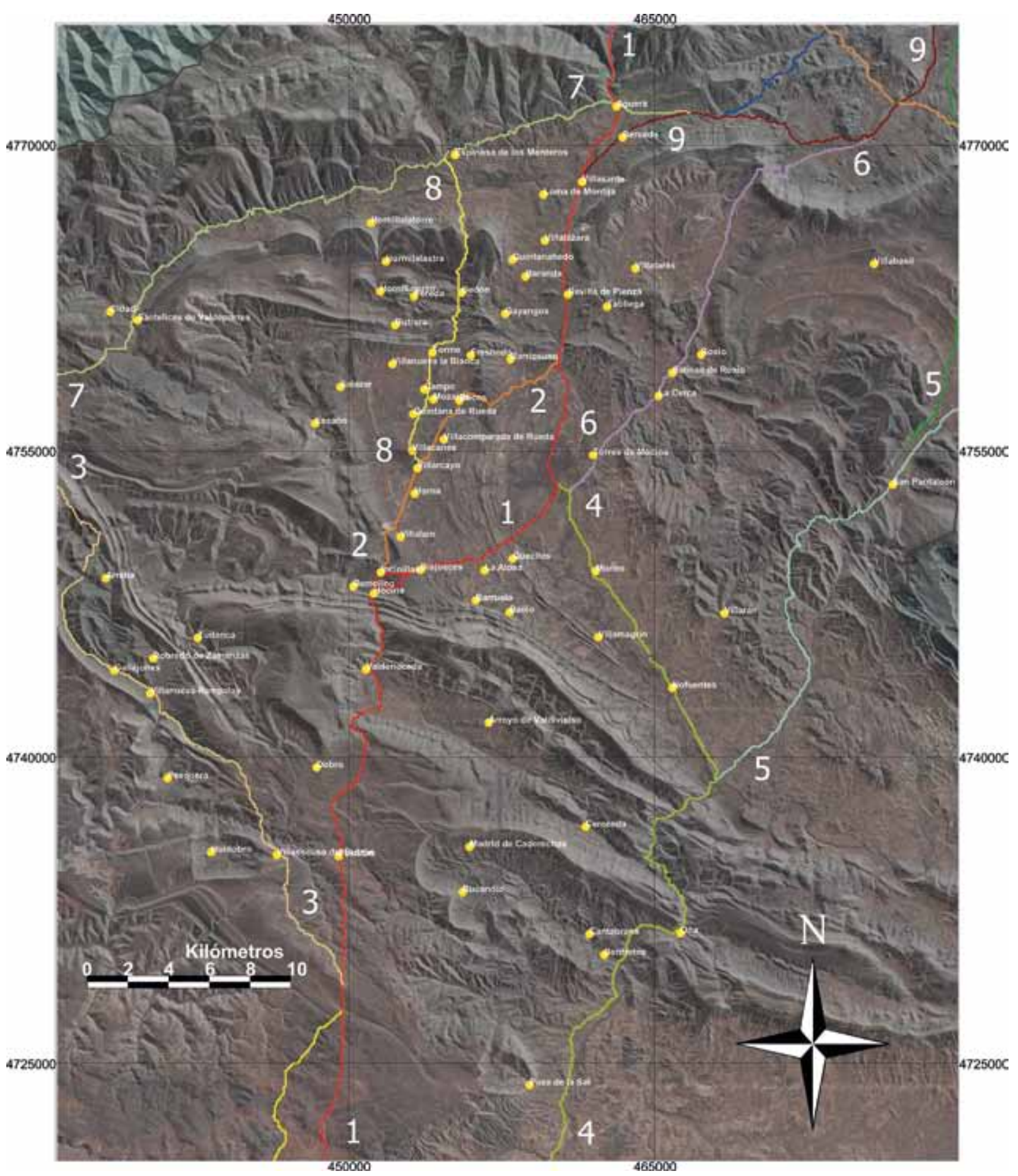

Distribución de los pueblos arrieriles en los siglos XV y XVI.

$5^{\circ}$. Las edades de los mulateros oscilan entre los treinta y los 75 años. Aunque las edades altas parecen corresponder a antiguos arrieros que aunque ya no ejercen, responden como testigos. No obstante, la mayoría tiene más de 45 años lo que es una edad muy alta para un trabajo tan duro. 


\section{- Caballerías por arriero.}

El número habitual de machos por arriero podía oscilar entre uno y siete, pero a veces este número era rebasado con creces. Tenemos un dato que corresponde al año 1587 cuando se indica que "en el lugar de Baabón, questá zerca de Aranda de Duero, hauía descaminado treze machos de vna rrequa que lleuaua Joán de Murua, vezino de la çiudad de Vitoria, porque no llebaua albalá de guía de los dichos machos"2098, aunque una recua de 13 machos era poco habitual por la dificultad en gobernar tan alto número de bestias. También el número de acémilas por reata dependía como es lógico de la dificultad del camino.

Aunque corresponde al año 1691, en un memorial de repartimiento efectuado en Poza de la Sal se nos informa que en ese año las bestias que llevaba cada uno de los 83 arrieros de Poza de la Sal ${ }^{2099}$ fueron:

\begin{tabular}{|c|c|c|}
\hline No de arrieros & $\begin{array}{c}\text { Animales por } \\
\text { arriero }\end{array}$ & Total animales \\
\hline 7 & 1 & 7 \\
\hline 16 & 2 & 32 \\
\hline 13 & 3 & 39 \\
\hline 16 & 4 & 64 \\
\hline 9 & 5 & 45 \\
\hline 12 & 6 & 72 \\
\hline 5 & 7 & 35 \\
\hline 2 & 8 & 16 \\
\hline 2 & 9 & 18 \\
\hline 1 & 10 & 10 \\
\hline Total & & 338 \\
\hline
\end{tabular}

En este caso las reatas o recuas más comunes estaban integradas entre dos a seis bestias por mulatero. Ya se ha indicado que era habitual que además de las bestias de carga, el arriero se desplazase a lomos de un caballo o rocín, jaca e incluso en menor medida de un asno. Es frecuente por ello que entre el grupo de animales que conduce el mulatero, se contabilicen junto a los mulos o machos un caballo o un asno.

En 1475 Martín Ortiz de Guecho, vecino de Martiarto, acompañado de gente armada robó en el lugar de Puentelarrá todo cuanto llevaba el arriero Juan de Arnoeta, criado de Juan Martínez de Arratia cuando iba a Bilbao "con çinco asemilas e vn asno cargados de vino de Sant Martin, con sus açacanes e cueros e todos sus aparejos"2100. En 1497 "yendo el dicho Ynnigo con dos mulos suyos cargados de lanas e vn roçin cargado de çebada", fueron apresados por ir descaminados en el vado de Echévarri2101. En un pleito de 1538, el arriero Juan Sáez de Igueribar indica que ve-

2098 A. J. G. A./ t. VIII/ Vitoria, 4 mayo 1587.

2099 A. M. Poza/ no 2.826/ Poza de la Sal, 4 febrero 1691.

2100 A. G. S./ Registro General del Sello, XII-1475, fol. 811/ diciembre 1475; ENRÍQUEZ FERNÁNDEZ, J., HIDALGO de CISNEROS AMESTOY, C. y MARTÍNEZ LAHIDALGA, A.: "Archivo General de Simancas. Registro General del Sello. Vizcaya (1475-1477)". 2002: doc. 25.

2101 A. M. Bilbao/ Cajón 12, reg. 1, nº 10-Caja 303, reg. 1, nํ10/ Bilbao, 28 septiembre 1497. 
nía con cuatro acémilas y un rocín cargados de vino blanco de la villa de Medina del Campo en compañía de otros mulateros ${ }^{2102}$.

Aunque de mediados del siglo XVIII, el Catastro del marqués de Ensenada nos informa sobre este hecho: Gregorio de Sarabia, vecino de Arroyuelo, "es arriero que transita de Madrid a Uilbao con seis machos y una mula en que anda a cauallo". En Castil de Peones Juan Conzález Arce, arriero, lleva "siete machos y un caballo". En Quintanavides, Francisco Barrio Canal Fuente lleva "tres machos y un caballo". En Torres de Losa, Antonio Álvarez, arriero, "con nueue machos, los ocho de carga y el ottro para ir y uenir el susodicho en el a cauallo", y Andrés de Pereda, trajinero, con "un cauallo y ocho pollinos". En Villanueva la Lastra Andrés de Pereda y José de Villamor, trajineros, "estte ultimo con un macho y quatro pollinos y aquel un cauallo y ocho pollinos"2103.

Existe una peculiaridad, que utiliza el caballo de manera individual como bestia de carga cuando es utilizado por los tratantes para realizar su comercio de compra y reventa de distintos géneros por las distintas localidades, como animal de monta y de carga a la vez. En el Catastro mencionado, encontramos en Fuentebureba que Ángel de Mijangos "con un cauallo trata en comprar y conduzir huebos". En Santa Olaja Joaquín de Arechavala trata "con vn caballo que tiene a bajar trigo y otras semillas de tierra de Losa para llebarlo a bender a el mercado de la villa de Arciniega"2104.

En el mencionado memorial de repartimiento realizado en Poza de la Sal en $1691^{2105}$, se destaca como se ha dicho que en la villa salinera hay ese año 83 arrieros, que manejan 338 caballerías, con el detalle de los animales que tenía cada arriero. Estos tenían un carácter singular al estar especializados en el transporte de la sal, y depender por ello de las cargas proporcionadas por la villa salinera. Su detalle es el siguiente:

\begin{tabular}{|l|c|c|}
\hline Nombre & No de acémilas & Contribución \\
\hline Domingo Santurde & 10 ganados & 165 rs. y $30 \mathrm{mrs}$ \\
\hline Pedro del Río Bárcena & 9 ganados & $149 \mathrm{rs}$ y $10 \mathrm{mrs}$ \\
\hline Juan Díez Matute & 9 ganados & $149 \mathrm{rs}$ y $10 \mathrm{mrs}$ \\
\hline José de Valdivielso & 8 ganados & $132 \mathrm{rs}$ y $24 \mathrm{mrs}$. \\
\hline Francisco Saiz de la Huerta & 8 ganados & $132 \mathrm{rs}$ y $24 \mathrm{mrs}$. \\
\hline Matías Arnaiz & 7 ganados & $116 \mathrm{rs}$ y $4 \mathrm{mrs}$. \\
\hline Juan Díaz de Tamayo & 7 ganados & $116 \mathrm{rs}$ y $4 \mathrm{mrs}$. \\
\hline Martín Saiz García & 7 ganados & $116 \mathrm{rs}$ y $4 \mathrm{mrs}$. \\
\hline Gaspar Díez & 7 ganados & $116 \mathrm{rs}$ y $4 \mathrm{mrs}$. \\
\hline Juan Martínez Calixto & 7 ganados & $116 \mathrm{rs}$ y $4 \mathrm{mrs}$. \\
\hline Bartolomé Diez Orza & 6 ganados & $99 \mathrm{rs}$ y $18 \mathrm{mrs}$. \\
\hline Juan de Gavilán & 6 ganados & $99 \mathrm{rs}$ y $18 \mathrm{mrs}$. \\
\hline
\end{tabular}

2102 A. Ch. V./ Salas de lo Criminal. Caja 253, 4/ 1538-1539.

2103 A. D. B./ Catastro Marqués de Ensenada, 1752. Respuesta 32: Arroyuelo t. 153, Castil de Peones t. 449, Quintanavides t. 1.518, Torres de Losa t. 2.071 y Villanueva la Lastra t. 2.378.

2104 A. D. B./ Catastro Marqués de Ensenada, 1752. Respuesta 32: Fuentebureba t. 744 y Santa Olaja t. 1.855.

2105 A. M. Poza/ no 2.826/ Poza de la Sal, 4 febrero 1691. 


\begin{tabular}{|c|c|c|}
\hline Pedro González Ortiz & 6 ganados & 99 rs. y 18 mrs. \\
\hline Juan de Nubla & 6 ganados & 99 rs. y 18 mrs. \\
\hline Juan Pérez Marañón & 6 ganados & 99 rs. y 18 mrs. \\
\hline İnigo Alonso de Prado & 6 ganados & 99 rs. y 18 mrs. \\
\hline Pedro Campino & 6 ganados & 99 rs. y 18 mrs. \\
\hline Francisco de $\mathrm{Hoz}$ & 6 ganados & 99 rs. y 18 mrs. \\
\hline Juan Díez de Pancorbo & 6 ganados & 99 rs. y 18 mrs. \\
\hline Juan Calvo Saiz & 6 ganados & 99 rs. y 18 mrs. \\
\hline Pedro Santurde & 6 ganados & 99 rs. y 18 mrs. \\
\hline Francisco González Saiz & 6 ganados & 99 rs. y 18 mrs. \\
\hline Juan Pérez & 5 ganados & 82 rs. y 32 mrs. \\
\hline Felipe Quintano & 5 ganados & 82 rs. y 32 mrs. \\
\hline Antonio Saiz de la Huerta & 5 ganados & 82 rs. y 32 mrs. \\
\hline Silvestre García & 5 ganados & 82 rs. y 32 mrs. \\
\hline Francisco Díez de Gregorio & 5 ganados & 82 rs. y 32 mrs. \\
\hline Felipe de Nubla & 5 ganados & 82 rs. y 32 mrs. \\
\hline Blas de Mijangos & 5 ganados & 82 rs. y 32 mrs. \\
\hline José González & 5 ganados & 82 rs. y 32 mrs. \\
\hline Jerónimo de Aguayo & 5 ganados & 82 rs. y 32 mrs. \\
\hline Domingo de Herrera & 4 ganados & 66 rs. y 12 mrs. \\
\hline Domingo Ruiz & 4 ganados & 66 rs. y 12 mrs. \\
\hline Juan de Cantabrana Villate & 4 ganados & 66 rs. y 12 mrs. \\
\hline Blas Saiz de Arconada & 4 ganados & 66 rs. y 12 mrs. \\
\hline Pedro González Calvo & 4 ganados & 66 rs. y 12 mrs. \\
\hline Manuel de Nubla & 4 ganados & 66 rs. y 12 mrs. \\
\hline Juan Ramos & 4 ganados & 66 rs. y 12 mrs. \\
\hline Matías de Nubla & 4 ganados & 66 rs. y 12 mrs. \\
\hline Pedro Pérez Beato & 4 ganados & 66 rs. y 12 mrs. \\
\hline Lucía Martínez & 4 ganados & 66 rs. y 12 mrs. \\
\hline Juan Saiz & 4 ganados & 66 rs. y 12 mrs. \\
\hline Francisco González de Pereda & 4 ganados & 66 rs. y 12 mrs. \\
\hline Juan González, su hijo & 4 ganados & 66 rs. y 12 mrs. \\
\hline Roque Pérez Marañón & 4 ganados & 66 rs. y 12 mrs. \\
\hline Juan de Espinosa Nubla & 4 ganados & 66 rs. y 12 mrs. \\
\hline Juan Quintano & 4 ganados & 66 rs. y 12 mrs. \\
\hline Juan González & 3 ganados & 49 rs. y 26 mrs. \\
\hline Francisco de Rojas & 3 ganados & 49 rs. y 26 mrs. \\
\hline Pedro Arnaiz Carambol & 3 ganados & 49 rs. y 26 mrs. \\
\hline Juan de Cantabrana & 3 ganados & 49 rs. y 26 mrs. \\
\hline Gaspar Ruiz Orza & 3 ganados & 49 rs. y 26 mrs. \\
\hline Andrés de Mijangos & 3 ganados & 49 rs. y 26 mrs. \\
\hline Felipe Díez, menor & 3 ganados & 49 rs. y 26 mrs. \\
\hline Simón Ibáñez & 3 ganados & 49 rs. y 26 mrs. \\
\hline
\end{tabular}




\begin{tabular}{|c|c|c|}
\hline Juan García Vallejo & 3 ganados & 49 rs. y 26 mrs. \\
\hline Baltasar Calvo & 3 ganados & 49 rs. y 26 mrs. \\
\hline José de Espinosa & 3 ganados & 49 rs. y 26 mrs. \\
\hline Manuel Saiz de Espiga & 3 ganados & 49 rs. y 26 mrs. \\
\hline José de Espinosa, menor & 3 ganados & 49 rs. y 26 mrs. \\
\hline Bartolomé de la Calle & 2 ganados & 33 rs. y 6 mrs. \\
\hline Coronas & 2 ganados & 33 rs. y 6 mrs. \\
\hline Domingo de Cuellar & 2 ganados & 33 rs. y 6 mrs. \\
\hline Blas Saiz & 2 ganados & 33 rs. y 6 mrs. \\
\hline Catalina de Melgosa & 2 ganados & 33 rs. y 6 mrs. \\
\hline Pedro Capacho & 2 ganados & 33 rs. y 6 mrs. \\
\hline Francisco Rojo & 2 ganados & 33 rs. y 6 mrs. \\
\hline Juan de Somovilla & 2 ganados & 33 rs. y 6 mrs. \\
\hline Francisco Álvarez & 2 ganados & 33 rs. y 6 mrs. \\
\hline Juan Ibáñez Herrera & 2 ganados & 33 rs. y 6 mrs. \\
\hline Diego de Mijangos & 2 ganados & 33 rs. y 6 mrs. \\
\hline Juan del Rio Argoñanos & 2 ganados & 33 rs. y 6 mrs. \\
\hline Juan de Espinosa Garrido & 2 ganados & 33 rs. y 6 mrs. \\
\hline Diego Saiz Martínez & 2 ganados & 33 rs. y 6 mrs. \\
\hline Tomás de Cuellar & 2 ganados & 33 rs. y 6 mrs. \\
\hline José de Cuellar & 2 ganados & 33 rs. y 6 mrs. \\
\hline Juan Ibáñez Pérez & 1 ganado & 16 rs. y 20 mrs. \\
\hline Bartolomé Ibáñez & 1 ganado & 16 rs. y 20 mrs. \\
\hline Sebastián Saiz & 1 ganado & 16 rs. y 20 mrs. \\
\hline Francisco de Mijangos, menor & 1 ganado & 16 rs. y 20 mrs. \\
\hline Francisco de Mijangos, mayor & 1 ganado & 11 rs. y 26 mrs. \\
\hline Juan Saiz de Arconada & 1 ganado & 16 rs. y 20 mrs. \\
\hline Antonio de Güemes & 1 ganado & 16 rs. y 20 mrs. \\
\hline TOTAL 83 arrieros & 338 animales & $5.602 \mathrm{rs}$. \\
\hline
\end{tabular}

\section{- Zonas arrieriles.}

Hemos establecido las zonas donde existe una mayor concentración de arrieros en el sector extendido entre Burgos y la costa del norte. Aunque somos conscientes de que existen muchos más arrieros de los recogidos en los documentos manejados, los datos que hemos podido obtener nos permiten extraer alguna conclusión. Sabemos por ejemplo que a pesar de que están ausentes en los interrogatorios, el valle de Mena era zona donde existían numerosos mulateros, ya que en septiembre de 1495 un arriero, testigo en un interrogatorio realizado sobre el camino que pasa por Valmaseda, declara que los arrieros que más de continuo andan y tratan en esta villa son los de "toda la junta e tierra e valle de Mena". Además, así se pondrá de manifiesto en el Catastro de Ensenada realizado a mediados del siglo XVIII. En el mismo interrogatorio de 1495, se indica que también pasan de continuo por Valmaseda arrieros de "toda la tierra e valle de Salzedo, e toda la tierra de Sopuerta, e valle de Caldames, e Somorrostro e su tyerra e Arzentales, e Troçios, e Carrança, e valle de Villaverde y el valle de Cordojuela, 


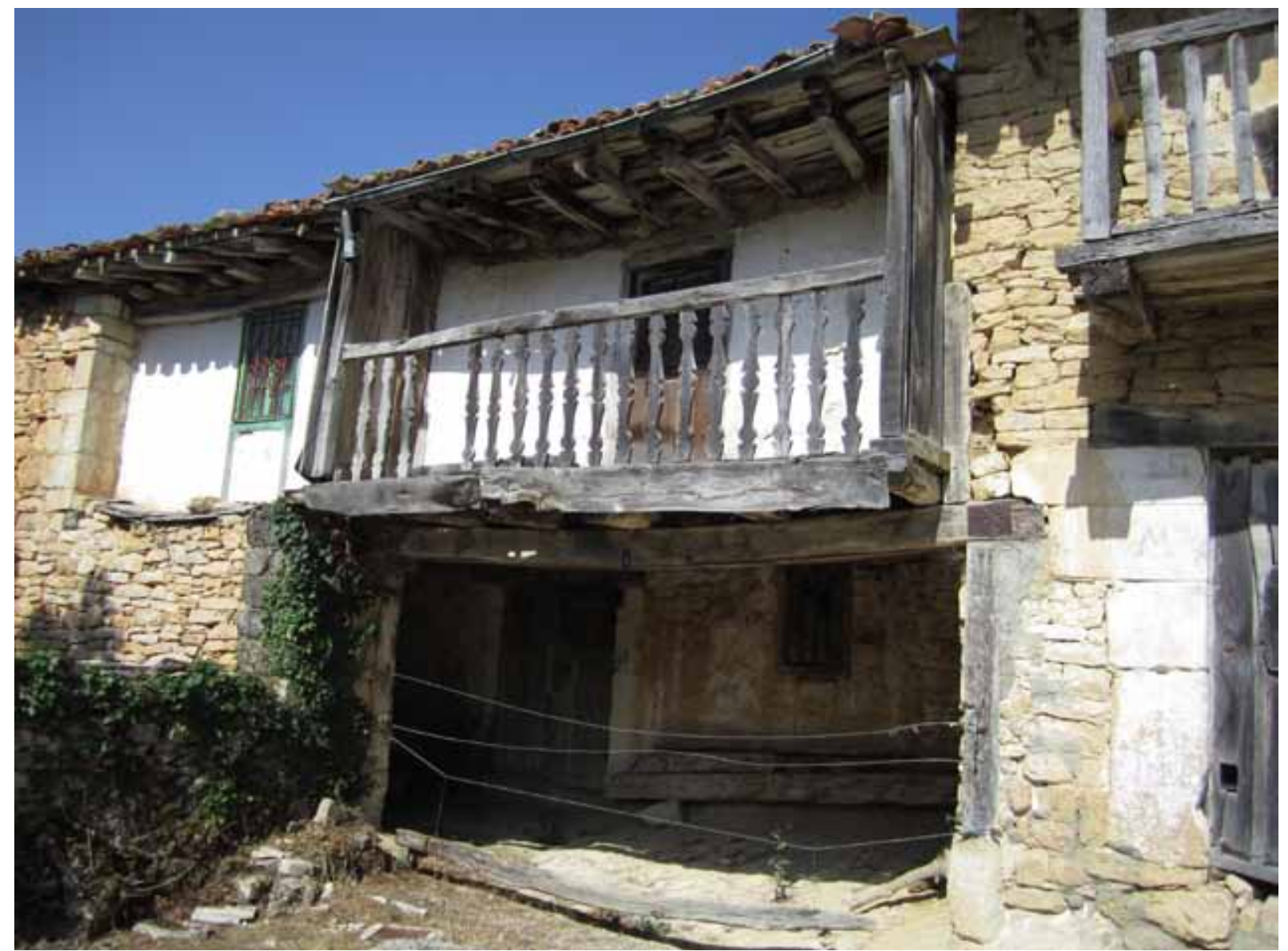

Casa carretera en Bedón.

e los de Arrigorriaga, e Llodio, e Luyando, e toda la tierra de Losa"2106. Otra ausencia notable es la de los mulateros de Poza de la Sal, que siempre mantuvo una cabaña arrieril muy notable, y en la documentación tan solo se menciona en 1495 a un tal Rodrigo como arriero de Poza. Estas ausencias se pondrán de manifiesto en el cuadro de los arrieros documentados en el Catastro del Marqués de Ensenada que incluiremos. De esta manera, las zonas que hemos podido destacar son las siguientes:

- La merindad de Montija. Posee cierta importancia por encontrarse en el camino de Burgos a Laredo; la merindad destaca con los lugares y villas de Villasante, Baranda, Quintanaedo, Bercedo, Agüera, Villalázara, Loma o Revilla de Pienza.

- Los partidos de las Cinco Villas y de la Sonsierra, Merindad de Sotoscueva. Zona de especial relevancia para la mulatería, cuenta con arrieros profesionales. El Partido de las Cinco Villas ${ }^{2107}$ con Bedón, Butrera, Hornillalastra, Hornillayuso y Pereda aglutina un número muy importante de arrieros, junto con Hornillalatorre que aunque se encontraba a dos km de Hornillalastra, pertenecía al Partido de la Sonsierra y Cornejo, y conservará

2106 A. G. S./ Cámara de Castilla. Pueblos, leg. 21-2, doc. 185/ Burgos, 17julio y Valmaseda, 10 agosto 1495.

2107 La Merindad de Sotoscueva se dividía en seis partidos. Uno de ellos era el de Las Cinco Villas, con las localidades de Bedón, Butrera, Hornillalastra, Hornillayuso y Pereda. Otro partido era el de la Sonsierra con Barcenillas de Cerezo, Cerezo, Herrera y Redondo, Hornillalaparte, Hornillalatorre, Quintanilla del Rebollar y El Rebollar. 
esta dedicación a lo largo de los siglos posteriores. Destacan las villas de Hornillayuso, Hornillalatorre y Pereda.

- La merindad de Castilla Vieja. Zona muy destacada en la arriería, contaba con arrieros profesionales y presentaba localidades como Villanueva de Ladrero, Torme, Campo, Salazar, Fresnedo, Mozares, Bisjueces, Villacomparada, Villalaín, Incinillas, Villacanes, Hocina o Barriosuso. También se cita en septiembre de 1495, cuando se declara que los arrieros que más de continuo andan y tratan en Valmaseda son entre otros los de "Castilla Vieja e toda su juridiçion"2108.

- La merindad de Valdeporres. Con una relevancia relativa, presenta Santelices, Brizuela y Valdeporres.

- Zona norte de Medina de Pomar. Con menor importancia se encuentra la zona norte de Medina de Pomar, que incluye La Cerca, Rosío, Salinas de Rosío, Tabliega, Torres y Villatarás. En el interrogatorio de septiembre de 1495, un arriero declara que los arrieros que más de continuo andan y tratan en Valmaseda, son entre otros "los de Salillinas de Rrosio" y los de "Medina de Pumar y toda su juridiçion"2109.

- Zona sur de Medina de Pomar. Era una pequeña zona pero con un alto número de mulateros, compuesta por Barruelo, La Aldea, Moneo, Queciles y Baillo, y se confirma en un documento de 1499 que indica que el "camino que ba de la puente del Bado a Bizuezes es el mas cursado, porque en los dichos lugares de la Aldea e Queçiles e Barruelo ay muchos mulateros e mesones"2110.

- Cuesta-Urria. Con menor relevancia según los datos que hemos podido obtener, presenta Nofuentes y Villamagrín.

- El valle de Valdivielso. Con cierta importancia se encuentra este otro grupo del valle de Valdivielso, con Valdenoceda, Arroyo y Cereceda. En el interrogatorio de septiembre de 1495, un arriero declara que los arrieros que más de continuo andan y tratan en Valmaseda son entre otros "los del balle de Valdevielso e su Merindad"2111.

- Butrón. Llamada también Hermandad y cofradía de Dobro, Villaescusa y Pesadas o Los Butrones, era una de las zonas más sobresalientes que mantuvo su actividad a lo largo de los siglos, con los lugares y villas de Dobro, Pesadas, Pesquera, Villaescusa, Ahedo y Huidobro. Son arrieros profesionales, también citados en septiembre de 1495 cuando se declara que los arrieros que más de continuo andan y tratan en Valmaseda son entre otros los de "los Butrones que es Dobro e Villascusa e Pesadas y Masa"2112.

- El valle de Caderechas. Ya con menos importancia, se encuentra este grupo que incluye Cantabrana, Rucandio, Madrid, Bentretea y Oña.

- Valdezamanzas. Existía en la zona oeste del mencionado pasillo otro grupo de cierta importancia arrieril pero también carretil, que estaba compuesto básicamente por las localidades de Gallejones, Villanueva-Rampalay, Cidad de Ebro, Tudanca, Arreba y Robredo de Zamanzas.

2108 A. G. S./ Cámara de Castilla. Pueblos, leg. 21-2, doc. 185/ Burgos, 17 julio y Valmaseda, 10 agosto 1495.

2109 A. G. S./ Cámara de Castilla. Pueblos, leg. 21-2, doc. 185/ Burgos, 17 julio y Valmaseda, 10 agosto 1495.

2110 A. H. N./ Nobleza. Frías, C. 235, D. 55/ Medina de Pomar, 15 enero 1499.

2111 A. G. S./ Cámara de Castilla. Pueblos, leg. 21-2, doc. 185/ Burgos, 17 julio y Valmaseda, 10 agosto 1495.

2112 A. G. S./ Cámara de Castilla. Pueblos, leg. 21-2, doc. 185/ Burgos, 17 julio y Valmaseda, 10 agosto 1495. 
Caso aparte era Poza de la Sal, ya que por ser la villa una gran productora de sal, tenía que transportar su producción y atender una amplia zona donde se ubicaban sus alfolíes. Necesitaba un conjunto importante y permanente de arrieros, capaces de realizar dicha labor. Naturalmente, procuraban cargar para el retorno, con los productos más necesarios y demandados en los lugares de la comarca pozana, como los pescados frescos y salazones. Ya hemos visto que en 1691, había en la villa 83 arrieros que utilizaban 338 bestias, cantidad muy alta y justificada por las necesidades mencionadas.

Las zonas indicadas conservan en su mayor parte la pervivencia de la mulatería un siglo y medio después. Así, en el Catastro del Marqués de Ensenada vemos que se mantienen con vitalidad las zonas del Butrón, Sotoscueva o Castilla Vieja. Irrumpe con fuerza no obstante el valle de Caderechas y el valle de Tobalina. Para hacer esta comparación, debemos tener en cuenta que el tipo de tráfico y algunas de las mercaderías acarreadas se han modificado, así como el régimen de muchos de los antiguos arrieros. De hecho, en el siglo XVIII, el número de trajineros ha aumentado considerablemente y destaca la estabilidad de la arriería vinculada al tráfico de la sal, dependiente de las salinas de Poza. Las cifras de arrieros y caballerías de 1691 son muy parecidas a las que presenta el Catastro en 1752 . Pasamos a presentar el resumen de las cifras relacionadas con la mulatería que ofrece el mencionado Catastro 2113 :

\begin{tabular}{|c|c|c|c|c|}
\hline Localidad & Arrieros & Trajineros & Cab. mayores & Cab. menores \\
\hline \multicolumn{5}{|c|}{ Valle de Mena Oeste } \\
\hline Arceo & & 15 & 16 & \\
\hline Burceña & 2 & & 13 & \\
\hline Cadagua y Sopeñano & 7 & & 31 & \\
\hline Campillo de Mena & & $x$ & 1 cada vecino & \\
\hline Irús & 11 & & 25 & 10 \\
\hline Lecinaña de Mena & 7 & 7 & 30 & 9 \\
\hline Lezana de Mena & 1 & 4 & 12 & \\
\hline Villasana & 1 & & 5 & \\
\hline Vivanco & & 3 & 6 & \\
\hline Total & 29 & 29 & 148 & 19 \\
\hline
\end{tabular}

\begin{tabular}{|l|c|c|c|c|}
\hline \multicolumn{5}{|c|}{ Valle de Mena Este } \\
\hline Artieta y Angostina & 3 & 4 & 15 & 2 \\
\hline Ayega & 2 & 28 & 48 & 4 \\
\hline Berrandúlez & & 3 & 3 & \\
\hline Bortedo de Mena & 1 & 1 & 5 & \\
\hline Gijano & 1 & & 6 & \\
\hline Haedillo de Mena & 1 & & 6 & \\
\hline
\end{tabular}

2113 A. D. B. / Catastro Marqués de Ensenada 1752. Respuesta 32. 


\begin{tabular}{|c|c|c|c|c|}
\hline Lorcio & 2 & 2 & 9 & 1 \\
\hline Montiano & & 7 & 5 & 3 \\
\hline Nava de Ordunte & 1 & & 3 & \\
\hline Opio & & 2 & 2 & \\
\hline Rio de Mena & 1 & 2 & 5 & \\
\hline Sta. Ma del Llano & & 1 & & 1 \\
\hline Santa Olaja & & 8 & 8 & 2 \\
\hline Santiago de Tudela & & 3 & 3 & \\
\hline Valluerca & & 3 & & 3 \\
\hline Viergol & & 4 & 4 & \\
\hline Total & 12 & 68 & 122 & 16 \\
\hline \multicolumn{5}{|c|}{ Merindad de Montija } \\
\hline Baranda & & 1 & & 2 \\
\hline Bárcena de Pienza & 4 & & 8 & 8 \\
\hline Cuestaedo & & 4 & & 13 \\
\hline Gayangos & 2 & 3 & 21 & 5 \\
\hline Quintanaedo & & 1 & & 4 \\
\hline Quintanilla de Pienza & 1 & 1 & 10 & \\
\hline Villasante & 3 & & 12 & \\
\hline Total & 10 & 10 & 51 & 32 \\
\hline
\end{tabular}

\begin{tabular}{|c|c|c|c|c|}
\hline \multicolumn{5}{|c|}{ Sotoscueva } \\
\hline Bedón & 9 & & 37 & 23 \\
\hline Cornejo & & 1 & 8 & \\
\hline Hornillalastra & 1 & & 8 & \\
\hline Hornillayuso & 3 & 1 & 24 & 1 \\
\hline Pereda & 1 & & 6 & \\
\hline Quintanilla-Sotoscueva & & 5 & & \\
\hline Villabáscones & & 2 & & \\
\hline Total & 14 & 9 & 83 & 24 \\
\hline
\end{tabular}

\begin{tabular}{|l|c|c|c|c|}
\hline \multicolumn{5}{|c|}{ Castilla Vieja } \\
\hline Barruelo & & 1 & 2 & 2 \\
\hline Fresnedo & 2 & & 1 & 8 \\
\hline Incinillas & 1 & & 3 & \\
\hline Medina de Pomar & 13 & & 12 & 40 \\
\hline Otedo & 1 & & 4 & 4 \\
\hline Salinas de Rosío & 5 & & 7 & \\
\hline Torme & 4 & & 18 & 7 \\
\hline & 26 & 1 & 47 & 61 \\
\hline
\end{tabular}




\begin{tabular}{|l|c|c|c|c|}
\hline \multicolumn{5}{|c|}{ Cuesta-Urria } \\
\hline Arroyuelo & 3 & & 10 & 2 \\
\hline Cebolleros & & 7 & 10 & 8 \\
\hline Mijangos & 1 & 3 & & \\
\hline Moneo & 5 & 3 & 53 & 5 \\
\hline Nofuentes & 1 & 2 & 10 & 3 \\
\hline Trespaderne & 2 & 1 & 9 & 5 \\
\hline Valdelacuesta & & 1 & & 3 \\
\hline Villamagrín & 2 & & 5 & 4 \\
\hline Villapanillo & 3 & & 19 & \\
\hline Villavedeo & 1 & & 7 & 30 \\
\hline
\end{tabular}

\begin{tabular}{|l|c|c|c|c|}
\hline \multicolumn{5}{|c|}{ Valle de Tobalina } \\
\hline Cadiñanos & & 3 & 6 & \\
\hline La Orden & & 1 & 4 & \\
\hline Parayuelo & & 3 & 5 & \\
\hline Pedrosa de Tobalina & 1 & & 2 & \\
\hline La Prada & & 10 & 13 & 10 \\
\hline Promediano-Ranedo & & 3 & 5 & \\
\hline Quintana-Martín-Galíndez & 1 & & 2 & \\
\hline Quintanilla-Montecabezas & 4 & & 17 & 5 \\
\hline La Revilla de Herrán & & 3 & & \\
\hline Rufrancos & 5 & & 15 & \\
\hline Valujera & 2 & & 8 & \\
\hline Las Viadas & 2 & 10 & 32 & 11 \\
\hline \multicolumn{1}{|c|}{ Total } & 15 & 33 & 109 & \\
\hline
\end{tabular}

\begin{tabular}{|l|c|c|c|c|}
\hline \multicolumn{5}{|c|}{ Valle de Valdivielso } \\
\hline Condado de Valdivielso & & 1 & & 3 \\
\hline Puente-Arenas & & 3 & 1 & 8 \\
\hline Santa Olalla de Valdivielso & 1 & & 8 & \\
\hline Total & 1 & 4 & 9 & 11 \\
\hline
\end{tabular}

\begin{tabular}{|l|c|c|c|c|}
\hline \multicolumn{5}{|c|}{ Butrón } \\
\hline Ahedo del Butrón & 1 & 1 & & 3 \\
\hline Cortiguera & & 7 & 8 & 6 \\
\hline Dobro & 12 & 1 & 41 & 2 \\
\hline Escóbados de Arriba & 1 & 2 & 2 & 5 \\
\hline Huidobro & 6 & 3 & 14 & 3 \\
\hline
\end{tabular}




\begin{tabular}{|c|c|c|c|c|}
\hline Pesadas & 3 & 5 & 13 & 6 \\
\hline Pesquera de Ebro & & 29 & 36 & 5 \\
\hline Porquera del Butrón & 3 & & 6 & \\
\hline Villaescusa del Butrón & 14 & 1 & 45 & 2 \\
\hline Villalta & 3 & 1 & 10 & 2 \\
\hline Total & 43 & 14 & 131 & 23 \\
\hline \multicolumn{5}{|c|}{ Valle de Caderechas } \\
\hline Aguas Cándidas & 11 & & 9 & 2 \\
\hline Bentretea & 18 & & 55 & \\
\hline Cantabrana & 31 & & 154 & \\
\hline Castellanos de Bureba & 2 & & 4 & \\
\hline Hozabejas & 8 & & 23 & \\
\hline Huéspeda & 2 & & 6 & \\
\hline Madrid de las Caderechas & 8 & & 18 & \\
\hline Oña & 3 & & 24 & \\
\hline Padrones de Bureba & & 20 & 5 & 18 \\
\hline Pino de Bureba & & 19 & 3 & 16 \\
\hline Quintanaopio & 3 & 7 & 4 & 7 \\
\hline Rio Quintanilla & 7 & 9 & 15 & 2 \\
\hline Rucandio & 8 & 3 & 23 & 3 \\
\hline Salas de Bureba & 1 & & & \\
\hline Tamayo & 12 & & 54 & \\
\hline Terminón & 8 & & 26 & \\
\hline Total & 122 & 58 & 423 & 48 \\
\hline
\end{tabular}

\begin{tabular}{|l|c|c|c|c|}
\hline \multicolumn{5}{|c|}{ Valdezamanzas } \\
\hline Arreba & 2 & & $\mathrm{x}$ & $\mathrm{x}$ \\
\hline Báscones de Zamanzas & 1 & & $\mathrm{x}$ & $\mathrm{x}$ \\
\hline Escalada & 17 & 4 & $\mathrm{x}$ & \\
\hline Gallejones & 12 & & $\mathrm{x}$ & $\mathrm{x}$ \\
\hline Gredilla & 4 & 2 & & 64 \\
\hline Masa & 15 & & 7 & 6 \\
\hline Nocedo & 1 & 5 & 3 & \\
\hline Quintanilla y Colina & 3 & & 9 & \\
\hline Quintanilla-Escalada & 13 & & & \\
\hline Robredo de Zamanzas & 1 & & & \\
\hline San Felices & & 9 & & \\
\hline Sedano & 2 & 7 & & \\
\hline Tubilla del Agua & & 8 & & \\
\hline
\end{tabular}




\begin{tabular}{|c|c|c|c|c|}
\hline Tubilleja & 5 & & 19 & \\
\hline Turzo & 19 & & 33 & 7 \\
\hline Valdelateja & & 2 & & 3 \\
\hline Villanueva-Rampalay & 4 & & & \\
\hline Total & 99 & 37 & 69 & 92 \\
\hline Poza de la Sal & 79 & & 185 & 154 \\
\hline
\end{tabular}

\section{d.- El transporte rodado. La carretería}

Una gran parte de los caminos del norte de la Península en los siglos XV y XVI no eran carreteros, sino irregulares, estrechos y con grandes pendientes, con unos firmes que no facilitaban el tráfico rodado. Por esta causa la arriería siempre tuvo un gran desarrollo y se mostró en muchos casos insustituible. No obstante, por resultar más seguro y económico el carro o carreta -una carreta podía llevar la carga de varios mulos- sustituyó siempre que fue posible al tráfico mulatero. No fue extraño el que una determinada carga se trasvasase de carro a mulo y viceversa varias veces a lo largo de un único trayecto, con el fin de adaptarse a las características del camino y superar así los pasos difíciles o las grandes pendientes.

Sobre este asunto tenemos un dato de 1555 que, no obstante, indica lo contrario sobre el camino a Santander por Reinosa. Santander propone que se pregunte a los testigos si saben que desde la villa hay caminos por los que "se pueden guiar todas mercaderias en carros y en mulos e bestias para todos estos reynos d'España, y de todos los dichos reynos para el dicho puerto, sin hazer carga ni descarga, mas de tomarlo al dicho puerto y llebarlo en los carros a los lugares que quisieren y traerlo de los dichos lugares, y con los carros ponerlo al dicho puerto enjuto"2114.

La carretería atormentaba y deshacía los caminos y los puentes y sus animales, consumían los pastos y montes y muchas veces los sembrados, viñas y dehesas. También consumía la madera para las reparaciones de los ejes, estacas, cambas y demás piezas de los carros y carretas que se deterioraban en el trayecto, además de la leña para el fuego en el descanso, algo que creó permanentes conflictos con los lugareños. En 1555 la villa de Santander se queja de que los carreteros, además de "los pastos que paçen con sus bueyes, siegan los panes y yerba de noche y de dia para les dar, y comen las ubas y fruta de las viñas y huertas y cortan los montes para exes y canbas y estadojos"2115. Para remediar los mencionados conflictos y facilitar algo tan vital para la Monarquía como era el transporte, los reyes dictaron normas de amparo y protección para lograr un tráfico fluido y eficaz.

Por cada carreta se podían llevar tres bueyes, dos para el tiro y un tercero de reserva y refresco para la remuda, así como para el apoyo para encuartar en los pasos más compli-

2114 A. M. S./ Leg. A-3, no 62/ 27 agosto 1555; SOLÓRZANO TELECHEA, J. A: "Patrimonio documental... ". 283-285: doc. 225 .

2115 A. M. S./ Leg. A-3, no 62/ 27 agosto 1555. 
cados. En 1499 se indica que "algunos de los dichos carreteros, tienen por costunbre de traher tres bueyes con cada carreta para los rremudar quando alguno dellos se cansa"2116.

Con ocasión del viaje a Castilla a través de Francia de los príncipes Felipe el Hermoso y su esposa Juana, se pone de manifiesto en 1501 la poca adecuación en esas fechas de los caminos peninsulares para el tráfico rodado. Se indica que “... a partir de Bayona fueron despedidos los carros y las carretas de Flandes que habian traido los bagajes de monseñor; porque no podian seguir mas adelante por las montañas, y fueron traidos grandes mulos de Vizcaya por orden del rey y de la reina de España, que llevaron dichos bagajes hasta Toledo..."2117.

Con motivo de se incautaban los carros necesarios para el transporte de los bagajes de la comitiva, para lo que se facultaba a un oficial real al objeto de realizar esta labor y fijar los precios del "alquiler”. Así, en septiembre de 1559 Gregorio Flórez, comisionado para hacer repartimiento de 150 carros por la venida del Rey a Laredo, da fe de que tiene mandado que todos los carros de bueyes que repartió el alguacil Juan Conzález y otras personas, así los 20 carros registrados en Castilla Vieja como en otros lugares, no vayan a Laredo sin su voluntad $^{2118}$.

\section{Las bestias}

La carretería en la zona que tratamos empleó básicamente la fuerza de tiro de los bueyes, mucho mejor adaptados a las características de una tierra irregular y de montaña. No faltaba no obstante la utilización de las mulas, implantadas en zonas más llanas situadas hacia el Sur. Estas iban uncidas a veces en gran número como indica un documento de 1544. El procurador mayor de Burgos dijo al Rey, que los puentes de los términos de su tierra, jurisdicción y comarca están hundidos de manera que por muchas partes no se puede pasar especialmente en invierno, lo cual dice que es "a causa de las grandes carretas que suelen yr a esa dicha çibdad, de Medina del Campo y otras partes, cargadas de grandes mercadurias y con cada quatro o çinco pares de mulas" y que si esto no se remedia, indica, no bastaría el reparo que en ellos se hace, por lo que pidió al Rey que mandase que no se consienta que "se truxesen las dichas carretas tan cargadas ni con tantos pares de mulas salbo con sendos pares". El Consejo acordó mandar al corregidor que, en 20 días, envíe relación del perjuicio mencionado a los puentes y caminos por el peso de las carretas para proveer lo que convenga ${ }^{2119}$.

Juan de Álava, en nombre de Burgos, dijo a Carlos I que estaba prohibido utilizar carretas con más de tres mulas, pero "muchas personas andan con quatro e seys mulas en esa dicha çiudad y en su jurisdiçion, e que a cabsa dello se destruyen las puentes, caminos y calçadas", por lo que los puentes de dentro y fuera de la ciudad, reciben mucho deterioro por el gran peso de las carretas de más de tres mulas. El Consejo dio carta en 1546 para todos los concejos, mandando que "nyngun carretero ni otra persona alguna, pueda traer carreta que trayga mas de tres mulas yendo o beniendo de camino, ni pasar por las dichas puentes ni por alguna dellas", so pena de $600 \mathrm{mrs}$.

2116 A. G. S./ Registro General del Sello, V-1499, fol. 52/ Madrid, 12 mayo 1499.

2117 GARCÍA MERCADAL, J.: 1952: 446: t. I. Antonio de Lalaing: Primer viaje de Felipe el "Hermoso" a España en 1501.

2118 A. C. V./ nำ1.873, doc. 1, hoja 5/ 14 septiembre 1559.

2119 A. M. B./ HI-3778/Valladolid, 27 octubre 1544. 
al carretero infractor y a los guardas portazgueros de esos puentes, que lo denuncien a las justicias para que lo hagan guardar y cumplir2120.

También encontramos menciones a caballos para el tiro de carros. En la relación del material y animales que para la comitiva de la Reina Ana de Austria se prepara en 1570 en Zelanda, se detallan para su embarque a Santander ocho ayudas de carreteros y cocheros, 32 caballos de carro, 17 carros, así como ocho "carros de su $M^{d " 2121}$.

Los bueyes se empleaban tradicionalmente cuando había que desplazar grandes cargas, como en 1410 cuando para llevar los pertrechos en la campaña de Zahara, el Infante mandó que "Juan Hernandez de Bovadilla tomase cargo de llevar la lombarda grande con su curueña, e de las carretas, e bueyes que le han de llevar, e hombres que han de ser docientos", y "Diego Rodriguez Zapata que tome cargo de llevar toda la pólvora, e de las carretas, e bueyes que la han de llevar, que son menester ochenta hombres, e que lleven mas cinco carretas vacías, porque si alguna se quebrare no se detenga la pólvora". Además "Martin Hernandez Nieto que tome cargo de hacer guardar todos los bueyes, así de los que van sobrados, como de los que llevan carga, para lo qual le den quarenta hombres para los guardar"2122. Como vemos, los bueyes y las carretas se convierten con el desarrollo de la artillería, en elementos imprescindibles para el movimiento de los ejércitos.

En 1485 el rey Fernando dice a los concejos y corregidores de todas las localidades del Reino, que ha mandado a Manuel de Cortinas que "todos los que vos quesierdes alquilar con los dichos bueys e carros para la dich a mi artylleria vos alquiledes"2123. En 1488 los Reyes comunican a todas las autoridades y vasallos, que han encargado a Pedro Fernández del Otero "que traynga para la nuestra artylleria quinientos pares de bueys para lleuar la dicha altylleria al rreal, que yo el rrey he de tener en tierra de moros, dellos con sus carretas e otros sueltos"2124. En 1489, la artillería que se había hecho en Vizcaya y Cuipúzcoa se debe embarcar en el puerto para llevarla a Sicilia, por lo que los Reyes mandan "que todas las carretas, e bueys e asemilas, e otras bestias, e fustas que fueren menester para lleuar las dichas artellerias e armas fasta los dichos puertos donde se an de cargar, las fagays dar"2125.

La utilización de bueyes obligaba a los carreteros a realizar descansos con frecuencia para que las bestias pudiesen apacentar, motivo por el que los pastizales situados en las orillas de los caminos eran tan importantes ${ }^{2126}$. Esta necesidad ocasionó no pocos conflictos con las gentes de cada lugar, que velaban por conservar los pastos para su propia ganadería. Ya en 1498 se indica que los carreteros debían "soltar sus bueys e ganados para paçer las yeruas e beuer las aguas", y que "yendo asy con... sus bueys e carretas e carros de paso caminando por muchas partes, por diversas personas les ha seydo y es defendido el dicho pasto y les prenden elleuan sus bueys"2127. Para ello se establecieron normas que regulaban estos aprovechamientos.

\footnotetext{
2120 A. M. B./ HI-1438/ Madrid, 12 enero 1546.

2121 A. G. S./ Patronato Real, leg 57, doc. 100/ Bergas, 23 agosto 1570.

2122 GALINDEZ de CARVAJAL, Dr L.: 1779: 79 y 83

2123 A. G. S./ Registro General del Sello, XII-1485, fol. 44/ Alcalá de Henares, 19 diciembre 1485.

2124 A. G. S./ Registro General del Sello, III-1488, fol. 27/ Valencia, 22 marzo 1488.

2125 A. G. S./ Registro General del Sello, I-1489, fol. 71/Valladolid, 20 enero 1489.

2126 RINGROSE, D. R.: 1987: 64

2127 A. G. S./ Registro General del Sello, III-1498, fol. 396/ Alcalá de Henares, 9 marzo 1498.
} 


\section{Las carretas y los carros}

Los vehículos de ruedas se emplearon para el transporte desde fechas tempranas, pero su utilización se complicaba para un trayecto largo, debido a que los caminos de estas tierras no permitían realizar el trayecto completo al tener que descargar las mercaderías en los lugares próximos a una gran pendiente o a un desfiladero complicado, para proseguir su acarreo a lomos de mulos. Después, con la mejora de los caminos y de los firmes, la carretería acabó imponiéndose aunque nunca hizo desaparecer el sistema de la mulatería.

Los carros se utilizaron, como es lógico, siempre que las características de los caminos y del territorio por donde discurrían lo permitían y las carretas, mucho más resistentes y propicias, fueron empleadas para desplazar cargas más pesadas por asociaciones como la Cabaña Real de Carreteros. Los carros solían tener una capacidad de carga de "un camino", y los más grandes de camino y medio, peso equivalente a 25 y 37 quintales respectivamente ( 1.150 y $1.700 \mathrm{~kg})$, siempre que la carga fuera de gran densidad. Si el material a transportar era de poca densidad y gran volumen, el empleo de los carros no era económico por el poco peso de la mercancía, debiendo recurrir a la utilización de carretas que tenían una mayor capacidad $^{2128}$. Cil Abad rebaja esta capacidad de cada carreta para ajustarla a unas cifras más reales, e indica que cada una podía trasladar entre 9 y 14 fanegas (entre 1.000 y 1.600 $\mathrm{kg})^{2129}$, o bien entre 21 y 26 quintales (entre 1.000 y $1.200 \mathrm{~kg}$ ) si el camino era irregular, y entre 26 y 32 quintales (entre 1.200 y $1.500 \mathrm{~kg}$ ) si el camino era regular.

Los carros podían ser agrícolas, y en este caso, eran utilizados por los campesinos para el transporte cuando el ciclo agrario lo permitía. Según Ringrose la capacidad de un carro de dos ruedas -entendemos que carro agrícola-, era cinco veces la de una bestia de carga pequeña, es decir entre 230 y $460 \mathrm{~kg}^{2130}$. Como prueba de la estacionalidad de este acarreo, en julio de 1582, cuando se debían trasladar desde la casa de la Vega a Burgos ciertos olmos para el aderezo del puente de Santa María, se indicaba que "los uecinos de Gamonal no les quieren traer, diçiendo estar ocupados en sus agostos e otras cosas, e bista la neçesidad que ay acordaron e mandaron que un ministro baya e conpela e apremie a los que tubieren carretas e bueis, que traigan las dichas maderas y que se les pague muy bien su trabaxo"2131.

Según Gil Abad la carreta serrana era un carro largo, estrecho y más bien bajo cuya plataforma o bastidor estaba formado por tres maderos gruesos separados entre sí. El madero central o pértiga era el más largo, y servía para sujetar los bueyes por medio del ubio o yugo. La carreta primitiva era más corta, más ancha y más ligera ${ }^{2132}$. Los carros de bueyes eran más sólidos y resistentes que los carros mulateros y estos, aunque más rápidos, eran menos propicios para trabajos pesados y terrenos irregulares. Los carros de mulas se utilizaban más al Sur como la Ribera del Duero o Tierra de Campos, y sobre todo al sur de la Meseta; mientras que en las tierras más accidentadas y montañosas como las serranas y entre la ciudad de Burgos hasta la costa, los carros son de bueyes como se indica en 1600

\footnotetext{
2128 IBÁÑ̃Z PÉREZ, A. C. 1990: 235.

2129 GILABAD, P.: 1983: 141-143.

2130 RINGROSE, D. R.: 1987: 64

2131 A. M. B./ HI-1680/ Burgos, 26 mayo a 1 diciembre 1582.

2132 GILABAD, P.: 1983: 136.
} 
en la Nueva Recopilación: "i en los adelantamientos de Leon, porque las carretas son de bueyes, i no de mulas, i en el partido de Burgos, que, no aviendo carretas de mulas, se los han de dar de bueyes,..."2133.

La mejora de los firmes y el aumento de las cargas provocó la aparición de prohibiciones o restricciones para el empleo de los carros con ruedas herradas, como consecuencia de que las cabezas de los clavos de sus llantas destruían los empedrados y las capas de rodadura. Se cobraba un impuesto especial a los carros con llantas herradas, con el fin de aplicar sus ingresos a la conservación de tales caminos. De hecho ya en 1061, tenemos noticia del empleo de este tipo de ruedas cuando García Zorraquín se entrega a San Millán con su haber en Terrero y Cordobín, dos pares de bueyes y un carro con ruedas de hierro ${ }^{2134}$. En 1601 la Junta mandó que los alcaldes ordinarios de las villas, alcaldías y valles de Guipúzcoa, ejecuten lo que está acordado en Juntas pasadas, contra los que llevaren carros herrados por los caminos públicos y reales en caso de que no tuvieren licencia de la justicia y regimiento por donde pasaren, ordenándoles que no los traigan so pena de 10.000 mrs. por cada vez y pérdida de los carros ${ }^{2135}$.

Sobre la utilización de carros tenemos referencias muy antiguas como la de 1032, cuando Oveco Beilaz y su mujer Urraca venden a los hermanos Oveco Belascoz y Citi Belascoz una viña situada en Grañón junto a la vía de carro ${ }^{2136}$.

Pedro I da una Provisión al concejo de León en 1363, anunciando que estando en la guerra con Aragón y habiendo entrado en Calatayud, necesitaba el envío sin demora de diez carretas para "leuar engennos" con todos los aparejos, tomándolas a quien las tuviere pagando su precio "et enviad con cada carreta tres bueyes, e dos exes, e un carretero que traya cada carreta e ande con ella, e un maestro que adobe las dichas carretas, e un ome que las traya sobre su cabeça e de recabdo dellas", dando 2 mrs. diarios por tres meses a cada carretero y al maestro tres. Y lo que montare este sueldo y costaren las dichas carretas, se reparta por la ciudad y su término. Los bueyes se deberán repartir entre todos los vecinos y moradores de León que tuvieren bueyes y, cuando volvieren, se devolverán a sus dueños. Pero si algunos murieren antes de volver, el concejo lo pagará a sus dueños ${ }^{2137}$.

Juan I exime en 1385 al hospital de Villafranca Montes de Oca y a sus vasallos de llevar pan a Santander y de dar galeotes, guía, carros, carretas o bueyes, aunque para ello

2133 LEYES DE LA NUEVA RECOPILACIÓN/ Libro III, Título IV, Ley LXXIX/ “Instruccion, i Ordenanzas para los Adelantamientos de Burgos, Campos, i Leon, i para la buena, i breve expedicion de los negocios, i administracion de la justicia, que en ellos se trata. D. Phelipe III. Visita de 2 de Julio de $1600 "$.

2134 A. H. N./ Cartulario de San Millán de la Cogolla. Becerro, fol. 22v/ 1061; SERRANO, L.: 1930: doc. 169, 178. "et dono unum malleolum in valle S. Christofori de Terrero, et unam sernam iuxta villulam que vocatur Cordobin, et duo iuga boum cum suis atondinis, et uno karro ferrato...".

2135 A. J. D. G./ (1601-1603. Documentos) t. XV/ Ordicia, 10 mayo-10 agosto 1601.

2136 A. H. N./ Cartulario de San Millán de la Cogolla. Becerro, fol. 74-74V/ 7 marzo 1032; SERRANO, L.: 1930: doc. 105, 118-119; UBIETO ARTETA, A.: 1976: 198: doc. 197. “...In Dei nomine. Ego Oveco Beilaz et uxor mea Urraca. Placuit nobis et vendimus ad vos germanos Oveco Belascoz et Citi Belascoz vinea nostra propria qui est in viniarum de Granione; vinea que dicunt de Mallelo, latus via de carro; alia pars, vina de sorores de Sancti Michael ...".

2137 A. M. León/ Doc. 177/ Madrid, 7 febrero 1363; DÍAZ MARTíN, L. V.: 1997: 124: t. IV. doc. 1.211. 
fuesen requeridos ${ }^{2138}$. Esta carta será confirmada por Enrique III en $1391^{2139}$ y por Juan II en $1408^{2140}$.

El Rey prohíbe en 1428 tomar guías contra la voluntad de sus dueños, para evitar los daños que sus súbditos reciben cuando son obligados a dar carretas, acémilas, y otras bestias para llevar cargas. No se podrán tomar, salvo para la Cámara del Rey, de la Reina y del Príncipe, pagándolas primeramente antes de que partan de los lugares donde se tomaren. Cualquier carta que se haya dado en contrario se revoca y anula2141.

En 1462 manda el Rey que cuando se hubieren de dar guías de carretas, acémilas, mulas o asnos para las personas que él mandare, que no las pueda dar ninguna persona por su propia autoridad sino el Juez del lugar, regidor o persona diputada por el Consejo, y las que sean necesarias se tasen justamente por cada día andando cargada a ocho leguas, y dos tercios de ello por la vuelta, y que las paguen antes de que partan ${ }^{2142}$.

Por evitar inconvenientes á sus súbditos y porque lo suplicaron los procuradores en las Cortes, los Reyes mandaron en 1480 que cuando ellos hubieren de partir de viaje y se necesiten para ello hombres, carretas o bestias de guía, que los mayordomos se junten con el Consejo Real y vean lo que fuere necesario, informándose sobre el camino, tiempo y costumbre de la tierra y el valor de cada cosa, y con ello hagan las cartas de nómina de lo necesario. Mandarán a los alguaciles que tomen las personas, bestias y carretas señaladas en la dicha nómina para cada uno, y que antes de que las entreguen, hagan pagar lo que mandare la tasa según el camino contando ocho leguas por día y por la vuelta dos tercios de lo que montare la ida, y hasta que paguen, no entreguen los alguaciles las bestias ni den los nombres para guía. Se manda a todas las personas, que sin la Carta real no tomen hombres, bestias, ni carretas de guía y a los alguaciles, que no tomen las dichas guías sin la Carta real2143.

El prior y monasterio de Santa María de Miraflores de Burgos dijeron en 1491 a los Reyes, que para hacer en el monasterio los bultos y sepulturas de Juan II y de Isabel de Portugal, padres de la Reina, faltaban 20 o 30 carretadas de alabastro para acabarlos y que se debía traer de Cogolludo y Beleña, lugares cercanos a Sigüenza. Para ello temiéndose que las personas y alcaldes de los dichos lugares les demandarían derechos y portazgos e impedirían pacer a los bueyes, los Reyes mandan que dejen circular libremente a los carreteros que lleven las 20 o 30 carretas con el alabastro, sin demandarles portazgos ni otros derechos y que dejen pacer a sus bueyes por todos los términos, guardando los panes, viñas y dehesas y les dejen cortar de cualquier monte los ejes, palos y la madera que necesitaren

2138 A. M. B./ HI-874/ Madrigal, 8 febrero 1385.

2139 A. M. B./ HI-874/ Cortes de Madrid, 20 abril 1391.

2140 A. M. B./ HI-974/ Alcalá de Henares, 13 febrero 1408.

2141 NOVÍSIMA RECOPILACIÓN DE LAS LEYES DE ESPAÑA. París, 1846. Tomo segundo/ Libro VI, Titulo XIX, Ley II/ Segovia, 24 octubre 1428.

2142 NOVÍSIMA RECOPILACIÓN DE LAS LEYES DE ESPAÑA. París, 1846. Tomo segundo/ Libro VI, Titulo XIX, Ley I/ VaIladolid, 1442, pet. 33; Toledo, 1462, pet. 8; Salamanca, 1465 pet. 11 y 1566.

2143 NOVÍSIMA RECOPILACIÓN DE LAS LEYES DE ESPAÑA. París, 1846. Tomo segundo/ Libro VI, Título XIX, Ley III/ Toledo, 1480 . 
para reparar las carretas, sin que se demande cosa alguna a los carreteros y oficiales que sacan el alabastro2144.

Los Reyes mandan en 1497 a las Justicias de todo el Reino, que en adelante dejen a los carreteros andar por los términos de las ciudades, villas y lugares, y no consientan que por las guardas ni otras personas, les sean llevadas ningunas penas desaforadas ni excesivas, más de lo que justamente se debiera llevar de los vecinos, de manera que no reciban agravio, ni paguen más penas que los vecinos ${ }^{2145}$.

En 1497 los concejos, justicias, regidores y oficiales de Valdeporres, Valdebezana, merindad de Sotoscueva, Sonsierra, Valdebodres y merindad de Castilla Vieja, dijeron que sus vecinos van con sus carros, bueyes y bestias a la tierra de Campos y otras partes para traer pan, vino y otros mantenimientos para su provisión, y que de mucho tiempo acá sus bueyes y bestias han pacido en cualquier prado baldío de los términos de las villas y lugares de su recorrido, guardando panes, viñas y prados de guadaña sin pagar por ello cantidad alguna, pero que de poco acá en algunos lugares los prendan y llevan muchas penas, por lo que no podrán llevar los abastecimientos necesarios. Se mandó a todos los concejos, que guarden a los carreteros la costumbre inmemorial de pacer libremente sus bueyes y bestias en cualquier término de sus jurisdicciones, guardando panes, viñas y dehesas dehesadas y prados de guadaña y las heredades de particulares sin que se les lleven penas ni cohechos por ello2146.

Los carreteros dijeron que andaban con sus carretas y carros, bueyes y mulas llevando madera, leña, carbón, lanas, hierro, sal, pan, vino y otras mercaderías de unas partes a otras y que necesitaban soltar sus bueyes y mulas para pacer y descansar, y que si entran en algunos panes, viñas o dehesas, las guardas de esos lugares les prenden y llevan penas desaforadas. Así ellos no pueden pasar por esos lugares y dicen que algunos de los "conçejos e personas partyculares dellos, les çerrais e arays los carriles e caminos por donde pasan e solian pasar e andar, e que no les dexays mas de quanto cabe e pase vna carreta", y como no pueden rodear, si salen del camino les llevan grandes penas y aunque se quejan a los concejos y justicias, dicen que no lo remedian ni reparan los caminos. Pidieron que las penas fuesen tasadas de manera que no quedasen agraviados y si hiciesen daño en panes o viñas, que pagasen lo que fuere tasado. Añaden que se debían dejar los caminos anchos, reparados y bien abiertos cuando estuviesen dañados por las aguas y avenidas. Los Reyes mandaron en 1497 a todos los concejos y corregidores, que dejen a los carreteros andar por los caminos de sus términos, no consientan que les sea llevada ninguna pena desaforada y las moderen para que no paguen más de lo que justamente debieren y que, si así no lo cumplen, mandarán tasar las penas enviando personas que lo hagan a costa de las justicias y concejos que no las moderen. Cada concejo arreglará los caminos y carriles de sus términos por donde suelen pasar las carretas y carros, para que tengan el ancho adecuado y puedan pasar sin que hayan de

2144 A. G. S./ Registro General del Sello, VIII-1491, fol. 331/ Burgos, 27 agosto 1491.

2145 NOVÍSIMA RECOPILACIÓN DE LAS LEYES DE ESPAÑA. París, 1846. Tomo tercero/ Libro VII, Titulo XXVIII, Ley I/ Medina del Campo, 1497 y 1516. Aranda de Duero, 1517. Toledo 1526 y Valladolid, 1553.

2146 A. G. S./ Registro General del Sello, II-1497, fol. 323/ Burgos, 12 febrero 1497. 
incurrir en pena alguna por falta de caminos, y no consientan que, en adelante, los caminos sean cerrados, arados, ensangostados, ni dañados ${ }^{2147}$.

Los carreteros se quejan porque cuando pasan con sus bueyes y mulas por las poblaciones, los portazgueros y aduaneros les llevan muchos derechos, y además deben pagar según los aranceles que los portazgueros tienen para justificar el cobro de tales portazgos y derechos, y que aunque les demandan el arancel por el que lo cobran, dicen que no se lo quieren mostrar poniendo escusas. Pero lo peor es que se les dice que los portazgueros están donde quieren y por bien tienen, y que si no los buscan para pagar los portazgos y derechos allí donde viven desviándose del camino por donde los carreteros pasan, dicen que les salen al camino a descaminarlos y llevarles el cuatro tanto del portazgo que debían pagar, alegando que lo debían pagar en sus casas. Los Reyes mandaron en 1498 a todos los corregidores, alcaldes, alguaciles, merinos, etc., y a los portazgueros y aduaneros que recaudan portazgos, pontajes u otros derechos, que "tengadeslugar e syno çierto e señalado, donde los dichos carreteros puedan yr a pagar e paguen el portadgo e derechos que fuesen obligados, en el camino por donde oviesen de pasar syn que para ello aya de rrodear cosa alguna ni vos ayan de buscar", y no pidan ni lleven a los carreteros más portazgo ni derechos de los que han de pagar según el arancel. Si los carreteros pidieren el arancel sobre esos derechos, deberán mostrarlo sin poner escusa alguna y si así no se hiciere, los carreteros no estarán obligados a pagar ningún portazgo ni derecho por ninguna mercadería ${ }^{2148}$.

En 1499, "los carreteros destos mis Rreynos que carretean con bueys e carretas por ellos", dijeron al rey Fernando que su oficio era caminar de unas partes a otras a llevar madera y otras cosas, y que por ello se les quiebran algunas carretas o partes de ellas. Para repararlas era necesario cortar en algunos montes madera y también leña para guisar de comer, pero algunos de los concejos y otras personas cuando cortan la madera para el reparo de sus carretas y leña para guisar, les prendan y llevan muchas penas desaforadas. Añaden que algunos carreteros tienen por costumbre traer tres bueyes con cada carreta para remudarlos cuando alguno de ellos se cansa, y que los portazgueros les hacen pagar portazgos y otros dineros por los bueyes que llevan sueltos para la remuda, no pudiéndolo hacer de derecho. El Rey manda a los concejos y corregidores que cuando los carreteros pasen por ellos o por sus términos y se les rompan los ejes y estacas de las carretas y carros, se les consienta cortar la madera necesaria de cualquier monte donde se hallare, "para las adobar e rreparar e para estacas, e exes, e camas de las tales carretas e carros e no mas" y se les deje además coger de los montes la leña que necesitaren para guisar yendo de camino, y que por ello no se les pida ni lleve pena alguna. Se manda además que de los bueyes (uno por yunta) que los carreteros llevaren sueltos para remudar los que van uncidos, no se les pida ni lleve portazgo, servicio, montazgo ni otro derecho alguno 2149 .

Carlos I manda en 1523 al corregidor de Burgos, que facilite a micer Antonio Vaguerot, encargado de la construcción de un puente en San Sebastián para el paso del ejército,

2147 A. G. S./ Registro General del Sello, III-1501, fol. 308/ Medina del Campo, 15 septiembre 1497.

2148 A. G. S./ Registro General del Sello, III-1501, fol. 308/ Alcalá de Henares, 28 febrero 1498 y A. G. S./ Registro General del Sello, V-1498, fol. 116/ mayo 1498; A. H. N./ Diversos-Mesta, 240, N. 38/ Alcalá de Henares, 28 febrero 1498 y Madrid, 5 febrero 1552

2149 A. G. S./ Registro General del Sello, V-1499, fol. 52/ Madrid, 12 mayo 1499. 
todos los oficiales y maestros que hubiese en la ciudad y su tierra para que ayuden a hacer las carretas, ya que "terna neçesidad de muchos maestros y ofiçiales que las sepan hazer", pagando micer Antonio sus justos jornales ${ }^{2150}$.

La ciudad de Burgos se quejaba de que Francisco de Rojas, capitán de la fábrica de munición y artillería en Burgos, tomaba las carretas que llevaban bastimentos a la ciudad, y que por ello los mantenimientos habían subido sus precios, porque al ser la ciudad de acarreo las carretas dejaban de venir. El Consejo mandó en 1543 que el dicho capitán con el corregidor, provea como se deben traer las carretas necesarias de fuera de la ciudad para hacerse la dicha munición y artillería, de manera que no se tomen las carretas que con mantenimientos lleguen a la ciudad ${ }^{2151}$.

También se adaptaban carros para ser utilizados en otras ocupaciones, como se pone de manifiesto en 1571, cuando se indica que la Universidad de Burgos paga 13.000 mrs. por un carro de Flandes "que se conpro en Santander para desenbaraçar una urca que lleuase mas sacas". En octubre, se pagan " $3.343 \mathrm{mrs} .$. del traer de Santander aqui dicho carro y del adreço para enbiarle a Madrid"2152.

En la Junta de mayo de 1606, el mayordomo de la cofradía de San Lázaro de Vitoria y el de la cofradía de arrieros y trajineros de Nuestra Señora la Antigua de Mendiguren, en nombre de los arrieros de dichas cofradías, dicen que la provincia de Álava "esta fundada en tierra montañosa, esteril y flaca y se probe de acarreto, y en la mayor parte della no se coge sino es vn poco de trigo y zeuada, que no es bastante para el sustento della" si no fuese por lo que viene de fuera. En los últimos años algunos mercaderes de Vitoria utilizan carretas pinariegas para llevar hierro, clavazón, herraje y otras mercaderías, cargas que habían utilizado los arrieros para el retorno de sus acarreos de trigo, vino, aceite, jabón y otros bastimentos, por lo que en verano dejan de venir con sus recuas, causando escasez y la subida de los precios y provocando que muchos arrieros se deshagan de sus recuas. Como los mercaderes sospechan que la ciudad trata de remediar la situación y para traer las carretas con más libertad, algunos que tienen casa en lugares del duque del Infantado almacenan las mercaderías para cargarlas en las carretas, causando además que sus bueyes consuman la poca hierba con la que se sustenta el ganado de labranza. Suplican que se prohíba almacenar hierro, clavazón, herraje, plomo, cobre ni otro metal ni género alguno para cargar en carretas de bueyes, y que no se permita el transporte de las dichas mercaderías en carros si no fuere hierro en barra y flejes de municiones para el servicio del Rey, porque con ello se aumentará la recua y bajará el precio de los portes y de las mercaderías. La Junta comisionó a los procuradores de Vitoria, Salvatierra, Laguardia y Cigoitia para que provean lo que convenga ${ }^{2153}$. Al día siguiente, la Junta mandó que nadie pueda cargar en carretas para llevar fuera ningún género de mercaderías, excepto hierro en barra, yunques y quintales y otras pesas de hierro y flejes de picas, balas y otras municiones y rejas de hierro que no se puedan llevar en acémilas, no pudiéndolas almacenar en ningún lugar de Álava para

2150 A. M. B./ HI-368/Valladolid, 23 agosto 1523.

2151 A. M. B./ HI-3320 y 3416/Valladolid, 30 agosto 1543. (Burgos, 15 junio 1597)

2152 A. D. B./ R-15/ Libro de caja o Mayor del Consulado/ Burgos, 1568-1577. fols. 112d, 120i y 143i.

2153 A. J. G. A./ t. XII, p. 105-107/ Eztarrona, 5 mayo 1606. 
cargarlas en las carretas, aunque traigan cédulas y provisiones reales, diciendo que esas mercaderías son para el real servicio, porque algunos mercaderes las ganan con siniestra intención para vender en sus tiendas ${ }^{2154}$.

\section{Los carros de cuatro ruedas}

Aunque los carros con dos ejes y cuatro ruedas se utilizaron cuando se requería para el transporte de grandes cargas, un carro de este tipo denominado galera comenzó a utilizarse en el siglo XVII. La galera era un carromato de cuatro ruedas, las delanteras más pequeñas que las traseras, de mayor volumen que la carreta y con una mayor capacidad de carga, utilizada preferentemente en transportes militares y tirada por cuatro $u$ ocho mulas ${ }^{2155}$. En el siglo XVIII se fue generalizando para el transporte de viajeros, incorporándole una cubierta o toldo de lienzo fuerte. En la zona que tratamos fue muy poco utilizada por lo agreste del territorio.

Para el transporte de la artillería se acondicionaron en 1522 unos carretones de dos ejes y cuatro ruedas. El emperador Carlos trajo consigo un importante conjunto de piezas de artillería que desembarcó en Santander en julio. Tal conjunto debía ser trasladado a Burgos, para lo que se tuvo que preparar un gran tren de artillería, con grandes y fuertes carretas tiradas por mulas. El resumen del tren es el siguiente:

\begin{tabular}{|c|c|c|c|c|c|c|c|}
\hline Tipo & $\mathbf{N}$ & Nombre & Longitud & Boca & Mulas/ tiro & Mulas & Arrieros \\
\hline falconetes & 28 & & 16 palmos & 1 puño grande & 5 pares & 280 & 140 \\
\hline cañones & 18 & & 17,5 palmos & casi 1 palmo & 8 pares & 288 & 144 \\
\hline serpentinas & 16 & & 16 palmos & 1 palmo & 22 pares & 704 & 352 \\
\hline bombarda & 1 & & 10 palmos & 2 palmos & 30 pares & 60 & 30 \\
\hline trabucos & 2 & & 4 palmos & 2 palmos & 20 pares & 80 & 40 \\
\hline trabuco & 1 & $\begin{array}{c}\text { Magnus } \\
\text { draco }\end{array}$ & 26 palmos & 1 palmo & 34 pares & 68 & 34 \\
\hline tiros & 2 & $\begin{array}{c}\text { El pollino } \\
\text { y la pollina }\end{array}$ & 16 palmos & 1,5 palmos & 34 pares & 136 & 68 \\
\hline tiro & 1 & $\begin{array}{c}\text { Esperame } \\
\text { que alla voy }\end{array}$ & 17 palmos & $\begin{array}{c}\text { casi 2 } \\
\text { palmos }\end{array}$ & 32 pares & 64 & 32 \\
\hline tiros & 2 & $\begin{array}{c}\text { Santiago y } \\
\text { Santiaguito }\end{array}$ & 26 palmos & 1 palmo & 36 pares & 144 & 72 \\
\hline tiro & 1 & & 16 palmos & 1,5 palmos & 34 pares & 68 & 34 \\
\hline & 1 & La Tetuda & 17 palmos & casi 2 palmos & 37 pares & 74 & 37 \\
\hline carretones & 1 & $\begin{array}{c}\text { El gran } \\
\text { diablo }\end{array}$ & 18 palmos & casi 2 palmos & 38 pares & 76 & 38 \\
\hline TOTAL & 74 & & & 7 pares & 126 & 63 \\
\hline
\end{tabular}

2154 A. J. G. A./ t. XII, p. 108-109/ Eztarrona, 6 mayo 1606.

2155 RINGROSE, D. R.: 1987: 63. 
Además, Sandoval indica que "afirmauan que quedauan en el puerto de municion y armas y de peloteria mas, que podian traer mil carros. Por manera que los tiros eran setenta y quatro mayores y menores. Los carretones de los dichos tiros eran nueue que venian vacios, y no trayan cosa alguna: sino que eran para el seruicio de la artilleria. Mas en cada par de mulas venia vn hombre para los guiar, que eran mil y setenta y quatro hombres: estos sin los que trayan prouisiones, y açadoneros para hazer los caminos"2156. Es evidente que son 1.084 arrieros y no los 1.074 que indica Sandoval. Hay que tener en cuenta que con este tren debían ir soldados, intendentes, maestros y peones de caminos, carpinteros, etc. con sus respectivos bagajes y carros, que convertían este tren en una muy complicada empresa.

Para llevar piezas de artillería desde San Sebastián a Pamplona y Estella en 1551, se indica que "todas las pieças que aqui han venido, estan guarneszidas al modo de Flandes para caminar con cada quatro rruedas, por ser la tierra de alla llana y aca es montosa y fragosa, y a esta cabsa sera mejor que uaya con esllas porque las culatas son muy pesadas y no abra par de bueyes que las puedan llevar"2157.

\section{Los carreteros}

Existían, como en la arriería, dos tipos de carreteros: los profesionales que carreteaban la mayor parte del año y se dedicaban de una manera permanente o semipermanente al transporte carretil, y los de media dedicación o dedicación esporádica que eran aquellos labradores que alternaban el trabajo de la agricultura con el acarreo de productos y cargas diversas, aprovechando las épocas del año en que el trabajo agrícola se lo permitía, utilizando sus animales de trabajo y su carro para ganarse un suplemento económico para su economía familiar.

En el libro de caja de la Universidad de los Mercaderes de Burgos consta la negociación con el corregidor de Reinosa sobre "lo de la hordenança de los carreteros que lleuan las sacas", ya que en junio de 1542 se dieron 1.020 mrs. a Toribio de Ribero escribano por que fuese a Reinosa para tal negociación ${ }^{2158}$.

Haciendo salvedad de los carreteros de la zona de Burgos-Soria, que no tuvo incidencia en el transporte de la zona y fechas que estudiamos, no hemos podido recoger datos numéricos sobre la carretería en el norte. Aparecen no obstante en los documentos los lugares de procedencia de algunos carreteros. En 1497 los concejos, justicias y regidores de las villas y lugares de "los valles de Porras, e Vezena, e de la merindad de Sotoscueva, e Sonsierra, e Valdebodres, e de las otras villas e lugares de la merindad de Castilla Vieja", dijeron que "los veçinos de las dichas villas e lugares van e enbian con sus carros e bueys e bestias, a las villas e lugares de tierra de Canpos e a otras partes para traer pan e vino e otros basteçimientos" para su provisión ${ }^{2159}$.

Como era lógico, junto a un camino apto para la carretería como era el de Reinosa surgían numerosos carreteros, como se refleja en 1542, cuando Carlos I manda a la justicia de la merindad de Campoo, que no permita que se use la ordenanza hecha para que ningun vecino de dicha Merindad, pudiese llevar ninguna saca de lana ni bala de pastel de

2156 SANDOVAL, F. P. de: 1634: 560-561.

2157 A. G. S./ Guerra y Marina. leg 42, fol. 119/ 1551.

2158 A. D. B./ R-3/ Libro de caja de la Universidad de Burgos, p. 58/ Burgos, 1539-1549.

2159 A. G. S./ Registro General del Sello, II-1497, fol. 323/ Burgos, 12 febrero 1497. 


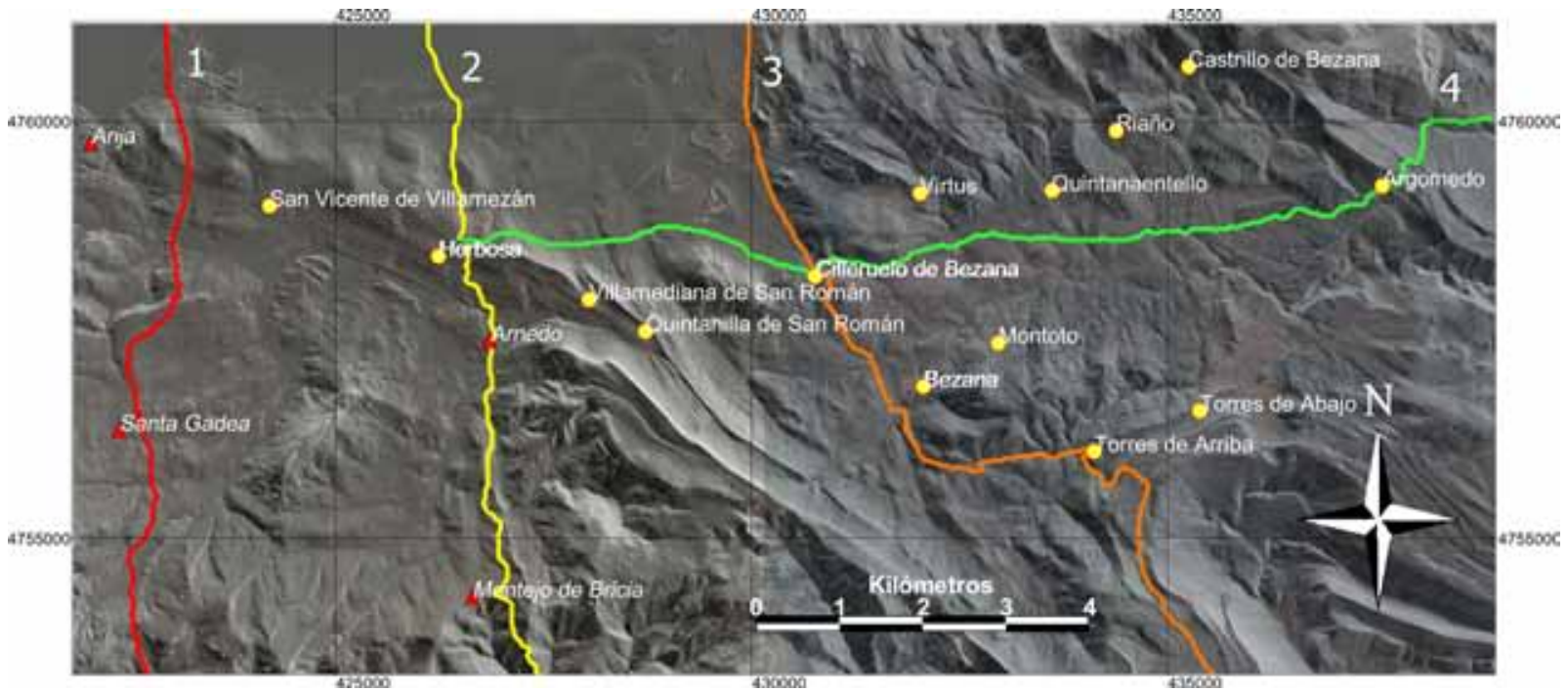

Zona de Valdebezana con los pueblos donde se concentran los carreteros, según el Catastro del Marqués de la Ensenada.

Lanchares a Santander ni de Santander a Lanchares por menos de 3,5 rs. por bala y saca, por "el gran daño que los vecinos desta Merindad que entendian en la lieua de las sacas e pasteles resçebian, a causa que... los mercaderes e sus faitores han acresçentado las sacas e balas de pastel por manera que son de tanto pesso tres de las que agora,... como quatro de las que solian hazer y alquilar", y porque los carreteros merecen los dichos 3,5 rs. "porque no lieuan dos pares de bueys saluo quatro o çinco pasteles o sacas y tardan en el camino ocho dias e con mal tiempo mas". Añaden que los que hicieron la ordenanza tenían muchos bueyes y traían gente a carretear por lo que "hera prohybido de dar y la gente comund de la dicha Merindad que biuian de la carreteria, a quien prinçipalmente tocaua lo contenido en la dicha hordenança"2160. En un interrogatorio para realizar en 1555, a propuesta del concejo de Santander, se debía preguntar al testigo si sabía que el "camino que va desde Santander, demas de ser como es camino de carro muy derecho y convenible para llebar y traer todas mercaderias al dicho puerto y del, ay muy grand aparejo de bueys e carros y honbres muy expertos en las carretear, y que ay tanta abundançia de carros e bueys e tan buenos y tan buen aparejo de pastos", y también si sabía que "toda la carreteria de Canpo y las Montañas comarcanas, que es la mas y mejor d'España, confina con el camino de Santander a Burgos"2161.

Tenemos los datos que nos aporta el Catastro del Marqués de Ensenada ${ }^{2162}$ que, aunque corresponde a fechas muy posteriores, nos confirman lo indicado en el documento de 1497. Existe en dicho Catastro una zona muy señalada y con una gran acumulación de carreteros, que destaca sobre otros lugares. De esta manera, en 14 localidades, muy concentradas junto a los caminos de Burgos a Santander, tenemos un mínimo de 87 carreteros, ya que en seis de dichas localidades se indica que hay dos o más carreteros, lo que es una cantidad muy alta. En consonancia con esta cifra, también el número de carros de 119 es muy elevado.

2160 A. D. B./ R-193/Valladolid, 22 noviembre 1542.

2161 A. M. S./ Leg. A-3, nº 62/ 27 agosto 1555; SOLÓRZANO TELECHEA, J. A.: “Patrimonio documental... ". 283-285: doc. 225.

2162 A. D. B./ Catastro Marqués de Ensenada, 1752. Respuesta 32. 


\begin{tabular}{|l|c|c|}
\hline Localidad & Carreteros & Carros \\
\hline Argomedo & 1 & 1 \\
\hline Bezana & dos o más & dos o más \\
\hline Castrillo de Bezana & 3 & 4 \\
\hline Cilleruelo de Bezana & dos o más & dos o más \\
\hline Herbosa & 19 & 28 \\
\hline Montoto & 5 & 6 \\
\hline Quintanaentello & 4 & 4 \\
\hline Quintanilla de San Román & dos o más & dos o más \\
\hline Riaño & 5 & 7 \\
\hline San Vicente de Villamezán & 12 & 17 \\
\hline Torres de Abajo & dos o más & dos o más \\
\hline Torres de Arriba & dos o más & dos o más \\
\hline Villamediana de San Román & dos o más & tres o más \\
\hline Virtus & 26 & 39 \\
\hline & 87 & 119 \\
\hline
\end{tabular}

\section{La Junta y Hermandad de la Cabaña Real de Carreteros}

La “Cabaña Real de Carreteros, Trajineros, Cabañiles y sus derramas”, instituida por los Reyes Católicos en 1497 como asociación o hermandad formada por todos los carreteros que se dedicaban en Castilla al transporte de mercancías, tuvo un importante papel en la vida económica y comercial de Castilla hasta el siglo XIX, y gozó de prerrogativas y ventajas que les permitía circular con garantías por toda la Península. Fue creada cuando dichos Reyes fueron conscientes, principalmente con motivo de la Guerra de Cranada, de la necesidad de impulsar el transporte en todos sus Reinos y de amparar y proteger a los carreteros profesionales, sus mayores protagonistas. En Burgos-Soria existió una Hermandad de Carreteros que parece arrancar a fines del siglo XV, y que englobaba a los carreteros de las localidades burgalesas de Canicosa de la Sierra, Hontoria del Pinar y sus aldeas de Aldea del Pinar y Navas del Pinar, Palacios de la Sierra, Quintanar de la Sierra, Regumiel de la Sierra y Vilviestre del Pinar y a las sorianas Covaleda, Duruelo, Molinos de Salduero y San Leonardo con sus cuatro aldeas de Arganza, Casarejos, Navaleno y Vadillo. A estos pueblos se unieron las derramas de las villas de Abejar, Cabrejas del Pinar, Herreros y Villaverde ${ }^{2163}$.

Hacia 1482 se hace información sobre las prendas que Salas de los Infantes hizo a los siete lugares de la Hermandad de los Pinares: Palacios de la Sierra, Vilviestre del Pinar, Canicosa de la Sierra, Quintanar de la Sierra, Duruelo de la Sierra, Regumiel de la Sierra y Covaleda, y daños en los sembrados y dehesas que estos hicieron ${ }^{2164}$.

Los Reyes mandan en 1496 a las justicias de Burgos y a las de los otros Reinos y Señoríos, que guarden a los vecinos de Duruelo el privilegio concedido por Juan II sobre que son

2163 GIL ABAD, P.: 1983: 87. Trata sobre todo de la Cabaña Real en los siglos XVIII y XIX.

2164 A. G. S./ Consejo Real de Castilla, leg. 6o, fol. 5/ 1482/1483. 
"libres e esentos... para que puedan andar salbos e seguros por qualquier çiudad villa o logar destos nuestros Rreynos e Señorios, con sus carretas e bueys e vyenes e mercaderias, paçiendo las yerbas e beuiendo las aguas, e guardando panes e vyñas e prados prebillejados que del guardaban, e para que ningund vezino del dicho logar non sea preso, ni detenido, ni enbargado su cuerpo ni vyenes por devdas que vn conçejo deva a otro, ni de un ome a otro salbo por sus devdas mismas", ya que algunos concejos, justicias y personas singulares, especialmente de la ciudad de Burgos, no lo guardan y prendan los bueyes de los vecinos de Duruelo, en algunos prados y términos de la ciudad, llevándoles penas y prendiéndoles por deudas 2165 .

Los concejos de los lugares de Palacios, Vilviestre, Quintanar, Canicosa, Regumiel, Duruelo, Covaleda y San Leonardo y sus aldeas, Hontoria y sus aldeas, Moncalvillo, Pinilla, La Gallega, Rabanera, Salas, Hacinas, Castrillo y Barbadillo del Mercado dijeron a los Reyes en 1496, que los vecinos y moradores de esos lugares acostumbran cortar maderas para llevarlas a vender por sus Reinos, y necesitan cuando van con sus carretas cargadas soltar sus bueyes y ganados en los prados para que puedan pastar respetando los panes, viñas y dehesas dehesadas y beber las aguas de sus términos, y en muchas partes se les impide y aunque lo querellan ante los jueces y justicias de las respectivas villas y lugares, no lo remedian. Los Reyes confirmaron la carta de mayo de 1488 que libró el Condestable de Castilla y mandaron que fuese guardado por todos los vecinos de los lugares de paso, y quedando los carreteros obligados "a saluar panes e viñas e defesas defesadas e prados de guadaña, $e$ los otros heredamientos propios que qualesquier personas traygan, e que en los otros pastos comunes no puedan paçer saluo con los bueys de carreteria"2166.

Los Reyes mandaron en 1498 dar una carta dirigida a todos los concejos, corregidores, alcaldes, etc. a petición de los carreteros, que decían que "avian servido a los Rreyes... en las guerras de los moros e en otras guerras, en llevar nuestras artylleryas e bastimentos e prouisiones, e que agora todos o los mas dellos acostunbran cortar madera para faser casas e leña e carbon, ellevarlo a vender con sus bueyes e mulas e carretas e carros, elleuar lanas e fierro e sal e carretas e mulas e pan e vino e otras mercaderias de vnas partes a otras" por todos sus Reinos y Señoríos, y añaden que en sus desplazamientos necesitan soltar sus bueyes y ganados, para pacer las hierbas y beber las aguas, y que en todos los términos y prados pueden soltar y pacer con sus bueyes y mulas sin pena alguna, pero que diversas personas les prohíben el pasto y los prendan, llevan sus bueyes y mulas y ponen penas y que aunque se querellan, los jueces y justicias no lo remedian. Los Reyes mandan que cuando los carreteros pasaren por las poblaciones con sus bueyes, mulas, carretas y carros se les deje pasar, estar y parar sus carretas y carros, soltar sus bueyes, vacas y mulas y pacer y beber sin pena alguna, con tanto que guarden los panes, viñas, huertas y prados de guadaña y las dehesas dehesadas que los concejos mantienen desde antiguo para sus ganados domados ${ }^{2167}$.

En la zona que estudiamos no obstante, la Cabaña Real no actuó de una manera significativa hasta bien entrado el siglo XVII. De hecho, en dicha zona no hemos encontrado

2165 A. G. S./ Registro General del Sello, X-1496, fol. 67/ Burgos, 10 octubre 1496.

2166 A. G. S./ Registro General del Sello, XI-1496, fol. 59/ Burgos, 15 noviembre 1496.

2167 A. G. S./ Registro General del Sello, III-1501, fol. 308/ Alcalá de Henares, 9 marzo 1498 y A. G. S./ Registro General del Sello, III-1498, fol. 396/ Alcalá de Henares, 9 marzo 1498. 
alusión alguna a la Cabaña hasta el año 1553, en que se indica de manera genérica que la apertura del camino de la Peña de Goldecho lo ha "fomentado y esforzado en los años pasados..., la dicha villa de Bilbao y su Casa de Contratacion y la Cabaña Real y los hombres de negocios de Segobia, Madrid, Cuenca y otras partes y por el contrario ha procurado, destruirla las dichas probincias de Alaba y Guipuzcua". Al tener dificultades la construcción del camino, Orduña acusa de pasividad a las partes a quien toca defender que se lleve efecto el reparo de "dicho camino biexo de Coldecho", que son "en primer lugar al Consejo de la Mesta y Cabaña Real y a la Casa de la Contratacion de la dicha villa de Vilbao y hombres de negocios de Segobia, Madrid, Cuenca y demas partes de Castilla y a la dicha villa de Bilbao"2168.

Después las menciones serán esporádicas, como en 1618, en que Andrés Alonso de la Sierra, vecino de Poza de la Sal, diputado de los herederos de las salinas, dice que el administrador general de las Salinas Reales del partido de Castilla la Vieja ha mandado que no se dé sal fiada a los carreteros, lo cual es perjudicial para la Real Hacienda y los herede$\operatorname{ros}^{2169}$. Otra más tardía es de 1663 , cuando para la reforma del paso de Goldecho en la Peña de Orduña se indica que se convocó a maestros y se hizo la planta, condiciones y postura, dando por supuesto que el maestro se obliga a cumplir con la "condiçion que el dicho camino ha de quedar a satisfaçion de la Cabaña Real, de suerte que pueda subir y bajar la carreteria castellana cargada y descargada"2170. En 1685 el procurador, regidores y todos los vecinos de la junta de Villalba "azerca de azer el ronpimiento de la Peña de Caldecho, y allanar el camino real", muestran recelo de que los bueyes de la Cabaña consuman las aguas de sus pozos, y acuerdan "que en los prados acopiados de la dicha villa de Villalba y esta jurisdizion, no puedan pastar los vueyes de la dicha cabaña ni otros de otros carreteros"2171.

\section{e.- Circulación de carros por los caminos de Santander}

Aunque los caminos de Burgos a los puertos del norte eran muy deficientes y debían superar terrenos muy complicados, siempre que existía una mínima posibilidad se empleaban los carros para el transporte, ya que con ello aumentaba la capacidad de carga y se reducían los costes. La utilización del carro desde Castilla tan sólo se logró en los caminos a Santander, y en muchos tramos de manera parcial.

En 1555 el concejo de Santander con el fin de promover el tráfico por su puerto indica que "los caminos de Santander son abyertos y mejores, porque della se pueden sacar las mercaderias en carretas y carros, y guiarse en ellos para todas las partes d'España lo que no puede ser hecho de Vilbao, ni Laredo syno por pie de mulo", y que desde los "puertos de Laredo e Vilvao no se pueden sacar, llebar ni traer mercaderias en carros para las guiar por los lugares destos dichos reynos" a sus destinos y, en especial, que "no se lleban de los dichos puertos ni traen a ellos, tan presto ni tantas mercaderias, sin carros como con ellos, ni tan segura"2172.

2168 A. H. F. B./ Munic. Orduña, caja nº 19, carp. 4/ Madrid, 17 mayo 1553.

2169 A. M. Poza/ no S-90/ Briviesca, 2 abril 1618.

2170 A. H. F. B./ Administrativo, T-00259/002// Orduña, 27 julio y 11 de agosto 1663; Munic. Orduña, caja no 19, carp. 5/ Orduña, 27 julio y 30 septiembre 1663

2171 A. Ch. V./ Sección de Pleitos Civiles. Zarandona y Walls (olv), C. 2.233-5/ Villalba de Losa, 15 febrero 1685.

2172 A. M. S./ Leg. A-3, no 62/ 27 agosto 1555; SOLÓRZANO TELECHEA, J. A.: “Patrimonio documental...." 283-285: doc. 225 . 
El camino a Santander por Reinosa era básicamente mulatero, aunque varios tramos podían ser utilizados por carretas como entre Gama y Villasirga, ya en la provincia de Palencia. El procurador del valle de Gama dijo en el Consejo que los vecinos y moradores del dicho valle, tierra y montañas, salen con sus carros a Castilla a por las provisiones y mantenimientos y añade que desde el valle de Gama hasta Villasirga, hay muchos caminos dañados por las muchas aguas y, aunque los carreteros los quieren reparar, no les dejan cortar leña y madera para ello. Como los vecinos de Gama y de las Montañas no pueden pasar con sus carros en algunas partes, suplicó que se mande a los vecinos de los concejos, que los arreglen o los dejen adobar. El Consejo mandó en 1498 que los reparen las villas aledañas ${ }^{2173}$.

El camino por Corconte fue utilizado por carros de manera habitual, por lo que nos aparecen muchas evidencias sobre dicha utilización. De hecho, en el siglo XVI, la Universidad de Burgos acondiciona un camino para carros que discurre por el Tozo y Ruerrero, aunque también tenemos referencias correspondientes al siglo anterior.

El concejo de Santander y la cofradía de los Mercaderes de Burgos tratan en 1453 las ordenanzas y capítulos para llevar "nuestras sacas e otras mercadorias de esta dicha çibdat a la villa de Santander". Para que los mercaderes de la Cofradía vayan a Santander "e traygan sus lanase otras mercadorias a ella libre e desenbargadamente", se recogen en una escritura algunas condiciones. Pagarán tan solo para el reparo de los muelles de la villa un mr. por saca, de la lana que llevaren en carros por tierra y por las rías, abras y puertos ${ }^{2174}$.

Ya en 1464 los hermanos Alonso y Juan Fernández de Espinosa, mercaderes de Medina de Rioseco, se obligaron ante el concejo de Santander a llevar a la villa 800 celemines de trigo castellano hasta mediado el mes de julio, por conducir por Santander 400 sacas de lana. Se puso entre otras, la condición de que traigan el trigo en carros y si no en rocines que no lleven otra carga, y no en los mulos en que acostumbraba llevar la carga a la villa 2175 .

La Universidad de Burgos contrataba los transportes para llevar sus sacas de lana y otras mercaderías a Santander, pero los que las cargaban en sus carros y acémilas se quejaban porque en dicha villa y en el marquesado de Santillana, condado de Castañeda y valles de Toranzo, Valdegama y otras partes, les quitaban las sacas para llevarlas ellos por el mismo precio. El Consejo mandó en 1520 que dejen llevar libremente los carros, carretas o acémilas con sacas y otras cargas ${ }^{2176}$.

El concejo de Santander y la Universidad de Burgos acuerdan en 1532, que estos deben pedir a la villa licencia cada año para cargar y descargar en los postodios de Solía y Mobardo, y la villa está obligada a darla mientras se hace el puente de Solía y se reparan los caminos a Santander desde el dicho puente. Hecho el puente y reparados los caminos, la Universidad se obliga a llevar por tierra a Santander todas las mercaderías que vayan o

2173 A. G. S./ Registro General del Sello, IX-1498, fol. 142/ Valladolid, 11 septiembre 1498.

2174 A. H. P. C./ Diversos. leg. 52, no 3/ Burgos, 5 julio 1453; SOLÓRZANO TELECHEA, J. A.: "Patrimonio documental... ". 126-128: doc. 52; A. H. P. C./ J. T. A. legs. 37-3, 4 y 5/ Santander, 8 agosto 1453.

2175 A. H. P. C./ J. T. A. leg. 37-6/ Santander, 30 octubre 1461- 18 junio 1470; A. H. P. C./ Diversos. leg 52, no 7, fols. 2r-3r/ Santander, 19 abril 1464.

2176 A. D. B./ C-206/Valladolid, 2 febrero 1520. 
vengan de su puerto. Si por no estar reparado el puente no pudieren pasar los carros, Santander deberá dar licencia para llevar las mercaderías por mar²17.

En 1542 y acabado el puente de Solía, Santander exige que todas las mercaderías se lleven a través del puente "para que con menos dapño e mas façil e seguramente asi en tienpo de ynbierno como de berano, puedan entrar y salir los carros e mulaterias por la dich a puente e caminos". Ambas partes acuerdan que las mercaderías han de ir y venir por tierra, y añaden que con toda carga de lana que en Santander entrare o carga de pasteles y otras mercaderías que de la villa se llevaren, ha de traer el carretero o mulatero cuatro celemines de trigo por carga, vayan las sacas en carros, rocines, machos, acémilas u otras bestias menores para que el trigo lo venda el carretero o su dueño. Asimismo la Universidad de Burgos y la villa convienen que todas las sacas y balas de los de la Universidad, que metieren o sacaren por tierra en carros o acémilas, paguen a la villa por cada una $3 \mathrm{mrs}$. sin que la villa pueda demandar derecho alguno a sus dueños, factores o criados, ni a los carros de bueyes o acémilas. El concejo procurará tener arreglados los caminos "desde la dicha villa hasta la dicha puente de Solia, de manera que los carros de bueis e azemilas que metieren las dichas sacas en la dicha villa de Santander, e sacaren della los dichos pasteles, puedan yr y benir por los dichos caminos y calçadas que ay de la dicha villa de Santander fasta el fyn de su juridisçion libremente". Los bueyes o acémilas podrán pacer en los términos comunes de la villa sin pagar cosa alguna, y los carreteros y dueños de las bestias podrán hacer cualquier suelta de bueyes y bestias en los ejidos y pastos acostumbrados ${ }^{2178}$.

En Reinosa, el regimiento de Campoo informó al corregidor en 1542 sobre el daño que recibían los vecinos que llevaban sacas y balas, porque los mercaderes habían aumentado su peso y antes solían alquilar el transporte de Solía a Burgos y de Burgos a Solía pero y ahora lo hacen desde Santander, aumentando más de dos leguas sin incrementarles cosa alguna. El corregidor mandó que ningún vecino pueda alquilar bala ni saca entre Lanchares y Santander por menos de 3,5 rs., so pena de 300 mrs. por cada carro que a menor precio se alquilare, pero el Consejo acordó mandar que no se aplique dicha orden, sin duda por las presiones de la Universidad ${ }^{2179}$.

En mayo de 1550 la Universidad paga los 12 ducados anuales a Juan de Santibáñez, vecino del valle de Toranzo, para que "ande en seguimiento de los carreteros y haga llebar las sacas", y asista "en el camino de aqui a Santander asi en hazerlos adrezar, como prinzipalmente para hazer entrar las sacas y andar sobre los carreteros, porque muchas bezes se las dexan en sus casas y en los caminos sin acabar el biaje". En agosto paga 1.020 mrs. a Pedro de Ochandiano para ir con un receptor a "Corconte, para que los lugares de aquella comarca no estorben el paso a los carreteros quelleban las sacas a Santander por Corconte" y en diciembre gasta $51.192 \mathrm{mrs}$. en los "rreparos de los caminos de Santander y Laredo... por donde bayan las sacas en carros"2180.

Para trasladar en 1551 un importante número de piezas de artillería desde Laredo, se utiliza el camino de los carros, por Espinosa de los Monteros hasta Herbosa, donde conec-

2177 A. H. P. C./ J. T. A. leg. 37-7/ Burgos, 30 junio y 17 agosto 1532.

2178 A. H. P. C./ J. T. A. leg. 37-8/ Santander, 29 mayo 1542.

2179 A. D. B./ R-193/Valladolid, 22 noviembre 1542.

2180 A. D. B./ R-12/ Libro de caja de la Universidad de Burgos/ Burgos, 1549-1557. 
taba con el camino que de Santander iba por Corconte, llano de La Virga, Herbosa, Valderredible y Tozo hasta Burgos ${ }^{2181}$.

En 1555 Santander presenta a la Universidad de Burgos una serie de peticiones, para que cumplan con los retornos cuando los mercaderes exporten las sacas de lana. Indica que los "que solian labrar las viñas y eredamientos de los veçinos desta villa, se an tornado carreteros en toda su comarca" y por ello no hay quien las labre. Todos los carreteros de la Montaña en los meses que habían de llevar a Santander pan y vino de Castilla, dejan de hacerlo por llevar sacas a la villa, desabasteciendo a sus vecinos y no se halla carretería que lo traiga y si hay alguna era tres veces más cara. Además, los carros y bueyes que llevan las sacas deterioran los puentes y caminos y los carreteros, además de los pastos para sus bueyes, siegan los panes e hierba, comen las uvas y fruta, cortan los montes para ejes, cambas y estadojos y hacen otros daños.

En dichas peticiones el concejo cree que Santander y su puerto tiene ventajas, porque sus caminos son abiertos y mejores y se pueden sacar las mercaderias en carretas y carros, lo que según ellos, no puede ser hecho desde Bilbao ni Laredo. Además guiándose en carros, no se "descabeçan sus mercaderias syno las guian enteras como vyenen de Flandes" y toda la carretería de Campoo y las montañas comarcanas confina con el camino de Santander a Burgos. La guía que se le quita, es de los fardeles de paños, lienzos y otras cosas semejantes, "pero sacas y pastel y pescado se guia siempre, y çera algunas bezes y los retablos y escaparates y cosas grandes que no se pueden descabeçar ni guiar en mulos sino en carros", se guían por Santander.

Para reforzar lo que pedían, la villa propuso preguntar a testigos si saben que desde Santander hay caminos y puentes por los que "se pueden guiar todas mercaderias en carros y en mulos e bestias para todos estos reynos d'España, y de todos los dichos reynos para el dicho puerto, sin hazer carga ni descarga mas de tomarlo al dicho puerto, y llebarlo en los carros a los lugares que quisieren y traerlo de los dichos lugares, y con los carros ponerlo al dicho puerto enjuto a do se carga y descarga en las naos", y que todo ello redunda en gran perjuicio de los dueños de las mercaderías, y en espeçial, en que no se llevan ni traer de los puertos de Laredo o Bilbao tan rápido "ni tantas mercaderias sin carros como con ellos ni tan seguras, y porque muchas dellas se an de descabeçar por ser grand carga y no la poder llebar en vn mulo, se a de partir para la llebar en dos o tres y en el partir, coser y descoser y cargar y descargar en tantas partes y enviar la partida e dismenbrada y en pedaços y no entera, se diminuye pierde y gasta mucho". También si saben que el "camino que va desde Santander, demas de ser... camino de carro muy derecho y convenible para llebar y traer todas mercaderias al dicho puerto y del, ay muy grand aparejo de bueys e carros y honbres muy expertos en las carretear, y que ay tanta abundançia de carros e bueys e tan buenos y tan buen aparejo de pastos"2182.

En 1560 la Universidad paga a Gutiérrez de Santiago 51.00o mrs. "para tomar carros para ymbiar las sacas a Santander" desde Burgos, y a Juan de la Sierra 6.800 mrs. para pagar a los carreteros "que llebaban sacas a Corconte"2183, y Rodrigo de Alcedo debe 52.894 mrs. que gastó en "adereçar los caminos para pasar los carros con las sacas a Santander", en el puente de Valcallejo,

2181 A. G. S./ Guerra y Marina. leg 42, fol. 118/1551.

2182 A. M. S./ Leg. A-3, no 62/ 27 agosto 1555; SOLÓRZANO TELECHEA, J. A.: "Patrimonio documental... ". 283-285: doc. 225.

2183 A. D. B./ R-29/ Diario de García y Miguel de Salamanca/ Burgos, 1560-1561. 
en el camino de Corconte, en el puente de la Virga y en el valle de Camargo2184. El año siguiente se pagan $32.187 \mathrm{mrs}$. a "los carreteros que llebaron de Burgos a Corconte 225 sacas de lana"2185.

En 1574 las carreterías de sacas enviadas de Burgos a Laredo y Santander deben 10.149 mrs. por llevar de Burgos a Corconte 63 sacas $^{2186}$ y las carreterías de Corconte a Santander tasadas ese año ascienden a 75.208 mrs.

\section{D.- LOS DESPLAZAMIENTOS. LOS VIAJES}

Los caminos se utilizan tanto para el transporte de mercancías, como base y conducto imprescindible para comunicar las diferentes comunidades y grupos humanos, facilitando con ello la aportación y el enriquecimiento de sus culturas. Fueron empleados por gentes de todo tipo a lo largo de los siglos como vías de comunicación, bien por intereses comerciales, económicos, culturales, sociales, políticos, religiosos, militares, etc. o bien obedeciendo en muchos casos a una necesidad ancestral como era la de desplazarse y conocer o descubrir espacios nuevos y desconocidos.

La zona que estudiamos, en la que predominan los caminos con dirección Norte-Sur, fue en lo relativo a la comunicación terrestre claramente secundaria durante la Edad Media, ya que al actuar los lugares de la costa como término o principio de viaje, tan solo se podía poner en relación el pasillo cantábrico que poseía una limitada población, con el interior de la Meseta castellana. Su principal funcionalidad caminera quedó supeditada a los desplazamientos que de Castilla se realizaban a la Europa costera Atlántica y viceversa, actuando como una zona intermedia, y fue al principio mucho más discreta que la que ostentaban otros espacios peninsulares que presentaban caminos en más direcciones, con más destinos y de más longitud y conectaban regiones más amplias discurriendo por lugares topográficamente más favorables. En las fechas objeto de nuestro trabajo, los caminos más transitados fueron los que con una marcada dirección Este-Oeste, comunicaban Europa y el oriente peninsular, con las tierras gallegas y el interior castellano tales como el camino de Bayona o el Francés y que por Burgos llegaban a Santiago, a Valladolid y a la villa de Madrid, que ya en el siglo XVI iba adquiriendo importancia como capital del Reino.

El itinerario Castilla-puertos del Cantábrico-puertos europeos fue esencialmente comercial y poco utilizado para el desplazamiento de personas, siendo el número de sus viajeros ciertamente mucho más reducido que los de las tierras del interior. Consecuencia de lo que apuntamos, es el escaso número de testimonios que tenemos de viajeros que utilizaron estos caminos y sus puertos, principalmente reyes y príncipes, frente a los que reflejan los viajes realizados por gentes diversas por las tierras del interior, muchísimo más numerosos. Además tales viajes de la realeza se centraron en un corto espacio de tiempo, condicionados por la relación que la casa de Trastámara estableció con la de Borgoña, fina-

2184 A. D. B./ R-14/ Libro de caja de la Universidad de Burgos/ Burgos, 1557-1567.

2185 A. D. B./ R-29/ Diario de García y Miguel de Salamanca/ Burgos, 1560-1561.

2186 A. D. B./ R-33/ Libro de Sierra/ Burgos, 1573-1575 
lizando cuando esta ruta marítima se vio afectada por los conflictos bélicos que la Corona castellana sostuvo con la Europa atlántica.

Respecto a la utilización de estos caminos, tenemos constancia de las escasas descripciones realizadas por los siguientes viajeros:

- La de León de Rosmithal, noble bohemio, que, con un séquito de caballeros, llegó a Bilbao y, por Valmaseda, Villasana de Mena, Salinas de Rosío, Medina de Pomar (donde se encontraba el 24 de junio de 1465) y Cernégula, llegó a Burgos ${ }^{2187}$.

- La de Eustache Delafosse, fechada en 1479, que, desde Brujas y por L'Ecluse y Pentecôte, alcanzó Castilla por el puerto de Laredo. Desde allí se trasladó a Burgos y, después se desplazó hacia Cádiz por Medina del Campo, Toledo, Córdoba y Sevilla²188.

- La de Roger Machado, que describió en su diario el viaje de una embajada inglesa a la corte de los Reyes Católicos. Los embajadores llegaron a Laredo el 16 de febrero de 1489, y el 23 salieron y durmieron en Lanestosa. El 24 almorzaron en Villasante y durmieron en Medina de Pomar. El 25 durmieron en El Cuerno ${ }^{2189}$ y el 26 comieron en Hontomín y llegaron a Burgos 2190 ;

- La del embajador inglés lord Nottingham, que, en 1605, detalla el retorno desde Valladolid a Santander, señalando en la jornada de Reinosa que, después de comer en Bárcena de Pie de Concha, llegó a Villasevil, en el camino de Corconte, donde durmió con su séquito ${ }^{2191}$.

- La de Sir Richard Wynn, caballero de Cámara del príncipe de Gales, Carlos Estuardo, que relata cómo salió con su comitiva en mayo de 1623 de Santander hacia Madrid pasando por Burgos. Hicieron la primera noche en un establo, y la siguiente durmieron en Cilleruelo. Después, siguiendo por Turzo y sobre Escalada, cruzaron el río Ebro por el puente de Pesquera ${ }^{2192}$.

- La de Pellegrino Zuyer, que salió de Burgos a mediados de octubre de 166o, dirigiéndose por Pancorbo y Orduña a Bilbao. Desde allí recorrió todo el litoral cantábrico hasta San Vicente de la Barquera y, por Cabuérniga, Valderredible y el páramo del Tozo retornó Burgos, donde llegó en diciembre 2193 .

\section{a.- A pie}

Aunque desde las fases más antiguas el hombre siempre aspiró a realizar los desplazamientos de una manera más cómoda, rápida y eficaz, para lo que utilizó cuando esto fue posible animales y vehículos de tracción animal, en realidad el viaje realizado a pie ha sido siempre el sistema básico y el más utilizado por el hombre. En la Edad Media y fases poste-

\footnotetext{
2187 GARCÍA MERCADAL, J.: 1952-1962; 259-306.

2188 FOULCHÉ-DELBOSCH, R.: 1896: Reedición 1991: 19.

2189 El Cuerno o El Cuerno de Butrón, se correspondía con la actual villa de Villalta.

2190 BELLO LEÓN, J. M. y HERNÁNDEZ PÉREZ, B.: 2003: 167-202.

2191 RIBAS de PINA, M.: 1949: 128-129; VILLA-URRUTIA, W. R. de: 1907: 45-68

2192 WYNN, R.: 1729: 297-341; CASADO SOTO, J. L.: 1980: 2ª edic. 2000: 198-253.

2193 CASADO SOTO, J. L.: 2000: 301.
} 
riores, aunque muchos desplazamientos se realizaban a lomos de caballerías, bien fuesen asnos, mulos o caballos, seguía siendo muy importante el desplazamiento a pie. El viandante, es decir, el viajero que utilizaba tan solo sus piernas para ir de un lugar a otro, fue la figura básica del traslado del pueblo llano y el caminante por excelencia era el peregrino o romero que, en las tierras objeto de nuestro estudio, fue principalmente aunque no en exclusiva el que se dirigía a Santiago de Compostela, que en los siglos XI y XII mayoritariamente se desplazaba a pie. La vía jacobea por antonomasia fue el Camino Francés, que discurría por Pamplona, Estella, Logroño, Nájera, Santo Domingo de la Calzada, Belorado, Burgos, Castrojeriz, Frómista, Carrión, Sahagún, León, Astorga, Ponferrada, Villafranca del Bierzo, Puertomarín hasta Santiago, pero en una fase que comienza en la segunda mitad del siglo XV hubo cierto tránsito de peregrinos por la vía de Bayona, que del puerto de San Adrián, pasaba por Vitoria, Miranda de Ebro, Pancorbo y Briviesca, para enlazar con el Camino Francés en Burgos, según las referencias que conocemos. Otras referencias también tardías, nos hablan de la presencia de peregrinos por la zona cercana a la costa.

En el año 800 se constata la existencia de un antiguo camino por Taranco en el Valle de Mena haciendo mención al servicio de los peregrinos, aunque esta fecha tan temprana nos indica que los peregrinos aludidos no pueden ser jacobeos, ya que la invención del sepulcro del Santo se produjo entre el 820 y el $830^{2194}$. Aunque la Edad de Oro de la peregrinación a Santiago tuvo lugar en los siglos XI, XII y primera mitad del XIII, entró en una profunda recesión desde esta fecha hasta la mitad del siglo XV. Su memoria y tradición se proyectó en siglos posteriores y, llegaron peregrinos de una manera más atemperada desde la segunda mitad del siglo XV, entrando de nuevo en franca decadencia en el siglo XVI. Pasemos a conocer algunos de los testimonios documentados en esta segunda fase, donde se combinan los desplazamientos a pie con la utilización de caballerías.

Como algunos romeros no iban caminando sino en palafrenes, Enrique III emitió en Tordesillas en 1404, ciertas leyes y manda que "los rromeros puedan sacar fuera de los mis reynos palafrenes que fueron manifiestos que no nacieron en esta tierra, e que a la entrada y a la salida no les tome cosa alguna"2195.

García Ruiz, vecino de Corral de la Fuente situado junto al camino a Santander, en nombre de su concejo indica en 1486 que se encargan de reparar el hospital de la alberguería y dice que si no lo reparan, "los rromeros que van al dicho ospital", recibirían mucho daño2196.

La primera cita sobre la utilización jacobea del camino de Bayona, se remonta a 1495 cuando Hermann Künig von Vach regresa de su peregrinación a Compostela2197. A la sali-

\footnotetext{
2194 A. H. N./ Cartulario de San Millán de la Cogolla. Becerro, fol. 179-180/ 15 septiembre 800; SERRANO, L.: 1930: 2-4: doc. 2; UBIETO ARTETA, A.: 1976: 10-12: doc. 2. "Ita tradimus et confirmamus per hanc scriptura omnem nostram facultatem hic supra notatas, et ipsas baselicas S. Martini, S. Romani et S. Stefani ad ecclesia S. Emeteri et Celedoni de Taranco, ut sint in auxilium servis Dei et peregrinorum vel ospitum qui hic viverint comuniter cum illis vivant".
}

2195 A. H. P. Álava/ Leg. CLXXI/ Tordesillas, 10 marzo 1404.

2196 A. G. S./ Registro General del Sello, IV-1486, fol. 64/ Medina del Campo, 4 abril 1486.

2197 PASCUAL VELÁZQUEZ, A. R.; ANGUITA JAEN, J. M. y BRAVO LOZANO, M.. 1996: 93, 94 y 101.

"Si quieres regresar desde Santiago a tu patria, debes volver de nuevo por Burgos, (Burgess)

donde encuentras, antes de entrar en la ciudad, una cruz de piedra, donde debes tomar a mano izquierda.

Alli puedes preguntar por dónde ir al puerto de montaña (porten berge) 
da de Burgos hacia Bayona alude a una bifurcación junto a una cruz de piedra. Sin duda se refiere a la cruz denominada Crucero de Gamonal situada junto al camino real y en el límite de los términos de Burgos y Camonal. En dicha bifurcación nos dice que se puede ir por la izquierda, es decir por Briviesca y Puerto de San Adrián o bien por la derecha por Atapuerca y Villafranca Montes de Oca. También al regreso de su peregrinación a Compostela en 1498, el peregrino alemán Arnold von Harff nos recuerda la misma bifurcación mencionada por von Vach, es decir, un camino por la derecha hacia Logroño y otro por la izquierda hacia Irún que es el que utiliza y que describe con detalle ${ }^{2198}$.

En 1498 el procurador de Colindres comunicó que en su término, desde la Magdalena al barco de Treto, había un puente y calzada que llevó el mar hacía 6 o 7 años. El Consejo mandó al corregidor que se informase sobre qué concejos los utilizan para que hagan repartimiento y "libremente puedan pasar e pasen los caminantes e rromeros e otras personas por la dicha puente e caminos e calçada"2199.

En 1502 se pretende reconstruir el puente que sobre el río Saja pone en comunicación Santander con Santillana y, como justificación de la necesidad de tal intervención, se apunta que "pasa vn rrio grande e peligroso, por el quel dis que pasan todos los rromeros e peligrinos que van de Rroma a Santiago e otras muchas personas e ganados e bestias, en el qual dicho rrio dis que solia estar vna puente, la qual se cayo e perdio e a las muchas cresidas e fortunas del dicho rrio, e nunca mas se torno a faser, $e$ que en tienpo de fortunas de aguas peligran y se ahogan... muchas personas e bestias", y se manda obtener información sobre "sy esta la dicha puente en logar e parte donde pasan muchas personas asy rromeros como caminantes e peregrinos"2200.

En Junta de Álava de noviembre de 1505 fue publicada, entre otras, la condena a la pena de azotes a Michel Arraya por público malhechor y porque "fue en matar a trayçión a vn rromero en el camino de Sant Andrian"2201.

El concejo de Orduña incluye en 1506 en las ordenanzas de la ciudad, las condiciones para los arrendadores de la guía del puerto de la Peña de San Bartolomé, y se indica que "qualquier que asi arrendare la dich a guia e penna, que no coja guia de ningund frayle, ni romero que pasare, ni de ningund clerigo que vaya en romeria a Santiago"2202.

Estando en ayuntamiento el concejo de Castro-Urdiales, dijo en 1507 que en Castro tenían puestos guardas porque había peste en Bilbao, pero como parecía que la villa estaba sana, mandaron "que acogiesen a qualesquier personas que benyesen de la dicha villa de Vilvao eçebto a los

...Puedes también, junto a la cruz, torcer a mano derecha,

y te mantienes en el camino alto hasta Pamplona (Pompelonia)"

2198 HERBERS, K. y PLÖTZ, R.: 1999: 222 y 229. "Item en Burgos,... nos sentamos de nuevo sobre nuestros caballos y cabalgamos hacia Parijs. Y antes de la ciudad hay un convento que se llama ad sanctam Maríam gaminael [Santa María de Gamonal]. Después de él se bifurca el camino, uno hacia la derecha, por el que habíamos venido desde Venecia, y otro hacia la izquierda en dirección a Parijs, que nosotros tomamos en dirección noreste".

2199 A. G. S./ Registro General del Sello, XII-1498, fol. 8/ Ocaña, 3 diciembre 1498.

2200 A. G. S./ Registro General del Sello, VI-1502, fol. 314/ Toledo, 9 Junio 1502.

2201 A. J. G. A./ t. I/ Vitoria, 18 noviembre 1505.

2202 A. H. F. B./ Munic. Orduña, Caja 84, leg. D, fol. 1 r.-6 v.; 33 r.o; 7 r.-32 v.; 34 r.- 51 r./ 1506-1527; ENRÍQUEZ FERNÁNDEZ, J., HIDALGO de CISNEROS AMESTOY, C.; LORENTE RUIGÓMEZ, A. y MARTÍNEZ LAHIDALGA, A.:"(1511-1520), de la Junta de Ruazábal y de la Aldea de Belandia. t. II". 1994: doc. 47. 
romeros, que mandavan a los de los ospytales de la dicha villa, que non acogan a los tales romeros salbo que les den a las puertas de la villa lo que ovieren mester para su pasadia"2203.

En momentos de guerra el peregrino francés es sospechoso en Castilla de ser enemigo. El Rey dice en 1512 que el ejército francés, "enemigos de la yglesia que han entrado en Navarra, han hecho y hazen algun daño en los peregrinos que vienen de señor Santiago, $y$ van" con fuero por sus Reinos, y que "algunos siendo espias de los contrarios toman abito de peregrinos". Para que los peregrinos no reciban daño y evitar el espionaje, el Rey manda al corregidor de Burgos que haga pregonar en la ciudad, que "ningun peregrino sea osado de entrar ni salir de estos Rreinos, por el Rreino de Nabarra ni por la prouincia de Guipuzcoa, ni por Rrioja, sino que baian y bengan por Calatayud y Perpiñan" so pena de que les den 100 azotes $^{2204}$.

Hacia 1540 Fernández de Oviedo recuerda que unos alemanes, haciendo bailar a dos o tres osos, pedían limosna en el Camino de Santiago y "se allegauan gentes comunes y muchachos, quantos se açercauan; e los miradores sacauan sus cuartos e blancas que echauan en vn chapeo, en que otro alemán recogia aquella limosna, que pedian como peregrinos que yvan en romería a Sanctiago de Galizia,... E no pocos dineros sacaron de España esos osos"2205.

En las Juntas de Vizcaya de mayo de 1580 se trató sobre lo que se mandó en el último regimiento, para que las justicias ordinarias y fieles de las anteiglesias visitasen a menudo "los ospitales y tubiesen mucha quenta de saver y aberiguar que personas baldias y bagamundos andan como romeros y pobres, no teniendo enferrmedad ni ynpedimiento, y azen muchos ladroniçios e delitos por los caminos"2206.

En Junta de Álava de mayo de 1597 se dijo que muchas villas y valles cercanos están contaminados por la peste. Se mandó que no se reciban frailes franciscanos, ya que se sabe que de Castro han salido algunos y que en la provincia no han de dejar entrar a ningún pobre que no sea vecino y conocido de la tierra, y tampoco han de recibir a ningún pobre francés ni de los que van en romería a Santiago2207.

En mayo de 1604 fue a la Junta de Álava Pedro de Recalde, comisario que dijo haber hecho "proceso de descamino de setenta reales, que se tomaron a un pelegrino que yba a Santiago de Caliçia sin aver echo magnifestaçion ni tomado su pasaporte", cuyo quinto de 14 rs., entregó en la dicha Junta 2208 .

Sobre viandantes tenemos un testimonio realizado por Tetzel2209, acompañante de León de Rosmithal en el viaje que hizo en 1465: "En España cuando viaja por tierra un personaje importante, cabalga él en una mula y todos sus servidores, con frecuencia en número de treinta o cuarenta, han de ir a pie al paso de su Señor andando a veces al día doce o catorce millas y precediéndole algunos. Cuando quiere

2203 A. M. Castro Urdiales/ Leg. 21, doc. 1/ Castro Urdiales, 19 junio 1507; BLANCO, E., ÁLVAREZ, E. y GARCÍA de CORTÁZAR, J. A.: 1996: 360: doc. 15 .

2204 A. M. B./ HI-322/ Logroño, 15 noviembre 1512.

2205 FERNÁNDEZ de OVIEDO y VALDÉS, G.: 1880: 121-122. Fernández de Oviedo, nació en Madrid en 1478 y murió en Valladolid en 1557.

2206 A. J. R. B./ Actas de Villas y Ciudad. t. II/ Bilbao, 10 mayo 1580.

2207 A. J. G. A./ t. X/ Zurbano, 7 mayo 1597.

2208 A. J. D. G./ (1604-1606. Documentos) t. XVI/ Tolosa, 10 mayo 1604.

2209 ROSMITHAL DE BLATNA, León de: "Dos relaciones del viaje: de Shaschek y de Gabriel Tetzel"/ 1465-1467; GARCÍA MERCADAL, J.: 1952: t. I, 263-266 y 295-297; HERBERS, K. y PLÖTZ, R.: 1999: 108-112. 
comer o dormir han de guisarle y prepararle la comida, y con lo que deja han de contentarse sus criados. Es este un pueblo que sufre bien el hambre y los trabajos".

Junto al puente de Arce cerca de Santander se menciona en 1482 el deterioro del camino real, "por donde todos los viandantes, camyneros e mulos e otras bestias solian pasar e camynar caualgando e a pie, para yr y venyr a la dicha villa de Santander e a otras partes,... e que los dichos viandantes camyneros, no avian lugar por donde podyesen pasar..., a cabsa de lo qual se les recreçian grandes dampnos, y an rodeos para aver de yr e venyr a la dicha villa de Santander por le ser ynpedido el dicho pasaje, y era neçesario que los tales camyneros e viandantes, asy cabalgando commo a pie e muleteros, avian de aver camyno libre $e$ desenbargado"2210.

Consideración aparte merecen los peones de los correos, peatones de los que tenemos referencias numerosas. Como ejemplo, en 1545 se dio libranza de 17 rs. a Alonso de Bocos, correo de a pie, por ciertas cartas de Diego Osorio que trajo de Valladolid ${ }^{2211}$. En 1550 Juan Vizcaíno, hoste de correos en Burgos, dijo que sus antecesores habían tenido principio hacía menos de 50 años en Juan de Arlanzón, y se entendía que "traya y llebaban aquellas cartas, peones y correos de naçion que andaban por sus jornadas, e no abia postas entonçes"2212.

Tras la sentencia de 28 de julio de 1551, Francisco Sánchez, en nombre del Correo mayor y Juan Vizcaíno, dijo ante el presidente y oidores de la Audiencia que hacía unos 50 años y antes, no había "correos de a caballo como entonçes los abia, ni ostes de correos ni maestros dellos, tan solamente abia peones de a pie o caballo que yban por jornadas, e por aquel dicho offiçio e dignidad, tenia muy grandes honrras, prerrogatibas e ynmunidades y derechos"2213.

En 1555 la Universidad pagó 1.125 mrs. a un "peon que bino de Ualladolid en un dia o poco mas", y 680 mrs. "a Pero Rruiz peon que fue a Portugalete y Biluao y Laredo y de alli otra bez a Uiluao y Laredo". También se pagaron " 476 que dio a un peon que fue a Ualladolid,... 1.125 que dio por nuestro mandado a un peon que fue a Ualladolid casi a las 20 leguas,... 612 que dio a otro peon que fue a Santander,... 1.500 que dio a un peon que fue a Ualladolid yente y biniente a las 15 leguas,... 884 que dio a otro peon que fue a Santander" $\mathrm{y}$ "1.258 que dio a otro peon que fue a Ualladolid a las 15 leguas y por traer una prouision se detubo 10 dias"2214.

\section{b.- A caballo o mulo}

Para el desplazamiento a lomos de un animal a la hora de realizar un viaje, se prefería a los mulos sobre los caballos, ya que aquellos aunque eran algo más lentos, eran más duros, necesitaban menos atenciones y eran más baratos.

De febrero de 1575 son unas cuentas de un viaje "sobre lo de la juresdiçion", que realizan Juan de Quintanadueñas y Andrés Cutiérrez a Madrid, cónsules de la Universidad de Burgos, en que se indica que se gastaron $181.362 \mathrm{mrs} .:$ "6.898 de alquiles de lleuary traer los lios y cofres de sus merçedes; 20.954 pagados de los alquileres de las azemilas y cabalgaduras que llebaron de la yda y benida

\footnotetext{
2210 A. M. S./ Leg. A-1, nº 24/ Puente Arce, 29 octubre 1482; SOLÓRZANO TELECHEA, J. A: "Colección Diplomática... ". 194-197: doc. 139

2211 A. H. P. C./ Laredo. Cuentas de la villa de Laredo, f. 88r-91v/ Laredo, 1545; VALDOR ARRIARÁN, M.: 2002: 194 : doc. 8.

2212 A. D. B./ C-58/ Burgos, 4 junio 1550.

2213 A. G. S./ Cámara de Castilla. Pueblos, leg. 5, doc. 250/ Castilla, 2 $2^{\underline{a}}$ mitad s. XVI.

2214 A. D. B./ R-12/ Libro de caja de la Universidad de Burgos/ Burgos, 1549-1557.
} 
computados los 9.350 que pago Andres de Muxica; 13.600 que pagaron del alquil de la posada en Madrid;30.140 que gastaron en el camino 7 dias de yda y 8 de buelta de todas costas del comer y posadas y 107.520 mrs. que gastaron en... comer y de leña y carbon y paja y zebada y lacayos de todo el tiempo que estubieron en Madrid y sus criados con sus merçedes y 2.250 dados a los porteros de palaçio de consejo rreal que son tres quadrillas a dos ducados a cada vna"2215.

La preferencia mencionada de los mulos sobre los caballos provocaba el rápido descenso de la cabaña ecuestre, lo que iba en perjuicio del mantenimiento de la caballería, cuerpo principal de los ejércitos de la época. Los reyes tuvieron siempre una especial preocupación para que la cabaña mantuviese en todo momento un número idóneo de caballos, capaz de permitir en todo momento movilizar el ejército para las numerosas intervenciones bélicas que sostenían las monarquías europeas. Así para garantizar que en Castilla existiese el número adecuado, Alfonso XI, en las Cortes de Alcalá de 1348, establece la prioridad de los caballos y su utilización sobre la de los mulos. Juan I en las Cortes de Valladolid de 1385, con el mismo fin, potenció el aumento de la caballería dictando providencias encaminadas a aumentar la cabaña equina de su Reino y para promover su utilización propuso medidas a fin de restringir el uso de las mulas. En 1396 Enrique III, en las Cortes de Segovia, emite una Cédula ordenando al concejo y merino de Burgos, que no permitan que ninguna persona del obispado mantenga mulas sino caballos ${ }^{2216}$.

Fernando V indica que para que el ejercicio militar y la nobleza de la caballería no se perdiese, había dado Provisión en 1493 mandando que todos los que quisiesen tener mulas de silla para andar debían tener caballo y, que los que lo contrario hiciesen, incurran en las penas contenidas en dicha Provisión. Para ello, quiere saber el número de caballos que hay en sus Reinos y manda en 1494 al corregidor o juez de residencia de Burgos, que se haga alarde de todos los caballos que en Burgos y su tierra hay y se registre su número, los nombres de sus dueños y cuales tienen armas, declarando cuáles son "de la guisa" y cuáles de la gineta, y en 20 días lo envíe ante el Rey²17.

Los Reyes dicen, en septiembre de 1499, que tras la conquista del reino de Cranada, muchos vendían sus caballos y los que los acostumbraban tener no los conservaban por lo que disminuyeron, y así, muy pronto se perdería en sus Reinos la nobleza de la caballería y se olvidaría el ejercicio militar "de que en los tienpos pasados la naçion de España [tuvo] gran fama eloor". Queriendo remediarlo, los Reyes acuerdan dar Pragmática sanción, para que desde el 1 de abril de 1500, nadie "de qualquier hedad, estado e grado e condiçion que sea, aunque sea infante 0 duque o marques o conde..., no ande ni caualgue en mula ni macho ni troton, ni haca ensillado ni aun aluardado con freno, syno que todos los que quisieren andar caualgando, anden a cauallo a la brida o a la gineta", y que el caballo o yegua de silla tenga más de 2 años y tal que "en el pueda andar vn honbre armado $e$ pelear en el quando fuere menester", y si alguien cabalgare en mula, macho, trotón o jaca con freno y silla aunque sea con albarda, si trajere freno, que las justicias le maten la mula o macho. Los Reyes mandan que los clérigos, los frailes, las mujeres y los embajadores que

2215 A. D. B./ R-15/ Libro de caja o Mayor del Consulado/ Burgos, 1568-1577. p. 317i.

2216 A. M. B./ HI-2971/ Madrid, 24 octubre 1396.

2217 A. M. B./ HI-2635/ Segovia, 28 julio 1494. 
fueren a la corte y sus acompañantes, puedan ir con las cabalgaduras que trajeren, y los correos que puedan correr en mulas, trotones, jacas o en otra cualquier bestia2218.

En las Cortes de Madrid de 1528 se trató sobre la falta de caballos que había, y el gran daño que por ello se causa si no se provee con urgencia lo mandado por los reyes, especialmente los Reyes Católicos. En Toledo, en marzo de 1534, Carlos I señala que se hizo en 1528 una ley y Pragmática sanción para evitar la mucha falta de caballos que había. Se vio que la dicha Pragmática no ha sido suficiente y por esto y por evitar los fraudes que se hacían, era necesario hacer nueva ley y Pragmática, sabiendo que la "caualleria que ay en los dichos nuestros reynos, que es muy grande y poderosa, se menoscaba por la falta de cauallos". Manda que desde el 1 de octubre próximo, ninguna persona de cualquier edad, dignidad y condición ande en mula, macho, trotón, jaca ni asno, ensillado ni albardado, con freno ni con mueso, sino que todos los que quisieren cabalgar, lo hagan a la brida o a la gineta en caballo o yegua de silla2219.

Carlos I dice, en enero de 1535, que habiendo en sus reinos falta de caballos, "la nobleza de la caualleria y exerçiçio militar se perdia, de que en los tienpos pasados la naçion d'España alcanço grand fama y loor de lo qual a nos se seguia desseruiçio y a nuestros Reynos podia venir mucho daño", pero que algunos defraudando lo mandado van en mulas con mueso de hierro encima del rostro, con camas como freno, guarniciones petrales y falsas riendas y además como se permitía que los clérigos, beneficiados y colegiales, pudiesen andar en mulas, muchos en menosprecio de su orden y de lo mandado, andan en ellas en hábito de legos. Manda que nadie pueda andar en mula ni en macho, con silla ni con albarda hecha a manera de silla con gualdrapa, aunque anden sin frenos trayendo mueso de hierro con riendas y petral ${ }^{2220}$. En 1538 dice al corregidor o juez de residencia de Burgos, que dio una cédula de acuerdo con la Pragmática que hizo para que en Castilla nadie pudiese andar ni cabalgar en mulas, cuartagos ni jacas, permite que por 2 años pudiesen andar en ellos, siendo del tamaño y medida declarados en la dicha Pragmática. Después prorrogó la dicha Provisión por otros 2 años, y ahora de nuevo la prorroga por otro año más ${ }^{2221}$. El Rey recuerda en 1539 a todos los corregidores, gobernadores, alcaldes, etc. que por Pragmática Sanción está vedado que ninguna persona pueda andar en mula y concede cédula para que todos los que tengan caballo de la marca contenida en la Pragmática, puedan caminar en mula o en macho, jaca y cuartago aunque no tengan la medida, con silla y freno o mueso ${ }^{2222}$.

En las Cortes de Valladolid de 1542, los procuradores dijeron entre otras cosas, que en las Cortes pasadas se había pedido al Rey muchas veces, que quitase "la plematica de las mulas e quartagos o moderarla, por causa de los muchos daños y muertes y costas superfluas que por ella an benido, y porque los mas y mejores de los cauallos estan, en poder de letrados y medicos y honbres viejos que los capan y se sirben dellos como de mulas", y por causa de los muchos "rroçines y cauallos mancos que ay, se a encarresçido la çeuada en tanto grado como se a bisto y bee, y son peores de aposentar en buestra corte los

\footnotetext{
2218 A. M. B./ HI-1045/ Granada, 30 septiembre 1499.

2219 A. M. B./ HI-1046/ Toledo, 9 marzo 1534.

2220 A. M. B./ HI-4611/ Madrid, 5 enero 1535.

2221 A. M. B./ HI-3112/ Barcelona, 22 abril y Valladolid, 7 mayo 1538.

2222 A. M. B./ HI-4611/Toledo, 30 marzo 1539 y HI-3.045/ Toledo, 30 marzo.1539.
} 
cauallos que los caualleros, de mas que ya no se hallan mulas con que los labradores labren las heredades". El Rey dice que no se haga novedad, pero autoriza a que cualquier persona en las poblaciones pueda llevar en las ancas a las mujeres ${ }^{2223}$.

En las Cortes de Valladolid de 1544, los procuradores pidieron al Príncipe que quite la pragmática de las mulas, como se ha pedido en todas las Cortes anteriores, pues "por espriençia se a visto el poco fruto que a sallido della y los muchos y grandes daños, peligros e bejaçiones y costas que por rrazon della, se an seguido a los naturales dellos, especialmente agora que andan muchos a mula por las liçençias que tienen mançebos y sanos que pudieran andar a caballo, y los biejos y enfermos y personas de letras que destruyen los caballos y los encarezen", y "ques cosa muy desygual" pues con las limitaciones que se han hecho, no está proveído lo que conviene. El Príncipe responde que el fin de la pragmática era que no se acabase con "los caballos que tanto conviene a la nobleza dellos" y que lo consultaría al Rey ${ }^{2224}$.

\section{C.- En vehículo}

El vehículo tenía la ventaja sobre la caballería de que permitía realizar el viaje de una manera más cómoda, si se pueden calificar así a unos desplazamientos por caminos incómodos e irregulares en vehículos cuyo interior ofrecía un escaso desahogo. Podían ser desplazados sobre personas o animales o bien sobre ruedas, adaptados los primeros mucho mejor a las características de los caminos y cuando estos no permitían la utilización de carruajes. En estos momentos los vehículos de ruedas tenían una escasa o nula suspensión, lo que convertía el viaje en una experiencia muy penosa.

\section{Sillas de manos 0 andas}

La silla de manos o andas es un vehículo con asiento para una persona a manera de caja de coche, con dos varas largas para ser portada por dos personas.

En el Libro de la Cámara Real del príncipe don Juan, primogénito de los Reyes Católicos, escrito en 1548 , se indica que "quando el prinçipe don Johan, mi señor, fue niño 2225 no avia cavallerizo de las andas o literas duplicadas..., porque estas andas eran anexas a la cavalleriza e cavallerizo mayor e en torno de las andas ivan çien ginetes de guarda; pero desque el prinçipe fue de mas edad çeso esto"2226.

Para el viaje del emperador Carlos V desde Laredo a Burgos, camino que emprendió el martes 6 de octubre de 1556, Sandoval, comenta que "de Laredo le traxeron poco a poco, vnas vezes en silla a brazos de hombres y otras en litera. Venian con el sus hermanas las Reynas Leonor y Maria"2227.

En los preparativos para la recepción de la Reina Ana de Austria, el Rey indica en 1570 que "me afirman que el camino es hecho de las dos leguas de Oña y de las dos leguas de los Hoçi-

\footnotetext{
2223 A. M. B./ HI-1438/Valladolid, 22 mayo 1542.

2224 A. M. B./ HI-1438/Valladolid, 6 mayo 1544.

2225 El príncipe don Juan, único hijo varón y heredero de los Reyes Católicos nació el 30 de junio de 1478 y murió el 4 de octubre de 1497

2226 FERNÁNDEZ de OVIEDO, G.: 2006.

2227 SANDOVAL, F. P. de: 1681: 607.
} 
nos,... y que se pueden muy bien andar en litera y se puede muy bien escusar lo de la silla a honbros como su magestad lo manda..."2228.

\section{Literas}

La litera es un vehículo capaz para una o dos personas con dos largas varas laterales que se afianzaban en dos mulas, una delantera y otra trasera. Es parecida a la silla de manos pero más grande, larga y a veces de mayor fondo, pudiendo en ocasiones ir acostados los viajeros.

En el Libro de la Cámara Real del príncipe don Juan ya mencionado, se indica que hacia 1497 en Castilla, "a causa de la comunicaçion de Flandes, ay muchas literas, e ovo un tiempo carros de quatro ruedas cada uno...; pero como esos carros no los podian sostener... sino personas de estado, e no son sino para tierra llana, e SuAlteza ${ }^{2229}$ despues que embiudo se torno a Flandes, çesaron tales carros, e quedose la costumbre de las literas e ase estendido mucho. E ya no solamente los señores e dueñas de estado las usan, pero andan ya en personas de muy menor calidad e meritos e en otros ofiçiales cortesanos de diversas maneras. Pero todavia son buen[a]s para enfermos e para niños, e en la corte de los principes todas estas cosas se sufren, e aun son adornamiento de la grandeza del estado todas essas ocurrençias. E espeçialmente son buenas estas literas para los ançianos señores del Consejo, que por su edad e por ser personas de cuya compañia e espiriençia, el reye el reyno tienen nesçessidad muy grande, estan bien empleados tales regalos para los conservar"223o.

En la "Relación de lo sucedido en la prisión del Rey Francisco de Francia”, Fernández de Oviedo nos relata la llegada de Germana de Foix a Toledo tras enviudar por segunda vez: "En veinte de enero del dicho año de 1526 entró la Reina Germana, muger segunda que fue del Rey Católico... Asi que viuda segunda vez, vino a Toledo... porque al tiempo que entraron en la puente, llegaron los pajes con hachas, e como la Reyna cavalgo, entro en vna litera de paño negro... e detrás de la litera tres o quatro dueñas ancianas, e mas atras diez o doze damas, e tras ellas vn carro frances de quatro ruedas con otras mugeres, todas vestidas de luto"2231.

Carlos I dice en 1535, que la Pragmática de marzo de 1534 sobre las restricciones en el uso de mulas, no se extienda a las acémilas o machos de litera, aunque yendo ensilladas o enfrenadas con el aparejo que suele llevar la litera, algún paje o mozo u otra persona vaya en sus ancas ${ }^{2232}$.

Para el último viaje del emperador Carlos $\mathrm{V}$, camino que emprendió desde Laredo a Burgos el 6 de octubre de 1556, Sandoval comenta que "le traxeron poco a poco, vnas vezes en silla a brazos de hombres y otras en litera"2233.

En la relación del material y animales que para la comitiva de la Reina se prepara en 1570, se menciona para su embarque a Bartolomé de Otajio, tenedor de literas junto con

2228 A. G. S./ Patronato Real, leg 57, doc. 32/ Laredo, 3 septiembre 1570.

2229 La princesa Margarita, archiduquesa de Austria, contrajo matrimonio con el príncipe Juan en 1497. Tras enviudar el 4 de octubre de ese año, regresó a Flandes en los primeros meses de 1499.

2230 FERNÁNDEZ de OVIEDO, G.: 2006.

2231 B. N./ ms. 8756, f. 37V-38v/ "Relación de lo sucedido en la prisión del Rey Francisco de Francia".

2232 A. M. B./ HI-4611/ Madrid, 5 enero 1535.

2233 SANDOVAL, F. P. de: 1681: 607. 
su ayuda y 3 mulos de litera, así como una litera ${ }^{2234}$. En los preparativos para su recepción, el Rey da una instrucción en agosto de 1570 que indica que "paresçe que se deue embiar la litera y coche de Su $M^{\text {ad }}$. para la persona de la Reyna, y otros 4 para mugeres, que se hallaran sin mucha difficultad y doze acaneas, las dos adereçadas para la persona de Su $M^{a d}$., nombrando Su $M^{\text {ad }}$. el cauallero que fuere seruido para que se encargue desto y lo lleue"2235. En septiembre, el alcalde Ortiz dice al secretario del Rey que "el camino de las carretas se a hecho e se acabara de hazer todo lo mejor que la dispusiçion de la tierra da lugar, y me afirman que el camino es hecho de las dos leguas de Oña y de las dos leguas de los Hoçinos..., y que se pueden muy bien andar en litera y se puede muy bien escusar lo de la silla a honbros como su magestad lo manda..."2236.

\section{Coches y carrozas}

Los caminos de Castilla en los siglos XV y XVI poseían unas características que facilitaban muy poco el tráfico rodado. No obstante, tenemos noticias de fines del siglo XV sobre el empleo de vehículos de cuatro ruedas para el transporte de personas procedentes de Flandes, territorio llano y más propicio para la utilización de este medio.

Ya en 1497 aparecen las primeras evidencias sobre la utilización de vehículos de cuatro ruedas. En marzo de ese año, desembarca en Santander procedente de Flandes la duquesa Margarita para contraer matrimonio con el príncipe Juan, y trajo un voluminoso y rico equipaje y "ciertos extraños vehículos de cuatro ruedas, llamados carrozas". Marchó hacia Burgos por el camino de Corconte encontrándose con el rey Fernando y el príncipe Juan en Villasevil y continuando juntos por el puerto de Corconte. De Santander a Burgos tardó la duquesa 9 jornadas, lentitud debida a que por lo áspero y poca adaptación del camino, se utilizaron las carrozas haciéndolas tirar por bueyes ${ }^{2237}$. Oviedo dice hacia 1540 que en Castilla "a causa de la comunicaçion de Flandes, ay muchas literas, e ovo un tiempo carros de quatro ruedas cada uno (que truxo a Castilla la prinçesa Madama Margarita,... en que, algunas veces, con particulares damas de Su Alteza, se salia al campo)". Añade que tras el regreso de la princesa a Flandes, cesó el uso de los carros de cuatro caballos y cuatro ruedas, fundamentalmente a causa de su alto coste y escasa adaptación a la accidentada orografía castellana, "pero como esos carros no los podian sostener (con cuatro o çinco cavallos que han menester) sino personas de estado, e no son sino para tierra llana e Su Alteza despues que embiudo, se torno a Flandes, çesaron tales carros, e quedose la costumbre de las literas..."2238.

La segunda noticia de la utilización de un coche se remonta al año 1502, cuando los príncipes Juana y Felipe llegan a la Península desde Flandes por Francia, Bayona y el túnel de San Adrián pasando por Burgos, para después ir por Santa $M^{a}$ del Campo a Valladolid. En su séquito venía Monseñor de Boussut, que "hizo pasar su coche mas alla de las montañas de Vizcaya, lo que jamas habiase visto en memoria de hombre. Y como los campesinos jamas habian visto coches en su pais, es de lo que mas maravillados se mostraron"2239.

2234 A. G. S./ Patronato Real, leg 57, doc. 100/ Bergas, 23 agosto 1570.

2235 A. G. S./ Patronato Real, leg 57, doc. 18/ Madrid, 3 agosto 1570.

2236 A. G. S./ Patronato Real, leg 57, doc. 32/ Laredo, 3 septiembre 1570.

2237 RIBAS de PINA, M.: 1949: 123-124.

2238 FERNÁNDEZ de OVIEDO, G.: 2006. La princesa regresó a Flandes en los primeros meses de 1499.

2239 GARCÍA MERCADAL, J.: 1952: t. I, 445. Antonio de Lalaing: Primer viaje de Felipe el "Hermoso" a España en 1501. 
Estos carruajes se seguirán viendo esporádicamente en Castilla, conviviendo con las mucho más populares literas y andas. Podemos comprobarlo en el siguiente pasaje de la "Relación de lo sucedido en la prisión del Rey Francisco de Francia”, en el que se menciona un carro francés, y el propio Fernández de Oviedo nos relata la llegada de Germana de Foix a Toledo, tras enviudar por segunda vez, ahora del hermano del duque de Brandemburgo. En 20 de enero de 1526 "entró la reina Germana, muger segunda que fue del Rey Católico.... Entró en una litera de paño negro... e detrás de la litera tres o cuatro dueñas ancianas, e más atrás diez o doze damas, e tras ellas un carro francés de cuatro ruedas con otras mugeres, todas vestidas de luto"2240.

En 1544 la Universidad de los Mercaderes de Burgos paga 1.500 mrs. por las albricias a un criado de los Fúcares que "bino por Ynglaterra en deligençia a haçer sauer la llegada de la flota"2241. En 1555 se pagan 15.000 "que libramos a Pedro de Ochandiano, parador, a una posta que fue e bino en diligençia de Yrun con cartas de Bartolome de Miranda" y en marzo de 1556 se pagan 136 mrs. a Toribio Hernández de Herrera, "por una guia que tomo de noche uiniendo de Santander en diligencia..."2242.

En la relación del material, animales y elementos que para la comitiva de la Reina Ana de Austria se preparaba en Zelanda, se detallan para su embarque 11 mozos de caballos, dos cocheros, ocho ayudas de carreteros y cocheros, 35 caballos de silla y 32 de carro, así como ocho "carros de su $M^{d " 2243}$. Para su llegada a Laredo el Rey da instrucciones en agosto de 1570 , e indica que "paresçe que se deue embiar la litera y coche de Su $M^{\text {ad }}$. para la persona de la Reyna, y otros 4 para mugeres, que se hallaran sin mucha difficultad"2244. En septiembre, el alcalde Ortiz dice al secretario del Rey que "el camino de las carretas se a hecho e se acabara de hazer todo lo mejor que la dispusiçion de la tierra da lugar, y me afirman que el camino es hecho de las dos leguas de Oña y de las dos leguas de los Hoçinos... y los coches se lleuaran en carretas muy bien hasta Burgos"2245.

En una relación detallada del camino "por donde pueden venir los coches" desde Laredo a Burgos, se indica que de Laredo a Colindres "los coches vernan mejor por Pereda que queda a la mano isquierda". Desde La Pared a La Calera una legua, donde se toma el camino de Hoz de Herada y derecho a Agüera, y "de aqui se an de apartar los coches a Espinosa de los Monteros" y a Ruerrero y a Rocamundo, y van dando la vuelta por tierra llana a Burgos "aunques rodeosa". Se propone que si la Reina decidiese no ir por este camino de carro por ser más largo, "puede yr en literas desde Aguera adelante". Ya en Hontomín "pueden uenir los coches a reçibir a su Magestad en çinco leguas de Burgos"2246. El 4 de octubre, el cardenal de Sevilla dice que como la Reina ha llegado a Santander, el que la comitiva vaya a Burgos por otro camino tiene alguna ventaja, ya que viniendo por Medina "no puede la Reyna nuestra señora, ni las mugeres que uienen con ella, aprouecharsse de los carros que traen y yendo por el camino de los carros desde Santander a Burgos pueden muy bien yr"2247.

2240 B. N./ ms. 8756, f. 37V-38v/ "Relación de lo sucedido en la prisión del Rey Francisco de Francia".

2241 A. D. B./ R-3/ Burgos, 1539-1549.

2242 A. D. B./ R-12/ Libro de caja de la Universidad de Burgos/ Burgos, 1549-1557.

2243 A. G. S./ Patronato Real, leg 57, doc. 100/ Bergas, 23 agosto 1570.

2244 A. G. S./ Patronato Real, leg 57, doc. 18/ Madrid, 3 agosto 1570.

2245 A. G. S./ Patronato Real, leg 57, doc. 32/ Laredo, 3 septiembre 1570.

2246 A. G. S./ Patronato Real, leg 57, doc. 90/ Antes del 3 septiembre 1570.

2247 A. G. S./ Patronato Real, leg 57, doc. 62/ Laredo, 4 octubre 1570. 
En 1571 el Consulado de Burgos paga 3.343 mrs. a Melchor de Múgica, que trajo el carro de Flandes y "pago del traer de Santander aqui dicho carro y del adreço para enbiarle a Madrid"2248. Aunque no se detalla, era posiblemente uno de los carros que trajo la Reina el año anterior.

En la Novísima Recopilación se manda, en las Cortes de 1578, que ninguna persona pueda andar por las ciudades, villas y lugares de Castilla, en sus arrabales ni cinco leguas alrededor de ellos, en coches ni en carrozas, si no fuere trayendo con cada uno cuatro caballos y que estos sean del dueño del coche o carroza, so pena de perder el vehículo y "la cubierta de él, y todo el demas aderezo de alfombras y al mohadas, y los caballos, mulas o acémilas que le llevaren con sus guarniciones". Se permite que los dichos coches y carrozas se puedan traer de camino con mulas o acémilas, o como cada uno quisiere, con tanto que el camino sea para jornada de cinco leguas o más 2249 .

En 1582 Diego de Sisniega, maestro de cantería, dijo que en el puente de Santa María de Burgos, que se quiere hacer de madera mientras se hace el de piedra, conviene que para hacer fuertes las vigas o carreras necesarias, se han de echar tornapuntas en la parte baja "por la mucha carga e trabajo que an de sustentar de carros y coches". La parte central del puente es "donde a de ser mas frequentada ansi de aguas y benidas del rrio como de carros, coches y rrecuas e otras cossas que por ello an de pasar" 2250 .

En 1588 en Sevilla "vn cauallero saco vn coche de los que solian traerse con quatro rruedas, hezeto que las dos de delante heran bajas y mas pegadas al coche que las otras y trayendole con vn cauallo fue denunçiado por vn aguazil" y siendo absuelto, lo que muchos otros que andan con uno y dos caballos en Sevilla lo han testificado. En Burgos algunos interesados en estos coches piden información a los procuradores de Sevilla, porque si "por este camino se pudiesen en esta çiudad yntroduçir de quatro rruedas, seria gran rregalo y descanso porque estas carrozillas son de poco serviçio y mucho enfado, porque estamos ya picados con este deseo"2251.

En la Novísima Recopilación se indica que en las Cortes de 1593 se trató sobre lo mandado en la ley de 1578 , que no se podían traer coches ni carrozas si no fueren con cuatro caballos. Como se han introducido los llamados carricoches con dos caballos, mulas o machos, y "con quatro ruedas, las dos pequeñas debaxo de la caxa y otras dos grandes de fuera y otros algunos con tres ruedas, una debaxo de la caxa y dos de fuera", se manda que lo proveído por la dicha ley, de no poder traer los coches con menos de cuatro caballos, se extienda a todos los carricoches, carros largos y otros cualesquiera y se ejecuten las penas en las personas que los trajeren $^{2252}$.

2248 A. D. B./ R-15, p. 143/ Libro de caja o Mayor del Consulado/ Burgos, 1568-1577.

2249 NOVÍSIMA RECOPILACIÓN DE LAS LEYES DE ESPAÑA/ París, 1846. Tomo segundo/ Libro VI, Titulo XIV, Ley IV/ Madrid, Cortes 1578. Pet. 6.

2250 A. M. B./ HI-1680/ Burgos, 26 mayo a 1 diciembre 1582.

2251 A. M. B./ HI-4843/ Burgos, 9 septiembre 1588.

2252 NOVÍSIMA RECOPILACIÓN DE LAS LEYES DE ESPAÑA/ París, 1846. Tomo segundo/ Libro VI, Titulo XIV, Ley V/ Madrid, Cortes 31 diciembre 1593. 


\section{d.- Los desplazamientos reales}

Aunque los reyes o personas pertenecientes a la corte y Casa Real utilizaron varios de los caminos objeto de nuestro estudio, las vías de Santander y de Laredo fueron las más cursadas, sobre todo, desde que Isabel I y Fernando V establecieron relaciones dinásticas y políticas con la casa de Austria y Flandes, que continuaban otras de tipo comercial. Con ello, los puertos de Santander y Laredo adquirieron un gran protagonismo como punto de salida o llegada de integrantes de la monarquía castellana Este periodo finalizará en la $2^{\underline{a}}$ mitad del siglo XVI, cuando la monarquía española entre en conflicto abierto con las potencias europeas del Atlántico, lo que provocará la inseguridad de esta vía marítima y su nula utilización por los Reyes, príncipes y familiares del Rey. Fuera de este periodo y circunstancia, Santander, Laredo, Bilbao u otros puertos de la costa cantábrica fueron muy poco visitados por dichas personas y en todo caso desde tierra y no a través de los puertos de mar. Los desplazamientos de los que tenemos constancia por el territorio y en el periodo estudiado fueron:

- En 1457 Enrique IV transita por Cuetaria, Guernica, Bermeo, Bilbao, Orduña, Vitoria y Burgos 2253 .

- En 1483 Isabel I se desplaza desde Santo Domingo de la Calzada por Pancorbo, Santa Gadea, Puentelarrá, Espejo, Berberana, Orduña, Llodio, y Arrigorriaga hasta Bilbao2254.

- La reina Isabel se trasladó en julio de 1496 desde Burgos por Peñahorada, Cernégula, Pesadas, Medina de Pomar, Villasante, El Prado, Ramales, Ampuero, Limpias y Colindres hasta Laredo para despedir a su hija Juana, que, en agosto de 1496, embarcó para reunirse con su marido Felipe en Flandes. Ese mismo mes la Reina emprendió el regreso siguiendo idéntico itinerario hasta Medina, y desde allí se trasladó a Burgos por Oña, Briviesca, Castil de Peones, Monasterio de Rodilla y Hurones 2255.

- Utilizando la misma flota que trasladó a su cuñada Juana, la princesa Margarita salió de Flandes para contraer matrimonio con el príncipe Juan y desembarcó en marzo de 1497 en Santander. Tras descansar unos días, marchó hacia Burgos, encontrándose con el rey Fernando y el príncipe Juan en Villasevil, prosiguiendo juntos por el puerto de Corconte. De Santander a Burgos tardó la comitiva 9 jornadas, fundamentalmente a causa de la lentitud de los bueyes que tiraban de las carrozas que venían de Flandes ${ }^{2256}$.

- En el verano de 1501, la armada real se dispuso a trasladar a la infanta Catalina para contraer matrimonio con el heredero de la corona inglesa. Tuvo dos salidas frustradas del puerto de La Coruña, teniendo que recalar la flota en la segunda en el puerto de Laredo, de donde salió para llegar sin contratiempo alguno a Plymouth.

- La princesa Juana, hizo otro viaje a Flandes desde Laredo en marzo de este año y en 9 días llegó a Blanckeberghe, en las inmediaciones de Brujas²257.

\footnotetext{
2253 TORRES FONTES, J.: 1953: 70-73.

2254 RUMEU de ARMAS, A.: 1973: 115-116.

2255 RUMEU de ARMAS, A.: 1973: 227-234.

2256 RIBAS de PINA, M.: 1949: 123-124.

2257 FERNÁNDEZ DURO, C.: 1895: T. I.
} 
- Los príncipes Felipe y Juana salieron de Bruselas hacia Castilla el 4 de noviembre de 1501 a través de Francia. El 1 de febrero de 1502 pasaron el túnel de San Adrián y llegaron a Salvatierra. El 4 entraron en Vitoria, el 7 durmieron en Miranda de Ebro, el 9 en Grisaleña, el 10 en Briviesca y el 11 en Monasterio de Rodilla. El 12 de febrero comieron a una legua de Burgos y llegaron al monasterio de las Huelgas. Permanecieron en Burgos hasta el día 23 de ese mismo mes ${ }^{2258}$.

- En su primer viaje a Castilla, Carlos I salió de Flandes y llegó a Villaviciosa el 20 de septiembre de 1517. Desde allí se trasladó a San Vicente de la Barquera, comiendo y durmiendo en Treceño. Pasó, después, por Cabezón, Cabuérniga, Los Tojos y Soto, llegando el 15 de octubre a Reinosa. Prosiguió el 22 por Nestares y Aguilar de Campoo, donde descansó hasta el 27. Continuó, seguidamente, por Herrera de Pisuerga, Abia de las Torres, Revenga de Campos y Becerril de Campos para alcanzar Valladolid. En cambio, la comitiva real con los equipajes enfiló el valle del Pas y, al llegar a Toranzo, recibieron la contraorden de variar la ruta. A través de Villasevil y Prases pasaron del valle del Pas al valle del Besaya y desde allí, bajando por las orillas del arroyo Casares, pasaron por Arenas de Iguña y Molledo 2259 .

- En otro viaje el rey Carlos desembarcó en Santander el 16 de julio de 1522. Abandonó la costa el 26 de ese mismo mes, comiendo en Parbayón y cenando y pernoctando en Villasevil. Al día siguiente, se desvío de ese camino hacia el de Reinosa, cenando y pernoctando en Molledo. El 28 llegó a Reinosa, el 29 a Brañosera y el 30 a Aguilar de Campoo, donde descansó. El 1 de agosto se desplazó hasta Herrera de Pisuerga y el 2 hasta Melgar de Fernamental. Desde allí prosiguió el día 4 hacia Palencia y Valladolid, durmiendo en Amusco 2260 .

- En el que sería su viaje de retiro, Carlos V llegó a Laredo el 28 de septiembre de 1556, y después de comer partió el martes 6 de octubre para ir a dormir a Ampuero. El 7 pernoctó en Lanestosa, el 8 en Agüera y el 9 alcanzó Medina de Pomar, donde permaneció enfermo el 10 de octubre. El 11 salió de Medina y durmió en Pesadas, el 12 pernoctó en Hontomín y el 13 llegó a Burgos, donde descansó hasta el 16 de octubre ${ }^{2261}$.

- Felipe II salió de Flesinga el 24 de agosto de 1559 y llegó a Laredo el 8 de septiembre. Al día siguiente, partió hacia Colindres. El 11 durmió en Medina de Pomar, el 12 en el monasterio de Oña y el 13 en Burgos para proseguir hacia Valladolid ${ }^{2262}$.

- La Reina Ana de Austria llegó a Santander, procedente de Flandes, el 3 de octubre de 1570. Salió el 16 y pernoctó en el valle de Camargo. El 17 durmió en Villasevil, el 18 en Luena y el 19 en Cilleruelo de Bezana. El 20 descansó y el 21 pernoctó en Pesadas. El 22 lo hizo en Hontomín, el 23 en el compás del monasterio de Las Huelgas y el 24 entró solemnemente en Burgos donde permaneció hasta el $28^{2263}$.

2258 GARCÍA MERCADAL, J.: 1952: t. I. 445. Antonio de Lalaing: Primer viaje de Felipe el "Hermoso" a España en 1501.

2259 RIBAS de PINA, M.: 1949: 127-128; CADENAS y VICENT, V. de: 1999: 164

2260 FORONDA y AGUILERA, M: 1914: 205-206; CADENAS y VICENT, V. de: 1999: 179.

2261 SANDOVAL, F. P. de: 1681: 607

2262 GARCÍA MERCADAL, J.: 1952: t. I: 1096-1097. Viaje descrito por Juan de Vandenesse.

2263 GARCÍA MERCADAL, J.: 1952-1962: 1.173. 
Cuando se esperaba la llegada del Rey, o alguien perteneciente a su Casa, por el puerto de Santander o de Laredo y a pesar de los costosos preparativos, reparos de caminos y desplazamientos de grandes personajes para hacer la oportuna recepción protocolaria y acompañamiento, rara vez se acertaba por lo que tras llegar a un puerto no previsto, se debían improvisar en el nuevo camino todas las medidas y atenciones de acuerdo con la nueva realidad. Así fue en las siguientes ocasiones:

- En 1497 se esperaba en Laredo la llegada de la princesa Margarita desde Flandes, pero desembarcó en Santander el 8 de marzo de 1497.

- Los príncipes Felipe y Juana debían desembarcar en Laredo, para lo que se dieron instrucciones a la ciudad de Burgos para realizar los preparativos en octubre de 1501, pero vinieron por Fuenterrabía y Vitoria y llegaron a Burgos en febrero de 1502.

- En su primer viaje a Castilla se esperaba a Carlos I en Santander, pero llegó frente a Tazones y desembarcó en Villaviciosa en septiembre de 1517.

- El rey Carlos había enviado una carta en junio de 1522 desde Londres, por la que comunicaba que venía de camino con su armada a la villa de Laredo, pero llegó a Santander en julio de 1522 .

- La Reina Ana de Austria debía desembarcar en Laredo procedente de Flandes, pero lo hizo en Santander en octubre de 1570.

En sus desplazamientos la comitiva real incluía un gran número de personal auxiliar, personas de la corte, oficiales, clérigos, transportistas, auxiliares, guardia real, etc. así como el parque móvil necesario para desplazar todo el material y los mantenimientos que necesitaba tal comitiva. Para estos viajes eran necesarios hombres, carretas y bestias de guía, por lo que los Reyes mandan en 1480 que los mayordomos destaquen lo que fuere necesario y se informen sobre el camino y costumbre de la tierra y el valor de cada cosa, y con ello hagan las cartas de nómina de lo que fuere preciso, y que los alguaciles tomen las personas, bestias y carretas que por la dicha nómina fueren señaladas para cada uno, entregándolas a quien las ha de llevar y hagan pagar lo que mandare la tasa según el camino utilizado, contando 8 leguas por día y por la vuelta 2/3 de lo que montare la ida, y hasta que paguen, no entreguen los alguaciles las bestias ni den los nombres para guía. Se manda a todos que sin la carta real, no tomen hombres, bestias, ni carretas de guía y el que hiciere lo contrario sea desterrado de la corte por 5 años y pierda los maravedís que tuviere, y si no los tuviere, pierda la mitad de sus bienes. Se manda a los alguaciles, que sin la carta real, no tomen las dichas guías 2264 .

Queriendo remediar el desorden existente cuando la corte se trasladaba al dar las guías de acémilas y carretas, así como las cédulas y cartas para el aposento de las personas de la corte y su acompañamiento, y procurando evitar gastos innecesarios a los súbditos, se manda en mayo de 1543 al presidente de la Audiencia y Consejo, que tan solo den carretas, bestias de guía, y provisiones de aposento para:

2264 NOVÍSIMA RECOPILACIÓN DE LAS LEYES DE ESPAÑA/ París, 1846. Tomo segundo/ Libro VI, Titulo XIX, Ley III/ Toledo, 1480. 
- El repuesto y recámara del Rey y los de su Casa.

- El Príncipe su hijo y la Princesa su mujer y los de sus Casas.

- Las Infantas sus hijas y su Casa.

- Los del Consejo Real y sus oficiales.

- Los del Consejo de Estado.

- Los Contadores mayores.

- Los del Consejo de la Guerra.

- Los Secretarios de la Corona de Castilla.

- Los Contadores mayores de Cuentas.

- Los del Consejo de la General Inquisición.

- Los del Consejo de Indias.

- Los del Consejo de las Órdenes.

- Los oficiales de los Consejos y Contadurías que residen en sus oficios, y personas necesarias en ellos 2265 .

De esta manera, el escribano del Rey y alcalde en su casa y corte para la comisión que tenía de obtener por repartimiento 150 carros para la venida del rey Felipe desde Flandes $^{2266}$, da fe que tiene mandado que todos los carros de bueyes que repartió el alguacil desde septiembre de 1559, así los 20 carros que estaban registrados en Castilla Vieja como en otros lugares, no vayan a Laredo sin su voluntad y les dio por libres del dicho repartimiento y si ellos quisieren ir, que vayan pero no forzados ${ }^{2267}$.

Un ejemplo de una comitiva excepcional es el de la Reina, recién casada con Felipe II y que llegaba a Castilla por primera vez. Se trata de una relación realizada en agosto de 1570, 32 días antes de su partida en Flesinga, de las personas, ropa, vituallas, criados y caballos que se debían embarcar en Zelanda con la reina Ana de Austria para España, haciendo un total de 595 personas, con 230 caballos, 612 cofres, cajas, maletones, almofrejes de camas y valijas y 17 carros con una litera ${ }^{2268}$.

Pretendiendo evitar a la ciudad de Burgos gastos inútiles, Felipe II envía una carta

2265 NOVÍSIMA RECOPILACIÓN DE LAS LEYES DE ESPAÑA/ París, 1846. Tomo segundo/ Libro VI, Titulo XIX, Ley V/ Barcelona, 1 mayo 1543.

2266 Felipe II salió el 20 de agosto de 1559 de Zelandia y llegó a Laredo el 29 de agosto según unos autores, y según otros salió el 24 de Flesinga para desembarcar en Laredo.

2267 A. C. V./ no 1.873, doc. 1, hoja 5/ 14 septiembre 1559.

2268 - Ropa que se ha hecho para servicio de la Reina y su embarcación para España:

En un cofre, va una cama de damasco carmesí con las apañaduras de terciopelo carmesí, cobertor y rodapié, y sobremesa con franjas y alamares de plata y seda negra, una colcha de tafetán encarnada carmesí, un travesero y dos almohadas de tafetán carmesí y un cobertor de saya entrapada y otro de paño blanco.

En otro cofre herrado cubierto de baqueta, van 12 cortinas grandes de damasco carmesí y blanco con randas de plata y seda negra para aderezar las dos saletas y cámara de la nave en que irá la Reina.

En otro cofre, va otra cama y una frazada blanca y otra ropa, un cobertor de paño blanco, dos almohadas grandes de tafetán carmesí guarecidas de pasamanos de seda carmesí, para la cama de día de la Reina y una colcha de tafetán encarnado.

En otro cofre herrado, van 30 sábanas para la cama y 30 almohadas, 15 traveseros y 18 cortinas para dicha cama. Dos cofres forrados en raso carmesí con franjas de plata por dentro, para la ropa de la cama, más dos piezas enteras de holanda y seis de holandilla de Cambray.

Un maletón de baqueta en que van cuatro colchones de holanda para la cama, en sus fundas de lienzo. 
Otro maletón de baqueta con cuatro colchones de damasco carmesí para la cama de día, metidos en sus fundas de lienzo.

Una caja blanca con la madera de la cama.

Un maletón de baqueta con dos sillas de terciopelo carmesí con sus franjas de oro y clavazón dorada y otro maletón de sayal con dos bufetes de nogal.

Otro maletón de sayal con seis sillas rasas de terciopelo carmesí.

Una caja pintada con 12 frascos de agua de olores.

Una caja grande herrada con seis almohadas de terciopelo carmesí con franjas de oro.

Dos cajas blancas con otras 8 almohadas similares, de terciopelo carmesí.

Una caja larga con tres doseles de telas de oro frisadas.

Un almofrej de sayal grande con tres sillas de tela de oro conforme a los tres doseles, y cada una de ellas va metida en una funda de paño colorado.

- Para los príncipes:

Dos camas de damasco carmesí con sus franjas y alamares de oro.

Dos maletones de baqueta con seis colchones de holanda metidos en sus fundas.

Dos traveseros de tafetán carmesí.

Cuatro almohadillas de tafetán carmesí y cuatro frazadas dos blancas y dos rojas.

24 sábanas, 12 traveseros y 24 almohadas de holanda

La madera de estas camas en dos cajas blancas.

- Para las damas:

25 almofrejes de sayal y cada uno de ellos con dos colchones de raso.

Dos frazadas la una blanca y otra roja, una colcha de tafetán carmesí, dos fundas de almohadas y 100 sábanas y 100 almohadas de holanda.

- Ropa para la mesa de la Reina:

20 telas de manteles a la medida de la mesa, hecha para que la Reina coma en la mar.

36 docenas de servilletas de 1,5 anas cada una.

Dos cajas con 24 cuchillos blancos.

Cuatro piezas de servilletas enteras que tienen 220 anas.

Seis piezas enteras de telas de manteles muy finas, de cuatro anas de ancho, de 315 anas de largo, las cuales van de respeto para cortar de ellas si fueren necesarias.

- Ropa de mesa para el mayordomo mayor, camarera mayor, damas y oficios:

120 telas de manteles largas para dos trozos de mesa finos de damasco.

100 docenas de servilletas de las mismas suertes de las telas de 1,5 anas de largo.

- Telas para las mesas de los oficiales y para poner las copas:

168 telas para una tabla de un trozo de tres anas de ancho.

41 telas de lienzo basto blanco para comer los ayudas de los oficiales.

300 paños de lienzo blanco de dos anas de largo para las cocinas y otros oficiales.

12 trozos de mesas de nogal con sus bancos y 24 bancos de nogal para asentar.

15 docenas de cuchillos con sus cajas.

Seis cajas de madera con 100 frascos de vidrio para llevar vino para la Reina.

Dos cajas de madera blanca en que van cuatro tapetes turquescos de diferentes colores, dos de a 9 anas de largo y

dos de a cinco.

Un horno de cobre para cocer pan.

Una bacía y dos salitreras para enfriar con salitre.

Tres cajas con tazas de vidrio y otros muchos vidrios para agua a la Reina y damas.

Una caja grande con cañones de vidrio para poner en los candeleros por el aire.

Dos fanales pequeños de cobre dorados para la cámara de la Reina y en la de los príncipes y tener lumbre de noche.

Una caja con 24 pispotes.

- Plata:

Dos enfriaderas para enfriar con salitre.

Un bacín de plata como de barbero para que la Reina se lave.

Otra pieza grande de plata para escupidero.

Una calderilla de plata con su cadena para sacar agua de las tinajas para la Reina.

Dos paletillas para bujías de plata.

Dos bacinillas de plata para el retrete.

Dos sillas para lo mismo con sus cortinillas de damasco carmesí y franjas de plata.

Unas cortinas de damasco carmesí, el cielo y goteras de terciopelo del mismo color, con franjas de oro para en que la Reina oiga misa.

Un sitial de terciopelo carmesí de cinco piernas para la capilla con franjas de oro.

Un tafetán grande para cubrir este estrado carmesí con pasamanos de oro.

Una alfombra grande sin las cuatro ya dichas para este estrado.

Dos tapetes azules y amarillos y encarnado para alrededor de la cama de la Reina.

Una sobremesa de un bufete de tela de oro encarnada. 
Otra sobremesa de bufete de terciopelo carmesí con franjas de plata.

- Vituallas que se han de embarcar:

150 quintales de bizcocho muy blanco y 150 quintales de bizcocho ordinario.

100 amas de vino del Rin añejo muy bueno para la boca de la Reina.

12 botas de vino clarete y 100 botas de vino blanco de Francia que tienen 300 amas.

Seis barriles de malvasía y seis barriles de vino de España muy bueno.

140 carneros, 12 bueyes gordos y 25 terneras vivas.

300 perniles de Maguncia, 150 lenguas de buey ahumadas y 150 salchichones de Bolonia.

1.758 libras de carne de buey salada gorda y 1.774 libras de carne salada ordinaria.

156 quesos de Holanda y tres quesos parmesanos.

Tres barriles grandes de benazon salada.

- Aves y caza:

400 capones gordos, 300 pollas gordas, 800 pollos, 800 palominos, 60 pavos y gallinas de Indias, 200 tórtolas y 200 codornices.

600 libras de lardo.

400 libras de manteca de puerco.

6 vacas vivas para leche.

50 gallinas ponederas para huevos frescos y 8.000 huevos.

- Barriles:

12 barriles de aceite en que hay tres amares, 9 de manteca de ganado, 14 de vinagre de vino a media ama cada uno, cuatro de vinagre de sauco y tres barriles de vinagre rosado.

- Conservas y confituras:

12 libras de ciruelas de Génova, 12 libras de orejones de Génova, 12 cajas de mermelada, 12 cajas de carne de membrillo y 18 libras de membrillos en conserva.

420 libras de azúcar y 12 libras de azúcar en conserva.

24 libras de costra de cidra, 24 libras de tallos de lechugas, 18 libras de naranjas enteras y 24 libras de calabazate.

60 libras de bizcocho de azúcar más 131 libras de bizcocho de azúcar, tres cajas.

15 libras de canelones.

g libras de confites de canela menuda, 15 de confites de piñones, 24 de confites de anís, 30 de confites de almendras y 24 libras de confites de avellanas.

100 mostachones.

60 libras de fruta de Génova de diversas maneras y 210 de pasas del sol en tres barriles.

Dos barriles de miel.

600 libras de arroz en cinco barriles.

38 libras de almendras en cuatro barriles.

- Especierías:

30 libras de pimienta, 30 de jengibre, 20 de canela larga, 20 de clavo, 8 de nuez moscada, dos de azafrán, dos de flor de nuez moscada, 12 de cominos, 12 de alcaravea y 29 libras de mostaza

Cuatro resmas de papel basto para cocina.

40 libras de ciruelas pasas.

20 barriles de aceitunas.

- Cera:

Seis cajas de cera en que van 100 hachas blancas, 1.000 velas blancas, 150 hachas amarillas, 1.000 velas amarillas y seis libras de bujías.

Cuatro quintales de salitre.

- 100 raseras de harina blanca para la boca de la Reina.

- Se han embarcado empanadas de benazones, capones, faisanes, pavos y de otras suertes.

- Pescados:

Seis botas de salmón salado de 300 libras cada una.

12 barriles de arenques salados, 18 barriles de bacalao de 200 libras cada uno y 12 salmones ahumados

1.075 libras destocafix seco. Sin esto se embarcarán escabeches y empanadas de pescados frescos.

- Personas que se embarcarán acompañando a la Reina:

El confesor fray Francisco de Lillo, 10 personas.

El limosnero Juanes Persin, dos personas.

Los capellanes Mateo Flecha y Francisco Attde, cuatro personas.

Del oratorio, Noe de Mani, cuatro personas.

Los mozos de capilla Sebastián Folque y Lambertus de Sayne, dos personas.

El mayordomo mayor Francisco Lasso de Castilla y Luis Benegas, 126 personas.

La camarera mayor Leonor de Guzman, seis personas.

El guardamayor de damas Sofía Mogueren, seis personas.

Ocho damas y sus criadas, 16 personas.

Seis mozas de cámara con las demás mujeres de retrete, 14 personas.

Lavanderas Jerónima Salinas de la Cámara y Catalina Ortiz de la Mesa con seis personas. 
a la ciudad en agosto de 1592 encargando que no haga ningún preparativo para su recibimiento, "porque hasta agora no estoy resuelto de passar por essa ciudad por depender de otras cosas que conciernen al seruicio de nuestro señor y tambien mio", aunque avisaría con tiempo lo que deter-

El Doctor Andrea Camuco, tres personas.

El boticario José de Arigon, tres personas.

Los secretarios Hernando de Mazuelo en alemán, cuatro personas.

El contador Juan de Escobedo que hace el oficio de guardajoyas, cuatro personas.

El escribano de cámara Juan Gómez de Santibáñez que sirve de camarero furrier y repostero de camas, 8 personas. Los reposteros de camas Juan Ortiz de Zárate, Bernardino de Miriel, Martín de Arteaga y Guillame Cubel, 8 personas.

Hombres de cámara Francisco Galisteo, Felipe Banonze, Ulrique Aquel y Pedro del Puerto, 8 personas

Los porteros de damas Alonso de Medina, seis personas.

El maestresala de damas Francisco Sánchez, cuatro personas.

Los maestresalas Bince Guerra conde Arcos y Alberto Estozinguez, 14 personas.

Los caballeros Hanz Yorgue Fonprauzinger y el embajador de la duquesa de Lorena, 11 personas

El repostero mayor de plata Rodrigo Barragán, 14 personas.

El guardamanteles Alonso García, seis personas.

El guardaplata Sebastián Ruiz, tres personas.

El mozo de plata Martin Trab, una persona.

El copero Diego de Acebes, tres personas.

El sumiller del agua Juan Folpeque, dos personas.

El tesorero y contralor Pedro López de Orduña, 16 personas.

El cuartiermaestre Benedicto Jarretón, cinco personas.

El tapicero mayor Juan Sáez de Salinas, cuatro personas.

Los reposteros de estrado Francisco Pacheco, Francisco Esprinol, Andrés Quelenberge, Jorge Constat y Juan Sánchez, cinco personas.

Los porteros de sala Francisco Ramírez, Jobs Corquet y Luis Langfelt, 12 personas.

Cocina Juan Nicolás, Juan Lorencio y otro cocinero, seis personas.

El que tiene cargo de los asados Nicolás Hastelez, una persona.

Portadores de cocina, dos personas.

Mozos de cocina, cuatro personas.

El pastelero Martín Rueber, seis personas.

El portero de cocina Antonio Salgado, dos personas.

El escribano de raciones Diego de Madaria, dos personas.

Cantina Nicolás Monfordono sumiller, Matías de Cunde escribano de cantina, una ayuda de cantina, cinco personas.

El carnicero Cristóbal Fuquer, tres personas.

El comprador Tomás Plenage, dos personas.

El guardamanjier Andrés Heben Estrait, dos personas.

Su ayuda Gaspar Sebolt, una persona.

Los portadores de la plaza, tres personas.

Oficiales de manos cerero Santiago de Andino, tres personas.

El cordonero Andrés de Benavente, dos personas.

El zapatero Marcos de Madrigal, seis personas.

El platero Juan de Mazuelo, dos personas.

El caballerizo mayor conde Gaspar de Lodron, 42 personas.

Pajes, 8 personas.

El ayo de pajes Joan Plumier, dos personas.

Los criados de pajes Fabian Enano, seis personas.

El furrier de la caballería Juan Pulguer, tres personas y su ayuda Daniel Quejart, dos personas

El guardasillas Segismundo Talhamer, dos personas y su ayuda Juan Curt, dos personas.

El herrador Bartolomé Senin y su ayuda, dos personas.

Los trompetas Carlos de Razin, Gaspar Bendinel, Jacobo Sempronio y Sempronio, 8 personas

Los lacayos son 8 y algunos casados, 14 personas.

Los mozos de caballos, 11 personas.

El tenedor de literas Bartolomé de Otajio, una persona y su ayuda Mateo Estarc, una persona.

Los carreteros, 7 personas y los cocheros, dos personas.

Ayuda de carreteros y cocheros, 8 personas.

El capitán de la guardia Juan Alfonso Gastaldos, 18 personas.

52 alabarderos, con el tambor y pífano algunos casados y con hijos, 66 personas.

- Caballos de la Reina, de silla 35, de carro 32 y mulos de litera tres.

- Carros de la Reina 8 y una litera. 
minase. Al final estará en Burgos entre el 6 y el 30 de septiembre de $1592^{2269}$. El Consejo, justicia y regimiento de la ciudad recibirá del Rey, en octubre, licencia para tomar a censo hasta 10.000 ds., con destino a la obra realizada en el monasterio de San Agustín donde fue aposentado, aderezar caminos y calzadas, y pagar las fiestas y otros gastos realizados en su recibimiento. Sabiendo que la ciudad no tiene propios para afrontar dicho gasto, se concede licencia para que pueda tomar a censo hasta 6.00o ds., los cuales con sus réditos manda que se paguen de lo que procediere de la sisa del vino que se vende por menudo, que con licencias reales está impuesta en la ciudad para otros efectos y que con lo que se fuere cobrando, se vaya quitando lo principal del censo y sus réditos sin invertirlos en otra cosa, y sacados dichos ducados cesará la sisa2270.

\section{e.- El alojamiento}

A la vera de los caminos más transitados irán surgiendo establecimientos para la atención de los viajeros y de los profesionales que transitaban por dichos caminos. Eran las ventas, los mesones, las posadas, las alberguerías, etc. En las Partidas se contempla la obligación del Rey, para que se acondicione el alojamiento pertinente para los transeúntes $^{2271}$ y en la séptima se trata sobre los anuncios de las posadas urbanas ${ }^{2272}$.

En 1480 los Reyes Católicos mandan que los mesoneros que quisieren vender cebada por granado o por celemín, no puedan ganar más del quinto de más de lo que valiere por fanega en la plaza o mercado donde estuviere el mesón. Los alcaldes, regidores u oficiales deberán dar medida á cada mesonero de la paja que hubiere de vender, y la tasarán de 6 en 6 meses. Por esa medida y precio venderá la paja por menudo el mesonero u otra cualquier persona. Como los mesoneros cobran demasiado por los aposentos, mandan que los alcaldes de casa y corte cuando llegaren a la localidad donde fuesen los Reyes, tasen lo que han de percibir los mesoneros por cada alojado con bestia o sin ella, o con mozo o sin él mientras allí estuviere la corte, y que en las localidades donde no estuviere la corte, sus justicias y regidores tasen al comienzo de cada año lo que en ellas y en sus términos han de

2269 A. M. B./ HI-485/Valladolid, 2 agosto 1592

2270 A. M. B./ HI-4191/ Santo Domingo de la Calzada, 6 octubre 1592 y Burgos, 27 junio 1593.

2271 LAS SIETE PARTIDAS/ Quinta Partida, Título VIII, Ley XXVII. Así se especifica que los Reyes deben "mandar fazer hospitales en las Villas, do se acojan los omes, que non ayan a yacer en las calles, por mengua de possadas. E deuen fazer Alberguerias en los logares yermos que entendieren que sera menester, porque ayan las gentes do se albergar seguramente con sus cosas, assi que non gelas puedan los malfechores furtar, ni toller". "Como los ostaleros, e los aluergadores, deuen recebir a los pelegrinos, e guardar a ellos, e a sus cosas" "... mandamos a todos los aluergueros, e los marineros de nuestro Señorio, que los resciban en sus casas, e en sus nauios, e les fagan todo el bien que pudieren; e les guarden las sus personas, e sus cosas, de daños, e de todo mal, e que les vendan todas las cosas que ouieren menester...".

2272 LAS SIETE PARTIDAS/ Séptima Partida, Título XV, ley XXVI. Los anuncios de los alojamientos urbanos que "cvelgan a las vegadas los hostaleros, e otros omes ante las puertas de sus casas algunas señales porque sean posadas mas conocidas por ello: assi como semejança de cauallo, o de leon, o de can, o de otra cosa semejante. E porque aquellas señales que ponen para esto, estan colgadas sobre las calles por do andan los omes, mandamos que aquellos que las y ponen, que las cuelguen de cadenas de fierro, o de otra cosa qualquier, de manera que non puedan caer, nin fazer daño. E si por auentura alguno tuuiesse la señal colgada, de guisa que sospechassen que podria caer, e lo acusassen dello, o lo fallassen en verdad que podria caer, e fazer daño, maguer non cayesse, nin lo hiciesse: mandamos que por la pereza que ouo en non la tener atada como deuia que peche diez marauedis de oro... E si aquella cosa que y estuuiesse colgada cayesse, e fiziesse daño a otro: tenudo es aquel cuya es la casa donde esta colgada de pechar el daño doblado. E si por auentura el daño fuesse de muerte de ome: mandamos que peche cinquenta marauedis de oro...". 
cobrar en los mesones por las posadas y lo hagan pregonar 2273. En 1496 mandan que "en cada lugar donde llegaren, o por donde pasaren los viandantes naturales y extrangeros de estos nuestros Reynos, les den... por sus dineros de comer y de beber para ellos y para sus bestias, pan y vino y cebada y las otras cosas que menester hobieren". Y si no lo quisieren vender o pidieren precios desmesurados, que los viandantes con dos homes buenos o con uno del dicho lugar puedan tomar las cosas necesarias pagando un precio razonable. Mandan a los alcaldes ordinarios de la Hermandad de esos lugares, que vigilen que se den las provisiones y mantenimientos que necesiten los caminantes ${ }^{2274}$.

Las ventas eran establecimientos que se situaban junto a las vías fuera de los cascos urbanos, muy frecuentemente en cruces de caminos, y que prestaban servicios imprescindibles a los caminantes, viajeros y principalmente a los arrieros. Podían ser propiedad del ventero o de villas, señores o monasterios que las arrendaban. En muchos casos, eran una importante fuente de ingresos además de ser punto de venta de los excedentes del propietario y, a veces, eran proveedores de alimentos perecederos o difíciles de conseguir como el pescado. Sus dueños debían pagar un impuesto por los mantenimientos que vendían tanto de personas como de bestias, por lo que muchos preferían ofrecer tan solo el alojamiento. En las ventas y mesones existía una picaresca al parecer bastante extendida, que consistía en cobrar a los viajeros precios abusivos por los productos más necesarios como era el pan, el vino, la cebada y la paja, En las ordenanzas de Madrigal dadas en abril de 1476 se dictan normas al respecto 2275 .

Existen dificultades a veces para hacer un seguimiento de la historia de algunas ventas porque suelen cambiar de nombre, recibiendo en muchos casos el del ventero del momento, o bien se abandonan y reocupan en diferentes ocasiones.

Ya en 1489 unos embajadores ingleses que van de Burgos a la corte de los Reyes Católicos en Valladolid, tuvieron una mala experiencia cuando en el pueblo de Revilla Vallegera solicitan alojamiento2276.

Los reyes Fernando e Isabel, que habían dado en Valladolid en 1492 una Pragmática sanción, sobre que algunos caballeros y personas ponen mesones en sus tierras y mandan que nadie pueda acoger en su casa particular a forastero, caminante ni otro huésped, ni les puedan vender pan, vino, cebada ni otros mantenimientos, por lo que los caminantes, mercaderes, recueros $u$ otras personas que necesitan posar y comprar lo necesario, hacen grandes gastos por lo mucho que les llevan de posada y los mantenimientos que les venden en las tiendas: especias, aceite, pescado o calzado, impidiendo que nadie más les pueda vender cosa alguna, salvo el que tiene arrendado el estanco. Como esto es contra derecho

\footnotetext{
2273 NOVİ́IMA RECOPILACIÓN DE LAS LEYES DE ESPAÑA/ París, 1846. Tomo tercero/ Libro VII, Titulo XXXVI, Ley IVI Toledo, 1480 .

2274 NOVÍSIMA RECOPILACIÓN DE LAS LEYES DE ESPAÑA/ París, 1846. Tomo tercero/ Libro VII, Titulo XXXVI, Ley V/ 1496.

2275 SERRANO-PIEDECASAS FERNÁNDEZ, L.: 1981: 192-193; SÁNCHEZ VILLAR, Mํ. D.: 1974.

2276 BELLO LEÓN, J. M. y HERNÁNDEZ PÉREZ, B.: 2003: 187. “En este pueblo fueron muy mal alojados, pues los hombres allí eran malos. Y el primer saludo que recibieron de la posadera con la que se hospedaron, fue que ella les pregunto que los había hecho tan valientes como para osar entrar en su casa sin su consentimiento. Y les grito que se fueran de su casa por todos los diablos, villanos indecentes. Este fue el primer saludo de la hostelera del pueblo de Revilla Vallegera. Por esa noche los embajadores tuvieron paciencia con estas palabras porque estaban forzados a hacerlo, al no tener otra eleccion".
} 
mandan a todos los notables, que quiten todos los estancos y vedamientos y deshagan los arrendamientos que tienen hechos, y que en adelante no los pongan y dejen libremente a los vecinos de cada villa que acojan en sus casas a los caminantes que quisieren y les dejen comprar los mantenimientos que necesiten, y que cualquiera de sus vasallos se los puedan vender libremente 2277 .

Ante el teniente de corregidor, regidores y mareantes de la villa, Juan Pérez de Mena y Sancho de Pez se obligaron con el concejo de Castro-Urdiales en 1497, a dar posada en sus casas en que vivieron toda su vida, "a todos los huespedes e mulateros e a sus bestias que benieran a posar e de los acoger en ellas", con las condiciones de que en los 2 años en que Juan Pérez tiene arrendada la renta de los cestos de pescado, el concejo les dará a cada uno de ellos 750 mrs. al año, y pasados los 2 años el arrendador que tuviere la renta de los cestos, dará a los dichos Juan Pérez y Sancho de Pez los cestos de besugos con sus juncias para sus huéspedes a 2 mrs. el cesto. Juan Pérez y Sancho de Pez no podrán tomar cestos ni juncias salvo del que tuviere arrendada su renta y no llevarán de sus huéspedes más de 5 mrs. por cesto de besugos, congrio, pescadas y otros pescados mayores a $6 \mathrm{mrs}$. de cada cesto atado. De los cestos mayores que ambos lleven $35 \mathrm{mrs}$. por cada carga, dándoselos a sus huéspedes atados y puestos para cargar según uso y costumbre, y estos derechos no podrán cobrarlos a sus huéspedes por darles posada 2278 .

Fernández de Oviedo dice hacia 1540 que "los que tractan por mesones son amigos de venteros. Las ventas e los mesones todo es tracto de acojer a los viandantes, y esos son de diuersas calidades; e como los vnos son los que son mouidos honestamente a caminar, $e$ yr de vnas partes a otras a sus negocios e cosas que les conuiene, asi otros ay que son mandados y embiados por sus señores con sus letras e mensajerías, e aquestos tanbien son honestos e nesesarios caminantes"2279.

En las Juntas de Vizcaya de abril de 1567 los síndicos dijeron que no había "en las tabernas y bentas deste Señorio pan, carne, pescado, azeyte, candela y cebada, camas y otros mantenimientos e bastimentos neçesarios". El corregidor mandó que los fieles de las anteiglesias puedan poner los precios justos y honestos a los mantenimientos, so pena que se procederá contra los fieles y personas rebeldes con todo rigor ${ }^{2280}$. En las Juntas de febrero de 1569 se acordó que conforme a lo proveído en otros regimientos, en las ventas y tabernas de la Tierra Llana "tengan buen recado para alojar a los bienandantes y tengan buen recado de pan y bino, carne, hazeyte, candelas, pesebre, tamo y çebada", y para ello se mande que los fieles lo hagan guardar y cumplir, no perdonando las primeras penas en que incurren, y a los que no quisieren tener todos esos bastimentos a precios justos, que los dichos fieles los pongan, reparen los pesebres, y no permitan que tengan vino para vender ${ }^{2281}$.

2277 A. G. S./ Registro General del Sello, VI-1502, fol. 254/Toledo, 3 junio 1502.

2278 A. M. Castro Urdiales/ Leg. 21, doc. 1/ Castro Urdiales, 7 febrero 1497; BLANCO, E.; ÁLVAREZ, E. y GARCÍA DE CORTÁZAR, J. A: 1996: 127: doC. 15

2279 FERNÁNDEZ de OVIEDO y VALDÉS, G.: 1880: 221.

2280 A. J. R. B./ Actas de la Tierra Llana. t. I/ Bilbao, 15 abril 1567.

2281 A. J. R. B./ Actas de la Tierra Llana. t. I/ Bilbao, 26 febrero 1569. 


\section{Ventas y mesones en los caminos de Santander}

La relación de las ventas y mesones que se han establecido junto a los caminos en todas las épocas puede ser muy extensa, y además en muchos casos tendríamos dificultades para documentarlas. Presentaremos no obstante dicha relación basada en la documentación que menciona algunas de ellas, aunque también hemos incluido aquellas que tan solo conocemos el dato de su existencia hasta nuestros días, siendo conscientes además, de que a pesar del intento, muchas quedarán ausentes.

En los caminos a Santander, encontramos al menos las siguientes ventas:

- Ventorro. En el camino de Quintanadueñas a dos km de Burgos, se detalla en el plano 1:50.00o de la Dirección general del Instituto Geográfico y Catastral.

- Ventorro Charro. Se hallaba esta venta en el camino de Quintanadueñas a 2,5 km de Burgos según testimonio toponímico y cartográfico.

- Venta del Hambre. Se sitúa en el plano 1:50.00o de la Dirección general del Instituto Geográfico y Catastral en el camino de Quintanadueñas a $3 \mathrm{~km}$ de Arroyal.

- Venta. Se reseña en el plano 1:50.ooo de la Dirección general del Instituto Geográfico y Catastral junto a Santibáñez Zarzaguda.

- Venta de Ruyales o de Arroyales. En el Itinerario de Matías Escribano de 1758 se cita esta venta como "Venta de Arroyales" entre Ros y Úrbel del Castillo, a una legua de ambas. También se incluye en el Itinerario de Santiago López 1809 y de Brusola de 1810, que reproducen básicamente el itinerario de Escribano. En el mapa de Francisco Coello de 1868 se menciona como Venta de Valtrasero y se encontraba frente a la localidad de Ruyales del Páramo.

- Venta del Tozo. Esta venta se sitúa en el mapa de Francisco Coello de 1868, enfrente de Trashaedo.

- Venta de Valladar ${ }^{2282}$. Se encontraba en el Camino por el Tozo. Hoy Valladar es un despoblado en el término de Basconcillos del Tozo, y a $800 \mathrm{~m}$ al Este-Nordeste en la entrada de la garganta atravesada por el camino de esta localidad a Barrio-Panizares, conocido como venta de Valladar. Se menciona en 1551 cuando se hace un itinerario para transportar un importante tren de artillería "Ay de Rrocamuda a Valladar dos leguas. De Valladar a Santa Cruz dos leguas"2283. En 1660 Pellegrino Zuyer dice que desde la Venta de Berzosilla "hasta otra que se llama Valladar hay otra legua y media de aspero camino"2284. Recogida como "Venta de Valladares" en el itinerario de Matías Escribano de $1758^{2285}$, entre Santa Cruz y Basconcillos en el camino nuevo de ruedas "Madrid para Santander". También se cita en el Itinerario de Santiago López 1809 y de Brusola de 1810 que reproducen básicamente el itinerario de Escribano.

- Venta de Berzosilla. Situada en el acortamiento del camino por el Tozo. En 1660 dice el canónigo suizo Pellegrino Zuyer que "se pasa junto a la aldea de Barcena, que es poca cosa. Y de aqui hasta la venta de Verzoncilla el camino es muy penoso y dificil de encontrar"2286. En el mapa provincial

\footnotetext{
2282 MARTÍNEZ DÍEZ, G.: 1987: 397.

2283 A. G. S./ Guerra y Marina. leg. 42, fol. 118/1551.

2284 CASADO SOTO, J. L.: 2000: 289-345

2285 ESCRIBANO, J. M.: 1758.

2286 CASADO SOTO, J. L.: 2000: 289-345.
} 
de Francisco Coello de 1868 se le da el nombre de Venta de la Herrería, que quizá es la que Escribano denomina de la Herreruela y sitúa entre Llanillo y Aguilar.

- Venta de la Herreruela. Recogida en el itinerario de Matías Escribano de 1758, a dos leguas entre Llanillo y Aguilar de Campoo.

- Venta Nueva. Se incluye en el itinerario de Escribano cerca de Matarrepudio, entre Aguilar de Campoo a dos leguas y la venta de Mataporquera a media.

- Venta de Mataporquera. Localizada en el itinerario de Matías Escribano de 1758, a media legua entre la venta Nueva y la venta de Pozazal.

- Venta de Pozazal. En 1660 Pellegrino Zuyer indica que "a una legua y media se pasa por la Venta de Pozaçal, dejando Cervatos a mano derecha"2287. Recogida en el itinerario de Matías Escribano a media legua entre la Venta de Mataporquera y Fombellida. Madoz indica en 1855 que pertenece a los canónigos de Cervatos, y se hallaba junto a una ermita dedicada a San Bartolomé. Añade que recibe el nombre de un gran pozo que hay en su inmediación 2288 .

- Venta del Río. Reseñada en el itinerario de Escribano de 1758, a media legua entre Lantueno y el ventorrillo de la Pesquera.

- Ventorrillo de la Pesquera. Situada en el itinerario de Escribano de 1758, se situaba junto a la localidad de Pesquera, a media legua entre la venta del Río y el ventorrillo de Aguayo.

- Ventorrillo de Aguayo. Se encontraba en el itinerario de Matías Escribano, a media legua entre el ventorrillo de Pesquera y Bárcena de Pie de Concha.

- Mesón de Ruiz García de Magujón. En 1535 los testigos de cierto interrogatorio dijeron que hacía más de 60 años que veían pasar a los trajineros, mulateros y mercaderes, por "casa de Rruys e del Margujon, vecino del balle de Buelna, que hera mesonero cosario en el dicho valle donde possaban los que yban e benian" de Santander cargados con fardeles y "merçeryas caxas dello, $e$ posaban alli en su casa del dicho Rruiz e descargaban alli" y comían ${ }^{2289}$.

- Ventas junto a Santander. Solo tenemos una referencia de estas ventas del año 1493, cuando los Reyes Católicos mandan al bachiller Gonzalo Sánchez de Castro que se informe acerca de una acusación de que se han levantado unas ventas fuera de Santander, donde se venden, cargan y descargan mercancías con perjuicio de la villa ${ }^{2290}$.

- Venta de Colmenares. Situada en el camino de Villadiego, se encontraba entre Villalbilla de Villadiego y Talamillo del Tozo.

- Venta Nueva. Localizada en lo alto del puerto del Escudo o de Corconte y citada por Madoz 2291.

2287 CASADO SOTO, J. L.: 2000: 289-345.

2288 MADOZ, P.: 1845-1850: 177. 16 tomos. Reeditado por Editorial Ámbito organizado por provincias. Valladolid, 1995. 2289 A. H. P. C. / J. T. A. leg. 37-2/ Los Corrales de Buelna, 14-15 mayo 1535.

2290 A. M. S./ Leg. A-1, no 37. fols. 7r-8r/ Zaragoza, 24 noviembre 1493; SOLÓRZANO TELECHEA, J. A.: "Colección Diplomática...". 268: doc. 177.

2291 MADOZ, P.: 1845-1850: 116: 16 tomos. Reeditado por Editorial Ámbito organizado por provincias. Valladolid, 1995. 
- Venta del Caballar. Ramón Lanza sitúa la venta del Caballar en Cayón entre Pomaluengo y Villanueva ${ }^{2292}$. En 1542 se encuentra citada en plural2293.

- Venta del Capador. Ubicada en el camino de Pomaluengo a Camargo 2294.

- Mesón de Quintanilla de Zamanzas. En Quintanilla-Colina existió un mesón en el "Camino Real que biene de Quintanilla" cuya existencia conocemos por un incidente acaecido en septiembre de 1721, cuando un grupo de tres individuos fueron detenidos por el regidor de la villa: "a cosa de las diez de la noche me abisaron abía en el mesón tres personas que parezían de mala vida"2295.

- Venta de Villalaín. Ubicada posiblemente a fines del siglo XVIII o principios del XIX en relación con el nuevo camino construido en esas fechas, junto a un cruce del camino de Burgos a Laredo con el de La Rioja a Santander, entre Incinillas y Villalaín.

- Venta de Villacomparada de Rueda. Localizada a $1 \mathrm{~km}$ largo al norte de Villarcayo en el camino de Laredo.

- La Ventuca. Situada en el camino de La Sía entre el Tabladillo y Angustina, según el plano 1:50.00o de la Dirección general del Instituto Geográfico y Catastral.

\section{Ventas y mesones en los caminos de Laredo}

Según Cadiñanos, algunas de las ventas de este camino dependieron del monasterio de Rioseco ${ }^{2296}$. En este camino se localizan las siguientes ventas:

- Venta de Vista Alegre. Se hallaba en el alto de la Cuesta del Crajo a dos km de la ciudad de Burgos. Encontramos su referencia en planos de mediados del siglo XIX.

- Ventorro de la Hogaza. Se encontraba cerca del cruce para Sotragero a 6,5 km de Burgos. La referencia procede del plano 1:50.00o de la Dirección general del Instituto Geográfico y Catastral.

- Ventas de Quintanilla. Reseñada junto a Quintanilla-Vivar, las ventas de Quintanilla vienen citadas tardíamente en el Itinerario de Matías Escribano de 1758 en el camino de ruedas desde Madrid "otros dos caminos para Bilbao"; se citan "Las Ventas de Quintanilla, y de Quintanaortuño" y también en el camino de "Laredo para Burgos" 2297 y en el Itinerario de Santiago López 1809 y de Brusola de 1810, que reproducen básicamente el itinerario de Escribano. Antes de las fechas mencionadas no hemos encontrado referencia alguna.

- Ventas de Sotopalacios. La referencia es muy tardía y puede tratarse de las de Quintanaortuño. En el camino de Burgos a Villarcayo del Itinerario de Miguel Bañuelos de 1771 se menciona "Soto Palacios, y Ventas" entre Quintanilla Vivar y Peñahorada2298. También en el camino de Burgos a Carriedo se cita de la misma manera entre Vivar y "Villaverde junto á Peñaorada".

\footnotetext{
2292 Ramón Lanza sitúa en Cayón la venta del Caballar. LANZA GARCíA, R.: 2010: 203.

2293 A. H. P. C./ J. T. A. leg. 37-8/ Santander, 29 mayo 1542.

2294 GONZÁLEZ de RIANCHO MAZO, J.: 1988: 26-27.

2295 A. C. V./ nº 433/ Villarcayo, 18, 19 y 20 septiembre y 9 octubre 1721.

2296 CADIÑANOS BARDECI, I.: 2002: 71.

2297 ESCRIBANO, J. M.: 1758.

2298 BAÑUELOS, M.: 1771.
} 


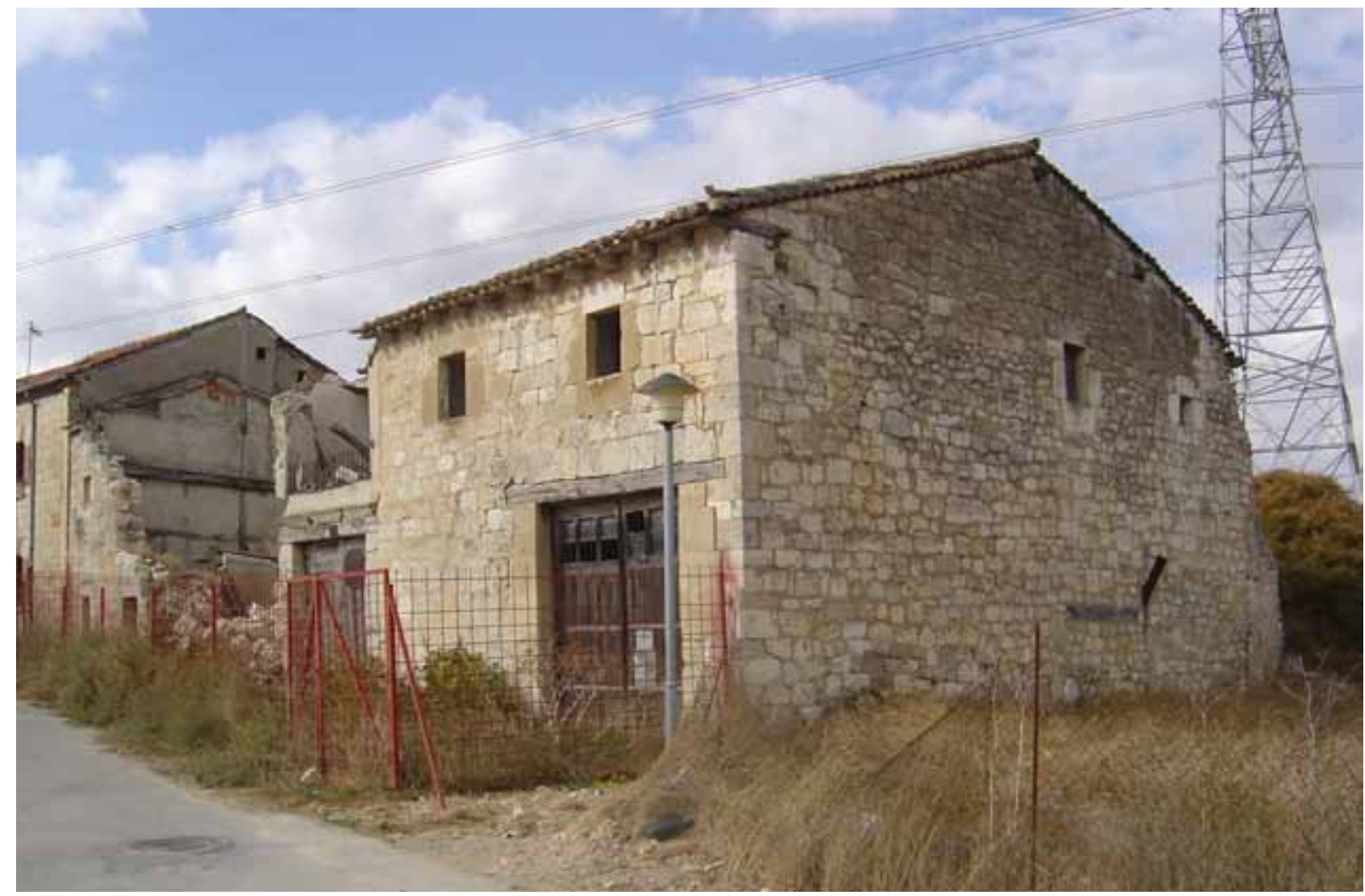

Ventas de Quintanaortuño.

- Ventas de Quintanaortuño. Aún hoy existen unas casas junto a la carretera de Burgos a Villarcayo que pertenecen a la localidad de Quintanaortuño, denominadas "las ventas de Quintanaortuño". Citadas ya el año $1499^{2299}$, encontramos referencias a lo largo del s. XVI y fechas posteriores. En el itinerario proyectado en 1551 para el transporte de un tren de piezas de artillería, se indica que se pasa por la venta de Quintanaortuño y Sotopala$\operatorname{cios}^{2300}$. En agosto de 1568 Juan López de Poza presentó ante el alcalde mayor de Sotopalacios una demanda contra Diego de Urbina y su mujer María de Montejo, vecinos de Burgos, porque ambos le "tomaron en rrenta... vna casa y benta que tenia en termino del lugar de Quintana Hurtuño e en el camino rreal a surco de otra venta del dicho lugar de Quintana Ortuña", con una heredad que estaba junto a ella por 2 años contados desde San Juan de junio de 1567 por 25 ds. al año. Como no habían pagado, Juan López pidió ejecución por los 25 ds. más 700 mrs. de alcabala y juro, dando el alcalde mayor mandamiento para que el juez de Quintanaortuño hiciese ejecución por la dicha cuantía. Ante la Chancillería, Urbina alegó que no había lugar para la ejecución, porque Juan López le debía dar la venta desembarazada para San Juan de 1567, y no lo hizo hasta fin de septiembre de ese año por estar en ella Pedro Cómez, de quien Juan López la había comprado, que no quería salir porque no estaba pagado y que Juan López no había cumplido porque cuando Urbina con su familia e hijos había ido a la venta, la había hallado ocupada y "auian estado en el canpo mas de tres meses perdiendo su hacienda e ganado" más el daño por lo que había dejado de ganar, por lo que Juan López le debía más

2299 A. H. N./ Nobleza. Frías, C. 235, D. 55/ Medina de Pomar, 15 enero 1499.

2300 A. G. S./ Guerra y Marina. leg 42, fol. 118/1551. 
de 100 ds., y no debía alquileres "porque la dicha casa e benta auia estado y estava mal rreparada $e$ ynabitable e auierta e para undirse, por lo qual no avia podido auitar en ella ni rrecoxer huespedes ni tener la prouision e bastimentos que convenian, ni estar guardada su haçienda, y los caminantes no querian posar ni caminar por la dicha uenta". La sentencia mandó la restitución a Urbina de todos los bienes que les hubieren tomado, y apelada por Juan López, la audiencia falla que la sentencia dada es buena y justa, y le condena a pagar a Urbina 8 ds. Recurrido por este, se pronunció sentencia definitiva en abril de 1570, confirmando la sentencia dada, pero en lugar de 8 ds. fueron 20, y las costas en que Juan López estaba condenado se tasaron en 5.500 mrs. ${ }^{2301}$.

En el Itinerario de Escribano, en camino de ruedas desde Madrid "otros dos caminos para Bilbao", se cita esta venta junto con las de Quintanilla. En uno de los caminos de Madrid a Santander, menciona también esta venta a dos leguas de Burgos, dentro del "Camino antiguo de Herradura", que por Robledillo de la Polera, Quintanajuar y Villalta llegará a Santander por Gallejones ${ }^{2302}$. También se incluyen en el Itinerario de Santiago López 1809 y de Brusola de 1810. En 1832, se indica que "Cerca de [Quintanaortuño], y en su mismo término hay dos posadas quellaman Las Ventas, en el camino que conduce desde Burgos a Medina de Pomar y Santander"2303.

- Venta de Quintanajuar. Lugar del primer emplazamiento del monasterio de Rioseco según Cadiñanos, Quintanajuar era un punto de enlace entre el valle del Ubierna y el páramo, así como entre el Homino y tierras de Sedano y Villadiego, junto a un transitado camino y en una estrecha hoz que comunica con el páramo. Era un lugar perteneciente al monasterio de Rioseco, por lo que sería un punto de acogida donde los monjes cistercienses asistirían a los viandantes en los días de invierno. Esto tuvo su reflejo en la permanencia, durante siglos, de una venta ${ }^{2304}$ situada sin duda en el antiguo camino que por Robredo Sobresierra llegaba a Villalta.

- Venta de la Perra. Es el nombre de un paraje que se encuentra en el cruce del camino entre Quintanajuar y Villalta y el que va a Villadiego, donde hoy no existen vestigios de su existencia. Tenemos noticia de la alberguería de Cernégula de fecha antigua, pero no sabemos si corresponde a dicha venta por estar esta a poco más de dos km de la villa y pertenecer a su término municipal. Conzalo Pedro y su mujer Elvira donan esta alberguería al abad Romero de Quintanajuar en 1182, acto que confirma Alfonso VIII ${ }^{2305}$. En la confirmación de Alonso VIII en 1189 del monasterio de Rioseco, Cendrera, Quintanajuar, etc. se menciona de nuevo la alberguería de Cernégula ${ }^{2306}$. En el mapa provincial de Francisco Coello de 1868 se sitúa claramente, con la indicación de que es arrieril.

- Ventas del Cuerno. Fueron el origen de la población que luego se denominará Villalta, situadas en el centro del desolado páramo de su nombre para dar apoyo a los caminantes y mulateros, en especial en tiempos de nieves. En 1200 el conde Gonzalo empeña sus

\footnotetext{
2301 A. Ch. V./ Registro de Ejecutorias, caja 1178.0021/Valladolid, 27 mayo 1570.

2302 ESCRIBANO, J. M.: 1758.

2303 Diccionario Geográfico Universal, tomo VII, Barcelona 1832. p. 892.

2304 CADIÑANOS BARDECI, I.: 2002: 19.

2305 CADIÑANOS BARDECI, I.: 2002: doc. 32: 134. “...et illam albergariam que est in Cernoga,..." $\mathrm{y}$ “... et albergariam de Cernoga, que est in Butrone,...".

2306 A. H. N./ Clero, carp. 352 (5)/ Carrión de los Condes, 18 mayo 1189; CADIÑANOS BARDECI, I.: 2002: doc. 55: 152.
} 

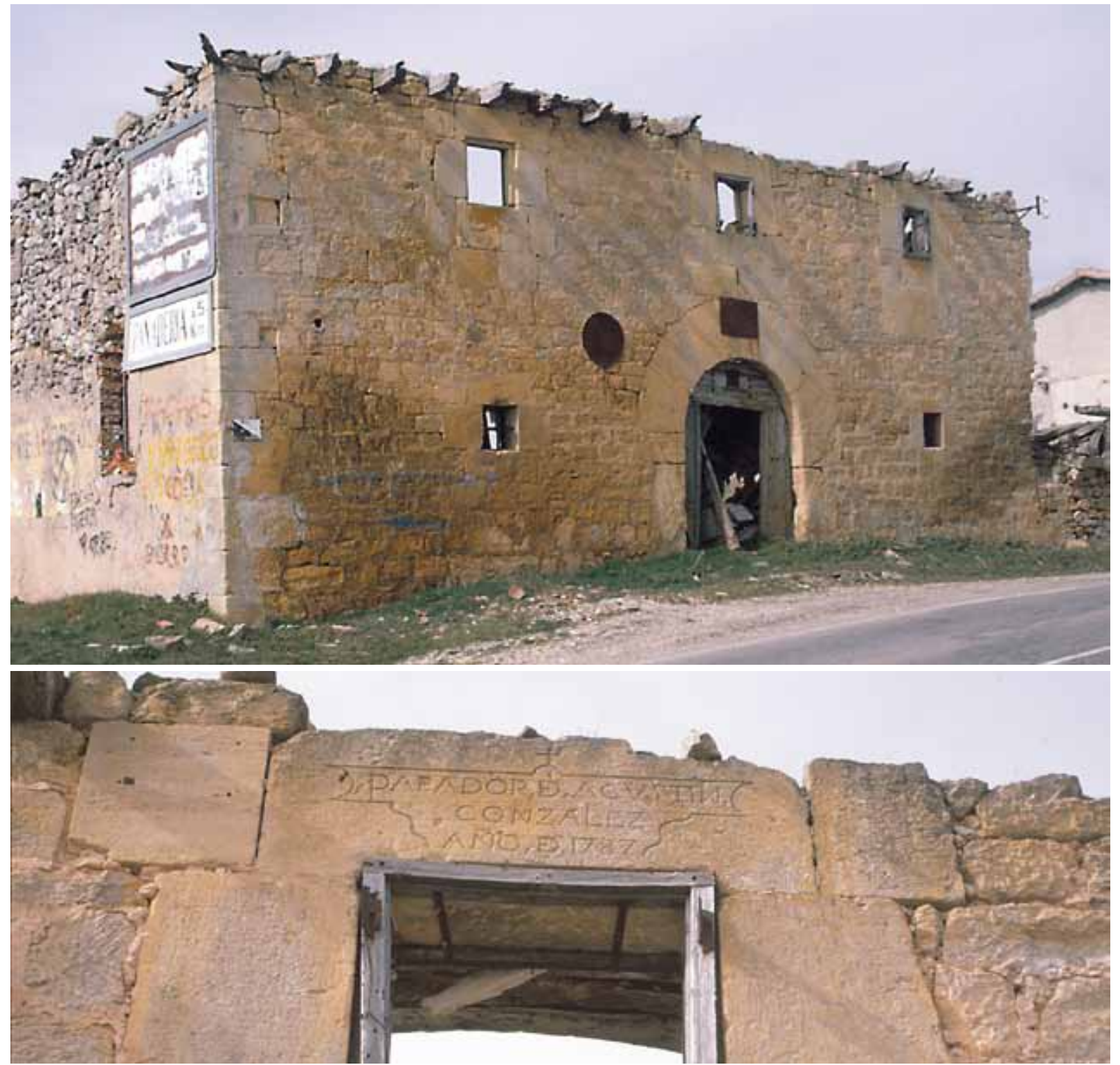

Parador de Villalta y detalle de inscripción.

heredades por 82 mrs. al prior de San Pedro de Tejada entre las que se cita la alberguería del Cuerno2307. En 1222 Fernando III da al monasterio de las Huelgas de Burgos el castillo de Butrón, situado entre la alberguería del Cuerno, Pesadas, Villaescusa y San Florencio2308. En 1499 se constata que en las ventas del lugar de El Cuerno hay mucha necesidad de agua, porque del Almiñé hasta Cernégula hay cinco leguas y "no ay en todo el camino agua ninguna salbo en las dichas ventas, e alli poca, espezialmente los meses de junyo, e jullio, e agosto, e setienbre e años ay no ay agua ninguna, ay mucha neçesidad de se fazer una fuente donde abia abasto de agua". A El Cuerno, Pesadas, Dobro, Escóbados y Quintanaloma se les repartirán 25.000 mrs. para la fuente

2307 A. H. N./ Clero. leg. 1308. Documentos..., fol. 1-1v/ 1200; OCEJA GONZALO, I.: 1983: doc. 90, 74. “... et illos colaços quos habeo in aluergueria del Cornu,...".

2308 A. M. H. B./ Leg. 4, num. 115/ Carrion de los Condes, 2 abril 1222; GONZÁLEZ y GONZÁLEZ, J.: 1983: 195: t. II doc. 161: "... dono uobis et concedo Castrielo quod est in Buetron, quod iacet inter illam albergueriam de Corno et Pesadas et Villam Scusam et Sanctum Florencium". 
del Cuerno "e ay en ellos quarenta mesones"2309. Los mesoneros del Cuerno han de pagar en 1501, 3.000 mrs. para los reparos de las calzadas de Burgos a Laredo, repartidos los 2.000 a los mesoneros y los 1.000 a Pesadas, El Almiñé y Puente-Arenas ${ }^{2310}$. En 1570 se hace un informe sobre el recorrido de la Reina para ir de Laredo a Burgos y se indica que de Pesadas a las ventas del Cuerno hay 1,5 leguas y a Cernégula otro tanto, siendo tres leguas de sierra llana aunque complicada con mal tiempo ${ }^{2311}$. En 1624 Pedro de Pereda dijo que el camino real que viene de los puertos para la corte y otras partes, va por las Merindades a las ventas del Cuerno ${ }^{2312}$. Como testimonio del pasado hospedero de Villalta, aún quedan las ruinas de un parador que ostenta en el dintel de la ventana central la inscripción "Parador deAgustin Gonzalez. Año de 1787". En esta venta se bifurca el camino para ir a Santander por Rampalay o bien a Laredo.

- Venta del Bolero. Situada a $48 \mathrm{~km}$ de Burgos, encontramos su referencia en el llamado "camino de Venta del Bolero" entre Escóbados de Arriba y este camino real en el plano 1:50.00o de la Dirección general del Instituto Ceográfico y Catastral de 1933, por lo que la venta se situaría en el entronque de ambos. No hemos encontrado ninguna otra referencia documental sobre esta venta al haber ya desaparecido en la fecha mencionada y haber dejado su recuerdo en la denominación del camino.

- La Venta. Se señala en el cruce para Dobro, en la cartografía 1:50.00o de la Dirección general del Instituto Geográfico y Catastral.

- Venta de El Almiñé. En el plan de intervención realizado en 1499 para reparar este camino, se indica que se deben hacer junto a la venta de El Almiñé 20 brazas de pared que han de salir debajo del arroyo de tres pies de ancho, y rellenar de tierra y piedra seca el hueco entre el camino y la pared"2313. En 1501 los mesoneros pagarán los 2/3 con "la venta en que biue Luxan", de los reparos a realizar entre El Cuerno y la Peña Palomera en los Hocinos $^{2314}$. Todavía hay una casa, la última de la villa hacia La Hoz, llamada por los vecinos "el Mesón".

- Venta de Quintana de Valdivielso. En 1131 Doña Legundia y sus hijos conceden la alberguería de San Julián al clérigo Juan, que se debía situar en esta zona, y otras heredades en Valdenoceda, Los Hocinos, Dobro, Incinillas y Valdivielso, con la condición de que a su muerte Juan lo donará a San Salvador de Oña y San Pedro de Tejada “...et de ista aluergueria de Sancte Iuliane..."2315. No sabemos si la venta de Quintana coincide con la alberguería mencionada ya que solo tenemos una sola referencia en que, en 1502, Pedro de Luc, vecino de Quintana de Valdivielso, tiene una venta en el término y a una legua de Quintana por la que "pasan muchos caminantes e rrecuerose otras personas", y que el concejo solo le permite vender el vino de dicho concejo porque si lo compra de fuera, le prenderían y le llevarían penas.

2309 A. H. N./ Nobleza. Frías, C. 235, D. 55/ Medina de Pomar, 15 enero 1499.

2310 A. G. S./ Registro General del Sello, VI-1501, fol. 460/Valladolid, 5 junio 1501; MOLÉNAT, J. P.: 1971: $157-160$.

2311 A. G. S./ Patronato Real, leg 57, doc. 90/ Antes del 3 octubre 1570.

2312 A. C. V./ no 83/ Madrid, 11 septiembre 1621 y Madrid, 9 octubre 1624.

2313 A. H. N./ Nobleza. Frías, C. 235, D. 55/ Medina de Pomar, 15 enero 1499.

2314 A. G. S./ Registro General del Sello, VI-1501, fol. 460/Valladolid, 5 junio 1501; MOLÉNAT, J. P.: 1971: $157-160$.

2315 OCEJA GONZALO, I.: 1983: doc. 47, 39. 
Indica que lo "fasen algunas personas veçinos del dicho lugar que el quyeren mal porque no tenga la dicha venta, e quel dicho vino es tal que ningund caminante quisyere beuer dello por ser muy malo". Además dice que le ponen recargos en los otros mantenimientos, lo que va contra las pragmáticas de estos reinos, por lo que pide que se mande al concejo que le deje vender y comprar libremente el vino de fuera y los mantenimientos que fueren necesarios, siempre que los fieles del concejo pusieren un precio de venta razonable y justo. El Consejo mandó al corregidor que haga cumplimiento de justicia2316.

- Venta de Adentro, de Valdemera o de los Paños. Se encontraba en pleno desfiladero de los Hocinos y la jurisdicción perteneció al Rey. El edificio que hoy permanece se le conoce como Valdemeruela y conserva junto a él una capillita románica en proceso de ruina, de una nave y ábside con bóveda de horno, que por la decoración de los capiteles, la ventana del ábside y la sección de cornisas y molduras, corresponde a principios del siglo XIII. Allí tuvo algunas propiedades el monasterio de Rioseco desde que se las concediera Alfonso VIII en $1186^{2317}$. En el informe realizado en 1499 para el acondicionamiento de este camino real, se propone hacer desde la venta de Medinilla "fasta la venta de Valdemera ques de Sancho Diez ques morador en ella", 48 brazas de pared de calicanto para ensanchar el camino para las vueltas del carro. Se ha de quebrar en el portillo asomando a la venta de Valdemera un pedazo de peña para ensanchar la entrada. Se midieron desde esta venta hasta el término de Villalaín, Bisjueces e Incinillas y ribera del Ebro, 515 brazas de pared de calicanto y se habían de hacer desde la venta de Valdemera hasta el término de Bisjueces y Villalaín 70 brazas de calzada y quebrar peñas. Para pagar estas obras se cargarían 6.000 mrs. a esta venta2318. Otro informe realizado en 1501 indica que desde la peña Palomera en los Hocinos, se deberán hacer paredes de cal y canto, quitar peñas si estuvieren sobre el camino y las calzadas necesarias hasta llegar al término del abad de Rioseco, y para ello pague "Sancho Dias de los Hoçinos quatro mill mrs. por su venta"2319. En el interrogatorio realizado a mulateros en 1515, se menciona que los oficiales del condestable hacen contra ellos "muchas fuerças e violençias, en espeçial entre Quintanahedos e Barzena e Gayangos Enzinillas e las ventas de Baldemera, que estan en los dichos caminos rreales"2320.

En la Cosmografía de Colón comenzada en $1517^{2321}$, se indica que "De la puente de baldivieso a valdemera una legua. De valdemera a bieneces una legua". El monasterio de Rioseco compra en 1518 la venta con el producto de ciertas enajenaciones de Valdivielso y la Nuez de Santibáñez, a Sancho y Francisco Díaz por 35.000 mrs. ${ }^{2322}$. En 1556 se pretenden reparar los caminos para la próxima venida del Emperador, y se pregunta a testigos cómo se han reparado otras veces, respondiendo un testigo que hará unos 32 años que se cobró el gasto de una

\footnotetext{
2316 A. G. S./ Registro General del Sello, VII-1502, fol. 114/ Toledo, 30 julio 1502.

2317 A. H. N./ Códices. 279-B, fol. 16/ 28 enero 1186; CADIÑANOS BARDECI, I.: 2002: doc. 38: 139. "...confirmo uobis uiIlam de Ocina quam ego ipse iam dudum uobis contuli, et Sanctum Felicem et domus Valdemera in alfoz de Tedeia sitas...".

2318 A. H. N./ Nobleza. Frías, C. 235, D. 55/ Medina de Pomar, 15 enero 1499.

2319 A. G. S./ Registro General del Sello, VI-1501, fol. 460/Valladolid, 5 junio 1501.

2320 A. G. S./ Consejo Real de Castilla, leg. 84, fol. 2-III/ Valladolid, 26 junio 1513 a Salazar, 25 septiembre 1515.

2321 COLÓN, F.: 1910, 1908 y 1915

2322 CADIÑANOS BARDECI, I.: 2002: 72.
} 


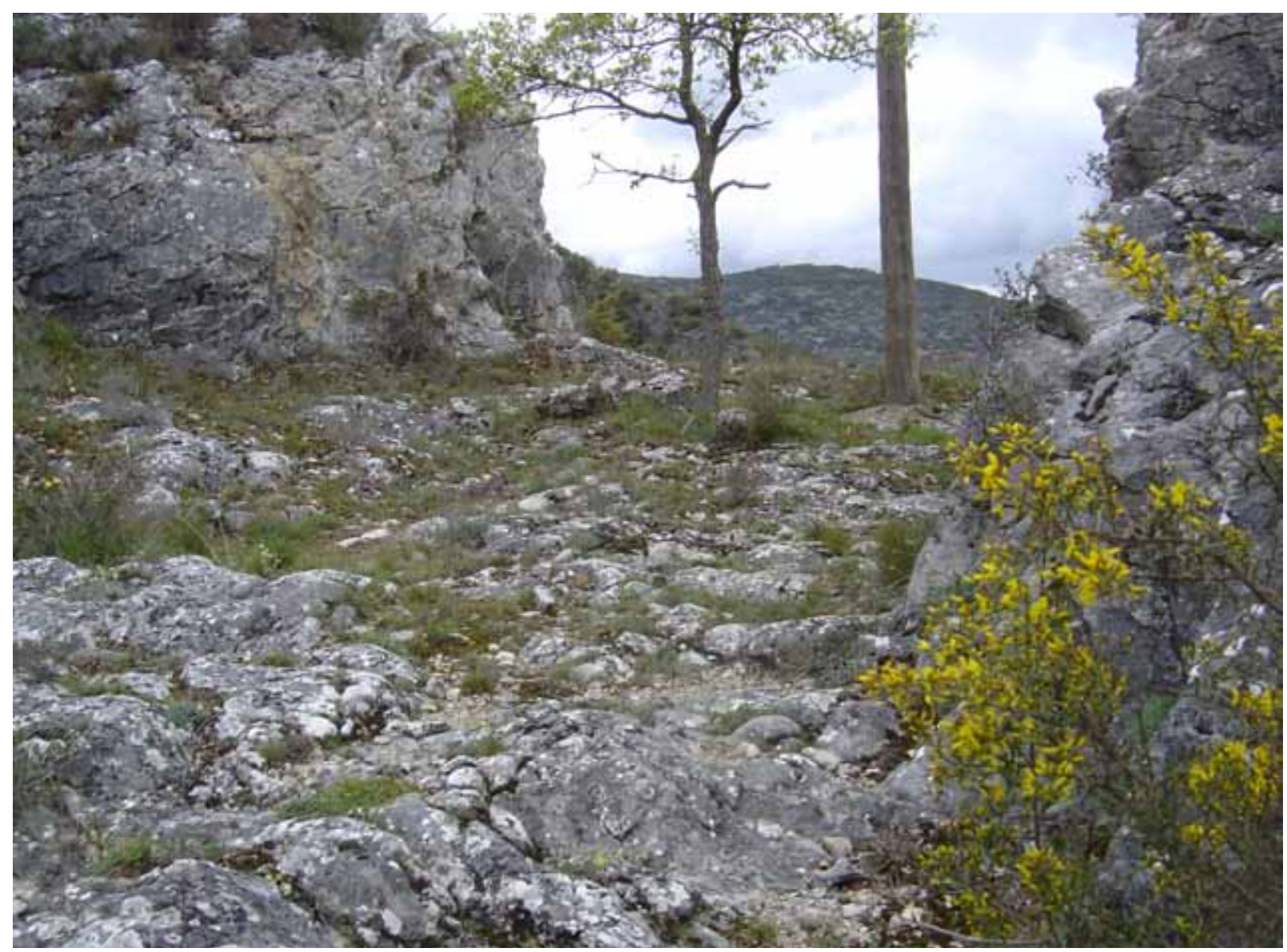

Portillo del camino anterior a 1830 entre las ventas de Adentro y de Afuera.

obra en ese camino a los mulateros y personas con bestias cargadas, y a uno de ellos se le pidió por una bestia asnal que pasó con leña hasta la venta de Valdemera en los Hocinos 8 u 8,5 mrs. ${ }^{2323}$. Con motivo de la esperada venida de la Reina en 1570 , se hace un informe sobre el camino que debía seguir y se detalla que para ir por Hontomín "se ha de venir desde Medina a las ventas de los Paños ques vna ribera del rio Ebro la qual es algo trabajosa aunque ay calçadas, ay vnas bueltas no buenas aunque se pueden pasar bien"2324. Las "ventas de los Paños" pueden corresponder a esta venta al aludir a las vueltas que aparecen entre esta y la de Afuera dentro del desfiladero del Ebro. En 1666 se realiza un informe que indica que conviene que en la venta de Adentro se haga un antepecho que comenzará desde el huerto de la dicha venta hasta más allá de la fuente de las Mimbreras. Ensanchar el camino desde la dicha venta hasta la fuente, picar la peña, dar más hueco al paredón y levantar la calzada para que no lo inunde el Ebro importará 2.600 rs. ${ }^{2325}$. En 1554 estuvo arrendada por 4.500 mrs., tres cántaras de vino blanco y dos cestos de besugos; en 1557 por 5.650 mrs. y las mismas cántaras y besugos; en 1561 por 82 fanegas de pan y 8 gallinas; en 1562 por 6.050 mrs. tres cántaras de vino blanco y dos cestos de besugos por Navidad; en 1573 por $5.650 \mathrm{mrs}$. y en 1586 por 4.100

2323 A. C. V./ no 18. doc. 3, hojas 28 a 48/ Medina de Pomar, 7, 8, 9 y 21 enero 1556.

2324 A. G. S./ Patronato Real, leg 57, doc. 90/ Antes del 3 octubre 1570.

2325 A. C. V./ no 1.995/ 24 diciembre 1665 a 29 junio 1667. 
mrs. 10 fanegas de pan, tres gallinas y un cesto de besugos ${ }^{2326}$. En 1770 un testigo dice que "pasada la Uentta de Adenttro yendo acia Ualdibielso, en dos parajes se llebo [el río] partte de el encascado y cascajo"2327. Desde esta venta el camino ganaba altura para pasar un portillo y llegar a la venta de Afuera.

- Venta de Afuera, de Hocina, de los Hocinos, Marroquina, de Medinilla o de Ríoseco. Se localiza a la salida del desfiladero de Los Hocinos, convertida hoy en una granja. Dependiente del monasterio de Rioseco, era una casa-torre con 10 camas, comedor, establos, pesas, fragua y casa del herrero. Para el servicio ordinario y asistencia a los viandantes, se adaptó una dependencia como ermita, dedicada a San Antonio ${ }^{2328}$. Es sin duda la que se cita en un documento de 1666: "Yten declararon que el antepecho de la ermita de señor San Anton despues que el maestro aga lo que tiene obligaçion en las condiçiones, comenzara del nogal que esta detras de la Uenta arriba"2329. En 1471 Fernando de Encinillas vendió un parral a Pedro Barrio, vecino de Incinillas, operación otorgada en una carta firmada en esta venta de los Hocinos ${ }^{2330}$. En el informe realizado en 1499 para el acondicionamiento del camino de Burgos a Laredo, se propone hacer "en termino de los dichos lugares en la venta de Medinilla ques del avad de Rrio Seco fasta la venta de Valdemera", 48 brazas de pared de calicanto para ensanchar el camino para las vueltas del carro. Para repartir los gastos se propone cargar a la venta de Medinilla 2.000 mrs. y al abad de Rioseco "porque consigue probecho", 3.000 mrs. ${ }^{2331}$. En 1515 un testigo indica que "beniendo este testigo de Castilla con otros mulateros cargados de bino e trigo, saliendo de los Oçinos a la venta de Marroquin, salieron a ellos vnos seys onbres de la villa de Medina de Pumar". Otro testigo dice que en "la benta de Rruseco... solia en ella vibir Marroquin puede aver tres años"2332.

En el repertorio de caminos de Villuga de $1546^{2333}$, aparece esta venta de Afuera como "la Venta de Moroquien", entre el puente de Valdivielso a tres leguas y Medina a dos, en el camino "de Medina de Pomar a Aranda de Duero". En 1556, con motivo de la esperada venida del Emperador, se pretende reparar los caminos y se pregunta cómo se pagaron en anteriores ocasiones, respondiendo un testigo que su coste "lo cobro de los mulateros que por el dicho camino pasaban Lope de Rutin, que hera bentero en una benta questa fuera de los dichos Ocinos", y oyó decir que le habían echado de pena 5.000 mrs. Otro testigo dice que "a causa de estar tomado el camino de los Ocinos, a visto estar aguardando los mulateros con requas de bestias a que abaxase la agua para pasar, y los a visto aguardar en una benta que esta fuera de los dichos Ocinos"2334. En 1666, maestros de cantería declararon que "la puente que esta detras de la Uenta de Afuera" se debía de hacer como en las condiciones se indica de rajola de 10 pies, que sea de 12 pies $^{2335}$. En 1557 esta venta

2326 CADIÑANOS BARDECI, I.: 2002: 72.

2327 A. C. V./ no 2.091/ 5 noviembre 1770 a 6 marzo 1771.

2328 CADIÑANOS BARDECI, I.: 2002: 71 .

2329 A. C. V./ no 1.995/ 24 diciembre 1665 a 29 junio 1667.

2330 A. H. N./ Clero, carp. 365 (9)/Venta de los Hocinos, 16 enero 1471; CADIÑANOS BARDECI, I.: 2002: doc. 440: 594

2331 A. H. N./ Nobleza. Frías, C. 235, D. 55/ Medina de Pomar, 15 enero 1499.

2332 A. G. S./ Consejo Real de Castilla, leg. 84, fol. 2-III/Valladolid, 26 junio 1513 a Salazar, 25 septiembre 1515.

2333 VILLUGA, P. J.: 1546.

2334 A. C. V./ nº 18. doc. 3, hojas 28 a 48/ Medina de Pomar, 7, 8, 9 y 21 enero 1556.

2335 A. C. V./ no 1.995/ 24 diciembre 1665 a 29 junio 1667. 
rentaba 9.000 mrs., cuatro cántaras de vino blanco, una de tinto y un cesto de besugos; en 1561, cuatro cántaras de vino blanco, una de tinto, un cesto de besugos, 4 capones y 12.000 mrs.; en 1562, cuatro cántaras de vino blanco, dos cestos de besugos y 12.500 mrs.; en 1573, cuatro cántaras de vino blanco y 9.000 mrs. y, en 1584, 8 fanegas de pan mediado y 10.000 mrs. Posteriormente estuvo arrendada con algunas fincas por 12.500 mrs., 15 fanegas de pan y los citados besugos y cántaras de vino. La crisis de final del s. XVI y comienzos del siguiente, obligó a rebajar la renta e incluso reducirla a especie ${ }^{2336}$. En 1768 se tuvo que reconstruir la venta por su mucha ruina y por los deterioros causados por una inundación del Ebro 2337 . Unos testigos, en 1770, declaran que al "salir de los ozinos juntto a la Uentta de Afuera a la rebuelta de la peña,... el rio Hebro en sus abenidas saliendo de madre a derribado una porzion de la banguardia o paredon que en aquel sittio hauia para la defensa de el camino"2338. Tras la construcción de la nueva carretera en 1832, se instaló en este lugar el portazgo y cadena de la nueva vía.

- Entre Incinillas y El Vado. Para el arreglo del camino a Laredo se propone que La Aldea, Queciles y Barruelo donde "ay algunos mesones e los otros mulateros" paguen $15.000 \mathrm{mrs}$. y Bisjueces, Villalaín e Incinillas con los mesones de Bisjueces e Incinillas 20.000 mrs. También se dice que si se desvía el camino, La Aldea, Queciles y Barruelo recibirían gran daño y se haría a la mulatería mucho mal por las buenas posadas que en estos lugares hay 2339 .

- Venta de Horna. El yacimiento medieval de La Legua, en la localidad de Horna junto al camino real, conserva un topónimo denominado de Las Ventas ${ }^{2340}$.

- Posada de Ruy Sáez Barahona en la villa de Campo. En un interrogatorio realizado a los mulateros en 1515 se indica que el corregidor de las Villas de la Costa de la Mar está en "la posada de Rrui Saes Uarahona donde el esta aposentado que es en el lugar de Canpo"2341.

- La Venta. En el plano 1:50.00o de la Dirección general del Instituto Geográfico y Catastral se señala la Venta junto a Céspedes.

- Venta de Pajares. Situada entre Céspedes y el puente de Quintanilla de Pienza, viene citada en el Itinerario de Escribano de $175^{2342}$ entre Bocos a una legua y la venta de Revilla a media. También en el camino "Laredo para Burgos" incluye esta venta entre El Ribero y Villarcayo.

- Merindad de Montija. En 1499 se reparten 20.000 mrs. a los mesoneros de Agüera, Villasante, venta de El Ribero y las ventas de Revilla ${ }^{2343}$.

- Ventas de Quintanilla de Pienza. En 1501 los mulateros pidieron que para las obras que se pretendían realizar debían contribuir entre otros, Quintanilla de Pienza y sus ven-

\footnotetext{
2336 CADIÑANOS BARDECI, I.: 2002: 71.

2337 CADIÑANOS BARDECI, I.: 2002: 71.

2338 A. C. V./ nº 2.091/ 5 noviembre 1770 a 6 marzo 1771.

2339 A. H. N./ Nobleza. Frías, C. 235, D. 55/ Medina de Pomar, 15 enero 1499.

2340 ARRIBAS MAGRO, M를 C. S.: 2012: 645.

2341 A. G. S./ Consejo Real de Castilla, leg. 84, fol. 2-III/ Valladolid, 26 junio 1513 a Salazar, 25 septiembre 1515.

2342 ESCRIBANO, J. M.: 1758.

2343 A. H. N./ Nobleza. Frías, C. 235, D. 55/ Medina de Pomar, 15 enero 1499.
} 
tas 2344 . En el Itinerario de Miguel Bañuelos de $1771^{2345}$ se menciona, en el camino "a Castrourdiales", la venta de Quintanilla a dos leguas entre Medina de Pomar y Villasante. En documento escrito en 1782 en Villarcayo y dirigido a Santander, se indica que "El camino unico, maesttro y mas breue desde Burgos para esa ciudad, Santtoña, Laredo y Casttro, es el que pasa por estta villa y desde ella a la ventta de Quinttanilla de Pienza"2346. Existe el recuerdo de una venta situada $500 \mathrm{~m}$ antes del puente denominada venta de Ontañón, y otra $300 \mathrm{~m}$ después de dicho puente.

- Ventas de Revilla. Se ubicaban en término de Revilla de Pienza. En 1499 se propone que para las obras de los caminos paguen los mesoneros de Agüera, Villasante, venta de El Ribero y las ventas de Revilla en proporción ${ }^{2347}$. Se menciona en "otros dos caminos para Bilbao" camino de ruedas del Itinerario de Escribano ${ }^{2348}$, entre la venta de Pajares a media legua y El Rivero a una. Se incluyen también de la misma manera en el Itinerario de Santiago López de $1809^{2349}$ y de Brusola de $1810^{2350}$, que reproducen básicamente el itinerario de Escribano.

- Venta de Isidoro. Se encontraba a un km de Villasante y se detalla en el plano de 1880 de la intervención realizada en este camino 2351.

- Venta de Timoteo. Situada a 1,6 km de Villasante, se encuentra citada en un plano de 1880 de la intervención realizada en este camino ${ }^{2352}$.

- Venta de El Ribero. En el repartimiento realizado en 1499, se propone que para las obras paguen en proporción los mesoneros de Agüera, Villasante, venta de El Ribero y las ventas de Revilla2353. Con motivo de la esperada venida del Emperador en 1556 y para establecer la contribución con el fin de reparar los caminos, responde un testigo que "paso por una puente que esta junto de la benta del Ribero, ques camino real que biene de Laredo para Burgos, y por alli fue e bino en un dia y atrabeso el camino que por alli pasa yiendo a Espinosa de los Monteros"2354. Para apercibir a los lugares de Villamor y Torres que no hagan las ferias francas que hacían, en 1622 el escribano buscó personas en la venta del Ribero a quien notificar lo contenido en una real Provisión, y no apareció más que Diego Ogazón, su ventero, a quien se la notificó y luego el pregonero la pregonó2355. Dicha venta, se menciona en otro documento de 1663: al "lugar de Quintanilla de Pienza otra legua, y desde el dicho lugar a la benta del Rribero otra legua, y desde la dicha benta a el de Villasante media"2356.

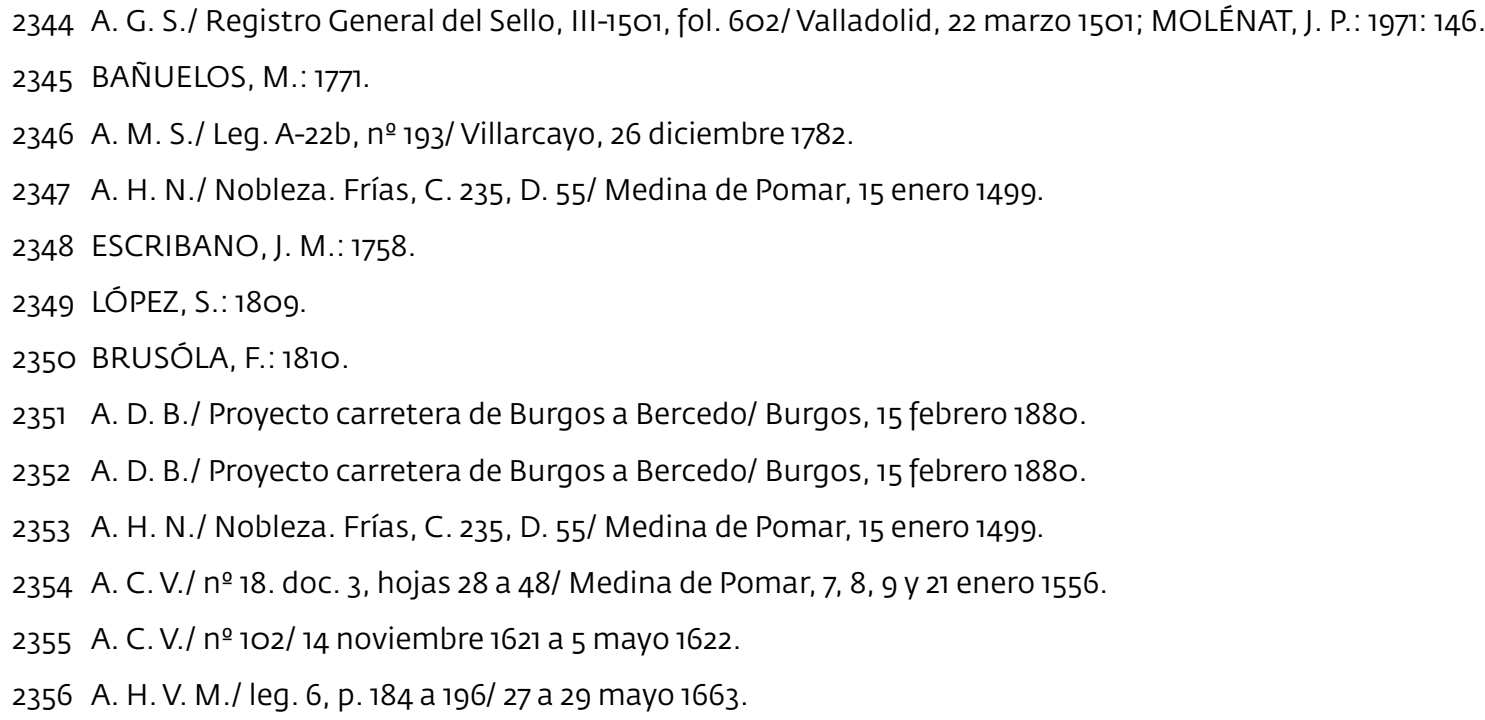




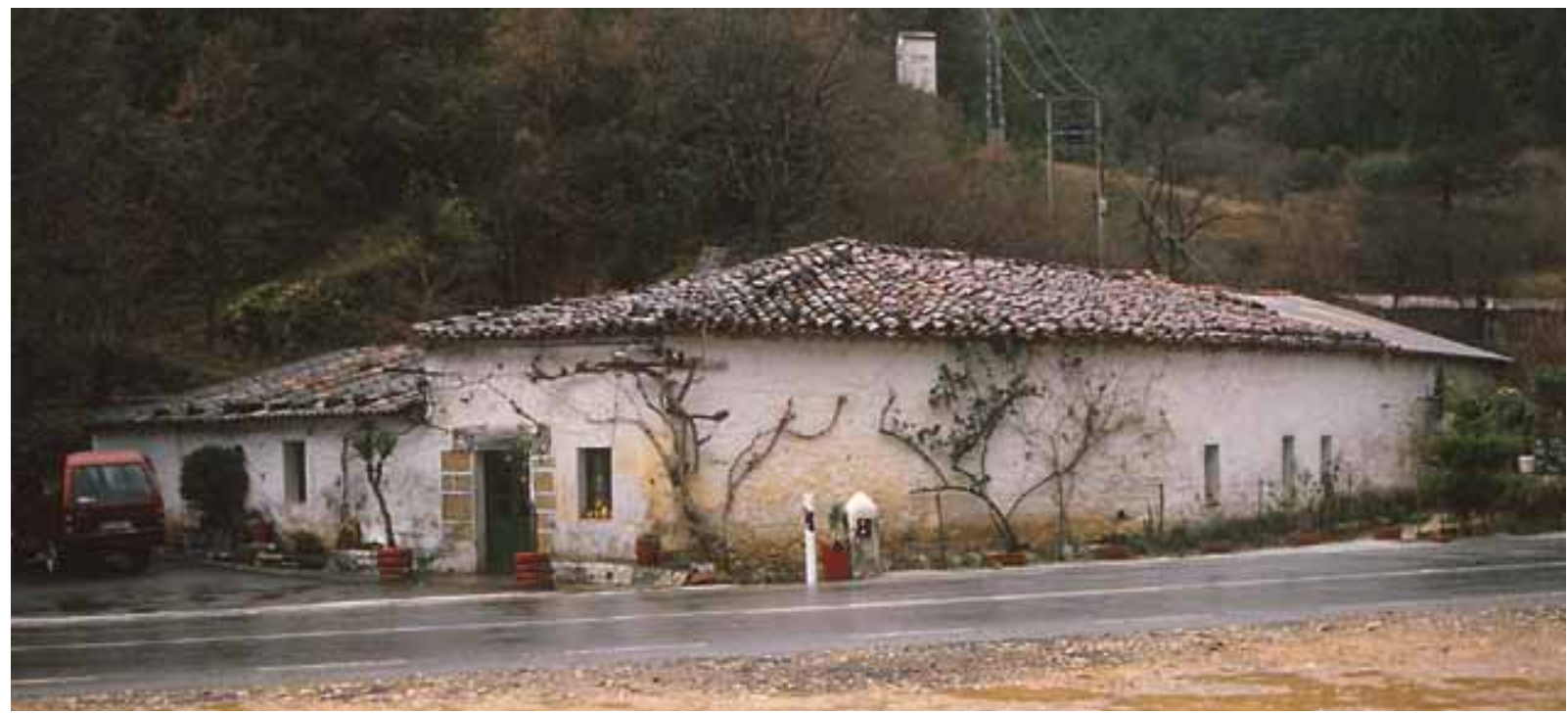

Venta de Oña.

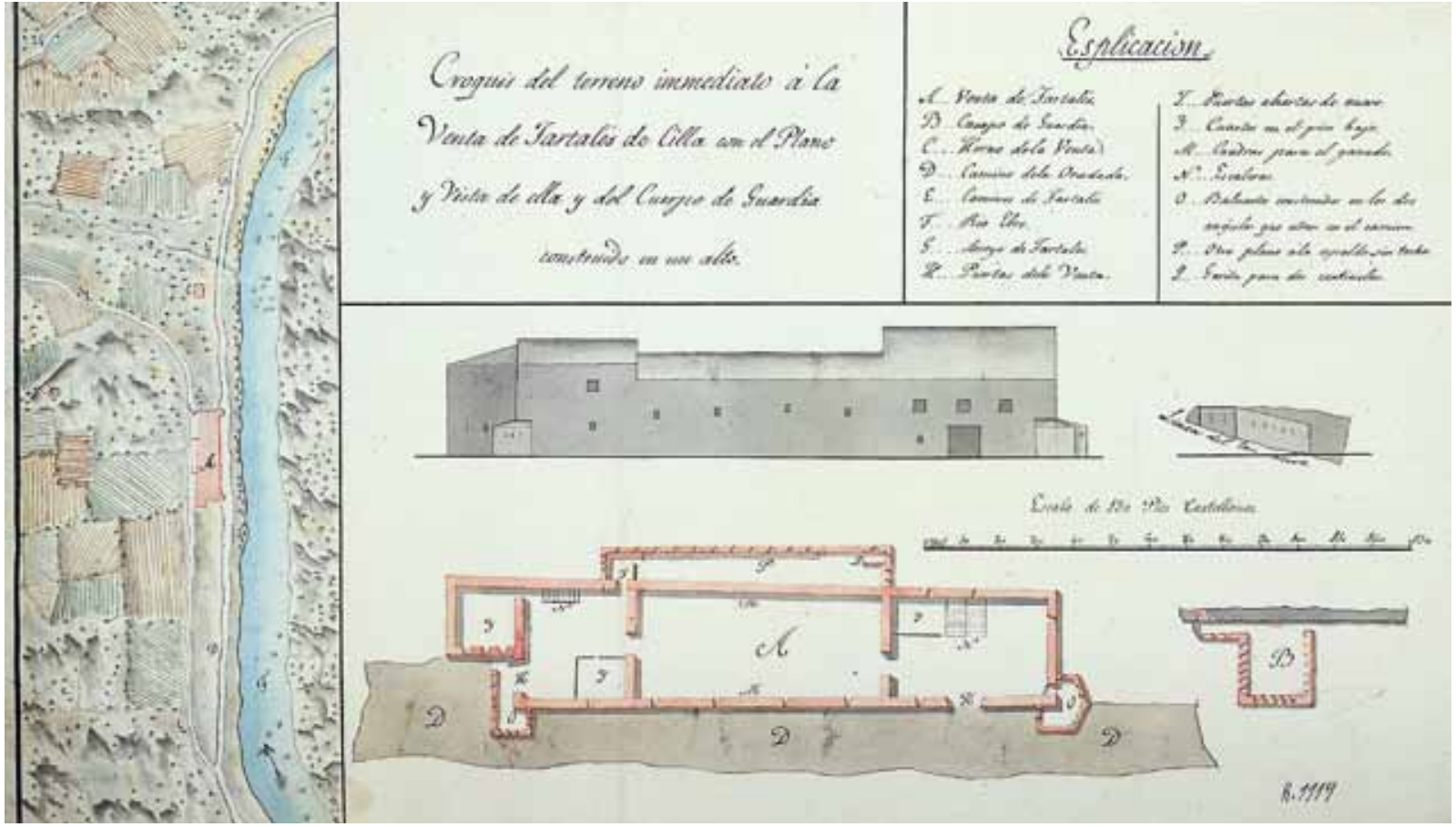

Plano de 1840 de la Venta de Tartalés de Cilla (B. N., R 1119).

- Venta de El Crucero. Hubo una venta en este lugar que se recoge en el mapa 1:50.00o de la Dirección general del Instituto Ceográfico y Catastral de 1942. No hemos encontrado ninguna referencia documental sobre esta venta en fechas anteriores al siglo XIX, por lo que pensamos que se construye tras la intervención realizada en este camino por el Real decreto de 1828, que convierte este punto en un lugar de cruce del camino Medina-Espinosa y el Burgos-Laredo, como su nombre indica.

- El Ventorrillo. Encontramos este término en el mencionado mapa 1:50.00o de la Dirección general del Instituto Geográfico y Catastral de 1942, junto al camino de Laredo, en el límite entre las provincias de Burgos y Cantabria. 
- Venta del Prado. Para los reparos de caminos se propone cargar en 1499 a "El Prado que ay ueinte e çinco vesinos son todos mesoneros" $20.000 \mathrm{mrs} .{ }^{2357}$. En 1501 se propone que colaboren en la financiación de las obras los tres mesoneros del Prado con 5.00o mrs. ${ }^{2358}$. En 1551, en el itinerario proyectado para el transporte de un tren de artillería, se dice que de Lanestosa el camino va "a la Uenta del Prado y buelbe sobre la mano derecha"2359. Entre 1590 y 1593, en la valoración de lo realizado, se menciona que se han hecho 12 brazas junto a la iglesia delante del mesón del Prado 2360 .

- Ventas de Valnera y la Calera. En un memorial de 1593 sobre los paredones hechos, se menciona lo que se hizo a la parte del río entre las ventas de Valnera y La Calera ${ }^{2361}$.

- Lanestosa. En 1499 se pretende cargar 20.000 mrs. a "La Nestosa que son çinquenta uesinos, e los mas dellos mesoneros, e sin el paso non podrian vivir"2362.

- Ampuero. Para los reparos de caminos que se pretenden realizar en 1499, se propone cargar 50.000 mrs. a Ampuero "porque la puente que se a de fazer en ella esta dentro del dicho lugar... e son los mas vesinos mesoneros"2363.

- Venta de Morquillas. Aparece reseñada en el camino de La Horadada frente a Villayerno-Morquillas en el plano 1:50.00o de la Dirección general del Instituto Geográfico y Catastral.

- Venta de Hurones. Situada en el camino de la Horadada, se menciona como "venta Boronos" en el Itinerario de Villuga de $1546^{2364}$, a dos leguas de Burgos, así como en el camino "Burgos para Bilbao" del Itinerario de Meneses de $1576^{2365}$. Se le llama "venta Hurron" en la Guía de caminos publicada en francés en 1674, traducida por Pedro Pontón y publicada en $1705^{2366}$.

- Alberguería de La Horadada. En 1320 se documenta una alberguería en el desfiladero de La Horadada fundada por el monasterio de Oña: "se determino hacer una venta meson por la villa de Oña en el sitio de Barcenillas para mayor acomodo de los transitantes”. La alberguería pasó a conocerse como Venta de Oña ${ }^{2367}$ en un edificio que hoy pervive.

- Venta de Tartalés de Cilla. Localizada en el desfiladero de La Horadada junto al camino, a poco menos de tres $\mathrm{km}$ de la venta de Oña hacia Trespaderne, el edificio se conserva hoy en día aunque ignoramos las fechas de su construcción. Es sin duda la que se representa en un plano de la Biblioteca Nacional del año 1840, con motivo de su utilización

\footnotetext{
2357 A. H. N./ Nobleza. Frías, C. 235, D. 55/ Medina de Pomar, 15 enero 1499.

2358 A. G. S./ Registro General del Sello, VI-1501, fol. 460/Valladolid, 5 junio 1501; MOLÉNAT, J. P.: 1971: $157-160$.

2359 A. G. S./ Guerra y Marina. leg 42, fol. 118/1551.

2360 A. H. P. C./ Laredo, leg. 22, num. 15/ Laredo, 23 febrero 1585 a 12 enero 1597.

2361 A. H. P. C./ Laredo, leg. 22, num. 15/ Laredo, 23 febrero 1585 a 12 enero 1597.

2362 A. H. N./ Nobleza. Frías, C. 235, D. 55/ Medina de Pomar, 15 enero 1499.

2363 A. H. N./ Nobleza. Frías, C. 235, D. 55/ Medina de Pomar, 15 enero 1499.

2364 VILLUGA, Pero J.: 1546.

2365 MENESES, A. de: 1576

2366 PONTÓN, P.: 1727.

2367 ARRIBAS MAGRO, M르 C. S.: 2012: 644.
} 


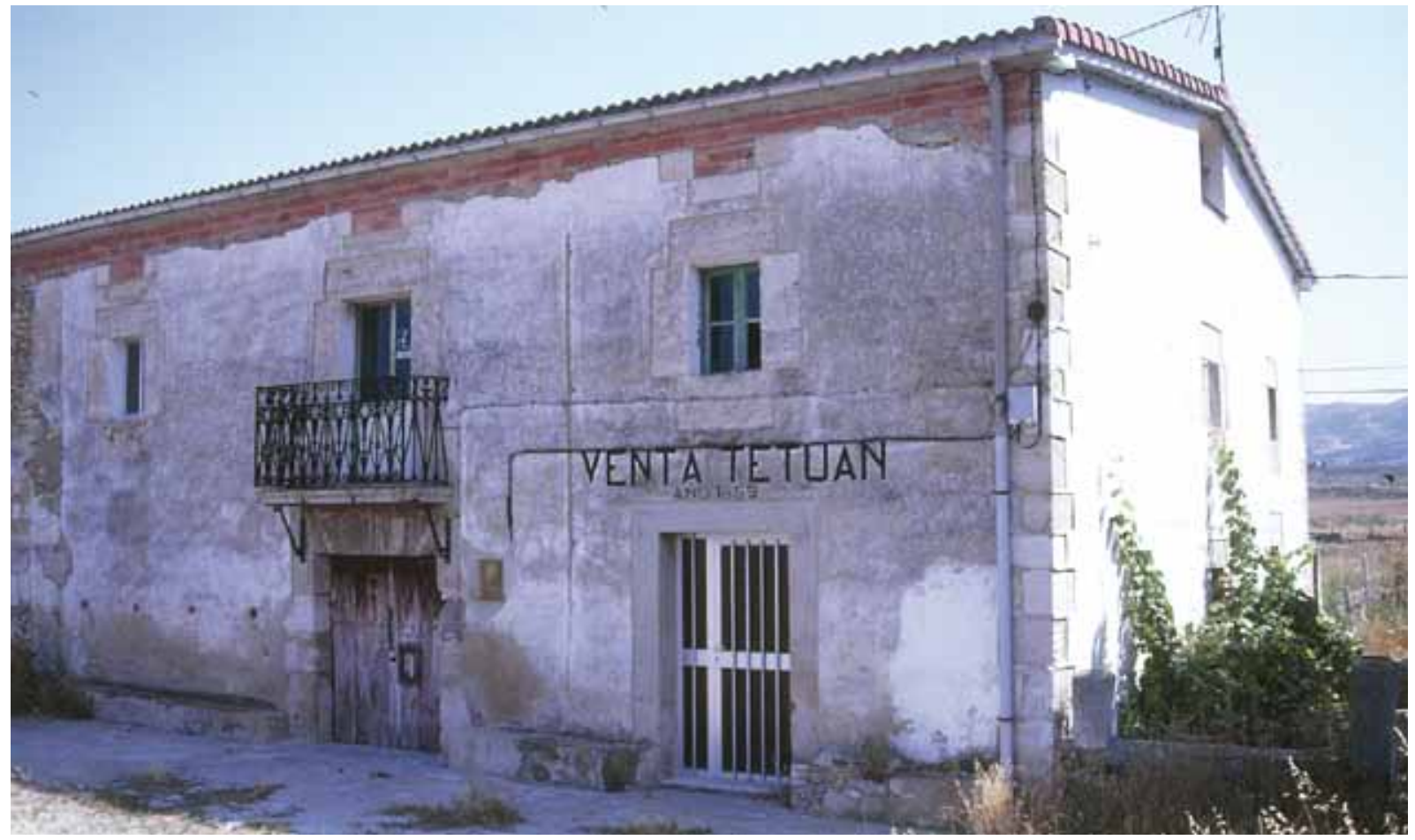

Venta de Tetuán.

militar en la I Guerra Carlista. Esta y la anterior vienen recogidas en el mapa 1:50.000, ํㅡㄴ 136 de Oña.

- Mesones de Trespaderne. En octubre de 1624 Pedro de Zárate llegó a Trespaderne como había hecho otras veces con una carga de pimentones para venderlos en Medina, y estando en uno de los mesones un hombre con una vara de justicia le dijo que si iba a vender los pimentones a Medina, perdería todo el pimentón²368.

- La Venta Vieja. Se señala entre Cebolleros y Moneo según consta en el plano 1:50.00o de la Dirección general del Instituto Geográfico y Catastral.

- Venta de Matías. Encontramos esta venta enfrente de Cebolleros, según vemos en el plano 1:50.00o de la Dirección general del Instituto Ceográfico y Catastral.

- La Venta de Tetuán. Se encuentra aún hoy día entre Moneo y Villacomparada y se recoge en el plano 1:50.00o de la Dirección general del Instituto Geográfico y Catastral.

- La Venta. Esta venta se sitúa cerca de Villatomil, según consta en el plano 1:50.00o de la Dirección general del Instituto Geográfico y Catastral.

Venta de la Perra. Otra Venta de la Perra se sitúa en el camino del Valle de Mena a Laredo por el puerto de Lanzas Agudas, en el límite del vizcaíno valle de Carranza con Cantabria. Se encuentra incluida en la hoja no 6o del mapa editado por la antigua Dirección general del Instituto Geográfico y Catastral.

\section{Ventas y mesones en el camino de Castro-Urdiales}

Desde Valmaseda tan solo tenemos la referencia de la Venta del Sol a un km de dicha villa y La Venta entre Rojadillo y Las Muñecas.

2368 A. C. V./ nº 99/ Madrid, 31 agosto a Valmaseda, 12 octubre 1624. 


\section{Ventas y mesones en los caminos de Bilbao}

- Venta de Hurones. Ya mencionada en el camino de la Horadada, coincidía también con el camino entre Burgos y Briviesca y se cita en el repertorio de caminos de Villuga de $1546^{2369}$, en la variante norte del tramo entre Burgos y Monasterio de Rodilla que discurre junto a "la venta Boronos" o venta de Hurones a dos leguas de Burgos y tres de Monasterio.

- La Venta. Se localizaba entre Quintanapalla y Monasterio de Rodilla junto al camino de Bayona, a la altura de Fresno de Rodilla. No tenemos más datos que los cartográficos del plano 1:50.00o de la Dirección general del Instituto Ceográfico.

- Venta de Prádanos. En el camino entre Burgos y Briviesca se cita en el repertorio de caminos de Villuga de $1546^{2370}$ a media legua de Castil de Peones y a una de Briviesca. Mencionada también en la Cuía de caminos publicada en francés en 1674 y traducida por Pedro Pontón ${ }^{2371}$.

- Venta de Quirico. Se reseña en el camino de Bayona frente a Cameno a dos km de Briviesca según el plano 1:50.00o de la Dirección general del Instituto Geográfico.

- Venta de Cameno o de Perico. Incluida en el Itinerario de Escribano ${ }^{2372}$ en el camino de Burgos a Laredo, a media legua de Briviesca y a dos de Cubo de Bureba.

- Parador. Situado en el camino de Bayona a 7,5 km de Briviesca, aparece reseñado en el mapa provincial de Coello.

- Parador antiguo. Ubicado en el camino de Bayona a la salida de Cubo de Bureba, se reseña en el plano 1:50.00o de la Dirección general del Instituto Geográfico.

- Venta de La Haya. También llamado hasta fechas recientes Mesón de Laya, se situaba a medio camino entre Irús y el alto del puerto del Cabrio junto a la ermita de San Sebastián. Mencionada por un testigo en 1593 cuando declara que en el "camino que entra por Cabrio y ua a Balmaseda por Burzeña... [hay un puente] ... en el lugar de Yrus que es zerca de la uenta de La Haya sobre el rio de Cabrio...”. Otro testigo se refiere al “...camino real que por el [valle de Mena] passa que comiença en el puerto de Cabrio y benta de La Haya y acaua en la puente de los Arroyos"2373.

- El Mesón. Encontramos esta reseña a la entrada de Criales en el plano 1:50.00o de la Dirección general del Instituto Geográfico y Catastral.

- Venta de Tejera. Se menciona en el camino de Angulo y Arciniega. El Itinerario de Escribano de 1758 lo incluye con el título "Camino de Herradura Para Bilbao desde Burgos"2374 entre Criales a media legua y San Llorente de Losa a una.

- La Venta. Se encuentra entre La Orden y Quintana-Entrepeñas en el plano 1:50.000 de la Dirección general del Instituto Geográfico y Catastral.

\footnotetext{
2369 VILLUGA, Pero J.: 1546.

2370 VILLUGA, Pero J.: 1546.

2371 PONTON, P.: 1705

2372 ESCRIBANO, J. M.: 1758

2373 A. H. V. M./ leg. 6, p. 221 a 336/ Madrid, 10 junio 1589 a 18 diciembre 1593.

2374 ESCRIBANO, J. M.: 1758
} 
- Venta de Ureta. Se situaba en el cruce del camino de Angulo y Arciniega entre Barratauren y Artecona y Las Llanas con el que viene de Llanteno e Inorza, muy cerca del límite entre Álava y Vizcaya.

- Las Ventas de Encío. Se hallan reseñadas en el plano 1:50.00o de la Dirección general del Instituto Geográfico y Catastral.

- Venta de Riogil. Según Cadiñanos se conserva un expediente del siglo XVIII, sobre los derechos que cobraba el duque de Medinaceli en esta venta situada junto al puente de Puentelarrá, e indica que a fines de ese siglo se arrendaba la venta y derechos de pontazgo del puente por 6.00o rs. al año2375.

- Venta Blanca. Incluida por Matías Escribano en el camino de Pancorbo a Orduña de su Itinerario de $1758^{2376}$, a media legua de Bergüenda y media de Espejo.

- Venta del Monte. Se localiza en el camino de Pancorbo a Orduña entre Espejo y Osma, junto al cruce con el camino que va a Villanueva de Valdegovía. Citada en el repertorio de Villuga de 1546 como "la Venta"2377 a una legua de Espejo y a dos de Berberana. Citada también por Ottavio Cotogno en su Itinerario de Postas de 1608 con el mismo nombre, a una legua de Santa Gadea y otra de Berberana. Pellegrino Zuyer describe este camino en $1660^{2378}$ diciendo que desde Espejo “... después de un cuarto de legua, se entra en el obispado de Calahorra, nada mas pasar la casa que llaman Venta del Monte, yen menos de legua y media se atraviesan las aldeas de Osma y Berberana,...". La Cuía de caminos publicada en francés en 1674 y traducida por Pedro Pontón también la denomina "la Venta" y Escribano la incluye en su Itinerario de $1758^{2379}$, a media legua de Espejo y media de Osma tras cruzar el río Omecillo.

- La Venta del Hambre. El Itinerario de Picquet ${ }^{2380}$ realizado en 1810 para el ejército de ocupación durante la Guerra de la Independencia, recoge en la vía de Madrid a Bilbao esta venta a cuatro leguas de Bergüenda y una de Orduña. Se sitúa en el puente Morano entre Osma y Berberana en el límite entre Burgos y Álava.

- Venta de Arbin. Según dice Armona y Murga en 1789, el camino más antiguo de acceso a la meseta se llamaba "y aun se llama" el camino de herradura de la venta de Arbin por la ermita de San Bartolomé de Orduña ${ }^{2381}$.

- La Venta de la Peña. Matías Escribano la menciona en su Itinerario de $1758^{2382}$ situada entre Berberana y Orduña, a una legua de ambas.

- Mesón de Sagarribay. Sagarribay es un barrio a un km al norte de Amurrio. En 1553 se alude a que desde el paso de Coldecho, existía la posibilidad de que "la requa... no llegara a [Orduña] pues por el momento atajan mas de una legua,... atrabesando por las aldeas estan en Sagaribay... y

\footnotetext{
2375 CADIÑANOS BARDECI, I.: 2008: 12.

2376 ESCRIBANO, J. M.: 1758.

2377 VILLUGA, Pero J.: 1546.

2378 Archivo Secreto Vaticano/ Archivo Consistorial. Acta Congregationis Consistorialis, vol. I, fols. 499-534/ 1669; CASADO SOTO, J. L.: 2000: 289-345.

2379 ESCRIBANO, J. M.: 1758.

2380 PICQUET, Ch.: 1810

2381 ARMONAY MURGA, J. A.: 2002: 135.

2382 ESCRIBANO, J. M.: 1758.
} 
los que hablan de quedar en esta ciudad iran a quedar en el meson de Sagaribay y en otro de la tierra de Ayala... $" 2383$.

- Luyando. En esta localidad hay en 1492 al menos nueve mesoneros, que cuando se les pregunta cuántos mulos pasarían por el camino al año "dixeron que podian ser... tres mill mulos pocos mas o menos"2384.

- La Venta Alta o de Beteluri. Matías Escribano la menciona en su Itinerario de $1758^{2385}$ a una legua de Arrigorriaga y media de Bilbao.

- Venta Pozo-Portillo. Se reseña en el camino del portillo del Aro poco antes de llegar a Oceca, según se constata en el plano 1:50.00o de la Dirección general del Instituto Ceográfico y Catastral.

\section{E.- EL CORREO Y LAS POSTAS}

Dice Fernández de Oviedo hacia 1540 que los correos "tienen por oficio correr las postas e yr a diuersas partes, porque se lo pagan, e son nesçessarios; y estos, vnos se exercitan a pie, e otros a cauallo, e, de qualquier manera que lo hagan, me paresçe que escogieron vn muy trabajoso oficio"2386.

En Castilla, las primeras noticias sobre la existencia de correos, proceden de los tiempos del reinado de Alfonso X. En las Partidas se menciona a los mandaderos como oficiales de la Casa real: "et mandaderos... que traen otras mandaderias por cartas, que son semejantes á los pies del home, que se mueven á las vegadas á recabdar su pro sin fablar"2387. A los correos de Juan II se les llama "troteros e mensajeros de a cavallo e de pie", en una cédula que decreta la exención de tributos a favor de los oficiales del Rey, lo que denota que ya existen correos a caballo para el servicio real.

Ya en 1498 los Reyes dicen que Pedro Vizcaíno, vecino de Virgala, les informó que estando ellos en Alcalá alquiló una mula "a Juan Çerrero correo para que fuese en ella cierto camino, ele pagase cierto alquiler, e que por la dich a mula e alquiler della, diz que le salió por fiador Beltran oste de correos, estante en nuestra corte e diz que nunca mas despues aca, el dicho Juan Çerrero le a buelto la dicha mula e alquiler della"2388.

Los contadores de cuentas dicen en 1547 que se deben pagar a los correos, según las distancias que deben recorrer, las siguientes cantidades ${ }^{2389}$ :

\footnotetext{
2383 A. H. F. B./ Munic. Orduña, caja no 19, carp. 4/ Madrid, 17 mayo 1553.

2384 A. G. S./ Cámara de Castilla. Pueblos, leg. 3-2, doc. 248/ Orduña, 20 enero 1492.

2385 ESCRIBANO, J. M.: 1758.

2386 FERNÁNDEZ de OVIEDO Y VALDÉS, G.: 1880: 221.

2387 LAS SIETE PARTIDAS/ Segunda Partida, Título IX, Ley XXI.

2388 A. G. S./ Registro General del Sello, VIII- 1498, fol. 48/ Zaragoza, 14 agosto 1498.

2389 A. G. S./ Consejo Real de Castilla. leg. 170/ 1547; MONTÁÑEZ MATILLA, M.: 1953: 197.
} 
- 10 leguas, 2,5 rs. cada día.

- 12 leguas, 3,5 rs. cada día.

- 15 leguas 1,5 ds. cada día.

- 20 leguas cuatro ds. cada día.

- De Burgos a Sevilla en dos días y medio le dan 40 ds.

- A Sevilla en tres días le dan 32 ds.

- A Roma "a diligencia" le dan 250 ds., y algunas veces 200 según el tiempo y la diligencia que tienen, y se tasa cumplido el viaje porque los viajes de toda diligencia sirven conforme al tiempo que emplean.

- Los otros viajes a Flandes y Alemania y otras partes fuera de los Reinos, se tasa según la diligencia que se tiene en cada viaje.

\section{a.- El Correo mayor}

El cargo de trotero o Correo mayor como jefe de los correos se crea en Castilla durante el reinado de los Reyes Católicos. En febrero de 1477 los Reyes nombran a Juan de Santa Coloma para que "toda vuestra vida seays nuestro trotero mayor en la nuestra corte, e en todos los nuestros rregnos e señorios, en lugar de Castilla", y mandan a todos los notables y a los concejos, justicias, regidores etc., de las ciudades de Sevilla y Burgos así como de todas las poblaciones de sus reinos y señoríos, "e a qualesquier troteros e correos que yran o vernan a nuestra corte e a los dichos nuestros rreynos", que le tengan por su trotero mayor. Le fijan una cantidad de 14.400 mrs. más 5.000 de quitación cada año $0^{2390}$.

El cargo de Correo mayor de España, fue creado en enero de 1505 por Felipe I y adjudicado a Francisco de Tassis, un lombardo que había organizado el sistema de correos de Borgoña y Países Bajos con Maximiliano I, que ya se ocupaba de los territorios dinásticos de Felipe en Flandes. En 1516 Tassis fue ratificado por Carlos I en este puesto, otorgándole el monopolio del correo en sus territorios con el compromiso de mejorar las postas, ampliar las rutas y reducir el tiempo para llevar los mensajes. Se crearían grandes rutas por toda Europa bajo el control casi monopolístico de la familia Tassis, las cuales superaban una distancia media de $1.500 \mathrm{~km}$ en 12 días en verano y catorce en invierno. A la muerte de Francisco de Tassis en 1517, tomaría el relevo su sobrino Juan Bautista de Tassis con el título de Correo mayor de España y Maestro General de Postas hasta su muerte.

Así, Carlos I en octubre de 1518 en virtud de los leales servicios que los hermanos Juan Bautista, Mafeo y Simón de Tassis, naturales de Cornello (Lombardía), habían prestado a su padre Felipe y a él, los hace naturales de sus reinos y manda que en adelante "seays nuestros maestros mayores de ostes e postas e correos de nuestra cassa y corte, y de todos los nuestros Reynos e señorios y fuera dello, que a nos se an de probeher, e bos el dicho Bautista de Taxis seays cabeça prinçipal del dicho offizio, en lugar e por fin y muerte de Françisco de Taxis buestro tio, nuestro correo mayor que fue" y que, como tales Maestros de Hostes, Postas y Correos, tendrán los derechos y salarios anexos a este oficio como los tenía Francisco y los Correos mayores anteriores, y cuando Juan Bautista estuviere ausente, lo servirá su hermano Mafeo, y si no, Simón, y después el que más

2390 A. G. S./ Registro General del Sello, II-1477, fol. 71/Toledo, 21 febrero 1477; MONTÁÑEZ MATILLA, M.: 1953. 
años viva. Podrá tener donde convenga hostes, postas y correos y cuando hubiere de despachar para cualquier parte, correos y peones con cartas, pliegos, despachos y viajes, que solo los despachen ellos, y que ni correo ni peón reciban los viajes sin que sean dados por Juan Bautista o sus hermanos. Manda también que todos los correos y peones que lleguen a la corte, se presenten ante Juan Bautista y solo a él le den los viajes para poder saber de dónde proceden. Manda también que ningún hoste, correo, ni posta pueda llevar las armas reales por sus Reinos ni fuera de ellos sin su licencia, y sin que primero sean vistos y recibidos por Juan Bautista o sus hermanos, so pena de muerte y de pérdida de todos sus bienes. También manda que Juan Bautista o sus hermanos en su ausencia, puedan nombrar y recibir los correos que sean convenientes al servicio real, y que estos correos "puedan traer armas para defensa de sus personas por la nuestra corte e por los dichos nuestros Reygnos y señorios, e que no les sean tomadas ni quitadas", y que sus casas sean francas y libres de pechos y monedas. Manda también que para los viajes les sean dados los mantenimientos y cabalgaduras necesarias pagando lo que fuere justo, y que al correo despachado por Juan Bautista o sus hermanos, las justicias no lo prendan ni detengan en el viaje por deuda que tenga, excepto si hubiere hecho algún delito criminal, y en tal caso, envíe la justicia a otra persona para que lleve el despacho en su lugar'2391.

Estando el Rey y su Real Consejo en Burgos en 1524, pareció Mafeo de Tassis, Correo mayor de su Majestad, estante en la corte, y dijo al alcalde que como él y sus hermanos tienen el oficio y derechos de postas y como eran tenidos por tales maestros, pedía al alcalde que mandase sacar copia del auto de pregón realizado en Zaragoza en octubre de 1518, lo que hizo el dicho alcalde ${ }^{2392}$.

Carlos I dice en 1539 que Juan Bautista de Tassis ha suplicado que por su edad y algunas indisposiciones no puede residir ni servir continuamente en la corte, por lo que dicho oficio se debía proveer para Raimundo de Tassis su hijo mayor, que desde hacía 6 o 7 años lo venía atendiendo. Sabiendo los servicios que Juan Bautista ha realizado y que Raimundo "tan bien nos abeys serbido en el dicho tiempo, siguiendo continuamente nuestra corte en persona en paz e guerra", tanto "en la jornada de Ungria que el año de quinientos y treynta y dos hizimos contra el turco" y después en 1536 "en la Goleta e Tunez y en la entrada de Françia", manda que sea su Maestro y Correo mayor de Hostes, Postas y Correos de su casa y corte y ejerza el oficio con todas las cosas a él anexas, de la manera que su padre lo tuvo y ejerció conforme a la dicha Provisión. Manda a todas las autoridades y personas principales y a todas las poblaciones, que le tengan por su Maestro y Correo mayor de Hostes, Postas y Correos, y si Raimundo falleciere antes que su padre, el dicho oficio vuelva a él para que lo tenga y use por vida ${ }^{2393}$. Tras la muerte de Juan Bautista en 1541, le sucederá Raimundo que ejercerá de Correo mayor hasta 1579. Después tomará el relevo Juan de Tassis y Acuña, hijo de Raimundo, que ejercerá el oficio hasta 1607.

\footnotetext{
2391 A. D. B./ C-58/Zaragoza, 28 agosto 1518; A. M. Bilbao/ Consulado de Bilbao. Cajón 4, reg. 2, no 18 (6V-11r)/ Zaragoza, 28 agosto 1518; ENRÍQUEZ FERNÁNDEZ, J.; HIDALGO de CISNEROS AMESTOY, C. y MARTÍNEZ LAHIDALGA, A.:

"Archivo Foral de Bizkaia. Sección Notarial (1459-1520). Consulado de Bilbao (1512-1520)". 2007: doc. 27.
}

2392 A. D. B./ C-58/ Burgos, 31 mayo 1524.

2393 A. D. B./ C-58/ Madrid, 8 noviembre 1539 
Con motivo de la inminente llegada de la Reina Ana de Austria, el Rey, deseando tener información detallada y puntual de su desplazamiento, manda a su Correo mayor que envíe a Laredo un oficial y correos para que asistan allí y despachen lo necesario, tanto ante el Rey como a cualquier otra parte que la Reina o el cardenal de Sevilla y el duque de Béjar mandaren, durante todo el tiempo hasta llegar a la corte, y todo lo que se gastare se pasará en cuenta en la nómina de gasto de correos, junto con la costa que el dicho oficial y correos hicieren en la jornada. Se estableció una intensa relación epistolar en la que dichos cardenal y duque dicen en una carta a Felipe II, que el 14 de octubre de 1570 recibieron su carta hecha en Madrid el 11 del mismo mes. Se tardaron tres días para hacer $400 \mathrm{~km}^{2394}$.

Juan de Tassis y Acuña, Correo mayor del Rey, dice en 1583 que en las villas y lugares de las Cuatro Villas de la Costa, siendo localidades tan importantes, convendría que hubiese oficio de Correo mayor y Maestro de Postas como los hay en todas las poblaciones semejantes, para que en los negocios que se puedan ofrecer "aya y pueda auer mexor esperiençia, poliçia y seruiçio y buen rrecaudo", y para ello, se acuerda que haya en las dichas villas y lugares el oficio de Correo mayor y de Postas, y confiando que Francisco de Cubillas, hijo de Juan Cómez de Cubillas, vecino de Cicero, dará el servicio que convenga, "nombro y crio y señalo y reçiuo, al dicho ofiçio de correo mayor y maestro de postas de las dichas villas y lugares, comprendidas en el dicho corregimiento de las Quatro Villas de la Costa de la Mar, al dicho Francisco de Cubillas" para que lo sea mientras fuere voluntad de Tassis, y lo ejercerá por las personas que él nombrare. Podrá llevar todos los derechos y salarios al dicho oficio anexos y podrá llevar por cada caballo que diere en posta a cualquier parte que sea, dos rs. por legua, requiriendo a las justicias y jueces de todas las dichas villas y lugares que tengan a Francisco de Cubillas por tal Correo mayor y Maestro de Postas de las villas y lugares del dicho Corregimiento, y que ningún correo y peón ose recibir ni entregar ninguna carta, pliego ni despacho, si no fuere por la mano de Cubillas 2395 .

En las Juntas de Vizcaya de la Tierra Llana de octubre de 1598 se ordenó por el corregidor que, como por la peste que hay en Bilbao no puede acudir a ella el Correo mayor de Vitoria y de las demás partes de Castilla, no llega la correspondencia. Para que esto se remedie se mandó que el Síndico Ceneral trate con el Correo mayor de Vitoria, que mientras no cese la peste en Bilbao, ponga su ordinario y correspondencia para el Señorío en el lugar de Zubiaur de Zornoza, donde asiste el corregidor, y en él haga el oficio de correo y ordinario el merino de la merindad de Zornoza ${ }^{2396}$.

\section{b.- El correo en Burgos}

En Burgos comienzan a aparecer noticias de correos en 1388, cuando mandaron dar carta a Bernardo Pérez para que pagase a Juan Ruiz de Hurones 21 mrs. y 6 dineros, por el

2394 A. G. S./ Patronato Real, leg 57, doc. 75/ Santander, 16 octubre 1570.

2395 A. G. S./ Mercedes y privilegios. leg. 116/ Madrid, 12 agosto 1583; MONTÁÑEZ MATILLA, M.: 1953: 208-209.

2396 A. J. R. B./ Actas de la Tierra Llana. t. VI/ Zubiaur de Zornoza, 1 octubre 1598. 
alquiler de la mula que llevaba para ir al Rey en Castrojeriz, y 36 mrs. por dos mulas que alquiló Pedro Sánchez por tres días a seis mrs. cada mula2397.

En los años 1396 y 1397 se pagaron en Burgos 70 mrs. por un trotero que enviaron a Pero Carrillo, a Juan López de Sanzoles, a Pero Sánchez de Laredo y a Juan López de Villate que estaban con el Rey. Mandaron también dar 200 mrs. a Pedro, criado de Juan Martínez Galisiano, por haber ido con cartas al Rey y a los otros señores de su Consejo; 6o mrs. por tres troteros que llevaron maravedís del concejo de Burgos a Miranda, Pancorbo, Lara, Barbadillo, Pampliega y Mazuela; 40 a otro trotero que fue á Covarrubias; 70 a un trotero que llevó peticiones a Madrid; 40 a otro trotero que fue a la corte a llevar los privilegios; 100 mrs. al trotero Toribio Ferrándiz que llevó cartas al procurador Pero García que estaba en casa del Rey; 30 al trotero Pero García cuando llevó cartas a Madrid y no halló a los mensajeros y hubo de llegar á Torrijos; 30 a otro trotero que enviaron a Medina con cartas de la ciudad; 100 a un trotero que llevó cartas a los procuradores a Toledo, y a otro trotero 100 mrs. por ir a Toledo a los procuradores, sobre los 300.000 mrs. que echaban a la ciudad ${ }^{2398}$.

La villa de Laredo registra pagos por correos. Así en 1541 se pagan 390 mrs. por "dos correos que se hizieron a Frias y a Balmaseda" al doctor Cerónimo ${ }^{2399}$. En 1545 pagan 17 rs. a Alonso de Bocos, correo de a pie, por ciertas cartas de Diego Osorio que trajo de Valladolid, además de otros 6 rs. que le dio Diego Osorio en Valladolid, más 6 rs. para dar al procurador y escribano que la villa tiene allí2400. En 1551 se paga a Juan de la Rúa, correo, 11 rs. por el trabajo y tiempo que ocupó en ir a Baños de Returbio ${ }^{2401}$ donde estaba el alcalde del Adelantamiento ${ }^{2402}$.

En la Chancillería se trató un pleito entre el Prior y cónsules de los Mercaderes de Burgos y Cristóbal de Covarrubias, Correo mayor de la Universidad y vecino de Burgos, de una parte, y Raimundo de Tassis Correo mayor y Juan Vizcaíno, hoste de correos y postas de Burgos, de la otra. En Burgos pareció en 1550 Cristóbal de Covarrubias ante el corregidor con una carta y Provisión real, y una demanda contra Juan Vizcaíno que decía que el Prior y cónsules de la Universidad y los Correos mayores puestos por ellos, tenían posesión pacífica y continua y derecho a recibir todos los despachos y cartas que las postas y correos traían a la ciudad, y de despachar los que de Burgos salían a cualquier parte cobrando los derechos correspondientes y hacer todo lo perteneciente al oficio de Correo mayor de la ciudad, estando él de tiempo inmemorial como tal Correo, con la prohibición de que otras personas se entrometiesen contra su voluntad. Pero dijo que "Juan Bizcayno clandestina y escondidamente, se abia entremetido y entrometia a exerçer y ussar el dicho offiçio, contra voluntad de los dichos prior y consules e suya", por lo que pidió que se obligase a Vizcaíno a no perturbar la dicha po-

2397 Ilustración Española y Americana/ 28 febrero 1897. p. 130/ Burgos, 1396 y 1397. Pardo de Figueroa, doctor Thebussem, escribió muchas noticias sobre el correo en España, y transcribe estas referidas a fines del s. XIV y s. XV.

2398 Ilustración Española y Americana/ 28 febrero 1897. p. 130/ Burgos, 1396 y 1397.

2399 A. H. P. C./ Laredo. Cuentas de la villa de Laredo, f. 43V-51V/ Laredo, 1541; VALDOR ARRIARÁN, M.: 2002: 116: doc. 4. 2400 A. H. P. C./ Laredo. Cuentas de la villa de Laredo, f. 88r-91v/ Laredo, 1545; VALDOR ARRIARÁN, M.: 2002: 194: doc. 8. 2401 Puede tratarse de Baños de Río Tobía en La Rioja.

2402 A. H. P. C./ Laredo. Cuentas de la villa de Laredo, f. 174V-191v/ Laredo, 1551; VALDOR ARRIARÁN, M.: 2002: 348372: doc. 14. 
sesión y le pagase 500 ds. de oro por el daño y pérdida causados, por los despachos y cartas que ha recibido y las postas que ha despachado 2403.

El procurador de Raimundo de Taxis y de Juan Vizcaíno presentó un documento en el que Raimundo otorgaba su poder a "Juan Bizcayno vezino de la çiudad de Burgos, espeçialmente para que por mi e mi nombre e como yo mismo, podays usar e useis de oste de correos en la dicha çiudad de Burgos, segund e de la manera que yo lo puedo ussar como se contiene en los preuillegios que yo tengo del dicho offiçio". También presentó una demanda contra Cristóbal de Covarrubias, en que decía que siendo Vizcaíno hoste de correos en Burgos nombrado Correo mayor, nadie podía ejercerlo sin licencia y Covarrubias se entrometía tomando el dicho nombre y oficio, e impedía a Vizcaíno que ejerciese libremente su oficio y que recibiese despachos de ninguna persona que quisiere enviarlos por la posta con diligencias, cartas, pliegos y viajes a otros lugares de estos Reinos y de fuera, procurando "que no resçibiesse en su casa los uiajes y despachos y cartas que les benian de Flandes y Françia e Ytalia e otras partes, para personas de la dicha çiudad”, e impedía dar las cartas, pliegos y despachos que traían, diciendo que él los había de recibir y despachar, llevando los derechos e imposiciones de los correos y mensajeros que llegaban o pasaban por la ciudad, y que a muchos correos suyos Covarrubias les hacía volver a la ciudad para cobrar los portes de las cartas y despachos que traían y habían puesto en su poder. Pidió que se prohiba a Covarrubias ejercer el oficio de hoste de correos y postas, no se impida a Vizcaíno el uso y ejercicio del dicho oficio y se le condene por haberlo ejercido sin tener título válido 2404 . Vizcaíno dice que "nunca se ha entrometido en cosa alguna tocante al dicho oficio, y solamente ha tenido los caballos de la posta como los tienen en Villanueva, Quintanapalla y en la venta del Moral", y añade que los correos de Burgos no eran más que "correos de la nación", cuya misión era ir de Burgos a Brujas pasando por Logroño, Nantes y Ruan tomando y dejando cartas de mercaderes, y que estos correos no iban con la posta y tardaban 25 días en cada trayecto de ida o de vuelta ${ }^{2405}$.

Covarrubias respondió que había hecho todo lo perteneciente al oficio de Correo mayor de la Universidad y llevado todos los derechos a él pertenecientes, porque para hacerlo, el Prior y cónsules tenían derecho y posesión de prohibir que nadie se entrometiese en la ciudad sin su licencia y Vizcaíno ni ningún otro en la ciudad, salvo los Correos mayores puestos por el Prior y cónsules, nunca se habían entrometido sino tan solo darles caballos para la posta y hospedar los correos, pero los despachos, pliegos y cartas que los correos traían, siempre los habían dado a él y a sus antecesores en el dicho oficio y que además era muy necesario para la conservación de la contratación, que la Universidad tuviese su Correo mayor. Pero Vizcaíno, pretendiendo usurpar el dicho oficio, había recibido y despachado en secreto postas y correos enviando cartas suyas y dejando otras que no lo eran, dando a sus amigos sus cartas mucho antes que las demás se enviasen a su casa y haciendo otras cosas no justas. Pidió al teniente que condenase a Vizcaíno al pago de 500 ds. de oro por el daño recibido por la pérdida de los viajes y despachos que Vizcaíno "abia resçebido y despachado ascondidamente sin lo saber los dichos prior y consules ni el dicho Cobarrubias". Además últi-

2403 A. D. B./ C-58/ Burgos, 20 mayo 1550.

2404 A. D. B./ C-58/ Burgos, 19 mayo 1550.

2405 A. Ch. V./ Lapuerta, leg. 232/ 2 mayo 1542; BASAS FERNÁNDEZ, M.: 1963 y 1994: 72 nota 103 y 74. 
mamente el Rey lo había aprobado y confirmado con las ordenanzas de la Universidad de $1538^{2406}$.

Juan Vizcaíno dijo que ningún particular tenía poder ni autoridad para proveer ni crear el dicho oficio sino solamente el Rey. Añadía que sus antecesores habían tenido principio hacía menos de 50 años en Juan de Arlanzón, tundidor que vivía en la Llana, el cual recibía y daba las cartas que llegaban a su casa para mercaderes de la Universidad, y se entendía que "traya y llebaban aquellas cartas, peones y correos de naçion que andaban por susjornadas, e no abia postas entonçes, e casso que las ubiesse, no se serbian dellas ni tenian que hazer con las postas que passaban, ni abian tenido jamas derecho ni costumbre de proibir e bedar a nadie que no despachasse como quissiese", siendo el oficio que sus partes ejercían real y libre y nunca nadie se lo había prohibido ni limitado, y Vizcaíno lo ejercía con toda fidelidad y sin perjuicio del Prior y cónsules de la Universidad ni de los particulares de ella 2407.

El teniente de corregidor condenó en julio de 1550 a Juan Vizcaíno, a que en adelante no moleste a Cristóbal de Covarrubias y le deje ejercer su oficio en lo tocante a la contratación de la Universidad, so pena de 50.000 mrs. y de pagar todos los menoscabos, y que Covarrubias en adelante pueda dar y recibir las cartas y recados de las contrataciones como hasta aquí lo ha hecho. El Correo mayor y Vizcaíno, recurrieron la sentencia y alegaron que el juez, innovando "en perjuizio de la dicha apelaçion..., abia tenido e tenia presso al dicho Juan Uizcayno".

El Prior y cónsules habían dicho al Rey que, de tiempo inmemorial, nombraban un Maestre de correos en la ciudad para recibir las cartas que fueren y vinieren para los mercaderes y miembros de la Universidad y darles aviso de las postas que pasan, y que las personas que han tenido las postas por Raimundo tan solo daban "los caballos a los correos que passaban y que agora, de dos messes a esta parte, [Vizcaíno y el que por este] tiene los caballos de la posta en la dicha çiudad, les han hecho y azen fuerça mandando a los correos que passan, que no lleben otras cartas algunas sino las que les diere el dicho oste de postas", por lo que piden que Vizcaíno dé tan solo los caballos a los correos que pasaren como hasta aquí se ha hecho. El Rey manda a Raimundo en agosto que en el ejercicio y uso del oficio de Maestro de postas de la Universidad no se entrometa ni haga novedad, y en octubre, la Universidad pagó $6.800 \mathrm{mrs}$, , por enviar a Valladolid la cédula "que nos ynbiaron de Flandes de su magestad para Rreymundo de Tarsis, por que no se entremetiese en perturbar a nuestro correo mayor su ofiçio"2408.

La sentencia definitiva pronunciada en 1551 mandó que debían amparar al Prior y cónsules de la Universidad de Burgos en la posesión en que estaban de nombrar y poner Maestro de Correos, que entienda en recibir y despachar los correos, cartas y despachos tocantes a sus negocios y distribuir los despachos que llegaren para el Prior y cónsules, y al Correo mayor y a Juan Vizcaíno que no perturben al Prior y cónsules y a Cristóbal de Covarrubias en la dicha posesión so pena de 50.000 mrs. para la Cámara del Rey, y mandan que Covarrubias y los que le sucedan, no puedan detener a los correos que pasaren a otros negocios por la ciudad.

2406 A. D. B./ C-58/ Burgos, 4 junio 1550.

2407 A. D. B./ C-58/ Burgos, 4 junio 1550.

2408 A. D. B./ R-12/ Libro de caja de la Universidad de Burgos/ Burgos, 1549-1557. fol. 6od. 
Francisco Sánchez, en nombre del Correo mayor y Juan Vizcaíno, dijo ante el presidente y oidores que en aquello que era en favor de sus partes la sentencia "hera justa, pero en quanto abian mandado anparar a la dicha vnibersidad en la possesion de nombrar e poner maestros de correos, que resçibiessen y entregassen sus despachos e negoçios" y en todo lo demás que era contra sus partes se debía revocar, e indica que la Universidad no podía nombrar ni tener Correo mayor ni Maestre de correos para sus negocios, y así lo mandaba el privilegio que tenía hecho nuevamente en menos de 50 años, y antes de aquel tiempo nunca había habido tal oficio ni dignidad, ni había "correos de a caballo como entonçes los abia, ni ostes de correos ni maestros dellos, tan solamente abia peones de a pie o caballo que yban por jornadas, e por aquel dicho offiçio e dignidad, tenia muy grandes honrras, prerrogatibas e ynmunidades y derechos", muchos de los cuales estaban especificados en los títulos de merced del dicho oficio, y porque en la pragmática de 1494 por la que había sido creada la Universidad, no se les daba tal poder.

El procurador de Cristóbal de Covarrubias presentó una petición diciendo que la sentencia no condenaba a Juan Vizcaíno en los intereses que había llevado, ni en los daños causados a su parte al haber tomado y usurpado los despachos y derechos de las cartas que habían venido al Prior, cónsules y mercaderes de la ciudad, ganando con ello más de 500 ducados por el despacho y los intereses y ganancias. Pidió que se mandase enmendar la sentencia y condenar a Vizcaíno en la dicha cantidad.

En la sentencia dada en Valladolid en mayo de 1552, confirma la anterior, y manda que Covarrubias "no se entrometa ni pueda entrometer, a detener correo alguno en la dicha çiudad ni en ningund otro negoçio, que no toque al dicho priory consules o a los mercaderes de la dicha vnibersidad, ni en otra preheminençia alguna, ni llebar derechos fuera de lo tocante a su offizio de maestre de correos entre los dichos prior y consules y mercaderes de la dicha unibersidad", y no hace condena de costas.

Diego Ruiz de Salazar, escribano, a pedimiento del Prior y cónsules de Burgos y su Correo mayor Gerónimo Pardo, requirió en 1561 con una real Ejecutoria que regulaba el uso del oficio de correo, a "Andres de Frias, correo vezino de la dicha çibdad en su persona, que al presente dize tener caballos de posta en el ospital del Rey" por Miguel de Peña Vera, para que la cumpla como en ella se contiene el cual dice que en ella no habló él ni él es parte sino Raimundo de Tassis, Correo mayor de su Majestad por quien él tiene los caballos de posta, por lo que es a él al que se ha de hacer el dicho requerimiento.

En la $2^{\mathrm{a}}$ mitad del siglo XVI se dirigen quejas al Rey sobre "el uso y exerçiçio de los correos o estafetas que nuebamente se an puesto e introduzido en las çiudades, villas y lugares de Castilla". Alegan que el oficio de correo es universal en toda Castilla y de gran interés y provecho para los correos principales y sus criados, de tal manera, que siendo hombres pobres en breve tiempo han adquirido mucha hacienda y edificado casas costosas, y se nombran Correos mayores en derogación del Correo mayor del Rey, y "porque algunas personas honrradas, hablando propiamente, les scriuen o llaman correos de las çiudades o villas donde uiuen, como al correo de Burgos, a fulano correo de Burgos, lo rreçiuen por injuria y agrauio". Añaden que tales correos fijan a según su voluntad los portes de las cartas, pliegos y despachos que llevan dándoles nuevas cubiertas, causando gran daño al Reino por no habérseles puesto arancel, tasa, peso, ni medida como está puesta en los correos de Italia y otras provincias extranjeras. Por ser tan gruesos los partes de los despachos, algunos de los mozos de los correos los ocultan algunos días en perjuicio de los interesados, y por no tener los correos la vigilancia y fidelidad a que están 
obligados, cuando llevan los despachos a los lugares de destino los llevan a otras partes y los interesados pierden sus negocios y ocasiones. Por todo ello, se suplica al Rey que ponga el remedio que más convenga ${ }^{2409}$.

\section{C.- El Consulado y el correo 2410}

La Universidad de los Mercaderes de Burgos sostuvo un servicio de correos propio y eficiente, que obedecía a la necesidad de sus miembros de mantener una relación fluida con sus corresponsales y lugares de llegada de sus lanas, con los puertos de carga y descarga y otros puntos. Las ordenanzas de la Universidad contemplaban la necesidad de afrontar sus gastos con el dinero obtenido de averías. Así en la ordenanza XXI del Consulado de Burgos de 1538 se indica que la Universidad tiene que hacer muchos gastos, entre los que se incluyen los referidos al maestro de Correos, a los andadores, y despachos de Correos ordinarios de veinte a 25 días para Flandes, Gran Bretaña, Lyon, Ruan, Sevilla, Portugal y otras partes ${ }^{2411}$. También los correos se trataban en la ordenanza número XXVIII de 1572, que indica que de las averías se pagarán los "despachos de correos, así en estos Reynos como para fuera de ellos"2412.

Los correos no solo llevaban cartas y despachos sino que también transportaban dinero, como en 1553 en que se menciona que se pagaron 9.486 mrs. por las "costas de llebar el dinero de Burgos a Balladolid", y "12.000 rs. que dio Hernando de Trezanos para le enviar a Portogalete con Juan de Basori correo, los quales el llebo por bia de Biluao", y "a Hernando de Trezanos que le sobraron del dinero que les llebo para las costas qui hizieron", o en 1556 "Melchior de Muxica deue... 102.000 que se le enbiaron a Santander con Juan de Losa"2413. También llevan noticias puntuales, como cuando en 1546 se pagan 750 mrs. a Juan Álvarez "que uino con la nueua que estaba la nao en Rribadeo"2414.

Los comerciantes que enviaban o recibían correspondencia pagaban a la Universidad cierta cantidad por el correo. Esto indica un asiento de 1551, cuando "se cobraron delas personas para quien uenian las cartas $11.144 "$ mrs. ${ }^{2415}$.

Iban a diferentes lugares del entorno, como Bilbao, Santander, Laredo, Portugalete, Valladolid, Logroño, Navarra y ya se comenzaba a ir a Madrid que iba adquiriendo importancia como capital del Reino, pero también los "correos fechos por bia de Yrun", llegaban a Ruan, Nantes, Calais, Lyon, La Rochelle o Flandes.

Francisco del Campo Santiago, en nombre del Prior y cónsules de la Universidad de Burgos, dijo al Emperador que con acuerdo de la mayor parte de la Universidad, habían

2409 A. G. S./ Cámara de Castilla. Pueblos, leg. 5, doc. 250/ Castilla, 2 2 1⁄2 S. XVI.

2410 Tratamos el Correo de la Universidad de manera más extensa en el apartado “El Correo Mayor de los Mercaderes", en BASAS FERNÁNDEZ, M.: 1963 y 1994: 68-79.

2411 Ordenanzas del Consulado de Burgos de 1538/Valladolid, 18 septiembre 1538; GARCÍA de QUEVEDO, E.: 1905 Y 1995: 199-203. Ordenanza XXI.

2412 Reales Ordenanzas del Consulado y Casa de Contratación de Burgos/ Ordenanza XXVIII/ Madrid, 1 agosto 1572; LARRUGA, E.: 1793: 216-297: t. XXVIII.

2413 A. D. B./ R-12/ Libro de caja de la Universidad de Burgos/ Burgos, 1549-1557. fols. 204i y $345 i$.

2414 A. D. B./ R-3/ Burgos, 1539-1549. fol. 227i.

2415 A. D. B./ R-12/ Libro de caja de la Universidad de Burgos/ Burgos, 1549-1557. 
hecho ciertas ordenanzas que presentó a su Consejo y que por ser muy útiles pidió que las mandase aprobar. Se indica en una de ellas que la Universidad para el ejercicio de su jurisdicción y para otros casos y cosas necesarias para su buena administración, tiene por costumbre nombrar como al presente lo tienen nombrado, Maestro de Correos y Correos solicitadores a los cuales se les da el salario según la calidad de su cargo y oficio. El Consejo acordó en septiembre de 1538 aprobar las ordenanzas, y el Rey manda que se guarden y cumplan ${ }^{2416}$.

La Universidad de Burgos registra numerosas referencias a los gastos realizados con los correos, por lo que incluimos tan solo un breve resumen. De esta manera, en 1542 se gastaron $8.006 \mathrm{mrs}$. en "correos ynbiados a la montaña, e uno a Lion y otro a Yrun", con los despachos de las cartas enviadas a Lyon y a Nantes por la vía de Irún y por portes de cartas de muchas partes. En 1544 se pagaron 3.056 mrs. a Juan Páez por 11 partidas a "mensajeros que hiço de Viluao, Santander, e Laredo a Burgos, e de Santander a Laredo e Uiluao". También se gastan 1.500 mrs. de albricias a un criado de los Fucares "que bino por Ynglaterra en deligençia a haçer sauer la llegada de la flota". En 1548 se pagan 10.549 mrs. en correos "de aqui a Laredo, Santander, Valladolid y Aranda" de los que 3.481 mrs. tocan a correos hechos para los pleitos y 7.068 de correos hechos para despacho de las flotas y Alonso de San Vitores debe $10.200 \mathrm{mrs}$. por 300 rs. que se le enviaron a Santander con un correo, para el aderezo de los caminos ${ }^{2417}$. En 1579 Juan de Ceballos pagó 954 mrs . a dos correos que envió de Santander a Burgos y 746 de tres correos que envió de Santander a Laredo ${ }^{2418}$ y Alonso de Compludo gastó 9.039 mrs. después de que fue al despacho de las naos, en correos que ha enviado a Burgos, Laredo, Portugalete, Castro y otras partes.

En 1550 Luis de Cumiel pagó 280 mrs. de "vnos portes de cartas que pago del emperador para el rrey de Françia" y 200 rs. que se le dieron cuando fue a Valladolid a presentar la cédula "que nos ynbiaron de Flandes de su magestad para Rreymundo de Tarsis, por que no se entremetiese en perturbar a nuestro correo mayor su ofiçio". También se gastaron 7.568 mrs. en "correos que se an ynbiado a la Montaña y Balladolid y otras partes" y portes de cartas y otras cosas. En 1551 se dieron $3.400 \mathrm{mrs}$. por un correo que Diego de Bernuy y el bachiller Juan Rodríguez enviaron de Valladolid por la posta, sobre el negocio de los portazgos de lo que toca al adelantado en lo de Santa Gadea.

En 1553 Trezanos gasta $187 \mathrm{mrs}$. de portes de cartas y se pagaron 1.122 mrs. para un mulatero por las costas de llevar el dinero a Valladolid, hacer el pago de $54 \mathrm{mrs}$. de llevarlo de la posada a casa de Diego Ochoa en Valladolid, $2.618 \mathrm{mrs}$. que gastó cuando volvió por la posta, 1.500 que gastó en la ida con 6 días que estuvo en Valladolid, 1.020 que costó llevar el segundo dinero, 680 de un correo que fue a Laredo y 472 de un correo que se despachó a Valladolid a Pedro de Aranda. También se gastaron 28.120 mrs.: 15.000 mrs. en la ida a Madrid en 40 postas que corrió de ida y vuelta y 11.250 de otra vez que fue a Madrid y de allí al Pardo, que cuenta de ida y venida 30 postas, con $1.875 \mathrm{mrs}$. que dio a los postillones.

En 1555 Conzalo de Salamanca debe 34.000 mrs. de la ida por la posta a Irún. También se libraron $15.000 \mathrm{mrs}$. a Pedro de Ochandiano, parador, por una posta que fue y vino

2416 A. D. B./ C-58/Valladolid, 18 septiembre 1538.

2417 A. D. B./ R-3/ Burgos, 1539-1549. fols. 55i, 138i, 322i y 323i.

2418 A. D. B./ R-6/ Manual del libro de cuentas de la Universidad de Burgos/ Burgos, 1549-1557. fol. 3V. 
en diligencia de Irún con cartas de Bartolomé de Miranda, y Ochandiano pagó 1.125 mrs. a un "peon que bino de Ualladolid en un dia o poco mas, con el despacho del desenbargo de dichas naos". En 1556 Toribio Hernández gastó 136 mrs. en una "guia que tomo de noche uiniendo de Santander en diligencia"2419. Diego de los Ríos hizo unos gastos de 2.924 mrs., que da por cuenta haber pagado a "çinco correos despachados, vno a Portogalete e otro a Bilvao e dos a Bitoria e de otro que bino de Rroa". También se deben de portes de cartas de todas partes $4.898 \mathrm{mrs} .{ }^{2420}$. En 1569 Madrid recibió 60.000 mrs. por sus costas y trabajo en "yr por la posta a Madrid, a hablar con su magestad sobre cosas de Ynglaterra" que en estar y volver se detuvo 66 días. En 1572 se pagaron 2.045 mrs. por un despacho a un correo francés a cuenta de la nao de Domingo de Gárate que fue tomada en la Rochelle, y 40.500 mrs. por tres correos que despachó a Bayona sobre la nao de Gárate ${ }^{2421}$.

\section{Los Correos mayores}

Las ordenanzas del Consulado de 1538 ya contemplaban el pago al Maestro de correos por sus servicios, algo vital para garantizar la buena y rápida comunicación entre los mercaderes y sus corresponsales y transportistas. Indican que la Universidad, Prior y cónsules de ella, tienen que hacer muchos gastos, "asi para pagar salarios... del maestro de correos, e para el solicitador e fiscal y andadores e despachos de correos ordinarios, de veynte, a veynte e cinco dias para Flandes e Gran Bretaña y León so la Rona ${ }^{2422}$, e Sevilla, Portugal y otras partes extraordinarias..."2423. Las nuevas ordenanzas de 1572 reconocen ya de manera clara la figura del Correo mayor y dicen que la Universidad tiene ejecutoria "de S. M. para poner y nombrar correo mayor de esta Universidad, y el dicho oficio es muy necesario al servicio de S. M. y para las cosas concernientes a la dicha Universidad, y que la persona que el oficio exerciere, se requiere sea persona de much legalidad, y verdad"2424.

La Universidad de los Mercaderes tenía Maestro de correos desde su fundación. En marzo de 1486 los Reyes Católicos expiden una Cédula nombrando Trotero mayor de Burgos a Álvaro de Cervantes ${ }^{2425}$. Pedro del Campo era correo de los Reyes Católicos cuando le nombraron hoste de correos y Correo mayor de Burgos, oficio que vendió en 1505 al Prior y cónsules del Consulado por 200 ds. Así pasó el cargo, de la ciudad a los mercaderes y estos nombraron como primer Maestre de correos del Consulado a "Juan de Arlançon, tundidor que possaua en la Llana de la dicha çiudad, debaxo de las casas que abian comprado los dichos prior y consules, el qual resçebia e daba las cartas que benian a su casa para mercaderes de la dicha unibersidad, y llebaba vn marabedi de cada carta" o pliego que entregaba o recibía ${ }^{2426}$. A Juan de Arlanzón le sucedieron en

2419 A. D. B./ R-12/ Libro de caja de la Universidad de Burgos/ Burgos, 1549-1557. fols. 32i, 6oi, 6od, 61i, 90i, 221d, 238i, $342 i$ y $343 i$

2420 A. D. B./ R-6/ Manual del libro de cuentas de la Universidad de Burgos/ Burgos, 1549-1557. fols. 86r y $117 \mathrm{~V}$.

2421 A. D. B./ R-15/ Libro de caja o Mayor del Consulado/ Burgos, 1568-1577. fols. 37i, 150d y 161d.

2422 Se refieren sin duda a Lyon y Ruán.

2423 Ordenanzas del Consulado de Burgos de 1538/ Valladolid, 18 septiembre 1538; GARCÍA de QUEVEDO, E.: 1905 Y 1995: 199-203. Se trata de la ordenanza número XXI.

2424 Reales Ordenanzas del Consulado y Casa de Contratación de Burgos/ Ordenanza nํXVI / Madrid, 1 agosto 1572; LARRUGA, E.: 1793: 216-297. t. XXVIII.

2425 A. M. B./ Actas Municipales, 1486, fol. 19/ Burgos, marzo 1486; BASAS FERNÁNDEZ, M.: 1963 y $1994: 70$.

2426 A. Ch. V./ Lapuerta, leg. 232. fol. 54; BASAS FERNÁNDEZ, M.: 1963 y 1994: 70; A. D. B./ C-58/ Burgos, 4 junio 1550. 
el cargo los hermanos Alonso y Juan de Covarrubias, uno tras otro, y a estos durante 4 años Juan de Crijalba, criado de los Covarrubias, al parecer con carácter interino hasta la mayoría de edad de Cristóbal de Covarrubias, hijo de Juan, que desempeñó el cargo desde 1542. Covarrubias fue Correo mayor de la Universidad hasta 1552, cuando a pesar de haber ganado en ese año el pleito interpuesto entre él y Juan Vizcaíno, se le quita el cargo en favor de este. Como compensación se le concede una pensión anual de 30.000 mrs. desde San Miguel de 1552 hasta San Miguel de 1553, "por el conçierto que con el se hizo quando se le quito el cargo de correo" y en octubre de 1554 se le dan 35.000 mrs. anuales "despues que dexo el cargo de correo mayor".

En el ejercicio de su cargo, Covarrubias debía 10.200 mrs. al Consulado en junio de 1549, recibidos en octubre de 1548 y en marzo de 1549. Ese año gastó $3.638 \mathrm{mrs}$. en portes de cartas del Consulado, así de Flandes como de Lyon, de los puertos, de Valladolid y de otras partes, y se le dieron en diciembre $5.888 \mathrm{mrs}$. por "correos que an benido de Santander y Laredo y Portugalete, y a correos que nosotros emos enbiado a los dichos puertos y a Valladolid". El censo que se paga a la Universidad y de las casas en que vive Covarrubias en julio de 1549 es de 2.782 mrs. En diciembre de 1550, se le dieron $7.568 \mathrm{mrs}$. por el gasto "en correos que se an ynbiado a la Montaña y Balladolid y otras partes, y portes de cartas de Flandes y Balladolid"2427.

Tras el fallecimiento de Covarrubias hacia 1555, Vizcaíno comprometerá el pago de una renta de $30.000 \mathrm{mrs}$. anuales a María de Arceo su viuda, "los quales le estan situados fasta que fuere la uoluntad de los señores prior e consules, por ser pobre y tener muchos hijos que mantener". Así, en 1555 se dieron 4.150 mrs. a la viuda y en abril de 1556, después que entraron el Prior y cónsules nuevos, se le pagan $10.000 \mathrm{mrs}$. de los meses de octubre, noviembre, diciembre y enero pasados. En octubre Vizcaíno pagó $20.000 \mathrm{mrs}$. en feria de mayo pasada por la pensión que se le echó el año pasado para ayuda de los 30.00o que se dan de limosna a María de Arceo.

Juan Vizcaíno fue Correo mayor de la Universidad tras hacer el Consulado una escritura de concierto en septiembre de 1552, por la que se le quitaba el cargo a Cristóbal de Covarrubias. Como compensación de los gastos ocasionados a la Universidad por el pleito y para indemnizar a Covarrubias, Vizcaíno debía pagar $30.000 \mathrm{mrs}$. anuales. En enero de 1561 o poco antes, había fallecido. Raimundo de Tassis le había nombrado en mayo de 1542, "oste de Correos y Postas por su Magestad" en Burgos, y teniente de Correo mayor en dicha ciudad.

En diciembre de 1550 se pagan 43.781 mrs., que los cónsules de Flandes toman sobre los de la Universidad para la feria de octubre, a pagar a Miguel y Juan de Lerma, por 200 florines de a 20 placas que se dieron por tener la cédula del emperador en "conserbaçion del ofiçio de correo mayor, por el pleito que nos mobieron Reymundo de Tasis correo mayor de Valladolid y Juan Bizcaino". Juan de Camargo, cónsul de Flandes, debe en enero de 1552 por las postas y trabajo 6.800 mrs. a "Oñate, criado de Juan Bizcaino, que fue a Madrid con cartas para el prinçipe nuestro señor, con una carta que le ynbiamos de la rreina Maria, que nos enbiaron los consoles de Flandes". También se le pagaron $1.038 \mathrm{mrs}$. del porte de las cartas de Flandes. En octubre de 1554 Vizcaíno recibe $4.275 \mathrm{mrs}$. de portes de cartas de más partes, y en diciembre de 1555 Bernardino de

2427 A. D. B./ R-12/ Libro de caja de la Universidad de Burgos/ Burgos, 1549-1557. fols. 26i, 29i, 32i, 82i, 209i, 262i, 326d, $353 i$ y $372 d$. 
Aragón y Francisco de Aguilar deben 15.000 mrs. de la cuenta de la feria de mayo que libró Vizcaíno. En junio de 1556 se le pagan 680 mrs. por un correo que hizo en diligencia a Valladolid ${ }^{2428}$, y 12.129 mrs. por los gastos de correos siguientes, despachados en 1555 por la Universidad:

\begin{tabular}{|c|c|l|}
\hline Fecha & Mrs. & Concepto \\
\hline 10 julio & 136 & A un mozo que fue a Irún \\
\hline 10 julio & 38 & De una carta de Flandes \\
\hline 8 agosto & 1.836 & $\begin{array}{l}\text { Pagados a Palencia correo, por dos viajes que hizo a Laredo y } \\
\text { Portugalete a las 12 leguas }\end{array}$ \\
\hline 12 agosto & 45 & De porte de una carta de Flandes \\
\hline 23 agosto & 680 & $\begin{array}{l}\text { Pagados a Pero Ruiz peón, que fue a Portugalete, Bilbao y Laredo y } \\
\text { de allí otra vez a Bilbao y Laredo. Le dio Arnao del Hoyo 42 rs. y aquí } \\
\text { se le pagó lo demás }\end{array}$ \\
\hline 23 agosto & 37 & Por una carta de Flandes \\
\hline 8 septiembre & 34 & De una carta de Bilbao \\
\hline 11 septiembre & 476 & Dados a un peón que fue a Valladolid \\
\hline 11 septiembre & 1.632 & Dados "a un honbre que bino de Ualladolid a las 20 leguas" \\
\hline 11 septiembre & 1.125 & Dados a un peón que fue a Valladolid casi a las 20 leguas \\
\hline 12 septiembre & 612 & Dados a un hombre que fue a Santander \\
\hline 14 septiembre & 748 & Dados "a otro honbre que fue a Santander en menos de 2 dias" \\
\hline 18 septiembre & 612 & Dados a otro peón que fue a Santander \\
\hline 23 septiembre & 1.500 & Dados a un peón que fue a Valladolid “yente y biniente a las 15 leguas" \\
\hline 25 septiembre & 884 & $\begin{array}{l}\text { Dados a otro peón que fue a Santander además de cuatro rs. que le } \\
\text { dio Mújica porque llevó 2.20o rs. }\end{array}$ \\
\hline 28 septiembre & 1.258 & $\begin{array}{l}\text { Dados a otro peón que fue a Valladolid a las 15 leguas, y por traer una } \\
\text { provisión, se detuvo 10 días }\end{array}$ \\
\hline 29 septiembre & 476 & Dados a un estudiante que fue a Santander "a seruir el biaje" \\
\hline
\end{tabular}

Cerónimo Pardo Orense fue mercader de la Universidad de Burgos y Correo mayor de ella desde 1561. En enero de 1573 ya había fallecido. En enero de 1561 el oficio de Correo mayor de la Universidad estaba vacante por fallecimiento de Juan Vizcaíno y para proveer el cargo por una persona hábil y suficiente, y "por conosçimiento e la presençia e buena relaçion que tenian e tienen de su persona", el Prior y cónsules nombraron a Gerónimo Pardo el joven, vecino de la ciudad y persona de la Universidad, "para que sea thenido e avido por tal correo mayor de la dicha Universidad" con todos los derechos correspondientes al dicho oficio. Gerónimo Pardo juró el oficio y que no llevaría más de los derechos justos y acostumbrados como lo llevara Juan Vizcaíno y los anteriores Correos mayores, guardando el secreto que se requiere ${ }^{2429}$. La pensión anual que debía pagar por desempeñar el oficio de Correo mayor era de 50.000 mrs. En junio de 1561 se hacen costas contra Miguel de Peña Vera en el oficio de Correo

2428 A. D. B./ R-12/ Libro de caja de la Universidad de Burgos/ Burgos, 1549-1557. fols. 82i, 138i, 148i, 209d, 225i, 301i, $343 i, 344 i$ y $372 d$.

2429 A. Ch. V./ Lapuerta. Fenecidos. leg. 232, pieza XXX, fol. 135-127/ Burgos, g enero 1561; BASAS FERNÁNDEZ, M.: 1963 y 1994: 271-274. 
mayor y debe 13.125 mrs. que dieron a Gerónimo Pardo "nuestro correo mayor" en abril, para despachar a Jordán para Flandes ${ }^{2430}$. Pardo debe en septiembre de 1568, 50.00o mrs. de la pensión anual desde el primer día de ese mes "por rrazon del ofizio que se le dio de correo y obste de cauallos" hasta primero de septiembre de 1569. En octubre de 1569 Pardo debe 50.000 mrs. que paga de pensión por el oficio desde primero de septiembre de 1568, y los ha de pagar por tercios de cuatro en 4 meses. Desde el uno de septiembre de 1569 al de 1570 debe 50.000 mrs. por la pensión, así como en septiembre de 1572 por la pensión anual y en 1573 se recoge que Gerónimo Pardo, difunto, debe $39.773 \mathrm{mrs}$. de resto de su cuenta y de las pensiones que de él se han de cobrar ${ }^{2431}$.

Francisco de Cuevas fue Correo mayor del Consulado entre abril de 1571 y al menos 1598. Desde el año en que tomó posesión, debe pagar 50.00o mrs. anuales de pensión contados de San Miguel a San Miguel, y tal pensión se contabiliza hasta el año 1579. Así en 1571: "Francisco de Cuebas nuestro correo mayor, deue en 20 de otubre 22.219 mrs. por lo corrido de los 50.000 de penssion por año que da a la Uniuersidad de 20 de abril de 71 a San Miguel". En 1572 se deben a Cuevas $40.500 \mathrm{mrs}$. de todos los correos y portes de cartas que por la Universidad ha pagado y en 1574 se pagan 13.244 mrs. para su mujer, por lo que se le debía del salario y costas del primer viaje que hizo a Burgos, Logroño y Navarra, sobre la nao de Domingo de Gárate que fue tomada en la Rochelle. En 1575 se le pagan 15.445 mrs. por los portes de cartas y correos que dio desde primero de octubre de 1572 hasta fin de septiembre de 1573 que se habían dejado de asentar ${ }^{2432}$ y en 1575 recibe 2.254 mrs. de resto de portes de cartas hasta fin de $1576^{2433}$. Debe $18.750 \mathrm{mrs}$. en 1578 por la mitad de 100 ds. que paga de pensión de medio año y se le pagan 3.920 mrs. de los portes de cartas y correos hasta agosto de 1578. En 1579 se le acepta el pago de $2.226 \mathrm{mrs}$. por un correo a Santander y portes de cartas. En 1580 Cuevas debe $5.495 \mathrm{mrs}$. de salario de su cuenta en la cual le está cargada la pensión que tenía hasta San Miguel de 1579. En 1581 Cuevas da cuenta de haber gastado 6.559 mrs. en portes de cartas hasta setiembre 1580, en que entran 2.034 de un correo que despachó a Valladolid en marzo de 1580 a las 20 leguas²434. En 1598 se le deben 238 rs. por dos correos que envió "á las beynte" 2435 a la villa de Madrid, con despachos para el Rey y sus procuradores de Cortes, sobre la concesión de los millones y del mercado franco de Burgos, y vuelta "álas diez".

\section{Los correos}

Citamos en este apartado los correos que se mencionan en los libros de cuentas de la Universidad de los Mercaderes donde se anotan los pagos a dichos correos por hacer portes

2430 A. D. B./ Libro de Caja de la Universidad. R-14/ 1557-67. fol. 55d.

2431 A. D. B./ R-15/ Libro de caja o Mayor del Consulado/ Burgos, 1568-1577. fols. 25i, 37i, 47d, 58i, 64i, 90i, 167d, 175i y $205 i$.

2432 A. D. B./ R-15/ Libro de caja o Mayor del Consulado/ Burgos, 1568-1577. fols. 111d, 142i, 161i, 177i, $268 \mathrm{i}, 317 \mathrm{i}$ y $349 \mathrm{i}$.

2433 A. D. B./ R-33/ Libro de Sierra/ Burgos, 1573-1575. fol. 136.

2434 A. D. B./ R-19/ Libro de caja o Mayor del Consulado de Burgos/ Burgos, 1578-1581. fols. 5i, 5d, 14d, 25i, 32d, 39d, 52i, 75i, 91i y $106 i$.

2435 El Diccionario de la Academia Española, en su edición de 1884, explicó, por primera vez, el significado de Correo á las diez, las doce, las quince, las veinte, etc. ó sea la obligación de caminar 10, 12, 15 ó 20 leguas por día. Naturalmente, el precio cambiaba al variar la rapidez del traslado. 
para la Institución. Aunque Diego de Mata declaró que él era "uno de los doce correos hordinarios nombrados por los dichos Prior y cónsules de la Universidad"2436, no tenemos seguridad de que todos los que hacían portes para ella, estuviesen dedicados en exclusiva, más bien pensamos que era al contrario, es decir que eran correos que desarrollaban su profesión con independencia de quién los contratase. Aunque se siguen anotando gastos de correos desde 1555 , si bien en menor medida, no aparecen nombres concretos de ningún correo salvo uno en 1566, y tan solo se reflejan los nombres de los Correos Mayores de manera repetitiva. Pasamos a resumir los trabajos realizados por cada uno de los correos que aparecen citados y sus cobros, presentados por orden cronológico:

Pedro de Losa. En mayo de 1539 se le pagaron 1.500 mrs., en mayo de 1540, otros 1.500 mrs. y en mayo de 1542, 9.500 mrs. que se le dieron en Flandes. En octubre de 1543 le dieron 3.000 mrs. por 8 ds. que se enviaron a Rioseco en posta, para avisar que había pólvora en el castillo y que se devolviese lo del almirante. En septiembre de 1546 se dieron 3.000 mrs. a Losa y Espinosa, correos que fueron a Lyon con los despachos de octubre de la feria de Villalón 2437.

Diego de Espinosa. En noviembre de 1541 se le pagan 1.500 mrs. por ir a Lyon a la feria de los Santos, y en diciembre otros 1.500 mrs. por ir a Lyon con los despachos de la feria de Villalón para la feria de Reyes. En septiembre de 1546 se dieron 3.000 mrs. a Losa y Espinosa, correos que fueron a Lyon con los despachos de octubre de la feria de Villalón ${ }^{2438}$. En octubre de 1554 se le pagan 612 mrs. por ir a Laredo 2439.

Salazar. En octubre de 1542 se pagaron 750 mrs. a Salazar, que se le envió a Bilbao para hacer saber que había pólvora y tenía que llegar en un día natural, y como "no cunplio no se le dio mas de lo dicho"2440.

Jacorre de Hastigar. En noviembre de 1542 se le dieron 1.125 mrs. por "correos fechos por bia de Yrun" para todas partes, y llevar "los despachos de Henantes, Lion, Rroan e Cales" En enero de 1543 se le pagan 4.500 mrs. por dicho viaje, seis ducados por un despacho que llevó a Flandes y Ruan y cinco por dos despachos para Lyon y Nantes. En febrero de 1543 se pagan 6.149 mrs. a Miguel de Amezcata, trotero de Jacorre de Hastigar para llevar a Irún los dichos 4.500 rs. que pagó al correo que trajo el despacho de Calais; 320 mrs. por 40 tarjas que pagó al dicho correo; más 204 que costó traer el despacho de Bayona a Irún; 1.125 al correo que lo trajo de Irún a Burgos y 187 por lo que esperó. En abril de 1543 se le pagan 4.200 mrs. por 12 días de un correo que despachó con cartas para Ruan y Flandes por vía de Calais, por 16 días y cobró en Ruan por las cartas que allí llevó2441.

Serna. En mayo de 1542 se gastan 15.000 mrs. en ir por la posta a Barcelona donde está el emperador, sobre lo de la pólvora, y en junio de 1543 se le envía de nuevo a Barcelona

2436 BASAS FERNÁNDEZ, M.: 1963 y 1994: 74 nota 114. Los otros eran Pedro del Campo, Sagredo, Brizuela, Mateo, Andrés Bretón, su sobrino, Guilloma, Lope Mata y Diego de Aviñón (faltan dos en la relación). Cobraban un ducado por viaje ordinario de Burgos a Brujas.

2437 A. D. B./ R-3/ Burgos, 1539-1549. fols. 10i, 13d, 6od, 68i y 211 i.

2438 A. D. B./ R-3/ Burgos, 1539-1549. fols. 55i y 211 i.

2439 A. D. B./ R-12/ Libro de caja de la Universidad de Burgos/ Burgos, 1549-1557. fol. 301 i.

2440 A. D. B./ R-3/ Burgos, 1539-1549. fol. 72i.

2441 A. D. B./ R-3/ Burgos, 1539-1549. fol. 73 i 
a lo mismo. En septiembre de 1546 se le pagaron 4.500 mrs. "quando le ynuiamos a Rribadeo a mandar que descargase alli las sacas mojadas y dañadas"2442.

Arceniega. En octubre de 1542 se le pagaron 731 mrs. por ir a Bilbao y de allí a Laredo y Santander ${ }^{2443}$. En abril de 1553 Hernando de Trezanos le pagó 204 mrs. que se le debían de un viaje realizado a Bilbao 2444 .

Salcedo. En octubre de 1542 se pagan a Salcedo 937 mrs. , por ir a Laredo y Santander y cobrar en la misma diligencia cuatro ds., "e porque no cunplio no se le dyo mas de lo dicho"2445. En octubre de 1554 se le pagan 3.000 mrs. por ir a Bilbao a las 20 leguas y volver a las 15. En julio de 1555 Pedro de Ochandiano paga a Salcedo 2.250 mrs. por ir a Dueñas por la posta a alcanzar a Gregorio de Lerma sobre el embargo de las naos con lanas ${ }^{2446}$.

Diego de Aviñón. En septiembre 1543 se pagan 3.000 mrs. a Diego de Aviñón, correo, para ayuda de las costas del viaje a Flandes por la Universidad, a condición de que no han de constar en las cartas de ida y vuelta más de a go mrs. la onza y en Flandes le han de dar otros 8 ds. ${ }^{2447}$.

Castañeda. En junio de 1543 se pagan a Castañeda 5.917 mrs. por "correos echos a Laredo e Balladolide Bilbao", y llevar cartas desde octubre de 1542. En febrero de 1547 se le dieron 1.496 mrs., por el viaje que hizo a Lyon con el segundo despacho de la feria de octubre ${ }^{2448}$.

Santurde. En octubre de 1543 se le dieron 3.750 mrs. por 10 días, utilizados en ir a Monzón sobre lo de la pólvora a las 15 leguas, y debía emplear por ida y venida 14 días, "epor que no cunplio, no se le dio mas de lo dicho". En agosto de 1545 se le dieron 1.500 mrs. para el viaje de Lyon. En febrero de 1547 se le pagaron 1.496 mrs. por otro viaje a Lyon, con los primeros despachos de la feria de Villalón de ese año 2449 , y en mayo de 1550 se dieron $1.500 \mathrm{mrs}$. a "Santurde correo que fue con los despachos para Leon", en feria de Reyes, de la feria de octubre pasada 2450 .

Barahona. En mayo de 1544 se pagaron a Barahona 6.375 mrs. por ir y venir en posta a Valladolid y por acompañar al diputado Diego Pérez de Martiarto2451.

Juan Álvarez. En septiembre de 1546 se pagaron 750 mrs. a Juan Álvarez "que uino con la nueua que estaba la nao en Rribadeo"2452.

Juan de Basori. En julio de 1547 se enviaron 13.600 mrs. con Basori, correo de Portugalete, para pagar la obra de los caminos que hace la Universidad ${ }^{2453}$. En abril de 1553 se

2442 A. D. B./ R-3/ Burgos, 1539-1549. fol. 61i, 69i y 227i.

2443 A. D. B./ R-3/ Burgos, 1539-1549. fol. 72i.

2444 A. D. B./ R-12/ Libro de caja de la Universidad de Burgos/ Burgos, 1549-1557. fol. 238 i.

2445 A. D. B./ R-3/ Burgos, 1539-1549. fol. 72i.

2446 A. D. B./ R-12/ Libro de caja de la Universidad de Burgos/ Burgos, 1549-1557. fols. 301i y 343 i.

2447 A. D. B./ R-3/ Burgos, 1539-1549. fol. 71i.

2448 A. D. B./ R-3/ Burgos, 1539-1549. fols. 70i y 252i.

2449 A. D. B./ R-3/ Burgos, 1539-1549. fol. 68i, 191 i y $252 i$.

2450 A. D. B./ R-12/ Libro de caja de la Universidad de Burgos/ Burgos, 1549-1557. fol. 63d.

2451 A. D. B./ R-3/ Burgos, 1539-1549. fol. 137i.

2452 A. D. B./ R-3/ Burgos, 1539-1549. fol. 227 i.

2453 A. D. B./ R-3/ Burgos, 1539-1549. fol. 256d. 
dieron 408.00o mrs. para enviar a Portugalete con Basori, que los llevó por vía de Bilbao con Martín de Pinedo, vecino de Alcedo, en febrero de $1553^{2454}$.

Tamayo. En enero de 1547 se le dieron 3.000 mrs. por ir de Burgos a Valladolid en posta cuando prendieron al Prior y cónsules 2455. En abril de 1553 se gastaron 49.562 mrs. por Diego López Gallo menor y Lores de Gaona en el viaje que hicieron a Monzón 40.562 mrs. de sus costas y los 9.00o dados a Tamayo, correo que fue con ellos. En mayo pagó 7.038 mrs. porque fue con los mismos a Madrid y le sobró del dinero que les llevó para pagar las costas que hicieron en el viaje ${ }^{2456}$.

Pierres. En julio de 1547 se le dieron 2.616 mrs. por los portes que llevó y trajo en el viaje a Nantes ${ }^{2457}$. En abril de 1553 se le pagan 1.122 mrs. cuando fue "en diligençia a Santander y Laredo a lleuar la probision del capitan Juan de Ugarte" y en octubre de 1554 se le pagan 374 mrs. por ir a Valladolid ${ }^{2458}$.

Juan de Cianca. En septiembre de 1550 se le pagaron 306 mrs. "de porte de vnas cartas de Laredo"2459.

Pedrosa. En agosto de 1550 se dieron a Pedrosa 1.496 mrs. "por el biaje que fue a Leon" 2460 , y se suele pagar por la Universidad. En julio de 1555 Pedro de Ochandiano le paga 3.00o mrs. por otro viaje que hizo a Santander a las 20 leguas, volviendo en la misma diligen$\operatorname{cia}^{2461}$.

Papillón. En septiembre de 1551 se pagan 1.308 mrs. a Diego de los Ríos, enviado por la posta por la Universidad para recuperar las cartas y el correo cuando en Burgos se supo que prendieron en Toloseta a Papillón correo, que venía de Ruan con dichas cartas, y los trajo. De las postas y de la ida y venida y de su trabajo se gastaron $12.452 \mathrm{mrs}$. y como se cobraron $11.144 \mathrm{mrs}$. de las personas para quien venían las cartas, faltaban los dichos 1.308 mrs. ${ }^{2462}$.

Juan de Manzanedo. En enero de 1552 se dieron 578 mrs. a Juan de Manzanedo, correo que fue a Santander 2463 .

Pedro de Sua. En enero de 1552 se registran pagos de 618 mrs. a Pedro de Sua, correo que fue a Santander en diciembre de $1551^{2464}$.

Sancho García. En octubre de 1554 se pagan 750 mrs. a Sancho García por ir a Deva ${ }^{2465}$.

2454 A. D. B./ R-12/ Libro de caja de la Universidad de Burgos/ Burgos, 1549-1557. fol. 204 i.

2455 A. D. B./ R-3/ Burgos, 1539-1549. fol. 252i.

2456 A. D. B./ R-12/ Libro de caja de la Universidad de Burgos/ Burgos, 1549-1557. fols. 208i y 217i.

2457 A. D. B./ R-3/ Burgos, 1539-1549. fol. 277 i.

2458 A. D. B./ R-12/ Libro de caja de la Universidad de Burgos/ Burgos, 1549-1557. fols. 204i y 301 i.

2459 A. D. B./ R-12/ Libro de caja de la Universidad de Burgos/ Burgos, 1549-1557. fol. 61i.

2460 Se trata de Lyon

2461 A. D. B./ R-12/ Libro de caja de la Universidad de Burgos/ Burgos, 1549-1557. fols. 61i y $343 i$.

2462 A. D. B./ R-12/ Libro de caja de la Universidad de Burgos/ Burgos, 1549-1557. fol. $120 i$.

2463 A. D. B./ R-12/ Libro de caja de la Universidad de Burgos/ Burgos, 1549-1557. fol. $129 \mathrm{i}$.

2464 A. D. B./ R-12/ Libro de caja de la Universidad de Burgos/ Burgos, 1549-1557. fol. 129i.

2465 A. D. B./ R-12/ Libro de caja de la Universidad de Burgos/ Burgos, 1549-1557. fol. 301 i. 
Pedro Ruiz. En diciembre de 1555 Arnao del Hoyo paga 680 mrs. a Pedro Ruiz, peón que fue a Portugalete, Bilbao y Laredo, y de allí otra vez a Bilbao y Laredo y en Burgos se le pagaron los 22 rs. del resto 2466 .

Palencia. En agosto de 1555 Juan Vizcaíno paga a 1.836 mrs. a Palencia, correo, por dos viajes que hizo a Laredo y Portugalete a las 12 leguas ${ }^{2467}$.

Zárate. En julio de 1555 Pedro de Ochandiano paga 612 mrs. a Zárate que fue a Santander a las 10 leguas ${ }^{2468}$.

Juan de Losa. En enero de 1556 Melchor de Mújica debe 102.000 mrs., que se le enviaron a Santander con Juan de Losa.

Gerónimo Pardo. En julio de 1582 tocan 9.375 mrs. a Cerónimo Pardo correo 2469 , por 125 ds. que tenía a 20\% y había recibido otros 10 que se dan a cuenta de 300 ds. que debe ${ }^{2470}$.

\section{d.- Las postas. Sus itinerarios}

El acierto de Francisco de Tassis fue el de la instalación de postas a lo largo de los recorridos, con estaciones distantes entre cinco y siete leguas para facilitar al correo caballos de refresco y recorrer así con mayor rapidez largas distancias. Esto obligaba a dotar a cada estación de un número suficiente de caballos, y a disponer de postillones para recuperar los caballos prestados.

En la concesión, realizada en 1505, del servicio de correos entre España y Flandes se determina que las cartas no debían tardar más de 4 días en ir de Irún a Bruselas; 12 días en verano y catorce en invierno de Toledo a Bruselas; y entre quince y 18 días desde Cranada. Se inicia entonces el establecimiento del servicio de postas entre los lugares donde reside la corte y las principales capitales europeas, algo que después se extenderá a otras ciudades españolas. Como un caballo podía aguantar al paso 9 o 10 horas, a algo más de una legua a la hora; al trote tres horas, a algo más de dos leguas a la hora y al galope hora y media, a cuatro leguas y media a la hora, era necesaria la instalación de un servicio de postas que permitiese el cambio de montura tras aprovechar el máximo rendimiento de cada caballería. De esta manera, se pudo lograr una gran rapidez, si tenemos en cuenta el deficiente estado de los caminos, como en julio de 1555 , cuando un "peon que bino de Ualladolid en un dia o poco mas", o en septiembre de ese año, cuando un "honbre que fue a Santander en menos de 2 dias"2471.

En las condiciones del apuntamiento hecho en diciembre de 1517 por el Rey a Juan Bautista y Mafeo de Tassis, sus Maestros de postas, para el entretenimiento de las postas se indica que "desde sus reynos despaña fasta en françia en sus tierras de abaxo, y desde alla al enperador en

2466 A. D. B./ R-12/ Libro de caja de la Universidad de Burgos/ Burgos, 1549-1557. fol. 343i.

2467 A. D. B./ R-12/ Libro de caja de la Universidad de Burgos/ Burgos, 1549-1557. fol. 343i.

2468 A. D. B./ R-12/ Libro de caja de la Universidad de Burgos/ Burgos, 1549-1557. fol. 343i.

2469 No confundir con el Gerónimo Pardo Correo Mayor, que en enero de 1573, ya había fallecido. Pudiera tratarse de un hijo.

2470 A. D. B./ R-30/ Libro de Caja del Consulado de Burgos/ Burgos, 1582-1588. fol. $32 i$.

2471 A. D. B./ R-12/ Libro de caja de la Universidad de Burgos/ Burgos, 1549-1557. fol. 343i. 
qualquier parte que sea en alemanya,... seran obligados los dichos maestros de postas de tener postas, desde el lugar donde sera el rey en sus dichos reynos d'españa, fasta en sus dichas tierras de abaxo en el lugar donde su lugar teniente e los del su consejo estobiere". Dichos Maestros deberán "poner e entretener en cada lugar e plaça donde las dichas postas sean asentadas, dos cavallos por cada una posta para fazer mejor diligençia, eçepto las que sean fuera del dicho camyno donde fuere el rey de françia, las quales no seruiran que vn cavallo". Deberán también "entregar las cartas que les seran dadas para enbiar desde Bruselas fasta Paris, en verano XXXVI oras y en invierno en XI oras, fasta Blays en verano en I y en invierno IX oras, fasta Lion so la Rona en verano en tres dias y medio y en ynvierno en IIII dias... desde Burgos fasta Bruselas en verano en VII dias y en ynvierno VIII dias". Se disponía que en los lugares donde se establecieran las postas debía haber, al menos, una persona encargada de la correspondencia que "ternan cargo de despachar y dar las letras y paquetes a los dichos maestros, o a sus tenientes y para las rescebir quando las respuestas vernan"2472.

En la ciudad de Burgos existió, al menos desde 1542, casa de postas dirigida por un hoste de correos. Se instala en el arrabal de Vega en la orilla izquierda del río Arlanzón, frente a la puerta de Santa María, para centralizar el recibo y expedición de cartas, pliegos y despachos, así como para facilitar los caballos necesarios para los correos. Era un negocio lucrativo y se concede en régimen de monopolio por el Correo mayor de la familia Tassis, que tiene a su vez el monopolio de los correos y postas del Reino. Así, Raimundo de Tassis "confiando de la fidelidad y deligençia de bos Juan Bizcayno, correo de sus Magestades bezino de la çiudad de Burgos", le nombra en mayo de 1542 "oste de correos de la dicha çiudad de Burgos", y le da licencia y facultad para que en adelante pueda usar del dicho oficio, y que ninguna otra persona lo pueda ejercer, y asimismo, "que todos los correos e otras personas que binieren o passaren por la dicha çiudad en posta, se bayan a apear en buestra cassa luego que llegaren, y bos den y entreguen las cartas, pliegos y biajes que traxeren, para que bos los deys a quien binieren e podays saber de donde bienen", y que pueda recibir todos los despachos y cartas que le fueren encomendados y enviados de cualquier parte y los encamine de su mano. Nombra a Juan Vizcaíno para que mientras viva pueda tener "la posta de la dicha çiudad de Burgos, segund e como al pressente la teneys e serbis... y pongais la dicha posta en el arrabal de Bega de la dich a çiudad, o en la parte elugar della que a uos os paresçiere e bien bisto fuere, e dar e deys a todos los correos y otras personas que por la dicha çiudad passaren o fueren, desdes de la dicha çiudad para qualesquier partes, todos los caballos y cabalgaduras e bestias de guia en posta" necesarios para hacer sus viajes.

Llevará por cada caballo, cabalgadura o bestia de guía que diere en "posta, desde la dicha çiudad a Billanueba de las Carretas que son çinco leguas, siete reales de plata, e a lugar de Quintanapalla que son tres leguas medio ducado de oro, e al lugar de Cogollos que son otras tres leguas otro medio ducado de oro, e si os paresçiere que conbiene al serbiçio de sus Magestades, poner caballos de posta entre la dicha çiudad de Burgos e Uillanueba"2473, los pueda poner en el lugar que le pareciere y "llebeys por cada caballo o cabalgadura o bestia de guia, que ansi dieredes en postas a cada parte, quatro reales de plata e no mas, so pena de beynte ducados de oro por cada uez que llebaredes mas derechos de los aqui espaçifficados", e de parte de sus Majestades, requiere que nadie "se entremetan a usar ni hussen del dicho offiçio de oste de correos

2472 A. G. S./ Contadurías. 1ae época. leg. 315/Valladolid, 20 diciembre 1517; MONTÁÑEZ MATILLA, M.: 1953: 184-186; URIOL SALCEDO, J. I.: 1990: t. I, 183-184.

2473 Entre Burgos y Villanueva de las Carretas, hay 33 kms. o 6 leguas, distancia que no hacía necesaria la instalación de ninguna posta intermedia. 
de la dicha çiudad de Burgos, ni de cossa a el tocante, ni dar ni den en la dicha çiudad ni entre medias della, del dicho lugar de Uillanueba ni con dos leguas en derredor, ningund caballo ni cabalgadura ni bestia de guia en posta a ningund correo"2474.

Los caminos de Burgos que primero alojaron una red de postas fueron el de Burgos a Valladolid, el de Burgos a Madrid por Segovia y el de Burgos a Bayona. Los caminos de Burgos a Bilbao, a Laredo y a Santander, aunque soportaron un intenso tráfico de correos de la Universidad como se ha manifestado en este capítulo, carecieron de este servicio en el siglo XVI. No obstante, de manera puntual sí se pudieron establecer postas, como en septiembre de 1570, cuando Felipe II manda al Correo mayor, que para el desplazamiento de la reina Ana, provea el camino de Laredo a Burgos y de Burgos a Madrid, con caballos de posta en que se pueda hacer diligencia, y haya previsión para los correos que por él se desplazaren por la posta hasta que la Reina llegase a Burgos, y que también se provean las postas del camino por donde la Reina ha de hacer su jornada de Burgos a Valladolid y a Segovia, y siendo necesario dar alguna ayuda de costa a las postas que se mudaren y sirvieren, el Correo mayor les mandará pagar lo que le pareciere justo2475. El 16 de septiembre se envía desde Laredo carta al secretario del Rey, dándole cuenta de las gestiones realizadas para el recibimiento de la Reina, y se le indica que "en teniendo algun prinçipio de buena nueua, se hara correo a toda fvria pues ay ya postas puestas aqui en Laredo de ayer aca y hasta Burgos..."2476.

En 1546, el valenciano Pero Juan Villuga publica el "Repertorio de todos Caminos de España"2477, la primera guía itineraria que trata sobre los caminos peninsulares de una manera completa. Villuga conocía bien los caminos principales de la Península, ya que aunque no lo indica, debió ejercer la profesión de correo. Los caminos de la zona que estudiamos, ya han sido incluidos en los apartados de cada camino por lo que no incidiremos en este punto. Alonso de Meneses, que ya indica que es correo, publica en 1576 el "Repertorio de Caminos”, que reproduce básicamente el de Villuga con algunas modificaciones ${ }^{2478}$.

El primer trabajo publicado como itinerario de postas y que recoge todas las carreras de la Península, fue realizado por Ottavio Cotogno, lugarteniente del Correo mayor de Milán. El "Nvovo Itinerario delle Poste, per tutto il Mondo"2479, vio la luz en Milán en 1608, y se reeditó seis veces, detallando las postas en el libro tercero. Sobre los caminos que tratamos

2474 A. D. B./ C-58/ Burgos, 2 mayo 1542.

2475 A. G. S./ Patronato Real, leg. 57, doc. 34/ Madrid, 4 septiembre 1570.

2476 A. G. S./ Patronato Real, leg 57, doc. 47/ Laredo, 16 septiembre 1570.

2477 VILLUGA, Pero J.: 1546.

2478 MENESES, A. de: 1576.

2479 COTOGNO, O.: 1608. 
incluye el de Bayona ${ }^{2480}$ y el de Madrid a Bilbao por Orduña ${ }^{2481}$. A lo largo del trabajo de Cotogno se van desglosando las diferentes rutas peninsulares, donde se incluyen varias que discurren por la provincia de Burgos:

- Poste dalla Santissima Casa di Loretto per infino à S. Giacomo di Galitia.

- Poste da Praga à Madrid.

- Poste da Roma à Madrid \& il camino, che fa l'Ordinario per Ispagna.

- Poste da Milano à Madrid per la più breue via.

- Poste de Madrid à Paris.

- Poste de Madrid à Burgos.

- Poste da Horiza à Vagliadolid (por Aranda de Duero)

- Poste da Vagliadolid à Madrid per Burgos.

- Poste da Burgos à Pamplona.

- Poste da Burgos à Barcelona.

- Poste de Saragoza à Bilbao (por Treviño)

- Poste da Madrid à Bilbao.

2480 "Poste dalla Santissima Casa di Loretto per infino à S. Giacomo di Galitia

A Vittoria Città paese d'Alua, oue li pàgano i Datii p. 1

Alla Pobla

p. 1

A Miranda d'Hebro Città, oue passa l'Hebro Fiume p. 1

A Meiugo

p. 1

A Panhuerba

p. 1

A Zugneda

p. 1

A Briuiesca

p. 1

A Castel di Peones

A Quintanapalia

p. 1

p. 1

A Burgos Città Metropoli della Castiglia Ia Vecchia, nella quale sono, infinite bellissime deuotioni"

"Poste da Milano à Madrid per la più breue via

A Vittoria Città paese d'Alua, oue si pagano i Datii p. 1

Alla Pobla p. 1

A Miranda d'Hebro Città oue passa l'Hebro p. 1

A Meijugo.

p. 1

A Panehuerba p. 1

A Zugneda p. 1

A Briuiesca p. 1

A Castel di Peones p. 1

A Quintanapaglia p. 1

A Burgos Città, Metropoli della Castiglia la vieja, nella quale vi sono bellissime diuotioni p. 1"

2481 "Poste da Madrid à Bilbao

Madrid Città.

Da essa Città per infino à Burgos, hauete le Poste che questo è il suo camino, e sono p. 16

$\begin{array}{ll}\text { Dapoi à Quintanapaglia } & \text { p. } 1 \\ \text { a Castel de Peones } & \text { p. } 1 \\ \text { a Briuiesca } & \text { p. } 1\end{array}$

Di quì auanti non vi sono le Poste frequenti, ma si possono concertare così.

$\begin{array}{ll}\text { A Pancorno } & \text { p. } 2 \\ \text { a Santa Gadea } & \text { p. } 1 \\ \text { alla Venta } & \text { p. } 1 \\ \text { a Beruerana } & p .7 \\ \text { a Orduña } & \text { p. } 1 \\ \text { a Lusciandro } & \text { p. } 1 \\ \text { a Mirauallis } & \text { p. } 7 \\ \text { a Bilbao Città, \& Port, e Metropoli di Biscaglia } & \text { p. }{ }^{\prime \prime}\end{array}$


- Poste da Saragoza à Salamanca (por Fresnillo de las Dueñas)

- Poste da Milano à Madrid per trauerso ma non si potrà correre che nen ui sara uno Caualli per la Guascogna, e Prouenza.

- Poste da Milano à San Giacomo di Galitia, \& i luoghi di diuotione che potrà uisitare per la uia.

- Nota delli Ordinarii, che passano, e partono dalla Citta di Burgos per diuerse parti. Da Burgos à Madrid; Da Burgos à Barcelona, \& Valenza; Da Burgos ad Italia; Da Burgos à Fiandra, \& Alemagna.

- Da Madrid à Italia.

- Da Brusseles à Ispagna.

\section{F.- LA SEGURIDAD DE LOS CAMINOS}

Los caminos eran por su propia situación y contexto, lugares favorables para ejercer la extorsión y a veces la emboscada y la violencia. Eran muchos los productos y riquezas que circulaban, transportados por arrieros y carreteros indefensos, que podían proporcionar pingües beneficios a los asaltantes. En las muchas leguas de sus trazados, existían lugares propicios para el asalto y el delito impune, algo que los Reyes Católicos intentaron atajar con la reactivación de las Hermandades. Pero a pesar de que los asaltos eran las acciones más llamativas y espectaculares, la mayor violencia y extorsión la ejercieron los señores de los territorios por donde circulaban las cargas, que utilizaban la fuerza y la coacción y desarrollaban unas acciones cuyo fin era el cobro de unos derechos que en la mayor parte de las ocasiones no poseían, o no para cobrar las cantidades que reclamaban. Además, tal inseguridad en los caminos se acrecentaba en épocas de debilidad de la autoridad y contienda, como en ciertos momentos del reinado de Enrique IV o en los conflictivos años de la sublevación comunera.

Por otro lado, existían otros aspectos como las inclemencias del tiempo, el estado de los puentes y vías y los animales salvajes, que provocaban cierta inseguridad en los caminos, y provocaban que el desplazamiento tuviese en ocasiones cierto grado de incertidumbre, riesgo y azar.

\section{a.- Robos y asaltos}

En 1450 se habla en el concejo de Burgos sobre la muerte de algunos hombres del merino, cuyos autores estaban en el Hospital del Rey, por lo que requieren a su administrador y freires a "que los entregasen a la justiçia de nuestro señor el rey, e de aquí adelante non acogiesen a ellos nyn a otros malfechores, porque era fama en esta çibdat que ende acogía muchos malfechores"2482. Al parecer dicho Hospital seguía acogiendo delincuentes, porque en 1479, Isabel I ordena a

2482 A. M. B./ Actas Municipales, 1450, f. 22V./ Burgos, 1450; RILOVA PÉREZ, I.: 2008: 133-134. 
su comendador que ningún malhechor encuentre amparo en dicho Hospital o en casa de sus freires ${ }^{2483}$.

Jorge Martínez de Fraga, escribano de Vitoria, en nombre de la viuda e hijos de Juan Ochoa de Guizábal, vecino de la anteiglesia de Ylameri en Vizcaya, dijo en el Consejo que cuando los Reyes estuvieron en Vitoria, comisionaron al doctor Pedro Pérez de Lequeitio, vecino de Vitoria, y a Pedro Alonso, vecino de Miranda de Ebro, para que resolviesen el conflicto que había entre el Condado y vecinos de Vizcaya y los vecinos de las villas de Miranda, Pancorbo y otras de Valdegovía y tierras de la comarca, sobre ciertos robos y represalias realizadas entre ellos, y como se oye que por el comercio y trato entre Juan Ochoa y Juan de la Suerte, vecino de Miranda, la dicha viuda e hijos han recibido mucho daño y Pérez de Lequeitio y Pedro Alonso debían conocerlo, y como el negocio no se determinaba por no estar juntos, pidió que como la mujer es viuda y sus hijos pequeños, huérfanos y pobres, se debía mandar que el doctor Salamanca determinase el pleito. Los Reyes mandan en 1483 a Diego de Proaño, alcalde en su casa y corte, que se junte con Lequeitio y vean el pleito y negocio 2484 .

En 1485 Andrés de la Cadena, procurador de los mercaderes de Burgos, dijo a los Reyes que Juan de Montellano, vecino de Portugalete, en deshonor de dichos mercaderes y no pudiéndolo hacer de derecho, retuvo ciertas mercaderías de sus partes en Portugalete, y no se las dejó llevar a la feria de Medina de octubre de ese año, por lo que el daño hecho fue de menos de 2.000 doblas de oro. El Consejo acordó mandar que Fernando de Salas, su escribano de cámara, vaya a Portugalete o donde Montellano estuviere, lo traiga preso a su costa ante el Consejo, lo entregue a los alcaldes de su corte y no lo suelten sin licencia real. Para hacerlo así ejecutar le dan poder cumplido, así como para las penas que le mande poner ${ }^{2485}$.

Bernardino de Valladolid, escribano de cámara, acusó a Jimen López de Marquina, a Juan de Marquina, su hijo, a Luis Barahona, a Alonso Barahona, a Álvaro de Pedrosa y a Lope Zorrilla y dijo que en febrero de 1486, yendo al lugar de Hornillos del Camino con Pedro de Avelar, alcalde ordinario de la villa de Muñó y su jurisdicción, por el camino real que va de Muñó a Hornillos a hacer ciertas pesquisas con la vara en la mano para su servicio y justicia, "no fasiendo ni disiendo por que mal ni daño e viese de rreçebir", los dichos "en sendos cauallos aparados de lanças, e coraças, e adargas, e otras armas dandose fabor e ayuda", les tomaron por fuerza "e non temiendo a Dios y a nuestra justiçia" les llevaron presos a Villadiego donde les tomaron la mula y lo que llevaban y les tuvieron presos en cadena 30 días. Tras la queja de la ciudad de Burgos, se envió a Cristóbal de Avelar a Burgos con provisiones reales para que los soltasen y procediesen contra los atacantes, y como Jimen López supo que Cristóbal de Avelar iba a ir a Villadiego con gentes, los llevó presos a la fortaleza de Herrera donde estuvieron 30 días o más, donde Avelar los halló allí presos, debiendo intervenir las Hermandades para que los soltasen, en lo cual, dice, que incurrieron en graves penas criminales. Los Reyes mandan en 1488 a los alcaldes de su casa y corte y Chancillería, que vean lo susodicho y

2483 A. M. B./ HI-1854/ Trujillo, 14 agosto 1479.

2484 A. G. S./ Registro General del Sello, XI-1483, fol. 263/Vitoria, 8 noviembre 1483.

2485 A. G. S./ Registro General del Sello, XI-1485, fol. 38/Valladolid, 29 noviembre 1485. 
oídas las partes determinen lo que hallaren por derecho, dándoles poder cumplido para pronunciar sentencia definitiva ${ }^{2486}$.

El Prior y cónsules de la Universidad de Burgos dijeron que hacía unos dos meses que les habían robado en Bilbao dos arrobas de lana, y que otras veces les habían hecho otros muchos hurtos. Pero por no haber en la villa personas que apremiasen a los malhechores no se han quejado pidiendo que se hiciese justicia. En enero de 1489 los Reyes encomiendan al corregidor y alcaldes de Bilbao, que se informen sobre quien hizo el hurto y "a los que fallaredes culpantes prendedles los cuerpos" 2487.

Los Reyes dicen en marzo de 1501 que Juan de Montehermosa, arriero, acusaba criminalmente a Andrés de Ancel, vecino de Palenzuela, porque estando él con una mujer en el lugar de Cogollos y queriendo ir a Bilbao, Ancel aguardó al arriero que la llevaba y fue en su compañía y mientras el dicho arriero volvió a buscar un asno que había perdido, Ancel dice que la llevó a un monte y la forzó, teniendo que subir la hermandad que la trajo a su tierra y que por ser ella mujer pobre y sin parientes, no ha podido alcanzar justicia. Visto en el Consejo se mandó a todos los corregidores, alcaldes y otras justicias, que reciban información y si se hallare que fue como se ha dicho se prenda a Andrés de Ancel y hagan justicia ${ }^{2488}$.

En Junta de Álava de noviembre de 1505 fueron publicadas las condenas de malhechores, y entre otras, se condenaba a la pena de azotes a Michel Arraya por público malhechor y porque "fue en matar a trayçión a vn rromero en el camino de Sant Andrian"2489.

\section{La Santa Hermandad}

La Santa Hermandad fue una institución compuesta por gente armada, movilizada y pagada por los concejos con el fin de garantizar el orden en cielo abierto y fuera de las poblaciones en caminos, campos y despoblados. Fue creada por Isabel I en las Cortes de Madrigal de 1476 a propuesta de los procuradores burgaleses, ya que necesitaban proteger su comercio, amparar el tránsito por los caminos y perseguir el bandolerismo, haciendo posible el que los Reyes, sobre la base preexistente de las hermandades que ya habían levantado algunas ciudades, propusiesen su creación, pero tendría una vida corta, pues desde 1498 quedó reducida a niveles estrictamente locales.

Desde el siglo XIII se habían constituido hermandades organizadas por ciudades y villas para velar por la seguridad de los caminos y el tráfico comercial en momentos concretos. Así en 1387 Juan I ordena a las autoridades de ciudades y villas del Reino, que organicen hermandades a tenor de lo dispuesto por la ordenanza elaborada en las Cortes de Segovia de $1386^{2490}$.

En la Crónica anónima de Enrique IV, se indica que hacia 1469 "la Hermandad se esforzó tanto desde el ayuntamiento que hizo en Tordesillas, que juntó 1.800 hombres de a caballo y ordenaron au-

2486 A. G. S./ Registro General del Sello, I-1488, fol. 113/ Zaragoza, 10 enero 1488.

2487 A. G. S./ Registro General del Sello, I-1489, fol. 167/ Valladolid, enero 1489.

2488 A. G. S./ Registro General del Sello, III-1501, fol. 432/ Valladolid, 20 marzo 1501.

2489 A. J. G. A./ t. I/ Vitoria, 18 noviembre 1505.

2490 A. M. B./ HI-2525/ Ávila, 20 febrero 1387. 
mentarlos hasta 3.000, con los que hicieron grandes servicios en la provincia de Toledo, en Castilla la Vieja y en Galicia, por lo que los partidarios del rey Alfonso como los de Enrique IV, intentaban tener la Hermandad de su parte"2491.

En marzo de 1476 los Reyes Católicos comunican al concejo burgalés, que ha sido establecida una Hermandad general en todo el Reino para vigilancia de los caminos, y con jurisdicción para juzgar sumariamente y castigar los delitos cometidos en despoblado ${ }^{2492}$, algo que se trató y acordó en las Cortes de Madrigal de abril de 1476, cuando los procuradores exponen a los Reyes que la situación de conflictividad y violencia en los caminos y en el Reino, ha provocado la entrada del rey de Portugal al que se suman caballeros rebeldes, y para atajar la situación de inseguridad y castigar a los responsables, se deben hacer hermandades en cada ciudad y villa del Reino 2493 .

En agosto de 1476 viendo Burgos que los robos y muertes en los caminos se acrecentaban, que las gentes no se atrevían a ir de unas partes a otras, los lugares de las comarcas sufrían con los que estaban sublevados con poderes que tenían del rey de Portugal y cobraban por fuerza los pechos y derechos reales, y como los Reyes no podían actuar por la guerra que tenían con el rey de Portugal, la ciudad estableció el servicio de Hermandades, creando un cuerpo de 150 hombres a caballo para que sirviesen a la Reina, y anduviesen en el campo por caminos y despoblados por 5 años, a los que pagó cierta cantidad por año y por cada día que salían de la ciudad para andar por la comarca, alcanzando todo el tiempo que estuvieron $500.000 \mathrm{mrs}$. La ciudad procuró hacer Hermandad con las villas y lugares de su comarca y escribió a las otras ciudades del Reino, rogando que cada uno hiciese hermandad con los lugares cercanos, porque haciéndose por partes, podrían hacer un cuerpo de hermandad en todo el Reino.

Esta Hermandad, que comenzó en Burgos con gentes de a caballo, sirvió de ejemplo y tras exhortar a las otras ciudades, villas y lugares del Reino que la hiciesen, se ordenó que por 2 años la ciudad diese de continuo 33 lanzas y un capitán con ellas, y tuvo diputados en la diputación general y en su provincia, en lo cual y en otras muchas cosas relacionadas con la hermandad, la ciudad gastó en ambos años 2.000.00o de mrs. Asimismo, en agosto de 1478 se alargó el periodo de la Hermandad por 3 años más, con las lanzas y diputado en la diputación general donde tiene puesto un hombre por mensajero para los hechos del

2491 Crónica anónima de Enrique IV de Castilla/ 1468 o 69. Edición de Ma Pilar Sánchez Parra. T. II. p. 234 y 236.

2492 A. M. B./ Actas Municipales, 1476, fol. 10/ Burgos, 30 marzo 1476.

2493 MARTÍNEZ PEÑAS, L. y FERNÁNDEZ RODRÍGUEZ, M.: 2014. Los procuradores dicen que "es notorio cuántos robos, y salteamientos, y muertes, y heridas, y prisiones de hombres se hacen e se cometen cada día en estos nuestros Reinos, en los caminos e yermos de ellos desde el tiempo que vuestra Real Señoría reina. A lo cual ha dado causa la entrada de vuestro adversario de Portugal en estos vuestros Reinos, y el favor que algunos caballeros vuestros, rebeldes y desleales, y enemigos de la patria le han dado, cuyas gentes, poniéndose en guarniciones, hacen y cometen de cada día los dichos delitos, y otros grandes insultos e maleficios; y como quiera que somos ciertos que Vuestra Alteza desea poner remedio en esto, y punir los malhechores; pero vemos que la guerra en que estáis metidos, y las necesidades que nos ocurren de proveer a los hechos de ellas, no os dan lugar a ello, y porque vemos que vuestros Reinos con las tales cosas son maltratados, hemos pensado en el remedio de esto. Y hemos suplicado a vuestra Alteza que lo mandare proveer, y vuestra Real Señoría mandó a los del vuestro Consejo que platicasen con nosotros sobre la forma que se debía tener en remediar esto, a lo menos mientras duraban los dichos movimientos y guerras en estos Reinos, porque entre tanto la gente pacífica tuviese seguridad para tratar de buscar su vida, y no fuesen así damnificados y robados". Añaden que para su remedio "parecionos ser el más cierto y el más sin costa vuestra, que para entre tanto se hiciesen hermandades en todos vuestros reinos, cada ciudad y villa con su tierra entre sí y las unas con las otras. Y después unos partidos con otros..., de la cual vuestra alteza mandó hacer sus ordenanzas. Por ende suplicamos que las mande dar por ley para en todos vuestros reinos, porque hayan mayor fuerza y vigor". 
Reino, en lo que la ciudad gasta cada año 332.000 mrs. , montando todo en los 5 años 3 millones de mrs. Todo lo gastaba la ciudad "con el grand çelo que tyene al serviçio del Rey e la Reyna,... e por el prouecho e bien comun de sus Reynos, pospuestas las muchas antyguas libertades e preuillejos que la dicha çibdad tiene, como çibdad que nasçio e fue syenpre libre para non contribuyr ni pechar, dando enxenplo a todas las otras çibdades e villas e lugares" para que así acordasen poner sus haciendas y vidas al servicio de los Reyes y por el bien común²494.

En junio de 1479 la Reina dice a los concejos, justicias, regidores, etc. de las poblaciones del Señorío de Vizcaya y Encartaciones, que para que la Hermandad de esa tierra se pueda prorrogar desde el día de Santiago que acabó hasta los 3 años siguientes, ha cometido al doctor Ruy Conzález de Puebla, de su Consejo, para que pueda hacer Hermandad y su reforma. Se ordena que los jueces de la Hermandad tengan jurisdicción, entre otros, en casos como quebrantamientos de caminos y "salteamiento o robamiento en el, e quier sea el robo en camino real o fuera del", ordenando que "qualquier que robare en camino o fuera de camino poco o mucho, o qualquier que furtare de quinientos maravedis arriba, que muera por ello". La muerte "sea desta manera, a qualquier ladron o furtador o robador que pena de muerte ouiere de padesçer, que le aten vna cuerda o dogal al pescueço e le enforquen en vna forca de tres palos o de vn rollo, de manera que non toque al suelo, de guisa que muera alli naturalmente", y que nadie ose quitarlos de allí sin expresa licencia y mandado de los jueces. Esta Hermandad durará 2 años, desde el día de San Miguel de $1479^{2495}$.

La reina Juana dice en 1506 a los diputados de la Hermandad de la ciudad de Burgos y de las otras localidades, a los alcaldes de la Hermandad y provincia y sus cuadrilleros, que por las leyes de la Hermandad está provista la forma de actuación en la ejecución de la justicia real así como en la seguridad de los caminos para que todos los caminantes anden seguros, y como para la paz de los Reinos conviene que se aplique la justicia a los delincuentes, "e que si algunos delinquentes ouieren, sean seguidos fasta tanto que sean puguidos e castigados $e$ seguidos, segund e por la forma e manera que las leys de la dicha hermandad lo disponen", les apercibe que si por negligencia de cualquiera de ellos no fueren perseguidos, los damnificados serán satisfechos con los bienes de los negligentes, y si necesitaren ayuda, la Reina manda en octubre de 1506 a todos los notables de todas las ciudades, villas y lugares de sus Reinos y señoríos que se junten con sus gentes y armas ${ }^{2496}$.

\section{Bandoleros y salteadores}

Debido a la situación de inseguridad que existía en Burgos, se realiza en 1411 una ordenanza para guardar la justicia del Rey y el concejo toma medidas prácticas, como solicitar de las vecindades 200 hombres de armas para formar un contingente que estuviese a disposición del merino y garantizar la defensa de la ciudad, de sus puertas y de sus alrededores. Por ello, "ordenaron que se fisiese requerimiento de los dichos dosientos ommes por las dichas vesindades en esta manera"2497:

2494 A. M. B./ HI-859/ 1478 aprox.

2495 A. G. S. V./ Casa de Juntas de Guernica. Escrituras del Señorío. Reg. 1- no 2/ Bermeo, 7 diciembre 1479; HIDALGO de CISNEROS AMESTOY, C.; LARGACHA RUBIO, E.; LORENTE RUIGÓMEZ, A. y MARTÍNEZ LAHIDALGA, A.: "Colección Documental del Archivo General del Señorío de Vizcaya". 1986: doc. 20.

2496 A. M. B./ HI-2357/ Burgos, 2 octubre 1506.

2497 A. M. B./ Actas Municipales, 1411, f. 47r./ Burgos, 8 de agosto de 1411; RILOVA PÉREZ, I.: 2008: 131. 


\begin{tabular}{|l|c|c|c|}
\hline Colación de San Esteban & 35 hombres & 23 lanceros & 12 ballesteros \\
\hline Colación de San Román & 20 hombres & 13 lanceros & 7 ballesteros \\
\hline Colación de Puebla Nueva & 20 hombres & 13 lanceros & 7 ballesteros \\
\hline Col. de Sta. María con S. Andrés & 10 hombres & 6 lanceros & 4 ballesteros \\
\hline Col. de Vieja Rúa y la Morería & 10 hombres & 6 lanceros & 4 ballesteros \\
\hline Colación de San Nicolás & 35 hombres & 23 lanceros & 12 ballesteros \\
\hline Colación de Sta. María la Mayor & 15 hombres & 10 lanceros & 5 ballesteros \\
\hline Colación de San Gil & 15 hombres & 10 lanceros & 5 ballesteros \\
\hline Colación de Santa María & 25 hombres & 16 lanceros & 9 ballesteros \\
\hline Colación de San Llorente & 5 hombres & 3 lanceros & 2 ballesteros \\
\hline Col. de Santiago con Sta. Gadea & 10 hombres & 6 lanceros & 4 ballesteros \\
\hline \multicolumn{1}{|c|}{ Total } & & 129 lanceros & 71 ballesteros \\
\hline
\end{tabular}

En febrero de 1417 se indica sobre las tierras de Vitoria, Salvatierra y Treviño, que "en esas dichas villas e sus tierras e en las comarcas dellas, se avian cometido e perpetrado muchos e enormes $e$ grandes delitos, asy de noche commo de dia rovando e furtando, e pediendo para vino e tomando viandas en poblado e en despoblado, e desafiando asin rason e matando a los ynoçentes e sin culpa"2498.

El concejo de Burgos al tratar en 1432 sobre la inseguridad de los caminos y la existencia de un ladrón detenido llamado Carrelaja, acordó que "por quanto que era fama que andauan en estas comarcas ladrones e robadores e los caminos non eran seguros, que fuese Juan Perez de Castro a Villadiego e a todas las villas e logares destas comarcas a hacer hermandades...". Y añade que "por quanto un ome que llaman Carrelaja esta preso en el dicho lugar de Santo Domingo [de Silos] por que se dise que es rrobador, el qual en esta dicha çibdat auya fecho muchos delitos, que le entregasen a esta dicha çibdat por que del se fesiese la justiçia"2499.

En junio de 1439 se comunicó a los procuradores de las vecindades de la ciudad de Burgos, que Rodrigo de Villandrando, conde de Ribadeo, había venido "ayer domingo çerca desta çibdat, e que asy por esto como porque se dise que rroban por los camynos, que era bien que ouiese guardas e que era bien rrondar e velar la cibdat"2500.

En 1451 se acusa a Juan de Lerma, hijo de Sancho Martínez de Lerma, uno de los alcaldes de la ciudad de Burgos, de haber cometido ciertos robos en Villariezo por lo que fue obligado a entregar a Pedro García de la Lo, canónigo procurador del cabildo, la parte que le había correspondido en el robo que ascendía a 350 mrs. , a pagar antes de la próxima Navidad, bajo pena de que se le impusiera el doble ${ }^{2501}$.

En los momentos que el concejo de Burgos estimaba que la ciudad corría grave peligro, se acudía al recurso de acordar hermandades con los pueblos próximos más importantes como se ha dicho, para obtener la seguridad que pretendían. En la crónica anónima de Enrique IV de Castilla, se indica en 1467 que "como entonçe çerca de Burgosla Hermandat mucho se

2498 A. P. Álava/ D-171-5/Valladolid, 6 febrero 1417.

2499 A. M. B./ Actas Municipales, 1432, ff. 64v. y 67r./ Burgos, 18 junio 1432.

2500 A. M. B./ Actas Municipales, 1439, f. 47v./ Burgos, 1439; RILOVA PÉREZ, I.: 2008: 132-133.

2501 A. M. B./ Actas Municipales. Libro Registro VII, 1451, f. 267V./ Burgos, 1451; RILOVA PÉREZ, I.: 2008: 134. 
esforçase, con dura mano castigaron muchos de los que syguian al rey don Enrrique, entre los quales mataron un famosso ladron llamado Persseval, que tenia ocupada la torre de Villassandino"2502.

Garci Méndez de Badajoz, "fazia muy grandes daños, donde quiera que podia, e tomo la villa llamada Villa Vaqueryn, que era del mariscal Yñigo, la qual la Hermandad siguio de manera quel ovo de fuyr a la tierra de Burgos...". En marzo de 1468, como Garci Méndez "estoviesse en tierra de Burgos usando de sus costunbres e queriendo tener favor para aquellas proseguir", ocurrió que Garci Méndez apresó "un mercador de Burgos ellevado a un monte, las manos atadas e amenazado de muerte, ovo de jurar de dar a çierto dia, çierta suma al dicho Garçi Mendez", y como el mercader fue a la ciudad, Méndez le pidió que le pagase lo convenido. Denunciado el caso a los alcaldes de la Hermandad, "con grand gente fueron de subito a lo prender, y el fuyo e se metio en el monesterio de Sant Iohan; e como los frayles conosçiessen ser manifiesto robador e tenedor de caminos, no curaron de lo defender, ni çerraron las puertas, ela gente entro e sacaronlo, e asi de subito lo llevavan para asaetear". El obispo Luis de Acuña y el alcaide de la fortaleza dijeron a la Hermandad que Méndez estaba bajo su protección, y que no les convenía hacer nada contra él, los cuales comenzaron a arrepentirse de lo que habían comenzado. Pero un vecino llamado Garci Nieto, a quien Garci Méndez "avia mancado de las manos amas a dos dias avie, dixo a grandes bozes: ¡O mezquinos çibdadanos no osays matar a este carniçero robador, malvado enemigo de nuestra çibdad! E dichas estas palabras pusso la mano al puñal, como quiera que a grand pena lo podia sacar, e pusoselo tantas vezes por el cuerpo fasta que lo mato". Los que venían a liberar a Méndez lo hicieron sepultar y no encontraron al asesino, pero como a todos los ciudadanos les pareció "cosa muy fazañosa lo que avia fecho el Carci Nieto", acordaron darle para siempre cierta cosa para él y sus herederos en memoria de este caso 2503.

Sancho de Andicona, vecino de Ochandiano, dijo al Consejo que hacía unos 3 años que "veniendo vn fijo suio por el camino que va de la Rebiera fasia Morillas saluo e seguro,... salieron a el çiertas personas que non pudo saber quien eran en sus nonbres, e que robaron en el dicho camino tres mulos $e$ vn asno suyos que leua cargados de vino blanco de Sant Martin", que podían valer hasta 22.000 mrs. Su hijo se quejó a la Hermandad y a los lugares de Morillas y Ribera que "siguieron tras los robadores fasta los meter en Pangua, lugar e juridiçion de la villa de Trevino, $e$ [como] los vesinos del dicho logar Pangua acogeron los dichos robadores con el dicho robo, e los defendieron e dieron pan e vino", no han podido obtener justicia y a pesar de que él ha requerido muchas veces a algunos vecinos de Pangua, para que paguen los dichos 22.000 mrs., no lo han querido hacer. Los Reyes mandan en mayo de 1480 a Antonio de Fonseca, capitán de la Hermandad, que sabida la verdad, libre sentencia sobre esto y le dan poder cumplido para que se ejecute de acuerdo con el fuero y el derecho2504.

Diego de Caicedo, vecino de Santa Gadea, recurre a la justicia real contra Juan Ortiz de Arandiaga, vecino de Durango, diciendo que 12 días antes envió un mozo con una acémila y 20 rs. de plata, y que viniendo por el camino real que va de Bilbao para la ciudad de Orduña, le asaltó el dicho Juan Ortiz y por fuerza se quedó la acémila y los 20 rs., y que a pesar de los requerimientos no se lo quiere devolver. Los Reyes mandan en noviembre

2502 Crónica anónima de Enrique IV de Castilla/ 1467; Edición de Mª Pilar Sánchez Parra. T. II. p. 192.

2503 Crónica anónima de Enrique IV de Castilla/ 1468 o 69. Edición de Mạ Pilar Sánchez Parra. T. II. p. 234 y 236.

2504 A. G. S./ Registro General del Sello, V-1480, fol. 97/ Toledo, 30 mayo 1480; ENRÍQUEZ FERNÁNDEZ, J.; HIDALGO de CISNEROS AMESTOY, C. y MARTÍNEZ LAHIDALGA, A.: "Archivo General de Simancas. Registro General del Sello. Vizcaya (1480-1482)". 2002: doc. 181. 
de 1483 a Juan Ortiz que restituya a Caicedo la acémila y los 20 rs. de plata, y pague todas las costas y daños causados, por cuanto lo dicho fue "por vos fecho con fuerza e con armas e en yermo"2505.

Martín, hermano de Ochoa de Hurtusaustegui, difunto, y Juan de Ybargüen, primo de Ochoa, vecinos de Gordejuela, dijeron al Consejo que "Diego de Larragorriaga e Juan de Çubieta, fijo del Çid, vesinos de la dicha Gordejuela, saltearon malamente en el camino real al dicho Ochoa de Hortusaustigui, yendo saluo e seguro por el dicho camino real, non faziendo nin disiendo porque mal nin dapno huviese resçebir, e diz que le mataron", sobre cuya muerte se trató pleito ante Pedro de Velasco, alcalde del valle y tierra de Cordejuela, entre los hijos de Ochoa de Hurtusuastegui y los delincuentes en ausencia y rebeldía, y dicho alcalde tras el proceso dio sentencia definitiva condenándolos a pena de muerte. Los Reyes mandan en diciembre de 1485 a todos los corregidores, alcaldes, etc. de sus reinos y señoríos, que la sentencia dada contra Larragorriaga y Zubieta la cumplan y ejecuten ${ }^{2506}$.

En octubre de 1489 se da una ejecutoria en Castro-Urdiales sobre unos testigos del valle de Guriezo, en que se dice que todos eran lacayos y salteadores de caminos y "robadores", robando a los viandantes que pasaban por los caminos, y andaban por los montes haciendo aquel oficio y robando y matando. Eran muy pobres, ya que ninguno tenía la cuantía que la ley exigía para poder atestiguar en aquella causa y "heran muy malos omes e encartados e sentençiados a muerte, e viles, e rahezes, e de ligera e liviana opinion e jugadores, e renegadores, e blasfemadores de Dios e de sus santos, e bevedores en las tavernas, e trasnochadores en ellas, e forçadores de mugeres $e$ echando se con ellas por fuerça". Y eran tan malos hombres y de tan mal trato y conversación, que por una taza de vino o por dádivas, promesas y cohechos, dirían lo contrario de la verdad en el pleito 2507.

Fernando de Riaño, alguacil en la casa y corte y procurador fiscal, pareció en el Consejo Real y acusó a Lope de Garrastachu y Pedro de Izarra, vecinos de la tierra de Ayala, diciendo que muchos días de marzo a septiembre entre los años 1486 y 1493, "con poco themor de Dyos e menos de nuestra rreal justiçia, diz que aveys saltado muchas e diversas veses a los caminantes que pasan por nuestros caminos rreales, e hechandos en çeladas por los montes, e diz que los aveys ferido y tomado por fuerça lo que lieban, e que asy mismo diz que muchas e diversas veses, aveys rrenegado e blasfemado de Nuestro Señor e de los Santos, en diversas veses e maneras, e que asi lo aveys por vso por lo qual diz que aveys caydo en grandes e graves penas crimynales, e capitales, e perdimiento de bos", por lo que pide que se les hiciese justicia. El Consejo, antes de pronunciar sentencia, manda a Garrastachu y a Izarra que se presenten en 30 días en la corte a decir y alegar lo que tuvieren por bien ${ }^{2508}$.

En Junta de Álava de noviembre de 1505 fueron publicadas las condenas de malhechores. Fueron sentenciados a ser azotados Fernando de Narvaja, vecino de Narvaja, Pericón,

2505 A. G. S./ Registro General del Sello, XI-1483, fol. 209/ Vitoria, 21 noviembre 1483; ENRÍQUEZ FERNÁNDEZ, J., HIDALGO de CISNEROS AMESTOY, C. y MARTÍNEZ LAHIDALGA, A.: "Archivo General de Simancas. Registro General del Sello. Vizcaya (1483)" 2002: doc. 283.

2506 A. G. S./ Registro General del Sello, XII-1485, fol. 66/ Valladolid, 22 diciembre 1485; ENRÍQUEZ FERNÁNDEZ, J.; HIDALGO de CISNEROS AMESTOY, C. y MARTÍNEZ LAHIDALGA, A.: "Archivo General de Simancas. Registro General del Sello. Vizcaya (1485-1486)". 2003: doc. 469.

2507 A. M. Castro Urdiales/ Leg. 23, doc. $2 / 23$ octubre 1489; BLANCO, E., ÁLVAREZ, E. y GARCíA de CORTÁZAR, J. A.: 1996: 49: doc. 13.

2508 A. G. S./ Registro General del Sello, XI-1493, fol. 122/ Valladolid, 28 noviembre 1493. 
vecino de Aramayona, por malhechor y famoso ladrón, Pascual de Elosu, vecino de Aramayona, por ladrón público, Michel Arraya por público malhechor y porque "fue en matar a trayçión a vn rromero en el camino de Sant Andrian", y a Juan de Torres, vecino de Arraya, que está sentenciado a pena de muerte, sentencia que está en el arca de la Provincia ${ }^{2509}$.

En Junta de Álava de noviembre de 1515 el procurador de la hermandad de Urcabustáiz dijo que a causa de los robos y asaltos que en el puerto de Dardoza y en el monte de Altube se hacían, y teniendo información de lo necesario para tener en aquellas partes un alcalde general, los señores de la Junta pusieron de alcalde general del campo en la Provincia para los dichos puertos y montes a Martín de Ondona, vecino de Urcabustáiz, y le dieron poder y facultad para llevar vara de justicia y usar el dicho oficio durante el tiempo que la Junta mandare 2510 .

En la Chancillería hay un pleito contra Miguel de Hergueta, alias Pedro Abad, y Juan de Moneo presos en la cárcel de Segovia, acusados de "ser ladrones famosos y auer salido a los caminos a saltear y rrouar a los que por ellos pasauan, y auer salteado a un Francisco Martin uecino de la ciudad de Auila y quitadole setecientos reales que lleuaua y ser hombres façinerosos", en el cual se dio sentencia en agosto de 1590, condenando a e Hergueta a que sea sacado de la cárcel en una bestia de albarda, y sea traído por las calles y llevado a la plaza, donde será ahorcado, y a la pérdida de sus bienes para la Cámara del Rey. También se condena a Juan de Moneo, a que "de la carçel y prision en que esta, sea sacado cauallero en una vestia de aluarda, atado pies y manos con una soga a la garganta y con boz de pregonero que manifieste su delito, sea traydo por las calles publicas acostunbradas desta çiudad a la plaça publica della, donde mando sea orcado publicamente en una horca de madera que mando se aga para este efeto en la dicha plaça, y alli este colgado asta que naturalmente muera y no sea quitado della sin mi licencia", y a la pérdida de todos sus bienes para la Cámara del Rey y en las costas de este proceso. Tras la apelación por parte de los reos, se revoca el juicio y sentencias en julio de 1591, y se les condena a que de la cárcel de Segovia, salgan "en sendas dos bestias de aluarda desnudos de la cinta arriua, atados pies y manos con sogas desparto a las gargantas y pregon publico que manifieste su delito, y la justiçia que dellos se manda hacer, sean traydos por las calles publicas acostunuradas de la dicha çiudad y le sean dados cada ducientos açotes públicamente". También les condenan a ser "lleuados a las galeras del rrey ..., en las quales esten y siruan por galeotes al rreino y sin sueldo, por tienpo y espacio el dicho Miguel d'Ergueta, alias Pedro Abad, de diez años, y el dicho Juan de Moneo de hocho años primeros cunplidos siguientes, y durante el dicho tiempo, no se uaya ni ausente del dicho seruicio so pena de muerte natural". Los alcaldes acordaron dar carta ejecutoria para que el corregidor de Segovia cumpla la sentencia. En octubre de 1591 se amplía la condena de galeras a Juan de Moneo, "por todos los dias de su bida e no le quebrante so pena de muerte de orca, en que desde luego le emos por condenado"2511.

\section{Los señores de los castillos y caballeros ladrones}

En ocasiones, los caballeros y señores utilizan sus casas fuertes y posesiones jurisdiccionales, para cobrar peajes a los mercaderes y mulateros que transitan por sus territorios,

2509 A. J. G. A./ t. I/ Vitoria, 18 noviembre 1505.

2510 A. J. G. A./ t. I/ Vitoria, 23 noviembre 1515.

2511 A. Ch. V./ Registro de Ejecutorias, caja 1697.0045/ Valladolid, 30 julio 1591. 
en base a supuestos derechos sobre el tráfico. Otras veces asaltan sin otro motivo a los caminantes, bien directamente o a través de sus oficiales y criados.

El concejo de Castro-Urdiales se querelló ante Alfonso X, porque los vecinos y viandantes recibían muchos daños, robos y violencias de algunos malhechores que andan en su término, entre la Haya de Antón hasta Son de Sámano, Umanas y el barco de Oriñón. Como los que tenían la autoridad en este término eran los merinos, alcaldes y oficiales de tierra de Vecio y no la ejercían como debían, los malhechores no dejaban de hacer daño a los viandantes y mercaderes y como algunos eran hijosdalgo, los perjudicados no obtenían justicia. El Rey manda que los alcaldes y merino de Castro ejerzan justicia dentro de los términos dichos y que emplace a los malhechores, así hijosdalgo como labradores para responder por sus fechorías, y manda que los hidalgos sean juzgados por sus delitos según su fuero por los alcaldes ordinarios de Castro. Los labradores y los no hijosdalgo serán juzgados por el fuero que tiene Castro. El Rey manda que ningún merino mayor de Castilla, alcalde ni oficial, se entrometa usando de merindad, y no prenda ni mate en el término de Castro a ningún malhechor ${ }^{2512}$.

Vecinos de Vitoria dicen que andan por los caminos de Castilla a Navarra y a otras partes con sus mercaderías y bestias, en que llevan vino y otras cosas a Vitoria por ser la villa de acarreo, y cuando van de Vitoria a Navarra y a otras partes de su señorío o vienen de Navarra a Castilla, "sallen a ellos otros ommes poderosos de y de la tierra e otros ommes, e que les toman e prendan forçudament lo que les ffallan, contra su voluntad, desiendo que les den de cada bestia e asemila çiertos dineros de guia que disen que an de auer", por lo que no andan seguros y reciben daño. Añaden que si los que suelen andar por estos caminos no se pueden mantener, se irían a vivir a otras partes y la villa se despoblaría. Pedro I manda en enero de 1358 a Pedro Conzález de Mendoza, merino mayor en tierra de Álava, o a cualquier merino que anduviere en la merindad, que impida que nadie prenda a ningún hombre de Vitoria que pasare por dichos caminos con sus bestias, ni tome dinero ni otra cosa por guía ni por otra razón. Que todos anden salvos y seguros y pechen tan solo los derechos que han de dar al Rey, y no sean prendados salvo por deuda o fiadura que ellos hubiesen otorgado, y si alguna cosa les han tomado lo deberán devolver. Manda que se pregone y a los que anduvieren por los dichos caminos como no deben, se les prenda y se vaya contra sus bienes ${ }^{2513}$.

En el artículo 33 de las ordenanzas de la Hermandad de Vitoria, Salvatierra y Treviño confirmadas por Juan II en febrero de 1417 , se señala que "por quanto los malfechores han tomado grant osadia e atrevimiento, porque los acogen e sostienen asy en publico commo en escondido algunos cavalleros e otras personas e lugares, por ende ordenamos que sy algunas personas han fecho o fesieren malefiçio en la dicha hermandat, que los alcaldes della requieran al cavallero o persona, o a las justiçias del conçejo con quien el tal malfechor andoviera o en cuya juridiçion estoviere, que fagan del, cunplimiento de derecho; e fecho el dicho requerimiento" si no lo hiciere, que la dicha hermandad lo pueda prender donde lo hallaren y ejecutar justicia2514.

2512 A. M. Castro Urdiales/ Leg. 41, doc. 3/ Segovia, 5 junio 1347; BLANCO, E., ÁLVAREZ, E. y GARCíA DE CORTÁZAR, J. A.: 1996: 34: doc. 8.

2513 A. M. Vitoria/ Sec. 8, leg. 10, núm. 20./ Sevilla, 20 enero 1358; GONZÁLEZ MíNGUEZ, C.:"Documentos de Pedro I y Enrique II en el Archivo Municipal de Vitoria". 1994: doc. XII.

2514 A. P. Álava/ D-171-5/Valladolid, 6 febrero 1417. 
El bachiller Pedro Alfonso de Miranda, alcalde del Rey en su casa y corte, con gentes armadas, prendió a Martín de Basozabala cuando pasaba por Monasterio de Rodilla en diciembre de 1463, y a Fortún Sánchez de Arana y Martín Sánchez de Jarabeitia, todos vecinos de Bilbao, cuando pasaban por Bergüenda, teniéndolos presos en Miranda y en la villa de Saja, reteniendo especialmente a Fortún Sánchez por espacio de tres meses y amenazándolos que si no pagaban cada uno 400 doblas no saldrían en libertad. También robó a Ochoa Pérez de Bilbao, a su hijo, a Martín Pérez Simón y a Sancho Pérez Simón, carniceros, también vecinos de Bilbao, 310 cerdos gruesos y dos caballos cuando pasaban por el puente de Puentelarrá guardando todo en la fortaleza del conde de Salinas cerca del dicho puente, devolviendo a los propietarios tan solo 100 cerdos a cambio de 50 doblas. Como consecuencia, todo el trato de Bilbao con Castilla había cesado. Ante la demanda interpuesta por Pedro Ochoa de Arana, procurador del corregidor y alcalde de la Hermandad de las Villas y Tierra Llana de Vizcaya, el Rey condena a Pedro Alfonso de Miranda a que sobresea todos los cobros, ponga en libertad a los presos y devuelva los cerdos y los dos caballos tan buenos como estaban, o si no, al pago de 77.500 mrs., cantidad estimada de su valor y otras 1.000 doblas por los daños recibidos, mandando que fuese apresado en el caso de no cumplir lo fallado2515.

En el partido y cercanías de Valmaseda, Lope Hurtado de Salcedo, Ochoa de Murga y Juan de Salcedo con algunos parientes suyos, robaban cebándose principalmente en los mercaderes de Burgos que por allí transitaban. "Bien es verdad, según Lope García de Salazar, que Lope Hurtado no robaba sino que tomaba la tercera parte de lo que los otros tomaban y robaban dándosela ellos". Ante tanta violencia el corregidor carecía de la fuerza necesaria para hacer justicia, pero uniéndose con él Lope García de Salazar, las villas de Vizcaya y los mercaderes de Burgos se dirigieron a Enrique IV pidiéndole un virrey con autoridad, enviándoles al conde de Haro que entró en Vizcaya en 1470 y fue muy bien recibido ${ }^{2516}$.

En 1473 Juan de Uribarri, criado de Martín de Enderica, vecino de Bilbao, cuando iba del reino de Aragón hacia Bilbao con una acémila y 100 libras de azafrán, en el puente de Puentelarrá el alcaide de su fortaleza vasallo del conde de Salinas junto con dos hombres, le apresaron llevándole a la torre para luego llevarle a Salinas de Añana donde estaba el Conde. El apresado tuvo que pagar para su rescate $15.000 \mathrm{mrs}$. perdiendo el azafrán y además el alcaide le tomó un enrique castellano. El Rey en 1476 mandó que el Conde devuelva a Uribarri los $15.000 \mathrm{mrs}$. y el enrique que le habían tomado, no sin antes fijar un plazo por si el Conde quisiere alegar en su favor ${ }^{2517}$.

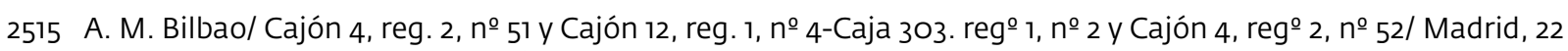
marzo y 25 abril 1464 y Salamanca, 7 junio 1465.

2516 MADOZ, P.: 1845-1850: 468: t. 15. Valmaseda. Reeditado por Editorial Ámbito organizado por provincias. Valladolid, p. 181.

2517 A. G. S./ Registro General del Sello, VII-1476, fol. 526/ Vitoria, 16 julio 1476; ENRÍQQUEZ FERNÁNDEZ, J., HIDALGO de CISNEROS AMESTOY, C. y MARTÍNEZ LAHIDALGA, A.: "Archivo General de Simancas. Registro General del Sello. Vizcaya (1475-1477)" 2002: doc. 44. "...viniendo del regno de Aragon para la dicha villa de Viluao e trayendo vna azemila consigo e en ella fasta çient libras de açafran del dicho su amo; e dis que pasando por la Puente de Larrada, el alcayde de la dicha fortaleza e otros dos omes suyos, por fuerça e contra su voluntad le tomaron en la dicha puente e le traxieron a la dicha torre e fortaleza, e que luego enbio a la villa de Salinas...". 
En 1475 Martín Ortiz de Guecho, vecino de Martiarto, "pariente mayor e ome poderoso", en el lugar de Puentelarrá y acompañado de gente armada robó todo lo que llevaban los arrieros Martín Sáez de Salices y Juan de Arnoeta, criado de Juan Martínez de Arratia, cuando iban a Bilbao con cinco acémilas y un asno cargados de vino de San Martín, con sus azacanes, cueros y todos sus aparejos lo que podía valer unos $65.000 \mathrm{mrs}$. En otra ocasión, Martín Ortiz tomó por fuerza dos acémilas cargadas de paveses, más 15 rs. de plata, al dicho Martín Sáez cerca de Ornasa y aunque devolvió las acémilas se quedó los paveses y los reales, que podían valer unos 2.00o mrs. Los Reyes mandan a Martín Ortiz que devuelva las cinco acémilas, asno, vino, cueros, azacanes, aparejos, paveses y reales robados, o bien los 67.000 mrs. de su estimación ${ }^{2518}$.

En marzo de 1480 se denuncia un robo realizado hacia 1473, por hombres del mariscal Carcía López de Ayala, señor de Ampudia, a Diego de Soria, Fernando de Mazuelo y Alfonso de Astudillo los tres, mercaderes de Burgos, cuando iban a la Montaña con una acémila cargada de trigo y 280.000 mrs. ocultos dentro de la carga. Cuando llegaron cerca de Orduña en el camino real, les salieron los escuderos del mariscal y les tomaron la acémila cargada con el dinero. Los Reyes mandan que se restituya a los dichos mercaderes, la acémila con los 280.000 mrs. más las costas y daños que se les han causado por las reclamaciones durante los 7 años transcurridos, dando al mariscal un plazo de 20 días para sus alegaciones ${ }^{2519}$.

Los Reyes dicen en junio de 1480 al adelantado Pero López de Padilla, que Fernando de los Ríos, vecino de Soria, dijo que hacía unos 5 años, trayendo un fardel de lienzos de Bretaña en que había 800 varas y que podía valer 25.000 mrs. , "por el camino fasta Burgos salistes a el vos e otros por vuestro mandado, ele tomastes e rrobastes el dicho su fardel de lienços" no debidamente y sin causa, y que como él le ha requerido muchas veces la devolución del fardel robado y no lo ha querido hacer, pidió a los Reyes justicia. Estos mandan al adelantado que devuelva el fardel de lienzos a de los Ríos que según dice le robó, o le pague los dichos 25.000 mrs. mas todas las costas y daños causados, y si tiene algo que alegar "por quanto vos dis que notoriamente soys cauallero e persona poderosa, e veuis en vuestra tierra do los alcaldes estan de vuestra mano, que non avra ante quien a vos demandase", mandan que se presente en el Consejo y alegue y presente los testigos que considere ${ }^{2520}$.

En 1490 los Reyes mandan al juez de residencia del condado de Vizcaya, que se informe sobre las muertes y robos efectuados por personas de la fortaleza de Orduña tras la denuncia del concejo y justicia de la ciudad, que decía que "desde la fortalesa de la dicha çibdad, el alcayde que la tyene e la gente que con el esta de çinco años a esta parte, desde la dicha fortalesa dis que han salido e muerto algunos veçinos de la dich a çibdad, e a otros acuchillando e apaleando e amagando, e estando ellos so nuestro seguro e anparo e defendimiento rreal, e que en la dicha fortalesa han rreçebtado e acogido e defendido dentro en ella algunos rrobadores e ladrones, e los no quisyeron entregar a las nuestras justiçias para que dellos se fysiese justiçia", y que averigüe quiénes son los que han cometido los crímenes, si

2518 A. G. S./ Registro General del Sello, XII-1475, fol. 811/ diciembre 1475; ENRÍQUEZ FERNÁNDEZ, J., HIDALGO de CISNEROS AMESTOY, C. y MARTÍNEZ LAHIDALGA, A.: "Archivo General de Simancas. Registro General del Sello. Vizcaya (1475-1477)" 2002: doc. 25

2519 A. G. S./ Registro General del Sello, III-1480, fol. 427/ Toledo, 15 marzo 1480.

2520 A. G. S./ Registro General del Sello, VI-1480, fol. 172/ Toledo, 16 junio 1480. 
se acogen en la fortaleza y cuántas personas son las que han sido muertas, heridas, apaleadas e injuriadas ${ }^{2521}$.

En octubre de 1498 Juan Ruiz de Bolívar, alguacil de la casa y corte de los Reyes, vecino y natural del valle de Salcedo y en nombre de sus vecinos y moradores, dijo que Juan de Salcedo, alcalde que fue del concejo de Güeñes, tenía una casa fuerte sobre un puente y camino real en el despoblado de Aranguren, y que por los robos, desafueros e imposiciones que desde su casa hacía él y los que estaban por él, y porque robó a mercaderes de Burgos y de otras partes, la justicia la derribó hacía unos 25 años, con la orden de no reedificarse. Juan de Salcedo, contra derecho y la dicha prohibición, volvió a edificar la casa en el mismo lugar y mucho más fuerte, con una altura de más de 15 tapias y un muro de más de 10 pies de grueso, tan fuerte que no se podría derribar con muy recia artillería, teniendo además su barrera muchas troneras y saeteras, y haciendo y mandando hacer los delitos dichos llevando imposiciones nuevas, y además con su oficio de alcaldía y porque es pariente mayor, tiene tan sojuzgada la tierra que con el pretexto de que le ayuden para alguna necesidad, hace repartimiento entre sí y sus parientes y amigos, llevando en total más de 1.000.00o de mrs. Pidió que la casa fuerte se mande demoler, se restituya todo lo que Salcedo había llevado injustamente, se ejecute en su persona y bienes las penas correspondientes y se mande que no tenga más el oficio de alcaldía. Salcedo respondió que no se debía hacer nada de lo pedido por Bolívar y se le diese por libre. Fue acordado que el corregidor de Vizcaya debía recabar información de todo ello y enviarla al Consejo para que se haga lo que fuere justo 2522 .

En Junta de septiembre de 1502 se acordó que como la provincia de Álava tiene muchos daños por la vejación de caballeros y otros comarcanos que roban en los caminos, y que por evitar lo susodicho y proteger la tierra en servicio de la justicia, cuando alguna violencia sucediere realizada "por caballeros o nabarros e otras qualesquier personas, de rrobo o fuerça 0 quebrantamiento de camino", quien el daño recibiere siga el pleito, la mitad a su costa y la otra mitad a cargo de la Provincia2523.

\section{Robos por cuentas impagadas}

Existió a fines del siglo XV una costumbre lesiva para los arrieros, que consistía en cobrarles cuando pasaban por localidades acreedoras, las deudas adquiridas por los lugares de donde eran vecinos a través de la incautación de sus cargas. De esta manera, en 1483 el concejo de Santa Gadea recurre a la justicia real contra Sancho Martínez de Arandia y Teresa su mujer, vecinos de Durango, porque como consecuencia de una deuda contraída por el concejo unos 25 años atrás, que ya había pagado en su mayor parte, y que con el fin de saldar la deuda les habían requerido para que viniesen sin lograrlo, el citado matrimonio como respuesta había tomado en los caminos a los vecinos de Santa Gadea tanto sus bienes y acémilas, como dineros y mercaderías por valor de $60.000 \mathrm{mrs}$. "syn alcaldes nin escriuano, como el derecho en tal caso lo quiere e manda". Como consecuencia de ello los de Santa

2521 A. G. S./ Registro General del Sello, XII-1490, fol. 160/ Sevilla, 15 diciembre 1490.

2522 A. G. S./ Registro General del Sello, X-1498, fol. 251/Valladolid, 30 octubre 1498.

2523 A. J. G. A./ t. I/ Vitoria, 22 septiembre 1502. 
Gadea no se atreven a andar por los caminos reales. Los Reyes mandan que se restituyan al concejo de Santa Gadea las acémilas y mercaderías que les han tomado, en las mismas condiciones que estaban y también los 60.000 mrs. estimados con las costas y daños que se habían provocado 2524 .

Diego de Mendieta, vecino de Sopuerta, dijo ante los Reyes que hacía unos 10 años que estuvo en la corte y que quería ir a vivir a Sopuerta y "andar por la tierra con bestias en recueria", pero temía que las personas o concejos a quienes el dicho lugar debe mrs. de los que reparten entre sí para sus necesidades, harán ejecución "en sus bienes o en sus bestias o otras cosas que asi traxere ganando su vida". Los Reyes mandan en febrero de 1485 a los corregidores, asistentes y alcaldes, que permitan a Mendieta andar por todo el Reino tratando, vendiendo y comprando mercaderías, y no le alteren a él ni a sus bienes por deudas que Sopuerta tenga, ni sea obligado a pagar salvo por deuda propia, por su propio delito o fianza que haya hecho, o por mrs. de las rentas, pechos y derechos reales o de la Hermandad de sus Reinos, y los Reyes le aseguran que sus vasallos "le non fieran, nin maten, nin lisien, nin prendan, nin prenden, nin tomen, nin enbarguen, nin secresten, nin ocupen sus bienes, nin cosa alguna de lo suyo" contra razón y derecho 2525 .

En un pleito tratado en la Chancillería entre Juan Sáez de Murga, vecino de Orduña, y Conzalo del Carrascal y Juan Bonifaz, vecinos de Briones, sobre que de Juan Sáez entre otras cosas, dijo que podía haber unos 13 años que envió con un hombre suyo desde Zaragoza para la Montaña 7 acémilas cargadas de cebada y aceite, y que pasando por el camino real entre Santo Domingo de la Calzada y Santa Gadea junto al lugar de Villalobar, le salieron los dichos Carrascal, Bonifaz y otros por su mandado, tomaron las acémilas con las mercaderías y las llevaron a Briones. Juan Sáez tuvo que rescatar las acémilas a cambio de las mercaderías, que consistían en 15 quintales de aceite a $1.800 \mathrm{mrs}$. el quintal, más 21 fanegas de cebada, a 80 mrs. la fanega, y el perjuicio causado por estar las acémilas represadas por mandato de los dichos, trabajándolas y aprovechándose de ellas, fue de otros 10.000 mrs. Como Juan Sáez había requerido a Carrascal y Bonifaz que le diesen la cebada y el aceite o su justa valoración y no lo habían querido hacer pidió justicia. Carrascal dijo que la toma de las acémilas y mercaderías, pudo hacerla justa y lícitamente porque a su parte le fueron tomadas antes otras muchas acémilas y mercaderías en Tarazona, donde Juan Sáez vivía y Bonifaz no acudió al emplazamiento. El presidente y oidores dieron sentencia en octubre de 1488, y condenaron a Carrascal y a Bonifaz en su ausencia y rebeldía, a que pagasen y restituyesen a Juan Sáez de Murga 1.000 mrs. por cada uno de los 14 quintales de aceite que le fueron tomados, 80 mrs. por cada una de las 21 fanegas de cebada y por los daños y costas que se le hicieron 5.000 mrs. y les condenan en las costas hechas tasadas en 2.503 mrs. ${ }^{2526}$.

2524 A. G. S./ Registro General del Sello, XI-1483, fol. 210/ Vitoria, 21 noviembre 1483; ENRÍQUEZ FERNÁNDEZ, J., HIDALGO de CISNEROS AMESTOY, C. y MARTÍNEZ LAHIDALGA, A.: "Archivo General de Simancas. Registro General del Sello. Vizcaya (1483)" 2002: doc. 282.

2525 A. G. S./ Registro General del Sello, II-1485, fol. 70/ Sevilla, 18 febrero 1485; ENRÍQUEZ FERNÁNDEZ, J.; HIDALGO de CISNEROS AMESTOY, C. y MARTÍNEZ LAHIDALGA, A.: "Archivo General de Simancas. Registro General del Sello. Vizcaya (1485-1486)" 2002: doc. 397.

2526 A. Ch. V./ Ejecutorias emitidas, caja 17, nำ1/Valladolid, 30 octubre 1488; ENRÍQUEZ FERNÁNDEZ, J.; SESMERO CUTANDA, E.; MARTÍNEZ LAHIDALGA, A. y HIDALGO de CISNEROS, Concepción: "Archivo de la Real Chancillería de 
Alonso del Paraíso presentó queja porque en octubre de 1496 envió a su criado Juan de Carranza desde Valmaseda a Castro-Urdiales en un trotón color castaño, y que llegado al lugar de la Piedra, en una casa del dicho lugar, en el término del valle de Salcedo, le salieron el bachiller Bernardino del Rebollar con otros tres vecinos de Valmaseda y por fuerza le tomaron el rocín, por lo que estos habían incurrido en graves penas y suplicaba justicia. Los Reyes mandan en enero de 1497 al corregidor de Vizcaya, que reciba información sobre lo dicho y si hallase que injustamente fue tomado el trotón, que lo devuelvan "libre e desenbargadamente e syn costa alguna", y así hecho, los prenda si por la pesquisa los hallare culpables 2527.

En febrero de 1497 Mencía Fernández, vecina de Espinosa de los Monteros, dijo a los Reyes que cuatro vecinos de Espinosa tenían en fieldad las alcabalas de la villa de los años 1493, 1494 y 1495, estando obligados a pagarlas al condestable de Castilla y monasterio de Santa Clara de Medina de Pomar por estar en ellos situadas, e indica que los merinos de Medina y de la merindad de Castilla Vieja, por mandato de su alcalde y a petición del recaudador del Condestable, le tomaron unas mulas con sus aparejos viniendo del valle de Tobalina, y las vendieron en Medina de Pomar para pagar los mrs. que debían. Mencía Fernández requirió al merino de Espinosa, para que vendiese los bueyes y vacas tomados de los fieles para pagar los mrs. debidos al Condestable y monasterio y con ello recuperar sus mulas, pues ella no estaba obligada a pago alguno, pero el merino no lo quiso hacer y sus mulas se vendieron con los aparejos, que podrían valer 15.000 mrs. con más de 13.000 mrs. por los daños causados, por lo que pidió a los Reyes que el corregidor de la merindad de Trasmiera provea de remedio con justicia, mandándole que apremie al merino a que le pagase las mulas y sus aparejos o los dichos 15.000 mrs. mas las costas causadas ${ }^{2528}$.

En marzo de 1498 Juan de Salcedo, en nombre de las Encartaciones, dijo que sus mulateros y recueros acostumbran andar con sus mercaderías para vender y tratar, y que en algunas poblaciones son embargados y tomadas sus bestias y mercaderías diciendo que los concejos y villas de las Encartaciones les deben muchas cuantías de mrs. o por represalia que contra ellos dice que tienen, de manera que no osan andar con sus bestias y mercaderías por estos reinos y señoríos. Los Reyes mandan a todos los corregidores, alcaldes y justicias, que consientan a los dichos mulateros y recueros andar libremente con sus bestias y con todas las mercaderías que llevaren, y que no los prendan ni embarguen por deuda alguna que los concejos de las Encartaciones o sus vecinos tengan salvo por deuda propia, y no consientan que les sea hecho otro mal ni daño en sus personas y bienes contra razón y derecho'2529.

Pedro Quirós en nombre de Juan de Rilova Suhero, vecinos ambos de San Vicente de la Barquera, dijo a los Reyes que en febrero de 1501 viniendo Juan de Rilova a Dueñas con siete cargas de pescado cecial y pasando por el valle de Cabuérniga que es del marquesado de Santillana, el alcalde mayor del dicho marquesado y otros que con él iban, por fuerza y

Valladolid. Registro de ejecutorias emitidas. Vizcaya (1486-1502). Regist. 1 a 20". 2010: doc. 59.

2527 A. G. S./ Registro General del Sello, I-1497, fol. 91/ Burgos, 31 enero 1497.

2528 A. G. S./ Registro General del Sello, II-1497, fol. 183/ Burgos, 16 febrero 1497.

2529 A. G. S./ Registro General del Sello, III-1498, fol. 129/ Alcalá de Henares, 15 marzo 1498. 
contra su voluntad, le tomaron las cargas, lo cual dice que lo hicieron por ciertos debates y diferencias que hay entre el marquesado de Santillana y la villa de San Vicente. Los Reyes mandan al alcalde mayor y alcalde de la villa y marquesado de Santillana que si por causa de lo susodicho tomó las cargas de pescado a Juan Rilova, las restituya sin coste alguno 2530 .

\section{Vagabundos y gitanos}

Fernández de Oviedo decía hacia 1540 sobre los vagabundos, que "ay otros caminantes que van de vnas partes a otras por su plazer, e se determinan con façilidad a yrse de vn cabo a otro, y estos son los que llama el vulgo vagamundos, o vagabundos; y estos tales se llaman invtiles, qui sine negocio modo huc modo illuc inutiliter discurrit,... Y estos mueuense con oçiosidad, e prendados, holgazanes, chocarreros, jugadores, viçiosos, e tales que, do quiera que vayan, son dañosos e dinos de castigo, e ser desechados de los pueblos, e acogidos en galeras, donde les saquen la pereza e haroneria del cuerpo"2531.

Un pueblo andaba vagando por la Península desde 1425, expiando sus pecados en peregrinación a Compostela. Decían ser naturales de Egipto por lo que se les llamaba "egipcianos", y venir del sureste de Europa donde los turcos les habían obligado a apostatar, y que el Papa les había impuesto la penitencia de vagar de santuario en santuario. Presentaban documentos del Emperador, del Papa, de los reyes de Bohemia, Hungría y otros príncipes y con este ardid disculparon su rechazo a la vida sedentaria y mantuvieron su régimen trashumante. Aunque en principio los reyes los protegieron, otorgando cartas de seguro o salvoconductos para facilitarles su peregrinación, cambiaron su política por los muchos abusos y delitos menores que cometían, y pasaron a ser víctimas de la hostilidad y medidas represivas, que pretendían su adaptación y estabilidad residencial ${ }^{2532}$. Al no ser fácilmente controlables por mantener su carácter nómada, la legislación se mostró dura con ellos y la Pragmática de los Reyes Católicos de 4 de marzo de 1499 decretó la expulsión de todos los que anduviesen vagando y no estuviesen dispuestos a vivir como los demás súbditos. Bajo severas penas se les obligaba a tomar vecindad y oficio y abandonar su lengua vernácula y sus vestidos 2533 .

Sin embargo, los gitanos continuaron con su vida errante desarrollando algunos oficios eventuales, como los de esquilador y herrador y las mujeres practicando la mendicidad y la quiromancia. Su aversión a la vida regular les abocaba al hurto y a veces al bandidaje. Ligados a ellos vivían otros marginados y fugitivos que eran temidos en todas partes. Los pastores de la Mesta, por ejemplo, tenían licencia para llevar armas y usarlas en su defensa contra gitanos y merodeadores. Las Cortes de Toledo de 1525 pidieron que se aplicara

\footnotetext{
2530 A. G. S./ Registro General del Sello, III-1501, fol. 598/ Valladolid, 27 marzo 1501.

2531 FERNÁNDEZ de OVIEDO y VALDÉS, G.: 1880: 221.

2532 SZÁSZDI, I.: 2009: 166.

2533 A. H. N./ Real Cédula. Inserta en pragmática de 1560 (n 69) Bca. 1.531/ Madrid, 4 marzo 1499. “y no andeys mas juntos vagando por estos nuestros reynos como agora vos fazeys, o dentro de otros sesenta dias despues primeros siguientes, salgays de nuestros reynos, y no voluays a ellos en manera alguna, so pena que si en ellos fuerdes hallados o tomados syn oficios o syn señores, o juntos, passados los dichos dias, que den a cada vno de vos cient açotes por la primera vez y le destierren perpetuamente destos nuestros reynos, y por la segunda vez que vos corten las orejas y esteys sesenta dias en la cadena, y torneys a ser desterrados como dicho es, y por la tercera vez que seays catiuos de los que os tomaren por toda vuestra vida...".
} 
una Real Pragmática, "que dispone que los de Egipto no anden por el rreyno..., porque roban los campos y destruyen las heredades e engañan a los que con ellos tratan y no tienen otra manera de vivienda"2534.

En mayo de 1539 Carlos I da una real Provisión que decía que por los muchos daños e inconvenientes que de los gitanos se siguen, y como las penas contenidas en las leyes no bastan para que los "exiçianos o de egito y aun con ellos, otros muchos naturales destos rreinos y de otras naciones que an tomado su lengua y abito y manera de vivir, no anden por las çiudades, uillas e lugares dellos vagando y hurtando, diziendo que son adivinos lo qual es en daño de nuestros subditos y mal exenplo de la rrepublica", se manda que los gitanos y los "que con ellos andan en su habito y trage", salgan de sus Reinos en tres meses, tomen oficios o asienten con señores, y si pasados los tres meses fueren hallados en cualquier población "de tres arriba dellos juntos sin officio, o viuir con señores, mandamos a las nuestrasjusticias los prendan, y presos los que fueren de edad de veynte años hasta cincuenta, los lleuen y envíen a las nuestras galeras para que siruan en ellas por termino de seys años al remo, como los otros que andan en ellas", y pasados los 6 años, manda a los capitanes de las galeras que los dejen libres. Y en los que tuvieren menos de 20 años y más de cincuenta, sean ejecutadas las penas contenidas en las leyes.

Felipe II dice en diciembre de 1558 a los corregidores y jueces de residencia y alcaldes mayores de Santa Gadea, que Juan de Urreta en nombre de dicho concejo le dijo que contra lo dispuesto por leyes y pragmáticas y en notable daño de sus partes, andan por Santa Cadea y lugares de su tierra "muchos que se dizen gitanos sin tener offiçios ni otra manera de vivir, vagando y haziendo hurtos y cometiendo otros delitos en mucho daño y perjuizio de los dichos sus partes", y suplica se mande dar la ley y Pragmática de mayo de 1539, para que los gitanos sean "echados de nuestros rreinos y llevados a galeras". El Consejo acordó mandar que se guarde dicha Pragmática2535.

En las Juntas de Vizcaya de julio de 1563 se trató cómo en los pueblos y anteiglesias del Señorío los gitanos que acudían a él hacían muchos hurtos y daños a sus vecinos, y por evitarlo, mandaron que se den mandamientos a los fieles de las anteiglesias para que no los admitan en sus pueblos y los expulsen ${ }^{2536}$. En dichas Juntas de enero de 1565 se mandó que como "andan muchos ygiçianos e bagamundos e pobres forasteros, yendo contra lo questa mandado por leies e pramaticas de su magestad, y cometen hurtos y robos e ocupan los ospitales", se den mandamientos del corregidor para los fieles y alcaldes de cada pueblo, para que los echen del Señorío y lleven presos a los rebeldes para su castigo2537.

En las Juntas de Vizcaya de junio de 1575 se dijo que en caso de que hubiere "algunos ladrones y hechizeros y bagabundos y otras gentes, que biben desonestamente y en escandalo y en perjuizio de las republicas", se haga la averiguación de ello y se encargue a las justicias ordinarias que hagan las diligencias necesarias en las Villas y Tierra Llana, para que los fieles y síndicos puedan prenderlos y llevarlos a la cárcel pública para que sean castigados ${ }^{2538}$. En las Juntas de mayo de 1580 se mandó que las justicias ordinarias y fieles de las anteiglesias, visitasen a menudo "los ospitales y tubiesen mucha quenta de saver y aberiguar que personas baldias y bagamundos

2534 VÁZQUEZ DE PRADA, V. (Dir.): 1978: 266-267.

2535 A. M. Santa Gadea/ doc. 5-33/ Toledo, 24 mayo 1539 y Valladolid 12 diciembre 1558.

2536 J. R. B./ Actas de la Tierra Llana. t. I/ Bilbao, 10 julio 1563.

2537 J. R. B./ Actas de la Tierra Llana. t. I/ Durango, 18 enero 1565.

2538 J. R. B./ Actas de Villas y Ciudad. t. II/ Guernica, 14 junio 1575 
andan como romeros y pobres, no teniendo enferrmedad ni ynpedimiento, y azen muchos ladroniçios e delitos por los caminos", dándoles poder y facultad para que por la averiguación que hicieren los lleven a la cárcel pública de Vizcaya 2539 .

En la Junta de Álava de noviembre de 1581 se quejaron algunos vecinos sobre la libertad con que muchos "moços bagamundos con nombre y lenguaje de egiçianos" que andan "juntamente con sus mugeres o amigas haziendo diuersos rrobos e insultos" en los lugares de poca población, se desenvuelven con mucho daño y escándalo. Se ordena que todos los procuradores de las hermandades, requieran a las justicias ordinarias para que guarden las leyes reales y en las partes donde la justicia ordinaria no pudiere prevalecer o que por ser los territorios limitados no pudieren ser presos, los alcaldes de hermandad vayan en su seguimiento ${ }^{2540}$.

A pesar de las medidas tan duras tomadas contra los gitanos desde el siglo XV ya dichas, y las que se seguirán promulgando en los siglos posteriores, este problema social seguirá sin resolverse, de tal manera que hoy día muchos de los casos denunciados siguen aún pendientes de resolver.

\section{b.- Obstáculos en los caminos}

En algunos casos y a pesar de las leyes promulgadas en su contra, algunos propietarios o personas vinculadas con la nobleza obstaculizan los caminos reales que deben quedar abiertos de manera permanente. Así, el concejo de Rendano en la tierra de Ayala, se dirigió en 1492 al Consejo Real diciendo que Ruy Sánchez de Saracho, vecino de Orduña, y Juan de Chimeleo, su yerno, vecino de Rendano y morador en la casa que llaman de Chimeleo que está en sus términos, tiene hecha la dicha casa en el camino real que ocupa y cierra con bardas, cerraduras y cantería y tiene ocupados unos 20 pasos. Juan Rodríguez de Mendieta alcalde ordinario en la tierra de Ayala, mandó que el camino fuese desembarazado y se quitasen todas las cerraduras, para que los mulateros y caminantes tanto a pie como a caballo pudiesen transitar libremente, y que se pusiesen allí mojones para que no se volviese a cerrar bajo las penas establecidas más su pena de $2.000 \mathrm{mrs}$. para reparos de los caminos. El dicho alcalde y el concejo fueron a ejecutar la sentencia y quitaron las cerraduras, pero Ruy Sánchez y Juan de Chimeleo volvieron a hacer las bardas y cerraduras de tapias de cantería y prendían a los caminantes que por allí pasaban, por lo que ningún caminante a pie ni a caballo puede pasar sin rodear el dicho lugar. Los vecinos reciben gran daño por lo que se pidió al Consejo que se condenase a Ruy Sánchez y Juan de Chimileo a las penas en que hayan incurrido. El Consejo acordó que llamadas y oídas las partes, se cumpla lo que sea de justicia "so las penas que deuian por tales, posyeredes e mandaredes poner"2541.

En Junta de Álava de noviembre de 1578 el diputado general dijo que en los caminos reales de Arcaute, Ilárraza, Abechuco y Yurre por donde pasan muchas gentes, hay montes muy espesos que impiden los pasos y donde además se esconden ladrones que pueden hacer asaltos y robos, y que por evitar estos daños, sería conveniente que se mandase a los

2539 J. R. B./ Actas de Villas y Ciudad. t. II/ Bilbao, 10 mayo 1580

2540 A. J. G. A./ t. VII/ Vitoria, 23 noviembre 1581.

2541 A. G. S./ Registro General del Sello, II-1492, fol. 167/ Burgos, 1 febrero 1492. 
vecinos de los dichos lugares, y así se hizo, que cortasen los robles, árboles, matas y zarzas que impiden el dicho paso, apercibiéndolos de que si no lo hacen se enviará un alcalde de hermandad que a su costa lo obligase ${ }^{2542}$.

\section{c.- La peste}

En marzo de 1497 llegó a Santander una epidemia de peste con el séquito de la princesa Margarita, que al parecer se mantuvo varios años porque en 1504 el concejo ordena que se haga una pesquisa sobre la grave situación en que se encuentra la villa a causa de dicha peste. Un testigo dice que en Santander "avia cargason de sacas de lanas de burgaleses para Flandes, e avia naos e carabelas en esta villa,... e agora non hae en la dich a villa segund la grande pestilençia de ella". Indicaron que desde que "bino aqui la nuestra prinçesa de Flandes, nunca ha faltado en esta villa pestilençia y es muerta mucha gente en ella, e non hay dosyentos vesinos,... e a esta cavsa esta toda esta villa perdida... y es notorio a cavsa de la grave pestilençia de los prençipales de la villa, avia çient vesinos que non hae agora en ella dies vesinos", "hasta agora en la dicha villa son muertos mas de seys myll personas" y los que quedan no son mas de 400 "onbres vesinos e casados en la dicha villa e sus alquerias e arrabales" 2543.

En Castro-Urdiales estando en junio de 1507 en ayuntamiento el alcalde, los regidores y el fiel y procurador con Sancho Sánchez de Cicero, procurador de los mareantes, dijeron que como en Castro tenían puestos guardas porque decían que había mortandad en Bilbao y parecía que la villa estaba sana, la justicia y regidores habían sido notificados de ello. Por esto mandaron "que acogiesen a qualesquier personas que benyesen de la dicha villa de Vilvao, eçebto a los romeros, que mandavan a los de los ospytales de la dicha villa que non acogan a los tales romeros, salbo que les den a las puertas de la villa lo que ovieren mester para su pasadia"2544.

En las Juntas de Vizcaya de julio de 1565 se acordó que se pongan en los puertos, caminos y lugares más convenientes personas hábiles y suficientes a costa del Señorío, con mandamiento del corregidor y vara de justicia con el fin de guardar los puertos y caminos y no dejen pasar ni andar por ellos a ninguna persona sospechosa ni de lugares contagiosos, se pregone este asunto en las villas del Señorío y se notifique mandamiento al corregidor para que nadie pase por otros caminos ni puertos apartados salvo por donde estuvieren las dichas guardas, y que nadie reciba a ningún caminante natural ni extranjero que entrare por los dichos caminos apartados, sin que traiga cédula de guía de las guardas, so pena que los que hicieren lo contrario sean echados del Señorío. Las guardas de los puertos y caminos no dejarán entrar a nadie sin que les muestren testimonios de que vienen de lugares sanos y no contagiosos ni sospechosos y darán las cédulas de guía a los que cumplan con esta orden ${ }^{2545}$.

Sobre la peste que había llegado a la zona de Burgos en 1565, Martín de Zaldívar dijo que en Burgos se solía hacer feria anual en el día de San Pedro, y como algunos pueblos

2542 A. J. G. A./ t. VII/ Vitoria, 19 noviembre 1578.

2543 A. M. S./ Leg. A 2, no 10 fols. 3r-23v/ Santander, 21 noviembre 1504; SOLÓRZANO TELECHEA; J. A.: "Colección Diplomática... ". 396-429: doc. 255.

2544 A. M. Castro Urdiales/ Leg. 21, doc. 1/ Castro Urdiales, 19 junio 1507; BLANCO, E., ÁLVAREZ, E. y GARCÍA de CORTÁZAR, J. A.: 1996: 360: doc. 15.

2545 J. R. B./ Actas de la Tierra Llana. t. I/ Bilbao, 18 julio 1565. 
comarcanos y otros más lejanos "estaban contagiosos de mal de peste de lo qual auian muerto e morian muchas personas", pretendían que no se hiciese la feria ese año porque de los dichos lugares iba a venir mucha gente a la feria, y por mucha guarda y prevención que hubiese, no dejarían de venir personas de pueblos donde tienen el dicho mal, causando tanto daño como en el pasado, algo que se evitaría si no se hiciese la feria. El Rey manda en junio de 1566 al corregidor y regimiento de la ciudad, que provean lo que vieren más conviene al bien público y se evite el inconvincente que podría resultar de hacerse la feria ${ }^{2546}$.

Peñalosa junto con Juan Díaz de Isla, receptor de la Merindades, envió informe favorable para hacer el mercado en Villarcayo, pero en 1566 llegaba la peste a Medina y Villarcayo, lo que alteró el traslado a esta villa y llevándose el mercado a las afueras de Medina y las ferias al lugar de Pomar ${ }^{2547}$.

En Junta de Álava de mayo de 1597 se dijo que Santander, Laredo y Castro y valles y tierra, Medina de Pomar y su tierra y los lugares de Soncillo, Herbosa y valles de Trasmiera, Santillana, Valdecayón, Toranzo, Valdebuena, Valdeiguña, Reinosa y Asturias hasta Oviedo están contaminados por la peste. Se mandó que no se reciban frailes franciscanos, ya que se sabe que de Castro han salido algunos, y que en la Provincia no se deje entrar a ningún pobre que no sea vecino y conocido de la tierra y se sepa que no ha salido de ella. Tampoco han de recibir a ningún pobre francés ni de los que van en romería a Santiago ${ }^{2548}$. Indican en dicha Junta "que la enfermedad de la peste siempre ba adelante, no solamente en las villas de Santander, Laredo y Castro", sino en otros muchos lugares circunvecinos, por lo que mandaron que en todas las hermandades se tenga cuidado para no recibir a nadie de las dichas partes y que ningún vecino de la Provincia trate ni comunique con ellos ${ }^{2549}$. Al día siguiente, se mandó que no venga nadie de las partes referidas, debiendo traer testimonio de escribano que diga de qué lugar viene y que ha estado allí por lo menos 30 días y dé fe que allí no hay ningún rastro de la enfermedad. Asimismo no han de dejar descargar naranjas y limones, ni mercaderías, ni mercerías que vengan de Flandes ni Francia ni a portugueses que vengan de allí, ni tampoco pescados frescos ni escabeches que no sean de los puertos del norte, como Lequeitio, Bermeo, Motrico y Alzola. No dejarán entrar en la Provincia ningún cantero ni oficial ni dejarles trabajar sino echarlos fuera de ella. Y que ningún vecino de la Provincia salga ni vaya a las dichas partes y lugares ni a las ferias de Orduña, Medina de Pomar, Quejana ni otros lugares de los referidos, ni se reciba ningún ganado traído de dichas ferias. No se recibirá a los mercaderes de la Provincia que estuvieren en dichas partes, ni los ganados y mercaderías que trajeren ${ }^{250}$.

Como en los puertos de Santander y Laredo que estaban a 20 y 22 leguas de Burgos había peste e iba en aumento, la ciudad de Burgos para evitar su extensión, necesitaba tomar a censo 4.000 ds. y que el principal y sus réditos se sacasen de la sisa del vino, por lo que pidió facultad al Rey. El Consejo acordó en diciembre de 1597 dar licencia y facultad para

\footnotetext{
2546 A. M. B./ HI-3392/ Madrid, 25 junio 1566.

2547 CADIÑANOS BARDECI, I.: 2007/1: 240.

2548 A. J. G. A./ t. X/Zurbano, 7 mayo 1597.

2549 A. J. G. A./ t. X/ Zurbano, 6 mayo 1597.

2550 A. J. G. A./ t. X/ Zurbano, 7 mayo 1597.
} 
que sobre los propios y rentas de la ciudad, se pueda tomar a censo al quitar hasta 2.00o ds. de cualquier persona o concejo que se lo quisiere dar para que se gasten en la guarda de la ciudad, con que no sea a menos de 14.000 el millar ni a más de 20.000 sin gastarlos en otra cosa, y para la seguridad de los concejos o personas que les dieren el censo, pueda la ciudad obligar sus propios y rentas y otorgar las escrituras y contratos que convengan ${ }^{2551}$. Al final, la peste llegó a Burgos en 1599.

En las Juntas de Vizcaya de diciembre de 1597 los síndicos dijeron que en todos los lugares del Señorío se deben tomar medidas para que no entre nadie de los lugares donde corre la peste, ni que en ellos hayan estado después de dicha enfermedad, y como en algunas poblaciones del Señorío sus justicias y vecinos particulares no han hecho la guardia y vigilancia que estaba ordenada ni sacar a los buhoneros, vagabundos y mendigos que corren por la tierra, pidieron que se mandase poner el debido remedio. Se mandó que sin dilación se visiten todas las anteiglesias del Señorío, y se reciba información de los que han sido remisos en poner las dichas guardas y en hacerlas, prendiendo a los culpables y llevándolos a la cárcel real del Señorío y lo mismo a los vagabundos, buhoneros y demás gente baldía 2552 .

En las Juntas de Vizcaya de septiembre de 1598 se trató sobre la necesidad de mandar hacer guardia en Bilbao y demás lugares que están apestados, imponiendo penas graves a los que fuesen remisos y nombrando para su ejecución personas de confianza, con facultad plena para hacer todo lo necesario. Como "corre enfermedad de peste en la dicha villa de Vilvao", mandó el corregidor que el Señorío dé a esta villa "asta mill anegas de trigo o lo que mas tuviere nesçesidad de vastimientos y cosas". Asimismo, mandó el corregidor que en todas las anteiglesias y concejos del Señorío, Encartaciones, merindad de Durango y Villas y Ciudad, cada uno en su distrito, "pongan contra todos los lugares apestados, asi del dicho Señorio como de fuera del, goardia conveniente de noche y de dia con much retitud y vigilancia", nombrando a todos los vecinos para que cada uno la hagan de día y de noche. Ninguna persona será admitida ni las guardas les dejarán pasar, sin que "las tales personas lleven testimonio de donde son vezinos e avitantes, y que en los tales lugares an morado y asistido de ochenta dias a aquella parte y en el dicho tiempo a avido e ay entera salud e sanidad, sin enfermedad contagiossa de peste". Mandó el corregidor que las guardas y justicias, "no dexen pasar ropa ninguna que salga ni aya salido de Vilvao". Como se había admitido en Portugalete mucha gente y ropa de Bilbao después de que en esta villa sobrevino la peste, hay recelo de que la enfermedad actúe en Portugalete porque algunas personas de esa villa han enfermado y muerto de pocos días a esta parte. El corregidor mandó que nadie de Portugalete, sea admitido "en todo el terretorio y distrito que ay de la canal de agua hazia la parte que dizen de Vizcaya ni a la anteiglesia de Baracaldo, y se haga goardia en la forma que se haze a la dicha villa de Vilvao"2553.

En las Juntas de Vizcaya de octubre de 1598 el regimiento dijo que si se permitiese que en Bilbao entrasen trajineros $u$ otras personas con bastimentos de partes sanas y sin sospecha de peste resultarían graves inconvenientes, por lo que el corregidor ordenó que

2551 A. M. B./ HI-248/ Madrid, 27 diciembre 1597.

2552 J. R. B./ Actas de la Tierra Llana. t. VI/ Bilbao, 4 diciembre 1597.

2553 J. R. B./ Actas de la Tierra Llana. t. VI/ Zubiaur de Zornoza, 25 septiembre 1598. 
dos personas de confianza asistan y residan la una en Beteluri y la otra en Castrejana, que son libres de la enfermedad y "por donde forçossamente an de pasar ansi de la çiudad de Urduña como de la villa de Valmaseda, en que se abraçan los caminos cosarios e frequentados que ay para la dicha villa de Vilvao, de las partes de Castilla la Vieja e todas las Montañas", y no dejen pasar a Bilbao ningún trigo, aceite, vino ni otros bastimentos, sino que los descarguen en estos sitios y vayan allí los que los quisieren comprar a precios justos. En los lugares por donde los trajineros pasaren de ida y vuelta para que con libertad se les dé el tránsito y lo demás que necesitaren, las dichas personas les darán certificado de como lo trajeron al puesto señalado, y que la carga que descargó y vendió es libre de enfermedad contagiosa ${ }^{2554}$. Trece días después se mandó que no se usen los mandamientos librados para que las guardas de Beteluri y Castrejana, lleven de cada carga de trigo y cebada, vino y aceite medio real, y que ni las guardas ni otra persona lleven esos derechos para que cesen las quejas que se dan. Los procuradores generales dijeron que se habían dado algunas quejas, porque estas guardas perjudican a Bilbao y anteiglesias de Abando, Begoña, Echávarri, Deusto y Portugalete, ya que al poner en la entrada estancos de los bastimentos podría provocar mucho hambre en esos lugares ${ }^{2555}$.

Al día siguiente, el fiel de la anteiglesia de Baracaldo dijo que tras el decreto para que en el puente de Castrejana y en Arrigorriaga hubiese guardas, asiste como tal en el puente Domingo de Tellaeche, escribano, que cobra medio real de cada carga a los arrieros que llevan bastimentos a Baracaldo, haciéndolos descargar y creando a la anteiglesia notorio agravio, por lo que pide que se reponga el dicho decreto, alegando que el medio real de cada macho no puede ser impuesto, y provocaría que ningún arriero quisiese traer mantenimientos, o vender los que trajesen a excesivos precios. Porque es tanta la nobleza del Señorío, "y sus vezinos tan libertados e ynbidiados por ello entre todos a quitarse el dicho medio real por carga a los arrieros, ellos que por la mayor parte son jente ynorante, publicarian en los pueblos y otras partes que en Vizcaya se pagan y ponen ynpusiçiones nuebas", lo que produciría una nota negativa contra los vizcaínos. Además, podría ser que por su propio interés, molestase a los arrieros encarcelándolos y haciéndoles otras extorsiones, y porque si pasando como pasan cada día, 200 o 300 machos por el puente y le diese cada uno medio real, resultaría un salario excesivo. Se mandó que las guardas en Beteluri y Castrejana no lleven de cada carga de trigo y cebada, vino y aceite el medio real ${ }^{2556}$.

También se mandó que ante la peste que había en Bilbao, se descarguen las mercaderías y bastimentos que llegan por la barra de Portugalete, en el puerto de Asua y lugares de Baracaldo y Zorroza, donde deberá haber persona de confianza que tenga especial vigilancia para que ni de día ni de noche lleven mercaderías de lugares contagiosos ni las traigan de Bilbao, Portugalete ni otras partes sospechosas, ni que la gente de ellas acuda a los dichos puestos y lugares, y se eviten así los contagios que podría haber. En la ribera de Olaveaga se pondrá la cadena que se hizo para que no pasen navíos ni bajeles de Bilbao y Portugalete, y se escriba al Consulado de Bilbao y al capitán Ojeda para poner la guardia

2554 J. R. B./ Actas de la Tierra Llana. t. VI/ Zubiaur de Zornoza, 1 octubre 1598.

2555 J. R. B./ Actas de Villas y Ciudad. t. III/ Zubiaur de Zornoza, 14 octubre 1598; Actas de la Tierra Llana. t. VI/ Zubiaur de Zornoza, 16 octubre 1598.

2556 J. R. B./ Actas de la Tierra Llana. t. VI/ Zubiaur de Zornoza, 15 octubre 1598. 
debida. Se mandó que en Bilbao y Portugalete las manifestaciones de todas las mercaderías que entraren por la barra de Portugalete se hagan ante el corregidor ${ }^{2557}$.

En Junta de Álava de julio de 1599 se acordó que con toda urgencia se despachen mandamientos para todas las hermandades de la Provincia, ordenando que no consientan que sus proveedores y trajineros vayan a por vino ni otros bastimentos a parte apestada, y que pongan gran cuidado para saber qué lugares están apestados en la Rioja o donde hubieren de ir. Deberán mandar a los trajineros, que no salgan de su casa sin testimonio de escribano o notario si lo hubiere, y si no del cura, y que declare qué bestia lleva y donde cargará, y el trajinero deberá tomar testimonio de escribano público sobre la salud que allí hay, y qué cargas de vino saca y de qué casa. Los trajineros lo deben cumplir so pena de 50.000 mrs., pérdida de las acémilas y bastimentos de vino que cargaren y destierro de la Provincia2558. En Junta de octubre se acordó que como en Miranda de Ebro, Armiñón, Haro, La Puebla de Arganzón, Pancorbo, Guipúzcoa, Vizcaya y otros lugares de los contornos, no dejan entrar a nadie de la provincia de Álava, aunque vaya de lugares sanos y lleve testimonio de salud, acordaron escribir a Andrés de Ermua, solicitador de la Provincia, para que pida Provisión al Consejo para que las dichas villas y lugares dejen entrar libremente a los que llevaren testimonios bastantes de salud y fueren de lugares sanos 2559 .

La Junta de Álava de septiembre de 1600 mandó que ningún arriero de la Provincia, que por su interés particular trata y comunica en Durango y lugares de la Rioja, Bureba, Condado de Treviño y otras partes donde hay enfermedad contagiosa, vaya con carga ni sin ella a Mondragón ni a las demás referidas, ni a otras donde se entienda que tienen la enfermedad, so pena de 10.000 mrs. y destierro perpetuo, debiendo traer testimonio de los lugares de donde trajinan a los lugares donde residen, para saber las jornadas que traen. Y que el diputado general despache mandamientos a todas las hermandades y concejos para que se notifique a todos los arrieros 2560 .

Como la epidemia se extendió a pesar de las medidas adoptadas, en Junta de Cuipúzcoa de octubre de 1601 se vio la relación de los lugares apestados que están en la tabla de Vitoria y otros que lo fueron después. Son Santa Gadea del Cid, Bozoo, Ameyugo, Ayuelas, Portilla, Villanueva-Soportilla, Santa María Ribarredonda, La Puebla de Arganzón, Pangua, San Esteban de Treviño, Villanueva de la Oca, Miranda de Ebro, Nanclares de la Oca, Salinas de Añana, Leciñana del Camino, Ormijana, Escota, Leciñana de la Oca, Tuyo, San Vicente de la Sonsierra, Villafría, Marquínez, Villarreal de Álava y Aranguiz. Se deberá poner remedio en la posada de Galarreta, casa de Bernal López sucesor de Martin Ruiz de Ibarreta y casa de postas, donde se recogen gentes que paran en Vitoria. Y leída esta relación se acordó que se dé noticia a las villas, alcaldías y valles de la Provincia para que pongan sus guardas en la forma acostumbrada y se guarden en Vitoria y en los demás lugares de la relación ${ }^{2561}$.

2557 J. R. B./ Actas de la Tierra Llana. t. VI/ Zubiaur de Zornoza, 6 octubre 1598.

2558 A. J. G. A./ t. X/ Salinas de Añana, 13 julio 1599.

2559 A. J. G. A./ t. X/ Mandojana, 11 octubre 1599.

2560 A. J. G. A./ t. XI, p. 61-62/Vitoria, 7 septiembre 1600.

2561 A. J. D. G./ (1601-1603. Documentos) t. XV/ Tolosa, 17 octubre 1601. 


\section{d.- El lobo y otros animales}

El lobo era el principal enemigo de la ganadería y como tal se le perseguía, aunque en ciertos momentos en que tales animales tenían escasez de alimentos, principalmente en invierno, se convertían en un peligro potencial de los caminantes solitarios, sobre todo en los páramos.

En mayo de 1542, se realizó en las Cortes de Valladolid, una petición al Rey que decía que "rresçiben mucho daño por causa de los muchos louos que ay en estos rreynos, y porquestos çesen suplicamos a buestra magestad mande dar liçençia a todas las ciudades, billas e lugares destos rreynos, para que si quisieren puedan dar orden en como se maten los dichos lobos aunque sea con yerua, y puedan señalar el premio por cada caueça de louo o por cada cama dellos que les traxeren"2562.

En las cuentas presentadas en junio de 1621 en Espinosa de los Monteros, sobre los mrs. en que se remataron las alcabalas de la dicha villa de ese año, consta que se pagaron 110 rs. a Juan Díez, vecino de Virtus, por una camada de lobos, más 7 pagados por "un lobo que abia muerto vn honbre de Birtus", más 12 que se dieron "a Juan Diez vezino de Birtus por siete lobos que mato pequeños", más otros 12 que se pagaron por mandado de la justicia y regimiento a Juan Muñoz "vezino del ualle de Soba de una camada de lobos". También se presentó una libranza de 16 rs. hecha a Juan Cutiérrez de San Martín, vecino de Agüera, "por un lobo que mato en el sitio do diçen el Poluo, termino desta billa" en julio de 1620, y dos ducados del pago de "un lobo quese mato en Birtus que por librança se los pago a un honbre"2563.

Sir Richard Wynn, caballero de la Cámara del príncipe de Gales Carlos Estuardo, sale en mayo de 1623 de Santander hacia Madrid pasando por Burgos 2564 . Escribe sobre los montes de este camino que "aunque sea maravillosamente seguro viajar por sus caminos reales, las montañas y los bosques estan llenos de osos salvajes y lobos que no solo causan estragos al ganado, sino que a veces matan hombres".

Se informa a los concejos, regidores, caballeros, etc. de los lugares de La Puente, Quintana, Valdenoceda, El Almiñé, Santaolalla y Toba, que según lo acordado en septiembre de 1675 en el ayuntamiento de El Almiñé, , se mandó repartir entre otros, cuatro ducados para pagar a Quintano, vecino de La Puente, "que mato vn oso en los Ozinos" y dos ds. para pagar a un vecino de Herrera "de la caza de vnos lobos"2565.

Aunque de fechas muy tardías, tenemos un testimonio de marzo de 1830, que nos informa de que en el lugar de Barrio-Panizares "en uno de los terminos del dicho lugar que llaman la Lora una legua del pueblo, camino que ba a Polientes, se allo el cadaber de un hombre dilaniado la mayor parte, de las abes o fieras"2566.

2562 A. M. B./ HI-1438/Valladolid, 22 mayo 1542.

2563 A. C. V./ no 1.997/ 13 diciembre 1621 a 27 mayo 1622

2564 WYNN, R.: 1729: 297-341; CASADO SOTO, J. L.: 2000: 198-253.

2565 A. Almiñé/ p. 1 y 2/ 15 septiembre 1675.

2566 A. Parroquial de Barrio-Panizares/ Libro de Finados, fol. 47 r./ Barrio-Panizares, 9 marzo 1830. 



\section{CONCLUSIONES GENERALES}



LEGADO, finalmente, al apartado de las conclusiones, me parece fundamental sentar dos premisas aclaratorias. En primer lugar, y antes de nada, quiero subrayar que el presente trabajo no es un estudio de historia económica y, por tanto, tampoco una historia del comercio entre Burgos y los puertos cantábricos durante los siglos XV y XVI. En la concepción y planificación de nuestro proyecto siempre estuvo muy clara la idea de que las referencias al trasiego de mercancías, a las características de los mercados y a la tipología de los individuos y de los medios de transporte no tenían ninguna otra misión primordial que la de ilustrar sobre la realidad, adecuación y dinámica de una caminería concreta, la del tramo oriental del centro-norte peninsular durante la transición de la Edad Media a la Moderna. Lógicamente, siempre he sido consciente de que los datos acopiados sobre el comercio no sólo son importantes para proporcionar cuerpo a la viaria investigada sino que pueden consituir un notable fondo informativo para uso de los expertos en economía.

En segundo lugar, quiero subrayar que la naturaleza del trabajo que someto a consideración y dictamen del Tribunal es, por encima de cualquier otra caracterización, estrictamente empírica, descriptiva, dirigida de manera casi exclusivamente a dar cuenta del trazado, desarrollo y dinámica de la viaria en cuestión. En este sentido, concibo mi aportación historiográfica como el resultado de un profundo y sostenido esfuerzo de anticuario, si por tal se entiende el cumplimiento de un empeño principal: aportar e interarticular la mayor cantidad de información posible sobre la red caminera que ponía en comunicación el corazón de la Meseta Norte con los puertos del Cantábrico centro-oriental durante los siglos XV y XVI.

He sido consciente en todo momento de que, para introducirme honorablemente en un tema como este y, por extensión, en el mundo que le daba sentido, quedaba imperativamente obligado a sumergirme en un largo, complejo y, a veces, cansino proceso de búsqueda de información de primera mano, con frecuencia por archivos oscuros y desabridos y, casi siempre, teniendo que compaginarlo con mi trabajo profesional. Sólo así me parecía que podría cobrar entidad un trabajo serio, a la altura de una Tesis de Doctorado, que, además de sustentarse en una irregular bibliografía, presentara nuevos conocimientos. Sólo así, cabría obtener deducciones solventes, capaces de convertirse en sustento de nuevas y más afinadas investigaciones. 
En el origen de este propósito científico, se encuentra una marcada propensión de tipo personal, pues, hasta donde se remontan mis recuerdos de juventud, siempre he sentido una fuerte inclinación por conocer al detalle y por transitar físicamente por los caminos antiguos, y de manera muy particular, los viejos caminos de montaña, fragmentos desdichadamente muy maltratados de un patrimonio histórico singular, no siempre valorados adecuadamente en el mundo académico.

En todo caso, en la medida en que dicha inclinación particular ha sido puesta al servicio de la ciencia histórica, el estudio que someto a consideración del Tribunal ha estado presidido en todo momento por un doble propósito fundamental: por un lado, la restitución más estricta y fidedigna posible del trazado habitual de la red caminera anteriormente referenciada, al igual, lógicamente, que de las principales variantes que generó con el paso del tiempo; por otro lado, la reconstrucción lo más ajustada posible del papel específico que cumplió dicha caminería como vehículo de personas y productos a finales de la Edad Media y comienzos de la Edad Moderna.

En términos, pues, concretos, cabe caracterizar la esencia del trabajo que presento como Tesis de Doctorado como el variado conjunto de inferencias de corto, medio y largo alcance que he sido capaz de entresacar sobre la naturaleza, trazado y función de los caminos burgaleses del Norte en los siglos XV y XVI a partir de un fondo informativo considerable, que integra la práctica totalidad del material bibliográfico y se nutre de un fondo documental original muy amplio, casi inabarcable y muy sustancioso por la variada riqueza informativa que contiene.

Una vez mencionada la finalidad del trabajo, establecido el método empleado, y manejado un amplio fondo informativo, en gran medida inédito, creo que estoy en condiciones de resumir lo sustancial del trabajo que acabo de concluir con la pretensión primordial de subrayar lo fundamental del mismo. He aquí, pues, los aspectos que considero más relevantes de la caminería desarrollada entre la ciudad de Burgos y los puertos del Cantábrico centro-oriental durante los siglos XV y XI:

1‥- Se trata de una caminería funcionalmente diversificada. Y ello a varios niveles y en diversos planos. En primer lugar, en virtud de la tipología de sus viandantes. Así, al principio, fue utilizada prioritariamente por modestos trajineros y tratantes solitarios. A estos se unieron los arrieros organizados en sólidas cofradías, que negociaban con productos eminentemente lucrativos, al igual que los mulateros que transportaban sacas de lana a la costa y retornaban con fardeles y sacones de paños y lienzos. A unos y otros les acompañaron los mulateros que acarreaban víveres para las tierras del Norte y volvían a Castilla con pescado. Finalmente, en tiempos relativamente avanzados del período estudiado, se produjo la concurrencia de individuos no relacionados con el tráfico mercantil, especialistas en transportes complejos, que trasladaban piezas de artillería desde la costa a la Meseta Superior, siempre inmersos en grandes retos ingenieriles en función de los inconvenientes de todo tipo que les salían al paso en un medio ecogeográfico y climatológico tan complejo. Aunque no deja de ser una caracterización un tanto artificial, cabe diversificar la caminería en función de la tipología dominante de los individuos y medios utilizados: caminos arrieriles, mulateros o trajineros y caminos carreteros. 
La diversificación de referencia cobra un tono más ajustado y pertinente en términos técnicos, cuando se la pone en relación con la tipología de los trazados. Así, entre los caminos que desde Burgos se dirigían al Cantábrico, cabe diferenciar aquellos que tuvieron un solo itinerario, como los que llegaban a Laredo o Castro-Urdiales, que se mantuvieron, además, durante el período estudiado sin grandes transformaciones técnicas, de los que llegaron a contar con varios trazados, como los que concluían en Bilbao o Santander, que llegaron a contar, según momentos, con varios itinerarios operativos a la vez. En concreto, el trayecto hacia el importante puerto de Santander no sólo era geográficamente diversificado sino que los propios ramales que le componían fueron modificados en varias ocasiones, ya con motivo de la construcción de un puente o por la creación de algún tramo nuevo. Esta diversificación condiciona fuertemente el tratamiento de la caminería norteña, ya que, mientras cabe hablar con propiedad, por ejemplo, del "camino de Laredo", no es posible hacer lo mismo con los de Santander o los de Bilbao, por existir más de una vía para tales destinos.

Por lo demás, es perfectamente posible discriminar/diversificar la caminería objeto de nuestra atención por el empaque e importancia de los itinerarios. Destacó sobremanera el camino de Burgos a Laredo por Medina o Villarcayo, que permaneció prácticamente inalterado durante los siglos aquí estudiados, al igual que sobresalieron los trayectos de Burgos a Bilbao y Portugalete, uno por Valmaseda -prolongación del camino de Laredo- y otro por Puentelarrá y Orduña.

Por su parte, la importancia de los caminos de Burgos a Santander fue variada y cambiante. Los de mayor entidad y consistencia fueron el que discurría por Reinosa y el que, por Luena y Toranzo, llegaba al puerto cántabro por el puente de Solía. Estas dos vías canalizaron gran parte del tráfico mercantil que procedía o dirigía hacia los países atlánticos europeos. Aunque los principales productos y las lanas también se encaminaban hacia Bilbao y Laredo, los caminos a Santander fueron tan importantes que la Universidad de los Mercaderes de Burgos intervino expresamente en el que transitaba por Solía para hacer un camino carretero, construyendo puentes y nuevos trazados, aunque también colaboró económicamente en la mejora del de Laredo. Por su parte, el camino a Santander por Reinosa llegó a suscitar la creación de una cierta estructura carreteril en las villas aledañas.

Hubo, naturalmente, un sinfín de trazados de menor rango, que actuaron como red divertícula de los caminos dignos de tal nombre. Por lo general, no aparecen mencionados en este trabajo, salvo como referencia incidental al tratar de las conexiones que intercomunicaban la viaria tratada.

2․- Es una caminería excepcional e inusitada. La zona por donde discurren los caminos estudiados en este trabajo no es, geográficamente hablando, la más adecuada para establecer unas vías de comunicación solventes y estables. La Cordillera Cantábrica, se comporta por lo general como una imponente barrera obstaculizadora entre la costa y el interior, obligando a discurrir por desfiladeros amenazadores y valles encajados y exigiendo superar puertos de circulación muy difícil, al menos en la época que centra nuestra atención. Todo ello salpicado, además, en los trayectos intermedios por las trabas que introducían las corrientes fluviales, los resecos páramos y los montes menores, preocupan- 
tes no sólo por su envergadura sino también por la textura de los mismos, que impedía crear firmes adecuados para los transportes.

De hecho, las condiciones estructurales adversas hubieran sido suficientes por sí mismas para reducir la caminería de la zona a poco más que una anécdota de no mediar, al menos para la época que centra nuestra atención, una razón poderosa: la imposibilidad de encontrar una salida adecuada por el Oeste. En efecto, la creación y consolidación de la caminería que nos ocupa no fue el resultado de una decisión alocada o insuficientemente meditada sino el producto de una necesidad, la que provocó la interrupción de la salida natural de Castilla hacia el Atlántico a través del curso del Duero, su eje vertebrador. La rígida frontera que incomunicó el corredor del Duero con Oporto obligó a la mulatería castellana a buscar otra salida para el comercio internacional. Dadas las circunstancias geopolíticas, no hubo otra opción que dirigirse hacia el Cantábrico, dando vida con ello a una red viaria verdaderamente inusitada, desalentadora y costosa, entre Castilla y la fachada septentrional oceánica.

$3^{\circ}$.- Se trata de una caminería muy compleja. La mulatería principalmente y, en menor medida, la carretería castellana, sobre cuyas espaldas gravitaría la comunicación comercial de Castilla con la Europa Atlántica, tuvieron que trabajar siempre en condiciones excepcionalmente duras, impuestas por las condiciones orográficas, hidrográficas y climatológicas de una poderosa zona de montaña.

Para ir a Santander, Laredo, Castro-Urdiales, Bilbao o Portugalete había que circular en dirección norte, por los desolados páramos burgaleses hasta alcanzar, más adelante, el río Ebro, cuyo decurso de sentido Este-Oeste imponía, al menos en determinados momentos, dificultades al tratar de vadearlo o de cruzarlo por sus inciertos puentes. Y esto no era más que el principio, pues, tras recorrer los espacios altamente irregulares de las merindades de Castilla, plagadas de desfiladeros y escabrosidades, había que afrontar el paso de la Cordillera Cantábrica propiamente dicha, con puertos siempre difíciles, que se convertían en impracticables durante una buena parte del año, especialmente a causa de la nieve. Ya en la vertiente norte de la cordillera, los caminos se encajaban en los estrechos valles tajados por los ríos montañeses, que en sus cortos recorridos buscaban las aguas del Cantábrico con frecuencia de manera torrencial.

La compleja climatología de la zona en su conjunto constituía otro obstáculo fundamental. Las nieves en invierno, el hielo y las lluvias o los deshielos eran enemigos irreconciables de la actividad caminera, que, con más frecuencia de la deseable, terminaban en riadas catastróficas, que arremetían contra los puentes y obras de fábrica e interrumpían la circulación, obligando a los caminantes y transportistas a improvisar caminos alternativos. Por otro lado, los veranos secos dificultaban el tránsito de las bestias al faltar los pastos que precisaban.

La infraestructura caminera que estudiamos nunca estuvo en consonancia con las necesidades del período que centra nuestra atención, al igual en materia comercial que puramente circulatoria, dotada de una gran cantidad de puentes y pontones de madera de escasa consistencia, que resistían con dificultad las acometidas de las grandes avenidas. 
Además, los caminos tenían en su mayor parte firmes de tierra sin compactar, que, en tiempos de grandes lluvias, se transformaban en auténticos barrizales.

$4^{\circ}$.- Es una caminería extremadamente costosa. Los caminos incurrían en deterioro tanto por el uso como, sobre todo, por las calamidades naturales que periódicamente les afectaban. Cuando les alcanzaba la adversidad y esta era particularmente dañina, se ponía en marcha un complejo proceso de reparación, que comportaba la intervención, en primera instancia, de los concejos en cuya jurisdicción se localizaban. Como estos acostumbraban a no disponer de recursos suficientes, se acudía a los repartimientos, modalidad que presuponía una larga y complicada tramitación para determinar las cuantías. En la época estudiada, el proceso generaba inexorablemente retraso, cuando no la completa paralización de las obras. La información disponible habla con cierta frecuencia de malos modos, irresponsabilidades personales, incumplimiento de contratos y encarcelamiento de personas. Una urgencia como aquella, que demandaba respuesta inmediata, podía alargarse sine die, con las consiguientes molestias personales y el correspondiente encarecimiento de las mercancías.

No siempre ni todo fue tan sórdido y negativo. En relación con la rectificación de algunos trazados y la mejora de los firmes, al igual que de la reconstrucción de no pocos puentes, se produjo una importante reactivación general a partir del último cuarto del siglo XV bajo el reinado de los Reyes Católicos, fruto de un creciente deseo de impulsar el comercio y las comunicaciones. A tal efecto, se estimuló la aplicación del mencionado sistema de los repartimientos, que se iría perfeccionando en reinados posteriores. Ahora bien, aunque la Corona se puso al frente de los procesos administrativos y ejecutivos por medio del Consejo Real y de los corregidores, no llegó a involucrarse económicamente, circunstancia que condicionó significativamente los resultados de las intervenciones.

En la tarea de reparación de los caminos y en lo concerniente a los itinerarios que nos ocupan, jugaron un papel importante las cofradías de mulateros y, muy especialmente, la Universidad de los Mercaderes de Burgos. En su haber cabe registrar dos grandes intervenciones: por un lado, la restauración de diversos tramos del camino que, por Rocamundo, en Valderredible, y por La Virga y Corconte, se dirigía a Santander, del que, además, sufragaron la reconstrucción de varios puentes; por otro lado, la reparación general, al unísono con los concejos locales, del camino de Laredo, llegando incluso a pagar por su propia cuenta varios tramos de nueva creación.

En virtud de la especial situación jurídico-administrativa del País Vasco, el peso de la promoción y reparación de caminos gravitó desde el siglo XVI sobre cada provincia y el Señorío. En el caso, bien conocido, del camino a Bilbao por Orduña, el concejo y el Consulado corrieron con la responsabilidad y la financiación del nuevo trazado de la Peña, destinado a la circulación de carros, aunque este primer intento no llegó a cuajar por completo.

Aunque los concejos fueron los responsables de la financiación de la construcción, reparo y mantenimiento de las infraestructuras camineras, se manifestaron por lo general reacios a participar en unas obras que, en muchos casos, no consideraban como propias, resistencia acrecentada cuando la intervención tenía que realizarse en términos municipales ajenos. Con frecuencia se convertía en obstáculo insuperable la rivalidad entre mu- 
nicipios y comunidades, que, en ocasiones, generó una resistencia cerrada a proyectos de mejora promovidos por otras localidades, cuando se creía que podían perjudicar sus propios intereses, sin considerar que algo tan importante como la mejora de las infraestructuras viarias, era algo beneficioso para todos. Un ejemplo muy revelador fue la oposición que los alaveses y guipuzcoanos manifestaron durante siglos, a veces de forma violenta, a cualquier iniciativa de los bilbaínos y orduñeses para mejorar el paso por Orduña y hacerle practicable para el tránsito carretero. La ciudad del Nervión se quejaba amargamente en 1553 de que han "procurado destruirla [la obra] las dichas probincias de Alaba y Guipuzcua, atrebiendose la de Alaba a desmoler y derribar, como en efecto desmolio y desizo, el camino de carro que por la parte de Unza hizo esta ciudad"2567.

En línea con estos comportamientos y, en general, por las mismas causas fue relativamente habitual que algunas poblaciones defendieran obsesivamente sus propias infraestructuras, ya fuesen caminos o puentes, con la finalidad de beneficiarse en régimen de monopolio del tráfico mercantil y trasiego de caminantes. No son escasas las acciones violentas encaminadas a obligar a los carreteros, mulateros y viandantes a pasar por una localidad determinada, para no ser considerados como "descaminados". Un ejemplo concreto fue el protagonizado por el concejo de Medina de Pomar, con la aquiescencia explícita del Condestable, al obligar a los usuarios del camino real a desviarse hacia dicha villa. Un testigo decía en 1515 que "todas las dichas premias e fuerças que han fecho a los dichos mulaterose viandantes, han seydo por escusarlos que no bayan por los dichos caminos rreales de las dichas merindades, e ques porque bayan por la dicha Medina a les comer sus viandas e mantenimientos e a les conprar çapatos $e$ pagar el dicho portazgo"2568.

En no pocas ocasiones, estas fuerzas y usos exclusivos, que iban directamentre en contra de una utilización racional de la caminería, estuvieron sustentados en monopolios y derechos otorgados por privilegio real, privilegio que la localidad beneficiada defendía con firmeza, si no con dureza y violencia. Tal fue el caso, por ejemplo, de Miranda de Ebro, que adquirió por el fuero de 1278 el derecho a impedir la existencia de puentes o pasos en barca entre ella y Logroño, de tal manera que todos cuantos desearan cruzar de una a otra orilla del Ebro, fueren de Burgos, la Rioja o Álava, tenían que hacerlo imperativamente por el puente de Miranda y no por ningún otro lugar.

$5^{\circ}$.- Es una caminería siempre desfasada. A pesar del impulso que experimentó durante el reinado de los Reyes Católicos, cabe concluir que la administración castellana fue manifiestamente incapaz de arbitrar y aplicar una política caminera digna de tal nombre. No existió durante el período objeto de este estudio una implicación decidida de la Corona a fin de planificar, crear, ordenar y potenciar una caminería a la altura de los tiempos y de las necesidades sociales, ni tan siquiera en lo concerniente a la preservación, reparo y mantenimiento de los existentes, afrontando los múltiples problemas que iban surgiendo. En el mejor de los casos, los poderes públicos se redujeron a incentivar el interés y la dedicación de los municipios comarcanos, renunciando a cualquier previsión ge-

2567 A. H. F. B./ Municipal de Orduña, caja nº 19, carp. 4/ Madrid, 17 mayo 1553.

2568 A. G. S./ Consejo Real de Castilla, leg. 84, fol. 2-III/ Valladolid, 26 junio 1513 a Salazar, 25 septiembre 1515. 
neral o planteamiento global. Esta postura tuvo efectos muy negativos para el desarrollo de la caminería y, por ende, para la integración de los territorios de la propia monarquía y para el desarrollo de su economía.

De esta manera, la infraestructura caminera castellana no pudo por menos que ser, durante los siglos XV y XVI, precaria e irregular. Muchos de los caminos existentes contaban con trazados heredados de épocas anteriores e inadecuados para las necesidades económicas y sociales de los nuevos tiempos. La textura de los firmes era muy elemental y el trazado comportaba desniveles abruptos, anchuras irregulares, pasos peligrosos y firmes de tierra que les hacían impracticables durante las épocas húmedas del año. Muchos de ellos, incluso tramos importantes de los caminos más reputados, no pasaban de ser otra cosa que meras sendas mulateras.

Ya hemos establecido que, en casos de reparación o adecuación de los firmes, las querellas entre los llamados al entretenimiento imponían con frecuencia demoras interminables, quedando los usuarios obligados a realizar rodeos o utilizar rutas nuevas menos conocidas, alargando con ello excesivamente las jornadas previstas. Por otro lado, en muchos casos no fue posible la utilización de carros en muchos tramos y, sobre todo, en los puertos de montaña, circunstancia que explica el predominio de la arriería en el transporte. Para mantener una mulatería y una carretería idóneas era fundamental facilitar el acceso de las bestias a unos pastos suficientes, cuestión que fue en todo momento fuente de problemas, asunto nunca resuelto de manera adecuada, pues contaba con la oposición permanente de los habitantes de las localidades aledañas, que necesitaban las brañas y praderas para su propia ganadería.

A estos problemas de pura funcionalidad, se añadían otros que dificultaban significativamente el mantenimiento de los caminos y el desarrollo de los transportes. Una compleja y extensa red de portazgos y de cobros de derechos se extendía por toda la geografía peninsular, a la que se añadía la existencia de aduanas interiores, que, además de encarecer los acarreos, retrasaba y molestaba a arrieros y carreteros. Todo esto contrastaba poderosamente con los transportes, considerablemente más baratos, cómodos y competitivos, que realizaban por entonces los franceses con carros y con los que efectuaban los flamencos, holandeses y lombardos por anchos y mansos ríos o por largas redes de canales.

6․- Se trata de una caminería de orientación económica. Los caminos aquí estudiados fueron los canales por los que discurrieron productos de alto valor económico, muy estimados en los mercados extranjeros por su alta calidad, como la lana, y por los que retornaban otros tan apreciados como los paños, los lienzos o el pastel. Pero no sólo fueron eso. También cumplieron un papel decisivo en la intercomunicación de las tierras del Cantábrico con el interior de la Península, haciendo llegar a la costa productos tan imprescindibles como el trigo, el centeno, la cebada o el vino y transportando al interior pescado o hierro.

La ciudad de Burgos, cuyo despegue inicial como ciudad quedó vinculado al desarrollo de las actividades artesanales y mercantiles, experimentó desde el siglo XII un fuerte desarrollo comercial y comenzó a adquirir un protagonismo especial tanto en el comercio interior castellano como en los mercados atlánticos. A partir de la primera mitad del si- 
glo XV, la ciudad experimentó una poderosa expansión, basada principalmente en dicha actividad, convirtiéndose en una dinámica y próspera plaza económica de proyección internacional, cuyos mercaderes jugaron papeles importantes en los principales mercados europeos e intensificaron su importante presencia en el interior peninsular.

No todo fue, sin embargo, bonancible. Al término del período que estudiamos en este trabajo, a finales del siglo XVI, la ciudad del Arlanzón entró en declive, arrastrando con ella al puerto de Santander, con quien siempre mantuvo una, tal vez, excesiva dependencia de la Universidad burgalesa. Por contra, el puerto de Bilbao consiguió mantener el rango e incluso potenciarle con un mayor control sobre la exportación de lanas y con la importación de productos industriales y de consumo.

En ocasiones, los caminos que nos ocupan cumplieron funciones distintas a las puramente económicas, como el transporte de convoyes especiales, principalmente de piezas artilleras, función para la que estaban, por lo general, mal pertrechados. Cumplieron, por descontado, la función de corredores de circulación de personas, aunque con bastante menor densidad que los caminos del interior peninsular. Esta función subsidiaria, secundaria, de los caminos del norte se visualiza perfectamente a través del mediocre uso que hizo de ellos la monarquía española, si se exceptúa el período en que el emparentamiento de los Trastámara con la casa de Borgoña obligó a relacionar la Península Ibérica con el mundo flamenco.

$7^{\circ}$.- Es una caminería con fuerte impacto social. En la transición de la Edad Media a la Edad Moderna, la sociedad castellana demandaba la existencia de unos caminos que garantizaran no sólo el desarrollo mercantil y comercial interno sino también el abastecimiento de productos foráneos. Como en el caso de las exportaciones, los caminos burgaleses que conectaban la ciudad del Arlanzón con los puertos cantábricos jugaron igualmente papeles importantes en las importaciones. Pero, también, al igual que sucedía con aquellas, la incuria política habitual y las adversidades connaturales a unos caminos predominantemente montanos determinaron el encarecimiento de las importaciones, es decir, arruinaron poco a poco la competitividad externa e interior de la economía de la zona. Este es uno de los factores determinatentes que lastró su crecimiento y una de las causas fundamentales que provocó su recesión. El interior castellano sufrió un estancamiento económico y fue perdiendo vitalidad en beneficio de la periferia peninsular, mucho mejor comunicada por mar, y que, a pesar de sus múltiples problemas, pudo remontar de manera mucho más eficaz los momentos de crisis, al poder abrir de forma más efectiva nuevos mercados y mantener los existentes.

A ras de suelo, llama poderosamente la atención la omnipresencia durante los siglos XV y XVI del Condestable, personaje feudalizante que, además de controlar el tráfico en muchos tramos de los caminos estudiados en función de sus extensos dominios señoriales, con el consiguiente cobro de derechos de tránsito, era beneficiario de la fabulosa renta que devengaban los diezmos de la mar. Controlaba por entonces la totalidad del tráfico comercial que dicurría entre Burgos y Laredo y una parte muy sustanciosa del que vehiculaban los caminos de Burgos a Santander y a Bilbao. A tal efecto, no tuvo empacho en adquirir o en apropiarse de importantes villas emplazadas en dichos itinerarios e incluso 
en desviar por medio del acoso y la violencia el tráfico comercial por las villas de su jurisdicción. Contra semejante control y omnipotencia actuó Felipe II en 1559, privando a los Velasco de las rentas de los diezmos de la mar, y en 1562, trasladando la capitalidad de las merindades de Castilla de Medina de Pomar a Villarcayo. Ambos acontecimientos han librado una documentación considerable, en forma de recursos y pleitos judiciales.

Este último acontecimiento, que denotaba el principio del fin del régimen feudal, no fue producto tan sólo de una determinada voluntad regia, sino también de la enconada resistencia que fueron capaces de oponer al Condestable los mercaderes y lugareños de Las Merindades. Este acontecimiento concreto, de orden incuestionablemente político pero también de orden social, no dejaba de tener profundas implicaciones económicas, que, a su vez, rebotaban sobre las colectividades afectadas, ya de forma negativa (con la ruina de los antiguos beneficiarios), ya de forma positiva (con el beneficio de los recién llegados). El empobrecimiento o enriquecimiento de aglomeraciones o comarcas en función del desvío de un camino de cierto rango cuenta con más ejemplos que el de Medina de Pomar y Villarcayo. Fue lo mismo que le sucedió a Frías cuando el impulso que se otorgó al camino de Burgos a Bilbao por Pancorbo y Berberana la dejó descolocada y marginada, golpe bajo del que no se recuperó jamás.

8․- Es una caminería basada en la arriería. El grueso del tráfico mercantil que circulaba por los caminos aquí estudiados gravitaba sobre transportistas que procedían de diversos puntos del reino, pero de manera preferente del norte de Burgos. Los mulateros eran originarios, principalmente, de las merindades de Castilla, es decir de los territorios de paso. Los más renombrados por su buen hacer eran los de la merindad de Castilla Vieja, del partido de las Cinco Villas y la Sonsierra y de la comarca de los Butrones, que contaban con aldeas cuyos vecinos eran masivamente mulateros. Tal sucedía, por ejemplo, en Villanueva la Blanca, Hornillayuso y Torme.

Muchos de ellos eran arrieros a tiempo completo, aunque el tráfico que tanta prosperidad y riqueza reportó a Burgos y a Castilla dependió también, en manera no desdeñable, de un fuerte contingente de arrieros a tiempo parcial. Unos y otros, además de tener que superar las dificultades del tráfico cotidiano, propiciadas por el frío, la nieve, la lluvia, las riadas, etc., en no pocas ocasiones debían cruzar pasos peligrosos, con gran riesgo de sus cargas, sus bestias y sus vidas. Estaban, además, expuestos a los ataques de los delicuentes, que nunca desaparecieron, y a las extorsiones y embargos que efectuaban algunos señores de las tierras por donde circulaban.

El desarrollo burgalés se produjo, entre otras razones, por la existencia de este amplio colectivo de mulateros que, al frente de sus recuas, medio de transporte perfectamente adaptado a las características de una red caminera tan compleja, garantizaron el trasiego de productos en una y otra dirección por los caminos burgaleses del Norte. Llama fuertemente la atención el hecho de que una organización comercial y económica tan consolidada y próspera por más de un siglo, gravitara predominantemente sobre una infraestructura transportista tan elemental, basada en lo fundamental en el tráfico a lomos de bestias y, de manera mucho más limitada, en la carretería. 
Valga, pues, este trabajo, como reconocimiento a aquellas personas que, con medios tan escasos, hicieron posible la pasada prosperidad de estas tierras, responsabilizándose de algo tan decisivo como era el transporte de mercaderías, tanto de las que generaban riqueza a través del tráfico comercial, como de las que posibilitaban la supervivencia cotidiana de amplios grupos de población.

Quisiera, finalmente, hacer hincapié en el hecho de que todos los elementos físicos relacionados con la caminería histórica, como los propios firmes, los empedrados, los puentes, las alcantarillas, los desmontes, las manguardias, los paredones, los mojones, los leguarios, las ventas y otras muchas modalidades constituyen parte fundamental de un patrimonio histórico de gran personalidad, que juega el importante papel de ilustrar el pasado y posibilitar la comprensión del presente. Lamentablemente, lo poco que queda de este patrimonio se encuentra en grave trance de desaparición por las concentraciones parcelarias, promovidas frecuentemente por las administraciones públicas, o por la desidia de los particulares, aunque me temo que todo ello se inscribe en el amplio manto de amnesia que la sociedad actual extiende sobre los fundamentos de su pasado. Sería altamente beneficiosa y conveniente una mayor protección de tan inestimable patrimonio, para que poder disfrutarlo y transmitirlo a las generaciones venideras. 